\title{
Recenzovaný sborník prríspěvků interdisciplinární mezinárodní vědecké konference doktorandů a odborných asistentů
}

\section{QUAERE 2021 roč. XI.}




\section{Mezinárodní vědecká konference | International Scientific Conference}

\section{Výbor konference | Conference Committee | Reviewed by}

Ing. Jiří Králík, Ph.D. - předseda výboru (kancelar@magnanimitas.cz)

Prof. dr hab. Jerzy Olszewski - Uniwersytet Ekonomiczny w Poznaniu, Polska.

Prof. dr hab. Włodzimierz Szpringer - Uniwersytet Warszawski, Polska.

Prof. dr hab. Marzanna Poniatowicz - Uniwersytet w Białymstoku, Polska.

Assoc. Prof. Martina Blašková, PhD. - University of Žilina, Slovak Republic.

Prof. Vladimiras Gražulis, DrSc. - Mykolas Romeris University, Lithuania.

Prof dr hab. Barbara Kryk - Uniwersytet Szczeciński, Polska.

Assoc. Prof. PhD. Jolita Vveinhardt - Vytautas Magnus University, Lithuania.

Assoc. Prof. Miloš Hitka, PhD - Technical University in Zvolen, Slovak Republic

Prof dr hab. Sylwia Pangsy - Kania Uniwersytet Gdański, Polska.

Prof. dr hab. Dorota Simpson - Uniwersytet Gdański, Polska.

Prof. zw. dr hab. Krystyna Lisiecka - Uniwersytet Ekonomiczny w Katowicach

Ass. Prof. Sándor Gyula Nagy - Corvinus University of Budapest, Hungary.

Prof. Ing Milota Vetráková, CSc. - Matej Bel University Banska Bystrica, Slovak Republic.

Prof. dr hab. Leon Tadeusz Dyczewski OFM Conv - Katolicki Uniwersytet Lubelski, Polska.

Assoc. Prof. Egle Stonkute, PhD. - Vytautas Magnus University, Lithuania.

doc. PaedDr. Daniela Valachová, PhD. - Univerzita Mateja Bela.

Assoc. Prof. Aleksey Khlopytskyi PhD. - Ukrainian State University of Chemical Technology, Ukraine.

doc. Ing. Ivana Rábová, Ph.D. - Mendelova univerzita v Brně.

doc. PhDr. L'ubica Derňarová, PhD., MPH - proděkanka pre VaVČ, Prešovská univerzita.

doc. PhDr. et PhDr. Martin Kaleja, Ph.D. - Slezská univerzita v Opavě.

Assoc. Prof. doc. Edita Hornáčková Klapicová, PhD. - SS Cyril and Methodius University.

PhDr. Iveta Ondriová, PhD. - Prešovská univerzita v Prešove, Slovak Republic.

PhDr. Terézia Fertal'ová, PhD. - Prešovská univerzita v Prešove, Slovak Republic.

Tomasz Kołakowski, Ph.D. - Wrocław University of Economics, Polska.

\section{Odborné sekce konference | Conference Sessions}

Management, marketing | Management, marketing; Ekonomika, bankovnictví, pojišt'ovnictví | Economy, Banking, Insurance

Management; Veřejná správa a makroprocesy | Public Administration, Macroprocesses; Přírodní vědy | Natural Sciences;

Psychologie, sociologie, pedagogika | Psychology, Sociology, Pedagogy; Informatika | Informatics; Technologie,

strojírenství, stavebnictví | Technologies, Engineering, Building Industry; Filosofie, dějiny, právo | Philosophy, History, Law

\section{Editor, úprava, realizace | Edit, Published by:}

(C) MAGNANIMITAS, Hradec Králové, Česká republika, 2021

Magnanimitas, Hradec Králové, 2021

ISBN 978-80-87952-34-4

\section{Upozornění | Warning:}

Všechna práva vyhrazena. Rozmnožování a šíření této publikace jakýmkoliv způsobem bez výslovného písemného svolení vydavatele je zakázané. | All rights reserved. Unauthorized duplication is a violation of applicable laws.

Certifikovaná vědecká konference | Certificate Conference No.: 2259662049

MAGNANIMITAS Assn. International and ECONFERENCE is a signatory of Berlin declaration on Open Access to knowledge in the sciences and humanities. (http://openaccess.mpg.de/3883/Signatories/)

for SCIEMCEE (https://oa2020.org/mission/\#other) 
Reviewed Proceedings of the Interdisciplinary Scientific International Conference for $\mathrm{PhD}$. students and assistants

\section{QUAERE 2021 vol. XI.}




\section{Obsah | Table of Contents}

\section{MANAGEMENT, MARKETING | MANAGEMENT, MARKETING}

DIAGNOSTIKA INOVAČNEJ DIMENZIE, KAPACITY A VITALITY PODNIKATELSKÝCH SUBJEKTOV

Tomáš Novotný

REKLAMA - VĚC VEŘEJNÁ 21

Oldrich Johannes Petr

NIEKTORÉ ŠPECIFIKÁ PROJEKTOVANIA INOVAČNÝCH NÁSTROJOV PRE TVORBU STRATÉGIE A PROCESNÉHO 28
RIADENIA PRIEMYSELNÝCH KLASTROV

Katarina Koporová, Tomáš Novotný, Ján Marcin, Róbert Kati

CORPORATE HOSPITALITY OF IBM AND DELL AS A PART OF THEIR CORPORATE IDENTITY 38

Sonia Krajčik Danišová

ZELENÉ INOVÁCIE V ORGANIZÁCIÁCH

Veronika Gajdošová Ladñáková

PODCAST SPECIFICATIONS IN SLOVAKIA $\quad 54$

Viera Krúpová, Zora Hudiková

Lucie Waleczek Zotyková

ROLE OF PLANNING AS A MANAGEMENT FUNCTION AND ITS APPLICATION IN COMPANIES IN SLOVAKIA 74

Andrea Čambalíková, Patrik Richnák

THE ENTERPRISE'S OBJECTIVE FOR BUILDING A RELATIONSHIP WITH IT'S SUPPLIERS AND REASONS WHY THE 81

ENTERPRISE DOES NOT PROVIDE VALUE INDICATORS

Dana Kušnirová, Mária Ďurišová

MOŽNOSTI STABILIZÁCIE SESTIER V SLOVENSKOM ZDRAVOTNÍCTVE Z POHLADU ŠTUDENTOV ODBORU

OŠETROVATEL'STVA

Livia Hadašová, Terézia Fertalová, Tatiana Šantová

INSTAGRAM A REKLAMA SKRYTÁ V DOPORUČENÍ 98

Lucie Kubičková

READER'S BEHAVIOR IN THE DIGITAL SPACE DURING THE COVID-19 PANDEMIC 114

Miriama Koliščáková, Jana Paveleková

OBJEKTÍVNOSŤ KOMUNIKOVANÝCH INFORMÁCIÍ V ČASE TECHNOLOGICKEJ INTERFERENCIE AKO

PREDPOKLAD REALIZÁCIE MEDZINÁRODNÉHO BENCHMARKINGU KLASTROV

Adam Madleñák

\section{EKONOMIKA, BANKOVNICTVÍ, POJIŠŤOVNICTVÍ| ECONOMY, BANKING, INSURANCE MANAGEMENT}

OBCHODNÍ DOHODY EU A MODEL SDÍLENÉ AGENTURY POHLEDEM EKONOMICKÉ DIPLOMACIE

Jana Marková

THE ETHICS AND ECONOMIC BENEFITS OF A DIGITAL SOCIETY

Thomas Meier, Helena Makyšová

ROA INDICATORS AS A PREDICTOR OF FINANCIAL HEALTH OF COMPANIES

Mária Michňová

\section{VEŘEJNÁ SPRÁVA A MAKROPROCESY | PUBLIC ADMINISTRATION, MACROPROCESSES}

KOMPETENCIE A FINANCOVANIE MESTSKÝCH ČASTÍ V MESTE KOŠICE

Jozef Andrejčák

ÚSTAVNOPRÁVNE POSTAVENIA MESTSKÝCH ČASTÍ V MESTE KOŠICE

Jozef Andrejč́k

POSTAVENIE A ÚLOHY ZASTUPITELSTVA SAMOSPRÁVNEHO KRAJA V SLOVENSKEJ REPUBLIKE

Lukášs Ivančik

MOŽNOSTI DEFRAGMENTÁCIE OBCÍ NA SLOVENSKU

Darina Koreňová 


\section{PŘíRODNÍ VĚDY | NATURAL SCIENCES}

RATLINNÉ KMEŇOVÉ BUNKY- PLATFORMA NA VÝROBU RASTLINNÝCH PRÍRODNÝCH PRODUKTOV PRE KOZMETICKÝ PRIEMYSEL

Šarlota Kaňuková, Marcela Gubišová, Ján Kraic

DOPLŇOVANIE OBSAHU ŽELEZA V ŽIVÝCH ORGANIZMOCH

Katarína Mitalová, Dušan Valigura

VPLYV EDUKÁCIE NA KVALITU ŽIVOTA PACIENTOV S DIABETES MELLITUS 2. TYPU

Andrea Šuličová, Tatiana Šantová, Zuzana Šimová, Jana Cinová, Lubica Derñarová, Zuzana Novotná, Lubomíra Lizáková,

Andrea Obročníková

VPLYV VYBRANÝCH RASTLINNÝCH SILÍC ČELADE LAMIACEAE NA RADIÁLNY RAST FUSARIUM GRAMINEARUM

Michaela Harčárová, Eva Čonková, Pavel Nad', Peter Váczi, Martina Proškovcová

NUTRIČNÁ PROBLEMATIKA U PACIENTOV S DEMENCIOU

Zuzana Novotná, Zuzana Šimová, Andrea Šuličová, Jana Cinová, Tatiana Šantová, Andrea Obročníková

KOMPARAČNÁ KAZUISTIKA ZAMERANÁ NA DIETOTERAPIU U HEMODIALYZOVANÉHO PACIENTA A

PACIENTA S PERITONEÁLNOU DIALÝZOU

Šantová Tatiana, Andrea Šuličová, Jana Cinová, Zuzana Šimová, Andrea Obročníková, Zuzana Novotná, Lubica Derňárová

POSTOJ RODIČOV K NEPOVINNEJ VAKCINÁCIÍ DETÍ

Jana Cinová, Tatiana Šantová, Andrea Šuličová, Zuzana Šimová, Zuzana Novotná, Lubica Derňárová, Lubomíra Lizáková,

Andrea Obročníková

RASTLINNÉ VÍRUSY INFIKUJÚCE ČELAD̆ FABACEAE

Simona Grešiková, Daniel Mihálik, Michaela Mrkvová

STRAVOVACIE NÝVYKY DETÍ POČAS LOCKDOWNU OCHORENIA COVID -19

Jana Cinová, Andrea Šuličová, Tatiana Šantová, Zuzana Šimová, Lubica Derňárová, Zuzana Novotná, Lubomíra Lizáková,

Andrea Obročníková

NÁSTROJE NA MERANIE KVALITY ŽIVOTA PACIENTOV SO SCLEROSIS MULTIPLEX

Andrea Obročniková

PROBLEMATIKA RÁN V ONKOLÓGII

Obročníková Andrea, Derňárová Lubica, Šantová Tatiana, Šimová Zuzana, Novotná Zuzana, Šuličová Andrea, Lizáková

Lubomíra, Cinová Jana

EFFECT OF CHAMOMILE AND COMMON AGRIMONY EXTRACTS ON BIOMASS OF PEA ROOTS IN THE CADMIUMPRESENT ENVIRONMENT

Marcel Roszival, Patrik Mészáros, Beáta Piršelová, Monika Koničková, Libuša Lengyelová, Ludmila Galuščáková

SKÚSENOSTI SESTIER S VYUŽITÍM VLHKEJ TERAPIE V KLINICKEJ PRAXI

Tatiana Šantová, Anna Eliášová, Terézia Fertalová, Livia Hadašová, Silvia Cibriková, Beáta Grešš-Halász

STAROSTLIVOSŤ O RANY V PREGRADUÁLNOM VZDELÁVANÍ SESTIER

Terézia Fertalová, Livia Hadašová, Anna Eliašová, Silvia Cibriková, Tatiana Šantová, Beáta Grě̌š Halász

HOJENIE RÁN PODTLAKOVOU TERAPIOU

Terézia Fertalová, Livia Hadašová, Anna Eliašová, Silvia Cibriková, Tatiana Šantová, Beáta Grešš Halász

VÝZNAM EDUKÁCIE O DARCOVSTVE KRVI

Andrea Šuličová, Andrea Obročniková, Lubica Derňarová, Zuzana Šimová, Jana Cinová, Tatiana Šantová, Zuzana Novotná,

Lubomíra Lizáková

VYŠETRENIE REZIDUÁLNEJ REAKTIVITY TROMBOCYTOV A JEHO VÝZNAM PRI ISCHEMICKEJ CIEVNEJ

MOZGOVEJ PRÍHODE

Katarína Pinčáková, Viktória Mikulášková, Vladimír Bošák

EXPERIMENTÁLNE ÚLOHY S TENZOMETROM

Michal Choma, Sergej Il'kovič

SROVNÁNÍ VYBRANÝCH PARAMETRŮ U PACIENTU゚ S LUPUS NEFRITIDOU A BEZ NÍ

Ján Sitko, Stanislava Blažíčková

\section{PSYCHOLOGIE, SOCIOLOGIE, PEDAGOGIKA | PSYCHOLOGY, SOCIOLOGY, PEDAGOGY}

ANALÝZA SOCIÁLNÍCH DOVEDNOSTÍ U PRACOVNÍKU゚ SOCIÁLNĚ PRÁVNÍ OCHRANY DĚTÍ

Jan Tirpák, Miriam Uhrinová, Tereza Ulrychová

ROZPRÁVKOVÁ TVORBA ANTONA HABOŠTIAKA A LATENTNÁ AGRESIA U DETÍ PREDŠKOLSKÉHO VEKU 
MODELS OF ALTERNATING PERSONAL CARE

Lucia Pažitná, Alena Novotná

MULTILATERÁLNÍ ZOBRAZENÍ UDÁLOSTÍ ŠOA V PUBLIKACI POSLALI JE NALEVO

Milan Mašát, Adéla Štěpánková, Andrea Bajnarová

SPOLEČENSKOVĚDNÍ PŘEDMĚTY NA TECHNICKÉ UNIVERZITĚ - VÝZNAM, PŘÍNOS A ZHODNOCENÍ

Jaroslav Lindr

PŘÍSTUPNOST V SOMATOPEDICKÉM KONTEXTU - MOŽNOSTI EVAKUACE A POSKYTOVÁNÍ PRVNÍ PSYCHICKÉ POMOCI OSOBÁM S OMEZENÍM HYBNOSTI V MIMOŘÁDNÝCH SITUACÍCH

Bianka Hudcová

REKVALIFIKACE V ČESKÉ REPUBLICE, JEJICH PROPOJENÍ S NÁRODNÍ SOUSTAVOU KVALIFIKACÍ A KOMPARACE SE ZAHRANIČÍM

Lenka Mužiková

KVANTITATIVNÍ VÝZKUMNÁ SONDA DO OBLASTI ÚPRAVY PROSTŘEDÍ POHLEDEM OSOB SE ZDRAVOTNÍM POSTIŽENÍM V ČESKÉ REPUBLICE

Adéla Hanáková, Miloň Potměšil, Eva Urbanovská, Bianka Hudcová, Gabriela Špinarová, Jana Zvěděliková

GUIDE TO TELEPRACTICE IN SPEECH THERAPY

Tereza Hrudová, Adéla Hanáková, Miloň Potměšil, Kristina Novotná

DIAGNOSTIKA KOMUNIKACE DĚTÍ PŘEDŠKOLNÍHO VĚKU S PORUHOU AUTISTICKÉHO SPEKTRA

Kristina Novotná, Adéla Hanáková, Milon̆ Potměšil, Eva Urbanovská, Tereza Hrudová

WORK STRESS AND STRESS MANAGEMENT STRATEGIES FOR SOCIAL WORKERS

Júlia Fričová

SCHEME OF OBJECTIVES FOR CHILD SEXUAL ABUSE PREVENTION

Anna Masariková

PRAKTICKÉ ZKUŠENOSTI DĚTSKÉHO DOMOVA S RŮZNÝMI FORMAMI NÁHRADNÍ RODINNÉ PÉČE Alois Danĕk

SPOJITOSŤ EMOCIONÁLNOU INTELIGENCIOU A OSOBNOSTNÝMI DIMENZIAMI PODL'A EYSENCKA U ŠTUDENTOV UČITELSKÝCH ODBOROV

Dominika Doktorová, Hubinská Jana, Varečková Lubica

SYMBIOTICKÉ VZŤAHY MEDZI VEDCAMI A UMELCAMI A SPROSTREDKOVANIE TÝCHTO VZŤAHOV POMOCOU DIDAKTICKÝCH METÓD V PEDAGOGICKOM PROCESE A ICH EVALVÁCIA V ZÁKLADNOM ŠKOLSTVE

Erika Miklóšová, Xénia Bergerová, Miloš Kmet'

ANALYSIS OF ACADEMIC TEXTS IN THE PROCESS OF LANGUAGE TRAINING OF FUTURE DIPLOMATS Martina Benčeková

KLINICKÁ VÝUČBA U ŠTUDENTOV OŠETROVATELSTVA

Anna Hudáková, Lubomíra Tkáčová

HODNOTENIE KVALITY ŽIVOTA PACIENTOV S CELIAKIOU

Zuzana Šimová, Andrea Šuličová, Tatiana Šantová, Jana Cinová, Zuzana Novotná, Lubica Derňárová, Lubomíra Lizáková,

Andrea Obročníková

VÝTVARNÉ UMENIE A UMELECKÁ ILUSTRÁCIA AKO REFLEXIA IMAGINÁCIE V ARTETERAPII

Alena Sedláková

KVALITA ŽIVOTA PACIENTA S NEUROLOGICKÝM OCHORENÍM

Ludmila Majerníková

PRÁCA S ODBORNÝM TEXTOM U ŠTUDENTOV MEEDZINÁRODNÝCH VZŤAHOV A DIPLOMACIE NA PRÍKLADE NEMECKÉHO POLITICKÉHO JAZYKA

Mária Polčicová

CONCEPTUAL AND THEORETICAL FRAMEWORK OF CONTENT AND LANGUAGE INTEGRATED LEARNING AT TERTIARY LEVEL EDUCATION

Mária Badinská

VÝZNAM SVOJPOMOCMÝCH SKUPÍN PRE CHRONICKY CHORÝCH PACIENTOV

Livia Hadašová, Terézia Fertalová, Beáta Grešš Halász, Anna Eliašová,

Tatiana Šantová

UPLATNENIE HIER S PRÍRODNÝM MATERIÁLOM VO VÝTVARNOTECHNICKÝCH ČINNOSTIACH V MATERSKEJ ŠKOLE

Mária Vargová, Jozef Zentko

SPOLUPRÁCA PACIENTA PRI KONZERVATÍVNEJ LIEČBE GLAUKÓMU A KVALITA ŽIVOTA

Mária Kašćáková, L'udmila Majerníková, Anna Hudáková, Andrea Obročniková

VYUŽÍVANIE PRVKOV ARTETERAPIE PRI VYTVÁRANÍ POZITÍVNEJ KLÍMY V INKLUZÍVNEJ TRIEDE

Barbora Sender 
A TYPOLOGY OF ADOLESCENTS IN TERMS OF RISKY BEHAVIOR

Kristína Mydlová

KREATÍVNE PRÍSTUPY K SPRACOVANIU TÉMY UMELECKÉHO PROJEKTU

Zuzana Hubinská

POJĘCIE PRESJI OSIĄGNIĘĆ EDUKACYJNYCH

Bartosz Atroszko

ŹRÓDŁA I KONSEKWENCJE STRESU SZKOLNEGO DOŚWIADCZANEGO PRZEZ UCZNIÓW

Bartosz Atroszko

DLACZEGO UCZNIOWIE POLSKICH SZKÓE SĄ PRZECIĄŻENI NAUKĄ?

Bartosz Atroszko

IMPULZIVITA ADOLESCENTOV A VÝCHOVNÉ ŠTÝLY RODIČOV V EXPERIMENTOVANÍ S FAJČENÍM

Zuzana Mičková, Sophia Mészárosová

HUDOBNÉ VNÍMANIE A UVEDOMELÉ POČÚVANIE HUDBY

ALKOHOLOVÉ SPRÁVANIE V SÚVISLOSTI S DEPRESIOU V OBDOBÍ VYNÁRAJÚCEJ SA DOSPELOSTI POČAS DIŠTANČNÉHO VZDELÁVANIA NA VYSOKEJ ŠKOLE

Rudolf Fábry, Dominika Minárová, Dominika Kochanová

YOUTUBE A ZÁVISLOST NA HRANÍ POČÍTAČOVÝCH HER

Pavel Vlk

INSCENOVÁNÍ JAKO SOUČÁST VYUČOVACÍHO PROCESU

Ladislav Tischler

VZTAH TRIVIALITY A UMĚLECKÝCH HODNOT V DÍLECH DAVIDA WALLIAMSE URČENÝCH DĚTEM A MLÁDEŽI Adéla Štépánková

KLÍČOVÉ SLOŽKY LITERÁRNÍ VÝCHOVY NA 2. STUPNI ZÁKLADNÍ ŠKOLY A ROLE OSOBNOSTI UČITELE

Lenka Nosková

MÚDROSŤ V KONTEXTE OSOBNOSTI U DOSPELÝCH

Andrea Baranovská, Dominika Doktorová

DETEKOVANIE VZÁJOMNÝCH KONEXIÍ A ROZDIELOV MEDZI EMOCIONÁLNOU INTELIGENCIOU A

EXTRAVERZIOU U VYSOKOŠKOLSKÝCH ŠTUDENTOV

Dominika Doktorová- Baranovská Andrea

ART ACTION VE SPOJENÍ S TRADIČNÍ LIDOVOU KULTUROU A LAND ARTEM

Patricia Biarincová

RIZIKOVÉ OBLASTI ŠKOLNÍHO ŽIVOTA Z HLEDISKA PROBLÉMOVÉHO CHOVÁNÍ ŽÁKŮ

Helena Vomáčková, Kristýna Kaprálová

ADAPTACJA KWESTIONARIUSZA DIABETES LOCUS OF CONTROL SCALE (DLCS) NA WARUNKI POLSKIE

Aleksandra Tuleja

O INKLUZÍVNÍ EDUKACI V SOUČASNÉ SLOVENSKÉ MATEŘSKÉ ŠKOLE

Jana Balážová

ASPEKTY ORGANIZAČNÉHO SPRÁVANIA: VŠEOBECNÝ PRACOVNÝ VÝKON A KONTEXTUÁLNY VÝKON

Katarína Hennelová, Laura Durinová

VÝSLEDKY AKTIVÍT NÁRODNÝCH PROJEKTOV V OBLASTI ROZVOJA KOMUNIKAČNÝCH SPÔSOBILOSTÍ DETÍ ZO SOCIÁLNE ZNEVÝHODNENÉHO PROSTREDIA

Alena Vráblová, Milena Lipnická

LITERÁRNÍ VÝCHOVA NA GYMNÁZIU V DOBĚ COVIDOVÉ: DIDAKTICKÉ ASPEKTY VYUŽITÍ E-LEARNINGU

V DISTANČNÍ VÝUCE

Eva Marková

INITIATIVES AGAINST DISINFORMATIONS ON THE INTERNET IN THE FIRST YEAR WITH COVID 19 IN

SLOVAKIA

Hedviga Tkáčová

THE IMPACT OF THE USE OF ONLINE EDITORS ON THE QUALITY OF STUDENTS' WRITING

Darina Halašová, Sonia Krajčik Danišová

\section{INFORMATIKA | INFORMATICS}

ZVYŠOVANIE POČÍTAČOVÝCH KOMPETENCIÍ ŠTUDENTOV ZDRAVOTNÍCKYCH ODBOROV 
VII. TECHNOLOGIE, STROJÍRENSTVÍ, STAVEBNICTVÍ| TECHNOLOGIES, ENGINEERING, BUILDING INDUSTRY

NÁVRH MANUÁLU ENERGETICKY EFEKTÍVNEHO RIADENIA OZE V PRIEMYSLE

Simona Novotná

APPLYING OF VIBRODIAGNOSTIC METHODS ON WATERPUMP'S KEY DEVICES AND EVALUATION

SUITABILITY OF THIS METHOD FOR MAINTENANCE REENGINEERING OF THE OFFSET PRINTING

MACHINE

Kristýna Kutiová, Michal Podstawka

BIG DATA A PREDIKTIVNÍ ANALYTIKA JAKO SOUČÁST STAVEBNICTVÍ 4.0 SE ZAMĚŘENÍM NA DOPRAVNÍ

Pavel Krupik

COMPUTER MODELING IN MSC ADAMS/VIEW AS PART OF A MODERN APPROACH TO THE DESIGN OF

TECHNICAL OBJECTS

Darina Hroncová, Erik Prada, Lubica Miková, Ivan Virgala, Michal Kelemen

VPLYV AUTOMOBILOVÉHO PRIEMYSLU NA ŽIVOTNÉ PROSTREDIE

Matúš Lavčák, Marieta Šoltésová, Michal Puškár

ENVIRONMENTÁLNE RIZIKÁ A CERTIFIKÁCIA VOZIDIEL POMOCOU NEW EUROPEAN DRIVING CYCLE (NEDC)

Michal Puškár, Marieta Šoltésová, Matúś Lavčák

OVĚŘENÍ NORMALITY JAKO ZÁKLADNÍHO PŘEDPOKLADU PRO POUŽITÍ NÁSTROJU゚ ŘÍZENÍ KVALITY

Kateřina Bícová, Josef Sklenička

THE ROLE OF ICT IN TRANSFORMING THE FACE OF EDUCATION: BOOK REVIEW

Avan Aziz

BARRIERS TO THE EFFECTIVE USE OF INFORMATION AND COMMUNICATION TECHNOLOGIES IN COLLABORATIVE LEARNING CLASSROOMS: A REVIEW OF LITERATURE

Avan Aziz

PRODUCTION PROCESS AS A TECHNICAL SYSTEM

Vladimír Sojka, Petr Lepšík

\section{FILOSOFIE, DĚJINY, PRÁVO | PHILOSOPHY, HISTORY, LAW}

THE STORY OF RESCUEING OF EUGEN MORGENBESSER

Stanislav Šveda, Eran Mor

VPLYV REKODIFIKÁCIE CIVILNÉHO PRÁVA PROCESNÉHO NA ČASOVÝ ROZMER ROZHODOVANIA O DOČASNOM POZASTAVENÍ ÚČINNOSTI VŠEOBECNE ZÁVÄZNÉHO NARIADENIA

Lukáš Tomaš

ZMENA VÝPOVEDE SVEDKA AKO DÔVOD OBNOVY TRESTNÉHO KONANIA

Lukáš Michal'ov, Martin Baločko

ESSENTIAL ETHICAL CONCEPTS WITH RESPECT TO PUBLIC ADMINISTRATION ETHICS

Petr Ondrušák, Jan Lípa, Ladislav Rozenský, Zdeněk Vrba, Josef Dolista

BIOPHILIC PHILOSOPHY OF JOSEF ŠMAJS

Jan Lípa, Ladislav Rozenský, Petr Ondrušák, Zdeněk Vrba, Josef Dolista

FENOMÉN TÁRANINY V MEDIÁLNEJ CELEBRITIZÁCII MARIÁNA KOČNERA

Anna Sámelová

LABOR LEGISLATION UNDER THE INFLUENCE OF THE COVID-19 PANDEMIC AND THE NEED OF HOME OFFICE / TELEWORK Silvia Trel'ová

A CAMP OF THREE TOTALITARIAN REGIMES IN SLOVAK MEMOIR AND FICTION

Sylvia Hrešková, Monika Adamická

DRAK SA VRACIA V ZNAMENÍ OHŇA

Sylvia Hrešková

FILOSOFIE A VĚDA V KONTEXTU LIDSKÉHO ZDRAVÍ

Klára Doláková

POTREBA ZMENY PRÁVNEJ ÚPRAVY PO ZAVEDENÍ INŠTITÚTU EURÓPSKEHO PROKURÁTORA DO PRAXE

Veronika Tóthová

MARKANTNÉ ZNAKY PÁCHATELA TRESTNÉHO ČINU Z POHLADU TRESTNÉHO PRÁVA, KRIMINOLÓGIE, PSYCHOLÓGIE A ICH EVENTUÁLNY VPLYV NA EFEKTÍVNOSŤ PRÍPRAVNÉHO KONANIA Patrícia Krásná

OPODSTATNENIE A VÝZNAM IMPLEMENTÁCIE KYBERŠIKANY DO LEGISLATÍVY V SLOVENSKEJ REPUBLIKE

Patrícia Krásná 
PRÍČINY VZNIKU PRIEŤAHOV V PRÍPRAVNOM KONANÍ A ICH VPLYV NA JEHO EFEKTÍVNOSŤ

Juraj Drugda

VYDÁVANIE PRÍKAZOV NA POUŽITIE PROSTRIEDKOV OPERATÍVNO-PÁTRACEJ ČINNOSTI A INFORMAČNOTECHNICKÝCH PROSTRIEDKOV V PRÍPRAVNOM KONANÍ

Juraj Drugda

ZROD NÁRODNEJ OPERY V POL'SKU

Dominika Sondorová

SVOBODA MÉDIÍ V MONGOLSKU

Hana Brodská

CORPORATE GOVERNANCE A ZÁKLADNÉ POVINNOSTI ŠTATUTÁRNYCH ORGÁNOV

Michal Sokol

VYUŽITÍ GRAFICKÝCH DĚL V SOUVISLOSTI S FANFICTION A JEHO AUTORSKOPRÁVNÍ ASPEKTY

Tereza Šmídová, Martin Šmíd, Barbora Kovářová

POSTAVENÍ ŽEN V MONGOLSKÉ SPOLEČNOSTI

Hana Brodská

KRIZE LIDSKÉHO VZTAHU V SOUČASNOSTI? LÁSKA JAKO KRITÉRIUM LIDSKÉHO VZTAHU

TEOLOGIA CHRZTU W KATECHIZMIE RAKOWSKIM (1605) NA TLE NAUCZANIA ORTODOKSYJNEJ REFORMACJI

Karolina Szymczyk

UTRPENÍ, ZÁRMUTEK A NADĚJE V SOUVISLOSTI S PERINATÁLNÍ ZTRÁTOU - VYBRANÉ ETICKÉ ASPEKTY

Markéta Královcová

ŠPECIFIKÁ KÚPNEJ ZMLUVY V OBČIANSKOM PRÁVE ČESKEJ REPUBLIKY

Marian Horváth

ATRIBÚTY PRACOVNÉHO PRÁVA V DIGITÁLNEJ ÉRE

Slávka Krásna

OSOBA PŘíMO POSTIŽENÁ SPÁCHÁNÍM PŘESTUPKU - RETROSPEKTIVA A PERSPEKTIVA

PÉČE NEFORMÁLNÍCH (LAICKÝCH, RODINNÝCH) PEČOVATELŮ O NEVYLÉČITELNĚ NEMOCNÉ DÍTĚ V ZÁVĚRU JEHO ŽIVOTA - NÁHLED Z ETICKÉ PERSPEKTIVY

Markéta Královcová 
MANAGEMENT, MARKETING MANAGEMENT, MARKETING

\section{QUAERE}




\title{
DIAGNOSTIKA INOVAČNEJ DIMENZIE, KAPACITY A VITALITY PODNIKATELSKÝCH SUBJEKTOV
}

\author{
DIAGNOSTIC OF THE INNOVATION DIMENZION, CAPACITY AND \\ VITALITY OF THE BUSINESS ENTITIES
}

\author{
Tomášs Novotný
}

\begin{abstract}
Abstrakt
Príspevok formuluje originálnu metodiku hodnotenia inovačných parametrov fungovania podnikatel'ských subjektov zo segmentu MSP. Ide o návrh komplexnej diagnostiky pre vytváranie vzorových nástrojov monitorovania, vyhodnocovania a podpory riadiacich inovačných procesov v manažmente firiem. Schopnost' poznat' vlastný inovačný potenciál a kapacitu komplexne, avšak jednoduchým spôsobom je nevyhnutnou podmienkou systémového vnímania a efektívneho riadenia moderných podnikatel'ských subjektov. Základný teoretický prínos spočíva v rozšírení manažérskej teórie o nové princípy a poznatky osobitne implementovatel'né v podmienkach MSP. Praktickým prínosom je vytvorenie rámcového návodu pre hodnotenie inovačných procesov a projektov manažmentmi pre podporu inovatívnosti, konkurencieschopnosti MSP.
\end{abstract}

Kl'účové slová: dimenzia, inovácia, kapacita, potenciál, vitalita,

\begin{abstract}
The paper formulates an original methodology for evaluating innovative parameters of the operation of business entities from the SME segment. The complex diagnostic of the creation of model tools for monitoring, evaluation and support of the management innovation process is described in the paper. The prerequisite of the systematic perception and effective management of the modern business is the ability to understand its own potential and capacity in comprehensive and simple way. The basic theoretical benefit consists of the extension of management theory with new principles and knowledge that can be implemented in the conditions of SMEs. The practical benefit is the creation of a framework guide for the evaluation of innovation processes and projects by management to support innovation, competitiveness of SMEs.
\end{abstract}

Keywords: innovation, dimension, capacity, potential, vitality

\section{1. ÚVOD DO PROBLEMATIKY}

Moderný manažment je dnes charakterizovaný zmenou prístupu $\mathrm{k}$ riadeniu, organizácii a tvorbe moderných podnikatel'ských programov firiem na trhu. Trendom doby je prechod od firmy produkcie $\mathrm{k}$ firme inovácie. Kým doteraz boli príznačné dlhé obdobia prosperity a krátke periódy chaosu a krízy, tak dnes je to už o dlhých obdobiach krízy a stagnácie, a len o krátkych zábleskoch prosperity a rastu. Napodobňovanie je prvým impulzom $\mathrm{k}$ vlastnej aktivite a prielomu v inovatívnom myslení [8], avšak v biznise nevyhrávajú napodobovatelia ale tí, čo vytvoria nové veci, otvoria nový trh a dosiahnu majstrovstvo. Dá sa tvrdit', že aj ked' väčšina manažérov uznáva moderné prístupy $\mathrm{k}$ riadeniu firiem ako sú inovatívnost' a riadenie kvality produkcie, vždy je vnútorne nespokojná so samotným spôsobom riadenia a mierou dosahovania úspechu a zisku. Problémom doby je preto podl'a názoru autora úloha: „hl'adá sa model malej, úspešnej, kreatívnej, vysoko inovatívnej, projektovo riadenej a super kvalitnej (excelentnej) firmy s nízkymi prevádzkovými nákladmi, plochou organizačnou štruktúrou, 
vzdelanými, aktívnymi a úspešnými l’ud'mi - $\mathrm{k}$ tejto podobe sa $\mathrm{v}$ skutočnosti dá len približovat' $\mathrm{v}$ určitom rozsahu a okruhu pôsobnosti aj to len ak sú známe všetky kl'účové vybrané atribúty jej inovačného potenciálu a definované schopnosti““ [18].

\section{INOVÁCIA, INOVAČNÝ POTENCIÁL, KAPACITA, VITALITA A DIMENZIA INOVATÍVNOSTI}

Už zakladatel' teórie inovácií J. A. Shumpeter uviedol, že: „Inovácia je praktické prenesenie ideí do nových produktov, procesov, systémov a spoločenských vzt'ahov" [19]. Potom je dôležité mat' na zreteli aj fakt, že „Inovácia je proces (nie akcia, udalost', či jav) a ako taký musí byt' riadený. Faktory, ktoré tento proces určujú možno ovplyvňovat' a tím ovplyvňovat' aj výsledok“ [5]. Inovačná kapacita a inovačná vitalita vytvára vo svojej synergii príslušný inovačný potenciál, ktorý hovorí o schopnosti firmy využit' svoje inovačné danosti na dosiahnutie zvýšenia konkurencieschopnosti [13] a prejavuje sa v konkrétnom priestore dimenzii inovatívnosti, pozostávajúcom z dimenzie hodnotenia (stav - dobrý, príjemný, úspešný, alebo zlý, nevhodný a pod.), d’alej z dimenzie sily (energetického náboja pojmu dominantný, silný, slabý, nevýrazný a pod.), nakoniec aj z dimenzie aktivity (jej vyjadrenia dynamický, či naopak pokojný a pasívny a pod.) [20].

Dimenzia inovatívnosti firmy (alebo aj inovačná dimenzia) nemá v odbornej terminológii priamy výklad a ide iba sémantické spojenie popisného atribútu (alebo aj charakteristiky údajov). Je to vlastne akýsi prehliadač uchovávania rôznych typov vzájomne súvisiacich údajov s meratel'nými parametrami [20] a v prípade hodnotenia fíriem najmä ich inovačnej kapacity a inovačnej vitality, poukazujúc tak na celkový inovačný potenciál danej firmy, ktorý korešponduje s d’alšími produktovými a organizačnými faktormi firmy a jej manažovaním.

Inovačná kapacita firmy je daná konkurenčnými prednost’ami a to $\mathrm{v}$ oblasti kvality, efektívnosti a flexibility. Sama firma ako producent a zároveň úspešný inovátor má spôsobilost' skúmat' neznáme a môžu kontinuálne, rýchlo a l'ahko pôsobit' na trhu inovácií pri cenovom zvýhodnení od konkurentov“ [14]. Inovačná kapacita firmy je daná konkurenčnými prednost'ami a to v oblasti kvality, efektívnosti a flexibility. Samé firmy ako producenti a zároveň úspešní inovátori majú spôsobilost' skúmat' neznáme a môžu kontinuálne, rýchlo a l'ahko pôsobit' na trhu inovácií pri cenovom zvýhodnení od konkurentov" [12]. Inovačná vitalita firmy je jej schopnost' preukázat' stav, kedy existuje v súčasnosti bez toho aby svojou prítomnou existenciou obmedzovala svoju budúcu existenciu nad mieru, ktorá je nevyhnutná. Ide teda o systém fungovania a manažovania, ktorý sa snaží byt' trvale udržatel'ným a úspešným [9].

Inovačný faktor vitality pritom odpovedá na schopnost' firmy v praxi zistit' ako dlho obstojí na spádovom trhu obchodného a produktového pôsobenia pritom, že samotná existencia firmy $\mathrm{v}$ reálnom čase a prostredí ju samotnú opotrebúva a spotrebúva a či jej výsledky sú trvalé alebo prechodné, úspešné alebo neúspešné, doslova márne i zbytočné, alebo efektívne a ekologicky čisté, prospešné alebo nebezpečné, čiže je to o úvahe že či firma existuje $v$ súlade $s$ prostredím svojej existencie alebo $\mathrm{v}$ konflikte $\mathrm{s}$ ním [3]. Je to tak hlavne o konkurencieschopnosti a schopnosti prežit' na trhu.

Uvedené pojmy inovačná kapacita, inovačná vitalita a inovačný potenciál i súvisiaca inovačná dimenzia pre účelnost' ich spolupôsobenia a popisovania v rámci tohto príspevku sú pomenované spoločne ako inovačné atribúty firmy. Na základe toho možno vyslovit' nasledujúcu vlastnú autorskú úvahu a špecifikáciu do diskusie a to, že z uvedeného rozboru pojmov a ich súvislostí je zrejmé, že pojem inovácia nie je iba všeobecnou frázou hovoriacou o recepte firiem na dosiahnutie úspešnosti, ale hlavne komplexným súborom osobitých pojmov vo vzájomnej prepojenosti a parametrizácii, vytvárajúcich zložitú dimenziu inovatívnosti tej ktorej firmy. Dimenziu inovatívnosti firmy potom možno (vlastná úvaha autora na diskusiu) definovat' ako: , súbornú hodnotu udávajúcu miery a vel'kost' skúmaného 
inovačného procesu. jeho faktorov a atribútov, jeho parametrov a intenzity citlivosti na produktové podnikatel'ské dianie v segmente pôsobnosti firiem “.

\section{KRITICKÝ POHLAD NA VYBRANÉ PROBLÉMY RIADENIA FIRIEM}

Manažéri podnikatel'ských subjektov a iných organizácií sa vo všeobecnosti (a je to dlhodobý trend) stavajú k svojmu riadenému subjektu ako k obyčajnej technickej veci: ak sa niečo kazí, tak sa to vymení, či zruší a možno bude náprava. Hlavne čím rýchlejšie a čo najlacnejšie. Hl'adá sa vždy iba jednoduché riešenie a také čo je poruke. Pritom manažéri nevidia mnohokrát veci inak ako akýsi súbor príkazov a stabilných úloh, ktoré ked' sa dobre vykonajú, tak plodia super výsledky. Negatívom je aj fakt, že za posledné desat'ročia sa $\mathrm{v}$ znalostnej i praktickej databáze riešení objavilo nespočetné množstvo „zaručene úspešných“ receptov, čo sú však vo výrazne prevažujúcej miere iba nesystémové všeobecné príklady, ktoré však sú v konkrétnych podmienkach konkrétnej firmy, pôsobiacej s daným produktom na konkrétnom trhu a $\mathrm{v}$ reálnom čase absolútne nepoužitel'né a chaotické a dokonca iba prehlbujú už existujúce zjavné alebo aj skryté problémy tej ktorej firmy. Je preukázatel'né [10], že skutočná hodnota mnohých riešení, manuálov a postupov a ich vzájomné previazanie a vplyv na tú ktorú firmu v rizikovom stave ohrozenia sa ako organický celok stráca. Je zrejmé z dlhodobej praxe, že sa k systémovým riešeniam nepristupuje $\mathrm{v}$ manažérskej praxi „systematicky a systémovo“, teda dnes sa z pojmu systémovost' stalo iba akési klišé a dnešné firmy sú uväznené $\mathrm{v}$ paradigme minulosti, ktorá ich chráni pred väčšou flexibilitou a dynamikou“ $[15,18]$. Ak teda manažéri riešia nejaký problém firmy, v skutočnosti investujú všetko svoje snaženie do jeho výstupov/dôsledkov a nie vstupov/príčin a tým sa celý efekt riešení stráca a to je často $\mathrm{v}$ danej fáze a danom čase doslova nepredstavitel'ne vel'ký problém, ohrozujúci práve budúcu existenciu podnikatel'ského subjektu. Najvýznamnejším krokom v posilnení svojej firmy je u manažmentu vytvorenie nového myšlienkového obrazu jej budúcnosti, formulovanie jej štruktúry, stratégie a identifikácia konkrétnych princípov a opatrení prekonávajúcich tradičné múdrosti a poznatky, teda riešenia nevšedné, originálne, aplikujúce nové prístupy [7]. Úspešné nastavenie inovačných procesov a poznanie reálneho inovačného potenciálu firiem prispieva $\mathrm{k}$ ich vít'aznej pozícii na trhu a trvalo nastavenej produktovej udržatel'nosti, tak ako je to spracované v prehl'ade v tabul'ke 1.

Tabul'ka 1: Kroky vytvorenia inovačne úspešnej pozície do budúcnosti [7]

\begin{tabular}{|l|l|}
\hline $\begin{array}{l}\text { Nové } \\
\text { ponímanie } \\
\text { princípov }\end{array}$ & $\begin{array}{l}\text { Prehodnotenie princípov, ktorými sa riadi firma, jej väzby na okolie i vnútorné } \\
\text { vzt'ahy i osobné faktory l'udí v nej. Hladanie nového uplatnenia, nového zmyslu } \\
\text { života a fungovania. }\end{array}$ \\
\hline $\begin{array}{l}\text { Nové } \\
\text { ponímanie } \\
\text { konkurencie }\end{array}$ & $\begin{array}{l}\text { Sústredenie na zásadné zmeny ku ktorým dochádza v charaktere výhod novými } \\
\text { netradičnými spôsobmi v dobe globalizácie s hl'adaním medzier v systéme pre } \\
\text { uchytenie sa firmy. }\end{array}$ \\
\hline $\begin{array}{l}\text { Nové } \\
\text { ponímanie } \\
\text { riadenia a } \\
\text { zložitosti }\end{array}$ & $\begin{array}{l}\text { Stanovenie akú štruktúru a aké riadenie dat' firme a ako vytvorit' nový prevádzkový } \\
\text { systém s kolektívnymi ambíciami systémovým myslením, proaktívnym konaním a } \\
\text { jednotlivcami - šampiónmi v tvorbe produktov, schopných sebareflexie a } \\
\text { samoštúdia. }\end{array}$ \\
\hline $\begin{array}{l}\text { Nové } \\
\text { ponímanie } \\
\text { vedenia }\end{array}$ & $\begin{array}{l}\text { Videnie nového postavenia manažmentu vo firme ako intelektuálnej kapacity } \\
\text { decentralizujúcej právomoci na l'udí a koordinujúcej tímovú prácu v podmienkach } \\
\text { danej firmy. }\end{array}$ \\
\hline $\begin{array}{l}\text { Nové } \\
\text { ponímanie } \\
\text { trhu }\end{array}$ & $\begin{array}{l}\text { Monitoring významných zmien v charaktere zákazníkov a marketingové } \\
\text { súvztažnosti medzi zákazníkmi a firmou, zohl'adnenie demografických faktorov } \\
\text { a špecifík zákazníkov v segmente MSP a klastrových zoskupeniach, } \\
\text { dekomponovanie ako moderné vyspelé technológie zásadne menia metódy } \\
\text { marketingu produktov firmy. }\end{array}$ \\
\hline $\begin{array}{l}\text { Nové } \\
\text { ponímanie } \\
\text { sveta }\end{array}$ & $\begin{array}{l}\text { Pojednávanie o zmenách v podnikaní a spoločnosti, o siet'ovaní odvetví, trhov, } \\
\text { konkurencie, o meniacom sa postavení štátov a o vplyve globálnych aplikácií } \\
\text { výsledkov vedecko - technického výskumu na pohl'ad manažérov firiem na svet. }\end{array}$ \\
\hline
\end{tabular}


Pred manažmentom firiem je v súčasnosti viacero výziev, dôležitá však je snaha utvárania podoby konkurencie a prevzatia osudu firmy do vlastných rúk a vytváranie zajtrajších výhod v konkurenčnom prostredí trhu je dnes najväčšou výzvou firiem [10]. Prístupy formovania inovačnej politiky majú tendenciu odvolávat' sa na špecifiká konkrétnej krajiny či regiónu a na tu platnú legislatívu a normy i dostupnú vedomostnú databázu, pritom zanedbávajú a prehliadajú tranzitný nacionálny prístup a spoločné, všeobecne vedecky platné elementy a pravidlá inovácií $\mathrm{v}$ danej hospodárskej politike štátu [1]. Je možné vyslovit' názor, že pre potreby skúmanej témy platí, že plánovanie kvality je neoddelitel'nou súčast'ou inovácií a obsahuje určenie zákazníkov, zistenie ich potrieb a očakávaní, preklopenie tohto poznania do produktov a služieb, určenie meratel'ných parametrov, vývoj a inováciu s následnou optimalizáciou a zavedením do nového portfólia ponuky firmy. A to je dnes o to dôležitejšie, čím viac sa globalizuje svet a zároveň budujú organizačné klastrové zoskupenia a siete.

\section{NÁVRH METODIKY HODNOTENIA INOVAČNÝCH ATRIBÚTOV FIRIEM} Metodika je postavená na vybraných nosných problémoch riadenia firiem, kde okrem strategického plánovania, zabezpečovania vlastnej produkcie a prevádzkového chodu, interného aplikovaného výskumu a vývoja/konštruovania nových firemných produktov, personálnej práce, organizačnej kultúry, vzdelávania a budovania vzt’ahov s prostredím pôsobnosti sa dôraz kladie práve na inovačnú dimenziu a súvisiace atribúty inovačnej kondicie firiem. Uvedené má osobitný význam v prípade ak firmy vytvárajú klastrové združenia a siete, kde je potrebná určitá súčinnost' a podobná miera dosahovaných výsledkov v hodnotení inovačnej kapacity a vitality pre lepšie prepojenie spoločných zámerov a projektov. Zvolený prístup k posudzovaniu problematiky kreativity a inovatívnosti je charakterizovaný ako psychometrický a zároveň kognitívny, kde je prioritou zameriavanie sa na rozsah tvorby, čiže na výkon manažmentu a projektových tímov firmy $\mathrm{v}$ úlohách obsahujúcich špecifické aspekty kreativity a inovatívnosti a zároveň aj inovatívnosti v komunikácii spoločných klastrových zámerov a ciel'ov. To je však za predpokladu že ide o meratel'né a hodnotitel'né veličiny (exaktne alebo verbálne) a že je uplatnitel'né v činnosti testovanie, ktoré kvantifikuje a kvalifikuje intuície a vzhl'ad a aktívne znalosti skúmaného objektu. Pritom sa zohl'adnia vel'kostné, sociografické, osobnostné, technické a technologické predpoklady a špecifiká skúmaných subjektov MSP, ako aj ich možnosti posilnenia podnikatel'ského prostredia v rámci vytvárania klastrových priemyselných zoskupení. Manažéri sa dnes učia ako chápat' inovácie nielen ako manažérsky nástroj, ale hlavne primárne ako proces, ktorý sa dá riadit', menit' a ovplyvňovat' účelne v záujme úspešnosti firmy, tak aby vznikol doslova organický typ firmy schopnej prispôsobovat' sa nestabilným a meniacim sa podmienkam a faktorom a schopnou neustále progresívne prekonávat' problémy.

\section{STANOVENIE CIELOV A ÚLOH PRE TVORBU METODIKY HODNOTENIA INOVAČNÝCH ATRIBÚTOV FIRIEM}

Každá firma má svoj inovačný potenciál no nie každá ho vie uplatňovat' a využívat' efektívne. Ovplyvňuje to hodnotenie štyroch charakteristík [13]:

- miera znalostí inovačných potrieb a súvisiacich nástrojov

- miera existencie inovačných príležitostí

- miera uplatnenia stupňa inovačnej organizačnej kultúry

- miera motivácie personálu inovovat' a byt' kreatívny.

Problémom súčasnej dynamickej doby vo firmách je podl’a názoru autora tohto príspevku, stručne povedané:

a) Nedostatok súčinnosti jednotlivých zložiek a tímov vo firmách,

b) Hierarchické organizovanie funkcií vo firmách zhora nadol v tzv. pyramídach, ktoré však nestotožňujú v sebe ciele a zámery firmy, 
c) Nekoncepčné, čiastkové riešenia problémov prístupom ad hoc a úpadok systémových teórií a zároveň aj uprednostňovanie analytického prístupu na úkor systémových koncepcií.

Metodika hodnotenia inovačnej kapacity a inovačnej vitality pozostáva z troch samostatných komponentov a to: analytická čast' A, vyhodnocovacia čast' B a čast' zistení a odporúčaní C. Pre prehl'adnost' metodiky je spracovaná nasledujúca tabul'ka 2 [autor]. Samotný princíp metodiky v rozhodujúcej vyhodnocovacej časti je postavený na použití síce známych a odskúšaných metód z ekonomickej teórie a praxe, avšak originálne prepracovaných práve pre podmienky a osobitosti procesov hodnotenia inovačnej dimenzie a inovačného potenciálu a to $\mathrm{v}$ účelovej synergii zjednodušenej aplikácie práve pre dynamické a jednoduché uplatnenie $\mathrm{v}$ inovačnej riadiacej práci manažérov a personálu. Podstatným princípom metodiky hodnotenia inovačnej kapacity a inovačnej vitality je posúdenie jednak súčasnej situácie a stavu a úrovne firmy a to ako celku a osobitne jej organizačných a strategických a produktových faktorov, silných a slabých miest a súvisiacich ohrození a príležitostí pre inovačný rast a jednak aj osobitne posudzovanie stavu a úrovne týchto inovačných atribútov na úrovni firmy ako celku a na úrovni samotného manažmentu, teda posudzovania toho, ako sú vlastne tieto pripravené a schopné realizovat' zmeny v prístupe k inováciám do budúcna.

\section{KOMPONENTY A OBSAH METODIKY HODNOTENIA INOVAČNÝCH ATRIBÚTOV FIRIEM}

Uvedená metodika je výsledkom dlhodobejšieho systematického skúmania problematiky hodnotenia inovačnej kapacity, inovačnej vitality a dimenzie inovatívnosti firiem z portfólia MSP a klastrových priemyselných združení [13,15,16,17]. V prvej časti A (A1 až A5) sú popísané definované hlavné oblasti zamerania analytického výskumu v rámci tvorby metodiky u hodnotenia inovačných atribútov firiem. Čast' B (B1 až B7) metodiky uvádza konkrétne analytické, zist'ovacie a vyhodnocovacie metódy a ich princípy a posledná čast' $\mathrm{C}$ (C1 až C4) prehl'adne uvádza očakávané výsledky a vhodné sledovanie opatrení pre riadenie inovačných procesov a zmenu - zlepšovanie inovačného stavu a úrovne inovatívnosti tej ktorej hodnotenej firmy v podnikatel'skej praxi.

6.1 A - Analytická čast' metodiky

A1: Analýza úrovne inovačnej kapacity firmy

A2: Analýza úrovne poznania manažérskych konceptov, metód a nástrojov

A3: Analýza úrovne aparátu riadenia firmy

A4: Analýza postoja firmy $\mathrm{k}$ manažérskym nástrojom

A5: Analýza postoja manažmentu $\mathrm{k}$ výberu manažérskych nástrojov

6.2 B - Vyhodnocovacia čast' metodiky:

B1: Primárna SWOT analýza na identifikovanie: že do akej miery je súčasná jestvujúca stratégia firmy a jej špecifické vnútorné faktory (silné a slabé miesta) a vplývajúce vonkajšie faktory (príležitosti a ohrozenia) relevantné a schopné sa vyrovnat' so zmenami vznikajúcimi $\mathrm{v}$ procese fungovania firmy. Pre potreby zmien $\mathrm{v}$ oblasti inovácií sa podrobne špecifikuje súbor jednotlivých faktorov a ich meratel'ných (ocenitel'ných/zhodnotitel'ných ) parametrov a to jednotlivo v každej skupine $\mathrm{S}, \mathrm{W}, \mathrm{O}, \mathrm{T}$. Následne sa vykonáva analýza a určenie výkonnosti, pomernej váhy, vypočítanej a maximálnej hodnoty pre každý jednotlivý parameter a to s dôrazom na sledovanie podielu inovatívnosti. Následne sa vykonajú samostatné matice výkonnosti a dôležitosti pre silné a slabé stránky SWOT a potom aj matice príležitosti a ohrození. Výsledky z jednotlivých parametrov sú podkladom pre uplatnenie d’alších nadväzujúcich metód pre posudzovanie inovačných faktorov firmy a jej manažmentu. B2: Analýza kapacity inovačného riadenia: vo firme spočíva v uplatnení troch vzájomne sa skúmanými parametrami a výsledkami prelínajúcich auditov z ktorých každý sa osobitne venuje príslušnému okruhu činností vo firmách.

B3: Audit stavu a úrovne inovačného riadenia: Tento je chápaný ako mechanizmus pre ul'ahčenie tvorby štruktúry hodnotenia firmy a jej stratégie viazanej na inovácie. Ide o procesy spojené s organizačnou kultúrou, technikou predaja, projektovým riadením u zákazníka 
a získavania znalostí a dynamiky riadenia. Je potrebné si stanovit' podl'a dostupných poznatkov súbor faktorov, ktoré v súčasnosti ovplyvňujú významne úspech či neúspech v inovatívnosti u firmy a prijatou škálou ohodnotenia, takto možno vytvorit’ profil terajšieho inovačného výkonu, čo má za následok (v spojení so závermi primárnej SWOT analýzy) formulovanie zásad nového inovatívneho prístupu ako rozhodujúceho prvku pre strategické riadenie a plánovanie v programe. Postup spočíva v zostavení a obodovaní súboru kontrolných otázok (vytvorených v súlade s posudzovaním parametrov zo SWOT analýzy a spracovaných interným dotazníkom pracovníkmi firmy) a ich zoskupenia do piatich oblastí riadenia inovácií (piatich stĺpcov) a to: Stratégia. Procesy produkcie a projektingu, Organizácia, Väzby/Vzt’ahy na okolie, Učenie sa a vyhotovia súčty bodov, ktoré sa spracujú do pomerných hodnôt.

B4: Určenie inovačného potenciálu: hovorí o tom odkial' - kam sa má firma posunút' v podnikatel'skom priestore. Asociácia inovačného podnikania v ČR napríklad vypracovala ešte v roku 2014 technický profil ukazujúci na stredný inovačný potenciál firmy. Sleduje sa tu 6 parametrov a to Stratégia a podnikanie, Štruktúra organizačná, Procesy, Tvorivý potenciál, Pracovníci a Stratégia firmy. Graf inovačného potenciálu v tabul'ke č.2 ukazuje priemernú známu polohu skúmaného typu firmy v tomto priestore, pričom je zrejmé, že najlepší záber je v stratégii, organizácii a kvalite, najslabší v marketingu a logistike. Všetky tu zistené a merané údaje sa porovnávajú s tzv. ideálnym skóre (t.j. údajmi ideálne firmy, ktorá vo všetkých sledovaných údajoch dosahuje maximálne hodnoty) a potom sa zakreslia do pentagramu a po vyznačení podielov za jednotlivé oblasti riadenia a spojení jednotlivých hodnôt podielov do obrázku úsečkami sa dá stanovit' súčasný skutočný stav a úroveň inovatívneho riadenia a vyslovit' konkrétny záver o pozícii.

B5: Diagnostika stavu a úrovne dimenzie inovatívnosti: K vykonaniu príslušnej diagnostiky sa opätovne účelne využije súbor meraní a zistení parametrov zo zvolených faktorov (spolu 30 údajov) v rámci už vykonanej SWOT analýzy a to jednotlivo pre každú súčast', t. j. silné stránky, slabé stránky, príležitosti a ohrozenia. Potom sa uskutoční porovnávacie hodnotenie, čiže u skúmaného subjektu sa uvedú k jednotlivým parametrom údaje zo SWOT a ich príslušné hodnotenie bodmi a následne sa vykonáva porovnávanie s prejudikovanými výsledkami tzv. vrcholových inovátorov, ktorí majú jednotne ako etalón určenú bodovú hodnotu pre každý parameter max. počet bodov. Potom sa spočítava koeficient novej pozície hladiny inovačného manažmentu ako pomer sumár počtu hodnotení k celkovému výsledku.

B6: Stanovenie dimenzie inovatívnosti firmy: Graf stanovenia dimenzie inovatívnosti je zloženým grafom troch sústredne organizovaných pravidelných štvorcov ( označujúcich hladinu bodového hodnotenia, so zakreslením kumulovaných hodnôt (červenou farbou) príslušných skupín parametrov podl'a percentuálneho výpočtu $\mathrm{z}$ analýzy SWOT. Z grafu jednoznačne je preukázané že vytvorený nepravidelný štvorec skutočného vyjadrenia dimenzie inovatívnosti je v priemere až podpriemere hodnotenia, pod hladinou hodnotenia príslušného hodnotenia a potvrdzujú sa predchádzajúce zistenia $\mathrm{z}$ ostatných analýz o priemernosti skúmaného subjektu. Z uvedeného je preto možné v podmienkach tej ktorej danej firmy prijímat' do budúcna presné postupy a opatrenia.

B7: Analýza súčasnej úrovne riadenia metódou QFM: Metóda QFM (Quality Function of Management), sa zaoberá sa v praxi generovaním možností ako vlastným riešením problémov a pre jej jednoduchost' aplikovania a zároveň pomerne vysokú výpovednú hodnotu a rýchlost' aplikácie autor dizertačnej práce nasledovne vykonal spracovanie analýzy riadenia kvality, kde kombináciou a využitím modulárnosti postupov výpočtov z oboch už spomenutých metód boli na základe vykonaného interwiev, brainstormingu a tímových konzultácií vyselektované a špecifikované tieto nosné požiadavky a súvisiace znaky:

Požiadavky: A - zvýšenie efektivity produkcie; B - zlepšenie komplexnosti služieb; C rozvoj pridanej hodnoty produkcie pre zákazníka; D - zvýšenie intenzity predaja produktov; E - zlepšenie servisu pre zákazníkov; F-zvýšenie úrovne personálnych kapacít 
Znaky: 1. strategické plánovanie a prieskum trhu; 2. realizácia produkcie pre zákazníka; 3. zabezpečenie kontroly kvality produkcie; 4. zabezpečenie financovania; 5. poskytovanie služieb; 6. vyhl’adávanie zákaziek; 7. analýza a zlepšovanie.

Tabul'ka 2: Prehl'ad ilustračných obrázkov k metódam B1 až B8 [autor]

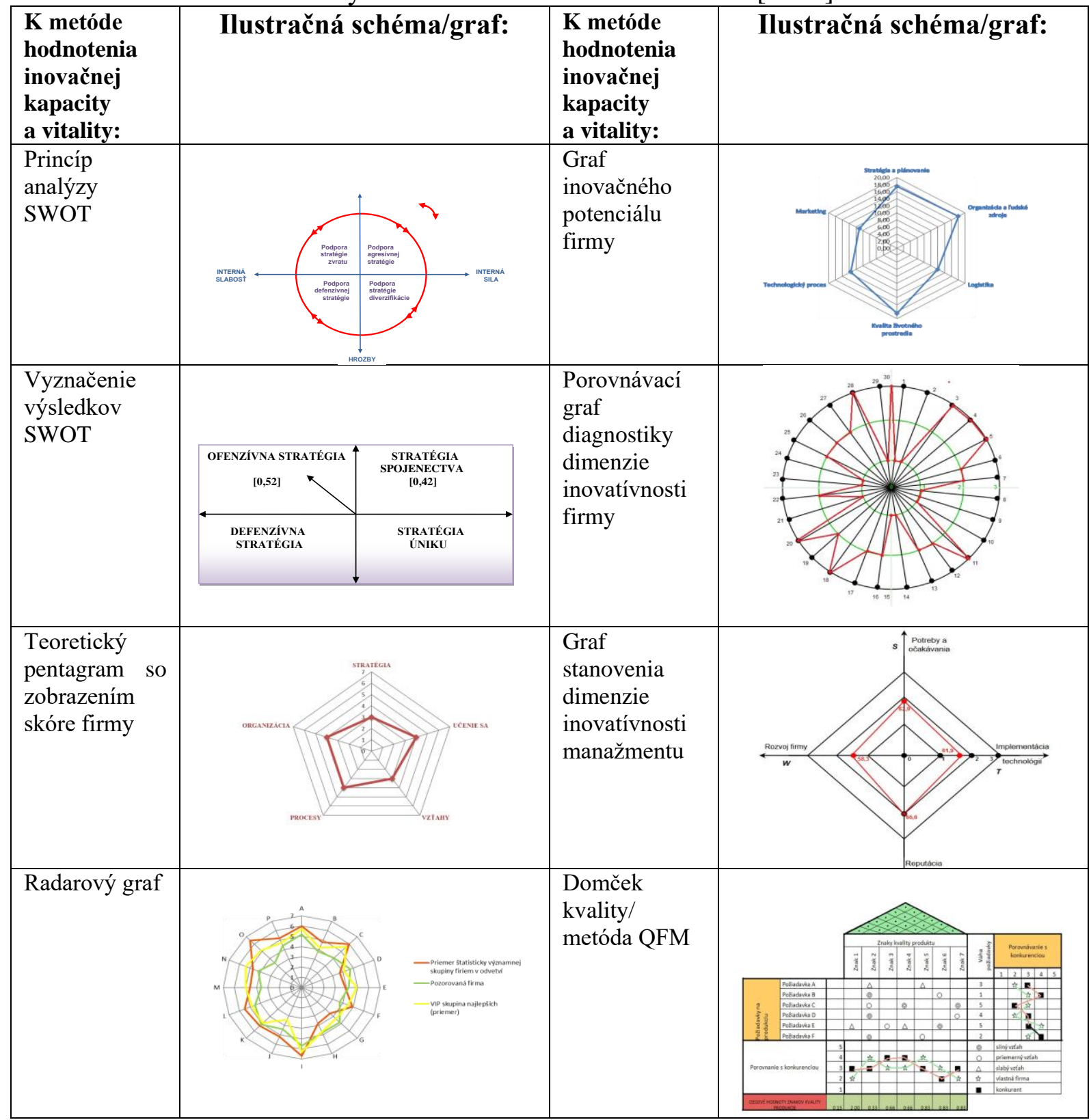

\subsection{C - čast' zistení a odporúčaní metodiky:}

Výsledky a odporúčania pre inovačné zásahy do riadenia firmy z jednotlivých aplikovaných metód $\mathrm{v}$ rámci metodiky sa dajú zhrnút' nasledovne:

C1: Výsledky Zo SWOT analýzy: Tak je možné zodpovedne získat' ucelený súbor údajov a vytvorit' portfólio výstupov z riešení, následne sa vypočítava a určuje príslušná stratégia zobrazuje do grafu s vyznačením vektora smerovania do príslušného pol'a firemnej stratégie a to bud' ofenzívna stratégia, stratégia spojenectva, alebo defenzívna stratégia či stratégia úniku. To je rozhodujúce zistenie $\mathrm{v}$ rámci SWOT a základ pre budúce smerovanie firmy v rámci rozvoja je inovačnej dimenzie, nakol'ko sú tak presne známe a porovnatel'né jednotlivé faktory/ich parametre a dá sa zodpovedne nastavit’ ich zlepšovanie a do akej miery. 
C2: Výsledky z auditu stavu a úrovne kapacity inovačného riadenia: Všetky tu zistené a merané údaje sa porovnávajú $s$ tzv. ideálnym skóre (t.j. údajmi ideálne firmy, ktorá vo všetkých sledovaných údajoch dosahuje maximálne hodnoty) a potom sa zakreslia do pentagramu a po vyznačení podielov za jednotlivé oblasti riadenia a spojení jednotlivých hodnôt podielov do obrázku úsečkami sa dá stanovit' súčasný skutočný stav a úroveň inovatívneho riadenia a vyslovit' tento záver: V porovnaní s ideálnym stavom firma dosahuje vysoké, priemerné, alebo iba podpriemerné hodnoty $v$ tej ktorej nosnej oblasti riadenia inovácií a je namieste potom stanovit' opatrenia pre zlepšenie, t.j. zvýšit' či udržat' určité parametre stavu a úrovne riadenia inovácií firmy.

C3: Výsledky z analýzy súčasnej úrovne riadenia metódou QFM: Kombinovaný výpočet celkových hodnôt jednotlivých znakov kvality produkcie a výpočet kumulovanej hodnoty/váhy príslušného znaku stanoví výslednú hodnotu a pomernú hodnotu úrovne riadenia kvality a jej inovačného potenciálu a dáva výsledok o tom, či je firma výborná, priemerná a či iba podpriemerná a v ktorých oblastiach riadenia je potrebné zlepšovanie. Pri správne a zodpovedne realizovanom hodnotení sa vel'mi približujú zistenia z oblasti posudzovania inovačných faktorov a z oblasti riadenia kvality vo firme, nakol'ko v praxi sú to spojené nádoby a úzko súvisiace atribúty firiem vo všeobecnosti.

C4: Výsledky z analýzy stavu a úrovne projektových inovácií vo firme: Zo zistených výsledkov - pozícií jednotlivých bublín je zrejmé to, čo už preukázala strategická SWOT analýza a audit inovačného riadenia - skúmaná firma sa pohybuje na takých a takých konkrétnych inovačných (najmä inkrementálnych a čiastočne radikálnych úrovniach s rôznorodou vel'kost'ou projektov) a z toho je potrebné vyvodit' v riešení práce zodpovedajúce závery.

\section{ZHRNUTIE}

Podnikatel'ské prostredie je dnes definované ako stav, kedy každá firma musí byt' spôsobilá žit' $\mathrm{s}$ rizikom úspešnosti $\mathrm{v}$ turbulentnom prostredí, mat' systém včasného varovania $\mathrm{a}$ rozpoznávania problémov, krízové záchranné scenáre a určené pravidlá pre pružné zvládnutie chaosu a operatívnost' $v$ riadení firmy a spôsobilost' spolupracovat' a kooperovat' aj $v$ rámci podnikatel'ských a výskumných klastrových zoskupení i sietí a je preto nanajvýš potrebné aby sa v manažmente namiesto eliminácie chýb a nevýhod hl'adali na základe poznania vlastnej inovačnej spôsobilosti, aktuálnej inovačnej dimenzie a kapacity vlastné postupy a budovanie výhod pre posilňovanie inovačnej vitality $[8,9]$. To sa dá overovat' $v$ rámci navrhovanej metodiky iba analýzou konceptov a prístupov súčasného riadenia kvality a produkcie $\mathrm{i}$ auditom stavu a úrovne inovačného riadenia a diagnostiky inovačnej dimenzie $\mathrm{v}$ každej firme segmentu MSP a každom priemyselnom klastrovom zoskupení, ktorým sa autor tohto príspevku podrobne venuje $\mathrm{v}$ iných svojich publikáciách a príspevkoch $[4,13,14,15,18]$. Implementáciou výsledkov a záverov strategickej analýzy a zist’ovaní a tiež všetkých tu aplikovaných analytických a diagnostických metód sa rozumie pre účely tejto práce plánovitá realizácia či pretvorenie do samotnej stratégie firiem, vyvodenie následkov pre strategické plánovanie a riadenie, pričom sa vytvoria pravidlá, princípy a opatrenia, ktoré zabezpečia inovatívnost', uplatňovanie novej kvality služieb a zodpovedný manažérsky systém riadenia. Publikovaný príspevok sa stáva súčast’ou riešení a očakávaných výsledkov práce $\mathrm{v}$ rámci riešenia grantového projektu NFP313020ANX5, financovaného z prostriedkov EŠIF Ministerstvom hospodárstva SR pod názvom: „Koncipovanie a rozvoj integrovanej inovačnej infraštruktúry a vedomostnej bázy v európskom priestore klastrovej organizácie NEK", výskumnej úlohy č. 1.1: „Tvorba spoločnej expertnej databázy a analýza energetického a environmentálneho prostredia v EÚ, SR a krajinách V4“. Zároveň prináleží do publikačných príspevkov autora $\mathrm{v}$ rámci štúdia DBA. 


\section{Použitá literatúra}

1. ADAIR, John. Efektívni inovace. Alfa Publishing. 2004. ISBN 80-86851-0.

2. BALOG, Miroslav. Klastrová politika v podmienkach Slovenska. SIEA, Bratislava: 2015. ISBN 978-80-88823-61-2.

3. CANTWELL, James, A. Technological Innovation and Multinational Corporations, Oxford: 1989, Basil Blackwell.

4. COLLINS, Jim., PORRAS, Jery. Jak vybudovat trvale úspěšnou firmu (BUILT to Last). Praha: Grada Publishing, 2016. ISBN 978-80-271-5638-7.

5. DYTRT, Zdeněk; STŘ́́TESKÁ, Michaela. Efektivní inovace, Odpovědnost v managementu. Brno: Computer Press, 2009. ISBN 978-80-251-2771-1.

6. Elektronická učebnica výskumu. Dostupné na: e-metodologia.fedn.uniba.sk/index. Php/kapitoly/semanticky-diferencial. php?id=i17

7. GIBSON, Rowan. Nový obraz budoucnosti: predni osobnosti světového managementu a sociálního myšlení o budoucnosti podnikání, konkurence, ř́zení a trhu. 3. dopl. vyd. Praha: Management Press. 2007. ISBN 978-80-7261-159-1.

8. GODIN, Benoit. Innovation: The History of a Category. [Online] (C) 2020 Science, technologie et innovation: histoires intellectuelles et conceptuelles Benoît Godin. [Cit. 15. 9. 2020.]. 2008.Dostupné z: http://www.csiic.ca/PDF/IntellectualNo1.pdf.

9. GRASSEOVÁ, Monika. Efektívní rozhodování. Analyzováni - Rozhodování Implementace a hodnocení. Brno. Edika.2013: ISBN 978-80-266.0179-1.

10. HOLLROYD, Chris. Science and Technology Policies National Competitiveness and The Innovation Divide. The Centre for International Governance Innovation Celektron. 2007. Working Paper No. 32.

11. JÁČ, Ivan, Petra RYDVALOVÁ a Miroslav ŽIŽKA. Inovace v malém a středním podnikání. Brno: Computer Press. Business books (Computer Press). 2005.ISBN 80251-0853-8

12. LAWSON, Benn, SAMSON, Chalis, D. Developing Innovation Capability in Organizations: A dinamic capabilities approach. In: International Journal of Innovation Management. Vol. 05, No. 03, pp. 377-400 (2001). DOI:10.1142/S13639 19601000427.

13. NOVOTNÝ, Tomáš. Diagnostika dimenzie inovatívnosti firiem. Národný energetický klaster NEK, Bratislava: 2018, ISBN 978-80-972637-1-3.

14. NOVOTNY, Tomáš, TICHÝ, Jaromír. Audit of innovation management and diagnostics of innovation capacity of a business entity. In: MMK: 2020, Mezinárodní Masarykova konference pro doktorandy a mladé vědecké pracovníky, ročník XI, Hradec Králové: MAGNANIMITAS. 2020. ISBN 978-80-87592-33-7.

15. NOVOTNÝ, Tomáš. Tvorba novej metodiky hodnotenia inovačných projektov vybraných podnikov MSP. Recenzovaný sborník př́spěvků. Mezinárodní online konference studentů DBA, Praha: CEMI, 2021. ISBN978-80-270-9271-1(online).

16. NOVOTNÝ, Tomáš., HRABOVSKÝ, Gabriel., MARCIN, Ján. Koncipovanie inovačných nástrojov energetických a environmentálnych klastrových habitatov. Bratislava: MH SR,NEK,2020.ISBN 978-80-973571-0-8.

17. PLAMÍNEK, Jiř́. Diagnostika a vitalizace firem a organizací: teorie vitality $v$ podnikatelské a manažerské praxi. Praha: Grada, 2014.ISBN 978-80-247-5323-2 
18. TICHÝ, Jaromír, NOVOTNÝ, Tomáš., The potential of the methodology of evaluation of innovative projects by SME management. In. CER Comparative European Research, 14th International Scientific Conference for PhD students of EU countries. Published in october, 2020 by Sciemcee Publishing, London, Volume 7. Issue 1.p.17-21. 209 p. ISBN 978-1-9993071-6-5.

19. TUREKOVÁ, Helena a Branislav MIČIETA. Inovačný manažment: východiská, overené postupy, odporúčania. V Žiline: EDIS, 2003. ISBN 80-8070-055-9.

20. Výklad pojmu dimenzie a metriky. Dostupné na: support.google.com/analytics/answ er/1033561, rok 2021.

\section{Kontaktné údaje}

Ing. Tomáš Novotný, Ph.D., MBA

Národný energetický klaster NEK

generálny sekretár,

Záhradnícka 72, 82108 Bratislava

Slovak Republic

Tel: (+421) 910961141

email: info@nek.sk 


\title{
REKLAMA - VĚC VEŘEJNÁ
}

\section{ADVERTISING - A PUBLIC MATTER}

\author{
Oldřich Johannes Petr
}

\begin{abstract}
Abstrakt
Jedním z úkolů reklamy je komunikace s veřejností. Reklamní styl se odlišuje od ostatních stylů, má jiné poslání a záměr. Reklama se prostřednictvím textu a obrazu snaží ovlivnit určitou cílovou skupinu, tento vliv můžeme bez pochyb nazvat manipulací. Nedílnou součástí jejího působení jsou média. Ta napomáhají uskutečnit záměr reklamy, poskytují spojení mezi značkou a zákazníkem. Reklamní vliv roste, umožňují to především globálně se rozvíjející trhy. Konkurenční tlak není jen směrem k zákazníkům, ale také ke tvůrcům reklamních komunikátů. Reklamní styl, který jsem zmínil, patří v současné době k nejrychleji se rozvíjejícím a měnícím stylům vůbec. Nároky cílové skupiny rostou, stejně jako nároky na propracované reklamní sdělení.
\end{abstract}

Klíčová slova: Reklama, veřejnost, persvaze, zákazník, média, cílová skupina, reklamní kampaň, reklamní rétorika, globální trh

\begin{abstract}
One of the tasks of advertising is to communicate with the public. Advertising style differs from other styles, it has a different mission and purpose. Through text and image, advertising tries to influence a certain target group, we can undoubtedly call this influence manipulation. The media are an integral part of its work. They help to realize the intention of advertising, provide a connection between the brand and the customer. The advertising influence is growing, especially due to globally developing markets. Competitive pressure is not only towards customers, but also towards the creators of advertising messages. The advertising style I mentioned is currently one of the fastest growing and changing styles ever. The demands of the target group are growing, as are the demands for a sophisticated advertising message.
\end{abstract}

Key words: Advertising, public, persuasion, customer, media, target group, advertising campaign, advertising rhetoric, global market

\section{Veřejná reklama - reklamní veřejnost}

$\mathrm{V}$ tomto př́spěvku bych navázal na můj článek Reklama - fenomén doby z loňského roku. Historie reklamy spadá ještě do doby kamenné, jenže dnes žijeme v 21. století, a ačkoli je reklama součástí našich životů, je úplně jiná, má jiné poslání, jinou funkci, jinou aroganci a jiný záměr. Od pouhopouhého předávání informací jsme se dnes dostali k silné manipulaci a persvazi. Dynamika vývoje celé společnosti nás „,nutí“ zrychlovat tep života a doby, ve které žijeme. Kličcoým slovem je bezesporu globalizace, snaha vidět a řešit věci globálně, tj. rychle, levně a ofenzivně. Není tedy divu, že podléháme diktátu okolí a naše chování nepodřizujeme nám samotným, ale vnějším vlivům. Ztrácíme tak do jisté míry svou vlastní identitu, kterou dobrovolně měníme za cizí. Toto všechno je podhoubím pro rozvoj reklamy. Dynamicky se rozvíjející trhy umožňují narůstající počet výrobců a tím i výrobků. Klíčovým pojmem je také konkurence. Stále větší nabídka na trhu s sebou přináší i větší boj o zákazníka. S větším počtem stejných nebo podobných výrobků na trhu se začíná vytrácet 
jejich exkluzivita a pro běžného spotřebitele to ve výsledku znamená ztrátu jednoznačné volby a problémy s rozhodováním, který výrobek zakoupit. Výrobci si začínají uvědomovat, že nestačí jen vyrobit a nabídnout, ale odlišit se od právě vznikajících konkurenčních výrobků, a hlavně najít takový způsob propagace, který bude ve své podstatě jedinečný. Výrobci značek si začínají uvědomovat, že nikoli ojedinělost výrobku, ale ojedinělost reklamní komunikace může jejich výrobek správně propagovat, odlišit a prodat. I přesto připadá reklama spoustě lidí zbytečná, otravující, ruší jejich zájmy při sledování filmů na internetu či v televizi, překáží jim v životě, mění vizuální podobu měst díky přemíře venkovní reklamy, investice do reklamy jsou vnímány spíše negativně jako vyhazování peněz. To všechno, a ještě mnohem více lze reklamně vyčíst. „Reklama přináší s sebou i své nedostatky. V prvé řadě platí, že reklamni sdělení jsou v dnešni době vystavena velké konkurenci. Lidé jsou reklamou zahlceni, ztrácejí při ní pozornost a reaguji často podrážděně. " (Karlíček, 2016, s.50).

\subsection{Média - ovlivnění i možnosti současné reklamní tvorby}

Aby mohla reklama naplňovat předpoklady na ni kladené, musíme zmínit naprosto jedinečnou úlohu médií. Právě rozvoj médií umožnil, nejen reklamě, ale mnoha odvětvím marketingové komunikace, neskutečný posun v rozvoji a nabídl možnosti lepšího zpracování reklamy a tím i mnohem lepšího oslovení zákazníků. Text a obraz, který se objevoval v tištěné inzerci, je nyní doplněn další neméně důležitou složkou, a to je audiovizuál v podobě rozhlasové a televizní reklamy. Tato možnost nám dává do ruky instrument, jak oslovit zákazníka nejen textem, ale ovlivnit i jeho emoce. Televizní a internetová reklama spojuje všechny technologické možnosti a má sílu, která dokáže to, co nikdy předtím. Do určité míry má reklama ulehčenou práci v tom, že se velké trhy homogenizují a nároky zákazníků se kopírují, tento trend umožnuje vznik globální reklamy. Globální reklama má bezesporu mnoho výhod, ale také nevýhod. Za výhodu lze považovat finanční náročnost tvorby globální reklamy. Ta není tak vysoká a lze ji použít pro velké světové trhy. Značka, která je vnímána globálně, může mít globální reklamu, její zadavatelé ušetří finanční prostředky spojené s její tvorbou, reklama se nemusí výrazně upravovat pro prezentaci v jednotlivých zemích světa. Další výhodou je, že zákazníci značku poznají, at' ji vidí kdekoli. At' už rodina nebo obchodní zástupce na služební cestě se lépe ztotožní s globální značkou, protože ji znají i ze své země, dají jí mnohdy přednost před lokální značkou, kterou neznají. Nevýhodou globální reklamy je, že ji lze použít jen pro velké globální značky, a že čelí velkým tlakům z vnějšího okolí. Její velikost je někdy na škodu. Další nevýhodou je trend odklonu obliby zákazníků od velkých značek a návrat k lokální výrobě, lokálním výrobkům.

Samozřejmě, že odlišné vnímání reklamy můžeme pozorovat i na základě prohlubujících se rozdílů ve společnosti. Na jedné straně výzkumy ukazují fakt, že lidstvo jako takové bohatne, ale faktem je také to, že se nůžky bohatství hodně rozevírají a rozdíly jsou propastné. Rozdíly v současné společnosti jsou nejen ekonomické, ale i sociální a demografické. To všechno se odráží na intenzitě vnímání reklamní komunikace. Práce tvůrců reklamních komunikátů by se mohla zdát na první pohled díky vysokému rozvoji technologií a nepřeberným možnostem jako snadná, opak je ale pravdou. Různorodost cílových skupiny je také čím dál větší. Nejdůležitější pro reklamu je to, aby vytvořila určité pouto mezi zákazníkem a značkou. Musí upoutat pozornost, vyvolat emoce, motivovat k nákupu. Důležité je tzv. oživování výrobků, přiřazováním kladných vlastností na základě pozitivních emocí zákazníků a zdůrazňování kvalit výrobků prostřednictvím reklamních textů. Vhodně zvolená struktura textu, výběr správné jazykové hry, mohou text udělat jedinečným. Propojení reklamního textu s vizuálem navodí dokonalé vnímání propagované značky. Současná média nám umožní bezpočet variant propagace a u zákazníků vytvoří asociační mapy. Reklamní tvůrce musí ale vycházet i ze vzdělaností úrovně zákazníků. Reklamní komunikát musí být přiměřený věku, vzdělání 
a rozpoznávacím schopnostem dané cílové skupiny. Autorka Vysekalová uvádí, že je spotřební chování každého z nás ovlivněno dvěma základními faktory. Jednak se jedná o materiální a psychické možnosti a dále o osobnostní orientaci každého jedince. „Jedním $z$ nich jsou jeho objektivni možnosti, a to jak materiální, tak i psychické povahy. Tyto možnosti představují souhrn různých zdrojü, které má člověk $k$ dispozici - vzdělání, př́jem, zdraví, sebevědomí, spotřebni apetit apod. Každá z těchto jednotlivých proměnných vstupuje do konstrukce s odlišnou vahou. Druhým faktorem, který ovlivňuje spotřebni a nákupní zvyklosti, je osobnostni orientace respondenta. Jedná se o vzorec postojů a jednání člověka, které se podle jeho očekávání maji odrazit v jeho image ve společnosti. “(Vysekalová, 2018, s.54-55).

Při reklamní tvorbě se stále více hledí na toho, komu je tato komunikace v prvé řadě určena na zákazníka, tj. cílovou skupinu. Tento postup při tvorbě reklamy se stále prohlubuje, čím dál víc se jeví jako produktivní hledět na zákazníka, na jeho chování a změnu nákupních zvyklostí. Odborníci ale nejsou zajedno v tom, zda je nutné provádět výzkumy, které by prokázaly účinky reklamy. Někteří odborníci (D. Ogilvy 1911-1999) se domnívají, že spotřebitel je inteligentní a požaduje informace, které mu napomohou v jeho nákupním rozhodování. Je také přesvědčen o tom, že i reklamní tvůrce musí být o přednostech propagovaného výrobku přesvědčen, a že není zapotřebí tvořit př́liš kreativní a odlišný reklamní komunikát. Jiní odborníci jsou ale názoru, že je nutné udělat výzkum ještě před tím, než se reklamní kampaň spustí, to ale Ogilvy také neodmítá. Rosser Reeves (1910-1984), americký pracovník v reklamě a průkopník televizní reklamy zavádí mimo jiného pojem „specifická nabídka prodeje“(USP - unique selling proposition), jedná se v podstatě o využití dominantní vlastnosti konkrétní značky a podtržení její odlišnosti od konkurence. Za zmínku ale stojí i další „průkopníci“ světa reklamy jako např́klad W. Bernbach (1911-1982), americký reklamní ředitel, známý jako propagátor filozofie tvořivé realizace reklamního sdělení a další známé osobnosti ze světa reklamy.

V každém př́ípadě se výsledek působení reklamního komunikátu neukáže ihned, to ukáže až čas, jak tento komunikát zapůsobil a ovlivnil cílovou skupinu. Při tvorbě každého dalšího komunikátu lze ale vycházet právě z předchozích zkušeností. Reklamní komunikát je jedním ze základních prostředků tvorby reklamy a je tvořen bud' samotným textem, nebo doplněn dalšími prostředky z hláskoslovné, gramatické či lexikální roviny jazyka. Tvorba reklamního textu nám umožňuje něco, co by asi při tvorbě jiného žánru nebylo akceptováno. Jazyková slovní hra, jazykové hříčky (kalambury) a další. Je téměř jisté, že samotný text by ale takový účinek nikdy neměl, tj. souhra textu a vizuálu (obrazu) je téměř neodmyslitelná. Např́íklad nám známá frazeologie, založená na více odlišných významech se v reklamě objevuje velmi často, jeden význam je zpracován spíše vizuálně, druhý význam pak textově a jeden bez druhého by šlo jen velmi špatně použít. Mám na mysli taková spojení jako být za vodou, mít pod čepicí, obout se do toho a další.

Ačkoli je text většinou nositelem obsahu, základní informace, obraz dokáže dotvořit atmosféru a vzniká tak celek. Jak ale můžeme pozorovat, globální reklama je více založená na obrazu než textu, důvodem bude menší nutnost takovou reklamu upravovat pro danou zemi. Textu je v takové reklamě málo, a proto mu musíme věnovat větší pozornost. V jednom z předchozích článků jsem napsal, že reklamní text je velmi propracované a sofistikované dílo, které by si zasloužilo větší pozornost, než se mu doposud dostává. Pokud vycházíme z pravidla, že je nutné vytvořit jednoduchý, krátký ale výstižný a emočně naplněný komunikát, pak se můžeme jen divit, proč není takovému dílu věnována větší pozornost. Laická veřejnost považuje reklamní text za klasické konzumní dílo, neuvědomuje si sílu jeho vlivu a už vůbec ne propracovanost a nápaditost. Málokdo ocení tento fenomén jako sociologicky, filozoficky, psychologicky, kulturně, a hlavně lingvisticky propracované dílo. Za tvorbou těchto reklamních komunikátů stojí jedna velká potřeba naší současné společnosti a tou je ekonomická snaha dosáhnout maximálních zisků, společnost je orientovaná na výkon. 
Reklama tak dostává možnost stát se nedílnou součásti ekonomiky země, hybnou silou, která dokáže rozproudit trhy, vynutit si pozornost zákazníků, přinutit je ke koupi, manipulovat lidi bez jejich vědomí, že se něco takového děje.

\subsection{Střet vnějš́iho světa s vnitřními potřebami zákazníků}

Intenzita působení reklamy na zákazníky neustále roste. Potřeba odlišit se od ostatních vede tvůrce reklamních sdělení $\mathrm{k}$ tomu, aby právě reklama byla jedním z hlavních článků hybného mechanismu. Mnohdy se jednotlivé výrobky od sebe liší jen nepatrně a jejich správná propagace je může ještě více odlišit. Tlak na zákazníka sílí a my můžeme v současné době pozorovat, jak reklama mění vnímání hodnot ve společnosti. Zákazník mění své postoje a návyky, jeho potřeby se mění velmi výrazně. Změna struktury společnosti celosvětově vyvolává mimo jiné i potřeby odlišit se od masy lidí a reklama k tomu velkou měrou přispívá. Reklama vytváří nové potřeby, mění zásadně hodnotový žebříček, čímž dochází k destrukci původních a základních hodnot ve společnosti. Ne zř́idka lidé posuzují svůj společenský statut podle majetku, tak tomu bylo, je a bude. Tato tendence má ale zesilující dynamiku. Posuzovat se podle značky a míry jejího luxusu se stává stále přirozenější a obvyklé. Reklama tak ovlivňuje nejen myšlení zákazníků, ale do jisté míry i kulturu dané společnosti. Za toto působení si reklama vysloužila mnohdy i velmi kritické pohledy a názory odborníků se tak velmi liší. Některé síly se snaží reklamu omezovat, usměrňovat, potlačovat její vlivy. Tyto tendence jsou ale projevem nepochopení reklamního působení jako celku, nepochopení postavení marketingové komunikace a její významné role v celosvětovém měřítku. Zákonná úprava dává reklamě jasné mantinely, kam až může zajít, co si může nebo nemůže dovolit. Mnohdy se tvưrci reklam sice pohybují na hraně zákonnosti, vždy se ale snaží, aby byl reklamní komunikát veřejně publikovatelný. Síla reklamy není v její neetičnosti, vulgárnosti, nezákonné podobě provedení, ale v jisté nevšednosti a sofistikovanosti, ve skrytém obsahu jejího sdělení. V reklamě se střetává vnější svět s našimi vnitřními potřebami. Vždy je to o zákaznících, jak reklamní sdělení přijmou, jaká symbióza se mezi nimi vytvoří, jak budou reklamu dále interpretovat, ale hlavně, co si z ní odnesou sami. Její vliv je na každého jednoho zákazníka jiný. Dopad reklamy je velmi nepředvídatelný, určitá jistota tam je vždy, ale její dopad je vždy překvapující. Zjednodušeně můžeme říci, že se zákazník sice nepřímo, ale aktivně spolupodílí na tvorbě reklamy, dotváří její obsah a zacílení, čímž přispívá ke kultivaci těchto sdělení $\mathrm{v}$ rámci celého mediálního prostředí. Rychlost vývoje reklamy je dán také tím, že se velmi snadno opotřebovává a je nutné jí stále aktualizovat. Mnoho značek mění své reklamní slogany i několikrát v roce, jiné značky si zakládají na tradiční reklamně, která se objevuje v mediích několik let bez jakékoli úpravy. Například můžeme zmínit Kofolu, s její legendární předvánoční reklamou tatínka a holčičky při řezání vánočního stromečku. Jak bylo již zmíněno, reklamu nevytváří jen kreativci v reklamních agenturách, jsou to i zákazníci, kteří dají reklamě směr, sílu vlivu a cíl. Č́m je práce reklamního tvưrce kreativnější, tím je reakce zákazníků výraznější. To dokládá i skutečnost, že se reklama jako i jiná umění stávají součástí jazykové kultury dané země.

\subsection{Reklamní styl - rétorika reklamy}

Reklamní komunikace se stává nedílnou součástí moderní stylistiky. Reklamní styl se na základě jasných kritérií odlišuje od ostatních funkčních stylů, i když s některými z nich má společnou manipulaci a persvazi, jako je tomu např́klad u stylu žurnalistického. Rozmanitost reklamního stylu je ale díky jeho použitelnosti a médiím opravdu velká. Verbální prostředky používané v tištěné reklamně, v internetové reklamě, v reklamě venkovní nebo vnitřní jsou velmi specifické a je nutné jim věnovat velkou pozornost. Reklamní komunikáty jsou všude kolem nás a musí bojovat o naši pozornost. Odborná literatura uvádí pojem reklamní slepota, ke které dochází právě díky přesycenosti a zahlcenosti reklamou. Mnohdy se reklama dostává 
na okraj zájmu společnosti, je považována za všudypř́ítomnou a otravnou. At' je názor na reklamu jakýkoli, její síla je tak velká, že dokáže ovlivnit nejen moderní jazykovědu, ale i kulturu médií. Hlavním důvodem tohoto vlivu je její ekonomická potřeba pro rozvoj hospodářství každé země. Je hybným motorem každé ekonomiky. Reklamní styl, který jsem zmínil, patří v současné době $\mathrm{k}$ nejrychleji se rozvíjejícím a měnícím stylům vůbec. Je to dáno především potřebou globální ekonomiky, rychle se rozvíjejícími trhy a přibývajícím počtem konkurentů. A co vlastně tvoří reklamní text jako takový? Stále se zabýváme tím, jak reklama ovlivňuje zákazníky, zda je tento vliv správný či nikoli, ale jak to reklama za pomoci slov vlastně dělá? Reklamní komunikát musí obsahovat především informace, zmínit značku, její hodnotu, přednosti, dostupnost, benefity s ní spojené. Takové sdělení ale může být neefektivní, nezajímavé, pouhý přenos informaci je neatraktivní a nikoho nezaujme. Je to zvláštní, na jedné straně jsou informace tak důležité, ale na straně druhé více záleží na tom, jak jsou prezentované. V moderní reklamní komunikaci jde ale především o dosažení efektivity dopadu reklamního sdělení než o pouhopouhé předání informací. Reklama musí nejprve zaujmout, zákazník si jí musí všimnout, pak předává obsah a tím si tvoří cestu pro svůj reklamní tlak. Vytvoření této cesty pro tlak je závislé na tom, jak reklama dokázala vystihnout potřeby a hodnotovou orientaci dané cílové skupiny, $\mathrm{v}$ jaké kultuře se cílová skupina pohybuje, jaké je její emoční naladění. Důležitá je celková rétorika, se kterou reklama veřejnost oslovuje. Reklamní rétorika je určitým druhem umění, dokáže propojit verbální a obrazovou složku reklamního sdělení. Rétorické figury, kterých využívá, jsou nedílnou součástí každého reklamního komunikátu a ve shodě sobsahem reklamy spoluvytváří integrovaný celek sdělení.

\subsection{Zapamatovatelnost - zaručený klíč k úspěchu}

Reklamní komunikáty, které jsou většinou tvořeny textem, mají jednu důležitou úlohu a tou je skutečnost, že si je zákazníci musí zapamatovat. Je to jejich poslání, být zasazeny do určitého kulturního či sociálního kontextu, stát se nositeli informací a zaútočit na emoční složku vnímání lidí. Aby tento úkol mohly komunikáty plnit na $100 \%$, musí být vytvořeny s velkou dávkou jednoduchosti, jednoznačnosti a zapamatovatelnosti. Autorka Vysekalová k výběru a délce slov uvádí: „Použitá slova a délka vět ovlivňuji porozumění reči, v našem prípadě reklamního sdělení. Srozumitelné jsou samozřejmě často použivané, všeobecně známé výrazy, krátká a ,obrazná“ slova. Pro délku vět platí jednoznačné pravidlo, že informace jsou nejsrozumitelnější v krátkých větách. "(Vysekalová, 2018, s. 81).

Bez obav můžeme říci, že reklamní texty nemají velkou hodnotu. Mnohdy jde o absurdní spojení slov, která by v jiném žánru těžko obstála. Jejich praktická hodnota je ale velmi vysoká. Působení na cílovou skupinu je mnohem důležitější, získání pozornosti a zapamatování je jejich hlavním úkolem. Různé cílové skupiny se vyznačují různou mírou schopností rozpoznání a pohotovosti kognitivního zpracování reklamního textu. Proměna v nákupní motivaci trvá u každého jedince jinak dlouho. Je ale dokázáno, že zapamatování je velmi důležitým a častým činitelem při nákupním rozhodování. Při tvorbě reklamních kampaní je velmi často zmiňována skutečnost, že má reklama nejen krátkodobé ale i dlouhodobé cíle. Je sice důležité, co zákazníci po zhlédnutí reklamy ř́ikají, důležitější je ale, co ve výsledku udělají. Nejenom přijetí obsahu reklamy a jeho akceptace ale také utváření si vlastního postoje ke značce, je jedním z dalších neméně důležitých poslání reklamního stylu. Někdy je dopad reklamy na adresáta - cílovou skupinu pomalejší. Změna zákaznických postojů je velmi často součástí marketingových výzkumů. Především reklamní agentury pracují s informacemi, do jaké míry bylo ovlivněné nákupní chování zákazníků po zhlédnutí určité reklamní kampaně. Někdy se vliv reklamy projeví okamžitě nárůstem poptávky po dané značce, někdy však ekonomické ukazatele selhávají, protože se dopad reklamní kampaně objeví až později. Velmi špatně se dá na 100 \% určit, co mělo vliv na zákazníka. S jistotou 
může ale říci, že oblast zkoumání reklamní efektivity je př́mo propojená s výzkumy nákupního chování zákazníků. Součástí prodeje značky není jen samotný reklamní text slogan, je to i obal, benefity, výrobkové charakteristiky odlišující jednotlivé značky a další atributy. Obraz a text v reklamě stále hrají velmi důležitou roli, jak uvádí i Vysekalová: „Zapamatování obrázku je mnohem rychlejší než zapamatování slovního sdělení. Nicméně oba typy jsou di̊ležité pro vytvoření celkového vnitřního obrazu. " (Vysekalová, 2018, s.79). U textu platí, že čím je jeho obsah více nečekaný či různorodý, tím je lépe zapamatovatelný.

\subsection{Reklamní publikum}

Reklamní text je bezesporu veřejnou záležitostí. Marketingová a potažmo i reklamní komunikace je tvořena zpravidla pro širokou veřejnost, její dosahy a dopady závisí na velkém množství faktorů. Reklama se stala součástí mediálně - komunikačního komplexu a její úspěšnost je přímo úměrná schopnosti reklamních tvůrců, jak dokážou prezentovat informace o značce nebo službě a to způsobem, který odpovídá schopnostem chápání jejích poselství užší nebo širší veřejností. Pokud zmíníme pojem veřejnost, je nutné dodat také skutečnost, že není každý reklamní text pro každého. Reklamní obsah je sice určen pro širokou veřejnost, ale i tato většinová veřejnost má jistá omezení, která přesně definují cílovou skupinu. Těmito kritérii se musí tvůrci reklamních textů řídit. Přeci jen má reklamní komunikace určité odlišnosti od jiných druhů komunikace, at' už je to obsah samotný nebo záměr jejího používání. Z reklamní komunikace je vyřazeno publikum, které má odlišné preference od záměru tvůrců reklamních komunikátů. Značka, typ výrobku nebo služby vždy určují míru „veřejnosti“ daného komunikátu. Při tvorbě reklamního textu neexistuje nějaký přesný vzor, který by jasně určoval pravidla jeho vzniku. Neexistuje ani jednotný klíč k určení výše finančních prostředků, které by se do tvorby reklamy měly investovat.

Jistý je ale fakt, že práce s veřejností patří mezi nejdůležitější faktory ovlivňující chápání reklamního sdělení. Cílová skupina je úzce spjatá s médii. Každý jedinec preferuje určité médium přsesně podle toho, jakou hodnotu tomuto médiu přisuzuje. Jako názorný př́íklad můžeme uvést mladší a starší generaci, kde je preference médií zcela patrná. Zatímco mladá generace upřednostňuje horká média typu internet, sociální sítě, starší publikum se zaměřuje na sledování chladných médií, jako jsou noviny, časopisy, nebo pro mladou generaci stále méně populární televizi. Obliba médií je dána také jejich obsahovým složením, zatímco si mladí lidé přečtou potřebné informace na internetu, starší generace kupuje noviny a časopisy. Mladá generace svůj volný čas tráví jinak než sledováním TV kanálů, starší generace však tento typ „zábavy“ vyhledává. Proto je pro úspěšnost reklamního poselství rozhodující, aby bylo šířeno v tu samou dobu různými médii a mělo tak široký zásah na velké publikum. Intenzita a časté opakování mohou také ovlivnit v pozitivním slova smyslu kladné vnímání značky, nebot' si tak značka na trhu vytváří image, která může předstihnout konkurenční značky.

\subsection{Reklamní persvaze}

Výraz persvaze pochází jako mnoho podobných slov z latiny, konkrétně z latinského persuasio, tj. umění ovlivnit někoho s motivem přesvědčení o vlastní pravdě a argumentech. Reklama je toho dobrým důkazem. Na jedné straně je zdroj informací, sdělující určitý obsah o značce nebo službě, na straně druhé je př́ijemce, tj. zákazník, spotřebitel, konzument, každý si zde může vybrat to své označení. Mezi zdrojem a adresátem je pak ještě zapotřebí vhodné a účinné médium, které kontakt mezi nimi zprostředkuje. Informace obsažené v reklamním sdělení mají tu moc, že dokážou u př́ijemce vyvolat pozornost, emoce a vyvolají také podnět k nakupování. Pokud se tak ale nestane, a reklama nevyvolá podnět k nakupování, vzbudí alespoň pozornost zákazníka. Co si ale představit pod pojmem persvaze v reklamě? Jak silná slova je nutno použít, abychom dosáhli té správné manipulace? Někdy stačí jen obyčejná 
informace, která dokáže svým obsahem zmanipulovat opravdu masu zákazníků. Je tím myšlena informace o ceně nebo akci či výprodeji. Jen tato slůvka stačí k tomu, abychom propagovanou značku uvedli do mysli našich zákazníků, do oblasti jejich zájmu. Reklama tímto způsobem pomáhá zákazníkovi v rozhodování o nákupu. Cena je jedním ze silných motivů vedoucí $\mathrm{k}$ uskutečnění nákupu. Zákazníkovi je dán pocit, že se může svobodně rozhodnout, že s ním vlastně nikdo nemanipuluje a že je to právě on, kdo nakonec rozhodne o nákupu. Opak je ale pravdou. Impulz k nakupování nedal zákazník, ale reklama. To ale většinou zákazník nevnímá a cítí se být tím, kdo má tu schopnost rozlišit, zda není náhodou manipulován. Oslovení zákazníka je přirozeně navozené, poselství reklamy musí odpovídat schopnostem cílové skupiny. Obsah reklamního sdělení má mít pro cílovou skupinu zákazníků určitou hodnotu. Přijetí benefitů, specifických charakteristik značky, argumentace pro nákup značky a další výhody s ní spojené vnímá cílová skupina pozitivně jen tehdy, pokud výše jmenované v zákazníkovi vytvář́ proces vnitřní aktivity, projev vlastního zájmu nejen o reklamní sdělení, ale i o jeho obsah. I přes velmi rychlý rozvoj reklamy se zatím nepodařilo určit teoretický rámec, který by přesně určoval, co je tím pravým impulzem pro vznik vazby mezi reklamou a zákazníkem, čím je tvořen reklamní tlak a již zmiňovaná persvaze. Na druhou stranu je nutno říci, že pokud by ale existoval určitý teoretický vzorec, podle kterého by bylo možné tvořit kreativní reklamní sdělení, kopíroval by jeden tvưrce toho druhého a nic kreativnějšího by již nevznikalo. Bohužel se v reklamně nic nedá použít dvakrát, respektive s každým opakováním se intenzita daného komunikátu snižuje.

Persvaze reklamy má svůj vývoj. Velký vliv měla změna na globálním trhu, doba, kdy se trhy začaly zaplavovat velkým množstvím zboží a značek. Alfou a omegou se stává konkurence a její výrobky. Stejné či velmi podobné výrobky začínají ztrácet svou exkluzivitu a zapadají mezi stovky podobných do průměru a všednosti. Frustrace zákazníků se zvyšuje. Jakou značku si vybrat, jakému výrobku dát přednost, jsou najednou otázky, které zákazník předtím nikdy řešit nemusel.

\section{Použitá literatura}

1. CRHA, I., KŘÍŽEK, Z. Jak psát reklamní text. Praha: Grada Publishing, 2003. 164 s. ISBN 80-247-0556-7

2. $\quad$ ČMEJRKOVÁ, S. Reklama v češtině. Voznice: LEDA, 2000. 258 s. ISBN 80-8592775-6

3. KARLÍČEK, M. Marketingová komunikace: jak komunikovat na našem trhu. 2., aktualizované a doplněné vydání. Praha: Grada Publishing, 2016. 224 s. ISBN 9788024757698

4. KRUPKA, J. Česká reklama, od pana Vajičcka po falešné soby. Brno: BizBooks, 2012. 264 s. ISBN 978-80-265-0046-9

5. OGILVY, D. O reklamě. Praha: Grada Publishing, 1996. 223 s. ISBN 80-85943-25-5

6. VYSEKALOVÁ, J., MIKEŠ, J. Reklama - Jak délat reklamu. Praha: Grada Publishing, 2018. 232 s. ISBN 978-80-247-5865-7

\section{Kontaktní údaje}

Ing. Mgr. Oldřich Johannes PETR

Vysoká škola finanční a správní, a.s., Fakulta ekonomických studií

Pionýrů 2806, 43401 Most

Tel: 724705320

email: oldrich.johannes.petr@vsfs.cz 


\title{
NIEKTORÉ ŠPECIFIKÁ PROJEKTOVANIA INOVAČNÝCH NÁSTROJOV PRE TVORBU STRATÉGIE A PROCESNÉHO RIADENIA PRIEMYSELNÝCH KLASTROV
}

\author{
SOME SPECIFICATIONS FOR DESIGNING INNOVATIVE TOOLS \\ FOR DEVELOPING STRATEGY AND PROCESS MANAGEMENT OF \\ INDUSTRIAL CLUSTERS
}

\author{
Katarína Koporová, Tomášs Novotný, Ján Marcin, Róbert Kati
}

\begin{abstract}
Abstrakt
Tento príspevok sa zaoberá špecifikáciou súčasného ponímania stratégie a stavu i úrovne procesného riadenia $\mathrm{v}$ osobitných organizačných štruktúrach, označovaných ako priemyselné klastre. Predstavuje vybrané špecifiká projektovania a uplatnenia inovačných nástrojov, systémovú integráciu a agilné projektové procesné manažovanie klastrov. Popisuje a vysvetl'uje súvislosti medzi stratégiou, organizačnou štruktúrou a potrebou projektového procesného riadenia pri súčasnej pozícii a konkurencieschopnosti klastrov na trhu v náročných energetických a environmentálnych podmienkach. V závere predkladá vlastnú autorskú schému návrhu novej organizačnej projektovo zameranej klastrovej štruktúry a návrh procesu riadenia a koordinácie projektov realizovaných klastrami pre ich klientov.
\end{abstract}

Kl'účové slová: inovačné nástroje, klastrová štruktúra, procesné riadenie, projektové riadenie, systémová integrácia

\begin{abstract}
This paper focuses on the specification of the understanding of the strategy, state and level of process management in the special organization structures, referred as industrial clusters. It represents the selected specifics of design and application of innovative tools, system integration and agile project process management of clusters. It describes and explains the connections between strategy, organization structure and the need of project process management at the current position and competitiveness of clusters in the market in demanding energy and environmental conditions. At the end of the paper, the author's own organization scheme of the design of the new organization project-oriented cluster structure and coordination of projects implemented by clusters for their clients is described.
\end{abstract}

Keywords: innovation tools, cluster structure, process management, project management, system integration

\section{VÝCHODISKOVÉ POZNÁMKY K PROBLEMATIKE}

Klastre sú podl'a nestora teórie klastrovania M. E. Portera [12] organizačnou formou a nástrojom geografickej koncentrácie vzájomne prepojených firiem, inštitúcií, špecializovaných dodávatel'ov a poskytovatel'ov služieb i partnerov s ciel'om uprednostnenia vzájomnej spolupráce pred konkurenciou na sofistikovanej úrovni. Podl'a autorov tohto príspevku sa dá vnímat' priemyselné klastre ako osobitne zamerané účelové produktové zoskupenia subjektov pre vytvorenie spoločnej synergie dosahovania produktových a procesných inovácií a vzájomnej podpory efektivity a transferu informácií. Inovácia v tvrdom trhovom prostredí nie je zábavou, a aj ked' sa na ňu pozerajú odborníci ako na silný nástroj pre konkurenčnú výhodu a bezpečný spôsob ako si udržiavat' svoju pozíciu, nie je to 
pre klastre garancia úspechu. V histórii priemyselnej produkcie je totiž mnoho príkladných inovácií a kreatívnych nápadov, ktorých výsledkom bolo sklamanie a fiasko. Úlohou pre klastrovú organizáciu je tak v reálnej podnikatel'skej praxi nájdenie nejakej osvedčenej internej metódy, ktorá bude schopná zvládnut' odpovede na otázky a to konkrétne: 1. Ako sa má inovačný proces optimálne manažovat? 2. Ako zaviest' efektívne modely správania sa a nájst' rutinné postupy pre inovovanie? 3. Ako prispôsobit'/vytvorit' inovácie a zabezpečit' správnu formu procesného riadenia, ktoré bude reagovat' na odlišné výzvy trhu a praxe ?

Priemyselná výroba a výstavba, energetika, environmentalistika či ekológia sú dlhodobo spoločensky, priemyselne a existenčne rozhodujúce pojmy ktorých vzájomná koexistencia je životne dôležitá a ktoré vyžadujú neskonale vel'ké schopnosti pre také manažovanie problémov, riešení a projektov, bez ktorých by už na súčasnom stave vývoja priemyslu nebolo možné zvládnut' energetickú bezpečnost', ale najmä ochranu životného prostredia. Preto sú inovácie spôsobom prístupu bez ktorého nie je myslitel’ný budúci vývoj - nové investície a projekty i diela a tak je vel'mi dôležité vyslovene nastavit' budúcich investorov a realizátorov stavebných a priemyselných investícií k vnútornému presvedčeniu, že mysliet' ekologicky znamená mysliet' do budúcna a pre vlastné prežitie. Rozloženie percentuálneho vplyvu jednotlivých prvkov riadenia, organizácie, plánovania a samotnej produkcie klastrov na celý systém je v teórii i praxi tiež dôležitý pri navrhovaní manažmentu kvality v klastrovej organizácii. Princípy takéhoto prístupu filozofie manažmentu sú: zameranie na zákazníka, vodcovstvo, tímová práca, učenie sa, flexibilita a adaptabilita, procesný prístup a systémovost', inovatívnost' a kreativita, spoločenská zodpovednost', vedenie k výsledkom a práca s dodávatel'mi [2]. Ak chce klaster na trhu uspiet' musí ponúkat' špičkové inovácie a vysokú kvalitu za primeranú cenu, nižšiu ako konkurencia [1]. Vysoká „kvalita“ sa v reálnom živote stala akousi vstupenkou na trh, no sama predajnost' produktov, či služieb nezaručí, pretože ju skôr či neskôr začnú poskytovat' aj konkurenti. Je možné vyslovit' názor, že pre potreby skúmanej témy platí, že plánovanie kvality je neoddelitel'nou súčast'ou inovácií a obsahuje určenie zákazníkov, zistenie ich potrieb a očakávaní, preklopenie tohto poznania do produktov a služieb, určenie meratel'ných parametrov, vývoj a inováciu s následnou optimalizáciou a zavedením do nového portfólia ponuky danej klastrovej organizácie $[6,10]$.

\section{PROJEKTOVÉ PROCESNÉ RIADENIE A ORGANIZAČNÁ ŠTRUKTÚRA}

\subsection{Manažérska a organizačná kultúra $v$ klastrových štruktúrach:}

$\mathrm{V}$ odbornej literatúre je viacero súvzt'ažných poznatkov priamo $\mathrm{k}$ téme vytvárania procesu, riadenia kl'účových zákazníkov, ku ktorým sa musí prispôsobovat' portfólio vnímania a rozlišovania, a teda aj celá podstata organizačnej kultúry a manažérskej štruktúry [3]. Firemná organizačná kultúra je vlastne kultúrou obsahujúcou hlavné prvky a to sú základné predpoklady, hodnoty, normy správania sa, artefakty materiálnej povahy a artefakty nemateriálnej povahy. Existujú rôzne vedecké elaboráty i pomerne zručné a overené firemné/klastrové interné manuály a high - tech metodiky pre ten ktorý priemyselný či obchodný segment na trhu, no nedá sa nájst' univerzálny recept a najlepší spôsob riešenia, ked’že každý klaster má iné východiská, predpoklady, personál i internú podnikatel'skú odvahu $[7,16]$. Pritom je potrebné sledovat' tzv. modifikátory základného modelu inovácie pri aplikovaní v procesnom riadení a to je poznanie, že inovácia spúšt’a šokovú terapiu - klaster a l’udia v nej dosiahnu prah únosnosti daného stavu a chcú zmenu; d’alej, že inovácia sa rozbehne $\mathrm{v}$ jednom smere - záber sa rozširuje a nastáva divergencia do mnohých smerov a oblastí pôsobnosti klastrov a nakoniec že inovácia prekonáva prekážky a koriguje pôvodné optimistické plány a omyly je receptom von zo začarovaného kruhu v klastri. Platí tiež všeobecné poznanie $z$ teórie manažmentu o tom [14], že inovácia mení štruktúru klastra dôsledok externých intervencií, personálnych zmien a meniacich sa potrieb, inovácia je ovplyvňovaná prístupom $\mathrm{k}$ veci zo strany projektového manažmentu a často sa zneužíva 
v personálnych stretoch a pritom inovácia zahrňuje učenie sa - výsledky často prichádzajú z dôvodov vzniku iných ako študovaných udalostí, čo vytvára omyl v nezáujme „učit’ sa“. Technologické, technické, organizačné a personálne vývojové cesty malých a stredných firiem v rámci členskej základne danej klastrovej organizácie v inováciách sú špecifické prevláda tendencia špecializovat' sa a diverzifikovat' na relevantnom trhu pre vybraný, príbuzný druh zákazníkov s možnou opakujúcou sa štruktúrou produktov a služieb [9]. Klastre pracujú na konkrétnych veciach, realizujú len málo výskumu, skôr iba pozorujú a operatívne prenášajú myšlienky a koncentrujú odborníkov vždy iba k jednej projektovej činnosti či tematike, čo je v podstate aj princípom ich existencie a networkingu. Pozornost' musí klaster venovat' i vzt’ahu medzi inováciami, tržným výkonom a hodnotou investície, ktorý projekt pre zákazníkov prinesie. Obrázok 1 hovorí a súvislostiach medzi inovačnými činnost’ami a tržbami [12].

Obrázok 1: Vzt’ahy medzi inováciami a tržným výkonom klastrovej organizácie [12,autori]

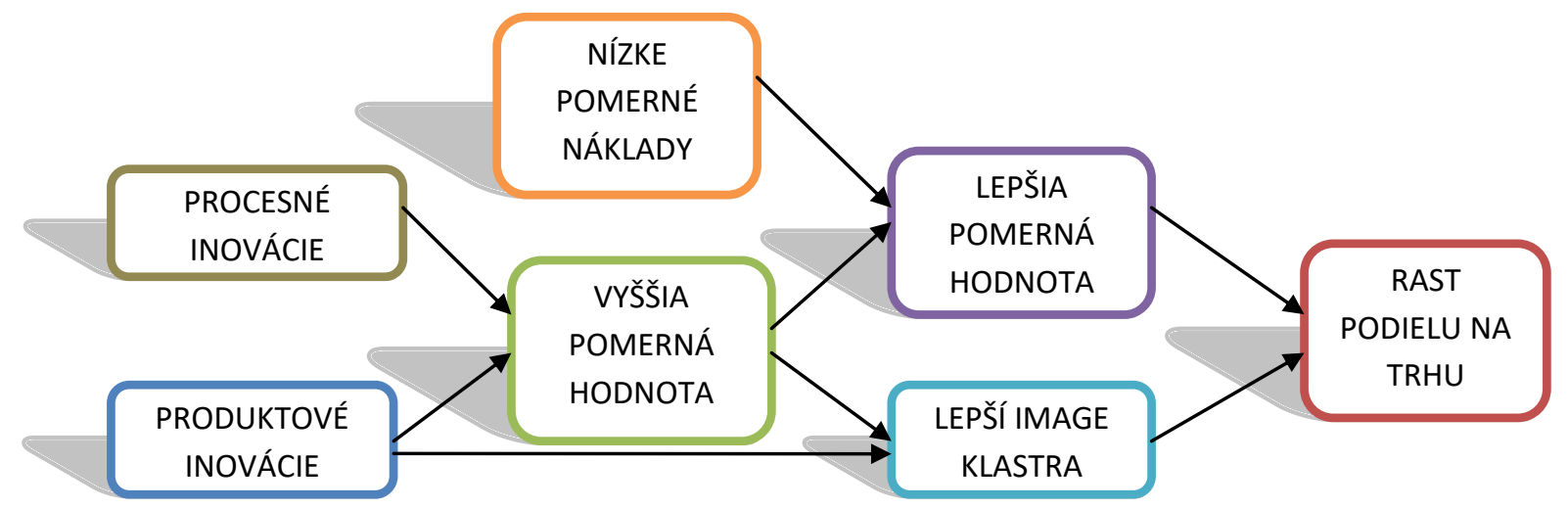

\subsection{Projektové procesné riadenie v klastroch:}

Riadenie procesov a činností v organizácii je jednou zo základných aktivít manažérov. Zlepšovanie procesov v organizáciách sa dnes považuje za nevyhnutnost'. Ciel'om každého klastra je stat' sa tak pružným, aby bol schopný s celým svojim aparátom rýchlo reagovat' na neustále zmeny prostredia, potreby zákazníkov a chovanie sa konkurencie. Kl'účová je však schopnost' zabehnuté procesy priebežne zlepšovat'. To sa ale neobíde bez l'udí, pretože návrhy aj samotné zlepšovanie musí vždy vychádzat' od l'udí. Prirodzenou vlastnost'ou človeka je že sa snaží nájst' cestu, ako urobit' veci jednoduchšie, rýchlejšie, lepšie [1]. Na procesnej úrovni rozhodujú o výkonnosti klastrovej organizácie tri hlavné faktory: ciele, štruktúra a riadenie procesov [6]. Pritom riadiace procesy by mali byt' logickými, jednoduchými cestami vedúcimi k naplneniu procesných ciel'ov. Obsah a význam procesného riadenia: Čo je to vlastne proces? Dá sa povedat', že proces je určitá usporiadaná skupina aktivít alebo činností, ktoré za sebou nasledujú a prinášajú určitý výsledok [2]. Každý proces musí teda mat' určité vstupy a výstupy. Procesy tiež musia mat' definované vstupy, ktoré môžu zahŕňat' l'udí, tovar, materiál ale i potrebné projekty dokumenty. Ciel'om procesu je teda popísat' chovanie alebo určitý postup, ktorý sa bude v tíme alebo v klastri používat'. Dôležité však je aby tento postup fungoval tak, aby proces mal len jeden výstup. Na toto sa výborne hodia informačné technológie, ktoré dokážu významne pomôct' a podporit' tvorbu procesov a definíciu výstupov [2]. Proces sa bežne chápe ako postup (napr. technologický proces, súdny proces, finančný proces). Týmto postupom autori rozumejú rad na seba nadväzujúcich činností, kde každá čiastková činnost' (prvkov tomto rade) je organizovaná prevažne funkčne [15]. Každá organizácia, ktorá zaviedla procesné riadenie, musí jednotlivé procesy neustále priebežne zlepšovat' a vyhodnocovat' ich výkonnost' a účinnost'. Ak chceme proces zlepšovat', musíme ho mat' pod dohl'adom a to tak, že sa tento preto musí najprv naplánovat', potom 
zrealizovat' a nakoniec kontrolovat'. Proces, ktorý nie je priebežne zlepšovaný, sa zhoršuje a jeho efekt vývojom konkurencie klesá. Riadenie procesov (Process management) - možno chápat' ako prístup manažmentu zameraný na monitoring existujúcich procesov, ich analýzu, prípadné zmeny, stabilizáciu, prípadne d’alšie zlepšenie [15]. Kl'účové postavenie medzi zložkami modelu riadenia majú procesy, predovšetkým procesy riadenia a tiež procesy produkčné. Aby klastre fungovali, musia preto podl'a definovat' a riadit' vel'ký počet vzájomné prepojených procesov. Na usporiadaní a riadení procesov záleží, ako efektívne prebiehajú činnosti vedúce od získania zákaziek k ich uspokojeniu, ako komplikovane alebo logicky sú prevádzané pomocné operácie $\mathrm{k}$ hlavným procesom. Tabul'ka 1 definuje druhy integrácie a záujmov i zásad zavádzania procesného manažmentu do klastrových štruktúr nasledovne:

Tabul'ka 1: Integrácie a implementácie procesného manažmentu [autori].

\begin{tabular}{|l|l|}
\hline $\begin{array}{l}\text { Druhy integrácie a záujmov u procesného } \\
\text { prístupu spočivajú v: }\end{array}$ & $\begin{array}{l}\text { Hlavné zásady zavádzania procesného } \\
\text { manažmentu sa dajú určit' ako: }\end{array}$ \\
\hline $\begin{array}{l}\text { Integrácia operácií - základ pre tímové riadenie. } \\
\text { V súčasnej dobe získava väčšiu pozornost' skôr } \\
\text { všestranne vzdelaný pracovník, ako jednostranne } \\
\text { zameraný, málo vzdelaný pracovník. }\end{array}$ & $\begin{array}{l}\text { Naštartovanie novej organizačnej klastrovej } \\
\text { kultúry - naučit' celý kolektív a manažment } \\
\text { procesne mysliet'. Proces začína školením } \\
\text { a výučbou. }\end{array}$ \\
\hline $\begin{array}{l}\text { Integrácia zákazníkov do procesu produkcie } \\
\text { klastra. Zákazník sa sám môže vyslovit' k tomu, } \\
\text { ako chce mat' výrobok či službu konfigurovanú } \\
\text { a až potom dáva signál k produkcii. }\end{array}$ & $\begin{array}{l}\text { Prehodnocovanie interného systému riadenia - } \\
\text { vypracovanie novej stratégie klastra a na ňu } \\
\text { nadväzujúce nové vytvorenie novej } \\
\text { organizačnej štruktúry. }\end{array}$ \\
\hline $\begin{array}{l}\text { Integrácia dodávatel'a do procesu produkcie. } \\
\text { Dodávatel' sa stáva priamo súčast'ou výroby a } \\
\text { služieb a nie je len dodávatel'om jednotlivých } \\
\text { komponentov. }\end{array}$ & $\begin{array}{l}\text { Preprojektovanie riadiacich procesov -vylúčenie } \\
\text { cinností zbytočných a duplicitných; doplnenie } \\
\text { činností chýbajúcich a inovácia neefektívne } \\
\text { prevádzaných činností. }\end{array}$ \\
\hline
\end{tabular}

Projektové procesné riadenie: Je osobitným a špecifickým spôsobom procesného riadenia, ktorého podstatou je plánovanie, organizovanie a riadenie činností a ich zdrojov v rámci uceleného projektu za rešpektovania časových, zdrojových a nákladových obmedzení, s ciel'om dosiahnutia maximálneho ekonomického efektu. Od líniového čí štábneho štýlu riadenia sa líši najmä v dočasnosti, dynamičnosti a pridelením zdrojom pre jeho realizáciu $[15,16]$. Ciel'om projektového riadenia je potom v klastri zaistit' naplánovanie a realizáciu nejakého špecifického úspešného projektu, ktorým sa rozumie prípad, kedy v plánovanom čase a s plánovanými nákladmi bolo dosiahnutie ciel’ov projektu. Projektové riadenie vychádza z poznania, že akonáhle rozsah, zložitost', rizikovost' projektu presiahnu určitú mieru, je nutné použit' adekvátnych metód pre riadenie celého projektu $[5,15]$.

\section{PROJEKTOVÝ PROCESNÝ MANAŽMENT KLASTROV}

$\mathrm{K}$ tomu aby sa podl'a autorov tohto príspevku ozrejmil rozdiel medzi bežne chápaným manažmentom a projektovým manažmentom sa musí vychádzat' zo všeobecnej terminológie a to: projektový procesný manažment je vnímaný jednak ako súhrn aktivít spočívajúci v plánovaní, organizovaní, riadení a kontrole zdrojov klastrovej organizácie s relatívne krátkodobým ciel'om stanoveným pre realizáciu špecifických ciel’ov a zámerov.; zároveň však tu ide aj o je aplikáciu znalostí, schopností, nástrojov a techník na aktivity projektov tak, aby boli splnené ich požiadavky. Nakoniec ide aj o existenciu osobitne koncipovaného a odborne spôsobilého tímu manažérov členov projektových tímov konkrétneho projektu pre konkrétneho zákazníka v rámci produkcie a projektov klastra. Aj ked' sa tieto definície navonok odlišujú, v skutočnosti majú rovnakú podstatu a sú zvlášt’ aktuálne pre použitie $\mathrm{v}$ podmienkach skúmaného a preferovaného typu klastra, podnikajúceho predovšetkým v individuálnej produktovej skladbe $v$ oblasti produkcie a riadenia špecifických stavebných strojnotechnologických, energetických a environmentálnych projektov a produktov riadenia, 
inžinieringu a konzultačnej činnosti. Obrázok 2 znázorňuje, ako vynaložené úsilie a aplikácie znalostí a skúseností klastra z prostredia predstavované organizovane pôsobením piatich základných elementov projektového manažmentu pôsobí na kategórie techník a nástrojov a zabezpečenia organizácie projektu [13]. Hlavnou a zásadnou črtou projektového manažmentu v praxi je, že sa líši od bežnej formy strategického, a tiež operatívneho riadenia v tzv. líniovo či štábne riadenej klastrovej organizácii (ktorá priebežne vyrába, či predáva skupinu totožných produktov alebo služieb a funguje na báze hierarchického postupného riadenia), predovšetkým svojou dočasnost'ou, jednorázovost’ou, pridelením materiálnych, l’udských, technických, či finančných zdrojov a jeho existencia je účelovo viazaná na konkrétny výstup (výsledok) u zákazníka. Hlavným elementom akéhokol’vek projektového diania a manažmentu je samotný projekt. Ide o jedinečný sled aktivít a úloh, ktorý má: daný špecifický ciel', ktorý sa má po jeho realizácii naplnit'; definovaný harmonogram a termíny plnenia; stanovený rámec pre čerpanie financií a režim prefinancovania samotného predmetu projektu (výstavba diela, realizácia, či inštalácia technológie, investičné postupy a pod.).

Obrázok 2: Základné elementy projektového manažmentu klastra [13, autori]:

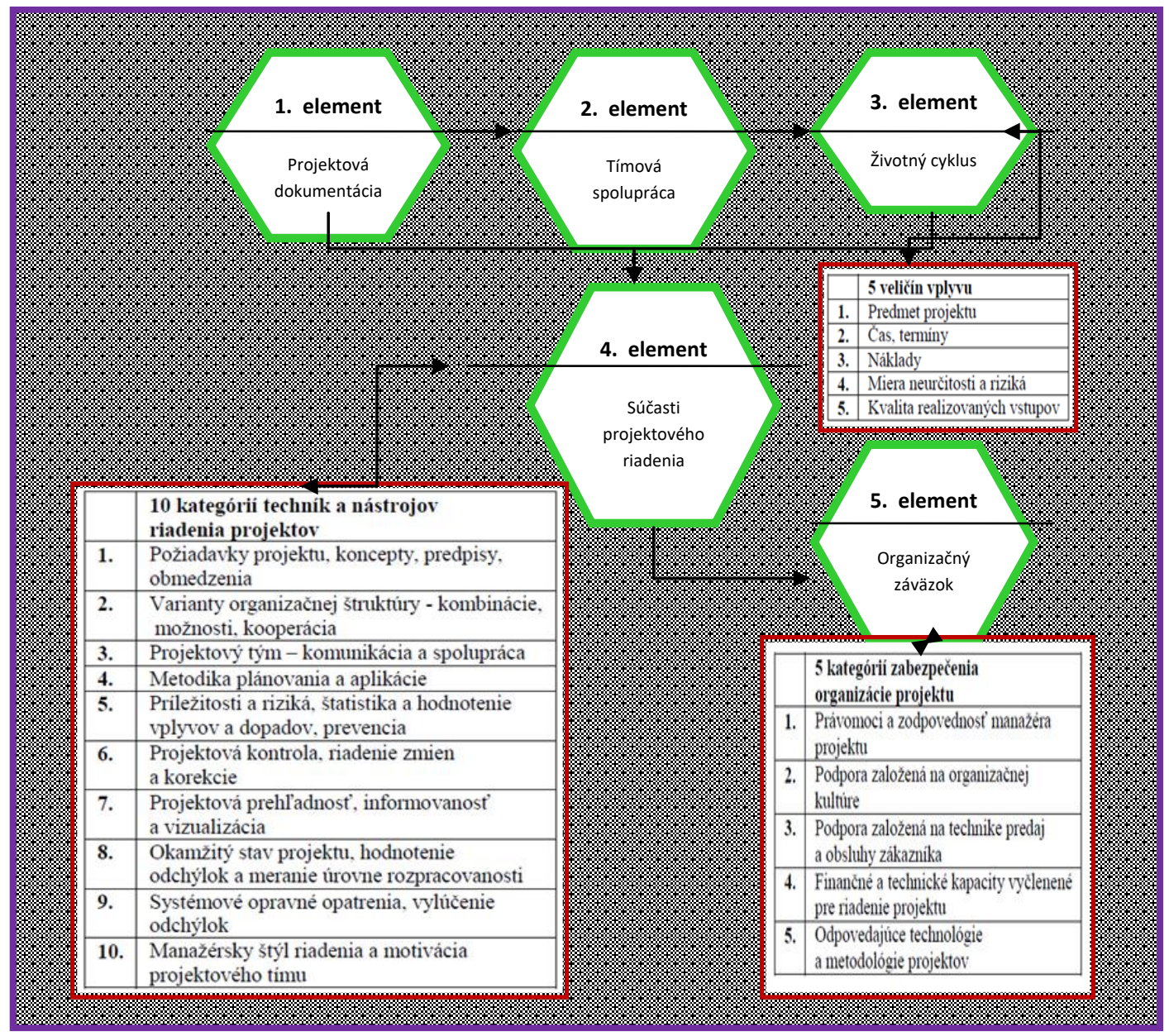

Z tohto zistenia môžeme reálne dedukovat', že projekt je vlastne dočasné úsilie vynaložené na vytvorenie a uskutočnenie unikátneho inžiniersko - technického produktu, či služby s definovaným výsledkom, a to výlučne pre zákazníka. Potom produktom (výsledkom/výstupom) projektu je ciel', výsledok, či iný hmotný determinant, ktorý má byt' realizáciou projektu vytvorený. Nové odborné požiadavky na tímové a manažérske pracovné sily a narastajúce očakávania spôsobujú, že klastre musia uvažovat’ so zmenou konvenčného spôsobu myslenia a prejst' na účinnejšie spôsoby procesného riadenia. Ak sa však neurčí 
nevyhnutnost' zmeny, nie je možné určit' ciel' a metódu uskutočnenia tejto zmeny. Na mieste je preto $\mathrm{v}$ rámci interného výskumu zistenie autorov, že ak sa nájdu odpovede na tieto nasledujúce otázky, tak je zrejmé či je pripravenost' klastrov na zmenu v riadení: 1. Aká hlboká zmena je vlastne potrebná? ; 2. Čo sa stane, ak sa organizácia vôbec nezmení?; 3. Čo ak sa kontrola riadenia zmien vymkne manažmentu z rúk? Takéto otázky je potrebné si klást' pred akýmkol'vek pokusom o zmenu a a navrhnutím nového procesného riadenia na základe poznatkov z teórie a analýz doterajšieho výskumu autorov, pričom možno vychádzat' z teórie [7, 16] a uplatnit' pritom desat' všeobecných princípov úspešného manažovania zmien tabul'ka 2:

Tabul'ka 2: Desat' platných princípov úspešného riadenia zmeny [7, 16, autori]:

\begin{tabular}{|l|l|}
\hline PRINCÍP 1 & Klúčovú úlohu pri riadení zmeny zohráva top manažment. \\
\hline PRINCÍP 2 & Vypracovanie vízie, ktorá musí byt' jasne formulovaná a zrozumitel'ná všetkým. \\
\hline PRINCÍP 3 & $\begin{array}{l}\text { Uvedomenie si nevyhnutnosti potreby zmeny (všetkým musí byt' jasné, že zmena je } \\
\text { podmienkou úspechu, aj ked' všetko funguje). }\end{array}$ \\
\hline PRINCÍP 4 & $\begin{array}{l}\text { Vypracovanie konkrétneho projektu, pomocou ktorého sa bude postupovat' pri zmene } \\
\text { klastrovej organizácie. }\end{array}$ \\
\hline PRINCÍP 5 & Nevyhnutnost' neustáleho vzdelávania sa všetkých zamestnancov organizácie. \\
\hline PRINCÍP 6 & Tímový prístup (zmeny nevykonávajú jednotlivci, ale projektové tímy). \\
\hline PRINCÍP 7 & Vypracovanie projektu postupnej realizácie zmeny. \\
\hline PRINCÍP 8 & $\begin{array}{l}\text { Monitorovanie, vyhodnocovanie a korigovanie všetkých činností, aby sa prípadne zistené } \\
\text { nedostatky dali odstránit'. }\end{array}$ \\
\hline PRINCÍP 9 & $\begin{array}{l}\text { Medzi manažmentom a ostatnými zamestnancami musí prebiehat' otvorená, priebežná } \\
\text { komunikácia. }\end{array}$ \\
\hline PRINCÍP 10 & Pri realizácií zmeny je výhodne spolupracovat's externými konzultantmi ako partnermi. \\
\hline
\end{tabular}

Jednou z najúčinnejších zmien vyzerá byt' podl’a týchto princípov zásadne riadenie interných riadiacich klastrových procesov. Prechod na nové spôsoby riadenia umožňujú aj nové inovačné prístupy a nové informačné technológie, ktoré sú súčastou manažérskeho informačného systému a predmetom samostatnej, pomerne rozsiahlej politiky podpory riadenia klastrov do budúcna [8]. Pritom tento rozvoj má byt' zameraný na kvalitu a zlepšovanie (inovácie a nové prístupy) v projektoch a produktoch klastra. Samotné procesy sú zabezpečované administratívou klastra (čo znamená jednak sledovanie nákladov a manažovanie účelnej techniky predaja, technickú prípravu a starostlivost' o zdroje a majetok) a zároveň je to servisná štábna zložka pre systém produkcie a služieb klastra [11]. jednak pre projektové tímy, ale hlavne pre zákazníkov - čo zastrešuje marketing a obchod, riadiace a servisné činnosti a firemný image. Nad produkciou je v hierarchii procesného projektového riadenia nadradená celková logistika fungovania - obstarávanie vstupov do projektov a produktov, inovácie a vývoj riešení pre trh a aj plánovanie a distribučné cesty v zákazníckom portfóliu klastra. Vrcholcom takto koncipovanej organizačnej štruktúry je samotná stratégia $\mathrm{s}$ jej ciel'mi, víziou a úlohami v rámci tvorby a realizácie projektov, ktorú zabezpečuje projektový manažment a ovplyvňuje celkovú organizačnú kultúru, prezentáciu a image klastra a jeho etické a spoločenské zázemie a postavenie. Ak sú už určené špecifikácie hlavných kompetencií organizačných zložiek klastrovej organizácie tak vyvstávajú všetky potrebné väzby a systémové prvky pre nastavenie prehl'adného a jednoducho ponímaného návrhu procesu riadenia projektov a koordinácie v klastri, ktoré vyvoláva samotnú schému návrhu novej organizačnej štruktúry, tak ako to zobrazuje schéma na obrázku 3. 
Obrázok 3: Schéma návrhu novej organizačnej štruktúry klastrovej organizácie [autori]

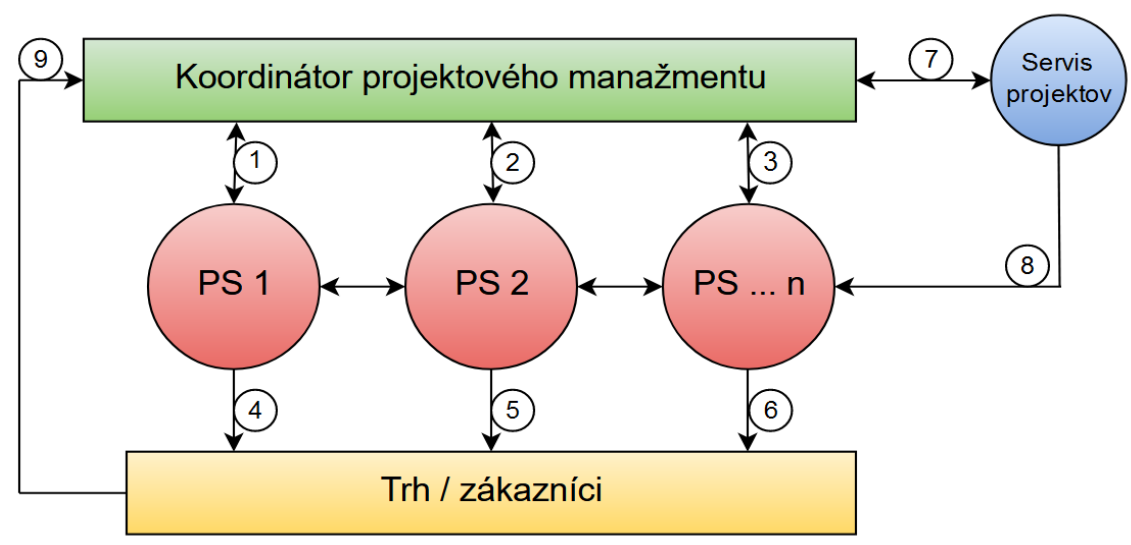

Princíp spočíva $\mathrm{v}$ zrušení štruktúry postavenej na štábnych funkciách s pevnou náplňou a kompetenciami a tvorbe pomerne vol'nej organizačnej štruktúry s rozhodujúcim postavením jednotlivých projektových/výkonných skupín PS 1, PS 2, až PS ...n, ktoré vol'ne a pomerne samostatne zabezpečujú rozhodujúce činnosti klastra (projekty, zákazky, poradenstvo, procesy a pod.) a ich kooperáciu a koordináciu zabezpečuje manažment v pozícii univerzálneho koordinátora. Súčast'ou tohto organizačného systému je aj samostatný tím, ponímaný ako servis projektov, zabezpečujúci ekonomické, právne, administratívne a d’alšie zabezpečovacie a obslužné činnosti a to súčasne pre všetky PS. Autorský návrh diagramu procesu inovatívneho projektového riadenia a koordinácie pre potreby riešenej klastrovej organizácie vidno v týchto súvislostiach a systémových prvkoch (obrázok 4).

Obrázok 4: Návrh procesu riadenia projektov a koordinácia v klastroch [15,autori]

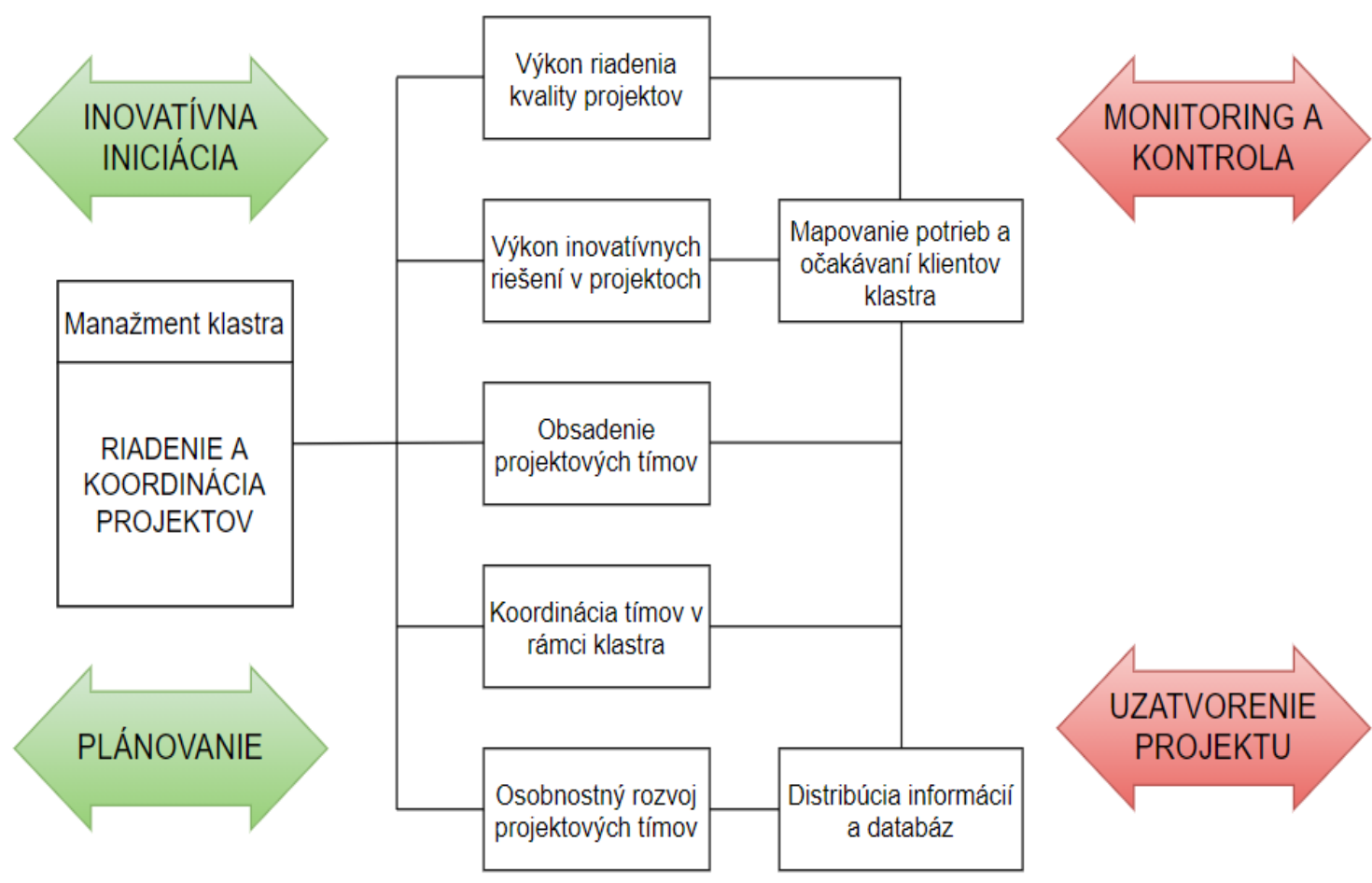


Uvedený návrh dostatočne zodpovedne, jednoznačne a vyčerpávajúco popisuje nosné prvky a väzby medzi nimi v podmienkach dvojstupňového riadenia projektov a inžinierskych činností v klastroch pre zákazníkov a je vlastnou aplikáciou autorov s úpravami už overeného riešenia. Pritom je na mieste zvýraznenie faktu, že výsledkom činnosti projektového procesného manažmentu ako spojenia invencie a síl je a bude vždy záväzok klastrovej organizácie na výskum, technický vývoj, produkciu a inovácie pre priemyselné investičné a komerčné využitie jej členskými firmami [4].

\section{NÁVRH AGILNÉHO PROJEKTOVÉHO MANAŽMENTU KLASTROV}

V súčasnej odbornej literatúre sa často píše o tzv. „agilnom projektovom manažmente“ ako riešení na prekonávanie tradičného priameho procesného modelu projektového manažmentu tak, ako to už bolo doteraz v texte uvádzané [15]. Takže o agilite sa hovorí, ak sa mení trojuholník zo stranami: ,predmet projektu, náklady, čas zhotovenia“ a konvertuje sa na obrazec s vrcholmi: „hodnota, kvalita, obmedzenia“ a zavádza sa inovačný cyklus riešenia projektov pozostávajúci z piatich blokov, a to: vizualizácia, špekulácia, skúmanie, tvorba, uzatváranie. Výsledný predmet projektu je prispôsobený osobitostiam manažovania klastrovej organizácie podl'a autorského návrhu a pozostáva z jednotlivých tzv. subcyklov realizačných prírastkov. Potom sa dajú pomerne prehl'adne znázornit' a prispôsobit' aj jednotlivé komponenty inovačného cyklu a jeho realizačných prírastkov v dôsledku pôsobnosti manažovania klastrových organizácií, tak ako je to na nasledujúcom obrázku 5.

Obrázok 5: Schéma agilného projektového manažmentu [15, autori]

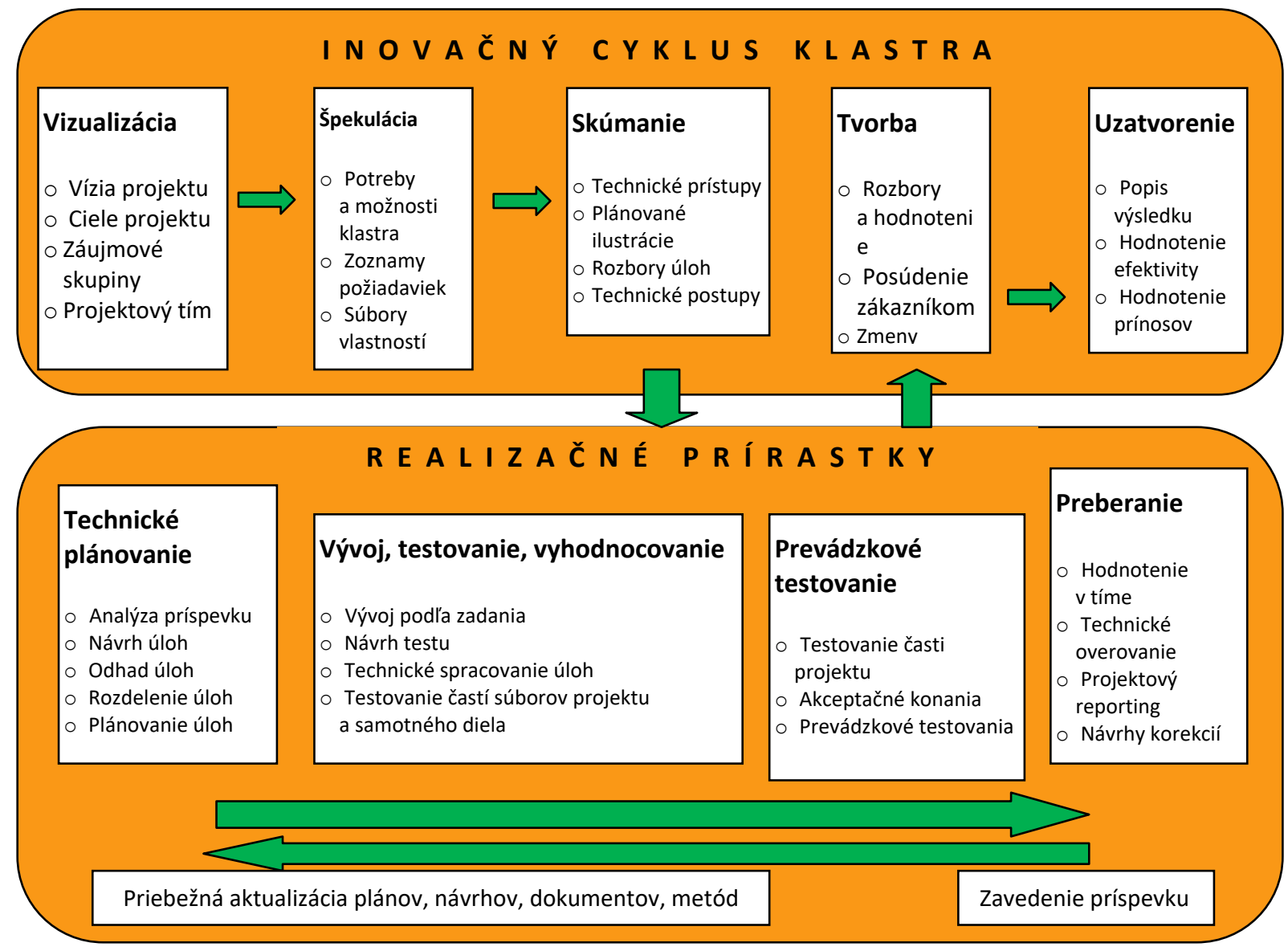

Už svetovo uznávaný odborník v tejto oblasti Jim Highsmith (Agile Project Management, Creating Innovative Products, 2010) uvádzaný v [3,15] definoval hlavné ciele agilného projektového manažmentu, ako priebežnú inováciu v turbulentnom prostredí, vhodnú pre 
klienta a priebežné prispôsobovanie tak, aby projekt naplnil a uspokojil predpovedané budúce požiadavky klientov, d'alej je to priebežné dynamické zavedenie projektu na trhu, priebežné prispôsobovanie procesov, l'udí a ich reakcií na zmeny požiadaviek počas realizácie projektu a nakoniec priebežné zabezpečovanie spol'ahlivosti a overovanie zistení a dielčich výsledkov z projektov. Tento typ projektového procesného riadenia klastra však nesie zo sebou značné nároky na profesionalitu a skúsenosti manažmentu a členov projektových realizačných tímov rovnako ako aj pomerne dobrú vybavenost' klastrovej organizácie technickými, technologickými a softvérovými nástrojmi.

\section{ZHRNUTIE}

Manažment projektov špecializovaných na oblast' priemyslu, stavebníctva, výroby a osobitne energetiky a ekológie vo vel'kých a medzinárodných obchodných spoločnostiach a holdingoch je bežným javom, no v klastrových zoskupeniach a ich firmách (členoch) ktoré sa projektom venujú, sú najčastejšie rozdiely voči tzv. „mega podnikom“ v jednorazovej tvorivej aktivite (v prípade, ak ide o projekt určený vlastným potrebám), alebo v krátkodobých, opakujúcich, či prelínajúcich sa aktivitách (v prípade, ak ide i manažérsky servis pri projektoch zákazníkov). Charakteristické pre takúto situáciu je, že $[11,15]$ : projekty majú kratší čas realizácie a to 3 mesiace až 1 rok; primerané finančné objemy a náklady na projekt s jednorazovými platbami; malý počet univerzálne odborne zdatných l'udí v tímoch; presný a konkrétny plán práce a harmonogramy; manažéri klastra sú často zároveň manažérmi projektov a projektové tímy pracujú v dennom kontakte; spracovanie úkonov a úloh projektu prebieha spravidla individuálne a manuálne; komunikačné kanály sú kratšie, rozhodovanie je rýchle, členovia tímu sa skôr a podrobnejšie poznajú, motivačné faktory sú pružnejšie a adresnejšie odhady a štúdie (ideové zámery) projektov, ktoré sú podkladom pre plánovanie, sú ovel’a presnejšie a jednoduchšie, nakol'ko je možné lepšie poznat' konkrétne podmienky i celkovú históriu a potreby zákazníka i toho ktorého projektu. Táto výhoda a pomerná jednoduchost' je však zároveň možným zdrojom niektorých problémov, ktoré môžu v procesnom riadení/manažovaní projektov u klastra nastat', a to: konflikty záujmov a priorít u manažérov projektu a šéfujúci tím zároveň nedostatok cenovo dostupných špecialistov a alternatívnych náhradných riešení v projekte; aj ked' je špecialista nasadený, rozsah projektu mu neumožní plné kapacitné nasadenie; často je čiastočne nadbytočný, časovo i finančne nákladný a neefektívny; väčšia citlivost' klastra i členov projektových tímov na konflikty a riziká, či nezhody v odbornom prístupe $\mathrm{k}$ obsahu projektov a súčasne paradoxné neformálne vzt'ahy môžu byt' prekážkou v pracovnej disciplíne; prípadné omeškania, či nedostatok v niektorom z manažovaných projektov môže mat' negatívny dopad na ostatné projekty (súslednost', previazanost' a pod.). Autorský kolektív tohto príspevkuvníma klastre ako moderný a úspešný nástroj inovácií a upevňovania konkurencieschopnosti Slovenska a dlhodobo sa zaoberá predmetnou problematikou príspevku a to aj $\mathrm{v}$ rámci riešenia grantového projektu NFP313020ANX5, financovaného z prostriedkov EŠIF Ministerstvom hospodárstva SR pod názvom: Koncipovanie a rozvoj integrovanej inovačnej infraštruktúry a vedomostnej bázy v európskom priestore klastrovej organizácie NEK.

\section{Použitá literatúra}

1. FOTR, Jiří; SOUČEK, Ivan. Investiční rozhodování a řizení projektio. Praha: Grada Publishing. 2011. ISBN 978-80-247-3293-0.

2. HROMKOVÁ, Ludmila; HOLOČIOVÁ, Zuzana. Teorie pri̊myslových podnikatelských systémů I. , Zlín: Univerzita Tomáše Bati ve Zlíně. 2005. ISBN 80731-8270-X

3. KARABÁČ, Štefan; KOPOROVÁ, Katarína; NOVOTNÁ, Simona. Spoločná expertná báza pre technologické mapy a inovačné stratégie $v$ priemyselných 
klastrových habitatoch - Expertný dokument. Komplexná záverečná výskumná správa. NEK, 2020, ISBN978-80-972637-99.

4. KATI, Róbert. Príklady implementácie inovačných projektov pre zvyšovanie konkurencieschopnosti a trvalú udržatel'nost' rozvoja MSP na Slovensku. In: Energofutura, Nitra: 2017. ISBN 978-80-972637-0-6.

5. KOPOROVÁ, Katarína. Inovačné faktory tvorby, poslania, premís a klúčových zmien v sektore stavebníctva do roku 2030. Príspevok v zborníku medzinárodnej konferencie ECO\&ENERGY Innovation, Košice: MH SR+NEK, 2020 ISBN 978-80-973571-1-5.

6. KOTLER, Philip; KELLER, Lane Kevin. Marketing management, analýza, plánovaní,využití, kontrola, Praha: Grada publishing. 2013. ISBN 978-80-2478970-7.

7. MAGRETTA, Joan; STONE, Nan. Co je management, Praha: Management Press, s.r.o. 2013. ISBN 978-80-726-1106-5.

8. NOVÁK, Adam. Inovace je rozhodnutí, Kompletní návod jak dělat inovace nejen v byznysu. Praha: 2017. Grada Publishing. ISBN 978-80-271-0333-1.

9. NOVOTNÝ, Tomáš. Diagnostika dimenzie inovatívnosti firiem. Národný energetický klaster NEK, Bratislava: 2018. ISBN 978-80-972637-1-3.

10. NOVOTNÝ, Tomáš; HRABOVSKÝ, Gabriel; MARCIN, Ján. Koncipovanie inovačných nástrojov energetických a environmentálnych klastrových habitatov. Bratislava:MH SR + NEK.2020. ISBN 978-80-973571-0-1.

11. NOVOTNÝ, Tomáš a kol. ENERGOFUTURA Stratégia a budúcnost' energetického a environmentálneho prostredia. Bratislava: MH SR. 2017. ISBN 978-80-972567-4-6

12. PAVELKOVÁ, Drahomíra. Možnosti spolupráce na úrovni klastrových politik a průmyslových klastrů. FaME. Účelová publikace. Zlín: 2017. ÚTB ve Zlíne.

13. PLAMÍNEK, Jiř́. Vedení lidí, týmu a firem. Praktický atlas managementu. Praha: Grada Publishing.2018. 5 vydanie. ISBN 978-80-271-0629-5.

14. SEDLÁK, Mikuláš (2012, 2. vydanie): Základy manažmentu: Bratislava: Iura Edition. ISBN 978-80-8078-455-3.

15. SVOZILOVÁ, Alena (2011): Projektový management. Systémový př́stup k řízení projektu. Praha: Grada Publishing. ISBN 978-80-247-3611-2.

16. VEBER Jaromír a kol. Management, Základy, moderní manažerské př́stupy, výkonnost a prosperita. Praha: Management Press. 2014. 2 vydanie. ISBN 978-807261-274-1.

\section{Kontaktné údaje}

Ing. Katarína Koporová, MBA

Ing. Tomáš Novotný, Ph.D., MBA

Ing. Ján Marcin, MBA

Ing. Róbert Kati

Projekt Management Group of NEK

National Energy Cluster NEK

Záhradnícka 72, 82108 Bratislava

Slovak Republic

Tel: (+421) 910961141

email: info@nek.sk 


\title{
CORPORATE HOSPITALITY OF IBM AND DELL AS A PART OF THEIR CORPORATE IDENTITY
}

\author{
Sonia Krajčík Danišová
}

\begin{abstract}
Corporate hospitality activities are one of many indicators of corporate identity of companies, specifically corporate image and corporate culture. The aim of the paper was to analyse the corporate hospitality activities of two American companies - Dell and IBM. The survey used the method of interviews with representatives of both companies in Slovakia and analysis of the websites of Slovak subsidiaries. The main finding was that the corporate hospitality activities in Slovakia in comparison with the USA are not given much attention, and that their promotion on the websites of Slovak subsidiaries is minimal. This fact negatively affects the building of a positive corporate image, regardless of whether these companies are one of the market leaders or have several powerful competitors.
\end{abstract}

Key words: corporate identity, corporate culture, corporate communication, corporate image, corporate (client) hospitality, transnational corporation (TNC)

\section{INTRODUCTION}

Over the last ten years, the business environment has been affected not only by the economic crisis of 2007, but has also been characterized by a constant change, a long process of globalization, turbulent fluctuations in stock markets, or alternating positive and negative economic developments. Since Corporate Identity (CI) is a strategic tool for companies to build them, it must represent specific characteristics, capabilities, strengths and personality of the company. The environment influences, shapes and causes changes in the strategies of all market players.

The phenomenon of corporate hospitality of companies began to appear on the Slovak market along with the arrival of foreign companies. Corporate hospitality is often mentioned in the codes of ethics of transnational corporations (hereinafter referred to as TNCs) and is often abbreviated as $\mathrm{CH}$. It is defined very broadly and variously and within $\mathrm{CI}$ also falls under the corporate image $(\mathrm{CIm})$, or under the corporate culture $(\mathrm{CC})$. It is any entertainment event organized by the company for either its employees or clients (or potential clients) or interested other parties in such a way that all costs are borne by the company itself. The goal is to strengthen relationships with clients, motivate employees and gain the trust of all stakeholders. As a specific example of $\mathrm{CH}$, we can mention, for example, horse racing, fashion shows, benefit concerts, rugby matches, golf tournaments and the like, often associated with the auction associated with charitable activities.

The different types of events organized by the company (as part of corporate hospitality) are: inaugural events - with a specific topic or intention, to attract attention, multi-course lunch / dinner - suitable for longer talks or negotiations, awards ceremony - to support guests with a vision to cooperate in future, charity events - often supplemented by an auction linked to charitable activities. The aim of the research was to analyse the corporate hospitality $(\mathrm{CH})$ activities of two American TNKs - Dell and IBM. The survey used interview methods with representatives of both companies in Slovakia and an analysis of the websites of Slovak subsidiaries. 


\section{THE IMPORTANCE OF BUILDING CORPORATE IDENTITY (CI) FOR THE SUCCESSFUL MARKET POSITION OF THE COMPANY AND AN OVERVIEW OF ITS THEORETICAL DEFINITION}

The aim of the first chapter is to identify and characterize the current development of the global business environment, summarize the theoretical knowledge of the concept of corporate identity - English Corporate Identity (CI) as a strategic tool used by companies in the market and point out the importance of this concept and its place in strategic management. Another goal of this chapter is to identify the individual dimensions of CI, the so-called CI mix (Corporate Culture - CC, Corporate Communication - CCom, Corporate Network - CN, Corporate Design - CD and Corporate Image - CIm). The term CI (as well as all its elements) is used in the Slovak scientific literature mostly in English, and its literal translation, which would be corporate identity, corporate identity or corporate identity, has not yet been unified. The article uses the term CI in English - in its abbreviated form CI, as well as terms related to the individual elements of CI - CC, CCom, CN, CD and CIm.

$\mathrm{CI}$ includes all tangible objects and manifestations of the company's behavior, with which the company presents itself externally. According to Zorkóciová, CI is a manifestation of the company's personality, which is reflected not only in CC but also in CIm. However, theoretically defining the term $\mathrm{CI}$ is very complicated, because the professional public is not uniform in specifying this phenomenon. This is mainly due to the fact that CI is a multidimensional and interdisciplinary phenomenon and is subject to change not only in space but also in time. According to CI, the company can be clearly identified and clearly distinguished from other competitors in the market. CI should include not only the history, philosophy and vision of the company, but also a comprehensive view of its employees and the ethical and moral values that the company professes.

According to Balmer, CI can also be understood as a coordinated and integrated activity (i.e. a strategy), within which CI should meet the criteria of multidimensionality, multispectral addressability and synergy. Just clearly defined corporate strategy can guarantee a functioning corporate communication, security and trust and overall uniformity in the company. According to the pair of American authors Kimberly and Bouchikhi, the company's CI should then be integrated into the company's product, pricing, marketing, communication and distribution strategies, so that all target groups can perceive the company equally. In addition to business entities, other market entities can also develop the CI concept. (e.g. states, world organizations, political parties or universities) that want to communicate clearly and distinctly with the external and internal environment and thus strategically build self-awareness.

According to Marwick and Fill, CI tells us what a company is, how it works, what it does, how it conducts its business activities, and what strategies it adopts and then implements into other processes. A company's CI is something that sets one company apart from another. Balmer and Gray pointed out the unique characteristics of the so-called Corporate Personality $(\mathrm{CPe})$, which $\mathrm{CI}$ reflects and which are deeply rooted in the behaviour of company members who help employees fully identify with the company. That is why we distinguish between the understanding of "how we perceive ourselves", which is reflected in CI, and "how we would like to be perceived by others", which represents the so-called "Desired CI". Greyser supplemented this theory with several other concepts, pointing to the need to distinguish between intentions, strategies, and various aspects of CI that create one's own identity. According to Chun, we distinguish such an identity from the company's identity, which is based on the subjective perception of the company's identity by their own shareholders, and we call it a "perceived identity". On the contrary, "desired identity" includes not only how society wants to perceive and present itself (ideal / desired identity), but also how it wants to be perceived by others - i.e. "Desired image". We also distinguish between the identity of the company and CI, with the fact that the identity of the company is a term falling under the 
company's behaviour and CI is a term falling under the identity at the strategic level. These terms are visually interchangeable and therefore often incorrectly translated. Hatch and Schultz pointed out that a company's identity refers to what its own shareholders think of its company, while CI refers to how a company operates on the basis of shared beliefs and common goals.

Within CI, Pérez and Rodríguez del Bosque distinguish the following five dominant attributes: identity as a personality of society, identity as an image of society, identity as a visual image, identity as a set of ways of expression by CCom and identity as an integrative concept. CI is also perceived as a set of corporate resources that are characteristic of a given company. Melevar summarizes them in a model that contains 21 internal factors grouped into seven categories.

Melevar and Karaosmanoglu also examined the interrelationships created by CI, and they concluded that $\mathrm{CC}$, based on the company's history, founder, country of origin, subcultures and containing the company's mission, vision and values, influences corporate strategy as well as $\mathrm{CB}$ (i.e. behaviour company, management and employees). The corporate strategy follows the corporate structure for the brand structure and organizational structure, which directly influence the manifestations of the CD (slogan, architecture, office layout, website, location). Corporate strategy, $\mathrm{CC}$ and $\mathrm{CB}$ together create CCom (marketing, management, communication in the company) which together with $\mathrm{CD}$ create $\mathrm{CI}$. The contrast between CI and $\mathrm{CC}$ is analysed by Reitter and Ramanantsoa, who pointed out that symbolic products (i.e. the visible part of society) have the function of communicating the so-called "Organizational imaginaire" (i.e. a hidden part of society). These two levels complement each other and allow you to understand the essence of society and its functioning.

The historical development of theoretical insights into the concept and formation of CI dates back to the 19th century, when CI was understood as a manifestation of the character of the person of the company's founder, who defined the company's strategy and the company's values. During this period, the visual side was not cared for at all, and this period lasted until the end of the First World War. The twenties and forties of the twentieth century were the socalled brand-technical, which means that the brand was important only from the technical and product sphere, and the products at that time were practically equivalent in quality and price. As mass media methods of communication were absent in the interwar period, CI could not yet be communicated to the public. In the 1960s and 1970s, CI began to gain in importance. The most important element of CI was the CD, logos were developed and they distinguished companies from their competitors. The customer orientation was supplemented by the opposite view and companies began to follow the attitudes and feelings of customers towards the company. Management of employee behaviour and motivational strategies came to the fore. By the end of the eighties, the CI phenomenon began to be understood as a strategic management tool. With the advent of globalization in the 1990s, large American and European TNCs began to take shape, entering different markets and business areas. The CI phenomenon gained global dimensions during this period, and thanks to informatization and the development of the Internet, online CI strategies have also developed.

Further understanding of $\mathrm{CI}$ is based on its dichotomous division into two different perspectives in defining its concept - Corporate Personality $(\mathrm{CPe})$ and $\mathrm{CI}$ mix, where the most important element of the company's CI mix was to be its visual presentation. However, the dichotomous division resonated most with the professional literature at the turn of the seventies and eighties. Theoretical concepts of the term CI at the turn of the twentieth and twenty-first centuries were stable and included the phenomenon of CPe, CI mix, the phenomenon of CED or CIm. The inability to establish a uniform definition of CI has led some authors to focus on understanding it instead of the exact concept, which later led to the creation of theses that analyse the concept of CI. Bouchikhi and Kimberly perceive CI as a set 
of business principles, company principles, measures, concepts, ideals and statutes, which both define the basic values and goals of the company and ensure their acceptance, but also determine strategies that guarantee the optimal path from the current state to the desired state, and also allocate resources to the activities required by these strategies. Based on such a theoretical definition of CI, they derived the basic functions of CI. The first of these is the information and communication function, which aims to achieve a clear and positive (association-associated) knowledge of the company, as well as a transparent (employeeunderstood and followed) CI concept. The second function of CI is the function of creating an image, which aims to build sympathy for the company in the eyes of certain interest groups. The third function is the integration function, which aims to create synergistic effects across the company, and the last is the function of influencing relationships.

Further understanding of $\mathrm{CI}$ is based on its dichotomous division into two different perspectives in defining its concept - Corporate Personality $(\mathrm{CPe})$ and $\mathrm{CI}$ mix, where the most important element of the company's CI mix was to be its visual presentation. However, the dichotomous division resonated most with the professional literature at the turn of the seventies and eighties. Theoretical concepts of the term CI at the turn of the twentieth and twenty-first centuries were stable and included the phenomenon of $\mathrm{CPe}, \mathrm{CI}$ mix, the phenomenon of CED or CIm. The inability to establish a uniform definition of CI has led some authors to focus on understanding it instead of the exact concept, which later led to the creation of theses that analyse the concept of CI. Bouchikhi and Kimberly perceive CI as a set of business principles, company principles, measures, concepts, ideals and statutes, which both define the basic values and goals of the company and ensure their acceptance, but also determine strategies that guarantee the optimal path from the current state to the desired state, and also allocate resources to the activities required by these strategies. Based on such a theoretical definition of CI, they derived the basic functions of CI. The first of these is the information and communication function, which aims to achieve a clear and positive (association-associated) knowledge of the company, as well as a transparent (employeeunderstood and followed) CI concept. The second function of CI is the function of creating an image, which aims to build sympathy for the company in the eyes of certain interest groups. The third function is the integration function, which aims to create synergistic effects across the company, and the last is the function of influencing relationships.

\section{IBM AND DELL'S CORPORATE HOSPITALITY AS PART OF THEIR CORPORATE IMAGE}

The analysis of the corporate hospitality activities of IBM and Dell is preceded by a brief description of both transnational companies with a focus on their corporate identity. The choice of companies was intentional, as they are in direct competition with each other and the degree of penetration into the company was relatively high, mainly due to external cooperation of both companies with partner Bratislava Business School (now part of the Lifelong Learning Centre of the University of Economics in Bratislava, which is a universitywide EUBA). In the following part of the second chapter, both researched companies are introduced in more detail.

IBM (International Business Machines) is an American international technology company headquartered in Armonk, New York, United States. Today, the company operates in more than 170 countries around the world. The corporation developed from CTR (CTR = Computing - Tabulating - Recording) and was not renamed IBM until 1924. IBM manufactures and markets computer hardware, software (and middleware), including moderation and consulting services in a wide range from computers to nanotechnology. The company is also engaged in extensive research, for which it also holds the record in the field of development in the highest number of patents in 25 years. Some of the inventions produced 
by IBM are, for example: ATMs, personal computers, floppy disks, hard disks, credit cards, Relational database, SQL programming language, barcode or DRAM memory. The dominant feature in the 1960s and 1970s was the IBM mainframe, such as System / 360. IBM adjusted its activities several times to changes in a dynamically functioning market with a focus on more profitable areas. These changes were related, for example, to participation in Lexmark printer production in 1991, the sale of the ThinkPad computer brand and x86 server to Lenovo, and the acquisition of companies such as PwC Consulting (2002), SPSS (2009) and Weather Company (2016). Along with the above, the company announced in 2014 that it would continue its journey in semiconductor design, but at the same time withdraw from production for Global Foundries. Nicknamed "Big Blue", IBM is one of 30 companies listed in the Dow Jones Industrial standard (sometimes referred to as DJIA) as one of the world's largest companies with nearly 380,000 employees. Under the auspices of IBM, some of them have won world-renowned awards such as: 5 Nobel Prizes, 6 Turing Prizes, 10 national medals in technology and 5 national medals for science. In the Forbes 500 ranking, it ranked 38 th in 2021.

Dell, Inc. is an American multinational computer company based in Round Rock, Texas, USA. The company develops, sells and supports computers and related products and services. The company, named after its founder Michael Dell, is one of the largest technology companies in the world with more than 103,300 employees. In 2009, the company sold personal computers, servers, recording media, network switches, software, and computer peripherals, and by 2014, it was the third largest computer manufacturer after HP and Lenovo. Dell also sells HDTVs, cameras, printers, MP3 players and other electronics made by other manufacturers. The company is known for its innovations in supply chain management and ecommerce. According to Fortune magazine, Dell is the sixth largest company in the state of Texas, USA in terms of total revenue. It is also the second largest non-oil company in Texas after AT\&T, and is the largest company in the Austin area of Texas. In the Forbes 500 ranking, Dell ranked 34th in 2021, 4 places higher than IBM.

The corporate hospitality of both companies is almost identical. Activities with clients, partners, or other third parties by IBM and Dell employees are limited to the following circumstances:

a) symposium / congress connected with lunch / dinner (including awards ceremony);

b) a professional conference for the professional development of the staff member;

c) working breakfasts / lunches / dinners, provided that the meeting serves a proper business purpose and does not encourage conduct contrary to the Code of Ethics or the law;

d) presentation of products, services, professional training programs related to professional development of employees.

In the case of corporate hospitality, the suitability of the venue, the cost in the context of the event, will always be considered. In the event that a company employee is invited for business breakfast / lunch / dinner, the hospitality received must be of a nature and scope no greater than that which the company is likely to provide in return and must be approved by the immediate superior. Approval is considered to be e.g. written communication e-mail, as well as the subsequent signing of expenses to direct superiors. Any hospitality provided or received must not give rise to any obligation for the recipient. In the case of the presentation of products, services, professional training programs related to the work development of employees of companies where participation is free and the cost of refreshments during the presentation is not significant, the employee may participate with prior presentation by the immediate superiors. In the case of corporate hospitality, both IBM and Dell prefer actions and activities for the professional development of employees, where there is a clear workprofessional agenda in the official program. In the case of corporate hospitality to the employee by the client, partner, or third party, if it does not contain a specific work- 
professional agenda (for example, a social partnership with a cultural program, social celebration of the anniversary of the company, etc.) and is associated with a socio-work discussion. For all corporate hospitality activities known or estimated at more than 100EUR per person, the consent of the immediate superior is required, which must be given in writing (e.g. by e-mail).

\section{CONCLUSION}

Corporate identity (CI) is of strategic importance for the company, and therefore it is included in strategic decisions that fall within the decision-making power of top management. According to the division of society into hierarchical levels, the concept of CI is at the level of the corporation, so this work deals with the highest level, and therefore corporate.

At the same time, the company must monitor and respond to external influences, because it is these signals that both real and potential customers respond to. Just a little inattention and the long-term built CIm will be destroyed within a few days or. hours. It is especially important to monitor all signals and messages from external as well as internal environment during the economic crisis or during the current pandemic of Covid 19. It can be said that threats become stronger than market opportunities and the company often faces declining sales or deteriorating CIm. It must have developed not only strategic but also contingency plans, which it will reach in cases such as the current situation in the international business environment.

Awareness of the importance and role of the concept of corporate identity $(\mathrm{CI})$ in corporate strategy is the key to the success and competitiveness of companies operating in a dynamic international business environment marked by significant turbulence and other cyclical and structural changes. Companies are based on the vision and mission that shape CI and on which CI is built. As the vision and mission are created at the beginning of building the company, so the CI is formed from the first mention of the company. CI provides the basis for a clear and lasting idea, on the basis of which the company is clearly identifiable and distinguishable from other companies in the industry and in world trade.

The need to develop corporate hospitality activities (either towards employees and their families in the form of so-called Family Days, or directly as events for existing customers) is increasingly urgent and in conjunction with the activities that both TNCs spend directly in the US, their presentation on Slovakia almost insignificant. The main finding was that the activities of corporate hospitality in Slovakia in comparison with the US is not given as much attention, respectively. their promotion on the websites of Slovak subsidiaries is minimal. This has a negative impact on building a positive corporate image, regardless of whether these companies are market leaders or have several strong competitors. In addition, such a targeted presentation of the company has a huge potential to reach potential customers who, through CCom, CC and CIm of a new competitor, may feel the need to become part of the company's hospitality activities and take full advantage of it.

\section{Bibliography}

\section{Textbooks and monographies}

1. BOUCHIKHI, H. - KIMBERLY, J. R. (2008): The Soul of the Corporation: How To Manage The Identity Of Your Company. New Jersey: Wharton School Publishing, 2008. ISBN 978-0-13-185726-1. 194 p.

2. BOUCHIKHI, H. - KIMBERLY, J.R. (2003): Escaping the Identity Trap. In: Sloan Management Review. Vol. 44, Issue 3. 2003. ISSN: 1532-9194

3. PELSMACKER, P. De - GEUENS, M. - BERGH, J. van den. (2010): Marketing Communications: A European Perspective. 4th ed. Harlow: Pearson Education Limited, 2010. xxiii, 660 p. ISBN 978-0-273-72138-3. 
4. ZORKÓCIOVÁ, O. a kol. (2007): Corporate Identity II. 2.vydanie. Bratislava: Ekonóm, 2007. 282 p. ISBN 978-80-225-2336-3

5. ZORKÓCIOVÁ, O. - RATKOVSKÁ, G. (2009): Osobitosti a ciel'ové subjekty späté s procesom budovania Corporate Identity nefiremných subjektov. In: Studia commercialia Bratislavensia. ISSN 1337-7493, 2009, roč. 2, n. 8, p. 143-162.

\section{Magazines}

1. BALMER, J.M.T. - GRAY, E.R. (2000): Corporate Identity and Corporate Communications: Creating a Competitive Advantage. In: Industrial and Commercial Training, Vol.32, n.7, p.256-261.

2. BALMER, J. - GREYSER, S. (2002): Perspectives on Identity, Image, Reputation, Corporate Branding, and Corporate-Level Marketing. Taylor \& Francis e-Library, p.41-42.

3. HATCH, M.J. - SCHULTZ, M. (2003): Bringing The Corporation into Corporate Branding. In: European Journal of Marketing, Vol.37, n.7-8., p. 1041-1064.

4. HE, H.-W. - BALMER, J.M.T. (2011): A Grounded Theory of the corporate identity and corporate strategy dynamic: a corporate marketing perspective. In: European Journal of Marketing. Vol.67, n.3-4, p.401-430.

5. CHUN, R. (2005): Corporate Reputation: Meaning and Measurement, In: International Journal of Management Reviews, Vol.7, n.2., p.91-109.

6. MARKWICK, N. - FILL, Ch. (1997): Towards a Framework for Managing Corporate Identity. In: European Journal of Marketing, Vol.31, n.5-6, p.396-409.

7. MELEVAR, T.C. (2003): Determinants of the Corporate Identity Construct: A Review of the Literature, In: Journal of MarketingCommunications, Vol.9., p. 195220.

8. MELEVAR, T.C. - KARAOSMANOGLU, E. (2006): Seven Dimensions of Corporate Identity. A Categorisation from the Practitioners' Perspectives. In: European Journal of Marketing. Vol.40, n.7-8, p. 846-869.

9. PÉREZ, A. - RODRÍGUEZ DEL BOSQUE, I. (2014): Customer CSR in the Banking Industry. In: International Journal of Bank Marketing, Emerald Group Publ. Ltd., Vol.32., n.3., p.223-244.

\section{Online Resorces}

1. Magazín Fortune - Zoznam Global 500 (2021). DOI: http://fortune.com/fortune500/dell/

2. Magazín Fortune - Zoznam Global 500 (2021). DOI: http://fortune.com/fortune 500/ibm/

3. Oficiálna slovenská webstránka spoločnosti IBM (2021). DOI: $\mathrm{https}: / / \mathrm{www} . \mathrm{ibm} . \mathrm{com} / \mathrm{ibm} / \mathrm{sk} / \mathrm{sk} /$ ?lnk=fab_sksk

4. Oficiálna slovenská webstránka spoločnosti Dell (2021). DOI: https://www.dell.com/learn/sk/sk/skcorp1/about-dell

\section{Kontaktní údaje}

Ing. Mgr. Sonia Krajčík Danišová, PhD.

Ekonomická univerzita, Fakulta aplikovaných jazykov

Dolnozemská cesta 1, 85235 Bratislava

e-mail: sonia.krajcik.danisova@euba.sk 


\title{
ZELENÉ INOVÁCIE V ORGANIZÁCIÁCH
}

\section{GREEN INOVATIONS IN THE ORGANISATIONS}

\author{
Veronika Gajdošová Ladňáková
}

\begin{abstract}
Abstrakt
Životné prostredie a jeho ochrana je v posledných rokoch stále viac diskutovanou témou. Ked’že sa hovorí o neustále narastajúcom negatívnom vplyve človeka, resp. l'udskej činnosti na prírodu, je nevyhnutné sa zaoberat' touto problematikou. Životné prostredie predstavuje všetko, čo máme, priestor, v ktorom žijeme a z ktorého čerpáme. Je to vzduch, ktorý dýchame, voda, ktorú pijeme, pôda, ktorá nás živí, ale aj organizmy, vrátane nás, l'udí. Spoločne tvoríme jeden celok, ktorého súčasti sú na sebe závislé a vzájomne sa ovplyvňujú. Žial', zdá sa, že bude náročné zvrátit' negatívne dôsledky nášho počínania, minimalizovat' jeho následky a revitalizovat' to, čo sa ešte dá zachránit'. V záujme prežitia a dlhodobej udržatel'nosti životného prostredia je dôležité si uvedomit', že každý jeden z nás môže byt' súčast'ou pozitívnej transformácie. Je nevyhnutné zodpovedne riešit' ekologické problémy a zavádzat' také zmeny, ktoré budú smerovat' $\mathrm{k}$ udržatel'nému a klimaticky neutrálnemu obehovému hospodárstvu. Ciel'om príspevku je načrtnút' problematiku dopadu činností organizácií na životné prostredie, ktoré $\mathrm{v}$ súčasnosti taktiež musia reagovat' na zmeny a uvedomit' si, že je nevyhnutné prijímat' riešenia. Opatrenia v podobe „zelených“ inovácií sú jednou z možností, ktorá by v budúcnosti mala priniest' efektívnejšie využívanie zdrojov a znižovanie negatívnych dopadov na životné prostredie. Príspevok sa venuje v tomto kontexte aj komparácii zavádzania ekologických inovácií na Slovensku a v zahraničí.
\end{abstract}

Kl’účové slová: životné prostredie, ekologické inovácie, organizácia.

\begin{abstract}
The environment and its protection has been an increasingly discussed topic in recent years. Since there is talk of a constantly growing negative impact of man, let us say human activity to nature, it is necessary to address this issue. The environment represents everything we have, the space in which we live and from which we draw. It is the air we breathe, the water we drink, the soil that feeds us, but also the organisms, including humans. Together we form a single whole, the components of which are dependent on each other. Unfortunately, it seems difficult to reverse the negative consequences of our actions, minimizes its consequences and revitalize what can still be saved. For the sake of survival and long-term environmental sustainability, it is important to remember that each and everyone can be part of a positive transformation. It is essential to tackle environmental problems responsibly and to introduce changes that are directed towards a carbon-neutral circular economy. The aim of this fee is to outline the issue of the impact of organization's activities on the environment which currently also need to respond to change and realize the need to adopt solutions. Measures in the form of "green" innovation are one of the options that should lead to a more efficient use of resources and a reduction of negative environmental impacts in the future. In this context, the fee also compares the introduction of eco-innovation in Slovakia and abroad.
\end{abstract}

Key words: environment, ecological innovation, organization. 


\section{ORGANIZÁCIE AKO SÚČASŤ ŽIVOTNÉHO PROSTREDIA}

Všetko, čo nás obklopuje a podmienky, vktorých žijeme a pôsobíme, to tvorí životné prostredie. Ide o komplex prírodných a antropologických elementov, ktoré sú vzájomne prepojené a ovplyvňujú ekologickú rovnováhu, kvalitu života a zdravia každého človeka, kultúrne a historické dedičstvo a krajinu. Významným prvkom, ktorý má negatívny dopad na životné prostredie, a tak sa podiel’a na zvyšovaní environmentálnych zát’aží, sú organizácie. Na jednej strane v neudržatel'nej miere čerpajú zdroje a na strane druhej ho znečist'ujú tak, že nie je schopné sa adekvátne regenerovat'. Dopady ich činností presahujú regióny a hranice štátov, preto sa ich úloha $\mathrm{v}$ dosahovaní trvalo udržatel'ného rozvoja stáva rozhodujúcou nielen na národnej, ale tiež na medzinárodnej úrovni. Významné medzinárodné a európske inštitúcie a spoločenstvá, ktorými sú OSN, EÚ či OECD, sa zhodujú na tom, že aktuálny model rozvoja, ktorý sa sústred’uje predovšetkým na ekonomické ciele, nie je v súlade so schopnost'ou Zeme podporovat' l'udskú civilizáciu. Preto sa v posledných rokoch stále častejšie skloňuje v spoločnosti pojem „ochrana životného prostredia“, ktorý vychádza zo zmeny postoja k prírode a životnému prostrediu. V roku 2015 OSN priniesla ambiciózny plán udržatel'ného rozvoja, ktorý je zakotvený v „Agende udržatel'ného rozvoja do roku 2030“. Organizácie by mali podniknút' kroky vedúce $\mathrm{k}$ udržatel'nej spotrebe a výrobe vychádzajúc z tohto dokumentu, ktorého hlavnými ciel'mi sú:

- realizovanie programov na udržatel'nú spotrebu a výrobu,

- dosiahnutie udržatel'ného riadenia a efektívneho využívania prírodných zdrojov,

- zníženie celosvetového potravinového odpadu,

- dosiahnutie environmentálne korektného riadenia znečist'ujúcich látok a odpadov,

- zníženie uvol'ňovania znečist'ujúcich látok a odpadov do ovzdušia, vody, pôdy tak, aby sa eliminovali negatívne dopady na zdravie l’udí a na životné prostredie,

- zamedzenie vzniku odpadov pomocou preventívnych opatrení, recyklácie, upcyklácie a zníženia ich množstva v obehu,

- podnietenie organizácií k zavádzaniu trvalo udržatel'ných postupov a zverejňovaniu správ o udržatel'nosti,

- podporovanie udržatel'ných stratégií v oblasti verejného obstarávania,

- informovanie a zvyšovanie povedomia o udržatel'nom rozvoji a ochrane životného prostredia,

- podporovanie vedeckej a technologickej kapacity na dosiahnutie udržatel'nej spotreby a výroby,

- vytvorenie a implementácia nástrojov monitoringu a hodnotenia,

- prehodnotenie dotovania fosílnych palív.

Manažment environmentálnej problematiky by mal byt' preto neoddelitel'nou súčast'ou každej organizácie, nakol'ko sa už niekol'ko rokov intenzívne diskutuje aj o environmentálnej kríze. V roku 2019 Európsky parlament schválil uznesenie o vyhlásení stavu klimatickej núdze v Európe, pričom uviedol, že je nutné tento stav vnímat' globálne, celosvetovo. V súčasnosti sa boj proti klimatickým zmenám a úsilie o znižovanie negatívnych dopadov na životné prostredie a podpora environmentálne orientovaných zmien neustále zintenzívňuje. Manažéri sa preto musia zaoberat' identifikáciou problematických oblastí v organizácii a hl'adaním riešení pre implementáciu environmentálne udržatel'ného modelu riadenia. Ich úlohou je identifikovat' súčasný stav organizácie a jej činností a priniest' nové, inovatívne postupy a technológie, ktoré budú $\mathrm{v}$ súlade $\mathrm{s}$ priaznivým vývojom životného prostredia. Čoraz väčší význam sa v tejto oblasti pripisuje vedecko-technickému rozvoju a tzv. zeleným, resp. ekologickým inováciám. 


\subsection{Zelené inovácie $\mathrm{v}$ organizáciách}

Inovatívne či zdokonalené produkty, procesy, technológie, organizačné modifikácie alebo marketingové riešenia, ktoré majú za následok znižovanie čerpania prírodných zdrojov, resp. ich efektívnejšie a zodpovednejšie využívanie a elimináciu produkcie látok, ktoré by mohli poškodit' životné prostredie, to všetko predstavujú zelené, resp. ekologické inovácie. Podl'a Európskej komisie ide o všetky formy inovácií, ktorých výsledkom sú kroky vedúce $\mathrm{k}$ naplneniu ciel'ov udržatel'ného rozvoja prostredníctvom znižovania negatívnych dôsledkov výroby na životné prostredie, nárastu rezistencie prírody voči ekologickým tlakom či rozumnejšieho využívania naturálnych zdrojov. Pojem ekologické inovácie, resp. ekoinovácie, je relatívne nový, ked’že životné prostredie sa stalo významnou spoločenskou témou až v polovici 20. storočia a ako súčast' podnikovej politiky sa tento pojem $\mathrm{v}$ širšom spektre objavil až začiatkom 21. storočia. Najčastejšie sa aplikovanie ekoinovácií v organizácii spája s týmito faktormi:

- politické stimuly, resp. platné legislatívne opatrenia,

- získanie konkurenčnej výhody pre organizáciu,

- vlastná motivácia vychádzajúca z vnútra organizácie,

- zníženie podnikových nákladov a rast úspor,

- vytvorenie pridanej hodnoty pre zákazníka,

- nové výrobky a služby,

- podpora a zlepšovanie životného prostredia,

- budovanie podnikovej imidž,

- nové obchodné príležitosti,

- zlepšenie kvality života,

- vytváranie nových spoločenstiev,

- tvorba nových pracovných miest,

- udržatel'ný manažment prírodných zdrojov.

Ekoinovácie teda nie sú len nástrojom ochrany životného prostredia, ich využitie je aj spôsob, ako ušetrit' a zvýšit' konkurencieschopnost' organizácie a v konečnom dôsledku môžu byt' aj významným ukazovatel'om konkurencieschopnosti ekonomiky ako celku. V tomto kontexte môžeme hovorit' o obehovom hospodárstve, resp. o cirkulárnej ekonomike, ktorá predstavuje koncept založený na efektívnom využívaní zdrojov, alternatívnych „zelených“ technológií a podporujúci využívanie ekoinovácií vo všetkých oblastiach výroby tak, aby boli zachované nasledujúce princípy:

- uzatváranie toku materiálov vo funkčných a nekončiacich cykloch tak, aby nestrácali hodnotu,

- čerpanie energie z obnovitel'ných a udržatel'ných zdrojov,

- navrhovanie takých produktov a služieb, ktoré nemajú negatívny dopad na ekosystémy a l'udské zdravie.

Životný cyklus do ktorého vstupujú ekoinovácie nie je len o poklese vstupov do výrobného procesu, resp. do produktu, ale je o celkovom zlepšení využívania vynaložených zdrojov, pričom občas môže dokonca dôjst' k zvýšeniu vstupov do výroby, ak výsledkom je vyššia účinnost', efektívnost' a najmä trvanlivost' a dlhšia životnost' inovatívneho riešenia. 
Obr. 1 Cirkulárna vs. lineárna ekonomika
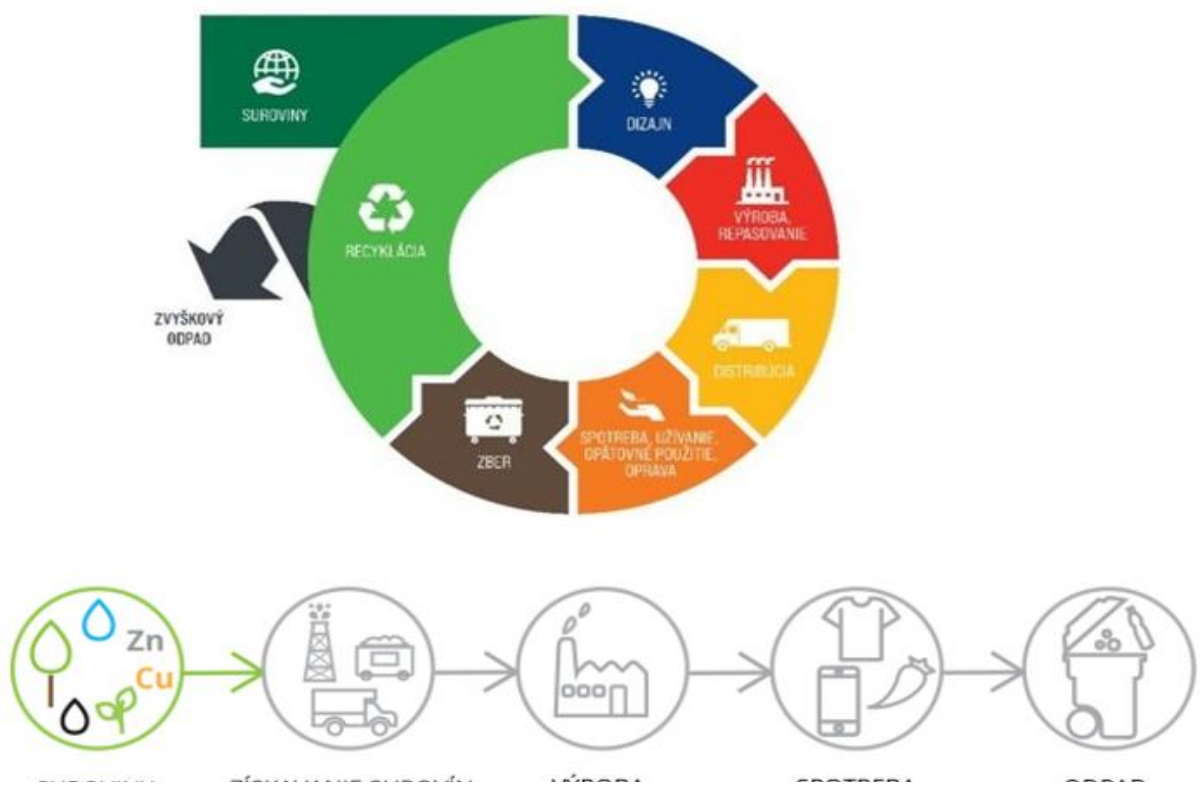

4Zdroj: Inštitút cirkulárnej ekonomiky, 2021

Problematika životného prostredia a s tým spojená orientácia na cirkulárnu ekonomiku a zavádzanie ekoinovácií v organizáciách je aktuálne celosvetovou témou. Vo všeobecnosti sa zmeny súvisiace s implementáciou ekoinovácií musia realizovat' predovšetkým na najvyššej úrovni, môžeme tak hovorit' o zmene zhora nadol. Primárne sa tento proces zameriava na transformáciu podnikovej stratégie, ktorá vychádza z ciel'ov a princípov trvalo udržatel'ného rozvoja, a spočíva $\mathrm{v}$ celostnom prístupe k organizácii a vo vzájomnej kooperácii. Zavádzanie ekoinovácií do všetkých podnikových činností je dlhodobý a náročný proces, ktorý však môže priniest' alternatívne spôsoby myslenia a správania sa, nové modely, postupy, technológie a riešenia, ktoré budú $\mathrm{v}$ harmónii so životným prostredím. Stále viac organizácí́ sa snaží realizovat' alternatívne spôsoby výroby a spotreby, no nie je to jednoduché, ked'že na ich ceste k obehovej ekonomike stojí mnoho prekážok. Preto zohrávajú vel'mi dôležitú úlohu $\mathrm{v}$ tomto procese verejné politiky a inštitúcie, ktoré by organizáciám svojou podporou v podobe financií, legislatívnych opatrení a pod. mali pomôct' prekážky prekonat'.

\subsection{Druhy ekoinovácií}

Každá organizácia sa môže rozhodnút' pre využitie rôznych ekoinovácií:

- inovácie v oblasti environmentálnych technológií - technológie na kontrolu znečistenia, technologicky čistejšie procesy, zariadenia na nakladanie s odpadmi, technológie ekologickej energie, zariadenia na monitorovanie životného prostredia, dodávky vody, manažment a monitorovanie hluku a vibrácií,

- organizačné inovácie - systémy na prevenciu znečistenia, systémy environmentálneho riadenia a auditu, riadenie obehu materiálu od výroby po likvidáciu,

- ekologické produkty a služby - eko dizajn, ekologické služby (nakladanie s odpadmi, zelené finančné služby, riadenie odpadových vôd, ekologické poradenstvo a pod.),

- zelené systémové inovácie - alternatívne systémy výroby a spotreby (doplnkové produkty, ktoré zlepšia ekologickú výkonnost' zákazníkov, čistejšie technologické procesy, obnovitel'né zdroje energií, organizačné zmeny, nové informačné a komunikačné technológie a pod.). 
Vel'ké zmeny v ekologickej transformácií, ktoré môžu mat' vplyv na celú ekonomiku však môže priniest' najmä kombinovanie rôznych inovácií spolu s novými organizačnými a manažérskymi prístupmi. Na rozhodovanie, ktoré inovácie sú pre organizáciu vhodné má vplyv množstvo faktorov. Môže íst' o regulácie, trhové faktory, špecifiká konkrétnej organizácie, dostupnost' finančných prostriedkov, zdroje financovania, mieru podpory, mieru efektívnosti ich využívania, dostupnost' technológií, legislatívne bariéry, obmedzený výskum a vývoj a pod.

\section{EKOINOVÁCIE NA SLOVENSKU A V ZAHRANIČÍ}

Slovenská republika mala vždy záujem sa zapájat' do aktivít, ktoré boli spojené s trvalo udržatel'ným rozvojom, čoho dôkazom je vypracovanie viacerých dokumentov, ktoré pojednávajú o environmentálne orientovaných technológiách a budúcom rozvoji $\mathrm{v}$ tejto oblasti.

V roku 2004 krajina vypracovala Akčný plán pre environmentálne technológie, na ktorý v roku 2011 nadviazal Akčný plán ekologických inovácií, ktorý mal širšie zameranie ako jeho predchodca a okrem technológií sa venoval všetkým oblastiam ekoinovácií, a to vrátane produktov a služieb. Podniky na Slovensku častokrát k implementácii ekoinovácií motivujú vlastné hodnoty a presvedčenie, že šetrenie životného prostredia je správne a prirodzené. Podla prieskumov viac ako $40 \%$ organizácií sa pre nich rozhodne na základe uplatňovania princípov spoločenskej zodpovednosti a $16 \%$ vychádza z prijatej legislatívy. Napriek snahe uspiet' v oblasti zlepšovania životného prostredia v podobe ekoinovácií v organizáciách a obehovej ekonomiky existujú zrejme stále bariéry, ktoré spôsobujú, že krajina v niektorých sférach zaostáva za výkonom ostatných štátov Európskej únie. V hodnotení zavádzania a využívania ekoinovácií sa v roku 2019 nachádzala hlboko pod priemerom EÚ. V oblasti ekologických patentov sa umiestnila v porovnaní s ostatnými krajinami tiež na chvoste spolu so štátmi, ktoré nedosahujú takú ekonomickú úroveň ako tie nad priemerom EÚ. Aj napriek tomu, že Slovensko má vysokú úroveň organizácií registrovaných podl’a požiadaviek medzinárodnej Normy ISO 140001, ktorá definuje požiadavky na systém environmentálneho manažérstva a na základe ktorej sa zavádza a certifikuje tento systém v organizáciách, nepatrí v Európskej únii medzi eko lídrov. 
Obr. 2 Organizácie, ktoré zaviedli inováciu s environmentálnymi výhodami pre zákazníka

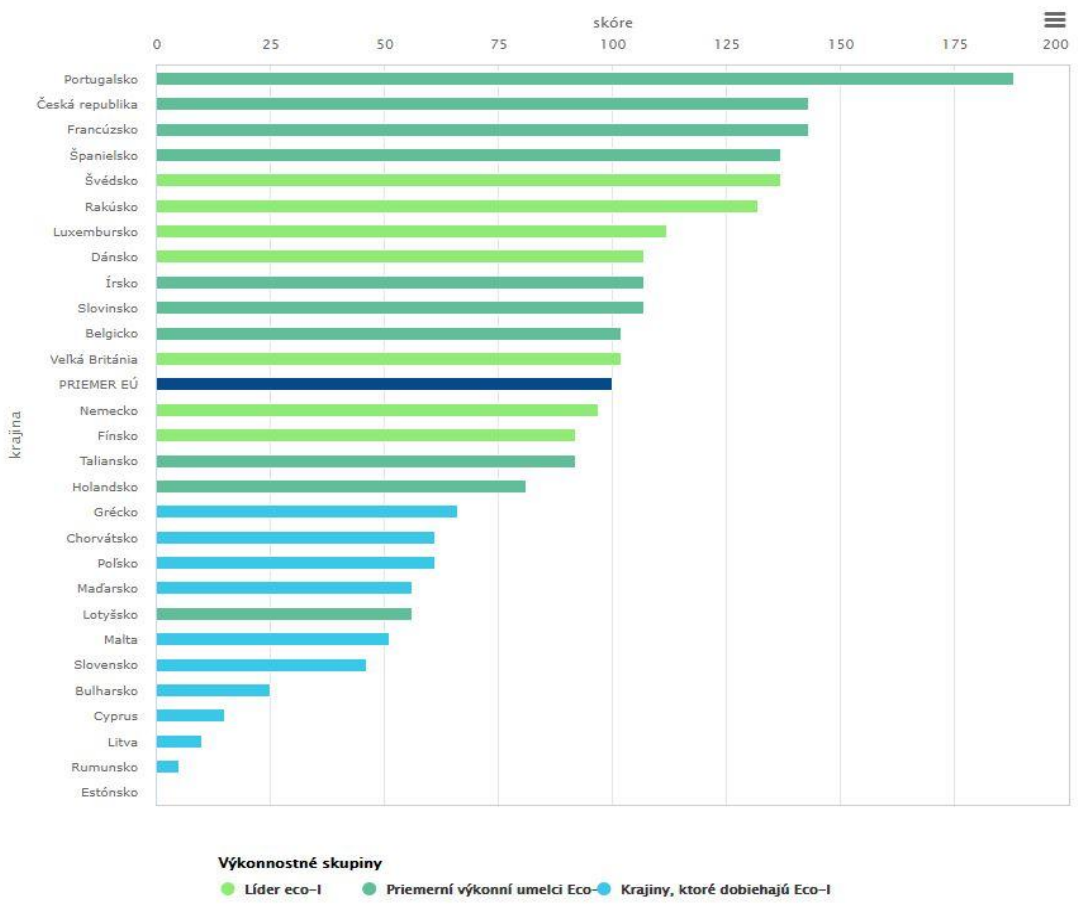

Zdroj: Eurostat, 2019

Obr. 3 Organizácie, ktoré zaviedli inováciu s environmentálnymi výhodami pre organizáciu

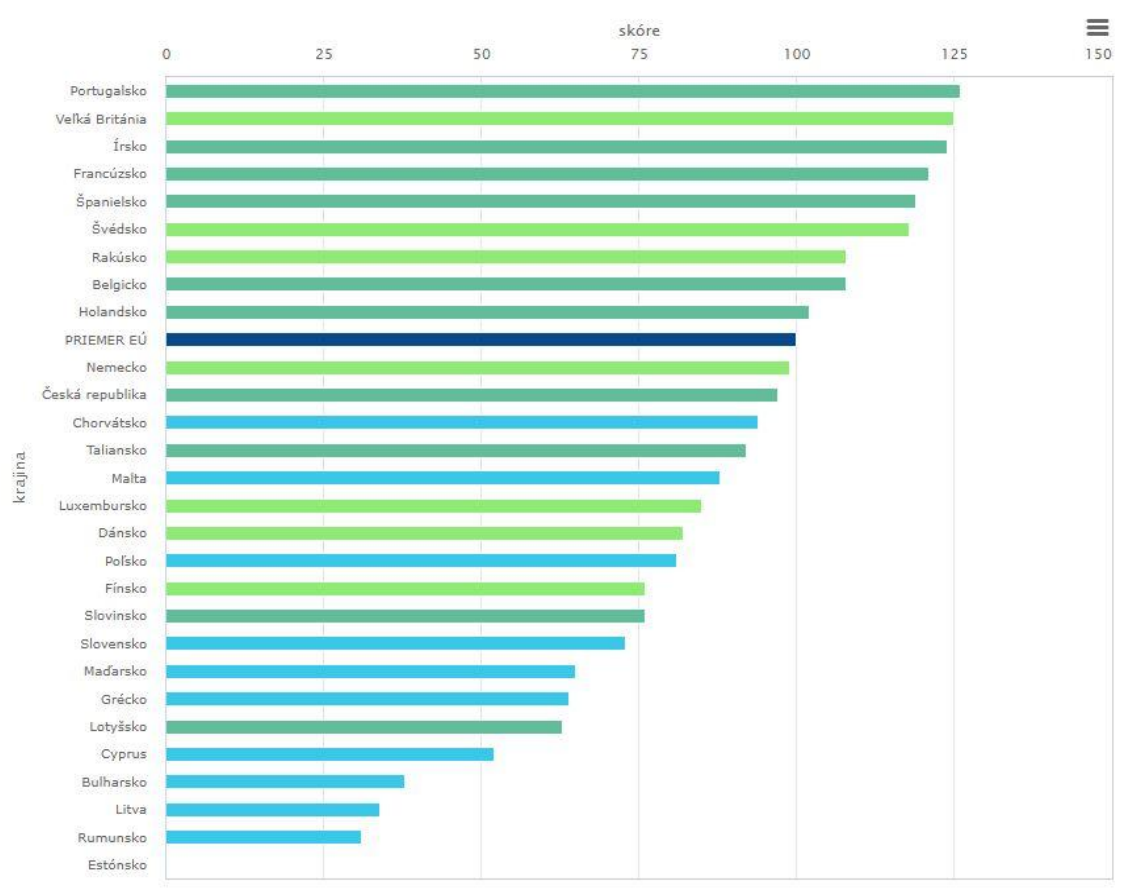

Výkonnostné skupiny

Zdroj: Eurostat, 2019

Ĺder eco-1 Priemerní výkonní umelci Eco-o Krajiny, ktoré dobiehajú Eco-I 
Obr. 4 Organizácie registrované podl’a Normy ISO 140001

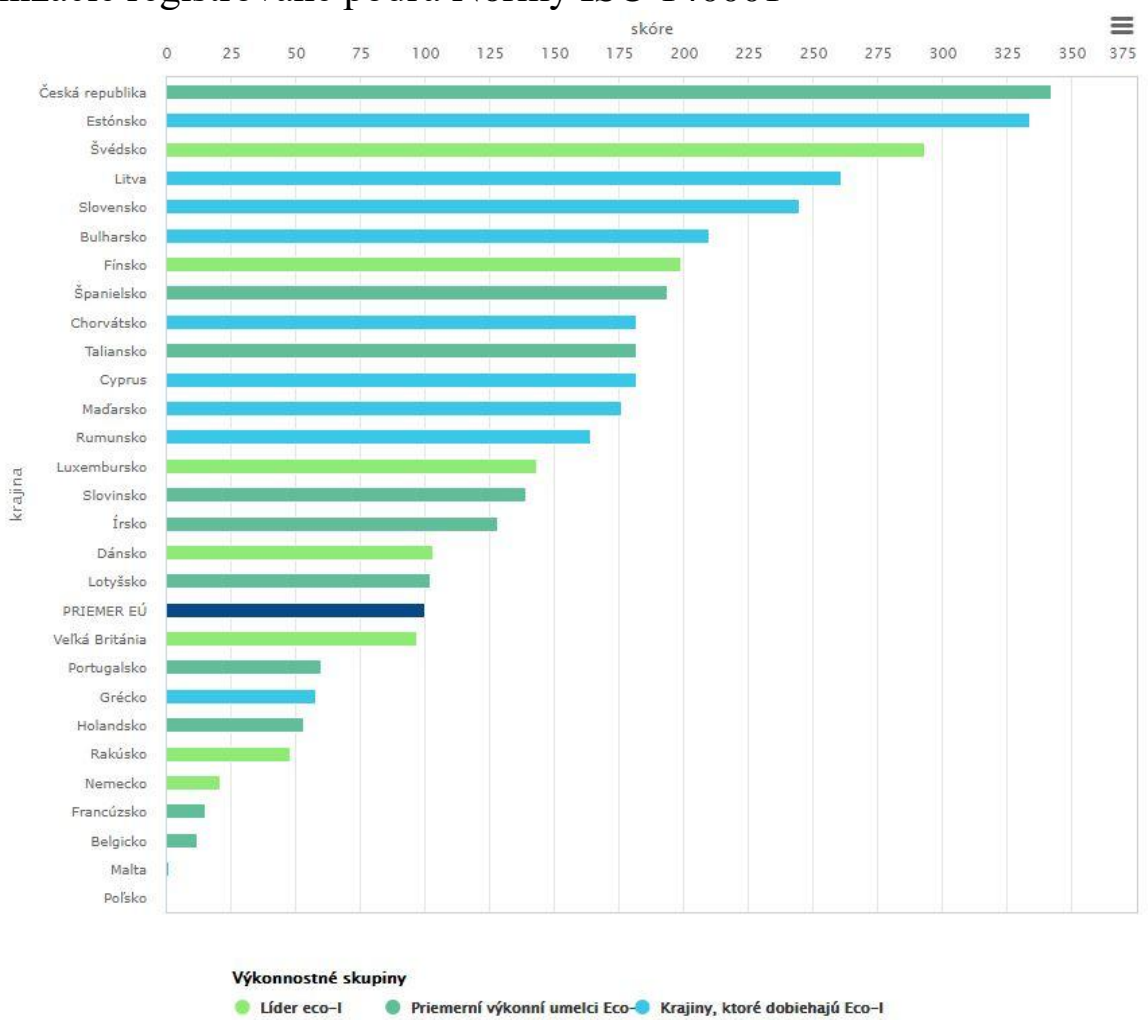

Zdroj: Eurostat, 2019

Obr. 5 Patenty súvisiace s ekologickými inováciami

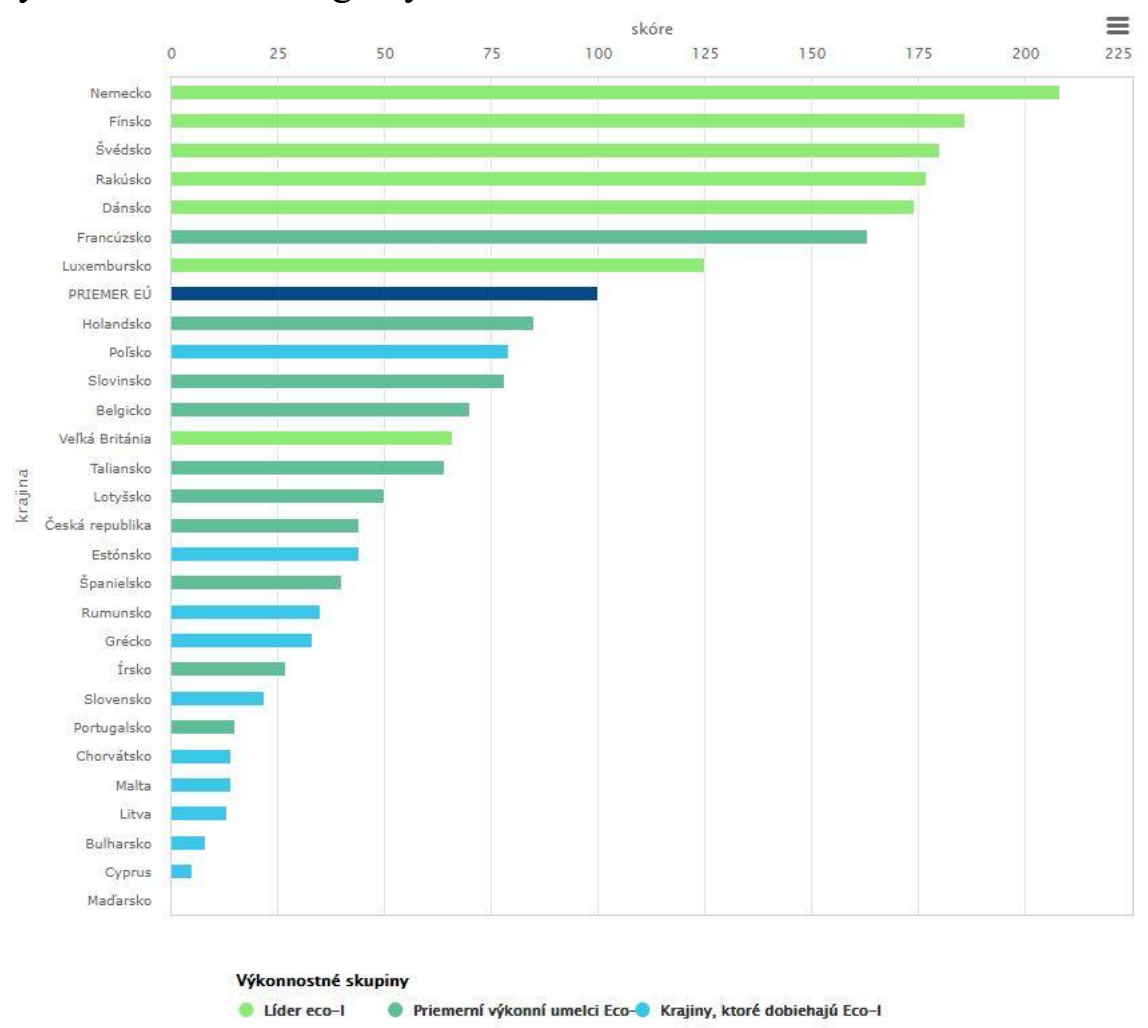

Zdroj: Eurostat, 2019 
Obr. 6 Index ekoinovácií

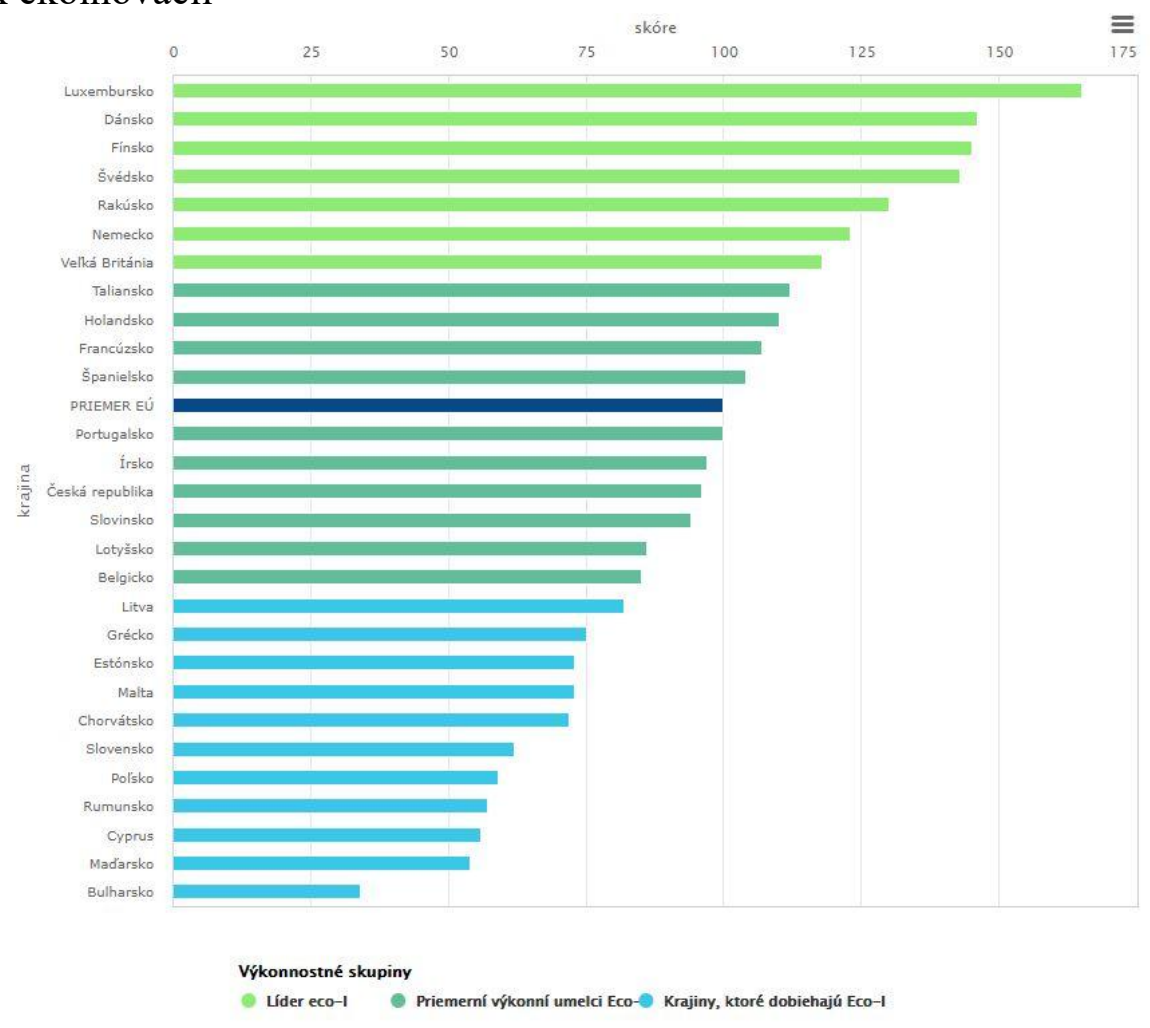

Zdroj: Eurostat, 2019

Obr. 7 Index ekoinovácií Slovensko vs. priemer EÚ

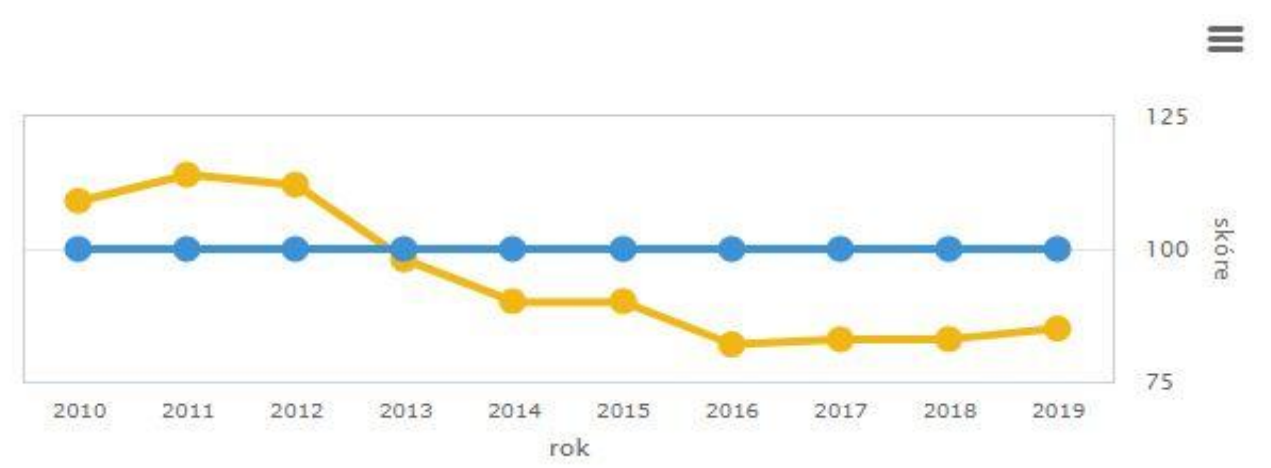

Zdroj: Eurostat, 2019

\section{Použitá literatúra}

1. AMBEC, S., LANOIE, P. Does It Pay To Be Green? Dostupné z: https://www.resea rchgate.net/publication/269844468_Does_It_Pay_to_be_Green_A_Systematic_Overview.

2. ANTON, D. K., SHELTON, D. L. Environmental protection and Human Rights. New York: Cambridge, 2011. 986 s. ISBN 978-0-521-74710-3.

3. CENTRUM SLEDOVANIA EKOLOGICKÝCH INOVÁCIÍ. Inovujte ekologicky! Príručka o ekologických inováciách pre malé astredné podniky a obchodných poradcov. Bratislava: SAŽP, 201869 s. ISBN 978-80-89503-68-1.

4. ENVIROPORTAL. Environmentálne technológie. Dostupné z: https://www.envirop ortal.sk/environmentalne-temy/starostlivost-o-zp/dobrovolne-nastroje-environmen talnej-politiky/environmentalne-technologie. 
5. EUROISO. ISO 140001 certifikát environmentu. Dostupné z: https://www.euroiso .sk/iso-14001.

6. EURÓPSKA ENVIRONMENTÁLNA AGENTÚRA. Zdravé životné prostredie je základom udržatelného hospodárstva a spravodlivej spoločnosti. Dostupné z: https://www.eea.europa.eu/sk/articles/zdrave-zivotne-prostredie-je-zakladom.

7. EURÓPSKA ENVIRONMENTÁLNA AGENTÚRA. Životné prostredie Európy. Stav a perspektíva 2020. Luxemburg: Úrad pre publikácie Európskej únie, 2019. 14 s. ISBN 978-92-9480-128-9.

8. EUROSTAT. The Eco-innovation Scoreboard and the Eco-innovation index. Dostupné z: https://ec.europa.eu/environment/ecoap/indicators/index_en.

9. FAKULTA PRÍRODNÝCH VIED UNIVERZITY MATEJA BELA. Globálna environmentálna kríza a ochrana biodiverzity v systémovom pohl'ade. Dostupné z: https://www.fpv.umb.sk/katedry/katedra-biologie-a-ekologie/veda-a-vyskum/konfere ncie/globalna-environmentalna-kriza-a-ochrana-biodiverzit y-v-systemovom-pohlade/.

10. HILL, P. Environmental protection. New York: Oxford University Press, 2017. ISBN 978-019-0-223-09-0

11. INŠTITÚT CIRKULÁRNEJ EKONOMIKY. Cirkulárna ekonomika. Dostupné z: https://www.incien.sk/cirkularna-ekonomika/

12. LESÁKOVÁ, L. a kol. Eko-inovácie a malé a stredné podniky. Banská Bystrica: Belianum, 2019. ISBN 978-80-557-1532-2.

13. SCARSE, I. J., STIRLING, A., GEELS, F.W., SMITH, A., VAN ZWANENBERG, P. Transformative Innovation. Dostupné $\mathrm{z}$ : https://www.researchgate.net/publication/2 72086124_Transformative_Innovation.

14. SLOVENSKÁ AGENTÚRA ŽIVOTNÉHO PROSTREDIA. Ekoinovácie. Dostupné z: https://www.sazp.sk/zivotne-prostredie/environmentalne-manazerstvo/ekoinovacie/

15. TOMÁS̆ JECK. Ekologické inovácie: teoretické a hospodársko-politické súvislosti. 2012. ISSN 1337-5598.

\section{Kontaktní údaje}

Mgr. Veronika Gajdošová Ladňáková

Katolícka univerzita v Ružomberku, Pedagogická fakulta

Hrabovská cesta 1 A, 03401 Ružomberok

Tel: +421914276876

email: ladnakova.veronika@gmail.com 


\title{
PODCAST SPECIFICATIONS IN SLOVAKIA
}

\author{
Viera Krúpová, Zora Hudíková
}

\begin{abstract}
The history of the emergence of podcasting around world is widely described in available literary or online sources. The situation in Slovakia differs. There is no relevant data or information regarding the emergence of podcasts, which is why, in preparation of this study, we approached the producers or creators of some of the first podcasts in Slovakia. Through a series of semi-structured interviews, we asked about the circumstances surrounding the emergence of podcasting, their initial strategies, the practical implementation of podcasting, listeners' reactions, success evaluation. We compared the information we had obtained with the described history from around the world, we defined the commonalities, the points of concurrence in the rise of podcasting in the world, as well as in Slovakia, while focusing on the exclusively local particularities. In the conclusion, the study addresses the prospects of podcasting expansion in the near future, through collecting the opinions of the respondents.
\end{abstract}

Keywords: auditory production, internet population, MP3 player, podcast, RSS technology

\section{INTRODUCTION}

Podcast - the new contemporary communication format - continues to further establish itself in Slovakia. Podcasts are produced by official media, celebrities, hosts and anchors, actors, influencers and youtubers. Increasingly, individuals with little to no experience in audio production are emerging among podcast producers. In Slovakia, the new communication phenomenon has received minimal analysis. A systematic collection of data is absent, the target group of listeners has not been clearly defined as of yet, and there exist no program evaluation, or rating. Among the first ones to carry out regular listenership surveys was 2 muse, an agency which began producing regular podcast listenership surveys in 2019. The data gathered by 2 muse suggests that the popularity of podcasts in Slovakia has been continually rising, in proportion to the number of listeners, who listen to podcasts regularly. According to the findings of 2muse from March 2021 "29 percent of the internet population in Slovakia listens to podcasts, which translates to approximately 1 million people. "l The increasing popularity of podcasts can be traced to its various particularities, which aptly reflect today's way of life - especially its rapid pace, mounting work load, or the need to do several things at a time, which appears the most convenient. In 2006 Deborah Potter recognised these benefits in her definition of podcasts, which she described as ,,digital files you can download from the Internet and listen to whenever and wherever you want." ". Generally podcasts can be characterised as an audio recording, which is uploaded to the Internet with the intention of distributing information and sharing particular knowledge. Users can listen to podcasts online, via an internet connection or offline, by downloading the file to a mobile device, which enables the user to listen to the podcast at a later time. The aforementioned service is referred to as audio on demand.

\footnotetext{
${ }^{1}$ Počúvanie podcastov. 2muse agency final report, 24th of March 2020. Material provided for the authors of the study. ${ }^{2}$ POTTER, D. L.: IPod, you pod, we all pod: eager to lure news consumers, media outlets are experimenting with news-ondemand podcasts. They're fun, fresh--and often unpolished. SemanticScholar. 2006. [online]. [2020-07-26]. Availabe at: https://www.semanticscholar.org/paper/iPod\%2C-you-pod\%2C-we-all-pod\%3A-eager-to-lure-newsmediaPotter/7465ac4537dfc82521a1d4e0a2c427c3279c9418
} 
Today, we are able to present the current listenership numbers, which indicate the interest of Slovak listeners in the new communication format. However, what preceded the present-day situation, how and when podcasting in Slovakia emerged, and what were the initial reactions from the receiving side remains unclear. An analysis of the mental processes and strategies of the creators of some of the first podcasts also appears as a worthy inquiry, together with an evaluation of the degree to which their "firstlings" could be considered a success. All these are inquiries, to which the existing sources in Slovakia offer no answer. The history of podcasting in Slovakia has not been adequately recorded, hence this study aspires, to at least partially, fill in this gap. To accomplish this, we approached the media and creators, who stood at the absolute beginning of podcasting in Slovakia. We utilised a qualitative method of semi-structured interviews. We discussed the conditions and context impacting the initial, as well as later stages of podcasting, including the continuous rise of podcasting across Slovakia. Naturally, no new communication format can emerge in isolation, in a vacuum of sorts. Instead, it is affected by the surrounding environment, such as developments in leading, more advanced countries or new global trends. Therefore, the emergence and development of podcasting in Slovakia has been influenced by the rise of podcasting across the globe. However, it goes without saying that inbound technologies and innovative technological solutions played a significant part in the process. Thus, we shall evaluate the situation in the local environment in the context of the development of this form of media presentation around the world, which was conditioned by the aforementioned technological advance.

\section{TECHNOLOGICAL PREREQUISITES}

While the history of podcasting traditionally dates back to 2004, its emergence is preceded by crucial technological prerequisites, which had been in development since 2000, most notably the introduction of RSS 0.92 (Really Simple Syndication or Rich Site Summary) ${ }^{3}$. RSS enables the user to create a personalised feed, which allows for an easy access to preferred shows or programs. ${ }^{4}$ It operates based on regular, or targeted subscription. Deborah Potter further emphasises the importance of RSS in simplifying content access. The listener subscribes to a podcast of choice, which is then regularly and automatically downloaded and transferred to a portable device, such as the then-popular iPod. ${ }^{5}$ Web 2.0. tools, like blogs, were essential, as oftentimes blogs figured as the platforms through which creators shared their podcasts, thus enabling audio files to be delivered in RSS feeds. " "Audioblogging" as initially used by Adam Curry, a former MTV VJ, is a term first used to describe the sharing of audio digital files via the Internet. ${ }^{7}$ The podcast-enabling technologies developed and introduced by Dave Winer in 2000 came to exist as a response to Curry's requests. ${ }^{8}$

By 2004, podcasts were considered a viable medium of content distribution, owing to Curry's iPodder, along with the launch of his very own podcast program, Daily Source Code, both of

\footnotetext{
${ }^{3}$ BOTTOMLEY, Andrew J.: Podcasting: A Decade in the Life of a "New" Audio Medium: Introduction. Journal of Radio \& Audio Media. 2015, 22(2), 164-169. DOI: 10.1080/19376529.2015.1082880. ISSN 1937-6529. p. 164.

${ }^{4}$ JOHNSON, Dave.: A guide to using RSS feeds, the files that contain real-time updates from websites. [online]. [2021-0430]. Available at: <https://www.businessinsider.com/what-is-rss-feed>.

${ }^{5}$ POTTER, Deborah L.: IPod, you pod, we all pod: eager to lure news consumers, media outlets are experimenting with news-on-demand podcasts. They're fun, fresh--and often unpolished. American Journalism Review. 2006, $28(1), 64$.

${ }^{6}$ BOTTOMLEY, Andrew J.: Podcasting: A Decade in the Life of a "New" Audio Medium: Introduction. Journal of Radio \& Audio Media. 2015, 22(2), 164-169. DOI: 10.1080/19376529.2015.1082880. ISSN 1937-6529. p. 164.

${ }^{7}$ BOTTOMLEY, Andrew J.: Podcasting: A Decade in the Life of a "New" Audio Medium: Introduction. Journal of Radio \& Audio Media. 2015, 22(2), 164-169. DOI: 10.1080/19376529.2015.1082880. ISSN 1937-6529. p. 164.

${ }^{8}$ BOTTOMLEY, Andrew J.: Podcasting: A Decade in the Life of a "New" Audio Medium: Introduction. Journal of Radio \& Audio Media. 2015, 22(2), 164-169. DOI: 10.1080/19376529.2015.1082880. ISSN 1937-6529. p. 164.
} 
which significantly contributed to the popularisation of this medium (media content). ${ }^{9}$ In the same year, Ben Hammersley releases „Audible Revolution“ an article published by the Guardian, in which he coins the term ,podcast. 'Surprisingly, Hammersley himself only came up with the term to fill in the word count requested by his publisher. ${ }^{10}$ A year later, ,podcast ${ }^{6}$ became New Oxford American Dictionary's word of the year. ${ }^{11}$ The year 2005 has been referred to as the ,year of the podcast," as suggested by numerous events, including significant growth in listenership. While in 2004, the Bridge Rating agency reports 820000 American listeners, the number in 2005 bordered 5 million listeners. ${ }^{12}$ Meanwhile, Apple introduces new version of its iTunes application, iTunes 4.9., which enables users to download podcasts directly via the iTunes app. This meant that podcasts were now accessible through a singular app - available to access whenever and wherever. ${ }^{13}$ However, at this time, we are still talking about technologies which only allowed for downloading, not streaming of podcasts. Nevertheless, the freedom, which came with these technologies, allowing listeners to choose when, where and to what to listen to became an advantage compared to the „tyranny of the live“. ${ }^{14}$ Aware of the virtues of podcasting, many networks entered the platform, offering newscasts, programs, or other segments in the form of a podcast. However, at the time, they served mostly secondary purposes, either as an extension to traditional broadcasting or as its by-product. ${ }^{15}$ Former Bush administration was no exception, having had G.W. Bush's weekly address delivered as a podcast. ${ }^{16}$ Furthermore, podcasting allowed for a more direct flow of communication between podcast creators and listeners, enabling listeners to provide content feedback more effectively, while enabling the creators to react to it or accommodate it. ${ }^{17}$ By 2005, BBC, a media network was producing its own podcast along other creators such as Ricky Gervais, a famous comedian, whose podcast came to set a record in the number of downloads, exceeding 4.5 million downloads within the show's first two months. ${ }^{18}$ A vast share of the available podcasts consisted of content created by ordinary users, amateurs. ${ }^{19}$ The accessibility of the technology, together with decent computer skills enabled virtually anyone to create a podcast.

\section{THE RISE OF PODCASTS IN THE WORLD}

While the number of podcast listeners in the period from 2005 to 2013 was growing steadily, the medium struggled to break through as a mass medium, being perceived as more of a niche

\footnotetext{
${ }^{9}$ BOTTOMLEY, Andrew J.: Podcasting: A Decade in the Life of a "New" Audio Medium: Introduction. Journal of Radio \& Audio Media. 2015, 22(2), 164-169. DOI: 10.1080/19376529.2015.1082880. ISSN 1937-6529. p. 164.

${ }^{10}$ ROBERTSON, Jamie.: How podcasts went from unlistenable to unmissable. [online]. [2019-09-26]. Available at: < https://www.bbc.com/news/business-49279177>.

11 BOWERS, Andy.: The Year of the Podcast. [online]. [2005-12-30]. Available at: <https://slate.com/news-andpolitics/2005/12/the-year-of-the-podcast.html>.

${ }^{12}$ POTTER, Deborah L.: IPod, you pod, we all pod: eager to lure news consumers, media outlets are experimenting with news-on-demand podcasts. They're fun, fresh--and often unpolished. American Journalism Review. 2006, 28(1), 64.

${ }^{13}$ BOTTOMLEY, Andrew J.: Podcasting: A Decade in the Life of a "New" Audio Medium: Introduction. Journal of Radio \& Audio Media. 2015, 22(2), 164-169. DOI: 10.1080/19376529.2015.1082880. ISSN 1937-6529. p. 164.

${ }^{14}$ BERRY, Richard. A Golden Age of Podcasting? Evaluating Serial in the Context of Podcast Histories. Journal of Radio \& Audio Media. 2015, 22(2), 170-178. DOI: 10.1080/19376529.2015.1083363. ISSN 1937-6529. p 172.

${ }^{15}$ POTTER, Deborah L.: IPod, you pod, we all pod: eager to lure news consumers, media outlets are experimenting with news-on-demand podcasts. They're fun, fresh--and often unpolished. American Journalism Review. 2006, $28(1), 64$.

16 Podcasting Historical Timeline and Milestones. [online]. (C) 2020. Available at: <https://internationalpodcastd ay.com/podcasting-history/>.

17 HAMMERSLEY, Ben.: Audible revolution. [online]. [2004-02-12]. Available at: <https://www.theguardian .com/media/2004/feb/12/broadcasting.digitalmedia>.

${ }^{18}$ HUDSON, Alex.: Podcasts: Who still listens to them?. [online]. [2011-07-23]. Available at: <http://news.bbc.co. uk/2/hi/programmes/click_online/9545533.stm>.

${ }^{19}$ ROBERTSON, Jamie.: How podcasts went from unlistenable to unmissable. [online]. [2019-09-26]. Available at: < https://www.bbc.com/news/business-49279177>.
} 
platform until 2013. ${ }^{20}$ Pew Research Center estimates that the number of listeners in 2015 has nearly doubled, as compared to $2008 .^{21}$ Podcasting's breakthrough arrives with the launch of Serial, which marks the beginning of ,the golden age of podcasts“ or as others may call it

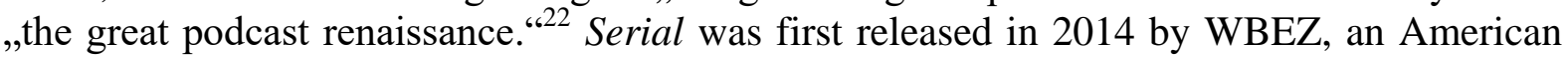
radio station, at a time at which Edison Research reports approximately 39 million podcast listeners across the US. ${ }^{23}$ An almost instantaneous sensation, Serial has often been referred to as the greatest podcast ever made, becoming the subject of countless talks and theories. ${ }^{24}$ With the central theme being unsolved, or mysterious murders, the podcast enabled the listeners to engage with it, producing a great deal of theories, which they then shared on social media platforms, such as Twitter, which further contributed to the show's popularity. ${ }^{25}$

In its first seven months the show amounted over 77 million downloads, while reaching the first 5 million in a record time. ${ }^{26}$ Still, Serial's success was prefaced with a series of technological advances. In 2012, Apple introduced the Podcasts app, an app designed specifically for iPhones for an easy access to podcasts. ${ }^{27}$ Further factors, which enabled the expansion of podcasting to a degree at which we know them today was the development of $4 \mathrm{G}$ mobile phone connections, as well as the widely accessible Wi-Fi connection. ${ }^{28}$ Such technologies enabled the listeners to enjoy any podcast, whenever, wherever. While then podcasting utilised technologies, which allowed users to download content, now listeners enjoyed true freedom in how, when and where they listened to podcasts. ${ }^{29}$ This freedom arises from the switch from downloading to streaming. Serial was further able to overcome issues, which plagued podcasts creators in the platform's humble beginnings, most notably complications monetising the media. Nevertheless, Serial managed to sell out all its advertising space in days by the time the second series came out. Together with the British podcast show My Dad Wrote a Porno, they succeeded in getting the attention of advertisers, who quickly recognised podcasts' monetary value. ${ }^{30}$ During this period, podcasts turn into an integral part of the traditional media landscape. D. Llinares estimates that in 2017 the number of American podcast listeners reached approximately $40 \%$ of the population. ${ }^{31}$

\footnotetext{
${ }^{20}$ BOTTOMLEY, Andrew J.: Podcasting: A Decade in the Life of a "New" Audio Medium: Introduction. Journal of Radio \& Audio Media. 2015, 22(2), 164-169. DOI: 10.1080/19376529.2015.1082880. ISSN 1937-6529. p. 165.

${ }^{21}$ BOTTOMLEY, Andrew J.: Podcasting: A Decade in the Life of a "New" Audio Medium: Introduction. Journal of Radio \& Audio Media. 2015, 22(2), 164-169. DOI: 10.1080/19376529.2015.1082880. ISSN 1937-6529. p. 165.

${ }^{22}$ BERRY, Richard. A Golden Age of Podcasting? Evaluating Serial in the Context of Podcast Histories. Journal of Radio \& Audio Media. 2015, 22(2), 170-178. DOI: 10.1080/19376529.2015.1083363. ISSN 1937-6529. p. 171

${ }^{23}$ BERRY, Richard. A Golden Age of Podcasting? Evaluating Serial in the Context of Podcast Histories. Journal of Radio \& Audio Media. 2015, 22(2), 170-178. DOI: 10.1080/19376529.2015.1083363. ISSN 1937-6529. p. 170, 173

${ }^{24}$ BERRY, Richard. A Golden Age of Podcasting? Evaluating Serial in the Context of Podcast Histories. Journal of Radio \& Audio Media. 2015, 22(2), 170-178. DOI: 10.1080/19376529.2015.1083363. ISSN 1937-6529. p. 170

${ }^{25}$ BERRY, Richard. A Golden Age of Podcasting? Evaluating Serial in the Context of Podcast Histories. Journal of Radio \& Audio Media. 2015, 22(2), 170-178. DOI: 10.1080/19376529.2015.1083363. ISSN 1937-6529. p. 171.

${ }^{26}$ BOTTOMLEY, Andrew J.: Podcasting: A Decade in the Life of a "New" Audio Medium: Introduction. Journal of Radio \& Audio Media. 2015, 22(2), 164-169. DOI: 10.1080/19376529.2015.1082880. ISSN 1937-6529. S. 165.; BERRY, Richard. A Golden Age of Podcasting? Evaluating Serial in the Context of Podcast Histories. Journal of Radio \& Audio Media. 2015, 22(2), 170-178. DOI: 10.1080/19376529.2015.1083363. ISSN 1937-6529. p. 170.

${ }^{27}$ ROBERTSON, Jamie.: How podcasts went from unlistenable to unmissable. [online]. [2019-09-26]. Available at: < https://www.bbc.com/news/business-49279177>.

${ }^{28}$ ROBERTSON, Jamie.: How podcasts went from unlistenable to unmissable. [online]. [2019-09-26]. Available at: < https://www.bbc.com/news/business-49279177>.

${ }^{29}$ ROBERTSON, Jamie.: How podcasts went from unlistenable to unmissable. [online]. [2019-09-26]. Available at: < https://www.bbc.com/news/business-49279177>.

${ }^{30}$ ROBERTSON, Jamie.: How podcasts went from unlistenable to unmissable. [online]. [2019-09-26]. Available at: < https://www.bbc.com/news/business-49279177>.

${ }^{31}$ LLINARES, Dario.: Podcasting: New Aural Cultures and Digital Media. Cham, Switzerland: Palgrave Macmillan, 2018. p. 190
} 


\section{PODCASTING IN SLOVAKIA}

Slovakia's first podcast arrived in 2005. On the 28th of July in 2005, Slovak author and journalist Tomáš Ulej began producing his own literary recordings, publishing them under the title „first Slovak podcast.“ Among the Slovak podcast pioneers belongs Radio FM. On the 1st of April in 2006, the Slovak public radio's third circuit launched a podcast service on its website. The radio representatives substantiated this move by emphasising the growing popularity of podcasts globally. Within the frame of the system, the software automatically followed any updates and downloaded files onto the drive, which were consequently copied onto a MP3 player. However, podcasting only started expanding more widely after the year of 2017, when other media and news portals began creating their own podcasts. To this day, Denník SME is one of the most important experimenters in Slovakia. Its first news podcast, Dobré ráno, was created in October 2017. According to SME, two years later they have "thirteen podcasts, tens of thousands of regular listeners with new ones constantly accruing, experimentation continues. ${ }^{\text {“32 }}$

For the purposes of our study, we decided to address the three already mentioned actors who stood at the birth of podcasting in Slovakia - writer and journalist Tomáš Ulej, at Radio FM we addressed Tomáš Vanča, who was responsible for the program, at SME Dávid Tvrdoň, who belonged to the main initiators of the beginning of the production of podcasts in this newspaper and still works in it to this day. In the form of semi-structured interviews, we asked them about the beginnings of their podcasting activities, about their successes or mistakes, the first reactions of the listeners or the environment. We also talked about the perspective development of podcasts in Slovakia, but also about how they define this communication format.

\section{4 "FATHER" OF SLOVAK PODCASTS}

Tomáš Ulej is a journalist by profession. From a young age, he was interested in new technologies, wrote about them, and created his own website about the Slovak Internet, when the Internet was only in its infancy. He later worked as a journalist for SME, where he led the digital section. He founded the SME Daily Fund. The purpose of this activity was to gather Slovak literature for the website. In 2012, when he ended his career as a journalist, he moved to the Martinus online bookstore, where he developed the website for many years. He is currently leading a research team of experts dedicated to new technologies and looking for innovative ways to work with the website.

He got to create the first podcast in Slovakia mainly due to his interest in new technologies, as he belonged to a group of technology enthusiasts. "With the advent of technology, sometime before 2005, people began to experience the need to get the spoken word into their MP3 player. It often happened that they converted TV shows to MP3 format and then listened to them later. I also reworked the Markiza 7sro TV show in this way so that I could listen to it undisturbed for 2-3 hours on the train. This is how many people made audio books, today they download the application for that, at that time it did not exist. ${ }^{33}{ }^{3} \mathrm{He}$ decided to make a podcast of his own after first getting a digital player. And since he knew podcasts from abroad, writing about them as a journalist, he decided to make his own podcast. "At that time I had my own website niemand.sk, where I created a podcast section. I started uploading various things here, mostly recordings of literature, short stories. However, sometimes I also

\footnotetext{
32 TVRDOŇ, D.: Stručné dejiny podcastov, a prečo za to môže Apple? 2019. [online]. [2020-09-22]. Available at: https://podcasty.sme.sk/c/22232563/ako-podcasty-zacali-kratka-historia-audioblogovania.html

${ }^{33}$ Tomáš Ulej, interview, 12.4.2021
} 
experimented, recording various interesting sounds, melodies and the like here. "34 His podcast production lasted for about a year, gaining several dozen listeners. Ulej, however, considers his activity a mere initial attempt, as, according to him, real podcasting in Slovakia originated later.

"When defining what a podcast is, there is a very fragile line. It's a spoken word, thus any radio show that someone uploads on the internet can be considered a podcast. The only thing that makes an actual podcast different is, in my opinion, the technological part, that it has some XML Feed, based on which one can download the recording and listen to it later." ${ }^{\text {"35 }}$ Tomáš Ulej does not currently produce podcasts, he only follows them as a listener. "In some countries, such as the US, podcasts have an already reputable tradition, with many American podcasts, originating at a time at which I was producing my first podcast, still running. In our country, I still perceive podcasts only as a marginal medium, they are still not reaching the listening of the official media, with many disappearing shortly after their release. But that will change. The only way is that in about 20-30 years we will pay for any quality content on the Internet, and it will serve as a motivation and a great challenge for podcast creators. " 36

\section{PROGRESSIVE RADIO}

Public radio FM, looking back at history, is also one of the pioneers of the podcast scene in Slovakia. Dušan Vančo, who was responsible for the program on Rádio FM at the time, is owned a great deal of credit for that. He considers himself a "radio" person. He has been pursuing a professional radio career since 1998, when he first started working for Radio Twist. He later received an offer to work on a new project, the rebranding of Rádio FM, where he was first responsible for the program and later, in 2007 he became the director of the entire radio. In 2013, he joined Radio Európa 2 as Program and Marketing Director. He is currently the director of a Trnava radio, while also being the director of the independent cultural centre Nádvorie in Trnava.

FM Radio began podcasting on April 1, 2006, almost two years after podcasts appeared worldwide. "I was listening to podcasts at the time, I was fascinated. Ifelt that this could become a successful product, once people get to control the radio themselves. Additionally, Rádio FM was just after its rebranding at the time and I wanted it to be perceived as a progressive brand. " ${ }^{37}$ Despite the fact that podcasts were dominated by the spoked word, Radio FM had a different strategy. "We started podcasting nightly music specials, such as the 4Elements podcast focused on dance music, later the Baláž and Hubinák talk format, the metal special Headbanger_FM, the Music Education music section. These were the firstlings, later the number of podcasts expanded to about 20 . “38

When deciding which shows will be turned into podcasts, the management of Radio FM acted more or less intuitively. "During the evening shows, we wanted to access the day-time listener or a listener who does not normally listen to the radio in the evening. "39 According to Dušan Vanča, the production of podcasts at the time was not complicated, as the radio runs 24/7. As he goes on to say, the next day, a particular show was selected, post-produced, and published. Mostly one person did it. "Somehow we didn't edit the shows, we tagged them, and at the beginning and at the end we did a self-promo for other podcasts. We also tried to

\footnotetext{
${ }^{34}$ Tomáš Ulej, interview, 12.4.2021

${ }^{35}$ Tomáš Ulej, interview, 12.4.2021

${ }^{36}$ Tomáš Ulej, interview, 12.4.2021

${ }^{37}$ Dušan Vančo, interview, 6.5.2021

${ }^{38}$ Dušan Vančo, interview, 6.5.2021

${ }^{39}$ Dušan Vančo, interview. 6.5.2021
} 
keep the length of the session as it was originally, but so that it would fit in about two hours." 40 Podcast listenership was not continuous, it had big fluctuations. "It ranged from a thousand to about ten thousand, of course, depending on the show." 41 That's why they decided to do an explanatory campaign for the listeners. "In a PDF manual, we explained to the listeners that it was not a web archive, but that, in fact, it was an MP3 link that could be opened in the MP3 player. But they didn't always understand it. Only after the first phones, the iPhones, came in, did the activity become meaningful, and people started using it the proper way.", 42

Despite the difficult beginnings, Radio FM continued to create podcasts, gradually reaching 20. "As daily podcasts began to appear, so did daily podcasts or weekly and daily sections. They were either music news or Kino FM or Feature - a more complex music format. The interviews from the FM morning began to be post-produced, the best passages were selected, with the scientific and technical column of Jan Mečiar joining in later." ${ }^{\text {"43 }}$ The Lampa show was an extremely successful format, also becoming a podcast. "We took it over after the show was canceled by the then director of Slovak Television, we made it into a radio format and as a podcast it became a talk format, with high numbers of downloads." Dušan Vančo also offers his perception of the future of podcasts in the coming years. "They will continue to rise, there will be various attempts, but I don't think there will be another mass boom. Rather, I think the market will become saturated. It will be done by the strongest and best, with the greatest numbers. The other tiny attempts will probably come and go." 44

\section{PODCASTS IN THE SME DAILY}

The daily SME started producing podcasts in 2017. Dávid Tvrdoň, who has been working at the SME publishing house Petit Press since 2015, was also involved in their creation. He started as a social media manager, later doing data things, currently being the product manager for online news. He initially devoted himself to podcasts not professionally, but with intrigue, being a listener himself since 2010. "The discussion about podcasts at SME started in the years 2015 to 2016. We thought it would be a good idea to try it. It seemed to us that the simplest podcast, when the two sit down, record an interview, publish it without editing, is minimalist in terms of production, but the interaction of the dialogue is all the greater there. So we set to work." 45 At the end of October 2017, Dobré Ráno was released. "We have been looking for a suitable structure for this podcast for quite a while. Throughout 2017, we observed the developments around daily news podcasts, such as the news podcast The Daily, produced by the New York Times. Their numbers started growing very fast, with now more than 4 million people listening to it every day. The podcast Up First by NPR became similarly popular. We primarily analysed these two when we were looking for the final structure of our podcast." 46 The result was a structure - introduction, 5 news reports, the main topic, conclusion, advertising breaks were designed from the very beginning. "The first couple of shows were more of a trial, we mostly sought for reactions, mainly from colleagues. Later, we also asked for reactions on Facebook. In the first month after the podcast released, we did statistics, where we linked moderators to the type of topic, selected topics, tracked download numbers, and then re-evaluated it. ",47

\footnotetext{
${ }^{40}$ Dušan Vančo, interview, 6.5.2021

${ }^{41}$ Dušan Vančo, interview, 6.5.2021

${ }^{42}$ Dušan Vančo, interview, 6.5.2021

${ }^{43}$ Dušan Vančo, interview, 6.5.2021

${ }^{44}$ Dušan Vančo, interview, 6.5.2021

${ }^{45}$ Dávid Tvrdoň, interview, 14.4.2021

${ }^{46}$ Dávid Tvrdoň, interview, 14.4.2021

${ }^{47}$ Dávid Tvrdoň, interview, 14.4.2021
} 
According to Dávid Tvrdon̆, they also experimented with the length of the Dobré Ráno podcast. "From the beginning we knew it had to last for at least 15 minutes. We started there, it gradually got longer and today it is 21 minutes." The first hosts were Tomáš Prokopčák, Peter Tkačenko, Zuzana Keplová. "We wanted the hosts to be already somewhat known and experienced so that they could hold the thread of the conversation and lead it. We didn't want it to be completely professional, structured, as it is on the radio. It was supposed to be much more relaxed, we were not afraid to sit there with colleagues from the editorial office, to leave pauses, occasional stuttering, all of which would not pass on the radio." 48

The first reactions to the Dobré Ráno podcast were mostly positive. "Of course, when you look back at the discussions under some of the first episodes - the reactions varied. According to some we were fooling the nation because we taught people not to read and so on. But gradually it broke down and the increase in listenership began breaking the record with each month." "${ }^{9}$ Today, according to Dávid Tvrdoň, the podcast Dobré Ráno is listened to by 32,000 listeners a day, the ambition is to have 40,000 daily listenings by the end of 2021. In addition to the podcast Dobré Ráno, SME now produces another 21 types of podcasts. Their focus is diverse - politics, new technologies, history, cooking, sports, fairy tales and more. "We were very open to new podcasts. After Dobre Rano, we called for public tenders, if anyone wants to have a podcast, let them come and try it, we wanted to have a wide variety of genres. It was only after a while that we decided that each new podcast must fulfil some parameters, ideally right from the beginning it has to have a sponsor who contributes financially to its production. Following the pilot works, we follow the listening curve. If it is low, we decide whether to change the format or stop the podcast. "50 Dávid Tvrdon sees the future of podcasts positively. "Almost anyone can make podcasts today, with the National Bank of Slovakia, the Slovak Academy of Sciences, public and private corporations having them. They perceive it as a content format that people consume, so it is something they think they should do. I think that the podcast is already one of the standard genres in our country." 51

\section{CONCLUSION}

If we were to compare the development of podcasts globally with the development in Slovakia in the form of an exact comparison, we would not find much congruity. However, there are several common areas that are comparable. First and foremost, it is the technological progress. This was the first condition for the creation of podcasts in the world, and it was no different in Slovakia. Although Slovakia has been lagging in development in this area by about 2-3 years, the arrival and spread of new technologies needed to download, play or listen to podcasts in recent years, conditioned their rapid development in Slovakia as well. The second commonality is the human factor, which is always behind every innovation, progress or a new discovery. In Slovakia, too, it was "technological" or "progressive" enthusiasts who discovered the format of podcasts, global appeal and believed in its success in the Slovak environment. In fact, they were able to present and promote their ideas in the official media. It was the FM Radio station of the public Slovak Radio (a station focused on young people, today part of RTVS) that implemented this idea on a regular basis and in a format similar to that in the world. Following their cue was SME, which began heavily utilising podcasts, thus contributing to its promotion across the Slovak media landscape. Today, SME stands among largest producers of its own podcasts in Slovakia. And thirdly, it

\footnotetext{
${ }^{48}$ Dávid Tvrdoň, interview, 14.4.2021

${ }^{49}$ Dávid Tvrdoň, interview, 14.4.2021

${ }^{50}$ Dávid Tvrdoň, interview, 14.4.2021

${ }^{51}$ Dávid Tvrdoň, interview, 14.4.2021
} 
was the podcast authors and creators themselves who had to learn "on the go", educate the listeners, look for optimal forms and content, but most importantly they persevered, with many of their products still on the podcast scene today.

Another, no less interesting question is how the podcast scene will develop further, what is the perspective of podcasts, how will it change, adapt its content, who will the podcasts primarily address. Our respondents believe that podcasts have become firmly established in Slovakia and now have a tendency to develop, grow. According to Tomáš Ulej, with the advent of the digital era, journalistic formats have also been changing. Just as Netflix is a modern alternative to watching television, so is podcasting a competition to radio shows. Therefore, he thinks that "podcasting will stay here, it will establish itself among the general public, but it will not curb radio broadcasting completely. "52 This statement is also supported by the fact that most official media currently produce their own podcasts - television, radio or periodicals, including online media. Additionally, in the informal Internet environment, podcasts are also being produced by professionals in the field of auditory work, but also by amateurs, or even various companies, institutions, civic associations, politicians, local government representatives, etc. Podcasting has become an integral part of their marketing communication, but also a form of individual or institutional presentation and communication within the digital environment. Even the professional from Denník Sme, who holds an important position in the production of podcasts, realistically admits that the number of podcasts will grow. According to Dávid Tvrdoň, they are looking at what is happening on the market. "The so-called crime wave, where podcasts discuss criminal cases has made its way to Slovakia. This current wave is now very popular abroad. However, in addition, we have many other ideas. "53 However, the growing number of podcasts produced is not always directly proportional to an increase in quality. Because a podcast can be produced by virtually anyone today, the substance of the information conveyed is sometimes of lower quality. Dušan Vančo estimates that only a third of the produced podcasts offer truly high-quality content, even warning that some of the information disseminated can be dangerous. "I think podcasts should be regulated and monitored just like radio broadcasting, for example by the Broadcasting and Retransmission Council, because the impact is sometimes similar to that of an official medium." 54

There remain several unanswered questions relating to the future of podcasting. In addition to their regulation, payment for podcast content is still being discussed. Non-existent monetization is often being discussed, including in the context of their wider expansion. Bottomley drew attention to this fact as early as 2015 , citing several factors that may have prevented podcasts from breaking through as a mass medium. "One of the main problems were the difficulties monetizing this medium." 55 Today, the issue is being primarily addressed by the producers of successful podcasts, through sponsoring or by placing ads directly into the podcast. It is not yet clear whether podcasts will be only available through paid subscription. If so, it will most likely become the solution for popular podcasts produced by large producers. However, the question of podcast revenue for small or medium-sized creators remains unanswered, with no solution as of yet. Currently, many survive by turning to their listeners in search of funding, or through various digital platforms, such as Patreon. However, this does not appear to be a long-term solution. Finding a unified technological

\footnotetext{
${ }^{52}$ Tomáš Ulej, interview, 12.4.2021

${ }^{53}$ Dávid Tvrdoň, interview, 14.4.2021

${ }^{54}$ Dušan Vančo, interview, 6.5.2021

${ }^{55}$ BOTTOMLEY, Andrew J.: Podcasting: A Decade in the Life of a "New" Audio Medium: Introduction. Journal of Radio \& Audio Media. 2015, 22(2), 164-169. DOI: 10.1080/19376529.2015.1082880. ISSN 1937-6529. p. 165.
} 
solution to podcast monetisation is not easy, since there are already several formats, or applications, through which people listen to podcasts. So whether there will be a systematic solution to the monetization of podcasts, whether the podcasts will only be accessible via a paid subscription, thus paying for really high-quality content - are all topics that the only the future can provide solutions or answers to.

Today, it can be stated with certainty that podcasts are a new communication phenomenon, with an ever-growing trend and a capacity to develop. New forms are constantly evolving, the content and technical processing are changing and improving. There is also a trend of adding visual images to podcasts, i.e. creating video podcasts. Which of the podcasts will reflect the real needs or requirements of the listeners in the coming years will be shown only by their success, measured by the number of listeners, the number of downloads, i.e. the increase in their popularity.

\section{Sources}

1. AFFLECK, Andy.: Podcasting: The People's Radio. [online]. [2005-02-14]. Available at: <https://tidbits.com/2005/02/14/podcasting-the-peoples-radio/> .

2. BERRY, Richard. A Golden Age of Podcasting? Evaluating Serial in the Context of Podcast Histories. Journal of Radio \& Audio Media. 2015, 22(2), 170-178. DOI: 10.1080/19376529.2015.1083363. ISSN 1937-6529.

3. BOTTOMLEY, Andrew J.: Podcasting: A Decade in the Life of a "New" Audio Medium: Introduction. Journal of Radio \& Audio Media. 2015, 22(2), 164-169. DOI: 10.1080/19376529.2015.1082880. ISSN 1937-6529.

4. BOWERS, Andy.: The Year of the Podcast. [online]. [2005-12-30]. Available at: <https://slate.com/news-and-politics/2005/12/the-year-of-the-podcast.html>.

5. Dávid Tvrdoň, interview, 14.4.2021.

6. Dušan Vančo, interview, 6.5.2021.

7. HAMMERSLEY, Ben.: Audible revolution. [online]. [2004-02-12]. Available at: <https://www.theguardian.com/media/2004/feb/12/broadcasting.digitalmedia .

8. HUDSON, Alex.: Podcasts: Who still listens to them?. [online]. [2011-07-23]. Available at: <http://news.bbc.co.uk/2/hi/programmes/click_online/9545533.stm>.

9. JOHNSON, Dave.: A guide to using RSS feeds, the files that contain real-time updates from websites. [online]. [2021-04-30]. Available at: <https://www.busines sinsider.com/what-is-rss-feed>.

10. Počúvanie podcastov. 2muse Agency final report, 24th of March, 2020. Material provided for the authors of the study.

11. Podcasting Historical Timeline and Milestones. [online]. (C) 2020. Available at: $<$ https://internationalpodcastday.com/podcasting-history/>.

12. POTTER, Deborah L.: IPod, you pod, we all pod: eager to lure news consumers, media outlets are experimenting with news-on-demand podcasts. They're fun, fresh-and often unpolished. American Journalism Review. 2006, 28(1), 64.

13. Rádio_FM spúšt'a podcast. [online]. [2006-04-04]. Available at: < https://medialne.tr end.sk/radia/radio-fm-spusta-podcast $>$.

14. ROBERTSON, Jamie.: How podcasts went from unlistenable to unmissable. [online]. [2019-09-26]. Available at: < https://www.bbc.com/news/business-49279177>.

15. Tomaš Ulej, interview, 12.4.2021.

16. TVRDOŇ, D.: Stručné dejiny podcastov, a prečo za to môže Apple? 2019. [online].[2020-09-22]. Available at: <https://podcasty.sme.sk/c/22232563/ako-podcas ty-zacali-kratka-historia-audioblogovania.html>. 


\section{Contact}

Ing. Viera Krúpová

viera.krupova@divydmedia.sk

Assoc. Prof. PhDr. Zora Hudíková, PhD.

zorahudikova@gmail.com

University of Ss Cyril and Methodius in Trnava

Faculty of Mass Media Communication

Námestie J. Herdu 2

91701 Trnava, Slovakia 


\title{
FENOMÉN DIGITÁLNÍ BUSINESS V ROCE 2021 A ZMĚNA NÁKUPNÍHO CHOVÁNÍ V ČESKÉ REPUBLICE
}

\section{THE DIGITAL BUSINESS IN 2021 AND CHANGES IN SHOPPING BEHAVIOR IN THE CZECH REPUBLIC}

\author{
Lucie Waleczek Zotyková
}

\begin{abstract}
Abstrakt
Tento článek představuje fenomén digitálního podnikání a jeho změny v době pandemie COVID-19, tedy jeho významný vývoj. Digitální podnikání samo o sobě je dlouhodobě na vzestupu, což současná situace ještě posiluje. Po představení teoretického i praktického rámce problematiky autorka článku, seznamuje s vlastním výzkumem meziročního nárustu on-line nakupování u respondentů z ČR ovlivněného právě pandemií COVID-19, vládními nařízeními spojenými s pandemickým vývojem a přirozené tendenci rozvoje on-line způsobu života. Toto srovnání bylo provedeno na základě výzkumu nákupního chování v ročním období před vyhlášením prvního nouzového stavu v roce 2020 a také za shodné období po tomto vyhlášení. Výzkum prokázal významný nárust a změnu v nákupním chování respondentů.
\end{abstract}

Klíčová slova: digitální business, on-line nakupování, nákupní chování, e-shopy, Covid-19

\begin{abstract}
This article presents the digital business in the COVID-19 pandemic and its significant development. Digital business has been on the rise for a long time, which further reinforces the current situation. After presenting the theoretical and practical framework of the issue, the author introduces her own research on the year-on-year increase in online shopping among respondents from the Czech Republic affected by the COVID-19 pandemic, government regulations related to pandemic development and the natural tendency to develop online lifestyle. This comparison was made on the basis of a survey of shopping behavior in the year before the declaration of the first state of emergency in 2020 and also for the same period after this declaration. The research showed a significant increase and change in the shopping behavior of respondents.
\end{abstract}

Key words: digital business, online shopping, shopping behavior, e-shops, Covid-19

\section{1 ÚVOD}

Tento článek představuje fenomén digitálního podnikání v době pandemie COVID-19, tedy jeho významného vývoje. Digitální podnikání samo o sobě je dlouhodobě na vzestupu, což současná situace ještě posiluje. Po představení teoretického i praktického rámce problematiky autorka seznamuje s vlastním výzkumem meziročního nárustu on-line nakupování u respondentů z ČR ovlivněného právě pandemií COVID-19.

Nyní ještě více než kdy dříve vzkvétá odvětví e-commerce. V moderním světě je čím dále tím běžnější podnikání na internetu. Vzhledem k aktuálním vládním nařízením spojeným $\mathrm{s}$ řešením epidemiologické situace $\mathrm{z}$ důvodu pandemie COVID-19 a s nemožností podnikání vůbec či v omezeném režimu dle daného odvětví, je pro většinu podnikatelů jediným řešením přenést své podnikání na internet. Samozřejmě se nejedná úplně o jednoduchý úkol, zvláště 
u společností, které se inovativním podnikáním do tohoto času př́liš nezabývaly. Podnikáním samotným to však zdaleka nekončí, ani kvalitní a vyhlášený e-shop se dnes neobejde bez investice do on-line marketingu, zbožových porovnávačů (Heureka, Zboží.cz, Srovname, ...), vyhledávačů, sociálních medií, CPC reklamy, SEO, spolupráce s influencery, youtubery apod. Tato problematika je velmi obsáhlá a i když má každý, at' už laik či odborník, do jisté míry povědomí o tom, co jednotlivé názvy znamenají, neznamená to, že se bude schopen $\mathrm{v}$ těchto vodách orientovat také z praktického hlediska. Nejvhodnější se jeví využít odborníky na jednotlivá odvětví, zaměstnat nebo využít outsourcing.

\section{DIGITÁLNí BUSINESS}

Samotný termín digitální business v sobě skrývá nepřeberné množství akcí. Pro jeho správné aplikování je potřeba strategicky uchopit digitální technologie pro podporu svého byznysu. Spolu s technologickým pokrokem se toto odvětví stále vyvíjí. I když se zdaleka nejedná o novinku, je stále co objevovat a na co se zaměřovat. Ještě existuje velmi mnoho firem, které nebyly schopny se přizpůsobit a využívat všechny komunikační kanály a inovativní digitální řešení.

Rostoucí trend využívání e-commerce se u nás projevuje dlouhodobě. Počet e-shopů v České republice vzrostl již v roce 2019, z 3100 na 46600 a zároveň se o 40 \% (na 14 140) zvýšil počet obchodů, které nabízejí možnost osobního vyzvednutí zboží. (ČTK, 2020) Ostatně i dle údajů Českého statistického úřadu (2019) se podíl osob, které nakoupí přes internet každoročně zvyšuje, v roce 2018 to mělo být $59 \%$, přičemž v roce 2005 takto nakupovalo pouze $6 \%$ osob. V evropském srovnání jsou Češi v nakupování na internetu těsně pod evropským průměrem (16-74 let). V Evropě v průměru nakoupilo v e-shopech v roce 2018 $60 \%$ osob, přičemž nejvíce Dánové 84 \% a Britové $83 \%$. Objektivně se jak u Čechů, tak v celém světě také zvyšuje průměrná maximální částka nákupu. Kromě nákupu z České republiky, si lidé objednávají i zboží ze zahraničí. V roce 2019 byl také významný nárust nákupů a objednávání služeb jako je ubytování či doprava. Zboží či služby v roce 2019 ze zahraničí pořídila třetina osob, které nakupovaly online.

Jak uvádí výzkum ČSÚ, někteří lidé nenakupují na internetu vůbec. Mají k tomu různé důvody, např síla zvyku. Starší 75 let pak přes internet nenakupovali z důvodu nedostatků znalostí - nepoužívali internet vůbec $(81 \%)$, nevěři si v oblasti počítačové gramotnosti natolik, aby nakupovali online (4\%). Ve výzkumné části tohoto článku se podíváme také na to, zda tyto osoby specifický vývoj roku 2020 - v souvislosti s pandemií COVID-19 donutil uchýlit se k nakupování online.

Server Novinky.cz uvádí, že Češi utratili v roce 2020 na e-commerce $16 \%$ z celkového maloobchodu. Na Vánoce navíc měli Češi odeslat 30 milionů objednávek. Dle Asociace pro elektronickou komerci (APEK) více než polovinu občanů motivovala pandemie COVID$19 \mathrm{k}$ tomu, aby si pořídili zboží navíc. Jako důvody pak uváděli zejména (46 \%) setrvání v domácím prostředí - doplnění zboží denní potřeby, $20 \%$ z respondentů měla zájem také o zábavu na doma (herní konzole, předplatné videoobsahu, hudby, her apod). V tomto období investovali Češi, dle výzkumu, také do sportovního vybavení (téměř $17 \%$ ). Práce na homeoffice motivovala tyto respondenty v $17 \%$ a online výuka dětí v $14 \%$. Celková útrata v předvánočním období $(1.10 .2020$ - 22.12.2020) v e-shopech měli Češi utratit 66 miliard korun. Celoročně pak částka dosáhla 196 miliard korun. V roce 2019, pak dle Asociace pro elektronickou komerci Češi na internetu utratili 155 miliard korun (tj. nárust oproti roku 2018 o 15 \%). (С̌TK, 2020). 
Nakupování na internetu je velmi úzce spojeno s růstem oblíbenosti sociálních médií, které se stávají téměř nevyhnutelnou součástí osobních i pracovních činností. Zejména mladí lidé tráví na sociálních sítích podstatnou část dne at' už plně aktivně, či pasivně, což se pro jejich budoucí život spíše nebude měnit. Budoucnost společností proto stojí zejména na využití těchto prostředků komunikace a prezentace.

Digitální trendy v oblasti sociálních sítí, webových řešení digitálního marketingu, analytiky přináší pro společnosti mnoho dobrého a výzev pro zlepšení vlastního podnikání, nicméně to znamená, pro společnosti, které zatím nebyly schopny se adaptovat, také ohrožení jejich úspěšnosti. Je proto potřeba být proaktivní, neusnout na vavř́nech a snažit se zefektivnit vlastní e-podnikání. Cílem každého kvalitně vedeného digitálního podnikání by mělo být získávání a posilování zákaznické věrnosti produktu, značce či firmě. Zákaznickou věrnost je možné získat či posílit mnoha způsoby, stejně tak je tomu u její ztráty. K té se však není $\mathrm{v}$ dnešním konkurenčním prostředí vůbec těžké propracovat. Velmi významnou roli zde hraje psychologie a př́mý kontakt se zákazníkem - samotný web a jeho funkčnost, konverzační modul okamžité odezvy, elektronická pošta, telefonický kontakt. Neodmyslitelnou součástí pak je propojení s třetími stranami, at' už se jedná o způsob dopravy, platby (platební karta), možnosti využití služeb hromadné korespondence pomocí newsletterů a další. Pro bezproblémový chod je pak potřebná co nejvyšší automatizace průběhu vyřizování objednávek. Velmi důležité je správné nastavení automatických zpráv, od potvrzení objednávky, po vyžádání hodnocení, s čím se pojí také spolupráce se zbožovými srovnávači. Věrnost zákazníků dále lze podporovat věrnostními slevami, dárky k objednávce, slevami na další nákup, body a dalšími výhodami oproti konkurenci. Nejlepším způsobem je získat spotřebitelskou věrnost vlastní kvalitou služeb, rychlostí vyřízení, kvalitou zabalení, to samotné však jistě nestačí a mnohdy je považováno za standard. Alfou a omegou úspěchu $\mathrm{v}$ tomto procesu je komunikace, ochota vyhovět zákazníkovi a schopnost funkčního řešení problémů.

Dalším cílem by mělo být zvyšování schopnosti personalizovat a individualizovat služby a produkty zákazníkům. K dosažení tohoto cíle mohou významně fírmě dopomoci třetí strany, v České republice se jedná zejména o CPC (Cost Per Click) od společností Facebook, Google a Seznam. Pokud zákazník nevysloví nesouhlas s personalizovanou reklamou je většina serverů přizpůsobená tomu, aby zobrazovala reklamu ve výsledcích vyhledávání na dalších webových stránkách českého internetu. Z těchto webů tak můžou vyhledávací servery (Google, Seznam, ...) sbírat informace o navštívených stránkách a způsobu jejich využivání. Taková data pak využívají k personalizované reklamě. Personalizovaná reklama však není př́nosem pouze pro samotnou firmu (nasbírání zákazníků, kteří se následně rozhodnou pro nákup, nebo také ne), ale také pro klienta, který pokud s personalizovanou reklamou souhlasí, není nadále vyrušován a obtěžován reklamou, která pro něj není nijak zajímavá. Stěžejní roli $\mathrm{v}$ tomto procesu hrají cookies uložené v prohlížeči na konkrétním počítači, pro využití a propojení na dané webové stránce, však musí každý uživatel dát souhlas.

Dále je pro digitální podnikání či spíše v užším slova smyslu digitální obchodování důležité zacílení služeb a produktů na nové segmenty a nové klienty. K nalákání nových zákazníků je $\mathrm{v}$ digitálním světě nejvyužívanější metodou právě již zmiňovaná CPC reklama, díky které se za relativně nízké náklady dosáhne požadovaného efektu. Tato metoda získávání nových klientů je vhodná zejména u položek s vyšší cenou, kdy náklad na zaplacení prokliků je úměrný a akceptovatelný. V každém př́ípadě se jedná o reklamu, která je pro firmy mnohem méně nákladná než např́klad reklama $\mathrm{v}$ televizi, na billboardech apod. a navíc mnohem efektivnější. Což jistě neznamená, že by tyto typy reklamy nebyly pro firmy prínosné, 
jen v dnešní „digitální době“ tvoří nejvíce návratný způsob propagace právě online marketing, který zároveň určuje téměř životaschopnost e-shopu. Další neodmyslitelnou částí strategie při zacílení na nové segmenty a klienty je spolupráce se zbožovými srovnávači. Tato je vhodná v př́ípadě, kdy se jedná o zboží, u kterého je firma schopná nabídnout konkurenční cenu nebo v př́ípadě že se jedná o jeden z velkých e-commerce společností jako je např́klad na českém internetu aktuálně mall.cz nebo alza.cz, u kterých je výhodou také široká nabídka a zákazník většinou vybere $\mathrm{z}$ důvodu, že zde nakoupí více věcí a využije tak třeba dopravu zdarma od určité částky. Dalším vhodným nástrojem, jak nalákat nové zákazníky je mnoho možností reklam na sociálních sítích. S tímto se pojí také další důležitý cíl dobře konstruované strategie digitálního podnikání, a to: zrychlování přenosu marketingových sdělení do trhu a získávání efektivní a okamžité zpětné vazby. Jedná se zejména o různé formy peněžité podpory zobrazování at' už personalizované nebo široce zaměřené reklamy na sociálních sítích, youtubu, ... Vhodným nástrojem je využití spolupráce se známými osobnostmi nebo osobnostmi s významnými počty sledujících (followerü), tzv. novými digitálními celebritami, které prezentují na sociálních sítích svoje názory, životní styl, apod. Spolupráce s takovými subjekty může probíhat jak na barterové bázi (zveřejnění hodnocení za produkt) nebo formou placené spolupráce, príípadně spolupráci na bázi zveřejnění soutěže pořadatele, př́ípadně slevového kódu pod záštitou dané osobnosti.

Tak jako u každého podnikání, také u podnikání na internetu je důležité udržet co nejnižší náklady. Proto je nutná co největší automatizace procesů, bedlivé sledování efektivity využitých akcí a průběžné úpravy v metodice na základě chování trhu, což souvisí s zavedením měřitelnosti do reklamy a marketingu. Při zrrizování zcela nového e-shopu je vhodné $v$ dnešní době spíše netvořit zcela nový web ale využít jednu z šablon dostupných webových platforem typu shoptet, eshop-rychle, webnode, prestashop, atomer, joomla, oxideshop, opencart, virtuemart, magento, aishop, oxyshop, clevero, shoppcentnk, fastcentrik ... Využití těchto služeb velmi usnadňuje samotnou administraci e-shopu. Pro jeho správu tak není potřeba žádného programátora, zpracování je velmi intuitivní a lze si plně přizpůsobit vlastním potřebám společnosti. Zároveň jejich výhoda spočívá také v minimalizaci rizika ztráty vynaložených prostředků na vytvoření nového propracovaného funkčního webu.

Další položkou digitálního marketingu, která zaznamenává ohromný nárust v posledních letech je nakupování přes chytré telefony. Pro nové e-shopy je proto již standardem myslet na přizpůsobení webu pro tato zařízení. Výzkum ukázal, že mnohem více lidí nakupuje online i prostřednictvím smartphonů, nakupují tak dokonce senioři, kteří ztrácejí postupně obavy z nového způsobu pořizování věcí a již tolik nemají problém s novými technologiemi. (Novák, 2017)

Další složku správné strategie digitálního podnikání činí zapojení vlastních zaměstnanců do inovací a sdílení znalostí. Pro úspěšnost digitálního podnikání je velmi důležitá součinnost zaměstnanců znalých produktu, logistické části firmy, účetnictví, marketingu, obchodu apod., je více než žádoucí sdílení informací např́ič odděleními a seznamování všech s digitálním prostředím, možnostmi automatizace, což přispívá k efektivitě všech procesů.

Velmi důležité je také využít maximum z dat získaných z webu o pohybu zákazníků, jejich aktivitách, segmentovat skupiny zákazníků a zaměřit na dané skupiny odpovídající nabídku.

K digitálnímu podnikání neodmyslitelně patří také platební metoda. Zatímco v roce 2019 často Češi využívali platbu na dobírku platilo zhruba 30 \% zákazníků e-shopů (zdroj: Heureka.cz, Tomáš Braverman) a kartou on-line 25 \% zákazníků, s př́chodem pandemie byly 
velmi ovlivněny i tyto faktory, a to jednak s ohledem na bezpečnost samotné platby (minimalizace kontaktu), druhak také z důvodu zvyšování důvěry v elektronické nakupování, větší gramotnosti zákazníků (ověřování kontaktu uvedených na e-shopu), rychlosti vyřrizení transakce, pohodlnost využití platebních bran, vyžadování rezignace z možnosti platby dobírkou v souvislosti s ochranou pracovníků kurýrských společností a v neposlední řadě také zákazníků samotných.

\section{METODOLOGIE}

V článku je použita metoda dotazníkového šetření, komparace nákupního chování respondentů - zákazníků on-line obchodů, meziroční srovnání frekvence online nákupů u dotyčných respondentů a je zde využit také Chí-kvadrát test nezávislosti.

Chí-kvadrát test lze uplatnit, když všechny výsledky $\mathrm{v}$ náhodném výběru lze roztřídit do určitého počtu vzájemně se nepřekrývajících trríd. Spočívá ve stanovení teoretických četností a porovnání těchto teoretických četností s empirickými ve výběrovém souboru. $\mathrm{K}$ ověření existence závislosti se využívá výpočtu známého vzorce testového kritéria (Ramík a Stoklasová, 2014):

$G=\sum_{i=1}^{k} \frac{\left(n_{i}-n_{i}^{\prime}\right)^{2}}{n_{i}^{\prime}}$

(kde $k$ představuje počet tříd výběrového souboru, $n_{i}$ představuje empirickou četnost a $n_{i}^{\prime}$, teoretickou četnost) a v nalezení kritické hodnoty v tabulkách rozdělení Chi-kvadrát $x_{\alpha}^{2}(d f)$. Pro hledání kritické hodnoty musí být stanovena hypotéza, hladina významnosti a stupně volnosti. Hypotézu $\mathrm{H}_{0}$ se stanoví vždy o nezávislosti znaků a hladiny významnosti se určují nejčastěji jako $1 \%, 5 \%$ nebo $10 \%$. V tomto článku jsou hypotézy ověřovány na $5 \%$ hladině významnosti. Stupně volnosti:

$d f=(m-1)(m-1)$.

Pokud testové kritérium padne do oboru kritických hodnot (hodnoty vyšší než kritická hodnota včetně), hypotéza o nezávislosti se zamítá a připouští se tak statisticky významná závislost znaků.

Schéma č. 1: Schéma přijetí nulové hypotézy

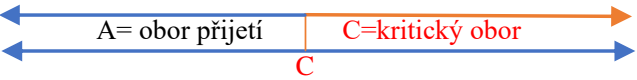

Zdroj: Vlastní zpracování

\section{VÝZKUM}

V období 7.3.2021 - 23.4.2021 byl proveden průzkum v online prostředí prostřednictvím webu survio.com a sociální sítě Instagram. Celkem dotazník vyplnilo 492 respondentů, po očištění od neúplných odpovědí bylo do průzkumu zařazeno 475 respondentů. V rámci výzkumu bylo zkoumáno, jak moc se změnilo zákaznické chování v oblasti online nakupování dle posouzení respondentů v ovlivnění pandemií COVID-19. Respondenti odpovídali pouze na 4 otázky: 2 výzkumné a 2 identifikační. Hlavními otázkami byly: Jak často nakupovali respondenti na internetu v rozmezí jednoho roku od vyhlášení nouzového stavu (prvního) souvisejícího s epidemií COVID-19 v roce 2020 (12.3.2020-11.3.2021) a jak často nakupovali přes internet $\mathrm{v}$ průběhu roku před vyhlášením (prvního) nouzového stavu 
(12.3.2019-11.3.2020). Obě tyto otázky měly shodné možnosti odpovědi: Na internetu jsem nenakupoval vůbec, na internetu jsem nakoupil do 5x, 5-20x, více jak 20x, na internetu jsem v tomto období nakupoval pravidelně také potraviny. U podstatné části respondentů, 40,21\% došlo ke zvýšení frekvence nakupování online. U žádného respondenta nedošlo ke snížení frekvence. Pouze $1,68 \%$ respondentů uvedlo, že na internetu nenakupovalo vůbec, a to jak v ročním období do vyhlášení prvního nouzového stavu, tak v období od vyhlášení prvního nouzového stavu.

Graf č. 1: Nakupování on-line 12.3.2019-11.3.2020

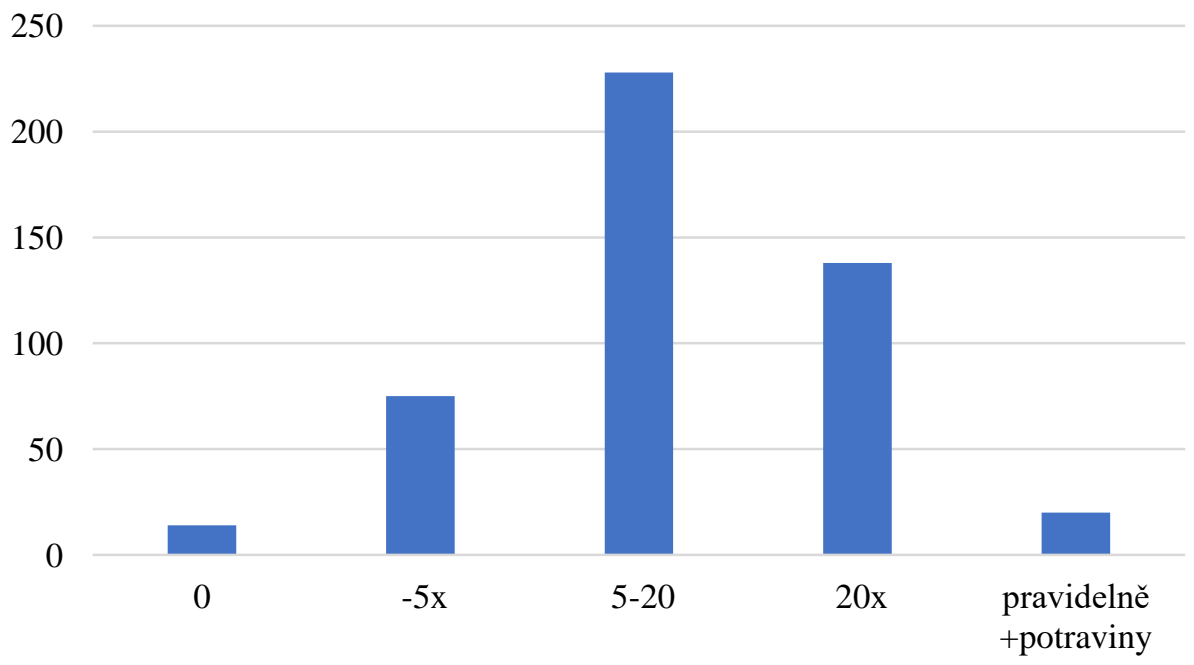

Zdroj: Vlastní zpracování

Graf č. 2: Nakupování on-line 12.-11.3.2021

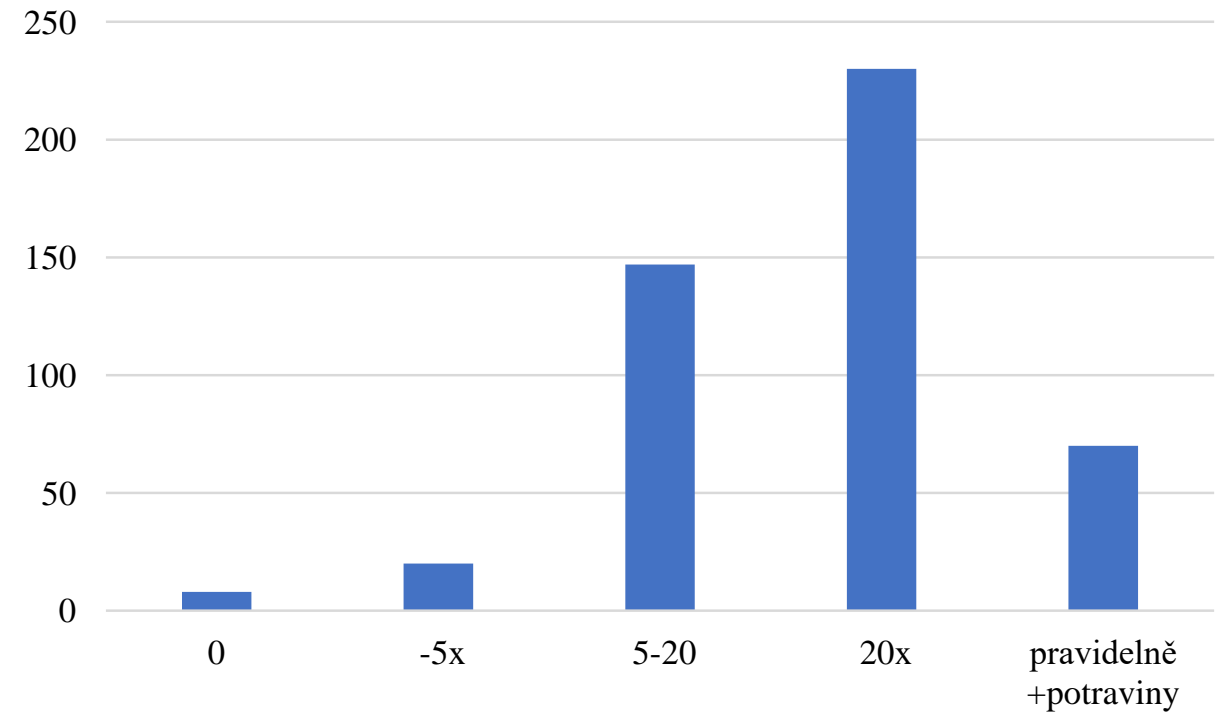

Zdroj: Vlastní zpracování

Na základě grafu 1 a 2 je zřetelně viditelný nárust frekvence nakupování online v meziročním srovnání na základě bodu zvratu - vyhlášení nouzového stavu v březnu 2020. Došlo, jak ke snížení počtu nákupů online u prvních tř́ možností - nenakupuji on-line vůbec, nakoupil jsem v průběhu roku do 5x, nakoupil jsem 5-20x, tak k výraznému nárustu odpovědí nakoupil jsem více jak 20x a nakupuji on-line pravidelně, také potraviny. Zatímco, $v$ roce před vyhlášením nouzového stavu zvolilo tyto dvě poslední možnosti pouze $33,26 \%$ respondentů, v roce 
po vyhlášení již nakupovalo online více jak 20x nebo pravidelně včetně potravin, již 63,16 \% respondentů.

Graf č. 3: Změna nákupního chování v rámci on-line nakupování potravin v meziročním srovnání

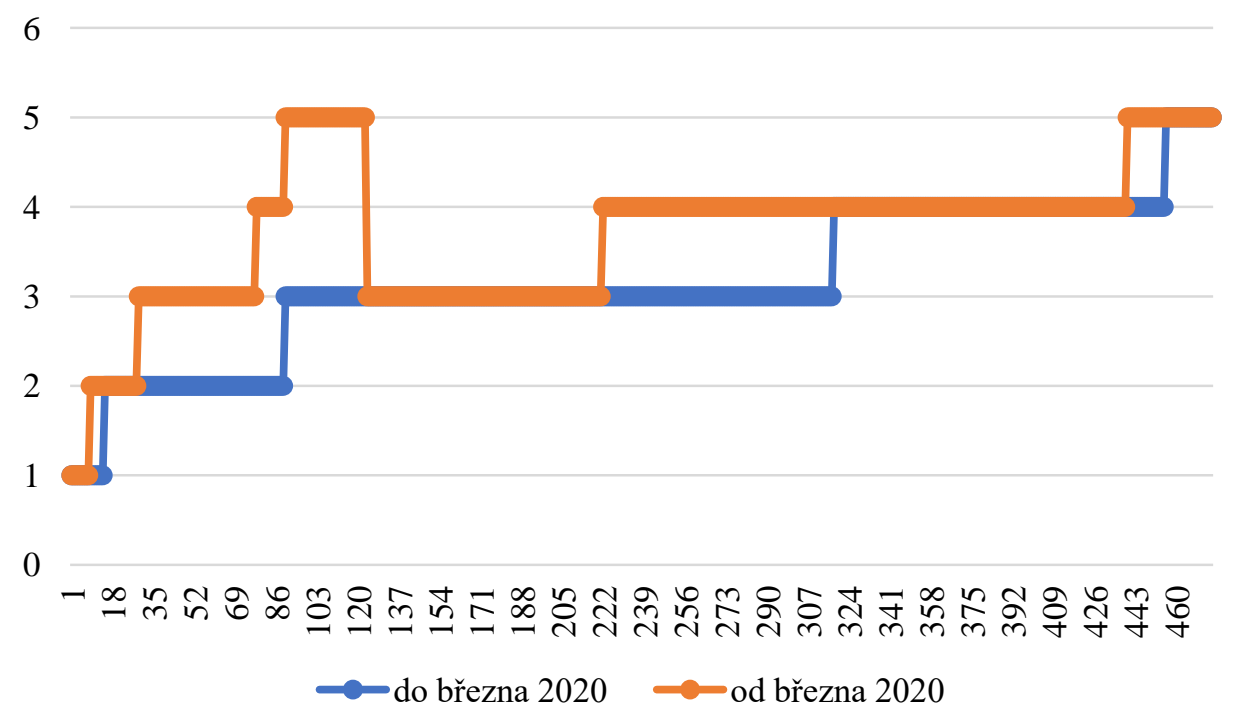

Zdroj: Vlastní zpracování.

Graf č. 3 znázorňuje nárust frekvence nakupování online - př̀ seřazených hodnotách a přiřazené bodové škále k odpovědím na výše zmíněné hlavní otázky (1-5 = nenakupuji nakupuji pravidelně také potraviny). Z grafu je viditelný nárust, nyní si tento nárust ještě podrobíme analýze závislosti odpovědí na věku respondenta pomocí chí-kvadrát testu nezávislosti.

Tabulka č. 1: Závislost změny chování na věku respondenta

\begin{tabular}{|c|c|c|c|}
\hline Věk & stejné & nárust 1 & nárust 2 \\
\hline $\mathbf{- 1 7}$ & 4 & 1 & 1 \\
\hline $\mathbf{1 8 - 2 5}$ & 35 & 23 & 8 \\
\hline $\mathbf{2 6 - 3 5}$ & 62 & 57 & 8 \\
\hline $\mathbf{3 6 - 4 5}$ & 74 & 33 & 9 \\
\hline $\mathbf{4 6 - 5 5}$ & 60 & 30 & 9 \\
\hline $\mathbf{5 6 - 6 5}$ & 18 & 16 & 8 \\
\hline $\mathbf{6 5 +}$ & 9 & 7 & 3 \\
\hline
\end{tabular}

Zdroj: Vlastní zpracování

Při statistickém testu nezávislosti jsme zkoumali závislost odpovědí respondentů na věku. Byly stanoveny tyto hypotézy:

H0: Změna chování respondenta při online nakupování na základě nařízení vlády a vyhlášení nouzového stavu v březnu 2020 nezávisí na věku respondenta.

H1: Změna chování respondenta při online nakupování na základě nařízení vlády a vyhlášení nouzového stavu v březnu 2020 závisí na věku respondenta. 
Přičemž testové kritérium G bylo 18,077 a kritická hodnota C 21,026. Čímž pádem nemůžeme zamítnout nulovou hypotézu o nezávislosti na věku. $Z$ uvedeného vyplývá, že respondenti odpovídali ohledně jejich zvýšení frekvence nakupování online (na základě vládního nařízení a vyhlášení nouzového stavu) v nezávislosti na vlastním věku.

Výzkum ukázal, že se potvrdila hypotéza o navýšení nákupů na internetu. Dokonce i zarytí odpůrci on-line nakupování se v rámci roku 2020 uchýlili k této formě nakupování. Tento ukazatel se navíc prokázal, že není dokonce závislý na věku respondenta. Ono nakonec nedostupnost, resp. nemožnost nakupovat některé komodity $\mathrm{v}$ kamenném obchodě v podstatě donutila tyto osoby nakoupit on-line. At' už tedy nakoupili sami, nebo postoupili tento úkol mladší generaci, nakonec jim v podstatě nic jiného nezbývalo.

\section{ZÁVĚR}

Tento článek se zabýval vývojem on-line podnikání a jeho ovlivněním pandemií COVID-19. Byl zde představen výzkum autorky proveden pomocí webu survio.com a sociální sítě Instagram,, který byl zaměřen na znázornění dopadu pandemie na on-line nakupování v samovyhodnocení respondentů ohledně vlastního nákupního chování ve srovnání roku před vyhlášením nouzového stavu $\mathrm{v}$ březnu 2020 a v roce po tomto vyhlášení. Na základě získaných dat byl prokázán významný vliv pandemie a vládních opatření na vývoj ecommerce v České republice.

Je více než pravděpodobné, že po překlenutí nejkritičtější situace v souvislosti s pandemií COVID-19 budou dopady na ekonomiku a životní styl dlouhodobější. Trendy v e-commerece tedy budou spíše zesilovat. Je žádoucí, aby v zájmu ochrany vlastního podnikání společnosti přistoupili $\mathrm{k}$ této formě prodeje zejména cílovému zákazníkovi.

\section{Použitá literatura}

1. ABDELRHIM, M., ELSAYED, A. (2020) The Effect of COVID-19 Spread on the ECommerce Market: The Case of the 5 Largest E-Commerce Companies in the World (June 7, 2020). Available at SSRN: https://ssrn.com/abstract= 3621166 or http://d x.doi.org/10.2139/ssrn.3621166.

2. ANDRIENKO, O. (2020). Ecommerce \& Consumer Trends During Coronavirus. From https://www.semrush.com/blog/ecommerce-covid-19/.

3. BHATTI, A., AKRAM, H., BASIT, H.M. , KHAN, A.U., NAQVI, S.M.R., BILAL, M. (2020) E-commerce trends during COVID-19 Pandemic, International Journal of Future Generation Communication and Networking Vol. 13, No. 2, 2020 pp.144914521449 ISSN: 2233-7857 IJFGCN from: https://lovacky.eu/ws/medialibrary/8291b8bb61d0458d9bec753432dc4842/qualitativepaper.pdf.

4. BHATTI, A. (2018). Consumer Purchase Intention Effect on Online Shopping Behavior with the Moderating Role of Attitude. Internat. J. Academic Management Sci. Res.(IJAMSR), 2(7), 44-50.

5. ČAMBORA, J. (2020) Útraty přes internet se zdvojnásobily, online nákupy potravin vzrostly téměr třikrát. (4. května 2020) Dostupné z URL: https://www.sve tchytre.cz/a/pMcXE/utraty-pres-internet-se-zdvojnasobily-online-nakupy-potravinvzrostly-temer-trikrat.

6. ČSÚ. (2019) Využívání informačních a komunikačních technologií v domácnostech a mezi jednotlivci - 2019. 16. Nakupování přes internet. Dostupné z: https://www.czso.cz/documents/ 10180/90577057/06200419k16.pdf/09083e6f-17b547a0-aaa4-021394bd86c5?version=1.1. 
7. ČTK. (2020) Počet e-shopů v Česku loni stoupl o 3100 na 46 600. (13.1.2020) Dostupné z URL: https://www.e15.cz/finexpert/nakupujeme/pocet-e-shopu-v-ceskuloni-stoupl-o-3100-na-46-600-1365762.

8. JONES, K. (2020). COVID-19The Pandemic Economy: What are Shoppers Buying Online During COVID-19? , from https://www.visualcapitalist.com/shoppersbuying-online-ecommerce-covid19/.

9. KARIMI-ZARCHI,M., NEAMATZADEH, H., DASTGHEIB, S., ABBASI, H., MIRJALILI, S. \& BEHFOROUZ, A. et all. (2020). Vertical Transmission of Coronavirus Disease 19 (COVID-19) from Infected Pregnant Mothers to Neonates: A Review. Fetal And Pediatric Pathology, 1-5. Available from: https://pubmed.ncbi.nlm.nih.gov/32238084/.

10. NOVÁK, D. (2017) Prodej potravin a módy ze-shopů skokově roste, mobilem nakupuji i senioři. (23.1.2017) Dostupný z URL: https://www.e15.cz/magazin/pro dej-potravin-a-mody-z-e-shopu-skokove-roste-mobilem-nakupuji-i-seniori-1327964.

11. Novinky.cz BAB (2021) Koronavirus a on-line nákupy: Každý druhý poř́ldil zboži navic. (5.1.2021) Dostupné z URL: https://www.novinky.cz/finance/clanek/ koronavirus-a-on-line-nakupy-kazdy-druhy-poridil-zbozi-navic-40346844.

12. POSPÍŠIL, A. (2019) Potraviny online Češi nakupují hlavně kvi̊li pohodlí, tvrdí průzkum. (13.5.2019) Dostupný z URL: https://www.e15.cz/finexpert/nakupujeme/ potraviny-online-cesi-nakupuji-hlavne-kvuli-pohodli-tvrdi-pruzkum-1358781.

13. RAMÍK, J. a R. STOKASOVÁ (2014). Statistika. Karviná: SU OPF. ISBN 978-807510-030-6.

14. WALIUL HASANAT, M., HOQUE, A., AFRIN SHIKHA, F., ANWAR, M., BAKAR, A., HAMID, A. and H. HON TAT. The Impact of Coronavirus (Covid-19) on E-Business in Malaysia. Asian Journal of multidisciplinary Studies Vol. 3, No. 1, (2020), ISSN 2651-6691 Available from: https://asianjournal.org/online/index.ph p/ajms/article/view/219.

15. WTO (2020). E-commerce to save the world economy. Available at SSRN: https://www.wto.org/.

16. ZOTYKOVÁ, L. (2014). Názor mladých českých a polských spotřebitelů na on-line nakupování potravin ve velkokapacitních maloobchodních řetězcích. V Recenzovaný sborník př́spěvků mezinárodni vědecké konference Trendy v podnikání 2014. 13.-14. listopad 2014, Plzeň: Západočeská univerzita v Plzni. s. 5. ISBN 978-80-261-0444-5.

\section{Kontaktní údaje}

Ing. Lucie Waleczek Zotyková, Ph.D.

Collegium Humanum, Varšavská univerzita managementu

Zahraniční pobočka ve Frýdku-Místku

Bruzovská 2589, 73801 Frýdek-Místek

email: luciezotykova@seznam.cz 


\title{
ROLE OF PLANNING AS A MANAGEMENT FUNCTION AND ITS APPLICATION IN COMPANIES IN SLOVAKIA
}

\author{
Andrea Čambalíková, Patrik Richnák
}

\begin{abstract}
Looking ahead into the future and predicting possible trends or occurrences that are likely to influence the working situation is the most vital quality and manager's job. Planning means setting an organization's goals and deciding how best to achieve them. Vision and mission statements help to describe the organization's purpose. Vision statements give direction for employee behaviour and help provide inspiration. Mission statements describe the company's mission as it is now and for the near future. Strategic plans may require a marketing strategy, which could include the vision statement to also help inspire consumers to work with the organization. The main aim of the paper is, based on the analysis of theoretical knowledge, to evaluate the management function of planning, in terms of vision, mission, and strategy application by different sized and different sector activity of companies in Slovak republic.
\end{abstract}

Keywords: management function, planning, vision, mission, strategy

\section{INTRODUCTION}

Planning in the company is a very important activity, it performs the function of management and according to the plans managers manage the company. The planning process can be defined in different ways, but the essence will always be the same. Planning is one of the basic functions of management and its main task is to set goals that the company will pursue and determine how to achieve these goals. Planning should identify what will happen in the future, it expresses what needs to be done to achieve the set goals. Planning is generally associated with entrepreneurship at all stages of a company's life cycle. It is a proposal for the desired future and the search for effective means for its implementation. Planning has its advantages and disadvantages. Among the advantages we can include that planning allows the company to prepare for possible changes in the future, creates a tool for control, the plan sets the date of start and end of work in the company and also leads to better use of production equipment and resources. Disadvantages include cost, because for small businesses, planning is very expensive, it is limited by accurate information, if this information is not accurate, the plan is distorted, to some extent oppresses the initiative, especially in larger companies.

Vision and mission statements have been strongly considered as a necessary aspect of the process of strategic management for various types of organizations, whether private or public sector, profit or non-profit, multinational or a small, medium and large-scale enterprise (Darbi, 2012). The aspirations and objectives of where the firm want to be in the long term are expressed in the vision statement. An organization's vision describes what the organization hopes to become in the future and helps guide its strategies. Well-constructed visions clearly articulate an organization's aspirations (Simpson et al., 2020). A better understanding of the organization's vision is needed to conduct an accurate performance analysis as well as to identify solutions that will address the gap and will align with the organization's desired future (Kirkpatrick, 2017). The major part played by mission statement is to effectively express the strategic way of the firm to stakeholders so as to guide strategic planning. Mission statement is rated as second most used tool specifically because they see it is as a useful substance in organizational integration which gets everybody focused on goals and working together to pull the same direction (Taiwo et al., 2016). Even if mission, vision, and values seem to be esoteric or abstract, they are very important for any organization. The 
mission represents the statement regarding the core purpose and must be written in the present tense. The vision represents the statement about where the organization wants to arrive and is better to be written in future tense. The values can be inspired by mission and vision and represent the way in which company's employees behave or interact (Dumitrascu and Feleaga, 2019).

Very important according to the planning process is setting of goals. Goals can drive strategy execution but only when they are aligned with strategic priorities, account for critical interdependencies across silos, and enable course corrections as circumstances change. If these conditions are not met, every employee could achieve their individual goals, but the organization as a whole could still fail to execute its strategy (Sull and Sull, 2018.)

The accelerating changes in the environment, stronger competition for extraordinary resources, the increasing need and strength of different groups and individuals have led to a stronger emphasis on strategic management (Pham et al., 2018). One of the most important processes is the strategic business objectives planning, creation of a strategy and its implementation into the structure of the business activity (Rajnoha et al., 2016). Strategic planning is closely related to the determination of mission statement and vision and their application represents 32\% of companies (Rigby and Bilodeau, 2018). All of this has a close connection with company strategy. The issue of setting strategic business objectives is considered to be one of the primary areas of strategic management (planning) which should be given more attention (Schmidtova and Formanek, 2019). Strategies refer, on the one hand, to strategic plans to guide the company's future and, on the other hand, to the current strategic position. It is therefore necessary to distinguish between intended strategies and realized strategies. As intended strategies can rarely be fully implemented, they normally diverge to a greater or lesser extent from realized strategies. Additionally, in some cases, a company may knowingly or unknowingly abstain from formulating an intended strategy to guide its actions in the long-term (Grünig and Kühn, 2015). There is a constant and reciprocal relationship between strategy and organizational structure. In particular cases, the structure models the strategy, and at other times the strategy determines the organizational structure (Neis et al., 2017).

\section{RESULTS AND DISCUSSION}

The topic of the paper was processed using the analysis of secondary data, especially the available professional foreign and domestic literature focused on the issue, which is listed in the list of used literature. We have relied on a wide range of internet sources and articles in professional journals related to the issues being processed. The paper includes data obtained by conducting a questionnaire survey using standardized questionnaires as a partial output of a comprehensive survey focused on innovative approaches and trends in management. The aim of this paper was to evaluate the management function of planning in the companies. The research sample consisted of 203 companies operating in the Slovak Republic. The data obtained by the questionnaire survey were processed into graphs and tables using the Microsoft Excel program using the graphical display method.

The prerequisite for the management of the company should be certain long-term goals, so in the managerial function of planning, we asked the respondents whether the vision and mission of the organization is formally determined. The vision very generally outlines the idea of the future direction and position of the company in the market. It answers the question of where the company wants to go. A well-defined vision activates, inspires, and mobilizes for action. All companies in the sample, i.e. 203 companies, answered this question. According to the Graph 1, as many as 90\% (183) of companies said they had a set vision for their business. While the vision is for the future, the mission is defined in relation to the present. By the company's mission we understand the company's idea of what the current and future meaning 
of its existence is and what functions it is trying to fulfil. At the same time, we examined whether companies have a defined mission, with the majority of companies answering this question in the affirmative, namely 167 (82\%), but this was less than in the case of the vision. If the companies did not have a set vision and mission, we found out the reasons. The most frequently cited reason was that this was not relevant, especially given the small size of the business. We also researched whether there is a difference in the knowledge and application of modern trends in management in companies that have a set vision and mission and those that do not. For companies that did not have a vision and mission, compared to companies that had a much higher level of ignorance of all methods and a lower rate of application of those methods. This can also be explained by the fact that the companies that did not have a vision and mission were micro-enterprises.

Graph 1: Determining the vision and mission by companies

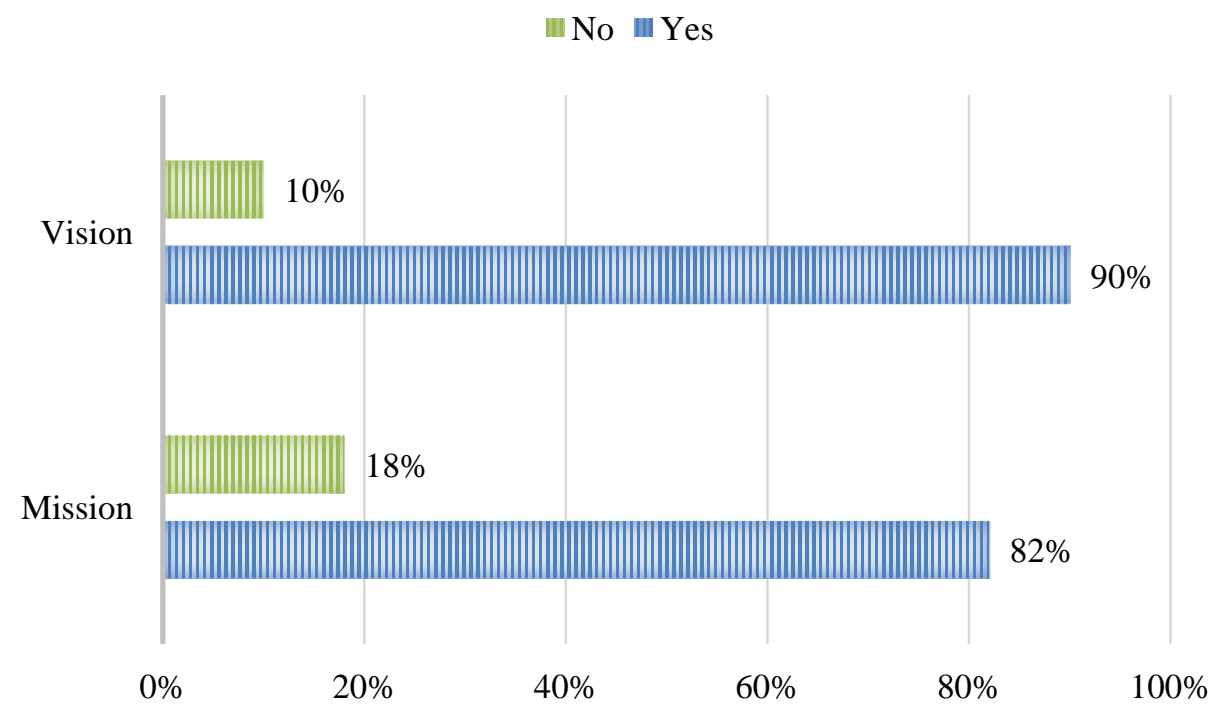

Source: own processing

We found out which of the strategic goals are companies currently pursuing, while the respondents had the opportunity to add other strategic goals to the question. The strategic goals we offered were: growth of company value, return on investment, profit, cost reduction, increasing market share, expansion into new markets, increasing product quality, satisfying customer needs, increasing labour productivity, human resources development and employee satisfaction. The respondents had to arrange the selected strategic goals, monitored by them, according to priority from 1 (highest priority) to 5. The results show that the highest priority of companies in terms of strategic goals is the profit reported by 72 companies, which represents $35 \%$ of the sample. Satisfaction of the needs of their customers was also mentioned as a priority by companies, while this goal was declared by 55 companies (27\%) and growth of the value of the company, namely 23 companies (11\%). In the open part of the question, where respondents had the opportunity to state other than the offered strategic goals, they most often stated that they did not set them, in most cases they were micro enterprises, or respondents stated too specific strategic objectives with respect to the subject of business or part of it.

The strategy serves to determine the basic long-term goals of the company, as well as ways to achieve them. The question of whether the company has a formulated strategy was answered by all respondents from the sample. From Graph 2 it can be seen that up to 175 companies, which represents $86 \%$, have a formulated strategy to achieve their goals. If the companies did not have a set strategy, we further investigated the reasons for its absence, most often 
including that they do not currently have the personnel capacity to process the strategy, do not consider the formulation of the strategy with respect to their business, or the strategy exists only in the mind written.

Graph 2: Strategy formulation in companies

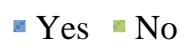

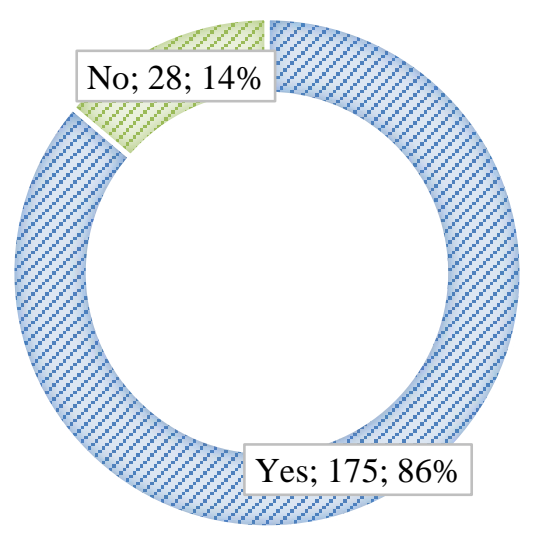

Source: own processing

As with the vision and mission, we also examined the difference in the knowledge and application of modern trends in management in companies that have a set strategy and those that do not. The companies that had a set strategy applied to a higher extent all the examined modern trends in management compared to those that did not. In most cases, the companies that did not have a set strategy were micro-enterprises.

In the next part, there are provided the results of applying vision, mission and strategy by companies regarding to the classification characteristics. Size categorization of companies was realized based on the number of employees for large (above 250 employees), medium (above 50, up to 250 employees), small (above 10, up to 50 employees) and micro (up to 10 employees). Based on the results from Graph 3, we can see the highest application of the vision, mission, and strategy by the large companies. Regarding to the vision, more than $80 \%$ of all sized companies declared its formulation and implementation. Less than $80 \%$ of small and micro companies declared application of the mission and $72 \%$ of micro companies have applied the strategy into their business. 
Graph 3: Vision, mission, and strategy application by different sized companies

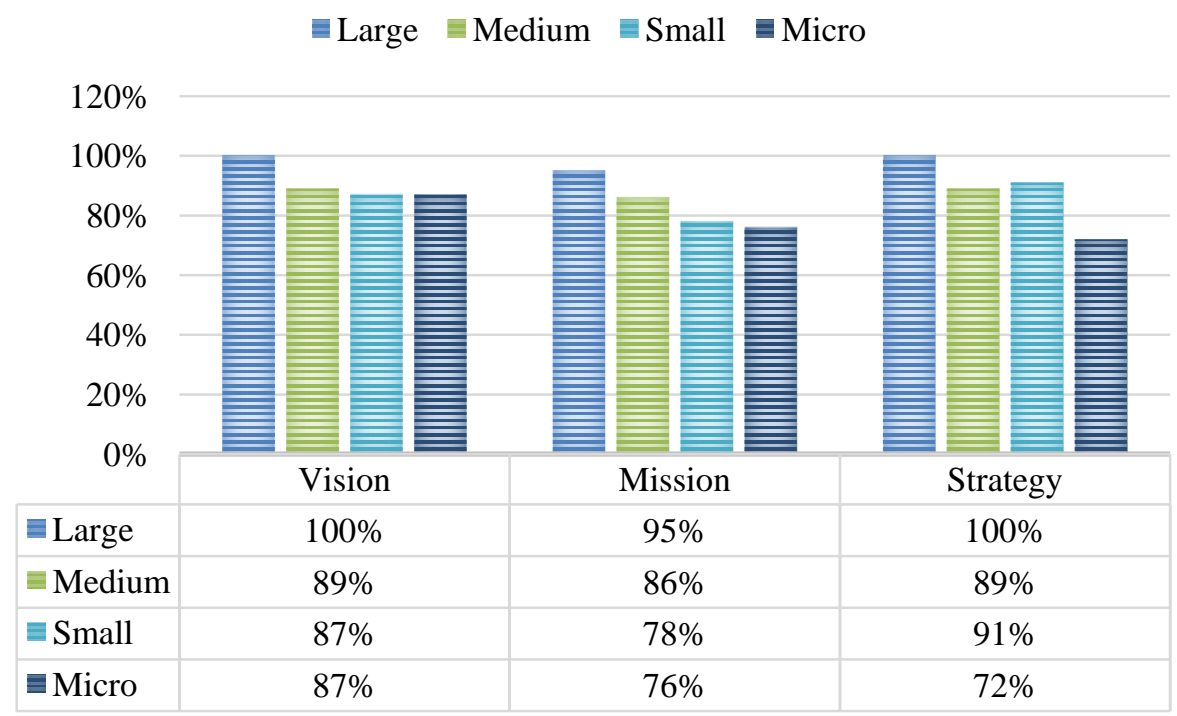

Source: own processing

We also have classified companies in terms of focus of their activities. More than half of enterprises $(53 \%)$ focuses on the service sector in their business activities. There were 52 commercial enterprises, which represents $26 \%$, and there were the least manufacturing enterprises, namely 43 enterprises (21\%). According to the Graph 4, enterprises in the manufacturing sector formulated their vision, mission, and strategy to a lesser extent than enterprises in the commerce and service sector.

Graph 4: Vision, mission, and strategy application by different activity sector of the companies

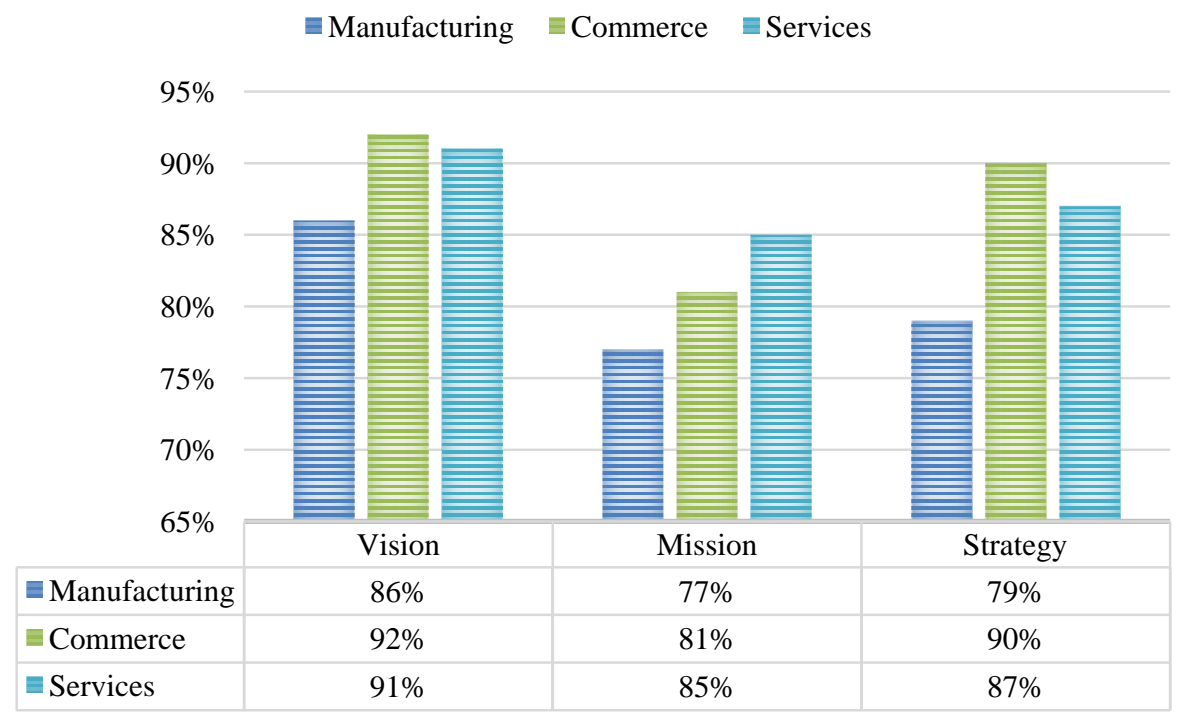

Source: own processing

\section{CONCLUSION}

Planning is an activity that we encounter every day, so it is important to be able to plan everything well in order to avoid negative events that could endanger us in the future and lead us out of our way for a specific goal. Just as planning is important in personal life, it is also important in work life. It is an activity that is crucial for the entrepreneurs and managers and 
accompanies them during all stages and phases of business. For the proper functioning and operation of the company, it is definitely the first step to have a well-developed business plan. The first is a statement of vision. It provides a destination for the organization. Next is a statement of mission. This is a guiding light of how to get to the destination. These are critical statements for the organization and the individuals who run the organization. Strategies are one or more ways to use the mission statement in order to achieve the vision statement. Although an organization will have just one vision statement and one mission statement, it may have several strategies. Change is an essential component of strategic planning. This involves moving the organization or program forward to create or change something. Some plans are created out of the need for the organization to move in a certain direction, and other plans develop organically. In the presented article we point out the importance and significance of the formulation and implementation of the vision, the mission of strategy in business. In the article we also evaluate the application rates of the vision, mission and strategy by companies operating in Slovakia, of different sizes and different activity sectors.

\section{Acknowledgment}

The paper is a partial output of VEGA No. 1/0375/20 research project titled „New dimension in the development of production management and logistics under the influence of Industry 4.0 in enterprises in Slovakia“.

\section{Sources}

1. DARBI, W. P. K. Mission and Vision Statements and their Potential Impact on Employee Behaviour and Attitudes: The case study of a public but profit oriented tertiary institution. In: International Journal of Business and Social Sciences. 2012, vol. 3. no. 14.

2. DUMITRAŞCU, M., FELEAGĂ, L. Mission, Vision, and Values of Organizations, the Catalysts of Corporate Social Responsibility. In: Audit financiar, 2019, 17.153.

3. GRÜNIG, R., KÜHN, R. Strategy Planning Process. In: The Strategy Planning Process. Springer, Berlin, Heidelberg, 2015. p. 41-52.

4. KIRKPATRICK, S. A. Understanding the role of vision, mission, and values in the HPT model. In: Performance Improvement, 2017, 56.3, p. 6-14.

5. NEIS, D. F., PEREIRA, M. F., MACCARI, E. A. Strategic planning process and organizational structure: Impacts, confluence, and similarities. BBR. In: Brazilian Business Review, 2017, 14.5, p. 479-492.

6. PHAM, N.T., PHAN, Q.P.T., TUČKOVÁ, Z., VO, N., NGUYEN, L.H. Enhancing the organizational citizenship behaviour for the environment: the roles of green training and organizational culture. In: Management \& Marketing. Challenges for the Knowledge Society, 2018, vol. 13, no 4, p.1174-1189.

7. RAJNOHA, R., LESNÍKOVÁ, P. Strategic Performance Management System and Corporate Sustainability Concept - Specific Parameters in Slovak Enterprises, In: Journal of competitiveness, 2016, vol. 8, no 3, p.107-124.

8. RIGBY, D., BILODEAU, B. Management Tools \& Trends, Bain \& Company, 2018, available at https://www.bain.com/contentassets/caa40128a49c4f34800a76eae1582 8e3/bain_briefmanagement_tools_and_trends.pdf, referred on 20/06/2021.

9. SCHMIDTOVA, J., FORMANEK, I. Transformations in strategic business planning in the context of sustainability and business goals setting. In: Transformations in Business \& Economics, 2019, 18.2, 47.

10. SIMPSON, J., et al. 2.2 Vision, Mission, and Goals. In: Strategic Management, 2020 . 
11. SULL, D., SULL, Ch. With goals, FAST beats SMART. In: MIT Sloan Management Review, 2018, 59.4: 1-11.

12. TAIWO, A. A., LAWAL, F. A., AGWU, E. Vision and Mission in Organization: Myth or Heuristic Device? In: The International Journal of Business \& Management, 2016, 4.3.

\section{Contact}

Ing. Andrea Čambalíková, PhD.

University of Economics in Bratislava, Faculty of Business Management Dolnozemska cesta 1, 85235 Bratislava, Slovakia

email: andrea.cambalikova@euba.sk

Ing. Patrik Richnák, PhD.

University of Economics in Bratislava, Faculty of Business Management Dolnozemska cesta 1, 85235 Bratislava, Slovakia

email: patrik.richnak@euba.sk 


\title{
THE ENTERPRISE'S OBJECTIVE FOR BUILDING A RELATIONSHIP WITH IT'S SUPPLIERS AND REASONS WHY THE ENTERPRISE DOES NOT PROVIDE VALUE INDICATORS
}

\author{
Dana Kušnírová, Mária Ďurišová
}

\begin{abstract}
The paper's primary focus is to point out the importance of creating and providing value to suppliers as one of the main stakeholders of the enterprise. Value creation and subsequent provision are the main points in building a relationship between the enterprise and its suppliers. The paper aims to use questionnaires to find out the real intention of the enterprise in building a relationship with its suppliers and, on the other hand, to summarize the reasons why the enterprise does not create value to suppliers if they see that providing a value is essential for building a relationship. Businesses should strive to build long-term and sustainable relationships, as they can provide them with long-term cooperation, reliability, or the loyalty of their suppliers.
\end{abstract}

Keywords: value creation indicators, value creation, suppliers

\section{INTRODUCTION}

At the current stage, value, value creation process, as well as its provision, are important subjects of research within the field of management. The value creation process focuses primarily on value creation for the customers, i.e. the final consumer, where the suppliers themselves are only links in the process. A value has several definitions. The theoretical basis for the research is the international standards EN 1325: 2014 - Value management - Glossary - Terms and definitions and EN 12973: 2020 - Value management. The given standards define value as a measure expressing how well a product, project, or organization satisfies the needs of stakeholders in relation to the consumed resources.

Building a relationship is important for the enterprise, not only in the case of the final consumer. Businesses are beginning to realize that also other stakeholders are essential. Building good and long-lasting relationships with suppliers subsequently leads to gaining their loyalty, the sustainability of these relationships, effective communication, and quick problem-solving. Long-term cooperation between the enterprise and suppliers facilitates the exchange of information, enables close monitoring of the production process, and leads to new ideas for improving products or services (Nguyen et al., 2020). Cooperation is a kind of partnership perceived as a relationship on a long-term contractual basis through which information, risks, and profits are shared over a relatively long time (Hon et al., 2002). Zeng (2020) characterized the basic distinguishing elements in building relationships that the enterprise should focus on. These elements include the status of the relationship, the volume of trade, organizational investment, commitment, trust, harmonization and communication. The fundamental indicators of forming a long-term mutual relationship include trust, which, according to Korsaard et al. (2018), changes over time and evolves through the maturation of the relationship. Building long-term relationships lead to both parties' benefits, i.e. for the enterprise and its supplier (Jaaskelainen, 2021). Within the established strong relationships, individual partners (the enterprise and its suppliers) invest and share resources, participate in joint value-creating activities and build synergies based on their resources and capabilities (Agarwal et al., 2010). So why do enterprises that know that working together, building relationships, communicating with suppliers leads to benefits for both parties does not build 
relationships with their suppliers, do not identify their needs, requirements and create value for them? Enterprises should no longer expect development and initiative from the supplier alone to meet their needs through the security of supply, as has been the case in the past (Krause and Ellram, 1997). The gratification of needs and satisfaction must be on both sides, on the side of the enterprise, as well as on the side of the supplier. Satisfaction is one of the primary factors influencing how long given business partners will cooperate. (Vos et al., 2016) (Schiele et al., 2012)

\section{METHODOLOGY}

The aim of the paper is divided into two parts:

1. To find out the real intention of the enterprise in building a relationship with its suppliers.

2. To summarize why the enterprise does not create value for suppliers if it sees that providing value is important for building a relationship.

The methods used in the research are logical methods: induction, deduction, analysis, synthesis. The content analysis of articles, books dealing with the topic of indicators, value creation, and case studies reporting on the need to maintain good, healthy and long-term relationships is used.

The research problem in the paper focuses on two aspects. The first one is why enterprises build relationships with their suppliers. The second one is why these enterprises do not provide value-added indicators to their suppliers if they see their importance.

Main research questions:

- What is the enterprise's goal in building good business relationships with suppliers?

- Are the goals of building good business relationships with suppliers different from those of Slovakia and other countries?

- What are the reasons an enterprise does not provide values (financial / non-financial) to its suppliers when it sees the importance in them?

- Are the reasons why an enterprise does not provide value to its suppliers different in the case of enterprises from Slovakia and other countries?

The research was carried out through questionnaires, which were sent to managers of manufacturing enterprises and enterprises providing services in Slovakia and abroad. The research managed to collect answers from 149 respondents. Of which 108 from Slovakia and 41 from abroad.

The foreign enterprises that participated in the research are from Europe, North, Latin and South America, Australia and Asia. The breakdown is as follows:

Table 1: Countries participated in the survey and number of respondents

\begin{tabular}{ccc}
\hline Europe & Countries & $\begin{array}{c}\text { Number of } \\
\text { respondents }\end{array}$ \\
\hline & $\begin{array}{c}\text { Belgium, France, Germany, } \\
\text { Ireland, Lithuania, Spain, } \\
\text { Switzerland, United Kingdom }\end{array}$ & 17 \\
\hline North America & Canada, USA & 14 \\
\hline Latin and South America & Mexico, Ecuador, Colombia, \\
Guatemala & 5 \\
\hline Asia & Nepal, Korea, Japan & 3 \\
\hline Australia & Australia and New Zealand & 2 \\
\hline Total (other countries) & & $\mathbf{4 1}$ \\
\hline Europe & Slovakia & $\mathbf{1 0 8}$ \\
\hline $\begin{array}{c}\text { Number of respondents in } \\
\text { total }\end{array}$ & & $\mathbf{1 4 9}$ \\
\hline
\end{tabular}


Within the paper, individual answers are evaluated for all respondents, separately for respondents from Slovakia and separately for respondents from other countries.

\section{RESULTS}

\subsection{The goal of the enterprise in building good business relationships with suppliers}

Slovak enterprises and enterprises from abroad answered questions regarding value creation and the reasons for their creation. In the questionnaire, enterprises had a choice of six main options, where they had to choose why they were interested in building good business relationships with suppliers. Enterprises could choose more options. The following options were stated as the main reasons for building relationships:

- Long-term cooperation

- Loyalty of suppliers

- Increasing the competitiveness of the enterprise

- More favourable business conditions

- Better price offers

- Effective mutual communication (quick feedback regarding the orders, suggestions for improvement, quick resolution of problems, complaints)

The main goal of most enterprises is effective mutual communication, which helps to provide quick feedback on orders, obtaining suggestions and suggestions for improvement, quick resolution of problems or complaints. It was this possibility that $76 \%$ of all enterprises identified. Long-term cooperation aims to build good business relationships with suppliers in $59 \%$ of all enterprises surveyed. In order to achieve better prices, 54\% of enterprises build a relationship with their suppliers. $40-44 \%$ of enterprises build these relationships with the vision of better business conditions and to ensure their suppliers' loyalty. Only $32 \%$ of enterprises surveyed said they saw the goal in increasing their competitiveness. The given data are stated in picture no. 1.

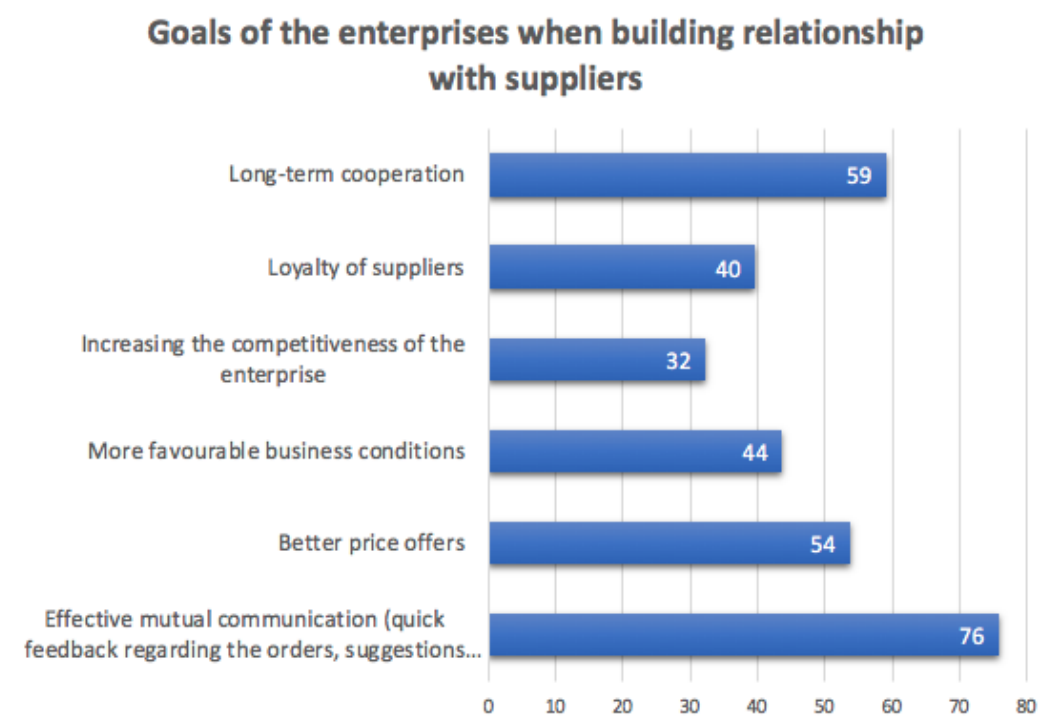

Fig. 1 Goals of the enterprises when building relationship with suppliers

Picture no. 2 shows a comparison of Slovak and foreign enterprises and their goals in building a relationship with suppliers. As many as $81 \%$ of Slovak enterprises stated that their goal is effective mutual communication. This communication is also a goal for $61 \%$ of foreign enterprises. Long-term cooperation is the reason for building a relationship with suppliers for $44 \%$ of Slovak enterprises and $29 \%$ of enterprises from other countries. For $44 \%$ of Slovak 
and $29 \%$ of foreign enterprises, the goal is the loyalty of suppliers. For $31 \%$ of Slovak and $37 \%$ of foreign enterprises, the goal is to increase the enterprise's competitiveness. The goal of more favourable business conditions was selected by $45 \%$ of Slovak and 39\% of foreign enterprises. The achievement of more favourable price offers was selected by $56 \%$ of Slovak enterprises and $46 \%$ of enterprises from other countries.

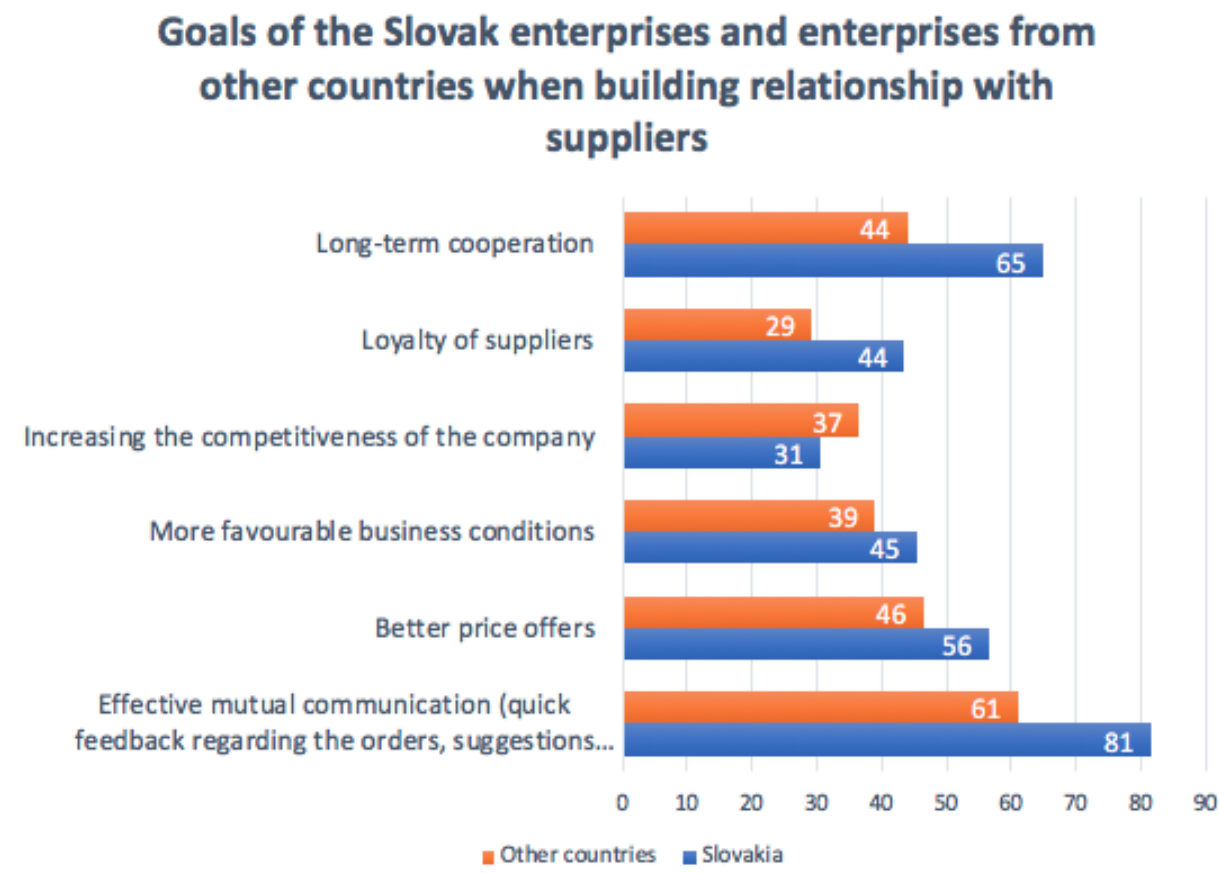

Fig. 2 Goals of the Slovak enterprises and enterprises from other countries when building relationship with suppliers

Enterprises could also set other goals or reasons for building good relationships with their suppliers. Slovak enterprises indicated other reasons for building a relationship with suppliers, such as meeting deadlines and building a good reputation. Enterprises from other countries set goals, which mainly concerned delivery conditions. These reasons included: fast and prompt delivery of goods or services, which further leads to maintaining the enterprise's competitiveness, a reliable delivery schedule.

\subsection{Reasons for not providing value to suppliers}

Suppose enterprises know the goal of building good long-term business relationships with their suppliers and also see the importance of building these relationships through value creation. Why don't they provide their suppliers with individual value creation indicators to meet these goals? Another part of the research was devoted to this topic. Enterprises answered the question: "Explain the reason why your enterprise does not provide (financial / nonfinancial) values to its suppliers when the enterprise sees importance in them?"

For Slovak enterprises, the main reason is the financial situation and other conditions of the enterprise. Several enterprises stated that the reason was the lack of funds that they would need to invest in individual indicators of value creation. Enterprises from other countries said that they do not have enough capacity to meet the needs of their business partners, or they do not have a budget. Some enterprises have stated that they are more dedicated to providing financial indicators of value creation than non-financial ones, as it is easier. Enterprises see the provision of value to their suppliers in buying their products/services. Thus, the suppliers 
can continue to produce the products/provide the services (i.e. the suppliers can continue with their businesses).

Many enterprises have responded that they provide value to their suppliers. Thus, they work on building good mutual business relationships. Although most still focus on providing financial value rather than non-financial.

Only $23.15 \%$ of respondents from Slovakia answered the question. Within enterprises from other countries, up to $51.22 \%$ of respondents expressed their opinion.

More than $80 \%$ of enterprises stated financial or capacity reasons for not providing the value to their suppliers. These reasons mainly concerned the lack of financial, capacity or time resources.

\section{CONCLUSION}

The aim of the paper was divided into two parts. The first one was to identify the enterprise's intentions in building a good business relationship with suppliers. The second one was to summarize why enterprises do not create value for suppliers when they see their importance. Within the given goal, a research problem was identified, and research questions were determined. The goal was fulfilled by implementing the research and its interpretation. One hundred forty-nine respondents from Slovakia and other countries participated in this research. Based on the reactions of the respondents, it was possible to answer the given research questions, which were as follows:

1) What is the enterprise's goal in building good business relationships with suppliers?

Most enterprises have set themselves the goal of effective communication with each other. $76 \%$ of all respondents chose the given answer. Based on the above, it is clear that enterprises see the importance of communication, which leads to quick feedback, quick processing of orders, obtaining suggestions for improvement, prompt handling of complaints, or problemsolving. The fewest enterprises see the reason for building relationships in increasing their competitiveness, which was selected by only $32 \%$ of respondents (see Figure 1).

\section{2) Are the goals of building good business relationships with suppliers different from those of Slovakia and other countries?}

Based on the results (see Figure 2), it is clear that enterprises in Slovakia see more reasons and benefits in building relationships with suppliers, as they chose more answers from the options provided. Up to $81 \%$ of enterprises from Slovakia and $61 \%$ of enterprises from other countries see the effectiveness of mutual communication as a positive result of building mutual relations. A significant reason for enterprises from Slovakia is the long-term cooperation, which was chosen by $65 \%$ of respondents and only $44 \%$ of respondents from other countries. On the contrary, enterprises from other countries see greater importance in building relationships and increasing their competitiveness, which was selected by $37 \%$ of respondents and only $31 \%$ of respondents from Slovakia.

3) What are the reasons an enterprise does not provide values (financial / non-financial) to its suppliers when it sees the importance in them?

Some enterprises do not see a reason to continue to provide value to suppliers, as they only create value for them by buying their products. Other enterprises see greater importance in providing financial value and do not see such importance in providing non-financial value to their suppliers.

4) Are the reasons why an enterprise does not provide value to its suppliers different in the case of enterprises from Slovakia and other countries? 
Slovak enterprises mostly stated as the main reason their lack of financial resources. On the other hand, foreign enterprises instead said that they create and provide value to their suppliers (more financial than non-financial values) or do not have the capacity (employees) to meet the needs of their suppliers.

Enterprises know what they would like to achieve based on the cooperation with their suppliers and what their goals are, but on the other hand, they do not always do something about it. To achieve the loyalty of their suppliers, improve their competitiveness, or ensure effective communication, they must first and foremost focus on their suppliers, their needs, opinions, attitudes. Subsequently, based on the information obtained, ensure their needs in creating and providing value.

The paper points out the importance of building a relationship between the enterprise and its suppliers, whether they are from Slovakia or other countries. At the same time, the paper highlights the reasons why an enterprise is not dedicated to creating and delivering value if it knows the importance of the value. This paper is a preparation for further research, which should focus on how an enterprise can focus on creating and delivering value to its suppliers within its financial, time and capacity capabilities.

\section{Acknowledgement}

This paper has been written with the support of VEGA 1/0382/19 - The building of sustainable relationship with the enterprise's stakeholder groups via the creation of value with the application of information-communication technology and Grant System of University of Zilina No. 8064/2020 - Indicators of the value creation in the enterprise for the suppliers in the context of managerial decision-making.

\section{Resources}

1. AGARWAL, R., MAHONEY, J.T., 2010. The role of incentives and communication in strategic alliances: an experimental investigation. In: Strategic Management Journal. Vol. 31, No. 4, pp. 413-437.

2. BS EN 12973:2020, Value management, 2020, ISBN: 978-0-580-88246-3.

3. BS EN 1325:2014, Value Management, Vocabulary. Terms and definitions, 2014, ISBN: 978-0-580-76368-7.

4. HON, Y., XIANGDONG, C., 2002. A study of International Supply Chain Cooperative Relationship in View of Suppliers Benefit, In: Industrial Engineering and Management, No. 4, pp. 24.

5. JAASKELAINEN, 2021. The relational outcomes of performance management in buyer-supplier relationships, In: International Journal of Production Economics, No. 232, pp. 1-14.

6. KORSGAARD, M.A., KAUTZ, J., BLIESE, P., SAMONSON, K., KOSTYSZYN, P., 2018. Conceptualising time as a level of analysis: New directions in the analysis of trust dynamics. In: Journal of Trust research, Vol. 8, No. 2, pp. 142-165.

7. KRAUSE, D.R., ELLRAM, L.M., 1997. Success factors in supplier development. In: International Journal of Physical Distribution and Logistics Management, vol 27 issue 1, pp 39-52

8. NGUYEN, T. L., NGUYEN, V. K., NGUYEN, T. C., 2020. Buyer-Supplier Contract Length and the Innovation of Supplier Firms, In: Journal of Open Innovation: Technology, market, and Complexity, Vol. 6, No. 52, pp. 1-16.

9. SCHIELE, H., CALCVI, R., GIBBERT, M., 2012. Customer attractiveness, supplier satisfaction and preferred customer status: Introduction, definitions and an overarching framework, In: Industrial marketing management, Vol. 41, No. 8, pp. 1178-1185. 
10. VOS, F.G., SCHIELE, H., HUTTINGER, L., 2016. Supplier satisfaction: explanation and out-of sample prediction, In: Journal of Business Research, Vol. 69, No. 10, pp: 4613-4623.

11. ZENG, X., 2020. Supplier Relationship Assessment, In: Learning and Education, Vol, 9, No. 4, pp. 226-229.

\section{Kontaktní údaje}

Ing. Dana Kušnírová

Doc. Ing. Mária Ďurišová, PhD.

Žilinská univerzita v Žiline, Fakulta riadenia a informatiky

Univerzitná 8215/1, 01026 Žilina, Slovensko

email: dana.kusnirova@fri.uniza.sk 


\title{
MOŽNOSTI STABILIZÁCIE SESTIER V SLOVENSKOM ZDRAVOTNÍCTVE Z POHLADU ŠTUDENTOV ODBORU OŠETROVATELSTVA
}

\author{
POSIBILIETIES OF NURSES IN THE SLOVAK HEALTHCARE \\ SYSTEM FROM THE POINT OF VIEW OF NURSING STUDENTS
}

\author{
Lívia Hadašová, Terézia Fertal'ová, Tatiana Šantová
}

\begin{abstract}
Abstrakt
Kvalitu a dostupnost' zdravotnej starostlivosti zásadne ovplyvňuje, či je v systéme dostatok kvalifikovaných pracovníkov. Mnohé zdravotnícke zariadenia zápasia s nedostatkom zdravotníckeho personálu, vysokou fluktuáciou, čo narúša kvalitu poskytovaných služieb, dostupnost' starostlivosti, produktivitu zdravotníckeho zariadenia i ohrozuje organizačnú kultúru a bezpečnost' pacienta. Vláda Slovenskej republiky prijala a zaviedla opaterenia podporujúce stabilizáciu sestier v systéme zdravotnej starostlivosti vo forme stabilizačných pôžičiek a rezidentského programu. $\mathrm{Na}$ základe prieskumu sme zozbierali informácie o postoji študentov ošetrovatel'stva na súčasný stav stabilizácie sestier na Slovensku. Zistovali sme, ako vnímajú nedostatok sestier a jeho dopad na fungovanie slovenského zdravotníctva.
\end{abstract}

Kl'účová slová: sestra, nedostatok, stabilizácia, zdravotníctvo, kvalita starostlivosti

\begin{abstract}
The quality and availability of health care is fundamentally affected by whether there are enough qualified staff in the system. Many medical facilities struggle with a shortage of medical staff, high turnover, which disrupts the quality of services provided, the availability of care, the productivity of the medical facility and endangers the organizational culture and patient safety. The Government of the Slovak Republic has adopted and implemented measures to support the stabilization of nurses in the health care system in the form of stabilization loans and a resident program. Based on the survey, we collected information on the attitude of nursing students to the current state of stabilization of nurses in Slovakia. We found out how they perceive the shortage of nurses and its impact on the health care system.
\end{abstract}

Key words: nurse, deficiency, stabilization, healthcare, quality of care

\section{LUDSKÉ ZDROJE V ZDRAVOTNÍCTVE}

Kvalita l'udských zdrojov predstavuje element podmieňujúci prosperitu, ako aj konkurenčnú schopnost' zdravotníckeho zariadenia. Za zdroj úspechu sa pokladá neustále posilňovanie kvality l'udských zdrojov a ich využitie na rast produktivity a kvality práce. Odborné vedomosti a praktické zručnosti zamestnancov, ich pracovná výkonnost', iniciatíva v práci či stotožnenie sa so stratégiou zdravotníckeho zariadenia a filozofiou zamestnávatel'a, je významnou hodnotou a potenciálom zdravotníckeho zariadenia (Hitka a kol. 2013). Výsledkom činnosti manažérov a personalistov v riadení l'udských zdrojov by mal byt' účelný a stabilný systém, v rámci ktorého budú obsiahnuté nie len strategicky významné ciele zdravotníckej organizácie, ale budú taktiež uspokojené aj špecifické potreby zamestnancov. 


\subsection{Príčiny personálnej destabilizácie sestier}

Profesia sestry je vel'mi náročná a pracovná zát’až je vysoká. Prácu sestry ovplyvňuje mnoho faktorov a rôzna zát'až podl'a charakteru pracoviska a náročnosti stavu sledovaných pacientov. L'udský organizmus je prirodzene nastavený na deň a noc. Trojzmenná prevádzka narúša túto fyziológiu a vyžaduje od sestier aby sa prispôsobili práci i v noci, kedy sa l'udskému organizmu pracuje omnoho t’ažšie a sústredná pracovná činnost' je namáhavejšou. K d’alším negatívnym vplyvom v práci sestier, ktoré môžu mat' negatívny vplyv na ich personálnu stabilizáciu radíme aj pracovné riziká ako fyzikálne faktory prostredia, biologické faktory prostredia sociálne faktory prostredia, s dôrazom na medzil'udské vzt'ahy v zdravotníckom tíme. Ďalším, pomerne podstatným, faktorom je finančné ohodnotenie sestier. Práca sestier je nedocenená nie len po finančnej ale i po stránke spoločenskej. Medzi d’alšie negatívne faktory ovplyvňujúce prácu sestry radíme: nedostatočné personálne a materiálno-technické vybavenie pracovísk, nemožnost' úplného uzdravenia pacienta, nepretržitá pozornost' a zodpovednost', dominancia nadmerne závažných stavov, konflikty a vzt’ahy na pracovisku (Farkašová, 2001). Okrem iného sa na pracovisku často vyskytuje neefektívna organizácia práce, kedy dochádza k nadmernej psychickej i fyzickej vyt’aženosti sestry (Gulášová, 2001). Okrem iného sestry vykonávajú aj iné činnosti, ktoré sú v kompetencii nižšieho zdravotníckeho personálu. Na kvalitné plnenie ich odbornej pracovnej činnosti vyplývajúcej z ich kompetencií im ostáva čoraz menej času. Nárast a kumulácia týchto, čoraz častejšie i menej odborných pracovných

činností sa každodenne objavuje v našich zdravotníckych zariadeniach ako dôsledok chýbajúcich personálných kapacít (Gondárova-Vyhničková, 2019).

\subsection{Dopady personálnej destabilizácie na systém zdravotnej starostlivosti}

Nedostatok personálu a personálna destabilizácia zdravotníckych pracovníkov ohrozuje kvalitu poskytovanej zdravotnej starostlivosti a to konkrétne:

- dochádza častejšie k nežiaducim a mimoriadnym situáciám v procese poskytovania, čo ohrozuje bezpečnost' pacienta,

- zhoršuje jej dostupnost', dochádza k pridel'ovanej a chýbajúcej starostlivosti (Eliašová, Hadašová, Fedurcová, 2020).

Pridel'ovanú zdravotnú starostlivost' môžeme definovat' ako prídel obmedzených prostriedkov, resp. hl'adanie opodstatnenia pre pridel'ovanie a odmietnutie zdravotníckych služieb. V praxi k pridel'ovanej zdravotnej starostlivosti dochádza, ked' nemáme dostatok zdrojov na poskytnutie starostlivosti pre všetkých pacientov. Výsledkom môžu byt' neuspokojené základné potreby pacientov. Ked’že v zdravotníctve je nedostatok zdrojov pre poskytnutie adekvátnej starostlivosti a potreba služieb presahuje zdroje pre poskytovanie služieb, dochádza $\mathrm{k}$ zastaveniu poskytovania prospešných služieb vzhl'adom na nedostatočné zdroje. Vzhl'adom na množstvo negatívnych vplyvov, nedostatok zdrojov a zvyšovanie nákladov je istá regulácia poskytovania služieb prípustná. Musí ale byt' realizovaná bez vplyvu na poskytovanie základnej a neodkladnej zdravotnej starostlivosti. Ak je ošetrovatel'ská starostlivost' poskytovaná na základe uváženia zdravotníckeho pracovníka a pacienta, hovoríme o implicitne poskytovanej zdravotnej starostlivosti. Ide o rozhodovanie lekárov a sestier o tom, akú starostlivost' poskytnú na základe medicínskeho opodstatnenia. Preferovaní sú akútni pacienti pred chronickými. Pri nedostatku zdrojov pre poskytovanie zdravotnej starostlivosti, dochádza k jej obmedzeniu, respektíve dôjde len k prideleniu takej starostlivosti, o ktorej rozhodne pracovník samotný. Ak hovoríme o explicitne pridel'ovanej zdravotnej starostlivosti, hovoríme o starostlivosti pridel'ovanej objektívne (Eliašová, Hadašová, Fedurcová, 2020). 


\section{STABILIZAČNÉ OPATRENIA PRE ABSOLVENTOV ODBORU OŠETROVATELSTVA}

Ministerstvo zdravotníctva SR sa v spolupráci s Ministerstvom školstva, vedy, výskumu a športu SR rozhodlo prijat' pre študentov odboru Ošetrovatel'stva stabilizačné návrhy tak, že im ponúka stabilizačné príspevky, ktoré majú napomôct' zastabilizovat' sestry v systéme Slovenského zdravotníctva po ukončení ich štúdia. Štát študentom ošetrovatel'stva ponúka ročný príspevok až do výšky 2000 eur. Študent sa ale zaviaže, že po ukončení štúdia ostane pracovat' v zdravotníctve na Slovensku šest' rokov. (Gondárova-Vyhničková, 2019). Rezidentský program je vhodný ako pre lekárov tak aj pre sestry. Do rezidentského štúdia, na štyroch univerzitách, sa dá prihlásit' za pomoci zamestnávatel'a. Rezidentské štúdium pôvodne reagovalo na nedostatok všeobecných lekárov pre dospelých a pediatrov. Od roku 2018 sa ale rozšírilo aj pre sestry, ktoré môžu v rámci rezidentského programu absolvovat' špecializačné štúdium v odboroch: anestéziológia a intenzívna medicína, inštrumentovanie v operačnej sále a ošetrovatel'ská starostlivost' $v$ psychiatrii. MZ SR v rámci rezidentského programu spolupracuje s viacerými univerzitami a to: SZU v Bratislave, LF UK v Bratislave, Jesseniovou LF UK v Martine a LF UPJŠ v Košiciach. Ciel'om rezidentského štúdia je zabezpečit' dostatočný počet sestier vo vybraných odboroch, znížit' vekový priemer sestier a podporit' d'alšie postgraduálne vzdelávanie $\mathrm{v}$ ošetrovatel'stve. Zaradenie do rezidenčného programu prebieha na základe žiadosti uchádzača a to za predpokladu, že získal odbornú spôsobilost' na výkon odborných pracovných činností a splnil podmienky zákonom definované pre rezidentské štúdium. Ministerstvo garantuje odbornú ale i finančnú podporu počas štúdia rezidentského programu, teda jeho plné hradenie z účelovo viazaných finančných prostriedkov ministerstva. Štúdium je hradené za predpokladu, že absolvent špecializačného štúdia bude najbližších 5 rokov poskytovat' zdravotnú starostlivost' v sfére slovenského zdravotníctva v odbore, ktorý vyštudoval. Rezidentské štúdium pre jeho absolventa ponúka viacero benefitov. Každý absolvent má istotu zamestnania na celom území SR, v samosprávnom kraji podl'a vlastného výberu a právo na refundáciu poplatkov za d’alšie vzdelávanie (MZ SR, 2021).

\section{POSTOJE ŠTUDENTOV K STABILIZAČNÝM OPATRENIAM PRE LUDSKÉ ZDROJE V ZDRAVOTNÍCTVE}

Realizovali sme prieskum medzi študentmi študijného odboru ošetrovatel'stvo na Fakulte zdravotníckych odborov Prešovskej univerzity v Prešove. Získavali sme informácie o tom, aké postoje zaujímajú študenti k téme stabilizačných opatrení a ako študenti vnímajú ich dopady na systém zdravotnej starostlivosti na Slovensku.

Hlavným ciel'om prieskumu bolo zistit' názory a postoje študentov odboru ošetrovatel'stvo k stabilizačným opatreniam pre profesiu sestry. V rámci hlavného ciel'a sme si zvolili štyri parciálne ciele prieskumu:

1. Zistit' ako vnímajú študenti odboru Ošetrovatel'stva súčasnú situáciu týkajúcu sa nedostatku sestier študenti ošetrovatel'stva.

2. Analyzovat' názory a postoje študentov odboru Ošetrovatel'stva týkajúce sa dopadov nedostatku sestier v systéme zdravotníctva .

3. Zistit' názory a postoje študentov odboru Ošetrovatel'stva k vnímaniu súčasných pracovných podmienok sestier.

4. Analyzovat' názory a postoje študentov odboru Ošetrovatel'stva k navrhovaným stabilizačným opatreniam.

Prieskum sme realizovali medzi študentmi ošetrovatel'stva bakalárskeho a magisterského študijného programu počas mesiacov február, marec a apríl roku 2021.Za hlavnú techniku prieskumu bol zvolený neštandardizovaný dotazník vlastnej konštrukcie. Ciel’om prieskumu 
bolo zistit' názory a postoje študentov k stabilizačným opatreniam zdravotníckych pracovníkov na Slovensku. Dotazník sme distribuovali velektronickej podobe, online formou, pomocou aplikácie Microsoft Forms. Prieskumnú vzorku tvorilo spolu 94 študentov odboru Ošetrovatel'stva $v$ dennej forme bakalárskeho a magisterského študijného programu ošetrovatel'stvo na Fakulte zdravotníckych odborov Prešovskej univerzity v Prešove. Vek respondentov bol od 19 do 26 rokov. Z celkového počtu respondentov bolo 85 žien a 9 mužov.

\subsection{Výsledky prieskumu}

Prehl'ad odpovedí respondentov na otázku „Aké sú podl'a Vás príčiny nedostatku sestier v systéme zdravotnej starostlivosti ?

\begin{tabular}{lcc}
\hline Príčiny nedostatku sestier & Počet & \% \\
\hline $\begin{array}{l}\text { Nedostatočné platové } \\
\text { ohodnotenie }\end{array}$ & 88 & 32 \\
\hline $\begin{array}{l}\text { Neefektívne riadenie } \\
\text { zdravotníckych zariadení }\end{array}$ & 32 & 12 \\
\hline $\begin{array}{l}\text { Nevyhovujúce pracovné } \\
\text { podmienky sestier }\end{array}$ & 74 & 27 \\
\hline Odchod sestier do zahraničia & 56 & 20 \\
\hline $\begin{array}{l}\text { Zlé medziludské vzt'ahy na } \\
\text { pracovisku }\end{array}$ & 26 & 9 \\
\hline Iné & 1 & 0 \\
\hline Spolu & 277 & 100 \\
\hline
\end{tabular}

Tabul'ka 1- Príčiny nedostatku sestier v systéme zdravotnej starostlivosti

Prehl'ad odpovedí respondentov na otázku „Využili ste ako študent ošetrovatel'stva stabilizačnú pôžičku? "

\begin{tabular}{lcc}
\hline $\begin{array}{l}\text { Využitie stabilizačnej } \\
\text { pôžičky }\end{array}$ & Počet & \% \\
\hline Áno & 7 & 7 \\
\hline Nie & 71 & 76 \\
\hline Neviem o takejto možnosti & 16 & 17 \\
\hline Spolu & 94 & 100 \\
\hline
\end{tabular}

Tabul'ka 2 - Využitie možnosti stabilizačnej pôžičky

Prehl'ad odpovedí respondentov na otázku: Plánujete sa po ukončení štúdia zamestnat' ako sestra?

\begin{tabular}{lcc}
\hline Možnosti & Počet & $\%$ \\
\hline Áno & 81 & 86 \\
\hline Nie & 2 & 2 \\
\hline Neviem & 11 & 12 \\
\hline Spolu & 94 & 100 \\
\hline
\end{tabular}

Tabul'ka 3 - Plánované zamestnanie po ukončení štúdia na pozícii sestra

Prehl'ad odpovedí respondentov na otázku: „Ako vnímate Vládou SR navrhované a realizované opatrenia na stabilizáciu sestier?"

\begin{tabular}{lcc}
\hline Možnosti & Počet & \% \\
\hline Pozitívne & 5 & 5 \\
Negatívne & 23 & 24 \\
Nemám o nich vedomost' & 48 & 51 \\
\hline
\end{tabular}




\begin{tabular}{lcc}
\hline Neviem sa vyjadrit' & 18 & 19 \\
Spolu & 94 & 100 \\
\hline
\end{tabular}

Tabul'ka 4 - Pohl’ad respondentov na Vládou SR navrhované a realizované stabilizačné opatrenia sestier

Prehl'ad odpovedí respondentov na otázku: „Podl'a vášho názoru, aké dopady hrozia $v$ systéme zdravotnej starostlivosti pri nedostatku sestier?

\begin{tabular}{lcc}
\hline Možnosti & Počet & \% \\
\hline Ohrozenie bezpečnosti pacienta & 55 & 25 \\
$\begin{array}{l}\text { Zhoršenie dostupnosti } \\
\text { starostlivosti }\end{array}$ & 76 & 35 \\
$\begin{array}{l}\text { Zhoršenie celkovej kvality } \\
\text { poskytovanej starostlivosti }\end{array}$ & 85 & 39 \\
Nehrozia žiadne dopady & 1 & 0 \\
Neviem sa vyjadrit' & 0 & 0 \\
Iné & 2 & 1 \\
Spolu & 219 & 100 \\
\hline
\end{tabular}

Tabul'ka 5- Dopady nedostatku sestier v systéme zdravotnej starostlivosti

Prehl'ad odpovedí respondentov na otázku, Čo môžu podl'a Vás urobit' manažéri zdravotnickych zariadeni na podporu stabilizácie sestier?"

\begin{tabular}{|c|c|c|}
\hline Podporné kroky & Počet & $\%$ \\
\hline Lepšie platové ohodnotenie & 75 & 16 \\
\hline $\begin{array}{l}\text { Lepšie finančné i nefinančné } \\
\text { benefity }\end{array}$ & 62 & 13 \\
\hline $\begin{array}{l}\text { Implementácia efektívneho } \\
\text { motivačného systému }\end{array}$ & 34 & 7 \\
\hline Lepšie pracovné podmienky & 81 & 17 \\
\hline $\begin{array}{l}\text { Lepšie materiálno-technické } \\
\text { vybavenie }\end{array}$ & 64 & 13 \\
\hline Efektívnejšia organizácia práce & 43 & 9 \\
\hline $\begin{array}{l}\text { Budovanie silnej organizačnej } \\
\text { kultúry }\end{array}$ & 29 & 6 \\
\hline Podpora psychohygieny & 65 & 14 \\
\hline Pravidelná supervízia & 25 & 5 \\
\hline Neviem sa vyjadrit' & 0 & 0 \\
\hline Iné & 1 & 0 \\
\hline Spolu & 479 & 100 \\
\hline
\end{tabular}

Tabul'ka 6 - Podporné kroky manažmentu pre stabilizáciu sestier v zdravotníckych zariadeniach

Prehl'ad odpovedí respondentov na otázku : „Myslite si, že sa podarí zastabilizovat' sestry $v$ Slovenskom zdravotnictve v obdobi najbližšich 5 rokov ?"

\begin{tabular}{lcc}
\hline Možnosti & Počet & \% \\
\hline $\begin{array}{l}\text { Som presvedčený/á že sa } \\
\text { podarí sestry stabilizovat’ }\end{array}$ & 2 & 2 \\
Myslím, že áno & 16 & 17 \\
Skôr nie & 54 & 58 \\
Určite sa zastabilizovanie & 16 & 17 \\
sestier nepodarí & 6 & 6 \\
Neviem sa vyjadrit' & 6 & \\
\hline
\end{tabular}




\begin{tabular}{|c|c|c|}
\hline Spolu & 94 & 100 \\
\hline $\begin{array}{l}\text { Tabul'ka } 7 \text { - Stab } \\
\text { Prehl'ad odpovedí respor } \\
\text { l'udských zdrojov je najvic }\end{array}$ & $\begin{array}{l}\text { ovensko } \\
\text { u:" } P o \\
\text { zdravo }\end{array}$ & $\begin{array}{l}5 \text { rokov } \\
\text { súčast' riadenia }\end{array}$ \\
\hline Podceňované súčasti & Počet & $\%$ \\
\hline Plánovanie & 37 & 14 \\
\hline $\begin{array}{l}\text { Adaptačný proces novo } \\
\text { nastupujúcich sestier }\end{array}$ & 45 & 16 \\
\hline Vzdelávanie sestier & 31 & 11 \\
\hline Hodnotenie zamestnancov & 45 & 16 \\
\hline Plán nástupníctva & 24 & 9 \\
\hline $\begin{array}{l}\text { Program finančných } \\
\text { i nefinančných benefitov }\end{array}$ & 36 & 13 \\
\hline $\begin{array}{l}\text { Starostlivost' o pracovné } \\
\text { podmienky }\end{array}$ & 50 & 18 \\
\hline Neviem sa vyjadrit' & 6 & 2 \\
\hline Iné & 0 & 0 \\
\hline Spolu & 274 & 100 \\
\hline
\end{tabular}

Tabul'ka 8 -Podceňované súčasti riadenia l’udských zdrojov v zdravotníckych zariadeniach

Odpovede študentov na otázku : Myslíte si, že návrhy na stabilizáciu sestier v Slovenskom zdravotníctve prilákajú väčši počet študentov?

\begin{tabular}{lcc}
\hline Možnosti & Počet & \% \\
\hline Áno, rozhodne & 10 & 11 \\
\hline Skôr áno & 43 & 45 \\
\hline Skôr nie & 25 & 27 \\
\hline Rozhodne nie & 3 & 3 \\
\hline
\end{tabular}

Tabul'ka 9- Záujem o štúdium ošetrovatel'stva v súvislostí so stabilizačními opatreniami

Odpovede študentov na otázku:“ Čo môžu a mali by podl’a Vášho názoru urobit’ vzdelávacie inštitúcie na podporu stabilizácie sestier $v$ Slovenskom zdravotníctve?

\begin{tabular}{lcc}
\hline $\begin{array}{l}\text { Kroky k podpore } \\
\text { stabilizácie }\end{array}$ & Počet & \% \\
\hline $\begin{array}{l}\text { Lepšie podmienky pre } \\
\text { realizáciu praktickej výučby }\end{array}$ & 78 & 36 \\
$\begin{array}{l}\text { Zefektívnenie marketingovej } \\
\text { stratégie }\end{array}$ & 26 & 12 \\
$\begin{array}{l}\text { Monitoring postrehov } \\
\text { študentov k praktickej výuke }\end{array}$ & 74 & 33 \\
$\begin{array}{l}\text { Vyššia angažovanost' } \\
\text { pedagógov }\end{array}$ & 30 & 14 \\
$\begin{array}{l}\text { Vzdelávacie inštitúcie nemajú } \\
\text { vplyv k podpore stabilizácie }\end{array}$ & 10 & 5 \\
$\begin{array}{l}\text { Neviem sa vyjadrit' } \\
\text { Spolu }\end{array}$ & 1 & 0 \\
\hline
\end{tabular}

Tabul'ka 10 - Kroky vzdelávacích inštitúcií k podpore stabilizácie sestier v systéme zdravotnej starostlivosti na Slovensku 


\section{DISKUSIA}

Prvým ciel'om prieskumu bolo zistit', ako vnímajú súčasnú situáciu týkajúcu sa nedostatku sestier. Ministerstvo zdravotníctva SR vo svojej správe vyčíslilo nedostatok niektorých zdravotníckych povolaní v systéme zdravotnej starostlivosti. Najnedostatkovejším povolaním je práve sestra. Súčasný a rastúci nedostatok registrovaných sestier v systémoch zdravotnej starostlivosti je globálnym problémom. Európska komisia odhadla, že v krajinách EÚ bude chýbat' o niekol'ko rokov viac ako 590000 sestier. Vekový priemer sestier je 47 rokov. V krajinách Európskej únie je priemerný počet sestier na 1000 obyvatel’ov 8,4, na Slovensku je to 5,7 sestry na 1000 obyvatel'ov. Ak by Slovensko chcelo dosiahnut' priemer počtu sestier EÚ, potrebovali by sme doplnit' 14000 sestier.(SKS APA, 2021). Študentov sme sa pýtali aké sú podl'a nich príčiny nedostatku sestier v systéme. $Z$ výsledkov vyplýva, že za nedostatkom sestier, je podl'a študentov, ich slabé platové hodnotenie (32\%) a nevyhovujúce pracovné podmienky sestier $(27 \%)$. O navrhovaných a realizovaných opatreniach na stabilizáciu sestier nemá vedomost' až $51 \%$ opýtaných študentov, a len 5\% opýtaných ich vníma pozitívne. Podl’a študentov najviac podceňovanou oblast'ou riadenia l'udských zdrojov v zdravotníckych zariadeniach starostlivost' o pracovné podmienky a motivácia a hodnotenie zamestnancov.

V druhom cieli sme analyzovali postoje študentov odboru Ošetrovatel'stva týkajúce sa dopadov nedostatku sestier na zdravotnú starostlivost'. Študenti považujú za dopady nedostatku sestier v systéme zdravotnej starostlivosti zhoršenie kvality celkovej poskytovanej starostlivosti, ktoré označilo $39 \%$ respondentov, iba $25 \%$ odpovedí zahŕnalo ako dopady nedostatku sestier ohrozenie bezpečnosti pacienta. Pre poskytovanie kvalitnej a bezpečnej zdravotnej starostlivosti potrebujeme dostatok sestier. Dobrou správou je, že 86\% opýtaných študentov chce po ukončení štúdia pracovat' v pozícií sestra $-69 \%$ respondentov plánuje po ukončení svojho štúdia ostat' pracovat' na Slovensku a $21 \%$ respondentov sa stále rozhoduje v akej krajine sa po ukončení štúdia zamestná. Slovenská komora sestier a pôrodných asistentiek (2021) na svojom web.portáli informuje, že väčšina krajín v rámci Organizácie pre hospodársku spoluprácu a rozvoj (OECD) uvádza nedostatok ošetrovatel'ských pracovných síl a tento trend sa rok čo rok zhoršuje. Nedostatok sestier ovplyvňuje poskytovanie zdravotnej starostlivosti s negatívnym dopadom na pacientov a zhoršujúcou sa pracovnou spokojnostou sestier, ktoré v systéme pracujú.

V tret'om cieli sme zist'ovali názory a postoje študentov ošetrovatel'stva $k$ vnímaniu súčasných pracovných podmienok sestier. 93\% respondentov považuje pracovné podmienky sestier za náročné až vel’mi náročné. Dimunová (2018) uvádza, že pracovná zát’až ma multikauzálnu etiológiu a jej psychické ako aj fyzické faktory môžu nepriaznivo zasahovat' do života sestier. Bosáková (2006) uvádza, že nepriaznivá personálna situácia núti sestry pracovat' i niekol'ko desiatok hodín nadčasov mesačne. Na mnohých pracoviskách sa stretávame sa aj s nariadeným nadčasom kedy prácu „,nadčas“ zarad’ujú priamo v rozpise služieb. Nariadené ale i dobrovol’né nadčasy „riešia“ nedostatok sestier na pracovisku. Rast nadčasov ohrozuje nie len zdravie sestier, ale bezpečnú a individualizovanú starostlivost' o pacientov. $45 \%$ respondentov si myslí že pandémia COVID-19 rozhodne ešte viac destabilizuje systém zdravotnej starostlivosti na Slovensku. Odpoved' v znení, že pandémia nebude mat' žiadny vplyv na zhoršenie destabilizácie neoznačil ani jeden respondent. 58\% respondentov si myslí že sa skôr nepodarí zastabilizovat' sestry v systéme Slovenského zdravotníctva v najbližších 5 rokoch.

Vo štvrtom cieli sme analyzovali názory a postoje študentov k navrhovaným stabilizačným opatreniam. Stabilizačné štipendium pre študentov ošetrovatel'stva bude prospešné, avšak neprinesie dostatočné zlepšenie, pretože nie je kl'účovým riešením. Medzi hlavné príčiny nedostatku sestier v prvom rade radíme nedostatočné mzdové ohodnotenie a kamuflovanie ich nedostatku (Visolajský, 2018). Nami oslovených študentov stabilizačnú pôžičku využilo len $7 \%$ z nich, 17\% opýtaných vôbec o možnosti stabilizačnej pôžičky nevie. Študenti uvádzajú, 
že manažmenty by sa mali sústredit' hlavne na poskytnutie lepších pracovných podmienok, ktoré označilo 81 respondentov; na ponuku lepšieho mzdového ohodnotenia, ktoré označilo $80 \%$ respondentov a $68 \%$ respondentov by privítalo lepšie materiálno-technické vybavenie pracovísk. $16 \%$ študentov sa vyjadrilo, že na ovplyvnenie stabilizácie sestier sú nevyhnutné aj zmeny v zákonníku práce. Na otvorenú otázku : „Aké zmeny v Zákonníku práce by ovplyvnili podl'a ich názoru proces stabilizácie sestier", odpovedalo 11 študentov. Najčastejšie odpovede sa týkali:

- dodržiavania personálnych normatívov,

- fixných hodín nadčasov,

- vyššej fixnej minimálnej mzdy,

- preplácania nadčasov.

$45 \%$ respondentov si myslí, že návrhy na stabilizáciu sestier skôr prilákajú viac absolventov SŠ, ktorí by mali záujem o štúdium ošetrovatel'stva, pričom $11 \%$ je o tom rozhodne presvedčených. Pri otázke aké kroky by mali urobit' vzdelávacie inštitúcie na podporu stabilizácie sa $83 \%$ respondentov vyjadrilo, že by privítali lepšie podmienky pre praktickú výučbu v nemocniciach a 78\% respondentov by privítalo monitoring ich spokojnosti a názorov v súvislosti s praktickou výučbou. SKSaPA vo svojej správe (2021) uvádza Health Care Institute o.p.s. realizoval od septembra do decembra 2020 medzinárodný prieskum „Barometer medzi sestrami“ do ktorého sa zapojili študenti stredných, vyšších a vysokých škôl, ktoré vzdelávajú sestry (spolu 1080 respondentov na Slovensku). Väčšina študentov ešte počas štúdia na Slovensku (76\%) plánuje zostat' pracovat' doma. Čo sa mení absolvovaním štúdia. Najviac nám migrujú absolventi do Českej republiky, napr. u Českých študentov je to Nemecko. Študenti považujú istotu a stabilitu práce za rozhodujúci faktor, kde budú v budúcnosti vykonávat' odbornú prax. Nevyhovujúce finančné ohodnotenie je najdôležitejší faktor, ktorý bol dôvodom k odmietnutiu pracovnej ponuky. Predstava študentov o výške mzdy na Slovensku je v rozmedzí 1150 - $1550 €$ (tj. mzda absolventa v hrubom: bez nadčasov, služieb, príplatkov), dnes predstavuje mzda väčšiny sestier a to aj 30 a viac ročnou praxou výšku $971 €$ v hrubom. 32 \% študentov na Slovensku, ktorí majú v pláne po ukončení štúdia odíst' do zahraničia, uvádzajú ako dôvody najmä lepšie platové podmienky. Okrem finančného ohodnotenia študenti vnímali za negatívne faktory pri rozhodovaní sa, či vstúpit', alebo nevstúpit' do praxe po ukončení štúdia zlé medzil’udské vzt'ahy na pracoviskách, vykonávanie práce, ktoré nezodpovedá vzdelaniu a študijnému odboru, absencia možnosti kariérneho a platového postupu, nevyhovujúca pracovná doba. V roku 2020 absolvovalo podl'a údajov Centra vedecko - technických informácií SR štúdium ošetrovatel'stva v rámci vysokoškolského vzdelávania a vyššieho odborného vzdelávania spolu 692 študentov. SKSaPA registrovala necelých $56 \%$ absolventov. Názory a samotné rozhodnutia študentov počas štúdia sa po ukončení štúdia výrazne líšia a percento tých, čo nenastúpia do systému zdravotníctva na Slovensku prudko narastá. Najmladšia generácia je najviac ochotná a odhodlaná opustit' profesiu. Vo väčšine Európskych krajín je zámer opustit' profesiu silný v generácii sestier vo veku od 25 do 35 rokov. So zámermi mladých sestier opustit' povolanie súvisí niekol'ko faktorov, medzi ktoré patrí nerovnováha medzi snažením sa a odmenou, vysoká psychická zát'až a vyššie pracovné zat'aženie, čo všetko ovplyvňuje zámer mladých sestier rezignovat' na svoju ošetrovatel'skú kariéru.

\section{NÁVRHY A ODPORÚČANIA PRE PRAX}

$\mathrm{Na}$ základe prieskumu, ktorého ciel'om bolo zistit' názory študentov ošetrovatel'stva k problematike stabilizačných opatrení zdravotníckych pracovníkov v systéme Slovenského zdravotníctva, navrhujeme :

- Navýšit’ mzdové ohodnotenie sestier v rámci základnej mzdy a jej pohyblivých zložiek. 
- Zlepšit' pracovné podmienky sestier, adekvátne navýšit' počet sestier podl'a počtu pacientov.

- Zlepšit' materiálno-technické vybavenia pracovísk.

- Zlepšit' komunikáciu s výučbovými základňami.

- Zlepšit' monitoring spokojnosti študentov s praktickou výučbou, reagovat' na podnety a vzniknuté problémy v praktickej výučbe okamžite ich riešit'.

- Zlepšit' pracovné podmienky sestier v štátnych nemocniciach a minimalizovat' tak odchod sestier do zahraničia.

- Uzákonit' fixné hodiny nadčasov a preplácanie nadčasov pre sestry.

- Motivovat' sestry formou finančných i nefinančných benefitov ktoré im môže MZ SR poskytnút'

- Zvýšit' informovanost' študentov ošetrovatel'stva o stabilizačných pôžičkách a rezidentských programoch.

- Zvýšit' informovanost' verejnosti o navrhovaných a realizovaných stabilizačných opatreniach v systéme.

- Zatraktívnit' povolanie sestry na Slovensku cez marketingové kampane, prilákat' tak vyšší počet absolventov do Slovenských nemocníc a zabezpečit’ tak vyššiu kvalitu poskytovanej zdravotnej starostlivosti v Slovenských nemocniciach.

\section{ZÁVER}

Situácia v zdravotníctve vyžaduje prehodnotit' a zamysliet' sa nad tým, ako d'alej postupovat' v prioritách zdravotnej politiky, najmä v zabezpečení dostupnej a zároveň kvalitnej zdravotnej starostlivosti pre všetkých občanov. Zdroje financií nestačia pokryt' nároky na zdravotnú starostlivost', chýbajú prostriedky na modernizáciu nemocníc, obmedzená je aj dostupnost' liekov a zdravotníckych pomôcok. Vel'kým problémom je nedostatok zdravotníckych pracovníkov, ich chýbajúca motivácia a nízke finančné ohodnotenie, čo má dopad na kvalitu poskytovanej starostlivosti. To môže viest' $k$ nespokojnosti pacientov a k iným negatívnym javom ako ohrozenie bezpečnosti pacienta, nízka dôveryhodnost' k zdravotníckym zariadeniam zo strany verejnosti. Takýto stav je v zdravotníctve dlhodobo neudržatel'ný a zdravotnícki manažéri sú zodpovední za riešenie ako nájst' prostriedky na zabezpečenie kvalitnej zdravotnej starostlivosti, prehodnotenie možností získania potrebných zdrojov,s ciel'om stabilizovat' a navrátit' spät' chýbajúce l'udské zdroje do zdravotnického systému (Eliašová, Hadašová, Fedurcová, 2020).

\section{Použitá literatura}

1. BOSÁKOVÁ,L. Sestry a nadčasy. In Sestra. Roč. 5, č.3-4. ISSN 1335-9444.

2. DIMUNOVÁ, L. a kol. Pracovná zát’až v profesii sestry, Praha:Powerprint, 2018. 75 s. ISBN 978-80-7568-097-6.

3. FARKAŠOVÁ, D. Zmeny v ošetrovatel'stve vo vztahu k psychickému zdraviu sestier. In: Revue ošetrovatel'stva a laboratórnych metodík.. 2001. Roč. 8, č. 3, ISSN 13355090.

4. ELIAŠOVÁ, A., HADAŠOVÁ, L., FEDURCOVÁ, I. Vybrané kapitoly zo zdravotnického manažmentu. Prešov: Vydavatel'stvo Prešovskej univerzity. 2017.164 s. ISBN 978-80-555-1823-7.

5. GONDÁROVÁ-VYHNIČKOVÁ, H. Situácia je katastrofálna a t’ahá sa už niekol'ko rokov. In: Zdravotnícke noviny: jediný odborný týždenník pre lekárov a farmaceutov na Slovensku. Bratislava: MAFRA Slovakia, 2019, č. 25, s. 1-4. ISSN 1335-4477.

6. GULÁŠOVÁ, I. Spokojnost' s prácou sestier. In: Revue ošetrovatel'stva a laboratórnych metodík.2001. Roč. 8, č. 4, ISSN 1335-5090. 
7. HITKA, M. et al. Rozvoj l'udských zdrojov II. 1. vyd. Zvolen: Vydavatel'stvo Technickej univerzity.2013. ISBN 978-80-228-2614-3.

8. VISOLAJSKÝ, P., 2018. Chýbajú tisíce lekárov a sestier. In: Zdravotnícke noviny. Bratislava: MAFRA Slovakia, 2018, č. 31, s.1,5, ISSN 1335-4477.

9. ZITKOVÁ, M. a kol. Vedení nových pracovníkù v ošetřovatelské praxi : pro staniční a vrchni sestry. Praha: Grada Publishing. 2015. 165 s. ISBN 978-80-2475-094-1.

10. Portál SKSaPA. Aj mladé sestry opúšt’ajú profesiu. [cit 2021-06-18] Dostupné z http://www.sksapa.sk

11. MINISTERSTVO FINANCIÍ SLOVENSKEJ REPUBLIKY, 2019. Revízia výdavkov na zdravotníctvo II, závěrečná správa [online]. Dostupné na: https://www.mfsr.sk/files/archiv/44/revizia_zdravotnictvo_2.pdf [cit. 2021-06-15]

12. MINISTERSTVO ZDRAVOTNÍCTVA SLOVENSKEJ REPUBLIKY, 2021. Rezidentské štúdium [online]. Dostupné na: https://www.health.gov.sk/?rezidenti [cit. 2021-03-15]

13. MINISTERSTVO ZDRAVOTNÍCTVA SLOVENSKEJ REPUBLIKY, 2021. Rezidentské štúdium - leták Sestra [online]. Dostupné na: https://www.health.gov. sk/Zdroje?/Sources/dokumenty/Rezidenti/RS-letak-Sestra.pdf_[cit. 2021-06-12]

\section{Kontaktné údaje}

PhDr.Lívia Hadašová, PhD.MBA

Prešovská univerzita v Prešove, Fakulta zdravotnických odborov

Partizánska 1

08001 Prešov

Tel: 00421517562461

Email: livia.hadasova@unipo.sk 


\title{
INSTAGRAM A REKLAMA SKRYTÁ V DOPORUČENÍ
}

\author{
INSTAGRAM AND ADVERTISING HIDDEN IN \\ RECOMMENDATIONS
}

\author{
Lucie Kubíčková
}

\begin{abstract}
Abstrakt
Tento článek se zabývá skrytou reklamou v prostředí sociální sítě Instagram. Sociální sít' Instagram totiž umožnila nový způsob komunikace reklamních sdělení formou osobních doporučení prostřednictvím influencerů. Tento způsob propagace produktů a služeb však nepřináší jen pozitiva, a proto se teoretická část článku zaměřuje jak na klady, tak na zápory influencer marketingu a představuje tento nový druh reklamy. Cúlem tohoto článku nicméně je pomocí diskursivní analýzy ukázat odlišnost v pojetí správnosti označovat reklamní fotografie dvou skupin uživatelů sociální sítě Instagram, tedy influencerů i běžných uživatelů, a odborníků zabývajících se influencer marketingem. Předpokladem tohoto článku totiž je, že v současnosti existuje nesoulad uvedených diskursů v názorech na správnost označovat skrytě propagující fotografie na této sociální síti jako reklamní žánr.
\end{abstract}

Klíčová slova: Instagram, reklamni fotografie, osobni doporučení, influencer marketing, regulace reklamy, klady a zápory influencer marketingu, diskursivní analýza, influenceři, běžni uživatelé, odbornici, Lev Manovich

\begin{abstract}
This article deals with hidden advertising in the Instagram social network environment. The Instagram social network has enabled a new way of communicating advertising messages in the form of personal recommendations via influencers. However, this way of promoting products and services does not bring only positives, and therefore the theoretical part of the article focuses on both the pros and cons of influencer marketing and introduces this new type of advertising. However, the aim of this article is to use discursive analysis to show the difference in the concept of accuracy to tag advertising photos of two groups of users of the Instagram social network, i.e. influencers and regular users, and experts dealing with influencer marketing. The assumption of this article is that there is currently a disagreement in the discourses, which lies in opinions on the accuracy of tagging photographs with hidden advertising as an advertising genre on this social network.
\end{abstract}

Keywords: Instagram, advertising photography, personal recommendations, influencer marketing, advertising regulation, pros and cons of influencer marketing, discursive analysis, influencers, regular users, experts, Lev Manovich

\section{1 ÚVOD}

V tomto článku se budu zabývat sociální sítí Instagram a skrytou reklamou na této sociální síti. Sociální sít' Instagram totiž umožnila zcela nový způsob komunikace reklamních sdělení formou osobních doporučení skrze influencery. Tato doporučení však mají stejně jako klasická reklama za cíl prodat výrobek nebo nějakou službu. Cílem teoretické části předloženého článku proto bude nejen postihnout zásadní skutečnosti týkající se tohoto fenoménu, ale také představit klady a zápory influencer marketingu na sociální síti Instagram. Př́nosem tohoto článku nicméně bude také vlastní kvalitativní výzkum založený na výzkumné metodě diskursivní analýzy, jehož cílem bude představit odlišnost v pojetí 
správnosti označovat reklamní fotografie dvou skupin uživatelů uvedené sociální sítě, konkrétně influencerů a běžných uživatelů, a odborníků zabývajících se problematikou influencer marketingu. Předpokladem článku totiž je, že v současné době dochází k nesouladu zmíněných diskursů $\mathrm{v}$ názorech na správnost označovat skrytě propagující fotografie na Instagramu jako reklamní žánr.

\section{INSTAGRAM}

Instagram je nejpoužívanější sociální platforma pro sdílení fotografií, která byla zprovozněna 6. ř́jina 2010. Jejími zakladateli jsou Kevin Systrom a Mike Krieger, kteří však již společnost Instagram opustili. ${ }^{1}$ Ačkoliv sociální sít’ Instagram ze začátku fungovala jako výhradní aplikace pro majitele zařízení iOS, do prosince roku 2010 si na Instagramu založilo účet milion uživatelů. ${ }^{2} \mathrm{~V}$ červenci roku 2015 sociální sít' Instagram používalo již 300 milionů aktivních uživatelů, jež, jak je uvedeno v knize Influencer Marketing For Dummies ${ }^{3}$, , sdíleli 30 miliard fotografií a generovali prüměrně 70 milionů fotografií denně. “4

Od roku 2012 mohou sociální sít' Instagram používat i uživatelé s operačním systémem Android a v témže roce tuto sociální sít' také koupila společnost Facebook za jednu miliardu dolarů. ${ }^{5}$ Následujícího roku pak Instagram umožnil sdílení videí a zavedl možnost zasílaní tzv. „přímých zpráv“ (Direct Messages). Roku 2015 Instagram dále rozšířil formáty fotografií a zavedl službu Boomerang ${ }^{6}$. Doposud tedy bylo možné na této sociální síti sdílet fotografie pouze v klasickém čtvercovém formátu. $\mathrm{O}$ rok později přichází Instagram s novým algoritmem pro zobrazování př́spěvků a dostává nový vzhled. Přelomové je v tomto roce zejména představení služby tzv. „příběhư“ (Stories), které za 24 hodin zmizí a možnosti živého vysílání. Instagram Stories jsou pak roku 2017 vylepšeny o možnost přidání lokace, hashtagů a AR efektů. Roku 2018 Instagram zavádí IGTV, tedy možnost sdílet v aplikaci dlouhá videa a do př́běhů umožňuje přidat hudbu. Následujícího roku přichází Instagram konečně s „nakupováním“, jak sám uvedl, „novým způsobem nakupování a koupě svých oblibených produktů, aniž byste opustili aplikaci. "T V prosinci téhož roku představuje Instagram dále nové nástroje proti šikaně a pokračuje v zaměření se na zdraví. Roku 2020 pak Instagram spouští Reels, tedy dle této společnosti ,,nový zpi̊sob vytváření, sdílení a sledování zábavného obsahu vašich oblibených tvưrcư. "8 Sociální sít' Instagram tedy, jak je patrné z výše uvedeného přehledu a jak sám uvádí i Lev Manovich, „je použivána stovkami různých způsobů stovkami milionů uživatelü, takže jakákoli odpověd” na otázku ,co je to “ je nedostatečná. “9

\footnotetext{
${ }^{1}$ Zakladatelé Instagramu opouštějí sít'. Plánují zřejmě nový projekt. IDnes.cz [online]. MAFRA, c1999-2021, 25. záŕí 2018 [cit. 2021-6-18]. Dostupné z: https://www.idnes.cz/technet/kratke-zpravy/instagram-facebookzakladatele-odchod-socialni-site.A180925_094800_tec-kratke-zpravy_hege

2 PRODUCT EVOLUTION: Celebrating 10 years of Instagram. About Instagram [online]. [cit. 2021-6-18]. Dostupné z: https://about.instagram.com/about-us/instagram-product-evolution

${ }^{3}$ SAMMIS, Kristy, Cat LINCOLN, Stefania POMPONI, Jenny NG, Edita GASSMANN RODRIGUEZ a Judy ZHOU. Influencer marketing for dummies. Hoboken, NJ: Wiley, 2016. --For dummies. ISBN 1119114098.

${ }^{4}$ Tamtéž, str. 89.

${ }^{5}$ Instagram je tu deset let. Slaví funkcí, která může někoho zarazit. IDnes.cz [online]. MAFRA, c1999-2021, 6. ř́ijna 2020 [cit. 2021-6-18]. Dostupné z: https:/www.idnes.cz/technet/internet/instagram-socialni-sit-vyrocizebricek.A201006_090253_sw_internet_vse

${ }^{6}$ Boomerang je aplikace od společnosti Instagram umožňující vytvářet poutavá mini videa, ve kterých se pohyb odehrává ve smyčce tam a zpět, a sdílet následně tyto videa s přáteli. In: App Store Preview: Boomerang from Instagram. App Store [online]. c2021 [cit. 2021-6-18]. Dostupné z: https://apps.apple.com/us/app/boomerangfrom-instagram/id1041596399

7 PRODUCT EVOLUTION: Celebrating 10 years of Instagram. About Instagram [online]. [cit. 2021-6-18]. Dostupné z: https://about.instagram.com/about-us/instagram-product-evolution

${ }^{8}$ Tamtéž.

9 MANOVICH, Lev. Instagram and Contemporary Image [online]. 2017 [cit. 2021-05-01]. Dostupné z: http://manovich.net/index.php/projects/instagram-and-contemporary-image, str. 11.
} 
Nicméně lze uvažovat nad tím, co znamená Instagram v kontextu historie médií. Touto otázkou se zabýval Manovich ve své knize Instagram and Contemporary Image ${ }^{10}$ vydané roku 2017. Podle něj se totiž „,různé prvky fotokultury, jež byly v průběhu 19. a 20. století samostatné, spojily nyní do jednoduché platformy. "11 Tento jev se dle Manoviche odehrál rovněž s hudbou, videem či psaním prostřednictvím aplikací SoundCloud ${ }^{12}$, YouTube a Medium $^{13}$. Podle něj tedy nyní ,fotoaparát, fotopapír, temná komora, výstavní prostory, jako jsou galerie, a publikační mista, jako jsou časopisy, existuji společně vjednom ručním zařizení. "14 Manovich považuje tato média spojená do jedné platformy za mimořádný vývoj v historii moderních médií. Instagram totiž dává uživatelům možnost, jak zachytit, upravit a publikovat fotografie, tak si prohlížet fotografie přátel či nalézat další fotografie skrze vyhledávání a interagovat s nimi prostřednictvím lajkování, komentování, přeposílání či zveřejňování na dalších sociálních sítích. Instagram svým uživatelům nicméně umožňuje i řadu dalších funkcí, od konverzování s autory fotografií či ostatními uživateli po tvoření sbírek fotografií a přeskupování jednotlivých snímků, a to vše díky jedinému zařízení. Dle Manoviche tak Instagram , ilustruje novou éru mobilni fotografie. “'

Podle spoluzakladatele Instagramu Kevina Systroma je totiž sociální sít' Instagram především „o vytvář́ní fotografii na cestách, ve skutečném světě, v reálném čase. "16 Doposud není ani možné na tuto sociální sít' nahrávat fotografie z počítače. ${ }^{17}$

\section{INSTAGRAM A REKLAMA}

Sociální sít' Instagram je dle knihy Influencer marketing for dummies ${ }^{18}$ navíc ideální vizuální platformou „pro vyprávění př́běhu značky a predstavení vašeho produktu nebo služby prostřednictvím úchvatných snímků. "19 Výhoda této sociální sítě tkví v tom, že může být použita samostatně jako prostředek vizuálního vyprávění. Obsah reklamních sdělení se tedy může vyskytovat pouze na sociální síti Instagram, aniž by musel být vázán pro další kontext na jinou sociální sít'. Firmy k marketingové komunikaci svých produktů či služeb na Instagramu využívají navíc jak firemních účtů, tak osob influencerů. Influenceři na Instagramu pak nesdílejí jen krásné fotografie, intimní medailónky ze svého života či selfie fotografie, ale také produkty, které mají rádi a za jejichž sdílení mnohdy dostanou zaplaceno. Nicméně nejlepší př́spěvky na Instagramu zobrazují snímky každodenního života či aspiračního životního stylu za využití chytré kompozice, zkušené úpravy fotografií či pečlivě sestaveného tematického obsahu. ${ }^{20}$

\footnotetext{
10 MANOVICH, Lev. Instagram and Contemporary Image [online]. 2017 [cit. 2021-05-01]. Dostupné z: http://manovich.net/index.php/projects/instagram-and-contemporary-image

${ }^{11}$ Tamtéž, str. 11.

12 SoundCloud je největší platforma pro streamování hudby a zvuku na světě. In: App Store Preview: SoundCloud - Music \& Songs. App Store [online]. c2021 [cit. 2021-6-18]. Dostupné z: https://apps.apple.co $\mathrm{m} / \mathrm{us} / \mathrm{app} /$ soundcloud-music-audio/id336353151

${ }^{13}$ Medium je otevřená platforma, kam 170 milionů čtenářů přichází najít hluboké a dynamické myšlení. In: App Store Preview: Medium. App Store [online]. c2021 [cit. 2021-6-18]. Dostupné z: https://apps.apple.com /us/app/medium/id828256236

14 MANOVICH, Lev. Instagram and Contemporary Image [online]. 2017 [cit. 2021-05-01]. Dostupné z: http://manovich.net/index.php/projects/instagram-and-contemporary-image, str. 11.

15 Tamtéž.

${ }^{16}$ Tamtéž, str. 12.

17 Tamtéž.

${ }^{18}$ SAMMIS, Kristy, Cat LINCOLN, Stefania POMPONI, Jenny NG, Edita GASSMANN RODRIGUEZ a Judy ZHOU. Influencer marketing for dummies. Hoboken, NJ: Wiley, 2016. --For dummies. ISBN 1119114098.

19 Tamtéž, str. 89.

${ }^{20}$ SAMMIS, Kristy, Cat LINCOLN, Stefania POMPONI, Jenny NG, Edita GASSMANN RODRIGUEZ a Judy ZHOU. Influencer marketing for dummies. Hoboken, NJ: Wiley, 2016. --For dummies, str. 89.
} 


\subsection{Reklama na Instagramu v číslech}

Sociální sít' Instagram představuje lákavý marketingový nástroj dle Terezy Semerádové a Petra Weinlicha nejen díky její výše popsané výhodě, ale také zejména zásluhou jejího „přvevážně estetického aspektu a snadnosti používání. “21 O stoupající popularitě používání sociální sítě Instagram pro marketingové účely svědčí i vzestup počtu firem o 48,8 \%, jež začaly tuto sociální sít' v roce 2017 nově využívat. Tento prudký nárůst společností využívajících Instagram pro své marketingové účely ovlivnilo také rozběhnutí firemních profilů (Instagram Business profiles) či nové reklamní platformy, na kterou jsou reklamy nahrávány skrze Facebook. ${ }^{22}$

Do konce roku 2017 si na této sociální síti vytvořilo účet dokonce více než 8 milionů firem. Co se týče sledování těchto firemních profilů, tak dle oficiálních statistik má ve svém seznamu sledovaných alespoň jeden firemní profil $80 \%$ běžných uživatelů. $\mathrm{O}$ tom, že se firmám na Instagramu skutečně vyplácí působit, vypovídají i další statistiky, dle kterých v březnu roku 2017 interagovalo přes 120 milionů uživatelů skrze sociální sít' Instagram s nějakou firmou a $30 \%$ běžných uživatelů si poté dokonce koupilo nějaký produkt, jenž na Instagramu nalezli. $^{23}$

Výhodou vytvoření si firemního profilu na sociální síti Instagram pro společnosti je pak právě možnost jednoduchého sledování jejich úspěšnosti pomocí detailních analytických nástrojů, které umožňují dle Semerádové a Weinlicha zejména ,vyhodnotit úspěšnost sdillených přispěvků, zjistit počet zobrazení, demografické údaje a dalši metriky. “24

Jedním z takových analytických a optimalizačních nástrojů jsou pro společnosti na Instagramu i hashtagy. Jak je uvedeno v knize Marketing na Facebooku a Instagramu, „, hashtagy jsou klícová slova umožňujíci uživateliom třídit a kategorizovat obsah. "26 Dle statistik z přelomu roku 2017/2018 se vztahovalo dokonce 7 z 10 sdílených hashtagů na sociální síti Instagram ke značkovému obsahu. Dle Semerádové a Weinlicha hashtagy totiž „,napomáhaji budovat vztah se značkou či firmou. “27 Navíc příspěvky s alespoň jedním hashtagem dosahují téměř o $13 \%$ více reakcí než př́íspěvky bez těchto klíčových slov. Hashtagů lze však na sociální síti Instagram nyní napsat maximálně 30. Nicméně dle statistik marketingových agentur je optimální pod př́íspěvky na Instagramu uvádět zhruba do deseti hashtagů. Některé společnosti také používají př́mo firemní nebo značkové (branded) hashtagy. Ty jsou dle Semerádové a Weinlicha ,,specifické pro danou firmu či kampaň. Může se jednat o jméno firmy či o motto s ní spojované. “28

Firmy na sociální síti Instagram však nevyužívají pouze možnosti propagace pomocí fotografických příspěvků, ale i videí, která mohou být od roku 2016 sdílena ve formě tzv. Stories. Dle knihy Marketing na Facebooku a Instagramu ${ }^{29}$ dokonce ,více než $25 \%$ instagramových reklam tvoři videospoty. “30 Reklama na Instagramu tvoří tedy značnou část jeho obsahu. Dle statistik narostl dokonce v druhé polovině roku 2017 počet reklam na této

\footnotetext{
21 SEMERÁDOVÁ, Tereza a Petr WEINLICH. Marketing na Facebooku a Instagramu: využijte naplno organický dosah i sponzorované přispěvky. Brno: Computer Press, 2019, str. 106.

${ }^{22}$ Tamtéž.

${ }^{23}$ Tamtéž.

${ }^{24}$ Tamtéž.

25 SEMERÁDOVÁ, Tereza a Petr WEINLICH. Marketing na Facebooku a Instagramu: využijte naplno organický dosah i sponzorované příspěvky. Brno: Computer Press, 2019. ISBN 9788025149591.

${ }^{26}$ Tamtéž, str. 106.

${ }^{27}$ Tamtéž.

${ }^{28}$ Tamtéž

29 SEMERÁDOVÁ, Tereza a Petr WEINLICH. Marketing na Facebooku a Instagramu: využijte naplno organický dosah i sponzorované přispěvky. Brno: Computer Press, 2019. ISBN 9788025149591.

30 Tamtéž, str. 106.
} 
sociální síti o $28 \%$. Konkrétně se v prosinci roku 2017 na Instagramu vyskytovalo 171000 aktivních propagací. $^{31}$

\subsection{Firemní účet na sociální síti Instagram}

Vytvoření firemního profilu na sociální síti Instagram je tedy jednou z cest, jak na Instagramu společnosti mohou zveřejňovat reklamu. Firmy této možnosti využívají zejména za účelem propagace svých produktů, služeb či značky samotné. Dle oficiálních statistik společnosti Instagram totiž v současné době použivá na celém světě tuto sociální sít' každý den přes 1 miliardu uživatelů. Nějaký firemní profil přitom nyní sleduje již $90 \%{ }^{32}$ uživatelů. Dalších 84 \% uživatelů má přímo zájem na sociální síti Instagram nalézat nové výrobky. Co se týče návštěv firemních účtů, tak 2 ze 3 návštěv nicméně provedou uživatelé, kteří vybraný firemní profil ještě nesledují. ${ }^{33}$

Firemní profil lze na Instagramu vytvořit snadno a jeho vytvoření je bezplatné. Nutností k založení firemního účtu na této sociální síti však zde je vlastnění osobního účtu. Firemní účet si uživatel Instagramu totiž vytvoří tak, že převede v nastavení aplikace osobní profil na firemní, což uživateli následně umožní dle knihy Marketing na Facebooku a Instagramu ${ }^{34}$ „přístup k pokročilým analytickým nástrojưm. “35 Uživatel nicméně musí taktéž v nastavení profilu přenastavit profil na veřejný a propojit ho se svou facebookovou stránkou. ${ }^{36}$ Po splnění všech předepsaných náležitostí může na sebe uživatel uvést kontaktní údaje, prohlížet si přehledy vztahující se k příspěvkům, příběhům či sledujícím a také dle stránky Instagram for Business , propagovat svoje príspěvky, aby oslovil víc lidí. “37

\subsection{Reklama pomocí influencerů}

Druhou z možností volby propagace, jež mají společnosti na sociální síti Instagram, je takzvaný influencer marketing. Tím jsem se již zabývala v předchozích dvou článcích nazvaných Vývoj reklamni fotografie na sociální síti Instagram: Zdánlivé mizeni žánru reklamni fotografie a Influencer marketing na sociální síti Instagram: Diskursivní analýza marketingových príruček ${ }^{39}$ a které bych tak chtěla doplnit. Jak už bylo představeno ve výše uvedených článcích, dle Duncana Browna a Nicka Hayese je „marketing prostřednictvím influencerů o umožnění influencerům mluvit o společnostech s potenciálními zákazníky. “"40 Influencer marketing má tedy spojitost s Word of Mouth marketingem. Word of Mouth (WOM) totiž spočívá především $\mathrm{v}$ tom, aby lidé mluvili pozitivně o dané věci. ${ }^{41}$ Tím na

\footnotetext{
31 Tamtéž.

32 Počet uživatelů na Instagramu sledujících nějaký firemní profil se tak dle původních statistik z knihy Marketing na Facebooku a Instagramu vydané roku 2019 zvýšil o 10 \%.

${ }_{33}$ Začínáme se službou Instagram for Business. Instagram for Business [online]. c2021 [cit. 2021-6-18]. Dostupné z: https://business.instagram.com/getting-started?locale=cs_CZ

34 SEMERÁDOVÁ, Tereza a Petr WEINLICH. Marketing na Facebooku a Instagramu: využijte naplno organický dosah i sponzorované př́spěvky. Brno: Computer Press, 2019. ISBN 9788025149591.

${ }^{35}$ Tamtéž, str. 107.

${ }^{36}$ Tamtéž.

37 Začínáme se službou Instagram for Business. Instagram for Business [online]. c2021 [cit. 2021-6-18]. Dostupné z: https://business.instagram.com/getting-started?locale=cs_CZ

${ }^{38}$ KUBÍČKOVÁ, Lucie. Vývoj reklamní fotografie na sociální síti Instagram: Zdánlivé mizení žánru reklamní fotografie. In: QUAERE 2019: Recenzovaný sborník př́spěvků interdisciplinární mezinárodní vědecké konference doktorandi̊ a odborných asistentů. Hradec Králové: Magnanimitas, 2019, s. 94-109. ISBN 978-8087952-30-6.

${ }^{39}$ KUBÍČKOVÁ, Lucie. Influencer marketing na sociální síti Instagram: Diskursivní analýza marketingových př́ruček. In: QUAERE 2020: Recenzovaný sborník přispěvkỉ interdisciplinární mezinárodní vědecké konference doktorandů a odborných asistentů. Hradec Králové: Magnanimitas, 2020, s. 70-83. ISBN 978-80-87952-32-0.

${ }^{40}$ DUNCAN BROWN AND NICK HAYES. Influencer marketing: who really influences your customers?. Amsterdam: Elsevier/Butterworth-Heinemann, 2008, str. 121. Vlastní překlad.

${ }^{41}$ Tamtéž.
} 
Instagramu dochází k efektu „skryté reklamy“, jelikož běžní uživatelé nevnímají elektronická doporučení $(\mathrm{eWOM})^{42} \mathrm{v}$ prostředí sociálních sítí jako reklamu.

Marketing prostřednictvím influencerů je tedy o vkládání sdělení o společnostech do jejich marketingu. Dle Browna a Hayese je tak zejména jeho cílem ,zvyšování povédomí a znalostí o firmě v rámci komunity potenciálních zákazníků. “43 Jako takový se může influencer marketing odehrávat na jakékoliv sociální platformě, jelikož dle Joa Sinkwitze „,jakákoli komunita nebo skupina, kde má člověk potenciální publikum, je technicky mistem, kde lze najit potenciální influencery. “44 Každá sociální sít’ však funguje odlišně. V tomto článku se proto soustředím pouze na fungování influencer marketingu na sociální síti Instagram.

Co se týče influencer marketingu na sociální síti Instagram, tak zde existuje široká škála influencerů. Sociální vliv se totiž netýká jen věkové skupiny „young adults“ (tzv. mladých dospělých). Podle výzkumu společnosti comScore ${ }^{45}$ dokonce velké množství uživatelů odpovídá věkové hranici 30 až 40 let. Tito vlivní jedinci využívají sociální sít' Instagram pro svou sebeprezentaci, ale také placenou propagaci různých firem. Nicméně velký počet influencerů použivá také dle výzkumu společnosti Orbit Media sociální platformy, obzvláště pak zmíněný Instagram, jako prostředek k přilákání pozornosti uživatelů na svůj blog. ${ }^{46}$ Dle Joa Sinkwitze však ,, spárování sociálních sití s recenzemi je výherní kombinace pro ovlivnění vašeho koncového zákazníka. "“7

Vzhledem k rozrůstajícímu se počtu placených propagací různých společností na této sociální síti vznikají zde již mechanismy pro označování reklamy. Influenceři jich však stále mnohdy nevyužívají, anebo placené propagace označují nedostatečným způsobem. V následující kapitole se proto zaměřím na možnosti regulace reklamy na sociální síti Instagram.

\section{INSTAGRAM A REGULACE REKLAMY}

V této kapitole se budu zabývat značkovým obsahem na sociální síti Instagram a jeho označováním. Dle stránky Instagram for Business ,značkový obsah umožňuje značkám najít nové zákazniky, budovat zájem a zvyšovat vliv firmy v mistě, kde se střetává kultura a inzerce. "48 Nicméně i na sociální síti Instagram by měla být reklama řádně označená a podléhat pravidlům regulace reklamy. Jak je také napsáno na výše uvedené stránce, tak na Instagramu ,firmy chtěji sdilet príběh své značky ve spolupráci s tvůrci a vytváret tak autentický, působivý a presvědčivý obsah, který jim prinese lepši obchodní výsledky. “"49 Mnohdy zde však tito tvưrci zapomínají značkový obsah označovat, nebo je jejich reklama $\mathrm{v}$ rozporu se zákony.

Při tvorbě příspěvků se značkovým obsahem na sociální síti Instagram by totiž influenceři měli brát v potaz několik předpisů, jež upravují, jak by reklama měla vypadat. Těmito závaznými předpisy jsou jednak Kodex reklamy, zákon o regulaci reklamy a zákon o ochraně spotřebitele. ${ }^{50}$ Výše dva uvedené zákony se mimo jiné zabývají i klamavými obchodními

\footnotetext{
${ }^{42}$ Electronic word-of-mouth komunikace.

${ }^{43}$ DUNCAN BROWN AND NICK HAYES. Influencer marketing: who really influences your customers?. Amsterdam: Elsevier/Butterworth-Heinemann, 2008, str. 122-123. Vlastní překlad.

${ }^{44}$ SINKWITZ, Joe. The Ultimate Guide To Using Influencer Marketing. Independently Published, 2018, str. 7. Vlastní překlad.

${ }^{45}$ ComScore je americká společnost pro měření a analýzu médií.

${ }^{46}$ SINKWITZ, Joe. The Ultimate Guide To Using Influencer Marketing. Independently Published, 2018 , str. 7.

${ }^{47}$ Tamtéž.

48 Instagram Business: Značkový obsah. Instagram for Business [online]. c2021 [cit. 2021-6-19]. Dostupné z: https://business.instagram.com/a/branded-content-ads?locale=cs_CZ

${ }^{49}$ Tamtéž.

${ }^{50}$ Označování placeného partnerství: Je označování placeného partnerství povinnost? Dost bylo mýtů, ted’ přijde zákon! Václav Blahout [online]. c2010-2019, 14. 1. 2019 [cit. 2021-6-19]. Dostupné z: https://blahout.com/jeoznacovani-placeneho-partnerstvi/
} 
praktikami, kam patří i sponzorovaný obsah na sociální síti Instagram, který influencer řádně neoznačí a snaží se, aby působil dojmem, že si danou věc či službu sám zakoupil. ${ }^{51}$

Co se týče zákona o regulaci reklamy č. 40/1995 Sb., tak ten rovněž upravuje pravidla pro reklamu na tabákové výrobky, elektronické cigarety, alkoholické nápoje, humánní léčivé př́pravky či potraviny a kojeneckou výživu, hazardní hry nebo střelné zbraně a střelivo. Z tohoto zákona např́íklad jasně vyplývá, že je reklama na elektronické cigarety zakázána a reklama na alkoholické nápoje nesmí cílit na osoby mladší 18 let, nebo prohlašovat, že alkohol obsažený v nápoji vykazuje léčebné účinky. ${ }^{52}$ Nicméně přesto na sociální síti Instagram nalezneme mnoho př́padů, které tento zákon nějakým způsobem porušují.

Tyto prrípady porušující výše uvedené zákony můžeme jednoduše nalézt např́klad na instagramovém účtu Svět influencerů, který sdružuje prríspěvky, v nichž se influenceři dopustili nějakého přestupku. Jedním z příspěvků porušujících zákon o regulaci reklamy byl kupříkladu ten Andrey Verešové, ve kterém zmíněná influencerka proklamovala, že tequilla má léčivé vlastnosti. Verešová $\mathrm{v}$ daném příspěvku konkrétně uvedla, že „,tequilla léčí vysoký krevní tlak, cukrovku, osteoporózu, zrychluje metabolismus, a dokonce se po ní hubne “53 Vzhledem ke kritice uvedeného př́íspěvku ho však záhy smazala. Na sociální síti Instagram můžeme nicméně nalézt i mnoho příspěvků propagujících elektronické cigarety, ačkoliv reklama na ně je dle zákona o regulaci reklamy zakázána. ${ }^{54}$

Sociální sít' Instagram však již na porušování zmíněných zákonů začala reagovat. Jak jsem již uvedla v článku nazvaném Vývoj reklamní fotografie na sociální síti Instagram: Zdánlivé mizení žánru reklamní fotografie, ${ }^{55}$ Instagram od roku 2017 influencerům umožňuje označit značkový obsah jako sponzorovaný. ${ }^{56}$ Pokud je tedy nahoře v př́spěvku nebo ve Stories uvedeno „Placené partnerství s“, vyjadřuje to dle Centra nápovědy pro Instagram, že „,člověk, který príspěvek sdílel, má s uvedeným obchodním partnerem obchodní vztah, a že daný př́spěvek byl nějakým způsobem zaplacen. “57 Tímto označením navíc influencer poskytne značce přehled dosahů či interakcí u jednotlivých př́spěvkủ. ${ }^{58}$

Dle webové stránky Instagram for Business byla výše uvedená funkce na Instagramu konkrétně vytvořena, ,, aby bylo upozornění na značkový obsah konzistentni a jednoduché, bez ohledu na to, kde uživatelé tento obsah na Instagramu uvidí. "59 Reklamu influenceři mohou totiž již sdílet a označovat jak v kanálu příspěvků, Stories, Reels, tak živém vysílání. ${ }^{60}$

Společnost Facebook, pod kterou Instagram nyní spadá, nicméně vyjádřila zakázáním rovněž nesouhlas se sdílením značkového obsahu na tabákové produkty a výrobky s nimi spjaté, nebezpečné doplňky stravy, zbraně, dále produkty či služby výhradně pro dospělé, alkohol,

\footnotetext{
${ }^{51}$ Tamtéž.

52 Zákon č. 40/1995 Sb. Zákony pro lidi [online]. c2010-2021 [cit. 2021-6-19]. Dostupné z: https://www.zakon yprolidi.cz/cs/1995-40

${ }_{53}$ Spolupráce s influencery má pro značky svá úskalí. MediaGuru [online]. c2021, 20. srpna 2019 [cit. 2021-619]. Dostupné z: https://www.mediaguru.cz/clanky/2019/08/spoluprace-s-influencery-ma-pro-znacky-sva-uskali/ 54 Tamtéž.

55 KUBÍČKOVÁ, Lucie. Vývoj reklamní fotografie na sociální síti Instagram: Zdánlivé mizení žánru reklamní fotografie. In: QUAERE 2019: Recenzovaný sborník přspěvků interdisciplinární mezinárodní vědecké konference doktorandi̊ a odborných asistentů. Hradec Králové: Magnanimitas, 2019, s. 94-109. ISBN 978-8087952-30-6.

56 Tamtéž.

57 Centrum nápovědy: Co znamená, když je u př́spěvku na Instagramu uvedeno, že se jedná o placené partnerství? Instagram [online]. c2021 [cit. 2021-6-19]. Dostupné z: https://www.facebook.com/help/ins tagram/1199202110205564

${ }^{58}$ VALIÁNOVÁ, Nikola. 9 možností influencer marketingu: Druhy spolupráce s influencery. Blog.socialpark: Sledujeme dění v online světě a nenecháváme si pro sebe komentáre a hodnocení [online]. c2020, 16. 9. 2020 [cit. 2021-6-19]. Dostupné z: https://blog.socialpark.cz/2020/09/16/druhy-spoluprace-s-influencery/

${ }^{59}$ Instagram Business: Značkový obsah. Instagram for Business [online]. c2021 [cit. 2021-6-19]. Dostupné z: https://business.instagram.com/a/branded-content-ads?locale=cs_CZ

${ }^{60}$ Tamtéž.
} 
ale také výrobky či příspěvky, jež působí jako podvodné, zavádějící, klamavé či urážlivé a tak podobně. Úplný seznam zakázaných položek se nachází v Centru nápovědy pro firmy na Facebooku. $^{61}$

\section{KLADY A ZÁPORY INFLUENCER MARKETINGU}

Influencer marketing může být účinným nástrojem pro zvýšení zájmu zákazníků o značku, ale vzhledem k výše uvedeným protizákonným reklamám může značce v důsledku také uškodit. Př́kladů, kdy byla spolupráce firmy s nějakým influencerem pro ni spíše na škodu, existuje totiž několik. Společnosti by si proto měly influencery vybírat velmi pečlivě a brát v potaz nejen jejich počet sledujících, ale dle Vladana Crhy, jednatele firmy AMI Digital s.r.o., také „,jejich kvalitu, styl komunikace, osobnost $i$ to, jak k př́slušné značce sedí. “62 Š Špatně zvolená spolupráce může nicméně poškodit rovněž samotného influencera. Influenceři by se tak dle Vladana Crhy ,,měli vyhýbat projektưm, které jsou pro ně nepřirozené “63 a nenavazovat př́liš mnoho spoluprací, jelikož si tím mohou u svých sledujících ubrat na důvěryhodnosti. ${ }^{64}$

$\mathrm{V}$ případě vhodně zvolené spolupráce mohou firmy čerpat $\mathrm{z}$ výhod influencer marketingu. Podle výzkumu nazvaného The impact of influencers from Instagram and YouTube on their followers ${ }^{65}$ zabývajícího se dopadem influencerů na své sledující bylo totiž zjištěno, že lidé dávají přednost recenzím produkti̊ před reklamou. ${ }^{66}$ Navíc z dalšího výzkumu nazvaného Social Butterflies: How Social Media Influencers are the New Celebrity Endorsement ${ }^{67}$ realizovaného Kayleigh Elizabeth Burke v roce 2017 ve Virginii v Americe pomocí dotazníků vyplynulo, že vnímání produktu je přímo determinováno tím, co influencer o produktu říká. ${ }^{6}$ Výše zmíněný výzkum uskutečněný autory Vaibhavi Nandagiri a Leena Philip dokonce také ukázal, že „práce influencera je pozitivní a že maji dopad na své sledující, jelikož sledující vidí, že influencer je důvěryhodným zdrojem, a proto jsou ochotni vyzkoušet recenzované a schválené produkty. “69

Influencer marketing je tedy v současnosti trendem v marketingu a stále více společností ho používá jako nástroj, protože jej dle výzkumu nazvaného The Dark Side of Influencer Marketing ${ }^{70}$ pokládají za „přesný a efektivní způsob marketingu. “" N1 Nicméně přes pozitiva

\footnotetext{
${ }^{61}$ Centrum nápovědy pro firmy: Zásady pro reklamy na nabídku. Facebook for Business [online]. c2021 [cit. 2021-6-19]. Dostupné z: https://www.facebook.com/business/help/358970040838616?id=404748470363829

${ }^{62}$ Spolupráce s influencery má pro značky svá úskalí. MediaGuru [online]. c2021, 20. srpna 2019 [cit. 2021-619]. Dostupné z: https:/www.mediaguru.cz/clanky/2019/08/spoluprace-s-influencery-ma-pro-znacky-sva-uskali/ ${ }^{63}$ Tamtéž.

${ }^{64}$ Tamtéž.

${ }^{65}$ NANDAGIRI, Vaibhavi a Leena PHILIP. Impact of influencers from Instagram and YouTube on their followers. International Journal of Multidisciplinary Research and Modern Education [online]. 2018, 4(1), 6165 [cit. 2021-6-1]. Dostupné z: http://doi.org/10.5281/zenodo.1207039

${ }^{66}$ Tamtéž.

${ }^{67}$ BURKE, Kayleigh Elizabeth. Social Butterflies: How Social Media Influencers are the New Celebrity Endorsement [online]. Blacksburg, Virginia, 2017 [cit. 2021-6-1]. Dostupné z: https://vtechworks. lib.vt.edu/bitstream/handle/10919/78221/Burke_KE_T_2017.pdf?sequence=1\&isAllowed=y. Masters Theses. Virginia Polytechnic Institute and State University.

${ }^{68}$ BURKE, Kayleigh Elizabeth. Social Butterflies: How Social Media Influencers are the New Celebrity Endorsement [online]. Blacksburg, Virginia, 2017 [cit. 2021-6-1]. Dostupné z: https://vtechwor ks.lib.vt.edu/bitstream/handle/10919/78221/Burke_KE_T_2017.pdf?sequence=1\&isAllowed=y. Masters Theses. Virginia Polytechnic Institute and State University.

${ }^{69}$ NANDAGIRI, Vaibhavi a Leena PHILIP. Impact of influencers from Instagram and YouTube on their followers. International Journal of Multidisciplinary Research and Modern Education [online]. 2018, 4(1), 6165 [cit. 2021-6-1]. Dostupné z: http://doi.org/10.5281/zenodo.1207039

70 ØDEGÅRD OLSEN, Camilla a Gina Marie SANDHOLMEN. The Dark Side of Influencer Marketing [online]. BI Oslo, 2019 [cit. 2021-6-5]. Dostupné z: https://biopen.bi.no/bi-xmlui/bitstream/ha ndle/11250/2622034/2287695.pdf?sequence=1. Master Thesis. BI Norwegian business school. Vedoucí práce Even Johan Lanseng.

${ }^{71}$ Tamtéž.
} 
influencer marketingu nelze opomíjet jeho nevýhody. Výše uvedený výzkum se proto zabývá nevýhodami influencer marketingu, a to tím, jak se může negativní chování influencera, jenž spolupracuje se značkou, dotknout jak samotného influencera, tak dané značky. Autoři této studie konkrétně zjistili, že společnosti, které spolupracují s negativně se chovajícími influencery, mají zkušenost s nějakou formou úpadku. Nevhodné chování influencerů totiž negativně ovlivňuje prrístup uživatelů a jejich ochotu zakoupit si produkt. Dle předvedeného výzkumu jsou však důsledky jejich nevhodného chování horší pro ně samotné než pro značku. ${ }^{72}$

Dle studie nazvané The influence of YouTube influencer marketing on attitudes of generation $Z^{73}$ autorky Viivi Reijonen je jednou $\mathrm{z}$ největších nevýhod influencer marketingu, že není jako tradiční marketing pro značky tak kontrolovatelný. Vzhledem k tomu je důležité, aby si značky vybíraly influencery velmi pečlivě. Zvolený influencer se totiž podle zmíněné studie stává tvář́ značky, a tak je „,nezbytné zajistit, aby daná osoba měla správné hodnoty za účelem udržení pozitivní image značky. "74 Nicméně vybraný influencer také musí reklamu zpracovat vhodným způsobem, jelikož jeho sledující ho mohou přestat sledovat jednak kvůli neautentickým příspěvkům či př́liš velkému počtu př́íspěvků se sponzorovaným obsahem. ${ }^{75}$ Velkou nevýhodou influencer marketingu však rovněž je, že se reklama na stejnou značku vyskytuje současně na profilech několika influencerů, což dle výše zmíněné studie „,kazí autenticitu kampaně a pocit jedinečnosti. “76 Tato skutečnost ovlivňuje také důvěryhodnost a ochotu jak influencera, tak propagované značky. ${ }^{77}$

$\mathrm{Na}$ druhou stranu má influencer marketing skutečně mnoho pozitiv, a proto ho firmy stále častěji zapojují do svých marketingových strategií. Kromě kladů již dříve uvedených je totiž jednou z nesporných výhod influencer marketingu př́stup k širokému publiku. Společnosti mají prostřednictvím influencerů přístup $\mathrm{k}$ tisícům uživatelů, jež mohou potenciálně oslovit. Dle studie The pros and cons of influencer marketing ${ }^{78}$ Andrey Fryrear tak influencer marketing ,,může vést $k$ možnému rychlému nárůstu povědomí o společnosti. “79 Uživatelé se totiž díky influencerovi dozvědí o značce a začnou ji poznávat. Influenceři mají tedy dle Reijonen ,schopnost vybudovat image značky, “80 čehož mohou využít značky, jež chtějí konkurovat jiným značkám. Výhodou pro firmy také je, že se influenceři často orientují na určitou oblast, jelikož tak mohou jednoduše oslovit cílové publikum. Další výhodou influencer marketingu je, že influenceři mají podobné postavení jako ostatní uživatelé, díky čemuž jsou vnímáni jako důvěryhodnější než celebrity. ${ }^{81}$

Nicméně výhodou influencer marketingu je také dle studie autorky Viivi Reijonen možnost „opětovného použití obsahu influencerù, jenž může živit sociální média značky. " ${ }^{82}$ Rozšíření povědomí o značce prostřednictvím influencerů je také nákladově efektivnější než využití

\footnotetext{
72 Tamtéž.

${ }^{73}$ REIJONEN, Viivi. The influence of YouTube influencer marketing on attitudes of generation $Z$ [online]. Helsinki, 2019 [cit. 2021-6-7]. Dostupné z: https:/www.theseus.fi/bitstream/handle/10024/264863/Reijon en_Viivi.pdf?sequence=2. Bachelor's Thesis. Haaga-Helia University of Applied Sciences.

${ }^{74}$ Tamtéž.

75 Tamtéž.

76 Tamtéž.

77 Tamtéž.

78 FRYREAR, Andrea. The pros and cons of influencer marketing. Idealpath [online]. 2015 [cit. 2021-6-7]. Dostupné $\quad$ z: https://www.idealpath.com/marketing-automation-blog/content-marketing/pros-and-consofinfluencer-marketing/

${ }^{79}$ Tamtéž.

${ }^{80}$ REIJONEN, Viivi. The influence of YouTube influencer marketing on attitudes of generation $Z$ [online]. Helsinki, 2019 [cit. 2021-6-7]. Dostupné z: https://www.theseus.fi/bitstream/handle/10024/264863/Reijon en_Viivi.pdf?sequence=2. Bachelor's Thesis. Haaga-Helia University of Applied Sciences.

${ }^{81}$ Tamtéž.

82 Tamtéž.
} 
interních designových týmů. V neposlední řadě je výhodou influencer marketingu také to, že si uživatelé mohou prohlížet produkty a služby i po ukončení kampaně, což dle Reijonen „, dává marketingovým kampaním pomocí influenceri̊ trvalý efekt. “" 83

\section{DISKURSIVNÍ ANALÝZA POJETÍ SPRÁVNOSTI OZNAČOVAT REKLAMNÍ FOTOGRAFIE}

V následující kapitole se pokusím pomocí kvalitativní analýzy představit odlišnost v pojetí správnosti označovat reklamní fotografie na Instagramu. Konkrétně se zde budu zabývat postojem dvou skupin uživatelů této sociální sítě, tedy influencerů a běžných uživatelů, a postojem odborníků, jež je jimi prezentován vodborných a populárně-návodných marketingových publikacích či článcích. Zmíněný kvalitativní výzkum bude založený na výzkumné metodě diskursivní analýzy vycházející z př́stupu Normana Fairclougha. Tato výzkumná metoda je zpravidla vymezována jako ,,sada metod a teorií pro zkoumáni běžně používaného jazyka v sociálním kontextu, " ${ }^{84}$ nicméně dle doktora Víta Beneše je ji možné pojímat jako „,studium lidských významotvorných praktik, “85 do nichž lze kromě verbální komunikace zařadit obrazová média nebo další lidské aktivity náležející do kategorie neverbální komunikace. ${ }^{86}$ Dle Normana Fairclougha navíc diskursivní analýza vychází z předpokladu, že ,jazyk je nedílnou součástí společenského života, dialekticky propojený s ostatními elementy společenského života tak, že společenská věda a výzkum musí vždy brát v úvahu jazyk. “87

Uplatnění diskursivní analýzy je oprávněné zejména vzhledem $\mathrm{k}$ analýze komunitních obrazů a řeči ve formě komentářů, popisků a hodnocení jak influencerů, tak běžných uživatelů sociální sítě Instagram, jež bude dána do kontrastu s analýzou odborných a populárněnávodných marketingových publikací či článků. Do kontrastu bude dán tedy diskurs sít’ových komunit s diskursem odborníků. Předpokladem článku totiž je, že v současné době dochází $\mathrm{k}$ nesouladu zmíněných diskursů $\mathrm{v}$ názorech na správnost označovat skrytě propagující fotografie na Instagramu jako reklamní žánr. Výše uvedená výzkumná metoda byla tedy vybrána především s ohledem na to, že umožní popsat a pochopit mocenské nastavení preferencí a limitu současného diskursu sociálních sítí.

\subsection{Pojetí influencerů}

Názory influencerů na správnost označování reklamních fotografií na Instagramu se rozchází. Zatímco jedni jsou zastánci toho označovat reklamní fotografie na zmíněné sociální síti, tak druzí smysl v označování sponzorovaného obsahu nevidí. Výše uvedené vyplynulo $\mathrm{z}$ diskursivní analýzy komunitních obrazů a řeči v podobě komentářů, popisků a hodnocení influencerů na sociální síti Instagram. Data pro tuto analýzu byla sbírána od roku 2019 do současnosti a jejich součástí byly jak příspěvky influencerů zobrazené v kanálu příspěvků, tak ve Stories a dále jejich popisky, hodnocení či komentáře získané na sociální síti Instagram.

Jedním ze zastánců označování sponzorovaného obsahu na sociální síti Instagram je např́íklad influencerka Adela Kožinová, kterou nyní sleduje 18 tisíc uživatelů. Adela Kožinová navíc nejenže reklamní prŕspěvky na svém profilu poctivě označuje, ale také se velmi často vyjadřuje k problematice neoznačování sponzorovaného obsahu na Instagramu. Ve svém Stories k tématu placených spoluprací dne 12. února 2021 naprríklad uvedla: „Taky

\footnotetext{
${ }^{83}$ Tamtéž.

${ }^{84}$ BENEŚ, Vít. Diskurzivní analýza. DRULÁK, Petr. Jak zkoumat politiku: kvalitativní metodologie v politologii a mezinárodních vztazích. Praha: Portál, 2008, s. 92-124. ISBN 978-80-7367-385-7.

${ }^{85}$ Tamtéž.

${ }^{86}$ Tamtéž.

87 FAIRCLOUGH, Norman. Analysing Discourse: Textual Analysis for Social Research. Psychology Press, 2003, str. 2.
} 
spolupracuju, snažím se spolupráce filtrovat, nedělat jich moc a dělat je jen se značkami a produkty, které bych si sama koupila... "88 Další influencerkou, která dle nasbíraných dat označuje sponzorovaný obsah i ve Stories je Karolina Králová alias „little.kao“. Karolina např́klad dne 26. listopadu 2020 zveřejnila ve svém Stories reklamu na paletku očních stínů Daily Dose of Love od firmy Essence a nezapomněla uvést, že se jedná o spolupráci. ${ }^{89}$ Zmínit bych zde dále mohla i Nikolu Čechovou alias „shopaholicnicol“, která dne 11. ř́jna 2019 taktéž označila sponzorovaný obsah i ve svém Stories. ${ }^{90}$

Na druhou stranu mnozí influenceři nepokládají za nutné reklamní př́íspěvky na sociální síti Instagram označovat, nebo je označují nedostatečným způsobem. Zástupcem těchto influencerů je dle nashromážděných dat např́iklad herečka Anna Kadeřávková, kterou nyní na sociální síti Instagram sleduje 319 tisíc uživatelů. Anna Kadeřávková totiž dne 17. prosince 2019 zveřejnila reklamní příspěvek na pračku LG, v jehož popisku jen uvedla, že uvedenou pračku dostala. V jejím př́spěvku tedy chybělo jakékoliv označení toho, že se jedná o placenou spolupráci, načež ji upozornil i jeden $\mathrm{z}$ běžných uživatelů komentářem pod př́spěvkem: „Ze zákona musí být reklama viditelně označena. Tady mi to jaksi chybí."'91 Kadeřávková však tomuto uživateli odpověděla pouze urážkou. ${ }^{92}$

Nicméně existují i influenceři, kteři se svých sledujících ptají, jak vnímají sponzorovaný obsah na jejich profilu, aby mohli placené spolupráce přizpůsobit jejich požadavkům. Jednou z těchto influencerek je například Barbora Sedláková se 31,1 tisícem sledujících. Sedláková se svých sledujících přímo zeptala, zda jim vadí placené spolupráce na jejím profilu a dodala „,Rozumějte, právě tyhle firmy nám platí to, že mám čas tu sdílet spoustu nekomerčních věcí. Taky je hodně důkladně vybírám a jsem v postech uprímná. Na druhou stranu vidím u některých placených postů, že jim dáte mín srdiček. Tak hledám cestu, jak to tu pro vás udělat zajímavější, př́nosnější, zábavnější..." "93 Podobně se svých sledujících dotazovala rovněž influencerka Dominika Št’ovíčková alias „mamadomisha“, která chtěla od běžných uživatelů vědět, s jakou firmou by podle nich měla ukončit placenou spolupráci. ${ }^{94}$

\subsection{Pojetí běžných uživatelů}

Co se týče názoru běžných uživatelů na správnost označování reklamních fotografií na Instagramu, tak $\mathrm{z}$ provedené analýzy komunitních obrazů a řeči $\mathrm{v}$ podobě komentářů, hodnocení a popisků na sociální síti Instagram vyplynulo, že se velké množství běžných uživatelů shoduje, aby influenceři na zmíněné sociální síti označovali sponzorovaný obsah. Př́kladem zde mohu uvést jednak výše představeného uživatele, který upozornil na nedostatečné označení sponzorovaného obsahu influencerku Annu Kadeřávkovou, ale také další uživatele, jež negativně reagují na neoznačenou reklamu na instagramovém profilu Svět influencera.

Nicméně díky uskutečněné analýze bylo rovněž zjištěno, že mnoho běžných uživatelů reklamu na sociální síti Instagram stále nerozezná. Jedním ze sponzorovaných př́spěvků, u kterého několik běžných uživatelů např́iklad nepoznalo, že se jedná o placenou spolupráci, byl modelky Terezy Budkové propagující oblečení značky Gap. Tereza Budková tento př́spěvek zveřejnila dne 5. prosince 2020 , načež ho následně dne 12 . prosince přesdílel instagramový profil Svět influencera jako jeden z př́íkladů neoznačené reklamy, kde ho však běžní uživatelé komentovali slovy: „A jsou něco fakt reklamy, nejsou to prostě jenom

\footnotetext{
${ }^{88}$ KOŽINOVÁ A. Instagram. 12. února 2021.

${ }^{89}$ KRÁLOVÁ K. Instagram. 26. listopadu 2020.

${ }^{90}$ ČECHOVÁ N. Instagram. 11. ř́jina 2019.

${ }^{91}$ KADEŘ́

${ }^{92}$ Tamtéž.

93 SEDLÁKOVÁ B. Instagram. 13. července 2019.

94 ŠŤOVÍČKOVÁ D. Instagram. 21. října 2020.
} 
fotky?“95 či „,Co tam je k označeni? “96 Od obyčejného příspěvku ale tuto reklamní fotografii odlišovala nabídka slevového kódu v jejím popisku na nákup u dané značky. ${ }^{97}$

\subsection{Pojetí odborníků}

Poslední skupinou, jejíž pojetí správnosti označovat reklamní fotografie na Instagramu zde budu rozebírat, jsou odborníci zabývající se problematikou influencer marketingu. $\mathrm{Na}$ základě diskursivní analýzy odborných a populárně-návodných marketingových publikací či internetových článků bylo konkrétně zjištěno, že u odborné veřejnosti převažuje tendence chápat označování reklamních fotografií na Instagramu jako správné. Odborníci se přitom opírají o zákony, dle nichž lze považovat neoznačený sponzorovaný obsah na sociální síti Instagram za klamavou obchodní praktiku. Těmito zákony konkrétně jsou zákon č. 40/1995 Sb. o regulaci reklamy a také zákon č. 634/1992 Sb. o ochraně spotřebitele, dle kterého je tedy obchodní praktika pokládána za klamavou v případě, že „prodávající využívá redakční prostor ve sdělovacich prostředcich k placené propagaci svého výrobku nebo služby, aniž by spotřebitel mohl z obsahu sdělení, z obrázkư nebo ze zvuků jednoznačně poznat, že se jedná o reklamu“ “98 Nicméně berou v potaz rovněž Etický kodex reklamy, jenž uveřejňuje Rada pro reklamu či Pravidla pro nativní reklamu Sdružení pro internetový rozvoj a samoregulační orgány jako zmíněnou Radu pro reklamu, Sdružení pro internetový rozvoj či Asociaci komunikačních agentur, Asociaci PR agentur a Syndikát novinářů ČR. ${ }^{99}$

Reklama na sociální síti Instagram by tedy dle názoru odborníků měla být vždy rádně označena. Za tímto účelem vznikla ve spolupráci s ,odborníky na reklamu, právo, influencer marketing, žurnalistiku, média, samotnými influencery a zejména pedagogy a studenty katedry Marketingové komunikace a public relations na Fakultě sociálních věd Univerzity Karlovy “100 v roce 2018 webová stránka Férová Reklama a následně také především díky Sdružení pro internetový rozvoj stránka Férový influencer, která nabádá influencery nejen $\mathrm{k}$ náležitému označování sponzorovaných př́íspěvků, ale také k upřímnosti během propagování produktů či služeb a představuje Kodex influencera, tedy „,sadu doporučení pro obě strany, kterými by se mély ř́dit, aby výsledky spolupráce byly v souladu se zákonem. “101

\section{ZÁVĚR}

Cílem teoretické části tohoto článku zabývajícího se sociální sítí Instagram a skrytou reklamou na této sociální síti bylo jednak představit zmíněnou sociální platformu a s ní spjatý nový způsob propagace produktů a služeb formou osobních doporučení prostřednictvím influencerů, ale také zhodnotit klady a zápory influencer marketingu na Instagramu. Výhodou uvedené sociální sítě totiž je, že může být použita samostatně jako prostředek vizuálního vyprávění. Obsah reklamních sdělení tedy nemusí být vázán na jinou sociální sít' a může se vyskytovat pouze na sociální síti Instagram. ${ }^{102}$ Společnosti mají navíc na Instagramu několik možností komunikace reklamních sdělení. Mohou bud' využít firemních účtů nebo influencerů. Influenceři tedy nevyužívají sociální sít' Instagram pouze ke své sebeprezentaci, ale také placené propagaci různých firem. Nicméně i na sociální síti Instagram by měla být

\footnotetext{
${ }^{95}$ SVĚT INFLUENCERA. Instagram. 12. prosince 2020.

${ }^{96}$ Tamtéž.

97 Tamtéž.

98 Děláš reklamu? Řekni to. Férová Reklama [online]. [cit. 2021-6-19]. Dostupné z: https://www.ferov areklama.cz/

${ }^{99}$ Tamtéž.

100 Tamtéž.

101 Fér_fluencer: Spolupráce značek a influencerů je reklama, která by měla být označená. Férový influencer [online]. c2020 [cit. 2021-6-19]. Dostupné z: https://ferovyinfluencer.cz/

${ }^{102}$ SAMMIS, Kristy, Cat LINCOLN, Stefania POMPONI, Jenny NG, Edita GASSMANN RODRIGUEZ a Judy ZHOU. Influencer marketing for dummies. Hoboken, NJ: Wiley, 2016. --For dummies, str. 89.
} 
reklama náležitě označená a podléhat pravidlům regulace reklamy. Influenceři však mnohdy na Instagramu značkový obsah ve svých př́spěvcích neoznačují, nebo je jejich reklama $\mathrm{v}$ rozporu se zákony, a proto jsem se $\mathrm{v}$ teoretické části také zaměřila na možnosti regulace reklamy na Instagramu.

Propagace produktů a služeb skrze influencery tedy nemá jen pozitiva, a tak jsem také v této části článku věnovala pozornost analýze kladů a záporů influencer marketingu. Při analýze kladů a záporů influencer marketingu jsem vycházela z několika aktuálních výzkumů zabývajících se problematikou influencer marketingu. Těmito výzkumy byly konkrétně studie The impact of influencers from Instagram and YouTube on their followers ${ }^{103}$ zabývající se dopadem influencerů na své sledující a studie Social Butterflies: How Social Media Influencers are the New Celebrity Endorsement ${ }^{104}$ autorky Kayleigh Elizabeth Burke, které se věnují zejména výhodám influencer marketingu. Dále jsem pracovala se studií autorky Andrey Fryrear nazvanou The pros and cons of influencer marketing ${ }^{105}$ či Viivi Reijonen nazvanou The influence of YouTube influencer marketing on attitudes of generation $Z^{106}$ a v neposlední řadě také studií The Dark Side of Influencer Marketing ${ }^{107}$ zaměřující se zase na nevýhody influencer marketingu.

Cílem tohoto článku nicméně bylo pomocí kvalitativního výzkumu založeného na výzkumné metodě diskursivní analýzy představit odlišnost v pojetí správnosti označovat reklamní fotografie na Instagramu dvou skupin uživatelů této sociální sítě, tedy influencerů a běžných uživatelů, a odborníků zabývajících se problematikou influencer marketingu. Předpokladem článku totiž bylo, že v současné době dochází $\mathrm{k}$ nesouladu zmíněných diskursů $\mathrm{v}$ názorech na správnost označovat skrytě propagující fotografie na Instagramu jako reklamní žánr. Na základě analýzy komunitních obrazů a řeči ve formě komentářŭ, popisků a hodnocení influencerů a běžných uživatelů sociální sítě Instagram, jež byla dána do kontrastu s analýzou odborných a populárně-návodných marketingových publikací či článků, bylo konkrétně zjištěno, že zatímco se názory influencerů na správnost označování reklamních fotografií na Instagramu rozchází, tak velké množství běžných uživatelů se shoduje, že by na zmíněné sociální síti měl být sponzorovaný obsah označen. Stejně tak převažuje tendence chápat označování reklamních fotografií na Instagramu jako správné u odborné veřejnosti.

\section{Použitá literatura}

1. BENEŠ, Vít. Diskurzivní analýza. DRULÁK, Petr. Jak zkoumat politiku: kvalitativní metodologie v politologii a mezinárodních vztazích. Praha: Portál, 2008, s. 92-124. ISBN 978-80-7367-385-7.

\footnotetext{
103 NANDAGIRI, Vaibhavi a Leena PHILIP. Impact of influencers from Instagram and YouTube on their followers. International Journal of Multidisciplinary Research and Modern Education [online]. 2018, 4(1), 6165 [cit. 2021-6-1]. Dostupné z: http://doi.org/10.5281/zenodo.1207039

104 BURKE, Kayleigh Elizabeth. Social Butterflies: How Social Media Influencers are the New Celebrity Endorsement [online]. Blacksburg, Virginia, 2017 [cit. 2021-6-1]. Dostupné z: https://vtechwor ks.lib.vt.edu/bitstream/handle/10919/78221/Burke_KE_T_2017.pdf?sequence=1\&isAllowed=y. Masters Theses. Virginia Polytechnic Institute and State University.

105 FRYREAR, Andrea. The pros and cons of influencer marketing. Idealpath [online]. 2015 [cit. 2021-6-7]. Dostupné z: https://www.idealpath.com/marketing-automation-blog/content-marketing/pros-and-consof-influ encer-marketing/

106 REIJONEN, Viivi. The influence of YouTube influencer marketing on attitudes of generation $Z$ [online]. Helsinki, 2019 [cit. 2021-6-7]. Dostupné z: https://www.theseus.fi/bitstream/handle/10024/264863/Rei jonen_Viivi.pdf?sequence=2. Bachelor's Thesis. Haaga-Helia University of Applied Sciences.

107 ØDDEGÅRD OLSEN, Camilla a Gina Marie SANDHOLMEN. The Dark Side of Influencer Marketing [online]. BI Oslo, 2019 [cit. 2021-6-5]. Dostupné z: https://biopen.bi.no/bi-xmlui/bitstream /handle/11250/2622034/2287695.pdf?sequence=1. Master Thesis. BI Norwegian business school. Vedoucí práce Even Johan Lanseng.
} 
2. DUNCAN BROWN AND NICK HAYES. Influencer marketing: who really influences your customers?. Amsterdam: Elsevier/Butterworth-Heinemann, 2008. ISBN 9780750686006.

3. FAIRCLOUGH, Norman. Analysing Discourse: Textual Analysis for Social Research. Psychology Press, 2003. ISBN 0-203-69707-3

4. KUBÍČKOVÁ, Lucie. Influencer marketing na sociální síti Instagram: Diskursivní analýza marketingových př́ruček. In: QUAERE 2020: Recenzovaný sborník př́spěvkủ interdisciplinární mezinárodní vědecké konference doktorandů a odborných asistentů. Hradec Králové: Magnanimitas, 2020, s. 70-83. ISBN 978-8087952-32-0.

5. KUBÍČCKOVÁ, Lucie. Vývoj reklamní fotografie na sociální síti Instagram: Zdánlivé mizení žánru reklamní fotografie. In: QUAERE 2019: Recenzovaný sborník príspěvkì interdisciplinární mezinárodní vědecké konference doktorandů a odborných asistentů. Hradec Králové: Magnanimitas, 2019, s. 94-109. ISBN 978-8087952-30-6.

6. MANOVICH, Lev. Instagram and Contemporary Image [online]. 2017 [cit. 201804-21]. Dostupné z: http://manovich.net/index.php/projects/instagram-andcontemporary-image

7. SAMMIS, Kristy, Cat LINCOLN, Stefania POMPONI, Jenny NG, Edita GASSMANN RODRIGUEZ a Judy ZHOU. Influencer marketing for dummies. Hoboken, NJ: Wiley, 2016. --For dummies. ISBN 1119114098.

8. SEMERÁDOVÁ, Tereza a Petr WEINLICH. Marketing na Facebooku a Instagramu: využijte naplno organický dosah i sponzorované př́spěvky. Brno: Computer Press, 2019. ISBN 9788025149591.

9. $\quad$ SINKWITZ, Joe. The Ultimate Guide To Using Influencer Marketing. Independently Published, 2018. ISBN 9781973473138.

\section{Internetové zdroje}

1. App Store Preview: Boomerang from Instagram. App Store [online]. c2021 [cit. 2021-6-18]. Dostupné z: https://apps.apple.com/us/app/boomerang-frominstagram/id1041596399

2. App Store Preview: Medium. App Store [online]. c2021 [cit. 2021-6-18]. Dostupné z: https://apps.apple.com/us/app/medium/id828256236

3. App Store Preview: SoundCloud - Music \& Songs. App Store [online]. c2021 [cit. 2021-6-18]. Dostupné z: https://apps.apple.com/us/app/soundcloud-music-audio/id 336353151

4. Centrum nápovědy pro firmy: Zásady pro reklamy na nabídku. Facebook for Business [online]. c2021 [cit. 2021-6-19]. Dostupné z: https://www.facebook.com/bu siness/help/358970040838616?id=404748470363829

5. Centrum nápovědy: Co znamená, když je u příspěvku na Instagramu uvedeno, že se jedná o placené partnerství? Instagram [online]. c2021 [cit. 2021-6-19]. Dostupné z: https://www.facebook.com/help/instagram/1199202110205564

6. Děláš reklamu? Řekni to. Férová Reklama [online]. [cit. 2021-6-19]. Dostupné z: https://www.ferovareklama.cz/

7. Fér_fluencer: Spolupráce značek a influencerů je reklama, která by měla být označená. Férový influencer [online]. c2020 [cit. 2021-6-19]. Dostupné z: https://ferovyinfluencer.cz/

8. FRYREAR, Andrea. The pros and cons of influencer marketing. Idealpath [online]. 2015 [cit. 2021-6-7]. Dostupné z: https:/www.idealpath.com/marketing-automationblog/content-marketing/pros-and-consof-influencer-marketing/ 
9. Instagram Business: Značkový obsah. Instagram for Business [online]. c2021 [cit. 2021-6-19]. Dostupné z: https://business.instagram.com/a/branded-content-ads?loc ale $=$ cs_CZ

10. Instagram je tu deset let. Slaví funkcí, která může někoho zarazit. IDnes.cz [online]. MAFRA, c1999-2021, 6. ř́ína 2020 [cit. 2021-6-18]. Dostupné z: https://www.idnes.cz/technet/internet/instagram-socialni-sit-vyroci-

zebricek.A201006_090253_sw_internet_vse

11. Označování placeného partnerství: Je označování placeného partnerství povinnost? Dost bylo mýtů, ted' přijde zákon! Václav Blahout [online]. c2010-2019, 14. 1. 2019 [cit. 2021-6-19]. Dostupné z: https://blahout.com/je-oznacovani-placenehopartnerstvi/

12. PRODUCT EVOLUTION: Celebrating 10 years of Instagram. About Instagram [online]. [cit. 2021-6-18]. Dostupné z: https://about.instagram.com/aboutus/instagram-product-evolution

13. Spolupráce s influencery má pro značky svá úskalí. MediaGuru [online]. c2021, 20. srpna 2019 [cit. 2021-6-19]. Dostupné z: https://www.mediaguru.cz/clan ky/2019/08/spoluprace-s-influencery-ma-pro-znacky-sva-uskali/

14. VALIÁNOVÁ, Nikola. 9 možností influencer marketingu: Druhy spolupráce s influencery. Blog.socialpark: Sledujeme dění v online světě a nenecháváme si pro sebe komentáre a hodnocení [online]. c2020, 16. 9. 2020 [cit. 2021-6-19]. Dostupné z: https://blog.socialpark.cz/2020/09/16/druhy-spoluprace-s-influencery/

15. Začínáme se službou Instagram for Business. Instagram for Business [online]. c2021 [cit. 2021-6-18]. Dostupné z: https://business.instagram.com/getting-started?1 ocale $=$ cs_CZ

16. Zakladatelé Instagramu opouštějí sít'. Plánují zřejmě nový projekt. IDnes.cz [online]. MAFRA, c1999-2021, 25. záŕí 2018 [cit. 2021-6-18]. Dostupné z: https://www.idn es.cz/technet/kratke-zpravy/instagram-facebook-zakladatele-odchod-socialnisite.A180925_094800_tec-kratke-zpravy_hege

17. Zákon č. 40/1995 Sb. Zákony pro lidi [online]. c2010-2021 [cit. 2021-6-19]. Dostupné z: https://www.zakonyprolidi.cz/cs/1995-40

\section{Vědecké články}

1. BURKE, Kayleigh Elizabeth. Social Butterflies: How Social Media Influencers are the New Celebrity Endorsement [online]. Blacksburg, Virginia, 2017 [cit. 2021-6-1]. Dostupné z: https://vtechworks.lib.vt.edu/bitstream/handle/10919/78221/Burke_K E_T_2017.pdf?sequence $=1 \&$ isAllowed $=y$. Masters Theses. Virginia Polytechnic Institute and State University.

2. NANDAGIRI, Vaibhavi a Leena PHILIP. Impact of influencers from Instagram and YouTube on their followers. International Journal of Multidisciplinary Research and Modern Education [online]. 2018,4(1), 61-65 [cit. 2021-6-1]. Dostupné z: http://doi.org/10.5281/zenodo.1207039

3. ØDEGÅRD OLSEN, Camilla a Gina Marie SANDHOLMEN. The Dark Side of Influencer Marketing [online]. BI Oslo, 2019 [cit. 2021-6-5]. Dostupné z: https://biopen.bi.no/bi-xmlui/bitstream/handle/11250/2622034/2287695.pdf?s equence $=1$. Master Thesis. BI Norwegian business school. Vedoucí práce Even Johan Lanseng.

4. REIJONEN, Viivi. The influence of YouTube influencer marketing on attitudes of generation $Z$ [online]. Helsinki, 2019 [cit. 2021-6-7]. Dostupné z: https://www.theseus.fi/bitstream/handle/10024/264863/Reijonen_Viivi.pdf?sequence $=2$. Bachelor's Thesis. Haaga-Helia University of Applied Sciences. 


\section{Jiné zdroje}

1. ČECHOVÁ N. Instagram. 11. října 2019.

2. KADEŘÁVKOVÁ A. Instagram. 17. prosince 2019.

3. KOŽINOVÁ A. Instagram. 12. února 2021.

4. KRÁLOVÁ K. Instagram. 26. listopadu 2020.

5. SEDLÁKOVÁ B. Instagram. 13. července 2019.

6. SVĚT INFLUENCERA. Instagram. 12. prosince 2020.

7. $\quad$ ŠŤOVÍČCKOVÁ D. Instagram. 21. ř́ijna 2020.

Článek byl vydán v rámci projektu Interního grantového systému MUP s interním číslem E59-79 a názvem „Instagram a reklama skrytá $v$ doporučení“ financovaného z podpory MŠMT na specifický vysokoškolský výzkum v letech 2020-2021.

\section{Kontaktní údaje}

Mgr. Lucie Kubíčková

Metropolitní univerzita Praha, o.p.s.

Budova MUP na Jarově

Učňovská 100/1, 19000 Praha 9

Tel: +420 721046585

e-mail: Kub-Lucie@ seznam.cz 


\title{
READER'S BEHAVIOR IN THE DIGITAL SPACE DURING THE COVID-19 PANDEMIC
}

\author{
Miriama Koliščáková, Jana Paveleková
}

\begin{abstract}
Knowing the shopping behavior of readers is extremely important for businesses in the book market, especially during the Covid-19 pandemic, when shopping preferences can change not only due to external economic conditions, but also readers' own preferences. In the theoretical part of the paper, the authors deal with the subject of consumer buying behavior and the factors that influence it. In the practical part, the authors examine the buying preferences of Slovak readers in the form of inquiries, trying to answer the question: "How does the reader behave in the digital space during the Covid-19 pandemic?". The results of the research will serve companies in the book market not only for more effective communication with regards to books and authors in their portfolio but also for a better understanding of the needs and requirements of readers in the Slovak market. The aim of the article is to summarize information about who a book consumer is, what influences them and how they behave in the book market.
\end{abstract}

Keywords: Reader, Consumer Buying Behavior, Covid-19, Digital Space, Slovak Book Market.

\section{CONSUMER BEHAVIOR}

The goal of almost every business is to sell as many products as it produces. In order for a business to sell as many of its products as possible, it needs to know what its customers need and how much they are willing to pay for it. Firstly, it is necessary to define the individual concepts for a better understanding of the issue. Who is the consumer and who is the customer? The concept of consumer is more general, as it also covers the consumption of products that one does not buy oneself. A customer is a person who acts, orders and pays by an act of their own will. According to Keller, a small child is also a consumer immediately after his/her birth, but such child only becomes a customer when he/she goes to the store on his/her own for the first time. ${ }^{1}$ The consumer is, in theory, the one who buys for their own use and consumes the product. In the professional and scientific literature, we may encounter various synonyms in this context, such as consumer, end consumer, purchaser, user, customer, buyer, partner, or shopping center and related consumer and buying behavior. ${ }^{2}$

Kulčáková and Richterová state that this is the behavior of consumers who seek, buy, use and evaluate ideas, products and services. Before the purchase, the consumer will feel a certain form of shortage, or rather the need, which they want to satisfy through the purchase. We can define this as a kind of mental process during which there are dynamic interactions that contain knowledge, action and emotions, which the individual then realizes in exchange, where their goal is to satisfy their needs. ${ }^{3}$ The study of consumer behavior reveals how we can divide individuals in spending the resources they have at their disposal, that is, money, time and effort for consumption. Consumer behavior also includes what consumers buy, why they buy it as well as how, when, where and how often they buy it. ${ }^{4}$ Kita et al. state that when monitoring consumer behavior, it is important to

\footnotetext{
${ }^{1}$ KELLER, K. L.: Conceptulalising, mesasuring and managing customer based brand equity. In: Journal of Marketing, vol. 57, no 1, 1993, p. 2-22.

2 PETROVIČOVÁ, J.: Modely spotrebitel'ského správania sociálnych tried pri tvorbe marketingovej stratégie. Bratislava : Wolters Kluwer, 2011, p. 34.

${ }^{3}$ KULČÁKOVÁ, M. - RICHTEROVÁ, K.: Spotrebitel' na trhu: Faktory - stratégia - reakcie. Bratislava : Sprint, 1997, p. 106.

${ }^{4}$ KULČÁKOVÁ, M., RICHTEROVÁ, K.: Spotrebitelské správanie. EKONÓM. Bratislava. 1996, p. 6 - 7.
} 
examine how consumers decide, why they act the way they do and what the outcome of that decision will be, i.e. whether the product has met their expectations for consumption and use and whether they will repeat the purchase with the same product at the next feeling of shortage. ${ }^{5}$

\subsection{Factors influencing consumer behavior}

Factors of consumer behavior can be distinguished on several levels. Figure 1 shows the individual factors according to Kotler and Armstrong that affect consumer buying behavior, divided into cultural, social, personal and psychological factors. ${ }^{6}$ Consumer behavior is influenced by many factors. Each of these factors influences consumer behavior and is reflected in purchasing decisions. Knowing them is important because it identifies customers' drivers and reasons for buying. Cultural factors are an important determining factor in human behavior in society. They are passed down from generation to generation and change as society per se changes. According to Kotler, each culture includes smaller subcultures that provide its members with better conditions for selfdetermination as well as inclusion. Subcultures then form groups of people with a similar system of values that results from everyday life experiences and life situations. ${ }^{7}$ Another factor that influences buying behavior is social factors. Social factors also include family and reference groups. Kotler states that family is the first large group to which one is aware of one's affiliation. It is a primary group because it helps the individual to develop from birth and influences the individual continuously and informally. A reference group is a social group that determines standards and values that influence consumers' buying behavior. It includes all groups that have a direct or indirect influence on the behavior and attitudes of individuals. ${ }^{8}$ Among the personality factors that affect consumer behavior we can include age, family life cycle, occupation, economic situation, personality, values, or lifestyle. Depending on these factors, people buy different products. A person faces certain transitions and transformations which also change his/her buying behavior. Economic conditions have a great influence, for example, on the possibilities of satisfying human needs and desires. Thus, a household with a higher income can satisfy its needs at a higher level and increase its requirements to satisfy its needs. An individual's lifestyle is reflected in his/her activities, interests and opinions, and depicts a person in relation to their environment. However, it is also determined by a number of factors, such as culture, values, social status, personality, marketing activities and the like. The last factor is psychological factor. Psychological factors play an important role in individuals' buying and consumer behavior. According to Kulčáková, we divide them into four main factors: motivation, perception, cognition and learning, belief and attitude. ${ }^{9}$ Motivation theories are based on two main principles that control the behavior of individuals or groups. The first principle is the principle of mental balance, which is based on the assumption that the individual has a constant need to maintain and restore his/her mental balance. The secondary principle speaks of a tendency that manifests itself in the search for pleasure (pleasant feelings) and the avoidance of suffering (pain or negative emotions). ${ }^{10}$ According to Kotler, perception is defined as a process during which an individual collects, sorts, as well as interprets input information to create a meaningful image of the world. By perception, a person recognizes a given product and its basic properties, which he/she then labels with their own terms, which he/she can place in the context of their own experience. ${ }^{11}$

\footnotetext{
${ }^{5}$ KITA, J. a kol.: Marketing. Bratislava : Jura edition, 2005. p. 192.

${ }^{6}$ KOTLER, P. - ARMSTRONG, G.: Marketing. Praha : Grada publishing, 2007. p. 123.

${ }^{7}$ KOTLER, P.: Marketing management - analýza, plánovaní, využití a kontrola. Bratislava : Victoria Publishing, 1992, p. 212.

${ }^{8}$ KOTLER, P.: Marketing Management. Praha : Grada Publishing 1998, p. 163.

${ }^{9}$ KULČÁKOVÁ, M: Marketing. 3. prepracované a doplnené vydanie. Bratislava : Jura edition, 2005. p. 75.

${ }^{10}$ JURŠOVÁ, D.: Klasické koncepcie výkonovej motivácie [online]. [2021-23-05]. Available at: <https://www.biznisnews.sk/klasicke-koncepcie-vykonovej-motivacie/>.

${ }^{11}$ KOTLER, P.: Marketing - Management. Praha : Grada Publishing, 1998, p. 174.
} 


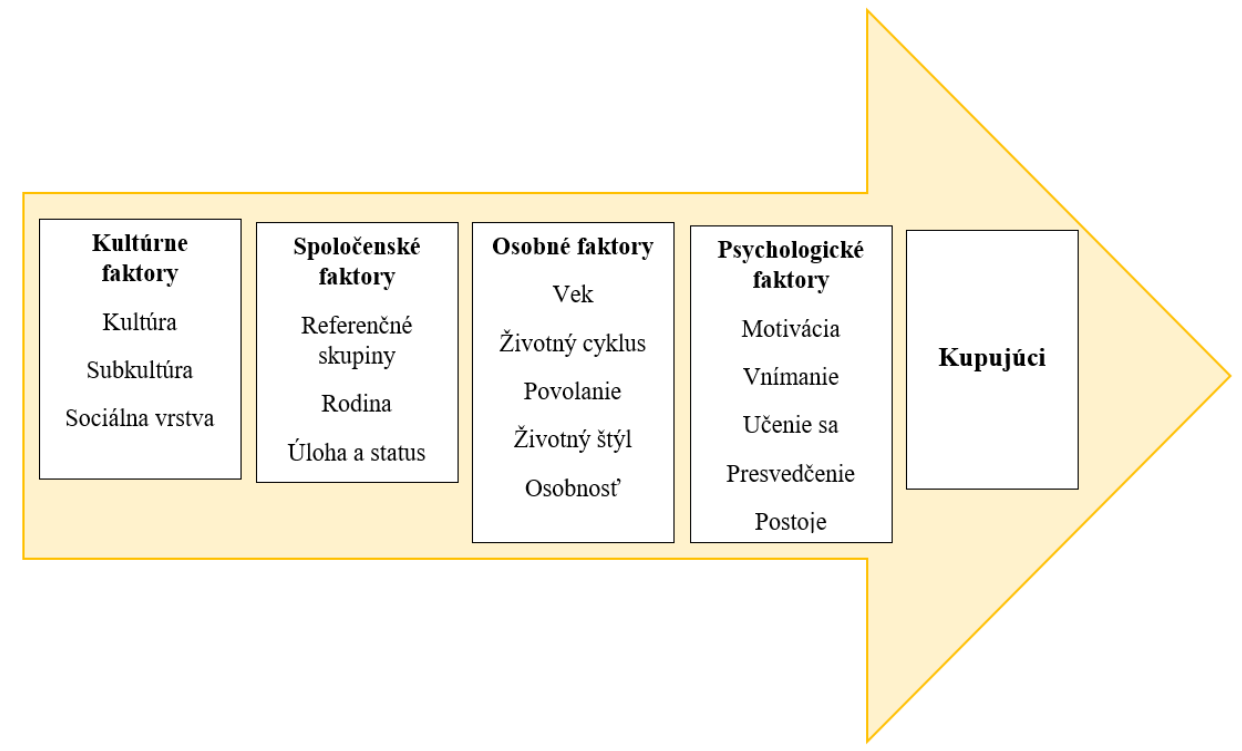

Figure 1 Factors influencing buying behavior Source: own processing, 2021; KOTLER, P. - ARMSTRONG, G.: Marketing.

\subsection{Consumer buying decision-making}

The consumer's decision to buy something consists of several phases, which are shown in Figure 2. The phases of the decision-making process consist of: identifying the problem, finding information, evaluating alternatives, purchasing decisions and the final post-purchase evaluation. From these individual phases, it is clear that the buying process begins before the actual purchase. In marketing, employees must focus on the entire decision-making process since this process does not end with the purchase. Marketers should also examine consumers' post-purchase behavior, satisfaction, response to purchased goods, or, for example, dissatisfaction with the purchase and the reasons for their dissatisfaction. ${ }^{12}$

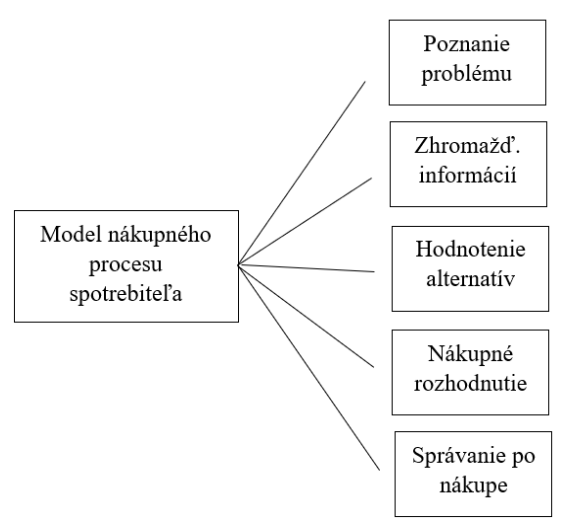

Figure 2 Purchasing decision-making process

Source: own processing, 2021; SCHIFFMAN, L. - KANUK, L.: Nákupní chování. Brno : Computer Press, 2004.

${ }^{12}$ DZUROVÁ, M. a kol.: Spotrebitel'ské teórie a reálie. Bratislava : EKONÓM, 2007, p. 293. 
According to Schiffman and Kanuk, buying behavior is defined as the behavior that consumers themselves experience in seeking, purchasing, using, evaluating and handling products and services from which they expect to meet their specific needs. ${ }^{13}$ In the context of consumer behavior, Richter divides consumers into these models based on consumer decision making:

- Economic man - „homo economicus“ in the field of examining consumer behavior, man makes rational decisions conditioned by the decision to buy as many goods as possible and as advantageous as possible. However, this model was later declared unrealistic as consumer shopping behavior is often influenced by a range of factors and not just economic motives.

- Passive man - according to this model, a consumer who is completely controlled by advertising, pressure to buy products from the surrounding environment and promotion. In this model, the equivalent role of the consumer in purchasing decisions is underestimated.

- Cognitive man - With this model, the consumer is perceptive and the product he/she buys must not only satisfy his/her need, but also enrich his/her life. The point is that the consumer, despite not having comprehensive knowledge of the product, seeks various information about the product and tries to make the most satisfactory decision.

- Emotional man - In this case, the consumer makes an emotional decision. The use of this model finds its application especially in advertising, which has as its goal to influence the consumer's feelings and force him/her to act impulsively and emotionally in his/her buying decisions. ${ }^{14}$

\subsection{Slovaks and reading books}

As part of marketing activities, it is necessary to monitor the behavior patterns of book consumers who are active in the market. According to the NMS Market research survey, it is clear that Slovaks most often believe in the recommendations of book publishers, and unlike Czech readers, Slovaks prefer to read professional literature instead of poetry. In Slovakia, however, novels are still read the most being popular with $48 \%$ of respondents. This is followed by the fantasy genre, adventure literature and detective stories. It is also interesting that despite technological progress, up to $89 \%$ of readers still prefer printed books to e-books. When asked how many books Slovaks read in a period of one year, respondents answered differently. 38\% of Slovaks read 5 books a year. In the same period, $17 \%$ of Slovaks manage to read more than 11 books. According to the survey, it seems that the summer period is the time when most Slovaks reach for literature. During the summer, up to $54 \%$ of Slovaks manage to read 1-2 books and $11 \%$ of young people can read 6 or more books during the summer. ${ }^{15}$ We attribute this to the fact that readers have more free time during the summer, so they can spend much more time reading than during the rest of the year. The number of Slovaks who shop online is increasing every year. A survey by Slovenská Sporitel'ňa shows that up to two thirds of people buy books via the Internet. ${ }^{16}$

\section{METHODOLOGY}

As part of our research, we focused on examining the buying behavior of readers on the Slovak book market in the digital space during the Covid-19 pandemic. Our main goal was to find out who the book consumer is, what books he/she reads, what his/her buying preferences are and what

\footnotetext{
13 SCHIFFMAN, L. - KANUK, L.: Nákupní chování. Brno : Computer Press, 2004, p. 14.

${ }^{14}$ RICHTEROVÁ, K.: Spotrebitel'ské správanie - Nákup organizácií. Bratislava : EKONÓM, 1999 p. 120.

${ }^{15}$ TS: Kto čita, pôjde do štúdii Harryho Pottera. Slubuje Mondelez v novej kampani. [online]. [2021-05-23]. Available at: <https://strategie.hnonline.sk/marketing/1986953-kto-cita-pojde-do-studii-harryho-pottera-slubuje-mondelez-v-nov ej-kampani.>.

${ }^{16}$ TS: Prieskum: 6 z 10 Slovákov nakupuje online. Najčastejšie knihy, najmenej jedlo. [online]. [2021-05-23]. Available at:<https://strategie.hnonline.sk/marketing/2055256-prieskum-6-z-10-slovakov-nakupuje-online-najcastejsie-knihynajmenej-jedlo\%C5\%88?fbclid=IwAR37MW7N8Chhk1-A0LrXz2RNSL8fptWTzlrCk4JyQ-2WEyDnN9KhZUhM60>.
} 
his/her behavior looks like in the digital space. We calculated the sample size using the following formula:

$$
\mathrm{n}=\frac{z_{1-\frac{\alpha^{2}}{2}} * \pi *(1-\pi)}{E^{2}}
$$

Where: $\pi=$ the occurrence ratio of the observed trait within the basic set; $\mathrm{E}=$ maximum acceptable error interval; $\mathrm{z}=$ quantile of the distribution function. We have conservatively determined the value as 0.5 , as we do not know the occurrence ratio of the observed trait within the basic set. The maximum acceptable error interval was determined at the level of $5 \%$ and the quantile of the distribution function was valued of 1.96 , which equals to $95 \%$ reliability. The minimum size of the selected set was 385 respondents. We addressed 430 respondents of various ages, residences and genders from all over Slovakia. The condition was that they were readers of books of various forms and genres. The questionnaire survey was conducted in March and was shared online using social media and email marketing with a focus on books. Figures 1, 2, 3 and 4 show the sample of respondents.

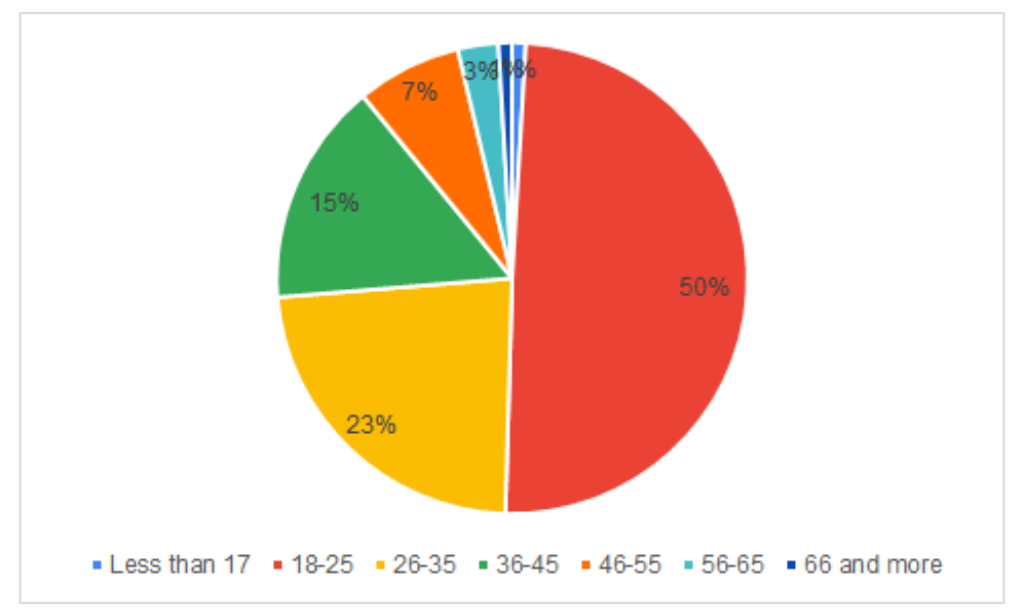

Figure 1: Age

Source: own processing, 2021

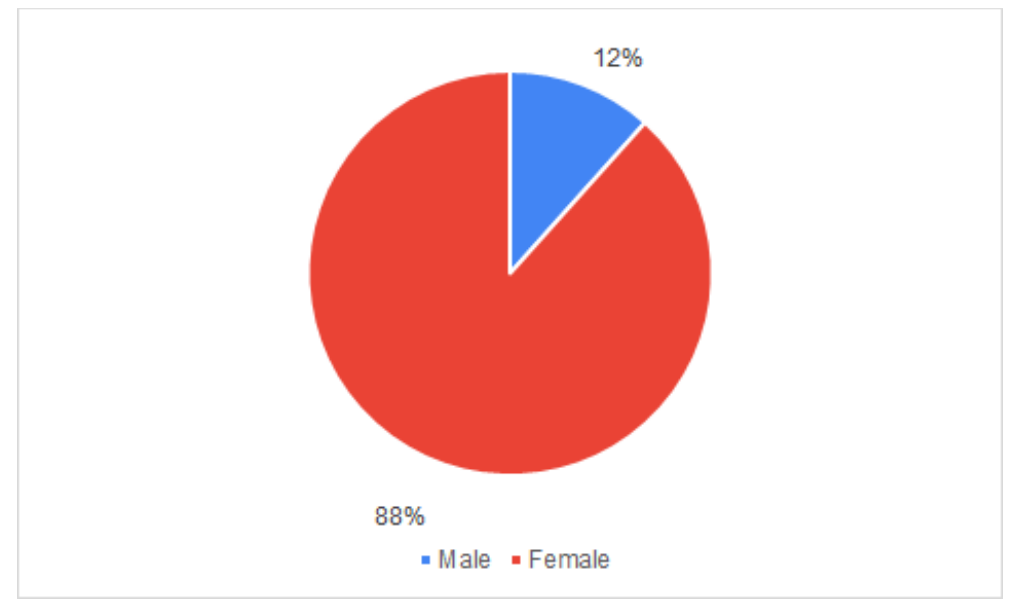

Figure: 2: Gender

Source: own processing, 2021 


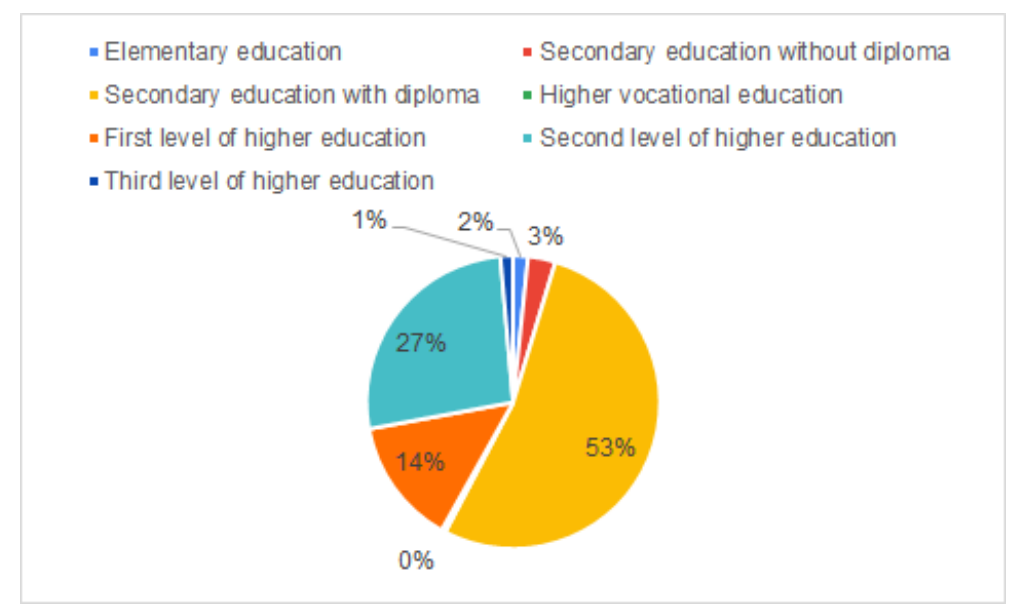

Figure 3: Education

Source: own processing, 2021

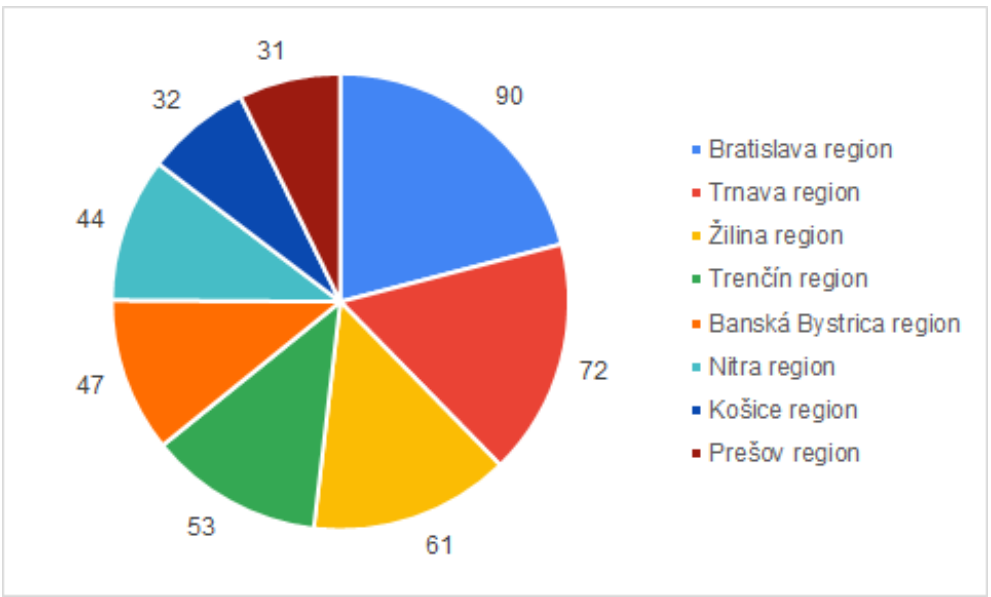

Figure 4: Region of Slovakia

Source: own processing, 2021

\section{RESULTS}

The respondents were asked whether they read domestic literature and 25 women responded "occasionally". Only 89 respondents answered "often", all of whom were women. This could be key for companies that focus mainly on women's literature from Slovak authors. 44 respondents answered "never" and 41 respondents said "sometimes" (Figure 5). We think that this number is negligible. Respondents include Arpád Soltézs, Jana Pronská, Lucia Sasková, Monika Wurm, Dominik Dán, František Kozmon, Katarína Holetzová, Eva Urbaníková, Zuzana Šulajová, Pavel Hirax Baričák, Michaela Zamari, Michaela Hajdúková, etc. among the favorite Slovak authors. The respondents were asked a supplementary question being "Why don't you read Slovak literature?". We could generalize the respondents' opinions to the following idea. Respondents who often do not read domestic literature or do not read it at all believe that domestic literature is not as good as foreign literature. In their opinion, it is not complicated to publish a book in Slovakia, therefore there is no filter for quality literature. In this way, even lower-quality books will get on the shelves of bookstores. If readers reach for them, they will be disappointed. If the negative experience is repeated, they resent literature from Slovak authors and focus only on translated books. 


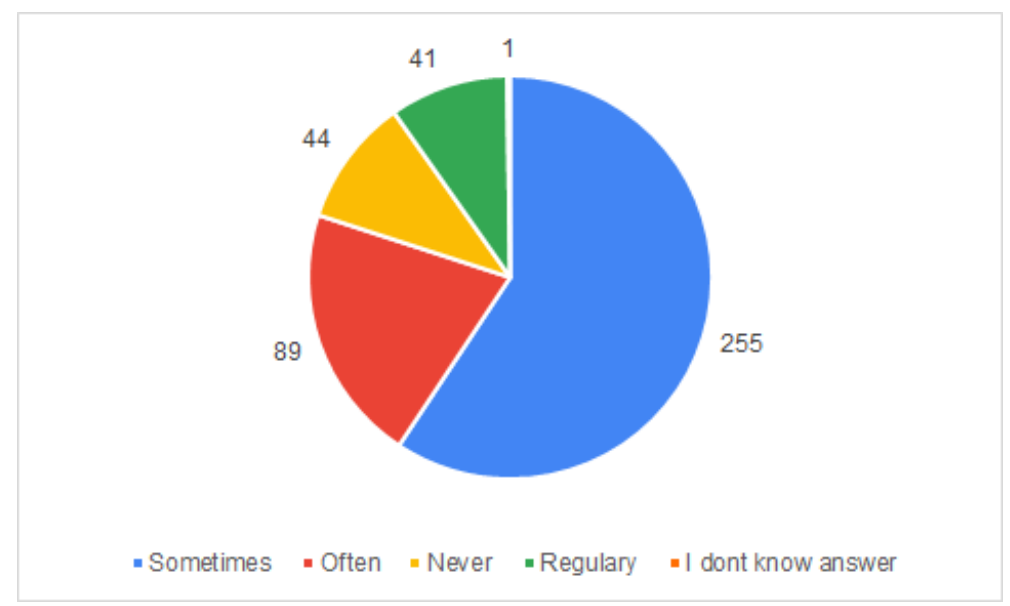

Figure 5: Reading Slovak literature

Source: own processing, 2021

200 respondents regularly read foreign literature translated into Slovak and 143 respondents often read it (Figure 6). Up to 109 of them often or regularly read Slovak literature. Only 14 respondents answered with "never". These are the respondents who mostly answered that they read Slovak literature from time to time. However, they regularly read foreign literature in the original language, most often in English. They reach for the original version because the original text is more authentic and unmodified by the Slovak translation. Of the entire sample of respondents, only 79 respondents regularly read books in the original version and 75 respondents do it "often". 105 respondents never reach for the original version. However, from the overall sample of respondents, we found that Slovak readers often reach for the Czech language (except for English and at least German and French). Slovak readers are still close to Czech and have no problem with the language barrier. This gives the opportunity either to Czech companies in Slovakia, which can import books to Slovak bookstores, or directly to Czech bookstores, which can deliver shipments to Slovakia and communicate in a targeted manner with Slovak readers.

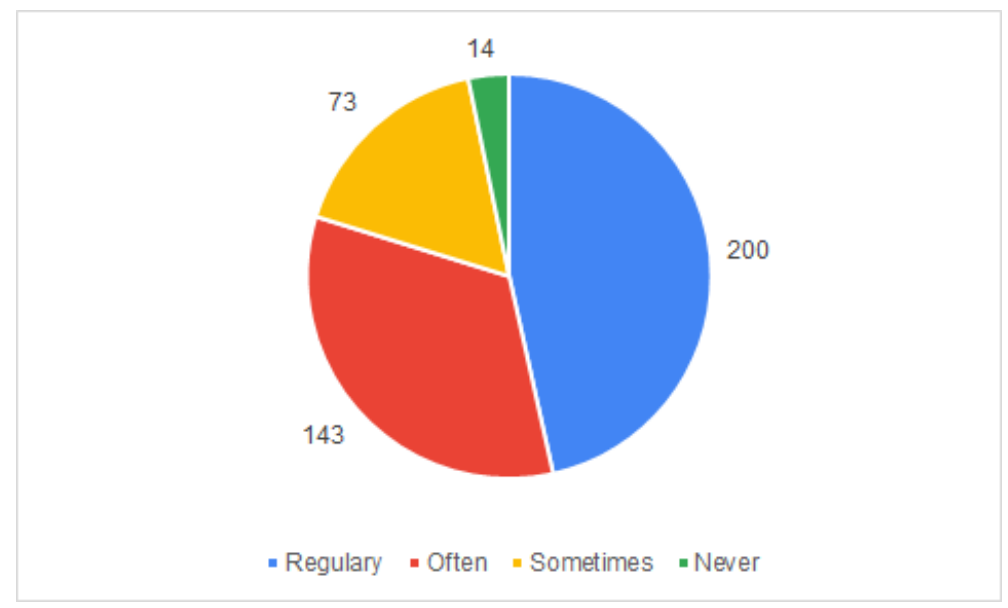

Figure 6: Reading translated literature

Source: own processing, 2021

Paper books are preferred by 326 respondents ("strongly agree"). 86 respondents answered with "agree". 3 respondents could not answer, 10 respondents disagreed and 5 respondents strongly disagreed. Paper books still have a strong presence on the Slovak market and constantly address readers. Respondents most often buy them or borrow from libraries or from their acquaintances. 
They are willing to pay an average of $€ 10-20$ for one paper book. It very much depends on whether they can illegally download the book online or on the very reason why they need to own the book. The respondents noted that some publishing houses increased their paper book prices by as much as $€ 3$ apiece during the Covid-19 pandemic. That's why they think carefully about buying a new book. Sometimes they also agree with an acquaintance that they will buy the book together and borrow it from each other or wait until the library in their place of residence buys it and offers it for borrowing. If there is a library near them that has funds to buy new books, the waiting time is not long. However, libraries in small towns or villages often do not have this budget which can complicate the way for respondents to a potential book.

E-books are preferred by only a small proportion of respondents (strongly agree - 18, rather agree 43 respondents). 19 respondents could not react to the statement. 177 respondents rather disagree and 173 respondents strongly disagree. E-books took their rightful place during the Covid-19 pandemic. Due to the closed bookstores, many respondents found that reading their favorite titles is quick, convenient, can happen anytime and, most importantly, cheaper. Although some e-titles have also become more expensive during the pandemic, they are still cheaper than paper ones. The respondents are willing to pay an average of $€$ 5-10 for an e-book. They believe that the cost of publishing an electronic version is lower and that is why they are not willing to pay more. That is especially because some respondents feel as if the experience of reading a paper book is "taken away" from them, even though they are aware of the benefits of the e-book.

Even in this case we encounter illegal e-book downloads. 89 respondents answered that they buy ebooks exclusively. 18 respondents borrow e-books from libraries for a definite period with a secure system. 91 respondents will download the e-book for free only if the book has a free license or is offered free of charge by the company or the author himself. 83 respondents illegally download ebooks from the Internet without exception. If they do not find the desired e-book online, they will look for it the legal way. If the price is right, they will buy it in electronic form. If the price is higher than they are willing to pay, they prefer to buy the paper form or not buy it at all.

Audiobooks are not popular among respondents. They are "definitely" preferred by only 9 respondents. Only 51 respondents "rather agree" with the statement. If respondents have the opportunity, they like to listen to audiobooks on Spotify or on YouTube or other available social networks. Only 14 respondents buy audiobooks and only 27 respondents listen in prepaid applications. They are willing to pay an average of 10-20€ for audiobooks. They are aware of the higher costs associated with the artistic performance as well as the complexity of preparing an audiobook.

In general, respondents choose the form of the book according to their personal budget and the availability of the book title they are interested in. When it comes to multi-page books, they see an advantage in e-books. This indisputable advantage is most noticeable when traveling, when respondents do not have heavy luggage or do not exceed the weight limit when traveling by plane. Nevertheless, they hold the view that "paper is paper" because they love its scent and the feeling that they can flip through the pages. It is precisely because of this custom that they still tend to have paper books even though they operate in a digital environment and communicate via social networks.

They most often read detective stories, thrillers, horrors, sci-fi, fantasy, romantic literature, historical literature, young adult literature, leisure literature and professional literature. They also buy these genres most often, respondents just do not see any difference.

220 respondents shop in the brick-and-mortar shops and e-shops without distinction. 83 respondents prefer to buy books through the e-shop. 61 respondents tend to buy more at the brick-and-stone branch. The rest of the respondents tend to borrow books from acquaintances, from the library or buy books in second-hand bookshops and bazaars. They choose the place of purchase of the book mainly for financial and time reasons. The branches of popular bookstores are not present in every city. From this we can come to a conclusion that the brand and communication of businesses on the 
Slovak book market is also important for readers. The price of the book itself is often decisive. In an e-shop, every form of a book is cheaper than in a brick-and-mortar or second-hand shop. On the contrary, bookstores are able to attract respondents especially through discounts, sales and various events. The most popular bookstore for respondents is Martinus. 236 respondents mentioned this brand bookstore. Among other ones, they mentioned Panta Rhei, Megaknihy, Knihy pre každého, Bux.sk and various other local bookstores. Only 12 respondents do not particularly care about the bookstore brand.

They decide to buy a book based on price (420 respondents), author (411 respondents), book cover (398 respondents), and genre (391 respondents). Respondents also stated that references from family and acquaintances, influencers, annotation of references in e-shops, display in shops as well as placement in TOP rankings are important to them. Publishing houses are the least important information for the respondents.

The most popular publishing houses of the respondents are: Ikar (169 respondents) and Slovart (125 respondents). 119 respondents have no favorite publishing houses and do not choose a book based on the house that publishes it. Respondents also mentioned others, such as Motýl', AlbatrosMedia and the like. As many as 264 respondents do not follow the publishing houses' social networks (Figure 7). It is the interest of consumers in social networks that is extremely important because publishing houses can communicate directly with their current or potential customers. There is more space for their own authors or books than on the social networks of other book businesses or influencers. Since the respondents usually do not care about the publishing house but rather about the author or genre, they can follow several publishing houses. These can appeal to potential customers with interesting and attractive content and gain their favor with other activities such as trouble-free shopping. Respondents most frequently follow the following publishing houses: Ikar, Slovart, Grada, Tatran and others.

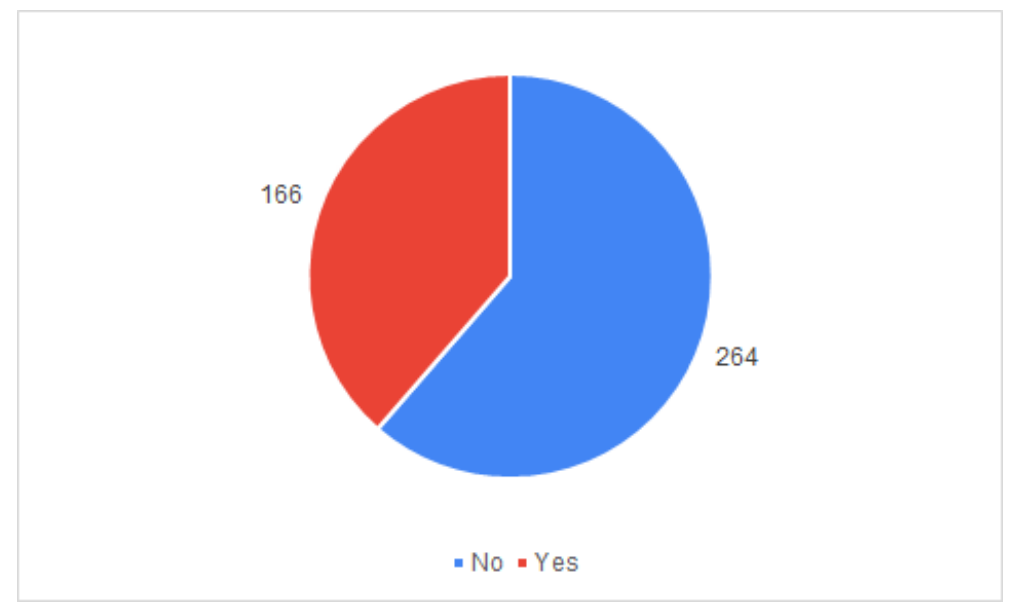

Figure 7: Following social networks of publishing houses

Source: own processing, 2021

On the contrary, respondents follow the social networks of bookstores more frequently. As many as 282 respondents follow the social networks of Slovak bookstores (Figure 8), while 132 of them also follow the social networks of publishing houses. That is why we can claim that if readers are interested in content on publishing house's social networks, they are also interested in content on bookstores' social networks, but this may not be the case vice versa. The most frequently followed ones are Martinus (277 respondents) and Panta Rhei (222 respondents). These are also bookstores that readers have indicated are among their favorites, where they like to buy the book. It is natural that they will also be interested in the content these brands publish on social media. 


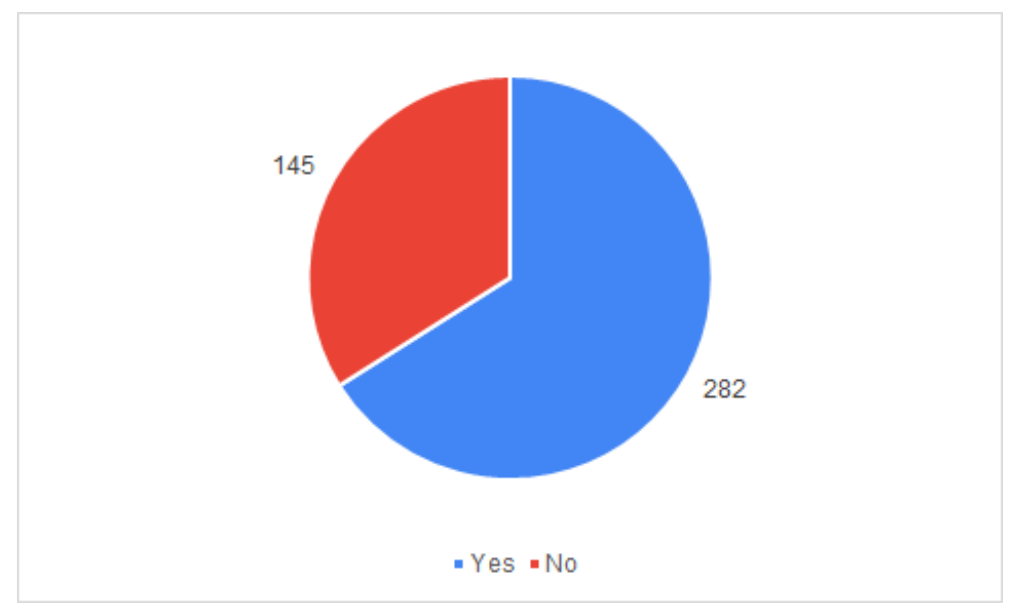

Figure 8: Following social networks of bookstores

Source: Own procesing, 2021

Despite the fact that book influencers are an indisputable part of the Slovak book market and help to build content not only for bookstores and publishing houses but also for the authors themselves, they are not followed by as many as 314 respondents. 116 respondents answered with "yes". The supplementary question being "Who is your favorite book influencer?" was answered indefinitely or with e.g. Lucieziel, Radši_knihu, By Jaji, Jana Šlinská, Drominika číta and the like. Readers like to watch the information from the book world through the brick-and-mortar branches of bookstores, in the library, but also on the social media of bookstores and favorite authors.

Although the world is becoming more and more digitized and due to the Covid-19 pandemic we are doing more things via the Internet, the buying behavior of readers in Slovakia is traditional. If we were to divide the readers into two groups, e-book readers and paper book readers, e-book readers are more inclined to follow the social networks of bookstores and publishing houses, and more stimuli from the digital environment can persuade them to buy. The reason may be that digital technologies and the associated environment are closer to them. Readers of paper books still like the classics - the smell of books and turning pages. Although they operate in the digital space, they still like to visit the brick-and-mortar branches of bookstores and are inspired when choosing a book also by the influence of the offline environment.

\section{Acknowledgement}

The paper is the outcome of the project FPPV-29-2021 named "Significance of digital marketing communication for the sale of e-books in the Slovak book market II.".

\section{Literature}

1. DZUROVÁ, M. a kol.: Spotrebitel'ské teórie a reálie. Bratislava : EKONÓM, 2007, p. 293. ISBN 978-90-225-2327-1.

2. JURŠOVÁ, D.: Klasické koncepcie výkonovej motivácie [online]. [2021-23-05]. Available at: <https://www.biznis-news.sk/klasicke-koncepcie-vykonovej-motivacie/>.

3. KELLER, K. L.: Conceptulalising, mesasuring and managing customer based brand equity. In: Journal of Marketing, vol. 57, no 1, 1993, p. 2-22.

4. KITA, J. a kol.: Marketing. Bratislava : Jura edition, 2005. ISBN 80-8078-049-8.

5. KOTLER, P.: Marketing - Management. Praha : Grada Publishing, 1998. ISBN 80-2470016-6.

6. KOTLER, P. - ARMSTRONG, G.: Marketing. Praha : Grada publishing, 2007. ISBN 802470-513-3. 
7. KOTLER, P.: Marketing management - analýza, plánovaní, využití a kontrola. Bratislava : Victoria Publishing, 1992, ISBN 80-7169-600-5.

8. KULČÁKOVÁ, M: Marketing. 3. prepracované a doplnené vydanie. Bratislava : Jura edition, 2005. ISBN 80-8078-049-8.

9. KULČÁKOVÁ, M., RICHTEROVÁ, K.: Spotrebitel'ské správanie. EKONÓM. Bratislava. 1996, p. 6 - 7. ISBN 80-2250-729-6.

10. KULĆÁKOVÁ, M. - RICHTEROVÁ, K.: Spotrebitel' na trhu: Faktory - stratégia reakcie. Bratislava : Sprint, 1997, p. 106.

11. PETROVIČOVÁ, J.: Modely spotrebitel'ského správania sociálnych tried pri tvorbe marketingovej stratégie. Bratislava : Wolters Kluwer, 2011, ISSN 978-80-8078-398-3

12. RICHTEROVÁ, K.: Spotrebitel'ské správanie - Nákup organizácií. Bratislava : EKONÓM, 1999. ISBN 80-225-1050-5.

13. SCHIFFMAN, L. - KANUK, L.: Nákupní chování. Brno : Computer Press, 2004. ISBN 802510-094-4.

14. TS: Kto číta, pôjde do štúdií Harryho Pottera. Slubuje Mondelez v novej kampani. [online]. [2021-05-23]. Available at: <https://strategie.hnonline.sk/marketing/1986953-kto-citapojde-do-studii-harryho-pottera-slubuje-mondelez-v-novej-kampani.>.

15. TS: Prieskum: 6 z 10 Slovákov nakupuje online. Najčastejšsie knihy, najmenej jedlo. [online]. [2021-05-23]. Available at: <https://strategie.hnonline.sk/marketing/2055256-prieskum-6-z10-slovakov-nakupuje-online-najcastejsie-knihy-najmenej-jedlo\%C5\%88?fbclid=IwAR 37MW7N8Chhk1-A0LrXz2RNSL8fptWTzlrCk4JyQ-2WEyDnN9KhZU-hM60>.

\section{Contact}

Mgr. Jana Paveleková

University of Ss. Cyril and Methodius in Trnava

Faculty of Mass Media Communication

Adress of University: Nám. J. Herdu 2, 91701 Trnava, Slovakia

E-mail: jana.pavelekova@ucm.sk

Mgr. Miriama Koliščáková

University of Ss. Cyril and Methodius in Trnava

Adress of University: Nám. J. Herdu 2, 91701 Trnava, Slovakia

E-mail: miriama.koliscakova@fmk.sk 


\title{
OBJEKTÍVNOSŤ KOMUNIKOVANÝCH INFORMÁCIÍ V ČASE TECHNOLOGICKEJ INTERFERENCIE AKO PREDPOKLAD REALIZÁCIE MEDZINÁRODNÉHO BENCHMARKINGU KLASTROV
}

\author{
OBJECTIVENESS OF COMMUNICATED INFORMATION IN TIMES \\ OF TECHNOLOGY INTERFERENCE AS A PREREQUISITE FOR THE \\ IMPLEMENTATION OF INTERNATIONAL CLUSTER \\ BENCHMARKING
}

\author{
Adam Madleňák
}

\begin{abstract}
Abstrakt
Účelom združovania subjektov pôsobiacich na hospodárskom trhu v klastroch je zdiel'anie vedomostí o ponúkaných produktoch a realizovaných procesoch v záujme vytvárania vhodných príležitostí pre podnikatel'skú činnost' v danom priemyselnom odvetví. Vzájomné porovnávanie klastrových organizácií by malo následne vychádzat' z komplexnosti a objektívnosti poskytnutých informácií súvisiacich s výkonnost'ou riadenia klastra počas posudzovaného obdobia. Vo svojom vedeckom príspevku sa autor zaoberá procesom hodnotenia excelentnosti klastrového manažmentu za pomoci benchmarkingu v súlade $\mathrm{s}$ medzinárodnými štandardami $\mathrm{v}$ čase technologickej interferencie. Zdôrazňuje pritom potrebu zrozumitel'nej komunikácie v snahe o získanie relevantnej spätnej väzby spôsobilej prispiet' k progresívnemu rastu a zvýšeniu konkurencieschopnosti klastra.
\end{abstract}

Kl’účové slová: klaster, benchmarking, marketingová stratégia, komunikácia, informácia, technologická interferencia

\begin{abstract}
The purpose of associating the entities operating on the market in clusters is to share knowledge about the products offered and the processes implemented in order to create suitable opportunities for business activities within the industry. The comparison of clusters should be based on complex and objective information on the performance of cluster management during the period considered. The paper deals with the process of evaluating the excellence of cluster management using benchmarking in accordance with international standards in times of technology interference. The paper emphasizes the need for clear communication in order to obtain relevant feedback which would contribute to the progressive growth and increase the competitiveness of the cluster.
\end{abstract}

Key words: cluster, benchmarking, marketing strategy, communication, information, technology interference

\section{1 ÚVOD}

Fenomén geografickej koncentrácie ekonomických aktivít v podobe klastrových organizácií, ktorý je všeobecne považovaný za významný faktor rozvoja príslušného teritória, nachádza postupne svoje významné a nezastupitel'né miesto aj u tvorcov národných sociálnych či hospodárskych politík. Hoci sa nedá kvantifikovat' tento vplyv existencie klastrov na konkurencieschopnost' a celkovú úroveň inovačného procesu v súkromnom sektore na národnej úrovni, resp. vo vybranom regionálnom teritóriu, určité sekundárne prvky v podobe zamestnanosti, rozvoja sociálneho prostredia a uspokojovania potrieb obyvatel'stva sa 
považujú za signifikantné dôkazy potvrdenia tohto konštatovania (Bezáková 2016). Pridanou hodnotou, ktorá sa v ostatných rokov stala určujúcou v tejto oblasti, je však práve snaha na kvalitatívnej úrovni posudzovat' úspešnost' pôsobenia klastrových organizácií na určitom území, a tak na jednej strane zvýšit' istotu orgánov verejnej správy s ohl'adom na posúdenie pozitívneho vplyvu klastrov, na druhej strane podporit' vo väčšej miere tie efekty, ktoré sú spôsobilé zabezpečit' ešte významnejší rozvoj združovania podnikatel'ských subjektov. V tomto ohl'ade sa nielen existencia klastra, ale skôr existencia úspešného a výkonného klastra stáva základnou požiadavkou a podmienkou pre riešenie prípadných sociálnych alebo ekonomických problémov, ktoré sa môžu vyskytnút', či razantnejší nástup a nárast inovácií v rámci udržatel'ného hospodárskeho rozvoja s predpokladom zmiernenia aj negatívnych následkov prípadných externých faktorov s priamym dopadom na konkrétne regionálne prostredie.

Na podklade predmetného prístupu preto aj Európska komisia prostredníctvom príslušných inštitucionálnych orgánov členských štátov Európskej únie vyvíja aktivity s ciel’om zásadnejšieho zapojenia existujúcich klastrových organizácií do procesu hodnotenia excelentnosti klastrového manažmentu formou využitia metodologického prístupu benchmarkingu Európskeho sekretariátu pre klastrové analýzy (d’alej aj ako „ESCA“). Samotný metodologický prístup ESCA nesmeruje výlučne k výsledku hodnotenia jednotlivých klastrových organizácií, ale súčasne využíva známu európsku politiku ,soft law“, ktorá sa v zásade objavuje takmer v každej jednej aktivite európskej hospodárskej politiky a politiky zamestnanosti, pričom dôraz sa kladie na šírenie pozitívnych príkladov z jednotlivých národných úrovní a následné vzájomné učenie práve z výsledkov komparácie klastrových organizácií v európskych i mimoeurópskych krajinách.

\section{CIEL' A METODIKA}

Ciel'om vedeckého príspevku je poukázat' na špecifiká benchmarkingu aplikovaného pri hodnotení kvalitatívnej úrovne riadenia klastrových organizácií pôsobiacich $\mathrm{v}$ regiónoch. Upriamujeme pozornost' na potrebu systematického prístupu a súčinnosti zainteresovaných $\mathrm{v}$ rámci komunikačného procesu, výstupom ktorého je identifikácia skutočného a objektívneho stavu klastrovej organizácie. Jednotlivé časti príspevku na seba odpovedajúcim spôsobom logicky nadväzujú so zretel'om na neskoršie vyvodzovanie záverov. Súhrnne sme okrem analyticko-syntetických použili aj indukčné, dedukčné a komparatívne metódy skúmania so zámerom priblíženia samotného priebehu certifikácie, prípadne recertifikácie riadenia klastrov v kontexte medzinárodných skúseností. K vymedzeniu kl'účového terminologického aparátu a prezentácii hodnotiacich kritérií vzt’ahujúcich sa na výkonnost' klastrov nám pomohli poznatky publikované nielen v domácej, ale i zahraničnej vedeckej a odbornej literatúre v podobe monografických diel a recenzovaných časopiseckých výstupov. Rovnako sme zapracovali do textu vlastné postrehy podložené niekol'koročným výskumom $\mathrm{v}$ rámci rozličných vedeckých projektov a grantov v snahe o bližšiu indikáciu výziev, ktorým musí manažment klastrových organizácií venovat' v blízkej budúcnosti zvýšenú pozornost'.

\section{VÝSLEDKY A DISKUSIA}

V súlade s deklarovaným prístupom identifikácie úspešných výkonných klastrových organizácií, ktorých predpokladom je odpovedajúci kvalitný proces riadenia klastra nielen v podobe nastavenia vnútorných procesov v rámci vlastnej organizačnej štruktúry, ale aj jej neskoršieho personálneho obsadenia, prišlo k vytvoreniu všeobecne uznávaného relevantného porovnávacieho mechanizmu v podobe metodologického prístupu benchmarkingu v snahe poskytnút' klastrovým organizáciám žiaducu spätnú väzbu. Ciel’om uplatňovanej metodiky 
benchmarkingu zo strany Európskeho sekretariátu pre klastrové analýzy so sídlom v Berlíne je poskytnutie objektívneho prehl'adu o existencii a miere výkonnosti jednotlivých klastrových organizácií a súčasne aj vytvorenie relevantnej porovnávacej analýzy, ktorá umožní identifikovat' určité fenomény pri vzniku a pôsobení klastrových organizácií (Burlina 2020). Obsah tohto metodologického prístupu benchmarkingu sa prejavuje nielen v oblasti vlastného posudzovania aktivít klastrovej organizácie, ale jeho formy majú viacdimenzionálny rozmer. Tieto spočívajú napr. v realizácii odborného poradenstva práve pri podpore vzniku a pôsobenia klastrových organizácií pri zameraní sa najmä na predstavitel'ov riadiacich klastrové organizácie a ostatných tvorcov politík alebo stakeholderov. Uplatňovanie benchmarkingu zo strany ESCA sa uskutočňuje prostredníctvom medzinárodnej siete špeciálne vyškolených expertov ESCA v spolupráci s partnerskými organizáciami na národných úrovniach. Do procesu posudzovania za pomoci benchmarkingu bolo od roku 2008 zapojených viac ako 1000 klastrových organizácií z viac než 35 európskych i mimoeurópskych krajín (Havierniková et al. 2018).

Výsledky dosiahnuté uplatnením metodologického prístupu benchmarkingu majú podstatný význam pre strategické rozhodovanie sa nielen existujúcich klastrových organizácií, ale potenciálne aj pre záujem podnikatel'ských subjektov uvažovat' o kreovaní d'alších klastrov s podobným či rovnakým hospodárskym zameraním (Valentová et al. 2020). Absolútne hodnoty získané hodnotením klastrov v rámci jednotlivých skúmaných kritérií i vo všeobecnosti ako záverečný výstup posudzovanej výkonnosti a konkurencieschopnosti klastrovej organizácie, prípadne jej členských organizácií, predstavujú kl’účový prvok úrovne samotného regiónu a jeho ekonomického potenciálu. Správne realizovaný proces benchmarkingu preto môže v mnohých ohl'adoch predstavovat' pomyselný lakmusový papierik aj vo vzt’ahu k hodnoteniu investičných a inovačných príležitostí pre zainteresované subjekty. Vychádzajúc z kvalitatívnych a kvantitatívnych hodnotiacich kritérií a porovnaním výsledkov špecifických pre klastrové organizácie medzi porovnatel'nými subjektmi (napr. klastre z rovnakej krajiny a/alebo z rovnakej technologickej oblasti/priemyselného odvetvia) sa benchmarking môže rovnako použit' na prezentovanie dosiahnutých úspechov, prípadne na identifikáciu príležitostí na zlepšenie pri nedostatkoch.

Pre účely zachovania požadovanej miery relevantnosti neskôr zistených výsledkov po uplatnení metodologického prístupu benchmarkingu sa za klastrové organizácie považujú najmä siete spoločností a výskumno-vývojových inštitúcií (vrátane univerzitných organizácií), ktoré majú tematické (hospodárske) zameranie, sú teritoriálne sústredené na regionálnom princípe, majú inštitucionalizovanú podobu v súlade $\mathrm{s}$ hmotnoprávnymi podmienkami národnej právnej úpravy a sú riadené prostredníctvom štruktúry zodpovedajúcej klastrovým organizáciám. Klaster však môže zahŕňat' aj iné zainteresované subjekty, ako sú verejnoprávne inštitúcie alebo agentúry. Za riadiacu štruktúru klastrovej organizácie sa pritom pokladá osoba alebo skupina osôb na zodpovedajúcich úrovniach riadenia, ktorí koordinujú a zabezpečujú nadväzovanie a realizáciu vnútorných a externých vzt’ahov s partnermi klastrovej organizácie, obdobne ako plnia ciele a úlohy vymedzené v zakladajúcich dokumentoch (Pavelková et al. 2017).

Prezentovaný metodologický prístup benchmarkingu je založený na analýze a komparácii vnútorných štruktúr, procesov, ponúkaných produktov a služieb klastrovej organizácie s klastrovými organizáciami $\mathrm{z}$ rovnakej alebo príbuznej technologickej či priemyselnej oblasti. Relevantnost' dosiahnutých výsledkov tak zaručuje, že výsledné hodnoty majú vypovedaciu schopnost' pre uvádzané subjekty, ktoré majú aj na základe ich poznania a interpretácie korigovat' svoje správanie a rozhodovanie v zmysle uvádzaného prístupu soft 
law a učenia sa $\mathrm{z}$ porovnávania s inými. Aktuálne uplatňovaný jednotný metodologický prístup benchmarkingu určený na porovnávanie hodnotenia riadenia štruktúr klastrovej organizácie a súčasne vnímaný aj ako nástroj na podporu klastrových organizácií v čase technologickej interferencie bol pôvodne predstavený v roku 2008. Súčasnú podobu získal prostredníctvom simultánneho rozvoja hodnotiacich kritérií a d'alších procesnoprávnych krokov v rámci rôznych národných i medzinárodných projektov (napr. Kompetenznetze Deutschland Initiative, The European Cluster Excellence Initiative, Cluster Excellence in the Nordic Countries, Germany and Poland, Go-Cluster a iné). Od roku 2011 zabezpečuje organizačné aktivity spojené so systémom uplatňovania benchmarkingu spoločnost' VDI/VDE Innovation + Technik GmbH, ktorá predstavuje sekretariát a kontaktné miesto ESCA a súčasne zodpovedný subjekt za uplatňovanie a d'alší rozvoj tohto hodnotiaceho systému benchmarkingu (Wilson 2019).

Fyzické uplatnenie metodologického princípu benchmarkingu je založené na poskytovaní informácií zo strany riadiacich štruktúr klastrovej organizácie externému expertovi ESCA, pričom sa predpokladá dodržanie zásad úplnosti, pravdivosti a objektívnosti komunikovaných informácií s predpokladom určenia skutočného a objektívneho stavu klastrovej organizácie. Nedodržanie predmetných zásad je spôsobilé skreslit' nielen skutočný stav riadenia klastrovej organizácie, ale ovplyvnit' aj následne vykonávané porovnávanie s ostatnými klastrovými organizáciami $\mathrm{v}$ dobe prebiehajúcej technologickej interferencie. $\mathrm{V}$ tomto ohl'ade tak benchmarking napomáha $\mathrm{k}$ určeniu relatívneho postavenia klastra v prostredí konkurenčného hospodárskeho trhu s následným posúdením výkonnosti jeho riadenia. Samotné hodnotenie výkonnosti riadenia klastrovej organizácie je realizované prizmou troch úrovní hodnotenia vyjadrenými tromi odlišnými farbami - zelenou, žltou a červenou, ktoré boli vymedzené na podklade skúseností z aplikačnej praxe zo strany ESCA. Zelená farba deklaruje výborné hodnotenie (excelentnost' splnenia hodnotiaceho kritéria), pričom ak sú možné, odporúča sa realizovat' nepatrné zlepšenia. Žltá farba deklaruje rozumné (odpovedajúce) naplnenie hodnotiaceho kritéria, pričom je tu priestor pre realizáciu zlepšovacích opatrení. Červená farba deklaruje, že určité minimálne kritériá týkajúce sa optimálneho riadenia klastrovej organizácie nie sú splnené, a preto sa odporúča zvážit' v krátkom čase realizáciu zlepšovacích opatrení v konkrétnej oblasti (Burger 2016). Praktické uplatňovanie týchto troch úrovní hodnotenia je pomerne jednoduché. Napríklad pri hodnotiacom kritériu doby pôsobenia klastrovej organizácie sa zelená farba udel'uje pri pôsobení klastrovej organizácie viac ako 4 roky, žltá farba od dvoch do štyroch rokov a červená farba pri menej ako dvoch rokoch. Obdobne napríklad pri posudzovaní geografickej koncentrácie členov klastrovej organizácie sa zelená farba udel'uje v situácii, ak sa viac ako $70 \%$ členov nachádza vo vzdialenosti do $150 \mathrm{~km}$ od sídla klastrovej organizácie alebo od jej regionálnej kancelárie, žltá farba, ak sa 50 až $70 \%$ členských organizácií nachádza vo vzdialenosti do $150 \mathrm{~km}$ od sídla klastrovej organizácie alebo jej regionálnej kancelárie a červená farba, ak sa menej ako 50 \% členských organizácií klastrovej organizácie nachádza vo vzdialenosti do $150 \mathrm{~km}$ od sídla klastra alebo jeho regionálnej kancelárie.

Výsledné použitie metodologického prístupu benchmarkingu sa završuje realizáciou procesu certifikácie $\mathrm{v}$ súlade $\mathrm{s}$ prezentovanými hodnotiacimi kritériami a následným pridel’ovaním odznakov excelentnosti na základe plnenia stanovených podmienok. Klastrovým organizáciám je tak následne pridel'ovaný bronzový, strieborný alebo zlatý odznak podl’a miery a kvality splnenia stanovených hodnotiacich kritérií na obdobie dvoch rokov, pričom tieto sú všeobecne akceptované v medzinárodnom odbornom prostredí (Lesáková et al. 2017). Zapojenie sa do procesu hodnotenia a následné získanie jedného z pridel'ovaných odznakov excelentnosti na jednej strane preukazuje schopnost' a záujem klastrovej organizácie 
zdokonal'ovat' a zlepšovat' svoje vnútorné a externé procesy s ciel'om dosiahnut' požadovanú výkonnost' a stanovené ciele, na druhej strane umožňuje nielen v marketingovej oblasti preukázat' úspešný príbeh vzniku a pôsobenia klastrovej organizácie na regionálnej, národnej i medzinárodnej úrovni.

Rozlíšenie jednotlivých odznakov excelentnosti sa uskutočňuje na základe stanovených kritérií, pričom ich pridel'ovanie má spravidla podmienený charakter od pridelenia prvého stupňa bronzového odznaku až po dosiahnutie najvyššieho ocenenia kvality riadenia klastrovej organizácie v podobe zlatého odznaku. Pridelenie bronzového odznaku ako prvého hodnotiaceho stupňa primárne nepredstavuje posúdenie kvality riadenia klastrovej organizácie, ale má povahu preukázania úsilia o dosiahnutie excelentnosti klastrovej organizácie a zlepšenia jej riadenia. Pridelenie bronzového odznaku predpokladá realizáciu niekol'kohodinového benchmarkingového rozhovoru predstavitel'ov klastrovej organizácie s expertom ESCA, pričom vecný obsah tohto rozhovoru približuje šest' základných oblastí vrátane štruktúry klastra, jeho manažmentu, financovania, marketingovej stratégie, poskytovaných služieb, vytvárania kontaktov s d’alšími aktérmi inovačného procesu, vnútornej dynamiky a internacionalizácie. Pridelenie strieborného odznaku excelentnosti ako druhého hodnotiaceho stupňa už predstavuje označenie vlastnej kvality riadenia klastrovej organizácie, pričom bezprostredne potvrdzuje úspešnú implementáciu zlepšovacích opatrení a procesov do vnútorného prostredia klastrovej organizácie získaných ako spätnú väzbu pri pridelení bronzového odznaku excelentnosti. Strieborný odznak excelentnosti je pridel'ovaný aj klastrovým organizáciám, ktoré síce nedosahujú odpovedajúce plnenie hodnotiacich kritérií pre pridelenie zlatého odznaku excelentnosti, ale majú záujem o preukázanie správnosti nastúpenej cesty pri zlepšovaní riadenia klastrovej organizácie s predpokladom získania zlatého odznaku excelentnosti. Strieborný odznak excelentnosti je pridelený po uskutočnení benchmarkingového sebahodnotenia klastrovej organizácie a uskutočnení posúdenia implementácie spomínaných zlepšovacích opatrení. Pridelenie zlatého odznaku excelentnosti ako tretieho hodnotiaceho stupňa už preukazuje najvyššiu kvalitu riadenia klastrovej organizácie a plnenie stanovených hodnotiacich kritérií na najvyššej úrovni s predpokladom d'alšieho progresívneho rastu a zlepšovania. V zásade sa zlatý odznak excelentnosti pridel'uje klastrovým organizáciám s vysoko sofistikovaným spôsobom riadenia vnútorných a vonkajších procesov klastrovej organizácie po úspešnom absolvovaní niekol'kodňového hodnotenia činnosti expertmi ESCA (Meshkov 2020).

Po uplatnení metodologického prístupu v podobe benchmarkingu dochádza k vypracovaniu komplexnej hodnotiacej správy, v ktorej sú popri samotnom posúdení splnenia hodnotiacich kritérií klastrovou organizáciou uvedené aj odporúčania smerujúce k progresívnemu zlepšeniu jej riadenia i vlastného pôsobenia zo strany ESCA, rovnako ako aj rôzne formy grafických porovnaní klastrovej organizácie s ostatnými najlepšími klastrovými organizáciami v rámci toho istého technologického portfólia v európskom priestore. Vypracúvanie hodnotiacich správ sekundárne umožňuje sledovat' vývoj klastrových organizácií v príslušných územných oblastiach, resp. ponúka zainteresovanej laickej i odbornej verejnosti možnost' oboznámit' sa $\mathrm{s}$ aktuálnym dianím. Uvádzané poznatky a informácie v komplexných hodnotiacich správach však musíme vnímat' prizmou ich individuálnej interpretácie vo väzbe na špecifické podmienky vzniku a pôsobenia klastrových organizácií, stanovené ciele a úlohy klastrovej organizácie v zakladajúcich dokumentoch, prípadne vkontexte d’alších osobitných charakteristík záujmového združenia.

Vzhl'adom k obsahu porovnávacieho mechanizmu v podobe benchmarkingu, ktorý zahŕňa rozsiahly aspekt kritérií, je možné realizovat' rôzne výsledné porovnávacie hodnotenia medzi 
klastrovými organizáciami. V zásade môžeme identifikovat' tri základné prístupy porovnávania klastrových organizácií, pričom rozlišujeme národné portfólio, technologické portfólio a portfólio excelentnosti klastrových organizácií (Machová et al. 2015). Pod národné portfólio sa subsumujú všetky klastrové organizácie, ktoré boli účastné procesu benchmarkingu a následnej certifikácie $\mathrm{v}$ rámci konkrétnej krajiny bez ohl'adu na úroveň ich výkonnosti vo vzt’ahu k riadeniu klastrovej organizácie. $\mathrm{V}$ tomto prípade predstavuje národné portfólio šancu porovnávat' klastrové organizácie navzájom v rámci vybranej krajiny s možnost'ou zistenia a posúdenia vlastnej úrovne kvality riadenia v národnom, hospodárskom a politickom kontexte. Možnost' zostavenia národného portfólia však predpokladá, že sú $\mathrm{k}$ dispozícii údaje (realizácia benchmarkingu) o najmenej desiatich klastrových organizáciách $\mathrm{z}$ analyzovanej krajiny. Do zostavovania technologického portfólia (príslušného hospodárskeho odvetvia) sú zaradené iba tie klastrové organizácie, ktoré dosahujú určitú minimálnu úroveň excelentnosti riadenia (výkonnosti riadenia klastrovej organizácie). Zohl'adňuje sa pritom aj rozsah (variabilita) a intenzita hlavných služieb poskytovaných konkrétnou klastrovou organizáciou. Klastrové organizácie, ktoré vznikli a pôsobia menej ako 36 kalendárnych mesiacov, nie sú $\mathrm{v}$ predmete zamerania tohto technologického portfólia (príslušné hospodárske odvetvie) zohl'adnené, ked’že sa v mnohých aspektoch a procesnoprávnych činnostiach líšia od už plne a dlhodobo fungujúcich klastrových organizácií. Výsledky posudzovaných klastrových organizácií sa tak porovnávajú s ostatnými klastrovými organizáciami, ktoré pôsobia v konkrétnej určitej špecifickej technologickej oblasti. Do portfólia excelentnosti sú zaradené iba tie klastrové organizácie, ktoré dosahujú vel'mi vysokú úroveň výkonnosti riadenia. Výsledky posudzovaných klastrových organizácií sa tak porovnávajú s ostatnými klastrami tvoriacimi portfólio excelentnosti. Portfólio excelentnosti nezohl'adňuje zaradenie klastrovej organizácie do technologického portfólia (príslušného hospodárskeho odvetvia) a viaže sa výlučne na úroveň riadenia klastrovej organizácie.

V nadväznosti na vyššie popísané východiská politiky hodnotenia klastrových organizácií môžeme konštatovat', že v súčasnosti pôsobí v Slovenskej republike viac ako 50 klastrov, ktoré splńnajú všeobecnú legálnu definíciu daného pojmu. Podl'a dostupných poznatkov je z nich aktívnych (teda fyzicky vykonávajú činnost' a plnia ciele vymedzené v zakladajúcich dokumentoch) 13 klastrových organizácií z oblastí jednotlivých priemyselných odvetví a 11 klastrových organizácií z odvetvia cestovného ruchu. Do uvádzaného sumáru sme zaradili klastrové organizácie, ktoré vykazujú činnost' v období od roku 2015. Doteraz bol pritom metodologický prístup benchmarkingu a následný proces certifikácie zo strany ESCA uplatnený pri vyše 20 klastrových organizáciách. Prvé pokusy o realizáciu procesu certifikácie riadenia klastrových organizácií v Slovenskej republike možno identifikovat' v priebehu kalendárneho roku 2013. Tieto predstavovali spravidla súčast' riešenia medzinárodných projektov (Cluster Excelence Network for Training and Mobility (CENTRAMO), Achieving Cluster Excellence (ACE) a pod.), v ktorých Slovenskú republiku zastupovala Slovenská inovačná a energetická agentúra (Balog 2015). Slovenská inovačná a energetická agentúra aktuálne ako stabilný partner ESCA disponuje vlastnými certifikovanými hodnotitel'mi spôsobilými posudzovat' kvalitu riadenie klastrových organizácií s celoeurópskou pôsobnost'ou v súlade s popisovaným metodologickým prístupom benchmarkingu. Na základe dosiahnutých výsledkov sa stali v priebehu rokov držitel'mi bronzového certifikátu napr. Národný energetický klaster v Bratislave, Automotiv Cluster Slovakia v Trnave, Slovak Plastic Cluster v Nitre, 1. slovenský strojársky klaster v Detve, In Tech v Žiari nad Hronom, IT Valley a Klaster automatizačnej techniky a robotiky v Košiciach. Z oblasti rozvoja cestovného ruchu to boli Klaster Orava v Dolnom Kubíne, Klaster Liptov v Liptovskom Mikuláši, Klaster Horehronie v Brezne a iné. V roku 2015 sa 
klastrovej organizácii IT Valley z Košíc zameranej na tvorbu priaznivého podnikatel'ského prostredia $\mathrm{v}$ odvetví informačných a komunikačných technológií dokonca podarilo získat' ako vôbec prvému klastru zo štátov strednej Európy najvyššie hodnotenie kvality riadenia v podobe zlatého odznaku excelentnosti. Tento si následne záujmové združenie udržalo aj v sledovanom hodnotiacom období v roku 2018. Organizácia tým preukázala schopnost' vysoko sofistikovaného riadenia $\mathrm{v}$ dlhodobom horizonte s predpokladom d'alšieho zlepšovania sa a dosiahnutia vyššej výkonnosti. Popritom aktuálne prebieha proces certifikácie d’alších nových klastrov a recertifikácie tých, ktorým medzičasom uplynula dvojročná platnost' pridelených odznakov excelentnosti. K uvádzanému progresívnemu rastu zapojených klastrov do procesu certifikácie prispieva najmä realizácia medzinárodného projektu z oblasti podpory klastrových organizácií s názvom ClusterFY a národného projektu Zvýšenie inovačnej výkonnosti slovenskej ekonomiky v rámci Operačného programu Výskum a inovácie.

\section{ZÁVER}

Európsky sekretariát pre klastrové analýzy sa usiluje dlhodobo o zlepšovanie metodologického prístupu benchmarkingu spôsobilého posudzovat' kvalitu riadenia klastrových organizácií, čím súčasne sekundárne konštituuje aj stálu referenčnú platformu na ich porovnávanie. Dosiahnuté výsledky hodnotenia úrovne riadenia záujmových združení vo vzt'ahu k ostatným klastrovým organizáciám závisia však od určenia konkrétneho okamihu uskutočnenia dopytovania $\mathrm{v}$ rámci benchmarkingu, ked’že sa plynutím času posudzovania pri jednotlivých klastroch mohlo vychádzat' $\mathrm{z}$ inej teoreticko-empirickej bázy. Z vykonanej analýzy vo väčšine prípadov vyplýva niekol'ko slabých stránok, ktorým by sa mala venovat' zvýšená pozornost' do budúcna $\mathrm{v}$ záujme zabezpečenia dlhodobej udržatel'nosti klastrovej organizácie v čase prebiehajúcej technologickej interferencie. Pri bližšej identifikácii oblastí, ku ktorým by mali smerovat' prijímané opatrenia, je následne nevyhnutné zohl'adnit' predovšetkým rozsah rámcových podmienok klastra, charakter jeho členskej základne v kontexte regionálneho potenciálu, ako i spôsob organizácie práce pri poskytovaní informácií internej a externej verejnosti.

Vedecký príspevok bol vypracovaný v rámci riešenia projektu Vedeckej grantovej agentúry Ministerstva školstva, vedy, výskumu a športu Slovenskej republiky a Slovenskej akadémie vied (VEGA, č. 1/0458/21) s názvom „Manažment konceptu "spodnej vlny" zo strany podnikatel'ských subjektov pri propagácii environmentálne vhodných produktov $\mathrm{v}$ čase technologickej interferencie“".

\section{Použitá literatúra}

1. BALOG, M., 2015. Klastrová politika vpodmienkach Slovenska. Bratislava: Slovenská inovačná a energetická agentúra. 100 s. ISBN 978-80-88823-61-2.

2. BEZÁKOVÁ, Z., 2016. Impact of the Globalization on the Process of Creating Marketing Communication and Its Importance in the Creation of Innovation. In: KLIESTIK, T. (ed.) Globalization and Its Socio-Economic Consequences. Žilina: Žilinská univerzita v Žiline, s. 175-182. ISBN 978-80-8154-191-9.

3. BURGER, P., 2016. Inovačná a klastrová politika. Košice: Technická univerzita v Košiciach. 109 s. ISBN 978-80-808-6257-2.

4. BURLINA, C., 2020. Networking Policy and Firm Performance. In: Growth and Change. Roč. 51, č. 1, s. 161-179. ISSN 1468-2257.

5. HAVIERNIKOVÁ, K. et al., 2018. Hodnotenie miery vplyvu klastrov na rozvoj regiónov. Trenčín: Trenčianska univerzita Alexandra Dubčeka v Trenčíne. 320 s. ISBN 978-80-8075-823-3. 
6. KUPEC, V., 2018. Risk Audit of Marketing Communication. In: European Research Studies Journal. Roč. 21, č. 1, s. 125-132. ISSN 1108-2976.

7. LESÁKOVÁ, L. et al., 2017. Súčasný stav a perspektívy rozvoja technologických klastrov v Slovenskej republike. Banská Bystrica: Univerzita Mateja Bela v Banskej Bystrici. 133 s. ISBN 978-80-557-1182-9.

8. MACHOVÁ, R. et al., 2015. Inovačné podnikanie a hodnotenie inovačného potenciálu podnikatel'ských sietí. Brno: Tribun EU. 219 s. ISBN 978-80-263-0598-9.

9. MESHKOV, I., 2020. Main Features of the EU Cluster Policy. In: Contemporary Europe - Sovremennaya Evropa. Č. 1, s. 182-190. ISSN 0201-7083.

10. ONDRUŠOVÁ, M., 2019. Nástroje inteligentných technologických inovácií v priemysle na Slovensku. In: MURA, L. (ed.) Mladi vedci 2019. Bratislava: Paneurópska vysoká škola, s. 147-159. ISBN 978-80-89453-62-7.

11. PAVELKOVÁ, D. et al., 2017. Impact of Cluster Policies on Structure and Management of Cluster Organisations in Czechia and Slovakia. In: Administratie si Management Public. Č. 29, s. 6-26. ISSN 1583-9583.

12. VALENTOVÁ, T. et al., 2020. GDPR v pracovnoprávnej praxi. Ako byt'v súlade $s$ nariadením o ochrane osobných údajov. Bratislava: Wolters Kluwer. 264 s. ISBN 978-80-571-0237-3.

13. WILSON, J., 2019. Cluster Policy Resilience: New Challenges for a Mature Policy. In: International Journal of Business Environment. Roč. 10, č. 4, s. 371-382. ISSN 1740-0589.

\section{Kontaktné údaje}

PhDr. Adam Madleňák, PhD., MBA

Univerzita sv. Cyrila a Metoda v Trnave, Fakulta masmediálnej komunikácie

Námestie J. Herdu 2, 91701 Trnava, Slovenská republika

email: adam.madlenak@ucm.sk 
EKONOMIKA, BANKOVNICTVÍ, POJIŠŤOVNICTVÍ ECONOMY, BANKING, INSURANCE MANAGEMENT

\section{QUAERE}




\title{
OBCHODNÍ DOHODY EU A MODEL SDÍLENÉ AGENTURY POHLEDEM EKONOMICKÉ DIPLOMACIE
}

\author{
EU TRADE AGREEMENTS AND THE SHARED AGENCY MODEL IN \\ TERMS OF ECONOMIC DIPLOMACY
}

\author{
Jana Marková
}

\begin{abstract}
Abstrakt
Ekonomická diplomacie má velmi úzký vztah $\mathrm{k}$ hospodářské politice, potažmo $\mathrm{k}$ zahraniční obchodní politice. Pokud je analyzována ekonomická diplomacie v prostoru EU, pak je tato diplomacie navázána na společnou obchodní politiku EU. Cílem příspěvku je hodnocení současného vlivu EU v rámci ekonomické diplomacie s ohledem na obchodní dohody EU. Pohled na ekonomickou diplomacii EU na světových trzích je $\mathrm{v}$ př́íspěvku posouzen podle typu modelu ekonomické diplomacie a také v souvislosti s obchodními dohodami, které jsou $\mathrm{v}$ rámci společné obchodní politiky uzavírány. Konkrétně jsou v př́spěvku uvedeny typy smluvních závazků EU v rámci společné obchodní politiky, následně je analyzován model sdílené agentury na př́kladu Singapuru a dále je rozebrána dohoda o volném obchodu mezi EU a Singapurem (EUSFTA).
\end{abstract}

Klíčová slova: ekonomická diplomacie, EU, společná obchodní politika, obchodní dohody, EUSFTA

\begin{abstract}
Economic diplomacy has a very close relationship to economic policy, hence trade policy to foreign countries. Economic diplomacy in the EU is linked to the EU's common trade policy. The aim of the paper is to evaluate the current influence of the EU in the field of economic diplomacy with regard to the EU trade agreement. A look at the EU's economic diplomacy on world markets is in a paper conducted with selected type of economic diplomacy model and also in connection with trade agreements that are concluded within the framework of the common trade policy. Specifically, the paper presents the types of EU contractual obligations under the common commercial policy, then analyzes the model implemented by the agency in Singapore and further discusses The European Union-Singapore Free Trade Agreement (EUSFTA).
\end{abstract}

Key words: economic diplomacy, EU, common trade policy, trade agreements, EUSFTA

\section{1 ÚVOD}

Ekonomická diplomacie se v kontextu globální ekonomiky významněji prosazuje od 90. let minulého století v rámci liberalizace trhů a rostoucí konkurence. Na jedné straně existuje rostoucí koncentrace ekonomické moci a monopolizace mnoha sektorů s konglomeráty a nadnárodními společnostmi, které zneužívají rostoucí tržní sílu omezováním a narušováním hospodářské soutěže. $\mathrm{Na}$ druhé straně je narůstající interference politických faktorů $\mathrm{v}$ ekonomických otázkách a vliv různých mocností, včetně například čínského státního kapitalistického modelu. V této souvislosti je opět globalizace pod tlakem mnoha negativ. Nestačí být efektivní, konkurenceschopný nebo být schopen řešit vnitřní strukturální problémy k tomu, aby bylo možné uspět v globální ekonomice. Nutné jsou i institucionální vazby. Být konkurenceschopný a mít inovativní ekonomiku je pouze nezbytná, ale ne 
dostačující podmínka pro řešení výzev globalizace a znalostní společnosti. Na ekonomickou diplomacii lze pohlížet převážně jako na strategii jak reagovat na tento paradox a rostoucí integraci ekonomických, politických a bezpečnostních rozměrů.

Cílem př́spěvku je hodnocení současného vlivu EU v rámci ekonomické diplomacie $\mathrm{s}$ ohledem na obchodní dohody EU. Použivám vysvětlující popisnou analýzu na základě syntézy z různých zdrojů. Pohled na ekonomickou diplomacii EU na evropských a světových trzích je v př́spěvku veden s ohledem na vybraný typ modelu ekonomické diplomacie a také $\mathrm{v}$ souvislosti $\mathrm{s}$ obchodními dohodami, které jsou $\mathrm{v}$ rámci společné obchodní politiky uzavírány. Konkrétně jsou v př́spěvku uvedeny typy smluvních závazků EU v rámci společné obchodní politiky, následně je analyzován model sdílené agentury na př́kladu Singapuru a dále je rozebrána dohoda o volném obchodu mezi EU a Singapurem (EUSFTA).

\section{EKONOMICKÁ DIPLOMACIE A OBCHODNÍ POLITIKA EU}

Ekonomická diplomacie má velmi úzký vztah $\mathrm{k}$ hospodářské politice, potažmo $\mathrm{k}$ obchodní politice ve vztahu k zahraničí. Pokud je analyzována ekonomická diplomacie v prostoru EU, pak je tato diplomacie navázána na společnou obchodní politiku EU.

Ekonomická diplomacie má za úkol účinně vykonávat zahraniční politiku ve prospěch hospodářské politiky daného státu. Klíčovým bodem pro vykonávání úspěšné ekonomické diplomacie jsou informace. Získávání informací pro aktéry ekonomické diplomacie patří mezi hlavní cíle $\mathrm{v}$ této oblasti. Na základě těchto obchodních a hospodářských dat je pak dále možné vyhodnocovat strategii, která by nejlépe propagovala stát jako ideálního adepta pro zahraniční investice. Prezentace státu je také velmi důležitá v otázce navazování bilaterálních a multilaterálních vztahů. ${ }^{1}$

Ekonomická diplomacie je od druhé poloviny 20. století v odborné veřejnosti chápána především jako ekonomická dimenze zahraniční politiky, kde zaujímá jednoznačně prioritní místo. Ekonomická diplomacie je kromě prostředku pro naplnění záměrů a cílů ekonomické dimenze zahraniční politiky též prostředkem, do určité míry i předpokladem realizace zahraniční dimenze vnitřní hospodářské politiky státu, především jeho proexportní politiky, politiky spjaté s př́livem zahraničních investic, $s$ programy podpory investování domácích podnikatelů $\mathrm{v}$ zahraniční, $\mathrm{v}$ neposlední řadě s programy podpory exportních aktivit malých a středních podniků a dalších. ${ }^{2}$

Ekonomická diplomacie v prostoru EU je lemována dalšími partnery EU z třetích zemí včetně mezinárodních institucí. V rámci komplexního zázemí v EU můžeme sledovat bilaterální i multilaterální vztahy $\mathrm{EU} \mathrm{s}$ třetími zeměmi. Ekonomická diplomacie je $\mathrm{v}$ rámci institucionálního fungování EU rozsáhlým souborem činností a ovlivňuje významně ekonomickou diplomacii každého členského státu.

Z hlediska teoretického pohledu na ekonomickou diplomacii lze sledovat některé nejistoty ohledně vymezení obsahu pojmu. Jde jednak o problematiku pojmového a obsahového vymezení mezi ekonomickou a politickou rovinou, zejména pak mezi mezinárodní ekonomií a mezinárodní politikou. Teoreticky je každý stát schopen důsledně odlišovat ekonomické záležitosti a politické záležitosti. V realitě jsou státy spíše subjekty politické než ekonomické. Nejednoznačné je také vymezení domácích a mezinárodních aktérů při tvorbě hospodářské

\footnotetext{
${ }^{1}$ HUBINGER, V. Encyklopedie diplomacie. Praha: Libri, 2006, s. 63, ISBN 80-7277-296-1.

2 ŠTOURAČOVÁ, J. Ekonomická diplomacie České republiky. Praha: Professional Publishing. 2008. 249 s. ISBN 978-80-86946-71-9. s. 29
} 
politiky. Nejmarkantnější je tento nedostatek v rámci domácích rozhodovacích procesů. V ekonomické diplomacii se často na národní úrovni rozdělují kompetence a i názory různých ministerstev a je třeba zdůraznit, kdo má v tomto ohledu vůdčí roli. Kromě ministerstva zahraničních věcí jde o vymezení prostoru pro zapojení se do procesu rozhodování dalších vládních rezortů a agentur. Vláda je také často $\mathrm{v}$ mnoha ohledech ovlivněna domácími i mezinárodními finančními institucemi, investory nebo podnikateli. Významnou roli hrají v ekonomické diplomacii také mezinárodní nevládní organizace.

V rámci společné obchodní politiky EU lze pozorovat tři typy obchodních dohod EU. Je to jednak celní unie, kdy jsou odstraněna cla $\mathrm{v}$ dvoustranném obchodu a zaveden společný celní tarif pro zahraniční dovozce. Dále jsou to dohody o přidružení, dohody o stabilizaci, hluboké a komplexní dohody o volném obchodu a dohody o hospodářském partnerství, které by měly odstranit nebo snížit celní tarify ve dvoustranném obchodu. Vždy záleží na vzájemných vztazích a postojích partnerů. A třetím typem dohod jsou dohody o partnerství a spolupráci, které mají za cíl pouze poskytnout obecný rámec pro dvoustranné hospodářské vztahy, avšak ponechat celní tarify tak, jak jsou. $\mathrm{V}$ současnosti platí pro společnou obchodní politiku ustanovení v rámci Lisabonské smlouvy z roku 2009.

Společná obchodní politika disponuje několika nástroji, kterými sleduje dva základní cíle: prosazování otevřeného a mnohostranného obchodního systému ve světě a ochranu zájmů EU a členských zemí zejména $\mathrm{v}$ př́padech, kdy by měl volný obchod nepříznivé dopady na ekonomickou situaci, prosperitu, zaměstnanost či obchodní bilanci v EU. Nástroje na ochranu obchodu v podstatě suplují neexistenci mechanismu proti nekalým soutěžním praktikám v rámci mezinárodního hospodářství, který na národní úrovni provádí úřady pro ochranu hospodářské soutěže. EU se řídí zásadami Světové obchodní organizace.

Autonomní obchodní politika zahrnuje nástroje, které Společenství uplatňuje mimo rámec smluvních závazků se třetími státy. Jsou to jednak cla, která chrání určitá odvětví před zahraniční konkurencí nebo naopak podporuje dovoz produktů, o které má zájem jako o vstupy nezbytné pro rozvoj výroby. Dále jsou to kvóty v obchodě se zeměmi, které nejsou členy Světové obchodní organizace (WTO) a dobrovolná exportní omezení.

Důležitý aspekt současné fáze globalizace je, že bývalé komunistické státy se staly tržně orientovanými ekonomikami a jsou stále více součástí světového ekonomického systému ${ }^{3}$. Van Bergeijk odkazuje na gravitační model jako na aplikovaný empirický obchodní model, který popisuje dvoustranné obchodní toky. Klíčovými faktory $\mathrm{v}$ tomto modelu jsou ekonomická hmotnost a vzdálenost. Model předpokládá, že interakce je slabší, pokud je vzdálenost větší, a propojení je silnější, když jsou objemy obchodu větší. Proto tedy velká země, která má značnou produkci a počet obyvatel, bude ceteris paribus obchodovat více než malá země. Podobně země, které jsou bližze $\mathrm{k}$ sobě budou obchodovat násobně více. ${ }^{4} \mathrm{~V}$ tomto směru jsou také sestavovány a vyjednávány mezinárodní obchodní smlouvy, které by měly všechny výhody gravitačního modelu využít a naopak překážky vzájemného obchodu co nejvíce odstranit.

Evropská unie se po roce 2000 v době velkého rozšiřování EU, a tedy i zvětšování vnitřního trhu, potýkala s problémy, které přináší světový trh bez jasného vedení ze strany Světové

\footnotetext{
${ }^{3}$ VAN BERGEIJK, Peter. Economic Diplomacy and the Geography of International Trade [online]. Edward Elgar Publishing, 2009 [cit. 2021-06-09]. ISBN 9781781007778. Dostupné z: doi:10.4337/9781781007778.

${ }^{4}$ Model zahrnuje i určitý počet faktorů odporu obchodu (např́iklad dovozní cla) a faktory zdokonalení obchodu (např́klad společný jazyk), které jsou na dvoustranná úrovni možné.
} 
obchodní organizace. WTO není dostatečně funkční organizací v rámci sjednávání dohod mezi jejími členy a Evropská unie se v roce 2006 rozhodla pro strategii sjednávání bilaterálních nebo i regionálních dohod o volném obchodu jako cestu při nedostatečné podpoře ze strany WTO. ${ }^{5}$ Nové dohody o volném obchodu by tak měly mít komplexní a ambiciózní pokrytí a usilovat o co nejvyšší míru liberalizace obchodu. Jednou z takových dohod je i dohoda EUSFTA mezi EU a Singapurem, jak bude dále rozvedeno.

\section{MODEL SDÍLENÉ AGENTURY - SINGAPUR}

Z celosvětového pohledu lze vysledovat několik základních modelů fungování ekonomické diplomacie, nejčastěji se odlišují tyto modely: integrovaný, duální a model třetí strany. Rana ${ }^{6}$ popisuje pět modelů, kterými jsou model integrovaný, částečně integrovaný, duální (respektive konkurenční), model sdílené agentury (respektive třetí strany) a model postoupení pravomoci. Pajtinka ${ }^{7}$ popisuje podobně jako Štouračová ${ }^{8}$ tři modely: integrovaný, duální a model třetí strany. Země se pak podle různých pohledů mohou řadit do některého $\mathrm{z}$ modelů. Vzhledem $\mathrm{k}$ významnému rozdílu mezi jednotlivými ekonomikami můžeme $\mathrm{v}$ důsledku historického vývoje i ekonomickému zaměření zemí popsat odlišnosti ve fungování jednotlivých institucí, které se ekonomické diplomacii věnují. Stejně jako systém státní a veřejné správy, tak i systém institucionálního zabezpečení ekonomické diplomacie není ani $\mathrm{v}$ rámci Evropské unie jednotný. Aplikace a využití nástrojů ekonomické diplomacie je zcela v kompetenci národních států. Zároveň není žádný z modelů využíván ve zcela čisté podobě. V̌̌dy jsou zahrnuta různá specifika národních států a ekonomik. ${ }^{9}$

Modely velmi často zahrnují z institucionálního hlediska zapojení ministerstev, a to podle vlastních kompetenčních pravidel. Některé státy postavily na fungování ekonomické diplomacie svůj záměr významného zapojení do světové ekonomiky a za tímto účelem vytváří i specifické instituce. Takovou zemí je Singapur, u kterého lze popsat v rámci ekonomické diplomacie model třetí strany, neboli model sdílené agentury. Tímto způsobem je pak země aktivně zapojena do mezinárodního obchodu.

Základním prvkem ekonomické diplomacie Singapuru je agentura Enterprise Singapore, která nově vznikla na jaře 2018 sloučením agentur International Enterprise Singapore (IE Singapore) a SPRING - Singapore Productivity and Standards Board (Singapurská rada pro produktivitu a standardy). IE Singapore byla založena v roce 1983 s cílem rozvíjet Singapur jako mezinárodní obchodní centrum propagující národní zboží a služby. Zároveň byla statutární radou pod ministerstvem obchodu a průmyslu singapurské vlády, která usnadňovala zámořský růst společností se sídlem v Singapuru a podporovala mezinárodní obchod. Činnost IE Singapore byla zaměřena na usnadňování obchodu a zlepšování marketingových politik a strategií, zkoumala prríležitosti na světových trzích a následně exportovala různorodé obchodní systémy včetně mezinárodního offshore obchodování. V obchodní politice

\footnotetext{
${ }^{5}$ Evropská komise. Sdělení Komise Globálni Evropa: konkurenceschopnost ve světě. KOM (2006) 567, 4. 10. 2006. [online]. [cit. 2021-06-03]. Dostupné z WWW: <https://www.mpo.cz/assets/dokumenty/33024/4 6147/555822/priloha003.pdf>

${ }^{6}$ RANA, K. S. Bilateral Diplomacy. Geneva: DiploFoundation, 2007. ISBN 99989-55-16-6.

${ }^{7}$ PAJTINKA, E. Hospodárska diplomacia: Hladanie efektívneho modelu riadenia, alebo boj o obchodných atašé? Medzinárodní politika, 2007, roč. 31, č. 10, s. 16-18. ISSN 0543-7962.

8 ŠTOURAČOVÁ, J. Ekonomická diplomacie České republiky. Praha: Professional Publishing. 2008. 249 s. ISBN 978-80-86946-71-9.

9 ŠTOURAČOVÁ, J. a KOL. Systém ř́zeni ekonomické diplomacie v České republice. 2010. [online]. Praha: Svaz průmyslu a dopravy ČR. [cit. 2021-06-03]. Dostupné z WWW: <http://www.spcr.cz/files/cz/dokument y/analyza.pdf $>$.
} 
zastupovala Singapur při jednáních ve Všeobecné dohodě o clech a obchodu (GATT), aby aktivně zajistila př́stup na světové trhy.

Vedle toho SPRING byla založena v dubnu 1996 sloučením National Productivity Board (Národní rady pro produktivitu), Singapore Institute of Standards and Industrial Research (Singapurského institutu pro standardy a průmyslový výzkum) a Economic Development Board (Rada pro hospodářský rozvoj), a to $\mathrm{v}$ oblasti rozvoje malých a středních podniků. Cílem fúze bylo spojit měkké dovednosti produktivity a technické aspekty rozvoje. V dubnu 2002 byla ustavena společnost SPRING Singapore, za účelem posunu rozhodování směrem k ekonomice zaměřené na inovace $\mathrm{s}$ důrazem na podporu kreativity, zvyšování produktivity domácího sektoru a udržení ekonomického růstu Singapuru.

Enterprise Singapore je vládní agentura prosazující rozvoj podnikání. Spolupracuje s mnoha světovými společnostmi, a to za účelem tvorby inovací a internacionalizace. Hlavním cílem je podpora růst Singapuru jako centra globálního obchodování a startupů. Jako národní normalizační a akreditační orgán podporuje důvěryhodnost produktů a služeb Singapuru prostřednictvím kvality a standardů. Enterprise Singapore podporuje růst singapurských společností prostřednictvím integrované podpůrné sítě a zlepšuje obchodní schopnosti a prístup na zámořské trhy.

Z hlediska ministerského zázemí je $\mathrm{v}$ rámci ekonomické diplomacie základní institucí Ministerstvo obchodu a průmyslu (Ministry of Trade and Industry Singapore), které se snaží vést Singapur jako globální centrum s dynamickou ekonomikou, světovými a inovativními podniky, př́znivým prostředím pro podnikatele, podniky a pracovní příležitosti. Pod toto ministerstvo spadá celkem 9 statutárních rad a vládní statistický úřad. Jednou takovou statutární radou je právě agentura Enterprise Singapore, ale také další agentury, např́íklad Agentura pro vědu, technologii a výzkum (A * STAR), Rada pro ekonomický rozvoj, Singapurská rada pro cestovní ruch, Soutěžní a spotřebitelská komise Singapuru nebo Úřad pro energetický trh. Rozsah jejich práce zahrnuje podporu výzkumu a inovací, vytváření progresivního energetického prostředí, podporu místních podniků a rozvoj cestovního ruchu.

Singapur v rámci modelu sdílené agentury (Enterprise Singapore) vytváŕí praktickou inovativní diplomacii, která vychází z toho, že je nutné stále hledat vlastní politický prostor, který by překonal určitou zranitelnost vyplývající z geopolitického umístění. Neustále tak propojuje vlastní ekonomiku s ostatním světem, hledá způsoby, jak se stát relevantním pro mezinárodní společenství, prostřednictvím specializované diplomacie a proaktivního stylu. Nejlepší efektivitu dosahuje již dlouhodobě při využívání regionální diplomacie. Provozuje relativně malou sít' ambasád se silnou centralizovanou kontrolou prostřednictvím svého ministerstva zahraničí a vyžívá nerezidentní velvyslance (non-resident ambassadors). V mnoha ohledech může být vzorem pro jiné malé státy. ${ }^{10}$

V porovnání s jinými modely ekonomické diplomacie je tento model sdílené agentury významně otevřen pro aktivní politiku se zahraničím bez ohledu na politické změny uvnitř ekonomiky. Liší se tak od jiných modelů ekonomické diplomacie, kde je primární vliv ministerstva (nebo více ministerstev) a tato ministerstva jsou vedena politickými subjekty podle aktuálního výsledku voleb. Dobře patrné je to na př́ikladu českého modelu ekonomické diplomacie (duální model nebo konkurenční model). V České republice je totiž vždy patrná určitá konkurence mezi Ministerstvem zahraničních věcí a Ministerstvem průmyslu a

\footnotetext{
${ }^{10}$ RANA, K. S., Singapore's Diplomacy: Vulnerability into Strength, The Hague Journal of Diplomacy, 2006, vol.1 no.1, pp.81-106.
} 
obchodu v rámci konkrétního rozdělení kompetencí, ačkoliv je vše dání Kompetenčním zákonem ${ }^{11}$. Záleží totiž na politickém složení vlády a rozdělení ministerstev mezi politické strany. Takové změny ve směřování ekonomické diplomacie nenastanou, pokud je svěřena vládní agentuře nezávislé na politickém dění země.

Singapur investuje mnoho institucionálních zdrojů na aktivity ekonomické diplomacie na různých frontách. Jako malá, otevřená a globalizovaná ekonomika městských států podporuje svou prosperitu v rámci mezinárodního ekonomického systému. Snaží se v rámci zahraniční politiky o využití různých forem mnohostranné ekonomické diplomacie, a to včetně hledání důležitých střetů zájmů. Jde o specifický př́stup Singapuru k regionálnímu ekonomickému multilateralismu ve východní Asii i ke globálnímu ekonomickém multilateralismu. Hospodářská politika sleduje kromě ekonomických cílů i problematiku kvality práce a životního prostředí. ${ }^{12}$

\section{EUSFTA - DOHODA O VOLNÉM OBCHODU MEZI EVROPSKOU UNIÍ A SINGAPUREM}

Evropská unie se v roce 2006 po období nečinnosti WTO rozhodla pro strategii Globální Evropa: konkurenceschopnost na světovém trhu. Tato strategie má za cíl sjednávání bilaterálních a regionálních dohod o volném obchodu. Dohody jsou uzavírány podle priorit na základě různých kritérií (např́iklad tržní potenciál). Mezi prioritní země byly zařazeny také státy Sdružení zemí jihovýchodní Asie (ASEAN).

Dohoda o volném obchodu mezi Evropskou unií a Singapurem (The European UnionSingapore Free Trade Agreement (EUSFTA)) byla první dohodou o volném obchodu vyjednanou mezi EU a zemí ASEAN. Je to jedna z prvních dvoustranných dohod o volném obchodu ve smyslu obchodních dohod „nové generace“. Taková obchodní dohoda zahrnuje kromě tradičních ustanovení týkajících se snížení cel a netarifních překážek v oblasti obchodu se zbožím a službami ustanovení v různých oblastech souvisejících s obchodem, jako jsou ochrana práv $\mathrm{k}$ duševnímu vlastnictví, investice, veřejné zakázky, hospodářská soutěž a udržitelný rozvoj.

Singapur a EU zahájily jednání o EUSFTA v roce 2009. Jednání o zboží a službách byla uzavřena v roce 2012, zatímco jednání o ochraně investic byla uzavřena v roce 2014. Prvky ochrany investic se později staly dohodou o ochraně investic mezi EU a Singapurem (EUSingapore Investment Protection Agreement (EUSIPA)).

EUSFTA a EUSIPA byly podepsány v říjnu 2018 a schváleny Evropským parlamentem v únoru 2019. EUSFTA byla schválena Radou EU dne 8. listopadu 2019 a vstoupila v platnost dne 21. listopadu 2019. EUSIPA prochází ratifikací regionálních a národních parlamentů členských států EU. Očekává se, že to bude trvat nejméně dva roky.

Dohoda EUSFTA ${ }^{13}$ se celkem skládá ze 17 kapitol a znamená komplexní moderní obchodní dohodu s širokým záběrem. Prvních šest kapitol se věnuje obchodu zbožím a upravují vstup

\footnotetext{
${ }^{11}$ Zákon č. 2/1969 Sb., o zřízení ministerstev a jiných ústř̌edních orgánů státní správy, ve znění pozdějších předpisů.

12 DENT, CHRISTOPHER M. Reconciling Multiple Economic Multilateralisms: The Case of Singapore. Contemporary Southeast Asia, vol. 24, no. 1, 2002, pp. 146-165. [online]. [cit. 2021-06-03]. Dostupné z WWW: <www.jstor.org/stable/25798584>.

${ }^{13}$ Council of the European Union. Free Trade Agreement between the European Union and the Republic of Singapore. Brussels. 2018. [online]. Interinstitutional File: 2018/0094 [cit. 2018-03-03]. Dostupné z WWW: <http://www.spcr.cz/files/cz/dokumenty/analyza.pdf>.https://www.mti.gov.sg/Improving-Trade/Free-TradeAgreements/-/media/MTI/Microsites/EUSFTA/EUSFTA-Full-Text_12Oct18.pdf>
} 
na trh se zbožím, ochranná opatření, technické překážky obchodu, sanitární a fytosanitární opatření, usnadňování celních procedur a odstranění netarifních překážek v zařízeních pro obnovitelnou energii a dalších konkrétních sektorech, jako automobily, elektronika či farmaceutika. Smluvní strany se zavázaly k odstranění všech cel během pěti let od vstupu dohody v platnost. V dalších dvou kapitolách jsou upraveny vztahy v oblasti služeb, usazení, elektronického obchodu a ochraně investic, včetně mechanismu řešení sporů investor - stát. V kapitolách jsou smluveny podrobné závazky $\mathrm{v}$ př́padě telekomunikačních, environmentálních, finančních, inženýrských, architektonických, poštovních, námořních a IT služeb. V oblasti ochrany investic dohoda zajišt'uje stabilní a spravedlivé prostředí pro př́mé i nepřímé investice při zachování práva smluvních stran regulovat právní prostředí ve veřejném zájmu.

Pravidla související $\mathrm{s}$ obchodem jsou upravena $\mathrm{v}$ pěti kapitolách, a to $\mathrm{v}$ oblasti veřejných zakázek, ochraně práv $\mathrm{k}$ duševnímu vlastnictví, hospodářské soutěže, vztahu obchodu a udržitelného rozvoje a transparentnosti. U veřejných zakázek jsou rozšířeny závazky nad Dohody WTO o vládních zakázkách, ke které už dříve státy přistoupily. Pokud jde o zeměpisná označení (GIs), smluvní strany se dohodly na vytvoření registru zajišt'ujícího ochranu GIs a poskytujícího tak větší transparentnost a jistotu.

V kapitole týkající se obchodu a udržitelného rozvoje je zakotveno dodržování mezinárodních standardů v oblasti pracovních podmínek a ochrany životního prostředí. Obsahuje také otázky odpovědného chování firem, udržitelného spravování přírodních zdrojů a způsob zapojení občanské společnosti. Tři závěrečné kapitoly upravují postup pro řešení sporů, který vychází zkušeností získaných z WTO a je proto formulován ještě detailněji. Založen byl společný výbor, který má zastřešovat specializované podvýbory a sloužit $\mathrm{k}$ diskuzi smluvních stran o implementaci dohody.

EUSFTA jako komplexní dohoda o volném obchodu upravující vzájemné obchodní vztahy mezi EU a Singapurem v celé jejich šíri je základem pro tvorbu obchodních vztahů s dalšími zeměmi ASEAN s perspektivou pozdější megaregionální dohody EU-ASEAN.

\section{ZÁVĚR}

Pro vykonávání efektivní ekonomické diplomacie by měly být splněny některé základní podmínky. Jednak je potřeba zajistit institucionální zázemí, určit, která agentura nebo ministerstvo bude zajišt'ovat zahraniční obchod a podporu investic, a nastavit způsob, jakým jsou harmonizovány akce různých zúčastněných aktérů, oficiálních i nestátních. Relevantní jsou také způsoby rozhodování. Dalším klíčovým faktorem je způsob, jakým jsou vyřizovány mezinárodní a regionální dohody. Na bilaterální úrovni je třeba podniknout mnoho klíčových opatření na podporu vývozu a př́mých zahraničních investic prostřednictvím řady konkrétních opatření, která mají přijmout domácí aktéři a diplomatické mise ř́zené ministerstvem zahraničí. Součástí ekonomické diplomacie je i rozvojová pomoc, a to nejen pro př́ijemce pomoci, ale i pro ty, kteří pomoc poskytují pomoc. Neopomenutelný je i turismus a image jako součást řízení ekonomické diplomacie při prosazování vnějších ekonomických zájmů zemé. ${ }^{14}$

V příspěvku byl představen model sdílené agentury na příkladu Singapuru, konkrétně ve spojitosti s Enterprise Singapore jako vládní agentury prosazující rozvoj podnikání. Dále byly

\footnotetext{
${ }^{14}$ RANA, K. S., Economic diplomacy: what might best serve a developing country?, International Journal of Diplomacy and Economy, 2013. Vol. 1, Nos. 3-4, pp.232-247.
} 
shrnuty základy společné obchodní politiky EU a na př́kladu dohody EU a Singapuru byly popsány hlavní prvky těchto vazeb. Na základě této dohody EUSFTA se do roku 2024 odstraní skoro všechny celní překážky při vzájemném obchodu.

Kromě rozvoje vzájemných obchodních vztahů mezi EU a Singapurem, který byl v únoru 2019 podpořen schválením obchodní a investiční dohody, bylo EU dále rozvíjeno obchodování i s dalšími zeměmi $\mathrm{v}$ asijském regionu. Jeto obchodní dohoda a dohoda o strategickém partnerství s Japonskem a obchodní a investiční dohoda s Vietnamem. Dohoda s Vietnamem je první dohodou s rozvojovou zemí, která odpovídá vysokým požadavkům záruk na ochranu pracovněprávních a environmentálních standardů. Vietnam je po Singapuru další zemí sdružení ASEAN, s níž se EU podařilo dosáhnout obchodní dohody, díky které firmy z EU získají lehčí prristup na rostoucí trh jihovýchodní Asie. Obchodní výměna s tímto regionem stále roste. Původní plán sjednat dohodu s ASEAN jako celkem se vzhledem $\mathrm{k}$ rozdílnému charakteru jednotlivých členů zatím nepodařilo naplnit. EU tak jedná se zeměmi ASEAN jednotlivě. Vyjednávání se Singapurem byla dokončena již v roce 2014, s Vietnamem o rok později, následně byly smlouvy dokončovány pro náročný ratifikační proces.

\section{Použitá literatura}

1. Council of the European Union. Free Trade Agreement between the European Union and the Republic of Singapore. Brussels. 2018. [online]. Interinstitutional File: 2018/0094 [cit. 2018-03-03]. Dostupné z WWW: <http://www.spcr.cz/files/cz/dok umenty/analyza.pdf>.https://www.mti.gov.sg/Improving-Trade/Free-TradeAgreements/-/media/MTI/Microsites/EUSFTA/EUSFTA-Full-Text_12Oct18.pdf>

2. DENT, CHRISTOPHER M. Reconciling Multiple Economic Multilateralisms: The Case of Singapore. Contemporary Southeast Asia, vol. 24, no. 1, 2002, pp. 146165. [online]. [cit. 2021-06-03]. Dostupné z WWW: <Www.jstor.org/stable/ 25798584>.

3. Evropská komise. Sdělení Komise Globální Evropa: konkurenceschopnost ve světě. KOM (2006) 567, 4. 10. 2006. [online]. [cit. 2021-06-03]. Dostupné z WWW: <https://www.mpo.cz/assets/dokumenty/33024/46147/555822/priloha003.pdf>.

4. HUBINGER, V. Encyklopedie diplomacie. Praha: Libri, 2006, s. 63, ISBN 80-7277296-1.

5. PAJTINKA, E. Hospodárska diplomacia: Hladanie efektívneho modelu riadenia, alebo boj o obchodných atašé? Medzinárodní politika, 2007, roč. 31, č. 10, s. 16-18. ISSN 0543-7962.

6. RANA, K. S., Singapore's Diplomacy: Vulnerability into Strength, The Hague Journal of Diplomacy, 2006, vol.1 no.1, pp.81-106.

7. RANA, K. S. Bilateral Diplomacy. Geneva: DiploFoundation, 2007. ISBN 9998955-16-6.

8. RANA, K. S., Economic diplomacy: what might best serve a developing country?, International Journal of Diplomacy and Economy, 2013. Vol. 1, Nos. 3-4, pp.232247.

9. ŠTOURAČOVÁ, J. a KOL. Systém řizeni ekonomické diplomacie v České republice. 2010. [online]. Praha: Svaz průmyslu a dopravy ČR. [cit. 2021-06-03]. Dostupné z WWW: 〈http://www.spcr.cz/files/cz/dokumenty/analyza.pdf>.

10. ŠTOURAČOVÁ, J. Ekonomická diplomacie České republiky. Praha: Professional Publishing. 2008. 249 s. ISBN 978-80-86946-71-9. 
11. VAN BERGEIJK, P. Economic Diplomacy and the Geography of International Trade [online]. Edward Elgar Publishing, 2009 [cit. 2021-6-9]. ISBN 9781781007778. Dostupné z: doi:10.4337/9781781007778

\section{Kontaktní údaje}

PhDr. Jana Marková, Ph.D.

Univerzita Jana Amose Komenského Praha s.r.o.

Roháčova 63, 13000 Praha 3

Tel: +420 724121581

email: janamarkova1@gmail.com

ORCIDiD: https://orcid.org/0000-0002-2321-2853 


\title{
THE ETHICS AND ECONOMIC BENEFITS OF A DIGITAL SOCIETY
}

\author{
Thomas Meier, Helena Makyšová
}

\begin{abstract}
Digitization is increasingly calling into question our society's previous understanding of values and at the same time placing great hopes in the benefits of digital technology. The subject of this article is which dangers and wrong turns, especially in the education sector accompanied by digitization, can be recognized. The main goal is to first identify values and, in this context, to embed them in the status quo of the economy. Building on this, the present article illuminates concrete research results of the use of digital technology in the education sector. In addition, recommendations for action are given for an ethically and socially compliant corporate culture. For this research, currently available literature, various articles and internet sources were systematically checked and evaluated.
\end{abstract}

Keywords: Ethics, education, digitization, virtues, learning success, progress

\section{INTRODUCTION}

\subsection{Values as a necessary component of ethics}

The challenges in the area of conflict between ethics and digitization have been an integral part of economic issues since the 2010 years at the latest, with the advent of big data and advancing digitization. Since the second industrial revolution at the latest, the dialectic of the economy has been understood as the translation of values into just one universal unit: money. Values that grew out of our culture, followed (and continue to follow) the theses of the Enlightenment, as described by Emanuel Kant, for example, and thus give direction to our human actions depending on culture and socialization, are increasingly taking a back seat in favor of efficiency. It is explicitly the values that hold a society together internally and that make it possible in the first place to evaluate actions, things and, above all, innovations in terms of whether these are accepted as actual progress by a society. In the economic context, values that are generally accepted as a consensus in Central Europe, for example, are hardly or not at all included in the calculations of the products or services offered. Projects are generally designed in such a way that, for example, a courier driver's route describes the shortest or fastest transport route, but not the most scenic route. The route is even less determined by the driver himself, who may attach particular priority to the value of "beauty". The value of "beauty" is therefore irrelevant. Values, and especially values of this kind, are phenomena that significantly determine feeling, thinking and thus acting. Values are, according to the German philosopher and sociologist Max Scheler, "[...] irrreducible basic phenomena of sentient perception." [1] In this way, people become value carriers and align their behavior accordingly. But not only people are value carriers but also things, actions, activities or relationships. Loyalty, courage, honesty or willpower are behavior patterns that are particularly important in an economic context but are difficult to translate into monetary values.

Basically it can be stated that individuals, groups and every society pursues certain goals, which in turn are based on certain values. Values are thus beliefs, attitudes and ideas of a certain normative way of living that are projected onto oneself, onto others and onto society. Inner values such as friendship and harmony and external values such as status, power and money influence each other. [2] 


\subsection{Conflicting goals of economic values}

In a democratic society, values such as freedom of the press, freedom of expression, freedom of assembly or, generally speaking, the "concept of freedom" are part of the basic order of the democratic legal system. In a democratic legal system, values are accepted even if they are anti-democratic, as long as its representatives adhere to the existing laws. This is what distinguishes a democracy fundamentally from a dictatorial system. However, values can also be in contradiction and compete with one another in a democratic system. The value of economic growth, which was anchored as a goal in the Stability and Growth Law of 1967 in Germany, is in conflict with sustainable ecological action in the long term. Here, the conflicting goals, and therefore the values that are in competition with one another, are repeatedly checked and questioned. [3] In particular, the value of steady economic growth requires critical appreciation, especially since the limits of the study of the same name on the future of the world economy were clearly shown as early as 1972. A study commissioned by the Club of Rome, which, based on a computer simulation, carried out a system analysis of various future scenarios with regard to tendencies of global impact. The result was clear: "If the current increase in world population, industrialization, environmental pollution, food production and the exploitation of natural resources continues unchanged, the absolute limits of growth on earth will be reached in the course of the next hundred years." [4] This example shows that values of societies have to be repeatedly examined and how values that have been deeply rooted in social thinking - since the beginning of the industrial revolutions - can be changed or eliminated.

\subsection{Virtues as a result of the definition of values}

In contrast to a value / a concept of values, which can also have a negative connotation (e.g. avarice), virtue is understood as an excellent quality or as an exemplary action of a person. Generally speaking, then, every virtue is a value, but not every value is a virtue. According to Aristotle, a virtue is that which "[...] makes him who possesses it good in his being and acting" [5et al.] Thus, action itself is emphasized and a distinction is made between "being good" and "doing well". A virtue can be described as a habitus that is only developed through a wealth of experiences and actions within a social framework. Translated, virtues are learned, good values which, however, are not developed by chance, but rather arise largely through the set framework conditions of a social, political and economic nature.

For this reason, it is essential to set the values for a successful life, for a free society and, last but not least, for a successful company in such a way that virtues develop that make this possible. This is a kind of circular argument, which, however, is to be understood as a constantly renewing process. In this context, the right questions need to be asked about the digital future. How do we want to live - not - how will we live? As a foundation for the future, a normative design by the companies that arose in Silicon Valley and currently dominate our economic landscape is less suitable, but rather enables a value system that is able to develop utopias that serve a free society stand.

\section{DIGITAL INNOVATIONS VS. SOCIAL PROGRESS}

The former CEO of IBM, Sr. Thomas John Watson, is credited with a significant quote which illustrates the prevailing zeitgeist at the time. In 1943 Watson is reported to have said (without evidence): "I believe that there will be a need for maybe five computers in the world." [6] The question that companies asked themselves at the time was the question of the benefit, and therefore why? At the beginning of the 1950s, industrial companies were the first to buy what were then very expensive and very large computers. The benefit for these companies, which is now interpreted ex post, was rather unclear at the time. Mathematicians in companies promised to solve complicated research tasks with it, but the conventional calculation 
challenges in everyday business life could also be tackled with conventional tools, which, in contrast to the newly emerging computers, were significantly cheaper. The usefulness of these calculators was only classified and assessed years later, meaning that the means and ends of an innovation on the way to progress have been reversed. David Gugerli, Professor of the History of Technology at ETH Zurich, talks about how the world came into the computer not the computer into the world. [7] The manufacturers of the first computers therefore had a problem with explaining the benefits and thus a sales problem. In the companies there were virtually no problems that could not have been solved conventionally. Only the former American computer manufacturer Remington Rand, who offered the first commercial computer (UNIVAC) in 1951, reacted to the problem of non-existent use with a promotional film. The slogan states that the machine is ideal for everything that has to be sorted, classified, calculated and decided. [8]

Digitization can be understood as a blueprint of this dialectic, because here too there is still a need to ask about a clear benefit that goes along with digitization. The innovations should thus be established in the form of progress as an integral part of living together if they are able to solve non-trivial problems and thus serve a higher social or societal purpose. Translated, this means that progress only becomes progress when it is socially accepted and describes a better and more livable condition in the sense of the established value system than the past.

\section{THE STIGMA OF ECONOMY}

\subsection{The job of the economy}

The economy with all its sub-areas that are taught at the universities of the world has turned more and more into an end in itself in the course of industrialization. However, the cofounders of modern economics such as Adam Smith, later John Maynard Keynes or the pioneer of the social market economy, Walter Eucken, saw in a just economy a supportive force for people that functions as a means, not an end. The questions about ethical and moral images in the economic sense were asked by the great economic philosophers and were included in their considerations. The question of the purpose that the economy should fulfill is an essential component of an ethical value system, which ultimately determines economic coexistence in a broader sense. The challenge of which value system should be applied to fair, ecologically sustainable economic activity must be mastered holistically and thus also socially and culturally. These questions cannot be answered within the boundaries of economics alone, but require an expanded focus. Economic issues are always embedded in a societal, social and ecological framework. Thus the purpose of the economy is a societal issue. Pope Francis, the current deputy head of the Catholic Church, defines the purpose of the economy as a noneconomist in his address on July 9, 2015 at the World Meeting of Popular Movements in Santa Cruz de la Sierra as follows: "The first task is to put the economy in the service of the people to ask: [...] A just economy must create the conditions so that every person can enjoy a childhood without deprivation, develop their talents during their youth, pursue a legally secure job during the years of activity and achieve a decent pension in old age . It is an economy in which man, in harmony with nature, designs the entire system of production and distribution in such a way that the skills and needs of each individual find an appropriate framework in the community. " [9] Francis also puts the economy as such in a conditional relationship in which he does not speak of "the" economy, but of a just economy that is earmarked. With regard to privation, the head of the church does not mean the material level, i.e. not the latest status product, digital device or branded clothing, but rather means the social values and achievements in a substantial sense, which are indispensable. Living a "good life" is not the same as living a "comfortable, carefree" life, continues the pontiff. The economy should serve a good life and digitization, artificial intelligence and big data, as described in the previous chapters, have considerable potential to fundamentally improve the "good life". 
So if the Pope's statement is supplemented by a digital dialectic, nothing should change in the ethical principles of this quote. As a tool, digital technologies can enable people, especially in the medical field, to lead a life that would be unthinkable without these innovations.

\subsection{Economy as an end in itself}

What has just been said, however, assumes that economic goals do not serve as a purpose, but that the primary goal of the technology is balanced. An example from the media should clarify this fact:

"Die Höhle Löwen" is a television show, the concept of which is that entrepreneurs, startups and inventors can advertise for venture capital to grow their mostly young company. The mostly innovative business concepts are presented to the "lions", i.e. the potential investors, who then invest their own capital and knowledge in these companies and provide advice and assistance and a large sales network. On April 5th, 2021, the innovative wheelchair control system from the young company "munevo DRIVE" was presented. [10] This technological innovation enables wheelchair users who suffer from multiple sclerosis, for example, and who are more and more restricted in their motor movement, to control their wheelchair with the help of smart glasses and an individually tailored head movement. The technology is complex and the public funding of health products is difficult due to the approval requirements. So the founding team sought financial help from the investors. The technical design of the product was convincing, but the economic evaluation was decisive for the investors in order not to enter into a deal. The profit margin was too small, the product was difficult to scale, the entrepreneurial (financial) risk too great. Hence, from the perspective of the "lions", a deal would have come about under economically profitable conditions, with better efficiency and growth forecasts. Economic, not ethical, goals were the goal here. Solutions outside of a purely economic perspective would have meant added value and an enormous relief for many affected people. Networks could have been used even without risk capital and know-how for the matter as such could have been brought in. Digital technologies could serve the well-being of many, especially in the medical-technical field, and should not only increase the economic benefit of a few.

This example, which was broadcast in German-speaking countries as part of the program, shows, as a blueprint, the ethical dilemma that can be transferred to the entire economy in a broader sense. The economy is an end, not a means.

\section{THE DIGITAL FUTURE OF THE EDUCATION SECTOR}

\subsection{Successful learning through digital technology in the education sector}

The current pandemic situation is affecting many areas of the economy as well as the education sector. Solutions are being sought to transfer education from classrooms to children's or teenagers' rooms at home. Here, after more than a year of homeschooling, it can be determined that the smart technology that has been developed over a good 25 years is able to transmit the transmission of acoustic and sometimes also visual signals, but the learning effect, the deep understanding, the penetration of a topic was fundamentally absent. This learning-pedagogical situation can be observed in schools as well as in colleges and universities. Here, too, the means seems to have become an end; digitization does not serve the primary goal of learning, but is itself the declared goal of institutions, politics and, above all, the economy. In educational institutions in particular, especially in grades 1 to 12 , it has been proven time and again that the use of digital devices reduces learning success. In 2012, for example, scientific papers on the use of digital learning media were published in the journal "Science". A study, carried out and published by Daniel Willingham, shows that with conventional books made of paper the learning success is significantly higher than with ebooks. [11] It has also been published that the learning effect when using search engines such 
as Google, Yahoo etc. is less than when using conventional sources such as newspaper articles or specialist literature. [12] These works, published in Science-Magazine - one of the most renowned specialist magazines worldwide - are only representative of the many other scientific publications that target the same topic and clearly prove that digitization in schools is an educational and educational step backwards. It prevents pupils and students from studying! The performance also decreases by up to $20 \%$, which applies in particular to the use of smartphones. [13]

\subsection{The digital pact}

Despite the clear recommendations from science that learning in the conventional sense takes place more sustainably, more deeply and more consciously, funding programs are decided to fully digitize schools. In 2018, for example, the Basic Law was changed in Germany as part of the "School Digital Pact". This guarantees the federal government's financial participation of 5 billion euros in WLAN and digital end devices for schools. However, the necessary investments in new teachers, the development and creation of innovative learning concepts and infrastructures that are more appropriate to learning, which could make necessary reforms in the school and education system possible, are ignored here - based on the latest scientific findings. Research clearly shows that investing in digital devices for the purpose of higher learning success cannot be adequately justified. Nevertheless, the use of information and communication technologies in various forms of education has been increasing steadily since 2013. 53\% of teachers in OECD countries reported using digital devices regularly or all the time. Teachers who are just starting their educational activities use digital technology disproportionately often compared to conventional teaching methods, e.g. the use of flip charts. Slightly more than half of the young professionals surveyed stated that, despite the prioritized use, they had not received a formal or informal introduction to digital information and communication technologies. On the other hand, $22 \%$ were assigned a mentor to support the less experienced teachers in using the digital end devices. [14]

The findings from these surveys are that the costs of digitization are not primarily attributable to the acquisition of the necessary hardware and the provision of the IT infrastructure, but that secondary costs for training and further education, software updates and IT services must be included. In total, the expansion of digital infrastructures in Germany amounted to around 6.6 billion euros in 2020. In addition, there are further investments that are to be added to the fund from various tranches by 2030. Among other things, these funds are to be made available to schools to expand the broadband network and used for other projects from the "School Digital Pact". [15] In the OECD countries, public and private spending on education, excluding investments in the digitization of educational institutions, averaged $4.9 \%$ of gross domestic product in 2017. In the European context, Norway invested $6.6 \%$ of GDP significantly more in the education of its population than, for example, Luxembourg with $3.2 \%$. Germany and Slovakia remained below the OECD average, at $4.2 \%$ and $3.6 \%$ of their respective GDPs, respectively. [14]

\subsection{Digital technology leads to poor school performance}

Describing digital technology as an investment in education should therefore not be seen as an increase in the education budget, on the contrary: It leads to a result that shows a clearly negative correlation between investments in the digitization of schools and changes in school performance. Ergo: The more a country invested in digital infrastructure, hardware and software, the worse the students' performance became. The following graphic illustrates the relationship between the change in the performance of 15-year-old students in mathematics in the observation period 2003-2012 as a function of investments in computers and digitized teaching in the respective OECD countries. The graphic (based on Schleicher) [16] shows a 
negative correlation of -0.56 and means that the performance of the students - not only in mathematics - decreased with increasing investment volume in the observation period.

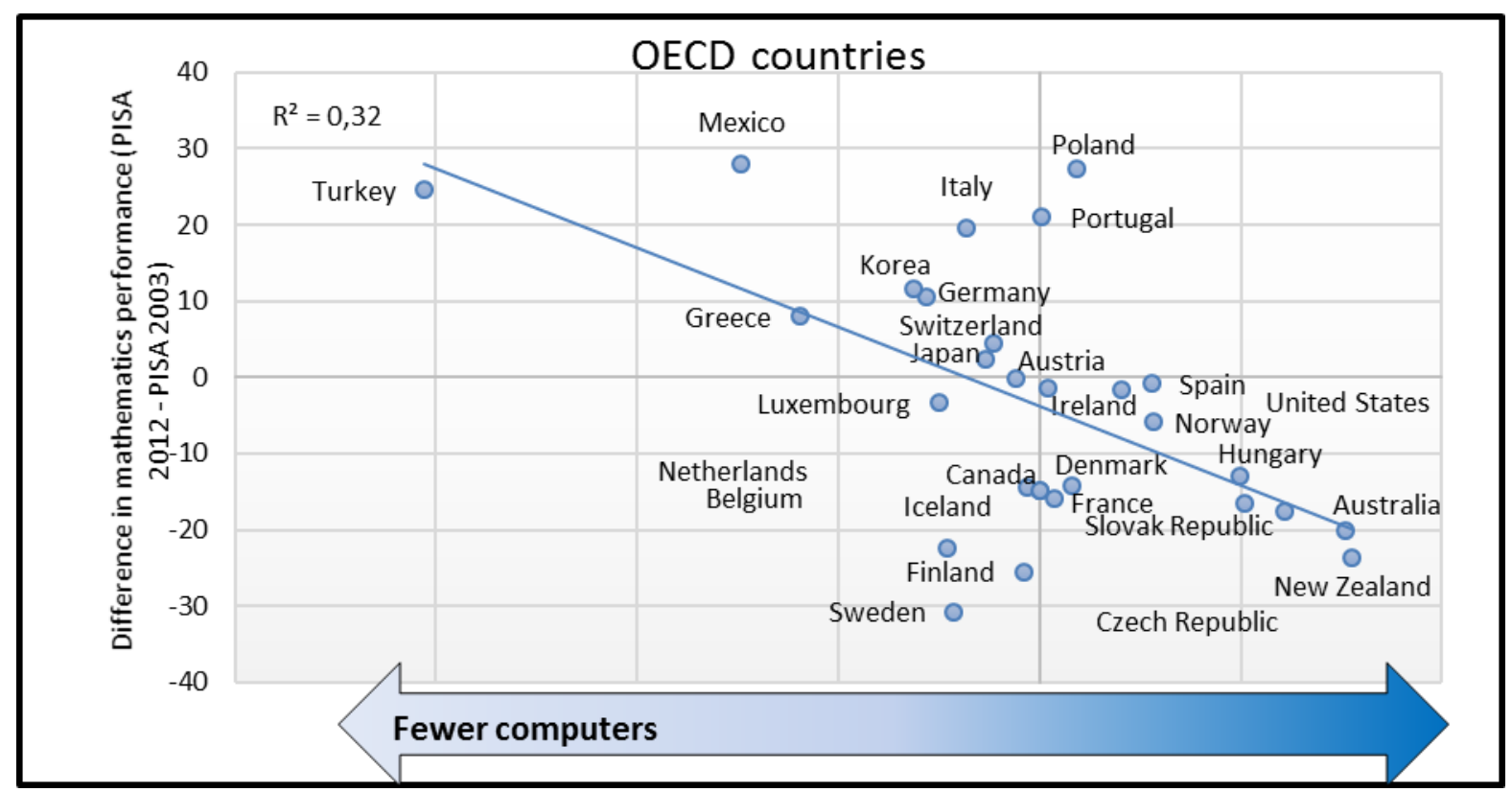

Figure 1 - Number of computers per student, after accounting for per capita GDP

In view of this development, politicians should reconsider whether further investments in digital technology should be taken into account in the education budget, or whether the money should be used to expand education funding (an average of $4.9 \%$, as shown above). The accumulation of capital in the five most valuable publicly traded companies in the world - Apple, Microsoft, Amazon, Alphabet Inc. (formerly Google), and Samsung - is enhanced by alliances between these companies and the education sector. Gartner predicts that global IT government spending will increase by an additional 5\% in 2021. The education sector is likely to have a significant share in this. Even today, every second school laptop including the software from Google is provided for a fee in the USA. [13] These statements are confirmed by the Gartner study carried out in February. The figure below shows the estimated global IT government spending, including investments to improve digital equity and access to remote management services, that Gartner predicts. [17]

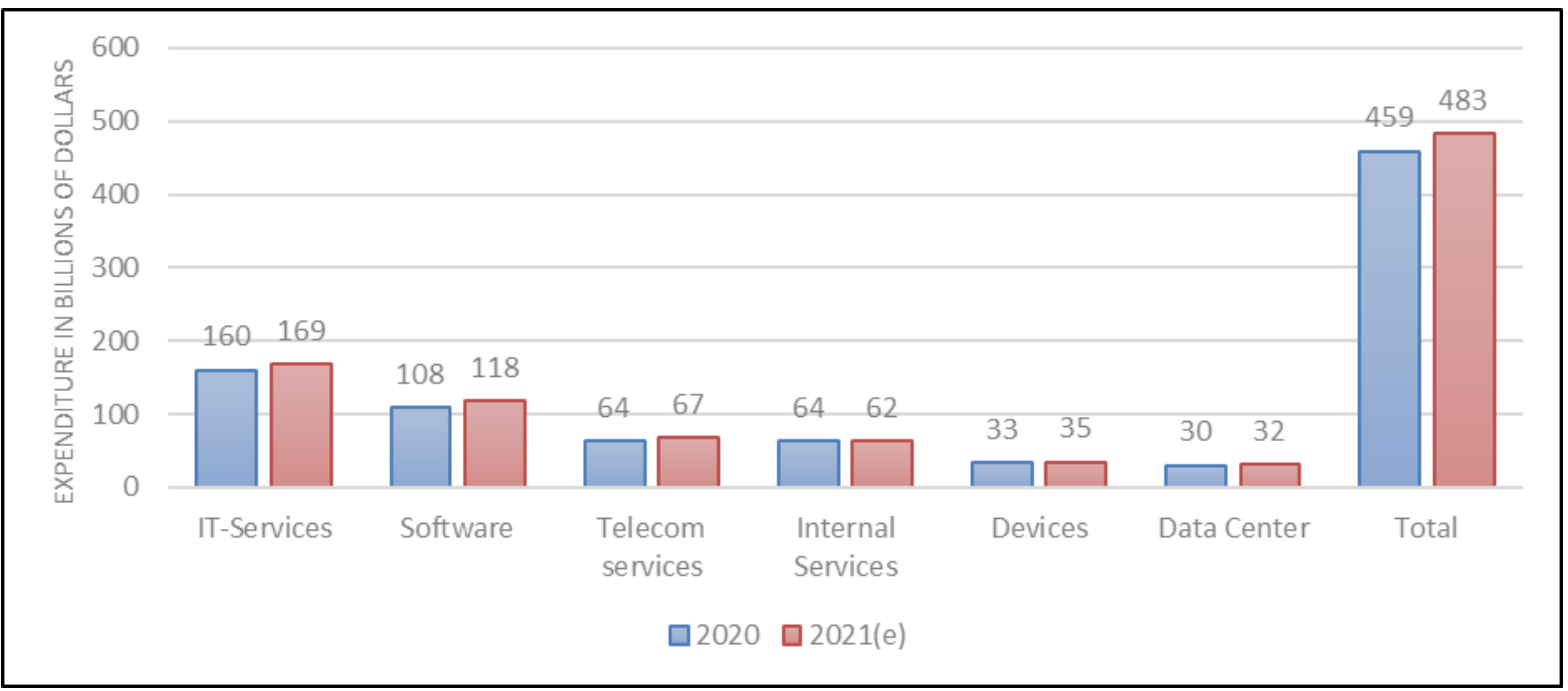

Figure 2 - Government IT expenditures worldwide by segment by 2021 (Own presentation) 
This trend is intensified by the current global pandemic situation. Homeschooling demands hardware and software that make digital education possible. According to the Gartner study, the software segment, consisting of applications, infrastructure and vertical software, will experience the strongest growth in 2021. Government organizations will in future rely on remote working and highly networked public services. This means that spending on IT equipment and related software is expected to increase by $5.1 \%$ in 2021 compared to the previous year.

\section{CONCLUSION AND RECOMMENDATIONS FOR ACTION}

In view of these developments, both in the area of changing values and in the use of digital media, especially in the education sector, it is necessary to make recommendations for action based on the research results based on ethical values and the knowledge in dealing with digital media. Digitalization is a blessing, especially in medicine (as described in point 3.2), but is increasingly being displaced by economic thinking precisely when the focus is purely on profit maximization. Digitization can also make processes more efficient and thus minimize costs. The acceleration and the disruptive character caused by digitization are obviously contrary to the values of our culture, although this does not have to be in contradiction with efficiency thinking and profit maximization. A survey of several hundred executives in Germany by the "Value Commission - Initiative Values Conscious Leadership e.V." shows that the importance of a credible value system for corporate success is "very high". Over 90 percent of managers agreed with this statement. [18] Even if short-term financial losses are to be expected as a result of value-oriented action, ethical action is essential for most of the managers surveyed. In the long term, the decision-makers expect permanent increases in value.

The principle of stakeholder value has so far been neglected to the extent that everyone involved in a company should benefit from entrepreneurial activities, including the state, customers and, in particular, employees. In order to achieve the primary goals of every company and at the same time to implement ethical values and thus moral behavior as a success concept in the company again, basic courses of action are recommended:

Identify employee values: A company that wants to establish a value-oriented standard of action should consider setting up an internal values committee. Possible measures would be, for example, to organize regular meetings of employees and have them write down their personal values. It should not only be about business indicators, but about values that are personally important to the employees, such as friendship, aesthetics, beauty, enjoyment or honesty.

Develop a new standard of values: When processes are optimized, one should not proceed exclusively according to business values (e.g. efficiency or speed), but the previously identified values should also be taken into account. For example, when planning a courier route, sharing coffee with a colleague could be included in the overall process. Furthermore, in addition to the profit maximization goals, new, socially fair goals should be agreed that are in line with all stakeholders.

Do not harm the customer with your own products: Especially here, in the field of education in connection with digital technology, there is a lot of catching up to do with regard to the education of the customer (in this case educational institutions, therefore the state) and the unconditional inclusion of scientific knowledge. But managers and employees should also be brought closer to the benefits and dangers of digital technology in schools through seminars, meetings, etc. At this point, it should be considered whether the state must intervene legislatively in order to enforce and implement the necessary information in the companies.

Executives as role models: In order to establish value-oriented leadership in the long term, managers are encouraged to lead by example. You should be aware of yourself on the one 
hand and trust the skills of your employees on the other. Furthermore, they should align their actions with their own personally identified values and take responsibility for their actions. Management coaching on this complex of topics in connection with digitization topics is offered in a variety of ways.

Etic questions in connection with digitization and education: Whether the medialization promotes pluralism of values, especially in classrooms, or destroys traditional values of a society, depends essentially on how and to what extent digital technology is used in the early stages of the learner - i.e. in everyday school life - and which concepts are predominant. From the aspects listed in point 4.3, recommendations for action in dealing with digital media in educational institutions, especially in the lower grades, can now be ascertained. In terms of research results, it would be more effective for educational institutions to use the funds to counter the prevailing teacher shortage and / or to train the existing teaching staff. Science has clearly shown that digital technology in the lowest grades leads to significant performance losses among students.

In addition, a clear work order in the ethical sense for computer scientists can be recorded. "The computer scientist is responsible for all consequences that his actions trigger directly or indirectly. In other words, basically also for what others do or can do with the products he has developed or the concepts he has devised" [19] At this point, a certain duty of care for this job description must be implemented as a set of values in the corporate culture. The designers of various learning programs have to take into account the latest psychological and ditactical findings in their work.

Providing information to customers or the public sector / schools:

Ultimately, the consumer, i.e. the customer, or the state and its purchasing power, decide what and how much to consume. It is therefore important to achieve a change in awareness on the part of consumers in general, which approaches a sustainable and socially acceptable way of thinking and includes ethical values in their purchase decisions. This clarification can take place in the form of communication on the part of the company, in which it is transparently demonstrated which benefits and which dangers are associated with IT products. Appropriate legislation on the part of the state would be helpful here, as is the case in the food industry, for example, and ingredients must be identified.

With the help of ethical values, the future of a modern, digitized economy can once again fulfill its socially beneficial purpose and, if used correctly, mean real progress for the community. This requires concrete action in the company as a result of the implementation of the ethical visions that have already been conceived. In this way, it can be possible to reconcile business and social values and establish them sustainably.

\section{References}

1. Scheler, M.: Der Formalismus in der Ethik und die materiale Wertethik. Neuer Versuch der Grundlegung eines ethischen Personalismus. Niemeyer, Halle.

2. Nietsch-Hach, C.: Ethisches Verhalten in der modernen Wirtschaftswelt. UVK Verlagsgesellschaft mbH, Konstanz 2016.

3. Michaelis, H; Elstner, $\mathrm{S}$; Schmidt, C.: Überprüfung des Stabilitäts- und Wachstumsgesetzes. Wirtschaftsdienst 95 (2015) 12, S. 830-836.

4. Meadows, D.: The limits to growth. Bericht des Club of Rome zur Lage der Menschheit. Universe Books, New York 1972.

5. Thomas: Die deutsche Thomas-Ausgabe. Vollständige, ungekürzte deutsch-lateinische Ausgabe der Summa theologica. vollständige, ungekürzte deutsch-lateinische Ausgabe der Summa theologica / Thomas von Aquin. Übers. von Dominikanern u. Benediktinern Deutschlands u. Österreichs. Hrsg. vom Kath. Akademikerverband ; Bd. 1: Die deutsche Thomas-Ausgabe. Verlag Styria [et al.], Graz [et al.] 1959-. 
6. Maney, K.: The maverick and his machine. Thomas Watson, Sr. and the making of IBM. Wiley, Hoboken, N.J 2003.

7. Gugerli, D.: Wie die Welt in den Computer kam. Zur Entstehung digitaler Wirklichkeit: S. Fischer Geschichte. S. Fischer, Frankfurt am Main 2018.

8. Lotter, W.: Echt digital. brand eins (2019) 03/2019, S. 40-46.

9. Francesco: Apostolic Journey - Bolivia: Participation at the Second World Meeting of Popular Movements at the Expo Feria Exhibition Centre (Santa Cruz de la Sierra, 9 July 2015) | Francis 2021. http://www.vatican.va/content/francesco/en/speeches/20 15/july/documents/papa-francesco_20150709_bolivia-movimenti-popolari.html.Zugri ff am 06.04.2021.

10. Robert: munevo DRIVE in Die Höhle der Löwen. DHDL, 01.04.2021. https://www.dh dl.info/gruender/munevo-drive/. Zugriff am 06.04.2021.

11. Daniel, D; Willingham, D.: Electronic textbooks: why the rush? Science (New York, N.Y.) 335 (2012) 6076, S. 1570-1571.

12. Sparrow, B; Liu, J; Wegner, D.: Google effects on memory: cognitive consequences of having information at our fingertips. Science (New York, N.Y.) 333 (2011) 6043, S. 776-778.

13. Spitzer, M.: Digitales Unbehagen. Risiken, Nebenwirkungen und Gefahren der Digitalisierung. mvg Verlag, München 2020.

14. OECD: Bildung auf einen Blick 2020: OECD-Indikatoren. wbv Media.

15. Statistisches Bundesamt: Bildungsfinanzbericht 2020 2020. https://www.destati s.de/DE/Themen/Gesellschaft-Umwelt/Bildung-Forschung-Kultur/BildungsfinanzenAusbildungsfoerderung/Publikationen/Downloads-Bildungsfinanzen/bild ungsfinanzbericht-1023206207004.html. Zugriff am 12.04.2021.

16. Schleicher, A.: Students, computers and learning. Making the connection: PISA. OECD, Paris 2015.

17. Gartner: Gartner Forecasts Global Government IT Spending to Grow 5\% in 2021 2021. https://www.gartner.com/en/newsroom/press-releases/2021-02-18-gartner-forec asts-global-government-it-spending-to-grow-5-\%-in-20210. Zugriff am 12.04.2021.

18. Führungskräftebefragung 2015. Studie der Wertekommission und des Reinhard MohnInstitutes der Universität Witten/Herdecke 2017.

19. Schefe, P. (Hrsg.): Informatik und Philosophie. 21.09. - 25.09.92. Band 48: DagstuhlSeminar-Report. Geschäftsstelle Schloss Dagstuhl, Saarbrücken 1992.

\section{Contact}

Thomas Meier, M.A.

Slovak University of Technology in Bratislava

Faculty of Materials Science and Technology in Trnava

Ulica Jána Bottu 2781/25, Trnava, 91724, Slovakia

E-mail: thomasmeier.chemnitz@gmail.com

Doc. Ing. Helena Makyšová, PhD.

Slovak University of Technology in Bratislava

Faculty of Materials Science and Technology in Trnava

Ulica Jána Bottu 2781/25, Trnava, 91724, Slovakia

E-mail: helena.makysova@stuba.sk 


\title{
ROA INDICATORS AS A PREDICTOR OF FINANCIAL HEALTH OF COMPANIES
}

\author{
Mária Michňová
}

\begin{abstract}
The financial health of the companies is one of the key aspects of their operation at the present and in the future. When assessing the financial health of a company, it is necessary to take the several factors that affect it and it is necessary to adapt the selection of indicators according to the nature of individual companies. The aim of financial analysis is to determine the position of the company in the market, compare it with competitors in the market and in the industry and at the same time we can analyze the development of its financial situation and based on some machine learning algorithms to predict its development in the future. In this paper, we focused on the ROA (Return on Assets) indicator, for which we examined its predictive power in the CHAID decision tree model. In the analysis, we used a database containing financial data of Slovak companies, in which we calculated several financial indicators to determine the impact of the ROA indicator on the prediction of financial health of companies.
\end{abstract}

Keywords: financial health, companies, ROA, decision tree, CHAID

\section{FINANCIAL HEALTH OF COMPANIES}

Manage with finance - to be financially healthy - is the key alement of an efficient company. Financial health or broader notion of financial well-being, have been subject of research for more than a decade, but have recently begun to be applied to low- and middle-income countries (Rhyne, 2020). Businesses have increasingly difficult and complex conditions to decide on the correctness of the steps they want to take in their economic environment. It is increasingly difficult for them to assess whether this is the right decision that will have an impact on the further successful operation of the company compared to other similarly focused companies. Financial stability, as a basic pillar of a company's financial health, is part of the company's competitiveness assessment and is also the key to the company's financial and economic efficiency (Yakovenko and Oleynik, 2019).

Financial analysis of a company is one of the basic methods that we use to determine financial stability within the company. The aim of financial analysis is to assess the financial health of the company and identify the factors that affect it. According to Lesáková (2007), we divide the factors into external, ie those that the company cannot influence (tax and monetary policy of the state) and internal (production volume, revenues, sales and efficiency of the company's transformation process).

In order to be able to use financial health as a useful indicator, it is first necessary to clarify what the term financial health means, how we can measure it and when and where it is appropriate to use it. Several authors of studies and scientific articles define financial health based on the following key elements:

- smooth short-term finances, including the ability to meet financial obligations,

- preparedness and recovery from financial shocks,

- long-term perspective including the fulfillment of goals and maintaining resp. improving well-being,

- a level of success above the minimum necessary, which represents a sense of confidence in security, well-being (this element is often used but not in all studies) (Rhyne, 2020). 


\subsection{Financial analysis}

For maximize profits, which is the main goal of the company, each company finds itself in a certain financial situation, which is determined primarily by the decisions of the company's management, as well as the effects of the economic environment in which it is located. The analysis of both the past, current and future financial situation of the company is called the financial analysis of the company.

Lesáková (2007) defines the economic analysis of a company as "the basic method of scientific cognition, where the object of research in the analysis is decomposed into individual parts so that by knowing their interrelationships a deeper understanding and determination of the object under study. In his publication, he defines three basic types of analysis:

- classification - the studied phenomena are classified on the basis of time, place and material composition,

- functional - research of relations by mathematical-statistical methods,

- causal - investigating the real cause of the development of phenomena.

In current practice, we encounter a number of methods that provide procedures that we get to the results of the entire financial analysis of the company. Although these methods differ from each other, they also complement and combine. Kovanicová et al. (2005) divides the methods according to:

- the nature of information sources - fundamental and technical analysis,

- complexity of algorithms - qualitative and quantitative analysis,

- theoretical and methodological basis - elementary and higher methods,

- time aspect of analysis - static and dynamic analysis,

- analyzed object - analysis of one or a group of comparable companies.

The basic decission of financial analysis is its devision in time into „ex-post“ and „ex-ante“ analysis. The ratios of financial analysis provide us with an immediate picture of the company, its financial situation, but they lack a time dimension. This is why the business analysis should be complemented by a trend analysis that provides an answer to the question of whether the business situation is improving or deteriorating over time. A common representation of this analysis is a graphical design as a time series. It is appropriate to monitor mutual trends in the development of financial indicators (Vochozka, 2011).

\section{ANALYSIS AND METHODS}

In analyzing the predictive power of individual indicators, we used a database consisting of financial data of 94,478 companies for the last 5 years, in which we calculated several financial indicators to determine whether the ROA indicator is important as a predictor of financial health of companies.

\subsection{CHAID Decision tree}

Machine learning and data mining-based approaches are becoming increasingly important in many areas. It is the classifiers of artificial intelligence that protect e.g. also our e-mail, when they can evaluate which e-mail they should assign to the spam category (Chen \& Guestrin, 2016).

Decision trees are among the nonparametric methods for classification and regression. Treebased learning algorithms are considered to be the best and most widely used methods due to the high accuracy of predictive models, stability, and ease of interpretation (Ramzai, 2020). The main task of decision tree algorithms is to apply inductive methods to certain values of attributes of an unknown object to determine the appropriate classification according to the rules of decision trees. Among the most commonly used types of decision trees are CHAID, CART, ID3 and C4.5 (Ramzai, 2020; Singh and Gupta, 2014). 
The CHAID (Chi-squared automatic interaction detection) algorithm was designed in 1980 by Kass. As the name implies, it is based on chi-square statistics. The result of the test is a probability that is between 0 and 1 . If the chi-square value approaches zero, there is a significant difference between the two classes being compared. If the value approaches the unit, it means that there is no significant difference between the two classes. CHAID is a segmentation method that can identify the relationship between a dependent variable and independent variables or predictors (Zounemat-Kermani et al., 2020). The following variables are used in the CHAID algorithm:

- dependent variable - continuous or categorical variable,

- independent variables - only categorical variables, and there can be more than two categories.

If there are continuous variables, they need to be transformed to categorical before being used in the model. Statistical tests are used to determine the best closest distribution:

- continuous dependent variable - F-test,

- categorical dependent variable - chi-square test.

\subsection{Neural network}

Neural networks within artificial intelligence represent a set of interconnected computing units or nodes called neurons, in several layers. Each neuron linearly combines its inputs and then passes them through gradually using the so-called activation function, which can be a linear or non-linear filter. The linear combination of inputs is calculated based on the sum of the products of the weights and the inputs. The artificial neural network then generates the target output using a reverse data stream, in which it updates the weights of the neurons based on the backward propagation of errors (Misra \& Li, 2020). Theoretically, the neural network method is able to achieve regression by adapting any nonlinear function, but the disadvantage is the stability and sensitivity to the amount of data (Lin et al., 2021).

\subsection{Analysis}

We divided companies according to size into four basic groups according to the number of employees:

Tab. 1 Division of companies by size

\begin{tabular}{|l|c|c|c|c|}
\hline Company size & Mikro & Small & Medium & Large \\
\hline Number of employees & $1-9$ & $10-49$ & $50-249$ & $250+$ \\
\hline
\end{tabular}

Source: Own processing

Indicator ROA was calculated as the ratio of earning after taxes to equity. Other indicators used in the analysis include Equity ratio (equity / total assets), QAS (current assets / sales), CFL (cash flow / liabilities), ROE (EAT / equity) and the company size.

Using this sample, we tested two ROA variables and business size, setting hypotheses:

H0: There is no difference between individual groups of companies.

H1: There is a difference between different groups of companies.

In the Kruskall- Wallis test, we wanted to find out whether there is a difference between the size of the ROA indicator in individual groups of companies.

At the level of alpha signifikance 0.05 , we reject the H0 hypothesis and admit that there is a difference between. 


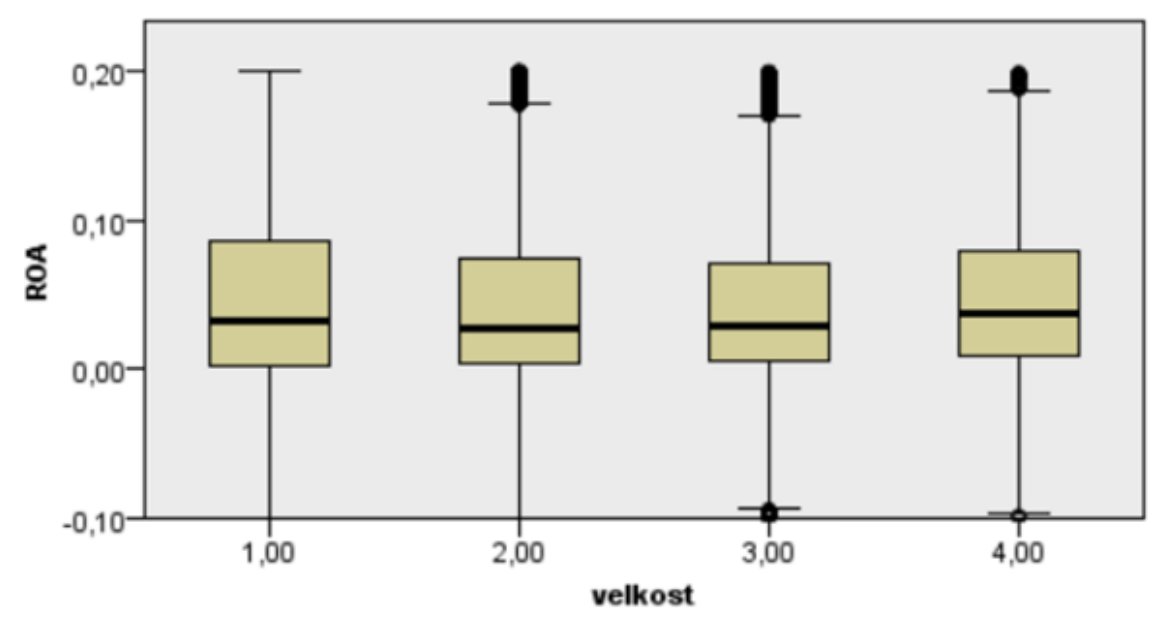

Fig. 1 Kruskall - Wallis test of the ROA indicator and company size Source: Own processing

The Fig. 1 shows the distribution of Box-plots in which we truncated ROA values from 0.2 to -0.1 for better visualization.

Subsequently, we continued the analysis using the CHAID decision tree, where we used predictor importance to determine whether the ROA indicator is a suitable predictor. We created the analysis with time $t+2$, ie based on data from 2017, we predicted efficiency in 2019 using the CHAID decision tree.

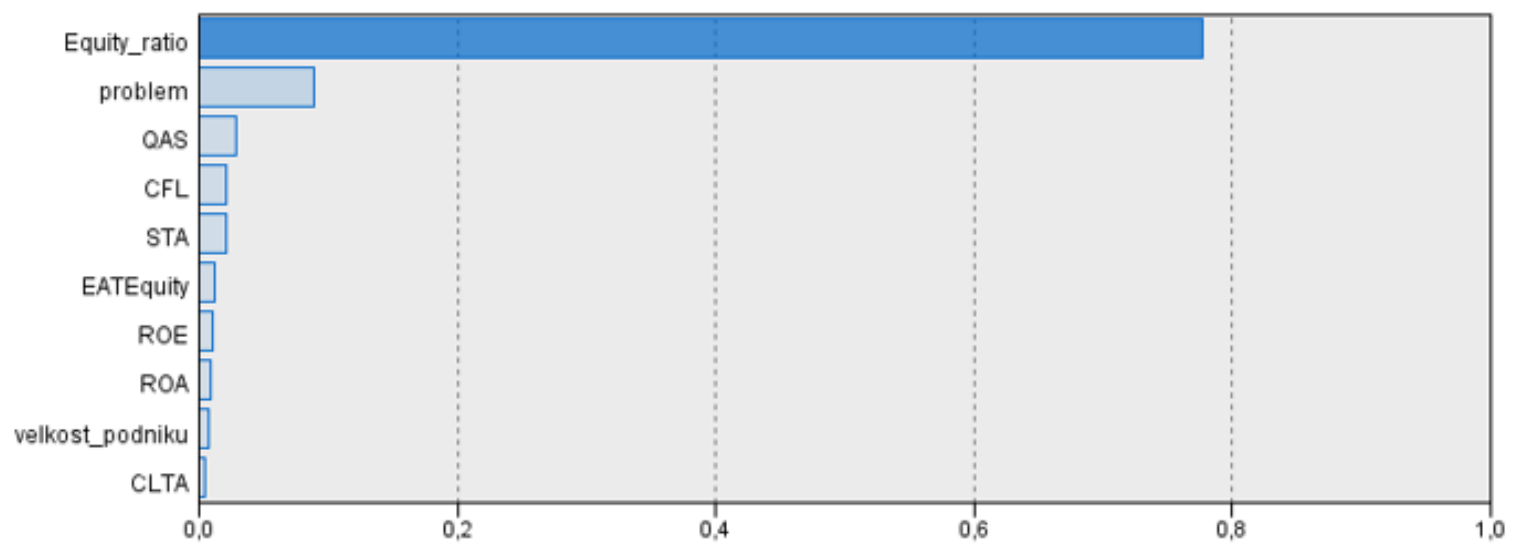

Fig. 2 Predictor importance

Source: Own processing

The strongest predictor was the Equity ratio, but the ROA indicator was the strong predictor too.

We tried to analyze the indicators using a neural network, where the ROA indicator came out as a predictor and with other financial indicators has the model high prediction power. 


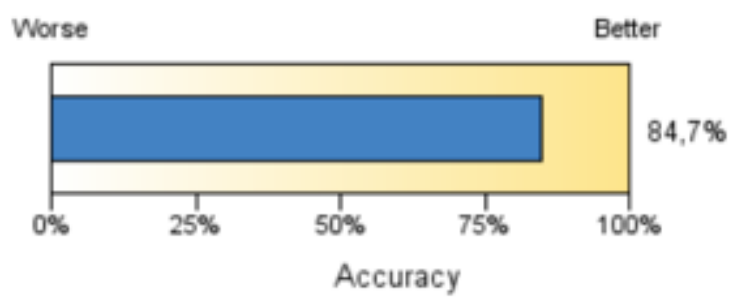

Fig. 3 Prediction power of neural networks

Source: Own processing

Total prediction power, of the model with financial indicators, was $84.7 \%$. The percentage of prediction accuracy tells us that how exactly can we predict whether a company will be financially sound or not, based on the indicators used.

\section{CONCLUSION AND RECOMMENDATIONS}

Assessing the financial health of companies is very important both for the country as a whole and for companies. There are several methods by which we can assess financial health. It is important to take into account several aspects, such as the size of the business, the sector in which it is located and also the region in which it is located.

In this analysis, we focused on the ROA indicator, in which we examined its predictive power. From the analysis we state that this predictor has an important role in predicting the financial health of companies, it is possible to use it to point out the differences between individual groups of companies and predict with high accuracy the development in the future. In further research, we will examine the predictive power of other financial indicators, their impact on the accuracy of the forecast, while it would be appropriate to focus on some nonfinancial indicators, which according to several studies have a significant impact on the accuracy of corporate financial health.

\section{Sources}

1. CHEN, T., GUESTRIN, C. 2016. XGBoost: A Scalable Tree Boosting System. DOI: 10.1145/2939672.2939785. Online: https://arxiv.org/abs/1603.02754

2. KOVANICOVÁ, D. a kol. 2005. Finanční účetníctví, světový koncept. IFRS/IAS. 5. vyd. Praha: Polygon. ISBN: 80-7273-129-7

3. LIN, J., QI, CH., WAN, H., MIN, J., CHEN, J., ZHANG, K., ZHANG, L. 2021. Prediction of Cross-Tension Strength of Self-Piercing Riveted Joints Using Finite Element Simulation and XGBoost Algorithm. Chinese Journal of Mechanical Engineering. Online: https://link.springer.com/article/10.1186/s10033-021-00551-w

4. LESÁKOVÁ, L', 2007. Finančno-ekonomická analýza podniku. Banská Bystrica: Univerzita Mateja Bela, 2007. 280 s. ISBN 978-80-8083-379-4

5. MISRA, S., LI, H. 2020. Comparative study of shallow and deep machine learning models for synthesizing in situ NMR T2 distributions. Machine Learning for Subsurface Characterization. https://doi.org/10.1016/B978-0-12-817736-5.00008-9. Online: https://www.sciencedirect.com/book/9780128177365/machine-learning-forsubsurface-characterization

6. RAMZAI, J. 2020. Simple guide for Top 2 types of Decision Trees: Chaid \& Cart. Machine Learning Fungamentals. Towards data science. Online: Simple guide for Top 2 Types of Decision Trees- CHAID \& CART | Towards Data Science

7. RHYNE, E. 2020. Measuring financial health: What policymakers need to know. Online:https://www.afiglobal.org/Measurement_framework/Downloads/Measuring\% 20Financial\%20Health.pdf 
8. SINGH, A., GUPTA, P. 2014. Comparative study ID3, CART and C4.5 decision tree algorithm: A survey. International Journal of Advanced Information Science and Technology (IJAIST). Vol.27, No.27. Online: http://citeseerx.ist.psu.edu/view doc/download?doi=10.1.1.685.4929\&rep=rep1\&type=pdf

9. VOCHOZKA, M. 2011. Metody komplexního hodnoceni podniku. 1. vyd. Praha: Grada Publishing, 246 s. ISBN 978-80-247-3647-1.

10. YAKOVENKO, V., OLEYNIK, O., BORISOVA, I., 2019. Impact of Design Company Financial Stability on Competitiveness on Regional Market. Atlantis Press. DOI: $10.2991 /$ cssdre-19.2019.20

11. ZOUNEMAT-KERMANI, M., STEPHAN, D., BARJENBRUCH, M., HINKELMANN, R. 2020. Ensemble data mining modeling in corrosion of concrete sewer: A comparative study of network-based (MLPNN \& RBFNN) and tree-based (RF, CHAID, \& CART) models. Advanced Engineering Informatics, 43,101030. DOI:10.1016/j.aei.2019.101030. Online:https://www.sciencedirect.com/science/artic le/abs/pii/S1474034619306032

\section{Contact}

Ing. Mária Michňová

Department of Quantitative Methods

Faculty of Business Economics with seat in Košice

University of Economics in Bratislava

Tajovského 13, 04130 Košice, Slovakia

e-mail: maria.michnova@euba.sk 


\title{
KOMPETENCIE A FINANCOVANIE MESTSKÝCH ČASTÍ V MESTE KOŠICE
}

\section{COMPETENCES AND FINANCING OF CITY DISTRICTS IN THE CITY OF KOŠICE}

\author{
Jozef Andrejčák
}

\begin{abstract}
Abstrakt
Príspevok sa zaoberá činnost'ou obcí a následnou kompetenciou a finančnou situáciou mestských častí v územnej samospráve mesta Košice. Po definovaní a rozdelení právomocí magistrátu sa príspevok zameriava na rozdelenie kompetencií medzi mestom a mestskými čast’ami v Košiciach aj z pohl'adu aplikačnej praxe. Rozdelenie zodpovednosti je presne definované v základnom internom dokumente mesta v Štatúte mesta Košice. Ciel'om príspevku je poukázat' na súčasný stav del'by kompetencií $\mathrm{v}$ územnej samospráve mesta Košice a $\mathrm{z}$ toho vyplývajúce financovanie.
\end{abstract}

Kl'účové slová: územná samospráva, štatút mesta, pôsobnost', kompetencie

\begin{abstract}
The paper deals with the activities of municipalities and the subsequent competence and financial position of city districts in the territorial self-government of the city of Košice. After defining and dividing the powers of the municipality, the paper focuses on the distribution of competencies between the city and city districts in Košice also from the point of view of application practice. The division of responsibilities is precisely defined in the basic internal document of the city in the Statute of the city of Košice. The aim of the paper is to point out the current state of the division of competences in the territorial self-government of the city of Košice and the resulting financing.
\end{abstract}

Key words: territorial self-government, city status, competence, competences

\section{Kompetencie a financovanie mestských častí $v$ meste Košice}

\subsection{Pôsobnost' obcí}

Pod pôsobnost'ou obce môžeme $\mathrm{v}$ širšom slova zmysle chápat' súhrn určitých práv a povinností, ktoré sú obci stanovené právnym poriadkom za účelom plnenia úloh. Samostatná, môžeme hovorit' aj o samostatnej pôsobnosti obce, predstavuje samosprávu v pravom zmysle. To znamená, že obce si spravujú svoje záležitosti relatívne samostatne. Pri tomto výkone koná vo vlastnom mene a nesie aj plnú zodpovednost' za výkon úloh spadajúcich pod samostatnú pôsobnost'. Z hl'adiska práva na samosprávu, obec ma na výkon záležitosti, ktoré spadajú do samostatnej pôsobnosti právny nárok (Palúš, Jesenko, Krunková 2010).

Obec má teda dvojakú pôsobnost': tzv. samostatnú ( územno samosprávnu) a prenesenú. V oblasti samostatnej pôsobnosti zabezpečuje obec výkon záležitostí vo vlastnom mene a na vlastnú zodpovednost'. V oblasti prenesenej ide o výkon záležitosti verejnej správy, ktoré sú na obec prenesené zo ,štátu“ právnymi predpismi. V tomto rozdelení môžeme vnímat' aj dualizmus verejnej správy na Slovensku. Samostatná pôsobnost' je výrazom decentralizácie, plnenie úloh v rámci prenesenej pôsobnosti znamená dekoncentráciu (Kiovská, 2000). 
Za ústavné východisko vymedzenia samostatnej pôsobnosti môžeme vnímat' čl. 65 ods. 1, ústavy, kde je obec definovaná ako právnická osoba, ktorá za podmienok stanovených zákonom samostatne hospodári s vlastným majetkom a so svojimi finančnými prostriedkami. Pokial' ide o vymedzenie vecného rozsahu samostatnej pôsobnosti tá je ponechaná na zákonnú úpravu a teda je riešená $\mathrm{v}$ zákone o obecnom zriadení ${ }^{1}$. V zákone o obecnom zriadení je vymedzená samostatná pôsobnost' na základe generálneho vymedzenia. To znamená, že okrem záležitostí stanovených zákonom, spadajú do samostatnej pôsobnosti aj iné záležitosti súvisiace so správou obce. Do samosprávnej pôsobnosti však patria len tie oblasti, ktoré nie sú osobitnými zákonmi zverené iným orgánom verejnej správy. Samostatnú pôsobnost' obec realizuje zodpovedajúcimi právnymi prostriedkami.

Tým, že je stanovená samostatná pôsobnost' obce generálnym spôsobom ( všetky úkony súvisiace so správou obce a jej majetku ), doplneným o demonštratívny výpočet a v nadväznosti na vymedzenie vo vzt’ahu k štátnej správe, môžeme vnímat' takéto vymedzenie ako za vhodné s prihliadnutím na podstatu a princíp územnej samosprávy. Tento univerzálny charakter dáva možnost' obciam, aby sa jednotlivé úlohy mohli plnit' efektívne s prihliadnutím na potreby obce a verejný záujem.

Úlohy spadajúce do samostatnej pôsobnosti obce môžu byt' formulované ako obligatórne a fakultatívne. Fakultatívne úlohy sú pre obec typické a zohl'adňujú charakter obce. V rámci týchto úloh sa obec rozhoduje samostatne, či bude určité záležitosti vykonávat' a akým spôsobom. Obligatórne úlohy má obec stanovené ako povinnost' a rozhoduje len o spôsobe ich plnenia (Sotoláŕ, 2000). Záležitosti samostatnej pôsobnosti obec vykonáva s vlastnými finančnými prostriedkami.

Za ústavné východisko prenesenej pôsobnosti môžeme vnímat' čl. 71 ods. 1 ústavy, na základe ktorého je možné zákonom preniest' na obec výkon určených úloh miestnej štátnej správy. Prenesená pôsobnost' je na obce delegovaná štátom a predstavuje záležitosti, ktoré vykonávajú obce v mene štátu a za kvalitu výkonu nesie zodpovednost' štát. Na výkon prenesenej pôsobnosti sú obce oprávnené len zákonom. Bez zákonného poverenie nesmú preberat' úlohy, ktorých výkon patrím orgánom miestnej štátnej správy.

Ako dôvod prenosu niektorých úloh môžeme vnímat' požiadavku efektívneho výkonu a priblíženie oblastí štátnej správy k občanovi. Finančné náklady spojené s plnením agendy prenesenej na obce sú zabezpečované z finančných prostriedkov štátu.

Aj napriek tomu, že pri výkone prenesenej pôsobnosti ide o uskutočňovanie štátnej správy, obce nie sú nositel'om štátnej moci a ani nemajú postavenie štátnych orgánov (Palúš, Jesenko, Krunková, 2010).

Konkrétny obsah a rozsah prenesenej resp. delegovanej pôsobnosti je stanovený osobitnými zákonmi z jednotlivých oblastí štátnej správy. V tomto platí, že ide o taxatívny výpočet, ak štát deleguje pôsobnost' na obec musí to byt' vyslovene stanovit'. Ak tomu tak nie je, môžeme hovorit' o výkone pôsobnosti v rámci samostatnej pôsobnosti.

Vnútorným a základným dokumentom územnej samosprávy mesta Košice, ktorý upravuje prerozdelenie úloh a samosprávnych resp. samostatných pôsobnosti mesta, nakladanie s majetkom mesta, vzt'ahy mesta s mestskými čast’ami a právnickými osobami zriadenými alebo založenými mestom a ich práva a povinnosti pri plnení zverených samosprávnych úloh je Štatút mesta Košice ( d’alej len štatút ).

Štatút je v súlade so zákonom o meste Košice. Prvé diskusie na štatúte boli priebežné v roku 1990 v súvislosti aj návrhom zákona o meste Košice. Následne po prvých komunálnych vol'bách v meste Košice existovala trojmesačná snaha o spracovanie štatútu, ktorý by upravoval kompetencie medzi mestom, mestskými čast’ami a organmi mestskej a miestnej

\footnotetext{
${ }^{1}$ Pozri: zákon SNR č. 369/1990 Zb. o obecnom zriadení v znení neskorších predpisov, § 4 ods. 1,3,4 a zákon č. 416/2001 o prechode niektorých pôsobností z orgánov štátnej správy na obce na vyššie územné celky v znení neskorších predpisov $\S 2$ a $\S 4$ ods. 2 .
} 
samosprávy. Pre prípravu štatútu boli zriadené tri odborné komisie právna, politická a ekonomická ( archív mesta Košice). Štatút po prvých komunálnych vol'bách bol mestských zastupitel'stvom schválene 14.3.1991. V rámci štatútu už boli zohl'adnené aj pripomienky a návrhy starostov mestských častí.

Štatút mesta Košice prešiel viacerými zmenami, ktoré zapracovali do štatútu zmeny zákona o meste Košice, osobitné právne úpravy, ktorými je zverená územno samosprávna pôsobnost' a prenesený výkon miestnej štátnej správy. Veci, ktoré nie sú upravené štatútom sa riadia zákonom o meste Košice a osobitnými právnymi predpismi.

Štatút je rozsiahly dokument, ktorý pozostáva z ôsmich častí, ktoré sa delia na hlavy a diely. Práv čast' sú základné ustanovenia vrátane členenia mesta na mestské časti. Druhá čast' definuje výkon samosprávy mesta a teda aj orgány mesta a mestských častí. Tretia čast' delí pôsobnost' medzi mesto a mestské časti. Štvrtá čast' pojednáva o ekonomike mesta a mestských častí. Piata čast' definuje symboly mesta. Šiesta čast' charakterizuje verejné ocenenia mesta. Siedma čast' sa venuje zásadám hospodárenia s majetkom mesta. Ide o rozsiahlu čast' štatútu, ktorá upravuje pôsobnost' mestského zastupitel'stva v súvislosti s majetkom mesta, správu majetku, prevody vlastníctva majetku, prenajímanie majetku, t’archy na majetku, iné užívanie majetku, správu pohl'adávok a nakladanie s bytmi mesta. Ôsma čast' sú prechodné, zrušovacie a záverečné ustanovenia ( Štatút mesta Košice ).

Podrobnejšie sa budeme venovat' del'be pôsobnosti medzi mestom a mestskými čast'ami a následne aj ekonomikou a financovaním mestských častí v zmysle rozpočtu mesta.

\subsection{Del'ba pôsobnosti - kompetencií medzi mestom a mestskými čast’ami}

Del'bu pôsobnosti - kompetencií medzi mesto a mestské časti upravuje štatút v tretej časti. Každá pôsobnost' $v$ štatúte je v súlade s príslušnými právnymi predpismi a odvoláva sa na ich ustanovenia. V zmysle tejto časti štatútu mesto môže preniest' výkon niektorých samosprávnych pôsobností určených obciam osobitnými predpismi na všetky mestské časti alebo len na niektoré. Samosprávne pôsobnosti, ktoré neboli a nie sú prenesené na mestské časti vykonáva mesto. Mesto si spravidla ponecháva pôsobnost' vo veciach celomestského významu ${ }^{2}$, kde spolupracuje a komunikuje s príslušnou mestskou čast’ou.

Mestské časti však môžu podl'a svojich možností prispiet' k rozvoju služieb obyvatel'ov mesta aj nad rámec samosprávnych pôsobností upravených štatútom. A to v oblasti informovania, komunikácie v rôznych oblastiach napr. pri verejnom prerokovaní územného plánu, parkovacej politiky a pod. Na mestské časti nemožno preniest' výkon štátnej správy, ktorý bol zákonom prenesený na mesto ( $§ 25$ zákon č. 401/1990 Zb o meste Košice ). Pôsobnost' stavebného úradu vykonáva mesto Košice ( $§ 140$ a ods. 2 zákona č. 50/1979 Zb. o územnom plánovaní a stavebnom poriadku v znení neskorších predpisov, stavebný zákon ).

Rozdelenie samosprávnych pôsobností jednotlivým mestským častiam je zatriedené do jednotlivých oblastí, ktoré sú presne definované v štatúte $\mathrm{v}$ jeho tretej časti a druhej hlave ( $\S 19$ až 35 Štatút mesta Košice ). V d’alšej časti predstavím jednotlivé oblasti pôsobnosti a kompetencie s prihliadnutím na aplikačnú prax a ich uplatňovanie.

Kompetencie v oblasti samostatnej pôsobnosti ( územno správne pôsobnosti).

Regulácia podnikatel'skej činnosti - v tejto oblasti majú kompetencie mestské časti ak ide o vec miestneho významu ${ }^{3}$. Ide o pôsobnost' vo veciach predaja, poskytovania služieb, dozor a kontrolná činnost' na trhových miestach. Mestské časti prijímajú oznámenia podnikatel'ov

\footnotetext{
${ }^{2}$ Celomestský význam sa vzt’ahuje najmä na, historické centrum mesta, prevádzky, podniky zariadenia, trhoviská, ktoré charakterom, významom a pod. sa dotýkajú územia viacerých mestských častí, orgány verejnej správy a iné inštitúcie s pôsobnost'ou okresnou, krajskou a celoštátnou, časti územia, ktoré svojim charakterom slúžia na kultúru, šport, a inú činnost' pre obyvatel'ov viacerých mestských častí, historické pamiatky, stavby, parky a iné

${ }_{3}^{3}$ Miestny význam sa vzt’ahuje výlučne na územie konkrétnej mestskej časti s prihliadnutím na jej špecifiká
} 
v súlade s mestským všeobecne záväzným nariadením, ktorým sa určujú pravidlá času predaja v obchode a času prevádzky služieb. K investičným zámerom tretích osôb na území mestskej časti podávajú mestu vyjadrenia k jednotlivým zámerom. Z pohl'adu aplikačnej praxe ostáva otázkou či takéto vyjadrenie má byt' formou uznesenia miestneho zastupitel'stva, alebo len vyjadrenie starostu poprípade miestneho úradu. Zo strany mesta je požiadavka pri schval'ovaní investičných zámerov, prenájmov a pod. v mestskom zastupitel'stve, o stanovisko mestskej časti, nie je však vyslovene spojené s uznesením miestneho zastupitel'stva. Zastávam názor, aby $\mathrm{k}$ investičným zámerom tretích osôb, zmenou právnych vzt'ahov, ktoré súvisia s výstavbou a väčším zásahom do verejného priestoru, boli vyjadrenia mestských častí na základe uznesení miestnych zastupitel'stiev. Zároveň podobné materiály by prerokovali aj odborné komisie a miestne rady, kde by došlo k väčšiemu zapojeniu a informovaniu poslancov a členov komisií z radov neposlancov pred rozhodovacím procesom v miestnych zastupitel'stvách. Takýto postup vnáša väčšiu transparentnost' v danej oblasti.

Nakladanie s komunálnym odpadom - v tejto oblasti je pôsobnost' mestských častí v oblasti vykonávania dozoru nad dodržiavaním podmienok určených $\mathrm{v}$ príslušnom všeobecne záväznom nariadení mesta, kontroly stanovíšt', zberných nádob a určovaní kontajnerových stanovíšs'. Mestské časti zároveň komunikujú a informujú občanov vo veci harmonogramov rozmiestňovania kontajnerov vrátane vel'kokapacitných, harmonogramu zberu a iných požiadaviek občanov. Prijímajú oznámenia o nezákonne umiestnenom odpade a následne ich ohlasujú mestu. Pôsobnost' v oblasti nakladania s komunálnym odpadom zabezpečuje aj mesto. Mesto má zároveň uzatvorené zmluvy na zber a likvidáciu odpadu vrátane separovaného s pôsobnost'ou na celé mesto a teda pre všetky mestské časti.

Čistota a údržba verejných priestranstiev - túto pôsobnost' nemajú všetky mestské časti. Mestské časti, ktoré disponujú s touto pôsobnost'ou sú sídlisko KVP, Barca, Kavečany, Košická Nová Ves, Krásna, Lorinčík, Luník IX, Myslava, Pereš, Pol’ov, Šebastovce, Ťahanovce, Vyšné Opátske, Šaca a Džungl'a. Tie vykonávajú na svojom území údržbu a čistou verejnej zelene a verejných priestranstiev. Zároveň sú tieto mestské časti aj správcami týchto verejných priestranstiev. V tejto pôsobnosti je badat' prvú vel'kú nerovnost' medzi kompetenciami. Tieto mestské časti sa $\mathrm{z}$ pohl'adu praxe nazývajú aj malé mestské časti mimo sídliska KVP. Tento pojem je zaužívaný len v praxi bez akejkol'vek právnej opory. Ostatným mestským častiam tzv. vel'kým ( opät' pojem zaužívaný z praxe ) túto pôsobnost' zabezpečuje mesto prostredníctvom mestského podniku Správy mestskej zelene a zazmluvnenej dodávatel'skej firmy. Vel'ké mestské časti však v tejto oblasti tiež vykonávajú činnosti, hlavne na úseku čistoty a úpravy verejných priestranstiev a úzko spolupracujú s mestskými podnikmi a samotným mestom. Túto pôsobnost' majú len malé mestské časti a KVP finančne zakomponovanú $\mathrm{v}$ podielových daniach pre mestské časti v rozpočte mesta. Vzniká d’alšia disproporcia aj v oblasti financovania mestských častí ( o tejto oblasti v d’alšej podkapitole ). V rámci tejto pôsobnosti mestské časti vykonávajú aj evidenciu psov, ustanovujú niektoré podmienky držania vlastnými všeobecne záväznými nariadeniami. V praxi zabezpečujú umiestňovanie na vhodných priestranstvách výbehy pre psov, nádoby na psie exkrementy a pod.

Správa cintorínov a iných pohrebísk - touto pôsobnost'ou disponujú len tzv. malé mestské časti a to tie, ktoré majú na svojom území cintorín - Barca, Kavečany, Košická Nová Ves, Krásna, Lorinčík, Myslava, Pereš, Pol’ov, Šebastovce, Ťahanovce, Vyšné Opátske, Šaca. Pôsobnost' vykonávajú aj podl'a osobitného právneho predpisu ( Zákon č. 131/2010 Z.z. o pohrebníctve).

Správa pozemných komunikácií - touto pôsobnost'ou opät' disponujú tie mestské časti, ktoré aj pôsobnost'ou v oblasti čistoty a údržby verejných priestranstiev. Ide o komunikácie na území mestskej časti II. III. a IV. triedy, na ktorých nepremáva mestská hromadná doprava. Mestské časti vykonávajú správu a údržbu týchto komunikácií ( cesty, chodníky, parkoviská, 
vpuste, priechody a pod. ) vrátane ich súčastí. Súčast'ou je aj zimná údržba a následná ich čistota. Ostatné mestské časti ( tzv. vel'ké mestské časti ) v tejto oblasti vo vzt’ahu ku komunikáciam komunikujú s mestom ako správcom všetkých komunikácií ( vid' vyššie ) na ich území. Teda celú údržbu vrátane rekonštrukcií a nového budovania zabezpečuje pre vel'ké mestské časti ( mimo sídliska KVP ) mesto. Z pohl'adu praxe však v istých oblastiach správy komunikácií vypomáhajú mestské časti mestu aj v zmysle rozvoja a starostlivosti o svoje územia. Ide hlavne o rekonštrukciu chodníkov, schodov, priechodov pre chodcov, ale aj $\mathrm{k}$ budovaniu nových parkovacích miest a chodníkov. Mestské časti k týmto krokom pristupujú hlavne z dôvodu, že mesto $\mathrm{v}$ danej oblasti nedokáže efektívne pokryt' všetky požiadavky. Mestské časti disponujú poznaním svojho územia ako aj požiadavkami občanov a poslancov. Túto pôsobnost' majú len malé mestské časti a KVP finančne zakomponovanú $\mathrm{v}$ podielových daniach pre mestské časti v rozpočte mesta.

Správa verejného osvetlenia - správu a údržbu verejného osvetlenia na svojom území vykonávajú mestské časti - Barca, Kavečany, Košická Nová Ves, Krásna, Lorinčík, Luník IX, Myslava, Pereš, Pol'ov, Šebastovce, Ťahanovce, Vyšné Opátske, Šaca a Džungl'a. Ide o všetky tzv. malé mestské časti. Touto pôsobnost'ou však nedisponuje sídlisko KVP. Tzv. vel'ké mestské časti v rámci tejto pôsobnosti z pohl'adu praxe kontrolujú verejné osvetlenie a následne komunikujú s mestom a jeho správcom verejného osvetlenia, ktorým je v súčasnosti Dopravný podnik mesta Košice. Viaceré mestské časti podl'a svojich možností a mimo svojej priamej pôsobnosti, avšak v zmysle rozvoja a starostlivosti o svoje územie riešia dobudovanie nových svetelných bodov.

Kultúra a šport - mestské časti v tejto oblasti pôsobnosti vytvárajú podmienky pre rozvoj a aktivity kultúrneho a športového života svojich obyvatel'ov. V oblasti kultúrnej a športovej infraštruktúry vykonávajú na svojom území údržbu a správu svojich kultúrnych a športových zariadení. Zároveň mestské časti pravidelne realizujú budovanie novej športovej infraštruktúry pre širokú verejnost'.

Sociálna oblast' - ide o širokú pôsobnost', ktorá je v štatúte podrobne definovaná a na ktorú sa vzt’ahuje viacero osobitných právnych úprav týkajúcich sa sociálnej oblasti. Mestské časti v tejto oblasti , sociálnych služieb ( Zákon č. 448/2008 Z. z. o sociálnych službách v znení neskorších predpisov), vyhl'adávajú osoby, ktorým treba poskytnút' sociálnu službu, zabezpečujú činnosti v dennom centre pre seniorov, podl'a možnosti tej k torej mestskej časti, zabezpečujú stravovanie dôchodcov, či už v stravovacom zariadení, alebo formou stravovacích lístkov. V oblasti hmotnej núdze mestské časti aj podl'a osobitného predpisu ( Zákon č. 417/2013 Z. z. o pomoci v hmotnej núdze v znení neskorších predpisov ) rozhodujú o jednorázovej dávke v hmotnej núdzi, podl'a možností mestskej časti.

V tejto pôsobnosti sú zahrnuté aj špeciálne pôsobnosti prenesené na niektoré mestské časti, ktoré ich zabezpečujú aj pre d’alšie mestské časti. Ide o výkon opatrovatel'skej služby a pomoci pri osobnej starostlivosti o diet’a vrátane uzatváranie príslušných zmlúv.

- Mestská čast' Sever, pre potreby obyvatel'ov svojej mestskej časti a na žiadost' mesta aj pre potreby obyvatel'ov mestských častí: Staré mesto, Sídlisko Ťahanovce, Ťahanovce, Kavečany a Džungl'a,

- Mestská čast' Západ pre potreby svojich obyvatel'ov a pre obyvatel'ov mestských častí: Sídlisko KVP, Luník IX, Myslava, Pereš, Lorinčík, Pol’ov a Šaca,

- Mestská dargovských hrdinov pre potreby svojich obyvatel'ov a pre obyvatel'ov mestských častí: Košická Nová Ves,

- Mestská čast' Juh pre potreby svojich obyvatel'ov a pre obyvatel'ov mestských častí: Barca, Šebastovce, Krásna Nad Jazerom a Vyšné Opátske.

Delenie mestských častí v tomto prípade kopíruje rozdelenie podl'a okresov v meste Košice.

Výkon funkcie zriad'ovatel'a, správcu a poskytovatel'a sociálnej služby v zariadeniach opatrovatel'skej služby zabezpečujú tri mestské časti a to Západ, Sever a Juh. V pôvodnom 
štatúte v rámci tejto oblasti bola aj mestská čast' Dargovských hrdinov, ktorá zabezpečovala zariadenia opatrovatel'skej služby. Po dohode s mestom v roku 2011 došlo k ukončeniu prevádzky zariadenia opatrovatel'skej služby a kapacita prešla na mestské zariadenia.

Výkon tzv. odl'ahčovacej služby t.j. poskytovanie terénnej formy opatrovatel'skej služby poskytujú mestské časti s pôsobnost'ou aj pre d’alšie mestské časti rovnako ako pri výkone opatrovatel'skej služby a pomoci pri osobnej starostlivosti o diet’a, vrátane uzatvárania zmlúv. V tejto časti štatútu sú definované pôsobnosti, ktoré v sociálnej oblasti zabezpečujú mestské časti a aj mesto ( $§ 28$ Štatút mesta Košice ).

V sociálnej v oblasti z pohl'adu praxe a uplatňovania jej pôsobnosti môžeme konštatovat', že funguje zabezpečovanie kompetencií jednou mestskou čast'ou aj pre d'alšie. Môžeme to vnímat' ako istý predpoklad pri potencionálnom zlučovaní mestských častí, alebo zlučovaní kompetencií.

Nakladanie s bytmi a nebytovými priestormi - v tejto majú mestské časti kompetencie v prípade ak vlastnia alebo spravujú byty. Ustanovujú pravidlá a zostavujú tzv. poradovníky uchádzačov. Všetko sa riadi aj osobitným predpisom (Zákon č. 189/1992 Zb. o úprave niektorých pomerov súvisiacich $\mathrm{s}$ nájmom bytova s bytovými náhradami $\mathrm{v}$ znení neskorších predpisov). V súčasnosti však bytmi disponuje len mesto a to bytmi sociálnymi, malometrážnymi a tzv. štartovacími pre mladé rodiny s det'mi.

Civilná ochrana obrana - mestské časti v rámci tejto pôsobnosti plnia úlohy v oblasti civilnej ochrany a riadenia štátu $\mathrm{v}$ krízových situáciách $\mathrm{v}$ súlade $\mathrm{s}$ osobitnými predpismi ( Zákon č. 42/1994 Z. z. o civilnej ochrane obyvatel'stva v znení neskorších predpisov a zákon č. 387/2002 Z. z. o riadení štátu v krízových situáciách mimo času vojny a vojnového stavu v znení neskorších predpisov ). Starosta mestskej je členom krízové štábu mesta a zároveň na základe svojho rozhodnutia zriad'uje aj krízový štáb mestskej časti. V rámci tejto pôsobnosti mestské časti s mestom priamo spolupracujú a komunikujú. Ide o širokospektrálnu oblast', ktorá je obsiahlo definovaná v štatúte ( $\$ 30$ Štatút mesta Košice ).

Oblast' školstva - pôsobnost' v oblasti školstva majú len dve mestské časti a to Staré mesto a Šaca, ktoré sú zriad'ovatel'om materských škôl na svojom území.

Referendum mesta - mestské časti zabezpečujú organizáciu referenda mesta a vykonávajú pôsobnosti v zmysle štatútu ( $§ 32$ Štatút mesta Košice ). Z pohl'adu praxe ide o organizáciu ako pri vol'bách, ktoré zabezpečujú mestské časti podl'a príslušných právnych predpisov.

Exekučné konanie a notárska činnost' - v tejto oblasti majú mestské časti pôsobnost' obce, ktorá sa riadi samozrejme osobitným právnym predpisom ( Zákon č. 233/1995 Z. z. o súdnych exekútoroch a exekučnej činnosti $\mathrm{v}$ znení neskorších predpisov). Mestské časti priamo zabezpečujú súčinnost' a prípadné uschovanie vecí tákajúce sa predmetného konania.

Oblast' hazardných hier - pôsobnost' mestských častí je v udel'ovaní individuálnych licencií, stanovísk pri vydávaní súhlasu s prevádzkovaním stávkových hier, vyjadrovaní k umiestneniu technických zariadení alebo zariadení používaných pri prevádzkovaní videohier. Mestské časti v tejto oblasti vykonávajú pôsobnost' obcí podl'a osobitného právneho predpisu (Zákon č. 171/2005 Z. z. o hazardných hrách v znení neskorších predpisov). V rámci výkonu tejto pôsobnosti mestské časti vykonávajú aj kontrolu jednotlivých prevádzok a zariadení podl'a prísnych pravidiel, ktoré ustanovuje príslušná právna úprava. Mestské časti majú $\mathrm{z}$ individuálnych licencií vlastný príjem, bližšie v d'alšej podkapitole týkajúcej sa ekonomiky a financovania mestských častí.

V̌̃eobecná vnútorná správa a ostatné pôsobnosti - do tejto pôsobnosti spadajú kompetencie týkajúce sa označovania ulíc a verejných priestranstiev, súpisných čísel a orientačných čísel bytovým a nebytovým budovám. Mestské časti môžu vykonávat osvedčovanie listín a podpisov, čo aj väčšina realizuje. V rámci tejto kategórie sú aj d’alšie pôsobnosti podl'a osobitných právnych predpisov ( $§ 35$ Štatútu mesta Košice ).

Kompetencie v prenesenej pôsobnosti, prenesený výkon štátnej správy. 
V rámci preneseného výkonu štátnej správy spomenieme niektoré kompetencie, ktoré sú aj všeobecne vnímané ako špecifické úlohy mestských častí a nie mesta Košice. Tie sú ukladané obciam v tomto prípade mestským častiam osobitnými právnymi predpismi.

Matričné úrady - táto pôsobnost' je daná v zmysle zákon č. 154/1994 Z. z. o matrikách v znení neskorších predpisov. V tomto prípade nie každá mestská čast' je aj matričným úradom. $Z$ dvadsiatich dvoch mestských častí je pät' mestských častí aj matričným úradom, ide o mestské časti Staré mesto, Západ, Dargovských hrdinov, Juh a Šaca Pôsobnost' týchto matričných úradov korenšponduje resp. zohl'adňuje územie okresov v meste Košice.

Evidencia obyvatel'stva - pôsobnost' na úseku evidencie obyvatel'stva je v zmysle zákona č. 253/1998 Z. z. o hlásení pobytu občanov Slovenskej republiky v znení neskorších predpisov. Mestské časti v zmysle tohto zákona majú pôsobnost' na úseku hlásenia, evidencie a vedenia registru pobytu občanov.

Vydávanie rybárskych povolení - zákon č. 216/2018 Z. z. o rybárstve v znení neskorších predpisov, je pôsobnost' mestských častí pri vydávaní rybárskych lístkov.

Pôsobnost' na úseku Štátneho fondu rozvoja a bývania - pôsobnost' určuje zákon č. 607/2003 Z.z. o štátnom fonde rozvoja bývania v znení neskorších predpisov. Pôsobnost' mestských častí $\mathrm{v}$ oblasti štátneho rozvoja $\mathrm{v}$ zmysle tohto zákona je podobná ako pri matričných úradoch. Pôsobnost' je daná štyrom mestským častiam Staré mesto, Západ, Dargovských hrdinov, Juh. Pôsobnost' je daná pri preberaní, spracovaní a samotnom podávaní žiadostí o podporu v oblasti štátneho fondu rozvoja bývania.

Pôsobnost', ktorá je zverená priamo pre mestské časti prostredníctvom spomenutých zákonov, ale aj iných, nemožno mestským častiam odobrat' zmenou štatútu mesta. Znamená to, že pôsobnost' pre mestské časti zostáva, pokial' nedôjde k zmene príslušných zákonov a ich ustanovení. Mestské časti môžu vykonávat' a vykonávajú aj d’alšiu pôsobnost', ktorú zverujú d’alšie osobitné zákony a ak to vyplýva z ustanovení Štatútu mesta. Kompetencia, ktorá je daná štatútom, však mesto Košice zmenou štatútu môže odňat'.

Na základe rozdelenia kompetencií medzi mesto a mestské časti môžeme pozorovat' nesúlad medzi kompetenciami jednotlivých mestských častí. Z hl'adiska aplikačnej praxe došlo k rozdeleniu mestských častí na vel'ké a malé mestské časti. Takéto delenie mestských častí nemá žiaden právny základ. Vel'ké mestské časti sú časti s prevažne sídliskovým charakterom a Staré mesto. Medzi týmito mestskými čast'ami však tiež neexistuje súlad medzi kompetenciami, ked’že sídlisko KVP má širšiu pôsobnost' ustanovenú štatútom. Malé mestské časti majú prevažne charakter vidieckeho sídla a sú to okrajové mestské časti vo viacerých prípadoch aj vzdialenejšie od centra mesta. $Z$ tohto nesúladu vplýva aj rozdielne financovania mestských častí, ktoré sú mestským častiam pridel'ované z rozpočtu mesta, v zmysle schváleného uznesenia na príslušný kalendárny rok.

\subsection{Financovanie mestských častí a mesta}

Územná samospráva je zodpovedná za zabezpečenie celého radu verejných statkov, služieb a tiež za vytváranie podmienok pre sociálno ekonomický rozvoj. Medzi predpoklady fungovania územnej samosprávy nepatrí len predpoklad legislatívny, ale aj ekonomický. Medzi ekonomické predpoklady môžeme zaradit': vlastníctvo majetku a právo s ním hospodárit', možnost' získavania vlastné finančné prostriedky ${ }^{4}$, zostavenie vlastného rozpočtu a hospodárenie v zmysle znenia schváleného rozpočtu.

Financovanie mestských častí a mesta respektíve ich ekonomika je obsiahnutá a definovaná v štvrtej časti štatútu. Pôsobnost' v oblasti ekonomiky definovaná v štatúte je v súlade s príslušnými osobitnými právnymi predpismi, ktoré ustanovujú aj konkrétne podmienky ( Zákon č. 583/2004 Z. z. o rozpočtových pravidlách územnej samosprávy v znení neskorších

\footnotetext{
${ }^{4}$ Sú to prevažne príjmy nedaňového charakteru napr. rôzne poplatky, príjmy z prenájmu a predaja majetku. Sú to vlastné prijmy do svojho rozpočtu
} 
predpisov, Zákon č. 582/2004 Z. z. o miestnych daniach a miestnom poplatku za komunálne odpady a drobné stavebné odpady v znení neskorších predpisov, Zákon č. 447/2005 Z. z. o miestnom poplatku za rozvoj v znení neskorších predpisov, Zákon č. 431/2020 Z. Z. o účtovníctve v znení neskorších predpisov ).

Mestské časti a mesto samostatne hospodária s vlastným a zvereným majetkom, ako aj s vlastnými a zverenými finančnými prostriedkami. Samostatne zostavujú, pripravujú a následné aj schval'ujú rozpočty vo svojich zastupitel'stvách. Rovnako tak, mesto aj mestské časti, vedú účtovníctvo a evidenciu o hospodárení, vykonávajú kontrolu hospodárenia právnických osôb, ktoré založili, alebo zriadili, ale taktiež aj v organizáciách napojené na ich rozpočty.

Rozpočet mestských časti a mesta - samotný rozpočet vyjadruje ich ekonomickú samostatnost'. Rozpočet mestských častí a mesta môžeme vnímat' aj ako vyjadrenie ich finančných vzt'ahov. Rozpočty vyjadrujú aj d’alšie vzt'ahy, či už k jednotlivým právnickým osobám a štátnemu rozpočtu. Mestské časti a mesto v zmysle štatútu spolupracujú pri príprave svojich rozpočtov a poskytujú si informácie a údaje, ktoré s tým súvisia. Ide o údaje týkajúce sa počtu obyvatel'ov, výšky podielových daní, údaje týkajúce sa výkonu opatrovatel'skej služby ako aj iné podnety a požiadavky zo strany mestských časti na rozpočet mesta. Rozpočet z pohl'adu aplikačnej praxe je zostavovaný príslušným odborom na úradoch resp. magistráte na základe jednotlivých požiadaviek, ktoré reflektujú na programy a projekty vedenia samosprávy, poslancov zastupitel'stiev. Návrh programového rozpočtu ${ }^{5}$ je následne prerokovaný na komisiách a rade zastupitel'stva. Samotné schval'ovanie je v kompetencii zastupitel'stva mestskej časti respektíve mesta. Zastupitel'stvá schval'ujú aj záverečný účet.

Súčast'ou štatútu je aj definovanie príjmov a výdavkov mesta a mestských častí, ktoré sú čast'ami rozpočtov.

Príjmami mesta sú finančné zdroje týkajúce sa podielu výnosu dane z príjmov fyzických osôb, miestne dane a poplatky, nedaňové príjmy $\mathrm{z}$ majetku mesta, príjmy z činností rozpočtových a príspevkových organizácií, účelové granty a transfery poskytnuté na bežné a kapitálové výdavky vrátane prostriedkov z Európskej únie, dotácie zo štátneho rozpočtu, administratívne a správne poplatky, dary, príspevky ako aj iné príjmy ustanovené osobitnými predpismi ( $§ 38$ Štatútu mesta Košice ).

Výdavky mesta sú uhrádzané z rozpočtu mesta. Patria sem výdavky súvisiace s výkonom samosprávnych funkcií mesta a preneseného výkonu štátnej správy, výdavky na činnost' rozpočtových a príspevkových organizácií, výdavky na rozvojové projektové zámery, podiel na miestnych daniach poskytnutých mestským častiam vo výške určenej v rozpočte na príslušný rok, účelové dotácie pre mestské časti podl'a jednotlivých pôsobností a iné výdavky ustanovené osobitnými právnymi predpismi ( $\$ 39$ štatútu mesta Košice ).

Príjmami mestských častí sú finančné zdroje a to predovšetkým podiely z výnosu dane z príjmov fyzických osôb v rozsahu schválenom rozpočtom mesta. Podiel z výnosu tejto dane a miestnych daní pre mestské časti je presne určená suma na hlavu obyvatel'a. V súčasnosti je táto suma pre mestské časti rôzna $\mathrm{v}$ závislosti od pôsobnosti a tiež aj podl'a rozdelenia mestských časti na tzv. vel'ké a malé mestské časti. Rozdelenie finančných prostriedkov pre mestské časti je uvedené v tabul'ke č.2. Medzi d'alšie príjmy rozpočtov mestských častí patria aj podiel na miestnych daniach poskytnutých mestom vo výške určenej v rozpočte poznámka pod čiaru mesto špecifikuje $\mathrm{v}$ rámci rozpočtu a uznesenia návrhu rozpočtu len daň za psa a to $50 \%$ podiel pre mestské časti, podiel na výnose poplatku za rozvoj v tomto prípade je to $50 \%$ podiel pre mestské časti, príjmy súvisiace s majetkom a to z prenájmu a predaja,

\footnotetext{
${ }^{5}$ Programové rozpočtovanie je systém založený na plánovaní úloh a aktivít. Rozpočtové zdroje sa alokujú do jednotlivých programov a následne podprogramov s presným popisom. Programovo sa rozpočtujú len výdavky. Dôraz sa kladie na efektivitu vynakladania verejných zdrojov a následnú prehl'adnejšiu kontrolu a transparentnost'.
} 
príjmy z hazardných hier, bežné a kapitálové granty, transfery, účelové dotácie pre mestské časti z rozpočtu mesta a iné príjmy ustanovené osobitnými predpismi ( $§ 40$ štatút mesta Košice ).

Výdavky mestských častí tvoria hlavne výdavky spojené so samosprávnou činnost'ou samotnej mestskej časti, financovania rozvojových programov, projektov miestneho významu, príspevky pre rozpočtové alebo príspevkové organizácie, dotácie mestských častí podl'a finančných možností jednotlivých mestských častí, rôzne splátky a d'alšie výdavky určujúce osobitné predpisy ( $§ 41$ štatútu mesta Košice ).

Zákon č. 582/2004 Z. z. o miestnych daniach a miestnom poplatku za komunálne odpady a drobné stavebné odpady v znení neskorších predpisov, určuje druhy miestnych daní, ktoré môže ukladat' obec formou všeobecne záväzného nariadenia. Druhy miestnych daní sú daň z nehnutel'nosti, za psa, za užívanie verejného priestranstva, ubytovanie, predajné automaty, nevýherné hracie prístroje, za vjazd a zotrvanie motorového vozidla v historickej časti mesta, za jadrové zariadenie. Obec ukladá aj poplatok za komunálny odpad a drobné stavebné odpady. Správcom miestnych daní je obec, v prípade mesta Košice je to mesto, ak štatút neustanoví správcu mestskú čast' ( $\$ 99$ Zákona č. 582/2004 Z. z. o miestnych daniach a miestnom poplatku za komunálne odpady a drobné stavebné odpady v znení neskorších predpisov ).

\section{Záver}

Pôsobnost' mestských častí a z nej vyplývajúce jednotlivé kompetencie pre mestské časti v meste Košice, poukazujú na skutočnost', že v rámci územnej samosprávy v Košiciach, existuje nesúlad medzi mestskými čast'ami. Tento nesúlad sa následne prejavuje aj vo financovaní mestských častí. Nesúlad, ktorý sa hlavne prejavuje v aplikačnej praxi a pri výkone samosprávnych úloh môžeme vnímat’ ako základný predpoklad pre širokú diskusiu za účelom efektívnejšieho prerozdelenia kompetencií medzi mestom a mestskými čast'ami v spojitosti s úpravou financovania mestských častí. Diskusia k prerozdeleniu kompetencií, alebo úprave územnej samosprávy mesta Košice, by mala mat' za ciel' efektívnejšie plnenie úloh mestských častí v súlade s jednotlivými právnymi predpismi. Príklady takéhoto riešenia vieme čerpat' v rámci princípu dobrej praxe napr. z mesta Bratislava, alebo z jednotlivých miest Českej republiky.

Tabul'ka č. 1: SÚČASNÉ ROZDELENIE KOMPETENCIÍ

\begin{tabular}{|c|c|c|c|}
\hline Kompetencia & Mesto & Vel'ká mestská čast' & Malá mestská čast' \\
\hline Trhoviská & áno mestské & áno lokálne & áno lokálne \\
\hline $\begin{array}{c}\text { Komunálny odpad } \\
\begin{array}{c}\text { Čistota a údržba } \\
\text { verejných } \\
\text { priestranstiev }\end{array}\end{array}$ & Áno pre všetky MĆn & Áno lokálne & Áno lokálne \\
\hline Pohrebiská & Áno mestské & Nie & Áno \\
\hline $\begin{array}{c}\text { Správa cestných } \\
\text { komunikácií }\end{array}$ & Áno pre vel'ké MČ & $\begin{array}{c}\text { Nie ( výnimka MČ } \\
\text { sídl.KVP) }\end{array}$ & Áno lokálne \\
\hline Verejné osvetlenie & Áno pre všetky MČ & áno \\
\hline Starostlivost' o zeleň & Áno pre všetky MČ & $\begin{array}{c}\text { Nie ( výnimka MČ } \\
\text { sídl KVP) }\end{array}$ & Áno lokálne \\
\hline Kultúra a šport & Áno & áno \\
\hline Sociálne bývanie & Áno & $\begin{array}{c}\text { Áno, opatrovatel'stvo } \\
4 \text { MČ, ZOS 3 MČ }\end{array}$ & $\begin{array}{c}\text { Nie okrem Luníka } \\
\text { IX }\end{array}$ \\
\hline Sociálne služby & & Nie \\
\hline
\end{tabular}




\begin{tabular}{|c|c|c|c|}
\hline $\begin{array}{c}\text { Civilná obrana } \\
\text { a ochrana }\end{array}$ & Áno & Áno lokálne & Áno lokálne \\
\hline $\begin{array}{c}\text { Predškolské } \\
\text { zariadenia }\end{array}$ & Áno & $\begin{array}{c}\text { Nie okrem MČ Staré } \\
\text { mesto }\end{array}$ & $\begin{array}{c}\text { Nie okrem MČ } \\
\text { Šaca }\end{array}$ \\
\hline Základné školstvo & Áno & Nie & Nie \\
\hline $\begin{array}{c}\text { Ostatné školy } \\
\text { a školské zriadenia } \\
\text { ZUŠ, JŠ́, CVČ }\end{array}$ & Áno & Nie & Nie \\
\hline $\begin{array}{c}\text { Licencie na } \\
\text { hazardné hry }\end{array}$ & Nie & Áno & Áno \\
\hline Miestne dane & Áno & $\begin{array}{c}\text { Nie ( } 50 \% \mathrm{z} \text { dane za } \\
\text { psa })\end{array}$ & $\begin{array}{c}\text { Nie ( } 50 \% \mathrm{z} \text { dane } \\
\text { za psa })\end{array}$ \\
\hline Miestne poplatky & Áno & Nie & Nie \\
\hline
\end{tabular}

\section{Literatúra}

1. KIOVSKÁ, M. a kol., 2000. Správne právo hmotné. Košice: Právnická fakulta, UPJŠ. ISBN 80-7097-387-0.

2. PALUŠ, I. a kol., 2016. Ústavné právo Slovenskej republiky. Košice: Fakulta verejnej správy, UPJŠ. ISBN 9788081524424.

3. PALÚŠ, I. a kol., 2018. Formy uskutočňovania obecnej samosprávy. Košice: Fakulta verejnej správy, UPJŠ. ISBN 978-80-8152-663-3.

4. SOTOLÁŘ, J., 2000. Kompetenčné právo v územnej samospráve. Košice: SOTAC. ISBN 8096835637.

5. Ústava SR č. 460/1992 Zb. v znení neskorších predpisov

6. Zákon č. 369/1990 Zb. o obecnom zriadení v znení neskorších predpisov

7. Zákon č. 401/1990 Zb. o meste Košice v znení neskorších predpisov

8. Zákon č. 582/2004 Z. z. o miestnych daniach a miestnom poplatku za komunálne odpady a drobné stavebné odpady v znení neskorších predpisov

9. Zákon č. 50/1979 Zb. o územnom plánovaní a stavebnom poriadku v znení neskorších predpisov

10. Zákon č. 131/2010 Z.z. o pohrebníctve v znení neskorších predpisov

11. Zákon č. 448/2008 Z. z. o sociálnych službách v znení neskorších predpisov

12. Zákon č. 154/1994 Z. z. o matrikách v znení neskorších predpisov.

13. Zákona č. 253/1998 Z. z. o hlásení pobytu občanov Slovenskej republiky v znení neskorších predpisov

14. Zákon č. 607/2003 Z.z. o štátnom fonde rozvoja bývania v znení neskorších predpisov

15. Štatút mesta Košice

\section{Kontaktné údaje}

Mgr. Jozef Andrejčák

Fakulta verejnej správy, UPJŠ v KE

Popradská 66, 04001 Košice

Tel: +421908367338

andrejcak20@gmail.com 


\title{
ÚSTAVNOPRÁVNE POSTAVENIA MESTSKÝCH ČASTÍ V MESTE KOŠICE
}

\section{CONSTITUTIONAL STATUS OF CITY DISTRICTS IN THE CITY OF KOŠICE}

\author{
Jozef Andrejčák
}

\begin{abstract}
Abstrakt
Príspevok sa zaoberá právnym postavením mestských častí v meste Košice z pohl’adu jednotlivých prameňov práva a následne vo vzt’ahu kzákonu o obecnom zriadení a v osobitnej právnej úprave a to zákona o meste Košice. Ciel'om je načrtnút' postavenie mestských častí vo vybraných právnych úpravách, tak aby následne sa vytvoril predpoklad pre d'alšie ponímanie postavenia mestských častí v meste Košice a to hlavne z pohladu ich pôsobnosti a realizácie územnej samosprávy. S následným zretel'om a upriamením na aplikačnú prax výkonu územnej samosprávy.
\end{abstract}

Kl'účové slová: mestská čast' , územná samospráva, zákon o obecnom zriadení, zákon o meste Košice

\begin{abstract}
The paper deals with the legal status of city districts in the city of Košice from the point of view of individual sources of law and subsequently in relation to the Act on Municipal Establishment and in a special legal regulation, namely the Act on the City of Košice. The aim is to outline the position of city districts in selected legal regulations, so that a recondition is subsequently created for further understanding of the position of city districts in the city of Košice, especially from the point of view of their competence and implementation of territorial self-government. With subsequent consideration and focus on the application practice of territorial self-government.
\end{abstract}

Keywords : city district, territorial self-government, law on municipal establishment, law on the city of Košice

\section{1. Ústavnoprávne postavenia mestských častí v meste Košice}

\subsection{Pramene práva dotýkajúce sa mestských častí a mesta Košice}

V tejto časti kapitoly sa pristavíme $\mathrm{v}$ krátkosti pri prameňoch práva, ktoré sa dotýkajú mestských častí a mesta Košice.

Pojem pramene práva znamená rôzne formy, v ktorých je konkrétne právo obsiahnuté. Právo je $\mathrm{v}$ týchto formách pevne zakotvené, vychádza $\mathrm{z}$ nich, a taktiež na základe týchto foriem dochádza $\mathrm{k}$ uplatňovaniu práva $\mathrm{v}$ spoločnosti.

Vychádzajúc zo všeobecných poznatkov právnej teórie a Ústavy Slovenskej republiky sú obce právnické osoby. Tie sú charakterizované základnými znakmi:

- sú samostatné územné samosprávne a správne celky (čl. 64a ústavy SR), ktoré na základe ústavy a zákonov sú oprávnené vykonávat' verejnú moc. Obce sú oprávnené vykonávat' verejnú moc vo forme výkonu územnej samosprávy a miestnej štátnej správy, ale len na svojom území

- V rámci výkonu územnej samosprávy si obce v medziach vymedzených ústavou a príslušnými zákonmi samostatne spravujú vlastné záležitosti (čl. 65 a nasl. ústavy SR) 
- miestnu štátnu správu vykonávajú obce v zákonom prenesenom rozsahu určených úloh miestnej štátnej správy (čl. 71 ods. 1 ústavy SR)

- Obce sú územné spoločenstvá osôb, ktoré majú trvalý alebo iný pobyt na ich území

Základy právneho postavenia obcí upravuje štvrtá hlava Ústavy SR (d’alej ústava). Ústava:

- Definuje obec (Ústav čl. 64a)

- Ustanovuje ich základné ústavné práva pri výkone územnej samosprávy (Ústava čl. 65, čl. 66 a čl .68 )

- Ustanovuje základné formy výkonu samosprávy (Ústava čl. 64 ods. 1)

- Ustanovuje základné orgány obce (Ústava čl. 69 ods. 1 až 3)

- Ustanovuje oprávnenie obcí na výkon miestnej štátnej správy v prenesenom zákonnom rozsahu (Ústava čl. 71)

Z obsahu štvrtej hlavy ústavy možno vyvodit', že postavenie obcí majú aj mestá. V ústave však nie je zmienka o mestských častiach s postavením obce. Ústavu vnímame ako všeobecný právny predpis, ktorý nemusí a ani neskíza k úpravám špecifických ustanovení. Na základe tejto skutočnosti ako aj podl'a názoru Orosza (právna analýza 02.2005) ${ }^{1}$ nemožno automaticky vyvodit' záver, že osobitný zákon nemôže mestským častiam priznat' právne postavenie obce. S názorom Orosza možno súhlasit' a teda konštatovat', že síce v ústave nie sú zakotvené mestské časti s právnym postavením obce, ale nie je to ani zakázané upravit' takúto možnost' osobitným zákonom.

Aj ked' mestské časti nie sú priamo uvedené v ústave zmieňuje sa však o nich ústavný zákon č 357/2004 Z.z. o ochrane verejného záujmu pri výkone funkcií verejných funkcionárov, ktorý pod svoju pôsobnost' v zmysle čl. 2 ods. 1 - 3 písm. o) a p) zarad'uje aj poslancov miestnych zastupitel'stiev v mestských častiach a starostov mestských častí. Môžeme konštatovat', že ústavodarca vychádzal $\mathrm{z}$ rovnakého právneho postavenia funkcionárov obcí, miest a mestských častí a akceptácie stavu a postavenia mestských častí ako obcí.

Ďalším právnym predpisom dotýkajúcim sa mestských častí je zákon č. 369/1s990 Zb. o obecnom zriadení v znení neskorších predpisov (d’alej zákon o obecnom zriadení). Zákon o obecnom zriadení v rámci viacerých ustanovení spomína mestské časti (§ 13a ods. 1 písm.g, $\S 23, \S 24$ ods. 1 písm. a, $\S 25$, ods. 2, písm. f) Z týchto ustanovení za klúčové môžeme považovat' $\S 23$ :

„(1) Mesto môže zriad'ovat'v mestských častiach s vlastným spravidla katastrálnym územím výbory. Členmi výborov sú všetci poslanci mestského zastupitel'stva zvolení v mestskej časti, členmi výborov môžu byt' aj obyvatelia mesta s trvalým pobytom v mestskej časti zvolení mestským zastupitel'stvom. Na čele výboru je predseda, ktorým je člen výboru zvolený výborom.

(2) Výbory v mestských častiach reprezentujú obyvatel'ov mestskej časti a podielajú sa na samospráve mesta.

(3) Oprávnenia a povinnosti výboru pri samospráve mesta, vztahy výboru a mestského zastupitel'stva, štruktúru a d'alšie potrebné veci upraví štatút mesta. “

Táto možnost' sa vzt'ahuje na všetky mestá. Zákon však týmto výborom v mestských častiach nepriznáva právnu subjektivitu a oprávnenia pri výkone verejnej moci. Môžeme konštatovat', že postavenie výborov v mestských častiach zmysle ustanovenia $§ 23$ zákona o obecnom zriadení je neporovnatel'né s postavením orgánov mestských častí podl'a zákona č. 401/1990 Zb o meste Košice v znení neskorších predpisov (d’alej zákon o meste Košice), ale aj podl'a zákona č. 377/1990 Zb. o hlavnom meste Bratislava v znení neskorších predpisov (d'alej zákon o meste Bratislava)

Zákon o obecnom zriadení ustanovuje právny základ pre vydanie zákona o meste Košice a to v §22 ods. 1, ,, (1) Právne postavenie, územné usporiadanie a orgány samosprávy miest

\footnotetext{
${ }^{1}$ Právna analýza prof. Ladislava Orosza spracovaná k návrhu novelizácie zákona č. 401/1990 Zb o meste Košice v znení neskorších predpisov, z roku 2005.
} 
s počtom obyvatel'ov nad 200000 upravuje osobitný zákon." Z tejto citácie vyplýva, že zákonodarca je povinný upravit' právne postavenie, územne usporiadanie a orgány samosprávy mesta s počtom obyvatel'ov nad 200000 obyvatel'ov.

Vzt'ah zákona o meste Košice k zákonu o obecnom zriadení je založený na všeobecných zásadách vzt'ahov špeciálnej právnej úpravy $\mathrm{k}$ všeobecnej právnej úprave.

$\mathrm{V}$ rámci zákona o meste Košice sa priamo týkajú mestských častí jeho úvodné ustanovenia a to konkrétne $\S 2$ ods. 2 :

„,(2) Mestské časti sú právnické osoby, ktoré za podmienok stanovených zákonom a štatútom mesta hospodária so zvereným a vlastným majetkom a so zverenými a vlastnými finančnými príjmami. Mestské časti vykonávajú samosprávu vrozsahu zverenom týmto zákonom aštatútom, vo zverenom rozsahu majú mestské časti postavenie obce. Mestské časti vykonávajú prenesený výkon štátnej správy v rozsahu vymedzenom zákonom, v tomto rozsahu majú mestské časti postavenie obce."

(3) Mestská čast’ ako právnická osoba podl’a ods. 2 má ako žiadatel’ na účely čerpania prostriedkov z fondov Európskej únie postavenie obce."

Z uvedeného môžeme skonštatovat', že mestským častiam je zverené jedno z najvýznamnejších práv súvisiacich s výkonom územnej samosprávy.

$\mathrm{V}$ rámci $\S 3$ zákona o meste Košice je definované územie mesta, ktoré môžeme vnímat' ako jeden zo základných znakov obce. $\S 3$ ods. 2 zákona o meste Košice ustanovuje, že mesto Košice sa člení na mestské časti, ktoré sú uvedené v prílohe zákona o meste Košice. Mestské časti sú spomínané aj v d'alších ustanoveniach zákona o meste, ktorými sa venujeme v d'alších podkapitolách.

Pre d'alší základný obraz postavenia mestských častí v meste Košice uvedieme niektoré osobitné zákony, ktoré zverujú určitú pôsobnost' priamo mestským častiam. Ide o pôsobnost' v oblasti miestnej štátnej správy ( Ústava čl. 71 ods. 1 ).

- Zákon č. 138/1991 Zb. o majetku obcí v znení neskorších predpisov

- Zákon č. 346/1990 Zb. o vol’bách do orgánov územnej samosprávy v znení neskorších predpisov

- Zákon č. 154/1994 Z. z. o matrikách v znení neskorších predpisov

- Zákon č. 253/1998 Z.z. o hlásení pobytu občanov Slovenskej republiky v znení neskorších predpisov

- Zákon č. 607/2003 Z.z. o štátnom fonde rozvoja bývania v znení neskorších predpisov

Podrobnejšie d’alšie osobitné zákony uvedieme $\mathrm{v}$ d'alších podkapitolách vrátane ich uplatňovania $\mathrm{v}$ aplikačnej praxi.

Takto zverenú pôsobnost' pre mestské časti, priamo osobitnými právnymi predpismi, nie je možné odňat' na základe zmeny štatútu mesta.

Postavenie mestských častí je ustanovené aj v d’alšej forme prameňov práva a to $\mathrm{v}$ štatúte mesta Košice. Samotný štatút môžeme vnímat' ako právny predpis, ktorý je výsledkom normotvorby obce. Štatút definuje základné vzt’ahy mesta, mestských častí a d'alších organizácií v rámci výkonu územnej samosprávy. Podrobnejšie štatútom sa zaoberáme v podkapitolách týkajúcich sa pôsobnosti a financovania mesta a mestských častí.

Záverom tejto časti môžeme konštatovat', že mestské časti spíňajú základné znaky obcí. Medzi základné znaky obcí z pohl'adu mestských častí v zmysle uvedených zistení a skutočností, môžeme uviest'. Podl'a zákona o meste Košice a osobitných zákonov sú mestské časti oprávnené vykonávat' verejnú moc. Priamo zákon o meste Košice oprávňuje mestské časti vykonávat' verejnú moc vo forme výkonu územnej samosprávy. Mestské časti majú oprávnenie vykonávat' verejnú moc vo forme výkonu miestnej štátnej správy. Mestské časti majú svoje vlastné územie, ktoré je zaručené v zákone o meste Košice. Mestské časti majú svoje obyvatel'stvo, občanov, ktorí majú na ich území trvalý pobyt. 
V d'alších podkapitolách sa budeme venovat' podrobnejšie vzt'ahu mestských častí a zákona o obecnom zriadení, zákonom o meste Košice.

\subsection{Mestské časti vo vzt’ahu so zákonom o obecnom zriadení}

Zákon o obecnom zriadení č. 369/1990 Zb. v znení neskorších predpisov ( d’alej zákon o obecnom zriadení ) ako základný právny rámec, ktorý určuje postavenie a právomoci obcí na Slovensku v rámci svojich ustanovení spomína aj mestské časti. Možno za hlavné môžeme považovat' ustanovenie $\S 23$ zákona o obecnom zriadení (zákon o obecnom zriadení...).

Spomínané ustanovenie dáva možnost' mestám zriad'ovat' v mestských častiach s vlastným spravidla katastrálnym územím výbory. Členmi výborov sú všetci poslanci mestského zastupitel'stva zvolení v mestskej časti. Na čele výboru stojí predseda, ktorý je zvolený z členov výboru. Výbory reprezentujú obyvatel'ov mestskej časti a podiel'ajú sa na samospráve mesta. Oprávnenia a povinnosti výborov vo vzt’ahu k samospráve mesta upravuje štatút mesta vrátane d’alších potrebných náležitosti ( $\$ 23$ zákon o obecnom zriadení ). Táto možnost' sa vzt'ahuje na všetky mestá. Zákon však týmto výborom v mestských častiach nepriznáva právnu subjektivitu a oprávnenia pri výkone verejnej moci. Ustanovuje len to, že sa podiel'ajú na samospráve mesta. Môžeme konštatovat', že postavenie výborov v mestských častiach zmysle ustanovenia $§ 23$ zákona o obecnom zriadení je neporovnatel'né s postavením orgánov mestských častí podla zákona č. 401/1990 Zb o meste Košice v znení neskorších predpisov (d’alej zákon o meste Košice), ale aj podl'a zákona č. 377/1990 Zb. o hlavnom meste Bratislava v znení neskorších predpisov (d’alej zákone o meste Bratislava). Z toho vyplýva aj to, že mestské časti v meste Košice a Bratislava majú iné principiálne postavenie.

Z právnej analýzy Orosza (právna analýza 02.2005) možno aj nepriamo vyvodit' záver o akceptácií mestských častí v Košiciach a v Bratislave ako obcí z ustanovení § 13a zákona o obecnom zriadení ods. 1 ktorý ustanovuje zánik mandátu starostu, písm. g) zmenou trvalého pobytu mimo územia obce, v mestách so samosprávou mestských častí aj v prípade zmeny trvalého pobytu mimo územia mestskej časti, v ktorej vykonáva funkciu starostu. Obdobné je to aj pri mandáte poslanca a jeho zániku, obsiahnutom v $§ 25$ zákona o obecnom zriadení, písm. f, zmenou trvalého pobytu mimo územia obce, $\mathrm{v}$ mestách so samosprávou v mestských častiach aj v prípade zmeny trvalého pobytu mimo územia mestskej časti, v ktorej funkciu poslanca vykonáva.

Z logického a systematického výkladu jednotlivých a príslušných ustanovení zákona o obecnom zriadení v zmysle spomínanej právnej analýzy prof. Orosza, možno jednoznačne súhlasit' a podporit' to, že v ustanoveniach podl'a $\$ 23$ zákona o obecnom zriadení nejde o mestské časti, ale o mestské časti podl'a osobitných zákonov nakol'ko sa v nich uvádza, že ide:

- o mestá so samosprávou mestských častí a nie len podielom na samospráve mesta, ktorý upravuje štatút mesta,

- výbory mestských častí podl'a $§ 23$ zákona o obecnom zriadení nemajú priamo voleného starostu, zatial' čo mestské časti spomínané v $\$ 13$ zákona o obecnom zriadení ho majú

- mandát poslanca mestskej časti podla 23 o obecnom zriadení by zanikol len v prípade zmeny trvalého pobytu mimo územia obce resp. mesta, nie zmenou trvalého pobytu mimo územia mestskej časti.

Na základe tejto argumentácie možno konštatovat', že zákon o obecnom zriadení počíta a dáva predpoklad k existencii miest, v ktorých bude ustanovená samospráva mestských častí a teda počíta s tým, že sa prostredníctvom osobitných zákonov ustanovia mestské časti s postavením obce.

Právny základ pre vydanie zákona o meste Bratislava je priamo obsiahnutý v ústave čl. 10 ods. 2 ústavy SR ,, postavenie Bratislavy ako hlavného mesta Slovenskej republiky ustanoví 
zákon " právny základ pre vydanie zákona o meste Košice je však obsiahnutý v zákone o obecnom zriadení a to v $\$ 22$ ods. 1, ,, (1) Právne postavenie, územné usporiadanie a orgány samosprávy miest s počtom obyvatel’ov nad 200000 upravuje osobitný zákon. " Z tejto citácie vyplýva, že zákonodarca je povinný upravit' právne postavenie, územne usporiadanie a orgány samosprávy mesta s počtom obyvatel'ov nad 200000 obyvatel'ov. Mesto Košice túto podmienku počtu obyvatel'ov spĺn̆alo a aj spíňa. Z uvedeného vyplýva, že v prípade ak by bol osobitný zákon o meste Košice zrušený, došlo by k rozporu so zákonom o obecnom zriadení. Z ustanovenia zákona o obecnom zriadení $§ 22$ ods. 1 a 2 je diskutabilné, či takáto právna úprava dáva automaticky základ pre existenciu mestských častí a dvoj úrovňovej samosprávy v spomínaných mestách.

Vzt'ahy oboch osobitných zákonov miest Košíc a Bratislavy vo vzt’ahu k zákonu obecnom zriadení sú založené na všeobecnej interpretačnej zásade. Zásady vzt'ahov špeciálnej právnej normy $\mathrm{k}$ všeobecnej právnej normy. Teda na spomínané mesta sa používa právna úprava zákona o obecnom zriadení len vtedy ak osobitné zákony neustanovujú inak. Jednoducho skonštatované, že prednostne sa používa právna úprava osobitných, špeciálnych zákonov o meste Košice a meste Bratislava.

\subsection{Zákon o meste Košice -všeobecná charakteristika.}

Zákon číslo 401/1990 Zb. o meste Košice v znení neskorších predpisov (d’alej len zákon o meste Košice), sa venuje všeobecne daným právnym predpisom a rozšíreným ustanoveniam postavenia mesta Košice. Zákon o meste Košice bol od svojho vydania desat' krát novelizovaný. Najnovšia aktualizácia bola schválená v decembri roku 2014, pričom účinnost' zákona bola $\mathrm{k}$ júnu roku 2015. Aktuálne znenie zákona pozostáva zo siedmich časti a 28 paragrafov (zákon o meste Košice).

Prvá čast' zákona o meste Košice pojednáva o postavení mesta Košice a má 4 paragrafové znenia. V § 1 je mesto Košice definované ako samostatný územný samosprávny a správny celok SR. Podl'a $\S 2$, je mesto Košice a jeho mestské časti definované ako právnické osoby. $\mathrm{V}$ jednotlivých odsekoch je definované, že mesto a jeho mestské časti majú právo hospodárit' s majetkom a financiami, ktoré vlastnia alebo im boli zverené. Rovnako tak je tu definované právo na čerpanie finančných prostriedkov $\mathrm{z}$ fondov Európskej únie. $\mathrm{V} \S 3$ je definované územie mesta. Jednotlivé odseky tohto paragrafu hovoria o vymedzení katastrálneho územia mesta, členenia na mestské časti a ich podrobné vymedzenie územia ako aj možnosti ich rušenia a zlučovania. Podrobnejšie týmto znením a možnost'ami sa budeme zaoberat' v IV. kapitole, vo vzt'ahu k možnému zlučovaniu mestských častí. Spoluprácu s obcami a d’alšími územnými a správnymi celkami upravuje § 4. Stanovuje podmienky za ktorých je možné uzatvárat' spoluprácu na domácej i medzinárodnej úrovni. Rovnako tak zriad'ovat' združenia podl'a zákona (1. čast' zákona o meste Košice).

Druhá čast' zákona o meste Košice pojednáva o samospráve mesta, ktorá má sedem paragrafov. § 5 stanovuje za akých podmienok sa uskutočňuje výkon samosprávy. V $§ 6$ sú definované orgány mesta, kto sú orgány mesta a kto sú orgány mestského zastupitel'stva. Rovnako tak za akých podmienok je možné zriadit' a zrušit' poradné a kontrolné orgány alebo jednotlivé komisie. Legislatívne znenie stanovuje aj ich náplň práce. Orgánom mestskej časti sa venuje $\S 7$ a rovnako ako $\mathrm{v} \S 6$ zákon o meste Košice pojednáva o tom istom, ale na úrovni mestských častí. V §7a definuje radu starostov. Ide o spoločný orgán mestských častí zložených zo starostov jednotlivých mestských častí. Táto rada zastupuje záujmy mestských častí, kde sa iniciujú vlastné návrhy, podnety a slúži aj ako komunikačný kanál medi mestskými čast'ami a mestom Košice. Rovnako tak zaujíma stanovisko $\mathrm{k}$ veciam, ktoré sú predmetom rokovania mestského zastupitel'stva. Jednou z najväčších právomoci je stanovisko rady starostov k rozpočtu mesta. Rada starostov nesmie rozhodovat' o veciach vyhradených mestskému zastupitel'stvu. Referendum $\mathrm{v}$ meste upravuje $\S 8, \mathrm{v}$ tomto paragrafe je 
definované, za akých podmienok mestské zastupitel'stvo vyhlási referendum mesta. V $\S 8 \mathrm{a}$ sa pojednáva o rovnakých záležitostiach ako $\mathrm{v} \S 8$, ale na úrovni mestskej časti. Posledný paragraf druhej časti zákona o meste Košice, pojednáva o zhromaždení obyvatel'ov. V tomto odseku sa hovorí, že na prerokovanie vecí, ktoré sa týkajú mesta alebo mestskej časti, môže dôjst' k zvolaniu takéhoto zhromaždenia zo strany občanov (2. čast' zákona o meste Košice). Tretia čast' zákona o meste Košice, ktorá ma 12 paragrafových znení sa zaoberá postavením orgánov mesta. V $\S 10$ sa upravuje postavenie a právomoci mestského zastupitel'stva. Postavenie primátora mesta Košice upravuje $\S 11$. Zastupovanie primátora je definované v $\S$ 11a. Obsahom tohto paragrafu je vymedzenie právomoci námestníka a stanovenia maximálneho počtu zástupcov resp. námestníkov primátora . Mestská rada je obsahom $§ 12$, ktorý definuje a vymedzuje pôsobnost' mestskej rady. Magistrát mesta je súčast'ou $\S 13 \mathrm{v}$ tomto paragrafe je definovaný magistrát ako organizačné a administratívne miesto, ktoré sa člení na oddelenia a referáty za účelom správneho chodu výkonu správy mesta. Na čele magistrátu stojí riaditel', ktorého postavenie a právomoci upravuje d’alšie legislatívne znenie. Miestne zastupitel'stvo je obsahom $\S 14$. Okrem definovania miestneho zastupitel'stva a jeho funkčného obdobia tu nájdeme jednotlivé právomoci zastupitel'stva. Obsahom je tiež počet poslancov miestnych zastupitel'stiev stanovený podl'a počtu obyvatel'ov. Starosta je definovaný $\mathrm{v} \S 15$ a jeho kompetencie a pôsobnost' sú stanovené podobne ako v prípade primátora mesta. Avšak v prípade starostu ide o vymedzenie právomoci iba na konkrétnu mestskú čast'. Zastupovanie starostu mestskej časti je stanovené v § 15a. V tomto paragrafe sú stanovené podmienky zastupovania starostu. Rovnako mestská Rada tak aj Miestna rada je súčast'ou samostatného paragrafového znenia a to $\mathrm{v} \S 16 \mathrm{a}$. Skladá sa zo zvolených poslancov a je iniciatívnym, výkonným a kontrolným orgánom miestneho zastupitel'stva. V $\S 17$ a je zahrnuté pomenovanie prednostu miestneho úradu a rovnako ako pri riaditel'ovi magistrátu sú legislatívne zakotvené jeho právomoci a postavenie, v prípade prednostu sú jeho právomoci obmedzené iba na konkrétnu mestskú čast' (3.čast' zákona o meste Košice).

Štvrtá čast' zákona o meste Košice pojednáva o štatúte mesta, ktorý je obsiahnutý v $§ 18$. Definuje základný vnútorný dokument územnej samosprávy mesta Košice. Štatút stanovuje plnenie jednotlivých záležitosti ako aj základne úlohy mesta, vzt’ahy s mestskými čast’ami a právnickými osobami. Bližšie štatútom mesta Košice sa budeme podrobnejšie zaoberat' v d'alších podkapitolách (4 čast' zákona o meste Košice).

Piata čast' zákona o meste definuje symboly mesta a mestských častí. V znení jedného ustanovenia $\mathrm{v} \S 19$ sa stanovuje pre mesto ako aj pre mestské časti používanie a vyobrazenie symbolov. Pod tieto symboly patrí erb, vlajka, zástava, pečat' a znelka ( 5.čast' zákona o meste Košice ).

Šiesta čast’ zákona o meste Košice nemá konkrétne pomenovanie. V § 20 zákona o meste Košice je definovaná spolupráca s orgánmi štátu, v súvislosti so zabezpečením potrieb za účelom odborných záležitostí patriacich do kompetencií štátnych orgánov. $§ 21$ pojednáva o spolupráci s právnickými a fyzickými osobami a definuje možnosti spolupráce medzi týmito osobami. Pomoc pri mimoriadnych situáciách je súčast’ou $\S 22$ šiestej časti zákona o meste Košice. V tomto odstavci je stanovené, za akých podmienok je možné žiadat' pomoc primátora alebo starostu mestskej časti od právnickej osoby. $\S 23$ pojednáva o pokutách. Definuje sa komu, dokedy a za akých podmienok je možné stanovit' pokutu. Pričom pokuta je príjmom mesta alebo mestskej časti, ktorá takúto pokutu uložila ( 6 . čast' zákona o meste Košice ).

Siedma čast' zákona o meste Košice sú prechodné a záverečné ustanovenia zložené. § 24 pojednáva o vol'bách a lehotách podania kandidátnych listín. V § 25 sa stanovuje del'ba pôsobnosti medzi orgánmi mesta a mestskými čast’ami. § 25a ustanovuje výkon lehoty zmien štatútu podl’a novelizácí́ zákona. Ďalšie znenie siedmej časti zákona o meste Košice sa týka 
opatrení vykonaných príslušnými orgánmi štátnej správy na prípravu volieb a jednotlivých prechodných ustanovení ( 7. čast' zákona o meste Košice ).

Neoddelitel’nou súčast’ou zákona o meste Košice je príloha, ktorá určuje mestské časti mesta Košice, v ktorých sa zriad’ujú orgány samosprávy mestských častí. Mesto Košice má zákon o meste Košice určených 22 mestských častí. Mesto Košice zároveň $z$ hl'adiska územnosprávneho členenia štátu pozostáva zo štyroch okresov, ktorých súčast'ou sú aj mestské časti.

Tab. 1 územné členenie mesta na jednotlivé okresy a mestské časti

\begin{tabular}{|c|c|c|c|}
\hline Košice I & Košice II. & Košice III. & Košice IV. \\
\hline Džungl'a & Sídlisko KVP & $\begin{array}{c}\text { Dargovských } \\
\text { hrdinov }\end{array}$ & Barca \\
\hline Kavečany & Lorinčík & Košická Nová Ves & Juh \\
\hline Sever & Luník IX & & Krásna \\
\hline Sídlisko Ťahanovce & Myslava & & Nad Jazerom \\
\hline Staré mesto & Pereš & & Vyšné Opátske \\
\hline & Šaca & & \\
\hline & Západ & & \\
\hline
\end{tabular}

\section{Mestské časti podl'a zákona o meste Košice}

V tejto podkapitole sa zamierame na vybrané ustanovenia zákona o meste Košice v kontexte s právnym postavením mestských častí $\mathrm{v}$ tejto právnej norme.

Základné ustanovenie zákona o Košiciach definuje mesto Košice $\mathrm{v}$ zásade tak, ako sú definované obce. $\S 1$ zákona o meste Košice znie, „, Mesto Košice je samostatným a samosprávnym územným celkom, združuje občanov, ktorí majú na území mesta trvalý pobyt. “Základná zákonná definícia mesta Košice je konkretizovaná v § 2 ods. 1 zákona o meste Košice.

„(1) Mesto je právnickou osobou, ktorá za podmienok ustanovených zákonom samostatne hospodári s vlastným majetkom as majetkom, ktorý mu bol zverený, a s vlastnými a zverenými finančnými príjmami “. Definované ustanovenie môžeme vnímat' ako porovnatel'né s ustanovením čl. 65 ods. 1 ústavy, ktoré garantuje obciam jedno z najdôležitejších a najvýznamnejších práv súvisiacich s výkonom územnej samosprávy.

Vo vzt’ahu k mestským častiam sa $\mathrm{v} \S 2$ ods. 2 zákona o meste Košice nachádza analogické ustanovenie. „, (2) Mestské časti sú právnickými osobami, ktoré za podmienok ustanovených zákonom a štatútom mesta (d'alej len "štatút") hospodária so zvereným a vlastným majetkom a so zverenými a vlastnými finančnými príjmami". Na základe citovaného ustanovenia môžeme skonštatovat', že aj mestské časti v rámci zákona o meste Košice majú zverené právo súvisiace s výkonom územnej samosprávy.

Jeden zo základných znakov obce, územie obce v tomto prípade mesta, je v zákone o meste Košice definovaný $\mathrm{v} \S 3$.

(1) Územie mesta tvoria katastrálne územia uvedené v štatúte,

(2) Mesto sa člení na mestské časti uvedené v prílohe tohto zákona. Podrobné vymedzenie územia mestských častí ustanoví štatút.

(3) Vytvorit', zrušit', zlúčit', alebo rozdelit' mestské časti alebo vykonat' iné zmeny ich hranic môže mestské zastupitel'stvo všeobecne záväzným nariadením...( § 3 zákona o meste Košice).

Podrobnejšie o možnostiach vyplývajúcich z d’alších ustanovení $§ 3$ zákona o meste Košice sa konkrétnejšie zaoberáme v kapitole IV.

Z citovaných ustanovení však vyplývajú a môžeme konštatovat' isté závery pre mestské časti.

- územia mestských častí sú integrálnou súčast'ou územia mesta,

- mestské časti majú samostatné katastrálne územia, 
- členenie mesta na mestské časti je prílohou a súčast'ou zákona,

- zákon garantuje mestským častiam ich územie a integritu, ked’že všeobecne záväzné nariadenie mesta Košice ktorým sa vytvárajú, zrušujú, zlučujú alebo rozdel'ujú mestské časti, môžu obyvatelia dotknutých mestských častiach odmietnut' v referende mestskej časti,

- mestské zastupitel'stvo je oprávnené „len“ podrobne vymedzit' všeobecne záväzným nariadením územie mestských častí, čo však nemožno považovat' za oprávnenie na zásah do ich územnej integrity.

Mestské časti sú spomínané aj v d’alších častiach zákona o meste Košice. V súvislosti so sledovaným zámerom právneho postavenia mestských častí, môžeme vybrat' nasledovné:

- Základné formy výkonu samosprávy v meste Košice upravuje $§ 5$ zákona o meste Košice ( 5 zákona o meste Košice ). Z textu tohto ustanovenia vyplýva, že samospráva v meste Košice sa uskutočňuje aj orgánmi mestských častí, hlasovaním obyvatel'ov mestských častí a verejným zhromaždením obyvatel’ov mestskej časti.

- Orgány mestských častí ustanovuje $§ 7$ a zároveň znenie $\S 14$ až 18 zákona o meste Košice vymedzuje právne postavenie, spôsob kreovania, úlohy a pôsobnost' jednotlivých orgánov mestských častí ( $\S 7,14-18$ zákona o meste Košice ). Z textu týchto ustanovení zákona o meste Košice vyplýva, že na úrovni mestských častí sa kreujú orgány územnej samosprávy ako na úrovni mesta - poznámka porovnaj $\S 10$ až 13 zákona o meste KE, Zároveň je to rovnako ako aj na úrovni iných obcí a miest, pričom spôsob kreovania kl'účových orgánov mestských častí a to starostu a miestneho zastupitel'stva je obdobný ako spôsob kreovania $v$ iných obciach a mestách $v$ zmysle osobitného zákona - zákon č. 346/1990 Zb. o vol'bách orgánov samosprávy obcí v znení neskorších predpisov. Výkon územnej samosprávy mestských častí je v porovnatel'nom rozsahu, ako je to v prípade iných obcí a miest podl'a zákona o obecnom zriadení. Postavenie miestnych zastupitel'stiev mestských častí a starostov mestských častí v Košiciach je porovnatel'né s postavením obecných a mestských zastupitel'stiev samozrejme, s príslušným rozsahom ich územnej pôsobnosti.

- V súvislosti s vyššie uvedenými faktami môžeme ešte spomenút' § 25 zákona o meste Košice, ktorý odkazuje podrobnejšiu del'bu pôsobnosti medzi orgánmi miestnej samosprávy a mestskej samosprávy na štatút ( $§ 25$ zákona o meste Košice ). S Štatút mesta Košice sa prijíma vo forme všeobecne záväzného nariadenia mesta a má nižšiu právnu silu ako zákon o Košiciach z čoho vyplýva, že musí byt' s ním v súlade. $\mathrm{Z}$ toho nám však aj vyplýva, že štatútom nemožno odňat' mestských častiam právomoci a pôsobnost', ktoré im zveruje zákon o Košiciach, prípadne osobitné zákony.

Pôsobnost' mestských častí vyplýva aj z osobitných zákonov. Rovnako ako je tomu pri obciach, ktorým možno zákonom určit' výkon územnej samosprávy, ale ja výkon v oblasti miestnej štátnej správy. Pre orgány samosprávy mesta Košice a mestských častí sú tieto úlohy určované zákonom o meste Košice, zákonom o obecnom zriadení, ale aj prostredníctvom osobitných zákonov.

V kontexte právneho postavenia mestských častí poukážeme aj na niektoré osobitné zákony, ktoré zverujú isté úlohy priamo mestským častiam. Zákonom možno určit' obciam mimo výkonu územnej samosprávy aj úlohy v oblasti miestnej štátnej správy ( čl. 71. ods. 1 ústavy SR ). Pre orgány samosprávy v meste Košice vrátane mestských častí sú takéto úlohy určené zákonom o meste Košice, zákonom o obecnom zriadení, ale aj osobitnými zákonmi. Z pohl'adu ich právneho postavenia spomenieme niektoré z nich, ktoré sú aj všeobecne vnímané ako špecifické úlohy mestských častí a nie mesta Košice.

Zákon č. 138/1991 Zb. o majetku obcí v znení neskorších predpisov. Z tohto zákona vyplýva pre mestské časti oprávnenie pre mestské časti nadobúdat' do vlastníctva alebo správy majetok v zmysle tohto zákona. Zákony súvisiace s vol'bami, zákon č. 346/1990 Zb. o 
vol'bách do orgánov územnej samosprávy v znení neskorších predpisov, zákon č. 3030/2001 Z. z. o vol'bách do orgánov samosprávnych krajov, zákon č. 46/1999 Z. z o vol'bách prezidenta Slovenskej republiky, zákon č. 331/2003 Z.z.. o vol'bách do Európskeho parlamentu, zákon č. 333/2004 Z. z. o vol'bách do Národnej rady Slovenskej republiky. Mestské časti v súvislosti s vol'bami zabezpečujú zoznamy voličov, voličské preukazy, príprava okrskových volebných komisií, ako aj samotnú organizáciu a priebeh volieb. Zákon č. 154/1994 Z. z. o matrikách v znení neskorších predpisov. Zákon č. 253/1998 Z. z. o hlásení pobytu občanov Slovenskej republiky, mestské časti v zmysle tohto zákona majú pôsobnost' na úseku hlásenia, evidencie a vedenia registru pobytu občanov. Zákon č. 139/1992 Z. z. o rybárstve, kde pôsobnost' mestských častí je pri vydávaní rybárskych lístkov. Zákon č. 607/2003 Z.z. o štátnom fonde rozvoja bývania v znení neskorších predpisov. Zákon č. 583/2004 Z. z. o rozpočtových pravidlách územnej samosprávy. Ústavný zákon č. 357/ 2004 Z. z. o ochrane verejného záujmu pri výkone funkcií verejných funkcionárov v tomto prípade, je daná jasná pôsobnost' pre orgány mestských častí v konaní o ochrane verejného záujmu.

Pôsobnost', ktorá je zverená priamo pre mestské časti prostredníctvom spomenutých zákonov, ale aj iných, nemožno mestských častiam odobrat' zmenou štatútu mesta. Znamená to, že pôsobnost' pre mestské časti zostáva, pokial' nedôjde k zmene príslušných zákonov a ich ustanovení. Mestské časti môžu vykonávat' a vykonávajú aj d’alšiu pôsobnost', ktorú zverujú d'alšie osobitné zákony a ak to vyplýva z ustanovení Štatútu mesta. Pôsobnost', ktorá je daná štatútom, však mesto Košice zmenou štatútu môže odňat'.

Územná samospráva v meste Košice je dvojstupňová, založená na zásade vzájomnej spolupráci a aj súčinnosti oboch stupňoch územnej samosprávy. Výkon územnej samosprávy, ale aj preneseného výkonu štátnej správy v meste Košice, je v záujme efektívneho plnenia zverených úloh a v rámci verejného záujmu.

\section{Literatúra}

1. PALUŠ, I. a kol., 2016. Ústavné právo Slovenskej republiky. Košice: Fakulta verejnej správy, UPJŠ. ISBN 9788081524424.

2. PALÚŠ, I. a kol., 2018. Formy uskutočňovania obecnej samosprávy. Košice: Fakulta verejnej správy, UPJŠ. ISBN 978-80-8152-663-3.

3. Ústava SR č. 460/1992 Zb. v znení neskorších predpisov

4. Zákon č. 369/1990 Zb. o obecnom zriadení v znení neskorších predpisov

5. Zákon č. 401/1990 Zb. o meste Košice v znení neskorších predpisov

6. Štatút mesta Košice

\section{Kontaktné údaje}

Mgr. Jozef Andrejčák

Fakulta verejnej správy, UPJŠ v KE

Popradská 66, 04001 Košice

Tel: +421908367338

andrejcak20@gmail.com 


\title{
POSTAVENIE A ÚLOHY ZASTUPITELSTVA SAMOSPRÁVNEHO KRAJA V SLOVENSKEJ REPUBLIKE
}

\section{POSITION AND COMPETENCES OF THE COUNCIL OF THE SELF- GOVERNING REGION IN SLOVAK REPUBLIC}

\author{
Lukáš Ivančík
}

\begin{abstract}
Abstrakt
Príspevok je zameraný na postavenie a úlohy zastupitel'stva samosprávneho kraja, ktoré získalo svoje právomoci zákonom č. 302/2001 Z. z. o samospráve vyšších územných celkov v znení neskorších predpisov. Krajské zastupitel'stvo je jedným z orgánov regionálnej samosprávy a predstavuje možnost' občanov podiel'at' sa na výkone regionálnej samosprávy nepriamo tak, že si do tohto orgánu zvolia svojich zástupcov teda poslancov. Ciel'om príspevku je analyzovat' súčasnú právnu úpravu a postavenie zastupitel'stva v legislatíve Slovenskej republiky. Ďalším ciel'om je poukázat' na nedostatky v právnej úpravy a konflikty, ktoré môžu nastat' najmä pri súčinnosti s predsedom samosprávneho kraja. V neposlednom rade je ciel'om poukázat' na možné zlepšenia, ktoré by zákonodarca mohol zapracovat' do právnej úpravy.
\end{abstract}

Kl'účové slová: krajské zastupitel'stvo, kraj, regionálna samospráva

\begin{abstract}
The paper focuses on the position and tasks of the council of the self-governing region, which acquired its competences by Act no. 302/2001 Coll. on self-government of higher territorial units, as amended. The regional council is one of the bodies of regional self-government and represents the possibility for citizens to participate in the administration of regional selfgovernment indirectly by electing their representatives to this body, ie deputies. The aim of the paper is to analyze the current legislation and the position of the council in the legislation of the Slovak Republic. Another goal is to point out the shortcomings in the legislation and conflicts that may occur, especially in cooperation with the president of the self-governing region. Last but not least, the aim is to point out possible improvements that the legislator could incorporate into the legislation.
\end{abstract}

Key words: regional council, region, regional self-government

\section{1 ÚVOD}

Neodmyslitel'nou súčast'ou demokratického a právneho štátu je územná samospráva. Po roku 1989 bola územná samospráva obnovená v dôsledku celospoločenských zmien. Bol prijatý zákon o obecnom zriadení, ktorý zakladal systém obecnej samosprávy. Na Slovensku bol vyšší územný celok ustanovený ako základ samosprávy na regionálnej úrovni a ako samostatný územný samosprávny a správny celok. Neúplný model územnej samosprávy potvrdzoval, že absencia samosprávy vyšších územných celkov brzdila racionálnu del'bu funkcií, podporovala byrokraciu a zvyšovala nákladovost' (Kováčová, 2014). Absencia vyšších územných celkov zabraňovala budovaniu regionálnej samosprávy a politika na regionálnej úrovni predpokladá existenciu inštitúcií, ktoré sú oprávnené spravovat' podstatnú čast' záležitostí verejného záujmu. Z politických dôvodov a pod tlakom EÚ, ktorá v kandidujúcich krajinách požadovala systém regionálnej samosprávy, prijala Slovenská 
republika zákon č. 302/2001 o samospráve vyšších územných celkov, ktorým bolo vytvorených 8 samosprávnych krajov. Pred prijatím zákona sa uskutočnila rozsiahla novela ústavy, ktorou sa doplnila 4. hlava Ústavy Slovenskej republiky a umožnilo sa vytvárat' vyššie územné celky ako právnické osoby, ktoré hospodária s vlastným majetkom a financiami.

Regionálna samospráva sa uskutočňuje prostredníctvom orgánov samosprávneho kraja ku ktorým patrí predseda a zastupitel'stvo. Úlohou zastupitel'stva je rozhodovat' a najdôležitejších otázkach, ktoré spadajú do pôsobnosti samosprávneho kraja. Do zastupitel'stva si volíme svojich zástupcov - poslancov. Ich úlohou pracovat' v prospech obyvatel'ov najlepšie ako dokážu. Nároky na prácu poslancov sa neustále zvyšujú a zároveň sa zvyšujú aj potreby obyvatel'ov a legislatíva častokrát nereaguje dostatočne dopredu, preto môžu mat' voliči niekedy pocit, že samospráva nefunguje tak ako má. S prácou zastupitel'stva sa tiež spájajú určité problémy, ktoré môžu nastat' najmä vtedy ak je v rozpore s predsedom alebo ak zastúpený poslanci sú z viacerých rôznych politických strán poprípade ide o poslancov, ktorí kandidovali ako nezávislý. Samotný poslanci by mali disponovat' určitými predpokladmi, aby mohli plnohodnotne vykonávat' svoje rozhodnutia a zabezpečit' rozvoj kraja a jeho obyvatel'ov.

\section{2 ÚSTAVNOPRÁVNE POSTAVENIE ZASTUPITELSTVA SAMOSPRÁVNEHO KRAJA V SLOVENSKEJ REPUBLIKE}

Ústavnoprávna koncepcia samosprávneho kraja sa riadi podl'a premisy, podl'a ktorej sú záležitosti samosprávy dvojaké. Ide o tie, ktoré sú zverené kolektívnemu orgánu a tie, ktoré je potrebné zverit' do pôsobnosti individuálneho orgánu (Palúš, 2016). Na základe toho Ústava SR v čl. 69 ods. 4 stanovuje, že orgánmi samosprávneho kraja sú predseda samosprávneho kraja a zastupitel'stvo samosprávneho kraja. Ústava teda vytvára základný rámec pre tvorbu zastupitel'stva na úrovni vyšších územných celkov (Ústavný zákon č. 460/1992 Zb. Ústava Slovenskej republiky).

Ďalej Ústava SR v čl. 69 ods. 5 hovorí, že zastupitel'stvo vyššieho územného celku tvoria poslanci, ktorých volia obyvatelia, ktorí majú trvalý pobyt v územnom obvode samosprávneho kraja. Poslanci sú volení na štvorročné obdobie a vol'by sa uskutočňujú na základe všeobecného, rovného a priameho volebného práva $\mathrm{s}$ tajným hlasovaním. V nadväznosti na vol'bu poslancov krajského zastupitel'stva je potrebné spomenút' ústavný zákon č. 44/2017 Z. z. ktorým sa dopĺn̆a Ústava Slovenskej republiky. Táto novela, v krajských vol'bách v roku 2017, jednorazovo predížila volebné obdobie poslancov vyššieho územného celku a predsedu kraja na 5 rokov. Hlavným zámerom tejto novely je spojit' vol'by do orgánov samosprávnych krajov s vol'bami do orgánov obcí a miest.

V neposlednom rade si zákonodarca od toho sl'ubuje ušetrenie finančných prostriedkov a súčasne aj zvýšenie účasti v krajských vol'bách nakol'ko sa tento druh volieb dlhodobo vyznačuje nízkou účast'ou voličov. V roku 2017 dosiahla volebná účast' 29,95\% čo predstavuje najvyššiu volebnú účast' v histórií krajských volieb (Štatistický úrad Slovenskej republiky, 2017). Avšak treba podotknút', že v porovnaní s ostatnými druhmi volieb v Slovenskej republike ide o podpriemernú účast'. Táto novela ústavy je podl'a nás správnym krokom k zvyšovaniu povedomia o samosprávnych krajoch a zároveň aj efektívny nástroj ako zvýšit' volebnú účast'. Za pozitívum možno požadovat' aj ušetrenie finančných prostriedkov, ktoré by $\mathrm{v}$ prípade dvoch samostatných volieb boli dvojnásobné. To či novela splnila požadované ciele sa dozvieme už v roku 2022 kedy sa spoločné vol'by do orgánov samosprávnych krajov a obcí uskutočnia po prvýkrát.

Z uvedeného je možné povedat', že Ústava SR poskytuje ústavný a právny základ pre vznik krajského zastupitel'stva ako kolektívneho orgánu, ktorého úlohou je reprezentovat' záujmy svojich obyvatel'ov a pracovat' pre všestranný rozvoj kraja. Zároveň ústavná úprava krajského zastupitel'stva zabezpečuje ochranu práva obyvatel'ov na územnú samosprávu a umožňuje im 
prostredníctvom volených zástupcov participovat' na rozhodovaní o dôležitých otázkach týkajúcich sa fungovania a rozvoja vyššieho územného celku.

Spomenuté ustanovenia ústavy realizuje zákon č. 302/2001 Z. z. o samospráve vyšších územných celkov v znení neskorších predpisov (d’alej ,zákon o samosprávnych krajoch“). Podl'a $\$ 11$ ods. 1 zákona o samosprávnych krajoch je zastupitel'stvo zbor zložený z poslancov samosprávneho kraja, ktorí sú zvolený v priamych vol'bách a to obyvatel'mi samosprávneho kraja na 4 roky. Pri týchto vol'bách sa využíva väčšinový volebný systém s relatívnou väčšinou. To znamená, že za poslancov sú zvolení tí kandidáti, ktorí získali najväčší počet hlasov. Napríklad ak je volebnému obvodu pridelených 5 mandátov a kandidátov je desat', tak poslancami sa stanú tí kandidáti, ktorí po sčítaní hlasov obsadili prvé až piate miesto. Počet poslancov určí, na celé volebné obdobie, zastupitel'stvo tak, aby na jedného poslanca pripadalo približne od 12000 do 15000 obyvatel'ov. Ďalej zákon uvádza, že funkčné obdobie zastupitel'stva sa končí zložením sl'ubu novozvolených poslancov zastupitel'stva.

V súvislosti s krajskými vol'bami je potrebné spomenút' zákon č. 180/2014 Z. Z. o podmienkach výkonu volebného práva a o zmene a doplnení niektorých zákonov (d’alej len „volebný kódex“). Podla $\$ 131$ volebného kódexu majú právo volit' do krajského zastupitel'stva občania Slovenskej republiky a cudzinci, ktorí majú trvalý pobyt v obci alebo vojenskom obvode nachádzajúcom sa na území samosprávneho kraja. V tomto prípade možno poukázat' na rozdiel oproti Českej republike kde pri krajských vol'bách cudzinci právo volit' nemajú. Možno teda povedat', že slovenský právny poriadok, vo veciach regionálnej samosprávy, poskytuje cudzincom širší okruh práv ako český právny poriadok.

Z uvedeného možno povedat', že zastupitel'stvo vyššieho územného celku má silné ústavné, ale aj zákonné postavenie čo zabezpečuje a chráni právo obyvatel'ov samosprávneho kraja na výkon samosprávy. Pozitívne možno hodnotit' snahu zákonodarcu spojit' krajské a lokálne vol'by a tým znížit' finančné náklady, ale aj zvýšit' volebnú účast' čo určite prispeje aj k zvyšovaniu povedomia o tomto druhu samosprávy v Slovenskej republike. Spojenie oboch typov volieb je určite správnym krokom na ceste za posilnením regionálnej samosprávy.

\section{PÔSOBNOSŤ ZASTUPITELSTVA SAMOSPRÁVNEHO KRAJA}

Základné a najdôležitejšie rozdelenie pôsobnosti krajského zastupitel'stva vyplýva priamo z ústavy. Čl. 67 Ústavy SR ustanovuje samostatnú pôsobnost' zastupitel'stva (pôsobnost' pri výkone územnej samosprávy) a zároveň aj upravuje akým spôsobom je možné zasahovat' do výkonu územnej samosprávy. Podl'a čl. 67 ods. 2 Ústavy SR je možné vyššiemu územnému celku ukladat' povinnosti len zákonom alebo na základe medzinárodnej zmluvy podl’a čl. 7 ods. 5 Ústavy SR. Dané ustanovenie chráni právo samosprávnych krajov na územnú samosprávu a zároveň garantuje to, že samosprávnu činnosti krajov nemožno obmedzovat' podzákonnými prostriedkami ako je napríklad nariadenie vlády či vyhláška ministerstva. Druhým typom pôsobnosti je pôsobnost' pri prenesenom výkone štátnej správy. Aj túto pôsobnost' zakladá ústava priamo vo svojich ustanoveniach. Konkrétne v čl. 71 ods. 1 stanovuje, že na vyšší územný celok možno zákonom preniest' výkon určených úloh miestnej štátnej správy a náklady na takýto prenesený výkon štátnej správy uhrádza štát.

\subsection{Samostatná pôsobnost' zastupitel'stva samosprávneho kraja}

Krajské zastupitel'stvo ako orgán samosprávneho kraja realizuje úlohy a rozhoduje vo veciach, ktoré patria do samostatnej pôsobnosti kraja. Pôsobnost' samosprávneho kraja je vyjadrená v $§ 4$ zákona o samosprávnych krajoch. Samosprávny kraj sa pri výkone samosprávy stará o všestranný rozvoj územia a o potreby svojich obyvatel'ov. Na zabezpečenie týchto úloh je zriadené zastupitel'stvo. Záležitosti, ktoré patria do samostatnej pôsobnosti zastupitel'stva vyššieho územného celku možno označit' za záležitosti vyhradenej pôsobnosti zastupitel'stva. Vyhradená pôsobnost' zastupitel'stva je vyjadrená v §11 ods. 2 
zákona o samosprávnych krajoch. Podla daného paragrafu je zastupitel'stvu vyhradené rozhodovat' o základných otázkach samosprávneho kraja, a to:

a) uznášat' sa na nariadeniach,

b) určovat' zásady hospodárenia a nakladania $\mathrm{s}$ majetkom samosprávneho kraja a $\mathrm{s}$ majetkom prenechaným do užívania samosprávnemu kraju,

c) schval'ovat' program sociálneho, ekonomického a kultúrneho rozvoja samosprávneho kraja, regionálnu stratégiu výchovy a vzdelávania $\mathrm{v}$ stredných školách, regionálne rozvojové plány a programy, ako aj územnoplánovacie podklady samosprávneho kraja a územné plány regiónov,

d) schval'ovat' rozpočet samosprávneho kraja a jeho zmeny, kontrolovat' čerpanie rozpočtu a schval'ovat' záverečný účet samosprávneho kraja; v rozsahu určenom zastupitel'stvom môže zmeny rozpočtu vykonávat' predseda,

e) o prijatí úveru alebo pôžičky samosprávneho kraja,

f) schval'ovat' poriadok odmeňovania zamestnancov samosprávneho kraja vypracovaný podl'a osobitného predpisu,

g) o vyhlásení referenda,

h) zriad'ovat', zakladat', zrušovat' a kontrolovat' právnické osoby samosprávneho kraja a na návrh predsedu vymenúvat' a odvolávat' ich vedúcich (riaditel'ov), ak osobitný zákon neustanovuje inak, ako aj schval'ovat' majetkovú účast' samosprávneho kraja v právnickej osobe,

i) schval'ovat' dohody, schval'ovat' združovanie prostriedkov a činností samosprávneho kraja, ako aj členstvo samosprávneho kraja v združeniach,

j) volit' a odvolávat' na návrh predsedu $\mathrm{z}$ poslancov zastupitel'stva podpredsedov samosprávneho kraja (d’alej len ,podpredseda“), ako aj určovat' podpredsedovi, ktorý je dlhodobo uvol'nený na výkon funkcie, primeranú odmenu,

k) zriad'ovat' komisie a iné orgány zastupitel'stva, určovat' im úlohy, volit' a odvolávat' ich predsedov a d'alších členov,

1) volit' na šest' rokov a odvolávat' hlavného kontrolóra a určovat' jeho odmenu,

m) určovat' odmenu poslancom,

n) určovat' odmenu členom komisií, ktorí nie sú poslancami,

o) zriad'ovat' úrad,

p) schval'ovat' rokovací poriadok zastupitel'stva,

q) o d'alších veciach, ktoré si môže vyhradit' v štatúte samosprávneho kraja, ak nie sú zákonom zverené predsedovi.

Pôsobnost' zastupitel'stva je najviac viditel'ná v oblasti normotvorby. V rámci normotvorby prijíma zastupitel'stvo všeobecne záväzné nariadenia. $\mathrm{Na}$ ich prijímanie sú vyššie územné celky splnomocnené ústavou a nie je potrebné zákonné splnomocnenie. Pri normotvorbe sa teda prejavuje samosprávny charakter krajov ked’že môžu rozhodovat' o veciach, ktoré patria do ich pôsobnosti bez zákonného splnomocnenia. Prijímanie VZN je však v tomto prípade obmedzené, ked’že podl'a čl. 68 ústavy samosprávne kraje nemôžu VZN ukladat' nové povinnosti. Krajské zastupitel'stvo nesmie svojim nariadením zasahovat' do základných práv a slobôd. Obmedzit' základné práva a slobody možno len zákonom a za podmienok, ktoré sú dané ústavou. Týmto spôsobom je obmedzený aj zákonodarca lebo ani on nie je oprávnený splnomocnit' zastupitel'stvo na to, aby vydalo VZN, ktoré by nejakým spôsobom zasahovalo alebo obmedzovalo základné práva a slobody. Zákonodarca teda nemôže svoju ústavnú právomoc preniest' na iné orgány verejnej moci a z toho vyplýva, že Národná rada Slovenskej republiky nemôže splnomocnit' orgány územnej samosprávy (v tomto prípade zastupitel'stvo VÚC), aby vydali všeobecne záväzné nariadenia, ktoré obmedzujú základné práva a slobody (Drgonec, 1997). 
Zastupitel'stvo v rámci normotvornej pôsobnosti prijíma aj uznesenia. V oboch prípadoch je však dôležitá súčinnost' s predsedom samosprávneho kraja. Predseda podpisuje v lehote 10 dní všeobecne záväzné nariadenia a uznesenia, ktoré prijíma zastupitel'stvo. Voči uzneseniam zastupitel'stva môže uplatnit' sistačné právo a to $\mathrm{v}$ tom prípade ak sa domnieva, že uznesenie je v rozpore so zákonom alebo je nevýhodné pre samosprávny kraj. Sistačné právo sa uplatňuje tak, že predseda nepodpíše uznesenie v lehote 10 dní od jeho schválenia zastupitel'stvom kraja. Zastupitel'stvo môže prelomit' uplatnené sistačné právo do dvoch mesiacov a to tak, že ho opätovne schváli $3 / 5$ väčšinou všetkých poslancov zastupitel'stva. Ak to zastupitel'stvo neurobí, tak uznesenie stráca platnost'. Takto schválené uznesenie už nemôže predseda kraja pozastavit'. Sistačné právo však predseda nemôže použit' voči uzneseniu, ktoré sa týka vol'by a odvolania hlavného kontrolóra čo tiež patrí do výhradnej právomoci zastupitel'stva (Palúš, 2016). Táto podmienka zabezpečuje neovplyvnitel'nost' vol'by hlavného kontrolóra predsedom a zabezpečuje, aby funkcia hlavného kontrolóra bola obsadzovaná konsenzom poslancov zastupitel'stva, ktorí reprezentujú širší okruh obyvatel'ov a ich záujmov.

Problém môže nastat' vtedy, ak aj po prelomení sistačného práva predseda odmietne uznesenie podpísat'. Podl'a zákona síce predseda nemôže pozastavit' výkon uznesenia avšak zákon vo svojich ustanoveniach nestanovuje ako sa v takejto situácií bude postupovat'. Jednou z možností je, že sa uznesenie jednoducho vykoná aj bez podpisu predsedu. V tomto prípade je potrebné zdôraznit' úlohu hlavného kontrolóra, ktorého úlohou je aj kontrolovat' výkon uznesení zastupitel'stva. Na druhej strane ak sa predseda rozhodne nepodpísat' opätovne schválené uznesenie, tak neexistuje žiadne opatrenie, poprípade sankcia, ktorá by mu v takomto konaní mohla zabránit'.

Ďalší problém, podl'a nás, môže nastat' pri spolupráci predsedu a zastupitel'stva napríklad pri financovaní alebo nakladaní s majetkom VÚC. Nakladanie s majetkom síce podlieha schváleniu zastupitel'stva, ale môže nastat' situácia, že došlo k schváleniu predaja a predseda sa rozhodne, že ho nepodpíše a bez jeho súhlasu je nakladanie s majetkom prakticky nemožné. Rovnaká situácia môže nastat' aj pri menovaní riaditel'ov právnických osôb. Zastupitel'stvo má síce právomoc ich vymenovat', ale predseda tým, že nepodpíše menovací dekrét môže zamedzit' nástup do ich funkcie. Pri týchto príkladoch je vhodné zamysliet' nad výrazne silnou pozíciou, ktorú má predseda voči zastupitel'stvu a či nie je vhodné určitým spôsobom obmedzit' jeho právomoci ked'že svojou činnost'ou môže výrazne bránit' zastupitel'stvu vykonávat' vlastné právomoci, ktoré má zverené zákonom.

Dôležitou právomocou zastupitel'stva je aj možnost' vyhlásit' referendum. Referendum rozoznávame dvojaké a to obligatórne a fakultatívne. Obligatórne referendum zastupitel'stvo vyhlási, ak ide o odvolanie predsedu samosprávneho kraja, ktorý hrubo alebo opakovane zanedbáva svoje povinnosti a tým vznikajú závažné nedostatky v správe kraja, ak ide o odvolanie predsedu samosprávneho kraja, ktorý pre neprítomnost' alebo zdravotnú nespôsobilost' nemôže vykonávat' funkciu predsedu viac ako 6 mesiacov. Posledným prípadom obligatórneho vyhlásenia krajského referenda je ak o to požiada petíciou $30 \%$ oprávnených voličov (zákon o samosprávnych krajoch).

Fakultatívne referendum môže vyhlásit' zastupitel'stvo z vlastnej iniciatívy o dôležitých otázkach, ktoré spadajú do samostatnej pôsobnosti kraja. V prípade referenda je potrebné zdôraznit', že počas 20 ročnej existencie samosprávnych krajov sa neuskutočnilo ani jedno krajské referendum. Domnievame sa, že je to spôsobené najmä politickou neochotou dat' nejakú dôležitú otázku na rozhodnutie obyvatel'om. To sa ukazuje aj na celoštátnej úrovni ked’že z iniciatívy Národnej rady SR sa v poslednom období neuskutočnilo žiadne referendum Referendum na regionálnej úrovni sa spája s viacerými problémami. Jedným z problémov je aj absencia právnej úpravy v samostatnom zákone. Pri vyhlásení obligatórneho referenda sa ako problematická môže javit' situácia, ak ide o odvolanie predsedu, ktorý hrubo alebo 
opakovane zanedbáva svoje povinnosti. Podl'a nás je sporné už to či je možné určit' čo znamená hrubé porušenie svojich povinností. Ked’že to nie je nikde definované tak ide čisto len o subjektívne posudzovanie. Pod hrubým porušením povinností so môže každý predstavit' niečo iné. Ďalším problémom môže byt' aj to kto posudzuje hrubé porušenie povinností. Nastáva teda otázka či poslanci majú dostatočnú odbornost' a kompetencie posúdit' či ide o hrubé porušenie povinností predsedu samosprávneho kraja.

Problematické je aj kvórum platnosti regionálneho referenda. Podl'a $§ 15$ ods. 5 zákona o samosprávnych krajoch sú výsledky referenda platné ak sa na ňom zúčastnilo aspoň 50\% oprávnených voličov. Praktické skúsenosti s celoštátnym a miestnym referendom poukazujú na to, že takéto kvórum je príliš vysoké. Naše tvrdenie deklaruje aj fakt, že účast' vo vol'bách do orgánov samosprávnych je dlhodobo nízka a ešte neprekročila $30 \%$ účast'. Preto sa dosiahnutie $50 \%$ účasti môže javit' ako nemožné. Na mieste je teda odporúčat' znížit' kvórum na úroveň $25-30 \%$ podobne ako to je upravené napríklad v Českej republike. V neposlednom rade je potrebné spomenút' aj to, že otázku záväznosti právna úprava nerieši. To znamená, že výsledok referenda má prakticky iba poradný hlas a zastupitel'stvo sa ním vôbec nemusí riadit'. Výnimku tvorí len odvolanie predsedu vyššieho územného celku, ktoré záväzné lebo jedným z dôvodov zániku funkcie predsedu je jeho odvolanie v referende.

Samostatnú pôsobnost' krajského zastupitel'stva je možné rozdelit' podl'a výsledku jeho činnosti na:

1) nariad'ovaciu pôsobnost' - jej obsahom je právo zastupitel'stva prijímat' a vydávat' všeobecne záväzné nariadenia vo veciach samostatnej pôsobnosti

2) organizačno-kreačnú pôsobnost' - ide o kreovanie vlastných orgánov zastupitel'stva (napríklad hlavný kontrolór, úrad kraja), do danej pôsobností patrí aj určovanie ich organizačnej štruktúry, náplň práce, zriad'ovanie a zrušovanie právnických osôb kraja, vyhlasovanie referenda atd'

3) ekonomickú pôsobnost' - ide o určovanie zásad hospodárenia a nakladania s majetkom kraja, schval'ovanie programov sociálneho a ekonomického rozvoja, schval'ovanie rozpočtu a kontrolu jeho plnenia

4) kontrolnú pôsobnost' - ide najmä o kontrolu vlastných orgánov a činnosti právnických osôb zriadených samosprávnym krajom

5) vnútornú pôsobnost' - zastupitel'stvo rozhoduje o počte svojich členov, o hraniciach volebných obvodov a prijímanie rokovacieho poriadku (Palúš, 2010).

\subsection{Komisie zastupitel'stva VÚC}

Do pôsobnosti zastupitel'stva patrí aj zriad'ovanie komisií čo sú jeho poradné a iniciatívne orgány. Komisie zároveň poskytujú aj možnost' participácie obyvatel'ov kraja ked’že ich členmi nemusia byt' len poslanci. Zastupitel'stvo si môže vytvorit' komisie podl'a potreby. Pre potreby tohto článku sme sa zamerali nato, aké druhy komisií boli zriadené v Košickom samosprávnom kraji. K týmto komisiám podl'a Rokovacieho poriadku Zastupitel'stva Košického samosprávneho kraja patria:

1) Mandátová komisia

2) Finančná komisia

3) Sociálna komisia

4) Kultúrna komisia

5) Zdravotná komisia

6) Dopravná komisia

7) Školská komisia

8) Komisia k hospodáreniu s majetkom

9) Komisia na ochranu verejného záujmu pri výkone funkcií verejných funkcionárov

10) Komisia regionálneho rozvoja 
11) Komisia cestovného ruchu a cezhraničnej spolupráce

12) Komisia územného plánovania a životného prostredia

13) Komisia pre cirkevné a spoločenské otázky

14) Rada predsedov komisií

Mandátová a finančná komisia musia byt' zriadené obligatórne pričom členmi mandátovej komisie môžu byt' len poslanci. Ostatné komisie si zastupitel'stvo vytvára podl'a potreby a môže ich aj rušit'.

Osobitne by sme chceli spomenút' Radu predsedov komisií. Rada je poradný orgán predsedu na prerokovanie materiálov určených na zasadnutie zastupitel'stva a d'alších otázok, ktoré sa týkajú samosprávneho kraja. Jej stanoviská majú charakter odporúčaní. Radu predsedov komisií tvoria predseda samosprávneho kraja, podpredsedovia a predsedovia komisií zriadených zastupitel'stvom. Účast' predsedu komisie je nezastupitel'ná. Ak sa rokovania nemôže zúčastnit' predseda samosprávneho kraja, tak môže vedením rokovania poverit' podpredsedu. Na zasadnutiach rady sa zúčastňuje aj riaditel' úradu, riaditel' kancelárie predsedu a zapisovatel'. Radu predsedov komisií zvoláva predseda spravidla pred zasadnutím zastupitel'stva. Na zasadnutí sa neprijíma uznesenie a ani sa nehlasuje, ale iba sa vyhotovuje zápis, ktorý je potom zverejnený. Zasadnutie rady je neverejné (Rokovací poriadok Zastupitel'stva Košického samosprávneho kraja).

\section{POSLANCI KRAJSKÉHO ZASTUPITELSTVA}

Poslanci vykonávajú svoju funkciu na základe reprezentatívneho mandátu čo znamená, že poslanec vykonáva svoju funkciu podl'a vlastného vedomia a svedomia v prospech obyvatel'ov a voliči mu nemôžu nič prikazovat'. Ďalej vykonáva svoju funkciu bez prerušenia pracovného pomeru alebo obdobného pracovného vzt'ahu. Poslancovi, ktorý je dlhodobo uvol'nený zo zamestnania na výkon jeho funkcie, patrí namiesto mzdy v zamestnaní odmena od samosprávneho kraja. Podl'a $§ 12$ ods. 1 zákona o samosprávnych krajoch je poslanec oprávnený najmä:

a) predkladat' zastupitel'stvu a jeho orgánom návrhy - bud' ústne alebo písomne na zasadnutí zastupitel'stva alebo priamo predsedovi. Musí však íst' o otázky, ktoré spadajú do pôsobnosti zastupitel'stva

b) interpelovat' predsedu vo veciach týkajúcich sa výkonu jeho činnosti

c) požadovat' od vedúcich (riaditel'ov) právnických osôb zriadených alebo založených samosprávnym krajom vysvetlenia vo veciach týkajúcich sa ich činnosti,

d) požadovat' informácie a vysvetlenia od fyzických osôb a právnických osôb, ktoré vykonávajú podnikatel'skú činnost' na území samosprávneho kraja, vo veciach týkajúcich sa ich podnikania,

e) zúčastňovat' sa na kontrolách, previerkach, vybavovaní st’ažností a iných podaní, ktoré uskutočňuje zastupitel'stvo a jeho orgány,

f) požadovat' vysvetlenia od štátnych orgánov vo veciach potrebných na riadny výkon poslaneckej funkcie.

Dôležitou právomocou poslancov je právo interpelovat' predsedu vo veciach, ktoré sa týkajú výkonu jeho činnosti. Za pozitívne $\mathrm{v}$ tomto prípade možno označit, že zákon o samosprávnych krajoch $\mathrm{v} \S 16$ ods. 8 stanovuje povinnost' predsedovi odpovedat' na takúto interpeláciu bud' ústne na zasadnutí zastupitel'stva alebo písomne do 30 dní. Tu je potrebné to dat' do kontrastu s obecným zriadením kde takáto povinnost' starostu nie je výslovne upravená. Teda na úrovni obce toto právo poslanca reálna stráca na dôležitosti a význame.

Ked’že všetci volený funkcionári disponujú určitou mocou je potrebné, aby existoval inštitút, ktorý by zabraňoval nahromadeniu moci v rukách volených predstavitel'ov. Na tento účel slúži inštitút nezlučitel'nosti funkcie. Funkcia poslanca je podl'a $\S 13$ ods. 1 nezlučitel'ná s funkciou predsedu kraja, zamestnanca samosprávneho kraja a podla osobitného zákona. 
V prípade nezlučitel'nosti s funkciou poslanca ide o logické ustanovenie, ked’že na úrovni kraja existujú dva rovnocenné orgány, ktoré by sa mali kontrolovat a vzájomne spolupracovat', preto je nemyslitel'né, aby tá istá osoba zastávala obe pozície. Dôležité je spomenút' aj funkcie, ktoré nesmie poslanec krajského zastupitel'stva vykonávat' podl'a osobitného zákona. Ide napríklad o zákon č. 154/2001 Z. z. o prokurátoroch a právnych čakatel'och prokuratúry. Podl'a $\$ 11$ tohto zákona je funkcia prokurátora nezlučitel'ná s funkciou v orgánoch územnej samosprávy. Ked’že krajské zastupitel'stvo je jedným z orgánov územnej samosprávy, tak možno konštatovat', že funkcia krajského poslanca je nezlučitel'ná s funkciou prokurátora

Nezlučitel'nost' funkcie je dôležitou súčast’ou verejných funkcií, ale podl'a nás je na úrovni poslanca krajského zastupitel'stva vel'mi stručne upravená a je potrebné ju rozšírit'. Súčasná úprava nevylučuje, aby bol krajský poslanec zároveň aj starostom. Prax so sebou prináša viaceré prípady kedy bol starosta obce zároveň aj poslancom krajského zastupitel'stva. Zastávanie viacerých volených funkcií so sebou prináša aj určité problémy. Prvým problémom je to, že akákol'vek verejná funkcia je náročná na čas a prácu. Domnievame sa, že osoba, ktorá vykonáva dve takéto volené funkcie bud' uprednostní jednu alebo bude zanedbávat' obe. Problémom môže byt' aj konflikt záujmov pri hlasovaní a môže nastat' situácia kedy je záujem obce postavený nad záujem kraja čo je podl’a nášho názoru neprípustné lebo starosta obce, ktorý je zvolený aj za poslanca krajského zastupitel'stva pracuje v prospech obyvatel'ov celého kraja. Zároveň nie je vylúčená aj jeho prítomnost' v štatutárnych orgánoch organizácií, ktoré boli zriadené samosprávnym krajom, tak ako je to vymedzené pri predsedovi kraja.

Nezlučitel'nost' funkcie poslanca je dôležitou súčast'ou výkonu jeho práce. Zabraňuje sa ňou najmä hromadenie moci v rukách jednej osoby a konfliktu záujmov. Preto je na mieste odporúčanie, aby zákonodarca rozšíril vymedzenie nezlučitel'nosti funkcií podl'a vyššie spomenutého.

\section{ZÁVER}

Zastupitel'stvo predstavuje dôležitú súčast' regionálnej samosprávy. V jeho činnosti však možno nájst' nedostatky, ktoré by bolo potrebné odstránit'. V prvom rade je potrebné legislatívne zakotvit' postup v situácií, ak predseda odmietne, po prelomení sistačného práva, podpísat' uznesenie. Zákonom by sa malo zabránit', aby existovalo vykonatel'né uznesenie, ktoré predseda odmietne realizovat' alebo predlžuje jeho vykonanie. Jednou z možností ako takúto situáciu vyriešit' je súdna cesta avšak myslím si, že riešenie tohto problému súdnou cestou je pre kraj nevýhodne a to $\mathrm{v}$ dôsledku dížky trvania súdneho procesu či nákladov. Dlhodobo je však takéto riešenie nepraktické najmä, ak sú predseda a zastupitel'stvo v neustálom spore.

Podobná situácia môže nastat' aj pri nakladaní s majetkom kraja alebo pri menovaní riaditel'ov právnických osôb, ktoré môže predseda svojim nepodpísaním znemožnit'. Riešenie týchto situácií je potrebné legislatívne upravit' a to napríklad tak, že by si zastupitel'stvo zvolili svojho zástupcu, ktorý by uznesenie podpísal ako zástupca zastupitel'stva v prípade, že by predseda odmietol uznesenie podpísat'. V týchto situáciách je vhodné uvažovat' aj o oslabení postavenia predsedu ked'že zastupitel'stvo by malo predstavovat' hlavný orgán, ktorý reprezentuje moc obyvatel'ov kraja a predseda ako výkonný orgán kraja by mal rešpektovat' vôl'u l'udu, ktorá mu je sprostredkovaná prostredníctvom poslancov zastupitel'stva. Ďalšou možnost'ou, ktorou disponuje zastupitel'stvo je vyhlásenie referenda o odvolaní predsedu. Avšak vzhl'adom na referendovú prax v Slovenskej republike a potrebe dosiahnut' $50 \%$ účast', aby bolo hlasovanie platné, je aj toto riešenie v dlhodobom horizonte nepraktické.

Závažným nedostatkom je aj stručná úprava nezlučitel'nosti funkcie poslanca. Nezlučitel'nost' funkcie je podl'a nás potrebné rozšírit’ o viacero funkcií. Ide napríklad o starostu obce či 
vedúceho orgánu štátnej správy, ale aj iných. Na záver je potrebné povedat', že zastupitel'stvo je dôležitým orgánom kraja a aby sa zabezpečilo jeho bezproblémové fungovanie je potrebné spomínané nedostatky odstránit' najmä ak ide o súčinnost' zastupitel'stva s predsedom.

\section{Použitá literatúra}

1. DRGONEC, J., Základné práva a slobody podla Ústavy Slovenskej republiky. Zväzok 1. Bratislava: MANZ, 1997. 264 s. ISBN 80-85719-13-4.

2. KOVÁC̆OVÁ, E., Teória a prax verejnej správy vpodmienkach Slovenskej republiky, Banská Bystrica: Belianum, 2014. 236 s. ISBN 978-80-557-0735-8.

3. PALÚŠ, I a kol., Ústavné právo Slovenskej republiky, Košice: UPJŠ v Košiciach, 2016. 462 s. ISBN 978-80-8152-442-4.

4. PALÚŠ, I a kol., Územná samospráva v procese decentralizácie verejnej správy, Košice: UPJŠ FVS, 2010. ISBN 978-80-8129-006-0

5. ROKOVACÍ PORIADOK ZASTUPITEl'STVA KOŠICKÉHO SAMOSPRÁVNEHO KRAJA 2020, Dostupné na: https://web.vucke.sk/files/dokum enty/zastupitelstvo/rokovacie-poriadky/rokovaci-poriadok-zastupitelstva\%20z\%20r oku\%202020.pdf

6. ŠTATISTICKÝ ÚRAD SLOVENSKEJ REPUBLIKY 2017, Dostupné na: https://volby.statistics.sk/osk/osk2017/sk/data01.html

7. Ústavný zákon č. 460/1992 Zb. Ústava Slovenskej republiky

8. Zákon NR SR č. 154/2001 Z. z. o prokurátoroch a právnych čakatel'och prokuratúry v znení neskorších predpisov

9. Zákon NR SR č, 302/2001 Z. z. o samospráve vyšších územných celkov v znení neskorších predpisov

10. Zákon NR SR č. 180/2014 Z. z. o podmienkach výkonu volebného práva a o zmene a doplnení neskorších predpisov

\section{Kontaktné údaje}

Mgr. Lukáś Ivančík

Univerzita Pavla Jozefa Šafárika v Košiciach, Fakulta verejnej správy

Popradská 66, 040 11, Košice, Slovenská republika

Tel: 0915040067

email: lukas.ivancik@student.upjs.sk 


\title{
MOŽNOSTI DEFRAGMENTÁCIE OBCÍ NA SLOVENSKU \\ POSSIBILITIES OF DEFRAGMENTATION OF MUNICIPALITIES IN SLOVAKIA
}

\author{
Darina Koreňová
}

\begin{abstract}
Abstrakt
Slovensko patrí medzi krajiny s najnižším priemerom počtu obyvatel'ov na jednu obec. Táto skutočnost' spôsobuje častokrát nemožnost' naplnenia základného poslania samosprávy, ktorým je poskytovanie miestnych služieb. Fragmentácia sídelnej štruktúry spôsobuje ekonomické, rozvojové, personálne a iné problémy. Ciel'om príspevku je ozrejmit' aktuálny stav rozdrobenosti v podmienkach Slovenskej republiky a načrtnút' jej možné riešenia.
\end{abstract}

Kl'účové slová: fragmentácia, malé obce, pandemická situácia

\begin{abstract}
Slovakia is one of the countries with the lowest average population per municipality. This fact often makes it impossible to fulfill the basic mission of self-government, which is to provide local services. The fragmentation of the territorial structure causes economic, developmental, personnel and other problems. The aim of the paper is to clarify the current state of fragmentation in the conditions of the Slovak Republic and to suggest possible solutions.
\end{abstract}

Key words: fragmentation, small municipalities, pandemic situation

\section{1 ÚVOD}

Fragmentácia obcí je na Slovensku dlhoročná a stále nevyriešená téma. V súčasnej pandemickej situácii sa naplno odhalili problémy s ňou spojené. Pandémia Covid-19 prispela $\mathrm{k}$ ich citel'nému prehĺbeniu. Stále sa však $\mathrm{z}$ dôvodu absentujúcej snahy zo strany štátu, samospráv či samotných obyvatel'ov obcí nad’alej opomína.

\section{LEGISLATIIVA V OBLASTI ZLUČOVANIA OBCÍ NA SLOVENSKU}

Legislatívne východiská pre zlučovanie obcí nachádzame v Ústave Slovenskej republiky. V 4. hlave ústavy, konkrétne v čl. 66 ods. 2, sa obciam dáva možnost' zlúčit' sa alebo rozdelit', pričom podrobnosti ponecháva ústava na zákonnú úpravu.

Bližšie toto právo ustanovuje zákon upravujúci komplexné fungovanie obcí. Ide o zákon č. 369/1990 Zb. o obecnom zriadení v znení neskorších predpisov, ktorý tento inštitút popisuje:

- v $\$ 2$ územie obce, ods. 3 - „Obec zriad’uje, zrušuje, rozdel'uje alebo obce zlučuje vláda nariadením. Rozhodnút' o tom možno iba so súhlasom obce a na základe stanoviska okresného úradu $\mathrm{v}$ sídle kraja, $\mathrm{v}$ ktorého územnom obvode sa obec nachádza."

- $\quad \mathrm{v} \S 2 \mathrm{a}$ zlučovanie a rozdelenie obce, kde je zlúčenie upravené nasledovne:

(1) Dve obce alebo viac obcí sa môžu zlúčit' do jednej obce. Zlúčením obcí zanikajú zlučované obce a vzniká nová obec. Zlúčit' obec možno len s účinnost'ou ku dňu konania všeobecných volieb do orgánov samosprávy obcí. 
(2) Súčast'ou návrhu na zlúčenie obcí je dohoda o zlúčení obcí a údaje o výsledkoch miestneho referenda zlučovaných obcí. Tento odsek upravuje aj obsahovú stránku tejto dohody o zlúčení (bližšie pozri zákon).

(3) Nová obec, ktorá vznikla zlúčením obcí, je právnym nástupcom každej z nich.

(4) Nová obec zasiela kópiu dohody o zlúčení samosprávnemu kraju, na ktorého území sa táto obec nachádza, Štatistickému úradu Slovenskej republiky, okresnému úradu a daňovému úradu.

\section{SÚČASNÝ STAV FRAGMENTÁCIE OBCÍ NA SLOVENSKU}

V ostatných dekádach sledujeme trend smerom k defragmentácii krajín. V mnohých štátoch samotné obce pochopili, že čoraz náročnejšie úlohy, ktoré im vyplývajú z kompetencií nedokážu realizovat' samé. Preto sa zlučovanie obcí do väčších celkov stáva nevyhnutným javom moderných samospráv. Vo vyspelej Európe je už len málo krajín, ktoré sa vyznačujú vel'kým množstvom územných jednotiek.

Z tabul'ky 1 je zrejmé, že rozdrobenost'ou trpí najmä Francúzsko, Slovensko, Česko a Mad'arsko. Naopak lídrami v celistvosti najnižších samosprávnych jednotiek medzi krajinami Európskej únie sú Írsko, Dánsko, Litva, Holandsko a Švédsko.

Tabul'ka 1: Krajiny EÚ z pohl'adu fragmentácie

\begin{tabular}{|c|c|c|c|c|c|}
\hline Krajina & $\begin{array}{l}\text { Rozloha } \\
\left.(\mathbf{v ~ k m})^{2}\right)\end{array}$ & $\begin{array}{c}\text { Počet } \\
\text { obyvatel'ov }\end{array}$ & Názov obce & $\begin{array}{c}\text { Počet } \\
\text { obcí }\end{array}$ & $\begin{array}{l}\text { Priemerný počet } \\
\text { obyvatel'ov obce }\end{array}$ \\
\hline Belgicko & 30326 & 11.348 mil. & communes, gemeenten & 589 & 19267 \\
\hline Bulharsko & 110372 & 7.076 mil. & obshtini & 265 & 26702 \\
\hline Chorvátsko & 56594 & 4.154 mil. & općina, grad & 556 & 7472 \\
\hline Cyprus & $\begin{array}{l}9250 / \\
5695 \\
\end{array}$ & $\begin{array}{c}1.180 / 0.855 \\
\text { mil. }\end{array}$ & demos, koinnotites & $526 / 380$ & $2242 / 2249$ \\
\hline Česko & 77219 & 10.590 mil. & obce & 6258 & 1692 \\
\hline Dánsko & 42924 & 5.767 mil. & kommuner & 98 & 58449 \\
\hline Estónsko & 43432 & 1.316 mil. & linnad, vallad & 79 & 16653 \\
\hline Fínsko & 338150 & 5.508 mil. & kuntaa & 311 & 17670 \\
\hline Francúzsko & 647795 & 66.865 mil. & communes & 35357 & 1891 \\
\hline Grécko & 130820 & 10.755 mil. & dimos & 325 & 33181 \\
\hline Holandsko & 33688 & 17.127 mil. & gemeenten & 380 & 45071 \\
\hline Írsko & 70280 & 4.802 mil. & $\begin{array}{l}\text { county councils, city } \\
\text { councils, city and } \\
\text { county councils }\end{array}$ & 31 & 154912 \\
\hline Litva & 65286 & 2.848 mil. & savivaldbyés & 60 & 47140 \\
\hline Lotyšsko & 64490 & 1.941 mil. & $\begin{array}{c}\text { Novads, Republikas } \\
\text { Pilseta }\end{array}$ & 119 & 16312 \\
\hline Luxembursko & 2586 & 0.597 mil. & communes & 102 & 5850 \\
\hline Mad'arsko & 93030 & 9.788 mil. & $\begin{array}{c}\text { települési } \\
\text { önkormányzatok }\end{array}$ & 3177 & 3081 \\
\hline Malta & 320 & $0.460 \mathrm{mil}$. & Kunsilli Lokali & 68 & 6500 \\
\hline Nemecko & 357580 & 82.657 mil. & gemeinden & 11054 & 7450 \\
\hline Pol'sko & 306194 & 38.422 mil. & gmina & 2478 & 15507 \\
\hline Portugalsko & 92226 & $10.291 \mathrm{mil}$. & municípios & 308 & 33524 \\
\hline Rakúsko & 83879 & 8.809 mil. & gemeinden & 2098 & 4200 \\
\hline Rumunsko & 238391 & 19.644 mil. & $\begin{array}{l}\text { municipii, orase, } \\
\text { comune }\end{array}$ & 3181 & 6990 \\
\hline Slovensko & 49036 & 5.438 mil. & obce & 2930 & 1856 \\
\hline Slovinsko & 20145 & 2.066 mil. & občine, mestne občine & 212 & 9744 \\
\hline Španielsko & 505940 & $46.534 \mathrm{mil}$ & municipios, ciudades & 8124 & 5728 \\
\hline
\end{tabular}




\begin{tabular}{|c|c|c|c|c|c|}
\hline & & & autónomas & & \\
\hline Švédsko & 447420 & 10.058 mil. & kommuner & 290 & 34217 \\
\hline Taliansko & 295114 & 60.537 mil. & comuni & 7960 & 7605 \\
\hline
\end{tabular}

Zdroj: vlastné spracovanie podl'a World Observatory on Subnational Government Finance and Investment 2019

Sídelná štruktúra v podmienkach Slovenka je vel'mi rozdrobená a prevažuje tu vysoký podiel malých obcí. Z tabul'ky 2 je možné konštatovat', že obce do 1000 obyvatel'ov tvoria až $65 \%$ všetkých obcí. Avšak dôležitý je aj fakt, že v nich žije len približne $15 \%$ populácie. K aktuálnemu stavu fragmentácie došlo po roku 1990. Kde počet obcí narástol z 2694 na 2891. Alarmujúce je, že obcí do len 100 obyvatel'ov je aktuálne až 139 pričom o funkčnosti takejto obce je možné objektívne pochybovat'. Na Slovensku platí, že všetky obce sú si rovnocenné, a teda každá obec musí plnit' tie isté zákonné povinnosti, resp. zverené kompetencie (t. z. malá obec plní tie isté povinnosti ako krajské mesto). Otázkou ostáva či si všetky povinnosti plní i tak malá vel'kostná kategória obcí. Podla Ministerstva vnútra SR (2020) sú najčastejšími problémami obcí s nízkym počtom obyvatel'ov nedostatok finančných prostriedkov, slabý l'udský kapitál a nezáujem o kandidatúru na lokálne volené funkcie. Ako d’alej správa ministerstva uvádza, niektoré príjmy sú viazané na počet obyvatel'ov, a preto malým obciam často chýbajú finančné prostriedky. Väčšina príjmov sa použije na chod obecného úradu, administratívu a mzdy a nie na služby, ktoré by mala obec zabezpečovat'. Ďalším problémom je nízka odbornost' a špecializácia zamestnancov obecných úradov malých obcí. Zákonodarca si začal uvedomovat' vážnost' situácie a v zákone o obecnom zriadení pribudla právna norma, podl'a ktorej nefunkčnú obec možno pričlenit' k inej (\$2aa pričlenenie obce).

Tabul'ka 2: Kategorizácia obcí na Slovensku so zameraním na malé obce

\begin{tabular}{|c|c|c|c|c|}
\hline \multirow{2}{*}{ Vel'kostná kategória } & \multicolumn{2}{|c|}{ obce } & \multicolumn{2}{c|}{ obyvatelia } \\
\cline { 2 - 5 } & počet & $\%$ & počet & 0,16 \\
\hline $\mathbf{1 - 9 9}$ & 139 & 4,81 & 8897 & 0,76 \\
\hline $\mathbf{1 0 0}-\mathbf{1 9 9}$ & 270 & 9,34 & 41431 & 4,46 \\
\hline $\mathbf{2 0 0}-\mathbf{4 9 9}$ & 705 & 24,39 & 243769 & 9,88 \\
\hline $\mathbf{5 0 0}-\mathbf{9 9 9}$ & 760 & 26,30 & 539616 & 14,86 \\
\hline $1000-1999$ & 577 & 19,97 & 811563 & 16,05 \\
\hline $2000-4999$ & 301 & 10,41 & 876514 & 8,26 \\
\hline $5000-9999$ & 67 & 2,32 & 450869 & 8,56 \\
\hline $10000-19999$ & 33 & 1,14 & 467306 & 14,54 \\
\hline $20000-49999$ & 28 & 0,97 & 793799 & 10,03 \\
\hline $50000-99999$ & 8 & 0,28 & 546931 & 12,44 \\
\hline $100000-$ viac & 2 & 0,07 & 679086 & 100,00 \\
\hline
\end{tabular}

Zdroj: vlastné spracovanie podl’a STATdat. (2021), stav k 31.12. 2020

Rozdrobenost' Slovenska negatívne dopín̆a existencia početných mestských častí pri mestách Bratislava a Košice. Bratislava je členená na 17 a menšie Košice až na 22 mestských častí. Pre porovnanie mesto Viedeň má 23 mestských častí pri takmer 1,9 mil. obyvatel'ov a mesto Budapešt' rovnako 23 mestských častí pri 1,6 mil. obyvatel'och. Ide o neefektívne spravovanie tak malého územia. Každá mestská čast' má svojho starostu, poslancov a miestny úrad s množstvom úradníkov, ktorí predstavujú nemalé náklady. Mestské časti by bolo vhodné rovnako výrazne zlúčit' alebo pri najodvážnejšom variante by správu týchto miest vedel zabezpečit' magistrát mesta s prípadnými pobočkami. 


\section{MOŽNOSTI EFEKTÍVNEJŠIEHO USPORIADANIA}

Spájanie obcí so sebou prináša pozitíva a negatíva, ktoré ovplyvňujú motiváciu samospráv ku zmene. Podl'a materiálu Komunálna reforma (2004) sú argumenty pre a proti fragmentácii nasledovné.

Argumenty za spájanie do väčších samospráv:

- Plnia si optimálnejšie svoje funkcie

- Poskytujú obyvatel’om väčšiu škálu kvalitnejších služieb

- Prinášajú možnost' využitia úspor z rozsahu - náklady na poskytovanie služieb sú nižšie pričom množstvo služieb väčšie

- Umožňujú podporu miestneho ekonomického rozvoja

- Dávajú priestor pre inovácie (napríklad smart riešenia a pod.)

- Môžu viest' k väčšiemu záujmu verejnosti na participácii v miestnej politike

- Poskytujú viac miesta pre záujmové skupiny, reprezentujúce pluralitnú spoločnost'

- Podnecujú vznik silnej občianskej spoločnosti

Argumenty za zotrvanie $\mathrm{v}$ rozdrobenosti:

- Malé obce sú homogénnejšie a je jednoduchšie implementovat' politiky, ktoré uspokoja preferencie väčšiny obyvatel'stva

- Je tu typickejšia silná väzba medzi poslancami a občanmi (politici sú viac zodpovední voči miestnym komunitám)

- V malých komunitách je viac motivačných faktorov pre spoluúčast' obyvatel'ov (viac im záleží na rozvoji ,ich“ územia)

- Sú menej byrokratické

- Argument ekonomiky z rozsahu je irelevantný, pretože zodpovednost' za službu možno oddelit' od jej reálneho poskytovania (kontrahovanie do súkromného sektora, privatizácia verejných služieb,...)

S príchodom pandémie Covid-19 sa ako hlavné negatíva malých obcí Slovenska prejavili problémy ekonomického a nadväzujúceho rozvojového charakteru. Reprezentanti obcí už verejne deklarujú, že z dôvodu finančnej zát'aže vyplývajúcej z nákladov vynaložených na protipandemické opatrenia a výpadku daňových príjmov budú musiet' zúžit' rozsah poskytovaných miestnych služieb. Rovnako limitované môžu byt' decentralizované povinnosti samospráv ako napríklad zabezpečenie údržby miestnych komunikácií, verejnej zelene a pod. Niektorým samosprávam hrozí rast zadlženosti, ozdravný režim či nútená správa. Napríklad obec Budimír s 1290 obyvatel'mi mala výpadok na dani z príjmov fyzických osôb 34150 eur (Ministerstvo financií SR 2021).

Podla vládnej strany Sloboda a Solidarita (SAS) je slovenská samospráva extrémne rozdrobená. Priemerný počet obyvatel’ov jednej obce je 20 násobne nižší ako je priemer OECD (pozri tabul'ku 1). Podl’a štúdie Inštitútu finančnej politiky (2017), s názvom Skrytý poklad v samospráve, zlúčením samospráv do väčších celkov na približne tretinu by sa mohlo ušetrit' približne 180 mil. eur ročne. Úlohou vlády SR je aktívne hladat' možnosti pre zlučovanie obcí, nakol'ko väčšie obce majú omnoho lepšie možnosti na čerpanie fondov EÚ.

\subsection{Príklady dobrej praxe}

Rozsiahle reformy $v$ štruktúre miestnej správy možno badat' najmä $v$ škandinávskych krajinách. Zatial' čo nórske reformy boli na začiatku (v 50. - 70. rokoch 20. storočia) pomerne skromné - zo 744 obcí sa znížil ich počet na 444. V roku 2020 sa znížil ich počet až na súčasných 358. Rovnako Fínsko nešlo drastickou cestou defragmentácie svojho územia. Ich 
počet sa znížil na začiatku 90. rokov zo 460 obcí na dnešných 311. Island od konca 80. rokov znížil počet obcí o polovicu. Lídrami v zlučovaní obcí boli Dánsko a Švédsko.

\section{Dánsko}

Dánsko implementovalo samosprávnu reformu v 2 fázach.

V prvej zredukovalo v priebehu necelých desiatich rokov (1965 - 1974) 1335 obcí na 278. Až $75 \%$ sa zlúčilo na dobrovol’nej báze. Samé si vybrali, s ktorou obcou sa chcú spojit'. Kritériá na spájanie obcí v prvej fáze boli najmä: minimálne 4000 - 6000 obyvatel'ov; existujúce obce nemali byt' pri zlučovaní rozdelené; predchádzajúce obchodné, ekonomické a l'udské vzt’ahy sa zachovajú; mal byt' zachovaný princíp subsidiarity.

V roku 2007 Dánsko pokračovalo v zavádzaní významných reforiem a znížilo počet samospráv na súčasných 98 . V druhej fáze reformy sa stanovil minimálny počet obyvatel'ov na 20 000. Preferovaný počet bol 30000 obyvatel'ov. Ciel'om druhej fázy bol významný presun kompetencií z krajov na obce a tým bol zvýraznený význam územnej samosprávy (niektoré kompetencie sa vrátili spät’ na štátnu úroveň) (Erlingsson, et al. 2020).

\section{Švédsko}

Niektorí autori označujú sériu reforiem, ktoré Švédsko uskutočnilo v rokoch 1952 až 1974 ako jednu z najrozsiahlejších územných reforiem v histórii vyspelých demokracií. V priebehu 22 rokov sa počet obcí znížil z 2498 na 278. V nasledujúcich dekádach sa trend mierne otočil a počet obcí sa ustálil na súčasných 290. Švédska forma zlučovania sa nazýva amalgamizácia.

V roku 1930 dosiahol počet obcí Švédska vrchol - bolo ich 2 532. Na základe toho bola zriadená „Komisia pre zlučovanie obcí“, ktorá v roku 1943 navrhla, aby bol počet obcí výrazne znížený. Po rokoch príprav bola prvá z celoštátnych obecných reforiem realizovaná v roku 1952. Počet obcí bol znížený na 816 (miest sa to nedotklo). Táto reforma však nebola dostatočne radikálna a tak nová Komisia z roku 1959 dospela k záveru, že je nevyhnutné spájat' obce do väčších celkov vo väčšom rozsahu (Hanes, Wikström 2010).

V roku 1962 švédsky parlament rozhodol, že nová reforma má byt' vykonávaná na základe dobrovol'nosti. Proces sa začal v roku 1964, kedy všetky obce boli zoskupené do 282 tzv. obecných blokov (kommunblock), čo boli vol'né združenia. Spolupráca mala viest' k ich postupnému oficiálnemu zlúčeniu. Ciel’ový bol rok 1971, kedy všetky obce mali mat' jednotný typ a všetky formálne rozdiely a výsady medzi obcami (aj mestami) mali byt' zrušené.

Tento dobrovol'ný proces bol však vel'mi pomalý, preto v roku 1971 bola dobrovol'nost' pri zlučovaní obcí zrušená. V tom istom roku tak počet subjektov klesol na 464, o tri roky neskôr už bol počet obcí 278. V niektorých prípadoch však bola koexistencia medzi zlúčenými obcami nemožná a došlo tak k rozdeleniu obcí. Z tohto dôvodu je dnes počet obcí 290 (Erlingsson, et al. 2020).

\section{Česká republika}

I ked' Česká republika nepatrí medzi krajiny s malým množstvom samospráv môže byt' inšpiráciou pre Slovensko z pohl'adu kategorizácie obcí. Ako je uvedené vyššie, Slovensko má len jeden typ obcí, ktoré musia plnit' tie isté funkcie (obec môže získat' štatút mesta pričom podmienky upravuje zákon). Naopak, Česká republika má 3 základné typy obcí:

1) Obec (neformálne sa označuje ako Obec typu I) - do tejto kategórie patria všetky obce. Obce sú v Českej republike základnou jednotkou územnej samosprávy. 
2) Obec s povereným obecným úradom (neformálne sa označuje ako Obec typu II) - je obecný úrad jednej obce, ktorý v rámci prenesenej pôsobnosti vykonáva na základe zmluvy (prenesenú) štátnu správu aj pre ostatné obce. Typickými pôsobnost'ami špecifickými pre poverené obecné úrady sú záležitosti matričného a stavebného úradu. Väčšina tohto typu obcí sú mestá.

3) Obec s rozšírenou pôsobnost'ou (neformálne sa označuje ako Obec typu III) - tieto obce majú oproti ostatným obciam rozšírené niektoré oblasti pôsobnosti, a to nielen pre svoj vlastný územný obvod, ale spravidla i pre d’alšie obce. V rámci II. etapy reformy územnej verejnej správy na tento typ obcí prešlo približne $80 \%$ kompetencií po zrušených okresných úradoch (Zákon č. 367/1990 Sb. „o obcích (obecní zřízení)“v znení neskorších predpisov).

\section{ZÁVER}

Pre podmienky Slovenskej republiky sa momentálne javí vo veci defragmentácie územia ako najinšpirujúcejšia krajina Švédsko. Mohli by sme sa poučit’ z chýb, ktoré sprevádzali ich amalgamizačný proces a neponechat' samosprávam taký výrazný priestor na dobrovol'né spájanie sa do väčších celkov. Švédsko muselo v konečnom dôsledku pristúpit' k obligatórnosti a zavedeniu striktných pravidiel defragmentácie. Tým by sme ušetrili niekol'ko rokov neefektívnych stretnutí a zbytočných negociácií. Preto sa domnievame, že je potrebné pripravit' kvalitný reformný plán zo strany odborníkov, ktorý stanoví jasné podmienky za ktorých sa obce budú povinné spájat' do väčších celkov. Pripomíname, že Švédsko má devät'krát väčšie územie ako Slovensko a má 290 obcí (Slovensko ich má desat'krát tol'ko).

\section{Použitá literatura}

1. ERLINGSSON, G. Ó.; ÖDALEN, J.; WÅNGMAR, E., 2020. How Coerced Municipal Amalgamations Thwart the Values of Local Self-Government. In Urban Affairs Review. [online] [cit. 1. 06. 2021]. Dostupné na: https://journals.sagepu b.com/doi/10.1177/1078087420921458

2. HANES, N., WIKSTRÖM, M., 2010. Amalgamation Impacts on Local Growth: Are Voluntary Municipal Amalgamations More Efficient Than Compulsory Amalgamations? In The Canadian journal of regional science $=L a$ revue canadienne des sciences regionales. Vol. 33. p. 57-70. ISSN 1925-2218.

3. INŠTITÚT FINANČNEJ POLITIKY - Ministerstvo financií Slovenskej republiky, 2017. Skrytý poklad v samospráve. [online] Bratislava [cit. 04. 05. 2021]. Dostupné na: https://www.mfsr.sk/files/archiv/priloha-stranky/19968/70/Skryty-poklad-samosp rave.pdf

4. KOMUNÁLNA REFORMA - Materiál pre verejnú diskusiu, 2004. [online] [cit. 20. 05. 2021]. Dostupné na: https://www.komunal.eu/images/pdf/komunalna_ref orma.pdf

5. MINISTERSTVO FINANCIÍ SR, 2021. Výpadok dane z prijmov fyzických osôb za rok 2020 pre obce [online] [cit. 20. 05. 2021]. Dostupné na: https://www.mfsr.sk/ files/archiv/9/Priloha_c_1_obce.pdf

6. MINISTERSTVO VNÚTRA SR, 2020. Obce o zlučovanie záujem nemajú [online] TASR, Prešovský kraj [cit. 25. 05. 2021]. Dostupné na: https://obce.tasr.sk/cla nok/2931/obce-o-zlucovanie-zaujem-nemaju

7. NAJVYŠŠÍ KONTROLNÝ ÚRAD SLOVENSKEJ REPUBLIKY 2013. PREDBEŽNÁ ŠTÚDIA ku kontrolnej akcii Kontrola procesu samointegrácie menšich obcí SR [online] NKÚ [cit. 10. 05. 2021]. Dostupné na: https://www.nku.gov.sk/do 
cuments/10157/1153463/Predbežná+štúdia+Samointegrácia+menš\%C3\%ADch+obc $\% \mathrm{C} 3 \% \mathrm{AD}+\mathrm{SR}$

8. SLOBODA A SOLIDARITA, 2020. Plán obnovy a odolnosti. [online] Bratislava [cit. 25. 05. 2021]. Dostupné na: https://www.sas.sk/admin/core/Main.php?filefile_id=442\&method=downloadFile\&download $=1 \& \_=1607190253054$

9. STATTdat.- Verejná databáza údajov, 2021. Vel'kostné skupiny obci - SR, oblasti, kraje, okresy, mesto, vidiek. [online] Štatistický úrad Slovenskej republiky [cit. 10. 05. 2021]. Dostupné na: http://statdat.statistics.sk/cognosext/cgi-bin/cognos.cg i?b_action=cognosViewer\&ui.action=run\&ui.object=storeID $\% 28 \% 22 \mathrm{i0C} 852 \mathrm{CAA} 54$ 51437C92774DB33EC08675\%22\%29\&ui.name $=\mathrm{Ve} \% \mathrm{C} 4 \%$ BEkostn\%C3\%A9\%20s kupiny\%20obc\%C3\%AD\%20-\%20SR\%2C\%20oblasti\%2C\%20kraje\%2C\% 20okresy\%2C\%20mesto\%2C\%20vidiek\%20\%5Bom7023rr\%5D\&run.outputFormat $=\&$ run.prompt $=$ true $\& \mathrm{cv} \cdot$ header $=$ false $\&$ ui.backURL $=\% 2 \mathrm{Fcognosext} \% 2 \mathrm{Fcps} 4 \% 2 \mathrm{Fpor}$ tlets $\% 2$ Fcommon $\% 2$ Fclose.html\&run.outputLocale $=$ sk

10. TEKELI, J., 2013. Zlučovanie a rozdelenie Slovenských obcí. In Ius et Administratio. s. 103-119. ISSN 2300-4797.

11. Ústava SR č. 460/1992 Zb.

12. WORLD OBSERVATORY ON SUBNATIONAL GOVERNMENT FINANCE AND INVESTMENT, 2019. Country and Territory Profiles. [online] OECD and UCLG [cit. 10. 05. 2021]. Dostupné na: https://www.sng-wofi.org/country-profiles/

13. Zákon č. $367 / 1990 \mathrm{Sb}$. o obcích (obecní zřízení) v znění pozdějších předpisů

14. Zákon č. 369/1990 Zb. o obecnom zriadení v znení neskorších predpisov

\section{Kontaktné údaje}

PhDr. Darina Koreňová, PhD.

Univerzita Pavla Jozefa Šafárika v Košiciach, Fakulta verejnej správy Popradská 66, 04132 Košice, Slovensko

Tel: +421552345139

email: darina.korenova@upjs.sk 
PŘÍRODNÍ VĚDY NATURAL SCIENCES

\section{QUAERE}




\title{
RATLINNÉ KMEŇOVÉ BUNKY - PLATFORMA NA VÝROBU RASTLINNÝCH PRÍRODNÝCH PRODUKTOV PRE KOZMETICKÝ PRIEMYSEL
}

\author{
PLANTS STEM CELLS - PLATFORM FOR THE PRODUCTION OF \\ PLANT NATURAL PRODUCTS FOR THE COSMETIC INDUSTRY
}

\author{
Šarlota Kaňuková, Marcela Gubišová, Ján Kraic
}

\begin{abstract}
Abstrakt
Pri rastúcom dopyte spotrebitel'ov po bezpečných prírodných produktoch (nakol'ko sa syntetické chemikálie považujú za potenciálne toxické) sa zvyšuje záujem o rastlinné metabolity $\mathrm{z}$ in vitro kultúr. Aktuálne sú využívané najmä vo výrobe špeciálnych kozmetických prípravkov, zvlášt' na ochranu a regeneráciu pokožky a vlasov (séra, krémy, masky, oleje, kondicionéry). Produkty majú krátke životné cykly a preto je nutné uvádzat' na trh stále inovatívnejšie produkty. Inovácia je zvyčajne limitovaná aktívnymi látkami, ktoré môžu byt' syntetické alebo prírodné. Vysoko inovatívnymi sú kozmetické prípravky s obsahom tzv. rastlinných kmeňových buniek. Na základe svojich ochranných a regeneračných vlastností sa javia ako vhodný materiál na použitie v kozmetike a estetickej dermatológii. Doteraz vykonané štúdie potvrdili potenciál týchto buniek v boji proti známkam starnutia pokožky a zdôraznili ich blahodarné účinky na kmeňové bunky, čo je rozhodujúce pre proces obnovy pokožky. Napriek všetkému tomuto sl'ubnému vývoju v oblasti rastlinných kmeňových buniek a ich rozmanitému použitiu ešte nie je jasné, či majú extrakty pochádzajúce z rastlín a z kmeňových buniek na človeka etnicky špecifické účinky.
\end{abstract}

Kl'účové slova: rastlinné kmeňové bunky, fytochemikálie, in vitro, kozmetický priemysel

\begin{abstract}
With the growing consumer demand for safe natural products (as synthetic chemicals are considered potentially toxic), there is an increasing interest in plant metabolites from in vitro cultures. They are currently used mainly in the production of special cosmetics, especially for the protection and regeneration of the skin and hair (serums, creams, masks, oils, conditioners). The products have short life cycles and therefore it is necessary to market increasingly innovative products. Innovation is usually limited by active substances, which can be synthetic or natural. Highly innovative are cosmetic products containing the so-called plant stem cells. Due to their protective and regenerative properties, they appear to be a suitable material for use in cosmetics and aesthetic dermatology. Studies to date have confirmed the potential of these cells to combat the signs of skin aging and highlighted their beneficial effects on stem cells, which is crucial for the skin renewal process. Despite all these promising developments in the field of plant stem cells and their diverse uses, it is not yet clear whether plant and stem cell extracts have ethnically specific effects on humans.
\end{abstract}

Key words: plant stem cells, phytochemicals, in vitro, cosmetics industry

\section{RASTLINNÉ KMEŇOVÉ BUNKY}

Kmeňové bunky sa nachádzajú v rastlinných a živočíšnych organizmoch. Od ostatných buniek sa líšia pre ich neobvyklé vlastnosti, vysokú proliferačnú schopnost', možnost' diferenciácie na špecializované bunky (v závislosti od orgánu, v ktorom sú prítomné) a sú 
zodpovedné aj za rast a opravu poškodených pletív/tkanív (Schurch a kol., 2008; Moruś a kol., 2014; Miastkowska a Sikora, 2018). Vol’né radikály sú považované za látky, ktoré spôsobujú starnutie pokožky, a to tým, že poškodzujú DNA, pomáhajú pri dehydrogenácii, hydroxylácii, proteínovej glykácii, ale taktiež poškodzujú lipidy nachádzajúce v hornej vrstve pokožky (stratum corneum). V dôsledku toho tkanivo stráca svoju pružnost', schopnost' regulovat' transepidermálnu stratu vody a replikácia buniek sa stáva menej účinnou (Rhein a Fluhr, 2013). Z tohto dôvodu extrakty z rastlinných kmeňových buniek predstavujú vhodný zdroj známych antioxidačných zlúčenín, ako sú polyfenoly, fenolové kyseliny, flavonoidy, triterpény, karotenoidy a peptidy, ktoré sú vhodné proti starnutiu (Knott a kol., 2008; Barbulova a kol., 2014; Georgiev a kol., 2018).

Rastlinné kmeňové bunky sa nachádzajú $\mathrm{v}$ apikálnych meristémoch výhonkov a koreňových laterálnych meristémoch. Na týchto miestach sa bunky delia po celý život rastliny a vytvárajú nové orgány. Pre kozmetické účely sa rastlinné kmeňové bunky množia v bunkovej kultúre pomocou metódy mikropropagácie $\mathrm{v}$ in vitro podmienkach (Obrázok 1).

Extrakty pochádzajúce $\mathrm{z}$ rastlinných kmeňových buniek sú zdrojom mnohých účinných látok, ktoré sú pre l'udské telo bezpečné, pretože nevyvolávajú nežiaducu reakciu imunitného systému (Miastkowska a Sikora, 2018). Ich získanie je šetrné k životnému prostrediu a možné aj $\mathrm{v}$ prípade ohrozených rastlín. Rastlinné kmeňové bunky sú zodpovedné za mnoho pozitívnych kozmetických účinkov, napríklad: predlžovanie životnosti fibroblastov a stimuláciu ich aktivity (Oryza sativa, Gardenia jasminoides); zvyšovanie flexibility epidermy (Symphytum officinale, Opuntia spp.); reguláciu bunkového delenia (Oryza sativa, Lotus japonicus); prestavbu poškodenej epidermy (Panax ginsgen, Opuntia spp.); aktiváciu opravy DNA buniek, ich ochranu pred oxidačným stresom (Lycopersicon esculentum, Citrus limon); a UV žiarením (Dolichos biflorus, Opuntia ficus indica) (Barbulova a kol., 2014; Georgiev a kol., 2018). Vo všeobecnosti je známe, že kmeňové bunky rastlín sú extrémne citlivé na vonkajšie faktory, ako je svetlo alebo teplota, a preto sa v kozmetických výrobkoch používajú najmä vo forme extraktov rozpustných v lipidoch (extrahovaných olejmi) a vode (extrahovaných glycerolom) (Draelos, 2012; Barbulova a kol., 2014; Georgiev a kol., 2018).

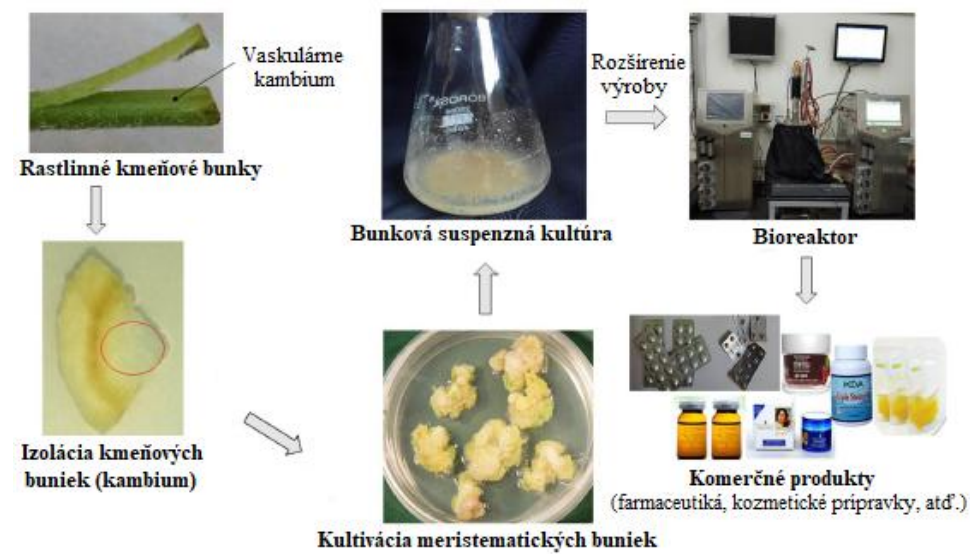

Obrázok 1: Schematické znázornenie výroby prírodných produktov z rastlinných kmeňových buniek (upravené podl'a Warghat a kol., 2018).

\subsection{Výhody meristematických (kmeňových) buniek oproti dediferencovaným bunkám}

Najnovším technologickým vývojom v rastlinných bunkových kultúrach je izolácia, kultivácia a aplikácia meristematických buniek na výrobu prírodného produktu vysokej hodnoty (Lee a kol., 2010). Typicky sú súčasné bunkové kultúry zložené z dediferencovaných buniek. Tieto bunky pozostávajú zo zmesi rôznych typov buniek, čo vedie k vysokej úrovni heterogenity, ktorá významne prispieva $\mathrm{k}$ variabilite rutiny spojenej so suspenznými 
kultúrami (Roberts a Kolewe, 2010). Pretože kambiálne meristematické bunky sú prirodzené nediferencované rastlinné kmeňové bunky, obchádzajú negatívne účinky spojené s krokom dediferenciácie a ponúkajú stabilitu v akumulácii produktu počas dlhších období (Lee a kol., 2010).

Produkcia biomasy je d'alším dôležitým faktorom, ktorý je potrebný na dosiahnutie vysokej úrovne syntézy prírodných produktov. Meristematické bunky z T. cuspidata vykazovali vynikajúci rast (na pevnom rastovom médiu) a zníženú agregáciu (v kvapalnom médiu), v porovnaní s dediferencovanými bunkami tej istej rastliny. Zníženie tvorby agregácií v kvapalnom médiu je považované za nesmierne dôležitý poznatok, pretože tvorba bunkových zhlukov môže inhibovat' distribúciu kyslíka a živín, čo výrazne znižuje výt’ažok prírodného produktu (Lee a kol., 2010).

Kambiálne meristematické bunky taktiež citlivejšie reagujú na samotnú elicitáciu. Napríklad pridanie kyseliny salicylovej a metyl-jasmonátu viedlo $\mathrm{k}$ zvýšeniu produkcie paklitaxelu v kambiálnych meristematických bunkách T. cuspidata o $14000 \%$ v porovnaní s $220 \%$ a $430 \%$ produkciou paklitaxelu v dediferencovaných bunkách získaných z embryí (Lee a kol., 2010). $\mathrm{V}$ meristematických bunkách $C$. roseus, pridanie kyseliny salicylovej a metyl-jasmonátu, $\beta$ cyklodextrínu alebo kombinácie oboch elicitorov, viedlo k zvýšeniu produkcie produkciu ajmalicínu o 15, 32 a 108\% v porovnaní s neošetrenými bunkami (Zhou a kol., 2015).

D̆alšou vel'mi podstatnou schopnost'ou kambiálnych meristematických buniek je uvol'nenie ciel'ového prírodného produktu do média (Wang a kol., 2001). Priama sekrécia vyrobených prírodných produktov do médií zjednodušuje a znižuje náklady na následné spracovanie, čo je zvlášt' dôležité pre priemyselnú výrobu prírodných produktov.

\subsection{Aktuálne trendy $v$ rastlinnej kozmetike}

Významnou výzvou pre kozmetický priemysel je poskytnút' funkčné, „moderné“, inovatívne a bezpečné výrobky s dlhšou trvanlivost'ou. Z etického hl'adiska odmietaného využívania l'udských alebo živočíšnych zdrojov sa všetok kozmetický výskum a vývoj nových výrobkov zameriava na biotechnológiu a technológiu kultivácie rastlinných buniek, aby sa prekonali priemyselné, spotrebitel'ské a legislatívne obmedzenia (Trehan a kol., 2017).

Priekopníkom vo výrobe rastlinných kmeňových buniek pre kozmetický priemysel je spoločnost' Mibelle AG Biochemistry (Švajčiarsko), ktorá v roku 2008 implementovala vo svojich výrobkoch kmeňové bunky jabĺk (PhytoCellTecTM Malus Domestica). Ako nosiče extraktu použili lipozómy. V roku 2008 boli uverejnené výsledky experimentu, v ktorom boli l'udské fibroblasty, s typickými príznakmi starnutia poškodením bunkovej DNA, inkubované v $2 \%$ extrakte kmeňových buniek, aby sa zvrátilo starnutie (Schmid a kol., 2008). Získané výsledky potvrdili účinnost' predíženia životnosti buniek izolovaných z l'udských vlasových folikulov a znižovania vrások na tvári. Následne spoločnost' Mibelle AG Biochemistry uviedla na trh extrakty z rastlinných kmeňových buniek Vitis vinifera (PhytoCellTec ${ }^{\mathrm{TM}}$ Solar Vitis), Saponaria pumila (PhytoCellTec ${ }^{\mathrm{TM}}$ nunatak $^{\circledR}$ ) alebo Argania spinosa (PhytoCellTec ${ }^{\mathrm{TM}}$ Argan) vo forme suspenzií, ktoré znižujú tvorbu vrások a zlepšujú aktivitu kmeňových buniek epidermy (Georgiev a kol., 2018). PhytoCELLTECH Malus domestica obsahuje množstvo extraktov z rastlinných buniek, ktoré používajú vo svojich kozmetických prípravkoch popredné značky kozmetiky, ako sú Dior, Lancôme, Guerlain a La Prairie. Konečné výrobky zahŕňajú plet'ové krémy a masky na tvár, očné krémy, výrobky na líčenie, vlasové oleje, vlasové séra a kondicionéry na vlasy. Vlastnosti proti starnutiu sa nachádzajú aj $\mathrm{v}$ glycerínových extraktoch získaných z kmeňových buniek spoločnost'ou Naolys (Francúzsko) z extraktov listových buniek zázvoru (Zingiber officinale) (Naolys, 2016). Klinické štúdie potvrdili zlepšenie štruktúry pokožky, zmenšenie vel'kosti pórov o $50 \%$, a po šiestich dňoch aplikácie sa pozoroval matovací efekt (zníženie lesku o 15\% a zníženie mazu o 19\%). Okrem toho spoločnost' Naolys taktiež ponúka glycerínový extrakt z kmeňových buniek Iris pallida 
(All Even Sweet Iris), Olea europea (All Fiber Booster Olive tree), Hibiscus rosa (All Fiber Booster Chinese hibiscus) a Camellia sinensis (All FiberBooster Green tea), ktoré vykazujú účinky proti starnutiu pokožky (Georgiev a kol., 2018). Na kozmetickom trhu existujú d'alšie spoločnosti, ktoré ponúkajú účinné látky vo forme extraktov kmeňových buniek, napríklad: Active Concepts LLC (USA), Akott Evolution S.R.L. (Taliansko), Biokosmetika (Francúzsko), Infinitec (Španielsko), Innova BM (Bulharsko), In vitro Plant-tech AB (Švédsko), Sederma (Croda Personal Care, Spojené král'ovstvo), Provital Group (Španielsko) a Vitalab s.r.l. (Arterra Bioscience s.r.l. Taliansko) (Georgiev a kol., 2018). Medzi významné extrakty kmeňových buniek, ktoré účinkujú proti starnutiu pleti, podporujú rast zdravej pokožky, prípadne sú schopné chránit' kožné bunky pred oxidačným stresom a poškodením spôsobeným t’ažkými kovmi (Tito a kol., 2011) patria: Syringa vulgaris (vd’aka obsahu verbascozidu) (Price, 2014); extrakt zo ženšenového kalusu obsahujúci užitočné metabolity ako ženšen saponíny a polysacharidy (Wu a Zhong, 1999); Lycopersicon esculentum, bohatý zdroj flavonoidov (rutín), fenolových kyselín (kyselina chlórovodíková, kyselina kumarová, kyselina protokatechová) a $\beta$-karoténu (Tito a kol., 2011); Citrus aurantium obsahujúci účinné antioxidanty ako neohesperidín a nirigín (Del Rio a kol., 1992); kmeňové bunky získané z kultúry Coffea bengalensis (Bimonte a kol., 2011) a Nicotiana sylvestris (Apone a kol., 2010) stimulujúce fibroblasty na syntézu kolagénu, ktorý podporuje regeneráciu kože. Ďalšími komerčne dostupných výrobkami v kozmetike sú šikonín ako kozmetický pigment (Payne a kol., 1991) (vyrobený z Lithospermum erythrorhizon od Mitsui Petrochemical Industries, Japonsko), arbutin ako bieliaca prísada (Misawa, 1994) (vyrobený z Catharanthus roseus spoločnost'ou Mitsui Petrochemical Industries, Japonsko) alebo kartamín ako kozmetický pigment (Yamamoto a kol., 2002; Oda, 2005; Haghbeen, 2006) (vyrobený z Carthamus tinctorius spoločnost'ou Kibun, Japonsko).

\section{Výskumný zámer, projekt}

Táto publikácia vznikla vd’aka podpore $\mathrm{v}$ rámci Operačného programu Integrovaná infraštruktúra pre projekt: Udržatel'né systémy inteligentného farmárstva zohl'adňujúce výzvy budúcnosti, ITMS: 313011W112, spolufinancovaný zo zdrojov Európskeho fondu regionálneho rozvoja a s podporou projektu FPPV-30-2021 „Technológie kultúr rastlín in vitro využitel'né na výrobu špeciálnych produktov" podporeného z grantu Fakulty Prírodných vied UCM.

\section{Použitá literatúra}

1. APONE, F. a kol. 2010. A mixture of peptides and sugars derived from plant cell walls increases plant defense responses to stress and attenuates ageing-associated molecular changes in cultured skin cells. Journal of Biotechnology. 145(4), 367-376. ISSN 0168-1656.

2. BARBUlOVA, A. - APONE, F. - COLLUCI, G. 2014. Plant cell cultures as source of cosmetic active ingredients. Comsmetics. 1(2), 94-104. ISSN 2079-9284.

3. BIMONTE, M. a kol. 2011. Coffea bengalensis for anti-wrinkle and skin toning applications. Cosmetics and Toiletries. 126(9), 644-650. ISSN 0361-4387.

4. DEL RIO, J. A. a kol. 1992. Bioproduction of neohesperidin and naringin in callus cultures of Citrus aurantium. Plant Cell Reports. 11(11), 592-596. ISSN 0721-7714.

5. DRAELOS, Z. 2012. Plant stem cells and skin care. Journal of Cosmetic Dermatology. 25(9), 395-396. ISSN 1473-2165.

6. GEORGIEV, V. a kol. 2018. Plant cell culture as emerging technology for production of active cosmetic ingredients. Engineering in Life Sciences. 18(11), 779798. ISSN 1618-2863. 
7. HAGHBEEN, K. 2006. Lithospermum officinale callus produces shikalin. Biologia. 61(4), 463-467. ISSN 1336-9563.

8. KNOTT, A. a kol. 2008. A novel treatment option for photoaged skin. Journal of Cosmetic Dermatology. 7(1), 15-22. ISSN 1473-2165.

9. LEE, E. K. a kol. 2010. Cultured cambial meristematic cells as a source of plant natural products. Nature Biotechnology. 28(11), 1213-1217. ISSN 1087-0156

10. MIASTKOWSKA, M. - SIKORA, R. 2018. Anti-aging properties of plant stem cell extracts. Comsmetics. 5(4), 1-8. ISSN 2079-9284.

11. MISAWA, M. 1994. Plant tissue culture: an alternative for production of useful metabolites. FAO Agricultural services bulletin No. 108. 1994. ISBN 92-5-1033919.

12. MORUS, M. a kol. 2014. Plant stem cells as innovation in cosmetics. Acta Poloniae Pharmaceutica. 71(5), 701-707. ISSN 0001-6837.

13. NAOLYS Nature Expanded [online]. 2016. [cit. 2021-03-16]. Refine Ginger: Restores skin texture. Dostupné na internete: <http://www.naolys.com/medi a/refine_ginger_en.pdf>

14. ODA, H. 2005. Utilization of natural colors: photostabilization of safflower (Carthamus tinctorius L.) Red Carthamin. Foods and food ingredients joural of Japan. 3, 207-213. ISSN 0919-9772.

15. PAYNE, G. F: a kol. 1991. Plant cell and tissue culture in liquid systems. WileyInterscience. 1991. 368 s. ISBN 978-0-471-03726-2.

16. PRICE, C. 2014. An in-depth look at lilac stem cell extract in skin care. Pract. Dermatol. [online]. ISSN 1547-7290, 2014, roč. 5, s. 46-48 [cit. 2021-03-16]. Dostupné na internete: <https://practicaldermatology.com/articles/2014-may/an-indepth-look-at-lilac-stem-cell-extract-in-skin-care/pdf $>$.

17. RHEIN, L. D. - FLUHR, J. W. 2013. Starzenie Skóry. Aktualne strategie terapeutyczne. Pol'sko: MedPharm Polska: Wroclaw, 2013. 450 s. ISBN 978-837846-004-6.

18. ROBERTS, S. - KOLEWE, M. 2010. Plant natural products from cultured multipotent cells. Nature Biotechnology. 28(11), 1175-1176. ISSN 1087-0156.

19. SCHMID, D. a kol. 2008. Plant stem cell extract for longevity of skin and hair. SOFW Journal [online]. 2008, roč. 134, s. 30-35 [cit. 2021-03-16]. Dostupné na internete: <https://pdfs.semanticscholar.org/117a/4f1c63ec31bb283f3eef9c1bbb9 ed5ccf408.pdf>.

20. SCHURCH, C. a kol. 2008. Potential of plant cells in culture for cosmetic application. Phytochemistry Reviews. 7(3), 599-605. ISSN 1568-7767.

21. TITO, A. a kol. 2011. A tomato stem cell extract, containing antioxidant compounds and metal chelating factors, protects skin cells from heavy metal induced damages. International journal of cosmetic science. 33(6), 543-552. ISSN 1468-2494.

22. TREHAN, S. - MICHNIAK-KOHN, B. - BERI, K. 2017. Plant stem cells in cosmetics: current trends and future directions. Future Science OA. 3(4), 1-5. ISSN 2056-5623.

23. WANG, C. - WU, J. - MEI, X. 2001. Enhanced taxol production and release in Taxus chinensis cell suspension cultures with selected organic solvents and sucrose feeding. Biotechnology Progress. 17(1), 89-94. ISSN 1520-6033.

24. WARGHAT, A. R. - THAKUR, K. - SOOD, A. 2018. Plant stem cells: what we know and what is anticipated. Molecular Biology Reports. 45(6), 2897-2905. ISSN 0301-4851. 
25. WU, J. - ZHONG, J. J. 1999. Production of ginseng and its bioactive components in plant cell culture: current technological and applied aspects. Journal of Biotechnology. 68(2-3), 89-99. ISSN 0168-1656.

26. YAMAMOTO, H. a kol. 2002. Regulation of lithospermic acid B and shikonin production in Lithospermum erythrorhizon cell suspension cultures. Chemical and Pharmaceutical Bulletin. 50(8), 1086-1090. ISSN 1347-5223.

27. ZHOU, P. a kol. 2015. Effects of $\beta$-cyclodextrin and methyl jasmonate on the production of vindoline, catharanthine, and ajmalicine in Catharanthus roseus cambial meristematic cell cultures. Applied Microbiology and Biotechnology. 99(17), 7035-7045. ISSN 0175-7598.

\section{Kontaktné údaje}

Mgr. Šarlota Kaňuková, prof. RNDr. Ján Kraic, PhD.

Univerzita sv. Cyrila a Metoda v Trnave, Fakulta prírodných vied, Katedra biotechnológie

Námestie Jozefa Herdu 577/2, 91701 Trnava

Tel: +421911465322

email: sarlota.kanukova@fpvucm.sk

Mgr. Marcela Gubišová, PhD., prof. RNDr. Ján Kraic, PhD.

Národné pol'nohospodárske a potravinárske centrum, Výskumný ústav rastlinnej výroby, Bratislavská cesta 122, 92168 Piešt’any 


\title{
DOPLŇOVANIE OBSAHU ŽELEZA V ŽIVÝCH ORGANIZMOCH
}

\section{IRON CONTENT SUPPLEMENTATION IN LIVING ORGANISMS}

\author{
Katarína Mital'ová, Dušan Valigura
}

\begin{abstract}
Abstrakt
Správne fungovanie živých organizmov si vyžaduje dostatočný príjem makro a mikronutrientov v potrave. Nedostatočný ale aj prebytočný príjem dokáže spôsobit' rôzne patologické stavy. Nedostatkom aspoň jedného mikronutrientu trpí minimálne 1,5 miliardy l'udí, pričom deficit železa je najčastejším prípadom nedostatku mikronutrientu v l'udskom organizme. Za synonymum deficitu železa sa považuje anémia. Je to ochorenie spôsobené nedostatočným príjmom a obsahom železa $\mathrm{v}$ živom organizme. Tento stav môže byt' napravený doplnkami výživy, ktoré dokážu zlepšit' obsah železa v živom organizme a tým zlepšit' kvalitu života pacientov. Táto práca je zameraná na vytvorenie prehl'adu zlúčenín železa ktoré sa využívajú na doplňovanie obsahu železa v organizmoch s jeho nedostatkom a inovácií v obohacovaní potravín.
\end{abstract}

Kl'účové slová: železo, deficit železa, doplnky výživy

\begin{abstract}
The proper functioning of living organisms requires a sufficient intake of macro and micronutrients in the diet. Insufficient but also excess intake can cause various pathological conditions. At least 1.5 billion people suffer from at least one micronutrient deficiency. Iron deficiency is the most common case of micronutrient deficiency in the human body. Anemia is considered to be synonymous with iron deficiency. It is a disease caused by insufficient intake and iron content in a living organism. This condition can be corrected by nutritional supplements that can improve the iron content in a living organism and thus improve the quality of life of patients. This work is focused on creating an overview of iron compounds that are used to supplement the iron content in deficient organisms and innovations in food fortification.
\end{abstract}

Key words: iron, iron deficiency, food supplements

Hoci sa biológia vo všeobecnosti spája skôr s organickou chémiou, život bežných živých organizmov je nepredstavitel'ný bez prítomnosti niektorých kovových prvkov v nich. Význam niektorých kovov je taký vel'ký, že hovoríme o esenciálnych kovoch, pričom železo je typickým predstavitel'om esenciálneho prvku do takej miery, že hovoríme o jeho esencialite pre všetko živé - od mikroorganizmov, cez rastlinstvo a živočíchov, vrátane človeka (LIPPARD, BERG, 1994). Aj napriek esenciálnemu charakteru železa má jeho získavanie, transport, skladovanie aj využitie v organizmoch komplexný charakter a sú to striktne regulované procesy, ktoré sú vd'aka svojej zložitosti vel'mi citlivé na vonkajšie zmeny. Komplexný charakter procesov a spomínaná citlivost' k okolitým zmenám majú za následok častý výskyt poruchy - deficitu železa, ktorý si vyžaduje vonkajší zásah suplementáciou. Rozsah problémov deficitu železa a jeho suplementácie dokumentujú tisícky vedeckých prác každoročne publikovaných v rozmanitých vedných disciplínach a tento príspevok je pokusom poukázat' na základné postupy riešenia deficitu železa jeho suplementáciou od klasických postupov po v súčasnosti používané postupy. 


\section{1. ŽELEZO V ŽIVÝCH ORGANIZMOCH}

Železo je v rastlinnom organizme uložené $v$ chloroplastoch a je dôležité v procese fotosyntézy. Pre rastliny je hlavným zdrojom železa pôda a koncentrácie železa sa v pol'nohospodárskych pôdach pohybujú v rozmedzí $10^{-8}-10^{-6} \mathrm{M}$. V alkalických a vápenatých pôdach sú tieto koncentrácie ešte nižšie (WHITE, GREENWOOD, 2013). Nedostatok železa v rastlinách sa častejšie spája s nízkou dostupnostou než s malým výskytom (FAGERIA, 2009). Deficit železa sa v rastlinnom organizme prejavuje zožltnutím listov a menším vzrastom rastliny. Tento stav sa nazýva chloróza. Odhaduje sa, že až jedna tretina svetovej pol'nohospodárskej pôdy je vápenatá a rastliny ktoré sú na takýchto pôdach pestované sú citlivé na vznik chlorózy. Koncentrácia železa v pôde je väčšinou o tri poriadky nižšia než v rastlinných pletivách. L’udský organizmus obsahuje asi $4 \mathrm{~g}$ železa. Väčšina tohoto železa je obsiahnutá v transportných proteínoch (hemoglobín a myoglobín) (BOTHWELL, CHARLTON, COOK, FINCH, 1980). Odporúčaná denná dávka železa pre mužský organizmus je 13,7mg/l (FAO, 1998). Denná dávka železa pre ženský organizmus je $29,5 \mathrm{mg} / \mathrm{l}$, pričom u žien v reprodukčnom veku je táto hodnota vyššia. Pre oblasti, kde je strava tvorená najmä cereáliami, je denná dávka kvôli prítomnosti inhibítorov absorpcie železa ešte o niečo vyššia (GIBSON, BAILEY, GIBBS, FERGUSON, 2010). Homeostáza železa v l'udskom organizme je vel'mi zložitý a komplexný proces na ktorom sa podiel'a množstvo mechanizmov. Je regulovaná absorpciou, recykláciou železa a uvol'ňovaním železa z jeho zásobární. V l'udskom organizme je železo uskladnené v molekule feritínu, ktorá dokáže v prípade potreby prebytočné železo uvol'nit'. Deficit železa v l'udskom organizme sa úzko spája s anémiou. Je definovaná ako ochorenie s nízkym obsahom hemoglobínu spolu s jedným alebo viacerými indikátormi, ako je napr. nízky obsah zásob železa (LYNCH, 2012). Ide o najčastejší prípad nedostatku mikronutrientu v l'udskom organizme a anémiou trpí viac ako 2000 miliónov l'udí (SILVA, DUTRA-DE-OLIVEIRA, MARCHINI, 2004). Deficit železa sa vyskytuje najmä v rozvojových krajinách, kde sa strava skladá hlavne z cereálií, ktoré obsahujú vel'ké množstvo inhibítorov absorpcie železa. Prevencia a liečba tejto situácie sa zakladá na zmene stravovacích návykov, obohatení potravín a farmaceutickom doplnení železa (SILVA, DUTRA-DE-OLIVEIRA, MARCHINI, 2004). V rozvojových krajinách sa na rozvoji anémie podiel'ajú aj faktory ako sú infekcie, zápalové ochorenia, strata krvi v dôsledku parazitických infekcií a iné nutričné deficity (deficit vitamínu A, riboflavínu, vitamínu B12) (BRABIN, et. al. 2001).

\section{STRATÉGIE ZVYŠOVANIA OBSAHU ŽELEZA}

$\mathrm{Na}$ zvýšenie príjmu mikronutrientov existuje viacero ciest ich doplnenia. Prvou cestou je potravinová diverzifikácia. V chudobnejších oblastiach sveta je strava tvorená najmä obilninami, ktoré predstavujú viac než $50 \%$ dodávok energie v potrave (JOY, et. al. 2015). Diverzifikácia stravy môže potenciálne zlepšit’ príjem viacerých mikroživín. Táto stratégia je pomerne problematická a limitovaná kúpnou silou domácností a vyžaduje intenzívnu finančnú podporu a vzdelávanie v oblasti výživy. Druhou stratégiou je biofortifikácia. Ide o biologické obohatenie a produkciu plodín s vyššími koncentráciami živín (WHITE, BROADLEY, 2009). Vyššie koncentrácie živín v plodinách sa dajú dosiahnut' šlachtením, získavaním plodín so zníženou koncentráciou molekúl inhibítorov alebo použitím hnojív. Tret'ou možnost'ou je obohacovanie potravy fortifikátormi. Jedná sa o obohacovanie samotných potravín, ktoré do potravného ret'azca vstupujú už ,vylepšené“، Príkladom je pridanie železa do potravín alebo jedál, ktoré sa bežne nachádzajú v potravných ret’azcoch vel'kého množstva populácie. Takéto prístupy vyžadujú menšie zmeny v strave obyvatel'stva (KUPER, et. al. 2015). Obohacujú sa zvyčajne základné potraviny ako sú obilné múky, raňajkové cereálie, jedlý olej a sol'. Tento prístup bude pravdepodobne menej účinný v oblastiach kde sú domácnosti závislé od 
existenčnej výroby (subsaharská Afrika a južná Ázia). Rôzne prípadové štúdie v Ázii a Južnej Amerike zaznamenali rozsiahly systematický prehl'ad účinnosti železom obohatenej múky. Tieto štúdie opisujú slabý dôkaz zníženia prevalencie anémie, hoci obohacovanie trvalo znižovalo prevalenciu nízkej hladiny feritínu u žien (PACHÓN, et. al. 2015). Do potravy sa väčšinou pridáva anorganická sol železa ako je síran železnatý, chlorid železnatý ale aj komplexy železa ako je napr. NaFeEDTA. Poslednou, najčastejšie využívanou a najúčinnejšou stratégiou je priame doplnenie, najčastejšie vo forme tabliet. Poznáme niekol'ko tabletových foriem doplnkov výživy ktoré obsahujú zlúčeniny železa ktoré znižujú deficit železa v živých organizmoch.

\section{ZDROJE ŽELEZA}

Poznáme niekol'ko zdrojov železa ktoré sú vhodné na zvyšovanie obsahu železa v živých organizmoch. Po väčšine sa jedná o anorganické soli alebo komplexy železa. Zlúčeniny sa líšia relatívnou biologickou dostupnost'ou, ich relatívnou cenou a takisto vedl'ajšími účinkami. Prehl'ad zlúčenín železa vhodných na suplementáciu uvádzame v Tabul'ke 1.

Tab.1. Tabul'ka zlúčenín železa vhodných na suplementáciu (HURRELL, 2002)

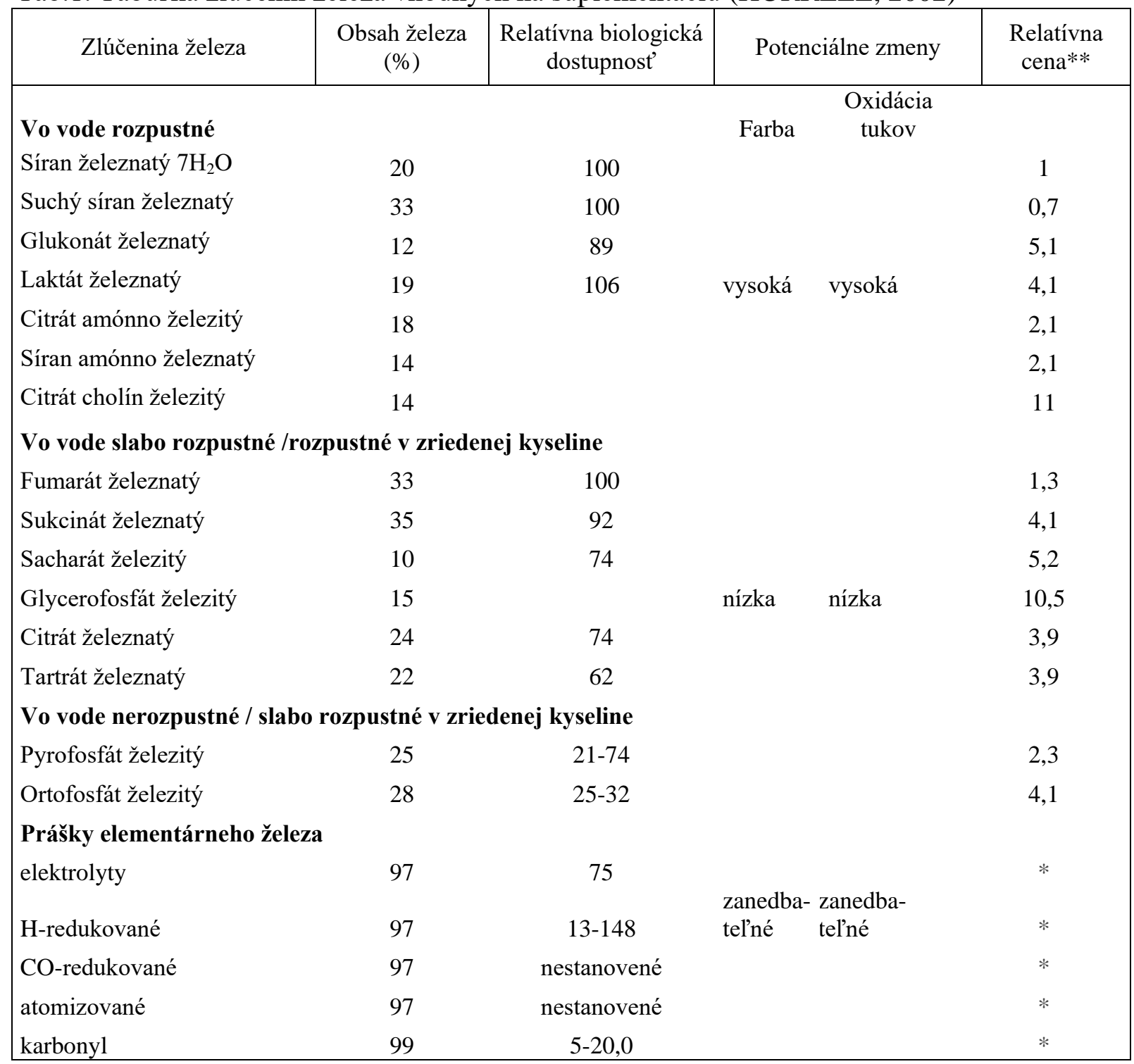

* vo všeobecnosti lacnejšie než síran železnatý, cena sa medzi rôznymi práškovými formami líši približne 7násobne, pričom karbonylové železo je najdrahšie

** relatívne k síranu železnatému $7 \mathrm{H}_{2} \mathrm{O}=1,0$ pre rovnakú hodnotu obsahu železa 
Zlúčeniny rozpustné vo vode majú z konvenčných zlúčenín železa najvyššiu relatívnu biologickú dostupnost' $(\mathrm{RBD}=100)$ a vo všeobecnosti by mali byt' pre potravinárske účely prvou vol'bou. V praxi je síran železnatý jediná vo vode rozpustná zlúčenina, ktorá sa bežne pridáva do potravín. Zároveň je to najznámejší a najdlhšie (od začiatku 19. stor.) využívaný zdroj železa. Ide o zlúčeninu s vysokou relatívnou biologickou dostupnost'ou a jeho dlhoročným využitím sa stal aj referenčným štandardom. Medzi jeho vedl'ajšie účinky patria gastrointestinálne problémy, ako je pálenie záhy, bolest' brucha, nevol'nost' alebo hnačka. Síran železnatý dokáže spôsobovat' aj neakceptovatel'nú zmenu chute a farby a preto sa dá pridat iba do malého počtu potravín. Pridáva sa do potravín ako je múka, chlieb a cereálie. $\mathrm{K}$ farebným zmenám dochádza v prípade kakaových produktov, detských cereálií, soli a v tortilách. Rozpustné zlúčeniny železa môžu spôsobit' kovovú príchut' bujónových kociek a ovocných nápojov a v sójovej omáčke, rybej omáčke a v čajoch môžu spôsobit' aj tvorbu precipitátov. Iné vo vode rozpustné zlúčeniny majú podobné RBD ale vyvolávajú podobné zmeny a sú drahšie (HURRELL, 2002). Zmeny farby a chute boli príčinou hl'adania vhodnejších alternatív zlúčenín železa.

Citrát amónno-železitý sa v potravinárskom priemysle využíva ako aditívum E381 a v medicíne sa vo forme tabliet Geritol využíva na liečbu anémie spôsobenej nedostatkom železa. Využíva sa tak u l'udí, ako aj u zvierat (OSOL, HOOVER, 1975; TENNE, BOGOSLAVSKY, BINO, 2015).

Ak dobre rozpustná zlúčenina železa spôsobuje v potravinách senzorické zmeny, d’alším krokom je vyhodnotenie zlúčenín ktoré sú síce slabo rozpustné vo vode, no sú l'ahko rozpustné v zriedenej kyseline. Tieto zlúčeniny majú podobné alebo mierne nižšie RBD v závislosti od toho, ako sa počas trávenia rozpustia v žalúdočnej št’ave. Najvhodnejšími zlúčeninami z tejto skupiny sú fumarát železnatý a sukcinát železnatý. Tieto zlúčeniny dokáže dospelý organizmus absorbovat' v rovnakom rozsahu ako síran železnatý. Vel'mi vhodnou alternatívou je sacharát železitý. Pri obohacovaní a príprave potravín by mal byt' braný do úvahy aj citrát železnatý, vínan železnatý a glycerofosforečnan železitý. $Z$ tejto skupiny sa v súčasnosti využíva iba fumarát a sacharát železnatý. Fumarát sa pridáva do komerčných dojčenských obilnín a sacharát do práškových čokoládových nápojov (HURRELL, 2002).

Zlúčeniny ktoré sú vo vode nerozpustné a v zriedenej kyseline sú slabo rozpustné majú najslabšiu absorpciu a pri výrobe potravín sú poslednou vol'bou. Počas trávenia sa v žalúdočnej št’ave rozpúštajú pomaly a neúplne. Miera ich rozpustnosti závisí od fyzikálnych charakteristík a od zloženia jedla, a z tohto dôvodu je ich absorpcia iba t'ažko predvídatel'ná. Do tejto skupiny sa zarad'ujú dva typy zlúčenín, a to práškové elementárne železo a zlúčeniny železa a fosforečnanu. Na obohacovanie detských cereálií a čokoládových práškových nápojov sa využíva pyrofosfát železitý a ortofosfát železitý. Pyrofosfát sa oproti síranu železnatému absorbuje na 25-75\%. V prípade ortofosfátu sa jedná o hodnoty 25-32\%. Práškové železo sa pridáva do cereálnej múky, raňajkových cereálií a cereálií pre deti. Existuje 5 typov elementárneho železa a každý typ je produkovaný iným postupom a má odlišnú vel'kost' častíc, hustotu, povrch, vlastnosti a tvar. Všetky tieto charakteristiky ovplyvňujú rozpustnost' prášku v žalúdku, čím ovplyvňujú biologickú dostupnost'. Doteraz publikované štúdie neumožňujú zhodnotit', či sú H-redukované, CO-redukované, atomizované alebo karbonylové železo vhodnými suplementami železa. Dáta efektívnosti v l'udských organizmoch pre tieto zlúčeniny neexistujú. Avšak prášky redukovaného železa s vel'kými časticami mali $\mathrm{v}$ štúdiách s potkanmi najslabšiu biologickú dostupnost' a tento výskum využitie lacných práškov železa ako suplementov železa neodporúča (HURRELL, 2002).

Poznáme ešte niekol'ko d'alších zlúčenín vhodných na doplnenie železa. Jednou z možností je aj využitie hemoglobínu vo forme vysušených hovädzích červených buniek $\mathrm{v}$ potrave. V tomto prípade je absorpcia relatívne dobre predpovedatel'ná. Enkapsulovaný síran a fumarát železnatý sú v súčasnosti komerčne dostupné. Enkapsulácia bráni senzorickým zmenám ktoré 
tieto zlúčeniny podporujú. Pot’ahovým materiálom je $\mathrm{v}$ tomto prípade maltodextrín, hydrogenovaný olej alebo etyl-celulóza. Enkapsulované železo sa preukázalo ako vhodná zlúčenina na obohacovanie cereálnej múky, no potenciálnym problémom ich použitia je ich tepelná nestabilita. Pred začlenením týchto zlúčenín do fortifikačných programov je potrebné preštudovat' biologickú dostupnost' a efektivitu týchto kapsúl. Takisto je potrebné zistit' či je kapsula počas trávenia odstránená a či je železo adekvátne absorbované (HURRELL, 2002).

Jednou z najnovších zlúčenín je glycinát železnatý. Táto zlúčenina sa v súčasnosti stáva jednou $\mathrm{z}$ najviac testovaných zlúčenín $\mathrm{v}$ súvislosti s deficitom železa. Za posledných 10-15 rokov sa stal účinným prostriedkom liečby anémie (SILVA, DUTRA-DE-OLIVEIRA, MARCHINI, 2004). Je definovaný ako chelát železa(II) s glycínom a v centre molekuly sa nachádza ión železa s naviazanými dvoma aniónmi glycínu. Existujú informácie, že prítomnost' glycinátu železnatého v potrave dokáže zabránit' interakcii železa s inhibítormi prítomnými v potrave (LINDSAY, 2002). Jedná sa o komerčne predávaný doplnok výživy, preto je informácií o jeho syntéze málo. Je vyrábaný firmou Albion Laboratories (USA) a proces výroby je chránený patentom (HURRELL, 2002).

V rastlinnej ríši sa využívajú najmä cheláty železa, pričom najčastejšie sa jedná o FeEDTA a FeDTPA. FeEDTA má na rastliny aj vedl'ajšie toxické efekty a preto je nutné hl'adanie vhodných alternatív. U rastlín paradajok bola vykonaná štúdia vyhodnocovania vplyvu a efektivity troch chelátov železa s aminokyselinami arginín, glycín a histidín. Komplexy železa s aminokyselinami mali v porovnaní s FeEDTA lepšie výsledky - zvýšili príjem a translokáciu železa, zinku, dusíka a tým zvýšili tvorbu koreňov a výhonkov paradajok. Zlepšenie nutričného statusu železa potvrdila aj zvýšená aktivita enzýmov (GHASEMI, et.al. 2012). Bolo vykonaných niekol'ko štúdií zameraných na vyhodnotenie efektívnosti glycinátu železnatého pri zvyšovaní obsahu železa a jeho vplyv bol vyhodnotený a potvrdený štúdiami (SZARFARC, et.al, 2001; BOVELL-BENJAMIN, et.al. 2000; OSMAN, et. al. 2002; PINEDA, et.al. 2001).

Ďalším pomerne známym a rozšíreným zdrojom železa je komplex NaFeEDTA. Tento komplex sa používa už od sedemdesiatych rokov a má dobrú biologickú dostupnost'. Zistilo sa však, že je menej účinný ako napr. askorbát železnatý a obohatenie kari prášku s NaFeEDTA znížilo počas dvojročnej štúdie v populácii Indie anémiu z 22\% na 5\% (BALLOT, MACPHAIL, BOTHWELL et. al. 1989). Porovnaním absorpcie železa zo síranu železnatého alebo NaFeEDTA sa zistilo, že NaFeEDTA sa z potravy absorbuje rýchlejšie. Jeho hlavnou výhodou je to, že železo chráni pred vytvorením väzby s inhibítormi absorpcie železa a s kyselinou fytovou. NaFeEDTA je vo vode rozpustný a môže preto spôsobit' neakceptovatel'né zmeny vo farbe potravín. Konzumácia rybej omáčky, cukru a kari prášku obohatených o NaFeEDTA zlepšila obsah železa v populácii. Táto zlúčenina je však 6 krát drahšia než síran železnatý (HURRELL, 2002).

\section{INOVÁCIE V OBLASTI OBOHACOVANIA POTRAVÍN A BIOFORTIFIKÁCIE}

Pokým budú deficity vitamínov a minerálov stále celosvetovým problémom, ktorý ovplyvňuje viac než dve miliardy l'udí alebo jedného jedinca z troch (FAO, IFAD, WFP, 2015), hl'adanie riešenia tejto situácie $\mathrm{v}$ snahe znížit' škodlivé účinky týchto nutričných ochorení je vel'mi dôležité (BLACK, et. al. 2008). K priamemu doplňovaniu železa vo forme tabliet je preto vhodné nájst' d'alšie, dodatočné stratégie ktoré by zvýšili efektivitu celého procesu. Takýmito prístupmi môžu byt' fortifikácia a biofortifikácia, ktorej sa v súčasnosti venuje vel'ká pozornost'. Tento prístup je zameraný na zavedenie mikronutrientu vo vysokej hustote do základných plodín a potravinárskych výrobkov rôznymi technikami bio inžinierstva. Pravidelný príjem vylepšených plodín a potravín dokáže bezpečne a efektívne zlepšit' hodnoty obsahu železa v organizme (BOUIS, SALTZMAN, 2017). 
Fortifikácia železa znamená pridanie železa do potravinových matríc s ciel'om zvýšit' ich nutričnú hodnotu a ich schopnost' poskytnút' obyvatel'stvu zdravotné benefity (WHO, 2015). Tvorba železom obohatených potravín je vel'mi zložitá, a to kvôli relatívne vel'mi reaktívnemu železu a kvôli jeho oxidačným vlastnostiam ktoré sú závislé od teploty a kontaktu so vzduchom. Dôsledkom týchto faktorov sú nežiaduce organoleptické fluktuácie (HUMA, N., SALIM-UR-REHMAN, ANJUM, F.M., MURTAZA, M.A., SHEIKH, M.A. 2007). Oxidačné procesy môžu zmenit' farbu obohacovanej potraviny, čím dochádza k znižovaniu kvality produktu. Vedeckou výzvou je preto dosiahnut' takú formu železa, ktorá má dostatočnú biologickú dostupnost' potrebnú na zvýšenie asimilácie železa a ktorá nevyvolá žiadne senzorické zmeny potravín a vedl'ajšie účinky. Táto metóda predstavuje z dlhodobého hl'adiska účinnú cestu zvyšovania obsahu železa normálnymi mechanizmami absorpcie železa z denného príjmu. Vel'kou výzvou je hl'adanie takej zlúčeniny železa, ktorá ponúka lepšiu absorpciu a zároveň nemení charakteristiky obohatenej potraviny.

Ako vhodné zdroje železa na účely fortifikácie boli inštitúciou European Food Safety Authority (EFSA) navrhnuté zlúčeniny - glycinát železnatý, NaFeEDTA, etyléndiamíntetraacetát, taurát železitý a L-pidolát železa (EFSA, 2010, EFSA, 2009, EFSA, 2007). Obohacovanou potravinou musí byt' potravina ktorá sa pravidelne konzumuje a do úvahy sa musí brat' aj ciel'ová skupina ktorá bude tieto potraviny konzumovat', ako aj kompozícia matrice potraviny kvôli efektom urýchl'ovačov a inhibítorov (BLANCO-ROJO, VAQUERO, 2019). I ked' enkapsulácia železa do potravinovej matrice dokáže bránit' interakcii železa s ostatnými zložkami potravín, experimentálne výsledky na l'udských a živočíšnych modeloch ukazujú, že nezáleží na tom aký dobrý je fortifikátor, no jeho konzumácia v kombinácii s urýchl'ovačmi alebo inhibítormi reguluje finálny výsledok (SHILPASHREE et. al. 2015).

Ked’že je výskum nových fortifikátorov železa vo vývoji, nanotechnologické inžinierstvo vyvinulo také formy železa a potravín, ktoré sa dobre absorbujú (GHARIBZAHEDI, JAFARI, 2017). Fortifikácia mliečnych produktov je kvôli oxidácii železa(II) na železo(III) vel'mi zložitá, ked’že táto redoxná zmena môže zmenit' farbu, chut', vôňu a textúru potravín. Cheng et. al. vyvinuli lipozómy síranu železitého, ako zdroja železa ktorý sa dá použit' ako fortifikátor mliečnych produktov (CHENG, et.al. 2020). Táto metóda v porovnaní s ostatnými zlepšila oxidačnú stabilitu a biokompatibilitu. Lipozomálna mikroenkapsulácia predstavuje technológiu, ktorá chráni železo pred priamou interakciou s ostatnými komponentami potravín, čím dochádza $\mathrm{k}$ minimalizovaniu oxidácie, zlepšeniu biologickej dostupnosti železa a kompenzácii senzorických zmien (KOSARAJU, TRAN, LAWRENCE, 2006). Ostatné techniky zamerané na zníženie vel'kosti častíc železa sú skúmané. Existuje predpoklad o využití nanočastíc feritínu ako zdroja železa, no mechanizmus jeho absorpcie nie je úplne známy (LATUNDE-DADA, et.al. 2014).

Prístupy genetického inžinierstva sú v porovnaní s konvenčnými a agronomickými prístupmi šlachtenia rastlín pri študovaní genotypových a fenotypových asociácií medzi rastlinami efektívne a konzistentné. Genetická biofortifikácia ja založená na prístupe k neobmedzenému genofondu na alokáciu a expresiu požadovaných génov z jedného rastlinného druhu na druhý, bez ohl'adu na ich vývojový stav alebo taxonómiu, s ciel'om manipulovat' s nukleovou kyselinou organizmu. Výsledok tejto techniky je uznávaný ako geneticky modifikovaný organizmus (SHARIATIPOUR, HEIDARI, 2020). Hlavným ciel'om genetickej biofortifikácie je zlepšit' biologickú dostupnost' mikronutrientu v jedlých častiach rastliny. Enzýmy ako nikotínamid syntáza, phytoén syntáza, feritín a karotén desaturáza boli použité v rozličných plodinách na zlepšenie nutričných vlastností. Nikotínamid je komplexujúci ligand a manipulácia s jeho koncentráciou môže zväčšit' obsah železa v rastlinách (BEASLEY, et.al. 2019) a feritín dokáže zlepšit' obsah železa v rastlinách kvôli kapacite uskladnenia železa (BOONYAVES, et. al. 2017). Metódy úpravy genómu, ako je zavedenie génov s 
požadovanými vlastnost’ami $\mathrm{z}$ iných organizmov, nadmerná expresia tých istých génov, interferencia tlmenia génov (RNAi) a vyradenie génov, sú transgénne prístupy používané na opis účelu génov ako náhrad, ak je nedostatočná genetická nepodobnost' v množstvách živín medzi odrodami rastlín (YIN, et. al. 2017). Genetická biofortifikácia prostredníctvom transkripčných faktorov má v porovnaní s GMO menej striktné usmernenia a monitoring či už vládnymi alebo nevládnymi inštitúciami (LIBERAL, et. al. 2020). Momentálne je vel'kou výzvou aj spájanie rôznych metód molekulárneho šlachtenia a genomických postupov, ako je selekcia pomocou markerov, asociačná genetika, vysokovýkonná fenotypizácia a genotypizácia pre špecifické znaky. Transgénne metódy možno použit' na súčasnú integráciu génov zamotaných do zlepšenia biologickej dostupnosti mikroživín (zníženie inhibítorov a zlepšenie zosilňovačov absorpcie železa) a ich koncentrácie v rastlinách (SHARIATIPOUR, HEIDARI, 2020).

Biofortifikácia plodín sa môže vykonávat' pomocou mikrobiálnych očkovacích látok/biofertilizátorov, ktoré organizujú minerálne mikronutrienty $\mathrm{v}$ pôde a tým ich robia dostupnejšími pre rastlinu. Spomedzi rozličných skupín mikroorganizmov, rhizobaktérie ovplyvňujú rast rastliny a využívajú jeden alebo viac priamych a sekundárnych mechanizmov pôsobenia na zvýšenie vývoja a dobrých životných podmienok rastlín, aj ked' hlavným prístupom k opatreniam je zlepšenie prístupu živín k rastline. (ANTOUN, PRÉVOST, 2006; LIBERAL, 2020).

Okrem komerčne využívaných suplementov vo forme tabliet, je do budúcnosti vhodné hl'adat' kombináciu fortifikácie a biofortifikácie. Je ale potrebné zohl'adnit' ciel'ovú skupinu, potrebný príjem a je potrebné vytvorit' vhodnejšiu kombináciu jednotlivých prístupov s jediným ciel'om - znížit' výskyt anémie, a to najmä v rozvojových krajinách.

\section{Použitá literatúra}

1. ANTOUN, Hani, PRÉVOST, Danielle. Ecology of plant growth promoting bacteria. In PGPR: Biocontrol and Biofertilization. Dordrecht : Springer Dordrecht, 2006, s.138. ISBN 1-4020-4002-4.

2. BALlOT, E. Daynia, MACPHAIL, A. Patrick, BOTHWELl, H. Thomas, GILLOOLY, Mary, MAYET, G. Fatima. Fortification of curry powder with $\mathrm{NaFe}(\mathrm{III})$ EDTA: report of a controlled iron fortification trial. The American Journal of Clinical Nutrition. 1989, 49, 156-161. ISSN 1938-3207.

3. BEASLEY, T. Jesse, BONNEAU, P. Julien, SÁNCHEZ-PALACIOS, T. José, MORENO-MOYANO, T. Laura, CALLAHAN, L. Damien, TAKO, Elad, GLAHN, P.Raymond, LOMBI, Enzo, JOHNSON, A.T Alexander. Metabolic engineering of bread wheat improves grain iron Concentration and Bioavailability. Plant Biotechnology Journal. 2019, 17, 1514-1526. ISSN 1467-7652.

4. BLACK, E. Robert, ALLEN, H. Lindsay, BHUTTA, A. Zulfiqar., CAULFIELD, E. Laura, de ONIS, Mercedes, EZZATI, Majid, MATHERS, Colin, RIVERA, Juan. Maternal and child undernutrition : Global and regional exposures and health consequences. Lancet. 2008, 371, 243-260. ISSN 0140-6736.

5. BLANCO-ROJO, Ruth, VAQUERO, M. Pilar. Iron Bioavailability from food fortification to precision Nutrition. A review. Innovative Food Science and Emerging Technologies. 2019, 51, 126-138. ISSN 1466-8564.

6. BOONYAVES, Kulaporn, WU, Ting-Ying, GRUISSEM, Wilhelm, BHULLAR, K. Navreet. Enhanced grain iron levels in iron-regulated metal transporter, nicotianamine synthase, and ferritin gene cassette. Frontiers in Plant Science. 2017, 8, 130. ISSN 1664-462X.

7. BOTHWELL, T.H., CHARLTON, R.W., COOK, J.D., FINCH, C.A. 1980. Iron Metabolism in Man. Experimental Physiology. 1980, 65, 255-256. ISSN 1469-445X. 
8. BOUIS, E. Howarth, SALTZMAN, Amy. Improving Nutrition through biofortification : A review of evidence from HarvestPlus, 2003 through 2016. Global Food Security. 2017, 12, 49-58. ISSN 2211-9124.

9. BOVELL-BENJAMIN, A.C., VITERI, F.E., ALLEN, A.H. Iron absorption from ferrous bisglycinate and ferric trisglycinate in whole maize is regulated by iron status. The American Journal of Clinical Nutrition. 2000, 71, 1563-9. ISSN 19383207.

10. BRABIN, J. Bernard, PREMJI, Zulfiqarali, VERHOEFF, Francine. An analysis of anemia and child mortality. Journal of Nutrition. 2001, 131, 636S-648S. ISSN 15416100.

11. EFSA. Panel on Food Additives and Nutrient Sources added to Food (ANS) Scientific Opinion on the use of ferric sodium EDTA as a source of iron added for nutritional purposes to foods for the general population (including food supplements) and to foods for particular nutritional uses. EFSA Journal. 2010, 8, 141414. ISSN $1831-4732$.

12. EFSA. Iron (II) taurate, magnesium taurate and magnesium acetyl taurate as sources of iron or magnesium added for nutritional purposes in food supplements. EFSA Journal. 2009, 7, 947. ISSN 1831-4732.

13. EFSA. Opinion of the Scientific Panel on food additives, flavourings, processing aids and materials in contact with food (AFC) related to Calcium, iron, magnesium, potassium and zinc L-pidolate as sources for calcium, iron, magnesium, potassium and zinc added for nutritional purposes to food supplements and to foods intended for particular nutritional uses. EFSA Journal. 2007, 5, 495. ISSN 1831-4732.

14. FAGERIA Nand Kumar. The use of Nutrients in Crop Plants. First edition. London : CRC Press, 2009. ISBN 978-1-4200-7510-6.

15. FAO, IFAD, WFP. The State of Food Insecurity in the World 2015. Meeting the 2015 International Hunger Targets: Taking Stock of Uneven Progress 2015. Available online: http://www.fao.org/3/i4646e/i4646e.pdf

16. FAO/WHO. Vitamin and Mineral Requirements in Human Nutrition. Second edition. Geneva : World Health Organization, 1998. ISBN 924154612.

17. GHARIBZAHEDI, Seyed, JAFARI, Seid. The importance of minerals in human Nutrition : Bioavailability, food fortification, processing effects and nanoencapsulation. Trends in Food Science and Technology. 2017, 62,119-132. ISSN 0924-2244.

18. GHASEMI, Somayeh et. al. Synthesis of iron - amino acid chelates and evaluation of their efficacy as iron source and growth stimulator for tomato in nutrient solution culture. Journal of Plant Growth Regulation. 2012, 31, 498-508. ISSN 1435-8107.

19. GIBSON, S. Rosalind, BAILEY, B. Karl, GIBBS, Michelle, FERGUSON, L. Elaine. A review of phytate, iron, zinc and calcium concentrations in plant-based complementary foods used in low-income countries and implications for bioavailability. Food and Nutrition Bulletin. 2010, 31, S134-S146. ISSN 1564-8265.

20. HUMA, Nuzhat, SALIM-UR-REHMAN, ANJUM, Faqir Muhammad, MURTAZA, M. Anjum, SHEIKH, A. Munir. Food fortification stratégy - Preventing iron deficiency anemia. A review. Critical Reviews in Food Science and Nutrition. 2007, 47, 259-265. ISSN 1549-7852.

21. HURRELL, Richard. How to Ensure Adequte Iron Absorption from Iron-fortified Food. Nutrition Reviews. 2002, 60, S7-S15. ISSN 1753-4887.

22. CHENG, Jin, KENAAN, Ahmad, ZHAO, Di, QI ME, Daizong, SONG, Jie. Photopolymerizable ferrous sulfate liposomes as vehicles for iron fortification of food. 
Nanomedicine: Nanotechnology Biology and Medicine. 2020, 30, 102286. ISSN 1549-9634.

23. JOY, Edward. et. al. Dietary mineral supplies in Malawi : spatial and socioeconomic assessment. BMC Nutrition. 2015b, 42, 1-25. ISSN 2055-0928.

24. KOSARAJU, L. Shantha, TRAN, Cindy, LAWRENCE, Andrew. Liposomal delivery systems for encapsualtion of ferrous sulfate : Preparation and characterization. Journal of Liposome Research. 2006, 16, 347-358. ISSN 1532-2394.

25. KUPER, Hannah et. al. Malnutrition and childhood disability in Turkana, Kenya : results from a case-control study. PLoS One. 2015, 10, 1-13. ISSN 1932-6203.

26. LATUNDE-DADA, Gladys, PEREIRA, Dora, TEMPEST, Bethan, ILYAS, Hibah, FLYNN, Angela, ASLAM, Mohamad, POWELL, Jonathan, SIMPSON, Robert. A nanoparticulate ferritin-core mimetic is well taken up by HuTu 80 duodenal cells and its absorption in mice is regulated by body iron. Journal of Nutrition. 2014, 144, 1896-1902. ISSN 1541-6100.

27. LIBERAL, Angela, PINELA, José, VÍVAR-QUINTANA, Ana Maria, FERREIRA, C.F.R. Isabel, BARROS, Lilian. Fighting Iron- Deficiency Anemia : Innovations in Food Fortificants and Biofortification Strategies. Foods. 2020, 9,1871. ISSN 2304-8518.

28. LINDSAY, H. Allen. Advantages and Limitations of Iron Amino Acid Chelates as Iron Fortificants. Nutrition Reviews. 2002, 60, S18-S21, ISSN 1753-4887.

29. LIPPARD, J. Stephen, BERG, M. Jeremy. Principles of bioinorganic chemistry. California : University Science Books, Mill Valley, 1994. ISBN 0-935702-73-3.

30. LYNCH, Sean. The rationale for selecting and standardizing iron status indicators. In : World Health Organization. Report : priorities in the assessment of vitamin A and iron status in populations, Panama City, Panama, 15-17 September 2010. Geneva. WHO, 2012.

31. OSMAN, A. Karrar, Al-OTHAIMEEN, Abdulaziz. Experience with Ferrous BisGlycine Chelate as an Iron Fortificant in Milk. International Journal for Vitamin and Nutrition Research. 2002, 72, 257-63. ISSN 0300-9831.

32. OSOL, Arthur, HOOVER, E. John. Remington's Pharmaceutical Sciences, Mack Publishing Co., 1975. s.777. ISBN 9780128223895.

33. PACHÓN, Helena et. al. Evidence of the effectiveness of flour fortification programs on iron status and anemia : a systematic review. Nutrition Reviews. 2015, 73, 780795. ISSN 1753-4887.

34. PINEDA, O., ASHMEAD, H.D. Effectiveness of treatment of iron-deficiency anemia in infants and young children with ferrous bis-glycinate chelate. Nutrition. 2001, 17, 381-4. ISSN 1873-1244.

35. SHARIATIPOUR, Nikwan, HEIDARI, Bahram. Genetic-Based Biofortification of Staple Food Crops to Meet Zinc and Iron Deficiency-Related Challenges. In : Plant Micronutrients. Berlin/Heidelberg : Springer International Publishing. 2020, s. 173223, ISBN 978-3-030-49856-6.

36. SHILPASHREE, B.G., ARORA, Sumit, SHARMA, Vivek, SINGH, A.K. Preparation of succinylated sodium caseinate-iron complex by adopting ultrafiltration technology : A novel food fortificant. Innovative Food Science and Emerging Technologies. 2015, 32, 165-171. ISSN 1466-8564.

37. SILVA, Luciana Ferreira, DUTRA-DE-OLIVEIRA, José, MARCHINI J. Sérgio. Serum iron analysis of adults receiving three differenct iron compounds. Nutrition Research. 2004, 24, 603-611. ISSN 0271-5317.

38. SZARFARC, Sophia Cornbluth et. al. Relative Effectiveness of iron bis-glycinate chelate (Ferrochel) and ferrous sulfate in the control of iron deficiency in pregnant women. Archivos Latinoamericanos de nutrición. 2001, 51, 42-47. ISSN 2309-5806. 
39. TENNE, Dana, BOGOSLAVSKY, Benny, BINO, Avi. Ferric Ammonium Citrate What's in it? European Journal of Inorganic Chemistry. 2015, 25, 4159-4161. ISSN 1099-0682.

40. WHITE, J. Philip, BROADLEY, R. Martin. Biofortification of crops with seven mineral elements often lacking in human diets-iron, zinc, copper, calcium, magnesium, selenium and iodine. New Phytologist. 2009, 182, 49-84. ISSN 1469-8137.

41. WHITE, J. Philip, GREENWOOD, J. Duncan. Properties and management of cationic elements for crop growth. In: Soil Conditions and Plant Growth. Chichester : Wiley - Blackwell Publishing, 2013. s. 160-164. ISBN 9781118337295.

42. World Health Organization. The Global Prevalence of Anaemia in 2011, Geneva World Health Organization : Geneva, Switzerland, 2015.

43. YIN, Xiaojia, BISWAL, K. Akshaya, DIONORA, Jacqueline, PERDIGON, M. Kristel, BALAHADIA, P. Christian, MAZUMDAR, Shamik, CHATER, Caspar, LIN, Hsiang-Chun, COE, A. Robert, KREZSCHMAR, Tobias. et. al. CRISPR-Cas9 and CRISPRT-Cpf1 mediated targetting of a stomatal developmental gene EPFL9 in rice. Plant Cell Reports. 2017, 36, 745-757. ISSN 1432-203X.

\section{Kontakt}

RNDr. Katarína Mital'ová

Univerzita sv. Cyrila a Metoda v Trnave, Fakulta prírodných vied

Nám. J. Herdu 2, 91701 Trnava

Tel: 033/5565398

email: katarinamitalova@gmail.com 


\title{
VPLYV EDUKÁCIE NA KVALITU ŽIVOTA PACIENTOV S DIABETES MELLITUS 2. TYPU
}

\section{EFFECT OF EDUCATION ON THE QUALITY OF LIFE OF PATIENTS WITH DIABETES MELLITUS TYPE 2}

\author{
Andrea Šuličová, Tatiana Šantová, Zuzana Šimová, Jana Cinová, Lubica \\ Derňarová, Zuzana Novotná, Lubomíra Lizáková, Andrea Obročníková
}

\begin{abstract}
Abstrakt
Diabetes mellitus 2. typu (DM 2) - cukrovka, patrí medzi najčastejšie sa vyskytujúce ochorenia modernej civilizácie. V dôsledku akútnych a chronických komplikácií významne zhoršuje kvalitu života a zvyšuje úmrtnost' pacientov. Efektívna edukácia sa pokladá za základ liečby DM. Vplyv efektívnej edukácie pozitívne koreluje s dodržiavaním liečebných opatrení a lepšou kvalitou života pacienta s DM. V príspevku uvádzame výsledky výskumu vplyvu edukácie na kvalitu života u 70 respondentov - pacientov s DM 2. typu.
\end{abstract}

Klíčová slova: diabetes mellitus 2. typu, pacient, edukácia, kvalita života

\begin{abstract}
Diabetes mellitus type 2 (DM 2) is one of the most common diseases of modern civilization. Due to acute and chronic complications, it significantly worsens the quality of life and increases patient mortality. Effective education is considered to be the basis of DM treatment. The impact of effective education is positively correlated with adherence to treatment measures and a better quality of life for patients with DM. In this paper, we present the results of research on the impact of education on quality of life in 70 respondents - patients with DM type 2 .
\end{abstract}

Key words: diabetes mellitus type 2, patient, education, quality of life

\section{EDUKÁCIA PACIENTOV S DIABETES MELLITUS}

Edukácia sa označuje ako proces vzdelávania a výchovy. Edukácia je celoživotný proces. Je to systém odovzdávania určitej sústavy teoretických vedomostí as nimi spojených intelektuálnych a manuálnych návykov a zručností. Zameriava sa na zdravých l'udí ako aj na l'udí v každom štádiu choroby, s ciel'om maximalizovat' l'udský potenciál pre zdravý život a lepšiu kvalitu jeho života. Pre edukáciu je charakteristický celostný prístup k človeku, zahŕňa fyzické, psychické, sociálne, emocionálne, duchovné a spoločenské aspekty. Ciel'om edukácie je dosiahnut' a udržat' pacienta vaktívnej a konštruktívnej úlohe spolutvorcu liečby. Za edukovaného pacienta považujeme takého pacienta, ktorý vie a dokáže realizovat' selfmonitoring, dokáže adekvátne reagovat' a prispôsobit' sa zmenám denného režimu (1). Medzi prvé základne liečebné postupy u diabetikov patrí udržanie optimálneho životného štýlu, ktorý zahŕňa edukačný proces orientovaný na zmeny v stravovaní - diétny režim a pohybovú aktivitu. Základ edukácie pacienta tvoria vedomosti a poznatky o cukrovke, ciele liečby, diétny a pohybový režim, selfmonitoring glykémie a glykozúrie a prevencia vzniku komplikácií, predovšetkým diabetickej nohy. Ďalšou prioritou je podstata liečby inzulínom, technika aplikácie inzulínu a prevencia a liečba hypoglykémie. Ciel'om diabetikov je zdravie, preto by sa edukácia mala stat' prioritou. Počas procesu edukácie je dôležitý vzt’ah lekára 
k pacientovi a vl'údny prístup (2). Aj sestra ako profesionál v ošetrovatel'stve musí okrem ostatných činností zvládat' aj rolu edukátora. Súčast'ou roly náročnej na čas a profesijné kompetencie je vyžadovanie riešenia multidimenzionálnych a multivariabilných edukačných situácií. Pozitívny prístup diabetika k edukácii a zaujatie správneho postoja je prospešná kompenzácia choroby. Edukátor sa snaží o zabezpečenie súladu medzi nadobudnutými vedomost’ami, zručnost’ami a prosperitou životného štýlu pacienta. Edukáciu prispôsobuje tomu, aby bol chorý schopný uspokojit' svoje premieňajúce sa potreby a podiel'at' sa na zlepšení vlastného života (3). Edukátor tak významne pomáha diabetikom pri preberaní zodpovednosti za celkové zdravie, selfmanažment DM, uvedomenie si súvislostí a nájdenie vlastných spôsobov na zabezpečenie primeranej kvality života aj napriek DM. Edukácia diabetikov odstraňuje deficit vedomostí a zručností, ktoré vznikli a mohli by pretrvávat' vzhl'adom k prítomnosti DM (4). Chronické choroby na celom svete pribúdajú a stali sa významnou zát'ažou pre osoby postihnuté týmito chorobami. Vzdelávacie programy špecifické pre jednotlivé choroby preukázali zlepšené výsledky, hoci l'udia rýchlo zabudnú na informácie alebo si ich nesprávne zapamätajú. Preto sa v praxi využíva aj metóda spätného učenia, ktorá má za ciel' posilnit' a upevnit' vedomosti a zručnosti pacientov $\mathrm{v}$ selfmanagemente ochorenia (5).

\subsection{Oblasti edukácie pacientov s DM}

Hlavným ciel'om edukácie je zlepšenie zdravotného stavu pacienta s diabetom, kompenzácia diabetu a podpora zdravia. Dobre edukovaný pacient podl'a ADA (2013, s. 11-66), zodpovedá za každodenné samostatné rozhodovanie o dodržiavaní liečby (úprava diéty, úprava dávok inzulínu a i.) - ide o tzv. selfmanagement diabetu. Selfmonitoring, alebo ako samostatné meranie a kontrola vybraných parametrov viažucich sa ku kompenzácii diabetu samotným pacientom, je neoddelitel'nou súčast'ou selfmanagementu diabetu. Do selfmonitoringu zarad’ujeme najmä samostatnú kontrolu glykémie a následnú úpravu režimu, tiež samostatnú kontrolu krvného tlaku, hmotnosti, prípadne aj glykozúrie a ketonúrie. Patrí sem však aj vedomé sledovanie predovšetkým HbAlc, krvných tukov a bielkovín v moči (najmä tzv. mikroalbuminúrie) (1).

\subsection{Kvalita života pacientov s DM}

Interpretáciu kvality života v súčasnosti ponímame ako predmetnú globálnu problematiku. V ostatnej dobe sa permanentne diskutuje o kvalite života a jej efektívnom pôsobení v rôznych aspektoch l'udského života (6). Pojem kvalita života reprezentuje rozličné aspekty života, a preto pokusy o jeho vymedzenie obsahu pojmu tvoria nejednotnost' (7). WHO uvádza, že kvalita života zahŕňa 6 hlavných domén: telesná doména, psychická doména, miera nezávislosti, spoločenské vzt’ahy, prostredie, spiritualita, náboženstvo, osobné presvedčenie (8).

Kvalita života sa stala významným ukazovatel'om vyhodnocovania vplyvov chronického ochorenia, ako je napríklad diabetes mellitus. Pri meraní kvality života u osôb s diabetom sú často využívané generické nástroje, ako napr. SF-36, WHO škála pohody (WHO Well Being Qustionnaire), škála psychosociálnej adaptácie na ochorenie (Psychosocial Adjustment to Illnes Scale), NHP, SIP, EQ-5D a mnohé d’alšie (9).

\section{HODNOTENIE SELFMANAGEMENTU PRI LIEČBE U PACIENTOV S DM 2. TYPU}

\subsection{Ciele výskumu}

Hlavným ciel'om štúdie bolo zistit' vnímanie svojich vedomostí a zručností v dodržiavaní liečebných opatrení a prevencii komplikácií ochorenia DM 2. typu prostredníctvom ich 
subjektívneho vyjadrenia. Na základe hlavného ciel'a sme si stanovili čiastkové ciele: zistit', do akej miery majú respondenti poskytnuté poradenstvo a edukáciu v súvislosti $\mathrm{s}$ liečbou diabetu, zistit' do akej miery hodnotia respondenti svoje vedomosti a zručnosti v súvislosti s diabetom, zistit', či respondenti dodržujú predpísanú diétu, zistit', či vedia oddialit' alebo predchádzat' jednotlivým problémom súvisiacimi s DM, identifikovat' bariéry pri cvičení a fyzickej aktivite, identifikovat' mieru prekážok selfmonitoringu a starostlivosti o seba.

\subsection{Súbor a metodika}

Výskumnú vzorku tvorilo 70 respondentov s ochorením diabetes mellitus 2. typu, z toho 40 respondentov (57\%) sú na perorálnych antidiabetikách (PAD), 27 (39\%) majú kombinovanú liečbu (PAD + inzulín) a 3 respondenti (4\%) si aplikujú len inzulín. Vzorku tvorilo 41 žien (59 \%) a 29 mužov (41 \%) vo vekovom rozhraní od 33 do 72 rokov. Na zber údajov sme použili štandardizovaný dotazník Michigan Diabetes Research and Training Center's Brief Diabetes Care Profil DCP. Jednotlivé položky dotazníka boli rozdelené do 6 oblastí, ktoré zahŕňali jednotlivé sekcie, sekcia edukácia / poskytnuté poradenstvo, sekcia porozumenie, sekcia diéta, sekcia význam dlhodobej starostlivosti, sekcia bariéry pri cvičení a fyzickej aktivite a sekcia monitoring prekážok selfmonitoringu a starostlivosti o seba.

\subsection{Výsledky}

Tabul'ka č. 1 Množstvo meraní hladiny cukru v krvi počas dňa

\begin{tabular}{|c|c|c|}
\hline Možnosti & Počet (n) & \% \\
\hline 1 x (ráno) & 34 & 81 \\
\hline 2 x (ráno, večer) & 6 & 14 \\
\hline 3 x (ráno, obed, večer) & 2 & 5 \\
\hline Spolu & $\mathbf{4 2}$ & $\mathbf{1 0 0}$ \\
\hline
\end{tabular}

Tabul'ka č. 2 Celková starostlivost' o diabetes

\begin{tabular}{|c|c|c|c|}
\hline Možnosti & $\begin{array}{c}\text { Stupeň Likertovej } \\
\text { škály }\end{array}$ & Počet (n) & \% \\
\hline Slabé & 1 & 4 & 6 \\
\hline Skôr slabé & 2 & 0 & 0 \\
\hline Dobré & 3 & 29 & 41 \\
\hline Skôr vynikajúce & 4 & 15 & 21 \\
\hline Vynikajúce & 5 & 22 & 31 \\
\hline Spolu & & $\mathbf{7 0}$ & $\mathbf{1 0 0}$ \\
\hline
\end{tabular}

Tabul'ka č. 3 Subjektívne zhodnotenie vedomostí o diabetickej diéte

\begin{tabular}{|c|c|c|c|}
\hline Možnosti & $\begin{array}{c}\text { Stupeň Likertovej } \\
\text { škály }\end{array}$ & Počet (n) & \% \\
\hline Slabé & 1 & 2 & 3 \\
\hline Skôr slabé & 2 & 1 & 1 \\
\hline Dobré & 3 & 9 & 13 \\
\hline Skôr vynikajúce & 4 & 21 & 30 \\
\hline Vynikajúce & 5 & 37 & 53 \\
\hline Spolu & & $\mathbf{7 0}$ & $\mathbf{1 0 0}$ \\
\hline
\end{tabular}


Tabul'ka č. 4 Dôležitost' cvičenia u diabetika

\begin{tabular}{|c|c|c|c|}
\hline Možnost' & $\begin{array}{c}\text { Stupeň Likertovej } \\
\text { škály }\end{array}$ & Počet (n) & \% \\
\hline Slabé & 1 & 7 & 10 \\
\hline Skôr slabé & 2 & 3 & 4 \\
\hline Dobré & 3 & 16 & 23 \\
\hline Skôr vynikajúce & 4 & 16 & 23 \\
\hline Vynikajúce & 5 & 28 & 40 \\
\hline Spolu & & $\mathbf{7 0}$ & $\mathbf{1 0 0}$ \\
\hline
\end{tabular}

Tabul'ka č. 5 Vplyv diéty, cvičenia a liekov na hladinu cukru v krvi

\begin{tabular}{|c|c|c|c|}
\hline Možnosti & $\begin{array}{c}\text { Stupeň Likertovej } \\
\text { škály }\end{array}$ & Počet (n) & \% \\
\hline Slabé & 1 & 6 & 9 \\
\hline Skôr slabé & 2 & 3 & 4 \\
\hline Dobré & 3 & 24 & 34 \\
\hline Skôr vynikajúce & 4 & 11 & 16 \\
\hline Vynikajúce & 5 & 26 & 37 \\
\hline Spolu & & $\mathbf{7 0}$ & $\mathbf{1 0 0}$ \\
\hline
\end{tabular}

\subsection{Diskusia}

Terapia diabetu zahŕňa selfmonitoring, diétoterapiu, pohybový režim, perorálnu liečbu antidiabetikami, inzulínoterapiu, prevenciu akútnych a chronických komplikácií diabetu. Bez primeranej edukácie je pacient s DM ohrozený vznikom závažných komplikácii, či už akútnych ako je hypoglykémia alebo chronických, tzv. neskorých ako je rozvoj mikro a makro angiopatie, diabetickej nohy, nefropatie, neuropatie alebo diabetickej retinopatie.

V príspevku hodnotíme výsledky štúdie zameranej na subjektívne hodnotenie úrovne svojich vedomostí a zručností pri liečbe DM po poskytnutej edukácii a tiež úroveň dodržiavania liečebno-preventívnych opatrení v každodennom živote pacientov s DM.

Prvou sledovanou oblast'ou liečby DM bolo meranie glykémie. Respondentov, ktorí si kontrolujú hladinu cukru v krvi, bolo percentuálne viac ako tých, ktorí si ju nekontrolujú. $\mathrm{Na}$ otázku kol'ko dní v týždni si merali hladinu cukru v krvi, 42 respondentov odpovedalo, že každý deň. Počas dňa si merajú hladinu cukru v krvi raz. Tí respondenti, ktorí si kontrolujú hladinu cukru v krvi, vedú si aj záznamy o nameraných hodnotách glykémie. Avšak viac ako polovica respondentov si nevedie záznamy o nameraných hodnotách glykémie. Ako najčastejšie prekážky selfmonitoringu a starostlivosti o seba respondenti identifikovali nevykonanie si testu na hladinu glukózy kvôli zábudlivosti, problému nájst' vhodný čas alebo miesto, kde by si zmerali hladinu glukózy glukomerom, dôjdenia zásob testovacích potrieb, financovania testu na cukor, problémom spojeného s realizáciou testu na cukor, t’ažkosti prečítania testov na cukor, samostatnosti vykonania testu na cukor, polovica respondentov vyjadrila, že si neurobí test na cukor z dôvodu, že sa im glykémia nemení vel'mi často, takmer polovica respondentov sa vyjadrila, že dôvodom, prečo si nemerajú hodnotu glykémie v krvi je časté a bolestivé pichanie do prstov (10).

Najvyšší počet respondentov považuje svoje vedomosti za „dobré“ v oblasti celkovej starostlivosti o diabetes a vyrovnávania sa so stresom. Subjektívne hodnotia ako vynikajúce svoje vedomosti v oblasti diabetickej diéty, dôležitosti cvičenia u diabetika, užívania liekov, sledovania výsledkov monitorovania hladiny cukru v krvi, vplyvu diéty, cvičenia a liekov na hladinu cukru v krvi, prevencie a liečby hypo- a hyperglykémie. Vedomosti v súvislosti s prevenciou komplikácií diabetu hodnotia ako dobré. Avšak respondenti vyjadrili, že majú problém v oblasti dodržiavania pravidelnej kontroly hladiny cukru v krvi a tiež v oblasti 
pravidelnej pohybovej aktivity. Pravidelná pohybová aktivita pacientov s diagnózou diabetes mellitus 2. typu je nevyhnutná pre udržiavanie správnej hladiny glykémie, pri predchádzaní možných komplikácií alebo eliminovaní následkov už vzniknutých komplikácií. V oblasti aplikácie inzulínu / užívania liekov, a v starostlivosti o nohy, respondenti označili, že majú vynikajúce zručnosti. Môžeme konštatovat', že skoro všetci respondenti pravidelne užívajú svoje lieky - antidiabetiká alebo si aplikujú inzulín pomocou inzulínového pera. Snahu o dodržiavanie diéty vyjadrila takmer polovica respondentov. Predpísanú diétu alebo plán stravovania je dôležité dodržiavat' pri diabete, pretože môžeme zabránit' kolísaniu glykémie (10). Edukácia pacientov s DM je špecifická z dôvodu celoživotnej problematiky, pretože kedykol'vek môžu nastat' udalosti, na ktoré pacient reaguje metabolickými výkyvmi, vrátane akútnych komplikácií (hypo - hyperglykémia až kóma). Nesmierne dôležitý je význam kontroly klinických a laboratórnych výsledkov - samostatný selfmonitoring, a vediet' správne a pohotovo reagovat' na laboratórne výsledky a klinické kontroly. Pri dodržiavaní všetkých liečebných opatrení je možné eliminovat’ riziko rozvoja akútnych a chronických komplikácií. Je nutné brat' do úvahy aj kolísanie motivácie - pacient počas života zažíva pocity vyhorenia, oslabuje sa jeho záujem o dodržiavanie terapeutického režimu. Systém sebakontroly nadväzuje na štruktúrovanú edukáciu, ktorá je súčast'ou liečby. Hodnotenie kompenzácie diabetu môžeme robit' na základe vyšetrovania krátkodobých aj dlhodobých parametrov. Krátkodobé parametre sú glykémia, glykozúria, ketonúria, glykemický profil. Diabetik, vykonávajúci selfmonitoring pomocou glukometra a testovacích prúžkov, musí byt' schopný výsledky meraní správne interpretovat' a vediet' na ne adekvátne reagovat' úpravou dávky inzulínu. Medzi dlhodobé parametre patrí glykovaný hemoglobín (HbA1c), ktorý odráža kompenzáciu v období približne 8 - 10 týždňov. Rovnako medzi uvedené markery patrí lipidový metabolizmus, výška a hmotnost', očné pozadie, stav periférneho nervového systému a funkcie obličiek $(11,12,13)$.

Efektivitu vhodnej edukácie pri DM potvrdzuje aj štúdia v ktorej bolo ciel'om zistit', či simulačné vzdelávanie a manažment prípadov mali nejaký vplyv na kontrolu glykémie u pacientov s diabetom 2. typu. Výskumnú vzorku tvorilo 100 pacientov s DM 2. typu, ktorí sa zúčastnili vzdelávania $\mathrm{v}$ oblasti sebakontroly diabetu Boli náhodne rozdelení do kontrolnej skupiny $(\mathrm{n}=50)$ a experimentálnej skupiny $(\mathrm{n}=50)$, ktorí absolvovali edukačný program zameraný na aspekty fyzickej aktivity a výživy, s otvorenými diskusiami a stanovovením ciel'ov a stratégií pre prekonávanie bariér selfmanagementu. Vyhodnotenie biochemických indexov sa uskutočnilo na začiatku a po 6 mesiacoch. Po 6 mesiacoch edukácie bolo zistené zlepšenie hladiny plazmatickej glukózy nalačno a postprandiálnej hladiny glukózy v krvi v experimentálnej skupine $\mathrm{v}$ porovnaní $\mathrm{s}$ kontrolnou skupinou $(\mathrm{P}<0,05)$. V experimentálnej skupine sa signifikantne zvýšilo dodržiavanie skóre zdravej výživy $(P=0,001)$, fyzickej aktivity $(\mathrm{P}=0,043)$, vlastného monitorovania hladiny glukózy v krvi $(\mathrm{P}<0,001)$ a zníženia rizík $(\mathrm{P}<0,001)$ v porovnaní $\mathrm{s}$ kontrolnou skupinou. Simulačné vzdelávanie a správa prípadov pridané k rutinnej liečbe účinne zlepšili kontrolu glykémie (14).

Aby liečebný efekt bol čo najväčší, je nutná permanentná edukácia pacienta s DM. Edukácia ako komplexná činnost' realizovaná všetkými dostupnými metódami, prostriedkami a formami má priaznivý efekt pre klúčcové kompetencie pri selfmanagemente diabetu.

\subsection{Záver}

Komplexná edukácia, ktorá sa realizuje počas ambulantnej liečby alebo hospitalizácie pacienta s DM neodmyslitel'ne patrí $\mathrm{k}$ jeho terapii. Pacient musí efektívne ovládat' selfmonitoring glykémie, správnu techniku aplikácie inzulínu, v niektorých prípadov aj úpravu dávky inzulínu $\mathrm{v}$ súvislosti so zmenami hladiny glykémie a iné požiadavky vyplývajúce z ochorenia. Je nevyhnutné, aby pacient bol súčast'ou liečby, pretože iba dobre 
edukovaný diabetik môže dobre kompenzovat' svoje ochorenie a zaistit' pozitívnu zmenu v spojitosti s kvalitou svojho života.

\section{Použitá literatura}

1. KUDLOVÁ, P. Pacient je naší prioritou. Sborník vědecké a odborné konference s mezinárodní účastí. Opava: Slezská univerzita v Opavě Fakulta veřejných politik v Opavě Ústav ošetřovatelství, 2017. str. 68- 72. ISBN 978-80-7510-226-3.

2. BABČÁK, M., F. NÉMETH a A. KIŠKO, 2016. Základy vnútorného lekárstva pre nelekárske odbory. 1. vyd. Prešov: Dah. ISBN 978-80-89682-10-2.

3. MAJERNÍKOVÁ, L. et al., 2013. Edukácia pacienta s diabetes mellitus. Prešovská univerzita v Prešove. ISBN 978-80-555-0741-5. Dostupné z: http://www.pulib.sk:2063/web/kniznica/elpub/dokument/Majernikova1

4. BUKOVSKÁ, A. Edukácia pacientov s hypoglykémiou. In: Forum diabeticom, 2020. 9 (1), str. 49 - 53. [online] [cit. 2021-04.29]. Dostupné z: https://www.prolekare.cz/casopisy/forum-diabetologicum/2020-1-27/edukaciapacientov-s-hypoglykemiou-122683

5. HA DINH TT, BONNER A, CLARK R, RAMSBOTHAM J, HINES S. The effectiveness of the teach-back method on adherence and self-management in health education for people with chronic disease: a systematic review. JBI Database System Rev Implement Rep. 2016 Jan;14(1):210-47. doi: 10.11124/jbisrir-2016-2296. PMID: 26878928.

6. S̆IP, M. - ŠIPOVÁ, M. Kvalita l’udského života v kontexte paliatívnej starostlivosti. 1. vyd. Prešov: vyd. Prešovskej univerzity, 2014. 158 s. ISBN 978-80-555-1223-5.

7. DŽUKA, J. Subjektívne hodnotená kvalita života - vadilita a reliabilita merania. 1. vyd. Prešov: Filozofická fakulta Prešovskej univerzity v Prešove, 2014. 103 s. ISBN 978-80-555-1096-5.

8. VATEHA, R. - VATEHOVÁ, D. Manažment ošetrovatel'skej starostlivosti o pacientov s vybranými chronickými chorobami. 1. vyd. Martin: Osveta, 2013. $200 \mathrm{~s}$. ISBN 978-80-8063-383-7.

9. GURKOVÁ, E. Hodnocení kvality života pro klinickou praxi a ošetřovatelský výzkum. 1. vyd. Praha: Grada, 2011. 224 s. ISBN 978-80-247-3625-9.

10. JANOVSKÁ, D. Kvalita života pacientov s diabetes mellitus 2. typu. Prešovská univerzita v Prešove. Fakulta zdravotníckych odborov. $66 \mathrm{~s}$.

11. MOJTO, V. Diabetes mellitus-komplikácie a liečba. 1. vyd. Bratislava: A-medi management s.r.o., 2019. ISBN 978-80-89797-41-7

12. BECK, J.; GREENWOOD, D.A.; BLANTON, L.; BOLLINGER, S.T.; BUTCHER, M.K.; CONDON, J.E.; JODI, L. National standards for diabetes self-management education and support. In: Diabetes Care, 2017, 40, 1409-1419.

13. ROSE, M.; FLIEGE, H.; HILDEBRANDT, M.; SCHIROP, T.; KLAPP, BURGHARD F. The network of psychological variables in patients with diabetes and their importance for quality of life and metabolic control. In: Diabetes Care, 2002. Vol. 25, Iss. 1, (Jan 2002): 35-42. [online] [cit. 2021-04.29]. Dostupné z: https://search.proquest.com/scholarly-journals/network-psychological-variables-pa tients-with/docview/223056931/se-2?accountid=201395.

14. JI H, CHEN R, HUANG Y, LI W, SHI C, ZHOU J. Effect of simulation education and case management on glycemic control in type 2 diabetes. In: Diabetes Metab Res Rev. 2019 Mar;35(3):e3112. doi: 10.1002/dmrr.3112. Epub 2018 Dec 21. PMID: 30520255; PMCID: PMC6590464. 


\section{Kontaktní údaje}

PhDr. Andrea Šuličová, PhD.

Prešovská univerzita v Prešove

Fakulta zdravotníckych odborov

Katedra ošetrovatel'stva

Partizánska 1, 08001 Prešov

email: andrea.sulicova@unipo.sk 


\title{
VPLYV VYBRANÝCH RASTLINNÝCH SILÍC ČELADE LAMIACEAE NA RADIÁLNY RAST FUSARIUM GRAMINEARUM
}

\author{
EFFECT OF SELECTED ESSENTIAL OILS OF THE LAMIACEAE \\ FAMILY ON THE RADIAL GROWTH OF FUSARIUM \\ GRAMINEARUM
}

\author{
Michaela Harčárová, Eva Čonková, Pavel Nad', Peter Váczi, Martina \\ Proškovcová
}

\begin{abstract}
Abstrakt
Fungálna kontaminácia plodín a finálnych produktov je častým problémom v pol'nohospodárskom a potravinárskom priemysle. Táto práca je zameraná na in vitro stanovenie inhibičného vplyvu vybraných rastlinných silíc z čel'ade Lamiaceae (dúška tymianová, pamajorán obyčajný a yzop lekársky) na radiálny rast mycélia dvoch kmeňov mikroskopickej vláknitej huby Fusarium graminearum CCM F-683 a CCM 8244. Najvyššia schopnost' inhibície $(100 \%)$ radiálneho rastu oboch kmeňov $F$. graminearum, pri všetkých testovaných koncentráciách $(1000 \mu \mathrm{g} / \mathrm{ml} ; 500 \mu \mathrm{g} / \mathrm{ml}$ a $100 \mu \mathrm{g} / \mathrm{ml})$, bola zaznamenaná pri rastlinnej silici z pamajoránu obyčajného. Pri silici z dúšky tymianovej bola pozorovaná $100 \%$ inhibícia radiálneho rastu oboch kmeňov fuzárí́ pri koncentráciách $1000 \mu \mathrm{g} / \mathrm{ml} \mathrm{a} 500$ $\mu \mathrm{g} / \mathrm{ml}$. Silica z yzopu lekárskeho bola najmenej účinná, $\mathrm{v}$ koncentrácii $100 \mu \mathrm{g} / \mathrm{ml}$ nevykazovala žiadny antifungálny efekt na testované kmene $F$. graminearum.
\end{abstract}

Keywords: rastlinné silice, Lamiaceae spp., antifungálny účinok

\begin{abstract}
Mold contamination of crops and final products is a common problem in agriculture and food industry. This work was focused on in vitro testing the effect of selected essential oils from the family Lamiaceae (thyme, oregano and hyssop) on the radial mycelial growth of two strains of the microscopic filamentous fungus Fusarium graminearum CCM F-683 and CCM 8244. The highest inhibitory effect $(100 \%)$ of radial growth of both strains of $F$. graminearum, at all tested concentrations $(1000 \mu \mathrm{g} / \mathrm{ml} ; 500 \mu \mathrm{g} / \mathrm{ml}$ and $100 \mu \mathrm{g} / \mathrm{ml})$, was recorded for oregano essential oil. For thyme essential oil, 100\% inhibition of radial growth of both strains of fusariums was observed at concentrations of $1000 \mu \mathrm{g} / \mathrm{ml}$ and $500 \mu \mathrm{g} / \mathrm{ml}$. Hyssop essential oil was the least effective, at a concentration of $100 \mu \mathrm{g} / \mathrm{ml}$ it showed no antifungal effect on the tested strains of $F$. graminearum.
\end{abstract}

Keywords: essential oils, Lamiaceae spp., antifungal effect

\section{1 ÚVOD}

Dopyt spotrebitel'ov po zdravotne nezávadných potravinách, pri výrobe ktorých sa používa čo najmenej syntetických látok, nasmeroval záujem pol'nohospodárskeho a potravinárskeho priemyslu na používanie prírodných konzervačných látok (Nieto, 2017). Konzervačné postupy majú za úlohu chránit' plodiny a finálne produkty pred rôznymi negatívnymi vplyvmi. Najčastejšie sa jedná o kontamináciu mikroskopickými vláknitými hubami. Okrem iných, sa v rámci fungálneho znehodnotenia, za najbežnejšieho kontaminanta obilnín považuje druh Fusarium graminearum (Shiro a kol., 2018). Tento druh, mikroskopickej huby je za vhodných environmentálnych podmienok schopný produkovat' sekundárne metabolity, 
mykotoxíny. Fusarium graminearum syntetizuje predovšetkým deoxynivalenol, zearalenón a ich deriváty. Mykotoxíny sú charakteristické širokým spektrom toxických účinkov, môžu pôsobit' karcinogénne, mutagénne, teratogénne a estrogénne (Assunção a kol., 2016). Vo všeobecnosti sú príčinou zdravotných komplikácií u l'udí a zvierat, ktoré sa prejavujú najmä ako intoxikácie tzv. mykotoxikózy (Rasiukevičiūtè a kol., 2018).

V ostatnej dobe sa skúmajú najmä antifungálne vlastnosti látok rastlinného pôvodu. Medicínsky významnú skupinu rastlín tvoria zástupcovia čel'ade Lamiaceae. Pôvodne pochádzajú zo Stredomoria a používajú sa na výrobu rastlinných silíc, ktoré disponujú okrem antifungálneho aj antioxidačnými a antimikrobiálnymi vlastnost'ami (Bounar a kol., 2020; Skendi a kol., 2020). Rastlinné silice sú prchavé, olejovité zlúčeniny, ktoré sa získavajú hydrodestiláciou z rôznych častí rastlín (listy, kôra, stonka, semená, korene, kvety, puky, plody). Z chemického hl'adiska sú rastlinné silice zmesi viac ako 20 chemických zlúčenín, hlavne monoterpénov a seskviterpénov (Akthar, 2014). Chemické zloženie silíc závisí od klimatického pásma a geografického výskytu, vegetačného štádia v období zberu a použitej extrakčnej metódy (Raut a Karuppayil, 2014). Ciel'om tejto práce bolo vyhodnotit' a porovnat' inhibičný vplyv vybraných rastlinných silíc čel'ade Lamiaceae (pamajoránová, tymianova a yzopová silica) na radiálny rast mycélia dvoch kmeňov mikroskopickej vláknitej huby Fusarium graminearum CCM F-683 a CCM 8244, in vitro.

\section{MATERIÁL A METODIKA}

\subsection{Príprava fungálnych kultúr}

Na testovanie boli použité desat'dňové kultúry $F$. graminearum (CCM F-683 a CCM 8244) porastené na PDA (Potato-dextrose agar) (HiMedia Laboratories Pvt. Ltd., Mumbai, India), pri laboratórnej teplote $25 \pm 1{ }^{\circ} \mathrm{C} \mathrm{v}$ tme.

\subsection{Testované rastlinné silice}

$\mathrm{Na}$ testovanie vplyvu rastlinných silíc na radiálny rast mikroskopickej vláknitej huby $F$. graminearum boli vybraté 3 silice z čel'ade Lamiaceae (hluchavkovité). Silice boli získané hydrodestiláciou a ich chemické zloženie bolo stanovené pomocou plynovej chromatografie:

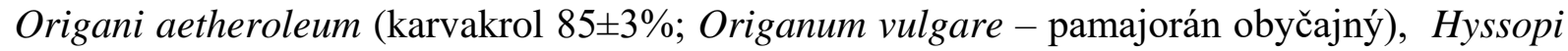
aetheroleum ( $\alpha$-pinén $11 \pm 1 \%$, pinokampfén $50 \pm 2 \%$, izopinokampfén $28 \pm 1 \%$; Hyssopus officinalis - yzop lekársky) a Thymi aetheroleum (tymol 32 $\pm 2 \%$, $\rho$-cymén 40 $\pm 3 \%$; Thymus vulgaris - dúška tymianová) (Calendula, a.s, Nová L'ubovňa, Slovenská republika). Silice boli nariedené sterilným DMSO (dimethylsulfoxid) (Sigma Aldrich, Schnelldorf, Germany) na koncentráciu $100 \mathrm{mg} / \mathrm{ml}$ a $500 \mathrm{mg} / \mathrm{ml}$, z ktorých sa do živného média pridalo také množstvo, aby výsledné koncentrácie dosahovali $1000 \mu \mathrm{g} / \mathrm{ml}, 500 \mu \mathrm{g} / \mathrm{ml}$ a $100 \mu \mathrm{g} / \mathrm{ml}$.

\subsection{Postup testovania}

Rastlinné silice rozpustené v DMSO boli pridané do PDA ešte pred naliatím do Petriho misiek $(6 \mathrm{~cm})$, pri teplote $40-45^{\circ} \mathrm{C}$. Ako kontrolné vzorky boli pripravené platne, v ktorých PDA obsahoval 1\% DMSO. Z kultúr $F$. graminearum CCM F-683, resp. F. graminearum CCM 8244 boli pomocou sterilnej sklenenej trubičky vyrezávané disky myceliálnej kultúry s priemerom 0,5 mm, ktoré boli asepticky prenesené do stredu pripravených Petriho misiek. Každá koncentrácia rastlinnej silice bola testovaná trikrát. Petriho misky boli inkubované v tme pri teplote $25 \pm 2{ }^{\circ} \mathrm{C}$ po dobu 10 dní. Na 10 . deň bol odmeraný priemer porasteného mycélia v kontrolných a pokusných skupinách. Inhibícia rastu mycélia (\%) bola vypočítaná podl'a vzorca, ktorý uvádzajú Badawy a Abdelgaleil (2014) nasledovne:

$$
\text { Inhibícia rastu mycélia }(\%)=\frac{D C-D T}{D C} \times 10
$$

DC - priemer porasteného fungálneho mycélia v kontrolných Petriho miskách 
DT - priemer porasteného fungálneho mycélia $\mathrm{v}$ Petriho miskách $\mathrm{s}$ obsahom testovanej rastlinnej silice

\subsection{Statistická analýza}

Výsledky boli vyhodnotené štatistickým programom GraphPad Prism 5.0 (GraphPad software Inc. CA, USA) pomocou jednocestného ANOVA testu, Dunnettov porovnávací test.

\section{VÝSLEDKY}

\subsection{Hodnotenie vplyvu rastlinných silíc na radiálny rast Fusarium graminearum CCM F- 683 a Fusarium graminearum CCM 8244}

Inhibičnú schopnost' vybraných rastlinných silíc na rast mycélia $F$. graminearum CCM F-683 vyhodnocuje tabul'ka č. 1 . V porovnaní s kontrolnou skupinou, pri ktorej priemerná vel'kost' mycélia predstavovala $49,0 \pm 0 \mathrm{~mm}$, bol zistený signifikantný $(\mathrm{p}<0,001)$ inhibičný efekt pri siliciach z dúšky tymianovej a pamajoránu obyčajného v koncentráciách $1000 \mu \mathrm{g} / \mathrm{ml}$ a 500 $\mu \mathrm{g} / \mathrm{ml}$, pri ktorých účinnost' dosahovala $100 \%$. Štatisticky významná $(\mathrm{p}<0,001)$ inhibícia radiálneho rastu mycélia bola zaznamenaná aj pri silici z yzopu lekárskeho v koncentrácii $1000 \mu \mathrm{g} / \mathrm{ml}$, avšak jej inhibičný účinok predstavoval iba 23,1\%. Slabú antifungálnu účinnost' vykazovali testované silice v najnižšej koncentrácii $(100 \mu \mathrm{g} / \mathrm{ml})$, pri ktorej inhibičná aktivita silice z dúšky tymianovej bola $20,4 \%$ a z pamajoránu obyčajného $37,4 \%$. Pri silici z yzopu lekárskeho nebola v tejto koncentrácii pozorovaná žiadna inhibícia rastu mycélia.

Tabul'ka č.1, Priemerné hodnoty vel'kosti mycélia (mm) a inhibícia rastu (\%) F. graminearum CCM F-683 rastlinnými silicami

\begin{tabular}{|c|c|c|c|c|c|c|}
\hline & $\mathbf{1 0 0 0} \boldsymbol{\mu g} / \mathbf{m l}$ & \multicolumn{2}{|c|}{$\mathbf{5 0 0} \boldsymbol{\mu g} / \mathbf{m l}$} & \multicolumn{2}{|c|}{$\mathbf{1 0 0} \boldsymbol{\mu g} / \mathbf{m l}$} \\
\hline $\begin{array}{c}\text { Testovaná } \\
\text { látka }\end{array}$ & $\begin{array}{c}\mathbf{x} \pm \mathbf{S D} \\
(\mathbf{m m})\end{array}$ & $\begin{array}{c}\mathbf{I} \\
(\mathbf{\%})\end{array}$ & $\begin{array}{c}\mathbf{x} \pm \mathbf{S D} \\
(\mathbf{m m})\end{array}$ & $\begin{array}{c}\mathbf{I} \\
(\mathbf{\%})\end{array}$ & $\begin{array}{c}\mathbf{x} \pm \mathbf{S D} \\
(\mathbf{m m})\end{array}$ & $\begin{array}{c}\mathbf{I} \\
(\mathbf{\%})\end{array}$ \\
\hline Tymian & $0^{* * *}$ & 100,0 & $0^{* * *}$ & 100,0 & $39,00 \pm 1,00^{* * * *}$ & 20,4 \\
\hline Pamajorán & $0^{* * *}$ & 100,0 & $0^{* * *}$ & 100,0 & $30,67 \pm 1,53^{* * *}$ & 37,4 \\
\hline Yzop & $37,67 \pm 1,15^{* * *}$ & 23,1 & $42,00 \pm 2,65^{* *}$ & 14,3 & $49,00 \pm 2,00$ & 0 \\
\hline
\end{tabular}

$\mathrm{x}$ - priemerná hodnota vel'kosti mycélia $F$. graminearum CCM F-683 v mm, SD - smerodajná odchýlka, I (\%) - inhibícia rastu, * - p<0,05; ** - p<0,01; *** - p<0,001 - štatistická významnost' oproti kontrolnej vzorke (ANOVA, Dunnettov test)

Tabul'ka č. 2 prezentuje výsledky inhibície radiálneho rastu mycélia $F$. graminearum CCM 8244 vybranými rastlinnými silicami. Inhibičná aktivita rastlinných silíc z dúšky tymianovej a pamajoránu obyčajného dosahovala $100 \%(\mathrm{p}<0,001)$ pri koncentráciách $1000 \mu \mathrm{g} / \mathrm{ml}$ a 500 $\mu \mathrm{g} / \mathrm{ml}$. Signifikantný efekt $(\mathrm{p}<0,001$, resp. $\mathrm{p}<0,01$ ) bol zaznamenaný aj pri silici z yzopu lekárskeho, ale jej účinnost' v týchto koncentráciách bola iba $21,3 \%$, resp. $18,7 \%$. Pri najnižšej testovanej koncentrácii $(100 \mu \mathrm{g} / \mathrm{ml})$, najlepšiu antifungálnu aktivitu vykazovala silica pamajoránu obyčajného $(40,7 \%, \mathrm{p}<0,001)$. Účinnost' silice $\mathrm{z}$ dúšky tymianovej bola $21,3 \%(\mathrm{p}<0,001)$. Silica z yzopu lekárskeho bola podobne ako pri $F$. graminearum CCM F683 neúčinná $(0 \%)$, vel'kost' mycélia $(50 \pm 0 \mathrm{~mm})$ bola takmer totožná s kontrolnou skupinou. 
Tabul'ka č.2, Priemerné hodnoty vel'kosti mycélia a inhibícia rastu (\%) F. graminearum CCM 8244 rastlinnými silicami

\begin{tabular}{|c|c|c|c|c|c|c|}
\hline & \multicolumn{2}{|c|}{$\mathbf{1 0 0 0} \boldsymbol{\mu g} / \mathbf{m l}$} & \multicolumn{2}{|c|}{$\mathbf{5 0 0} \boldsymbol{\mu g} / \mathbf{m l}$} & \multicolumn{2}{|c|}{$\mathbf{1 0 0} \boldsymbol{\mu g} / \mathbf{m l}$} \\
\hline Testovaná látka & $\begin{array}{c}\mathbf{x} \pm \mathbf{S D} \\
(\mathbf{m m})\end{array}$ & $\begin{array}{c}\mathbf{I} \\
(\boldsymbol{\%})\end{array}$ & $\begin{array}{c}\mathbf{x} \pm \mathbf{S D} \\
(\mathbf{m m})\end{array}$ & $\begin{array}{c}\mathbf{I} \\
(\boldsymbol{\%})\end{array}$ & $\begin{array}{c}\mathbf{x} \pm \mathbf{S D} \\
(\mathbf{m m})\end{array}$ & $\begin{array}{c}\mathbf{I} \\
(\boldsymbol{\%})\end{array}$ \\
\hline Tymian & $0^{* * *}$ & 100,0 & $0^{* * *}$ & 100,0 & $39,33 \pm 1,15^{* * *}$ & 21,3 \\
\hline Pamajorán & $0^{* * *}$ & 100,0 & $0^{* * *}$ & 100,0 & $29,67 \pm 1,15^{* * *}$ & 40,7 \\
\hline Yzop & $39,33 \pm 0,58^{* * *}$ & 21,3 & $40,67 \pm 1,15^{* *}$ & 18,7 & $50,00 \pm 0,00$ & 0 \\
\hline
\end{tabular}

x - priemerná hodnota vel'kosti mycélia $F$. graminearum CCM $8244 \mathrm{v} \mathrm{mm}$, SD - smerodajná odchýlka, I (\%) - inhibícia rastu, * - p<0,05; ** - p<0,01; *** - p<0,001 - štatistická významnost' oproti kontrolnej vzorke (ANOVA, Dunnettov test)

\section{DISKUSIA}

Produkcia zdravotne nezávadných plodín a potravín závisí aj od použitých konzervačných postupov, ktoré majú za úlohu chránit' produkty pred znehodnotením. V súčasnosti sa upriamuje pozornost' na používanie látok, ktoré majú minimálny negatívny dopad na životné prostredie. Efektívnym sa javí používanie rastlinných silíc. V našich experimentoch bol zist'ovaný antifungálny účinok vybraných silíc rastlín z čel'ade Lamiaceae. Rastlinné silice $\mathrm{z}$ dúšky tymianovej a pamajoránu obyčajného vykazovali v koncentráciách $1000 \mu \mathrm{g} / \mathrm{ml}$, resp. $500 \mu \mathrm{g} / \mathrm{ml} \mathrm{100 \%} \mathrm{inhibíciu} \mathrm{rastu} \mathrm{oboch} \mathrm{testovaných} \mathrm{kmeňov} \mathrm{mikroskopickej} \mathrm{vláknitej} \mathrm{huby}$ Fusarium graminearum. Podobné výsledky prezentovali vo svojich experimentoch Matušinský a kol. (2016), ktorí zaznamenali 100\% inhibíciu rastu $F$. culmorum silicou z dúšky tymianovej. Massoud a kol. (2012), ktorí overovali inhibičné účinky silice z dúšky tymianovej na rast $F$. moniliforme zaznamenali $100 \%$ inhibičný efekt pri koncentrácii $5 \mu$ l. Tomescu a kol. (2015) testovali aj iné druhy rastlinných silíc z čel'ade Lamiaceae. Stopercentný inhibičný účinok zaznamenali pri silici z mäty piepornej v koncentráciách od 5 $\mathrm{mg} / \mathrm{l}$ do $20 \mathrm{mg} / \mathrm{l}$ a pri silici zo šalvie lekárskej v koncentráciách od $15 \mathrm{mg} / \mathrm{l}$ do $20 \mathrm{mg} / \mathrm{l}$. Krzyśko-Łupicka a kol. (2019) testovali a vyhodnotili antifungálny účinok rôznych druhov silíc (silica $\mathrm{z}$ citrónovníka pravého, ružového dreva, muškátu omamného a rozmarínu lekárskeho) na radiálny rast dvoch kmeňov Fusarium graminearum ZALF 339 a ZALF 24. Pri siliciach z muškátu omamného a ružového dreva zaznamenali pri všetkých testovaných koncentráciách $(1,25 \mathrm{mg} / \mathrm{ml} ; 2,5 \mathrm{mg} / \mathrm{ml} ; 5 \mathrm{mg} / \mathrm{ml} ; 10 \mathrm{mg} / \mathrm{ml} \mathrm{a} 20 \mathrm{mg} / \mathrm{ml}) 100 \%$ inhibičný účinok rastu oboch kmeňov $F$. graminearum. Silica z yzopu lekárskeho bola v našej štúdii $\mathrm{v}$ koncentráciách $1000 \mu \mathrm{g} / \mathrm{ml}$ a $500 \mu \mathrm{g} / \mathrm{ml}$ pri oboch kmeňoch Fusarium graminearum menej účinná a v koncentrácii $100 \mu \mathrm{g} / \mathrm{ml}$ nevykazovala žiadny inhibičný vplyv na radiálny rast mycélia $F$. graminearum. Fraternale a kol. (2004) testovali rastlinné silice yzopu lekárskeho, ktorý bol pestovaný v dvoch rôznych lokalitách. Antifungálne účinky vykazovali nielen voči F. graminearum, ale aj na rôzne iné fytopatogénne huby. Najlepší inhibičný účinok zaznamenali pri silici z yzopu lekárskeho, ktorý bol pestovaný v nadmorských výškach viac ako 1000 m n.m. (Fraternale a kol., 2004).

Výsledky našej práce poukazujú, že najvyššiu schopnost' inhibície rastu mikroskopickej vláknitej huby Fusarium graminearum má rastlinná silica z pamajoránu obyčajného. Podobné zistenie je prezentované aj v štúdii Bouhdida a kol. (2008), ktorí testovali antifungálnu a antibakteriálnu aktivitu rastlinnej silice z pamajoránu obyčajného. Predpokladá sa, že účinnost' tejto silice je daná prítomnost'ou monoterpénu karvakrolu (Chun a kol., 2005; Lucini a kol., 2006). Monoterpény dokážu zvyšovat' koncentrácie lipidových peroxidov (Badawy a Abdelgaleil, 2014) a okrem toho majú negatívne účinky na bunkovú stenu, bunkový cyklus a celkovú morfogenézu bunky patogéna (Raut a Karuppayil, 2014). 


\section{ZÁVER}

Neustále sa zvyšujúca rezistencia patogénov, vrátane toxinogénnych mikroskopických vláknitých húb, vedie $\mathrm{k}$ hl'adaniu nových alternatívnych spôsobov ochrany plodín a finálnych produktov z nich. Použitie rastlinných silíc ako antifungálnych látok otvára široký priestor pre d’alšie skúmanie mechanizmu ich účinku, ale aj vzájomného synergizmu jednotlivých rastlinných silíc $\mathrm{v}$ rámci ich antifungálneho pôsobenia. Okrem benefitov v podobe ich antifungálnych, antimikrobiálnych a antioxidačných vlastností, neohrozujú životné prostredie do takej miery ako synteticky vyrábané látky.

\section{Pod'akovanie}

Táto práca bola podporená Ministerstvom školstva, vedy, výskumu a športu Slovenskej republiky prostredníctvom grantu VEGA č. 1/0402/20.

\section{Použitá literatúra}

1. AKTHAR, M. S., DEGAGA, B., AZAM, T. Antimicrobial activity of essential oils extracted from medicinal plants against the pathogenic microorganisms: a review. Issues of Biological Sciences and Pharmaceutical Research. 2014, 2, 001-007.

2. ASSUNÇÃO, R., SILVA, M.J., ALVITO, P. Challenges in risk assessment of multiple mycotoxins in food. World Mycotoxin Journal. 2016, 9, 791-811.

3. BADAWY, M.E. and ABDELGALEIL, S.A. Composition and antimicrobial activity of essential oils isolated from Egyptian plants against plant pathogenic bacteria and fungi. Industrial Crops and Products. 2014, 52, 776-82.

4. BOUHDID, S., SKALI, S.N., IDAOMAR, M., et al. Antibacterial and antioxidant activities of Origanum compactum essential oil. African Journal of Biotechnology. 2008, 7, 1563-1570.

5. BOUNAR, R., KRIMAT, S., BOUREGHDA, H., DOB, T. Chemical analyses, antioxidant and antifungal effects of oregano and thyme essential oils alone or in combination against selected Fusarium species. International Food Research Journal. 2020, 27, 66-77.

6. FRATERNALE, D., RICCI, D., EPIFANO, F., et al. Composition and antifungal activity of two essential oils of hyssop (Hyssopus officinalis L.). Journal of Essential Oil Research. 2004, 16, 617-622

7. CHUN, S.S., VATTEM, D.A., LIN, Y.T., et al. Phenolic antioxidants from clonal oregano (Origanum vulgare) with antimicrobial activity against Helicobacter pylori. Process Biochemistry. 2005, 40, 809-16.

8. KRZYŚKO-ŁUPICKA, T., WALKOWIAK, W., BIAŁOŃ, M. Comparison of the fungistatic activity of selected essential oils relative to Fusarium graminearum isolates. Molecules. 2019, 24, 311.

9. LUCINI, E..I, ZUNINO, M.P., LÓPEZ, M.L., et al. Effect of monoterpenes on lipid composition and sclerotial development of Sclerotium cepivorum Berk. Journal of Phytopathology. 2006, 154, 441-6.

10. MASSOUD, M.A., SAAD, A.S., SOLIMAN, E.A., et al. Antifungal activity of some essential oils applied as fumigants against two stored grains fungi. Journal of the Advances in Agricultural Researches. 2012, 17, 296-306.

11. MATUŠINSKÝ, P., ZOUHAR, M., PAVELA, R., et al. Výzkum alternativnych zpusobu ochrany obilnín proti houbovým patogénum. Obilnářske listy. 2016, 24, 38-40.

12. NIETO, G. Biological activities of three essential oils of the Lamiaceae family. Medicines. 2017,4, 63.

13. RASIUKEVIČIŪTĖ, N., SUPRONIENE, S., KELPŠIENE, J., et al. Susceptibility of non-cereal crops to Fusarium graminearum complex and their role within cereal crop 
rotation as a source of inoculum for Fusarium head blight. Spanish Journal of Agricultural Research. 2018, 16, 1-12.

14. RAUT, J.S., KARUPPAYIL, S.M. A status review on the medicinal properties of essential oils. Industrial Crops and Products. 2014, 62, 250-64.

15. SCHIRO, G., VERCH, G., GRIMM, V., et al. Alternaria and Fusarium fungi: differences in distribution and spore deposition in a topographically heterogeneous wheat field. Journal of Fungi. 2018, 4, 63.

16. SKENDI, A., KATSANTONIS, D.N., CHATZOPOULOU, P., et al. Antifungal Activity of Aromatic Plants of the Lamiaceae Family in Bread. Foods. 2020, 11, 1642.

17. TOMESCU, A., SUMALAN, R., POP, G., ALEXA, E., et al. Chemical Composition and Protective Antifugal Activity of Mentha Piperita L. and Salvia Officinalis L. Essential Oils Against Fusarium Graminearum Spp. Revista de Chimie. 2015, 1027 1030.

\section{Kontakty}

MVDr. Michaela Harčárová, PhD.

Katedra výživy a chovu zvierat

Univerzita veterinárskeho lekárstva a farmácie v Košiciach

Komenského 73, 04181 Košice, Slovenská republika

Tel: +421910504880

email: michaela.harcarova@uvlf.sk

doc. MVDr. Eva Čonková, PhD.

Katedra farmakológie a toxikológie

Univerzita veterinárskeho lekárstva a farmácie v Košiciach

Komenského 73, 04181 Košice, Slovenská republika

Tel: +421915984766

email: eva.conkova@uvlf.sk

doc. MVDr. Pavel Nad', PhD.

Katedra výživy a chovu zvierat

Univerzita veterinárskeho lekárstva a farmácie v Košiciach

Komenského 73, 04181 Košice, Slovenská republika

Tel: +421907923235

email: pavel.nad@uvlf.sk

MVDr. Peter Váczi, PhD.

Katedra farmakológie a toxikológie

Univerzita veterinárskeho lekárstva a farmácie v Košiciach

Komenského 73, 04181 Košice, Slovenská republika

Tel: +421918919685

email: peter.vaczi@uvlf.sk

Mgr. Martina Proškovcová

Katedra farmakológie a toxikológie

Univerzita veterinárskeho lekárstva a farmácie v Košiciach

Komenského 73, 04181 Košice, Slovenská republika

Tel: +421915541991

email: martina.proskovcova@student.uvlf.sk 


\title{
NUTRIČNÁ PROBLEMATIKA U PACIENTOV S DEMENCIOU
}

\author{
NUTRITIONAL ISSUES IN PATIENTS WITH DEMENTIA
}

\author{
Zuzana Novotná, Zuzana Šímová, Andrea Šuličová, Jana Cinová, Tatiana \\ Šantová, Andrea Obročníková
}

\begin{abstract}
Abstrakt
Jednou zo závažných komplikácií demencie v pokročilom štádiu je závažná porucha príjmu potravy, ktorá vedie u pacienta k nebezpečne sa rozvíjajúcemu syndrómu malnutrície. Najčastejším typom demencie je Alzheimerova choroba, pri ktorej má u pacienta vznik malnutrície nielen závažné zdravotné následky, ale výrazným spôsobom zhoršuje priebeh samotného ochorenia a skracuje život pacienta. Efektívnymi možnost'ami ako udržat' primeranú kvalitu života čo najdlhšie, sú pravidelné hodnotenie nutričného stavu, včasné rozpoznanie poruchy výživy a hlavne včasná nutričná intervencia, ktoré môžu predíst' t’ažkej forme malnutrície až kachektizácii. Komplikácie spojené s nedostatočnou výživou sú preventabilné, preto je v klinickej ošetrovatel'skej praxi vel'mi dôležité venovat' problematike primeranú pozornost', čo môže napomôct' zaistit' u pacientov s demenciou dlhodobejšie udržanie funkčných schopností a nezávislosti.
\end{abstract}

Klíčová slova: demencia, Alzheimerova choroba, malnutrícia, pacient, nutričný stav, nutričná intervencia.

\begin{abstract}
One of the serious complications of advanced dementia is a severe eating disorder that leads to the patient's dangerously developing malnutrition syndrome. The most common type of dementia is Alzheimer's disease, in which a patient develops malnutrition not only with serious health consequences, but also significantly worsens the course of the disease itself and shortens the patient's life. Effective options for maintaining an adequate quality of life for as long as possible are regular assessment of nutritional status, early detection of eating disorders and especially early nutritional intervention, which can prevent severe malnutrition or even cachectization. Complications associated with malnutrition are preventable, so it is very important in clinical nursing practice to pay adequate attention to the issue, which can help ensure longer-term maintenance of functional abilities and independence in patients with dementia.
\end{abstract}

Key words: dementia, Alzheimer's disease, malnutrition, patient, nutritional status, nutritional intervention.

\section{PORUCHY VÝŽIVY VO VYŠŠOM VEKU}

U pacientov, ktorí trpia demenciou dochádza k závažným, až devastačným zmenám v mnohých oblastiach života. V klinickom obraze je okrem iných závažných prejavov, charakteristický postupný vznik porúch výživy, najčastejšie proteinoenergetická malnutrícia.

Výživu človeka vo všeobecnosti ovplyvňuje množstvo faktorov. K najvýznamnejším patrí vyšší vek a prítomnost' ochorenia a jeho charakter. Prirodzené procesy starnutia sú spojené s involučnými zmenami na úrovni centrálnej a periférnej. Dochádza k strate zubov, poklesu čuchových a chut'ových schopností, mení sa štruktúra a funkcia tráviacich orgánov, množstvo a zloženie tráviacich štiav, zhoršuje sa vstrebávanie živín, znižuje sa pocit smädu a menia sa 
hladiny niektorých hormónov, ktoré majú vplyv na proces trávenia. Starnutím tiež prirodzene klesá energetický príjem súčasne s poklesom celkového výdaja. Dôsledkom mnohých regulačných zmien, ktoré sú typické pre starnutie je starecká anorexia, pričom u mužov je senilná anorexia výraznejšia ako u žien. Ďalšou častou príčinou problémov s príjmom potravy a vznikom malnutrície vo vyššom veku je prítomnost' jedného alebo viacerých ochorení (polymorbidita) a geriatrické syndrómy, ktoré sú spojené užívaním viacerých liekov (polypragmázia). Mnohé lieky, ktoré seniori užívajú spôsobujú tráviace t’ažkosti ako sú nechutenstvo, obstipácia, hnačky alebo poruchy vnímania chuti a vône. Niektoré lieky majú vplyv na vstrebávanie, metabolizmus v pečeni a vylučovanie (Hegyi, Krajčík 2015). Následkom malnutrície dochádza u seniora k vzniku komplikácií (znížená svalová sila, poruchy imunity, hypomobilita, opuchy, zhoršené hojenie rán, spomalená črevná peristaltika, anémia), ktoré môžu vzájomne utvorit' tzv. circulus vitiosus (bludný, začarovaný kruh) a tým negatívne ovplyvnit' stav a prognózu pacienta (Kubešová, Weber 2008). K vyššiemu veku patrí aj sociálny a ekonomický aspekt stravovania, ktorý je dôležité brat' do úvahy pri hodnotení kvality, množstva a prípravy stravy, ktorú senior preferuje a prijíma. Hoozová (2015) uvádza, že dôležitou podmienkou primeraného stravovania vo vyššom veku je tiež dispozícia seniora postarat' sa o nákup potravín, schopnost' prípravy jedla a prípadne pomoc pri príjme potravy. Kumulácia týchto rizikových faktorov v starobe vedie k vzniku chronickej straty hmotnosti. Vo všeobecnosti sa dajú príčiny dlhodobej straty hmotnosti rozdelit' na fyziologické - involučné zmeny a nefyziologické, ktorých podstatou je znížený príjem potravy, zvýšené straty živín, zvýšené nároky na výživu, alebo ich vzájomná kombinácia (tabul'ka 1).

Tabul'ka 1. Príčiny dlhodobej straty hmotnosti v starobe (Hegyi, Krajčík 2015)

\begin{tabular}{|l|l|}
\hline Starobné zmeny & $\begin{array}{l}\text { starecká anorexia, strata chrupu, xerostómia, } \\
\text { poruchy zraku }\end{array}$ \\
\hline Vnútorné ochorenia & $\begin{array}{l}\text { chronické zlyhávanie orgánu, srdce, pečeň, } \\
\text { obličky), malignity, chronická obštrukčná choroba } \\
\text { plúc, malabsorpcia, maldigescia, atrofická } \\
\text { gastritída, HP pozitivita, reumatologické } \\
\text { ochorenia, diabetes mellitus, chronické infekcie, } \\
\text { tyreopatie }\end{array}$ \\
\hline $\begin{array}{l}\text { Neurologické } \\
\text { príčiny }\end{array}$ & $\begin{array}{l}\text { delírium, demencia, psychotické stavy, následky } \\
\text { mozgovo-cievnych príhod, Parkinsonova choroba, } \\
\text { depresia, úzkostné stavy, alkoholizmus }\end{array}$ \\
\hline Sociálne faktory & $\begin{array}{l}\text { chudoba, izolácia, trúchlenie, odkázanost', } \\
\text { zanedbávanie, týranie, nedostatočná } \\
\text { informovanost' a motivácia, inštitucionalizácia }\end{array}$ \\
\hline Iné príčiny & $\begin{array}{l}\text { dysfágia rôznej etiológie, polypragmázia, } \\
\text { nežiadúce účinky liekov, hospitalizácia, dekubity } \\
\text { a iné chronické rany }\end{array}$ \\
\hline
\end{tabular}

\subsection{Alzheimerova demencia}

Alzheimerova demencia je najčastejším typom demencie spôsobujúcim trvalé poškodenie mentálnych funkcií človeka. Akceleruje v priebehu niekol'kých mesiacov až rokov, a medzi jej najtypickejšie symptómy patrí postupná strata pamäti, zhoršujúce sa t’ažkosti pri realizácii bežných činností, st’ažené vyjadrovanie a zhoršenie úsudku, porucha abstraktného myslenia, zmeny nálad a poruchy správania, dezorientácia v čase, priestore, neskôr aj v osobe, neustále hl'adanie vecí a zmeny osobnosti. AD predstavuje približne $60 \%$ zo všetkých demencií a jej prevalencia v populácii sa pohybuje okolo $1,5 \%$. Jej výskyt sa so stúpajúcim vekom zvyšuje, 
u l'udí nad 80 rokov sa pohybuje medzi 30-50\%. Dôsledkom narušených kognitívnych a intelektuálnych funkcií dochádza postupne k narušeniu funkčných schopností pacienta a narastá aj pacientova spoločenská nekompetentnost' (Jirák, Laňková 2007).

Jedným zo sprievodných javov uvádzaných zmien je malnutrícia, ktorá sa prejavuje v rôznej forme a stupni a najčastejšie súvisí s poruchou príjmu potravy. V t’ažkých štádiách ochorenia dominujú hlavne poruchy prehítania (dysfágie). Prehítanie je mechanizmus, ktorý posúva potravu u úst do pažeráka a žalúdka. Je to reflexný dej, ktorý je iba v orálnej fáze ovládaný vôl'ou, ostatné fázy (faryngeálna a ezofageálna) sú riadené podkôrovými centrami CNS a vyžadujú si presnú koordináciu svalových skupín. Dysfágie u demencií môžu byt' spôsobené poruchou synchronizácie v ktorejkol'vek fáze (vôl'ovej a nevôl'ovej) a často sa kombinujú (Těšínsky 2003 a ). Vážnym problémom je aj riziko aspirácie, ktoré sa pri dysfágii zvyšuje a býva príčinou d’alších komplikácií ako sú: chemická pneumonitída, aspiračná pneumónia, mechanická obštrukcia dýchacích ciest. Těšínsky (2003 a) d’alej uvádza, že uplatnenie pri AD majú aj špecifické metabolické zmeny, ktorých patofyziologické mechanizmy nie sú zatial' celkom jasné, ale môžu súvisiet' s ovplyvnením regulácie výdaja energie na centrálnej úrovni. Malnutrícia môže mat' u pacientov formu nedostatočnej výživy v zmysle hmotnostného úbytku, alebo aj naopak v začiatočných štádiách demencie to môže byt' hmotnostný prírastok v oblasti neaktívnej telesnej hmoty. Ako príčinu predpokladá zmenu pohybového stereotypu s nižším výdajom energie. V pokročilejších štádiách choroby dochádza $\mathrm{k}$ znižovaniu hmotnosti následkom úbytku svalovej hmoty pri zníženej fyzickej aktivite. Z týchto dôvodov považuje za dôležité zvýšit' vo vyššom štádiu demencie energetický príjem, s ciel’om čo najdlhšieho udržania aktívnej telesnej hmoty.

\subsection{Výživa pacienta pri Azheimerovej demencii}

Intervencie v oblasti výživy sa u pacientov s Alzheimerovou demenciou (AD) líšia podl'a toho, aký je pacientov aktuálny stav výživy, miera kooperácie pacienta a jeho opatrovatel'ov, štádia ochorenia a prítomnosti iných ochorení. Aj ked' si samotné ochorenie nevyžaduje špeciálnu diétu, príjem vyváženej stravy v primeranom množstve je u pacientov, ktorí sú schopní perorálneho príjmu pre prevenciu malnutície vel'mi dôležitý. Špeciálny prístup pri výbere nutričných prípravkov a ich podávaní, si vyžadujú pacienti, ktorí odmietajú príjem potravy, majú závažnú formu malnutrície, sú v pokročilom štádiu ochorenia alebo trpia d'alšími vážnymi ochoreniami. Starostlivost' o pacientov s AD je možné rozdelit' do skupín podl'a toho aký prístup a rozsah pomoci je $\mathrm{v}$ rámci zaistenia primeraného nutričného stavu potrebný:

- pacient s $\mathrm{AD}$ schopný samostatného perorálneho príjmu,

- pacient v pokročilom štádiu AD, odkázaný na domácu ošetrovatel'skú starostlivost',

- pacient v pokročilom štádiu AD s manifestnou poruchou výživy zvládnutelnou ambulantne,

- pacient s $\mathrm{AD}$ s t’ažkou kachektizáciou vyžadujúci nutričnú intervenciu pri hospitalizácii (Těšínsky 2003).

K základným opatreniam, ktoré je potrebné uplatňovat' u pacientov s demenciou patrí podávanie pestrej a kvalitnej stravy, primeraná fyzická aktivita, kontrola a udržiavanie stabilnej hmotnosti, obmedzovanie sacharidov a soli a dostatočná hydratácia. U seniorov vo všeobecnosti a u dementných osôb zvlášt' je oslabený pocit smädu a zvýšené riziko hypohydratácie. Kl'účové opatrenie spočíva v nácviku rituálu príjmu tekutín v priebehu celého dňa, prostredníctvom určitého počtu pohárov vody/tekutín, pričom denný príjem má prevyšovat' o 0,5-1 liter straty tekutín. Ak pacient užíva väčšie množstvo liekov, z ktorých niektoré môžu mat' vplyv na príjem potravy, je vhodné ak lekár prehodnotí a upraví jeho medikáciu. Častým problémom, ktorým pacienti trpia je obstipácia. V rámci ošetrovatel’skej starostlivosti je potrebné sa zamerat' na pravidelné sledovanie vyprázdňovania hrubého čreva, 
podávanie optimálneho množstva tekutín, podávanie vlákniny vo forme ovocia, zeleniny a cereálií, nácvik a udržiavanie defekačného reflexu. Pri jedení nezabúdat' na kultúru stolovania, hygienu, pokoj a koncentráciu na jedlo. Tieto aktivity budujú u pacienta určité stereotypy a denné rituály, ktoré majú pre pacienta $\mathrm{v}$ štruktúre celého dňa význam a to sa často u tejto skupiny pacientov podceňuje. Príčinou poruchy príjmu potravy a tekutín, a oslabovania záujmu o jedlo bývajú aj problémy s chrupom, slizničné zmeny pri zlej ústnej hygiene, dehydratácia, nefunkčné a problematické zubné náhrady (Petrová 2015). Správna a dostatočná výživa je dôležitým aspektom zvládania progresie demencie. Špecifické poruchy príjmu potravy často súvisia so štádiom demencie, a sú ovplyvňované závažnost'ou kognitívneho deficitu a postihnutia CNS (tabul'ka 2).

Tabul'ka 2. Poruchy príjmu potravy z hl'adiska štádií demencie (Holmerová 2009)

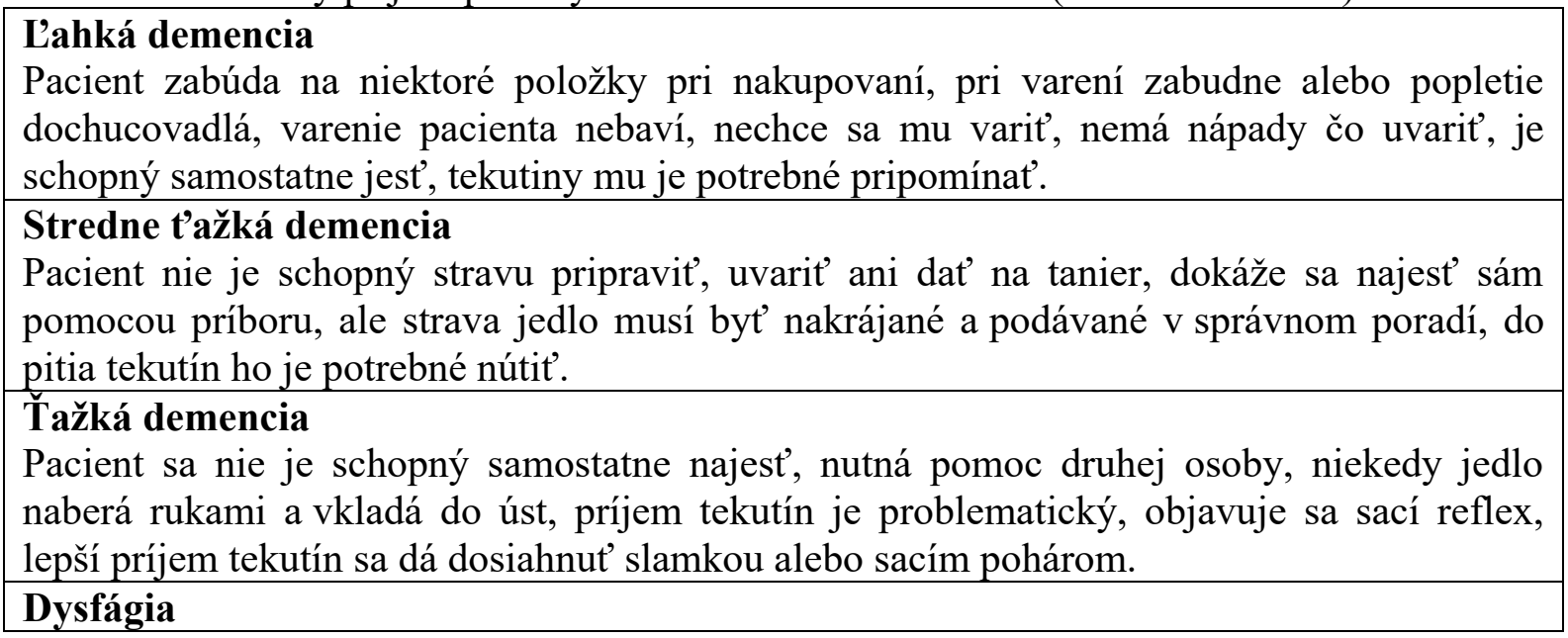

\subsection{Možnosti diagnostiky malnutrície u pacienta s demenciou}

Vývoj príznakov malnutrície je často nenápadný. Najčastejšia je postupná strata hmotnosti, ktorá je následkom nedostatočného množstva prijímanej potravy pri anorexii, alebo neschopnosti dementného pacienta si jedlo pripravit' a zaistit' jeho konzumáciu. Takto vzniká marazmus, ktorý je spôsobený nedostatočným príjmom energie a bielkovín, bez výraznej straty viscerálneho proteínu. Malnutrícia typu kwashiorkor býva u týchto pacientov vzácna, podobne zriedkavá je obezita, ktorá súvisí s príjmom energeticky bohatých potravín (sladkosti, sladené nápoje a pod.) pri sklone pacienta k maškrteniu. Pravidelné meranie hmotnosti pacienta je najjednoduchším spôsobom hodnotenia nutričného stavu pacienta, vhodným indikátorom kontroly adekvátneho príjmu potravy a sledovania efektu nutričnej intervencie. Významným parametrom je index telesnej hmotnosti (BMI), ktorého optimálna hodnota je 24-26. K d’alším antropometrickým parametrom patrí meranie obvodu nedominantného ramena (stav svalovej hmoty), svalová sila (handgrip, dynamometer), výška kožnej riasy nad tricepsom a klinické prejavy stavu výživy ako sú stav kože, vlasov, nechtov, ústnej dutiny a pod. Vyšetrenia mineralogramu, sérovej hladiny albumínu (norma: 35-45 g/l), glykémie (norma: 3,3-5,5 mmol/1), urey ((do $8,0 \mathrm{~mol} / \mathrm{l})$, cholesterolu, transferínu a krvného obrazu patria k základným biochemickým markerom, ktoré môžu signalizovat' zmeny nutričného stavu pacienta. Významné informácie o stravovaní môže poskytnút' samotný pacient alebo jeho opatrovatel' v rámci nutričnej anamnézy. Otázky by mali byt' zamerané na stravovacie návyky, množstvo a zloženie stravy, zaobstarávanie a prípravu stravy, preferenciu jedál a chutí (Jirák, Laňková 2007). V praxi sa používajú aj rôzne škály a dotazníky, ktoré pomáhajú identifikovat' jedinca s malnutríciou alebo rizikom jej vzniku. Niektoré sú špecifické pre určitú klinickú situáciu alebo vekovú skupinu. V našich podmienkach je najčastejšie používaný MNA (Mini-Nutritional Assessment). Je to kompletný nástroj na 
diagnostiku prítomnosti malnutrície alebo rizika jej vzniku. Obsahuje antropometrické parametre - BMI, obvod ramena a lýtka, úbytok hmotnosti za 3 mesiace, anamnestické údaje - prítomnost' somatických ochorení a chronických rán, druh medikácie, ktorú pacient užíva, údaje o funkčnom stave - samoobslužné schopnosti, informácie o psychickom zdraví a subjektívnom vnímaní zdravotného stavu a výživy. Malnutríciu v klinickej praxi nestačí diagnostikovat' a liečit', ale zároveň je potrebné ju predvídat' a venovat' pozornost' jej skríningu, prevencii a liečbe, a tým predchádzat' stavom t’ažkej malnutrície s jej závažnými komplikáciami (Topinková 2003).

\subsection{Možnosti odhadu energetickej potreby a nutričnej intervencie}

$\mathrm{K}$ odhadu, výpočtu alebo meraniu energetickej potreby slúži v klinickej praxi viacero parametrov a výpočtov. Najbližší klinickej realite je parameter označovaný ako pokojový energetický výdaj (REE - resting energy expenditure), ktorý je podl'a Tešínskeho (2004) vhodný na základnú orientáciu pri odhade energetickej potreby pacienta. K jeho výpočtu existuje niekol'ko matematických vzorcov, avšak ako základný odhad stačí vynásobenie telesnej hmotnosti $(\mathrm{kg})$ koeficientom 25 . Vypočítané číslo udáva približný REE v kcal/d (REE u pacienta s hmotnost'ou $70 \mathrm{~kg}$ je približne $1850 \mathrm{kcal} / \mathrm{den}$ ). Presnejším údajom $\mathrm{k}$ výpočtu základného energetického výdaja (BMR - basal metabolic rate) je HarrisBenedictova rovnica:

- muž: BMR $(\mathrm{kcal} / \mathrm{d})=66,5+13,75$ x hmotnost' $(\mathrm{kg})+5 x$ výška $(\mathrm{cm})-6,77 x$ vek (roky)

- žena: BMR $(\mathrm{kcal} / \mathrm{d})=655,1+9,56 \mathrm{x}$ hmotnost' $(\mathrm{kg})+1,85$ x výška $(\mathrm{cm})-4,67$ x vek (roky).

K získaniu klinicky relevantného výsledku sa BMR násobí koeficientom aktivity, ktorý kvantifikuje telesnú aktivitu od pokoja na lôžku až po fyzickú prácu (koeficient 1,2 až 1,7). Energetický výdaj sa dá merat' aj indirektnou kalorimetriou. Analýzou anamnestických údajov, objektívneho vyšetrenia, laboratórnych vyšetrení a odhadu energetickej potreby je možné naplánovat' individuálnu nutričnú stratégiu pre pacienta a zvolit' adekvátnu nutričnú intervenciu (Tešínsky 2004).

Tešínský (2003) medzi základné formy nutričnej podpory a umelej výživy radí: kontrolovaný perorálny príjem, popíjanie nutričných roztokov, enterálna výživa, parenterálna výživa alebo ich kombinácie. Ak je nutričný príjem pacienta používaním týchto metód kvalitatívne a kvantitatívne nedostatočný po dobu dlhšiu ako 2-3 týždne, zvažuje sa aplikačný systém podávania enterálnej výživy prostredníctvom perkutánnej endoskopickej gastrostómie (PEG). V tejto súvislosti by sa mali brat' do úvahy niektoré dôležité aspekty: klinická situácia, diagnóza, prognóza, etické otázky, očakávaný vplyv na kvalitu života a vlastné priania pacienta.

Kontrolovaný perorálny prijem je formou výživy, ktorá je najmenej agresívna, najlacnejšia a najjednoduchšia. Je to prirodzená metóda, ktorá vychádza z diétneho systému nemocnice alebo obvyklej domácej stravy pacienta. Podstatou je kontrola množstva a zloženia jedla ktoré pacient dostáva a preverovanie aké množstvo jedla naozaj skonzumoval. Objektívny denný príjem si pacient zaznamenáva sám, alebo jeho opatrovatel', počas hospitalizácie zdravotnícky pracovník. Nasledujúci deň sa záznamy vyhodnocujú a porovnávajú s optimálnym príjmom. Nutričné hodnoty potravín sú bežne dostupné v tabul'kách a u hospitalizovaných pacientov je možné vyhodnocovat' aj zmerané odpady napr. dusíka alebo minerálov v moči. Na základe výsledkov sa môže diéta pacienta doplnit' proteínmi, minerálmi, chýbajúcimi mikronutrientmi alebo vodou. Tento spôsob výživy sa uplatňuje u pacientov s normálnym stavom nutrície alebo u l'ahkých foriem proteinoenergetickej malnutrície (Těšínsky 2003a).

Popíjanie (sipping) tekutých nutričných substrátov sa kombinuje s perorálnym príjmom alebo s parenterálnou výživou u dobre spolupracujúcich pacientov. Indikáciou je laahká až stredne t’ažká forma proteinoenergetickej malnutrície so zachovanou funkciou hornej časti 
tráviaceho systému. Pacient počas dňa v dohodnutých intervaloch popíja nutričný roztok, ktorý je čo do zloženia a konzistencie podobný roztokom podávaným sondou. Rozdiel je v chut'ovej úprave, ktorá je rozmanitá a výber záleží od pacientových preferencií. Jeden mililiter roztoku obsahuje 1,0-1,5 kcal čo umožňuje bilanciu za predpokladu prehl'adu o množstve vypitého roztoku (Hoozová 2015).

Enterálna výživa je podmienená aspoň minimálnou spoluprácou pacienta. Je spojená s rizikom aspirácie, infekcie a hnačiek. Táto metóda je preferovaná u pacientov, ktorí nedokážu prehítat' a majú funkčné tenké črevo. Základnou zásadou je zavedenie nazogastrickej sondy s predpokladom vyživovania maximálne na 2 týždne, následne by mal byt' podl'a stavu pacienta plánovaný prechod na perorálny príjem, alebo na iný dlhodobý prístup do tráviaceho systému, najčastejšie PEG. Výživové substráty, ktoré sa používajú sú bez chut'ovej úpravy, ich množstvo a zloženie je presne definované, čo umožňuje bilančné sledovanie. Sondou sa pacientovi podávajú aj tekutiny, lieky a nutričné doplnky ako vitamíny, minerálne látky a stopové prvky (Hegyi, Krajčík 2015).

Parenterálna výživa nie je z dlhodobého hl'adiska vhodná pre pacientov s $\mathrm{AD}$ z dôvodu náročnosti metodiky podávania $\mathrm{v}$ domácej aj inštitucionalizovanej starostlivosti, problematickej spolupráce pacienta, a závažných komplikácií, ktoré sú spojené s podávaním výživy do periférnych a centrálnych žilových katétrov. V praxi predstavuje parenterálna výživa najnákladnejší a najnáročnejší spôsob umelej výživy, preto sa u dementných pacientov indikuje skôr na zvládnutie akútnej nutričnej a metabolickej komplikácie pri hospitalizácii, a jej využitie býva dočasné a krátkodobé. Vhodným dočasným spôsobom aplikácie parenterálnej výživy u týchto pacientov by mohli byt' špeciálne periférne alebo centrálne venózne katétre (CVK), ktoré sú bud' tunelizované CVK (Hickman, Broviac), periférne zavádzané CVK (PICC), alebo totálne implantované venózne porty (Porth-a-cath. Mediport) (Tešínsky 2004). Výber vhodného typu katétra závisí od faktorov ako sú: dížka a frekvencia parenterálnej výživy, typ podávaných roztokov, podporná liečba, schopnost' zabezpečit' adekvátnu starostlivost' o katéter, komfort a preferencie samotného pacienta a tiež jeho opatrovatel'a. Ich využitie znižuje výskyt infekčných komplikácií, ktoré vznikajú migráciou mikroorganizmov kožnej flóry pozdĺž katétra, jeho následnú kolonizáciu a vznik katétrovej infekcie. (Nemčíková, Bednarovská 2017). Parenterálna výživa umožňuje rýchlu reakciu na stav pacienta, presnú metabolickú korekciu na podklade bilančného sledovania a cielený farmakologický nutričný zásah. Najčastejšou formou je systém all-in-one (AIO), čo predstavuje kompatibilnú zmes roztoku glukózy, aminokyselín a tukovej emulzie. Súčast'ou zmesi sú minerály, stopové prvky a vitamíny. Vaky s roztokom sa aplikujú pomocou infúznej pumpy do periférnej alebo centrálnej žily (podl'a zloženia a koncentrácie). Režim podávania je bud' kontinuálny (podávanie 24 hodín konštantnou rýchlost'ou), alebo cyklický (podávanie $\mathrm{v}$ noci alebo cez deň), ktorý je vhodný pre podávanie $\mathrm{v}$ domácich podmienkach (Těšínsky 2003a).

Perkutánna endoskopická gastrostómia je indikovaná v prípadoch, ked' nutričný príjem pacienta je nedostatočný po dobu dlhšiu ako 2-3 týždne. Poruchy prehítania a s nimi spojené riziko aspirácie, dehydratácie a progresie podvýživy vyvolávajú potrebu realimentácie invazívnou cestou prostredníctvom PEG. Pred jej zavedením, by mali byt' individuálne prehodnotené prínosy pre pacienta a dôležité je tiež zvážit', či výživa cestou PEG dokáže udržat' či zlepšit' kvalitu jeho života. U pacientov s demenciou sú závažné poruchy príjmu potravy najčastejšie v t’ažkom až terminálnom štádiu choroby. Pri tomto invazívnom spôsobe realimentácie je nutné dodržiavat' indikačné a kontraindikačné kritériá. Podl'a guidelines ESPEN by zavedenie PEG nemalo byt' terminálnym, či dokonca symbolickým opatrením u pacientov s nepriaznivou prognózou, alebo nevyliečitel'nou chorobou a je podl'a súčasných poznatkov a chápania vel’mi zriedka indikované u pacientov s krátkou perspektívou prežitia či pokročilou demenciou. Ďalej uvádza, že zavedenie PEG by malo mat' vždy medicínske 
dôvody a naopak, nemalo by byt' nástrojom ul'ahčenia starostlivosti - úsporou času, finančných prostriedkov, alebo pracovnej sily, rovnako by nemal byt' PEG náhradou dobrej ošetrovatel'skej starostlivosti (Löser 2005). Diskusie odborníkov vyvolávajú otázky, kedy je od tohto spôsobu výživy ustúpit'. Pre ošetrujúceho lekára je vel'akrát t’ažké nepodl'ahnút' tlaku personálu alebo príbuzných a neindikovat' zavedenie PEG v terminálnych štádiách demencie. Na druhej strane, pri správnej indikácii, zaistenie výživy pacienta týmto spôsobom môže riešit' reverzibilnú, alebo čiastočne reverzibilnú situáciu a zlepšit' kvalitu d’alšieho života pacienta (Volicer 2003).

\subsection{Výživa a hydratácia u pacientov v terminálnom štádiu demencie}

V terminálnom štádiu demencie je výskyt poruchy prijímania jedla a tekutín vel'mi častým sprievodným javom zhoršovania celkového stavu pacienta. Niektorí pacienti jedlo a tekutiny odmietajú, ale väčšina $\mathrm{z}$ nich má problémy s prehítaním. Zo závažným nechutenstvom, nevol'nost'ou a problémami s prehítaním úzko súvisí nedostatočný perorálny príjem tekutín, ktorý je v pokročilom štádiu mnohých chronických ochorení pomerne častý. U pacientov sa vyskytuje celková dehydratácia, ktorú navyše zhoršujú zvýšené straty tekutín hnačkami, zvracaním alebo potením. Otázky indikácie parenterálnej výživy a hydratácie u terminálne chorých je kontroverznou a dlhodobou témou mnohých špecialistov v odbore paliatívnej medicíny, geriatrie, neurológie, psychiatrie a lekárskej etiky (Sláma 2008). Vzhl’adom k etickému rovine danej problematiky je nutné postupovat' prísne individuálne, pričom dôležité je akceptovat' aj prianie rodiny, ked'že pacient v tomto štádiu obyčajne nie je schopný vyslovit' svoje prianie a urobit' rozhodnutie. Naopak často je odmietnutie jedla a tekutín pacientom s pokročilou demenciou jedna s posledných možností, ako môže prejavit' svoju vôlu. Holmerová (2009) zdôrazňuje, že v terminálnom štádiu ochorení spôsobujúcich demenciu sa jednoznačne neodporúča aplikácia umelej výživy, a to ani sondou, PEGom, ani intravenóznou aplikáciou tekutín. Tieto spôsoby pacientovi zhoršujú komfort a neprinášajú žiaden prospech. Odporúča zvlhčovanie úst a v rozumnej miere podkožne aplikovat' infúziu (hypodermoklýza) fyziologického roztoku v množstve 500-1000ml.

\subsection{Základné odporúčania nutričnej podpory u pacientov s AD}

\section{Základné opatrenia:}

- včasná diagnostika zníženého záujmu o jedlo,

- sledovanie telesnej hmotnosti a svalovej sily pacienta,

- ritualizácia príjmu jedla pri zachovaní estetiky a úrovne stolovania,

- zachovanie kvality a správneho zloženia jedla, adekvátny príjem tekutín,

- monitoring skutočnej konzumácie jedla,

- zapojit' pacienta do prípravy jedla a jeho podávania.

Opatrenia pri riziku malnutrície, alebo l’ahkej malnutrícii:

- zistenie nutričného stavu a stanovenie jeho nutričných potrieb,

- doplnenie modulárnych prípravkov: proteíny, sacharidy,

- zahájenie sippingu (mimo hlavných jedál).

Opatrenia pri manifestnej, resp. t’ažkej malnutrícii:

- kontrolovaný perorálny príjem a sipping,

- pri zlyhaní základných intervencií je indikovaná enterálna výživa nazogastrickou sondou,

- pri nemožnosti návratu k perorálnemu príjmu potravy je vhodné uvažovat' nad PEG,

- metabolická dysbalancia a t’ažká porucha výživy je indikáciou pre podávanie parenterálnej výživy počas hospitalizácie pacienta, ako definitívna forma výživy sa u pacientov s demenciou využíva zriedka.

Nutričné opatrenia u pacientov s Alzheimerovou demenciou $\mathrm{v}$ zariadeniach dlhodobej starostlivosti: 
- uplatňujú sa všetky spôsoby a metódy nutričnej podpory vrátane postupov zaist’ujúcich hydratáciu, okrem parenterálnej výživy, ktorá sa indikuje akje to potrebné počas hospitalizácie pacienta v nemocničnom zariadení (Tešínsky 2004).

\section{Použitá literatura}

1. HEGYI, L., KRAJČÍK, Š. 2015. Poruchy výživy. Geriatria pre praktického lekára. Vyd. 3. Bratislava: Herba, 2015. 408 s., ISBN 80-89171-36-2.

2. HOLMEROVÁ, I., JAROLÍMOVÁ, E., SUCHÁ, J. a kol. 2009. Péče o pacienty s kognitivní poruchou. Česká alzheimerovská společnost. 2009. 2.vyd., 299 s., ISBN 978-80-86541-28-0.

3. HOOZOVÁ, J. 2015. Malnutrícia u seniorov. Paliatívna medicína a liečba bolesti. 2015, r.8, č. 1e, s. 6-11. ISSN 1339-4193 (online).

4. JIRÁK, R., LAŇKOVÁ, j. 2007. Demence. Doporučený diagnostický a léčebný postup pro všeobecné lékaře. 2007.

5. JIRÁK, R., HOLMEROVÁ, I., BORZOVÁ, C. Demence a jiné poruchy paměti.

6. KUBEŠOVÁ, H., WEBER, P. 2008. Poruchy príjmu potravy ve stárí. Interní medicina pro praxi. 2008. R. 10, č. 2, s. 64-68. ISSN 1803-5256 (on-line verze).

7. LÖSER, ET AL. Doporučení ESPEN k umělé enterální výživě - Perkutánní endoskopické gastrostomii (PEG). Clinical Nutrition 2005.

8. PETROVÁ, R. 2015. Nutriční podpora unemocných s demencí. Geriatrie a Gerontologie. 2015. r. 4, č. 2., s. 87-91. ISSN 1803-6597.

9. TEŠÍNSKY, P. 2003. Výživa u Alzheimerovy demence. Interní medicína pro praxi. 2003. roč. 5, č. 8, s. 13-17. ISSN 1803-5256 (on-line verze).

10. TEŠÍNSKY, P. 2003a. Poruchy výživy u Alzheimerovy demence a možnosti jejich ovlivnení. Psychiatrie pro praxi. 2003, č. 6, s .248-253. ISSN 1803-5272 (on-line verze).

11. TOPINKOVÁ, E. 2003. Využití standardizovaných škál pro hodnocení stavu výživy u staršich nemocných. Česká geriatrická revue 2003, r.1, s. 6-11. ISSN 1214-0732.

12. VOLICER, L. Paliativní př́stupy k pacientiom s demencí. Česká geriatrická revue 2003, r. 2, s. 16-19. ISSN 1214-0732.

\section{Kontakt}

PhDr. Mgr. Zuzana Novotná, PhD.

Katedra ošetrovatel'stva

Fakulta zdravotníckych odborov PU v Prešove

Partizánska 1, Prešov 08001

e-mail: zuzana.novotna@unipo.sk 


\title{
KOMPARAČNÁ KAZUISTIKA ZAMERANÁ NA DIETOTERAPIU \\ U HEMODIALYZOVANÉHO PACIENTA A PACIENTA S PERITONEÁLNOU DIALÝZOU
}

\section{COMPARATIVE CASE FOCUSED ON DIETHERAPY IN A HEMODIALYSISED PATIENT AND A PATIENT WITH PERITONEAL DIALYSIS}

\author{
Šantová Tatiana, Andrea Šuličová, Jana Cinová, Zuzana Šimová, Andrea \\ Obročníková, Zuzana Novotná, L’ubica Derňárová
}

\begin{abstract}
Abstrakt
Chronická renálna insuficiencia (CHRI) patrí medzi významné problémy verejného zdravia nie len na Slovensku, ale aj vo svete. Výskyt tohto ochorenia sa podl'a National Kidney Foundation odhaduje na 9-13\% populácie. Podl'a štatistického prehl'adu Národného centra zdravotníckych informácií sa na Slovensku za rok 2019 liečilo 44181 pacientov s chronickou renálnou insuficienciou v 3. a 4. štádiu. Význam výživy zohráva v súvislosti s ochorením obličiek dôležitú úlohu nie len z hl'adiska terapeutického ale aj preventívneho. Dobrý nutričný stav pacienta $\mathrm{v}$ chronickom dialyzačnom režime je predpokladom pre úspešnú dialyzačnú liečbu, zlepšenie celkovej prognózy ochorenia a minimalizáciu rozvoja sekundárnych ochorení.
\end{abstract}

Kl'účové slová: chronická renálna insuficiencia, dietoterapia, kazuistika, hemodialýza, peritoneálna dialýza,

\begin{abstract}
Chronic renal insufficiency (CHRI) is one of the major public health problems not only in Slovakia but also in the world. According to the National Kidney Foundation, the incidence of this disease is estimated at $9-13 \%$ of the population. According to the statistical survey of the National Center for Health Information, 44,181 patients with chronic renal insufficiency in stages 3 and 4 were treated in Slovakia in 2019. The importance of nutrition plays an important role in connection with kidney disease, not only from a therapeutic but also a preventive point of view. Good nutritional status of the patient in a chronic dialysis regimen is a prerequisite for successful dialysis treatment, improving the overall prognosis of the disease and minimizing the development of secondary diseases.
\end{abstract}

Key words: chronic renal insufficiency, diet therapy, case report, hemodialysis, peritoneal dialysis,

\section{VÝŽIVA PRI CHRONICKOM ZLÝHAVANÍ OBLIČIEK}

Ludia s chronickou renálnou insuficienciou musia prispôsobit' svoje stravovacie návyky ochoreniu a prijat' ich ako neoddelitel'nú súčast' liečebného režimu. Diétne obmedzenia sú rozhodujúce $\mathrm{k}$ udržaniu optimálneho stavu pre pacientov s CHRI, pretože ak sú určité látky prijímane v nadmernom množstve, môže dôjst' k rýchlejšej progresií ochorenia a zhoršeniu celkového zdravotného stavu. $Z$ tohto dôvodu príjem niektorých látok musí byt' regulovaný. Aj ked' úprava stravy priamo nemôže zlepšit' funkciu obličiek, dokáže znížit' nadbytočnú zát’až na obličky a zlepšit' kvalitu života chorých. 


\subsection{Výživa hemodialyzovaných pacientov}

Základom nutričnej terapie u pacientov podstupujúcich HD je zabezpečenie dostatočného prívodu bielkovín a energie. Stimulom pre stratu proteínov je samotná dialyzačná liečba, počas ktorej dochádza $\mathrm{k}$ stratám bielkovín, čo následne zvyšuje riziko vzniku malnutrície a anorexie. Odporúčaný príjem bielkovín pre hemodialyzovaných pacientov predstavuje $1,2-$ $1,4 \mathrm{~g} / \mathrm{kg}$ hmotnosti a potreba energie je 30 - 35kcal $/ \mathrm{kg}$. Medzi štandardné metódy patrí zabezpečenie adekvátnej dialýzy, liečba metabolickej acidózy, úprava stravovacieho režimu individuálne pre každého pacienta a liečba druhotnej infekcie. Ďalšie faktory, ktoré úzko súvisia s nutričným stavom pacienta s CHRI je korekcia príjmu tekutín a liečba komorbidít, najčastejšie zastúpené cukrovkou, kardiovaskulárnymi ochoreniami a infekčnými chorobami. Významným aspektom v stratégií na liečbu je zníženie príjmu škodlivých látok, spravidla obmedzenie fosfóru a draslíka v strave. Nutričný paradox v strave pacientov predstavuje nutnost' dostatočného množstva bielkovín v strave a zároveň zníženie príjmu fosfóru, pretože bielkoviny živočíšneho pôvodu vysokej kvality majú rovnako vysoký podiel práve fosfóru (1).

\subsection{Výživa pacientov s peritoneálnou dialýzou (PD)}

Úprava stravovacích návykov u pacientov podstupujúcich liečbu PD nie je tak prísna ako pri HD liečbe no je rovnako významná. Pri PD realizovanej v domácom prostredí prebieha očist'ovanie tela niekol'kokrát počas dňa, čím sa znižuje riziko hromadenia draslíka v tele a tak opatrenia sú miernejšie a diétny režim vol'nejší. Energetická potreba organizmu pri PD predstavuje 30 - 25kcal/kg hmotnosti. Proteín je makroživina, ktorá je obzvlášt' dôležitá u pacientov liečených PD z toho dôvodu, že počas samotnej realizácie PD dochádza k zvýšenému prechodu bielkovín a albumínov cez peritoneum do dialyzačného roztoku. To zvyšuje deficit proteínov v organizme a významne sa podiel'a na vzniku malnutrície. Pri PD je potrebné rátat' $\mathrm{s}$ kompenzáciou aminokyselín o $2-4 \mathrm{~g} /$ deň a proteínov o $5-15 \mathrm{~g} / \mathrm{den̆}$. Odporúčaný denný príjem je rozmedzí $1,2-1,4 \mathrm{~g} / \mathrm{kg}$. Následné zvyšovanie príjmu bielkovín je v súvislosti so zvýšenou stratou aminokyselín počas PD. Preferované sú proteíny živočíšneho pôvodu a tvoria $2 / 3$ celkového príjmu bielkovín. Bielkoviny rastlinného pôvodu zastávajú $1 / 3$ z množstva bielkovín za deň. U pacientov $\mathrm{s} P$ a príjmom bielkovín rovným alebo vyšším ako $1 \mathrm{~g} / \mathrm{kg} / \mathrm{den}$ sa nachádza dusíková bilancia $\mathrm{v}$ neutrálnom alebo pozitívnom rozhraní, zatial' čo pri dennom príjme bielkovín pod $1,0 \mathrm{~g} / \mathrm{kg}$ sa zvyšuje riziko negatívneho výsledku a vplyvu na organizmus. PD je efektívnejšia v porovnaní s HD, avšak množstvo fosfátov, ktoré možno vylúčit' počas PD je limitované na 300mg a doporučený príjem je do $1 \mathrm{~g}$ fosfátov denne. V rámci prevencie vzniku osteopatií sa odporúča znížit príjem fosfóru v strave (do 4000mg), suplementovat' aktívny vitamín D a užívat' viazače fosfátov aby sa predišlo škodlivým následkom hyperfosfatémie. Vitamíny A a E majú u PD pacientov vyššiu hladinu ako pri hemodialýze a vitamíny B1, B6, kyselina listová a vitamín C sa vplyvom strát do dialyzačného roztoku nachádzajú v zníženom množstve (2).

\subsection{Diétne odporúčania po transplantácií obličky}

Dietoterapia po transplantácií obličky sa riadi konkrétnym stavom metabolizmu po samotnej realizácií transplantácie a prítomnost'ou komplikácií, najmä vedl'ajších účinkov imunosupresie. Správnou diétou po transplantácií sa dá predíst' možným kardiovaskulárnym problémom, dyslipidémií, novovzniknutému diabetu alebo rozvoju malnutrície. Po realizácií transplantácie sa podáva parenterálna výživa, ktorá sa neskôr kombinuje s perorálnou. Energetická potreba organizmu po transplantácií obličky je $30-35 \mathrm{kcal} / \mathrm{kg}$ hmotnosti. Lipidy v potrave môžu mat' priamy vplyv na zdravie a funkciu obličiek. Odporúčania týkajúce sa bielkovín sa pohybujú od $1,2-1,4 \mathrm{~g} / \mathrm{kg}$ hmotnosti na deň. Množstvo bielkovín sa môže individuálne upravit', zvýšit' na $1,5-1,7 \mathrm{~g} / \mathrm{kg}$ hmotnosti alebo znížit' na množstvo 0,8 - 
$1,0 \mathrm{~g} / \mathrm{kg}$ hmotnosti denne. Zásadný rozdiel oproti dialyzačnému režimu je v príjme tekutín. Po transplantácií sa príjem tekutín zvyšuje, optimálne na $2-3$ litre tekutín denne, avšak stále sa sleduje stav hydratácie a diuréza. $Z$ bielkovinových zdrojov sa uprednostňuje hydina a ryby, vajíčka. Diéta má obsahovat' dostatočné množstvo netučných mliečnych výrobkov, ktoré zabezpečia dostatočný prívod vápnika. Vhodné tekutiny sú čistá voda, nesladené minerálky s nízkym obsahom sodíka, horké čaje a pasterizované mlieko (nízkotučné). Strava by mala obsahovat' dostatok ovocia a zeleniny, sledovanie kália už nie je prioritou ale je rozumné vyhýbat' sa potravinám vysoko bohatým na draslík. Zelenina ako je mrkva, petržlen, zeler a zemiaky sa odporúča varit’ dokonalo olúpené. Aby sa zachoval čo najvyšší pomer vitamínov $\mathrm{v}$ tepelne upravovanej zelenine, odporúča sa varenie v tlakovom hrnci (3).

\section{KAZUISTIKA ZAMERANÁ NA DIETOTERAPIU U HEMODIALYZOVANÉHO PACIENTA A PACIENTA S PERITONEÁLNOU DIALÝZOU}

\subsection{Ciele prieskumu}

Hlavným ciel'om bolo posúdit' a poukázat' na stravovacie návyky hemodialyzovaného pacienta a pacienta liečeného prostredníctvom peritoneálnej dialýzy. Čiastkovými ciel'mi sme chceli zistit' stravovacie návyky respondentov, porovnat' postoj respondentov k dodržiavaniu diétneho režimu pri HD a PD, poukázat' na špecifiká diétneho režimu pri dialýze a odhalit' problémy v oblastiach diétneho režimu dialyzovaných pacientov.

\subsection{Metodika}

Použili sme kvalitatívnu metódu kazuistiku. Prvá kazuistika bola spracovaná u pacienta zaradeného do dialyzačného programu, druhým zaujímavým prípadom sme chceli poukázat' na diétne obmedzenia u pacienta PD. Použili sme aj metódu neštandardizovaného rozhovoru s respondentami, ktorý sa zameriaval na stravovacie návyky a stravovací režim oboch respondentov a metódu analýzy dokumentácie respondenta. Všetky informácie boli získavané so súhlasom oboch respondentov.

\subsection{Súbor}

Respondenti boli vyberaní zámerne, na základe vopred stanovených kritérií. Obaja respondenti museli mat' diagnostikované ochorenie chronická renálna insuficiencia, zaradení do dlhodobej dialyzačnej liečby a liečení prostredníctvom jednej z jej metód ( HD alebo PD).

\subsection{Kazuistika u pacienta liečeného hemodialýzou (HD)}

\section{Anamnéza}

Prvá kazuistika sa zaoberá 33-ročným respondentom v konečnom štádiu chronického zlyhania obličiek (KDIGO G5A3). Respondent je zaradený do dlhodobého dialyzačného režimu, liečený prostredníctvom hemodialýzy.

Osobná anamnéza: v detstve sa u respondenta opakovane vyskytovali rinofaringitídy, vo veku 15 rokov vykonaná tonzilektómia. Počas hospitalizácie respondenta na internom oddelení v roku $2016 \mathrm{mu}$ bola diagnostikovaná arteriálna hypertenzia 2. stupňa. U respondenta sa vyskytla obličková kolika v roku 2013 a opätovne v roku 2015, kedy bola dokázaná prítomnost' obličkových konkrementov a následne vykonaná extrakorporálna litotripsia (ESWL). Od septembra 2016 je respondent zaradený do dlhodobého dialyzačného programu pre CHRI, ktorá vznikla na podklade chronickej pyelonefrídy. V anamnéze respondenta sa nachádza aj vredová choroba žalúdka, na ktorú sa lieči od roku 2019. 


\section{Katamnéza}

Prvé príznaky ochorenia obličiek sa u respondneta prejavili približne okolo 24. roku života.. V prvých štádiách ochorenia prevládali nešpecifické príznaky, ako bolo zvýšenie krvného tlaku, časté bolesti hlavy, únava a st’ažené dýchanie. Nepripisoval im žiadnu dôležitost'. Respondent bol prvýkrát vyšetrený nefrológom v roku 2015, kedy bol hospitalizovaný na urologickom oddelení pre prítomnost' hematúrie a obličkovej koliky. Po vykonaní ESWR a pred prepustením respondenta z oddelenia mu bolo doporučené navštívit' nefrologickú ambulanciu pre príznaky chronickej pyelonefritídy. Respondent ani na odporúčanie praktického lekára odbornú ambulanciu nenavštívil. Respondent sa hospitalizácií nevyhol a v septembri 2016 bol hospitalizovaný na internom oddelení pre vystupňovanú hypertenziu, prítomnost' nauzei a opakované bolesti hlavy, ktoré však on odmietol priznat'. Laboratórne vyšetrenia odhalili vysokú hladinu kreatíninu, $430 \mu \mathrm{mol} / 1$. Bolo indikované konziliárne vyšetrenie nefrológom. Ultrasonografické vyšetrenie odhalilo patologické zmeny kalichovopanvičkového systému obličiek $\mathrm{v}$ zmysle jeho dilatácie a obraz obojstrannej chronickej pyelonefritídy. Na podklade tohto ochorenia sa u respondenta vyvinula chronická renálna insuficiencia v poslednom štádiu s nutnost'ou okamžitej dialyzačnej liečby. Možnost' liečby peritoneálnou dialýzou bola u tohto pacienta zamietnutá z dôvodu nespolupráce respondenta počas hospitalizácie a nezodpovednosti pri dodržiavaní farmakologickej liečby. Respondent liečbu dialýzou zo začiatku odmietal. Napokon po opakovaných rozhovoroch s lekárom situáciu prijal a začal sa zmierovat' so svojou novou diagnózou. Bola vytvorená A-V fistula vo vena jugularis interna vpravo. Od 21. septembra 2016 prebieha pravidelná dialyzačná liečba, stabilizoval sa aj krvný tlak, zmiernili sa opuchy. U respondenta bola realizovaná edukácia ohl'adom režimových a diétnych opatrení. V roku 2017 sa respondent aj s rodinou prest'ahovali do Anglicka. Počas tohto pobytu respondent prestal dodržiavat' režimové opatrenia. V januári 2021 sa respondent aj s rodinou vrátil na Slovensko. Navštevuje dialyzačné centrum štyrikrát týždenne, liečba trvá 4 hodiny. Respondent bol koncom januára 2021 hospitalizovaný na internom oddelení, kam bol prevezený z dialyzačného zariadenia pre t’ažkú anémiu. Už počas pobytu v hemodialyzačnom centre bolo personálu zrejmé, že respondent nedodržiava režimové opatrenia. Podl'a správ z dialýzy, respondent je hyperhydratovaný, často prichádza s vysokým krvným tlakom - podávajú mu Nitresan $20 \mathrm{mg}$ per os. Aj napriek opakovanému poučeniu respondent nedodržiava pitný režim, predpokladajú že ani diétne opatrenia a farmakoterapiu, pokial' nemá zrejmé t’ažkosti. Pri prijatí na oddelenie sa respondent cítil slabý, nevýkonný, t’ažšie sa mu dýchalo. Udával zníženú chut' do jedla a prítomnost' nauzei. Laboratórne hemoglobín $67 \mathrm{~g} / 1$. Respondent bol na oddelení hospitalizovaný osem dní, na konci ktorých bol jeho stav vyhodnotený ako renálna anémia pri CHRI. Respondentovi bola znova pripomenutá dôležitost' a nevyhnutnost' dodržiavania liečby, režimových opatrení a diétnych odporúčaní.

\section{Analýza}

S respondentom sme viedli rozhovor zameraný na jeho režim stravovania, stravovacie návyky a kvalitu potravín v jeho jedálničku.. Následne sme si vyselektovali a analyzovali vybrané oblasti problematiky stravovania. Diétny režim hemodialyzovaného pacienta so sebou prináša celý rad obmedzení. Zaujímali sme sa aj o to, ako sú jednotlivé obmedzenia vnímané zo subjektívnej stránky pacienta. „Prídu mi obmedzujúce. To je asi hlavný dôvod toho, prečo diétu viac-menej nedodržiavam. Nerád sa v niečom obmedzujem. " Význam jednotlivých reštrikcií je dôležité vysvetlit' pacientovi ešte pred začatím liečby. Práve tieto obmedzenia vo výžive sú najčastejším dôvodom non-compliancie pacienta. Respondent na konci prejavil záujem o získanie nových informácií, predovšetkým v oblasti správneho príjmu tekutín, vhodných a nevhodných potravín a možných komplikácií, ktoré môžu vzniknút' pri nedodržaní diétnych obmedzení. Prvá vybraná oblast' sa zaoberala samotným stravovacím 
režimom respondenta a nutričnou anamnézou. U hemodialyzovaných pacientov je dôležitý dostatočný príjem energie. Problémy kalorického príjmu s následnou malnutríciou sú spájané s vyššou morbiditou a mortalitou. Medzinárodná organizácia ISRNM odporučila pojem protein-energy waste (PEW), vzhl'adom na komplexnost' problému. Pojem PEW popisuje stav nutričnej poruchy a metabolizmu u pacientov s CHRI charakterizovaný úbytkom zásob proteínu a energie. To vedie $\mathrm{k}$ následnej strate svalovej hmoty, tukového tkaniva a kachexií.. U respondenta sa nenachádzajú žiadne doplnky výživy v zmysle vitamínov. Hemodialyzovaní pacienti sú často ohrození rozvojom anémie. $Z$ anamnézy respondenta vieme, že sa na anémiu lieči od januára 2021. V rámci efektívnej prevencie a zároveň aj liečby je relevantná suplementácia železa vhodnou formou (4). Druhá oblast' bola orientovaná na príjem tekutín. Jednou z hlavných funkcií obličiek je udržiavanie elektrolytovej rovnováhy a počas CHRI dochádza k progresívnej strate schopnosti obličiek udržiavat' homeostázu vnútorného prostredia. (5). Ak pacient, ktorý je liečený HD príjme počas dňa viac tekutín ako má dovolené, nadbytočná voda sa začne hromadit' v organizme. Prvým viditel'ným prejavom sú opuchy, najmä v oblasti členkov a viditel'né sú aj opuchy tváre (6). V rámci posúdenia tekutín sme sa zaujímali o množstvo tekutín, ktoré respondent môže prijat'. Viem, že príjem tekutín sa odvija od množstva vylúčeného moču a k tomu sa pripočita $500 \mathrm{ml}$ tekutín. Presné množstvo povolených tekutín nám nevedel udat'. Vyššie spomenuté komplikácie sa vyskytli u prvého respondenta, čo len potvrdilo jeho výrok o nedodržiavaní pitného režimu. V súvislosti s tekutinami je dôležité spomenút' pojem suchá hmotnost'. Pacient uviedol, že je to váha medzi jednou a druhou dialýzou. Ide o ideálnu hmotnost' pacienta, pri ktorej u pacienta nie sú prítomné príznaky hromadenia tekutín v organizme (6).

Tretia a posledná čast' analyzovala kvalitu potravín, ktoré sú obsiahnuté v respondentovom jedálničku. Základom dietoterapie pri CHRI je správny príjem bielkovín, ktorý sa počíta pre každého pacienta zvlášt'. Dôležité je, aby mal pacient vedomosti o tom, aké je jeho povolené množstvo a aké bielkoviny je vhodné prijímat'. „Aj mi to bolo povedané ale neviem Vám povedat'. Ako som Vám hovoril tak diétu nejako nedodržiavam a nesledujem ani bielkoviny. “ Neprimeraný príjem bielkovín v zmysle ich nadmerného množstva má za následok zát'až pre obličky s následným rozvojom uremického syndrómu. Pokial' tento stav ostane neriešený, môže ohrozit’ život pacienta. Na druhej strane, znížený príjem bielkovín ohrozuje pacientov rozvojom malnutrície. Pri CHRI je dôležité telu dodávat' kvalitné bielkoviny, bez zbytočného obsahu nasýtených tukov. Na otázku zameranú na príjem mäsa sme dostali odpoved': Najskôr to bude hydina. Tú chováme aj doma tak sa to väčšinou strieda, hydina s bravčovinou. Obmedzenie sodíka a draslíka v strave je d'alší dôležitý atribút diétneho režimu pacienta s HD. Sodík a draslík spoločne s chlórom ovplyvňujú osmotický tlak v krvnej plazme a pri ich deficite sa môžu vyskytovat' bolesti hlavy, kŕče, poruchy krvného obehu a život ohrozujúce narušenie acidobazickej rovnováhy. Pri pozitívnej sodíkovej bilancií organizmu vznikajú opuchy, zvyšuje sa krvný tlak a narastá proteínúria a telesná hmotnost'. Hladina draslíka v potravinách sa dá jednoducho znížit' ich tepelnou úpravou alebo vylúhovaním (5). $\mathrm{V}$ jedálničku respondenta nachádzame aj mlieko, jogurt a tvaroch. Bez doplnenia fosfátových viazačov v strave môže u pacienta dôjst' $\mathrm{k}$ hyperfosfátemií. Na otázku týkajúcu sa príjmu ovocia a zeleniny odpovedal respondent: „,Jablká alebo hrušky, máme doma aj ovocné stromy tak mám vždy nejaké po ruke. Zjem možno jedno-dve jablko denne. Povedal by som zeleninu, že aj každý den̆. Paprika, paradajky, cibul'a, kapusta, najčastejšie v polievke alebo bez nejakej d’alšej úpravy. " Jablká spolu s hruškami patria do skupiny nízkodraslíkových potravín, ktoré sú povolené ale ich nadmerné užívanie sa neodporúča. Pri zvýšenej konzumácií jabík je potrebné ich započítat' do príjmu kália a vody (7). 


\subsection{Kazuistika u pacienta liečeného peritoneálnou dialýzou (PD)}

\section{Anamnéza}

Druhá kazuistika je zameraná na 59 - ročného respondenta v poslednom štádiu chronického ochorenia obličiek (KDIGO G5). Respondent je zaradený do dlhodobého dialyzačného programu, liečba sa u tohto respondenta vykonáva formou peritoneálnej dialýzy.

Osobná anamnéza: v detstve prekonal bežné detské ochorenia, s výnimkou prekonania novorodeneckej žltačky. V roku 2012, počas hospitalizácie na internom oddelení mu bola diagnostikovaná arteriálna hypertenzia 3. stupňa, v roku 2013 vykonaná gastrofibroskopia pre potvrdenie erózivnej gastropatie a duodenopatie. $\mathrm{V}$ tom istom roku sa u respondenta prvýkrát vyskytli vonkajšie hemoroidy, ktoré lieči konzervatívnou metódou. V roku 2014 zistená chronická nefropatia na podklade nefroangiosklerózy v koincidencií s chronickou renálnou insuficienciou, ktorá vznikla v dôsledku tubulointersticiálnej nefritídy. Od mája 2014 zaradený do dlhodobého dialyzačného programu, liečený formou peritoneálnej dialýzy. V súvislosti s CHRI sa lieči na prítomnost' sekundárnej hyperparatyreózy, sekundárnu poruchu kalcio-fosfátového metabolizmu a anemický syndróm l'ahkého stupňa (normocytárny, normochrómny). V decembri 2020 prekonal COVID-19 infekciu.

\section{Katamnéza}

U respondenta sa prvé príznaky objavili v roku 2002, kedy bol prvýkrát hospitalizovaný na internom oddelení. Vtedajšie t’ažkosti boli zastúpené vysokými telesnými teplotami (nad $39^{\circ} \mathrm{C}$ ), bolest’ami v krížovej oblasti, mierne zvýšeným krvným tlakom a st’aženým dýchaním. Respondentovi bola na základe d'alších vyšetrení stanovená diagnóza chronickej glomerulonefritídy. Po úprave klinického obrazu bol respondent prepustený do domácej liečby s odporúčaním nefrologickej dispenzarizácie. Ťažkosti sa vrátili v roku 2012 a tak sa respondent rozhodol na odporúčanie praktického lekára navštívit' nefrologickú ambulanciu. $\mathrm{Na}$ základe odborných vyšetrení bola určená diagnóza CKD G3a podla KDIGO a pre respondenta bola odporúčaná konzervatívna liečba, úprava stravy a životosprávy. V tomto období sa respondent cítil nevýkonný, malátny a strácala sa chut' do jedla, následne sa pridružili aj problémy s vylučovaním moču v zmysle polyúrie. Respondentovi už počas návštev nefrologickej ambulancie bolo povedané, že jedného dňa bude musiet' prejst' na dialyzačnú liečbu.

Počas návštevy obvodného lekára v roku 2014 prítomná hypertenzia 215/115 mmHg, tachykardia 105 pulzov za minútu. Pri odbere zistená zvýšená hladina kreatíninu - 556,5 $\mu \mathrm{mol} / 1$. Respondent bol pre diskorigovanú hypertenziu opakovane prijatý na interné oddelenie. Dalšie testy a vyšetrenia potvrdili prítomnost' zníženej glomerulárnej filtrácie, proteinúrie stredne t’ažkého stupňa v močovom sedimente $2,9 \mathrm{~g} / 24$ hodín a mikroskopickú hematúriu. Diagnóza bola uzavretá ako Hypertenzná nefroskleróza s redukciou glomerulárnej filtrácie. Respondentovi bolo oznámené, že jeho obličky zlyhávajú natol'ko, že je nevyhnutné začatie dialyzačnej liečby. Boli mu vysvetlené obe možnosti dialýzy, navrhnuté dochádzanie do dialyzačného strediska štyrikrát týždenne, alebo realizovat' peritoneálnu dialýzu v domácom prostredí. Respondent sa rozhodol pre liečbu PD, bol preložený na chirurgické oddelenie za účelom vytvorenia CAPD katétra pre potreby dialýzy. Po stabilizácií stavu respondenta bol preložený naspät' na interné oddelenie, kde nasledovala d'alšia liečba. V rámci tejto druhej hospitalizácie bola respondentovi upravená farmakologická liečba pre pridruženie normocytárnej, normochrómnej anémie stredne t’ažkého stupňa. V súčasnosti respondent vykonáva dialýzu v režime CAPD. 


\section{Analýza}

Z hl'adiska nutričnej anamnézy sme analyzovali predovšetkým stravovacie návyky respondenta počas dňa. „Snažím sa jest'v pravidelných intervaloch, tie 3 hlavné jedlá počas dňa a k tomu zvyčajne nejakú malú desiatu a olovrant. Väčšinou mám so sebou v práci nejaké ovocie. "Správne rozloženie energetického príjmu počas dňa zabezpečuje, že organizmus pacienta má dostatok síl k využitiu všetkých zložiek potravy (8). Pacienti s CHRI sú ohrození poruchou metabolizmu kalcia a fosfóru. Práve regulácia týchto dvoch látok je závislá od funkcie obličiek, pri ich poruche dochádza k zníženému vylučovaniu fosfóru a následnej hyperfosfátemie. Spoločne s hypokalciémiou a so zníženou hladinou kalcitonínu sa stimuluje sekrécia parathormónu, ktorý spätne uvol’ňuje vápnik z kostí. $\mathrm{Na}$ podklade týchto zmien vzniká hyperparatyreóza a renálna osteopatia. Vhodným diétnym režimom a liekmi sa dá udržat' hladina fosfóru a kalcia v norme (5). Z toho dôvodu je pozitívnym prínosom zaradit' viazače fosfóru a doplnok vitamínu $\mathrm{D}$ do jedálnička. Obe sú zaradené v liečbe druhého respondenta vo forme kapsúl Sevelamer Carbonate Mylan 800mg a Zemplar 1mcg. Na otázku zaoberajúcu sa problémami s príjmom potravy a zmenou chuti do jedla respondent odpovedal negatívne, tak sme otázku d’alej nerozvíjali.

$\mathrm{Aj}$ u druhého respondenta sme sa zaoberali množstvom povolených tekutín. Na túto problematiku nám respondent poskytol jasnú odpoved’. „Podla množstva vylúčeného moču a $500 \mathrm{ml}$ navyše. Snažím sa to dodržiavat' ale niekedy na to aj pozabudnem. Väčšinou si to odsledujem tak, že vypijem najviac tri 0,3l poháre. Mávam na obed aj polievku a dám si aj kávu tak beriem ohl'ad aj na to. Naposledy čo som to sledoval tak som mal diurézu 600ml." Pre pacientov podstupujúcich dialyzačnú liečbu je výhodné poznat' rôzne metódy pre zamedzenie smädu. Aj na túto problematiku nám respondent poskytol príklad. Vyplachovanie úst, cmúl'anie cukrikov alebo l'adu. " Rovnako ako u hemodialyzovaných pacientov, aj pre pacientov s peritoneálnou dialýzou platí odporúčanie pravidelného váženia a sledovanie suchej hmotnosti v domácom prostredí. Respondent vníma pojem suchá hmotnost' ako: „, Stav ked' sa cítim dobre, nemám zvýšený krvný tlak a nemám žiadne opuchy. " Pravidelné sledovanie suchej hmotnosti dokáže výrazne dopomôct' k zachyteniu hyperhydratácie organizmu, ktoré sa môže prejavit' ako zvýšený krvný tlak, edémy, nárast hmotnosti, kašel' a dychová nedostatočnost'. Chronická hyperhydratácia môže mat' za následok hypertenziu až zlyhanie srdca. Avšak respondent odpovedal, že pravidelné váženie v domácom prostredí nerealizuje. $\mathrm{Na}$ otázku o obl'úbených tekutinách odpovedal, že najradšej má neochutenú, neperlivú vodu a počas dňa vypije dve kávy.

Poslednou oblast'ou bola kvalita potravín. Prvá otázka sa týkala povoleného množstva bielkovín. Druhý respondent má stanovený príjem bielkovín na množstvo $1,0-1,1 \mathrm{~g}$ bielkovín na kg hmotnosti. Dôležité je poznamenat' význam dostatočného príjmu bielkovín. Dialyzovaní pacienti môžu počas jedného dňa s realizáciou dialýzou stratit' až $12 \mathrm{~g}$ bielkovín. Náchylnost' k vzniku malnutrície zo zníženého príjmu bielkovín a energie sa môže znížit' prostredníctvom doplnkov výživy. Ich podávanie je spájané najmä s optimalizáciou rovnováhy bielkovinového metabolizmu, bez negatívnych účinkov na stav elektrolytov. Malnutrícia d'alej prispieva k častejšiemu výskytu infekčných ochorení so závažnejším priebehom, ako je napríklad zápal plúc (9). Hlavný zdroj bielkovín u respondenta predstavuje mäso. Najčastejšie hydina. Hovädzie som nikdy nemal nejako extrémne v oblube. Sem tam manželka urobi niečo z bravčového. Do stravy zaradzuje aj mliečne výrobky, ovocie a zeleninu. Z hl'adiska príjmu ovocia a zeleniny sa PD pacienti nemusia obmedzovat' až v takej miere ako pacienti na HD. Ďalšou dôležitou súčast'ou liečebnej výživy je reštrikcia sodíka v strave. Ten sa dá dostatočne regulovat' zamedzením nadmerného solenia jedál. Zaujímali sme sa o vedomosti respondenta v oblasti obmedzenia prísunu práve týchto dvoch látok. „Namiesto soli využivat' bylinky. Obmedzit' príjem surovej zeleniny, ovocia, orechov, sušeného ovocia. Zeleninu tepelne upravovat." Pri záverečnej otázke zaoberajúcej sa 
výskytom komplikácií respondent uviedol, že pri nedodržaní pitného režimu v zmysle hyperhydratácie subjektívne pocit'oval pocit búšenia srdca a prítomný bol aj zvýšený počet pulzov.

\subsection{Diskusia}

\section{Porovnat' postoj respondentov k dodržiavaniu diétneho režimu pri HD a PD}

Respondent č. 1 hned' na začiatku zberu informácií uviedol, že diétu nedodržiava. Respondent uviedol, že obmedzenia súvisiace shemodialýzou sú pre neho obmedzujúce. Podl'a dokumentácie sme zistili, že respondent na dialýzu často prichádza hyperhydratovaný, na povolené množstvo tekutín odpovedat' nevedel. Respondent nemá stály stravovací režim, nesleduje príjem bielkovín, množstvo kália a soli $\mathrm{v}$ jedle. U prvého respondenta bol pozorovaný častejší výskyt komplikácií, ktoré súvisia s primárnym ochorením. Vyskytla sa znížená chut' do jedla, ktorá je v prípade ochorenia obličiek spájaná s vyššou sérovou koncentráciou uremických toxínov. Prítomne boli aj malé opuchy tváre a dolných končatín, ktoré podporujú tvrdenie o nedodržiavaní pitného režimu.

U respondenta č. 2 bola pozorovaná vyššia ochota sa aktívne podiel'at' na liečebnom procese práve dodržiavaním diétnych opatrení. Respondent v rámci možností dodržiava bielkovinovú reštrikciu, má stanovený stravovací režim, ktorý si prispôsobil režimu dialýzy. Respondent má vysokú úroveň vedomostí o príjme tekutín, sleduje si množstvo prijatých tekutín, bola zistená aj vysoká úroveň vedomostí týkajúcich sa obmedzenia sodíka a zamedzeniu smädu ako aj o pojme „suchá hmotnost“، Tieto tvrdenia nám podporila dokumentácia respondenta, kde je uvedená suchá hmotnost' respondenta $63,0 \mathrm{~kg}$ a súčasná hmotnost' respondenta $63,2 \mathrm{~kg}$.

\section{Poukázat' na špecifiká diétneho režimu pri dialýze}

V strave hemodialyzovaného pacienta sú preferované živočíšne bielkoviny obsiahnuté predovšetkým v mäse, vajíčkach, mlieku a mliečnych výrobkoch. Neodporúčajú sa údeniny, ktoré majú nízky obsah bielkovín no vysoký obsah tuku a energie. V syroch sa sleduje obsah soli a pomer bielkovín - fosfóru a vápniku - fosfóru. Neodporúča sa do stravy zaradzovat' tavené syry a plesňové syry, ktoré majú vysoký obsah fosfóru a soli. Vajíčka sú bohatým zdrojom kvalitných bielkovín, vitamínov A a D, kalcia, železa a lecitínu avšak konzumácia žltka sa obmedzuje kvôli vysokému obsahu fosfóru $(250 \mathrm{mg} / 1$ kus $)$ a cholesterolu (320mg/1kus). Povolené je konzumovat' $1 / 2$ žltka na deň. Z mäsa sa uprednostňuje biele a hovädzie alebo tel'acie mäso. Ryby sú v strave zastúpené aspoň $1 \mathrm{x}$ týždenne $\mathrm{z}$ dôvodu vysokého obsahu omega 3 mastných kyselín. Ich negatívom je vysoký obsah fosfóru. Pre hemodialyzovaných pacientov sú vhodnejšie rastlinné tuky, tuky živočíšne sú v strave zastúpene v menšom množstve. Energia, rastlinné bielkoviny, draslík, fosfór a sodík je obsiahnutý v pečive, chlebe a pekárenských výrobkoch, ktoré predstavujú sacharidovú zložku potravy. Zemiaky sa nachádzajú uprostred medzi plnohodnotnými a neplnohodnotnými bielkovinami. Ovocie a zelenina patrí do skupiny neplnohodnotných bielkovín a ich množstvo záleží od povoleného množstva draslíka. Doporučuje sa čerstvé ovocie, ovocné št'avy sú obmedzené až zakázané (8). Nutné je obmedzit' príjem kuchynskej soli pre vysoký obsah sodíka, ktorý poškodené obličky nie sú schopné regulovat'. Vo vel'kom množstve sa nachádza najmä v údeninách, polotovaroch a hotových jedlách, solených orieškov a lupienkoch. Potraviny rastlinného pôvodu, predovšetkým čerstvá zelenina ovocie ako sú banány, marhule, hrozno, pomaranče, grepy, avokádo, paradajky, špenát, ružičková kapusta, huby, orechy, čokoláda a sušené ovocie obsahujú vysoký podiel draslíka, ktorý je pri zníženej GF škodlivý pre činnost' srdca. Množstvo draslíka v jednotlivých potravinách možno znížit' ich tepelnou úpravou, a to varením či vylúhovaním. Aby sa zamedzilo nadmernému príjmu fosfóru sleduje sa jeho obsah v potravinách ako sú mliečne výrobky, paštéty, strukoviny, orechy, čokoláda, instantné polievky a sýtené nápoje Režim PD pacienta dodržiava všetky technologické 
postupy a zásady ako počas HD, avšak aj tá má svoje špecifiká. Diétna výživa je v prípade PD pacienta o čosi vol'nejšia, najmä v príjme tekutín a draslíka, ked'že proces očist'ovania tela prebieha niekol'kokrát denne. Počas PD je menšie riziko vzniku hyperkaliémie, teda títo pacienti sa nemusia striktne obmedzovat' v príjme ovocia a zeleniny (10).

\section{Odhalit' problémy v oblastiach diétneho režimu dialyzovaných pacientov.}

V oblasti týkajúcej sa stravovacieho režimu bol u prvého respondenta identifikovaný problém v samotnom režime stravovania. Respondent nemá stanovený stály režim a v strave chýbajú doplnky stravy, ktoré dokážu zabránit' rozvoju d’alších komplikácií. Druhý respondent má stanovený režim, ktorý zodpovedá požiadavkám diétneho režimu ako aj doplnok vitamínu $\mathrm{D}$ a viazače fosfátov. $\mathrm{V}$ druhej skúmanej oblasti sme u oboch respondentoch mohli pozorovat' nedostatok informácií o výhodách pravidelného váženia. Pravidelné váženie v domácom prostredí nie je podmienkou režimu, avšak sa vysoko odporúča, pre jeho prínos pri sledovaní celkového zdravotného stavu. Váženie v domácom prostredí sa odporúča predovšetkým pacientom s PD, z dôvodu kontrolnej návštevy dialyzačného centra raz za 6 týždňov. U prvého respondenta sme mohli pozorovat' aj určitý stupeň l'ahostajnosti k dodržaniu pitného režimu, ako aj sledovaniu diurézy. V poslednom skúmanom okruhu, kde sme hodnotili kvalitu potravín, sme si nemohli nevšimnút' určitý stupeň stagnácie vo výbere ovocia do jedálneho lístka u oboch respondentov. Pacienti si v domácom prostredí môžu stravovanie v určitej miere prispôsobit' svojim individuálnym potrebám avšak so zachovaním odporúčaných zásad. Ako samostatný problém $\mathrm{v}$ rámci diétneho režimu je na mieste uviest' nedostatok vedomostí respondentov o možných komplikáciách, ktoré môžu vzniknút' práve z jeho nedodržania. Obaja respondenti uviedli, že v prípade realizácie opätovnej edukácie by mali záujem o informácie týkajúce sa prevencie metabolických komplikácií CHRI. Metabolické komplikácie CHRI súvisia predovšetkým s nadmerným príjmom sodíka - zvýšenie tlaku krvi a zadržiavanie vody v tele, draslíka - poruchy srdcového rytmu, fosfóru - poškodenie kostí, nadmerný príjem tekutín - zvýšenie telesnej hmotnosti a problémy s dýchaním a napokon rozvojom malnutrície. V práci Nikolić (2017) zaoberajúcej sa rovnako stravovacími zvyklost'ami dialyzovaných pacientov bolo zistené, že najmenšia úroveň vedomostí pacientov o komplikáciách sa týkala nadmerného príjmu sodíka a fosfóru. Rovnako bola u piatich pacientov (z 30 sledovaných) zistená znížená chut' do jedla v súvislosti so vzostupom sérovej hladiny uremických toxínov, ako tomu bolo aj u prvého respondenta. Práca Andrýsovej (2015) zistila, že väčšia polovica sledovaných pacientov (26 dialyzovaných pacientov) si nemyslí, že sú ohrození malnutríciou. Štúdie dokazujú, že malnutríciou je ohrozených 40 $70 \%$ pacientov podstupujúcich dialyzačnú liečbu. Rovnaký problém sme sledovali aj u našich respondentov. Predpokladá sa, že príčinou by mohla byt' nedostatočná informovanost' pacientov a nedostatočný dôraz na možné následky (11).

\subsection{ZÁVER}

Úspešná nutričná terapia je u pacientov, ktorí sú liečení prostredníctvom jednej z foriem dialýzy neodmyslitel'nou súčast'ou ošetrovatel'skej starostlivosti. Poznat' individuálne potreby klienta zaradeného do dlhodobého dialyzačného programu má nezastupitel'nú úlohu pre správne pochopenie diétneho režimu. Diétny režim pacienta s CHRI je iný v každom štádiu ochorenia, ale vždy má svoje opodstatnenie. Pacient jeho dodržiavaním znižuje možnost' rozvoja d’alších metabolických komplikácií spojených s primárnym ochorením a zvyšuje možnost' kvalitnejšieho života. 


\section{Použitá literatúra}

1. 1.SASÁKOVÁ, D., MATĚJKOVÁ, M., 2012. Výživový průvodce dialyzovaného pacienta. Praha: Mladá fronta a.s., 35s.

2. 2.BEDNÁŘOVÁ, V., DUSILOVÁ SULKOVÁ, S. a kol., 2007. Peritoneální dialýza. 2. rozšířené a přepracované vydání. Praha: Maxdorf, 334 s. ISBN 978-807345-005-2.

3. 3.DEDINSKÁ I., ŽILINSKÁ, Z., 2018. Nefrológia pre študentov lekárskych fakúlt. Multimediálna podpora výučby klinických a zdravotníckych odborov: Portál Lekárskej fakulty Univerzity Komenského v Bratislave [online], 163 s. [cit. 28.12.2021] ISSN 1337-9577. Dostupný z: https://portal.fmed.uniba.sk/clanky.ph p?aid=312.

4. 4.DHONDUP, T., QIAN, Q. 2017. Electrolyte and acid-base disorders in chronic kidney disease and end-stage kidney failure. In: Blood Purification. [online] Vyd. 43, č. 1-3, 179-188s. [cit.28.12.2020] ISSN: 1421-9735 Dostupné z: https://www.Karg er.com/Article/Pdf/452725

5. 5.FONG, J., MOORE, L., 2018. Nutrition Trends in Kidney Transplant Recipients: the Importance of Dietary Monitoring and Need for Evidence-Based Recommendations. In: Frontiers in medicine. [online] Roč. 5, 302 s. ISSN: 2296-858X [cit. 18.1.2021] Dostupné z: https://www.frontiersin.org/articles/10.3389/fmed.2018.00302/full

6. 6.HRUBÝ, M., MENGEROVÁ O., 2010. Dieta u chronických onemocnéní ledvin. Praha: Forsapi, 149 s. ISBN 978-80-87250-07-5.

7. 7.STRAUSSOVÁ, Z., 2011. Diétny režim. In: Fresenius Medical Care: Príručka pacienta liečeného hemodialýzou. s. 112

8. 8.TEPLAN, V., 2013. Nefrologické minimum pro klinickou praxi. 1. vyd. Mladá fronta, 320s. ISBN 978-80-2042-881-3.

9. 9.VOJANSKÁ, E., 2011. Životospráva pacienta. In: Fresenius Medical Care: Príručka pacienta liečeného hemodialýzou. s. 112

10. 10.VIKLICKÝ, O., TESAR̆, V. a kol., 2010. Doporučené postupy a algoritmy $v$ nefrologii. Praha: Grada, 192 s. ISBN 978-80-247-3227-5

11. FERENCOVÁ, T., Výživa u pacienta s ochorením chronická renálna insuficiencia. [bakalárska práca]. Prešovská univerzita v Prešove . Fakulta zdravotníckych odborov, Katedra ošetrovatel'stva. 2021. 54s

\section{Kontaktné údaje}

PhDr. Mgr. Tatiana Šantová, PhD.

Prešovská univerzita $v$ Prešove

Fakulta zdravotníckych odborov

Partizánska 1

08001 Prešov

Email: Tatiana.Santova@unipo.sk 


\title{
POSTOJ RODIČOV K NEPOVINNEJ VAKCINÁCIÍ DETÍ
}

\section{ATTITUDES OF PARENTS TO OPTIONAL CHILD VACCINATIONS}

\author{
Jana Cinová, Tatiana Šantová, Andrea Šuličová, Zuzana Šimová, Zuzana \\ Novotná, L'ubica Derňárová, Lubomíra Lizáková, Andrea Obročníková
}

\begin{abstract}
Abstrakt
Očkovanie je už dlhodobo predmetom záujmu laickej i odbornej verejnosti. Celosvetovo má nespochybnitel'ný význam v prevencií vzniku infekčných ochorení. Autorky v príspevku uvádzajú do pozornosti výsledky prieskumu zameraného na postoj rodičov k nepovinnému očkovaniu detí. $\mathrm{Na}$ základe výsledkov prieskumu konštatujú, že rodičia si uvedomujú dôležitost' povinného očkovania u detí, ale oblasti nepovinného očkovania nepripisujú vážnost' alebo sa o túto oblast' vôbec nezaujímajú. Zároveň zistili aj fakt, že väčšina rodičov je v oblasti nepovinného očkovania nedostatočne informovaná.
\end{abstract}

Kl'účové slová: vakcinácia, nepovinné očkovanie, imunita, infekčné ochorenie, ošetrovatel'stvo, diet'a, prieskum.

\begin{abstract}
The vaccination is long time of interest to the lay and professional public. It is of worldwide unquestionable importance in the prevention of infectious diseases. The authors point to on the results of a survey focused on the attitude of parents to the optional vaccination of children. Based on the results of the survey, they state the parents are aware of the importance of compulsory vaccination in children, but areas of optional vaccination do not attach seriousness or interest at all. They also found that most parents are poorly informed about optional vaccination.
\end{abstract}

Key words: vaccination, optional vaccination, immunity, infectious disease, nursing, child, survey.

\section{ÚVOD}

Oblast' vakcinácie detí je diskutovanou témou odbornej verejnosti, politického diania a nepochybne je aj stredobodom záujmu laickej verejnosti, či už rodičov, ako aj školských zariadení. Očkovanie má nespochybnitel'ný význam v prevencií vzniku infekčných ochorení. No napriek tomuto faktu, ešte $\mathrm{v}$ mnohých krajinách je žiadna alebo nízka zaočkovanost' $\mathrm{v}$ súvislosti s nedostatočnou ekonomickou situáciou krajiny, neefektívnou osvetou či aktivitami odporcov očkovania. Je pozitívnym konštatovaním, že Slovensko je krajinou, ktorá apeluje na dôležitost' a význam očkovania a zvlášt' v súčasnosti, ked' klesla zaočkovanost' pri viacerých druhoch povinného očkovania s rizikom návratu infekčných ochorení. Očkovanie bolo na Slovensku zavedené $\mathrm{v}$ pät'desiatych rokoch 20. storočia. V praxi je riadené jednotným Národným imunizačným programom. Aktívnym povinným očkovaním sa na Slovensku podarilo zničit' množstvo závažných infekčných ochorení. Tiež výskyt ostatných ochorení, ktorým možno predchádzat' nepovinným očkovaním sa výrazne redukoval. Kolektívna imunita je ukazovatel'om stavu imunity v populácií. Vyjadruje sa v percentách a jej úroveň je pre každé ochorenie odlišná. V podpore kolektívnej imunity je dôležité, aby sa udržal vysoký podiel očkovaných a nízky podiel neočkovaných osôb, tým sa znížil počet infekcií v populácii a ochorenie sa prestalo šírit'. 


\section{OČKOVANIE DETÍ V SÚČASNOSTI}

Podl'a Svetovej zdravotníckej organizácie (WHO) má každé diet’a právo na ochranu proti infekčným ochoreniam, a to imunizáciou. Vychádzajúc z tohto práva diet’at'a majú štát, lekári i rodičia morálnu povinnost' uvedené právo diet’at'a rešpektovat'. V súčasnosti sa zaznamenáva nárast odmietnutia, negácie očkovania detí z rôznych osobnostných či názorových dôvodov rodičov, čo časom môže viest' $\mathrm{k}$ opätovnému výskytu infekčných ochorení, až epidémií.

\subsection{Klasifikácia očkovania a jeho legislatívne normy na Slovensku}

Povinné očkovanie je regulované a hradené štátom. Má zabránit' t’ažkým prejavom infekčných chorôb či dokonca úmrtí na nich, trvalému poškodeniu po prekonaní ochorenia, obmedzit' šírenie nákazy a vzniku epidémií. Podl'a okolností, za ktorých sa očkovanie vykonáva sa rozlišuje:

- pravidelné povinné očkovanie - predstavuje očkovanie detí podl’a očkovacieho kalendára. Očkovanie sa plánuje, organizuje, koordinuje a kontroluje ho Úrad verejného zdravotníctva Slovenskej republiky v spolupráci s regionálnymi úradmi v Slovenskej republike. Očkuje sa proti detskej obrne, tetanu, čiernemu kašlu, osýpkam, proti hemofilovým infekciám, mumpse, ružienke, záškrtu, pneumokokovým invazívnym ochoreniam a hepatitide typu B;

- zvláštne očkovanie - je realizované u osôb, ktoré sú vystavené riziku príslušnej infekcie a mimoriadne očkovanie. Realizuje sa v prípade výskytu nebezpečnej epidémie alebo si to vyžadujú iné dôležité zdravotné okolnosti. Očkovanie nariad’uje aj riadi hlavný hygienik alebo regionálny hygienik so súhlasom hlavného hygienika.

Nepovinné očkovanie alebo očkovanie na vlastnú žiadost' predstavuje možnost' nechat' sa očkovat' aj dobrovol'ne čiže nepovinne alebo na vlastnú žiadost'. V praxi sa realizuje aj odporúčané očkovanie osôb, ktoré sú vystavené zvýšenému nebezpečenstvu vybraných nákaz, bud' profesionálne alebo nariadené ošetrujúcim lekárom. V neposlednom rade je to očkovanie osôb, cestujúcich do cudziny alebo z cudziny, ktoré sa vykonáva v súlade s medzinárodnými dohovormi, podla nariadenia Svetovej zdravotníckej organizácie a podla aktuálnej epidemiologickej situácie krajiny, do ktorej alebo z ktorej osoba cestuje. Do tejto kategórie taktiež patrí aj profylaktické resp. preventívne očkovanie.

\section{Legislatíva očkovania na Slovensku}

$\mathrm{Na}$ Slovensku existuje povinné očkovanie osôb proti vybraným ochoreniam, týka sa to najmä detí, ktoré dovíšili určitý vek a osôb pôsobiacich v niektorých povolaniach. Legislatíva v očkovaní vychádza zo zákona č. 355/2007 Z. z. o ochrane, podpore a rozvoji verejného zdravia a o zmene a doplnení niektorých zákonov a z vyhlášky MZ SR č. 585/2008 Z. Z., ktorou sa ustanovujú podrobnosti o prevencii a kontrole prenosných ochorení v znení vyhlášky MZ SR č. 544/2011 Z. z. Od 1.1.2009 je v platnosti Vyhláška 585/2008 Z. z. Ministerstva zdravotníctva Slovenskej republiky, ktorou sa ustanovujú podrobnosti o prevencii a kontrole prenosných ochorení. Táto vyhláška ukladá občanovi všeobecnú povinnost' podrobit' sa v súvislosti s predchádzaním prenosným ochoreniam lekárskym vyšetreniam a diagnostickým skúškam, ktoré nie sú spojené s nebezpečenstvom pre zdravie, preventívnemu podávaniu protilátok a iných prípravkov, povinnému očkovaniu, liečeniu prenosných ochorení, izolácii a karanténnym opatreniam. V súlade s Vyhláškou č. $585 \mathrm{MZ}$ SR z roku 2008, ktorou sa ustanovujú podrobnosti o prevencii a kontrole prenosných ochorení, sa každý rok vykonáva administratívna kontrola pravidelného povinného očkovania, pri ktorej sa sleduje zaočkovanost' detí vzhl'adom na dosiahnutý vek. Zároveň sa kontroluje skladovanie očkovacích látok, správnost' postupu pri očkovaní a úplnost' záznamov o očkovani vdokumentácii a kontraindikácii očkovania. Zaočkovanost' sa vyhodnocuje na 
úrovni obvodov, okresov, krajov a celého Slovenska. V prípade odmietnutia očkovania u detí sa začína proti rodičom, resp. zákonným zástupcom konanie o priestupku na úseku zdravotníctva podl'a $\S 56$ ods. 1 písm. a) zákon č. 355/2007 Z. z. o ochrane a rozvoji verejného zdravia. Rodičia svojim konaním neplnia povinnost' ustanovenú na predchádzanie vzniku a šírenia infekčných chorôb. Za dané odmietnutie očkovania diet'at'a im je možné uložit’ pokutu až do súhrnnej výšky 331 eur, a to každému rodičovi zvlášt'.

\subsection{Nepovinné očkovanie u detí}

Podla vyhlášky č. 585/2008 MZ SR, ktorou sa ustanovujú podrobnosti o prevencii a kontrole prenosných ochorení, možno deti očkovat' aj v iných prípadoch, nie len v prípade povinného očkovania, a to na žiadost' zákonného zástupcu. O vhodnosti nepovinného očkovania diet'at'a vždy rozhoduje jeho ošetrujúci lekár. Dobrovol’né očkovanie resp. očkovanie na vlastnú žiadost' si každý pacient financuje sám. Aj napriek skutočnosti, že vakcíny pre potreby nepovinného očkovania nie sú lacné, ich finančná náročnost' je $\mathrm{v}$ porovnaní s možnými následkami infekčného ochorenia zanedbatel'ná. $\mathrm{K}$ realizácii nepovinného očkovania diet'at'a je potrebný informovaný súhlas rodičov.

$\mathrm{K}$ nepovinnej vakcinácií v súčasnosti patrí vakcinácia proti chrípke, klieštovej encefalitíde, HPV vírusu, menigokokom, rotavíruse, pneumokokom, hepatitíde typu A a B a d'alšie. Uvedené očkovania na Slovensku síce finančne nie sú v plnom rozsahu financované štátom, avšak sú do istej miery financované zdravotnými poist'ovňami.

\section{ANALÝZA PARCIÁLNYCH VÝSLEDKOV PRIESKUMU}

\subsection{Problém, ciel', vzorka respondentov a metodológia prieskumu}

Realizovaný prieskum, ktorého sa celkovo zúčastnilo 100 rodičov detí bol zameraný na súčasný postoj rodičov k nepovinnému očkovaniu detí a realizovaný v mesiacoch december február 2021. Ciel'om prieskumu bolo zistit', ako rodičia v súčasnosti vnímajú nepovinné očkovanie detí a zároveň identifikovat' ich najčastejšie dôvody v rámci rozhodovania sa pre alebo proti možnosti nepovinného očkovania detí. Prieskum bol realizovaný využitím metódy neštandardizovaného dotazníka, ktorý bol respondentom administrovaný online a konštruovaný celkovo z 28 položiek a identifikačných údajov.

\subsection{Kvantitatívna analýza významných prieskumných zistení a diskusia}

Kvantitatívnu analýzu demografických údajov a jednotlivých položiek neštandardizovaného dotazníka interpretujeme prostredníctvom grafov a tabuliek. Získané údaje vyhodnocujeme početnost'ou (n) a percentuálne (\%).

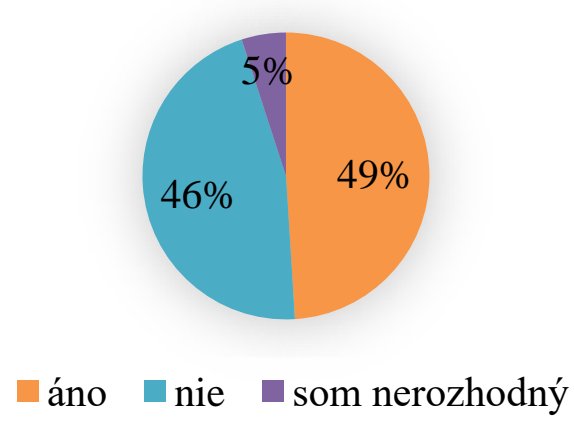

Graf 1 Postoj rodičov k možnosti nepovinného očkovania diet’at’a 


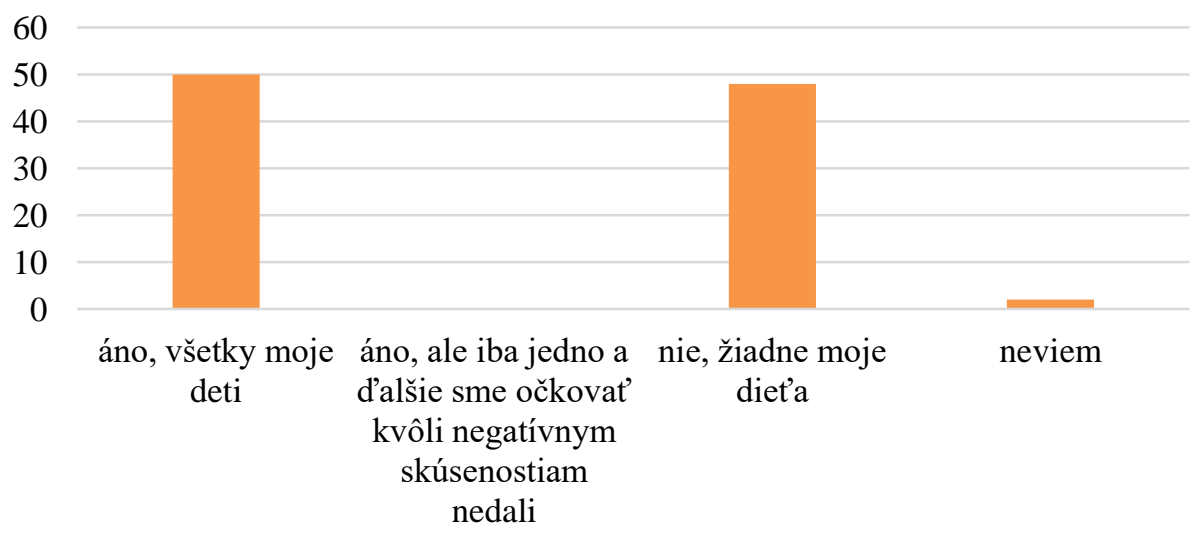

Graf 2 Absolvovanie nepovinného očkovania u detí respondentov

Tab. 1 Najčastejšie preferované nepovinné očkovania u detí respondentov

\begin{tabular}{|l|c|c|}
\hline \multicolumn{1}{|c|}{ možnosti } & $\begin{array}{c}\text { n } \\
\text { početnost }\end{array}$ & $\begin{array}{c}\text { \% } \\
\text { percentá }\end{array}$ \\
\hline proti chripke & 14 & 15,4 \\
\hline proti meningokokom & 8 & 8,8 \\
\hline proti hepatitíde typu B & 17 & 18,7 \\
\hline proti rotavírusom & 14 & 15,4 \\
\hline proti klieštovej encefalitide & 11 & 12,1 \\
\hline proti hepatitíde typu A & 8 & 8,8 \\
\hline proti pneumokokom & 10 & 10,9 \\
\hline proti HPV & 9 & 9,9 \\
\hline
\end{tabular}

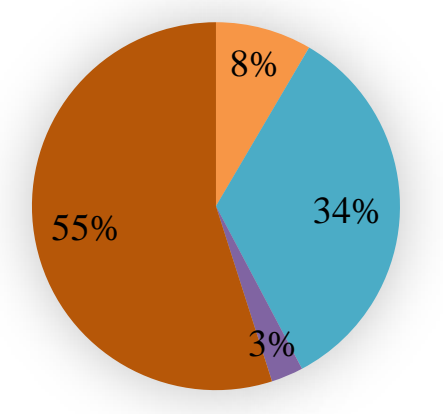

匹 častá chorobnost' diet'at’a

" odporúčanie detského lekára

- na podnet známych - pozitívne skúsenosti

- považujem očkovanie za dôležité pre ochranu zdravia

Graf 3 Dôvody nepovinného očkovania detí respondentov

Tab. 2 Dôvody negácie nepovinného očkovania detí respondentov

\begin{tabular}{|l|c|c|}
\hline \multicolumn{1}{|c|}{ možnosti } & $\begin{array}{c}\mathbf{n} \\
\text { početnost' }\end{array}$ & $\begin{array}{c}\% \\
\text { percentá }\end{array}$ \\
\hline finančná náročnost' nepovinných očkovaní & 3 & 5,9 \\
\hline nepovažujem to za dôležité & 19 & 37,3 \\
\hline
\end{tabular}




\begin{tabular}{|l|c|c|}
\hline obavy vzniku komplikácií, možných ochorení & 25 & 49 \\
\hline náboženské predsudky & 1 & 1,9 \\
\hline negatívne podnety, skúsenosti okolia & 3 & 5,9 \\
\hline
\end{tabular}

Tab. 3 Vedomost' respondentov o typoch nepovinného očkovania

\begin{tabular}{|l|c|c|}
\hline \multicolumn{1}{|c|}{ možnosti } & $\begin{array}{c}\text { n } \\
\text { početnost }\end{array}$ & $\begin{array}{c}\text { \% } \\
\text { percentá }\end{array}$ \\
\hline proti chrípke & 1 & 0,8 \\
\hline proti meningokokom & 9 & 7,1 \\
\hline proti hepatitíde typu B & 2 & 1,6 \\
\hline proti rotavírusom & 10 & 7,9 \\
\hline proti klieštovej encefalitíde & 0 & 0 \\
\hline proti hepatitíde typu A & 2 & 1,6 \\
\hline proti pneumokokom & 7 & 5,6 \\
\hline proti HPV & 14 & 11,1 \\
\hline poznám v̌̌etky & 81 & 64,3 \\
\hline
\end{tabular}

Tab. 4 Zdroje získavania informácií o nepovinnom očkovaní

\begin{tabular}{|l|c|c|}
\hline \multicolumn{1}{|c|}{ možnosti } & $\begin{array}{c}\mathbf{n} \\
\text { početnost' }\end{array}$ & $\begin{array}{c}\text { \% } \\
\text { percentá }\end{array}$ \\
\hline detský lekár & 24 & 49 \\
\hline známy & 4 & 8,2 \\
\hline odborné knihy, časopisy, webové stránky & 18 & 36,7 \\
\hline rodina & 0 & 0 \\
\hline masovokomunikačné prostriedky & 1 & 2 \\
\hline iné & 2 & 4,1 \\
\hline
\end{tabular}

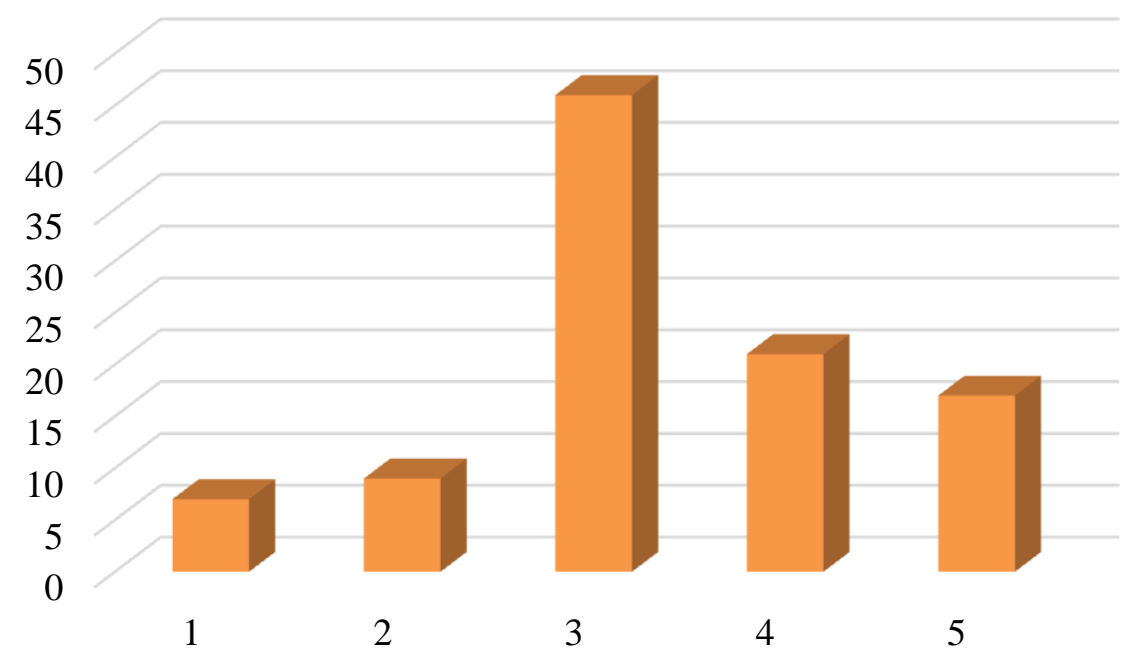

Graf 4 Hodnotenie osvety v súvislosti s nepovinnom očkovaní 


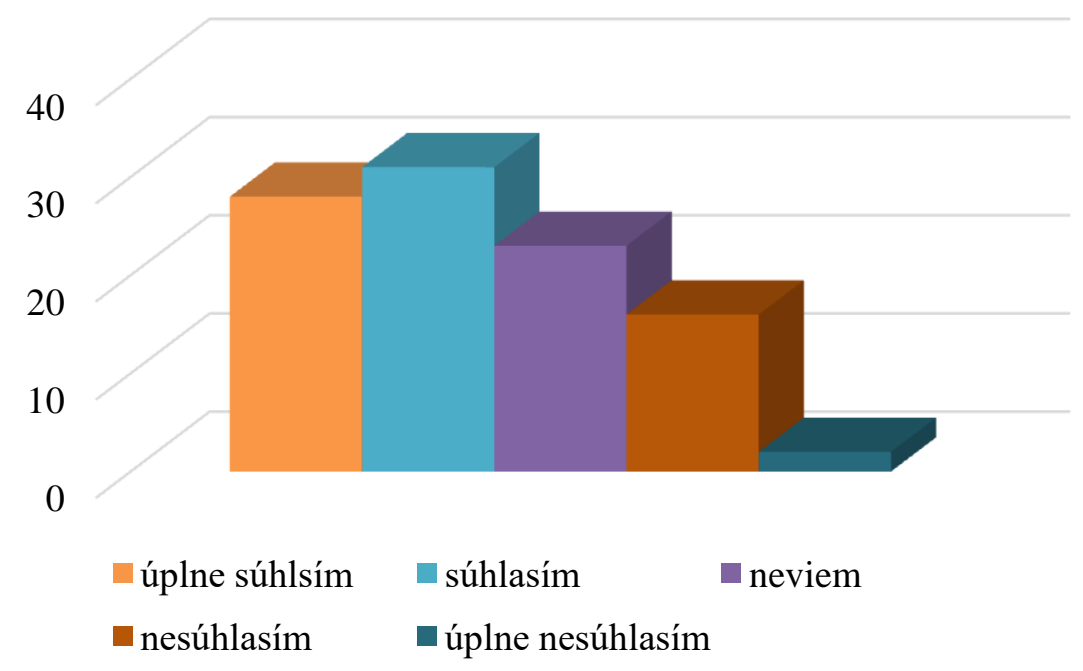

Graf 5 Úplné financovanie nepovinného očkovania poist'ovňami

\section{Diskusia}

Na základe výsledkov prieskumu konštatujeme, že rodičia detí sa zaoberajú problematikou nepovinného očkovania, aj ked' niektorí sú v tejto oblasti ešte stále nerozhodní. Má na to vplyv zrejme aj nedostatočne intenzívna osveta, nakol'ko sme prieskumom zistili aj skutočnost', že respondenti nie vel'mi pozitívne hodnotia sprístupnenie informácií v oblasti týkajúcej sa nepovinnej vakcinácie detí. Respondenti uvádzali, že informácie o možnostiach nepovinného očkovania sú nedostatočné, avšak aj napriek tomuto faktu, takmer polovica respondentov, informácie o možnostiach nepovinného očkovania aktívne vyhl'adáva. Za najčastejší zdroj získavania informácií respondenti uviedli, že preferujú odporúčania detského lekára, odborné články, knihy či webové stránky. Polovica respondentov nami realizovaného prieskumu uviedla, že pre nepovinné očkovanie svojho diet'at'a sa aj rozhodli. Deti respondentov boli vrámci nepovinnej vakcinácie najčastejšie očkované proti hepatitíde typu $\mathrm{B}$, chrípke, rotavírusom a klieštovej encefalitíde, ale l'ahostajné respondentom nie sú ani očkovania proti pneumokokom, HPV, hepatitíde typu A a meningokokom. Aj napriek tomu, že dali svoje deti zaočkovat', čast' z nich uviedla, že mali z nepovinného očkovania ich detí aj obavy. Tiež sme zistili, že určitý počet respondentov nepovinné očkovanie neguje a ich dôvody sú rôznorodé. Najčastejšie dôvody, ktoré respondenti uviedli boli obavy zo vzniku komplikácií, možných ochorení, ako aj fakt, že nepovažujú nepovinné očkovanie za dôležité. Ďalej uviedli finančnú náročnost' nepovinných očkovaní, negatívne podnety, skúsenosti okolia a náboženské predsudky. Respondenti, ktorí sa rozhodli pristúpit' k nepovinnému očkovaniu uviedli dôvody, pre ktoré tak urobili a bolo ich viacero. Väčšina uviedla, že považuje očkovanie za dôležité pre ochranu zdravia. Ďalšími dôvodmi bolo odporúčanie detského lekára, častá chorobnost' diet'at’a a taktiež vycestovanie do zahraničia.

\subsection{Odporúčania pre prax}

Na základe analýzy výsledkov prieskumu navrhujeme odporúčania pre prax určené pre:

- masovokomunikačné prostriedky: podporovat' a zvyšovat' osvetu aj v oblasti očkovania, nevynímajúc ani nepovinné; oboznámit' širokú verejnost' o možnostiach nepovinného očkovania; poukázat' na jeho význam;

- zdravotné poistovne - sprístupnit' efektívnejšie financovanie nepovinného očkovania aj sociálne slabším skupinám v spoločnosti; finančne hradit' väčšiu čast' nepovinného 
očkovania; hradit' nepovinné očkovanie v plnom rozsahu, ak je na podnet a odporúčanie detského lekára;

- osveta v ambulanciách - informovat' rodičov aj o možnostiach nepovinného očkovania; byt' zo strany zdravotníckych pracovníkov všímavejší pre záujem rodičov; informácie podávat' zrozumitel'nejšie.

\section{ZÁVER}

Pri mnohých ochoreniach predstavuje vakcinácia nevyhnutný spôsob, ako ich efektívne medicínsky zvládnut'. Tak ako v minulosti sa vd’aka vakcinácii dosiahlo zničenie či eliminovanie niektorých závažných ochorení, rovnako aj v súčasnosti vakcinácia predstavuje významný element ochrany a podpory zdravia. Z tohto dôvodu je potrebné apelovat', zdôrazňovat', zaoberat' sa aj oblast'ou nepovinného očkovania. Praktizovaním nepovinného očkovania môžeme v budúcnosti zmenit' mnoho nepriaznivých situácí́. Netreba opomenút', že napriek vel'mi vážnemu ochoreniu s t’ažkým priebehom, dlhotrvajúcimi následkami a vysokou úmrtnost'ou, vel'a l'udí k ochoreniu, ale rovnako aj $\mathrm{k}$ vakcinácii pristupuje l'ahostajne a negáciou. Dokonca $v$ posledných rokoch bolo založených aj niekol'ko antivakcinačných hnutí, ktoré argumentujú, že očkovanie je nielen nebezpečné, ale zároveň narúša právo človeka slobodne sa rozhodnút'. Uvádzajú síce rad pravdivých faktov, avšak informácie sa obmedzujú a do popredia uvádzajú len nežiadúce účinky očkovania. Z tohto dôvodu je potrebné, aby sme zodpovedne pristupovali k ochrane svojho zdravia, ale aj zdravia našich blízkych, nášho okolia a tým celej spoločnosti. Je potrebné šírit' osvetu významu, benefitov nepovinného očkovania a tým chránit' bezpečnost' svojho zdravia a podporovat' kolektívnu imunitu. Zároveň je potrebné šírit' informácie, že aj nepovinné očkovanie môže mat' dôležitý dopad na l'udský život.

\section{Použitá literatúra}

1. HUDEČKOVÁ, H. ŠVIHROVÁ, V. Očkovanie. Martin: Osveta.2013, ISBN 80-8063396-7.

2. KOŠŤÁLOVÁ, L. a kol. Úvod do pediatrie. Skriptá pre nelekárske predmety, Lekárska fakulta Univerzity Komenského v Bratislave. Bratislava, 2015.

3. Očkování [online]. 2013. [cit. 2020-12-02]. Dostupné na internete: http://www.losanovapediamed.cz/ockovani-ditete.

4. Očkovanie [online]. 2006. [cit. 2006-01-23]. Dostupné na internete: https://www.epi s.sk/InformacnaCast/Ockovanie.aspx.

5. Očkovanie [online]. 2011. [cit. 2020-12-02]. Dostupné na internete: http://www.ock va nie.org/odmietnutie-povinneho-ockovania.html.

6. ONDRIOVÁ I., CINOVÁ, J. Postoj rodičov k povinnému očkovaniu. In: Sestra odborný časopis s recenzovanou prílohou pre sestry, pôrodné asistentky, lekárov a iných zdravotníckych pracovníkov, Bratislava č.11-12, roč. XIX, 2020, s. 29-31 ISSN13359444.

7. Úrad verejného zdravotníctva Slovenskej republiky [online]. 2020. [cit. 2020-12-02]. Dostupné na internete: https://www.uvzsr.sk/.

8. VAŠKOVÁ, K. Postoj rodičov k problematike nepovinnej vakcinácie v detskom veku. bakalárska práca, Prešovská univerzita v Prešove (Prešov, Slovensko). Fakulta zdravotníckych odborov, Katedra ošetrovatel'stva. Školitel': PhDr. Mgr. Jana Cinová, PhD. Stupeň odbornej kvalifikácie: bakalár. Prešov: FZO PU,2021. 51s.

9. Vyhláška MZ SR č.585/2008 Z. z., ktorou sa ustanovujú podrobnosti o prevencii a kontrole prenosných ochorení. 


\section{Kontaktné údaje}

PhDr. Mgr. Jana Cinová, PhD.

PU v Prešove, Fakulta zdravotníckych odborov

Partizánska 1, 08001 Prešov

Tel: 051/ 7562463

email: jana.cinova@unipo.sk 


\title{
RASTLINNÉ VÍRUSY INFIKUJÚCE ČELAĎ FABACEAE
}

\section{PLANT VIRUSES INFECTING FABACEAE FAMILY}

\author{
Simona Grešíková, Daniel Mihálik, Michaela Mrkvová
}

\begin{abstract}
Abstrakt
Review je zamerané na charakteristiku vírusových patogénov infikujúcich hospodársky významné druhy rastlín z čel'ade Fabaceae. Do dnešného dňa bolo zatriedených niekol'ko rodín a viac ako tisíc vírusov. Tento prehl'ad zdôraznil hlavné črty vírusov, ktoré napádajú rastliny patriace do čel'ade bôbovité. Tieto vírusy boli klasifikované na úrovni čel'adí a rodov. Do roku 2018 bolo zistené, že tieto rastliny prirodzene infikuje celkovo 213 rastlinných vírusov a 6 druhov viroidov patriacich k 57 rodom, 22 čel'adiam a 6 radom, oficiálne uznaným ICTV Strukoviny patria do čel'ade bôbovitých (Fabaceae). Fabaceae pozostáva z viac ako 770 rodov a 19000 druhov rastlín. Medzi najdôležitejšie komerčné využívané druhy patria sója fazul'ová (Glycine max L. MERR), hrach siaty (Pisum sativum L.), podzemnica olejná (Arachis hypogaea L.), lucerna siata (Medicago sativa).
\end{abstract}

Kl'účové slová: rastlinné vírusy, Fabaceae, infekcia, potyvirus, interakcie rastlinných vírusov

\begin{abstract}
Review is aimed at characteristics of viral pathogens infecting economic significant types of plants from Fabaceae family. Several families and more than a thousand viruses were classified to this day. This overview has emphasized the main features of viruses that attack the plants belonging to the bean family. These viruses were classified at the level of families and genera. By 2018, it was found that these plants are naturally infected by a total of 213 plant viruses and 6 species of viroids belonging to 57 genera, 22 families and 6 series, officially recognized by ICTV. Legumes belong to the legume family (Fabaceae). Fabaceae consists of more than 670 genera. The most important commercially used species include soybeans (Glycine max L. MERR), peas (Pisum sativum L.), peanuts (Arachis hypogaea L.), alfalfa (Medicago sativa).
\end{abstract}

Key words: plant viruses, Fabaceae, potyvirus, infection, interaction of plant viruses

\section{1 ÚVOD}

Fabaceae sú tret'ou najväčšou skupinou medzi krytosemennými rastlinami po Orchidaceae a Asteraceae. Čel'ad' Fabaceae zahŕńa 770 rodov s viac ako 19000 druhov rastlín. Do roku 2018 bolo zistené, že tieto rastliny prirodzene infikuje celkovo 213 rastlinných vírusov a 6 druhov viroidov patriacich k 57 rodom, 22 čel'adiam a 6 radom, oficiálne uznaným ICTV. Najviac zastúpené sú rody Begomovirus a Potyvirus, ktoré majú 424 a 183 druhov. Patrí medzi najdôležitejšiu čel'ad' z ekonomického hl'adiska, pretože k nej patria rastliny s vysokým obsahom bielkovín ako napríklad hrach, šošovica a fazul'a [1]. Strukoviny sa považujú za výživné z hladiska obsahu lipidov, vlákniny, sacharidov, bielkovín, vitamínov a minerálov [2]. Strukoviny majú vysokú energetickú hodnotu. Majú nízky glykemický index. Sója obsahuje väčšie množstvo rastlinných tukov $24 \%$. Len 1,0 \% sú tuky obsahujúce nasýtene mastné kyseliny [2]. Strukoviny sú t’ažko strávitel'né a spôsobujú nadúvanie. V zelenom stave majú vel'ký význam i ako krmoviny. Obsahom dietetickým účinkom a živín patria $\mathrm{k}$ najkvalitnejším krmovinám. Strukoviny vynikajú cennými biologickými a agronomickými 
vlastnost'ami, ktoré priaznivo ovplyvňujú úrodnost' pôdy. Najvýznamnejším prínosom vzt'ahujúcim sa na celé spektrum bôbovitých rastlín pestovaných v záhradách a na poliach, je výrazne pozitívny vplyv na pôdu. Sú aj melioračnými rastlinami, obohacujú pôdu o dusík, preto sa pestujú ako aj zelené hnojivo [1]. Korene majú symbiotickú asociáciu s baktériami fixujúcimi dusík (Rhizobium spp.), ktoré vytvárajú na koreňoch hrčky (uzlíky). Tento dôležitý faktor sa týka celej rozsiahlej skupiny bôbovitých rastlín, kde sa $\mathrm{z}$ agronomického hl'adiska radia d'atel'oviny a strukoviny [1]. Pestovanie týchto rastlín je ovplyvňované vel'kým množstvom negatívnych faktorov. Vážny dopad na celkový výnos semien a zelenej hmoty môžu mat' vírusové ochorenia.

\subsection{Rastlinné vírusy}

Rastlinné vírusy reprezentujú rôznorodú skupinu obligátnych vnútrobunkových parazitov rastlín. Od viroidov sa odlišujú komplexnejšou štruktúrou. Častica vírusu je zložená z genómu a bielkovinového obalu. Genómy rastlinných vírusov pozostávajú z ssDNA, dsRNA, RNA s pozitívnym jednovláknovým ret’azcom alebo RNA s negatívnym jednovláknovým ret’azcom [3]. Opísané boli aj genómy vírusu ssRNA alebo dsDNA s reverznou transkripciou [3]. Pozitívne jednovláknové RNA vírusy sú najpočetnejšou skupinou rastlinných vírusov zahŕňajúcou rody Bromovirus, Cucumovirus, Potexvirus, Potyvirus, Tobomavirus a Tombusvirus. Medzi vírusy s negatívnym jednovláknovým RNA patria Ortotospovírusy [3]. Najväčším rodom rastlinných vírusov je Potyvírus, ktorý spôsobuje značné straty na výnosoch [4]. Niektoré vírusy majú obmedzený rozsah hostitel'ov. Tieto vírusy na rozdiel od živočíšnych a l'udských infikujú hostitel'a pasívne, tzn. cestou poranení rastlinných povrchových pletív a bunkových stien pomocou vektorov (hmyz, hád’atká, plazmodioforidy napr. Polymyxa graminis), manipuláciou s rastlinou, vrúbl'ami a očkami, semenom a pel’om [5]. Vírusové proteíny musia byt' translatované a musia sa podiel'at' na replikácii vírusu, zostavení viriónov a pohybe vírusu do susedných buniek. V každej novo infikovanej bunke sa cyklus opakuje [6]. Po dosiahnutí cievneho systému sa vírusy pohybujú na vel'ké vzdialenosti [7]. Replikácia a pohyb rastlinného vírusu sa geneticky určuje kombináciou vírusových a hostitel'ských faktorov, ktoré sú časovo a priestorovo koordinovaných [8]. Vírusy exprimujú svoje gény prostredníctvom medziproduktu RNA [9], [10], [11] . Pohyb rastlinných vírusov z bunky do bunky nastáva prostredníctvom plasmodesmaty [7]. Rastliny sa pred vírusmi chránia rôznymi mechanizmami zameranými na vírusové nukleové kyseliny alebo proteíny. Antivírusová ochrana obmedzuje transláciu vírusovej RNA, replikáciu vírusu, pohyb a zostavenie viriónu, čo vedie $\mathrm{k}$ zníženej akumulácii vírusu alebo oneskoreniu vírusového pohybu s hypersenzitívnou citlivost'ou [12]. Genómy majú dížku od 8,3 do 11,3 kb s priemernou vel'kost'ou 9,7 kb. Väčšina genómov je monopartitná (Obr.1), ale genotyp z rodu Bymovirus je bipartitný [13]. Virióny obsahujú okolo $5 \%$ hmotnosti RNA a $95 \%$ bielkovín [14]. Tieto virióny sú mierne imunogénne. Molekula VPg je kovalentne spojená na 5' konci a 3' koniec je polyadenylovaný s rôznym počtom adenozínov.

\subsection{Genómové funkcie}

Replikácia genómu je typická pre (+) ssRNA vírusy, kde jedno pozitívne RNA vlákno je transkribované, tak že produkuje (-) RNA vlákno, ktoré slúži ako templát na produkciu RNA molekúl progénového $(+)$ RNA [4]. Tento proces pravdepodobne prebieha v cytoplazme infikovaných buniek. Väčšina zrelých vírusových proteínov sú multifunkčné a interakcie medzi nimi sú bežné. P1 proteín je serínová proteáza, ktorá má vel'mi variabilnú vel'kost' a štiepi polyproteín na rozhraní medzi P1 C-koncom a susedným produktom [4]. Štúdie ukázali, že proteín P1 je neesenciálnym doplnkovým faktorom pre amplifikáciu genómu a niektoré výskumy naznačujú, že sa podiel'ajú spolu s HC-Pro na potláčaní génov [4]. 


\subsection{Prenos a šírenie}

Buriny významne ovplyvňujú epidemiológiu vírusov. $\mathrm{V}$ zamorených burinách $\mathrm{z}$ predchádzajúcej sezóny sa často vyskytujú prezimujúce vírusové rezervoáre, ktoré sa na začiatku vegetačnej sezóny môžu stat' virulentnými [4]. Rastliny majú robustnú bunkovú stenu. Väčšina rastlinných vírusov je preto prenášaná vektorovým organizmom, ktorý sa živý rastlinou [4]. Druhým spôsobom prenosu sú rany, ktoré vznikajú pri prerezávaní kultúrnych drevín. V prírode prenos rastlinných vírusov prebieha prostredníctvom húb, hád'atiek, vošiek, roztočov, molíc, chrobákov a hlíst [15] . Najčastejšie voškami z rodov Hemiptera a Homoptera, ako napr. Acyrthosiphon pisum, Aphis fabae, Aphis gossypi, Aphis craccivora, Brevicoryne brassicae, Myzus persicae, Marcosiphum euprhorbia a Rhopalosiphum padi [16]. Môžu byt' prenášané mechanicky (štepením), osivom (Bean common mosaic virus až 83 $\%$ pri Phaseolus vulgaris) a pel'om [17]. Až 39 vírusov je prenášaných pel'om. Väčšina týchto vírusov patrí do rodov Alphacryptovirus, Ilarvirus, Nepovirus alebo Potyvirus. Až štyri rody chrobákov prenášajú rastlinné vírusy a to Chrysomellidae, Coccinellidae, Curculionidae a Meloidae [18]. (Southern bean mosaic virus, SBMV) je prenášaný chrobákmi Chrysomelidae. $\mathrm{K}$ sekundárnemu prenosu dochádza pri niektorých druhoch z radu Coleoptera ako Cerotoma facialis, Cerotoma trifurcate a Epilachna varivestis [18].

\subsection{Symptómy}

Prejavy spôsobené vírusmi sú vel'mi odlišné a závisia od kultivaru, kmeňa vírusu, podmienok prostredia a vývojového štádia rastliny pri infekcii. Pri skorých infekciách dochádza v rastlinách k závažným symptómom [19]. Vírusy znižujú rýchlost' fotosyntézy infikovaných listov prostredníctvom inhibície aktivity fotosystému II a poklesu obsahu chlorofylu [20]. Taktiež znižujú obsah pignmentu v rastlinách a akumuláciu škrobu [4]. Podl'a [21] vírusy zvyšujú respiráciu rastlín. Znižovanie týchto fyziologických procesov vedie $\mathrm{k}$ celkovej inhibícii rastu [22]. Listy sa mierne stáčajú, vädnú vytvára sa silná škvrnitost' a zelené pl'uzgiere [23]. V infikovaných jedincoch boli pozorované prasknuté edoplazmatické retikulá [23]. Podl'a [23] dochádza k častej inhibícii výhonkov. Na niektorých odrodách dochádza $\mathrm{k}$ vysychaniu pupeňov a kvetov. Internodiá sú kratšie a struky menšie, s menším počtom semien [23]. Prítomné môžu byt' jasné žlté škvrny na listoch. Malformácia a mramorovanie primárnych listov je znakom toho, že k primárnej infekcii došlo prostredníctvom semien [23]. Hlavnými príznakmi sú však diskoloračné zmeny. Sfarbenie listov má mozaikový charakter. Infekcia spôsobuje zvýšenú tvorbu tmavozelených pl'uzgierov a inhibíciu rastu pri citlivých odrodách [24]. V dôsledku nerovnomerného rastu sa listy lyžicovito vydúvajú a okraje sa stáčajú smerom nadol. Struky nemávajú chlorotické ani mozaikovité príznaky, ale bývajú menšie s malým množstvom semien [24]. Infikované tobolky môžu byt' niekedy pokryté malými tmavozelenými škvrnami a dozriet' neskôr môžu ako neinfikované tobolky. Systémová nekróza vaskulárneho systému sa vyskytuje iba u kultivarov, ktoré majú dominantný gén rezistencie $I$. Táto nekróza sa rozširuje na korene, kmeň a meristém, môže mat' za následok smrt' rastlín, ak je rastlina infikovaná v skorom štádiu. Ak je infikovaná v neskoršom štádiu, rastlina môže prežit' [24].

Tabul'ka 1. Pol'nohospodársky najdôležitejšie vírusy [25]

\begin{tabular}{|c|c|cc|}
\hline \multirow{2}{*}{ Rod } & \multirow{2}{*}{ Vírus } & \multicolumn{2}{c|}{ Prenos } \\
& Sap & Vektor \\
\hline Carlavirus & Pea streak & + & vošky \\
\hline Cucumovirus & Cucumber mosaic & + & vošky \\
\hline Ilarvirus & Tobacco streak & - & strapky \\
\hline Luteovirus & Bean (pea) leafroll & \multicolumn{2}{c}{} \\
\hline
\end{tabular}




\begin{tabular}{|c|c|cc|}
\hline & Legume yellows & - & vošky \\
\hline & Beet western yellows & - & vošky \\
\hline Nepovirus & Tobacco ringspot & + & ND \\
\hline Enamovirus & Pea enation mosaic & + & vošky \\
\hline Potyvirus & Bean yellow mosaic & + & vošky \\
\hline & Bean common mosaic virus & + & vošky \\
\hline & Pea seed-borne mosaic virus & + & vošky \\
\hline & Chickpea distortion mosaic & + & vošky \\
\hline & Chickpea filiform & + & vošky \\
\hline & Lettuce mosaic virus & + & vošky \\
\hline & Potato virus $Y$ & - & vošky \\
\hline Rhabdovirus & Soybean mosaic virus & - & vošky \\
\hline Sobemovirus & Lettuce necrotic yellows & + & vošky \\
\hline
\end{tabular}

\subsection{Možnosti ochrany a predchádzanie šírenia infekcie}

Vírusové infekcie rastlín vo všeobecnosti nie je možné chemicky eliminovat'. Z tohto dôvodu je potrebné dodržiavat' konvenčné zásady zmierňovania rizika šírenia infekcie. Až $90 \%$ všetkých pol'nohospodárskych plodín sa pestuje prostredníctvom semien (najdôležitejší generatívny materiál) [26]. Testovanie semien na prítomnost' fytopatogénu je nevyhnutným krokom v procese eliminácie rozširovania. Bolo dokázané že $20 \%$ rastlinných vírusov sa prenáša $\mathrm{z}$ generácie na generáciu práve semenami [26]. Monitoring a samotné testovanie zaoberajúce sa kvalitou osiva využíva kvalitatívne dáta vzt'ahujúce sa na prítomnost' alebo neprítomnost' patogénu [26]. Vírus prežíva na povrchu semena, zriedkavo v osemení a endosperme [27]. Avšak niektorí autori uvádzajú, že vírus obyčajnej moziaky rastlín (Bean common mosaic virus, BCMV) môže v semenách fazule prežívat' i viac ako 20 rokov [17]. Chemické ošetrovanie plodín proti voškám je neúčinné.

$\mathrm{Z}$ dôvodu pestovania bolo navrhnutých niekol'ko alternatívnych metód ošetrenia:

- sterilizácia pôdy s použitím štandardných komerčných párnych zariadení,

- sterilizácia záhradných nástrojov, hygiena rúk,

- použitie certifikovaných semien získaných zo zdravých zdrojov,

- gernicídne žiariče-dezinfekcia použitím ultrafialového žiarenia spektra C,

- termoterapia,

- sterilizácia semien pôsobením vyššej teploty $\left(70{ }^{\circ} \mathrm{C}\right)$ po dobu 4 dní alebo premytie $\mathrm{v}$ sterilizačnom roztoku,

- zamedzenie výsadby v oblastiach s odhalenou prítomnost'ou vírusu,

- použitie chemických látok,

- ošetrenie foforečnanom sodným po dobu 15 minút [28] (nedochádza k úplnému odstráneniu patogénu), 5,25\% roztokom chlórnanu sodného [29],

- dôkladná selekcia zdravých a infikovaných rastlín.

Pol’nohospodári a pestovatelia prijímajú opatrenia na minimalizáciu prenosu vírusu na plodinu a v rámci plodiny. Aby tieto opatrenia boli efektívne je dôležité pochopit' ako sa vírusy šíria a presúvajú z jednej rastliny na druhú.

\section{Použitá literatúra}

1. LEWIS, G., SCHRIRE, B., MACKINDER, B., LOCK, M. Royal Botanic Gardens, Kew Scientist,2005, ISSN 0967-8018, č. 28, s. 8.

2. KOURIS-BLAZOS, A., BELSKI, R. Asia Pacific Journal of Clinical Nutrition, 2016, roč. 25, č. 1, s. 1-17.

3. HULL, R. Plant Virology. 5th ed. Elsevier; New York, NY, USA. 2014, s. 1118. 
4. LÓPEZ-MOYA, J. J., VALLI, A., GARCÍA, J. A. Potyviridae. In: Encyclopedia of Life Sciences (ELS). John Wiley and Sons, Ltd: Chichester, 2009

5. ZAITLIN, M., PALUKAIDIS, P. Advances in understanding plant viruses and virus diseases. Annual Review of Phytopathology. ISSN 0066-4286, 2000, roč. 38, č. 1, s. 117-143.

6. MÄKINEN, K., HAFRÉN, A. Intracellular coordination of potyviral RNA functions in infection. Frontiers in Plant Science. 2014, roč. 5, č. 110.

7. HEINLEIN, M. 2015. Plant virus replication and movement. Virology. ISSN 00426822, 2015, s. 657-71.

8. JIN, X., CAO, X., WANG, X.Three-Dimensional Architecture and Biogenesis of Membrane Structures Associated with Plant Virus Replication. Frontiers in Plant Science. ISSN 2018- 00057,2018, roč. 9, s. 57.

9. HYODO, K., OKUNO, T. Pathogenesis mediated by proviral host factors involved in translation and replication of plant positive-strand RNA viruses. Current Opinion in Virology. ISSN 1879-6257, 2016, roč. 17, s. 11-18.

10. WANG, A. Dissecting the molecular network of virus-plant interactions: the complex roles of host factors. Annual Review of Phytopathogy. 2015, roč. 53, č. 1, s. 45- 66.

11. OUEIRY, A. O., DIEZ, J., FALK, S. P.Yeast Lsm1p-7p/Pat1p deadenylation. dependent mRNA-decapping factors are required for brome mosaic virus genomic RNA translation. Mollecular and Cellular Biology. ISSN 0270-7306, 2003, roč. 23, č. 12, s. 4094-106.

12. KANG, B.C., YEAM, I., JAHN, M. M.Genetics of Plant Virus Resistance. Annual Review of Phytopathology. 2005, roč. 43, č. 1, s. 581-621.

13. WYLIE, S. J., ADAMS, M., CHALAM, C. ICTV Virus Taxonomy Profile: Potyviridae. Journal of General Virology. 2017, roč. 98, č. 3, s. 352-354.

14. ADAMS, M. J., ANTONIW, J. F., BEAUDOIN, F. Overview and analysis of the polyprotein cleavage sites in the family Potyviridae. Molecular Plant Pathology. ISSN 1364- 3703, 2005, roč. 6 , č. 4, s. 471-487.

15. SINGH, S., AWASTHI, L. P., JANGRE, A. Transmission of plant viruses in fields through various vectors. 2020, s. 682 .

16. JONES, R. A. C. Annals of Applied Biology.2014, roč. 164, č. 3, s. 320-347.

17. HRUDOVÁ, E., POKORNÝ, R., VÍCHOROVÁ, J. Integrovaná ochrana rostlin. 1. vyd. Brno: Mendelova zemědělská a lesnická univerzita v Brně. 2006, s. 151. ISBN 978-80-7157- 980-9

18. OZATO, J. T., GASPAR, J. O., BELINTANI, P. Journal of Phytopathology. 2009, roč. 157, č. 9 , s. 573-575.

19. PROVVIDENTI, R., MORALES, F. J. In: H.F. Schwartz, J.R. Steadman, R. Hall, and R.L. Forster, editors, Compendium of bean diseases. 2nd ed. APS Press, St. Paul, MN. 2005, s. 73-74.

20. ZECHMANN, B., MULLER, M., ZELLNIG., G. Archives of Virology, 2003, roč. 148 , č. 6, s. 1119-33.

21. SHALITIN, D., WOLF, S. Plant Physiology, 2000, roč. 123, č. 2, s.597-604.

22. ARFAN, M., ATHAR, H. R., ASHRAF, M. Journal of Plant Physiology, 2007, ISSN 0176-1617, roč. 164, č. 6, s. 685-94.

23. RADWAN, DEM., FAYEZ, K. A., MAHMOUD, S. Y. Plant Physiology and Biochemistry, 2007, roč. 45, s. 480-9.

24. Duraisamy, G. S., Pokorný, R. Acta Universitatis Agriculturae et Silviculturae Mendelianae Brunensis, 2009, roč. 57, č. 5, s. 79-86.

25. KAISER, W. J., GHANEKAR, A. M., NENE, Y. L., RAO, B. S., ANJAIAH, V. Viral diseases of chickpea. In: ICRISAT (International Crops Research Institute for 
the Semi-Arid Tropics) Chickpea in the nineties: Proceedings of the Second International Workshop on Chickpea Improvement. 1990.

26. SEVÍK, M, A., TOHUMCU, E. K. The ELISA analysis results in tomato (Lycopersicon esculenutm MILL.) seed health testing fot Tobacco mosaic virus. In Žemdirbyste $=$ Agriculture . ISSN 1392-3196, 2011, roč. 98, č. 3, s. 301-306.

27. PRADHANANG, P. M. Tomato Mosaic Virus: Does it Transmit through Tomato Seeds?. In Acta horticulturae. ISSN 2406-6168, 2009, roč. 808, č. 11, s. 87-94.

28. GOODING, J. R., SUGGS, E. G.Seed borne tobacco mosaic virus in commercial sources of tomato seed. In Plant Dissease Report. ISSN 0032-0811, 1976, roč. 60, s. 441- 442.

29. AVERRE, C. W., GOODING, L. Virus diseases of greenhouse tomato and their managment. [online]. 2010. [cit. 2020-22-11]. Dostupné na internete: <cesnesu.ed u/depts.//pp/notes/oldnites/v g15.htm>.

\section{Kontaktné údaje}

Ing. Simona Grešíková

Univerzita sv. Cyrila a Metoda v Trnave

Námestie J. Herdu 2, 91701 Trnava

simonagresikova@gmail.com

doc. Mgr. Daniel Mihálik, PhD.

Univerzita sv. Cyrila a Metoda v Trnave

Námestie J. Herdu 2, 91701 Trnava

daniel.mihalik@ucm.sk

RNDr. Michaela Mrkvová, PhD.

Univerzita sv. Cyrila a Metoda v Trnave

Námestie J. Herdu 2, 91701 Trnava

michaela.mrkvova@ucm.sk 


\title{
STRAVOVACIE NÝVYKY DETÍ POČAS LOCKDOWNU OCHORENIA COVID -19
}

\author{
EATING HABITS OF CHILDREN DURING LOCKDOWN \\ TO COVID -19
}

\author{
Jana Cinová, Andrea Šuličová, Tatiana Šantová, Zuzana Šimová, L’ubica \\ Derñárová, Zuzana Novotná, L’ubomíra Lizáková, Andrea Obročníková
}

\begin{abstract}
Abstrakt
Zdravie detí sa celosvetovo každým rokom zhoršuje aj v dôsledku obezity, ktorá sa stala pandémiou 21.storočia. Dôležitú úlohu pri jej zvládaní predstavuje prevencia, ktorej významným atribútom je zloženie stravy a stravovacie návyky diet’at'a, ako aj celej rodiny. Autorky v príspevku uvádzajú do pozornosti problematiku obezity v detskom veku a výsledky prieskumu zameraného na stravovacie návyky detí počas lockdownu ochorenia Covid- 19. Na základe výsledkov prieskumu konštatujú, že rodičia si uvedomujú dôležitost' správnej výživy u diet'at'a. Zároveň konštatujú, že deti sa počas obdobia lockdownu v súvislosti s ochorením Covid - 19 stravovali zdravo, dodržiavali pitný režim i správne stravovacie návyky.
\end{abstract}

Kl'účové slová: obezita, prevencia, stravovacie návyky, Covid-19, diet’a, ošetrovatel'stvo, prieskum.

\begin{abstract}
The health of children preparing every year is also deteriorating due to obesity, which has become a pandemic of the 21 st century. The most important role is prevention about the composition of the diet and eating habits of the child, as well as the whole family. The authors point to the issue of obesity in childhood and the results of a survey focused on the eating habits of children during the lockdown of Covid-19. Based on the results of the survey the authors provide, the parents are aware of the importance of proper nutrition for the child. Also the authors provide, children ate healthy during lockdown to Covid - 19 disease adhered to a drinking regime and proper eating habits.
\end{abstract}

Key words: obesity, prevention, eating habits, Covid-19, child, nursing, research.

\section{ÚVOD}

Obezita v súčasnosti patrí celosvetovo medzi štatisticky najčastejšie sa vyskytujúce ochorenia v detskej populácií. Dokonca je považovaná za pandémiu 21. storočia, nie len pre vyspelé krajiny, ale jej zvyšujúci nárast je uvádzaný aj v rozvojových krajinách. Obezita je definovaná, ako hromadenie vel'kého objemu tukového tkaniva, kedy energetický príjem potravy je vyšší, ako jej výdaj. Ranný vývoj obezity nastáva už v období dojčat'a, kedy rodičia diet'at'u často podávajú aj stravu, ktorá je navyše. Obezitu je tiež možné definovat', aj ako dôsledok energetickej nerovnováhy v tele, kedy energetický príjem, ktorý diet’a prijalo, je vyšší ako jeho energetický výdaj. V dôsledku obezity vznikajú u detí rôzne komplikácie, ktoré čoraz vážnejšie ovplyvňujú ich zdravie a tým následne súvisiacu kvalitu ich života. Príčiny obezity u detí sú rôznorodé, no významným faktorom jej vzniku je nevhodné stravovanie, ako aj neefektívne dodržiavanie resp. absencia vhodných stravovacích návykov. Stravovacie návyky detí sú v súčasnosti vel'mi negatívne ovplyvňované tempom a životným štýlom života rodín a celej konzumnej spoločnosti. Zároveň aj iné okolností dnešnej doby, 
nevynímajúc ani epidemiologickú situáciu v súvislosti s ochorením Covid - 19 majú vplyv na zdravie, životný štýl a kvalitu života diet'at’a a jeho rodiny.

\section{CELOSVETOVÝ ŠTATISTICKÝ VÝSKYT OBETITY V DETSKEJ POPULÁCIÍ}

Prevalencia detskej obezity za posledné desiatky rokov celosvetovo výrazne stúpla. Svetová zdravotnícka organizácia (WHO) v spolupráci s členskými štátmi schválila ciel', aby do roku 2025 detská obezita nemala stúpajúci charakter. Unicef, WHO a Svetová banka zverejnili štatistické ukazovatele výskytu obezity u detí v apríli 2019 a konštatujú, že detská obezita je globálnym problémom, ktorý postihuje všetky krajiny a obývané kontinenty. Africký kontinent sa medzi rokmi 1990 a 2018 v prevalencii obezity u deti výrazne nezmenil, nárast bol zaznamenaný prevažne v severnej a južnej časti Afriky. Avšak vo všetkých častiach Ázie sa výskyt obezity zvýšil, výnimkou bola len východná čast'. Latinská Amerika a Karibik neboli pri náraste obezity výnimkou. Výrazný vzostup sa zaznamenal v Strednej Amerike. Austrália a Nový Zéland vykazovali prevalenciu detskej obezity v markantnom, až trojnásobnom náraste. $\mathrm{V}$ roku 2016 trpelo nadváhou a obezitou cez 40 miliónov detí mladších ako 5 rokov a cez 330 miliónov detí a dospievajúcich nad 5 rokov až do 19.roku života Medzi rokmi 1980 a 2015 sa obezita alarmujúco zvýšila u dievčat z 3,7 \% na 6,4 \%. U chlapcov bol zaznamenaný nárast z 3,9\% na 7,2 \% vo vekovej skupine od 2 do 4 rokov. Najviac postihnutou krajinou obéznymi det'mi v tejto vekovej skupine bola americká Samoa, kde z celkového počtu detí bolo až $50 \%$ dievčat a chlapov obéznych. Výnimkou nárastu obezity u detí nebola ani krajina v Oceánií - Kiribati, kde bolo obézne každé tretie dievča, v Kuvajte bolo obézne každé štvrté. Naopak najnižší výskyt obezity u detí bol zaznamenaný u oboch pohlaví v Severnej Kórei, Eritreu, Bangladéši a Burundi. Do roku 2015 patrila Rovníková Guinea tiež k štátom s vysokou prevalenciou obezity. V Latinskej Amerike boli najviac obézne dievčatá. Naopak najnižšia úroveň obezity u dievčat bola zaznamenaná v Kolumbii a u chlapcov to bol Honduras. Výskyt obezity alarmujúco postihol aj kontinent Európy. V strednej a východnej Európe bola obezita vel'mi vysoká najmä v Albánsku u dievčat, v Čiernej Hore a Bosne a Hercegovine.

\subsection{Výskyt obezity na Slovensku}

Epidémia obezity na Slovensku, oproti iným krajinám sa začala vyskytovat' s mierným oneskorením. Podl'a štúdie, ktorá bola realizovaná v roku 2015 Svetovou zdravotníckou organizáciou, bolo na Slovensku 9,9 \% chlapcov, ktorí trpeli nadhmotnost'ou a 8,8 \% chlapcov bolo obéznych. Výsledky sa týkali skupiny chlapcov, ktorí mali 8 rokov. V rovnakej vekovej kategórii boli aj dievčatá, u ktorých nadhmotnost' bola zistená u 7,5 \% dievčat. Obezitou trpelo 9,5\% dievčat. Svetová zdravotnícka organizácia tiež zverejnila údaje výskytu obezity u slovenských adolescentov z rokov 2009/2010, podl'a ktorých obezitou trpelo $29 \%$ chlapcov a $13 \%$ dievčat vo veku 11 rokov. Vo veku 13 rokov trpelo obezitou $28 \%$ chlapcov a $10 \%$ dievčat. Vo vekovej skupine do 15 rokov obezitou trpelo $18 \%$ chlapcov a $8 \%$ dievčat. Na stredných školách v Bratislavskom kraji v školskom roku 2011/2012 sa organizoval projekt, ktorého sa zúčastnilo 4552 adolescentov vo veku 15 - 19 rokov. Realizovalo sa hodnotenie BMI podl'a veku a pohlavia adolescentov a výsledky poukazujú na skutočnost', že nadhmotnost'ou trpelo $17,8 \%$ chlapcov a $14,9 \%$ dievčat.

\subsection{Najčastejšie príčiny obezity}

Príčin detskej obezity existuje viacero. Na podklade hormonálnej príčiny je iba malé percento predpokladu jej vzniku. Výskyt obezity sa viac pripisuje genetike, ktorú diet’a zdedí. Na základe štatistických výsledkov sa zistilo, že ak je jeden z rodičov diet’at’a obézny, diet’a má $50 \%$ pravdepodobnost', že bude tiež obézne. V prípade, ak sú obézni obaja z rodičov, predpoklad obezity u diet'at'a je až $80 \%$. Napriek faktu, že obezita vzniká na podklade 
energetickej nerovnováhy, ovel'a l'ahšie sa vyvinie u geneticky predisponovaných jedincov. Medzi významné príčiny obezity patrí nevhodné stravovanie a stravovacie návyky. V oblasti stravovania, návykov a vzt'ahu k jedlu sa u diet'at'a budujú tieto návyky už v rannom veku. Z tohto dôvodu vel'ký vplyv majú rodičia, školské zariadenia, nevynímajúc aj vplyv rovesníkov. Deti po vzore svojich rodičov si vel'mi intenzívne a nevedome osvojujú stravovacie návyky. Tiež nevhodná strava, vplyv rodiny a životný štýl, ktorý je v rodiny zaužívaný zohráva významnú úlohu.

\section{ANALÝZA PARCIÁLNYCH VÝSLEDKOV PRIESKUMU}

\subsection{Problém, ciel', vzorka respondentov a metodológia prieskumu}

Prieskum realizovaný v mesiaci február 2021 bol zameraný na postoj rodičov k stravovacím návykom detí počas lockdownu v súvislosti s ochorením Covid - 19. Celkovo sa prieskumu zúčastnilo 161 rodičov a ciel'om bolo zistit', aké zloženie stravy a stravovacie návyky preferovali deti počas lockdownu, dodržiavanie pitného režimu a tiež poukázat', do akej miery ovplyvnil lockdown telesnú hmotnost' detí. Prieskum bol realizovaný použitím metódy neštandardizovaného dotazníka, ktorý bol respondentom administrovaný online a konštruovaný celkovo z 21 položiek a identifikačných údajov.

\subsection{Kvantitatívna analýza významných prieskumných zistení a diskusia}

Kvantitatívnu analýzu demografických údajov a jednotlivých položiek neštandardizovaného dotazníka interpretujeme prostredníctvom grafov a tabuliek. Získané údaje vyhodnocujeme početnost'ou (n) a percentuálne (\%).

Tabul'ka 1 Spôsob práce rodičov počas lockdownu

\begin{tabular}{|l|c|c|}
\hline \multicolumn{1}{|c|}{ Možnost' odpovede } & n-početnost' & \% - percentá \\
\hline home office & 38 & 23 \\
\hline dochádzal/a som do zamestnania & 88 & 55 \\
\hline nie som zamestnaný/á & 35 & 22 \\
\hline
\end{tabular}

Tabul'ka 2 Zmena stravovacích návykov detí počas lockdownu

\begin{tabular}{|l|c|c|}
\hline \multicolumn{1}{|c|}{ Možnost' odpovede } & n-početnost' & \% - percentá \\
\hline$a ́ n o ~$ & 67 & 42 \\
\hline nie & 86 & 53 \\
\hline neviem & 8 & 5 \\
\hline
\end{tabular}

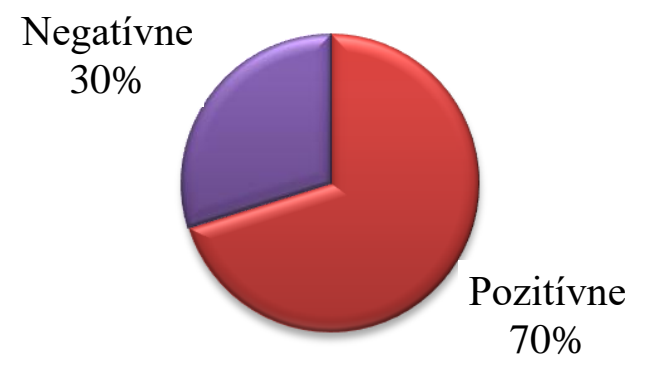

$\square$ Pozitívne $\square$ Negatívne

Graf 1 Zmena stravovania detí počas lockdownu ochorenia Covid -19 


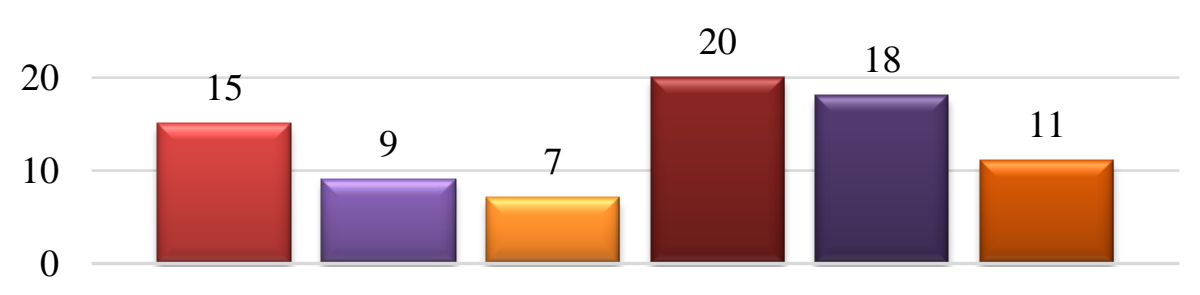

\vynechávanie (raňajky, desiata, obed, olovrant, večera)

凹 obedovali skôr/neskôr ako vy

$\square$ odmietanie stravy

$\square$ nepravidelné stravovanie

■neskoré večerné pojedanie

$\square$ jedli prevažne nezdravú stravu

Graf 2 Prehl'ad negatívnych zmien v stravovaní detí počas lockdownu

Tabul'ka 3 Počet teplých porcii jedla za deň počas lockdownu

\begin{tabular}{|l|c|c|}
\hline \multicolumn{1}{|c|}{ Možnost' odpovede } & n- početnost' & \% - percentá \\
\hline $1-2 x$ & 121 & 75 \\
\hline $3-4 x$ & 35 & 22 \\
\hline 5 a viackrát & 5 & 3 \\
\hline bez teplej stravy & 0 & 0 \\
\hline
\end{tabular}

Tabul'ka 4 Preferovaná príprava stravy rodičmi počas lockdownu

\begin{tabular}{|l|c|c|}
\hline \multicolumn{1}{|c|}{ Možnost' odpovede } & n- početnost' & \% - percentá \\
\hline domáca strava & 157 & 98 \\
\hline polotovary & 4 & 2 \\
\hline fast-food & 0 & 0 \\
\hline
\end{tabular}

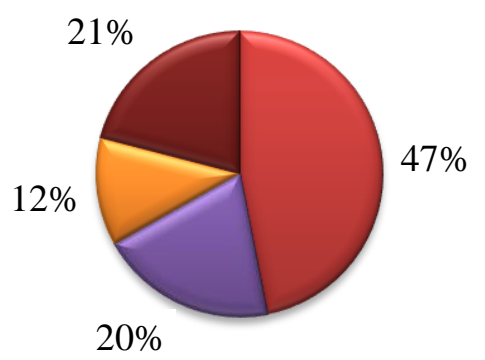

■ kuchyni/jedálni - stolovacie návyky

■ obývačke

$\square \mathrm{V}$ detskej izbe

๑ Podl’a situácie

Graf 3 Najčastejšie preferované miesto stravovania detí počas lockdownu 


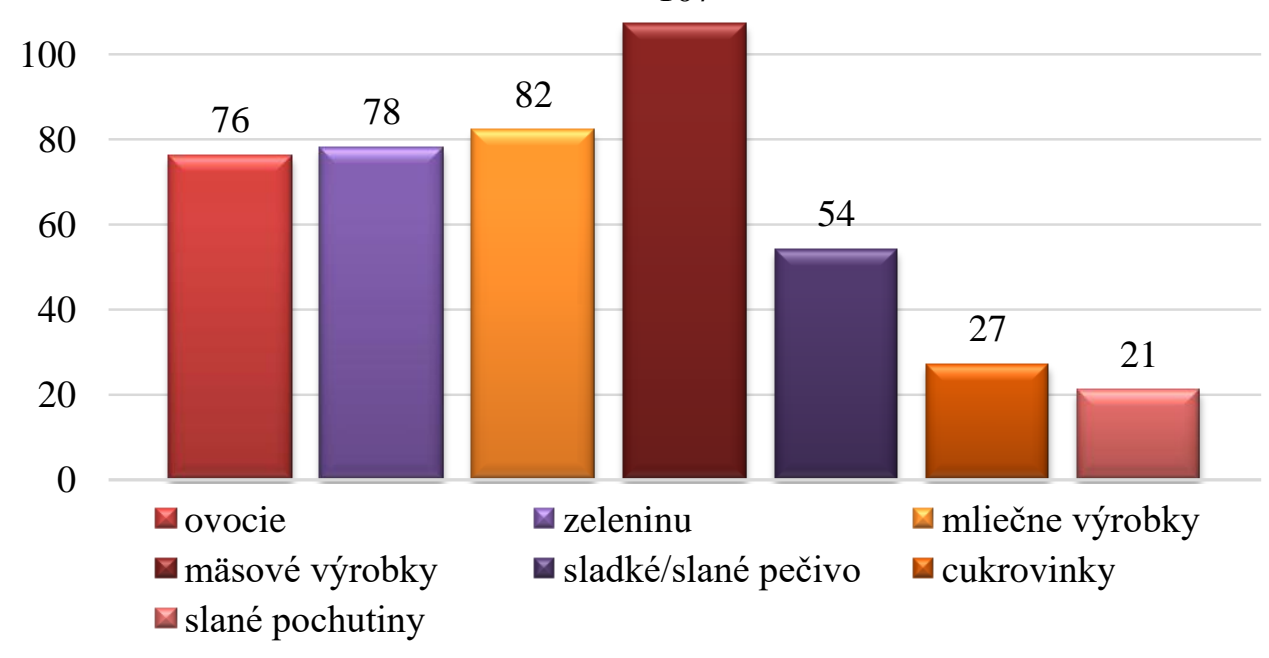

Graf 4 Najčastejšie preferované kategórie jedál detí počas lockdownu

Tabul'ka 5 Záujem rodičov o pitný režim detí počas lockdownu

\begin{tabular}{|l|c|c|}
\hline \multicolumn{1}{|c|}{ Možnost' odpovede } & n- početnost' & $\%$ - percentá \\
\hline áno & 140 & 87 \\
\hline nie & 21 & 13 \\
\hline
\end{tabular}

Tabul'ka 6 Dodržiavanie pitného režimu u detí

\begin{tabular}{|l|c|c|}
\hline \multicolumn{1}{|c|}{ Možnost' odpovede } & n-početnost' & \% - percentá \\
\hline áno & 123 & 76 \\
\hline nie & 18 & 11 \\
\hline neviem sa vyjadrit' & 20 & 12 \\
\hline
\end{tabular}

Tabul'ka 7 Zmena telesnej hmotnosti u detí počas lockdownu ochorenia Covid - 19

\begin{tabular}{|l|c|c|}
\hline \multicolumn{1}{|c|}{ Možnost' odpovede } & n- početnost' & \% - percentá \\
\hline diet'a pribralo & 53 & 76 \\
\hline diet'a schudlo & 17 & 24 \\
\hline
\end{tabular}

\section{Diskusia}

Vhodné zloženie stravy a stravovacie návyky detí patria k významnej zložke prevencie obezity v detskom veku. Aj nedávno prežitá nepriaznivá situácia lockdownu v súvislosti s ochorením Covid -19 predstavovala riziko vzniku nadváhy a obezity u detí. Deti počas tejto situácie trávili celý čas izolované v domácom prostredí, nenavštevovali školské zariadenia a ovel'a viac času pracovali s počítačom, nakol'ko sa vzdelávali dištančnou formou. Ich pohybová aktivita bola minimálna. Dokonca niektoré detí začali pocit’ovat' úzkostné stavy alebo sa ovel'a viac nudili. Z tohoto dôvodu sme sa rozhodli venovat' problematike stravovania a pitného režimu u detí počas lockdownu ochorenia Covid- 19. Na základe výsledkov prieskumu konštatujeme pozitívne zistenie, nakol'ko rodičia, ktorí počas lockdownu dochádzali do zamestnania svojim det’om vždy zabezpečili teplé jedlo denne a 
preferovali varenú domácu stravu. Avšak rodičia uvádzali, že u detí spozorovali negatívne zmeny v stravovaní, ktoré sa týkali hlavne nepravidelného stravovania a častého večerného prejedania sa. Pozitívnym zistením je aj fakt, že rodičia dohliadali, aby sa deti stravovali v kuchyni a dodržiavali stolovacie návyky. Zloženie stavy detí bolo pestré a vhodné, tiež aj dodržiavanie pitného režimu, ktorému rodičia venovali pozornost'. Čistá voda a čaje patrili k tekutinám, ktoré rodičia det’om ponúkali a preferovali najviac. Negatívnym zistením prieskumu je skutočnost', že u detí počas trvajúceho lockdownu v súvislosti s ochorením Covid- 19 došlo k zmene telesnej hmotnosti a väčšina deti respondentov svoju hmotnost' zvýšila.

\section{Odporúčania pre prax}

Na základe analýzy výsledkov prieskumu navrhujeme odporúčania pre prax, akými sú apelácia na rodičov $\mathrm{v}$ efektívnom dodržiavaní stravovacích návykov, pitného režimu, pohybovej aktivity a psychohygieny u detí; zapájat' študentov odboru ošetrovatel'stva do osvety a podporovat' ich participáciu v rámci preventívnych programov detskej obezity; neustála podpora fungujúcich aktívnych programov v prevencii obezity u detí aj zo strany mestských samospráv; podporovat' už fungujúce programy prevencie detskej obezity aj v školských zariadeniach v zameraní sa na zdravé stravovanie detí, pitný režim a pohybovú aktivitu; významným prínosom by bolo aj opätovné zavedenie školskej sestry do praxe.

\section{ZÁVER}

Za posledné obdobie sa výskyt obezity u detí rapídne zvýšil, čo v konečnom dôsledku predstavuje riziku vzniku vážnych komplikácií ovplyvňujúce zdravie detskej populácie, a tým aj nepriaznivý dopad na celú spoločnost'. V súčasnosti sa obezita považuje za civilizačnú chorobu, ktorej úmrtnost' a chorobnost' v detskej populácií je čoraz alarmujúcejšia. Základom zdravia detí je prevencia, a to už od ranného veku. Tejto skutočnosti by si mali byt' vedomí nielen zdravotníci, ale aj rodičia, pedagógovia, nevynímajúc ani verejných činitel'ov štátu či mestských samospráv.

\section{Použitá literatúra}

1. ALDHOON HAINEROVÁ, I. Detská obezita, Praha: Maxdorf s.r.o., 114 s., ISBN: 978-80-7345-196-7

2. ALDHOON HAINEROVÁ, I., ZAMRAZILOVÁ, H. Zdravotni a psychosociálni komplikace obezity u dètí a dospivajicich. [online]. [citované 12.12.2020] Dostupné z: https://www.internimedicina.cz/pdfs/ped/2015/03/03.pdf

3. ANTOŠOVÁ, M. Obezita u detí, 2019. [online]. [citované 18.11.2020] Dostupné z: https://mamaaja.sk/chore-dieta/vyziva-a-poruchy-vyzivy-deti/obezita-u-deti

4. DI CESARE, M., SORIC, M. a kol. The epidemiological burden of obesity in childhood: o worldwide epidemic requiring urgent action. [online]. [citované 11.11.2020] Dostupné z: https://bmcmedicine.biomedcentral.com/articles/10.1186/s12 916-019-1449-8

5. FÁBRYOVÁ, L. Epidemiológia diabezity, 2020. [online]. [citované 22.3.2021] Dostupné z: https://www.solen.sk/storage/file/article/VIA_3_2020_final\%20\%E2\%8 0\%93\%20Fabryova.pdf

6. KOVAL', J. a kol. Pediatria a pediatrické ošetrovatel'stvo - vybrané kapitoly, Prešovská univerzita v Prešove, Fakulta zdravotníckych odborov, 200 s., ISBN: 97880-8068-787-8

7. ONDRIOVÁ, I., CINOVÁ, J., LIZÁKOVÁ, L., 2018. Vybrané ošetrovatel'ské postupy v pediatrii, Prešov: Vydavatel'stvo Prešovskej univerzity, 200 s., ISBN: 97880-555-2055-1 
8. ¿̌RPOVÁ, A. Obezita u detí: aká je najlepšia prevencia? [online]. [citované 28.12.2020] Dostupné z: https://www.nutriklub.sk/clanok/obezita-u-deti-aka-je-naj1 epsia-prevencia

9. URBANOVÁ, Z. Mužeme ovlivnit obezitu v dětství?. [online]. [citované 8.12.2020] Dostupné z: https://www.pediatriepropraxi.cz/pdfs/ped/2008/04/06.pdf

10. UVZSR Národný akčný plán v prevencii obezity na roky 2015 - 2025, [online]. [citované 12.2.2021] Dostupné z: https://www.uvzsr.sk/docs/info/podpora/NAPPO_ 2015-2025.pdf

11. VARGOVÁ, L'ubomíra. Obezita v detskom veku zhl'adiska ošetrovatel'stva [bakalárska práca]. Prešovská univerzita v Prešove (Prešov, Slovensko). Fakulta zdravotníckych odborov, Katedra Ošetrovatel'stva. Školitel': PhDr. Mgr. Jana Cinová, PhD. Stupeň odbornej kvalifikácie: bakalár. Prešov: FZO PU, 2021. 38 s.

\section{Kontaktné údaje}

PhDr. Mgr. Jana Cinová, PhD

PU v Prešove, Fakulta zdravotníckych odborov

Partizánska 1, 08001 Prešov

Tel: 051/ 7562463

email: jana.cinova@unipo.sk 


\title{
NÁSTROJE NA MERANIE KVALITY ŽIVOTA PACIENTOV SO SCLEROSIS MULTIPLEX
}

\section{TOOLS FOR MEASURING THE QUALITY OF LIFE OF PATIENTS WITH SCLEROSIS MULTIPLEX}

\begin{abstract}
Andrea Obročníková
Abstrakt

Aj ked' aspekt fyzického poškodenia roztrúsenej sklerózy (MS) má vel'ký význam, merania kvality života (QoL) sa považujú za čoraz dôležitejšie pri hodnotení progresie ochorenia, liečby a riadenia starostlivosti poskytovanej pacientom s MS. Napriek uznanej potrebe riešit' problémy QoL zostáva hodnotenie QoL v klinickej praxi nedostatočne využívané. Príspevok ponúka niekol'ko nástrojov vhodných $\mathrm{k}$ hodnoteniu kvality života pacientov s SM z dôvodu zvýšenia ich poznania a využitia $v$ klinickej praxi, pretože pacient je ústredným členom starostlivosti a hodnotitel'om spokojnosti s poskytovanou starostlivost'ou.
\end{abstract}

Kl'účové slová: skleróza multiplex, kvalita života, dotazníky, meranie

\begin{abstract}
Although the aspect of physical impairment of multiple sclerosis (MS) is of great importance, measures of quality of life $(\mathrm{QoL})$ are considered increasingly important in assessing disease progression, treatment and management of care provided to patients with MS. Despite the recognized need to address QoL issues, QoL assessment remains underused in clinical practice. The paper offers several tools suitable for assessing the quality of life of patients with MS in order to increase knowledge and their use in clinical practice, because the patient is a central member of care and an evaluator of satisfaction with the care provided.
\end{abstract}

Key words: multiple sclerosis, quality of life, questionnaires, measurment

\section{SCLEROSIS MULTIPLEX}

Sclerosis multiplex (d’alej SM) je imunopatologické ochorenie, pre ktoré je charakteristické zápalové postihnutie mechanizmov centrálneho nervového systému (d’alej len CNS) a tiež neurodegeneratívnymi zmenami mozgu. Vo svete postihuje zväčša mladú generáciu vo veku medzi dvadsiatym a štyridsiatym rokom života, priemerom je 31,7 rokov. Táto dlhodobo trvajúca choroba je spojená so zníženou kvalitou života a tiež vysokým socioekonomickým dopadom (Vališ a kol., 2018). Slovenská republika patrí do kategórie krajín s vysokým výskytom SM. Prevalencia je asi 100 - 150 prípadov na stotisíc obyvatel'ov. Ochorenie je viazané na pohlavie jedinca a jeho existencia je 2 - 3krát vyššia u žien ako u mužov (Klímová, Lengyelová, 2007; Szilasiová, 2013; Donáth, 2017, Kantorová, 2018). Ciel’om príspevku je poukázat' bližšie na kvalitu života pacienta s SM a popísat' nástroje hodnotiace kvalitu života, ktoré ul'ahčujú prácu a starostlivost' o l’udí s SM. V súčasnosti v zahraničných publikáciách sa dočítame o množstve nástrojov, ktoré hodnotia KŽ pacientov s SM a dopad príznakov choroby na d’alšie oblasti života (Zeleníková a kol., 2018). Na Slovenku sa tieto nástroje používajú vo vel'mi malej miere v porovnaní s inými krajinami sveta. Nástroj slúži ako pomôcka, ktorej účelom je identifikovat', diferencovat' a lepšie porozumiet' problémom (potrebám) l’udí s SM, čím zvyšujú kvalitu diagnostiky. Umožňuje správne a efektívne poskytovat' zdravotnú starostlivost' $\mathrm{v}$ dysfunkčných oblastiach a sledovat' pokroky $\mathrm{v}$ starostlivosti. 


\subsection{Obt’ažujúce symptómy SM a kvalita života}

Vznik neurologických príznakov je závislý od miesta poškodenia, na ktorom došlo $\mathrm{k}$ demyelinizácii nervových dráh a tým je pridelený súvisiaci klinický obraz. Prvotné príznaky SM sa vyskytujú u mladšej generácie l’udí. Vzhl'adom na miesto postihnutia CNS môže zapríčinit' širokú škálu prvých symptómov. Preto nejestvuje žiadne definitívne a presné poradie včasných príznakov. Poruchy citlivosti sú najčastejšie iniciovaný symptóm, môžu zahŕňat' prejavy parestézie, hyperestézie, dysestézie alebo naopak zníženie citlivosti polovice tela. Najznámejší je tzv. Lhermittov príznak, ktorý sa prejavuje (brnením) v chrbtici pri predklone hlavy. Porucha citlivosti úzko súvisí aj s poruchou chôdze. Poruchy zraku sú d’alším najčastejšie prvotným príznakom ochorenia SM, charakteru optickej neuritídy. Pacienti popisujú pocit hmlistého videnia alebo až úplnú stratu zraku, ktorá je sprevádzaná aj retrobulbárnou bolest'ou. Pri poškodení iných hlavových nervov, pacienti môžu udávat' diplopiu, výpadky zorného pol’a, znížené vnímanie farieb, občas aj neuralgiu trigeminu. Slabost' v končatinách môže postihovat' len jednu končatinu (monoparéza), teda môže sa prejavit' postihnutím jednej polovice tela (hemiparéza) alebo postihnutím oboch dolných končatín (paraparéza). Až 64-85\% pacientov so SM má poruchu chôdze. Pre pacientov s poruchou chôdze pozorujeme problém pri presúvaní, problém s rovnováhou, koordináciou pohybov, ako aj svalové kŕče a t’ahanie končatiny za sebou. Subjektívne pacienti uvádzajú slabost' v končatinách, pocit t’ažkých nôh. Následne s progresiou sa vyvíja paréza, spasticita, kontraktúry. Pacient môže udávat' zhoršenie fyzického výkonu, zakopávanie, pocit celkovej slabosti a vertigo. Únava je symptómom, ktorým trpí až $90 \%$ pacientov s SM. Negatívne vplýva na osobný, rodinný aj sociálny život a narúša kvalitu života. Unavený pacient je podráždený, odmieta chodit' do spoločnosti, komunikovat', hrozí úplná izolácia. Súčastou terapeutického postupu je zmena spánkového režimu, využívanie farmakoterapie, ako aj aplikácia chladu (Mikul'ová, Kociová, Longauerová 2012). Minimálne polovica pacientov jej prikladá najväčší význam z faktorov ovplyvňujúcich kvalitu života, kde radíme aj bolest’. Sfinkterové poruchy sú vel'mi nepríjemné poruchy s močením, ale aj so stolicou. Využívajú sa nefarmakologické metódy riešenia týchto problémov ako napr. autokateterizácia pri retencii, odporúčajú sa používat' absorbčné pomôcky a posilňovat' svalstvo panvového dna pri inkontinencii. Uvedené poruchy úzko súvisia so sexuálnymi poruchami. Môžu byt' následkom ložiskového postihnutia CNS, rovnako aj následkom únavy, spasticity a iných psychosociálnych faktorov. Takmer $60 \%$ mužov trpí erektilnou dysfunkciou, objavuje sa pokles libida, to isté platí aj u žien. Najčastejšie je to porucha erekcie, zníženie alebo absencia libida a retardovaná ejakulácia. Absencia orgazmu vedie k poklesu záujmu o sexuálny život (Kantorová, Kurča, Michalik, 2012). Nemenej závažné sú neuropsychiatrické poruchy, ktoré je vhodné diferencovat' na poruchy nálady a správania, emócie a kognitívne poruchy. Progresia ochorenia vyvoláva u každého pacienta strach, zmeny vnímania seba a svojho tela vedie $\mathrm{k}$ zníženiu sebavedomia. Emocionálne reakcie sú variabilné v závislosti od postoja $\mathrm{k}$ prvým príznakom (náhlym, postupným) choroby, od postoja k diagnóze SM, od celkového postoja k chorobe a limitáciám (Gulášová, 2004). Z emočných zmien sa objavujú zmeny nálad v podobe zvýšenej iritability, úzkosti, nekontrolovatel'ného smiechu alebo plaču a depresia. Depresia je považovaná za neuropsychiatrický syndróm SM. Vzniká následkom stresu, ale aj imunologických alebo neurologických procesov, ktoré postihujú CNS, či ako nežiaduci efekt liečby. Prítomnost' kognitívnych porúch sa prejavuje prítomným deficitom verbálnej a neverbálnej pracovnej pamäte, narušením koncentrácia, rečových funkcií, rýchlosti myslenia, schopnosti pochopenia informácií. Zavedenie diárov a písanie všetkých činností potrebných vykonat', dodržiavanie denného rutinného režimu pomáha zlepšit' pamät'. Prevalencia porúch sa u pacientov s SM pohybuje medzi $40-70 \%$. Závažnost' výskytu kognitívnych porúch sa stupňuje v pediatrickej populácii, symptómy sú pozorované až u $30 \%$ 
postihnutých detí. Kognitívne poruchy významne ovplyvňujú fungovanie jedinca v bežnom, pracovnom, školskom živote (Havrdová, 2015; Donáth, 2017; Vališ a kol., 2018).

Prítomnost' tremoru, porucha chôdze, rovnováhy, únava, poruchy spánku, depresia, parestézie, spasticita a kognitívne poruchy majú vplyv na schopnost' sebaopatery. S postupujúcou progresiou ochorenia dochádza $\mathrm{k}$ poruche jemnej motoriky a koordinácie pohybov. K udržaniu sebestačnosti sa odporúčajú kompenzačné pomôcky, napr. mäkkú špongiu z bavlny alebo froté materiálu ul'ahčujúce manipuláciu a samotnú starostlivost' o hygienu, sprchovanie s použitím sedačky. Pri čistení zubov majú pacienti problém v dôsledku poruchy jemnej motoriky s otváraním a zatváraním zubnej pasty. Na ul'ahčenie sedu pacienta na WC používame nadstavec na WC dosku (Magurová a kol., 2020).

Medzi menej frekventované symptómy SM sa radia poruchy prehltávania, tremor, poruchy sluchu, dýchania, ale aj paroxyzmálne prejavy, ku ktorým patria epileptické záchvaty. Trpia nimi $2-3 \%$ pacientov SM a tiež môžu byt' prvými príznakmi ochorenia (Vališ a kol., 2018).

Kvalita života je u pacientov so SM výrazne znížená, napriek jej multidimenzionalite, signifikantným parametrom hodnotenia kvality života je porucha hybnosti. SM zasahuje do života pacienta, rovnako aj do života rodiny, v dôsledku postupujúcej sa sociálnej izolácii a straty aktivít. Zmeny v životnom štýle sa týkajú najmä cvičenia a pohybovej aktivity, stravovania, odstránenia nežiaducich škodlivých návykov a zmeny myslenia. Sociálny dopad je vnímaný pre zmeny $\mathrm{v}$ rodinných, pracovných a ostatných sociálnych vzt'ahov pacienta a rodiny. SM s t'ažkým fyzickým postihnutím mení sociálny status a postavenie človeka $\mathrm{v}$ spoločnosti. Vyskytujú sa poruchy reči. Reč je pomalá, s dlhými pauzami, občas aj nezrozumitel'ná. Pacient má zábrany komunikovat', uzatvára sa a ut’ahuje pred spoločnost'ou, čo vedie $\mathrm{k}$ úplnej izolácii. Pacienti často hlásia redukciu interpersonálnych vzt’ahov. Perspektívy do budúcna si vyžadujú modifikácie pre zabránenie sklamania z nedosiahnutia osobných či profesionálnych rolí. U pacientov sa vyskytujú pocity sebal'útosti, viny, až straty zmyslu života (Gul'ášová, 2004).

Majerníková a kol. (2020) uvádzajú, že kvalita života pacientov so SM je nižšia než u zdravého jedinca, ktorá je však determinovaná okrem včas poskytnutej farmakologickej liečby aj psychoterapeutickou intervenciou. Akcentujú význam a zameranie centier starostlivosti o chorých so SM a podporných organizácií. Zdravotnícki pracovníci sú erudovaní odborníci a zároveň validnými zdrojmi informácií ako pre pacienta tak aj pre jeho rodinu, priatel'ov. Podceňovanie problémov potenciuje nepohodu pacienta, čo vedie $\mathrm{k}$ zhoršovaniu jeho zdravotného stavu. Compliance režimových opatrení a liečebného režimu vyžaduje podporu i ostatných členov rodiny. Je žiaduce, aby sa edukácie rovnako aj kontrolných vyšetrení zúčastňoval nejaký člen rodiny alebo blízka osoba. V záujme zvýšenia alebo udržania kvality života je potrebné okrem fyziologických potrieb saturovat' i ostatné potreby (psychologické, sociálne, spirituálne) pacienta. Sestra môže na základe individuálnych potrieb a požiadaviek sprostredkovat' psychologickú, psychoterapeutickú, psychiatrickú starostlivost', ako i ergoterapiu, sociálno-aktivizačné činnosti, účast' na prednáškach (o životnom štýle) či spirituálnu starostlivost' (Magurová, Majerníková, 2016).

\section{2 Špecifické meracie nástroje kvality života pri SM}

Hodnotiace nástroje sú určené pre konkrétnu skupinu alebo ochorenie, ktoré dokážu citlivejšie určit' a zachytit' zmeny, či symptómy, ktoré sú vhodnými ukazovatel'mi KŽ pre lekárov, zdravotnícky personál, ale aj pre samotného človeka, ktorého sa to týka. Umožňujú hodnotit' vývoj zdravotného stavu v čase i škálu faktorov vo vzt'ahu s konkrétnym ochorením (Gurková, 2011; Kačmárová, 2013). Tieto nástroje dosahujú väčšiu citlivost' merania a validitu v porovnaní s generickými nástrojmi. V rámci neurologických ochorení, existujú mnohé špecifické nástroje na hodnotenie kvality života. Medzi špecifické nástroje pre ochorenie sclerosis multiplex patria: 
- Functional Assessment of Multiple Sclerosis (FAMS), sebahodnotiaci nástroj pozostáva z 59 položiek, avšak 44 z nich je skórovaných položiek. Hodnotí úroveň kvality života v šiestich oblastiach: mobilita, symptómy, všeobecná spokojnost', emocionálna a sociálna pohoda, rodina, myslenie a únava. Odpovede sa zapisujú na pät'bodovej Likertovej stupnici: 0 - vôbec, 4 - vel'mi, vyššie skóre indikuje lepší funkčný stav pacienta alebo QoL. Čas potrebný k vyplneniu dotazníka je 20 minút (Cella et al., 1996).

- Functional Index for Living with Multiple Sclerosis (FILMS), sebahodnotiaci nástroj, obsahuje 25 položiek a posudzuje sedem subškál: celkové zdravie, kognitívne fungovanie, telesná bolest', únava, emocionálny distres, dôvera v liečbu a fyzické fungovanie. Odpovede sa uvádzajú na pät'bodovej Likertovej stupnici: 1 - vždy/často/vel'mi nespokojný, 5 - nikdy/vel'mi spokojný, nižšie skóre znamená negatívny dopad na QoL (Wesson et al., 2009).

- Hamburg Quality of Life Questionnaire in Multiple Sclerosis (HAQUAMS), nástroj je skonštruovaný na základe spojenia oboch nástrojov FAMS a SF-36. Obsahuje 38 položiek a hodnotí pät' subškály: pohyblivost' horných končatín, pohyblivost' dolných končatín, únava, nálada a sociálne fungovanie. Odpovede sú zaznamenané podl'a Likertovej stupnici $(1-5)$, vyššie skóre znamená nižšiu QoL (Gold et al., 2001).

- Leeds Multiple Sclerosis Quality of Life scale (LMSQoL) je to krátky a stručný sebaposudzovací nástroj. Je to unidimenzionálny nástroj, obsahuje 8 položiek, ktoré sa zaoberajú únavou, energiou, obavou o svoje zdravie, osamelost'ou, vzhl'adom, rodinnými vzt'ahmi, postojom k iným l'ud'om a budúcnost'ou. Odpovede sa uvádzajú na štvorbodovej stupnici: 0 - vôbec, 3 - väčšinu času. Celkové skóre je v rozsahu $0-24$, avšak vyššie skóre naznačuje horšiu kvalitu života. Hodnotenie zahŕňa stav za uplynulé mesačné obdobie (Ford et al., 2001).

- Multiple Sclerosis Impact Scale (MSIS-29), sebaposudzovací nástroj obsahuje 29 položiek a hodnotí dopad choroby na psychologickú a fyzickú oblast' života pacienta s SM. Výsledky sú zaznamenané na pät'bodovej stupnici: 1 - vôbec, 5 - extrémny dopad. Nástroj hodnotí stav kvality života za posledné 2 týždne a vyššie skóre svedčí o horšie vnímanej kvalite života (Hobart et al., 2001).

- Multiple Sclerosis International Quality of Life questionnaire (MusiQoL) je validovaný, špecifický, multidimenzionálny nástroj QoL, ktorý bol preložený v 14 jazykoch. Dotazník MusiQoL bol medzinárodne validovaný v 15 krajinách u približne 2000 pacientov $\mathrm{s}$ rôznym typom a závažnost'ou SM. Obsahuje 31 položiek a skúma devät' oblastí, ako sú každodenné aktivity, psychologická pohoda alebo well-being, rodinné vzt'ahy, vzt'ahy s priatel'mi, symptómy, spokojnost' so zdravotnou starostlivost'ou, sexuálny a emocionálny život, zvládanie choroby (potlačenie a coping), sondujúc ich stav za posledné 4 týždne. Odpoved'ový formát zahŕňa 6 bodovú stupnicu. Celkové skóre sa transformuje v rozmedzí 0 - 100, vyššie skóre vyjadruje lepšiu kvalitu života. Čas potrebný k jeho vyplneniu je okolo $11 \pm 23$ minút (Simeoni et al., 2008).

- Multiple Sclerosis Quality of Life Inventory (MSQLI), ide o sebahodnotiacu testovú bariéru desiatich nástrojov, ktorá meria kvalitu života pacientov so SM. Obsahuje 138 položiek a skladá sa z viacerých škál a dotazníkov: SF-36 questionnaire, Modified Fatigue Impact Scale (MFIS), Pain Effects Scale (PES), Sexual Satisfaction Scale (SSS), Bladder Control Scale (BLCS), Bowel Control Scale (BWCS), Impact of Visual Impairment Scale (IVIS), Perceived Deficits Questionnaire (PDQ), Mental Health Inventory (MHI), Modified Social Support Survey (MSSS). Čas potrebný k jeho vyplneniu sa pohybuje od 30 do 45 minút v závislosti od využitia 5 skrátených foriem škál. Každá z jednotlivých škál generuje samostatné skóre, a preto skórovací manuál je dostupný na stránke https://www.nationalmssociety.org/For-Professionals/Researchers/Resources-for-MS-

Researchers/Research-Tools/Clinical-Study-Measures/Multiple-Sclerosis-Quality-of-Life- 
Inventory-(MSQL (National Multiple Sclerosis Society Consortium of Multiple Sclerosis Centers, 1997)

- Multiple Sclerosis Quality of Life-54 questionnaire (MSQoL-54), ide o nástroj kombinovaný s SF-36 dotazníkom. Tento nástroj sa skladá z dvoch hlavných častí. Prvú čast' tvorí 36 položiek, ktoré pochádzajú z SF-36, posudzujúce všeobecné zdravie. Druhú čast' tvorí 18 špecifických položiek, ktoré sa vzt’ahujú na ochorenie v skúmaných 12 subškálach a 2 samostatné položky, ktoré respondent hodnotí za posledné 4 týždne od dňa hodnotenia. Výsledky sa zapisujú podl'a Likertovej škály a celkové skóre sa transformuje v rozsahu od 0 do 100 podl'a manuálu. Čas strávený pri vyplňovaní dotazníka je približne 11-18 minút (Vickrey et al., 1995).

Vo vedeckých publikáciách sa objavujú nástroje hodnotiace špecifické potreby pacientov:

- Patient-reported outcome indices for multiple sclerosis (PRIMUS), hodnotiaci nástroj meria škály v troch oblastiach - kvalita života, symptómy a obmedzenia aktivít. Škála symptómy a kvalita života obsahujú položky vo forme jednoduchých príkazov sprevádzaných možnost’ami dichotomickej odpovede. Pre obe škály platí skórovanie nasledovne, položky sú sčítané tak, aby poskytovali celkové skóre v rozmedzí od 0 do 22 . Škála aktivít obsahuje 15 položiek popisujúcich konkrétne úlohy. Jednotlivci hodnotia mieru, do akej sú schopní vykonávat' úlohy, na trojbodovej stupnici. Rozpätie výsledného skóre je od 0 do 30 . Pre všetky škály platí, vyššie skóre znamená negatívny výsledok (vyšší stupeň obmedzenia aktivít, nižšia kvalita života, závažnejšie symptómy) (Doward et al., 2009).

- Multiple Sclerosis Functional Composite (MFSC), nástroj hodnotí dizabilitu pri SM $\mathrm{v}$ troch dimenziách - motorickú funkciu dolných končatín, horných končatín a kognitívne funkcie (Polman, Rudick, 2010).

- Multiple Sclerosis Walking Scale - 12 (MSWS-12), hodnotiaci nástroj meria vplyv choroby SM chôdzu prostredníctvom 12 položiek s možnost’ami odpovede na škále od 1 do 5 (vôbec - extrémne). Celkové skóre sa hodnotí od 0 do 100 a platí, že čím vyššie skóre, tým je porucha chôdze výraznejšia (Hobart et al., 2003).

- Multiple Sclerosis Questionnaire for Job Difficulties (MSQ-Job), nástroj hodnotí dopad SM na plnenie úloh v pracovnom prostredí. Skladá sa zo 42 položiek rozdelených do šiestich škál - vnímanie a jemný pohyb, mentálne funkcie a telesné funkcie spoločné s únavou, psychologické aspekty a vzt’ahy, časová a organizačná flexibilita na pracovisku. Vyššie skóre predstavuje výraznejšie problémy (Raggi et al., 2015).

- Multiple Sclerosis Intimacy and Sexuality Questionnaire-19 (MSISQ-19) hodnotí vplyv symptómov SM na sexuálnu aktivitu a QoL intímnych vzt'ahov. Obsahuje 19 položiek zatriedených do troch subškál: primárna, sekundárna a terciárna sexuálna dysfunkcia. Hodnotenie sa vykonáva na Likertovej škále od 1 do 5 (nikdy-vždy) (Sanders et al., 2000). Vedecká obec okrem vyššie uvedených použiva aj iné nástroje k meraniu a hodnoteniu kvality života pacientov s SM, čo svedčí o záujme mnohých odborníkov participujúcich na starostlivosti zvyšovat' kvalitu života.

Publikácia vznikla na základe riešenia projektu KEGA 002PU-4/2020 Návrh metodiky hodnotenia kvality života pacientov so sclerosis multiplex.

\section{Použitá literatúra}

1. CELLA DF. et al. Validation of the functional assessment of multiple sclerosis quality of life instrument. Neurology. 1996 Jul; 47(1):129-39. doi: 10.1212/wnl.47.1.129.

2. DONATH, V., 2017. Prvé príznaky sclerosis multiplex a význam včasnej liečby. 2017. [online]. [cit.2020-11-20]. Dostupné z: https://www.solen.sk/storage/file/article/a5f 336758b132facbac3e772647d4869.pdf 
3. DOWARD, L. C. 2009. The developmentof patient-reported outcome indices formultiple sclerosis (PRIMUS). Multiple Sclerosis Journal, 2009, roč. 15, č. 9, s. $1092-$ 102. ISSN 1352-4585.

4. FORD, H. L. 2001. Developing a disease-specific quality of life measure for peoplewith multiple sclerosis. Clinical Rehabilitation, 2001, roč. 15, č. 3, s. 247-258. ISSN 02692155.

5. GOLD, S. M. et al. 2001. Disease specific quality of life instruments in multiple sclerosis: Validation of the Hamburg Quality of Life Questionnaire in MultipleSclerosis (HAQUAMS). Multiple Sclerosis Journal, 2001, roč. 7, s. 119-130. ISSN 1352-4585.

6. GULÁS̆OVÁ, I. Psychické problémy pacienta s diagnózou sclerosis multiplex. In Meduca. [online]. 2004. [cit. 2019-02-11]. č.1, s. 47-50. Dostupné na: <http://www.so len.sk/pdf/Gulasova.pdf>.

7. GURKOVÁ, E. Hodnocení kvality života. 1. vydanie. Praha: Grada. 2011. 223 s. ISBN 978-80-247-3625-9.

8. HAVRDOVÁ, E. et al. Roztroušená skleróza v praxi. Praha: Galén. 161 s. 2015. ISBN 978-80-7492-189-6.

9. HOBART, J. 2001. The Multiple Sclerosis Impact Scale (MSIS-29): a new patientbased outcome measure. Brain: a journal of neurology, 2001, roč. 124, č. 5, s. 962-973. ISSN 0006-8950.

10. HOBART, J. C. 2003. Measuring the impact of MS on walking ability: the 12-item MS Walking Scale (MSWS-12). Neurology, 2003, roč. 60, s. 31-36. ISSN 0028-3878.

11. HUDÁKOVÁ, A. a kol. 2020. Nástroje hodnotenia pacientov so sklerózou multiplex. QUAERE 2020 [elektronický dokument]: recenzovaný sborník př́spěvků interdisciplinární mezinárodní vědecké konference doktorandů a odborných asistentů, Hradec Králové, 22. - 26. 6. 2020, vyd. Hradec Králové: Magnanimitas akademické sdružení, 2020, s. 508-514. ISBN 978-80-87952-32-0.

12. KAČMÁROVÁ, M. a kol. 2013. Teórie a nástroje merania subjektívne hodnotenej kvality života. Prešov: Filozofická fakulta PU, 2013. 254 s. ISBN: 978-80-555-0972-3.

13. KANTOROVÁ, E. Typické prvotné príznaky sclerosis multiplex. Via practica, 2018, roč. 15, č. 4, s. 194-198. ISSN 1336-4790.

14. KANTOROVÁ, E., 2017. Sclerosis multiplex. Martin: Univerzita Komenského v Bratislave, Jesseniova lekárska fakulta v Martine, 2017. 97 s. ISBN 978-80-8187-029-3.

15. KANTOROVÁ, E., KURČA, E., MICHALIK, J. Hodnotenie kvality života pacientov so sclerosis multiplex. Neurológie v praxi. 2012, roč. 13, č. 4, s. 211-214. ISSN1213-1814.

16. KLÍMOVÁ, E., LENGYELOVÁ, A. 2007. Demyelizačné ochorenia nervového systému. In ŠANTA, M. a kol. 2007. Neurológia a neurologické ošetrovatel'stvo. 1. vyd. Prešov: Prešovská univerzita v Prešove fakulta zdravotníctva, 2007. 216 s. ISBN 97880-8068-578-2.

17. MAGUROVÁ, D. a kol. 2020. Kvalita života pacienta s ochorením sclerosis multiplex. QUAERE 2020 [elektronický dokument]: recenzovaný sborník př́spěvků interdisciplinární mezinárodní vědecké konference doktorandů a odborných asistentů, Hradec Králové, 22. - 26. 6. 2020, vyd. Hradec Králové: Magnanimitas akademické sdružení, 2020, s. 488-495. ISBN 978-80-87952-32-0.

18. MAGUROVÁ, D., MAJERNÍKOVÁ, L'. 2016. Teoretické východiská edukácie v zdravotnickej praxi. Lipovce pri Prešove: A-print, 2016. 172. s. ISBN 978-80-89721-13-9.

19. MAJERNÍKOVÁ, L'. a kol. 2020. Skleróza multiplex ako ošetrovatel'ský problém. QUAERE 2020 [elektronický dokument]: recenzovaný sborník příspěvků interdisciplinární mezinárodní vědecké konference doktorandů a odborných asistentů, Hradec Králové, 22. - 26. 6. 2020, vyd. Hradec Králové: Magnanimitas akademické sdružení, 2020, s. 470-475. ISBN 978-80-87952-32-0. 
20. MIKULÁKOVÁ, W., KOCIOVÁ, K., LONGAUEROVÁ A. Únava u pacientov so sklerózou multiplex. Prešovská univerzita v Prešove. [online]. 2012. [cit. 2019-01-15]. Dostupné na: <https://www.unipo.sk/public/media/10304/Mikulakova,\%20Kociova,\% 20Longauerova_\%C3\%BAnava\%20pacientov\%20so\%20SM.pdf $>$.

21. POLMAN, C.H., RUDICK, R. A. 2017. The multiple sclerosis functionalcomposite: a clinically meaningful measureof disability. Neurology, 2010, roč. 74, č. Suppl 3, s. S815. ISSN 0028-3878.

22. RAGGI, A. et al. 2015. Development andvalidation of the multiple sclerosisquestionnaire for the evaluation of jobdifficulties (MSQ-Job). Acta Neurologica Scandinavica, 2015, roč. 132, č. 4, s. 226-234. ISSN 1600-0404.

23. SANDERS, A. S. et al. 2000. The multiplesclerosis intimacy and sexualityquestionnaire-19 [MSISQ-19]. Sexuality and Disability, 2000, roč. 18, s. 3-26. ISSN 0146-1044.

24. SIMEONI, M. et al. 2008. Validation of the Multiple Sclerosis International Quality ofLife questionnaire. Multiple Sclerosis Journal, 2008, roč. 14, s. 219-230. ISSN 1352-4585.

25. SZILASIOVÁ, J. 2013. Sclerosis multiplex - klinický obraz, diagnostika a liečba. Medikom. 2013, roč. 3, č. 2. ISSN 1338-340X.

26. The Consortium of Multiple Sclerosis Centers Health Services Research Subcommittee, funded by National Multiple Sclerosis Society. Multiple Sclerosis Quality of Life Inventory: A User's Manual [online]. National Multiple Sclerosis Society, 1997. 65 s. [cit. 2021-03-24]. Dostupné z: https://www.nationalmssociety.org/NationalMSSociety/ media/MSNationalFiles/Brochures/MSQLI_-A-User-s-Manual.pdf

27. VALIŠ, M. a kol. 2018. Roztrušená skleróza pro praxi. Praha: Maxdorf, 2018. ISBN: 978-80-7345-573-6.

28. VICKREY, B.G. et al. A health-related quality of life measure for multiple sclerosis. Qual Life Res. 1995, roč. 4, č. 3, s. 187-206. ISSN 1573-2649.

29. WESSON J. et al. The functional index for living with multiple sclerosis: development and validation of a new quality of life questionnaire. Multiple Sclerosis Journal. 2009;15(10):1239-1249. doi:10.1177/1352458509107019.

30. ZELENÍKOVÁ, R. a kol. 2018. Nástroje hodnotící kvalitu života a potřeby pacietu s roztušenou sklerozou: využití v rehabilitaci. Rehabilitácia, 2018, roč. 55, č. 3, s. 151163. [online]. [citované 2020-11-12]. Dostupné z: https://www.rehabilitacia.sk/archiv/c isla/3REH2018-m.pdf

\section{Kontaktné údaje}

PhDr. Andrea Obročníková, PhD.

Prešovská univerzita v Prešove, Fakulta zdravotníckych odborov

Partizánska 1, 08001 Prešov

Tel: +421 517562460

email: andrea.obrocnikova@unipo.sk 


\title{
PROBLEMATIKA RÁN V ONKOLÓGII
}

\section{WOUNDS IN ONCOLOGY}

\author{
Obročníková Andrea, Derňárová L’ubica, Šantová Tatiana, Šimová Zuzana, \\ Novotná Zuzana, Šuličová Andrea, Lizáková Lubomíra, Cinová Jana
}

\begin{abstract}
Abstrakt
Malígne rany môžu byt' spôsobené primárnym karcinómom kože, metastázami rakoviny iných lokalít $\mathrm{v}$ organizme alebo eróziou kože $\mathrm{z}$ dôvodu malignity. Rovnako aj chronické rany môžu potenciovat' vývin malígnych buniek na spodine rany. Malígne rany sa vyznačujú nízkym potenciálom hojenia, sú sprevádzané príznakmi ako zápach, bolest' a zvýšená hladina exsudátu, dokonca aj smrt'ou. Bremeno utrpenia a starostlivosti o jedinca s ranou na konci života je neutíchajúce a dôsledky tak náročnej situácie pretrvávajú u opatrovatel'ov ešte mnoho rokov. Paliatívna starostlivost' o rany často nie je zameraná na úplné vyliečenie; ide o symptomatickú starostlivost', s ciel'om zlepšit' kvalitu života. Jedinec a jeho opatrovatelia vyžadujú spolu s poskytovaním fyzickej starostlivosti psychologickú, duchovnú a emocionálnu podporu.
\end{abstract}

Kl'účové slová: rana, rakovina, ošetrovatel’ská starostlivost', posudzovanie

\begin{abstract}
Malignant wounds can be caused by primary skin cancer, cancer metastases from other sites in the body, or skin erosion due to malignancy. Likewise, chronic wounds may to potentiate the development of malignant cells at the base of the wound. Malignant wounds are characterized by a low healing potential, accompanied by symptoms such as odor, pain and increased exudate levels, even death. The burden of suffering and caring for an individual with an end-of-life wound is relentless, and the consequences of such a difficult situation persist for many years for carers. Palliative wound care is often not aimed at complete healing; it is a symptomatic care, in order to improve the quality of life. The individual and his caregivers require psychological, spiritual and emotional support along with the provision of physical care.
\end{abstract}

Key words: wound, cancer, nursing care, assessment

\section{MALÍGNA RANA}

Malígna rana je tiež známa ako nekrózna lézia, funginózna rana, ulcerujúca nádorová rana alebo zhubná kožná rana. Funginózne a ulcerované rany sú nevzhl'adné, zapáchajúce a bolestivé, sú znakom progresie ochorenia. Často sú príčinou sociálnej izolácie v čase, ked' pacient vyžaduje sociálny kontakt s rodinou a priatel'mi. Napriek významným pokrokom a úspechom vonkologickej liečbe sú prítomné t’ažko zvládnutel'né oblasti starostlivosti o onkologicky chorého jedinca. Malígne rany sú výzvou pre všetkých zúčastnených na starostlivosti, ich výskyt sa pohybuje 5-10\% u onkologických pacientov. Postihujú viac mužov (32,3 \%) ako ženy (12,0 \%), najviac vekovú kategóriu medzi 60. - 70. rokom života (O'Connor, Aranda, 2005). Ich výskyt môže byt' vyšší z dôvodu metastázovania primárneho nádoru, najmä v priebehu posledného roku života pacienta. Výskyt varíruje s ohl'adom na typ rakoviny, najvyšší percentuálny podiel malígnych rán je pozorovaný pri karcinóme prsníka $(70,7 \%)$, pri rakovine plúc $(11,08 \%)$ a pri kolorektálnom karcinóme $(11,00 \%)$. Medzi nádory, ktoré majú tendenciu vytvárat' malígne rany patria aj nádory kože, hlavy, krku, 
obličiek, vaječníkov, krčka maternice, penisu, močového mechúra, sarkómy, ale taktiež aj lymfómy a leukémie. Primárne kožné nádory zahŕňajú bazocelulárne karcinómy, ktoré sú zvyčajne lokalizované $\mathrm{v}$ mieste a dobre reagujúce na chirurgické odstránenie alebo kryoterapiu a spinocelulárne karcinómy, u ktorých je vyššia pravdepodobnost' vzniku systémových metastáz (O'Connor, Aranda, 2005; Morison et al., 2004). Malígny melanóm je najrýchlejšie sa šíriaci primárny karcinóm kože s metastázami pravdepodobne v kostiach, mozgu a koži. Medzi menej časté primárne nádory kože patrí Karposiho sarkóm a kožný Tbunkový lymfóm (Maida et al., 2016). Ošetrovatel'ská starostlivost' o pacientov s malígnou ranou je v porovnaní s ošetrovaním pacientov s inými nehojacimi sa ranami komplikovanejšia a náročnejšia. Malígne rany majú rôznu etiológiu a vel'ký rozsah narušenia kožnej integrity s následkom krvácania, infekcie a diskomfortu. Liečba malígnych rán je súčastou protinádorovej liečby. V starostlivosti o malígnu ranu ide predovšetkým o poskytnutie podpornej starostlivosti, ktorej ciel'om je vyliečenie len zriedka. Všetky intervencie sú orientované na zlepšenie komfortu pacientov (Nemcová, Hlinková, 2019).

\subsection{Patofyziológia malígnej rany}

Malígne rany sú spôsobené infiltráciou epidermy primárnym alebo metastatickým nádorom, kožná infiltrácia nastáva v dôsledku šírenia nádorových buniek lymfatickým alebo krvným systémom alebo priamou inváziou z primárnej lézie (Ferrell, Coyle, 2001). Akonáhle sa vyvinie funginózna alebo ulcerujúca rana, zmení sa perfúzia tkanív a masa sa rozšíri, centrum nádoru sa stane hypoxickým a vedie k nekróze. Nádorové bunky začínajú vylučovat' rastové faktory, ktoré podporujú proliferáciu nádoru. V týchto ranách sú často prítomné vel'ké množstvá nekrotického materiálu, ktoré zodpovedajú za zápach. Tumor sa môže rozširovat' do hlbších štruktúr s vývojom sínusov alebo fistúl, obvykle vyskytujúce pri brušných a peritoneálnych ranách. Malígna rana sa zvyčajne prejavuje ako diskrétny uzlík, tónovaný $\mathrm{v}$ koži, ružovej, fialovomodrej alebo čiernohnedej farby (Trudie, 2017).

Sprievodné príznaky malígnych rán sú krvácanie, nekrotické tkanivo, silná sekrécia, infekcia rany, nepríjemný zápach, bolest', poškodenie okolia kože sekrétom. Malígne rany sa hoja zriedkavo, a preto je základom liečby zmiernenie symptómov v rámci modelu paliatívnej starostlivosti. Ciel'om liečby malígnych rán je znížit' devastačný dopad rany na jednotlivca a jeho ošetrujúci tím, zároveň uvedomit' si potenciál pre vznik nových rán pri eskalácii karcinómu alebo vzniku dekubitov pri zlyhaní napr. obranných mechanizmov kože.

\subsection{Posudzovanie pacienta s malígnou ranou}

Komplexné hodnotenie stavu pacientov s malígnou ranou vrátane posudzovania je dôležité pre rozhodovanie o stratégiách efektívnej liečby a ošetrovania. Posudzovanie musí zohl'adňovat':

- hodnotenie zdravotného stavu a funkčných deficitov (stav dýchania a srdcovej činností, výživy, vyprázdňovania, aktivity a odpočinku),

- hodnotenie vplyvu ochorenia na život pacienta (úroveň schopnosti pacienta postarat' sa sám o seba, emocionálna stránka prežívania ochorenia),

- hodnotenie sociálnych pomerov (bytové podmienky, vplyv ochorenia na vzt'ahy v rodine),

- hodnotenie podpory zo strany zdravotníkov,

- hodnotenie rany a jej okolia (vzhl'ad, lokalizácia a iné atribúty),

- posudzovanie symptómov (bolest', prítomnost' infekcie, exsudácia, zápach, krvácanie, svrbenie) (Nemcová, Hlinková, 2019).

\section{Posudzovanie a manažment symptómov}

Sprievodné symptómy malígnej rany determinujú rozhodnutie liečebného postupu a výber optimálneho lokálneho manažmentu. 


\begin{tabular}{|c|c|}
\hline $\begin{array}{l}\text { Infekcie } \\
\text { a zápach } \\
\text { Lokálna infekcia: } \\
\text { začervenanie, } \\
\text { opuch, zvýšená } \\
\text { bolestivost', } \\
\text { exsudát, } \\
\text { leukocytóza a } \\
\text { horúčka. }\end{array}$ & $\begin{array}{l}\text { Pri malígnej rane dochádza k narušeniu kožnej integrity, opakujúcim } \\
\text { množením mikroorganizmov dochádza k jej kolonizácii a koža tak } \\
\text { prestáva plnit' svoju funkciu. Dôležité je dodiferencovat', či ide o } \\
\text { klinicky manifestovanú infekciu alebo o lokálnu infekciu rany. } \\
\text { Aplikácia antibiotík je indikované pri systémovej infekcii, môžeme } \\
\text { tým dosiahnut' redukciu bakteriálneho osídlenia rany, elimináciu } \\
\text { infekcie a prínosom je zníženie zápachu. } \\
\text { Súčast'ou starostlivosti je toaleta rany a jej okolia, irigácia } \\
\text { fyziologickým roztokom alebo aj čistou (prevarenou) vodou. Vhodné } \\
\text { je čistenie rany pomocou antiseptických roztokov (jodovaný povidón, } \\
\text { polyhexanid), ktoré napomáha k zníženiu exsudácie. Na primárne } \\
\text { krytie sú vhodné materiály s obsahom uhlia alebo striebra. K } \\
\text { odstraňovaniu nekrotického tkaniva je optimálne použitie } \\
\text { autolytického debridementu (hydrovlákna, hydrogély a algináty), } \\
\text { rovnako je vhodná medová terapia. Šetrný mechanický debridement je } \\
\text { možné vykonat' navlhčenou gázou. Ostrý debridement zvažuje lekár } \\
\text { pre riziko k poškodenia vitálneho tkaniva a krvácania. }\end{array}$ \\
\hline $\begin{array}{l}\text { Exsudát } \\
\text { Posúdenie: } \\
\text { množstvo, } \\
\text { viskozita a } \\
\text { príčina. }\end{array}$ & $\begin{array}{l}\text { Príčinou exsudátu je katabolizmus tkaniva vyvolaný bakteriálnymi } \\
\text { proteázami, zápalovým procesom spojeným s infekciou a vysokou } \\
\text { permeabilitou ciev } \mathrm{v} \text { nádore. Na odstránenie exsudátu za účelom } \\
\text { prevencie macerácie a infekcie } \mathrm{v} \text { okolí rany je vhodné použit' sterilnú } \\
\text { gázu, neadherentné krytie so sterilnou gázou napustenou vazelínou a } \\
\text { spodinu rany vyplnit' l'ahko absorbujúcim kompresom, s obsahom } \\
\text { metronidazol gélu, príp. krytie impregnované striebrom alebo s } \\
\text { aktívnym uhlím alebo sterilný mastný tyl } \mathrm{v} \text { kombinácii so } \\
\text { sekundárnym krytím z gázy. Okolie kože pri silne secernujúcej rane } \\
\text { môžeme chránit' použitím stomickej podložky alebo zinkovej pasty. } \\
\text { Na macerovanú a poškodenú kožu sa odporúča krátkodobo aplikovat' } \\
\text { lokálne kortikosteroidy. K d'alším postupom redukcie sekrécie patrí } \\
\text { aplikácia rádioterapia a chemoterapia. }\end{array}$ \\
\hline Svrb & $\begin{array}{l}\text { Tento nepríjemný príznak popisujú pacienti aj pri neporušenej koži. } \\
\text { Predpokladá sa, že svrbenie vzniká z podráždených nervových } \\
\text { zakončení v dôsledku infiltrácie nádoru, miestneho uvol'nenenia } \\
\text { zápalových mediátorov pre prítomný nádor a dermatitídy spojenej s } \\
\text { vlhkostou v okolí rany. Svrbenie však nemusí reagovat' na liečbu } \\
\text { antihistaminikami, v literatúre sa popisuje liečba antidepresívami, } \\
\text { lokálnymi kortikoidmi, ktorá však musí byt' prísne individualizovaná. } \\
\text { Z nefarmakologických intervencií sa javí ako účinná transkutánna } \\
\text { elektrická nervová stimulácia (TENS). } \\
\text { Eliminácii svrbenia napomáha aj použitie hydrogélov pri preväze } \\
\text { malígnej rany, ktoré udržiavajú kožu hydratovanú (nevhodné však pri } \\
\text { silnej exsudácii). Preventívne kožu hydratovat' zvýšením príjmu } \\
\text { tekutín a nanášaním hydratačných krémov. Pre redukciu pruritu sa } \\
\text { pacientom odporúča bavlnená osobná a postel'ná bielizeň. }\end{array}$ \\
\hline $\begin{array}{l}\text { Monitorujeme: } \\
\text { hemoglobín } \\
\text { (anémia), objem }\end{array}$ & $\begin{array}{l}\text { Krvácanie je vážnou komplikáciou rany, najmä ak je príčinou } \\
\text { poškodenie ciev nádorom, krvácanie môže byt' smrtel'né. Rizikové sú } \\
\text { najmä nádory susediace s vel'kými cievami - nádory hlavy a krku, } \\
\text { nádory panvy pri prerastaní do slabín. Riziko krvácania môže zvyšovat' } \\
\text { aj predchádzajúca rádioterapia, užívanie perorálnych antikoagulancií a }\end{array}$ \\
\hline
\end{tabular}




\begin{tabular}{|c|c|}
\hline $\begin{array}{l}\text { telesných tekutín } \\
\text { (pri silne } \\
\text { secernujúcich } \\
\text { ranách). }\end{array}$ & $\begin{array}{l}\text { antitrombotík, trombocytopénia, nedostatok vitamínu K a iné poruchy } \\
\text { koagulácie. Krvácanie môže byt' spôsobené aj nešetrným preväzom } \\
\text { rany a strhávaním zaschnutého krytia. Ak je tkanivo v malígnej lézii } \\
\text { vel'mi krehké, krvácanie môže nastat' aj pri minimálnom dotyku. } \\
\text { Odporúča sa používat' hydrogély, ak silno nesecernuje rana. Nevhodné } \\
\text { sú algináty pre možnost' hemorágie v rane. K lokálnej hemostáze sa } \\
\text { využiva lokálna kompresia s l'adovaním, príp. kalcium alginát, gáza } \\
\text { s epinefrinom, sukralfát pasta, hemostatické špongie na báze želatíny, } \\
\text { kolagénu alebo oxidačnej celulózy (Gelfoam, GelitaSpon, Surgispon, } \\
\text { Traumacel Biodress), krytie s dusičnanom strieborným. Iné postupy } \\
\text { hemostázy zahŕňajú rádioterapiu, chemoterapiu reagujúcich malignít, } \\
\text { chirurgia (kauterizácia, ligácia), radiologické techniky - napr. } \\
\text { intravaskulárna embolizácia na pretrvávajúce silné krvácanie. }\end{array}$ \\
\hline $\begin{array}{l}\text { Bolest' } \\
\text { Posudzujeme } \\
\text { závažnost' bolesti: } \\
\text { Edmontonská } \\
\text { škála na } \\
\text { hodnotenie } \\
\text { symptómov, škála } \\
\text { VAS škála 0-10 } \\
\text { alebo Wong- } \\
\text { Baker Faces } \\
\text { Scale. }\end{array}$ & $\begin{array}{l}\text { Ďalším závažným a komplexným sprievodným príznakom pri } \\
\text { malígnych ranách je bolest'. Príčinou môže byt' kompresia nádoru na } \\
\text { okolité tkanivá, poškodenie nervov pri raste nádoru, edém pre } \\
\text { nedostatočný prietok kapilárami a lymfatickými cievami, infekcia a } \\
\text { odhalenie nervových zakončení pri poškodení kože, ale aj nešetrná } \\
\text { technika pri preväze. Bolest' rany môže byt' spôsobená stimuláciou } \\
\text { nervových zakončení (nociceptívna bolest') a / alebo bolest'ou } \\
\text { spôsobenou nervovou dysfunkciou (neuropatická bolest'). Identifikácia } \\
\text { zúčastnených nociceptorov umožňuje optimálnu analgéziu. V tomto } \\
\text { prípade hovoríme aj o komplexnej bolesti, ktorá zasahuje fyzickú, } \\
\text { psychosociálnu aj duchovnú oblast' života pacienta. Analgézia zahŕña } \\
\text { neopioidy aj opioidy na zvládnutie bolesti nociceptívnej bolesti. } \\
\text { Neuropatická bolest' môže vyžadovat' iné lieky ako opioidy, ako sú } \\
\text { antikonvulzíva (napr. gabapentín), antidepresíva (napr. amitryptylín) } \\
\text { alebo nervové bloky. Miestne opiáty alebo antagonisti NMDA } \\
\text { receptorov, anestetické krémy, gély alebo spreje môžu byt' užitočné pri } \\
\text { tlmení bolesti a minimalizovat' použitie systémových liekov. Pri } \\
\text { povrchovej bolesti kože sa môžu používat' nesteroidné protizápalové } \\
\text { lieky. Vel'mi krátkodobo pôsobiace lieky, ako napríklad - fentanyl, } \\
\text { sufentanil a oxid dusnatý, môžu byt' užitočné pri bolestiach, ktoré sa } \\
\text { vyskytujú pri preväzoch. Používanie neadherentných obväzov a } \\
\text { udržiavanie vlhkého prostredia rany môže pomôct' znížit' bolest' a } \\
\text { chránit' odhalené nervové zakončenia. Z nefarmakologických postupov } \\
\text { sa onkologickým pacientom odporúča využívat' relaxačné, odpútavacie } \\
\text { techniky, terapeutický dotyk a iné. }\end{array}$ \\
\hline
\end{tabular}

(modifikované podl'a: Nemcová, Hlinková, 2019; Hlinková a kol., 2019; Hlinková a kol., 2015; BC Cancer, 2015; Trudie, 2017; EONS, 2015; Woo et al., 2015).

\subsection{Psycho-sociálny dopad}

Prítomnost' malígnej rany je viditel'nou pripomienkou rakovinového procesu; pokročilej nevyliečitel'nej choroby a hroziacej smrti (Alexander, 2010; Watret, 2011). Pacienti s malígnou ranou si častokrát vyžadujú paliatívnu starostlivost' zameranú okrem manažmentu symptómov hlavne na problémy telesného, psychického, spirituálneho a sociálneho charakteru. Malígne rany často sprevádza t’ažko kontrolovatel’ný zápach pripomínajúci napr. hnijúce mäso, ktorý má negatívny dopad na kvalitu života pacientov aj opatrovatel'ov. Vedie $\mathrm{k}$ pocitom viny, odporu, k sociálnej izolácii (rodiny, známych) a depresii. Pacienti sa cítia zahanbení a ponížení. Exsudát často znečistí odev a postel'nú bielizeň, čo môže u pacienta 
prehlbovat' nepríjemné pocity viny alebo straty kontroly nad svojím telom a zníženej sebaúcty.

Probst a kol. (2013) zistili, že ženy s malígnou ranou prsníka boli znepokojené narušením telesnej schránky a jej obmedzením, rovnako vyjadrili pocit straty kontroly nad svojím telom a svojím životom. Znetvorenie má kozmetické aj estetické dôsledky a môže vyústit' do izolácie, psychického a duchovného utrpenia (Tilley et al., 2016). Reynolds a Gethin (2015) uvádzajú, že zápach a svrbenie vyskytujúci pri malígnych ranách nepriaznivo ovplyvňujú vychutnávanie chvíl' sexuálnej intimity. Životní partneri vyjadrujú obavy, že počas sexuálneho zblíženia spôsobia bolest' a nepohodlie chorému partnerovi. Tieto situácie môžu viest' $\mathrm{k}$ strate sexuálnej identity v čase, ked' fyzická blízkost' a intimita má poskytnút' pohodlie a potešenie. Malígna rana môže byt' spojená výskytom klinickej depresie. K jej zvládaniu môžu pomôct' vhodné farmakologické a nefarmakologické intervencie, kognitívna behaviorálna terapia. Aspekt, ktorý môže pozitívne ovplyvnit' kvalitu života je prítomnost' nádeje. Niekedy je t’ažké udržat' si nádej, ked' je malígna rana trvalou vizuálnou pripomienkou blížiacej sa smrti (Verdon, 2015). Nádej sa však nemusí týkat' uzdravenia, ale pokojnej a bezbolestnej smrti (Maida et al, 2016). Rodina je vystavená vel'kej psychickej a telesnej zát'aži pre starostlivost', ktorá je dynamická v dôsledku meniacej sa povahy symptómov sprevádzajúcich ranu. Minimalizovat' psychickú a emocionálnu úzkost' pomáhajú sestry a lekári so skúsenost’ami s ošetrovaním chronických rán (Hlinková a kol., 2019).

\section{ZÁVER}

Malígna rana sa vyznačuje množstvom nepríjemných príznakov vrátane zápachu, bolesti, krvácania a nadmernej sekrécie. Úplné zacelenie kožného defektu často nie je terapeutickou realitou a kontrola symptómov je prioritou zahŕňajúcou liečebné režimy, ktoré sú mimo bežnej praxe $\mathrm{v}$ starostlivosti o rany. Prítomnost' malígnej rany je viditel'ným znakom základného chorobného procesu a bezprostrednej smrti. Jedinec s malígnou ranou môže utrpiet' fyzickú a sociálnu smrt' v dôsledku neprijatel'nej až odpudzujúcej prítomnosti rany. Zmena doterajšieho života dostáva jedinca do bolestivej a nežiaducej situácie, ktorou sú konfrontovaní formálni aj neformálni opatrovatelia. Paliatívna starostlivost' o rany upriamuje pozornost' na zvládanie bolesti a symptómov súvisiacich s ranou. Hospicová starostlivost' v rámci paliatívneho modelu pomáha zvýšit' skúsenost' všetkých zúčastnených a zvýšit' tak kvalitu života jednotlivca (Hudáková, Majerníková, 2013).

Príspevok bol podporený grantom KEGA projekt č. 031PU-4/2019 Multimediálny simulátor plánovania a overovania ošetrovatel'skej starostlivosti prostredníctvom ošetrovatel'ských kazuistik.

\section{Použitá literatúra}

1. ALEXANDER, SJ. An intense and unforgettable experience: the lived experience of malignant wounds from the perspectives of patients, caregivers and nurses. Int Wound J. 2010; 7(6): 456-65.

2. BC Cancer. Symptom management guidelines: Care of malignant wounds. 2015. Available at: http://www.bccancer.bc.ca/nursing-site/Documents/10.\%20Malignant\% 20Wounds.pdf

3. EONS. 2015. Recommendations for the Care of Patients with Malignant Fungating Wounds. 1st. ed. London: European Oncology Nursing Society (EONS). 2015. 29 p.

4. FERRELL B. R., COYLE, N. Oxford textbook of palliative nursing. 4th ed. New York, NY: Oxford University Press. 861 p. ISBN 0-19-513574-1.

5. HLINKOVÁ, E. a kol. Management chronických ran. Praha: Grada Publishing, a.s., 2019, 232 s., ISBN 978-80-271-0620-2. 
6. HLINKOVÁ, E. a kol. Nehojace sa rany. Martin: Vydavatel'stvo Osveta, 2015. 284 s. ISBN 978-80-8063-433-9

7. HUDÁKOVÁ, A., MAJERNÍKOVÁ, L. Kvalita života seniorů $v$ kontextu ošetrovatel'ství. Praha: Grada, a.s., 2013. 128 s. ISBN 978-80-247-4772-9.

8. MAIDA, V. et al. Malignant wound management. Public Health and Emergency. 2016; 1(12):33.

9. MORISON MJ. et al. Chronic Wound Care. Mosby, Edinburgh: 2004. 167 p.

10. NEMCOVÁ, J., HLINKOVÁ, E. Manažment pacienta smalígnou ranou. Paliat. med. liec. boles., 2019;12(2e):74-77.

11. O'CONNOR, M., ARANDA, S. Paliativní péče pro sestry všech obori̊. Praha: Grada Publishing, a.s., 2005, 324 s. ISBN 80-247-1295-4.

12. PROBST, S. et al. Malignant fungating wounds-the meaning of living in an unbounded body. Eur J Oncol Nurs. 2013; 17(1): 38-45.

13. REYNOLDS, H., GETHIN, G. The psychological effects of malignant fungating wounds. EWMA Journal. 2015; 15(2): 29-32.

14. TILLEY C. et al. Palliative wound care for malignant fungating wounds: holistic considerations at end-of-life. Nurs Clin North Am. 2016; 51(3): 513-31.

15. TRUDIE, Y. Caring for patients with Malignant and end-of-life wounds. Wounds UK. 2017; 13. 20-29.

16. VERDON, A. Fungating wounds: causes, characteristics and impact on patients. Wound Essentials. 2015; 10(2): 60-3.

17. WATRET, L. Management of a fungating wound. Journal of Community Nursing. $2011 ; 25(2): 31$.

18. WOO, KY. et al. Palliative wound care management strategies for palliative patients and their circles of care. Adv Skin Wound Care. 2015; 28(3): 130-40.

\section{Kontaktné údaje}

PhDr. Andrea Obročníková, Ph.D.

Prešovská univerzita v Prešove, Fakulta zdravotníckych odborov

Partizánska 1, 08001 Prešov

Tel: +421517562460

email: andrea.obrocnikova@unipo.sk 


\title{
EFFECT OF CHAMOMILE AND COMMON AGRIMONY EXTRACTS ON BIOMASS OF PEA ROOTS IN THE CADMIUM- PRESENT ENVIRONMENT
}

\author{
Marcel Roszival, Patrik Mészáros, Beáta Piršelová, Monika Koníčková, \\ Libuša Lengyelová, L'udmila Galuščáková
}

\begin{abstract}
The paper is focused on the evaluation of the allelopathic effect of Matricaria chamomilla L. and Agrimonia eupatoria L. shoot extracts of two concentrations $\left(5 \mathrm{~g} . \mathrm{dm}^{-3} ; 10 \mathrm{~g} . \mathrm{dm}^{-3}\right)$ on fresh (FW) and dry weight (DW) of pea roots. Effects of herbal extracts were tested also in roots exposed to cadmium $\left(5 \mathrm{mg} \cdot \mathrm{dm}^{-3}\right)$. The results of the experiments point to a significant effect of the herbal extracts themselves on the growth of pea roots, with the observed changes varied depending on the source of extract as well as on their concentration. The effect of the herbal extract was different in the conditions influenced by cadmium, depending on the tested extract and its concentration. Despite to the fact that the protective effect of plant extracts on the pea roots growing in an environment contaminated with $\mathrm{Cd}^{2+}$ ions was not confirmed, an interaction between the effects of plant extracts and cadmium ions on the examined growth parameters was recorded.
\end{abstract}

Key words: chamomile, common agrimony, allelopathy, pea, cadmium

\section{INTRODUCTION}

Contamination of soil with heavy metals represents a serious environmental issue with risky impact on the health of living organisms including humans. During their lives, plants are, however, often subjected to multiple types of stress concurrently - various interactions between abiotic and biotic stressors arise. Heavy metals effects on plants are studied mainly in laboratory conditions often not taking into consideration the other factors of the environment. Specific effects of plant species on germination, growth and development of other species is called allelopathy and substances with the given effect secreted by a plant are named allelochemicals. Allelochemicals are also natural herbicides, and are produced also by crop plants. Allelochemicals include mainly alkaloids, phenols, terpenoids and glycosides (for instance benzoic acid, ferulic acid, juglone and others). Most of the allelochemicals exist in plant tissues in a non-active form, and through various chemical reactions (hydrolysis, oxidation-reduction reactions, methylation, dimethylation, etc.) compounds with specific allelopathic effects are formed (Whittaker and Fenny, 1971; Cheng and Cheng, 2015). The key factor determining the phytotoxic effect of allelochemicals is their concentration in soil water. However, similar to herbicides, in the soil environment these compounds are subjected to some retention, transformation and transport processes (Weidenhamer, 1996).

Allelopathic effects on plant germination and growth are caused by various mechanisms, including the decrease of the mitotic activity of cells in roots and shoots, the inhibition of hormonal and enzyme activity, the reduction of mineral intake, inhibition of photosynthesis and respiration, as well as the permeability of cell membranes (Gniazdowska and Bogatek, 2005; Scavo et al., 2019). The effects of allelochemicals are usually nonspecific: low concentration and short-term effect mostly stimulate all processes in plants, while at higher concentration and longer-term effect the life activity of plants is suppressed or even ceased. 
Cadmium $(\mathrm{Cd})$ is a non-essential element whose higher doses have negative effect on growth and metabolism of plants, and which can contaminate the different links of food chain. Significant factors that affect mobility and plant availability of cadmium in the soil comprise $\mathrm{pH}$ value, amount and quality of organic matter, redox potential and presence of other elements or substances. Besides the above-mentioned factors, the absorption of cadmium by plants is also affected by the species and variety of the plant, fertilization and way of cultivation (Makovníková et al., 2006). In majority of plants, cadmium is primarily accumulated in their roots, which at many plants lead to growth inhibition, changes in water regime, respiration and photosynthesis (Benavides et al., 2005).

There is a very little knowledge on the allelopathic effect of plants on other plants in the conditions of concurrent influence by heavy metals as well as on the effect of allelochemicals on the accumulation of metals in plants. Studies of Wang et al. (2018) and Wei et al. (2020) showed that heavy metals $(\mathrm{Cu}, \mathrm{Pb})$ promoted the invasion of some plant species (Solidago canadensis, Erigeron annuus, Conyza canadensis) and allelopathic phenomena were more severe in the presence of heavy metals. Increased accumulation of $\mathrm{Cd}$ by tissues of potato weed (Galinsoga parviflora) was observed at application of shoots of Ramunculus sieboldii, Clinopodium confine, Mazus japonicus and Plantago asiatica on the soil surface (Lin et al., 2014).

Extracts of medicinal plants are studied mainly in connection with their effects on human health, while little is known on their effects on other plants. The aim of the work was to verify the allelopathic effect of the extract of chamomile (Matricaria chamomilla L.) and common agrimony (Agrimonia eupatoria L.) on the content of root biomass of pea. The effects of the herbal extract were simultaneously tested also in plants exposed to cadmium.

\section{MATERIALS AND METHODS}

Seeds of pea (Pisum sativum L. cv. Gloriosa) were surface-sterilized for 5 minutes with sodium hypochlorite prior to germination. Water extract from dry matter of shoots of chamomile (Matricaria chamomilla L.) and common agrimony (Agrimonia eupatoria L.) were prepared as follows: $1 \mathrm{~g}$ of dry matter was flooded with $100 \mathrm{ml}$ of distilled water (10 g. $\mathrm{dm}^{-3}$ ) and was left to extract for 24 hours at $25^{\circ} \mathrm{C}$ (Javaid et al., 2006). The extracts were filtered through a Whatman No. 1 filter paper. These extracts were further diluted to obtain solutions of concentrations $5 \mathrm{~g} \cdot \mathrm{dm}^{-3}$. The sterilized seeds (22 seeds) were placed onto Petri dishes lined with double layer of filter paper and flooded with the individual extract of chamomile, common agrimony and cadmium solution $\left(5 \mathrm{mg} \cdot \mathrm{dm}^{-3}\right)$ according to the scheme presented below (Tab. 1). Cadmium was applied in the form of solution of $\mathrm{Cd}\left(\mathrm{NO}_{3}\right) \cdot 4 \mathrm{H}_{2} \mathrm{O}$. The volume of the distilled water and extracts applied in each variant of the experiment was $20 \mathrm{ml}$.

Table 1 The scheme of the experiments.

\begin{tabular}{|l|l|l|l|}
\hline $\begin{array}{l}\text { Variant of the } \\
\text { experiment }\end{array}$ & Control samples & $\begin{array}{l}\text { Samples with the extracts of medicinal plant } \\
\text { and cadmium }\end{array}$ \\
\hline Extract of chamomile & Distilled water & $\begin{array}{l}\text { Extract of chamomile } \\
\left(5 \mathrm{~g} \cdot \mathrm{dm}^{-3}\right)\end{array}$ & $\begin{array}{l}\text { Extract of chamomile } \\
\left(10 \mathrm{~g} \cdot \mathrm{dm}^{-3}\right)\end{array}$ \\
\hline $\begin{array}{l}\text { Extract of chamomile } \\
\text { and ions of } \mathrm{Cd}^{2+}\end{array}$ & $\begin{array}{l}\text { Extract of } \mathrm{Cd}^{2+} \\
\left(5 \mathrm{mg} \cdot \mathrm{dm}^{-3}\right)\end{array}$ & $\begin{array}{l}\text { Extract of chamomile } \\
\left(5 \mathrm{~g} \cdot \mathrm{dm}^{-3}\right)+\mathrm{Cd}^{2+} \\
\left(5 \mathrm{mg} \cdot \mathrm{dm}^{-3}\right)\end{array}$ & $\begin{array}{l}\text { Extract of chamomile } \\
\left(10 \mathrm{~g} \cdot \mathrm{dm}^{-3}\right)+\mathrm{Cd}^{2+} \\
\left(5 \mathrm{mg} \cdot \mathrm{dm}^{-3}\right)\end{array}$ \\
\hline
\end{tabular}




\begin{tabular}{|l|l|l|l|}
$\begin{array}{l}\text { Extract of common } \\
\text { agrimony }\end{array}$ & Distilled water & $\begin{array}{l}\text { Extract of common } \\
\text { agrimony }\left(5 \mathrm{~g} \cdot \mathrm{dm}^{-3}\right)\end{array}$ & $\begin{array}{l}\text { Extract of common } \\
\text { agrimony }\left(10 \mathrm{~g} \cdot \mathrm{dm}^{-3}\right)\end{array}$ \\
\hline $\begin{array}{l}\text { Extract of common } \\
\text { agrimony and ions of } \\
\mathrm{Cd}^{2+}\end{array}$ & $\begin{array}{l}\text { Extract of } \mathrm{Cd}^{2+} \\
\left(5 \mathrm{mg} \cdot \mathrm{dm}^{-3}\right)\end{array}$ & $\begin{array}{l}\text { Extract of common } \\
\text { agrimony }\left(5 \mathrm{~g} \cdot \mathrm{dm}^{-3}\right) \\
+\mathrm{Cd}^{2+}\left(5 \mathrm{mg} \cdot \mathrm{dm}^{-3}\right)\end{array}$ & $\begin{array}{l}\text { Extract of common } \\
\text { agrimony }\left(10 \mathrm{~g} \cdot \mathrm{dm}^{-3}\right)+ \\
\mathrm{Cd}^{2+}\left(5 \mathrm{mg} \cdot \mathrm{dm}^{-3}\right)\end{array}$ \\
\hline
\end{tabular}

The seeds of pea were subsequently left to germinate in an incubator for 4 days (96 hours) at the temperature of $25^{\circ} \mathrm{C}$. After the 4 days, the fresh weight (FW) and the dry weight (DW) of the roots were determined. For each treatment, three replicates were carried out in a completely randomized design. Data for the examined parameters were statistically processed with software MS Excel 2010 and XLSTAT 2003. The differences between the data sets were determined through Student's t-test and Kruskal-Wallis' non-parametric test. The effects of herbal extract and heavy metal on the examined parameter were evaluated by two-way analysis of variance - ANOVA.

\section{RESULTS AND DISCUSSION}

Effects of medicinal plants (chamomile, common agrimony) extracts on fresh and dry weight of roots of pea at early stages of ontogenesis (4th day of germination) were evaluated. Two concentrations of extracts $\left(5\right.$ and $\left.10 \mathrm{~g} . \mathrm{dm}^{-3}\right)$ were applied. The effect of the herbal extracts on the examined growth parameter was evaluated also along with concurrent influence of cadmium $\left(5 \mathrm{~g} \cdot \mathrm{dm}^{-3}\right)$. The changes were evaluated compared to the control (water).

The weaker extract of common agrimony caused decrease in FW of pea roots by $21 \%$. In contrast, the applied concentration of cadmium showed stimulatory effect on root growth (increase in FW by $21 \%$ ). Considering the observed insignificant changes in growth of roots of faba bean caused by a wide concentration range of $\mathrm{Cd}\left(\mathrm{NO}_{3}\right) \cdot 4 \mathrm{H}_{2} \mathrm{O}$ (Piršelová and Ondrušková, 2021), we assume that the observed stimulatory effect is most likely a manifestation of so called hormesis (stimulation by low dose of metal) (Calabrese and Mattson, 2011; Piršelová et al., 2018).

Almost the same level of growth inhibition was caused by the stronger extract of common agrimony, and extracts of common agrimony with cadmium (Fig. 1). The weaker extract of chamomile had, on the contrary, a stimulatory effect (increase in FW by $13 \%$ ). Stimulatory effect ( 8 and $10 \%$ ) was observed also in variants where $\mathrm{Cd}$ solution and extracts of chamomile were applied simultaneously (Fig. 1). 

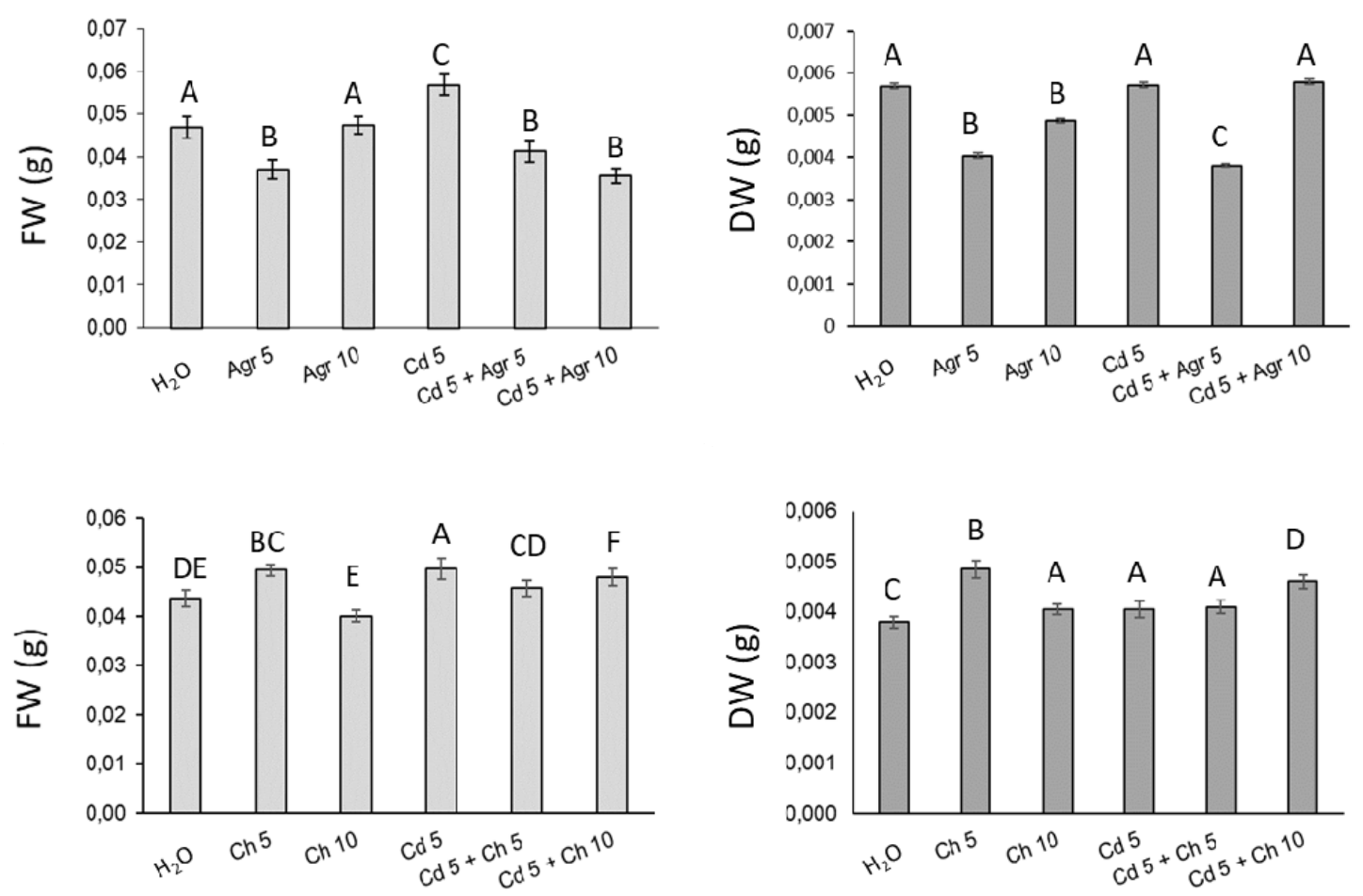

Figure 1. Effect of extracts of common agrimony (Agr), chamomile (Ch), cadmium (Cd) and their combination on fresh (FW) and dry weight (DW) of pea roots. The values represent the arithmetic mean \pm standard error. Different letters indicate significant differences between samples at $\mathrm{p}<0.05$. The applied dose of herbal extract is expressed in $\mathrm{g} . \mathrm{dm}^{-3}$ solution and $\mathrm{Cd}$ in $\mathrm{mg} \cdot \mathrm{dm}^{-3}$.

With regard to the stimulatory effect of the weaker chamomile extract on FW, we assumed it to have a protective effect in the cadmium contaminated environment. The cadmium solution alone at the applied concentration, however, did not have a toxic effect on the germinating plants (a stimulation of growth was actually observed); thus the protective effect of the herbal extract was not shown, and, on the contrary, growth inhibition appeared. The results of the two-way analysis of variance (ANOVA) pointed to the fact that the observed inhibition rate was affected by the applied cadmium solution and the interaction between the effects of cadmium and chamomile extract $(p<0.05)$. The effect of the chamomile extract alone on the changes of $\mathrm{FW}$ of roots was not proven (Tab. 2). In the case of common agrimony, Cd alone did not have any effect on the biomass of pea roots (Tab. 3). To similar conclusion came, in their study, Yadav and Singh (2013) who observed lower germination of wheat seeds as well as lower content of photosynthetic pigments due to the effect of benzoic acid, but not due to the effect of $\mathrm{Cd}\left(7 \mathrm{mg} \cdot \mathrm{dm}^{-3}\right)$. An interaction between the effects of $\mathrm{Cd}$ and benzoic acid was also observed.

Table 2 Two-way ANOVA results of the effect of chamomile (Ch) extract, cadmium (Cd) and their interaction on the fresh weight of pea roots.

\begin{tabular}{lrrll}
\hline $\begin{array}{l}\text { Source of } \\
\text { variation }\end{array}$ & Mean square & $\begin{array}{l}\text { Degrees of } \\
\text { freedom }\end{array}$ & F ratio & P value \\
\hline Ch extract & 0.000548 & 2 & 2.696709 & 0.0696 \\
Cd & 0.000796 & 1 & 7.8314819 & $\mathrm{P}<0.05 *$
\end{tabular}




$\begin{array}{lllll}\text { Interaction } & 0.00157 & 2 & 7.7222871 & \mathrm{P}<0.05 * \\ * \text { Significance at } p<0.05 & & \end{array}$

In the case of application of common agrimony, two-way analysis of variance (ANOVA) confirmed again that inhibition rate in the case of variant with cadmium is a result of interaction between the effects of cadmium and common agrimony extract. The herbal extract alone also affects the above-mentioned changes (Tab. 2).

Table 3 Two-way ANOVA results of the effect of common agrimony extract (Agr), cadmium $(\mathrm{Cd})$ and their interaction on the fresh weight of pea roots.

\begin{tabular}{llcll}
\hline Source of variation & Mean square & $\begin{array}{c}\text { Degrees of } \\
\text { freedom }\end{array}$ & F ratio & P value \\
\hline Agr extract & 0.005371 & 2 & 15.9759 & $\mathrm{P}<0.05^{*}$ \\
Cd & $6.68 \mathrm{E}-05$ & 1 & 0.397651 & 0.52910 \\
Interaction & 0.003932 & 2 & 11.69726 & $\mathrm{P}<0.05^{*}$ \\
\hline
\end{tabular}

* Significance at $p<0,05$

Dry matter content of common agrimony roots decreased (by $29 \%$ and $14 \%$ ) due to the effect of weaker and stronger extracts of common agrimony (Fig. 1). The tested dose of cadmium did not affect the dry matter content, however the simultaneous application of cadmium and weaker extract of common agrimony resulted in decrease in dry matter content by $33 \%$. In contrast to the FW, simultaneous application of cadmium and stronger extract of common agrimony did not result in statistically significant changes in dry matter content (Fig. 1).

Nevertheless, in contrast to FW, the stronger extract of chamomile caused a statistically significant increase in DW content by $7 \%$ (Fig. 1).

Effects of plants' water extracts on germination and growth parameters of plants have been examined by several authors, with most of them observing their inhibitory effect. AlvarezInglesias et al. (2014) examined for example phytotoxic potential of water extract of faba bean (Vicia faba L.) seeds on weeds: Amaranthus retroflexus, Echinochloa crus-galli and Digitaria sanguinalis. An inhibitory effect of rape (Brassica napus) water extract on the growth of Phalus minor (Retz.), Convolvulus avensis (L.) and Sorghum halepense (L.) was described also by Aliki et al. (2014). The inhibitory effects varied depending on the concentration of the applied extract.

\section{CONCLUSIONS}

Results of the experiments pointed out a significant effect of the herbal extracts alone on the growth of pea roots, with the given changes being dependent on the source of herbal extract as well as on the concentration of the extract. An interesting finding is the fact that, while the herbal extract alone had, in some variants of the experiment, an inhibitory effects on the roots' biomass content, the simultaneous application of the extract with the cadmium lead, on the contrary, to growth stimulation. Despite to the fact that the protective effect of plant extracts on the pea roots growing in an environment contaminated with $\mathrm{Cd}^{2+}$ ions was not confirmed, an interaction between the effects of plant extracts and cadmium ions on the examined growth parameters was recorded, which suggests the need to exploring the plants tolerance to heavy metals in broader contexts. 


\section{Acknowledgments}

This research was funded by The Ministry of Education, Science, Research and Sport of the Slovak Republic: grants VEGA 1/0073/20 and KEGA 029UKF-4/2020.

\section{Sources}

1. ALIKI, H. M., READE, J. P. H.; BACK, M. A.: Effects of concentrations of Brassica napus (L.) water extracts on the germination and growth of weed species. Allelopathy Journal, 34(2), 2014, 287-298.

2. ÁlvareZ-IGlesias, L., PUiG, C. G., GARABAtOS, A., REIGOSA, M. J., PEDROL, N.: Vicia faba aqueous extracts and plant material can suppress weeds and enhance crops. Allelopathy Journal, 34, 2014, 299-314.

3. BENAVIDES, M. P., GALLEGO, S. M., TOMARO, M.L.: Cadmium toxicity in plants. Brazilian Journal of Plant Physiology, 17, 2005, 21-34.

4. CALABRESE, E. J., MATTSON, M. P.: Hormesis provides a generalized quantitative estimate of biological plasticity. The Journal of Cell Communication and Signaling, 5(1), 2011, 25-38.

5. CHENG, F., CHENG, Z.: Research progress on the use of plant allelopathy in agriculture and the physiological and ecological mechanisms of allelopathy. Frontiers in Plant Science, 6, 2015, 1020.

6. GNIAZDOWSKA, A., BOGATEK, R.: Allelopathic interactions between plants. Multisite action of allelochemicals. Acta Physiologiae Plantarum, 27(3), 2005, 395 407.

7. JAVAID, A., SHAFIQUE, S., BAJWA, R., SHAFIQUE, S.: Effect of aqueous extracts of allelopathic crops on germination and growth of Parthenium hysterophorus L. South African Journal of Botany, 72, 2006, 609-612.

8. LIN L., LIAO M., REN Y., LUO, L., ZHANG, X., YANG, D., HE, J.: Effects of mulching tolerant plant straw on soil surface on growth and cadmium accumulation of Galinsoga parviflora. PLoS One, 9(12), 2014, e114957.

9. MAKOVNÍKOVÁ, J., BARANČíKOVÁ, G., DLAPA, P., DERCOVÁ, K.: Anorganické kontaminanty v pôdnom ekosystéme. Chemické Listy, 100(6), 2006, s. 424-432.

10. PIRŠELOVÁ, B., GALUŠČÁKOVÁ, L., LENGYELOVÁ, L.: Hormetic response of plants to metals and metalloids. Chemické Listy, 2018, 112, 317-323.

11. PIRŠELOVÁ, B., ONDRUŠKOVÁ, E.: Effect of cadmium chloride and cadmium nitrate on growth and mineral nutrient content in the root of fava bean (Vicia faba L.). Plants, 10(5), 2021, 1007.

12. SCAVO, A., ABBATE, C., MAUROMICALE, G.: Plant allelochemicals: agronomic, nutritional and ecological relevance in the soil system. Plant and Soil, 442, 2019, 23-48.

13. WANG, C, JIANG, K., WU, B., ZHOU, J.: The combined treatments of Canada goldenrod leaf extracts and cadmium pollution confer an inhibitory effect on seed germination and seedling development of lettuce. Australian Journal of Botany, 66(4), 2018, 331-337.

14. WEI, M. S WANG, B WU, H CHENG, C WANG.: Heavy metal pollution improves allelopathic effects of Canada goldenrod on lettuce germination. Plant Biology (Stuttg), 22(5), 2020, 832-838.

15. WEIDENHAMER, J. D.: Distinguishing resource competition and chemical interference: Overcoming the methodological im-passe. Agronomy Journal, 8, 1996, 866-875. 
16. WHITTAKER, R. H., FENNY, P. P.: Allelochemicals.: Chemical interactions between species. Science (NY), 171, 1971, 575-570.

17. YADAV, K., SINGH, N. B.: Effects of benzoic acid and cadmium toxicity on wheat seedlings. Chilean Journal of Agricultural Research, 73(2), 2013, 168-174.

\section{Contact}

Mgr. Marcel Roszival

Katedra botaniky a genetiky

Univerzita Konštantína Filozofa v Nitre

Fakulta prírodných vied

Tel: +421907233452

email: marcel.roszival@ukf.sk 


\title{
SKÚSENOSTI SESTIER S VYUŽITÍM VLHKEJ TERAPIE V KLINICKEJ PRAXI
}

\section{EXPERIENCE OF NURSES USING MOISTURE WOUND THERAPY IN CLINICAL PRACTICE}

\author{
Tatiana Šantová, Anna Eliášová, Terézia Fertal'ová, Lívia Hadašová, Silvia \\ Cibriková, Beáta Grešš-Halász.
}

\begin{abstract}
Abstrakt
Vlhká terapia je založená na poznatku, že hojenie najlepšie prebieha vo vlhkom prostredí a jednotlivé prípravky by mali byt' predovšetkým mimoriadne účinné s jednoduchým použitím, bezpečné a šetrné pre pacienta i ošetrujúci personál a ekonomicky výhodné. Vd’aka vlastnostiam produktov vlhkej terapie sa uskutočňuje ovel'a menej preväzov, ktoré pacienta traumatizujú, liečba je navyše rýchlejšia a efektívnejšia ako v prípade použitia tradičných krycích materiálov na ranu (3).
\end{abstract}

Klíčová slova: chronické rany, vlhká terapia, prieskum, ošetrovatel'stvo

\begin{abstract}
Wet therapy is based on the knowledge that healing is best in a humid environment and individual products should be extremely effective easy to use, safe and gentle for both patient and nursing staff and economically advantageous. Due to the properties of wet therapy products, there are far fewer dressings that traumatize the patient, and treatment is faster and more effective than with traditional wound dressings (3).
\end{abstract}

Key words: chronic wounds, wet therapy, research, nursing

\section{CHARAKTERISTIKA VLHKEJ TERAPIE A JEJ VYUŽITIE V KLINICKEJ PRAXI}

Vlhké hojenie rán nielen spol'ahlivo absorbuje exsudáty, zabraňuje macerácií a iritácií jemných granulácií, epitelizácie a okolia rany, ale podporuje tiež aj granulačný a epitelizačný proces, pričom dodané substancie môžu mat' spol'ahlivý, dezinfekčný a analgetický účinok Materiály vlhkej terapie:

- optimalizujú proces hojenia,

- zaist'ujú vlhké prostredie počas procesu hojenia,

- netraumatizujú ranu behom preväzu,

- ochraňujú granulujúcu ranu pred mechanickým poškodením,

- znižujú frekvenciu preväzov,

- obsahujú špeciálne jadro, ktoré pohltí mikroorganizmy a neuvol'ní ich spät' do rany,

- rešpektujú fázu hojenia rany,

- majú spongiózny efekt, čo znamená, že po absorpcii exsudátu materiálom nedochádza k jeho spätnému uvol'neniu do spodiny defektu,

- selektívne prepúšstajú plyny a vodné pary,

- tvoria účinnú bariéru proti infekcii,

- variabilita materiálov umožňuje ich cielené použitie podl’a fázového hojenia rán,

- zabraňujú macerácii kože v okolí rany (11). 


\subsection{História vlhkej terapie}

Otázky okolo hojenia rán sprevádzajú l’udstvo už od jeho vzniku. Už starovekí Egypt’ania poznali možnosti ako uzatvorit' ranu pomocou sútury. Požívali primitívne antiseptiká ako napríklad med alebo cukor .Začiatok 20. storočia je charakterizovaný užívaním strieborných solí k liečbe najrôznejších zápalov, chronických rán a rôznych hnisavých ochorení. V roku 1962 britský chirurg prof. Georgie Winter na základe vedeckých a praktických poznatkov prichádza $\mathrm{s}$ teóriou, že pomocou vlhkého prostredia $\mathrm{v}$ rane sa proces hojenia urýchli až o 40\%. Na základe tejto teórie sa začali na krytie rán používat' filmové obväzy, ktorých pôvod siaha až do 18. storočia. Vtedy sa k ošetreniu rany používali fólie pripravené z rybích plávacích mechúrov. Potom sa používali alginátové prostriedky, ktoré boli vyrobené $\mathrm{z}$ calcium alebo natrium alginátu (morské riasy). História hojenia rán je bohatá na príklady podivuhodných liečebných metód, ktoré sa $\mathrm{v}$ rôznych dobách prijímali bez podloženia vedeckých dôkazov.(1) V súčasnej dobe máme a budeme mat' k dispozícii vel'kú škálu lokálnych prostriedkov $\mathrm{k}$ riešeniu rán a defektov podloženou jasnými vedeckými faktami. K modernému hojeniu rán však nepatria iba excelentné obväzy, ktoré nahrádzajú kožu, ale aj komplexnost' terapie s individuálnym a citlivým prístupom zdravotníckych pracovníkov(2).

\subsection{Rozdelenie prípravkov vlhkej terapie}

Súčasná doba nám ponúka vel'ké množstvo moderných krycích obväzov, ktoré je možné použit' špecificky, podl'a charakteru rany a podl'a jednotlivých fáz hojenia od fázy čistenia až po úplnú epitelizáciu. Z praktického hl'adiska výrobky určené na vlhké hojenie rán delíme do viacerých skupín:

Algináty - sú vysoko absorpčné materiály z hnedých morských rias, indikované pri stredne až silno secernujúcich ranách, vo fáze čistenia ale môžeme ich použit' aj vo fáze granulácie. Princíp mechanizmu účinku spočíva vo výmene iontov čím dochádza $\mathrm{k}$ premene suchého materiálu na vlhký hydrofilný gél, ktorý absorbuje prebytočný exsudát a zároveň dochádza $\mathrm{k}$ odstráneniu choroboplodných zárodkov. Indikuje sa ako primárne krytie na povrchové a hlboké rany so strednou až silnou sekréciou, vrátane infikovaných rán s podmínovanými okrajmi. Algináty sú nevhodné na suché rany a rany pokryté suchou nekrózou (13).

Antiseptické materiály - ich využitie je v profylaxii a pri liečbe lokálnej infekcie, pretože sú napustené antibakteriálnou látkou, vyžadujú si ale sekundárne krytie (14). Základná funkcia týchto materiálov spočíva $\mathrm{v}$ umožnení vol'nej pasáže exsudátu do sacieho krytia (sekundárneho krytia) a ochrana granulačného tkaniva pred traumatickými preväzmi. Nevýhodou je vyššia frekvencia preväzov v prítomnosti infekcie a naopak výhodou je rýchly nástup účinku (2).

Filmové krytie - ide o tenké krytie, ktoré po priložení adheruje iba na kožu, nie na ranu. Pôsobí ako bakteriálna bariéra a používa sa výlučne ako sekundárne krytie (14). Pre zaistenie vlhkosti, fixáciu katétrov a primárnych obväzov, v prevencii dekubitov u fragilnej kože seniorov či ochranu nového tkaniva pred mechanickým poškodením sú tieto materiály vel'mi vhodné a $\mathrm{v}$ posledných rokoch často využívané. Základnou podmienkou pre fungovanie týchto materiálov je absencia sekrétu z rany. Sú to vode odolné materiály, ktoré si vo väčšine prípadov nevyžadujú sekundárne krytie a dokonale chránia epitelizujúcu ranu až 7 dní (8).

Hydroaktívne krytie - absorbujú ranný exsudát vrátane zníženia mikrobiálnej zát’aže a podporujú čistenie rany. Udržujú vlhké prostredie, podporujú granuláciu, sanácia hlbokých i povrchových rán. Kontraindikáciou je masívne infikovaná rana s hojnou sekréciou. Výhodou je hydratácia 12, resp. 24 hodín, majú vel'kú účinnost' aj pod priloženou kompresívnou bandážou, redukujú počet baktérií na spodine rany (13).

Hydrogély - sú amorfné hydrofilné sterilné akrylátové a škrobové polyméry, ktoré obsahujú vodu až v $90 \%$ a sú vhodné pre rehydratáciu suchých nekrotických rán s nečistou spodinou alebo pre secernujúce rany. Aplikujú sa vždy na suchú spodinu rany pre zvýšenie hydratácie, 
medzi ich základnú funkciu patrí hydratácia spodiny defektu a podpora granulácie. Využívajú sa najčastejšie pri popáleninách, ischemických defektoch a a pri syndróme diabetickej nohy. Gél po aplikácii na ranu chladí a tým sa znižuje bolestivost'. Transparentnost' materiálov umožňuje zrakovú kontrolu rany a zároveň signalizuje dobu, kedy je potrebné gél doplnit'. Hlavné uplatnenie týchto materiálov je vo fáze čistenia ale môžeme ich aplikovat' vo všetkých fázach hojenia od nekrózy až po fázu epitelizácie. Materiály majú schopnost' absorbovat' nadbytočný sekrét a tým udržiavajú optimálnu vlhkost', autolyticky odstraňujú nekrózu, povlaky a neporušujú zdravé bunky.

Hydrokoloidy - sú absorpčné, semipermeabilné krytia s lepivým alebo nelepivým okrajom, môžu byt' aj vo forme pást, práškov a hydrovlákien. Ide o najstaršie materiály na vlhké hojenie rán, vytvárajú hypoxické prostredie s nízkym $\mathrm{pH}$ a tým napomáhajú granulácii rany. Absolútnou kontraindikáciou využitia hydrokoloidov je vždy aktuálna prítomnost' či riziko vzniku infekcie. Využívajú sa pri málo až stredne secernujúcich ranách vo fáze granulácie (4). Hydrovlákna - krytie, ktoré je schopné absorbovat' vel'ké množstvo exsudátu za vzniku gélu zadržujúceho baktérie. Je prispôsobivé tvaru spodiny rany. Používa sa pri silno secernujúcich ranách (12).

Neadherentné materiály - ich hlavnou funkciou je umožnit' vol’nú pasáž exsudátu do sekundárneho krytia, zároveň ochraňujú a podporujú novovzniknutú granuláciu, zabraňujú možnej hypergranulácii a umožňujú spätnú priestupnost' pre lokálne aplikované lieky.Aplikujú sa pri suchých ale aj pri silno secernujúcich ranách (4). Kontraindikáciou je alergia na účinnú látku a silno secernujúce rany $\mathrm{z}$ dôvodu vyššieho rizika macerácie $\mathrm{v}$ okolí rany.

Obväzy s aktívnym uhlím a striebrom - aktívne uhlie má schopnost' absorbovat' mikroorganizmy a striebro svojimi antibakteriálnymi účinkami ničí baktérie absorbované uhlím (14). Hlavnou a základnou úlohou je podporit' fyziologické čistenie rany a zmiernit' až odstránit' zápach. Výber materiálu závisí od aktuálneho stavu a typu rany - silne, stredne secernujúce rany alebo suchý defekt bez známok exsudátu. Priamou kontraindikáciou pre použitie aktívneho uhlia je nekrotická suchá rana. Tieto materiály sa aplikujú v kombinácii s hydrogélom pri defektoch s vel'mi malou sekréciou. Ak chceme zaistit' neutralizáciu zápachu a zároveň aj dekontamináciu spodiny rany, volíme kombináciu aktívneho uhlia nielen s alginátom ale aj so striebrom. Z praktického hl'adiska je potrebné upozornit' na riziko prisychania materiálov na báze aktívneho uhlia ku spodine rany, preto je nutné opatrné snímanie pri preväzoch lebo hrozí traumatizácia spodiny rany (4).

Polyuretánové peny a hydropolyméry - sú podobné ako hydrokoloidy, majú schopnost' kopírovat' reliéf rany, dochádza $\mathrm{k}$ mechanickému masírovaniu spodiny a $\mathrm{k}$ absorpcii prebytočného exsudátu (14). Výhodou sú intervaly medzi jednotlivými preväzmi, ktoré sa predížili na 5 a viac dní. Po absorpcii exsudátu materiálom dochádza k jeho ukladaniu do jednotlivých vrstiev až do doby vyčerpania absorpčnej kapacity daného materiálu, ktorá v ideálnych prípadoch trvá až 7 dní. Ukladaním absorbovaného exsudátu zároveň dochádza ku znižovaniu bakteriálnej zát'aže $v$ rane. Tvárová variabilita je vel'mi široká a máme $\mathrm{k}$ dispozícii materiály s okrajom, bez okrajov, materiály lepiace alebo nelepiace s potrebou sekundárnej fixácie. Polyuretánové peny používame ku stimulácii čistenia rany, účinné sú pri prevencii macerácie a minimalizácii traumy pri jednotlivých preväzoch (6).

Klasifikácia jednotlivých typov materiálu môže byt' ovplyvnená mnohými determinantami a uchopená z rôznych uhlov pohl'adu, preto je dôležité upozornit' na nutnost' komplexného prístupu. Nemožno predpokladat', že chronická/nehojaca rana môže byt' vyliečená obyčajnou aplikáciou určitého lokálneho prostriedku aj ked' lokálna terapia môže mat' v krátkom časovom horizonte viditel'ný efekt. Ide však väčšinou o symptomatickú liečbu a k nej musí byt' zaistená tiež kauzálna terapia na základe zhodnotenia celkového stavu pacienta a kompenzácia d'alších problémov a chronických ochorení. Účelné hojenie rán zahrňuje 
systémový prístup k liečbe pacienta i rany s využitím medziodborovej spolupráce a vhodnej lokálnej terapie podl'a aktuálnych požiadaviek na proces hojenia (13).Vo všeobecnosti možno o použití vlhkého krytia povedat', že tieto prípravky by sa nemali používat' na infikované rany a na rany ohrozené infekciou (napr. syndróm diabetickej nohy), navyše pri týchto ranách je potrebný monitoring rany a a tiež je potrebné individuálne upravit' interval preväzov. Pri dodržaní tejto zásady je vlhká terapia vel'mi bezpečný postup pri liečbe chronických rán, ktorý si vd’aka vysokej účinnosti získal vo svete popularitu a rešpekt (5). Pri výbere prípravku pre konkrétneho pacienta sa musíme riadit' typom rany, zdravotným stavom, skúsenost'ami a v neposlednom rade aj rozsahom vlastných vedomostí o procese hojenia rany a vlastnostiach jednotlivých prípravkov. Neexistuje jednotný, štandardný postup kedy, ako a ktorý prípravok na daný typ defektu použit'. Len kombináciou vedomostí a získaných skúseností môžeme správne indikovat' konkrétny spôsob liečby .

\subsection{Výhody používania vlhkej terapie}

Prípravky určené na vlhkú terapiu sú v súlade s konceptom fázového liečenia. Vo fáze čistenia tieto prípravky zhromažd’ujú exsudát, ktorý obsahuje odumreté bunky, zvyšky tkaniva, nečistoty, choroboplodné zárodky a tiež odsávajú nadbytočný sekrét. Vo fáze granulácie prípravky vyvážia vlhké prostredie v rane, absorbujú nadbytočný sekrét, zabránia vysychaniu a ochránia pred traumatizáciou. Vo fáze epitelizácie prípravky nad’alej udržujú ranu primerane vlhkú,sú prevenciou vzniku krusty, ktorá ovplyvňuje epitelizáciu, zabraňujú poškodeniu novovytvorených buniek (14). Tekutina, ktorú rana vylučuje, obsahuje rastové faktory a výživné látky, ktoré sa podiel'ajú na úspešnom hojení rany. Moderné materiály používané $\mathrm{k}$ ošetrovaniu rán sú prispôsobené $\mathrm{k}$ tomu, aby v rane udržiavali vlhké prostredie. Medzi výhody vlhkej terapie patrí : úspora času, menší počet preväzov, l’ahšia manipulácia, účinnejšia liečba, menšia bolest', kratšia doba hojenia a hospitalizácie, zníženie komplikácií, obmedzené riziko recidívy, zníženie výsledných ekonomických nákladov (8). Výhodou vlhkej terapie je, že zmäkčuje a oddel'uje nekrotické tkanivo hydroaktívnym krytím, z rany odsáva sekrét s choroboplodnými zárodkami, rozpúšt'a povlaky, dodáva rane vlhkost', vytvára fyziologickú klímu a zabezpečuje kontinuálny výplach. Prípravky vlhkej terapie sú prevenciou sekundárnej infekcie, ochranou pred mechanickými vplyvmi, vysychaním, stratou telesných tekutín, ochranou pred stratami tepla (14).Spoločnými vlastnost’ami prípravkov na vlhkú terapiu je schopnost' vytvorit' a udržat' vlhké a teplé prostredie v rane, optimálne pre hojenie, pričom ostáva zabezpečená výmena plynov medzi ranou a okolitým prostredím (semipermeabilita). Ďalej je to schopnost' odvádzat' a uzamykat' vo svojej štruktúre exsudát z rany, schopnost' chránit' ranu pred infekciou, schopnost' neadherovat' na plochu rany (preväz je bezbolestný) a dokážu stimulovat' autolytické čistenie rany (5).Moderné krytia spĺñajú požiadavky na tzv. vlhké hojenie rán a sú kompatibilné s ostatnými metódami vlhkej liečby. Medzi d'alšie výhody používania vlhkej terapie zarad'ujeme:

- znížený počet preväzov s vlhkým krytím o 4-5 násobok oproti klasickej výmene,

- menšiu bolestivost', menšia spotreba analgetík, menšie krvné straty pri preväzoch,

- menší počet vykonaných nekrektómií,

- rýchlejšie čistenie spodiny,

- skrátenie celkovej doby liečenia na približne 50-75\%,

- menšia pracovná zát’až ošetrujúceho personálu,

- zníženie nákladov na celkovú liečbu (13).

Klasické obväzové materiály majú tendenciu traumatizovat' ranu, pretože prisychajú ku spodine rany. Pri častej frekvencii preväzov dochádza k ochladzovaniu rany $\mathrm{z} 37^{\circ} \mathrm{C}$ na asi $28^{\circ} \mathrm{C}$ a toto ochladzovanie môže spôsobit' i zmeny $\mathrm{v} \mathrm{pH} v \mathrm{rane}$ a zároveň ovplyvnit' množenie prítomných mikroorganizmov. Materiály na vlhké hojenie, ktoré sa v zahraničí používajú zhruba 40 rokov, dostatočne preukázali, že práve hydratácia rany a riadené odsávanie 
exsudátu, spojené s možnost'ou týchto materiálov kopírovat' spodinu rany, zaistia efektívne hojenie chronických rán (11).Klasické ovínadla a gázu v dnešnej dobe nahradili moderné obväzové a krycie materiály. Použitie suchého krytia rán sa dnes obmedzuje len na ošetrenie $\mathrm{v}$ rámci prvej pomoci prípadne na ošetrenie hojacich sa uzavretých operačných rán alebo sa používajú ako sekundárne krytie, t.j. cez materiály vlhkého hojenia sa používa d’alšie krytie potrebné na udržanie vlhkosti v rane. $V$ dnešnej dobe je vlhký spôsob ošetrovania rán považovaný už za štandard pre všetky sekundárne sa hojace rany (8).

\section{SKÚSENOSTI SESTIER S VYUŽITÍM VLHKEJ TERAPIE}

\subsection{Ciele prieskumu}

Hlavným ciel'om bolo zistit', analyzovat' a zhodnotit' aké skúsenosti majú sestry s využitím vlhkej terapie rán v klinickej praxi.

\subsection{Metodika}

Použili sme kvantitatívnu metódu neštandardizovaný dotazník. Dotazník obsahoval 20 položiek. Z toho 14 položiek formy zatvorenej, 4 položky v polo uzatvorenej forme a 1 položka je uvedená prostredníctvom Likertovej škály. Získané údaje sme matematicky spracovali a zaznamenali do tabuliek.

\subsection{Súbor}

Reprezentatívnu vzorku tvorilo 50 respondentov - sestier ženského pohlavia pracujúcich na chirurgických oddeleniach (úrazovej, brušnej, plastickej a cievnej chirurgie) vo Fakultnej nemocnici J.A Reimana.

\subsection{Výsledky prieskumu}

Tab. 1 Výskyt najčastejších chronických rán na chirurgických pracoviskách

\begin{tabular}{|l|c|c|}
\hline Možnosti & $\mathbf{n}$ & $\mathbf{\%}$ \\
\hline bercové vredy & 0 & 0 \\
\hline dekubity & 10 & 20 \\
\hline sekundárne sa hojace operačné rany & $\mathbf{3 0}$ & $\mathbf{6 0}$ \\
\hline nádorové ochorenia kože & 8 & 16 \\
\hline syndróm diabetickej nohy & 2 & 4 \\
\hline Spolu & $\mathbf{5 0}$ & $\mathbf{1 0 0 \%}$ \\
\hline
\end{tabular}

Z analýzy získaných údajov vyplýva, že na chirurgických oddeleniach sa na najčastejšie vyskytujú sekundárne sa hojace operačné rany a najmenej syndróm diabetickej nohy

Tab. 2 Realizácia preväzu

\begin{tabular}{|l|c|c|}
\hline Možnosti & n & \% \\
\hline klasické obväzové materiály & 5 & 10 \\
\hline dezinfekčné roztoky s následným sekundárnym krytím & 20 & 40 \\
\hline materiály vlhkej terapie so sekundárnym krytím & $\mathbf{2 5}$ & $\mathbf{5 0}$ \\
\hline iné & 0 & 0 \\
\hline Spolu & $\mathbf{5 0}$ & $\mathbf{1 0 0 \%}$ \\
\hline
\end{tabular}

Z analýzy vyplýva, že pri preväze chronickej rany sa najčastejšie na chirurgických oddeleniach používajú materiály vlhkej terapie so sekundárnym krytím. 
Tab. 3 Použitie vlhkej terapie pri chronických ranách

\begin{tabular}{|l|c|c|}
\hline Možnosti & $\mathbf{n}$ & $\mathbf{\%}$ \\
\hline áno & 15 & 30 \\
\hline nie & 12 & 24 \\
\hline záleží od typu chronickej rany & $\mathbf{1 8}$ & $\mathbf{3 6}$ \\
\hline neviem & 5 & 10 \\
\hline používame inú metódu & 0 & 0 \\
\hline Spolu & $\mathbf{5 0}$ & $\mathbf{1 0 0 \%}$ \\
\hline
\end{tabular}

Z analýzy zistených údajov vyplýva, že prípravky vlhkej terapie sa na chirurgických oddeleniach aplikujú v závislosti od typu chronickej rany.

Tab. 4 Najčastejšie používané prípravky

\begin{tabular}{|l|c|c|}
\hline Možnosti & $\mathbf{n}$ & $\mathbf{\%}$ \\
\hline hydrogély & 33 & 30 \\
\hline hydrokoloidy & 13 & 12 \\
\hline algináty & 10 & 9 \\
\hline polyuretánové peny a hydropolyméry & 4 & 3,6 \\
\hline filmové krytie & 16 & 14,5 \\
\hline obväzy s aktívnym uhlím a striebrom & 17 & 15,5 \\
\hline antiseptické materiály & 15 & 13,6 \\
\hline hydrovlákna & 2 & 1,8 \\
\hline nepoužívame žiadne & 0 & 0 \\
\hline iné & 0 & 0 \\
\hline Spolu & $\mathbf{1 1 0}$ & $\mathbf{1 0 0 \%}$ \\
\hline
\end{tabular}

$\mathrm{Z}$ analýzy získaných údajov sme zistili, že sestry na chirurgických oddeleniach najčastejšie používajú pri liečbe chronických rán hydrogély a najmenej používanými sú hydrovlákna.

Tab. 5 Účinnost' a efektívnost' prípravkov

\begin{tabular}{|l|c|c|}
\hline Možnosti & $\mathbf{n}$ & $\mathbf{\%}$ \\
\hline určite áno & $\mathbf{2 9}$ & $\mathbf{5 8}$ \\
\hline áno & 16 & 32 \\
\hline skôr nie & 3 & 6 \\
\hline nie & 0 & 0 \\
\hline neviem to posúdit’ & 2 & 4 \\
\hline Spolu & $\mathbf{5 0}$ & $\mathbf{1 0 0 \%}$ \\
\hline
\end{tabular}

Z analýzy získaných údajov vyplýva, že väčšina sestier si myslí že prípravky vlhkej terapie v liečbe chronických rán naozaj preukazujú účinnost' a efektívnost'.

Tab. 6 Dôležitost' prihliadania na fázu hojenia

\begin{tabular}{|l|c|c|}
\hline Možnosti & $\mathbf{n}$ & $\mathbf{\%}$ \\
\hline určite áno & $\mathbf{2 4}$ & $\mathbf{4 8}$ \\
\hline fázy hojenia nemajú žiadny súvis s výberom materiálu & 7 & 14 \\
\hline iba pri niektorých typoch chronických rán & 7 & 14 \\
\hline nie je potrebné prihliadat' na fázu hojenia & 8 & 16 \\
\hline neviem to posúdit' & 4 & 8 \\
\hline Spolu & $\mathbf{5 0}$ & $\mathbf{1 0 0 \%}$ \\
\hline
\end{tabular}


Z analýzy výsledkov vyplýva, že sestry vedia, že je potrebné prihliadat' na fázu hojenia.

Tab. 7 Doterajšie skúsenosti sestier s aplikáciou prípravkov vlhkej terapie

\begin{tabular}{|l|l|l|}
\hline Možnosti & $\mathbf{n}$ & \% \\
\hline mám vel'mi dobré skúsenosti & 8 & 16 \\
\hline mám dobré skúsenosti & $\mathbf{2 5}$ & $\mathbf{5 0}$ \\
\hline mám zlé skúsenosti & 3 & 6 \\
\hline neviem aplikovat' tieto prípravky & 4 & 8 \\
\hline neviem to posúdit' & 10 & 20 \\
\hline Spolu & $\mathbf{5 0}$ & $\mathbf{1 0 0 \%}$ \\
\hline
\end{tabular}

Z analýzy výsledkov vyplýva, že väčšina sestier má dobré skúsenosti s aplikáciou prípravkov vlhkej terapie.

Tab. 8 Miera náročnosti

\begin{tabular}{|l|l|l|}
\hline Miera náročnosti & $\mathbf{n}$ & $\mathbf{\%}$ \\
\hline 1 - vel'mi jednoduché & 5 & 10 \\
\hline 2 - jednoduché & 12 & 24 \\
\hline 3 - stredne náročné & $\mathbf{1 6}$ & $\mathbf{3 2}$ \\
\hline 4 - náročné & 12 & 24 \\
\hline 5 - vel'mi náročné & 5 & 10 \\
\hline Spolu & $\mathbf{5 0}$ & $\mathbf{1 0 0 \%}$ \\
\hline
\end{tabular}

Použitím Likertovej škály sme zistili, že najväčší počet sestier považuje zaobchádzanie s materiálmi vlhkej terapie za stredne náročné.

\subsection{Diskusia}

Výskyt chronických rán má stúpajúcu tendenciu, preto je dôležité, aby ošetrujúci personál mal potrebné teoretické vedomosti a praktické skúsenosti voblasti starostlivosti o pacienta s chronickými ranami a využívaním prostriedkov vlhkej terapie. Ciel’om prieskumnej časti príspevku, bolo zistit' skúsenosti sestier s aplikáciou a využitím vlhkej terapie v klinickej praxi na chirurgických pracoviskách. Z analýzy získaných údajov vyplýva, že na chirurgických oddeleniach sa v $60 \%$ vyskytujú sekundárne sa hojace operačné rany a najmenej syndróm diabetickej nohy. $Z$ analýzy vyplýva, že pri preväze chronickej rany sa v $50 \%$ na chirurgických oddeleniach použivajú materiály vlhkej terapie so sekundárnym krytím. V 36\% sa prípravky vlhkej terapie na chirurgických oddeleniach aplikujú v závislosti od typu chronickej rany. Zistili sme, že sestry na chirurgických oddeleniach najčastejšie používajú pri liečbe chronických rán hydrogély a najmenej používanými sú hydrovlákna. Z našich zistení vyplýva, že sestry až v $58 \%$ sa stretávajú s viditel'ným efektom účinnosti vlhkej terapie v liečbe chronických rán počas hospitalizácie pacienta. Až $48 \%$ sestier vie, že je potrebné prihliadat' na fázu hojenia rany. 50\% sestier má dobré skúsenosti s aplikáciou prípravkov vlhkej terapie Naše výsledky prieskumnej časti sme porovnávali s výsledkami diplomových prác študentiek Wilczovej a Macháčkovej, ktoré sa tiež zaoberali podobnou problematikou. Starostlivost' o pacienta s chronickou ranou je náročná vo všetkých oblastiach a vyžaduje si multidisciplinárny prístup ako uvádzajú Pokorná a Mrázová v článku Hojení rán z pohledu všeobecné sestry v časopise Florence (9). Spôsob liečby prípravkami vlhkej terapie využívajú aj sestry na chirurgických oddeleniach v Brne, a to potvrdzujú výsledky práce Macháčkovej (7). V súčasnosti je na trhu množstvo rozličných prípravkov vlhkej terapie od rôznych farmaceutických firiem. Zistili sme, že 30\% respondentov používa prípravky zo 
skupiny Hydrogély a tieto výsledky môžeme porovnat' s výsledkami Macháčkovej (7), kde rovnako najčastejšie používanými prípravkami sú práve Hydrogély. Sestry považujú prípravky vlhkej terapie za účinné a efektívne ako to uvádza aj Molčanová (8) vo svojom článku. $87,5 \%$ respondentov sa s týmto tvrdením stotožňuje a 77,5\% respondentov sa stretlo s viditel'ným efektom účinnosti počas hospitalizácie pacienta. Ak chceme pacientovi poskytnút' adekvátnu liečbu prostredníctvom vlhkej terapie, musíme brat' do úvahy fázu hojenia rany a podl'a nej zvolit' vhodný prípravok. Hrbatý (3) v liečbe chronických rán považuje za najväčšiu chybu vzájomnú kombináciu prípravkov vlhkej terapie, čím sa proces hojenia spomalí. Z výsledkov práce Wilczkovej (15) vyplýva, že sestry pre svoju prácu s vlhkou terapiou majú dostatok potrebných materiálov. Škochová (11) uvádza, že pri častej frekvencii preväzov dochádza k ochladzovaniu rany, čo spôsobuje stagnáciu hojenia. Prípravky vlhkej terapie je možné ponechat' v rane aj niekol'ko dní, čím sa frekvencia preväzov znižuje a nedochádza tak k úniku tepla. Pri aplikácii prípravkov vlhkej terapie sa vyžaduje určitý postup, čo môžu niektoré sestry pokladat' za náročné čo sa nám potvrdilo. Prezentovali sme to prostredníctvom Likertovej škály. 32\% respondentov uviedlo, že zaobchádzanie s materiálmi vlhkej terapie považuje za stredne náročné.

\subsection{Záver}

Chronické rany predstavujú v súčasnosti závažný medicínsky a ošetrovatel'ský problém, s ktorým sestry prichádzajú do styku takmer každodenne počas svojej praxe. Sestry zohrávajú významnú úlohu v starostlivosti o pacienta s chronickou ranou, preto je potrebné aby disponovali dostatkom vedomostí o problematike hojenia rán a tým môžu pacientovi poskytnút' primeranú a adekvátnu starostlivost'. Nový moderný spôsob liečby sa čoraz viac dostáva do popredia a v súčasnosti máme $\mathrm{k}$ dispozícií množstvo rozličných prípravkov vlhkej terapie. Preto je dôležité, aby sestry vedeli posúdit' stav rany, vybrat' vhodný prípravok vlhkej terapie a správne ho aplikovat', čo môže pacientovi výrazne ovplyvnit' a zlepšit' kvalitu jeho života. Túto starostlivost' môžu sestry poskytnút' len vtedy, ak budú mat' dostatok informácií o problematike vlhkej terapie s následným využitím vo svojej praxi. Súčasná medicína nedokáže úplne vyliečit' všetky chronické rany, ale správnym výberom prípravkov vlhkej terapie a stanovením adekvátnej liečby dokáže pacientovi zlepšit' kvalitu jeho života. Je potrebné si uvedomit', že v liečbe chronickej rany je prvotné rozpoznat' a eliminovat' základnú príčinu ochorenia, pretože bez toho sa nemôže vlhká terapia stat’ účinnou.

\section{Použitá literatura}

1. ČAMBAL, M., ZONĆA, P., LABAŠ, P. a spol. 2012. Metódy debridementu v liečbe chronických rán. In Slovenská chirurgia. ISSN: 1338-2551, 2012, roč. 9, č. 4, s. 126.

2. DRAHOŠOVÁ, R. 2011. Léčba chronických ran. In Sestra. ISSN: 1210-0404, 2011, roč. 21, č. 9, s. 30-31.

3. HRBATÝ, B., ČAMBAL, M., LABAS̆, P. 2011. Vlhká terapia rán a moderné trendy. In Bedeker zdravia [ on line ]. 2011, č. 5. [ citované 5. 2. 2013 ]. Dostupné na: < http: www.zzz.sk/?clanok $=11075>$

4. KÓŇA, Š. 2012. Manažment ošetrovania chronických rán s využitím NIC a NOC klasifikačných systémov. In Diagnóza v ošetrovatelství. ISSN: 1801-1349, 2012, roč. 8 , č. 1 , s. 16 .

5. KOUTNÁ, M. 2012. Chyby a omyly v hojení chronických ran. In Diagnóza $v$ ošetrovatelství. ISSN: 1801-1349, 2012, roč. 6, č. 5, s. 17.

6. LABA ̌̆, P., ČAMBAL, M. 2012. Manažment ošetrovania chronických rán s využitím NIC a NOC klasifikačných systémov. In Diagnóza vošetrovatelství. ISSN: 1801-1349, 2012, roč. 8, č. 1, s. 16. 
7. MACHÁČKOVÁ, L., 2012. Znalosti všeobecných sester o současných trendech v hojení chronických ran. Diplomová práca, Masarykova Univerzita, Lékařska Fakulta, Katedra ošetřovatelství, Brno, 2012. 126 s.

8. MOLČANOVÁ, J., ČECH, M. 2011. Hojení rán vlhkou cestou. In Diagnóza v ošetrovatelství. ISSN: 1801-1349, 2011, roč. 7, č. 9, s. 9.

9. POKORNÁ, A., MRÁZOVÁ, R. 2012. Kompendium hojení ran pro sestry. 1. vyd. Praha: Grada Publishing, 2012. 191 s. ISBN: 978-80-247-3371-5.

10. POLÁKOVÁ, K. 2012. Hojenie rán pomocou kyseliny hyalurónovej. In Dermatológia pre prax. ISSN: 1337-1746, 2012, roč. 6, č.1, s. 17.

11. ŠKOCHOVÁ, D., MRÁZOVÁ, R., HUBÍK, J. 2011. Chronické kožní defekty. In Krška, Z. a kol. Techniky a technologie v chirurgických oborech.1.vyd. Praha: Grada Publishing, 2011. 264 s. ISBN: 978-80-247-3815-4.

12. SLANINOVÁ, I.,VEGERBAUER, M.,MALÝ, J. 2012. Přostredky k prevenci a léčbe dekubitů pohledem farmaceuta. In Dermatologie pro praxi. ISSN: 18035337, 2012, roč. 1 , č.6, s.35.

13. STRYJA, J. 2012. Quo vadis, hojení ran?. In Florence. ISSN: 1801-464X, 2012, roč. 8, č. 3, s.29-30.

14. TEREKOVÁ, V., KUBICOVÁ, L', OZOGÁNYOVÁ, M. 2011. Moderné trendy ošetrovania chronických rán. In Ošetrovatel'ský obzor. ISSN: 1336-5606, 2011, roč. 8, č. 1-2, s.9-10.

15. WILCZKOVÁ, M., 2011. Znalosti všeobecných sester o moderních způsobech hojení chronických ran. Diplomová práca, Masarykova Univerzita, Lékařska Fakulta, Katedra ošetřovatelství, Brno, 2011. $96 \mathrm{~s}$.

\section{Kontaktní údaje}

PhDr. Mgr. Tatiana Šantová, PhD.

Prešovská univerzita $v$ Prešove

Fakulta zdravotníckych odborov

Partizánska 1

08001 Prešov

Email: Tatiana.Santova@unipo.sk 


\title{
STAROSTLIVOSŤ O RANY V PREGRADUÁLNOM VZDELÁVANÍ SESTIER
}

\section{CARE OF WOUNDS IN PREGRADUATE EDUCATION NURSES}

\author{
Terézia Fertal'ová, Lívia Hadašová, Anna Eliašová, Silvia Cibríková, \\ Tatiana Šantová, Beáta Grešš Halász
}

\begin{abstract}
Abstrakt
Sestra koordinuje ošetrovatel'skú starostlivost' o pacienta poskytovanú metódou ošetrovatel'ského procesu. V rámci ošetrovania rán v rozsahu odbornej spôsobilosti zodpovedá za komplexný manažment pacienta. Kompetenciu nadobúda ukončeným vzdelaním v bakalárskom stupni v študijnom programe ošetrovatel'stvo. Chronické rany sú vážnou komplikáciou manažmentu zdravotnej starostlivosti a predstavujú značnú ekonomickú a sociálnu zát'až. Náklady na poskytovanú ošetrovatel'skú starostlivost' zdôrazňujú potrebu implementácie intervencií na prevenciu a liečbu rán vo vzdelávaní sestier. V predkladanom príspevku popisujeme rozdelenie rán a fázy hojenia rán a starostlivost' o rany $\mathrm{v}$ rámci pregraduálneho vzdelávania sestier.
\end{abstract}

Kl'účové slova: rana, hojenie, sestra, ošetrovanie, vzdelávanie

\begin{abstract}
Nurse coordinates nursing care for the patient provided by the nursing process method. As part of the treatment of wounds in the scope of professional competence, it is responsible for comprehensive patient management. The competence acquires ended education in a bachelor stage in the Nursing Study Program. Chronic wounds are a serious complication of healthcare management and represent a significant economic and social burden. Nursing Care costs emphasize the need to implement interventions to prevent and treat wounds in education of nurses. In the submitted contribution we describe the distribution of wound and healing phase wounds and wound care in the framework of peer education nurses.
\end{abstract}

Key words: wound, healing, nurse, nursing, education

\section{RANY A ICH ROZDELENIE}

Rana sa definuje ako narušenie celistvosti tkanív telesného povrchu v rôznom rozsahu a híbke postihnutia jednotlivých anatomických vrstiev: pokožky, zamše a podkožia. Dochádza k narušeniu niektorých fyziologických funkcií kože, napríklad ochrannej, imunitnej, termoregulačnej, senzitívnej, metabolickej, sekrečnej, resorpčnej, komunikačnej, tvorby pigmentu a rohovatenia. Následne môže nastat' progresia do híbkových tkanivových štruktúr. Vznik rany súvisí s viacerými príčinami, ktoré možno rozdelit' na vnútorné a vonkajšie súvisiace faktory (Hlinková et al., 2015).

Rany delíme na akútne a chronické. Akútne rany sú rany hojace sa bez komplikácií označujeme ich per primam. Chronické rany nazývame tie, ktoré sa hoja dlhšie ako 6 alebo 9 týždňov a viac, tie označujeme per secundam. Chronická rana je definovaná časovým faktorom hojenia, kde narušenie hojenia môžu vyvolávat' aj akútne rany (Stryja, 2011). Počet pacientov vyžadujúcich starostlivost' o rany sa neustále zvyšuje z dôvodu lekárskych a epidemiologických faktorov, ako je napríklad obezita a diabetes mellitus. V USA je chronickými ranami postihnutých viac ako 6,5 milióna l'udí, čo vedie k ročným nákladom na 
liečbu až 25 miliárd dolárov. Odhaduje sa, že chronické rany postihujú približne $2 \%$ populácie (Criscitelli, 2018).

Podla uvedených odhadov, na Slovensku by malo byt' 109000 pacientov s chronickými ranami, ktoré si vyžadujú ošetrovatel'skú intervenciu.

Rany sú rozdelené podl'a priebehu a ich dľ̌ky hojenia.

Akútne rany sa hoja per primam do 6 týždňov. Vznikajú pri operáciách alebo pri traume. Chronické rany vznikajú troficky tkanivovou zmenu aj sekundárnou dehiscenciou. Hoja sa dlhšie ako 9 týždňov sú to rany napríklad ulcus cruris, dekubit, diabetický vred, postradiačná rana, posttraumatická rana aj exulcerované nádory.

Rany podl'a rozsahu aj híbky poškodených tkanív.

- Plošné rany vznikajú pri odtrhnutí kože spolu s podkožím.

- Povrchové rany ak sa poškodí kožný kryt aj časti podkožia.

- Híbkové rany - tie postihujú epidermis, dermis aj podkožné tkaniva a hlbšie vrstvy. Delia sa na penetrujúce hlboké rany, ich poranenie zasahuje do telových dutín a spája ich $\mathrm{s}$ povrchom a nepenetrujúce hlboké rany, tieto rany nesiahajú do telových dutín.

Delenie chronických rán podla etiológie:

Dekubity sú zmeny na koži spôsobené tlakom, maceráciou tkaniva, imobilitou, inkontinenciou moču a stolice. Vznikajú do 24 hodín. Intervencie ošetrovania sú polohovanie pacienta cez deň každé tri hodiny a v noci každé dve hodiny, rehabilitácia vykonávaná na posteli. Faktory, ktoré ovplyvňujú bolest' sú ošetrovanie a pohyb pacienta vo vyššom štádiu dekubitu. Charakteristika bolesti: pálenie, bodanie, šklbkanie, ostrá pulzácia.

Ulcus cruris je rana, pri ktorej je bolest' udávaná ako chronická aj akútna. Prítomnost' bolesti je v noci aj cez deň. Dôvody sú fyzická aktivita, plynulá chôdza, chôdza po schodoch. Na kompresívnu terapiu sa používa kompresívna vysoká a nízka bandáž. U pacientov s ulcus cruris venosum je viditel'ný edém, kožné ochorenia, flebitídy a pri ulcus cruris arteriosum je ischémia, nekróza, a kŕče v dolných končatinách. Pri akútnej bolesti u tohto typu rany môže vzniknút' zápalový proces povrchová flebitída, žilová trombóza. Intenzita bolesti závisí od faktorov, ktoré na ranu pôsobia. Pacient pocit’uje väčšiu bolest' pri vykonávaní fyzikálneho vyšetrenia palpáciou, pri postavení, stati a ak je výskyt dermatitídy na okolí rany. Dermatitída vzniká pri lokálnom ošetrovaní alebo pri kompresívnej terapii. Bolest' je označovaná ak svrbenie a pálenie (Pokorná, Mrázová, 2012).

Diabetické ulcerácie vznikajú u pacientov s ochorením diabetes mellitus. Bolest' je akútna aj chronická vyskytuje sa cez deň aj v noci, ked' pacient chodí, stojí a v pokoji. Jej charakterizácia je: pálenie, ostrost', pulzujúca, bolest’ je vyčerpávajúca a mučivá. Liečba spočíva v polohovaní, rehabilitácii a preväzovaní rany (Hlinková et al., 2015).

Mechanické rany sú spôsobené vplyvom mechanických faktorov patria sem rany operačné, tie sú spôsobené incíziou odlišnej dížky. Traumatické rany vznikajú pri úrazoch a delíme ich na:

- Rezné rany (vulvus scissum) - vznikajú pri tlaku alebo t’ahom ostrého nástroja. Rana nie je hlboká, v prostriedku rany je najhlbšia a pri okrajoch plytšia.

- Sečné rany (vulvus sectum) - spôsobuje ich dopad nástroja s ostrou hranou na povrch tela.

- Bodné rany (vulnus punctum) - vznikajú, ak do rany vnikne konický nástroj po dížke svojej osi.

- Tržné rany (vulvus lacerum) - vzniknú, ak pokožka praskne vplývaním patologického t’ahu.

- Pomliaždenie (contusio) - je na tele, ak naňho pôsobí tupí tlak.

- Odreniny (excoriatio) - poškodzuje sa vrstva kože epidermis.

- Strelné rany (vulvus sclopetarium) - spôsobujú ich projektily strelných zbraní a inými úlomkami črepín nábojov a mín. 
- Uhryznutia (vulvus morsum) - spájajú sa často so stratou tkaniva. Jednoduché uhryznutia majú odtlačku chrupu zvierat’a. Rany sú infikované, hoja sa sekundárne.

Termické a chemické rany.

Vznikajú ak na povrch tela pôsobí chlad, teplo, kyseliny alebo škodlivé žiarenie. Do tejto kategórie patria:

- Popáleniny (combustio) - priamym aj nepriamym pôsobením tepelnej energie na telový povrch.

- Omrzliny (congaletio) - vznikajú, ak na povrch jednotlivej časti tela pôsobí chlad.

- Vredy vznikajú z porúch vyživovania kože, cievnych aj neurologických porúch alebo dlhodobo pôsobiaceho lokálneho tlaku. Vyvolávajú ich aj choroby krvi, obličiek a diabetes mellitus (Zeman et al., 2000).

Podl'a dĺžky a trvania delíme rany na:

- čerstvé rany trvajú do 6 hodín

- zastaralé rany viac ako 6 hodín.

Podl'a tvaru rozpoznáme rany: pozdĺžne, priečne, šikmé a cirkulárne.

Delenie rán podl'a pritomnosti choroboplodných zárodkov:

- Čisté rany sú rany ako napríklad neinfikovaná operačná rana, elektívna operácia, operačná rana, ktorá je uzavretá primárnou suturou alebo rany, ktoré sú drenované uzavretou drenážou. Rany, ktoré nie sú infikované, bez známok zápalu, bez otvorenia hepatobiliárneho, gastrointerstinálneho, respiračného a genitourinálneho traktu. Akceptuje sa $1,5 \%$ vzniknutej infekcie.

- Čisté kontaminované rany delíme na akútne, chirurgické rany, urgentné operácie, ktoré nejavia žiadne známky infekcie. Operované orgány pohlavného, dýchacieho, tráviaceho aj močového ústrojenstva. Riziko, ktoré sa akceptuje je $8 \%$.

- Kontaminované rany sú penetrujúce traumatické rany a chirurgické rany, kde sú prítomné známky zápalu ale sekrécia je bez hnisu. Ak je napríklad otvorený genitourinálny trakt a do dutiny brušnej odteká napríklad moč, riziko vzniku je do 15 až $20 \%$.

- Znečistené infikované rany sú zastaralé traumatické rany, ktoré obsahujú odumreté tkanivo a klinickú infekciu (napríklad absces). Riziko infekcie je do 30 až 40\% (Hlinková et al., 2015).

\subsection{Hojenie rán}

Hojenie rán predstavuje komplexný proces, ktorého ciel'om je reepitelizácia kože so znovunadobudnutím jej bariérovej funkcie. Existujú štyri základné chirurgické typy hojenia rán: primárne, odložené primárne, sekundárne a hojenie povrchových rán. Z hl'adiska kvality výsledného stavu rozoznávame dva druhy hojenia:

1. Regenerácia - ide o hojenie ad integrum, kedy dochádza $\mathrm{k}$ obnove tvaru a funkcie.

2. Reparácia - výsledkom hojenia je jazva, čo znamená neúplnú obnovu tvaru a funkcie (Bukovčan, 2019).

Priebeh fyziologického hojenia rany sa rozdel'uje do troch fáz: zápalová (exudatívna), granulačná (proliferačná) a epitalizačná (remodelačná)“ (Schremla, in Hlinková et al., 2015, s.32).

Zápalová exudatívna fáza je nazývaná čistiaca fáza. Nastáva v čase poranenia. Jej dížka je 2 až 3 dni. Nastáva vtedy, ak sa poškodí tkanivová integrita. Krvné doštičky a koagulačné faktory pomáhajú pri zastavení krvácania, kde sa začne tvorit' fibrín. Ako prvá je vazokonstrikcia, tá je dôležitá nato, aby sa krvácanie zastavilo. Po nej nasleduje vazodilatancia, ktorá extravazuje s krvnou plazmou. Na hojení rany sa podiel'ajú aj systémové faktory. Zápalová fáza je predlžená, ak je v tkanivách nedostatočná výživa. Ak sa rana nehojí z dôvodu nekrózy a fibrinového povlaku na spodine rany, tak sa zápalová fáza 
časovo predĺži, napríklad ak sa v rane vyskytla infekcia, ktorú sprevádza zápal (Pokorná, Mrázová, 2012).

Proliferačná fáza, dížka trvania je od 4 do 14 dňa. Tu začína pracovat' rastový faktor, ktorý je vel'mi dôležitý pre rast nových ciev a na tvorbu granulačného tkaniva, ktorého úlohou je nahradit' defekt v rane. Niekedy sa v rane vyskytne aj sekrét. Ciel'om ošetrovania je zanechat' ranu čistú v určitej vel'kosti a optimálnej telesnej teplote. Ak je rana už v tejto fáze hojenia, najvýhodnejšou terapiou je vlhká metóda hojenia (Pejznochová, 2010).

Epitelizačná fáza tato fáza je konečná. Trvá od 21 do 24 dňa. Začína sa delením buniek. Tie sa presúvajú do časti rany, ktorá nie je zahojená, a tam sa ustal'ujú. Aby sa mohli presúvat', potrebujú na pomoc dostatok rastových faktorov. Z nových a aj epitelových buniek, ktoré neboli napadnuté sa tvoria nové cievy. Ak sa rana zrastie na jej povrchu je epitelizovaná retrahovaná jazva. Kolagénové vlákna vytvárajú zväzok. Do siete vytvorenej z kolagénu sa pripevňujú fibroplasty, a tie vytvárajú stiahnutie rany (Pokorná, Mrázová, 2012).

\subsubsection{Faktory ovplyvňujúce hojenie rán}

Ranu môžu ovplyvňovat' systémové a miestne faktory. Vel'mi často je ovplyvnená psychika, ktorá je podmienená bolest’ami a nesebestačnost'ou chorého (Pokorná, Mrázová, 2012).

Medzi systémové faktory, ktoré ovplyvňujú hojenie rán patrí:

- Vek. Je vel'mi dôležitý pre hojenie rany, u starších pacientov je spomalenie niektorých funkcií a dôsledkom je zhoršené hojenie rán.

- Pohlavie. Štúdie dokazujú, že androgény v porovnaní s estrogénmi na akútnu ranu reagujú negatívne, a tým sa u žien rany hoja lepšie ako u mužov. Estrogén ovplyvňuje hojenie rán reguláciou génov spojených s regeneráciou, tvorbou matrix a inhibíciou protézy. Z toho vyplýva, že u žien vplyvom estrogénov sa rany hoja skôr ako u mužov.

- Diabetes mellitus a systémové ochorenia. Pri ochorení diabetes mellitus sa rana hojí dlhšie, čo spájame s hypoxiou, dysfunkciou fibroplastov, poruchou angiogenézy a neutroapatiou. Iné systémové ochorenia, ktoré ovplyvňujú hojenie rany sú imunodeficiencia, závažné ochorenie srdca a pl’úc, zlyhávanie obličiek a pečene.

- Výživa a dostatočná hydratácia. Sú nevyhnutné faktory dôležité pre hojenie rán. Vitamíny A, B, C, D, E, K napomáhajú pri rýchlejšom hojení rán ,ako aj minerály: med', vápnik, selén, železo, horčík, zinok. Nesmú chýbat' ani proteíny, ktoré sú takisto vel'mi potrebné.

- Obezita. Je d’alším podliehajúcim faktorom pri vzniknutí pooperačných komplikácií. Vzniká hematóm, infekcia a taktiež dehiscencia rany. Kožné záhyby u takýchto pacientov sú miestom pre mikrobiálne kolonizácie. U obéznych pacientov je častou komplikáciou vznik dekubitu.

- Lieky. Glukokortikoidy, nesteroidné antiflogistiká, cytostatiká a radiačná liečba vedú $\mathrm{k}$ zhoršenému hojeniu.

- Imunita. Pacienti, ktorý majú zníženú imunitu sú ovel’a náchylnejší na vznik bakteriálnej, vírusovej a kvasinkovej infekcie.

- Návykové látky. Fajčenie zabraňuje prísunu kyslíka do rany. Takisto škodiace látky sú alkohol a drogy.

- Inkontinencia. Je stupňom nadmernej vlhkosti. Pri inkontinencii moču a stolice nastáva narušenie ochrany kožnej bariéry. Môže zmenit' pH pokožky pretože moč je vel'mi kyslý a stolica, ktorá je hnačkovitá obsahuje enzýmy, ktoré napomáhajú k rozpadu epidermis.

- Imobilita a narušenie zmyslového vnímania. Ak pacient je fyzicky aktívny, vie kontrolovat' polohu tela a cíti nepohodlie, polohovaním svojho tela tak predchádza vzniku ranových komplikácií a znižuje riziko vzniku dekubitov. Rizikové skupiny pacientov, u ktorých vznikajú najčastejšie dekubity sú pacienti v bezvedomí, pacienti pod vplyvom sedatív, paretickí, zmätení a plegickí. (Hlinková et al., 2015).

Medzi miestne faktory, ktoré ovplyvňujú hojenie rán patrí: 
- Porucha hemodynamiky. Nastáva porucha krvného zásobenia, ktorá súvisí zo zníženou perfúziou kyslíka a iných nutričných látok, ktoré sú potrebné k tkanivovej reparácií.

- Híbka rany. Potrebuje k vytvoreniu vaskularizovaného granulačného tkaniva väčší časový faktor ako povrchová rana.

- Vel'kost' rany. Dížka hojenia rany závisí od jej vel'kosti.

- Spodina rany. Ak je k spodine rany prilipnutá nekróza alebo ak sa v rane vytvoria zrazeniny či povlaky, tým sa predíži hojenie rany.

- Mikrobiálna infekcia. Infekcia v rane stagnuje vo fáze zápalovej, kde môže nastat' flegmóna mäkkých tkanív na okolí rany.

- Lokalizácia rany. Vznik rany na mieste, kde je znížená nutricia sa prejavuje zhoršenými známkami hojenia.

- Okraje rany. Ak sú okraje zavalité a podmínované sú vhodnou živnou pôdou pre baktérie.

- Hypoxia rany. Kyslík je potrebný pre každú fázu hojenia rany. Ak je ho v rane málo vzniká hypoxia, ktorá znižuje rezistenciu k infekcii zníženou fagocytárnou schopnost’ou leukocytov (Pospíšilová, 2010).

Psychické faktory sú depresia, strach stres, ktorý negatívne vplýva na bunkovú imunitu nachádzajúcu sa v rane, a tým predlžuje proces hojenia rán. Pacienti sa často izolujú, a to vplýva na zhoršenú kvalitu života (Pospíšilová, Švestková, 2001).

\subsection{Starostlivost' o rany vo vzdelávaní sestier}

Sestra na základe kompetencií vymedzených Vyhláškou č. 95/2018 Ministerstva zdravotníctva Slovenskej republiky z 12. marca 2018, ktorou sa určuje rozsah ošetrovatel'skej praxe poskytovanej sestrou samostatne, samostatne na základe indikácie lekára a v spolupráci s lekárom a rozsah praxe pôrodnej asistencie poskytovanej pôrodnou asistentkou samostatne, samostatne na základe indikácie lekára a $\mathrm{v}$ spolupráci $\mathrm{s}$ lekárom samostatne hodnotí a ošetruje poruchy celistvosti kože a slizníc a na základe indikácie lekára preväzuje a ošetruje rany s výnimkou rán, ktoré svojim priebehom hojenia vyžadujú zásah lekára. Sestra s pokročilou praxou indikuje ošetrovanie primárne sa hojacej rany. Chronické rany sú vážnou komplikáciou manažmentu zdravotnej starostlivosti. Náklady na poskytovanú ošetrovatel'skú starostlivost' zdôrazňujú potrebu implementácie intervencií na prevenciu a liečbu rán. Náklady na použitie obväzového materiálu na rany samo o sebe sa pokladá za hlavný činitel' nákladov na liečbu. V skutočnosti je to však čas potrebný na poskytovanie komplexnej starostlivosti a náklady na hospitalizáciu, čo tvorí približne $80-85 \%$ celkových nákladov (Lindholm, Searle, 2016).

Starostlivost' o rany si vyžaduje pochopenie problematiky hojenia rán. Vedomosti o dostupných liečebných intervenciách sú predpokladom úspešnosti. Nevhodné použitie liečebnej metódy odd'al'uje proces úspešného hojenia rán (Balsa, Culp, 2015).

V rámci pregraduálneho vzdelávania sestier sa sústred’ujeme na odovzdávanie najnovších poznatkov v oblasti manažmentu chronických rán vychádzajúc z platných štandardných postupov Komplexného ošetrovatel'ského manažmentu pacienta s chronickou ranou. Zároveň vychádzame z medzinárodných guedelinov, odporúčaní EPUAP (European Pressure Ulcer Advisory Panel), NPIAP (National Pressure Injury Advisory Panel) a Pan Pacific Pressure Injury Alliance. V rámci postgraduálneho vzdelávania sestier chceme vytvorit' a pripravit' podmienky pre akreditáciu certifikovanej pracovnej činnosti: „Ošetrovatel'ská starostlivost' o chronické rany“, na Fakulte zdravotníckych odborov Prešovskej univerzity v Prešove.

Starostlivost' o rany je súčast'ou osnovy predmetu Ošetrovatel'ské postupy II v prvom ročníku v letnom semestri. Starostlivost' o rany je implementovaná v rámci chirurgického bloku ošetrovatel'ských postupov. Výučba prebieha v simulačnom laboratóriu. V súvislosti so starostlivost'ou o rany sa sústred'ujeme na preväz aseptickej rany. Dôraz kladieme na dodržiavanie aseptických postupov práce, hygienu a dezinfekciu rúk, manipuláciu so 
sterilným materiálom. Osobitnú pozornost' venujeme bariérovej ošetrovacej technike. Nevyhnutnou súčast'ou starostlivosti o rany je vedenie dokumentácie a odkaz na dôkaz.

V rámci zvyšovania kvality vysokoškolského vzdelávania $\mathrm{v}$ študijnom programe ošetrovatel'stvo, sme získali finančnú dotáciu Kultúrnej a edukačnej grantovej agentúry Ministerstva školstva, vedy, výskumu a športu Slovenskej republiky na implementáciu projektu s názvom: „Simulačné centrum starostlivosti o chronické rany“. V rámci realizácie projektu je našim zámerom zakúpit’ simulačné modely, ktoré využijeme na praktickú výučbu starostlivosti o rany v pregraduálnom a následne v postgraduálnom vzdelávaní sestier.

Preväz chronickej rany je súčast'ou disciplíny Chirurgia a chirurgické ošetrovatel'stvo, s orientáciou na teoretické východiská starostlivosti o chronické rany, ktoré sú nevyhnutnost'ou pri realizovaní klinických cvičení v zmluvných zdravotníckych zariadeniach. So starostlivost'ou o chronické rany sa najčastejšie stretávame na Oddelení cievnej chirurgie, Oddelení dlhodobo chorých, Geriatrickom a Onkologickom oddelení. Na pracoviskách chirurgických odborov sa stretávame s komplikovaným hojením operačných rán.

\subsubsection{Preväz aseptickej rany}

Ciel'om preväzu je kontrola rany, jej sterilné ošetrenie a prekrytie. Pri preväze sestra spolupracuje s lekárom.

- Sterilné pomôcky, ktoré sestra potrebuje na preväz rany sú: sterilné krycie tampóny alebo štvorce; dve emitné misky; dezinfekčný roztok; nožnice; sterilná anatomická pinzeta; paličkové sondy; náplast'; sterilný obväzový materiál; antiseptický roztok; sterilné rukavice; nástroj na odstraňovanie svoriek; roztoky: Ringerov roztok, fyziologický roztok, Dermacyn, roztok na odmast'ovanie a iné roztoky; sterilné striekačky a skalpel.

- Nesterilné pomôcky, ktoré potrebuje sestra na preväz rany sú: pomôcky na fixovanie; hypoalergénne náplasti; dve emitné misky; buničitá vata; obväzové nožnice; nepremokavé podložky; na odpad kontajner alebo nepremokavé vrece.

Vykonáme hygienickú dezinfekciu rúk. Oblečieme si ochranný plášt' a tvarovú masku. Pacienta informujeme o preväze a zistíme alergie na náplast' či jódové prípravky. Ak je potrebné, 30 minút pred začatím preväzu aplikujeme pacientovi analgetiká podl'a ordinácie lekára. Zachováme intimitu pacienta, pri preväze uložíme pacienta do vhodnej polohy. Odstránime krytie s rany. Navlhčíme tampónom napríklad Ringerovým roztokom a postupujeme čistením od strán $\mathrm{k}$ incízii. Do sterilného peanu uchytíme sterilný tampón a polejeme ho z výšky $10 \mathrm{~cm}$ antiseptikom nad emitnou miskou. Ranu čistíme s zhora nadol, ak začíname $\mathrm{v}$ strede postupuje smerom von. Na každý iný smer používame nový tampón. Ak je $\mathrm{v}$ rane zavedený drén, musíme ho očistit'. Ranu posúdime, takisto posúdime drén a okolie drénu. Na ranu priložíme štvorce navlhčené antiseptickým roztokom. Po aplikácií antiseptika na ranu priložíme suchý sterilný štvorec a prelepíme náplast'ou ku koži.

Pacienta edukujeme ako ma ranu chránit' pri vykonávaní sebaobslužných činností ako napríklad obliekanie, celkový kúpel', rannú toaletu, pohyb na posteli a d’alšie iné. Po dokončení preväzu zabezpečíme dekontamináciu, dezinfekciu a sterilizáciu použitých nástrojov. Po ukončení preväzu urobíme záznam do pacientovej dokumentácie (Obročníková et al., 2016).

\section{ZÁVER}

Rany najmä chronické sú významnou klinickou, sociálnou a ekonomickou výzvou. Moderné ošetrovatel'stvo otvára cestu vzdelaným sestrám, ktoré budú schopné poskytovat' vysoko kvalitnú ošetrovatel'skú starostlivost' a využívat' intelektový potenciál, ktorý zaručuje rozvíjanie profesionálneho rastu. 
Príspevok vznikol sfinančnou podporu projektu KEGA č. 003PU-4/2021 s názvom: Simulačné centrum starostlivosti o chronické rany.

\section{Použitá literatúra}

1. BALSA, I. M., CULP, W. T. 2015. Wound Care. The Veterinary clinics of North America. Small animal practice, 45(5), 1049-1065. https://doi.org/10.1016/j.cv sm.2015.04.009

2. BUKOVČAN, P. 2019. Hojenie rán. Bratislava: Univerzita Komenského v Bratislave, 2019. 92s. ISBN 978-80-223-4793-8.

3. CRISCITELLI, T. 2018. The Future of Wound Care. AORN journal, 107(4), 427429. https://doi.org/10.1002/aorn.12118

4. HLINKOVÁ, E. et al., 2015. Nehojace sa rany. Martin: Osveta, spol. s.r.o. ISBN 978-80-8063-433-9.

5. LINDHOLM, C.,SEARLE, R. 2016. Wound management for the 21st century: combining effectiveness and efficiency. International wound journal, 13 Suppl 2, 515. https://doi.org/10.1111/iwj.12623

6. OBROČNÍKOVÁ, A. et al. 2016. Vybrané ošetrovatel'ské postupy v chirurgických odboroch. Prešov: A- print s.r.o. ISBN 978-80-89721-21-4.

7. PEJZNOCHOVÁ, I. 2010. Lokálni ošetřování ran a defektů na kưži. Praha: Grada. ISBN 978-80-247-2682-3.

8. POKORNÁ, A., MRÁZOVÁ, R. 2012. Kompendium hojení ran pro sestry. Praha: Grada. ISBN 978-80-247-3371-5.

9. POSPÍŠILOVÁ, A. 2010. Léčba ran a péče o pokožku. Olomouc: Solen, s.r.o. ISBN 978-80-87327-36-4.

10. POSPÍŠILOVÁ, A., ŠVESTKOVÁ, S. 2001. Léčba chronických ran.1.vyd. Brno: IDPVZ. ISBN 80-7013-348-1.

11. STRYJA, J. 2015. Débridement a jeho úloha v managementu ran. Semily: Geum. ISBN 978-80-879-6913-7.

12. ZEMAN, M. et al. 2000. Chirurgická propedeutika. 2.vyd. Praha: Grada. ISBN 807169-705-2.

\section{Kontaktné údaje}

PhDr. Terézia Fertal'ová, PhD.

Prešovská univerzita v Prešove, Fakulta zdravotníckych odborov

Partizánska 1, 08001 Prešov

Tel: 00421517562461

email: terezia.fertalova@unipo.sk 


\title{
HOJENIE RÁN PODTLAKOVOU TERAPIOU
}

\section{HEALING WOUND WITH VACUUM THERAPY}

\section{Terézia Fertal'ová, Lívia Hadašová, Anna Eliašová, Silvia Cibríková, Tatiana Šantová, Beáta Grešš Halász}

\begin{abstract}
Abstrakt
Podtlaková terapia má pozitívny vplyv na hojenie rán. Publikované práce svedčia pre použitel'nost' na hojenie infikovaných rán, hojenie rán $\mathrm{v}$ hrudníkovej chirurgii a traumatológii. Využitie má aj v liečbe diabetických gangrén. Sporné je využitie tejto liečebnej metódy u onkologických pacientov. Pozitívny efekt je dokázatel'ný pri chronicite hojenia. Podtlaková terapia predstavuje bezpečnú a efektívnu alternatívu v hojení chronických rán.
\end{abstract}

Kl'účové slová: rana, hojenie, podtlak, liečba

\begin{abstract}
Vacuum therapy has a positive impact on wound healing. Published works testify for usability for healing infected wounds, wound healing in chest surgery and traumatology. Use also has in the treatment of diabetic gangrene. The use of this treatment method in oncological patients is disputed. The positive effect is proven in healing chronicite. Vacuum therapy is a safe and efficient alternative in chronic wound healing.
\end{abstract}

Key words: wound, healing, vacuum, treatment

\section{LIEČBA CHRONICKÝCH RÁN}

Liečba chronických rán je zložitý proces vyžadujúci multidisciplinárny prístup, postupnost' na seba nadviazaných krokov na základe presných kompetencií určitej zodpovedností (Hlinková et al., 2015).

Členovia, ktorí tvoria multidisciplinárny tím sú: dermatológovia, špecializovaní lekári, napríklad diabetológ, sestra ktorá ma špecializáciu na chronické rany, chirurgovia, ortoprotetici, fyzioterapeuti a sociálni pracovníci. Základným postupovaním je zistit' anamnestické údaje, zhodnotit' zdravotný stav pacienta. Vykonat' klinické vyšetrenia pomocou prístrojov a laboratórnych vyšetrení. Posúdit' ranu, zistit' príčiny vzniku, určit' fázu, $\mathrm{v}$ ktorej rana je. Navrhnút' liečebný postup rany, tlmenie bolesti a celkový prístup $\mathrm{k}$ pacientovi.

Liečba obsahuje vel’a možností a tie závisia od druhu rany a naliehavosti pacienta. Liečba smeruje $\mathrm{k}$ dosiahnutiu zdravotného stavu pacienta na úroveň, ktorú považuje za najvýhodnejšiu, týkajúcu sa liečby rany napríklad: sanácia spodiny rany, kompenzácia diabetu (Pospíšilová, 2010).

\subsection{Vlhká terapia}

Vlhká terapia je liečba rán vo vlhkom prostredí, kde rany majú tendenciu rýchlejšieho hojenia. Prostriedky, ktoré sa používajú na vlhké hojenie, majú schopnost' vytvorit' prostredie, v ktorom sa rana hojí. Ranu neutralizujú, chránia okolie kože pred mechanickými vplyvmi, sú schopné prepustit' paru a vodu do rany a slúžia ako bariéra pred vniknutím infekcie. Nie sú cenovo náročné, preto pomáhajú liečbe $\mathrm{v}$ domácom prostredí a na zlepšenie kvality života $\mathrm{u}$ pacientov s chronickou ranou (Vytejčková et al., 2015). 
- Algináty. Obsahujú kyselinu algonovú, vyrobené sú z morských rias. Spolu s exudátom vytvárajú gél - hlboké, plytké infikované a neinfikované rany; 2 - 5 dní.

- Bioaktívne krytie. Obsahuje kyselinu hyalurónovú, hyiodín, kolagén, celulózu-fáza granulácie a epitelizácie, stagnujúce rany; 2 - 3 dni.

- Hydrogély. Obsahujú amorfný gél na vodnej báze, gél obsahuje Ringerov roztok, vhodné pre všetky fázy hojenia; 4 dni.

- Hydrokoloidy .Obsahujú mikrogranulárne suspenzie tvorené polymérmi - prevencia dekubitov, plytké rany, fáza granulácie; 3 - 5 dní.

- Neadherentné krytie. Obsahuje bavlnené, viskózne a nylonové vlákna - popáleniny, povrchové rany, krytie na chirurgické rany - každých 24 hodín, obsahom striebra každých 5 dní.

- Polyuretány. Obsahujú polyuretánovú penu s vysokou absorpciou - vlhká nekróza, infikované rany, popáleniny 2. stupňa, rany po nekrektómii, plytké rany, epitelizačná a granulačná fáza; 4 - 7 dní.

- Polyakryláty. So superabsorčným jadrom - nekrotické a infikované rany, rany s povlakom a kavitami, hlboké rany; každých 12 až 24 hodín.

- Filmové krytia. Vyrobené z polyuretanového filmu - krytie operačných rán, dekubity 1. stupňa , sutur a venóznych kanýl, na drobné trhliny a pooperačné rany hojace sa per primam; 3 - 7 dní (Hlinková et al., 2015).

\subsection{Podtlaková terapia rán}

Liečba rán podtlakovú terapiou je všeobecne akceptovaná liečebná metóda pre otvorené alebo infikované rany (Janssen et al., 2016). Liečba rán pod tlakom je jedným z najúspešnejších mechanických doplnkov hojenia rán v humánnej medicíne (Stanley, 2017). Podtlakové uzatváranie rán (VAC terapia) je základným prvkom pri liečbe problémových akútnych a chronických rán (El-Sabbagh, 2017).

Princípom podtlakovej terapie je prístroj, ktorý tvorí subatmosferický tlak. Od prístroja vedie hadica napojená k penovému krytiu polyuretanu. Kontinuálny podtlak je prichytený fóliou, ktorá je založená na princípe tesnenia rany. Podtlak, ktorý sa používa štandardne je 100-200 $\mathrm{mm} \mathrm{Hg}$, Najúčinnejšie hojenie je pri hodnote $125 \mathrm{~mm} \mathrm{Hg}$, Väčší tlak by mohol spôsobit' ischémiu granulačného tkaniva, ktoré následne odumrie (Koutná et al., 2015).

Podporuje čistenie a hojenie rôznych typov rán. Napríklad traumatické a infikované rany, dehiscencie, fixácia kožného laloku, dekubity, syndróm diabetickej nohy a vredu predkolenia. Podtlaková terapia sa môže aplikovat' na ranu po chirurgickom výkone ak je vykonaná nekrektómia, pri otvorenej amputácií, rozsiahlych defektoch. Podtlaková terapia sa nemôže podávat' ak je nekrotické tkanivo alebo suchá gangréna, malignita $\mathrm{v}$ rane, neliečená osteomyelitída, obnažené cievy a fistula, ktorá komunikuje s telovými dutinami. Nevhodné je používat' podtlakovú terapiu u pacientov, ktorí nespolupracujú a na ranu, ktorá prilieha na tumor. Podtlak z rany odstraňuje exsudát, znižuje počet baktérií, znižuje tkanivový odtok, zvyšuje prekrvenie a povzbudzuje rast granulácie. Ak je rana kontaminovaná a odsáva sekrét, doporučuje sa preväzovat' raz za 2 dni. Ak je rana čistá a tvorí sa v nej granulácia je vhodné ju preväzovat' raz za 4 dni.

Samotný preväz rany sa robí za sterilných podmienok v preväzovej miestnosti a s využitím bariérovej ošetorvacej techniky. Preväz vykonáva lekár v spolupráci so sestrou. Pred preväzom ak je potrebné pacientovi podáme analgetikum podla ordinácie lekára. Pod postihnutú končatinu podložíme sterilnú rúšku a očistíme ulceráciu. Prístroj zapojíme do zásuvky. Lekár si navlečie sterilné rukavice, ktorými vytiahne penu z obalu. Penu vystrihne do tvaru, ktorá ranu vyplní. Sestra fóliou prekryje penu. Do peny sa zavedie odsávacia drenová hadička, ktorá vedie do prístroja a spája ranu s kanystrom, do ktorého sa odsáva sekrét z rany. Kanyster obsahuje filter s aktívnym uhlím, ktorý zabraňuje vniknutiu baktérií 
a prenikaniu zápachu. Zvolíme režim podtlaku kontinuálneho alebo intermitentného a intenzitu podtlaku. Najvhodnejšia je aplikácia 2 až 3 týždne, 16 hodín denne. Pacienta edukujeme ako sa prístroj ovláda v prípade jeho odpojenia. Sestra každý deň pozoruje okolie rany, množstvo exsudátu a charakter, známky infekcie, bolest’ a teplotu v okolí rany.

Počas terapie sledujeme bolest' pacienta, funkčnost' prístroja, priliehavost' fólie na ranu, zmeny negatívneho tlaku, farbu a množstvo sekrétu a zmeny farby kože v okolí rany (Vytejčková et al., 2015).

Účinné liečenie rán zahŕňa komplexné posúdenie pacienta a rany s ciel'om určit' optimálny plán liečby rany. Pred výberom najvhodnejšej liečby pre každého pacienta je rozhodujúce identifikovat' a riešit' faktory, ktoré môžu zhoršit' hojenie rán. V súčasnosti prinieslo výhody pri hojení rán okrem podtlakovej terapie súčasne aplikácia preplachového roztoku (Gupta et al., 2016).

V nasledujúcej časti uvádzame konkrétny prípad, na ktorom ilustrujeme podtlakovú terapiu u pacienta s dehiscenciou operačnej rany.

Dehiscencia rany, čiže rozpad rany je komplikácia hojenia predovšetkým pri akútnych ranách, najčastejšie pooperačných. Dehiscencia môže byt' čiastočná alebo úplná. Príčinou sú poruchy v procese hojenia rán, reakcia na použitý materiál pri šití, metabolické poruchy, vysoký vek, prítomnost' malignity a obezity. Základom liečby je predovšetkým zvládnutie infekcie, opätovná sutura rany. Podtlaková terapia je vhodnou alternatívou úspešnej liečby.

60 ročný pacient sa 8 rokov lieči na arteriálnu hypertenziu, 30 rokov má reflexnú chorobu pažeráka, lieči sa na ischemickú choroba srdca a trombocytopéniu. Na Chirurgickú kliniku je prijatý s lekárskou diagnózou: polytraumatizmus, ileus, poranenie obličky bližšie neurčené. Má alergiu na kontrastné látky, Telebrit a Jód. Výška - 187 cm, váha - 80 kg, BMI: 22,8, utrpel autonehodu, v dôsledku ktorej bol s polytraumou hospitalizovaný 22 dní na Oddelení anestéziológie a intenzívnej medicíny. Následne bol preložený pre vzniknutý ileózny stav na Kliniku Chirurgie, kde bol hospitalizovaný 38 dní za účelom chirurgickej liečby. Po operačnom výkone došlo po 7 . dňoch $\mathrm{k}$ dehiscencii rany, kde bola následne nasadená podtlaková terapia. Po 26. dňoch bola ukončená podtlaková terapia a následne vykonaná resutura rany. Po zhojení rany bol preložený na Kliniku Urológie pre plánovanú operáciu obličky. Po tomto operačnom výkone sa operačná rana hojila per primam. Na 19. deň po operačnom výkone bol prepustený do domáceho liečenia. Od autonehody bol celkovo pacient hospitalizovaný 79 dní.

Stredná laparotómia predstavuje najväčšie riziko dehiscencie operačnej rany vo včasnom pooperačnom období. U sledovaného pacienta bol jedným z prispievajúcich faktorov k dehiscencii ileus s vysokým intraabdominálnym tlakom, ako uvádza Prochotský, Dolák a Hut'an (2015).

Prevenciou tejto komplikácie je už na operačnom stole dobre vedená anestézia dbajúca na elimináciu vysokých intraabdominálnych tlakov pri extubácii pacienta. Rizikovým pacientom sa odporúča naložit' bindu alebo vopred odmeraný brušný pás (Prochotský, Dolák a Hut'an, 2015).

\section{ZÁVER}

Pacienti s chronickými ranami predstavujú výrazný medicínsky a ošetrovatel'ský problém, Chronická rana znevýhodňuje pacienta spoločensky, zhoršuje mu kvalitu života a vo viacerých aspektoch obmedzuje. Úspešnost' terapie je závislá na viacerých faktoroch jednou $\mathrm{z}$ vhodných alternatív je využitie podtlakovej terapie. 
Príspevok vznikol s finančnou podporu projektu KEGA č. 003PU-4/2021 s názvom: Simulačné centrum starostlivosti o chronické rany.

\section{Použitá literatura}

1. HLINKOVÁ, E. et al., 2015. Nehojace sa rany. Martin: Osveta, spol. s.r.o. ISBN 978-80-8063-433-9.

2. EL-SABBAGH A. H. (2017). Negative pressure wound therapy: An update. Chinese journal of traumatology = Zhonghua chuang shang za zhi, 20(2), 103-107. https://doi.org/10.1016/j.cjtee.2016.09.004

3. GUPTA S, GABRIEL A, LANTIS J, TÉOT L. Clinical recommendations and practical guide for negative pressure wound therapy with instillation. Int Wound $\mathrm{J}$. 2016 Apr;13(2):159-74. doi: 10.1111/iwj.12452. Epub 2015 May 23. PMID: 26011379.

4. JANSSEN, A. H., MOMMERS, E. H., NOTTER, J., de VRIES REILINGH, T. S., \& Wegdam, J. A. (2016). Negative pressure wound therapy versus standard wound care on quality of life: a systematic review. Journal of wound care, 25(3), 154-159. https://doi.org/10.12968/jowc.2016.25.3.154

5. KOUTNÁ, M. 2015. Manuál hojení ran v intenzivní péči. Galén. ISBN 978-87-0492190-2.

6. PROCHOTSKÝ, A., DOLÁK, S., HUŤAN, M. 2015. Komplikácie chirurgickej liečby kolorektálneho karcinómu. In Slovenská chirurgia roč, 12., č. 1, 2015 str. 7-11 ISSN 1339-4169

7. STANLEY B. J. (2017). Negative Pressure Wound Therapy. The Veterinary clinics of North America. Small animal practice, 47(6), 1203-1220. https://doi.org/10.1016/j.cvsm.2017.06.006

8. VYTEJČKOVÁ, R. et at. 2015. Ošetřovatelské postupyv péči o nemocné III. Praha: Grada a.s. ISBN 978-80-247-3421-7.

\section{Kontaktné údaje}

PhDr. Terézia Fertal'ová, PhD.

Prešovská univerzita v Prešove, Fakulta zdravotníckych odborov

Partizánska 1, 08001 Prešov

Tel: 00421517562461

email: terezia.fertalova@unipo.sk 


\title{
VÝZNAM EDUKÁCIE O DARCOVSTVE KRVI
}

\section{THE IMPORTANCE OF BLOOD DONATION EDUCATION}

\author{
Andrea Šuličová, Andrea Obročníková, L’ubica Derňarová, Zuzana Šimová, \\ Jana Cinová, Tatiana Šantová, Zuzana Novotná, L'ubomíra Lizáková
}

\begin{abstract}
Abstrakt
Darcovstvo krvi je humánnym, nezištným a šlachetným činom. Zaslúži si najvyššie morálne uznanie. Má nezastupitel'nú úlohu v záchrane života a v liečbe chorých. Nemocnice túto hodnotnú tekutinu získavajú jedine od dobrovol'ných darcov. Ciel'om príspevku je poukázat' na význam a nenahraditel'nost' darcovstva krvi, oslovit' potenciálnych darcov krvi, a posilnit' a rozš́írit’ tak darovaciu základňu ako aj rady darcov.
\end{abstract}

Kl'účové slová: darcovstvo krvi, hemoterapia, transfúzia, krvné prípravky, edukácia

\begin{abstract}
Blood donation is a humane and selfless and act. He deserves the highest moral recognition. It has an irreplaceable role in saving lives and treating the sick. Hospitals obtain this valuable fluid only from voluntary donors. The aim of the paper is to point out the importance and irreplaceability of blood donation, to address potential blood donors, and to strengthen and expand both the donation base and the advice of donors.
\end{abstract}

Key Word: blood donation, hemotherapy, transfusion, blood preparations, education

\section{VÝZNAM HEMOTERAPIE}

Krv a jej súčasti možno využit' ako liečebný prostriedok, ktorý nahrádza chorému jej nedostatok následkom choroby alebo škodlivého vplyvu z vonkajších príčin. Môže sa jednat' o nedostatok krvi ako celku, nedostatok jej zložiek, látok potrebných na zrážanie krvi, obranných alebo iných bielkovín, príp. iných látok potrebných na zvládnutie ochorenia alebo jeho komplikácií (1). Riešením všetkých zložitých otázok hemoterapie sa zaoberajú špecialisti - hematológovia a transfuziológovia, ale základné zásady zlučitel'nej, úspešnej a bezpečnej hemoterapie musí ovládat' každý lekár a sestra, pretože od úspešnej transfúzie často závisí pacientov život. Celá transfuziológia je úzko spojená s kl'účovou postavou - s darcom krvi a so zdravotnými otázkami súvisiacimi s darcovstvom krvi (2).

Ak zdravým mladým l'udom nepomôžeme nájst' cestu do transfúznych staníc, stále sa budeme pasovat's nedostatkom krvi pre chorých. Liečba krvou a jej komponentmi v plnej miere závisí od dobrovol'níkov ochotných darovat' krv. Definíciu bezpríspevkového darovania krvi sformulovala Liga spoločnosti Červeného kríža a Červeného polmesiaca: Bezpríspevkoví dobrovol'ní darcovia krvi (BDK) sú takí, ktorí darujú krv, plazmu alebo d’alšie súčasti krvi zo svojej vlastnej vôle, bez toho, aby za to dostali odmenu vo finančnej forme alebo iného zisku, čo môže byt' považované za ekvivalent peňazí (napríklad čas pracovnej doby presahujúci čas potrebný na odber a cestu tam aj spät'. Princíp bezpríspevkového darcovstva spočíva v tom, že len darca, ktorý nie je motivovaný finančnou odmenou, je z hl'adiska moderného poňatia transfúznej služby dostatočne bezpečný (3). 


\subsection{Výber darcov krvi}

Hlavnou zásadou pri odbere krvi od darcu je zabránit' prenosu infekčných chorôb cestou transfúzií. Nebezpečenstvo prenosu infekčných agens sa minimalizuje výberom vhodných darcov a vyšetreniami odobratej krvi pri každom odbere. Na samotné darovanie krvi by sa mal darca pripravit'. Má byt oddýchnutý, má zvýšit' príjem tekutín a nemá byt' hladný. Stačia l'ahké raňajky (pečivo, chlieb, ovocie a pod.) Potraviny s vysokým obsahom tuku a alkoholické nápoje treba vylúčit' a najmenej 12 hodín pred odberom nefajčit'. Pri príchode na transfúzne oddelenie darca predloží občiansky preukaz, preukaz poistenca a legitimáciu darcu. Pred každým odberom krvi alebo zložky krvi sa uskutočňuje rozhovor s darcom, pri ktorom sa mu vysvetlí význam dobrovol'ného a bezpríspevkového darovania krvi. Vyplní „, Dotazník pre darcu krvi“, ktorým poskytuje transfúziologickému zariadeniu potrebné informácie, pričom ochrana osobných údajov darcu musí byt' samozrejmost'ou. Pred lekárskou prehliadkou sa mu odoberie krv na krvný obraz a na vyšetrenie alanínaminotransferázy (ALT) (4).

U darcu nie je potrebné vykonat' kompletnú lekársku prehliadku. Je možné spol'ahnút' sa na anamnézu a celkové objektívne vyšetrenie. Súčast'ou prehliadky je okrem interného vyšetrenia, kontroly telesnej teploty (nemá presahovat' $37{ }^{\circ} \mathrm{C}$ ), merania krvného tlaku (hodnoty nemajú presahovat' 180/100 $\mathrm{mm} \mathrm{Hg}$ ), posúdenia základného krvného obrazu (u mužov majú byt' hodnoty hemoglobínu aspoň $135 \mathrm{~g} / \mathrm{l}$, u žien $125 \mathrm{~g} / \mathrm{l})$, hlavne pohovor a posúdenie odpovedí darcu v uvedenom dotazníku. Otázky sú zamerané na jeho zdravotný stav, prekonané ochorenia, rizikové správanie a užívanie liekov. Dotazník sa inovuje každý rok, pričom sa vychádza $\mathrm{z}$ aktuálnych pokynov Rady Európy a Svetovej zdravotníckej organizácie. Podstatné je, aby v rámci anamnézy lekár získal od darcu pravdivé odpovede. Všetci darcovia majú byt patrične poučení o možných následkoch pri udaní nepravdivých odpovedí. Pred každým odberom podpisujú informovaný súhlas. Darca sa môže aj sám vylúčit' z darcovstva po zvážení svojho stavu. $\mathrm{K}$ tomu slúžia na to určené informačné materiály, ktoré si môže preštudovat' pred odberom.

Darcu krvi je možné dočasné alebo natrvalo vylúčit' z darcovstva krvi. Dôvody presne definujú predpisy transfúznej služby. Muži môžu darovat' krv maximálne 4-krát do roka s minimálnym odstupom dvoch mesiacov medzi dvoma odbermi. Ženy môžu darovat' krv maximálne 3-krát do roka s minimálnym odstupom troch mesiacov medzi dvoma odbermi. Po odbere celej krvi je možné uskutočnit' odber trombocytov alebo plazmy už o jeden mesiac. Hmotnost' darcu musí byt aspoň 50 kilogramov. Odbery krvi sa vykonávajú u osôb od 18 rokov s hornou hranicou 60 - 65 rokov so súhlasom lekára, darovat' môže aj osoba nad 17 rokov so súhlasom zákonného zástupcu. Odbery krvi sa vykonávajú na pracoviskách Národnej transfúznej služby alebo formou výjazdov za darcami mobilnými odberovými jednotkami, ktoré sú mimoriadne oblúbené a poskytujú im rôzne výhody (darovanie $\mathrm{v}$ im známom prostredí bez nutnosti cestovania a straty času, podpora kolegov a priatel'ov na mieste a pod.) (5).

\subsection{Proces odberu krvi pri darovaní krvi}

Pri bežnom odbere sa darcovi odoberie krv alebo niektorá čast' krvi. Odber sa vykonáva uzavretým spôsobom do plastového vaku. Osoba, ktorá dozerá na odber je zodpovedná za správnu identifikáciu darcu, dokumentáciu, označenie krvného vaku a skúmaviek na laboratórne vyšetrenia a kontrolu kvality. Obvykle sa odoberá 450 +/- $10 \mathrm{ml}$ krvi. Zvyčajne odber trvá cca 10 minút. Odobratá krv sa prenáša do spracovatel'skej časti transfúzneho oddelenia. Celý proces je registrovaný pod identifikačným kódom, ktorý sa darcovi pridelí na začiatku a ktorým je označený dotazník, evidenčná karta, skúmavka na laboratórne vyšetrenia, odberový vak a satelitné vaky $(5,8)$. 


\subsection{Trvalé a dočasné kontraindikácie darovania krvi}

$\mathrm{Z}$ darcovstva krvi sa trvalo vyrad'ujú osoby, ktoré v anamnéze uvádzajú ochorenia:

- syfilis (získaný, vrodený),

- všetky formy TBC,

- vírusový zápal pečene, nosičstvo HbsAg,

- choroby srdcovo-cievneho systému,

- chronické choroby GIT-u,

- poruchy metabolizmu a výživy (diabetes mellitus),

- alergické choroby (astma, alergický ekzém),

- malária a iné tropické choroby,

- zoonózy,

- choroby obličiek,

- choroby krvi a získané či vrodené krvácavé ochorenia,

- choroby pečene a pankreasu,

- nádory s výnimkou dokázaných benígnych nádorov,

- stavy po vel'kých operáciách (napr. resekcia žalúdka),

- organické ochorenia (epilepsia),

- duševné choroby,

- generalizované generatívne zápalové choroby kože,

- ochorenia a zväčšenie sleziny,

- opakované kolapsy po odbere,

- homosexuálne, bisexuálne a promiskuitné žijúce osoby, osoby s podozrením na

- AIDS, nosiči vírusu HIV,

- osoby, ktoré sa v minulosti liečili extraktom z l'udskej hypofýzy.

K dočasným kontraindikáciám darovania krvi patrí:

- gravidita a obdobie dojčenia - odber možný najskôr po 12 mesiacoch po normálnom pôrode a 3 mesiace po ukončení dojčenia,

- menštruácia - odber možný 2 dni pred ňou a 3 dni po nej,

- l'ahko prebiehajúce horúčkovité ochorenia (chrípka, angína, zápaly HDC) - odber možný po 1 týždni od uzdravenia,

- transfúzia krvi - odber možný po 12 mesiacoch,

- parazitárne choroby,

- akútne a subakútne zápalové procesy,

- kontakt s osobou na vírusovú hepatitídu - odber možný po 12 mesiacoch pri negatívnych výsledkoch,

- pobyt v trópoch a subtrópoch - odber možný po 6 mesiacoch,

- očkovanie (aktívna a pasívna imunizácia - odber sa môže uskutočnit’ 4 - 6 týždňov po očkovaní),

- väčšia strata hmotnosti za posledné 3 mesiace,

- malý chirurgický zákrok (prietrž, apendektómia, tonzilektómia) - odber možný po 6 mesiacoch,

- darcovia, ktorí sú pred odberom pod vplyvom alkoholu a iných drog (6).

\subsection{Vyšetrenia po odbere krvi}

Po odbere sa vyšetrí krvná skupina (KS) AB0 a Rh (D) a vykoná sa skríning nepravidelných antierytrocytových protilátok. V záujme prevencie prenosu infekčných ochorení sa povinne urobia tieto vyšetrenia v každej jednotke odobratej krvi HbsAg, anti-HCV, anti-HIV $1+2$, protilátky proti Treponema pallidum - ich prítomnost' svedčí o prekonanom či prebiehajúcom syfilise, ALT - enzým alanínaminotransferáza (jeho zvýšená hodnota svedčí o poškodení pečene), anti-CMV - protilátky proti cytomegalovírusu, ich prítomnost' svedčí o prekonanej 
či prebiehajúcej infekcii (2). Ak je ktorýkol’vek z uvedených testov pozitívny, krv sa nesmie použit' na transfúziu a darca je trvale vyradený z darovania krvi.

Motto „daruj krv, zachrániš život“ platí len symbolicky. V skutočnosti sa na záchrane jedného l'udského života podiel'ajú desiatky až stovky darcov krvi. Darovat' vlastnú krv na záchranu iného (často neznámeho) človeka je vysoko mravný a humánny skutok. Zaistenie dostatočného množstva krvi a krvných produktov podstatne znižuje životné riziká všetkých občanov, lebo platí, ráno som darca - večer môžem byt' príjemca. Nemocnice zápasia $\mathrm{s}$ nedostatkom krvi, pribúda počet pacientov, ktorým je t’ažko vybrat' vhodnú krv, následkom čoho často dochádza k posunu plánovaných operácií.

\section{PRIESKUM INFORMOVANOSTI U POTENCIÁLNYCH DARCOV O DARCOVSTVE KRVI}

Zist’ovali sme úroveň vedomostí a informácií študentov maturitných ročníkov o problematike darcovstva krvi. Našim hlavným ciel'om bolo zistit' mieru ich informovanosti o darcovstve krvi, ich vedomosti o význame a podmienkach za akých môžu darovat' krv, zistit' aké sú ich skúsenosti v súvislosti s darovaním krvi a vzbudit' záujem študentov o darovanie krvi. Na základe výsledkov prieskumu sme zrealizovali edukačné stretnutie so študentmi stredných škôl a doplnili a rozšírili ich vedomosti o darcovstve krvi. Použili sme dotazník, ktorý bol zároveň vstupným vedomostným monitoringom realizovaným pred edukáciou. Poslúžil nám taktiež na porovnanie úrovne vedomosti pred a po realizovanej edukácí́.

\subsection{Opodstatnenost’ edukácie vyplývajúca zo zistených nedostatkov.}

$\mathrm{V}$ rámci posúdenia pred samotnou edukáciou sme realizovali už spomínaný prieskum, ktorý nám poskytol cenné informácie o vedomostnej úrovni študentov. $Z$ vyhodnotenia dotazníka vyplývalo, že celková informovanost' mladých l'udí o problematike darcovstva krvi je nedostatočná. Ved' už samotný fakt, že len $13 \%$ respondentov si uvedomuje nedostatok darcov krvi a $\mathrm{z}$ toho vyplývajúci deficit krvi v nemocniciach je zarážajúci. Až $70 \%$ respondentov plánuje stat' sa darcom krvi, 14\% študentov uviedlo, že neplánuje darovat' krv. Avšak 16\% respondentov sa touto otázkou nezaoberalo, preto je potrebné vynaložit' úsilie, aby ich názor na darovanie krvi bol pozitívny. Až 40\% respondentov nemá žiadne skúsenosti s darovaním krvi. 10\% respondentov nemá dostatok vedomosti týkajúcich sa ochorenia a následného darovania krvi po ochorení. Len $20 \%$ respondentov má poznatky o tom, aké množstvo krvi sa odoberá pri bežnom odbere. V dotazníku bola aj otázka týkajúca sa estetických úprav na tele, ako napr. tetovanie alebo piercing. Opýtali sme sa respondentov, či vedia po akom čaše po absolvovaní takýchto úprav môžu darovat' krv a polovica respondentov odpovedala správne. Druhá polovica respondentov nepoznala správnu odpoved'. Po vyhodnotení dotazníka sme sa utvrdili o nevyhnutnosti realizovat' edukačné stretnutie na túto tému. Pre správne pochopenie stanoveného problému je nutné, aby mladí l'udia vedeli o potrebe darovania krvi, o podmienkach za akých sa môžu stat' darcami krvi.

Študenti po absolvovaní edukácie pochopili význam darovania krvi, prekonali aj strach z ihiel, prišli darovat' najvzácnejšiu tekutinu - krv, v rámci Valentínskej kvapky krvi. Po prvý a pevne veríme, že nie posledný krát prekročili prah hematologicko-transfúzneho oddelenia, stali sa bezpríspevkovými darcami krvi a posilnili tak rady dobrovol’ných darcov (7).

\section{ZÁVER}

V súčasnosti, ked' zdravotníckym zariadeniam často chýba krv, by prvoradou úlohou mala byt výchova $\mathrm{k}$ darcovstvu. Ak sa podarí det'om a mládeži vštepit' dôležitost' myšlienky pomáhat' iným, perspektívne sa dosiahne nielen iný pohl'ad na darcovstvo krvi, ale aj zvýšenie morálnej podpory l'ud'om ochotným poskytovat' dar najcennejší - krv. Chceme upriamit' pozornost' na 
neustále stúpajúcu potrebu krvi a zároveň skutočnost', že $v$ mladých l'ud'och je vel'ký potenciál novej darcovskej základne.

\section{Použitá literatúra}

1. ADAM, Z., VORLIIČEK, J. a kol. Hematologie. Praha: Grada, 2010. 390 s. ISBN 80-247-0116-2.

2. KUBISZ, P. a kol. 2006. Hematológia a transfuziológia. 1 vyd. Bratislava: Grada Slovakia, spol. s.r.o. 2006. 324s. ISBN 80-8090-000-0.

3. FÁBRYOVÁ, V. 2011. Výhody a nevýhody transfúznej liečby. In Revue mediciny v praxi. ISSN 1336-202X, 2011, roč. 9, c. 4, s. 8-10.

4. ČERNÁKOVÁ, G., GASPEROVÁ, N. Darcovstvo krvi a nábor darcov. In Sestra. 2005. ISSN 1335-9444, roč. IV, c. 4, s. 38-40.

5. FÁBRYOVÁ, V. 2011. Súčasný pohl'ad na darcovstvo krvi. In Revue medicíny $v$ praxi. ISSN 1336-202X, roč. 9, c. 6, s. 5-8.

6. SAKALOVÁ, A., BÁTOROVÁ, A., MISTRÍK, M., HRUBIŠKO, M. a kol. Klinická hematológia. Martin: Osveta, 2010. 295 s. ISBN 978-80-8063-324-0.

7. PRISTAŠOVÁ, M. Ošetrovatel'stvo $v$ kontexte $s$ darcovstvom krvi. Prešovská univerzita v Prešove, Fakulta zdravotníckych odborov. 2012. $42 \mathrm{~s}$.

8. FABRYOVÁ, V., CUPANÍKOVÁ, D., SVITEKOVÁ, K. Knižka o krvi pre darcov a pacientov. 2013. Samedi, s.r.o. 67 s. ISBN 978-80-970825-4-3

\section{Kontakt}

PhDr. Andrea Šuličová, PhD.

Prešovská univerzita v Prešove

Fakulta zdravotníckych odborov

Partizánska 1, 08001 Prešov

Email: andrea.sulicova@unipo.sk 


\title{
VYŠETRENIE REZIDUÁLNEJ REAKTIVITY TROMBOCYTOV A JEHO VÝZNAM PRI ISCHEMICKEJ CIEVNEJ MOZGOVEJ PRÍHODE
}

\author{
RESIDUAL PLATELET REACTIVITY TESTING AND ITS \\ IMPORTANCE IN ISCHEMIC STROKE
}

\author{
Katarína Pinčáková, Viktória Mikulášková, Vladimír Bošák
}

\begin{abstract}
Abstrakt
Cievna mozgová príhoda je dlhodobo jednou z vedúcich príčin celosvetovej mortality dospelej populácie. Napriek medikamentóznej sekundárnej prevencii však u značného množstva pacientov dochádza $\mathrm{k}$ recidíve ischemického iktu, ktorý je $\mathrm{v}$ porovnaní $\mathrm{s}$ incidentným iktom navyše častokrát spojený s t'ažším neurologickým deficitom a vyšším stupňom krátkodobej funkčnej nezávislosti. Jedným $\mathrm{z}$ hlavných dôvodov zlyhania sekundárnej prevencie ischemickej cievnej mozgovej príhody je nízka odpovedavovat' pacientov na protidoštičkovú liečbu, známa aj ako reziduálna reaktivita trombocytov. Jej príčinou môžu byt' extrinsické (znížená absorbcia a biotransformácia liečiva, poddávkovanie) a intrinsické faktory (genetická variabilita), ako aj noncompliance pacienta. Detekcia reziduálnej reaktivity trombocytov je aktuálne možná vyšetrením funkcie trombocytov.
\end{abstract}

Kl'účová slová: ischemická cievna mozgová príhoda, protidoštičková liečba, reziduálna reaktivita trombocytov

\begin{abstract}
A stroke has been one of the leading causes of an adult population mortality worldwide for a long time. Despite of a drug-based secondary prevention, at a considerable amount of patients there is a recurrence of an ischemic stroke. Moreover, in comparison with an incident stroke it is many times associated with a severe neurological deficit and a higher level of a shortterm functional independence. One of the main reasons of secondary prevention failure of ischemic stroke is the patients' low response for antiplatelet therapy also knows as a residual platelet reactivity. It can be caused by an extrinsic (reduced absorption and a drug biotransformation, underdosing) and an intrinsic factors (genetic variability) but also a noncompliance of a patient. Currently, the residual platelet reactivity detection is possible thanks to a platelet functions examination.
\end{abstract}

Key words: ischemic stroke, antiplatelet therapy, high on-treatment platelet reactivity

\section{1 ÚVOD}

Náhla cievna mozgová príhoda (CMP) je celosvetovo druhou najčastejšou príčinou mortality, pričom s jej následkami žije viac ako 80 miliónov l'udí. U viac ako $20 \%$ zanechá CMP aj t’ažkú trvalú invaliditu, čím sa stáva vôbec najčastejšou príčinou invalidity, predovšetkým u staršej populácie. Individuálny, sociálny a v neposlednom rade ekonomický dopad CMP je enormný. Ekonomický význam tohoto ochorenia dokladá aj fakt, že len v krajinách Európskej únie sa v roku 2017 odhadovali priame a nepriame náklady spojené s poskytovaním zdravotnej starostlivosti pacientom s CMP na 45 biliónov EUR. Súhrnne môžeme konštatovat', že CMP predstavuje ochorenie $\mathrm{s}$ jedným $\mathrm{z}$ najväčších zdravotníckych a socioekonomických dopadov na spoločnost' (1). Podl'a údajov z roku 2016 je každoročne na 
svete diagnostikovaných takmer 14 miliónov prípadov CMP, z čoho vyše $80 \%$ tvorí ischemická cievna mozgová príhoda (iCMP) (2). Náhla iCMP je nesmierne heterogénnym ochorením, a to ako podl'a príčiny, tak podla priebehu. V súčasnosti radíme medzi tri najčastejšie etiopatogenetické príčiny aterotrombózu (40\% až 57\%), tromboembolizmus (16\% až $23 \%$ ) a oklúziu malých tepien (14\%), ktoré sa podiel'ajú na etiopatogenéze u približne $80 \%$ pacientov s mozgovou ischémiou (3). Zistenie etiológie iCMP je esenciálne nielen pre špecifikáciu liečby akútnej fázy iktu, ale hlavne pre výber adekvátnej sekundárnej prevencie znižujúcej riziko recidívy iktu až o $28 \%$. Riziko recidívy nie je u všetkých pacientov po incidentnom ikte rovnaké. Je závislé na veku, prítomnosti rizikových aterogénnych faktorov, stupni stenózy magistrálnych artérií, hypertenzie a d’alších konkomitujúcich ochorení. Aj napriek pokrokom v liečbe iCMP tak viaceré štúdie demonštrujú práve dôležitost' sekundárnej prevencie, vrátane protidoštičkovej terapie $\mathrm{v}$ prvých týždňov po prekonaní iktu, ktoré je $\mathrm{v}$ tomto období najvyššie. V posledných desat'ročiach sa však čoraz častejšie stretávame $\mathrm{s}$ interindividálnou variabilitou $\mathrm{v}$ odpovedi pacientov na protidoštičkovú liečbu. Ide o nedostatočnú odpoved', tzv. reziduálnu reaktivitu trombocytov, ktorá je významným rizikovým faktorom recidívy ischemickej CMP (4). Predkladaný príspevok pokytuje komplexný pohl'ad na patogenézu iCMP, farmaká používané aktuálne $\mathrm{v}$ sekundárnej prevencii a problematiku reziduálnej reaktivity trombocytov, vrátane aktuálnych prástupov jej riešenia $\mathrm{v}$ klincikej praxi.

\subsection{Patogenéza ischemickej cievnej mozgovej príhody}

Hlavnou príčinou aterotrombotického subtypu iCMP je ateroskleróza - pomaly progredujúce multifaktoriálne ochorenie artérií. K rozvoju iCMP dochádza akútne, pri ruptúre nestabilného aterosklerotického plátu alebo chronicky, zúžením lumenu postihnutej artérie. Aterosklerotické lézie nie sú rozložené náhodne, sú lokalizované v určitých predilekčných miestach. Najčastejšie je postihnutá bifurkácia arteria carotis communis, karotický sifón a M1 úsek arteria cerebri media (5). Na základe aktuálnych experimentálnych dôkazov sa za hlavných iniciátorov aterosklerózy pokladajú trombocyty. Iniciujú vznik aterosklerotických lézií na endotele, podporujú ateroprogresiu a sú kl'účové pri vzniku aterotrombózy vedúcej k iCMP. Za fyziologických podmienok bráni adhézii trombocytov $\mathrm{k}$ cievnej stene intaktný, neaktivovaný endotel. V zápalových podmienkach však dokážu trombocyty adherovat' aj $\mathrm{k}$ intaktnej, aktivovanej vrstve endoteliálnych buniek. V prípade aktivácie trombocytov je navyše možná adhézia i k neaktivovanému endotelu. Adhézia trombocytov na endotel mení aktivačný a zápalový potenciál endotelových buniek. V predilekčných miestach aterosklerózy adherujú trombocyty k intaktnému endotelu, čo je vyvolané turbulentným krvným prietokom. Uvedený proces má niekol'ko krokov, vrátane prichytenia trombocytov, ich rolovania po endotelovej vrstve a finálnej pevnej adhézii. Tieto procesy sú závislé na interakciách selektínov, integrínov a imunoglobulínových receptorov, vedúcich $\mathrm{k}$ receptor-špecifickým aktivačným signálom, ako u trombocytov, tak i u partnera ich cell-to-cell interakcie. Výsledkom je iniciácia formácie aterosklerotického zápalového ložiska a akumulácia lipidov (3). Reaktivita trombocytov je ovplyvnená početnými klinickými faktormi, vrátane diabetes mellitus, dyslipidémie, zvýšeného BMI, renálneho zlyhania a vyššieho veku, ktoré zároveň predstavujú rizikové faktory vzniku iCMP. Pozornost' vedeckej sféry sa momentálne zameriava na zistenie, že trombocyty môžu prispievat' ako $\mathrm{k}$ včasnej, tak i $\mathrm{k}$ pokročilej aterotrombóze, prostredníctvom väzby, pohltenia a transportu modifikovaných lipoproteínov. Príčinou sú pozorované abnormality $\mathrm{v}$ zložení a funkcii trombocytov, vrátane hyperagregability, u pacientov s hypercholesterolémiou. Interakcia lipidov s trombocytmi ovplyvňuje nie len aktiváciu trombocytov, ale aj ich apoptózu a d’alšiu asociáciu s monocytmi/makrofágmi. Teóriu o ovplyvnení vlastností trombocytov cirkulujúcimi lipoproteíny podporuje aj fakt, že aplikácia liečiv znižujúcich hladinu lipidov znižuje 
reaktivitu trombocytov. Doposial' bolo publikovaných množstvo štúdií spájajúcich zvýšenú systémovú aktiváciu trombocytov a ich hyperreaktivitu s nepriaznivou klinickou prognózou a progresiou ochorenia koronárnych artérií. Komplexné štúdie zamerané na cerebrovaskulárne ochorenia stále chýbajú (6).

\section{PROTIDOŠTIČKOVÁ LIEČBA}

Protidoštičková liečba je podla aktuálnych odporúčaní základným stavebným kameňom sekundárnej prevencie recidívy všetkých subtypov iCMP, s výnimkou kardioembolického subtypu. Jej účinok je dôsledkom schopnosti protidoštičkových liečiv blokovat' funkcie trombocytov na rôznych stupňoch. Ciel'om inhibície môžu byt' mechanizmy podiel'ajúce sa na aktivácii, adhézii, agregácii trombocytov či mechanizmy uvol'ňovania substancií podporujúcich agregáciu. Protidoštičková liečba je tak účinná najmä v prevencii vzniku arteriálnych trombov bohatých na trombocyty. Dôležitými aspektmi sekundárnej prevencie iCMP sú vhodný výber, správne dávkovanie a adekvátne načasovanie terapie po incidentnom ikte (7). V klinickej praxi sa aktuálne používa najmä kyselina acetylsalicylová, klopidogrel a tikagrelor.

\subsection{Kyselina acetylsalicylová}

Kyselina acetylsalicylová (ASA) je najvýznamnejším predstavitel'om inhibítorov cyklooxygenázy-1 (COX-1). Podstatou účinku ASA je schopnost' inaktivácie cyklooxygenázovej aktivity enzýmov PGH-syntáza-1 (PGHS-1) a PGHS-2, známych aj ako COX-1 a COX-2. Tieto izoenzýmy za fyziologických okolností katalyzujú prvý krok biosyntézy prostanoidov, konverziu kyseliny arachidónovej na prostagladnín H2 (PGH2). PGH2 je prostaglandínov PGD, PGE, PGF, prostacyklínu I2 a tromboxánu A2 (TXA2). V aktivácii trombocytov je významný najmä TXA2, a to silným proagregačným a vazokonstrikčným účinkom. Molekulárny mechanizmus ireverzibilnej COX aktivity aspirínom spočíva $\mathrm{v}$ blokácii COX kanálu v dôsledku acetylácie hydroxylovej skupiny serínového rezidua (Ser529 pre COX-1, Ser516 pre COX-2). Substrát tak stráca prístup k aktívnemu miestu enzýmu. Vzhl’adom na fakt, že trombocyty, ako bezjadrové bunky nedokážu syntetizovat' vlastnú COX-1, je inhibícia aspirínom ireverzibilná a trvá počas celého životného cyklu trombocytov (sedem až desat' dní). K acetylácii COX-1 dochádza už v megakaryocytoch, čo znamená, že každodenne je $10 \%$ až $12 \%$ cirkulujúcich trombocytov nahradených novými, už inhibovanými trombocytmi. K obnoveniu TXA2-dependentných funkcií postačuje približne $20 \%$ trombocytov, ktoré nie sú blokované ASA. Pri prerušení užívania dochádza k obnove funkcií trombocytov do dvoch až troch dní. Vd'aka rýchlej pasívnej difúzii sliznicou žalúdka a tenkého čreva je inhibičný efekt TXA2-dependentných funkcií trombocytov laboratórne detekovatel'ný približne po hodine. Biologická dostupnost' klasických orálne užívaných tabliet varíruje od $40 \%$ do $50 \%$, v závislosti od dávky ASA Optimálna dávka $\mathrm{v}$ sekundárnej prevencii ASA bolo dlhodobo predmetom mnohých odborných debát. Súčasné odporúčania z roku 2018 preferujú na základe záverov klinických štúdií začat' sekundárnu prevenciu podaním 160 až 300 mg ASA. Táto, tzv. loadovacia dávka sa má podat' v čase od 24 do 48 hodín od vzniku iCMP. Bežná denná dávka ASA v následnej monoterapii, ktorá dokáže inhibovat' COX-1-dependentné funkcie trombocytov, predstavuje 75 až $150 \mathrm{mg}$ jedenkrát denne. Vzhl'adom na dostupnost' stomiligramových tabliet predstavuje štandardná dávka ASA v sekundárnej prevencii iCMP na Slovensku $100 \mathrm{mg}$ $(8,9)$.

\subsection{Klopidogrel}

Klopidogrel je predstavitel'om druhej generácie tienopyridínov. Tienopyridíny sa radia medzi selektívne inhibítory purinergných P2Y12 receptorov membrány trombocytov. Patria medzi 
tzv. prodgrugy, ktoré sú inaktívne in vitro a svoju protidoštičkovú aktivitu získavajú až po metabolickej aktivácii in vivo. Po absorpcii klopidogrelu $\mathrm{v}$ črevnom trakte je jeho biotransformácia je lokalizovaná $\mathrm{v}$ pečeni. Účinný aktívny metabolit klopidogrelu vzniká dvojkrokovou oxidáciou systémom cytochrómu P450. Výsledkom prvej oxidácie je 2-oxoklopidogrel, ktorého 2-oxo-thiofénový kruh sa po druhej oxidácii otvára a odhal'uje vol'nú thiolovú a karboxylovú skupinu. Medzi thiolovou skupinou aktívneho metabolitu a extracelulárnym cysteínovým reziduom P2Y12 receptora sa formuje disulfidický mostík, ktorý irreverzibilne modifikuje väzbové miesto pre ADP. Výsledkom je nielen inhibícia ADPdependentnej aktivácie GPIIb/IIa, ale aj inhibícia agregácie trombocytov indukovanej niektorými d'alšími agonistami. Uvedený jav vzniká supresiou amplifikačného efektu, ku ktorému za fyziologických okolností dochádza po uvol’není ADP z $\delta$-granúl trombocytov. Podobne ako u ASA, pretrváva protidoštičkový účinok klopidogrelom inhibovaných trombocytov počas celého životného cyklu. Pre dosiahnutie normálnej funkcie primárnej hemostázy je potrebné prerušit' liečbu klopidogrelom minimálne na pät' dní. K signifikantnej inhibícii ADP-dependentnej agregácie trombocytov dochádza pri $40 \%$ až $60 \%$ inhibícii P2Y12 receptorov. Účinná hladina sa pri odporúčanom dennom dávkovaní (75 mg) vzhl’adom na potrebu metabolickej aktivácie dosahuje po štyroch až piatich dňoch. Pre rýchly nástup účinku a aktuálnu dostupnost' $75 \mathrm{mg}$ tabliet sa pri začatí sekundárnej prevencie využíva podanie $375 \mathrm{mg}$ loadovacej dávky. Plný protidoštičkový účinok sa pri uvedenom postupe dostaví do dvoch až piatich hodín $(10,11)$.

\subsection{Tikagrelor}

Tikagrelor je prvým z triedy cyklopentyltriazolopyrimidínov, ktoré rovnako ako tienopyridíny radíme medzi antagonistov $\mathrm{P} 2 \mathrm{Y} 12$ receptorov. Dlho sa predpokladalo, že na rozdiel od tienopyridínov sa tikagrelor viaže v mieste odlišnom od väzbového miesta pre ADP. Zistenia najnovších štúdií však podporujú teóriu prekrývania sa uvedených väzbových miest na P2Y12 receptoroch. Zároveň poukazujú na schopnost' tikagreloru inhibovat' absorpciu molekúl adenozínu erytrocytmi sprostredkovanú ekvilibratívnym nukleozidovým transportérom 1 (ENT-1). Reverzibilná inhibícia ADP-dependentnej agregácie trombocytov tikagrelorom je tak ovel'a komplexnejšia a je amplifikovaná jeho prídavnými funkciami. Tikagrelor je priamo aktívnym liekom, avšak systémom cytochrómu P450 sa môže d'alej konvertovat' na trojnásobne účinnejší aktívny metabolit. Vzhl'adom na pomerne krátky plazmatický polčas (6 až 8 hodín) je na rozdiel od ASA a klopidogrelu potrebné užívanie $90 \mathrm{mg}$ dávky dvakrát denne. Po užití loadovacej dávky $(180 \mathrm{mg})$ sa maximálna plazmatická koncentrácia ako aj laboratórne detekovatel'ný inhibičný efekt sa dosahuje po dvoch hodinách. K úplnému klírensu tikagreloru, jeho metabolitu a obnoveniu funkcií krvných doštičiek dochádza za 48 hodín od prerušenia užívania (12). $\mathrm{Na}$ porovnanie efektivity tikagreloru a aspirínu $\mathrm{v}$ sekundárnej prevencii trombotických udalostí sa zamerala klinická štúdia SOCRATES. Štúdia síce nepotvrdila vyššiu účinnost' tikagreloru $(180 \mathrm{mg}$ loadovacia dávka nasledovaná $90 \mathrm{mg}$ dennou dávkou) oproti ASA (300 mg loadovacia dávka nasledovaná 100 mg dennou dávkou), avšak výskyt nežiaducich účinkov bol v oboch ramenách porovnatel'ný. Vo výnimočných prípadoch tak môže byt' tikagrelor podl'a aktuálnych guidelinov vhodnou alternatívou sekundárnej prevencie pri kontraindikácii užívania ASA. V súčasnosti je však na jeho použitie pre tieto účely nutné schválenie úhrady poist'ovňou (8).

\section{REZIDUÁLNA REAKTIVITA TROMBOCYTOV}

Riziko rekurencie iCMP sa $\mathrm{v}$ prvých dvoch týždňoch od prekonania incidentného iktu pohybuje od 5\% do 11,7\%. Niekol'ko významných klinických štúdií, vrátane štúdií CHANCE a POINT, poukázalo na $28 \%$ až 33\% redukciu rizika rekurencie iCMP v prípade, že sa do 24 hodín od incidentného iktu začne užívat' kombinácia ASA a klopidogrelu - tzv. duálna 
protidoštičková liečba (DAPT). Po zvážení pomeru benefitu a rizika odporúčajú aktuálne guideliny krátkodobé užívanie DAPT počas nasledujúcich 10 až 21 dní. Po ukončení DAPT by malo nasledovat' dlhodobé uživanie ASA alebo klopidogrelu v monoterapii $(9,13)$. Uvedený synergizmus medzi tienopyridínmi a aspirínom je odôvodnený faktom, že každé z týchto liečiv samostatne inhibuje jednu $\mathrm{z}$ dvoch najvýznamnejších fyziologických dráh vedúcich $\mathrm{k}$ amplifikácii aktivácie trombocytov - cestu ADP a cestu kyseliny arachidónovej/TXA2. V porovnaní s individuálnym účinkom tak DAPT ovel'a silnejšie inhibuje agregáciu trombocytov a formáciu patologického trombu. Najväčší problém $\mathrm{v}$ súčasnosti predstavujú pacienti, u ktorých sa vyvinie recidíva iCMP aj napriek užívaniu protidoštičkovej liečby. Ku zhruba $75 \%$ všetkých recidív iCMP dochádza počas prvých dvoch týždňov od incidentného iktu. Užívanie DAPT je kl'účovou a efektívnou stratégiou na zníženie vyššie uvedeného rizika, ktoré eliminuje o približne 30\%. Nedostatočná odpoved' na DAPT je významným rizikovým faktorom recidív ischemických príhod, vrátane iCMP (14). Nedostatočná odpoved' trombocytov na ASA a klopidogrel je definovaná ako reziduálna reaktivita trombocytov (HTPR - High On-Treatment Platelet Reactivity). V literatúre sa často stretávame s označením „rezistencia“. HTPR v skutočnosti nezodpovedá skutočnej farmakologickej rezistencii - ide o interindividuálnu odpoved' pacientov na protidoštičkovú liečbu. V praxi je však tento pojem často používaný a umožňuje definíciu klinickej rezistencie, kedy dochádza $\mathrm{k}$ recidíve iCMP aj napriek svedomitému užívaniu protidoštičkových liečiv, a laboratórnej rezistencie, ktorá odhal'uje nedostatočne inhibované funkcie trombocytov pomocou rôznych testovacích systémov. Negatívom sú nejednotné cutoff hodnoty pre používané testovacie systémy, čo vytvára potrebu d’alšej štandardizácie (15). Príčiny HTPR zahŕňajú ako extrinsické faktory (napr. absorbcia, biotransformácia, liekové interakcie, poddávkovanie, zvýšený obrat trombocytov) tak i intrinsické faktory (denzita a afinita P2Y12 receptorov, variabilita prenosu intracelulárnych signálov). V neposlednom rade je nutné spomenút' noncompliance pacienta, ktorá môže v prípade protidoštičkových liečiv dosahovat' až $22 \%$ (16).

\subsection{Príčiny reziduálnej reaktivity trombocytov}

V preskripcii ASA jednoznačne dominujú liekové formy s okamžitým uvol’nením. Užívanie enterosolventných foriem ASA sa pre výrazne predížený čas do dosiahnutia účinnej plazmatickej koncentrácie (od troch do štyroch hodín) v sekundárnej prevencii neodporúča. Enterosolventné tablety ASA majú navyše preukázanú nižšiu biologickú dostupnost', čo môže viest' $\mathrm{k}$ nedostatočnej inhibícii trombocytov, predovšetkým u pacientov s vyššou hmotnost'ou. V liekových interakciách je ako príčinu HTPR pri liečbe ASA nevyhnutné spomenút' nesteroidné antiflogistiká ako ibuprofén a naproxén, ktorých väzobné miesto leží v tesnej blízkost' väzbového miesta ASA a ich pravidelné užívanie vedie ku kompetetívnej interakcii liečiv. Významným mechanizmom vedúcim k rýchlejšej obnove doštičkovej COX-1, a tým i funkcií trombocytov, je ich zvýšený obrat. Uvedený mechanizmus sa často pokladá za jednu z príčin HTPR, predovšetkým u pacientov s DM. Štandardne sa však za najčastejšiu príčinu HTPR pri liečbe ASA, ale i klopidogrelom, pokladá noncompliance pacienta (6). V súčasnosti sú známe tri hlavné genetické polymorfizmy CYP2C19, enzýmu cytochrómového systému P450, zodpovedného za biotransformáciu klopidogrelu na jeho aktívny metabolit. Najčastejšie sa vyskytujúca alela (tzv. „wild type“) CYP2C19*1 prevláda u väčšiny svetovej populácie. Zhruba $15 \%$ európskych a $30 \%$ mongoloidných populácií je však nositel'om alel CYP2C19*2 a CYP2C19*3 v homozygotnej alebo heterozygotnej forme a je považovaných slabých responderov na liečbu klopidogrelom (17). Okrem geneticky zapríčinenej HTPR je problémom i značná, až $85 \%$ degradácia absorbovaného klopidogrelu esterázami, ešte pred jeho biotransformáciou. K interindividuálnej varibilite pri liečbe klopidogrelom však prispieva i interferencia s liečivami, ktoré rovnako ako klopidogrel, vyžadujú aktiváciu 
cytochrómovým systémom P450 (inhibítory protónovej pumpy, inhibítory kalciového kanála). Objavujú sa taktiež podozrenia, že medzi liečivá interferujúce s klopidogrelom by mohli patrit' i lipofilné statíny. Vzhl'adom na fakt, že statíny sú rovnako ako protidoštičková liečba, integrálnou častou sekundárnej prevencie iCMP, nie je overenie týchto podozrení prospektívnymi štúdiami jednoduché. S rizikom HTPR pri liečbe ASA a klopidogrelom sa často spája i vek nad 75 rokov, obezita, diabetes mellitus, chronické ochorenie obličiek a fajčenie, ktoré sú mnohokrát uvádzané ako rizikové faktory vzniku iCMP (3).

\subsection{Súčasné stratégie riešenia rezisuálnej reaktivity trombocytov}

Otázka prítomnosti HTPR sa naskytá v prípade klinického zlyhania sekundárnej prevencie pri recidíve iCMP, v prípade, že je jednoznačne vylúčená noncompliance pacienta. Aktuálne klinické a laboratórne skúsenosti poukazujú na pomerne vysokú prevalenciu HTPR a nízkej responzibility na protidoštičkovú liečbu. U pacienta $\mathrm{s}$ HTPR má d’alšie užívanie protidoštičkového liečiva $\mathrm{v}$ sekundárnej prevencii rovnaký efekt ako užívanie placeba. Pri využití prístupov personalizovanej medicíny sa pacientovi po nasadení sekundárnej prevencie realizujú testy zamerané na účinnost' ASA a klopidogrelu pomocou vyšetrenia funkcie trombocytov. V prípade laboratórnej rezistencie je možné najprv navýšit' dennú dávku liečiva, avšak tento postup vedie častokrát $\mathrm{k}$ nepozmenenému výsledku. $\mathrm{V}$ prípade negatívneho výsledku poukazuje skôr na noncompliance pacienta. Inou alternatívou je nasadenie sekundárnej prevencie vo forme tikagreloru. Na základe výsledkov klinickej štúdie SOCRATES prichádza tikagrelor do úvahy ako liek vol'by v prípade dokázanej rezistencie na ASA a klopidogrel. Výhodou je aj fakt, že rezistencia na tikagrelor je dokumentovaná len v ojedinelých prípadoch. Uvedený postup je už v limitovanej miere zavedený v Slovenskej republike, kde je pri dokázanej rezistencie na klopidogrel indikované podávanie kombinácie tikagreloru a ASA, pričom takáto liečba je podmienená žiadost'ou o výnimku (16). Aktuálne je na účinok tikagreloru zameraná štúdia THALES, ktorá na základe výsledkov subanalýz štúdie SOCRATES selektuje len pacientov s aterosklerózou vel'kých tepien (18). Vyšetrenie účinnosti protidoštičkových liečiv však nepatrí medzi rutinné vyšetrenia, ktorými laboratóriá bežne disponujú. $\mathrm{V}$ poslednej dekáde preto možno pozorovat' zvýšenú snahu klinických a laboratórnych pracovísk o identifikáciu rutinne dostupných laboratórnych markerov, ktoré by umožnili predikciu HTPR. Pozornost' sa v súčasnosti sústred'uje predovšetkým na parametre krvného obrazu a ich kombinácie, ale aj biochemické markery, vrátane markerov metabolizmu železa (19). Inú perspektívu v uvedenej problematike prinášajú recentné štúdie poukazujúce na narastajúcu aktivitu trombocytov pri užívaní štandardnej dávky ASA, a to predovšetkým s blížiacim sa koncom 24 hodinového intervalu. Ako vysvetlenie možno uviest' produkciu nových, retikulovaných trombocytov, ktorých uvol’ňovanie $\mathrm{z}$ megakaryocytov podlieha cirkadiánnemu rytmu a vrchol dosahuje počas neskorej noci a skorého rána. Uvedenú teóriu podporuje aj fakt, že megakaryocyty sú bunky schopné syntetizovat' COX-1 a ich inhibícia trvá nanajvýš 12 hodín. V uvedenom časovom okne dochádza zároveň najčastejšie k výskytu ischemických udalostí, ktoré sú klinicky závažnejšie a sú spojené $\mathrm{s}$ horšou prognózou. Toto kritické časové okno by potenciálne mohlo byt' kl’účové z hl'adiska nastavenia adekvátnej inhibície funkcie trombocytov. Vedecká komunita sa aktuálne zameriava na dve možné riešenia jej zvýšenia: užívanie dennej dávky ASA vo večerných hodinách a jej rozdelenie do dvoch 12 hodinových intervalov. Výrazne zvýšená reaktivita trombocytov $\mathrm{v}$ skorých ranných hodinách bola dokázaná aj u pacientov uživajúcich klopidogrel a predpokladá sa, že súvisí s HTPR (20). 


\section{Použitá literatúra}

1. WAFA, H. A. et al. Burden of Stroke in Europe: Thirty-Year Projections of Incidence, Prevalence, Deaths, and Disability-Adjusted Life Years. Stroke. 2020, 51(8), 2418-2427. ISSN 0039-2499.

2. BENJAMIN, E. J. et al. Heart Disease and Stroke Statistics-2019 Update: A Report From the American Heart Association. Circulation. 2019, 139(10), 56-528. ISSN 0009-7322.

3. MICHELSON, A. et al. Platelets. 4. vydanie. Cambridge: Academic Press, 2019. 1268 s. ISBN 978-0-12-813456-6.

4. GALlO, A., GALliAZZO, S., GRAZIOLI, S. Epidemiology and secondary prevention of ischemic stroke in patients on antiplatelet drug: a retrospective cohort study. Journal of Thrombosis and Thrombolysis. 2019, 48(2), 336-344. ISSN 09295305.

5. $\quad$ S̆TEFANIČ, P. et al. Markery mäkkého plátu pri aterosklerotickom postihnutí arteria carotis interna. Vaskulárna medicína. 2016, 8(1), 24-27. ISSN 1338-0206.

6. GOROG, D. A. Potentiation of thrombus instability: a contributory mechanism to the effectiveness of antithrombotic medications. Journal of Thrombosis and Thrombolysis. 2018, 45(4), 593-602. ISSN 0929-5305.

7. SZUMITA, R. P., SZUMITA P. M. Hemostasis in Dentistry. 1. vydanie. Cham: Springer International Publishing AG, 2018. 204 s. ISBN 978-3-319-71240-6.

8. MAGEROVÁ, H. Indikace antitrombotické terapie $\mathrm{v}$ sekundární prevenci ischemické CMP. Neurológia pre prax. 2019, 20(1), 14-17. ISSN 1335-9592.

9. POWERS, W. J. et al. 2018 Guidelines for the Early Management of Patients With Acute Ischemic Stroke: A Guideline for Healthcare Professionals From the American Heart Association/American Stroke Association. Stroke. 2018, 49(3), 46-110. ISSN 0039-2499.

10. BERGER, J. S. Oral Antiplatelet Therapy for Secondary Prevention of Acute Coronary Syndrome. American Journal of Cardiovascular Drugs : Drugs, Devices, and Other Interventions. 2018, 18(6), 457-472. ISSN 1175-3277.

11. GIROTRA, T., LOWE, F., FENG, W. Antiplatelet Agents in Secondary Stroke Prevention: Selection, Timing, and Dose. Current Treatment Options in Neurology. 2018, 20(8), 1-23. ISSN 1092-8480.

12. FARAG, E. et al. Basic Sciences in Anesthesia. 1. vydanie. Cham: Springer International Publishing AG, 2018. 651 s. ISBN 978-3-319-62065-7.

13. RAHMAN, H. et al. Optimal Duration of Aspirin Plus Clopidogrel After Ischemic Stroke or Transient Ischemic Attack. Stroke. 2019, 50(4), 947-953. ISSN 0039-2499.

14. WANG, Y. et al. Acute dual antiplatelet therapy for minor ischaemic stroke or transient ischaemic attack. British Medical Journal. 2019, 364(895), 1-23. ISSN 1756-1833.

15. NOSÁL, V. Predstavujú ticagrelor a prasugrel alternatívu v protidoštičkovej liečbe ischemických CMP? ANO. American Journal of Cardiovascular Drugs : Drugs, Devices, and Other Interventions. 2020, 82/115(6), 613-615. ISSN 1210-7859.

16. HARING, J. et al. Výsledky BATTS registra mechanických trombektómií akútnej ischemickej cievnej mozgovej príhody. Neurológia. 2016, 11(3), 111-118. ISSN 1336-8621.

17. CHEN, H. Integrative Medicine on Optimizing Clopidogrel and Aspirin Therapy. Chinese Journal of Integrative Medicine. 2019, 25(5), 395-400. ISSN 1672-0415.

18. TOMEK, A. Základní algoritmus vyšetrení etiologie ischemické cévní mozkové prŕhody. Neurológia pre prax. 2019, 20(1), 35-41. ISSN 1335-9592. 
19. BARALE, C. et al. Transferrin Saturation Inversely Correlates with Platelet Function. Thrombosis and Haemostasis. 2019, 119(5), 766-778. ISSN 0340-6245.

20. RACCA, C. et al. Aspirin intake in the morning is associated with suboptimal platelet inhibition, as measured by serum Thromboxane B 2, during infarct-prone early-morning hours. Platelets. 2019, 30(7), 871-877. ISSN 0953-7104.

\section{Kontaktné údaje}

Mgr. Katarína Pinčáková

Trnavská univerzita v Trnave, Fakulta zdravotnítva a sociálnej práce

Katedra laboratórnych vyšetrovacích metód v zdravotníctve

Univerzitné námestie 1, 91701 Trnava

Tel: +421910571271

email: katarina.pincakova@tvu.sk 


\title{
EXPERIMENTÁLNE ÚLOHY S TENZOMETROM
}

\section{EXPERIMENTAL TASKS WITH STRAIN GAUGE}

\author{
Michal Choma, Sergej Il'kovič
}

\begin{abstract}
Abstrakt
$\mathrm{V}$ súčasnosti dochádza $\mathrm{k}$ masívnej penetrácii IKT technológií do rôznych oblastí každodenného života, vzdelávanie nevynímajúc. Vysoká výpočtová kapacita a nízka cena komponentov umožňuje vytváranie vlastných digitálnych meracích systémov, ktoré môžu byt' využité napríklad aj na laboratórnych cvičeniach z fyziky. Autori v príspevku demonštrujú možnosti využitia tenzometra pri realizácii fyzikálnych experimentálnych úloh, ktorých súčast'ou sú ukážky nameraných dát.
\end{abstract}

Klíčová slova: tenzometer, sila, experiment

\begin{abstract}
Currently is a massive penetration of ICT technologies into various areas of everyday life, not excluding education. The high computing capacity and low cost of components allows you to create your own digital measuring systems, which can be used, for example, in laboratory exercises in physics. The authors demonstrate the possibilities of using a strain gauge in the implementation of physical experimental tasks, which include examples of measured data.
\end{abstract}

Key words: strain gauge, force, experiment

\section{1 ÚVOD}

Zmena organizácie vyučovania na všetkých stupňoch prinútila vyučujúcich prispôsobit' sa situácii, kedy bola prezenčná výučba výrazne redukovaná $\mathrm{v}$ dôsledku zavedenia protipandemických opatrení. Najviac boli touto situáciou zasiahnuté predmety, ktorých súčast’ou je praktická, resp. experimentálna činnost'. Ako jedno z riešení sa ponúka využitie meracích systémov, ktoré môžu byt' na hodinách využívané ako pri realizácii demonštračných experimentov, tak aj pri realizácii žiackeho experimentu či na laboratórnych cvičeniach. Využitie meracích systémov pritom nie je obmedzené iba na dištančnú výučbu, ale meracie systémy môžu byt' využívané aj na prezenčnej forme vyučovania. Využitie meracieho systému vo vyučovaní má rad výhod:

- Využitie meracieho systému rozvíja úrovne myšlienkových operácií u žiaka podl’a revidovanej Bloomovej taxonómie kognitívnych funkcií [3]. Praktická ukážka merania s využitím vizualizácie prostredníctvom interaktívnej tabule zlepšuje schopnost' porozumenia vyučovaného učiva a analýzy preberaného učiva. Žiak tak vie jednoduchšie rozložit' problém na čiastkové problémy a osvojené učivo tak lepšie aplikuje pri riešení fyzikálnych úloh.

- Práca $\mathrm{s}$ meracím systémom je pre žiakov atraktívna. V prípade, že je ovládanie meracieho systému intuitívne, žiaci to nepocit'ujú ako prít’až napriek tomu, že so systémom nemali predošlú skúsenost'.

- Rozvoj interdisciplinárnych vzt'ahov. Žiaci majú možnost' počas vyučovania fyziky využívat' poznatky z viacerých oblastí, napríklad z informatiky, elektrotechniky, elektroniky, matematiky, alebo štatistiky. 
- Zefektívnenie vyučovania. Využitie meracích systémov môže vo významnej miere odbremenit' žiakov od vykonávania monotónnych a nezaujímavých činností, vd’aka čomu sa vytvorí čas pre objavné a tvorivé aktivity.

\section{CHARAKTERISTIKA TENZOMETRA}

Tenzometer predstavuje rezistor, ktorého elektrický odpor sa mení v závislosti od jeho lineárnej deformácie (zmena odporu je spôsobená pri deformácii iba $\mathrm{v}$ jednom smere). Pôsobením vonkajšej sily v materiáli tenzometra, dochádza k elastickej deformácií, a teda aj k zmene mechanického napätia materiálu, čo spôsobuje zmenu jeho elektrického odporu [4].

$\mathrm{K}$ realizácii školských meraní sme využili drôtený tenzometer v tvare obdížnikovej fólie nalepenej na hliníkový profil (tzv. páskový tenzometer). Použitý tenzometer je vyrobený $\mathrm{z}$ materiálu, ktorý pri mechanickom napätí vykazuje zmeny $\mathrm{v}$ jeho mikroštruktúre. Krátkodobé pret’aženie tenzometra je nedeštruktívne, avšak pri trvalom a dlhodobom pret’ažení dochádza $\mathrm{k}$ plastickej deformácii a jeho poškodeniu.

Meranie sily sa tak transformuje na meranie elektrického odporu. Ked’že je zmena elektrického odporu tenzometra pomerne malá, na jeho meranie sa preto využíva Wheatstonov mostík, ktorý pozostáva z obvodu so 4 tenzometrami (load cell na Obrázku 1).

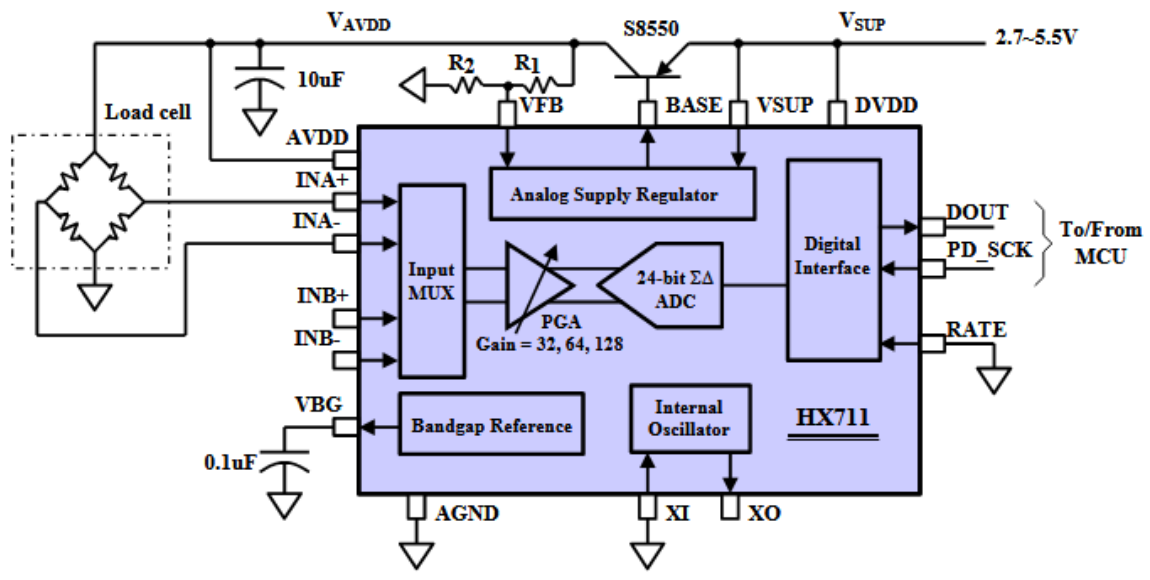

Obrázok 1: Schéma zapojenia Wheatstonovho mostíka Zdroj: [1]

Hodnota elektrického napätia medzi protil’ahlými uzlami mostíka, ktorá závisí od deformácie je analógovo-digitálnym prevodníkom prevedená na digitálnu hodnotu, ktorú je možné d'alej spracovávat' [6]. Ako prevodník bol použitý obvod HX711 [1]. Pri 24bitovom prevode je pre tenzometer s maximálnym rozsahom $10 \mathrm{~N}$ presnost' merania sily približne $0,01 \mathrm{~N}$. Presnost' merania ovplyvňujú aj d'alšie parametre [4]:

- Teplotná závislost' odporu tenzometra.

- Tečenie (angl. creep). Jedná sa o stratu citlivosti tenzometra v dôsledku trvalého zat'aženiu tenzometra.

- Elastická hysterézia. Pri odstránení zát'aže sa deformácia vytráca postupne po určitej dobe.

- Vplyv vlhkosti. Tenzometer je nalepený na hliníkový profil lepidlom, ktoré môže menit' svoje vlastnosti vplyvom vlhkosti. Tento nedostatok je odstránený tým, že použité tenzometre sú natreté ochranou vrstvou proti vlhkosti.

Na trhu existujú tenzometre s maximálnym zat'ažením do 100 g, 1 kg, $5 \mathrm{~kg}$ a $10 \mathrm{~kg}$. Pre účely merania v rámci školských experimentálnych úloh sme využili tenzometer s rozsahom $1 \mathrm{~kg}$. 


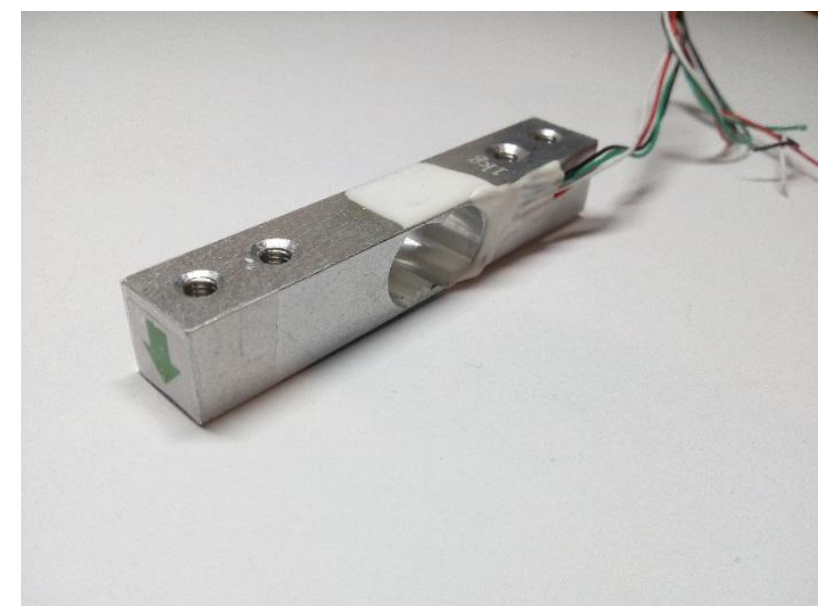

Obrázok 2: Hliníkový profil s tenzometrami Zdroj: vlastné spracovanie

\section{3 ŠKOLSKÉ POKUSY S VYUŽITÍM TENZOMETRA}

Pri realizácii meraní sme využili vlastný merací systém, v ktorom bol implementovaný tenzometer ako súčast' senzorickej jednotky. Merací systém ponúka možnost' realizovat' časové závislosti meraných veličín, a teda otvára nové možnosti pre laboratórne úlohy $\mathrm{s}$ kontinuálnym meraním sily či hmotnosti. V rámci štátneho vzdelávacieho programu pre gymnázia

(ISCED 3 A) je pre celok sila a pohyb vyčlenených 18 hodín na výklad (súčast’ou týchto hodín je odporúčanie pre realizáciu demonštračných experimentov). Tenzometer je možné využit' napríklad pri:

- meraní tiažovej sily telesa a rozklade sily na zložky. Tenzometrom je možné odmerat' tiažovú silu pôsobiacu na teleso na naklonenej rovine a meraním určit pohybovú zložku.

- meraní t'ahovej a tlakovej sily. Ked’že použitý prevodní meria aj záporného hodnoty, učitel' môže využit' tenzometer ako demonštračnú pomôcku pochopenie súvislosti smeru a znamienka pri meraní sily (kladné hodnoty nadobúda senzor sily pri pôsobení t’ahovej sily, záporne hodnoty pri pôsobení tlakovej sily)

- určení vztlakovej sily pôsobiacej na teleso v kvapaline meraním sily pôsobiacej na teleso vo vzduchu a v kvapaline, prípadne overenie Archimedovho zákona.

- meraní trecej sily. Prostredníctvom časovej závislostí sily sa dá určit' koeficient statického a dynamického trenia a experimentálne tak odlíšit' silu statického a dynamického trenia.

- určení mechanickej práce pri pohybe telesa po podložke.

- určení práce potrebnej k deformácii pružiny, určenie tuhosti pružiny a sily pružnosti.

- demonštrácii Hookovho zákona.

- určení periódy kmitania matematického kyvadla a následného určenia tiažového zrýchlenia.

- určení periódy pružinového oscilátora (závažia zaveseného na pružine) a demonštrácia útlmu amplitúdy kmitania.

V nasledujúcej časti uvádzame niektoré experimenty z uvedeného zoznamu. 


\subsection{Meranie statického a dynamického trenia}

Pri pohybe telesa po podložke vzniká trenie, ktoré brzdí jeho pohyb. Príčinou vzniku trenia sú nerovnosti styčných plôch. Trecia sila $F_{t}$ pôsobí proti smeru pohybu telesa, pre ktorú platí vzt'ah:

$$
F_{t}=f F_{n}
$$

kde $F_{n}$ je normálová sila, pôsobiaca na teleso v smere kolmice na podložku a $f$ je koeficient šmykového trenia. Pre vodorovný pohyb telesa po podložke, normálovú silu stotožníme s tiažovou silou $F_{G}$ :

$$
F_{t}=f F_{G}
$$

kde $m$ je hmotnost' telesa a $g$ je tiažové zrýchlenie. Pre koeficient trenia platí vzt'ah:

$$
f=\frac{F_{t}}{F_{G}}=\frac{F_{t}}{m g}
$$

Trecia sila závisí od toho, či je teleso $\mathrm{v}$ pokoji, alebo sa pohybuje rovnomerným priamočiarym pohybom, podl'a toho rozlišujeme statické a dynamické trenie. Statické trenie popisuje sila statického trenia $F_{t 0}$ a koeficient statického trenia $f_{0}$. Trenie, ktoré vzniká pri rovnomernom pohybe telesa po podložke označujeme ako dynamické a priradíme mu silu dynamického trenia $F_{t}$ a koeficient dynamického trenia $f$. Pre určenie koeficientu statického a dynamického trenia študenti využívajú väčšinou silomer, ktorým určujú celkovú silu pôsobiacu na kváder pri jeho rovnomernom pohybe. Realizácia experimentu pomocou silomeru má svoje nedostatky (nepresné určenie sily, nerovnomerný pohyb kvádra po podložke a pod.). Využitie tenzometra ako senzora sily umožňuje kontinuálne meranie a zostrojenie grafu, z ktorého študent vie určit' silu statického trenia a priemernú hodnotu sily dynamického trenia pri rovnomernom pohybe telesa. Pre samotné meranie sme využili teleso o hmotnosti približne $2 \mathrm{~kg}$ (kniha zat'ažená závažím), ktoré sme t’ahali pomocou špagátu po drevenom stole. V grafe 1 je znázornená časová závislost' sily pri t’ahaní telesa, z ktorej boli určené výsledné parametre uvedené v tabul'ke 1 .

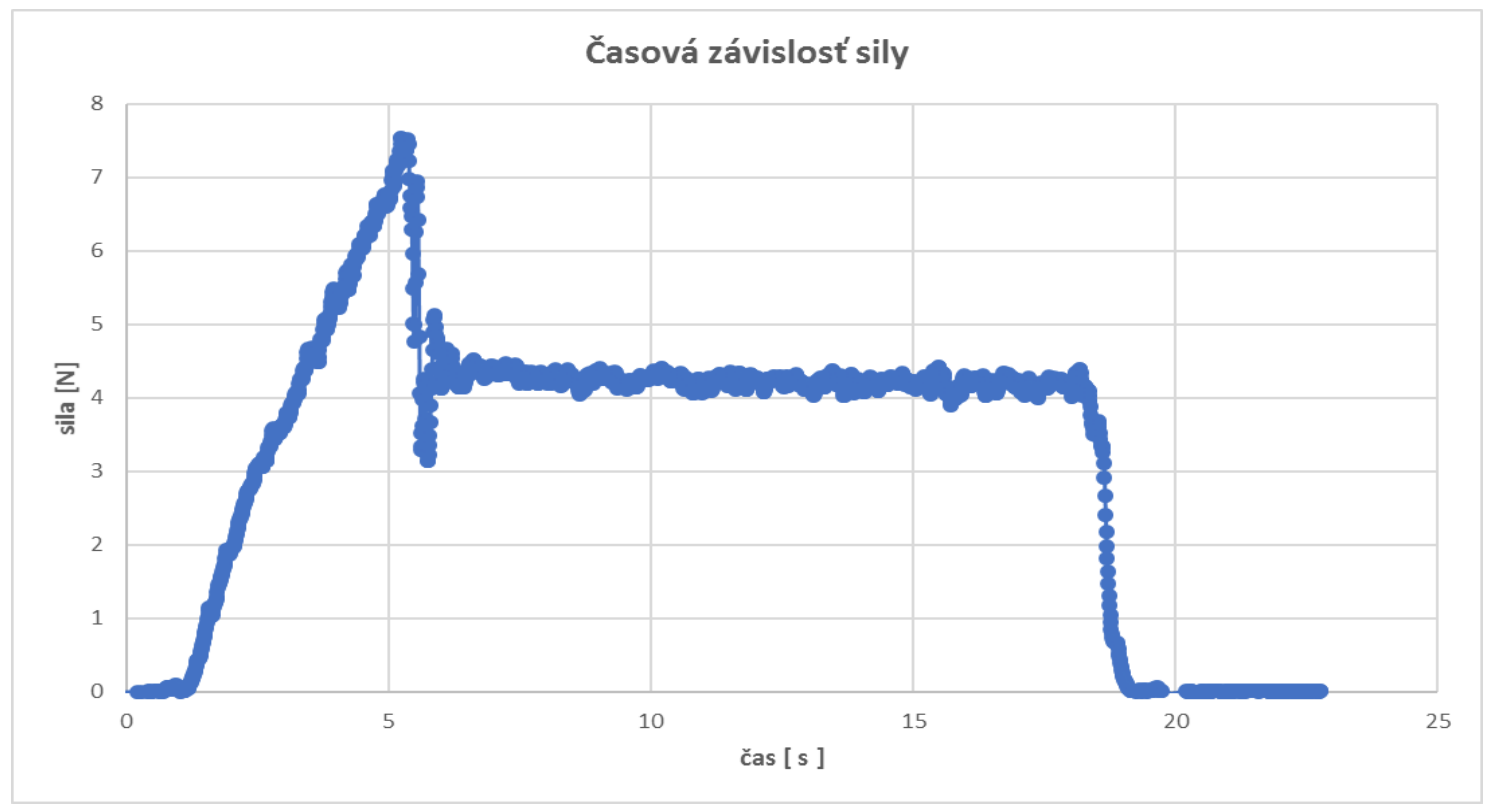

Graf 1: Časová závislost' trecej sily pre určenie statického a dynamického trenia Zdroj: vlastné spracovanie 
Tabul'ka 1

\begin{tabular}{|c|c|}
\hline$F_{\mathrm{n}}[\mathrm{N}]$ & 19,62 \\
\hline $\mathrm{F}_{\mathrm{t} 0}[\mathrm{~N}]$ & 7,45 \\
\hline $\mathrm{F}_{\mathrm{t}}[\mathrm{N}]$ & 4,20 \\
\hline $\mathrm{f}_{0}[-]$ & 0,38 \\
\hline $\mathrm{f}[-]$ & 0,21 \\
\hline
\end{tabular}

Zdroj: vlastné spracovanie

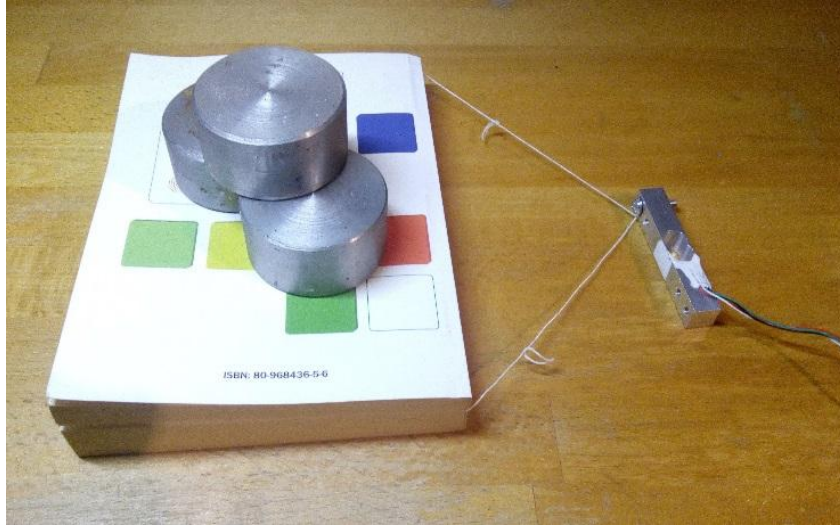

Obrázok 3: Meranie trecej sily Zdroj: vlastné spracovanie

\subsection{Určenie tiažového zrýchlenia}

Tiažové zrýchlenie je možné určit' meraním periódy matematického kyvadla pri známej dížke kyvadla (vzdialenost' bodu závesu a t’ažiska). Matematické kyvadlo je kyvadlo, ktoré pozostáva $z$ hmotného bodu zaveseného na tenkom dokonale pevnom vlákne zanedbatel'nej hmotnosti, pričom sa zanedbáva odpor vzduchu pri pohybe kyvadla i trenie $\mathrm{v}$ závese. Pri malých výchylkách $\left(<5^{\circ}\right)$ kyvadla $\mathrm{z}$ rovnovážnej polohy, možno považovat' kmitanie kyvadla za harmonické a dá sa popísat' funkciou sínus. Pre periódu harmonického pohybu matematického kyvadla platí vzt’ah:

$$
T=2 \pi \sqrt{\frac{l}{g}}
$$

Potom pre tiažové zrýchlenie platí:

$$
g=4 \pi^{2} \frac{l}{T^{2}}
$$

Počas vyučovania fyziky na stredných školách študenti realizujú meranie periódy kmitu pomocou stopiek. Pre zistenie periódy kmitania môžeme využit' senzor sily, na ktorý zavesíme závažie. Silu, ktorou teleso pôsobí na vlákno, môžeme graficky znázornit’ v grafe:

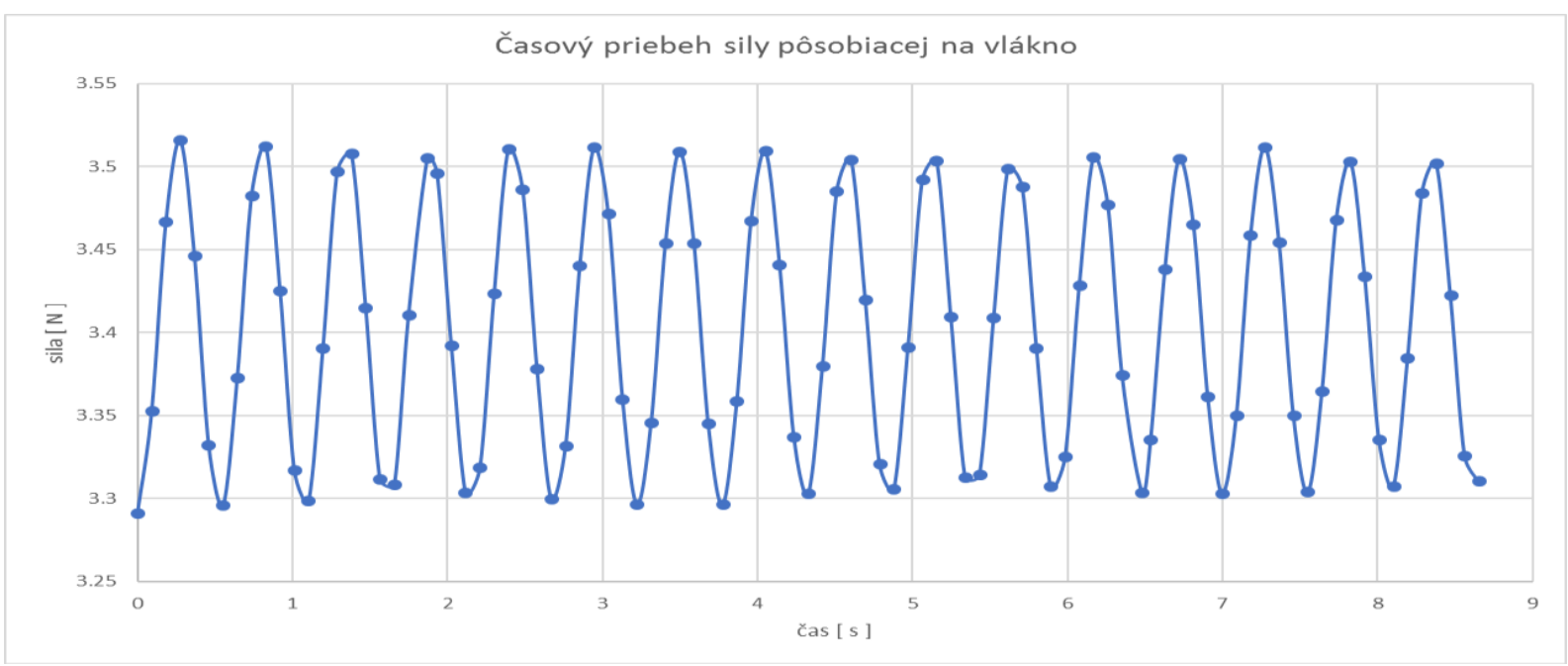

Graf 2: Kmitanie matematického kyvadla Zdroj: vlastné spracovanie 
Pre zistenie tiažového zrýchlenia je nutné určit' dížku kyvadla $l$, a periódu kmitu $T$. Dížku kyvadla sme odmerali dížkovým meradlom. Meraním časovej závislosti sily sme určili čas ôsmich kmitov a následne sme určili periódu kmitov.

Tabul'ka 2

\begin{tabular}{|c|c|c|c|}
\hline $1[\mathrm{~m}]$ & $\mathrm{n}$ & $\mathrm{T}[\mathrm{s}]$ & $\mathrm{g}\left[\mathrm{m} / \mathrm{s}^{2}\right]$ \\
\hline 0,29 & 8 & 1,08 & 9,81 \\
\hline
\end{tabular}

Zdroj: vlastné spracovanie

\subsection{Určenie tuhosti pružiny}

Pružina sa vyznačuje elastickými vlastnost’ami, ktoré popisuje koeficient tuhosti pružiny $k$. Pri predpoklade dokonalej pružnosti je sila pružnosti $F_{p}$ priamo úmerná predíženiu pružiny $\Delta l$, platí vzt’ah:

$$
F_{p}=k \Delta \mathrm{l}(*)
$$

Pre koeficient $k$ dostávame vzt’ah:

$$
k=\frac{F_{p}}{\Delta l}
$$

Koeficient tuhosti pružiny $k$ je $\mathrm{v}$ istom intervale predíženia pružiny konštantný. Vtedy hovoríme o elastickej deformácii pružiny, pri ktorej sa pružina vráti do pôvodného tvaru. Tomu zodpovedá lineárna závislost' sily pružnosti od predíženia pružiny.

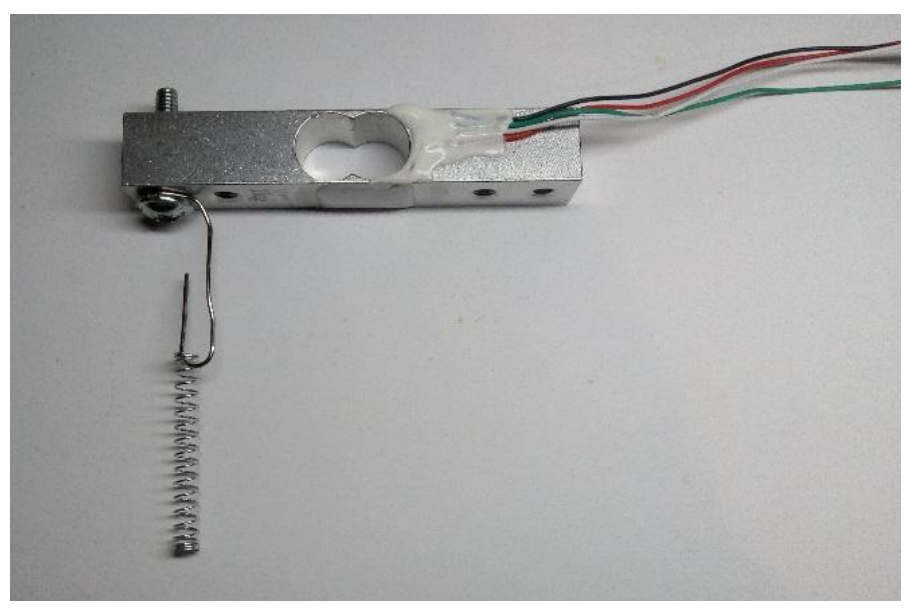

Obrázok 4: Meranie tuhosti pružiny

Zdroj: vlastné spracovanie

Pri presiahnutí medze pružnosti dochádza k plastickej deformácii, po ktorej sa pružina nevráti do pôvodného tvaru, ale nadobudne nový tvar. Pri meraní sme využili senzor sily, na ktorý sme zavesili pružinu, ktorú sme postupne zat’ažovali, až kým sme nedosiahli plastickú deformáciu. $Z$ nameraných údajov sme zostrojili Graf 3, z ktorého sme určili interval lineárnej závislosti sily pružnosti od predíženia v súlade $\mathrm{s}(*)$. Pre tento interval sme určili tuhost' pružiny, ktorá má význam smernice priamky lineárnej oblasti, ktorú reprezentuje fitovaná priamka. 


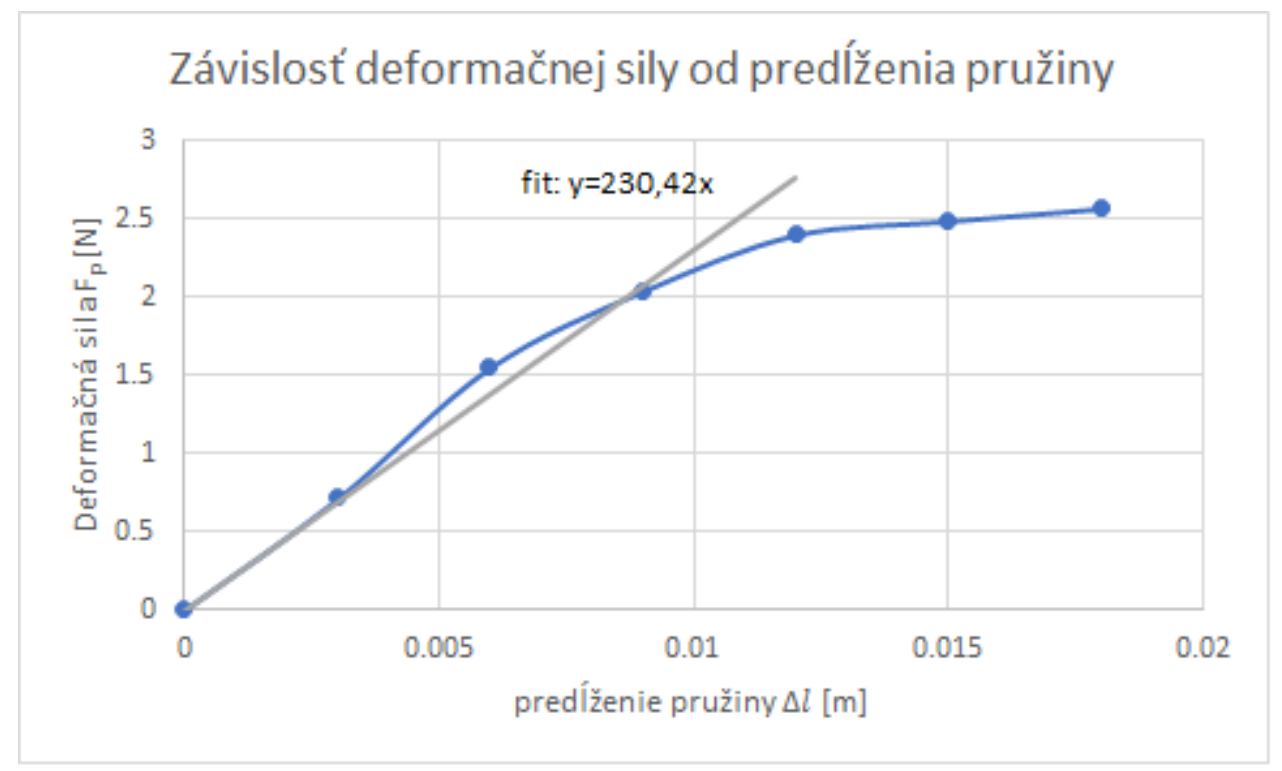

Graf 3: Demonštrácia Hookovho zákona

Zdroj: vlastné spracovanie

\subsection{Určenie vztlakovej sily}

Tenzometer je možné využit' aj na určenie sily pôsobiacej na teleso ponorené v kvapaline, a takým spôsobom určit' vel'kost' vztlakovej sily. V prípade znalosti objemu ponorného telieska je možné v prípade úplného ponorenia telieska určit' hustotu kvapaliny. Odporúča sa senzor sily (jeden koniec) upevnit' do stojana a na druhý koniec tenzometra upevníme háčik so šnúrkou, ktorý predstavuje záves. Na meranie možno použit' l'ubovol'né teleso s hmotnost'ou do $1 \mathrm{~kg}$, ktoré ma väčšiu hustotu ako voda, napr. kovový valček. Vyhýbame sa telesám, pri kontakte s vodou menia svoje vlastnosti, napríklad v dôsledku chemickej reakcii, alebo rozpustnosti. Ako kvapalinu využijeme vodu, prípadne iné kvapaliny (napr. olej). Meranie sme realizovali s kovovým závažím s hmotnost'ou 350 g. Najprv sme odmerali silu $F_{1}$, ktorou pôsobí závažie na tenzometer vo vzduchu, a následne odmeriame silu $F_{2}$ pri úplnom ponorení závažia do vody. Je nutné upozornit' najmä mladších žiakov, že meriame celkovú silu, ktorou závažie pôsobí na senzor, a teda sila, ktorou pôsobí závažie na senzor vo vode je vektorovým súčtom tiažovej sily a vztlakovej sily. Vel'kost' vztlakovej sily vypočítame odčítaním síl $F_{1}$ a $F_{2}$. V našom prípade je tiažová sila $3,44 \mathrm{~N}$ a vztlaková sila 0,44 N.

V prípade známej hodnoty objemu ponorného telieska je možné určit' hustotu kvapaliny zo vzt'ahu [2]:

$$
F_{v z}=\rho_{k} V g
$$

kde $\rho_{k}$ je hustota kvapaliny, $V$ je objem ponorenej časti telesa a $g$ je tiažové zrýchlenie. Hustotu kvapaliny môžeme určit' aj zo znalosti hustoty ponorného telieska:

$$
\frac{F_{v z}}{F_{g}}=\rho_{k} \frac{V}{m}=\frac{\rho_{k}}{\rho_{t}},
$$

kde $\rho_{t}$ je hustota ponorného telieska a $m$ je jeho hmotnost'. Pre hustotu kvapaliny dostávame vzt'ah: 


$$
\rho_{k}=\frac{F_{v Z}}{F_{g}} \rho_{t}
$$

Pre naše meranie sme dostali pre hustotu vody $1004 \mathrm{~kg} / \mathrm{m}^{3}$. Meranie hustoty kvapaliny pomocou merania vztlakovej sily je ovplyvnené najmä presnost'ou merania sily resp. rozsahom použitého tenzometra.

Učitel' môže využit' senzor sily napr. aj na odvodenie matematického vzt'ahu pre vztlakovú silu (demonštrácia závislosti vztlakovej sily od objemu ponorenej časti telesa príp. demonštrácia vel'kosti vztlakovej sily pre dve kvapaliny s rôznou hustotou).

\section{ZÁVER}

V článku autori prezentovali možnosti využitia tenzometra $\mathrm{v}$ rámci súboru experimentálnych úloh z fyziky. Pre vizualizáciu a spracovanie dát sme využili merací systém a l'ubovol’ný dostupný tabul'kový procesor, čo podstatne zjednodušilo prácu s dátami. Práca s tenzometrom rozvíja medzipredmetové vzt'ahy, ked’že študenti pri spracovaní dát musia využívat' poznatky z rôznych oblastí. Pri realizácii demonštračných meraní s využitím vizualizácie študenti môžu lepšie pochopit' preberanú problematiku než pri klasickom vyučovaní bez zaradenia experimentov vd’aka vyššej názornosti a získaniu vlastnej skúsenosti bez redukcie obsahu.

Tento príspevok vznikol s podporou grantu KEGA 009PU-4/2020: Využitie pokročilých technológií s prvkami automatizácie vo fyzikálnom vzdelávaní.

\section{Použitá literatura}

1. Avia Semiconductor . [online katalógový list]. HX711. [cit. 22-10-2020]. Dostupné z https://cdn.sparkfun.com/datasheets/Sensors/ForceFlex/hx711_english.pd

2. BEŇUŠKA, J. 2013. Vlastností kvapalín a plynov, fyzika pre gymnáziá a SOŠ. $62 \mathrm{~s}$. ISBN 978-80-89692-06-4.

3. DARWAZEH, Afnan N.; BRANCH, Robert Maribe. A revision to the revised Bloom's taxonomy. 2015 Annual Proceedings-Indianapolis, 2015, 2: 220-225.

4. MULLER, Ivan, et al. Load cells in force sensing analysis--theory and a novel application. IEEE Instrumentation \& Measurement Magazine, 2010, 13.1: 15-19.

5. ŠSTÁTNÝ PEDAGOGICKÝ ÚSTAV, Bratislava. Štátny vzdelávací program pre gymnázia v Slovenskej republike: ISCED 3 A-vyššie sekundárne vzdelávanie. Dostupné z: https://www.statpedu.sk/files/articles/dokumenty/statny-vzdelavaci program/fyzika_isced3.pdf

6. WALDEN, Robert H. Analog-to-digital converter survey and analysis. IEEE Journal on selected areas in communications, 1999, 17.4: 539-550.

\section{Kontaktní údaje}

RNDr. Michal Choma

Prešovská univerzita v Prešove, Fakulta humanitných a prírodných vied

U1. 17. novembra č.1, 08116 Prešov

email: michal.choma@smail.unipo.sk

doc. RNDr. Sergej Il'kovič, PhD.

Prešovská univerzita v Prešove, Fakulta humanitných a prírodných vied U1. 17. novembra č.1, 08116 Prešov

email: sergej.ilkovic@unipo.sk 


\title{
SROVNÁNÍ VYBRANÝCH PARAMETRŮ U PACIENTU゚ S LUPUS NEFRITIDOU A BEZ NÍ
}

\section{COMPARISON OF SELECTED PARAMETERS IN PATIENTS WITH LUPUS NEPHRITIS AND WITHOUT IT}

\author{
Ján Sitko, Stanislava Blažíčková
}

\begin{abstract}
Abstrakt
Systémový lupus erythematosus (SLE) je autoimunitné multifaktoriálne multisystémové ochorenie pri ktorom sa vyskytuje predčasná ateroskleróza a jej najdôležitejší tradičný faktor je dyslipoproteinémia. Preto ciel’om práce je porovnanie nielen lipidového profilu pacientov s lupus nefritídou (LN) voči ostatným pacientom so SLE ale aj rastových a zápalových faktorov a faktorov aktivity ochorenia. Skupinu s LN tvorilo 36 pacientov s priemernou dížkou ochorenia 14 rokov a skupinu bez LN tvorilo 53 pacientov s priemernou dížkou ochorenia 18 rokov. V našej štúdii sme nezaznamenali žiaden štatisticky významný rozdiel v parametroch okrem IL2. Hoci sa štatisticky hladiny lipidov nelíšili, pozorovali sme rozličný výskyt zvýšených hladín u týchto dvoch skupín. Preto by sa nemalo nikdy zabúdat' pri liečbe SLE na liečbu dyslipidémie.
\end{abstract}

Klíčová slova: Systémový lupus erthematosus, kardiovaskulárne ochorenia, lipidy, zápalové markery

\begin{abstract}
Systemic lupus erythematosus (SLE) is an autoimmune multifactorial multisystem disease in which premature atherosclerosis occurs and its most important traditional factor is dyslipoproteinemia. Therefore, the aim of this work is to compare not only the lipid profile of patients with lupus nephritis (LN) to other patients with SLE but also growth and inflammatory factors and disease activity factors. The LN group consisted of 36 patients with a mean disease duration of 14 years and the LN group consisted of 53 patients with a mean disease duration of 18 years. In our study, we did not observe any statistically significant difference in parameters other than IL2. Although lipid levels did not differ statistically, we observed a different incidence of elevated levels in the two groups. Therefore, the treatment of dyslipidemia should never be forgotten in the treatment of SLE.
\end{abstract}

Key words: Systemic lupus erythematosus, cardiovascular diseases, lipids, inflammatory markers

\section{1. ÚVOD}

Systémový lupus erythematosus (SLE) je chronická autoimunitná porucha, ktorá postihuje rôzne orgány, je charakterizovaná špecifickými klinickými príznakmi, priebehom remisií a exacerbácií, tvorbou protilátok spojených so zápalom (1). Etiológia ochorenia je rôznorodá, vrátane genetických, hormonálnych a environmentálnych faktorov. V pokročilejšom štádiu ovplyvňuje renálny, plúcny, kardiovaskulárny a centrálny nervový systém (2), zatial' čo život ohrozujúce komplikácie, ako je lupusová nefritída, sa vyskytujú až u $1 / 3$ pacientov (3). Kardiovaskulárne choroby $(\mathrm{KVCH})$ sú považované za jednu z hlavných príčin smrti spojené so zvýšeným rizikom ženského pohlavia, dlhším trvaním choroby a dyslipidémiou (4). Dyslipidémia pri chronickom implantačnom autoimunitnom ochorení SLE je výsledkom 
účinku cytokínov na tukové tkanivo, ktoré uvol'ňuje vol'né mastné kyseliny, čo vedie $\mathrm{k}$ zvýšeniu syntézy triglyceridov a mastných kyselín $\mathrm{v}$ pečeni a $\mathrm{k}$ zníženiu aktivity lipoproteín lipázy, ktorá má katabolickú funkciu vo vaskulárnom endoteli, kde pôsobí na triglyceridy bohaté na lipidy. Vysoké hladiny triglyceridov $\mathrm{v}$ dôsledku výmeny neutrálnych lipidov podporujú syntézu LDL a znižujú hladinu HDL (5). 5-ročná prospektívna štúdia zistila, že u $32 \%$ pacientov so SLE sa vyvinula ateroskleróza karotíd v porovnaní so $4 \%$ zdravých kontrolných osôb (6). Dyslipidémia je závažnejšia u pacientov s lupusovou nefritídou v porovnaní s pacientmi bez SLE, ale s podobným stupňom chronického ochorenia obličiek. Aj ked' práve zmenené hladiny alebo funkcie lipidov môžu hrat' úlohu vo vývoji glomerulárnej aterosklerózy (3). Dyslipidémia ako jedna z príčin $\mathrm{KVCH}$ a rizikový faktor, ktorý môže byt' ovplyvnený cvičením, životným štýlom a liečbou, sa musí u pacientov monitorovat', aby sa určili rizikoví pacienti, čím sa zvyšuje chorobnost' a úmrtnost'.

\section{MATERIÁL A METÓDY}

Súbor pacientov pozostával z dvoch skupín prvá skupina s LN bola tvorená 36 pacientmi s priemerným vekom 44 rokov a s priemernou dížkou ochorenia 14 rokov a skupinu bez LN tvorilo 53 pacientov s priemerným vekom 45 rokov a s priemernou dĺžkou ochorenia 18 rokov. Pacienti boli diagnostikovaní na základe ACR SLE kritérií v Národnom ústave reumatických chorôb (NÚRCH) v Pieštanoch. Dáta boli spracované po schválení etickou komisiou. Pacientom sa odobrala krv a zo séra boli vyhodnotené parametre lipidového metabolizmu ( celkový cholesterol (TC), HDL, LDL, triglyceridy (TG), apolipoproteín A (APOA) apolipoproteín B (APOB) a lipoproteín A (LpA)), cytokíny a rastové faktory ( interleukíny (IL1A, IL1B, IL2, IL4, IL6, IL8, IL10), cievny endoteliálny rastový faktor (VEGF), interferón $\gamma$ (IFN $\gamma$ ), tumor necrosis faktor $\alpha$ (TNF $\alpha$ ), monocytárny chemoatraktívny proteín 1 (MCP-1), epidermálny rastový faktor (EGF), adiponektín (ADPN), cystacín C (CYSC) a CRP. Merali sme aj parametre aktivity ochorenia - antinukleárne protilátky (ANA), protilátky proti extrahovatelným nukleárnym antigénom (ENA), protilátky proti kardiolipínom (ACLA), protilátky proti hladkému svalstvu (antiSm) a hemolytická aktivita komplementu (CH50). Po zbere vzoriek od pacientov a nameraní jednotlivých parametrov sme výsledky štatisticky vyhodnotili a určili priemer \pm štandardnú odchýlku. Na stanovenie normality rozloženia údajov sa využíval Shapiro-Wilkov test. Pri premenných, ktoré neboli rozložené normálne (pri neparametrických premenných) sa následne využíval KruskalWallisov test. Pri premenných, ktoré boli rozložené normálne (parametrických premenných) bol využívaný test Anova. Hladina významnosti sa stanovila na $5 \%$ (t. j. p < 0,05). Statistická analýza bola uskutočnená v programe R-project.

\section{VÝSLEDKY}

Všetci pacienti užívali počas svojej liečby antimalariká, skupina s LN užívala prednison v priemernej dávke $9,52 \mathrm{mg} /$ deň, skupina bez $\mathrm{LN}$ užívala prednison v dávke $6,85 \mathrm{mg}$. Priemerná hodnota BMI v skupine s LN bola 24,04 a v skupine bez LN bola 25,80. Priemerná nameraná hladina glukózy u pacientov s LN bola $5,15 \mathrm{mmol} / \mathrm{L}$ a u pacientov bez $\mathrm{LN}$ bola 5,23 mmol/L. Z dôvodu lepšieho porovnania skupín boli do skupín zahrnutí len pacienti, ktorí nemali diabetes. V tabul'kách sú zhrnuté dáta meraných parametrov, pri parametroch lipidového metabolizmu a parametroch aktivity ochorenia sme medzi skupinami nenašli žiaden štatisticky významný rozdiel. V skupine vyšetrení cytokínov a rastových faktorov u pacientov SLE s LN a bez LN sme zistili štatisticky významný rozdiel jedine pri IL2. 
Tabul'ka 1 Porovnanie nameraných hodnôt lipidového metabolizmu pacientov SLE s LN a bez LN

\begin{tabular}{|c|c|c|c|c|c|}
\hline Parameter & & Priemer \pm SD & Median & Min - max & p hodnota \\
\hline \multirow{2}{*}{$\begin{array}{c}\mathrm{TC} \\
(\mathrm{mmol} / \mathrm{l})\end{array}$} & S LN & $5,56 \pm 1,07$ & 5,63 & $2,60-7,52$ & \multirow{2}{*}{$\mathrm{p}>0,05$} \\
\hline & Bez LN & $5,39 \pm 1,36$ & 5,35 & $3,04-9,23$ & \\
\hline \multirow{2}{*}{$\begin{array}{c}\text { HDL } \\
(\mathrm{mmol} / \mathrm{l})\end{array}$} & S LN & $1,60 \pm 0,56$ & 1,52 & $0,71-3,53$ & \multirow{2}{*}{$p>0,05$} \\
\hline & Bez LN & $1,58 \pm 0,54$ & 1,53 & $0,76-2,98$ & \\
\hline \multirow{2}{*}{$\begin{array}{c}\mathrm{LDL} \\
(\mathrm{mmol} / \mathrm{l})\end{array}$} & S LN & $3,59 \pm 1,02$ & 3,81 & $1,60-5,44$ & \multirow{2}{*}{$p>0,05$} \\
\hline & Bez LN & $3,59 \pm 1,18$ & 3,81 & $1,60-5,44$ & \\
\hline \multirow{2}{*}{$\begin{array}{c}\mathrm{TG} \\
(\mathrm{mmol} / \mathrm{l})\end{array}$} & S LN & $1,50 \pm 0,87$ & 1,20 & $0,48-4,31$ & \multirow{2}{*}{$p>0,05$} \\
\hline & Bez LN & $1,49 \pm 0,66$ & 1,35 & $0,47-3,24$ & \\
\hline \multirow{2}{*}{$\begin{array}{c}\text { APOA } \\
(\mathrm{g} / \mathrm{l})\end{array}$} & S LN & $1,65 \pm 0,34$ & 1,58 & $0,96-2,61$ & \multirow{2}{*}{$p>0,05$} \\
\hline & Bez LN & $1,65 \pm 0,38$ & 1,72 & $1,10-2,67$ & \\
\hline \multirow{2}{*}{$\begin{array}{c}\text { APOB } \\
(\mathrm{g} / \mathrm{l})\end{array}$} & S LN & $1,22 \pm 0,41$ & 1,23 & $0,63-2,80$ & \multirow{2}{*}{$\mathrm{p}>0,05$} \\
\hline & Bez LN & $1,11 \pm 0,34$ & 1,05 & $0,62-1,77$ & \\
\hline \multirow{2}{*}{ LpA } & S LN & $56,32 \pm 90,70$ & 18,20 & $0,80-358,20$ & \multirow{2}{*}{$\mathrm{P}>0,05$} \\
\hline & Bez LN & $72,03 \pm 117,90$ & 19,20 & $0,50-630,20$ & \\
\hline
\end{tabular}

Tabul'ka 2 Porovnanie nameraných hodnôt cytokínov a rastových faktorov u pacientov SLE $\mathrm{s}$ LN a bez LN

\begin{tabular}{|c|c|c|c|c|c|}
\hline Parameter & & Priemer \pm SD & Median & Min - max & p hodnota \\
\hline \multirow{2}{*}{$\begin{array}{c}\text { IL2 } \\
(\mathrm{pg} / \mathrm{ml})\end{array}$} & S LN & $6,11 \pm 18,87$ & 2,88 & $1,89-117,65$ & \multirow{2}{*}{$\mathrm{p}<0,05$} \\
\hline & Bez LN & $2,67 \pm 0,78$ & 2,64 & $1,06-5,88$ & \\
\hline \multirow{2}{*}{$\begin{array}{c}\text { IL4 } \\
(\mathrm{pg} / \mathrm{ml})\end{array}$} & S LN & $2,42 \pm 0,57$ & 2,40 & $1,43-4,44$ & \multirow{2}{*}{$p>0,05$} \\
\hline & Bez LN & $2,24 \pm 0,73$ & 2,16 & $1,08-5,57$ & \\
\hline \multirow{2}{*}{$\begin{array}{c}\text { IL6 } \\
\text { (pg/ml) }\end{array}$} & S LN & $2,20 \pm 1,36$ & 1,71 & $0,64-6,88$ & \multirow{2}{*}{$p>0,05$} \\
\hline & Bez LN & $3,30 \pm, 08$ & 2,12 & $0,69-16,26$ & \\
\hline \multirow{2}{*}{$\begin{array}{c}\text { IL8 } \\
(\mathrm{pg} / \mathrm{ml})\end{array}$} & S LN & $8,47 \pm 4,75$ & 7,29 & $1,36-25,15$ & \multirow{2}{*}{$p>0,05$} \\
\hline & Bez LN & $12,32 \pm 11,93$ & 8,42 & $1,61-58,75$ & \\
\hline \multirow{2}{*}{$\begin{array}{c}\text { IL10 } \\
(\mathrm{pg} / \mathrm{ml})\end{array}$} & S LN & $1,71 \pm 1,58$ & 1,22 & $0,70-8,36$ & \multirow{2}{*}{$\mathrm{P}>0,05$} \\
\hline & Bez LN & $1,79 \pm 2,07$ & 1,35 & $0,64-14,59$ & \\
\hline \multirow{2}{*}{$\begin{array}{l}\text { VEGF } \\
(\mathrm{pg} / \mathrm{ml})\end{array}$} & S LN & $81,75 \pm 76,66$ & 50,48 & $7,03-341,56$ & \multirow{2}{*}{$p>0,05$} \\
\hline & Bez LN & $75,02 \pm 61,07$ & 55,31 & $7,64-252,60$ & \\
\hline \multirow{2}{*}{$\begin{array}{c}\text { IFNG } \\
(\mathrm{pg} / \mathrm{ml})\end{array}$} & S LN & $0,87 \pm 0,66$ & 0,65 & $0,30-3,71$ & \multirow{2}{*}{$p>0,05$} \\
\hline & Bez LN & $1,54 \pm 3,54$ & 0,64 & $0,00-19,67$ & \\
\hline \multirow{2}{*}{$\begin{array}{l}\text { TNFA } \\
(\mathrm{pg} / \mathrm{ml})\end{array}$} & S LN & $2,49 \pm 1,01$ & 2,17 & $1,19-4,92$ & \multirow{2}{*}{$\mathrm{p}>0,05$} \\
\hline & Bez LN & $2,53 \pm 1,16$ & 2,15 & $0,85-6,00$ & \\
\hline \multirow{2}{*}{$\begin{array}{c}\text { IL1A } \\
\text { (pg/ml) }\end{array}$} & S LN & $0,37 \pm 0,11$ & 0,39 & $0,06-0,63$ & \multirow{2}{*}{$\mathrm{p}>0,05$} \\
\hline & Bez LN & $0,39 \pm 0,15$ & 0,37 & $0,12-1,01$ & \\
\hline \multirow{2}{*}{$\begin{array}{c}\text { IL1B } \\
(\mathrm{pg} / \mathrm{ml})\end{array}$} & S LN & $1,66 \pm 0,27$ & 1,64 & $1,22-2,36$ & \multirow[t]{2}{*}{$\mathrm{p}>0,05$} \\
\hline & Bez LN & $1,55 \pm 0,44$ & 1,59 & $0,43-2,87$ & \\
\hline \multirow{2}{*}{$\begin{array}{c}\text { MCP1 } \\
\text { (pg/ml) }\end{array}$} & S LN & $239,99 \pm 161,44$ & 185,97 & $26,06-781,00$ & \multirow[t]{2}{*}{$\mathrm{p}>0,05$} \\
\hline & Bez LN & $260,73 \pm 170,65$ & 224,95 & $43,95-781,00$ & \\
\hline \multirow{2}{*}{$\begin{array}{c}\text { EGF } \\
(\mathrm{pg} / \mathrm{ml})\end{array}$} & S LN & $34,32 \pm 34,07$ & 19,41 & $0,70-108,16$ & \multirow[t]{2}{*}{$\mathrm{P}>0,05$} \\
\hline & Bez LN & $31,18 \pm 34,73$ & 18,52 & $0,00-137,79$ & \\
\hline \multirow{2}{*}{$\begin{array}{l}\text { ADPN } \\
\text { (ng/ml) }\end{array}$} & $\mathrm{S} \mathrm{LN}$ & $68,89 \pm 52,34$ & 52,28 & $7,38-194,00$ & \multirow[t]{2}{*}{$p>0,05$} \\
\hline & Bez LN & $72,47 \pm 51,88$ & 57,19 & $0,00-194,00$ & \\
\hline \multirow{2}{*}{$\begin{array}{c}\text { CYSC } \\
(\mathrm{ng} / \mathrm{ml})\end{array}$} & S LN & $12,05 \pm 7,42$ & 8,49 & $3,16-21,00$ & \multirow[t]{2}{*}{$p>0,05$} \\
\hline & Bez LN & $14,27 \pm 7,01$ & 16,62 & $0,00-21,00$ & \\
\hline CRP & S LN & $43,42 \pm 62,02$ & 13,46 & $4,56-233,00$ & $\mathrm{P}>0,05$ \\
\hline
\end{tabular}


\begin{tabular}{l|c|c|c|c|}
$(\mathrm{ng} / \mathrm{ml})$ & Bez LN & $54,64 \pm 75,82$ & 21,74 & $4,16-233,00$ \\
\hline
\end{tabular}

Tabul'ka 3 Porovnanie nameraných hodnôt parametrov charakterizujúcich aktivitu ochorenia u pacientov SLE s LN a bez LN

\begin{tabular}{|c|c|c|c|c|c|c|}
\hline \multicolumn{2}{|c|}{ Parameter } & & Priemer \pm SD & Median & Min - max & p hodnota \\
\hline \multirow{4}{*}{ ANA } & dsDNA & S LN & $105,77 \pm 91,12$ & 82,90 & $18,50-263,6$ & \multirow{2}{*}{$\mathrm{p}>0,05$} \\
\hline & $\mathrm{U} / \mathrm{mL}$ & Bez LN & $68,50 \pm 50,18$ & 62,60 & $21,0-159,6$ & \\
\hline & \multirow{2}{*}{$\begin{array}{l}\text { DNP } \\
\text { U/mL }\end{array}$} & S LN & $34,25 \pm 22,13$ & 34,25 & $18,60-49,90$ & \multirow{2}{*}{$\mathrm{p}>0,05$} \\
\hline & & Bez LN & $22,05 \pm 3,46$ & 22,05 & $19,60-24,50$ & \\
\hline \multirow{4}{*}{ ENA } & SSA & S LN & $150,60 \pm 63,92$ & 151,40 & $68,90-258,4$ & \multirow{2}{*}{$\mathrm{p}>0,05$} \\
\hline & $\mathrm{U} / \mathrm{mL}$ & Bez LN & $99,86 \pm 94,37$ & 45,90 & $20,90-278,3$ & \\
\hline & \multirow{2}{*}{$\begin{array}{l}\text { RNP } \\
\text { U/mL }\end{array}$} & S LN & $94,62 \pm 1,6,64$ & 46,10 & $21,50-281,3$ & \multirow{2}{*}{$\mathrm{p}>0,05$} \\
\hline & & Bez LN & $185,90 \pm 141,28$ & 185,90 & $86,0-285,8$ & \\
\hline \multirow{2}{*}{\multicolumn{2}{|c|}{$\begin{array}{l}\text { ACLA } \\
\mathrm{U} / \mathrm{mL}\end{array}$}} & S LN & $82,63 \pm 88,79$ & 45,80 & $24,30-37,00$ & \multirow{2}{*}{$\mathrm{p}>0,05$} \\
\hline & & Bez LN & $90,12 \pm 87,88$ & 57,30 & $31,60-244,0$ & \\
\hline \multirow{2}{*}{\multicolumn{2}{|c|}{$\begin{array}{l}\text { CH50 } \\
\mathrm{U} / \mathrm{mL}\end{array}$}} & S LN & $160,88 \pm 74,21$ & 146,00 & $44,0-300$ & \multirow{2}{*}{$\mathrm{p}>0,05$} \\
\hline & & Bez LN & $145,69 \pm 62,87$ & 138,50 & $51,0-300$ & \\
\hline \multirow{2}{*}{\multicolumn{2}{|c|}{$\begin{array}{c}\text { antiSm } \\
\mathrm{U} / \mathrm{mL}\end{array}$}} & S LN & $31,85 \pm 19,87$ & 23,35 & $19,20-61,50$ & \multirow{2}{*}{$\mathrm{p}>0,05$} \\
\hline & & Bez LN & $71,07 \pm 50,11$ & 100 & $13,20-100$ & \\
\hline
\end{tabular}

Pri štatistickom vyhodnocovaní sme robili aj korelácie medzi parametrami lipidov a cytokínov a zápalových faktorov ktoré sú zhrnuté v tabul'ke 4.

Tabul'ka 4 Štatistické vyhodnotenie korelácie lipidových parametrov so zápalovými faktormi a cytokínmi pri pacientoch $\mathrm{s} \mathrm{LN}$ a bez $\mathrm{LN}$

\begin{tabular}{|c|c|c|c|}
\hline \multicolumn{2}{|c|}{ Pacienti s LN } & \multicolumn{2}{|c|}{ Pacienti bez LN } \\
\hline \multicolumn{4}{|c|}{ Pozitívne korelácie } \\
\hline CRP a VLDL & $\mathrm{R}=0,44$ & HDL a ADPN & $\mathrm{R}=0,45$ \\
\hline CRP a TG & $\mathrm{R}=0,44$ & ApoA a ADPN & $\mathrm{R}=0,44$ \\
\hline CRP a ApoB & $\mathrm{R}=0,43$ & & \\
\hline CYSC a TC & $\mathrm{R}=0,41$ & & \\
\hline CYSC a LDL & $\mathrm{R}=0,37$ & & \\
\hline CYSC a ApoB & $\mathrm{R}=0,48$ & & \\
\hline \multicolumn{4}{|c|}{ Negatívne korelácie } \\
\hline CRP a HDL & $\mathrm{R}=0,41$ & & \\
\hline
\end{tabular}

Hypertenziu v skupine s LN malo 52,77\%, kardiovaskulárne ochorenie zahrňujúce mítvicu, tromboflebitídu a ischemickú chorobu dolných končatín malo $27,77 \%$ pacientov od určenia diagnózy SLE. V skupine bez LN malo hypertenziu 37,74 \% a kardiovaskulárne ochorenie sa vyskytlo u 18,87\%. Podrobnejšie dáta sú v tabul'ke 5 .

Tabul'ka 5 Porovnanie vybraných ochorení pri pacientoch s LN a bez LN

\begin{tabular}{|l|c|c|}
\hline Patienti & S LN & Bez LN \\
\hline Počet (n) & 36 & 53 \\
\hline Priemerná dížka ochorenia & 14 rokov & 18 rokov \\
\hline Hypertenzia & 19 & 15 \\
\hline Antifosfolipidový syndróm & 2 & 5 \\
\hline Mŕtvica & 1 & 5 \\
\hline Tromboflebitída & 8 & 5 \\
\hline Ischemická choroba dolných končatín & 1 & 5 \\
\hline
\end{tabular}




\section{DISKUSIA}

Úmrtnost' pacientov so SLE v porovnaní s bežnou populáciou predstavuje 3-násobné zvýšenie rizika kardiovaskulárnej smrti u pacientov so SLE a 8-násobné zvýšenie rizika pri renálnom postihnutí (7). V niekol'kých štúdiách o vplyve dyslipidémie pri SLE na KVCH sa ukazuje, že zvýšená hladina TC je nezávislým prediktorom kardiovaskulárnych príhod a neočakávane LDL nebol nezávislým faktorom kardiovaskulárnych príhod (8). Prevalencia zvýšených hodnôt TC v tejto štúdii bola $61,8 \%$ a v iných štúdiách bola prevalencia zvýšených hodnôt TC 33,6-51,1\% (9). Sajjad so svojimi kolegami nameral zvýšenú hladinu TC, LDL a TG u 55,4\%, $30,8 \%$ a $58,5 \%$ u pacientov so SLE s lupusovou nefritídou (3) Wijaya hlásil zvýšenú hladinu TC, LDL a TG u 43\%, 26,4 \%, 44,2\% (10) a v našej štúdii sme hlásili u pacientov s lupusovou nefritídou zvýšenú hladinu TC, LDL a TG u 72,22\%, 77,77\% a 27,77\%. Nízka hladina HDL v našej štúdii u pacientov s lupusovou nefritídou bola u 19,44\% a Sajjad nameral nízku hladinu HDL u 21,5\% pacientov s LN (3). Abnormálny lipidový profil u pacientov so SLE nazývajú niektorí autori „lupusový vzorec dyslipoproteinémie“ a je charakterizovaný zvýšenými hladinami TC, TG, LDL a zníženými hladinami HDL. Haddiya v štúdii zaznamenal prevalenciu dyslipidémie so zvýšenými hladinami TC, LDL, TG zo 41\% pri stanovení diagnózy na $59,7 \%$ po 24 mesiacoch (11). Kiss a kol. síce popisuje vo svojej štúdii významný rozdiel v týchto dvoch skupinách pri parametroch TC, LDL, TG a APOB (12), no v našej štúdii sme nepozorovali štatisticky významný rozdiel hladín lipidov, avšak pozorujeme rozličný výskyt zvýšených hladín u týchto dvoch skupín. Pri pacientoch s LN sa zvýšene hladiny TC, LDL a TG vyskytli u 72,22\%, 77,77\% a 27,77\%, pričom u pacientoch bez LN sa vyskytli pri 56,60\%, 71,69\% a 43,40\%. Častejší výskyt dislipidémie u pacientov s LN ako bez LN potvrdzuje aj štúdia Mirgani a kol. (13). LpA je považovaný za nezávislý rizikový faktor aterosklerózy a očakávali sme aj štatisticky významný rozdiel medzi týmito dvoma skupinami ako to potvrdzuje aj Kiss a kol. (12) vo svojej štúdii no v našej sa to nepotvrdilo. Nízke hladiny HDL boli pri pacientoch s LN 19,44\% a paradoxne až u 26,42\% pacientov bez LN. Ked’že sme v našej štúdii nepotvrdili štatisticky významné rozdiely medzi skupinami pri rastových faktoroch, zápalových markeroch a markeroch aktivity ochorenia okrem IL2, zamerali sme sa na zist'ovanie korelácie medzi markermi lipidového metabolizmu a zápalovými a rastovými markermi. Pri LN sme pozorovali pozitívnu koreláciu medzi CYSC a TC $(\mathrm{R}=0,41)$, medzi CYSC a LDL $(\mathrm{R}=0,37)$ a CYSC a APOB $(\mathrm{R}=0,48)$. Renálna dysfunkcia je rizikovým faktorom progresie $\mathrm{KVCH}$ a pre funkciu obličiek je cystatín $\mathrm{C}$ citlivejším indikátorom ako sérový kreatinín. So sérovými hladinami cystatínu $\mathrm{C}$ súvisí aj arteriálna stuhnutost'. Riziko dyslipidémie stúpa so zvyšujúcimi sa hladinami cystacínu C (14). Žiadne korelácie medzi CYSC a parametrami lipidov u pacientov bez LN neboli v našej štúdii zaznamenané, na základe čoho možno predpokladat', že CYSC je vhodným ukazovatel'om budúcej či prebiehajúcej dyslipidémie a vzniku KVCH. Stredne silná pozitívna korelácia v našej štúdii bola medzi CRP a VLDL $(\mathrm{R}=0,44), \mathrm{CRP}$ a TG $(\mathrm{R}=0,44)$, CRP a $\operatorname{ApoB}(\mathrm{R}=0,43)$ a stredne silná negatívna korelácia bola medzi $\operatorname{HDL}$ a $\mathrm{CRP}(\mathrm{R}=-0,41)$. Podobne, negatívna korelácia medzi HDL a CRP bola v štúdii so 110 pacientmi SLE, pričom pozorovali aj negatívnu koreláciu medzi IL-6 resp. TNFa a HDL, čo sme v našej štúdii nepozorovali. Zároveň bola $\mathrm{v}$ danej štúdii pozorovaná pozitívna korelácia medzi CRP a TG (15). Asanuma a kol., 2006 vo svojej štúdii so 74 pacientmi SLE uvádza negatívnu koreláciu medzi MCP-1 a HDL (16), ktorú sme taktiež v našej štúdii nepozorovali. Negatívnu koreláciu medzi CRP a HDL $(\mathrm{R}=0,41)$ podporuje štúdia Szabó et al (1) v ktorej túto negatívnu koreláciu taktiež pozorovali. V danej štúdii pozorovali negatívnu koreláciu medzi HDL a IL6 a HDL a MCP-1, ktoré sa u nás nepotvrdili. TNF a znižuje aktivitu LPL čím podporuje zvýšenie hladín TG, pričom je dokázané, že vysoké hladiny TG sú spôsobené syntézou de novo v pečeni z VLDL (17), čo potvrdzuje aj štúdia kde korelovala hladina TNF $\alpha$ a TG (18), no my sme pozorovali len koreláciu medzi CRP a TG a CRP a VLDL. 


\section{ZÁVER}

Napriek tomu, že sa v našej štúdii nepreukázala štatisticky významný rozdiel v parametroch medzi skupinou s LN a bez LN okrem IL2, neznamená to, že je aj rovnaké riziko KVCH medzi týmito skupinami. Dyslipidémia je viacnásobný patogenetický mechanizmus kde CRP a sedimentácia erytrocytov (ESR) môže potláčat' HDL a zvýšit' TG, autoprotilátky spôsobujú poškodenie endotelu, cirkulujúce zápalové markery a protilátky znižujú lipoproteínovú lipázu (LPL), zvýšený oxidatívny stres môže spustit’ široku škálu pro aterogénnych modifikácii lipidov. Preto by sa nemalo nikdy zabúdat' pri liečbe SLE na liečbu dyslipidémie.

\section{Použitá literatura}

1. Szabó MZ, Szodoray P, Kiss E, Dyslipidemia in systemic lupus erythematosus, Immunol Res. 2017 Apr;65(2):543-550

2. Barbary H, Liu X, Ayatollahi Y et al. Favorable effects of hydroxychloroquine on serum low density lipid in patients with systemic lupus erythematosus: A systematic review and meta-analysis, Int J Rheum Dis. 2018 Jan;21(1):84-92.

3. Sajjad S, Farman S, Saeed MA et al., Frequency of Dyslipidemia in patients with Lupus Nephritis, Pak J Med Sci. 2017 Mar-Apr;33(2):358-362. doi: 10.12669/pjms.332.12410.

4. Croca S, Rahman A, Atherosclerosis in systemic lupus erythematosus, Best Practice \& Research Clinical Rheumatology (2017), https://doi.org/10.1016/j.berh.2017.09.012

5. Batún Garrido JA, Radilo Alba HA, Herníndes Núnez E et al., Dyslipidaemia and atherogenic risk in patients with systemic lupus erythematosus, Med Clin (Barc). 2016 Jul 15;147(2):63-6

6. Liu Y, Kaplan M, Cardiovascular disease in systemic lupus erythematosus: an update, Current Opinion in Rheumatology: September 2018 - Volume 30 - Issue 5 - p 441-448

7. Yurkovich M, Vostretsova K, Chen W, Aviňa-Zubieta JA, Overall and Cause-Specific Mortality in Patients with Systemic Lupus Erythematosus: A Meta-Analysis of Observational Studies, Arthritis Care Res (Hoboken). 2014 Apr;66(4):608-16. doi: 10.1002/acr.22173.

8. Tselios K, Koumaras Ch, Gladman DD, Urowitz MB, Dyslipidemia in systemic lupus erythemotosus: just another comorbidity? Semin Arthritis Rheum. 2016 Apr;45(5):604-10. doi: 10.1016/j.semarthrit.2015.10.010. Epub 2015 Oct 29.

9. Ali Abdalla $\mathrm{M}$ et al. Clinical significance of lipid profile in systemic lupus erythematosus patients: Relation to disease activity and therapeutic potential of drugs, The Egyptian Rheumatologist (2016), http://dx.doi.org/10.1016/j.ejr.2016.08.004

10. Wijaya LK, Kasjmir YI, Skumana $\mathrm{N}$ et al., The proportion of dyslipidemia in systemic lupus erythematosus patient and distribution of correlated factors, Acta Med Indones. 2005 Jul-Sep;37(3):132--44.

11. Haddiya I, PS8:169 Prevalence and impact of dyslipidemia in lupus nephritis patients Lupus Science \& Medicine 2018;5:doi: 10.1136/lupus-2018- abstract.212

12. Kiss E, Fazekas B, Tarr T, Muszbek L, Zeher M, Szegedi G. Lipid profile in patients with systemic lupus erythematosus, with special focus on lipoprotein(a) in lupus nephritis. Orv Hetil. 2004 Feb 1;145(5):217-22. Hungarian. PMID: 15024932.

13. Mirghani, H. O., Abdul Khalig Alyoussef, A., \& Mohammed, O. S. (2020). The relationship between dyslipidemia and lupus nephritis in systemic lupus erythematosus patients attending a Saudi Rheumatic Center, Tabuk. Sudan Journal of Medical Sciences (SJMS), 15(1), 10-19. https://doi.org/10.18502/sjms.v15i1.6697

14. Huang X, Jiang X, Wang L, et al. Serum Cystatin C and Arterial Stiffness in MiddleAged and Elderly Adults without Chronic Kidney Disease: A Population-Based 
Study. Med Sci Monit. 2019;25:9207-9215. Published 2019 Dec 3. doi:10.12659/M SM.916630

15. Chung CP, Avalos I, Oeser A, et al, High prevalence of the metabolic syndrome in patients with systemic lupus erythematosus: association with disease characteristics and cardiovascular risk factors, Annals of the Rheumatic Diseases 2007;66:208-214. DOI: $10.1136 /$ ard.2006.054973

16. Asanuma Y, et al. Increased concentration of proatherogenic inflammatory cytokines in systemic lupus erythematosus: relationship to cardiovascular risk factors. The Journal of Rheumatology March 2006, 33 (3) 539-545; PMID: 16463434.

17. Feinberg B, Kurzrock R, Talpaz M, Blick M, Saks S, Gutterman JU. A phase I trial of intravenously-administered recombinant tumor necrosis factor-alpha in cancer patients. J Clin Oncol. 1988;6: 1328-34.

18. Svenungsson E, Fei GZ, Jensen-Urstad K, et al. TNF-alpha: a link between hypertriglyceridaemia and inflammation in SLE patients with cardiovascular disease. Lupus. 2003a;12(6):454-61.

\section{Kontaktní údaje}

Mgr. et Mgr. Ján Sitko

Trnavská univerzita v Trnave, Fakulta zdravotníctva a sociálnej práce

Udavské 86, 067 31, Udavské

Tel: +421949333826

email:ss.sitko@gmail.com 
PSYCHOLOGIE, SOCIOLOGIE, PEDAGOGIKA PSYCHOLOGY, SOCIOLOGY, PEDAGOGY

\section{QUAERE}




\title{
ANALÝZA SOCIÁLNÍCH DOVEDNOSTÍ U PRACOVNÍKŮ SOCIÁLNĚ PRÁVNÍ OCHRANY DĚTí
}

\author{
ANALYSIS OF SOCIAL SKILLS FOR WORKERS OF SOCIAL LEGAL \\ PROTECTION OF CHILDREN
}

\author{
Jan Tirpák, Miriam Uhrinová, Tereza Ulrychová
}

\begin{abstract}
Abstrakt
Př́spěvek se zaměřuje na analýzu sociálních dovedností u pracovníků sociálně právní ochrany dětí v závislosti na délce jejich praxe. Výzkum byl proveden standardizovaným šetřením pomocí výzkumného nástroje SSI-Social skills inventory (Riggio, Carney, 2007). Výzkumný záměr jsme realizovali na vzorku 100 vybraných respondentů v Ústeckém kraji. Daný výzkumný soubor byl dále vnitřně diferencován. Článek reflektuje klíčové aspekty související s tímto výzkumem.
\end{abstract}

Klíčová slova: sociálni dovednosti, sociálni pracovnik, sociálně právní ochrana dètí, standardizovaný dotazník, ANOVA

\begin{abstract}
The paper focuses on the analysis of social skills of social and legal protection of children depending on the length of their practice. The research was conducted by a standardized survey using the research tool SSI-Social skills inventory (Riggio, Carney, 2007). We implemented the research plan on a sample of 100 selected respondents in the Ústí Region. The research set was further internally differentiated. The article reflects key aspects related to this research.
\end{abstract}

Key words: social skills, social worker, social and legal protection of children, standardized questionnaire, ANOVA

\section{1 ÚVOD A TEORETICKÁ VÝCHODISKA}

\subsection{Obecná charakteristika základních pojmů}

Oblast sociálně právní ochrany dětí je velmi široká a klade zvýšené nároky na jednotlivé pracovníky. Jejím cílem je totiž $\mathrm{v}$ obecné rovině zajistit důslednou ochranu práv každého dítěte a naplnění jeho individuálních potřeb, podpořit kvalitu života dětí a rodiny, eliminovat diskriminaci a nerovný prrístup $\mathrm{k}$ dětem, podporovat všestranný rozvoj dítěte doma $\mathrm{v}$ jeho přirozeném rodinném prostředí, a nebude-li to možné, tak primárně v náhradním rodinném prostředí, podpořit účast dítěte na rozhodování o záležitostech, které se ho týkají. Mezi hlavní činnosti pracovníků sociálně právní ochrany dětí tudíž patří především preventivní a poradenská činnost, výchovná opatření a opatření na ochranu dětí, činnosti při svěření dítěte do péče jiné osoby odpovědné za výchovu dítěte, zprostředkování osvojení a pěstounské péče, pěstounská péče na přechodnou dobu, péče o děti vyžadující zvýšenou pozornost, sociálně právní ochrana ve vztahu k cizině a ve zvláštních př́ípadech (Šíp, Hájková, 2019). Potřeba adekvátních profesních a osobnostních kompetencí u pracovníků sociálně právní ochrany dětí je proto naprosto stěžejním tématem.

Při samotném vymezování oblasti kompetencí můžeme využít všeobecně přijímané dělení na kompetence odborné, metodické a sociální (Beneš, 2014). K odborným kompetencím se vztahují obsahy, předměty a prostředky práce, tedy při výkonu pracovní činnosti získané kompetence. Sociální (týmové) kompetence mají zaručit zvládání sociálních interakcí, 
komunikačních strategií, konfliktů a moderace. Pod metodickými kompetencemi se rozumí schopnost vyhledávat a zpracovat informace. Dále pak úroveň logického, abstraktního, deduktivního a induktivního myšlení. Řadíme sem i určitou soudnost a schopnost úsudku, řešení problémů, vedení projektů a obecné pracovní techniky. Kompetence mají nejen individuální, ale i sociální dimenzi. Na rozdíl od kvalifikace kompetence vyjadřují jednání $\mathrm{v}$ reálných situacích. Jsou tedy relativní, nebot' situace a okolnosti se mění (Veteška, Tureckiová, 2008). Pokud mluvíme o profesním uplatnění, bude se kompetence projevovat v chování spojeném s plněním pracovních úkolů a realizovat jako dosažený výkon při použití určitého lidského potenciálu (Hroník, 2006). Jsou výrazem schopnosti člověka chovat se prriměřeně situaci, v souladu sám se sebou, tedy jednat kompetentně (Belz, Siegrist, 2001). Důležitým poznatkem je i to, že klíčové kompetence mají delší životnost než kvalifikace vázané na samotnou profesi. Ovládnout definitivně klíčové kompetence přitom není možné, nebot' proces učení u kompetencí v oblasti metod či sociálních kompetencí nelze nikdy ukončit. Klíčové kompetence tak vybízejí k celoživotnímu učení, k procesům stálých změn a k možnostem dalšího rozvoje osob a společnosti (Hroník, 2006).

Jelikož je sociálně právní ochrana dětí součástí sítě služeb pro ohrožené rodiny s dětmi, kompetence těchto pracovníků tvoří v jistém ohledu strategické kompetence organizace jako celku a pomáhají naplňovat úlohu v síti ostatních služeb (Šíp, Hájková, 2019). Aby mohl pracovník sociálně právní ochrany vykonávat svou činnost $\mathrm{v}$ požadované míre, být zodpovědný za optimální proces zajišt'ování sociálně právní ochrany dětí a prostřednictvím hodnocení svého výkonu i schopný adekvátním způsobem volit vhodné oblasti svého profesního rozvoje, musí být jeho pozice srozumitelně definovaná pro všechny zúčastněné strany. Pracovník musí vědět, jaké role zastává, jaké činnosti jeho role obnáší a jaké druhy kompetencí jsou pro tyto činnosti nutné. Již nyní by (dle standardů) mělo každé pracoviště oddělení sociálně právní ochrany dětí zpracovávat pracovní profily pro jednotlivé pozice. Profily by měly obsahovat popis pracovní náplně (pracovní činnost, úkoly a procesy/role, jichž se pracovník zúčastňuje) a popis požadovaných kompetencí.

$\mathrm{V}$ další části tohoto textu se $\mathrm{z}$ hlediska našeho zaměření budeme věnovat především kompetencím sociálním. Je však nutné na tomto místě říci, že některé teoretické pojmy nejsou vykládány víceméně jednoznačně. Nejinak je tomu ve vymezení pojmu sociální kompetence (Vališová, Kasíková, 2011). Nejčastěji se setkáváme v odborné literatuře s pojmem sociální kompetence neboli sociální způsobilost či sociální zdatnost (dovednost). Ve svém terminologickém vymezení se jedná o přiměřené použití motorických, duševních a emocionálních způsobů jednání, schopností, postojů i dovedností tak, aby bylo možno úspěšně se vyrovnávat $\mathrm{s}$ konkrétními a důležitými životními situacemi. Velmi úzce proto souvisí sociální kompetence $\mathrm{s}$ uplatněním osobní nezávislosti člověka (tedy dovedností $\mathrm{k}$ sobě, k jiným osobám a k celé společnosti).

Sociální dovednost (sociální inteligence) neboli společenská obratnost je schopnost navázat a udržet vztah s druhými lidmi. Je charakterizována komunikativností, asociováním, vytvářením smyslu činnosti, řešením problému pokusem a omylem, intuicí, citem, celostní zaměřením, uměním efektivní spolupráce či jednáním a vyjednáváním $\mathrm{s}$ lidmi, vedením a řízením druhých lidí, jejich motivováním $\mathrm{k}$ větším výkonům, naučenými dovednostmi, jež jsou založené na pravidlech. Dále pak uměním si vybírat vhodnou chvíli k rozhovoru, $\mathrm{k}$ prosbě o pomoc. Připravit si podmínky pro výměnu názorů bez zbytečných emocí a hádek. Schopností přiznat chybu a napravit ji i s pomocí druhých (Brenner, Brenner, 2004).

Obecně lze sociální dovednosti vymezit jako učením získané předpoklady pro adekvátní sociální interakce a komunikaci. Sociální dovednosti (sociální inteligence, emoční inteligence) jsou pojmy, které vyjadřují část schopností a dovedností jedince pro psychologicky přiměřené poznávání a ovládání sebe samého a jednání s ostatními lidmi. $\mathrm{V}$ obecné rovině tyto pojmy vyjadřují sociální obratnost $\mathrm{v}$ interpersonálních vztazích. $\mathrm{V}$ 
souvislosti se sociálním učením však zahrnují sociální dovednosti percepci určitých signálů, reakcí závislých na zpracování informací, jež souvisejí se zpětnovazebními a seberegulačními postupy. Podílejí se a jsou výsledkem interakce a komunikace. Sociální dovedností tedy rozumíme komplexnější způsobilost subjektu jednat $\mathrm{v}$ různě složitých a náročných sociálních situacích, tedy vyznat se v těchto situacích a umět je zvládat optimálním způsobem (optimálním z hlediska jednotlivce i z hlediska spoluaktérů, partnerů v sociální situaci). Sociální situaci lze tudíž chápat jako dynamický systém sociálních interakcí subjektů nebo sociálních skupin, který je vymezen obsahem (tedy tím, o co v interakcích jde) i podmínkami (sociálními, časovými, prostorovými). Důležité sociální dovednosti se vztahují k procesům sebepoznávání a poznávání druhých, komunikaci, zvládání konfliktů a náročných životních situací. Obvykle se v sociálních dovednostech rozlišují prvky vztahující se k sobě samému (např́klad sebepoznání a sebereflexe, přiměřené projevování emocí, autenticita) a prvky týkající se mezilidských vztahů (empatie, akceptace druhých, otevřené vyjadřování za sebe sama, naslouchání, pochopení stanoviska druhého člověka, tolerování odlišných pohledů, poznávání druhých, mezilidská komunikace, zvládání konfliktů). Sociální dovednosti jsou definovány jako na cíl zaměřené a vzájemně propojené sociální reakce, které je možné se naučit a jež jsou pod kontrolou jedince (Gillernová a kol., 2012).

Pokud bychom tedy měli shrnout odbornosti sociálního pracovníka v rámci sociálně právní ochrany dětí, můžeme využít tento model odbornosti (obr. 1).

Obr. 1: Odbornosti sociálního pracovníka (Pémová, Ptáček, 2012)

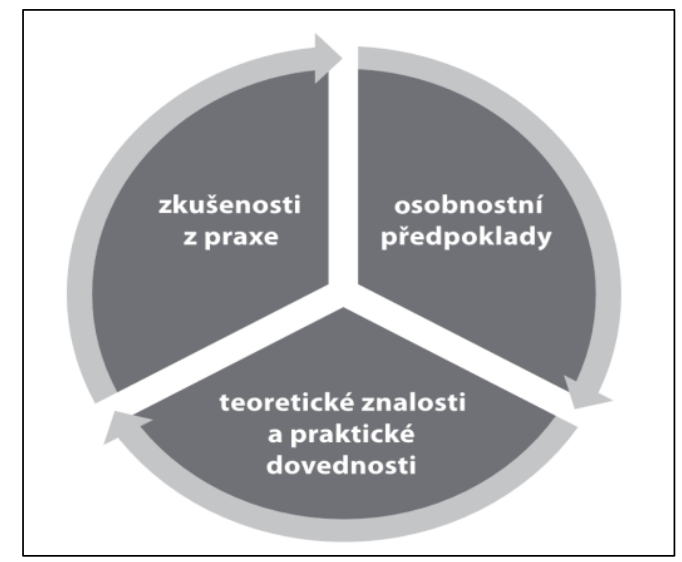

Teoretické znalosti a praktické dovednosti si sociální pracovník osvojuje především prostřednictvím formalizovaného kvalifikačního studia. Přestože dosavadní zákon o sociálněprávní ochraně dětí nedefinuje kvalifikační profil sociálního pracovníka, zákon o sociálních službách požaduje, aby sociální pracovník dosáhl minimálně vyššího odborného nebo vysokoškolské vzdělání bakalářského stupně v oboru sociální práce. Naproti tomu praktické dovednosti jsou nedílnou součástí profesionality sociálního pracovníka. Na tuto oblast nelze pohlížet pouhým kvantifikačním měřítkem, tedy nelze automaticky odvozovat míru praktických dovedností od délky praxe. Proto je potřeba, aby sociální pracovník ihned od nástupu do praxe začal systematicky a pravidelně zpracovávat zkušenosti, které při výkonu ochrany dětí nabývá. Znamená to průběžnou a podrobnou reflexi konkrétních situací, rozhodovacích procesů, vztahů s klienty, eticky komplikovaných př́padů. Tato sebereflexe může probíhat jak na individuální úrovni (supervize, intervize, mentoringu), tak na úrovni daného pracoviště (kazuistické semináře, proces vyhodnocování mimořádných situací). Poslední kategorií odbornosti sociálního pracovníka jsou osobnostní předpoklady. Použití vlastní osobnosti sociálního pracovníka v praxi je dáno kombinací znalostí, hodnot a dovedností získaných v sociální práci s aspekty svého osobního já, mezi které patří rysy 
osobnosti, systémy víry, životní zkušenosti a kulturní dědictví. V daném kontextu se jedná o využití vlastního já, jež umožňuje sociálnímu pracovníkovi usilovat o pravost a autentičnost v kontaktu s klienty, a zároveň ctít hodnoty a etiku oboru. Sociální pracovník se totiž musí být schopen potkávat s klienty na dvou rovinách, a to na úrovni profesní role odvíjející se od jeho odbornosti a pravomoci, tak na úrovni ryze lidské. Samotný koncept sociální práce by měl mít vždy i tento aspekt, tedy setkání dvou autentických a jedinečných lidských bytostí (Pémová, Ptáček, 2012).

Faktický výkon role sociálního pracovníka oddělení sociálně-právní ochrany dětí tudíž spojuje ve své podstatě roli hodnotitele klientů, jejich obhajovatele, poradce, zprostředkovatele dalších služeb, poskytovatele prŕmé pomoci, mediátora, administrátora, vyhodnocovatele kvality své práce, obhajovatele i vysvětlovatele vlastní práce $\mathrm{v}$ rámci vlastního úřadu, koordinátora činnosti jiných pomáhajících nebo zasahujících subjektů, plánovače rozvoje sociálních služeb. Někdy je to i role oznamovatele skutečnosti, že byl porušen zákon a to orgánům činným v trestním řízení, z čehož pro klienty vyplynou př́islušné důsledky. Sociální pracovník tudíž hledá ve své práci rovnováhu mezi pomocí a kontrolou, přičemž se tyto dva aspekty jeho práce mohou v rámci jednoho konkrétního případu průběžně měnit. Práce na oddělení sociálně-právní ochrany dětí je práce s lidmi. Pracovníci s nimi navazují vztahy. Většinou jde o lidi ve vážných těžkostech, z nichž mohou vyplývat nereálná očekávání vůči profesionálům, kteří se s nimi pokoušejí jejich těžkosti řešit. Zklamaná očekávání mohou vést následně $\mathrm{k}$ silným emočním reakcím, přičemž se od samotných pracovníků očekává, že je budou zvládat (Matoušek, Pazlarová, 2009).

\section{METODOLOGIE}

Celkem se daného šetření bakalářské práce účastnil 100 respondentů, s průměrným věkem 40 let. Z hlediska pohlaví se jednalo o 73 žen a 27 mužů. Cílem empirického šetření bylo za použití standardizovaného šetření pomocí výzkumného nástroje SSI-Social skills inventory (Riggio, Carney, 2007) zjistit a porovnat sociální dovednosti u vybrané skupiny respondentů. Na tomto místě je proto nutná jeho stručná charakteristika $\mathrm{z}$ hlediska zaměření tohoto textu. $\mathrm{V}$ rámci tohoto standardizovaného dotazníku můžeme chápat sociální inteligenci jako soubor základních sociálních komunikačních dovedností, mezi které patří vyjadřování (expresivita), vnímavost (senzitivita), kontrola (regulace) emočních a sociálních informací. Tyto tři základní komunikační dovednosti se projevují nejen v oblasti verbálního společenského dorozumívání, ale také v neverbální emoční sféře. Samotný standardizovaný dotazník SSI-Social skills inventory se skládá ze šesti dílčích škál, jež korespondují s výše uvedenými komunikačními kompetencemi. Patří mezi ně škály emoční i sociální expresivity, emoční i sociální senzitivity a emočního i sociálního řízení. Níže uvedené škály emočních dovedností zachycují zejména schopnost vyjadřovat emoce, sledovat a regulovat své emoce a chápat emoce druhých.

První je emoční vyjadřování (emotional expressivity = EE), jež měří schopnosti jedince neverbálně komunikovat, tedy sdělovat své postoje, emoce, dominanci či interpersonální orientaci. Tato škála mimo to měří schopnost přesně vyjádřit prožívané emoční stavy. Jedinci s vysokým skóre mají obvykle velmi živá gesta i mimiku, jsou emočně angažováni a mají schopnost přenášet prožitky na druhé a inspirovat je.

Druhou škálou je emoční vnímavost (emotional sensitivity = ES) sledující schopnost přijímat a interpretovat neverbální sdělení ostatních osob. Emočně vnímaví jedinci dokážou přesně interpretovat i velmi jemné neverbální náznaky druhých osob. Osoby s vysokým skóre se nechají snadno ovlivnit prožíváním druhých a empaticky se vyladí na jejich emoční stavy. Třetí je kategorie emoční kontroly (emotional control $=$ EC). Ta se zaměřuje na schopnosti jedince kontrolovat a regulovat své vlastní emoční a neverbální projevy. Představuje schopnost vyjádřit konkrétní emoce tak, aby druzí pochopili dané sdělení. Vyjadřuje však 
naopak i schopnost zakrývat své vlastní pocity. Osoby s vysokým skórem mohou mít tendenci výrazně kontrolovat projevy svých emocí.

Níže uvedené další tř̌i oblasti sociálních dovedností mohou být následně využity $\mathrm{k}$ měření sociální inteligence.

Sociální vyjadřování (social expressivity $=\mathrm{SE}$ ) diagnostikuje verbální dovednosti a schopnosti zapojit se do interpersonální komunikace. Vysoký skór je typický pro verbálně zdatné jedince, často velmi družné a společenské, kteři snadno dokážou zahájit a vést rozhovor na jakékoli téma. Je také třeba zdůraznit, že ačkoli se škála sociálního vyjadřování jeví jako totožná s extroverzí, teoreticky i statisticky je jí vzdálená. Jako extroverti jsou charakterizováni jedinci, kteří rádi tráví čas ve společnosti dalších osob a preferují sociální interakce. Toto však nemusí znamenat, že se v takových situacích dokáží verbálně i neverbálně adekvátně vyjadřovat.

Škála sociální vnímavosti ( social sensitivity $=$ SS) vyjadřuje schopnost interpretovat verbální sdělení druhých osob. Mimo to postihuje pochopení vhodných norem společenského chování. Jedinci s vysokým skórem jsou pozorní vůči společenskému chování a reflektují adekvátnost svého vlastního jednání. Extrémně vysoký skór ve spojení s mírným až nízkým skórem na škále sociálního vyjadřování nebo sociální kontroly může poukazovat na jedince, jehož zájem zapojit se do sociálních interakcí je značně inhibován.

Poslední je škála sociální kontroly (social control $=\mathrm{SC}$ ) vystihující schopnost vhodné sebeprezentace a adekvátního chování $\mathrm{v}$ různých sociálních situacích. Jedinci s dostatečně rozvinutou schopností sociální kontroly působí obvykle v sociálních situacích obratně, jsou taktní, sebevědomí a dokážou se přizpůsobit různorodým okolnostem. Sociální kontrola je také významná pro udržení tématu komunikace či v orientaci v různých sociálních situacích a jednáních. Př́liš mnoho emoční a sociální kontroly však může být pro jedince, jak kognitivně, tak i interpersonálně velmi náročné.

Metoda SSI je administrována $\mathrm{v}$ devadesáti položkové sebeposuzovací metodě, kde jsou odpovědi zaznamenávány na stupnici 1-5 (vůbec mě nevystihuje - zcela mě vystihuje) (Krejčová, 2007).

Tab. I: Jednotlivé sledované dimenze sociálních dovedností ( $\mathrm{EE}=$ emoční vyjadřování, $\mathrm{ES}=$ emoční vnímavost, $\mathrm{EC}=$ emoční kontrola, $\mathrm{TE}=$ celková emoční dimenze, $\mathrm{SE}=$ sociální vyjadřování, $\mathrm{SS}=$ sociální vnímavost, $\mathrm{SC}$ = sociální kontrola; $\mathrm{TS}$ = celková sociální dimenze, TEx $=$ celkové vyjadřrování, TSe = celková vnímavost, TCo $=$ celková kontrola, TSSI = celková sociální dovednost)

\begin{tabular}{|lcccc|}
\hline & Vyjadřování & Vnímavost & Kontrola & Celkové skóre \\
\hline Emoční dimenze & EE & ES & EC & TE \\
\hline Sociální dimenze & SE & SS & SC & TS \\
\hline Celkové skóre & TEx & TSe & TCo & TSSI \\
\hline
\end{tabular}

\section{VÝSLEDKY ŠETŘENÍ A JEJICH DISKUSE}

Z hlediska analýzy dat výzkumného šetření byla využita statistická metoda analýza rozptylu ANOVA, která je základní metodou pro testování hypotéz o středních hodnotách více než dvou skupin a která využívá srovnání pozorované variability mezi výběry a pozorované variability uvnitř výběrových souborů. Vícenásobná komparace dat v rámci analýzy rozptylu ANOVA byla provedena pomocí softwaru Statgraphics Centurion XVI.II na hladině významnosti $\alpha=0,05$. Z výpočtů ANOVA-testu nás zajímala především hodnota testového kritéria $\mathrm{F}$ a jemu prŕslušející hodnota pozorované hladiny významnosti $\mathrm{P}$. 
Aritmetické průměry odpovědí byly vypočítány z jednotlivých skórů dotazníkového šetření, kde: $\mathrm{EE}=$ emoční vyjadřování, $\mathrm{ES}=$ emoční vnímavost, $\mathrm{EC}=$ emoční kontrola, $\mathrm{SE}=$ sociální vyjadřování, $\mathrm{SS}=$ sociální vnímavost, $\mathrm{SC}=$ sociální kontrola, $\mathrm{SD}=$ směrodatná odchylka. V rámci měření analýzy rozptylu ANOVA jsme zjistili v závislosti na celkovém hrubém skóre v jednotlivých sledovaných škálách u všech respondentů výzkumného šetření dvě základní hodnoty. F hodnota byla 0,69 a Phodnota 0,632 , tedy větší než 0,05 . Mezi komparovanými soubory jsou proto sledované rozptyly shodné. Demonstraci celé situace prezentuje i intervalový graf $1, \mathrm{kdy} \mathrm{EE}=41,400, \mathrm{SD}_{\mathrm{EE}}=7,839, \mathrm{ES}=42,770, \mathrm{SD}_{\mathrm{ES}}=$ $7,275 \mathrm{EC}=42,420, \mathrm{SD}_{\mathrm{EC}}=7,854, \mathrm{SE}=43,180, \mathrm{SD}_{\mathrm{SE}}=7,491, \mathrm{SS}=42,730, \mathrm{SD}_{\mathrm{SS}}=7,300, \mathrm{SC}$ $=42,120, \mathrm{SD}_{\mathrm{SC}}=7,059, \mathrm{TOT}=42,437, \mathrm{SD}_{\mathrm{TOT}}=7,466$.

Graf 1: Intervalový graf výsledků v závislosti na celkovém hrubém skóre v jednotlivých sledovaných škálách/deskripce všichni respondenti výzkumného šetření (EE $=$ emoční vyjadř̌ování, $\mathrm{ES}=$ emoční vnímavost, $\mathrm{EC}=$ emoční kontrola, $\mathrm{SE}=$ sociální vyjadřování, $\mathrm{SS}=$ sociální vnímavost, $\mathrm{SC}=$ sociální kontrola)

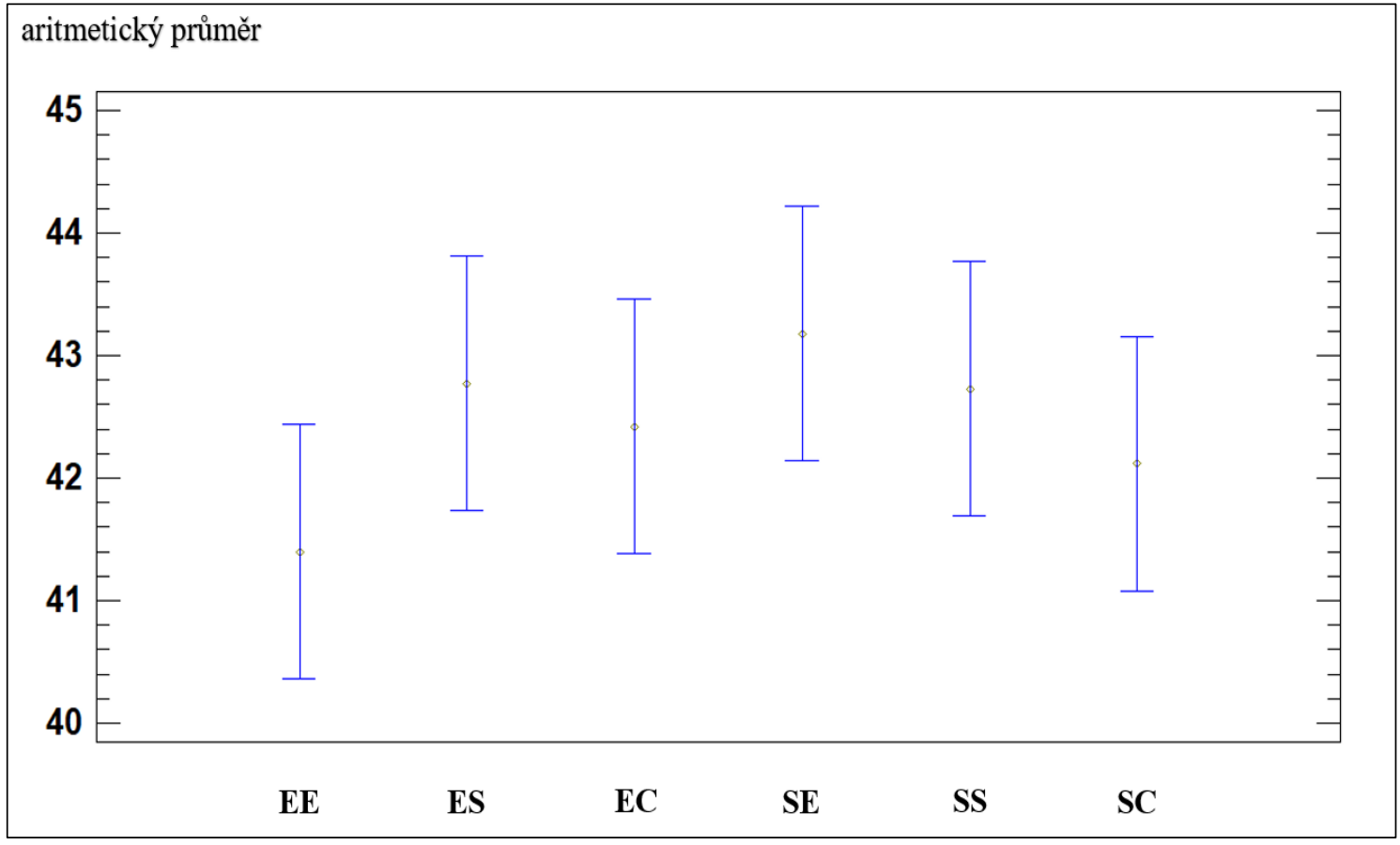

Zdroj: vlastní zpracování

To je z našeho pohledu zajímavý výsledek výzkumného šetření. Z hlediska aritmetických průměrů a jejich vzájemným porovnáním v rámci analýzy rozptylu ANOVA nebyly totiž zjištěny statisticky významné rozdíly ani $\mathrm{v}$ jednom $\mathrm{z}$ jednotlivých skórů dotazníkového šetření. Relativně pozitivní hodnocení v rámci dotazníkového šetření poukazuje (či spíše jejich sebehodnocení pracovníky sociálně právní ochrany dětí) na stabilní sociální dovednosti u vybrané skupiny respondentů.

Je nutné si tudíž uvědomit že vnímání druhých lidí mohou na straně subjektu ovlivňovat jak faktory fyziologické, tak i četné charakteristiky psychologické. Jsou to především zkušenosti, motivační zaměření a emocionální stav daného jedince (Bedrnová, Nový, 1998). Proto jsme se v rámci výzkumného šetření zaměřili i na proměnnou výzkumného šetření, mezi kterou patří délka praxe respondentů. Zkušenosti totiž dle našeho názoru představují jeden z nejdůležitějších faktorů, který ovlivňuje proces vnímání. Minulá zkušenost totiž vytváří určitá očekávání a tato očekávání mohou výrazně změnit vnímání probíhající v současnosti.

Relevantní proměnnou se pro nás stala tudíž délka praxe. 
Zaměřili jsme se na to, zda se budou lišit sledované škály $(E E=$ emoční vyjadřování, $E S=$ emoční vnímavost, $\mathrm{EC}=$ emoční kontrola, $\mathrm{SE}=$ sociální vyjadřování, $\mathrm{SS}=$ sociální vnímavost, $\mathrm{SC}=$ sociální kontrola) u respondentů v závislosti na délce praxe.

Skupiny jsme rozdělili na dvě části zcela záměrně a to $\mathrm{z}$ hlediska počtu tak, abychom dostali dvě homogenní skupiny (proto skupina s praxí do 10 let a nad 10 let). Naměřený výsledek u skupiny sociálních pracovníků do 10 let praxe nám ukázal hodnotu $\mathrm{F} 1,18$ a $\mathrm{P}$ hodnotu 0,320 , tedy větší než 0,05 . Mezi komparovanými soubory jsou proto sledované rozptyly opět shodné. Demonstraci celé situace prezentuje i intervalový graf 2, kdy $\mathrm{EE}=41,635, \mathrm{SD}_{\mathrm{EE}}=$ 7,797, $\mathrm{ES}=42,808, \mathrm{SD}_{\mathrm{ES}}=6,300, \mathrm{EC}=43,596, \mathrm{SD}_{\mathrm{EC}}=7,974, \mathrm{SE}=43,039, \mathrm{SD}_{\mathrm{SE}}=6,700$, $\mathrm{SS}=44,769, \mathrm{SD}_{\mathrm{SS}}=6,876, \mathrm{SC}=42,423, \mathrm{SD}_{\mathrm{SC}}=6,494, \mathrm{TOT}=42,423, \mathrm{SD}_{\mathrm{TOT}}=6,494$.

Graf 2: Intervalový graf výsledků v závislosti na celkovém hrubém skóre v jednotlivých sledovaných škálách/deskripce respondenti s praxí do 10 let (EE = emoční vyjadřování, ES = emoční vnímavost, $\mathrm{EC}=$ emoční kontrola, $\mathrm{SE}=$ sociální vyjadřování, $\mathrm{SS}=$ sociální vnímavost, $\mathrm{SC}=$ sociální kontrola)

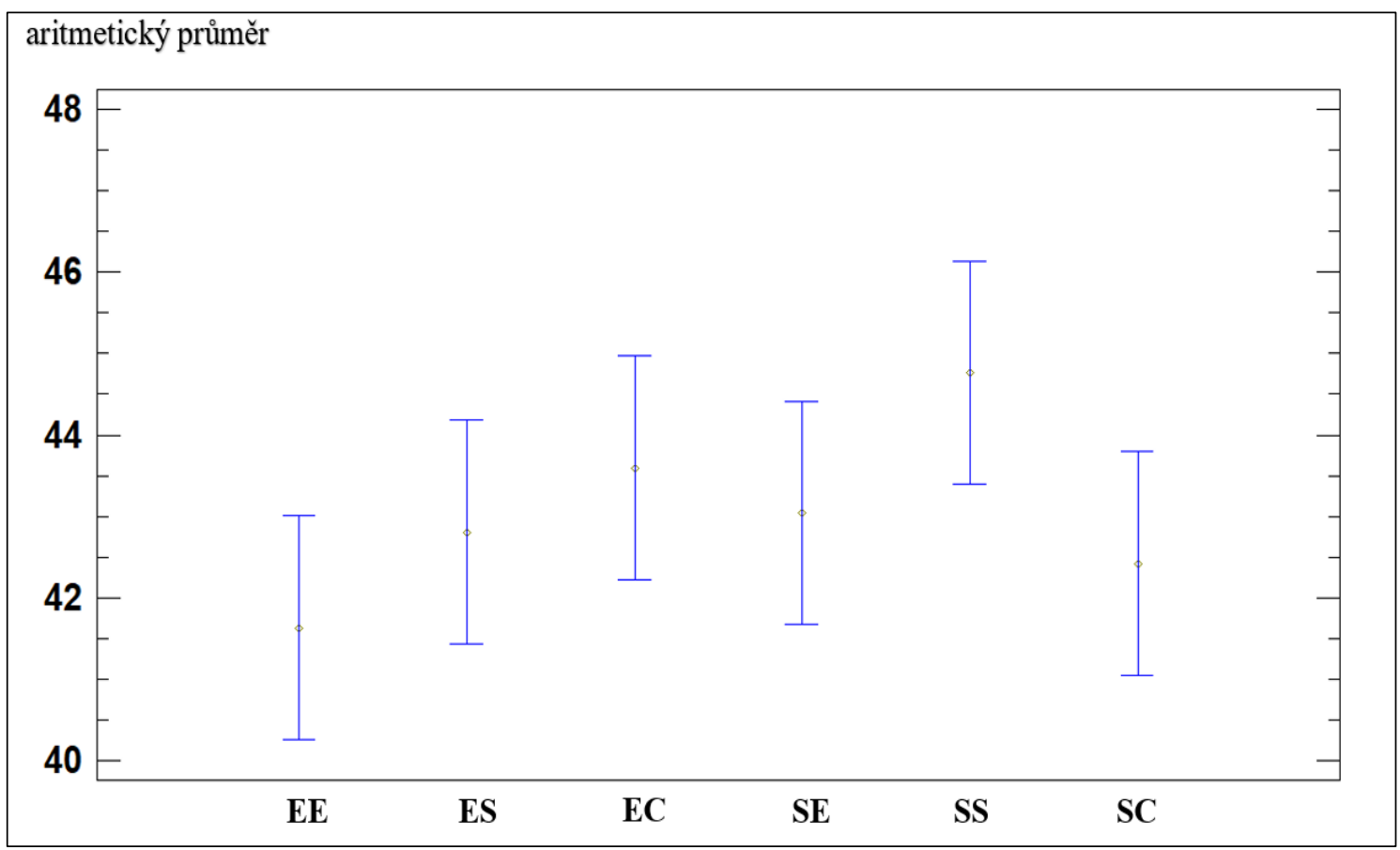

Zdroj: vlastní zpracování

Nebyly zjištěny žádné statisticky významné rozdíly. Při celkové intepretaci výsledků v dotazníku SSI je však třeba mít vždy na paměti, že zjišt'uje sebepojetí daného jedince, přičemž odpovědi na některé položky mohou být ovlivněny faktorem společenské žádoucnosti. Výsledky některých studií však nicméně nasvědčují tomu, že subjektivní posouzení sociálních kompetencí koresponduje např́íklad s trvalostí partnerského vztahu i kvalitou soužití. Dále pak s celkovou životní spokojeností nebo nadprůměrnými výkony $\mathrm{v}$ některých profesích (Plháková, Reiterová, 2010).

Druhou skupinou pracovníků sociálně právní ochrany dětí byla ta, jejichž délka praxe přesahovala 10 let a více. Výsledek $\mathrm{F}$ hodnoty byl 0,90 a $\mathrm{P}$ hodnota 0,481 tedy větší než 0,05 . Mezi komparovanými soubory jsou proto sledované rozptyly shodné. Demonstraci celé situace prezentuje i intervalový graf 5, $\mathrm{kdy} \mathrm{EE}=41,146 \mathrm{SD}_{\mathrm{EE}}=7,960, \mathrm{ES}=42,729, \mathrm{SD}_{\mathrm{ES}}=$ $8,271, \mathrm{EC}=41,146, \mathrm{SD}_{\mathrm{EC}}=7,599, \mathrm{SE}=43,333, \mathrm{SD}_{\mathrm{SE}}=8,062, \mathrm{SS}=40,521, \mathrm{SD}_{\mathrm{SS}}=7,167, \mathrm{SC}$ $=41,792, \mathrm{SD}_{\mathrm{SC}}=7,680, \mathrm{TOT}=41,778, \mathrm{SD}_{\mathrm{TOT}}=7,791$. 
Graf 3: Intervalový graf výsledků v závislosti na celkovém hrubém skóre v jednotlivých sledovaných škálách/deskripce respondenti s praxí nad 10 let a více $(\mathrm{EE}=$ emoční vyjadřování, $\mathrm{ES}=$ emoční vnímavost, $\mathrm{EC}=$ emoční kontrola, $\mathrm{SE}=$ sociální vyjadřování, $\mathrm{SS}=$ sociální vnímavost, $\mathrm{SC}=$ sociální kontrola)

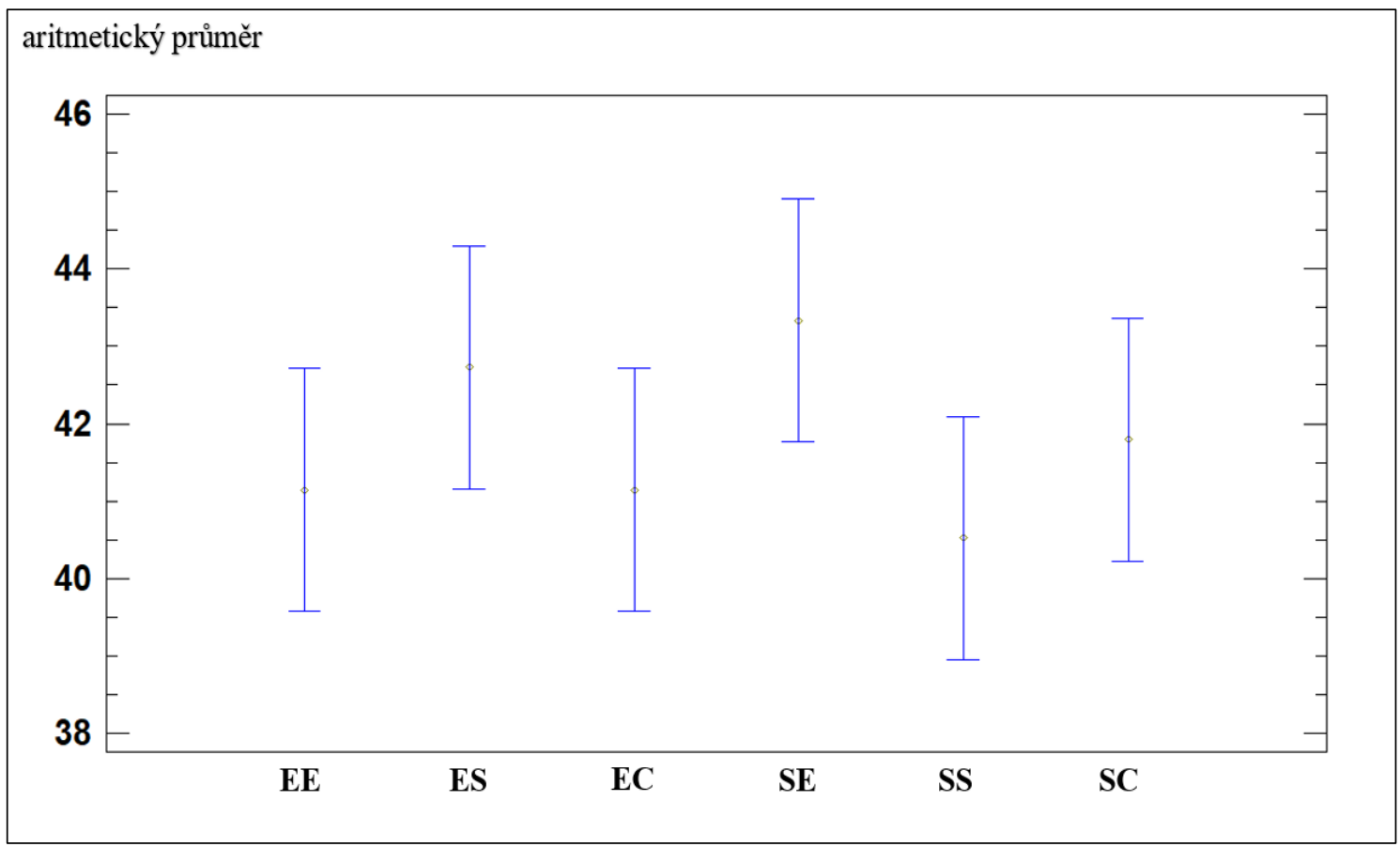

Zdroj: vlastní zpracování

\section{ZÁVĚR}

Domníváme se, že naše šetření je vhodnou úvodní sondou do dané problematiky, na kterou je možné navázat dalšími výzkumy, zaměřenými například na oblast sociálních služeb a jejich pracovníků. Celkové výsledky jsou dle našeho názoru zajímavé a ukazují stabilitu sociálních dovedností u pracovníků sociálně právní ochraně dětí. Můžeme se tudíž domnívat, že dosažený osobní standard vybraných respondentů voblasti sociálních dovedností, je nekolísající. Tedy jejich schopnost reagovat, jednat a podávat výkon na určité požadované úrovni je stabilní. Lze se v daném ohledu bavit o určité oblasti emočních kompetencí.

Zastáváme názor, že námi zjištěné výsledky mohou korelovat i s nastaveným systémem vzdělávání pracovníků sociálně právní ochrany, jež je zaměřený na cílený rozvoj jejich kompetencí. Mezi nástroje využívané v procesu vzdělávání zaměstnanců patří, pracovní profil, adaptační plán, hodnocení pracovníků a individuální vzdělávací plán. Pracovní profil v tomto pojetí obsahuje souhrn kvalifikačních a dalších požadavků kladených na pracovníky, kteří budou na dané pozici působit, je uvedený v pracovním profilu (v popisu pracovního místa). Povinnost mít zpracované pracovní profily, vyplývá z požadavků standardů kvality sociálně právní ochrany dětí. Pracovní profil obsahuje požadované vzdělání či kvalifikaci na výkon práce na dané pozici, další specifické dovednosti, požadovanou praxi, osobnostní předpoklady zaměstnance a pracovní náplň obsahující konkrétní pracovní činnosti, které by měl pracovník $\mathrm{v}$ rámci dané pozice vykonávat. Naproti tomu adaptační plán je vnitřní nastavení pravidel zaškolování nového zaměstnance (například stanovená témata zaškolení, dobu, časový harmonogram a plánování zaškolení, kdo se na něm bude podílet, způsob ukončení zaškolení). Jednotlivá pracoviště mají nastavené vlastní způsoby zaškolování nových zaměstnanců, které se odrážejí v jejich vnitřních pravidlech, metodikách či příručkách nebo $v$ různých formách adaptačního plánu. Dle zákona č. 312/2002 Sb., o úřednících 
územních samosprávných celků a o změně některých zákonů, vybavuje vstupní vzdělání zaměstnance zejména kompetencemi znalostními, $\mathrm{v}$ menší míře pak kompetencemi dovednostními. Jedná se především o znalosti základů veřejné správy, zvláště obecných zásad organizace a činnosti veřejné správy a územního samosprávného celku, základy veřejného práva, veřejných financí, evropského správního práva, práv a povinností a pravidel etiky úředníka. Dále pak základními dovednosti a návyky potřebné pro výkon správních činností. V neposlední řadě znalostmi základů užívání informačních technologií, základní komunikační, organizační a další dovednosti vztahující se k jeho pracovnímu zařazení.

Další důležitou oblastí je pravidelné hodnocení zaměstnanců sociálně právní ochrany dětí, jež vyplývá z kritéria standardů kvality. V rámci sebehodnocení a hodnocení vedoucím prostřednictvím hodnoticích formulářu jsou pracovníci hodnoceni např́íklad $\mathrm{v}$ těchto oblastech. Jejich odbornost (profesní zkušenost, orientace $\mathrm{v}$ dané problematice, samostatnost při zpracování úkolů). Integrita a zodpovědnost (pozitivní přístup, schopnost přijmout zpětnou vazbu, dodržování pravidel, zodpovědnost za své jednání). Důslednost (spolehlivost, systematičnost, pečlivost, přesnost, schopnost dotahovat věci do konce). Nasazení (chut' do práce, časová flexibilita, schopnost přicházet s novými nápady, aktivní př́istup). Flexibilita (schopnost přizpůsobit se dané situaci, učit se novým věcem, přijmout změnu, odhadovat možná rizika). Organizační schopnosti (koordinace činností, systematičnost, schopnost si určit priority, analyzovat situaci, rozhodnout se, uvažování v širších souvislostech). Strategické uvažování a kreativita (sledování trendů, schopnost uvažování v souvislostech, hledání inovativních řešení, schopnost analytického myšlení). Komunikační dovednosti (schopnost předat a získat informace, vyjadřovací schopnosti, asertivita, diplomatické vystupování). Práce v týmu (schopnost vzájemné tolerance a respektování, mezioborové spolupráce, loajalita $\mathrm{k}$ týmu, otevřená, aktivní komunikace a př́mé řešení problémů). Empatie (zájem o druhé, schopnost naslouchat, schopnost vcítit se a pochopit danou situaci, tolerance $\mathrm{k}$ ostatním). Kultivované vystupování (např. užívání spisovného jazyka, úprava zevnějšku, vstř́icná verbální i neverbální komunikace, schopnost sebeovládání, diplomatické jednání). Manažerské dovednosti (schopnost vést a řídit podřízené, rozhodnost, schopnost plánovat, řešit problémy, motivovat podřizené) (MPSV, 2019). Z našeho pohledu jsou velmi důležité (a výsledky mohou také s tímto úzce souviset) pravidelné (a povinné) supervize u pracovníků sociálně právní ochrany dětí.

$\mathrm{Z}$ našich výsledků však vyplývá stabilita $\mathrm{v}$ jednotlivých oblastech sociálních dovedností z hlediska jednotlivých sledovaných škál standardizovaného dotazníku SSI-Social skills inventory (Riggio, Carney, 2007).

Z našeho pohledu by měl být kladen velký důraz především na osobnostní předpoklady pro výkon dané profese. Kvalifikace získaná prostřednictvím studia je totiž samožrejmě velice důležitá, nicméně takové vlastnosti, jako je empatie a schopnost naslouchat svým klientům, náleží mezi naprosto nezastupitelné charakteristiky osobnosti. Požadavek na zúčastněné naslouchání náleží k vůbec nejvýraznějším. Co se týče dalších kompetencí, zcela zásadní je z našeho pohledu význam praxe, jež může kompetence rozvinout na požadovanou úroveň. Dostatečná úroveň kompetencí by pak ovšem měla jít ruku v ruce také s uvědoměním si veškerých povinností sociálního pracovníka. Uvědomujeme si, že platnost těchto konstatování je sice obecná, nicméně se zvláštní naléhavostí se vztahuje na sociální pracovníky profesně se angažující v rámci orgánů sociálně právní ochrany dětí, protože právě děti představují zranitelné klienty.

\section{Použitá literatura}

1. BEDRNOVÁ, E., NOVÝ, I. a kol. Psychologie a sociologie řizení. Praha: Management Press, 1998. 559 s. ISBN 80-85943-57-3. 
2. BELZ, H., SIEGRIST, M. Klićové kompetence a jejich rozvíjení. Praha: Portál, 2001. 376 s. ISBN 978-80-7367-930-9.

3. BENES̆, M. Andragogika. Praha: Grada, 2014. 176 s. ISBN 978-80-247-4824-5.

4. BRENNER, D., BRENNER, F. Poznejte své silné a slabé stránky. Základ úspěšného stanovení cilu a plánů v kariére. Praha: Grada, 2004. 171 s. ISBN 978-80-247-2691-5.

5. HRONÍK, F. Hodnocení pracovníkü. Praha: Grada, 2006. 128 s. ISBN 80-247-1458-2.

6. MATOUŠEK, O., PAZLAROVÁ, H. Státni orgány sociálněprávní ochrany dětí. Dobrá praxe z pohledu rodin a pracovníkü. Praha: Karolinum, 2016. 168 s. ISBN 978-80-246-3336-7.

7. PEMOVÁ, T., PTÁČEK, R. Sociálně-právní ochrana dětí pro praxi. Praha: Grada, 2012. 193 s. ISBN 978-80-247-4317-2.

8. PLHÁKOVÁ, A., REITEROVÁ, Eva. (2010). Rozdíly v pěti dimenzích osobnosti a sociální inteligence mezi studenty exaktních a humanitních věd. Československa Psychologie, Praha, 2010. 54(2), 359-394.

9. ŠÍP, M., HÁJKOVÁ, Z. Vzdělávání jako cílený rozvoj kompetencí. Soubor doporučení pro optimalizaci systému vzdělávání pracovníki̊ OSPOD. Praha: MPSV, 2019. 92 s. ISBN 978-80-7421-163-8.

10. VALIŠOVÁ, A., KASÍKOVÁ, H. Pedagogika pro učitele, 2011. Praha: Grada, 2011. 456 s. ISBN 978-80-247-3357-9.

11. VETEŠKA, J., TURECKIOVÁ, M. Kompetence ve vzdělávání. Praha: Grada, 2008. 160 s. ISBN 978-80-247-1770-8.

\section{Kontaktní údaje}

PaedDr. Ing. Jan Tirpák

Univerzita J. E. Purkyně v Ústí nad Labem, Pedagogická fakulta

Hoření 13, 40096 Ústí nad Labem

Tel.: 723021946

E-mail: JanTirpak@seznam.cz

PaedDr. Miriam Uhrinová PhD.

Katolícka univerzita v Ružomberku, Pedagogická fakulta

Hrabovská cesta 1, 03401 Ružomberok

E-mail: miriam.uhrinova@ku.sk

Bc. Tereza Ulrychová

Univerzita J. E. Purkyně v Ústí nad Labem, Pedagogická fakulta

E-mail: ulrychova.t@kr-ustecky.cz 


\title{
ROZPRÁVKOVÁ TVORBA ANTONA HABOŠTIAKA A LATENTNÁ AGRESIA U DETÍ PREDŠKOLSKÉHO VEKU
}

\section{ANTON HABOŠTIAK'S FAIRY TALE AND LATENT AGGRESSION IN PRESCHOOL CHILDREN}

\author{
Zuzana Chanasová
}

\begin{abstract}
Abstrakt
Ciel’om príspevku je charakterizovat' Antona Habovštiaka, slovenského etnológa minulého storočia, ktorý bol zároveň aj významným spisovatel’om pre deti zameraným na región Liptov a Orava. V príspevku krátko predstavíme jeho život a rozprávkovú tvorbu. Zároveň v príspevku zadefinujeme latentnú agresiu u detí predškolského veku, ktorou sa zaoberáme $\mathrm{v}$ projekte VEGA 1/0452/18 s názvom Identifikácia, analýza a inhibicia latentne agresívneho konania detí v obdobi predškolského veku. Záver príspevku budú tvorit' odporúčania do praxe smerujúce $\mathrm{k}$ využitiu rozprávkovej tvorby Antona Habovštiaka zameranej na elimináciu latentnej agresie u detí.
\end{abstract}

Klíčová slova: Anton Habovštiak, rozprávka, latentná agresia, diet’a predškolského veku

\begin{abstract}
The aim of the article is to characterize Anton Habovštiak, a Slovak ethnologist of the last century, who was also an important writer for children focused on the Liptov and Orava region. In the article we will briefly present his life and fairy tale work. At the same time, in the article we define latent aggression in preschool children, which we deal with in the project VEGA 1/0452/18 entitled Identification, analysis and inhibition of latent aggressive behavior of children in preschool age. The conclusion of the article will be recommendations for practice aimed at the use of fairy tale work of Anton Habovštiak aimed at eliminating latent aggression in children.
\end{abstract}

Key words: Anton Habovštiak, fairy tale, latent aggression, preschool child

\section{ÚVOD}

Rozprávka má aj pre súčasné diet’a predškolského veku vel'ký význam. Kováčová-Švecová spája rozprávky $(2017$, s. 55) „s obdobím detstva, v ktorom poskytujú det'om iný rozmer prežívania a chápania sveta okolo seba, nový pohl'ad na nepoznané a zatial' nepochopené javy, vd'aka ktorému sa stiera hranica medzi realitou a fantáziou, čo je najmä z hl'adiska psychického vývinu typické práve pre prežívanie diet’at’a v predškolskom veku."

$\mathrm{V}$ našom príspevku sa zaoberáme využitím rozprávkovej tvorby spisovatel'a Antona Habovštiaka v procese eliminácie latentnej agresie u detí predškolského veku. Ide o parciálny výstup projektu VEGA 1/0452/18 Identifikácia, analýza a inhibícia latentne agresívneho konania detí v obdobi predškolského veku. V závere prezentujeme odporúčania pre pedagogickú, ako aj terapeutickú prax.

\section{ROZPRÁVKA A DIEŤA}

Rozprávka je pre diet’a predškolského veku prirodzenou súčast'ou. Vd'aka rozprávkam sa deti stretávajú s tradíciou (Šimonová, 1994), či tvoria morálny kontext posilňujúci ich vieru v to, že dobro zvít'azí nad zlom (Rusnák, 2005). Vychádzajúc z ontogenetického vývinu „vel’a 
odborníkov považuje vek do šiestich rokov za zvlášt' dôležitý pre vývoj osobnosti. Podla niektorých je charakter $\mathrm{v}$ podstate sformovaný práve $\mathrm{v}$ tomto období " (Čáp - Mareš, 2001, s. 227).

$\mathrm{V}$ rozprávkach vychádzajúcich z l’udovej tradície, ktorých autor je neznámy, alebo inšpirovaný práve folklórnym pozadím, sú hlavnými hrdinami obyčajní l'udia, často žijúci na okraji spoločnosti. Patria medzi nich chudobní remeselníci, rol’níci, pastieri, kováči a pod. Sú nositel'mi cností (spravodlivosti, rozvážnosti, odvahy a pod.) prejavujúcimi sa v jasnom konaní, ktoré je pre diet'a jasne čitatel'né a z ktorého vie určit' ich polaritu smerom k dobru. Často sú títo hrdinovia žijúci na okraji spoločnosti (najhlúpejší z bratov, sirota a pod. ) (Zigová - Obert, 1981, 72 - 73), (Kováčová-Švecová, 2017, s. 67 - 68), ktorí však napriek nástrahám a skúškam dosiahnu št’astný koniec a úspech (Pius, 2012).

\section{ANTON HABOVŠTIAK}

V našom príspevku predstavujeme tvorbu slovenského zberatel'a, ako aj autora rozprávok Antona Habovštiaka. Narodil v roku 1924 v obci Krivá na Orave a zomrel v roku 2004 v Bratislave. Vyštudoval slovenčinu a francúzštinu na Filozofickej fakulte v Bratislave. Celý svoj život bol vedecky činný v Jazykovednom ústave Ludovíta Štúra SAV v Bratislave, kde spracovával jazykovedný materiál, predovšetkým l’udové rozprávky a autorské podania l'udových povestí predovšetkým regiónov Liptov a Orava (Sliacky, 2005). Zozbieraný materiál aj literárne aj jazykovo dotváral. Zaujímal ho výskum slovanských a slovenských nárečí. Mal účast' na viac ako dvadsiatich vlastivedných regionálnych monografiách. (Chanasová, 2014). Zhromaždil množstvo záznamov l'udového rozprávania, v ktorom bolo vel'a rozprávok a povestí tradovaných ústnym podaním slovenského l'udu (Chanasová, 2012). Dá sa povedat', že vd’aka nemu bola doplňaná tzv. Povestová mapa Slovenska. Vo svojich Slovenských povestiach II., ktoré vydal v roku 2003 je možné nájst' aj slovník vysvetl'ujúci rôzne historické skutočnosti a postavy Slovenska (Lauček, 2004).

Jeho texty majú vysoko etnologickú hodnotu. „Rešpektovanie osobitostí detského adresáta sa vjeho tvorbe prejavuje dôsledným eliminovaním drastických motivov, zdôrazňovaním kontrastu dobra a sklonom k harmonickému riešeniu konfliktov. Aj zásluhou takéhoto pristupu k folklórnemu materiálu dochádza vo vel'kej časti jeho tvorby k žánrovému kríženiu povesti s rozprávkou, resp. s moralizujúcou poviedkou“ (Sliacky, 2005, s. 106). Pre Habovštiakove povesti je typické vystopovanie topografických názvov a to často názvov dedín, riek a vrchov v regiónoch Liptov a Orava. Jazykovednému účelu podrobuje aj estetickú účinnost' povestí (Sedlák, 1981).

Okrem zberu a tvorby regionálneho rozmeru, je podnetná aj jeho rozprávková tvorba, často s duchovným rozmerom. V knihe rozprávok Poklad nad všetky poklady (Habovštiak, 1991) sú v názvoch obsiahnuté dôležité hodnoty ako láska, pomoc a pod; Kde je láska, tam sa aj slniečko rado pozerá, alebo Každému na svete treba pomáhat', či K štastiu vedie dlhá cesta a Lepšie je l'udi milovat'(Habovštiak, 1991) a pod. Medzi jeho významné diela pre deti patria:

- Zakliate ovečky pod Rozsutcom (1966)

- Oravské povesti (1978)

- Jánošíková studnička (1980)

- Kniha rozprávok (1997)

- Malé biblické príbehy (1995 - 1998) - televízny seriál (Chanasová, 2014).

Čast' tvorby realizuje spolu so svojom manželkou Katarínou Habovštiakovou ako napríklad rozprávková kniha Remeslo má zlaté dno z roku 1998 (Chanasová, 2020). V niektorých jeho knihách je zachytená aj história plátenníckeho remesla, ale aj iných remesiel (Sliacky, 2005). $\mathrm{V}$ jeho dielach nájdeme priblíženie zvykov, životného kolobehu daného región, ale aj krest'anských tradícií predovšetkým z obdobia Vianoc. Nachádzajú sa tam aj betlehemské hry (Zentko - Kováčová, 2017). 
Vo všetkých jeho rozprávkach sú obsiahnuté hodnoty vít'azstva dobra a zla, ale aj objasnenie slovenských tradícii (Chanasová, 2020).

\section{LATENTNÁ AGRESIA}

Kováčová (2018) definuje latentne agresívne správanie ako zámerný a opakovaný úmysel nepriamo ublížit' druhému človeku. Toto ubližovanie sa môže diat' na fyzickej, ale aj psychickej rovine. Niekedy je takéto premyslené ubližovanie jednému alebo viacerým osobám prehliadnuté a postrehnutel'né až neskôr v psychickom prežívaní a správaní diet’at'a.

Toto správanie narúša sociálne vzt'ahy $v$ kolektívne od raného veku a ked’že diet'a predškolského veku považuje priatel'stvá za vel'mi významné, je vel'mi rozhodujúce pre vlastnú existenciu diet'at’a (Kováčová, 2020a). Z daného vyplýva, že je nevyhnutné s týmto nežiaducim javov pracovat' a venovat' mu dostatočnú pozornost'.

Kováčová (2020a) navrhuje inhibičné opatrenia zamerané na riešenie takéhoto správania, z ktorých vyberáme modulové učenie sa v riešení skrytého šikanovania. „Pracovat' na minimalizácii skrytej agresie $\mathrm{v}$ triednom kolektíve znamená využit' reálne situácie ako modulové, s možnost’ou hl'adania východísk" (Kováčová, 2020a, s. 29). Ten, kto celý proces riadi, často ním môže byt' učitel' v materskej škole, je v pozícii režiséra, rozdel'uje role, analyzuje proces ako aj jeho výsledok. Toto učenie môže preto obsahovat' určité prvky iných terapií, ako dramatoterapie, či biblioterapie a jeho ciel'om je podporit' zmenu v skupine detí smerom k neagresívnemu správaniu.

Skúsenost' ukazuje, že je dôležité, aby boli det’om rozprávané príbehy, pretože ich počúvaním si deti rozširujú nielen slovnú zásobu, učia sa mysliet', ale príbehy sa stávajú aj jednou z foriem pomoci. Diet'a prostredníctvom nich spoznáva v príbehu nielen emócie, ktoré ono samo zažíva, ale objavuje, že aj iní sa dokážu hnevat', mat' rád, alebo bát'. V príbehoch diet'a objavuje, že konanie jednej postavy môže ovplyvnit' ostatných. V súvislosti s našim projektom VEGA zameraným na identifikáciu, analýzu a inhibíciu latentne agresívneho konania detí v obdobi predškolského veku práve literárne texty Antona Habovštiaka môžu byt' nápomocné $\mathrm{v}$ eliminácii agresívneho konania $\mathrm{v}$ skupinách detí. $\mathrm{V}$ práci $\mathrm{s}$ príbehmi prostredníctvom modulového učenia sa môže rodič, učitel', terapeut objavit' pozície detí v skupinách. Môže nielen objavit' agresora, obet' a pod., ale celý proces mu môže napomôct' v pochopení motívov detí.

\section{PRÁCA S ROZPRÁVKAMI}

Pri našich odporúčania pre prax budeme pracovat's knihou od Antona Habovštiaka - Kniha rozprávok (1997). Uvádzame tri konkrétne rozprávky.

- Hadova koruna. V tejto rozprávke dobrý mládenec Juraj v lese uvidel hada nešt'astne zapleteného do konárov, ktorý sa nemohol pohnút'. Bolo mu ho l'úto a vyslobodil ho. Ked' had utiekol, ostala po ňom na zemi zlatá korunka. Pravdepodobne vel'a l'udí by si ju privlastnilo, ale Juraj žil s presvedčením, že ju hadovi treba vrátit'. Napokon sa mu to podarilo a hadí král' ho za to vel'mi odmenil.

Ked’že pre latentnú agresiu sú typické priame a nepriame útoky agresora voči obeti a často k takémuto správaniu stačí jednoduchá formulácia, že sa s niekým nebudú hrat' a pod. môžeme využit' prvú čast' rozprávky, kde det'om vyrozprávame len úvod, ako Juraj našiel hada a necháme ich dokončit', čo sa asi v príbehu dialo. Diet’a, ktoré je latentne šikanované bude predstavovat' hada a agresor bude predstavovat' Juraja. Necháme deti aby danú scénu znázornili. Predpokladáme, že diet’a - agresor bude voči diet'at'u - hadovi agresívne, čo nám môže potvrdit' nás predpoklad. Bude zaujímavé následne po realizácii hrania rolí prečítat' det'om rozprávku, ako sa rozprávka skutočne môže skončit'. Ako Jurko hada nezabil, ani na neho neútočil a ako si neponechal korunu, za čo ho had odmenil. 
- O múdrom Jankovi. V Habovštiakových rozprávkach nájdeme vel'a remesiel, ktoré sú pre súčasné predprimárne vzdelávanie vel'mi inšpiratívne, ked’že v nich ide o špecifickú nepol'nohospodársku malovýrobu založenú na ručnej práci realizovanej prostredníctvom vlastných nástrojov (Kováčová, 2019). V rozprávke $O$ múdrom Jankovi hlavný hrdina Janko slúžil u baču, ktorý choval ovce. Janko bol vel'mi pracovitý. „Valasi ho mali radi, lebo vždy ochotne zabehol ta, kde ho poslali." (Habovštiak, 1997, s.88) Byt' ochotným sa v procese latentne agresívneho správania pre agresora môže javit' ako slabost' a často môže byt' takýto rys u iného diet'at'a spúšt’ačom šikanovania. V rozprávke Janko stretol starčeka, ktorý ho poprosil o vodu. Janko mu ochotne dal napit’ a starček sa ho opýtal, čo chce za odmenu. Janko nechcel za vodu žiadne peniaze, ani drahú odmenu, chcel rozumiet' vtáčikom a všetkým zvieratkám. Starček mu to splnil. Janko potom vd’aka tejto svojej schopnosti pomáhal zvieratkám a oni mu za odmenu zase radili v tom, kedy bude pršat' a pod. Darilo sa mu.

V súvislosti s latentnou agresiou sa deti môžu rozdelit' na rôzne zvieratká, ktoré majú nejaké túžby a pani učitel'ka bude múdry Janko. Ku každému z detí príde a do uška jej každé diet'a zašepká, čo by chcelo. Predpokladáme, že aj v týchto túžbach sa opät' agresor, ako aj obet' môžu prezradit'. Zároveň pre spracovávanie latentnej agresie môže poslúžit' čast' z rozprávky, kedy l'udia zvieratkám ubližovali a oni prosili Janka o pomoc. Opät' využijeme hranie rolí $\mathrm{v}$ ktorých predpokladáme priestor na prezentáciu agresívneho správania, ako aj znaky šikany. Zároveň ked’že v rozprávke išlo aj o nové remeslo pasenie ovečiek, môžeme niektoré $\mathrm{z}$ remeselných činností zaradit' do výchovnovzdelávacieho procesu, pričom ho mierne smerovat' $\mathrm{k}$ ergoterapetuckému rozmeru. „Diet’a tým, že je stimulované $\mathrm{v}$ rozličných zamestnávaniach si zároveň obohacuje vlastný repertoár doterajších akcií” (Kováčová, 2020b, s. 182), čo môže poslúžit' k eliminácii agresívneho správania.

- Ako Marienka slúžila. Posledná, tretia rozprávka hovorí o dievčati, ktoré slúžilo u grófky, ktorá nebola dobrej povahy. Nemala nikoho rada a bola vel'mi lakomá. Ked’že Marienka mala dobré srdce, grófka jej túto svoju nespokojnost's pomocou druhým dávala často najavo. Ked' zaklopal nejaký chudobný žobrák, Marienka mu vždy pomohla. Grófke sa to nepáčilo a vždy ju za to hrešila. Radšej zvyšný chlieb hodila sviniam a mlieko vyliala, ako by ho mala darovat' chudobným. No Marienke sa za dobrotu dostalo odmeny. Našiel ju jeden mládenec, ktorý si ju vzal za ženu.

Pri latentne agresívnom správaní je vhodné využit' aj prvky terapie s bábkou. Je dobré mat' bábku zlej grófky, a bábku dobrej Marienky. Agresora zo skupiny detí môžeme najprv dat' do role zlej grófky a obet' do pozície Marienky a následne pozície vymenit'. Bude vel'mi zaujímavé sledovat' aké slovné komentáre od detí budeme počut'. Terapia $\mathrm{s}$ bábkou má vel’a pozitív, lebo „sa cielene zameriava na podporu psychickej integrácie, na opätovnú akceptáciu traumatických zážitkov z minulosti, na transformáciu pasivity $\mathrm{k}$ aktivite, na diferencovanie fantázie od reality a pod. Hodnota terapie s bábkou je nielen $\mathrm{v}$ odreagovaní, ktoré poskytuje tento model terapeutickej podpory a pomoci, ale taktiež ide o možnost' vyjadrit' skúsenosti, ktoré pôsobia traumatizujúco vo svete reality cez bábky vo svete fikcie” (Kováčová, 2020c, s.75 - 76).

\section{ZÁVER}

Aj prostredníctvom príbehov je možné napomôct' situácii s latentnou agresiou v skupinách detí predškolského veku. „Pre terapeutickú prácu a výchovné pôsobenie je podstatný výber knihy" (Kaščáková, 2020, s 127). Rozprávky Antona Habovštiaka majú hlboké morálne posolstvo, ktoré vrámci svojho celoživotného diela autor priniesol Slovenskému národu. Hodnoty ukryté v histórii prezentoval spôsobom jemu prirodzeným, prostredníctvom humoru. 
V jeho rozprávkach a povestiach je ukryté posolstvo života, ktoré hovorí, že byt' dobrým človekom sa naozaj oplatí (Chanasová, 2020).

Objavit' latentnú agresiu v skupinách detí predškolského veku nie je l'ahké a je potrebné určité pedagogicko-terapeutické majstrovstvo, vd'aka ktorému môže dôjst' $\mathrm{k}$ eliminácii tohto typu šikanovania. Je vel'mi dobré, že existuje literárny text, ktorý v tomto procese môže byt' nápomocným.

Príspevok je parciálnym výstupom projektu VEGA 1/0452/18 s názvom Identifikácia, analýza a inhibícia latentne agresívneho konania detí v období predškolského veku.

\section{Použitá literatura}

1. $\quad$ ČÁP, J., MAREŠ, J. Psychológie pro učitele. Praha: Portál, 2001. 655 s. ISBN 97880-7178-463-0.

2. HABOVŠTIAK, A. Poklad nad všetky poklady. Bratislava: LÚČ, 1991. ISBN 807114-024-4.

3. HABOVŠTIAK, A. Kniha rozprávok, 1997. Bratislava: Príroda. 136 s. ISBN 80-0700968-X.

4. CHANASOVÁ, Z. Duchovnoje poslanie v tvorčestve Antona Gabovštiaka dl'a detej $i$ molod'oži. In: Tvorčeskaja individual'nost' pisatel'a v konekste kul'turnoj tradicii : sbornik statej regional'noj naučno-praktičeskoj konferencii s meždunarodnym učastiem : 23 - 24 nojabrja goda. Surgut : RIO SurGPU, 2012. ISBN 978-5-9931-0220-7. s. 153-158.

5. CHANASOVÁ, Z. La bellezza spirituale di Suor Zdenka nelle opere di Anton Habovštiak. In: Pedagogia e Vita [elektronický dokument] : Rivista di problemi pedagogici, educativi e didattici. - Rím (Taliansko) : Edizioni Studium. - ISSN (online) 0031-3777. - Roč. 76, č. 2 (2018), s. 103-114.

6. CHANASOVÁ, Z. Návrat k slovenským tradíciám prostredníctvom literárnej tvorby Antona Habovštiaka. In: Studia Scientifica Facultatis Paedagogicae [textový dokument (print)] Ružomberok: Katolícka univerzita v Ružomberku. VERBUM vydavatel'stvo KU. ISSN 1336-2232. Roč. 19, č. 2 (2020), s. 58-64.

7. CHANASOVÁ, Z. Vybrané kapitoly z literatúry pre deti so zameraním na výchovu $k$ cnostiam. Ružomberok: Verbum - vydavatel'stvo Katolíckej univerzity v Ružomberku, 2014. 80 s. ISBN 978-80-561-0158-2.

8. KAŠČÁKOVÁ, S. Expresivita v ranej biblioterapii. In: Expresivita v (art)terapii III [elektronický dokument] : zborník.: Univerzita Komenského v Bratislave, 2020. 196 s. ISBN 978-80-223-5021-1, s. 123 - 132.

9. KOVÁČOVÁ, B. Kreatívne zamestnávania v ranej ergoterapii. In: Expresivita vo výchove III [elektronický dokument] : zborník ; Bratislava : Univerzita Komenského v Bratislave, 2020b. ISBN 978-80-223-4931-4, s. 181-201.

10. KOVÁČOVÁ, B. Raná ergoterapeutická intervencia u detí so zmyslovým znevýhodnením. In. Expresivita v (art)terapii II. Ružomberok: Katolícka univerzita v Ružomberku. VERBUM - vydavatel'stvo KU, 2019. 162 s. ISBN 978-80-561-06907, s. 98 - 110.

11. KOVÁČOVÁ, B., Skrytá agresia v predškolskom veku (z výskumu). In: Studia Scientifica Facultatis Paedagogicae, 2018, ISSN 1336-2232. Roč. 17, č. 4, s. 111-117.

12. KOVÁČOVÁ, B. Teoretické východiská $\mathrm{v}$ terapii $\mathrm{s}$ bábkou. In: Expresivita $v$ (art)terapii III [elektronický dokument] : zborník.: Univerzita Komenského v Bratislave, 2020c. 196 s. ISBN 978-80-223-5021-1, s. 71. - 82.

13. KOVÁČOVÁ, B., Zoznámme sa so skrytou agresiou v predškolskom veku. Ružomberok, Verbum, 2020a, 60 s. ISBN 978-80-561-0715-7. 
14. KOVÁČOVÁ-ŠVECOVÁ, Z. Ludová slovesnost'v literatúre pre deti a mládež. Banská Bystrica: Belianum, 2017. 168 s. ISBN 978-80-557-1388-5.

15. LAUČEK, A. Slovenská literatúre pre deti a mládež 1990 - 2004. Ružomberok: KU, 2004. 71 s. ISBN 80-89039-82-0.

16. PIUS, M. Od mýtov k rozprávkam. Bratislava: Goralinga, 2012. 262 s. ISBN 978-80970042-9-3.

17. RUSNÁK, R. Mytológia ako archetyp tradičných rozprávok. In: Slovo o slove (11): zborník Katedry komunikačnej a literárej výchovy Pedagogickej fakulty v Prešove. Prešov: Katedra komunikačnej a literárnej výchovy Pedagogickej fakulty Prešovskej univerzity, 2005. ISBN 80 - 8068 - 362 - X. s. 176 - 179.

18. SEDLÁK, J. Epické žánre v literatúre pre deti a mládež. Bratislava: SPN, 1981. $354 \mathrm{~s}$.

19. SLIACKY, O. Slovník slovenských spisovatel'ov pre deti a mládež. Bratislava: LIC, 2005. ISBN 978-80-888-7897-1.

20. ŠIMONOVÁ, B. Žáner $v$ pohybe: reflexie o rozprávke. Banská Bystrica: Pedagogická fakulta UMB. 1994. 92 s. ISBN 978-80-851-6265-3.

21. ZIGOVÁ, E. - OBERT, V. Literatúra pre deti a mládež s metodikou. Bratislava: SPN, 1981. $232 \mathrm{~s}$.

\section{Kontaktní údaje}

Doc. PaedDr. Zuzana Chanasová, PhD.

Katolícka univerzita v Ružomberku, Pedagogická fakulta

Hrabovská cesta 1, 03401 Ružomberok

Tel: +421444326842

e-mail: zuzana.chanasova@ku.sk 


\title{
OD VÍCEMÍSTNÉ ETNOGRAFIE K AUTOETNOGRAFICKÉ KREATIVNÍ NONFIKCI VE VÝZKUMU ,TRANSFORMACE LINEÁRNÍ TELEVIZE OPTIKOU KONVERGENTNÍCH VLIVŮ““
}

\author{
FROM MULTI-SITED ETHNOGRAPHY TO AUTOETHNOGRAPHIC \\ CREATIVE NONFICTION IN THE RESEARCH OF \\ „TRANSFORMATION OF THE LINEAR TV THROUGH THE MEDIA \\ CONVERGENCE PERSPECTIVE
}

\author{
Jana Kubíčková
}

\begin{abstract}
Abstrakt
Metodologická stat' zvažuje vhodné interpretační metody pro výzkum „transformace lineární televize optikou konvergentních jevů“. Popisuje postupný vývoj metodologického designu celého výzkumu. Začíná zdůvodněním volby vícemístné etnografie ve třech konstrukčních režimech. Dále se zabývá možnými způsoby prezentace výzkumných výsledků. V ukázkách se věnuje autoetnografickému psaní, tradičnímu vědeckému psaní a etnografické kreativní nonfikci. Každý ze zvolených způsobů prezentace má své výhody i nevýhody. Konečnou volbou formy prezentace etnografických dat z výzkumu je forma autoetnografické kreativní nonfikce. Jedná se o metaforický prŕběh celebrity Lality, která je produktem schopného týmu obchodních, PR a marketingových manažerů.
\end{abstract}

Klíčová slova: Vicemístná etnografie, autoetnografie, etnografická kreativni nonfikce, metaforický př́běh, kvalitativní výzkum, konvergence, lineární televize.

\begin{abstract}
The methodological review considers appropriate interpretative methods for research of "transformation of linear television through the convergent phenomena perspective." It describes the gradual evolution of methodological design of the compact research. It begins by justifying the choice of multi-site ethnography in three construction modes. In the text, there are explored possible ways of the research results presentation. In the examples, there are analyzed autoethnographic writing, traditional scientific writing, and ethnographic creative nonfiction. Each present method chosen has its advantages and disadvantages. The final choice for the presentation of ethnographic research data is a form of autoethnographic creative nonfiction. This is the metaphorical story of celebrity Lalita, who is the product of a capable team of business, PR and marketing managers.
\end{abstract}

Key words: Multi-sited ethnography, autoethnography, ethnographical creative nonfiction, metaphorical story, qualitative research, convergency, linear TV.

\section{1 ÚVOD DO TÉMATU KONVERGENCE TELEVIZE}

Pojem konvergence, čili „sbližování“, se v mediálních studiích používá od počátku televizní digitalizace pro změny nejen v oblasti technologické, ale také ekonomické, sociální či právní (srov. Sparviero et al. 2017). V dostupných výzkumech se představuje jako stav, jev i proces. Samotná podstata konvergence, rozličné jevy, kterými se projevuje, i šíře jejich typologie z ní činí fenomenologický předmět zájmu. Proměnlivost jevů se odráží také v dílčích projevech konvergence na odlišných trzích. V celosvětovém měřítku se televizní trhy digitalizují postupně již třetí desítku let. Výchozí podmínky nově digitalizovaných trhů jsou výrazně 
ovlivněny už zkušenostmi a dosavadním vývojem trhů, kde je digitální technologie již plně etablována. To ovlivňuje i odlišné konvergentní projevy i procesy. Transformace lineární televize tedy nabývá odlišných fází a podob ve vztahu k vývojovému stádiu digitalizace, technologické vyspělosti, ekonomické dostupnosti lokálních trhů i technologické gramotnosti uživatelů každé země.

Z časového hlediska je také možné ukázat konvergenci v definičním rozsahu jako pojem, který v konkrétní formě vždy nabývá odlišné konotace a je definován jinými proměnnými. Konvergence je proměnlivá jak z pohledu času, tak z pohledu prostoru čili místa. Jinou definici je možné sestavit pro krajiny konvergované a jiná definice vznikne z pohledu krajin konvergujících. Stejně tak dochází k neustálému přeskupování a souběhu jednotlivých proměnných, které vytvářejí unikátní podmínky a uskupení pro konkrétní konvergentní jevy. Konvergence je podobně jako ,globalizace“ obecně přijatý sociální fenomén, který se realizuje v podobě „sdílených sociálně normativních představ“ (Mansell 2012, s. 1). Tyto sociální shody vznikají, jsou přijímány a následně považovány za samozřejmé, protože „lidé usilují o určitou soudržnost ve své zkušenosti s realitou svého života ve světě rychle se měnících technologií a kulturních a sociálních norem“ (Mansell 2012, s. 31). Základní metodologickou otázkou ve výzkumném procesu je, jak konvergenci, která má více než bohatý teoretický základ, zkoumat empiricky př́mo v terénu.

\section{VÍCEMÍSTNÁ ETNOGRAFIE (MULTI-SITED ETHNOGRAPHY)}

Etnografování jako kreativní proces (srov. Ghosh et al. 2013) nabízí vhodný metodologický aparát pro zkoumání konvergence v dílčích mediálních institucích. Průběžně mezi lety 20072019 jsem realizovala sběr dat pro výzkum mediální konvergence v prostředí soukromých lineárních televizí. Počáteční role externího akademického výzkumníka se v krátké době proměnila a nabídkou interní pracovní pozice jsem se stala součástí zkoumaného prostředí. Pozice ,insidera“ už neumožňovala odstup od sledovaného dění, a tím se výrazně proměnily zápisy ze zúčastněného pozorování ve výzkumných denících. Změna výzkumného pole, z původní televize Prima (v období konvergence mezinárodní mediální skupina MTG) do televize Nova (v období pozdní konvergence a dekonvergence mezinárodní mediální skupina CME), otevřela prostor realizovat etnografický výzkum vícemístnou etnografií (multi-sited ethnography) podle George Marcuse (1998). Vícemístná etnografie rozšírila sledované konvergentní fenomény, které měly povahu sítě (srov. Marcus 1995, s. 105-106). Marcus hovoří o sedmi konstrukčních režimech, ze kterých jsem pro svůj výzkum zvolila tři. Prvním byla „strategicky situovaná etnografie“, druhým „následuj život či biografii“ a třetím „,postupuj podle metafory“, přičemž každý užívám v odlišné fázi výzkumného procesu.

\subsection{Režim strategicky situované etnografie}

Režim strategicky situované etnografie definoval výzkum lokačně a určoval výzkumný prostor. Jednalo se o dvě české soukromé televize, které patřily do mezinárodních mediálních skupin - TV Prima (MTG) a TV Nova (CME). Zpočátku dvě odlišná místa, dvě televizní společnosti, které představují dva odlišné světy jednoho předmětu výzkumného zájmu „televizní konvergence“. Výzkumné pole, jež definuje mezinárodní skladba manažerů, kteří sledovaný prostor utvářejí a zároveň se stávají sledovanými optikou sledovaného předmětu zájmu, to jest konvergentních změn. Z pohledu výzkumného objektu přicházejí prostřednictvím konvergence do televizí národního charakteru různé kultury, mediální obsahy, strategické směry i manažerské zvyklosti.

Strategicky situovaná etnografie mi umožnila porozumět lokálnímu televiznímu trhu v širokém kontextu změn dominujícího kapitalistického systému. Zároveň globální aspekt konvergence nebylo možné vyjmout z pozorování lokálního pole. Marcus vyzvedává potřebu neustálého trrídění vztahů mezi lokálním a globálním a nutnost rozpoznávat a objevovat 
diskurzy současných sítí, které lze definovat jejich vztahem ke světovému systému (srov. Marcus 1998; 1995). Díky vícemístné etnografii reflektuji odlišné diskurzy a zároveň sebeidentifikaci v roli výzkumníka, která je podmínkou neustálého vyjednávání výzkumných pozic v každodenních situacích. Vlastní sebeidentifikace ve výzkumu mě vedla ke druhému Marcuseho režimu ,následuj život nebo biografii““.

\subsection{Režim následuj život či biografii}

Biografické vyprávění se ve vícemístné etnografii užívá zřídka (Marcus 1995), ale v př́ípadě dlouhodobého výzkumu televizní konvergence určuje výzkumný terén parametrem času. Vzhledem k výše zmíněné sebeidentifikaci jsem zvolila biografii vlastní. Čili jako výzkumník se nestávám objektem výzkumu, ale z pohledu času autobiograficky definuji časový interval, ve kterém období se sběr dat realizoval. Vlastní pracovní kariéra definuje zároveň časoprostorový rámec výzkumu. „Historie života odhaluje vzájemné sousedství společenských kontextů vedle vyprávěných individuálních zážitků, které mohou být ve strukturálním studiu procesů skryty. Jsou potencionálními průvodci k vymezení etnografických prostorů $\mathrm{v}$ systémech formovaných kategorickými rozdíly, díky nimž by tyto prostory byly jinak neviditelné. Tyto prostory nemusí být nutně vedlejšími prostory, ačkoliv mohou být odhaleny $\mathrm{v}$ dílčích životních historiích, ale jsou utvářeny neočekávanými nebo novými asociacemi mezi různými životními kontexty“ (Marcus 1995, s. 110).

Následování vlastní biografie mi dovolilo roku 2019 rozšiřit výzkumné pole a přidat do vícemístné etnografie třetí sledovanou televizi, kterou byla nově spuštěná lineární TV Seznam. Krátké působení v tomto prostředí uzavřelo kompletní sběr dat a poskytlo mi z pohledu konvergence pochopit některé sledované jevy z přechozích tradičních lineárních televizí. V období „transmediálním“ (srov. Jin 2020), které je definováno sociálními sítěmi, sdíleným obsahem a v televizním prostoru digitálními televizemi typu Netflix či Amazon, vstupuje na lokální trh TV Seznam s novou lineární televizí. Nový terén redefinuje dosavadní výzkum a odkrývá zcela nové souvislosti. Zatímco z pohledu globálního ztrácí lineární televize zejména $\mathrm{v}$ distribuci zahraničního obsahu svoji sílu, z pohledu lokálního narůstá její důležitost i postavení. Přidružení nového výzkumného terénu v rámci metodologie vícemístné etnografie odkrylo ve výzkumu výrazný trend.

\subsection{Režim postupuj podle metafory}

Poslední, tř̌etí konstrukční režim vícemístné etnografie je režim „postupuj podle metafory“. Sledovaný předmět výzkumu, konvergence, byl od počátku skrytý v manažerském diskurzu řízení televize. Ve sledovaném prostředí rutinní praxe jsem zpočátku doslova stopovala klíčové pojmy, které zahraniční autoři ve svých výzkumných projektech k termínu konvergence přiřadili jako průvodní jevy. Autoři jako Jin (2013), Sparviero (2017) a další opírají své teoretické studie o termíny multimediálnosti, komercionalizace, globalizace obsahu, koncentrace a mnohé další. Proto bylo primárním zájmem při sběru dat zaznamenávat do výzkumných deníků situace, které se dotýkaly definovaných, operacionalizovaných pojmů vztahujících se ke konvergenci. Pojem „konvergence“ není v praxi v jednotlivých terénech používán. Ani ve volné konotaci k obsahu termínu konvergence manažeři nenašli adekvátní pojmenování procesů z jejich praxe.

Při trrídění deníkových dat však jedno slovo diskurzem rezonovalo. Objevuje se jak v denících, v rozhovorech s manažery i v záznamech dialogů, a tímto slovem je „synergie“. Synergie označuje jev, jímž dochází k tomu, že celkový výsledek je větší než prostý součet zapojených částí. Synergie vzniká společným působením, spoluprací a spojováním rozdílných př́stupů. Ve výzkumu se často jedná o spojování dílčích podniků fúzí; např̀. televize Nova získala fúzí produkční společnost Media Pro Pictures či koupila distribuční společnost Bonton Film. Prostý součet $1+1+1$ v konečném výsledku byl více než 3 a CME udělala další krok 
k přechodu k multimediální společnosti, což je základní projev konvergence. Režim „následuj metaforu“ z metodologie vícemístné etnografie pomohl, zejména $\mathrm{v}$ analytické a interpretační části výzkumu, odkrývat jevy spojené s teoretickým konceptem konvergence. Shodný jev popisuje Jin (2013) v knize „De-convergence of Global Media Industries“, kde také píše o synergiích v souvislosti s mediální konvergencí. Metaforické vyjádření „konvergence“ coby „synergie“ překlenulo diskurz televizních manažerů a akademické teorie.

\section{AUTOETNOGRAFIE V REŽIMU „NÁSLEDUJ AUTOBIOGRAFII“}

Soubor sebraných etnografických dat nabídl široké možnosti zpracování. V běžných vědeckých textech se často potýkám se ztrátou kontextů, proto jsem hledala způsoby prezentace sebraných dat, která umožní hlubší zachycení a následně pochopení dané problematiky. Stejně důležitým faktorem je také možnost zahrnout do výzkumu vlastní zkušenosti z období etnografování televizního prostoru. Autoetnografie je kvalitativní výzkumná metoda, která spojuje analýzu a interpretaci s narativními detaily vlastní žité zkušenosti. Podle Bartona jsou etnografickými daty emoce, vlastní biografie i poznámky z pozorování (Barton 2011, s. 432). Zahrnutí osobního postoje a kritičnost k osobní zkušenosti konotuje se zvoleným, výše zmiňovaným autobiografickým režimem vícemístné etnografie. Volbou režimu „následuj biografii“, v tomto př́padě biografii výzkumníka čili autobiografii, se od počátku nabízí držet také interpretaci v rovině autoetnografie.

Autoetnografie využívá údaje o osobě výzkumníka a kontextu výzkumu k rozvoji porozumění zkoumané problematiky (srov. Das a Mullick 2015). Ve výzkumu konvergence v televizním prostoru vypravuje autoetnografie příběh s vlastními prožitky, které se vztahují ke zkoumanému fenoménu. Autoetnografii užívám pouze v prezentaci výzkumných dat, protože výzkumník sám se nikdy nestává objektem ani předmětem výzkumu. Sebereflexe osoby výzkumníka mi odkrývá složité vrstvy $\mathrm{v}$ kontextu konvergentní strategie $\mathrm{v}$ manažerském rozhodování, nařízení zahraničních vlastníků, v osobních zájmech manažera či autoritativních př́kazech v hierarchizovaném pracovním prostředí. Podle Leavy (2020) je autoetnografie metoda samostudia, při němž se na výzkumníka pohlíží jako na životaschopný zdroj dat, který zasazuje jeho vlastní zkušenost do širšího kulturního kontextu.

Podle Andersona (2006, s. 3) splňuje předložený výzkum konvergence lineární televize klíčové faktory autoetnografického přístupu. Jako výzkumník jsem získala plný status člena zkoumané skupiny a jsem ochotná obětovat soukromí v analytické sebereflexi. V prezentaci výzkumných dat je můj pohled identifikovatelný a zřetelně odděluji pohled výzkumníka od sociální reality. Autoetnografická interpretace začíná v př́ípadě našeho výzkumu vnitřním dilematem výzkumníka $\mathrm{k}$ řešení tradiční terénní práce. Pozice výzkumníka není zaměňována s pozicí „informátora“ či objektu výzkumu. Stejně tak dochází k naplnění závazku k teoretické analýze, čímž překračuji empirická data ve vztahu k širší sociální perspektivě. Využitím autoetnografického pohledu k interpretaci dat zohledňuji zejména osobní zkušenost ze zúčastněného pozorování. Těžiště Andersonových diskuzí o analytické autoetnografii nepředkládá stereotypní vodítko pro provádění autoetnografie, ale naopak naznačuje koncepci (srov. Anderson 2006).

\subsection{Ukázka autoetnografického textu}

Pro konkrétní představu autoetnografické formy prezentace výzkumu uvádím př́klad hotového textu.

FTV Prima (výzkumný deník 1/2006, řijen 2006, TV Prima)

Podle mapy pokrytí digitálním signálem je aktuálně Prima vjedné třetině přechodu na digitální vysílání. Kúplnému vypnutí analogového signálu má dojít v roce 2012. Se svým nadřizeným, ředitelem marketingu JM, řešim každodenní agendu. Já potřebuji vyřešit 
výpadky dat čisel sledovanosti, on se neustále toči nad výsledky marketingového výzkumu externí agentury nad ukazatelem ,positioning brandu" na trhu:

Ředitel marketingu JM (dále pouze ředitel): „,...jako vždy Prima čtyřka“... , ,proč nás mají všichni na ovladači jako čtyřku"? To neni ani na bednu"!... Je to na bednu!

Analytik (dále já): ,,To asi nebudou nijak složité důvody, ČT1 je 1 a ČT2 je 2, prostě jasná volba a tradice, nejsledovanějši je Nova, navíc terestricky pokrývá významně větši plochu, tak ji (myšleno diváci) dali pod 3, pokud ji naladí, a pak jsme my - mně to smysl dává“.... „Potřebuju vyřešit, jak doplnit heat mapy pro plánování selfỉ, když mi vypadnou data kvůli údržbám vysílaču nebo kvůli prechodi̊m na digitál. “

Ředitel: „Nechápu, proč jsme čtyřka, kdyby jsme byli trojka, máme lepši čísla. “

Já: „Lepši čisla budeme mít, když budeme mít lepši obsah a dobrý marketing, který stojí na číslech, které nemám!“

Ředitel: „Takže s tím souhlasíš, když budeme trojka, budeme mít lepši čisla, protože máme lepši marketing. “

Já: „Ne, nesouhlasím... potřebuju vyřešit data, když vypadne signál, jsme bez dat. Digitalizace stejně trhem zamává, za několik let budou desitky nových stanic a z pohledu technologie bude úplně jedno, jestli má Prima laděni 4, nebo 39."

Ředitel: „Odmítám ř řsit futuristický témata, v roce 2012 už tady nikdo z nás nebude..." . „Vyřě to, jak chcě̌, stejně tady tomu nikdo nerozumí.“

Počátkem digitalizace televizního trhu konči na Televizi Prima výše ilustrovaná éra „manažerské pocitovosti a dojmologie“. Marketingový ředitel, který nebyl ochotný přijmout marketing jako část jednoho celku, byl odvolán po roce a půl svého pưsobení a švédská mediální skupina Modern Times Group (dále jen MTG), která odkoupila v roce 2005 od společnosti GES Holding 50\% podíl za částku přibližně Kč 2,8 mld. (Marketing a Média, 2005), dosadila do vedení televize Prima svého člověka, generálního ředitele Alexandra Česnavičuse (řijen 2005 - březen 2008), který započal éru nové lineární televize „,moderního stylu“, zároveň však éru bolestných inovací a prešlapư.

\subsection{Sebereflexe a kritika}

Výše zmíněná ukázka prezentace dat získaných vícemístnou etnografií je definována autoetnografickým přístupem. Forma trpí mnohými nedostatky, které mě nutí hledat nové možnosti prezentace. Prvním problémem je užívání názvů pracovních pozic, přičemž dochází k prrílišnému zosobňování, které odvádí čtenáře od podstaty výzkumu. Po etické stránce je v některých př́ípadech možné užít jméno konkrétního manažera čili informátora, protože se jedná o obecně známý fakt, který je dohledatelný také v masových médiích. Eticky sporné jsou zejména ty pozice, na nichž výkonný manažer pracuje dodnes a ve vztahu $\mathrm{k}$ jeho trvajícímu pracovnímu poměru může být, i přes dříve vyslovený souhlas, problematické ho ve výzkumu identifikovat. Dalším nedostatkem předložené ukázky je upozadění výzkumného tématu konvergence. Popis situace a postoje manažerů převažují nad výzkumným tématem, o který má jít především. Za třetí přetrvává moje nespokojenost ohledně plochosti interpretace dat. Konvergenci za každé situace a v každé instituci doprovází atmosféra strachu a obav o ztrátu pracovního místa. Manažeři žijí svojí prací na úkor soukromí ve falešné naději, že verdikt o ukončení pracovního poměru můžou zvrátit nadprůměrným pracovním vytížením. To vše a mnohem více $v$ předložené formě chybí.

Z pohledu výzkumníka, i přes veškerou zmíněnou sebekritiku, se mi daří zaujímat od skupiny výrazný odstup. I když jsem součástí pracovního kolektivu, nejsem z pohledu výzkumného pole „insider“، Zápisy a následné interpretace jsou věcné, fakticky přesné a odosobnělé. I skupina manažerů, kolegové, udržují odstup, zažívám pocity ,jinakosti“. Ve formě interpretace výsledků výzkumu postrádám možnost podělit se o pocity ,jinakosti“ a „,nepatřičnosti““ (srov. Ghosh et al. 2013), které jsou podstatné z hlediska vývoje výzkumu. 
Změnou výzkumného terénu se později změnil také můj přístup. Novým cílem bylo plně proniknout do skupiny a stát se plnohodnotným členem pracovního kolektivu, i za cenu změny $\mathrm{v}$ technice sběru etnografických dat. To mi dovolilo lépe sledovat konvergentní jevy v televizním prostředí a opustit postoje manažerů. Heterogenní data nabízí interpretaci konvergence televize $\mathrm{z}$ pohledu televizních manažerů pouze $\mathrm{v}$ jednom výzkumném poli. Naopak kompatibilitu dat z obou prostředí shledávám přes předmět výzkumu, tedy lineární televizi. Dílčí prŕípadové studie tedy rozděluji na menší celky a různé části výzkumu prezentuji různými kratšími vědeckými studiemi. Stále však hledám jednu formu, ve které bych mohla kompaktně prezentovat výzkum konvergence v lineárních televizích.

\section{AUTOETNOGRAFICKÁ KREATIVNÍ NONFIKCE}

Tradiční způsoby vědecké prezentace a interpretace výzkumných výsledků, které předkládají soubory pečlivě upravených dat, mají své limity. Ze sebraných etnografických dat je možné sdělit více než tradičním vědeckým psaním, navíc širšímu publiku a hlavně přesněji a hlouběji. Cílem nové formy prezentace etnografických dat je předložit výsledky výzkumu jednotnou formou a zároveň opustit optiku manažerů a zaměřit se na lineární televizi. Řešení se nabízí v kreativní analytické praxi (CAP - Creative Analytical Practice) konkrétně v interpretační metodě kreativní nonfikce (srov. Smith et al. 2015). Kreativní nonfikce představuje legitimní způsob prezentování etnografických výsledků výzkumu. Vědecká kreativní nonfikce se řadí do oblasti kreativní literatury faktu. Prezentuje systematicky sbíraná výzkumná data v podobě literárního prríběhu či vyprávění a využívá literárních pravidel. Etnografové zjednodušeně hovoří o kreativní nefiktivní reprezentaci výzkumných dat (srov. Smith et al. 2015). Př́běh je fiktivní pouze svojí formou, jinak je obsahově věcný. Zakládá se na skutečných událostech a datech, které výzkumník během výzkumu posbíral, at' už např. rozhovorem, zúčastněným pozorováním, analýzou dokumentů či analýzou př́spěvků internetového blogu, vlogu nebo analýzou jiné kreativní nonfikce (srov. Clayton 2010; Cheney 2000; Smith et al. 2015; Leavy 2020).

Volba etnografické kreativní nonfikce s sebou přináší rizika stejně jako každá jiná vědecká prezentace. Základním důvodem, proč ji zvolit v př́ípadě nastoleného designu etnografického výzkumu, je následná analýza dat v procesu psaní a možnost díky sjednocení dat vidět výzkum z jiného úhlu pohledu. Richardson a Lockridge (1998) považují psaní za metodu dotazování, za způsob, jak zjistit více o sobě i o tématu. Je to metoda objevování a analýzy. V př́padě etnografické studie lineárních televizí řeší forma kreativní nonfikce i etické parametry výzkumu. Zejména chrání identitu zúčastněných manažerů a zároveň udrží skutečné události a fakta ve své šiři i hloubce. Kreativní nonfikce využívá různá teoretická východiska. Výzkum se vrství a spojováním odlišných diskurzů se objevují nové souvislosti i teoretické možnosti. Narace otevírá možnosti porozumění tématu a drží čtenářovu pozornost v uceleném vidění světa výzkumníka. Pracuje s emocemi a ztotožňuje se s prostředím i tématem výzkumu.

Podle Cheney (2000) a Leavy (2020) vypráví kreativní nonfikce příběh pomocí faktů s využitím mnoha fikčních technik. Kreativní nonfikce předkládá fakta způsoby, které čtenáře posunou k hlubšímu pochopení tématu. Kreativní nonfikce se výrazně liší od tradičních způsobů prezentace vědecké praxe, přesto musí zůstat a priori tvarem vědeckým. Výzkum konvergence lineární televize prezentuje svojí povahou dat a zvolenou metodou vícemístné etnografie data jak tradiční cestou, tak etnografickou kreativní nonfikcí.

\subsection{Ukázka textu v autoetnografické kreativní nonfikce}

V této části nejdříve uvádím př́iklad, jak by etnografická nonfikce studie konvergence lineární televize mohla vypadat.

$V$ kódu synergie Lalita 
Lalita působí na českém mediálním trhu již 27 let a snad mi promine moji upřimnost, i když již dovršila 68 let, je stále mladá a plná síly. Jeji producenti ji stvořili jako klasický spotřební produkt, který od počátku svého uvedení na trh generuje miliónové zisky. Už v roce 1994 si ji Češi velice oblibili a během prvního roku svého pưsobeni oslovila každého, kdo vlastnil televizni prijímač. Kolem Lality byla brzy vybudována rozsáhlá obchodní společnost a její životní styl se stal vysoce nákladným, ale výhodným businessem. Na jejím úspěchu se stále podileji stovky lidí. Dnes si Češi bez Lality neuměji predstavit život, i když se jeji přitomnost stala pro mnohé spíše zvykem než atraktivní přiležitostí pro zábavu.

Lalita se poprvé představila svým fanouškům prostřednictvím filmu Obecná škola Zdeňka Svěráka, což ji také pưvodně profilovalo $k$ intelektuálnější části fanouškovského spektra. Nicméně Lalita chtěla víc. Její sláva rostla a Lalita postupně získávala větší oblibu u fanoušků, což ji vedlo od českého filmu k produkci zábavy, dlouhohrajících seriálů, ale také sportu, kulinářství, soutěži a dalším aktivitám. Lalita se slávou proměnila a byla spojována s budováním kultu osobnosti. Na její slávě se přiživoval kdekdo. Dokázala vybudovat jména jako Lucie Borhyová či Slávek Boura anebo Vladimír Železný. Nikdo z nich však nikdy neprekročil vlastni stín. Výsluni patřilo stále Lalitě.

Do manažerského týmu $k$ Lalitě jsem nastoupil v únoru roku 2009. Lalita byla na vrcholu slávy. Byla arogantní, sebestředná, neohrožená, přesto jsem si ji velmi rychle oblíbil. Lalita byla nejzkušenějši celebritou národního rozměru a byla to pro mě čest, že si mě vybrala do svého týmu. Hodně jsem se od ní naučil a nastupující těžké roky nás propojily v nejlepši prátele. Zatímco Lalita dozrávala a stávala se pokornějši ke své slávě, která prestala být samožrejmostí, já rostl a stával se arogantnějším, sebestředným a neohroženým, jen abych jí pomohl udržet její slávu, její výsluní. Byla to dlouhá, dvanáctiletá cesta, cesta synergie. Společně jsme proživali každý úspěch $i$ neúspěch. Jednoho dne se Lalita ocitla na resuscitačním li̊žku, a přestože vím, jak jí pomoci, už k ní nemám př́stup. ,Lalito!!!“”

\subsection{Kritická analýza ukázky}

Předložená ukázka textu je metaforickým příběhem největší české celebrity „Lality“, která je zosobněním lineární televize. V osobě Lality je možné spojit vícemístný výzkum do jedné postavy. Lalita může reprezentovat všechna tři výzkumná pole, tedy TV Prima, Nova i Seznam, anebo může být př́ípadovou studií, tedy jednou z nich. V ukázce je Lalita televizí Nova, a ze své pozice má Lalita možnost hovořit o ostatních, méně úspěšných kolegyních na trhu. V charakteru Lality se odráží arogance manažerů pracujících tou dobou pro TV Nova, stejně jako se $\mathrm{v}$ charakterech ostatních Lalitiných kolegyň zrcadlí typické rysy managementů, které je řídí. Lalita prochází složitým životním cyklem, který představují jednotlivé fáze konvergence a výrazně se různými vlivy proměňuje jak její podoba, tak i např́ílad sebevědomí. Jméno či název „Lalita“ je přesmyčkou sousloví „lineární televize“, je záměrně provokativní a nese psychoanalytickou symboliku archetypu Animy podle Gustava Junga. Lality strmý pád byl následkem konvergentních změn televizního trhu, které jí způsobí těžké duševní stavy a které se nakonec promítnou i do její fyzické kondice. Ukázka si zároveň zachovává autoetnografický záměr, jelikož př́běh Lality vyprávím jako výzkumník a zároveň jako klíčový informátor čili člen manažerského týmu. Jasně jsou díky postavám odděleny pocity výzkumníka a výzkumná fakta.

\subsection{Ukázka tradiční prezentace výzkumu}

Pro plnou představu předkládám ukázku tradiční formy vědeckého psaní, která byla předlohou pro psaní výše uvedené pasáže ve stylu kreativní nonfikce.

Televizní stanice Nova 
Televizní stanice Nova oficiálně vznikla na počátku roku 1993 na základě získání televizní licence opravňujici společnost CET 21 s. r. o. (Central European Television for 21th Centrury) $k$ provozování televizního vysílání. Televizní stanice Nova zpočátku vysílala pouze pro Prahu a středni Čechy. Následně 4. února 1994 začala vysilat jako první celoplošná soukromá televizní stanice na základě získání licence pro celoplošné televizní vysilání s dobou platnosti 12 let. Televize Nova prevzala vysílací frekvenci dosavadního programu ČT2 (dř́vějši F1). Následně v květnu roku 1993 společnost CET 21 s. r. o., Česká spořitelna a CEDS uzavřely smlouvy týkající se založení České nezávislé televizní společnosti s. $r$. o. (ČNTS), jakožto servisní organizace, která si kladla za cíl zajištovat televizní program a televizní vysíleni televize Nova.

Prvním televizním pořadem byl film Obecná škola od režiséra Z. Svěráka, což mělo odrážet také původní myšlenku vzniku této televizní stanice, tj. podle zakladatelů vznikla TV Nova jakožto televizní stanice určená pro intelektuální část společnosti. Na základě této skutečnosti obdržela také licenci, a to i přes skutečnost, že nikdy tento záměr nenaplnila. Dưvodem tohoto bylo předevšim získat vysokou sledovat a oblibu $u$ diváků, což vedlo $k$ nahrazení intelektuálních pořadi̊ pořady zábavními, sportovními, kulinářskými, rodinnými, sportovními apod. Př́značným rysem této televizní stanice byl také dưraz kladený na neformálnost $v$ komunikaci, neobvyklost v pojetí televizního programu apod. (Jirák a kol., 2005, s. 19).

Televizni stanice Nova rovněž změnila př́stup $k$ divákovi, nebot' se vyznačovala budováním kultu osobnosti. Např́klad dřive neznámé osobnosti Lucie Borhyová či Pavel Poulíček se stali za pomérně krátkou dobu hvězdami televize Nova. ...

\subsection{Kritická reflexe}

Kreativní nonfikce se může zdát snazší než tradiční vědecké formy psaní, ale je tomu právě naopak. Nic, co je ve vědecké kreativní nonfikci užíváno, nesmí být samoúčelné, bezúčelné či pouze líbivé. Podle Smithe (2015) není dostatečným důvodem pro výběr prezentace výsledků kreativní nonfikcí např. to, že je módní. Také nestačí umělecký talent anebo obliba kreativní nonfikce, ačkoliv jistou výhodou být může. Kreativní nonfikce naopak může ukázat v jednom příspěvku řadu poznatků, kontextů a vrstev, které jsou svojí povahou velmi složité. Jak jsem zmínila výše, i v príípadě studie konvergence chrání kreativní nonfikce identitu účastníků, která navíc pro závěry výzkumu není nijak podstatná. V dlouhodobém výzkumu sjednocuje čas a prostor. Doslova čas komprimuje a prostor realizuje ve fikčním matrixu. Výraznou výhodou této vědecké netradiční formy je také snadná identifikace s „hrdinkou“, čili se samotným předmětem zájmu.

Z pohledu vědecké publikační strategie nabízí kreativní nonfikce nové možnosti publikační činnosti, jelikož již existují mnohé specializované vědecké časopisy. Kreativní nonfikci lze dle potřeb výzkumu kombinovat s tradičním vědeckým psaním. Vědeckou nonfikcí může být napsané celé dílo, či jeho části, př́lohy, stejně tak může být přepisem tradiční studie. Všechny způsoby vědeckého psaní mají své výhody a nevýhody, proto se nabízí varianta vytěžit $\mathrm{z}$ dostupných dat všechny možnosti, které nabízejí.

\section{Použitá literatura}

1. ADAMS, Tony, Stacy JONES-HOLMAN a Carrolyn ELLIS, 2015. Autoethnography. Oxford: Oxford University Press. ISBN 978-0-19-020886-8.

2. ANDERSON, Leon, 2006. Analytic Autoethnography. Journal of Contemporary Ethnography [online]. 35(4), 373-395. ISSN 0891-2416. Dostupné z: doi:10.1177/0 891241605280449

3. BARTON, Bernadette, 2011. My Auto/Ethnographic Dilemma: Who Owns the Story? Qualitative Sociology [online]. 34(3), 431. ISSN 1573-7837. Dostupné z: doi:10.1007/s11133-011-9197-x 
4. BOCHNER, Arthur, 2016. Evocative Autoethnography. 1st edition. Walnut Creek, California: Routledge. ISBN 978-1-62958-215-3.

5. CLAYTON, Ben, 2010. Ten minutes with the Boys, the thoroughly academic task and the semi-naked celebrity: Football masculinities in the classroom or pursuing security in a 'liquid' world. Qualitative Research in Sport and Exercise [online]. 2, 371-384. Dostupné z: doi:10.1080/19398441.2010.517043

6. DAS, Kaustav a P. MULLICK, 2015. Autoethnography: An introductionrnto the art of representing the author's voice and experience in social research. [online]. Dostupné: https://www.academia.edu/13176755/Autoethnography_An_Introduction _to_the_Art_of_Representing_the_Author_s_Voice_and_Experience_in_Social_Res earch

7. DVOŘÁKOVÁ, Tereza, Tereza STÖCKELOVÁ a Yasar ABU GHOSH, 2013. Etnografie: improvizace $v$ teorii a terénni praxi [online]. B.m.: Sociologické nakladatelství (SLON). ISBN 978-80-7419-148-0.

8. CHENEY, Theodore A. Rees, 2000. Writing Creative Nonfiction: Fiction Techniques for Crafting Great Nonfiction. Revised edition. Berkeley, CA: Ten Speed Press. ISBN 978-1-58008-229-7.

9. JIN, Dal Yong, 2013. De-Convergence of Global Media Industries. New York, Routledge. ISBN 9781138922167

10. JIN, Dal Yong, ed., 2020. Transmedia Storytelling in East Asia: The Age of Digital Media. New York, Routledge. ISBN 9780367246532

11. LEAVY, Patricia, 2020. The Oxford Handbook of Qualitative Research. 2nd edition. New York: Oxford University Press. ISBN 978-0-19-084738-8.

12. MANSELL, Robin, 2012. Imagining the Internet: Communication, Innovation, and Governance.

13. MARCUS, George E., ed., 1995. Technoscientific Imaginaries: Conversations, Profiles, and Memoirs. 1st edition. Chicago: University of Chicago Press. ISBN 9780-226-50444-5.

14. MARCUS, George E., 1998. Ethnography through Thick and Thin. Princeton, NJ: Princeton University Press. ISBN 978-0-691-00253-8.

15. RICHARDSON, Laurel a Ernest LOCKRIDGE, 1998. Fiction and Ethnography: A Conversation. Qualitative Inquiry [online]. 4(3), 328-336. ISSN 1077-8004. Dostupné z: doi:10.1177/107780049800400302

16. SMITH, Brett, Kerry MCGANNON a Toni WILLIAMS, 2015. Ethnographic creative non-fiction: Exploring the what's, why's and how's. In: Ethnographies in Sport and Exercise Research. Routledge. ISBN 9781315794457

17. SPARVIERO, Sergio, Corinna PEIL a Gabriele BALBI, 2017. Media Convergence and Deconvergence. London: Palgrave. ISBN 978-3-319-51289-1.

\section{Kontakt}

Mgr. et Mgr. Jana Kubíčková

FAMU - Film and TV Faculty of Academy of Performing Arts Department of Production Smetanovo nábřeží 1022/2

11000 Praha 1

email: janina.kubickova@gmail.com 


\title{
MODELS OF ALTERNATING PERSONAL CARE
}

\author{
Lucia Pažitná, Alena Novotná
}

\begin{abstract}
The work presents the development of alternating personal care (joint custody) and the models of alternating personal care of minor children after the divorce or separation of parents in the Slovak Republic. The research object within the presented work is the institute of alternating personal care of minor children, which in the Slovak Republic is legislatively amended under the Slovak Family Act No. 36/2005 on the family. We provide a brief overview of the development of children allocation with individual parents or into the system of alternating personal care. We further present the empiric findings of the experience of the research participants who apply this system in taking care of their children. The aim of this work is to refer to various views on and experience with the system of alternating personal care, and to define the models of alternating personal care.
\end{abstract}

Key words: care for a minor child, alternating personal care, models of care for a child

\section{THE DEVELOPMENT AND FORMATION OF ALTERNATING PERSONAL CARE}

The legislative definition of alternating personal care was formed on the Act No. 217/2010 as amended, changing and supplementing the Act No. 36/2005 on the family and on changes and amendments to certain acts, effective since 1 July 2010. The aim of the amendment of the Act No. 36/2005 on the family was to put into practice of the Slovak courts and post-divorce care for minor children the system of alternating personal care of parents, which works in many countries. Alternating personal care also interferes with the amendment of the Code of Civil Procedure, thanks to which the possibility of courts to decide through interim measure about alternating personal care was edited (Hurtaj, 2015).

Alternating personal care is "the form of care for children which brings gender equality into the post-divorce care for children" (Ďrček, 2011, p. 54). It was the civic association Liga otcov (The League of Fathers) which mainly fought for the implementation of alternating personal care in the Slovak Republic. This association was established in 2009 with the enthusiasm to enforce and defend the needs and rights of children as well as fight for the equality in the post-break childcare. In 2010, the civic association Liga otcov significantly affected the Slovak public awareness mainly by enforcing of the above-mentioned system. But, despite the positive start, the association got under the attacks and opposition from numerous women organisations and maternity centres, and gender equality agenda according to Durkovič (2015) just then showed its true colours that it is only women equality that matters, not real gender equality. He also adds that as for parental care, this association faced massive opposition to gender equality in childcare after the divorce of parents, and with the equal opposition to the institute of alternating care. As the former member of the civic association, Durkovič further claims that in up to $90 \%$ cases only one parent - mother - has the sole custody without any reason, enabling the whole machinery of frauds, manipulations, never ending trials and cases. The activity of Liga otcov in enforcing alternating personal care was huge or even useful. Currently, the civic association Liga otcov no longer exists. Its activity was reduced in 2013, and, subsequently, the civic association ceased to exist. The institute of alternating personal care for minor children after divorce has been part of our legislation for 11 years, and we can, therefore, consider its benefits and impacts. Within its realization over the years, lots of beneficial facts as well as problems or risks have arisen 
which alternating personal care and its application in practice brings. Except for the abovementioned resistance against alternating personal care pointed out by Durkovič, we should also mention the opposite view which is the misuse of alternating personal care by fathers to blackmail mothers, or real disinterest of some fathers in the everyday upbringing of children. We may also question and dispute the stability and compatibility of the two educational environments in which a child in alternating personal care lives, which is not always to their benefit. The views of experts (psychologists, psychiatrists, teachers, doctors, and social workers) on the suitability of alternating personal care also vary. To a great extent, the realization of alternating personal care is also influenced by the ability of parents to make a deal. In many cases, older children themselves are the ones who finally create a certain form of alternating personal care, or they end it according to their preferences of the environment they want to live in. Over the years, it is becoming apparent that the dominant factor of successful alternating personal care for minor children after divorce is the parents' ability to respect each other, make a deal, and create a certain specific model of alternating personal care, which will suit the particular family. Therefore, except for the statistic indicators of entrusting children to alternating personal care, we are also interested in the models of this care in those families which carry out alternating personal care for minor children after the divorce of parents.

\section{CURRENT STATE OF THE USE OF ALTERNATING PERSONAL CARE}

Nowadays, such situations still prevail when mothers are awarded sole custody of children after divorce. This information is also proved by the statistic data presented in Table 1 and Table 2. The reasons for this state vary and are interesting for research. Malíková (2011) claims, for instance, that the system of alternating personal care is often being misused. She gives an example when a woman demanded the maintenance for her children from her exhusband. She considered the amount of maintenance suggested by the ex-husband as low. He replied that if she did not agree with the suggested amount, he would request alternating personal care. The reason for the divorce of this couple was long-term psychological abuse and several physical assaults. Malíková (2011) presents lots of such examples. In her practice, she witnesses the good idea of alternating personal care being misused also to blackmail and bully women by aggressive men, leaving the abused women and their children double trapped. As Durkovič (2021) claims, also the opposite problem is a very frequent phenomenon, when the term domestic violence is being misused. We speak about the cases, when a woman wants to revenge her ex-husband and part him from the children, and therefore fakes the domestic violence accusation.

In the following tables we present the state of the use of alternating personal care in the Slovak Republic according to specific months in the years 2015 and 2020. The years have been selected for the illustrative comparison of the development of the abundance of the use of alternating personal care institute by parents in the course of time.

Table 1 Entrustment of a child into alternating personal care in the Slovak Republic in 2020

\begin{tabular}{|c|c|c|c|c|c|}
\hline \multirow{2}{*}{ PERIOD } & \multicolumn{2}{|c|}{ Number of entrusted children in the Slovak Republic } & \multirow{2}{*}{ SUM } \\
\cline { 2 - 5 } & \multirow{2}{*}{ To mother } & \multirow{2}{*}{ To father } & \multicolumn{2}{c|}{ To alternating personal care } & \multirow{2}{*}{ SUM } \\
\cline { 4 - 5 } & & & Number & Percentage & \\
\hline January & 513 & 63 & 83 & $12,59 \%$ & 659 \\
\hline February & 535 & 70 & 84 & $12,19 \%$ & 689 \\
\hline March & 323 & 51 & 41 & $9,88 \%$ & 415 \\
\hline April & 87 & 7 & 11 & $10,48 \%$ & 105 \\
\hline May & 496 & 48 & 76 & $12,26 \%$ & 620 \\
\hline June & 910 & 101 & 128 & $11,24 \%$ & 1139 \\
\hline
\end{tabular}




\begin{tabular}{|c|c|c|c|c|c|}
\hline July & 648 & 84 & 111 & $13,17 \%$ & 843 \\
\hline August & 378 & 49 & 46 & $9,73 \%$ & 473 \\
\hline September & 653 & 82 & 88 & $10,69 \%$ & 823 \\
\hline October & 592 & 81 & 97 & $12,6 \%$ & 770 \\
\hline November & 522 & 60 & 73 & $11,15 \%$ & 655 \\
\hline December & 507 & 84 & 80 & $11,92 \%$ & 671 \\
\hline $\begin{array}{c}\text { Together in } \\
2020\end{array}$ & $\mathbf{6 1 6 4}$ & $\mathbf{7 8 0}$ & $\mathbf{9 1 8}$ & $\mathbf{1 1 , 6 8 \%}$ & $\mathbf{7 8 6 2}$ \\
\hline
\end{tabular}

Source: own elaboration according to Office of Labour, Social Affairs and Family

Table 2 Use of alternating personal care in the Slovak Republic in 2015

\begin{tabular}{|c|c|c|c|c|c|}
\hline \multirow{3}{*}{ PERIOD } & \multicolumn{4}{|c|}{ Number of entrusted children in the Slovak Republic } & \multirow{3}{*}{ SUM } \\
\hline & \multirow{2}{*}{ To mother } & \multirow{2}{*}{ To father } & \multicolumn{2}{|c|}{ To alternating personal care } & \\
\hline & & & Number & Percentage & \\
\hline January & 964 & 75 & 74 & $6,65 \%$ & 1113 \\
\hline February & 1100 & 109 & 82 & $6,35 \%$ & 1291 \\
\hline March & 1145 & 119 & 91 & $6,72 \%$ & 1355 \\
\hline April & 1127 & 131 & 79 & $5,91 \%$ & 1337 \\
\hline May & 1002 & 99 & 92 & $7,71 \%$ & 1193 \\
\hline June & 1216 & 122 & 126 & $8,61 \%$ & 1464 \\
\hline July & 725 & 95 & 47 & $5,42 \%$ & 867 \\
\hline August & 642 & 51 & 47 & $6,35 \%$ & 740 \\
\hline September & 961 & 90 & 73 & $6,49 \%$ & 1124 \\
\hline October & 1121 & 130 & 101 & $7,47 \%$ & 1352 \\
\hline November & 1093 & 145 & 83 & $6,28 \%$ & 1321 \\
\hline December & 854 & 83 & 55 & $5,54 \%$ & 992 \\
\hline $\begin{array}{c}\text { Together in } \\
2015\end{array}$ & 11950 & 1249 & 950 & $6,63 \%$ & 14149 \\
\hline
\end{tabular}

Source: Bellová, 2016

At comparing the results from Tables 1 and 2 we can see in the time interval of 5 years the shift towards the increase of deciding in favour of alternating personal care. While in 2015 there were $6,63 \%$ of children entrusted into the system of alternating personal care by court, 5 years later it increased to $11,68 \%$, which is the increase in entrusting children to alternating personal care by $5,05 \%$.

However, the difference can also be seen in the number of divorces and verdicts about the entrustment of a child. In 5 years, it decreased by 6287 in total. We suppose that in 2020, this number could also be affected by Covid-19 pandemic, as the judiciary was working in a changed mode, and court hearings were postponed.

\section{EMPIRE}

The following part of the work is aimed at the models of alternating personal care we have been studying within the carried out research. 5 parents have taken part in the qualitative research by the method of a structured interview (within phenomenological analysis), having or having had minor children in alternating personal care. Therefore, it was the criteria-based choice of participants, based on the criterion of the experience with the examined phenomena. Within the research we have been finding out whether the alternating personal care was decided by the agreement of both parents or on the proposal of one of them, or by the court decision. We have been further interested in how many children the parents have in 
alternating care, and how long they have been / were using this system. The third area of research has been the time period in which the children alternate the environment and stay with parents. We have been further interested in how the alternation of children between parents takes place. The last topic we have dealt with are the feelings and impressions of this type of childcare.

\subsection{The interpretation of the results}

When asked whether alternating personal care was decided mutually or by the court, 4 participants have answered that they agreed on alternating personal care mutually. One participant replied that they suggested alternating personal care, and the other parent agreed after consideration.

We have been interested in how many children the parents have in alternating care. Two participants both have 3 children in alternating personal care. One of them has been using the system of alternating personal care for 8 years, and the other for 3 years. The remaining three participants have one child in alternating personal care. One participant stated they have 3 children with the ex-husband. One child is in their sole custody, second child is in the exhusband's sole custody, and third child was entrusted in alternating personal care after they agreement to try. This lasted for approximately three quarters of a year. Then they changed alternating personal care into sole custody of one parent with the unlimited contact of the other parent since the educational methods of the ex-partners were completely different, which had a bad impact on the development of the minor child. Another participant stated they had a minor child in sole custody after the divorce at first. Later, after a mutual agreement, they started to practise the model of alternating personal care, and after less than two years they also asked for the change at court. The last participant replied that after the split-up, they both agreed on alternating personal care without the decision of court, and they have been practising it for more than a year now. They have 1 child.

All the participants agreed that the time period when their children alternate with either parent, is one week. In two cases, the children alternate on Fridays. Two participants alternate the children on Sundays, and in 1 case the child alternates their stay on Mondays after school. In the morning, the child is taken to school by the parent who took care for them the previous week, and, in the afternoon, the child leaves with the parent who will take care for them the following week.

The penultimate area we have been interested in was the alternation of the child's stay. This is also connected with switching of clothes and school aids. 3 participants have stated that the children have two sets of clothes and all other things. One set is provided by one parent, and the other set is provided by the other parent. The sets of things also include toys and other aids. The parents see the advantage of this especially when alternating the child. Two participants have replied that the child carries the clothes and aids with them when alternating from one parent to the other. This makes the process of alternation more lengthy at the end of the week. 4 participants have agreed that they share the costs equally. One parent brings the bill, and the other parent always pays the half of all the costs. One participant have replied that they alternate in covering the costs every other school year. One school year, all the costs are covered by one parent, and the next school year, all the costs are covered by the other parent. Bigger expenses, such as swimming or skiing courses, are shared equally. The main advantage for them is that they do not have to discuss every small purchase of the aids. None of the participants pays or gets maintenance for the minor child.

Two participants have agreed that thanks to alternating personal care the children have become more independent. However, they also think that it is a difficult model of childcare as they live farther from each other. In one case, the participant commutes more than 100 kilometres every week so that the children do not have to alternate the school and the 
environment. The participant themselves realizes it is a very complicated, long-term process, and they together with the children see it as temporary ("I wish it was over") and not as something natural, automatic and permanent. The children would love to have one permanent home, not the never ending alternating of two different environments, but, at the same time, they do not wish to lose contact with either parent. One participant who was trying alternating personal care just for some time has replied that it did not have good impact on the development of the child as they had different educational methods and the child started to misuse them - one parent wanted to win the child over so the child did not have to tidy up, could stay up longer, etc. One participant has stated that at the beginning, the child felt the need to slander the other parent they had just stayed with. Both of the parents had to stop this behaviour together, and now it has gradually disappeared.

\subsection{Analysis and discussion}

In the empiric part we have mainly concentrated on the question whether alternating personal care has been decided after the agreement of both parents or on the proposal of one of them or by the decision of court. We have also been interested in how many children the parents have in alternating care, and how long they have been / were using this system. Another area has been the time period after which the children alternate the environment and stay with their parents. We have also been interested in what the alternation of the children between the parents looks like. And the last area we have dealt with have been the feelings and impressions of this type of childcare.

All the participants have agreed that alternating care had been decided after the agreement, not after the decision of court without the consent of one of the parents or both parents.

The number of the children in alternating personal care has varied, 3 being the highest, but most participants have had 1 child in alternating personal care. The longest time period in which one participant has been using the system of alternating personal care has been for 8 years already. The shortest time period one participant was using it was for 3/4 of a year, and it was subsequently changed into sole custody of one parent.

All the participants practise the alternation of children in a one-week interval; only the days of alternation vary. Some alternate the children on Sundays, others on Fridays, and one participant on Mondays. The process of alternation of the children varies with each participant according to the common habits. 3 participants have stated that the children have two sets of clothes and aids, and, therefore, it is not necessary to shift them. The children of the 2 remaining participants carry their clothes and aids with them from one parent to the other. The majority of the participants have stated that they share all the costs equally. One participant has agreed to cover the costs for every second school year - one parent covers all the costs during the whole school year, the other parent covers all the cost the whole following school year.

The last area has been the perception of the system of alternating personal care by the participants. 2 participants see greater independence and earlier maturity in their children. One of them also states that not only them but the children as well subconsciously see this model - constant alternation of homes - as "temporary" and "wait" for it to end. The children would like to have one home, and not alternate the environments all the time, but, at the same time, they do not want to lose either parent. Another participant has replied that alternating personal care did not work in their case. As the biggest disadvantage they see when parents use different educational methods as it was in their case. Olejníková (in Bellová, 2016) states that one of the main conditions for the use of alternating personal care is, according to her, the ability of parents to use similar or the same educational styles. Malíková (2011) adds that incompatible educational styles of parents may violate child's integrity. Another participant has noticed that on implementing this model of care, the child always felt the need to slander 
the other parent they had just stayed with. Both of the parents had to stop this behaviour together, and now it has gradually disappeared.

We agree with the statement of social worker Olejníková (in Bellová, 2016) identical to Malíková (2011) that if parents want to implement the model of alternating personal care, the cooperation of both parents is essential, and so is their mutual communication. If parents do not cooperate, or they do not communicate with each other, or provoke each other on purpose, it will have bad impact on the child's further development, or a child will learn how to misuse this system and use it against their parents.

\section{SUMMARY}

The aim of this work has been to refer to specific models of alternating personal care, which we have been able to study within the research. In the introduction, we have presented the legislative definition of the origin of alternating personal care, and also its definition as such. We have mentioned the period of legislative anchoring of alternating personal care in the Slovak Republic, within which we have also mentioned the civic association Liga otcov, that raised the public awareness mainly through enforcing and supporting the system of alternating personal care.

In the next part we have presented the data about the number of children entrusted to the sole custody of either mother, father, or to alternating personal care by court in the years 2015 and 2020. This data has been fragmented according to individual months and districts all around Slovakia, therefore, we had to obtain them in a complicated way, and process them. For clarity, we have decided to fill it in into the transparent tables so that the subsequent comparison of the results in individual years could be clearer and simpler for readers. Thanks to this, we have gained clear information on the increase in entrusting children to alternating personal care. On comparing the years 2015 and 2020, we can see that there is an increase by $5,05 \%$ in 5 years. Despite the increase, when looking at the overall numbers, we can state that still alternating personal care has been used to a small extent. $6,63 \%$ of entrusted children were under alternating personal care in 2015 , and it was $11,68 \%$ of children in 2020 . The sole custody of mother still prevails as it is clear from the Tables 1 and 2. To only interpret this data by bias, unwillingness and intentions as it is clear from the statements of L. Durkovič, and as we mention above, would be really one-sided. That is why, except for the views of experts, arguments for and against alternating personal care, which we do not analyze in this work, we have also been interested in the experience of the participants of this research with alternating personal care, from which we are able to deduce the models and conditions of functioning of alternating personal care for minor children. In this work, we have tried to present an impartial attitude of the researchers, which neither favours the side of sole custody nor the side of alternating personal care.

\section{Bibliography}

1. BELLOVÁ, L. 2016. Výhody a obmedzenia vsystéme striedavej osobnej starostlivosti. Diploma thesis. Ružomberok : Verbum. 2016, 61 p.

2. ĎURČEK, J. 2011. Striedavá osobná starostlivost' (SOS) a rodová rovnost'. In Striedavá starostlivost' a rovnoprávne rodičovstvo. Zborník z panelovej diskusie. Bratislava : Ministerstvo práce, sociálnych vecí a rodiny, odbor rodovej rovnosti a rovnosti príležitostí,2011. p. 53 - 67.

3. ĎURKOVIČ, L. Internetová komunikácia

4. ĎURKOVIČ, L. Povinná striedavá osobná starostlivost' oslobodí deti od sporov rodičov. In Striedavá osobná starostlivost'. Zborník odborných materiálov, rád, informácií a praktických skúseností o spoločnej porozchodovej starostlivosti o deti. 
[online]. [cit. 2015. 111. 28.]. Available at: <http://www.ligaotcov.sk/cache/docu ments/KNIHA- striedavka--Liga-otcov.pdf>.

5. HURTAJ, M. Zverenie mal. dietat'a do striedavej osobnej starostlivosti rodičov. [online]. [cit. 2021. 05. 21.]. Available at: <http://www.hurtaj.sk/zverenie-mal-diet ata.html>.

6. MALÍKOVÁ, D. 2011. Striedavá starostlivost' v prípadoch prítomnosti násilia $\mathrm{v}$ rodine. In Striedavá starostlivost' a rovnoprávne rodičovstvo. Zborník z panelovej diskusie. Bratislava : Ministerstvo práce, sociálnych vecí a rodiny, odbor rodovej rovnosti a rovnosti príležitostí, 2011. p. 43 - 51.

7. ÚRAD PRÁCE, SOCIÁLNYCH VECÍ A RODINY. 2015 2015- Sociálnoprávna ochrana detí - zverenie detí do starostlivosti jednému z rodičov a do striedavej osobnej starostlivosti. [online]. [cit. 2021. 05. 21.]. Available at: <https://www.upsvr.g ov.sk/statistiky/socialne-veci-statistiky/2015/2015-socialnopravna-ochrana-deti-zver enie-deti-do-starostlivosti-jednemu-z-rodicov-a-do-striedavej-osobnej-starostlivos ti.html?page_id=465894>

8. Act No. $36 / 2005$ on the family and on changes and amendments to certain acts

9. Act No. 217/2010 changing and supplementing Act No. 36/2005 on the family and on changes and amendments to certain acts

\section{Contact}

Mgr. Lucia Pažitná

Catholic University in Ružomberok, Faculty of Education

Hrabovská cesta 1, 03401 Ružomberok

Tel.: +421 (0)908959508

email: bellova.lucia@gmail.com

doc. PhDr. Alena Novotná, PhD.

Catholic University in Ružomberok, Faculty of Education

Hrabovská cesta 1, 03401 Ružomberok

Tel.: +421 (0)905 277629

email:novotna.a@gmail.com 


\title{
MULTILATERÁLNÍ ZOBRAZENÍ UDÁLOSTÍ ŠOA V PUBLIKACI POSLALI JE NALEVO
}

\section{MULTILATERAL REPRESENTATION OF SHOAH EVENTS IN THE PUBLICATION THEY WENT LEFT}

\author{
Milan Mašát, Adéla Štěpánková, Andrea Bajnarová
}

\begin{abstract}
Abstrakt
Př́ispěvek se věnuje vybraným tématům, která konotují multilaterální pohled na události šoa, jež jsou integrována do knihy Moniky Hesseové Poslali je nalevo (2020). Multilateralitu v dané oblasti jsme rozdělili do šesti okruhů: 1) návrat židů do svých domovů; 2) pocit méněcennosti pramenící z relativně snazšího průběhu internace, 3) dopady internace na poválečný život židů; 4) dezertéři z německé armády; 5) vražda z milosti; 6) já, nebo ty. Prezentace vymezených událostí i $z$ jiného pohledu, než se kterým jsou čtenáři prostřednictvím literárních textů ve většině případů seznamováni, může zabránit jistému schematickému nazírání na jednu linii událostí druhé světové války a může zvýšit impakt upozornění, která z této etapy dvacátého století vyplývají.
\end{abstract}

Klíčová slova: Poslali je nalevo, Monika Hesseová, šoa, holokaust, multilaterální pohled, druhá světová válka

\begin{abstract}
The paper deals with selected topics that connote a multilateral view of the Shoah events, which are integrated into Monica Hesse's book They Went Left (2020). We divided multilateralism into six areas: 1) the return of Jews to their homes; 2) the feeling of inferiority stemming from the relatively easier course of internment, 3) the effects of internment on the post-war life of Jews; 4) deserters from the German army; 5) murder by grace; 6) me or you. Presenting specific events from another perspective than that readers are familiar with in most cases through literary texts may prevent some schematic view of one line of World War II events and may increase the impact of warnings arising from this phase of the twentieth century.
\end{abstract}

Key words: They Went Left, Monica Hesse, Shoah, Holocaust, multilateral view, World War II

\section{1 ÚVOD}

Publikace Moniky Hesseové Poslali je nalevo vyšla poprvé v nakladatelství Little, Brown and Company v roce 2020; v témže roce byla vydána v České republice v př̀kladu Lucie Schürerové $\mathrm{v}$ nakladatelství Fragment. $\mathrm{V}$ rámci př́spěvku se zaměříme na zobrazení multilaterálního pohledu na jednu linii událostí druhé světové války - šoa - v př́iběhu, který se odehrává v poválečné Evropě (v rámci článku vnímáme termíny šoa a holokaust jako synonyma). Již tento faktor, tedy místo a čas, kdy se děj odehrává, splňuje požadavky na jiné, multilaterální, vykreslení jedné etapy dvacátého století. Většina beletristických vyprávění, v jejichž centru se nalézá zobrazení druhé světové války, je časově zasazena do válečných let a $\mathrm{v}$ jejich centru se ve značném množství př́ípadů nachází obraz útrap osob, které nacistický režim definoval jako židy (v rámci příspěvku vnímáme tuto skupinu osob jako vyznavače 
judaismu). Linie těchto př́běhů většinou končí v situaci, kdy je prostředí, ve kterém se daný př́běh odehrává, osvobozeno sovětskou armádou nebo západními spojeneckými vojsky.

S naznačeným úhlem pohledu jsou ve většině př́padů seznamováni i čeští žáci a studenti na různých stupních institucionálního vzdělávání v hodinách literární výchovy, ve kterých jsou jim prezentována umělecká vyprávění s tematikou šoa. Nechceme zpochybňovat skutečnost, že události šoa byly namířeny primárně proti osobám židovské národnosti či židovského vyznání, nicméně představování této linie druhé světové války pouze prostř̌ednictvím osudů jedné - i když nejvíce zasazené - skupiny může vést $\mathrm{k}$ určitému zploštění pohledu na vymezenou problematiku. Zastáváme názor, že by (nejenom) žákům a studentům měly být nabízeny i texty, ve kterých je tematizován osud židů navrátivších se z koncentračních a vyhlazovacích táborů (pro účely příspěvku vnímáme sousloví koncentrační a vyhlazovací tábor jako synonyma), vyprávění, v jejichž centru se nalézá zobrazení života této skupiny osob v zemích, kde se po válce prosadil komunistický režim či beletristické texty, které ukazují jejich peripetie provázející Aliyu (at' už oficiální, či nelegální) do Palestiny. Multilaterální pohled na vymezené události lze vést rovněž v rovině seznámení recipienti̊ $\mathrm{s}$ osudy dalších skupin osob, které nacistický režim označil za nežádoucí. Jedná se např́íklad o homosexuály, Svědky Jehovovi, Romy a podobě.

$\mathrm{V}$ rámci př́íspěvku se zaměříme na zobrazení osudu židů po konci druhé světové války. $\mathrm{Na}$ př́kladu vybraných pasáží z románu Moniky Hesseové Poslali je nalevo ukážeme, jak je lze využít $\mathrm{k}$ prezentaci aktuálnosti událostí šoa pro současnou, čím dál více se globalizující společnost, a to ve spojení s projevy antisemitismu, rasismu, xenofobie či stigmatizace určitých, zejména menšinových, skupin osob. Hlavní myšlenku vybraných úryvků usouvztažňujeme s obecným historicko-společenským kontextem, který provázel nucený pobyt osob židovské národnosti v koncentračních táborech, i v souvislosti s útrapami, které je provázely při návratu z těchto internačních zařízení.

\section{NÁVRAT ŽIDŮ DO SVÝCH DOMOVŮ}

Jedním z hlavních témat multilaterálního pohledu na události šoa z fokusu osob židovské národnosti je zobrazení jejich návratu do svých domovů. Tato problematika není př́liš často ve středu uměleckých vyprávění, a to možná kvůli určité kontroverznosti daného tématu. Mnozí přeživší vzpomínají na situaci, kdy byli svými sousedy po svém návratu přivítáni přinejmenším chladně, mnozí očití svědkové tvrdí, že ze setkání se svými sousedy po návratu do místa bydliště cítili antisemitský podtext, určitou výčitku, že právě oni přežili. Důkazem přetrvávajícího antisemitského chování mnohých obyvatel, představitelů politické reprezentace i policie může být pogrom namířený proti židům, kteří přežili nacistickou vyhlazovací mašinerii, v roce 1946 v Polsku. Právě o existenci protižidovského smýšlení, které v myslích většinové společnosti přetrvávalo i po hrůzách holokaustu, považujeme za jeden $\mathrm{z}$ faktorů, na němž lze demonstrovat nutnost nadále o hrůzách druhé světové války hovořit a nabízet čtenářùm i texty, které danou problematiku obsahují.

$\mathrm{V}$ publikaci, která se nalézá ve středu našeho př́spěvku, je dané téma zakomponováno $\mathrm{v}$ úvodu př́běhu, kdy se Žofie Ledermanová, protagonistka románu, po různých peripetiích vrací do svého rodného města $\mathrm{v}$ Polsku a do bytu, ze kterého byla i se svou rodinou vyhnána. „Pani Wojcyková?" vydechla jsem a dbala, abych použila správné zdvořilé oslovení. Ve tváři méla vrásky, které v době, kdy jsem ji znala, nemívala, a vlasy jí úplně zešedivěly. „Paní Wojcyková, já jsem Žofie Ledermanová. “ Zamrkala; koště neodložila, ale trochu je sklopila. „Žofie?" Přistoupila jsem bliž. Znávala jsem paní Wojcykovou z našich tři sousedů na patře nejméně, ale stejně mě nyní pohled na ni dojímal téměř $k$ slzám. Ona byla $z$ doby Předtím. Jediný důkaz, který jsem zatím měla, že části mého života z té doby ještě stále existují. „Ano, to jsem já. Kdo jste si myslela, že by to mohl být?“ „Vandráci,“ zamumlá. (...) „Těsně predtím, než to skončilo. Od té doby jenom tuláci. Musela jsem je vyhánět. V domě pak není 
bezpečno “. Podívala se na mě, jako by čekala, že přitomnost tuláků vysvětlím, a když jsem to neučinila, lehce si povzdechla. „No, na každý pád jsi zpátky.“ „,Jsem zpátky,“ zopakovala jsem zbytečně. Spustila koště na zem a prohližela si zařizení bytu, rozesetý nábytek a polámané židle. „Moc toho taky nezbylo, že?" „Myslím, že vandráci si věci odnášeli." Pokrčila rameny. „Nebo je pálili. Byla zima.“ „Ach,“ vydechla jsem a zahleděly jsme se jedna na druhou. Už jsem neuměla mluvit se svými sousedy. Ještě pořád vám pěkně kvetou máky? Žijí ještě vaši psi? Poslední vzpomínkou, kterou jsem na paní Wojcykovou měla, bylo, jak venči své psy na ulici zrovna ve chvíli, kdy mě zastavil voják a chtěl vidět moje papíry. Pak o ně požádal i muže vedle mé, ale toho pak odvlekli. Viděla jste ještě mnoho lidí odvlečených vojáky, paní Wojcyková? Jaký byl zbytek vaši války? (Hesseová, 2020, s. 31-32)

Z citace je patrné rozčarování paní Wojcykové nad návratem Žofie. Negativně zabarvené překvapení paní Wojcykové je explicitně vyjádřeno $\mathrm{v}$ určité komparaci vandráků $\mathrm{s}$ navrátivšími se židy či $\mathrm{v}$ podtextu její promluvy nad problematikou bezpečnosti a nebezpečnosti pobytu $\mathrm{v}$ domě způsobené přítomností tuláků. $Z$ celého rozhovoru je jasně patrné implicitní zklamání polské sousedky nad Žofiiným návratem; lze se pouze domnívat, zda v bytě opravdu během války přebývali zmiňovaní tuláci, nebo zda slovanští sousedé byty transportovaných vyrabovali. Dané lze doložit úryvkem: „Nevěřila jsem, že se kdokoliv z vás ještě vrátí. Tak to řekla pani Wojcyková. Ale neřikala to s vděčností v hlase. Nemyslela to jako - hrozně se mi ulevilo, že tě vidim. Jeji hlas nezněl št’astně. Jeji hlas zněl zklamaně. Měla totiž na mysli, myslela jsem, že vás zabili všechny. “(Hesseová, 2020, s. 36)

\section{POCIT MÉNĚCENNOSTI PRAMENÍCÍ Z RELATIVNĚ SNAZŠÍHO PRŮBĚHU INTERNACE}

Mnozí židé navrátivší se z koncentračních táborů pocitovali pocit viny pramenící ze skutečnosti, že útrapy druhé světové války přežili. Měli pocit, že hrůzy internace neprožili zcela. Z této skutečnosti také vychází teze mnohých odborníků, kteří tvrdí, že tyto osoby po válce nerady podávaly svědectví o útrapách internace, protože měly pocit, že nemají právo vypovídat.

Přežití ve vyhlazovacích táborech mnohdy záviselo na štěstí. Někteří z uvězněných během svého pobytu $\mathrm{v}$ těchto zařízeních plnily funkce, jejichž náplň jim alespoň zčásti internaci usnadňovala. Obdobná situace nastala i v př́padě, kdy byli tito lidé díky svému pracovnímu zařazení do určité míry po nějaký čas před transporty „na východ“ uchráněni. I tyto skutečnosti podle našeho názoru naplňují multilaterální pohled na události šoa. V Hesseové publikaci je dané tematizováno v setkání Žofie a její kamarádky Goši. Goša se začervenala a zahleděla se na svoje boty. „Měla jsem výjimku. Protože jsem pracovala v nemocnici, byla jsem nepostradatelný zaměstnanec. Když výjimka vypršela, jeden z doktorů mě schoval ve svém sklepě. Bylo to nebezpečné, až na pár posledních měsíců. Pak Flossenbürg. Ale jenom několik měsícù. “ Ústa se jí rozpačitě zkroutila; styděla se za to, že měla štěstí. „I pár měsíců je dlouhá doba; jsem za tebe ráda, “ uklidňovala jsem ji. „,Jsem ráda, že jsi byla v bezpečí, jak nejdéle to šlo. Ted' bydlím se sestrou a jejím mužem. Jejich úkryt nikdy neobjevili. (Hesseová, 2020, s. 41-42)

\section{DOPADY INTERNACE NA POVÁLEČNÝ ŽIVOT ŽIDŮ}

Mnozí židé, kteří měli štěstí a nacistickou vyhlazovací mašinerii přežili, se vyrovnávali s různými důsledky svého nuceného pobytu v internačních táborech mnoho let po konci druhé světové války, mnozí se s nimi nevyrovnali do konce života. Přetrpěné hrůzy, kterým byli tito lidé vystaveni, se mnohdy přenesly i na jejich potomky i na děti jejich dětí, tj. druhou generaci potomků přeživších pobyt ve vyhlazovacích táborech. Těmito dopady se v posledních několika desetiletích intenzivně zabývají psychologové, kteří se snaží postihnout, jak zážitky osob z táborů ovlivnily život jejich potomků, kteří tyto hrůzy př́mo nezažili. 
Jedním s nejviditelnějších dopadů na poválečný život židů, kteří druhý světový konflikt přežili, byl neustálý strach o dostatek jídla. Samozřejmě v prvním období po válce byly tyto osoby vyhladovělé a snažily se zahnat pocit hladu, který se v nich pevně uhnízdil během pobytu $\mathrm{v}$ nacistických vyhlazovacích táborech. Tato situace přímo souvisí s jednou $\mathrm{z}$ praktik nacistů v oblasti cíleného vyhlazení vybraných skupin osob - vyhladovět je. Toto trauma se však přeneslo do života přeživších i poté, co primární hlad zahnali a potravin byl relativní dostatek (v komparaci s absolutním nedostatkem jídla $\mathrm{v}$ táborech smrti). Hesseová i tyto skutečnosti do narativu knihy Poslali je nalevo integrovala, a to v rovině srovnání prŕstupu k jídlu židů vracejících se z koncentračních táborů a osob, které měly relativní dostatek jídla. Posbirala jsem talíre od večeře, ale neměla jsem tekoucí vodu, abych je umyla. My s Gošou jsme vyjedly talíre dočista. Dima a velitel Kuzněcov nechali zbytky: kưrka chleba, pár listů zelí. Na velitelově talíri zbyl i kousek masa, zřejmě flaksa, kterou asi diskrétně vyplivnul. Flaksa ležela na talíři jako sežvýkaná medúza plovoucí ve sražené rajské omáčce. Chvíli jsem na ni hleděla a dělalo se mi z toho zle. Ale pak jsem všechny ty zbytky strčila do pusy. Prstem jsem vytřela konzervu, ani jsem se neobtěžovala použit vidličku. Flaksa se mi zasekávala v krku, ale přinutila jsem se ji spolknout. Hnusila jsem se sama sobě, ale také jsem měla hlad; nebo jsem si ještě živě pamatovala, jaké to je, mít hlad. (Hesseová, 2020, s. 55)

Tato situace provázela i děti, které byly nuceny se během válečných let postarat samy o sebe bud' během jejich pobytu $\mathrm{v}$ koncentračních táborech, nebo při ukrývání se před transporty do vyhlazovacích táborů. Spisovatelka implementuje dopady pramenící z nedostatku jídla do publikace $\mathrm{v}$ místě, kdy Žofie navštíví jeden $\mathrm{z}$ táborů, který vznikl po válce a jehož účelem bylo postarat se o děti, které válku přežily a které se ocitly bez rodičů. Pracovníci těchto zařízení se pokoušeli různými cestami děti předat jejich přeživším rodičům nebo jiným př́buzným, kteří měli štěstí a dočkali se konce války. Naproti mně u stolu seděl jeden $z$ menšich chlapců. Nemohlo mu být víc než deset nebo jedenáct, měl špičaté uši a ostré rysy. Neobtěžoval se se lžicí. Prsty si dával kousky masa př́mo na chleba. Seděl s lokty vystrčenými, nahrbený u svého talíre a vytvářel obranný štit, aby si uchránil jídlo. Už měl u talíre dvě housky, ale když měl pocit, že se nikdo nedivá, natáhl se do společného košiku uprostřed stolu a popadl další. Pak si ji schoval do rukávu. Když si všiml, že se na něho divám, věnoval mi výhružný pohled. Jeho tělo bylo tak malé. Měl by být větší, nebo tlustší. Jeho oči by neměly být tak staré. Neměl by tu vi̊bec být. Neměl by jist jako zviŕre. (Hesseová. 2020, s. 141) V šeru mistnosti jsem poznala chlapce, který spal v posteli nejbliž ke dveřim. Byl to ten malý hoch od večeře, který si tajně bral dalši jídlo. Když spal, měl kolena těsně u brady a objímal si je rukama. Sestra Tereza tichounce, aby spícího chlapce nevzbudila, nazdvihla rok deky a ukázala mi jeho matraci. Byla rozř́znutá a uvnitř cosi, co na pohled pripomínalo kameny, ale ve skutečnosti to byly kusy chleba. „Bojí se, že jídlo dojde, “ zašeptala. „Oni se pořád bojí, že nebude dost jídla “. (Hesseová, 2020, s. 150)

\section{DEZERTÉŘI Z NĚMECKÉ ARMÁDY}

Hesseová do vyprávění zařadila rovněž problematiku vyrovnávání se členů německé armády se skutečností, že byli součástí nacistické mašinerie. I když je v publikace Poslali je nalevo tato tematika do jisté míry eufemizovaná, a to díky tomu, že muž, který pobýval stejně jako Žofie Ledermanová $\mathrm{v}$ táboře pro židy, kteří přežili válečné pronásledování či internaci $\mathrm{v}$ koncentračních táborech, z německé armády dezertoval. Mezi Žofií a Josefem vznikne silné citové pouto, které je narušeno v situaci, kdy se podivné Josefovo chování v táboře vysvětlí. Když jí vysvětlí své počínání během válečných let, je postavena před situaci, která je velmi známá již z Wiesenthalovy publikace The Sunflower. On the Possibilities and Limits of Forgiveness (česky Slunečnice: vyprávění o vině a odpuštěni). Simon Wiesenthal, který byl uvězněn v nacistických koncentračních táborech, byl jednoho dne odvezen z jeho pracovního prostoru $k$ posteli umírajícího člena SS. Voják, kterého dostihlo svědomí z věcí, kterých se 
zúčastnil, se chtěl přiznat - a získat rozhřešení - od žida. Tvář́ v tvář volbě mezi soucitem a spravedlností, tichem a pravdou, Wiesenthal nic neřekl. Ale i roky poté, co válka skončila, uvažoval: Udělal jsem správnou věc? Co byste na jeho mistě udělali? (Wiesenthal, 1997, přebal publikace; volný překlad autoři př́íspěvku). Žofie je postavena před volbu, zda Josefovi jeho počínání odpustit a začít nový život po jeho boku, nebo zda se od něj nadobro distancovat a přijmout tezi, že lidé jsou odpovědní za své konání, i když třeba neměli na výběr nebo když $\mathrm{k}$ němu byli donuceni. Tato problematika by měla tvořit jádro multilaterálního pohledu na události šoa: nahlížení na dané skutečnosti pohledem nacistů, Němců sloužících v armádě nebo z fokusu prostých Němců, jejichž značná část hitlerovské počínání schvalovala, nebo alespoň slepě tolerovala. Honem pokračoval dál, aniž mi dal šanci odmítnout. „, Byl jsem $v$ armádě. Ale po chvíli jsem zjistil, že v ní nechci být. Byl jsem dezertér, rozumišs? Utekl jsem pryč. Jednou uprostřed noci jsem prostě odešel, s civilním oblečením v batohu. Spal jsem v prázdných stodolách a ve sklepích. Esesáci by mě zastřelili, kdyby se dozvěděli, kdo jsem; byl jsem dezertér, také jejich nepř́tel. " (Hesseová, 2020, s. 286)

\section{VRAŽDA Z MILOSTI}

Další tematikou, kterou autorka románu do uměleckého vyprávění zařadila, je vražda blízkého člověka, vražda z milosti. Může být zavraždění člověka omlouváno tím, že jej tento čin uchránil před větším strádáním, před nejistou budoucností, před hrůzným koncem? Situace, kdy se Žofie rozhodla svého bratra uchránit před budoucností, se odehrává v dobytčím vagónu, který celou její rodinu spolu se stovkami dalších židů transportoval do koncentračního tábora. V tu chvili uběhlo snad sto let, když jsem si uvědomila, že můj bratr je přiliš slabý, než aby dokázal polykat, a já jsem nevěděla, jak ho $k$ tomu mám primět. Určitě jsem měla také žizeň; určitě jsem sama také trpěla bolestí, ale to jediné, co si pamatuji, bylo, že můj bratr nedokázal polykat a já jsem v tu chvili prožila celé století. Nahoře pod střechou vagónu byly otvory. Skrze ně jsem viděla, co se děje. Viděla jsem, jak strážce seřadil tři lidi za sebe do fronty a pak jim všem najednou prostřelil hlavu a použil přitom jen jednu kulku. V duchu jsem viděla obraz mého vlastního táty, jak ho kulka zasáhla do čela a jak se pak mékce složil k zemi. Jak dlouho potrvá, ne zastřelí i nás? Viděla jsem v duchu, co se stane. Nakonec otevřou dveře našeho vagónu. Vyloží nás ven a já budu muset nést Abeka, protože nedokáže chodit. A ponesu ho vstřic smrti. Položim ho k nohám nacistických strážných, kteři ho ode mě oddělí, a až bude úplně sám, tak ho zabijí. V tu chvili jsem věděla, že jeho smrt je nevyhnutelná. Byl př́liš slabý. Jeho smrt byla zakončovacím stehem na oděvu, který byl již téměr dokončený. To jediné, co jsem mohla v téhle situaci mít pod kontrolou, bylo, jaký druh stehu se použije. Sundala jsem předtím Abekovi bundu a použila ji jako polštár̆ pod jeho hlavu. Nyní jsem ji uchopila do rukou. Začala jsem mu potichu vyprávět jeho oblíbené pohádky. Pak jsem mu přiložila bundu přes ústa a nos. Nebránil se. Už nebyl při vědomí. Dokonce ani nevím, jestli byl ještě naživu. Možná, že už nás opustil; byl tak nehybný a ani jsem neviděla, že by se jeho hrudník zdvihal a klesal. Přesto jsem s každou uplývající vteřinou přicházela o kousek svojí duše. Přesto věř́m, že to byl akt milosrdenství. (Hesseová, 2020, s. 292-293)

\section{JÁ, NEBO TY}

Multilaterální pohled na vymezené události podle našeho názoru naplňují i situace, kdy byli internovaní židé postaveni před další volbu: tentokrát před výběr, zda udělat vše pro záchranu svých blízkých, nebo zda se řídit darwinovským pravidlem o přežití silnějšího. Pasáž, ve které Hesseová tuto volbu ukládá chlapci, který se vydává za Žofiina bratra, připomíná obdobnou situaci z Wieselovy Noci. Ten chlapec viděl, jak všichni, které miloval, zemřeli př́mo před ním. Máma a dèda byli zabiti hned, jak přijeli do Birkenau. Strýc, který jednoho dne nedokázal vstát a jít do práce a druhý den nevstal vůbec. Táta, který celé dny křičel v 
bolestech, než konečně zavřel oči. A chlapec přemital, jestli bylo správné nosit tátovi vodu, když byl nemocný, nebo jestli ho to jen udržovalo naživu o něco déle. Neprodlužoval tím jeho utrpeni? A nakonec - nakonec ten chlapec ztratil svoji sestru. (Hesseová, 2020, s. 295)

Pro komparaci uvádíme úryvek z Noci, v jehož středu se nachází obdobná situace. Byl to jen zlomek vteřiny, ale přesto jsem se cítil vinen. Běžel jsem pro trochu polévky a donesl ji otci. Neměl na ni chut'; chtěl jenom vodu. „Nepij vodu, jez polévku... “ „Jsem na dně... Proč jsi na mě tak zlý, synku?... Vodu... "Donesl jsem vodu. Pak jsem odešel z bloku na apel. Vzápétí jsem se však vrátil a natáhl se na nejvyšši palandu. Nemocní směli zůstat na bloku. Budu tedy nemocný. Nechtěl jsem opustit otce. Kolem vládlo ticho, přerušované jen sténáním. Před blokem vyřvávali esesáci své rozkazy. Kolem postelí prošel nějaký důstojník. Otec žadonil: „,Synu, dones mi vodu... Trpím... Mé útroby... " „Ticho tam!“ zařval důstojník. „Eliezere“, pokračoval otec, „vodu... “ Düstojník k němu přistoupil a křičel, at’ mlčí. Otec ho neslyšel. Neustále mě volal. Esesák je prudce udeřil obuškem do hlavy. Nehýbal jsem se. Měl jsem strach, mé tělo se obávalo dalších ran. Otec cosi zachroptěl - bylo to moje jméno: „Eliezer“. Viděl jsem, že ještě trhaně dýchá. Nehýbal jsem se. (Wiesel, 2004, 104-106)

\section{ZÁVĚR}

V př́ispěvku jsme prezentovali možné využití témat z publikace Moniky Hesseové Poslali je nalevo a diferencovali jsme je do šesti okruhů: 1) návrat židů do svých domovů; 2) pocit méněcennosti pramenící z relativně snazšího průběhu internace, 3) dopady internace na poválečný život židů; 4) dezertéři z německé armády; 5) vražda z milosti; 6) já, nebo ty.

Integraci vybraných témat usouvztažňujeme s prožíváním jedné linie událostí druhé světové války $\mathrm{z}$ pozice židů, přičemž uvedené rozdělení spojujeme $\mathrm{s}$ multilaterálním pohledem na vymezenou etapu druhé světové války. Domníváme se, že právě multilaterální pohled je stejně důležitý jako zobrazení daného fenoménu z fokusu osob židovské národnosti sensu stricto. Publikace Poslali je nalevo slučuje oba př́stupy, což podle našeho názoru z tohoto uměleckého vyprávění činí vhodný prostředek k seznámení recipientů (zejména žáků a studenti̊ na různých stupních intencionálního vzdělávání) s literárně ztvárněnou tematikou šoa prostřednictvím různých úhlů pohledu.

Uvědomujeme si důležitost zobrazení vymezené linie druhé světové války především prostřednictvím životního osudu židů zasažených nacistickou perzekuční politikou, poněvadž tato skupina jí byla nejvíce zasažená. $\mathrm{Na}$ druhou stranu si myslíme, že seznamovat čtenáře $\mathrm{s}$ událostmi šoa pouze $\mathrm{z}$ fokusu osob židovské národnosti může vést $\mathrm{k}$ jistému zploštění vnímání těchto poměrně komplikovaných událostí, což může vést k černobílému či schematickému názoru na vybrané události druhé světové války. Porozumění různým jevům spojeným s šoa lze tříbit prostřednictvím vhodně vybraných uměleckých vyprávění. Publikace Poslali je nalevo propojuje různé pohledy na druhou světovou válku. Právě tento aspekt je stěžejním argumentem, proč lze tuto knihu využít k prezentaci multilaterálního pohledu na jednu linii událostí druhé světové války.

Př́spěvek byl podpořen projektem IGA_PdF_2021_001_Multilaterální zobrazení událostí šoa v literatuře Univerzity Palackého.

\section{Použitá literatura}

1. HESSEOVÁ, M. Poslali je nalevo. 1. vydání. Praha: Fragment, 2020. 310 s. ISBN 978-80-253-4927-4.

2. WIESEL, E. Noc. 3. vydání. Brno: Kartuziánské nakladatelství, 2014. 108 s. ISBN 978-80-87864-16-6.

3. WIESENTHAL, S. Slunečnice: vyprávění o vině a odpuštění. 1. vydání. Jinočany: H \& H, 2005. 126 s. ISBN 80-7319-041-9. 


\section{Kontaktní údaje}

Mgr. Milan Mašát

Univerzita Palackého v Olomouci, Pedagogická fakulta Žižkovo náměstí 5, 77140 Olomouc

email: milan.masat01@upol.cz

Mgr. et Mgr. Adéla Štěpánková

Univerzita Palackého v Olomouci, Pedagogická fakulta Žižkovo náměstí 5, 77140 Olomouc

email: adela.stepankova01@upol.cz

Bc. Andrea Bajnarová

Univerzita Palackého v Olomouci, Pedagogická fakulta Žižkovo náměstí 5, 77140 Olomouc

email: andrea.bajnarova01@upol.cz 


\title{
SPOLEČENSKOVĚDNÍ PŘEDMĚTY NA TECHNICKÉ UNIVERZITĚ - VÝZNAM, PŘíNOS A ZHODNOCENÍ
}

\author{
SOCIAL SCIENCE COURSES AT A TECHNICAL UNIVERSITY - \\ IMPORTANCE, BENEFIT AND EVALUATION
}

\author{
Jaroslav Lindr
}

\begin{abstract}
Abstrakt
Společenskovědní předměty na technické univerzitě přispívají k všestranné kultivaci studentů. Jejich posláním je rozvoj těch klíčových kompetencí a soft skills, které vhodně doplňují kompetence získané v odborných předmětech. Př́spěvek se zabývá zhodnocením celkového dojmu $\mathrm{z}$ výuky u třech vybraných společenskovědních předmětů na technické univerzitě, a to Etika v podnikání, Prezentační dovednosti a Sociologie. Na základě dlouhodobé zkušenosti s výukou a zpětnovazební ankety Hodnocení kvality výuky lze zjistit, jak je pro studenty př́nosná. Jednorozměrnou statistickou analýzou lze vysledovat trend ukazující spokojenost s výukou a potřebnost soustavného vyhodnocení kvality výuky. Obecně se ukazuje, že společenskovědní předměty plní své poslání a že významnou měrou napomáhají všestrannému rozvoji studentů.
\end{abstract}

Klíčová slova: společenskovědni predměty, celkový dojem, prínos, poslání předmětu, hodnocení kvality výuky, statistické zpracování

\begin{abstract}
Social science courses at the technical university contribute to the general cultivation of students. Their mission is to develop these key competencies and soft skills that suitably complement the competencies acquired in specialised subjects. The paper deals with the evaluation of the overall impression of teaching in three selected social science courses at the technical university, namely Ethics in Business, Presentation Skills and Sociology. Based on long-term experience with teaching and the feedback survey Evaluation of Teaching Quality, it is possible to find out how it is beneficial for them. One-dimensional statistical analysis can be used to trace a trend showing satisfaction with teaching and the need for continuous assessment of the quality of teaching. In general, it turns out that social science courses fulfil their mission and that they significantly help to the general development of students.
\end{abstract}

Key words: social science courses, overall impression, benefit, subject function, teaching quality evaluation, statistical processing

\section{1 ÚVOD - ZDŮVODNĚNÍ POTŘEBNOSTI VŠEOBECNOSTI VE VZDĚLÁVÁNÍ}

Dichotomie všeobecnosti a odbornosti patří mezi aktuální otázky pedagogiky. Nároky současného světa a praxe vyžadují univerzálnost absolventů vysokých škol. Je třeba zvládnout nejen odbornost, ale osvojit si též další klíčové kompetence potřebné pro úspěšné působení $\mathrm{v}$ praxi.

Jak dosáhnout naplnění myšlenky všestrannosti na školách? Na vybrané technické univerzitě k tomu slouží zařazení alespoň jednoho společenskovědního předmětu do akademického studijního plánu. Výběr konkrétního $\mathrm{z}$ nich se děje formou povinně volitelných předmětů.

Záměr, smysl, poslání a cíl společenskovědních předmětů je zřejmý - rozvinout znalosti a klíčové kompetence tak, aby doplňovaly předměty odborné, a rovněž tak, aby vyplňovaly 
mezery, které by jejich absencí mohly vzniknout. Např́klad předmět Prezentační dovednosti, o němž ještě bude $v$ následujícím textu řeč, má za cíl naučit komunikovat a prezentovat na veřejnosti, což lze využít i v ostatních odborných předmětech.

Př́spěvek se podívá na zkušenosti s výukou společenskovědních předmětů očima studentů. V centru pozornosti bude zejména zhodnocení celkového dojmu z předmětů. Jinými slovy př́spěvek se pokusí najít odpověd' na otázku, jaký smysl výuka zvolených společenskovědních předmětů pro studenty má, jak jsou spokojeni s existencí, a hlavně realizací daného předmětu a jak hodnotí př́nos daného předmětu pro svůj osobní rozvoj.

\section{STRUČNÉ TEORETICKÉ ZAKOTVENÍ VÝZNAMU EVALUACE VÝUKY}

Plánovaná a realizovaná výuka se liší. Na jedné straně je patrný úmysl navrhnout takový akademický program, který bude po všech stránkách co nejlepší s ohledem na výše zmíněnou univerzálnost, na druhé straně je třeba pohlédnout do edukační reality a zhodnotit, jak se vymezené cíle podařilo naplnit.

Potřeba inovace školství a vzdělávacích systémů vysvítá z konceptu tzv. „dobré školy“, která ve svém rozvoji dbá na neustálou zpětnovazební sebereflexi své činnosti (srv. Rýdl, 2003, s. 45-47), tj. na autoevaluaci, která je chápána jako tvorba nástrojů k vlastnímu rozvoji, ve které se objevují stěžejní oblasti jako je např. skládání účtů ze své činnosti, kultura pedagogů a prostředí školy, spolupodílení pedagogů na rozhodovacích procesech, reflexe vlastní činnosti i školního působení, motivace, očekávání do budoucna, možnost aplikace změn aj. (srv. Rýdl, 1998, s. 6-8).

K tématu evaluace školských systémů a škol lze připomenout koncept „skládání účtů ze své práce“ a „učící se organizace“ a fenomén zodpovědnosti, „komu a za co a jakou“ zodpovědnost škola má. (srv. Pol, 2009, s. 41-53). Autor upozorňuje zejména na to, že současná škola se ocitá ve víru výzev, vizí, pnutí, každodenních problémů a očekávání splnění požadavků všech, kteří se školou interagují, což jí přináší nemalé plánovací, organizační a rozhodovací těžkosti takřka každý den své existence. Výsledkem toho je úskalí zachytit inovativní trendy a úspěšně obstát v proměnách školy dneška i v budoucích výzvách.

Evaluaci výuky můžeme chápat jako ,systematické zkoumání kurčení hodnoty nebo přednosti programu, opatření nebo postupu pečlivým zhodnocením a studiem založeným na relevantních metodách, kritériích a standardech “. (Michek, 2009, s. 3). Rozpracováním teoretického rámce evaluace a úvahami vedoucími přes plánované a realizované kurikulum a přes různé hierarchické stupně lze dospět až ke kritériím kvality výuky konkrétního předmětu a zhodnocení jeho př́nosu pro studenty. O to se snaží empirická část příspěvku.

Nároky na posuzování a zlepšování kvality vzdělávací praxe navozují téma vztahů mezi normativním pojetím výuky, teoretickými koncepty a empiricko-výzkumným vysvětlením procesů výuky. ,Pro normativní př́stup jsou príznačné hodnotící soudy, svázané s tvorbou normativnich rámci̊, etalonů a pravidel, tj. s tvorbou programů, predpisu či metodik, jak $v$ praxi postupovat... Podmínkou pro formulaci poznávacich soudi̊ jsou empiricky stanovené paritní kategorie, které vypovídají o vlastnostech a stavech reálných jevi̊ vzdèlávací praxe. " (Slavík, a kol., s. 179). Pro účely př́spěvku je jednak dobré si toto uvědomit, tedy rozlišovat mezi zamýšleným a realizovaným, př́p. osvojeným kurikulem a z toho plynoucím dosažením klíčových kompetencí, jednak inspirativně pohlédnout, jak uchopit otázku hodnocení kvality výuky prizmatem možného empirického vědeckého šetření.

Kvalitu výuky lze posuzovat, lépe řečeno uvědomovat si, ve vztahu ke škole, k sobě samému, k úrovni vzdělávání obecně. Napřr. kritéria výuka je: užitečná - neužitečná, slabá - silná, jednotvárná - pestrá, vzdálená - blízká, pasivní - aktivní aj. (Pöschl, 2011, s. 92-93) představují polaritní kategorie, které v sobě zahrnují celkový dojem z výuky předmětu, i když jsou mnohdy pocit'ovány respondenty intuitivně a podvědomě. Mohou však sloužit k rozvitějšímu průzkumu, který na fenomén „celkového dojmu“ z výuky může navázat. 


\section{CELKOVÝ DOJEM VÝUKY SPOLEČENSKOVĚDNÍCH PŘEDMĚTŮ - ROZBOR A INTERPRETACE ÚDAJŮ}

K vyhodnocení celkového dojmu byla použita agenda Hodnocení kvality výuky, která je každoročně k dispozici jako zpětnovazební hodnocení výuky. Studenti se na škále 1-6 vyjadřují zejména k celkovému prrínosu předmětu po obsahové a pedagogické stránce, včetně hodnocení osobnosti vyučujícího. Zjištěné údaje byly systematicky sledovány po dobu celkově 11 let, konkrétně za roky 2010-2021. Bohatost zjištěných výsledků proto umožňuje učinit fundované závěry, jak se v průběhu jednoho desetiletí kvalita, efektivita a př́nos výuky změnil. Nové předměty reprezentuje předmět Prezentační dovednosti, kde se podařilo údaje shromáždit za roky 2016-2021.

Prvním vybraným společenskovědním předmětem je Etika v podnikání. Cíl a poslání tohoto předmětu spočívá ve snaze uvést studenty do poznání etiky jako vědy, představit některé etické koncepty v historickém vývoji a soudobé etické teorie. Dále převést pozornost studentů na aplikaci teoretických etických zásad do podnikatelského prostředí, podnikatelské a manažerské etiky a posléze se zamyslet nad otázkou implementace etiky ve firmách, např. etických kodexů apod.

Výsledky hodnocení prŕnosu předmětu za jednotlivá období, kdy byl vyučován, ukazuje tabulka 1 a graf 1 .

\begin{tabular}{|c|c|c|}
\hline \multicolumn{2}{|c|}{ Společenskovědní předmět/Období } & $\begin{array}{l}\text { Celkový dojem } \\
\text { z předmětu } \\
\text { na škále 1-6 } \\
\text { (1-malý, } \\
\text { 6-velký) }\end{array}$ \\
\hline Etika v podnikání & LS 2010/11 & 3,64 \\
\hline Etika v podnikání & LS 2011/12 & 3,06 \\
\hline Etika v podnikání & LS 2012/13 & 3,33 \\
\hline Etika v podnikání & LS 2013/14 & 4,44 \\
\hline Etika v podnikání & LS 2014/15 & 4,04 \\
\hline Etika v podnikání & LS 2015/16 & 3,79 \\
\hline Etika v podnikání & ZS 2016/17 & 3,34 \\
\hline Etika v podnikání & LS 2016/17 & 3,65 \\
\hline Etika v podnikání & ZS 2017/18 & 4,14 \\
\hline Etika v podnikání & LS 2017/18 & 4,22 \\
\hline Etika v podnikání & ZS 2020/21 & 3,60 \\
\hline Etika v podnikání & LS 2020/21 & 5,00 \\
\hline \multicolumn{2}{|l|}{ Průmér } & 3,85 \\
\hline
\end{tabular}

Tab. 1 Hodnocení celkového dojmu předmětu Etika v podnikání na základě Hodnocení kvality výuky 2010/11 až 2020/21

(zpracováno autorem)

Výsledky hodnocení celkového dojmu z předmětu vykazují nadprůměrné hodnocení kolísající kolem aritmetického průměru $m=3,85$. Lineární regrese ukázala rostoucí trend, což svědčí o snaze nejen zkvalitňovat výuku z vědecko-didaktického a obsahového hlediska. Pojmout rozsah a obsah předmětu s ohledem na problematičnost témat tak, aby zaujal, není snadné. Přiznejme otevřeně, že etika v podnikání již z věcného významu slova s sebou nese nemalá úskalí v nejen ve stavařské praxi, nebot' současné podnikatelské prostředí se ne vždy etickými principy ř́dí. Proto je pro vnímavé studenty znající poměry v podnikání či mající již nějakou zkušenost z praxe mírně řečeno mnohdy rozporuplné přijmout vyučované etické principy za vlastní obzvláště když se setkávají s protichůdnou skutečností. 
Etika v podnikání
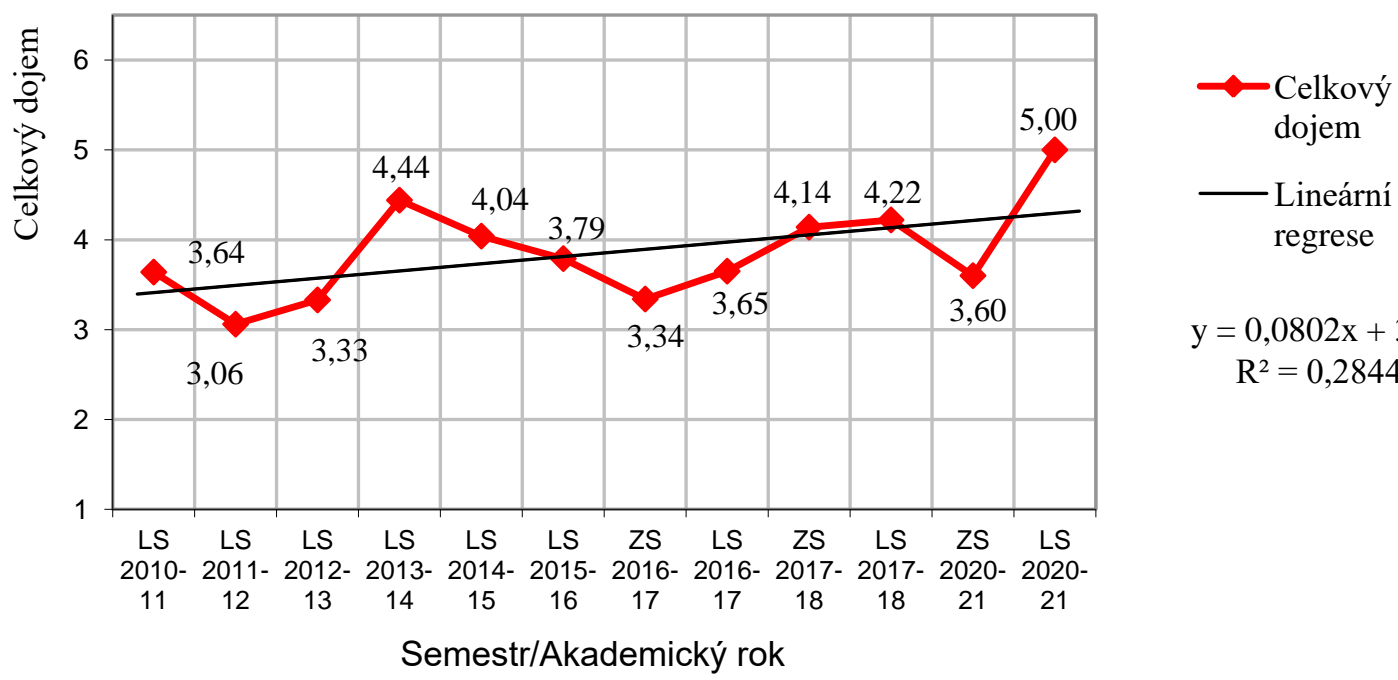

$\mathrm{y}=0,0802 \mathrm{x}+3,333$

$\mathrm{R}^{2}=0,2844$

Graf 1 Znázornění celkového dojmu předmětu Etika v podnikání na základě Hodnocení kvality výuky 2010/11 až 2020/21

(zpracováno autorem)

Druhým analyzovaným předmětem je předmět Prezentační dovednosti zařazený do 1. ročníku a 2. ročníku navazujícího magisterského studia. Jeho cílem je především zlepšit celkovou prezentační úroveň studentů sohledem na rétorické, jazykové a obecné psychosociální dovednosti. Je pamatováno i na zlepšení graficko-estetické stránky prezentace. Cílem předmětu je překonat bariéry bránící realizaci kvalitní prezentace a povýšit úroveň stávajícího prezentování studentů na kvalitativně vyšší stupeň profesionálně zvládnuté prezentace po odborné, jazykové a psychologické stránce.

Výsledky hodnocení prínosu předmětu za jednotlivé akademické roky a semestry ukazuje tabulka 2 a graf 2.

\begin{tabular}{|l|c|c|}
\hline \multicolumn{2}{|c|}{ Společenskovědní předmět/Období } & $\begin{array}{c}\text { Celkový dojem } \\
\text { z předmětu } \\
\text { na škále 1-6 } \\
\text { (-malý, 6-velký) }\end{array}$ \\
\hline Prezentační dovednosti & ZS 2016/17 & 5,44 \\
\hline Prezentační dovednosti & LS 2016/17 & 5,38 \\
\hline Prezentační dovednosti & ZS 2017/18 & 3,50 \\
\hline Prezentační dovednosti & LS 2017/18 & 5,33 \\
\hline Prezentační dovednosti & ZS 2018/19 & 5,50 \\
\hline Prezentační dovednosti & LS 2018/19 & 4,25 \\
\hline Prezentační dovednosti & ZS 2019/20 & 5,00 \\
\hline Prezentační dovednosti & LS 2019/20 & 5,00 \\
\hline Prezentační dovednosti & LS 2020/21 & 5,54 \\
\hline Průměr & & 4,99 \\
\hline
\end{tabular}

Tab. 2 Hodnocení celkového dojmu předmětu Prezentačni dovednosti na základě Hodnocení kvality výuky 2016/17 až 2020/21

(zpracováno autorem) 
Prezentační dovednosti

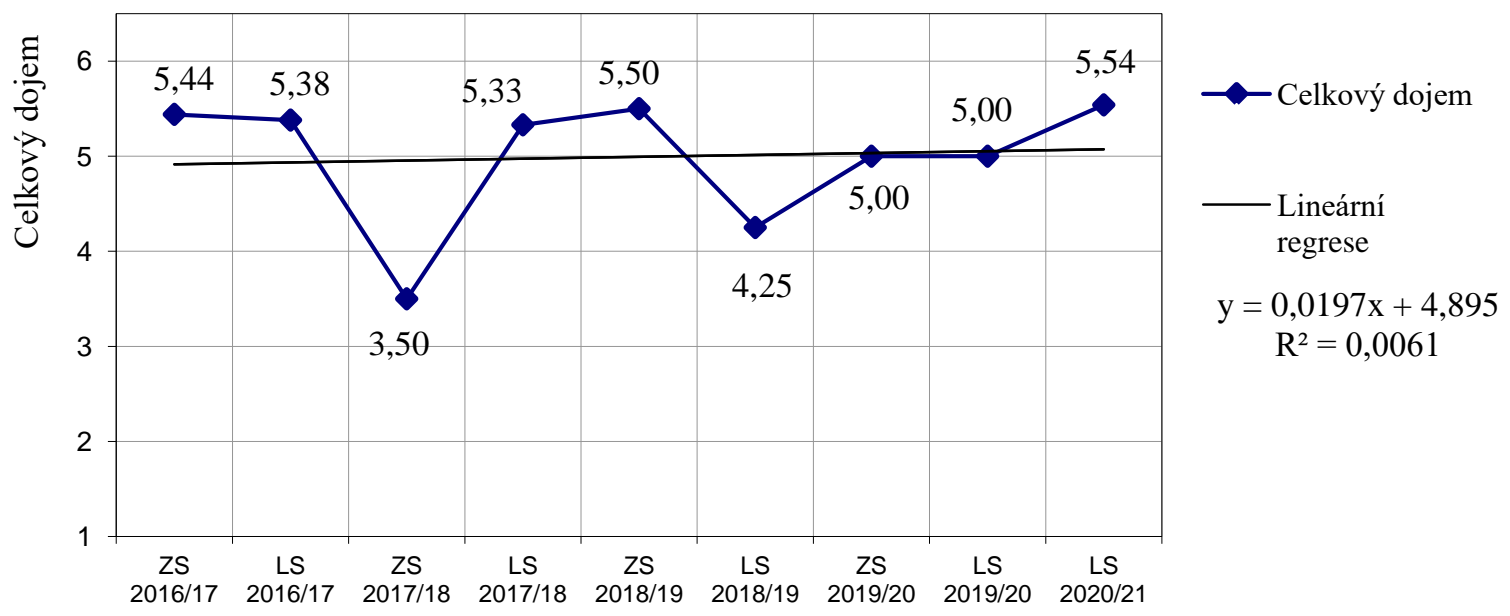

Semestr/Akademický rok

Graf 2 Znázornění celkového dojmu předmětu Prezentační dovednosti na základě Hodnocení kvality výuky 2016/17 až 2020/21

(zpracováno autorem)

Výsledky hodnocení celkového dojmu z předmětu vykazují nadprůměrné hodnocení kolísající kolem aritmetického průměru $m=4,99$. Lineární regrese ukázala mírně rostoucí trend, proto lze konstatovat, že jsou studenti s úrovní výuky spokojeni a že vidí předmět př́nosně.

Třetím analyzovaným předmětem je předmět Sociologie zařazený v bakalářském studiu u oboru Architektura. Studenti se v něm seznamují se základy poznání společnosti a lidí. Poznání „člověka“ je pro architekty důležité už z principu, nebot’ pro lidi své objekty navrhují. Pozornost je věnována také sociologickým aspektům v architektuře, např. vstup veřejnosti do stavebního řízení aj. Předmět má za cíl provázat architekturu a sociologii.

Výsledky hodnocení celkového dojmu z předmětu ukazuje tabulka 3 a graf 3.

\begin{tabular}{|l|c|c|}
\hline \multicolumn{2}{|c|}{ Společenskovědní předmět/Období } & $\begin{array}{c}\text { Celkovýy dojem } \\
\text { z předmětu } \\
\text { na škále 1-6 } \\
\text { (1-malý, 6-velký) }\end{array}$ \\
\hline Sociologie & ZS 2011/12 & 5,23 \\
\hline Sociologie & ZS 2012/13 & 4,68 \\
\hline Sociologie & ZS 2013/14 & 5,26 \\
\hline Sociologie & ZS 2014/15 & 5,79 \\
\hline Sociologie & ZS 2015/16 & 5,33 \\
\hline Sociologie & ZS 2016/17 & 5,12 \\
\hline Sociologie & ZS 2017/18 & 4,57 \\
\hline Sociologie & ZS 2018/19 & 5,14 \\
\hline Sociologie & ZS 2019/20 & 5,30 \\
\hline Sociologie & ZS 2020/21 & 5,25 \\
\hline Prìměr & & 5,17 \\
\hline
\end{tabular}

Tab. 3 Hodnocení celkového dojmu předmětu Sociologie na základě Hodnocení kvality výuky 2011/12 až 2020/21

(zpracováno autorem) 
Sociologie

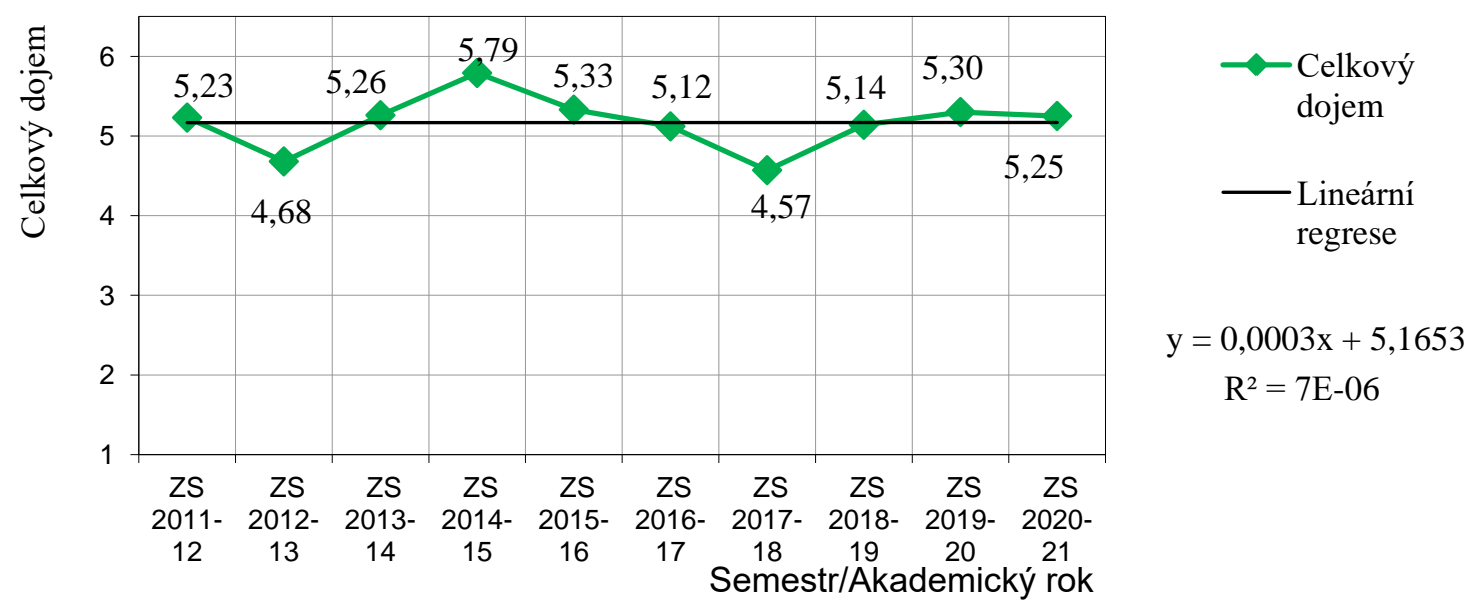

Graf 3 Znázornění celkového dojmu předmětu Sociologie na základě Hodnocení kvality výuky 2011/12 až 2020/21

(zpracováno autorem)

Výsledky hodnocení celkového dojmu z předmětu vykazují nadprůměrné hodnocení kolísající kolem aritmetického průměru $m=5,17$. Lineární regrese ukázala mírně rostoucí trend, který se vzhledem k vysokým hodnotám již výrazně zvyšovat nebude. Předmět si udržuje vysokou kvalitu a úroveň výuky. Je vnímán jako vysoce nadprůměrně přínosný. $Z$ toho plyne, že předmět plní své poslání a cíle úspěšně.

\section{ZÁVĚREČNÁ OHLÉDNUTí}

V teoretické části byla rámcově zdůvodněna nutnost všeobecného rozvoje studentů technické univerzity skrze společenskovědní předměty. Byla též stručně popsána potřebnost soustavné evaluace výuky s cílem zvýšit její kvalitu a efektivitu.

V empirické části byly představeny výsledky dlouhodobého sledování celkového dojmu z výuky třech vybraných společenskovědních předmětů. Ukázalo se, že studenti vnímají tyto předměty velmi pozitivně. Roste kvalita a úroveň výuky a permanentním sledováním autoevaluačních kritérií a modernizačními zásahy se zlepšuje př́nos výuky.

Teoretická východiska a empirická studie naznačily, že studenti vnímají snahu o všestrannou kultivaci osobnosti skrze společenskovědní předměty pozitivně. To potvrzuje nejen správnost teoretického koncepčního nastavení, promyšlenost a citlivost zařazení těchto předmětů do repertoáru ostatních předmětů $\mathrm{v}$ akademickém studijním plánu na fakultě, ale též smysluplnost a kvalitu výuky v realizační rovině vyučovacího procesu. Takové poznání je cenné z hlediska retrospektivního i pedagogicko-didaktického výhledu do budoucna.

Společenskovědní předměty plní své poslání a významně přispívají k všeobecnému rozvoji absolventů technické univerzity.

\section{Použitá literatura a zdroje}

1. Hodnocení kvality výuky 2011/12-2020/21. Fakulta stavební VUT v Brně. 20112020, archiv výsledků [cit. 2020-03-06]. Dostupné na: <https://intranet.fce.vutbr.cz/ pedagog/prehledy/hkv/hkv_vysledky.asp>.

2. Hodnocení kvality výuky 2020/21. Fakulta stavební VUT v Brně [online]. 2021. [cit. 2021-05-29]. Dostupné na: <https://intranet.fce.vutbr.cz/pedagog/prehledy/h kv/hkv_vysledky.asp>. 
3. MICHEK, Stanislav. Možné výzkumné strategie při hledání vazeb mezi autoevaluací a kolegiální evaluací škol. In: FUGLÍK, Viktor (ed.). Kvalita vzdělávání v reflexi pedagogických teorií a výzkumi̊. Praha: Pierot, 2009, s. 1-11. ISBN 978-80-7290-400-6.

4. POL, Milan. Škola v proměnách. Brno: MU, 2009, 194 s. ISBN 978-80-210-4499-9.

5. PÖSCHL, Radko. 25. Postoje žáků ke škole. In: Cesta ke kvalitě. [online] Dostupné na: <http://www.nuov.cz/ae>.

6. RÝDL, Karel. Inovace školských systémů. Praha: ISV, 2003. 281 s. ISBN 80-86642-17-8.

7. RÝDL, Karel, a kol. Sebehodnocení školy. Jak hodnotit kvalitu školy. Praha: Strom, 1998. 48 s. ISBN 80-86106-04-7.

8. SLAVÍK, Jan, a kol. Transdisciplinární didaktika. Brno: MU, 2017. 455 s. ISBN 978-80-210-8568-8.

\section{Kontaktní údaje}

RNDr. Mgr. Ing. Mgr. Bc. Jaroslav Lindr, Ph.D.

Vysoké učení technické v Brně

Fakulta stavební

Ústav společenských věd

Veveří 331/95, Brno

Tel: 541147693

email: lindr.j@fce.vutbr.cz 


\title{
PŘÍSTUPNOST V SOMATOPEDICKÉM KONTEXTU - MOŽNOSTI EVAKUACE A POSKYTOVÁNÍ PRVNÍ PSYCHICKÉ POMOCI OSOBÁM S OMEZENÍM HYBNOSTI V MIMOŘÁDNÝCH SITUACÍCH
}

\author{
ACCESSIBILITY IN A SOMATOPEDIC CONTEXT - POSSIBILITIES \\ OF EVACUATION AND PROVISION OF PSYCHOLOGICAL FIRST \\ AID TO PEOPLE WITH REDUCED MOBILITY IN EMERGENCY \\ SITUATIONS
}

\author{
Bianka Hudcová
}

\begin{abstract}
Abstrakt
Mimořádné situace přicházejí vždy zcela nečekaně a náhle. Je tedy třeba se na ně důkladně a průběžně prripravovat. To platí nejen u intaktní populace, ale také v př́padě osob s omezením hybnosti. Právě tyto osoby se mohou při zvládání mimořádných situací potýkat $\mathrm{s}$ různými překážkami (např. bariéry v prostředí, bariéry v komunikaci). Př́spěvek prezentuje výsledky přehledové studie týkající se možností evakuace, evakuačních strategií, pomůcek a následného využití psychosociální pomoci s důrazem na psychickou první pomoc jako neformální (laickou) pomoc osobám v krizi.
\end{abstract}

Klićová slova: mimořádná situace, krize, osoba s omezením hybnosti, přistupnost, evakuace, psychosociální pomoc v krizi, psychická první pomoc v krizi

\begin{abstract}
Emergency situations always come completely unexpectedly and suddenly. It is therefore necessary to prepare thoroughly and continuously for them. This applies not only to the intact population, but also to people with reduced mobility. It is these people who may face various obstacles when dealing with emergency situations (eg. environmental barriers, communication barriers). The paper presents the results of a review study on the possibilities of evacuation, evacuation strategies, aids and the subsequent use of psychosocial assistance with an emphasis on psychological first aid as informal (lay) help for people in crisis.
\end{abstract}

Key words: emergency situation, crisis, person with reduced mobility, accessibility, evacuation, psychosocial help in crisis, psychological first aid in crisis

\section{1 ÚVOD}

V současné době je užití pojmů krize, krizová situace, mimořádná situace, pandemie, havárie nebo katastrofa ve společnosti velmi frekventované. Krize je většinou vnímána jako něco „,nenormálního“, něco extrémního, něco, co zasaženého jedince „vytrhne“ z jeho běžného, každodenního fungování (Špatenková et al., 2004). Krize je situace, kdy dochází k vážnému narušení fungujícího systému nebo jeho části. Dané narušení s sebou nese potřebu bezodkladného rozhodnutí a řešení (MV ČR, 2016). Jedná se o situaci, kterou zasažená osoba není schopna efektivně řešit sama za pomocí obranných mechanismů nebo osvojených copingových strategií (Růžička et al., 2013). Je to stav dočasné nerovnováhy organismu a prostředí, který je zapříčiněný událostí související se zásadními změnami a řešeními nebo kritickou událostí. Společnost často milně vnímá krizi jako něco „patologického“. Na krizi lze však pohlížet také jako na vývoj nebo příležitost ke změně (Špatenková et al., 2017). 
Krize a krizové situace jsou a s největší pravděpodobností i budou neodmyslitelnou, neoddělitelnou a přirozenou součástí života každého z nás. Tyto situace se nevyhýbají nikomu (Špatenková et al., 2004). Dějí se v životech osob intaktních stejně tak jako v blízkosti osob se zdravotním postižením - osob s mentálním (duševním) postižením včetně autismu, osob s omezením hybnosti, osob se smyslovým postižením, osob s poruchami chování, seniorů a dalších (McGuire et al., 2007).

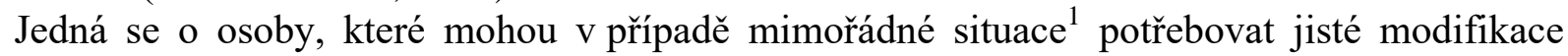
př́stupu, pomoci. Přítomnost zdravotního postižení může představovat nemalou „bariéru“ např. u osob s omezením hybnosti (dále jen $\mathrm{OH}$ ). Tyto osoby disponují specifickými potřebami a požadavky v prŕstupu (komunikace, postoje, názory apod.), které je nezbytné ze strany pomáhajících $\operatorname{osob}^{2} \mathrm{v}$ mimořádné situaci znát, reflektovat a bezpodmínečně respektovat.

Osoby s omezením hybnosti mohou, stejně tak jako osoby intaktní, při zvládání mimořádné situace využít hned několik možností podpory. Jedná se o tzv. psychosociální pomoc. Ta může mít podobu formální a neformální pomoci v krizi. Formální pomoc je cílená a profesionální pomoc, kterou většinou poskytují pracovníci pomáhajících profesí - tedy např. pracovníci profesionálního Psychosociálního intervenčního týmu (PIT), psychologové, psychiatři, záchranáři, hasiči, policisté, krizový interventi a další (Baštecká et al., 2005). V př́ípadě formální pomoci lze tedy hovořit o tzv. specializované pomoci zasaženým osobám v mimořádných situacích (Špatenková et al. 2011). Naopak neformální pomoc zasaženým osobám v mimořádných situacích je vnímána jako pomoc „laická“. Do této oblasti pomoci a podpory je řazena svépomoc, vzájemná pomoc a psychologická první pomoc ${ }^{3}$. Svépomoc je aplikována $\mathrm{v}$ situacích, ve kterých si zasažená osoba chce a dokáže pomoci sama (Špatenková et al., 2017). Vzájemná pomoc je specifickou formou sociální interakce, do které se zapojují např. příbuzní, blízcí, známí, práátelé, sousedé, spolupracovníci, spoluobčané, ale i náhodní kolemjdoucí a další osoby z okolí zasaženého (Baštecká, 2009). Na PFA je pak nahlíženo obdobně jako na zdravotnickou první pomoc, kterou by měl být schopný poskytnou každý bez ohledu na vzdělání nebo profesní zaměření (Špatenková et al., 2017).

Zvládání mimořádných situací u osob s $\mathrm{OH}$, může být v důsledku specifik a individuálních potřeb doprovázejících jednotlivé kategorie $\mathrm{OH}$, značně komplikované. Je společnost schopna těmto osobám $\mathrm{v}$ mimořádných situacích efektivně pomoci? Mají osoby $\mathrm{s} \mathrm{OH}$ při zvládání mimořádných situací vůbec ,přístupnou“ dostatečnou pomoc a podporu? Jaká jsou specifika (překážky, potřeby) a možnosti osob s $\mathrm{OH}$ při mimořádných situacích vyžadujících evakuaci? Mají tyto osoby ( $\mathrm{v}$ př́padě potřeby) $\mathrm{k}$ dispozici využití bezodkladné, efektivní pomoci $\mathrm{v}$ průběhu mimořádné situace nebo krátce po ní?

\section{METODOLOGIE}

Za účelem identifikace témat spojených s problematikou specifik a možností evakuace a poskytování PFA osobám $\mathrm{s} \mathrm{OH} \mathrm{v}$ mimořádných situacích byla vyhotovena přehledová studie. Jedná se o analýzu dostupných plnotextů, které byly vyhledány v databázi EBSCO za využití následující kombinace klíčových slov a Booleovských operátorů - emergency situation, crisis, crisis situation, crisis intervention, crisis support, crisis counselling,

\footnotetext{
${ }^{1} \mathrm{Za}$ „mimořádné situace“ jsou pro účely textu považovány takové situace, které vyžadují evakuaci osob se zdravotním postižením (konkrétně s omezením hybnosti). Jedná se např. o požár, povodeň, výbuch, vichřici teroristický útok apod.

${ }^{2} \mathrm{Za}$,pomáhajicí osoby“ lze většinou považovat odborníky z řad profesionálů jako např. zdravotníky, hasiče, policisty, psychology, speciální pedagogy, sociální pracovníky, krizové interventy, ale také kohokoli, kdo je v mimořádné ochotný bezodkladně pomoci.

${ }_{3}^{3}$ „Psychologická první pomoc“ bývá označována také jako „psychická první pomoc“ nebo „psychosociální první pomoc“. V textu bude používáno označení ,psychologická první pomoc“, ve zkrácené podobě pojmu jako „PFA“ (z angl. ,psychological first aid“).
} 
psychological first aid, psychological support, evacuation AND disability or disabilities or disabled, person* with disability, disabil*, person with reduced mobility."

Pro rešeršní strategii byla stanovena tato rešeršní otázka: „Jak je dosud řě̌ena otázka evakuace osob s OH a poskytování PFA těmto osobám mimořádných situacích?"“

Kritéria pro zařazení dohledaných studií do přehledové studie byla relevantnost studie vzhledem ke zkoumanému tématu, datum vydání - primárně studie vydané v letech 2000 2021 a dostupnost v podobě plnotextu. Jako metoda zpracování finálního souboru studií byla použita obsahová interpretativní analýza.

\section{SUMARIZACE DOHLEDANÝCH STUDIÍ: KLÍČOVÁ TÉMATA ZKOUMANÉ PROBLEMATIKY}

Za pomocí výše uvedených klíčových slov a jejich kombinací byly vyhledány studie týkající se evakuace osob s omezením hybnosti v mimořádných situacích. Tyto studie byly zaměřeny především na oblast evakuačních strategií, celkového procesu a průběhu evakuace v jednotlivých krocích, modifikaci evakuačních plánů, identifikaci a odstraňování bariér v prostředí, materiální zabezpečení evakuačních pomůcek, diference v evakuaci osob intaktních a osob s $\mathrm{OH}$, dále pak na vlastní připravenost osob s $\mathrm{OH}$ k zvládání mimořádných situací (Boyce, 2017; Butler et al., 2017; Kuligowski et al., 2013; Koo et al., 2012; Loy et al. 2006). V dohledaných studiích byla u osob s OH řešena evakuace pouze ve smyslu „bezpečného přemístění / přesunu“ těchto osob z místa ohrožení. Nebyly dohledány studie zabývající se prací s psychikou těchto jedinců zasažených mimořádnou situací.

Naopak, byly dohledány studie o vlastní připravenosti osob s $\mathrm{OH}$ na zvládání mimořádných situací vyžadujících, již zmíněnou, evakuaci. Konkrétně jsou tyto studie zaměřeny na zjištění úrovně aktuálních evakuačních strategií, plánů a postupů osobami s $\mathrm{OH}$ v budovách ,jejich pohybu“, dále pak jejich self-efficacy v mimořádných situacích nebo např. možnosti využití smart aplikací ulehčujících a urychlujících proces evakuace. V dohledaných studiích jsou také zmínky o individuálních potřebách a specificích osob s $\mathrm{OH}$ v mimořádných situacích s důrazem na nezbytnost modifikací evakuačních plánů, strategií, prostředí, přístupu apod (Wilson, 2016; Koo et al. 2014; Kailes, 2002).

Důkladnou, dlouhodobou a komplexní přípravu a modifikaci evakuačních strategií, plánů a postupů (s ohledem na individuální potřeby a specifika osob s $\mathrm{OH}$ ), lze považovat za klíčovou a přispívající $\mathrm{k}$ bezproblémovému zvládnutí mimořádné situace. V některých př́padech může tato „(ne)připravenost" mít i fatální následky (Alexander, 2015; Suttell, 2003). Fatálním následkům mimořádné situace vyžadující evakuaci osob s $\mathrm{OH}$, lze předcházet také využitím modifikovaných evakuačních pomůcek (Hashemi, 2018a; McGuire et al., 2007). I přes skutečnost širokého výběru evakuačních pomůcek pro osoby s $\mathrm{OH}$, se v praxi pomáhající osoby potýkají s jejich nedostatkem na místě mimořádné události. Děje se tak např. z důvodu nepř́tomnosti nebo nedostačujícího množství evakuačních pomůcek při evakuaci, jejich zanedbanosti (zanedbané technické kontroly), nedostupnosti (uzamčení ve sklepě, skříni, skladu) nebo neznalosti správného užití pomůcek pomáhajícími osobami (Suttell, 2003).

Podle dohledaných studií se ve vztahu k osobám s $\mathrm{OH}$ může $\mathrm{v}$ př́padě mimořádné situace vyžadující evakuaci jevit jako problematické využití takových evakuačních pomůcek, jejichž užití je závislé na připojení $\mathrm{k}$ elektrické síti. Jedná se např. o „klasické“ výtahy nebo schodišt'ové plošiny. Tyto evakuační „,prvky“ nejsou pro osoby s $\mathrm{OH}$ považovány za vhodné. Osoby s $\mathrm{OH}$ mohou pak mít v př́ípadě evakuace problémy při překonávání architektonických překážek (Hashemi, 2018b). Evakuace osob s OH je v takových př́padech pozdržena z důvodu nezbytnosti čekání na př́ijezd profesionálů složek Integrovaného záchranného systému. Danou skutečností se však celý proces evakuace pozdrží a osoby s OH jsou vystaveny vyššímu riziku ohrožení života (Alexander, 2015; Suttell, 2003). Pro tyto osoby 
jsou za účelem bezpečné a bezodkladné evakuace určeny např. tyto pomůcky - evakuační křesla, evakuační rohože, evakuační popruhy, evakuační triangl, evakuační nosítka, evakuační rukávce (tunely), evakuační výtahy a další (Marsden Fire Safety Ltd., 2017-2019; Galušková 2013).

Pro osoby s $\mathrm{OH}$ je neméně důležité jasné značení a př́stupnost únikových cest v budově. Dané označení by mělo být umístěno tak, aby bylo dobře viditelné a kontrastní s pozadím. Při vstupu do budovy by měl být pro osoby s $\mathrm{OH}$ k dispozici dostatečný počet př́ruček vyznačujících a popisujících půdorys a možnosti únikových cest $\mathrm{z}$ budovy. Pro osoby s $\mathrm{OH}$ by měly být modifikovány také dveře, kliky, západky zámků apod (NFPA, 2007).

Další problematickou oblast může $\mathrm{v}$ prŕípadě evakuace osob na vozíku představovat potřeba evakuace jedince i s vozíkem. Podle výzkumu, který realizovali autoři Willigen et al. (2002), by se většina jejich participantů s $\mathrm{OH}$, nenechala evakuovat bez svého vozíku. V některých př́padech je však $\mathrm{v}$ důsledku enviromentálních bariér přítomných při mimořádných situacích znemožněna evakuace osoby s $\mathrm{OH}$ i s vozíkem. To u osoby s $\mathrm{OH}$ zvyšuje úzkost, a naopak snižuje jeho self-efficacy při zvládání mimořádných situací. Autoři považují za nezbytné preventivní př́ípravu detailního evakuačního plánu. Př́ruček a doporučených evakuačních pokynů byla již sepsána celá řada, v některých případech však chybí praktické ověření jejich funkčnosti (American Red Cross Disaster Services, 2016; National Fire Protection Association, 2016; Server, 2015; City of Los Angeles Department on Disability, 2002).

Při zvládání mimořádných situací u osob s $\mathrm{OH}$ je nezbytné si uvědomit, že každá tato osoba může mít velmi specifické a odlišné potřeby. Z daného důvodu je nezbytné o možnosti, že nastane situace vyžadující evakuaci s osobami s $\mathrm{OH}$ otevřeně komunikovat. Podle Federal Office of Civil Protection and Disaster Assistance (2017) je právě komunikace jednou $\mathrm{z}$ dalších možných problematických oblastí, se kterou se osoby $\mathrm{s} \mathrm{OH}$ mohou v případě zvládání mimořádných situací potýkat. Komunikace o takových situacích je nezbytná nejen s jedincem s $\mathrm{OH}$, ale především s osobami v jeho okolí (s rodinou, přáteli, kolegy apod). Protože právě tyto osoby jsou s největší pravděpodobností ty, které budou na místě mimořádné situace jedni $z$ prvních. Je důležité, aby se evakuace odehrávala v co možná největší míře podle představ a přání osoby s $\mathrm{OH}$. V praxi se stává, že profesionálové z řad Záchranného integrovaného systému, nekomunikují př́mo $\mathrm{s}$ osobou $\mathrm{s} \mathrm{OH}$, ale $\mathrm{s}$ jejich blízkými. Osoby s omezením hybnosti si pak mohou přijít méněcenné. Je tedy nezbytné $\mathrm{s}$ touto skutečností ( $\mathrm{v}$ prŕpadě potřeby) pomáhající profesionály seznámit. Komunikace s profesionály je důležitá také $\mathrm{z}$ důvodu správné manipulace s osobou $\mathrm{s} \mathrm{OH}$ při přesunu na bezpečnější místo. Např. se nedoporučuje zvedat osobu na vozíku vysoko do vzduchu - vozík má spoustu pohyblivých i slabých částí, které nejsou konstruovány tak, aby zdvih vydržely, hrozí také nebezpečí zakopnutí pomáhající osoby. Některé osoby s $\mathrm{OH}$ potřebují k životu další kompenzační a zdravotní pomůcky, při evakuaci je tak potřeba vykomunikovat i jejich přsun (UC San Diego, 2021).

Komunikace úzce souvisí s mírou dopadu důsledků mimořádné situace na psychiku zasaženého jedince. Osoba s omezením hybnosti může v rámci psychosociální pomoci využívat formální pomoci v krizi, tedy psychosociální pomoci odborníků. Jedná se např. o zdravotníky, hasiče, policisty, psychology, psychiatry, krizové interventy a další. Tato forma pomoci vyžaduje k poskytování určitý stupeň znalostí. $Z$ daného důvodu nemusí být na místě mimořádné situace dostupná jako první. V takových případech se doporučuje spíše využití laické neformální pomoci. V rámci přehledové studie byla pozornost věnována především psychické první pomoci (PFA). Jedná se o pomoc, která je srovnatelná se zdravotní první pomocí, kterou by měl dokázat poskytnout každý (Špatenková et al., 2017). PFA je psychická pomoc a podpora zasaženým osobám v akutní krizi. Pomáhající osoba tak bezodkladně reaguje na aktuální psychosociální potřeby zasažené osoby. Tato reakce spočívá videntifikaci a saturaci bazálních potřeb vedoucích k psychické stabilizaci a předání 
zasaženého jedince do další péče (pouze $\mathrm{v}$ príípadě potřeby). Jedná se o pomoc, která by měla být zasaženým osobám $\mathrm{v}$ mimořádných situacích $\mathrm{k}$ dispozici, neměla by jim však být vnucována (Australian Red Cross, 2020; Špatenková et al., 2017; Snider at al., 2011; Brymer et al., 2006).

Interpretativní obsahovou analýzou dohledaných studií bylo zjištěno, že mezi nejčastěji používané přístupy PFA patří - PFA podle Critical Incident Stress Management, PFA podle National Child Traumatic Stress Network \& National Centre for PTSD, PFA podle World Health Organization. Tyto př́stupy se od sebe navzájem sice mírně liší, ale základní charakteristiky mají stejné. Jedná se např. o: zajištění bezpečí pomáhajícího i zasaženého; navázání prvotního kontaktu; získání vzájemné důvěry; akceptace a respekt prožívání, chování, emocí, reakcí zasažené osoby; identifikaci a saturaci psychosociálních potřeb zasaženého; poskytování pravdivých informací, které musí probíhat srozumitelným způsobem (např. využitím krátkých, jasných vět); sledování projevů neverbální komunikace; aktivní naslouchání; ověřování porozumění; identifikace a předání další pomoci / podpory (Australian Red Cross, 2020; Špatenková et al., 2017; Snider at al., 2011).

Vybrané př́istupy PFA nejsou primárně určeny osobám s $\mathrm{OH}$, ale i tak je lze modifikovat tak, aby vyhovovaly jejich specifikům, individuálním potřebám a možnostem. U osob s $\mathrm{OH}$ je $\mathrm{v}$ př́padě výskytu mimořádné událostí nutné brát $\mathrm{v}$ potaz, že může dojít např. $\mathrm{k}$ náhlému zhoršením zdravotního stavu, ztížené orientací v prostoru nebo situaci. Je také nutné počítat s potřebou užívání prostř̌edků zdravotní techniky, kompenzačních pomůcek, využíváním alternativních a augmentativních způsobů komunikace a dalšími (Snider at al., 2011).

Poskytování PFA osobám s OH vyžaduje kvalitativně odlišné řízení intervence (průběhu a postupu) než u intaktní populace. Rozdíl je spatř̌ován především v intenzitě a délce poskytované intervence (vyšší intenzita a časová náročnost) (Stough et al., 2010). V př́padě poskytování PFA osobám s $\mathrm{OH}$ by ke zkvalitnění intervence mohla být nápomocná přítomnost pracovníků z řad pomáhajících profesí - speciálních pedagogů, sociálních pracovníků, psychologů apod. Jedná se o pracovníky, kteř́ by z povahy svého profesního zaměření měli znát a respektovat specifika přistupu a individuálních potřeb osob $\mathrm{s}$ různými kategoriemi $\mathrm{OH}$.

\section{ZÁVĚR}

Zvládání mimořádných situací u osob $\mathrm{s} \mathrm{OH}$, může být v důsledku specifik a individuálních potřeb doprovázejících jednotlivé kategorie $\mathrm{OH}$, značně specifické a komplikované. Tato pomoc a podpora vyžaduje jisté modifikace. Osoba s $\mathrm{OH}$ může v př́padě výskytu mimořádné situace využít různé možnosti psychosociální podpory a pomoci. Pomoc je těmto osobám př́stupná, záleží jen na ochotě osoby s $\mathrm{OH}$ (popř́ípadě jejího okolí), danou pomoc vyhledat a také na ochotě pomáhajících pracovníků, danou pomoc cíleně modifikovat tak, aby odpovídala potřebám a specifikům zasažené osoby. Na možné překážky, které by mohly bránit bezpečné evakuaci nebo poskytnutí následné psychické pomoci, je třeba pomatovat dř́ve, než mimořádná situace nastane (např. tvorbou evakuačních plánů, pořizováním a umístováním evakuačních pomůcek, školením v oblasti užití evakuačních pomůcek, školením v oblasti poskytování PFA). Mimořádné situace bývají sice mimořádné, ale i tak je nezbytné se na ně důkladně připravit.

S ohledem na neustále rostoucí výskyt mimořádných situací ve společnosti, lze na téma př́stupnosti pomoci a podpory osobám s OH pohlížet jako na aktuální a zasluhující další pozornost v oblasti vědy a výzkumu. Nabízí se např́íklad výzkumy v oblasti připravenosti pracovníků rezidenčních služeb na zvládání mimořádných situací - právě zde, lze předpokládat vyšší výskyt osob $\mathrm{s} \mathrm{OH}$, což by $\mathrm{v}$ prŕípadě mimořádné situace mohlo mít fatální důsledky. 
Tento př́spěvek byl financován projektem IGA: „Přístupnost v kontextu osob se zdravotním postižením “(IGA_PdF_2021_006).

\section{Použitá literatura}

1. ALEXANDR, D. Disaster and Emergency Planning for Preparedness, Response, and Recovery, Oxford Research Encyclopedia of Natural Hazard Science. 2015. Oxford University Press USA.

2. AMERICAN RED CROSS DISASTER SERVICES. Disaster for people with disabilities. 2016.

3. AUSTRALIAN RED CROSS. Psychological First Aid: Supporting people affected by disaster in Australia. Melbourne. [online]. 2020 [cit. 2020-06-06]. Dostupné z: https://www.redcross.org.au/getmedia/dc21542f-16e4-44ba-

8e3a4f6b907bba6f/Psychological-First-Aid-An-Australian-Guide-04-20.pdf.aspx.

4. BAS̆TECKÁ, B. et al. Terénní krizová práce: psychosociální intervenční týmy. Vyd. 1. Praha: Grada. 2005. 300 s. ISBN 80-247-0708-X.

5. BAŠTECKÁ, B. Psychologická encyklopedie: aplikovaná psychologie. Vyd. 1. Praha: Portál. 2009. 515 s. ISBN 978-80-7367-470-0.

6. BOYCE, K. Safe evacuation for all - Fact or Fantasy? Past experiences, current understanding and future challenges. Fire Safety Journal, 2017. vol. 91, pp. 28-40.

7. BRYMER, M. et al. Psychological First Aid: Field operations guide (2nd ed.). Los Angeles: National Child Traumatic Stress Network and National Center for PTSD. 2006.

8. BUTLER, K. et. al. Perspectives of occupants with mobility impairments on evacuation methods for use during fire emergencies. Fire Safety Journal, 2017. vol. 91, pp. 955-963.

9. CITY OF LOS ANGELES DEPARTMENT ON DISABILITY. Emergency Preparedness For People with Disabilities. LA. 2002.

10. FEDERAL OFFICE OF CIVIL PROTECTION AND DISASTER ASSISTANCE. Assisting People with Disabilities in Case of Disaster European Network for Psychosocial Crisis Management Recommendations for Preparedness, Response and Recovery. Frankfurt am Main, Germany. 2017. 220 s. ISBN-13: 978-3-939347-85-9.

11. GALUŠKOVÁ, T. Posouzení rizik evakuace osob se sniženou pohyblivostí. (Bakalářská práce). 2013. Zlín: Univerzita Tomáše Bati ve Zlíně.

12. HASHEMI, M. Dynamic, Stream-Balancing, Turn-Minimizing, Accessible Wayfinding for Emergency Evacuation of People Who Use a Wheelchair. Fire Technology, 2018a. vol. 54, pp. 1195-1217.

13. HASHEMI, M. Emergency evacuation of people with disabilities: A survey of drills, simulations, and accessibility, Cogent Engineering. 2018b. University of Pittsburgh.

14. KAILES, J. I. Emergency evacuation preparedness, taking responsibility for your safety: a guide for people with disabilities and other activity limitations. Pomona, Calif.: Center for Disability Issues and the Health Professions, Western University of Health Sciences, 2002. 36 pp.

15. KOO, J. et al. Estimating the effects of mental disorientation and physical fatigue in a semi-panic evacuation. Expert Systems with Applications, 2014. vol. 41/issue 5, pp. 2379-2390.

16. KOO, J. et al. Estimating the impact of residents with disabilities on the evacuation in a high-rise building: A simulation study. Simulation Modelling Practice and Theory, 2012. vol. 24, pp. 71-83.

17. KULIGOWSKI, E. et. al. Stair evacuation of older adults and people with mobility impairments, Fire Safety Journal, 2013. vol. 62(Part C), pp. 230-237. 
18. LOY, B. et al. Including employees with disabilities in emergency evacuation plans: 9/11's Effect on the demand for information. Work, 2006. vol. 27/issue 4, pp. 407-411.

19. MARSDEN FIRE SAFETY LTD. Evacuation aids. 2017-2019. dostupné z: https://www.marsden-fire-safety.co.uk/t/categories/evacuation/evacuation-aids.

20. McGUIRE, L. et al. Natural disasters and older US adults with disabilities: implications for evacuation. Disasters, 2007. vol. 31(1), pp. 49-56.

21. MV ČR. Terminologický slovník pojmu z oblasti krizového ř́zení, ochrany obyvatelstva, enviromentální bezpečnosti a plánování obrany státu. Odbor bezpečnostní politiky a prevence kriminality. Praha. 2016. [online]. [cit. 2021-0606]. Dostupné z: http://www.mvcr.cz/soubor/terminologicky-slovnik-offline-verz e.aspx

22. NATIONAL FIRE PROTECTION ASSOCIATION. Emergency Evacuation Planning Guide for People with Disabilities. 2016. Quincy, MA.

23. NFPA. Emergency Evacuation Planning Guide For People with Disabilities. 2007. pp. 60.

24. RUZEK, I., J. et al. Psychological First Aid. Journal of Mental Health Counseling. 2007. vol. 29(1), pp. 17-49.

25. RŮŽIČKA, M. et al. Krizová intervence pro speciální pedagogy. 1. vyd. Olomouc: Univerzita Palackého v Olomouci. 2013. 168 s. ISBN 978-80-244-3305-9

26. SERVER, R. Extra Fragile in Disaster. People with Disabilities in a Bombarded Zone. Disaster Management Enabling Resilience. Berlin: Springer. 2015. pp. 201226.

27. SNIDER, L. et al. Psychological first aid: guide for field workers. Geneva, Switzerland: World Health Organization. 2011. ISBN 9789241548205.

28. STOUGH, M., L. et al. Disaster Case Management and Individuals With Disabilities. Rehabilitation Psychology. 2010. vol. 55/issue 3, pp. 211-220.

29. SUTTEL, R. Prepared for Safety. Buildings, 2003. pp. 32-34.

30. S̆PATENKOVÁ, N. et al. Krize a krizová intervence. Vydání 1. Praha: Grada. 2017. 288 s. ISBN 978-80-247-5327-0.

31. ŠPATENKOVÁ, N. et al. Krize: psychologický a sociologický fenomén. Vyd. 1. Praha: Grada. 2004. 132 s. ISBN 80-247-0888-4.

32. ŠPATENKOVÁ, N. et al. Krizová intervence pro praxi. 2., aktualiz. a dopl. vyd. Praha: Grada. 2011. 195 s. ISBN 978-80-247-2624-3.

33. UC SAN DIEGO. Emergency Evacuation for People With Disabilities. UC San Diego 9500 Gilman Dr. La Jolla. 2021. CA 92093 (858) 534-2230. dostupné z: https://blink.ucsd.edu/safety/emergencies/preparedness/getready/disabilities.html\#Know-how-to-help-people-who-use.

34. WILLIGEN, M. et al. Riding Out the Storm: Experiences of the Physically Disabled during Hurricanes Bonnie, Dennis, and Floyd. Natural Hazards Review. 2002. 3(3), pp. 98-106.

35. WILSON, L. Evacuation of People with Disability \& Emergent Limitations: Considerations for Safer Buildings. (The Guidebook), 2016. Edition 2.0, pp. 169.

\section{Kontaktní údaje}

Mgr. et Mgr. Bianka Hudcová

Univerzita Palackého v Olomouci

Pedagogická fakulta, Ústav speciálněpedagogických studií

Žižkovo nám. 5, 779 00, Olomouc

email: bianka.hudcova01@upol.cz 


\title{
REKVALIFIKACE V ČESKÉ REPUBLICE, JEJICH PROPOJENÍ S NÁRODNÍ SOUSTAVOU KVALIFIKACÍ A KOMPARACE SE ZAHRANIČÍM
}

\author{
RETRAINING IN THE CZECH REPUBLIC, ITS LINK WITH THE \\ NATIONAL QUALIFICATIONS FRAMEWORK AND COMPARISON \\ WITH ABROAD
}

\author{
Lenka Mužíková
}

\begin{abstract}
Abstrakt
Cílem tohoto článku je popsat ukotvení rekvalifikací v právních předpisech existujících v České republice, jejich fungování a návaznost na ostatní právní předpisy existující v ČR. Článek se zaměruje i na popsání České Národní soustavy kvalifikací a profesních kvalifikací, které vznikají od roku 2007 na základě zákona o uznávání výsledků dalšího vzdělávání. Přidanou hodnotou tohoto článku jsou i aktuální údaje o nejčastěji realizovaných rekvalifikačních programech v ČR.
\end{abstract}

Klíčová slova: dalši vzdělávání, akreditace, rekvalifikace, Národní soustava kvalifikací, Profesní kvalifikace

\begin{abstract}
The aim of this article is to describe the anchoring of retraining in existing legislation in the Czech Republic, their functioning and connection to other legal regulations existing in the Czech Republic and. The article also focuses on the description of the Czech National Qualifications Framework and vocational qualifications, which have been established since 2007 on the basis of the Act on the Recognition of Further Education Results. The added value of this article is also current information on the most frequently implemented retraining programs in the Czech Republic.
\end{abstract}

Keywords: Further education, accreditation, retraining, the National Qualifications Framework, Vocational Qualifications

\section{REKVALIFIKACE V ČESKÉ REPUBLICE}

Vzdělání je velmi důležitou veřejnou investicí. Další vzdělávání, a to především oblast dalšího profesního vzdělávání, je dnes považováno za jeden z důležitých faktorů udržení nepřetržitého ekonomického růstu a udržování konkurenceschopnosti občanů v mezinárodním měřítku. Další vzdělávání neustále narůstá na významu, a to zejména $\mathrm{v}$ období, kdy celá společnost byla zasažena epidemií Covid-19 a mnoho lidí bylo nuceno rozšírit svoji kvalifikaci v oblasti výpočetní techniky, nebo svoji kvalifikaci zcela změnit. Právě rekvalifikace, kterými se rozumí získání nové kvalifikace nebo zvýšení, rozšiřrení a prohloubení stávající kvalifikace, mohou být stěžejním nástrojem při uplatnění občanů na trhu práce.

S pojmem rekvalifikace se můžeme setkat $\mathrm{v}$ různých materiálech a publikacích. Výkladový slovník Lidské zdroje popisuje rekvalifikace jako ,změnu dosavadní kvalifikace zaměstnance nebo uchazeče o zaměstnání, kterou získává nové znalosti a dovednosti" (Palán, 2002). Publikace Řizení lidských zdrojů Základy moderní personalistiky uvádí, že „Přeškolování (rekvalifikace) je takové formování pracovnich schopností člověka, které směruje k osvojeni si 
nového povolání, nových pracovních schopností." (Koubek, 2003). Rekvalifikace jsou ukotveny i prrímo v zákoně č. 435/2004 Sb., o zaměstnanosti, ve znění pozdějších předpisů, kde jsou rekvalifikace definovány jako ,ziskání nové kvalifikace a zvýšení, rozšírení nebo prohloubeni dosavadni kvalifikace, včetně jejího udržování nebo obnovováni" (MPSV, 2004). Ačkoliv odpovědnost za činnosti související s legislativním ukotvením a vytvářením celkové koncepce vzdělávání má v ČR Ministerstvo školství, mládeže a tělovýchovy, oblast rekvalifikací spadá v ČR do gesce dvou ministerstev. Ministerstvo práce a sociálních věcí řeší problematiku zabezpečování a poskytování rekvalifikací prostřednictvím úřadů práce a Ministerstvo školství, mládeže a tělovýchovy (dále jen „MŠMT“) zabezpečuje proces udělování akreditací pro jednotlivé rekvalifikační programy. V oblasti rekvalifikací je pro obě ministerstva stěžejní zákon č. 435/2004 Sb., o zaměstnanosti, ve znění pozdějších předpisů, který je v platnosti od 23. 7. 2004 a nabyl účinnosti dne 1.10.2004. Od této doby byl již několikrát novelizován.

Novelizace zákona o zaměstnanosti $\mathrm{v}$ roce 2009 přinesla pro rekvalifikace řadu zpřesnění a novinek. Jednou $\mathrm{z}$ nejdůležitějších novinek je výčet vzdělávacích zařízení, která smějí realizovat rekvalifikace. Dle $\S 108$ odst. 2 zákona o zaměstnanosti, může rekvalifikace provádět pouze:

a) zařízení s akreditovaným vzdělávacím programem podle tohoto zákona;

b) zařízení s akreditovaným vzdělávacím programem podle zvláštního právního předpisu;

c) škola $v$ rámci oboru vzdělání, který má zapsaný v rejstř́ku škol a školských zařízení nebo vysoká škola s akreditovaným studijním programem podle zvláštního právního předpisu;

d) zařízení se vzdělávacím programem podle zvláštního právního předpisu (např. zákon č. 179/2006 Sb., o ověřování výsledků dalšího vzdělávání a vyhláška č. 77/1965 Sb., o výcviku, způsobilosti a registraci obsluh stavebních strojů).

Poslední novelizace zákona proběhla $v$ roce 2020 a upravuje např.:

- zprostředkování zaměstnání

- zaměstnávání osob se zdravotním postižením

- zaměstnávání zaměstnanců ze zahraničí

- aktivní politika zaměstnanosti

- opatření a nástroje

- rekvalifikace

- další nástroje aktivní politiky zaměstnanosti (např. veřejně prospěšné práce, společensky účelná pracovní místa)

Dle zákona č. 435/2004 Sb., o zaměstnanosti, ve znění pozdějších předpisů, tedy MŠMT akredituje rekvalifikační programy, které připravují k výkonu konkrétní pracovní činnosti uplatnitelné na trhu práce nebo připravují k získání konkrétních pracovních dovedností.

Dle zákona č. 435/2004 Sb., o zaměstnanosti, ve znění pozdějších předpisů, má MŠMT např. i oprávnění realizovat kontroly $\mathrm{v}$ akreditovaných vzdělávacích zařízení nebo udělené akreditace $\mathrm{k}$ pořádání rekvalifikačních programů odejímat.

\subsection{Udělování akreditací pro rekvalifikační programy}

Regulace rekvalifikačních programů má dlouholetou tradici. První vyhláška k rekvalifikacím, byla vyhláška č. 21/1991 Sb., o bližších podmínkách zabezpečování rekvalifikace uchazečů o zaměstnání a zaměstnanců. Jednalo se vyhlášku ministerstva práce a sociálních věcí České republiky.

Druhou vyhláškou byla vyhláška č. 524/2004 Sb., o akreditaci zařízení k provádění rekvalifikace uchazečů o zaměstnání a zájemců o zaměstnání, která byla již v gesci MŠMT.

Třetí a poslední vyhláškou je vyhláška č. 176/2009 Sb., kterou se kterou se stanoví náležitosti žádosti o akreditaci vzdělávacího programu, organizace a zpo̊sob ukončení vzdělávání v rekvalifikačním zařízení. Tato vyhláška je rovněž v gesci MŠMT. Aktuální znění vyhlášky 
č. 176/2009 Sb., kterou se kterou se stanoví náležitosti žádosti o akreditaci vzdělávacího programu, organizace a způsob ukončení vzdělávání v rekvalifikačním zařízení je v platnosti od 28. 3. 2018. Vyhláška je prováděcím právním předpisem k zákonu č. 435/2004 Sb., o zaměstnanosti, ve znění pozdějších předpisů.

Vyhláška č. 176/2009 Sb., přináší nové systémové pojetí rekvalifikací a zpřísňuje náležitosti podávaných žádostí o akreditaci i realizovaných rekvalifikací. Vyhláška přináší provázání rekvalifikací s již platnými právními předpisy, a to např. se zákonem č. 179/2006 Sb., o ověřování a uznávání výsledků dalšího vzdělávání a o změně některých zákonů (zákon o uznávání výsledků dalšího vzdělávání).

Vyhláška č. 176/2009 Sb., ukotvuje např. následující:

- náležitosti žádosti o akreditaci vzdělávacího programu;

- organizaci vzdělávání podle rekvalifikačního programu;

- způsob ukončení vzdělávání;

- závěrečnou zkoušku;

- náležitosti osvědčení o rekvalifikaci a potvrzení o účasti v akreditovaném vzdělávacím programu.

O udělení akreditace je MŠMT povinno rozhodnout nejpozději do 90 dnů ode dne doručení žádosti o akreditaci. K posouzení žádosti o akreditaci si MŠMT může zřídit akreditační komisi jako svi̊j poradní orgán a může si vyžádat stanovisko Ministerstva práce a sociálních věcí $\mathrm{k}$ situaci na trhu práce. Akreditace se uděluje na dobu 3 let ode dne právní moci rozhodnutí o jejím udělení.

Akreditace jsou udělovány pro všechny rekvalifikační programy, které připravují k výkonu konkrétní pracovní činnosti uplatnitelné na trhu práce nebo připravují k získání konkrétních pracovních dovedností. Jedná se napřr. o tyto vzdělávací programy:

- vzdělávací programy k získání plné kvalifikace k výkonu konkrétní pracovní činnosti uplatnitelné na trhu práce (např. Počítačový grafik, Instruktor lyžování...);

- vzdělávací programy k získání konkrétních pracovních dovedností (např. počítačové kurzy, základy podnikání...);

- vzdělávací programy vedoucí k profesním kvalifikacím dle Národní soustavy kvalifikací dle zákona č. 179/2006 Sb., o uznávání výsledků dalšího vzdělávání (např. malíř, manažer prodeje, př́prava teplých pokrmů...). Jedná se o př́pravný kurz $\mathrm{k}$ závěrečné zkoušce, která je definována hodnotícím a kvalifikačním standardem konkrétní profesní kvalifikace;

- vzdělávací programy vedoucí k závěrečné zkoušce dle zvláštních právních předpisů (např. Pracovník znalý práce v elektrotechnice, Osoba odborně způsobilá pro úkoly v prevenci rizik $\mathrm{v}$ oblasti bezpečnosti a ochrany zdraví při práci...). Jedná se o prrípravný kurz k závěrečné zkoušce, která je definována př́íslušným zvláštním právním předpisem.

Součástí žádosti o akreditaci je např. i učební plán a učební osnovy, které musí být při výuce dodržovány. Obsah učebního plánu a učebních osnov je stanoven pouze u těch př́ipadů, kdy rekvalifikační kurz připravuje $\mathrm{k}$ závěrečné zkoušce dle jiných právních předpisů (např̀. kurz vedoucí k profesní kvalifikaci). V těchto případech musí být učební plán kurzu zpracován v souladu s př́slušným právním předpisem nebo standardem konkrétní profesní kvalifikace. Existující právní předpis nebo hodnotící standard konkrétní profesní kvalifikace přesně stanovuje obsah závěrečné zkoušky a kurzy jsou tedy kurzy přípravnými k závěrečné zkoušce. Výstupem ze všech rekvalifikačních kurzů je bud' „Osvědčení o rekvalifikaci“ (v případě čisté rekvalifikace) nebo „Potvrzení o účasti v akreditovaném vzdělávacím programu“ (v prípadě, že kurz připravuje na složení závěrečné zkoušky dle jiného právního předpisu), které má doživotní platnost. 
V návaznosti na udělené akreditace, spravuje MŠMT Databázi udělených akreditací, která je zveřejněna na webových stránkách MŠMT, a která slouží jako transparentní ukazatel výstupů $\mathrm{z}$ akreditačního procesu např. pro veřejnost, živnostenské úřady a úřady práce. Vedení databáze je důležité i z důvodu, že vzdělávací zařízení mohou na základě udělené akreditace MŠMT a zákona č. 435/2004 Sb., o zaměstnanosti, spolupracovat s úřady práce a nabízet akreditované vzdělávací programy pro provádění rekvalifikace nezaměstnaným.

Kromě provázanosti rekvalifikací se zákonem č. 179/2006 Sb., a dalšími právními předpisy, které bylo popsáno výše, mají udělované akreditace MŠMT návaznost i na další zákony, např̀. na zákon č. 455/1991 Sb., o živnostenském podnikání (živnostenský zákon), kdy osvědčení o rekvalifikaci, je v některých př́padech (zejména pokud se týká řemeslných činností) dostačujícím dokladem i pro získání živnostenského oprávnění.

\subsection{Nejčastěji realizované rekvalifikační programy v ČR}

V současné době existuje velmi málo dat týkajících se skutečně realizovaných rekvalifikačních programů $\mathrm{v}$ ČR. Nejaktuálnější údaje o realizovaných rekvalifikačních programech lze vyčíst z výzkumu, který se uskutečnil koncem roku 2020 prostřednictvím projektu Interní grantové soutěže Univerzity Jana Amose Komenského Praha s.r.o.. Výzkum byl zaměřen na akreditované rekvalifikační a neakreditované vzdělávací programy realizované v roce 2019 a byla oslovena všechna vzdělávací zařízení uvedená v databázi udělených akreditací MŠMT, která měla v roce 2019 platnou akreditaci k pořádání rekvalifikačních programů. Celkem bylo osloveno 393 vzdělávacích zařízení (podnikající fyzické osoby a právnické osoby) a návratnost dotazníku činila cca 18,8\%.

Výzkum zjišt'oval např. informace o rekvalifikačních vzdělávacích programech s největším počtem účastníků, realizovaných v roce 2019. Zjištěné údaje jsou patrné z následujícího grafu:

Graf č. 1: Akreditované rekvalifikační programy s největším počtem účastníků

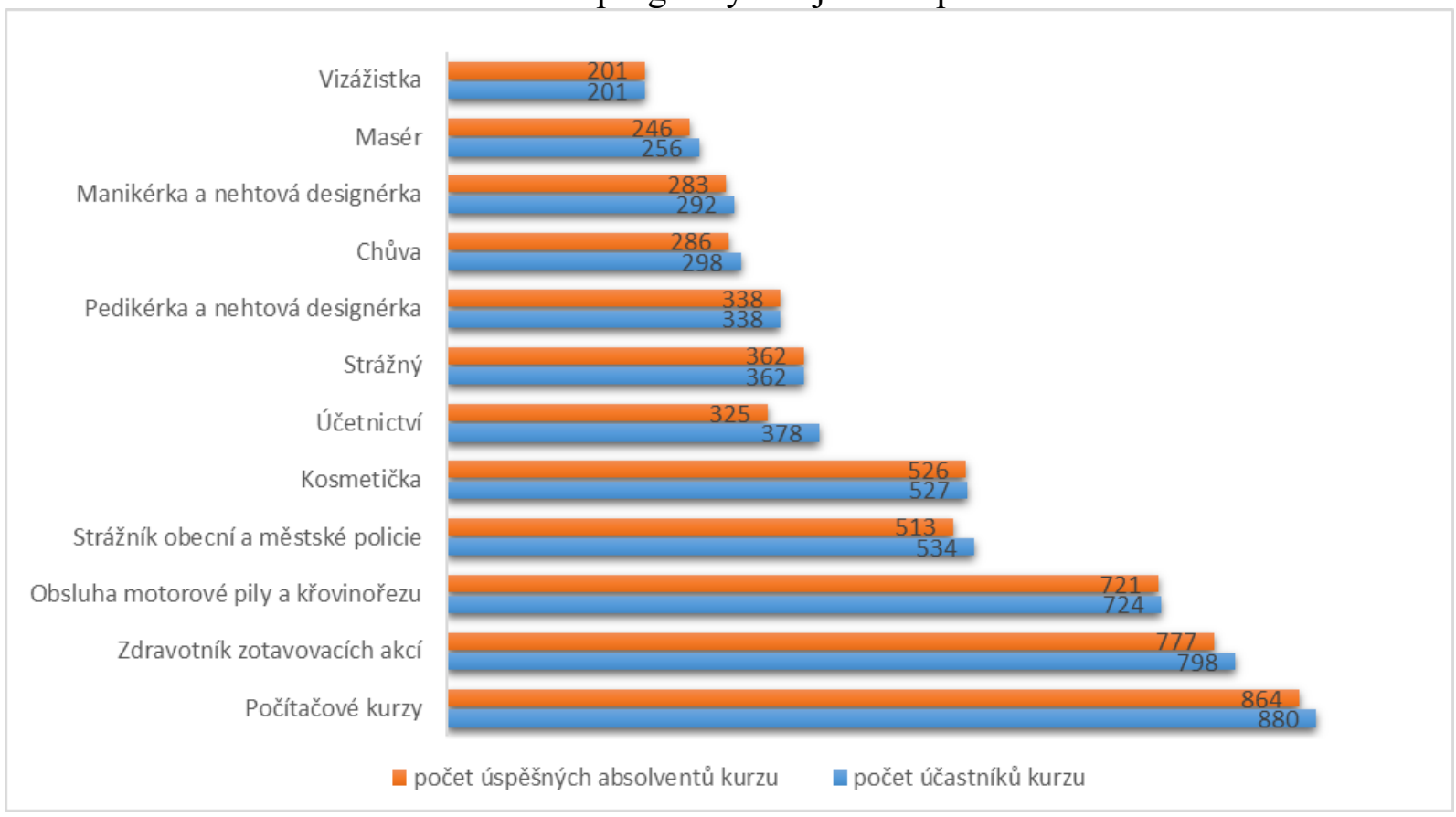

Zdroj: autorka tohoto článku

Z výše uvedeného grafu vyplývá, že nejvíce účastníků mají Počítačové kurzy, které mají více jak 98\% úspěšných absolventů. Následují kurzy zdravotníka zotavovacích akcí a kurzy zaměřené na obsluhu motorové pily nebo křovinořezu. Velký podíl na trhu zaujímají 
i kurzy zaměřené na osobní služby. Pokud bychom sečetli kurzy zaměřené na vizážistiku, manikúru, pedikúru a kosmetiku, činil by součet u těchto kurzů 1358 účastníků, což by vysoce převyšovalo ostatní realizované kurzy. Tento údaj je zajímavý zejména $\mathrm{z}$ důvodu, že při obdobném šetření, které realizovalo MŠMT v roce 2014, byly nejvíce realizovány kurzy právě v oblasti osobních služeb, což ukazuje, že zájem o tyto kurzy je dlouhodobý.

V každé z výše uvedené oblasti jsou zpracovány profesní kvalifikace, což ukazuje shodu jak tvůrců profesních kvalifikací, tak zájemců o kurzy a závěrečné zkoušky. Pouze v oblasti Zdravotníka zotavovacích akcí není zpracována žádná profesní kvalifikace. Závěrem lze tedy říci, že výše uvedené a zjištěné skutečnosti potvrzují to, že Národní soustava kvalifikací obsahuje skutečně požadované a poptávané pracovní činnosti na trhu práce. To, že rekvalifikační kurzy jsou ukončovány zkouškami z profesních kvalifikací (pokud je profesní kvalifikace schválena), je zajisté cesta správným směrem a to např. i z důvodu, že absolventi takto zakončených rekvalifikačních kurzů mají srovnatelné znalosti a dovednosti, což je důležité jak pro jejich potencionální zaměstnavatele, tak pro výkon samotné činnosti.

\section{NÁRODNÍ SOUSTAVA KVALIFIKACÍ}

V roce 2006 byl schválen zákon č. 179/2006 Sb., o ověřování a uznávání výsledků dalšího vzdělávání a o změně některých zákonů (zákon o uznávání výsledků dalšího vzdělávání), který byl v roce 2017 byl novelizován. Podstatou tohoto zákona je na základě standardizované zkoušky ověrit reálné znalosti a dovednosti potřebné k výkonu konkrétní pracovní činnosti, a to bez ohledu na to, jak je získali (zda ve škole, v kurzu, samostudiem či v praxi). Klíčovým nástrojem naplnění zákona č. 179/2006 Sb. v praxi je Národní soustava kvalifikací.

Cílem Národní soustavy kvalifikací je vytvoření systémového prostředí, které bude podporovat:

- srovnatelnost výsledků učení dosažených různými cestami;

- uznávání skutečných znalostí a dovedností nezávisle na způsobu jejich získání;

- srovnatelnost kvalifikací uznávaných v České republice s kvalifikacemi uznávanými $\mathrm{v}$ jiných evropských státech;

- přenos požadavků trhu práce do vzdělávání;

- veřejnou informovanost o všech celostátně uznávaných kvalifikacích.

Národní soustava kvalifikací vychází z Národní soustavy povolání a lze ji charakterizovat jako veřejně dostupnou databázi všech profesních kvalifikací a úplných profesních kvalifikací, které jsou na území České republiky uznávány.

Základní stavební kámen Národní soustavy kvalifikací tvoří tzv. profesní kvalifikace, což jsou samostatně uplatnitelné činnosti na trhu práce (např. trenér golfu, správce depozitáře, kosmetička apod.), které jsou na území České republiky uznávány. V dubnu roku 2021 bylo schváleno 1398 profesních kvalifikací.

Gestorem zákona 179/2006 Sb. a Národní soustavy kvalifikací je MŠMT, avšak jednotlivé Profesní kvalifikace spadají do gesce jednotlivým Autorizujícím orgánům, které následně udělují autorizace tzv. Autorizovaným osobám. Autorizujícími orgány jsou jednotlivá ministerstva, která mají v gesci uvedený obor (např. Ministerstvo kultury je Autorizujícím orgánem pro profesní kvalifikace v oblasti kultury apod.).

Naplňování Národní soustavy kvalifikací je založeno na činnosti sektorových rad a pracovních skupin, které jsou složeny $\mathrm{z}$ odborníků $\mathrm{v}$ daném oboru (např. zástupců vzdělávatelů, zaměstnavatelů a dalších odborníků). Tato skutečnost zabezpečuje, že profesní kvalifikace jsou odrazem skutečných potřeb a požadavků zaměstnavatelů. Vytvořené profesní kvalifikace následně podléhají složitému procesu kontroly a schvalování. Po jejich schválení jsou standardy profesních kvalifikací zveřejněny na www.narodnikvalifikace.cz. I když se všichni snaží, o vytvoření a následné schválení co nejvyššího počtu profesních kvalifikací, často se potýkají s rozdílnými názory ze strany zástupců zaměstnavatelů, sdružení a komor, 
což v ojedinělých případech vede k nemožnosti se na obsahu profesní kvalifikace dohodnout. Ačkoliv je Národní soustava kvalifikací budována již od roku 2006, stále ještě nejsou vytvořeny profesní kvalifikace pro všechny činnosti existující na trhu práce. Vzhledem k tomu, že Národní soustava kvalifikací má odrážet aktuální požadavky trhu práce, je vhodné na tuto soustavu pohlížet jako na živý organizmus, který se neustále vyvíjí, zdokonaluje a mění, nebot' jen tak lze zabezpečit její skutečnou aktuálnost.

Principem Národní soustavy kvalifikací je, že účastníci závěrečné zkoušky mohou absolvovat pouze závěrečnou zkoušku z profesní kvalifikace a nemusí před zkouškou absolvovat žádný vzdělávací program. Ke zkouškám jednotlivých profesní kvalifikací však mohou připravovat i různé vzdělávací programy, a to jak výše uvedené akreditované rekvalifikační programy, tak neakreditované vzdělávací programy, které nejsou v ČR nijak upravovány ani regulovány.

\section{KOMPARACE REKVALIFIKACÍ V ČR A V ZAHRANIČÍ}

Je třeba si uvědomit, že neexistuje žádný „univerzální model rekvalifikačního vzdělávání“, který by fungoval např́č jednotlivými státy. Vždy je potřeba respektovat situaci v hospodářství jednotlivých zemí, situaci v kvalitě lidského kapitálu a situaci ve školském systému. Je však možné využít následujících zjištění ze systému dalšího vzdělávání a rekvalifikací např. z Německa, Rakouska a Švýcarska:

1. Po vzoru Rakouska by bylo i nás vhodné zvážit zřízení tzv. Státního rekvalifikačního centra. Toto centrum by centrálně realizovalo ty rekvalifikační kurzy, jejichž četnost je na celém území vysoká, např. účetnictví a IT technologií.

2. Pod vlivem zkušeností zejména z Německa a Rakouska se jeví jako prrínosné doplnit systém akreditace rekvalifikačních programů o další systémy, jako jsou standardizace a certifikace. Standardizaci lze chápat jako stanovení jednotných požadavků na jejich činnost. Certifikace je konkrétní ověření způsobilosti poskytovat tyto služby. V SRN a Rakousku je díky těmto opatřením trh vzdělávání dospělých čitelnější a průhlednější.

3. V Německu, Rakousku i ve Švýcarsku funguje velmi propracovaný systém poradenství v oblasti vzdělávání. Tamější zkušenosti ukazují, že poradenské aktivity jsou vhodné před zahájením rekvalifikačních kurzů i po jejich skončení. Představuji jaké „dotažení“ výukové činnosti a zlepšují individuální schopnosti lidí uplatnit se a trhu práce.

4. V Německu, Švýcarsku a částečně i v Rakousku probíhá výrazná modularizace rekvalifikačních kurzů. Výhoda této praxe je, že účastníkovi stačí obecnější moduly absolvovat jednou a v dalších kurzech může absolvovat jen profesní část.

V případě Finska, Velké Británie a Irska se ukázalo, že naše vzdálenost od tamějšího dění je větší a že distanc od tamějších problémů je větší než u německy mluvící Evropy. Nicméně i v této situaci lze uvažovat nad jistými konkrétními náměty:

1. Vedle financování ze státních a veřejných zdrojů existují v těchto zemích i další formy neprímé podpory na úhradu doprovodných nákladů výuky a různé způsoby financování dalšího vzdělávání (vzdělávací poukázky, dotace zaměstnavatelům apod.).

2. Jeden konkrétní námět pro Českou republiku přináší Irsko. Tamější sít' technologických institutů, které se zaměřují na další vzdělávání pracovníků v technických profesích. Trh práce by potřeboval nejen větší ,prrísun“ odborníků z těchto profesí, ale také jejich vysoce specializované další vzdělávání.

3. Další konkrétní námět je $\mathrm{z}$ Velké Británie. Země v nedávné sobě zahájila další vzdělávání a rekvalifikace cílené na „těžkou“ profesní skupinu a tou jsou tzv. chudí pracující. Jde o nízko kvalifikovanou pracovní sílu, částečně i ze zahraničí, která má př́ijmy nad hranicí „chudoby“ (u nás je to 15-17 tis. Kč měsíčně). Cílem těchto aktivit je zlepšení odborných kompetencí těchto lidí vedoucí i k lepšímu zaměstnání. 


\section{Poděkování}

Tento článek je výstupem projektu specifického vysokoškolského výzkum Univerzity Jana Amose Komenského Praha s názvem „Komparace rekvalifikačního vzdělávání a Národní soustavy kvalifikací v ČR $\mathrm{s}$ jinými nástroji stimulace a regulace trhu práce v zahraničí“ realizovaného v letech 2020 a 2021.

\section{Použitá literatura}

1. KOUBEK, J. Řizení lidských zdrojů Základy moderní personalistiky. Praha: Management Press, 2003. ISBN 80-7261-033-3

2. PALÁN, Z. Výkladový slovník Lidské zdroje. Praha: Academia, 2002. ISBN 80-2000950-7

3. Vyhláška č. 176/2009 Sb. ze dne 22. června 2009, kterou se stanoví náležitosti žádosti o akreditaci vzdělávacího programu, organizace vzdělávání v rekvalifikačním zařízení a způsob jeho ukončení, ve znění pozdějších předpisů

4. Zákon č. 179/2006 Sb. ze dne 5. května 2006, o ověřování a uznávání výsledků dalšího vzdělávání a o změně některých zákonů, ve znění pozdějších předpisů

5. Zákon č. 435/2004 Sb. ze dne 23. července 2004, o zaměstnanosti, ve znění pozdějších předpisů

\section{Kontaktní údaje}

PhDr. Lenka Mužíková

Univerzita Jana Amose Komenského Praha s.r.o.

Roháčova 1148/63, 13000 Praha 3, Česká republika

Tel: 777613731

email: 1302190008@student.ujak.cz 


\title{
KVANTITATIVNÍ VÝZKUMNÁ SONDA DO OBLASTI ÚPRAVY PROSTŘEDÍ POHLEDEM OSOB SE ZDRAVOTNÍM POSTIŽENÍM V ČESKÉ REPUBLICE
}

\author{
QUANTITATIVE RESEARCH PROBE INTO THE FIELD OF \\ ENVIRONMENTAL MODIFICATIONS FROM THE PERSPECTIVE OF \\ PEOPLE WITH DISABILITIES IN THE CZECH REPUBLIC
}

\author{
Adéla Hanáková, Miloň Potměšil, Eva Urbanovská, Bianka Hudcová, \\ Gabriela Špinarová, Jana Zvěděliková
}

\begin{abstract}
Abstrakt
Cílem primární kvantitativní výzkumné sondy bylo identifikovat klíčové faktory v prostředí ovlivňující kvalitu života osob se zdravotním postižením. Oslovili jsme rodiče dětí se zdravotním postižením ve věku 0-14 let a osoby se zdravotním postižením ve věku $15+$. V intencích fyzických parametrů prostředí se $\mathrm{z}$ dat vynořily konkrétní aspekty ideálního prostředí, a to jak $\mathrm{z}$ pohledu pečujících osob $\mathrm{v}$ rámci proxy ratingu, tak na základě subjektivního posouzení samotnými osobami se zdravotním postižením. Jako dominantní se zde manifestovaly nejen klasické materiálně-technické podmínky ve smyslu bezbariérovosti, ale do popředí se dostaly i psychosociální determinanty. Psychosociální rozměr se stal jakousi všepronikající ideou. Myšlenka „společnosti bez předsudkư“ a sociální opora v rodině i širším sociálním prostředí se manifestovala v obou výzkumných souborech.
\end{abstract}

Klíčová slova: úprava prostředí pro osoby se zdravotním postižením, kvantitativní výzkumná sonda, člověk se zdravotním postižením

\begin{abstract}
The primary quantitative research probe aimed to identify key factors in the environment affecting the quality of life of people with disabilities. We addressed parents of children with disabilities aged $0-14$ years and people with disabilities aged 15+. In terms of the physical parameters of the environment, specific aspects of the ideal environment emerged from the data, both from the point of view of caregivers within the proxy rating and based on a subjective assessment by the disabled people themselves. Not only did the classical material and technical conditions in the sense of barrier-free manifest themselves as dominant here, but psychosocial determinants also came to the fore. The psychosocial dimension has become a kind of pervasive idea. The idea of a "society without prejudices" and social support in the family and the broader social environment manifested itself in both research sets.
\end{abstract}

Key words: adaptation of the environment for people with disabilities, quantitative research probe, people with disabilities

\section{1 ÚVOD}

Vlastnosti prostředí, v kterém žijeme, mají zásadní vliv na složky kvality života, jako je mobilita, nezávislost a sama schopnost „stárnutí v místě“. Podle autorů Čevely a kol. (2014) místo prátelské ke stárnutí je takové, které poskytuje dostatečné podmínky pro zdraví, participaci a bezpečnost při zohlednění sociálních, osobních i ekonomických charakteristik jedince a jejich interakce s prostředím fyzickým. Prostředí lze totiž vnímat jako významný mediátor, který může usnadnit ,život se zdravotním postižením v přirozeném prostředí“ 
(Kalvach a kol., 2011, s. 150). Autor (tamtéž) zahrnuje do přirozeného prostředí: bezbariérové prostředí veřejných prostor a dopravy, univerzální design, chráněné bydlení, ambient assisted living (AAL, prostředí podporující život) - informační a komunikační technologie (ICT), tísňovou péči, telemonitoring $\mathrm{v}$ rámci home care, centra zaměřená na podporu lidí $\mathrm{s}$ určitým zdravotním postižením.

Holistické pojetí člověka ve smyslu bio-psycho-socio-spirituálního komplexu předurčuje, jak široký záběr má téma úprav a modifikace prostředí pro potřeby osob se zdravotním postižením a dalšími specifickými potřebami (Kroupová, Hanáková, 2020).

\section{KLÍČOVÉ OTÁZKY}

Článek shrnuje výsledky výzkumného projektu pro rok 2020 („Úprava prostředí pohledem osob se zdravotním postižením“), který byl primární sondou popisující veškeré faktory prostředí, které determinují kvalitu života člověka se zdravotním postižením a kvalitu života pečujících osob. Cílem iniciální analýzy bylo charakterizovat faktory prostředí, které vnímá cílová skupina osob se zdravotním postižením a pečujících osob jako problematické, popsat postoje, obavy, které se v souvislosti s nevyhovujícími podmínkami v prostředí vynořují. Při tvorbě výzkumného nástroje jsme si kladli následující otázky:

- Jaké jsou fyzické parametry prostředi osob s postižením či specifickými potřebami?

- Jaké psychosociální determinanty vykazuje prostředí osob s postižením či specifickými potrebami?

- Jaké charakteristiky má vyžadovaná materiálně-technická podpora?

- Jaké charakteristiky mají bariéry v komunikaci a dalši socializační faktory?

\section{VÝSLEDKY INICIÁLNÍ KVANTITATIVNÍ SONDY}

Výzkumného šetření se zúčastnilo 237 rodičů dětí se specifickými potřebami ve věku 0-14 let a 233 osob se zdravotním postižením ve věku 15+. V intencích fyzických parametrů prostředí se $\mathrm{z}$ dat vynořily konkrétní aspekty ideálního prostředí, a to jak z pohledu pečujících osob $\mathrm{v}$ rámci proxy ratingu, tak na základě subjektivního posouzení samotnými osobami se zdravotním postižením či dalšími specifickými potřebami. Jako dominantní se zde manifestovaly nejen klasické materiálně-technické podmínky ve smyslu bezbariérovosti naprríč celým spektrem typů specifických potřeb, ale do popředí se dostaly i psychosociální determinanty. Psychosociální rozměr se stal jakousi všepronikající ideou. Myšlenka „společnosti bez předsudkư“ a sociální opora v rodině i širším sociálním prostředí se manifestovala $\mathrm{v}$ obou výzkumných souborech. Výpovědi zaznamenané $\mathrm{v}$ souboru respondentů 15+ velmi explicitně dokazují eminentní význam psychosociálního rozměru zdravotního postižení, resp. jinakosti jako takové. Potřebu materiálně-technických úprav prostředí deklaruje více než polovina dotázaných $\mathrm{v}$ široce pojaté oblasti dotazníku orientované na technické aspekty.

Psychosociální oblast je $\mathrm{v}$ nejširším slova smyslu determinována úrovní akceptace zdravotního postižení. Ve skupině pečujících lze úroveň postižení/znevýhodnění dítěte do jisté míry interpretovat na základě emoční složky $\mathrm{v}$ postoji $\mathrm{k}$ této skutečnosti ambivalentnost pocitů pečujících osob prožívaných při výpovědi „Mám dítě s postižením“ je do jisté míry předobrazem úrovně akceptace či nonakceptace postižení dítěte (přibližně polovina respondentů při tomto sdělení prožívá pozitivní emoce, stejné množství respondentů negativní emoce naznačující potenciální nonakceptaci postižení dítěte). Současně lze usuzovat, že pozitivní emoce provázející tuto výpověd' mohou být určitým důkazem měnícího se postoje společnosti ve smyslu větší tolerance k jinakosti a odlišnosti. 
K samotnému jádru výzkumu se dostáváme v intencích položky orientované na potenciální prínos a efektivitu úprav prostředí - „Vhodným uspořádáním prostředí lze eliminovat některé př́znaky nemoci či zdravotního postižení“. S tímto výrokem souhlasilo $74 \%$ respondentů ze skupiny 15+. Tato tendence je patrná i $\mathrm{v}$ souboru pečujících osob napříč položkami orientovanými na konkrétní materiálně-technická a režimová opatření. Právě tento aspekt považujeme za jeden z klíčových výstupů výzkumu se značným potenciálem v aplikovaném výzkumu $\mathrm{v}$ dalších plánovaných etapách. Úprava životního prostoru se tak může zcela signifikantně stát prostředkem nejen ke snížení dopadů postižení či limitů z něj vyplývajících, ale i prostředkem ke zvýšení subjektivně pocit’ované kvality života naprríč fyzickým, materiálně-technickým, psychosociálním i komunikačním rozměrem navržených premis koncepce výzkumu.

Identifikované aspekty modifikace a úprav prostředí vyžadují další zkoumání a zejména pak kvalitativní analýzu v intencích kvalitativního výzkumného designu. Nicméně na základě hloubkové analýzy můžeme konstatovat, že dílčí úpravy prostředí v ryze individuální, ale i veřejné rovině mohou významnou měrou přispět ke zkvalitnění života osob se zdravotním postižením a dalšími specifickými potřebami, prričemž prostředí je zde pojímáno v nejširším, holistickém, slova smyslu na bio-psycho-socio-spirituální úrovni.

\section{ZÁVĚR}

Zaměřili jsme se na oblast úprav prostředí ve vztahu k lidem se zdravotním postižením. Jedná se o oblast nesmírně širokou svým zaměřením a důležitou svým dopadem na kvalitu života těchto lidí.

V duchu aplikovatelnosti do praxe, považujeme za klíčové realizovat úpravu v prostředí $\mathrm{v}$ konceptu univerzálního designu, který je směřován na všechny lidi bez ohledu na jejich věk, zdravotní stav, fyzické možnosti, národnost, kulturní, náboženské či sociální zázemí. Zdá se totiž, že v návaznosti na výše uvedené charakteristiky je důležité vytvářet prostředí a výrobky, které vyhovují všem lidem. Vzrůstá totiž zájem o design, který neplní pouze stránky časopisů, ale dokáže efektivně řešit problémy společnosti, zejména pak globální trend stárnutí populace. $\mathrm{Na}$ základě výše uvedeného, vnímáme velký potenciál $\mathrm{v}$ př́pravě budoucích speciálních pedagogů. Na základě získaných poznatků je nezbytné učit studenty nad úpravou prostředí přemýšlet $\mathrm{v}$ souvislostech, aby dokázali navrhnout řešení pro potřeby konkrétních uživatelů se specifickými potřebami.

V neposlední řadě je to multidisciplinární spolupráce studentů, firem, orgánů státní správy, obyvatel města, odborníků z řad speciálních pedagogů a architektů, která pomáhá plány, spojené s úpravou prostředí pro osoby se specifickými potřebami, naplňovat.

\section{Použitá literatura}

1. ČEVELA, R. et al. Sociální gerontologie: východiska ke zdravotni politice a podpoře zdravi ve stárí. 1. vyd. Praha: Grada, 2014. 238 s. ISBN 978-80-247-4544-2.

2. KALVACH, Z. et al. Křehký pacient a primární péče. 1. vyd. Praha: Grada, 2011. 399 s. ISBN 978-80-247-4026-3

3. KROUPOVÁ, K., HANÁKOVÁ, A., a kol. Úprava prostředí pohledem osob se zdravotním postižením. Olomouc: Univerzita Palackého v Olomouci, 2020. ISBN 978-80-244-5897-7. 


\section{Kontaktní údaje}

Mgr. Adéla Hanáková, Ph.D.

Univerzita Palackého v Olomouci, Pedagogická fakulta

Žižkovo nám. 5, Olomouc 77140

Tel: 608961401

email: adela.hanakova@upol.cz

prof. PhDr. PaedDr. Miloň Potměšil, Ph.D., Ph.D.

Univerzita Palackého v Olomouci, Pedagogická fakulta

Žižkovo nám. 5, Olomouc 77140

Tel: 585635334

email: milon.potmesil@upol.cz

Mgr. Eva Urbanovská, Ph.D.

Univerzita Palackého v Olomouci, Pedagogická fakulta

Žižkovo nám. 5, Olomouc 77140

Tel: 585635343

email: e.urbanovska@upol.cz

Mgr. et Mgr. Bianka Hudcová

Univerzita Palackého v Olomouci, Pedagogická fakulta

Žižkovo nám. 5, Olomouc 77140

email: bianka.hudcova01@upol.cz

Mgr. Gabriela Špinarová

Univerzita Palackého v Olomouci, Pedagogická fakulta

Žižkovo nám. 5, Olomouc 77140

email: gabriela.spinarova01@upol.cz

Mgr. Jana Zvědělíková

Univerzita Palackého v Olomouci, Pedagogická fakulta

Žižkovo nám. 5, Olomouc 77140

email: jana.zvedelikova01@upol.cz 


\title{
GUIDE TO TELEPRACTICE IN SPEECH THERAPY
}

\author{
Tereza Hrudová, Adéla Hanáková, Milon̆ Potměšil, Kristina Novotná
}

\begin{abstract}
The paper presents the material "Guide to Telepractice in Speech Therapy", which aims to provide sufficiently clear and comprehensive information about telepractice in speech therapy to professionals, students, and those interested in this issue. The impetus for creating this material was that there is not enough literature to address remote speech therapy intervention and the ever-increasing demand for such material, which would provide basic information about the possibilities of video conferencing platforms or the concept of remote services.
\end{abstract}

Keywords: Guide, Telepractice, Speech Therapy

\section{INTRODUCTION}

Various modern technologies have become an integral part of life. Their often breathtaking functions were subjected to the most significant test during a pandemic situation (COVID-19), which significantly affected and suspended the stereotype of human existence across continents. These technologies have played the role of many irreplaceable institutions, and their use has appeared in other areas, including the field of speech therapy intervention. Towey (2012) was one of the first to describe the emerging trend in providing speech therapy services, which began to emerge as a standard of care and began to consider telepractice as a relevant way of intervention. Towey (2012) also denied that this would be the last resort if nothing else were available, arguing that web technology delivers highly personalized and engaging activities so that clients' interactions with these high-interest tasks often continue beyond the framework of therapeutic sessions. Durdilova (2014) drew attention to the potential of this modern phenomenon in the Czech conditions, which needs to be constantly fine-tuned and adapted for its higher efficiency and to maintain ethical and moral responsibility on the part of the provider.

The reason for the considerable interest, both from experts and patients or clients themselves, was the crisis caused by the COVID-19 pandemic. The rules were set so that there was as little personal contact as possible and people switched to the use of information and communication technologies on their initiative. "The dormitories to which health care will return after the COVID-19 epidemic will not be the same as those from which it was derailed." (Medical Tribune, 2020)

Even before the pandemic itself, this trend slowly began to appear in connection with application possibilities in the intervention of patients with aphasia. Weidner and Lowman (2020) conducted a literature search from 2014 to 2019 to find evidence on the feasibility and effectiveness of providing distance services to patients in individuals with aphasia. Zatloukalova (2019) described an overview of current alternative options for speech therapy intervention for teleworking when she also identified individuals with diffuse brain damage and communication pathology related to it as the target group.

Hall, Boisvert, and Steele (2014) assessed, based on the available results of the studies, that the effectiveness and feasibility compared to interventions carried out in person is not significantly higher than services provided through information and communication technologies. According to Hall, Boisvert, and Steele (2014), these were most often satisfaction surveys and case studies. 
Veverkova (2020) focused her interest in a slightly different direction, on bilingual clients who could not participate in the intervention of a Czech-speaking speech therapist due to living abroad and thus compared the effectiveness and possibilities of the mentioned method even after the return of these students to the Czech environment. In this case, it was the use of distance services based on distance from the expert, which is a frequent reason for choosing an intervention in telepractice.

The area of videoconferencing and its specifics from the point of view of education also brought new knowledge about pupils with learning disabilities when Kkese (2020) pointed out the benefits of using headphones to improve information reception and hearing perception. In connection with the knowledge about audio-verbal perception and the use of distance speech therapy services, Vitaskova (2020) draws attention to the limitations of nonverbal communication and the associated difficulty in speech perception in a specific population such as individuals with autism spectrum disorders, ADHD, CAPD or APD.

\section{MATERIAL "GUIDE TO TELEPRACTICE IN SPEECH THERAPY"}

The starting point for the creation of educational material was the realization of the lack of Czech literature dealing with distance-directed speech therapy. Many respondents indicated that no document in the Czech environment would provide basic information about the possibilities of video conferencing platforms or the very concept of distance services (Hrudova, 2020). Foreign websites and portals provide more links to telepractice, but cultural, linguistic, and legislative differences, information from abroad is not enough for us.

The document aims to provide clear and comprehensive information to the speech therapists, students, and those interested in telepractice from the general public. Furthermore, to show how the technique can be used in favor of speech therapy and find a solution for the provision of speech therapy services even in difficult distance conditions.

In creating the material, we relied on a document presenting telepractice as an option in providing speech therapy services in schools, created by Cristina Garcia (2013) ("Online Manual for the Telepractice Paraprofessional").

This American version already describes completely outdated technical equipment and focuses mainly on speech therapy in the pedagogical sector. However, the concept is invaluable. It introduces telepractice in detail, performs the necessary equipment, and refers to auxiliary materials.

The impetus for creating such a guide was collecting quantitative data in our research (Hrudova, 2020), in which the interviewed speech therapists lacked basic information about the technical equipment, platforms, and the concept of data transmission.

The proposed material is not suitable for diagnostic or therapeutic purposes. It is primarily a source of valuable information and a simple summary on the topic of telepractice. Its content can use students looking for a comprehensive overview and speech therapists who have no experience with distance therapy and are reluctant to provide it. However, it can also help patients gain insight into distance therapy and determine whether telepractice would allow them to find a solution to their situation (impossibility of transport to the ambulance).

The material is usually educational. It helps explain the term telepractice, provides tips for practice, and tries to update outdated information, and accompanies the issue itself with an active topic.

The material contains 15 chapters, which are called in the form of a question that a speech therapist or client can ask. Each chapter has its specific design, which should captivate the reader with its clarity, simplicity, imaginativeness, and format.

Below are the sheets from this material, which we leave purposefully in the original (Czech) version, as we distributed among Czech speech therapists. The introductory topic introduces the concept of "telepractice" very briefly and provides the reader with an initial idea of the 
topic covered by the entire brochure. In the section "How can telepractice take place?", The reader learns in detail what ways of transmitting information we can choose. We mention here which transmission models we can use, what exactly these models look like and how they can be combined. The next part deals with a brief description of the arguments for and against the provision of telepractice. Therefore, it is an overview of the advantages and disadvantages that this method brings and can complicate the distance intervention itself. In the form of a picture, the next chapter presents equipment that we should not miss during telepractice. It gives an idea of the financial costs and briefly describes each hardware device. Additional sheets of material guide speech therapists to make the right choice of video conferencing software and are closely related to the content of the following pages. Every job requires principles to achieve the expected results. Here, too, some principles increase the likelihood of successful video conferencing. The principles are listed in words so that their meaning is unambiguous and does not need further explanation.

We have included a section, "How does such therapy work ideally?". Seven steps need to be taken before, during, and after the transmission. The chapter "How to ensure a suitable environment?" describes the factors that we should avoid so that the transmission is not subject to adverse effects. The following figure shows the material described above. 


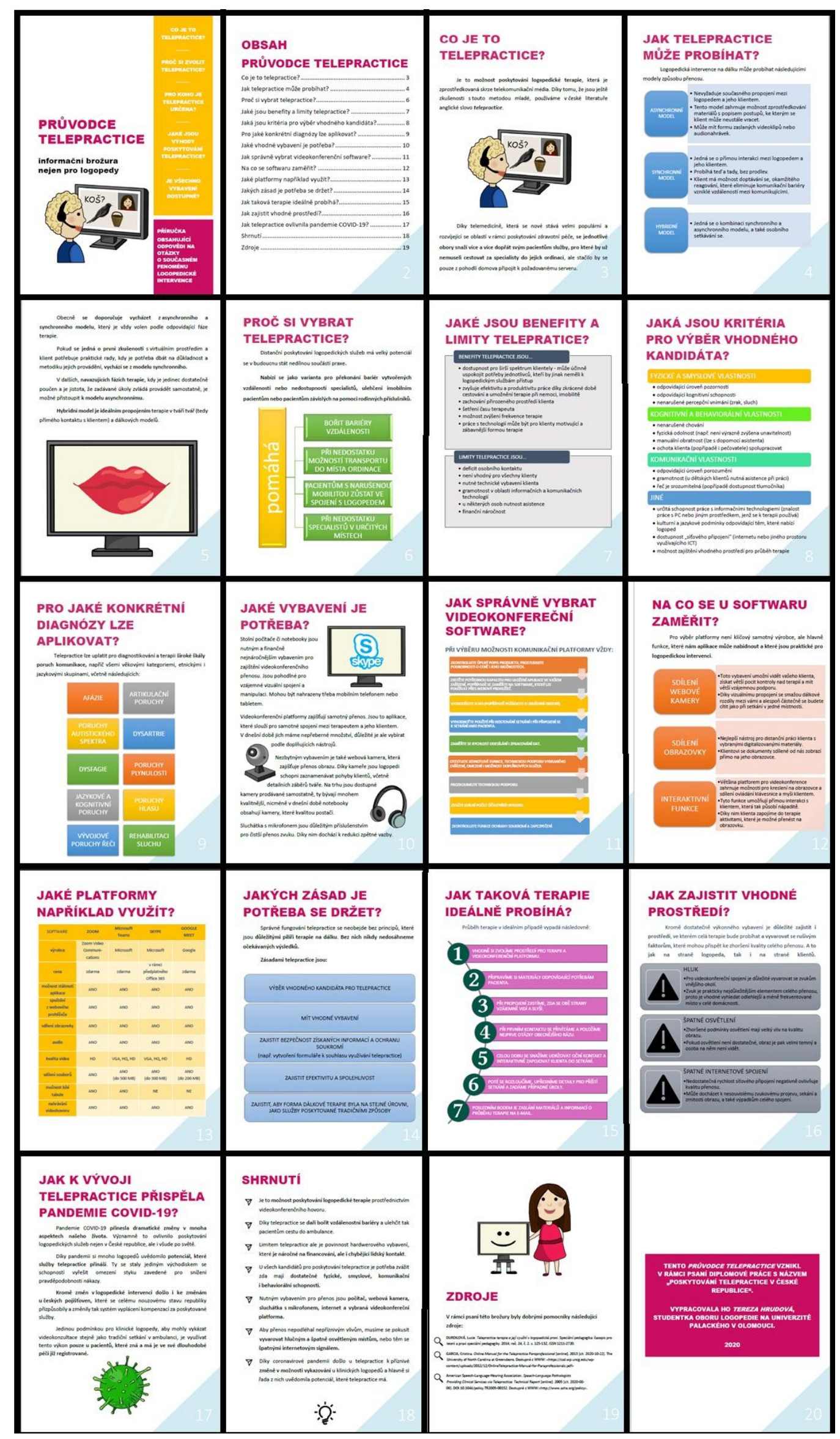

Figure 1 - Guide to telepractice in speech therapy. 


\section{CONCLUSION}

Providing distance speech therapy care in the field of Czech speech therapy is practically a young and untouched trend, which was widespread due to anti-epidemic measures related to the COVID-19 pandemic. Thanks to this, many experts tried to work with modern technologies, which were always backward and perceived as the last starting point for the intervention of individuals with impaired communication skills.

Based on foreign research, where the choice of telepractice is available to clients for a more extended period, regardless of the pandemic situation that makes personal encounters difficult, the effectiveness of distance care is based on continuous research. We believe that the created material will support the functional concept of distance speech therapy intervention for individuals with impaired communication skills, which therapists would fully and effectively use in speech therapy practice in the Czech Republic.

\section{Sources}

1. DURDILOVÁ, L. Telepractice terapie a její využití v logopedické praxi. Speciální pedagogika: časopis pro teorii a praxi speciální pedagogiky [online]. 2014 Praha: Univerzita Karlova, 24(2), 125-133 [cit. 2021-05-23]. ISSN 1211-2720. Dostupné z: http://dspace.specpeda.cz/bitstream/handle/0/1573/2014_2_04.pdf?sequence=1

2. GARCIA, C. Online Manual for the Telepractice Paraprofessional [online]. 2013 [cit. 2020-10-22]. The University of North Carolina at Greensboro. Dostupné z WWW: https:// csd.wp.uncg.edu/wp-content/uploads/2012/12/OnlineTelepractice-ManualforParaprofessionals.pdf

3. HALL, N., BOISVERT, M., STEELE, R. Telepractice in the Assessment and Treatment of Individuals with Aphasia: A Systematic Review. International Journal of Telerehabilitation [online]. 2013 [cit. 2021-05-23]. DOI: 10.5195/ijt.2013.6119. ISSN 19452020. Dostupné na WWW: http://telerehab.pitt.edu/ojs/index.php/Telerehab/ article/view/6119/6435

4. HRUDOVÁ, T. Poskytování telepractice v České republice. 2020, 141 s. +41 s. př́loh. Diplomové práce. Univerzita Palackého, Ústav speciálněpedagogických studií. Vedoucí práce Adéla Hanáková. https://library.upol.cz/arl-upol/cs/detail-upol_us_cat0327486-Poskytovani-telepractice-v-ceske-republice/

5. KKESE,E. McGurk effect and audiovisual speech perception in students with learning disabilities exposed to online teaching during the COVID-19 pandemic [online]. 2020 [cit. 2021-05-23] Medical Hypotheses,144,110233. https://doi.org/10.1 016/j.mehy.2020.110233

6. Pandemie COVID-19 může být průlomem v online konzultacích, 2020. Medical tribune [online]. 16(5), A8 [cit. 2021-05-23]. ISSN 1214-8911. Dostupné z: https://www.tribune.cz/clanek/45468-pandemie-covid-muze-byt-prulomem-v-onlinekonzultacich

7. TOWEY, M. Speech telepractice: Installing a speech therapy upgrade for the 21ST century. International journal of telerehabilitation [online]. 2012 [cit. 2021-05-23], Vol. 4, n. 2. Dostupné z WWW: http://telerehab.pitt.edu/ojs/index.php/Telerehab/ article/view/6112/6414

8. VEVERKOVÁ, E. Logopedické terapie online. Hradec Králové: Pedagogická fakulta Univerzity Hradec Králové, 2020. 88 s. Bakalářská práce.

9. VITÁSKOVÁ, K. Potencionální vlivy na percepci a produkci řeči v důsledku opatření souvisejícími s prevencí SARS CoV-2 (COVID-19) [online]. Pohled logopeda. 2020 [cit. 2021-05-23] Logopedia Silesiana,(9),1-18. https://journals.us.edu.pl/index .php/LOGOPEDIASILESIANA/article/view/11620/9110 
10. WEIDNER, K., LOWMAN, J. Telepractice for Adult Speech-Language Pathology Services: A Systematic Review. Perspectives of the ASHA Special Interest Groups [online]. 2020 [cit. 2021-05-23], 5(1), 326-338. DOI: 10.1044/2019_PERSP-1900146. ISSN 2381473X. Dostupné z WWW: https://pubs.asha.org/doi/pdf/10.1044/ 2019_PERSP-19-00146

11. ZATLOUKALOVÁ, M. Current telerehabilitation options in aphasia. Listy klinické logopedie. 2019 (3), 8-12. DOI: 10.36833/lk1.2019.024. ISSN 2570-6179. Dostupné z: https://casopis.aklcr.cz/pdfs/lk1/2019/02/02.pdf

\section{Contact}

Mgr. Tereza Hrudová

Univerzita Palackého v Olomouci, Pedagogická fakulta

Žižkovo nám. 5, Olomouc 77140

Tel: 730145666

email: hrudova.tereza@gmail.com

Mgr. Adéla Hanáková, Ph.D.

Univerzita Palackého v Olomouci, Pedagogická fakulta Žižkovo nám. 5, Olomouc 77140

Tel: 608961401

email: adela.hanakova@upol.cz

prof. PhDr. PaedDr. Miloň Potměšil, Ph.D., Ph.D.

Univerzita Palackého v Olomouci, Pedagogická fakulta

Žižkovo nám. 5, Olomouc 77140

Tel: 585635334

email: milon.potmesil@upol.cz

Mgr. Kristina Novotná

Univerzita Palackého v Olomouci, Pedagogická fakulta

Žižkovo nám. 5, Olomouc 77140

Tel: 731039692

email: kristina.novotna01@upol.cz 


\title{
DIAGNOSTIKA KOMUNIKACE DĚTÍ PŘEDŠKOLNÍHO VĚKU S PORUHOU AUTISTICKÉHO SPEKTRA
}

\section{DIAGNOSTIC OF COMMUNICATION OF PRE-SCHOOL CHILDREN WITH AUTISM SPECTRUM DISORDERS}

\author{
Kristina Novotná, Adéla Hanáková, Milon̆ Potměšil, \\ Eva Urbanovská, Tereza Hrudová
}

\begin{abstract}
Abstrakt
Poruchy autistického spektra jsou v současné době často skloňovaným výrazem, je jim věnována významná část výzkumné práce v oblasti medicíny i pedagogiky. Článek nabízí pohled logopeda zaměřený na diagnostickou část intervenčního procesu. Diagnostika komunikace $\mathrm{u}$ jedinců s poruchou autistického spektra zůstává náročnou aktivitou. Snaha odborníků je diagnostickou část logopedické intervence zefektivnit, zjednodušit a nalézt adekvátní diagnostické nástroje a metody. Zaměřili jsme se na jeden ze základních symptomů poruch autistického spektra, komunikaci, a snažili se rozpracovat její diagnostiku. Základním stavebním kamenem shledáváme navázání pozitivního vztahu s klientem a pozorování jeho chování, to předchází samotné diagnostice. Byl sestrojen dotazník a schéma k pozorování, podle kterých můžeme v praxi postupovat.
\end{abstract}

Klíčová slova: diagnostika komunikace, poruchy autistického spektra, autismus, logopedie, narušená komunikační schopnost

\begin{abstract}
Autism spectrum disorders are currently an inflected term, a significant part of research work in the field of medicine and pedagogy is devoted to them. The article offers a speech therapist's view focused on the diagnostic part of the intervention process. Diagnostics of communication in clients with Autism Spectrum Disorders remains a challenging activity. The professionals try to streamline, simplify, and find adequate diagnostic tools and methods for the diagnostic part speech therapy intervention. We focused on communication and try to develop its diagnostic process. We find the basic building block - positive relationship with the client and observe his behavior. We proposed a questionnaire and a scheme for observation with which we can work in speech therapy practice.
\end{abstract}

Key words: diagnostics of communication, Autism Spectrum Disorders, autism, speech therapy, communication disorders

\section{1 ÚVOD DO PROBLEMATIKY}

\subsection{Poruchy autistického spektra}

Poruchy autistického spektra (PAS), tedy skupina vývojových poruch, které se projevují od raného věku odlišným vývojem a vnímáním okolního světa. U jedinců s autismem se setkáváme s narušenou komunikací, sociálním myšlením a dovednostmi, vnímáním a exekutivními funkcemi. (Adamus, Vančová, Löfflerová, 2017). V České republice se diagnostice PAS věnují kliničtí psychologové, kteři diagnostikují poruchu jako soubor symptomů, které je nutné odhalit. V logopedické praxi se s dětmi s PAS setkáváme taktéž, pracujeme s narušenou komunikační schopností jako jedním ze symptomů PAS. Avšak 
neexistuje ucelený diagnostický nástroj, který by mohli odborníci na poli komunikace využívat.

PAS se po dobu své existence vyvíjely velmi různorodě. Do současné doby neexistuje ucelený náhled na tuto skupinu poruch. Jak tvrdí Thorová (2016, s. 31), česká klinická psycholožka: ,za padesát let své oficiální existence názory na poruchy autistického spektra prošly bouřlivým vývojem. Ačkoli přičiny autismu doposud nebyly odhaleny a základní jádrové potiže pretrvávají po celý život, byl zaznamenán pozitivní vývoj v porozumění príčinám problémů, terapii i vzdělávacích strategiích“.

Autismus je velmi nejednoznačně vymezen, i z toho důvodu se snažíme o vlastní pojetí. Mohli bychom PAS shrnout jako spektrum neurovývojových poruch, které jsou velmi různorodé a variabilní, promítají se do sociální interakce, komunikace a chování jedince. Nápadnosti v chování se projevují stereotypními zájmy a aktivitami, odlišným vnímáním okolí. První př́znaky a nápadnosti se projeví již v raném dětství a prostupují celou osobností jedince, což se promítne ve zvládání každodenních situací běžného života. Symptomy tohoto spektra variují do mnoha kombinací, a proto je velmi obtížná diagnostika a následné uživání jednoho uceleného př́stupu $v$ terapii. Každý jedinec $\mathrm{s} P A S$ je jedinečný stejně tak jako navazující intervence. (Novotná, 2020).

Mezinárodní klasifikace nemocí $(\mathrm{MKN})$ ve své 10. revizi uvádí termín pervazivní vývojové poruchy (PVP), který je řazen do páté kapitoly: Poruchy duševní a poruchy chování. PVP slučuje kategorie F84, kde nacházíme jednotlivé typy PVP. (Světová zdravotnická organizace, 2018). Současnou MKN-10 bude v blízké době nahrazovat MKN-11, kde pojem pervazivní vývojové poruchy bude nahrazen velkou kategorií poruch autistického spektra, která by se již neměla dále členit, ale pouze specifikovat za pomoci tzv. specifikátorů. (ICD-11, 2018). Diagnostický a statistický manuál (DSM) ve své aktuální revizi nabízí termín poruchy autistického spektra (Autism Spectrum Disorders, ASD), který spadá pod nadřazenou skupinu neurovývojových poruch. (American Psychiatric Association, 2015).

\subsection{Diagnostika poruch autistického spektra}

Diagnostika PAS je složitým procesem, který je v kompetenci klinického psychologa nebo pedopsychiatra. Je nutné vytvořit si ucelený obraz posuzované osobnosti za pomoci multidisciplinarity, která by mělo být součástí diagnostického procesu osob s PAS. Součástí týmu odborníků by měl být vedle psychologa či psychiatra i pediatr, neurolog, audiolog, logoped, pedagog a speciální pedagog. (Říhová, Vitásková, 2012). Psychologický diagnostický proces vyžaduje řadu systematických vyšetření všech oblastí vývoje jedince. PAS mohou být diagnostikovány pouze na základě celkového chování v určitých oblastech. (Thorová, 2008). Doposud neexistuje žádný biologický test, který by PAS mohl s jistotou potvrdit. Diagnostický proces je tedy velmi náročný a zasluhuje vysokou pozornost, trpělivost a erudovanost specialistů, kteří pracují na specializovaných pracovištích. (Beranová, Thorová, Hrdlička, Propper, 2014).

Evropská MKN posuzuje PAS dle tří hlavních kritérií, tzv. diagnostické triády: reciprocita sociální interakce, komunikace, opakující se a omezené stereotypní chování. (Světová zdravotnická organizace, 2018). Americká DSM pojednává s termínem dyáda, dvě hlavní diagnostická kritéria: „přetrvávající narušení reciproční sociální komunikace a interakce (kritérium A), omezené repetitivní vzorce chování, zájmů a aktivit (kritérium B) “. (American Psychiatric Association, 2015, s. 51-56). 
Klasické hodnocení není přesné a neposkytne nám informace, které potřebujeme. Opíráme se o pozorování, které by mělo být opakované, vodítkem jsou diagnostické manuály, anamnestické údaje rodiny o podrobném vývoji jedince. Pro zpřesnění autistických projevů byly vytvořeny standardizované diagnostické nástroje, které se stávají součástí diagnostického procesu. (Beranová, Thorová, Hrdlička, Propper, 2014). Zastáváme názor, že by mělo být použito více rozličných diagnostických materiálů, které poté v rámci procesu diagnostiky mezi sebou porovnáváme a získáváme tak vyšší validitu proběhlé diagnostiky.

K psychologické diagnostice PAS je v České republice nejčastěji využíváno materiálů, které jsou standardizované. Jedná se např. o CARS (Childhood Autism Rating Scale), ADI-R (Autism Diagnostic Interview - Revised), ADOS (Autism Diagnostic Observation Schedule). (Hrdlička, Komárek, 2014). Mezi screeningová vyšetření spadají nástroje M-CHAT (Modified Checklist for Autism in Toddlers) a DACH (Dětské autistické chování). (Beranová, Thorová, Hrdlička, Propper, 2014). V zahraničí poté nalezneme mnohem více materiálů, které lze $\mathrm{k}$ diagnostice pervazivních poruch (především oblasti symptomů komunikace) využít. Jedná se např. o TPBA (Transdisciplinary Play-Based Assessment), ABC (Autism Behavior Checklist), A. S. A. S. (The Australian Scale for Asperger's syndrome), ASSQ (Asperger Syndrome Screening Questionnaire), CAST (Childhood Asperger Syndrome Test), DISCO (Diagnostic Interview for Social and Communication Disorders), PDDST (Pervasive Developmental Disorders Screening Test), E-2 Form (Diagnostic Checklist), GARS (Gilliam Autism Rating Scale), HBS (Schedule of Handicaps and Behavior and Skills), SLDTElementary (Social Language Development Test-Elementary), SLDT-Adolescent (Social Language Development Test-Adolescent), ASDS (Asperger Syndrom Diagnostic Scale), SEE (Social Emotional Evaluation), TECEL (Test of Early Communication and Emerging Language). (Beranová, Thorová, Hrdlička, Propper, 2014).

\subsection{Komunikace a její diagnostika}

Komunikace je přirozenou součástí života každého jedince, zároveň se jedná o nejvyšší formu interakce. Slouží k dosažení základních potřeb jedince, ale i k předávání zvyklostí, tradic a zkušeností. (Dlouhá, 2017). Komunikační schopnost řadíme k nejdůležitějším lidských schopnostem. Díky ní vědomě používáme jazyk jako složitý komunikační systém. (Lechta, 1990 in Klenková, 2006). Komunikační kompetence zahrnuje dovednosti a znalosti kulturní, interpersonální a lingvistické, které uplatňujeme v určitých situacích a sociálních kontextech. (Rice in Cole, 1992 in Vitásková, 2005). Mluvíme o konverzační a interakční dovednosti jedince - řadíme ji tedy do pragmatické jazykové roviny. (Cole, 1992 in Vitásková, 2005).

Vývoj dětské komunikace se může uskutečnit jen a pouze v sociálním prostředí, v sociální interakci - dospělí působí podněty verbální i neverbální povahy na děti, děti reagují a podávají zpětnou vazbu chováním (to nazýváme preverbálním chováním). Zpětná vazba od dětí ovlivňuje další podněty, které dospělí směrem $\mathrm{k}$ dětem vysílají. (Průcha, 2011). Jedinci s PAS si komunikaci v rámci sociální interakce osvojují problematicky z důvodu celkového narušení sociálního chování. Komunikace a sociální interakce u dětí s jakoukoli formou PAS neprobíhá přirozeně. Odlišný vývoj sociální interakce se odráží na dalším vývoji komunikace a komunikačních schopností. K tomu dochází z důvodu podmíněnosti mezi vývojem komunikace a vývojem sociálních dovedností. (Čadilová, Thorová, Žampachová, 2012). Komunikace je tedy vysoce komplexní schopnost jedince, kterou je nutné hodnotit v každé její složce - narušenou komunikační schopnost (NKS) zjišt'ujeme na úrovni recepce i exprese a ve všech jejích formách. U jedinců s diagnózou PAS není NKS druhotnou symptomatologií, jedná se o základní symptom, který je předpokladem stanovení diagnózy. Autismus je vývojovou poruchou, tedy i NKS se manifestuje na úrovni př́pravného období řeči. Již 
nezáměrná komunikace v kojeneckém období může být narušena. Logoped by si měl všímat podmínek, za kterých se jazyk a řeč vyvíjí správně a případné odchylky správně analyzovat. Mezi podmínky patří vnímání stálosti předmětu, sledování a hledání předmětu, ukazování a napodobování, dále zrakový kontakt a sdílená pozornost. (Kerekrétiová, 2009).

Deficity se u klientů s PAS objevují ve verbální i neverbální složce komunikace (viz tabulka). Největším a nejzásadnějším problémem je chápání smyslu sociální komunikace, jedinci s PAS nerozumí situacím a neuvědomují si, že mohou svým jednáním situace ovlivňovat. Nenalézají funkční komunikaci, jedná se o sociálně-komunikační deficit. (Šporclová, 2018).

\begin{tabular}{|c|c|}
\hline Verbálni komunikace & Neverbální komunikace \\
\hline \multirow{7}{*}{ 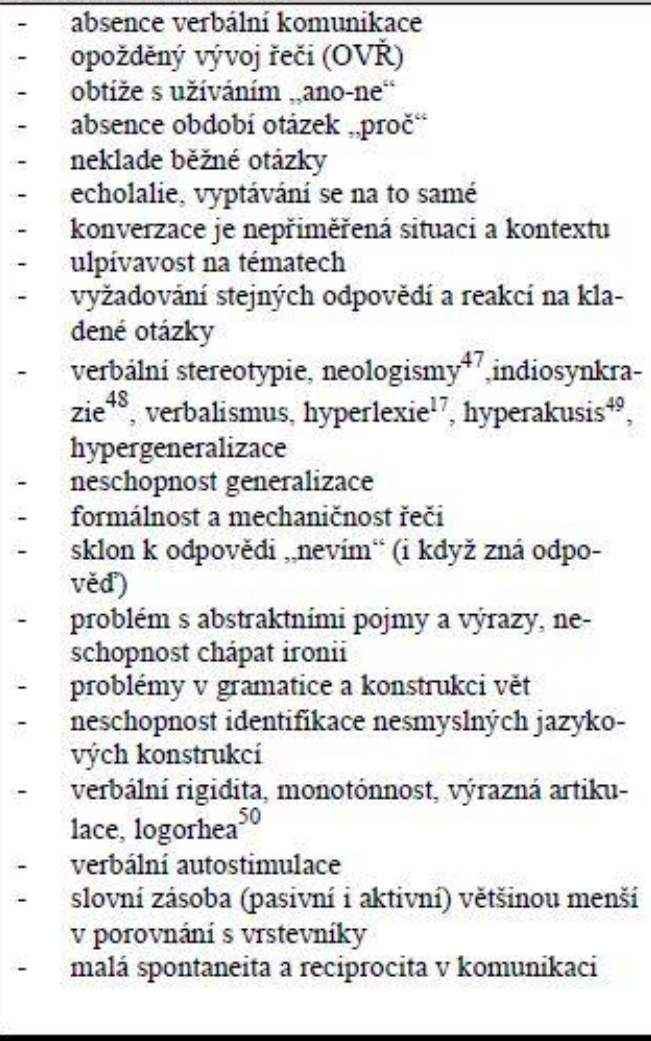 } & $\begin{array}{l}\text { Zrakový kontakt } \\
\text { - } \quad \text { nenavazováni } \\
\text { - } \quad \text { krátký a těkavý } \\
\text { - } \quad \text { ulpivavý } \\
\end{array}$ \\
\hline & $\begin{array}{l}\text { Mimika } \\
\text { - } \quad \text { hypomimie } \\
\text { - } \quad \text { neadekvátnost v expresi } \\
\text { - } \quad \text { nedostatečná či odchylná percepce }\end{array}$ \\
\hline & $\begin{array}{l}\text { Gestikulace } \\
\text { - } \quad \text { obtižná nápodoba, fixováni a generalizace } \\
\text { běžných komunikačnich gest } \\
\text { - } \quad \text { absence deklarativního ukazováni } \\
\text { - nedostatečná či odchylná percepce }\end{array}$ \\
\hline & $\begin{array}{l}\text { Postura těla } \\
\text { - neadekvátni postoj (kýváni, točeni, svě- } \\
\text { šená ramena apod.) }\end{array}$ \\
\hline & $\begin{array}{l}\text { Komunikačni zóny } \\
\text { - } \quad \text { neadekvátnost } \\
\text { - } \quad \text { velký nebo naopak malý komunikačni pro- } \\
\text { stor }\end{array}$ \\
\hline & $\begin{array}{l}\text { Prozodické faktory } \\
\text { - } \quad \text { monotónnost } \\
\text { staccato (krátký a sekaný projev) či legato } \\
\text { (prodlužováni, vázaný projev) v mluvnim } \\
\text { projevu } \\
\text { - neadekvátnost ve výšce hlasu (nizko či vy- } \\
\text { soko položený hlas) }\end{array}$ \\
\hline & $\begin{array}{l}\text { Jiné formy komunikace } \\
\text { - uprednostřováni užiti části těla jiné osoby } \\
\text { k dosažení cile }\end{array}$ \\
\hline
\end{tabular}

Obrázek 1: Tabulka se základními deficity ve verbální a neverbální komunikaci jedinců s PAS (Říhová, Vitásková, 2012, s. 121-122)

\section{METODOLOGIE}

Zkoumanou oblastí byla diagnostika komunikace u dětí předškolního s poruchou autistického spektra. U vybraných jedinců jsme detekovali jazykový vývoj, sesbírali potřebné anamnestické údaje a poté sestrojili př́ípadové studie, které nejsou součástí tohoto př́spěvku.

Z výše uvedeného výčtu dostupných nástrojů k diagnostice PAS je nutné konstatovat, že v České republice logopedická praxe nemá nástroj, který by mohla využívat $\mathrm{k}$ diagnostice a navazující terapii s osobou s PAS. Uvědomujeme si, že je nutné zajistit komplexní pojetí diagnostického nástroje, který obsáhne komunikaci jako celistvou a komplexní schopnost.

Cílem bylo vytvořit nástroj, který by sloužil logopedům pečujícím o osoby s PAS, dále analyzovat situaci a postoupit ji směrem ke klinické praxi. V současné době je sestavena baterie pro detekci a reflexi jazykového vývoje klienta, která je hlavním předmětem tohoto 
př́íspěvku. Pro zhodnocení dosavadní úrovně jazykových a komunikačních schopností byl využit polostrukturovaný rozhovor a pozorování jedinců.

Výzkumný vzorek byl vybírán záměrnou metodou výběru výzkumného vzorku. Záměrný výběr byl podmíněn kritérii: předškolní věk (3 roky - nástup na ZŠ), stanovená diagnóza PAS, jedinci s vysokofunkčním a středněfunkčním PAS. Oslovili jsme organizace pracující s rodinami s dětmi $\mathrm{s}$ PAS v předškolním věku, jednalo se zejména o organizace rané péče.

Výzkum probíhal v domácím prostředí klienta, v přirozeném sociálním prostředí. Rozhodli jsme se tak na základě faktu, že symptomatologie PAS je sociálně zatížena a nechtěli jsme, aby neznámé a nové prostředí zasahovalo do pozorování jedince. I samotný prvek neznámé osoby je zkreslujícím faktorem. „Bylo nám tak umožněno pozorovat spontánní aktivity dětí v prírozeném sociálním prostředí. Získali jsme informace podstatné $k$ tvorbě anamnestických dat, bylo nám umožněno nahlédnout do zpráv odborných pracovišt', která rodina spolu s ditětem navštívila. Mohli jsme zjištovat informace o dosavadním jazykovém a komunikačním vývoji jedince." (Novotná, 2020, s. 83).

\section{BATERIE PRO DETEKCI A REFLEXI JAZYKOVÉHO VÝVOJE}

V rámci výzkumného šetření jsme sestavili podklady pro polostrukturovaný rozhovor s pečující osobou a také schéma pro pozorování jedinců s PAS. Vznik záznamový arch pro Rozhovor s pečujíci osobou klientů s PAS kjazykovému a komunikačnímu vývoji, jeho součástí je i Schéma pro pozorování. Shromáždili jsme anamnestická data a informace od dalších odborníků, kteří s klienty pracovali. Z dostupných lékařských a pedagogických zpráv jsme taktéž získali významné informace. Na konci šetření jsme z dostupných získaných informací o klientech sestavili případové studie (ty nejsou předmětem tohoto článku).

Využili jsme metodu polostrukturovaného rozhovoru, který byl vždy veden s pečující osobou klienta s PAS. Inspirací pro vytvoření otázek nám byl test používaný v USA - TECEL (Test of Early Communication and Emerging Language). (Huer, Miller, 2011). Tento test je používaný pro zjištění jazykových schopností na úrovni receptivní i expresivní, a je určen pro raný věk.

Jedna z významných metod diagnostiky PAS je pozorování chování. Využili jsme metodu zúčastněného prrimého otevřeného pozorování. V logopedické diagnostice jsme tuto metodu využili jako doplňující metodu k získání dalších informací o klientovi. Úkolem logopeda či výzkumného pracovníka při pozorování je být otevřen přicházejícím situacím a adekvátně na ně reagovat. Zapojovat se do interakcí s klientem a zaznamenávat důležité body formou poznámek.

\subsection{Polostrukturovaný rozhovor}

Rozhovor a k němu vytvořený záznamový arch je složený z úvodní strany s identifikací klienta, třinácti jádrových otázek, a nakonec otázek doplňkových. Uvádíme i prŕíklady, aby došlo k úplnému a přesnému pochopení ze strany zadavatele i pečující osoby. Cílem je od pečující osoby získat co nejvíce informací, klademe otázky tak, abychom získali odpovědi v celých větách, nejlépe popis konkrétních situací.

Jádrové otázky jsou konstruovány a voleny s ohledem na předškolní věk klientů a zaměřují se na receptivní (modré položky) i expresivní (zelené položky) jazykové a komunikační schopnosti klienta. Jedná se o následující jádrové otázky (Novotná, 2020, s. 91):

(1) Jaká je reakce na pokyn ,ne“?

(2) Pozorujete, že produkuje sled slov podobající se větě? 
(3) Jak probíhá prohlížení obrázků nebo čtení knížky? Dokáže udržet pozornost na obrázcích?

(4) Dokáže adekvátně odpovědět na otázky? „Kde je ...?“, „Jaká to je barva?“

(5) Jak reaguje na oslovení jeho jménem?

(6) Jakým způsobem probíhá jeho hra? Hraje si sám, zvládne si hrát s vámi?

(7) Používá gesta a zvuky z vlastního repertoáru?

(8) Reaguje adekvátně na „ano-ne“ otázky? Rozumí „ano-ne“ otázkám?

(9) Dokáže napodobit vaše gesta?

(10) Zná osobní zájmena?

(11) Rozlišuje (případně i používá) přídavná jména? Rozumí konceptu velikosti?

(12) Rozumí množnému číslu?

(13) Rozumí minulým výpovědím?

Obrázek 2: Ukázka ze záznamového archu pro polostrukturovaný rozhovor

\begin{tabular}{|c|c|c|c|}
\hline POLOŽKA ROZHOVORU & ODPOVÉDI / POZNÁMKY & $\begin{array}{c}\text { POZOROVÁNÍ/ PŔÍMÉ } \\
\text { HODNOCENÍ }\end{array}$ & $\begin{array}{l}\text { HODNOTICI KRITÉRIA } \\
\text { (pozn.) }\end{array}$ \\
\hline 1 Jaká je reakce na pokyn „ne"-? & & & $\begin{array}{l}\text { Ditẽ se vždy zastaví na pokyn, } \\
\text { alespoñ na okamżik. }\end{array}$ \\
\hline \multicolumn{4}{|l|}{$\begin{array}{l}\text { Reaguje konzistentnè na pokyn } \\
\text {,ne". }\end{array}$} \\
\hline $\begin{array}{l}\text { 2. Pozorujete, że produkuje sled } \\
\text { slov podobajici se vêté? } \\
\text { Vokalizuje sled slov podobný } \\
\text { vétám". }\end{array}$ & & & 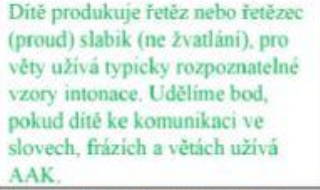 \\
\hline $\begin{array}{l}\text { 3. Jak probihá prohližzeni obrázkú } \\
\text { nebo čteni knižky? Dokả̌re udržet } \\
\text { pozomost na obrazzcich? }\end{array}$ & & & $\begin{array}{l}\text { Díț kouká na obrázky nebo se } \\
\text { jich dotýkả po dobu jedné minuty. }\end{array}$ \\
\hline \multicolumn{4}{|l|}{$\begin{array}{l}\text { Prohlliži si nebo projevi zajem o } \\
\text { obrázek po dobu } 1 \text { minuty. }\end{array}$} \\
\hline 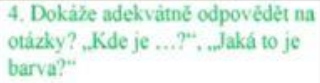 & & & 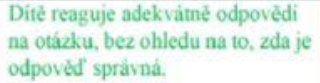 \\
\hline $\begin{array}{l}\text { Reaguje adekváatnê na otiazky } \\
\text { (Kdo, Co, Kdy, Kde, Jak). }\end{array}$ & & & \\
\hline
\end{tabular}

Doplňkové otázky se týkají vzdělávacího systému a dosavadní péče, která byla klientovi poskytována, zároveň se ptáme na péči, která je poskytována v současné době. Významná je pro nás logopedická péče a také poznatky prospěšné pro samotnou diagnostiku - motivační činitele, hračky, podněty, kterých se bojí a naopak, které jej zaujmou. (Novotná, 2020).

\subsection{Schéma pro pozorování klientů s PAS}

K pozorování dochází $\mathrm{v}$ rámci celé návštěvy logopeda (výzkumného pracovníka), dále $\mathrm{v}$ průběhu rozhovoru s pečující osobou, $\mathrm{v}$ závěrečné fázi je žádoucí prř́mé zapojení do spontánní aktivity klienty.

Při tvorbě pomocného schématu jsme vycházeli z oblastí, které vymezil Pečeňák $(2003$, s. 275-278). Oblasti jsme upravili a z původních dvaceti jsme sestavili patnáct, které jsme v pozorování klienta $\mathrm{v}$ přirozených podmínkách uplatňovali. Jedná se o následující oblasti: zrakový kontakt, mimický projev a gestikulace, projevování aktivního zájmu o ostatní děti, použíání těla jiné osoby, sdílená pozornost a úsilí podělit se s druhými o vlastní potěšení, 
ukazování na objekty, imitace a imaginativní hra, sociální komunikace, echolalie, nesprávné používání zájmen, zvláštnosti v mluvním projevu, ohraničené a neobvyklé zájmy, trvání na neměnnosti prostředí spojené s rituály a pohybovými stereotypiemi, použivání předmětů, mimořádné schopnosti.

Obrázek 3: Schéma pro pozorování klientůs PAS (Novotná, 2020, Přiloha č. 3)

\begin{tabular}{|l|l|}
\hline \multicolumn{2}{|l|}{ Základni oblasti pozorováni ditěte: } \\
\hline Zrakový kontakt & \\
\hline Mimický projev a gestikulace & \\
\hline Projevování aktivniho zájmu o ostatni děti & \\
\hline Použiváni těla jiné osoby & \\
\hline Sdilenả pozornost, úsili podēlit se s druhými o vlastni potěšeni & \\
\hline Ukazováni na objekty & \\
\hline Imitace a imaginativni hra & \\
\hline Sociálni komunikace & \\
\hline Echolalie & \\
\hline Nesprávné použiváni zájmen & \\
\hline Zvláštnosti v mluvnim projevu & \\
\hline Ohraničené a neobvyklé zájmy & \\
\hline Trváni na neměnnosti prostredi, rituály, pohybové stereotypie & \\
\hline Použiváni předmětũ & \\
\hline Mimorádné schopnosti & \\
\hline
\end{tabular}

\section{DISKUSE A ZÁVĚRY}

V rámci výzkumného šetření jsme nasbírali data, která jsou pro nás vysoce cenným materiálem, ze kterého budeme čerpat i v následujících výzkumných projektech. Uvědomujeme si rozdílnost a individualitu každého klienta s PAS - z tohoto základního principu vychází naše diagnostika. Každý bod a úkol by měl být modifikovatelný a přizpůsobitelný pro každého jediného klienta. Taktéž hodnocení by mělo být spíše kvalitativní než kvantitativní, představa tvoření tabulek pro standardizované testy pro klienty s PAS nám osobně nedává smysl.

Přikláníme se k průběžné diagnostické práci jako základní formě logopedické diagnostiky u jedinců s PAS. Průběžně vyhodnocovat jednotlivé subtesty a aktivity, hledat zvládnuté a nezvládnuté oblasti vývoje komunikace. Stanovení logopedické diagnózy nepovažujeme za primární úkol diagnostického procesu.

Všechny prvky nově vzniklých diagnostických pomůcek a materiálů je nutné podrobovat dlouhodobému testování a analyzování. Testovat a vyhodnocovat reakce klientů, v této návaznosti materiály upravovat a zefektivňovat. Jde o dlouhodobý vývoj a spolupráci několika odborníků.

Významným činitelem logopedického intervenčního procesu je adaptace na nové prostředí a nového komunikačního partnera. Samotný proces adaptace je pro jedince s PAS náročný, 
časově a psychicky. Logoped musí být na tuto skutečnost připraven a věnovat $v$ začátku intervence kvalitní adaptaci čas.

Závěrem musíme konstatovat, že tvorba diagnostických materiálů je velmi zajímavou činností. Jedná se o činnost složitou a nekončící, proces tvorby logopedického diagnostického materiálu je dynamický. Dle našeho názoru je potřebné rozšiřovat logopedický diagnostický instrumentár o materiály zhotovené primárně pro jedince s PAS. Hlavním důvodem je nedostatek těchto materiálů $\mathrm{v}$ české logopedické praxi. Ve výzkumné práci budeme pokračovat a doufáme, že dáme vzniku dalším materiálům, které by sloužili logopedům, kteří pečují o osoby s PAS.

\section{Zkratky}

DSM - Diagnostický a statistický manuál

ICD - International Classification of Diseases

MKN - Mezinárodní klasifikace nemocí

NKS - narušená komunikační schopnost

PAS - poruchy autistického spektra

PVP - pervazivní vývojové poruchy

TECEL - Test of Early Communication and Emerging Language

USA - United States of America

Článek byl podpořen projektem Studentské grantové soutěže Univerzity Palackého v Olomouci IGA_PdF_2021_006 Př́ístupnost v kontextu osob se zdravotním postižením.

\section{Použitá literatura}

1. ADAMUS, P., A. VANČOVÁ, M. LÖFFLEROVÁ, 2017. Poruchy autistického spektra $v$ kontextu aktuálních interdisciplinárních poznatki̊. Ostrava: Pedagogická fakulta Ostravské univerzity. ISBN 978-80-7464-957-8.

2. AMERICAN PSYCHIATRIC ASSOCIATION, 2015. Diagnostický a statistický manuál duševních poruch, DSM-5. Praha: Hogrefe - Testcentrum. ISBN 978-8086471-52-5.

3. BERANOVÁ, I., K. THROVÁ, M. HRDLIČKA, L. PROPPER, 2014. Specifické diagnostické metody. HRDLIČKA, M., V. KOMÁREK, ed. Dětský autismus: přehled současných poznatků. 2., doplněné. Praha: Portál. s. 91-106. ISBN 978-80262-0686-6.

4. BERANOVÁ, I., K. THROVÁ, M. HRDLIČKA, L. PROPPER, 2014. Specifické diagnostické metody. HRDLIČKA, M., V. KOMÁREK, ed. Dětský autismus: přehled současných poznatků. 2., doplněné. Praha: Portál. s. 91-106. ISBN 978-80262-0686-6.

5. COLE, E. B., 1992. Listening and talking: A guide to promoting spoken language in young hearing-impaired children. Washington, D. C.: Alexander Graham Bell Association for the Deaf. ISBN 0-88200-172-8."

6. ČADILOVÁ, V., K. THOROVÁ, Z. ŽAMPACHOVÁ, 2012. Katalog posuzování míry speciálních vzdělávacích potřeb. Část II., (Diagnostické domény pro žáky $\mathrm{s}$ poruchami autistického spektra). Olomouc: Univerzita Palackého v Olomouci. ISBN 978-80-244-3054-6.

7. DLOUHÁ, O. et al., 2017. Poruchy vývoje řeči. Praha: Galén. ISBN 978-80-7492314-2. 
8. HRDLIČKA, M., V. KOMÁREK, ed., 2014. Dětský autismus: přehled současných poznatků. 2., doplněné. Praha: Portál. ISBN 978-80-262-0686-6.

9. HUER, M. B., L. MILLER, 2011. Test of Early Communication and Emerging Language, TECEL. Texas: PRO-ED, Inc.

10. ICD-11: browser [online], 2018. World Health Organizations, [cit. 2019-08-01]. Dostupné z: https://icd.wh.int/browse11/l-m/en

11. KEREKRÉTIOVÁ, A., 2009. Základy logopédie. Bratislava: Univerzita Komenského. ISBN 978-80-223-2574-5.

12. KLENKOVÁ, J., 2006. Logopedie. Praha: Grada Publishing. ISBN 80-247-1110-9.

13. LECHTA, V. et al., 1990. Logopedické repetitorium. Bratislav: SPN. ISBN 80-0800447-9.

14. NOVOTNÁ, K. Diagnostika komunikace předškolních dětí s poruchou autistického spektra optikou předvýzkumu. Olomouc, 2020. Diplomová práce. Pedagogická fakulta, Univerzita Palackého v Olomouci. Vedoucí práce Adéla Hanáková.

15. PEČENÁK, J. 2003. Diagnostika dětského autismu. In: LECHTA, V. et al. Diagnostika narušené komunikačni schopnosti. 1. vyd. Praha: Portál. s. 262-279. ISBN 80-7178-801-5.

16. PRŮCHA, J., 2011. Dětská řeč a komunikace. Praha: Grada. ISBN 978-80-2473181-0.

17. ŘÍHOVÁ, A., K. VITÁSKOVÁ, 2012. Logopedická intervence u osob s poruchou autistického spektra. Odborná publikace pro logopedy. Olomouc: Univerzita Palackého v Olomouci. ISBN 978-80-244-2908-3.

18. SVĚTOVÁ ZDRAVOTNICKÁ ORGANIZACE, 2018. Mezinárodní statistická klasifikace nemoci a přidružených zdravotnich problémů, MKN 10. revize. Praha: Ústav zdravotnických informací a statistiky ČR. ISBN 978-80-7472-168-7.

19. ŠPORCLOVÁ, V., 2018. Autismus od A do Z. Praha: PASPARTA Publishing. ISBN 978-80-88163-98-5.

20. THOROVÁ, K., 2008. Poruchy autistického spektra: včasná diagnóza branou $k$ účinné pomoci. 2. Praha: APLA. ISBN 978-80-254-6339-0.

21. THOROVÁ, K., 2016. Poruchy autistického spektra. 3., přepracované a rozšířené. Praha: Portál. ISBN 978-80-262-0768-9.

22. VITÁSKOVÁ, K., A. PEUTELSCHMIEDOVÁ, 2005. Logopedie. Olomouc: Univerzita Palackého v Olomouci. ISBN 80-224-1088-5.

\section{Kontaktní údaje}

Mgr. Kristina Novotná

Univerzita Palackého v Olomouci, Pedagogická fakulta

Žižkovo nám. 5, 77900 Olomouc

tel: 731039692

e-mail: kristina.novotna01@upol.cz 


\title{
WORK STRESS AND STRESS MANAGEMENT STRATEGIES FOR SOCIAL WORKERS
}

\author{
Júlia Fričová
}

\begin{abstract}
In the presented article, the author deals with the presence of stress in the performance of the profession of social workers, the causes of its origin and its manifestations in the physical, cognitive, emotional and social. The aim of the paper is to identify strategies for managing work-related stress by social workers, which the author fulfilled in the third part of the paper. To fulfill the goal, the author used the content analysis of available professional literature and compilation, which she supplemented with secondary data of domestic and foreign research.
\end{abstract}

Key words: Coping. Social workers. Stress. Work-related stress.

\section{INTRODUCTION}

Everyday responsibilities, lifestyle or aspirations in various areas of life place a certain degree of demands on a person. Fulfillment of working tasks, looking after the family and household, meeting deadlines, unexpected events, trying to set aside time for your hobbies or relaxation require discipline and effective time management. When a person gradually becomes overwhelmed with responsibilities and the associated pressure and time constraints, he may feel uncomfortable, anxious or even depressed, unable to maintain relationships with people, concentrate and responsibly perform assigned tasks, experiences worries and fears. So, we can say that at certain moments a person experiences stress.

\section{STRESS AND CAUSES OF STRESS}

The American physiologist Walter B. Cannon was the first to deal with the issue of stress, whose key concept in the study of stress was homeostasis, which indicates the body's effort to return the internal environment to physiological balance (Večeřová-Procházková - Honzák, 2008). Stress is a burden on the body that threatens and disturbs its balance and causes changes in the immune and circulatory system (Paulík, 2010).

According to Hartl and Hartlová (2010, p. 555), stress is "the physiological response of an organism to an overload of a non-escape species that leads to a stress response." The difference between load and stress is that the load represents a certain measure of the requirements placed on the individual, and stress occurs when this load is disproportionate for the individual (Komárková - Slameník - Výrost, 2001; Křivohlavý, 2010).

Thus, stress does not appear suddenly and unexpectedly in an individual, but its occurrence is preceded by stressful situations, which the individual can identify in time and eliminate their development. The human body perceives and responds to excessive stress from the very beginning, when it also issues warning signals in the form of various physiological reactions (e.g. increase in blood pressure, increase in adrenaline levels, etc.). In this case, the first stage of stress occurs. If a person is still exposed to a stressful situation, he switches to the so-called stages of resisting stress, when deciding between two options, attack or escape. At this stage, a person can adapt to a stressful situation, return to normal his physiological functions and overcome a difficult situation, but a long-term effort to adapt can lead to exhaustion, which is the last stage of stress. At this stage, a person experiences fatigue, anxiety or depression (Bursová, 2020). The development of these stress stages is shown in the following graph: 
Figure 1 Stages of stress

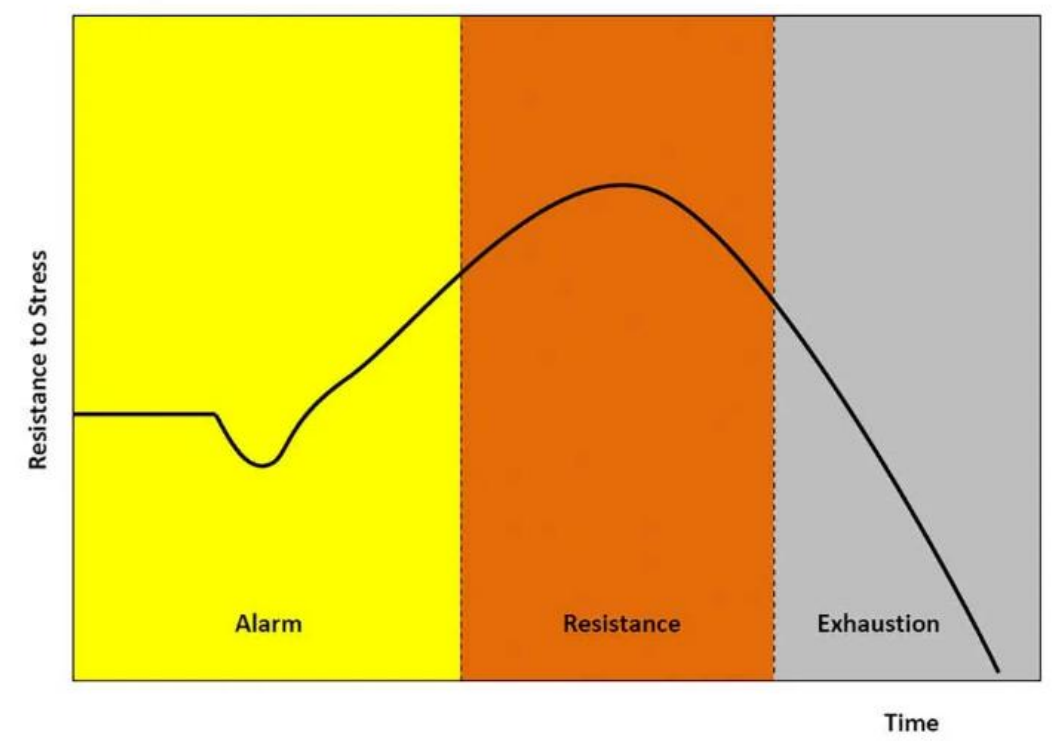

Source: www.healthline.com

Křivohlavý (2012, s. 51) defines stress ,, as a relationship between two opposing forces “. One of the pair of these opposing forces are the so-called stressors, it means triggers of stress response, or causes of stress, which can be divided into subjective and objective.

Objective causes of stress include serious life events and minor daily situations.

Serious life situations are:

- relatively persistent problems related to the performance of social roles (eg interpersonal conflicts, care of a sick family member, etc.),

- situations related to the social environment and living circumstances (e.g. insufficient social conditions, serious chronic illness, etc.),

- socio-economic status,

- sociocultural macro factors.

Minor daily situations include:

- responses to monotonous daily activities,

- cumulation of several minor obligations,

- the unexpected need to deal with "small" issues at the expense of "important" ones.

The subjective causes of stress are in particular:

- personal characteristics (e.g. patterns of behavior),

- education, abilities, skills, experience,

- customs and habits,

- genetic equipment and biological characteristics (e.g. age, sex, current health status, etc.) (Komárková - Slameník - Výrost, 2001).

In addition to these subjective and objective stressors, the author Stock (2010) distinguishes three types of stressors, which is shown in the following graph: 
Figure 2 Types of stressors

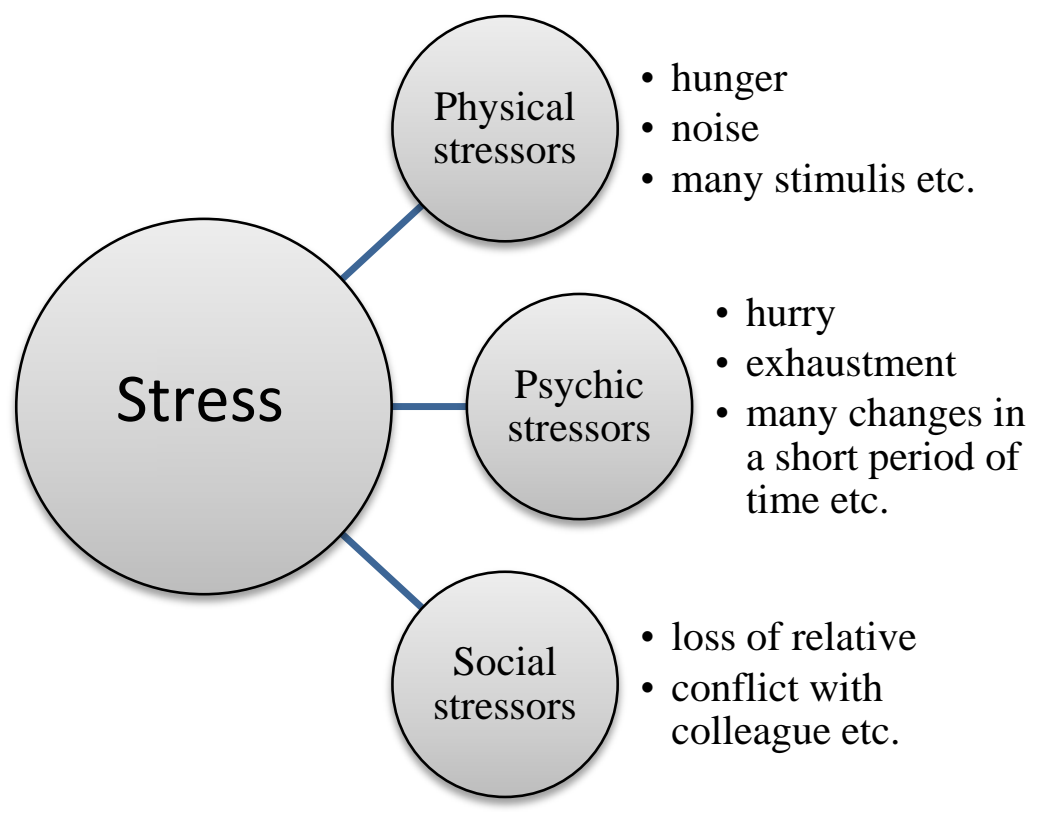

Source: own processing

When stressors occur in connection with an individual's work activity, we speak of work stress, which the World Health Organization (WHO) defines as ,pattern of reactions that occurs when workers are presented with work demands not matched to their knowledge, skills or abilities and which challenge their ability to cope". The cause of stress in such a case may be the fear of insufficient or unsuccessful work performance, fear of the negative consequences of professional conduct, absent help and support from colleagues and the employer.

The results of research by Tham and Linch (2020) state that social workers working in the field of social services are stressed mainly by high workload, time pressure, chaotic work environment with high employee turnover and lack of professional autonomy.

According to Gažiková (2019), social workers practicing their profession in the departments of social protection of children and social guardianship may encounter stressors such as working with high-risk clients, a high number of clients, low salary or administrative burden. Administrative activities as a negative factor are also indicated by the results of the Report on the Conditions of Activities of Child Social Protection Bodies (2012), in which social workers stated that performing administrative activities is much more stressful for them than direct contact with the client in his natural environment or participation in court hearings.

In the current situation, we consider it necessary to mention the relatively specific stressor, which is the disease COVID-19. The permanent risk of infection with the virus, antipandemic measures, the need to use protective equipment, the provision or mediation of longdistance contact present new challenges for social workers, which can be an excessive burden (Radut-Seliste, 2021).

\section{STRESS REACTIONS}

Stressors can appear as something that one would like to remove from one's life because one considers these phenomena to be uncomfortable, threatening, dangerous or harmful. However, it is necessary to realize that the presence of stressors in an individual's life is essential for his functioning and development. Depending on whether stressors elicit positive actions or negative reactions in humans, we can differentiate stress into eustress or distress. According 
to Bryce (2001), eustress is a motivating and creative force that enables a person to perform unexpected performances and achieve unbelievable goals. We can also describe it as a stimulant that activates and empowers a person to solve common everyday tasks, but also unexpected challenging situations. In contrast, distress, or chronic traumatic stress, is extremely destructive and damaging not only physical or mental health, but also human life itself (Večeřová-Procházková, 2004).

In the case of the presence of eustress or distress in an individual's life, stress reactions subsequently occur, which, according to Vancáková (2020), manifest themselves in three levels:

- cognitive level (e.g. unpredictable speed of reactions, increase in error rate, memory impairment, etc.),

- emotional level (e.g. depression, decrease in self-confidence, emotional tension, deterioration of negative personality traits, etc.),

- behavioral level (e.g. energy loss, sleep problems, substance abuse, suicide threats, etc.).

In their research on work-related stress in social workers, Beer, Phillips and Quinn (2020) identified four categories of stress manifestations based on a qualitative research strategy. In addition to the above-mentioned cognitive, emotional and behavioral level, they also talk about manifestations on the social level. The manifestations reported by social workers are listed in the following table:

Table 1 Manifestations of stress among social workers

\begin{tabular}{|c|c|c|c|}
\hline Physical & Cognitive & Emotional & Social \\
\hline $\begin{array}{l}\text { Tension (e.g. neck, } \\
\text { shoulders); Fatigue; } \\
\text { Weight increase; } \\
\text { Sleep disturbance }\end{array}$ & $\begin{array}{l}\text { Rumination on } \\
\text { decision-making; } \\
\text { Not perceiving } \\
\text { oneself as valued by } \\
\text { their clients or } \\
\text { organisations; } \\
\text { Cognitive } \\
\text { dissonance (e.g. } \\
\text { values) }\end{array}$ & $\begin{array}{l}\text { Depression; Anxiety; } \\
\text { Emotional } \\
\text { numbness; Fear (e.g. } \\
\text { client suicide); } \\
\text { Feeling powerless } \\
\text { (e.g. autonomy) }\end{array}$ & $\begin{array}{l}\text { Difficulties } \\
\text { interacting with } \\
\text { family members and } \\
\text { friends; Challenges } \\
\text { with and importance } \\
\text { of Professional and } \\
\text { personal } \\
\text { relationships; Fear of } \\
\text { stigma }\end{array}$ \\
\hline
\end{tabular}

Source: Beer, Phillips, Quinn, 2020

\section{STRESS MANAGEMENT STRATEGIES}

Dealing with stressful situations takes place differently for each individual because it depends on the character, lived experiences or preferred life principles of the person. The process in which a person tries to cope with a stressful situation is called coping. It is about ,the ability of a person to cope in a reasonable way with the demands placed on him, or to handle excessive stress" (Hartl - Hartlová, 2010, p. 77). According to Křivohlavý (1994, p. 42) coping means ,, being able to cope with an extremely difficult, almost unmanageable situation, enough for an unusually difficult task, or in other words, it means fighting someone, literally 'fighting', trying to overcome him, and thus to deal with him, to manage him, to tame him and to subject him to one's own will - in that sense also to manage the life crisis, conflict tensions and the dispute between the enemy forces".

In the literature, we most often encounter coping strategies according to the authors Lazarus and Folkman (1984), who divide them into problem-oriented coping strategies and emotionoriented coping strategies. Křivohlavý (In Komárková - Slaměník - Výrost, 2001) describes problem-oriented coping as an effort to influence and change the environment, analyze an existing problem and develop a plan of action, distinguishing between two options for coping 
with stress. The first option is to implement a change on the burden side, for example by delegating tasks or looking for positive aspects. The second option is to achieve a change in the resources available to a person, for example by obtaining the necessary information, practicing missing or insufficient skills or changing lifestyles. We can therefore say that in applying this strategy, a person plans and implements conscious and concrete steps by which he tries to eliminate or at least alleviate the stressful situation in which he currently is. Emotion-focused coping consists of regulating the emotions that accompany stressful situations, but also in an effort to minimize negative emotions. Within this type of coping strategy, activities such as expressive expression of emotions, reinterpretation of phenomena, acceptance of the situation, search for social support, conversion to faith can be applied (Šrobárová, 2016; Baumgartner - Molčanová - Chylová, 2010; Hybenová, 2004). The authors Endler and Parker (1990) present a third type of coping strategies, the so-called escapeoriented coping, which is, however, an ineffective way of coping with stressful situations because it consists of activating the human defense mechanisms by which the stressor is modified or denied. In human behavior, inappropriate or overly aggressive reactions, selfblaming reactions, projection, displacement, denial, intellectualization, rationalization, daydreaming, alcohol or psychotropic substance use appear in human behavior (Stanton et al., 2000; Komárková - Slaměník - Výrost, 2001).

To overcome work stress, the World Health Organization recommends the use of a problemoriented strategy that includes the following five steps:

Figure 3 Process of Stress Prevention

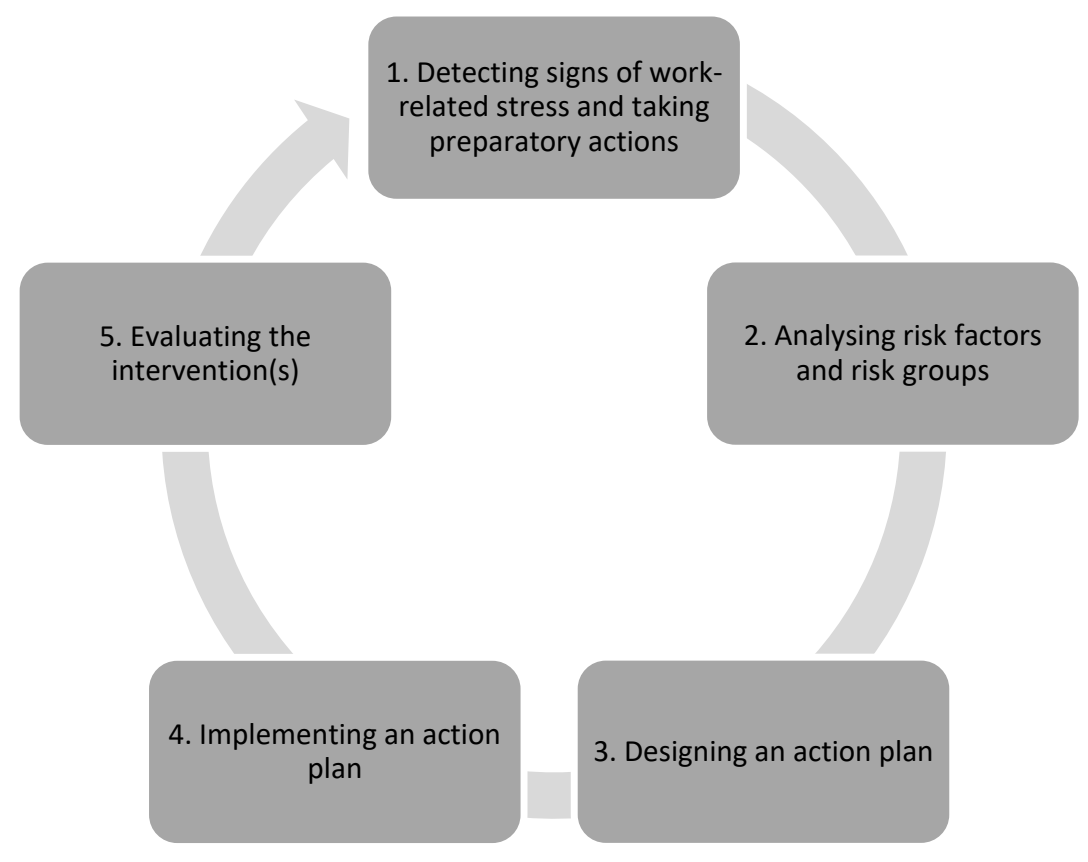

Source: World Health Organization

According to the research of the authors Šiňanská and Šandlová (2013), the three most common stress management strategies used by social workers are active management, planning and instrumental social support, which we rank among problem-oriented strategies, or adaptive strategies. The use of instrumental social support as an active strategy for coping with stress is also confirmed by the results of Dimunová and Bérešová (2015), which also state that instrumental social support, as a concrete, material form of human assistance, belongs to basic coping strategies. 
In order for an individual to be able to make full use of active coping strategies, one first needs to break down negative emotions caused by the presence of one or more stressors, it means to use emotion-oriented strategies. Within this type of strategy, social workers most often use emotional support, in which they turn to a person whom they can trust with their current experience. Other means of managing their emotions for them are acceptance or reformulation of the current situation or religiosity (Dimunová - Bérešová, 2015).

The use of escape strategies is evidenced by the results of research by Beer, Phillips and Quinn (2020), according to which social workers in overcoming stressful situations suppress their feelings and emotions, resort to social isolation in work and private life, use substitutions in watching television, overeating or alcohol consumption.

Social workers strive to actively overcome stress not only in their free time, but especially directly in their workplace, through supervision, participation in educational activities that will allow them to grow professionally and acquire new skills needed to work with the client, more efficient organization of work time and work responsibilities or by creating a favorable and positive work environment in the form of a cozy workplace or building good relationships with colleagues (Köverová, 2018).

\section{CONCLUSION}

The performance of each profession carries with it a certain degree of stress caused by the presence of various factors, the so-called stressors and their gradual accumulation. For social workers, work stress can be caused by a high number of clients, demanding administrative activities, fears of unsuccessful help to their clients, but also general stressors that can occur in the performance of any other profession - time pressure, high workload, lack of support from the colleagues or the employer. We dare to state that individual stressors may differ depending on the area in which social workers perform their profession, it means whether it is, for example, the performance of direct social work with the client in his natural environment or the performance of social work within the public administration or vice versa in the private sector. The presence of these stressors can subsequently cause stress reactions in the physical (e.g. heart palpitations, sleep disorders, etc.), cognitive (inattention, memory impairment, etc.), emotional (fear, anxiety, depression, helplessness, etc.) and social areas (social isolation, etc.). Identification of the stressors present leads the individual to choose a strategy for managing a stressful situation. In the professional literature (Šrobárová, 2016; Baumgartner - Molčanová - Chylová, 2010; Komárková - Slaměník - Výrost, 2001; Stanton et al., 2000; Endler and Parker, 1990) we can encounter three types of coping strategies problem-oriented strategies, emotional and escape strategies. The available research shows that social workers use all three types of coping strategies. In their answers, they presented strategies such as the use of instrumental social support, planning, emotional support, reformulation and acceptance of the situation, conversion to faith, social isolation, substitution of stress or suppression of one's own feelings and emotions. However, due to the size of the research samples of the processed research, we cannot generalize the mentioned results to all social workers. Our intention was to draw attention to the existence of stress in the profession of social workers, which may ultimately result in burnout, but may also make ineffective or limit the possibilities of helping the client himself. We therefore consider it important to lead social workers to be able to identify and eliminate overburden themselves and thus prevent the various types of problems that can arise as a result of stress. At the same time, we dare to appeal to superior employees and employers, who are responsible not only for the work performance of their subordinates, but also for their personal and professional growth, to which the elimination of stress in the workplace can also contribute. 


\section{Bibliography}

1. BAUMGARTNER, F. - MOLČANOVÁ, Z. - CHYLOVÁ, M. 2010. Emočná inteligencia vo vzt'ahu ku copingu (Emotional Intelligence in Relation to Coping) In RUISEL, I. - PROKOPČÁKOVÁ, A. Kognitívny portrét človeka (Cognitive portrait of a man). Bratislava: Ústav experimentálnej psychológie SAV, 2010. ISBN 978-8088910-29-9. s. 186 - 204.

2. BEER, O. W. J. - PHILIPS, R. - QUINN, C. R. 2020. Exploring stress, coping, and health outcomes among social workers In European Social Work. ISSN 1369-1457, 2020, 24(2). p. $317-330$.

3. BRYCE, C. P. 2001. Insight to the Concept of Stress. Washington, D. C.: Pan American Health Organization, Regional Office of WHO, 2001. Dostupné na internete: <https://www.eird.org/isdr-biblio/PDF/Insights\%20into\%20the\%20conce pt.pdf $>$.

4. BURSOVÁ, J. 2020. Stres, jeho príčiny a dôsledky (Stress, Its Causes and Consequences) In Disputationes Scientificae Universitatis Catholicae in Ružomberok. ISSN 1335-9185, 2020, roč. 20, nr. 1. s. $45-55$.

5. DIMUNOVÁ, L. - BÉREŠOVÁ, A. 2015. Využivanie copingových stratégií zvládania zátaže u sociálnych pracovnikov (Using of Coping Strategies of Social Workers). [online]. [cit. 2021-06-18]. Dostupné na internete: <https://www.prohuma n.sk/socialna-praca/vyuzivanie-copingovych-strategii-zvladania-zataze-u-socialnychpracovnikov>.

6. ENDLER, N. S. - PARKER, J. D. A. 1990. Multidimensional Assessment of Coping: A Critical Evaluation In Journal of Personality and Social Psychology, 1990. ISSN 0022-3514, vol. 58, nr. 5. P. $844-854$.

7. GAŽIKOVÁ, E. 2019. Syndróm vyhorenia v kontexte činností pracovníkov oddelenia sociálnoprávnej ochrany detí a sociálnej kurately (Burn-Out Syndrome in the Context of Activities of Employees of the Department of Social Protection of Children and Social Guardianship). Nitra: FSVaZ UKF v Nitre, 2019. 148 s. ISBN 978-80-5581420-9.

8. HARTL, P. - HARTLOVÁ, H. 2010. Vel'ký psychologický slovník (A Great Psychological Dictionary). 4. vyd. Praha: Portál, 2010. 800 s. ISBN 978-80-7367-686-5.

9. HYBENOVÁ, V. 2004. Zvládanie zátažových situácií a relaxačné techniky v práci výchovného poradcu (Coping with Stressful Situations and Relaxation Techniques in the Work of an Educational Counselor) In: Hargasová, M. Efektívna prevencia pred nezamestnanostou začina kariérovou výchovou a kariérovým poradenstvom v školách a školských zariadeniach (An Effective Prevention of Unemployment Begins with Career Education and Career Guidance in Schools and School Facilities). Bratislava: Metodicko-pedagogické centrum, 2004. Dostupné na internete: <https://pp.fberg .tuke.sk/optilog/pub19/lf/207552.pdf>.

10. KOMÁRKOVÁ, R. - SLAMĚNÍK, I. - VÝROST, J. 2001. Aplikovaná sociální psychologie III. Sociálněpsychologický výcvik (Applied Social Psychology III. Sociopsychological Training). Praha: Grada Publishing, a. s., 2001. 224 s. ISBN 80-2470180-4.

11. KÖVEROVÁ, M. 2018. Zát’až v práci, jej zdroje a spôsoby zvládania u pomáhajúcich profesionálov (Workloads, Its Resources and Ways of Coping with Helping Professionals) In Pomáhajúce profesie a starostlivost' o seba z pohl'adu psychológie a sociálnej práce (Assisting Professions and Self-Care from the point of view of Psychology and Social Work). Košice: FF UPJŠ v Košiciach, 2018. ISBN 978-808152-606-0. s. 135 - 145. 
12. Ǩ̌IVOHLAVÝ, J. 2010. Sestra a stres, přiručka pro duševní pohodu (Nurse and Stress, a Guide to Mental Well-Being). Praha: Prada Publishing, a. s., 2010. 128 s. ISBN 978-80-247-3149-0.

13. Ǩ̌IVOHLAVÝ, J. 2012. Horiet', ale nevyhoriet' (Burn but not to Burn Out). Bratislava: Karmelitánske nakladatel'stvo, 2012. 214 s. ISBN 978-80-8135-003-0.

14. KŘIVOHLAVÝ, J. 1994. Jak prekonat stres (How to Overcome Stress). Praha: Grada, 1994. 190 s. ISBN 80-7169-121-6.

15. LAZARUS, G. - FOLKMAN, S. 1984. Stress, Appraisal and Coping. New York: Springer publishing company, 1984. 456 p. ISBN 978-08-261-4192-7.

16. PAULÍK, K. 2010. Psychologie lidské odolnosti (Psychology of Human Resilience). Praha: Prada Publishing, a. s., 2010. 240 s. ISBN 978-80-247-2959-6.

17. RADUT-SELISTE, D. 2021. Avoiding Burn-Out during the Corona Virus Pandemic: Self-Care Practices among Worldwide Social Workers In Овластяване на работещите в сочиилната сфера в малките населени места предизвикателства и възможности [Empowerment of Workers in the Social Sphere in Rural Areas - Challenges and Opportunities]. ISBN 978-619-208-249-9. p. $36-44$.

18. Správa o podmienkach činnosti orgánov sociálnoprávnej ochrany detí (Report on the Conditions of Activity of Social Protection Bodies for Children). 2012. Kancelária verejného ochrancu práv. [online]. [cit. 2021-06-15]. Dostupné na internete: < https://www.vop.gov.sk/files/Sprava_SPOD.pdf >.

19. STANTON, A. L. et al. 2000. Coping through emotional approach: Scale construction and validation In Journal of Personality and Social Psychology, 2000. ISSN 00223514. vol. 78, nr. 6. p. 1150-1169.

20. STOCK, CH. 2010. Syndrom vyhořeni a jak jej zvládnout (Burn-Out Syndrome and how to Manage It). Praha: Grada Publishing, a. s., 2010. 112 s. ISBN 978-80-2473553-5.

21. ŠIŇANSKÁ, K. - ŠANDLOVÁ, V. 2013. Vyrovnávanie sa so stresom a zát’ažovými situáciami terénnymi sociálnymi pracovníkmi (Coping with Stress and Stressful Situations by Field Social Workers) In GRANT Journal. ISSN 1805-062X, 2013, roč. 2, vol. 1 , s. $41-45$.

22. ŠROBÁROVÁ, S. 2016. Krízová intervencia v multidisciplinárnom ponímaní $v$ riešení vybraných akútnych sociálnych problémov (Crisis Intervention in a Multidisciplinary Understanding in Solving Selected Acute Social Problems). Ružomberok: Verbum, 2016. 2014 s. ISBN 978-80-561-1375-3.

23. THAM, P. - LYNCH, D. 2020. Perhaps I should be working with potted plants or standing at the fish counter instead?: newly educated social workers reflections on their first years in practice In European Journal of Social Work, 2020, 24(3). p. 541 553.

24. VEČEǨOVÁ-PROCHÁZKOVÁ, A. - HONZÁK, R. 2008. Stres, eustres a distres (Stress, Eustress and Distress) In Interní medicina pro praxi (Internal Medicine for Practice). ISSN 1803-5256, roč. 2008, 10(4). P. 188 - 192.

25. VEČEǨOVÁ-PROCHÁZKOVÁ, A. 2004. Psychoneuroimunologie (Psychoimmunology) In Acta psychiatrica postgradualia bohemica. Praha: Galén, 2004. ISBN 80-726-2271-4. s. $164-175$.

26. www.healthline.com

27. VANCÁKOVÁ, S. a kol. 2020. Kriza a čo s ňou? Pribehy, ktoré piše život a riešia odbornici (The Crisis and what about It? Stories written by Life and Solved by Experts). Košice: Equilibria, s. r. o., 2020. 218 s. ISBN 978-80-8143-266-8. 
28. WORLD HEALTH ORGANISATION. Raising Awareness of Stress at Work in Developing Countries. A modern hazard in a traditional working environment. Advice to employers and worker representatives. Dostupné online: $<$ https://www.who.int/oc cupational_health/publications/raisingawarenessofstress.pdf?ua $=1>$.

\section{Contact}

Mgr. Júlia Fričová

Catholic University in Ružomberok, Faculty of Pedagogy

Hrabovská cesta 1A, 03401 Ružomberok

Tel: +421944141222

email: julia.fricova801@edu.ku.sk 


\title{
SCHEME OF OBJECTIVES FOR CHILD SEXUAL ABUSE PREVENTION
}

\author{
Anna Masariková
}

\begin{abstract}
Child sexual abuse is one of serious socio-pathological phenomena and it is a crime. It has grave consequences for the children's lives, so it is important to focus on its prevention. We perceive as problematic that there is only a low number of prevention programmes implemented in the field of primary prevention of child sexual abuse in Slovak schools. This may be linked to a lack of information on the objectives that these programmes should pursue. The main objective of our qualitative research is to identify the objectives set by prevention programmes implemented at schools in selected countries of the European Union. By analysing 14 foreign programmes, we have created a system of goals that can inspire the creation of new or adjustment of already existing prevention programmes in Slovakia.
\end{abstract}

Keywords: objectives, prevention programmes, primary prevention, child sexual abuse

\section{CHARACTERISTICS OF CHILD SEXUAL ABUSE}

Child Sexual Abuse (CSA) is a subsystem of the CAN syndrome, which stands for Child Abuse and Neglect (or sometimes is referred to as cruelty, abuse, and negligence). The Council of Europe Health Commission defines child sexual abuse as "undue exposure of a child to sexual contacts, activities or behaviour, such as touching, intercourse or exploitation, by anyone to whom the child has been placed in custody or by anyone who abuses the child" (Mitlohner, 2005). According to Cviková, it means "any sexual activities of an adult aimed at a child who, at the current level of their emotional and intellectual development, is unable to consent to these sexual activities knowingly and freely" (Cviková, 1997, p.1). The ultimate goal of abusive behaviour is sexual satisfaction of the perpetrator. As for the forms of sexual abuse, we can distinguish between contact and contactless abuse, depending on whether the perpetrator directly touches the child's body or abuses them with no direct physical contact. Based on the family ties between the perpetrator and the victim, we can talk about a form of intra-family or extra-family abuse. Abuse has consequences for the life of the child and later of the adult. Both women and men may be victims. The consequences may manifest in the physical, mental, social or spiritual level (Karkošková, 2014). A whole spectrum of negative consequences can be observed, such as depression, anxiety, isolation from the environment, self-harm, problems with food intake, suicidal attempts and completed suicides, hypersexuality or hyposexuality, various types of addictions, problems in interpersonal relationships, burdensome spiritual issues and conflicts (Hullová, 2014).

\subsection{Prevalence}

One of the prevailing myths in connection with CSA is the idea that it is a statistically insignificant phenomenon that only a minimum of members of society suffer. According to one of the most recent meta-analyses, its incidence ranges from 8 to $31 \%$ in women and from 3 to $17 \%$ in men (Barth et al., 2014). Results of selected studies from 11 European countries show that $2.9-10.5 \%$ of girls and $0.6-5.5 \%$ of boys experienced penetrative forms of CSA; while using a broader definition of CSA contact forms, their incidence ranged from 10-39.8\% in girls and 6-16.2\% in boys (Lalor, McElvaney, 2011). According to research conducted in 2018 at Slovak secondary schools on 2,186 students aged up to 18 years, 5.6\% of girls and $1.3 \%$ of boys experienced penetrative forms of CSA, $30.2 \%$ of girls and $11.6 \%$ of boys 
experienced tactile forms of CSA, and $40.6 \%$ of girls and $17.7 \%$ of boys confirmed their experience with non-tactile forms of CSA. More than a half of CSA actions took place in the post-pubescent period (Karkošková, Ropovik, 2018). CSA is a highly latent phenomenon, hidden from the public, little reported to law enforcement authorities, and many victims remain silent about abuse throughout their lives and will not confide event to their loved ones.

\subsection{Prevention}

Given the severity of the consequences for the victim's life and the prevalence of CSA both abroad and in Slovakia, it is important to emphasise the prevention of child abuse. According to Šiňanská, prevention is the most effective way of solving social problems, which is why more and more attention has been paid to it in the world and Slovakia recently (Šiňanská, 2012). An important part of prevention is upbringing of children in families, education at schools and utilization of extracurricular activities. In the school environment, primary prevention is most often encountered, also called universal prevention. It is a strategy that focuses on the prevention of this undesirable social phenomenon, not creating conditions for its occurrence, or inhibiting the occurrence in the very beginning (Täubner, 2005). The result of these efforts is the creation of prevention programmes addressed to children in kindergartens, primary or secondary schools.

\subsubsection{Recipients of prevention}

In schools, children are the most frequent recipients of prevention. Other possible recipients may be: (1) professionals who come into contact with children; (2) other adults who are in the position of parents, grandparents, other relatives, friends, acquaintances or neighbours of children and youth (Michančová, 2011). CSA experts differ in their perspectives on the position of children as recipients of prevention. Some consider that putting responsibility for prevention into the hands of children themselves is a low-efficiency approach. One of such authors is a Slovak expert on CSA Karkošková, who claims: "If children's knowledge is measured before and after the programme, a significant positive shift can be noted. However, such a figure does not say anything about how children will behave in a real situation of danger. Moreover, the offender's approach to the potential victim may be so subtle and insidious that it may not be easy even for a conscious child to recognize it." (Michančová, 2011, pp. 233-234). This leaves us wondering whether prevention addressed to children is desirable and necessary. The question was partly answered by researchers Gibson and Leitenberg who studied the CSA rate in the university student population to see if there is a correlation between CSA and participation in a school prevention programme during childhood. In a large but homogeneous sample $(n=825), 62 \%$ of women reported having participated in a children's programme based on the concepts of "good and bad touch" (Gibson and Leitenberg, 2000, p. 1118). Only 8\% of those participating in a school prevention programme reported personal experience with CSA. On the other hand, $16 \%$ of participants reported that they had personal experience with CSA and never participated in any school prevention programme. Gibson and Leitenberg concluded that early childhood education about self-protection against CSA could have helped prevent CSA. On the other hand, however, scientists have also acknowledged that their study is limited by its retrospective design as well as by the unclear effects of the programme's participation on the occurrence of CSA. Women who have participated in research and have not been victims of CSA throughout their lives may have developed other resistance to abuse that has not been taken into account in the research. The absence of abuse may not have been related to being subjected to a prevention programme at school and thus to the acquired ability to protect oneself against abuse (Gibson, Leitenberg 2000). Another reservation against the children as prevention recipients is that prevention programmes may be ineffective if they avoid explicit 
anatomical expressions and thus do not help the children adequately describe a possible encounter with abuse (Renk et al., 2002). A serious problem is when children participate in prevention programmes that are inadequately and insensitively administered. In this case, they feel unprepared for the topic, surprised or frightened by the content of the programme (Renk et al., 2002). Elliott, on the other hand, points to the great importance and positive experience of parents and children who have undergone prevention programmes. According to Elliott, the principles of how to protect a child are important not only in families and extracurricular interest groups, but also in the school environment, especially in kindergartens and primary schools (Elliott, 1995).

\subsubsection{Prevention Objectives}

Successful school prevention programmes include those that: (1) provide opportunities for children to play roles and to practice safety strategies and responses; (2) provide information tailored to developmental standards and cognitive abilities; (3) stress the need for emotional expression and safe disclosure; (4) contain formal and extensive training elements for parents and teachers; (5) are integrated into mainstream curriculum but also include extracurricular components and create space and opportunities for discussion (Kopp, 2008). In addition to these important principles, it is crucial for the effectiveness of the programme that a clearly formulated goal or set of goals are pursued and that they are achieved in the most engaging and experiential way. The objectives of Slovak prevention programmes in the field of CSA prevention have been analysed in this paper. Table 1 shows the objectives that have been identified in the Slovak prevention programmes.

\begin{tabular}{|c|c|c|}
\hline $\begin{array}{l}\mathbf{N} \\
\mathbf{0}\end{array}$ & Programme title & $\begin{array}{c}\text { Objectives of Slovak CSA prevention } \\
\text { programmes: }\end{array}$ \\
\hline 1 & Kiko a ruka (Kiko and a Hand) & $\begin{array}{l}\text { Objective: To teach the children a rule: } \\
\text { "Don't touch me here" and help parents } \\
\text { and educators communicate this topic to } \\
\text { the children as part of primary } \\
\text { prevention. }\end{array}$ \\
\hline 2 & $\begin{array}{c}\text { Bezpečne od útleho veku (Safe From an } \\
\text { Early Age) }\end{array}$ & $\begin{array}{l}\text { Objective: To expand the child's } \\
\text { knowledge to assess when violence is } \\
\text { taking place; when it is right not to } \\
\text { reveal secrets; and when it is right and } \\
\text { necessary to share with parents or other } \\
\text { adults whom the child trusts. }\end{array}$ \\
\hline 3 & $\begin{array}{c}\text { Kozmo a jeho dobrodružstvá (Cosmo and } \\
\text { His Adventures) }\end{array}$ & $\begin{array}{l}\text { Objective: Development of emotional } \\
\text { intelligence, pro-social behaviour, } \\
\text { cooperation and empathy in children. } \\
\text { Being able to act correctly when faced } \\
\text { with violence. }\end{array}$ \\
\hline 4 & $\begin{array}{c}\text { Póla radí det'om (Pola's Advice for } \\
\text { Children) }\end{array}$ & $\begin{array}{l}\text { Objective: To teach children behaving } \\
\text { safely in risky situations, to prepare } \\
\text { them for taking responsibility for their } \\
\text { health and their belongings, to provide }\end{array}$ \\
\hline
\end{tabular}




\begin{tabular}{|c|c|c|}
\hline & & $\begin{array}{l}\text { information aimed at raising children's } \\
\text { legal and social awareness. }\end{array}$ \\
\hline 5 & Ovce.sk (Sheeplive.eu) & $\begin{array}{l}\text { Objective: To raise awareness of the } \\
\text { risks of the Internet, mobile phones and } \\
\text { new technologies. }\end{array}$ \\
\hline 6 & $\begin{array}{c}\text { Mne sa to nemôže stat' (It Can't Happen } \\
\text { to Me) }\end{array}$ & $\begin{array}{l}\text { Objective: To prevent young people } \\
\text { from becoming victims of trafficking for } \\
\text { sexual exploitation. }\end{array}$ \\
\hline 7 & $\begin{array}{c}\text { Detská policajná akadémia (Children's } \\
\text { Police Academy) }\end{array}$ & $\begin{array}{l}\text { Objective: Prevention of crime, other } \\
\text { anti-social activities and socio- } \\
\text { pathological phenomena. The aim is also } \\
\text { to educate the pupils to take } \\
\text { responsibility for their own behaviour } \\
\text { and actions. }\end{array}$ \\
\hline 8 & Ako sa chránit' (How to Protect Yourself) & $\begin{array}{l}\text { Objective: To teach children how to } \\
\text { face different kinds of threats. }\end{array}$ \\
\hline 9 & Prevention in Secondary Schools & $\begin{array}{l}\text { Objective: Recognize red flags in } \\
\text { partnerships in relation to violence. }\end{array}$ \\
\hline
\end{tabular}

We assume that the low number of CSA prevention programmes in Slovakia may be related to low awareness of prevention programmes existing abroad and the goals they set.

\section{METHODOLOGY}

The research strategy of the presented research is qualitative in nature. The data were obtained by qualitative analysis of prevention programmes. We were drawing from a study created as a result of cooperation between the European Union's programme Erasmus and the organization called Breaking the Silence Together (2016). It is a study that maps implemented prevention programmes aimed at preventing CSA in European schools in 2016-2018. The data obtained in the study are processed for the purposes of our research goal, which is to identify the goals pursued by prevention programmes implemented at schools in selected countries of the European Union as an inspiration for the Slovak context. From the basic set of 16 prevention programmes, we created a research set of 14 prevention programmes based on a critical selection. Our criteria are:

a. The country where the programme was implemented: We have focused on the countries of the European Union because of their easier cultural transfer to Slovak culture. The research group consisted of programmes implemented in 8 countries: Austria, Cyprus, Greece, Ireland, Italy, Poland, Scotland, and Spain.

b. Programme recipients: We focused on the children as prevention recipients. The youngest children in the prevention programme were 4 years of age and the oldest were 16 years of age. The most frequent recipients of prevention were children aged 10 years. Under the Convention on the Rights of the Child, we considered children as persons under the age of 18. 
c. Implementation environment: We analysed the objectives set by the programmes carried out in the school environment. Analysed programmes include the ones used in kindergartens, primary and secondary schools.

Two prevention programmes were excluded from the research package on the grounds that one of them was not intended for the children as prevention recipients, but for parents and educators, and the other was not implemented in a member state of the European Union. The titles of the analysed prevention programmes in English are: the "Tweenees" programme; the "Stay Safe" programme; "Prevention of Child Sexual Abuse"; "We Protect Children"; "The Hedgedogs"; "Know Speak Change"; "Shsh.. it is a secret"; "One in Five" campaign; "Quite intimate"; "From I to You"; "Because I am a Girl \& For Boys Only"; "My Invisible Garden's Fence”; "Friendship, Love and More”; „Hey! Don't Get Distracted!” We processed the data using a qualitative analysis method. Qualitative analysis was performed in the Atlas.ti programme, which is designed to analyse qualitative studies. Open and axial coding method was followed, creating categories and subcategories.

\section{RESULTS}

In selected EU prevention programmes, based on their analysis, we have identified objectives that help the children to protect themselves. We have classified prevention goals into the following logical categories: a, cognitive self-protection; b, self-protection at the body level; c, legal self-protection; d, intrapersonal self-protection; e, self-protection through orientation in a risk situation; f, self-protection through positive social relationships; g, self-protection against negative behaviour and thus protection of society. To each category we have assigned a goal (subcategory) that the category is tracking (see Figure 1).

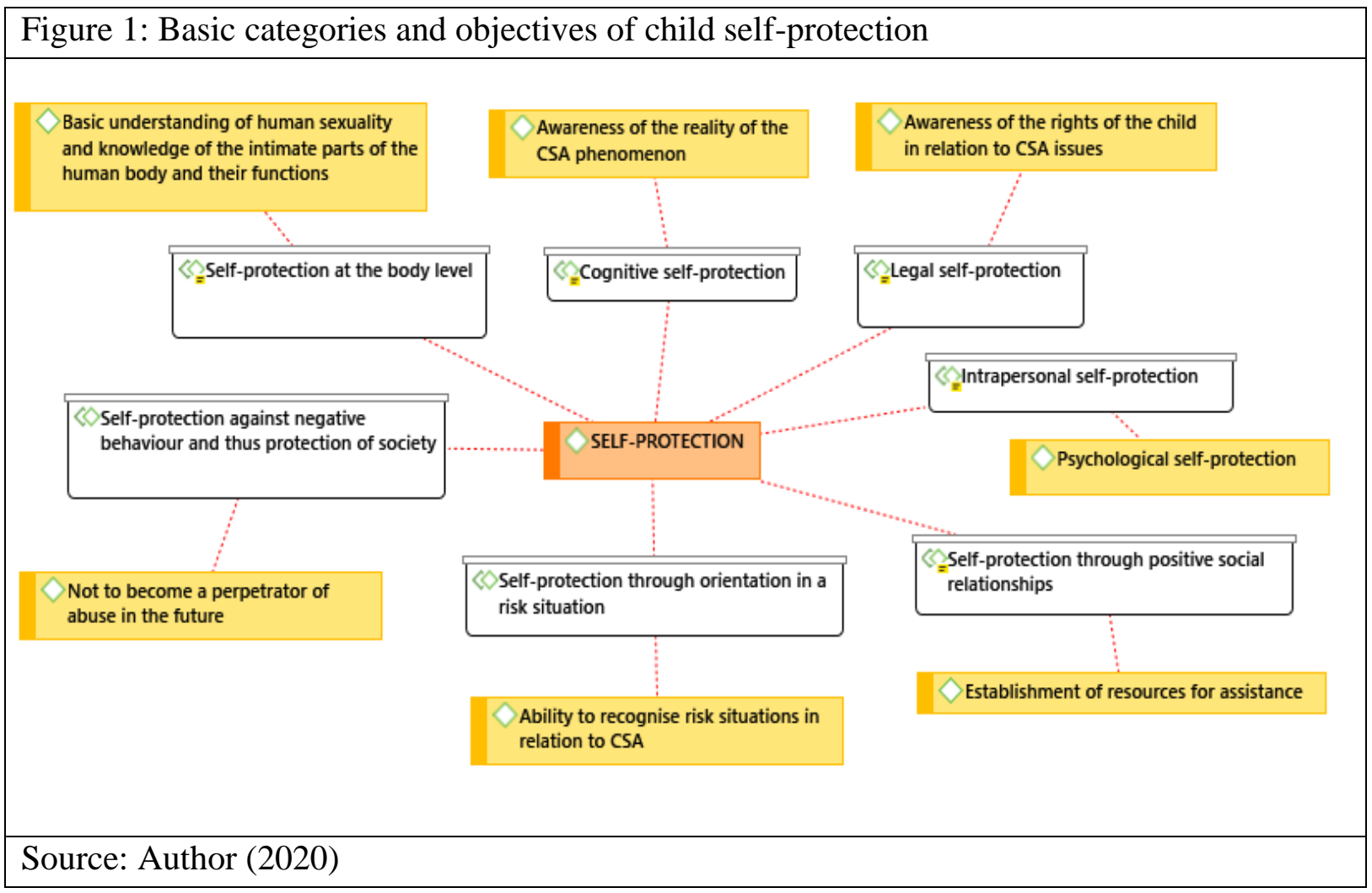

Based on the content analysis of the prevention programmes, we assigned each of the seven categories an objective (subcategory) to which it is directed: (1) Awareness of the reality of the CSA phenomenon occurrence; (2) Basic understanding of human sexuality and knowledge 
of the intimate parts of the human body and their functions; (3) Awareness of the rights of the child in relation to CSA issues; (4) Psychological self-protection; (5) Ability to recognise risk situations in relation to CSA; (6) Establishment of resources for assistance; (7) Not to become a perpetrator of abuse in the future. Each of the seven objectives was teaching the children, as part of their self-protection, some important sub-objectives that the prevention programme should take into account in its content. The sub-objectives are presented in Figure 2.

Figure 2: Sub-objectives of prevention programmes

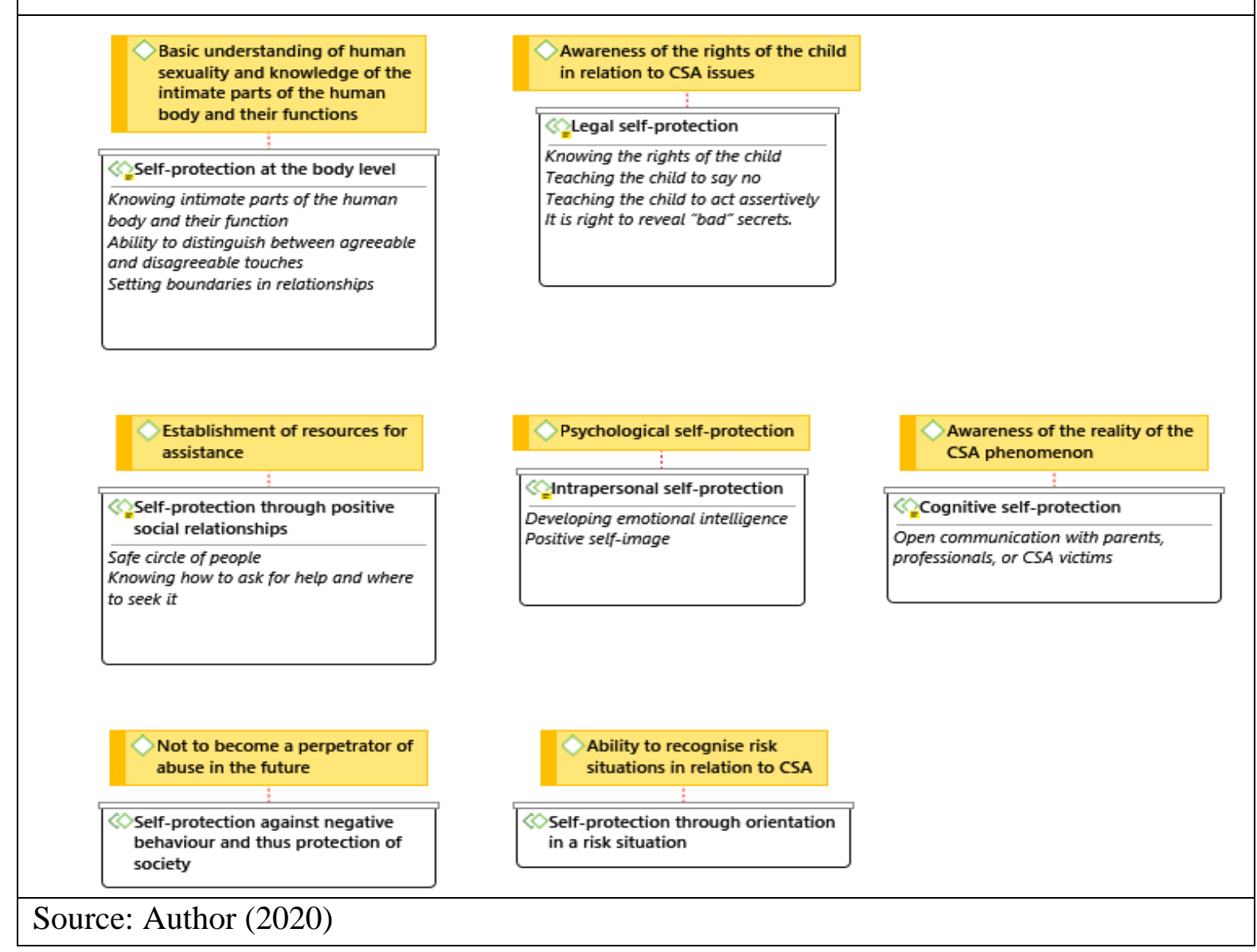

\section{DISCUSSION}

By analysing prevention programmes, we have created a set of goals. Just as the consequences of abuse leave traces on all levels of the child: physical, mental, social and spiritual, the prevention should also take into account all these levels. The created set of goals is complex, taking into account all levels of the children's personality up to the spiritual level. Adding the spiritual objectives is proposed that are absent in foreign programmes. Objectives of Slovak prevention programmes obtained by their analysis: (1) to gain the ability to recognise violence; (2) to distinguish between good and bad touches and secrets; (3) to teach the children who to turn to when they have a problem; (4) to minimize confrontation with risky situations (risky online behaviour; human trafficking). In addition to these valuable prevention areas, foreign prevention programmes offer objectives aimed at: (1) Teaching sexual education of children. The children know the parts of their body and the body of the opposite sex, and understand what behaviour is unacceptable in intimate relationships, which can help to protect them; (2) Discussion with the victims of CSA as a way for the children to become aware of the reality of CSA occurrence. Victims and perpetrators form a large group of society, of which little is known; (3) Legal self-protection. The children know their rights, 
know how to exercise them, and practice assertiveness; (4) Defending the children by developing their self-esteem and emotional intelligence; (5) Preventing people from becoming CSA perpetrators by developing their empathy with the victims of CSA through prevention programmes, understanding the issue from the very childhood. We can state that the protection of society against CSA offenders is a secondary objective of all prevention activities.

\section{CONCLUSION}

Although experts' views on the effectiveness of child-focused prevention differ, none of the authors expressly reject it. The authors draw attention to its possible pitfalls and suggest using the possibility of expanding the groups of recipients who can be involved in prevention programmes simultaneously with the child. Preventive action will become more effective when parents, grandparents or professionals entering the children's life (pedagogue, coach, paediatrician, priest) are also involved in prevention programmes. It is crucial that prevention is carried out by an expert who respects the developmental specificities of the child's age and has specific knowledge of CSA issues. The objectives of preventive action should be comprehensive, focusing on the bio-psycho-social and spiritual aspects of the child.

\section{References}

1. Barth, J., Bermetz, L., Heim, E., Trelle, S., Tonia, T. The current prevalence of child sexual abuse worldwide: a systematic review and meta-analysis. In: International Journal of Public Health, 2013, vol. 58, No. 3, 469-483 pp.

2. Cviková, J. To najdrahšie, čo máme? [The most precious thing we have?] In: Aspekt, [online] 1997, No. 2, 3 p. http://www.ruzovyamodrysvet.sk/sk/hlavne-menu/cit aren/clanky-a-studie/empty-title [25.2.2021]

3. Elliott, M.: Jak ochránit své dítě. [How to Protect Your Child]. Praha: Portál, 1995. 173 p. ISBN 80-7178-157-6.

4. Erasmus; Breaking the Silence Together. Learning from experience - Breaking the Silence Together: Academic success for all by preventing child sexual abuse. [online] 2016. Project no.: 2016-1-ES01-KA201-025370. [cit.13.5.2020] Available online: http://www.preventingchildsexualabuse.eu/wpcontent/uploads/2018/11/O 1_EN_final_version_OK.pdf

5. Gibson, L. E., Leitenberg, H. Child sexual abuse prevention programmes: Do they decrease the occurrence of child sexual abuse? Child Abuse \& Neglect, 24 (9), 11151125 pp. https://doi.org/10.1016/S0145-2134(00)00179-4

6. Hullová, M. et al. Scientific research task project: Problémy pri odhal'ovaní a objasňovaní vybraných druhov trestných činov mravnostnej kriminality. [Problems in the detection and clarification of selected types of vice crimes.] Academy of the Police Force: Bratislava 2014, 43 p.

7. Karkošková, S. Obete sexuálneho zneuživania detí medzi nami [Victims of sexual abuse of children among us], Vel'ký Šariš-Kanaš: ASCEND, 2014, 20 p. ISBN 97880-971470-1-3.

8. Karkošková, S., Ropovik, I. The prevalence of child sexual abuse among Slovak late adolescents. In: Journal of Child Sexual Abuse, 2018, 1-20 pp. DOI: 10.1080/105 38712.2018.1553224

9. Kopp, L. Child Sexual Abuse Prevention and Social Connection. In: Advocate's forum. Chicago: The University of Chicago. 2008. 78-100 p. Available online: https://crownschool.uchicago.edu/sites/default/files/uploads/AdvocatesForum_2008_ web.pdf 
10. Lalor, K., McElvaney, L. Overview of the nature and extent of child sexual abuse in Europe. In: Protecting children from sexual violence: A comprehensive approach. Strasbourg: Council of Europe, 2011, 13-43 pp. ISBN 978-92-871-7114

11. Masariková, A. Rigorous work, Komparácia programov prevencie sexuálneho zneuživania detí vo vybraných štátoch Európskej únie [Comparison of child sexual abuse prevention programs in selected countries of the European Union], Ružomberok, Catholic University in Ružomberok, 2020, 119 p.

12. Michančová, S. Prevencia sexuálneho zneužívania detí. [Prevention of child sexual abuse]. In: Theologos: Theological Revue, 2, vol. XIII, Prešov, University of Prešov, 2011, 226-243 pp.

13. Mitlohner, M. Právní aspekty pohlavního zneužívání [Legal aspects of sexual abuse]. In: Weiss, P. et al. Sexuální zneužívanání dětí [Child sexual abuse]. Praha: GRADA, 2005, p. 33.

14. Ol’šavská, M. Niektoré základné informácie k prevencii sociálno-patologických javov [Some basic information on the prevention of socio-pathological phenomena], Part 1. Bratislava: The Methodology and Pedagogy Centre. 2014. p. 52. ISBN 978-808052-684-9.

15. Renk, K. et al. Prevention of child sexual abuse: Are we doing enough? Trauma, Violence, \& Abuse, 3 (1), 2002. 68-84. https://doi.org/10.1177/15248380020031004

16. Šiňanská, K. Prevencia v sociálnej práci a jej význam pre prax sociálneho pracovníka [Prevention in social work and its importance for the practice of a social worker] In: Žiaková, Eva et al. Sociálna práca: teoretické východiská a praktické kontexty [Social work: Theoretical background and practical contexts]. Košice: Pavol Jozef Šafárik University in Košice, 2012. 286 p. ISBN 978-80-7097-870-2.

17. Täubner, V. Prevence sexuálního zneužívaní dětí [Prevention of child sexual abuse]. In: Weiss, P. et al. Sexuální zneuživaní dětí [Child sexual abuse]. Praha: Grada Publishing, 2005. p. 57. ISBN 80-247-0929-5.

\section{Contact details}

PhDr. Anna Masariková

Catholic University in Ružomberok, Faculty of Education

Hrabovská cesta 1A, 03401 Ružomberok

Phone: +421444304693

email: anna.masarikova177@edu.ku.sk 


\title{
PRAKTICKÉ ZKUŠENOSTI DĚTSKÉHO DOMOVA S RŮZNÝMI FORMAMI NÁHRADNÍ RODINNÉ PÉČE
}

\author{
PRACTICAL EXPERIENCE OF THE CHILDREN'S HOME WITH \\ VARIOUS FORMS OF SUBSTITUTE FAMILY CARE
}

\begin{abstract}
Alois Daněk
Abstrakt

Př́ispěvek se klade za cíl představit odborné veřejnosti zkušenosti školského zařízení pro výkon ústavní výchovy s různými formami náhradní rodinné péče. Zvolili jsme kvalitativní výzkumné metody, informace nám poskytly rozhovory, pozorování, a především analýza pedagogické dokumentace. Naše výstupy poukazují na řadu výzev, které současný systém přináší. Respondenti upozorňují na potřebu užší mezioborové spolupráce, a především na nutnost odborné erudice pěstounů. $\mathrm{V}$ diskusi nad výsledky se pokusíme nabídnout možné modifikace dnešního stavu, které by vedly $\mathrm{k}$ bohatší nabídce podnětných a bezpečných prostředí pro naše znevýhodněné děti.
\end{abstract}

Klíčová slova: ústavní výchova, náhradní rodinná péče, pěstounství, dětský domov

\begin{abstract}
The paper aims to present to the professional public the experience of the school facility for institutional care with various forms of substitute family care. We have chosen qualitative research methods, information provided by interviews, observations, and above all analysis of pedagogical documentation. Our results point to some challenges posed by the current system. Respondents point to the need for closer interdisciplinary collaboration especially the need for professional erudition of foster parents. In our discussion of the results, we attempt to offer possible modifications to the current situation, leading to a richer range of stimulating and safe environments for our disadvantaged children.
\end{abstract}

Key words: institutional care, substitute family care, foster care, children's home

\section{1 ÚVOD}

Př́ispěvek nabízí odborné veřejnosti dílčí výsledky dlouhodobého výzkumu, který probíhá ve školském zařízení pro výkon ústavní výchovy, v Dětském domově Klánovice. Prostředí Dětského domova Klánovice je komplexní edukační realita, ve které má svoje místo i problematika náhradní rodinné péče. Hlavním cílem př́íspěvku je představit naše zkušenosti s rozličnými formami náhradní rodinné péče. Cíl př́spěvku se budeme snažit naplnit za pomoci akčního kvalitativního výzkumného designu. Nejprve představíme možnosti, které náš stát má $\mathrm{k}$ dispozici $\mathrm{v}$ okamžiku, $\mathrm{kdy}$ je třeba intervenovat $\mathrm{v}$ zájmu ochrany dítěte. Následně seznámíme čtenáře s prostředím Dětského domova Klánovice a s dětmi zde žijícími. Změříme se zejména na zkušenosti, které naše děti mají s různými formami náhradní rodinné péče. Oslovíme také pedagogické pracovníky našeho domova. Důležité informace nám poskytli pěstouni a hostitelé, kteří spolupracovali, nebo stále spolupracují s naším dětským domovem. V závěru zhodnotíme získané výsledky a budeme diskutovat nad možnými cestami, které by umožnily zlepšení současného stavu. 


\section{SOUČASNÝ STAV POZNÁNÍ}

Může nastat celá řada situací, kdy rodina není schopna dítěti zajistit adekvátní podmínky. Pakliže tato skutečnost začne negativně působit na život dítěte a zájem dítěte vyžaduje poskytnutí bezpečného prostředí je třeba, aby zakročil stát. Je zcela bez debaty, že intervence státu je závažným zásahem, a proto je nutné rozhodnutí soudu. Nicméně v určitých př́ípadech o pomoc může zažádat samotný zákonný zástupce, nebo dítě ${ }^{1}$. Naše republika nabízí potřebným dětem bezpečné prostředí dvěma formami. Náhradní rodinnou a náhradní ústavní péči.

\subsection{Náhradní rodinná péče}

Náhradní rodinná péče je poskytována v několika formách. Osvojením, svěřením dítěte do péče jiné osoby, poručenstvím, pěstounskou péčí a pěstounskou péčí na dobu přechodnou ${ }^{2}$. Osvojení je synonymem pro termín „adopce“, je to jediná forma náhradní rodinné péče, kdy mezi dítětem vzniká stejný právní vztah, jako má s biologickými rodiči. U ostatních forem zůstávají zachována rodičovská práva. Pěstounská péče je jedna z nejrozšířenějších forem náhradní rodinné péče. Tento druh náhradní rodinné péče je $\mathrm{z}$ právního hlediska volnější než při klasickém osvojením. V rámci pěstounské péče, která je státem garantovaná a kontrolovaná, je dítěti poskytnuto postačující hmotné zabezpečení dítěte i přiměřená odměna pěstounů, kteř́ o něj řádně pečují. Předpokládá se, že bude probíhat kontakt s původní rodinou a pěstouny ${ }^{3}$. Formou pěstounské péče je pěstounská péče na dobu přechodnou. Zde se předpokládá, že dítě $\mathrm{v}$ péči profesionálních pěstounů bude nejdéle po jednom roce mít možnost návratu do jeho původního rodinného prostředí. Pěstounská péče na dobu přechodnou je poměrně novým fenoménem, který si teprve buduje svoje místo mezi ostatními formami náhradní rodinné péče. Výše jmenované druhy náhradní péče probíhají v rodinných prostředích. Péče o potřebné děti ale probíhá i institucionální formou. Ústavní péče je označována jako ústavní výchova.

\section{2 Ústavní výchova}

Ústavní výchova je právně ukotvena v zákoně č. 89/2012 Sb., tedy v Novém občanském zákoníku, její výkon se řídí zákonem č. 109/2002 Sb. o výkonu ústavní výchovy nebo ochranné výchovy ve školských zařízeních a o preventivně výchovné péči ve školských zařizeních. Ústavní výchova může probíhat v diagnostickém ústavu, v dětském domově, v dětském domově se školou, nebo ve výchovném ústavu. Tyto instituce jsou v gesci Ministerstva školství, mládeže a tělovýchovy. Zařízení typu „Klokánkư“ jsou pod hlavičkou Ministerstva práce a sociálních věcí. Nelze opomenout kojenecké ústavy, které zřizuje Ministerstvo zdravotnictví ${ }^{4}$. Důležitá skutečnost je ta, že ústavní výchova je ukládána až v situaci, kdy se vyčerpají možnosti náhradní rodinné péče. Náhradní rodinná péče má přednost před ústavní výchovou 5 . Toto je klíčový fakt, který zásadně ovlivňuje celou tuto předkládanou práci. Pakliže je náhradní rodinná péče upřednostňována před ústavní

\footnotetext{
${ }^{1} \mathrm{O}$ umístění v zařízení typu „ZDVOP“ lze požádat i bez rozhodnutí soudu. „ZDVOP“ je zkratka pro Zařízení pro děti vyžadující okamžitou pomoc. Vžilo se označení „Klokánek“, podle zařízeních provozovanými Fondem ohrožených dětí. Dítě může být umístěno do ZDVOP podle $§ 42$ zákona č. 359/1999 Sb., o sociálně-právní ochraně dětí. V této práci nebudeme rozlišovat mezi jednotlivými zařízeními, budeme používat termín Klokánek. ${ }^{2}$ STÁREK, Lukáš. Definition of Substitute Family Care and Issues of the School Environment. Str. 46.

${ }^{3}$ Pěstoun má povinnost udržovat, rozvíjet a prohlubovat sounáležitost dítěte s rodiči, s př́ibuznými a s osobami dítěti blízkými. MACELA, Miloslav. Krátkodobá pěstounská péče: Historie, praxe, perspektivy. Str. 34.

${ }^{4}$ Právě roztř́íštěnost mezi celou řadu ministerstev značně ztěžuje kvalitní práci. Kořeny této neutěšené situace můžeme vystopovat do padesátých let minulého století, kdy nastupující vláda strany a lidu zrušila sociální služby jako buržoazní přežitek. MUŽÁKOVÁ, Monika a Alois DANĚK. Dětský domov Klánovice v období 19481989 aneb čest práci, soudružko vychovatelko!

${ }^{5}$ Zákon č. 359/1999 Sb. § 9a, odst. 2.
} 
výchovou, můžeme tedy logicky vyvodit, že do Dětského domova Klánovice přicházejí děti až v situaci, kdy náhradní rodinná péče již nemůže úspěšně plnit svoji funkci a ústavní výchova se stala jedinou možnou alternativou. Ačkoli můžeme pozorovat intenzivní snahy o podporu náhradní rodinné péče ${ }^{6}$, reálně málokteré dítě z Dětského domova Klánovice odchází do některé z forem náhradní rodinné péče. V našem výzkumu se budeme snažit zjistit, proč tomu tak je.

\section{POUŽITÁ METODOLOGIE A PRŮBĚH VÝZKUMU}

V rámci výzkumu jsme mapovali, jaké mají naše děti zkušenosti s náhradní rodinnou péčí z období před př́íchodem do Dětského domova Klánovice a jak probíhá interakce mezi Dětským domovem Klánovice a jakoukoli formou náhradní rodinné péče. Zvolili jsme kombinaci kvalitativních výzkumných metod. Použili jsme rozhovory, pozorování a analýzu dostupné pedagogické dokumentace. Profitovali jsme ze znalosti zkoumaného prostředí, a především z benefitu, že autor je dětmi chápán jako jeho součást, pracuje zde jako vychovatel a metodik prevence. Toto se opakovaně při našich dříve realizovaných výzkumech prokázalo jako nesmírně prospěšné pro př́istup $\mathrm{k}$ informacím. Jsme si ale vědomi rizika konfirmačního zkreslení a naše výsledky neustále revidujeme s vědomím naprosté nezbytnosti kritického myšlení. Všechny děti byly požádány o souhlas s provedením rozhovorů7. Bylo jim jasně vysvětleno, za jakým účelem bude probíhat. Především jsme se zaměřili na dvě rodinné skupinky, na kterých autor působí. Dále jsme provedli několik rozhovorů s ostatními vychovateli a s pedagogy místní základní školy. Rozhovory byly provedeny od poloviny září do konce roku 2020. Podařilo se nám kontaktovat několik pěstounských rodin, které s naším domovem $\mathrm{v}$ minulosti spolupracovaly a úspěšně převzaly do péče naše bývalé klienty. Cenným zdrojem se ukázala pedagogická dokumentace našich dětí, která je jinak pro výzkumníky nedostupná, zejména jejich kazuistiky. Zkoumali jsme především kazuistiky dětí žijících v Dětském domově Klánovice mezi lety 2010 až 2020, ale důležité informace nám poskytly i archivní materiály ze samých počátků domova. Získané informace jsme zpracovali s pomocí zakotvené teorie a interpretační fenomenologické analýzy.

\subsection{Popis cílové skupiny}

Dětský domov a školní jídelna Klánovice je školské zařízení pro výkon ústavní výchovy ${ }^{8}$ zřizované Hlavním městem Prahou. Domov je podle zákona určen pro děti bez závažných poruch chování ${ }^{9}$. Kapacita Dětského domova Klánovice zcela naplněna, žije zde tedy 54 dětí. Nejmladšímu jsou čtyři roky, nejstarší letos oslaví dvacáté páté narozeniny ${ }^{10}$. Poměr chlapců a dívek je vyrovnaný. V poslední době můžeme sledovat změnu ve věkovém rozložení našeho domova. Zvyšuje se věk nově prríchozích ${ }^{11}$. Další změnou je zřetelný nárůst nově příchozích dětí, které vyžadují psychiatrickou péči. Jinak naše děti v naprosté většině nemají zdravotní specifické potřeby ${ }^{12}$, což nelze říct o speciálních vzdělávacích a speciálních psychických

\footnotetext{
${ }^{6}$ Například každé dítě je zaneseno orgánem pro sociálně právní ochranu dětí do evidence možných adeptů pro náhradní rodinnou péči.

7 Nebylo možné o souhlas požádat zákonné zástupce. Obdrželi jsme povolení k provedení výzkumu od statutárního zástupce Dětského domova Klánovice.

${ }^{8}$ Zákon č. 89/2012 Sb. § 971, odstavec 1 . Ústavní výchovu nařizuje soud v případě, že bylo prokázáno ohrožení, nebo narušení výchovy, duševního, tělesného či rozumového stavu nebo vývoj dítěte Vedle těchto uvedených důvodů ústavní výchova může být nařízena také v př́padě, že rodiče nemohou výchovu zabezpečit.

${ }^{9}$ Zákon č. 109/2002 Sb. § 12, odstavec 2.

${ }^{10} \mathrm{I}$ po skončení ústavní výchovy dítě může zůstat v dětském domově za předpokladu, že se dále vzdělává.

${ }^{11}$ Před deseti lety převažovali žáci ZŠ a předškoláci, dnes dominují spíše žáci druhého stupně a středoškoláci.

${ }^{12}$ Což paradoxně vede $\mathrm{k}$ dojmu, že naše děti se nikterak neodlišují od intaktní populace. Na první pohled je zcela nemožné rozpoznat, jestli dítě, které potkáme na ulicích Klánovic, je naším chovancem, nebo míří ke svým rodičům žijícím v luxusní vile.
} 
potřebách. Jsou to děti alkoholiků, násilníků, řada z nich byla pohlavně zneužita, odvržena rodiči, zanechána vlastnímu neštěstí1 ${ }^{13}$. Rodiče nespolupracují, vinu přenáší na osud v lepším, na děti $\mathrm{v}$ tom horším případě. Děti $\mathrm{k}$ nám přicházejí po edukační stránce zanedbané a po emoční a psychické stránce zdevastované.

\section{VÝSLEDKY VÝZKUMU}

Do výzkumu jsme vstupovali s předpokladem, že naše děti do Dětského domova Klánovice přicházejí primárně z rozvrácených rodinných prostředí. Když jsme se ale detailněji podívali do minulosti našich dětí, zjistili jsme zajímavou skutečnost. Naprostá většina dětí v minulosti nepřišla př́mo $\mathrm{z}$ rodin, ale již absolvovala pobyt bud' $\mathrm{v}$ různých formách náhradní rodinné nebo ústavní péče. Např́klad na rodinných skupinkách, na kterých autor působí, prímo z rodiny, bez zkušenosti s náhradní rodinnou, nebo ústavní péčí, za posledních několik let přišel pouze jediný chlapec, který byl navíc výjimkou potvrzující pravidlo, protože zcela osiřel $^{14}$. Situaci jsme porovnali se statistikami kolegů působících v zařízeních typu Klokánek. Tam přicházejí děti v naprosté většině výhradně z rodin. Také je zřejmé, že do Klokánku děti přicházejí v mladším věku ${ }^{15}$. V kazuistikách dětí ze zkoumaných rodinných skupinek jsme dohledali informace o jejich předešlých pobytech ve Klokáncích, v diagnostických ústavech ${ }^{16}$, o několika neúspěšných pobytech $\mathrm{v}$ pěstounských rodinách, o jednom případě pěstounské péče na dobu přechodnou.

\subsection{Předchozí pobyty dětí $v$ jiných formách náhradní péče}

Zjistili jsme, že naprostá většina dětí má za sebou pobyt v zařízení typu Klokánek. Některé děti absolvovaly pobyt $\mathrm{v}$ Klokánku několikrát. Jak děti na tuto zkušenost vzpomínají? Při rozhovorech jsme nezaznamenali výrazně pozitivní odpovědi. Děti nejčastěji zmiňovaly rozdílnou materiální úroveň Klokánků. Tvrdily nám, že oproti Dětskému domovu Klánovice měly menší kapesné a horší vybavení. Dále si děti stěžovaly, že se jim personál Klokánků málo věnoval při školní prrípravě. Děti také poukazovaly na méně volnosti a přísnější řád. Jednoznačně tvrdily, že by se do Klokánku nevrátily a pobyt v Dětském domově jim vyhovuje. Takové odpovědi se samozřejmě pracovníkovi dětského domova pěkně poslouchají, ale jsou objektivní? Autor osobně několikrát byl pověřen převzetím dítěte z Klokánku. Je třeba zdůraznit, že tvrzení dětí, pokud jde o materiální stránku, se nezakládají na pravdě. Navštívené Klokánky jsou vybavené podle moderních standardů, děti jsou kvalitně oblečeny a vybaveny. Mají mobilní telefony, přístup $\mathrm{k}$ bezdrátovému připojení. Je jim nabízena celá řada volnočasových aktivit, velkou roli zde hraje neziskový sektor. Pokud jde o otázku volnosti a školní př́pravy, můžeme spekulovat, že pohled dětí byl zkonfirmován skutečností, že pobyt v Klokánku byla jejich převážně první zkušenost se zařízením náhradní výchovy. Chápeme tedy, že děti na personál a prostředí Klokánku nereflektovaly objektivně. Dále je nutné si uvědomit, že princip Klokánků je postaven na myšlence, že během pobytu v Klokánku se vyřeší problémy, které dítě do Klokánku přivedly. Tudíž do Dětského domova

\footnotetext{
13 DANĚK, Alois. Dětský domov Klánovice-vybrané sociologické otázky. Naše děti přicházejí v naprosté většině z rodinných prostředí, které lze s klidem v duši označit jako deviantní.

${ }^{14}$ Ačkoli se v kazuistikách našich dětí můžeme setkat se smrtí jednoho z rodičů, čistí sirotci, o které se nemá kdo $\mathrm{z}$ rodiny postarat, $\mathrm{k}$ nám nepřicházejí. Největší počty sirotků jsme zaznamenali při studiu archivních materiálů ze začátků existence Dětského domova Klánovice, tedy po skončení II. světové války.

15 BARVÍKOVÁ, Jana, Jana PALONCYOVÁ a Jana MACHOVÁ. Zařízení pro děti vyžadující okamžitou pomoc - umíst’ování dětí, podmínky péče o děti, financování provozu. Tamtéž, str. 25-27.

${ }^{16}$ Před deseti lety děti přicházeli především $\mathrm{z}$ diagnostických ústavů Toto se změnilo. V reakci na novelu občanského zákoníku novelizovalo ministerstvo školství i zákon o ústavní výchově. Změna se týkala rozhodování o umístění dítěte do konkrétního ústavu, což v současnosti bylo $\mathrm{v}$ kompetenci odborníků $\mathrm{v}$ diagnostickém ústavu (ve spolupráci s pracovníky OSPOD), po novele tato kompetence přešla do rukou soudce. $\mathrm{V}$ praxi to nám přináší řadu potíží. U dítěte bez kvalitní diagnostiky je náročné určit jeho potřeby.
} 
Klánovice přicházejí děti, jejichž rodiny nebyly schopny se asanovat. Co z tohoto faktu vyplývá? V prostředí dětského domova se nesetkáváme s úspěchy Klokánků, ale naši klienti přicházejí z rodin, které lze chápat jako zcela mimo normu. Taková patologická prostředí jsou natolik destruktivní pro dětskou duši, že náprava je extrémně náročná a $\mathrm{v}$ mnoha př́padech je víceméně nemožné jizvy zacelit. Nikoli dítě, ale rodina je problém. Na tuto skutečnost se často zapomíná. Již delší dobu na tento fakt upozorňujeme. Vysvětluje totiž potíže při výchovném procesu našeho domova. U dětí se speciálními vzdělávacími potřebami nelze uspět bez speciálně pedagogických metod. Kolegové v Klokáncích pracují v odlišném paradigmatu. Jejich snahou je poskytnout dítěti bezpečné a láskyplné prostředí, v kterém dítě může pobývat do doby, než se rodinná situace zlepší natolik, že je možný bezpečný návrat. Můžeme tedy pobyt v Klokánku označit jako dočasný. To nelze říci o dětských domovech. V naprosté většině dítě po př́íchodu do dětského domova zde zůstává do plnoletosti, v řadě př́padů i déle. Je zcela bez debaty, že prostředí dětského domova nemůže nabídnout dítěti to, co poskytuje normální rodina. Mưže však dítě ochránit před tím, co vyplývá z pobytu v rodině patologické. Normální rodina, byt' i s dílčími potížemi, nedopustí, aby dítě bylo z rodiny odebráno. Pokud se tak stane, udělá vše pro to, aby se dítě vrátilo zpět. Rodiny našich dětí nelze označit jako normální. Selhaly rodiny, systém možné sanace se vyčerpal, dítě přichází do dětského domova. Jaké má dítě možnosti odchodu před ukončením ústavní výchovy?

\subsection{Př́íklad dobré praxe}

Ačkoli v médiích je často prezentováno, kolik nešt’astných bezdětných rodin hledá dítě, realita $\mathrm{z}$ pohledu dětského domova je poněkud smutnější. Za posledních deset let se u nás vážný zájemce o adopci neobjevil. Kdo by také hledal pubescentního chlapce s ADHD? Pokud bychom ale měli rodinné skupinky osazené roztomilými blondýnkami předškolního věku, jsme přesvědčeni, že by si po př́ijezdu k nám ani nestačily vybalit a byly by osvojeny. V našem domově máme ale velice dobré zkušenosti s pěstounskou péčí. Zajímavé je, že všechny pěstouny oslovil náš domov sám, ze spolupráce s OSPOD pěstoun nevzešel ani jednou ${ }^{17}$. Proces vyhledávání pěstounů je dlouhodobý, náročný na všechny zapojené a rozhodně není prost zklamání a neúspěchů. Na dvou sledovaných rodinných skupinkách se v posledních deseti letech podařilo úspěšně zrealizovat přechod $\mathrm{z}$ dětského domova do pěstounské rodiny ve čtyřech př́padech, kdy celkem odešlo $\mathrm{k}$ pěstounům šest dětí. Jeden $\mathrm{z}$ největších pěstounských úspěchů byl $\mathrm{v}$ príṕpadě sourozenců, jména pozměňme na Jana a Jiř́ího. Chlapci přišli do dětského domova v naprosto zuboženém stavu. Rodiče nezvládli svoji závislost na alkoholu a zcela rezignovali na rodičovské povinnosti. Chlapci absolvovali pobyt v diagnostickém ústavu a po zotavení byli přijati do Klánovic. Starší Jan byl žákem školy praktické, pohyboval se v pásmu lehké mentální retardace. Dále se u Jana projevovaly poměrně vážné poruchy motoriky. Netrpěl poruchami chování. Mladší Jiří byl inteligentní a více si uvědomoval situaci spojenou s alkoholismem rodičů. Byl tichý, uzavřený do sebe, na stresory reagoval agresivními záchvaty. Rodiče s dětským domovem nespolupracovali, o chlapce nejevili zájem. Hoši dětský domov přijali jako svoje prostředí a neuvažovali o jiné alternativě. Ředitelství dětského domova získalo kontakt na bezdětný manželský. Manželé se dlouhodobě angažovali ve výměnných studijních pobytech, oba byli extrémně akademicky zdatní. V určité fázi jejich života se rozhodli, že je třeba postoupit výše a nabídnout bezpečné prostředí potřebnějším dětem, než jsou zahraniční studenti. Původně měli představu pouze jednoho dítěte, ale podařilo se nám je přesvědčit, aby se pokusili začít se stýkat $\mathrm{s}$ Jiřím a $\mathrm{s}$ Janem. Od počátečního setkání do přechodu do pěstounské péče uběhly velice náročné dva roky. Chlapci nejdříve odmítali spolupracovat, nebyli př́istupni jakékoli debatě o možnosti pěstounství. Proto jsme se prriklonili k námi osvědčenému modelu, že jsme chlapcům nejdříve

\footnotetext{
${ }^{17}$ Což by potvrzovalo naši teorii o roztomilých blondýnkách.
} 
nabídli možnost hostitelské péče ${ }^{18}$. V podobných případech doufáme, že během hostitelské péče děti ztratí negativní př́stup a najdou si k hostitelům. Nejnáročnější je úvodní etapa. Hostitelé se snaží děti získat a zahrnují je dary, aktivitami a pozorností. Často se stává, že děti toho vyloženě využívají a $\mathrm{v}$ okamžiku, kdy hostitel přestane být pouze zdrojem a začíná mít požadavky, děti hostitelskou rodinu opouštějí. Manželský pár tuto etapu zvládl a chlapci si dokázali vybudovat $\mathrm{k}$ tehdejším hostitelům vztah. Následovala prŕíprava $\mathrm{k}$ pěstounství a chlapci opustili dětský domov. Zpočátku byli chlapci velice nesamostatní, odpovědnost přenášeli na vnější faktory, měli potíže strávit čas bez dozoru. Při zátěžových situacích měli tendence od problému odejít. Všichni ale napnuli síly a překážky překonali. Šest let po odchodu z dětského domova Jan studuje již druhé učiliště, Jiří odmaturoval a uvažuje o vysoké škole. Když dnes s Janem a Jiřím hovoříme jednoznačně tvrdí, že by v dětském domově nebyli schopni dosáhnout výsledků, které jim umožnila pěstounská rodina. Sami hodnotí jejich život s pěstouny jako náročný, ale mnohem smysluplnější než život v dětském domově. Udržujeme s novou rodinou úzký kontakt. Pěstouni několikrát zmínili výzvy, s kterými museli pracovat. Uvítali by kvalitnější kooperaci mezi jednotlivými organizacemi, se kterými spolupracovali. Dalším požadavkem byl přístup ke kontinuálnímu vzdělávání. Z těchto cenných podnětů čerpáme při dalších projektech vyhledávání vhodných pěstounů pro naše děti.

\subsection{Otázka dostupnosti pěstounské péče}

Podobných scénářu jsme prožili několik. Pokud se všichni zapojení nenechají odradit náročností procesu, výsledky jsou pro dítě neoddiskutovatelné ${ }^{19}$. Je ale na místě upozornit i na př́pady, kdy pěstounská péče selže a dítě se vrací zpět do dětského domova. V minulosti jsme řešili dva takové př́ipady. První chlapec se vrátil po několikaletém pobytu u pěstounů, kdy ani jedna strana nezvládla jeho speciální vzdělávací potřeby. Chlapec návrat do dětského domova nesl velice těžce. Nicméně po se po několika letech podařilo vyhledat pro hocha další pěstounskou rodinu, v které je podle našich informací vše v naprostém pořádku. Druhý chlapec $\mathrm{k}$ nám přišel $\mathrm{z}$ pěstounské péče na dobu přechodnou. Ani po roce se nepodařilo sanovat jeho rodinu, proto byl chlapce umístěn do dětského domova. Ze současných psychologických vyšetření hocha vyplývá, že jeho aktuální sociální a emoční potíže lze přičíst velkému zklamání, které při ukončení pobytu u pěstounů na dobu přechodnou chlapec zažil. Vytvořil si totiž $\mathrm{k}$ nim silné pouto a ukončení pěstounské péče s následným umístěním do dětského domova chápe jako zradu dospělých, ke kterým si tak složitě hledal cestu. Nevěří dospělým autoritám, prognóza jeho dalšího vývoje není dobrá. Ačkoli se jedná o vysoce inteligentního hocha, v současnosti se potýká s celou řadou problémů ve škole a začínají se u něj projevovat poruchy chování. Dětský domov vyhledal pomoc psychologů a zajistil chlapci terapeutickou podporu. Musel se však vracet do dětského domova? Musel. Pěstounská péče na dobu přechodnou může být prodloužena pouze ve výjimečných případech. Podle našeho názoru je chybou dítě, které zažilo bezproblémovou náhradní rodinnou péči, navracet zpět do náhradní ústavní výchovy. Protože stabilita náhradní rodinné péče je zásadním fenoménem, který je klíčový pro rozvoj dítěte ${ }^{20}$. Stát by měl zajistit dostatečné množství kvalitně vzdělaných pěstounů, kteři by byli schopni pracovat $\mathrm{s}$ dětmi se speciálními vzdělávacími

\footnotetext{
${ }^{18}$ Hostitelská péče je forma pomoci dětem žijícím v ústavní péči, nejedná se však o institut náhradní rodinné péče. Ředitel zařízení může po obdržení souhlasu OSPOD povolit pobyt dítěte mimo dětský domov.

${ }^{19} \mathrm{~S}$ našimi bývalými chovanci jsme v kontaktu a s velkou radostí se dovídáme, že by se do Dětského domova Klánovice za žádných okolností už nevrátili. Děti poukazují na úspěchy jak v edukační, tak i v sociální oblasti.

${ }^{20}$ YI, Youngmin, and Christopher WILDEMAN. Can Foster Care Interventions Diminish Justice System Inequality? Str. 52.
} 
potřebami. Dále je třeba vzít v potaz potřebu dostatečného počtu pěstounů, kteří zvládají práci s dětmi z odlišných kulturních prostředí a s dětmi se zdravotními potížemi ${ }^{21}$.

\subsection{Možnosti hostitelství}

Pěstounů je naprostý nedostatek. V Dětském domově Klánovice bychom uvítali budoucí pěstouny s otevřenou náručí. Vítáme ale i hostitele. Naši hostitelé jsou vyzrálé osobnosti, které zaslouží velké uznání a poděkování. Svoji energii do našich dětí investují bez nároku na honorár̆, nikdo jim jejich náklady neproplatí. Dlouhodobě sledujeme u našich dětí změny, které jsou spojené s hostitelskou péči. Jako př́iklad si dovolíme užít hostitelku, která již čtyři roky intenzivně pracuje s naší dvanáctiletou dívkou. Dívka přišla do dětského domova v zoufalém stavu. Neměla hygienické návyky, vyjadřovací schopnosti měla hluboce pod normálem, vyšetření ukazovala na spodní hranici lehké mentální retardace. Vychovatelé neustále byli konfrontováni s jejím náročným chováním, kde se výzvy mentální retardace kombinovaly s poruchami autistického spektra. Podařilo se zajistit hostitelku, která postupně začala s dívkou pracovat. Nejprve navázala důvěrný a bezpečný vztah, následně všechny síly napnula k jedinému cíli, zlepšit dívčinu situaci. Dívka hostitelku přijala jako důležitou blízkou osobu a přes počáteční odpor začala spolupracovat. Výsledek? Dívka na posledním vyšetření v poradně poměrně šokovala svými výsledky. Ukázalo se, že není mentálně retardovaná, ani nemá poruchy autistického spektra, ale byla pouze značně zanedbaná ${ }^{22}$. Její případ není výjimečný. Pokud děti s hostiteli udrží dlouhodobý vztah, můžeme sledovat značný progres v celé řadě oblastí. Jednoznačně se dětem zvedají sociální kompetence, kolegové hovoří také o lepším vyjadřování.

\subsection{Problematika zákonných zástupců}

Pro naše děti je hostitelská a pěstounská péče př́nosem. Pro dětský domov je hostitelská a pěstounská péče prŕnosem. Pro celou společnost také. Má snad někdo s těmito formami pomoci dětem zásadní problém? Ano, má. A jsou to ty osoby, kvůli kterým naše děti do domova přišly, jsou to rodiče a ostatní rodinní př́íslušníci. Ačkoli rodiče pocházejí z různých vrstev společnosti, jsou různého věku a vzdělání, jednu věc mají povětšině společnou. Pokud se nastolí otázka možné náhradní rodinné péče, i rodič, který se několik roků na svoje dítě žijící v Dětském domově Klánovice ani nevzpomněl, kategoricky se staví proti a ohání se svými rodičovskými právy. V naprosté většině príípadů jsou rodiče tím faktorem, který generuje komplikace. V současnosti máme v péči sourozence, jejichž matka se v posledních několika letech snaží intenzivně upít. Ačkoli matka bydlí od našeho domova dvacet minut cestou autobusem, děti navštěvuje velmi zřídka. O jejich prospěch nejeví zájem, zajímá se pouze o datum výplaty sirotčího důchodu, aby jej mohla směnit za lihovinu. Oslovili jsme možnou hostitelskou rodinu a k jednání jsme přizvali matku. V okamžiku, když matka zjistila, že by děti mohly přijít do kontaktu s jiným rodinným prostředím, okamžitě si vzpomněla na rodičovská práva. Odmítala jakoukoli spolupráci, plakala a vzpínala ruce. Zapř́sahala děti, aby za žádných okolností neopouštěly nemohou maminku a neodcházely k cizím lidem. Trvalo nám přibližně dva měsíce, než jsme ji přesvědčili, že hostitelská péče je pro její děti výhodná a není třeba proti ní bojovat. Matka sice umožnila dětem návštěvy u hostitelů, ale podle vyjádření dětí se neustále snaží dětem rozmluvit kontakt s hostitelskou rodinu. Tato matka není výjimkou. Zákonní zástupci jsou schopni po několika letech naprostého nezájmu tvrdit, jak hluboce děti milují, jak se pro ně obětují a jak jim záleží na jejich štěstí. Mnoho hostitelů a pěstounů bylo odrazeno a v očích dětí rodiči očerněno. Opět musíme zopakovat, že problém nejsou děti, ale výhradně rodiče.

\footnotetext{
${ }^{21}$ KONEČNÁ, Hana a Markéta SUDOVÁ. Jak dál s pěstounskou péčí na přechodnou dobu? Str. 42.

${ }^{22}$ Těžko uvěřit, že i v dnešní době se můžeme setkat s téměř vlčími dětmi. Smutné! Alarmující!
} 


\section{ZÁVĚR A DOPORUČENÍ PRO PRAXI}

Cílem tohoto př́spěvku bylo seznámit čtenáře se zkušenostmi s náhradní rodinnou péčí v Dětském domově Klánovice. Pokusili jsme se představit pohled na problematiku z perspektivy jednoho školského zařízení pro výkon ústavní výchovy. Naše výstupy nelze generalizovat, prezentujeme je pouze jako inspirativní sondu do zkoumaného prostředí. Výsledky nám připomněly, z jakých prostředí naše děti pocházejí. Uvědomili jsme si skutečnost, že do dětských domovů přicházejí děti až v okamžiku, když selžou všechny ostatní pokusy zvrátit nepř́iznivou situaci. Tento fakt bývá často opomíjen, což může být příčinou nepřesné představy veřejnosti o dětských domovech. $Z$ naši výsledků je dále zřejmé, že náhradní rodinná péče může být úspěšnou alternativou výchovy ústavní, ale bude potřeba překonat řadu překážek a současný systém bude nutné podrobit revizi.

$\mathrm{Na}$ základě našich zjištění bychom si dovolili nastínit dílčí inovace. Oslovení pěstouni opakovaně zdůrazňovali potřebu mezioborové spolupráce, což chápeme jako zcela zásadní. Jednotlivé zapojené resorty by mohly vytvořit úzce specializovaný úřad, který by zastřešil všechny zapojené instituce a svoji energii by věnoval otázkám náhradní rodinné péče a ústavní výchovy. K úvaze se dále nabízí prrehodnocení institutu zákonného zástupce dítěte s nařízenou ústavní výchovou. Velice by usnadnilo práci, pokud by dětský domov mohl během pobytu dítěte operovat většími pravomocemi. Chápeme, že jde o citlivou otázku, ale prezentujeme pouze náš názor opřený o zkušenosti z praxe. Dále bychom uvítali větší podporu ze strany médii ${ }^{23}$. Je na čase se zaměřit na primární problém, tedy na existenci rodin, které nemohou, nebo neumí se o svoje děti postarat. Je třeba veřejnosti prezentovat potřebu pěstounských a hostitelských rodin, je třeba přiznat, že je jich nedostatek. Pěstouni by měli být nikoli pouze proškoleni sedmdesáti hodinami, nabízí se myšlenka bakalářského studijního programu. Po jeho absolvování by budoucí pěstouni měli garantovaný státní př́ijem, coby vysokoškoláci by poskytovali motivaci jejich budoucím dětem. Problematice by prospěla masivní mediální podpora, politické špičky by měly přehodnotit své programy a přesunout otázku náhradní rodinné péče do oblasti prioritního státního zájmu. Ve společnosti se vede debata, nakolik jsou dětské domovy v naší společnosti potřebné. Nejedná se ani o nový, ani o lehce řešitelný problém ${ }^{24}$. Dokud mezi námi budou děti, které nemohou vyrůstat ve svých vlastních rodinách, jsme povinni pro ně zajistit bezpečné a podnětné prostředí. Je třeba na problematiku pohlížet komplexně a chápat ji $\mathrm{v}$ širším kontextu. Zajištěním pouhého přístřeší problém vyřešen není. Podle našeho názoru se poněkud pozapomíná na následnou péči. Přitom právě následná péče hraje klíčovou roli po odchodu dětí z náhradní péče ${ }^{25}$, protože i ta sebelepší náhradní péče může mít negativní dopad na život jedince ${ }^{26}$, což může eskalovat do problémů spojeným s přechodem do samostatného života. Nelze také opominout otázku prevence, je vždy snazší problémům předcházet, než je řešit. Stát by měl aktivně vyhledávat možné problémové rodiny a poskytnout jim adekvátní podporu. Investované prostředky se naší společnosti mnohonásobně vrátí.

Pojd'me se společně vydat na náročnou cestu, na jejímž konci bude společnost, ve které bude méně dětí, které potřebují Klokánek, nebo dětský domov. A pro ty, které pomoc potřebovat budou, at' je dostupná paleta širokého spektra podpůrných opatření, na které bude vhodné řešení pro každé dítě.

\footnotetext{
${ }^{23}$ Instituce jsou často líčeny jako nepodnětná prostředí, která jsou navíc ekonomicky náročnější než formy náhradní rodinné péče. Ano, tento typ péče je finančně náročný, ale my chápeme dětské domovy jako státem garantovanou pojistku pro děti, jejichž rodiny nebylo možné sanovat.

${ }^{24}$ GOLDBERGER, Kurt, Děti bez lásky. Na minutáži 35:20 tohoto skvělého dokumentu sám profesor Matějček hovoří o strádání dětí nejen v ústavech, ale i v rodinách. Tvrdí, a my můžeme pouze souhlasit, že čím méně dětí $\mathrm{v}$ ústavech bude, tím více sil bude zbývat na práci s nimi.

${ }^{25}$ HÄGGMAN-LAITILA, Arja et al. Transition to adult life of young people leaving foster care. Str. 142.

${ }^{26}$ VAN IJZENDOORN, Marinus H. Children in institutional care: delayed development and resilience. Str. 704.
} 


\section{Poděkování}

Velké poděkování patří všem pěstounům a hostitelům, kteří pomáhají našim dětem na cestě jejich životy. Slova nejsou schopna vypovědět, jak si vážíme jejich nasazení.

\section{Použitá literatura}

1. BARVÍKOVÁ, Jana, Jana PALONCYOVÁ a Jana MACHOVÁ. Zařizení pro dèti vyžadující okamžitou pomoc - umistování dětí, podmínky péče o děti, financování provozu. Praha: VÚPSV, 2012. ISBN 978-80-7416-100-1.

2. DANĚK, Alois. Dětský domov Klánovice - vybrané sociologické otázky. In: $M M K$ 2020: mezinárodni Masarykova konference pro doktorandy a mladé védecké pracovniky. Hradec Králové: Magnanimitas, 2020, s. 704-712. ISBN 978-80-8795233-7.

3. GOLDBERGER, Kurt [filmový dokument], 1963. [online], Děti bez lásky. Dostupné z: https://www.youtube.com/watch?v=iLjHAP9Cho4

4. HÄGGMAN-LAITILA, Arja, Pirkko SALOKEKKILÄ a Suyen KARKI. Transition to adult life of young people leaving foster care: A qualitative systematic review. Children and Youth Services Review. 2018, 95, 134-143. ISSN 0190-7409. Dostupné z: doi:10.1016/j.childyouth.2018.08.017

5. KONEČNÁ, Hana a Markéta SUDOVÁ. Jak dál s pěstounskou péči na prechodnou dobu? Praha: Středisko náhradní rodinné péče, 2011. ISBN 978-80-87455-08-1.

6. MACELA, Miloslav. Krátkodobá pěstounská péče: Historie, praxe, perspektivy. Praha: Sdružení pěstounských rodin, 2019. ISBN 978-80-270-5530-2.

7. MUŽÁKOVÁ, Monika a Alois DANĚK. Dětský domov Klánovice v období 19481989 aneb čest práci, soudružko vychovatelko! Speciální pedagogika: časopis pro teorii a praxi speciální pedagogiky. Praha: Pedagogická fakulta Univerzity Karlovy, 2020, 30(1-2), 83-99. ISSN 1211-2720.

8. STÁREK, Lukáš. Definition of Substitute Family Care and Issues of the School Environment. Journal of Education and Training Studies [online]. 2020, 8(9), 43. ISSN 2324-8068, 2324-805X. Dostupné z: doi:10.11114/jets.v8i9.4954

9. VAN IJZENDOORN, Marinus H. a et al. Children in Institutional Care: Delayed Development and Resilience. Monographs of the Society for Research in Child Development. 2011, 76(4), 8-30. ISSN 0037976X. Dostupné z: doi:10.1111/j.15405834.2011.00626.X

10. YI, Youngmin a Christopher WILDEMAN. Can Foster Care Interventions Diminish Justice System Inequality? The Future of Children. 2018, 28(1), 37-58. ISSN 15501558. Dostupné z: doi:10.1353/foc.2018.0002

11. Zákon č. 359/1999 Sb., o sociálně-právní ochraně dětí.

12. Zákon č. 109/2002 Sb. o výkonu ústavní výchovy nebo ochranné výchovy ve školských zařízeních a o preventivně výchovné péči ve školských zařízeních.

13. Zákon č. 89/2012 Sb. Nový občanský zákoník.

\section{Kontaktní údaje}

PhDr. Alois Daněk, Ph.D.

Univerzita Karlova, Fakulta pedagogická

Katedra speciální pedagogiky

Magdalény Rettigové 4, 11000 Praha

Tel: 775525759

email: danek@ddklanovice.cz 


\title{
SPOJITOSŤ EMOCIONÁLNOU INTELIGENCIOU A OSOBNOSTNÝMI DIMENZIAMI PODL'A EYSENCKA U ŠTUDENTOV UČITELSKÝCH ODBOROV
}

\author{
CONNECTION WITH EMOTIONAL INTELLIGENCE AND \\ PERSONAL DIMENSIONS ACCORDING TO EYSENKA IN TEACHER \\ STUDENTS
}

\author{
Dominika Doktorová, Hubinská Jana, Varečková L’ubica
}

\begin{abstract}
Abstrakt
V našom výskume sa zamerali na zist'ovanie vzt'ahu črtovej emocionálnej inteligencie TEIQue-SF a osobnostným typom meraným pomocou Eysenckovho dotazníka EPQ-R rozlišujúceho úroveň extraverzie, neuroticizmu a psychotizmu. Skúmali sme zároveň vzt’ah typu osobnosti meraným dotazníkom EPQ-R a úrovňou emocionálnej inteligencie TEIQueSF. V našich výsledkoch sme zaznamenali signifikantné rozdiely v úrovni črtovej emocionálnej inteligencii vzhl'adom na Eysenckovu typológiu.
\end{abstract}

Kl'účové slová: emocionálna inteligencia, osobnostné dimenzie, vzájomné konexie

\begin{abstract}
In our work we aimed to explore the relationship with factors of Well-Being, sociability, emotionality as well as self-control, as well as the total value of emotional intelligence through short-form questionnaire emotional feature intelligence TEIQue-SF and also by personalized type of measurements using the Eysenck EPQ-R questionnaire distinguished level of extraversion, neuroticism and psychoticism. We also examined the relationship type of personality measured by the questionnaire EPQ-R and the level of emotional intelligence TEIQue-SF. In our results we have seen different abilities to recognize emotion in facial appearance to personality type determined on the basis of a questionnaire Eysenck EPQ-R, equally significant differences in the level of emotional feature intelligence considering Eysenck typology
\end{abstract}

Keywords: emotional intelligence, personality dimensions, connections

\section{ÚVOD}

Emocionálna inteligencia podlieha viacerým vplyvom, ale najmä prostrediu, v ktorom vyrastáme a je výsledkom výchovy rodičov. Na jej rozvoj má vplyv i vytváranie sociálnych vzt'ahoch vrstovníkmi (Sparitt, 1996). Viacerí odborníci (napríklad Zimbardo, 1995, Goleman, 2011) sa zhodli, že každá vzniknutá emócia môže byt' vnímaná ako konkrétna tendencia jedinca správat' sa určitým spôsobom. U l'udí s vyššou emocionálnou inteligenciou je zvýšená vnútorná tenziu (Märtin- Boeck, 1996). P. Salovey a J. D. Mayer (1990), ktorí ju definovali ako schopnost' monitorovat' vlastné emócie, ale i emócie u druhých, ako i kompetenciu rozlišovat' medzi nimi a využivat' nadobudnuté poznatky pri regulácii svojho myslenia a správania sa. Pri tvorbe danej definície sa inšpirovali poznatkami J.E LeDouxa (1987 in LeDoux, 2000), ktorý zastával názor, že jedna čast' zo stimulu vyvolávajúceho emócie sa nespracováva $\mathrm{v}$ kortexte, ale $\mathrm{v}$ amygdale. Osobnost' je do značnej miery ovplyvňovaná povolaním a zložkami emocionálnej inteligencie (Helmke, Schrader, 2006). Md Nawi, Nurul Hudani, Redzuan, Ma'rof (2011) zist'ovali spojitost' medzi emocionálnou 
inteligenciou s osobnostnými faktormi vymedzenými Eysensckom (Nolen-Hoeksema, 2012). Medzi neurotizmom a emocionálnou inteligenciou zaznamenali štatistky významný vzt’ah v negatívnom smere. Taktiež i medzi emocionálnou inteligenciou a psychotizmus zaznamenali negatívnu koreláciu. Medzi extraverziou a emocionálnou inteligenciou sa potvrdil pozitívny vzt’ah. Atta, Ather, Bano ( 2013) vo svojom výskume zaznamenali signifikantne významnú pozitívnu spojitost' medzi emocionálnou inteligenciou a extraverziou, svedomitost'ou, otvorenost'ou voči skúsenosti a významnú reverzibilnú koreláciu s neurotizmom. Matthews et al (2006) zistili, že emocionálna inteligencia súvisí s extraverziou v pozitívnom smere a v negatívnom s neurotizmom (Matthews a kol., 2006, in Iruloh, Ukeagbu ,2015, Yosooff, Ibrahim, Abd Kadir, Ab Rahman,2014). Hlavným ciel'om výskumu je zistit', či existujú štatisticky významne vzt’ahy medzi:celkovou úrovňou emocionálnej inteligencie a osobnostnými dimenziami, jednotlivými zložkami emocionálnej inteligencie a osobnostnými dimenziami,

Našu prvú hypotézu sme vytvorili na základe zistení odborníkov (Aluja a kol., 2002, Carver a White, 1994, Ekman, 2014, Eysenck a Eysencková, 1991, Matthews a kol., 2006, in Iruloh, Ukeagbu ,2015, Yosooff, Ibrahim, Abd Kadir, Ab Rahman,2014) a sformulovali sme ju nasledovne:

H1: Predpokladáme že medzi zaznamenanými osobnostnými dimenziami podl’a Eysenca neuroticizmus, extraverzia a celkovou úrovňou emocionálnej inteligencie meranej TEIQue existuje spojitost'.

VO1: Existujú signifikantne významný vzt’ah medzi osobnostných osobnostnými dimenziami podl'a Eysencka (neurotizmus, extraverzia a psychotizmus) a zložkami emocionálnej inteligencie?

\section{METÓDY}

\subsection{Výskumný súbor}

Výskumný súbor pozostával z 200 participantov. Všetci boli študentmi jednej vysokej školy učitel'ského odboru na FF UCM, TRUNI vo veku $19-27$ rokov. Skupinu tvorilo 22 mužov a 78 žien s vekovým priemerom 21,4 roka. Študenti boli porovnatel'ní z hl'adiska úrovne školy, odboru a lokality, v ktorej sa škola nachádzala. Použili sme zámerný výber. Výskumnú vzorku sme vybrali na základe testových metód, s ktorými sme pracovali.

\subsection{Materiály a aparatúry získavania údajov}

Úroveň emocionálnej inteligencie $\mathrm{u}$ tej istej skupiny respondentov pomocou dotazníka TEIQue skrátená forma (Nabelková, 2015) obsahuje 30 položiek, zodpovedajúcej 7-bodovej Likertovej mierke, kedy 1 znamená ,úplný nesúhlas“, a 7 znamená „úplný súhlas“. Z 15 subškál na každú otázku pripadajú dve, ktoré boli v TEIQue vybrané pre integráciu, založené predovšetkým na ich vzájomnej korelácii s celkovým subškálovým skóre.

Osobnostné dimenzie pomocou Eysenckovho osobnostného dotazníka- EPQ-R, (Eysenck Personality Questionnaire, Hodde, Stoughton, 1991, Reštandardizovaný: Psychodiagnostika s. r. o. Bratislava 1993), ktorá obsahuje 48 položiek, je jednoduchšie administrovatel'ná a participanti majú kratší čas na odpovede. Tento dotazník je možné použit' v základnom i aplikovanom výskume pre klinické i poradenské účely.

V tejto sa nachádza 48 otázok, na ktoré odpovedajú respondenti zaškrtnutím ÁNO - NIE, odpovede sú následne vyhodnotené podl’a šablóny, kde nám každá dimenzia určuje hodnotu jednotlivých faktorov. Sledujeme škálu N - neurotizmus a rovnako škálu E - extraverzia či P - psychotizmus. 


\subsection{Procedúra}

Na spracovanie a analýzu získaných dát skupín sme použili štatistický program SPSS 22 . Na zist'ovanie vzt'ahov medzi premennými sme využili v závislosti od testov normality (Kolgornov-Smirnov pre žiakov) neparametrické testy. Pre dosiahnutie ciel'ov nášho výskumu sme sa rozhodli použit' korelačný výskum. Zaujímali nás vzt’ahy medzi emočnou inteligenciou a osobnost'ou. Za účelom získania odpovedí na dané výskumné otázky a hypotézy použili sme Spearmanov koeficient, pretože sme pracovali s poradovými premennými. Spearmanov koeficient korelácie nám určuje rôznu mieru závislosti, ktorú budeme interpretovat' na základe tejto schémy:

Hodnota do 0,3 mierna závislost'

Hodnota od 0,3 do 0,6 stredná závislost'

Hodnota nad 0,6. silná závislost'

\section{VÝSLEDKY}

H1: Predpokladáme že medzi zaznamenanými osobnostnými dimenziami podl’a Eysencka neuroticizmus, extraverzia a celkovou úrovňou emocionálnej inteligencie meranej TEIQue existuje spojitost'.

Pri zist’ovaní spojitosti úrovne emocionálnej inteligencie pre zaznamenané osobnostné typy sme dospeli k štatisticky významným výsledkom na základe týchto zistení môžeme našu hypotézu prijat'. Výsledky nám poukazujú na to , že extraverti dosahujú signifikantne vyššie hodnoty $\mathrm{v}$ úrovni emocionálnej inteligencie, čo uvádzame v tab. č. 1. Sila korelačného koeficientu je stredne silná a koeficient je záporný, čo znamená v našom prípade, že čím je úroveň neurotizmu u respondentov vyššia tým je celkové skóre v TEIQue nižšie. Signifikancia $\mathrm{P}=0,000$, v prípade extraverzie výsledok je siginfikantný.

Tab. č. 1: vzájomné konexie emocionálna inteligencia a extraverzia a neurotizmus

\begin{tabular}{|lll|l|l|}
\hline & & Extraverzia & Neurotizmus \\
\hline Spearmanovo rho & TEIQue & Korelačný & $310^{* *}$ &,$- 649 * *$ \\
& & Koeficient & 002 &, 000 \\
& Sig. (2-tailed) & 002 & 200 \\
\hline & $\mathrm{N}$ & 200 & \\
\hline
\end{tabular}

*. Korelácia je významná na úrovni 0.05 .

**. Korelácia je významná na úrovni 0.01 .

Zdroj: autorky práce

VO1: Existujú signifikatne významný vzt’ah medzi osobnostných osobnostnými dimenziami podl'a Eysencka (neurotizmus, extraverzia a psychotizmus) a zložkami emocionálnej inteligencie?

Z hl'adiska vzt'ahu jednotlivých osobnostných charakteristík a zložiek emocionálnej inteligencie sme dospeli $\mathrm{k}$ nasledujúcim záverom. Zložka emocionálnej inteligencie, wellbeing, vytvára signifikantný vzt'ah $\mathrm{s}$ úrovňou extraverzie $\mathrm{P}=0,017$ a neurotizmu kde $\mathrm{P}=$ 0,000. Well-being v súvislosti s extraverziou vytvára pozitívny, avšak nízky vzt’ah, pričom s neurotizmom sme zaznamenali negatívnu koreláciu, ktorej sila vzt'ahu dosahovala taktiež nízke hodnoty. Pri zložke sociability sme zaznamenali negatívny signifikantný vzt’ah $\mathrm{s}$ úrovňou neurotizmu kde $\mathrm{P}=0.000$ a pozitívny signifikantný vzt'ah $\mathrm{s}$ úrovňou extraverzie kde $\mathrm{P}=0.000$. Sila zaznamenaných vzt’ahov bola vyššia ako pri zložke well-beingu a dosahovala stredné hodnoty. $\mathrm{V}$ rámci emocionality sme zistili vytváranie signifikantného negatívneho vzt'ahu s neurotizmom kde $\mathrm{P}=0.000$, pričom sila vzt'ahu bola nízka. Pri zist'ovaní vzt'ahu sebakontroly a neurotizmu sme evidovali negatívnu, stredne silnú, signifikantnú koreláciu kde $\mathrm{P}=0.000$. Vzt'ah sebakontroly a extraverzie bol pozitívny 
a signifikantný kde $\mathrm{P}=0.000$, avšak sila vzt'ahu bola zanedbatel'ná. Najsilnejšiu negatívnu koreláciu sme zaznamenali medzi sebakontrolou a extraverziou. Najslabší negatívny vzt’ah sme zaznamenali medzi emocionalitou a neurotizmom. V rámci pozitívnych vzt'ahoch dosahovali najvyššiu silu vzt'ahu sociabilita s extraverziou a najslabší vzt'ah vytvárala sebakontrola a neurotizmus. Všetky zaznamenané vzt’ahy uvádzame v tabul'ke č. 2.

Tab. č. 2: Vzt’ah zložiek emocionálnej inteligencie a osobnostných charakteristík.

\begin{tabular}{|c|c|c|c|c|}
\hline \multicolumn{3}{|c|}{ Úroveň faktorov EI } & Extraverzia & Neurotizmus \\
\hline \multirow{15}{*}{$\begin{array}{l}\text { Spearmanovo } \\
\text { rho }\end{array}$} & \multirow[t]{3}{*}{ Well-Being } & Korelačný koeficient & $238 *$ &,$- 391 * *$ \\
\hline & & Sig. (2-tailed) &, 017 &, 000 \\
\hline & & $\mathrm{N}$ & 200 & 200 \\
\hline & \multirow[t]{3}{*}{ Sociabilita } & Korelačný koeficient & , $496 * *$ &,$- 490 * *$ \\
\hline & & Sig. (2-tailed) & .000 &, 000 \\
\hline & & $\mathrm{N}$ & 200 & 200 \\
\hline & \multirow[t]{3}{*}{ Emocionalita } & Korelačný koeficient &, 170 &,$- 361 * *$ \\
\hline & & Sig. (2-tailed) &, 092 &, 000 \\
\hline & & $\mathrm{N}$ & 200 & 200 \\
\hline & \multirow[t]{3}{*}{ Sebakontrola } & Korelačný koeficient & $199 *$ &,$- 543 * *$ \\
\hline & & Sig. (2-tailed) & .047 &, 000 \\
\hline & & $\mathrm{N}$ & 200 & 200 \\
\hline & \multirow{3}{*}{$\begin{array}{l}\text { TEIQue } \\
\text { Celkové Skó } \\
\text { Emocionálnej } \\
\text { inteligencie }\end{array}$} & Korelačný koeficient & $310 * *$ &,$- 649 * *$ \\
\hline & & eSig. (2-tailed) &, 002 &, 000 \\
\hline & & $\mathrm{N}$ & 200 & 200 \\
\hline
\end{tabular}

*. Korelácia je významná na úrovni 0.05 .

**. Korelácia je významná na úrovni 0.01 .

Zdroj: autorky práce

\section{DISKUSIA}

\subsection{Interpretácia výsledkov}

Ciel'om našej práce bolo potvrdit' signifikantný vzt’ah medzi celkovou úrovňou emocionálnej inteligencie meranou skrátenou formou dotazníka črtovej emocionálnej inteligencie TEIQueSF a osobnostným typom určeným pomocou Eysenckovho osobnostného dotazníka EPQ-R. Rovnako bolo naším ciel'om zistit' vzt'ah úrovne jednotlivých zložiek meraných dotazníkom črtovej emocionálnej inteligencie TEIQue-SF, Well-Being, Emocionalita, Sociabilita a osobnostným typom určeným pomocou Eysenckovho osobnostného dotazníka EPQ-R.

V rámci prvej hypotézy sme zist’ovali spojitost' medzi celkovou úrovňou črtovej emocionálnej inteligencie a osobnostných dimenzií. Zaznamenali sme štatisticky významné vzt’ahy medzi premennými. Zistili sme, že existuje spojitost' medzi extraverziou a emocionálnou inteligenciou a medzi neurotizmom a emocionálnou inteligenciou. V rámci našej výskumnej vzorky sme nemali žiadneho participanta, ktorý by dosiahol vyššie skóre voblasti psychotizmu. Ak by naša vzorka pozostávala i z participantov signujúcich voblasti psychotizmu predpokladáme, že by sme zaznamenali štatisticky významnú spojitost' v negatívnom smere, čo vyplýva zo zistení odborníkov (Aluja a kol., 2002, Gable a kol, 2003). Naše zistenia sú v súlade s výskumnými zisteniami odborníkov (Carver a White, 1994, Ekman, 2014, Eysenk a Eysenková , 1991, Gable a kol, 2003). Zaujímavost'ou je, že sme na rozdiel od výskumných zistení (Carver a White, 1994, Ekman, 2014, Eysenk a Eysenková, 
1991) sme zaznamenali len mierny korelačný vzt’ah medzi extraverziou a celkovou emocionálnou inteligenciou. Toto zistenie interpretujeme tak, že dimenzia extraverzia verzus introverzia nedeterminuje emocionálnu inteligenciu do takej miery, ale u extravertov je možné ju identifikovat' v komunikácii (Gardner, 2011) a taktiež sa rozvíja v prostredí (Goleman, 2011), v ktorom je jedinec pomerne aktívnym článkom. Medzi neurotizmom a emocionálnou inteligenciou sme zaznamenali silný negatívny vzt’ah, čo je v súlade so zisteniami odborníkov (Gable a kol, 2003). Toto zistenie interpretujeme tak, že l'udia signujúci výraznejšie v dimenzii neurotizmu, pre ktorých je charakteristická zvýšená senzibilita v CNS, majú tendenciu reagovat' úzkostne (Kulišsták, 2003). Na základe tohto zistenia sme prišli k záveru, že by bolo zaujímavé zistit' spojitost' medzi úzkostlivostou a emocionálnou inteligenciou, prípadne rozšírit' poznatky a výskum o biologický komponent zameraný na zist'ovanie génu súvisiaceho s úrovňou dopamínu, ktorý súvisí s rozkošou ( Ebstein, Belmark, 1996 in Goleman,2011).

Vo výskumnej otázke sme zist'ovali súvislost' medzi úrovňou jednotlivých faktorov črtovej emocionálnej inteligencie a osobnostnými dimenziami. V tomto prípade sme dospeli k nasledovným záverom. Zložka emocionálnej inteligencie well-being, signifikantne významne koreluje vzt'ah súrovňou extraverzie a neurotizmu. Medzi well-beingom a extraverziou sme zaznamenali pozitívny mierny vzt'ah. Toto zistenie interpretujeme tak, že prežívanie spokojnosti nemusí byt' determinované len extraverziou, ale i inými premennými, ktoré pôsobia na danú zložku emocionálnej inteligencie. Pre extravertov je charakteristické, že sa rýchlo nadchnú pre nejakú aktivitu, ale vo väčšine prípadov stratia záujem (LeDoux, 2000, Matthews a kol., 2006, in Iruloh, Ukeagbu, 2015), čo sa môže prejavit' i v prežívaní well-beingu. Napríklad môžu zažívat' well-being v dôsledku nadväzovania nových kontaktov. Medzi neurotizmom a well-beingom sme zaznamenali negatívnu koreláciu na strednej úrovni. Toto zistenie interpretujeme tak, že i jedinec, u ktorého prevládajú obavy a ich charakteristickou osobnostnou črtou je úzkostlivost' môžu byt' št’astní (Eysenck, 1986). $\mathrm{Z}$ tohto zistenia vyplýva, že ak by sme pracovali na eliminácii obáv u jedinca zvyšoval by sa i jeho well-being. Pri zložke sociabilita sme zaznamenali negatívny signifikantný vzt'ah s úrovňou neurotizmu a pozitívny signifikantný vzt'ah súrovňou extraverzie. Sila zaznamenaných vzt'ahov bola dosahovala v oboch prípadoch stredné hodnoty. Spojitost' medzi extraverziou a sociabilitou interpretujeme na základe charakteritiky extravertov, pre ktorých je charakteristické rýchle nadväzovanie kontaktov (Eysenk, 1986) a začlenenie sa do skupiny (Goleman, 2011, Nolen-Hoeksema, 2012). Negatívny vzt'ah medzi sociabilitou a neurotizmom je možné interpretovat' na základe obáv pri vytváraní sociálnych kontaktov. Toto zistenie je v súlade s charakteristikami osobnosti (Eysenck, 1986) a emocionálnej inteligencie (Schulze, 2005) V rámci emocionality sme zistili signifikantne významný vzt’ah s emocionalitou, čo interpretujeme tak, že aktivácia amygdaly je u neurotických jedincov výraznejšia, čo spôsobuje, že dokážu reagovat' najmä na výraznejšie emocinálne podnety (LeDoux, 2000, Goleman, 2011). Medzi emocionalitou a extraverziou sme nezaznamenali štatisticky významnú spojitost', ale potvrdila sa pozitívna tendencia. Toto zistenie je v súlade so zisteniami odborníkov, ktorý zastávajú názor, že emocionálna bohatost' nesúvisí výhradne s osobnostnými charakteristikami, ale s prostredím (Spearit, 1996). Medzi sebakontrolou a neurotizmom sme zaznamenali stredne silnú negatívnu koreláciu. Toto zistenie interpretujeme tak, že neurotici nemajú pod kontrolou svoje vlastné správanie v jednotlivých životných situáciách. Naše tvrdenie je totožné s názormi odborníkov (Gable a kol., 2003, Eysenck, 1986). Vzt'ah sebakontroly a extraverzie bol pozitívny a signifikantný, avšak sila vzt'ahu bola zanedbatel'ná. Znamená to, že extraverti nemajú pod kontrolou vlastné správanie, alebo sa na tento jav nezameriavajú, čo je v súlade s charakteristikou extravertov (Eysenk, 1986). 


\subsection{Limity výskumných metód}

Po zrealizovaní výskumu sme zaznamenali nedostatky, ktorým sme pri realizácii samotného výskumu nevenovali dostatok pozornosti, napriek našej snahe predikovat' a predchádzat' všetkým nežiaducim činitel'om, ktoré samotná realizácia výskumu indukovala.

Prvým z limitov je naša výskumná vzorka.. Pri výbere sme sa nezamerali na fakt, že študenti učitel'stva môžu predkladané dotazníky poznat', čo môže viest' k celkovému skresleniu získaných dát. Ďalším nedostatkom je nemožnost' zovšeobecnenie získaných dát na celú populáciu, ale len na konkrétnu skupinu, ktorou v našom prípade boli študenti na UCM a TRUNI. Výskumu sa zúčastnili študenti, u ktorých môžeme predpokladat', že budú mat' vyššiu mieru emočnej inteligencie ako by mala iná vzorka $\mathrm{z}$ bežnej populácie. V budúcich výskumoch sa dostatočne zameriame na reprezentatívnost' vzorky, čo nám umožní vytvárat' závery vzt’ahujúce sa k slovenskej populácii. Hoci sme sa nesústredili na medzi pohlavné rozdiely, pokladáme za dôležité spomenút', že sme nemali dostatočne vyrovnanú vzorku $\mathrm{z}$ hl'adiska počtu mužov a žien. Tento jav vnímame ako jeden z výrazných nedostatkov. Vyrovnanie vzorky zhl'adiska zastúpenia pohlavia by poskytlo objektívnejší pohl'ad na komparáciu medzi danými premennými. Nakol'ko medzi študentmi učitel'stva výrazne prevažuje počet žien v porovnaní s mužmi, v budúcich výskumoch sa zameriame na vytvorenie výskumnej vzorky pozostávajúcej zo študentov humanitných a technických odborov.

Druhým limitom je vol'ba jednotlivých dotazníkov. Na zist'ovanie osobnostných dimenzií sme použili Eysenckov osobnostný inventár, ktorý býva súčast'ou mnohých testových batérií. V rámci výskumu sme využívali seba hodnotiace výskumné metódy, ktoré majú vel'mi vel'ké množstvo nedostatkov. Participanti majú v nich tendenciu sa nadhodnocovat' a charakterizovat' sa na základe predpokladu, aké reakcie sa od nich očakávajú v spoločnosti. Relevantnejšie výsledky by mohli priniest' výkonové testy, ktoré sú však časovo náročnejšie. Prípadne by sme mohli využit' seba hodnotiace metódy v kombinácii s hodnotením jedinca prostredníctvom nezainteresovanej osoby. Taktiež na zist'ovanie osobnosti by bolo vhodné využit' iný osobnostný dotazník, ktorý nie je participantom známy.

V rámci výskumu sme sa nesústredili sa na elimináciu prechodných faktorov na strane participantov, nemali sme takmer žiaden vplyv na participantov. Nakol'ko sme ich nepoznali, nedokázali sme zistit', či sa u nich vyvinul stres zo samotného testovania, i ked' vedeli, že ich výsledky budú využité len na účely práce, mohlo dôjst' k skresleniam.

Za výrazný nedostatok nášho výskumu považujeme fakt, že sme minimálne znižovali zdroje chybovosti vo výskume. V budúcom výskume sa pokúsime vyvinút' väčšiu snahu na štandardizáciu podmienok testovania, aspoň vzhl'adom na všetkých participantov, ktorí sa zúčastnia nášho výskumu.

\subsection{Dôsledky vyplývajúce z výsledkov}

Napriek vyššie uvedeným limitom je nutné brat' do úvahy zistenia, ktoré z nášho výskumu vyplývajú.

Z našich výsledkov je zrejmé, že každý konštrukt (osobnost', emocionálna inteligencia a schopnost' rozpoznávat' emócie z výrazov tvári) má svoju charakteristickú multidimenzionalitu z čoho vyplýva, že môže byt' ovplyvnený množstvom premenných.

Emočná inteligencia je samostatný konštrukt, ktorý je vel'mi komplikovaný a na jeho vznik a vývoj vplýva množstvo premenných. Pred realizáciou výskumu sme predpokladali, že je možné emocionálnu inteligenciu pomerne jednoduchým spôsobom zachytit'. Práca s dotazníkom nám priniesla množstvo otázok a záver, že sa tento konštrukt rozvíja a prejavuje vel'mi odlišne.

Osobnost' má podl’a Eysencka viac, či menej stabilnú organizáciu charakteru, intelektu, temperamentu a fyzickej stánky, ktorú determinuje neopakovatel'né prispôsobenie osoby 
prostrediu. Znamená to, že celý konštrukt osobnosti je do značnej miery výsledkom interakcie prostredia a genetiky. Na rozvoji jednotlivých dimenzií u človeka počas jeho vývinu pôsobia najmä rodičia, ale i vrstovníci, ktoré nedokážeme predikovat' a vel'mi často nie sme schopní ich eliminovat'.

\subsection{Budúce zámery}

Vel'mi zaujímavé by bolo spojit' náš súčasný koncept so vzt'ahovou väzbou a perfekcionizmom. Náš budúci zámer bude vyzerat' nasledovne:

Obr. Vzt'ah medzi osobnost'ou (O), emocionálnou inteligenciou (EI), vzt'ahovou väzbou a perfekcionizmom(VV) .

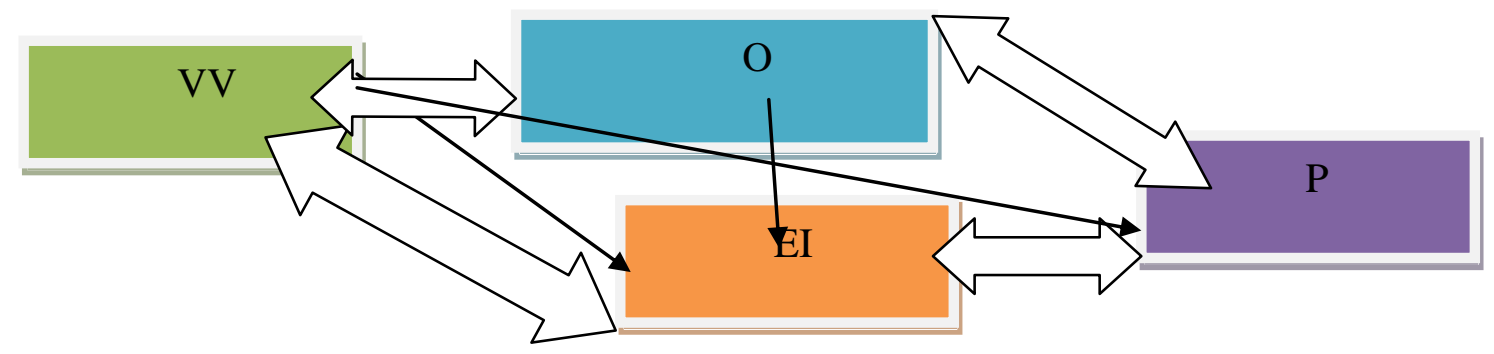

Zdroj: autorky práce

Za vel'mi zaujímavé považujeme najmä zistenie, či existuje prepojenie medzi premennými vo forme jednotlivých výskumných otázok, vzhl’adom na to, že na danú problematiku, sa nám nepodarilo nájst' dostatočné množstvo výskumov.

Predpokladáme, že emočná inteligencia bude preukazovat' reverzne signifikantný vzt'ah s perfekcionizmom a negatívnou vzt'ahovou väzbou. Tento vzt’ah dedukujeme aj z vyššie uvádzaných údajov, ktoré poukazujú na to, že emočná inteligencia je spojená s pozitívnym pracovným modelom, v ktorého vybudovaní by mali byt' vyššie spomenuté premenné významnou prekážkou.

Osobnost', ktorá inklinuje k sociálne determinovanému perfekcionizmu, by sa mala preukazovat' negatívna vzt’ahová väzba, nižšia úroveň v emocionálnej inteligencii. Tento jav vyplýva z internalizácie externých požiadaviek, ktoré sú nekriticky prebrané od iných osôb. Na potvrdenie svojej vlastnej identity, musí človek dosahovat' určité štandardy, ktoré mu explicitnou formou vyjadria jeho hodnotu.

Vzt'ahová väzba by sa tak mohla stat' určitou spojnicou medzi emočnou inteligenciou, osobnost'ou a perfekcionizmom. Preskúmaním týchto vzt'ahov by sme mohli hlbšie nahliadnut' a presnejšie si overit' náš prvotný model.

Na základe našich zistení v zrealizovanom výskume uvádzame nasledovné odporúčania:

1. Vhodné je zrealizovat' tréning emocionálnej inteligencie, aby sme zistili, či je možné zvyšovat' emocionálnu inteligenciu pri konkrétnych osobnostných dimenziách.

2. Osobnost' determinuje emocionálnu inteligenciu

\section{Použitá literatúra}

1. ALUJA, A.- GARCÍA, O.- GARCÍA, L. F.: A comparative study of Zuckerman's three structural models for personality through the NEO-PI-R, ZKPQ-III-R, EPQ-RS and Goldberg's 50-bipolar adjectives., Personality and Individual Differences, 33, 2002.

2. ATTA, M.- ATHER, M.- BANO, M. Emotional Intelligence and Personality Traits among University Teachers: Relationship and Gender Differences. in International Journal of Business and Social Science Vol. 4 No. 17. 2013. 
3. CARVER, C.S.- WHITE, T. L. Behavioral inhibition, behavioral activation, and affective responses to impending reward and punishment: The BIS/BAS scales, Journal of Personality and Social Psychology, 67.1994, 2,

4. EKMAN PAUL, Odhalene emócie, Braingy, Bratislava, 2014, ISBN 987-80971082-0-5

5. EBSTEIN R.P., NOVICK O., UMANSKY R., PRIEL B., OSHER Y., BLAINE D., BENNETT E.R., NEMANOV L., KATZ M., BELMARK R.H.. Dopamine D4 receptor (D4DR) exon III polymorphism associated with the human personality trait of Novelty Seeking. Nature Genetics, 12,1996

6. EYSENCK, H. J. Can personality study ever be scientific?, Journal of Social Behavior and Personality, 1., 1986

7. EYSENCK, H. J.-EYSENCK, S. B. G. Manual of the Eysenck Personality Scales (EPS adult), comprising the EPQ-revised(EPQ-R)(including addiction and criminality scales) EPQ-R short scale impulsiveness (IVE) questionnaire (impulsiveness/venturesome/empathy). London: Hodder \& Stoughton, s.15-20, 1991

8. GABLE, S. L.- REIS, H. T. - ELLIOT, A. J. Evidence for bivariate systems: An empirical test of appetition and aversion across domains, Journal of Research in Personality, 37, 2003, 5, p.349-372

9. GARDNER, H. Frames of Mind: The Theory of Multiple Intelligences. Basic Books, 2011, ISBN: 978-0-465-02433-9

10. GOLEMAN, D. Emoční inteligence. Metafora ,2011 ISBN: 9788073593346

11. HELMKE, A. \& SCHRADER, F.-W. (2006). Determinanten der Schulleistung. In D. H. Rost (Hrsg.),Handwörterbuch Pädagogische Psychologie (3. überarb. u. erw. Aufl., S. 83-94). Weinheim: Beltz Psychologie Verlags Union.

12. IRULOH, B-R. N.- UKAEGBU, H.M. Big Five Personality traits as predictosrt og emotional intelligence of secondary schol teachers in rivers state of Nigeria. . European Journal of Psychological Research, Vol. 2 No. 2, 2015 ISSN 2057-4794.

13. KULIŠŤÁK, P. Neuropsychologie. Praha: Portál, 2003.

14. LEDOUX JOSEPH, (2000). Synaptic Self: How Our Brains Become Who We Are, Penguin Books, ISBN-13: 978-0142001783

15. MATTHEWS, G., ZEIDNER, M., ROBERTS, R. D. Emotional intelligence: science and myth (718 p.). MIT Press., 2006 ISBN 0262632969

16. MARTIN, DORIS Y BOECK, KARIN QIEE es inteligencia emocional. Cómo lograr que las emociones determinen nuestro triunfo en todos los ámbitosde la vida, Edaf, 1996, Madrid.

17. MD NAWI- NURIL HUSANI- REDZUAN, MA'ROF. Emotional intelligence, personality and self esteem: a comparison of the characteristics among two categories of subjects. [online] International Journal of Humanities and Social Science, 1 (8). pp. 238-247. 2011. ISSN 2220-8488

18. Nolen-Hoeksema, S. a kol. (2012). Psychologie Atkinsonové a Hilgarda. 3. vyd. Praha: Portál, 2012. 888 s. ISBN 978-80-262-0083-3

19. PETRIDES, K.V.; FREDERICKSON, N.; AND FURNHAM, A. The role of trait emotional intelligence in academic performance and deviant behavior at school. Personality and Individual Differences, 36(2), 277-293,2003.

20. SALOVEY, P. \& MAYER, J. D. Emotional intelligence. Imagination, Cognition and Personality, 9, 185-211, 1990 ISSN: 0276-2366

21. SCHULZE, R. Modeling structures of intelligence.2005 In: Wilhelm, O. \& Engele, R. W. (Eds.), Understanding and measuring intelligence. Thousand Oaks, CA: Sage. 241-263. ISBN: 978-0761928874 
22. SPARITT, D. Carroll's model of cognitive abilities: Educational implications. International Journal of Educational Research, 25, 107-197, 1996.. ISSN: 1873-538X

23. YOSOOFF, F.- IBRAHIM, A.- ABD KADIR, N. B- AB RAHMAN, M. A study of the relationship between $E Q$ and personality amog lectures at a research unoversity. Procedia- Social and Behavioral Sciences, 2014.

24. ZIMBARDO, P. G. Psychologie (6. Aufl.), Berlin \& Heidelberg: Springer.1995 ISBN: 978-3540593812

\section{Kontaktné údaje}

PhDr. Dominika Doktorová, Ph.D.

Univerzita sv. Cyrila a Metoda v Trnave

Námestie Herdu 2, Trnava 91701

Tel: 0904696500

dominikka.doktorova@gmail.com /dominika.doktorova@ucm.sk 


\title{
SYMBIOTICKÉ VZŤAHY MEDZI VEDCAMI A UMELCAMI A SPROSTREDKOVANIE TÝCHTO VZŤAHOV POMOCOU DIDAKTICKÝCH METÓD V PEDAGOGICKOM PROCESE A ICH EVALVÁCIA V ZÁKLADNOM ŠKOLSTVE
}

\author{
SYMBIOTIC RELATIONS BETWEEN SCIENTISTS AND ARTISTS \\ AND INTERMEDIATION OF THESE RELATIONS USING DIDACTIC \\ METHODS IN THE EDUCATIONAL PROCESS AND THEIR \\ EVALUATION IN PRIMARY EDUCATION
}

\author{
Erika Miklóšová, Xénia Bergerová, Miloš Kmet’
}

\begin{abstract}
Abstrakt
Práca upozorn̆uje na rôzne prístupy vedcov, ktorí sa vo svojej profesii zaoberajú výskumnými procesmi, ktoré dokážeme prirovnat' ku kreatívnym až umeleckým procesom. Ich protipól tvoria súčasní umelci, ktorých diela vznikajú v procese, ktoré sú vedecké, dokonca sa prelínajú s vedou. Hlavným zámerom práce je predstavit' týchto adeptov v stredoeurópskom kontexte. Ďalej sa zamerat' na otázku ako predstavit' jednotlivé prírodné vedné disciplíny det'om v základnom školstve a na základe akých predmetov a akého prostredia. Ďalším zámerom práce je pokúsit' sa nájst' vhodné didaktické metódy, na základe ktorých je možné zhodnotit' aktivitu žiaka v základnom školstve.
\end{abstract}

Kl'účové slová: umenie, pedagogika, vedné disciplíny, technológia, ekológia, hodnotenie

\begin{abstract}
The work draws attention to the different approaches of scientists who in their profession deal with research processes that we can compare to creative and artistic processes. Their counterpart is formed by contemporary artists, whose works are created in a process that is scientific, even intertwined with science. The main purpose of the work is to present these adepts in the Central European context. Furthermore, to focus on the question of how to introduce individual natural scientific disciplines to children in primary education and on the basis of what subjects and what environment. Another aim of the work is to try to find suitable didactic methods, based on which it is possible to evaluate the activity of students in primary education.
\end{abstract}

Key words: art, pedagogy, scientific disciplines, technology, ecology, evaluation

\section{VÝBER PREDMETOV V ZÁKLADNOM ŠKOLSTVE, KDE JE MOŽNÉ VYUŽITIE SYMBIOTICKÝCH VZŤAHOV MEDZI VEDCAMI A UMELCAMI}

Hlavným ciel'om práce je v prvom rade podporit' v konkrétnom veku diet'at'a jeho kreativitu a nájst' riešenia ako $\mathrm{s}$ ním rovnocenne spolupracovat'. Podnietit' $\mathrm{v}$ ňom tieto schopnosti pomôže výchova umením a výchova pozorovaním/ pozeraním sa na okolitý svet, ktorý sa tak rýchlo mení okolo nás. Pomocou týchto „barličiek“ v ňom autorka chce prebudit' prirodzené estetické cítenie, prirodzenú zvedavost', záujem o svoje okolie a v neposlednom rade posilnit’ sebavedomie a sebainterpretáciu diet’at’a, ktoré je možné učinit' prichádzajúcimi skúsenost’ami z tvorivých činností a z podnetných diskusií. Príklady použité z tohto výskumu 
sú aplikovatel'né na základnú školu so zameraním na prírodovedné predmety a výtvarnú výchovu.

\section{POZNANIE}

Oblast' tvorivosti, kreativity diet'at'a je d'alší aspekt, ktorý ponúka široký potenciál preto je dôležité toto detské myslenie podnietit' smerom k činnostiam, ktoré by podporovali ich tvorivost' a kreativitu. Zároveň tieto činnosti spadajú do úlohy vedy. Sem patria: pozorovat', napodobňovat', počúvat', vnímat', mysliet', porovnávat', predstavovat' si, interpretovat', vymýšl'at', tvorit', overovat' si, spoznávat'.

Podla Šobáňovej, Peirc delil poznanie na štyri metódy. Prvá sa volala metóda tradície preberanie modelov po predkoch, druhá metóda autority - pevný stanovený názor využívaný hlavne vo vede pri odborných textoch, ked’že potom text pôsobí dôveryhodnejšie a exaktnejšie. Predposledná metóda a priori využíva princíp intuície a tvorivosti, ktoré rovnako využívajú pri vede ako pri umení a posledná metóda je metóda vedy.

Pomocou vedeckej činnosti sa usiluje človek zistit' ako funguje poznatel'ný svet.

$\mathrm{Z}$ historického vývoja až $\mathrm{v}$ novoveku prišlo $\mathrm{k}$ reformácii poznania. V 17. - 18. storočí nadobudla matematika základ pre každú vedu, hlavnými predstavitel'mi - vzormi pre vedcov sa stal: Galilei, Newton, či Boyle. Hlásali priame štúdium a výskum samotnej skutočnosti, usilovali o empirické, avšak nie kopírované poznanie v zmysle: „študuj skutočnost', pozoruj, objavuj nové veci, neopakuj po druhých ich slová!“‘

V 18. storočí prinieslo francúzske osvietenstvo projekt Encyklopédie spojený s menami Diderot, Voltaire, Rousseau. V roku 1859 prichádza so svojím dielom O pôvode druhov Ch. Darwin, podl'a ktorého sa nazýva celé hnutie darwinizmus.

\section{SYMBIOTICKÉ VZŤAHY MEDZI VEDCAMI A UMELCAMI - PREDSTAVITELIA}

Príroda a biológia je pre človeka - výskumníka a pozorovatel’a od nepamäti inšpiráciou vo vede i vo výtvarnom umení. Myslím si, že školské predmety so zameraním na prírodovedu a biológiu ponúkajú priestor, ktorý je ideálnym miestom pre výskum, kde je potrebné žiakov vychovávat' $\mathrm{k}$ pocitu zodpovednosti a spolupatričnosti k prírode.

\subsection{Greta Thunbergová}

Krajina, ktorú majú žiaci okolo seba nie je prirodzene daná a taká aj zostane. Takže je potrebné si prostredie - environment uchovat' v čo najmenej poškodenom stave, pre d'alšie generácie. Príkladom je hnutie The Global Climate Strike, ktoré pravidelne usporadúva Greta Thunbergová, švédska aktivistka a školáčka. Všetky tieto aktivity sa navalujú a majú efekt zväčšujúcej sa snehovej gule. Podl'a žiačky Thunbergerovej ekologické otázky nevyriešime posúvaním si ich pred sebou. Chceme predíst' svetu bez stromov, bez včiel, bez l'adovcov, bez čistého vzduchu, alebo bez čistej vody. Toto riešenie/prístup patrí medzi jedno z najviditel'nejších a najzásadnejších, ked’že Thunbergerová vytvára politický a ekonomický tlak a podnecuje neustálu komunikáciu. Thunbergerová má vel'ký vplyv na d’alšie generácie detí.

Ďalej budem v tomto projekte hl'adat' symbiózu medzi súčasným umením a vedou, cez optiku spolupráce umelcov a vedcov vo svete a na Slovensku. Na túto existujúcu problematiku poukázala Šobáňová (Užitečná symbioza, 2013), ktorá hovorí, že veda a umenie je cesta k poznaniu. Šobáňová sa pýta, kedy robí veda umenie a umenie vedu?

\subsection{Olafur Eliasson}

Medzi takýchto významných umelcov patrí Olafur Eliasson, ktorý už dlhší čas prepája umenie s vedou, už vyše dve desat'ročia a jeho výstavy sú vždy zážitok pre všetky l'udské 
zmysly (pre hmat, pre čuch, pre chut', pre sluch a pre l'udské oko). V jednom rozhovore prezradil, že dlhé roky spolupracuje s matematikom Einar Thorsteinom. Ďalej spomína, že impulz pre vznik jeho modelov, je častokrát idea, význam, či samotná intuícia.

\subsection{Galériu TBA21 (Thyssen - Bornemisza Art Contemporary)}

Nájdu sa aj významné organizácie, ktoré fungujú ako galérie súčasného umenia - Galéria TBA21 (Thyssen-Bornemisza Art Contemporary) vo Viedni. Galéria sa zaoberá s environmentálnymi a vedeckými témami. Prezentuje v širokom spektre rôznorodé prístupy ekologické, politické, ideologické, environmentálne. Predstavuje práce umelcov, vedcov v rôznych médiách, ktorí sa snažia uchopit' a vysvetlit' súčasné mechanizmy fungovania sveta. Organizácia zanikla v roku 2017, ale stále poskytuje informácie o svojej činnosti prostredníctvom verejnej knižnice.

\subsection{Martin Mrva}

V oblasti škôl a univerzít, ktoré vytvárajú podmienky pre takúto spoluprácu vo svete je na Slovensku Univerzita Komenského v Bratislave. Nasledujúci autor je vedec RNDR. Martin Mrva, PhD, ktorý pracuje na UK na Prírodovednej fakulte na Katedre Zoológia na Univerzite Komenského, kde prednáša, publikuje a pracuje na vedeckých výskumoch. Jeho oblast' výskumu sa volá Taxonómia a morfológia nahých meňaviek, identifikácia patogénnych améb, výskum potenciálnych terapeutík amébových infekcií. Martin Mrva zároveň ilustruje detské knižky a odborné knihy s vel'mi precíznymi a perfekcionistickými kresbami.

\subsection{Carsten Höller}

Vo svojich inštaláciách, videách a objektoch sa Höller venuje alternatívnym alebo utopistickým priestorom pre život človeka, pri ktorých často nastolí otázky: „Čo keby sa to stalo? Čo ked' urobím/zvolím tak alebo onak? Predstavte si, že... Tvár sa ako keby...

Carsten Höller, v roku 1991 ako súčast' svojho diela - happening, plánoval vel'kú demonštráciu, na ktorú malo príst' 500 detí a niest' cez mesto malé transparenty s nápisom Future. Happening bol nakoniec odvolaný kvôli malému počtu účastníkov. Vel'mi mi to pripomína súčasné štrajky G. Thunbergerovej, kde deti mávajú transparentami nesúce nápis: „There is no plan B!““

Dnes je vývoj didaktiky učenia omnoho vyvinutejší a otvorenejší pre detskú fantáziu a mysel'. Neurológ Martin Ján Stránsky tvrdí, že,“ Najhoršie je, ked’ žiak sedí a učitel'ka prednáša. Bifl'ovanie mozog nudí."

Čo je to vlastne detská kresba a detská mal'ba? Je to spontánny prejav diet’at’a v určitom veku, prejav čistej naivnej a autentickej radosti, kde diet’a za sebou necháva určitú stopu, ktorá má hodnotu sebarealizácie, práce a vizuálneho zážitku.

Aké má podoby z hl'adiska vekového vývoja medzi vekom mladšieho školského veku $7-8$ rokov? Diet'a postupuje od jednoduchších námetov ku komplikovanejším, postupuje paralelne podl'a svojho mentálneho vývoja.

Podl'a pedagogičky Cindy Foley je jedna z možností ako sa prostredníctvom didaktiky učenia dopracovat' $\mathrm{k}$ požadovanému ciel'u, je rozmýšl'anie spôsobom ako to robí umelec.

Z psychologickej stránky sa učenie delí na formy, na širšiu a užšiu formu. Za širšiu formu učenia sa označuje každé získavanie individuálnej skúsenosti v priebehu života diet’at'a. Užšia forma učenia predstavuje zámerné a systematické nadobúdanie vedomostí, zručností a návykov, spôsobov správania, osobných vlastností pod vedením učitel'a, majstra v organizovaných podmienkach. Väčšina psychológov by súhlasila s formuláciou, že učenie je pomerne trvalá zmena $\mathrm{v}$ potenciálnom správaní jedinca $\mathrm{v}$ dôsledku skúseností. Jeho definícia znie, že je to relatívne trvalá zmena vo vedomostiach, alebo v správaní, rezultujúca zo skúseností. Relatívne môže byt' zmenená novými skúsenost’ami. 


\subsection{Pina Bausch a Jan Minařík}

Ďalší podnet, ktorý je dôležitý v kreatívnom procese je samotný zážitok, ktorý môže podporit' d'alší druh umenia, a tým je tanec. V tejto kategórií by som upozornila na Pinu Bausch, choreografku a riaditel'ku Tanztheater $\mathrm{v}$ meste Wuppertal a Jána Minaříka, ktorý tancoval v jej súbore.

Na záver práce si dovolím sprostredkovat' svoj osobný zážitok. Jan Minařík bol v roku 2015 v Bratislave, kde sa konal festival pod názvom Synergia tvorby Piny Bausch, odkial mám naňho vel'mi milú spomienku. Rozprával nám svoje zážitky $\mathrm{z}$ tanečných prijímačiek, kde sa nevedel roztancovat'. Jeho pedagóg mal na to jednu fintu, zakričal nan̆ho počas choreografie: „Jano, skoč, jako přes potok!““ Chápem, že toto gesto bola metóda, ako zo žiaka dostat' maximálny výkon.

Metóda choreografie Piny Bausch bola založená na osobných príbehoch tanečníkov. Ona povedala sloveso, oni ho predviedli svojím telom. Podl'a Piny Bausch je treba mysliet' inak, potom sa riešenie objaví.

Domnievam sa, že genialita niektorých umelcov a vedcov tkvie v tom, že dokážu na jednoduchých metódach ukázat' komplikované procesy.

\section{Použitá literatura}

1. Benjamin, W., Umelecké dielo vo veku svojej technickej reprodukovatelnosti, In: Iluminácie, Kaligram, Bratislava, 1999, 286s. ISBN 8071492485

2. Berger, J., About looking, Bloomsburry London, 1980, 199s. ISBN 978- 0-74759957-9

3. Bergerová, X. 2013. Malý príbeh farby. RECO : Senica, 2013, 63s. ISBN 80-8946208-7

4. Birnbaum, D. 2011., Defining Contemporary Art: 25 Years in 200 Pivotal Artworks. 1. vyd. London : Phaidon, 2011, 480 s. ISBN: 0-7148-6209-5

5. Bluhová, I., Bauhaus očami bývalého študenta, 1969, In: Kolek. autorov, Ars časopis, SAV, 2/1969 Ročník III, Slovak Academic Press, 177s. ISSN 71-008-70

6. Byrne, D. Wie musik wirkt, S.Fischer, Frankfurt am Main, 2012, 425s. ISBN 978-310-397417-1

7. Čarná, D. Po stopách umenia, GMB a Artfriends OZ, Bratislava, 2009, 69 S., ISBN 978-80-89340-13-2

8. Čarná D. Kotvanová L. Nakresli si ovečku, Slovart, Bratislava, 2019, 80 s. ISBN 9788055643847

9. Čarný, L., Výtvarná Výchova pre 5. ročník základných škôl, 1. Vydanie, Expol Padagogika, Bratislava, 2009, 111 s. ISBN 978 - 80-8091-177-5

10. Čarný, L., Výtvarná Výchova pre 6. ročník základných škôl a 1. ročník osemročných gymnázií, 1. Vydanie, Združenie Educo, Bratislava, 2010, 113 s. ISBN 978 - 8089431-08-3

11. Čarný, L., Výtvarná Výchova pre 7. ročník základných škôl a 2. ročník osemročných gymnázií, 1. Vydanie, Združenie Educo, Bratislava, 2011, ISBN 978 - 8 s. 0-8943122-9

12. Davido, R., 2008. Kresba jako nástroj poznání dítěte. Praha : Portál, 2008. ISBN 80-7367-415-1

13. Debord G., Společnost spektáklu, :intu: Praha, 2007, 157s. ISBN 8090335554

14. Dungel J., Biologie umění, Academia, Praha, 2020, 269 s. ISBN 978 - 80 - 200 $3077-1$

15. Ferencová, Y., 2009. Apozice obrazu. 1. vyd. Brno : Nakladatelství Pavel Křepela, 2009, 183 s. ISBN 80-86669-12-0 
16. Filla, R., Načo nám je umenie, Mladé letá, Bratislava, 1991, 150 s. ISBN 80-0600296-7

17. Fink, E., 1993. Hra jako symbol světa. Český spisovatel, Praha, 1993. 268 s. ISBN 80-202-0410-5

18. Fulková, M., HAJDUŠKOVÁ, L., SEHNALÍKOVÁ, V. 2011. Galerijní a muzejní edukace 1. Galerie Praha : Rudolfinum, Uměleckoprůmyslové muzeum v Praze, Pedagogická fakulta Univerzity Karlovy, 2011, 315 s. ISBN 80-7290-535-5

19. Gavora, P. A KOL. 2010. Elektronická učebnica pedagogického výskumu. [online]. Bratislava : Univerzita Komenského, 2010. Dostupné na: http://www.emetodologia.fedu.uniba.sk/. ISBN 80-223-2951-4.

20. Gavora, P. 2008. Úvod do pedagogického výskumu. 4. vyd. Bratislava : Univerzita Komenského, 2008, 236 s. ISBN 978-80-223-2391-8.

21. Geržová, J. Mal'ba v kontextoch, kontexty mal'by (Zborník česko-slovenského sympózia venovaného problémom súčasnej mal'by). Bratislava: SLOVART a VŠVU, 2012. 231 s. ISBN 80-556-0793-1

22. Geržová, J. Mal'ba v postmediálnom veku (Zborník medzinárodného sympózia venovaného problémom súčasnej mal'by). Bratislava: SLOVART a VŠVU, 2012. 231 s. ISBN 80-556-0793-1

23. Hanáková, P., Teoretická kritika (modernistického) múzea - exemplárny terč newyorské MoMA (The Museum of Modern Art), 2002, In: Ars časopis, SAV, 13/2002, Slovak Academic Press, Bratislava, 2002, 280s. ISSN 0044-9008

24. Hessler, S., Tidalectics (Imagining an oceanic worldview through art and science), TBA21 -Academy London, 2019,240s. ISBN 9780262038096

25. Hudec I., Kováč L', Ekológia I (Všeobecná ekológia), Prírodovedecká fakulta UPJŠ Košice, 2011, 135 s. ISBN 978 - 80 - 7097-848 - 1

26. Ingerle, P., Př́běh perspektivy, Moravská galerie, Brno, 2010, 221s. ISBN 978-8087474-09-9

27. Iser, W., Jak se delá teorie, Karolinum, Praha, 2009, 243s. ISBN 978-80-246-1672-8

28. Koldehoff, S., O - ton Pina Bausch, Nimbus, Wädenswil 2016, 317s. ISBN 978-303850-021-6

29. Komárik, E. 2002. Metódy vedeckého poznávania človeka. Bratislava : Univerzita Komenského, 2002, 210 s. ISBN 80-223-1717-9

30. Lahoda, T., Carsten Holler, In:Labyrint Revue, kolek. autorov,, Prostory pro život č 11-12/2002, Via Vestra, Praha, 2002, 288 s. ISSN 1210-6887

31. Lukáčová, M. 2010. Čo letí v múzejnej pedagogike. Bratislava : Slovenské národné múzeum, 2010, 112 s. ISBN 80-8060-252-9

32. Pachmanová, M., Ex - pozice. O vystvavování muzejních sbírek, umění, designu a architektury, UMPRUM, Praha, 2018, 223 s., ISBN 978 - 80 - $87989-54$-7

33. Piaget J, Inherdel B., Psychologie ditěte, 1997,Portál, Praha, 143s. ISBN 8085752336

34. Rádl, E., 1999, Dějiny filosofie III, Novověk, Praha, Votobia, 668s. ISBN 80-7220064-X., In:

35. Šobáňová, P. a kol.,Užitečná symbioza, Saublau, Univerzita Palackého Olomouc, 2013, 18s. ISBN 978-80-904512-1-6

36. Roeselová, V., Námèty ve výtvarné výchově, 1997, Sarah, Praha, 1997, 195 s. ISBN $80-238-3744-3$

37. Roeselová, V., Proudy ve výtvarné výchově, 2000, Sarah, Praha, 2000, 217 s. ISBN 8090226736

38. Roeselová, V., Řada a projekty ve výtvarné výchově, 1997, Sarah, Praha, 1997, 219 s. ISBN $80-90-2267-2-8$ 
39. Roeselová, V., Techniky výtvarné výchově, 1996, Sarah, Praha, 1996, 241 s. ISBN 80 $-902267-1-\mathrm{X}$

40. Rozsypal, S. a kol. Nový přehled biologie, Scientia, Praha, 2003, 796 s. ISBN 97880-86960-23-4

41. Slánský, B. Technika v malířské tvorbě (Malířský a restaurátorský materiál). Praha : SNTL, 1973, $186 \mathrm{s.}$

42. Sokolová, K. 2010. Galerijná pedagogika - stručný nárys jej vývoja, teórie a praxe. 1. vyd. Banská Bystrica : Univerzita Mateja Bela, Pedagogická fakulta v Banskej Bystrici, 2010, 131 s. ISBN 80-8083-981-9

43. Strauss, C. L., Myšlení přirodných národů, Dauphin 1996, Praha, 365 s. ISBN 80 901842-9-4

44. Strauss, C.,L., Smutné trópy, Libraire Plon, Praha, 2011, 478s., ISBN 978 - 80 87067-11-6

45. Sturken, M., Cartwtright,L. Studia Vizuální kultury. Praha: Portál, 2009. 462s. ISBN 80-7367-556-1

46. Šebešová P., Šimonová P., Enviromentální výchova pro ZŠ a SŠ, Tři kroky k aktívnímu vyučování, Portál, Praha 2013, 222 s. ISBN: 978 - 80 - 262 - 0503 -6

47. Šerák, M. 2009. Volný čas a zájmové vzdělávání. In: Chomová, S. 2009. Vol'ný čas: príležitost' na rozvoj kreativity, inovácií a vzdelávania. Bratislava : Národné osvetové centrum, 2009, 87 s. ISBN 80-7121-313-0.

48. Šicková-Fabrici, J. 2005. Obrazy vnútra In: Obrazy vnútra. Bratislava : OZ Terra Therapeutica, 2005, s. 6 - 7. ISBN 80-969376-3-4

49. Šicková-Fabrici, J. 2008. Základy arteterapie. 2. vyd. Praha : Portál, 2008, 176 s.ISBN 80-7367-408-0

50. Šobáňová, P. 2014. Muzejni expozice jako edukačni médium. 1. díl. 1. vyd. Univerzita Palackého : Olomouc, 2014, 364 s. ISBN 80-244-4303-7

51. Šobáňová, P. 2014. Muzejní expozice jako edukační médium. 2. díl. 1. vyd. Univerzita Palackého : Olomouc, 2014, 364 s. ISBN 80-244-4394-2

52. Šobáňová, P. a kol.,Užitečná symbioza, Saublau, Univerzita Palackého Olomouc, 2013, 18s. ISBN 978-80-904512-1-6

53. Švařiček, R., Šed’ová, K. 2014. Kvalitativní výzkum v pedagogických vědách. 2. vyd. Praha : Portál, 2014, 377 s. ISBN 80-262-0644-6

54. Valachová, D. 2009. Povedzme to farbami. Brno : Tribun EU, 2009, 146 s. ISBN 807399-855-4

55. Whitford F., Bauhaus, Rubato eseje, Praha, 2015, 229s., ISBN 978-80-87705-34-6

\section{Kontaktné údaje}

Mgr. art. Miklóšová Erika

Doc. Xénia Bergerová, ArtD.

Mgr. Miloš Kmet', PhD.

Univerzita Komenského v Bratislave, Pedagogická fakulta

Račianska 59, 813 34, Bratislava I

erika21miklosov38@gmail.com

bergerova@fedu.uniba.sk

kmet@fedu.uniba.sk 


\title{
ANALYSIS OF ACADEMIC TEXTS IN THE PROCESS OF LANGUAGE TRAINING OF FUTURE DIPLOMATS
}

\author{
Martina Benčeková
}

\begin{abstract}
The paper deals with the analysis of the academic texts from the point of view of the language analyse. It compares the text from the special and the language point of view. After the introductory characteristics of the professional text and professional language, we focus on the criteria for selecting an academic text for the needs of language teaching in the fields of international relations, diplomacy and political science. Afterwards it deals with detailed analysis of the individual steps of the language analysis. Towards the end, the paper emphasises the necessity of the language analysis of the academic texts in the process of language training for specific purposes of the students of diplomacy and political science.
\end{abstract}

Key words: academic text, terminology, interdisciplinarity, language analysis, country studies, political history, intercultural communication

\section{INTRODUCTION}

Current linguistic trends abandon the separate study of individual linguistic disciplines, subjects, phenomena and increasingly prefer interdisciplinarity. This tendency is reflected not only in cooperation between linguistics and other social sciences (psychology, sociology, history and others), but also in cooperation between different linguistic disciplines. We follow similar developmental changes in the area of our interest in the teaching of a foreign language at non-philological faculties. In the last two decades, the interest of linguistics (especially under the influence of changing social conditions) has focused on communication, functional, pragmatic and cultural-anthropological focus, the key concepts of which have become the terms field of study, text, communication, context and culture. In connection with the current trend of the educational society, professional communication has gained an important position in the entire cultural and social existence of every educated individual. It has become an important part of the language disposition of members of society in addition to everyday communication and has helped them to function more effectively in everyday life and professional practice. As we have stated in the previous lines, the current trend in linguistics is the interconnection of several scientific disciplines and disciplines. The linguistic view is confronted with sociological, psychological and cultural research, which results in the analysis of professional communication in many scientific disciplines - in science and technology, but also in the economic, legal and political science fields. Such a comprehensive approach to research includes not only linguistic but also professional requirements, which in turn results in more effective communication of experts on a global scale.

\section{LANGUAGE TRAINING AT THE FACULTY OF POLITICAL SCIENCE AND INTERNATIONAL RELATIONS, MBU}

An essential part of the teaching program of non-philological faculties of the humanities, e.g. law, political science, economics and other types of faculties is the teaching of foreign languages. Mastery of at least two of the world's most widely used languages is currently a matter of course for graduates of international relations and diplomacy.

In this paper we will provide our view on the conditions for successful study of foreign languages at non-philological universities, entry criteria for students and textual material, together with the expected final output. We are based on the current language program for 
teaching academic English at the Faculty of Political Science and International Relations of Matej Bel University in Banska Bystrica. Language teaching at our faculty is not focused on general language, but on acquiring and deepening lexical knowledge in the field of study, therefore the main source of new language knowledge is political science texts, texts on international relations, basics of law and economics and humanities according to the chosen language - country studies and history of selected countries of the given language area. In the English-speaking field, we focused on the political studies and history of Great Britain and the USA.

\section{CONDITIONS FOR SUCCESSFUL TEACHING OF PROFESSIONAL LANGUAGE AT NON-PHILOLOGICAL FACULTIES}

\subsection{Academic text in the process of teaching a foreign language}

The basic focus and goal of the professional text is defined by J. Mistrík as the mediation of work information, publication of acquired knowledge and recording of important ideas acquired through scientific research, reflections and experiences of people. (Mistrík, 1977) This intention is supported by the choice of means of expression that are strongly contextually bound, interrelated and overlap with other styles. All of these are conceptual expressions that are able to transmit the results of the human intellect quickly, in a condensed form and with maximum accuracy. (Mistrík, 1977) The above definitions indicate the dominance of the reference and metalanguage function of the academic text, which is reflected in the choice of language means, mostly of a terminological nature. Non-terminological means, including phraseology, are used to a lesser extent due to the function of professional texts. Nevertheless, it is necessary to pay attention to them and detailed research, because their atypicality and unexpected occurrence in the text disrupts the conventional understanding of the content and function of the academic text and contributes to their attractiveness. However, the primary functions of academic texts remain descriptive, directive and instructive functions, which are dominant and essential even in political science texts.

\subsection{Criteria for selecting an academic text}

The basic precondition for successful language teaching is a qualified selection of an academic text according to several qualitative and quantitative criteria. The first criterion is the focus on the field of study. With the current demands placed on students, it is not effective to deal with academic texts that are unrelated or only very marginally related to a given scientific area. In our case, we give priority to areas related to political science, such as international relations, political science and the political history of Great Britain and the USA. The latter texts are the subject of our practice and therefore we pay attention to them in further analysis.

Another criterion for selecting a text is its topicality. Nowadays, it is necessary to adapt professional texts to rapidly advancing changes and updates in all areas of study. In the case of texts from history, topicality is ensured by additional materials from contemporary journals, which are directly or indirectly related to the analysed topic.

An important criterion for choosing an adequate text is the language level of the target group of students. According to the required level, it is necessary to choose the text of reasonable difficulty. Poor assessment of students' previous knowledge leads to too fast processing of material, lack of activity in seminars and poor knowledge and language progress. Overestimation of student abilities and knowledge by submitting too demanding a text leads to disgust, demotivation and does not have the required didactic qualities leading to effective progress. The opposite situation also has a negative effect, when the students are presented with a text that is too simple and thus does not represent any enrichment of their lexical or proficiency. A similar effect is brought by the disproportionate length of the text, so in our 
case we proceeded to create our own teaching texts, which provide an overview of the political development of Great Britain and the United States in a condensed form, focusing on the most important events, personalities, contexts.

\subsection{The position of academic language}

The struggle concerning the definitive determination of the position of academic language in the linguistic system, which is taking place between linguists dealing with general and academic language, has been going on for many levels at a long time. Academic language is sometimes wrongly considered "insufficiently scientifically based" and is included in a not very important branch of lexicology. In the first half of the 20th century, some members of the Prague Linguistic Circle drew attention to the theoretically professional function of language. We met with the most concise definition of professional language in English Special Languages by Sager, Dungworth, McDonald from 1980 - special languages are semiautonomous, complex semiotic systems based on and derived from general language; their use presupposes special education and is restricted to communication among specialists in the same or closely related fields. (Sager, Dungworth, McDonald, 1980)

\subsection{Academic language}

A general prerequisite for the effectiveness of education in academic language is the use of academic terminology. Academic texts combine instructive, descriptive and directive function with communicative function. The carrier of academic communication is academic language. Academic language is defined as a set of language items that are tied to a certain area of human activity. (Drozd, Seibicke, 1973) Borsuková understands academic language as an abstract concept, which does not exist as a separate linguistic expression, but is updated in academic texts. (Borsuková, 1995) This author further characterizes academic language as a summary of lexical and syntactic starting points, as a potential for the creation of professional, that means not only strictly educational communications. Academic communication is characterized by any structure with bound semantic content. It aims to convey information from various fields of science, research and human thinking. We encounter the use of academic terminology not only in texts of educational style, but also in administrative and journalistic style. With the growing level of education and expertise in all spheres of society, academic terminology is penetrating many areas of human activity, it is becoming a natural part of everyday communication. However, academic terms lose their strict terminological character in ordinary communication. (Jelínek, 1995) In connection with the expansion of academic language, there is an internationalization of terms and the emergence and gradual establishment of new technical terms, reflecting the latest trends. On the other hand, older terms disappear. Simultaneously with this process, academic terms penetrate into ordinary language and vice versa. The language of academic texts is used to name subjects and terms, so it is oriented towards a specific vocabulary, which in this case has a reference function. The term in academic language becomes a linguistic feature with a strictly defined defined content. With respect to terminological normalization, which is based on the precision of naming, the technical term is perceived as an axiom that is exactly defined and independent of context.

\section{LANGUAGE ANALYSIS OF THE ACADEMIC TEXT}

If the text meets all professional and linguistic criteria, we proceed to the linguistic analysis itself. We divide it into several parts, while due to the complex processing it is necessary to go through all stages and it is recommended to follow the order of individual parts of the language analysis. 


\subsection{Semantic analysis}

The first part is semantic analysis. Depending on the level of students and time constraints, this stage can be solved by home self-study or collective processing in seminars. Semantic analysis is closely related to the second stage of linguistic analysis of an academic text and that is the lexical part. These two parts cannot be separated or skipped because they represent an understanding of the content of the text, an explanation of unknown terminology, and these activities are necessary for further work with the text. To master the content and lexical side of the text, it is necessary to work with a quality dictionary, preferably monolinguistic, again depending on the achieved language level of students. The work cannot be limited to monotonous reading and translation of the text, because this type of activity will soon become not only inanimate for students, but also tiring and will not bring the desired result or interest in further work with the text. The best is the independent work of students, who first master the text using the scan reading method to get acquainted with its approximate content. They also deal with detailed reading, in which they underline the unknown terminology. Finally, it is possible to select the terms that are necessary for understanding the text and, depending on the language level of the students, there is a realistic assumption that they will not be able to master them.

\subsection{Lexical analysis}

The selected (not only unknown, but also above all key) terminology is the subject of further processing in lexical analysis. Subsequent exercises are used to confirm comprehension of the text (comprehension tasks) and to work with terminology. Questions analysing text comprehension can take several forms:

- control questions for which the creation of precise answers according to the content of the text is required,

- yes-no questions, in which students decide whether opinions are true or false, again depending on the content of the text,

- multiple-choice questions, that means questions with multiple answers provided, from which students have to determine the right one.

Lexical analysis, that means work with vocabulary, presents endless possibilities for further processing. Some of them are:

- search for synonyms,

- searching for oppositions,

- creation of Slovak equivalents,

- explanation of meanings, as well as

- elaboration of abbreviations is a very good possibility for consolidating new vocabulary, its further use and searching for connections with other terminology.

Familiarization with the new terminology should be followed by consolidation of new knowledge and practice of old ones:

- use of new terms in sentences,

- creating your own sentences, not content-related to the text,

- adding words to sentences, as well as

- combining words with their meaning, these are all exercises that strengthen the newly acquired terminology and contribute to a better understanding of the text.

\subsection{Morphological analysis}

The third part of the linguistic analysis of an academic text is the morphological part, which uses the newly acquired vocabulary and deepens the knowledge of the grammatical structure of the language. Possible alternatives are:

- completion of appropriate prepositions, 
- giving the verbs into the proper tense,

- creating new part of speech,

- search for metaphorical expressions.

\subsection{Verbal expression}

The last stage, but very important for consolidating all the acquired knowledge and skills, is verbal word processing. This can take many forms, the most commonly used being:

- discussion

- presentation.

Both forms require not only the use of newly acquired vocabulary, but also the development of students' expressive abilities, either in verbal or written form.

The development of students' language and communicative competences corresponds to the priorities that determine them in their future professional practice:

- ability to communicate professionally

- to develop, promote and increase students' cultural awareness

- to be able to adequately orientate oneself in cultural peculiarities and institutions

- cultivate sensitive behaviour in contact with people from a foreign language environment as one of the determining factors of successful international contacts.

The language program of a faculty of any kind and department requires two main characteristics: complexity and continuity. Complexity in this context means above all the connection of language teaching with the field of study. This means not interfering in other scientific disciplines, but developing language knowledge and skills in the field. The basic precondition for continuity as another factor influencing the language program is the fact that students come to university at a certain level of knowledge of a foreign language. Further language study thus represents a certain "superstructure" - it does not focus on basic language knowledge, but develops and expands the knowledge already acquired by gradually adding additional language information, not only in the grammatical, morphological and syntactic areas, but especially in the lexical area.

\subsection{Practical application}

For the specification of the given issue and the application of my own experience from teaching, I will prefer the analysis of the English language at our faculty. The language program is divided into different levels, depending on whether it is a first or a second foreign language, but the system and content remain the same. The program is based on the main subjects - landscape science and history of English-speaking countries, academic texts from international relations, political science texts, the basics of economic law, texts on the European Union. Due to time constraints, current professional texts in an optional form are included during the semesters. In the academic texts of individual types, students get acquainted not only with specialized knowledge (this is mainly the role of specialized subjects), but especially with their lexical side. After completing the courses, the student must be able to present their specialized knowledge in a foreign language. Against the background of increasing specialized knowledge, these texts are also used for further expansion and deepening of language knowledge from the morphological and syntactic point of view.

The country studies as well as the history of the selected region depend on the chosen language. In the English-speaking area, it is Great Britain and the USA. On the example of the history teaching system, we will also offer a specific system of one of the basic subjects of the language program of our faculty. The basic goal is to mediate and consolidate knowledge about the historical development of society, the political and governmental system, as well as about individual significant events and contexts in the history of the mentioned countries. The topic is chronologically divided into chapters. These gradually touch on the most important 
periods. Their basic characteristics and subsequent analysis of individual events, personalities and contexts provide students with a general overview of history, develop their vocabulary and language and communication skills.

In the following examples, we will present some examples of the application and validation of new knowledge and skills selected from the History of Great Britain university textbooks (Benčeková, 2011). ${ }^{1}$ The basic goal of teaching history is to mediate and consolidate knowledge about the historical development of society, the political and governmental system, as well as about individual significant events and contexts in history. The topics are chronologically divided into individual chapters. These gradually touch on the most important periods in history. The basic characteristics and subsequent analysis of significant events (war conflicts, rulers, courts, presidents, governments) give students a general overview of historical contexts, develop their vocabulary and language skills. Based on the studied materials, students present a brief overview of the historical period and a more detailed description of the most important, respectively the most interesting facts (that is, events, personalities) against the background of world history. Related presentations deepen the knowledge provided in the basic texts and provide students with the opportunity for individual presentation. They verify the acquired knowledge by elaborating lexical exercises, answering questions and discussing them. The teaching process is focused on the development of several language skills that follow each other.

\subsubsection{Vocabulary selection}

In this necessary procedure, students independently, by reading a selected academic text, select an unknown vocabulary, especially in the field of specialized terminology, which they then process in cooperation with the teacher, specialized literature and in semantic contexts. The next step is to set aside the keywords that most accurately characterize the individual texts.

Example:

Useful vocabulary:

tribe - a large group of people who live in the same area and share a common language, religion and customs; a social division of (usually preliterate)e people

literacy - the ability to read and write

clan - a large group of families that are related to each other

$\mathrm{BC}$ - before Christ; abbreviation used after a date to show that it refers to a time before the birth of Jesus Christ

$\mathrm{AD}$ - anno domini, abbreviation used after a date to show that it refers to a time after the birth of Jesus Christ (Benčeková, 2011, s. 12)

\subsubsection{Comprehension check and topics for discussion}

Necessity for the verification of the knowledge acquired during the seminars is the correct answer to the comprehension check questions, which always follow the individual chapters. Students must not only answer the control questions at the end of the text, but also the specific and detailed questions of the teacher, they must combine the knowledge already acquired with the newly acquired on the basis of historical and political contexts. The answers to the comprehension check questions may be the subject of discussion.

Example:

What were the reasons for the Hanoverians to come to the English throne?

Characterize the first Cabinet and its functions.

Summarize the foreign conflicts of Britain during the 18th century. (Benčeková, 2011, s. 57)

\footnotetext{
${ }^{1}$ BENČEKOVÁ, M. History of Great Britain. Vysokoškolské učebné texty. 1. vydanie. Banská Bystrica: UMB, 2011. 85 p. ISBN: 978-80-557-0236-0
} 


\subsubsection{Practicing lexical and grammar skills}

With the use of historical and political texts, it is also possible to practice language skills. Usually, a specific text is used, passages from which are adapted to various grammatical activities. Practically all phenomena from morphology and syntax can be practiced. The teacher, at his / her own discretion and as necessary, complements his / her own phenomena, for example in the field of phraseology (the position of phrases in professional text and in teaching will be addressed in one of the following papers).

Example:

Fulfil the gaps with an appropriate preposition:

Methodism was a religious movement, led

Charles and John Wesley and George

Whitefield, which originated as a reaction the apathy and the emphasis on logic and reason that characterized the Anglican Church the early 18 th century. The term was originally applied a religious society which was established Oxford University in 1729 by Whitefield and the Wesley brothers (nicknamed the "Holy Club," its members were young men who, order to promote piety and morality, observed strict rules of fasting and prayer)... (Benčeková, 2011, s. 58-59)

The division of the topic into separate units - the History of Great Britain and the History of the USA gives us the opportunity to focus on important milestones in the development of these two countries, as well as their comparison. The diversifying component of teaching is examples of contemporary literature, presidential speeches, portraits, maps, and graphs. At present, within the possibilities of the faculty, we are inclined to use multimedia and modern technology in the teaching process. As part of our topic, we present interactive exercises, but also additional information, e.g. graphs, diagrams of individual dynasties, sketches of war conflicts using power-point presentations. A similar form of presentations is recommended for students in the preparation of seminar papers on selected topics. Using this form of presentation is excellent for easier remembering of facts, because students will receive information in written, verbal and visual form.

\section{CONCLUSION}

The aim of the paper was to emphasize the importance of linguistic analysis of an academic texts in the process of teaching foreign languages at non-philological universities. It is not possible or beneficial to separate this teaching from the specialized part. On the contrary, the combination of both elements leads to the consolidation and practice of not only new specialized knowledge and skills, but also the language aspects of the study. Given that these are usually students with a higher language level, it is not appropriate to separate the specialized and language parts of the study, but on the contrary, their symbiosis in favour of further education is welcome. Linguistic analysis of an academic texts represents the concept of an interdisciplinary application of the connection between the department and language education with a focus on the development of intercultural communication.

The paper is published with the financial support of the Scientific Grant Agency of the Ministry of Education, Youth and Sports of the Slovak Republic and the VEGA project no. 1/0437/19 "The importance of the internationalization of higher education for the construction of the identity of the European Union and increasing competitiveness in the European area"

\section{Sources}

1. BENČEKOVÁ, M. History of Great Britain. Vysokoškolské učebné texty. 1. issue. Banská Bystrica: UMB, 2011. 85 p. ISBN: 978-80-557-0236-0. 
2. BORSUKOVÁ, H. Odborný text - východisko a ciel' cudzojazyčného vyučovania na odborných školách. In: Medacta 95. Nitra: Slovdidac, 1995, pp. 229-233.

3. DROZD, L., SEIBICKE, W. Deutsche Fach- und Wissenschaftssprache. Bestandsaufnahme - Theorie - Geschichte. Wiesbaden: Oscar Brandstetter Verlag, 1973.

4. FLOWERDEW,J., PEACOCK,M.: Research Perspectives on English for Specific Purposes. Cambridge: Cambridge University Press, 1999.

5. HARMER, J. The Practise of English Language Teaching. Longman. London: 1994.

6. JELÍNEK, M. Kultura jazyka a odborný styl. In.: Termina 94. Konference o odborném stylu a terminologii. Liberec: PF TU, 1995, pp. 7-29.

7. MISTRÍK, J. Štylistika slovenského jazyka. Bratislava: SPN, 1977.

8. RICHARDS, J. C., RENANDYA,W. A. Methodology in Language Teaching. Cambridge: 2003.

9. SAGER, DUNGWORTH, MCDONALD. English Special Languages. Stuttgart: Brandstetter 1980.

\section{Contact}

PhDr. Martina Benčeková, PhD.

Katedra medzinárodných vzt'ahov a diplomacie

Fakulta politických vied a medzinárodných vzt’ahov

Univerzita Mateja Bela

Kuzmányho 1

974 01, Banská Bystrica, SR

Tel: +421 484461918

email: martina.bencekova@umb.sk 


\title{
KLINICKÁ VÝUČBA U ŠTUDENTOV OŠETROVATELSTVA
}

\section{CLINICAL EDUCATION FOR STUDENTS OF NURSING}

\author{
Anna Hudáková, Lubomíra Tkáčová
}

\begin{abstract}
Abstrakt
Komplex činností pri poskytovaní ošetrovatel'skej starostlivosti vyžaduje získanie odbornej spôsobilosti. Klinické prostredie rozvíja odborné zručnosti a je podporným činitel'om k získaniu praktických skúseností. Krajiny Európskej únie využívajú rozličné modely klinického vzdelávania. Študent by mal porozumiet' hodnoteniu, ktoré získal za dosiahnuté študijné výsledky. Ohodnotenie - pozitívne alebo negatívne by malo byt' pre študenta motívom $\mathrm{k}$ zlepšovaniu svojich študijných výsledkov. Využívame $\mathrm{v}$ našich podmienkach štruktúrované pozorovanie výkonov študentov, záznamníky klinickej praxe a hodnotenie ošetrovatel'ského procesu.
\end{abstract}

Klíčová slova: ošetrovatel'ská starostlivost', metódy hodnotenia, hodnotenie klinickej praxe.

\begin{abstract}
The complex of activities in the provision of nursing care requires the acquisition of professional competence. The clinical environment develops professional skills and is a supportive factor for gaining practical experiences. European Union countries use different models of clinical education. The student should understand the evaluation obtained for the achieved study results. Evaluation - positive or negative should be a motive for the student to improve their learning outcomes. we use in our conditions structured observation of student performance, clinical practice recorders and evaluation of the nursing process.
\end{abstract}

Key words: nursing care, evaluation methods, evaluation of clinical practice.

\section{KOMPETENCIE POVOLANIA SESTRY}

Sestra je pracovník, kvalifikovaný na rozvoj a vykonávanie činností, ktoré slúžia na podporu a udržanie zdravia a predchádzanie chorobám. V rámci svojej profesie sestra podporuje aktívne zapájanie sa jednotlivcov, rodín a skupín do všetkých aspektov zdravotníckej starostlivosti. Z tohto dôvodu sestra musí disponovat' kompetenciami, aby mohla uskutočňovat' činnosti, ktoré podporujú, udržiavajú zdravie a zabraňujú chorobe (Judičáková et al., 2013).

Výkon zdravotníckeho povolania je vysoko náročným povolaním vo fyzickej a v psychickej oblasti, ktoré zahŕňa stanovené požiadavky na kvalifikačnú prípravu (Šamaj, Mikšová, 2013). V slovenskom právnom systéme je spôsobilost' sestry charakterizovaná nadobudnutím vysokoškolského vzdelania 1. stupňa (alebo vyššieho odborného vzdelania), ktoré trvá v dennej forme štúdia najmenej tri roky, zahŕňa 4600 hodín teoretickej a praktickej výučby a spĺña minimálne požiadavky na obsah študijného programu (NV SR č.324/2006).

Komplex činností pri poskytovaní ošetrovatel'skej starostlivosti vyžaduje získanie odbornej spôsobilosti a v praxi sa vykonáva metódou ošetrovatel'ského procesu. Samotný ošetrovatel'ský proces je základným metodickým rámcom pre realizáciu cielov v ošetrovatel'stve. Predstavuje metódu moderného ošetrovatel'stva, teda spôsob, akým sestra starostlivost' o človeka realizuje. Východiskové princípy ošetrovatel'ského procesu sú založené na detekcii potrieb človeka, ktoré sú následne uspokojované podl'a ich priority (Tóthová a kol., 2009). 
Ošetrovatel'ský proces pozostáva z piatich fáz, ktoré sú usporiadané v chronologickej postupnosti:

1. Posudzovanie. Sestra zbiera, overuje a triedi údajov o zdravotnom stave pacienta (klienta). Podmienkou pre kvalitné posúdenie je zručnost' sestry v pozorovaní, komunikácií a realizácií fyzikálneho vyšetrenia. Táto fáza je základom pre aktivitu a rozhodnutia v nasledovných fázach.

2. Diagnostika. V tejto fáze sestra realizuje analýzu údajov, ktorej záverom je stanovenie problémov pacienta (klienta), a následne sa určí sesterská diagnóza.

3. Plánovanie. Sestra a pacient určujú prioritné problémy, zaznamenávajú ciele a očakávané výsledky. Výsledkom tejto fázy je stanovenie plánu ošetrovatel'skej starostlivosti, ktorého ciel'om je odstránenie, zmiernenie alebo prevencia zistených problémov.

4. Realizácia. Ide o vykonanie naplánovaného procesu ošetrovatel'skej starostlivosti, ktorého výsledkom je docielenie očakávaných výsledkov.

5. Vyhodnotenie. Stanovujú sa kritériá, ktorými sestra zist'uje do akej miery sa stanovené ciele splnili (Derňárová, Rybárová, 2008).

Pri realizácii ošetrovatel'skej praxe sestra poskytuje ošetrovatel'skú starostlivost' v súlade s legislatívou, v rozsahu získaných vedomostí a zručností štúdiom a odbornou praxou. Poskytovatelia zdravotnej starostlivosti sú povinní kontinuálne zabezpečovat' systém kvality, ktorého ciel'om je poskytovanie štandardizovanej starostlivosti na úrovni minimálnych štandardov. Systém kvality zabezpečuje poskytovanie ošetrovatel'skej starostlivosti podl'a štandardizovaných postupov, dodržiavaním minimálneho normatívu personálneho zabezpečenia a materiálno-technického vybavenia, ktoré splńajú požiadavky na bezpečnost', systém celoživotného vzdelávania, registrácie a certifikátov kvality, tiež pre účely štatistického vyhodnocovania výsledkov poskytovanej starostlivosti. Kvalita ošetrovatel'skej starostlivosti sa hodnotí podla indikátorov kvality, ktoré sú zamerané na vyjadrenie spokojnosti pacientov s poskytovanou starostlivost'ou. Podl'a Európskeho kvalifikačného rámca pre celoživotné vzdelávanie (EKR, 2009) sú výsledky vzdelávania definované prostredníctvom opisu vedomostí, zručností a kompetencií, ktoré sú chápané nasledovne:

1. Vedomosti: sú výsledkom osvojenia si informácií prostredníctvom učenia. Vedomosti sú súborom faktov, zásad, teórií a postupov, ktoré sa vzt'ahujú na oblast' práce a štúdia. V kontexte Európskeho kvalifikačného rámca sa vedomosti opisujú ako teoretické a/alebo faktické.

2. Zručnosti: predstavujú spôsobilost' uplatňovat' vedomosti a využívat' know-how na splnenie úloh a riešenie problémov. V kontexte Európskeho kvalifikačného rámca sú zručnosti opísané ako kognitívne zručnosti (vrátane využívania logického, intuitívneho a kreatívneho myslenia) alebo praktické zručnosti (vyžadujúce manuálnu zručnost' a použivanie metód, materiálov, prostriedkov a nástrojov).

3. Kompetencie: ide o preukázanie spôsobilosti s ciel'om použit' vedomosti, zručnosti a osobné, sociálne a/alebo metodologické schopnosti v pracovných alebo študijných situáciách a $\mathrm{v}$ odbornom a osobnom rozvoji. V kontexte Európskeho kvalifikačného rámca je kompetencia opísaná vo vzt’ahu k zodpovednosti a samostatnosti.

\subsection{Klinická prax u študentov ošetrovatel'stva}

Odborná ošetrovatel'ská prax poskytuje študentom priestor na skvalitnenie návykov a zručností, pomáha podporovat' ich nezávislost', zodpovednost' a tímovost' pri práci v zdravotníckom tíme (Zanovitová a kol., 2014).

Klinická prax študentov v zdravotníckych zariadeniach ako typická forma študijnej praxe je vnímaná ako podstatný komponent kvalifikovanej prípravy sestier. Proces vzdelávania prebieha $\mathrm{v}$ praktických podmienkach a konfrontácia študenta s reálnymi klinickými situáciami tvorí komplexný postup pri výučbe študentov ošetrovatel'stva. Výučba zahíňa široké spektrum 
ošetrovatel'ských kompetencií, ktorými sú psychomotorické a komunikačné zručnosti, uplatnenie kritického myslenia, manažovanie času a riešenie problémov. Tradičná klinická výučba v ošetrovatel'stve je založená na vopred stanovených výsledkoch v dosahovaní konkrétnych výchovno-vzdelávacích ciel'och. Z behaviorálneho hl'adiska sa postupne premieta aj do hodnotenia študentov a vymedzeniu klinických spôsobilostí študentov (Gurková, Cibriková, Žiaková, 2015). Klinické prostredie, v ktorom sa študent pripravuje na výkon povolania rozvíja odborné zručnosti, napomáha $\mathrm{k}$ stimulácii ich učenia v klinickej praxi a je podporným činitel'om k získaniu praktických skúseností (Hosoda, 2006; Andrews, Roberts, 2011).

\subsection{Model klinickej výučby u študentov v odbore ošetrovatel'stvo}

Štandardné vzdelávacie metódy, ktoré sú v súlade s uznanými študijnými programami a finálnymi kvalifikáciami, ktoré by mal študent po absolvovaní štúdia ovládat', sú potrebné pre kvalitu vzdelávania zdravotníkov (Kuriplachová a kol., 2015).

Krajiny Európskej únie využívajú rozličné modely klinického vzdelávania. Berntsenov model (obr. 1) sa využíva v našich podmienkach a zabezpečuje klinickú výučbu na troch úrovniach:

1. Organizácia a podmienky zmluvného vzt’ahu vyjadrujú zmluvný vzt'ah medzi zdravotníckym zaradením a vzdelávacou inštitúciou

2. Proces vzdelávania na pracovisku opisuje jednotlivé kroky výučby počas klinickej praxe, vzt’ahuje sa na vyučujúcich a študentov

3. Hodnotenie a následná revízia konkrétnych aspektov klinického prostredia (Berntsen et al., 2015).

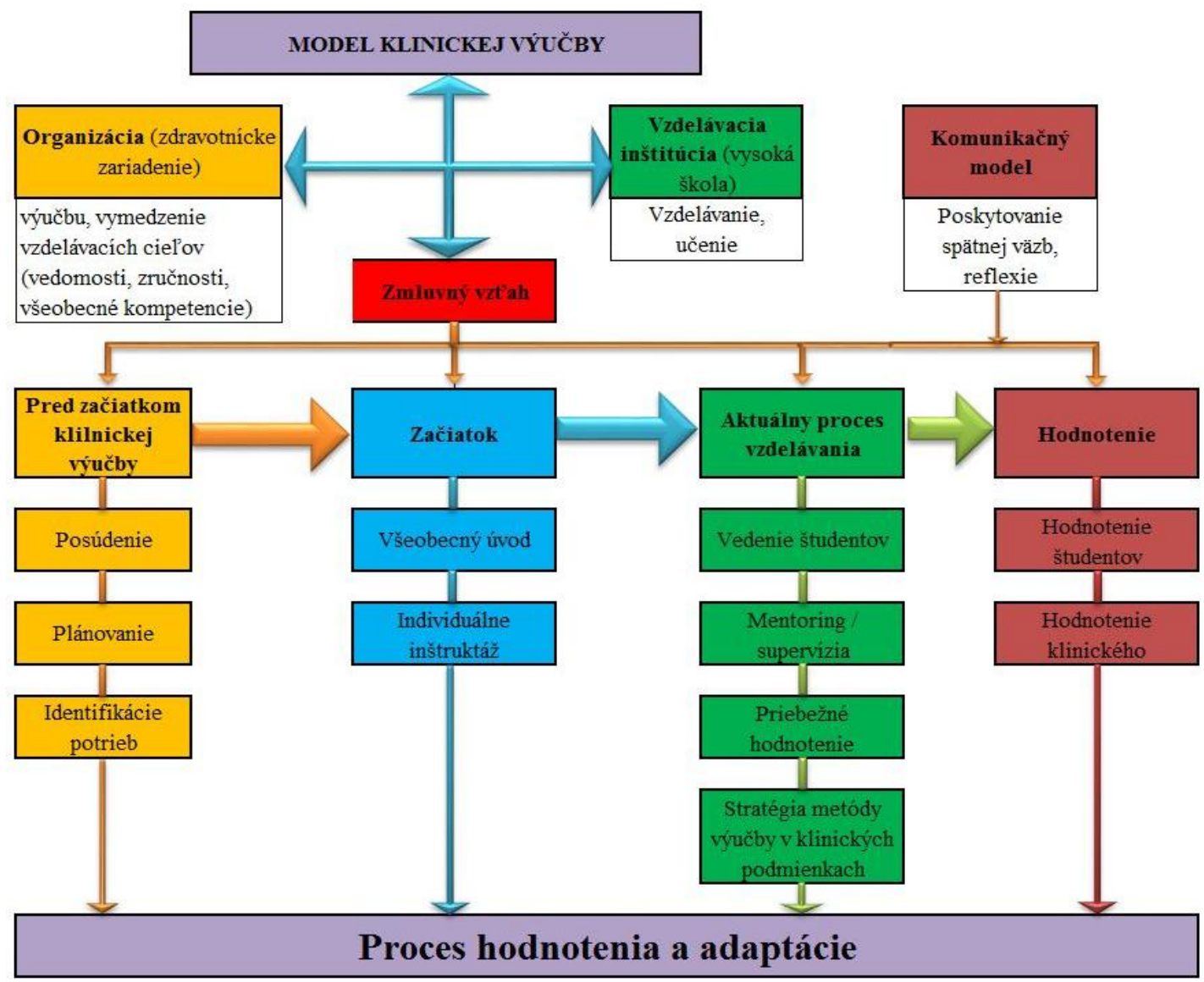

Obrázok 1 Model klinickej výučby (Berntsen et al., 2015). 
Čast’ úloh v prvotnej fáze prípravy na klinickú prax zabezpečuje vzdelávacie zariadenie, ale niektoré špecifické odvetvia môžu byt' objektom konzultácií s nemocničným pracoviskom a mentormi. Tieto kroky procesu vzdelávania študentov zobrazuje obrázok 2.

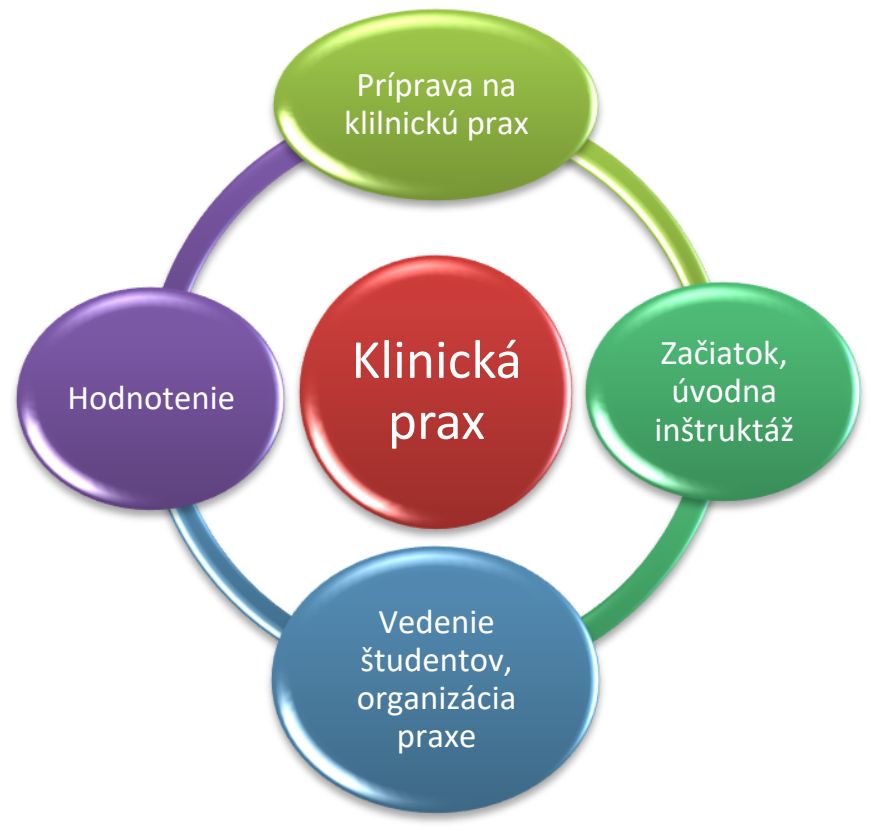

Obrázok 2 Jednotlivé kroky procesu vzdelávania na pracovisku (Berntsen et al., 2015).

Ďalšie kroky procesu vzdelávania na pracovisku možno popísat' v chronologickom poradí.

Zhodnotenie a identifikácia ciel'ov výučby. Potrebné je vyselektovat' a určit' klinické kompetencie, ktoré by mal študent za dané študijné obdobie dosiahnut', podl'a čoho sa určujú ciele. Zdravotnícke zariadenie ako partner pri výučbe študentov by malo zodpovedat' požiadavkám výučby a špecifickým podmienkam študijného programu.

Plánovanie. Po začlenení študenta ku konkrétnemu mentorovi a na konkrétne pracovisko klinickej praxe s vopred vytýčenými ciel'mi, mentor poskytne študentovi potrebnú inštruktáž o chode, vel'kosti a charaktere práce na ošetrovacej jednotke, prípadne oddelení.

Poučenie študujúcich, zabezpečené vzdelávacou inštitúciou. Študenti by mali byt' oboznámení s požiadavkami, aké sú na nich kladené, s koordináciou klinickej praxe. Vzdelávacia inštitúcia oboznamuje študentov s medicínsko-ošetrovatel'skými aspektmi pri ochoreniach, ktoré sú charakteristické pre jednotlivé oddelenia a zároveň môžu byt' so zvládnutia daných oblastí ohodnotení vstupným testom.

Úvodná inštruktáž (začiatok klinickej praxe). Úvodnú inštruktáž skupinovou alebo individuálnou formou realizuje mentor na danom oddelení. Študujúci je poučený a oboznámený s pracovným harmonogramom, pravidlami BOZP, zoznámi sa s personálom a pacientmi (zdravotný stav, špecifiká ošetrovatel'skej starostlivosti) na oddelení. Mentor študenta oboznámi $\mathrm{s}$ organizáciou vedenia klinickej praxe, spôsobom spolupráce, odporúčanou literatúrou a inými faktami potrebnými pre dosiahnutie študijných ciel'ov.

Mentoring študentov na klinickom pracovisku zahŕňa implementáciu vzdelávacích postupov do praxe, využitie rôznych stratégii klinického vyučovania (simulácia, demonštrácia, využitie prípadových štúdií), poskytnutie podnetnej spätnej väzby a využite možných foriem hodnotenia. V tejto fáze je podstatné identifikovat' úrovne teoretických vedomostí a praktických zručností študenta a posilnit' jeho slabé oblasti, aktívne podporovat' účast' na zdokonal'ovaní vzdelania a sebareflexie, pomôct' študentovi pri dosahovaní ciel'ov, získat' informácie o osobnosti študenta od zdravotníckeho tímu na konkrétnej ošetrovacej jednotke. 
Vol'ba metód, ktoré sa využívajú pri hodnotení študentov súvisí hlavne s formou hodnotenia (Berntsen et al. 2015).

\subsection{Faktory vplývajúce na hodnotenie študentov}

Externé faktory môžu pôsobit' ako na študenta, ktorý môže horšie zvládat' stres, mat' „okno“, byt' fyzicky znevýhodnený, rovnako aj na skúšajúceho v zmysle výpadku koncentrácie, nepozornosti, sympatii/antipatii voči študentovi. Následkom sú fundamentálne nerovnaké podmienky pri hodnotení študentov, ktoré vedú kskresleniu hodnotenia dosiahnutých študijných výsledkov študenta.

Čierna a Rábek (2013) v súvislosti so „skresl'ovaním“ výsledkov hodnotenia študenta najčastejšie hovoria o týchto faktoroch, ktoré môžu byt' jeho príčinou: pohlavie študenta, skúšajúceho, príslušnost' študenta k istej etnickej skupine alebo spoločenskej triede. Taktiež hodnotenie študenta ovplyvňujú faktory, ktoré súvisia so situačnými a procedurálnymi podmienkami hodnotenia, napr. časové obmedzenie testu, spôsob zadania inštrukcií, postoj a prítomnost' skúšajúceho, faktory súvisiace s motiváciou, postojom a osobnostou študenta (strach a obavy $\mathrm{z}$ hodnotenia, motivácia $\mathrm{k}$ dosiahnutiu úspechu, sebaoceňovanie, temperament študenta. Najčastejšie sa za hlavné faktory ovplyvňujúce hodnotenie študenta považuje tréma a strach študenta, rozdiely v osobnostiach študenta a učitel'a, vzt'ah medzi učitel'om a žiakom, psychická klíma, vplyv prostredia a predstavy žiaka o správnom/nesprávnom priebehu hodnotenia, predstavy vyučujúceho o správnom/nesprávnom známkovaní a podobne. Je nevyhnutné, aby študenti mali dostupné všetky informácie o jednotlivých metódach a spôsoboch hodnotenia. Študent by mal porozumiet' hodnoteniu, ktoré obsiahol za dosiahnuté študijné výsledky. Ohodnotenie, či už pozitívne alebo negatívne, by malo byt' pre študenta motívom k zlepšovaniu svojich študijných výsledkov.

Jako logický sa ukazuje fakt, že skúšajúci by mal hodnotit' iba tie vedomosti a zručnosti, ktoré mal študent možnost' získat' počas výučby, prípadne bol odporúčaný na publikácie, ktoré sú k zvládnutiu štúdia potrebné (Čierna, Rábek, 2013). V klinických cvičeniach v zdravotníckych zariadeniach by hodnotenie študenta malo prebiehat' na základe pozorovania študenta mentorom pri odborných činnostiach. Študent by sa mal vediet' orientovat' $\mathrm{v}$ zdravotníckom prostredí a teoretické poznatky získané štúdiom vediet' aplikovat' do praxe.

\section{HODNOTENIE KLINICKÝCH SPÔSOBILOSTÍ U ŠTUDENTOV OŠETROVATELSTVA}

Kompetencie študenta na klinickej praxi sú definované ako činnost', výstup alebo výsledok, ktorý je možné pozorovat' a vyhodnotit'. Hodnotenie študenta $v$ klinickom prostredí sa vzt’ahuje na jeho výkon. Ku výučbe a hodnoteniu študentov v klinických situáciách sa využívajú hodnotiace škály. Hodnotenie má obsahovat' racionálne argumenty, že vzdelávanie študentov je efektívne, prípadne aké sú príčiny neefektivity. Metódy hodnotenia majú byt' spol'ahlivé a konzistentné, aby zaručovali že výsledok hodnotenia je odrazom skutočných vedomostí a schopností študenta (Hudáková a kol., 2016). Metódy zberu údajov možno definovat' nasledovne:

Dotazník. Je jednou z najčastejšie používaných empirických metód, ktorá je založená na nepriamom kladení otázok s použitím predformulovanných písomných položiek. Dotazník je finančne nenáročný a z časového hl'adiska ekonomickou metódou. Využíva sa pre zber informácií pri vel'kom počte respondentov v pomerne krátkom čase. Je jednoducho spracovatel'ný. Dotazníkovou formou zberu dát sa eliminuje možný negatívny účinok prieskumníka na respondenta (Gavora a kol., 2010).

Rozhovor. Prieskumník zhromažd’uje údaje od respondenta priamym opytovaním sa. Od zvyčajného rozhovoru sa odlišuje tým, že ma jasne stanovený prieskumný ciel', implikuje 
štandardizované otázky, ktoré sú zamerané na jednotlivé oblasti. Analýza informácií prebieha po kvantitatívnej aj kvalitatívnej stránke. Rozhovor je možné prispôsobit' rôznym okolnostiam. Detekuje nielen fakty, ale aj postoje a motívy respondentov. Kladenie otázok môžeme usmernit' na základe reakcií účastníka rozhovoru. Rozhovor ako prieskumnú metódu môžeme využit' ako exploratívnu techniku na dosiahnutie základnej orientácie v problematike.

Pozorovanie. Celoplošnou podstatou empirického skúmania je pozorovanie. Jeho zámerom je nadobudnutie nových poznatkov, spresnenie alebo doplnenie terajších informácií. Vedecké pozorovanie je strategické, uvedomené, organizované a vopred pripravené (Hanáček a kol., 2010). Efektívnost' hodnotenia študentov počas klinickej praxe má priamy vzt'ah so správnym výberom formy hodnotenia. Vyberáme $\mathrm{z}$ formatívneho a sumatívneho hodnotenia. Formatívne (priebežné) hodnotenie je chápané ako stratégia výučby, ktorá zabezpečuje spätnú väzbu medzi mentorom a študentom v priebehu semestra. Úlohou tejto formy hodnotenia je identifikácia oblastí, ktoré je potrebné sa zlepšit', aby študent dosiahol predpokladané učebné ciele. Sumatívne (výsledné) hodnotenie poskytuje finálne posúdenie, či študent dosiahol vytýčené ciele vzdelávania na konci semestra. Mentor sa pri hodnotení študentov zameriava na získané vedomosti (kognitívna oblast'), postoje (afektívna oblast') a zručnosti (psychomotorická oblast'). Ich bližší popis uvádzame na obrázku 3.

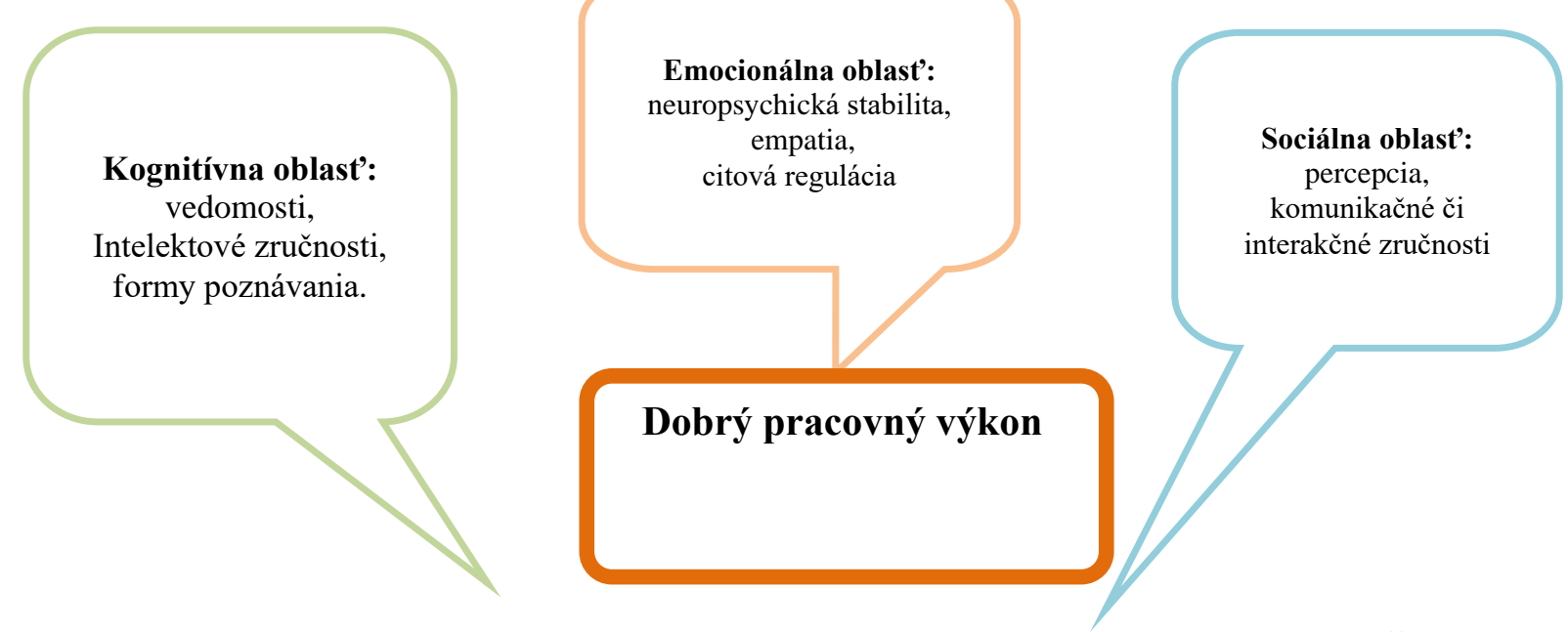

Obrázok 3 Klasifikácia kompetencií vo vzt’ahu k dobrému pracovnému výkonu (Špirudová, 2015).

Priebežné a výsledné hodnotenie by sa malo uskutočňovat' v určitej klinickej situácii. Nástroje hodnotenia klinických kompetencií študentov ošetrovatel'stva by mali obsahovat' komplexné skúšanie, zlepšovat' spätnú väzbu a motiváciu študentov v pschomotorických a komunikačných schopnostiach (Hudáková a kol. 2016). Objektívne hodnotenie študenta zahŕňa pocit istoty a satisfakcie pri vykonaní ošetrovatel'ských intervencií, najmä u chronických pacientov s využitím dostupných možnosti zvyšovania ich kvality života (Obročníková, Kaščáková, Majerníková, 2020).

V záujme objektívneho hodnotenia klinických spôsobilostí u študentov ošetrovatel'stva je dostupných viacero škál, ktoré sú využívané v rôznych vzdelávacích inštitúciách najmä v zahraničí. V našich podmienkach sú využívané:

- štruktúrované pozorovanie výkonov študentov,

- záznamníky klinickej praxe,

- hodnotenie ošetrovatel'ského procesu (Berntsen et al. 2015). 
V rámci úspešnosti praktického hodnotenia študentov ošetrovatel'ského odboru je kl'účovou zmenou využívanie validných a reliabilných hodnotiacich nástrojov: Clinical Evaluation Tool, Clinical Performance Remediation Tool, Clinical Competency Rating Scale, Nursing Student Clinical Performance Evaluation Scale (Gurková, Cibriková, Žiaková, 2015)

V súčasnosti sa percepcia úlohy študenta zmenila. Viedli k tomu zmeny v spoločnosti, zmeny v samotnej percepcii statusu sestry. Študent je v súčasnosti vnímaný ako partner pri výučbe. Obzvlášt' pri štúdiu lekárskych a nelekárskych študijných odborov sú na študenta kladené vysoké nároky. Študent, ktorý sa pripravuje na tak náročné povolanie, musí spĺn̆at' určité podmienky, fyzické, psychické a morálne. Každý študent potrebuje byt' hodnotený skúseným pedagógom, aby zistil, či má dostatočné vedomosti a zručnosti s cielom poskyovat' v budúcnosti kvalitnú ošetrovatel'skú starostlivost'. Hodnotenie študenta, jeho vedomostí a zručností je náročná činnost', na ktorú je potrebná vel'ká dávka objektívnosti. V minulosti neexistovali validné nástroje na hodnotenie klinickej spôsobilosti študentov. V súčasnosti sa použivajú niektoré z týchto nástrojov výnimočne a častejšie v zahraničí. Zavedením takýchto validných nástrojov v našich podmienkach by výrazne ul'ahčilo hodnotenie študentov.

Štandardné a profesionálne hodnotenie študenta počas klinických cvičení vedie k zvyšovaniu odbornosti a profesionality u študentov, $\mathrm{k}$ lepším študijným výsledkom, čoho výsledkom bude aj skvalitnenie poskytovanej ošetrovatel'skej starostlivosti (Obročníková, Andraščíková, Majerníková, 2013).

Tento príspevok bol vydaný v rámci riešenia grantového projektu KEGA: 002PU-4/2020 Návrh metodiky hodnotenia kvality života pacientov so sclerosis multiplex.

\section{Použitá literatura}

1. ANDREWS, M., ROBERTS, D. Supporting student nurses learning in and through clinical practice: the role of the clinical guide. In: Journal of Clinical Nursing. [online]. 2011. Roč. 20, č. 19 - 20, s. 2854 - 2867. ISSN 1365-2702. [cit. 15. 9. 2020]. Dostupné z: https://www.nurseeducationtoday.com/article/S0260-6917(0 3)00076-5/fulltext

2. BERNTSEN, K. et al. Vzdelávanie sestier $v$ klinických podmienkach. [online]. Prešov: Prešovská univerzita v Prešove, Fakulta zdravotníckych odborov. 2015. [cit. 28. 5. 2021]. Dostupné na internete: http://www.unipo.sk/public/media/20076/ BROZURA \%20LdV\% 20mentori.pdf

3. ČIERNA, Z., RÁBEK, T. Životný štýl študentov a systém hodnotenia ich vedomostí na SPU v Nitre. 1. vyd. Nitra: Slovenská pol'nohospodárska univerzita v Nitre. 2013. ISBN 978-80-552-1005-6

4. DERÑÁROVÁ, L., RYBÁROVÁ, L'. Potreby človeka a ošetrovatel'ský proces II. Prešov: Prešovská univerzita v Prešove, 2008. 190 s. ISBN 978-80-8068-859-2.

5. EKR. 2009. Európsky kvalifikačný rámec pre celoživotné vzdelávanie. Luxemburg: Úrad pre vydávanie úradných publikácií Európskych spoločenstiev, 2009. 15 s. ISBN 978-92-79-08489-8. Doi 10.2766/28316.

6. GAVORA, P. a kol. Elektronická učebnica pedagogického výskumu. [online]. Bratislava: Univerzita Komenského. 2010. [cit. 02. 06. 2021]. Dostupné na: http://www.e-metodologia.fedu.uniba.sk/ ISBN 978-80-223-2951-4.

7. GURKOVÁ, E., CIBRÍKOVÁ, S., ŽIAKOVÁ, K. Metódy hodnotenia študentov v klinických podmienkach. In: Ošetrovatel'stvo: teória, výskum, vzdelávanie [online]. 2015. Roč.5, č.1, s. 31-37 [cit. 28. marca 2018]. ISSN 1338-6263. Dostupné na: http://www.osetrovatelstvo.eu/archiv/2015-rocnik-5/cislo-1/metody-hodnoteniastudentov-v-klinickych-podmienkach. 
8. HANÁČEK, J. et al. Vedecká príprava. Martin: Osveta. 2010. ISBN 978-80-8063328-8.

9. HOSODA, Y. Development and testing of a Clinical Learning Environment Diagnostic Inventory for baccalaureate nursing students. In: Journal of Advanced Nursing. [online]. 2006. Roč. 56, č. 5, s. 480-490. ISSN 1365-2648. [cit. 25.5. 2021]. Dostupné na: https://www.ncbi.nlm.nih.gov/pubmed/17078824

10. HUDÁKOVÁ, A, a kol. Nástroje hodnotenia spôsobilosti študentov v klinickom prostredí. In: QUAERE 2016: Recenzovaný sborník príspevku vědecké interdisciplinárni mezinárodni konferencie doktorandu a odborných asistentu. [online]. Hradec Králové: Magnanimitas. 2016. Roč. 6, s. 504 - 511. ISBN 978 - 80 - 87952-15-3. [cit. 28. 5. 2021]. Dostupné na: file:///C:/Users/acer/Desktop/b6dquaere-2016-str-517-hudakova. pdf

11. JUDIČÁKOVÁ, M., DYSKOVÁ, T., ŽEMLIČKOVÁ, T. Jedinečná úloha sestry v ošetrovatel'skej starostlivosti. In: JUDIČÁKOVÁ M., M. IŠTOŇOVÁ a J. BUJŇÁK, eds. Preklenutím rozdielov zvyšujeme dostupnost' a rovnost' $v$ starostlivosti pacienta/klienta. Zborník referátov z V. Slovenského chirurgického dňa v Prešove. Prešov: Prešovská univerzita v Prešove, Fakulta zdravotníckych odborov. 2013, s. 67-76. ISBN 978-80-555-0736-1.

12. KURIPLACHOVÁ, G. a kol. New teaching methods for practical training in nursing within the project Tempus IV. In: Mefanet Journal [online]. 2015. Roč. 3, č. 2, s. 6468. ISSN 1805-9171. [cit. 04. 06. 2021]. Dostupné na: http://mj.mefanet.cz/index. php?pg=articles--mj-20151202.pdf.

13. Nariadenie vlády Slovenskej republiky č.324/2006, ktorým sa mení a dopín̆a nariadenie vlády Slovenskej republiky č.742/2004 Z.z. o odbornej spôsobilosti na výkon zdravotníckeho povolania

14. OBROČNÍKOVÁ, A., ANDRAŠČÍKOVÁ, Š., MAJERNÍKOVÁ, L'. Analýza kompetencií sestier západnej a strednej Európy v onkologickej prevencii. Pezinok: Via Bibliotheca, 2013, 119 s. ISBN 978-80-89527-42-7.

15. OBROČNÍKOVÁ, A., KAŠČÁKOVÁ, M., MAJERNÍKOVÁ, L. Kvalita života pacienta V kontexte chronického ochorenia. QUAERE 2020 [elektronický dokument]: recenzovaný sborník př́íspěvků interdisciplinární mezinárodní vědecké konference doktorandů a odborných asistentů, Hradec Králové, 22. - 26. 6.2020. [online]. Hradec Králové: Magnanimitas akademické sdružení, 2020; s. 791-796. ISBN 978-80-87952-32-0. [cit. 26. 5. 2021]. Dostupné na: http://vedeckekonfe rence.cz/library/proceedings/quaere_2020.pdf

16. ŠAMAJ, M., MIKŠOVÁ, Z. Analýza stavu nelékařrských zdravotnických povolání $v \check{C} R$ (Hodnoceni a doporučeni pracovni komise $M Z \check{C} R$ ktransformaci NLZP $v \check{C} R$ ). 1. vyd. Olomouc: Univerzita Palackého v Olomouci. 2013. ISBN 978-80-2443860-3.

17. ŠPIRUDOVÁ, L. Doprovázení v ošetřovatelství I. Praha: Grada Publishing. 2015. ISBN 978-80-247-5710-0

18. TÓTHOVÁ, V. a kol. Ošetřovatelský proces a jeho realizace. Praha: Triton. 2009. ISBN978-80-7387-286-1

19. ZANOVITOVÁ, M. a kol. Hodnotenie výučby a supervízie v klinickej ošetrovatel'skej praxi. In: I.BÓRIKOVÁ, I. FARSKÝ a K. ŽIAKOVÁ, eds. Teória, výskum a vzdelávanie $v$ ošetrovatel'stve. Martin: Univerzita Komenského $\mathrm{v}$ Bratislave, Jesseniova lekárska fakulta v Martine, 2014, s. 343-353. ISBN 978-8089544-68-4. 


\section{Kontaktní údaje}

PhDr. Anna Hudáková, $\mathrm{PhD}$.

Prešovská univerzita v Prešove/University of Presov in Presov

Fakulta zdravotníckych odborov/Faculty of Health Care

Katedra ošetrovatel'stva/Department of Nursing

Partizánska, 1; 08001 Prešov

mail: Anna.Hudakova@unipo.sk

tel.: +421517562460 


\title{
HODNOTENIE KVALITY ŽIVOTA PACIENTOV S CELIAKIOU
}

\section{EVALUATION OF THE QUALITY OF LIFE OF PATIENTS WITH CELIAC DISEASE}

\author{
Zuzana Šimová, Andrea Šuličová, Tatiana Šantová, Jana Cinová, Zuzana \\ Novotná, Lubica Derňárová, L'ubomíra Lizáková, Andrea Obročníková
}

\begin{abstract}
Abstrakt
Celiakia je ochorenie, ktorého výskyt má v súčasnosti stúpajúcu tendenciu. Toto ochorenie je autoimunitné, chronické a celoživotné. Celiakia je ochorenie, ktoré významne ovplyvňuje kvalitu života pacientov. Nutnost' zmeny stravovacích návykov so sebou prináša pocity obmedzenia, strachu, obáv o zdravie, a pocity nedostatočných možností liečby. Choroba sa stáva súčast'ou životného štýlu a je potrebné naučit' sa žit's pravidlami diétneho režimu. V kontexte s ochorením pozorujeme aj psychický a fyzický dopad na životnú spokojnost' a celkový spôsob života jedinca, jeho rodinu a bezprostredne okolie. Ciel'om príspevku bolo zistit', aká je kvalita života pacientov s celiakiou vzhl'adom na dížku trvania ich ochorenia.
\end{abstract}

Kl'účové slová: Kvalita života. Pacient. Celiakia.

\begin{abstract}
Celiac disease is a disease that is currently on the rise. The disease is autoimmune, chronic and lifelong. Celiac disease is a disease that significantly affects the quality of life of patients. The need to change eating habits brings with it feelings of limitation, fear, health concerns, and feelings of inadequate treatment options. The disease becomes part of the lifestyle and it is necessary to learn to live with the rules of the diet. In the context of the disease, we also observe the mental and physical impact on life satisfaction and the overall lifestyle of the individual, his family and the immediate environment. The aim of the article was to find out the quality of life of patients with celiac disease with respect to the duration of their diseas.
\end{abstract}

Keywords: Quality of life. Patient. Celiac disease.

\section{CHARAKTERISTIKA CELIAKIE}

Celiakia, alebo glutén senzitívna enteropatia, je chronické zápalové ochorenie tenkého čreva, ktoré vzniká na autoimunitnom podklade. Ide o celoživotné ochorenie, ktoré vedie $\mathrm{k}$ malabsorbčnému syndrómu (7).

Celiakia je trvalá neznášanlivost' imunitného systému voči lepkovej bielkovine gluténu, ktorý sa nachádza v obilí ako je pšenica, raž, jačmeň, ovos, špalda. Celiakia je ochorenie, ktoré sa môže prejavit' v ktoromkol'vek veku (10). Udáva sa však dvojvrcholový výskyt ochorenia, najčastejšie sa prvé klinické prejavy objavia do tretieho roku života, alebo v tret'om až štvrtom decéniu. Častejšie bývajú postihnuté ženy (8).

Symptómy a celkový klinický obraz celiakie je mimoriadne variabilný. Príznaky sú závislé od doby, kedy bolo ochorenie diagnostikované a taktiež aj od prítomnosti mimočrevných príznakov Prieskumy poukazujú na to, že príznaky celiakie sa neprejavujú výlučne v tráviacom trakte, ale aj v nervovom, endokrinnom, ortopedickom, reprodukčnom a obehovom systéme. Príznaky môžeme teda rozdelit' na príznaky gastrointestinálneho pôvodu a negastrointestinálneho pôvodu (7). 


\subsection{Kvalita života pacientov s celiakiou}

Svetová zdravotnícka organizácia definuje kvalitu života ako vnímanie jej pozície v kontexte kultúry, v ktorej žije a vo vzt'ahu k ciel'om, očakávaniam, životného štýlu a záujmom (1). Pojem kvality života by mal obsahovat' údaje o fyzickom, psychickom a sociálnom stave jedinca (11).

K faktorom, ktoré ovplyvňujú kvalitu života radíme vek, pohlavie, vzdelanie, polymorbidita, rodinná situácia, socioekonomický status, životný štýl a nevhodná životospráva, telesná inaktivita, fajčenie, stres, psychosociálne faktory a kultúrne zázemie (12).

Celiakia je ochorenie, ktoré významne ovplyvňuje kvalitu života pacientov. Vzhl'adom na to, že jedinou možnost'ou liečby je celoživotné dodržiavanie bezlepkovej diéty, má toto ochorenie nesmierny dopad na kvalitu života týchto pacientov. Pacienti musia zo stravy vylúčit' výrobky, ktoré obsahujú obilniny s lepkom. Nutnost' zmeny stravovacích návykov so sebou prináša pocity obmedzenia, strachu, obáv o zdravie, a pocity nedostatočných možností liečby. Všetky tieto faktory majú vplyv na celkovú kvalitu života a subjektívne prežívanie pacientov s celiakiou. V kontexte s ochorením pozorujeme, aký psychický a fyzický dopad na životnú spokojnost' a celkový spôsob života má ochorenie na jedinca, jeho rodinu a bezprostredné okolie. Choroba sa stáva súčast'ou životného štýlu a je potrebné naučit' sa žit's pravidlami diétneho režimu. Život s gluténovou enteropatiou neznamená len dodržiavanie bezlepkovej diéty, ale i psychicky a finančne náročnú situáciu (4).

Vyrovnat' sa s diagnózou nie je jednoduché, osoby prechádzajú novou životnou situáciou, ktorá býva t’ažká a musia sa naučit' inému životnému štýlu. Novo diagnostikovaný pacient je vystavený stresu z novovzniknutej situácie a hlavne zmenám v stravovacích zvyklostiach. Rodičia detí s celiakiou bývajú často zúfalí, pretože nevedia ako situáciu zvládnut' a obávajú sa vyradenia diet'at'a $\mathrm{z}$ kolektívu ich rovesníkov. Bezlepková diéta zat'aží rodinu nielen psychicky, ale aj ekonomicky. Rodina sa môže stretávat' s finančnými problémami, dospelí musia vyriešit' stravovanie mimo domova a detí často diéta obmedzuje v školskej jedálni. Po psychickej stránke pacienti často pocit'ujú negatívne emócie, vzdor, smútok, bezmocnost' a sklamanie (5).

\section{PRIESKUM U PACIENTOV S CELIAKIOU}

V tomto príspevku sa zaoberáme štúdiou zameranou na hodnotenie kvality života pacientov s celiakiou. Hlavným ciel'om bolo zistit', v ktorých oblastiach života označujú pacienti svoju kvalitu života ako zhoršenú a ako sa v súvislosti s dížkou trvania ochorenia ich kvalita života zlepšuje, respektíve zhoršuje.

\subsection{Súbor a metodika}

Prieskum sme realizovali u 100 pacientov s celiakiou. Z hl'adiska pohlavia sa prieskumu zúčastnilo 89 žien a 11 mužov. Celá vzorka respondentov bola rozdelená do dvoch skupín. Do prvej skupiny sme zaradili 47 pacientov s dížkou trvania ochorenia do 3 rokov. Druhá skupina respondentov pozostáva z 53 pacientov s trvaním ochorenia viac ako 3 roky. Na získanie potrebných údajov od pacientov sme použili štandardizovaný dotazník hodnotenia kvality života pacientov s celiakiou - Celiac disease quality of life (CD-QOL). Otázky v dotazníku sú kategorizovaného do štyroch domén: obmedzenia vyplývajúce $\mathrm{z}$ každodenného života, dysfória (pocity úzkosti, nepokoja či hnevu), obavy o zdravie a nedostatočné možností v oblasti liečby. 


\subsection{Interpretácia parciálnych výsledkov}

Tab.1 Pocit obmedzenia v dôsledku ochorenia

\begin{tabular}{|l|r|r|r|c|}
\hline \multirow{2}{*}{} & \multicolumn{2}{|c|}{ do 3rokov } & \multicolumn{2}{c|}{ nad 3 roky } \\
\cline { 2 - 5 } & $\mathbf{N}$ & $\mathbf{\%}$ & $\mathbf{n}$ & \% \\
\hline Vôbec nie & 1 & 2 & 6 & 11 \\
\hline Trochu & 22 & 46 & 18 & 34 \\
\hline Mierne & 12 & 26 & 12 & 23 \\
\hline Celkom dost' & 12 & 26 & 15 & 28 \\
\hline Vel'mi & 0 & 0 & 2 & 4 \\
\hline SPOLU & $\mathbf{4 7}$ & $\mathbf{1 0 0}$ & $\mathbf{5 3}$ & $\mathbf{1 0 0}$ \\
\hline
\end{tabular}

Na základe výsledkov konštatujeme, že pacienti s dížkou ochorenia do 3 rokov majú väčšinou pocit obmedzenia $\mathrm{v}$ dôsledku ochorenia trochu (47\%), mierne a celkom dost' (26\%). Respondenti s dížkou ochorenia viac ako 3 roky uviedli pocit obmedzenia v dôsledku ochorenia vo frekvencii trochu (34\%) a celkom dost' (28\%).

Tab. 2 Pocit obmedzenia pri stravovaní s kolegami

\begin{tabular}{|l|r|r|r|r|}
\hline \multirow{2}{*}{} & \multicolumn{2}{|c|}{ do 3rokov } & \multicolumn{2}{c|}{ nad 3 roky } \\
\cline { 2 - 5 } & $\mathbf{n}$ & $\mathbf{\%}$ & $\mathbf{n}$ & \% \\
\hline Tôbec nie & 2 & 4 & 12 & 23 \\
\hline Mierne & 20 & 43 & 12 & 23 \\
\hline Celkom dost' & 9 & 19 & 3 & 6 \\
\hline Vel'mi & 8 & 17 & 20 & 38 \\
\hline SPOLU & 8 & 17 & 6 & 11 \\
\hline
\end{tabular}

$\mathrm{Z}$ analýzy výsledkov vyplýva, že $43 \%$ respondentov s dížkou ochorenia do 3 rokov má trochu pocit obmedzenia pri stravovaní sa s kolegami. V skupine respondentov s dížkou ochorenia nad 3 roky uviedlo $38 \%$, že pocit'ujú pocit obmedzenia pri stravovaní sa s kolegami celkom dost'.

Tab. 3 Pocit obmedzenia a obavy zo stravovania sa v reštauráciách

\begin{tabular}{|l|c|c|c|c|}
\hline \multirow{2}{*}{} & \multicolumn{2}{|c|}{ do 3rokov } & \multicolumn{2}{c|}{ nad 3 roky } \\
\cline { 2 - 5 } & $\mathbf{n}$ & $\mathbf{\%}$ & $\mathbf{n}$ & \% \\
\hline Vôbec nie & 3 & 6 & 13 & 25 \\
\hline Trochu & 15 & 32 & 17 & 32 \\
\hline Mierne & 9 & 19 & 6 & 11 \\
\hline Celkom dost' & 10 & 21 & 9 & 17 \\
\hline Vel'mi & 10 & 21 & 8 & 15 \\
\hline SPOLU & $\mathbf{4 7}$ & $\mathbf{1 0 0}$ & $\mathbf{5 3}$ & $\mathbf{1 0 0}$ \\
\hline
\end{tabular}

Na základe výsledkov konštatujeme, že 32\% respondentov obidvoch skupín má trochu pocit obmedzenia zo stravovania sa v reštauráciách. Možnost' vel'mi uviedlo $21 \%$ respondentov s dížkou ochorenia do 3 rokov a $15 \%$ respondentov s ochorením nad 3 roky. 
Tab. 4 Problém začlenit’ sa do spoločnosti

\begin{tabular}{|l|r|r|r|c|}
\hline \multirow{2}{*}{} & \multicolumn{2}{|c|}{ do 3rokov } & \multicolumn{2}{c|}{ nad 3 roky } \\
\cline { 2 - 5 } & $\mathbf{N}$ & $\mathbf{\%}$ & $\mathbf{n}$ & \% \\
\hline Vôbec nie & 38 & 81 & 42 & 79 \\
\hline Trochu & 4 & 9 & 6 & 11 \\
\hline Mierne & 3 & 6 & 5 & 10 \\
\hline Celkom dost' & 1 & 2 & 0 & 0 \\
\hline Vel'mi & 1 & 2 & 0 & 0 \\
\hline SPOLU & $\mathbf{4 7}$ & $\mathbf{1 0 0}$ & $\mathbf{5 3}$ & $\mathbf{1 0 0}$ \\
\hline
\end{tabular}

$\mathrm{Na}$ základe výsledkov konštatujeme, že v skupine respondentov s trvaním ochorenia do 3 rokov uviedlo až $81 \%$, že vôbec nemajú problém začlenit' sa do spoločnosti. Taktiež väčšina respondentov s trvaním ochorenia nad 3 roky uviedlo možnost' vôbec nie $(79 \%)$.

Tab. 5 Pocit obmedzenia pri cestovaní

\begin{tabular}{|l|c|c|c|c|}
\hline \multirow{2}{*}{} & \multicolumn{2}{|c|}{ do 3rokov } & \multicolumn{2}{c|}{ nad 3 roky } \\
\cline { 2 - 5 } & $\mathbf{N}$ & $\mathbf{\%}$ & $\mathbf{n}$ & \% \\
\hline Vôbec nie & 10 & 21 & 18 & 34 \\
\hline Trochu & 18 & 38 & 20 & 38 \\
\hline Mierne & 6 & 13 & 3 & 6 \\
\hline Celkom dost' & 8 & 17 & 11 & 21 \\
\hline Vel'mi & 5 & 11 & 1 & 2 \\
\hline SPOLU & $\mathbf{4 7}$ & $\mathbf{1 0 0}$ & $\mathbf{5 3}$ & $\mathbf{1 0 0}$ \\
\hline
\end{tabular}

Z analýzy výsledkov vyplýva, že väčšina respondentov obidvoch skupín nemajú vôbec pocit obmedzenia pri cestovaní v dôsledku ochorenia alebo len trochu.

Tab. 6 Pocit deprivácie z ochorenia

\begin{tabular}{|l|c|c|c|c|}
\hline \multirow{2}{*}{} & \multicolumn{2}{|c|}{ do 3rokov } & \multicolumn{2}{c|}{ nad 3 roky } \\
\cline { 2 - 5 } & $\mathbf{N}$ & $\mathbf{\%}$ & $\mathbf{n}$ & \% \\
\hline Vôbec nie & 22 & 47 & 25 & 47 \\
\hline Trochu & 14 & 30 & 12 & 23 \\
\hline Mierne & 7 & 15 & 13 & 25 \\
\hline Velk'mi & 3 & 6 & 3 & 6 \\
\hline SPOLU & 1 & 2 & 0 & 0 \\
\hline
\end{tabular}

$\mathrm{Na}$ otázku, cítim sa deprimovaný pre moje ochorenie, väčšina respondentov oboch skupín uviedla možnost' vôbec nie (47\%). Len $6 \%$ respondentov obidvoch skupín uviedlo možnost' celkom dost' a $2 \%$ respondentov s dížkou ochorenia do 3 rokov uviedlo možnost' vel'mi.

\section{DISKUSIA}

Ciel'om práce bolo zistit', ako ovplyvňuje celiakia kvalitu života pacientov vzhl'adom na dížku trvania ich ochorenia. Celiakia je chronické ochorenie a do značnej miery ovplyvňuje kvalitu života pacientov. Vzhl'adom na to, že jedinou možnost'ou liečby je celoživotné dodržiavanie bezlepkovej diéty, má toto ochorenie nesmierny dopad na kvalitu života týchto pacientov. Stravovanie $\mathrm{v}$ reštauráciách považujú pacienti s celiakiou za nesmierne náročné, pretože je t’ažké identifikovat', ktoré jedlá sú bezlepkové. Mnohí z pacientov uvádzajú, že im chýbajú informácie o prípadnej kontaminácii pripravovaných pokrmov (6). Aj ked' si objednajú jedlo, v ktorom nie je žiadna zložka obsahujúce lepok, môže dôjst' ku kontaminácii počas prípravy 
napríklad tým, že sa bezlepkové potraviny spracovávajú na rovnakom mieste, ako potraviny s lepkom (4).

Zaujímalo nás teda, či respondenti majú obavy zo stravovania $\mathrm{v}$ reštauráciách pre kontamináciu pokrmov. Analýzou výsledkov sme zistili, že najviac respondentov obidvoch skupín má trochu obavy zo stravovania $\mathrm{v}$ reštauráciách. Taktiež výsledky nášho prieskumu dokazujú, že väčšina respondentov s dížkou trvania ochorenia do 3 rokov uvádza, že sa cítia byt' trochu obmedzení pri stravovaní s kolegami. V skupine respondentov, u ktorých ochorenie pretrváva viac ako 3 roky uvádzajú väčšinou možnost' celkom dost'. Na základe výsledkov môžeme teda konštatovat', že v rámci sledovaných skupín sme zaznamenali v oblasti obáv zo stravovania len minimálne rozdiely.

V oblasti začlenenia respondentov do spoločnosti sme v rámci sledovaných skupín pacientov nezaznamenali rozdiely vzhl'adom na dížku trvania ich ochorenia. Obidve skupiny respondentov uviedli, že nemajú problém začlenit' sa so svojim ochorením do spoločnosti. Môžeme teda konštatovat', že nebol preukázaný vzt'ah medzi dížkou trvania ochorenia a problémom spoločenského začlenenia sa.

Prieskum autora Lee a kol. potvrdzuje, že zložitejšie sa prispôsobujú pacienti, ktorým bola celiakia diagnostikovaná neskôr, $v$ dospelosti. Táto životná zmena predstavuje povinnost' vzdat' sa mnohých oblúbených pokrmov, čo vedie u pacientov k pocitom vyčlenenia $\mathrm{z}$ kruhu svojich známych (9). Menší vplyv celiakie na kvalitu života je pozorovaný u pacientov, ktorým bolo ochorenie diagnostikované ešte $\mathrm{v}$ rannom detstve. Takýto pacienti vykazujú väčšiu disciplinovanost' v dodržiavaní bezlepkovej diéty (3).

Sociálne aspekty kvality života pacientov s celiakiou, v zmysle každodenného života, rozoberá a hodnotí kolektív autorov, ktorí zistili, že pacienti s celiakiou zaujímajú skôr negatívny postoj $\mathrm{k}$ celkovému vnímaniu svojho zdravia. Ten sa odrazil najmä v sociálnej oblasti. Obmedzenia pocit’ujú pri cestovaní, stravovaní v reštauráciách čo považujú za negatívny vplyv na ich spoločenský a rodinný život. Stravovanie v reštauráciách a iné spoločenské aktivity sú vo väčšine prípadov spúšt’ačom porušenia bezlepkovej diéty. Ako najčastejšie dôvody boli uvedené že bezlepková diéta je nepraktická, je finančne náročná, je bez chuti a je t'ažké ju sústavne dodržiavat' (9).

Tieto zistenia nekorešpondujú s našimi zisteniami. Respondenti nášho súboru pocit’ujú obmedzenie pri cestovaní len v minimálnej miere a to vo frekvencii trochu. O čosi väčší dopad má ich ochorenie na oblast' stravovania sa v reštauráciách, či s kolegami. Taktiež na položku cítim sa týmto ochorením obmedzený, uviedli respondenti obidvoch sledovaných skupín najčastejšie možnost' trochu.

V oblasti pocitov deprivácie $\mathrm{z}$ ochorenia celiakia, sme taktiež nezaznamenali $\mathrm{v}$ rámci sledovaných skupín respondentov výrazné rozdiely. V prípade oboch skupín respondentov môžeme zhodnotit', že nemajú pocit deprivácie z tohto ochorenia, Len minimálne percento respondentov obidvoch skupín uviedlo, že má pocit deprivácie vo frekvencii trochu a mierne.

\section{ZÁVER}

Z hl'adiska dížky trvania ochorenia $\mathrm{v}$ sledovanom súbore nebol preukázaný rozdiel v zhoršení ich kvality života. V približne rovnakej miere pacienti pocit'ujú obmedzenie pri cestovaní, stravovaní sa v reštauráciách, či s kolegami v dôsledku ich ochorenia. Väčšina pacientov obidvoch skupín, nemá problém so svojim ochorením začlenit' sa do spoločnosti. Pozitívnym zistením bolo, že respondenti v rámci porovnávaných skupín, nevykazujú známky deprivácie a strachu z prítomnosti tohto ochorenia. 


\section{Použitá literatúra}

1. BABINČÁK, P. Spokojnost’ so životom ako psychologická dimenzia kvality života. Prešov: Prešovská univerzita v Prešove, Filozofická fakulta, 2008. 95 s. ISBN 978-88068-749-6.

2. BARTALOŠOVÁ, J. Hodnotenie kvality života pacientov s celiakiou. Prešovská univerzita v Prešove (Prešov, SR). Fakulta zdravotníckych odborov. Katedra ošetrovatel'stva. 2015. $57 \mathrm{~s}$.

3. DOORN, R. K. et al. CDDUX: A Disease-specific Health-related Quality-of-life Questionnaire for Children With Celiac Diseasel. In: Journal of Pediatric Gastroenterology and Nutririon, 2008. vol. 47, no. 2, s. 147-152, ISSN 1536-4801.

4. FRIČ, P., MENGEROVÁ, O. Celiakie: bezlepková dieta a rady lékaře. Čestlice: Madica Publishing. 2008. 186 s. ISBN 978-80-85936-62-9.

5. FRÜHAUF, P. a kol. Celiakie vdětském věku. 1. vyd. Šumperk: Solen Print. 2009. 48 s. ISBN 978-80-87290-00-2.

6. HOLMES, S. Coeliac disease: symptoms, complications and patient support. In: Nursing Standard. vol. 24, no. 35, s. 50-56. ISSN 0029-657.

7. JURÍKOVÁ, T., BELANOVÁ, K., BALLA, Š. Celiakia - sprievodca ochorením a výživou. Nitra: Fakulta stredoeurópskych štúdií UKF v Nitre. 140 s. ISBN 978-80558-0087-5

8. LACKO, A., RENKER, B., HRUBOŇ, A. et al. Vnútorné lekárstvo pre ošetrovatel'stvo II. 2. vyd. Ružomberok: Katolícka univerzita v Ružomberku. 2007. 170 s. ISBN 978-80-8084-146-1.

9. LEE, A. R. et al. Living with coeliacdisease: survey results from the USA. In: Journal of Human Nutrition and Dietetics. [online]. 2012. vol. 25, s. 223-238. ISSN 1365-277. [cit. 2021.05.23.]. Dostupné na internete: https://celiacdiseasecenter.co lumbia.edu/wp-content/uploads/2018/12/Living-with-coeliac-disease-survey-resultsfrom-the-USA.pdf

10. MOŽNÁ, L. Bezlepkářrum od A do Z. Ostrava: Ringier Print. 2006. 186 s. ISBN 40566-9107-4

11. PAYNE, J., et al. Kvalita života a zdraví. Praha: Triton. 2005.630 s. ISBN 80-7254657-0.

12. SLOVÁČEK, L., et al. Kvalita života nemocných - jeden $\mathrm{z}$ dôležitých parametrů komplexního hodnocení léčby. In: Vojenské a zdravotnícke listy. 2004. roč.73, č. 1, s. 6-9. ISSN 0372-7025.

\section{Kontaktné údaje}

PhDr. Zuzana Šimová, PhD.

Fakulta zdravotníckych odborov Prešovská univerzita v Prešove

Partizánska 1

08001 Prešov

email: zuzana.simova@unipo.sk 


\title{
VÝTVARNÉ UMENIE A UMELECKÁ ILUSTRÁCIA AKO REFLEXIA IMAGINÁCIE V ARTETERAPII
}

\author{
FINE ART AND ARTISTIC ILLUSTRATION AS THE REFLECTION \\ OF IMAGINATION IN THE ART THERAPY
}

\author{
Alena Sedláková
}

\begin{abstract}
Abstrakt
Príspevok predkladá otázky o výtvarnom umení a umeleckej ilustrácii, ktoré sa za určitých okolností môžu stat' súčast'ou arteterapie. Pojednáva tak o reflexii a imaginácii, ktorá je zároveň umeleckou metódou arteterapie. Výtvarné dielo v polohe umeleckej ilustrácie tak stojí aj v úlohách biblioterapie, ktorá je expresívnou terapiou v širšom slova zmysle arteterapie. Arteterapia ako expresia ponúka možnost' realizácie výtvarným dielom a umelecká ilustrácia tvorí súčast' knihy ako nástroja v biblioterapii. Všetky výsledky tvorivých aktivít sa vo výsledkoch javia ako osobná výpoved' autora v arteterapii. Výtvarná činnost je tak reflexiou na rôzne podnety. Imaginácia sa usiluje o sponntánnu komunikáciu človeka $\mathrm{v}$ arteterapii. V príspevku predkládáme aj konkrétnu umeleckú ilustráciu ako podnet $\mathrm{k}$ tvorbe $\mathrm{v}$ intenciách arteterapie a reflexie $\mathrm{v}$ kontaktoch $\mathrm{s}$ imagináciou. $\mathrm{K}$ tomu ponúkame vlastnú výtvarnú ukážku.
\end{abstract}

Klićová slova: výtvarné umenie, arteterapia, reflexia, imaginácia, autorská tvorba, dielo.

\begin{abstract}
The paper presents questions about fine arts and artistic illustration. It deals with reflection and imagination, which is also an artistic method of the art therapy. The work of art in the position of artistic illustration thus also stands in the tasks of bibliotherapy, which is an expressive therapy in the broader sense of art therapy. Art therapy as an expression offers the possibility of realization by a work of art and artistic illustration forms part of the book as a tool in bibliotherapy. All the results of creative activities appear in the results as a personal statement of the author in art therapy. Artistic activity is thus a reflection on various stimuli. Imagination seeks spontaneous human communication in art therapy. In the article, we also present a specific artistic illustration as a stimulus for creation in the intentions of art therapy and reflection in contacts with the imagination. To do this, we offer our own art sample.
\end{abstract}

Key words: fine arts, art therapy, reflection, imagination, authorial work, artwork.

\section{O VÝTVARNOM UMENÍ A UMELECKEJ ILUSTRÁCII}

Výtvarné umenie je súčast'ou života človeka. Sprevádza ho od útleho veku a prostredníctvom obrazov a umeleckých metód komunikuje rôzne myšlienky. Vnútorná spätost' umenia a psychológie je všetkým dobre známa. Dielo predstavuje samotnú myšlienku svojho autora. Umenie svojím obsahom prispieva $\mathrm{k}$ hlbšiemu poznávaniu človeka. Je dôležitým prostriedkom sebareflexie. Umenie zasahuje širokú škálu l'udského snaženia, a to tak, že ide viac menej o činnost o postoj (Kulka, J. 2008). Historik kultúry Raymond Williams (In: Kulka, J. 2008) o umení hovorí ako o jednom z kl'účových slov, ktoré by sme mali pochopit', aby sme mohli rozumiet' vzájomným vzt'ahom medzi kultúrou a spoločnost'ou. E. Souriau (In: Kulka, J. 2008) píše o umení, že je to použitie istých duchovných kvalít alebo manuálnych zručností pri realizácii určitého diela. Zahŕňa tvorivú činnost človeka v protiklade 
k pôsobeniu prírody, ide o špecializovanú techniku, poznanie a intelektuálnu disciplínu, krásne umenia, obratnost' pri používaní prostriedkov umožňujúcich vytvárat' hodnotné diela, či schopnost neredukovatel'nú na pravidlá a predpísané postupy.

Súčasný vývoj umenia predpokladá, že by sme mali pripojit' d’alšie aspekty, ktoré by zohl'adňovali vecnú, obrazovú, výrazovú, znakovú a modelovú povahu umeleckého diela. Podl'a Kulku, J. (2008) dielo ako model nemôže existovat' bez predpokladu diela ako znaku, ktoré je dielom - obrazom (zobrazenie a výraz), ktoré je materiálne fixované ako dielo - vec. Je teda jasné, že dielo je zložitá štruktúra. V zložitej štruktúre sa však prejavia aj iné umelecké diela, ktoré sú spojené s umením a umeleckými metódami. Tie sa uplatňujú už v konkrétnej tvorbe autorov - umelcov. Môžu to byt' napríklad techniky land artu, koláže, asambláže, performancie či akcie alebo digitálne umenie. Tie sa od obrazu odlišujú viacerými prvkami, čo sa týka priestoru alebo plochy. Autori teda využívajú ku výtvarnej komunikácii mnoho postupov a techník, ktoré niekedy aj kombinujú.

Do úvahy však prichádza aj otázka, kadial' povedie hranica medzi umením a neumením. Podl'a Kulku, T. a D. Ciporanova (2010) sa názory rôznia. Konceptuálni umelci začali tvrdit', že podstatou umeleckého diela je sprostredkovanie myšlienky, alebo vytvorenie konceptu, ktorého materiálne ukotvenie v objekte či médiu, ktoré by vykazovali nejaké estetické kvality, je celkom nepodstatné. Podstatou umenia je intelektuálna a sebareflektujúca otázka. Umelecké diela musia samé komentovat' umenie, musia si klást' otázku, čo je umenie a kde je jeho hranica. Autori zvýrazňujú pojmy estetická a umelecká hodnota.

J. Levinson (In: Kulka, T. a D. Ciporanov 2010, s. 135) kladie otázku, čo je umenie. „,Dovolil bych si naopak tvrdit, že může existovat soukromé, izolované umění, které se stáva uměním $v$ mysli umèlce - a to jedině pro nej a pro potenciální recipienty. (Předpokládám, že pouze to ke vzniku světa uměni nestačí, jinak by byl tento pojem triviální a zbytečný.) "V žiadnom prípade nemusí nikto tvrdit', aby sa to, čo robí, stalo umením. Zdá sa, že ak chceme rozlíšit' umeleckú tvorbu od tvorby neumeleckej, musíme sa to pokúsit' určit'. Umenie si vyžaduje vnímanie, percepciu. Nové umenie je umením vd’aka vzt’ahu k umeniu ešte staršiemu a podobne k ešte staršiemu. Umelecké dielo, na rozdiel od auta, stoličky alebo človeka postráda vopred definované hranice v podobe inherentných vlastností, akokol'vek premenlivých. Nedá sa zakaždým určit', čo je a čo nie je umenie, porovnávaním s nejakým archetypom. Originálne umelecké dielo je novým dielom, ktoré svojimi štruktúrami a estetickými vlastnost’ami sa líši od všetkých predošlých umeleckých diel.

Doposial' neexistuje jednoznačná charakteristika čo je umenie, aj ked' ju definujú mnohí autori z vlastných skúseností s umením. Nick McAdoo (In: Kulka, T. 2000) sa pozastavuje nad poznámkou, že by umelecké dielo malo maximalizovat' hodnotu estetickú a hodnotu umeleckú. Odkazuje k vývoju súčasného umenia, kde sa výrazne uplatňujú trendy, ktoré sa snažia estetické aspekty negovat'. G. Graham (2004) píše, že niektorí filozofi sa domnievajú, že hodnota umenia sa na potešenie alebo pôžitok viaže bezpodmienečne, pretože označit' nejaké dielo za dobré je podl'a ich názorov to isté ako povedat', že je to pekné alebo príjemné. Najznámejším autorom podobnej myšlienky bol škótsky filozof David Hume. Podl'a neho, estetické sklony sú výrazom vkusu pozorovatel'a, nie výrokmi o objekte a rôznorodost' názorov na umenie, s ktorými sa vo svete stretávame, považuje za doklad tejto skutočnosti.

Za umeleckú ilustráciu, ktorú tiež považujeme za výtvarné umenie, považujeme obrázky v knihách s umeleckým textom. Okrem umeleckej ilustrácie existuje aj vedecká ilustrácia. Umelecká ilustrácia sa viaže na diela poézie a rozprávok či poviedok. Vo svojej podstate doplńa text a je vizuálnym obsahom textu v knihe, najmä pre deti a mládež. Ilustrovat' tak 
znamená osvetl'ovat' textovú čast' knihy, ktorou môže byt' už kniha pre nejmenších - leporelo. Ide o knihu, ktorá môže slúžit' aj ako hračka. Umelecká ilustrácia vo vzt'ahu ku knihám má aj prívlastok knižná ilustrácia. Ilustrácia je výtvarné stvárnenie myšlienky textu diela. Ilustrácia zjednodušuje text, jeho t’ažšie opísatel'né časti, ul'ahčuje orientáciu v texte a podporuje stotožnenie predstáv autora a čitatel'a. Tvorca ilustrácií vyjadrujúci myšlienky $\mathrm{v}$ texte pomocou obrazov, alebo odborník z určitej oblasti tvoriaci technickú ilustráciu sa nazýva ilustrátor.

\subsection{Umelecká ilustrácia v knihe pre deti a mládež - Květa Pacovská a reflexia k vybraným ilustráciám}

Umelecká ilustrácia je ako myslenie obrazom. Autor ilustrácií myslí svojimi obrazmi a dopíña text vizuálnou komunikáciou. M. Petř́ček (2009) opisuje vo svojom diele myslenie obrazom. Myslenie obrazom kladie do vzájomnej súvislosti myslenie a obraz. Sú dve možnosti: myslenie je niečo iné ako obraz alebo čím sa myslenie líši od tvorby či štruktúry obrazov, od obrazného chápania, v čom sú obrazy iné, než myšlienky a podobne. Alebo druhá možnost', že je medzi myslením a obrazom nejaká vel’mi tesná súvislost'. Prvá alternativa, ktorá myšlienku a obraz kladie do ostrého protikladu, zodpovedá protikladu vedy a umeniu, prísnemu mysleniu a slobodnej hry imaginácie. Dominantná je zodpovednost', racionalita a logika. Úvaha, ktorá vedl'a seba kladie obraz a myslenie má zmysel vtedy, ked' pracuje so vzájomným osvetl'ovaním.

Na tomto mieste by sme upriamili pozornost na tvorbu ilustrácií autorkou Květou Pacovskou. V jej myslení obrazmi sa v každej knihe odráža expresívne a imaginatívne myslenie, vo farbách a kompozíciách zobrazuje svoje ilustrácie s jemnou hravost'ou a citlivost’ou. Okrem malieb, grafík a vol'nej tvorby vytvárala aj objekty, často monumentálne diela s pohyblivými a statickými detailmi. Tvorila aj experimentálne knihy, ktoré boli dotvárané rafinovane a s prvkami detských hier. Ziskala množstvo cien za svoju tvorbu, nevynímajúc Cenu Hansa Christiana Andersena (1992). V jej ilustráciách sa objavuje princíp detskej tvorivosti, spontánne tvorený znak a modernost' jej výtvarného umenia. V jej tvorbe prevládajú expresívne farby - červená, tmavo zelená či čierna. Má blízko aj k jemným tónom a vel'kým formátom, a to aj v grafike. Vel'kú úlohu zohráva imaginácia.

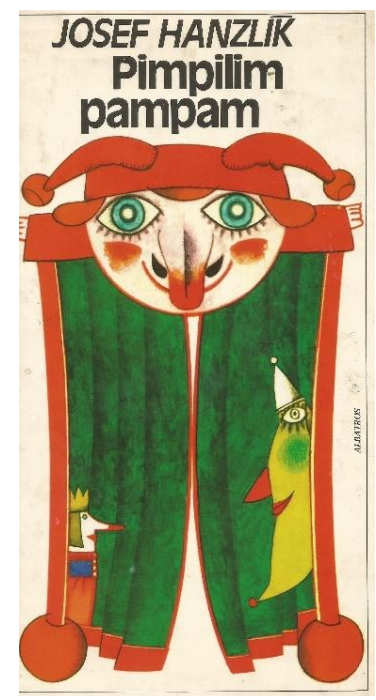

Obrázok 1 Obálka ku knihe Pimpilim pampam, ktorá je ilustrovaná Květou Pacovskou (1988).

Květa Pacovská využívala výraznost' a kontrastnost' vo svojich ilustráciách. Dominuje hra ako základná myšlienka v tvorbe pre deti. Obrázok 1 nám predkladá možnost' zobrazenia vstupu 
do rozprávky. Postava Šaša tu slúži ako priestor tajomstva a imaginácie. V celej knihe sa striedajú mal'by s výrazným detailom a farebným prostredím. Detskú poéziu knihy Pimpilim pampam dotvára mal'bami a grafickými obrazmi.

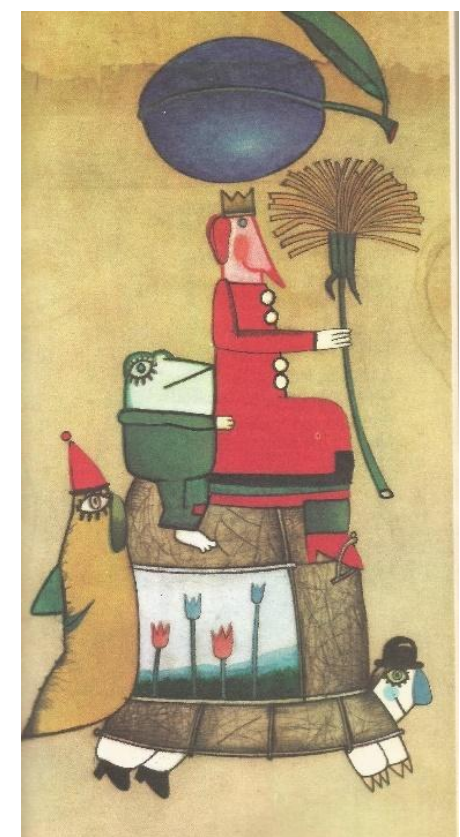

Obrázok 2 predstavuje ilustráciu k poetickému útvaru v knihe Pimpilim pampam, Loudálkův návrat zo strany 25.

Kompozične tvorí vrstvením a skladaním motívov. Tieto postupy K. Pacovská uplatňovala aj v experimentálních knihách a priestorovej tvorbe.

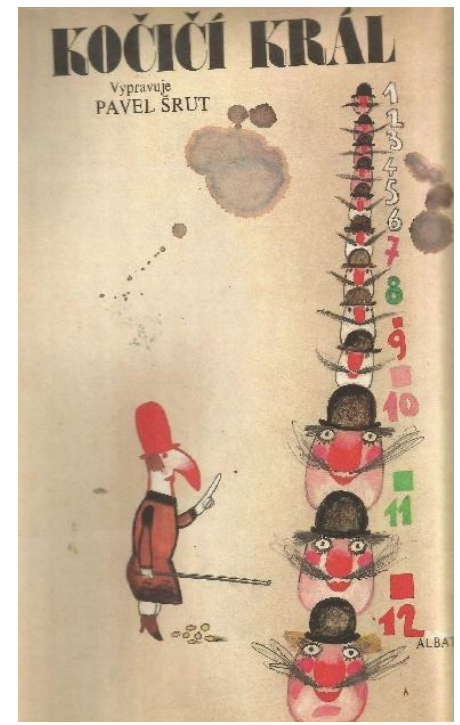

Obrázok 3 predstavuje obálku ku knihe rozprávok Kočičí král.

V tejto ilustrácii K. Pacovská vytvára priestor zmnožovaním jedného motívu, či aj uplatnením automatizmu, ako znaku detskej kresby - opakovanie motívu hlavy v kontrastných farbách. Tvary sú doplnené číslicami. 


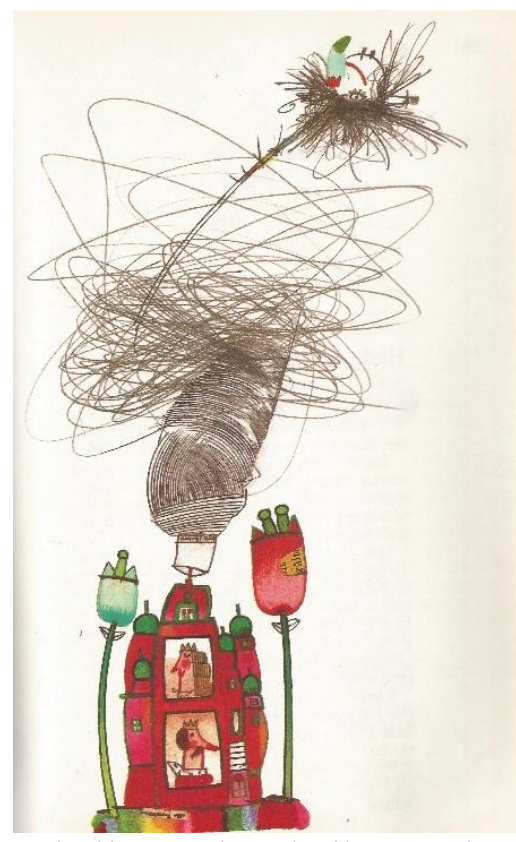

Obrázok 4 predstavuje ilustráciu z knihy Kočičí král (1989, s.259).

Ilustrácia je tvorená technikou grafickou a kolorovanou kresbou. Je vzdušná a výrazná vo svojej farebnosti, dominuje červená farba. Ako kontrast v kompozícií je uplatnená kresba línií do zaujímavého tvaru. Dá sa povedat', že môže íst' o motív obsahovej čmáranice ako hravej formy kresby predškolákov.

\section{IMAGINÁCIA V ARTETERAPII PROSTREDNÍCTVOM VLASTNEJ TVORBY S PRVKOM ILUSTRÁCIE}

Imaginácia je schopnost predstavy. V arteterapii je imaginácia jednou z arteterapeutických metód, ktoré využívajú aj výtvarnú tvorbu a umenie. Liečba skrz výtvarnú tvorbu je známa už od nepamäti.

Šicková-Fabrici, J. (2006) píše o imaginácii ako metóde spirituálno-ekologickej arteterapie. Pomocou imaginácie sa človek môže vrátit' k niektorým situáciám. Môže ich znova prežit’ či reflektovat' do výtvarnej tvorby. Tak ich môže zhmotnit'. Imaginácia je sprostredkovatel'om medzi svetom hmotným a nehmotným. Riadená imaginácia je niekedy nazývaná aj vizualizáciou. Stratégie vizualizácie sú totožné s riadenou imagináciou. Využíva sa aj $\mathrm{v}$ diagnostike.

E. Wallaceová (In: Rubinová, J., A. 2008) píše o jungiánskom prístupe v tvorbe pomocou výtvarnej tvorby. Je to t'ažšia úloha, ked’že ide o zobrazovanie prostredníctvom vizuálnych obrazov. Vo svojej práci využíva imagináciu aktívnu. Používa prvky predstáv, ktoré sú založené na skutočnosti. Táto metóda je založená na tom, že pravda je ukrytá v nevedomí, ego $\mathrm{v}$ rovine ale ako skutočná historická pravda, prejavujúca sa archetypálnych obrazoch založených na kolektívnom nevedomí. Dominantný archetyp, ktorý Jung nazval "Self", má pre liečbu zvláštny význam. Plní regulačnú a stabilizačnú funkciu, kompenzujúcu akúkol’vek nerovnováhu, ktorá môže nastat'. Podl'a Junga to môže byt' prospešné ale aj zničujúce. Aktívna imaginácia teda dominuje ako prvok k výtvarnej tvorbe, je jej nástrojom. Imaginácia je predstavivost', obrazotvornost', vedome ovládaná tvorivá fantázia. 


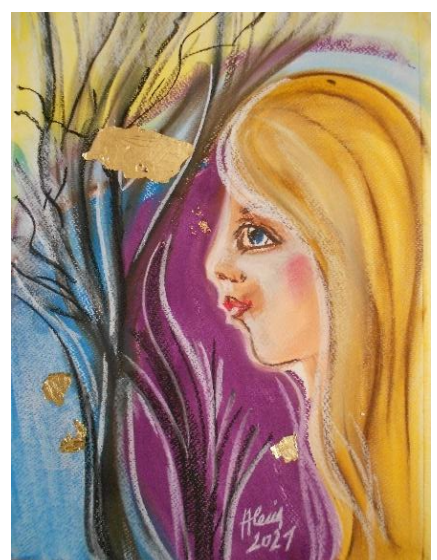

Obrázok 5 Mal'ba suchým pastelom, aktívna imaginácia v procese tvorby - Návrat ku koreňom.

Obrázok 5 predstavuje vlastnú tvorbu aktívnou imagináciou. Predostiera pohl’ad ku koreňom, ktoré paradoxne tvorí zobrazenie stromu. Dôraz bol kladený na farebnost' a kompozíciu. Nánosy suchého pastelu predstavujú nánosy životných okamihov a ich výraz.

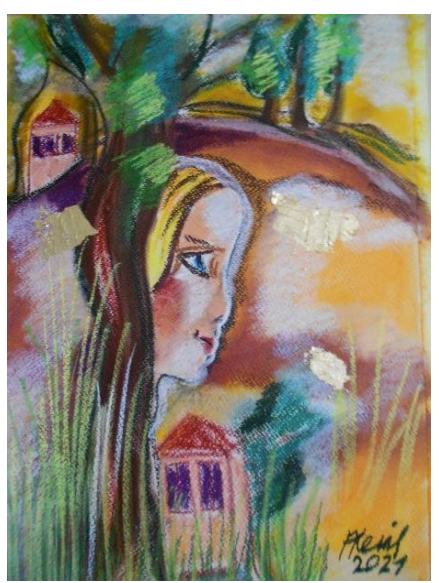

Obrázok 6 predstavuje mal'bu suchým pastelom a jeho vrstvením. Zobrazuje archetyp domova.

Na Obrázku 6 je aj motív tváre ako predstava osobného „Ja“ ako selfu. V aktívnej imaginácii je predložený motív domu a lesa ako spojenia vedomého a nevedomia.

Všetky obrázky môžu zároveň slúžit’ aj ako umelecká ilustrácia za predpokladu, že vytvoríme autorský text, poézie alebo prózy, no túto vlastnost umeleckej ilustrácie nadobudnú až v spojení s textom. Takto môžeme kombinovat' umeleckú ilustráciu s textom ako verbálne orientovanú aktívnu imagináciu a výtvarné dielo ako samostatnú výtvarnú tvorbu. 


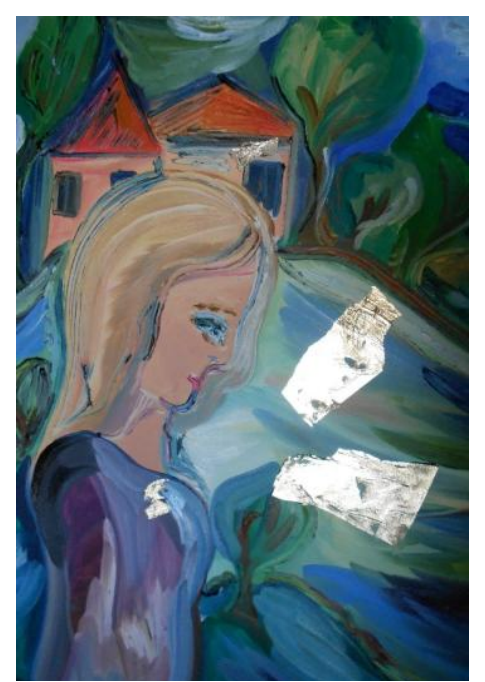

Obrázok 7 mal'ba olejovými farbami predstavuje aktívnu imagináciu na tému „Ja a spomienky“ alebo „Samota v spomienkach“

Obrázok 7 prináša náhl'ad do spirituálneho vnímania skutočnosti, predstavuje domov a cestu $\mathrm{z}$ domova.

S. McNiff (In: Rubinová, J., A. 2008) uvádza myšlienku využit' v arteterapii všetky druhy umení, ktoré vzbudzujú u jedných obavy a u druhých vzrušenie. Ďalej uvádza ako výtvarná tvorba, rovnako ako je tomu v prípade všetkých tvorivých postupov, vyžaduje multisenzoriálnu činnost. Z hl'adiska rytmu môžeme nazerat' aj na obrazy samotné. Vizuálne vzorce, ktoré pri opakovaní využívala aj ilustrátorka K. Pacovská vo svojej ilustračnej tvorbe, opakovanie, vzostupné a zostupné línie a d’alšie charakteristické znaky sa vzt'ahujú $\mathrm{k}$ hudobným prvkom. Ak zapojíme rozmanité formy umelecké a naše pohyby sa odohrávajú v bezpečí, známom prostredí, ktoré prejavy podporujú, pravdepodobne sa zvýši naše sebaprežívanie. Metóda využitia všetkých druhov umenia v terapii buduje prostredie tvorivej energie, ktorá l'udí ovplyvňuje, čo je v kontraste stým, ked' kladieme pri jednotlivých pacientoch dôraz na lineárny plán liečby. Tvorivá atmosféra je sprostredkovatel'om terapeutickej zmeny. Táto forma arteterapie doplńna ostatné liečebné metódy.

Podl'a M. Lhotovej a E. Perouta (2018) je imaginácia súčast'ou názorov kognitívnych psychológov. Predstavivost' slúži k vytváraniu mentálnych reprezentácií vonkajšieho sveta, prípadne k ich d’alšiemu spracovaniu. Predstavy človeka projikujú jeho aktuálny emočný stav a problémy. Práca $\mathrm{s}$ imagináciami $\mathrm{v}$ arteterapii spočíva $\mathrm{v}$ tom, že imaginácia tvorí predprípravu pre mal'ovanie, čo býva častejší spôsob práce, nie menej účinné je vychádzat' už z hotového obrázku, vstúpit' do obrázku a imaginovat na jeho základe. Namal'ovat' čast' svojej imaginácie prinesie poznanie toho, čo je v životnom dianí klienta natol'ko dôležité, že sa rozhodne to zarámovat' a namal'ovat', prípadne zaradit' do kontextu dotvorením pri pridaní priestoru okolo namalovaného alebo nalepeného centrálneho obrázku. Potom je potrebné pracovat's týmto výsekom. Imaginatívny vstup do vlastného obrázku prináša možnost' cesty. Aktívna imaginácia je aj námetom pre vol’né koláže a vol'né témy, s aktívnymi imagináciami možno rozvíjat' už vytvorené artefakty.

\subsection{Imaginácia s ilustráciou}

V tejto časti predstavíme dve výtvarné práce s umeleckou ilustráciou Květy Pacovskej, ktorej vd’ačíme za poetické prejavy. Vybrali sme ilustráciu z knihy Kočičí král. 


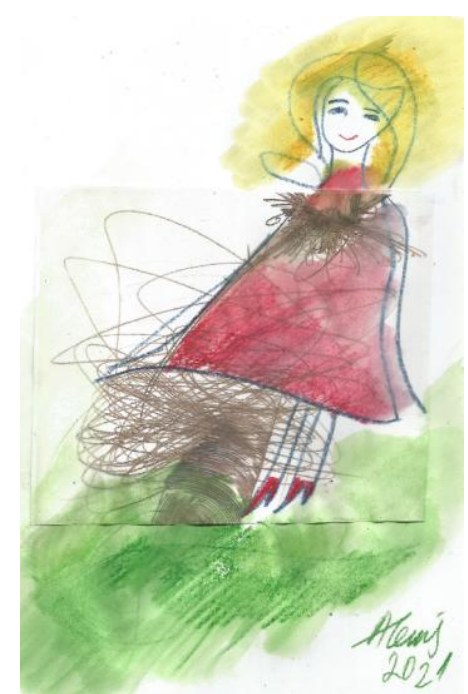

Obrázok 8 predstavuje fragment umeleckej ilustrácie s domal'ovaním.

Na Obrázku 8 sme vytvorili imagináciou pomocou uplatnenia umeleckej ilustrácie z vyššie uvedeného Obrázka 4, kterého je autorkou Květa Pacovská. Vytvorili sme domal'ovanú koláž, kde sme použili akvarelové pastelky a fragment výstrižku. Koláž sme domal'ovali, resp. rozmal'ovali sme línie nanesených akvarelových pasteliek. Obsahovú čmáraninu sme pretvorili na telo postavy a umiestnili sme ju do zelenej plochy. Tvorili sme spontánne, bez prípravy, a to aktívnou imagináciou motívov, ktoré boli na výstrižku.

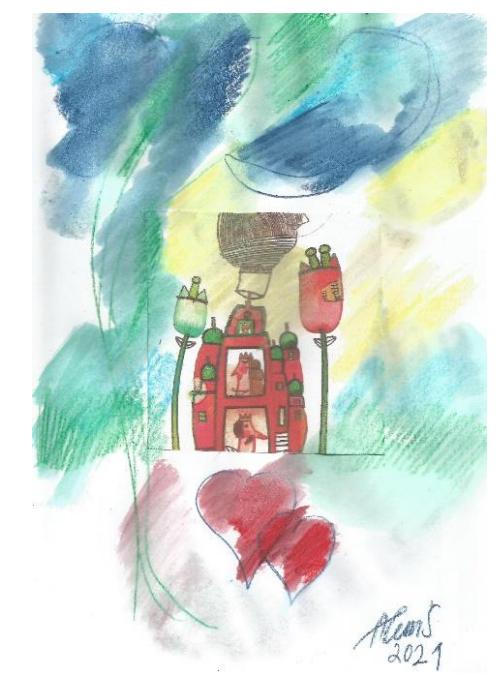

Obrázok 9 predstavuje druhú čast' pôvodnej umeleckej ilustrácie Květy Pacovskej.

Na Obrázku 9 sme dotvorili druhú čast' ilustrácie - fragmentu diela Květy Pacovskej. Doplnili sme ho o motív dvoch spojených sŕdc a domal'ovali sme krajinu ako pozadie. Uplatnili sme základné a komplementárne farby. Technikou domal'ovanej koláže sme vytvorili interpretáciu novej umeleckej ilustrácie z fragmentu, ktorý sme nalepili a domal'ovali akvarelovými pastelkami. Týmto spôsobom môžeme tvorit' aj pomocou d'alších umeleckých ilustrácií nové podoby výtvarných prác aktívnou imagináciou. Môžeme si tvary predpripravit' alebo tvorit' podl'a toho, čo si pri danom fragmente představíme. Takouto cestou aktívnej imaginácie môžeme docielit' v arteterapii zaujímavú tému s využitím umeleckej ilustrácie. Vybrali sme pre náš príspevok prácu autorky Květy Pacovskej ako hommage pre jej tvorbu a kreatívne principy. Pri tejto technike pracujeme s reprodukciami, ktoré si môžeme oskenovat z kníh a vytlačit' alebo oxeroxovat' a tak využit' rozstrihané časti - fragmenty ilustrácie. 


\section{Použitá literatura}

1. GRAHAM, G. Filosofie umění. 1. vydanie. Brno: BARRISTER\&PRINCIPAL 2004. 251 s. ISBN 80-85947-53-6.

2. HANZLÍK, J. Pimpilim pampam. 2. vydanie. Praha: Albatros 1988. Ilustrovala Květa Pacovská. $79 \mathrm{~s}$.

3. KULKA, J. Psychologie umění. 2. vydanie. Praha: Grada Publishing, a. s. 2008. 435 s. ISBN 978-80-247-2329-7.

4. KULKA, T. a D. CIPORANOV. Co je umění? Texty angloamerické estetiky 20. století. 1. vydanie. Červený Kostelec: Pavel Mervart 2010. 437 s. ISBN 978-80-87378-46-5.

5. KULKA, T. Umění a kýč. 2. vydanie. Praha: Torst 2000. 292 s. ISBN 80-7215-128-2.

6. LHOTOVÁ, M. a E. PEROUT. Arteterapie v souvislostech. 1. vydanie. Praha: Portál, s. r. o. 2018. 246 s. ISBN 978-80-262-1272-0.

7. PETŘÍČEK, M. Myšlení obrazem. 1. vydanie. Praha: Herrmann \&synové 2009. 203 s. ISBN 978-80-87054-18-5.

8. RUBINOVÁ, J., A. Prístupy varteterapii. Teorie \&technika. 1. vydanie. Praha: TRITON 2008. 543 s. ISBN 978-80-7387-093-5.

9. ŠICKOVÁ-FABRICI, J. Arteterapia - uzážitkové umenie? 1. vydanie. Bratislava: Petrus 2006. 273 s. ISBN 80-89233-10-4.

10. ŠRUT, P. Kočičí král. 1. vydanie. Praha: Albatros 1989. Ilustrovala Květa Pacovská. 348 s.

\section{Kontaktní údaje}

Mgr. Alena Sedláková, PhD.

Prešovská univerzita v Prešove, Pedagogická fakulta

Katedra hudobnej, výtvarnej a telesnej výchovy

U1. 17. novembra 15, 08001 Prešov, Slovensko

Telefón: +421517470 594

email: alena.sedlakova@unipo.sk 


\title{
KVALITA ŽIVOTA PACIENTA S NEUROLOGICKÝM OCHORENÍM \\ QUALITY OF LIFE OF A PATIENT WITH NEUROLOGICAL DISEASE
}

\author{
L’udmila Majerníková
}

\begin{abstract}
Abstrakt
Sclerosis multiplex patrí medzi chronické demyelinizačné ochorenia nervového systému a vedie k širokému spektru klinických príznakov. Má výrazný funkčný dopad na pacienta, hendikepuje pacienta a obmedzuje jeho schopnost' vykonávat' bežné aktivity. Tým, že invalidizuje prevažne l’udí v mladom a strednom veku, má výrazný celospoločenský dosah. Skleróza multiplex je teda považované za závažné neurologické degeneratívne ochorenie, ktoré výrazne zasahuje do kvality života všetkých pacientov.
\end{abstract}

Kl'účové slová: sclerosis multiplex, kvalita života, ošetrovatel'stvo.

\begin{abstract}
Multiple sclerosis is a chronic demyelinating disease of the nervous system and leads to a wide range of clinical symptoms. It has a significant functional impact on the patient, handicaps the patient and limits his ability to perform normal activities. By disabling predominantly young and middle-aged people, it has a significant societal impact. Multiple sclerosis is therefore considered a serious neurological degenerative disease that significantly affects the quality of life of all patients.
\end{abstract}

Key words: multiple sclerosis, quality of life, nursing.

\section{1 ÚVOD}

Sclerosis multiplex (roztrúsená skleróza) je jedno z najčastejších chronických autoimunitných neurozápalových degeneratívnych ochorení centrálnej nervovej sústavy, ktoré postihuje zväčša mladú populáciu vo veku 20 - 40 rokov. Zriedkavejšie sa môže vyskytovat' v detskom alebo seniorskom veku. Ochorenie postihuje viac ženské pohlavie ako mužské (Suchý a kol. 2012). Existujú klinické štúdie, ktoré dokazujú prítomnost' sclerosis multiplex u jedincov najmä europoidnej rasy. Počty postihnutých s týmto ochorením narastajú so vzdialenost'ou od rovníka, rovnako na severnej aj na južnej pologuli (Šanta a kol., 2007).

\subsection{Priebeh ochorenia}

Skleróza multiplex je ochorenie s extrémne variabilnými príznakmi. Preto je náročnejšie s určitost'ou stanovit' diagnózu. Postihuje rôzne systémy l'udského tela, najmä motorický, senzitívny a autonómny systém (Drobný, 2002). Rozvoj symptómov závisí od miesta zápalu (Havrdová a kol., 2013). Za začiatok chorenia sa dá považovat' úvodný atak, kedy nastáva neočakávaná epizóda neurologickej nefunkčnosti z dôvodu poškodenia myelinových vláken a vzniku lézií v priebehu optického nervu, miechy, mozgového kmeňa a mozočka alebo mozgovej hemisféry. Vzniká teda optická neuritída, myelitída, kmeňovo - mozočkový syndróm alebo mozgový hemisferálny syndróm (Filippi, 2018).

Príznaky ochorenia spôsobujú rôzne poruchy:

- Poruchy videnia - vznikajú pri optickej neuritíde, môžu sa prejavit' ako strata videnia unilaterálne, ktorá sa vyvíja niekol'ko hodín, poprípade dní. Pacient pocit’uje bolest' za 
okom pri pohybe očnou bul'vou. Môžu byt' prítomné poruchy farbeného videnia, diplopia, kmitanie obrazu, poruchy sústredenia pohl'adu na určitý bod, zahmlenie zraku - porucha ostrosti, výpadky zorného pol’a až strata zraku (Havrdová a kol., 2013).

- Poruchy citlivosti - prítomné hyperstézie (zvýšená citlivost'), hypostézie (znížená citlivost'), parestézie - mravčenie, svrbenie, tuhnutie, opuch, vnímanie vibrácií (Filippi, 2018).

- Porucha mobility - je hlavnou príčinou, ktorá negatívne vplýva na kvalitu života pacientov. Chôdza sa v priebehu ochorenia líši, znižuje sa jej rýchlost', skracuje sa dížka kroku. Nastávajú poruchy rovnováhy. Pozorovanie tohto javu slúži ako meradlo na určenie stupňa závažnosti postihnutia (Novotná a kol., 2013). Poruchy hybnosti zvyknú byt' prvým prejavom ochorenia, postihujú takmer všetkých pacientov počas priebehu ochorenia. Vyskytuje sa spasticita (stuhnutost' svalov) alebo paréza (čiastočné ochrnutie svalov) (Filippi, 2018).

- Poruchy funkcie mozgového kmeňa - je prítomné vertigo, ilúzie pohyblivosti, bolest' trojklanného nervu (charakter bolesti je šl'ahavý, trvá niekol'ko sekúnd až minút), čiastočná strata hybnosti lícneho nervu, dysfágia, dysartria.

- Poruchy vestibulárneho systému a mozočka - poruchy rovnováhy, stability, nepresné pohyby horných končatín, intenčný tras, zhoršená koordinácia rečových a dýchacích svalov.

- Poruchy vylučovania - t'ažkosti a bolestivost' pri močení, nyktúria (nočné močenie), časté močenie, neschopnost' úplne vyprázdnit' močový mechúr (Havrdová a kol., 2013). Môžu sa vyskytnút' poruchy sfinkterov - inkontinencia moču alebo stolice, častejšia je však obstipácia (Filippi, 2018).

- Poruchy sexuality - postihujú obe pohlavia. Muži často trpia poruchami erekcie, ejakulácie, impotenciou, znížením libida alebo sekundárnou hypotestosteronémiou. U žien sa prejavuje poruchami orgazmu, znížením libida a vzrušivosti a poruchou vaginálnej lubrikácie (Havrdová a kol., 2013).

- Poruchy kognície - môže byt' rôzna miera postihnutia kognitívnych funkcií. Najviac je postihnutá schopnost' spracovávat' informácie súvisiaca s poruchami pozornosti. Poruchy dlhodobej pamäti, funkčnosti rozhodovania sa alebo riešenia problémov.

- Únava - je najčastejším subjektívnym príznakom ovplyvňujúcim kvalitu života. Súvisí s depresiou a so stupňom invalidity (Hynčicová a kol., 2017). Môžu sa vyskytovat' poruchy spánku. Pri akomkol’vek zhoršení zdravotného stavu nastáva výrazný vzostup stupňa únavy (̌̌asová a kol., 2008).

\section{KVALITA ŽIVOTA PACIENTOV SO SCLEROSIS MULTIPLEX}

Ak hovoríme o kvalite života, môžeme povedat', že hovoríme o vysoko spektrálnom pojme. Mnohí autori používajú rozdielne charakteristiky, no jednou z najstarších a najznámejších definícií, je definícia zdravia, ktorú v roku 1948 predložila a schválila Svetová zdravotnícka organizácia (WHO). Poukazuje na to, že ,zdravie nie je len absencia choroby či poruchy, ale je to komplexný stav telesnej, duševnej aj sociálnej pohody. " Táto definícia sa tiež zameriava aj na subjektívnu a sociálnu stránku l'udského bytia, a teda na primárne potreby človeka. Významovo sa prikláňa k chápaniu dnešnej subjektívnej kvality života (Heřmanová 2012). Podla Murgaša (2009) je typickým znakom slovného spojenia kvalita života vymedzenie oproti pojmu kvantita $v$ prípade hodnoteného života. Kvantitu je možné zvyšovat', no na rozdiel od kvantity, kvalitu nie je možné zvyšovat', ale len zlepšovat'.

Kvalitu života je teda možné rozdelit' do dvoch základných dimenzií - subjektívna a objektívna. 
Subjektívna kvalita života má súvis so psychickou pohodou a celkovou spokojnost'ou so svojím životom. Pod pojmom subjektívna kvalita života sa rozumie, ako každý jednotlivec individuálne vníma kvalitu svojho života. Ide o vlastný pohl'ad, ktorý zahŕňa rôzne prvky:

- celková spokojnost' so svojím životom,

- spokojnost' so špecifickými sférami (významné udalosti) života,

- pozitívny efekt - frekvencia prežívania pozitívnych pocitov,

- negatívny efekt - frekvencia prežívania negatívnych pocitov.

K týmto štyrom položkám subjektívneho prežívania, ktoré zodpovedajú teoretickej koncepcii subjektívnej spokojnosti možno priradit' aj št'astie, zmysel života alebo iné perspektívy kvality života vychádzajúce zo subjektívneho posúdenia jednotlivca (Babinčák, 2008). Existuje mnoho spôsobov ako môže byt' subjektívny názor jednotlivca na kvalitu života zistený alebo zhodnotený. Najčastejšie metódy, ktoré sú využívané sú výpovede o vlastných pocitoch a emóciách alebo o prístupe a správaní sa jednotlivcov. Typickým príkladom je rozhovor, dotazník alebo záznamové hárky pri sledovaní a posudzovaní správania, niekedy obrázky alebo kresby (Masárová, Živčicová 2012).

Z pohl'adu dimenzie objektívnej kvality života môžeme hovorit' o uspokojení potrieb bežného života. Zahŕňa potreby materiálne, sociálne a fyzické zdravie (Payne a kol., 2005). Teda pod pojmom objektívna kvalita života sa zvyčajne rozumejú meratel'né životné podmienky a dosiahnutá životná úroveň bud' jednotlivca alebo celého obyvatel'stva (Heřmanová, 2012). Ciel'om objektívnej kvality je poukázat' na rozvoj l'udstva jednej krajiny a medzinárodne ho porovnat' s druhou krajinou. Najčastejšie porovnávané položky sú ekonomický rast, zdravotný stav danej populácie a úroveň vzdelania obyvatel'stva. K d’alším ukazovatel'om patrí vnímanie korupcie, ekonomická sloboda a ukazovatel' lepšieho života (Masárová, Živčicová 2012).

Podl'a Džuku (2014) sa v posledných desat'ročiach čoraz viac vedných disciplín začína zaujímat' o kvalitu života - vznikli rôzne definície, ktoré ju popisujú z odlišných pohl'adov a existuje množstvo meracích nástrojov na jej hodnotenie. Kvalitu života môct' demonštrovat' v 3 rozdielnych prístupoch:

1. Sociálne a ekonomické indikátory - životné podmienky (sloboda rozhodovania sa v politickej oblasti a nezávislost', zabezpečenie materiálnych potrieb, zdravotná starostlivost', právne a sociálne istoty.

2. Subjektívne indikátory - spokojnost' so životom u jednotlivcov.

Zdravotné indikátory - súvisia so zdravím jednotlivca, ako jednotlivec s ochorením zvláda svoj zdravotný stav.

\subsection{Faktory ovplyvňujúce kvalitu života}

Kvalita života sa stáva podstatným kritériom na posúdenie závažnosti zdravotného stavu. Je náročné definovat', čo charakterizuje nedostatočnú kvalitu života, ked’že ide zväčša o subjektívne prvky. Faktory, ktoré ju však výrazne zhoršujú sú diskomfort, bolest' a obmedzovanie aktivít bežného života (Bártlová, 2005). Ďalšie faktory, ktoré ovplyvňujú kvalitu života sú:

1. Fyzický stav - závisí od prítomností symptómov ochorení alebo od vedl'ajších účinkov aktuálne poskytovanej liečby.

2. Fyzická zdatnost' - zaoberá sa telesnou aktivitou, schopnost'ou komunikácie v sociálnom prostredí, schopnost'ou uplatnit' sa $\mathrm{v}$ pracovnom alebo osobnom (rodinnom) živote.

3. Psychické rozpoloženie - zvyčajne sa posudzuje podl'a prevažne vyskytujúcej sa nálady, prístupom k životu a ochoreniu, spôsobu zmierovania sa a prijatia ochorenia s potrebou podstúpenia liečby a následne zvládania a prežívania bolesti. 
4. Spokojnost' s terapiou - jedná sa o celkové zhodnotenie prostredia, v ktorom pacient podstupuje liečbu, zručnost' zdravotníckych pracovníkov, prístup a spôsob komunikácie s pacientom.

5. Sociálny stav - zaoberá sa medzil’udskými vzt'ahmi, spoločenskou rolou pacienta v sociálnom prostredí a jeho komunikáciou s ostatnými l’ud’mi (Slováček, 2004).

\subsection{Meracie nástroje kvality života}

Meranie je proces, pri ktorom sa určeným javom priradzuje číslo, ktoré udáva závažnost' alebo postihnutie v danej oblasti. Meranie sa zvyčajne uskutočňuje v týchto rovinách:

- pomerová rovina,

- intervalová rovina - poukazuje na rozdielnost' medzi premennými,

- ordinálna rovina - premenné sú chronologicky usporiadané podl'a postupnosti,

- nominálna rovina - premenné sú len vymenované (Ludíková a kol., 2012).

Pri vol'be adekvátneho meracieho nástroja kvality života je potrebné upriamit' pozornost' na potreby jednotlivca alebo celej komunity. Taktiež je podstatné zohl'adnit' špecifiká momentálne prítomného ochorenia. Dvomi základnými hlavnými charakteristickými črtami nástrojov hodnotenia kvality sú:

1. Validita vypovedá o tom, či nástroj reálne meria daný predmet merania a či je možné spravit' záver, aký bol v úmysle. Je rozhodujúce či sa jedná o konštruktovú alebo kriteriálnu validitu.

a) Konštruktová validita - hlavným zámerom je zistit', či test reálne meria naplánovaný konštrukt, prípadne čiastočne alebo celkom niečo iné. Pri konečnom posudzovaní sa zohl'adňuje či boli aplikované adekvátne analytické postupy, či výskumné súbory korešpondujú populácií, pre ktorú bol test stanovený, vel'kost' výskumných súborov a podobne. Za metódy konštruktovej validity možno označit':

- exploratívna faktorová anylýza,

- konfirmátová faktorová analýza,

- vnútroškálové korelácie,

- porovnanie priemerov rozdielnosti medzi skupinami,

- verifikovanie nemennej faktorovej štruktúry,

- vzájomné vzt’ahy medzi nástrojmi, ktoré hodnotia tie isté alebo rozdielne konštrukty,

- matica mnohých metód a mnohých znakov,

- pokusné projekty a ich uplatnenie.

b) Kriteriálna validita (niekedy sa používa aj označenie diskriminačná validita) - súvisí s výskumami, v ktorých je vzájomný vzt’ah medzi objektívnym kritériom a so stupnicou nástroja.

c) Celková validita - pri stanovení konečného výsledku sa hodnotenie validity rovná bud' hodnoteniu konštruktovej alebo kriteriálnej validity. Závisí to podl'a toho, ktorá má väčšiu prevahu alebo od vyššej dôležitosti daného typu. Celkové hodnotenie by nemalo byt' priemerom oboch typov.

2. Reliabilita je označenie pre štatistickú veličinu, ktorá udáva spol’ahlivost' meracích nástrojov pri skúmaní daného deja. Prakticky je nereálne určit' presné podmienky na zhodnotenie funkčných kvalít nástroja pretože, čo pre jeden nástroj môže znamenat' „dobrá“ hodnota, pre druhý merací nástroj môže byt' nepodstatný ukazovatel' kvality meracieho nástroja. Preto je pri uplatňovaní meracieho nástroja podstatné prihliadat' na fakt, či sa jedná o skupinu l'udí alebo sa bude uplatňovat' pri individuálnych vyšetreniach, pretože si vyžadujú vyšší stupeň reliability. Ďalším hodnotiacim kritériom je posúdenie vhodnosti využitia vnútornej konzistencie (nie je citlivá na testy rýchlosti, heterogénne škály alebo indikátory efektu) alebo retestových dát (týka sa na krátkeho časového intervalu . Pred samotným 
hodnotením reliability meracích nástrojov je najprv potrebné posúdit' zozbierané dáta z aspektu kompletnosti (Džuka 2014).

Existujú presne stanovené hodnotiace stupnice, ktoré slúžia na realizáciu merania kvality života. Patria sem:

- oddelené odpovede - využíva odpovede typu výborný, dobrý, primeraný, zlý,

- LIKERT škála - odpoved' na danú otázku je vyjadrená na škále od "úplne súhlasím" po "nesúhlasím vôbec", výhodou tejto metódy je, že získané údaje je relatívne l'ahké štatisticky vyhodnotit',

- vizuálna analógová škála - pomáha určovat' napríklad intenzitu bolesti na stupnici od 0 10, 0 znamená minimálnu hodnotu a 10 maximálnu hodnotu, teda intenzitu,

- adjektívna škála - využíva slovné súvislé odpovede (Vad’urová, Mühlpachr 2005).

\subsection{Význam hodnotenia kvality života u pacientov z pohl’adu ošetrovatel'stva}

V klinickej praxi sa hodnotí kvalita života u pacientov, ktorých diagnóza sa popisuje ako nevyliečitel'ná, progredujúca, ochorenie, ktoré vedie k trvalej invalidite, ktoré si vyžaduje celoživotné dodržiavanie stanovených liečebných režimov a opatrení, ktoré obmedzujú v aktivitách bežného života. Teda ide zväčša o chronické ochorenia. Pacienti s chronickým ochorením majú mnohostranne obmedzenú kvalitu života. Faktory, ktoré ovplyvňujú kvalitu života sú:

- zaradenie ochorenia do bežného každodenného života, zmena životosprávy,

- doživotná liečba ochorenia - pacient musí rátat's tým, že liečba prináša nežiadúce alebo nepravidelné účinky,

- nepredvídatel'nost' vývoja ochorenia - intenzita a lokalizácia pretrvávania symptómov,

- psychické a sociálne faktory - postoj k ochoreniu, psychický stav, podpora blízkych,

- hrozba akútnych stavov a následných komplikácií, ktoré môžu prejst' do chronicity - môže to spôsobit' napr. nedodržiavanie terapeutického režimu,

- pacient je zodpovedný sám za seba pri dodržiavaní terapeutického režimu v domácej liečbe.

Ošetrovatel'ská starostlivost' by mala byt' zameraná na podporu, ochranu zdravia a návrat do bežného života. Pacient by mal teda dokázat' zvládat' aktivity každodenného života, v čo najvyššej miere ako pred diagnostikovaním chronického ochorenia. Vel'mi dôležitá je taktiež sociálna podpora.

Závery výskumov kvality života u pacientov s chronickým ochorením poukazujú na oblasti života s najvyšším stupňom poškodenia a obmedzenia v bežnom živote (Gurková, 2011). Pomáhajú zdravotníckemu personálu lepšie pochopit' priebeh ochorenia, zlepšit' komunikáciu s pacientom, a tým aj jeho prístup k ochoreniu, zlepšit' pacientovu psychoadaptáciu na ochorenie, poskytnút' lepšiu individualizovanú ošetrovatel'skú starostlivost' podl'a priorít v liečbe a taktiež slúžia ako súčast' auditu v klinickej praxi (Fayers, Machin, 2000, Obročníková a kol., 2020).

Nástroje merania kvality života vyplňuje sestra počas odoberania anamnézy od pacienta alebo pacient samostatne zaznamenáva odpovede napr. do dotazníka. V niektorých prípadoch sa môžu obe tieto formy získavania informácií o posudzovaní kvality života kombinovat'. Môžu sa využívat' generické alebo špecifické nástroje. Dôležité je aby boli validné a reliabilné v jazyku, v ktorom sa budú používat', aby boli rozsahovo primerané a je potrebný súhlas organizácie, ktorá disponuje autorskými právami s použitím určitého nástroja (Gurková, 2011, Tkáčová a kol., 2020).

Generické (všeobecné) nástroje merania kvality života sú vhodné pre akýchkol'vek pacientov. Zameriavajú sa na širšie porovnávanie. Nevýhodou je, že pozostávajú z mnohých nepodstatných položiek pre špecifických pacientov. Na druhej strane výhodou je širšia možnost' validizácie nástroja. (Speight a kol. 2009). 
Špecifické nástroje merania kvality života slúžia na čo najpresnejšie identifikovanie faktorov, ktoré ovplyvňujú bežné každodenné aktivity života, a tým aj jeho kvalitu. Väčšina dotazníkov je zostavených tak, aby ich pacienti dokázali samostatne vyplnit' bez inej potrebnej pomoci. Ked’že kvalifikujú úzke spektrum faktorov, zaoberajú sa len konkrétnym ochorením. Zahŕňajú subškály, ktoré vyplývajú z daného špecifického ochorenia a jeho potrieb, a preto sú senzitívnejšie na meranie a disponujú väčšou dikriminačnou validitou oproti generickým nástrojom (Gurková, 2011, Tkáčová a kol. 2020).

\subsection{Možnosti merania kvality života u pacienta so sclerosis multiplex}

Najznámejší prakticisticky orientovaný model posudzovania kvality života predstavuje model WHO - quality of life assessment, ktorý bol výsledkom medzinárodného projektu realizovaného v 15 krajinách, publikovaný v roku 1997. Ide v ňom o určenie základných oblastí kvality života ako aj vnútorných komponentov, indikátorov v každej z týchto oblasti. Ide o nasledovné oblasti:

- telesné zdravie -indikátory: energia a únava, bolest' a diskomfort, spánok a odpočinok,

- psychické funkcie -indikátory: imidž vlastného tela a zjavu, negatívne a pozitívne emócie,

- sebahodnotenie, myslenie, učenie, pamät' a pozornost',

- úroveň nezávislosti -indikátory: mobilita, aktivity v každodennom živote, závislost' od liekov a zdravotných pomôcok a pracovná kapacita,

- sociálne vzt'ahy -indikátory: osobné vzt’ahy, sociálna podpora a sexuálne aktivity,

- prostredie -indikátory: finančné zdroje, sloboda, fyzická bezpečnost', zdravie a sociálna starostlivost', prostredie domova, možnost' získat' informácie a kompetencie

- fyzikálne prostredie, doprava,

- spiritualita-osobné presvedčenie.

Dotazník má 100 položiek označuje sa skratkou WHOQOL-100. Potreby klinickej praxe viedli k vytvoreniu skrátenej verzie tohto dotazníku WHOQOL-BREF, ktorý obsahuje 26 položiek v 4 doménach: fyzické zdravie, prežívanie, sociálne vzt’ahy a prostredie (Koňošová, 2015).

Kvalitu života autori definujú rovnako ako Svetová zdravotnícka organizácia, teda že kvalita života je to, ako človek vníma svoje postavenie v živote v kontexte kultúry, v ktorej žije, a vo vzt’ahu k svojim ciel'om, očakávaniam, životnému štýlu a záujmom.

Krátky formulár o zdravotnom prieskume (SF-36) - Short form health survey - tento dotazník je používaným nástrojom na hodnotenie kvality života $v$ rôznych odvetviach medicíny vzhl'adom na jeho dobré výpovedné hodnoty. Obsahuje 36 jednotiek zahrnutých v 8 oblastiach: 1. obmedzenie v spoločenských aktivitách, 2. obmedzenie vo fyzickej aktivite $\mathrm{z}$ dôvodu zdravotných problémov, 3. obmedzenie $\mathrm{v}$ bežných aktivitách $\mathrm{z}$ dôvodu fyzického zdravia, 4. telesná bolest', 5. duševné zdravie, 6. obmedzenie z dôvodov citových, 7. vitalita, 8. všeobecný pocit zdravia.

„Celkový čas potrebný na jeho vyplnenie sa odhaduje na $15 \mathrm{~min}$. Výsledky sú transformované do stupnice od 0 do100, kde vyšší výsledok znamená vyššiu funkčnost'. Existujú už aj skrátené verzie SF-12 a SF-8, ktoré sa často využívajú predovšetkým kvôli ešte kratšiemu času na vyplnenie. Je to však na úkor presnosti "(Koňošová, 2015).

Medzi najznámejšie dotazníky špecifické pre SM patrí dotazník MSQoL-54 (Multiple sclerosis quality of life 54), ktorý vznikol spojením všeobecných otázok dotazníka SF-36 a otázok, ktoré sú cielene zamerané na špecifické problémy SM pacientov (Vitková, 2016).

Od roku 2020 prebieha projekt pod vedením PhDr. Ludmily Majerníkovej, PhD., ktorého ciel'om je skúmat' multidimenzionalitu kvality života pacientov so SM. Vychádzajúc zo súčasného stavu predmetnej problematiky, absentuje hodnotiaci nástroj (jeho následná verifikácia pre slovenské pomery), ktorý zohl'adňuje špecifiká potrieb a percepciu zmeny kvality života pacienta so SM. Skúmaním kvality života pacientov so SM bude ciel'om 
projektu vypracovat', overit' a sprístupnit' jednotnú, medzinárodne akceptovanú a odporúčanú metodiku jej hodnotenia. Projekt je zameraný na vysokoškolské prostredie vzdelávania $\mathrm{v}$ študijných odboroch ošetrovatel'stvo, pôrodná asistencia a zdravotnícke vedy, kde verifikovaný nástroj a jeho implementácia do praxe poslúži v rámci klinickej výučby študentom, klinickým a vedeckopedagogickým pracovníkom. Očakávaným prínosom pre spoločenskú oblast' je verifikovanie a validovanie jednotnej a medzinárodne akceptovanej metodiky hodnotenia kvality života pacientov so SM, konkrétne MSQOL-54 (Multiple Sclerosis Quality of Life Questionnaire) s akceptovaním jeho bio-psychosociálnych potrieb. Prínosom pre výučbu je aplikácia a implementácia metódy hodnotenia kvality života pacientov so SM. Aplikácia jednotnej a komplexnej metodiky hodnotenia kvality života pacientov so SM umožní vzájomné porovnávanie dosiahnutých výsledkov hodnotenia na národnej a medzinárodnej úrovni, čím sa výrazne posilní konkurencieschopnost' Slovenska vo vedeckej oblasti.

Dotazník MSQOL-54 bol pôvodne vytvorený pre anglicky hovoriacich pacientov so SM doktorkou Barbarou G. Vickrey et al. a skladá sa z dvoch častí. Prvú čast' tvoria otázky, hodnotiace všeobecné zdravie, ktoré vychádzajú z dotazníka SF-36. Druhá čast' je tvorená osemnástimi otázkami, vytvorenými špeciálne pre pacientov so SM k popísaniu ich špecifických problémov a vychádzajú z názorov odborníkov a rešerše odbornej literatúry. Dovedna, pät'desiatštyri otázok je rozdelených do niekol'kých okruhov a zist'ujú údaje o fyzickom, duševnom a citovom zdraví respondentov, ich kognitívnych schopnostiach, spoločenských aktivitách, obmedzeniach, vyplývajúcich $\mathrm{z}$ fyzických a afektívnych ukazovatel'ov, intenzite bolesti, únave, energii, o sexuálnom živote respondentov, otázky zamerané na subjektívne vnímanie zdravia, zdravotnej zát'aže a kvality života (Nortved, Rise, 2003, Hudáková a kol. 2020). Vzhl'adom na jeho multidimenzionálne a obsahové zameranie je žiaduca ich validácia a inkorporácia do klinickej praxe (Vickrey et al., 1995). Proces validácie dotazníka bude uskutočnený po konzultácii s prof. Barbarou Vickrey z University of California, Los Angeles, US. Samotný validovaný dotazník bude využívaný vo vzdelávacom procese vysokoškolského štúdia $\mathrm{v}$ odbore ošetrovatel'stvo, pôrodnej asistencie a iných zdravotníckych vied. Študent bude môct' osobne získat' skúsenost' s vedeckou prácou priamo vo vyučovacom procese $v$ jeho teoretickej ako aj praktickej rovine.

29-položková škála dopadu na roztrúsenú sklerózu - Multiple sclerosis impact scale (MSIS29) je psychometricky overené pacientom uvádzané výsledné opatrenie, ktoré sa čoraz viac používa v štúdiách liečby roztrúsenej sklerózy. Nie je však založený na preferenciách a nie je vhodný na použitie $\mathrm{v}$ kontextoch politického rozhodovania. Škála bola špeciálne skonštruovaná tak, aby hodnotila vplyv SM na HRQOL l'udí z hl'adiska ich fyzickej a psychickej pohody. Toto opatrenie je založené na kvalitatívnych rozhovoroch s l'ud'mi s SM a bolo vyvinuté pomocou tradičných a súčasných psychometrických techník. Bola preukázaná jeho flexibilita pre použitie $v$ rôznych prostrediach (napr. nemocnica a komunita) je možné ho doplnit' zástupcami . Preukázalo sa, že reaguje pohotovo a pre jeho fyzickú subškálu bol navrhnutý minimálny rozdiel. MSIS-29 je teraz vo svojej druhej verzii a vzhl'adom na svoje silné základy ako vhodný ukazovatel' výsledku pre klinické skúšky účinnosti liečby SM sa čoraz viac používa (Hawton, 2012).

Hodnotenie klinického výsledku pri SM je náročné z dôvodu rozmanitosti a kolísavého charakteru symptómov SM. Tradičné klinické stupnice, ako napríklad EDSS, nie sú dostatočné na hodnotenie klúčových klinických dimenzií SM (napr. kognitívne funkcie) a majú tiež psychometrické obmedzenia.

Pracovná skupina pre hodnotenie klinických výsledkov Národnej spoločnosti pre MS vyvinula a odporučila multidimenzionálne meranie klinických výsledkov, konkrétne funkčný kompozit pre roztrúsenú sklerózu - The multiple sclerosis functional composite measure (MSFC). To umožňuje merat' vplyv SM v troch kl’účových klinických dimenziách: funkcia a 
pohyb nôh, funkcia paží a rúk, a kognitívne funkcie. Skóre v rôznych meracích škálach sa transformuje na štandardné porovnatel'né skóre (z-skóre) a vypočíta sa celkové zložené skóre. Skóre $\mathrm{v}$ rámci tejto škály sa pohybuje od 0.0 do 10.0 , pričom $\mathrm{s}$ vyšším skóre stúpa aj obmedzenie funkčného stavu. Bodovacie systémy sú potrebné na meranie klinického stavu, závažnosti ochorenia a klinického výsledku tak počas individuálneho klinického sledovania pacienta, ako aj v klinických štúdiách. Na hodnotenie klinickej závažnosti a funkčných deficitov u pacientov so SM bolo vyvinutých niekol'ko indexov alebo skórovacích systémov (Tiftikçioğlu, 2018).

Profil vplyvu choroby alebo Sickness impact profile (SIP) .Tento dotazník obsahuje 136 položiek týkajúce sa denných aktivít. Existuje aj skrátená verzia tohto dotazníka so 68 položkami. Dotazník bol vytvorený za účelom širšieho použitia a to bez ohl'adu na typ, závažnost' choroby, demografické a kultúrne aspekty (Hudáková a kol, 2020).

Publikácia vznikla na základe riešenia projektu KEGA 002PU-4/2020 Návrh metodiky hodnotenia kvality života pacientov so sclerosis multiplex.

\section{Použitá literatúra}

1. BABINČÁK, P., 2008. Spokojnost’ so životom ako psychologická dimenzia kvality života. Prešov: Filozofická fakulta Prešovskej univerzity v Prešove. ISBN 978-808068-749-6.

2. BÁRTLOVÁ, S., 2005. Sociologie medicíny a zdravotnictví. 1.vyd. Praha: GRADA Publishing. ISBN 80-247-1197-4.

3. DROBNÝ, M., 2002. Sclerosis multiplex: Epidemiológia. Patogenéza. Klinické obrazy. Diagnostika. Liečba. 1. vyd. Martin: Reklas. ISBN 809-68-7920-0.

4. DŽUKA, J., 2014. Subjektívne hodnotená kvalita života - validita a reliabilita merania. 1. vyd. Prešov: Prešovská univerzita, Filozofická fakulta. ISBN 978-80-5551096-5.

5. FAYERS, P., M., MACHIN, D., 2000. Quality of life: Assessment, Analysis and Interpretation. 1. vyd. Chichister: John Wiley \& Sons Ltd. ISBN 978-04-719-6861-0.

6. FILIPPI M., BAR-OR, A., PIEHL, F. et. al., 2018. Multiple sclerosis. In: Nature Reviews Disease Primers [online]. Roč. 4, č. 1, s. 1 - 27 [cit. 2021-03-12]. ISSN 2056-676X. Dostupné z: https://doi.org/10.1038/s41572-018-0041-4

7. GURKOVÁ, E., 2011. Hodnoceni kvality života pro klinickou praxi a ošetřovatelský výzkum. 1. vyd. Praha: GRADA Publishing. ISBN: 978-80-247-3625-9.

8. HAVRDOVÁ, E., a kol., 2013. Roztroušená skleróza. 1. vyd. Praha: Mladá fronta a. s. ISBN: 978-80-204-3154-7.

9. HAWTON A, GREEN C, TELFORD C, ZAJICEK J, WRIGHT D. 2012. Using the Multiple Sclerosis Impact Scale to estimate health state utility values: mapping from the MSIS-29, version 2, to the EQ-5D and the SF-6D. In Value Health. č. 8, 2012.

10. HEǨMANOVÁ, E., 2012. Koncepty, teórie a měreni kvality života. 1. vyd. Praha: Sociologické nakladatelství (SLON). ISBN 978-80-7419-106-0.

11. HUDÁKOVÁ A., GREŠŠS-HALÁSZ B., TKÁČOVÁ L'; MAGUROVÁ D. Nástroje hodnotenia pacientov so sklerózou multiplex [elektronický dokument]. QUAERE 2020 [elektronický dokument]: recenzovaný sborník př́spěvků interdisciplinární mezinárodní vědecké konference doktorandů a odborných asistentů, Hradec Králové, 22. - 26. 6.2020. Hradec Králové : Magnanimitas akademické sdružení, 2020; s. 508514. ISBN 978-80-87952-32-0.

12. HYNČICOVÁ, E., MELUZÍNOVÁ, E., LACZÓ, J., 2017. Kognice a roztroušená skleróza. In: Neurologie pro praxi [online]. Roč. 18, č. 6, s. 394 - 398 [cit. 2020-11- 
30]. ISSN: 1803-5280. Dostupné z: https://www.neurologiepropraxi.cz/pdfs/neu/ 2017/06/08.pdf

13. KOŇOŠOVÁ, H. 2015. Ošetrovatel'stvo a posudzovanie kvality života. In Zdravotnicke listy, 2015 , roč. 3, č. 2, s.30-36. ISSN 1339-30223.

14. LUDÍKOVÁ, L. a kol., 2012. Pohledy na kvalitu života osob se senzorickým postižením. 1. vyd. Olomouc: Univerzita Palackého. ISBN 978-80-244-3286-1.

15. MASÁROVÁ, T., ŽIVČICOVÁ, E., 2012. Meranie kvality života. 1. vyd. Žilina: GEORG. ISBN 978-80-8154-003-5.

16. MURGAŠ, F., 2009. Kvalita života a jej priestorová diferenciácia v okresoch Slovenska. In: Geografický časopis [online]. Roč. 61, č. 2, s. 121 - 138 [cit. 2021-0219]. ISSN 2453-8787. Dostupné z: https://www.sav.sk/journals/uploads/03121108GC09-2_Murgas.pdf

17. NOVOTNÁ, K., LÍZROVÁ PREININGEROVÁ, J., 2013. Poruchy chůze u pacientů s roztroušenou sklerózou. In: Neurologie pro praxi [online]. Roč. 14, č. 4, s. 185 - 187 [cit. 2020-11-30]. ISSN: 1803-5280. Dostupné z: https://www.neurologieproprax i.cz/pdfs/neu/2013/04/06.pdf

18. OBROČNÍKOVÁ A., HUDÁKOVÁ A., JASELSKÁ M.. Quality of life in women with breast cancer In: Mefanet journal. ISSN 1805-9171. - Roč. 5, č. 2 (2018), s. 54-61.

19. ̌̌ASOVÁ, K. a kol., 2008. Možnosti fyzioterapie v léčbě roztroušené sklerózy mozkomíšni. 2. vyd. Praha: Unie Roska. ISBN 978-80-254-3704-9.

20. SEIDL, Z., 2015. Neurologie pro studium i praxi. 1. vyd. Praha: Grada Publishing. ISBN: 978-80-247-5247-1.

21. SLOVÁČEK, L., 2004. Kvalita života nemocných. In: Vojenské zdravotnícke listy [online]. Roč. 73, č. 1, s. 6 - 9 [cit. 2020-12-02]. ISSN 0372 - 7025. Dostupné z: https://www.mmsl.cz/pdfs/mms/2004/01/02.pdf

22. SPEIGHT, J., REANEY, M. D., BARNARD, K. D., 2009. Not all roads lead to Rome-a review of quality of life measurement in adults with diabetes. In: Diabetic Medicine [online]. Roč. 26, č. 4, s. 315 - 327 [cit. 2020-11-03]. ISSN 1464-5491. Dostupné z: 10.1111/j.1464-5491.2009.02682.x

23. SUCHÝ, M., BEDNÁŘÍK, J., a kol., 2012. Klinické doporučené metódy v neurológii I. 1. vyd. Olomouc: Univerzita Palackého. ISBN: 978-80-244-3004-1.

24. ŠANTA, M., KLÍMOVÁ, E., a kol., 2007. Neurológia a neurologické ošetrovatel'stvo. 1. vyd. Prešov: Prešovská univerzita, Fakulta zdravotníctva. ISBN: 978-80-8068-578-2.

25. TIFTIKÇIOĞLU Bİ. Funkčný kompozitný materiál pre roztrúsenú sklerózu (MSFC): Pokyny na skórovanie. Noro Psikiyatr Ars . 2018; 55 (Suppl 1).

26. TKÁČOVÁ L'; MAGUROVÁ D.; OBROČNÍKOVÁ A.; MROSKOVÁ S. Uplatnenie princípov holizmu pri ošetrovatel'skej starostlivosti o pacienta so sklerózou multiplex. [elektronický dokument]. QUAERE 2020 [elektronický dokument]: recenzovaný sborník př́ispěvků interdisciplinární mezinárodní vědecké konference doktorandů a odborných asistentů, Hradec Králové, 22. - 26. 6.2020. Hradec Králové: Magnanimitas akademické sdružení, 2020; s. 482-487. ISBN 978-80-87952-32-0.

27. VAĎUROVÁ, H., MÜHLPACHR, P., 2005. Kvalita života: teoretická a metodologická východiska. 1. vyd. Brno: Masarykova univerzita. ISBN 80-2103754-7.

28. VICKREY, B.G. et al. 1995. A health-related quality of life measure for multiple sclerosis. In Qual Life Res. 1995, vol. 4, No. 3, pp. 187-206. ISS: 1573-2649.

29. VITKOVÁ, M. 2016. Kvalita života pacientov so sclerosis multiplex. In Via Practica 2016, č.6, s.248-250. ISSN 1339-424X. 


\section{Kontaktné údaje}

PhDr. Ludmila Majerníková, PhD.

Prešovská univerzita $v$ Prešove

Fakulta zdravotníckych odborov

Katedra ošetrovatel'stva

Partizánska, 1; 08001 Prešov

e-mail: ludmila.majernikova@unipo.sk

tel.: +421517562460

web. www.unipo.sk 


\title{
PRÁCA S ODBORNÝM TEXTOM U ŠTUDENTOV MEEDZINÁRODNÝCH VZŤAHOV A DIPLOMACIE NA PRÍKLADE NEMECKÉHO POLITICKÉHO JAZYKA
}

\author{
WORKING WITH ACADEMIC TEXT BY STUDENTS OF \\ INTERNATIONAL RELATIONS AND DIPLOMACY ON THE \\ EXAMPLE OF A GERMAN POLITICAL LANGUAGE
}

\author{
Mária Polčicová
}

\begin{abstract}
Abstrakt
$\mathrm{V}$ dnešnom globalizovanom svete je základným predpokladom úspešného absolventa akéhokol'vek vysokoškolského odboru nevyhnutnost' ovládania minimálne dvoch odborných cudzích jazyk (nielen na všeobecnej úrovni európskeho referenčného rámca). Výučbe cudzích jazykov na nefilologických fakultách sa v súčasnosti venuje zvýšená pozornost' ako na teoretickej rovine, tak aj na praktickej rovine. Ciel'om nášho príspevku je predstavit' model výučby cudzích jazykov na fakulte nefilologického zamerania na príklade práce s odborným textom v rámci výučby nemeckého odborného jazyka so zameraním na medzinárodné vzt'ahy, diplomaciu a politológiu. Zefektívnenie procesu vzdelávania $\mathrm{v}$ rámci výučby odborných cudzích jazykov v odbore medzinárodných vzt’ahov, diplomacie a politológie je $\mathrm{v}$ súčasnosti základným predpokladom, ktorý ovplyvňuje kvalitu a výsledky dosiahnuté $\mathrm{v}$ edukačnom procese. Tá sa následne prejaví v konkurencieschopnosti absolventov uvedeného štúdia na medzinárodnom (európskom) trhu prácu. $\mathrm{Na}$ strane druhej je odrazom celej spoločnosti, pretože títo absolventi pôsobia následne v popredných štátnych funkciách, reprezentujú štát v medzinárodných inštitúciách, na zahraničných fórach, vytvárajú obraz systému a kvality cudzojazyčného vysokoškolského vzdelávania na Slovensku.
\end{abstract}

Klíčová slova: odborný text, medzinárodné vztahy, politický jazyk, výučba cudzích jazykov, fakulta nefilologického zamerania, európska vzdelávacia politika, metodika

\begin{abstract}
In today's globalized world, the basic precondition for a successful graduate of any university is the need to master at least two professional foreign languages (not only at the general level of the European Framework of Reference). The teaching of foreign languages at nonphilological faculties is currently receiving increased attention both on a theoretical level and on a practical level. The aim of our paper is to present a model of foreign language teaching at the Faculty of Non-Philology with an example of working with a professional text in the teaching of German professional language with a focus on international relations, diplomacy and political science. Streamlining the educational process in the teaching of academic foreign languages in the field of international relations, diplomacy and political science is currently a basic prerequisite that affects the quality and results achieved in the educational process. This will subsequently be reflected in the competitiveness of the graduates of this study on the international (European) labor market. On the other hand, it is a reflection of the whole society, because these graduates subsequently work in leading state positions, represent the state in international institutions, in foreign forums, create an image of the system and quality of foreign language academic education in Slovakia.
\end{abstract}

Key words: academic text, International Relations, political language, teaching of foreign languages, Faculty of Non-philology, European education policy, methodology 


\section{1 ÚVOD}

Pre praktickú ale aj odbornú sféru života každého jedinca $v$ dnešnej spoločnosti je nevyhnutnou súčastou poznanie a aktívne využívanie jazyka ako nástroja komunikácie. Zvlášt' pre oblast' medzinárodnej politiky a diplomacie, v ktorých by neprimeraná, resp. nesprávne interpretovaná komunikácia (v cudzom jazyku) mohla mat' negatívne dopady na dianie celej spoločnosti. Cudzojazyčnej príprave odborníkov voblasti medzinárodných vzt’ahov a diplomacie sa venujú predovšetkým nefilologické fakulty. Ide o náročnú prácu aj z metodologického hl'adiska, ked’že v rámci každej výučby cudzích jazykov na nefilologických fakultách ide o interdisciplinárne prepojenie odbornej a jazykovej prípravy. Efektívnost' metodologických postupov v edukačnom procese na akomkol'vek stupni vzdelávania je predmetom ako teoretických tak aj praktických úvah.

Jazyk politiky, resp. medzinárodných vzt’ahov a diplomacie je jedným zo špecifických odborných jazykov. Popri tradičných funkciách, ktorých je nositel’om v spoločnosti, sa $\mathrm{v}$ rámci politickej komunikácie stáva nástrojom manipulácie, presviedčania, argumentácie i obhajoby. Častým javom v jazyku politiky je aj expresívnost', metaforickost', viaczmyslovost', ktorá sa často prejavuje na úrovni textu. Práca s odborným textom je aj preto jednou z kl'účových odborných jazykových kompetencií všetkých politikov, diplomatov, analytikov medzinárodných vzt'ahov či politológov.

\section{VÝZVY VÝUČBY CUDZÍCH JAZYKOV NA NEFILOLOGICKÝCH FAKULTÁCH}

Výučbe cudzích jazykov (i v rámci európskej vzdelávacej politiky) sa pripisuje v poslednom období dôležitost' a opodstatnenost' ako na teoretickej tak aj na praktickej úrovni. Hladajú sa nové prístupy a metódy, pomocou ktorých by sa cudzojazyčné zručnosti študentov rozvíjali rýchlejšie a efektívnejšie. V rámci budovania európskeho výskumného priestoru je potrebné plnit' viacero ciel'ov európskych vzdelávacích systémov, ktoré, okrem iného, zahíňajú okrem zaručenia všeobecného prístupu $\mathrm{k}$ informačným a komunikačným technológiám, otvorenia priestoru vzdelávania a zvýšenia atraktívnosti vzdelávania, najmä zlepšenie vyučovania cudzích jazykov (Horváthová, 2008).

Výsledkom záujmu o výučbu cudzích jazykov na nefilologických fakultách je zostavovanie dvojjazyčných glosárov odbornej slovnej zásoby, vydanie rôznych podporných elektronických materiálov na rozvoj čitatel'skej kompetentnosti študentov, realizácia viacerých vedeckých seminárov a konferencií s danou problematikou, v neposlednom rade už vydané početné monografie, vedecké príspevky a články, ktoré sa zaoberajú uvedenou problematikou aj na teoretickej báze.

Ciel'om, resp. snahou výučby cudzieho jazyka pre nefilologické študijné programy je vyzbrojit' poslucháča zručnost’ami pre zvládnutie akademického textu, či v písanej alebo zvukovej podobe, čo znamená osvojenie si základnej odbornej lexiky a primárnych zásad odborného štýlu, schopnost' vyslovit' a obhájit' názor na problematiku relevantnú pre študovaný odbor, komunikovat's inými odborníkmi, technika prezentácie, písanie anotácií a resumé (Waldnerová, 2012). Teoreticky by mala jazyková príprava na terciálnej úrovni vyzbrojit' poslucháča tak, aby bol schopný komunikovat' v oblasti svojho študijného zamerania, nadobúdat' poznatky z cudzojazyčnej odbornej literatúry a tiež prezentovat' vlastné projekty, čo však predpokladá, že študent do tohto procesu vstupuje s istou - a nie malou všeobecnou jazykovou kompetenciou ( $v$ ideálnom prípade úroveň B2 európskeho referenčného rámca). V súčasnosti nám však prax ukazuje, že tento predpoklad je nerealizovatel'ný, minimálne pri tzv. druhých cudzích jazykoch. Štúdium cudzích jazykov na stredných školách je primárne zamerané na anglický jazyk, druhé cudzie jazyky sú 
doplnkovými jazykmi. Z toho vyplýva aj samotná jazyková úroveň absolventov stredných škôl, ktorá sa pohybuje $\mathrm{v}$ hodnotení európskeho referenčného rámca $\mathrm{v}$ rozmedzí A1-B1, s ktorou prichádzajú na našu fakultu. V podstate tu nastáva hned' v prvom semestri štúdia na našej fakulte pre pedagóga hlavný problém, pretože primárne je štúdium cudzích jazykov na fakulte zamerané na osvojovanie si odbornej terminológie s predpokladom ovládania všeobecného cudzieho jazyka na úrovni minimálne B2. S tým súvisí konkrétne aj samotná realizácia a metodika práce $\mathrm{s}$ textom. Pedagóg je tým nútený prispôsobovat' najmä výber textov minimálne počas prvého semestra stupňu ovládania jazyka študentov ${ }^{1}$.

Základným predpokladom úspešnosti akejkol’vek jazykovej prípravy aj na vysokých školách je vychádzat' z potrieb študenta a viac-menej ušit' kurz a tempo osvojovania si jednotlivých rečových prostriedkov na mieru. Úsilie pedagóga sa však často končí frustráciou, lebo práve poslucháči, ktorí prichádzajú až neuveritel'ne slabo pripravení, chápu jazykové vyučovanie iba ako nevyhnutné zlo (Hrotková, 2010).

Jazyková politika na našej fakulte je v tomto zmysle ústretová. Napriek tomu, že síce predmety výučby cudzích jazykov nie sú zaradené do skupiny povinne volitel'ných predmetov, úspešné ukončenie celého magisterského i bakalárského štúdia v odboroch medzinárodné vzt'ahy, diplomacia a bezpečnostné štúdiá je podmienené absolvovaním súbornej skúšky $\mathrm{z}$ cudzieho jazyka, $\mathrm{v}$ rámci bakalárskeho štúdia je to súborná skúška $\mathrm{z}$ anglického jazyka, následne $\mathrm{v}$ rámci magisterského štúdia musí každý potencionálny absolvent vyhoviet' aj na súbornej skúške $z$ druhého cudzieho jazyka (nemeckého, španielskeho, ruského, francúzskeho). Obsahovú náplň skúšky tvoria sylaby celého 5-ročného štúdia odborného cudzieho jazyka. Ide o oblast' politických systémov nemecky (španielsky, francúzsky, rusky) hovoriacich krajín v komparácii so Slovenskom, politických dejín nemecky hovoriacich krajín v komparácii so Slovenskom, diplomacie, medzinárodných vzt'ahov, medzinárodných inštitúcií, medzinárodného práva. Študent musí ovládat' najmä terminológiu uvedených oblastí, aktívne ju používat' a primerane reagovat' na problematiku.

Za problém považujeme po skúsenostiach s výučbou odborných cudzích jazykov na našej fakulte aj nedostatočnost' čitatel'skej gramotnosti, ktorá je predpokladom pre úspešnú prácu s akýmkol'vek, nielen odborným textom.

\section{PRÁCA S TEXTOM AKO DIDAKTICKÁ METÓDA NA ZÍSKANIE ODBORNEJ JAZYKOVEJ KOMPETENCIE}

Na realizáciu ciel'ov vyučovania vo vzdelávacej oblasti Jazyk a komunikácia ${ }^{2}$ je dôležité klást' dôraz na praktické aktivity - práca s knihou, textom (čítanie s porozumením, spracovanie textových informácií, učenie sa z textu, orientácia v texte, vyhl'adávanie triedenie, využívanie podstatných informácií, samostatné učenie prostredníctvom informačno-komunikatívnych technológií.

Práca s textom je edukačná metóda založená na spracovaní textových informácií. Ide o formu učebnicových, ale i neučebnicových didaktických textov, pričom dominuje práca študenta. Pri práci s textom ide o to, aby mu študent porozumel, dokázal vyčlenit' a označit' $v$ texte

\footnotetext{
${ }^{1}$ Na pedagóga ako na integrujúci prvok vzdelávacieho procesu, sú kladené vysoké nároky aj z dôvodu akceptácie Európskou úniou prijatého a v pedagogickej praxi aj na našej fakulte používaného komunikatívneho prístupu zameraného na žiaka, podporovaného myšlienkou humanizácie vyučovania.

${ }^{2}$ Ide o oblast' ISCED 2 Vzdelávacia oblast', primárne venovaná vzdelávaniu na základných a stredných školách, avšak metodika práce stextom je aplikovatel'ná aj pre štúdium na vysokých školách. Pozri bližšie https://www.mine du.sk/data/att/7828.pdf
} 
kl'účové informácie a hlavné myšlienky, stanovit' vzt'ah medzi informáciami, usporiadat' kl'účové informácie podl'a určitého kritéria, vyjadrit' usporiadané informácie graficky vo forme vlastnej prezentácie, prezentovat' obsah textu vlastnými slovami, zaujat' k hlavným myšlienkam textu vlastné stanovisko, sformulovat' otázky k textu a doplnit' text vlastným hodnotiacim komentárom. Pri práci s textom sa rozvíja nielen schopnost' mysliet', ale aj učit' sa a organizovat' vlastný proces učenia - rozvíjajú sa tzv. metakognitívne zručnosti (zručnosti aktívne sledovat' a riadit' vlastnú poznávaciu činnost' - stanovit' si ciele učenia sa $\mathrm{z}$ textu; odhadnút' obtiažnost' textu i dobu na jeho prečítanie a spracovanie; monitorovat' úspešnost' vlastného postupu; skontrolovat' a zhodnotit' vlastnú úspešnost' učenia sa z textu). Uvedené kompetencie sú následne vítanou pridanou hodnotou celkovej odbornej kompetencie študenta ako absolventa odboru.

Odborná literatúra rozlišuje viacero stratégií a typov práce $\mathrm{s}$ textom ${ }^{3}$. V našom príspevku uvedieme niektoré z nich, ktorých komponenty sa využívajú aj v rámci seminárov a domácej prípravy študentov našej fakulty. Súčasne predstavíme model výučby nemeckého odborného jazyka na našej fakulte v jednotlivých semestrech.

V prvom ročníku bakalárskeho štúdia (v letnom i zimnom semestri ${ }^{4}$ ) je často používanou metódou metóda Sprievodca predpovedí, ktorej ciel'om je aktivovat' a zhodnotit' predchádzajúce vedomosti žiakov ${ }^{5}$, motivovat' a stimulovat' ich záujem o tému. Pri metóde je dôležité určit' v prvom rade pojmy, ktoré si študenti majú osvojit'. Následne sa vytvorí 4-6 tvrdení, ktoré súvisia s identifikovanými pojmami. Študenti majú k tvrdeniam napísat' svoje stanovisko, a až potom prečítat' text s ciel'om nachádzat' dôkazy pre jednotlivé tvrdenia a vypísat' ich. Nakoniec sa vedie diskusia o potvrdení alebo vyvrátení prvotných tvrdení, príp. sa rozhoduje, ktoré d’alšie informácie sú potrebné. V tomto ročníku sa v skupinách osvedčili texty náučno populárneho charakteru, pri ktorých sa študenti postupne zoznamujú $\mathrm{s}$ odbornými výrazmi, alebo sa využívajú adaptované akademické texty, kde študentom ul'ahčuje prácu glosár uvádzaný v závere.

V prvom ročníku, ked’že ide primárne o úvodné semestre v štúdiu, využívame aj stratégiu $\mathrm{K}$ $\mathrm{W}-\mathrm{L}^{6}$, ktorá je založená na troch základných krokoch: $\mathrm{K}$ - uvedomenie si, čo už viem; W určenie si, čo chcem vediet'; L - rozpamätanie sa na to, čo som sa naučil. Pri realizácii tejto stratégie študent pracuje s jednoduchým hárkom v troch etapách. Stratégia SQ3R ${ }^{7}$ je typ práce s textom, pri ktorom je možno rozdelenie práce do viacerých etáp:

- S - uvedomenie si dôležitosti prvotného zoznámenia sa s určitou logickou osnovou knihy, kapitoly alebo časti učiva.

- Q - študent si kladie otázky typu: Aký je môj ciel?? Ako môžem zaradit' novú problematiku do mne už známeho kontextu? Čo mi chce autor povedat'? Kedy? Kde? Prečo? Kto?

- $\mathrm{R}$ - aktívne čítanie textu. V priebehu prvého čítania sa hl'adajú odpovede na otázky položené v predošlej fáze. Pri druhom čítaní sa už podčiarkujú dôležité informácie, ale len tie, ktoré si chce študent zapamätat'.

\footnotetext{
${ }^{3}$ Pri ich definovaní sme vychádzali najmä z prác Petlák (1997), Bajtoš (2003), Turek (1998, 2004), László.Škvarková (2009).

${ }^{4}$ Je to úvodný semester celého štúdia odborných cudzích jazykov na našej fakulte, čomu je prispôsobený i obsah a sylaby predmetu - úvod do terminológie medzinárodných vzt'ahov, diplomacie, politológie a základná práca s dôležitými pojmami.

${ }^{5}$ Ide najmä o vedomosti zo stredných škôl, v rámci jazykovej kompetencie i odbornej kompetencie.

6 angl. Know - want - learned

${ }^{7}$ Názov tejto metódy je akronym pozostávajúci z prvých písmen anglických slov (Survey, Question, Read, Recite, Review), ktoré vyjadrujú postupnost' činností pri tejto metóde.
} 
- $\mathrm{R}$ - uloženie čítaného textu do pamäti.

- R - finálny krok, ktorým je v skratke zhrnutie všetkých predchádzajúcich častí.

Uvedená metóda sa využíva aj následne $\mathrm{v}$ d’alšom semestri štúdia pri práci s odbornými textami pri predmete Politische Systeme der deutschsprachigen Länder/Politické systémy v nemecky hovoriacich krajinách. ${ }^{8}$ Aktívne pracujeme s textami vlastných i adaptovaných akademických textov a skrípt.

Často využívanou metódou práce s textom na predmete Internationale Beziehungen / Medzinárodné vzt'ahy ${ }^{9}$ je aj tzv. pojmová mapa. Ide o grafickú reprezentáciu vedomostnej štruktúry študenta $z$ príslušného učiva, kde uzly (body) reprezentujú pojmy a spojnice (oblúky a čiary) reprezentujú vzt'ahy medzi pojmami. Pri zostavovaní pojmovej mapy vzniká určitá schéma (diagram). Pojmy, ktoré navzájom súvisia, sa spájajú čiarami a reprezentujú akési tvrdenie (propozíciu). Charakter vzt'ahu medzi pojmami sa vyjadruje stručným popisom nad spojnicou. Dôraz sa kladie aj na správne hierarchické usporiadanie pojmov, v ktorom sú špecifické pojmy umiestnené pod všeobecnejšími. Využitie uvedenej metódy je efektívne najmä z hl'adiska opakovania už nadobudnutej odbornej terminológie z úvodných semestroch v 1. ročníku a následné doplnenie o odborné pojmy v rámci prehlbovania znalostí študenta v odbore. Študent v magisterskom stupni štúdia je už schopný aplikovat' odbornú slovnú zásobu na vlastnú cudzojazyčnú analýzu problematiky medzinárodných vzt'ahov a medzinárodných inštitúcií $\mathrm{s}$ ciel'om pripravit' ho na jeho budúcu aktívnu účast' v európskych, resp. medzinárodných inštitúciách.

Predovšetkým pri predmete Politische Geschichte der deutschsprachigen Länder/Politické dejiny nemecky hovoriacich krajín ${ }^{10}$ (či už priamo na seminároch alebo aj v rámci domácej prípravy na seminár) využívame na seminároch techniku recipročného vyučovania, ktorej hlavným ciel'om je rozvinút' učebné zručnosti potrebné pre prácu s textom (sumarizovat', formulovat' otázky, robit' predpovede), pomôct' pochopit' text. Postup pri využití metódy je nasledovný:

- rozdelenie textu na časti.

- rozdelenie študentov do skupín v takom počte, kol'ko častí má text.

- pridelenie každému študentovi jednu čast' textu, ktorú má spracovat' a analyzovat' a následne výsledky odprezentovat'.

V danom ročníku jazykovej odbornej prípravy študentov začínáme aj k nácviku počúvania a spracovania odbornej prednášky, ktorej obsah je doplnený o odborný text, s ktorým sa pracuje následne na seminároch. Výsledkom je príprava vlastného odborného textu na danú odbornú problematiku, ktorého následná prezentácia $\mathrm{v}$ podobe vlastného záverečného projektu je súčast'ou ciel'ovej zručnosti $\mathrm{v}$ danom ročníku. Študent má $\mathrm{k}$ dispozícii $\mathrm{v}$ rámci domácej prípravy aj link na jazykovo primárny audiovizuálny text, ktorý obsahovo samozrejme korešponduje s preberanou tematikou. Počúvaniu prednášky a následnému zhrnutiu obsahu, interpretácie počutého a tvorbe vlastného textu predchádza dôsledná lexikálna príprava a didaktické cvičenia zameriavajúce pozornost’ študenta na preberaný problém.

\footnotetext{
${ }^{8}$ Uvedený predmet sa vyučuje na našej fakulte v 2. ročníku bakalárského štúdia

${ }^{9}$ Predmet sa vyučuje v 1. ročníku magisterského štúdia a predpokladajú sa už pokročilé vedomosti v rámci odboru i jazyka.

${ }^{10}$ Predmet sa vyučuje v 3. ročníku bakalárského štúdia na našej fakulte a korešponduje s obsahovou náplňou odborných predmetov $\mathrm{v}$ danom semestri v materinskom (slovenskom) jazyku, čo umožňuje upevňovanie si najmä odborných vedomostí študentov doplnených o jazykovú mutáciu vo vybranom cudzom jazyku.
} 
Pri práci s textom využívame napriek tomu, že nevzdelávame primárne filológov, aj prekladové cvičenia. Tie zarad'ujeme na záver práce s tematickým celkom, vysvetl'ujeme rozdiel medzi doslovným a vol'ným prekladom, prípadne parafrázou, odstraňujeme vplyv interferencie a nástojíme na korektnom používaní odborných pojmov, resp. kl'účových pojmov odbornej terminológie. Priamo na seminári precvičujeme ústny preklad, písomný preklad sa zväčša zadáva $\mathrm{v}$ rámci domácej prípravy. V súvislosti s posledním obdobím online výuky sa však táto metóda uplatňovala $\mathrm{v}$ zvýšenej miere. Každá typológia práce s textom sa overuje v podtextových úlohách rôzneho druhu (od úloh typu gap-filling, yes-no questions, true-false až po syntetické úlohy vyžadujúce tvorivost' a aplikáciu nadobudnutých informácií ${ }^{11}$. Všetky uvedené didaktické postupy a metódy práce s odborným textom majú primárny ciel’ získania a rozširovania odbornej jazykovej komunikácie.

\section{DEFINÍCIA ODBORNEJ JAZYKOVEJ KOMPETENCIE}

Štúdium cudzích jazykov na vysokých školách nefilologického zamerania považujeme za špecifickú oblast' vzdelávania na vysokých školách. Absolventi takéhoto typu štúdia musia preukázat' nielen vysokú jazykovú kompetenciu v oblasti všeobecného jazyka, ale najmä vysokú kompetenciu $\mathrm{v}$ danom odbore. $\mathrm{V}$ našom prípade Fakulty politických vied a medzinárodných vzt'ahov zohráva o to väčšiu váhu ovládanie odborného cudzieho jazyka (resp. minimálne dvoch odborných cudzích jazykov) na úrovni referenčného rámca $\mathrm{C} 1$ pri absolventoch štúdia odboru medzinárodných vzt'ahov a diplomacie priam kl'účovú úlohu. Práca diplomata, politika či experta $v$ oblasti medzinárodných vzt’ahov je priamo založená na interakcii s cudzím prostredím. V prípade, že zlyhá jazykovo-odborná kompetencia diplomata, má to priamy dopad na celý vývoj spoločnosti. $Z$ tohto dôvodu pripisujeme problematike primeranej jazykovej kompetencie, a najmä jej získavania u odborníkov v oblasti diplomacie, medzinárodných vzt’ahov, bezpečnoestných štúdií i politológie celospoločenský význam.

V súčasnom svete globalizácie sa efektívna výmena informácií, a tým podmienená erudícia $\mathrm{V}$ oblasti ovládania cudzích jazykov, stáva neodmyslitel'nou súčastou prípravy odborníkov v jednotlivých vedných odboroch. Pre študentov vysokých škôl nefilologického zamerania je potreba poznania jazyka odbornej komunikácie jedným z predpokladov ich úspešného integrovania v medzinárodných štruktúrach a uplatnenia v súčasnom globalizovanom svete.

Za odbornú jazykovú kompetenciu absolventov štúdia medzinárodných vzt'ahov a diplomacie, bezpečnostných štúdií a politológie na Fakulte politických vied a medzinárodných vzt'ahov považujeme znalost' problematiky v cudzom vybranom jazyku. Zadefinovali sme si ju ako bázu jazykových kompetencií v oblasti odbornej terminológie a jej využitia v odbornej komunikácii, či už v rámci ústneho alebo písomného prejavu v oblasti základných teoreticko-metodologických východísk teórie medzinárodných vzt’ahov, ako aj d'alších nadväzujúcich a príbuzných vedných odborov, akými sú medzinárodné právo, medzinárodná ekonómia, európske právo, politická geografia, hospodárska geografia, medzinárodná ekonomická integrácia, bezpečnoetné štúdiá a základy diplomacie. ${ }^{12}$ Absolvent štúdia odboru medzinárodné vzt'ahy a diplomacia, ktorý disponuje odbornou jazykovou kompetenciou, je následne teda schopný odborne prezentovat' $\mathrm{v}$ cudzom jazyku témy z oblastí medzinárodných vzt’ahov - politických, medzinárodných ekonomických vzt’ahov, medzinárodného práva, medzinárodných organizácií, zahraničnej politiky, zahraničnej

\footnotetext{
${ }^{11}$ Neporozumenie je často dôvodom na stratu motivácie, a preto pri tomto type úloh uprednostňujeme spoluprácu dvojíc, prípadne väšších skupín.

${ }_{12}$ Tomu je podmienená samotná skladba jednotlivých predmetov cudzieho odborného jazyka od 1. semestra bakalárskeho štúdia po končiaci 4.semester magisterského štúdia.
} 
politiky Slovenskej republiky, teórie a praxe diplomacie, diplomatického a konzulárneho práva, histórie a vývoja európskej integrácie, práva Európskej únie, sociálno-ekonomického a kultúrneho vývoja jednotlivých svetových makroregiónov.

V rámci nášho výskumu, $\mathrm{v}$ ktorom sa primárne venujeme obrazným metaforickým vyjadreniam v odbornom jazyku, považujeme za súčast' celkovej odbornej kompetencie aj metaforickú kompetenciu ${ }^{13}$. Metafory ako jedna $\mathrm{z}$ významných foriem obrazných vyjadrovacích prostriedkov formujú život a dianie v každom vednom odbore. Ako dokazuje súčasný vedecký výskum, tvoria neoddelitel'nú súčast' odbornej komunikácie najmä prostredníctvom odborných textov.

Význam ovládania cudzích jazykov v súčasnosti deklaruje aj stanovisko Európskej komisie, ktorá uvádza viacjazyčnost' za devízu pre Európu a spoločný záväzok. Za jej priority patrí napr. aj zhromažd'ovanie údajov na monitorovanie pokroku $\mathrm{v}$ oblasti výučby a štúdia jazykov. Celý projekt Európskej únie je postavený na princípe jednoty v rozmanitosti. Jazyk má silu l'udí spájat', otvárat' im nové možnosti poznania iných kultúr a prostredníctvom nich aj seba samých. Ovládanie cudzích jazykov je následne prvotným nástrojom úspechu a uplatnenia absolventov vysokých škôl. Na štátnej úrovni ale aj na medzinárodnej úrovni $\mathrm{v}$ rámci európskej vzdelávacej politiky sa nestretáváme $\mathrm{s}$ jednotnostou v kritériách, $\mathrm{v}$ metodike štúdia cudzích jazykov na vysokých školách nefilologického zamerania ${ }^{14}$. Samotná Európska únia má v celej oblasti vzdelávania len podpornú a odporúčaciu funkciu ${ }^{15}$.

\section{ZÁVER}

Oblast' vzdelávania je v súčasnosti významnou súčast'ou spoločenského i politického života. Je predmetom záujmu odbornej verejnosti nielen z teoretického ale aj z praktického hl'adiska. Vzdelávanie odborníkov v oblasti diplomacie a medzinárodných vzt’ahov, bezpečnostných štúdií i politológie musí byt' zamerané nielen na samotné odborné vedomosti a znalosti, ale z dôvodu rozšírenej globalizácie, otvorenosti i samotnej podstaty medzinárodnej politiky ako takej predovšetkým na získavanie kompetencií ovládat' odbornú problematiku v cudzom jazyku (resp. vo viacerých cudzích jazykoch). Kvalitné vysokoškolské vzdelávanie v takomto odbore je následne odrazom fungovania celej spoločnosti a v budúcnosti zrkadlom celej krajiny. Absolventi štúdia sú nositel'mi kvality vzdelávania nielen v európskom alej aj vo svetovom formáte, ich kvalitná, cielená príprava prispieva vich samotnej konkurencieschopnosti na európskom i svetovom pracovnom trhu. Práca s cudzojazyčným odborným textom je popri iných jazykových kompetenciách nevyhnutnou súčastou práce diplomata i experta na medzinárodné vzt’ahy. Analýzy medzinárodných zmlúv, právnych dokumentov, historických zdrojov sú každodennou súčast'ou ich pracovnej činnosti.

\footnotetext{
${ }^{13}$ Metafory ako jedna z významných foriem obrazných vyjadrovacích prostriedkov formujú život a dianie v každom vednom odbore. Ako dokazuje súčasný vedecký výskum, tvoria neoddelitel’nú súčast' odbornej komunikácie najmä prostredníctvom odborných textov. Ovládanie podstaty vzniku metafory v jazyku, ich správnu interpretáciu a aktívne používanie v písomnom i ústnom prejave, ktorú sme si zadefinovali ako metaforickú kompetenciu, považujeme za jednu zo súčastí cudzojazyčnej kompetencie. Pozri bližšie Polčicová (2007).

${ }^{14}$ Za prínos úsilia o univerzalizáciu najmä v rámci výučby cudzích jazykov považujeme vytvorenie Spoločného európskeho referenčného rámca pre jazyky (CEFRL), na základe ktorého je vyučovanie moderných jazykov zostavené do 6 úrovní s úmyslom vytvorit' väčšie možnosti medzinárodnej výmeny pri vyučovaní moderných cudzích jazykov $\mathrm{v}$ jednotlivých krajinách. Pozri Common European Framework of Reference for Languages: Learning, Teaching, Assessment (CEFR) (coe.int).

${ }^{15}$ Za prínos považujeme aspoň skutočnost', že existuje v niektorých jej segmentoch zhoda o spoločných aktivitách a ciel’och týkajúcich sa vzdelávacej politiky v EU.
} 
Príspevok vznikol v rámci riešenia projektu VEGA č. 1/0437/19 Význam internacionalizácie vysokoškolského vzdelávania pre konštrukciu identity Európskej únie a zvyšovanie konkurencieschopnosti v európskom priestore.

\section{Použitá literatura}

1. BAJTOŠ, J. 2003. Teória a prax didaktiky. Žilina : EDIS. ISBN 80-8070-130-X.

2. COUNCIL OF EUROPE 2001. Common European Framework of Reference for Languages: Learning, Teaching, Assessment (CEFR) (coe.int)

3. HORVÁTHOVÁ, J. 2008. Masmédiá, mediálna výchova a výučba cudzích jazykov. In: Multimédiá vo vyučovaní cudzích jazykov IV. Nitra: SPU, 2008. ISBN 978-80552-0001-9.

4. HROTKOVÁ, S. 2010. Hl'adanie nových ciest s ciel'om zefektívnit' vyučovanie cudzich jazykov. In: Zborník z odborného seminára Perspektívy výučby cudzích jazykov pre 21. storočie. Trnava : 2010. ISBN 978-80-8105-219-4.

5. PETLÁK, E. 1997. V̌̌eobecná didaktika. Bratislava : IRIS. ISBN 8089018645.

6. LÁSZLÓ K. - ŠKVARKOVÁ, Z. 2009. Didaktika. Banská Bystrica.

7. POLČICOVÁ, M. 2007. Modely obraznosti v jazyku odbornej komunikácie. Studia linguistica 3. Banská Bystrica : EF UMB

8. TUREK, I. 1998. Kapitoly z didaktiky vysokej školy. Košice. ISBN 80-7099-322-7.

9. TUREK, I. 2004. Inovácie v didaktike. Bratislava : MPC Tomášikova, ISBN 808052-230-8.

10. WALDNEROVÁ, J. 2012. Jazyk, kultúra, spoločnost' a vyučovanie cudzích jazykov. In: Jazyk - kultúra - spoločnost' (vzájomné súvislosti), Nitra: UKF, 2012. ISBN 97880-558-0117-9.

11. https://www.minedu.sk/data/att/7828.pdf

\section{Kontaktní údaje}

$\mathrm{PhDr}$. Mária Polčicová, $\mathrm{PhD}$.

Univerzita Mateja Bela v Banskej Bystrici, FPVaMV

Kuzmányho 1, 97401 Banská Bystrica

Tel: +421 48

email: maria.polcicova@umb.sk 


\title{
CONCEPTUAL AND THEORETICAL FRAMEWORK OF CONTENT AND LANGUAGE INTEGRATED LEARNING AT TERTIARY LEVEL EDUCATION
}

\author{
Mária Badinská
}

\begin{abstract}
There is a persisting concern from English language teachers in Slovakia in effective learning approaches and strategies supporting learner-centered orientation at the beginning of the new millennium when CLIL - Content and Language Integrated learning has become a priority approach in teaching country studies of English speaking countries as it is highly motivating because students are learning language skills, academic skills, learning strategies and special subject concepts at the same time. An inseparable part of this methodology is critical thinking. In this paper we will look at how this issue can be presented within the theory of Richard Paul which is aimed at developing critical thinking strategies and traits in student demanding their active engagement in class if foreign language students are to be communicatively competent in English.
\end{abstract}

Key words: Content and Language Integrated Learning (CLIL), learning strategies, critical thinking, Richard Paul, learner-centered orientation

\section{FROM GRAMMAR-BASED APPROACHES TO COMMUNICATIVE APPROACH}

Since the mid-19 to mid-20th century, the second and foreign language teaching methods typically focused on the grammatical system of the language rather than the content. This approach was evident for example in grammar-translation, audiolingualism (ALM), cognitive approaches, and the direct method among others.

However, in the last decades we have witnessed an effort to move away from grammatical syllabuses to situational syllabuses - described also as notional, functional or communicative syllabuses (Wilkins, 1976, Widdowson, 1978) which emphasized the sociocultural aspects that involve students in meaningful context. A number of theories and hypotheses for second and foreign language acquisition have been developed (The Acculturation Model, Accomodation Theory, Discourse Theory, The Monitor Model, The Variable Competence Model, The Universal Hypothesis, Neurofunctional Theory etc.) which play an important role in research and praxis. (Richard-Amato, 1988, pp. 302-330). As the example can serve Ellis's Variable Competence Model (Ellis, 2015) where the interaction in a variety of situations is highlighted with the aim to build students' knowledge of linguistic rules in order to use them in situational contexts. "Ellis reflects recent trends in looking at cognitive a social aspects of second language acquisition trying to answer the question of understanding of how learners learn a foreign language. In that way, this is a much needed source to solve the imperatives in this field." (Richard-Amato, 1988, p. 426)

These theories which became an intrinsic part of the methodological principles of language learning and teaching resulted in CLIL (Content and Language Integrated Learning) approach which has expended during the last years in Europe. ${ }^{1}$ Among the pedagogical principles underlying CLIL, there is also the Monitor model proposed by Krashen (1982), despite the critique which these his ideas received. The Monitor model consists of five hypothesis - The Acquisition Learning Hypothesis, the Natural Order Hypothesis, The Monitor Hypothesis,

\footnotetext{
${ }^{1}$ The EU has supported many CLIL projects, e.g. Content and Language Integrated Classroms, EuroCLIL etc.
} 
The Input Hypothesis and Affective Filter Hypothesis. Krashen distinguishes between two systems of second language performance: the acquired subconscious system and the learnt conscious system, which is the product of formal instruction and highlights an important issue - that the formal instructions in the target language should provide the kind of "input" that is comprehensible, communicative, interesting and highly motivated, which means that it contains information that students need to know. In this, through comprehensible input, affective filter and language acquisition device (LAD) students acquire knowledge, which leads to the learnt knowledge - "output". ${ }^{2}$

"In summary, teaching and learning in a second language provides an educational experience which may be advantageous or detrimental to the interests of any specific social group. As such, it is necessary for practitioners, researchers and administrators alike, to be clear in their understanding of the usage, overlap distinctiveness of terminology, which may be used to describe the approaches and methods used in this respect." (Nikula \& Marsh, 1998, p. 13)

\section{CLIL - CONTENT AND LANGUAGE INTERGRATED LEARNING}

Comparison and evaluation of many previous and current studies and findings on second/foreign language teaching and learning led to the highly motivated approach called Content and Language Integrated Learning (CLIL) in order to increase unity and competitiveness in Europe in the process of globalization where integrated learning is considered to be a modern form of education. ${ }^{3}$ What is more, while in the past good general knowledge was expected of university-educated people, today's professionals have to be highly qualified and skilled to perform their work. To reflect these changes this paper focuses on effective learning strategies and integrated approaches which can be applied in real life situations, and once learned, they become an integral part of the future professional career of students in an effort to be successful in the labor market. "The period of 1990s up to present covers almost thirty-year span when many academic subjects taught at Slovak universities underwent the process of complex transformation. Legislative changes included the adoption of the European Credit Transfer System in 2001, formal alternations resulted in the switch from teacher-centred education to student-centred computer-supported courses and content-related transformations frequently resulted in upgrades of traditional teaching contents and adoption of the CLIL method." (Javorčíková, Zelenková, 2019, p. 18)

CLIL, according to the leading experts in this issue "...is a dual-focused educational approach in which and additional language is used for the learning and teaching both content and language." (Mehisto, Marsh \& Frigols, 2018, p. 9). In their view the CLIL model respects the following principles as they follow: cognition, community, content, communication. In cognition learning is based "...on a student's existing knowledge, skills, attitudes...". Students analyze their achievements and "synthesize, evaluate and apply knowledge and skills acquired in several subjects". "... community is enriching, students have the self-confidence and skills to work within a group and the local community, balancing personal interests with those of others." Content "is substantive...content from various subjects is integrated, cultural content is integrated into all subjects". In communication "students actively use the right to participate in activities...communication skills are developed in all subjects." (Mehisto, Marsh \& Frigols, 2018, p. 31)

\footnotetext{
${ }^{2}$ For more information see also Richard- Amato 1988, pp. 330-342

${ }^{3}$ This fully corresponds to the VEGA project No. 1/0437/19 "The importance of the internationalization of higher education for the construction of the identity of the European Union and increasing competitveness in the European area" within which this paper is published.
} 
Coyle $(2007,2008)$ also finds the applicability of the "4Cs" conceptual framework for CLIL - content, communication, culture and cognition. In reality content (subject matter) stands for the course you teach, in our case Country studies, where you are free to decide what content to teach to your students. Cognition stands for thinking skills which can be classified in loworder thinking skills and high-order thinking skills. Communication is devoted to the language skills, specific vocabulary related to the content - content words and academic vocabulary, especially function words. The aim is to build students' store of vocabulary and complex grammar structure (Gura, 2005) through practice supported by the scaffolding in developing their arguments following the line of reasoning using signal words as opening phrases, reinforcing and contrasting them with similar or different reasons and consequences in order to come to conclusions. Culture (awareness of self and others) and the development of intercultural competences is an insertion principle as any learning skills should encompass cultural awareness resulted from students' different beliefs and values, rooted in the history of their countries in order to avoid ethnocentrism, stereotypes and prejudice. (Benčeková, 2019). These intrinsic parts in this 4Cs paradigm integrated learning are intertwined.

Coyle (2005) also created the "3As" tool which enriches this integrated learning approach. It comprises 3 stages: the $1^{\text {st }}$ stage - "analyze" content for the language of learning (key words, specific words, phrases, grammatical functions for concept and comprehension), the $2^{\text {nd }}$ stage - "add" to content language for learning (metacognitive or learner strategies, discussion, task demands ) and the $3^{\text {rd }}$ stage (improvement of cognitive skills and cultural awareness) "apply" to content language through learning. "The 3As tool uses a pragmatic rather than a linguistic approach to language using and development. It is not built on a progressive grammatical model where there is chronology according to the perceived difficulty of acquiring grammatical concepts. Instead the language is related to the perceived progression of conceptual understanding." (Coyle, 2005, p. 7) Intercultural aspect, as intrinsic part of teaching and learning foreign languages is again accentuated. (Polčicová, 2019)

Cummins holds that language is the means for understanding and cognition. He developed a matrix for exploring the relationship between cognition and language, which has been adopted in CLIL settings where language is acquired also unconsciously. This matrix comprises 4 quadrants entitled as low linguistic demands, high linguistic demands, low cognitive demands and high cognitive demands (Cummins, 1984) which has become a tool for revising the adequacy of teaching materials - they should be linguistically achievable whilst being cognitively demanding. Such materials are fundamental to teaching and learning process and "in this, the CLIL class differs from traditional formal language teaching." (Javorčíková\&Zelenková, 2019, p. 25)

\section{LEARNING STRATEGIES AND CRITICAL THINKING}

Learning strategies which are defined as "thoughts or activities that assist in enhancing learning outcomes." (Chamot \& O'Malley, 1994, p. 60) These learning strategies have been proposed in three broad categories: metacognitive strategies - "planning for learning, monitoring one's own comprehension and production, and evaluating how well one has achieved a learning objective", cognitive strategies - "manipulating materials to be leaned mentally...or physically ..." and social/affective strategies - "either interacting with another person in order to assist learning, as in cooperative learning and asking questions for clarification, or using affective control to assist learning tasks." ( Chamot \& O'Malley , 1994, p. 60) By modeling and scaffolding strategies students are pushed beyond content language to higher order thinking skills to solve and assess problems independently while thinking critically. 
Teaching and learning through a foreign language becomes cognitively demanding but inspiring because it requires creative and critical thinking. "Creative thinking involves the generation of further development of ideas, processes, objects, relational links, synergies and quality relationship while critical thinking can be described as mental processes that learners use to plan, describe and evaluate their thinking and learning. It is self-directed thinking and thus fundamental learning. By working to improve the quality of our thinking, we improve learning." (Mehisto, Marsh, Frigols, 2008, p. 153)

The well-known Bloom's model of thinking ${ }^{4}$ developed by Anderson and Krathwol has become the basis for world leading researchers in this field. They further expanded critical thinking examined by many disciplines and experts. One of them, Richard Paul, introduced completely new attitude in education and teaching ${ }^{5}$ when he introduced learning strategies aimed at improving our critical thinking in order to make it better by means of intellectual traits and standards in order to become intellectually capable to avoid shallow values and self-deceptive tendencies, overcome egocentrism and sociocentrism and become a good critical thinker by imposing temperance on our thinking in a rapidly changing world (Paul, 1995). In this, "critical thinking is the intellectually disciplined process of actively and skillfully conceptualizing, applying, analyzing, synthesizing, and/or evaluating information gathered from, or generated by, observation, experience, reflection, reasoning, or communication, as a guide to belief and action. In its exemplary form, it is based on universal intellectual values that transcend subject matter divisions: clarity, accuracy, precision, consistency, relevance, sound evidence, good reasons, depth, breadth, and fairness". (Scriven, Paul, 2013, p. 1)

Paul's practical teaching and learning methods encourage students to analyze their own thoughts, think independently and listen to the thoughts of others. The important component domains of critical thinking and their implications in higher order thinking are underlined. These include elements of thoughts as they follow: purpose (What are we trying to accomplish?), questions at issue, information (facts, date evidence, experience), concepts (ideas, theories, law, principles), assumptions (beliefs one take for granted), implications and consequences, point of view, inferences - interpretations or conclusions you come to. (Paul, Elder, 1997) They also include 35 strategies of critical thoughts ${ }^{6}$ which are comprised of cognitive strategies - marco abilities (e.g. analyzing or evaluating arguments, interpretations, beliefs, or theories; reading critically: clarifying or critiquing texts; listening critically: the art of silent listening etc.), cognitive strategies - micro skills (e.g. noting significant similarities and differences; examining or evaluating assumptions; exploring implications and consequences etc. ), affective dimensions (e.g. thinking independently, developing insight into egocentricity or socio-centricity, exercising fair-mindedness, developing confidence in reason etc. ). Each of these deserves attention in turn.

We have chosen Paulian framework for his advocacy of moral virtues and also because his practical teaching and learning methods encourage students to analyze their own thoughts, think independently and listen to the thoughts of others. The skill of asking high level questions improve class participation, reduces teachers domination and supports learnercentred orientation. Moreover, affective dimensions are closely related to the development of

\footnotetext{
${ }^{4}$ See: Amstrong, P. 2010

${ }^{5}$ Material provided by University of Oregon, USA, during online teacher training course "Critical Thinking for English Language Teaching Curriculum". The author of this paper took part and successfuly completed this course in 2012.

${ }^{6}$ See also Binker, A.J.A: Strategies: Thirty Five Dimentions for Critical Thinking
} 
the intercultural communicative competences (Benčeková, 2019) in order to prepare students for dialogues with people of other cultures respecting their beliefs, values and behaviors. Understanding the cultural differences between different subcultures in a pluralistic society is very important, as peaceful coexistence and progress depend on mutual tolerance and cooperation. Language and culture are inseparable. The role of language is to express meaning, meaning is determined by culture. Any international and intercultural communication depends on the ability to get to know social, political and cultural reality, in our case, provided by teaching Country studies of English speaking countries.

\section{CONCLUSION}

All the above-mentioned theories and approaches underline the learner-centred philosophy that means teaching those aspects of the subjects that have resulted from the latest trends and requirements, which increase learners motivation and interest. What is more, while one major aim will relate to the teaching of specific courses, other aims will relate to the development of effective learning strategies in order to improve learners'skill in selfevaluation which enhance learning outcomes. This approach, cognitively demanding, without any doubts, requires creative and critical thinking due to globalization, mixture of cultures, Erasmus students coming from different parts of the world with different values and beliefs. "Mobility is becoming an ever-increasing reality and this is having an impact on languages." (Mehisto, 2008, 10)

The above-mentioned proposed models are not uniform, this issue is still in its infancy and has to reflect the prerequisites arising from the local conditions, needs and different contexts. However, there are particular pedagogical principles for planning courses and lessons which should be taken into consideration. These principles of communicative approach, interaction and cooperation within groups in a classroom environment as well as the outside world, have shown a wider perspective for foreign language and subject teachers. The communicative approach and intercultural competence elicit critical awareness on the basis of the criteria perspectives and practices in one's own and other cultures (Byram, 2000) However, we still face the obstacles in enhancing critical thinking of students in the Slovak education system despite the efforts made. It is the impact of the era "in the second part of the $20^{\text {th }}$ century when criticism was considered to be a grave social threat at that time". (Larson, 2013, p.16)

The research of the effectiveness of the CLIL method has already been partially carried out in Slovakia (Javorčíková, Zelenková, 2019) which proved the necessity of the implementation of this approach to the educational system in Slovakia in order to prepare students for the world of rational people able to judge their acts and decisions critically, to respect common decency and ethics rather than turn blind eye to matters of morality and disregard for inalienable human rights of peoples all over the world.

The paper is published with the financial support of the Scientific Grant Agency of the Ministry of Education, Youth and Sport of the Slovak Republic and the VEGA project No. 1/0437/19 "The importance of the internationalization of higher education for the construction of identity of the European Union and increasing competitiveness in the European area".

\section{Sources}

1. Amstrong, P. 2010. Bloom's Taxonomy. Vanderbilt University Center for Teaching. Retrieved June 14, 2021 from: https://cft.vanderbilt.edu/guides-sub-pages/bloomstaxonomy/ 
2. Benčeková, M. 2019. Rozvoj interkultúrnych kompetencii ako klúčová oblast' edukačnej prípravy budúcich diplomatov na diplomatickú prax vpodmienkach globalizácie. In: Premeny diplomacie v globalizovaných medzinárodných vzt'ahoch v kontexte mäkkej moci. Nakladatel'stvo Naše Vojsko, Praha 2019. 71 s. ss. 43-55. ISBN: 978-80-206-1846-7

3. Binker, A. J. A. Strategies: Thirty Five Dimensions for Critical Thinking. Retrieved April, 4, 2021 from https://www.criticalthinking.org/data/pages/93/2dc1156cb91 5ed5e2d4de94d2bfe79e9513644fd4c683.pdf

4. Coyle, D. 2005. Planning Tools for Teachers. University of Notthingham. Retrieved March 7, 2021 https://www.unifg.it/sites/default/files/allegatiparagrafo/20-012014/coyle_clil_planningtool_kit.pdf

5. Coyle, D. 2007. Content and Language Integrated Learning Motivating Learners and Teachers. Retriewed June 3, 2018 from https://blocs.xtec.cat/clicpractiques1/files/ 2008/11/slrcoyle.pdf

6. Coyle, D. 2008. CLIL - a pedagogical approach. In N. Van Deusen-Scholl, \& N. Hornberger, Encyclopedia of Language and Education, 2nd edition (pp. 97-111). Springer. Retrieved June 2, 2019 from https://clilingmesoftly.wordpress.com/clilmodels-3/the-4-cs-model-docoyle/

7. Cummins, J. 1984 Bilingual Education and Special Education: Issues in Assessment and Pedagogy. San Diego: College Hill. ISBN-13 978-0905028132

8. Elder, L, Richard, P. 2010. Universal Intellectual Standards. Retrieved April 4, 2021 from https://www.criticalthinking.org/pages/universal-intellectual-standards/52

9. Ellis, R. (2015): Understanding Second Language Acquisition. Oxford 2015. 376 p. ISBN: 9780194422048

10. Gura, R. 2005. Práca s odborným písaným textom - Compte Rendu. In: Sborník př́spěvků z conference Profilingua, edited by Zlata Hokrová. Plzeň: Západočeská univerzita 2005. S 114-118. ISBN 80-7043-424-4.

11. Chamot, A.U. \& O'Malley J.M. 1994. The CALLA Handbook. Implementing the Cognitive Academic Language Learning Approaches. White Planes, NY: Addison Wesley Publishing Company.

12. Javorčíková, J. \& Zelenková, A. 2019. CLIL: Conceptual differences in teaching realia to philological and non-philological students. Journal of Language and Cultural Education, 2019, 7 (3) pp. 18-34. ISSN 13-39-4584.

13. Kreshen, S.D. 1982. Principles and Practice in Second Language Acquisition. Publisher: Alemany Pr. ISBN-10:0137100477. ISBN-13:978-0137100477.

14. Larson, J.L. 2013. Critical Thinking in Slovakia after Socialism. 1. Vydanie. Rochester: University of Rochester Press, 2013. 240 s. ISBN 978-1-58046-437-6.

15. Nikula, T. \& Marsh D. 1998. Terminological Consideration Regarding Content and Language Integrated Learning. Bulletin suisse de linguistique appliquée, 67/1998, 13 -18. Retriewed March 11, 2021 from https://files.eric.ed.gov/fulltext/ED422727.pdf

16. Mehisto, P., Marsh, D. \& Frigols, M.J. 2008. Uncovering CLIL: Content and Language Integrated Learning in Bilingual and Multilingual Education. Macmillan Publishers Limited 2008. 238 p. ISBN 978-0-230-02719-0

17. Paul, R. 1988. Ethics without Indoctrination. Retriewed March 12, 2021 from http://www.criticalthinking.org/pages/ethics-without-indoctrination/494.html

18. Paul, R. 1995. How to Prepare Students for a Rapidly Changing World. Edited by Jane Wilsen\&A.J.A. Binker, Foudation for Critical Thinking. ISBN 0-944583-09-01

19. Paul, R., Elder, L. 1997. The elements of reasoning and intellectual standards. The Foundation for Critical Thinking. Center for critical thinking online. Retrieved April 
4, 2021 from: https://www.criticalthinking.org/pages/the-elements-of-reasoning-andthe-intellectual-standards/480

20. Polčicová, M. 2019. Interkultúrny aspect výucby cudzích jazykov ako súčast' politického vzdelávania. In Grant Journal, Hradec Králové: Magnanimitas, 2019. ISSN 1805-062X Vol. 8, No 1, pp. 38-43

21. Richard-Amato, P.A. 1988. Making it happen. Interaction in the Second Language Classroom. From Theory to Practice. Longman. 426 p. ISBN 0-8013-0027-4.

22. Scriven, M., Paul, R. 2013. Defining critical thinking. A statement by Michael Scriven \& Richard Paul for the National Council for Excellence in Critical Thinking Instruction. Retriewed March 12, 2021 from http://www.criticalthinking.org/pages/defining-critical-thinking/410

23. Widdowson, H.G. 1978. Teaching Language as Communication. Oxford University Press. ISBN-10:0194370771. ISBN-13:978-0194370776

24. Wilkins, D.A. 1976. Notional Syllabuses. A taxonomy and its relevance to foreign language curriculum development. Oxford University Press. ISBN 019437072.

\section{Contact}

PaedDr. Mária Badinská, PhD.

Fakulta politických vied a medzinárodných vzt’ahov

Univerzita Mateja Bela

Tel: +421484461511

Email: maria.badinska@umb.sk 


\title{
VÝZNAM SVOJPOMOCMÝCH SKUPÍN PRE CHRONICKY CHORÝCH PACIENTOV
}

\section{THE IMPORTANCE OF SELF-HELP GROUPS FOR CHRONICALLY ILL PATIENTS}

\author{
Lívia Hadašová, Terézia Fertal'ová, Beáta Grešš Halász, Anna Eliašová, \\ Tatiana Šantová
}

\begin{abstract}
Abstrakt
Svojpomocné skupiny združujú l’udí ktorých spája vzájomná podpora a pomoc pri riešení problémov. Medzi znaky svojpomocných skupín radíme vzájomnú pomoc, oporu, dobrovol'nost', poskytovanie perspektív, bezprostredné interakcie, a zdiel'anie skúseností. Sociálna opora je vel'mi dôležitá, posilňuje pacientove vlastné stratégie zvládanie choroby, uspokojuje sociálne potreby, ako potreba súhlasu, náklonnosti a sociálnej interakcie. Výsledky prieskumu poukázali na dostatočnú úroveň informácii a vedomostí o fungovaní svojpomocných skupín u študentov odboru ošetrovatel'stvo, avšak chýbajú im praktické skúsenosti a spolupráca s uvedenými skupinami. Pre lepšiu podporu kvality života pacientov s chronickými ochoreniami je dôležitá informovanost' o činnosti svojpomocných skupín, aktívna spolupráca pacientov a zdravotnických pracovníkov a smerom k širokej verejnosti aj marketingová podpora aktivít svojpomocných skupín.
\end{abstract}

Kl'účcová slová: svojpomocná skupina, chronické ochorenie, coping, študent ošetrovatel'stva

\begin{abstract}
Self-help groups bring together people who are united by mutual support and help in solving problems. Among the features of self-help groups we include mutual help, support, volunteering, providing perspectives, immediate interactions, sharing experiences. Social support is very important, it strengthens the patient's own coping strategies, and satisfies social needs such as the need for consent, affection and social interaction. The results of the survey pointed to a sufficient level of information and knowledge about the functioning of self-help groups among nursing students, but they lack practical experience and cooperation with these groups. To better support the quality of life of patients with chronic diseases, it is important to be aware of the activities of self-help groups, active cooperation and, towards the general public, marketing support for the activities of self-help groups.
\end{abstract}

Key words: self - help group, chronic disease, coping, nursing student

\section{CHRONICKÉ OCHORENIE}

Chronické ochorenie ovplyvňuje v značnej miere život človeka. Dochádza k zmene zamestnania, k zmene sociálneho postavenia čo môže častokrát viest' k depresiám. Ohrozený zväčša býva príjem finančných prostriedkov, dochádza $\mathrm{k}$ strate sociálnych kontaktov, čím sa môže človek dostat' do určitej stigmatizácie. Ochorenie ktorým človek trpí, nepostihuje iba jeho samotného ale predovšetkým aj jeho rodinu (Ondriová, Cinová, 2020).

U chronických ochorení je problematickou oblastou motivácia a adherencia pacienta. Pacienti s chronickým ochorením spolupracujú s lekármi menej a majú menšiu adherenciu $\mathrm{k}$ terapeutickému režimu než pacienti s akútnym ochorením. Adherencia pacienta $\mathrm{k}$ liečbe predstavuje jeden zo základných predpokladov kontroly choroby a úspešnosti liečby 
chronických chorôb. Adherencia sa netýka iba správnosti o dodržiavaní terapeutických a režimových opatrení ale aj dížky ich dodržiavaní. V adherencii sa odráža postoj pacienta k ochoreniu, ktorý zahrňuje akceptáciu samotného ochorenia a dodržiavanie terapeutického režimu. Príčiny nedostatočnej adherencie pacienta, môžu vyplývat' jednak zo strany zdravotného stavu pacienta ale aj samotnej liečby. Významný je pre pacienta vplyv ochorenia na pokračovanie normálneho bežného života a predošlých aktivít. Pokial' ochorenie a liečba zasahujú do denných aktivít, pacient môže svoje ochorenie a jednotlivé symptómy a rovnako aj svoju funkčnú schopnost' vnímat' negatívnejšie. Pri podpore adherencie pacientov k liečbe chronických somatických ochorení sa často pri edukácii pacientov domnievame, že znalosti pacientov usmerňujú ich správanie vo vzt'ahu k ich ochoreniu a liečbe. Význam znalostí je samozrejme pre žiaducu zmenu ich postoja a správania sa nepopieratel'ný. Správanie pacientov vo vzt'ahu k zdraviu je ovplyvnené niekol'kými faktormi ako je tendencia zotrvávat' $\mathrm{v}$ určitom životnom stereotype a životnom štýle pod vplyvom silne pôsobiaceho prežitku straty predstavy o ochorení, postojom a presvedčením o ochorení, liečbe a zdravotnej starostlivosti. Pri chronickom ochorení je dôležitá zdravá sebakoncepcia a sebaúcta, ktorá prospieva k tomu, aby pacient prijal svoje ochorenie čo najlepšie a zabránilo sa tak rôznym pocitom bezmocnosti, nenávisti a nespokojnosti, ktoré môžu vyústit' do samovražedných sklonov. Subjektívne prežívanie choroby nazýváme autoplastický obraz choroby. Gurková (2017) uvádza, že subjektívne prijatie ochorenia a liečby ovplyvňuje aj to, ako sa bude pacient s daným ochorením vyrovnávat' a zároveň vysvetl'uje výskyt individuálnych rozdielov v adaptácii jednotlivcov na chronické ochorenie. Napríklad presvedčenie pacienta, že jeho schopnost' byt' ešte $\mathrm{v}$ živote prospešný chorobou končí, môže viest' $\mathrm{k}$ depresiám a vyhýbaniu sa aktivitám ktoré mu predtým prinášali uspokojenie. Naopak presvedčenie, že sa jeho život zmení a môže nájst' iné spôsoby, ako byt' v živote užitočný, zvyšuje pravdepodobnost' efektívneho prispôsobenia sa ochoreniu. Pacientovo subjektívne prijatie choroby a liečby má klúčový význam pre správanie pacientov vo vzt’ahu k ich zdraviu pre včasné vyhl'adanie odbornej pomoci, self-manažmentu ochorenia, spoluprácu v liečbe, vyrovnávania sa s chorobou a kvalitu života

\subsection{Stratégia vyrovnávania sa s chorobou}

Poznáme stratégiu riešenia problémov, v ktorej sa snažíme znížit' dopad choroby na človeka. Zahŕňa vyhl'adávanie pomoci a podpory v ktorej sa človek snaží získat' vedomosti o liečbe. Takisto zahŕňa aj riešenie problémov a obranu vlastných práv. Ďalšou stratégiou je redukcia emócií, ktorá obsahuje vyjadrovanie pocitov, vyhýbaniu sa konverzácií o vlastnej chorobe, snaženie sa o pozitívny nadhl'ad k chorobe. Patrí sem aj preberanie zodpovednosti. Poslednou je stratégia maladaptívna, ktorá hovorí o nahromadení problémov z ktorých môže dôjst' u človeka $\mathrm{k}$ následkom, a to požívaniu alkoholických nápojov, zmeny $\mathrm{v}$ správaní alebo sebapoškodzovaniu (Ondriová, Cinová, 2020). Proces vyrovnávania sa chronickým ochorením je u človeka sprevádzaný v rôznych štádiách frustráciou, nepokojom a stresom. Pre aktívne a vedomé zvládanie stresu sa ustálilo slovné spojenie nazývané coping. Z terminologického hl'adiska je vhodné rozlišovat' rozdiel medzi adaptáciou a copingom. Adaptácia sa vzt'ahuje k zvládaniu zát’aže ako takej. Coping sa uplatňuje v prípadoch, kde je zát'až vzhl'adom $\mathrm{k}$ odolnosti osobnosti nadlimitná alebo podlimitná a je potrebné vyvinút' zvýšené úsilie $\mathrm{k}$ vyrovnávaniu sa $\mathrm{s}$ ňou. Coping predstavuje zvládanie náročných či stresových situácií. Coping predstavuje stabilizačný faktor ktorým môžeme pomôct' udržat' psychosociálnu adaptáciu v priebehu stresu. Poznáme dva typy copingu. Coping zameraný na problém, ktorý sa snaží zmenit' situáciu $\mathrm{k}$ lepšiemu prostredníctvom úpravy okolností alebo vlastného správania a coping zameraný na emócie, ktorým jedinec dostáva svoje emócie pod kontrolu, aby nenarušovali jeho integritu a vzt’ahy s l'ud'mi v jeho okolí (Paulík, 2017). 


\section{SVOJPOMOCNÉ SKUPINY}

Svojpomocné skupiny sú malé skupiny dobrovol'ne sa združujúcich l'udí, s podobnými zdravotnými alebo životnými problémami. Spoločným prežívaním situácií a emocionálnou podporou nachádzajú jednoduchšie riešenie svojho zložitého zdravotného či sociálneho stavu. Tieto skupiny sa vytvorili z potrieb l'udí, ktorí nemohli byt' uspokojení existujúcim systémom zdravotníckych služieb. Všetci účastníci takejto skupiny sú si rovní, všetci sa schádzajú dobrovol'ne a tak dlho ako chcú. Jedinci získavajú vo svojpomocných skupinách posilnenie a podporu, prekonávajú izoláciu a osamelost' (Bártlová, Matulay, 2009). Často je pojem svojpomocná skupina zamieňaný, či stotožňovaný so svojpomocným hnutím. Pod svojpomocným hnutím rozumieme v širšom význame celú škálu najrôznejších svojpomocných aktivit: svojpomocné skupiny, svojpomocné organizácie, a podporné systémy i alternatívnu starostlivost'. Svojpomocné skupiny a ich vznik siahal dávno do histórie. Zo sociologického hl'adiska môžeme svojpomocné skupiny považovat' za fenomén, ktorý súvisí s prudkým rozvojom medicíny v 20. storočí. Pomoc medzi l'ud'mi bola odjakživa prirodzeným javom, vd’aka čomu sa chorý človek cítil lepšie po psychickej stránke a nebol na svoje ochorenie sám. Vznik svojpomocných skupín výrazne podporil informovanost' l'udí a ich rodín o danej chorobe, o možnosti liečby, o tom ako môže aj účast' v svojpomocnej skupine napomáhat' $\mathrm{k}$ tomu, aby sa pacient dokázal vyrovnat' $\mathrm{s}$ chorobou, a tým dopomôct' $\mathrm{k}$ zlepšeniu zdravotného stavu. Svojpomocné skupiny fungujú na základe rozhodnutia všetkých členov skupiny, pretože v nich absentuje prítomnost' profesionálnej osoby. Tieto skupiny sú zväčša bez finančnej podpory, no častokrát sú sponzorované organizáciami, akými sú napríklad rôzne nadácie alebo nemocnice. Skupiny slúžia najmä na výmenu informácií, emocionálnu oporu alebo osobnú zmenu (Balogová, 2017).

Majerníková, Obročníková (2020) uvádzajú tieto znaky svojpomocnej skupiny:

1. Rovnaký spoločný osud, skúsenost', symptóm, stav alebo postihnutie členov.

2. Možnost' poskytnutia vzájomnej pomoci.

3. Vzájomné poskytovanie informácií a rád, sprostredkovanie odborných poznatkov .

4. Rovnocennost' a rovnoprávnost' členov.

5. Umožňuje spoliehat' sa na vlastné sily, byt' sebestačným a autonómnym.

6. Dôležitá a nevyhnutná je interakcia tvárou v tvár .

7. Skupina sa orientuje na konanie-spoločne vykonávaná činnost'.

8. Je pre ňu charakteristický spontánny vznik, autonómia, samoregulácia.

9. Nevyhnutná je kolektívna energia a vôl'a, skupinové cítenie.

10. Má určitý kódex pravidiel správania sa, istých presvedčení, spoločných ideológií"

Zdiel'anie skupinovej skúsenosti s d'alšími l’ud'mi, ktorí majú podobné záujmy alebo ciele sa ukázalo ako vel'mi užitočné. Pre človeka, ktorý si pripadol so svojim problémom osamotený alebo priamo vyčlenený zo spoločnosti “normálnych" l’udí prináša úl'avu a posilu zistenie, že nie je vo svojej situácii sám, že takisto aj niekto iný, má rovnaké trápenie ako on. Otvára sa tak možnost' hovorit' o starostiach doposial' nezdiel'atel'ných s niekým kto má rovnaké alebo podobné obtiaže. Každý sebemenší úspech v riešení problému jedného člena skupiny je pre všetkých ostatných zdrojom nádeje a povzbudenia (Matoušek, 2008). Svojpomocné skupiny fungujú na báze sebestačnosti. Svojpomoc začína tvorit' súčast' sociálnej práce a tým podporujú profesionálnu pomoc. Členov svojpomocnej skupiny tvoria laici, ktorí chcú pomôct' l'ud'om s rovnakým problémom ktorí prekonali alebo prekonávajú. Majerníková, Obročníková (2020) uvádzajú, že svojpomocné skupiny orientované na pomoc chorým a ich rodinám nemajú za úlohu kompenzovat' poskytovanú odbornú starostlivost', ale zlepšovat' psychickú, emocionálnu, edukačnú a inú potrebnú rovinu z hl'adiska potreby jej členov. Klinické pozorovania a výsledky štúdii ukazujú, že sociálna opora poskytovaná pacientovi môže byt' vel'mi užitočná. Sociálnou oporou rozumieme prítomnost' inej živej bytosti rovnakého druhu, ktorá na postihnutého jedinca pôsobí priaznivo, prípadne upokojuje jeho 
sociálne potreby, jako sú potřeba náklonnosti, istoty, súhlasu a sociálnej interakcie. Sociálna opora posilňuje pacientove vlastné stratégie zvládania choroby. Očakávania, ktoré majú pacienti od svojho užšieho sociálneho okolia sú skôr emocionálneho charakteru. Sociálna opora je komponentom chronického ochorenia. Dôležitý je výskyt významných vztahových osob, či už sa jedná o pocit hodnotného bytia, pocit podpory pri zvládaní choroby. Je potrebné si uvedomit', že l'udia sú primárne sociálnými bytost’ami a pre pocit zmysluplného bytia potrebujú niekoho d’alšieho.

\section{SKÚSENOSTI ŠTUDENTOV ODBORU OŠETROVATELSTVA SO SVOJPOMOCNÝMI SKUPINAMI}

Hlavným ciel'om prieskumu bolo zistit', ako vnímajú študenti odboru Ošetrovatel'stva význam svojpomocných skupín pre chronicky chorých pacientov

Čiastkové ciele:

1. Zistit' názory a postoje študentov odboru Ošetrovatel'stvo $\mathrm{k}$ fungovaniu a aktivitám svojpomocných skupín.

2. Zistit' úroveň vedomostí študentov odboru Ošetrovatel'stva o pacientskych organizáciách.

3. Zistit', aké majú študenti odboru Ošetrovatel'stva praktické skúsenosti a úroveň spolupráce so svojpomocnými skupinami.

4. Zistit' názory a postoje študentov odboru Ošetrovatel'stva $\mathrm{k}$ možnosti zlepšovania fungovania svopomocných skupín.

5. Zistit' názory študentov odboru Ošetrovatel'stva na oporu poskytovanú chronicky chorým pacientom.

$\mathrm{Na}$ získanie informácií z prieskumu sme zvolili zber dát pomocou neštandardizovaného dotazníka, ktorý pozostával z 15 otázok. Dotazník obsahoval taktiež demografické údaje študentov ako sú vek, dosiahnuté vzdelanie a ročník. Prieskumu sa zúčastnilo 101 respondentov. Respondenti boli študentmi prvého, druhého a tretieho ročníka bakalárského stupňa vzdelania v odbore Ošetrovatel'stvo na Fakulte zdravotníckych odborov Prešovskej univerzity v Prešove.

Výsledky prieskumu poukázali na skutočnost', že študenti Ošetrovatel'stva, síce majú vedomosti o svojpomocných skupinách, no nemajú s nimi akúkol'vek praktickú skúsenost'. $89 \%$ respondentov malo vedomosti o svojpomocnej skupine a definovali ju ako skupinu, s dobrovol’ne združujúcimi sa l'ud'mi ktorí majú podobné životné alebo zdravotné problémy. Pri otázke aké znaky sú charakteristické pre svojpomocnú skupinu uviedla väčšina respondentov možnosti, ako sú rovnaký spoločný osud, skúsenost', symptóm, stav alebo postihnutie členov, možnost' poskytovania vzájomnej pomoci alebo vzájomné poskytovanie informácií a sprostredkovanie odborných rád. Z prieskumu môžme konštatovat' že, respondenti mali vedomosti aj o tom, ako pomáhajú takéto združenia pacientom. Respondenti uviedli, že vedomosti o ciel'och, aktivitách a fungovaní svojpomocých skupín získali na predmetoch komunitné ošetrovatel'stvo (37\%), aplikovaná psychológia vošetrovatel'stve (21\%), a sociológia $14 \%$ resppondentov. Na otázku, akým spôsobom pomáhajú svojpomocné skupiny pacientom, 26\% respondentov uviedlo, že svojpomocné skupiny pomáhajú zlepšit' psychický stav pacienta, a sú pre pacienta emocionálnou oporou pri preživaní náročných životných situácií. Taktiež boli názoru, že skupiny pomáhajú pacientom zmenit' pohl'ad na dané ochorenie a a snažia sa o zlepšenie kvality života pacienta. $58 \%$ respondentov uviedlo že fungovanie svojpomocných skupín výrazne pomáha pacientom s chronickým ochorením. $\mathrm{O}$ niečo menšie zastúpenie študentov Pri otázke o úlohách a činnostiach svojpomocných skupin bolo $27 \%$ študentov názoru že ich hlavnou úlohou a činnost'ou je zvyšovanie verejného povedomia o zdravotných poruchách, ich predchádzaniach, ale aj o špecifických chorobách a spôsoboch ich liečenia, $18 \%$ respondentov uviedlo, že ich činnost'ou je informovat'o novinkách o zdravotnej starostlivosti alebo umožnit' stretnutia medzi pacientmi a lekármi. Z 
prieskumu vyplýva, že poskytovanie pomoci a opory jednotlivcom, zabezpečenie fungovania psychosociálneho rozvoja členov skupiny $\mathrm{z}$ pohl'adu študentov prispieva $\mathrm{k}$ rozvoju individuálnych potenciálov členov skupiny a tým zvyšovaniu kvality ich života. 40\% respondentov uviedlo, že podl'a ich názoru chronicky pacienti nevyužívajú aktivity svojpomocných skupín. U respondentov sme zist'ovali, aký je ich názor na efektívnost' spolupráce medzi zdravotníckymi zariadeniami, zdravotnickými pracovníkmi a svojpomocnými skupinami. $75 \%$ respondentov si myslí, že spolupráca medzi uvedenými inštitúciami je efektívna. Prieskumom sme zistili, že $91 \%$ respondentov nemá skúsenost' s aktivitami svojpomocných skupín na profesionálnej úrovni, 77\% respondentov dokonca uviedlo, že sa počas výkonu svojej školskej praxe ani nestretlo so skutočnost'ou, že sestry chronicky chorým pacientom odporúčali spoluprácu so svojpomocnými skupinami. 42\% respondentov uviedlo, že svojpomocné skupiny by si za účelom podpory a osvety o svojej činnosti mali vytvorit' výraznejšiu marketingovú kampaň prostredníctvom web.stránok, prezentácie v rozhlase a televízii, $37 \%$ respondentov si myslí, že by mali viac spolupracovat' so zdravotnickými inštitúciami a lekármi a $21 \%$ respondentov uviedlo na podporu informovanosti o činnosti a aktivitách svojpomocných skupín publikovat' bulletiny a brožúry. Pre efektívnu podporu činnosti a aktivít svojpomocných skupín na základe výsledkov prieskumu navrhujeme odporúčania pre prax:

- Pre študentov vo výučbe danej problematiky rozšírit' vedomosti a podporit' záujem organizovaním odborných exkurzií do centier svojpomocných skupín.

- Podporovat' študentov k zapájaniu sa do dobrovol'níckych aktivit a spolupráce so svojpomocnými skupinami vo svojom okolí.

- Zefektívnit' spoluprácu medzi poskytovatel'mi ambulantnej, ústavnej, zdravotnej starostlivosti a organizáciami združujúcimi svojpomocné skupiny v oblasti edukácie pacientov, odporúčania a odosielania do pacientských komunít.

- Rôznymi formami marketingovej komunikácie zviditel'nit' fungovanie pacientskych organizácií pre pacientov, zdravotnických pracovníkov aj širokú verejnost' (rozhlasové a televízne média, odborné konferencie, príspevky v časopisoch, webové stránky, bulletiny, bilbordy,..)

- Edukovat' a podporovat' pacientov, ktorí trpia chronickým ochorením k spolupráci s pacientskými organizáciami.

- Organizovat' pacientske konferencie pre podporu vzdelávania chronicky chorých pacientov, vytvorit' online poradenstvo pre pacientov a ich príbuznych

- Uverejňovat' brožúry s problematikou svojpomocných skupín v čakárňach ambulancií alebo v nemocničných zariadeniach.

\section{ZÁVER}

Mnohé chronické ochorenia predstavujú pre pacienta náročnú životnú situáciu, zásah do životných plánov a nútiaho $\mathrm{k}$ zmene a väčšinou $\mathrm{k}$ akejsi núdzovej variante so zhoršenými či obmedzenými podmienkami. Pacient s chronickým ochorením je postavený do situácie, v ktorej musí pristúpit' na určité skutočnosti, vzhl'adom k svojmu ochoreniu. Musí ich zakomponovat' do svojho života so zmenou životných návykov a správania (Gurková, 2017). Chronicky chorí pacienti majú potrebu mat' pri sebe niekoho kto im rozumie, kto chápe ich trápenie. $\mathrm{Na}$ základe takejto pomoci chronicky chorým pacientom vznikli svojpomocné skupiny. Výsledky štúdií potvrdzujú, že členovia svojpomocných skupín trpia menej depresiami, duševne podmienenými telesnými t’ažkost’ami, pacienti sú samostatnejší a sebavedomejší, disponujú sociálnymi kontaktmi v porovnaní s l'ud'mi bez sociálnej podpory (Ondrejka, Adamicová, 2001, Majerníková, Obročníková, 2020). 
Príspevok vznikol s podporou Kultúrno edukačnej agentury KEGA č.003 PU - 4/2021 s názvom „Simulačné centrum starostlivosti o chronické rany“.

\section{Použitá literatúra}

1. BALOGOVÁ, B. a kol. Vademecum sociálnej práce. Košice: UPJŠ Filozofická fakulta. 2017, ISBN 978-80-8152-483-7.

2. BÁRTLOVÁ, S. MATULAY, S. Sociologie zdraví, nemoci a rodiny. Martin: Osveta 2009, 141 s. ISBN 978-80-8063-306-6.

3. GURKOVÁ, E. Nemocný a chronické onemocnení. Praha: Grada Publishing. a.s. 2017, 192 s. ISBN 978-80-271-9917-4.

4. MAJERNÍKOVÁ, L., OBROČNÍKOVÁ, A. Vplyv svojpomocnej skupiny na kvalitu života pacienta a jeho rodinu. Prešov: Vydavatel'stvo: Prešovskej univerzity. 2020. 118 s. ISBN 978-80-555-2589-1.

5. ONDRIOVÁ, I. CINOVÁ, J. Psychosociálne aspekty zdravotníckej praxe. Prešov: Vydavatel'stvo: Prešovskej univerzity.2020. 160s. ISBN 978-80-555-2416-0.

6. MATOUŠEK, O. Slovník sociální práce. Praha: Portál, s.r.o. 2003, 288 s. ISBN 807178-549-0 .

7. ONDREJKA, I., ADAMICOVÁ, K. Komplexne o o kvalite života pacienta. Sestra. 2003; II(8-):16-18.

8. PAULÍK, K. 2017. Psychologie lidské odolnosti. 2vyd. Praha: Grada Publishing, a.s. 2017, 368 s. ISBN 978-80-247-5646-2.

\section{Kontaktné údaje}

PhDr. Lívia Hadašová, Ph.D., MBA

Prešovská univerzita $v$ Prešove

Fakulta zdravotnických odborov

Partizánska 1, 08001 Prešov

Tel: 00421517562461

email: livia.hadasova@unipo.sk 


\title{
UPLATNENIE HIER S PRÍRODNÝM MATERIÁLOM VO VÝTVARNO- TECHNICKÝCH ČINNOSTIACH V MATERSKEJ ŠKOLE
}

\author{
APPLICATION OF GAMES WITH NATURAL MATERIAL IN ART- \\ TECHNICAL ACTIVITIES IN KINDERGARTEN
}

\author{
Mária Vargová, Jozef Zentko
}

\begin{abstract}
Abstrakt
Autori v príspevku venujú pozornost' uplatneniu využívania výtvarno-technickej tvorivosti pri práci s prírodným materiálom v predprimárnom vzdelávaní. Prezentujú možnosti uplatnenia technických a výtvarných postupov v predprimárnom vzdelávaní, ktoré sú nosnou základňou pri rozvoji tvorivosti, výtvarnej predstavivosti a technického myslenia. Pozornost' venujú dôležitým aspektom v technickej a umeleckej práci so zretel'om na interdisciplinárne presahy v edukačnom procese v materskej škole. Poukazujú na súvzt'ažnost' výtvarného a technického spolu s ich potenciálom pri rozvoji výtvarnej a technickej tvorivosti. Ponúkajú možnosti konkrétnych aktivít uplatnitel'ných v súčasnej pedagogickej praxi.
\end{abstract}

Kl'účové slova: výtvarná aktivita, technická aktivita, prírodný materiál, predprimárne vzdelávanie

\begin{abstract}
The authors pay attention to the application of the use of artistic and technical creativity when working with natural materials in pre-primary education. They present the possibilities of applying technical and artistic procedures in pre-primary education, which are the mainstay in the development of creativity, artistic imagination and technical thinking. They pay attention to important aspects in technical and artistic work with regard to interdisciplinary overlaps in the educational process in kindergarten. They point out the interconnection of artistic and technical together with their potential in the development of artistic and technical creativity. They offer possibilities of specific activities applicable in current pedagogical practice.
\end{abstract}

Key words: art activity, technical activity, natural material, preprimary education

\section{ÚVOD}

V priestore súčasnej pedagogickej reality má významné postavenie aplikácia interdisciplinárnych vzt'ahov a súvislosti $\mathrm{v}$ jednotlivých vzdelávacích oblastiach. Ideálne postavenie týchto aspektov a implementácie sa ponúka už v predprimárnej edukácií, kedy si diet'a začína rozvíjat' technické a výtvarné zručnosti. Rovnako sa pri týchto výchovných, technických či estetických zložkách využíva v edukačnom procese princíp súvzt'ažnosti a zásada umeleckých či manuálnych presahov. Implementácia viacerých druhov tvorivých činností či už umelecky, alebo technicky orientovaných je nevyhnutnou súčast'ou každého výchovno-vzdelávacieho procesu v predprimárnom vzdelávaní. Vhodne navrhnuté a realizované aktivity prispievajú k efektívnemu edukačnému procesu v ktorom sa rozvíjajú viaceré kl'účové kompetencie zamerané na technické a umelecké zručnosti. Pre rozvoj oboch zložiek je ideálne využívat' prírodný materiál, ktorý podporuje aj environmentálne cítenie. 


\section{VÝTVARNO-TECHNICKÉ ČINNOSTI V MATERSKEJ ŠKOLE}

Výtvarné aktivity sú úzko prepojené s technickými činnostami. Už v predprimárnej edukácií je potrebné rozširovat' oba aspekty a podporovat' tak rozvoj tvorivosti, technického myslenia a tiež priestorovej predstavivosti. Výtvarné a technické činnosti sú dôležitou platformou pre efektívny a originálny edukačný proces, ktorý sa tak stáva pre deti pútavým a atraktívnym. Každá oblast' má svoje špecifické ciele a dôležitú výpoved', je však na tvorivosti pedagóga ako jednotlivé presahy vhodne prepojit'.

Jedným z nosných aspektov výtvarnej edukácie v predprimárnom edukačnom procese je vnímanie a spoznávanie podnetov z prírody, spoločnosti ako aj výtvarných diel rôznych autorov (Kováčová, Guillaume, 2010). Pri jednoduchých výtvarných aktivitách však deti rýchlo zistia, že oni sami sa môžu stat' umelcami.

Pri práci s prírodným materiálom sa v rámci podnetov zo sveta výtvarného umenia, ponúka inšpirácia $\mathrm{v}$ landarte. $\mathrm{V}$ tomto prípade ide o umelecký prúd druhej polovice 20 . storočia. Landart môžeme vnímat' ako tendenciu vo výtvarnom umení, ktorá využíva metódu tvorby diel a vytvárania rôznych objektov priamo vo vol’nej prírode, alebo zahŕña vytváranie diel $\mathrm{z}$ prírodných materiálov $\mathrm{v}$ interiéri. Deti teda môžu zasahovat' výtvarným spôsobom do prírodného terénu, prípadne sa sústredia na zber prírodného materiálu a následne $\mathrm{z}$ neho vytvárajú objekty v prírode alebo v priestoroch materskej školy (Borbélyová, 2013). Táto alternatíva je efektívne a tvorivo využitel'ná práve $\mathrm{v}$ priestore súčasnej edukačnej reality v kontexte predprimárneho vzdelávania. $\mathrm{V}$ umení land-artu sa dielo viaže ku konkrétnemu miestu s ktorým vytvára vnútorný vzt’ah. Jeho prostredníctvom reflektuje a reaguje na civilizačno-prírodne prepojenia (Beskid, In Geržová, 1999). Možno ho teda charakterizovat', ako moderný umelecký prúd, ktorý prekrýva vel'ké formácie krajiny formotvornými štruktúrami meniacimi jej tvár (Šupšáková, 1999).

Tvorivá a efektívna transmisia súboru prvkov, ktoré využiva táto činnost', môže prechádzat' viacerými vzdelávacími oblastami, ktoré nám ponúka Štátny vzdelávací program pre predprimárne vzdelávanie $\mathrm{v}$ materských školách. Interdisciplinárne presahy môžu edukačný proces výrazne zatraktívnit'. Konkrétne sa zameriame na prepojenie dvoch vzdelávacích oblastí: Umenie a kultúra a Človek a svet práce.

Skúmaniu technickej gramotnosti sa venovali a venujú mnohí odborníci s dlhoročnou praxou (Hul'ová, 2015, Žoldošová, 2016 a iní). Ak pracovné schopnosti detí nie sú dostatočne rozvinuté, môžeme pozorovat' nevyzretost' u diet'ata. V metodickej príručke ku vzdelávacej oblasti Človek a svet práce čítame: „Významnú súčast’ vzdelávacieho obsahu tvorí rozvíjanie elementárneho technického premýšl'ania. Diet’a spoznáva vlastnosti materiálov a učí sa využívat' to, čo o materiáloch vie. Aby bolo diet’a úspešné v technických zadaniach, musí byt' vnímavé voči prostrediu, pozorovat' vlastnosti predmetov, pokusom a omylom skúšat' rôzne riešenia, tvorivo pristupovat' $\mathrm{k}$ využívaniu dostupných materiálov a nástrojov. $\mathrm{V}$ uvedenom procese nie je učitel'kinou úlohou zadávat' nemenné postupy, ale viest' deti $\mathrm{k}$ tvorbe vlastných postupov, resp. k spontánnej modifikácii zadávaných postupov“ (Žoldošová, 2016, s. 6).

Pre uskutočnenie presahov sme si zvolili dva najčastejšie materiály, ktoré s det’mi môžeme nazberat' na vychádzke: horniny a drevo.

\section{Horniny, súčast' prírodného materiálu}

Kameň patri medzi základný prírodný materiál, ktorý má svoje dôležité postavenie v edukačnom procese materskej školy. Pre aktivitu resp. aktivity, ktoré rozvíjajú, výtvarné, estetické a umelecké cítenie, matematické, technické a logické myslenie a kreativitu postačia vol’ne dostupné kamene hranatých alebo oblých tvarov a rôzneho druhu. Počet závisí od zamerania zvolených aktivít. Pre rozvoj výtvarnej tvorivosti, môžeme jednotlivé kamene maliarsky či kresebne umelecky dotvárat'. Môžeme ich komponovat' do pripraveného 
podkladu na spôsob kamennej mozaiky, ale môžeme tiež vytvárat' rôzne priestorové kompozície a objekty.

Hier s kameňmi si môžeme vytvorit' vel'a, napr. skladat' z nich múry (ako s kockami), vyskladat' chodníček pre rôzne bytosti (chrobáčiky, víly, škriatkov), ale tiež to môžu byt' rôzne obrazce, ktoré sú súčast’ou land-artu, popr. deti môžu inšpirovat' spoločenské hry, napr. domino či pexeso.

Kameň môžeme v tomto prípade považovat' za didaktický materiál a deti s ním môžu pracovat' v exteriéri, ale aj v interiéri. Najlepšie je, ak si materiál deti hl'adajú sami a zároveň spoznávajú krásy krajiny, v ktorej sa nachádzajú. Môžu mat' pomocný materiál ako vedierko, lopatku a štetec.

V materskej škole sa stretávame pri práci s kameňom najčastejšie s výtvarnou technikou mal'ovania a kreslenia, teda mal'ovaním na podklad, ktorým je kameň. S pomocou učitel'a však môžeme využívat' aj techniku spájania kameňov lepením. Táto technika je uplatnitel'ná pri tvorbe objektov. Používa sa spôsob lepenia rôznymi lepidlami, alebo ekologické lepenie blatom či hlinou. Ideálne je pri jednotlivých činnostiach využívat' princípy priameho zásahu v krajine, radenie, prekrývanie, ukladanie kameňov na seba resp. vedl'a seba.

V materskej škole je však najviac uplatnitel'né práve mal'ovanie kameňov. Ide o jednoduché a pomerne oblúbené aktivity, ktoré v sebe nesú množstvo čiastkových výtvarných, ale aj technických či logických aktivít (Zentko, 2019/2020).

\section{Drevo, súčast' prírodného materiálu}

Podobne ako kameň aj drevo patri medzi základný prírodný materiál, ktorý má svoje nosné postavenie v edukačnom procese materskej školy. Či už ide o prírodné či technologicky spracované. Pre aktivitu resp. aktivity, postačia vol’ne dostupné halúzky či konáre rôzneho druhu, či už suchých stromov bez výraznej poveternostnej úpravy, alebo s ňou. Myslíme tým napr. naplavené resp. vyplavené drobné halúzky dreva, ktoré je oblé. Počet závisí od druhu zvolených aktivít. Aktivity môžu byt' obdobné ako s kameňmi. Deti môžu pri práci s drevom zistit', že práca s ním je iná. Drevo ponúka množstvo podnetných inšpirácií, ktoré výrazne rozvíjajú technickú zručnost' a výtvarnú tvorivost' detí predškolského veku. Vo výtvarnej oblasti môžeme jednotlivé prírodné materiály zdobit' kresbou, alebo mal'bou a vytvárat' tak rôzne plošne dekorácie na drevenom podklade. Ideálny prístup sa však ponúka práve pri tvorbe priestorových objektov, ktoré vytvárame spájaním pomocou povrazu, lepením, skladaním, radením, ohýbaním a pod. S drevom môžeme vytvárat' rôzne asambláže, akumulácie, objekty či priestorové kompozície.

Pre prácu s drevom je vhodné využívat' výtvarné hry a priestorové etudy, ktoré vedú diet’a $\mathrm{k}$ poznávaniu vlastností rôznych materiálov. Pri výtvarných hrách má diet’a možnost' spoznat' cez hmatové vnímanie reč výtvarných materiálov a neskôr ju vie tvorivo uplatnit' vo vlastnom výtvarnom vyjadrení či prejave (Pondelíková, 2015).

\section{PREČO JE POTREBNÁ HRA PRE DETI S PRÍRODNÝM MATERIÁLOM}

Rozvoj fantázie a tvorivosti je pre diet’a dôležité. Učí sa premýšl’at', rozvíja svoje možnosti a neriadi sa iba predpísanými pokynmi. Hl'adá riešenia. K tomu je dôležitá hra, ktorá je pre diet’a prirodzená. Tvorivost' je možnost', ktorá je v každom diet’ati, teda každý človek je tvorivý a má predpoklady svoju tvorivost' rozvíjat'.

Vlastnosti a prvky hry podl'a D. Waloszeka (2006, s. 258 - 260):

- jasnost' - hra zviditel'ňuje, sprítomňuje potrebu byt' aktívnym, prebieha rýchlo, prejavuje preživanie, schopnosti, stavy, diet’a „sa prenáša“ do označovaných vecí a robí ich „,viditel'nými““, slová a skutky sú tvorené tak, že niet pochybností, čo predškolák predstavuje, 
- vznešenost' - hra vystupuje poza pospolitost', bežnost', schematickost', priemernost' v skutkoch, veciach a slovách; je sviatočná, iná, neopakovatel'ná, pretvorená; diet’a jej dáva vlastnú interpretáciu a vlastný rozmer; chce konat' vo forme, ktorá ho uspokojuje,

- krása - hra obsahuje nebývalý súlad činov a slov, ktoré ju tvoria; je v nej plno harmónie, symetrie, miery, rytmu, celku formy, koloritu, sústred'uje v sebe šl'achetnost', dobro, št’astie, radost', dokonalost', premyslené konanie; hrajúce sa diet'a je géniom a umelcom,

- dynamickost' - dáva hre živý pohyb, bystrost', sugestívnost', zdôrazňovanie; diet'a robí dojem, že sa niekam a pre niečo ponáhl'a, l'ahko prechádza od jednej konvencie k druhej, hl'adá iný plán a riešenia, niet pochybností o tom, na čo sa hrá; hra nikdy neustáva, a ak to má svoje miesto, je to prejav bud' únavy, alebo vyčerpania nápadu,

- pravdivost', autentickost' - hra robí dojem, že to, čo diet’a robí a hovorí, nie je vymyslené, ale zhodné s tým, čo cíti, každá činnost' je nová, prvá a pravdivá,

- dôležitost' a nedôležitost' - hra nikdy nie je nedôležitá, má silu, rozhodnost', energiu, je dôstojná a vznešená; stráca vážnost', ked' prestane byt' vol'ná, alebo ked' je diet’a zabávané niekým iným. Vtedy sa stáva karikatúrou.

Cez pozorovanie detí, môže učitel' zistit', či je diet'a zvedavé, či má chut' sa hrat', aké je zaujaté a pod. Tiež je zaujímavé si všímat', či činnost', ktorú diet’a začne, aj dokončí a čo robí, ak sa mu nedarí činnost' dokončit'.

Na základe stanovenia ciel’a vyberieme adekvátnu hru na realizáciu (Vankúš, 2014), ktorou je možné utvárat' pozitívny vzt'ah k technickým zručnostiam, učitel'ovi, vzdelávacej oblasti, kultúre aj škole. Je dôležité dodržat' zásadu vekovej primeranosti. Netreba tiež zabúdat' na bezpečnost' pri hre a práci. Pred realizáciou je potrebné si okrem vhodnej vekovej skupiny uvedomit', aké sú individuálne predispozície detí, do akej miery je hra prít’ažlivá a správne vysvetlit' pravidlá a dbat' na ich dodržiavanie. Cez didaktickú hru sa môže učitel' lepšie priblížit' $\mathrm{k}$ diet'at'u ako $\mathrm{k}$ individualite a zároveň obohatit' edukačný proces.

Hra nemusí byt' iba zámerná. Diet’a sa rozvíja hlavne pri vol’nej hre, rozvíja sa jeho tvorivost', fantázia, myšlienkové procesy. Nekladie si medze a je spontánna. Aj z toho dôvodu je prírodný materiál vel'mi žiadaný pre diet’a. Zároveň sa stretáva s prírodou, je na čerstvom vzduchu a uvedomuje si prístupnost' materiálu a práce s ním. Kúsok konárika môže byt' komínom, ale aj udicou. U diet'at'a môže nastat' „well-being“, čo môžeme považovat' za osobnú pohodu. Hrou si diet’a napíňa svoje potreby a získava pocit št’astia.

\section{PRÁCA S PRÍRODNÝM MATERIÁLOM - SONDÁŽ}

Vo výskumnej sondáži prezentujeme priebežné výsledky aplikovaného výskumu realizovaného v školskom roku a 2019/20 a 2020/21 v rámci projektu VEGA č. 1/0383/1. Realizácia prebiehala cez dve vzdelávacej oblasti Umenie a kultúra a Človek a svet práce.

Ciel'om sondáže bolo zistit' vhodnost' aplikácie vybraných materiálov pri práci s det'mi v predprimárnom vzdelávaní a následne implementovat' cez kamene a drevo.

Pri sondáži sme sa zamerali na dve roviny - vek detí 2-6 rokov a zakomponovanie hier s prírodným materiálom.

Medzi hlavné výskumné nástroje patrilo pozorovanie a interview realizované s det'mi vo veku 2-6 rokov. Skúmali sme u deti zaujatie materiálom, prácu s ním, samotnú kompozíciu a tvorivé činnosti detí cez hrové aktivity. Pozorovanie a následné interview cez fokusové skupiny bolo realizované bezprostredne po činnosti. Zároveň sme zist'ovali názory učitel'ov na realizáciu prvkov technického a výtvarného vzdelávania v materskej škole.

Pri pozorovaniach a interview sme vychádzali z nasledujúcich výskumných otázok:

1. Ktorý z vybraných materiálov deti najviac preferujú?

2. Aké aktivity s prírodným materiálom u deti rozvíjajú výtvarnú tvorivost' a technické zručnosti?

3. Je diet'a schopné samostatne pracovat' s prírodným materiálom? 


\section{Realizované aktivity s det'mi}

V príspevku uvádzame krátke ukážky z uskutočnených aktivít, ktoré boli realizované v mesačnom cykle s názvom Príroda, náš dar. Konkrétne sme sa zamerali na dva materiály kamene a drevo. S det'mi sme vstupovali do čarovných krajín, ktoré sa volali Královstvo kameňov a Král'ovstvo stromov.

\section{Královstvo kameňov}

V čarovnej krajine-nekrajine, kde mali vel'a kamenia, vládol král' Kameň I. Bol to dobrý král' a snažil sa svojmu l'udu čo najviac pomáhat'. Nechcel, aby niekto bol chudobný a preto dal príkaz, že každý si môže vziat' tol'ko kamenia, kol'ko potrebuje. Ludia boli radi za takéhoto dobrého král'a. Nosili si kameň domov, do práce a vyrábali z neho všetko to, čo potrebovali.

Toto je úryvok z motivačného príbehu, ktorý je dlhší a každý deň je v ňom rozpracovaná nová zápletka. V žiadnom dni nie je konkrétny produkt, aby sme det'om nevkladali naše myšlienky. Deti samé vymýšl'ali komponenty, ktoré sa dajú pripravit' z kameňa. Najskôr zist'ovali tvrdost', tiež hmotnost' (ponorením do vody, spadnutím na zem, do vedierka, vážením na váhach), farbu, štruktúru. Za pomoci učitel'ky si vyrobili tabul'ku, do ktorej si zapisovali poznatky.

Zaujímavé bolo pozorovat' objavy detí. Prv, než začali s kameňom pracovat', najskôr ho museli nájst' - na vychádzke a na školskom dvore. Používali vedierko, lopatku a zaujal ich aj štetec. Tu sa niektorí cítili ako malí archeológovia.

V prírode začali kamienky spájat' a zaujímavé ich bolo pozorovat'. Hl'adali kamienky, aby vytvorili kvietok, či chodník pre lesné bytosti. Deti do štyroch rokov pracovali zväčša samostatne, staršie deti si hl'adali dvojice, trojice podl'a svojich kamarátov.

Niektoré kamene si mohli priniest' aj so sebou do materskej školy. Boli oboznámení s tým, že všetky kamienky si priniest' nemôžu, lebo kamene v prírode slúžia aj ako domov pre rôzny hmyz.

Vybrané kamienky si deti zobrali do triedy a vytvorili rôzne obrázky, zvierat, budov, napodobnili spoločenské hry a pod. Uvádzame aspoň vybranú fotodokumentáciu. Deti vymysleli za pomoci učitel'ky pieseň o kameňoch s rytmickým sprievodom malých kamienkov.

Prelínani vzdelávacich oblastí: Človek a svet práce, Umenie a kultúra, Človek a príroda, Matematika a práca s informáciami.

Reflexia: Zaujímavá a inšpirujúca je práca s vekovo zmiešanou skupinou. Individuálna práca bola pozorovaná u mladších detí a od približne štyroch rokov sme videli začiatky spolupráce medzi det'mi. Stredná veková skupina si volila diet'a-kamaráta, šest' ročné diet’a si zobralo k sebe aj diet'a, ktoré nepatrilo medzi jeho najobl'úbenejších kamarátov. Prirodzené sociálne zoskupenie bolo zjavné. Úvodne hl'adanie kameňov a kontrola, či nenarušia domov chrobáčikov deti zaujala. Niektorí sa vyhrali so štetcom a lopatkou - lovili kamienky v zemi. Zaujalo ich to viac, než výtvory z nich. Učitel'ka preto na nasledujúci deň pripravila na školskom dvore nádoby, kde bol piesok a v ňom ukryté kamene. Iných zaujala práca so samotným materiálom. Boli to prevažne dievčatá, čo sa venovali obrazcom a cyklicky za sebou nasledujúcim vzorom, chlapci skôr robili rôzne výtvory.

V interiéri to už bola práca s čistými kameňmi. Niektorí využili farby, d’alší kombinovali farebné s prírodným kameňom. S niektorými pasážami pracovali dlhšie a počas samotnej inštalácie menili tému a zameranie - najskôr to bol múr, potom sa $\mathrm{z}$ neho vykl’ul had, pri d'alšom dotvorení krokodíl a nakoniec rozprávková ryba. Hotové materiály si deti s pomocou odfotili.

Zloženie piesne a rytmizácia bolo zavŕšením niekol'kodňových aktivít. 
Práca s kameňom deti zaujala. Aj po skončení témy sa deti rady vracali k materiálu, s ktorým sa im vel'mi dobre pracovalo.

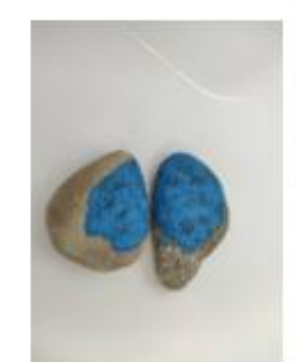

Domino

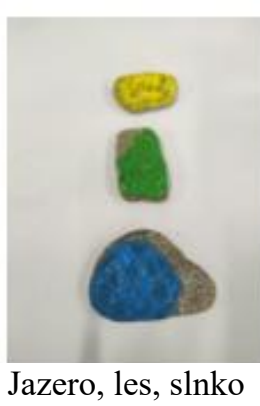

Jazero, les, slnko

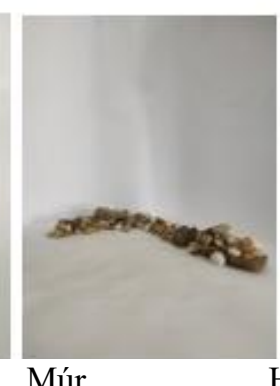

Múr

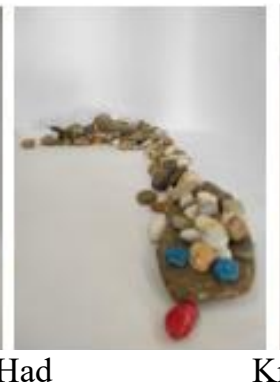

Krokodíl

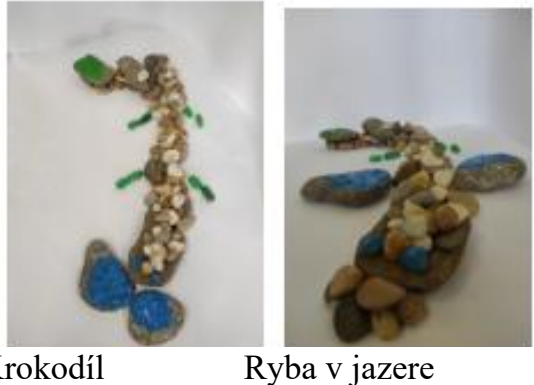

Ryba v jazere

\section{Královstvo stromov}

Za lúkou a priezračným jazierkom sa rozpínal košatý les. Stromy v ňom boli malé i vel'ké, svetlé i tmavé a keby sme prišli bližšie, uvideli by sme, že sú to listnaté i ihličnaté dreviny. Medzi všetkými týmito jedinečnými stromami bol jeden, ktorý sa na každého priam usmieval. Počas vetra hladkal svojimi konármi iné stromy, počas búrky skláňal svoje konáre k zemi, aby ochraňoval malé stromčeky. Strom sa volal Dub obranca. Stromy ho mali rady a zvolili si ho za král'a. Dub ochranca bol spravodlivý a starostlivý. Jedného dňa zvolal poradu všetkých stromov. Mal starost', čo robit's vyschnutými halúzkami, ktoré sa poval'ovali po lese. Jeden z najbližších priatel'ov stromov, povedal, že tie sa rozpadnú počas roka a zem bude mat' výživu. Ďalší pripomenul, že vtáci budú mat' d'alší materiál k stavbe hniezda. Iní zase pripomenuli, že huby, machy a lišaje sa môžu na nich zachytit'. Dub sa ale zamyslel, a spýtal sa: môžu sa ešte suché halúzky a konáriky nejako využit?

Opät' vidíme úryvok z príbehu, ktorý deti zaujal a začala sa vyvíjat' d'alšia etuda problémovej úlohy pre deti. Tak ako s kameňom, aj pri halúzkach a konárikoch deti rozmýšl’ali nad d'alším využitím. Zist'ovali lámavost', dížku, ktorú merali motúzikom, hmotnost' a pod.

Aj v tomto prípade nedostali materiál priamo, ale si ho museli nazberat'. Dávali pozor, aby nezlomili živý konárik, ale aby si zobrali iba starší, ktorý leží na zemi.

V exteriéri použili aj lupu a hrali sa na detektívov. Opät'sa rozdelili na hl'adačov a umelcov. Niektoré deti si vyskúšali obe úlohy. Činnost' ich zaujala a každý deň objavili niečo nové.

Práca v interiéri bola zase odlišná, ale zároveň ponúkala nové možnosti. Materiál pre prácu si deti priniesli v prútených košíkoch.

Konáriky, ktoré zostali, det’om poslúžili ako prekážky pri pohybovej hre.

Prelínaní vzdelávacích oblastí: Človek a svet práce, Umenie a kultúra, Človek a príroda, Matematika a práca s informáciami, Zdravie a pohyb.

Reflexia: Prvky socializácie boli nezmenené. U niektorých detí sa vystriedali partneri hry a nadväzovali sa nové kamarátstva. Deti prejavili vel'ký záujem o hru. Zaujímavé boli nové tvorivé aktivity, ktoré si deti za pomoci učitel'ky pripravili. Konáriky a halúzky deti zaujali, ale nie $\mathrm{v}$ takej miere ako kamene. Obrazce tvorili v exteriéri i interiéri. Z interiéru prikladáme obrazovú prílohu. Ako prvú vidíme udicu, ktorú začal vytvárat' iba trojročný chlapec, ktorý ma dedka rybára. Ďalšie, ktoré vidíme, sú krajina, les, ale deti začali stavat' domy v obci a zvieratá na hospodárskom dvore. V ukážke vidíme dom a prasiatko.

Zaujímavým ukončením činnosti bolo, že zo zvyšného materiálu urobili prekážkovú dráhu. Pohybovej hre dali vlastné pravidlá a bola zjavná radost' z hry. 


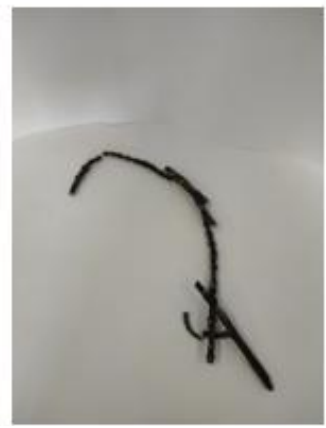

Udica

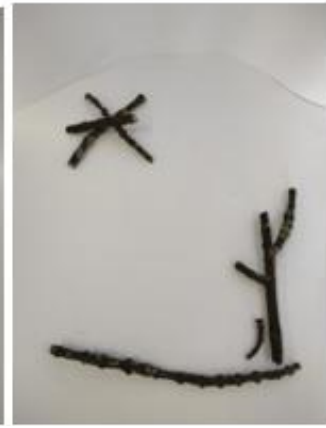

Krajina

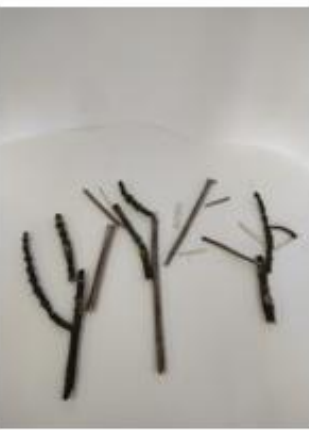

Les

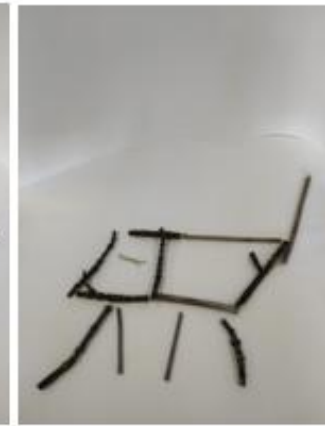

Prasa

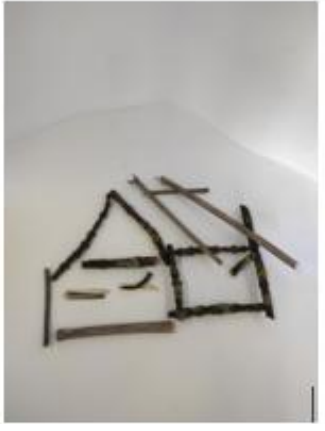

Dom

\section{Výskumné zistenia}

Uvádzame len výber získaných dát a naše základne zistenia.

1. Ktorý z vybraných materiálov deti najviac preferujú? Deti najviac tvrdili, že sa im lepšie pracovalo s kameňom. Pozorovania to potvrdili. Zaujímavé bolo pozorovat' chlapcov s kameňmi na školskom dvore, kde si vo vedierku zmiešali piesok s vodou a $\mathrm{z}$ kameňov a mokrého piesku stavali hrádzu. Krhlou liali vodu do jazierka a snažili sa vytvorit' vodopád. Táto aktivita nastala po prvotnom zoznámení sa s kameňom v polovici druhého týždňa. Predchádzali tomu bádatel'ské aktivity, v ktorých deti skúmali kameň, jeho vlastnosti a spôsoby ako sa dá sním pracovat'. U učiteliek sme zistili, že téma voda sa det'om vel'mi páčila. Na tomto mieste nie je zanedbatel'né podotknút', že zaujímavým spôsobom deti prepojili dve témy, ktoré ich zaujali.

2. Aké aktivity s prírodným materiálom u deti rozvíjajú výtvarnú tvorivost' a technické zručnosti? Vol'né hry s prírodným materiálom boli vel'mi vhodne zvolené. Pozorovanie deti následné interview potvrdilo záujem a snahu deti pracovat' aj s možnost'ou námetových hier, napr. pri udici, ktorú si vyskladalo diet’a $\mathrm{z}$ halúzok, napodobňoval chlapec svojho otca a časti prútu ,pajkoval“ s d'alšou halúzkou. Učitel'ky tiež potvrdili, že často deti zrkadlia činnosti dospelých zo svojho sociálneho prostredia.

3. Je diet'a schopné samostatne pracovat' s prírodným materiálom? Je vhodné, aby si učitel' pripravil vhodné námety pre deti. V praktickom výstupe sme prišli aj k záverom, že je potrebné, aby sme nechali aj det'om vol'nost'. Hra je pre diet'a zaujímavejšia a pútavejšia, ak si ju diet’a vymyslí samo. Vracia sa k nej aj s rôznymi obmenami a ak je deti viac, je bežná aj variácia pravidiel.

\section{ZÁVER}

Detská hra mnohokrát fascinuje nielen diet'a, ale aj jeho rodičov a učitel'ov. V dnešnom svete plnom mediálnych stôp vidíme zmenu $\mathrm{v}$ detských hrách so zameraním, s prístupom i sociálnom rozmere. Hra ako základná činnost' diet’at'a prispieva k formovaniu osobnosti diet'at'a, jeho postojom i spôsobu učenia sa. Aj toho dôvodu zmena a zámer hry s prírodným materiálom môže u diet'at'a priniest' pozitívne zameranie a zmenu k lepšiemu.

Príspevok vznikol v rámci grantovej úlohy VEGA č. 1/0383/19 Analýza stavu v technickom vzdelávani a rozvoj technických zručností žiakov na primárnom stupni školy, ktorého zodpovedná riešitel'ka je doc. PaedDr. Zlatica Hul'ová, PhD., (2019 - 2021).

\section{Použitá literatúra}

1. BESKID, V. Land art. In. GERŽOVÁ, J. a kol. Slovník svetového a slovenského výtvarného umenia druhej polovice 20. storočia. Bratislava: PROFIL, 1999. ISBN 80-968283-0-4. 
2. BORBÉLYOVÁ, D. Metodika výtvarnej výchovy pre materské školy. Bratislava: Metodicko-pedagogické centrum, 2013, ISBN 978-80-8052-543-9.

3. HUL'OVÁ, Z. Bezpieczeństwo ekologiczne w pracach technicznych w przedskolnej i szkolnej edukacji. In: Bezpieczeństwo wielorakie perspektywy: bezpieczeństwo zperspektywy środowisk iobszarów. Poznań: Wydawnictwo Wyżsej Szkoły Bezpieczeństwa, 2015. ISBN 978-83-65096-12-8. s. 323-336.

4. KOVÁČOVÁ, B., GUILlAUME, M. Art vo vzdelávaní. Trnava: Trnavská univerzita v Trnave, Pedagogická fakulta, 2010. ISBN 978 -80-8082-401-3.

5. PONDELÍKOVÁ, R. Výtvarné techniky na rozvoj tvorivosti. Bratislava: Metodickopedagogické v Bratislave, 2015. ISBN 978-80-565-1358-3.

6. ŠUPŚÁKOVÁ, B. Projekty a alternativne formy vo výtvarnej výchove. Bratislava: Gradient, 1999. ISBN 80-967231-4-6.

7. VANKÚŠ, P. Zistovanie efektívnosti vyučovacích metód. Bratislava: Univerzita Komenského v Bratislave, Fakulta matematiky, fyziky a informatiky, 2014. 155 s. ISBN 978-80-8147-024-0.

8. VARGOVÁ, M. Cez hru k technickej gramotnosti detí. In: QUAERE 2020: recenzovaný sborník př́íspěvků interdisciplinární mezinárodní vědecké konference doktorandů a odborných asistentů, Hradec Králové, 22. - 26. 6.2020. Roč. 10. Hradec Králové (Česko) : Magnanimitas akademické sdružení, 2020. ISBN 978-8087952-32-0, s. 805-812.

9. WALOSZEK, D. Pedagogika przedszkolna; metamorfoza statusu i przedmiotu badań. Kraków : 2006. 400 s. ISBN 83-7271-397-9

10. ZENTKO, J. Prírodný ateliér v materskej škole v medzipredmetových súvislostiach. In: Predškolská výchova 4, 2019/2020, ročník LXXIV, ISSN 0032 -7220.

11. ŽOLDOŠOVÁ, K. Človek a svet práce. Metodická príručka $k$ vzdelávacej oblasti Štátneho vzdelávacieho programu pre predprimárne vzdelávanie v materských školách. Bratislava: ŠPÚ, 2016. 30 s. Dostupné na internete: https://www.statpe du.sk/files/sk/svp/zavadzanie-isvp-ms-zs-gym/materska-skola/zrevidovane_cloveksvet-prace_na-zverejnenie.pdf

\section{Kontaktné údaje}

PaedDr. Mária Vargová, PhD.

Katolícka Univerzita v Ružomberku, Pedagogická fakulta

Hrabovská cesta 1, 034 01, Ružomberok

e-mail: maria.vargova@ku.sk

PaedDr. Jozef Zentko, PhD.

Katolícka Univerzita v Ružomberku, Pedagogická fakulta

Hrabovská cesta 1, 034 01, Ružomberok

e-mail: jozef.zentko@ku.sk 


\title{
SPOLUPRÁCA PACIENTA PRI KONZERVATÍVNEJ LIEČBE GLAUKÓMU A KVALITA ŽIVOTA
}

\section{PATIENT COOPERATION IN THE CONSERVATIVE TREATMENT OF GLAUCOMA AND QUALITY OF LIFE}

\author{
Mária Kaščáková, Ludmila Majerníková, \\ Anna Hudáková, Andrea Obročníková
}

\begin{abstract}
Abstrakt
Ciel'om príspevku je priblížit' pojmy súvisiace so spoluprácou pacienta pri konzervatívnej liečbe glaukómu. Opisuje vzájomné súvislosti compliancie, adherencie, perzistencie a noncompliancie pri aplikácii liekov do oka. Glaukóm je chronické ochorenie, ktoré si vyžaduje priamu a aktívnu účast' pacienta pri liečbe glaukómu pre zachovanie zrakových funkcii a kvality života.
\end{abstract}

Kl'účové slová: glaukóm, pacient, compliancia adherencia, concordancia, persistencia

\begin{abstract}
Abstrakt
Aim of this contribution, is to present concepts related to patient compliance for the conservative treatment of glaucoma. It describes the interrelationships between compliance, adherence, persistence and non-compliance when administering drugs to the eye. Glaucoma is a chronic disease that requires the direct and active involvement of the patient in the treatment of glaucoma to maintain visual function and quality of life.
\end{abstract}

Key words: glaucoma, patient, compliance adherence, concordance, persistence

\section{Všeobecná charakteristika pojmov}

So skúmaním problematiky spolupráce pacienta sa začalo začiatkom 20. storočia, kedy prax potvrdila dôležitost' dodržiavania rád lekára. V minulosti sa vzt'ah medzi lekárom a pacientom realizoval pri akútnych medicínskych zásahoch. Ludia predtým zomierali skôr, choroby nemali chronický charakter, ako je tomu v súčasnosti, ked' si vyžadujú dlhodobú spoluprácu pacienta a niekedy aj hlboké zmeny v jeho životnom štýle, ovplyvňujúce aj kvalitu života (Vrablík, 2014). Úzka spolupráca pacienta s lekárom je vzhl'adom na komplexný charakter chronického ochorenia neodmyslitel'nou podmienkou úspešnej starostlivosti. V odbornej literatúre je vyjadrená termínmi compliancia, adherencia, concordancia, persistencia:

- Doteraz častejšie používaný termín compliance je určený ako miera dodržiavania pokynov lekára. Vyjadruje skôr pasívny prístup pacienta, je chápaná ako osvojenie a dodržiavanie pokynov lekára.

- Adherencia charakterizuje pacientov ako nezávislých, inteligentných a samostatných l'udí, ktorí sa aktívne a dobrovol'ne zúčastňujú na určení a dodržiavaní ciel'ov liečby. Zahŕňa širší rozsah spoločensko-sociálnych, osobných problémov a otázok, než compliance.

- Concordancia je zameraná na konzultačný proces, v ktorom sa lekár a pacient dohodnú na terapeutických postupoch. V nich sú obsiahnuté ich individuálne názory a smeruje $\mathrm{k}$ podpore pacienta $\mathrm{v}$ užívaní liekov.

- Persistencia zhíňa vytrvalost' v dodržiavaní liečebných režimových opatrení. V odbornej literatúre dominuje skôr pojem adherencia (Gajdošík, Dukát, 2014). 


\subsection{Compliancia pri konzervatívnej liečbe glaukómu}

Súčasná medicína založená na dôkazoch mení v procese liečenia rolu pacienta s glaukómom tým, že sa od neho vyžaduje aktívny prístup v rozhodovaní o svojom zraku a zdraví. Má to byt' predovšetkým pacient, ktorý zváži prínos a riziká odporúčaného liečebného režimu. Zhodnotí ich vo vzt'ahu k svojím prianiam, predstavám, kvalite života a spolu s lekárom rozhoduje. Oftalmológovia a sestry budú musiet' pacienta s glaukómom povzbudit', aby si osvojil tento nový prístup. Získat' si dôveru pacienta a schopnost' efektívne komunikovat' a spolupracovat' je v súlade s ciel'om aktívneho prístupu pacienta a snahou o zachovanie dobrej kvality života (Kuchynka a kol., 2007). V rámci dosiahnutia adherencie je vel'mi dôležité pacienta s glaukómom poučit' tak, aby správne pochopil podstatu svojho ochorenia a ochotu prijímat' odporúčania po vzájomnej dohode, s ciel'om zodpovedného uvedomenia si nutnosti dodržiavania liečby, potreby účasti na pravidelných kontrolách a dôsledkoch ich nedodržiavania na zrak a kvalitu života. Je dôležité, aby bol presvedčený o tom, že výsledok liečby, a tým aj kvalitu života, má z vel'kej časti vo svojich rukách Ak pacient s glaukómom odporúčaniam lekára a sestry verí, tak ich aj reálne praktizuje. Spomínané faktory ovplyvňuje osobnostná charakteristika pacienta, znaky jeho ochorenia, zameranie liečebného režimu, povaha vzt'ahu medzi pacientom a zdravotníkom, ktorý považujú odborníci za najdôležitejší faktor (Nešpor, 2014).

Glaukóm je chronické a progresívne ochorenie, preto základom pre jeho úspešné zvládnutie je adherencia pacienta. Adherencia je kl’účovým preventívnym opatrením straty zraku, ktorá je nevyhnutná na zachovanie dobrej kvality života, ktorá je s ňou spojená. Pomocou adherencie sa pacient snaží zachovat' si dobrý zrak tým, že spolupracuje so zdravotníckym personálom pri dodržiavaní liečebného režimu (Raudenská, Javůrková, 2011).

Podl'a Európskej glaukómovej spoločnosti má adherencia, t.j. dodržiavanie odporúčaného liečebného režimu u pacienta s glaukómom dve zložky:

1. complianciu (vyhovenie) - aplikácia liekov do oka podl'a nariadenia lekára

- správna dávka, čas a spôsob aplikácie,

2. perzistenciu (vytrvalost') - pokračovanie vaplikácii liekov do oka, ktoré boli predpísané

- opakovane vyplnený lekársky predpis po určitom období.

\subsection{Noncompliancia pri konzervatívnej liečbe glaukómu}

V princípe nie je možná compliancia bez perzistencie, pacient si musí dávat' predpisovat' lieky do oka predtým, ako ich začne používat'. V priebehu času pacienti, ktorí si nedajú predpísat' lieky, nepodstupujú adekvátnu liečbu, čím nedodržiavajú perzistenciu, čo je vlastne znakom odstúpenia od liečby. Čo sa týka compliancie, u niektorých pacientov je značne znížená a vel'a pacientov nedodržiava kontrolné prehliadky u oftalmológa. Noncompliancia môže zohrávat' dôležitú úlohu pri progresii straty zraku spôsobenej glaukómom. Pacienti s glaukómom často patria do vyšších vekových kategórií, môžu mat' znížené kognitívne schopnosti, slabý sluch a d'alšie ochorenia, napr. artritídu, ktoré môžu znížit' ich schopnost' aktuálne aplikovat' lieky do oka. Aj mladší pacienti s dobrým zrakom sú pri compliancii vo vyššom riziku. Musí sa brat' do úvahy aj interakcia liekov a znížená tolerancia liekov do oka. Pri výbere typu liečby je potrebné zohl'adnit' problémy s complianciou a perzistenciou (Európska glaukómová spoločnost', 2008).

Noncompliancia je bezpochyby jedným z hlavných limitujúcich faktorov v konzervatívnej liečbe glaukómu a podiel'a sa na prípadoch zhoršenia zrakových funkcií u pacientov 
s glaukómom až v 20,0\%. Percentuálne rozpätie výskytu noncompliancie u pacientov s glaukómom v odbornej literatúre kolíše, uvádza sa 5,0 \% - 80,0 \% (Výborný, Sičáková, 2011).

Znížená noncompliancia sa dá zosumarizovat' nasledovne:

- zlyhanie pri aplikácii liekov do oka (vrátane neúčinnej techniky pri self-managmente),

- nadmerné používanie liekov do oka (celkové vedl'ajšie účinky),

- vlastné dávkovanie predpísaných liekov do oka,

- nevhodné načasovanie aplikácie liekov je častý problém, ak sa aplikujú viaceré druhy liekov do oka a mení sa častejšie časový režim aplikácie,

- svojvol’né prerušenie liečby (Európska glaukómová spoločnost', 2008).

Pokles compliancie pod určitú hranicu miery môže predstavovat' závažné ohrozenie zraku a kvality života pacienta s glaukómom. Oftalmológ a sestra musia poznat' pacientovu mieru compliancie, aby prispôsobili liečebný plán pacientovým potrebám a kvalite života. Ak zdravotníci nezist'ujú mieru compliancie, pacient sa môže domnievat', že nepovažujú liečbu za dôležitú a neveria jej účinkom. Compliancia pacienta potom klesá. Medzi spôsoby zist'ovania miery compliancie patria: objektívne metódy (biochemické a biofyzikálne merania, štúdium záznamov, pozorovanie) a subjektívne metódy (vyplňovanie záznamov pacientom, opytovanie sa pacienta, jeho blízkych alebo iných zdravotníckych pracovníkov). Nedodržiavanie odporúčaní a pokynov zdravotníckych pracovníkov pacientom predstavuje vážny a t’ažko riešitel'ný problém (Morovicsová, 2009).

\subsection{Edukácia v procese compliancie pri konzervatívnej liečba glaukómu}

Úspešnú a prospešnú complianciu pacienta v liečebnom režime je možné dosiahnut' napríklad aj správnou a efektívnou edukáciou o glaukóme, motiváciou, optimalizáciou časovej schémy aplikácie liekov do oka, zlepšením dostupnosti lekárskej starostlivosti, stanovením liečby s ohl'adom na kvalitu pacientovho života, dobrým vzt’ahom lekára, sestry a pacienta. Indikácia takejto liečby, ktorú bude pacient tolerovat', je samozrejmým predpokladom úspechu. Liečba očnými kvapkami bez konzervačných látok je významným prínosom v tomto úsilí (Výborný, Sičáková, 2011). Nováková (2011) uvádza, že je nevyhnutné pacienta s glaukómom informovat' o potrebe a význame jeho aktívnej účasti na liečebnom manažmente, pričom musí byt' poučený o vedlajššch účinkoch liekov do oka, ktoré sa môžu vyskytnút' počas aplikácie. Pacient má byt' dôsledne a zrozumitel'ne edukovaný, ako si správne podl'a zásad aplikovat' lieky do oka $\mathrm{v}$ domácom prostredí, s použitím tlačených a audiovizuálnych edukačných materiálov, doplňujúcou inštruktážou a s opakovaným nácvikom self-manažmentu aplikácie. Neodmyslitel'nou a dôležitou súčast’ou edukácie je vzájomná verbálna komunikácia a podla zistenia edukovanie rodiny alebo opatrovatel'a. V tomto procese má nezastupitel'né postavenie sestra.

\section{Záver}

Nonadherencia je jednou z príčin nedostatočnej úspešnosti liečby chronického ochorenia. Dôvody sú multifaktoriálne, tomu musia zodpovedat' stratégie zlepšovania adherencie. Návrhy ako zlepšit' danú situáciu závisia iba z časti na zdravotníctve a zdravotníckom personáli, jednostranné úsilie výlučne zdravotníkov neprináša očakávaný výsledok. Väčšina je závislá na spoločenskom systéme, zdravotnej politike štátu, ekonomike a záujme riadiacich pracovníkov vôbec. Do riešení problému je dôležité angažovat' celú spoločnost', nevyhnutná je široká spolupráca naprieč všetkými zložkami spoločnosti. Hlavný faktor určujúci kvalitu i dížku života je psychosociálny stav spoločnosti určujúci životný štýl občanov. Dôležitá je 
dôvera občanov vo vedenie krajiny, ktoré zlepší morálne parametre spoločnosti a zaistí mierny, ale trvalý rast ich ekonomickej situácie. Vzdelaný, demokraticky orientovaný občan/pacient chápe možnosti vlastnou aktivitou ovplyvnit' svoj zdravotný stav. Na druhej strane málo vzdelaný občan/pacient l'ahšie podl'ahne pesimizmu a frustrácii a stáva sa pasívnym i vo vzt'ahu k vlastnému zdraviu. Vzdelanostná úroveň slovenskej populácie a jej životný štýl je stále nedostatočný. Ďalší vývoj zdravotného stavu obyvatel'ov SR nebude závisiet' iba od pozitívnych zmien v organizácii zdravotníctva, ale hlavne od celkového vývoja spoločnosti, rešpektujúcej normy civilizovaného sveta (Gajdošík, 2017).

Príspevok vznikol za podpory projektu:

Názov projektu: Návrh hodnotenia kvality života pacientov so sclerosis multiplex Identifikačné číslo projektu: 002PU-4/2020

\section{Literatúra}

1. GAJDOŠÍK, J. Adherencia $\mathrm{k}$ liečbe - dôležitá súčast' dosiahnutia účinku terapie pri chronických ochoreniach. In: Athero Review. Roč. 2, č.1 2017, s.15-19. ISSN 18036597

2. GAJDOŠÍK, J., DUKÁT, A. Má nonadherencia pacientov k liečbe diabetes mellitus 2. typu klinický a ekonomický dopad? In: Súčasná klinická prax. Roč. 2, 2014, s. 13-17. ISSN 1214-7036

3. KUCHYNKA, P. et al. Oční lékařství. 1. vyd. Praha: Grada, 2007. 812 s. ISBN 97880-247-1163-8

4. MOROVICSOVÁ, E. Problematika compliancie vklinickej praxi. In: ČÁP, J., ŽIAKOVÁ, K. (eds.). Teória, výskum a vzdelávanie v ošetrovatel'stve a v pôrodnej asistencii. Martin: UK Komenského v Bratislave, 2009, s. 502-507. ISBN 978-8088866-61-9

5. NEŠPOR, K. Nekonformní pacient. In: Bulletin Sdružení prektických lékařu ČR. Roč. 24, 2014, č. 3, s. 61-64. ISSN 1212-6152

6. NOVÁKOVÁ, I. Ošetřovatelství ve vybraných oborech. Praha: Grada, 2011. 235 s. ISBN 978-80 247-3422-4

7. RAUDENSKÁ, J., JAVU゚RKOVÁ. 2011. Lékařská psychologie ve zdravotnictví. 1. vyd. Praha: Grada Publishing 2011. 304 s. ISBN 978-80-247-2223-8

8. VRABLÍK, M. Adherence a možnosti jejího ovlivnění. In: Via practica. Roč. 11, 2014, č. 2, s. 59-61. ISSN 1336-4790

9. VÝBORNÝ, P., SIČÁKOVÁ, S. Denní dávka benzalkonium chloridu - významné kritérium v léčbě glaukomu. In: Česká a slovenská oftalmologie. Roč. 67, 2011, č. 2, s. 63-66. ISSN 1803-6597

10. EURÓPSKA GLAUKOMOVÁ SPOLOČNOSŤ [online] 2008. [cit. 2013-11-09]. Dostupné z: http://www.dansk-oftalmologisk- selskab.dk/Patiensforl\%C3\%B8b/EG S_Guidelines_English.pdf

\section{Kontakt}

PhDr. Mária Kaščáková, PhD.,

Prešovská univerzita v Prešove

Fakulta zdravotníckych odborov

Partizánska č.1,08001 Prešov

Email: maria.kascakova@unipo.sk 


\title{
VYUŽÍVANIE PRVKOV ARTETERAPIE PRI VYTVÁRANÍ POZITÍVNEJ KLÍMY V INKLUZÍVNEJ TRIEDE
}

\author{
USE OF ART THERAPY ELEMENTS IN CREATING A POSITIVE \\ CLIMATE IN THE INCLUSIVE CLASS
}

\author{
Barbora Sender
}

\begin{abstract}
Abstrakt
Článok sa popisuje problematiku edukácie žiakov so špeciálnymi výchovno-vzdelávacími potrebami v inkluzívnej triede. Ako jeden $\mathrm{z}$ efektívnych pedagogických prístupov navrhuje využitie prvkov arteterapie. Vysvetl'uje možnosti a formy aplikovania týchto prvkov počas vyučovacieho či výchovného procesu pedagógom. Taktiež popisuje pozitívnu inkluzívnu triednu klímu a miesto arteterapie pri jej vytváraní.
\end{abstract}

Kl'účové slová: arteterapia, špeciálne výchovno-vzdelávacie potreby, edukácia, triedna klíma, pozitívna klíma, inkluzívna trieda

\begin{abstract}
The article describes the issue of education of students with special educational needs in an inclusive classroom. It proposes the use of elements of art therapy as one of the effective pedagogical approaches and explains the possibilities and forms of application of these elements during the educational process by teachers. It also describes the positive inclusive classroom climate and the place of art therapy in its formation.
\end{abstract}

Keywords: art therapy, special educational needs, education, classroom climate, positive climate, inclusive classroom

\section{1 ÚVOD}

Vzdelávaním žiakov so špeciálnymi výchovno-vzdelávacími potrebami (d’alej len ŠVVP) sa zaoberá najmä špeciálna a inkluzívna pedagogika. Žiaci so ŠVVP sa môžu vzdelávat' v špeciálnych školách, ale čoraz viac sa uplatňuje spôsob ich začleňovania, resp. integrácie do bežných škôl. Inklúzia je vyšším stupňom integrácie a netýka sa len niektorých špecifických skupín žiakov. Inklúzia sa zameriava na všetkých žiakov, ktorí sú v procese vzdelávania. Skupina žiakov so ŠVVP je však najvýraznejšia a má najvýraznejšie individuálne potreby. V roku 2018 sa $\mathrm{v}$ slovenských školách vzdelávalo viac ako 41000 detí so špeciálnymi výchovno-vzdelávacími potrebami (d’alej len ŠVVP). Využívanie rôznych prvkov z expresívnych terapií vo vyučovaní je nesmierne dôležité pri práci v inkluzívnej triede. Deti a mládež so ŠVVP majú totiž tendenciu byt' v škole demotivované, unavené a l'ahko sa vzdávajú. Ak si však budú vedomé problémov, ktoré majú (problémy s učením, pozornost’ou, organizáciou času a priestoru, emocionálne problémy, problémy v správaní a pod.), môžu tieto problémy prijat' a naučit' sa s nimi žit'. Zároveň im však treba ukázat', že hoci majú v niektorej oblasti t'ažkosti, sú oblasti, v ktorých môžu vynikat'. To zvyšuje ich sebauvedomenie, sebaprijatie av dlhodobom horizonte aj ich sebavedomie a sebaistotu. Rodičia, ktorí bojujú v školskom systéme o prispôsobenie učebných osnov pre individuálne potreby svojich detí, často cítia, že by v škole mohol byt' čas využívaný efektívnejšie. Zároveň je potrebné do učenia zapájat' emócie a učit' žiakov prijímat' a vytvárat' spätnú väzbu. Úloha učitel'ov sa tak v budúcnosti bude musiet' zmenit' z obyčajného sprostredkovávania informácií 
a vedomostí na sprevádzanie žiakov pri poznávaní sveta a rozvoja ich schopností a pozitívnych vlastností. Prvky $\mathrm{z}$ expresívnych terapií, najmä $\mathrm{z}$ arteterapie, rešpektujú individuálne tempo žiakov, zvyšujú predstavivost', tvorivé a kritické myslenie. Podporujú žiacku kreativitu prostredníctvom aktivít aj domácich projektov a zároveň zavádzajú nové príležitosti na vzdelávanie $\mathrm{v}$ bezpečnom a podpornom prostredí. Edukácia je zameraná na všestranný rozvoj a preto je žiaduce zarad'ovat' do vyučovania také aktivity a hry, pomocou ktorých je možné napíňat' intelektové, fyzické i citové prvky (Balážová, 2011). Podporovanie kladných emócií ul’ahčuje žiakom osvojovanie si aj náročnejších úloh, ktoré si vyžadujú prekonávanie prekážok. Využívanie arteterapeutických prvkov vo vyučovaní pomáha diet’at’u nepoddávat' sa stresu a odolávat' aj nepriaznivým okolnostiam. Ide o faktory, ktoré im pomáhajú prekonávat' t'ažké životné situácie. Pokial' sa jedinec vyrovná so svojimi problémami, arteterapeutické techniky mu môžu ponúknut' návod, ako reagovat' pri d'alšom stretnutí s t'ažkost’ami. Škola by mala posilňovat' kompetencie, ktoré sú neodmyslitel'ným základom zvládania života (Líšková, 2014).

\section{VYUŽITIE ARTETERAPIE V INKLUZÍVNEJ TRIEDE}

$\mathrm{Na}$ to, aby boli deti schopné porozumiet' svojim emóciám, si musia uvedomit', ako emócie fungujú, ako vznikajú a aké fyziologické reakcie ich sprevádzajú. Vd’aka tomu, budú neskôr schopné svoje pocity pomenovat' a efektívne bojovat' proti ich negatívnym prejavom (Líšková, 2014). Práve arteterapia sa javí, ako vhodná metóda pre prácu s emóciami. Arteterapia je chápaná rôzne. Najčastejšie je vnímaná ako terapeutický proces. V poslednej dobe sa však častejšie objavuje aj názor, že ide z časti o proces pedagogický. Najmä pokial' máme na mysli prvky arteterapie aplikované v školskom prostredí. V inkluzívnej triede môžeme arteterapeuticky pracovat' bud' preventívne, alebo intervenčne pomáhat' žiakom so ŠVVP. Problémy týchto žiakov najčastejšie spadajú do oblasti špecifických vývinových porúch učenia, porúch správania, fyzického či zmyslového postihnutia či porúch autistického spektra. S tým samozrejme súvisia aj konkrétne t’ažkosti. Arteterapiu je možné využit' pri kompenzácii zdravotného znevýhodnenia a $\mathrm{k}$ podpore snahy o využitie celého potenciálu žiaka. Pri každej arteterapeutickej práci je teda dobré si hned' na začiatku procesu ujasnit', čí budeme vykonávat' činnost' terapeutickú alebo napomáhame pedagogickej činnosti. Vd'aka tomu, budeme schopní si vhodne formulovat' arteterapeutický ciel' (Gerlichová, 2014). Pravidelná tvorivá činnosti alebo len intenzívne prežívanie a vnímanie krásy a estetiky zlepšuje úroveň kognitívnych schopností, najmä žiacku pozornost'. Arteterapia si kladie za ciel' prinavrátit' jedincovi stav harmónie a umožnit' mu pozitívnym spôsobom vyjadrovat' svoje pocity a emócie a zároveň slúži na zmierňovanie porúch a tiež na stabilizáciu psychického a emocionálneho stavu žiakov v inkluzívnej triede. Inkluzívny prístup vo vzdelávaní charakterizuje najmä rešpektovanie práv všetkých detí na kvalitné vzdelanie $\mathrm{s}$ dôrazom na búranie bariér v škole. Hlavnou úlohou je zabezpečovanie rovnakých príležitostí prostredníctvom efektívnych a podporných služieb v triedach (Bagalová, Bizíková, Fatulová, 2015). Medzi takéto služby zarad’ujeme aj prvky prevzaté z expresívnych terapií. Umelecká a tvorivá činnost' ponúka vel'ký potenciál na relaxáciu, odreagovanie a posilňovanie sebahodnotenia a vnútorného prežívania, preto sa domnievame, že tieto postupy sú využitel'né pre všetkých pedagógov pri práci s det’mi a dospievajúcimi. Pedagogický proces, ktorý sa realizuje na našich školách má dve základné zložky: výchovu a vzdelávanie. Ide o proces, pri ktorom sa utvára osobnost' človeka. Oblast' edukácie a terapie sa teda v mnohých oblastiach prelínajú. Kompetentný pedagóg je schopný počas pedagogického procesu využívat' rôzne arteterapeutické prvky a tým prispievat' k zlepšeniu školskej a triednej klímy, vzt’ahov v triede, učebných výsledkov a výkonov žiakov, ich radosti z umenia a tvorby a tým aj ku zvýšeniu kreativity a tvorivého myslenia 


\subsection{Inkluzívna trieda a sociálna triedna klíma}

Klíma školy a triedy súvisí s emocionálnou odozvou na kultúru školy (Gerlichová, 2014). Klíma inkluzívnej triedy je samozrejme viac ako len fyzické prostredie triedy. Je to proces, ktorý buduje psychologický rámec pre všetky aktivity, ktoré sa odohrávajú v triede. Klíma inkluzívnej triedy nie je len o motivácii a subjektívnej pohode (well-being) všetkých žiakov, je to hlavná zložka kontextu úspešného vzdelávania. Kvalitné vzdelávanie sa nemôže odohrávat' v negatívnej klíme. B. Kosová (2000) zároveň hovorí, že prostredie inkluzívnej triedy má byt' podnetovo bohaté, vhodne upravené a priestorovo usporiadané, aby boli splnené štyri základné požiadavky: požiadavka viditel'nosti, blízkosti, dostupnosti a bezpečnosti. Zároveň však dodáva, že dôležitejšie a významnejšie ako samotné materiálne vybavenie je klíma a atmosféra inkluzívnej triedy. Atmosféra triedy je „momentálna, krátkodobá situácia v triede, ktorá sa často mení, niekedy aj v priebehu vyučovacej hodiny. Sú to teda premenlivé vlyvy, ktoré pôsobia na obsah a charakter komunikácie medzi účastníkmi edukačného procesu“ (Petlák, 2006, s. 27). J. Mareš (1998) uvažuje o tzv. nepravidelnom „spúšt’ači“ spomínaných zmien. Označuje ho ako kritickú udalost', ktorá je pre aktérov edukačného procesu impulzom ku zmene vnímania a prežívania toho, čo sa deje v triede alebo je impulzom ku zmene ich konania. Táto kritická udalost' sa môže okrem atmosféry týkat' aj klímy triedy. I. Kovalčíková (2003) zahŕňa tieto pojmy do tzv. kontextov edukačných procesov. Kontextom nazýva „konkrétne prostredie, ktoré výrazne ovplyvňuje výsledky výchovno-vzdelávacieho procesu.“ Tieto kontexty delí na vonkajšie (komplexné okolie školy) a vnútorné (fyzikálne: ergonomické parametre a psychosociálne: učebná klíma a atmosféra). „Klíma triedy predstavuje dlhodobejšie sociálno-emocionálne naladenie, zovšeobecnené postoje a vzt'ahy, emocionálne odpovede žiakov danej triedy na udalosti v triede (vrátane pedagogického pôsobenia učitel'ov)“ (Průcha a kol., 1998, s. 98). P. Gavora (1999, s. 137) hovorí, že: „klíma triedy vyjadruje do akej miery je žiak v triede spokojný, či si žiaci vzájomne dostatočne rozumejú, aký je stupeň sút’aživosti a konkurencie medzi nimi a aká je súdržnost' triedy.“ Podl'a Douškovej a Wágnerovej (1996, s. 33-34, In: Verbovská, 2006) sa klíma prejavuje najmä:

- V dimenzii vzájomných vzt'ahov (spokojnost', trenice, sympatie, vzájomná podpora a pod.)

- V dimenzii rozvoja jedinca (možnost' dosahovania osobných ciel'ov, možnost' vlastného tempa, nezávislost', sút'aživost' a pod.)

- V systémovej dimenzii, ktorá vyjadruje stálost' alebo možnost' zmeny klímy (rozmanitost', inovácia, jasnost' pravidiel, kontrola, vplyv žiaka na vyučovanie a pod.)

Každý učitel' musí brat' do úvahy, že trieda v ktorej vyučuje predstavuje jedinečnú sociálnu skupinu, ktorá je formovaná na základe menších skupín organizovaných žiakmi, ktoré na seba vzájomne pôsobia. Triedny kolektív predstavuje základnú školskú sociálnu skupinu, kde sa stretávajú jedinci oboch pohlaví približne rovnakého veku (Lašek, Mareš, 1991). Každý jedinec, člen skupiny sa svojou osobnost'ou a výsledkami podiel'a na utváraní klímy tejto sociálnej skupiny. Učitelia v praxi čoskoro spozorujú, že v každej triede je osobitá klíma. Ale zároveň, je dôležité, na základe nami spomenutých faktov, si uvedomit', že na výsledky a celkovú klímu vyučovania má okrem učitel'a vplyv aj celý triedny kolektív a vzt’ahy medzi jeho členmi. Klusák (1994) hovorí o tzv. fluide triedy, ktoré chápe ako synonymum pojmu klíma triedy. Ide vlastne aj o pocite učitel'a, či do triedy chodí učit' rád alebo nie. Ďalej tiež autor tvrdí, že prakticky neexistujú dve triedy, ktoré by boli rovnaké. Tento termín označuje multidimenzionálny jav. Pojem klíma triedy sa v slovenskom jazykovom prostredí zaužíval a prevažná čast' autorov ho používa $\mathrm{v}$ zmysle dlhodobejších javov, vyskytujúcich sa počas vyučovania $\mathrm{v}$ triede. Spadajú sem pocity, s akými žiak vchádza do triedy, ako vníma učitel'ovu osobnost' a zároveň učitel'ove emócie, prístup a didaktické schopnosti, ktoré ovplyvňujú správanie žiakov a vzájomné sociálne vzt’ahy v triede. Sociálna klíma triedy je, 
bez ohl'adu na to, či si jej charakter všímame alebo nie. Je chybou tento fakt úplne ignorovat'. Naopak je potrebné klímu triedy brat' do úvahy a v súvislosti so skvalitňovaním edukačného procesu sa ňou zaoberat' podrobnejšie a to nielen teoreticky, ale aj praktický sledovat' danú problematiku v praxi. Škola reprezentuje podporný systém mimo rodiny. Polovica detí, ktoré vyrástli v plnohodnotných dospelých hovoria, že podporujúci učitel' vytvoril pozitívny model v ich živote. Školy sú významných ochranným prostredím v živote detí a vytváranie podporujúceho školského prostredia pomáha det’om vo všetkých smeroch (Gilman, Huebner, Furlong, 2009).

M. Zelina (In: Hlásna, 2005) tvrdí, že klímu v triede vytvárajú najmä osoba učitel'a a samotní žiaci. Okrem týchto základných faktorov sú to ešte činnosti a úlohy účastníkov života triedy.

B. Doll (2009) vymedzil 5 faktorov pozitívneho školského prostredia a triednej klímy, a to:

- podpora a autentické vzt'ahy medzi dospelými a žiakmi (vzt'ah učitel'- žiak),

- zvyšovanie príležitostí na utváranie prospešných vzt'ahov s rovesníkmi (vzt’ah žiak- žiak),

- podporovanie žiackej identity ako komponentu efektívnej výučby (akademická efektívnost'),

- podpora žiakov vo vytváraní svojich osobných ciel'ov a ambícií (sebadeterminácia),

- podporovanie sebakontroly, aby sa správali vhodne a adaptívne (sebakontrola).

Od toho, aké činnosti sa počas vyučovacie procesu v triede realizujú sa odvíja žiakova zameranost', aktivita a motivácia. V súčasnosti sa čoraz viac používa pojem suportívna klíma triedy. Suportívna klíma triedy sa snaží „,ventilovat' energiu žiakov, ktorú by inak previedli do nevhodného správania. Žiaci a študenti pracujú pretože chcú, komunikujú, pretože môžu a učitel' sa im venuje tak, že cítia jeho záujem“ (Čapek, 2010, s.34). Suportívne vyučovacie metódy (Čapek, 2010) sú:

- Aktivita: aktivizovanie žiakov tvorivými, hravými a simulačnými činnost'ami, podnecovanie aktívnej role žiakov a študentov pri vzdelávaní a podpora kreativity, primeranou mierou sút’aživosti, zmysluplné zapájanie všetkých žiakov, s rôznymi stupňami znalostí.

- Pozitívny prístup: snaha o prostredie bez obáv a strachu priznat' chybu, pochvala a odmena sú využívané častejšie, komunikácie v triede je priatel'ská a optimistická, učitel' podporuje snahu o splnenie úloh správnou motiváciou, panuje pokojná pracovná atmosféra a atmosféra bez stresu.

- Sloboda: je dôležitým činitel'om pre rozhodovanie žiakov a rozvíjaní ich spoluúčasti a spoluzodpovednosti za celé vyučovanie, prehlbuje legitimitu hl'adania vlastných riešení a obhajovania svojich názorov, predpokladá však aj rešpektovanie druhých a vedomie si vlastných práv a povinností. Je dôležité rešpektovat', kde je naša osobná hranica slobody a to zároveň vedie $\mathrm{k}$ rešpektovaniu demokratických princípov. Je nutná samostatnost' a vol’nost' pri hl'adaní správnych riešení a postupov, teda posilňovanie vlastnej cesty $\mathrm{k}$ poznaniu.

Stotožňujeme sa so slovami A. Klimentovej (2005), ktorá hovorí, že pozitívnu klímu triedy je možné realizovat' len s kvalitnými učitel'mi, ktorí na jednej strane neodmietajú tradičný prístup a činnosti ale zároveň tieto postupy prispôsobujú zvláštnym a meniacim sa podmienkam a potrebám žiakov. Ďalej hovorí, že v dnešnej dobe nie je možné vyučovat' tak ako kedysi. Treba si uvedomovat', že v triedach sú žiaci so ŠVVP a rôznymi druhmi nadania. Je potrebné si uvedomit', že žiaci v škole strávia desiatky až stovky hodín a preto by malo všetkým aktérom záležat' a vytvorení priaznivej klímy. Učitelia môžu l'ahšie pochopit', čo sa odohráva vo vnútri triedy a na základe toho situáciu sami zmenit'.

\subsection{Využívanie prvkov arteterapie pri práci so žiakmi so ŠVVP}

Umenie a tvorivá činnost' predstavuje vel'mi dobrú prevenciu negatívnych javov, ako napr. pret'aženost' žiakov počítačmi a technológiami, prítomnost' sociálno-patologických javov 
v školskom prostredí (šikanovanie, záškoláctvo, látkové i nelátkové závislosti, agresivita, negativita a pod.). Arteterapia býva taktiež nápomocná pri prevencii komunikačných problémov, porúch reči a môže byt' prostriedkom vyrovnávania sa $\mathrm{s}$ bežnými emocionálnymi výkyvmi. To, že arteterapia je nápomocná v rámci prevencie problémov žiakov so ŠVVP je zapríčinené niekol'kými dôvodmi. Aktívna výtvarná činnost' aktivuje predstavivost', obrazotvornost' a kreativitu a tým aj emócie s tým spojené. Pasívne vnímanie umenia dovol'uje žiakom zapojit' vedomé aj nevedomé obsahy, ktoré s nimi rezonujú (Gerlichová, 2014).

Arteterapia predstavuje efektívnu metódu predchádzania vzniku problémov v správaní a zároveň sprevádzania žiakov $\mathrm{s}$ diagnostikovanými ŠVVP v škole. B. Jankovská a J. Jankovský (2001) ju popisujú ako liečbu využívajúcu výtvarné prostriedky, ktorú zarad’ujú do liečebnej rehabilitácie (psychoterapie) a tiež do rehabilitácie pedagogickej. Nachádza sa na hranici medzi zdravotnou a výchovno-vzdelávacou starostlivost'ou. M. Lhotová (2010) chápe arteterapiu ako priestor, kde sa stretávajú a preklápajú ciele aktivít $\mathrm{v}$ rámci vol’ného času, vzdelávania, výchovy, liečby, psychoterapie či sociálnej práce. Ide zároveň o súbor rôznych umeleckých techník a postupov, ktoré si kladú za ciel' zmenit' sebahodnotenie človeka, zvýšit' jeho sebavedomie a celkovo integrovat' jeho osobnost'. Využívajú sa pritom poznatky zo psychológie, výtvarnej výchovy či rôznych pedagogických disciplín, napr. aj špeciálnej pedagogiky (Šicková - Fabrici, 2002). Aplikácia prostriedkov výtvarného umenia je taktiež snahou o zmenu správania, myslenia a emócií spoločensky prijatel’ným smerom (Müller, 2014) a zmenu v oblasti pozitívnejších prejavov voči sebe i okoliu, empatie, spolupráce aj v zlepšení vyjadrovacích schopností (Kučerová, 2013). Výtvarný prejav je tu vnímaný ako prostriedok sebavyjadrenia a spôsob komunikácie (Lhotová, 2010). Zicha (1981) arteterapiu definuje ako zámerné upravovanie narušenej činnosti organizmu psychologickými a edukačnými prvkami, ktoré sú imanentné výtvarnej činnosti. Autorky I. Ulrichová a Z. Sládečková (1992) vo svojej štúdii popisujú pozitívne vplyvy umeleckých aktivít v zariadeniach pre deti s poruchami správania. Kreslenie či mal'ovanie sú, podla nich, pre deti a dospievajúcich vel'mi pútavé činnosti, čo samo o seba zaist'uje dobrú motiváciu pre prácu. Diet’a rado rozpráva o tom, čo vytvorilo. To je prínosné jednak pre diagnostiku ale tiež pre nadviazanie kvalitného vzt'ahu, ktorý je nosný pri budovaní pozitívnych vzorcov správania. U diet’at’a dochádza počas arteterapeutického procesu $\mathrm{k}$ relaxácii, celkovému upokojeniu a jednoduchšie potom pristupuje $\mathrm{k}$ d'alšej práci. U detí a dospievajúcich so ŠVVP je výtvarná činnost' vhodným prostriedkom pre tréning vôle, trpezlivosti, koncentrácie, zároveň podporuje fantáziu a kreativitu. Prebudenie záujmu i výtvarné zobrazenie žiakov podmieňuje citový vzt’ah $\mathrm{k}$ námetu, preto by mali byt' námety známe, blízke, citovo prítažlivé, vychádzajúce zo silných zmyslových dojmov, alebo tvoriace súhrn predchádzajúcich zážitkov (Balážová. 2011). Nezanedbatel'ným kladom výtvarnej terapie je tiež fakt, že deti sú vedené k hlbšiemu záujmu, nútené tlmit' svoje deštruktívne tendencie, učia sa vážit' si svoju prácu ale aj diela ostatných. Kožnár (1999) vidí potenciál umeleckého vyjadrovania najmä tam, kde nestačia slová. Takúto úlohu zohráva okrem kresby aj mal'ba, modelovanie, či práca s rôznymi plastickými materiálmi a technika koláže. Nad jednotlivými výtvormi je potrebné rozvinút' diskusiu, objasňujúcu intrapsychické súvislosti, vzt'ahy a interakcie a to aj v prípade, že sa diet’at'u o nich nechce vel'mi rozprávat'. Je tiež možné si prostredníctvom výtvarnej činnosti odreagovat' negatívne emócie, vyladit' citový stav, rozvíjat' tvorivost', zefektívňovat' komunikáciu a ventilovat' rôzne problémy. Každá arteterapeutická intervencia musí byt' cielená, pričom samotný terapeuticko-tvorivý proces je dôležitejší ako výsledný artefakt, resp. vytvorené dielo. Pri práci v inkluzívnej triede treba mat' na zreteli, že všetky činnosti zamerané na riešenie problémových situácií musia byt' vopred vhodne organizačne naplánované, aby bol dosiahnutý pozitívny efekt. Prostredníctvom kreatívnych činností možno u žiakov pôsobit' na pozitívny sebaobraz a tým 
vytvorit' podmienky pre vyjadrenie vlastných emócií (Majzlanová, 2017). M. Liebmann (2010) zároveň zdôrazňuje význam tvorivého procesu ako prostriedku osobného vyjadrenia a uprednostňuje ho pred esteticky uspokojivým konečným produktom. U žiakov so ŠVVP je dôležité okrem autenticity podporovat' sebaúctu, ktorá ovplyvňuje ich vzt'ah k sebe a iným l'ud'om. Kreslenie, mal'ovanie či modelovanie sú najčastejšie využívanými prostriedkami, ktoré ponúkame diet'at'u, aby vyjadrilo vlastné videnie sveta, vlastné pocity a vzt'ahy vo svojom okolí. L. Bosgraaf, M. Spreen, K. Pattiselanno a S. Van Horeen, (2020) analyzovali výsledky 37 výskumných prác zameraných na aplikáciu arteterapeutických metód pri práci s det'mi a mládežou s poruchami správania. Účelom ich systematického naratívneho skúmania bolo poskytnút' prehl'ad arteterapeutických intervencií, ktoré boli účinné pri znižovaní porúch správania. Hlavné výsledky preukázali, že využívanie širokého spektra umeleckých činností a materiálov pri práci v triede, môže viest' k zlepšeniu problémov v správaní. Autori CohenYatziv a Regev (2019) taktiež potvrdzujú pozitívne účinky arteterapie u detí prežívajúcich traumu či mladistvých páchatel’ov. Ulrichová a Sládečková (1992) vo svojej výskumnej štúdii zase sledovali vplyv týchto metód na klientov diagnostického centra. Zameriavala sa konkrétne na zmeny v emocionálnom ladení, aktivity, pozornosti, zlepšenie somatického stavu a subjektívneho pocitu pohody. Výsledky ukázali zlepšenie vo všetkých sledovaných oblastiach. S. Furneaux-Blick (2019) sa vo svojej štúdii venovala technike spoločného mal'ovania (klient a arteterapeut) s det'mi s poruchami učenia. Ako sama autorka uvádza, spoločná aktivita odzrkadl'uje dyadické stretnutie rodiča s diet’at'om. Práca na spoločnej aktivite s diet’at’om s poruchami učenia umožnila vytvorenie pevného vzt'ahu. Jej prípadová štúdia dokumentuje, ako môže spoločná aktivita umožnit' diet'at'u s poruchami učenia rozvíjat' väčšiu sebadôveru a vytvárat' silnejší pocit seba samého.

\section{ZÁVER}

Využitie arteterapeutických techník môže byt' pri práci v inkluzívnej triede vel'mi nápomocné, vd'aka ich schopnosti upokojovat' a regulovat' nervový systém. Poskytujú pedagógovi celý rad možností a techník, ktoré môže využívat' $s$ ohl'adom na individuálne charakteristiky konkrétneho žiaka. Umeleckými aktivitami je možné pomôct' diet'at'u, aby sa pozitívne vyvíjalo. Pedagóg vyberá námet, vedie žiakov k dosiahnutiu náhl'adu, pochopeniu problému. Pomáha rozvíjat' poznanie a stimuluje kognitívne procesy v tvorivej činnosti. Počas takýchto aktivít, nie je dôležitý výsledok, ale priebeh tvorby. Ešte dôležitejšie je samotná interpretácia produktu žiakmi, pri ktorej môžu porozprávat' aj to, čo nestihli dotvorit'. Tu dostávajú možnost' aj žiaci úzkostní, ktorí inak nedostanú možnost' sa prejavit'. Za pomoci arteterapeutických prvkov vo vyučovaní môžu postupne nadobúdat' sebavedomie a prežívat' radost' z práce a príjemného zážitku. Neskôr vzniká priestor pre rozhovor o tom, čo sa dialo v rámci tvorivého procesu, aj pre rozhovor o výsledku tejto práce.

\section{Použitá literatúra}

1. BAGALOVÁ, L', BIZÍKOVÁ, L., FATULOVÁ, Z. Metodika podporujúca inkluzívne vzdelávanie v školách. ŠPÚ: Bratislava, 2015. ISBN 978-80-8118-143-6.

2. BALÁŽOVÁ, J. Možnosti zážitku vo výtvarnej výchove v primárnom vzdelávaní. In Pán učitel'. 2010/2011. roč. 4, č. 5. s. 24 - 26. ISSN 1336-7161.

3. BALÁŽOVÁ, J. Projektové vyučovanie s prvkami umenia nielen v špeciálnej základnej škole. In Vychovávatel'. 2011. roč. LX, č. 7 - 8. s. 39 - 46. ISSN 0139-6919.

4. BOSGRAAF L, SPREEN M, PATTISELANNO K AND HOOREN S. Art Therapy for Psychosocial Problems in Children and Adolescents: A Systematic Narrative Review on Art Therapeutic Means and Forms of Expression, Therapist Behavior, and Supposed Mechanisms of Change. Front. Psychol. 2020. 11:584685. doi: 10.3389/fpsyg.2020.584685 
5. ČAPEK, R. Tř́dni klima a školni klima. Praha: Grada, 2010. s. 329. ISBN 978-80247-2742-4.

6. DOLL, B. a kol. Student Perceptions of Classroom Learning Enviroments: Development of ClassMaps Survey. School Psychology Review, 2010, roč. 39, č. 2, s. 203-218. ISSN 0279-6015.

7. FURNEAUX-BLICK, S. Painting together: how joint activity reinforces the therapeutic relationship with a young person with learning disabilities. International Journal of Art Therapy Ročník 24, 2019 - Číslo 4, s. 169 -180, ISSN 1745-4832.

8. GAVORA, P. Akí sú moji žiaci. Bratislava: Práca, 1999, s. 239. ISBN 80-7094-335-1.

9. GERLICHOVÁ, M. Muzikoterapie v praxi. Praha : Grada. 2014. ISBN 978-80-2474581-7.

10. GILMAN, R., HUEBNER E., S., FURLONG, M., J. Handbook of Positive Psychology in Schools. New York: Rotledge, 2009, s. 502. ISBN 978-0-8058-6361-1.

11. HLÁSNA, S., HORVÁTHOVÁ, K., MUCHA, M., TÓTHOVÁ. Úvod do pedagogiky. Nitra: Enigma, 2006, s. 356. ISBN 80-89132-29-4.

12. JANKOVSKÁ, B., JANKOVSKÝ, J. Arterapie jako součást ucelené rehabilitace dětí s tělesným postižením, In: Specialní pedagogika - 11;4, 2001. s. 243-247, ISSN: 1211-2720.

13. KLIMENTOVÁ, A. Manažment klímy triedy. In: Kapitoly zo súčasnej didaktiky: E. PETLÁK ET AL. IRIS, 2005, s. 189. ISBN 80-89018-89-0.

14. KLUSÁK, M., ŠKALOUDOVÁ, A. Školní klima z perspektivy žáků. In: KUČERA, M. et al. Co se v mládí naučís. Praha: Pedagogická fakulta UK, 1994, s. 229.. ISBN 80-7290-046-3.

15. KOSOVÁ, B. Rozvoj osobnosti žiaka. Prešov: Rokus, 2000, s. 121. ISBN 80-968452-2-5.

16. KOŽNAR, J. Psychoterapeutické prístupy v prevýchove II. Banská Bystrica : KPÚ, 1999. ISBN 80-85415-10-0.

17. MAREŠ, J. Sociální klima školní třídy. Přehledová studie. Asociace školní psychologie $\check{C} R$ a SR, Institut pedagogicko-psychologického poradenství. [online] 1998, [cit. 2020-05-01]. Dostupné na internete: <http://www.klima.pedagogika.cz/t rida/doc/Mares_Klima_tridy.pdf>.

18. LHOTOVÁ, M. Proměny výtvarné tvorby v arteterapii. Jihočeská univerzita České Budejovice, Teologická fakulta: Scientia 04, 2010. ISBN 978-80-7394-209-0.

19. LIEBMANN, M. Skupinová arteterapie. Praha: Portál, 2010. ISBN80-7178-864-3.

20. LÍŠKKOVÁ, B. Citová a emocionální výchova v rodině a ve škole. Hradec Králové: Gaudeamus, 2014. ISBN 978-80-7435-398-7.

21. MAJZLANOVÁ, K. Liečebnopedagogická intervencia prostredníctvom dramatoterapie a biblioterapie pri problémoch $\mathrm{v}$ správaní detí. In: LESSNER LIŠTIAKOVÁ, I. 2017. Liečebnopedagogické intervencie pri poruchách správania detí. Bratislava : UK, 2017. ISBN 978-80-223-4454-8.

22. PETLÁK, E. Klíma školy a klíma triedy. Bratislava: Iris, 2006, s. 119. ISBN 8089018-97-1.

23. PRŮCHA, J., a kol. Pedagogický slovnik. Praha: Portál, 1998, s. 400. ISBN 80-7178-252-1.

24. ŠICKOVÁ - FABRICI, J. Základy arteterapie. Praha : Portál, 2002. ISBN 80-7178-616-0.

25. ŤULÁK KRČMÁRIKOVÁ, Z. Liečebnopedagogická intervencia prostredníctvom arteterapie pri problémoch v správaní detí. In: LESSNER LIŠTIAKOVÁ, I. 2017. Liečebnopedagogické intervencie pri poruchách správania detí. Bratislava : UK, ISBN 978-80-223-4454-8.

26. ULRICHOVÁ, I., SLÁDEČKOVÁ, Z. Muzikoterapie a arteterapie v etopedických zařízeních. Speciální pedagogika - 2;3. 26-33, 1992. ISSN: 0862-1632.

27. ZICHA, Z. Úvod do speciální výtvarné výchovy. Praha: Univerzita Karlova, s. 145. 1981. 


\section{Kontaktné údaje}

Mgr. Barbora Sender, PhD.

Univerzita Konštantína Filozofa v Nitre

Pedagogická fakulta, Katedra pedagogiky

Dražovská 4, 94974 Nitra

Tel: +421376408315

email: bsender@ukf.sk 


\title{
A TYPOLOGY OF ADOLESCENTS IN TERMS OF RISKY BEHAVIOR
}

\author{
Kristína Mydlová
}

\begin{abstract}
This study is concerned with generating a typology of adolescents according to selected types of risky behavior, specifically risky eating habits, alcohol consumption, smoking, cannabis consumption, illegal drug use, problematic and delinquent behavior, risky sexual behavior and promiscuity. The aim of this study is to define the risk rate in selected types, as well as to generate a typology of adolescents according to selected types of risky behavior, gender and age group (early adolescence, late adolescence). The result is a typology of adolescents, within which 3 types of adolescents have been generated through cluster analysis, and which are in terms of risk rate particularly different among types of risky behavior- problematic behavior, risky sexual behavior, promiscuity, alcohol consumption and smoking.
\end{abstract}

Key words: typology, adolescence, risk behavior

\section{Introduction}

Many authors have verified the existence of the phenomenon of risky behavior. Non-native research (Lubman et al., 2008; Institute of medicine and national research council, 2011), as well as native research (Juhásová, Gatial, 2019; Nociar, 2019), suggest a continuously increasing trend of risky behavior, predominantly among the population of adolescents. Many studies regarding this matter imply that said topic has been dealt with long term within research; however, there has not been an evident decrease in risky behavior among adolescents. The society, in which adolescents are developing, is constantly changing, and the influence affecting adolescents is changing as well. Adolescents are considered to be the riskiest age group from a developmental perspective (Ballocchini et al., 2013). It is estimated that up to $50 \%$ of adolescents have at least once displayed risky behavior during the developmental stage of adolescence (Čerešník, Dolejš, 2015), which is a rather broad statement, within which we cannot fathom the extent of affect it has on adolescents, or what the consequences might be. The criterion for evaluating risky behavior is not firmly established in society, which is the reason for our consideration that the problem lies in the necessity of defining the risk rate within every type of risky behavior, which will subsequently enable the differentiation of the seriousness of risk rate among adolescents. The assessment of risk rate can contribute to the distinction of adolescents, which will subsequently ease the categorization into individual types of risky behavior. Some studies observe the collective occurrence of types of risky behavior; however, only a few are associated. Risky behavior is a broad matter, encompassing many types, all of which have their own particularities. Research concerned with risky behavior among adolescents are often aimed at a specific type of risky behavior, for instance: alcohol consumption among adolescents (Ballocchini, 2013; Nociar, 2019, Rojková, Vavrová, 2017), illegal drug use (Kraus, Hroncová, 2007; Kresánek, 2007), risky sexual behavior (Wiess, Zveřina, 2009; Čerešník, Gatial, 2014; Janošová, 2016), etc. Such approach represents relatively single-sided interest of research among the matter of risky behavior. For a more structured perspective on the matter, authors Blatný et al. (2016) suggest generating a typology. The advantages of a typological approach include the ability to put emphasis on specific associated attributes and to aggregate them into associative clusters. This strategy of research also emphasizes similar patterns of behavior across the current situation in society (Stier et al., 2001). The value of processing a typology can be found in the practical application within intervention programs or psychological counseling. The construction of a typology has essential value in 
psychosocial research, within which it clarifies the matter and provides an identification of types. The generation of types of risky behavior among adolescents, including other current characteristics, can serve as a model of risky behavior among adolescents (Blatný et al., 2016). Chronically well-known typologies are older, but still used in present day. In the present, this strategy of research has slightly fallen behind. The current typologies are processed exceedingly unilaterally, and are concerned with only a few types of risky behavior. For instance, attention is exclusively focused on particular types of risky behaviorconsumption of drugs in relation to sexual behavior of adolescents (Sherman et al., 2007). Some typologies of risky behavior compare specific groups of adolescents, as in the instance of authors Daubner et al. (2009), in which they compare adolescent girls of different ethnicities, or in the instance of the research of Hunter (2017), in which the typology is generated among deaf adolescents. Research of Selecká et al. (2017) was processed into a concept of a typology of adolescents within antisocial behavior; however, data was assessed in the Czech Republic. There is a lack of processed typologies of adolescents, which would be concerned with risky behavior in relation to various types of risky behavior.

\section{Methods}

\subsection{Research sample}

Intentional sampling was used to assess the research sample. The research sample consists of Slovak adolescents, studying in elementary school and high school across the Slovak Republic (21 cities). The research sample consists of 2438 adolescents with an average age of 16,07 years, and a span of 12-19 years of age. Based on gender, girls made up 59,35\% $(n=1447)$ of the research sample and boys made up 40,65 $(n=991)$ of the research sample. Based on age, the research sample was divided into a group of early adolescence (up to 15 years of age), which consisted of $43,4 \% \quad(n=1058)$ of adolescents, and a group of late adolescence (from 16 to 19 years of age), which consisted of $56,6 \%(n=1380)$ of adolescents.

\subsection{Instruments and Data Collection}

The instrument, which was chosen for this study is the SAHA (Social and Health Assessment) Questionnaire, a multiscale broad-spectrum questionnaire, which observes risky behavior (risky eating habits, addictive drug use, delinquency, risky sexual behavior, etc.). This instrument was developed by Weissenberg et al. (1991) and adapted by Ruchkin et al. (2004). The SAHA Project grasps the occurrence of risky behavior itself, as well as the psychological and psychiatrical context of the matter (also the Slovak version) (Rojková, 2017). Due to the rate of risky behavior not being uniform among every type of behavior, we made the decision to assess the risk rate for every type of risky behavior, based off the SAHA Questionnaire.

The risk rate of the behavior of adolescents portrays what the risk of said behavior is for the adolescent, as well as how the risk will present itself in the consequences of adolescents' behavior. The risk rate encompasses a certain risk rate for society. In our study, we will assess the risk rate, which presents risky behavior of the adolescent, due to the aim of our study, to generate a typology of a risky adolescent. We explored the potential risk consequences of every behavior that is registered by the SAHA Questionnaire, depending on the severity and we subsequently defined the risk rate. Within the selected types of behavior that we analyzed, we have included: risky eating habits, alcohol consumption, illegal drug use, tobacco smoking, delinquent behavior, problematic behavior and risky sexual behavior. Based off diverse items and different matters, we approached every display of risky behavior through individual and content analysis of the specific type of behavior. The eventual risk rate of behavior is subsequently defined on the basis of frequency and descriptive statistics, as well as content analysis. We generally defined the risk rate- „no risk“, „moderate risk“ and „high risk". The same principle will be used to analogically proceed with every type of risky 
behavior. Individual definitions of defining risk rate for every type of risky behavior were further validated by four experts of practice, clinical psychologists, who verified our proposition of risk rate among every type of behavior.

\subsection{Research objectives and Research question}

- define the risk rate of behavior among selected types of risky behavior;

- generate a typology of adolescents regarding selected types of risky behavior, gender and age group;

RQ1: Is it possible to identify types of adolescents based off of risk rate, gender and age group within selected types of risky behavior?

\section{Results}

The study is concerned with the identification of types of adolescents based off of the risk rate within selected types of risky behavior. By the means of multivariate statistics, specifically cluster analysis, 3 clusters of individual types of adolescents were generated. The statistical program SPSS based off of similarity generated 3 clusters, while working with 11 variables ( 9 types of risky behavior, gender and age group). The biggest cluster, cluster 3 , is equal to $39,6 \%(n=832)$, cluster 1 is equal to $31,1 \%(n=616)$ and cluster 2 is equal to $29,3 \%(n=653)$. Table 1 presents the 3 generated clusters. Cluster analysis classified data and separated it into 3 clusters, therefore 3 types of adolescents, with the use of variables- individual levels of risk rate. The table presents color-based division of the importance of the introductory predictor (types of risky behavior), while 1 is of highest value among every cluster of the types of risky behavior- problematic behavior, promiscuity, sexual behavior and alcohol consumption (dark gray color). The remaining types- tobacco smoking, delinquency, cannabis consumption, illegal drug use, risky eating habits, age groups and gender are classified as of less importance $<0,8$ (light gray). The table presents newly generated 3 clusters (types of adolescents). Type 1 adolescent consists of types of risky behavior and the risk rate of said behavior- moderate risk of problematic behavior $(56,2 \%)$, moderate risk of promiscuity $(88,8 \%)$, moderate risk of sexual behavior $(88,8 \%)$, high risk of alcohol consumption $(79,9 \%)$, moderate risk of smoking tobacco cigarettes $(68,3 \%)$, no risk of delinquency $(68,9 \%)$, no risk of cannabis consumption $(89 \%)$, no risk of illegal drug use $(74,4 \%)$, no risk of risky eating habits $(76,6 \%)$; within the age group it is the group of late adolescence $(61,6 \%)$ and within the gender it is of male gender $(51,9 \%)$. Type 2 adolescent consists of types of risky behavior and the risk rate of said behavior- no risk of problematic behavior $(95,5 \%)$, no risk of promiscuity $(99,5 \%)$, no risk of sexual behavior $(99,5 \%)$, moderate risk of alcohol consumption $(74 \%)$, moderate risk of smoking tobacco cigarettes $(93,7 \%)$, no risk of delinquency $(99,4 \%)$, no risk of cannabis consumption (100\%), no risk of illegal drug use (86\%), no risk of risky eating habits $(80,2 \%)$; within the age group it is the group of late adolescence $(67,2 \%)$ and within the gender it is of male gender $(50,2 \%)$. Type 3 adolescent consists of types of risky behavior and the risk rate of said behavior- moderate risk of problematic behavior $(82,9 \%)$, no risk of promiscuity (100\%), no risk of sexual behavior (100\%), high risk of alcohol consumption $(99,6 \%)$, moderate risk of smoking tobacco cigarettes $(91 \%)$, no risk of delinquency $(83,9 \%)$, no risk of cannabis consumption $(95,3 \%)$, no risk of illegal drug use $(79,2 \%)$, no risk of risky eating habits $(76,4 \%)$; within the age group it is the group of late adolescence $(64,9 \%)$ and within the gender it is of female gender $(51,1 \%)$. 
Table 1 Generated clusters - types of adolescents

\begin{tabular}{|c|c|c|c|}
\hline & \multicolumn{3}{|c|}{ Clusters } \\
\hline Types & TYPE 1 & TYPE 2 & TYPE 3 \\
\hline $\begin{array}{c}\text { Cluster } \\
\text { size }\end{array}$ & $31,10 \%$ & $29,30 \%$ & $39,60 \%$ \\
\hline & $\begin{array}{l}\text { Problematic behavior } \\
\text { moderate risk }(56,2 \%)\end{array}$ & $\begin{array}{c}\text { Problematic behavior } \\
\text { no risk }(95,5 \%)\end{array}$ & $\begin{array}{l}\text { Problematic behavior } \\
\text { moderate risk }(82,9 \%)\end{array}$ \\
\hline & $\begin{array}{c}\text { Promiscuity } \\
\text { moderate risk }(88,8 \%)\end{array}$ & $\begin{array}{c}\text { Promiscuity } \\
\text { no risk }(100 \%)\end{array}$ & $\begin{array}{c}\text { Promiscuity } \\
\text { no risk }(100 \%)\end{array}$ \\
\hline & $\begin{array}{c}\text { Sexual behavior } \\
\text { moderate risk }(88,8 \%) \\
\end{array}$ & $\begin{array}{c}\text { Sexual behavior } \\
\text { no risk }(99,5 \%) \\
\end{array}$ & $\begin{array}{c}\text { Sexual behavior } \\
\text { no risk }(100 \%) \\
\end{array}$ \\
\hline & $\begin{array}{l}\text { Alcohol consumption } \\
\text { high risk }(79,9 \%)\end{array}$ & $\begin{array}{l}\text { Alcohol consumption } \\
\text { moderate risk }(74,0 \%)\end{array}$ & $\begin{array}{c}\text { Alcohol consumption } \\
\text { high risk }(99,6 \%)\end{array}$ \\
\hline & $\begin{array}{c}\text { Tobacco cigarette } \\
\text { smoking } \\
\text { moderate risk }(68,3 \%) \\
\end{array}$ & $\begin{array}{c}\text { Tobacco cigarette } \\
\text { smoking } \\
\text { moderate risk }(93,7 \%) \\
\end{array}$ & $\begin{array}{c}\text { Tobacco cigarette } \\
\text { smoking } \\
\text { moderate risk }(91,0 \%) \\
\end{array}$ \\
\hline & $\begin{array}{c}\text { Delinquency } \\
\text { no risk }(68,9 \%)\end{array}$ & $\begin{array}{c}\text { Delinquency } \\
\text { no risk }(99,4 \%)\end{array}$ & $\begin{array}{c}\text { Delinquency } \\
\text { no risk }(83,9 \%)\end{array}$ \\
\hline & $\begin{array}{c}\text { Cannabis consumption } \\
\text { no risk }(89,0 \%)\end{array}$ & $\begin{array}{c}\text { Cannabis consumption } \\
\text { no risk }(100 \%)\end{array}$ & $\begin{array}{c}\text { Cannabis consumption } \\
\text { no risk }(95,3 \%)\end{array}$ \\
\hline & $\begin{array}{l}\text { Illegal drug use } \\
\text { no risk }(74,4 \%)\end{array}$ & $\begin{array}{c}\text { Illegal drug use } \\
\text { no risk }(86,0 \%)\end{array}$ & $\begin{array}{c}\text { Illegal drug use } \\
\text { no risk }(79,2 \%)\end{array}$ \\
\hline & $\begin{array}{c}\text { Age group } \\
\text { late adolescence }(61,6 \%)\end{array}$ & $\begin{array}{c}\text { Age group } \\
\text { late adolescence }(67,2 \%)\end{array}$ & $\begin{array}{c}\text { Age group } \\
\text { late adolescence }(64,9 \%)\end{array}$ \\
\hline & $\begin{array}{c}\text { Risky eating habits } \\
\text { no risk }(76,6 \%)\end{array}$ & $\begin{array}{c}\text { Risky eating habits } \\
\text { no risk }(80,2 \%)\end{array}$ & $\begin{array}{c}\text { Risky eating habits } \\
\text { no risk }(76,4 \%)\end{array}$ \\
\hline & $\begin{array}{c}\text { Gender } \\
\text { male }(51,9 \%)\end{array}$ & $\begin{array}{c}\text { Gender } \\
\text { male }(50,2 \%)\end{array}$ & $\begin{array}{c}\text { Gender } \\
\text { female }(51,1 \%)\end{array}$ \\
\hline
\end{tabular}

\section{Discussion and conclusion}

Individual types of risky behavior are connected with one another, having integrated relation and sequence, which is the reason for our decision to use a typological approach in exploring the matter of risky behavior, which simultaneously enables the assessment of a rather structured perspective on the types of risky behavior. By the means of cluster analysis, 3 individual types of adolescents, consisting of risk rate in all selected types of risky behavior, were generated. Cluster analysis, with the use of importance rate, classified the following as important (said types of behavior are statistically similar)- problematic behavior, sexual behavior, promiscuity and alcohol consumption. Of less importance are considered smoking and delinquency, and of the least importance within the classification into individual clusters are- cannabis consumption, illegal drug use and risky eating habits. One of the aims of this study was to define the risk rate of behavior among all selected types of risky behavior; we acknowledged the exact risk rate, in which risky behavior had occurred, which enables effortless characterization.

Types of adolescents:

Type 1 accords to $31,10 \%$ ( $n=616$ ) of adolescents, and consists of problematic behavior with the occurrence of risky behavior in a moderate risk rate of $56,2 \%$. The moderate risk implies that, as of last year, adolescents have engaged at least twice in one type of problematic 
behavior, or once in a maximum of four types of problematic behavior. That means the adolescent had undertaken the risk of lying to their parents or teachers, sneaking out at night, playing truant, destroying public property, stealing, engaging in a fight, or being punished for inappropriate behavior towards authority. Problematic behavior of moderate risk can represent a trigger for the adolescent, as well as a following transition into other types of risky behavior, for instance, into delinquent behavior. This layering of risky behavior can demonstrate a potential risk into the future of the adolescent. It does not necessarily demonstrate an imminent life threat, while we do not exclude this possibility; however, we perceive the possibility of being expelled due to problematic behavior, as of higher risk, whereas this can lead to problems in the future of the adolescent, who can become part of a group, which will encourage and expand their risky behavior. Another type befitting the first type is promiscuity with the occurrence of risky behavior in a moderate risk of $88 \%$. Due to the sensitivity of sexual behavior as a topic, we have differentiated promiscuity by the age of adolescents, because the representation of what risky behavior is for an adolescent with the age of up to 15 years, does not have to represent risky behavior for an adolescent who is of legal age- 18 years. Promiscuity with a moderate risk presents the change of 2 sexual partners until reaching 15 years of age within the group of early adolescence. Moderate risk for late adolescence is presented in the change of 2 to 5 sexual partners. If the adolescent of up to 15 years of age changes 2 sexual partners, there is a possibility of risk that they will continue with this behavior in the future. In present day, the trend of having one partner for life is no longer prominent, as well as the principle of being in a relationship with the person we have sexual intercourse with. In the present, there is a lot of pressure put onto adolescents by the media, society, which both create the vision of early adulthood, and so we want to emphasize that of high risk is the change of 2 partners in early adolescence, and 2 to 5 sexual partners in late adolescence. It is plausible to claim that adolescents, who during adolescence have had many sexual experiences, will continue in gaining short-lasting sexual experiences, and therefore put themselves at risk in the future. Sexual behavior with a rate of moderate risk at $88 \%$ is another type of risky behavior branched under type 1 adolescent. The moderate risk entails the adolescent being involved in one of the types risky sexual behavior, either having unprotected sexual intercourse or having sexual intercourse under the influence of alcohol. While the adolescent consciously and regularly engages in unprotected sexual intercourse, they put themselves at risk for contracting sexually transmitted diseases, as well as the risk of pregnancy, which in the case of adolescents, does not have to be wanted. The risk increases if the adolescent does not know their partner, and the encounter has the character of casual sex. The risk of unwanted pregnancy involves certain emotional trauma, which is associated with the decision to undergo abortion. Emotional trauma can be caused by having sexual intercourse under the influence of alcohol, during which one of the people involved does not have to have full consciousness of the state they are in, the effect of alcohol lies within their complaisance, as this situation would, with probability, not have taken place without the consumption of alcohol. Another type, characteristic of type 1 adolescent, is alcohol consumption with the occurrence of risky behavior in a high risk of $79,9 \%$. With high risk, the adolescent has at least once engaged in risky alcohol consumption with the frequency of 3 to 5 times within the last month. With this frequency, the adolescent could have exposed themselves to heavy, episodic drinking (binge drinking), which according to NIAAA (National Institute on Alcohol Abuse and Alcoholism), represents the consumption of a minimum of 3 alcoholic beverages among girls and 4 alcoholic beverages among boys, within one event and the course of 2 hours (Selecká a kol., 2017). Alcohol consumption of a greater extent is highly risky, as the direct effect of alcohol can threaten the adolescents' life, or as the secondary effects, which come about under the influence of alcohol, can cause the adolescents' transition to other types of risky behavior. Of less importance based on 
cluster analysis is cigarette smoking with the occurrence of risky behavior in a moderate risk of $68,3 \%$, as the moderate risk represents smoking at least one cigarette over the course of a couple days, which classifies the adolescent as a moderate smoker, and this type of smoking is associated with the development of addiction, which will follow along for the rest of their life. Delinquent behavior with the occurrence of risky behavior with no risk of $68,9 \%$ presents that the adolescent does not have tendencies to engage in delinquent behavior. The other types of risky behavior- cannabis consumption, illegal drug use, risky eating habits and the variables of gender and age group, have been evaluated as unimportant; all of said types of risky behavior have shown no risk among adolescents. Late adolescence was predominant with the percentage of 51,9\%. This type of adolescent is considered as a high risk type, which leads to the name Risky Adolescent Type.

Type 2 accords to 29,30\% ( $\mathrm{n}=653)$ of adolescents, and consists of problematic behavior with the occurrence of risky behavior with no risk of $95,5 \%$, which means adolescents do not engage in problematic behavior, and consequently is not exposed to any risk; however, there is a possibility of being secretive due to the sensitivity. Another type of risky behavior is promiscuity with the occurrence of risky behavior of no risk of $100 \%$, similarly indicating adolescents do not change sexual partners, or even does not engage in sexual relations at all. Sexual behavior is similarly characterized by the occurrence of risky behavior of no risk of $99,5 \%$, which likewise implies the adolescent behaves sexually in a responsible manner, or has not started a sexual life. Another type is alcohol consumption with the occurrence of risky behavior in a moderate risk of $74 \%$. The moderate risk accords to the frequency of consumption with a minimum of once or twice over the course of a month, while the adolescent consumed at least one beer, one glass of wine and one shot of hard liquor. The moderate risk can be explained by the adolescent's interest in experimenting, which accords to moderate consumption of alcohol in sequence to dishonesty of the adolescent, who could have concealed higher alcohol consumption, and it can accord to the susceptibility to lean towards higher alcohol consumption in the future. An adolescent under the influence is more susceptible towards other types of risky behavior, within which this type does not present any risk; however, alcohol consumption and cigarette smoking in moderation is a predictor of risky behavior as well. Cigarette smoking within the cluster is of less importance, with the occurrence or risky behavior in a moderate risk of $93,7 \%$, implying the adolescent smokes occasionally, and delinquent behavior with the occurrence of risky behavior with no risk of 99,4\% implies the adolescent does not engage in this type of risky behavior, and so no risk can stem from this. Remaining types of risky behavior- cannabis consumption, illegal drug use, risky eating habits and the variables of gender and age group were evaluated as unimportant, as all selected types of risky behavior have the occurrence of no risk among adolescents. Late adolescence was predominant with the percentage $67,2 \%$, and within gender, boys were predominant over girls with the percentage of 50,2\%. An adolescent, who is considered type 2 adolescent, could be classified as a typical adolescent with an interest to experiment. As Moffit and Caspije presented, we suppose that this type of adolescent will not carry risky behavior through into the future; however, if this behavior evolves during adolescence, the adolescent can transition into a different type of adolescent within generated typology. This type has been given the name Low Risk Adolescent Type (Sherman a kol., 2007).

Type 3 accords to $39,60 \%$ ( $n=832$ ) of adolescents, and consists of problematic behavior with the occurrence of risky behavior in a moderate risk of $82,9 \%$, while the exposure to moderate risk applies to adolescents, who have at least twice engaged in one type of problematic behavior, or once in a maximum of four types of problematic behavior, over the course of last year. Adolescents could have engaged in a smaller fight, lied to authority, snuck out at night, ran away from home, played truant, or committed a theft. Another type of behavior 
characteristic for type 3 adolescent is alcohol consumption with the occurrence of risky behavior in a high risk of $99,6 \%$, which accords to at least one instance of risky consumption of alcohol with the frequency of 3 to 5 times over the course of one month. Within this risky consumption, binge drinking can be an occurrence, which is a burden for the adolescents' organism. Adolescents often resort to binge drinking as a way to avoid problems, but it also can be a source of social entertainment. Cluster analysis also recognized sexual behavior and promiscuity as important, and which are no risk at $100 \%$. This risk does not present a threat for the adolescent, as it seems the adolescent behave sexually in a responsible manner, or they have not yet started a sexual life. As of less importance within the cluster are cigarette smoking with the occurrence of risky behavior in moderate risk of $91,0 \%$, which accords to occasional smoking, and delinquent behavior with the occurrence of risky behavior with no risk at $83,9 \%$, which does not represent the risk of engaging in delinquent risky behavior. Remaining types of risky behavior- cannabis consumption, illegal drug use, risky eating habits and the variables of gender and age group, were evaluated as unimportant, as all said types of risky behavior have occurred with no risk among adolescents. Late adolescents were predominant with the percentage of $64,9 \%$ and within the gender, girls were predominant with the percentage of $51,1 \%$. We classified this type of adolescent as the one with the highest percentual representation (highest percentage among the population), which includes elements of experimenting with risky behavior; however, it is of moderate risk, unlike type 2 . This type of adolescent has been given the name Moderately Risky and Rebellious Adolescent Type.

Every adolescent has been characterized by a current characteristic type of adolescent, according to selected types of risk within characteristic risk rates. Based on the results we can claim cluster analysis has proven important types of risky behavior, which are related to one another- problematic behavior promiscuity, sexual behavior, alcohol consumption and cigarette smoking. Cigarette smoking has been presented as of less importance within cluster analysis; however, there is similar risk-moderate risk, for every type. We can assume the majority of adolescents smokes one or two cigarettes a month, which could be classified as social smoking (Shane et al., 2009; Sonf, Ling, 2011). Social smoking is typical of adolescents and young adults, who are part of the group of highest risk (Stier et al., 2001). These smokers do not smoke due to an addiction to nicotine, but they smoke because their environment smokes, and would not light a cigarette when alone. The majority of adolescents start experimenting with smoking in this developmental stage; however, social smoking is a significant factor in this developmental stage, as unconscious addiction can develop. For further exploration, specifically a more in depth exploration of the factor of social smoking, we would add items within the questionnaire, which would grasp this type of behavior and expand present findings. We can also assume that there is wide-spread combination of problematic behavior, alcohol consumption and cigarette smoking, among adolescents, which has occurred in a certain rate among every type of adolescent. The consumption of alcohol is generally a trigger of problematic behavior in adolescence (Wies, Zveřina, 2009; Hunter, 2017). If the adolescent behaves problematically, there is a certain tolerance rate when problematic behavior occurred under the influence of alcohol. The adolescents are aware that alcohol can modify their behavior, they are more courageous, they try to gain attention, they try to act more adult like and therefore use alcohol as an excuse in front of authority. As alcohol consumption je more tolerated in today's society, the problematic behavior, which comes about under the influence of alcohol, is more tolerated, unless there has not been caused damage on public property, or no harm has been inflicted. We assume low importance as a limitation, within which cluster analysis included variables gender and age group, which could have helped distinguish age and gender characteristics among individual clusters, which is worth consideration even in present day; however, among the compared age groups, the first cluster analysis excluded early adolescence, and the ratio of girls and boys in individual 
clusters ranged around 50-50, and is considered a coincidence. We consider the chosen instrument as another limitation, due to the need of psychometrical validation, so it could be a complex instrument. For further exploration, we would like to include more complex exploring and an expansion of this typology, which could provide a complex perspective on risky behavior of adolescents.

The research study presented in the article was created within the grant VEGA: VEGA 1/0203/20- Development and standardization of a screening methodology for identifying the incidence and risks of problem legal drug use in adolescents.

\section{References}

1. BALLOCHICHINI, E., CHIAMENTI, G., LAMBORGHINI, A. 2013. Adolescents: whichrisksfortheirlife and health? Journal of PreventiveMedicine and Hygiene, vol. 54(4), p.191-194.

2. BLATNÝ, M., JELÍNEK, M., HRDLIČKA, M. 2016. Typologiec antisociálního chovaní ve střední adolescenci a její vzt’ah k užívaní návykových látek. In: Česká a Slovenská Psychiatrie, 2016, 112(3), s. 107 -113

3. ČEREŠNÍK, M., DOLEJŠ M. 2015. Spoločný projekt dvoch národov alebo podobnosti a rozdiely $\mathrm{v}$ procese a výsledkoch výskumu zameraného na rizikové správanie a osobnostné rysy dospievajúcich na Slovensku a v Českej republike. In: MAJEROVÁ, E. a kol. Česko-slovenská psychologická konference (nejen) pro doktorandy a odoktorandech. Olomouc: Univerzita Palackého, s. 203-219(online) [cit. 2020-09-01]. Dostupné na internete: $<$ https://www.researchgate.net/publicati on/3015 59660_Rizikove_spravanie_dospievajucich_-_vyskumne_vysledky_a_diagnosticke_v yzvy>

4. DAUBnER, S., HOGUE, A., PAULSON, J. F. 2009. Typology of Alcohol Use in White and African American Adolescent Girls. In: Substance Use \& Misuse, 44:8, 1121-1141, DOI: 10.1080/10826080802494727

5. HUNTER, A. 2017. Attitudes, Risk Behavior, and Noise Exposure among Young Adults with Hearing Problems: Identifying a Typology. In: Seminar in hearing, vol. 38, issue 4, p. 332-347

6. INSTITUTE OF MEDICINE AND NATIONAL RESEARCH COUNCIL. 2011. TheScience of Adolescent Risk-Taking: Workshop Report. Washington (DC): National Academies Press (US); 2011. ISBN-13: 978-0-309-15852-7

7. JANOŠOVÁ, P. 2016. Adolescence. In: Blatný, M. (ed.): Psychologie celoživotního vývoje. Praha: Karolinum, 2016, s. 99-111. ISBN 978-80-246-3462-3

8. JUHÁSOVÁ, A., GATIAL, V. 2019. Exekutívne funkcie a rizikové správanie dospievajúcich. Nitra: UKF. 128 s. ISBN 978-80-558-1462-9

9. KERR, M., STATTIN, H., ÖZDEMIR, M. 2012. Perceived parenting style and adolescent adjustment: Revisiting directions of effects and the role of parental knowledge. Developmental Psychology, 48(6), 1540-1553. https://doi.org/10.1037/a 0027720

10. KRAUS, B., HRONCOVÁ, J. 2007.Sociálni patologie. Hradec Králové: UHK Gaudeamus. 325 s. ISBN 978-80-7041-896-3.

11. KRESÁNEK, J. 2004. Posudzovanie zdravotného stavu mladistvých: 2. vyd. Levoča, Polypress 2004, s. 13 - 19.

12. LAKON, C.M., HIPP, J.R., TIMBERLAKE, D. S. 2010. The social context of adolescent smoking: a systems perspective. In: American journal of publichealth, 100(7), 1218-1228. https://doi.org/10.2105/AJPH.2009.167973 
13. LUBMAN, D.I., YUCEL, M., LAWRENCE, A.J. 2008. Inhalant abuse among adolescents: neurobiological considerations. In: British journal of pharmacology, 154(2), 316-326. doi:10.1038/bjp.2008.76

14. MOFFITT, T. E., CASPI, A. 2001. Childhood predictors differentiate life-course persistent and adolescence-limited antisocial pathways among males and females. In Development and Psychopathology, Vol. 13, p. 355-375.

15. NATIONAL INSTITUTE ON ALCOHOL ABUSE AND ALCOHOLISM. 2004. Council approves definition of bingedrinking. In:NIAAA [online] [cit. 2020-03-01]. Dostupnéinternete: $<$ http://pubs.niaaa.nih.gov/publications/Newsletter/winter2004/Ne wsletter_Number3.pdf $>$

16. NOCIAR, A. 2019. Tabak- alkohol- drogy (prieskum 2018). Bratislava: VÚDPaP. 87 s.

17. PÉTIOVÁ, M. 2019. Vplyv legálnych a nelegálnych drog na život žiakov základných a stredných škôl. Bratislava: Centrum vedecko-technických informácií SR. ISBN 97880-89965-34-2

18. ROJKOVÁ, Z. 2017. Slovenská verzia dotazníka SAHA a jej pilotné overovanie = Slovak version of the questionnaireSAHA and its pilot validation 2017.In: Psychologické aspekty pomáhání 2016 : sborník př́spěvkủ z mezinárodni konference I editor: Zdeněk Mlčák ; recenzovali: Helena Záškodná, Marek Malůš. - Ostrava : Ostravská univerzita, 2017. - ISBN 978-80-7464-922-6, S. 87-93.

19. ROJKOVÁ, Z., VAVROVÁ, M. 2017. Situačno-motivačné faktory alkoholového správania : metodológia merania a aplikácia v praxi; recenzenti Gabriela Šeboková, Slávka Démuthová. - 1. vyd. - Trnava : Univerzita sv. Cyrila a Metoda v Trnave, Filozofická fakulta, 2017. - 97 s. ISBN 978-80-8105-887-5.

20. RUCHKIN, V., SCHWAB-STONE, M.E., VERMEIREN, R. 2004. Social and Health Assessment (SAHA): Psychometric Development Summary.

21. SAUNDERS, J.B.- REY, J.M. 2001. Young people \& alcohol. Impact, polocy, prevention, treatment.Oxford: BlackwellPublishinfLtd, 356 p., ISBN: 978-1-44433598-9

22. SElECKÁ, L., VÁClAVIKOVÁ, I., BLATNÝ, M., HRDLiČKA, M. 2017. Typológia antisociálneho správania: špecifiká prejavov adolescentných chlapcov a dievčat vo vzt’ahu $\mathrm{k}$ rizikovému sexuálnemu správaniu. In Česká a slovenská psychiatrie. 113(6), s. 258-267.

23. SHERMAN, S. G., GERMAN, D., GANN, D. 2007. A qualitative study of sexual behaviours among methamphetamin eusers in ChiangMai, Thailand: a typology of risk. In: Drug and alcoholreview, vol.27, issue 3, p. 263-269, 2007

24. SCHANE, R. E., GLANTZ, S. A., LING, P. M. 2009. Social smoking implications for public health, clinical practice, and intervention research. In: American journal of preventivemedicine, 37(2), 124-131. https://doi.org/10.1016/j.amepre.2009.03.020

25. SONF, A. V., LING, P. M. 2011. Social smoking among young adults: investigation of intentions and attempts to quit. In: American journal of publichealth, 101(7), 12911296. https://doi.org/10.2105/AJPH.2010.300012

26. STIER, H., LEWIN-EPSTEIN, N., BRAUN, M., 2001. Welfareregime, family supportivepolicy, and Women's Employment along the Life Course. In: American Journal od Sociology, vol. 106, p. 1731 - 1760

27. WEISS, P., ZVĚŘINA, J. 2009. Sexuální chování české populace. In Urologie pro praxi (online), 10(3), 160-163. [cit. 2020-10-01]. ISSN 1803-5299. Dostupné na internete:<http://www.urologiepropraxi.cz/pdfs/uro/2009/03/02.pdf>

28. WEISSBERG, R. P., et al. 1991. The Social and Health Assesment. New Haven: Authors, 1991. 


\section{Kontakt}

Mgr. Kristína Mydlová, student Ph.D

University of Ss. Cyril and Methodius in Trnava

Nám. J. Herdu 2, 91701

Mydlova1@ucm.sk 


\title{
KREATÍVNE PRÍSTUPY K SPRACOVANIU TÉMY UMELECKÉHO PROJEKTU
}

\author{
CREATIVE APPROACHES TO THE PROCESSING OF AN ART \\ PROJECT THEME
}

\section{Zuzana Hubinská}

\begin{abstract}
Abstrakt
Tvorivost' alebo kreativita je nástroj, ktorému sa v súčasnosti venuje čoraz viac pozornosti. Kreativitu je nutné rozvíjat' nielen preto, aby žiak či študent dokázal riešit' problémy súvisiace s obsahom vyučovania, ale tiež problémy, ktoré sa bežne vyskytujú v reálnom živote. Podpora tvorivých procesov dovol'uje prirodzene objavovat' a skúšat' všetko nové, vytvárat' si nový pohl'ad na poznané veci a zážitky, nájst' nové riešenia problémov a zároveň poskytuje priestor na sebarealizáciu. V predkladanom príspevku ponúkame praktické príklady kreatívneho prístupu študentov k spracovaniu zadanej témy pre hudobno-dramatické predstavenia, v rámci výučby predmetu choreografia. Tieto námety môžu využit' napríklad pedagógovia na základných umeleckých školách, ako inšpiráciu pri tvorbe záverečných predstavení.
\end{abstract}

Kl'účové slová: umelecký projekt, choreografia, kreativita, prax, pedagogika

\begin{abstract}
Creativity is a tool that is currently receiving more and more attention. Creativity must be developed not only so that the pupil or student can solve problems related to the content of teaching, but also problems that commonly occur in real life. Support for creative processes allows you to naturally discover and try everything new, create a new perspective on known things and experiences, find new solutions to problems and at the same time provide space for self-realization. In this paper, we offer practical examples of a creative approach of students to the processing of the assigned topic for music and drama performances, within the teaching of the subject of choreography. This ideas can be used, for example, by teachers at primary art schools as an inspiration for the creation of final performances.
\end{abstract}

Key words: art project, choreography, creativity, practice, pedagogy

\section{1 ÚVOD}

Hudobno-dramatické umenie je syntetizujúca oblast', ktorá zahŕňa dramatické, pohybové a slovesné činnosti. Táto sféra je charakteristická prepojením individuálneho prejavu (herecký, spevácky prednes) a kolektívnych aktivít (tanečné čísla, zborový spev) do komplexného umeleckého celku - hudobno-dramatického predstavenia. ${ }^{1}$ Príprava hudobno-dramatického projektu predstavuje tvorivý proces, $\mathrm{v}$ ktorom sa vytvárajú podmienky pre rozvoj kreativity. Je to $\mathrm{v}$ podstate javisková forma, ktorá prepája jednotlivé umelecké zložky ako herectvo, hudbu a pohyb (prípadne tanec). ${ }^{2}$ Pod pojmom choreografia $\mathrm{v}$ našom prípade rozumieme tvorivý proces, ktorého ciel’om je vytvorit' tanečnú kompozíciu spracovaním literárnej,

\footnotetext{
${ }^{1}$ Vzdelávacie štandardy pre jednotlivé umelecké odbory ZUŠ, literárno-dramatický odbor. 2015. [online]. Oficiálne stránky Štátneho pedagogického ústavu. [cit. 2021-06-17]. s. 818,819. 924 s.

${ }^{2}$ CVIKOVÁ, D. 2016. Tanec ako výrazový prostriedok v hudobno-dramatickom projekte. Nitra: UKF, 2016. s. 16. $50 \mathrm{~s}$.
} 
hudobnej alebo inej predlohy. Výsledkom je teda sled tanečných krokov do finálnej, logicky štruktúrovanej tanečnej podoby. ${ }^{3}$ Realizačná fáza hudobno-dramatického predstavenia, je z časového hl'adiska vel'mi náročná, preto sme sa na vyučovacích hodinách predmetu choreografia rozhodli realizovat' len pohybovú zložku, respektíve študentmi vybrané tanečné choreografie, ktoré tvorili súčast' celého celku. Študenti však museli pripravit' a odovzdat' celý hudobno-dramatický projekt v konkrétnych obrazoch. Popisovali námet, charakter postáv, scénografiu, hudobnú zložku (aj s odôvodneným výberu skladieb) a konkrétne obrazy predstavenia aj s priestorovou kresbou jednotlivých tancov.

Pri samotnej edukačnej praxi, kedy sa študenti navzájom učili vybrané choreografie, sme kládli dôraz na to, aby rozvíjali nielen svoju kreativitu, ale aj osobnost' ako pedagóga. Ked’že títo študenti sú budúci pedagógovia, mali by byt' v prvom rade schopní verit' v to čo učia, čo v našom prípade znamenalo, poznat' a ovládat' pohybový materiál využitý $\mathrm{v}$ tanečnej kompozícii. Nekládli sme však dôraz na ich výkon, teda na fyzické dispozície, ale na to, ako tanec zapadá do kontextu predstavenia, či posúva dej alebo ho len dopĺn̆a, aký použili pohybový materiál a či má nejakú výpovednú hodnotu. ${ }^{4}$ Ďalším aspektom bolo v tomto konkrétnom prípade rozvíjat' muzikalitu, to znamená ako pracovat's hudobným sprievodom. Pri prezentácii sme sledovali či študenti cítia frázovanie, rytmus, a tiež ako to prezentujú svojím žiakom. Vzhl'adom na to, že sme pracovali s pohybom, ukázali sa aj ich choreografické zručnosti, teda či boli študenti schopní vytvorit' štruktúrované pohybové kombinácie v logickej nadväznosti, a či ich kreativita v tomto smere neovplyvnila negatívnym smerom. Vo všeobecnosti sme tiež pozorovali, či sú študenti schopní zachytit' a definovat' prípadné problémy svojich žiakov pri učení sa vybraných choreografií, a ako zvládajú ich korekciu. Dalej schopnost' vyjadrovat' sa, schopnost' vytvorit' na hodine pozitívnu atmosféru a udržat' si zdravý rešpekt. ${ }^{5}$

V nasledujúcich kapitolách popisujeme konkrétne hudobno-dramatické predstavenia, ktoré študenti vytvorili na základe prvotného, všeobecného zadania.

\section{HUDOBNO-DRAMATICKÝ PROJEKT PRE DETI}

Základné zadanie znelo pripravit’ hudobno-dramatické predstavenie pre deti. Študenti museli dodržat' pravidlo, že aj účinkujúci aj diváci sú deti (l'ubovol'nej vekovej kategórie).

Študent 1: Príbeh o neposlušnej hviezdičke, pre deti vo veku 8 - 10 rokov.

Počet detí, ktoré by mali vystupovat' v predstavení je aspoň 12. Žiaci sú rozdelení na hviezdičky, svätojánske mušky, víly, mesiac, vodníka, pavúka a vetrík. Hviezdičky majú oblečené čierne tričká a nohavice, so zlatého papiera vyrobenú hviezdu a klobúk (ako cíp hviezdy). Mesiac má oblečené čierne tričko a nohavice s potlačou $\mathrm{v}$ tvare mesiaca. Svätojánske mušky majú opät' čierne tričká a nohavice (univerzálne oblečenie, keby niektorí žiaci zároveň hrali aj hviezdičky), neónovú gul'ôčku na zadnej strane tela, na hlave čelenku so svetlozelenými tykadlami a lampáš s umelým svetlom. Vodník je ladený do zelenej farby, má aj klobúk a pomal'ovanú tvár. Víly sú v bielom s farebnými sukňami, majú farebné krídla a kvetinové čelenky. Pavúk je celý v čiernom s prišitými, pančuchovými vypchávkami, ktoré predstavujú jeho d'alšie nohy. Vetrík je v bielom alebo modrom tričku, ku ktorému má poprišívané biele a modré kratšie látky, ktoré pri pohybe vejú za ním.

Celý príbeh sa odohráva v noci, je tomu prispôsobená aj scéna. Príbeh začína naháňačkou hviezdičiek po oblohe, ktoré stráži mesiac. Jedna z nich sa potkne a spadne z oblohy na zem.

\footnotetext{
${ }^{3}$ BARTKO, E. 2018. Stručná encyklopédia tanečného umenia. Bratislava: Verbunk, 2018. s. 225.637 s.

${ }^{4}$ FORDHAM, J. 1996. Jazz. Praha: Slovart, 1996. s. 145. 216 s.

5 LETENAJOVÁ, O. 2010. Tanečná technika Marthy Grahamovej jej formovanie a didaktika. Bratislava: Vysoká škola múzických umení, 2010. s. 63,64. 87 s.
} 
Po páde je najskôr vystrašená, ale potom sa rozhodne, že chce spoznat' svet. Na zemi sa stretáva so svätojánskymi muškami, neskôr s vodníkom, ktorý ju vyhreší, že odišla z oblohy a nahnevala tým mesiac. To hviezdičku opät' vystraší a uvedomí si, že sa chce vrátit', no vodník nevie ako jej pomôct' a tak zavolá víly. Tie sa ju snažia odniest' na oblohu, no je pre nich vel'mi t’ažká. Spoločne vymyslia, že zavolajú pavúka, ktorý spriada dlhé pavučinové nite a siete. Ako hviezdička v nádeji lezie po dlhej pavučine smerom na najvyšší strom v lese, príde silný vetrík a hviezdičku spolu s pavučinou odnáša preč až k samotným hviezdam na oblohe.

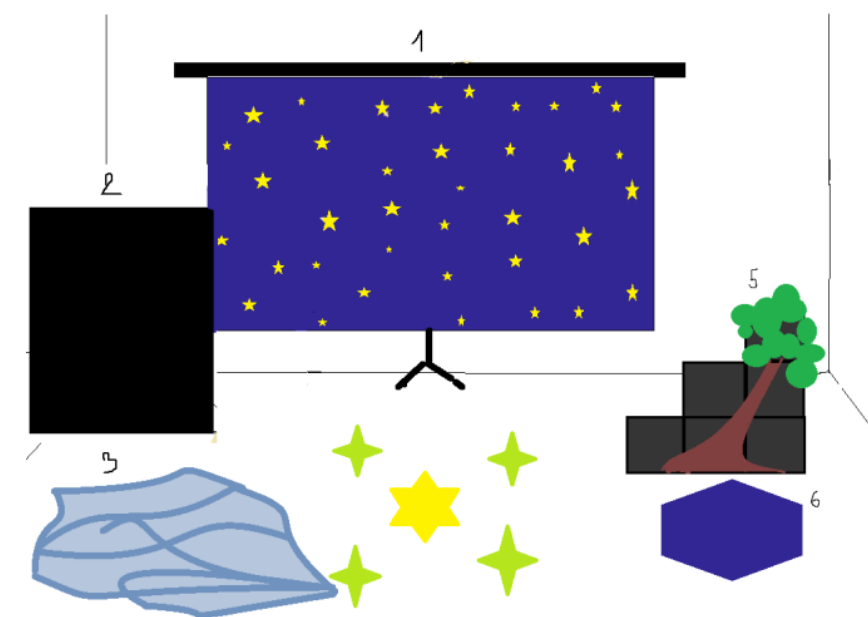

Obrázok 1 Návrh scény hudobno-dramatického predstavenia ${ }^{6}$

\section{MUZIKÁL}

Základné zadanie znelo pripravit' hudobno-dramatické predstavenie, teda konkrétne muzikál (spojenie libreta, hudby a tanca). Študenti si mohli zvolit' akúkolvek vekovú kategóriu participantov, ale aj percipientov. Mohli si vytvorit' autorské muzikálové predstavenia alebo sa inšpirovat' libretom/hudbou známejších muzikálov (Hello, Dolly!, Cats, Cabaret, My Fair Lady a iné), ${ }^{7}$ ktoré podl'a svojich predstáv bud' zasadili do iného prostredia, mierne prepracovali, upravili, modifikovali a iné.

Študent 2: Príbeh inšpirovaný muzikálom Pomáda s názvom - Zamlada, možno raz. Vystupuje v ňom kolektív študentov 9. ročníka ZŠ (l'ubovol'ný počet) spolu s troma staršími osobami (napríklad učitelia). Jedna staršia osoba stvárňuje hlavnú postavu Sandy, ktorá má oblečené čierne sako a ružovú sukňu, v d'alšom obraze krátke, bledomodré večerné šaty s výrazným líčením. Jedna zo študentiek hrá Sandy za mlada, má oblečené farebné plážové šaty a kvet vo vlasoch. Jeden zo žiakov predstavuje Dannyho v mladosti, má oblečenú bielu košel'u a modré krátke nohavice. Žiaci najskôr hrajú normálnych študentov, majú oblečené moderné oblečenie - dievčatá šaty, sukne, nohavice; chlapci rifle, mikiny, košele a podobne. V d'alšom obraze stvárňujú žiaci l'udí na večierku, dievčatá majú oblečené spoločenské šaty; chlapci biele/čierne košele, čierne/hnedé nohavice a spoločenské topánky v čiernej farbe. Ďalší so starších hercov predstavuje dospelého Dannyho, ktorý má sveter, pohodlné nohavice a papuče. Poslednou postavou je jeho sluha, ktorý má čierny oblek.

\footnotetext{
${ }^{6}$ Číslo 1 predstavuje projektor, číslo 2 čierny paraván na kolieskach, číslo 3 igelit ako jazero, číslo 5 kocky ako schody a na nich prichytený strom, číslo 6 podložku ako tlmič dopadov. Zlatá hviezda je hlavná postava, okolo nej tancujú svätojánske mušky.

${ }^{7}$ PROSTĚJOVSKÝ, M. 2008. Muzikál expres - malý průvodce velkým muzikálem. Brno: Větrné mlýny, 2008. s. $11,12.487 \mathrm{~s}$.
} 
Tento muzikál hovorí o 45 ročnej učitel'ke Sandy, ktorá je talentovaná speváčka, no kvôli rodinnej situácii si nemohla dovolit' uskutočnit' svoj životný sen - stat' sa slávnou speváčkou. Pri snahe utíšit' svojich študentov im raz na hodine zaspieva a oni ostanú unesení jej talentom. Rozpovie im preto svoj príbeh, ako chcela byt' $v$ mladosti speváčkou a precestovat' svet, no musela sa starat' o svojich chorých rodičov, ktorí boli konzervatívny a nepodporovali jej kariéru. Žiakom je učitel'ky l'úto a rozhodnú sa jej pomôct', cez priblíženie spomienok na mladost'. Tak zorganizujú stretnutie s jej najlepšími kamarátmi zo strednej školy. Medzi pozvanými je aj jej stredoškolská láska Danny. Sandy je so stretnutia s ním nervózna, no ked’že ho stále miluje, aj sa vel'mi teší. V d'alšom obraze sa objavuje dospelý Danny u seba doma, sluha mu prináša pozvánku. Danny je smrtel'ne chorý a tuší, že stretnutia sa nedožije, preto sa rozhodne napísat' list. V nasledujúcom obraze sa ocitáme na večierku, postupne prichádzajú jej spolužiaci no chýba jeden človek. Do miestnosti vstupuje Dannyho sluha a Sandy podá list. Obsah listu tvoria jeho spomienky na mladost' a na ňu. Danny hovorí o tom, že síce žil ako slávny umelec no ona mu stále chýbala, ale nemal odvahu sa jej ozvat'. Listom jej chcel dodat' odvahu a odkázat' aby si začala plnit' svoje sny, lebo nikdy nie je neskoro.

\section{HUDOBNO-DRAMATICKÝ PROJEKT S ABSTRAKTNOU TEMATIKOU}

Základné zadanie znelo pripravit' hudobno-dramatické predstavenie s abstraktnou tematikou. Študenti sa mohli inšpirovat' literárnym, výtvarným, hudobným umením, vymysliet' vlastný originálny námet alebo spracovat' súčasnú problematiku (politická/kultúrna/spoločenská situácia) a podobne. Mali absolútne vol’nú ruku, čo mohlo podnietit' ich kreativitu.

Študent 3: Príbeh pojednáva o živote na zemi a na iných planétach s názvom - Svet podl'a $m \check{a} a$. Predstavenie je určené pre percipientov vo veku minimálne 18 rokov. Počet účinkujúcich aspoň $13, \mathrm{z}$ toho jedna hlavná postava a 12 tanečníkov.

Námet: Žijeme na planéte Zem. Niektorým z nás sa tu ale nepáči. Je to preto, že nám naša planéta nevyhovuje? Alebo je to l'ud'mi, ktorí s nami na nej žijú? Niekomu vadí spoločnost' známych, niekomu človek, ktorého ani nepozná. Niekomu vadí hmyz, pel', hustá premávka, nespravodlivost', vraždy, politika a mnoho d'alších vecí, ktoré nedokáže do značnej miery ovplyvnit'. Ale čo ak by si človek mohol vybrat', kde bude žit? Napríklad inú planétu, kde by si uvedomil, že bez niektorých vecí, ktoré máme aj tu na Zemi, jednoducho nedokáže existovat'. To by bolo jedným s kritérií pri vyberaní „svojej“ planéty. Musí mat' teda Slnko, vodu, vzduch i zem. A čo ostatné veci? My sa pozrieme na svet, ktorý by si vybralo jedno mladé blond’avé dievča. Možno sa aj vy stotožníte s jej výberom. Pretože, máme vôbec na výber?

Hlavná postava je Blondína, ktorá objavuje taje našej planéty a popri tom vedie sama so sebou monológ o tom, čo je v živote dobré alebo zlé a kto to vlastne môže hodnotit'. V predstavení prevláda pohybové zobrazenie vnútorných emócií a nálad. Jednotlivé obrazy sú uzavreté menšie celky, ktoré rozoberajú konkrétnu myšlienku. Ako príklad uvádzame úryvok z monológu v druhom obraze: „Dni plynú d’alej a ja zistím, že sa chcem zhovárat' aj s inými živlami či tvormi. Preto si kladiem otázku. Dá sa rozprávat's vodou, kvetmi či motýlmi? Chcem to zažit'. S tou najväčsou pokorou by som prijala aj rozhovor s Bohom. Som však presvedčená, že by mi to aj tak nik neuveril. A práve to by bolo na tom to úžasné. Privlastky typu - tá baba je bláznivá, či chorá fanatička by viac-menej prichádzali od l'udí, ktorých $k$ svojmu životu vlastne ani nepotrebujem. Vrátili sme sa do doby kamennej, ktorú sme tu už raz mali. Najradšej by sme ukameňovali jeden druhého. Vôkol samá závist', nenávist', vojny, pretvárka, intrigy, falošné priatel'stvá a potom sa nerozprávaj s kvetmi, riekou či zvieratami. 
A to zaručene nie som šibnutá, $i$ ked' jeden nikdy nevie. Som predsa blondina, tak by mala moja hlava zivat' prázdnotou. Lebo to raz niekto tak povedal. "Zuzana Selecká8

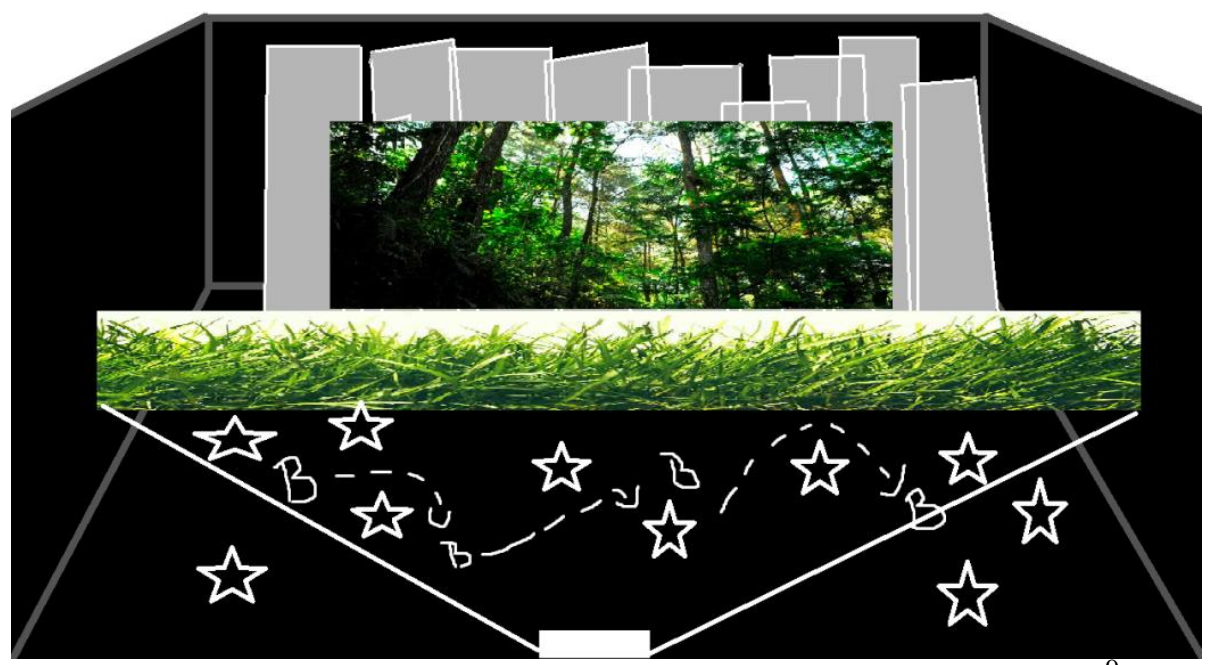

Obrázok 2 Návrh scény hudobno-dramatického predstavenia ${ }^{9}$

\section{ZÁVER}

„,Tvorivý l’udia sú inteligentnejší ale aj detinskejší súčasne, hraví a zároveñ disciplinovaní, extroverti azároven̆ introverti, alternujú medzi imagináciou, fantáziou a zakotvením $v$ zmysluplnej realite. Majú vel'a energie a majú váśnivo radi svoju prácu. "Miron Zelina ${ }^{10}$

Týmto výrokom sme sa inšpirovali aj pri príprave vyučovania na predmet choreografia. $\mathrm{Na}$ vyučovacích hodinách sme sa teda rozhodli vytvorit' prostredie, v ktorom by študenti mohli objavit' a rozvíjat' svoju umeleckú kreativitu. Preto sme im zadali vytvorit' tri hudobnodramatické projekty $\mathrm{s}$ vel'mi všeobecnými témami a pozorovali sme, ako pristúpia $\mathrm{k}$ ich spracovaniu. Či sa budú držat' naučených vzorcov a ostanú vo svojej komfortnej zóne (použitie postáv a príbehov, ktoré dobre poznajú - o víle, zvieratkách v lese, v cirkuse a podobne) alebo naopak, budú tvoriví a budú hl'adat' nové, nepoznané oblasti. Zo šiestich žiakov dvaja sledovali svoje zaužívané postupy a stratégie, ostatní sa nebáli experimentovat' a priniest' viaceré kreatívne nápady. $\mathrm{V}$ rámci spätnej väzby sme sa utvrdili v tom, že takýto prístup dal niektorým študentom mnoho nových skúseností, informácií a tiež zážitkov, či už spojených s tvorivým procesom alebo pri samotnom vyučovaní. Zároveň sme pozorovali zvýšenú motiváciu k činnosti, nakol'ko sme študentom dali len základné prostriedky, ktoré mohli podl'a svojho vlastného uváženia d'alej spracovat'. Možnost' slobodnej vol'by im na jednej strane spôsobovala miernu neistotu, na strane druhej však pôsobila na schopnost' niest' zodpovednost' za svoje rozhodnutia. Záverečné hodnotenie finálnych hudobno-dramatických predstavení spočívalo $\mathrm{v}$ spoločnej diskusii o tom, ako pristupovali študenti k tvorbe a čo by eventuálne zmenili. Tento postup sme zvolili preto, aby sme sa vyhli prípadnej kritike, či dokonca vyvolali v študentoch pocit, že niečo spravili zle. Naše usmernenia smerovali len $\mathrm{k}$ ich pedagogickému pôsobeniu, teda na tie vyučovacie hodiny, počas ktorých sa navzájom učili vybrané choreografie. Z nášho pozorovania vyplynulo, že niektorí žiaci k vyučovaniu

\footnotetext{
${ }^{8}$ SELECKÁ, Z. 2021. Svet podl’a mňa. [Seminárna práca]. Nitra: Univerzita Konštantína Filozofa v Nitre, 2021. S. $3.7 \mathrm{~s}$.

${ }^{9}$ Písmeno B predstavuje pohyb hlavnej postavy - Blondíny po priestore, hviezdy predstavujú priestorové rozostavenie tanečníkov, biela kocka vpredu je premietač a na zadných plátnach pripevnený obraz lesa.

${ }^{10}$ ZELINA, M., ZELINOVÁ, M. 1997. Tvorivý učitel': Osobnost' a práca tvorivého učitel'a v systéme tvorivohumanistickej výchovy. Bratislava: Metodické centrum, 1997. s. 11. 77 s.
} 
pristupovali povrchne, svojich žiakov si neboli schopní všímat' a priebeh učenia jednotlivých kombinácii neprispôsobili ich schopnostiam. Na tieto nedostatky sme študentov v diskusii upozornili. Atmosféra na hodinách (ktoré prebiehali online) bola vo všeobecnosti pozitívna. Mohlo to byt' spôsobené tým, že študenti sa dobre poznajú a mali záujem si navzájom pomáhat'.

\section{Použitá literatúra}

1. BARTKO, E. 2018. Stručná encyklopédia tanečného umenia. Bratislava: Verbunk, 2018. 637 s. ISBN 978-80-972203-2-7

2. CVIKOVÁ, D. 2016. Tanec ako výrazový prostriedok v hudobno-dramatickom projekte. [Bakalárska práca]. Nitra: Univerzita Konštantína Filozofa v Nitre, 2016. $50 \mathrm{~s}$.

3. FORDHAM, J. 1996. Jazz. Praha: Slovart, 1996. 216 s. ISBN 80-85871-99-8

4. LETENAJOVÁ, O. 2010. Tanečná technika Marthy Grahamovej jej formovanie a didaktika. Bratislava: Vysoká škola múzických umení, 2010. 87 s. ISBN 978-8089439-06-5

5. PROSTĚJOVSKÝ, M. 2008. Muzikál expres - malý průvodce velkým muzikálem. Brno: Větrné mlýny, 2008. 487 s. ISBN 978-80-86907-49-9

6. SELECKÁ, Z. 2021. Svet podl'a mn̆a. [Seminárna práca]. Nitra: Univerzita Konštantína Filozofa v Nitre, 2021. 7 s.

7. Vzdelávacie štandardy pre jednotlivé umelecké odbory ZUŠ, literárno-dramatický odbor. 2015. [online]. Oficiálne stránky Štátneho pedagogického ústavu. [cit. 202106-17]. 924 s. Dostupné na internete: https://www.statpedu.sk/files/articles/doku menty/inovovany-statny-vzdelavaci-program/vzdel--vacie--tandardy-z--kladn--umeleck----koly.pdf

8. ZELINA, M., ZELINOVÁ, M. 1997. Tvorivý učitel': Osobnost' a práca tvorivého učitel'a v systéme tvorivo-humanistickej výchovy. Bratislava: Metodické centrum, 1997. 77 s. ISBN 978-80-71641-92-6

\section{Kontaktné údaje}

Mgr. art. Zuzana Hubinská, PhD.

Univerzita Konštantína Filozofa v Nitre, Pedagogická fakulta, Katedra hudby

Dražovská 4, 94901 Nitra

Tel: 0902504183

email: zhubinska@ukf.sk 


\title{
POJĘCIE PRESJI OSIĄGNIĘĆ EDUKACYJNYCH
}

\section{THE CONCEPT OF ACADEMIC ACHIEVEMENT PRESSURE}

\author{
Bartosz Atroszko
}

\begin{abstract}
Abstrakt
Celem niniejszego artykułu jest przedstawienie konceptualizacji pojęcia presji osiągnięć edukacyjnych. Najczęściej w literaturze naukowej pisząc o stresie odczuwanym przez uczniów używa się pojęcia stresu szkolnego. Jednak jest to pojęcie bardzo ogólne, gdyż składa się na nie całe spektrum bardzo różnorodnych zjawisk, których wspólnym mianownikiem jest to, że są one związane w jakiś sposób ze szkołą lub szkolną edukacją. W niniejszym artykule zaproponowano wyróżnienie pojęcia presji osiągnięć edukacyjnych na oznaczenie tego rodzaju stresu, którego doświadczają uczniowie i studenci dążąc do osiągnięcia wąsko rozumianego sukcesu edukacyjnego.
\end{abstract}

Stowa kluczowe: osiagnięcia edukacyjne, presja osiagnięć, stres szkolny

\begin{abstract}
The purpose of this article is to present a conceptualization of the pressure of educational achievement. In the context of stress experienced by students, the term school stress is most often used. However, it is a very broad concept, as it comprises a whole spectrum of very diverse phenomena, the common denominator of which is that they are related in some way to school or school education. In this article, it is proposed to distinguish the concept of pressure of educational achievement to denote the type of stress that school or university students experience while striving to achieve a (narrowly understood) educational success.
\end{abstract}

Keywords: achievement pressure, educational achievements, school stress

\section{WPROWADZENIE}

Najmłodsze pokolenia Polaków coraz częściej cierpią na różnego rodzaju zaburzenia psychiczne (Tabak, 2014; Szredzińska, 2017). Jak twierdzą Oblacińska i Woynarowska (2014), nie znamy rzeczywistej skali tego zjawiska, ale szacuje się, że problem ten może dotyczyć od $10 \%$ do $20 \%$ populacji nastolatków. Właściwie nie wiadomo, co leży u podłoża tego problemu, gdyż brakuje precyzyjnych i systematycznych badań $\mathrm{w}$ tej dziedzinie (Atroszko, Atroszko, 2020, w druku). Potencjalnych czynników ryzyka zaburzeń psychicznych najmłodszych jest bardzo wiele, a jednym z ważniejszych jest stres odczuwany przez uczniów w szkole lub w związku z nauką szkolną. Pojęcie stresu szkolnego jest jednak bardzo szerokie, gdyż składa się na nie całe spektrum bardzo różnorodnych zjawisk (od niedogodności związanych ze zbyt wczesnym wstawaniem do szkoły, poprzez problemy z nauką, szkolny hałas w czasie przerw, aż do doznawania przemocy fizycznej od równieśników), których wspólnym mianownikiem jest to, że są one związane w jakiś sposób ze szkołą lub szkolną edukacją. Aby móc bardziej precyzyjnie określić związek pomiędzy stresem odczuwanym przez uczniów a występowaniem zaburzeń psychicznych, konieczne jest posługiwanie się bardziej precyzyjnym konstruktem niż stres szkolny.

Celem niniejszego rozdziału jest przedstawienie konceptualizacji pojęcia presji osiągnięć edukacyjnych. Zaproponowano wyróżnienie tego pojęcia na oznaczenie tego rodzaju stresu, którego doświadczają uczniowie i studenci dążąc do osiągnięcia wąsko rozumianego sukcesu 
edukacyjnego. Dzięki konceptualizacji, a w przyszłości operacjonalizacji pojęcia presji edukacyjnej, możliwe będzie stworzenie na tej podstawie narzędzia pomiarowego umożliwiającego rozwój badań nad negatywnymi konsekwencjami nauki szkolnej (wypaleniem młodzieży, uzależnieniem od uczenia się itd.) i predyktorami zaburzeń psychicznych dzieci i młodzież w sposób znacznie bardziej precyzyjny. W literaturze naukowej wyróżniono już co prawda pojęcie lęku egzaminacyjnego, co należy uznać za krok w dobrym kierunku, jednak pojęcie to jest zbyt wąskie i z tego względu niewystarczające $\mathrm{z}$ perspektywy badań nad konsekwencjami stresu odczuwanego przez uczniów każdego dnia (a nie tylko w okresie poprzedzającym udział w ważnym pomiarze szkolnym).

\section{CZYNNIKI RYZYKA ZABURZEŃ PSYCHICZNYCH DZIECI I MLODZIEŻY}

Potencjalnych determinantów zaburzeń psychicznych dzieci i młodzieży jest bardzo wiele (Kieling i inni, 2011), przy czym można je podzielić na te o podłożu biologicznym oraz psychospołecznym (Tabak, 2014). Do tej pierwszej kategorii należą uwarunkowania genetyczne (Kieling i inni, 2011), wcześniactwo (wiąże się ono z częstszymi problemami poznawczymi i emocjonalnymi; Chrzan-Dętkoś, Bogdanowicz, 2009; oraz z większym ryzykiem wystąpienia ADHD; Lindström, Lindblad, Hjern, 2011; Sucksdorff i inni, 2015), niezdrowa dieta (Jacka i inni, 2011; O’Neil i inni, 2014), działanie toksyn zawartych w pożywieniu (np. bisfenolu A; Nowosad, 2020) oraz dodatków do żywności (Kapczuk i inni, 2020), choroby, w tym przede wszystkim te o charakterze przewlekłym: otyłość (Sagar, Gupta, 2018) i choroby metaboliczne (Duda-Sobczak, Wierusz-Wysocka, 2011). Z kolei do tej drugiej kategorii należy ogół problemów związanych $\mathrm{z}$ funkcjonowaniem dziecka w rodzinie, w szkole oraz w grupie rówieśniczej (Tabak, 2014). Wymienia się w tym kontekście ekspozycję na przemoc, różnego rodzaju nadużycia i zaniedbania (Kieling i inni, 2011), rozpad więzi rodzinnych i wychowanie dziecka bez przynajmniej jednego z rodziców (Bramlett, Blumberg, 2007), rozwody (Fagan, Churchill, 2012; Anderson, 2014), separację i emigrację ekonomiczną jednego lub dwójki rodziców za granicę (zjawisko tzw. „eurosieroctwa“ Nowak, Gawęda, Janas-Kozik, 2012), brak wsparcia społecznego (Wight, Botticello, Aneshensel, 2006), nadużywanie substancji (Kieling i inni, 2011), aktywność seksualna we wczesnym wieku (Kieling i inni, 2011), niekorzystna sytuacja socjoekonomiczna (Reiss, 2013), wysoki poziom nierówności społecznych (Friedli, WHO 2009), niestandardowe godziny pracy rodziców (Dockery, Li, Kendall, 2009), większe zaangażowanie czasowe i emocjonalne rodziców w pracę zawodową (Polok i inni, 2018), czy brak poczucia bezpieczeństwa socjalnego rodzin wynikający $\mathrm{z}$ niepewności zatrudnienia (Sverke, Hellgren, Näswall, 2002), zmian na rynku pracy (Charles, DeCicca, 2008) i wysokiego poziom zadłużenia rodzin (Fitch i inni, 2011).

Czynnikiem ryzyka jest również upowszechnienie mediów społecznościowych (Woods, Scott, 2016) oraz zagrożeń związanych z nieograniczonym dostępem dzieci i młodzieży do Internetu (Twenge i inni, 2018). Skutkować to może problemami, które jeszcze kilka dekad temu w ogóle nie były znane, takimi jak uzależnienie od Internetu (Munno i inni, 2017), od gier komputerowych (Weinstein, 2010), od pornografii internetowej (Love i inni, 2015), od mediów społecznościowych (D’Arienzo, Boursier, Griffiths, 2019), od Facebooka (Atroszko i inni, 2018), od Instagrama (Kircaburun, Griffiths, 2018), od zakupów internetowych (Lam, Lam 2017), od Smartphonów (Wolniewicz i inni, 2018), od hazardu internetowego (King, Russell, Hing, 2020), czy nadużywanie komunikacji tekstowej za pomocą urządzeń mobilnych (Lee i inni, 2016). Internet posiada olbrzymi potencjał uzależniania dzieci i młodzieży, w wyniku czego staje się dla nich źródłem nowych problemów i zagrożeń. Ponadto warto zaznaczyć, że media społecznościowe, technologie mobilne i serwisy internetowe dynamicznie się zmieniają, wciąż są rozwijane, udoskonalane i przez to z czasem prawdopodobnie będą postrzegane jako coraz bardziej atrakcyjne dla swoich użytkowników. 
W związku z tym można się spodziewać, że w przyszłości ich potencjał uzależniania dzieci, młodzieży i osób dorosłych będzie jeszcze większy niż jest obecnie.

\section{STRES SZKOLNY JAKO CZYNNIK RYZYKA ZABURZEŃ PSYCHICZNYCH}

Szkolna edukacja jest jednym z najważniejszych źródeł stresu odczuwanego przez dzieci i młodzież (Talik, 2011; Van Schalkwijk i inni, 2015). Wynika to najprawdopodobniej z tego, że stawia ona przed najmłodszymi wyzwania z którymi nigdy wcześniej nie musieli oni sobie radzić, takie jak wypowiadanie się w większej grupie osób (na forum klasy), sytuacja bycia ocenianym, uczestnictwo w sprawdzianach i egzaminach, konkurowanie z innymi uczniami itd. Źródłem stresu może być również asymetria w relacji nauczyciel-uczeń, podporządkowanie osobie dorosłej, konieczność wykonywania jej poleceń i bycia przez nią dyscyplinowanym. Istotnym problemem jest również przeciążenie uczniów nauką (Atroszko, 2021, w druku). Stres występujący w szkole nie jest zjawiskiem nowym, gdyż o tym, że szkoła budziła w uczniach ogromny strach i wielką niechęć możemy przeczytać już u autorów żyjących w poprzednich stuleciach (Komeński, 1956; Chojnacki, 1815). W przeszłości silnym źródłem strachu uczniów były występujące w szkołach kary cielesne, jednak ich usunięcie ze szkół nie zlikwidowało stresu szkolnego. Całkowite usunięcie stresu ze szkół wydaje się nie tylko niemożliwe, ale wręcz niepożądane, gdyż podejmowaniu nowych wyzwań przez dzieci i młodzież zawsze towarzyszy jakiś poziom odczuwanego stresu. Z kolei trudno sobie wyobrazić edukację i rozwój uczniów bez podejmowania działań, które (przynajmniej początkowo) wydają się nowe, trudne, nie do końca zrozumiałe lub skomplikowane. Można też argumentować, że jeśli szkoła ma przygotować uczniów do życia w dorosłości, to odczuwanie stresu jest potrzebne uczniom, aby mogli nauczyć się skutecznych strategii radzenia sobie $\mathrm{z}$ nim. Należy podkreślić, że problemem nie jest więc samo występowanie stresu w szkole, ale jego nadmiar, jego przewklekły charakter i destruktywny wpływ na najmłodszych. Na podstawie literatury naukowej można założyć, że stres odczuwany przez uczniów nierzadko przekracza ich możliwości adaptacyjne i niszczy ich dobrostan psychicznych. Z badań wynika, że stres szkolny wiąże się z pogorszeniem stanu zdrowia uczniów (Torsheim, Wold, 2001), w tym również ich zdrowia psychicznego (Thapar i inni, 2012; Glozah, Pevalin, 2014; LeMoult i inni, 2020). Wiele też wskazuje na to, że jest on ważnym czynnikiem stojącym u podłoża podejmowania przez dzieci i młodzież prób samobójczych (Richardson i inni, 2005; Greydanus, Calles, 2007; Napieralska i inni, 2010; Mishra i inni, 2013).

\section{DEFINICJA PRESJI OSIĄGNIĘĆ EDUKACYJNYCH}

Jak już wspomniano, ponieważ pojęcie stresu szkolnego jest bardzo szerokie, dlatego potrzebny jest bardziej precyzyjny konstrukt. Presja osiągnięć edukacyjnych (czy krócej: presja edukacyjna) to stres, którego doświadczają uczniowie i studenci w związku z dążeniem do wąsko definiowanego sukcesu edukacyjnego, rozumianego na ogół jako wysoka średnia z ocen i/lub wysoki wynik na egzaminach zewnętrznych (por. Atroszko, Atroszko, 2020, w druku). Konstrukt ten obejmuje wyłącznie kwestie związane bezpośrednio z nauką i odwołuje się do pojęcia sukcesu edukacyjnego, rozumianego jako ostateczny cel procesu kształcenia.

Pojęcie sukcesu edukacyjnego można zdefiniować na wiele różnych sposobów, zaś obszerny przegląd literatury na ten temat przedstawili York, Gibson i Rankin (2015). Z jednej strony jest ono bardzo nieprecyzyjne i wieloznaczne, z drugiej zaś jest powszechnie używane i służy organizowaniu myślenia o funkcjonowaniu systemu edukacyjnego. Przyjmuje się założenie, że poszczególne osiągnięcia dzieci i młodzież są odpowiednio nagradzane (w formie dobrych ocen, plusów za aktywność, itd.) i zbliżają je coraz bardziej do pożądanego celu, którym jest sukces edukacyjny. Można go utożsamiać ze zdobyciem odpowiedniej wiedzy, umiejętności i postaw, które $\mathrm{w}$ przyszłości zapewnią zdobycie dobrej pracy i osiągnięcie sukcesu 
życiowego. Sukces szkolny czy akademicki nie jest więc celem samym w sobie, lecz raczej środkiem do osiągnięcia bardziej dalekosiężnych celów, którymi są dobrobyt materialny i zajęcie uprzywilejowanej pozycji w hierarchii społecznej. Należy podkreślić, że dla pojęcia presji osiągnięć edukacyjnych znaczenie mają wyłącznie wymierne osiągnięcia, a więc takie, które z założenia mogą być podstawą podziału uczniów na „gorszych“ i „lepszych“ i które mają wpływ na status osób uczących się np. na to, czy otrzymają nagrodę w postaci świadectwa z czerwonym paskiem, stypendium naukowego, dostępu do wyższej uczelni itd. Skupienie edukacji wyłącznie na wymiernych osiągnięciach osób uczących się jest pod wieloma względami problematyczne. Może to skutkować tym, że ważniejsze od zdobycia przez ucznia wiedzy czy rozwoju jego umiejętności będą de facto idące za tym oceny i punkty na egzaminach, gdyż to właśnie one są symbolem sukcesu edukacyjnego (w wąskim rozumieniu), umożliwiającym z założenia dostęp do cennych zasobów społecznych w przyszłości (lepszej pracy, wyższych zarobków, wyższego statusu społecznego itd.).

Z oczywistych względów ideologia stojąca za wąsko definiowanym sukcesem edukacyjnym budowana jest na wątpliwych przesłankach. Związek pomiędzy wynikami w nauce a sukcesem zawodowym i życiowym nie jest wcale ani konieczny, ani pewny. Jak ujął to P. Stańczyk (2009), młodzi ludzie, którzy uwierzyli w merytokratyczną wizję społeczeństwa, są „oszukanym pokoleniem”. Obecnie sukces edukacyjny nie gwarantuje zdobycia wysokopłatnej pracy, dobrobytu materialnego, ani uprzywilejowanej pozycji w hierarchii społecznej, lecz co najwyżej zwiększa w jakimś stopniu prawdopodobieństwo ich osiągnięcia. Wiele innych czynników, takich jak pozycja społeczna i materialna rodziców ucznia czy studenta, sieć kontaktów towarzyskich i zawodowych, silny charakter i odpowiednie cechy osobowości, dobra koniunktura gospodarcza, czy wreszcie szczęśliwy zbieg okoliczności mogą okazać się ważniejsze w osiągnięciu celów życiowych od dyplomu wyższej uczelni.

Należy nadmienić, że chociaż presja osiągnięć edukacyjnych nie była konceptualizowana jako osobny konstrukt, to zbliżone konstrukty były już badane $w$ sposób empiryczny. Przykładowo, Stres związany z presja osiagnięć jest jedną z podskal Inwentarza źródeł stresu szkolnego młodzieży autorstwa Skowrońskiego i Pabicha (2015). Również w innych kwestionariuszach badających stres szkolny lub bardziej ogólnie stres odczuwany przez młodzież, jednym z kluczowych elementów jest stres związany z wynikami szkolnymi np. podskala Stress of School Performance w kwestionariuszu Adolescent stress questionnaire (ASQ) autorstwa Byrne'a, Davenporta i Mazanova (2007).

\section{PODSUMOWANIE}

W niniejszym rozdziale przedstawiono konceptualizację pojęcia presji osiągnięć edukacyjnych. Stanowi ona wstępny krok do jej operacjonalizacji, a w dalszej perspektywie stworzenia narzędzia do jej pomiaru. W założeniu konstrukcja tego typu narzędzia umożliwi prowadzenie badań edukacyjnych i psychologicznych w sposób bardziej precyzyjny niż miało to miejsce $\mathrm{z}$ wykorzystaniem konstruktu stresu szkolnego. Jest to konieczne, aby w sposób bardziej szczegółowy poznać determinanty pogorszającego się stanu zdrowia psychicznego polskich dzieci i młodzieży.

Wydaje się również zasadne zbadanie roli oczekiwań rodzicielskich w powstawaniu i nasileniu owej presji. Prawdopodobnie jest ona związana nie tylko z aspiracjami rodziców uczniów, ich pragnieniem sukcesu dla swoich dzieci, ale również ze zjawiskami w skali makrospołecznej, takimi jak np. dominujący w społeczeństwach zachodnich kult sukcesu (Długosz, 2017), kultura rywalizacyjności (Stadnik, 2008; Di Stasio, Savage, Burgos, 2016), czy oddziaływanie mediów i kreowanych przez nie wzorców osobowych (Kolber, 2016). 


\section{Źródla}

1. ANDERSON, J. The impact of family structure on the health of children: Effects of divorce. The Linacre Quarterly, 81(4), 2014, s. 378-387.

2. ATROSZKO, B., Dlaczego uczniowie polskich szkót sa przeciążeni nauką? W druku, 2021.

3. ATROSZKO, B., ATROSZKO, P.A. Presja edukacyjna a rozwój uzależnienia od uczenia się, uzależnienia od pracy oraz innych zaburzeń psychicznych. Ars Educandi, 2020, w druku.

4. ATROSZKO, P.A., BALCEROWSKA, J.M., BEREZNOWSKI, P., BIERNATOWSKA, A., PALLESEN, S., ANDREASSEN, C.S. Facebook addiction among Polish undergraduate students: Validity of measurement and relationship with personality and well-being. Computers in Human Behavior, 85, 2018, s. 329-338.

5. BRAMLETT, M.D., BLUMBERG, S.J. Family structure and children's physical and mental health. Health Affairs, 26(2), 2007, s. 549-558.

6. BYRNE, D.G., DAVENPORT, S.C., MAZANOV, J. Profiles of adolescent stress: The development of the adolescent stress questionnaire (ASQ). Journal of Adolescence, 30(3), 2007, s. 393-416.

7. CHARLES, K.K., DECICCA, P. Local labor market fluctuations and health: is there a connection and for whom? Journal of Health Economics, 27(6), 2008, s. 15321550 .

8. CHOJNACKI, W.I. Zasady piérwiástkowé pedagogiki i metodyki. Dziéto mogacé stużyć dla trudniacych się edukacyia publiczna i prywatna elementarna. Warszawa: Drukarnia Wiktora Dąbrowskiego, 1815.

9. CHRZAN-DĘTKOŚ, M., BOGDANOWICZ, M. Rozwój poznawczy i emocjonalnospołeczny wcześniaków w wieku przedszkolnym. Pediatria Polska, 84(6), 2009, s. 517-523.

10. D'ARIENZO, M.C., BOURSIER, V., GRIFFITHS, M.D. Addiction to social media and attachment styles: a systematic literature review. International Journal of Mental Health and Addiction, 17(4), 2019, s. 1094-1118.

11. DI STASIO, M.R., SAVAGE, R., BURGOS, G. Social comparison, competition and teacher-student relationships in junior high school classrooms predicts bullying and victimization. Journal of Adolescence, 53, 2016, s. 207-216.

12. DŁUGOSZ, K. Kult sukcesu w kontekście kształcenia uczniów ze specjalnymi potrzebami edukacyjnymi. [W:] red. M. Humeniuk, I.Paszenda, W. Żłobicki, Sukces jako zjawisko edukacyjne (s. 241-250). Wrocław: Instytut Pedagogiki Uniwersytetu Wrocławskiego, 2017. ISBN 978-83-62618-27-9.

13. DOCKERY, A., LI, J., KENDALL, G. Parents' work patterns and adolescent mental health. Social Science \& Medicine, 68(4), 2009, s. 689-698.

14. DUDA-SOBCZAK, A., WIERUSZ-WYSOCKA, B. Cukrzyca a choroby psychiczne. Psychiatria Polska, 45(4), 2011, s. 589-598.

15. FAGAN, P.F., CHURCHILL, A. The effects of divorce on children. Marri Research, 1, 2012, s. 1-48.

16. FITCH, C., HAMILTON, S., BASSETT, P., DAVEY, R. The relationship between personal debt and mental health: a systematic review. Mental Health Review Journal, 16(4), 2011, s. 153-166.

17. FRIEDLI, L., WORLD HEALTH ORGANIZATION, Mental health, resilience and inequalities. Copenhagen: WHO Regional Office for Europe, 2009. No. EU/08/508 7203. 
18. GLOZAH, F.N., PEVALIN, D.J. Social support, stress, health, and academic success in Ghanaian adolescents: A path analysis. Journal of Adolescence, 37(4), 2014, s. 451-460.

19. GREYDANUS, D.E., CALLES, Jr J., Suicide in children and adolescents. Primary Care: Clinics in Office Practice, 34(2), 2007, s. 259-273.

20. JACKA, F.N., KREMER, P.J., BERK, M., DE SILVA-SANIGORSKI, A.M., MOODIE, M., LESLIE, E.R.,... SWINBURN, B.A. A prospective study of diet quality and mental health in adolescents. PloS One, 6(9), 2011, e24805.

21. KAPCZUK, P., KOMORNIAK, N., ROGULSKA, K., BOSIACKI, M., CHLUBEK, D. Żywność wysokoprzetworzona i jej wpływ na zdrowie dzieci i osób dorosłych. Postępy Biochemii, 66(1), 2020, s. 23-29.

22. KIELING, C., BAKER-HENNINGHAM, H., BELFER, M., CONTI, G., ERTEM, I., OMIGBODUN, O.,... RAHMAN, A., Child and adolescent mental health worldwide: Evidence for action. The Lancet, 378(9801), 2011, s. 1515-1525.

23. KING, D.L., RUSSELL, A., HING, N. Adolescent land-based and internet gambling: Australian and international prevalence rates and measurement issues. Current Addiction Reports, 7(2), 2020, s. 137-148.

24. KIRCABURUN, K., GRIFFITHS, M.D. Instagram addiction and the Big Five of personality: The mediating role of self-liking. Journal of Behavioral Addictions, 7(1), 2018, s. 158-170.

25. KOLBER, M. Wirtualna koncepcja człowieka sukcesu - codzienność rzeczywistość szkolna. Przegląd Pedagogiczny, 2, 2016, s. 78-87.

26. KOMEŃSKI, J.A., Wielka dydaktyka. Wrocław: Zakład imienia Ossolińskich Wydawnictwo Polskiej Akademii Nauk, 1956.

27. LAM, L.T., LAM, M.K. The association between financial literacy and Problematic Internet Shopping in a multinational sample. Addictive Behaviors Reports, 6, 2017, s. 123-127.

28. LEE, Y.L., VERMA, R.K., YADAV, H., BARUA, A. Health impacts of Facebook usage and mobile texting among undergraduate dental students: it's time to understand the difference between usage and an excessive use. European Journal of Dental Education, 20(4), 2016, s. 218-228.

29. LEMOULT, J., HUMPHREYS, K.L., TRACY, A., HOFFMEISTER, J.A., IP, E., GOTLIB, I.H. Meta-analysis: exposure to early life stress and risk for depression in childhood and adolescence. Journal of the American Academy of Child \& Adolescent Psychiatry, 59(7), 2020, s. 842-855.

30. LINDSTRÖM, K., LINDBLAD, F., HJERN, A. Preterm birth and attentiondeficit/hyperactivity disorder in schoolchildren. Pediatrics, 127(5), 2011, s. 858-865.

31. LOVE, T., LAIER, C., BRAND, M., HATCH, L., HAJELA, R. Neuroscience of Internet pornography addiction: A review and update. Behavioral Sciences, 5(3), 2015, s. 388-433.

32. MISHRA, N., SHRESTHA, D., POUDYAL, R., MISHRA, P., Retrospective study of suicide among children and young adults. Journal of Nepal Paediatric Society, 33(2), 2013, s. 110-116.

33. MUNNO, D., CAPPELLIN, F., SAROLDI, M., BECHON, E., GUGLIELMUCCI, F., PASSERA, R., ZULLO, G. Internet Addiction Disorder: Personality characteristics and risk of pathological overuse in adolescents. Psychiatry Research, 248, 2017, s. 1-5.

34. NAPIERALSKA, E., KUŁAGA, Z., GURZKOWSKA, B., GRAJDA, A. Epidemiologia zgonów dzieci i młodzieży z powodu samobójstw w Polsce w latach 1999-2006. Problemy Higieny i Epidemiologii, 91(1), 2010, s. 92-98. 
35. NOWAK, M., GAWĘDA, A., JANAS-KOZIK, M. Zjawisko eurosieroctwa a kierunki pracy terapeutycznej i leczenia psychiatrycznego - prezentacja przypadku. Psychiatria Polska, 46(2), 2012, s. 295-304.

36. NOWOSAD, K. Wpływ bisfenolu A na zdrowie człowieka. Wiadomości Chemiczne, 74(5-6), 2020, s. 411-422.

37. OBLACIŃSKA, A., WOYNAROWSKA, B. Stan zdrowia dzieci i młodzieży w Polsce. Najważniejsze problemy zdrowotne. Studia Bas, 2, 2014, s. 41-64.

38. O'NEIL, A., QUIRK, S.E., HOUSDEN, S., BRENNAN, S.L., WILLIAMS, L.J., PASCO, J.A.,... JACKA, F.N., Relationship between diet and mental health in children and adolescents: a systematic review. American Journal of Public Health, 104(10), 2014, e31-e42.

39. POLOK, G., SZROMEK, A.R., KRANNICH, M, WYBRAŃCZYK, K. Wpływ uzależnienia od pracy zawodowej, rozpadu rodziny oraz alkoholizmu na współistniejące zachowania wśród osób do 35 roku życia. Zeszyty Naukowe. Organizacja i Zarządzanie/Politechnika Ślaska, 131, 2018, s. 453-465.

40. REISS, F. Socioeconomic inequalities and mental health problems in children and adolescents: a systematic review. Social Science \& Medicine, 90, 2013, s. 24-31.

41. RICHARDSON, A.S., BERGEN, H.A., MARTIN, G., ROEGER, L., ALLISON, S. Perceived academic performance as an indicator of risk of attempted suicide in young adolescents. Archives of Suicide Research, 9(2), 2005, s. 163-176.

42. SAGAR, R., GUPTA, T. Psychological aspects of obesity in children and adolescents. The Indian Journal of Pediatrics, 85(7), 2018, s. 554-559.

43. SKOWROŃSKI, B., PABICH, R. Inwentarz źródeł stresu szkolnego młodzieży opis konstrukcji i własności psychometryczne. Profilaktyka Społeczna $i$ Resocjalizacja, 28, 2015, s. 7-35.

44. STADNIK, K. Walka młodych kotek. Kultura ukrytej agresji i rywalizacji jako wszechobecny element dziewczęcej codzienności w perspektywie socjologii. Kultura i Edukacja, 68(4), 2008, s. 56-72.

45. STAŃCZYK, P. Młodzież wobec ideologii merytokracji - pozytywna socjalizacja oszukanego pokolenia. Forum Oświatowe, 21(1)(40), 2009, s. 17-38.

46. SUCKSDORFF, M., LEHTONEN, L., CHUDAL, R., SUOMINEN, A., JOELSSON, P., GISSLER, M., SOURANDER, A. Preterm birth and poor fetal growth as risk factors of attention-deficit/hyperactivity disorder. Pediatrics, 136(3), 2015, e599-e608.

47. SVERKE, M., HELLGREN, J., NÄSWALL, K. No security: a meta-analysis and review of job insecurity and its consequences. Journal of Occupational Health Psychology, 7(3), 2002, 242.

48. SZREDZIŃSKA, R. Zdrowie dzieci i młodzieży. [W:] red. M. Sajkowska, Dzieci się liczą. Raport z zagrożeń bezpieczeństwa i rozwoju dzieci w Polsce (s. 92-129). Warszawa: Fundacja Dajemy Dzieciom Siłę, 2017.

49. TABAK, I. Zdrowie psychiczne dzieci i młodzieży. Wsparcie dzieci i młodzieży w pokonywaniu problemów. Studia BAS, 2, 2014, s. 113-138.

50. TALIK, E. Specyfika stresu szkolnego i strategie radzenia sobie z nim przez młodzież w okresie dorastania. Horyzonty Psychologii i Nauk o Człowieku, 1(1), 2011, s. 127-137.

51. THAPAR, A., COLliShaW, S., PINE, D.S., THAPAR, A.K. Depression in adolescence. The Lancet, 379(9820), 2012, s. 1056-1067.

52. TORSHEIM, T., WOLD, B. School-related stress, school support, and somatic complaints: A general population study. Journal of Adolescent Research, 16(3), 2001, s. 293-303. 
53. TWENGE, J.M., JOINER, T.E., ROGERS, M.L., MARTIN, G.N. Increases in depressive symptoms, suicide-related outcomes, and suicide rates among US adolescents after 2010 and links to increased new media screen time. Clinical Psychological Science, 6(1), 2018, s. 3-17.

54. VAN SCHALKWIJK, F.J., BLESSINGA, A.N., WILLEMEN, A.M., VAN DER WERF, Y.D., SCHUENGEL, C. Social support moderates the effects of stress on sleep in adolescents. Journal of Sleep Research, 24(4), 2015, s. 407-413.

55. WEINSTEIN, A.M. Computer and video game addiction - a comparison between game users and non-game users. The American Journal of Drug and Alcohol Abuse, 36(5), 2010, s. 268-276.

56. WIGHT, R.G., BOTTICELLO, A.L., ANESHENSEL, C.S. Socioeconomic context, social support, and adolescent mental health: A multilevel investigation. Journal of Youth and Adolescence, 35(1), 2006, 109.

57. WOLNIEWICZ, C.A., TIAMIYU, M.F., WEEKS, J.W., ELHAI, J.D. Problematic smartphone use and relations with negative affect, fear of missing out, and fear of negative and positive evaluation. Psychiatry Research, 262, 2018, s. 618-623.

58. WOODS, H.C., SCOTT, H. \# Sleepyteens: Social media use in adolescence is associated with poor sleep quality, anxiety, depression and low self-esteem. Journal of Adolescence, 51, 2016, s. 41-49.

59. YORK, T.T., GIBSON, C., RANKIN, S. Defining and measuring academic success. Practical Assessment, Research, and Evaluation, 20(1), 2015.

\section{Kontakt}

Mgr Bartosz Atroszko

Uniwersytet Gdański

Bażyńskiego 8, Gdańsk, Polska

Tel: 603112458

email: bartosz.atroszko@gmail.com 


\title{
ŹRÓDLA I KONSEKWENCJE STRESU SZKOLNEGO DOŚWIADCZANEGO PRZEZ UCZNIÓW
}

\section{SCHOOL STUDENTS' STRESS: SOURCES AND CONSEQUENCES}

\author{
Bartosz Atroszko
}

\begin{abstract}
Abstrakt
Szkolna edukacja jest jednym z głównych źródeł stresu odczuwanego przez dorastającą młodzież. Źródłem stresu szkolnego dla uczniów są problemy z relacjach interpersonalnych z rówieśnikami i nauczycielami, sytuacje ekspozycji społecznej (występowania publicznego i bycia ocenianym), oczekiwania rodziców dotyczące wyników w nauce, nadmiar nauki i sposób jej organizacji, odczuwanie nudy przez uczniów oraz nowe sytuacje związane ze szkołą. Z kolei konsekwencjami odczuwania przez uczniów stresu szkolnego jest pogorszenie stanu zdrowia fizycznego i psychicznego, różnego rodzaju dolegliwości somatyczne, problemy ze snem, otyłość, a także (rzadziej) podejmowanie prób samobójczych.
\end{abstract}

Keywords: konsekwencje stresu, młodzież, stres szkolny, źródła stresu

\begin{abstract}
School education is one of the main sources of stress experienced by adolescents. The sources of school stress for students are problems with interpersonal relationships with peers and teachers, situations of social exposure (public speaking and being judged), parents' expectations of learning outcomes, excess of learning and the way it is organized, students feeling bored and new situations related to school. In turn, the consequences of students experiencing school stress are the deterioration of their physical and mental health, various somatic ailments, sleep problems, obesity, and even suicide attempts.
\end{abstract}

Keywords: adolescents, consequences of stress, school stress, sources of stress

\section{WPROWADZENIE}

Szkolna edukacja jest jednym z głównych źródeł stresu odczuwanego przez dorastającą młodzież (Van Schalkwijk i inni, 2015). Pojęcie stresu szkolnego jest złożonym konstruktem, gdyż de facto obejmuje ono bardzo różne sytuacje w których dzieci i młodzież doświadczają wzmożonego napięcia psychicznego. Ich wspólnym mianownikiem jest to, że owe sytuacje mają miejsce w szkole lub bezpośrednio wiążą się ze szkolną edukacją. Najmłodsi stresują się zarówno samą nauką (sprawdzianami, ocenami, pracami domowymi itd.), jak i relacjami z innymi osobami zaangażowanym w proces nauczania (uczniami, nauczycielami itd.)(Sikora, 2010). Przegląd różnych definicji stresu szkolnego przedstawili D'aurora i Fimian (1988). Można przyjąć, że problem ten występuje od początku istnienia szkoły jako instytucji życia społecznego, gdyż na silne, negatywne emocje odczuwane przez uczniów w czasie trwania lekcji zwracał uwage już Jan Amos Komeński ponad 350 lat temu. Autor tak opisywał ówczesne szkoły i dominujące w nich metody:

(...) $w$ ksztatceniu mtodzieży stosowano przeważnie tak surowa metodę, że szkoty uważane byty powszechnie za postrach dla chłopców i za miejsce kaźni umysłowej; toteż większość uczniów zbrzydziwszy sobie nauke i ksiązki przyspieszała swe przejście do warsztatów rzemieślniczych czy do innych zawodów (Komeński, 1956, s. 84).

Chociaż problem stresu szkolnego istnieje od stuleci, to jest on systematycznie badany dopiero od kilku dekad. 


\section{JAKIE SĄ ŹRÓDLA STRESU SZKOLNEGO?}

Źródła stresu szkolnego są wyjątkowo złożone. Jednym z ważniejszych źródeł stresu dla uczniów są problemy w relacjach z rówieśnikami (Skowroński, Pabich, 2015; Sikora, 2010; Korczyński, 2014). Problemem jest przemoc, której doznają lub której obawiają się uczniowie (Skowroński, Pabich, 2015) i brak poczucia bezpieczeństwa (Korczyński, 2014), zjawisko bullyingu i cyberbullyingu (Twardowska-Staszek, Zych, 2019), dyskryminacja ze strony rówieśników (Grzymała-Moszczyńska, Stoecker, 2015; Gawlicz, Rudnicki, Starnawski, 2015), niezdrowa rywalizacja z innymi uczniami (Talik, 2011) i związane z tym uczucie zazdrości (Korczyński, 2014), czy choćby brak akceptacji wyglądu przez rówieśników (Skowroński, Pabich, 2015). Ważnym źródłem stresu dla uczniów są relacje z nauczycielem, a zwłaszcza $\mathrm{z}$ nauczycielami przejawiającymi niekorzystne postawy wobec ucznia (Skowroński, Pabich, 2015; Sikora, 2010). Nauczyciele, podobnie jak uczniowie, bywają również źródłem dyskryminacji (Grzymała-Moszczyńska, Stoecker, 2015).

Uczniowie stresują się sytuacjami ekspozycji społecznej, a więc sytuacjami w których przykładowo występują na apelu szkolnym, recytują wiersz przed całą klasą, są odpytywani przy tablicy lub muszą przeczytać własne opowiadanie lub pracę domową na głos etc. Z jednej strony jest to więc sytuacja wystąpienia publicznego, z drugiej zaś sytuacja bycia ocenianym, co wiąże się z ryzykiem otrzymania negatywnej oceny, uwagi do dziennika lub bycia ośmieszonym publicznie. Na tego rodzaju źródła stresu szkolnego zwracają uwagę Skowroński i Pabich (2015), Korczyński (2014), czy Leśniak (2015).

Jednym z głównych źródeł stresu szkolnego jest przeciążenie nauką pod pojęciem którym należy rozumieć zmęczenie, brak czasu na odpoczynek po szkole oraz brak równowagi pomiędzy nauką i odpoczynkiem (Sikora, 2010; Leśniak, 2015; Korczyński, 2014; LewickaZelent, Trojanowska, 2018). Problem ten polega między innymi na konieczności odrabiania czasochłonnych prac domowych (Sikora, 2010; Leśniak, 2015). Uczniowie stresują się koniecznością spełnienia oczekiwań rodzicielskich związanych $\mathrm{z}$ wynikami $\mathrm{w}$ nauce (Skowroński, Pabich, 2015) i odczuwają presję osiągnięć edukacyjnych (Atroszko, 2021, w druku).

Czynnikiem, który niewątpliwie wywołuje w uczniach stres jest sposób organizacji nauki szkolnej, a więc konieczność bardzo wczesnego wstawania do szkoły (w sytuacji kiedy lekcje zaczynają się o godz. 8.00), znaczna liczba lekcji w ciągu jednego dnia, konieczność zachowania milczenia $\mathrm{w}$ trakcie lekcji i pozostawania przez 45 minut $\mathrm{w}$ jednej pozycji etc. Problemem jest też to, że spora część czasu spędzanego w szkole przez uczniów jest marnowana (Kwieciński, 1992; Groenwald, 2020). Uczniowie nudzą się w szkole (Stańczyk, 2012; Szmidt, 2013), tymczasem w literaturze naukowej zwraca się uwagę, że nudę $\mathrm{i}$ monotonię należy uznać za stresory (Thackray, 1981).

Zmiana środowiska szkolnego jest dla uczniów sytuacją stresującą (Skowroński, Pabich, 2015). Stres wywołuje sama konieczność poruszania się po zazwyczaj dużym i nieznanym dotychczas budynku szkolnym (Sikora, 2010; Leśniak, 2015), a dla młodszych uczniów problemem jest samodzielne dotarcie do domu po zakończeniu ostatniej lekcji i otworzenie drzwi do mieszkania (Sikora, 2010).

\section{JAKIE SĄ KONSEKWENCJE DOŚWIADCZANIA PRZEZ UCZNIÓW STRESU ZWIĄZANEGO Z NAUKĄ SZKOLNĄ?}

W literaturze naukowej podkreśla się związek stresu szkolnego odczuwanego przez dzieci i młodzież z gorszym stanem zdrowia fizycznego (Supranowicz, Wysocki, 2010), z częstszym występowaniem chorób somatycznych, częstszymi bólami głowy, brzucha, pleców, zawrotami głowy i wspólistniejącymi dolegliwościami somatycznymi (Torsheim, Wold, 
2001). Stres odczuwany przez młodzież jest ważnym czynnikiem ryzyka wystąpienia problemów ze snem (Chung, Cheung, 2008; Van Schalkwijk i inni, 2015; Yan i inni, 2018).

Chroniczny stres odczuwany przez młodzież jest związany pozytywnie z występowaniem otyłości (De Vriendt, Moreno, De Henauw, 2009; Wilson, Sato, 2014), chociaż należy podkreślić, że mechanizm związany z tym zjawiskiem nie jest prosty. Z jednej strony napięcie psychiczne może skłaniać do przyjmowania zbyt dużej liczby kalorii, ale $\mathrm{z}$ drugiej strony bycie otyłym może być źródłem stresu, negatywnego obrazu samego siebie i pretekstem do upokarzających uwag ze strony innych osób (Pervanidou, Chrousos, 2011).

Stres odczuwany przez nastolatków wywiera negatywny wpływ na stan ich zdrowia psychicznego (Glozah, Pevalin, 2014). Wyższy poziom stresu szkolnego wiąże się z z częstszym występowaniem zaburzeń psychicznych, w tym objawów depresji (Moksnes i inni, 2016; Thapar i inni, 2012; LeMoult i inni, 2020), gorszym samopoczuciem i wyższym poziomem lęku społecznego (Verma, Sharma, Larson, 2002).

Wiele też wskazuje na to, że edukacja szkolna i związany z nią silny stres mogą kryć się za wieloma samobójstwami popełnianymi przez najmłodszych. Zarówno polscy badacze (Makara-Studzińska, 2013; Napieralska i inni, 2010), jak i badacze z innych państw (Greydanus, Calles, 2007; Mishra i inni, 2013; Richardson i inni, 2005) wskazują na niepowodzenia szkolne jako istotny czynnik skłaniający dzieci i młodzież do zakończenia swojego życia.

Konsekwencjami przewlekłego stresu szkolnego może być rozwój takich zaburzeń jak uzależnienie od uczenia się, fobia szkolna czy wypalenie szkolne. Są to zaburzenia dotykające wyłącznie osób uczących się.

Uzależnienie od uczenia się jest definiowane jako kompulsywne, nadmierne zaangażowanie w uczenie się, utrudniające funkcjonowanie $\mathrm{w}$ innych sferach życia oraz mające szkodliwy wpływ na jednostkę i/lub jej otoczenie (Atroszko i inni, 2015). Zakłada się, że może być ono wczesną formą uzależnienia od pracy (Atroszko i inni, 2016). Szacuje się, że problem ten może dotyczyć 15\% uczniów szkół średnich (Wróbel, 2020) i 16\% studentów akademii muzycznych (Lawendowski i inni, 2020). Rozwój uzależnienia od uczenia się jest ściśle związany ze stresem odczuwanym przez osoby uczące się (Atroszko, 2015).

Z kolei fobia szkolna przynależy do kategorii zaburzeń lękowych i objawia się tym, że uczeń reaguje na sytuacje związane ze szkołą i szkolną nauką bardzo silnym lękiem, nieproporcjonalnym do realnego zagrożenia (Regulska, 2014). Szacuje się, że problem ten może dotyczyć 5\% ogółu uczniów szkół podstawowych i średnich niższego szczebla (ang. middle school - odpowiedniki gimnazjów)(Tyrrell, 2005). Badania nad tym zaburzeniem prowadzone są co najmniej od lat 40. XX wieku (Johnson i inni, 1941; Jacobsen, 1948; van Houten, 1948). Z oczywistych względów fobia szkolna ma wyjątkowo negatywny wpływ na życie młodego człowieka i jego osiągnięcia edukacyjne, a nawet na możliwość realizacji obowiązku nauki. Zakłada się, że rozwój tej formy zaburzenia lękowego wiąże się ze stresem szkolnym, a zwłaszcza z poczuciem zagrożenia psychicznego i fizycznego, wynikającym np. z przemocy rówieśniczej (Tabak, 2014).

Wypalenie szkolne jest odczuwanym przez uczniów poczuciem wyczerpania i zniechęcenia do nauki szkolnej. Zakłada się, że syndrom ten składa się z trzech komponentów: emocjonalnego wyczerpania, depersonalizacji oraz obniżenia poziomu zadowolenia z wykonywanych aktywności (Muchacka-Cymerman, Tomaszek, 2017). Pojęcie wypalenia początkowo było odnoszone wyłącznie do pracy zawodowej. Z czasem zauważono, że problem ten dotyczy również studentów, a nawet uczniów szkół średnich (Walburg, 2014). Z badania przeprowadzonego w Słowenii wynika, że wypalenie szkolne dotyczy $6,7 \%$ badanych uczniów szkół średnich (Slivar, 2001). 


\section{PODSUMOWANIE}

Szkoła i szkolna edukacja należą do głównych źródeł stresu odczuwanego przez dzieci i młodzież. Ponieważ pojęcie stresu szkolnego jest wyjątkowo złożone, warto zadawać bardziej precyzyjne pytania dotyczące tego, czym konkretnie stresują się najmłodsi, jakiego typu sytuacje i elementy edukacji szkolnej są dla nich najtrudniejsze, najbardziej obciążające. Na podstawie przeprowadzonego przeglądu literatury wyróżniono podstawowe kategorie źródeł stresu szkolnego, do których zaliczają się: problemy w relacjach interpersonalnych (z innymi uczniami oraz z nauczycielami), sytuacje ekspozycji społecznej (a więc wystąpień publicznych i bycia ocenianym), konieczność spełniania oczekiwań rodziców dotyczących ocen, presja osiągnięć edukacyjnych, nadmiar nauki (i związane $z$ tym poczucie przeciążenia), sposób organizacji nauki, poczucie nudy oraz nowe sytuacje szkolne.

W artykule przedstawiono również wyróżnione na podstawie przeglądu literatury konsekwencje doświadczania przez uczniów stresu szkolnego. Są nimi pogorszenie stanu zdrowia fizycznego i psychicznego, różnego rodzaju dolegliwości o charakterze somatycznym (bóle głowy itd.), problemy ze snem, otyłość, a także w skrajnych przypadkach podejmowanie prób samobójczych.

\section{Źródla}

1. ATROSZKO, B. Pojęcie presji osiagnięć edukacyjnych. W druku, 2021.

2. ATROSZKO, P.A. Struktura uzależnienia studentów od uczenia się: wybrane czynniki ryzyka, zwiazek ze stresem $i$ strategiami radzenia sobie oraz funkcjonowaniem psychospolecznym. Niepublikowana rozprawa doktorska. Uniwersytet Gdański, Wydział Nauk Społecznych, Instytut Psychologii, 2015.

3. ATROSZKO, P.A., ANDREASSEN, C.S., GRIFFITHS, M.D., PALLESEN, S. Study addiction-A new area of psychological study: Conceptualization, assessment, and preliminary empirical findings. Journal of Behavioral Addictions, 4(2), 2015, s. 75-84.

4. ATROSZKO, P.A., ANDREASSEN, C.S., GRIFFITHS, M.D., PALLESEN, S. The relationship between study addiction and work addiction: A cross-cultural longitudinal study. Journal of Behavioral Addictions, 5(4), 2016, s. 708-714.

5. CHUNG, K.F., CHEUNG, M.M. Sleep-wake patterns and sleep disturbance among Hong Kong Chinese adolescents. Sleep, 31(2), 2008, s. 185-194.

6. D'AURORA, D.L., FIMIAN, M.J. Dimensions of life and school stress experienced by young people. Psychology in the Schools, 25(1), 1988, s. 44-53.

7. DE VRIENDT, T., MORENO, L.A., DE HENAUW, S. Chronic stress and obesity in adolescents: scientific evidence and methodological issues for epidemiological research. Nutrition, Metabolism and Cardiovascular Diseases, 19(7), 2009, s. 511519.

8. GAWLICZ, K., RUDNICKI, P., STARNAWSKI, M. Dyskryminacja w edukacji przegląd wybranych polskich badań. [W:] red. K. Gawlicz, P. Rudnicki, M. Starnawski, Dyskryminacja w szkole - obecność nieusprawiedliwiona: o budowaniu edukacji antydyskryminacyjnej $w$ systemie edukacji formalnej $w$ Polsce: raport $z$ badań (s. 10-57). Warszawa: Towarzystwo Edukacji Antydyskryminacyjnej, 2015.

9. GLOZAH, F.N., PEVALIN, D.J. Social support, stress, health, and academic success in Ghanaian adolescents: A path analysis. Journal of Adolescence, 37(4), 2014, s. 451-460.

10. GREYDANUS, D.E., CALLES, Jr J. Suicide in children and adolescents. Primary Care: Clinics in Office Practice, 34(2), 2007, s. 259-273.

11. GROENWALD, M. Czas w uczeniu się. Analiza krytyczna perspektywy obiektywistycznej. Problemy Wczesnej Edukacji, 48(1), 2020, s. 7-17. 
12. GRZYMAŁA-MOSZCZYŃSKA, J., STOECKER, E. Dlaczego warto przeciwdziałać dyskryminacji w szkole? [W:] red. G. Mazurkiewicz, Jak budować dobra szkołę? Potencjat i bariery ewaluacji $w$ oświacie. Kraków: Wydawnictwo Uniwersytetu Jagiellońskiego, 2015. ISBN 978-83-233-9285-9.

13. JACOBSEN, V. Influential factors in the outcome of treatment of school phobia. Smith College Studies in Social Work, 18(3), 1948, s. 181-202.

14. JOHNSON, A.M., FALSTEIN, E.I., SZUREK, S.A., SVENDSEN, M. School phobia. American Journal of Orthopsychiatry, 11(4), 1941, s. 702-711.

15. KOMEŃSKI, J.A., Wielka dydaktyka. Wrocław: Zakład imienia Ossolińskich Wydawnictwo Polskiej Akademii Nauk, 1956.

16. KORCZYŃSKI, S. Stres edukacyjny gimnazjalistów. Rocznik Polsko-Ukraiński, 16, 2014, s. 89-110.

17. KWIECIŃSKI, Z. Socjopatologia edukacji. Warszawa: Edytor, 1992.

18. LAWENDOWSKI, R., BEREZNOWSKI, P., WRÓBEL, W.K., KIERZKOWSKI, M., ATROSZKO, P.A. Study addiction among musicians: Measurement, and relationship with personality, social anxiety, performance, and psychosocial functioning. Musicae Scientiae, 24(4), 2020, s. 449-474.

19. LEMOULT, J., HUMPHREYS, K.L., TRACY, A., HOFFMEISTER, J.A., IP, E., GOTLIB, I.H. Meta-analysis: exposure to early life stress and risk for depression in childhood and adolescence. Journal of the American Academy of Child \& Adolescent Psychiatry, 59(7), 2020, s. 842-855.

20. LEŚNIAK, B. Szkoła jako źródło sytuacji trudnych. Teraźniejszość-CzłowiekEdukacja, 18(3 (71)), 2015, s. 101-112.

21. LEWICKA-ZELENT, A., TROJANOWSKA, E. Psychospołeczne funkcjonowanie uczniów klas siódmych w zreformowanej szkole podstawowej w kontekście zdrowia psychicznego. Annales Universitatis Mariae Curie-Skłodowska, sectio JPaedagogia-Psychologia, 31(2), 2018, s. 123-144.

22. MAKARA-STUDZIŃSKA, M., Przyczyny prób samobójczych u młodzieży w wieku 14-18 lat. Psychiatria, 10(2), 2013, s. 76-83.

23. MISHRA, N., SHRESTHA, D., POUDYAL, R., MISHRA, P., Retrospective study of suicide among children and young adults. Journal of Nepal Paediatric Society, 33(2), 2013, s. 110-116.

24. MOKSNES, U.K., LØHRE, A., LILlEFJELL, M., BYRNE, D.G., HAUGAN, G. The association between school stress, life satisfaction and depressive symptoms in adolescents: Life satisfaction as a potential mediator. Social Indicators Research, 125(1), 2016, s. 339-357.

25. MUCHACKA-CYMERMAN, A., TOMASZEK, K. Syndrom wypalenia w zawodzie nauczyciela i w roli ucznia. Przegląd literaturowy. Forum Oświatowe, 29, 2(58), 2017, s. 95-115.

26. NAPIERALSKA, E., KUŁAGA, Z., GURZKOWSKA, B., GRAJDA, A. Epidemiologia zgonów dzieci i młodzieży z powodu samobójstw w Polsce w latach 1999-2006. Problemy Higieny i Epidemiologii, 91(1), 2010, s. 92-98.

27. PERVANIDOU, P., CHROUSOS, G.P. Stress and obesity/metabolic syndrome in childhood and adolescence. International Journal of Pediatric Obesity, 6(S1), 2011, s. 21-28.

28. REGULSKA, A. Zagrożone poczucie bezpieczeństwa u uczniów a zjawisko fobii szkolnej. [W:] red. L. Buller, Socjotechniczne aspekty bezpieczeństwa w szkole (s. 84-94). Warszawa: Polskie Towarzystwo Socjologiczne, 2014. 
29. RICHARDSON, A.S., BERGEN, H.A., MARTIN, G., ROEGER, L., ALLISON, S. Perceived academic performance as an indicator of risk of attempted suicide in young adolescents. Archives of Suicide Research, 9(2), 2005, s. 163-176.

30. SIKORA, R. Stres szkolny u dzieci rozpoczynających naukę w klasie czwartej. Forum Oświatowe, 22, 2(43), 2010, s. 37-48.

31. SKOWROŃSKI, B., PABICH, R. Inwentarz źródeł stresu szkolnego młodzieży opis konstrukcji i własności psychometryczne. Profilaktyka Społeczna $i$ Resocjalizacja, 28, 2015, s. 7-35.

32. SLIVAR, B. The syndrome of burnout, self-image, and anxiety with grammar school students. Horizons of Psychology, 10(2), 2001, s. 21-32.

33. STAŃCZYK, P. Nuda w szkole - między alienacją a emancypacją. TeraźniejszośćCzłowiek-Edukacja, 15, 3(59), 2012, s. 35-56.

34. SUPRANOWICZ, P., WYSOCKI, M.J. Stres szkolny a zaburzenia zdrowia młodzieży gimnazjalnej. Roczniki Państwowego Zakładu Higieny, 61(2), 2010.

35. SZMIDT, K.J. Nuda jako problem pedagogiczny. Teraźniejszość-CzłowiekEdukacja, 16(3)(63), 2013, s. 55-69.

36. TABAK, I., Zdrowie psychiczne dzieci i młodzieży. Wsparcie dzieci i młodzieży w pokonywaniu problemów. Studia BAS, 2, 2014, s. 113-138.

37. TALIK, E. Specyfika stresu szkolnego i strategie radzenia sobie z nim przez młodzież w okresie dorastania. Horyzonty Psychologii i Nauk o Człowieku, 1(1), 2011.

38. THACKRAY, R.I. The stress of boredom and monotony: a consideration of the evidence. Psychosomatic Medicine, 1981.

39. THAPAR, A., COLliShaW, S., PINE, D.S., THAPAR, A.K. Depression in adolescence. The Lancet, 379(9820), 2012, s. 1056-1067.

40. TORSHEIM, T., WOLD, B. School-related stress, school support, and somatic complaints: A general population study. Journal of Adolescent Research, 16(3), 2001, s. 293-303.

41. TWARDOWSKA-STASZEK, E., ZYCH, I. Bullying i cyberbullying wśród dzieci i młodzieży. Analiza porównawcza wyników badań prowadzonych w Polsce i Hiszpanii. Studia Paedagogica Ignatiana, 22(3), 2019.

42. TYRRELL, M. School phobia. The Journal of School Nursing, 21(3), 2005, s. 147151.

43. VAN HOUTEN, J. Mother-child relationships in twelve cases of school phobia. Smith College Studies in Social Work, 18(3), 1948, s. 161-180.

44. VAN SCHALKWIJK, F.J., BLESSINGA, A.N., WILLEMEN, A.M., VAN DER WERF, Y.D., SCHUENGEL, C. Social support moderates the effects of stress on sleep in adolescents. Journal of Sleep Research, 24(4), 2015, s. 407-413.

45. VERMA, S., SHARMA, D., LARSON, R.W. School stress in India: Effects on time and daily emotions. International Journal of Behavioral Development, 26(6), 2002, s. 500-508.

46. WALBURG, V. Burnout among high school students: A literature review. Children and Youth Services Review, 42, 2014, s. 28-33.

47. WILSON, S.M., SATO, A.F. Stress and paediatric obesity: what we know and where to go. Stress and Health, 30(2), 2014, s. 91-102.

48. WRÓBEL, W.K., Study addiction among high school students: Measurement and relationship with psychopathology, personality, quality of life, and school variables. Niepublikowana praca magisterska. Uniwersytet Gdański, Wydział Nauk Społecznych, 2020. 
49. YAN, Y.W., LIN, R.M., SU, Y.K., LIU, M.Y. The relationship between adolescent academic stress and sleep quality: A multiple mediation model. Social Behavior and Personality: An International Journal, 46(1), 2018, s. 63-77.

\section{Kontakt}

Mgr Bartosz Atroszko

Uniwersytet Gdański

Bażyńskiego 8, Gdańsk, Polska

Tel: 603112458

email: bartosz.atroszko@gmail.com 


\title{
DLACZEGO UCZNIOWIE POLSKICH SZKÓŁ SĄ PRZECIĄŻENI NAUKĄ?
}

\author{
WHY ARE POLISH SCHOOL STUDENTS OVERWORKED?
}

\author{
Bartosz Atroszko
}

\begin{abstract}
Abstrakt
Na podstawie dotychczas prowadzonych badań można sformułować wniosek, że uczniowie polskich szkół czują się przeciążeni nauką. Celem niniejszego artykułu jest próba udzielenia odpowiedzi na pytanie o przyczyny zaistnienia tego problemu. Wydaje się, że problem przeciążenia uczniów polskich szkół jest złożony i wynika on ze współwystępowania wielu niesprzyjających czynników jednocześnie.
\end{abstract}

Słowa kluczowe: przeciązenie nauka, stres szkolny, uczniowie, zmęczenie

\begin{abstract}
Based on the research conducted so far, it can be concluded that students of Polish schools feel overloaded. The purpose of this article is to answer the question about the reasons for this problem. It seems that the problem of overburdening students with work in Polish schools is complex and results from the coexistence of many unfavorable factors at the same time.
\end{abstract}

Keywords: fatigue, school stress, students

\section{WPROWADZENIE}

Wiele wskazuje na to, że uczniowie polskich szkół są przeciążeni nauką mającą miejsce w szkole i w domu. Świadczą o tym prowadzone badania z których wynika, że uczniowie czują się zmęczeni (Sikora, 2010, s. 42; Korczyński, 2014, s. 93-94), skarżą się na konieczność odrabiania zróżnicowanych i czasochłonnych prac domowych (Sikora, 2010, s. 42; Leśniak, 2015, s. 105; Korczyński, 2014, s. 95), brakuje im czasu na odpoczynek i rekreację po szkole (Sikora, 2010, s. 42; Leśniak, 2015, s. 105; Korczyński, 2014, s. 95; Pyzik, RodziewiczGruhn, 2007), czują się obciążeni pisaniem kilku sprawdzianów/kartkówek w ciągu jednego dnia lub jednego tygodnia (Sikora, 2010, s. 42), mają trudności związane z uczestniczeniem w wielu różnych zajęciach/lekcjach jednego dnia (Sikora, 2010, s. 42), zaś materiał lekcyjny, który muszą przyswoić, jest zbyt obszerny (Leśniak, 2015, s. 106). Z badania LewickiejZelent i Trojanowskiej (2018) wynika, że szkoła kojarzy się uczniom ponad trzy razy częściej ze zmęczeniem (74\% odpowiedzi) niż z możliwością zdobywania nowej wiedzy $(21 \%$ odpowiedzi). Autorki, podsumowując wyniki swoich badań, stwierdziły, że głównym źródłem stresu dla uczniów klas siódmych jest przeciążenie, stanowiące sytuację, w której uczeń musi wykonywać zadania przekraczające jego możliwości psychiczne oraz fizyczne lub znajdujące się na granicy tych możliwości (Lewicka-Zelent, Trojanowska, 2018, s. 142).

Przeciążenie uczniów obowiązkami szkolnymi jest zjawiskiem szkodliwym dla ich zdrowia, dobrostanu psychicznego i rozwoju. Konsekwencją długotrwałego przeciążenia może być pojawienie się syndromu wypalenia w roli ucznia (wypalenia szkolnego)(Kwiatkowski, 2019; Muchacka-Cymerman, Tomaszek, 2017; Salmela-Aro i inni, 2009; Tomaszek, 2017; Luo i inni, 2016). Poczucie zmęczenia i znużenia odczuwane przez młodzież może być jedną z przyczyn rozpowszechnienia spożywania napojów energetycznych w tej grupie osób. Odsetek nastolatków sięgających po tego typu szkodliwe dla zdrowia produkty spożywcze waha się 
od 27\% w grupie licealistów (Wanat, Woźniak-Holecka, 2011, s. 697), 35\% w grupie uczniów różnych rodzajów szkół średnich (Zięba-Kołodziej, 2012), aż do 48\% w grupie gimnazjalistów (Górnicka i inni, 2014). Konsekwencją przeciążenia nauką szkolną i poczucia zmęczenia może być też wagarowanie uczniów (Zińczuk, 2019, s. 70).

\section{CZY PROBLEM PRZECIĄŻENIA UCZNIÓW NAUKĄ JEST NOWYM ZJAWISKIEM?}

Problem przeciążenia dzieci i młodzieży nauką nie jest zjawiskiem nowym, specyficznym dla współczesnych uczniów. Na problem nadmiernej liczby godzin spędzanych przez uczniów w szkole i na prywatnych lekcjach oraz przeciążania uczniów koniecznością opanowywania pamięciowego obszernego materiału zwracał uwagę już Jan Amos Komeński w dziele „Wielka Dydaktyka“ napisanym w XVII wieku. Podkreślał, że szkolna nauka jest wyjątkowo uciążliwa, że trudno dostrzec w niej postępy, że przebiega ona w nieprzyjemnej atmosferze i w oparciu o przymus (przez co uczniowie zniechęcają się do niej). Autor stwierdził wręcz, że było to więc dla młodzieży torturą. Zauważył:

Już choćby tylko nauka języka tacińskiego (by dotknąć pobieżnie na przykład tej sprawy) mój dobry Boże! - jakże zawita, jak trudna była i rozwlekła. Różne kuchty, ciury czy rzemieślnicy przy swych kuchennych, wojskowych i innych niższych pracach łatwiej naucza się języka, choćby i różniącego się od rodzinnej mowy, a nawet dwu i trzech języków, niż wychowankowie szkót, którzy przy najzupetniej wolnym czasie, z największym wysitkiem ucza się tej jednej jedynej łaciny (Komeński, 1956, s. 85).

Dla ojca nowożytnej pedagogiki oczywiste było, że problemem nie jest sama wiedza i umiejętności, które muszą zdobyć uczniowie, lecz niewłaściwe metody nauczania używane w szkole i sposób organizacji procesu edukacyjnego. A owo fatalne trwonienie czasu i pracy skąḋe może pochodzić, jeśli nie z błędnej metody? - pytał retorycznie (Komeński, 1956, s. 85-86).

$\mathrm{Na}$ problem przeciążenia uczniów nauką zwracali uwagę również polscy autorzy dziewiętnastowieczni. Na szczególną uwagę zasługuje Henryk Jordan, profesor medycyny, lekarz-ginekolog i położnik, a z zamiłowania społecznik i pedagog (Wagner, 1999-2001; Żmichrowska, 2012). Wspomina on o tym, że kwestia przeciążenia szkolnego (nazywana przez niego przeciązeniem naukowym) była popularnym tematem ówczesnych rozmów i publikacji, lecz zaznacza, że jego zdaniem problemem ten jest mylnie rozumiany. Argumentował, że uczniowie być może mają zbyt wiele nauki, ale ich poczucie przeciążenia wynikać może $\mathrm{w}$ głównej mierze $\mathrm{z}$ braku równowagi pomiędzy nauką i aktywnym spędzaniem czasu na świeżym powietrzu, niewystarczającym uprawianiem gimnastyki, sportu i zabaw dziecięcych (Jordan, 1891). Kwestię tę postrzegał w szerszym kontekście ogólnych warunków życia dzieci i młodzieży, związanych z utrzymaniem przez nich higieny i zdrowia. Pisat:

Podczas mojej podróży ostatniej do Niemiec, mówiłem wiele o tej sprawie z rozmaitymi pedagogami i zapewniam, iż wszędzie, gdzie młodzież obowiąkowo kilka godzin dziennie się bawi, skarg na przeciażenie bardzo mało się styszy. (...) Kwestya przeciażenia jest $w$ pewnej mierze kwestya względna; dziś jest przeciązenie $w$ szkołach, ale bez nadzwyczajnego uszczuplenia planu naukowego mogło by go nie być. (...) Chowajmy inaczej naszych synów $i$ córki, nie pozwalajmy im mitrężyć dnia całego przy książkach; owszem niech się ucza, ale dażmy do tego, by czas nauki inaczej rozłożono, by nasza młodzież przez kilka godzin codziennie bawiła się rozsadnie, higijenicznie, a i przeciążenie zniknie $i$ zdrowie sie poprawi (Jordan, 1891, s. 44-45).

Warto zauważyć, że ten punkt widzenia został rozwinięty dwie dekady później przez Jana Władysława Dawida, który zwracał uwagę na to, że na karb przeciążenia szkolnego składane są skutki nieodpowiednich dla higieny i zdrowia warunków życia młodzieży, zarówno w 
szkole, jak i w domu. Nieergonomiczne ławki szkolne, nieodpowiednia dieta, zła jakość powietrza w pomieszczeniach, czy niedobór snu przyczyniają się do tego, co nazywano chorobami szkolnymi. Stanowią one podłoże dla przeciążenia, gdyż zmniejszać odporność organizmu na zmęczenie. Jednak, jak wyjaśnia autor, przeciążeniu jako skutki jego przypisywane być nie mogą. O przecią̇eniu można mówić tylko w zwiąku z praca $i$ powodowanym przez nia zmęczeniem (Dawid 1966, s. 441-442). Jego zdaniem rzeczywista skala problemu jest prawdopodobnie mniejsza niż sądzono jeszcze pod koniec XIX wieku, gdyż nie odróżniano wtedy skutków samej nauki od towarzyszących im niesprzyjających zdrowiu warunków życia dzieci i młodzieży. Natomiast na podstawie własnych doświadczeń zauważył, że przypadki rzeczywistego przeciążenia uczniów spotykał wyłącznie u osobników niezrównoważonych, psychopatycznych, o sztucznie wybujałej ambicji przy skromnym uzdolnieniu umysłowym, a poza tym dość często u dziewcząt z wyższych klas pensji żeńskich $w$ okresie egzaminów (Dawid, 1966, s. 442-443).

\section{DLACZEGO UCZNIOWIE POLSKICH SZKÓL SĄ PRZECIĄŻENI?}

Wydaje się, że problem przeciążenia uczniów polskich szkół jest złożony i wynika on ze współwystępowania wielu niesprzyjających czynników jednocześnie, takich jak znaczna liczba godzin poświęcanych na naukę w szkole $\mathrm{i}$ w domu, brak odpowiedniej ilości wolnego czasu, który mógłby być przeznaczony na wypoczynek, rekreację oraz życie rodzinne i towarzyskie, napięcie odczuwane przez uczniów w szkole, częsty udział w zajęciach pozaszkolnych (np. korepetycjach) itd. Można przyjąć (podobnie jak to uczynili Jordan i Dawid ponad sto lal temu), że problemem nie jest sama nauka uczniów, lecz sposób jej organizacji, zachwianie równowagi pomiędzy nauką i wypoczynkiem oraz szerszy kontekst warunków życiowych dzieci i młodzieży.

Problem ten polega między innymi na konieczności odrabiania czasochłonnych prac domowych (Sikora, 2010; Leśniak, 2015). Samo istnienie prac domowych jest zjawiskiem mocno kontrowersyjnym, coraz częściej kwestionuje się ich zasadność (Vatterott, 2018), wzbudzającym wręcz konflikty między rodzicami uczniów i ich nauczycielami (Cooper, 2015). Dzieje się tak, gdyż nauczyciele, jak się okazuje, mają bardziej pozytywne zdanie o pracach domowych od uczniów i ich rodziców (Davidovitch, Yavich, 2017). Z założenia konieczność ich odrabiania ogranicza wolny czas uczniów po powrocie ze szkoły do domu, sprzyja kształtowaniu siedzącego trybu życia i wynikających z tego dolegliwości. Tymczasem badacze alarmują, że problem bólów w odcinku lędźwiowo-krzyżowym kręgosłupa, których jedną z głównych przyczyn jest właśnie siedzący tryb życia, dotyczy coraz młodszych osób (Martyniuk, Górski, Górska, 2016).

Warto zauważyć w tym kontekście, że warunki w których odbywa się nauka mogą przyczyniać do ich przeciążenia fizycznego uczniów. Problemem jest nadmierne obciążenie kręgosłupów uczniów tornistrami, co przyczynia się do powstawania wad postawy dzieci i młodzieży w wieku szkolnym (Grajda, Kułaga, 2007). Przykładowo, z badań A. Lasoty (2014) wynika, że ponad $78 \%$ pierwszoklasistów nosi do szkoły plecaki, których waga przekracza rekomendowany limit $10 \%$ masy ciała ucznia. Zbliżone wyniki uzyskali Malinowska-Borowska i Flajszok (2020). Na poczucie zmęczenia nauką w szkole mogą mieć wpływ fizyczne warunki placówki edukacyjnej. Problemem może być hałas, zatłoczenie uczniów na korytarzu w czasie przerw, czy nieodpowiednie oświetlenie sal lekcyjnych (Topoła, 2003, s. 166).

Co ciekawe, jak wynika z badań Leśniak (2015, s. 105), niektóre aspekty instytucjonalne działania szkoły i związane z tym zachowania nauczycieli, utrudniają uczniom wypoczynek w trakcie szkolnych przerw. Okazuje się, że źródłem trudności dla uczniów jest konieczność przebywania na przerwie jedynie $w$ miejscach wyznaczonych przez nauczycieli np. na określonym piętrze, korytarzu itp., zakaz wychodzenia poza teren szkoły (np. do pobliskiego 
sklepu spożywczego), a także zakaz odpoczynku w sali lekcyjnej. Możemy się domyśleć na podstawie danych zaprezentowanych przez Leśniak (2015), że w czasie przerwy szkolnej uczniowie nie mają de facto możliwości uniknięcia przebywania na korytarzach, które często są zatłoczone i wypełnione hałasem. Tymczasem, jak zauważyli na podstawie przeglądu literatury Augustyńska i Radosz (2009, s. 9-10), hałas szkolny jest czynnikiem uciążliwym i stresującym, powodującym u uczniów (i również u nauczycieli) stany rozdrażnienia, zmęczenia, agresji, czy braku koncentracji uwagi. Wpływa to nie tylko na efektywność pracy szkolnej, ale też tego typu reakcje stresowe mogą przyczyniać się do niekorzystanych zmian ogólnoustrojowych oraz do rozwoju różnego typu chorób (Augustyńska, Radosz, 2009, s. 9$10)$.

\section{SPÓR WOKÓŁ PRAC DOMOWYCH}

Prace domowe zadawane uczniom mogą być jednym $\mathrm{z}$ kluczowych czynników determinujących odczuwanie przez nich poczucia przeciążenia. Z założenia ograniczają one zasoby czasu wolnego pozostające do dyspozycji uczniów, nie pozwalają ,zapomniećc“ o szkole po powrocie do domu i zaburzają równowagę między nauką i wypoczynkiem. Co ciekawe, o ile w przypadku osób dorosłych podkreśla się często konieczność zachowania równowagi pomiędzy życiem zawodowym i prywatnym (ang. work-life balance; Hildt-

Ciupińska, 2014), wskazując na destruktywny wpływ przedłużających się godzin pracy na zdrowie, życie rodzinne itd., o tyle w przypadku dzieci i młodzieży problem ograniczania ich czasu wolnego jest słabiej dostrzegany przez ogół społeczeństwa. Dopiero niedawno problem nadmiernej (zdaniem części rodziców) liczby prac domowych uczniów polskich szkół stał się tematem ożywionej debaty społecznej (Iluk, 2020), w której zabrali głos Rzecznik Praw Dziecka (RPD) Marek Michalak (oraz jego następca na stanowisku Mikołaj Pawlak) oraz Rzecznik Praw Obywatelskich (RPO) Adam Bodnar. Jej początki wiążą się z działalnością rodziców, którzy czuli się zaniepokojeni tym, jak wiele czasu i energii ich dzieci muszą poświęcać na ich odrabianie. Powstały inicjatywy skupione wokół tego problemu, wśród których należy wymienić takie akcje jak działalność facebookowej grupy „Dom nie jest filią szkoły“, projekt edukacyjny „Budząca się szkoła“, czy akcja „Szkoła bez zadań domowych“ (zainicjowana przez Jakuba Tylmana i Marcina Jędroszkowiaka) (Wojciechowski, 2019). Pełniący funkcję RPD Marek Michalak dwukrotnie apelował w tej sprawie do Ministra Edukacji Narodowej, zauważając między innymi, że:

Ilość zadawanych prac domowych niejednokrotnie powoduje, że dzieci $i$ młodzież maja ograniczona możliwość aktywnego uczestniczenia $w$ życiu rodzinnym, $w$ tym kultywowania tradycji wspólnego spędzania czasu z rodzicami i rodzeństwem, a także wywiązywania się z obowiazków domowych, które również odgrywaja istotna funkcję wychowawcza (Rzecznik Praw Dziecka przywołany za portalem https://epedagogika.pl).

Mikołaj Pawlak, następca Marka Michalaka na stanowisku RPD, nie przejawiał podobnego krytycyzmu wobec prac domowych i odciął się od stanowiska swego poprzednika (Klyta, 2020). Do problemu odniósł się również Rzecznik Praw Obywatelskich, który w piśmie do Minister Edukacji Narodowej Anny Zalewskiej stwierdził:

Do Rzecznika Praw Obywatelskich wpływaja skargi od rodziców uczniów, którzy zgłaszaja problem nadmiernego obciążania uczniów pracami domowymi. Skarżacy twierdza, że ich dzieci czuja się przemęczone $i$ zniechęcone do zajęć szkolnych. Z uwagi na brak wolnego czasu nie moga dostatecznie wypoczać oraz rozwijać swoich pasji. Oburzenie wyrażaja także rodzice zmuszeni do poświęcania czasu wolnego na pomoc dzieciom w nadrabianiu zaległości lub praca nad materiatem, który nie zostal $w$ sposób wystarczajacy wythmaczony na lekcjach. Zakłóca to ich życie rodzinne, utrudnia podejmowanie innych wspólnych aktywności i uniemożliwia odpoczynek. Sprawa dotyczy więc realizacji z jednej strony prawa do nauki, wyrażonego $w$ art. 70 Konstytucji RP oraz prawa do ochrony życia prywatnego i rodzinnego, 
określonego $w$ art. 47 Konstytucji RP, z drugiej (Biuro Rzecznika Praw Obywatelskich, 2019).

Warto zauważyć, że podobne spory dotyczące prac domowych zadawanych uczniom miały miejsce również w Stanach Zjednoczonych. Pierwsza z tzw. wojen o prace domowe (ang. homework wars) miała miejsce już w 1900 r., a jej sprawcą był Edward Bok i jego tekst pt. A „National Crime at the Feet of American Parents“ opublikowany w czasopiśmie „Ladies Home Journal“" (Pressman i inni, 2015).

\section{SPOSÓB ORGANIZACJI NAUKI W SZKOLE}

Należy zauważyć, że wiele czasu spędzanego przez ucznia w szkole jest przeznaczana na czynności, które $\mathrm{z}$ perspektywy młodego człowieka nie mają żadnego znaczenia rozwojowego. Szczegółowe badanie empiryczne na ten temat przedstawił Z. Kwieciński (1992). Takie czynności nauczyciela jak np. sprawdzanie obecności, uzupełnianie dziennika, zwracanie uwagi uczniom i dbanie o dyscyplinę w klasie szkolnej etc., które zajmują sporą część lekcji, z perspektywy ucznia są marnowaniem jego czasu (Kwieciński, 1992). Z kolei teoretyczną analizę sposobów w jaki szkoła zarządza czasem nauki uczniów, w jaki sposób ten cenny zasób marnuje i zarazem krzywdzi uczniów przedstawiła M. Groenwald (2020). Jej zdaniem u podłoża tego problemu leży osadzenie dominującego w polskiej szkole modelu kształcenia w paradygmacie dydaktyki obiektywistycznej.

Jak wynika z badań nad rodzicami prowadzącymi edukację domową swoich dzieci, jednym z kluczowych powodów dla których zdecydowali się na tę formę kształcenia było przekonanie, że nauka szkolna pochłania zbyt wiele czasu, ograniczając możliwości wypoczynku uczniów, ich rekreacji, spędzania czasu z rodziną etc. (Szafrańska, Pawlak, 2020, s. 210). Również doświadczenia rodziców dzieci uczących się w szkołach alternatywnych wskazują na to, że kształcenie poza tradycyjną szkołą może zachodzić w sposób znacznie bardziej efektywny. K. Gawlicz (2018) zauważyła interesujące zjawisko występujące w przypadku uczniów szkół demokratycznych. Dzieci te, aby móc kontynuować naukę w placówce alternatywnej, muszą raz w roku zdać egzamin z realizacji podstawy programowej. Ponieważ lubią swoją szkołę i zazwyczaj zależy im na tym, to są w stanie w krótkim czasie - jak twierdzą ich rodzice osiągać imponujące rezultaty w krótkim czasie. Autorka ujęła to następująco: [Dzieci] gdy wiedza, że maja egzamin, musza go zdać, bo jeśli go nie zdadza to moga musieć wrócić do zwyktej szkoły. Regularnie słyszymy zachwyty osób dorostych nad tym, co się dzieje, gdy dzieci zaczynaja się uczyć, ponieważ tego chcą: ktoś się nauczy czytać w miesiac, ktoś opanuje materiat przewidziany podstawa programowa na rok $w$ pare tygodni (Gawlicz, 2018). Być może problem przeciążenia uczniów wynika w głównej mierze nie z nadmiaru nauki, ale z niedostrzegania przez uczących się sensu w tym, co robią w szkole.

Nieefektywność nauki w ,zwykłej“ szkole, poczucie marnowania czasu i wynikające z tego znudzenie można traktować jako potencjalne źródło poczucia przeciążenia uczniów. Badacze zwracają uwagę, że nuda jest stanem skrajnie nieprzyjemnym i stresującym (Martin, Sadlo, Stew, 2006). Thackray (1981) na podstawie przeglądu literatury stwierdził, że nudę i monotonię należy uznać za stresory. Występowanie owego stanu wiąże się z gorszym deklarowanym stanem zdrowia (Weissinger, 1995; Binnema, 2004; Crockett, Myhre, Rokke, 2015). Jest ona niestety codziennością sporej liczby polskich uczniów. P. Stańczyk (2012) na podstawie wywiadów przeprowadzonych z uczniami gdańskich gimnazjów zauważył, że nuda jest znaczacym elementem doświadczenia szkoły. Ujmując to $w$ języku bardziej technicznym: pojęcie nudy stanowi element definiujacy to, czego uczniowie doświadczaja jako pracy w szkole. Również badania ilościowe prowadzą do podobnych wniosków. Ponad $80 \%$ badanych studentów zgodziło się ze stwierdzeniem, że sposób prowadzenia zajęć w polskiej szkole powoduje, że uczniowie często nudzą się na lekcjach (Atroszko, Sendal, Swarra, 2017). Na problem poczucia znudzenia, którego doświadczają uczniowie polskich 
szkół, zwracali uwagę również inni autorzy (Motyl, 2014). Można uznać za Szmidtem (2013), że nuda jest problemem pedagogicznym. Nie powinno zatem dziwić, że stała się ona również głównym tematem rozprawy doktorskiej z dziedziny pedagogiki (Kazimierczyk, 2020).

Problem przeciążenia uczniów wynikać może również z częstego uczestnictwa dzieci i młodzieży w edukacji pozaszkolnej, w tym korzystania przez nich z korepetycji. Jak zauważyła D. Klus-Stańska (2017), upowszechnienie tego zjawiska może być związane z maskowaniem niewydolności dydaktycznej szkoły, natomiast względnie wysokie wyniki testowe polskich uczniów w badaniach międzynarodowych są osiągane kosztem ogromnego wysitku ekonomicznego polskich rodzin, przy jednoczesnym redukowaniu czasu na wieloaspektowe przeżywanie dzieciństwa i młodości przez uczniów. Już ponad 15 lat temu E. Putkiewicz (2005) zwróciła uwagę na to, że w Polsce potrzebna jest debata dotycząca naprawy funkcji dydaktycznej szkoły, wspólne zastanowienie się nad tym, dlaczego „,szkoła wymaga, a nie pomaga“".

\section{PODSUMOWANIE}

Wiele wskazuje na to, że przeciążenie nauką jest istotnym problemem, którego doświadczają uczniowie polskich szkół. Konsekwencją przeciążenia uczniów nauką mogą być liczne i zróżnicowane problemy, począwszy od wagarowania, nadużywania napojów energetycznych aż do syndromu wypalenia w roli ucznia.

W niniejszym artykule dokonano próby udzielenia odpowiedzi na pytanie o przyczyny zaistnienia tego problemu. Wydaje się, że problem przeciążenia uczniów polskich szkół jest złożony i wynika on ze współwystępowania wielu niesprzyjających czynników jednocześnie, takich jak znaczna liczba godzin poświęcanych na naukę w szkole, w domu oraz na korepetycjach, nadmiar prac domowych, brak odpowiedniej ilości wolnego czasu, który mógłby być przeznaczony na wypoczynek, rekreację oraz życie rodzinne i towarzyskie, czy choćby napięcie odczuwane przez uczniów w szkole. Najprawdopodobniej problemem nie jest sama nauka, lecz przede wszystkim sposób jej organizacji w szkole, zachwianie równowagi pomiędzy nauką i wypoczynkiem i szerszy kontekst warunków życiowych najmłodszych. Należy podkreślić, że kwestia przeciążenia uczniów polskich szkół wymaga bardziej szczegółowych badań.

\section{Źródla}

1. ATROSZKO, B., SENDAL, L., SWARRA, A. Pedagogy students' opinions on education in Poland. [W:] red. M. McGreevy, R. Rita, CER Comparative European Research 2017 (s. 115-119). London, UK: Sciemcee, 2017. ISBN 978-0-9935191-47.

2. AUGUSTYŃSKA, D., RADOSZ, J. Hałas w szkołach (2)-wpływ hałasu szkolnego na uczniów i nauczycieli oraz jego profilaktyka. Bezpieczeństwo Pracy, 10, 2009, s. 8-10.

3. BINNEMA, D. Interrelations of psychiatric patient experiences of boredom and mental health. Issues in Mental Health Nursing, 25(8), 2004, s. 833-842.

4. BIURO RZECZNIKA PRAW OBYWATELSKICH, Pismo Adama Bodnara do Minister Edukacji Narodowej Anny Zalewskiej. Warszawa 21.01.2019 r., VII.501.68.2018.AT.

5. COOPER, H.M. The battle over homework: Common ground for administrators, teachers, and parents. Simon and Schuster, 2015.

6. CROCKETT, A.C., MYHRE, S.K., ROKKE, P.D. Boredom proneness and emotion regulation predict emotional eating. Journal of Health Psychology, 20(5), 2015, s. 670-680. 
7. DAVIDOVITCH, N., YAVICH, R. Views of students, parents, and teachers on homework in elementary school. International Education Studies, 10(10), 2017, s. 90-108.

8. DAWID, J.W. Inteligencja, wola i zdolność do pracy. Wrocław-Warszawa-Kraków: Zakład Narodowy Imienia Ossolińskich Wydawnictwo Polskiej Akademii Nauk, 1966.

9. GÓRNICKA, M., PIERZYNOWSKA, J., KANIEWSKA, E., KOSSAKOWSKA, K., WOZNIAK, A. School pupils and university students surveyed for drinking beverages containing caffeine. Roczniki Państwowego Zakładu Higieny, 65(2), 2014.

10. GRAJDA, A., KUŁAGA, Z. Nadmierne obciążenie kręgosłupa uczniów tornistrami. Bezpieczeństwo Pracy, 9, 2007, s. 4-7.

11. GROENWALD, M. Czas w uczeniu się. Analiza krytyczna perspektywy obiektywistycznej. Problemy Wczesnej Edukacji, 48(1), 2020, s. 7-17.

12. HILDT-CIUPIŃSKA, K. Work-life balance a wiek pracowników. Bezpieczeństwo Pracy, 10, 2014, s. 14-17.

13. ILUK, J. Zadania domowe w teorii, badaniach naukowych i praktyce. Języki Obce w Szkole, 2, 2020, s. 79-88

14. JORDAN, H. O zabawach młodzieży. Odczyt prof. Dr Henryka Jordana wygłoszony we Lwowie w Sali „Sokoła“, dnia 4 stycznia 1891 roku. Przewodnik Higijeniczny. Organ Towarzystwa Opieki zdrowia, 2, 15 lutego 1891.

15. KAZIMIERCZYK, I. Nuda szkolna $i$ jej oblicza. Nieopublikowana rozprawa doktorska. Warszawa: Uniwersytet Warszawski, Wydział Pedagogiczny, 2020.

16. KLUS-STAŃSKA, D. Walka o testo-maniakalne przetrwanie, czyli po co i czego uczą się przyszli polscy nauczyciele. Rocznik Pedagogiczny, 40, 2017, s. 71-87.

17. KOMEŃSKI, J.A. Wielka dydaktyka. Wrocław: Zakład imienia Ossolińskich Wydawnictwo Polskiej Akademii Nauk, 1956.

18. KORCZYŃSKI, S. Stres edukacyjny gimnazjalistów. Rocznik Polsko-Ukraiński, 16, 2014, s. 89-110.

19. KWIATKOWSKI, P. Wypalenie uczniowskie - erozja pozytywnych stanów mentalnych $\mathrm{w}$ toku pełnienia roli ucznia i jej wybrane uwarunkowania. [W:] red. nauk. Z.B. Gaś, Profilaktyka zachowań ryzykownych $w$ teorii i praktyce. Lublin: Innovatio Press, Wydawnictwo Naukowe Wyższej Szkoły Ekonomii i Innowacji, 2019.

20. KWIECIŃSKI, Z. Socjopatologia edukacji. Warszawa: Edytor, 1992.

21. LASOTA, A. Schoolbag weight carriage by primary school pupils. Work, 48, 2014, s. $21-26$

22. LEŚNIAK, B. Szkoła jako źródło sytuacji trudnych. Teraźniejszośśc-CzłowiekEdukacja, 18(3)(71), 2015, s. 101-112.

23. LEWICKA-ZELENT, A., TROJANOWSKA, E. Psychospołeczne funkcjonowanie uczniów klas siódmych w zreformowanej szkole podstawowej w kontekście zdrowia psychicznego. Annales Universitatis Mariae Curie-Skłodowska, sectio J Paedagogia Psychologia, 31(2), 2018, s. 123-144.

24. LUO, Y., WANG, Z., ZHANG, H., CHEN, A., QUAN, S. The effect of perfectionism on school burnout among adolescence: The mediator of self-esteem and coping style. Personality and Individual Differences, 88, 2016, s. 202-208.

25. MALINOWSKA-BOROWSKA, J., FLAJSZOK, K. Czy wymagania zawarte w rozporządzeniu $\mathrm{w}$ sprawie bezpieczeństwa i higieny pracy w szkołach zapobiegają noszeniu przez dzieci zbyt ciężkich tornistrów? Medycyna Pracy, 71(6), 2020, s. 687-697. 
26. MARTIN, M., SADLO, G., STEW, G. The phenomenon of boredom. Qualitative Research in Psychology, 3(3), 2006, s. 193-211.

27. MARTYNIUK, A., GÓRSKI, S., GÓRSKA, A. Bóle w odcinku lędźwiowokrzyżowym kręgosłupa: istotny i narastający problem u dzieci i młodzieży: przegląd piśmiennictwa. Problemy Pielegniarstwa, 24(1), 2016.

28. MOTYL, K. O szkole jako fabryce nudy i śmiechu. Podstawy Edukacji, 7, 2014, s. 141-165.

29. MUCHACKA-CYMERMAN, A., TOMASZEK, K. Syndrom wypalenia w zawodzie nauczyciela i w roli ucznia. Przegląd literaturowy. Forum Oświatowe, 29(2)(58), 2017, s. 95-115.

30. PRESSMAN, R.M., SUGARMAN, D.B., NEMON, M.L., DESJARLAIS, J., OWENS, J.A., SCHETTINI-EVANS, A. Homework and family stress: With consideration of parents' self confidence, educational level, and cultural background. The American Journal of Family Therapy, 43(4), 2015, s. 297-313.

31. PUTKIEWICZ, E. Korepetycje - szara strefa edukacji. Instytut Spraw Publicznych, seria Analizy i Opinie, 56, 2005.

32. PYZIK, M., RODZIEWICZ-GRUHN, J. Rekreacja uczniów szkół częstochowskichpotrzeby a możliwości ich realizacji. Prace Naukowe Akademii im. Jana Dlugosza w Częstochowie: Seria: Kultura Fizyczna, 7, 2007, s. 127-134.

33. SALMELA-ARO, K., KIURU, M., LESKINEN, E., NURMI, J.E. School Burnout Inventory. European Journal of Psychological Assesment, 25(1), 2009, s. 48-57.

34. SIKORA, R. Stres szkolny u dzieci rozpoczynających naukę w klasie czwartej. Forum Oświatowe, 22(2)(43), 2010, s. 37-48.

35. STAŃCZYK, P. Nuda w szkole - między alienacją a emancypacją. TeraźniejszośćCzłowiek-Edukacja, 15, 3(59), 2012, s. 35-56.

36. SZAFRAŃSKA, A., PAWLAK, J. W poszukiwaniu lepszych możliwości kształcenia dla własnego dziecka. Edukacja domowa z perspektywy rodziców. Przeglad Pedagogiczny, 1, 2020, s. 203-218.

37. SZMIDT, K.J. Nuda jako problem pedagogiczny. Teraźniejszość-CzłowiekEdukacja, 16(3)(63), 2013, s. 55-69.

38. THACKRAY, R.I. The stress of boredom and monotony: a consideration of the evidence. Psychosomatic Medicine, 43(2), 1981, s. 165-176.

39. TOMASZEK, K. Samoocena i jakość relacji społecznych jako czynniki chroniące przed syndromem wypalenia szkolnego. Ruch Pedagogiczny, 4, 2017, s. 87-105.

40. TOPOŁA, K. Główne zagrożenia życia i zdrowia w szkołach. Prace Naukowe. Pedagogika, 12, 2003, s. 165-173.

41. VATTEROTT, C. Rethinking Homework: Best Practices That Support Diverse Needs. 2nd Edition. Alexandria (USA): ASCD, 2018.

42. WAGNER, H. Henryk Jordan - prekursor wychowania fizycznego. Pedagogika, Prace Naukowe Wyższej Szkoły Pedagogicznej w Częstochowie. Częstochowa: Wydawnictwo Wyższej Szkoły Pedagogicznej w Częstochowie, 1999-2001, s. 809813, T. 8, 9, 10. ISBN 83-7098-711-7, ISSN 0860-0880.

43. WANAT, G., WOŹNIAK-HOLECKA, J. Ocena konsumpcji produktów zawierających kofeinę wśród młodzieży akademickiej i licealnej. Problemy Higieny $i$ Epidemiologii, 92(3), 2011, s. 695-699.

44. WEISSINGER, E. Effects of boredom on self-reported health. Loisir et societél Society and Leisure, 18(1), 1995, s. 21-32.

45. ZIĘBA-KOLODZIEJ, B. Na marginesie zdrowia, czyli o zachowaniach zdrowotnych młodzieży szkół ponadgimnazjalnych. Nowiny Lekarskie, 81(4), 2012, s. 330-336. 
46. ZIŃCZUK, M. Wagary jako obszar edukacyjnych bezdroży. Problemy OpiekuńczoWychowawcze, 7, 2019, s. 62-76.

47. ŻMICHROWSKA, M.J. Działalność pedagogiczna Henryka Jordana (1842-1907). Prace naukowe Watbrzyskiej Wyższej Szkoły Zarządzania i Przedsiębiorczości. Zeszyty Pedagogiczno-Medyczne, T. 18(2), 2012. ISSN 2084-2686.

\section{Źródla internetowe:}

48. ePedagogika.pl. Pobrane z: https://epedagogika.pl/aktualnosci/nadmiar-prac-domow ych-ponowny-apel-rzecznika-praw-dziecka-2079.html [data dostępu: 28 maja 2021 r.].

49. GAWLICZ, K., wystąpienie zatytułowane: Szkoły demokratyczne w Polsce: raport z badań Dolnoślaskiej Szkoły Wyższej i Instytutu Badań Edukacyjnych wygłoszone 11 czerwca 2018 r. w Rzeszowie w czasie ogólnopolskiego seminarium naukowego pt. „Czy w Polsce potrzebna jest edukacja alternatywna?” odbywającego się w Wyższej Szkole Informatyki i Zarządzania. Pobrane z: https://www.youtube.com/watch? $\mathrm{v}=\mathrm{AVe}$ 0N1MrZ58 [data wejścia 21.05.2021 r.].

50. KLYTA, T. Nowa opinia rzecznika ws. prac domowych. Poprzednia zniknęła. Pobrane z: https://www.portalsamorzadowy.pl/edukacja/nowa-opinia-rzecznika-wsprac-domowych-poprzednia-zniknela, 145669.html [data dostępu: 28 maja 2021 r.].

51. WOJCIECHOWSKI, K. "Dom nie jest filia szkoty". Rodzice sprzeciwiaja sie edukacji na wynos. Pobrane z: https://forsal.pl/artykuly/1404463, nadgodziny-szkolyw-domu-rodzice-chca-czasu-wolnego.html [data dostępu: 28.05.2021 r.].

\section{Kontakt}

Mgr Bartosz Atroszko

Uniwersytet Gdański

Bażyńskiego 8, Gdańsk, Polska

Tel: 603112458

email: bartosz.atroszko@gmail.com 


\title{
IMPULZIVITA ADOLESCENTOV A VÝCHOVNÉ ŠTÝLY RODIČOV V EXPERIMENTOVANÍ S FAJČENÍM
}

\author{
IMPULSIVITY OF ADOLESCENTS AND PARENTAL \\ EDUCATIONAL STYLES IN EXPERIMENTATION WITH SMOKING
}

\author{
Zuzana Mičková, Sophia Mészárosová
}

\begin{abstract}
Abstrakt
Štúdia skúma tabakové správanie v rodine v súvislosti s experimentáciou fajčenia, uplatnenie výchovných rodičovských štýlov a impulzivity adolescentov v tabakovom správaní. Výskumný súbor tvorilo spolu $\mathrm{N}(548)$ adolescentov, $\mathrm{N}(\mathrm{CH})=247, \mathrm{~N}(\mathrm{D})=301$, priemerný vek adolescentov $\mathrm{AM}=16,3$. Vo výskume boli použité dotazníkové metódy: demografický dotazník (iniciácia fajčenia, tabakové správanie). Dotazník situačno-motivačných faktorov fajčenia - doplnková škála tabakového správania v rodine (Rojková, Gálová, 2015), Dotazník impulzivity IVE (Eysenck \& Eysenck, 1985), Dotazník rodičovskej autority - zist'ovanie výchovných štýlov (Buri, 1991). Najvýznamnejšie zistenia: Pri autoritatívnom výchovnom štýle je experimentovanie s fajčením najnižšie a experimentovanie s fajčením narastá pri impulzivite adolescentov.
\end{abstract}

Klíčová slova: experimentovanie, fajčenie, výchovné štýly, impulzivita

\begin{abstract}
The study examines tobacco behavior in the family in connection with smoking experimentation, the application of educational parenting styles and the impulsivity in adolescents in tobacco behavior. The research group consisted of a total of $\mathrm{N}(548)$ adolescents, $\mathrm{N}(\mathrm{CH})=247, \mathrm{~N}(\mathrm{D})=301$, mean age of adolescents $\mathrm{AM}=16.3$. Questionnaire methods were used in the research: demographic questionnaire (initiation of smoking, occurrence of tobacco behavior, frequency of smoking). Questionnaire of situationalmotivational factors of smoking (Rojková, Gálová, 2015), Questionnaire of impulsivity IVE (Eysenck, Eysenck, 1985), Questionnaire of parental authority - searching for educational styles (Buri, 1991). Results: In the authoritarian educational style, smoking experimentation is lowest and smoking experiments increase with the impulsiveness of adolescents.
\end{abstract}

Key words: experimentation, smoking, educational styles, impulsivity

\section{CHARAKTERISTIKA PROBLÉMU}

Fajčenie je celospoločenský problém a je považovaný za jedným z významných prediktorov zdravotných problémov a ochorení, pričom je zaznamenaný nárast experimetnovania s fajčením a znižovanie vekovej hranice fajčiarov. Realizované výskumy potvrdzujú nárast ako i znižovanie vekovej hranice prvého kontaktu s fajčením (Jurkovičová, 2005). Nárast experimentovania $\mathrm{s}$ fajčením je podporovaný vysokou spoločenskou toleranciou, nerešpektovaním platnej legislatívy ako i podceňovaním negatívnych účinkov na organizmus. Vzt’ah k fajčeniu sa utvára prostredníctvom fyzických, psychických a spoločenských zážitkov, pričom dochádza k vzniku naučeného správania (Klimáková, 2012). Príležitostné situácie, opakované situačné podnety a experimentovanie s tabakovými výrobkami vytvárajú podporu pre vznik tabakového správania (Bieliková et. al. 2003). Prvé skúsenosti s fajčením prostredníctvom príležitosti sú zaznamenávané už v detskom veku, 
pričom experimentovaním $\mathrm{v}$ období adolescencie dochádza $\mathrm{k}$ vzniku návykového správania, pričom závislost' na nikotíne sa formuje postupne a adolescent má tendenciu podceňovat' alebo popierat' dôsledky fajčenia (Baška, 2008; Ellickson, et. al., 2001; Heretík, at.al. 2008; Kimáková, et.al., 2013). Návyk nie je výsledkom racionálneho uvažovania následkov konania, vzniká spontánne. Spúšt’ače experimentovania a tabakového správania môžu byt' v genetických dispozíciách - iritabilita, impulzivita, zníženie zábran, vyhl'adávanie vzrušenia apod. Whiteside, Lynam, 2001). Impulzivita ako osobnostný konštrukt zaznamenáva nárast v období dospievania a má klesajúcu tendenciu (Steinberg, 2008). Impulzivita sa spája s pravdepodobným rizikom udržiavania návyku užívania tabakových výrobkov (Mathew, et.al., 2015; Jančovičová, a kol. 2004). Podl’a Blooma at. al.(2014) sa vysoká úroveň impulzivity spája s výraznejšou citlivost'ou na nikotín $v$ počiatočnom štádiu experimentovania. Výskum Bolda a kol. (2017), preukázal, že vyššie skóre impulzivity u dospievajúceho je spojené $s$ nižším vekom prvotnej iniciácie a začiatku fajčenia elektronických cigariet. Kvaavik a Rise (2012) považujú impulzivitu, za významný prediktor zdôvodu iniciácie fajčenia. V behaviorálnom správaní adolescenta predstavuje významné miesto impulzivita. Možno na ňu nahliadat' ako na dôležitý osobnostný konštrukt, tendenciu riskovat', tendencia k impulzívnemu rozhodovaniu (Zuckerman, Cloninger, 1996), biologicky podmienená osobnostná črta (Čerešník, a kol. 2018).

Prediktory k návyku na fajčenie nachádzame tiež v sociálnych determinantoch. Významným faktorom pri experimentovaní, je rodičovský príklad (Rojková, 2016; Rojková, Vavrová, 2017, 2020; Wang, et. al. 2015; Ondrušková, et. al., 2016). Fajčenie rodičov a súrodencov ovplyvňuje pravdepodobnost', že deti začnú fajčit' a budú sa u nich rozvíjat' tieto fajčiarske návyky. Štúdia Exter et.al. (2007) popisuje tabakové správanie v rodine, ako spôsob modelovania rizikového správania adolescentov. Adolescenti vnímajú fajčenie ako prostriedok pre nadväzovanie kontaktov a prostriedok umožňujúci uvol’nenie na spoločenských príležitostiach. Tlaku prostredia, ktorému sú adolescenti vystavení v sociálnom kontakte podliehajú najmä mladší adolescenti - jedinci so sklonom k depresii, úzkostí (Heretík, a kol. 2008; Ellickson a kol. 2001; Baška, 2008). Osobnostné prediktory experimentovania a tabakového správania predstavujú reziliencia, impulzivita (Vavrová, Gálová, 2017), úzkostlivost', frustračná tolerancia, svedomitost', sebaúčinnost', dobrodružnost' (Dolejš, Skopal, 2014). Za významné prediktory sú d’alej považované rodičovské výchovné štýly a rodičovská autorita Výskumné štúdie napr. (Manniová, 2007; Huwer, et. al., 2007; Wang et.al., 2015) zaoberajúce sa spojitost'ou výchovných štýlov a fajčením poukazujú na väčšiu pravdepodobnost' začiatku fajčenia a pravidelného fajčenia u adolescentov, ktorí prežívajú emocionálne problémy v rodine a rodičia ich neakceptujú. Rodičovské štýly ako autoritatívny a autoritársky znižujú pravdepodobnost' užívania tabakových výrobkov a predstavujú určitý protektívny faktor voči experimentovaniu a celkovému fajčiarskemu správaniu adolescentov (Huver, et.al. 2007; Courtois et. al., 2007, Wang et. al., 2015). Výsledky výskumu Bronte-Tinkew, et. al. (2006) preukázali význam autoritatívnej výchovy otca pri eliminovaní rizika experimentovania s fajčením.

\subsection{Ciel vyskumu}

Zistit' súvislostí medzi experimentovaním adolescentov $\mathrm{s}$ fajčením a prítomnostou výchovných rodičovských štýlov. Analyzovat' tabakové správanie rodičov vo vzt'ahu $\mathrm{k}$ experimentovaniu s fajčením u adolescentov a zistit' súvislost' impulzivity a experimentácie s fajčením. Ďalším ciel'om je zistit' silu prediktorov (výchovné štýly, impulzivita) a na a vymedzit’ rizikové faktory návyku na fajčenie. 


\subsection{Hypotézy a výskumné otázky}

\section{Hypotézy}

H1 Predpokladáme vyššiu impulzivitu u adolescentov experimentujúcich $\mathrm{s}$ fajčením

H2 Predpokladáme výraznejšiu experimentáciu s fajčením pri autoritatívnom výchovnom štýle u oboch rodičov

Výskumné otázky

VO1 Ktorý z prediktorov (impulzivita, výchovné štýly) predstavujú výraznejší prediktor experimentácie s fajčením?

VO2 Aký je vzt'ah medzi impulzivitou a vekom adolescentov pri experimentovaní s fajčením?

VO3 Začínajú experimentovat' skôr adolescenti ak ich rodičia fajčia?

\section{METÓDY}

\subsection{Výskumná vzorka}

Výskumnú vzorku tvorili adolescenti vo vekovom rozpätí 15-19 rokov, študenti stredných škôl z rôznych regiónov Slovenska. Výskumný súbor bol vytvorený skupinovým výberom, jediné kritérium výberu predstavoval vek adolescentov. Výskumný súbor tvorilo $\mathrm{N}=548$ adolescentov (247 chlapcov a 301 dievčat), priemerný vek 16,3.

\subsection{Výskumné metódy}

Základné údaje o veku, o experimentovaní s fajčením u adolescenta boli získané prostredníctvom vlastného dotazníka. Tabakové správanie v rodine bolo zist'ované prostredníctvom Dotazníka situačno-motivačných faktorov fajčenia (Rojková, Gálová, 2015). Dotazník predstavuje modifikáciu Dotazníka situačno-motivačných faktorov alkoholového správania (Rojková, Vavrová, 2017). Bola použitá doplnková škála uvedeného dotazníka, obsahuje 20 položiek a zistuje tabakové správanie v rodine adolescentov). Odpovede sú zaznamenávané na 5 stupňovej Likertovej škále (úplne súhlasím - skôr súhlasím - neviem posúdit' - skôr nesúhlasím - vôbec nesúhlasím). K zisteniu impulzivity bol použitý štandardizovaný dotazník IVE - škála impulzivity (Eysenck \& Eysenck, 1985). Odpovede v dotazníku sú dichotomické, dotazník obsahuje 54 položiek. Reliabilita dotazníkovej metódy bola overovaná zistením vnútornej konzistencie, hodnota Cronbachovej alfy 0,77 - 0,90. Nás zaujímal počet bodov, ktoré získal respondent pre faktor impulzivity. Škála impulzivity tvorí 19 položiek. Dotazník Rodičovskej autority (Buri, 1991), bol použitý k zisteniu výchovných štýlov v rodine (autoritatívny, autoritársky, zhovievavý) zvlášt' u oboch rodičov. Dotazník tvorí 30 výrokov, zist'uje subjektívne vnímanie rodičovskej výchovy - odpovede boli zaznamenávané na 5 bodovej Likertovej škále (úplne súhlasím - skôr súhlasím - neviem posúdit' - skôr nesúhlasím - vôbec nesúhlasím). Dotazník je validný, Cronbachová alfa 0,74-0,87. Psychometrické parametre dotazníka umožňujú jeho využitie pre výskumné účely. Získané dáta boli spracované do databázy v programe SPSS.

\subsection{Výsledky a interpretácia}

Tab. 1 Mann-Whitney $U$ test : Rozdiely $\mathrm{v}$ miere impulzivity u adolescentov experimentujúcich s fajčením a adolescentov, ktorí nefajčia

\begin{tabular}{|c|cc|cc|}
\hline & Počet & Priemerné poradie & Mann-Whitney U test \\
\hline Neexperimentovali s fajčením & 153 & 198,06 & $\mathrm{U}$ & 18522 \\
\hline
\end{tabular}




\begin{tabular}{|cc|cc|cc|}
\hline Impulzivita & Experimentovali s fajčením & 345 & 272,31 & $\mathrm{Z}$ & $-5,328$ \\
& Spolu & 498 & Sig. & 0,000 \\
\hline
\end{tabular}

Hypotéza H1 bola testovaná Mann-Whitney U testom, ktorý porovnával rozloženie premennej impulzivity medzi respondentami, ktorí experimentovali $\mathrm{s}$ fajčením a tými, čo neexperimentovali. Výsledok testu bol $U=18522 ; Z=-5,328$; Sig. $<0,001$. Výsledok poukazuje na štatistickú významnost' rozdielov medzi skupinami z hl'adiska dosiahnutého skóre impulzivity. Na základe priemerných poradí sa preukázali vyššie hodnoty impulzivity u respondentov, ktorí experimentovali s fajčením $(\mathrm{MR}=272,31)$ v porovnaní s respondentmi, ktorí neexperimentovali s fajčením (MR $=198,06)$. Hypotézu H1 prijímame.

$\mathrm{Na}$ overenie hypotézy $\mathrm{H} 2$ bol použitý Chi kvadrát test, boli zist'ované rozdiely medzi výchovnými štýlmi využívanými rodičmi $\mathrm{v}$ závislosti od skupín adolescentov, ktorí experimentovali alebo neexperimentovali $\mathrm{s}$ fajčením. Výsledok použitého testu bol $\mathrm{x}^{2}=$ 0,423; Sig. > 0,05. Medzi jednotlivými štýlmi výchovy rodičov sa nepreukázali štatisticky významné rozdiely v kategóriách experimentovania s fajčením u respondentov. Hypotézu H2 zamietame. Uvedené výsledky nachádzame v tab.2. Rozdiely medzi štýlom výchovy, ktorý zastávala matka a experimentovaním $\mathrm{s}$ fajčením u respondentov sme skúmali pomocou Chikvadrát testu, ktorého výsledok sa nepreukázal ako štatistiky významný $\left(\mathrm{x}^{2}=2,402\right.$; Sig. > 0,05). Medzi výchovnými štýlmi matky a kategóriami experimentovania $\mathrm{s}$ fajčením dospievajúcich neexistujú významné rozdiely. Hypotézu H2a zamietame. Chi-kvadrát test sme využili taktiež pri zist'ovaní rozdielnosti medzi skupinami respondentov, ktorí experimentovali a neexperimentovali s fajčením a výchovným štýlom otca. Test preukázal štatisticky významné rozdiely $\left(\mathrm{x}^{2}=6,767\right.$; Sig. $\left.<0,05\right)$ v početnostiach v bunkách krížovej tabul'ky. Experimentovanie s fajčením sa vyskytlo u 28,60\% respondentov, ktorí boli vychovávaní zhovievavým a autoritárskym výchovným štýlom. U respondentov vychovávaných autoritatívnym výchovným štýlom experimentovalo s fajčením $42,80 \%$. Naproti tomu 53,90\% respondentov vychovávaných autoritatívnym výchovným štýlom, $27,70 \%$ autoritárskym a $18,40 \%$ respondentov vychovávaných zhovievavým štýlom otca neexperimentovalo $\mathrm{s}$ fajčením. Jednotlivci, ktorí boli vychovávaní autoritatívnym výchovným štýlom otca menej často experimentovali $\mathrm{s}$ fajčením $\mathrm{v}$ porovnaní $\mathrm{s}$ jedincami vychovávanými ostatnými výchovnými štýlmi. Uvedená súvislost' experimentovania a autoritatívneho štýlu matky nebola zistená, preto Hypotézu H2 zamietame.

Tab. 2 Krížová tabul'ka Chí-kvadrát test (rodičia spolu)

\begin{tabular}{|c|c|c|c|c|c|}
\hline \multirow{2}{*}{\multicolumn{2}{|c|}{ Experimentovanie s fajčením }} & \multicolumn{3}{|c|}{ Výchovný štýl rodičov } & \multirow{3}{*}{$\begin{array}{c}\text { Spolu } \\
112 \\
112,00 \\
100 \%\end{array}$} \\
\hline & & \multirow{2}{*}{$\begin{array}{c}\text { Zhovievavý } \\
29 \\
26,86 \\
26 \%\end{array}$} & \multirow{2}{*}{$\begin{array}{c}\text { Autoritársky } \\
23 \\
24,72 \\
21 \%\end{array}$} & \multirow{2}{*}{$\begin{array}{c}\text { Autoritatívny } \\
60 \\
60,43 \\
53 \%\end{array}$} & \\
\hline $\begin{array}{l}\text { Neexperimentovali s } \\
\text { fajčením }\end{array}$ & $\begin{array}{c}\text { Počet } \\
\text { Očakávaný počet } \\
\%\end{array}$ & & & & \\
\hline $\begin{array}{l}\text { Experimentovali s } \\
\text { fajčením }\end{array}$ & $\begin{array}{c}\text { Počet } \\
\text { Očakávaný počet } \\
\% \\
\end{array}$ & $\begin{array}{c}59 \\
61,14 \\
23 \% \\
\end{array}$ & $\begin{array}{c}58 \\
56,28 \\
23 \% \\
\end{array}$ & $\begin{array}{c}138 \\
137,57 \\
54 \% \\
\end{array}$ & $\begin{array}{c}255 \\
255,00 \\
100 \% \\
\end{array}$ \\
\hline \multirow[t]{2}{*}{ Spolu } & $\begin{array}{c}\text { Počet } \\
\text { Očakávaný počet } \\
\%\end{array}$ & $\begin{array}{c}88 \\
88,00 \\
24 \% \\
\end{array}$ & $\begin{array}{c}81 \\
81 \\
22 \%\end{array}$ & $\begin{array}{c}198 \\
198,00 \\
54 \%\end{array}$ & $\begin{array}{c}367 \\
367,00 \\
100 \% \\
\end{array}$ \\
\hline & & \multicolumn{2}{|c|}{ Hodnota } & df & Sig. \\
\hline \multicolumn{2}{|c|}{ Chi-kvadrát } & \multicolumn{2}{|c|}{0,423} & 2 & 0,809 \\
\hline
\end{tabular}


Tab.2a: Krížová tabul'ka Chí-kvadrát test (výchovný štýl matka)

\begin{tabular}{|c|c|c|c|c|c|}
\hline \multirow{2}{*}{\multicolumn{2}{|c|}{ Experimentovanie s fajčením }} & \multicolumn{3}{|c|}{ Výchovný štýl matky } & \multirow[b]{2}{*}{ Spolu } \\
\hline & & \multirow{2}{*}{$\frac{\text { Zhovievavý }}{40}$} & \multirow{2}{*}{$\frac{\text { Autoritársky }}{31}$} & \multirow{2}{*}{ Autoritatívny } & \\
\hline \multirow{3}{*}{$\begin{array}{l}\text { Neexperimentoval s } \\
\text { fajčením }\end{array}$} & Počet & & & & 148 \\
\hline & Očakávaný počet & 33,8 & 35,2 & 79 & 148 \\
\hline & $\%$ & $27,00 \%$ & $20,90 \%$ & $52,00 \%$ & $100,00 \%$ \\
\hline \multirow{3}{*}{$\begin{array}{l}\text { Experimentovali s } \\
\text { fajčením }\end{array}$} & Počet & 77 & 91 & 197 & 365 \\
\hline & Očakávaný počet & 83,2 & 86,8 & 195 & 365 \\
\hline & $\%$ & $21,10 \%$ & $24,90 \%$ & $54,00 \%$ & $100,00 \%$ \\
\hline \multirow[b]{3}{*}{ Spolu } & Počet & 117 & 122 & 274 & 513 \\
\hline & Očakávaný počet & 117 & 122 & 274 & 513 \\
\hline & $\%$ & $22,80 \%$ & $23,80 \%$ & $53,40 \%$ & $100,00 \%$ \\
\hline & & \multicolumn{2}{|c|}{ Hodnota } & $\mathrm{df}$ & Sig. \\
\hline \multicolumn{2}{|c|}{ Chi-kvadrát } & \multicolumn{2}{|c|}{2,402} & 1 & 0,301 \\
\hline
\end{tabular}

Tab. 2b: Krížová tabul'ka Chí-kvadrát test (výchovný štýl otec)

\begin{tabular}{|c|c|c|c|c|c|}
\hline \multirow{2}{*}{\multicolumn{2}{|c|}{ Experimentovanie s fajčením }} & \multicolumn{3}{|c|}{ Výchovný štýl otca } & \multirow{2}{*}{ Spolu } \\
\hline & & Zhovievavý & Autoritársky & Autoritatívny & \\
\hline $\begin{array}{l}\text { Neexperimentovali s } \\
\text { fajčením }\end{array}$ & $\begin{array}{c}\text { Počet } \\
\text { Očakávaný počet } \\
\%\end{array}$ & $\begin{array}{c}26 \\
36,2 \\
18,40 \%\end{array}$ & $\begin{array}{c}39 \\
40 \\
27,70 \%\end{array}$ & $\begin{array}{c}76 \\
64,9 \\
53,90 \%\end{array}$ & $\begin{array}{c}141 \\
141 \\
100,00 \%\end{array}$ \\
\hline $\begin{array}{l}\text { Experimentovali s } \\
\text { fajčením }\end{array}$ & $\begin{array}{c}\text { Počet } \\
\text { Očakávaný počet } \\
\% \\
\end{array}$ & $\begin{array}{c}99 \\
88,8 \\
28,60 \% \\
\end{array}$ & $\begin{array}{c}99 \\
98 \\
28,60 \% \\
\end{array}$ & $\begin{array}{c}148 \\
159,1 \\
42,80 \% \\
\end{array}$ & $\begin{array}{c}346 \\
346 \\
100,00 \% \\
\end{array}$ \\
\hline Spolu & $\begin{array}{c}\text { Počet } \\
\text { Očakávaný počet } \\
\%\end{array}$ & $\begin{array}{c}125 \\
125 \\
25,70 \% \\
\end{array}$ & $\begin{array}{c}138 \\
138 \\
28,30 \% \\
\end{array}$ & $\begin{array}{c}224 \\
224 \\
46,00 \%\end{array}$ & $\begin{array}{c}487 \\
487 \\
100,00 \% \\
\end{array}$ \\
\hline & & \multicolumn{2}{|c|}{ Hodnota } & $\mathrm{df}$ & Sig. \\
\hline \multicolumn{2}{|c|}{ Chi-kvadrát } & \multicolumn{2}{|c|}{6,767} & 1 & 0,034 \\
\hline
\end{tabular}

Tab. 3 Výsledky binárnej logistickej regresnej analýzy so závislou premennou Experimentovanie s fajčením a prediktormi Impulzivita, Fajčenie rodičov a Autoritatívny výchovný štýl otca

\begin{tabular}{|c|c|c|c|c|c|c|}
\hline & \multicolumn{2}{|c|}{ Chi-kvadrát } & \multicolumn{2}{|c|}{$\mathrm{df}$} & Sig. & \\
\hline & \multicolumn{2}{|c|}{28,392} & \multicolumn{2}{|c|}{4} & 0,000 & \\
\hline & \multicolumn{2}{|c|}{$\begin{array}{c}-2 \text { Log } \\
\text { pravdepodobnost' }\end{array}$} & \multicolumn{2}{|c|}{ Cox \& Snell $\mathrm{R}^{2}$} & Nagelkerke $\mathrm{R}^{2}$ & \\
\hline & \multicolumn{2}{|c|}{$446,839^{\mathrm{a}}$} & \multicolumn{2}{|c|}{0,071} & 0,100 & \\
\hline & B & S.E. & Wald & Df & Sig. & $\operatorname{Exp}(B)$ \\
\hline Impulzivita & 0,117 & 0,031 & 14,263 & 1 & 0,000 & 1,124 \\
\hline Fajčenie v rodine(1) & 0,654 & 0,230 & 8,104 & 1 & 0,004 & 1,923 \\
\hline Autoritatívny vých.štýl otca & $-0,016$ & 0,014 & 1,375 & 1 & 0,241 & 0,984 \\
\hline Konštanta & $-0,107$ & 0,605 & 0,032 & 1 & 0,859 & 0,898 \\
\hline
\end{tabular}

(1) referenčná skupina je skupina respondentov, u ktorých sa v rodine nefajčí

$\mathrm{Z}$ tab. 3 Model bol testovaný logistickou regresnou analýzou a preukázal sa ako platný $\left(\mathrm{x}^{2}=\right.$ 28,392; Sig. < 0,001). Tento model s prediktormi impulzivita, fajčenie rodičov a autoritatívny výchovný štýl otca vysvetl'uje $7,1-10 \%$ etiológiu experimentovania $\mathrm{s}$ fajčením u 
dospievajúcich. $Z$ uvedených prediktorov sa nepreukázal autoritatívny výchovný štýl otca ako štatisticky významný prediktor (Sig. > 0,05). Najsilnejším prediktorom bola impulzivita (Sig. $<0,001)$. Ak sa impulzivita respondenta zvýši o 1 bod, riziko adolescentovho experimentovania sa zvýši 1,124 krát. Fajčenie v rodine taktiež predstavovalo štatisticky významný prediktor (Sig. $<0,01$ ), pokial' sa v rodine adolescenta fajčí, jeho šanca, že bude experimentovat' $\mathrm{s}$ fajčením je 1,923 vyššia ako u adolescenta, ktorého členovia rodiny nefajčia. VO1: Najsilnejším prediktorom bola impulzivita (Sig. $<0,001)$.

$\mathrm{V}$ tab. 4 vidíme percentuálne zastúpenie experimentovania $\mathrm{s}$ fajčením u adolescentov podla tabakového správania u rodičov adolescentov. Skupinu neexperimentujúcich s fajčením, ktorých matka nefajčila tvorilo $62,20 \%$ adolescentov. Respondentov, ktorí experimentovali s fajčením a ich matka nefajčila bolo $60,60 \%$. skupinu experimentujúcu s fajčením $(37,30 \%)$ experimentujúcich $\mathrm{s}$ fajčením vyrastalo $\mathrm{v}$ domácnosti, kde matka fajčila počas ich dospievania. Skupinu respondentov, ktorí neexperimentovali s fajčením a ich otec nefajčil počas ich dospievania tvorí $(56,70 \%)$, a $(36,60 \%)$ neexperimentovalo s fajčením a ich otec fajčil počas dospievania. Dospievajúci, ktorých otec fajčil tvorili 50,70\% skupiny experimentujúcich respondentov s fajčením respondenti, ktorých otec nefajčil tvorili 47,30\% súboru experimentujúcich $\mathrm{s}$ fajčením a 2,10\% dospievajúcich tvorili chýbajúce údaje ohl'adom fajčenia otca.

Tab. 4 Frekvencia fajčenia u rodičov v skupine experimentujúcich a neexperimentujúcich adolescentov

\begin{tabular}{|c|c|c|c|c|c|c|}
\hline $\begin{array}{c}\text { Adolescenti } \\
\text { experimentácia }\end{array}$ & $\begin{array}{c}\text { Fajčenie } \\
\text { matka }\end{array}$ & $\mathrm{N}$ & $\%$ & $\begin{array}{c}\text { Fajčenie } \\
\text { otec }\end{array}$ & $\mathrm{N}$ & $\%$ \\
\hline $\begin{array}{c}\text { Neexperimentovali } \\
\text { s fajčením }\end{array}$ & Nie & 102 & 62,20 & Nie & 93 & 56,70 \\
\cline { 2 - 7 } & Áno & 53 & 32,30 & Áno & 60 & 36,60 \\
\hline $\begin{array}{c}\text { Experimentovali s } \\
\text { fajčením }\end{array}$ & Nie & 232 & 60,60 & Nie & 181 & 47,30 \\
\cline { 2 - 7 } & Áno & 143 & 37,30 & Áno & 194 & 50,70 \\
\hline
\end{tabular}

Tab. 5 Spearmanov koeficient poradovej korelácie: Súvislost' medzi vekom experimentovania a impulzivitou

\begin{tabular}{|c|c|c|c|}
\hline & & $\begin{array}{c}\text { Vek experimentovania s } \\
\text { fajčením }\end{array}$ & Impulzivita \\
\hline $\begin{array}{c}\text { Vek experimentovania } \\
\text { s fajčením }\end{array}$ & $\begin{array}{c}\text { Spearmanov } \\
\text { rho }\end{array}$ & & $-0,129$ \\
\cline { 2 - 4 } & Sig. & & 0,074 \\
\cline { 2 - 4 } & $\mathrm{N}$ & & 194 \\
\hline
\end{tabular}

Výsledok koeficientu poradovej korelácie bol $\rho=-0,129$; Sig. > 0,05. Medzi vekom experimentovania $\mathrm{s}$ fajčením dospievajúcich a impulzivitou respondentov sa nepreukázala spojitost' VO2 : nebol zistený štatisticky významný vzt’ah medzi vekom experimentovania dospievajúcich s fajčením a ich impulzivitou.

Tab. 6 Mann-Whitney test: Rozdiel vo veku experimentovania s fajčením na základe tabakového správania rodičov

\begin{tabular}{|c|c|c|c|c|c|}
\hline & & $\mathrm{N}$ & $\begin{array}{c}\text { Priemerné } \\
\text { poradie }\end{array}$ & \multicolumn{2}{|c|}{ Mann-Whitney test } \\
\hline $\begin{array}{c}\text { Vek } \\
\text { experimentovania }\end{array}$ & $\begin{array}{c}\text { Nefajčili } \\
\text { rodičia }\end{array}$ & 74 & 115,14 & $\mathrm{U}$ & 4022,5 \\
\hline
\end{tabular}




\begin{tabular}{|c|c|c|c|c|c|}
\hline & Fajčili rodičia & 132 & 96,97 & $Z$ & $-2,127$ \\
\cline { 2 - 6 } & Spolu & 206 & & Sig. & 0,033 \\
\hline
\end{tabular}

Vyšší vek pri experimentovaní s fajčením bol špecifický u respondentov, u ktorých sa v rodine nefajčilo $(\mathrm{MR}=115,14)$ a zase nižší vek respondentov pri ich experimentovaní $\mathrm{s}$ fajčením sa spájal $\mathrm{s}$ fajčením $\mathrm{v}$ rodine počas ich dospievania (MR $=96,97)$. VO3: Vek experimentovania s fajčením adolescentov sa znižuje s prítomnost'ou tabakového správania rodičov.

\section{DISKUSIA}

Výsledky predloženej štúdie poukazujú na súvislost' impulzivity a experimentovania s fajčením u adolescentov. Naše zistenia podporujú Kvaavik, Rise (2012, Granö et. al.,2004, Mitchell, 2004). Podl'a autorov Raynoldsa a Fieldsa (2012) mladí l'udia, ktorí experimentujú s cigaretami, môžu byt' podobní tým, ktorí fajčia pravidelne, pokial' ide o tendenciu odkladat' budúce zisky a vykazovat' impulzívne tendencie častejšie ako l'udia, ktorí neexperimentujú $\mathrm{s}$ fajčením. Settles, et. al. (2010) uvádzajú, že impulzivita po prvotnej skúsenosti s cigaretou môžu byt' zdrojom posilnenia pozitívnych účinkov užívania čo zvyšuje pravdepodobnost' experimentácie. Leventhal a Schmitz, (2006) zdôrazňujú pravdepodobnost' rozvíjania návyku v súvislosti s modelom u dospelých. Dôsledky tohto modelu môžu vidiet' dospievajúci v médiách alebo $\mathrm{v}$ ich životoch. Experimentovanie $\mathrm{s}$ fajčením dospievajúcich $\mathrm{v}$ závislosti od kategórií výchovného štýlu otca priniesli významné zistenia. Adolescenti, ktorí boli vychovávaní otcom autoritatívnym výchovným štýlom, experimentovali menej často $\mathrm{s}$ fajčením v porovnaní s jedincami vychovávanými autoritárskym a zhovievavým výchovným štýlom. Výsledok je $\mathrm{v}$ zhode so zisteniami (Bronte-Tinkew, et. al. 2006). Kontrola a podpora otca, ktoré sú špecifické pre autoritatívny výchovný štýl, predstavujú významnú stratégiu proti užívaniu návykových látok u adolescentov (Li, et. al. 2000). Výsledky nášho výskumu preukázali štatisticky významné rozdiely medzi experimentovaním s fajčením u dospievajúcich a fajčením príslušníkov rodiny. Adolescenti, u ktorých sa v rodine fajčilo, častejšie experimentovali $\mathrm{s}$ fajčením $\mathrm{v}$ porovnaní $\mathrm{s}$ tými, ktorých členovia rodiny nefajčili. Výsledky sú v súlade s (Leonardi-Bee, et. al. 2011). Fajčenie v rodine môže slúžit' ako dôležitý indikátor skúšania tabakových výrobkov adolescentmi (Hill, et. al., 2005). Vplyv rodiny je dôležitý nielen pri experimentovaní s fajčením, ale môže ovplyvňovat' aj d’al'šie fázy fajčenia, ako napríklad denné fajčenie (Mayhew, et. al., 2000). Ďalšie zistenia uvedenej štúdii deklarujú význam rodičov ako vzorov pre správanie adolescentov. Bolo zistené, že experimentovanie rodičov nesie so sebou aspekt skoršej iniciácie, experimentácie $\mathrm{s}$ fajčením. Experimentovanie $\mathrm{s}$ fajčením $\mathrm{v}$ mladom veku predpovedá budúce fajčiarske vzorce vrátane denného fajčenia, intenzity fajčenia, závislosti na nikotíne a t’ažkosti s odvykaním si od tejto látky (Hu, Davies, Kandel, 2006; Wilkinson, et. al., 2007).

\section{ZÁVER}

Výskyt experimentácie s fajčením adolescentov sa vyskytuje u adolescentov, kterých rodičia majú vytvorený návyk i bez návyku. Experimentácia s fajčením je determinovaná impulzivitou a tabakovým správaním rodičov. Fajčenie rodičov v období dospievania adolescentov je jedným z prediktorov skoršieho experientovania s fajčením u adolescentov.

Príspevok vznikol za podpory projektu: VEGA 1/0203/20

Vývoj a štandardizácia skríningovej metodiky na identifikáciu výskytu a rizika problémového uživania legálnych drog u adolescentov 


\section{Použitá literatura}

1. BIELIKOVÁ, M., PÉTIOVÁ, M., DRNZÍKOVÁ, E. Fajčenie žiakov základných a stredných škôl. Bratislava: Ústav informácií a prognóz školstva, 2003. $38 \mathrm{~s}$.

2. $\quad$ BAŠKA, T. Prevencia užívania tabaku u školskej mládeže. Martin: Národná koalícia pre kontrolu tabaku v SR. 2008. 64 s. ISBN 978-80-969767-1-3.

3. BOLD, K., MOREAN, M., KONG, G., SIMON, P., CAMENGA, D., CAVALLO, D., KRISHNAN-SARIN. S. Early age of e-cigarette use onset mediates the association between impulsivity and e-cigarette use frequency in youth. Drug and Alcohol Dependence. 2017. 181, 146-151s. ISSN 0376-8716.

4. BURI, J. Parental Authority Questionnaire. Journal of Personality Assessment, 57(1), 1991. 110-119s. ISSN 1532-7752.

5. BLOOM, E. L., MATSKO, S. V., CIMINO, C. R. The relationship between cigarette smoking and impulsivity: A review of personality, behavioral, and neurobiological assessment. Addiction Research and Theory. 2014. 22(5), 386-397 s. ISSN 16066359.

6. BRONTE-TINKEW, J., MOORE, K., CARRANO, J. The Father-Child Relationship, Parenting Styles, and Adolescent Risk Behaviors in Intact Families. Journal of Family Issues, 2006. 27(6), 850-881 s. ISSN 1552-5481.

7. COURTOIS, R., CAUDRELIER, N., LEGAY, E., LALANDE, G., HALIMI, A., JONAS, C. Influence of parental tobacco dependence and parenting styles on adolescents' tobacco use. La Presse Médicale. 2007. 37(10), 1341-1349 s. ISSN 0755-4982.

8. Č́EREŠNÍK, M., TOMŠIK, R., DOLEJŠ, M., SUCHÁ, J. Impulzivita ako prediktor rizikového správania adolescentov. Československá psychologie, 2018. 62(5), 503512 s. ISSN 0009-062X.

9. DOLEJŠ, M., SKOPAL, O., SUCHÁ, J. Protektivni a rizikové osobností rysy u adolescentů. I. vyd. Olomouc: Univerzita Palackého. 2014. 154 s. ISBN 978-80244-4181-8

10. EYSENCK, H., EYSENCK, S.. T-9 Eysenckove osobnostné dotazníky pre dospelých. Psychodiagnostika s. r. o. 1985.

11. ELLICKSON, P., MCGUIGAN, K., KLEIN, D. Predictors of late-onset smokin an cessation over 10 years. Journal of Adolescent Health. 2001. 29(3), 101-108 s. ISSN 1054139XISSN.

12. EXTER BLOKLAND, E., HALE, W., MEEUS, W., ENGELS, R. Parental Support and Control and Early Adolescent Smoking: A Longitudinal Study. Substance use and misuse. 2007. 42, 2223-2232 s. ISSN 1532-2491.

13. GRANÖ, N., VIRTANEN, M., VAHTERA, J., ELOVAINIO, M. Impulsivity as a predictor of smoking an alcohol consumption. Personality and Individual Differences, 2004. 37(8), 1693 -1700 s. ISSN 0191-8869.

14. HERETÍK, A., HERETÍK, A. S., NOVOTNÝ, V., RITOMSKÝ, A., PEČENÁK, J. EPIAF. Nové Zámky: Psychoprof. 2008. 31 s. ISSN 1335-423X.

15. HUVER, R. M., ENGELS, R. C., BREUKELEN, G., VRIES, H. D. Parenting style and adolescent smoking cognitions and behaviour. Psychology and Health, 2007. 22(5), 575- 593 s. ISSN 08870446.

JANČOVIČOVÁ, H., RITOMSKÝ, A., HERETIK, A. Osobnostné faktory adolescentov konzumujúcich legálne psychoaktívne látky-nikotínové cigarety. ALKOHOLIZMUS A DROGOVÉ ZÁVISLOSTI, 2004. 39(1), 3-15 s. ISSN 8022310786.

16. JURKOVIČOVÁ, J. Vieme zdravo žit? Bratislava: LF UK. 2005. 166 s. ISBN 80223-2132-X. 
17. KIMÁKOVÁ, T., BERNADIČ, M., BERNADIČ, M., BIELIK, I., ROVNÝ , I., MÁCOVÁ, Ž., NEVOLNÁ, Z. Fajčenie ako jeden z najzávažnejších celospoločenských zdravotníckych problémov súčasnej doby. PsychiatriaPsychoterapia-Psychosomatika, 2012. 19-26 s. ISSN 1338-7030.

18. KVAAVIK, E., RISE, J. How Do Impulsivity and Education Relate to Smoking Initiation and Cessation Among Young Adults? Journal of Studies on Alcohol and Drugs, 2012. 73(5), 804-810 s. ISSN 1938-4114.

19. MITCHELL, S. Measuring Impulsivity and Modeling Its Association With Cigarette Smoking. Behavioral and Cognitive Neuroscience Reviews. Neuroscience Reviews, 2004. 261-275 s. 2191-0200.

20. MATHEW, A. R., BURRIS, J. L., FROELINGER, B., SALADIN, M. E., CARPENTER, M. Impulsivity and Cigarette Craving among Adolescent Daily and Occasional Smokers. Addict Behavior, 2015. 45, 134-138.

21. MAYHEW, K., FLAY, B.,MOTT, J. Stages in the development of adolescent smoking. Drug Alcohol Depend, 2000. 59, 61-81. ISSN 03768716.

22. MANNIOVÁ, J. Rodičovská autorita a štýly výchovy - činitele ovplyvňujúce výchovu v rodine. Pedagogická orientace. 2007. 1, 34-44 s. ISSN 1805-9511.

23. ONDRUŠKOVÁ, E., PRUŽINSKÁ, J., PAVELOVÁ, L. Rodina,vol'ný čas, psychoaktívne láatky a delikvencia. 1 vyd. Bratislava: Univerzita Komenského v Bratislave. 2016. 205 s. ISBN 978-80-223-4236-0.

24. STEINBERG, L., ALBERT, D., CAUFFMAN, E., BANICH, M., GRAHAM, S., WOOLARD, J. Age differences in sensation seeking and impulsivity as indexed by behavior and self-report: evidence for a dual systems model. Developmental Psychology, 2008. 44(6), 1764-1778 s. ISSN 1939-0599.

25. ROJKOVÁ, Z. Situačno-motivačné faktory alkoholového správania. Trnava: Univerzita sv. Cyrila a Metoda v Trnave. 2016. 104 s. ISBN 978-80-8105-801-1.

26. ROJKOVÁ, Z., GÁLOVÁ, K. Situačno-motivačné faktory experimentovania s fajčením. Kondášove dni 2014 . Trnava: Univerzita sv. Cyrila a Metoda. 2015. 128139 s. ISBN 978 80-8105-795-3,

27. ROJKOVÁ, Z., VAVROVÁ, M. Situačno-motivačné faktory alkoholového správania. Metodológia merania a aplikácia v praxi. Trnava: Univerzita sv. Cyrila a Metoda v Trnave. 2017. 97 s. ISBN 978-80-8105-887-5.

28. ROJKOVÁ, Z., VAVROVÁ, M. A description of drug use among adolescents in Slovakia in different age and gender groups. Technium Social Sciences Journal, 2020. 10, 344-357 s. ISSN 2668-7798.

29. VAVROVÁ, M., GÁLOVÁ, K. Selected personality traits and situation-motivational factors of tobacco behavior in adult smokers and former smokers. MMK 2017. Hradec Králové: MAGNANIMITAS. 2017. 713-721 s. ISBN 978-80-87952-22-1

30. WANG, Y., HO, S., WANG, M., LO, W., LAI, H., LAM, T. HONG KONG CHINESE Adolescents' Self-Reported Smoking and Perceptions of Parenting Styles. International journal of behavioral medicine, 2015. 22, 268-275 s. ISSN 1532-7558.

31. ZUCKERMAN, M. The psychobiological basis of personality. The scientific study of human nature: Tribute to Hans J. Eysenck at eighty, University of Aarhus, Risskov, Denmark. 1997. 3-16 s., ISBN 0-08-042787-1.

32. ZUCKERMAN, M., CLONINGER, C. Relationships between Cloninger's, Zuckerman's, and Eysenck's dimensions of personality. Journal of Personality, 1996. 21(2), 283-285 s. ISSN 1467-6494. 
33. WANG, Y., HO, S., WANG, M., LO, W., LAI, H., LAM, T. Hong Kong Chinese Adolescents' Self-Reported Smoking and Perceptions of Parenting Styles. International journal of behavioral medicine, 2015. 22, 268-275 s. ISSN 15733521.

34. WHITESIDE, S., LYNAM, D. The Five Factor Model and impulsivity: Using a structural model of personality to understand impulsivity. Personality and Individual Differences, 2001. 30(4), 669-689 s. ISSN 0191-8869.

35. RAYNOLDS, B., FIELDS, S. Delay discounting by adolescents experimenting with cigarette smoking. 2012. Addiction, 107(2), 417-424. ISSN 1360-0443.

36. SETTLES, R., CYDERS, M., SMITH, G. Longitudinal Validation of the Acquired Preparedness Model of Drinking Risk. 2010. Psychology of Addictive Behaviors, 24(2), 198-208 s. 0893-164X.

37. LI, X., STANTON, B., FEIGELMAN, S. Impact of perceived parental monitoring on adolescent risk behavior over 4 years. 2000. Adolescent health, 27(1), 49-56 s. 1054$139 \mathrm{X}$

38. LEONARDI-BEE, L., JERE, M., BRITTON, J. Exposure to parental and sibling smoking and the risk of smoking uptake in childhood and adolescence: a systematic review and meta-analysis. Thorax, 2011. 66 (10), 847-855 s. ISSN 1468-3296.

\section{Kontaktní údaje}

$\mathrm{PhDr}$. Zuzana Mičková, PhD.

Univerzita sv. Cyrila a Metóda v Trnave

J. Herdu 2, 91701 Trnava

Tel. +421905344198

email: zuzana.mickova@ucm.sk

Mgr. Sophia Mészarosová

Univerzita sv. Cyrila a Metóda v Trnave

J. Herdu 2, 91701 Trnava

email:meszarosova5@ucm.sk 


\title{
HUDOBNÉ VNÍMANIE A UVEDOMELÉ POČÚVANIE HUDBY
}

\author{
MUSIC PERCEPCION AND CRITICAL LISTENING
}

\author{
Ivana Lacková
}

\begin{abstract}
Abstrakt
Príspevok sa zaoberá hudobným vnímaním a uvedomelým počúvaním hudby. Približuje predmet a faktory ovplyvňujúce hudobné vnímanie, pozornost' tiež venuje jeho základným procesom - percepcii, apercepcii a recepcii. Príspevok má za ciel' predstavit' metódy a postupy, ktorými pedagóg privedie svojich percipientov $\mathrm{k}$ aktívnemu a uvedomelému počúvaniu hudby, pochopeniu významu hudby, zámeru skladatel'a a v neposlednom rade k pochopeniu výberu zvolených hudobno-výrazových prostriedkov hudobnej skladby.
\end{abstract}

Kl'účové slová: hudobné vnímanie, uvedomelé počúvanie hudby, percepcia, apercepcia, recepcia

\begin{abstract}
The paper deals with musical perception and crical listening music. It introduces the subject and factors influencing musical perception, it also pays attention to its basic processes perception, apperception and reception. The paper aims to present the methods and procedures by which the teacher leads his percipients to active and conscious listening to music, understanding the meaning of music, the composer's intention and to understand the choice of selected musical means of expression.
\end{abstract}

Key words: music percepcion, critical listening, perception, apperception, reception.

\section{ÚVOD}

Hudobné vnímanie možno charakterizovat' ako špecifickú hudobnú aktivitu, psychofyziologický proces, počas ktorého dochádza k aktívnemu, výberovému a zmysluplnému prijímaniu hudby. Ide o štrukturálne zložitý proces dekódovania a tvorivého spracovania informácií, o psychickú tvorivú činnost' a ret’azec percepčných aktov ako je identifikovanie a rozlišovanie hudobnej skladby. ${ }^{1}$ Hudobné vnímanie je zamerané na objasnenie všetkých významov, ktorými hudba disponuje. Vnímanie hudby sa uskutočňuje na základe zmyslových vnemov tónov a zvukov, ktoré u percipienta pretvárajú predstavy na zažité citové skúsenosti, ale rovnako $\mathrm{v}$ ňom vytvárajú nové asociatívne predstavy. ${ }^{2}$ Výrazové prostriedky hudby tak priamo navodzujú a podnecujú vytváranie predstáv. Pri vnímaní hudby teda dochádza k tomu, že na základe svojich doterajších skúseností si jednotlivé vnemy dopĺn̆ame, upravujeme a kompletizujeme do jedného celku. ${ }^{3} \mathrm{~S}$ hudobným vnímaním je tiež úzko spätá emocionálna pamät' a estetické vnímanie hudby. Emocionálna pamät' je jedným z kl'účových aspektov l'udskej identity a predstavuje naše najživšie autobiografické spomienky. Čím je skúsenost' percipienta s počúvaním hudby väčšia, tým bohatšie sú jeho emocionálne predstavy a emocionálna pamät' je citlivejšia. ${ }^{4}$ Estetické vnímanie hudobného diela je myšlienkový, psychický a fyziologický proces, počas ktorého dochádza k zhromažd'ovaniu estetických

\footnotetext{
${ }^{1}$ SEDLÁK - VAŇOVÁ, 2013, s. 245.

${ }^{2}$ MICHALOVÁ, 1998, s. 62.

${ }^{3}$ HOLAS, 1998, s. 59.

${ }^{4}$ MICHALOVÁ, 1998, s. 62.
} 
schopností. Od jedinca si vyžaduje byt' pripravený na proces vnímania hudobného diela. ${ }^{5}$ Vnímanie hudobného diela sa stáva interakciou - prostredníctvom hudobného diela sa percipient dostáva do kontaktu s autorom a spoznáva kontext doby, vktorej skladbu komponoval. ${ }^{6}$ Vnímatel' je však ovplyvnený rozsahom svojich duševných schopností, vlastnou skúsenost’ou a poznatkami, sociálnym aspektom a prostredím. ${ }^{7}$

\section{PREDMET A FAKTORY HUDOBNÉHO VNÍMANIA}

Jevgenij Vladimirovič Nazajkinskij (1926 - 2006) vymedzuje štyri základné otázky, ktoré sú predmetom psychológie hudobného vnímania: (1) ako poslucháč vníma v detailoch hudobné dielo, (2) aké sú psychologické predpoklady, ktoré zaručujú umelecký a estetický zážitok, pochopenie diela a adekvátnost' vnímania vzhl'adom na zámer skladatel'a, (3) ako sa zákonitosti vnímania odrážajú v hudobnom jazyku a vo výstavbe konkrétneho hudobného diela, (4) aké sú psychologické mechanizmy vzájomných vzt'ahov medzi hudbou a skutočnost'ou. ${ }^{8}$ Hudobné vnímanie vychádza $\mathrm{z}$ dvoch predpokladov - zo schopnosti sluchovej a hudobnej percepcie a $\mathrm{z}$ esteticko-citovej dešifrácii a reakcii na hudbu. ${ }^{9}$ Rozlišujeme tiež dva základné faktory hudobného vnímania: vnútorný a vonkajší. Medzi vnútorné faktory zarad'ujeme celkovú hudobnú pripravenost' percipienta (žiaka) - hudobné dispozície, schopnost' dešifrácie hudby, miera znalosti typu vnímanej hudby, životné skúsenosti, či otázky motivácie. Vonkajšie faktory tvoria objektívne podmienky, akými sú konkrétne miesto, priestor, čas, technické podmienky sluchu a pod. ${ }^{10}$ Tieto faktory tvoria základ hudobného vnímania a zároveň umožňujú realizáciu procesu hudobného prežívania. ${ }^{11}$ Celkový proces vnímania hudby prebiehajúci v psychike percipienta je ovplyvnený (1) hudobným dielom, ktoré je zároveň objektom vnímania, (2) osobnost’ou vnímajúceho jedinca a jeho reakciami na hudbu, (3) aktívnym hudobným vnímaním. ${ }^{12}$

\section{PERCEPCIA, APERCEPCIA, RECEPCIA}

Medzi základné procesy hudobného vnímania patrí percepcia, apercepcia a recepcia. Pod pojmom percepcia hudby možno rozumiet' psychický proces, ktorý zahrňuje vnímanie tónov, motívov, piesní až po vnímanie rozsiahlych hudobných diel. ${ }^{13}$ Ide o vstupnú čast' bezprostredného vnímania hudobného diela, ktoré výsledkom je emocionálny zážitok. Druhým stupňom hudobného vnímania je apercepcia, kedy do percepcie vstupujú aj psychické funkcie a doterajšie hudobné skúsenosti. Apercepciu teda možno definovat' ako proces, počas ktorého žiaci prenikajú do samotného obsahu hudobnej skladby, prostredníctvom priebežného osvojovania základných rytmicko-melodických, harmonických a tektonických charakteristík hudobného diela. ${ }^{14}$ Najvyšším stupňom hudobného vnímania je recepcia. Ciel'om vnímania hudby je nie len pozitívne či negatívne prijatie hudby, resp. vybranej skladby, ale tiež vytvorenie podmienok pre diskusiu, počas ktorej žiaci prezentujú svoje pocity z danej ukážky a sú schopní ju ohodnotit'. Pri recepcii percipienti zapájajú svoju predstavivost', tvorivost', myslenie a fantáziu. Výsledkom recepcie je estetický zážitok, žiak sa stotožňuje s hudobným dielom. Úroveň receptívnych procesov je podmienená napríklad

\footnotetext{
${ }^{5}$ MEDŇANSKÁ, 2015, s.11.

${ }^{6}$ MEDŇANSKÁ, 2015, s.11.

${ }^{7}$ MEDŇANSKÁ, 2015, s.11.

${ }^{8}$ HOLAS, 1998, s. 59.

${ }^{9}$ ELSCHER, 1984, s. 137.

${ }^{10}$ ELSCHER, 1984, s. 137.

${ }^{11}$ ELSCHER, 1984, s. 137.

12 SEDLÁK - VAŇOVÁ, 2013, s. 246.

${ }^{13}$ LANGSTEINOVÁ, 1998, s. 67.

${ }^{14}$ SEDLÁK - VAŇOVÁ, 2013, s. 245.
} 
vekom percipienta, jeho skúsenost’ami, hodnotiacimi kritériami, vkusovými preferenciami, temperamentom a pod. ${ }^{15}$

\section{UVEDOMELÉ POČÚVANIE HUDBY}

Zámerom edukátora je poskytnút' edukantom ideály, správne ich motivovat', viest' ich $\mathrm{k}$ tolerancii a rešpektovaniu svojho okolia. Pedagóg hudobnej výchovy učí svojich žiakov hudbu prežívat', čím sa formuje osobnost' edukanta. ${ }^{16}$ Ak chce percipient prežívat' hudbu, musí prekonat' egocentrizmus, byt' schopný chápat' ideový svet iného človeka, pochopit' jeho citový a myšlienkový svet a do určitej miery sa s ním stotožnit'. Takéto etické momenty vnímania hudby smerujú k socializácii. ${ }^{17}$ Uvedomelé počúvanie hudby je preto jeden z cielov hudobnej výchovy. Śtátny vzdelávací program taktiež akcentuje dôležitost' aktívneho vnímania a počúvania hudby prostredníctvom percepčných činností žiakov, ktoré môžu pomôct' riešit' problémy ostatných hudobných činností. Základnými formami percepčných činností sú sluchová analýza a počúvanie hudby. ${ }^{18}$ Schopnost' vnímat' a preživat' hudbu je neodmyslitel'nou súčast'ou hudobno-edukačného procesu. Percipient prostredníctvom počúvania hudobného diela „,vstupuje“ do sveta hudby, učí sa ju vnímat', prijímat' a rozumiet' jej. Vnímanie hudobného diela možno delit' na celostné (emocionálna sféra) a parciálne vnímanie (racionálna sféra). Percipient si z celostného vnímania odnáša hudobný zážitok, pri parciálnom vnímaní sa u neho dostaví stav odreagovania od životných realít, pocit uvol'nenia a relaxu - katarzia, pričom oba aspekty smerujú k estetickému účinku. Takéto chápanie vnímania hudobného diela je relevantným východiskom pre pedagogickú interpretáciu hudby a tiež môže slúžit' ako metodický postup pre počúvanie hudby. ${ }^{19}$

\subsection{ZÁSADY A ŠTÁDIÁ POČÚVANIA HUDBY}

Úlohou pedagóga pri počúvaní hudby je rozvíjat' hudobné schopnosti žiakov, poskytovat' im uvedomelé hudobné zážitky, pestovat' v nich pocit vnútornej potreby počúvat' hudbu. Svojich žiakov by mal tiež viest' tak, aby boli schopní chápat' zámer autora, pochopit' a zdôvodnit' spôsob realizácie tohto zámeru hudobno-výrazovými prostriedkami, vnímat' variačné zmeny a ich návrat, napätie a uvol'nenie v hudobnej skladbe. To je možné docielit' len viacnásobným počúvaním hudby. Burlas (1998) vyčleňuje niekol'ko zásad ako správne počúvat' hudbu. Prvou z nich je samotné „dávkovanie“ hudby. Je logické, že detský percipient nie je schopný zvládnut' také množstvo hudby ako dospelý. Z toho dôvodu je dôležité nepočúvat' celé dielo, ale len kratšie úseky, prípadne vyberat' krátke hudobné skladby. Druhou zásadou je správne volená motivácia. Je kontraproduktívne nútit' žiakov počúvat' konkrétnu hudbu bez toho, aby v nich vyvolal skutočný záujem. Preto je najefektívnejším činitel'om ako vzbudit' záujem detí prostredníctvom využívania hudobných činností, na ktorých sú žiaci aktívne zúčastnení (vokálne činnosti, pohybové činnosti, kontakt s hudobným nástrojom a pod.). Tretia zásada je zameraná na hudobnú percepciu, ktorá sa umocňuje verbálnym výkladom. Ak chceme aby si diet'a osvojilo nové poznatky, musí ich vediet' jasne pomenovat'. Aj hudbu si diet'a potrebuje verbalizovat', vizuálne predstavit' či pohybom vyjadrit'. ${ }^{20}$

Langsteinová (1998) odporúča počúvat' hudbu v troch fázach. Prvým krokom je celostné počúvanie hudby, to znamená bez prerušovania. $\mathrm{V}$ tejto fáze percipientovi neoznamujeme názov diela, pretože ten môže o skladbe vypovedat' privel'a (percipientovi neostane priestor na vlastné objavovanie). Ak ide o skladbu menšieho rozsahu, edukátor ju

\footnotetext{
${ }^{15}$ HOLAS, 1998, s. 59.

${ }^{16}$ LANGSTEINOVÁ, 1998, s. 68.

${ }^{17}$ LANGSTEINOVÁ, 1998, s. 72.

${ }^{18}$ LANGSTEINOVÁ, 1998, s. 68.

${ }^{19}$ LANGSTEINOVÁ, 1998, s. 67.

${ }^{20}$ BURLAS, 1998, s. 47.
} 
pustí celú, ak je skladba rozsiahlejšia, púšt’ame žiakom len jej ucelené časti. Vypočutie si neznámeho hudobného diela u percipienta vyvolá prvotnú bezprostrednú emocionálnu reakciu, ktorá nie je ovplyvnená inými faktormi. Následne by mal pedagóg vytvorit' priestor pre diskusiu, počas ktorej žiaci prezentujú svoju pocity a dojmy z počúvanej skladby a snažia sa odhalit' zámer autora. Druhým stupňom je analytické počúvanie skladby. Tu môže pedagóg uplatnit' prístup prerušovaného počúvania hudby zo zámerom upriamit' pozornost' percipienta na dominujúce hudobno-výrazové prostriedky skladby a hlavné hudobné myšlienky. Je vhodné zahrnút' aj tvorivé činnosti a aktivity žiakov ako napr. pohybová improvizácia, dramatizácia zhudobneného textu, prvky tvorivej dramatiky a pod. Poslednou fázou je syntetizujúce počúvanie skladby. Realizuje sa podobne ako celostné počúvanie hudby - bez prerušovania. $\mathrm{V}$ tejto fáze dochádza $\mathrm{k}$ integrácii všetkých poznatkov a skúseností. Zámerom takéhoto počúvania skladby je „hudobný zážitok, ktorý vznikne zapojením emocionálnej a racionálnej stránky osobnosti žiaka“. ${ }^{21}$ Učitel' by si tiež mal pripravit' osnovu počúvanej skladby, ktorá bude obsahovat' notové ukážky dominantných hudobných myšlienok a hudobno-výrazových prostriedkov. Zvukovú ukážku tak edukátor efektívne dopíña o vizuálnu prezentáciu notového materiálu. Po jednotlivých fázach počúvania hudobnej skladby opätovne nasleduje rozhovor o hudobnom skladatel'ovi, zaujímavých príhodách z jeho života, integrácia jeho života a počúvanej skladby do celkového učiva. ${ }^{22}$

Z vyššie uvedeného možno konštatovat', že počúvanie hudby prebieha $\mathrm{v}$ troch štádiách. Nazajkinski (1980) tieto štádia nazýva tri časopriestorové proporčné roviny, ktoré sa na seba postupne nabal'ujú. Prvú proporčnú rovinu predstavujú jednotlivé tóny a krátke hudobné motívy. Ciel'om vnímania počas tejto roviny je bezprostredná práca sluchových analyzátorov. Druhá rovina reprezentuje vnímanie väšších hudobných útvarov, čiže viet, periód, a hudobných fráz. V tretej rovine začína percipient vnímat' hudobné dielo ako celok. Táto rovina je však ovplyvnená hudobnou pamätou, ale tiež logických myslením a schopnostou rytmického vnímania. Uvedené roviny na seba nadväzujú, postupne sa dopíñajú a prelínajú. ${ }^{23}$

\section{ZÁVER}

Aktívne vnímanie a počúvanie hudby môže rozvíjat' nie len hudobné schopnosti, ale tiež kritické myslenie, fantáziu, tvorivost' a vkus žiakov. Je nutné akcentovat', že efektívne vnímanie hudby možno dosiahnut' jedine aktívnou činnost'ou percipientov. Pedagóg by sa preto mal snažit' vyhýbat' prebytočnej verbalizácii, presadzovaniu vlastných myšlienok a mal by nechat' dostatočné dlhý priestor na diskusiu. Jeho primárnou úlohou má byt' predstavit' svojim detským percipientom počúvanie hudby ako príležitost' na emocionálne hlboký a obohacujúci zážitok. Výsledkom počúvania hudby tak nie je len prijatie či odmietnutie počúvanej skladby, ale vytvorenie podmienok pre diskusiu, v ktorej môžu percipienti vyjadrit' svoje pocity, dojmy, názory a myšlienky o počúvanej skladbe.

\section{Literatúra}

1. BURLAS, L. 1998. Hudba - komunikatívny dynamizmus. Bratislava: Národné hudobné centrum, 1998. 35 - 54 s. ISBN 80-88884-10-1

2. ELSCHEK, Oscar. 1984. Hudobná veda súčasnosti. Systematika, teória, vývin. Bratislava: Veda 1984. s. 388.

3. HOLAS, Milan. 1998. Psychologie hudby v profesionální hudebni výchově. Akademie múzických uméní. 1998.

\footnotetext{
${ }^{21}$ LANGSTEINOVÁ, 1998, s. 71.

${ }^{22}$ LANGSTEINOVÁ, 1998, s. 71.

${ }^{23}$ NAZAKINSKIJ, 1980. s. 64.
} 
4. LANGSTEINOVÁ, Eva. 1998. Pedagogická interpretácia hudobného diela a metodika počúvania hudby. In: Acta Universitatis Matthiae Belli, Sekcia vied o umení a vied o športe. Banská Bystrica: UMB FHV, s.

5. MEDŇANSKÝ, Karol a kol. 2015. Dejiny a súčasnost’ hudby. Prešovská univerzita v Prešove, 2015. ISBN 978-80-555-1268-6.

6. MICHALOVÁ, Eva. 1998. Pedagogická interpretácia hudobného diela. In: Acta Universitatis Matthiae Belli, Sekcia vied o umení a vied o športe. Banská Bystrica: UMB FHV, s.

7. NAZAKINSKIJ, Jevgenij Vladimirovič. 1980. O psychológii hudobného vnímania. Opus 1980.

8. SEDLÁK, František - VAŇOVÁ, Hana. 2013. Hudebni psychologie pro učitele. Karolinum. 2013. s. 390. ISBN 9788024620602.

\section{Mgr. Ivana Lacková}

Katedra hudby, Pedagogická fakulta

Univerzita Konštantína Filozofa v Nitre

Drážovská cesta 4, 94974 Nitra

email: ivana.lackova@ukf.sk 


\title{
ALKOHOLOVÉ SPRÁVANIE V SÚVISLOSTI S DEPRESIOU V OBDOBÍ VYNÁRAJÚCEJ SA DOSPELOSTI POČAS DIŠTANČNÉHO VZDELÁVANIA NA VYSOKEJ ŠKOLE
}

\section{ALCOHOL BEHAVIOUR IN RELATION TO DEPRESSION WITHIN EMERGING ADULTHOOD DURING DISTANCE LEARNING AT UNIVERSITY}

\author{
Rudolf Fábry, Dominika Minárová, Dominika Kochanová
}

\begin{abstract}
Abstrakt
Nútené dištančné vzdelávanie na vysokých školách v kontexte COVID krízy a lockdownu predstavovalo enormnú psychologickú zát’až. Jedným z následkov je i zvýšené riziko rozvoja depresie. Depresia je psychické ochorenie spájané s výskytom alkoholového správania. Zámerom štúdie je explorácia a objasnenie vzt’ahu medzi depresiou a alkoholovým správaním so zahrnutím faktoru pohlavia. Výskumnú vzorku tvorilo 152 vysokoškolských študentov, 74 mužov a 78 žien (18 až 25 rokov). Na zber dát boli použité dve dotazníkové metódy, a to konkrétne Beckov inventár depresie a Dotazník situačno-motivačných faktorov alkoholového správania. Výsledky preukázali vyššiu mieru depresie u žien a vyššie alkoholové správanie u mužov. V rámci regresného modelu sa pohlavie nepreukázalo ako významný prediktor, ale Depresia a Situačno-motivačný faktor Únik z problémov sa preukázali ako významné prediktory alkoholového správania.
\end{abstract}

Kl'účové slová: alkoholové správanie, depresia, situačno-motivačné faktory, vynárajúca sa dospelost'

\begin{abstract}
Forced distance learning at universities in the context of the COVID crisis and lockdown was an enormous psychological burden. One of the consequences is an increased risk of developing depression. The depression is a mental illness associated with alcohol behaviour. The study aims to explore and explain the mutual connections between depression and alcohol behaviour, including the gender factor. The research group consists of 162 university students, 74 men and 78 women (18 to 25 years old). Two questionnaires were used during the research, namely the Beck depression inventory and the questionnaire on situationmotivational alcohol behaviour factors. The results show a higher rate of depression in women and higher rate of alcohol behaviour in men. In the regression model, gender did not prove to be a significant predictor, but Depression and the situation-motivational factor Escape from Problems proved to be significant predictors of alcohol behaviour.
\end{abstract}

Key words: alcohol behaviour, depression, situation-motivational factors, emerging adulthood

\section{1 ÚVOD}

Vynárajúca sa dospelost' bola navrhnutá americkým psychológom Arnettom, ako nová životná etapa medzi dospievaním a mladou dospelost'ou, ktorá trvá zhruba od 18 do 25 rokov života a vznikla ako odpoved' na rôzne zmeny (napr. demografické, sociokultúrne). Vynárajúca sa dospelost' sa vyskytuje hlavne v priemyselne vyspelých krajinách, kde väčšina mladých l'udí získa terciárne vzdelanie a priemerný vek vstupu do manželstva a rodičovstva je 
okolo 30 rokov života (Arnett, 2000). Vynárajúca sa dospelost' ponúka najväčšiu príležitost' na skúmanie identity v oblastiach lásky, práce a svetonázorov. Počas tejto doby si jednotlivci začnú rozvíjat' charakteristické vlastnosti potrebné na to, aby sa stali sebestačnými, zapájajú sa do vyspelých, oddaných vzt'ahov, preberajú úlohy a zodpovednosti dospelých a získavajú úroveň vzdelávania a odbornej prípravy, ktorá vytvára základ dospelosti (Halfon, Forrest, Lerner, \& Faustman, 2018).

\subsection{Alkoholové správanie vo vynárajúcej sa dospelosti}

Intenzita pitia sa podla Rojkovej (2016) chápe ako frekvencia pitia krát počet štandardných pohárikov v dotazníku Situačno-motivačných faktorov alkoholového správania. Pojem štandardný pohárik (alkoholová jednotka) sa líši v jednotlivých krajinách, no vo väčšine európskych krajín je $8-10$ g alkoholu, kým podl'a WHO a amerických odporúčaní je to až 14 g alkoholu (Campbell, 2016). Pitie počas dospievania môže slúžit' napríklad na ul'ahčovaniu vytvárania priatel'stva. Problémy spojené s alkoholom vynárajúcej sa dospelosti môžu mat' dlhodobý vplyv na fyzickú a psychickú pohodu a taktiež môžu mat' dôsledky na dosiahnutie tradičných rolí dospelých (napr. pitie alkoholu vedie k zlým akademickým výsledkom, čo naopak vedie k menej priaznivým pracovným príležitostiam) (White \& Jackson, 2004). V súčasnej koronavírusovej situácií vznikli nové štúdie sledujúce dopad lockdown-u na prežívanie jedinca. Jednou z nich je štúdia o pití alkoholu počas izolácie, ktorá upozorňuje na zložitú situáciu s následkami zvýšených finančných t’ažkostí, sociálnej izolácie, neistoty, atd'. Vo Vel'kej Británii až 21\% l’udí zvýšilo konzumáciu alkoholických nápojov. Lockdown predstavuje rizikový faktor pre zvýšenie konzumácie alkoholu a taktiež aj zvýšené riziko relapsu u l'udí, ktorí sú abstinenti (Kim a kol., 2020). U mladých l'udí je časté únikové pitie alkoholu, pretože alkohol je mierne anestetikum. Únikové pitie sa chápe ako užívanie alkoholu s funkciou vyrovnávania zát'ažových, prípadne krízových situácií. Ide o situácie a motívy, ktoré nevyplývajú zo špecifika vývinového obdobia, ale skôr sú negatívnym dôsledkom zlyhania plnenia vývinových úloh. Ide o zát’ažové a stresové životné situácie externé a interné (osobné problémy jednotlivca - psychické, súkromné problémy, frustrácia, deprivácia, depresia, zúfalstvo, pocity nepotrebnosti, opustenosti, nedostatok lásky, a pod.). Pitie alkoholu môže byt' sčasti sprevádzané túžbou po účinku, ale aj pre potreby kompenzácie, zabudnutia, odreagovania od prežívanej zát'aže (Rojková \& Popelková, 2010, Rojková \& Vavrová, 2017). Pitie mladých dospelých osôb je dôležitým ciel'om preventívnych zásahov, pretože prechod zo strednej školy sa javí ako ideálny vývinový bod obratu, počas ktorého je potrebné zamerat' sa na intervencie. Populácia vysokoškolských študentov čelí vysokému riziku negatívnych následkov požívania alkoholu, pretože mladí l'udia nemajú tendenciu identifikovat' sa ako osoby, ktoré majú problémy s alkoholom. Napriek tomu, že u vynárajúcich sa dospelých je užívanie alkoholu v istom slova zmysle vývinovo normatívne, aj jedna epizóda nadmerného užívania alkoholu môže mat' vážne následky, napríklad autonehody spojené s alkoholom, neplánované tehotenstvo, problémy s políciou, fyzické násilie, a pod. Vynárajúci sa dospelí, ktorí sa opakovane stretávajú s t’ažkými alkoholovými epizódami môžu mat' za následok zdravotné problémy. Na amerických univerzitných internátoch $\mathrm{v}$ rokoch 1998 až 2001 bolo viac ako 500000 študentov zranených pri pití alkoholu a až 1600 študentov zomrelo na zranenia súvisiace s užitím alkoholu (Monti, Tevyaw \& Borsari, 2004)

\subsection{Depresia vo vynárajúcej sa dospelosti}

Veda sa už dlho snaží o odhalenie príčin depresie. Najviac pravdepodobná je však kombinácia genetických, biochemických, psychologických a environmentálnych faktorov. Depresia sa môže vyskytnút' spolu s d'alšími závažnými chorobami, ako sú napr. cukrovka, rakovina, srdcové choroby a Parkinsonova choroba. Niektoré lieky môžu spôsobit' vedl'ajšie účinky, 
ktoré prispievajú k vzniku depresie (NIH, 2016). Galbiscek (2019) uvádza, že l'udia, ktorí zápasia s depresiou užívajú alkohol na potlačenie symptómov súvisiacich s ich stavom. Pitie alkoholu sa stáva spôsobom, ako uniknút' $\mathrm{z}$ problémov a relaxovat'. Existuje mnoho výskumov, ktoré sa snažia o odhalenie, či je depresia následkom pitia alkoholu, alebo či l’udia pijú alkohol, aby zmiernili svoje symptómy. Väčšina expertov tvrdí, že depresia je prítomná prvá. U žien je viac ako dvakrát vyššia pravdepodobnost', že začnú nadmerne pit', ak sa u nich vyskytnú depresívne symptómy. Čas na vysokej škole môže byt' stresujúci a človek sa môže po prvýkrát stretnút' s iným životným štýlom. Niektorí študenti majú t’ažkosti s zvládnutím týchto zmien a môže sa u nich prejavit' depresia, úzkost' alebo oboje. Medzi príznaky depresie u študentov univerzity patria t’ažkosti so sústredením sa na školské práce, nespavost', či naopak príliš vel'a spánku, zníženie alebo zvýšenie chuti do jedla, vyhýbanie sa sociálnym situáciám a činnostiam, ktoré ich predtým bavili (Legg, 2019). Prechod na vysokú školu je zložitý aj prijímaním nového životného štýlu, pre ktorý môžu byt' typické nepravidelné spánkové návyky, nevýživná (alebo žiadna) strava a neštruktúrovaný rozvrh hodín (najmä ak študenti vynechávajú hodiny). Zistit' depresiu u študentov vysokých škôl, ktorí nie sú doma, môže byt' tažké. 26 Niektoré príznaky depresie, ako napríklad netypický smútok a plač, sú priame a pozorovatel'né, no iné, napríklad problémy so sústredením a podráždenost' už priame nie sú. L'udia s depresiou majú tiež tendenciu izolovat' sa a majú menšie potešenie $\mathrm{z}$ vecí, ktoré ich predtým bavili. Znamením môže byt' aj znepokojujúce užívanie alkoholu a návykových látok. U mnohých sa problémy zhoršia na konci semestra, ked' sa akademické požiadavky stávajú čoraz naliehavejšími a zdajú sa neprekonatel'né (Ehmke, 2020). Mladí l'udia často riešia svoje psychické problémy užívaním alkoholu. Mnohí pijú alkohol najmä v snahe vyrovnania sa s depresiou. L'udí môžu prit'ahovat' sedatívne účinky alkoholu ako druh liekov, ktoré pomáhajú odvrátit' pozornost' od pretrvávajúcich pocitov smútku. Aj ked' alkohol môže dočasne zmiernit' niektoré príznaky depresie, v konečnom dôsledku slúži na dlhodobé zhoršovanie depresie. Koronavírus COVID-19 a izolácia zhoršujú psychický stav populáre. Jednotlivci sú vystavení stresu, ktorý zvyšuje riziko relapsu (The Lancet Gastroenterology \& Hepatology, 2020). Izolácia zvyšuje riziko depresie, dokonca mnohé krajiny zaznamenali až trojnásobný nárast prevalencie problémov $\mathrm{s}$ depresiou a úzkost'ou $\mathrm{v}$ dospelej populácii počas lockdown-u, a to je dôkazom, že Covid-19 je správne spájaný s krízou duševného zdravia. Výskum vo Vel'kej Británii ukázal, že počas aprílového lockdownu dosiahol podiel l'udí, ktorí hlásili klinicky významné problémy s depresiou a úzkost’ou, 52 \%, číže trikrát viac ako priemer $17 \%$ pred vypuknutím ochorenia COVID-19 (Griffiths, 2020).

\subsection{Výskumný problém, výskumné otázky a hypotézy}

Dôvodom na realizáciu štúdie je aktuálny trend zvyšujúceho sa pitia alkoholu počas dištančného vzdelávania, ktorého príčinou je stresová, či smútiaca situácia. COVID-19 sa javí ako jeden z hlavných príčin smrti, takže existujú mnohé dôvody týkajúce sa vzorcov konzumácie alkoholu počas izolácie. Ak vezmeme do úvahy, že pandémia je skúsenost’ou potenciálnej hroziacej smrti, a pretože sa podobá skúsenosti s prírodnými traumatizujúcimi zážitkami, môžeme predpokladat', že neskoršie vzorce konzumácie alkoholu sa zvýšia s dôsledkami pre príslušnú úmrtnost' a chorobnost', izoláciu a opustenost' (Garciá \& Sanchez, 2020). Výskumným problémom je explorácia alkoholového správania l'udí v období vynárajúcej sa dospelosti, mužov a žien, v spojitosti s depresiou a situačno-motivačným faktorom Únik z problémov pri pravidelnom uživaní alkoholu. Zo situačno-motivačných faktorov pravidelného pitia alkoholu sme vybrali Únik z problémov. V štúdií skúmame vzt’ah faktora Únik z problémov a depresie, pretože bol Rojkovou a Popelkovou (2010) identifikovaný ako faktor, ktorý sa integruje s funkciou vyrovnávania sa so zát’ažovými situáciami. Intenzita pitia je objektívnym faktorom a výsledkom násobku ako často 
respondent pije alkohol a kol'ko štandardných pohárikov vypije pri jednej príležitosti. Termín depresia patrí medzi afektívne poruchy (poruchy nálady), má rôzne symptómy a depresiu možno rozdelit' do niekol'kých kategórií v závislosti od závažnosti príznakov. V štúdií pracujeme s rozdelením depresie podla Beckovho dotazníku (Legg, 2020). Výskumný problém sa rieši pomocou korelačno-komparačného výskumného plánu. $\mathrm{Na}$ základe uvedeného výskumného problému sme si stanovili nasledovné výskumné otázky:

VO1: Vykazujú muži a ženy v pásme Strednej depresie vyššie skóre SMF Úniku z problémov?

VO2: Majú ženy s vyššou Intenzitou pitia vyššiu Depresiu ako muži s vyššou Intenzitou pitia? VO3a: Aký je vzt'ah medzi Depresiou a Intenzitou pitia?

VO3b: Aký je vzt'ah medzi SMF Únikom z problémov a Intenzitou pitia?

VO4: Majú prediktory Pohlavie a Depresia význam pre Intenzitu pitia alkoholu v rámci spoločného regresného modelu?

VO5: Majú prediktory Pohlavie a SMF Únik z problémov význam pre Intenzitu pitia alkoholu $\mathrm{v}$ rámci spoločného regresného modelu?

\section{METÓDY}

\subsection{Výskumný súbor}

Ciel'ovou populáciou výskumu boli študenti/študentky vysokých škôl vo veku od 18 do 25 rokov, čiže vo vývinovom období vynárajúcej sa dospelosti (Arnett, 2000). Pre spodnú hranicu sme sa rozhodli kvôli zákonom povolenému požívaniu alkoholických nápojov od 18 rokov. Horná hranica predstavuje vek, kedy približne študenti končia druhý stupeň vysokoškolského štúdia. Výber výskumného súboru je zámerný. Respondenti museli spíňat' sociálny status vysokoškolského študenta, vek od 18 do 25 rokov, slovenská národnost'. Respondenti boli oslovení osobne a cez internet.

\subsection{Metódy zberu dát a operacionalizácia}

Na zber dát sme použili dotazníkové metódy, ktoré sú kvantitatívnymi metódami a sú zvolené na základe výskumného problému a spolu tvoria dotazníkovú batériu. Spôsob administrácie bol zabezpečený prostredníctvom internetu. Vyplnenie testu trvalo približne 15 minút.

Prvým z použitých dotazníkov bol Dotazník Situačno-motivačných faktorov alkoholového správania, ktorý zist'uje situačno-motivačné faktory (SMF) pri experimentovaní a pravidelnom užívaní alkoholu. Dotazník pozostával zo 4 častí. Prvá čast' sa týkala základných osobných otázok, ako sú vek, mesto, pohlavie, sociálny status, dosiahnuté vzdelanie a bývanie počas vysokej školy. Ďalšia čast' sa zameriavala na zist'ovanie prvého užívania alkoholu a výskytu alkoholu v rodine respondenta a tiež priatel'ov (5-bodová Likertova škála). Ďalšia čast' sa zameriavala na SMF pravidelného užívania alkoholu, taktiež na 5 bodovej škále sa respondent vyjadril k 15 tvrdeniam (úplne súhlasím, ...vôbec nesúhlasím). Výstupom sú 3 premenné SMF: Vplyv skupiny, Túžba po účinku a Únik z problémov, každú premennú sýti 5 položiek (5 až 25 bodov, podl'a Rojková, Vavrová, 2017). Z dotazníka SMF bola odvodená i premenná Intenzita pitia alkoholu (kardinálna premenná), ktorá sa vypočíta ako frekvencia pitia x počet štandardných pohárikov (0 až 63 bodov). Pre potreby logistickej regresnej analýzy bola Intenzita pitia transformovaná na dichotomickú premennú podl’a mediánu $(0$ nízka intenzita, 1 - vysoká intenzita).

Druhým dotazníkom bol Beckov inventár depresie, ktorý je sebaposudzovacou škálou pre zistenie závažnosti depresie vo veku od 13 do 80 rokov a bol vytvorený v roku 1961 Aaronom T. Beckom. Inventár sa skladá z 21 položiek, odpovede sú zaznamenávané na štvorbodovej 
škále 0-3. Sčítaním všetkých položiek sa dosiahne celkového skóre reprezentujúce hladinu depresie. Na základe štandardizačnej štúdie bolo Beckom navrhnuté cut-off skóre pre stupne depresie (0 - 13 minimálna alebo žiadna depresia, 14 - 19 mierna depresia, 20 - 28 stredná depresia a 29 - 63 t’ažká depresia). Časový rámec pre odpovede sú posledné dva týždne (Ptáček, Raboch, Vnuková, Hlinka, \& Anders, 2016). V štúdii sme použili dve premenné, depresiu (kardinálnu) a pásmo depresie (ordinálnu).

\section{VÝSLEDKY}

VO1: Vykazujú muži a ženy v pásme Strednej depresie vyššie skóre SMF Úniku z problémov?

Výskumná otázka bola overovaná Kruskal Wallisovým testom s výsledkom x2 $=18,555$ pri df = 2; Sig. < 0,001 (Tabul'ka 1). Na základe priemerných poradí evidujeme najvyššie hodnoty Úniku z problémov u mužov $\mathrm{v}$ pásme Stredne t’ažkej depresie $(\mathrm{MR}=58,5)$ a najnižšie u mužov v pásme Minimálnej depresie $(M R=31,65)$. U žien bol predpoklad takisto overovaný Kruskal Wallisovým testom s výsledkom x2 $=13,651$ pri df $=2$; Sig. $<0,05$ (Tabul'ka 1). Na základe priemerných poradí evidujeme najvyššie hodnoty Úniku z problémov u žien v pásme Stredne t’ažkej depresie $(\mathrm{MR}=61,9)$ a najnižšie u žien v pásme Minimálnej depresie (MR = 34,09).

Tabul'ka 1 Výsledky testovania VO1: Kruskal Wallisov test

\begin{tabular}{|ccc|cc|cc|}
\hline Pohlavie & & Pásmo depresie & N & $\begin{array}{c}\text { Priemerné } \\
\text { poradie }\end{array}$ & \multicolumn{2}{|c|}{ Kruskal Wallisov test } \\
\hline \multirow{4}{*}{ Muž } & SMF Únik z & Minimálna depresia & 57 & 31,65 & Chí-kvadrát & 18,555 \\
& problémov & Mierna depresia & 13 & 56,69 & df. & 2 \\
& & Stredná depresia & 4 & 58,5 & Sig. & 0,000 \\
\hline \multirow{2}{*}{ Žena } & Spolu & 74 & & Chí-kvadrát & 13,651 \\
& SMF Únik z & Mierna depresia & 15 & 52,93 & df. & 2 \\
& problémov & Stredná depresia & 5 & 61,9 & Sig. & 0,001 \\
& & Spolu & 78 & & & \\
\hline
\end{tabular}

VO2: Majú ženy s vyššou Intenzitou pitia vyššiu Depresiu ako muži s vyššou Intenzitou pitia?

Odpoved' sme získali prostredníctvom Chí-kvadrátu, ktorým boli preskúmané rozdiely v pásmach depresie medzi jedincami s nízkou a vysokou Intenzitou pitia, a to u mužov a žien samostatne (Tabul'ka 2). U mužov i žien výsledky vypovedajú o významných rozdieloch, u mužov na úrovni Sig. < 0,05, u žien Sig. < 0,001. Stredne t’ažká depresia sa vyskytla u 12,5\% mužov, ktorí majú vysokú intenzitu pitia a u 7,7\% žien, ktoré majú Vysokú intenzitu pitia. Z uvedeného vyplýva, že muži, ktorí majú vysokú intenzitu pitia majú častejšie stredne t’ažkú depresiu ako ženy. 
Tabul'ka 2 Krížová tabul'ka a výsledok testovania VO2: Chí-kvadrát test

\begin{tabular}{|c|c|c|c|c|c|c|c|c|c|c|c|}
\hline \multirow{2}{*}{\multicolumn{2}{|c|}{$\begin{array}{c}\text { Intenzita } \\
\text { pitia }\end{array}$}} & \multicolumn{4}{|c|}{ Pásmo depresie } & \multirow{2}{*}{\multicolumn{2}{|c|}{$\begin{array}{c}\text { Intenzita } \\
\text { pitia }\end{array}$}} & \multicolumn{4}{|c|}{ Pásmo depresie } \\
\hline & & $\begin{array}{c}\text { Min. } \\
\text { depresia }\end{array}$ & $\begin{array}{c}\text { Mierna } \\
\text { depresia }\end{array}$ & $\begin{array}{l}\text { Stredná } \\
\text { depresia }\end{array}$ & Spolu & & & $\begin{array}{c}\text { Min. } \\
\text { depresia }\end{array}$ & $\begin{array}{l}\text { Mierna } \\
\text { depresia }\end{array}$ & $\begin{array}{l}\text { Stredná } \\
\text { depresia }\end{array}$ & Spolu \\
\hline \multirow[t]{3}{*}{$\mathrm{N}^{*}$} & Počet & 30 & 3 & 0 & 33 & $\mathrm{~N}^{*}$ & Počet & 35 & 2 & 1 & 38 \\
\hline & $\begin{array}{l}\text { Očak. } \\
\text { počet }\end{array}$ & 25,4 & 5,6 & 2 & 33 & & $\begin{array}{l}\text { Očak. } \\
\text { počet }\end{array}$ & 27,9 & 8,3 & 1,8 & 38 \\
\hline & $\%$ & 90,9 & 9,1 & 0 & 100 & & $\%$ & 92,1 & 5,3 & 2,6 & 100 \\
\hline \multirow[t]{3}{*}{$\mathrm{V}^{*}$} & Počet & 20 & 8 & 4 & 32 & $\mathrm{~V}^{*}$ & Počet & 12 & 12 & 2 & 26 \\
\hline & $\begin{array}{l}\text { Očak. } \\
\text { počet }\end{array}$ & 24,6 & 5,4 & 2 & 32 & & $\begin{array}{l}\text { Očak. } \\
\text { počet }\end{array}$ & 19,1 & 5,7 & 1,2 & 26 \\
\hline & \multirow[t]{2}{*}{$\%$} & 62,5 & 25 & 12,5 & 100 & & $\%$ & 46,2 & 46,2 & 7,7 & 100 \\
\hline & & Hodnota & df & Sig. & & & & Hodnota & df & Sig. & \\
\hline & $\begin{array}{c}\text { Chí- } \\
\text { kvadrát }\end{array}$ & 8,259 & 2 & 0,016 & & & $\begin{array}{l}\text { Chí- } \\
\text { kvadrát }\end{array}$ & 17,082 & 2 & 0,000 & \\
\hline
\end{tabular}

* $\mathrm{N}=$ nízka; $\mathrm{V}=$ vysoká

VO3a: Aký je vzt'ah medzi Depresiou a Intenzitou pitia?

VO3b: Aký je vzt’ah medzi SMF Únikom z problémov a Intenzitou pitia?

Otázky boli zodpovedané prostredníctvom Spearmanovej korelácie (Tabul'ka 3). Na základe zistenej štatistickej významnosti Sig. < 0,001 iterpretujeme oba vzt’ahy ako významné, pozitívne, stredne silné, čo znamená, že medzi premennými je priama úmernost'.

Tabul'ka 3 Výsledok testovania VO3a a VO3b: Spearmanov koeficient poradovej korelácie

\begin{tabular}{|cc|c|cc|c|}
\hline & & Intenzita pitia & & Intenzita pitia \\
\hline \multirow{2}{*}{ Depresia } & Spearman $\rho$ & 0,345 & SMF Únik z problémov & Spearman $\rho$ & 0,302 \\
& Sig. & 0,000 & Sig. & 0,000 \\
& $\mathrm{~N}$ & 152 & $\mathrm{~N}$ & 152 \\
\hline
\end{tabular}

VO4: Majú prediktory Pohlavie a Depresia význam pre Intenzitu pitia alkoholu v rámci spoločného regresného modelu?

Výskumnú otázku č. 4 sme testovali logistickou regresnou analýzou a výsledky uvádzame v tabul'ke (Tabul'ka 4). Model je platný na základe signifikancie Sig. $<0,001$ a Chí-kvadrát = 16,896. Prediktory (Pohlavie a Depresia) sa spolupodiel'ajú na výskyte Intenzity pitia alkoholu v rozmedzí 12,3 až $16,4 \%$. Pohlavie sa nejaví ako významný prediktor na základe signifikancie Sig. $>0,05$. Depresia je významný prediktor Sig. $<0,001$. Ak sa u jedinca Depresia zvýši o 1 bod, tak sa šanca na výskyt Vysokej intenzity pitia zvýši 1,115x. 
Tabul'ka 4 Výsledky testovania VO4: Výsledky binárnej logistickej regresnej analýzy závislá premenná: Intenzita pitia alkoholu, prediktory: Pohlavie, Depresia

\begin{tabular}{|c|c|c|c|c|c|c|}
\hline STEP 1 & $\begin{array}{r}\text { Chi-kvadrát } \\
16,896 \\
\end{array}$ & & $\begin{array}{l}\mathrm{df} \\
2\end{array}$ & & $\begin{array}{l}\text { Sig. } \\
0,000\end{array}$ & \\
\hline \multirow[t]{2}{*}{ STEP 1} & \multicolumn{2}{|c|}{$\begin{array}{c}-2 \text { Log pravdepodobnost' } \\
160,623 \\
\end{array}$} & \multicolumn{2}{|c|}{$\begin{array}{c}\text { Cox \& Snell } \mathrm{R}^{2} \\
0,123 \\
\end{array}$} & $\begin{array}{c}\text { Nagelkerke } \mathrm{R}^{2} \\
0,164 \\
\end{array}$ & \\
\hline & B & S.E. & Wald & $\mathrm{df}$ & Sig. & $\operatorname{Exp}(B)$ \\
\hline Pohlavie(1) & $-0,437$ & 0,380 & 1,322 & 1 & 0,250 & 0,646 \\
\hline Depresia & 0,109 & 0,030 & 13,536 & 1 & 0,000 & 1,115 \\
\hline Constant & $-0,885$ & 0,346 & 0,346 & 1 & 0,011 & 0,413 \\
\hline
\end{tabular}

VO5: Majú prediktory Pohlavie a SMF Únik z problémov význam pre Intenzitu pitia alkoholu v rámci spoločného regresného modelu?

Výskumnú otázku č.5 sme testovali logistickou regresnou analýzou a výsledky uvádzame v tabul'ke (Tabul'ka 5). Model je platný na základe signifikancie Sig. $<0,05$ a Chí-kvadrát = 10,449. Prediktory (Pohlavie a SMF Únik z problémov) sa spolupodiel'ajú na výskyte Intenzity pitia alkoholu v rozmedzí 7,8 až 10,4\%. Pohlavie sa nejaví ako významný prediktor na základe signifikancie Sig. > 0,05. SMF Únik z problémov je významný prediktor Sig. < 0,05 . Ak sa u jedinca SMF Únik z problémov zvýši o 1 bod, tak sa šanca na výskyt Vysokej intenzitu pitia zvýši 1,118x.

Tabul'ka 5 Výsledky testovania VO5: Výsledky binárnej logistickej regresnej analýzy závislá premenná:Intenzita pitia alkoholu, prediktory: Pohlavie, SMF Únik z problémov

\begin{tabular}{|c|c|c|c|c|c|c|}
\hline STEP 1 & $\begin{array}{r}\text { Chi-kvadr } \\
10,449 \\
\end{array}$ & & $\begin{array}{l}\mathrm{df} \\
2\end{array}$ & & $\begin{array}{c}\text { Sig. } \\
0,005\end{array}$ & \\
\hline \multirow[t]{2}{*}{ STEP 1} & \multicolumn{2}{|c|}{$\begin{array}{c}-2 \text { Log pravdepodobnost' } \\
167,071 \\
\end{array}$} & \multicolumn{2}{|c|}{$\begin{array}{c}\text { Cox \& Snell R }{ }^{2} \\
0,078 \\
\end{array}$} & $\begin{array}{c}\text { Nagelkerke } \mathrm{R}^{2} \\
0,104\end{array}$ & \\
\hline & $\mathrm{B}$ & S.E. & Wald & $\mathrm{df}$ & Sig. & $\operatorname{Exp}(B)$ \\
\hline Pohlavie(1) & $-0,257$ & 0,370 & 0,482 & 1 & 0,488 & 0,774 \\
\hline SMF Únik z problémov & 0,112 & 0,038 & 8,635 & 1 & 0,003 & 1,118 \\
\hline Constant & $-1,255$ & 0,483 & 6,744 & 1 & 0,009 & 0,285 \\
\hline
\end{tabular}

\section{DISKUSIA A ZÁVERY}

Vypuknutie nového koronavírusu (COVID-19) v decembri 2019 postúpilo do stavu globálnej pandémie. Väčšina krajín prijala opatrenia k obmedzeniu šírenia vírusu, a to plošnú karanténu (lockdown), sociálny dištanc, udržiavanie rozostupov medzi l'ud'mi, nosenie rúšok a respirátorov a odporúčanú dobrovol'nú izoláciu. Nielen koronavírusové ochorenie, ale aj samotné opatrenia majú vplyv na duševné zdravie jedinca. Dopad pocítili ako nakazené osoby, ich rodiny, záchranné zložky, tak aj široká verejnost', nevynímajúc študentov vysokých škôl. Z výskumov prechádzajúcich epidemiologických kríz je známe, že zvyšujú úroveň stresu a majú negatívne účinky na l’udskú psychiku. Napríklad SARS v Hong Kongu v roku 2003 vedci opisovali ako katastrofu v oblasti duševného zdravia s dlhodobými následkami podobnými posttratumatickej stresovej poruche alebo depresii. Treba však zdôraznit', že populácia netrpí psychickými problémami kvôli pandémii samotnej, ale kvôli strachu z nákazy, úmrtia, predlžovania karantény, nedostatočnému kontaktu s l'ud’mi, geopolitickej nestability a pod. (Haider, Tiwana, \& Tahir, 2020). Diskusia a závery naznačujú, že počas 
prvého mesiaca COVID-19 sa osamelost' zvýšila o 20 až $30 \%$ a emočné t'ažkosti sa strojnásobili. Aj ked' stále prebieha mnoho prieskumov, ktoré majú zachytit' celý rozsah problému, súčasné dôkazy naznačujú, že už existujúca kríza v oblasti verejného zdravia so sociálnou izoláciou a osamelost'ou môže byt' ovel'a rozsiahlejšia, ako sa doteraz odhadovalo. Ked' nemáme osobný kontakt $\mathrm{s}$ blízkymi l'ud'mi, náš mozog a telo môžu reagovat' stavom zvýšenej pohotovosti. To môže mat' za následok zvýšenie krvného tlaku, stresových hormónov a zápalových reakcií - čo nás môže vystavit' zvýšenému riziku vzniku rôznych chronických chorôb. U tých, ktorí mali zdravotné, či psychické t’ažkosti už pred vypuknutím pandémie, by zmeny vo fyziológii mohli potenciálne zhoršit' stav, urýchlit' nástup akútnej príhody alebo urýchlit' progres ochorenia. Okamžité účinky sociálnej izolácie súvisiace $\mathrm{s}$ pandémiou už boli pozorované. Ide najmä o prudký nárast ochorení psychického zdravia, zhoršenie depresie, zvýšené zneužívanie návykových látok. V súčasnosti sa vytvoril sociálny odstup v živote, práci, vzdelávaní (Holt-Lunstad, 2020).

Výsledky štúdie preukázali, že u mužov je únikové pitie alkoholu najvyššie v stredne t’ažkej depresii a najnižšie v pásme minimálnej depresie. Rovnaké výsledky sme zaznamenali aj u žien, kde únikové pitie alkoholu je najvyššie $\mathrm{v}$ pásme stredne t’ažkej depresie a najnižšie $\mathrm{v}$ pásme minimálnej depresie. Výsledok testovania je zrejmý, pretože únikové pitie je typické pri depresii, preto čím je respondent $\mathrm{v}$ horšom stupni depresie, tým sa u neho zhorší aj únikové pitie alkoholu. Avšak pri overovaní predpokladu nedošlo k rozdielom medzi mužmi a ženami, čo by sme mohli interpretovat' ako fakt, že pokial' ide o potrebu uniknút' pred depresívnymi myšlienkami, depresívnou náladou, tak sa alkohol javí ako vhodná cesta pre obe pohlavia. Dalej sme zaznamenali u mužov s vysokou intenzitou pitia alkoholu štyri prípady stredne t’ažkej depresie, a u žien s vysokou intenzitou pitia sme v pásme strednej depresie zaznamenali dva prípady. Nakol'ko mužov sme mali vo výskumnej vzorke menej, môžeme usudzovat', že muži s vyššou intenzitou pitia alkoholu majú vyššiu depresiu ako ženy. Prežívanie depresie u mužov a u žien je značne odlišné, líšia sa aj copingové stratégie zvládania. Výskum Nierenberga (2016) uvádza, že muži pijú alkohol pred objavením depresie a nadmerným užívaním môže vzniknút' depresia. U žien je to naopak. Ženy môžu začat' pit' alkohol postupne s nástupom depresie, či úzkosti.

V štúdií sme sa zamerali a na zistenie vzt'ahu medzi SMF Únikom z problémov a intenzitou pitia alkoholu. Zaznamenali sme pozitívny, stredne silný vzt’ah medzi danými premennými, čo znamená, že čím je hodnota úniku z problémov vyššia, tým je vyššia intenzita pitia alkoholu. Únikové pitie slúži na vyrovnávanie sa so zát'ažovými, prípadne krízovými situáciami, ktorým boli študenti vystavení práve v čase lockdownu. Výskum na vzorke 173 vysokoškolských študentov preukázal, že študenti, ktorí majú tendenciu k únikovému pitiu, majú vo väššej miere v rodinnej anamnéze alkoholizmus Forestell, Dickter, \& Young, 2012). Až 53\% celkovej vzorky boli únikoví konzumenti alkoholu, čo autori vysvetlovali statusom vysokoškolského študenta. Ich východiskovou teóriou bolo, že vysokoškolskí študenti nadmerne pijú alkohol (Forestell, Dickter, \& Young, 2012). Rovnako sme zist'ovali vzt'ah medzi depresiou a intenzitou pitia. Výsledky preukázali, že vzt’ah depresie a intenzity pitia je významný. $Z$ výsledkov je rovnako zrejmé, že ide o pozitívny, stredne silný vzt’ah. Čím je teda u jedinca vyššia depresia, tým je intenzita pitia vyššia. Recovery (in Tune, 2019) potvrdzuje, že intenzita pitia a depresia spolu súvisia v pozitívnom smere. Na základe týchto výsledkov, ako i našich výsledkov môžeme tvrdit', že zneužívanie alkoholu a depresia spolu úzko súvisia. Dlhodobé zneužívanie alkoholu môže dramaticky zmenit' mozog a ovplyvnit' chemické rovnováhy $\mathrm{v}$ tele. To platí najmä pre neurotransmitery mozgu, ktoré regulujú emócie, čo môže d'alej vyústit' do depresie (Recovery in Tune, 2019). Ide teda o dva pohl'ady 
na kauzálne prepojenie depresia - užívanie alkoholu. Prikláňame sa k užívaniu alkoholu ako následku, ako tlmenie či únik zo stavov negatívneho prežívania.

$\mathrm{V}$ rámci posledných výskumných otázok sme testovali 2 regresné modely s vysokou intenzitou pitia ako následkom, pohlavím + Únikom z problémov (SMF) $\mathrm{v}$ jednom a pohlavím + Depresia v druhom modely. Výsledky preukazujú nevýznamnost' pohlavia, pokial' je zohl'adnená depresia alebo SMF Únik z problémov, ktoré sú významnými prediktormi pre výskyt intenzívneho pitia. Odborníci tvrdia, že u žien je viac ako dvakrát vyššia pravdepodobnost', že začnú nadmerne pit', ak mali v minulosti depresiu. Naopak výskum Millera a kol. (2020) preukazuje, že depresívne príznaky súvisia s väčším pitím u mužov, ale $\mathrm{s}$ nižším pitím u žien. SMF Únik z problémov súvisí s depresiou, tým pádom výsledok podporuje úvahy o pití ako následku depresie.

Za limity výskumu považujeme spôsob výberu vzorky, ktorá bola získaná na základe dobrovol'nosti a nie náhodným výberom. Ďalším limitom je online administrácia dotazníka, ktorú sme však nevedeli alternovat', vzhl'adom k situácii nebol možný iný spôsob. Limitom práce je aj pokyn v administrovaní testu, ktorý znel, že respondenti majú vyplňat' dotazník na základe posledných dvoch týždňov, preto môžu byt' výsledky mierne skreslené zo strany respondentov, tým že nemuseli vediet' odpovedat' na niektoré otázky a tak sa rozhodli zvolit' neutrálnu, strednú odpoved'.

Za najväčší prínos štúdie považujeme aktuálnost' hlavnej témy v súčasnej pandemickej situácii, v ktorej vzniká mnoho výskumov o dopade na psychické zdravie. Čo sa d’alej týka prínosu a odporúčaní pre použitie výsledkov do praxe, myslíme, že zistenia môžu pomôct' vytvárat' podklady pre preventívne zásahy odborníkov. Zistili sme, že až $24 \%$ respondentov vykazuje príznaky miernej alebo stredne závažnej depresie a $21 \%$ respondentov užíva alkohol vo vysokej intenzite. $Z$ výskumov je značné, že riziko vzniku depresie je v súčasnej dobe vyššie, preto si treba viac všímat' svoje okolie a rovesníkov. Na vysokých školách by mohol vzniknút' online skríning na identifikáciu, aká je prevalencia študentov s depresiou. Takisto by mohli vzniknút' online príručky, ktoré by poskytli informácie na koho sa obrátit' v prípade zhoršujúceho sa psychického stavu, alebo by poskytli informácie o rizikách pitia alkoholu. Štúdia môže napomôct' $\mathrm{k}$ vytvoreniu preventívnych programov týkajúcich sa pandemického dopadu na jedinca, či prevalencie depresie v populácii vysokoškolských študentov v súvislosti s užívaním alkoholu. Výskum Rigaberta a kol. (2020) preukázal, že online psychologické intervencie zamerané na depresiu sú účinné iba pri znižovaní depresívnych symptómov u l’udí bez depresie. Vzhl'adom na to, že online typy intervencií sú vel'mi dostupné a je možné ich vykonávat' v širokom rozsahu, mali by sa d'alej rozvíjat' a implementovat'. Online intervencie sú tiež vel'mi flexibilné a prispôsobivé, pretože účastníci ich môžu upravovat' a spravovat' ich slobodne, pretože sú prístupné prostredníctvom rôznych zariadení (mobilné telefóny, počítače, tablety atd'.).

Príspevok vznikol za podpory projektu: VEGA 1/0203/20 Vývoj a štandardizácia skríningovej metodiky na identifikáciu výskytu a rizika problémového uživania legálnych drog u adolescentov

\section{Použitá literatúra}

1. ARNETT, J. J. Emerging Adulthood, A Theory of Development From the Late Teens Through the Twenties. American Psychologist, 2000, 55(5), 469-480.

2. CAMPBELL, B. What's a standard drink? 2016, Cit. 21. 10 2020. Dostupné na Internete: https://www.therealreview.com/2016/02/06/whats-a-standard-drink/ 
3. DŽAMBAZOVIČ, R. Neskorá mladost'. Nový generačný model prechodu do dospelosti. 2018, In: Beáta Balogová, Martin Hamadej (Eds.). Aktuálne oblasti spoločenskovedného výskumu. Zborník príspevkov z VIII. doktorandskej konferencie. Prešov, 2018, 17-29, ISBN 978-80-555-1989-0.

4. EHMKE, R. Helping College Kids With Depression. 2020, Cit. 15. 102020. Dostupné na Internete: https://childmind.org/article/helping-college-kids-with-depre ssion/\#

5. FORESTELL, C. A., DICKTER, CH. L., YOUNG, CH. M. Take me away: The relationship between escape drinking and attentional bias for alcohol-related cues. Alcohol, 2012, 46(6), s. 543-549, ISSN: 0741-8329.

6. GALBISCEK, C. Alcohol and depression. 2019, Cit. 19. 04 2020. Dostupné na Internete: https://www.alcoholrehabguide.org/resources/dual-diagnosis/alcohol-anddepression/

7. GARCIÁ, L. P., SANCHEZ, Z. Alcohol consumption during the COVID-19 pandemic: a necessary reflection for confronting the situation. 2020, Cit. 15. 02 2021. Dostupné na Internete: https://www.scielo.br/scielo.php?pid=S0102311X2020 001000501\&script=sci_arttext\&tlng=en

8. GRIFFITHS, E. Depression and anxiety tripled during the height of lockdown, new studyshows. 2020, Cit. 02. 15 2021. Dostupné na internete: https://www.sheffield. ac.uk/news/nr/depression-anxiety-tripled-during-lockdown-1.916391

9. HAIDER, I. I., TIWANA, F., MUMTAZ TAHIR, S.Impact of the COVID-19 Pandemic on Adult Mental Health. Pakistan Journal of Medical Sciences. 2020, (36), 90-94.

10. HALFON, N., FORREST, C. B., LERNER, R. M., FAUSTMAN, E. M. Emerging Adulthood as a Critical Stage in the Life Course. 2018, Cit. 20. 08 2020. Dostupné na Internete: https://link.springer.com/chapter/10.1007/978-3-319-47143-3_7

11. HOLT-LUNSTAD, J. The Double Pandemic of Social Isolation And COVID-19: Cross-Sector Policy Must Address Both. 2020, Cit. 22. 03. 2021. Dostupné na internete: https://www.healthaffairs.org/do/10.1377/hblog20200609.53823

12. KIM, J. U., MAJID, A., JUDGE, R., CROOK, P., NATHWANI, R., SELVAPATT, N. Effect of COVID-19 lockdown on alcohol consumption in patients with preexisting alcohol use disorder. 2020, Cit. 08. 02 2021. Dostupné na Internete: https://www.thelancet.com/journals/langas/article/PIIS2468-1253(20)30251-

$\mathrm{X} /$ fulltext

13. LEGG, T. J. What is depression and what can I do about it? 2019, Cit. 05.102020. Dostupné na Internete: https://www.medicalnewstoday.com/articles/8933\#supporthotline

14. LEGG, T. J. Everything You Want to Know About Depression. 2020, Cit. 11. 10. 2020. Dostupné na Internete: https://www.healthline.com/health/ depression

15. MILLER, M. B., HALL, N., MIBELlO, A., PARK, CH. J., FREEMAN, L.,MEIER, E., A KOL. Depressive symptoms as a moderator of college student response to computerized alcohol intervention. Journal of Substance Abuse Treatment, 2020, (115).

16. MONTI, P. M., TEVYAW, T. O., BORSARI, B. Drinking among yound Adults. 2004, Cit. 15. 02 2021. Dostupné na Internete: https://pubs.niaaa.nih.gov/publicatio ns/arh284/236-244.pdf

17. NIH. Depression Basic. 2016, Cit. 20. 08 2020. Dostupné na Internete: https://www.nimh.nih.gov/health/publications/depression/19-mh-8079depression basics_140843.pdf 
18. NIERENBERG, C. 7 Ways Depression Differs in Men and Women. 2016, Cit. 21. 03. 2021. Dostupné na internete: https://www.livescience.com/56599-depression-dif fers-men-women-symptoms.html

19. RECOVERY IN TUNE. Alcohol and Depression. 2019, Cit. 21. 03. 2021. Dostupné na internete: https://www.recoveryintune.com/alcohol-and-depression/

20. RIGABERT, A., MOTRICO, E., MORENO-PERAL, P., RESURRECCIÓN, D. M., CONEJO-CERÓN, S., CUIJPERS, P., A KOL. Effectiveness of online psychological and psychoeducational interventions to prevent depression: Systematic review and meta-analysis of randomized controlled trials. Clinical Psychology Review, 2020, (82).

21. ROJKOVÁ, Z., POPELKOVÁ, M. Vzt'ahy medzi rodinnými, osobnostnými a situačno-motivačnými faktormi z perspektívy alkoholovej závislosti. 2010, Cit. 12. 03 2020. Dostupné na Internete: https://psychkont.osu.cz/fulltext/2010/Rojkova,Pop elkova_2010_2.pdf

22. ROJKOVÁ, Z. Situačno-motivačné faktory alkoholového správania: konceptmeranie-overovanie. Trnava: Univerzita sv. Cyrila a Metoda v Trnave, 2016.103 s. ISBN 978-80-8105-801-1.

23. ROJKOVÁ, Z., VAVROVÁ, M. Situačno-motivačné faktory alkoholového správania: metodológia merania a aplikácia $v$ praxil Zuzana Rojková, Marta Vavrová ; recenzenti Gabriela Šeboková, Slávka Démuthová. - 1. vyd. - Trnava : Univerzita sv. Cyrila a Metoda v Trnave, Filozofická fakulta, 2017. - 97 s. + 1 CDROM. - ISBN 978-80-8105-887-5.

24. THE LANCET GASTROENTEROLOGY \& HEPATOLOGY. Drinking alone: COVID-19, lockdown, and alcohol-related harm. Elsevier Public Health Emergency Collection, 2020, 5(7), 625.

25. WHITE, H. R., JACKSON, K. Social and Psychological Influences on Emerging Adult Drinking Behavior. Alcohol Research \& Health, 2004, 28(4), 182-190.

\section{Kontaktné údaje}

PhDr. Rudolf Fábry, PhD.

Univerzita sv. Cyrila a Metoda v Trnave, Filozofická fakulta

Námestie J. Herdu 2, 91701 Trnava

email: rudolf.fabry@ucm.sk

Mgr. Dominika Minárová

Univerzita sv. Cyrila a Metoda v Trnave, Filozofická fakulta

Námestie J. Herdu 2, 91701 Trnava

email: minarova.dominika@gmail.com

Mgr. Dominika Kochanová

Univerzita sv. Cyrila a Metoda v Trnave, Filozofická fakulta

Námestie J. Herdu 2, 91701 Trnava

email:kochanova3@ucm.sk 


\title{
YOUTUBE A ZÁVISLOST NA HRANÍ POČÍTAČOVÝCH HER
}

\section{YOUTUBE AND ADDICTION TO PLAYING COMPUTER GAMES}

\author{
Pavel Vlk
}

\begin{abstract}
Abstrakt
Předkládaný text se zabývá analýzou nesouladu mezi diskursy opozičních komunit vystupujících pro a proti počítačovému hraní. Projekt zkoumá rozpor mezi „normalitou“ ve vztahu k počítačovému hraní prosazovanou příznivci počítačových her a „normalitou“ prosazovanou jejich odpůrci, a to jak ve sfére odborných komunit zkoumajících problematiku videoherní závislosti, tak v prostředí YouTube, kde je herní závislost předmětem rozsáhlých polemik tvůrců vybraných videokanálů i běžných uživatelů. Cílem vlastního výzkumu je ověřit předpoklad, že v otázce videoherní závislosti dochází $\mathrm{k}$ dvojímu nesouladu diskursu, tedy $\mathrm{k}$ rozporu $\mathrm{v}$ chápání patologického hráčství opozičními komunitami odborníků a současnému nesouladu mezi opozičními sítovými komunitami tvůrců a uživatelů videoportálu YouTube, kteří problematiku závislosti na počítačových hrách v prostředí svých videokanálů tematizují.
\end{abstract}

Klíčová slova: YouTube, počitačové hráčství, videoherni závislost, let's play videa, vědecká komunita, hráčská komunita, diskursivní analýza, nová média

\begin{abstract}
The present text deals with the analysis of the disagreement in discourses of opposition communities advocating for and against computer gambling. The project examines the disagreement in "normality" in relation to computer gaming promoted by computer game fans and "normality" promoted by their opponents, both in the realm of expert communities researching video game addiction and in the YouTube environment, where game addiction is the subject of extensive controversy of video channel creators and regular users. The aim of the research is to verify the assumption that there is a double disagreement in discourses in the issue of video game addiction, i.e. the disagreement in the understanding of pathological gambling by opposition expert communities and the current disagreement among opposition network communities of YouTube video portal creators and users, who thematize the problem of computer gaming addiction in the environment of their own video channels.
\end{abstract}

Keywords: YouTube, computer gambling, video game addiction, let's play videos, scientific community, gaming community, discursive analysis, new media

\section{1 ÚVOD}

Předkládaný text přináší vhled do problematiky videoherní závislosti, kdy nejprve prostřrednictvím sondy do diskursu odborníků čtenáře seznamuje s vědeckými publikacemi a vybranými studiemi, jež ilustrují názorový nesoulad mezi odborníky akcentujícími benefity počítačového hraní a odborníky upozorňujícími na jeho negativní vlivy. Problematika závislosti na počítačových hrách se tak stává centrem sporu těchto opozičních vědeckých komunit, protože zatímco část odborné veřejnosti řadí nadměrné hraní počítačových her mezi duševní onemocnění, druhá část vědecké komunity s tímto zařazením nesouhlasí a zdůrazňuje naopak př́nosy, které může časté hraní počítačových her pro jedince mít. Stejně jako $\mathrm{v}$ př́padě vědeckých komunit pak dochází $\mathrm{k}$ názorovému rozporu $\mathrm{v}$ otázce videoherní závislosti rovněž v prostředí videoportálu YouTube, kde je problematika nadměrného hraní 
počítačových her tematizována řadou videí, v rámci kterých vybrané opoziční YouTube kanály prezentují výrazně odlišné pojetí „normálního“ chování člověka ve vztahu k počítačovým hrám a snaží se tak u svých diváků vyvolávat rozdílnou afektivitu.

\section{YOUTUBE A POČÍTAČOVÉ HRY}

YouTube a počítačové hry patři mezi fenomény dnešní doby a jsou nedílnou součástí jak světa dnešních dětí a mladistvých, kteři již nepoznali svět bez internetu a digitálních technologií, tak světa většiny dospělých, kteří zažili nástup nových médií až v průběhu svého života. To, jaké popularitě se těší videoserver YouTube dokládá například výzkum České děti $v$ kybersvětě ${ }^{1}$ realizovaný $\mathrm{v}$ roce 2019, jehož autoři na základě sebraných dat uvádí, že YouTube je v České republice dominantním online médiem, které pravidelně sleduje většina (89,51\%) dětí a dospívajících ve věku mezi 7 a 17 lety. Videoportál YouTube tak v této věkové kategorii sleduje více lidí, než např́íklad sociální sít' Facebook $(72,19 \%)$, nebo Instagram $(68,83 \%) .^{2}$

Podobné popularitě se těši i druhý z fenoménů, kterým jsou počítačové hry, jejichž hraním, dle studie HBSC z roku 2018, české děti a dospívající ve věku mezi 11 a 15 lety průměrně tráví „,v pracovní den cca 1,60 hodin a o víkendu přibližně o necelou hodinu více, tedy 2,37 hodiny. ${ }^{3}$ Výzkum však současně poukázal také na skutečnost, že $16,88 \%$ adolescentů každodenně stráví hraním počítačových her 4 a více hodin. ${ }^{4}$ V souvislosti s oblibou počítačových her a množstvím času, který děti a dospívající hraním každodenně tráví, byl předmětem odborné studie také výzkum závislosti na počítačovém hraní, který v českém prostředí ukázal, „že přibližně každý 30. adolescent má již závažné problémy s hraním počitačových her. '”

Kombinace těchto dvou populárních fenoménů, tedy YouTube a počítačových her, dala navíc vzniknout žánru let's play videí, jenž se mezi dětmi a mladistvými ve věku od 7 do 17 let stal třetím nejčastěji sledovaným videožánrem na YouTube, přičemž větší oblibě se těší již pouze vtipná videa v čele s tzv. pranky a nejrůznější výzvy (challenge) ${ }^{6}$

\subsection{Popularita žánru let's play v prostředí YouTube}

Jak již bylo naznačeno v předchozí kapitole, značnou část virtuální komunity videoportálu YouTube tvoří hráči a př́znivci počítačových her, kteří se sdružují zejména $\mathrm{v}$ prostředí videokanálů zaměřených na sdílení let's play videí. Let's play videa jsou obvykle tvořena youtubery, kteří jsou pro svou tvorbu označováni jako „letsplayeři“. Letsplayeři jsou tedy tvůrci videí z řad hráčů počítačových her, kteří sdílí záznamy vlastních herních relací v rámci svých YouTube kanálů. Náplní let's play videí však není prostý přenos herního postupu, ale klíčovou roli zde hraje rovněž osobnost samotného tvůrce videa, který do herního přenosu mnohdy sám aktivně vstupuje a doprovází zobrazovaný videoobsah vlastním komentářem. Dokladem celosvětové popularity, jaké se v prostředí YouTube těši komentované přenosy

\footnotetext{
1 KOPECKÝ, Kamil a René SZOTKOWSKI. České děti v kybersvětě: Jak se chovaji online a co jim hrozi [online]. O2 Czech Republic \& Univerzita Palackého v Olomouci. Centrum prevence rizikové virtuální komunikace, 2019, , 1-32 [cit. 2020-04-14]. Dostupné z: https://www.o2chytraskola.cz/data/files/ceske-deti-vkybersvete-vyzkumna-zprava-2-1-5ykpxkxges.pdf

2 Tamtéž.

3 Zaostřeno: HRANÍ DIGITÁLNÍCH HER U ČESKÝCH ADOLESCENTU゚ [online]. 2019. Praha: Úřad vlády České republiky, 2019 [cit. 2021-6-19]. ISSN 2336-8241. Dostupné z: https://www.drogyinfo.cz/data/obj_files/33090/861/Zaostreno_2019-04_Hrani\%20digitalnich\%20her\%20u\%20adolescentu.pdf

4 Tamtéž.

${ }^{5}$ Tamtéž.

${ }^{6}$ KOPECKÝ, Kamil a René SZOTKOWSKI. České děti v kybersvětě: Jak se chovají online a co jim hrozi [online]. O2 Czech Republic \& Univerzita Palackého v Olomouci. Centrum prevence rizikové virtuální komunikace, 2019, , 1-32 [cit. 2020-04-14]. Dostupné z: https://www.o2chytraskola.cz/data/files/ceske-deti-vkybersvete-vyzkumna-zprava-2-1-5ykpxkxges.pdf
} 
počítačového hraní, pak dokládá autor donedávna nejodebíranějšího kanálu Felix Kjellberg, vystupující pod přezdívkou PewDiePie, jenž svou internetovou popularitu založil právě na zveřejňování let's play videí monitorujících jeho videoherní zážitky. Popularita žánru let's play má také přesah do celého videoherního odvětví, kdy se nedílnou součástí většiny dnešních videoherních konzolí i herních počítačů stává software a webové aplikace zjednodušující př́mé sdílení vlastních herních relací do prostředí YouTube. Možnost tvorby a sdílení let's play videí je tak v současnosti dostupná téměř každému hráči počítačových her.

\subsection{YouTube jako sociální sít'}

Ačkoliv je videoportál YouTube primárně webovou službou pro sdílení a přehrávání videí, řada mediálních odborníků jej řadí také mezi sociální sítě, protože nabízí možnost vytvoření uživatelského profilu, uživatelé s vlastním profilem tak mohou nejen sledovat videa a odebírat jednotlivé kanály, ale mají rovněž možnost videa hodnotit, komunikovat s ostatními uživateli a psát své názory do komentárư pod sdílenými videi. ${ }^{8}$ Webové nástroje YouTube navíc komunikační aktivitu svých uživatelů výrazně podporují tím, že uživatele pravidelně vybízí např́klad k tomu, aby dali odběr svému oblíbenému kanálu, ohodnotili video, sdíleli jej s ostatními, nebo se zapojili do diskuse pod videem. ${ }^{9}$ V prostředí YouTube tak vznikají online komunity uživatelů sdružující se kolem vybraných youtuberů, témat a zájmů. Jak uvádí autorky Rotmanová a Preecová, uvnitř konkrétních Youtube komunit je charakteristický určitý pocit důvěry a sounáležitosti mezi jednotlivými členy, který je podporován osobnostmi youtuberů, kteří produkují videa a aktivně tvoři svou komunitu. ${ }^{10}$ Právě způsob fungování YouTube, jenž je založen na vzájemné sociální interakci uživatelů a tvorbě aktivních uživatelských komunit, tvoří dle Davida Gauntletta hlavní motivaci k tomu, aby se uživatelé na YouTube opakovaně vraceli sledovat a přidávat nová videa. ${ }^{11}$

\subsection{Hráčská komunita v prostředí videoportálu YouTube}

Z vlastního výzkumu společnosti Google, pod kterou videoportál YouTube spadá, vyplynulo, že ,"̌́tyřicet osm procent hráčů na YouTube řiká, že tráví více času sledováním herních videí, než hraním her. “12 Dle zmíněného výzkumu je nejčastějším důvodem, který hráče počítačových her k pravidelnému sledování herních videí na YouTube vede právě již zmíněná sounáležitost $\mathrm{s}$ virtuální hráčskou komunitou, která v prostředí YouTube působí. Hráčskou komunitu na YouTube spojuje právě záliba v počítačových hrách, každý fanoušek

\footnotetext{
7 PFEIL, Darren Mathew. Let's Play, Let's Infringe? Let's Play Videos Uploaded to YouTube, Copyright Infringement, and the Fair Use Defense. Law School Student Scholarship. Paper 700, 2015. Dostupné z: https://scholarship.shu.edu/cgi/viewcontent.cgi?article=1701\&context=student_scholarship

8 KOPECKÝ, Kamil a René SZOTKOWSKI. České děti v kybersvětě: Jak se chovaji online a co jim hrozi [online]. O2 Czech Republic \& Univerzita Palackého v Olomouci. Centrum prevence rizikové virtuální komunikace, 2019, , 1-32 [cit. 2020-04-14]. Dostupné z: https://www.o2chytraskola.cz/data/files/ceske-deti-vkybersvete-vyzkumna-zprava-2-1-5ykpxkxges.pdf

${ }^{9}$ GAUNTLETT, David. Making is Connecting: The social power of creativity, from craft and knitting to digital everything. 2. Polity, 2018. ISBN 978-1509513482, str. 153-154.

${ }^{10}$ ROTMAN, Dana a Jennifer PREECE. The 'WeTube' in YouTube - creating an online community through video sharing. International Journal of Web Based Communities [online]. 2010, 2010, (3), 317-333 [cit. 2020 04-20]. ISSN 1741-8216. Dostupné z: https://pdfs.semanticscholar.org/6ea3/7f25174eae5371461abd2 e35805bc6a71db9.pdf, str. 320.

${ }^{11}$ GAUNTLETT, David. Making is Connecting: The social power of creativity, from craft and knitting to digital everything. 2. Polity, 2018. ISBN 978-1509513482, str. 93.

12 PETROVA, Ekaterina a Netta GROSS. 4 reasons people watch gaming content on YouTube. Think with Google [online]. 2017 [cit. 2021-6-19]. Dostupné z: https://www.thinkwithgoogle.com/intl/en-cee/marketingstrategies/video/statistics-youtube-gaming-content/
} 
počítačových her se tak bez ohledu na svůj věk, pohlaví, nebo zaměstnání cítí komunitou přijatý a může se jednoduše spojit se všemi lidmi, kteří sdílí stejný koníček jako on. ${ }^{13}$

Dalšími nejčastěji uváděnými motivy, které hráče vedou ke sledování herních videí, je pak prostá touha se sledováním let's play videí odreagovat a pobavit, či se inspirovat hraním jiných hráčů a zlepšit tak vlastní herních dovednosti. Existuje však celá řada dalších motivů, které hráče a fanoušky vedou ke sledování let's play videí na YouTube. Patří mezi ně např́klad touha získat informace o nových hrách, prohlédnout si podobu hry ještě před jejím zakoupením, nebo si užít herní příběh bez nutnosti finanční investice do vlastní hry, nebo herního zařízení. Jeden z respondentů výzkumu společnosti Google pak ve své odpovědi uvedl: „Sleduji toho chlápka Dunkeyho a je skvělý, ale co opravdu miluji, je číst komentáre na jeho stránce a reakce na jeho videa. “14 Zmíněná výpověd' tak potvrzuje, že pro řadu uživatelů YouTube z řad hráčů počítačových her je sociální interakce odehrávající se v komentáŕích pod herními videi ještě větší motivací k návštěvě videoportálu YouTube, než sledování samotných videí. Příslušníci virtuální hráčské komunity působící v prostředí videoportálu YouTube, tak nejsou pouhými pasivními diváky, ale většina z nich se aktivně podílí na tvorbě obsahu, at' už sdílením vlastních herních videí, nebo hodnocením a komentováním videí ostatních.

\section{ZÁVISLOST NA HRANÍ POČÍTAČOVÝCH HER}

S počítačovými hrami se již od doby, kdy došlo k jejich masovému rozšíření ve společnosti, pojí rovněž snaha odborných institucí, co nejpřesněji definovat hranici mezi tím, kdy je u jedince hraní počítačových her neškodnou zálibou a kdy už v sobě nese patologické jevy spojené se závislostí. Ve snaze o přesné stanovení této hranice představily Americká psychiatrická asociace a Světová zdravotnická organizace vlastní definice patologického herního chování. Kromě samotných definic patologického hráčství pak zmíněné instituce přišly rovněž s návrhem diagnostických kritérií, které umožní poruchu u hráčů počítačových her rozpoznat. Zařazení nadměrného počítačového hraní mezi psychiatrická onemocnění a definování diagnostických kritérií se však setkalo také s řadou kritik, a to jak ze strany zástupců videoherního průmyslu, tak ze strany odborníků z oblasti psychologie.

\subsection{Definice, ,internetové herní poruchy“ dle Americké psychiatrické asociace}

Závislost na počítačových hrách je uváděna pod názvem „Internet gaming disorder“ v celosvětově používaném Diagnostickém a statistickém manuálu mentálních poruch ${ }^{15}$ (DSM) vydávaném Americkou psychiatrickou asociací (APA). Podle nejnovějšího, pátého vydání Diagnostického a statického manuálu mentálních poruch, vydávaného pod zkratkou $D S M-5^{16}$, se člověk stává závislým na internetu a hraní počítačových her, pokud po dobu dvanácti měsíců trvale a opakovaně používá internet $\mathrm{k}$ hraní her, hraje tyto hry často i $\mathrm{s}$ dalšími hráči a přitom u něj toto chování vede ke klinicky významnému postižení, či utrpení. ${ }^{17}$ Člověk trpící „internetovou herní poruchou“ musí současně splňovat také alespoň

\footnotetext{
13 PETROVA, Ekaterina a Netta GROSS. 4 reasons people watch gaming content on YouTube. Think with Google [online]. 2017 [cit. 2021-6-19]. Dostupné z: https://www.thinkwithgoogle.com/intl/en-cee/marketingstrategies/video/statistics-youtube-gaming-content/

${ }^{14}$ Tamtéž.

${ }^{15}$ DSM-5: DIAGNOSTIC AND STATISTICAL MANUAL OF MENTAL DISORDERS [online]. FIFTH EDITION. Edwards Brothers Malloy, 2013 [cit. 2021-6-19]. ISBN 978-0-89042-554-1. Dostupné z: https://cdn.websiteeditor.net/30f11123991548a0af708722d458e476/files/uploaded/DSM\%2520V.pdf.

${ }^{16}$ Tamtéž, str. 795.

${ }^{17}$ DSM-5: DIAGNOSTIC AND STATISTICAL MANUAL OF MENTAL DISORDERS [online]. FIFTH EDITION. Edwards Brothers Malloy, 2013 [cit. 2021-6-19]. ISBN 978-0-89042-554-1. Dostupné z: https://cdn.websiteeditor.net/30f11123991548a0af708722d458e476/files/uploaded/DSM\%2520V.pdf, str. 795.
} 
pět z celkových devíti diagnostických kritérií uváděných v manuálu $D S M-5,{ }^{18}$ přičemž těmito kritérii jsou:

1. Posedlost internetovými hrami. (Jedinec myslí na předchozí herní aktivitu, nebo již přemýšlí, jak si zahraje další hru; Internetové hraní se stává dominantní činností v každodenním životě).

2. Nástup abstinenčních příznaků při znemožnění internetového hraní.

3. Stále narůstající množství času věnovaného hraní internetových her.

4. Neschopnost převzít kontrolu a omezit svou účast v internetových hrách.

5. Ztráta zájmu o veškeré dřivější koníčky a zájmy s výjimkou právě internetových her.

6. Pokračování $\mathrm{v}$ nadměrném hraní internetových her navzdory povědomí o psychosociálních problémech, které toto chování způsobuje.

7. Lhaní členům rodiny, terapeutům a dalším osobám v otázce množství času stráveného internetovým hraním.

8. Hraní počítačových her z důvodu zahnání, nebo zmírnění negativní nálady.

9. Ohrožení, nebo ztráta důležitého vztahu, práce, či vzdělávací, nebo kariérní př́ležitosti zapříčiněná právě účastí v internetových hrách.

\subsection{Kritika pojetí „internetové herní poruchy“ v DSM-5}

Způsob, jakým Americká psychiatrická asociace definovala „internetovou herní poruchu“a vymezila kritéria pro její diagnostikování, se stal předmětem kritiky odborníků z oblasti psychologie. Hlavním problémem spojovaným s diagnózou „internetové herní poruchy“ dle DSM-5 je její nejednoznačná definice, jež navíc pod jednu diagnózu sdružuje dvě zcela odlišné závislosti, tedy závislost na internetu a závislost na počítačovém hraní. Projevy obou těchto závislostí se navíc v praxi mohou významně lišit, což problematizuje použití jednotných diagnostických kritérií. Obdobně problematickým se jeví také chybějící rozlišení mezi počítačovým hráčstvím a hraním her na mobilních zařízeních, či celková absence diferenciace mezi jednotlivými online aktivitami, jejichž návykovost se rovněž různí. ${ }^{19}$

Kolektiv autorů Katedry psychologie na Nottingham Trent University v závěru své studie nazvané „Chaos and confusion in DSM-5 diagnosis of Internet Gaming Disorder: Issues, concerns, and recommendations for clarity in the field“20 vydané roku 2017 navrhuje řešení spočívající v nutnosti odlišení závislosti na internetu od „internetové herní poruchy“ a s tím související potřebě změny názvu, který by měl být nahrazen přesnějším termínem „,videoherní porucha“, či zkrátka „herní porucha“. Změna pojmenování diagnózy by dle autorů přispěla rovněž k ozřejmění skutečnosti, že závislost může vzniknout i v souvislosti s offline hrami, $\mathrm{k}$ jejichž hraní jedinec nepotřebuje připojení $\mathrm{k}$ internetu. ${ }^{21}$

\subsection{Definice „herní poruchy“ dle Světové zdravotnické organizace}

Další z definic závislosti na počítačových hrách je obsažena v 11. revizi Mezinárodní klasifikace nemocí (MKN-11), která byla vydána v roce 2018 Světovou zdravotnickou organizací (WHO). „Herní porucha“ je zde charakterizována jako vytrvalé, nebo opakující se herní chování, které může probíhat jak v souvislosti s hraním počítačových her v prostředí internetu (online), tak rovněž s hraním počítačových her offline, tedy bez nutnosti použití internetu. Dle Světové zdravotnické organizace se „herní porucha“ u jedince projevuje

\footnotetext{
${ }^{18}$ Tamtéž.

${ }^{19}$ KUSS, Daria J., Mark D. GRIFFITHS a Halley M. PONTES. Chaos and confusion in DSM-5 diagnosis of Internet Gaming Disorder: Issues, concerns, and recommendations for clarity in the field. Journal of Behavioral Addictions [online]. 2017, 1. 6. 2017,6(2), 103-109 [cit. 2021-6-19]. ISSN 2063-5303. Dostupné z: doi:https://doi.org/10.1556/2006.5.2016.062

${ }^{20}$ Tamtéž.

${ }^{21}$ Tamtéž.
} 
zhoršenou kontrolou nad hraním a stále se zvyšující prioritou počítačového hraní na úkor ostatních zájmů a každodenních činností. Jedinec s ,herní poruchou“ rovněž v hraní her pokračuje, či svou herní aktivitu navyšuje, a to navzdory negativním dopadům, jež má počítačové hraní na jeho život. Důsledkem tohoto patologického hraní počítačových her, které u jedince může probíhat jak kontinuálně, tak epizodicky a opakovaně, je dle Světové zdravotnické organizace „výrazná úzkost a významné zhoršení vosobnich, rodinných, sociálních, vzdělávacích, pracovních či jiných důležitých oblastech fungování. " ${ }^{22}$ Aby mohla být „herní porucha“ u jedince diagnostikována, měly by se u něj výše zmíněné projevy patologického hraní počítačových her obvykle objevovat alespoň po dobu 12 měsíců, avšak „,požadovaná doba müže být zkrácena, pokud jsou splněny všechny diagnostické požadavky a př́znaky jsou závažné. “23

Světová zdravotnická organizace však na svých webových stránkách uvádí, že „herní porucha“" se týká pouze malé části lidí, kteří se baví hraním digitálních her. Hráčům videoher WHO současně doporučuje monitorovat dobu, kterou tráví digitálním hraním, a to zejména pokud u nich začne docházet k zanedbávání každodenních činností, nebo u sebe zpozorují negativní změny ve fyzickém a duševním zdraví či sociálním životě, jejichž příčinou by mohl být nadměrný čas, který hraní videoher věnují. ${ }^{24}$

\subsection{Kritika WHO v souvislosti se zařazením ,herní poruchy“ do MKN-11}

V reakci na rozhodnutí Světové zdravotnické organizace (WHO) týkajícího se zařazení „herní poruchy“ do Mezinárodní klasifikace nemocí (MKN-11) kriticky vystoupila Asociace zábavního softwaru ${ }^{25}$ (ESA), která ve svém prohlášení ze dne 5. ledna 2018 uvádí, že hráči počítačových her se výrazněji neliší například od sportovních fanouškủ, protože k hraní počítačových her přistupují s obdobnou zaníceností a věnují tak hraní her svůj čas stejně jako konzumenti kterékoliv jiné formy zábavy. ESA dále poukazuje na skutečnost, že hraní videoher má již více než čtyřicetiletou tradici, přičemž se jím baví přes 2 miliardy lidí na světě. ESA proto nepovažuje za správné řadit „herní poruchu“ do stejné kategorie jako vážná duševní onemocnění, kterými jsou např́íklad deprese či sociální fobie, protože tím dochází $\mathrm{k}$ trivializaci těchto závažných psychických poruch, jež zasluhují plnou pozornost lékařské komunity a náležitou léčbu. ${ }^{26}$ Jak ESA ve svém textu také uvádí, „, Světová zdravotnická organizace ví, že zdravý rozum a objektivní výzkumy dokazují, že videohry nejsou návykové. “27

\section{NESOULAD DISKURSU ODBORNÍKŮ A SÍŤOVÝCH KOMUNIT V OTÁZCE ZÁVISLOSTI NA POČíTAČOVÝCH HRÁCH}

I přes výše zmíněné odborné ustanovení definic a charakteristik závislosti na počítačových hrách, zůstává zařazení „herní poruchy“ mezi psychiatrická onemocnění předmětem vědeckých sporů a diskusí, přičemž k tomuto názorovému rozkolu dochází jak mezi odborníky naprríč vědními obory, tak mnohdy i mezi zástupci stejného vědního oboru.

\footnotetext{
22 6C51: Gaming disorder. WHO: World Health Organization [online]. 2018 [cit. 2021-6-19]. Dostupné z: https://icd.who.int/dev11/1-m/en\#http\%3a\%2f\%2fid.who.int\%2ficd\%2fentity\%2f1448597234

23 Tamtéž.

${ }^{24}$ Addictive behaviours: Gaming disorder. WHO: World Health Organization [online]. 2021, 14. 9.2018 [cit. 2021-6-19]. Dostupné z: https:/www.who.int/news-room/q-a-detail/addictive-behaviours-gaming-disorder

25 ESA Responds to WHO's Proposed Disorder Classification. ESA: Entertainment Software Association [online]. Washington, DC, 2021, 5. 1. 2018 [cit. 2021-6-19]. Dostupné z: https://www.theesa.com/ news/esa-responds-to-whos-proposed-disorder-classification/

26 ESA Responds to WHO's Proposed Disorder Classification. ESA: Entertainment Software Association [online]. Washington, DC, 2021, 5. 1. 2018 [cit. 2021-6-19]. Dostupné z: https://www.theesa.com/ne ws/esa-responds-to-whos-proposed-disorder-classification/

${ }^{27}$ Tamtéž.
} 
V souvislosti se závislostí na počítačových hrách a hranicemi vzniku této závislosti se tak vedou rozsáhlé polemiky na úrovni vědeckých oborů jako je psychologie, psychiatrie, neurověda nebo mediální a herní teorie, přičemž zástupci těchto vědních disciplín stále přicházejí s novými teoriemi upozorňujícími na negativní, nebo naopak pozitivní vliv, jaký může mít časté hraní počítačových her na duševní zdraví hráčů.

$\mathrm{V}$ následující kapitole tak prostřednictvím sondy do diskursu komunit odborníků a YouTube komunit představím způsob, jakým je problematika závislosti na počítačových hrách $\mathrm{v}$ rámci těchto dvou prostředí nahlížena, přičemž cílem této vlastní analýzy bude ověřit předpoklad spočívající v tvrzení, že v otázce videoherní závislosti dochází k dvojímu nesouladu diskursu, tedy $\mathrm{k}$ rozporu $\mathrm{v}$ chápání patologického hráčství opozičními komunitami odborníků a současnému názorovému nesouladu mezi tvưrci videí působícími v prostředí videoportálu YouTube.

\subsection{Závislost na počítačových hrách perspektivou odborných publikací}

Jedním z předních zástupců odborné komunity zaměřené na kritiku počítačového hraní je neurovědec a mediální teoretik Manfred Spitzer, který se ve svých publikacích Digitální demence $^{28}$ a Kybernemoc ${ }^{29}$ prezentuje problematiku počítačového hraní a s tím spjaté riziko vzniku závislosti na počítačových hrách jako jeden ze závažných problémů, které s sebou přinesl rozvoj digitálních technologií a jejich masové rozššření ve společnosti.

Dle Spitzera dokáží počítačové hry v mozku aktivovat centrum, které u člověka navozuje pocit štěstí, čímž se prakticky neliší od jakýchkoliv jiných závislostních látek, jakými jsou drogy, alkohol, či nikotin. Závislost je pak podněcována také určitou nahodilostí neodmyslitelně spjatou s úspěchem v počítačových hrách, za nějž se dá považovat např́íklad úspěšný zásah protivníka v akční hře. Právě při takovém herním „úspěchu“ dochází k aktivování výše zmíněného centra zodpovědného za pocit štěstí, jenž ke své aktivaci potřebuje právě, aby se jedinci stalo něco ,nečekaně pozitivního, přičemž důležitou roli hraje doručujicí látka dopamin, “30 která v návaznosti na to způsobí vylučování endorfinů v předním mozku, které jedinec vnímá jako příjemné a odměňující. ,Z toho di̊vodu jsou všechny úspěšné počitačové hry vybaveny touto náhodnou komponentou; vědomě jsou tedy programovány tak, aby podnécovaly vznik závislosti. “31

V souvislosti s tím Spitzer poukazuje na závěry Kriminologického výzkumného ústavu Dolního Saska, který ve své rozsáhlé studii věnované problematice závislosti na počítačových hrách u dětí a dospívajících představil výčet konkrétních charakteristik, jež shodně vykazují počítačové hry s největším závislostním potenciálem. Dle autorů výzkumu je u her s vysokou mírou návykovosti často využíváno odměňování hráčů prostřednictvím virtuálních ocenění, které mohou mít podobu různých achievementů, odznáčků, či prémiové herní výbavy, apod. Míra, do jaké je hráč herním softwarem odměňován, pak obvykle bývá prímo úměrná množstvím času, který hráč ve hře stráví. Jednoduše řečeno, čím více se hráč hře věnuje, tím vyšší jsou jeho herní odměny. Hry s vysokým závislostním potenciálem se dále vyznačují velmi zdlouhavým systémem navyšování úrovně vlastní herní postavy, přičemž dosažení jejího finálního levelu bývá zpravidla výsledkem několikaměsíčního vytrvalého hraní. Kromě vylepšování herní postavy vede hráče k usilovnému a dlouhodobému hraní také průzkum a objevování všech možností rozsáhlého a komplexního herního světa, v rámci kterého se hráč se svou postavou pohybuje. ${ }^{32}$

\footnotetext{
${ }^{28}$ SPITZER, Manfred. Digitální demence: jak připravujeme sami sebe a naše děti o rozum. Brno: Host, 2014.

${ }^{29}$ SPITZER, Manfred. Kybernemoc!: jak nám digitalizovaný život ničí zdraví. Přeložil Iva KRATOCHVÍLOVÁ. Brno: Host - vydavatelství, 2016.

${ }^{30}$ SPITZER, Manfred. Digitální demence: jak připravujeme sami sebe a naše děti o rozum. Brno: Host, 2014, str. 241.

${ }^{31}$ SPITZER, Manfred. Digitální demence: jak připravujeme sami sebe a naše děti o rozum. Brno: Host, 2014, str. 242.

32 Tamtéž, str. 242-243.
} 
Kolektiv odborníků z Radboud University v Nijmegenu však ve své studii upozorňuje, že právě snaha o dosažení těchto virtuálních odměn nemusí mít pro život hráče pouze negativní dopady v podobě vzniku závislosti. Jak autoři textu dokládají, virtuální achievementy a herní odměny, které jsou do většiny dnešních počítačových her zakomponovány, pomáhají u hráčů rozvíjet pozitivní návyky, jakými jsou vytrvalost, cílevědomost, nebo snaha nenechat se odradit neúspěchem a setrvat ve svém snažení o dosažení vytyčeného herního cíle. Hlavním důvodem, který vede k rozvoji těchto pozitivních návyků je skutečnost, že v prostředí počítačových her není neúspěch provázen pouze negativními pocity frustrace, vzteku, nebo smutku, ale i v případě neúspěchu převažují u hráčů pozitivní emoce spjaté právě s motivací dosáhnout vytouženého cíle hry. Hráči tak čerpají ze své vnitřní pozitivní motivace, která jim napomáhá vytrvat, vylepšit své herní schopnosti a překonávat překážky. Návyk spočívající v udržování si vnitřní pozitivní motivace při snaze o dosažení vytyčených cílů si pak dětští hráči počítačových her přenáší z virtuálního prostředí také do svého reálného života, kde pozitivní návyky osvojené hraním her mohou využívat na své cestě ke splnění studijních, sportovních, nebo pracovních cílů. ${ }^{33}$

Dalším klíčovým aspektem vedoucím ke vzniku závislosti na počítačových hrách je dle poznatků Kriminologického výzkumného ústavu Dolního Saska také skutečnost, že ve fiktivních herních světech, v nichž se dnešní online počítačové hry odehrávají, musí hráč plnit řadu úkolů, a to často v kooperaci s jinými hráči. Ke vzniku závislosti na hře tak přispívá rovněž pocit sounáležitosti a zodpovědnosti vưči ostatním spoluhráčům, kteří jsou součástí dané herní komunity. Dle Floriana Rehbeina a jeho kolegů tak ,prritomnost v herním světě nelze redukovat bez většich nesnázi vnitřnich (pocit zodpovědnosti vůči spoluhráčùm, špatné svědomí) nebo vnějších (spoluhráči hrozi vyloučením ze skupiny nebo prerušením kontaktů). “34

Právě sociální povaha dnešních online her je však dle odborné komunity zastánců počítačových her naopak výhodou oproti minulosti, protože hráči přestávají být pouhými izolovanými samotáři, ale mohou při hraní her komunikovat se svými spoluhráči, setkávat se $\mathrm{s}$ přáteli z reálného světa, či se stát součástí rozmanitých herních komunit a poznávat tak nové lidi se stejnými zájmy. Na rozdíl od starších počítačových her, které jedinec hrál osamoceně bez prripojení $\mathrm{k}$ internetu, tak dnešní kooperativní online hry pomáhají rozvíjet prosociální chování člověka, zlepšovat jeho komunikační schopnosti a rozšiřovat okruh jeho sociálních kontaktů. Současné hry totiž při dosahování herních cílů podporují a také odměňují spolupráci, vzájemnou pomoc a komunikaci mezi jednotlivými hráči, čímž se hráč učí řadu sociálních dovedností jako ,komu důvěrovat, koho odmítnout, či jak co nejefektivněji vést skupinu“35. Všechny tyto sociální dovednosti, které si člověk během hraní osvojí, může následně využívat rovněž v prostředí mimo počítačovou hru. Současné studie tak poukazují např́íklad na to, že hráči, kteří se podílí na komunikaci a organizaci herních skupin v rámci online kooperativních her pak projevují zvýšenou občanskou angažovanost i v reálném světě. Granic, Lobel a Engels současně podotýkají, že sociální schopnosti rozvíjí dokonce i často

\footnotetext{
33 GRANIC, Isabela, Adam LOBEL a Rutger C. M. E. ENGELS. The Benefits of Playing Video Games. American Psychologist [online]. American Psychological Association, 2014, 69(1), 66-78 [cit. 2021-619]. ISSN 1935-990X. Dostupné z: doi:https://doi.org/10.1037/a0034857

${ }^{34}$ Rehbein F., Kleinmann M., Mößle Spitzer T. (2009): Computerspielabhängigkeit im Kindes- und Jugendalter. Empirische Befunde zu Ursachen, Diagnostik und Komorbiditäten unter besonderer Berücksichtigung spielimmanenter Abhängigskeitsmerkmale. Kriminologisches Forschungsinstitut Niedersachen (KFN) Schriftenreihe Bd. 108, In: Digitální demence, str. 243.

35 GRANIC, Isabela, Adam LOBEL a Rutger C. M. E. ENGELS. The Benefits of Playing Video Games. American Psychologist [online]. American Psychological Association, 2014, 69(1), 66-78 [cit. 2021-619]. ISSN 1935-990X. Dostupné z: doi:https://doi.org/10.1037/a0034857
} 
kritizované násilné počítačové hry, a to zejména v prrípadě, že je hráč hraje v kooperativním módu vyžadujícím kolektivní spolupráci mezi jednotlivými hráči. ${ }^{36}$

Ve své další knize př́značně nazvané Kybernemoc ${ }^{37}$ pak Spitzer v souvislosti se svým tvrzením, ,„̌e počitačové hry jsou naprogramované tak, aby vytvářely závislost, “38 akcentuje zejména schopnost herního softwaru navodit a udržet u hráčů počítačových her duševní stav flow, což je stav maximálního a hlubokého zaměření mysli na určitou činnost, při které „, člověk zapomíná na čas i sám na sebe, je plně soustředěný a má u toho dobrý pocit. " ${ }^{39}$ Dle Spitzera je počítačový software naprogramován právě tak, aby zmíněný duševní stav u hráčů vyvolával a současně jej udržoval tím, že před hráče klade neustále nové cíle, úkoly a překážky, jejichž zvládnutí je pro ně sotva zvládnutelnou výzvou. V souvislosti s tím se hráč počítačové hry musí neustále snažit zlepšovat své herní schopnosti a dovednosti, aby byl schopen reagovat na stále náročnější výzvy, které před něj hra staví. Dle Spitzera má však navození duševního stavu flow v životě člověka význam při učení se novým a prospěšným věcem, kdy jedinci umožňuje se myšlenkově ponořit do konkrétní činnosti, aby mohl zdolávat překážky, zdokonalovat své dovednosti a podávat maximální výkony. V př́padě hraní počítačových her se však biologický smysl flow vytrácí a jeho navození přestává být pro člověka prŕnosem, ale stává se pouhým nástrojem herního softwaru k připoutání jedince $\mathrm{k}$ počítačovému monitoru. ${ }^{40}$

Granic, Lobel a Engels však ve své studii poukazují na emoční benefity, které duševní stav flow navozený počítačovým hraním může člověku přinést. Autoři předkládají výzkum dokazující, že již některé dostupné hry s jednoduchým rozhraním, mezi které se řadí např́íklad hry Angry Birds či Bejewled 2, „,mohou zlepšit náladu hráčů, podporovat relaxaci a odvrátit úzkost, "41 a to právě díky př́nosu duševního stavu flow, do kterého se jedinci během hraní těchto her dostávají. Právě pozitivní emoce, které jsou s hraním počítačových her a prožíváním stavu flow spojeny, mají dle autorů studie neoddiskutovatelný vliv na zlepšení nálady a navození pocitu štěstí u jedince, který počítačové hry hraje. ${ }^{42}$

\subsection{Závislost na počítačových hrách ve videích sdílených v prostředí YouTube}

Obdobně kritickou argumentaci v souvislosti s nadměrným hraním, jakou zastává Manfred Spitzer, prezentují v prostředí YouTube např́iklad videa sdílená publicistickými kanály DVTV a XTV. Odborníci, kteří jsou hosty těchto videí tak, stejně jako Manfred Spitzer ve své knize Digitální demence ${ }^{43}$, přirovnávají závislost na počítačových hrách k závislosti na návykových látkách, jako jsou drogy, alkohol, nebo nikotin. Přirovnání počítačových her $\mathrm{k}$ drogám se tak objevuje např́klad $\mathrm{v}$ rozhovoru s klinickým psychologem a psychoterapeutem Janem Kulhánkem, jenž byl publikován v rámci YouTube kanálu DVTV pod názvem „Fortnite? Viděl jsem desitky závislých dètí, hra je návyková jako heroin, ř́ká expert. “44 Ve videu samotném se pak přirovnání závislosti na počítačové hře Fortnite $\mathrm{k}$

\footnotetext{
${ }^{36}$ Tamtéž.

${ }^{37}$ SPITZER, Manfred. Kybernemoc!: jak nám digitalizovaný život ničí zdraví. Přeložil Iva KRATOCHVÍLOVÁ. Brno: Host - vydavatelství, 2016.

${ }^{38}$ Tamtéž, str. 77.

${ }^{39}$ Tamtéž, str. 78.

40 Tamtéž, str. 78-84.

41 GRANIC, Isabela, Adam LOBEL a Rutger C. M. E. ENGELS. The Benefits of Playing Video Games. American Psychologist [online]. American Psychological Association, 2014, 69(1), 66-78 [cit. 2021-619]. ISSN 1935-990X. Dostupné z: doi:https://doi.org/10.1037/a0034857

42 GRANIC, Isabela, Adam LOBEL a Rutger C. M. E. ENGELS. The Benefits of Playing Video Games. American Psychologist [online]. American Psychological Association, 2014, 69(1), 66-78 [cit. 2021-619]. ISSN 1935-990X. Dostupné z: doi:https://doi.org/10.1037/a0034857

${ }^{43}$ SPITZER, Manfred. Digitální demence: jak připravujeme sami sebe a naše děti o rozum. Brno: Host, 2014

${ }^{44}$ Fortnite? Viděl jsem desítky závislých dětí, hra je návyková jako heroin, ř́íká expert. YouTube [online]. 6. 2. 2019 [cit. 2021-6-20]. Dostupné z: https://www.youtube.com/watch?v=KkUKsHEKw-M\&t=18s
} 
drogové závislosti objevuje hned v úvodu rozhovoru, kdy moderátor Martin Venclovský cituje zahraničního specialistu na herní závislosti, který pro agenturu Bloomberg vydal prohlášení, že hra Fortnite se podobá heroinu. Se zmíněným přirovnáním pak pozvaný psychoterapeut Jan Kulhánek souhlasí a současně podotýká, že v př́padě počítačové hry Fortnite je riziko vzniku závislosti závažnější než u jiných her, a to už jenom z toho důvodu, že hra je dostupná zdarma, protože stejně jako v př́ípadě drog platí i u počítačových her, že „, droga je tím nebezpečnější, čím snadněji je dostupná. “45

Přirovnání počítačových her k drogám je pak součástí i jedné z reportáží publicistického kanálu XTV, kde byl pod názvem „Někteři závisli na počitačových hrách nosí pleny, aby nemuseli odcházet...ř́ḱ́ terapeut Milan Krejči “46 publikován rozhovor věnovaný problematice závislosti na digitálních technologiích, a to zejména na počítačových hrách, internetu a sociálních sítích. Podle terapeuta Milana Krejčího jsou projevy závislosti na počítačových hrách a internetu podobné ,jako závislost na alkoholu, nikotinu, nebo gamblerstvi, “47 protože podobně jako trpí závislý člověk, kterému se nedostává drogy, trpí i hráč závislý na počítačových hrách, když je mu hraní odpíráno, nebo nemá k hernímu zařízení momentálně přístup. ${ }^{48}$

Problematika závislosti na počítačových hrách je však kromě publicistických videí často tematizována také ve videích youtuberů a letsplayerů, kteří však nadměrné hraní počítačových her prezentují výrazně odlišným způsobem než výše představené publicistické kanály a svou argumentací se tak blíží vědecké komunitě zastánců počítačových her. Podobně jako autoři článku The Benefits of Playing Video Games ${ }^{49}$ tak čeští youtubeři a letsplayeři ve svých YouTube videích akcentují zejména benefity, které mohou počítačové hry svým hráčům přinášet.

Zatímco publicistické pořady často přirovnávají počítačovou herní závislost $\mathrm{k}$ drogové závislosti, youtubeři a letsplayeři ve svých videích naopak upozorňují, že časté hraní počítačových her může u dětí a mladistvých fungovat jako prevence problémového chování spojeného se závislostí na návykových látkách, kterými jsou dnešní děti a mladiství ohrožováni. K problematice závislosti na počítačovém hraní se ve svém videu nazvaném „,Videohry zničí svět!! | TV Nova vám to vysvětlí :) “50 vyjadřuje např́iklad letsplayer Petr Žalud, na YouTube vystupující pod jménem CzechCloud, který v souvislosti s démonizováním počítačového hraní publicistickými pořady uvádí: „Mezi námi přáteli, všichni víme, jak to vypadá na vesnici, nikdo se nikoho na nic neptá, děti kouři a pijí, ale za všechno můžou hry... Daleko radši budu, když mé děti budou hrát, než aby se vystavovaly problémům s drogami. “51 Odborníky předkládaný názor, že agresivita a problémové chování u dětí mohou být způsobeny počítačovými hrami, je pak dle CzechClouda zpátečnický. Hry jsou podle něj totiž pouze novým typem zábavy, kterou děti tráví svůj volný čas, takže zatímco dříve si děti hrály s Legem, dnes stejné děti hrají počítačovou hru Minecraft, jež je dle autorova tvrzení v podstatě dnešní digitální alternativou Lega. Agresivní chování dětí často spojované se závislostí na počítačových hrách tak dle CzechClouda není zapříciněno

\footnotetext{
45 Tamtéž.

46 „Někteří závislí na hrách používají pleny, aby nemuseli odcházet...“ říká terapeut Matěj Krejčí. YouTube [online]. 21. 2. 2019 [cit. 2021-6-20]. Dostupné z: https://www.youtube.com/watch?v=INm zIc7QP4o

${ }^{47}$ Tamtéž.

${ }^{48}$ Tamtéž.

49 GRANIC, Isabela, Adam LOBEL a Rutger C. M. E. ENGELS. The Benefits of Playing Video Games. American Psychologist [online]. American Psychological Association, 2014, 69(1), 66-78 [cit. 2021-619]. ISSN 1935-990X. Dostupné z: doi:https://doi.org/10.1037/a0034857

${ }^{50}$ Videohry zničí svět!! | TV Nova vám to vysvětlí :). YouTube [online]. 7. 6. 2020 [cit. 2021-6-20]. Dostupné z: https://www.youtube.com/watch?v=-gYDn9NREJ8\&t=499s

${ }^{51}$ Tamtéž.
} 
počítačovými hrami jako takovými, ale souvisí spíše s problémovou osobností daného jedince, kterou mnohem více než počítačové hry ovlivňuje například rodina, sociální kontakty a také prostředí, ve kterém daný člověk žije. ${ }^{52}$

Další reakcí na rozhodnutí Světové zdravotnické organizace o zařazení „herní poruchy“ mezi duševní onemocnění je video nazvané „Závislost na počítačových hrách jako nemoc-proč to řešime? \#251 “53, které bylo publikované v rámci YouTube kanálu Zvědátoři, jehož autory jsou Patrik Kořenář a Martin Rota. Autoři zde upozorňují na skutečnost, že hraní počítačových her je ve srovnání s jinými volnočasovými aktivitami většinovou odbornou i laickou veřejností vnímáno jako méněhodnotné, což vede $\mathrm{k}$ tomu, že se stává terčem častých a mnohdy neoprávněných kritik. Zmíněný postoj většinové společnosti k počítačovým hrám lze dle autorů ilustrovat například přirovnáním počítačového hraní k četbě literatury, kdy ačkoliv může být hodnota poselství klasického literárního díla mnohdy srovnatelná s hodnotou poselství předávaného příběhem v počítačové hře, je na čtení společensky nahlíženo jako na záslužnou činnost, zatímco hraní počítačových her je obecně považováno za „ztrátu času“. Stejně jako může být čtení i hraní počítačových her pro člověka v mnoha ohledech př́nosné, může být nadměrná četba literárních př́iběhů obdobně patologická jako nadměrné hraní počítačových her a může tak mít pro život jedince podobně negativní důsledky. Vášnivý čtenář dle autorů rovněž může trpět sociální izolací, narušením vztahů s okolím, nebo zanedbáváním studijních, či pracovních povinností v souvislosti s četbou, což jsou stejné problémy, jaké jsou často zmiňovány ve spojitosti s nadměrným hraním. Hraní počítačových her se tedy nijak neliší od jiných volnočasových aktivit. Zařazení „herní poruchy“ mezi skutečné duševní nemoci je však dle autorů pozitivní alespoň v tom smyslu, že umožňuje pomoci lidem, kteří si hraním her skutečně zničili život, přišli o práci, nebo o rodinu. ${ }^{54}$

YouTuber vystupující pod jménem czMarv pak ve svém videu pojmenovaném „Jsem závislý na počitačových hrách!"'55 představil přehled motivů, které ho vedou k častému hraní počítačových her. Video má podobu osobní zpovědi, ve které autor uvádí např́íklad následující: „Jsem Vladimír Marvan, je mi 22 let a jsem závislý na počitačových hrách... Jsem závislý budovat, tvořit a rozšiřovat obzory své fantazie. Jsem závislý na soutěživosti, jsem závislý na komunikaci s celým světem,... ${ }^{56}$ Autor videa dále zdůrazňuje zejména pozitivní emoce radost a štěstí, které díky počítačovému hraní může prožívat. Současně však zmiňuje také neporozumění, s nímž se v souvislosti se svou zálibou v hraní počítačových her u ostatních lidí často setkává. Po zveřejnění této osobní zpovědi se autorovi videa dostalo v rámci virtuální komunity př́iznivců počítačových her působících v prostředí YouTube velkého porozumění, podpory a přijetí, kdy ostatní hráči v komentářích pod videem společně sdíleli své pozitivní pocity, které zažívají během hraní, přičemž souhlasně prohlašovali, že jsou na své časté hraní pyšní a nestydí se za něj. Řada uživatelů YouTube rovněž v komentářích argumentovala, že hraní není pouze o násilí, jak někteří kritici počítačových her tvrdí, ale kromě toho, že počítačové hry přináší řadu herních zážitků a zábavy, může jejich hraní přispívat také ke zlepšení fantazie, předvídavosti či $\mathrm{v}$ případě akčních her také $\mathrm{k}$ tréninku reakční rychlosti. Řada diskutujících rovněž vlastní časté hraní obhajovala svou snahou o splnění snu stát se profesionálním hráčem, nebo streamerem. ${ }^{57}$

\footnotetext{
${ }^{52}$ Tamtéž.

${ }^{53}$ Závislost na počítačových hrách jako nemoc - Proč to řešíme? \#251. YouTube [online]. 22. 1. 2018 [cit. 2021 6-20]. Dostupné z: https://www.youtube.com/watch?v=Af4lIGtwdG0

${ }^{54}$ Závislost na počítačových hrách jako nemoc - Proč to řešíme? \#251. YouTube [online]. 22. 1. 2018 [cit. 2021 6-20]. Dostupné z: https://www.youtube.com/watch?v=Af4lIGtwdG0

55 Jsem závislý na počítačových hrách! YouTube [online]. 14. 8. 2015 [cit. 2021-6-20]. Dostupné z: https://www.youtube.com/watch?v=vyV0oM3VWMY

${ }^{56}$ Tamtéž.

${ }^{57}$ Tamtéž.
} 


\section{ZÁVĚR}

Počítačové hry jsou fenoménem dneška a jejich hraní se ve svém volném čase věnuje čím dál více lidí. V prostředí videoportálu YouTube daly počítačové hry vzniknout novému oblíbenému žánru tzv. let's play videí, kolem kterých se sdružují celé komunity hráčů počítačových her. V souvislosti s nárůstem popularity počítačového hraní se však v rámci odborné i laické veřejnosti začaly objevovat rovněž diskuse tematizující riziko závislosti, která se ve spojitosti s častým hraním počítačových her může u hráčů začít projevovat. Problematika závislosti na počítačových hrách se stala aktuální zejména poté, co „internetovou herní poruchu“, respektive „herní poruchu“ zařadily Americká psychiatrická asociace a Mezinárodní zdravotnická organizace do svých seznamů psychiatrických onemocnění. Správnost definice problémového hraní a oprávněnost zařazení nadměrného počítačového hraní mezi psychiatrická onemocnění však dodnes zůstává předmětem častých polemik.

Jednou z přičin této celospolečenské názorové nejednotnosti je argumentační rozpor, ke kterému v rámci odborné komunity dochází. Zatímco jedna skupina odborníků akcentuje $\mathrm{v}$ souvislosti s častým hraním počítačových her a jeho sociálním dopadem na jedince převážně negativní vlivy, druhá skupina odborníků upozorňuje na nejednoznačnost tohoto kritického pojetí a přináší argumenty dokazující, že časté hraní může mít rovněž pozitivní vliv, a to jak na psychiku, tak sociální život hráče. Důvodem tohoto názorového rozkolu v rámci vědecké komunity je, že mezi těmito dvěma opozičními skupinami odborníků dochází k nesouladu diskursu, kdy každá z komunit na rozlišování hranice mezi „normálním“ a patologickým hraním počítačových her nahlíží vzájemně nesouměřitelnou perspektivou.

Nesoulad odborného diskursu v otázce závislosti na počítačových hrách se promítá rovněž do prostředí videoportálu YouTube, kde na jedné straně stojí publicistické kanály, které ve svých videích upozorňují na řadu negativních dopadů častého hraní a závislost na počítačových hrách opakovaně přirovnávají k závislosti na drogách. Časté hraní je tak v rámci těchto publicistických videí prezentováno jako problémové chování, které vyžaduje odbornou pomoc. Publicistické YouTube kanály tedy využívají obdobnou argumentaci jako kritici počítačového hraní z řad vědecké komunity. Na opačnou stranu názorového spektra se pak staví youtubeři, kteří se obsahem svých videí sdílených v prostředí YouTube argumentačně blíži vědecké komunitě zastánců počítačových her. Youtubeři tedy ve své videotvorbě kladou důraz především na skutečnost, že by počítačové hry neměly být démonizovány a současně by neměla být opomíjena pozitiva, jež se s hraním počítačových her pojí.

Článek byl vydán v rámci projektu Interního grantového systému MUP s interním číslem E62-79 a názvem „YouTube a závislost na počítačovém gamblingu“ financovaného z podpory MŠMT na specifický vysokoškolský výzkum v letech 2020-2021.

\section{Použitá literatura}

1. GAUNTLETT, David. Making is Connecting: The social power of creativity, from craft and knitting to digital everything. 2. Polity, 2018. ISBN 978-1509513482

2. SPITZER, Manfred. Digitální demence: jak připravujeme sami sebe a naše děti o rozum. Brno: Host, 2014. ISBN 978-80-7294-872-7.

3. SPITZER, Manfred. Kybernemoc!: jak nám digitalizovaný život ničí zdraví. Přeložil Iva KRATOCHVÍLOVÁ. Brno: Host - vydavatelství, 2016. ISBN 978-80-7491-792-9.

\section{Internetové zdroje}

1. „Někteří závislí na hrách používají pleny, aby nemuseli odcházet...“ říká terapeut Matěj Krejčí. YouTube [online]. 21. 2. 2019 [cit. 2021-6-20]. Dostupné z: https://www.youtube.com/watch?v=INmzIc7QP4o 
2. 6C51: Gaming disorder. WHO: World Health Organization [online]. 2018 [cit. 20216-19]. Dostupné z: https://icd.who.int/dev11/1-m/en\#http\%3a\%2f\%2fid.who.in t\%2ficd\%2fentity\%2f1448597234

3. Addictive behaviours: Gaming disorder. WHO: World Health Organization [online]. 2021, 14. 9. 2018 [cit. 2021-6-19]. Dostupné z: https://www.who.int/news-room/q-adetail/addictive-behaviours-gaming-disorder

4. ESA Responds to WHO's Proposed Disorder Classification. ESA: Entertainment Software Association [online]. Washington, DC, 2021, 5. 1. 2018 [cit. 2021-6-19]. Dostupné z: https://www.theesa.com/news/esa-responds-to-whos-proposed-disorderclassification/

5. Fortnite? Viděl jsem desítky závislých dětí, hra je návyková jako heroin, říká expert. YouTube [online]. 6. 2. 2019 [cit. 2021-6-20]. Dostupné z: https://www.youtube.com/watch?v=KkUKsHEKw-M\&t=18s

6. Jsem závislý na počítačových hrách! YouTube [online]. 14. 8. 2015 [cit. 2021-6-20]. Dostupné z: https://www.youtube.com/watch?v=vyV0oM3VWMY

7. PETROVA, Ekaterina a Netta GROSS. 4 reasons people watch gaming content on YouTube. Think with Google [online]. 2017 [cit. 2021-6-19]. Dostupné z: https://www.thinkwithgoogle.com/intl/en-cee/marketing-strategies/video/statisticsyoutube-gaming-content/

8. Videohry zničí svět!! | TV Nova vám to vysvětlí :). YouTube [online]. 7. 6. 2020 [cit. 2021-6-20]. Dostupné z: https://www.youtube.com/watch? $v=-g$ YDnNREJ8\&t=499s

9. Závislost na počítačových hrách jako nemoc - Proč to řešíme? \#251. YouTube [online]. 22. 1. 2018 [cit. 2021-6-20]. Dostupné z: https://www.you tube.com/watch? $\mathrm{v}=$ Af4lIGtwdG0

\section{Vědecké články}

1. DSM-5: DIAGNOSTIC AND STATISTICAL MANUAL OF MENTAL DISORDERS [online]. FIFTH EDITION. Edwards Brothers Malloy, 2013 [cit. 20216-19]. ISBN 978-0-89042-554-1. Dostupné z: https://cdn.website-editor.net/30f 11123991548a0af708722d458e476/files/uploaded/DSM\%2520V.pdf

2. GRANIC, Isabela, Adam LOBEL a Rutger C. M. E. ENGELS. The Benefits of Playing Video Games. American Psychologist [online]. American Psychological Association, 2014, 69(1), 66-78 [cit. 2021-6-19]. ISSN 1935-990X. Dostupné z: doi:https://doi.org/10.1037/a0034857

3. KOPECKÝ, Kamil a René SZOTKOWSKI. České děti v kybersvětě: Jak se chovají online a co jim hrozi [online]. O2 Czech Republic \& Univerzita Palackého v Olomouci. Centrum prevence rizikové virtuální komunikace, 2019, , 1-32 [cit. 202004-14]. Dostupné z: https://www.o2chytraskola.cz/data/files/ceske-deti-v-kybersvetevyzkumna-zprava-2-1-5ykpxkxges.pdf

4. KUSS, Daria J., Mark D. GRIFFITHS a Halley M. PONTES. Chaos and confusion in DSM-5 diagnosis of Internet Gaming Disorder: Issues, concerns, and recommendations for clarity in the field. Journal of Behavioral Addictions [online]. 2017, 1. 6. 2017, 6(2), 103-109 [cit. 2021-6-19]. ISSN 2063-5303. Dostupné z: doi:https://doi.org/10.1556/2006.5.2016.062

5. PFEIL, Darren Mathew. Let's Play, Let's Infringe? Let's Play Videos Uploaded to YouTube, Copyright Infringement, and the Fair Use Defense. Law School Student Scholarship. Paper 700, 2015. Dostupné z: https://scholarship.shu.edu/cgi/viewconte nt.cgi?article $=1701 \&$ context=student_scholarship

6. ROTMAN, Dana a Jennifer PREECE. The 'WeTube' in YouTube - creating an online community through video sharing. International Journal of Web Based 
Communities [online]. 2010, 2010, (3), 317-333 [cit. 2020-04-20]. ISSN 1741-8216. Dostupné z: https://pdfs.semanticscholar.org/6ea3/7f25174eae5371461abd2e35805 bc6a71db9.pdf

7. Zaostřeno: HRANÍ DIGITÁLNÍCH HER U ČESKÝCH ADOLESCENTU゚ [online]. 2019. Praha: Úřad vlády České republiky, 2019 [cit. 2021-6-19]. ISSN 2336-8241. Dostupné z: https://www.drogy-info.cz/data/obj_files/33090/861/Zaostreno_201904_Hrani\%20digitalnich\%20her\%20u\%20adolescentu.pdf

\section{Kontaktní údaje}

Mgr. Pavel Vlk

Metropolitní univerzita Praha, o.p.s.

Budova MUP na Jarově

Učňovská 100/1, 19000 Praha 9

Tel: +420 774538523

e-mail: vlkpavel.pb@gmail.com 


\title{
INSCENOVÁNÍ JAKO SOUČÁST VYUČOVACÍHO PROCESU
}

\author{
STAGING AS PART OF THE TEACHING PROCESS
}

\author{
Ladislav Tischler
}

\begin{abstract}
Abstrakt
Príspevok sa zaoberá inscenovaním vo vyučovacom procese. Inscenačný proces ponúka vel'ký priestor pre rozvoj tvorivého a kritického myslenia, učí žiakov spolupráci, komunikácii v skupine a rozvíja schopnot' študentov adaptovat' sa na meniace podmienky prostredia. $\mathrm{V}$ metodike sa stretávame s rôznymi pojmami ako dráma $\mathrm{v}$ edukácii, alebo inscenačná metóda, avšak možnosti využitia inscenačného procesu prebratého $\mathrm{z}$ dramatického umenia vo vyučovaní sú ovel'a väčšie.
\end{abstract}

Klíčová slova: inscenovanie, vyučovací proces, téma, idea, divadelný obraz, scéna

\begin{abstract}
The paper deals with staging in the teaching process. The staging process offers a great space for the development of creative and critical thinking, teaches students cooperation, group communication and develops students' ability to adapt to changing environmental conditions. In the methodology, we encounter various concepts such as Drama in Education or the staging method, but the possibilities of using the staging process taken over from the dramatic art in teaching are much greater.
\end{abstract}

Key words: staging, teaching process, theme, idea, theatrical image, stage

\section{PRÍPRAVNÁ FÁZA INSCENAČNÉHO PROCESU}

Súčasné trendy vo vytváraní a organizovaní vyučovacieho procesu si postavili nel'ahkú úlohu ako skombinovat' rozvíjanie kreativity a kritického myslenia s nadobúdaním teoretických poznatkov. Najnovšie sa ukazuje ako nutnost' rozvíjat' u študentov aj schopnost' adaptovat' sa na neustále meniace sa podmienky prostredia a spoločnosti, ktorá ich obklopuje. Prichádzame preto s ideou intenzívnejšieho využívania inscenačného procesu v klasickom vyučovaní. Tento proces učí žiakov pracovat' v skupine, komunikovat', nachádzat' nové spôsoby riešenia problémových situácií a tvorivo pristupovat' k zvolenej téme.

Vo výstavbe inscenačného procesu sme sa rozhodli využivat' nielen teoretické poznatky týkajúce sa hudobno-dramatickej tvorby, ale ich aj kombinovat' s niektorými vybranými poznatkami z modernej ekonómie, aplikovanej matematiky, informatiky, psychológie, hudobnej teórie a výtvarnej tvorby. Vychádzali sme pri tom z teórie výstavby divadelnej metafory, čiže pomocou kombinácie dvoch existujúcich realít (dvoch rôznych poznatkov z rôznych vedných disciplín) sme sa snažili nachádzat' tretiu realitu, nové postupy v tvorbe a vo vyučovacom procese. Prioritne však pri inscenovaní v školskom prostredí vychádzame z postupov renesančnej Commedie dell'arte', ktorá sa svojou flexibilitou asi najviac hodí k inscenovaniu s neprofesionálnymi hercami (žiakmi).

\footnotetext{
1 Commedia dell'arte prevažne komediálne divadlo predvádzané profesionálnymi talianskymi hercami od polovice 16 . storočia do konca 18 . storočia.
} 
„Pre Commediu dell'arte je charakteristická kolektívna tvorba hercov, ktorí vytvárajú predstavenie pomocou slovnej a pohybovej improvizácie, pričom sa opierajú o predlohu, ktorú však nenapísal nijaký dramatik, je to vždy len stručný náčrt (inštrukcie o príchodoch a odchodoch zo scény a o hlavných zápletkách fabuly). Herci čerpajú inšpiráciu z dramatickej látky, ktorú si vypožičajú z (antickej, alebo modernej) komédie alebo si ju vymyslia. Ked' je herecký scenár (akčný plán) hotový, potom už každý herec improvizuje a pridŕža sa lazzi (poznámok, ako hrat' komické neverbálne scény), charakteristických pre vlastnú rolu, a reakcii publika. ${ }^{\circ 2}$

Hodiny inscenovania preto spravidla nemajú presnú štruktúru. Učitel' sa väčšinou snaží čo najviac prispôsobit' vyučovací proces žiakovi, jeho náladám, vnímaniu situácie, momentálnej dispozícii, alebo indispozícii, preto sú založené na neustálej improvizácii pedagóga inšpirovaného podnetmi od žiakov. Pri výstavbe vyučovacej jednotky pomocou techník Commedie dell'arte pedagóg prináša vstupné teoretické a praktické informácie vychádzajúce z odbornej literatúry a vlastných skúseností. Po zadefinovaní ciel'a a základných dejových faktov študenti následne pracujú so vstupnými informáciami, kombinujú ich a obmieňajú (využívajú improvizačné cvičenia a hry, v ktorých uplatňujú nadobudnuté poznatky). Učitel' spolupracuje so žiakmi, aplikuje vstupné informácie do praktických ukážok a ako jediný člen tvorivého tímu môže proces riadit', prispôsobovat' vstupné informácie, zastavit' a menit' ho, alebo prispôsobovat' vonkajším a vnútorným podmienkam. Študenti si počas hodín robia vlastné poznámky a tým vytvárajú vlastný poznámkový aparát (akési lazziª) podložené praktickými skúsenost’ami.

Úvodné stretnutia sú venované budovaniu tvorivého tímu. Žiaci sa medzi sebou učia spolupracovat' a osvojujú si základné postupy tvorivého procesu. Vzájomná spolupráca a dôvera pri vytváraní vyučovacej jednotky, na ktorej sa zúčastňuje viacero osôb, je jedným $\mathrm{z}$ najdôležitejších faktorov pre úspech inscenačného procesu. V tomto prípade vychádzame z teórie Johna Forbesa Nasha, ${ }^{4}$ ktorý sa zaoberal aplikovanou matematikou, teóriou hier a tvrdil, že najlepší výsledok sa nedosiahne vtedy, ked' každý v skupine robí to, čo je pre neho najlepšie, ale ked' každý v skupine robí to, čo je najlepšie pre neho a zároveň aj pre skupinu. ${ }^{5}$ V tvorivých skupinách sa totiž často stáva, že každý sa snaží dosiahnut' čo najlepší výsledok na úkor skupiny. Počas inscenovania vo vyučovacom procese sa práve túto skutočnost' snažíme eliminovat', a to napríklad tak, že všetky úspechy, alebo neúspechy prináležia celému kolektívu. Ruší sa v ňom vnímanie vel'kých a malých rolí alebo dobrých a zlých výkonov jednotlivca. Vo výsledku zostávajú len jednotlivé herecké úlohy a výsledný výkon danej skupiny. Ak vznikne problém, tak jeho následky nesie celý kolektív a nie jednotlivci. Vzájomnú dôveru a spoluprácu počas úvodných stretnutí podporujeme organizovaním spoločných akcií, rôznymi cvičeniami a aktivitami, ktoré študenti počas hodín (alebo a aj mimo nich) riešili. Následne sa začína konkrétny inscenačný proces. Prípravná fáza spočíva v tom, že tvorivá skupina (pedagóg a študenti) hl'adá vhodnú tému, ktorá by komunikovala aktuálne potreby skupiny a reflektuje aktuálne spoločenské témy. Počas tvorivého procesu vol'ne pokračujú rôzne cvičenia a aktivity, ktoré slúžia ako praktická príprava pre inscenačnú fázu projektu. Po dôkladnej príprave začína tvorivý tím samotné inscenovanie.

\footnotetext{
${ }^{2}$ PAVIS, P. Divadelný slovník. Bratislava: Divadelný ústav, 2004. s. 57.

${ }^{3}$ Lazzi označuje mimický alebo improvizovaný prvok, ktorý slúži hercovi na komickú charakteristiku postavy.

${ }^{4}$ John Forbes Nash (13. jún 1928) - americký matematik a ekonóm, známy svojou prácou v oblasti teórie hier a diferenciálnej geometrie. Jeho sl'ubne sa rozvíjajúcu kariéru matematika na takmer tridsat' rokov výrazne skomplikovala vážna duševná porucha, napriek tomu zotrval pri svojej práci. V roku 1994 získal spolu s Reihardom Seltenom a Johnom Harsanyim Nobelovu cenu za ekonómiu.

${ }^{5}$ [cit. 2021-06-21] Dostupné na internete: http://sk.wikipedia.org/wiki/Nashova rovnov\%C3\%A1ha
} 


\subsection{Prípravná fáza inscenovania}

Základné predpoklady:

- povedat' každý nápad

- vytvorit' pocit osobnej bezpečnosti a dôvery každého účastníka

- v každom prípade priaznivo prijímat’ nápady vyslovené inými a rozvíjat' ich

- spojovat' a zdokonal'ovat' nápady

- nepriznávat' autorstvo nápadov

- neponáhl'at' sa s hodnotením nápadov

- vážit’ si rôznost’ členov kolektívu'

Výber témy

Prvky obsahu nazývame témy (vedúce myšlienky, obrazy, leitmotívy, to o čom sa hovorí). Motívy pre konanie postáv sú abstraktné a univerzálne pojmy (napríklad motív zrady), témy sú na rozdiel od motívov konkrétne a individuálne (napríklad téma Faidrinej ${ }^{7}$ zrady manžela). ${ }^{8}$ Hoci divadelné predstavenie môže mat' akokol'vek nápadité spracovanie alebo ušl'achtilý odkaz (ideu), kvôli neaktuálnosti môže stratit’ svoju hodnotu. Budúci tvorcovia divadelnej inscenácie sa musia naučit' vybrat' aktuálny problém spoločnosti a vediet' ho atraktívne spracovat'. Študenti počas hl'adania vhodnej témy dostávajú rôzne úlohy, aby sa naučili pracovat' a vyhl'adávat' informácie z rôznych zdrojov. Mali by sa naučit' pomenovávat' aktuálne problémy rezonujúce v spoločnosti. Okrem klasických úloh zameraných na prácu s literatúrou, vyhl'adávajú rôzne indície v reálnom živote, vo filmoch, hudbe či výtvarnom umení. Prvou úlohou učitel'a je vybudovat'vzt’ah tvorivého tímu k vybranej téme. Žiaci majú preto za úlohu v prvej fáze inscenovania vyhl'adat' všetky dostupné informácie týkajúce sa vybranej problematiky. Učia sa základným princípom kritického myslenia a triedenia informácií.

Zadefinovanie idey projektu

Jednou z prvých otázok, na ktorú musí vediet' tvorca odpovedat' je, prečo chcú vytvorit' inscenáciu a s akým zámerom. Učitel' si s pomocou žiakov stanoví hlavnú myšlienku projektu, teda ideu. Vo všeobecnosti platí, že tvorcovia by nemali dávat' jednoznačnú odpoved', ale skôr klást' otázky a nabádat' divákov $\mathrm{k}$ diskusii. Inscenátor by však nemal zabudnút' interpretovat' svoj vlastný pohl'ad na zvolenú problematiku, alebo aspoň pohl'ad z perspektívy, do ktorej sa dostal vd'aka štúdiu vybranej problematiky. Po objavení inšpiračných zdrojov tvorivý tím so žiakmi analyzuje ich význam a opodstatnenost'. Následne po zadefinovaní základnej myšlienky pripravovanej inscenácie je ich d’alšou úlohou nájst' správneho príjemcu.

Ciel'ová skupina

Ďalším krokom pri príprave inscenovania projektu je pomenovat' adresáta našej divadelnej výpovede. Zadefinovaním ciel'ovej skupiny je možné zvolit' divadelný jazyk, ktorý je pre zvolenú skupinu l'udí najvhodnejší. Tvorivý tím má za úlohu preskúmat', pre ktorú sociálnu skupinu a vekovú kategóriu sú vybrané témy aktuálne. Žiaci robia prieskum spoločnosti, kontaktujú sa na rôzne skupiny l'udí a zist'ujú, či ich predpoklad o aktuálnosti témy je správny a vhodný pre zvolenú ciel'ovú skupinu.

\footnotetext{
${ }^{6}$ INŠTITORISOVÁ, D. a kol. Peter Scherhaufer-učitel „, šaškü“. Bratislava: BB print, 2006. s. 247

${ }^{7}$ Faidra je postava z gréckej mytológie, ktorá zradí svojho manžela a následne spácha samovraždu

${ }^{8}$ PAVIS, P.: c. d., s. 411
} 


\section{Zber informácií}

Ciel'om týchto hodín je naučit' žiakov efektívne získavat' relevantné informácie o zvolenej problematike. Internet nám ponúka pomerne rýchlo vel'ké množstvo informácií, avšak ich pravdivost' nie je vždy vel'ká. Dôležité je, aby sa žiaci naučili využívat' aj dôveryhodnejšie zdroje pri vyhl’adávaní informácií. Rôzne poznatky, ktoré žiaci skúmaním získajú, môžu využívat' v medzipredmetových prepojeniach, ktoré im ponúkajú nové príležitosti na obohatenie vyučovacieho procesu. Každú tému, ktorú sa chceme pokúsit' zinscenovat', je potrebné poznat' do najmenších detailov a vediet' o nej všetky dostupné informácie. Ak sa napríklad rozhodneme pracovat' s konkrétnou divadelnou hrou alebo adaptovat' známe literárne dielo, mali by sme zozbierat' všetky dostupné informácie o autorovi. Nestačí len prečítat' literatúru, ktorú daný tvorca predlohy napísal, ale dôsledný inscenačný tím si preštuduje všetko o dobe, v ktorej spisovatel' tvoril, o dobe, v ktorej sa príbeh odohráva, o krajine v ktorej sa narodil, mal by poznat' jeho životopis, osobnosti, ktoré ho inšpirovali, životnú filozofiu a ak je dostupná korešpondencia, ktorú autor písal, tvorivý tím by mal podniknút' všetky kroky k jej získaniu.

\section{Tvorba scenára inscenácie}

Pri samotnom vytváraní scenára divadelnej inscenácie je dôležité si určit’ základné dejové fakty. Podrobne vypracovat' štruktúru inscenácie, v ktorej pomenujeme základné konflikty a jednotlivé divadelné obrazy. Následne môžeme študentov rozdelit' do tvorivých tímov. Každý tím dostane divadelný obraz, v ktorom detailne popisuje všetky akcie a ak je to nutné, vymyslí texty pre jednotlivé postavy. Skupiny prezentujú svoje štúdie pred tvorivým tímom. Ak tvorivý tím odsúhlasí návrh, divadelný obraz je pridaný do scenára. V opačnom prípade je návrh vrátený na dopracovanie. Týmto spôsobom sa dá vyhotovit' kompletný scenár projektu. Vol'ba autorského prístupu k vytváraniu scenára v sebe nesie určité riziká, ale tie prevyšujú klady tejto činnosti, pretože členovia inscenačného tímu sa učia tvorivému a kritickému mysleniu, získavajú bližší vzt'ah k zvolenému textu, charakteristike postáv, pomenovávajú konfliktné situácie, motivácie postáv ku konaniu a učia sa budovat' príbehový oblúk.

Výber, charakteristika a analýza postáv

$\mathrm{Na}$ to, aby mal projekt úspech, je dôležité vybrat' hercov, ktorí z fyziologického a psychosomatického hl'adiska budú čo najviac podobní našej predstave o postavách inscenácie. Každý herec má dispozície, ktoré ho predurčujú pre určité typy postáv. Počas prípravy projektu si môžeme vypísat' každú postavu, ktorá zasahuje do deja a dat' jej pracovný názov. Tvorivý tím má potom za úlohu vytvorit' životopis a základnú charakteristiku jednotlivých predstavitel'ov. Následným porovnávaním prirad’ujeme každej postave herca a k nemu aj jednu alternáciu. Hereckí predstavitelia môžu pomenovávat' jednotlivé konania svojich postáv, ktoré vyplývajú z dramatického kontextu. Pomocou pripravených životopisov a charakteristík študenti analyzujú reakcie a motivácie konania jednotlivých postáv. Až po tejto nevyhnutnej teoretickej príprave sa môžu herci začat' učit' texty pridelenej postavy. V divadelnom projekte, kde sa držíme autorského prístupu, je vhodnejší tento spôsob výberu postáv, pretože herci k nim budú mat' bližší vzt'ah a zjednoduší sa im tak práca na postave.

Návrh scény a výber miesta inscenovania

Zvolením témy a idey projektu a základnou analýzou postáv pristupujeme v d’alšom kroku $\mathrm{k}$ navrhnutiu scény pre inscenáciu. Scénografia by mala vychádzat' z témy, idey a umeleckého jazyka, ktorým sa tvorcovia rozhodli komunikovat'. Tvorivá skupina dostane za úlohu na základe získaných informácií navrhnút', ako by mohla vyzerat' scéna, aké rekvizity sú potrebné a pomenovat' vzt'ah výtvarnej koncepcie projektu kzvolenej téme a idey. Pri 
vytváraní tejto zložky inscenácie platí zásada účelovosti, čo znamená, že všetko, čo sa objaví na javisku, by malo mat' svoj význam a opodstatnenie vo vzt'ahu k danému divadelnému obrazu. Pridanou hodnotou pri inscenovaní v školskom prostredí je využívanie scény tak, aby sa predmety a objekty nachádzajúce sa v nej dokázali využit' na viacero spôsobov. Tvorcovia sa tak učia využívat' symbolickost' daného predmetu, čo v konečnom dôsledku nepodporuje len výslednú umeleckú hodnotu projektu, ale hlavne učí študentov nachádzat' nové riešenia inscenačných problémov.

\subsection{Hodiny inscenovania $\mathbf{v}$ priestore}

Práca s divadelnými obrazmi

Divadelnú inscenáciu môžeme rozdelit' do určitých častí - obrazov (z aspektu divadelnej terminológie): „Réžia je vždy ukladanie do obrazu, je viac-menej obrazná a obrazotvorná: namiesto mimetickej figurácie alebo symbolickej abstrakcie dnes často nachádzame scénu vytvorenú sledom nádherných obrazov. “9

Divadelný obraz „Obraz je vôbec najdôležitejším prvkom vášho scenára. Práve v ňom sa odohráva niečo konkrétne. Obraz je konkrétnou jednotkou deja a miestom rozprávania vášho príbehu. "Io je priestorovo vymedzený javiskom, jeho základnými jednotkami sú herci, rekvizity, ktoré herci používajú a scéna. Od výtvarného obrazu sa odlišuje svojou dynamickost’ou a tým, že je trojrozmerný. Základ dobrej inscenácie tvorí bodový scenár, obsahujúci všetky divadelné obrazy, ktoré sa v divadelnom predstavení nachádzajú. Metóda, podl'a ktorej môžeme študentov jednoducho naučit' správne vytvorit' divadelný aranžmán, vychádza z pochopenia situácie, ktorá je jeho základom, správneho výkladu charakterov postáv, ich vzt'ahov a konfliktov. Po zadefinovaní základných pilierov divadelného obrazu študenti tvorivo pristupujú k téme tak, že na javisku vytvárajú statický obraz pomocou vlastných tiel. Musí v ňom byt' zachytený konflikt, jednotlivé postavy, ich vzt'ahy a charaktery. Následne máme útvar, v ktorom študenti využívajú princíp analógií osvojeného z predchádzajúcich hodín. Statický divadelný obraz zachytávajúci určitú situáciu môžeme po chvíli zdynamizovat'. Postavy ožívajú a pokračujú v deji. Učitel' môže obraz posúvat' dopredu, dozadu, zrýchlit', spomalit' alebo opät' zastavit' podl'a toho, či si to daná situácia vyžaduje alebo nie.

Po tom, ako študenti vytvoria a zdynamizujú situáciu z každého obrazu, ktorý si rozvrhli v prípravnej fáze, budú mat' základnú kostru inscenácie hotovú. Následne záleží na učitel'ovi, aby strážil významovú čistotu jednotlivých scén a po porade so študentmi rozhodol, čo ponechá a čo nie. Postupne takto môžeme vyskladat' základnú podobu inscenácie. Po tejto fáze nastane čas prehodnotit' dôležitost' jednotlivých obrazov, ich zrozumitel'nost', invenčnost' a logickú postupnost'. Následne nastáva fáza, kedy neustálym opakovaním a precvičovaním jednotlivých divadelných scén herci získavali istotu vo svojom konaní, divadelné obrazy sa stávali presnejšie a predstavenie sa ,čistíc“ od zbytočných akcií a fráz.

\section{Premiéra inscenácie}

Vyvrcholením inscenovania vo vyučovacom procese je premiéra inscenácie. Samotnou prezentáciou si žiaci môžu overit' reakcie divákov na ich inscenáciu. Uvedením pred obecenstvom (napríklad inou triedou) si študenti nielen overujú svoje počiatočné hypotézy,

\footnotetext{
${ }^{9}$ PAVIS, P.: c. d, s. 284.

${ }^{10}$ FIELD, S. Jak napsat dobrý scenář. Praha: Rybka Publishers, 2007 s. 146
} 
ale hlavne komunikujú tému s ciel'ovou skupinou. Tá im následne poskytne spätnú väzbu, ktorá im pomôže uzavriet' prácu na zvolenej téme pomocou inscenovania.

\section{Použitá literatura}

1. FIELD, S. Jak napsat dobrý scenář. Praha: Rybka Publishers, 2007. 277 s. ISBN 8087067-65-7

2. INŠTITORISOVÁ, D. a kol. Peter Scherhaufer - Učitel „šašků“. Bratislava: BB Print, 2006. 390 s. ISBN 80-969195-1-2

3. PAVIS, P. Divadelný slovník. Bratislava: Divadelný ústav, 2004. 542 s. ISBN 8088987-24-5

\section{Kontaktní údaje}

Mgr. Ladislav Tischler, PhD.

Univerzita Konštantína filozofa v Nitre, Pedagogická fakulta

Trieda Andreja Hlinku 1, Nitra 94901

Tel: 0903716706

email: 1tischler@ukf.sk 


\title{
VZTAH TRIVIALITY A UMĚLECKÝCH HODNOT V DÍLECH DAVIDA WALLIAMSE URČENÝCH DĚTEM A MLÁDEŽI
}

\section{THE RELATION BETWEEN TRIVIALITY AND ARTISTIC VALUES IN CHILDREN'S LITERATURE BY DAVID WALLIAMS}

\author{
Adéla Štěpánková
}

\begin{abstract}
Abstrakt
Př́spěvek se zabývá některými dosud vydanými díly britského spisovatele Davida Walliamse z oblasti literatury pro děti a mládež. Charakterizuje tyto knihy a pro přesnější představu z nich také cituje. Dále shrnuje myšlenky různých autorit zabývajících se trivialitou, uměleckými hodnotami a souvisejícími tématy a hledá vhodnou definici, dle které by bylo možné z uvedeného hlediska posoudit díla $\mathrm{D}$. Walliamse. Cílem příspěvku je provést toto posouzení a prezentovat jeho závěry.
\end{abstract}

Klíčová slova: trivialita, umělecké hodnoty, literatura pro děti a mládež, David Walliams

\begin{abstract}
The article deals with some books which were published by a British writer named David Walliams and belong to the field of literature for children and youth. It characterizes these books and also cites them for a more accurate view. There are also summarized ideas of various authorities dealing with triviality, artistic values and related topics. What is more, the paper also seeks a suitable definition according to which it would be possible to assess the works of Walliams. The aim here is to make the mentioned assessment and to present its conclusions.
\end{abstract}

Key words: triviality, artistic values, children's literature, David Walliams

\section{1 ÚVOD}

Příspěvek se zaměřuje na beletristická díla britského spisovatele Davida Walliamse. Ten se narodil roku 1971 a v současné době náleží k úspěšným spisovatelům literatury pro děti a mládež, napsal pro ně již více než deset románů a věnuje se i dalším typům děl. Jeho knihy se velmi dobře prodávají a jsou překládány do mnoha jazyků, internetová encyklopedie Wikipedie jich uvádí čtyřicet šest. Všechny Walliamsovy knihy jsou od roku 2012, kdy v České repubice vyšel titul Babička drsňačka, př̀kládány také do českého jazyka, v posledních letech dokonce velmi brzy po britském vydání. Bez obtíží lze jeho díla vypůjčit v českých knihovnách, vodděleních pro děti a mládež. Walliamsovy tituly jsou u nás dostupné také v podobě audioknih. S tímto faktem souvisí skutečnost, že Walliamsovo dílo ještě zdaleka není uzavřeno a pravděpodobně se bude dále hojně rozrůstat. Přredmětem předkládaného textu tedy mohou být pouze některé zatím vydané tituly. Př́íspěvek se pokusí přinést odpověd' na otázku: Patři knihy D. Walliamse do oblasti triviální literatury, nebo $v$ nich můžeme nalézt skutečné umělecké hodnoty?

\section{O DÍLE DAVIDA WALLIAMSE}

Knihy Davida Walliamse určené dětským čtenářům působí na první pohled dojmem pokleslejší literatury. Snaži se upoutat čtenářskou pozornost již svým názvem, mnohdy překvapivým - jmenujme např́klad tituly The Boy in the Dress (v češtině Kluk v sukních) 
nebo Gangsta Granny (v češtině Babička drsňačka). Nápadný a lákavý titul knihy je dle Oldřicha Sirovátky jedním ze znaků konzumní literatury. ${ }^{1}$

Při zběžném prolistování Walliamsovými knihami zaujme potenciální čtenáře i grafické řešení publikací. Knihy jsou totiž bohatě ilustrovány, i když většina z nich jen černobíle, a stř́dají se v nich různé styly a velikosti písma. Pro obálky knihy je typická pestrobarevnost, lákavé obrázky a nápisy. Jedna z knih např́klad přitahuje pozornost nápisem na obálce, který oznamuje, že uvnitř se nachází obrovský diamant, u malé hvězdičky se nalézá vysvětlení, že je pouze na obrázku. Jiná kniha zase inzeruje, že obsahuje auto označované př́izviskem mini. Tyto nápisy cílí na dětského čtenáře jako reklama a prímo ho nutí knihu otevřít a podívat se, jak takové nabízené bonusy vypadají. Možná se zde skrývá i jakýsi obchodní trik, přáním některých dětí by mohlo být pořídit si knihu právě kvůli těmto bonusům, ve kterých by mohly spatřovat zisk bohatství.

D. Walliams bývá přirovnáván ${ }^{2} \mathrm{k}$ anglickému prozaikovi norského původu Roaldu Dahlovi (1916-1990). Ten, jak uvádí Vlasta Řeřichová, pro dětské čtenáře vytvořil mnoho pohádkových př́běhů, ve kterých osobitě zpracoval některá obvyklá témata. Dahlovi hrdinové např́iklad již ztratili jednoho nebo oba rodiče. V. Řeřichová uvádí charakteristické rysy autorovy tvorby: „K typickým znakủm jeho pohádek patří prolínání reality a fantazie, hyperbola a nonsens.“ Komentář věnuje také recepci Dahlových děl: „Dospělými byly pohádky často přijímány s rozpaky a byly považovány za ,nevýchovné‘. Dětské čtenáře si však autor získal osobitým humorem balancujícím na hranici ironie a satiry i schopností vcítit se do jejich myšlení.“ Velká část jeho knih obsahuje ilustrace Quentina Blakea. ${ }^{3}$

Také první dva tituly D. Walliamse (Kluk v sukních, Pan Smrad'och) ilustroval tento umělec. Další Walliamsovy knihy již zdobí ilustrace, které vytvořil Tony Ross. Příběhy bývají vyprávěny v er-formě. Typickým hrdinou Walliamsových knih je chlapec ve věku jedenácti či dvanácti let, existují i př́běhy s hlavní hrdinkou totožného věku. Tyto postavy bývají označovány jménem i prŕíjmením a jejich věk bývá v textu přímo uváděn. Dětští čtenáři se tedy snadno mohou identifikovat s hlavními představiteli. Knihy jsou srozumitelné i dětem v nižším věku, než se právě nachází hrdinové prríběhů.

Příběhy bývají zasazovány do čtenáři dobře známých míst, místem děje se tak stává například domov hlavního hrdiny, škola, obchod, zubní ordinace, muzeum nebo nemocnice. Některé části příběhů se odehrávají i v méně obvyklých lokalitách, ku prríkladu v sídle mafiána, na závodní dráze nebo ve starém dole.

Ve Walliamsových knihách je zpracováno velké množství závažných témat. Jmenujme třeba nemoc a smrt prarodiče v knihách Babička drsňačka a Dědečkův velký útěk. V obou př́padech se dětští hrdinové musí vyrovnat $\mathrm{s}$ tím, že jejich prarodiče jsou nemocní a následně zemřou. Postava babičky drsňačky podlehne rakovině, postavu dědečka Buntinga evidentně trápí Alzheimerova choroba, i když nemoc v textu není př́mo pojmenována. Způsob, jakým se oba

\footnotetext{
${ }^{1}$ SIROVÁTKA, Oldřich. Literatura na okraji. Praha: Československý spisovatel, 1990, s. 48-49.

${ }^{2} \mathrm{~S}$ touto informací se setkáváme například na titulní straně českého vydání knihy Babička drsňačka. Sám D. Walliams vliv R. Dahla na své dílo nerozporuje, viz např́íklad THOMAS, Sarah. How Little Britain's David Walliams became the new Roald Dahl. The Sydney Morning Herald [online]. 2015 [cit. 2021-01-01]. Dostupné z: https://www.smh.com.au/entertainment/books/how-little-britains-david-walliams-became-the-new-roald-dahl20150521-gh6hhl.html

3 ŘEŘICHOVÁ, Vlasta. DAHL Roald. In: ŘĚrICHOVÁ, Vlasta., SLADOVÁ, Jana., VÁŇOVÁ, Kateřina., HOMOLOVÁ, Kateřina. Literatura pro děti a mládež anglicky mluvících zemí. Olomouc: Hanex, 2008, s. 315.
} 
dětští hrdinové s touto rodinnou ztrátou vyrovnávají, může být pro dětské čtenáře nápomocný při zvládání obdobné životní situace v realitě.

Dětským hrdinou knihy Babička drsňačka je jedenáctiletý Ben, pro ilustraci uved’me ukázku z textu, která popisuje jeho poslední chvíle strávené s babičkou: „Za dvě hodiny už Ben, máma a táta stáli u babiččiny postele. Byla v hospicu, to je zařizení pro lidi, pro které už $v$ nemocnici nemůžou nic udělat. Moc života jí nezbývalo. Snad hodiny. Sestry řikaly, že může každou chvilku odejit.

Ben si celý vylekaný sedl vedle babiččiny postele. I když měla zavřené oči a zřejmě nemohla mluvit, jen sedèt s ní v té místnosti byl strašně silný zážitek.

Táta precházel před posteli tam a zpátky a nevéděl, co dělat nebo říct.

Máma sedéla, dívala se a pripadala si bezmocná.

Ben prostě držel babičku za ruku.

Nechtěl, aby do té temnoty odešla sama.

Poslouchali její chraplavý dech. Byl to strašný zvuk. Ale jen jedna věc byla ještě horší.

Ticho.

To bude znamenat, že odešla.

Pak $k$ překvapení všech babička zamrkala a otevřela oči. Usmála se, když ty tři viděla.

,Mám... hlad, 'řekla třaslavým hlasem. Sáhla pod pokrývku a vytáhla něco zamotaného do potravinárské fólie. Začala to rozbalovat.

,Co to je?'zeptal se Ben.

,Kus kapustového koláče, 'sípala babička. ,Jidlo je tady strašné. '

Chvilku nato si máma s tátou šli do automatu pro kávu. Ben nechtěl od babičky odejít ani na vteřinu. Natáhl se a vzal ji za ruku. Byla suchá a strašně lehká.

Babička se k němu pomalu obrátila. Ben viděl, že moc času jí už nezbývá. Mrkla. ,Vždycky budeš můj malý Beník, 'zašeptala.

Ben si vzpomněl, jak to jméno nenáviděl. Ted’ se mu strašně líbilo. ,Já vím, ' usmál se. ,A ty vždycky budeš moje babička drš̌ačka. " "“4

Kniha Dědečkưv velký útěk se dotýká také další závažné problematiky, a to péče o seniory. Dědeček je v průběhu děje umístěn do domova důchodců, ve kterém staří lidé vinou majitelky a personálu opravdu trpí. Autor tyto útrapy popisuje s velkou nadsázkou, někdy až komicky, což je ale s ohledem na cílového čtenáře pochopitelné. Hlavní hrdina pomůže dědečkovi a dalším obyvatelům domova uprchnout na svobodu. Způsob, jakým to uskuteční, je opravdu nereálný. Stejně tak postava dědečka podniká bláznivé kousky, které by se v běžném životě $\mathrm{v}$ popsané podobě odehrát nemohly. Dětského čtenáře by pasáže $\mathrm{z}$ knihy věnující se péči o seniory mohly vést $\mathrm{k}$ tomu, aby se začal zajímat o to, v jakých podmínkách žijí jeho prríbuzní, kteří se už o sebe nejsou schopni sami postarat.

Walliams píše stejně jako výše jmenovaný Roald Dahl o dětech, které jsou sirotky či polosirotky. S takovým osudem se potýkají dětští hrdinové knih Ď́belská zubařka a Př́išerná teta. Alfie z knihy Ďábelská zubařka svou matku ani nepoznal, protože zemřela při porodu. Žije s nemocným otcem, ten v závěru př́běhu hrdinsky umírá. Alfieho se ujme jeho sociální pracovnice, která později uzavře manželství s trafikantem Rádžem, postavou objevující se napříč Walliamsovými knihami. Hrdina se dostává do dobrých rukou. V tomto příběhu je tedy řšena také problematika adopce.

\footnotetext{
${ }^{4}$ WALLIAMS, David. Babička drsňačka. Praha: Argo, 2012, s. 237-239.
} 
Méně št'astný osud připravil autor hrdince knihy Př́šerná teta, Stelle. Ta vyrůstá v úplné rodině, idylu ale ukončí autonehoda, při které oba rodiče umírají. O Stellu se stará její zlá teta, jejímž cílem je jakýmkoli způsobem získat pro sebe rodinné sídlo. Ve svém plánu se před ničím nezastaví, Stella postupně odhalí, že zapř́íinila i smrt jejích rodičů. I Stella se nakonec ocitne $\mathrm{v}$ bezpečném prostředí, a to $\mathrm{v}$ sirotčinci. Tento př́běh poukazuje také na to, že by lidé neměli podepisovat nic, co si dopředu nepřečtou. Stella zde působí jako pozitivní vzor pro dětského čtenáře.

Následující ukázka zachycuje situaci, kdy se Stellina př́íšerná teta Alberta vydává za detektiva Strausse: „, Samozřejmě budu muset podat hlášení, až se do Scotland Yardu vrátím. Takže potřebuji, abyste mi podepsala prohlášeni, které jsem připravil. '

,Prohlášení?' opakovala Stella.

,Ano, slečno, to je standardní policejní procedura. Semhle dolů napište datum a podepište to. ' Detektiv ji zamával před obličejem nějakým oficiálně vyhližejícím dokumentem, ale pak ho otočil tak rychle, že si ho nemohla prečist.

,Co v něm je?' Otec vždycky Stellu učil, aby nepodepisovala nic, co si nejdř́v důkladně neprečte.

„Jaké ,co v něm je'? Je to shrnutí vaši výpovědi, slečno. A potvrzuje, že berete svá obvinění zpátky, protože jste si uvědomila, že to je úplný a naprostý nesmysl. ‘

"Není to nesmysl!"

,Je to nesmysl.'

,Není!

,Je!"

,Ne! ‘

,Jo!

,NE! ‘

,JO! ‘

Kdyby Stella s touhle slovní přestřelkou nepřestala, táhla by se až do večera. ,Tohle začiná být trochu dètinské, detektive Straussi. A krom toho, pokud mám vůbec uvažovat, že bych něco podepsala, musím si to nejdřiv prečist. '

Detektiv začal rudnout a vytáhl z kapsy tlusté černé pero. S každým proneseným slovem bodl jeho zlatou špičkou směrem k holčičce. Stella polkla. Bála se, že ji bodne doopravdy.

,PODEPIŠTE. TO. PROHLÁŠENÍ. ‘

,Nejdřiv si ho prěčtu! “.

V knihách jsou řešena i další závažná témata, např́klad vážná nemoc dítěte (Pưlnoční gang), homosexualita a fyzické zdravotní postižení (Táta za všechny prachy), bezdomovectví (Pan Smrad’och), negativní vliv špatného nakládání s velkým majetkem, šikana a kamarádství (Malý miliardář ). V některých titulech se pracuje také $\mathrm{s}$ tématem pokřivených vztahů mezi rodiči hlavních hrdinů (např́klad Táta za všechny prachy, Pan Smrad’och, Dědečkův velký útěk). Tyto disharmonické vztahy mezi rodiči pochopitelně mají vliv na jejich potomky. Zde je na místě upozornit na skutečnost, že v textu je vina za špatné vztahy vždy spíše svalována na postavu matky. Např́iklad je to matka, kdo odchází od rodiny k milenci, jindy je to matka, která se snaží v rodině vládnout a upřednostňuje své zájmy, nebo je to matka, která hledá řešení přijatelná především pro ni samotnou. Partneři takových matek bývají zobrazováni jako chudáci, čtenár je veden $\mathrm{k}$ tomu, aby mu byli sympatičtí a aby s nimi soucítil. Např́klad o otci Jacka Buntinga z knihy Dědečkưv velký útěk se čtenáři dozvídají následující informaci: „Byl

\footnotetext{
${ }^{5}$ WALLIAMS, David. Př́íserná teta. Praha: Argo, 2015, s. 253-255.
} 
hubený a bledý, nosil brýle a vypadal starší, než byl. Jeho syn si občas říkal, jestli to nemůže být tím, že je ženatýs mámou. “"

Nutno podotknout, že toto černobílé zobrazování postav bývá v některých dílech alespoň vyváženo částečnou nebo úplnou možností rodinné vztahy napravit. Tak se stane ku př́kladu v knize Pan Smrad'och, kde se stejnojmenná postava prričiněním dívky Chloe ocitne v centru její rodiny. Postupně se díky němu rodinné vztahy urovnají a zlepší. Ve chvíli, kdy rodina začne fungovat ideálně, od ní tulák dobrovolně odejde.

Pokud se v textu objeví složitější termín nebo výraz, kterému by dětský čtenář nemusel automaticky porozumět, bývá jasně vysvětlen, aniž by to ohrozilo děj vyprávění. Př́íkladem takového vysvětlení je např́klad slovo hospic použité v knize Babička drsňačka v citaci uvedené výše. Obsáhlejší objasnění se nachází v knize Dědečki̊v velký útěk, v její závěrečné části je otištěn srozumitelný slovníček, který čtenáře seznamuje s pojmy souvisejícími s 2 . světovou válkou. Té se totiž v mládí účastnil hrdinův dědeček a kvůli své nemoci žije v domnění, že tento válečný konflikt právě probíhá.

\section{O TRIVIALITĚ A UMĚLECKÝCH HODNOTÁCH}

Svatava Urbanová řadí do sféry triviální literatury např́íklad detektivní romány, strašidelné povídky, thrillery, westerny, fantasy a sci-fi. Autor a čtenár triviální literatury si podle ní tuto oblast samostatně vybírají, nacházejí se v ní tedy dobrovolně. Neznamená to, že by nějak klesli. Termínem triviální literatura označuje takovou „literaturu, kterou autor vytváŕí zcela vědomě, protože chce čtenáře bavit a ten ji vyhledává, aby prožíval krajní emoce strachu a lásky, dostával se jejím prostřednictvím do neznámých světů, do ,jiné ‘ prostorové dimenze, prožil dobrodružství s úlevným rozuzlením. “7

Ladislava Lederbuchová uvádí, že pojem triviální literatura změnil v průběhu času význam. Původně se jednalo o „označení literatury prozaické, pokládané antickou poetikou za umění nižšího, lidového stylu“. Pro moderní dobu už je typické, že označení triviální literatura je určeno „pro literaturu umělecky substandardní, pokleslou na naplňování a obměňování kompozičních schémat". Takovou literaturu autorka označuje jako bulvární, či jako brak nebo kýč. ${ }^{8}$ Tyto tři oblasti se od sebe dle L. Lederbuchové odlišují např́iklad dominantní literární funkcí. U bulvární literatury převládá funkce zábavná a relaxační, pro brak je typické to, že pracuje s pudy, u kýče převažuje funkce emocionální. Ve svůj prospěch využívá citové vzrušení, tedy jednu z potřeb čtenáře. Čerpá proto z reálných okamžiků, které automaticky souvisí s emocemi, aniž by je bylo nutné umělecky zpracovávat. Jako př́klady autorka uvádí lásku, neštěstí a smrt. ${ }^{9}$

Také Lexikon teorie literatury a kultury upozorňuje v oblasti literatury na podobnost triviální literatury a kýče. Vznik slova kýč autoři hesla datují do poslední třetiny 19. století, konkrétně zmiňují rok 1875 a umělecké kruhy v Mnichově. Tento výraz podle nich označuje „stylistické a estetické znehodnocení“. Dále uvádí, že „pranýřruje př́slušné užitkové předměty, předměty

\footnotetext{
${ }^{6}$ WALLIAMS, David. Dědečkův velký útěk. Praha: Argo, 2016, s. 60.

7 URBANOVÁ, Svatava. Triviální literatura ve světle emocí. In: URBANOVÁ, Svatava. Meandry a metamorfózy dětské literatury. Olomouc: Votobia, 2003, s. 292-293.

${ }^{8}$ LEDERBUCHOVÁ, Ladislava. Triviální literatura. In: LEDERBUCHOVÁ, Ladislava. Průvodce literárním dílem. Výkladový slovník základních pojmů literární teorie. Jinočany: H\&H, 2002, s. 333.

9 LEDERBUCHOVÁ, Ladislava. Kýč. In: LEDERBUCHOVÁ, Ladislava. Prưvodce literárním dílem. Výkladový slovník základních pojmů literární teorie. Jinočany: H\&H, 2002, s. 165-167.
} 
užitého umění, umělecké a kulturní produkty jakož i city jako umělecky nízké, klišovité, přepjaté a nepravé, ba bezduché a vylhané.“10

Lze souhlasit s konstatováním Hermanna Brocha, že lidé jsou s kýčem v hojném kontaktu. Broch přemýšlí o tomto fenoménu a jeho myšlenky se pohybují v oblasti filozofie umění. Kýč podle něj nemá jen jednu podobu, rozeznává např́iklad kýč špatný, dobrý či geniální. Tvrdí o něm, že představuje „zlo v hodnotovém systému umění“, ale popisuje ho jako přirozenou součást umění a života, ne jako negativní jev, který je nutné vymýtit. ${ }^{11}$

Brochovy ideje zmiňuje ve svém díle také Umberto Eco. Ten na adresu kýče poznamenává mimo jiné následující dobře srozumitelnou myšlenkou vyjádřenou pomocí zdařilého přirovnání: „Kýč coby lehce stravitelný Ersatz (náhrada, pozn. AŠ) umění se logicky nabízí jako ideální strava pro lenivé publikum, které by rádo přilnulo $\mathrm{k}$ ideálům krásy a samo sebe přesvědčilo, že jich užívá, aniž by marnilo energii v nějakých nesnázích.“12

Poznatky týkající se umění představuje zajímavým způsobem Miroslav Míčko, nechává je totiž vyslovovat různé postavy ve fiktivních rozhovorech. Jedna z těchto postav se trefně táže: „Ale jak určit spolehlivě hranici, kde umění přestává a začíná kýč? Máme tento pojem omezit na nejodpornější projevy nevkusu, na pornografie a krváky, na komické strakatiny za výkladní skříní předměstských sklenářù, na sentimentální šlágry z operet, na repertoár venkovské šmíry, na nemožné slátaniny toho druhu, které zrovna volají do nebe?" A ve své řeči dále pokračuje: „Přiznáte jistě, že je třeba posunout hranici výš, až tam, kde se pro méně pěstěný cit stává neznatelná, kde nevkus a zkaženost užívá jemnějších šminků. Kýč je název moderní a mohlo by se se značným oprávněním říci, že i věc, již označuje, je nová - alespoň ve svém zdůraznění a ve svém hromadném výskytu je to produkt XIX. století, jev zpovrchnělé kultury, jeden z rysů komercialistického věku. Je to umění nové společenské trrídy, již vynesl hospodářský rozmach, lidí přes noc zbohatlých a vytržených z kořenů, je to kulturní allura parvenuů. A právě v tom, že se kýč dovede tvářit kulturně, je nesnáz jeho rozpoznání.“13 Když se ke slovu dostává další postava, věnuje se i znakům kýče: „Prvním znamením kýče je, že se líbí, že se chce líbit. Sahá neostyšně po všem, co mu může dopomoci $\mathrm{k}$ tomuto cíli. Proto ve své řeči volí výrazy křiklavé a dráždivé a přitom co nejotřelejší, aby nedělaly potíží čitelnosti. Umí prŕijemně pošimrat, polaskat, rozveselit, nahnat mráz hrůzy, dojmout až k slzám, umí se vlísat a vlichotit v přízeň svého publika, jemuž co nejponíženěji služebníčkuje. Je to umění ulízané, napomádované a nalíčené, znemravnělé a koketní, v obojím smyslu prodejné: i že se lehko prodává, i že je vyráběno s myšlenkou na prodej. Nežádá od svého diváka, čtenáře, posluchače, jedním slovem zákazníka, nejmenší námahy a duševního úsilí, nechce být dobýváno, ale vydává se samo a napoprvé jako holka z ulice. Obrací se k jeho nejpřístupnějším pudům. Nabízí mu jako sladkou limonádu obarvenou a parfémovanou močủvku, lže mu a chlácholí a opíjí ho, zastírá mu životní skutečnost lichým přeludem. Ne že by se skutečné umění nesmělo líbit, ne že by muselo být nesrozumitelné. Vždyt' často bývá tak prosté, vždyt' dovede leckdy hovořit i k dítěti! Ale prostota, jíž někdy dosáhne opravdový umělec, není šestáková jako prostota kýče, není zadarmo ani pro něho, ani pro jeho obecenstvo.“" ${ }^{14}$ Další z postav upozorňuje na skutečnost, že na kýč bychom neměli

\footnotetext{
${ }^{10}$ VOLKMANN, Laurenz., TRÁVNÍČEK, Jiří. Kýč. In: NÜNNING, Ansgar., TRÁVNÍČEK, Jiří., HOLÝ, Jiří. (eds.) Lexikon teorie literatury a kultury: koncepce, osobnosti, základní pojmy. Brno: Host, 2006, s. 434.

${ }^{11}$ BROCH, Hermann. Několik poznámek k problému kýče. In: BROCH, Hermann. Román - mýtus - kýč. Eseje. Praha: Dauphin, 2009, s. 55-78.

${ }^{12}$ ECO, Umberto. Skeptikové a těšitelé. Praha: Svoboda, 1995, s. 79.

${ }^{13}$ MÍČKO, Miroslav. Umění nebo život. Rozhovory a vyznání. 2. vyd. Praha: Academia, 2004, s. 110.

${ }^{14}$ MÍČKO, Miroslav. Umění nebo život. Rozhovory a vyznání. 2. vyd. Praha: Academia, 2004, s. 112-113.
} 
nahlížet pouze negativně: „Jeho výmluvnost, proto tak sugestivní, že je tak banální, by z něho mohla činit užitečného kulturního prostředníka, protože mu otvírá přístup do nejširších vrstev." “15

Karel Krejčí poznamenává, že přesná definice kýče i přes četné diskuze zatím nebyla vytvořena. V literární oblasti připodobňuje kýč k plebejci. Ten se podle něj vloudil do lepší společnosti a pokouší se skrýt, odkud pochází. A to tak, že kopíruje zvyklosti prostředí, ve kterém se ocitl. Pro tohoto plebejce užívá rovněž výrazy snob a parvenu. ${ }^{16}$ Také Tomáš Kulka konstatuje, že definovat estetickou kategorii kýče není jednoduché. ${ }^{17}$

V oblasti literatury pro děti a mládež poskytuje vysvětlení pojmu triviální literatura např́íklad Jaroslav Toman, který podává její definici takto: „Triviální literaturu lze obecně charakterizovat jako typ masové produkce s výhradně zábavnou a relaxační funkcí, postrádající tvưrčí invenci, původnost a uměleckou kvalitu, vyznačující se konvenčními př́stupy, atraktivními náměty, obsahovou srozumitelností, nekomplikovaným, iluzorním a idealizovaným obrazem skutečnosti, syžetovými schématy a stereotypy, jednostrannou orientací na dobrodružný děj, happyendovým zakončením př́iběhů, zjednodušenou povahokresbou postav, neobvyklým prostředním a jazykovými klišé. Tato literatura se podbízí zvláště nenáročným čtenářum a manipulačně jim vnucuje deformované pojetí života a světa. Zároveň je utvrzuje v jejich čtenářských preferencích. Svým autorům a vydavatelům zaručuje maximální čtenářský úspěch a peněžní zisk.“18

\section{TRIVIÁLNÍ A UMĚLECKÉ PRVKY V DÍLE DAVIDA WALLIAMSE}

Výše zmíněná Tomanova definice se, jak již bylo zmíněno, týká přímo literatury pro děti a mládež, $\mathrm{z}$ tohoto důvodu z ní budeme dále čerpat. Jeví se nám jako nejvhodnější vymezení zkoumaného jevu, její obsah použijeme pro srovnání s typickými znaky Walliamsových děl. Pro přehlednost jsou informace zpracovány do následující tabulky.

\section{Tab. č. 1: Srovnání rysů triviální literatury se znaky děl D. Walliamse}

\begin{tabular}{|c|c|}
\hline Rysy triviální literatury dle J. Tomana & Ne/odpovídající znaky děl D. Walliamse \\
\hline $\begin{array}{l}\text { „masová produkce s výhradně zábavnou a } \\
\text { relaxační funkcí“ }\end{array}$ & $\begin{array}{l}\text { Knihy D. Walliamse vycházejí ve velkém } \\
\text { nákladu v mnoha zemích, jejich produkci by } \\
\text { tedy bylo možné označit adjektivem } \\
\text { masová. Příběhy mají funkci zábavnou a } \\
\text { relaxační, ale uplatňují se v nich rovněž } \\
\text { další funkce, například informativní a } \\
\text { formativní, a to v nezanedbatelné míře. }\end{array}$ \\
\hline $\begin{array}{l}\text { „postrádající tvůrčí invenci, původnost a } \\
\text { uměleckou kvalitu““ }\end{array}$ & $\begin{array}{l}\text { Autor bývá označován jako „nový Roald } \\
\text { Dahl““, sám přiznává, že tento spisovatel pro } \\
\text { něj je inspirativní. Walliamsovy knihy ale } \\
\text { obsahují originální př́běhy, ve kterých se } \\
\text { čtenář setkává s různými vtipnými nápady a } \\
\text { vynalézavostí hrdinů. }\end{array}$ \\
\hline $\begin{array}{lcr}\text { „vyznačující se } & \begin{array}{c}\text { konvenčními přístupy, } \\
\text { náměty, obsahovou } \\
\text { atraktivními } \\
\text { srozumitelností, }\end{array} & \text { nekomplikovaným } \\
\end{array}$ & $\begin{array}{l}\text { Některé uvedené body Walliamsova tvorba } \\
\text { splňuje, a to např́klad atraktivní náměty a } \\
\text { obsahovou } \quad \text { srozumitelnost. }\end{array}$ \\
\hline
\end{tabular}

\footnotetext{
${ }^{15}$ MÍČKO, Miroslav. Umění nebo život. Rozhovory a vyznání. 2. vyd. Praha: Academia, 2004, s. 115.

${ }^{16}$ KREJČÍ, Karel. Sociologie literatury. Praha: Grada, 2008, s. 94.

${ }^{17}$ KULKA, Tomáš. Uméní a kýč. 3. vyd. Praha: Torst, 2014, 292 s.

${ }^{18}$ TOMAN, Jaroslav. Trivialita a kýč v literatuře pro děti a mládež. Brno: Cerm, 2000, s. 3-4.
} 


\begin{tabular}{|c|c|}
\hline 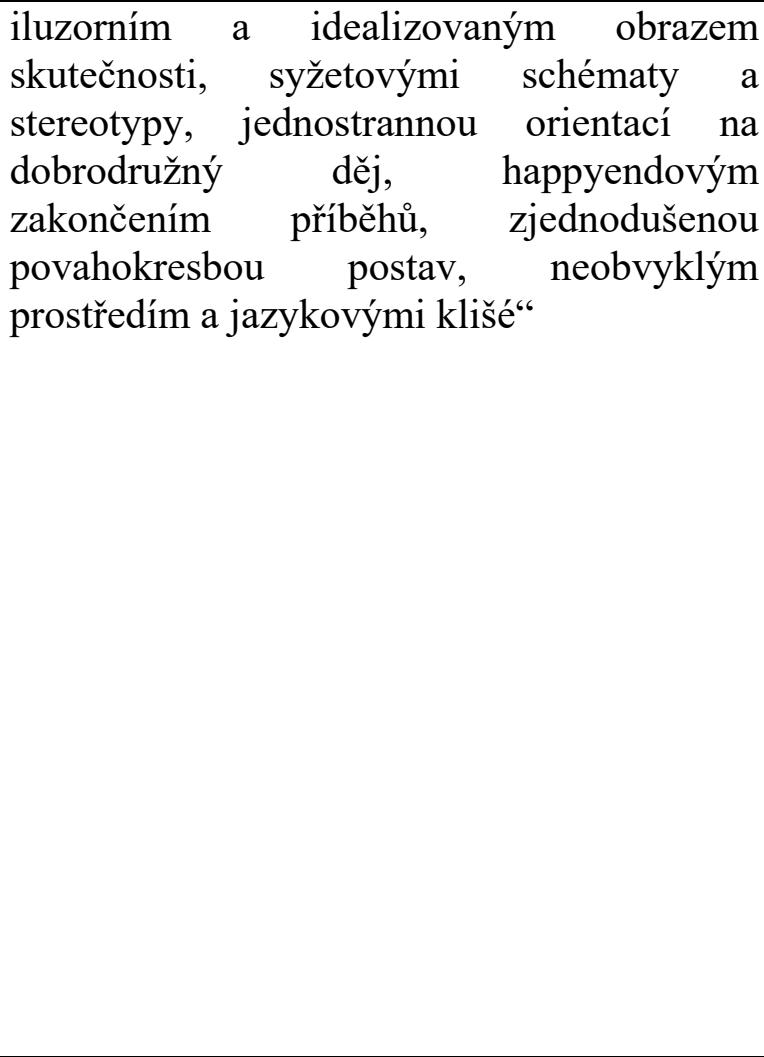 & $\begin{array}{l}\text { skutečnosti sice bývá zobrazen nereálně, ale } \\
\text { není idealizovaný, hrdinové prožívají i } \\
\text { nepř́ijemnosti a vyrovnávají se } \\
\text { s komplikovanými situacemi, které často } \\
\text { dopředu nemohli ovlivnit. Děj představuje } \\
\text { důležitou složku Walliamsových děl, ovšem } \\
\text { nezáleží pouze na něm, důraz je kladen i na } \\
\text { zpracovávaná témata. Příběhy jsou } \\
\text { umist'ovány velkou měrou do cutenáři } \\
\text { známých míst, některé jejich části se } \\
\text { odehrávají v méně př́istupných lokalitách, } \\
\text { jako je domov mafiána nebo starý důl. Díla } \\
\text { se vyznačují dobrým koncem, ne vždy jde } \\
\text { ale o typický happyend, hrdina často musí } \\
\text { něco obětovat, nebo je nenávratně } \\
\text { poznamenán nějakým životním zážitkem. } \\
\text { Důležité postavy prríběhů bývají pomocí } \\
\text { postupů př́mé i nepř́mé charakteristiky } \\
\text { představeny barvitě, jejich chování odpovídá } \\
\text { i jejich vyjadřování, např́klad typickým } \\
\text { rysem pro trafikanta Rádže je komolení } \\
\text { jmen a názvů. }\end{array}$ \\
\hline $\begin{array}{l}\text { „podbízí se zvláště nenáročným čtenářům a } \\
\text { manipulačně jim vnucuje deformované } \\
\text { pojetí života a světa, zároveň je utvrzuje } \\
\text { v jejich čtenářských preferencích“ }\end{array}$ & $\begin{array}{l}\text { Texty se svým čtenářům přizpůsobují a jsou } \\
\text { psány tak, aby si je udržely a aby bylo vše } \\
\text { naprosto jasné. Od čtenáře se vlastně } \\
\text { nevyžaduje čtení mezi řádky nebo nějaké } \\
\text { výraznější domýšlení skutečností. Život a } \\
\text { svět je popisován s nadsázkou, ovšem nelze } \\
\text { tvrdit, že by jejich pojetí bylo vyloženě } \\
\text { deformované. Je pouze upravené v souladu } \\
\text { se záměrem díla a s ohledem na věk cílové } \\
\text { skupiny čtenářu. }\end{array}$ \\
\hline $\begin{array}{l}\text { „Svým autorům a vydavatelům zaručuje } \\
\text { maximální čtenářský úspěch a peněžní zisk“ }\end{array}$ & $\begin{array}{l}\text { Ano, s tímto bodem je možné zcela } \\
\text { souhlasit. }\end{array}$ \\
\hline
\end{tabular}

Díla D. Walliamse sice částečně nebo zcela naplňují některé z rysů triviální literatury uvedené v definici J. Tomana, není ale možné je pojmem triviální literatura označit. Ve spoustě ohledů do této skupiny děl totiž nenáleží. Pravděpodobně nejvýstižnější bude konstatovat o tvorbě $\mathrm{D}$. Walliamse to, že se vyznačuje i některými prvky typickými pro triviální literaturu, produkce knih je masová a jejich obsah bývá čtenáři zcela srozumitelný, nevede je k hlubšímu přemýšlení nad textem.

J. Toman zformuloval také definici umělecky hodnotné literatury. Je méně obsáhlá než definice literatury triviální. Toman říká, že „umělecky hodnotná, tzv. vysoká literatura je naopak originální, problémová, druhoplánová, nesnadno pochopitelná, vyvolává pochybnosti, klade otázky, připouští různost interpretací. Oslovuje především kulturní a zainteresované čtenáře, obráží se v ní umělecký a literární vkus doby, stává se trvalým objektem literárněvědného zkoumání a kritické reflexe.“19

\footnotetext{
${ }^{19}$ TOMAN, Jaroslav. Trivialita a kýč v literatuře pro děti a mládež. Brno: Cerm, 2000, s. 4.
} 
Tab. č. 2: Srovnání rysů umělecky hodnotné literatury se znaky děl D. Walliamse

\begin{tabular}{|c|c|}
\hline $\begin{array}{l}\text { Rysy umělecky hodnotné literatury dle J. } \\
\text { Tomana }\end{array}$ & Ne/odpovídající znaky děl D. Walliamse \\
\hline $\begin{array}{l}\text { „originální, problémová, druhoplánová, } \\
\text { nesnadno pochopitelná“ }\end{array}$ & $\begin{array}{l}\text { Díla D. Walliamse mají svou inspiraci, } \\
\text { obsahují ale originální př́iběhy a } \\
\text { zpracovávají aktuální společenská témata. } \\
\text { Čtenáři dílům snadno porozumí, ale zvraty } \\
\text { v př́íběhu je dokáží překvapit. I když se } \\
\text { někdy zdá, že je jasné, jak se bude děj dále } \\
\text { vyvíjet, ne vždy tomu tak skutečně je. }\end{array}$ \\
\hline $\begin{array}{l}\text { „Vyvolává pochybnosti, klade otázky, } \\
\text { připouští různost interpretací“ }\end{array}$ & $\begin{array}{l}\text { Př́iběhy lze ve velké většině případů } \\
\text { interpretovat jednoznačně a nedá se říci, že } \\
\text { by díla vyvolávala pochybnosti. Otázky } \\
\text { přímo neklade, ale otevírá závažná témata. }\end{array}$ \\
\hline $\begin{array}{l}\text { „oslovuje především kulturní } \\
\text { zainteresované čtenáře, obráží se v ní } \\
\text { umělecký a literární vkus doby, stává se } \\
\text { trvalým objektem literárněvědného } \\
\text { zkoumání a kritické reflexe“ }\end{array}$ & $\begin{array}{l}\text { Walliamsovy knihy oslovují nejen kulturní a } \\
\text { zainteresované čtenáře, ale zaujmou i ty } \\
\text { méně zdatné. Mezi dětskými čtenáři jsou } \\
\text { oblíbené, takže lze konstatovat, že zrcadlí } \\
\text { literární vkus současné doby. O tom, zda } \\
\text { bude tato tvorba trvale v hledáčku literární } \\
\text { vědy zatím nelze rozhodnout. }\end{array}$ \\
\hline
\end{tabular}

Tvorba D. Walliamse jednoznačně nespadá ani do kategorie umělecky hodnotné literatury, opět naplňuje pouze některé její rysy. Jedná se o originální díla, která v nějakém ohledu reagují na aktuální společenská témata a odpovídají literárnímu vkusu současných dětských čtenářů.

\section{ZÁVĚR}

Knihy Davida Walliamse obsahují na první pohled triviální příběhy. Tyto texty ale zpracovávají také společensky závažná témata, např́íklad nemoc, odchod ze života nebo homosexualitu. Své čtenáře o nich srozumitelným způsobem informují a snaží se jim prostřednictvím literárních postav ukázat, jak je na ně možné reagovat. Některé postavy tedy mohou působit jako pozitivní vzory s formativní funkcí. Nelze se jimi ale inspirovat doslovně, protože $\mathrm{v}$ př́ibězích se hojně pracuje s přeháněním a nereálnými situacemi. Autor kombinuje skutečnost s nadsázkou, a tím ji přibližuje dětskému čtenáři a přispívá $\mathrm{k}$ rozvoji jeho představivosti, zároveň se přizpůsobuje jeho věku a částečně se mu i podbízí. Pro správné vyznění děl je proto důležité, aby dětští čtenáři byli v textu schopni správně odlišit realitu od umělecké fikce. Některé skutečnosti jsou v textech zobrazovány stereotypně. Můžeme konstatovat, že romány $\mathrm{D}$. Walliamse určené dětskému čtenáři zároveň obsahují prvky umělecké i triviální literatury a tyto prvky jsou v díle různými způsoby propojeny.

Příspěvek vznikl v rámci projektu IGA_PdF_2021_020 Učitelská reflexe literární výchovy na 2. stupni Z $\breve{S}$ jako nástroj optimalizace výuky.

\section{Použitá literatura}

1. BROCH, H. Několik poznámek k problému kýče. In: BROCH, H. Román - mýtus kýč. Eseje. Praha: Dauphin, 2009. S. 55-78. ISBN 978-80-7272-215-0.

2. ECO, U. Skeptikové a těšitelé. Praha: Svoboda, 1995. 417 s. ISBN 80-205-0472-9.

3. KREJČÍ, K. Sociologie literatury. Praha: Grada, 2008. 160 s. ISBN 978-80-2472623-6. 
4. KULKA, T. Umění a kýč. 3. vyd. Praha: Torst, 2014. 292 s. ISBN 978-80-7215-477-7.

5. LEDERBUCHOVÁ, L. Prưvodce literárním dílem. Výkladový slovník základních pojmů literárni teorie. Jinočany: H\&H, 2002. 355 s. ISBN 80-7319-020-6.

6. MÍČKO, M. Umění nebo život. Rozhovory a vyznání. 2. vyd. Praha: Academia, 2004. 155 s. ISBN 80-200-1232-X.

7. Ґ̌ĚrICHOVÁ, V. DAHL Roald. In: ŘEǨICHOVÁ, V., SLADOVÁ, J., VÁŇOVÁ, K., HOMOLOVÁ, K. Literatura pro dèti a mládež anglicky mluvících zemí. Olomouc: Hanex, 2008. S. 314-326. ISBN 978-80-7409-019-6.

8. SIROVÁTKA, O. Technika konzumní literatury. In: SIROVÁTKA, O. Literatura na okraji. Praha: Československý spisovatel, 1990. S. 45-55. ISBN 80-202-0122-X.

9. THOMAS, S. How Little Britain's David Walliams became the new Roald Dahl. The Sydney Morning Herald [online]. 2015 [cit. 2021-01-01]. Dostupné z: https://www.smh.com.au/entertainment/books/how-little-britains-david-walliamsbecame-the-new-roald-dahl-20150521-gh6hhl.html

10. TOMAN, J. Trivialita a kýč v literatuře pro děti a mládež. Brno: Cerm, 2000. $28 \mathrm{~s}$. ISBN 80-7204-140-1.

11. URBANOVÁ, S. Triviální literatura ve světle emocí. In: URBANOVÁ, S. Meandry a metamorfózy dětské literatury. Olomouc: Votobia, 2003. S. 292-306. ISBN 807198-548-1.

12. VOLKMANN, L., TRÁVNÍČEK, J. Kýč. In: NÜNNING, A., TRÁVNÍČEK, J., HOLÝ, J. (eds.) Lexikon teorie literatury a kultury: koncepce, osobnosti, základní pojmy. Brno: Host, 2006. S. 434. ISBN 80-7294-170-4.

13. WALLIAMS, D. Babička drsňačka. Praha: Argo, 2012. $250 \mathrm{~s}$.

14. WALliAMS, D. D́ábelská zubařka. Praha: Argo, 2014. 383 s. ISBN 978-80-2571304-4.

15. WALLIAMS, D. Dědečkiov velký útěk. Praha: Argo, 2016. 463 s. ISBN 978-80-2571818-6.

16. WALLIAMS, D. Klukv sukních. Praha: Argo, 2013. 197 s. ISBN 978-80-257-0839-2.

17. WALLIAMS, D. Malý miliardár. Praha: Argo, 2013. 232 s. ISBN 978-80-257-0858-3.

18. WALLIAMS, D. Pan Smrad'och. Praha: Argo, 2012. 221 s. ISBN 978-80-257-0754-8.

19. WALLIAMS, D. Př́šerná teta. Praha: Argo, 2015. 403 s. ISBN 978-80-257-1562-8.

20. WALLIAMS, D. Půlnoční gang. Praha: Argo, 2017. 472 s. ISBN 978-80-257-2268-8.

21. WALLIAMS, D. Táta za všechny prachy. Praha: Argo, 2018. 456 s. ISBN 978-80257-2578-8.

\section{Kontaktní údaje}

Mgr. et Mgr. Adéla Štěpánková

Univerzita Palackého v Olomouci

Pedagogická fakulta

Žižkovo náměstí 5, 77140 Olomouc

e-mail: adela.stepankova01@upol.cz 


\title{
KLÍČOVÉ SLOŽKY LITERÁRNÍ VÝCHOVY NA 2. STUPNI ZÁKLADNÍ ŠKOLY A ROLE OSOBNOSTI UČITELE
}

\author{
KEY COMPONENTS OF LITERATURE EDUCATION AT LOWER- \\ SECONDARY SCHOOLS AND THE ROLE OF THE TEACHER
}

\author{
Lenka Nosková
}

\begin{abstract}
Abstrakt
V článku jsou na základě vybraných empirických výzkumů výuky literární výchovy popsány komponenty výuky, které jsou stěžejní pro naplňování cílů vzhledem k RVP ZV - adekvátní umělecký text v centru výuky a rozvíjející pedagogická komunikace při interpretaci textů. Výzkumy se žáky ukazují, že vedle těchto komponentů se objevuje stěžejní faktor, který významně ovlivňuje předchozí jmenované, má velký vliv na průběh výuky a dosahování cílů, a především využívání formativních možností literární výchovy. Tímto faktorem je osobnost učitele. Je to učitel, který vybírá texty, aby využil jejich potenciálu - aby mluvily ke čtenáŕi, inspirovaly ho, aby mu umožnily prožít, pocítit či objevit něco, co je obohatí. Učitel literatury by si měl být této moci vědom a dobře ji užívat pro rozvoj svých žáků.
\end{abstract}

Klíčová slova: literární výchova, umělecký text, pedagogická komunikace, osobnost učitele

\begin{abstract}
This article summarizes selected empirical researches from school lessons of literature. According to the current discussion in methodology of literature, there are described key components of teaching literature - work with texts of appropriate level and respectful and motivating pedagogical communication. Researches with students in the Czech Republic show that besides those components, there is one factor which influences the literature lessons to great extent in terms of reaching the goals of education, students' attitude towards the subject and their willingness to participate in lessons. This factor is the character of the teacher. It is the teacher who can use the potential of literary text to speak to the reader, to inspire reader, to make the reader experience something new, to feel, to explore. The teacher of literature should be aware of their power and use it well for the development of their students.
\end{abstract}

Key words: teaching literature, literary text, pedagogical communication, character of the teacher

\section{1 ÚVOD}

Cíle literární části vzdělávacího oboru český jazyk a literatura jsou v RVP ZV vymezeny takto: prostřednictvím četby se žák učí poznávat základní literární druhy, vnímat jejich specifické znaky, postihovat umělecké záměry autora a formulovat vlastní názory o přečteném díle. Tím se rozvíjejí jeho základní čtenářské návyky a schopnosti tvořivé recepce, interpretace a produkce literárního textu. Žák dospívá k poznatkům a prožitkům, které mohou pozitivně ovlivnit jejich postoje, životní hodnotovou orientaci a také obohatit jejich duchovní život (RVP ZV, s. 16; zdůraznění autorů).

V článku uvádíme pojetí výuky, které tyto cíle v různé intenzitě odrážejí. Výsledky výzkumů poukazují na nedostatky, které se ve výuce stále objevují. Autoři zpravidla navrhují možné postupy pro zlepšení (srov. Jindráček, 2018). Konstatování, že každou ze tří oblastí významně 
ovlivňuje osobnost učitele, nejspíš nikoho nepřekvapí. Učitel vede výukový proces a vstupuje do něj nejen jako odborník, ale také jako člověk se svými přesvědčeními, charakterovými vlastnostmi, komunikačními dovednostmi apod., učitel do výuky nutně vnáší svou osobnost. A je to právě osobnost učitele, co se ukazuje jako stěžejní faktor, který ovlivňuje to, jak žáci výuku vnímají, jak se v ní cítí, i to, jak v ní pracují (srov. Vala, Nosková, Franěcová, 2021). Jelikož jakákoli změna ve výukovém procesu, pojetí a cílech závisí na osobním přesvědčení učitele, vidíme jako klíčové se $\mathrm{v}$ př́ípravě budoucích učitelů práci $\mathrm{v}$ oblasti názorů a přesvědčení (prekonceptů) důsledně věnovat. Širší otázkou je výchova osobnosti/charakteru (character education) učitelů, která by určitým způsobem na pedagogických fakultách měla být zastoupena, na což v posledních letech poukazuje mimo jiné J. Hábl (2020).

\section{CÍL ČLÁNKU A METODOLOGIE}

V článku popisujeme dvě oblasti, které jsou zkoumané ve výzkumech školní literární výchovy (dále LV) v posledních několika letech. Nejde o vyčerpávající výčet, výběr oblastí byl zvolen na základě diskuzí v oborové didaktice ohledně pojetí oboru a jeho cílů. Vybrali jsme takové výzkumy, jejichž respondenty byli žáci 2 . stupně ZŠ a SŠ. Představujeme zejména menší kvalitativní výzkumy, které realizovali diplomanti a doktorandi v předchozích pěti letech. Jejich zjištění od žáků formou skupinových diskuzí a individuálních rozhovorů považujeme za přínosné pro úvahy nad výukou. Větší výzkumy kvantitativní či se smíšeným designem skvěle shrnul ve své metaanalýze Jindráček (2018), poznatky z jeho práce byly pro tento článek důležitým vodítkem.

\section{TEORETICKÁ VÝCHODISKA}

Výuku LV lze pojmout různě. Současné práce věnující se oborové didaktice LV uvádějí několik pojetí, které respektují literární text a kultivaci žáka jako východisko i cíl oboru. Jedná se o čtenářské či interpretativni pojetí, zážitkové pojetí a tvořivé či tvořivě-expresivní pojetí (Hník, 2014, s. 34-36). Společné znaky těchto pojetí jsou literární text, tedy četba a interpretace (,poznávání díla a poznávání o díle“ - Hník, 2014, s. 116-117) a žák a rozvoj jeho osobnosti (žákovo aktivní učení - aktivita při četbě, interpretaci, tvorbě) - tedy výchova. Výchovou spolu s Hníkem (2014) myslíme výchovu „ke čtenářství a prostřednictvím působení uměleckého textu na city, vůli a charakter dítěte výchovu k lidskosti“ (s. 32; zdůraznění původního autora). Výchovný koncept nahlíží dítě jako osobnost a bytost a učitele jako vychovatele, vzdělavatele, partnera a pomocníka. Hník (2014) dále uvádí imaginaci a tvořivost jako důležité složky osobnosti žáka, které se dají v LV rozvíjet: „Tvořivost je komplexní lidskou schopností - působí na racionální stránku osobnosti, tak afektivní dociluje se tím jisté harmonie; reflexí tvorby dítě vyvažuje pamět'ové osvojování učiva“ (s. 54-55). Smyslem výchov je vycházet z psychiky žákovy osobnosti a navazovat na jeho vnitřní svět (s. 39). Realizace tohoto přístupu předpokládá učitelův zájem o žáky a o jejich vnitřní rozvoj, a zároveň jeho schopnosti využít práci v hodinách literatury také k tomu.

Pro výše uvedené dílčí pojetí výuky používá Hník (2014) pojem inovativní výuka jako zastř̌šující a vyjadřující protiváhu $\mathrm{k}$ tradični výuce - takové, která má v centru faktografii a rozvoj žákových vědomostí, nikoli žáka jako takového. Klíčové rozdíly v inovativni a tradiční výuce jsou komponenty - četba jako zážitek, interpretace jako tvořivá aktivita, tvorba jako expresivní vyjádření, a především orientace na žáka a rozvíjení jeho kompetencí a osobnosti (srov. Hník, 2014).

Cílem autorů přispívajících $\mathrm{k}$ rozvoji oborové didaktiky není zbavit hodiny LV literární a literárněhistorické teorie (srov. Hník, 2014; Vala, 2017; Jindráček, 2018), nýbrž uvádět ji do souladu s cíli oboru (viz RVP ZV, s. 16-18), s principy konstruktivistického pojetí výuky a se záměrem naplňovat výchovnou stránku předmětu a využívat textů $\mathrm{k}$ obohacování duševního a duchovního života žáků. Jak uvádí Jindráček et al. (2011), texty učí žáky komunikovat 
a jejich prostřednictvím mají být vedeni $\mathrm{k}$ aktivnímu a hloubavému čtenářství a „k rozvíjení vlastní kreativity a k pochopení širšího literárněhistorického kontextu“ (s. 12). Žáci si tyto znalosti ,(re)konstruují, postupně vytvářejí a budují interpretačními a produkčními aktivitami př́mo v komunikaci $\mathrm{s}$ uměleckou literaturou a v následné reflexi vědomě korigované učitelem“ (Jindráček, 2018). Učitel navozuje učební situace, které podporují interakci žáka s umělecký textem, a vede ho k porozumění dílu. Proto jsme k bližšímu zkoumání vybrali následující oblasti.

\section{KOMPONENTY LITERÁRNÍ VÝCHOVY}

\section{1 Četba uměleckých textů a jejich interpretace}

Výzkum Věry Radvákové (2012) ukazuje, že práce s literárním textem není základem hodin LV na většině českých gymnázií. Texty v hodinách někdy chybí úplně, často je s nimi pracováno pouze formálně jako ilustrace k výkladu o spisovateli, epoše či díle (Jindráček, 2018). Porozumění textu, vlastní interpretace a hledání aktualizací díla není obvyklé pro většinu z dotázaných studentů, dotazníkového šetření se zúčastnilo 1462 studentů. K podobným závěrům dochází i Hník (2010).

Moldanová (2011) se zamýšlí nad důvodem této skutečnosti: „Zůstáváme mnohdy u zbytků marxistické sociologické koncepce, která chápe literaturu jako funkci politického (historického, společenského) dění“ (Moldanová, 2011 s. 240). Uvádí př́iklad díla Karla Čapka, které je často interpretováno pouze ve směru boje proti fašismu a o Čapkovi samotném jako o prredstaviteli demokratického proudu, ale už se nezabýváme jeho experimentátorstvím, které ovlivnilo další vývoj české prózy. Moldanová (2011) upozorňuje, že zůstáváme u východiska textu jako odrazu skutečnosti, kdežto literární věda se posunula mnohem dál a výuka nereflektuje jiné př́stupy $\mathrm{k}$ textu - text jako znak (sémiotika) či fikčnost literárního díla.

„Četba je proces komunikace mezi čtenářem a aktualizovanými významy uměleckého textu“ (Lederbuchová, 2004). Pohled na proces četby jako aktivního (re)konstruování významu se objevují v Evropě i v Čechách ve druhé polovině minulého století. V Evropě je to zejména prací kostnické školy a jejich recepční estetiky.

Aktualizovanými významy textu se zabýval Iser (2001). Podle něho neexistuje význam (či významy) textu, který je možno najít a který je nějakým způsobem neměnný. ,... kdyby texty měly skutečně jen ty významy, které vyprodukuje interpretace, už by čtenáři mnoho nezbylo. Mohl by je pouze bud' přijmout, nebo zavrhnout.“ Významy textu jsou stejně individuální jako proces čtení. Čtenář spoluvytváří význam literárního textu, proto mluvíme o aktualizovaném významu. Prostor pro možné aktualizace Iser nazval tzv. princip nedourčenosti. Někdy se hovoří o teorii tzv. bílých míst v literatuře. Bílá místa označují prostor, který má čtenář možnost při aktivní četbě zaplnit svou myšlenkovou činností a fantazií.

V LV se mnohdy snažíme objevit význam díla v domnění, že je jeden správný, nebo odhalit, jaký byl autorův záměr ve volbě právě těchto slov, symbolů, metafor apod. Pokud je toto náš jediný přistup, může docházet ke zploštování díla i procesu jeho čtení. Hrozí, že se žáci budou orientovat pouze na nalezení pravděpodobného významu (či v horším př́padě významu, který chce slyšet učitel) a čtení bude výhradně procesem detektivního pátrání.

Americká profesorka Louise Rosenblatt vytvořila tzv. transakční teorii, teorii komunikace čtenáře a textu. $\mathrm{V}$ souvislosti s tím se objevují pojmy jako responsive reading, readerresponse theory a literary response - response znamená odezva, odpověd', ohlas či reakce a označuje reakci čtenáře na čtený text, a to jak prvotní - dekódování textu (význam slov), tak následující, při níž čtenář aktivně pracuje s textem již dekódovaným (Slavíková, 2008). Transakční teorie sestává ze dvou fází - evokace a interpretace. Evokace je zážitek díla v reálném světě, čtenář oživuje dílo již jednou vytvořené, začíná tam, kde autor skončil, 
zapojuje se proud pocitů a postojů vyvolaných textem. Ve fázi interpretace se čtenář snaží popsat prožitou evokaci díla a hledá smysl textu z hlediska významu slov (např. význam metafor v básni), ale také smysl textu pro sebe samého. „Čtenář nejprve hledá význam slova v kontextu ostatních slov a poté v kontextu své zkušenosti““ (Slavíková, 2008).

Poznatky o procesu čtení, at' už dřívější teoretické či pozdější empirické, mění pohled na čtení. Jelikož je čtení (text, recepce textu) v centru výuky LV, měl by se změnit pohled i na ni. V Čechách byly podobné názory na proces četby výsledkem strukturalistické literární vědy. Úvahy o smyslu LV se odehrávaly na univerzitních a pedagogických pracovištích (K. Hausenblas, J. Jelínek, B. Havránek, F. Vodička ad.). Z nich vzniklo pojetí výuky, které mělo za cíl překlenout kritizované přetížení teorií $\mathrm{s}$ pamětovým osvojováním učiva (Jindráček, 2018). Cíle bylo „vytvořit přímý kontakt žáků s literaturou“, „přiblížit žákům smysl literatury samé“ a umělecké literární dílo se pro ni stalo „pouhou pomůckou materiálem, na němž lze doložit předem stanovené teze“ (Jindráček, 2018). Důraz byl kladen na „vlastní čtenářské aktivity žáků a jejich individuální zaujetí knihou“ tak, aby LV „více než dosud stimulovala $\mathrm{v}$ žácích vlastní vztah $\mathrm{k}$ četbě“ a posilovala $\mathrm{v}$ nich „schopnost výběru a interpretace díla“" (tamtéž).

Jindráček (2018) dobře vystihuje důležitou schopnost učitele LV: „Autoři všech těchto koncepcí LV se shodují v názoru, že sám literární text dokáže čtenáře oslovovat a provokovat otevřeností svých sdělení. Aby učitel zohlednil tyto kvality literárních textů, při vstupech do prostoru mezi dílo a mladého čtenáře si musí počínat velmi obezřetně a spíše než direktivně určovat, jakých míst v textu si musejí žáci všímat, má vytvářet př́ležitosti $\mathrm{k}$ tomu, aby si sami žáci dokázali formulovat otázky nad dílem, aby text především uměli důkladně přečíst a pozorovat zvláštnosti utváření jeho smyslu.“

\subsection{Výběr adekvátních uměleckých textů}

Vycházíme $\mathrm{z}$ přesvědčení, že jedním z cílů výuky LV na základní škole je rozvoj vlastního čtenářství, nebo přinejmenším učitelova snaha o něj. Je přirozené, že ne všichni budou vášnivými čtenáři a sáhnou po knize v každé volné chvíli. Toto ani nemůže být učitelovým cílem. Učitel LV by však měl umožnit žákům cestu ke čtení nalézat, dát jim zažít, že knihy mohou obohatit jejich život a ukázat jim čtení jako adekvátní možnost trávení volného času (srov. Vala, 2017, s. 281; Moldanová, 2011, s. 241). Vztah ke čtení je jednou z definovaných oblastí čtenářské gramotnosti (srov. NúV, 2011, s. 8).

Pokud je toto naším cílem, výběr textů hraje důležitou roli, protože umělecké texty jsou „specifický typ učebních úloh, které jsou jedním z faktorů ovlivňující kvalitu výuky. (...) Pro smysluplnou výuku je potřeba vybírat vhodné texty - takové, které budou adekvátní věku, intelektové, osobnostní a emoční zralosti žáků“ (Vala, 2017, s. 280).

Vala dále podotýká, že „úvahy o výběru vhodných textů do LV se však odvíjejí především z pozice osobního přesvědčení učitelů. (...) Současné čítanky ve velké míře obsahují ukázky, jejichž hlavním cílem je žáky primárně literárněhistoricky vzdělávat, př́ípadně $v$ nich probouzet vlastenecké cítění. Nabízí se otázka, nakolik (a zda vůbec) žáci těmto textům rozumí a zda jsou schopni z nich pro sebe získat etické, estetické či obecně kulturní hodnoty a do jaké míry my učitelé zůstáváme u povrchní, formální znalosti o existenci daného autora a jeho knih“ (Vala, Šmakalová, Válková, 2019, s. 65). Autoři zvou k přemýšlení nad tím, které texty mají potenciál nastartovat, př́ípadně rozvíjet čtenářství žáků.

Výzkum recepce uměleckých textů u žáků 12-15 let (Vala, 2017) přinesl důležité podněty pro diskuzi nad adekvátností textů do výuky. Výzkumu se účastnilo 610 žáků 7.-9. ročníků, kteř́ četli tři sady texti̊ po osmi ukázkách a následně o tom diskutovali v ohniskových skupinách. Několik ukázek bylo vybráno z čítanek pro dané ročníky a několik z umělecké literatury pro mládež a dospělé. Zde uvádíme pouze několik závěrů z části výzkumu $\mathrm{s}$ žáky 9. ročníků, žáků bylo dohromady 203. Četli texty ze starších období - Labyrint světa a ráj 
srdce; Filozofská historie; Faust, a několik knih novějších - Hrdý Budžes; Like me: každé kliknutí se počítá; Já jsem Malála; On je fakt božı́!; Zlodějka knih.

U textů starších a jazykově složitějších většina žáků nebyla schopna proniknout do obsahu a významu textů. Roli hrál jak archaický jazyk (Komenský), př́padně náročný překlad (Faust). Jiráskův text byl vnímán poměrně srozumitelně, ale tematicky žáky nijak neoslovil. Téma je jim vzdálené, a pokud je taková ukázka čtena bez kontextu doby a vysvětlení dějinných souvislostí, je velmi pravděpodobné, že žákům mnoho nepřinese. Komplikovaný jazyk, nesrozumitelná témata a vzdálenost časová nebo tematická jsou při recepci textu pro většinu žáků nepřekonatelnými bariérami, kvůli kterým se k textu nedostanou.

„Žáci oceňovali především texty, které jsou schopni vztáhnout ke svému životu i dnešnímu světu. (...) Žáci oceňovali, že těmto ukázkám rozuměli: z pohledu doby, témat, jazyka, postav, prostředí apod. Je to přirozené, nebot' čteme proto, abychom se něco dozvěděli o světě i o sobě, abychom na přečtených knihách vnitřně rostli. Představuje typ textu, který pomáhá žákům porozumět současnému světu: jeho rozmanitosti i nepochopitelným krutostem. Je-li autorkou jejich vrstevnice, dostává celý text pro žáky ještě intenzivnější nádech“ (Vala, 2019, s. 290).

Vybírat a zařazovat do výuky jazykově i tematicky př́stupné texty je cestou k naplňování cíle rozvoje čtenářství. „Setkávají-li se žáci s texty v dosahu své úrovně chápání, můžeme rozvíjet i jejich poznatkovou bázi, a to nejen ve vztahu k literární historii a teorii. Jde zároveň a především o vztah k naší současnosti, text dětem musí ř́ikat něco o nich, o nás, o naší době. A to i prostřednictvím různých historických událostí s přesahem do dneška. Takový prŕístup klade značné nároky na učitele, na jejich schopnost propojovat minulost a současnost, hledat a vidět nové vazby, které aktualizují starší texty“ (Vala, 2019, s. 292).

Totéž uvádí Moldanová (2011), která zasazuje výuku mateřského jazyka a literatury (zejména pak národní) do kontextu výchovy dětí - občanů a zralých osobností, které se vnímají jako součást kultury konkrétního národa. Uvádí, že tyto důrazy jsou dokonce zakotveny ve vzdělávacích programech některých evropských zemí (Německo, Norsko aj.). Sama spatřuje jako důležité, aby v hodinách literatury nechyběly ani texty starší a jazykově náročnější, protože mají svůj velký význam pro budování povědomí o vlastním původu. Opět v tom hraje důležitou roli učitel. „Člověk, aby byl důstojně živ a těšil se úctě druhých, potřebuje být někým, s něčím se ztotožnit, mít své kořeny a ne jen se přizpůsobovat proudům, které přicházejí a odcházejí. Objevovat své kořeny může dítě prostřednictvím literatury, vyrostlé $\mathrm{z}$ domácích tradic a reflektující historickou pamět' národa lépe než jakýmkoli jiným způsobem. Proto je důležité nevytlačovat z literárního vzdělávání naše klasické autory s poukazem, že jsou zastaralí, a klást důraz na hvězdy moderní světové literatury, jak se mnohdy děje. (...) Záleží totiž na tom, jak je uchopíme, jak dokážeme najít jejich živou a trvalou hodnotu“" (Moldanová, 2011, s. 243).

Závěrem spolu s autory konstatujeme, že při práci s ukázkami umělecké literatury by učitel sám „měl mít o daný text zájem, chápat smysl své práce a zvážit, proč je důležité, aby se s vybranými texty setkali již žáci na základní škole“ (Vala, Šmakalová, Válková, 2019, s. 71).

\subsection{Pedagogická komunikace při práci s textem}

Pedagogická komunikace je specifická forma sociální komunikace, jejíž prostřednictvím se uskutečňuje výchovně-vzdělávací proces. Probíhá mezi učitelem a žákem a také mezi žáky mezi sebou. Účastníci komunikují o nějakých faktech, vyjadřují svoje stanoviska, názory, přání či pokyny. Jde se o dvousměrný proces. Hlavní funkcí je realizace výchovy a vzdělávání a zprostředkování vztahů a společné činnosti mezi účastníky komunikace. Tato komunikace je určitou formou spolupráce. Je mimo jiné zdrojem zpětné vazby, bez komunikace by učitel nezjistil, zda žák učivu rozumí, potřebuje změnit tempo, má doplňující otázky apod. (Nelešovská, 2002, s. 25-26). 
V nejčastější organizační formě vyučování - v hromadném (frontálním) vyučování - dochází ke třem typům komunikace: obousměrná komunikace mezi učitelem a jedním žákem, jednosměrná komunikace od učitele ke třídě a jednosměrná komunikace učitele k žákovi jako jednotlivci (Nelešovská, 2002). Obousměrná komunikace je zpravidla rozhovor, který probíhá tak, že učitel klade otázky a žák odpovídá. Je podstatné, jak učitel dokáže formulovat své otázky a jak žáky do rozhovoru zapojí. Jednosměrná komunikace učitele se trrídou je monologem učitele, jde tedy o situaci, kdy učitel vede výklad, vypráví či hodnotí žáky (Novotná, 2006). Učitel je ve středu komunikace a určuje téměř všechny náležitosti - určuje téma komunikace, může mluvit, jak dlouho chce, kde $\mathrm{v}$ rámci třídy a $\mathrm{v}$ pozici, kterou považuje za vhodnou (vestoje, vsedě, v chůzi), s kým chce (jednotlivcem, skupinou, celou třídou). Pro rozvoj komunikace ve trrídě je důležitých mnoho faktorů, např́íklad uspořádání učebny, klima a atmosféra třídy (Nelešovská, 2002).

Sedláček a Šed'ová (2015) provedli výzkum komunikace ve tř́́dě v souvislosti se žákovským učením. Předmětem zkoumání byl charakter výukové komunikace - zda ovlivňuje učení žáků v humanitních předmětech. Zaměřili se na vztah mezi způsobem, kterým učitel interaguje s žáky a učením žáků. Zkoumané faktory ze strany učitele byly jasnost a kredibilita, u žáků komunikační angažovanost. Jasnost je definována schopností učitele prezentovat informace tak, aby jim žáci rozuměli, kredibilita je dána tím, $v$ jaké míře ho žáci vnímají jako důvěryhodného, což se zpravidla opírá o pocit, že je učitel expertem ve svém oboru, má morální kvality a jedná v zájmu žáků. „Výzkumy věnované kredibilitě poukazují na to, že tato učitelská charakteristika ovlivňuje všechny komunikační události. Pokud žáci nevnímají učitele jako kredibilního, jsou méně ochotni mu naslouchat a nechat se jím ovlivnit“ (Sedláček, Šed’ová, 2015, s. 86). Angažovaností žáků ve výukové komunikaci se rozumí míra ochoty a prripravenosti zapojit se do komunikace a ochota komunikovat a naslouchat.

Studie ukazuje, že je třeba zvýšit zapojení žáků do komunikace, pokud se má posílit žákovské učení a tím zvýšit kvalitu výuky. „(...) data ukazují na zásadní význam komunikace na subjektivně vnímané učení“ (Sedláček, Šed’ová, 2015, s. 98). Je to právě učitel, kdo vytváří komunikační prostor a svými vlastními komunikačními aktivitami žákovské angažovanosti bud' napomáhá, nebo ji utlumuje.

Ke komunikaci mezi učitelem a žáky a žáky mezi sebou dochází v LV velmi často. A nejčastěji při práci s textem, at' už je LV čtenářsky či zážitkově orientovaná, nebo tradiční i v tradičních hodinách je prítomen umělecký text a dochází k práci s ním. Pedagogickou komunikací při práci s textem se zabývá např. Šalamounová (2016). Ve své studii analyzovala výukovou situaci práce s přečteným uměleckým textem, konkrétně ukázky z knihy Útěk Oty Hofmana.

Ve své didaktické kazuistice vychází z metodiky AAA - anotace-analýza-alterace (více v Janík et al., 2013). V rámci analýzy byla provedena strukturace obsahu s využitím konceptového diagramu ve třech vrstvách - tematické, konceptové a kompetenční. „Uvedená výuková situace představila typický způsob, jímž učitelka Hana se svými žáky pracuje s literárním textem. Jedná se o práci probíhající téměř výhradně na úrovni tzv. tematické vrstvy, se slabou návazností na vrstvu konceptovou či kompetenční“ (Šalamounová, 2016, s. 93).

Dále uvažuje, že taková práce $\mathrm{s}$ textem je jedním z možných důvodů, proč se pojetí LV v mnohých př́padech stále nemění. „Tento způsob práce s literárními texty, jenž nenabízí přesah mimo text samotný, může být jedním ze zásadních důvodů, proč je práce s literárním textem ve výuce trvale podhodnocena. Pokud totiž při práci s textem nedochází $\mathrm{k}$ propojení s oborovými poznatky v rámci vrstvy konceptové, mohou učitelé snadno nabýt dojmu, že ve výuce absentuje učivo a probíhá ,pouhé povídání nad textem, které je vhodnější nahradit pevně daným učivem v podobě výčtů děl a jejich autorů. (...) V tomto pojetí je totiž pro 
učitele zřejmé, kolik toho v hodině s žáky probrali, jak mohou žáky hodnotit a na co se lze v př́ští hodině ptát" (tamtéž).

Problematiku pedagogické komunikace popisují také zahraniční výzkumy ve školním prostředí. Za mnohé uvádíme výzkum z USA, který analyzoval výukové situace v hodině př́rodopisu (Barnes et al., 2010). V dané situaci se paní učitelka snažila zapojit mnoho žáků, což sklouzlo v klasický model - učitel položí otázku a vyvolá žáka, žák odpoví, učitel odpověd' zopakuje, okomentuje. V prŕípadě špatné odpovědi vyvolá někoho jiného, aby odpověd' opravil.

V hodinách LV velmi často probíhá na rozdíl od jiných vzdělávacích oborů sdílení vlastní interpretace uměleckého textu, vlastních názorů a poznatků. Je to specifická komunikace, která vyžaduje učitelův citlivý př́stup.

Ve výzkumu čtenářských prekonceptů formou diskuzí v ohniskových skupinách (Vala, Nosková, Franěcová, 2021) zaznělo mnoho komentářů ke způsobu komunikace v hodině, především k postoji učitele. Žáci pozitivně hodnotili, že mohou vyjádřit svůj pohled na čtenou ukázku a sdílet své názory a prožitky se svými spolužáky. Mnozí konstatovali, že by na sdílení názorů měl být v LV větší prostor. Byli by za to rádi a oceňují, když ho učitel poskytuje. V diskuzích několikrát zazněly výroky, ze kterých bylo zřjejmé, jak si žáci váží toho, když se učitel zajímá o jejich názory. Když je vyslechne a př́ípadně s nimi diskutuje, rozvádí, doptává se.

Když učitel naopak diskuzi otevřený není, může v žácích způsobit negativní postoj k celému oboru a návazně pak k jeho obsahu - ke čtení a literatuře samotné. U žáků takových učitelů zaznívaly výrazy typu - „nezajímá ji náš názor“, ,jenom její odpověd’ je správná“, „když nikdo nic neřekne, odpoví si sama“. Žáci negativně hodnotili př́stup učitele, který se odmítavě vyjadřuje k názorům žáků, jejich reakce hodnotí (někdy odsuzuje, zesměšňuje), neumožňuje diskuze $v$ prípadě rozdílných názorů a vystupuje s postojem jedné správné odpovědi na otázky. $\mathrm{V}$ takových hodinách jim není př́ijemně a po několika neúspěšných pokusech o sdílení nemají chut' se do hodiny zapojovat. $Z$ hodin literatury i ze čtení se potom pro mnohé stává hodina, ,jenom to přežít“.

Je to zcela logické a přirozené - je to lidské. Jistě v tom žáky dokážeme pochopit. Učitel by si měl tyto skutečnosti uvědomovat a reflektovat svůj způsob komunikace se žáky. Jak zaznělo $\mathrm{v}$ úvodu, díky některým textům se učitel může dostat $\mathrm{k}$ žákům velmi blízko. Když jsou společně čteny silné životní příběhy, vytvárí se speciální prostor sdíleného okamžiku, společného prožitku. To je prostor, který když učitel dobře využije, může zanechat v žácích trvalou stopu. V tomto speciálním prostoru je potřeba citlivosti učitele, aby podchytil situaci a vytvořil pocit důvěry, přijetí, porozumění. Když v takové chvíli zazní odsuzující poznámka nebo necitlivý soud, může to žáky zavřít na velmi dlouhou dobu.

Pokud učitel reaguje takto, diskuze a sdílení nejsou možné a z literárních hodin se může stát nudné čtení a zapisování hlavní myšlenky, kterou nadiktuje učitel. Zatímco když učitel vytváří bezpečné, respektující prostředí, může dostat literatura v životě dospívajícího žáka důležitou roli. O touze žáků sdílet své názory a diskutovat není pochyb (viz Vala, Nosková, Franěcová, 2021).

\section{ZÁVĚR}

Literární výchova je výchovou, výchovou literaturou a výchovou k literatuře (ke čtení). Tyto tři aspekty považujeme za stěžejní - př́ítomnost uměleckého textu a jeho interpretace, výběr adekvátních textů vzhledem $\mathrm{k}$ věku žáků, aby mohlo docházet k zážitku ze čtení a obohacování života a pedagogická komunikace. Poslední uvedené může podpořit i znehodnotit všechno ostatní. Do komunikace vstupuje nejen komunikační dovednosti učitele a znalosti o vhodném kladení otázek, naslouchání a vedení žáků k přemýšlení a k diskuzi, ale 
také osobnost učitele. Jsme přesvědčeni, že právě osobnost učitele nejvýznamnější ovlivňuje jeho komunikaci a přístup $\mathrm{k}$ žákům.

Učitel má v literární výchově vystupovat jako vychovatel, vzdělavatel, partner, pomocník (Hník, 2014). Tento postoj se projevuje i v komunikaci. Zároveň je to něco, co je v samotné osobnosti učitele a co si učitel musí uvědomovat a pracovat s tím. Způsobem své komunikace a př́stupem $\mathrm{k}$ žákům má moc žáky otevřít i zatvrdit, povzbudit i zranit. Učitel má velkou zodpovědnost a velké př́ležitosti a je proto potřeba formovat a vést citlivě. Možná se vše skrývá v jediné věci - respekt k osobě žáka a jeho osobnosti, tedy i k jeho názorům.

Článek vznikl v rámci projektu IGA_PdF_2021_020 Učitelská reflexe literární výchovy na 2. stupni Z $\breve{S}$ jako nástroj optimalizace výuky.

\section{Použitá literatura}

1. BARNES, Douglas, Nancy FREY a Carol ROTHENBERG. Content-area conversations: how to plan discussion-based lessons for diverse language learners [online]. Alexandria, Va: Association for Supervision and Curriculum Development. [Cit. 2021-06-08]. 2008. Dostupné z: http://www.ascd.org/publications/bo oks/10 8035/chapters/Why-Talk-Is-Important-in-Classrooms.aspx

2. Čtenářská gramotnost ve výuce. Metodická př́ručka [online]. Praha: Národní ústav pro vzdělávání, divize VÚP, 2011 [cit. 2021-06-08]. ISBN 978-80-87000-99-1. Dostupné z: http://www.nuv.cz/uploads/Publikace/vup/ctenarskagramotnost_fin al.pdf

3. FRANĚCOVÁ, Renata. Analýza žákovských prekonceptů výuky literární výchovy na 2. stupni ZŠ. Olomouc, 2018. Diplomová práce [online]. Vedoucí práce Jaroslav Vala [cit. 2021-06-09]. Dostupné z: https://theses.cz/id/dq5jpy/Diplomov_prce_ Francov.pdf

4. HÁBL, Jan. Na charakteru záleží: Problém učitelnosti dobra / Je možné naučit dobru? 1. vyd. Červený Kostelec: Pavel Mervart, 2020. ISBN 978-80-7465-443-5.

5. HNÍK, O. Současná podoba výuky literární výchovy podle výpovědí studentů. Český jazyk a literatura, 60(3), 2009-2010, 130-134. ISSN 0009-0786.

6. HNÍK, Ondřej. Didaktika literatury: výzvy oboru. 1. vyd. Praha: Karolinum, 2014. ISBN 978-80-2446-2626-0.

7. ISER, W. (2001). Apelová struktura textů. Nedourčenost jako podmínka účinku literární prózy. In Čtenár jako výzva. Výbor z prací kostnické recepční estetiky, s. 3961. Brno: Host.

8. JANÍK, Tomáš, Jan SLAVÍK et al. Kvalita (ve) vzdělávání: obsahově zaměřený př́stup ke zkoumání a zlepšování výuky. Brno: Masarykova univerzita, 2013. $434 \mathrm{~s}$. ISBN 978-80-210-8258-8.

9. JINDRÁČEK, Václav. Dětská pojetí uměleckého textu jako východisko školní interpretace. Ústí nad Labem: Univerzita J. E. Purkyně, Pedagogická fakulta, 2011. 282 s. ISBN, 8074144291.

10. JINDRÁČEK, Václav. Literární výchova v období kurikulární reformy: rekapitulace vzdělávacích koncepcí, kvalita výuky a její výzkum [online]. Paidagogos, 2018, 12(4), 42-80 [cit: 2021-06-06]. Dostupné na: http://www.paidagogos.net/issues/2 018/1-2/article.php?id=4

11. Kolektiv autorů. (2010). Gramotnost jako vzdělávací cíl pro každého žáka. Praha. [online]. [cit. 17-04-2020]. Dostupné z https://digifolio.rvp.cz/artefact/file/download .php?file $=78120 \&$ view $=2935$.

12. LNĚNIČKOVÁ, Magdalena. Prekoncepce čtení a čtenářství žáků druhého stupně základni školy. Olomouc, 2020. Diplomová práce [online]. Vedoucí práce Jaroslav 
Vala [cit. 2021-06-09]. Dostupné z: https://theses.cz/id/poaffk/Prekoncepce_cteni_a _ctenarstvi_zaku_druheho_stupne_zaklad.pdf

13. MOLDANOVÁ, Dobrava. Nesoustavné úvahy o výuce (české) literatury. Pedagogická orientace, 2011, 21(2), 240-243.

14. NOVOTNÁ, Jarmila a kol. Př́prava a analýza didaktických situací. Praha: JČMF, 2006.

15. RADVÁKOVÁ, Věra. (2012). [online]. Interpretace textu na gymnáziu. (Disertační práce). [cit. 2021-06-05]. Dostupné z https://dspace5.zcu.cz/bitstream/11025/1078 4/1/Disertacni\%20prace.pdf.

16. Rámcový vzdělávaci program pro základni vzdělávání [online]. MŠMT, 2021 [cit. 2021-05-31]. Dostupné z: http://www.nuv.cz/file/4983/

17. SLAVÍKOVÁ, Denisa. Reflektivni aktivity ve výuce literatury. Praha, 2008. Diplomová práce [online]. Univerzita Karlova. Fakulta pedagogická. Vedoucí práce Ondřej Hausenblas. Dostupné z: https://dspace.cuni.cz/bitstream/handle/20. 500.11956/19135/DPTX_2008_1_11410_OSZD001_72945_0_67587.pdf?sequence $=1 \&$ isAllowed $=\mathrm{y}$

18. ŠALAMOUNOVÁ, Z. Když je práce s uměleckým textem v literární výchově víc než jen povídání. In J. Slavík, J. Stará, K. Uličná, \& P. Najvar, et al., Didaktické kazuistiky v oborech školního vzdělávání, s. 79-94. Brno: Masarykova univerzita.

19. VALA, Jaroslav, Kristýna ŠMAKALOVÁ a Kristina VÁLKOVÁ. Jak čtou osmáci? Český jazyk a literatura, 70(2), 64-71. Praha: Fraus, 2019. ISSN 0009-0786.

20. VALA, Jaroslav, Lenka NOSKOVÁ a Renata FRANĚCOVÁ. Literární výchova očima žáků 2. stupně ZŠ. Český jazyk a literatura, 71(3), 122-127. Praha: Fraus, 2020-2021. ISSN 0009-0786.

21. VALA, Jaroslav. Poezie, studenti a učitelé. Recepce, interpretace, výuka. Olomouc: Univerzita Palackého, 2013. ISBN 9788024439228.

\section{Kontaktní údaje}

Mgr. Lenka Nosková

Univerzita Palackého v Olomouc, Pedagogická fakulta

Žižkovo náměstí 5, 77140 Olomouc

Tel: 774345789

email: lenka.noskova@upol.cz 


\title{
MÚDROSŤ V KONTEXTE OSOBNOSTI U DOSPELÝCH
}

\author{
WISDOM IN ADULT
}

\author{
Andrea Baranovská, Dominika Doktorová
}

\begin{abstract}
Abstrakt
V rámci príspevku sa zameriavame na problematiku múdrosti a jej prepojením s prežívanou kontrolou situácie, zmysluplnost'ou života a osobnostnými charakteristikami. Výskum je počiatočnou sondou do problematiky. Použitými metódami - PIL, NEO-FFI, Dotazník životných ciel'ov, 3DŠM, PSS - sme skúmali jednotlivé premenné. V rámci výskumu sme zistili spojenie medzi mierou neuroticizmu a existenciálnou frustráciou a tiež múdrostou a prežívanou bezmocnost'ou.
\end{abstract}

Klíčová slova: múdrost', bezmocnost', osobnost', neuroticizmus, miera kontroly

\begin{abstract}
Within the article we focus on the issue of wisdom and its connection with the experienced control of the situation, the meaning of life and personal characteristics. Research is an initial probe into the issue. We examined the individual variables by using the methods - PIL, NEOFFI, the survey of life goals, 3DŠM, PSS. In the research, we found a connection between the degree of neuroticism and existential frustration, as well as wisdom and experienced helplessness.
\end{abstract}

Key words: wisdom, helplessness, personality, neuroticism, control

\section{MÚDROSŤ}

Múdrost' ako téma výskumu sa začala presadzovat' v 70.-ych rokoch 20. storočia. Rozmach záujmu o túto tému bol zaznamenaný v 90.-ych rokoch s rozvíjaním pozitívnej psychológie (Bange, Meeks, Ještě, 2013). K známym predstavitel'om, ktorý sa zaoberali múdrost’ou zarad’ujeme Junga, Eriksona, Piageta, Sternberga, Ruisela a d'alších. Ranné koncepty múdrosti vychádzali z laického vnímania tejto problematiky. Tieto teórie nazývame implicitnými. Najznámejším výskumom je výskum z roku 1980 Claytona a Birrena, ktorý múdrost' definovali ako integráciu kognitívnych, reflektívnych a afektívnych osobnostných charakteristík. Táto definícia bola podnetom pre výskum a formulovanie teórie Ardeltovej (2005). Ona vnímala múdrost' ako stabilnú charakteristiku osobnosti. Vytvorila trojdimenzionálny model múdrosti, v ktorom ju definuje podobne ako už spomínaný Clayton a Birren. V kognitívnej rovine sa podla nej nachádza túžba híbkovo porozumiet' intrapersonálnym aj interpersonálnym aspektom života a prijat' pozitívna aj negatívne stránky l'udskej podstaty. V tejto úrovni sa podl'a nej tiež nachádza aj prijatie limitov l'udského poznania a nepredvídatel'nosti a neistoty života. Aby sme dosiahli takýto stupeň porozumenia je potrebná reflexná dimenzia, ktorá obsahuje schopnost' vnímat' javy a udalosti z viacerých perspektív a nenechat' svoj pohl'ad skreslit' sebectvom, subjektívnost'ou a projekciou. Posledná afektívna dimenzia sa prejavuje ako súcitný, empatický a láskavý postoj k sebe, druhým aj svetu. Podl'a Ardeltovej ju môžeme tiež popísat' ako láska (2003, 2019). Bluck a Glück (2005) definovali múdrost' ako schopnost' učit' sa zo životných skúseností. Rovnako identifikovali 5 aspektov múdrosti: kognitívne schopnosti, vhl’ad, reflektujúci postoj, záujem 
o ostatných a praktické zručnosti. Ked’že sa zamerali na spôsoby rozvíjania a získavania múdrosti popísali tiež zdroje, ktoré l’ud’om napomáhajú v rozvíjaní múdrosti - MORE:

- mastery - aktívna snaha zmenit', čo je možné zmenit', súčasne prijat' nepredvídatel'nost' a nekontrolovatel'nost' života a tiež nechat' veci, ktoré nie je možné ovplyvnit' tak;

- openess - otvorenost' voči nových skúsenostiam, luud’om, nápadom, toleranciu;

- reflectivity - reflektivita - túžba porozumiet' javom a súvislostiam, sebareflexia;

- emotional regulation - emocionálna regulácia - schopnost' rozlíšit' a popísat' vlastné emócie a ich regulovanie;

- empathy - empatia.

Z empirického hl'adiska vel'mi podrobne múdrost' rozpracovali autori z berlínskej školy Blates a Staudinger (1993). Berlínska paradigma múdrosti predstavuje jeden z najznámejších modelov, v ktorom sa múdrost' vníma ako klúčová pre plánovanie a uskutočňovanie dobrého života, pričom si múdri l'udia aj uvedomujú, čo dobrý život je. Tvrdia, že múdrost' môžeme definovat' ako systém vedomostí a informácií o zásadných praktických otázkach života na úrovni experta, ktoré jednotlivcovi umožňujú výnimočný vhl'ad a úsudok ohl'adom komplexných a neistých otázok l'udského bytia. Pričom ho to oprávňuje aj $\mathrm{k}$ tomu, aby poskytoval rady ostatným. Múdrost' sa podl'a Baltesa a Smitha (2008) tiež prejavuje v oblasti životného plánovania, určovania životných ciel'ov a spôsobov ich dosahovania. Rovnako sa prejavuje aj evalvácii vlastného života a určovaní jeho významu. Špecifikovali 5 kritérií expernosti, ktoré delia na dve úrovne:

1. úroveň:

a. porozumenie podstate l'udskosti, vývinu života, sociálnym normám, vzt'ahom medzi l'ud'mi, identite apod.

b. procedurálne vedomosti - schopnost' aplikácie vlastné vedomosti pri stanovovaní si životných ciel'ov, plánovaní, riešení dilem a konfliktov;

2. úroveň:

a. kontextualizmu - schopnost' uvažovat' v širších súvislostiach;

b. relativizmus hodnôt a priorít - tolerancia odlišnosti a jej rešpektovanie;

c. uvedomovanie a zvládanie životných neistôt a nepredvídatel'nosti života a bytia (Baltes, Smith, 2008; Baltes, Staudinger, 2000).

Berlínska škola nevníma múdrost' ako osobnostnú charakteristiku - zameriavajú sa na múdre uvažovanie, čím dochádza k preceňovaniu porozumenia a podceňovaniu zážitku uvedomenia si vedenia.

Ďalším už spomínaným autorom, ktorý sa zaoberal múdrost'ou bol Sternberg, ktorý inteligenciu a kreativitu považuje za základ múdrosti - pretože tá práve spočíva v aplikácii úspešnej inteligencie a kreativity za účelom dosiahnutia všeobecného dobra (Sternberg, 2003). Táto teória je o interakcii medzi jednotlivcom a prostredím v ktorom žije, o adaptačných procesoch a schopnosti vlastné prostredie pretvárat'. Táto teória tiež kladie zvýšený dôraz na kognitívnu dimenziu.

Grossman (2017) vníma múdrost' ako schopnost' alebo zručnost' s dispozičným aj situačným kontextom. Rozvíja sa v procese interakcie medzi jednotlivcom a prostredím, ale je vnímaná skôr ako schopnost' uvažovat'. Súčast'ou múdrosti je podl'a Grossmana uznanie a akceptácia neistoty a premenlivosti, uvažovanie nad kontextom, zvažovanie rôznych perspektív a schopnosti kompromisu.

V súvislosti s múdrost'ou je vel'mi dôležitý vek, kedy jednotlivec múdrost' dosahuje. Podl'a niektorých autorov sa múdrost' rozvinie až v staršej dospelosti spoločne so životnými skúsenost'ami (Clayton, Birren, 1980; Jordan, 2005; Kramer, 2000), ale Kunzmann a Baltes (2005) uvádzajú, že primárnym obdobím objavenia sa múdrosti ako vedomostného systému je neskorá adolescencia a skorá dospelost' (Richardson, Pasupathi, 2005). Dôvodom pre toto tvrdenie je, že v neskorej adolescencii sa rozvíjajú kognitívne schopnosti dialektického 
uvažovania, oceňovania komplexnosti a recipročnosti vzt’ahov s rodinou a rovesníkmi, ale tiež aj porozumenie vlastnému životnému príbehu (Kramer, 2000; Bluck, Glück, 2004). Avšak berlínska škola preukázala, že vek nie je signifikantným ukazovatel’om múdrosti (Staudinger et al., 1998). Podla Staudingera a Baltesa (1994) sa na rozvíjaní múdrosti podiel'ajú jak kreativita, otvorenost' voči skúsenosti - ako osobnostné vlastnosti, tak aj skúsenost' a širší kontext - vek, profesia, historické pozadie.

Santos et al. (2017) skúmali, či je múdrost' stabilnou osobnostnou tendenciou, alebo má situačne-podmienený kontext. Objavujú sa názory, že múdrost' je nemennou vlastnost'ou, ktorá sa prejavuje $\mathrm{v}$ rôznych situáciách, rovnako ako názory, ktoré poukazujú na zmenu úrovne múdrosti počas života a v rôznych situáciách (Westrate, Ferrar, Ardelt, 2016; Baltes, Staudinger, 2000; Staudinter, Glück, 2011; Grossmann, Kross, 2014). Podl'a Grossmanna (2017) existuje intraindividuálna variabilita a stabilita múdreho uvažovania, ktorá sa prepája s konštruktami Big Five.

Erikson (1999) prepája múdrost' s posledným - ôsmym - štádiom vo vývine človeka ako cnost', ktorá sa v tomto období rozvíja. Posledné štádium je podl'a neho charakteristické krízou medzi integritou a zúfalstvom ako úplným koncom nepredvídatel'ným v čase a spôsobe priebehu života a nádejou a nárokom na zrelost' - integritou. Múdrost' je špecifickou cnost'ou, ktorá zreje $\mathrm{v}$ tomto poslednom období. Integrita je prepojená s nádejou, ktorá označuje najzákladnejšiu kvalitu Ja. Erikson (1999) tvrdil, že posledné štádium života je výrazne prepojené s prvým - deti v životaschopných kultúrach „,rastú a múdrejúc prostredníctvom vzt'ahu so starými l'ud'mi. Vo vzt'ahu k múdrosti, ju Erikson (1963) definoval ako trvalý výsledok úspešne zvládnutých t’ažkostí v živote jednotlivca. Jedná sa o vykryštalizovanú schopnost' prijímat's nadhl'adom úspech aj neúspech a dosiahnut' integritu a harmonický stav osobnosti, prekonat' zúfalstvo a beznádej. Ten, kto dosiahne múdrost' je presvedčený o zmysluplnosti svojho života. Kováč (2007) sa vyjadruje o zmysle života ako vrcholovom psychoregulátore komponentov kvality života, ktorý je zdrojom stálej spokojnosti človeka s vlastným životom. Frankl (2006) chápe zmysel života ako túžbu najzmysluplnejšie naplnit' svoju existenciu. Podl'a Battistu a Almonda (1973) človek so zmyslom života má životný rámec, prostredníctvom ktorého môže interpretovat' svet a odvodit' z neho svoje životné ciele. Hermans (1989) chápe zmysel života ako proces hodnotenia a pripisovania dôležitosti životným udalostiam a situáciám jednotlivca.

Môžeme teda konštatovat', že zmysel života je fenomén, ktorý sa skladá z viacerých aspektov, ktoré sú vo vzájomnej interakcii. Jedná sa o viacdimenzionálny konštrukt. Podla Halamu (2007) teórie môžeme usporiadat' ako:

- dvojkomponentové - napr. koncept životných schém Thompsona a Janigiansa (1998); interpretatívny a smerový aspekt osobného zmyslu Dittman-Kohli (2000); Shapirov dvojfaktorový model životného zmyslu (1988);

- trojkomponentové - Reker a Wong (1988);

- štvorkomponentové - Popielski (1987).

\section{VÝSKUMNÝ PROBLÉM}

V našom výskume sme sa zamerali na zistenie vzájomného vzt’ahu medzi mierou múdrosti a prežívanej zmysluplnosti života a naplnenia životných ciel'ov u dospelých l'udí.

Primárnym ciel'om bolo zistit' vzájomné prepojenie medzi sledovanými premennými. Zároveň sme sa zamerali aj na osobnostné charakteristiky respondentov.

\subsection{Výskumné otázky}

Na základe výskumného ciel’a sme si stanovili nasledujúce výskumné otázky:

VO1 Existuje súvislost' medzi osobnostnými charakteristikami respondentov a ich prežívaním zmysluplnosti? 
VO2 Aký bude vzájomný vzt'ah medzi múdrost'ou a subjektívnou mierou kontroly u respondentov?

VO3 Existuje vzt'ah medzi mierou prežívanej zmysluplnosti a mierou naplnenia životných ciel'ov?

\subsection{Charakteristika výskumnej vzorky}

Respondenti do výskumu boli vybraný zámerným výberom. Kritériom pre výber bol vek respondentov. Do vzorky sme zaradili 30 respondentov vo veku 50 - 55 rokov života. Priemerný vek respondentov bol 53,9 roka. Výskumnú vzorku tvorilo 14 žien a 16 mužov. Všetci respondenti dosiahli vysokoškolské vzdelanie.

\subsection{Výskumné metódy}

Pre potreby nášho výskumu sme použili nasledujúce metodiky:

PIL - dotazník zmyslu života - Crumbaugh, Maholick.

Dotazník je zameraný na zist'ovanie stavu existenciálnej frustrácie. Využili sme čast' dotazníka, ktorá sa zameriava na mieru zmysluplnosti alebo existenciálnej frustrácie. $\mathrm{Na}$ stanovenie hranice sme využili výskum Nakhlé, ktorá stanovila orientačnú hranicu stavu frustrácie 100 bodov. Respondenti s súčtom bodov nad 100 sa nachádzajú v stave prežívania zmysluplnosti. Hodnota Cronbachovej alfy bola viac ako 0,80 , čo sa považuje za optimálnu hodnotu.

NEO-FFI - Costa a McCrae.

Osobnostný inventár posudzujúci pät' dimenzií - neuroticizmus, extroverziu, otvorenost' prívetivost' a svedomitost'.

Dotazník životných ciel’ov - Taročková.

Zameriava sa na 7 dimenzií - študijno-vzdelávaciu, pracovno-profesionálnu, partnerstvomanželstvo-rodičovstvo, intrapersonálnu, intrapersonálnu, vol'nočasovú a dimenziu materiálneho zabezpečenia.

Trojdimenzionálna škála múdrosti - 3DŠM - Ardelt.

Obsahuje tri škály - kognitívnu, reflektívnu a afektívnu. Dotazník má 39 položiek. Respondenti odpovedali na Likertovej škále. Kognitívna škála sa zameriava na schopnost' a ochotu porozumiet' situácii alebo javom, uznanie nejednoznačnosti, komplexnosti a neistoty života. Reflektívna škála na schopnost' a ochotu pozerat' na situácie z rôznych hl'adísk bez predsudkov a projekcií. Afektívna škála zist’uje motiváciu k starostlivosti o psychickú pohodu druhých. Cronbachova alfa pre jednotlivé subškály a celý dotazník bola na miere uspokojivosti - viac ako 0,7 .

Škála vnímaného stresu - PSS - Cohen Williamson

Skrátený variant - 10 položiek, ktorý je zameraný na mieru pocitu kontroly nad svojim životom. Jedná sa o dva faktory, ktoré dotazník meria - vnímaná bezmocnost' a kontrola nad životom. Cronbachova alfa dotazníku bola viac ako 0,8 .

\subsection{Interpretácia výskumných zistení a diskusia}

VO1 Existuje súvislost' medzi osobnostnými charakteristikami respondentov a ich prežívaním zmysluplnosti?

V rámci prvej výskumnej otázky sme sa zamerali na zist'ovanie vzt'ahu medzi jednotlivými osobnostnými charakteristikami respondentov meranými NEO - FFI a mierou preživanej zmysluplnosti. Zistili sme, že neexistuje významný vzt'ah medzi jednotlivými charakteristikami a prežívanou zmysluplnost'ou. Slabá súvislost' sa preukázala medzi neuroticizmom a existenciálnou frustráciou, ale nebola štatisticky významná $(\mathrm{r}=0,231)$.

VO2 Aký bude vzájomný vzt'ah medzi múdrost'ou a subjektívnou mierou kontroly u respondentov? 
V rámci výskumu sme sa zamerali na vzájomný vzt'ah medzi múdrost'ou a vnímanou bezmocnost'ou a kontrolou nad životom. Zistili sme, že vnímaná bezmocnost' stredne silne a negatívne koreluje s reflektívnou dimenziou múdrosti $(\mathrm{r}=-0,382, \mathrm{p}<0,01)$. Kontrola nad životom korelovala pozitívne s reflektívnou dimenziou múdrosti $(r=264, p<0,05)$. Zároveň táto dimenzia pozitívne korelovala s celkovým skóre múdrosti $(\mathrm{r}=0,361 ; \mathrm{p}<0,01)$.

VO3 Existuje vzt’ah medzi mierou preživanej zmysluplnosti a mierou naplnenia životných ciel'ov?

Na základe porovnania sa nám potvrdil pozitívny vzt’ah medzi mierou naplnenia životných ciel'ov a mierou prežívanej zmysluplnosti u respondentov $(\mathrm{r}=0,434, \mathrm{p}<0,05)$. Pri kvalitatívnej analýze získaných výsledkov sa však nezistil rozdiel medzi participantami, ktorí vnímajú svoje životné ciele ako podstatne naplnené a úplne naplnené v súvislosti s mierou životnej zmysluplnosti.

Na základe našich zistení môžeme konštatovat', že sa preukázala stredne silná pozitívna korelácia medzi reflektívnou dimenziou múdrosti a mierou subjektívnej kontroly nad situáciou. Tieto zistenia sú v súlade s výskumami Etezadiho a Pushara, 2012 v súvislosti s výskumami self-efficacy a múdrosti DiGangiho et al (2013) a Sveceho a Greavesa (2013). Reflektívna dimenzia múdrosti obsahuje položky zamerané na neprítomnost' subjetkivity a projekcie ako obranného mechanizmu, ktoré by sa dali prepojit' s miestom kontroly - čo by bolo potrebné bližšie preskúmat'. Ďalej je reflektívna dimenzia prepojená so schopnost'ou a ochotou pozriet' sa na javy s rôznych uhlov pohl'adu, čo môže naznačovat' presvedčenie o možnosti kontrolovat' situáciu a vlastnú činnost'. Presvedčenie o vlastnej neschopnosti kontrolovat' dianie vo svojom živote vedie k rezignácii a únikovým tendenciám. Tie môžu byt' prehĺbené práve zvýšenou mierou neuroticizmu, ale aj mierou prežívanej zmysluplnosti.

Limity výskumu:

Výskum bol limitovaný malým rozsahom výskumného súboru a pravdepodobne aj pandemickou situáciou a jej prežívaním.

Výskum bol realizovaný v rámci projektu: The Pursuit of Wisdom in Adult Education - No 2020-1-PL01-KA204-082037

\section{Použitá literatura}

1. ARDELT, M. (2003). Empirical assessment of a Three-dimensional wisdom scale. Research on Aging, 25(3), 275-324.

2. ARDELT, M. (2005). How wise people cope with crises and obstacles in life. Revision, 28(1), 7-19.

3. ARDELT, M. (2019). Wisdom and well-being. In R. J. Sternberg \& J. Glück (Eds.), The Cambridge handbook of wisdom (p. 602-625). Cambridge University Press. https://doi.org/10.1017/9781108568272.028

4. BALTES, P. B., STAUDINGER, U. M. (1993). The search for a psychology of wisdom. Current Directions In Psychological Science, 2(3), 75-80.

5. BALTES, P. B., \& STAUDINGER, U. M. (2000). Wisdom: A metaheuristic (pragmatic) to orchestrate mind and virtue toward excellence. American Psychologist, 55(1), 122-136.

6. BALTES, P. B., SMITH, J. (2008). The fascination of wisdom: Its nature, ontogeny, and function. Perspectives On Psychological Science: A Journal Of The Association For Psychological Science, 3(1), 56-64.

7. BANGEN, K. J., MEEKS, T. W., JESTE, D. V. (2013). Defining and assessing wisdom: A review of the literature. American Journal of Geriatric Psychiatry, 21(12): 1254-1266. 
8. BATTISTA, J.; ALMOND, R. (1973). The Development of Meaning in Life. Psychiatry Interpersonal \& Biological Processes, 36(4): 409 - 27. DOI:10.1080/00332747.1973.11023774

9. BLUCK, S., GLÜCK, J. (2004). Making things better and learning a lesson: Experiencing wisdom across the lifespan. Journal of personality, 72(3), 543-572.

10. BLUCK, S., GLÜCK, J. (2005). From the Inside Out. In R. Sternberg \& J. Jordan (Eds.), A Handbook of Wisdom: Psychological Perspectives (pp. 84-109). Cambridge: Cambridge University Press.

11. CLAYTON, V. P., BIRREN, J. E. (1980). The development of wisdom across the lifespan: A re-examination of an ancient topic. In Baltes, P. B., \& Brim O. G. Jr. (Eds.). Life-span development and behavior, 3, 103-135. New York: Academic Press.

12. DigAnGI, J. A., JASON, L. A., MENDOZA, L., MILlER, S. A., CONTRERAS, R. (2013). The relationship between wisdom and abstinence behaviors in women in recovery from substance abuse. The American journal of drug and alcohol abuse, 39(1), 33-37.

13. ERIKSON, E. H. (1963). Childhood and Society. 2nd ed. New York: W. W. Norton .

14. ERIKSON, E. H. (1999). Životní cyklus rozšírený a dokončený. Praha: Nakladatelství Lidové noviny. ISBN 978802620786

15. ETEZADI, S., PUSHKAR, D. (2013). Why are wise people happier? An explanatory model of wisdom and emotional well-being in older adults. Journal of happiness studies, 14(3), 929-950.

16. FRANKL, V. E. (2006). A přesto říci životu ano. Praha: Karmelitánské nakladatelství, 2006. 176s. ISBN 978-80-7192-866-9.

17. GROSSMANN, I. (2017). Wisdom and how to cultivate it: Review of emerging evidence for a constructivist model of wise thinking. Dostupné $\mathrm{z}$ : psyarxiv.com/qkm6v

18. HALAMA, P. (2007). Zmysel života z pohl'adu psychológie. Bratislava: Slovak Academic Press, 2007.223 s. ISBN 978- 80- 8095- 023-1

19. HERMANS, H. J. M. (1989). The meaning of life as an organized process. Psychotherapy: Theory, Research, Practice, Training, 26(1), 11-22. https://doi.org/10.1037/h0085395

20. JORDAN, J. (2005). The Quest for Wisdom in Adulthood: A Psychological Perspective. In R. STERNBERG, J., JORDAN, J. (Eds.), A handbook of wisdom: Psychological perspectives (p. 160-188). Cambridge University Press.

21. KOVÁČ, D. (2007). Psychológiou k metanoi. Bratislava: Veda, 2007. ISBN 978-80224-0965-0.

22. KRAMER, D. A. (2000). Wisdom as a classical source of human strength: Conceptualization and empirical inquiry. Journal of social and clinical psychology, 19(1), 83-101.

23. KROSS, E., GROSSMANN, I. (2012). Boosting wisdom: Distance from the self enhances wise reasoning, attitudes, and behavior. Journal of Experimental Psychology: General, 141, 43-48. oi:10.1037/a0024158 141, 43-48. doi:10.1037/a0024158

24. KUNZMANN, U., BALTES, P. B. (2005). The Psychology of Wisdom: Theoretical and Empirical Challenges. In R. J. Sternberg \& J. Jordan (Eds.), A handbook of wisdom: Psychological perspectives (p. 110-135). Cambridge University Press.

25. MEEKS, T. W., JESTE, D. V. (2009). Neurobiology of wisdom: a literature overview. Archives Of General Psychiatry, 66(4), 355-365. 
26. POPIELSKI, K. (1987). Testy egzystencjalne: Metody badania frustracji egzystencjalnej i nerwicy noogennej (Tests existentiels: Méthodes d'étude de la frustration existentielle et névrose noogčne). In K. Popielski (Ed.), Człowiek pytanie otwarte (Homme-question ouverte) (pp. 237-261). Lublin: KUL.

27. RICHARDSON, M. J., PASUPATHI, M. (2005). Young and Growing Wiser: Wisdom during Adolescence and Young Adulthood. In R. J. Sternberg \& J. Jordan (Eds.), A handbook of wisdom: Psychological perspectives (p. 139-159). Cambridge University Press.

28. SANTOS, H. C., HUYNH, A. C., \& GROSSMANN, I. (2017). Wisdom in a complex world: A situated account of wise reasoning and its development. Social and Personality Psychology Compass, 11(10), e12341.

29. STAUDINGER, U. M., BALTES, P. B. (1994). Psychology of wisdom. Encyclopedia of human intelligence (pp. 1143-1152). Macmillan.

30. STAUDINGER, U. M., GLÜCK, J. (2011). Psychological wisdom research: Commonalities and differences in a growing field. Annual review of psychology, 62, 215-241.

31. STAUDINGER, U. M., MACIEL, A. G., SMITH, J., BALTES, P. B. (1998). What predicts wisdom-related performance? A first look at personality, intelligence, and facilitative experiential contexts. European Journal Of Personality, 12(1), 1-17.

32. STERNBERG, R. (2003). The Balance Theory of Wisdom. In Wisdom, Intelligence, and Creativity Synthesized (pp. 152-174). Cambridge: Cambridge University Press. doi:10.1017/CBO9780511509612.008

33. WESTSTRATE, N. M., FERRARI, M., ARDELT, M. (2016). The many faces of wisdom: An investigation of cultural-historical wisdom exemplars reveals practical, philosophical, and benevolent prototypes. Personality and Social Psychology Bulletin, 42(5), 662-676.

\section{Kontaktní údaje}

PhDr. Andrea Baranovská PhD.

PhDr. Dominika Doktorová PhD.

Univerzita sv. Cyrila a Metoda v Trnave

J. Herdu 2, Trnava

Tel: 033/5565295

email: andrea.baranovska@ucm.sk 


\title{
DETEKOVANIE VZÁJOMNÝCH KONEXIÍ A ROZDIELOV MEDZI EMOCIONÁLNOU INTELIGENCIOU A EXTRAVERZIOU U VYSOKOŠKOLSKÝCH ŠTUDENTOV
}

\author{
DETECTION OF MUTUAL CONNECTIONS AND DIFFERENCES \\ BETWEEN EMOTIONAL INTELLIGENCE AND EXTRAVERSION IN \\ UNIVERSITY STUDENTS
}

\author{
Dominika Doktorová- Baranovská Andrea
}

\begin{abstract}
Abstrakt
Výskum je zameraný na problematiku emocionálnej inteligencie v kontexte s vybranými osobnostnými charakteristikami a úzkostlivost'ou u študentov. Ciel'om práce je zmapovat' mieru emocionálnej inteligencie $\mathrm{v}$ závislosti od pohlavia a mieru osobnostných charakteristík u študentov. Vo výskume je použitý Dotazník emocionálnej inteligencie (UMEQ-i) a Eysenckov osobnostný dotazník (EOD). Výskumný súbor tvorí 100 respondentov vo veku od 18 do 28 rokov. Výskumnú vzorku tvorila aj ženy aj muži, ktorí boli kategorizovaní do 4 skupín podl'a zamerania štúdia. Výsledky výskumu vyhodnocujeme pomocou štatistického programu SPSS statistics 25. Zistili sme, že muži vykazujú vyššiu mieru emocionálnej inteligencie. Vyššiu mieru emocionálnej inteligencie vykazovali aj študenti humanitných odborov a študenti prírodných vied. Taktiež sa preukázal prítomný rozdiel v miere extraverzie u študentov, pričom najvyššia miera sa vyskytovala u študentov humanitných odborov.
\end{abstract}

Kl'účové slová: emocionálna inteligencia, osobnost', vysokoškolski študenti

\begin{abstract}
The research is focused on emotional intelligence in context with selected personality characteristics in students. The thesis explores the context between individual aspects. The thesis describes emotional intelligence and their manifestations and extraversion od students depending on the study department. The purpose od the work was to map the emotional intelligence rate depending on the gender and measure of personality characteristics od studennts. The Emotional Intelligence Questionnaire (UMEQ-i), and Eysenck's PErsonality Questionnaire (EOD) had been used to in the research. The research file consisted of 100 respondents aged 18 to 28 . The research sample also accounted for women and men who have been categorized into 4 groups according to study focus. We evaluated the research results using the Statistical Program SPSS Statistics 25. We found that men show higher emotional intelligence. Higher emotional intelligence also showed students od humanities and natural science students.
\end{abstract}

Key words: emotional intelligence, personality, college students

\section{ÚVOD}

Emocionálna inteligencia ako schopnost', predstavuje súbor schopností a zručností, ktoré sa vzt'ahujú k spracovaniu emocionálne relevantnej informácie (Baumtgartner, 2011). Pozostáva z piatich klúčových zručností, z ktorých každá vychádza z predchádzajúcej- schopnost' rýchlo redukovat' stres, schopnost' rozpoznat' a zvládnut' svoje emócie, schopnost' spojit' sa s ostatnými na základe neverbálnej komunikácie, schopnost' používat' hru a humor na zvládnutie stresovej situácie a schopnost' riešit' konflikt pozitívne a s dôverou (Segal, 2008, 
Petrides, 2010). Emocionálnu inteligenciu ako schopnost' účelovo prispôsobit', vybrat' a upravit' prostredie, použitím emocionálne dôležitých problémov vymedzil Gignac (2010). Podl'a Golemana (2011) do nej môžeme zaradit' schopnost' pracovat' v kolektíve, komunikačnú schopnost', schopnost' integrácie, samostatnost', celkovú motiváciu a záujem prevziat' zodpovednost'. Schopnost' rozpoznat', používat', porozumiet' a riadit' emócie s pozitívnymi výsledkami, a to s úmyslom odbúrania stresu, zefektívnenia komunikácie, empatie, efektívnejšieho zvládania problémov a elimináciu problémov (Segal, Smithová, 2014, Weinberger, 2016, Kotsou a kol. 2018). Vermová (2013) uvádza, že mužský a ženský mozog má rozličnú štruktúru a rozdielnost' štruktúr spôsobuje rozličnú činnost' mozgu pri rôznych úlohách. Bradberry (2005) zistil, že muži a ženy sa v úrovni emocionálnej inteligencie diferencujú. Ženy sú vo vyjadrovaní emócií ovel’a výraznejšie. Sanchez- Nunuňez (2008) tvrdí, že rozdiely v emocionálnej inteligencii medzi mužmi a ženami sú spôsobené už v detstve učením. V detstve nás učia určitým stereoptypom, kde ženy sú emotívnejšie, dokážu lepšie vyjadrit' svoje emócie. Ženy sa dokážu viac vcítit' do druhých l'udí. Rabazo a Moreno (2006) zistili, že rodičia ovplyvňujú emocionalitu svojich detí už od útleho veku napríklad čítaním príbehov. Ak rodičia čítajú dievčatám, zvyknú sa ovel'a viac rozprávat' o emóciách jednotlivých postáv ako s chlapcami. Používajú širšie spektrum emócií, pri komunikácií s dievčatami. Preto sú dievčatá časom emocionálne vyspelejšie. Dokážu lepšie rozpoznat' a vyjadrit' verbálne aj neverbálne emócie ako chlapci (Sanchez- Nunuňez, 2008). Diferenciámi a zaoberali mnohí výskumníci ako sú napríklad Nábělková (2011), Petrides, Furnham (2006) zistili významne rozdiely v zložkách emocionálnej inteligencie. U žien bolo preukázatel'né vyššie skóre v dimenziách emocionálne uznanie, empatia a v sociálnych vzt’ahoch. S týmto tvrdením nesúhlasí Čerešník (2011), ktorý uvádza, že rodové rozdiely v emocionalite doposial' neboli preukázané. Prínosom do oblasti rodových rozdielov bol Khalili (2011), ktorý skúmal rodové rozdiely $\mathrm{v}$ jednotlivých zložkách emocionálnej inteligencii. Výsledky jeho výskumu preukázali rodové rozdiely na úrovni sebauvedomenia, sebakontroly, sociability a riadenia vzt'ahov v prospech mužov (Birknerová, Frankovský, 2014). Spojitost' medzi emocionálnou inteligenciou a osobnostnými faktormi skúmali Md Nawi, Nurul Hudani, Redzuan, Ma'rof v roku 2011, ktorí v premennej emocionálna inteligencia a extraverzia potvrdili pozitívny vzt'ah (Nolen-Hoeksema, 2012). Výskum Brackett, Mayer, Warner (2004) taktiež potvrdzuje existenciu štatisticky významného vzt’ahu medzi spomínanými premennými, výsledky ich výskumu poukazujú na prítomnost' extraverzie u viac emocionálne inteligentných študentov (Iruloh, Ukeagbu, 2015). Yosooff, Desa, Ibrahim, Abd Kadir, Ab Rahman (2014) uvádzajú, že medzi emocionálnou inteligenciou a extraverziou je prítomná spojitost'. Podl'a zistení odborníkov (Goleman, 2011, Preiser, 2006, Saiful, Fuad, Rahman, 2010) má pre humanitné odbory väčší význam emocionálna inteligencia, ako pre technické. Lindebaum (2013) potvrdil, že existujú v emocionálnej inteligencii existujú medzi odbormi štatisticky významné rozdiely, čo je totožné so zisteniami odborníkov (Benson, Ploeg, Brown, 2010, Kong, Zhao, You, 2012, Schutte, Parker, Summerfeldt, Hogan, Majeski, 2004). Ciel'om výskumu je zistit', či existuje rozdiel v miere úrovne emocionálnej inteligencie medzi pohlavím, spojitost' medzi extraverziou a emocionálnou inteligenciou, rozdiely $\mathrm{v}$ úrovni emocionálnej inteligencii medzi technickými,

Hypotézu formulujeme na základe výskumu Carr (2009) a Mishra a Ranjan (2008), ktorí vo svojom výskume uvádzajú, že muži dosahujú vyššie EQ ako ženy.

H1: Predpokladáme, že muži budú dosahovat' vyššie skóre v celkovej úrovni EQ ako ženy.

Hypotézu formulujeme na základe výskumu Carr (2009) a Mishra a Ranjan (2008), ktorí vo svojom výskume uvádzajú, že muži dosahujú vyššie EQ ako ženy.

H2: Predpokladáme, že medzi premennou emocionálna inteligencia a premennou extraverzia existuje štatisticky významný pozitívny vzt'ah. 
Hypotézu formulujeme na základe výskumu Brackett a Mayer (2004), v ktorom uvádzajú zistenie, že medzi EI a extraverziou existuje štatisticky významný vzt’ah.

$\mathrm{Na}$ základe porovnávania emocionálnej inteligencie u rôznych odborov sme stanovili výskumnú otázku (Benson, Ploeg, Brown, 2010, Kong, Zhao, You, 2012, Schutte, Parker, Summerfeldt, Hogan, Majeski, 2004)

VO: Existuje štatisticky významný rozdiel v premennej emocionálna inteligencia medzi študentmi prírodných vied a humanitného zamerania?

\section{METÓDY}

\subsection{Výskumný súbor}

Do výskumu sa zapojili študenti z celého územia Slovenskej republiky vo veku od 18 do 28 rokov. Priemerný vek žien bol 21,9 $(\mathrm{N}=54)$ a priemerný vek mužov bol 21,7 $(\mathrm{N}=46)$. Participantov sme podl'a typu štúdia kategorizovali do 4 skupín, rozdelili sme ich na študentov humanitných vied, prírodných vied, na študentov umeleckého zamerania technického zamerania. Vo výskume bolo zapojených 112 respondentov, ale $12 \mathrm{z}$ nich sme museli vylúčit', pretože nevyplnili batériu dotazníkov kompletne. V štatistickej analýze teda nakoniec pracujeme s počtom zapojených participantov 100. Forma výberu participantov bola nepravdepodobnostný výber, nakol'ko sme študentov kategorizovali zámerne- podl'a typu štúdia. Pre podrobný popis výskumnej vzorky prikladáme graf č.1, tabul'ku č.1.

Graf č.1: Znázornenie pomeru mužov a žien vo výskumnom súbore

Pohlavie

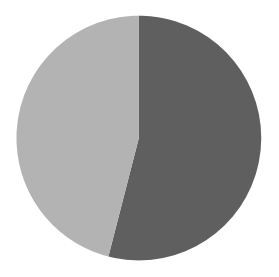

Tabul'ka č.1: Percentuálne znázornenie mužov a žien vo výskumnom súbore

\begin{tabular}{|c|c|c|}
\hline Pohlavie & Početnost & Percentá \% \\
\hline Ženy & 54 & 54 \\
Muži & 46 & 46 \\
\hline Spolu & 100 & 100 \\
\hline
\end{tabular}

Tabul'ka č.2: Štatistické ukazovatele v premennej vek v súbore žien vo veku od 18 do 28 rokov

\begin{tabular}{|l|l|}
\hline Vek u žien \\
\hline Priemer & 21,9815 \\
Štatistická odchýlka priemeru & 0,36961 \\
Medián & 22 \\
Modus & 21 \\
Smerodajná odchýlka & 2,71607 \\
Rozptyl & 1187,0 \\
\hline
\end{tabular}


Tabul'ka č.3: Štatistické ukazovatele v premennej vek v súbore mužov vo veku od 18 do 28 rokov

\begin{tabular}{|l|l|}
\hline Vek u mužov \\
\hline Priemer & 21,7391 \\
Štatistická odchýlka priemeru & 0,38503 \\
Medián & 22 \\
Modus & 24 \\
Smerodajná odchýlka & 2,61138 \\
Rozptyl & 1000 \\
\hline
\end{tabular}

\subsection{Výskumné metódy}

$\mathrm{Na}$ zber dát sme vytvorili batériu, ktorá pozostávala z troch dotazníkov, ktoré boli zamerané na emocionálnu inteligenciu a osobnostné charakteristiky- extraverziu/introverziu. Participanti na začiatku dotazníka vypĺn̆ali demografické údaje- vek, pohlavie a zameranie štúdia, ktoré slúžili ako doplnkové informácie pre výskum.

$\mathrm{Na}$ zistenie úrovne emocionálnej inteligencie použijeme dotazník USMEQ-i - emotional quotient inventory. Zostrojili ho autori M. Saiful, A. Fuad a A. Rahman v roku 2010. Tento dotazník obsahuje 46 položiek. Respondent musí označit' mieru súhlasu, ktorá ho najviac vystihuje, na škále od 1 (úplne nesúhlasím) po 5 (úplne súhlasím). V tomto dotazníku je emocionálna inteligencia zoskupená do siedmich dimenzií- emocionálna regulácia, emocionálna zrelost', emocionálna svedomitost', emocionálne povedomie, emocionálne záväzky, emocionálna statočnost' a emocionálne vyjadrenie (Saiful a kol., 2010). Hodnota Cronbachovho koeficientu alfa je v tomto dotazníku 0.96, čo znamená, že má vysokú vnútornú konzistenciu. Dotazník je reliabilný aj validný. V našom súbore vyšla hodnota Cronbachovho koeficientu 0.96, takže môžeme konštatovat', že dotazník je reliabilný a validný.

Pri meraní osobnostných charakteristík extroverzie a introverzie sme sa rozhodli použit' Eysenckov osobnostný dotazník, ktorý sa odvíja od Eysenckovej štruktúry osobnosti. Pozostáva z 57 otázok, ktoré sú rozdelené do 3 škál- E škála (24 otázok), N škála (24 otázok) a L škála (9 otázok). Respondent neodpovedá na otázky na škále ani na stupnici, ale odpovedá áno-nie, pričom vždy môže označit' len 1 odpoved'. Odpovede vyhodnocujeme podla šablóny, pričom pri každej dimenzii môžeme získat' hodnotu jednotlivých faktorov (Svoboda, 2005).

Vo výskumne sme sa zamerali na sledovanie škály E- extroverzie. V súbore sme namerali hodnotu vnútornej konzistencie 0,86 , čo znamená, že dotazník je raliabilný.

\subsection{Zber dát a štatistické vyhodnotenie}

Zbierat' dáta sme začali v mesiaci máj 2021, toto zbieranie sme ukončili v júni 2021, kedy sme nazbierali dostatočný počet dát, pre náš výskum. Inštrukcie $\mathrm{k}$ dotazníkom $\mathrm{v}$ nami vytvorenej batérii boli podané stručne, jasne a zretel'ne. Batériu sme podali študentom osobne, pričom sme vypíňanie neohraničili časom, nechceli sme vytvárat' nátlak. Zozbierané dáta boli spracované prostredníctvom štatistického programu SPSS 25. Na základe získaných čísel sme overili normálne rozoženie súboru, pričom sa nám tento predpoklad potvrdil. $\mathrm{Na}$ základe výsledkov testu normality budeme pracovat' v súbore s parametrickými testami. $\mathrm{Na}$ zist'ovanie vzt'ahu medzi premennými budeme používat' bivariačnú analýzu a na zist'ovanie rozdielov použijeme Studentov T- test, Pearsonov korelačný koeficient sme použili na výpočet vzt’ahu medzi emocionálnou inteligenciou a extraverziou. Hodnoty korelačného koeficientu od 0 do 0,4 považujeme za slabé, od 0,4 do 0,8 za stredne silné a silné za hodnoty považujeme hodnoty od 0,8 do 1 . 


\section{VÝSLEDKY}

V tejto časti bakalárskej práce sa zameriavame na prezentovanie jednotlivých výsledkov. Pod každou hypotézou a výskumnou otázkou prezentujeme tabul'ky a následne i zistenia.

H1: Predpokladáme, že muži budú dosahovat' vyššie EQ ako ženy.

Tabul'ka č.4: Studentov T-test - komparácia súborov v miere emocionálnej inteligencie

\begin{tabular}{|l|l|l|l|l|l|l|l|l|l|}
\hline \multirow{2}{*}{$\begin{array}{l}\text { Emocionálna } \\
\text { inteligencia }\end{array}$} & \multicolumn{4}{|l|}{ Muži } & Ženy & df & Sig. & T-test \\
\cline { 2 - 11 } & $\mathbf{N}$ & $\mathbf{M}$ & SD & N & M & SD & & & \\
\cline { 2 - 10 } & 44 & 3,45 & 9,22 & 56 & 2,66 & 8,57 & 119 & $\mathbf{0 0 0}$ & $\mathbf{4 , 1 1 5}$ \\
\hline
\end{tabular}

Studentov T-test sme použili na výpočet rozdielu v miere emocionálnej inteligencie medzi mužmi a ženami. Výsledky zobrazujeme v tabul'ke č.5. Štatistická analýza preukázala štatisticky významný rozdiel $v$ miere emocionálnej inteligencie $(\mathrm{t}=4,115)$ medzi mužmi a ženami, na hladine štatistickej významnosti ( $\mathrm{p} \leq 0,001)$. Muži vykazujú vyššiu mieru emocionálnej inteligencie $(\mathrm{M}=3,45)$ ako ženy $(\mathrm{M}=2,66)$. Na základe výsledkov hodnotíme, že muži dosahujú vyššie EQ ako ženy. Hypotézu H1 prijímame.

H2: Predpokladáme, že medzi premennou emocionálna inteligencia a premennou extraverzia existuje štatisticky významný pozitívny vzt’ah.

Tabul'ka č.5: Pearsonov korelačný koeficient- Výsledky vzt’ahu medzi emocionálnou inteligenciou a premennou extraverzia

\begin{tabular}{|l|l|l|}
\hline & \multicolumn{2}{|l|}{ Extraverzia } \\
\hline \multirow{3}{*}{ Emocionálna inteligencia } & r &, 455 \\
\cline { 2 - 3 } & Sig. &, 000 \\
\cline { 2 - 3 } & $\mathbf{N}$ & 100 \\
\hline
\end{tabular}

Štatistická analýza preukázala významný, silný pozitívny vzt'ah $(\mathrm{r}=0,455)$ medzi premennými emocionálna inteligencia a úzkostlivost', na hladine štatistickej významnosti ( $\mathrm{p} \leq$ 0,05). Hypotézu H2 prijímame.

VO: Existuje štatisticky významný rozdiel v premennej emocionálna inteligencia medzi študentmi prírodných vied a humanitného zamerania?

Tabul'ka č.6 : Studentov T-test - komparácia súborov v miere emocionálnej inteligencie

\begin{tabular}{|c|c|c|c|c|c|c|c|c|c|}
\hline \multirow{3}{*}{$\begin{array}{l}\text { Emocionálna } \\
\text { inteligencia }\end{array}$} & \multicolumn{3}{|c|}{$\begin{array}{l}\text { Humanitné } \\
\text { zameranie }\end{array}$} & \multicolumn{3}{|c|}{ Prírodné vedy } & df & Sig. & T-test \\
\hline & $\mathbf{N}$ & $\mathbf{M}$ & SD & $\mathbf{N}$ & $\mathbf{M}$ & SD & \multirow[b]{2}{*}{127} & \multirow[b]{2}{*}{, 000} & \multirow[b]{2}{*}{4,005} \\
\hline & 25 & 3,17 & 9,87 & 75 & 2,05 & 6,20 & & & \\
\hline
\end{tabular}

$\mathrm{Na}$ výpočet rozdielu v miere emocionálnej inteligencie medzi súbormi študentov prírodných vied a umeleckého zamerania sme použili Studentov T-test. Výsledky zobrazujeme v tabul'ke č.6. Štatistická analýza preukázala štatisticky významný rozdiel v miere emocionálnej inteligencie $(\mathrm{t}=4,005)$ na hladine štatistickej významnosti $(\mathrm{p} \leq 0,001)$. Śtudenti humanitných odborov vykazujú vyššiu mieru emocionálnej inteligencie $(M=3,17)$ ako študenti prírodovedného zamerania $(\mathrm{M}=2,05)$. Na základe výsledkov hodnotíme, že študenti prírodných vied dosahujú vyššie EQ.

\section{DISKUSIA}

\subsection{Interpretácia výsledkov}

V prvej výskumnej hypotéze sme zist'ovali rozdiel medzi mužmi a ženami v premennej emocionálna inteligencia, pričom muži mali dosahovat' vyššie skóre. Naše zistenia sú v súlade s autormi štúdií (Mishra a Ranjan, 2008; Carr, 2009), ktorí vo svojich výskumoch potvrdili, že 
muži dosahujú vyššie skóre v emocionálnej inteligencii v porovnaní so ženskou populáciou. Vyššie skóre v EI v mužskej populácii v našom súbore znemená, že muži sú schopní ovládat' svoje emócie, sú zruční v usmerňovaní svojich emócií k dosiahnutiu stanoveného ciel’a, sú to l'udia so silnými vnútornými hodnotami, taktiež to naznačuje aj zručnost' v efektívnom vnímaní, vyjadrovaní porozumenia, motivácii, kontrole a refulácií svojich emócií (Saiful a kol., 2010). McIntyre at al. (2009) zdôrazňujú nevyhnutnost' prihliadat' na to, že pohlavie ako vysvetl'ujúci faktor vždy funguje $\mathrm{v}$ interakciách s inými faktormi, napríklad s demografickými, ale aj sociálno- kultúrnymi. V minulosti boli považované ženy za viac emocionálne inteligentné ako muži, a to najmä z dôvodov a $\mathrm{z}$ predpokladov, ktoré považovala spoločnost' za typické pre ženské pohlavie (Goleman, 2011, Abbass, 2011). Pre ženy je typické, že vedia vyjadrit' svoje emócie, vedia kontrolovat' svoje emócie a regulovat' zlé nálady a pocity, často krát sa vedia vyhýbat' citovým rozpoloženiam a cítia sa sami so sebou spokojne. Salguero (2012) vychádzal z biologických zistení, že ženy a muži sa lišia v mozgovej aktivite. Rozdiely medzi mužmi a ženami sú vo všetkých úrovniach života, takže aj v emocionálnej inteligencii (Bhosle, 1999, Sutarso, 1999).

Vo výskumnej hypotéze druhej sme zist'ovali existenciu štatisticky významného pozitívneho vzt’ahu medzi premennými emocionálna inteligencia a extraverzia. Vo výskume Brackett, Mayer, 2004 bola potvrdená existencia štatisticky významného vzt’ahu medzi spomínanými premennými, na základe výsledkov z nášho výskumu môžeme potvrdit' súlad s výskumom Breckett, Mayer, 2004. Na základe výsledkov výskumu môžeme skonštatovat', že u viac emocionálne inteligentných študentov, bude vyššia miera extraverzie. V rámci extraverzie je typické nadväzovanie nových kontaktov a stretávanie sa s novými l'ud'mi (Vágnerová, 2010). Extrovertní l’udia, sú často krát priatel'ský a plný pozitívnej energie, čo v druhých l'ud'och evokuje to, že sú populárni vo svojom okolí. Podl'a Vágnerovej (2010), je pre extravertov typické a charakteristické sociálne zameranie. $Z$ tohto tvrdenia môžeme usúdit', že extrovertní l'udia, prejavujú záujem o iných l'udí aj o okolité prostredie, z čoho vyplýva, že by mali byt' aj emocionálne inteligentní. Autori P. Salovey a J. Mayer (in Schulze, Roberts (eds.) 2007) k nej prirad'ujú aj vlastnosti, ktoré by mohli byt' prediktorom k tomu, aby človek dosiahol úspech- vcítenie, vyjadrovanie a chápanie pocitov, oblúbenost', ovládanie nálad, vytrvalost', priatel'skost' a láskavost' (Schulze, Roberts, 2007).

Študenti humanitných odborov vykazujú vyššiu mieru emocionálnej inteligencie (ako študenti prírodovedného zamerania, čo je v súlade s Lindebaumom (2003). Vo výskume bol potvrdený štatisticky významný rozdiel, čo môžeme prepojit' s tvrdením autorov Goleman (2011), Preiser, 2006, Saiful, Fuad, Rahman, (2010) , ktorí vnímajú emocionálnu inteligenciu ako viac významnú a dôležitejšiu v humanitnom odbore. Tieto zistenia znamenajú, že študenti humanitných odborov, ktorí dosiahli v našom súbore vyššie skóre v emocionálnej inteligencii oproti ostatným odborom, majú vyššie predpoklady rozoznávat' a používat' emócie, rozumiet' emóciám a tak isto ich vediet' aj zvládat' (Wilding 2010). Študenti humanitných odborov sú pomerne často orientovaní na prácu s l’ud'mi a predpokladáme, že by mali mat' vyššiu úroveň emocionálnej inteligencie, na kol'ko sa to pri ich štúdiu a budúcemu zameraniu predpokladá. Študenti prírodovednom zameraní sú zväčša zvyknutí pracovat’ individuálne, to znamená, že nie je nutné klást' dôraz na ich schopnost' spolupracovat' s ostatnými. Pri humanitnom a prírodovednom smere je naopak nutné zdôraznit' to, že dokážu otvorene vyjadrit' svoje emócie, ked’že je to charakteristické pre ich budúce povolanie (Goleman, 2011, Lindebaum, 2013, Kong, Zhao, You, 2012).

\subsection{Limity práce a budúce zámery}

Jeden z faktorov, ktorý mohol ovplyvnit' výsledky nášho výskumu je výskumná vzorka a jej nerovnomerné zastúpenie respondentov. 
Ako d'alší faktor ovplyvňujúci výsledky výskumu môžeme považovat' premenné na strane respondentov. Našich respondentov mohol ovplyvnit' ich aktuálny psychický či fyzický stav, aktuálna nálada, či nečakané zapojenie sa do výskumu. Tiež ich mohla ovplyvnit klíma v triede, blížiace sa skúškové obdobie, alebo iné faktory. Taktiež vnímame za neprospech nenavodenie správnej atmosféry $\mathrm{v}$ triedach. Pri navodení atmosféry $\mathrm{v}$ triede by mohli byt' respondenti viac pokojnejší, uvol'nenejší a úprimnejší.

Ďalší vplyv na vypíňanie dotazníkov mohlo mat' to, že študenti nemali žiadnu motiváciu $\mathrm{k}$ zapojeniu sa do výskumu. V neposlednom rade vnímame ako mínus nedostatočnú znalost' administrátora. S použitými metódami sa ako študenti psychológie nestretávame dennodenne a preto máme poväčšine nedostatočnú znalost'.

Skreslenie našich výsledkov mohlo nastat' aj z dôvodu použitia dotazníkov, ktoré mali podobu sebaposudzovacích škál, kde mohli jedinci vedome menit' odpovede za účelom ukázat' sa v lepšom svetle, alebo zadávali sociálne žiaduce odpovede. Taktiež mohlo k skresleniu dôjst' aj nevedome, pretože mnohokrát človek nevie sám seba objektívne ohodnotit', teda by mal byt' radšej hodnotený iným. Ked’že dotazníky majú mnoho nevýhod ako napríklad aj obmedzenie odpovedí a zvolenie odpovede len z daných položiek, alebo nepochopenie požadovaných otázok, $\mathrm{v}$ budúcnosti by sme sa vyvarovali dotazníkovým metódam a na realizáciu nášho výskumu zvolili inú metódu, napríklad experiment.

\subsection{Budúce zámery}

Emocionálna inteligencia má vel'ký význam vo výchove a vzdelávaní, pretože dokáže výrazne ovplyvnit' medzil'udské vzt'ahy a výrazne zasahuje do pracovnej oblasti (Antoničová, Pochanič, 2006). Vedomosti sú dôležité a zaručujú prijatie do zamestnania, ale emocionálna inteligencia zabezpečí postup a úspešnost' v zamestnaní (Antoničová, Pochanič, 2006). Emocionálna inteligencia je menej geneticky podmienená, v porovnaní so všeobecnou inteligenciou, ktorá sa po dosiahnutí určitého veku, už nejako významne nemení, kvality emocionálnej inteligencie sa dlhodobo vyvíjajú a dajú sa naučit' (Antoničová, Pochanič, 2006). Práve preto sme sa $v$ rámci nášho budúceho výskumu zameriame na rozvoj emocionálnej inteligencie. Jednotlivé zložky emocionálnej inteligencie sú dôležité $\mathrm{v} z ̌ i v o t e$ každého človeka. Bar- On (2006) tiež hovorí o potrebe neustáleho zvyšovania emocionálnej inteligencie počas života. Zložky emocionálnej inteligencie sa dajú naučit' a rozvíja. Nie len $\mathrm{v}$ detstve, ale aj v dospelosti. Je vel'mi dôležité, aby rodičia venovali väčšiu pozornost' tomu, aby svoje deti naučili porozumiet' a podelit' sa o svoje emócie. Deti majú často problém vyjadrit' svoje emócie, pocity. V tom prípade rodičia môžu vymysliet' príbeh, s ktorým sa diet'a stotožní Ako sme už spomínali, pri výchove dievčat je to prirodzenejšie ako u chlapcov. My sme si pre našu prácu vybrali adolescentov. Rozvíjanie emocionálnej inteligencie v tomto období je vel'mi dôležité.

\section{Zoznam použitej literatúry}

1. ABBAS, L., HAJIHASHEMI, S., STEAD, L.F., COOPER, G.J., WARE, T.L., MUNSEY, T.S., WHITFIELD, T.T., AND WHITE, S.J. (2011) Functional and developmental expression of a zebrafish Kir1.1 (ROMK) potassium channel homologue Kcnj1. The Journal of physiology. 589(Pt 6):1489-503.

2. ANTONIČOVÁ, I., POCHANIČ, J., (2006). Emocionálna inteligencia- jednota srdca a rozumu. In: Psychologická reveu [online]. Prešov: Prešovská univerzita V Prešove, 2006. Dostupné na internete: http://www.pulib.sk/elpub2/FHPV/Kuba ni2/2.pdf

3. BAUMGARTNER T, KNOCH D, HOTZ P, EISENEGGER C, FEHR E. (2011)Dorsolateral and ventromedial prefrontal cortex orchestrate normative 
choice. Nat Neurosci. 2011 Oct 2;14(11):1468-74. doi: 10.1038/nn.2933. PMID: 21964488

4. BAR- ON, R. (2006). The Bar- On model of social and emotional intelligence. In Psicothema [online]. 2006, č. 18. Dostupné na internete: http://www.eiconsortiu m.org/reprints/bar-on_model_of_emotional-social_intelligence.htm

5. BENSON, G.; PLOEG, J.; AND BROWN, B. (2010). A cross-sectional study of emotional intelligence in baccalaureate nursing students. Nurse Education Today, 30(1), 49-53.

6. BRADBERRY, T., \&GREAVES, J. (2005). Emotional intelligence quick book. Translated by: M. Ganji. Tehran: Savalan Publication. Denham SA, Blair KA, DeMulder E, Levitas J, Sawyer K, Auerbach-Major S.;1; 2003. Preschool emotional competence: pathway to social competence. Child Dev. 74:238-56.

7. BIRKNEROVÁ, Z., FRANKOVSKÝ, M., (2014). Rodové diferencie v prejavoch sociálne, emocionálnej inteligencie a machiavellizmu v manažérskej práci. 1.vyd. Praha: Radix, 2014. 100 s. ISBN 978- 80- 87573- 12- 9

8. Bhosle, S. (1999). Gender differences in Emotional Quotient. New Delhi: Sage Publications

9. BRACKETT,M. A., MAYER, J. D., WARNER, R.M. (2004). Emotional Intelligence and the Prediction of Behaviour. Personality and Individual Differences.

10. CARR, S. E. (2009). Emotional intelligence in medical students: Does it correlate with selection measures? Medical Education.

11. Čerešník, M. (2011). O mužoch a o ženách. Psychologický pohl'ad na problematiku rodu. Nitra: PF UKF. $122 \mathrm{~s}$.

12. GIGNAC, G. E. (2010). On a nomenclature for emotional intelligence research.Industrial and Organizational Psycholog, 3 (2), 131-135.

13. GOLEMAN, D. 2011. Emoční inteligence. Praha: Metafora, 2011. 336 s. ISBN 97880- 735-9334-6.

14. IRULOH, B-R. N.- UKAEGBU, H.M. (2015.) Big Five Personality traits as predictosrt og emotional intelligence of secondary schol teachers in rivers state of Nigeria. European Journal of Psychological Research, Vol. 2 No. 2, 2015 ISSN 2057-4794.

15. KHALILI, A. 2011. Gender Differences in Emotional Intelligence Among Employees of Small and Medium Enterprise: An Empirical Study. Journal of International Management Studies, Vol. 6, No. 2, 2011. p. 184 - 193.

16. KONG, F.; ZHAO, J.; AND YOU, X. (2012). Social support mediates the impact of emotional intelligence on mental distress and life satisfaction in Chinese young adults. Personality and Individual Differences, 53(4), 513-517.

17. KOTSOU, M. a kol. (2018). Improving Emotional Intelligence: A Systematic Review of Existing Work and Future Research Article https://doi.org/10.1177/17540 73917735902

18. LINDEBAUM, D. (2013). Does emotional intelligence moderate the relationship between mental health and job performance? An exploratory study. European Management Journal, 31(6), 538-548. 11.

19. MCINTYRE, M. H. (2010). Gender differences in the nature and linkage of higherorder personality factors to trait and ability emotional intelligence. Personality and Individual Differences, 48, 617-622.

20. MD NAWI- NURIL HUSANI- REDZUAN, MA'ROF. (2011). Emotional intelligence, personality and self esteem: a comparison of the characteristics among two categories of subjects. [online] International Journal of Humanities and Social Science, 1 (8). pp. 238-247. 2011. ISSN 2220-8488 
21. MISHRA ,R., RANJAN,P. (2008). Emotional Intelligence as realted to Self esteem of adolescents. Indian Journal of Human Relation, vyd.34.

22. NÁBĚLKOVÁ, E. (2012). Psychometric properties of the questionaire of trait emotional intelligence for adults (TEIQue). In Psychologica Universitas Comeniana - zborník Filozofickej fakulty Univerzity Komenského v Bratislave XLI (CD-rom), s. 657-675.

23. NOLEN-HOEKSEMA, S. A KOL. (2012). Psychologie Atkinsonové a Hilgarda. 3. vyd. Praha: Portál, 2012. 888 s. ISBN 978-80-262-0083-3.

24. PETRIDES, K.V.; FREDERICKSON, N.; AND FURNHAM, A. (2006). The role of trait emotional intelligence in academic performance and deviant behavior at school. Personality and Individual Differences, 36(2), 277-293.

25. RABAZO MÉNDEZ, M. J., \& MORENO MANSO, J. M. (2006). Estilo interactivo durante la lectura de cuentos infantiles de contenido engañoso [Interactive Style during the Reading of Sánchez-Núñez, M. T. et al. -472- Electronic Journal of Research in Educational Psychology. . ISSN. 1696-2095. No 15, Vol 6 (2) 2008, pp: 455-474 Children's Stories with Deceptive Contents] Revista Electrónica de Investigación Psicoeducativa, 4(3), 493-512.

26. SAIFUL, M., FUAD, A., RAHMAN, A. (2010). The USM Emotional Quotient Inventory (ESMEQi) Manual (21 p.). KKMED Publications. ISBN 978-967-554700-3.

27. SALGUERO, J. M., (2012). Emotional intelligence and depression: The moderator role of gender. In Personality and Individual differences [online]. Vol. 53, no. 1. Dostupné na internete: http://www.sciencedirect.com/science/article/pii/S01918869 $1200075 \mathrm{X}$

28. SANCHEZ- NUNUŇEZ, M. T., (2008). Does emotional intelligencedepend on gender: The socialization of emotional competencies in men and women and its implications. In Electronic Journal of research in educational psychology [online]. 2008, Vol. 6, no. 15. [cit.2008- 05-27]. Dostupné na internete: http://www.investi gacion-psicopedagogica.org/revista/articulos/15/english/Art_15_253.pdf

29. Schutte, N.S., Malouff, J.M., Hall, L.E., Haggerty, D.J., Cooper, J.T., Golden, C.J. a nd Dornheim, L. 1998. Development and validation of a measure of emotional intelligence. Personality and Individual Differences, 25: 167-77

30. SCHULZE, R. - ROBERTS, R. D. (2007). Emoční inteligence: prehled základních prístupů a aplikací. Praha: Portál, 2007. 368 s. ISBN 80-7367-229-4

31. SEGAL, J. (2008). The Language of Emotional Intelligence: The Five key skills for building powerful and effective relationships. New York: McGraw Hill.

32. SEGAL, J. SMITH, M. (2014). Emotional Intelligence (EQ) Key Skills for Raising Emotional Intelligence.

33. SUTARSO, P. (1999). Gender differences on the emotional intelligence inventory (EQI). Dissert. Abst.Int.

34. VÁGNEROVÁ, M. (2010). Psychologie osobnosti. Praha: Karolinum, ISBN 978-802461832-6.

35. YOSOOFF, F.- IBRAHIM, A.- ABD KADIR, N. B- AB RAHMAN, M. (2014). A study of the relationship between $E Q$ and personality amog lectures at a research unoversity. Procedia- Social and Behavioral Sciences, 2014.

36. Weinberger L, Ayyash M, Novershtern N, Hanna JH.(2016) Dynamic stem cell states: naive to primed pluripotency in rodents and humans. Nat Rev Mol Cell Biol. 2016 Mar;17(3):155-69. doi: 10.1038/nrm.2015.28. PMID: 26860365. 
Tento článok vznikol na základe podpory z grantu: Emocionálna inteligencia ako sociálna podpora pri zvládaní stresu v osobnom aj pracovnom živote u dospelých 2020-1-SK01KA204-078380

\section{Kontaktné údaje}

PhDr. Dominika Doktorová, Ph.D.

Univerzita sv. Cyrila a Metoda v Trnave

Námestie Herdu 2, Trnava 91701

Tel: 0904696500

dominikka.doktorova@gmail.com /dominika.doktorova@ucm.sk 


\title{
ART ACTION VE SPOJENÍ S TRADIČNÍ LIDOVOU KULTUROU A LAND ARTEM
}

\author{
ART ACTION IN CONNECTION WITH TRADITIONAL FOLK \\ CULTURE AND LAND ART
}

\author{
Patricia Biarincová
}

\begin{abstract}
Abstrakt
Príspevok je zameraný na priblíženie a konkretizáciu možnosti ako pracovat' s art action v spojení s tradičnou l'udovou kultúrou $\mathrm{v}$ štýle land art. V texte konkretizujeme praktické aktivity budúcich učitel'ov výtvarnej výchovy, ktoré boli realizované počas mimo ateliérového štúdia študentov Katedry výtvarnej výchovy. Ťažisko problematiky sme skoncentrovali na tradičnú l'udovú kultúru a jej potenciál v edukačnej praxi. Orientovali sme sa na školský vek až dospelost' v kontexte spracovania nami riešenej problematiky a názornej modelovej situácie/akcie v rámci umeleckej činnosti dospelej populácie/študentov.
\end{abstract}

Kličová slova: výtvarná výchova, l’udová kultúra, edukačná prax, land art, art action

\begin{abstract}
The paper is focused on approaching and concretizing the possibility of working with art action in connection with traditional folk culture in the style of land art. In the text, we concretize the practical activities of future teachers of art education, which were carried out during the studio studies of students of the Department of Art Education. We focused the focus on the issue of traditional folk culture and its potential in educational practice. We focused on school age to adulthood in the context of processing the issues addressed by us and an illustrative model situation / action within the artistic activity of the adult population /students.
\end{abstract}

Key words: Art education, folk culture, educational practice, land art, art action

\section{AKČNÉ UMENIE A BIODROMÁLNY PROCES}

Prioritnú úlohu v projekte hrá akčné umenie v živote človeka. V rámci uchopenia projektu sa teda orientujeme na dve základné premisy: akčné umenie a biodromálny proces.

Akčné umenie/umenie akcie je prezentované rôznymi formami intermediálneho umenia, ktorý kladie akcent na živé predvádzanie deja/akcie, priamy kontakt s divákom $\mathrm{v}$ rátane jeho bezprostrednej participácie či bezprostrednej spoluúčasti (Geržová, Hrubaničová, 1998) zasadené do konkrétneho prostredia, odohrávajúce sa v konkrétnom čase. Súvisí s tendenciami stierania hraníc medzi umením a životom (Geržová, 1999). Výsledkom nie je tvorba hmotného artefaktu, ale proces, hra, udalost', dianie $\mathrm{v}$ čase a priestore, ktorý má efemérnu povahu a býva komunikovaný druhotným/dokumentačným zápisom - textom, fotografiou, videom, filmom a iné (Štofko, 2007).

Biodromálny proces. V biodromálnej koncepcii charakterizujeme psychický vývin jednak ako proces nevyhnutných vývinových zmien danej osoby a rovnako tak aj ako proces možných rozvojových zmien danej osoby. Vývinové zmeny a rozvojové zmeny sú predovšetkým výsledkom toho, čo sa človek naučil (prijat' za vlastné, zvnútornil) a ako to, čo sa naučil dokáže uplatnit' vo svojom konaní a v rozmanitých činnostiach. V rámci chápania biodromálneho procesu vychádzame z Eriksonovej koncepcie epigenézy psychiky. Jeho 
koncepcia vychádza z toho, že l'udský život je ako rad krokov, ktoré vedú k výšinám vedl'a priepastí. Ústredným bodom tejto koncepcie je postupné potvrdzovanie identity, a tým aj integrity osobnosti ako základu plnohodnotného a plodného života. Eriksonove štádiá pokrývajú celé rozpätie života človeka. Viac pozornosti sústredil na kultúrne faktory, menej na biologické čo sa aj odzrkadl'uje v jeho teórii. Erikson vychádzal zo skutočnosti, že človek má vrodenú tendenciu zmysluplne sa rozvíjat' ako osobnost' (Erikson, 2015).

Naším zámerom je realizovat' a prezentovat' situačno-art-akčné modely s využitím uplatnenia akčného umenia pri práci $\mathrm{s}$ človekom počas jeho biodromálnej cesty. V príspevku prezentujeme koncept a uchopenie problematiky s prihliadnutím na eko/environmentálne stratégie, ktoré sú spojené s históriou a tradičnou l'udovou kultúrou.

Akčné umenie v našom ponímaní, v kontexte projektu, umožňuje na základe tvorivých výtvarných aktivít vykonávaných $\mathrm{v}$ exteriéry $\mathrm{v}$ priestore prírody relaxačné a zároveň psychohygienické a psychorelaxačné uvol'nenie a to prostredníctvom akcií/aktivít vykonávaných umeleckou stratégiou land art. Tvorba $\mathrm{v}$ prírode uplatňuje princípy, ktoré rešpektujú jednotu človeka a prírody, symbiózu človeka s krajinou a prírodou. Práca $\mathrm{s}$ fundamentálnymi prírodnými prvkami pôsobí terapeuticky a zároveň upokojujúco, navodzuje pocity radosti z príjemne stráveného času, pocity sebauspokojenia, pocity očisty, ktoré sa dostavia počas alebo po ukončení aktivít v prírode. $\mathrm{V}$ súvislosti s projektom nachádzame možnosti ako sa cez situačno-akčné modely môžeme sústredit' na citlivé oblasti ako sú minority, etniká či globalizáciu sveta, ktorá s časti potiera jedinečnost' vlastných kultúr a subkutúr. Tradičná l’udová kultúra patrí k prejavom našej kultúry, preto považujeme za vel'mi dôležité a aj aktuálne pracovat' v súčasnej dobe $\mathrm{s}$ touto oblast'ou/problematikou, ktorá nás diferencuje a definuje vo svetovom priestore cez špecifické charakteristiky (Biarincová, 2020).

Koncepcie a umelecké stratégie, ktoré vznikli v histórii l'udstva nám umožňujú pracovat' v oblasti našej problematiky odrážajúc sa od ich ideového základu. V našom konkrétnom situačno-art-akčnom modely sme spojili l’udovú kultúru s akčným umením v duchu Land art \& Folk art \& Action art.

\section{LAND ART}

Na konci 60-tych rokov 20. storočia sa v USA vyvinul umelecký smer súvisiaci s postojom ku komercionalizácii umenia. Čast' sochárov ovplyvnená minimalizmom opúšt'a priestory galérií a začína tvorit' vo vol'nej prírode/krajine uvedomujúc si spojenie človeka a krajiny a ekologickú devastáciu prírody civilizáciou.

Land art v 70-tych rokoch 20. storočia začal smerovat' $\mathrm{k}$ autentickej spätosti človeka s prírodou. Táto spätost' sa diala prostredníctvom syntézy jazyka romantizmu, minimalizmu, konceptualizmu a procesuálneho umenia. Spojením istých prvkov výtvarného jazyka z vymenovaných umeleckých stratégii vznikol smer, ktorý predstavoval návrat do prírody založený na romantickom úteku $\mathrm{z}$ civilizácie, ktorý pracoval $\mathrm{s}$ primárnymi štruktúrami $\mathrm{v}$ zhode s minimalizmom. $Z$ konceptualizmu prebral plánovanie, $\mathrm{z}$ akčného umenia ritualizoval $\mathrm{V}$ krajine médium l'udského tela, pohybu, gesta a $\mathrm{z}$ procesuálneho umenia prebral pominutel'nost' materiálov, založenú na nestálosti a rozklade. V americkom prostredí sa pre land art ujali názvy earth art (zemné umenie) alebo earth work (zemné práce). Doménou land artu bol otvorený časopriestor krajiny a fundamentálny materiál, ktorý sa $\mathrm{v}$ nej nachádzal. Prírodné materiály hlina, kameň, piesok, drevo, lístie, obilné lány atd'. a tiež prírodné živly ako oheň, voda, slnko či vietor sa stali pracovným materiálom land artistov (Štofko, 2007).

Land art vychádza z reflexie krajiny, viaže sa ku konkrétnemu miestu, vytvára s ním vnútorné vzt’ahy. Reflektuje civilizačno-prírodné prepojenia vel'korysými umeleckými zásahmi do krajiny v podobe dominantných útvarov, často krát s ekologickým kontextom a podtextom, alebo intímnejším spôsobom, citlivým zásahom autora do krajinárskeho kontextu s tendenciou 
splynutia diela s prírodou (Geržová, 1999). Land artisti znovu objavili tajomné stránky krajiny a prírodné dianie $\mathrm{v}$ nej. Umelecké artefakty vytvárali často na odl'ahlých miestach, kde boli vystavené premenám prírody a neodvratnému zániku.

Umenie v krajine, $\mathrm{v}$ ktorom sa prekrýva earth art i land art, environmentálne umenie sa zameriava na vzt'ah človeka ku prírode/krajine, na vytvorenie jedného organického celku a síce na prírodnú realitu a zásah človeka. Činnost', akcia v teréne je zameraná na zem, hlinu, piesok, prírodniny, kamene, trávu, všetky tieto hmoty sa stávajú umeleckým materiálom. Land artisti premiestňujú materiál, kreslia v krajine, robia akcie s ekologickým podtextom, pracujú s fyzikálnymi vlastnost’ami krajinného prostredia, ako aj so sedimentmi kultúrnej pamäti v krajine (Geržová, Hrubaničová, 1998).

\section{FOLK ART}

Ludové textilné remeslá minulých storočí patria k našej histórii, sú súčast'ou nášho kultúrneho dedičstva a dodnes nás inšpirujú.

Tradičná l'udová kultúra bola vo svojej podstate lokálna. Viazala sa na spoločenstvo, čo sa odzrkadlilo aj v tvorbe artefaktov. Niektoré artefakty sa vytvárali v takých malých množstvách, že neprekročili geografické hranice obce, či oblasti (Danglová, 2001). Ludové umenie bolo úzko zrastené zo životným prostredím, krajinou a praktickými potrebami vyplývajúcimi $\mathrm{z}$ potrieb každodenného života. Takisto záviselo od prírodných a geografických podmienok. Od nich sa odvíjal charakter l'udovej tvorby, myšlienkové a emocionálne postoje.

V l'udovom prejave nachádzame osobité druhy výtvarného prejavu, ktoré poukazujú na fakt, že jeden predmet mohol mat' za rozličných okolností úžitkovú, magickú, ochrannú i reprezentačnú funkciu. Táto polyfunkčnost' so synkretickými vlastnost'ami súvisela s fázami historického vývoja l'udovej umeleckej tvorby.

Ludový výtvarný prejav sa uplatňoval v celej oblasti hmotnej aj nehmotnej kultúry, ako súčast' života jednotlivcov i celých komunít. Vel'kú úlohu v predmetnom svete l'udových vrstiev hrala dôverná znalost' materiálov, metódy spracovania, spôsoby estetického skrášlenia, ktoré sa uplatňovali v bohatej škále materiálov. V ich okruhu vznikali jednotlivé výtvarné druhy: drevo (rezbárstvo), textil (modrotlač, výšivka, čipka, tkanina), kov (drotárstvo, šperkárstvo), hlina (keramika), sklo, koža, kameň (kameňosochárstvo). V slovenskom l'udovom umení sa prelínali a pretvárali výtvarné tradície teritoriálne blízkych národov často súvisiace s pastierskym elementom.

Všetky prejavy l'udového umenia charakterizovala predovšetkým úžitková funkcia, ktorej sa podriad'oval aj estetický zámer. Estetické cítenie tvorcov l’udového umenia tvorilo súlad funkcie, materiálu, tvaru a dekoru. Úžitkovost' predmetov bola doplnená dekoratívnou formou. Tvorba v l'udovom umení bola vždy úzko spätá s domácimi prírodnými materiálmi. Úžitkový tvar často závisel od vlastností materiálu, ktoré boli rešpektované. Jednoduché/minimalistické formy súviseli s účelom predmetu. Hoci v l’udovom umení nachádzame dekoratívnu zložku, ktorá tvorí neodmyslitel'nú súčast' výzdoby l'udových predmetov/objektov, bohatstvo vzorov ornamentov a kompozičných väzieb vytvára organickú jednotu produktu. V l'udovom umení nachádzame prvky abstrakcie, výtvarnej jedinečnosti, dômyselnosti a emocionálnej/citovej zaujatosti (Michalides, 1984) ale aj neopakovatel'nú vekmi nahromadenú životnú skúsenost' majstrov a tvorcov výtvarných prejavov v l'udovom umení.

S pozvol'ným nástupom industrializácie a urbanizácie, rušením kultúrnej uzavretosti vidieka na konci 19. storočia nastáva úpadok l’udového remesla a rol’níctva. L’udové umenie vo svojej tradičnej podstate postupne zaniklo. Oslabil sa synkretizmus funkcie a dekorácie, dochádzalo k zámene autentickej domácej výroby za spotrebu priemyselných produktov. Výtvarná kultúra vidieka sa postupne urbanizovala (Danglová, 2001). 


\section{LAND ART\& FOLK ART SPOLOČNÉ CHARAKTERISTIKY}

$\mathrm{V}$ rámci projektu sa $\mathrm{v}$ tejto fáze riešenia orientujeme aj na zdokumentovanie procesu akčnej tvorby človeka počas jeho celoživotnej cesty. Zameriavame sa na identifikovanie možností a limitov art action v spojitosti s návrhmi a odporúčaniami pre d’alšie využitie v praxi. Hl'adáme cesty ako verejne prezentovat' art action ako súčast' umeleckej podpory $\mathrm{v}$ rámci zvýšenia záujmu verejnosti o umenie $\mathrm{v}$ živote človeka. Zároveň svoju činnost' v rámci projektu smerujeme aj do oblasti inovácie a skvalitnenia odbornej prípravy študentov a študijných odborov, ktoré sú rozhodujúce pre zabezpečovanie profesionálnej starostlivosti o kultúru a umenie. Na základe uvedených podnetov, cielov a stanovených úloh z projektu $K E G A$ 002KU-4/2019 Stelesnená skúsenost's využitím art action, sme sa orientovali na modelové hodiny, ktoré predstavujú možnosti ako pracovat's témou action art vo vysokoškolskom vzdelávaní a vzdelávaní.

V našom konkrétnom situačno-art-akčnom modely sme spojili l’udovú kultúru s akčným umením v duchu Land art \& Folk art \& Action art. Východiská, ktoré tvoria podstatu aktivít/akcie sme zvolili na základe okruhu záujmu a okruhu problematiky, ktorej sa dlhodobo venujeme. Prioritne nás zaujíma, ako dokážu študenti pracovat's tradičným l'udovým umením v rámci výtvarných aktivít/tvorby, ako ju dokážu uchopit' ako inšpiračný zdroj, ako ju vedia transformovat', respektíve redefinovat' do novej podoby v kontexte rôznych výtvarných problémov. Spojenie folk artu s land artom nie je náhodné. Land art ako aj tradičné umenie majú isté spoločné východiská a charakteristiky, ktoré sa stali z hl'adiska art action platformou pre tvorbu konkrétneho situačno-art-akčného modelu.

Schéma 1

Spoločné charakteristiky pre Land art\& Folk art východiská pre tvorbu situačno-artakčných modelov

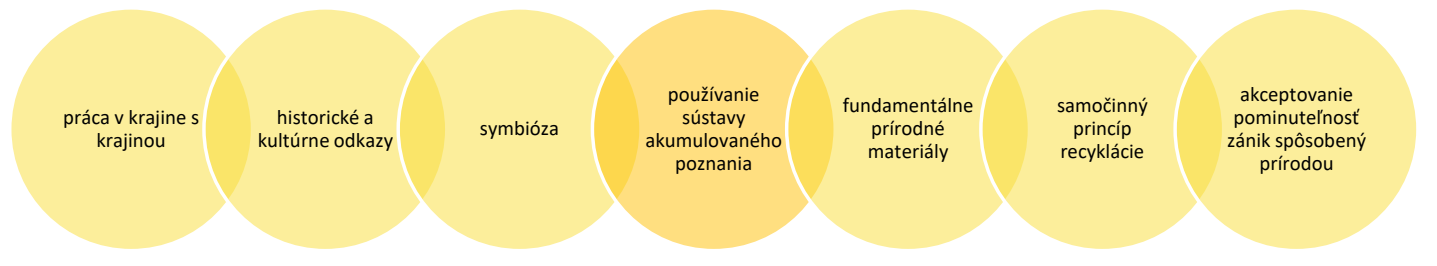

Zdroj: vlastné spracovanie

Prístupy land artu reflektujú civilizačno-prírodné prepojenia, zameriavajú sa na vzt’ah človeka ku prírode/krajine. Ludové umenie bolo úzko prepojené s prírodou, prostredím, krajinou a všestrannými potrebami, ktoré poskytla príroda, prírodne zdroje a materiály.

Podstatné východiská pre tvorbu situačno-art-akčných modelov v našom koncepte Land art\& Folk art:

- umenie v krajine, earth art i land art $\rightarrow$ environmentálne umenie sa zameriava na vzt'ah človeka $\mathrm{k}$ prírode/krajine,

- earth art i land art sa zameriava na vytvorenie jedného organického celku $\rightarrow$ na prírodnú realitu so zásahom človeka,

- l'udová kultúra je súčast'ou našej identity a histórie,

- obsahuje sústavu akumulovaného poznania, správania, vzorov materiálnych a nemateriálnych produktov l'udskej činnosti prenášaných z generácie na generáciu,

- obsahuje databázu vzorov, produktov duchovnej a materiálnej povahy,

- prenášaním vzorov materiálnych a nemateriálnych produktov vznikli a boli uchované historické artefakty, ktoré dnes môžeme študovat' a d'alej aktualizovat', 
- recyklovaním a redefinovaním prenášaných vzorov materiálnych a nemateriálnych produktov vytvárame nové produkty, ktoré v sebe nesú odkaz histórie.

\section{Schéma 2}

Spoločné charakteristiky pre Land art\& Folk art z hl'adiska aktivít a funkcií umenia spojených s art action $\mathrm{v}$ kontexte projektu

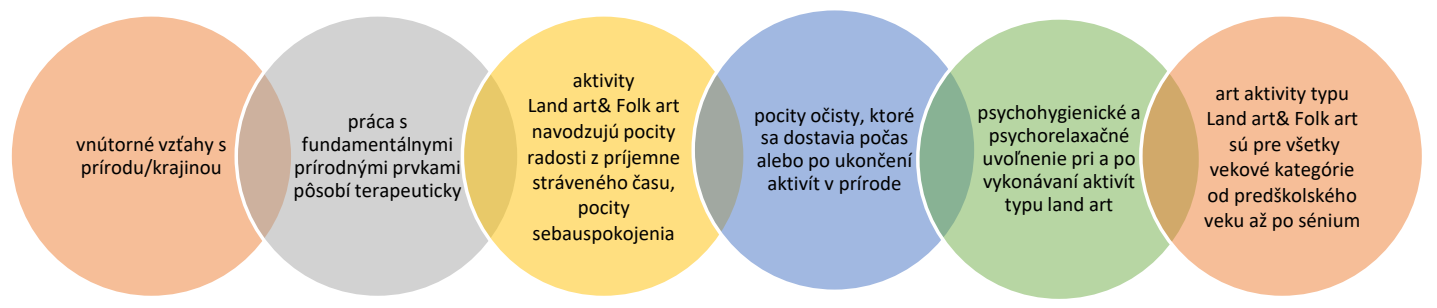

Zdroj: vlastné spracovanie

Pri výtvarných činnostiach/aktivitách dochádza medzi subjektom (diet’a, adolescent, dospelý človek, senior) a rôznymi druhmi médií, tém, štýlov a foriem $\mathrm{k}$ vzájomnej interakcii. $\mathrm{V}$ procese tvorivých činností/aktivít prichádza k tvorivému operovaniu (manipulovaniu, transformovaniu, kombinovaniu, redefinovaniu atd'.) s rôznymi médiami, témami a formami, ktoré prebieha cez invenčnú činnost'/aktivity. Súčast'ou tvorivého diania sú psychomotorické procesy, ktoré sa prejavujú v mentálnej rovine l'udského prežívania (emócie, vnemy, predstavy, fantázia, myslenie, motivácia atd'.) ale aj v behaviorálnej rovine cez správanie (konanie, prejav, emočné výrazy). Štofko uvádza, že: „Psychomotorický proces je intencionálne zameranou tvorivou činnostou. Intencionalita dodáva psychomotorickému procesu zmysluplné smerovanie k nejakému konečnému tvorivému cielu' "(Štofko, 2010, s.43). Pri konvergentnom postupe je intencionalita dopredu daná, pri divergentnom tvorivom procese autor hl'adá konečnú podobu artefaktu v priebehu samotnej tvorivej činnosti, kedy často používa nekonvenčné postupy a experimentovanie, ktoré postupne definujú/určujú konečný tvar/stav tvorivého produktu (Štofko, 2010).

Každý výtvarný produkt alebo umelecká aktivita/akcia kódujú určitý mentálny, technický a formálny proces. Výtvarný produkt teda nesie v sebe isté informácie, ktoré sú zakódované a stávajú sa podnetom pre vznik rôznych asociácií, imaginatívnych obrazov, emócií a synestézií, ktoré ovplyvňujú konečné reflexívne myslenie percipientov.

Schéma 3

Proces/fázy vzniku a priebehu modelu Land art\& Folk art\& Art action z hl'adiska aktivít

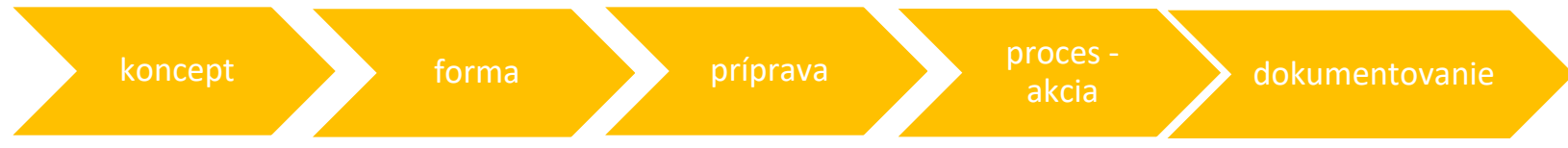

\section{LAND ART\& FOLK ART PROCES/FÁZY}

Zdroj: vlastné spracovanie

Koncept $\rightarrow$ východisko modelu: l'udová kultúra je súčast'ou našej identity a histórie. L'udové umenie a l'udová kultúra obsahuje sústavu akumulovaného poznania, správania, vzorov materiálnych a nemateriálnych produktov l'udskej činnosti. Prenášaním vzorov materiálnych a nemateriálnych produktov vznikli a boli uchované historické artefakty, ktoré dnes môžeme 
študovat' a d'alej aktualizovat'. Vzhl'adom k l'ahkej dostupnosti, širokému spektru produktov, respektíve textilných artefaktov sme sa v našom koncepte pre tvorbu situačno-akčného modelu orientovali práve na textilné techniky a textilné l'udové artefakty. Tie sme koncepčne spojili s art action do celku spolu s umením v krajine s umeleckou stratégiou land art.

Forma aktivít: aktivity sme rozdelili na čast' prípravnú $\mathrm{v}$ interiéry $\rightarrow$ štúdium materiálu $\mathrm{z}$ oblasti folk artu a čast' realizačno-akčnú z oblasti land artu, ktorú sme naplánovali do exteriéru. Študenti pracovali jednotlivo, každý sám na svojom výtvarnom probléme.

Príprava: v prípravnej fáze sme sa zamerali na nadobudnutie informácii z oblasti land artu a folk artu. Z oblasti land artu sme naštudovali východiskovú ideu umeleckej stratégie, oboznámili sme sa s vybranými výtvarník a ich tvorbou, ktorá je realizovaná prístupmi land artu. Štúdiom artefaktov, objektov $\mathrm{z}$ depozitu CET ART-u sme nadobudli základné informácie o výšivkách, vzoroch, technikách. Študenti v procese štúdia artefaktov vytvárali kresebné záznamy, ktoré následne $\mathrm{v}$ d’alšej fáze pomocou kresieb, skíc umiestňovali do krajiny. Takto nám vznikali prvé návrhy ktoré sme neskôr rozvinuli a v d'alšej fáze zrealizovali v teréne/krajine.

Štruktúra a materiál: na prácu v teréne/krajine si študenti mohli zvolit' rôzne spôsoby vyjadrenia, rôznorodý materiál a techniky, ktoré súvisia l’udovým umením, rešpektujú environmentálny prístup ku krajine a v krajine. Základným materiálom bol textil, prírodniny, prírodný materiál a farba. Textílie sme považovali v našom koncepte ako priatel'ské materiály, ktoré neničia prírodu necitlivým spôsobom. Textilné materiály sa nám v našom koncepte javili ako materiály s ktorým sa príjemne a l'ahko pracuje. Vyznačujú sa vlastnost’ami ako mäkkost', tvárnost', farebnost' a ako bonus sú príjemné na dotyk, práca s nimi je príjemná. Študenti mali k dispozícii lokálne materiály, ktoré ich obklopovali, čiže v našom prípade prírodniny, ktoré sa nachádzali v nami dostupnom okolí. Miestna ponuka krajinných zdrojov určila možnosti prirodzeného výberu zdrojov. Z prírodných zdrojov sme pracovali s listami, hlinou, machom, ihličím, kôrou a konármi.

Proces - akcia: realizačná fáza $\rightarrow$ pohyb v teréne prebiehal v rámci mimo ateliérového štúdia. Študenti sa pokúsili transformovat' l'udovú výšivku v nimi zvolenom materiály. Prepis výšivky prebiehal rôznymi spôsobmi, technikami a prístupmi. Každý študent si v teréne sám našiel miesto, ktoré sa mu javilo ako najvhodnejšie pre akciu. Vzhl'adom k práci v teréne a tiež vzhl'adom k materiálom a ročnému obdobiu vzniklo širšie spektrum možností AKO a KDE.

Dokumentačná fáza: počas celého procesu tvorby v krajine si študenti robili dokumentačné záznamy z procesu tvorby obr. č. 1 - č.12. Po dokončení akcie finálne fotografické záznamy, $\mathrm{s}$ ktorými neskôr pracovali $\mathrm{v}$ rôznych počítačových programoch pri postprodukčných úpravách.
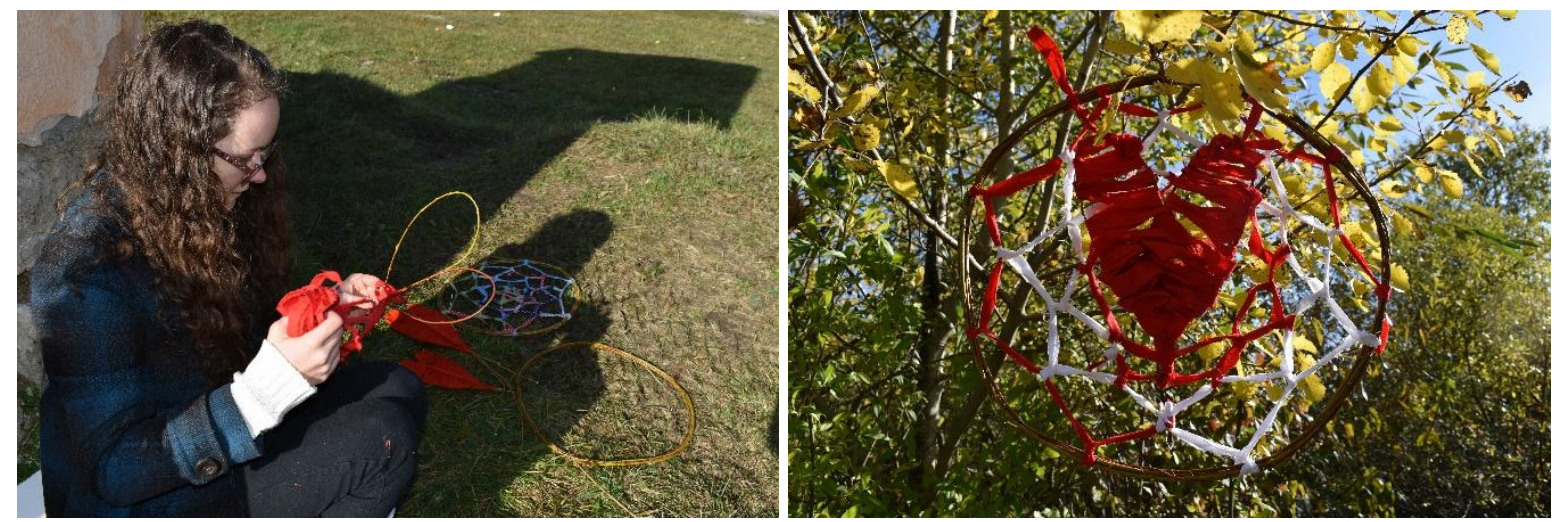

Obr. č. 1 - 2 štylizované l'udové ornamenty z prírodných materiálov a textilu, študentka KU. Práca v krajine art action, tvorba ornamentu motív srdca, ktorý sa často vyskytuje v l'udovej 
výšivke. Zoštylizovaný l'udový ornament transformovaný do výslednej podoby systémom umeleckej stratégie land art.
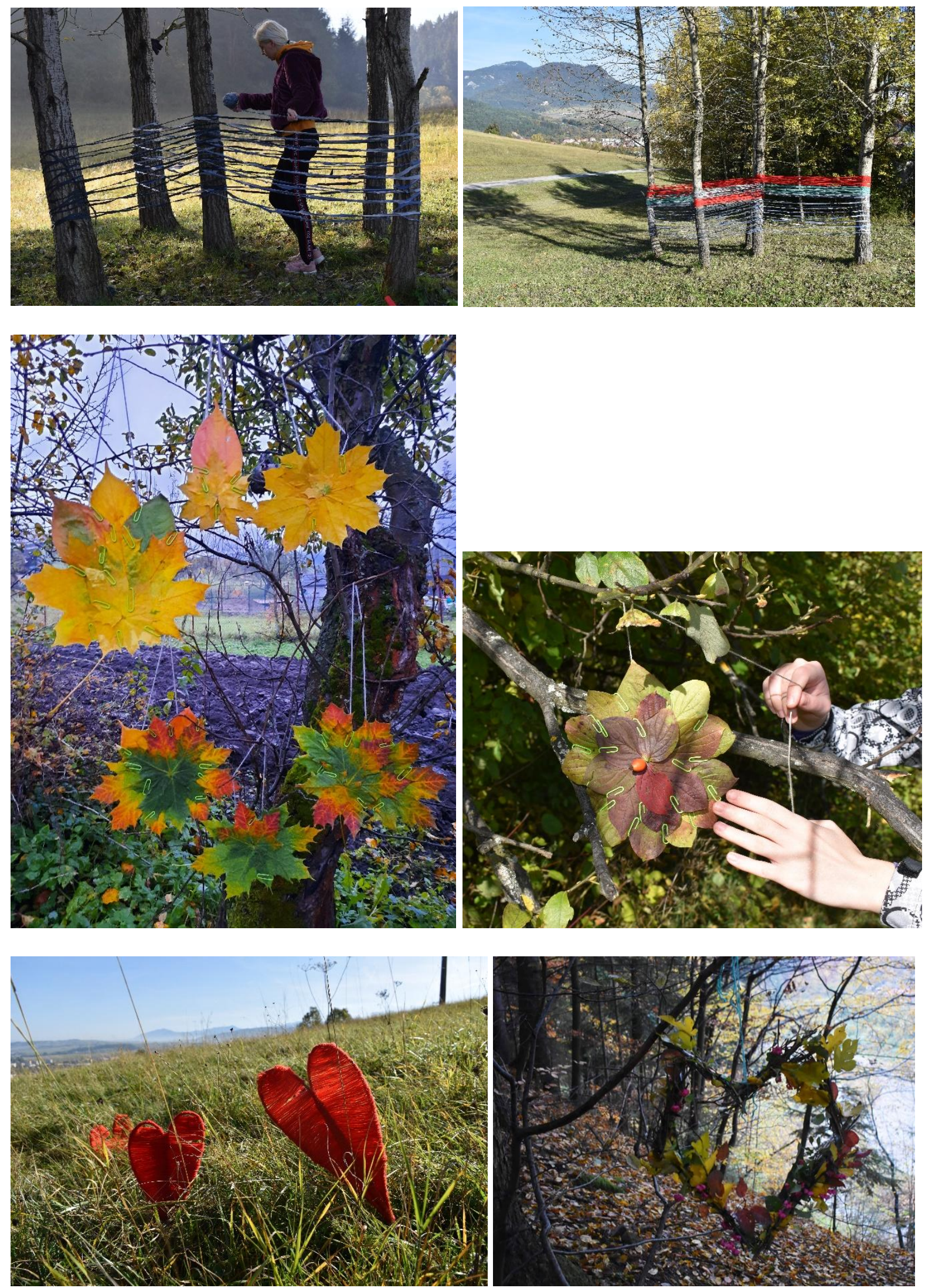
Obr. č. 3 - 8 Štylizované l’udové ornamenty z prírodnín, textilných materiálov, študenti KU. Práca v krajine art acton, tvorba zoštylizovaných l'udových ornamentov, ktoré boli v teréne transformované do výslednej podoby systémom umeleckej stratégie land art.
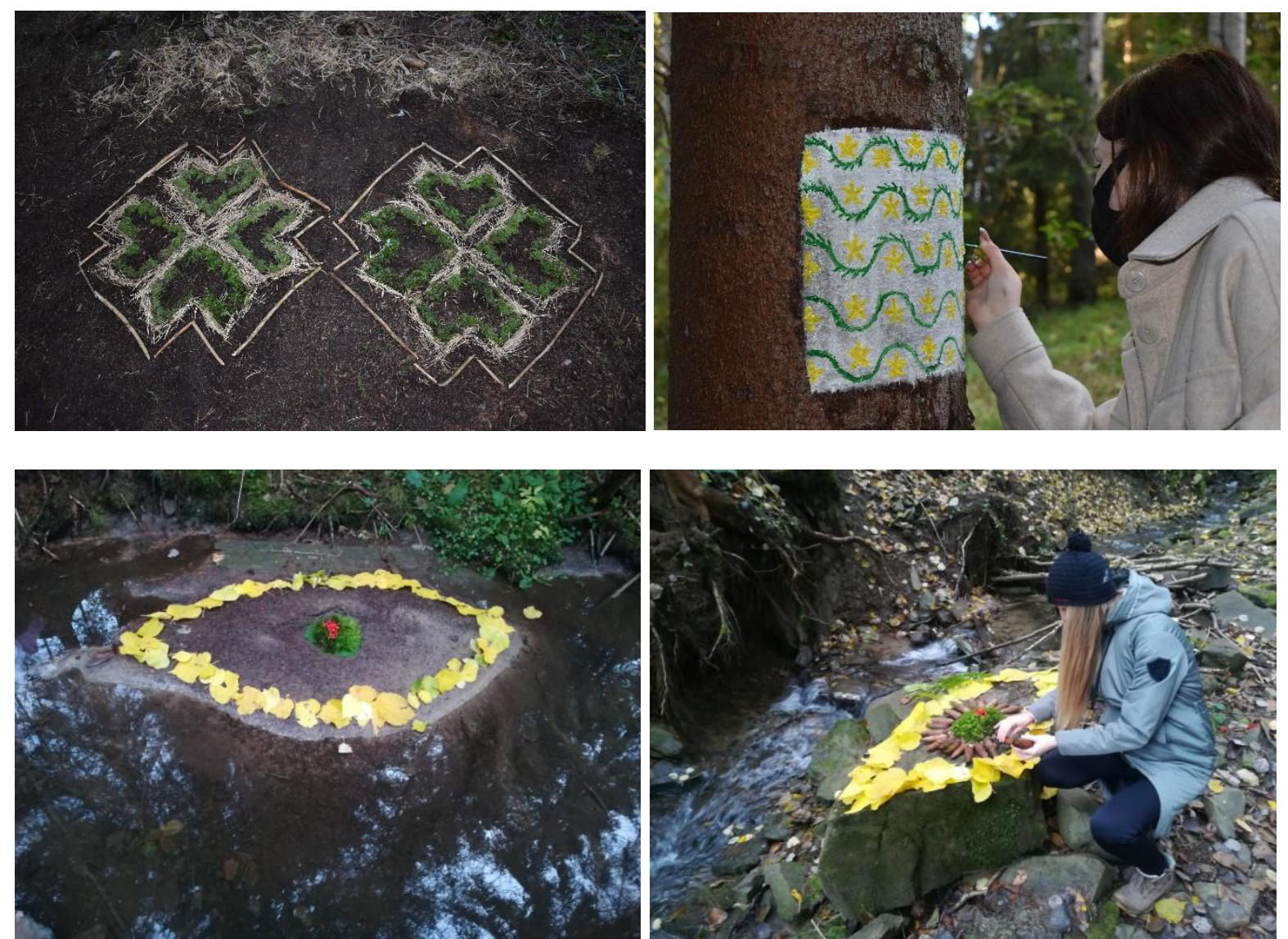

Obr. č. 9 - 12 Štylizované l’udové ornamenty z prírodnín, hliny, lístia, študenti KU. Práca $\mathrm{v}$ krajine art acton, tvorba zoštylizovaných l’udových ornamentov, ktoré boli v teréne transformované do výslednej podoby systémom umeleckej stratégie land art.

\section{ZÁVER}

V okruhu realizovaných aktivít si študenti vyskúšali možnosti inšpirácie a interpretáciu tradičnej l'udovej výšivky do land artového produktu, kompozície vytvorenej stratégiou land art. Pri zostavovaní modelovej aktivity sme vychádzali:

- z vytvárania situácií, ktoré nútia hl'adat' riešenia v neobvyklých/netypických podmienkach, ktoré podnecujú premýšl'at' a koncipovat',

- z vytvárania situácií, ktoré umožňujú pracovat' systémom akcie/art action pri dosiahnutí vytýčeného ciel'a,

- z vytvárania situácií, ktoré vyprovokujú k spontánnej reakcii $\rightarrow$ na prebiehajúcej činnosti/tvorbe,

- z vytvárania situácií, ktoré podnecujú získanie pozitívneho zážitku,

- z vytvárania situácií, ktoré podnecujú $\mathrm{k}$ prejavom pocity radosti $\mathrm{z}$ akčného zážitku spojeného z tvorbou land artových kompozícii.

Navrhli sme modelovú aktivitu, zdokumentovali proces akčnej tvorby, popísali postup pri tvorbe výstupných aktivít zo zameraním do praxe. Prostredníctvom modelovej aktivity sme testovali možnosti ako pracovat's art action. Tiež sme sa zamerali na možnosti ako obohatit' a skvalitnit' odbornú prípravu študentov pedagogických škôl v kontexte úloh z projektu KEGA 002KU-4/2019 Stelesnená skúsenost's využitím art action. 
Príspevok vznikol ako súčast' úloh ktoré boli stanovené v rámci riešenia projektu KEGA 002KU-4/2019 Stelesnená skúsenost' s využitím art action. Hlavným cielom projektu je zostavit', realizovat' a prezentovat' situačno-art-akčné modely so zužitkovaním art action $\mathrm{v}$ rámci umeleckej činnosti vykonávanej človekom, počas jeho biodromálnej cesty, v zmysle od predškolského veku, cez školský vek k obdobiu adolescencie, dospelosti až po sénium. Súčast'ou projektu je aplikovaný výskum v rozličných prostrediach/situáciách. Orientácia projektu smeruje od konštrukcie k realizácii systémom verejnej umelecko-vizuálnej prezentácie možností a hraníc art action $\mathrm{v}$ kontexte realizovaných situačno-art-akčných modelov v jednotlivých vývinových obdobiach človeka.

\section{Použitá literatura}

1. BIARINCOVÁ, P. Art action v tvorbe človeka počas životnej cesty. 1. vyd. Ružomberok: Verbum, 2020. ISBN978-80-561-0787-4.

2. DANGLOVÁ, O. Dekor a symbol. Dekoratívna tradícia na Slovensku a európsky kontext. Bratislava: Veda vydavatel'stvo Slovenskej akadémie vied. 2001. ISBN 80224-0675-9.

3. DANGLOVÁ, O. In: MEŠŠA, M. (zostavovatel'). Tradicia dnes? Bratislava: Ústredie l'udovej umeleckej výroby. 2007.

4. DANGLOVÁ, O. Výśivka na Slovensku. ÚL'UV, Bratislava. 2009. ISBN 978-8088852-66-7.

5. GERŽOVÁ, J. Slovnik svetového výtvarného umenia druhej polovice 20.storočia. Bratislava: Kruh súčasného umenia PROFIL. 1999. ISBN 80-968283-0-4.

6. GERŽOVÁ, J., HRUBANIČOVÁ, I. Klúčové termíny výtvarného umenia druhej polovice 20.storočia. Bratislava: Kruh súčasného umenia PROFIL. 1998. ISBN 8088675-55-3.

7. ERIKSON, E. H. Životni cyklus rozširený a dokončený. Praha: Portál. 2015. ISBN 978-80-262-0786-3.

8. MICHALIDES, P. Výtvarná kultúra tvorby. Bratislava: SPN. 1984.

9. ŠTOFKO, M. Od abstrakcie po živé umenie. Bratislava: Slovart. 2007. ISBN 97880-8085-108-8.

10. ŠTOFKO, M. Psychodidaktika procesuálnej výtvarnej výchovy. Bratislava: Veda. 2010. s. 43. ISBN 978-80-224-1110-3.

\section{Kontaktní údaje}

Patricia Biarincová, PaedDr. Mgr. art. PhD.

KU PF Ružomberok

Hrabovská cesta 1, 03401 Ružomberok

Tel: 0908160004

email: patricia.biarincova@ku.sk 


\title{
RIZIKOVÉ OBLASTI ŠKOLNÍHO ŽIVOTA Z HLEDISKA \\ PROBLÉMOVÉHO CHOVÁNÍ ŽÁKŮ
}

\author{
RISK AREAS OF SCHOOL LIFE \\ IN TERMS OF STUDENTS' PROBLEM BEHAVIOUR
}

\author{
Helena Vomáčková, Kristýna Kaprálová
}

\begin{abstract}
Abstrakt
Příspěvek mapuje oblasti školního života související s problémy $\mathrm{v}$ chování žáků na jedné základní škole ze Středočeského kraje. Na vybraném vzorku 122 respondentů - žáků 8. a 9. tř́d zjišt'uje pomocí standardizovaného dotazníku, které školní oblasti mají pro žáky rizikový a které naopak podpůrný charakter. Celkem bylo sledováno sedm školních oblastí, které byly vyhodnoceny pomocí základních ukazatelů popisné statistiky. Výzkumným úkolem bylo získat reálná data a poskytnout škole informace, které oblasti života školy žáci vnímají negativně. Tyto oblasti z hlediska vývoje jejich chování představují určité riziko pro budoucí školní práci a jsou důležité pro prevenci ze strany školy.
\end{abstract}

Klićová slova: starši školní věk, oblasti školního života, pozitivní a negativní vnímání žáky, problémového chování, prevence

\begin{abstract}
The paper maps the areas of school life related to problems in the students' behaviour at one primary school in the Central Bohemian Region. It uses a standardized questionnaire for a selected sample of 122 respondents, i.e. students of 8th and 9th grades, to find out which of these school areas are risky for these students and which of them, on the contrary, are supportive. A total of seven school areas have been monitored and evaluated with the use of basic indicators of descriptive statistics. The research task was to obtain real data and provide researchers information about the areas of school life which are perceived negatively by the students. These areas, in terms of the development of their behaviour, represent a certain risk for future school work and are important for prevention on the part of the school.
\end{abstract}

Key words: older school age, areas of school life, students' positive and negative perception, problem behaviour, prevention

\section{1 ÚVOD}

Problémové chování je zpravidla definováno jako souhrn vnějších projevů, které se v určitém věku jedince, v určitých situacích a za určitých podmínek dostává do rozporu s obecně přijímanou normou (Průcha, 2013). Společenská norma chování a očekávání se nemusí zcela překrývat s konsenzuální normou vyplývající ze zkušeností např. učitelů a rodičů (Průcha, Walterová, Mareš, 1995). Totéž platí i o normě individuální, kterou si nastavuje konkrétní jedinec. Ve školním prostředí má přitom problémové chování minimálně dvě hlediska (Vágnerová, 2005). První je hledisko rozporu žáka se školními požadavky v podobě jeho vnímání, prožívání a projevů chování, druhé je hledisko připravenosti a vhodné reakce učitelů na nežádoucí projevy žáků. Problémové chování velmi poznamenává kvalitu a efektivitu výchovně vzdělávacího procesu (Helus, 2009), komplikuje třídní a školní vztahy nejenom mezi žáky navzájem, mezi učiteli a žáky (Vojtová, 2010), ale i ve vztahu žáků k učivu, $\mathrm{k}$ poznávání jako takovému. Zejména $\mathrm{z}$ těchto důvodů je třeba usilovat o jeho minimalizaci. 


\section{VÝZNAM ŠKOLNÍHO PROSTŘEDÍ}

Školní prostředí je považováno za zásadní faktor sekundární socializace žáka, který může významně podpořit a rozvinout žádoucí modely chování a minimalizovat ty nežádoucí. Klíčová role připadá učitelům (Vágnerová, 1997), kteří vytvářejí prostředí posilující kázeň a motivaci žáků (Bendl, 2011). Důraz na to, co je vhodné, průchodné a pozitivně oceňované dává prostor žákům pro sběr pozitivních zkušeností, tj. vědomí toho, co funguje. Pozitivní zkušenost (Vojtová, 2010) představuje tak jakýsi „nástroj navigace“, který žáka směruje k projevům chování, které jsou zhlediska řízení edukace učitelem průchodné a akceptovatelné, a které umožňují, aby žák i jeho okolí bylo spokojené a žák mohl být chválen. Naopak učitelovo poukazování na negativní projevy, na to, co je chybné, špatné, nežádoucí a následně i trestané přináší žákovi negativní zkušenost, odpor k daným činnostem a posléze $\mathrm{i}$ $\mathrm{k}$ učivu, učitelům a škole.

Vzdor a vnitřní nespokojenost žáka mohou být navíc umocněny, pokud jsou spojeny s vývojovými poruchami typu ADD nebo ADHD (Šauerová a kol., 2012). Problémové chování žáků může být projevem, za kterým se skrývá explozivita a emoční labilita žáka, impulzivita, hyperaktivita či neadekvátní kontrola reakcí žáka k okolí, které žákovi nerozumí (Malá, 2000). Jeho nedostatečná pozornost, motivace, úsilí a vytrvalost ho zviditelňují ve tř́dním kolektivu a ovlivňují vztahy ostatních aktérů edukačního procesu k němu. Tyto projevy tak ohrožují žáky nejen po stránce naukové, ale i po stránce sociální, nebot' zasahují pozici žáka ve třídní skupině (Pokorná, 2005). Oblast afektivní se jeví z tohoto pohledu ještě důležitější než oblast kognitivní (Navrátil, Mattioli, 2011): žák by měl být formován nejen $\mathrm{k}$ tomu, aby věděl a znal, ale zejména $\mathrm{k}$ tomu, aby pozitivně konal. Školní prostředí (Čapek, 2010), třídní kolektiv vrstevníků a vztahy mezi nimi (Pecha, 1999) mu k tomu mohou za přispění školních psychologů a speciálních pedagogů (Fischer a kol., 2014) významně napomoci.

\section{CÍL A METODY PRÁCE}

Cílem bylo pomocí standardizovaného dotazníku získat poznatky o převažujícím charakteru vnímání školy žáky 8. a 9. třídy vybrané základní školy za účelem zmapování školních oblastí, které mohou z hlediska jejich budoucího chování představovat rizika. Cílem bylo rovněž komparovat výsledky aktuálního setření v roce 2021 s výstupy pilotního projektu Vojtové a Fučíka (2012), který ověřil funkčnost použitého dotazníku. Ten obsahoval 35 položek, kde žáci na čtyřstupňové škále (1=rozhodně ano, 2=spíše ano, 3=spíše ne, 4=rozhodně ne) vyjadřovali svá stanoviska. Seskupením vybraných položek bylo možné charakterizovat sedm oblastí školního prostředí: celkovou spokojnost se školou, úspěch a př́ležitost, negativní prožívání, vztah učitel-žák, školní status, formování identity a interakce s vrstevníky. Jako základní statistický nástroj byl využit aritmetický průměr, který umožnil vyjádřit celkové bodové skóre získané jak za každou dotazníkovou položku, tak a za každou oblast školního prostředí v rámci všech zúčastněných respondentů školy (122) a následně v členění na skupinu chlapců (58) a dívek (64). Čím nižších hodnot bylo v průměru dosaženo, tím spokojenější byli respondenti při hodnocení jednotlivých položek a daných oblastí ${ }^{1}$. Prostřednictvím směrodatné odchylky byli žáci sledovaného vzorku rozdělení do pěti skupin dle úrovně svého vnímání školy:

- $\quad$ výrazně pozitivní (více než Ø $2 \mathrm{SD}$ ),

- $\quad$ spíše pozitivní $(\varnothing+\mathrm{SD} ; \varnothing+2 \mathrm{SD}>)$,

- neutrální postoj $(<\varnothing-\mathrm{SD} ; \varnothing-\mathrm{SD}\rangle)$,

- $\quad$ spíše negativní (Ø - 2SD; Ø - SD>),

\footnotetext{
${ }^{1} \mathrm{U}$ negativního prožívání byly vzhledem $\mathrm{k}$ charakteru dotazníkových položek výzkumně použity inverzní hodnoty
} 
- Výrazně negativní (méně než Ø - 2SD).

V rámci stanoveného cíle byl formulován předpoklad, že rizikové oblasti nebudou u žáků a žákyň shodné.

\section{VÝSLEDKY VÝZKUMU}

V komparaci s pilotním šetřením Vojtové a Fučíka (2012) bylo celkové skóre námi sledovaných respondentů i přes časový odstup téměř totožné. Zatímco naši „osmáci“ (67\% respondentů) byli méně spokojeni, tak naopak naši „devát’áci“ (33\% respondentů) byli spokojenější, než tomu vylo v pilotním šetření - viz tabulka 1.

Tabulka 1: Celkové skóre skupiny dle rozložení ročníki̊

\begin{tabular}{|c|c|c|c|}
\hline Ročník & $\begin{array}{c}\text { Dílčí šetření 2020 } \\
\text { celkové skóre }\end{array}$ & $\begin{array}{c}\text { Pilotní šetření 2012 } \\
\text { celkové skóre }\end{array}$ & Rozdíl 2020-2012 \\
\hline 8. & 2,14 & 1,94 & 0,20 \\
\hline 9. & 2,07 & 2,21 & $-0,14$ \\
\hline Celkem & 2,11 & 2,08 & 0,03 \\
\hline
\end{tabular}

V tabulce uvedené hodnoty celkového skóre lze využít v následných analýzách jako měřítko hodnocení spokojenosti respondentů se školou. V prŕpadě pilotního šetření z roku 2012 je o 0,03 bodů „přísnější “. Při porovnání celkového skóre za skupinu žáků a žákyň byly žáci méně spokojení $(2,17)$ než žákyně $(2,06)$, ale stejně jako v předešlém případě nemají rozdíly zásadní charakter. Celý vzorek respondentů přitom vykázal normální rozložení četností žáků dle př́slušnosti ke skupině dle charakteru vnímání školy:

- 1,00-1,54 výrazně pozitivní vnímání $\mathrm{y}$,

- $1,55-1,82$ spíše pozitivní vnímání,

- 1,83-2,39 neutrální vnímání,

- 2,40-2,67 spíše negativní vnímání,

- 2,68 - více výrazně negativní vnímání - viz graf 1 .

Graf 1: Rozložení četností respondentio dle úrovně vnímání školy

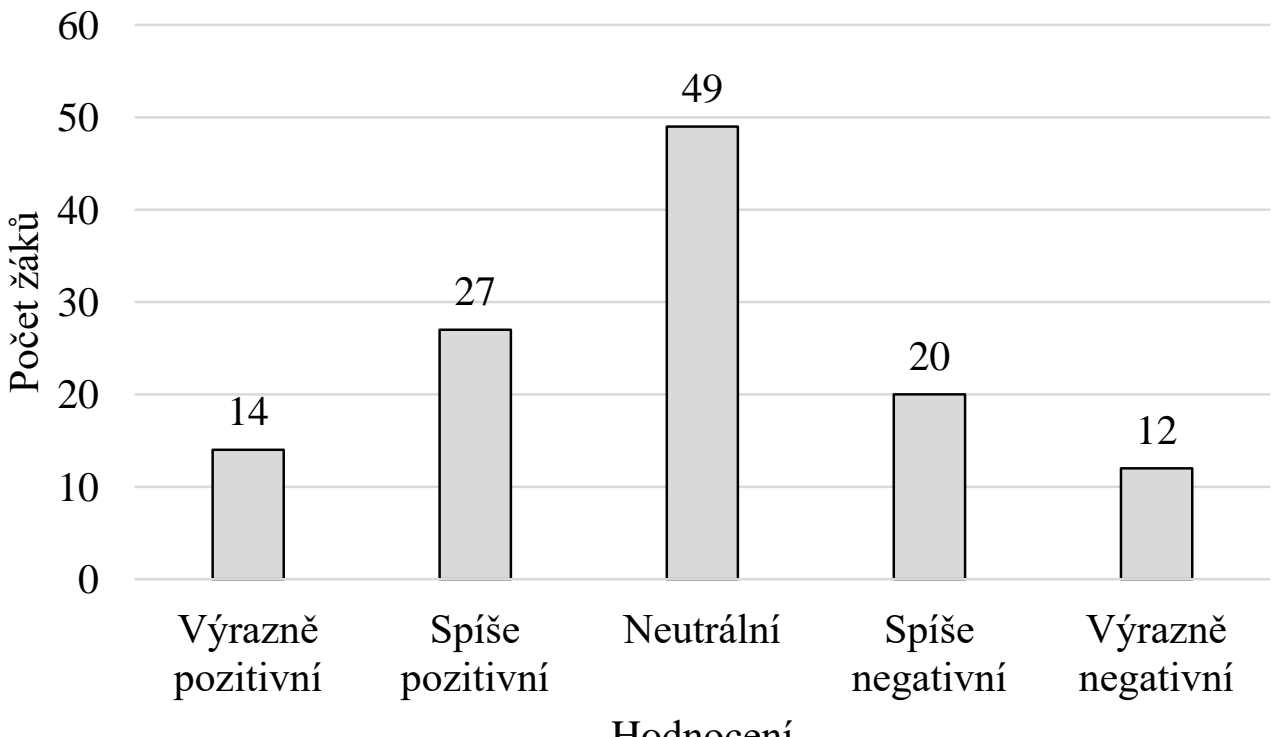

Jak vyplývá z grafu 1 zaujali respondenti v našem vzorku ze 40 \% neutrální stanovisko, 34 \% vyjádřilo stanovisko pozitivní a 26 \% stanovisko negativní. Ve srovnání s pilotním projektem 
jde v př́ípadě negativního vnímání o číslo více než dvojnásobné, které naznačuje větší rizika $\mathrm{v}$ chování respondentů našeho vzorku. Na základě analýzy celkových skóre dle jednotlivých položek dotazníku byly vymezeny položky s vysokou mírou pozitivního vnímání školy (do hodnoty 1,82 včetně) a naopak položky rizikové (nad hodnotu 2,40 včetně) - viz graf 2 .

Graf 2: Výsledná skóre jednotlivých výroků

Škola je místo...

01 kde se rád(a) učím.

02 kde učitelé naslouchají tomu, co.

03 kde se více poznávám.

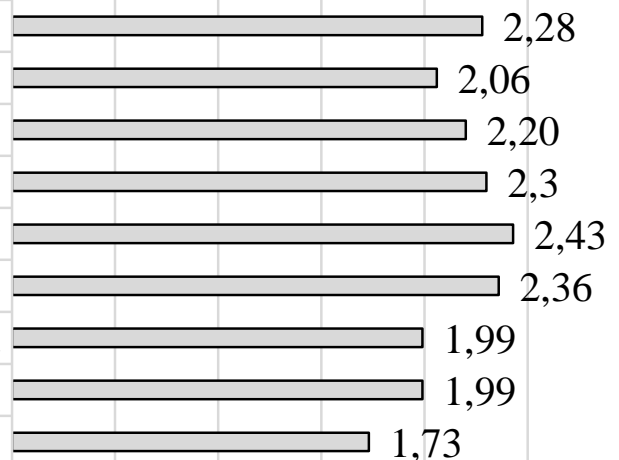

10 kde vím, co po mně učitel požaduje.

11 kde se těším na přestávku.

12 kde mě učitelé nemají rádi.

13 kde mám rád(a) většinu předmětů.

14 kde jsem se naučil(a) brát ostatní.

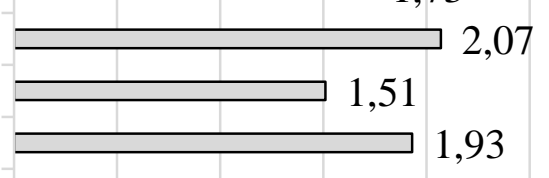

04 kde se učitelé při vyučování.

5 kam skutečně rád(a) chodím.

07 kde vím, že mohu dosáhnout.

08 kde se mohu obrátit na učitele,.

09 kde se cítím osaměle.

15 kde jsem často zvědavý(á).

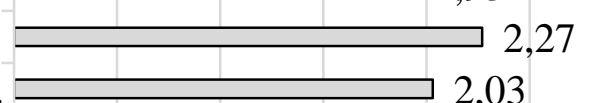

2,03

16 kde jsou učitelé spravedliví v. .

17 kde mi setkávání s jinými lidmi. .

18 kde mi učitel pomůže, když si..

19 kde mám pocit, že jsem důležitý(á).

20 kde mě spolužáci přibírají $\mathrm{k}$.

21 kde jsem št’astný(á).

22 kde mi učitelé dávají známky,.

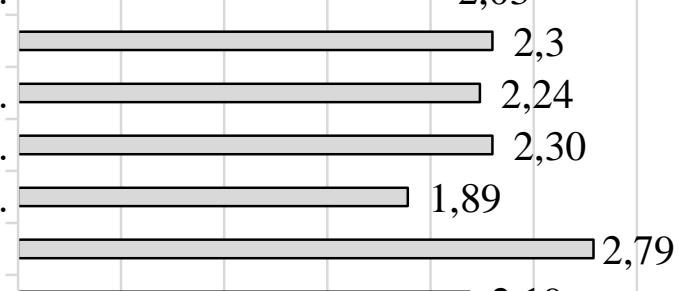

23 kde mají žáci s postižením stejný..

24 kde zjišt'uji, že učení je i legrace.

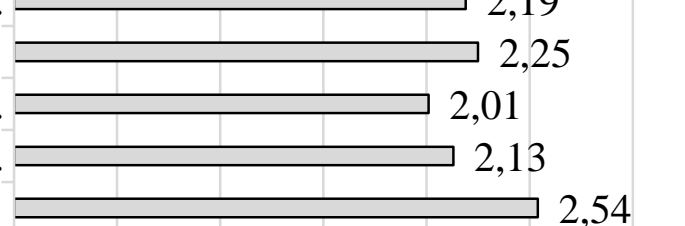

25 kde učitelé některé žáky.. 2,64

26 kde vím o mnoha věcech, které..

27 kde mi učitelé nezazlívají chyby.

28 kde je o přestávkách dobrá zábava.

29 kde bývám spokojen(a) s tím, co.

30 kde se učím rozumět spolužákům.

31 kde mi učitelé pomáhají $\mathrm{k}$

32 kde si se spolužáky rádi povídáme.

33 kde mi pomůže můj spolužák,.

34 kde se toho hodně naučím.

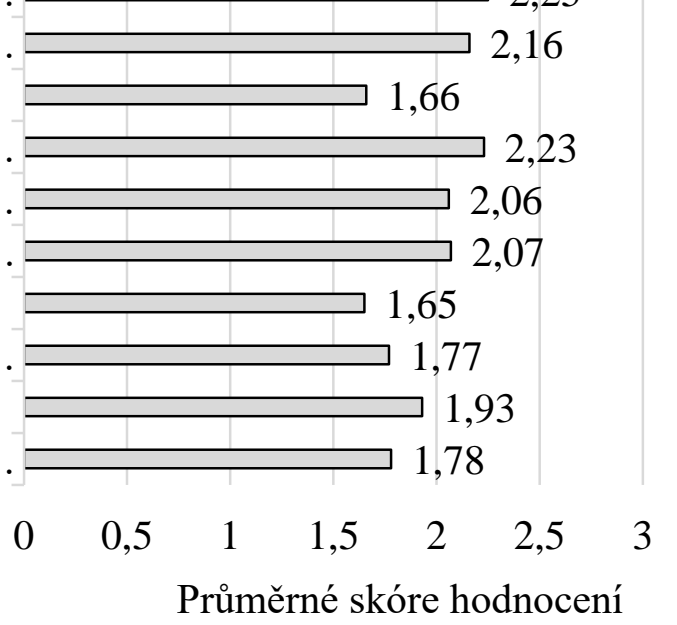

35 kde děláme s kamarády mnoho..

Prüměrné skóre hodnoceni 
Jak je uvedeno v grafu patří podle výše uvedeného kritéria k pozitivně hodnoceným položkám školy položky $9,11,28,32,33$ a 35 a naopak k položkám negativním, tj. rizikovým patří položky 5, 19, 24, 25.

Při sledování každé ze sedmi oblastí života školy a jejich hodnocení žáky a žákyněmi jsme došli k následujícím výsledkům - viz tabulka 2.

Tabulka 2: Průměrné skóre oblastí života školy

\begin{tabular}{|c|c|c|c|c|}
\hline \multicolumn{2}{|r|}{ Oblasti života školy } & $\begin{array}{l}\emptyset \text { skóre } \\
\text { celkem }\end{array}$ & $\begin{array}{l}\text { Ø skóre } \\
\text { žáci }\end{array}$ & $\begin{array}{l}\text { Ø skóre } \\
\text { žákyně }\end{array}$ \\
\hline 1 & $\begin{array}{l}\text { Celková spokojenost se školou } \\
\text { Položky dotazníku } 5+13+29+10+27+24+21\end{array}$ & 2,28 & 2,37 & 2,19 \\
\hline 2 & $\begin{array}{l}\text { Úspěch a příležitost } \\
\text { Položky dotazníku } 1+7+15+34+4\end{array}$ & 2,16 & 2,23 & 2,09 \\
\hline 3 & $\begin{array}{l}\text { Negativní prožívání } \\
\text { Položky dotazníku } 9+12+25\end{array}$ & 2,10 & 2,06 & 2,13 \\
\hline 4 & $\begin{array}{l}\text { Vztah učitel-žák } \\
\text { Položky dotazníku } 8+16+18+2+31+22\end{array}$ & 2,04 & 2,07 & 2,02 \\
\hline 5 & $\begin{array}{l}\text { Školní status } \\
\text { Položky dotazníku } 6+14+23+33+19\end{array}$ & 2,22 & 2,26 & 2,17 \\
\hline 6 & $\begin{array}{l}\text { Formování identity } \\
\text { Položky dotazníku } 26+17+30+3\end{array}$ & 2,20 & 2,34 & 2,07 \\
\hline 7 & $\begin{array}{l}\text { Interakce s vrstevníky } \\
\text { Položky dotazníku } 11+20+28+32+35\end{array}$ & 1,76 & 1,78 & 1,73 \\
\hline
\end{tabular}

Z tabulky 2 vyplývá, že mezní hodnotu 2,11 z tabulky 1

- převýšil vzorek respondentů jako celek ve čtyřech př́ípadech ze sedmi, což signalizuje horší než průměrné vnímání školy respondenty našeho vzorku v těchto oblastech (celková spokojenost se školou, úspěch a př́ležitost, školní status, formování identity),

- nepřekročil vzorek žáků ve třech oblastech (negativní prožívání, vztah učitel-žák, interakce s vrstevníky), což vypovídá o lepším než průměrném vnímání školy žáky,

- nedosáhl vzorek žákyň ve čtyřech oblastech (úspěch a př́ležitost, vztah učitel-žák, formování identity, interakce s vrstevníky), což svědčí o lepším než průměrném vnímání školy žákyněmi.

Tabulka 2 rovněž dokladuje, že dle mezních hodnot normálního rozložení do skupin, uvedených v grafu 1

- byla jedinou oblastí s vysokou mírou pozitivního vnímání (do hodnoty 1,82 včetně) oblast interakce s vrstevníky, a to jak v úhrnu respondentů, tak v členění na žáky a žákyně,

- nevykázala žádná oblast vysokou míru negativního vnímání (nad hodnotu 2,40 včetně), ačkoli ve skupině žáků se jí významně přiblížilo vnímání v oblasti celkové spokojenosti se školou $(2,37)$ a formování identity $(2,34)$.

Tabulka 2 potvrzuje z hlediska komparace vnímání školy žáky a žákyněmi, že jejich výpovědi nejsou identické. Žákyně s výjimkou jediné oblasti (negativní prožíání) byly v našem vzorku vždy spokojenější se školou, než jejich spolužáci.

\section{DISKUSE A ZÁVĚR}

Šetření poukázalo na uvedeném vzorku respondentů na odchylky ve vnímání školního prostředí ve srovnání s pilotním šetřením v roce 2012. Svou roli přitom sehrál bezesporu časový odstup devíti let, stejně tak jako rozdíly v četnosti a charakteru respondentů. Celkové vnímání školy žáky, měřeno úhrnným průměrným skóre se $\mathrm{v}$ našem šetření posunulo 
negativním směrem - viz tabulka 1 , což naznačuje zhoršení vnímání školy žáky a zvýšení rizika problémového chování. Vyjádřeno pomocí směrodatné odchylky a pásem v normálním rozložení našeho vzorku - viz graf 1 , představuje 26 \% žáků s vysokou mírou negativního vnímání školy zásadní informaci, která v sobě nese současně hrozbu i výzvu. Proč jsou žáci tak negativně vyhraněni? Co je př́íčinou jejich nepř́iznivého hodnocení školy? Může to škola ovlivnit a do jaké míry? Co by se na škole muselo změnit, aby byla pozitivní změna realizovatelná? Tyto a další otázky a hledání odpovědí na ně přísluší konkrétní škole, ačkoli na mnohé faktory „nedosáhne“. Patří sem zejména nejednotnost odborné př́pravy v učitelských programech na pedagogických a nepedagogických fakultách našich vysokých škol (Doulík, Škoda, 2014), nekoncepčnost bez kontinuity v politických rozhodnutích celkem 21 ministrů školství za uplynulých 30 let, nepropojení obsahového standardu učitelské profese s kariérním systémem učitelů (Janík, Spilková, Píšová, 2014), nepropojení mzdové politiky s požadavky profesionální edukace (Vomáčková a kol., 2015) apod. Řada faktorů je ale v kompetenci školy a patří do ní i podněty vyplývající z dílčí analýzy našeho šetření, které v rámci položek dotazníku odhalila ty, které lze považovat za vyhraněné z pozitivní či negativní úrovně vnímání. Nebezpečí rizikového chování v našem vzorku naznačily položky dotazníku:

5 - Škola je místo, kam chodím rád (vyjadřuje vztah ke škole jako instituci, která má rozvíjet potenciál žáků: negace $\mathrm{v}$ sobě nese nejistotu, zda to skutečně dělá, a když, zda to dělá kvalifikovaně a poctivě),

19 - Škola je místo, kde mám pocit, že jsem důležitý (vyjadřuje pozici žáka z hlediska vnímání hodnoty své osobnosti a stavu podřízenosti, závislosti, samostatnosti či důstojnosti a dotýká se otázky, zda je důležitější učivo nebo žák),

24 - Škola je místo, kde zjišt’uji, že učení je i legrace (vyjadřuje stanovisko vůči metodám práce učitelů, které mohou být poutavé a zajímavé nebo nudné a nezáživné, bez ohledu na obsah, který by měl být propojen s praktickou využitelností a smysluplností),

25 - Škola je místo, kde učitelé některé žáky upřednostňují (vyjadřují pocit nespravedlnosti v př́stupu k ostatním v duchu porušení pravidla „padni komu padni“, případně v sobě nesou informaci o nedostatečném vysvětlení, proč někdo má tzv. „výhody“ např. z důvodu těžkých projevů ADHD).

Naopak jako podpůrné pro bezproblémové působení respondentů na jejich škole se ukázaly položky dotazníku:

9 - Škola je místo, kde se cítím osaměle (charakterizuje význam školního kolektivu pro žáka, v němž nachází kamarády, s nimiž konfrontuje svoje vidění světa a učí se od nich jiným př́stupům a pohledům na svoje záležitosti),

11 - Škola je místo, kde se těším na přestávku (podporuje pozitivní vnímání třídního kolektivu, který využívá přestávky ke sdílení, komunikování školních i mimoškolních prožitků),

28 - Škola je místo, kde je o přestávkách dobrá zábava (bezprostředně souvisí s výše uvedeným a promítá $\mathrm{i}$ aktivity školy $\mathrm{v}$ př́ípadě, že o přestávkách umožňuje škola např. na chodbách hrát ping pong, basketball na školním dvoře, odpočívat v houpací síti apod.),

32 - Škola je místo, kde si se spolužáky rádi povídáme (vyjadřuje důležitost sdílení prožitků s vrstevníky, jejichž pohled na dané skutečnosti na rozdíl od učitelů a rodičů má pro žáka jinou vypovídací hodnotu),

33 - Škola je místo, kde mi pomůže můj spolužák, pokud si nebudu vědět rady s úkolem (naznačuje stav důvěry a vzájemnosti, který posiluje jistotu žáka v jeho působení na škole),

35 - Škola je místo, kde děláme s kamarády mnoho zajímavého i mimo výuku (upozorňuje na důležitost pozitivních vzájemných vztahů spolužáků, které přerůstají do aktivit mimo školu a rozšiřují oblast socializace). 
Výše uvedené informace o rizikových a podpůrných oblastech naznačují směr, kterým by škola měla např́t svou pozornost. Neobejde se přitom bez spolupracujícího a komunikativního týmu pedagogů, bez jasně formulovaných pravidel, která budou racionální, dodržovaná a v opačném př́padě i vymahatelná. Pro vedení školy to znamená prokázat odvahu ke spravedlivé diferenciaci učitelů při hodnocení jejich pedagogické práce a jednoznačné vymezení kritérí́ jejich hodnocení a oceňování, nebot' práce s problémovými žáky klade na učitele zvýšené nároky (Stuchlíková, 2005).

Co se týče odlišností ve vnímání školy žákyněmi a žáky, potvrdil se v našem šetření známý fakt, že zde působí jak biologické faktory odlišnosti pohlaví (Dluzen, 2005), tak odlišná úroveň socializace z hlediska poslušnosti a revolty (Hebdige, 2012), ale i prožívání např́. úspěchu, př́ležitosti být aktivní, zaujmout, vyniknout apod.

Př́spěvek vznikl v rámci projektu SGS 4320115 2003-43 01 Rozvoj disponibilit žáka a jeho měření v běžné pedagogické praxi ZŠ na Univerzitě J. E. Purkyně v Ústí nad Labem.

\section{Použitá literatura}

1. AUGER, M., T. Učitel a problémový žák: strategie pro řešení problémů s kázní a učením. Praha: Portál, 2005. 128 s. ISBN 80-7178-907-0.

2. $\quad$ BENDL, S. Školní kázeň: metody a strategie. Praha: ISV, 2001. Pedagogika. 267 s. ISBN 80-85866-80-3.

3. BENDL, S. Kázeňské problémy ve škole. Aktualiz. a dopl. vyd. Praha: Triton, 2011. 264 s. ISBN 978-80-7387-436-0.

4. $\quad$ ČAPEK, R. Tř́dni klima a školni klima. Praha: Grada, 2010. 325 s. ISBN 978-80247-2742-4.

5. DLUZEN, D. E. Estrogen, Testosterone and Gender Differences. Endocrine, 27(3), 259-268, Humana Press, 2005.

6. DOULÍK, P., ŠKODA, J. Příprava učitelů v kontextu kontinuální optimalizace. Pedagogická orientace, 2014, 24(5), 818-837.

7. FISCHER, S., ŠKODA, J., SVOBODA, Z., ZILCHER, L. Speciální pedagogika: edukace a rozvoj osob se specifickými potřebami v oblasti somatické, psychické a sociální: učebnice pro studenty učitelství. Praha: Triton, 2014. 299 s. ISBN 978-807387-792-7.

8. HEBDIGE, D. Subkultura a styl. Praha: Dauphin, 2012. 248 S. ISBN 978-80-7272197-9.

9. HELUS, Z. Dítě v osobnostním pojetí: obrat $k$ dítěti jako výzva a úkol pro učitele $i$ rodiče. 2. vydání. Praha: Portál, 2009. 286 s. ISBN 978-80-7367-628-5.

10. JANÍK, T., SPILKOVÁ, V., PÍŠOVÁ, M. Standard a kariérní systém učitele: problémy předložené koncepce v širších souvislostech. Pedagogická orientace, 22(1), 259-274.

11. MALÁ, E. Hyperkinetické poruchy. In HORT, V. a kol. Dětská a adolescentní psychiatrie. Praha: Portál, 2000. 492 S. ISBN 80-7178-472-9.

12. MERTIN, V. Problémy s chováním ve škole. Praha: Wolters Kluwer, 2013. $200 \mathrm{~s}$. ISBN 978-80-7478-026-4.

13. NAVRÁTIL, S., MATTIOLI, J. Problémové chováni dètí a mládeže: [jak mu předcházet, jak ho eliminovat]. Praha: Grada, 2011. 120 s. ISBN 978-80-247-36723.

14. PECHA, L. Krutá poema. Makarenko - jak ho neznáme. Brno: Doplněk, 1999. 250 s. ISBN 80-7239-027-9. 
15. POKORNÁ, V. Porucha aktivity, pozornosti a hyperkinetické poruchy. In HADJ MOUSSOVÁ, Z. a kol. Pedagogicko-psychologické poradenství I. Vybrané problémy. Praha. PedF UK, 2005. 207 S. ISBN 80-7290-215-6.

16. PRŮCHA, J. Moderní pedagogika. 5. vydání. Praha: Portál, 2013. 483 s. ISBN 97880-262-0456-5.

17. PRŮCHA, J., WALTEROVÁ, E., MAREŠ, J. Pedagogický slovník. 4. vyd. Praha: Portál, 1995. 292 s. ISBN 80-7178-029-4.

18. STUCHLÍKOVÁ, I. a kol. Zvládáni emočních problémů školáků. Praha: Portál, 2005. 167 s. ISBN 80-7178-534-2.

19. ŠAUEROVÁ, M, ŠPAČKOVÁ, K., NECHLEBOVÁ, E. Speciální pedagogika v praxi. Komplexní péče o děti se SPUCH. Praha: Grada, 2012. 248 s. ISBN 978-80247-4369-1.

20. VÁGNEROVÁ, M. Psychologie problémového ditěte školního věku. Praha: Karolinum, 1997. 170 s. ISBN 80-7184-488-8.

21. VÁGNEROVÁ, M. Vývojová psychologie I., Dětství a dospívání. Praha: Karolinum, 2005. 467 s. ISBN 978-80-246-0956-0.

22. VOJTOVÁ, V. Inkluzivní vzděláváni žáků v riziku a s poruchami chování jako perspektiva kvality života v dospělosti. Brno: Masarykova univerzita, 2010. $330 \mathrm{~s}$. ISBN 978-80-210-5159-1.

23. VOJTOVÁ, V., FUČÍK, P. Předcházení problémům v chováni žáků: dotazník pro žáky. Praha: Národní ústav pro vzdělávání, 2012. Evaluační nástroje. 35 s. ISBN 978-80-87063-66-8.

24. VOMÁČKOVÁ, H. a kol. Výzkumný pohled na inkluzi a její determinanty. Ústí nad Labem: UJEP, 2015. 240 s. ISBN 978-80-7414-933-7.

\section{Kontaktní údaje}

doc. Ing. Helena Vomáčková, CSc., Krystýna Kaprálová

Univerzita J. E. Purkyně v Ústí nad Labem, Pedagogická fakulta

Pasteurova 3544/1, 40096 Ústí nad Labem

Tel: 475286127

email: helena.vomackova@ujep.cz; kristyna.kapralova@seznam.cz 


\title{
ADAPTACJA KWESTIONARIUSZA DIABETES LOCUS OF CONTROL SCALE (DLCS) NA WARUNKI POLSKIE
}

\author{
POLISH ADAPTATION OF THE DIABETES LOCUS OF CONTROL \\ SCALE (DLCS)
}

\author{
Aleksandra Tuleja
}

\begin{abstract}
Abstrakt
Celem niniejszego badania była adaptacja kwestionariusza DLCS (Ferraro i in., 1987) do warunków polskich. Po translacji i retranslacji skali została przeprowadzona analiza czynnikowa metodą osi głównych z rotacją Varimax. Wyłoniona 3-czynnikowa struktura w postaci podskal Kontroli wewnętrznej, Przypadku i Wpływu innych pokrywa się z wersją anglojęzyczną. 3 itemy o niskich ładunkach czynnikowych zostały odrzucone, dając w efekcie 15-itemową skalę. Tak podskale, jak i cała skala są zgodne wewnętrznie, $\mathrm{z} \alpha=0,756$ dla całości oraz $\alpha=0,725$ dla Kontroli wewnętrznej; $\alpha=0,840$ dla Przypadku; $\alpha=0,798$ dla Wpływu innych. Trafność zbieżna została potwierdzona przy pomocy Wielowymiarowej Skali Umiejscowienia Kontroli Zdrowia (MHLC). Kolejne badania powinny skupić się na dalszym ugruntowaniu właściwości psychometrycznych tego kwestionariusza.
\end{abstract}

Keywords: cukrzyca, teoria umiejscowienia kontroli, Diabetes Locus of Control Scale, DLCS

\begin{abstract}
The purpose of this study was to adapt the DLCS (Ferraro et al., 1987) to Polish conditions. After translating and re-translating the scale, a factor analysis was conducted, utilizing Varimax orthogonal rotation. The identified three factors: Internal (5 items), Chance (6 items) and Powerful Others (4 items) are consistent with the English version. 1 item was discarded from the Internal scale and 2 more were discarded from the Powerful Others scale due to their minimal factor loadings. The result is a 15 -item, internally consistent scale, with Cronbach alpha $=0,756$ for the entire questionnaire, $\alpha=0,725$ for Internal, $\alpha=0,840$ for Chance and $\alpha=0,798$ for Powerful Others scales. Criterion-related validity was established with the Multidimensional Health Locus of Control scale. Additional studies should be carried out to further assess psychometric values of the Polish version of the DLCS scale.
\end{abstract}

Keywords: diabetes, locus of control, Diabetes Locus of Control Scale, DLCS

\section{WPROWADZENIE}

Cukrzyca to grupa chorób metabolicznych, która charakteryzuje się podwyższonym poziomem glukozy we krwi w wyniku defektu działania lub wydzielania insuliny przez trzustkę (tzw. hiperglikemia). Konsekwencją przewlekłej hiperglikemii może być uszkodzenie i zaburzenie pracy różnych narządów, skutkujących często ślepotą, zawałem, udarem lub amputacją dolnych kończyn (WHO, 2020). Rozpowszechnienie najczęściej spotykanego 2 typu cukrzycy przez ostatnie trzydzieści lat gwałtownie wzrosło, a dane wskazują na 422 miliony osób, które chorują na którąś z odmian cukrzycy (WHO, 2020). W Polsce trend ten również jest wzrostowy; ocenia się, że w 2014 roku, cukrzykami było 9,8\% mężczyzn i 9,3\% kobiet, razem 9,5\% populacji (WHO, 2016). 
Z powodu powszechności tej choroby oraz kosztowności jej leczenia, nie tylko dla jednostki, ale również dla systemu opieki zdrowotnej (WHO, 2020), wiele pracy zostało poświęcone zrozumieniu tego, jak osoba chora się $\mathrm{z}$ nią mierzy $\mathrm{w}$ kontekście zmiennych o naturze psychospołecznej (Talbot i in., 1997). Jedną ze szczególnych koncepcji, która znalazła swoje miejsce w literaturze na temat psychologicznego kontekstu cukrzycy jest teoria umiejscowienia poczucia kontroli (locus of control, LOC) Juliana Rottera (Rotter, 1966). Zdefiniował on pojęcie umiejscowienia poczucia kontroli; zewnętrznego oraz wewnętrznego. Osoby charakteryzujące się zewnętrznym poczuciem kontroli są przekonane, iż ich życiem kieruje los, przypadek, bóg lub inna siła od nich niezależna, w tym i ważne osoby dookoła nich. Osoby o wewnętrznym poczuciu kontroli z kolei mają poczucie, że ich życie jest od nich zależne, a ich wybory mają kluczowe znaczenie (Lefcourt i in., 1981; Rotter, 1966; Wojciszke, 2011). Jak się okazało w kolejnych badaniach, teoria ta, w późniejszym czasie przeformułowana tak, aby uwzględniać wielowymiarowość konstruktu poczucia kontroli (Lefcourt i in., 1981; Levenson, 1974; Robinson-Whelen i Storandt, 1992), pozwala na przewidywanie pewnych zachowań prozdrowotnych, m.in. wyszukiwaniem informacji na temat swojej choroby, by skuteczniej z nią walczyć, związki te nie są jednak jeszcze w pełni jasne (Edelstein i Linn, 1987; Lefcourt i in., 1981; B. S. Wallston i Wallston, 1978).

Pierwszym narzędziem wykorzystującym teorię umiejscowienia kontroli w kontekście zdrowia jednostki była Health Locus of Control Scale, stworzona przez Wallston i in. (B. S. Wallston

i in., 1976). Składała się ona z 11 itemów i osadzona była w modelu jednowymiarowym wewnętrzne i zewnętrzne umiejscowienie kontroli traktowane były jak dwa krańce jednego kontinuum. Badania $\mathrm{z}$ wykorzystaniem tej skali potwierdzały hipotezę, iż osoby o wewnętrznym poczuciu kontroli będą bardziej skłonne do wyszukiwania informacji na temat swojego zdrowia. Pod wpływem prac Levenson (1974), która udoskonaliła model poczucia kontroli wyróżniając trzy wymiary: kontrolę wewnętrzną, wpływ innych oraz przypadek, zespół Wallstona (K. A. Wallston, 2005; K. A. Wallston i in., 1978) stworzył Wielowymiarową Skalę Umiejscowienia Kontroli Zdrowia (Multidimensional Health Locus of Control Scale, MHLC).

MHLC została skonstruowana przy użyciu 11 itemów pochodzących z Health Locus of Control Scale oraz dodatkowo wygenerowanej puli 70 itemów; po odrzuceniu zbędnych pozycji na podstawie kryteriów psychometrycznych, powstały dwa kwestionariusze o budowie równoległej (Hubley i Wagner, 2004; Ross i in., 2015), składające się z 18 itemów, po 6 na każdą podskalę. Pytania MHLC są sformułowane tak, aby nie wskazywać na żadną konkretną chorobę, ale neutralnie odnosić się do zdrowia. Wszystkie itemy mierzone są za pomocą 6-punktowej skali Likerta (1 - zdecydowanie się nie zgadzam, 2 - zdecydowanie się zgadzam). Maksymalny wynik każdej ze skal z osobna wynosi 36 punktów. Wysokie wyniki na skali Kontrola wewnętrzna oznaczają wewnętrzne poczucie kontroli, zaś niskie zewnętrzne. Wysokie wyniki na skali Wpływ innych oznaczają wiarę w kontrolę sprawowaną z zewnątrz przez znaczących innych, a na skali Przypadek - iż osoba badana jest przekonana, że jej zdrowie jest zdeterminowane przez los, szczęście, Boga lub inne siły, na działanie których nie ma wpływu (Ross i in., 2015; K. A. Wallston i in., 1978). Wykazano, że osoby o niższym poziomie edukacji mają większą tendencję do kierowania się w stronę zewnętrznego poczucia kontroli, czyli wpływu innych i wpływu przypadku (Ross i in., 2015). MHLC posiada polską adaptację, autorstwa Zygfryda Juczyńskiego (1999). Charakteryzuje się ona dobrymi właściwościami psychometrycznymi.

Użycie jedynie skali mierzących umiejscowienie poczucia kontroli w odniesieniu do zdrowia rozumianego ogólnie jednak niesie ze sobą wiele wad, m.in. trudności interpretacyjne (Edelstein i Linn, 1987; Ferraro i in., 1987; Lefcourt, 1984; Ludenia i Russell, 1983). Stąd 
potrzeba stworzenia skal umiejscowienia poczucia kontroli dla poszczególnych chorób. Ferraro i in. (1987) skonstruowali Diabetes Locus of Control Scale (DLCS) właśnie w tym celu.

DLCS, autorstwa Ferraro i in. (1987) jest testem papier-ołówek i posiada trzy podskale, zgodnie $\mathrm{z}$ wielowymiarową koncepcją poczucia umiejscowienia kontroli: Kontrola wewnętrzna, Wpływ innych i Przypadek. Zawiera 18 itemów, po 6 na każdą podskalę, ocenianych na 6-punktowej skali Likerta $(1$ - zdecydowanie się nie zgadzam, 6 zdecydowanie się zgadzam). Rzetelność test-retest angielskiej wersji wynosiła $\alpha=0,75$ dla skali Kontrola wewnętrzna, $\alpha=0,77$ dla skali Przypadek oraz $\alpha=0,72$ dla skali Wpływ innych. Podczas konstrukcji kwestionariusza, wszystkie itemy zostały ocenione poprzez sędziów kompetentnych i uznane za adekwatne i trafne treściowo w odniesieniu do badanego konstruktu. Trafność kryterialna została wykazana poprzez skorelowanie korespondujących skal DLCS ze skalami MHLC; wszystkie wykazały istotne, wysokie korelacje, zgodnie z przewidywaniami autorów. Interkorelacje dla skal DLCS wynosiły: (1) Kontrola wewnętrzna $\mathrm{x}$ Przypadek, $\mathrm{r}=-0,22$; (2) Kontrola wewnętrzna $\mathrm{x}$ Wpływ innych, $\mathrm{r}=0,14$; (3) Przypadek $\mathrm{x}$ Wpływ innych, $\mathrm{r}=0,25(\mathrm{p}<0,05)$. Trafność treściowa została potwierdzona za pomocą analizy czynnikowej, która dowiodła istnienia trzech zakładanych czynników. Skala ta może być wykorzystywana do badania osób w wieku licealnym oraz dorosłych.

Celem badania zaprezentowanego $\mathrm{w}$ artykule było stworzenie polskiej adaptacji DLCS. Głównym powodem był brak narzędzia w wersji polskiej, które mierzyłoby poczucie umiejscowienia kontroli konkretnie w cukrzycy, i którego itemy uwzględniałyby specyfikę tej choroby. Jest to istotne o tyle, że jak wykazano w badaniach nad diabetykami, wykorzystanie skali sprofilowanej pod kątem tej choroby daje pewniejsze rezultaty, niż użycie skali ogólnej, gdyż normy dla skali ogólnej mogą się drastycznie różnić dla różnych typów chorób, co utrudnia interpretację wyników (Ferraro i in., 1987; Rotter, 1975). Ważną zaletą DLCS jest także dobre ugruntowanie teoretyczne tego narzędzia, co daje możliwość generowania i weryfikowania wielu interesujących hipotez na temat wpływu przekonań odnośnie czynników warunkujących chorobę na jej przebieg i konsekwencje.

Została ona również wybrana ze względu na niejasność wyników otrzymywanych przy badaniu relacji pomiędzy umiejscowieniem poczucia kontroli a funkcjonowaniem chorych na cukrzycę (Przybylski, 2010). Chociaż większość badań sugeruje, że wewnętrzne umiejscowienie kontroli poprawia jakość życia chorych na cukrzycę (Gregg i in., 1996; Indelicato i in., 2017; Nuccitelli i in., 2018; Schwartz i in., 1991), a zewnętrzne poczucie kontroli (zwłaszcza wiara w przypadek) ma negatywny wpływ na ich funkcjonowanie (Aflakseir i ZarrinPour, 2013; Miazgowski i in., 2018), to jednak niektórzy autorzy poddają W wątpliwość bezwzględną korzystność wewnętrznego poczucia kontroli sugerując, że znaczenie mogą mieć tu takie czynniki, jak realny wpływ jednostki na swoją chorobę (Aflakseir i ZarrinPour, 2013; Gillibrand i Flynn, 2001; O'Hea i in., 2009; Surgenor i in., 2000; B. S. Wallston i in., 1976). W końcu część badań wskazuje na brak relacji pomiędzy tymi obszarami życia (Hummer et al., 2011). Stąd potrzeba dalszych badań nad związkiem tych dwóch zmiennych.

\section{METODA}

Tłumaczenie na język polski zostało wykonane przez autorkę artykułu. Trafność treściowa oraz poprawność językowa została oceniona przez dwóch sędziów kompetentnych posiadających doktorat z psychologii. Tłumaczenie zwrotne do języka angielskiego zostało wykonane przez zawodowego tłumacza, który nie posiadał wykształcenia psychologicznego i nie posiadał wiedzy o zamierzonych badaniach. 


\subsection{Osoby badane}

Weryfikacja właściwości psychometrycznej narzędzia odbyła się na próbie 118 uczestników chorych na cukrzycę, zarówno typu 1, 2 jak i cukrzycę ciążową $(\mathrm{K}=85 ; \mathrm{M}=33$; Mwiek $=39 ; \mathrm{SD}=18,42$ ). Były to zarówno osoby pracujące, jak i studenci, uczniowie, bezrobotni, emeryci oraz renciści, o zróżnicowanym wykształceniu (podstawowym, gimnazjalnym, zawodowym, średnim oraz wyższym - tabela 1).

\begin{tabular}{|c|c|c|c|c|c|c|}
\hline PŁeĆ & $\begin{array}{c}\text { Mężczyzna } \\
33\end{array}$ & $\begin{array}{c}\text { Kobieta } \\
85\end{array}$ & & & & \\
\hline WYKSZTALCENIE & $\begin{array}{c}\text { Podstawowe } \\
9 \\
\end{array}$ & $\begin{array}{c}\text { Gimnazjalne } \\
1 \\
\end{array}$ & $\begin{array}{c}\text { Zawodowe } \\
11 \\
\end{array}$ & $\begin{array}{c}\text { Średnie } \\
48 \\
\end{array}$ & $\begin{array}{c}\text { Wyższe } \\
49 \\
\end{array}$ & \\
\hline SYTUACJA & Uczeń & Student & Bezrobotny & Pracujący & Emeryt & Rencista \\
\hline ZAWODOWA & 12 & 15 & 10 & 66 & 15 & 1 \\
\hline ZAMIESZKANIE & $\begin{array}{c}\text { Wieś } \\
26 \\
\end{array}$ & $\begin{array}{c}\text { Miasto do } 50 \\
\text { tys. } \\
27 \\
\end{array}$ & $\begin{array}{l}\text { Miasto do } 100 \\
\text { tys. } \\
16\end{array}$ & $\begin{array}{c}\text { Miasto do } \\
250 \text { tys. } \\
16\end{array}$ & $\begin{array}{c}\text { Miasto } \\
250 \text { tys+ } \\
33\end{array}$ & \\
\hline TYP CUKRZYCY & $\begin{array}{c}\mathbf{I} \\
74\end{array}$ & $\begin{array}{l}\text { II } \\
42\end{array}$ & $\begin{array}{c}\text { Cukrzyca } \\
\text { ciążowa } \\
2\end{array}$ & & & \\
\hline
\end{tabular}

Tabela 1. Charakterystyki próby badawczej.

\subsection{Procedura badania i zastosowane narzędzia}

Praca nad adaptacją DLCS rozpoczęła się od przekładu skali, czyli translacji i retranslacji testu. Badani byli rekrutowani poprzez platformę Facebook i zamieszczone tam grupy poświęcone tematyce cukrzycy - do nich rozsyłana była ankieta internetowa, utworzona na platformie Google Forms. Część badanych, klientów apteki $(\mathrm{N}=12)$, wzięła udział w badaniu poprzez test papier-ołówek.

Obie wersje ankiety zawierały na początku metryczkę z podstawowymi pytaniami nt. osoby badanej, takimi jak jej wiek, płeć, typ cukrzycy, wykształcenie, sytuację zawodową oraz miejsce zamieszkania. Osoby badane zostały również poproszone o ogólną ocenę swojego zdrowia na 5-stopniowej skali Likerta. Następnie rozwiązywały kwestionariusz MHLC (Juczyński, 1999; Wallston et al., 1978), a potem przetłumaczoną na język polski wersję DLCS (Ferraro et al., 1987).

Ze względu na usterki, część badanych $(\mathrm{N}=87)$ wypełniła wersję ankiety internetowej, która nie zawierała pytania $8 \mathrm{z}$ przetłumaczonego kwestionariusza DLCS (Moja rodzina ma znaczący wpływ na to, czy rozwiną się u mnie powikłania związane z cukrzycą). Ankieta została poprawiona, gdy ten błąd wyszedł na jaw.

\section{WYNIKI}

\subsection{Analiza czynnikowa}

Aby zweryfikować strukturę kwestionariusza przeprowadzono analizę czynnikową metodą osi głównych. Test KMO wykazał zadowalającą wartość rzędu 0,752, co potwierdza, iż wielkość zebranej próby jest adekwatna do przeprowadzenia analizy czynnikowej.

Macierz przeciwobrazów korelacji wykazała, że pytania nr 1 (Jeśli przestaję kontrolować cukrzycę, to moje zachowanie decyduje o tym, kiedy kontrolę tę odzyskam) oraz nr 8 (Moja rodzina ma znaczący wpływ na to, czy rozwiną się u mnie powikłania związane z cukrzycą) nie przekraczają kryterium wartości 0,5 , osiągając kolejno 0,425 dla pytania $\mathrm{nr} 1$ oraz 0,448 dla pytania $\mathrm{nr}$ 8, co może sugerować konieczność odrzucenia ich $\mathrm{z}$ dalszej analizy. 
Satysfakcjonujący wynik testu KMO jednak sprawia, że zostaną one uwzględnione w dalszych obliczeniach.

Wykres osypiska oraz analiza całkowitej wariancji wyjaśnianej wskazały na 3 czynniki, które należy wyodrębnić (rysunek 1). Czynnik nr 1 okazał się korelować ujemnie z czynnikiem nr 3 na poziomie $\mathrm{r}=-0,184(\mathrm{p}<0,05)$. Czynniki 1 oraz 2 korelowały dodatnio na poziomie $\mathrm{r}=0,210(\mathrm{p}<0,05)$. Zgodnie $\mathrm{z}$ rekomendacją Tabachnick i Fidell (2012), gdy korelacja między czynnikami jest mniejsza od wartości 0.32 należy zastosować rotację ortogonalną, stąd wybrano rotację Varimax.

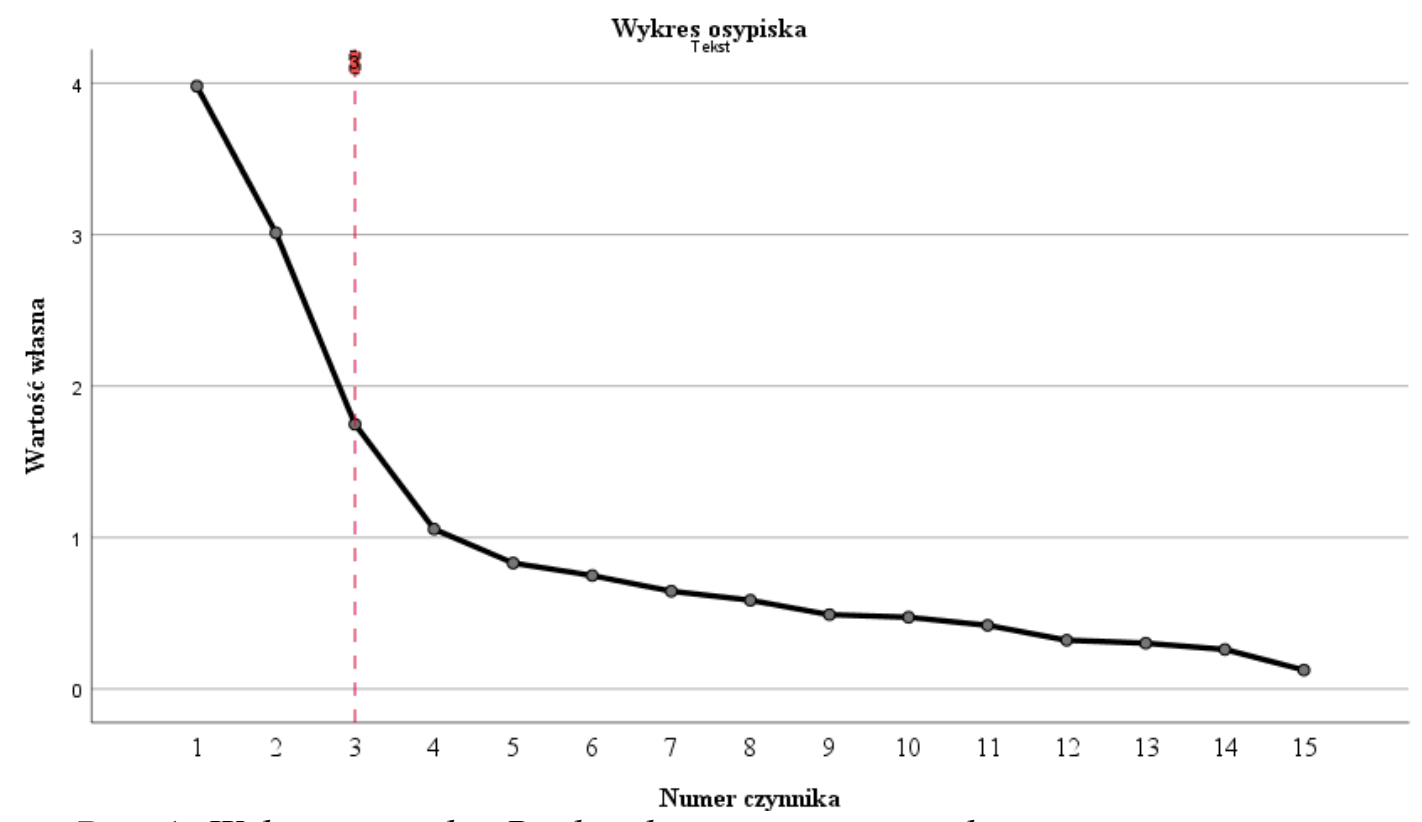

Rys. 1. Wykres osypiska. Punkt odcięcia zaznaczony linia przerywana.

Braki danych w pytaniu nr 8 (Moja rodzina ma znaczący wpływ na to, czy rozwiną się u mnie powikłania związane z cukrzycą) zostały zastąpione średnią.

\begin{tabular}{|c|c|c|c|c|c|c|c|c|c|c|c|c|c|c|c|c|c|c|}
\hline Czynnik & 1 & 2 & 3 & 4 & 5 & 6 & 7 & 8 & 9 & 10 & 11 & 12 & 13 & 14 & 15 & 16 & 17 & 18 \\
\hline 1 & - & 0,674 & - & 0,336 & 0,654 & - & - & - & - & 0,710 & 0,751 & - & - & - & - & 0,725 & 0,749 & - \\
\hline 2 & - & - & 0,616 & - & - & - & 0,444 & - & - & - & - & - & - & 0,920 & 0,859 & - & - & - \\
\hline 3 & - & - & - & - & - & 0,539 & - & - & 0,618 & - & 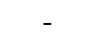 & 0,590 & 0,506 & - & - & - & - & 0,632 \\
\hline
\end{tabular}

Tabela 2. Macierz rotowanych czynników. Metoda wyodrębniania czynników - czynnika głównego. Metoda rotacji - Varimax z normalizacja Kaisera. Rotacja osiagnęła zbieżność w 4 iteracjach.

Item nr 1 (Jeśli przestaję kontrolować cukrzycę, to moje zachowanie decyduje o tym, kiedy kontrolę tę odzyskam), item nr 4 (Regularny kontakt z innymi chorymi na cukrzycę jest dla mnie najlepszym sposobem na to, by nie wytworzyły się u mnie powikłania związane z cukrzycą) oraz item nr 8 (Moja rodzina ma znaczący wpływ na to, czy rozwiną się u mnie powikłania związane z cukrzycą) nie przekroczyły sugerowanego przez Stevensa (2002, za: Field, 2009) kryterium ładunku powyżej 0,4, co potwierdziło zasadność odrzucenia itemów nr 1 oraz 8 (tabela 2). Item nr 4 został również odrzucony ze względu na rozbieżność od tego kryterium (ładunek rzędu 0,336). 
Po wykluczeniu itemów nr 1, 4 oraz 8, ponownie przeprowadzono analizę czynnikową. Miara KMO adekwatności doboru próby podniosła się, osiągając wartość 0,771 , zgodnie z danymi przedstawianymi przez poprzednio otrzymaną macierz przeciwobrazów. Wykres osypiska oraz procent całkowitej wyjaśnionej wariancji wciąż wskazywały na adekwatność wyodrębnienia

3 czynników, co również jest wsparte przez teorię (Lefcourt i in., 1981; Levenson, 1974; Robinson-Whelen i Storandt, 1992) oraz pokrywa się z wersją anglojęzyczną (Ferraro i in., 1987; Ross i in., 2015).

Drogą interpretacji, wyróżnione czynniki zostały zinterpretowane w podskalach jako: 1) Przypadek, 2) Wpływ innych oraz 3) Kontrola wewnętrzna. Skala Kontrola wewnętrzna zawiera 5 itemów, skala Przypadek: 5, a skala Wpływ innych: 4 (tabela 3).

\begin{tabular}{|c|l|}
\hline KONTROLA WEWNĘTRZNA & $6,9,12,13,18$ \\
\hline PRZYPADEK & $2,5,10,11,16,17$ \\
\hline WPLYW INNYCH & $3,7,14,15$ \\
\hline
\end{tabular}

Tabela 3. Przyporzadkowanie itemów do wyodrębnionych skal.

Po utworzeniu trzech skal zbadane zostały ich właściwości statystyczne. Skala Kontrola wewnętrzna okazała się mieć rozkład lewoskośny (kurtoza $=0,369$, błąd standardowy $=$ 0,442). Skala Przypadek wykazała się rozkładem zbliżonym do normalnego, podobnie skala Wpływ innych.

\subsection{Rzetelność}

Dla skali Kontrola wewnętrzna $\alpha$ Cronbacha wyniosła 0,725. Każda z pozycji miała adekwatny wkład w powiększenie rzetelności tej skali (tabela 4).

\begin{tabular}{|l|c|c|}
\hline \multicolumn{1}{|c|}{ ITEM } & SKIS & APUP \\
\hline $\begin{array}{l}\text { 6. Kiedy unikam powikłań związanych z cukrzycą, dzieje się to dzięki } \\
\text { moim wysiłkom. }\end{array}$ & 0,437 & 0,698 \\
\hline $\begin{array}{l}\text { 9. To, co robię dla siebie ma największy wpływ na to, czy wytworzą się u } \\
\text { mnie powikłania związane z cukrzycą. }\end{array}$ & 0,551 & 0,650 \\
\hline $\begin{array}{l}\text { 12. To, co robię dla siebie ma największy wpływ na moją kontrolę nad } \\
\text { cukrzycą. }\end{array}$ & 0,531 & 0,661 \\
\hline $\begin{array}{l}\text { 13. Jeśli o siebie dbam, jestem w stanie zminimalizować powikłania } \\
\text { związane z cukrzycą. }\end{array}$ & 0,397 & 0,711 \\
\hline $\begin{array}{l}\text { 18. Jeśli będę podejmować odpowiednie kroki, cukrzyca będzie pod moją } \\
\text { kontrolą. }\end{array}$ & 0,514 & 0,668 \\
\hline
\end{tabular}

Tabela 4. Wartości SKIS (skorygowana korelacja item-skala) i APUP (alfa po wykluczeniu pytania) dla skali Kontrola wewnętrzna.

Skala Przypadek wykazała się rzetelnością rzędu $\alpha=0,840$. Podobnie jak w skali pierwszej, nie wystąpiła potrzeba usuwania żadnego z itemów (tabela 5). 


\begin{tabular}{|l|c|c|}
\hline \multicolumn{1}{|c|}{ ITEM } & SKIS & APUP \\
\hline $\begin{array}{l}\text { 2. Bez względu na to co robię, zapewne pojawią się u mnie powikłania } \\
\text { związane z cukrzycą. }\end{array}$ & 0,541 & 0,698 \\
\hline $\begin{array}{l}\text { 5. Większość rzeczy, które mają wpływ na moją cukrzycę, dzieje się przez } \\
\text { przypadek. }\end{array}$ & 0,551 & 0,697 \\
\hline $\begin{array}{l}\text { 10. Kiedy moja cukrzyca wymyka się spod kontroli, dzieje się to zwykle } \\
\text { przez przypadek. }\end{array}$ & 0,580 & 0,825 \\
\hline $\begin{array}{l}\text { 11. Brak powikłań związanych z cukrzycą to w głównej mierze kwestia } \\
\text { szczę́liwego trafu. }\end{array}$ & 0,713 & 0,788 \\
\hline $\begin{array}{l}\text { 16. Nieważne, co robię, moja cukrzyca prawdopodobnie wymknie się spod } \\
\text { kontroli. }\end{array}$ & 0,623 & 0,672 \\
\hline 17. Jeśli jest mi to pisane, moja cukrzyca będzie pod kontrolą. & 0,660 & 0,660 \\
\hline
\end{tabular}

Tabela 5. Wartości SKIS i APUP dla skali Przypadek.

Dla skali Wpływ innych $\alpha=0,798$. Co ciekawe, pytanie $\mathrm{nr} 7$ (Moja rodzina ma spory wpływ na to, czy moja cukrzyca jest lub nie jest pod kontrolą) okazało się zaniżać rzetelność skali (tabela 6). Najprawdopodobniej wydarzyło się tak z powodu, iż pozostałe pytania dotyczyły znaczących innych w postaci lekarzy, a jedynie to pytanie odnosiło się do wspierającej roli rodziny.

Ze względu na zadowalającą rzetelność podskali i wysoki ładunek czynnikowy itemu, zdecydowano pozostawić go w skali.

\begin{tabular}{|l|c|c|}
\hline \multicolumn{1}{|c|}{ ITEM } & SKIS & APUP \\
\hline $\begin{array}{l}\text { 3. Regularny kontakt z moim lekarzem to dla mnie najlepszy sposób, by } \\
\text { utrzymać kontrolę nad moją cukrzycą. }\end{array}$ & 0,556 & 0,775 \\
\hline $\begin{array}{l}\text { 7. Moja rodzina ma spory wpływ na to, czy moja cukrzyca jest lub nie jest } \\
\text { pod kontrolą. }\end{array}$ & 0,412 & 0,844 \\
\hline $\begin{array}{l}\text { 14. Kiedy jestem w stanie kontrolować swoją cukrzyce, to zazwyczaj } \\
\text { dzięki temu, że inni ludzie (np. lekarze, pielęgniarki, rodzina, przyjaciele) } \\
\text { dobrze się mną opiekują. }\end{array}$ & 0,769 & 0,669 \\
\hline $\begin{array}{l}\text { 15. Jeśli udaje mi się uniknąć powikłań związanych z cukrzyca, to dzięki } \\
\text { temu, iż inni ludzie (np. lekarze, pielęgniarki, rodzina, przyjaciele) dobrze } \\
\text { się mną opiekują. }\end{array}$ & 0,745 & 0,683 \\
\hline
\end{tabular}

Tabela 6. Wartości SKIS i APUP dla skali Wptyw innych.

Dla całego kwestionariusza $\alpha=0,756$, co wskazuje na odpowiedni poziom rzetelności.

\subsection{Trafność}

Wyniki kwestionariusza DLCS zostały skorelowane z korespondującymi skalami MHLC. Korelacje między skalami wynosiły: $r=0,572(\mathrm{p}<0,01)$ dla Wpływu innych; $r=0,634$ $(\mathrm{p}<0,01)$ dla Przypadku; oraz $\mathrm{r}=0,470(\mathrm{p}<0,01)$ dla Kontroli wewnętrznej. 


\section{DYSKUSJA}

Celem niniejszego artykułu była adaptacja kwestionariusza DLCS (Ferraro i in., 1987) do warunków polskich. Przetłumaczona wersja wykazała się wstępnie odpowiednimi charakterystykami psychometrycznymi i jej podskale okazały się korelować z korespondującymi skalami kwestionariusza MHLC na umiarkowanym poziomie, co wskazuje na to, iż badane konstrukty są sobie bliskie, jednak nie tożsame. Zjawisko takie jest wsparte przez teorię, jako że DLCS w oryginale jest kwestionariuszem stworzonym w oparciu o MHLC (Juczyński, 1999; Wallston et al., 1978), lecz różni się tym, iż jest wprost sprofilowany dla osób chorych na cukrzycę. Również interkorelacje skal DLCS okazały się być bardzo zbliżone do wersji anglojęzycznej. Kwestionariusz charakteryzuje się dobrą rzetelnością. Alfa Cronbacha zarówno dla całości, jak i poszczególnych podskal utrzymuje się na zadowalającym poziomie, dla skali Przypadek oraz Wpływ innych osiągając nawet wyższe wartości niż w wersji oryginalnej, dla Kontroli wewnętrznej będąc zaś porównywalna (Ferraro $\mathrm{i}$ in., 1987).

Badania potwierdziły postulowaną przez autorów strukturę 3-czynnikową narzędzia. Wyodrębnione wskutek analiz czynniki pokrywały się w większości z wersją anglojęzyczną (Ferraro i in., 1987). W przeciwieństwie do wersji anglojęzycznej, wersja polska liczy jednak nie 18 , a 15 itemów.

Ograniczeniem obecnych badań była duża ilość braków danych w przypadku pytania 8 , która wynikała $\mathrm{z}$ pominięcia go $\mathrm{w}$ pierwotnej wersji ankiety. Finalnie zostało ono odrzucone $\mathrm{z}$ ostatecznej wersji kwestionariusza, niemniej jednak $\mathrm{w}$ przyszłych badaniach warto by uwzględnić to pytanie, aby sprawdzić jego wpływ na właściwości psychometryczne polskiej wersji DLCS. Badania były przeprowadzone na próbie o umiarkowanej wielkości, co zawęża możliwość formułowania wniosków. Należy jednak nadmienić, że podstawowy wymóg analizy czynnikowej - tj. więcej niż stu respondentów (Hornowska, 2010) - został spełniony. Nie przeprowadzono również szerszego badania trafności zbieżnej i różnicowej. Procedura nie była także w pełni ujednolicona - osoby badane wypełniały kwestionariusze w wersjach zarówno papierowej, jak i online. Wersje papierowe były wypełniane prawie wyłącznie przez kobiety

w wieku senioralnym. Dodatkowa analiza różnic między dwiema grupami wykazała, iż średnie w tych grupach nie różniły się znacznie dla podskal Kontroli wewnętrznej i Wpływu innych. Jednak podskala Przypadek w grupie osób, które wypełniały ankietę online osiągnęła średnią wartość 16,6 , podczas gdy w drugiej grupie aż 24,3. Może to być związane z wiekiem osób wypełniających ankietę papierową, gdyż po 60 roku życia zaczyna zwiększać się zewnętrzne poczucie kontroli (Bradley i Webb, 1976).

Podsumowując, kwestionariusz DLCS w wersji 15-itemowej to rzetelne i trafne narzędzie, które może znaleźć użytek w zarządzaniu terapią u osób chorych na cukrzycę oraz pozwala na wgląd w część biopsychospołecznych zmiennych wpływających na jej skuteczność. Informacje te $z$ kolei mogą być szansą do wsparcia osoby chorej i ułatwienia jej adaptacji do cukrzycy. DLCS jest również atrakcyjnym narzędziem dla badaczy zajmujących się korelatami umiejscowienia poczucia kontroli zdrowia u cukrzyków. Kolejne badania powinny skupić się na dalszym ugruntowaniu właściwości psychometrycznych tego kwestionariusza.

\section{Literatura cytowana}

1. AFLAKSEIR, A. I ZARRINPOUR, R. (2013). Predicting Adherence to Diet Regimen Based on Health Locus of Control: A Cross Sectional Study. Iranian Journal of Diabetes and Obesity, 5(2), 71-76. 
2. BRADLEY, R. H., WEBB, R. (1976). Age-Related Differences in Locus of Control Orientation in Three Behavior Domains. Human Development, 19, 40-55.

3. EDELSTEIN, J. I LINN, M. W. (1987). Locus of control and the control of diabetes. The Diabetes Educator, 13(1), 51-54. https://doi.org/10.1177/014572178701300111

4. FERRARO, L. A., PRICE, J. H., DESMOND, S. M.I ROBERTS, S. M. (1987). Development of a diabetes locus of control scale. Psychological Reports, 61, 763770.

5. FIELD, A. (2009). Discovering statistics using SPSS. Third Edition. London: Sage Publications Ltd.

6. GILLIBRAND, W.I FLYNN, M. (2001). Forced externalization of control in people with diabetes: A qualitative exploratory study. Journal of Advanced Nursing, 34(4), 501-510. https://doi.org/10.1046/j.1365-2648.2001.01779.x

7. GREGG, E. W., NARAYAN, K. M. V., KRISKA, A. M. I KNOWLER, W. C. (1996). Relationship of locus of control to physical activity among people with and without diabetes. Diabetes Care, 19(10), 1118-1121. https://doi.org/10.2337/diac are.19.10.1118

8. HORNOWSKA, E. (2010). Testy psychologiczne. Teoria i praktyka. Warszawa: Wydawnictwo Naukowe Scholar.

9. HUBLEY, A. M. I WAGNER, S. (2004). Using alternate forms of the multidimensional health locus of control scale: Caveat emptor. Social Indicators Research, 65(2), 167-186. https://doi.org/10.1023/A:1025809921592

10. HUMMER, K., VANNATTA, J. I THOMPSON, D. (2011). Locus of Control and Metabolic Control of Diabetes: A Meta-Analysis. The Diabetes Educator, 37(1), 104-110. https://doi.org/10.1177/0145721710388425

11. INDELICATO, L., MARIANO, V., GALASSO, S., BOSCARI, F., CIPPONERI, E., NEGRI, C., FRIGO, A., AVOGARO, A., BONORA, E., TROMBETTA, M. I BRUTTOMESSO, D. (2017). Research: Educational and Psychological Aspects Influence of health locus of control and fear of hypoglycaemia on glycaemic control and treatment satisfaction in people with Type 1 diabetes on insulin pump therapy. Diabetic Medicine, 34, 691-697. https://doi.org/10.1111/dme.13321

12. JUCZYŃSKI, Z. (1999). Narzędzia pomiaru w promocji i psychologii zdrowia. Przegląd Psychologiczny.

13. LEFCOURT, H. M. (1984). Review of Research with the locus of control construct, vol. 3: Extensions and limitations. In H. M. Lefcourt (Ed.), Canadian Psychology/Psychologie canadienne. Academic Press, Inc. https://doi.org/10.1037/ h0084457

14. LEFCOURT, H. M., SUBSIDIARY, A. I BRACE, H. (1981). Research with the Locus of Control Construct. In Research with the Locus of Control Construct (Vol. 1). https://doi.org/10.1016/c2013-0-11068-9

15. LEVENSON, H. (1974). Activism and Powerful Others: Distinctions Within the Concept of Internal-External Control. Journal of Personality Assessment, 38(4), 377-383. https://doi.org/10.1080/00223891.1974.10119988

16. LUDENIA, K. I RUSSELL, S. F. (1983). The relationship between health locus of control beliefs and the MMPI with an alcoholic population. Journal of Clinical Psychology, 39(4), 624-627. https://doi.org/10.1002/1097-4679(198307)39:4<624 ::AID-JCLP2270390430>3.0.CO;2-8

17. MIAZGOWSKI, T., BIKOWSKA, M., OGONOWSKI, J. I TASZAREK, A. (2018). The Impact of Health Locus of Control and Anxiety on Self-Monitored Blood Glucose Concentration in Women with Gestational Diabetes Mellitus. Journal of Women's Health, 27(2), 209-215. https://doi.org/10.1089/jwh.2017.6366 
18. NUCCITELLI, C., VALENTINI, A., CALETTI, M. T., CASELLI, C., MAZZELLA, N., FORLANI, G. I MARCHESINI, G. (2018). Sense of coherence, self-esteem, and health locus of control in subjects with type 1 diabetes mellitus with/without satisfactory metabolic control. Journal of Endocrinological Investigation, 41(3), 307-314. https://doi.org/10.1007/s40618-017-0741-8

19. O'HEA, E. L., MOON, S., GROTHE, K. B., BOUDREAUX, E., BODENLOS, J. S., WALLSTON, K. I BRANTLEY, P. J. (2009). The interaction of locus of control, self-efficacy, and outcome expectancy in relation to HbA1c in medically underserved individuals with type 2 diabetes. Journal of Behavioral Medicine, 32(1), 106-117. https://doi.org/10.1007/s10865-008-9188-x

20. PRZYBYLSKI, M. (2010). Health locus of control theory in diabetes: A worthwhile approach in managing diabetic foot ulcers? Journal of Wound Care, 19(6), 228-233. https://doi.org/10.12968/jowc.2010.19.6.48470

21. ROBINSON-WHELEN, S. I STORANDT, M. (1992). Factorial structure of two health belief measures among older adults. Psychology and Aging, 7(2), 209-213. https://doi.org/10.1037/0882-7974.7.2.209

22. ROSS, T. P., ROSS, L. T., SHORT, S. D. I CATALDO, S. (2015). The multidimensional health locus of control scale: Psychometric properties and form equivalence. Psychological Reports, 116(3), 889-913. https://doi.org/10.2466/ 09.02.PR0.116k29w3

23. ROTTER, J. B. (1966). Generalized Expectancies for Internal Versus External Control of Reinforcement. Psychological Monographs: General and Applied, 80(1), 1-28. https://doi.org/10.1037/h0092976

24. ROTTER, J. B. (1975). Some Problems and Misconceptions Related to the Construct of Internal versus External Control of Reinforcement. Journal of Consulting and Clinical Psychology, 43(1), 56-67.

25. SCHWARTZ, L. S., COULSON, L. R., TOOVY, D., LYONS, J. S. I FLAHERTY, J. A. (1991). A biopsychosocial treatment approach to the management of diabetes mellitus. General Hospital Psychiatry, 13(1), 19-26. https://doi.org/10.1016/01638343(91)90005-H

26. SURGENOR, L. J., HORN, J., HUDSON, S. M., LUNT, H. I TENNENT, J. (2000). Metabolic control and psychological sense of control in women with diabetes mellitus: Alternative considerations of the relationship. Journal of Psychosomatic Research, 49(4), 267-273. https://doi.org/10.1016/S0022-3999(00)00181-1

27. TABACHNICK, B.G. AND FIDELL, L.S. (2012) Using Multivariate Statistics. 6h Edition, Person Education, Boston.

28. TAlBOT, F., NOUWEN, A., GINGRAS, J., GOSSELIN, M. I AUDET, J. (1997). The assessment of diabetes-related cognitive and social factors: The multidimensional diabetes questionnaire. Journal of Behavioral Medicine, 20(3), 291-312. https://doi.org/10.1023/A:1025508928696

29. WALLSTON, B. S. I WALLSTON, K. A. (1978). Locus of Control and Health: A Review of the Literature. Health Education \& Behavior, 6(1), 107-117. https://doi.org/10.1177/109019817800600102

30. WAllston, B. S., WAllston, K. A., KAPlAn, G. D. I MAIDES, S. A. (1976). The development and validation of the health related locus of control (HLC) scale. Journal of Consulting and Clinical Psychology, 44, 580-585.

31. WALLSTON, K. A. (2005). The validity of the Multidimensional Health Locus of Control scales. Journal of Health Psychology, 10(5), 623-631. https://doi.org/10.1177/1359105305055304 
32. WALLSTON, K. A., WALLSTON, B. S. I DEVELLIS, R. (1978). Development of the Multidimensional Health Locus of Control (MHLC) Scales. Health Education Monographs, 6(2), 160-170.

33. WORLD HEALTH ORGANISATION, (2020). Diabetes. Pobrane z: https://www.who.int/health-topics/diabetes\#tab=tab_1

34. WORLD HEALTH ORGANISATION, (2016). Diabetes country profiles. Poland. Pobrane z: https://www.who.int/diabetes/country-profiles/pol_en.pdf

35. WOJCISZKE, B. (2011). Psychologia spoleczna. Warszawa: Wydawnictwo Naukowe SCHOLAR.

\section{Kontakt}

Aleksandra Tuleja

Uniwersytet Jagielloński, Instytut Psychologii

Ingardena 6, Kraków, Polska

Tel: 888494043

email: a.tuleja@student.uj.edu.pl 


\title{
O INKLUZÍVNÍ EDUKACI V SOUČASNÉ SLOVENSKÉ MATEŘSKÉ ŠKOLE
}

\author{
ON INCLUSIVE EDUCATION IN THE CURRENT SLOVAK \\ PRESCHOOL
}

\author{
Jana Balážová
}

\begin{abstract}
Abstrakt
Obhajoba inkluzívnej edukácie a opodstatnenia jej realizácie voblasti inštitucionálnej edukácie, ktorá je neodmyslitel’nou súčast'ou života l'udí v súčasnej spoločnosti. Pripomenutie dôležitosti malých krokov na ceste premeny v inkluzívnu spoločnost'. Priblíženie pohl'adu na predškolské zariadenia - materské školy, ktoré aj napriek pretrvávajúcim predsudkom, strachom, negatívnym postojom voči det’om s postihnutím, narušením a ohrozením je možné vnímat' ako vhodný priestor realizácie inkluzívnej edukácie.
\end{abstract}

Klíčové slova: inkluzívna edukácia, inkluzívna spoločnost', predškolské zariadenia, materské školy, determinanty inkluzívnej edukácie, deti s postihnutím, narušením a ohrozením

\begin{abstract}
Defending inclusive education and justifying its implementation in the field of institutional education, which is an integral part of people's lives in today's society. A reminder of the importance of small steps on the path to transforming into an inclusive society. Approaching the view of preschool facilities - Kindergartens, which, despite persistent prejudice, fear, negative attitudes towards children with special edukational needs and disabilities, can be perceived as a suitable space for the implementation of inclusive education.
\end{abstract}

Key words: inclusive education, inclusive society, preschool facilities, kindergartens, determinants of inclusive education, children with special edukational needs and disabilities

\section{INKLUZÍVNA EDUKÁCIA}

Popri rodine pri formovaní osobnosti diet'at'a dôležitú úlohu zohráva inštitucionálna výchova meniaca sa v závislosti od konkrétneho obdobia vývoja l’udskej spoločnosti. Kučerová (In Kudláčová, 2006, s. 141) upresňuje: „,celá výchovná činnost’ smeruje oddávna k premenlivým cielom, v ktorých sa odráža určitá koncepcia sveta aj l'udského života, $k$ ciel'om, ktoré sú určitým výkladom človeka a jeho postavenia v prírode a v l'udskej spoločnosti, $k$ ciel'om, ktoré sú výrazom určitého pochopenia zmyslu l’udskej existencie, l’udského usilovania, l’udskej tvorivosti, l'udských kultúrnych hodnôt."

V posledných troch desat'ročiach edukáciu (výchovu i vzdelávanie) vo vel'kej časti sveta ovplyvňuje inkluzívny trend - najprogresívnejší smer vývinu v edukácii vychádzajúci z tzv. „vyššieho princípu“, kde každý človek (s aj bez postihnutia, narušenia, ohrozenia) je prijímaný bez akýchkol'vek podmienok, t. j. taký, aký je, a má možnost' prispiet' k rastu spoločnosti - inkluzívnej spoločnosti.

Jednou z možností je realizácia inkluzívnej edukácie, ktorá sa okrem základných princípov humanizmu, demokracie vyznačuje týmito dominujúcimi princípmi (Bilčík, Balážová, 2021):

- princíp heterogénnosti (rôznorodost', odlišnost', diverzita); 
- princíp kooperácie a individualizácie (spolupráca počas spoločného projektu, kooperatívna komunikácia, akceptovanie jedinečnosti, individuality a umožnenie rozvíjat' sa každému podl'a jeho/jej momentálnych schopností, možností atd');

- princíp transdisciplinarity (diskusia, kooperácia, riešenie problémov sa tak uskutočňuje v širších súvislostiach v teoretickej i praktickej rovine);

- princíp regionalizácie (schopnosti škôl edukovat' všetky deti v mieste bydliska);

- princíp aktívneho poznávania (aktívne skúmanie a nielen pasívne prijímanie informácií);

- princíp ucelenosti (zdravotná, kognitívna, emocionálna, sociálna oblast').

Stále sme však na začiatku dlhej cesty postupných zmien uplatňovania uvedených princípov dotýkajúcich sa mnohých oblastí. Taktiež, všetci dobre vieme, že nie je l'ahké a dokonca je nereálne mysliet' si, že sme schopní zmenit' seba a súčasnú (i budúcu) spoločnost' v krátkom čase. Akceptáciu odlišnosti druhého je potrebné brat' ako vel'kú výzvu do budúcna, na ktorej treba pracovat' postupne a motiváciou by nám mala byt' skutočnost', že ak prekonáme bariéru postihnutia $\mathrm{v}$ širšom zmysle (nie popieraním, ale prijatím a rešpektovaním), tak pochopíme druhého človeka (porov. Speck, In Horňáková, 2010) a budeme ho vediet' správne edukovat'. Čo vyjadril aj Moor (In Horňáková, 2010) tvrdiac, že najskôr treba pochopit' a potom edukovat'.

Je potrebné si uvedomit', že urýchlená, nemúdra aplikácia edukácie spôsobuje neželaný efekt prejavujúci sa napríklad neúspešnou realizáciou inkluzívnej edukácie, čím podl’a Lechtu (2011) rozumieme neschopnost' zabezpečit' všetkým členom heterogénnej školskej komunity adekvátnu edukáciu. Príčinami neúspešnej realizácie inkluzívnej edukácie v základných školách sú:

- neprimerané sebavedomie žiaka (neprijatie seba samého);

- strach zo školy ako vzdelávacej inštitúcie (kladenie dôrazu na výkon);

- zúžený pohl'ad na edukáciu;

- strach zo školy ako priestoru (materiálne a priestorové obmedzenia);

- nezvládnutie heterogenity edukačného prostredia, t. j. nielen nepripravenost' pedagógov, ale celej súčasnej spoločnosti;

- strach zo školy ako miesta sociálneho kontaktu (t'ažkosti s komunikáciou, vyplývajúce z osobitostí komunikácie s l'ud'mi s postihnutím, narušením, ohrozením;

- naivné presvedčenie o úspešnej realizácii inkluzívnej edukácie konkrétneho žiaka s postihnutím, narušením, ohrozením zo strany osoby (osôb), s ktorou má žiak s postihnutím, narušením, ohrozením vzt'ah, príp. presvedčenie o jej neúspešnej realizácii ešte skôr ako sa začala;

- nespolupráca - neschopnost' kooperovat' (Balážová, 2012).

Vhodné je sa zamysliet', či uvedené príčiny neúspešnej realizácie inkluzívnej edukácie v základných školách sa týkajú iba žiakov základných škôl, či by nebolo žiaduce na dané oblasti vplývat' už v ranom a predškolskom veku detí.

\section{BUDOVANIE INKLUZÍVNEHO POVEDOMIA OD RANÉHO VEKU}

Základnú výbavu na tejto ceste tvorí raná intervencia, na ktorú nadväzuje alebo ju podporuje inkluzívna edukačná činnost' v predškolských zariadeniach.

V prvom rade je potrebné poukázat' na vel'ký význam rodičovskej kompetencie pre celkový vývin diet’at'a, ktorú potvrdzujú aktuálne poznatky z výskumov mozgu a teórie pripútania (Andress, Horvath, 2012). Je klinicky overené, že mozgové neuróny (aj ked' sú poškodené) môžu v optimálnom intervenčnom prostredí vytvárat' maličké výbežky, ktoré im umožňujú prepojit' sa s inými neurónmi. Zároveň - ak nejaký neurón odumrie alebo prestane dostávat' vstupné informácie, výbežky susedného neurónu majú schopnost' narást' až o $2 \mathrm{~mm}$, aby situáciu vykompenzovali (Taub a kol. 2004). Ďalej Požár (2010) uviedol, že výchova rodičov sa môže stat' determinantom objavenia sa patologických odchýlok pri utváraní osobnosti 
diet'at'a s postihnutím v širšom zmysle, čo sa prejaví aj v procese jeho inkluzívnej edukácie. Naopak rodičovská výchova môže napomôct' k optimálnejšiemu vývinu diet'at'a po všetkých stránkach a napomôct' $\mathrm{k}$ úspešnej realizácii inkluzívnej edukácie.

Podobný vplyv na optimálny vývin diet'at'a (s a aj bez postihnutia) majú aj predškolské zariadenia, ktoré saturujú mnohé potreby diet'at'a alebo dokonca často kompenzujú viaceré deficity rodinnej výchovy. Ved' so vstupom do predškolského zariadenia sa akoby diet'at'u skutočne otváral svet. Preto možno tvrdit', že sú najideálnejším raným prostredím pre realizáciu filozofie inklúzie v správaní, myslení a konaní všetkých zúčastnených (Kováčová, 2010; Andress, 2010 a iní). Možno tu hrovými aktivitami naṕlnat' ciel' inklúzie ,.... nie odstránit' rozdiely medzi det'mi, ale umožnit', aby deti s rozmanitými schopnost'ami a možnost’ami tvorili spoločnú komunitu na základe ich práv a akceptácie individuality celou komunitou" (Podhájecká, 2008, s. 77) a vštepovat' pohl'ady na postihnutie, narušenie, ohrozenie v idei chápania inklúzie s entuziazmom „sme si rovní, a tak rozdielni “, a nie so súcitom, podceňovaním a inými emocionálnymi dôvodmi (Kováčová, 2010b, s. 134).

\section{REALIZÁCIA INKLUZÍVNEJ EDUKÁCIE V PREDŠKOLSKÝCH ZARIADENIACH}

Rodina diet'at'a s postihnutím, narušením, $\mathrm{t} \mathrm{j}$. s rizikovým vývinom prijíma diet'a a primerane stimuluje jeho vývin po všetkých stránkach (emocionálna, zdravotná, sociálna, kognitívna). Diet'a s postihnutím, narušením, ohrozením tak nadobúda základnú istotu, primerané sebavedomie, sebaúctu atd'., na ktorých sa neskôr stavia v predškolskom zariadení v blízkosti bydliska. Takéto predškolské zariadenie poskytuje všetkým det'om optimálnu podporu a vývin podl'a individuálnych aktuálnych možností, schopností, vedomostí. Osobný záujem zo strany učitel'ov materskej školy je u detí s rizikovým vývinom najdôležitejší. Vysoké očakávania spoločne so starostlivost'ou majú pozitívny vplyv na život diet'at'a a na jeho školskú a sociálnu úspešnost' aj v budúcnosti (Sender, 2020). Ako píše Kováčová (2010) zakomponovávanie do každodenných činností hrové aktivity, počas ktorých deti bez postihnutia, narušenia, ohrozenia majú možnost' prirodzene získat' reálnu predstavu o diet'ati s postihnutím, narušením - ich správanie je primerane a správne korigované a ich žiaduce správanie je podporované (deti v danom veku zrkadlia postoje, ktoré vidia vo svojom okolí vrátane pohl'adu na odlišnosti a akceptáciu všetkých l’udí bez rozdielu).

$\mathrm{Na}$ podporu optimálnej realizácie inkluzívnej edukácie v predškolskom zariadení Andress (2010) konkrétne odporúča, aby sa riadili príručkou na rozvoj škôl s dôrazom na inkluzívne hodnoty - Indexom inklúzie, autormi ktorej sú Booth a Ainscow (2019), čo v praxi znamená napríklad využívat' aktuálne zdroje, odbúravat' bariéry, tímovo spolupracovat', podporovat' autonómne učenie sa, zohl'adňovat' rodinné podmienky pri vypracúvaní ponuky podpory.

Úlohou inkluzívneho predškolského zariadenia by mala byt' snaha poskytnút' všetkým det'om s jedinečnými osobnost’ami, prejavujúcimi sa rôznymi osobnostnými rysmi, schopnost'ami, zručnost’ami, také edukačné prostredie, v ktorom si nájdu optimálne podnety pre svoj rozvoj. Týka sa to aj skupiny detí s ohrozením, napr. detí príliš chudých, obéznych (nie z dôvodu ochorenia), detí, ktorých rodičia sa rozvádzajú/rozviedli, alebo ide o deti s odlišným materinským jazykom. Danišková (2019/2020, s. 20) v tejto súvislosti uvádza, že „Ministerstvo školstva alebo Štátny pedagogický ústav nevytvárajú podporné opatrenia alebo dokumenty, ktoré by učitel'kám materských škôl pomohli pri práci s det’mi z iného jazykového prostredia. " Otázne však je, či by pomohli.

Horňáková (2014) na posúdenie stupňa inklúzie v materskej škole uvádza škálu od Cliforta:

- Nedostatočný stupeň inklúzie: Pri tomto stupni sa zamestnanci materskej školy neusilujú o posúdenie a napíňanie špecifických potrieb diet’at’a s postihnutím, narušením, ohrozením. Účast' diet'at’a na aktivitách s kolektívom je vel'mi malá. 
- Minimálny stupeň inklúzie: Materská škola využíva minimum možnosti pre naplnenie potrieb diet’at’a. V minimálnej miere tiež využíva spoluprácu s rodičmi či zapájanie diet'at'a do aktivít spoločne s ostatnými det'mi.

- Dobrý stupeň inklúzie: Zamestnanci materskej školy rešpektujú odporúčania odborníkov a snažia sa ich napĺn̆at'. Spolupracujú tiež s rodičmi a pravidelne si vymieňajú informácie o diet’ati. Deti s postihnutím, narušením, ohrozením sa zúčastňujú aktivít spoločne s ostatnými det'mi.

- Výborný stupeň inklúzie: Deti s postihnutím, narušením, ohrozením sú včlenené do skupiny a zúčastňujú sa väčšiny aktivít, pričom aj odborné intervencie sa uskutočňujú počas týchto aktivít. Zamestnanci materskej školy sa usilujú o rozvoj diet’at'a v čo najväčšej miere.

Inkluzívne predškolské zariadenie by malo byt' rodinné a sociálne prostredie, kde je dostatok priestoru na komunikáciu, vzt'ahy, záujmy, kde sa akceptuje rozdielnost', a kde je možné v procese edukácie zažívat' spokojnost'. Preto zdôrazňujeme všestrannú edukáciu - nezabúdat' na emocionálnu, psychomotorickú a sociálnu oblast’ popri intelektuálnej (Balážová, 2012).

Domnievam sa, že nápomocní môžu byt' svojim prístupom a vlastným príkladom edukátori snažiaci sa o svoj osobnostný rast (schopnost' efektívne využívat' odborné poznatky, nadväzovat' kontakt, komunikovat', kooperovat', povzbudzovat', formulovat' konštruktívnu kritiku, objektívne reflektovat', posudzovat' a hodnotit', pozitívne hl'adiet' do budúcna atd'.), prejavujúci sa vo vzt’ahu k sebe samému, ku všetkým det'om a ich rodičom, súrodencom, ale aj k iným l'ud'om, a tým prispiet' $\mathrm{k}$ budovaniu inkluzívnej spoločnosti.

\section{DETERMINANTY REALIZÁCIE INKLUZÍVNEJ EDUKÁCIE V SLOVENSKÝCH MATERSKÝCH ŠKOLÁCH}

V slovenských materských školách, ktoré deti s postihnutím, narušením, ohrozením integrujú - platný školský zákon umožňuje školskú integráciu detí so špeciálnymi výchovnovzdelávacími potrebami - sa posledných 10 rokov (vychádzajúcich z prieskumov študentov) stretáme s nasledujúcimi determinantami inkluzívnej edukácie:

- Nie všetci rodičia detí s postihnutím, narušením, ohrozením si uvedomujú potrebu zohl'adňovania potrieb všetkých aktérov edukácie, t. j. aby prítomnost' diet'at'a s postihnutím, narušením, ohrozením v materskej škole nebola v rozpore s potrebami detí bez postihnutia, narušenia, ohrozenia a pedagógov.

- Rodičia detí s postihnutím, narušením, ohrozením si vel'mi neuvedomujú pozitívny vplyv prítomnosti ich diet'at'a $\mathrm{v}$ materskej škole na rozvoj sociálnych zručnosti detí bez postihnutia, narušenia, ohrozenia.

- Rodičia deti s postihnutím, narušením, ohrozením pocit’ujú častokrát zbytočne vel'ké obavy z posmechu, vyčleňovania zo strany pedagógov, detí i ostatných zamestnancov.

- Učitelia sa obávajú negatívneho vplyvu prítomnosti diet'at'a s postihnutím, narušením, ohrozením v materskej škole na deti bez postihnutia, narušenia, ohrozenia.

- Učitelia sa boja, že kvôli zvýšenej starostlivosti, dozoru budú mat' menej času na ostatné deti bez postihnutia, narušenia, ohrozenia.

- Učitelia pocit'ujú bezradnost', ak sú na heterogénnu skupinu sami, t. j. ak so skupinou detí je iba jeden učitel' bez asistenta pedagóga (záchranou nie je ani výpomoc prevádzkového zamestnanca, ktorá je možná napríklad počas pobytu vonku).

- Naopak, učitelia majú problém kooperovat' s asistentom pedagóga (nie sú zvyknutí pracovat' $\mathrm{v}$ tíme a boja sa hodnotenia druhou osobou), ak si ho náhodou rodičia vybavia (asistenti pedagóga sú $\mathrm{v}$ materskej škole iba výnimočne, a to bud' prostredníctvom spolupráce zriad'ovatel'a a Úradu práce, sociálnych vecí a rodiny, alebo cez projekt, či iný alternatívny spôsob financovania). 
- Spoločnost' neverí, že skúsenost' detí s odlišnost'ou už od útleho veku by mohla byt' účinnou prevenciou voči predsudkom.

\section{ZÁVER}

Stretanie sa s problémami je prirodzené, ved’ práve o tom je život - o postupnom prekonávaní prekážok, riešení problémov, hl'adaní odpovedí, výsledkom čoho je viditel’ná zmena kvality nášho života a života spoločnosti. Aj prvé kamarátstva s rovesníkmi prinášajú nové skúsenosti, zároveň i príležitosti pre prežívanie št'astia, radosti aj plaču (Kováčová, 2020/2021). Dovolím si povzbudit' zainteresovaných k tomu, aby sa nevzdali a pokračovali v začatej ceste, a to slovami Raschkeho a Bronsonsa (1999), podla ktorých edukácia ovplyvnená inkluzívnym trendom maximalizuje individuálny rast, čo vyplýva z faktu, že deti, ktoré sa učia spolu, zároveň sa učia aj spolu žit'. A zároveň pripomenút' potrebu si neustále opakovat', že inkluzívny trend si vyžaduje postupné zavádzanie a mysliet' na dôležitost' transdisciplinarity, kooperácie, nádeje a ochoty menit' sa.

\section{Použitá literatura}

1. ANDERLIKOVÁ, L. Cesta $k$ inkluzi. Úvahy z praxe a pro praxi. Praha/Kroměříž: TRITON, 2014. preložila: Irena Marušincová. 210 s. ISBN 978-80-7387-765-1.

2. ANDRESS, M. Inkluzívna predškolská pedagogika. In LECHTA, V. (ed.) Transdisciplinárne aspekty inkluzívnej pedagogiky. Bratislava: EMITplus s. r. o. 2010. ISBN 978-80-970623-2-3. s. 147-150.

3. ANDRESS, M., HORVATH, J. Zdroje v detstve - inkluzívne vzdelávacie a výchovné úlohy v predškolskej výchove v Bavorsku. In LECHTA, V. (ed.) Inkluzívna edukácia ako multidimenzionálny výchovný problém. Bratislava: Iris, 2012. ISBN 978-8089256-69-3. s. 211-219.

4. BILČÍK, A., BALÁŽOVÁ, J. Na ceste ku kvalite a inklúzii v strednej škole. Tým nad Vltavou - Malá strana: Nová Forma s. r. o., 2021. 156 s. ISBN 978-80-7612-323-6.

5. BOOTH, T., AINSCOW, M. Index inklúzie. Príručka na rozvoj škôl s dôrazom na inkluzívne hodnoty. 1. vyd. (preklad 4. vydania z roku 2016: Žitňanská, L.). Nadácia pre deti Slovenska, 2019. 253 s. ISBN 978-80-89403-19-6. [online]. [citované 20. februára 2021]. Dostupné na: https://www.ktochyba.sk/webroot/video/indexinkluzie.pdf.

6. DANIŠKOVÁ, Z. Deti s odlišným materinským jazykom v materskej škole. In Predškolská výchova. Hliník nad Hronom: REZILIENCIA, 2019/2020. č. 4, roč. LXXIV. ISSN 0031-7220. s. $20-22$.

7. HORŇÁKOVÁ, M. Nebyt' normálny je normálne. In LECHTA, V. (ed.) Transdisciplinárne aspekty inkluzívnej pedagogiky. EMITplus s. r. o. 2010. ISBN 97880-970623-2-3. s. 107-112.

8. HORŇÁKOVÁ, M. Kroky k inkluzívnej škole. Ružomberok: Verbum, 2014. $160 \mathrm{~s}$. ISBN 978-80-561-0187-2.

9. KOVÁČOVÁ, B. Utváranie inkluzívneho po(vedomia) v začiatkoch inštitucionálneho začleňovania detí. In LECHTA, V. (ed.) Transdisciplinárne aspekty inkluzívnej pedagogiky. Bratislava: EMITplus s. r. o. 2010. ISBN 978-80-970623-2-3. s. 130-135.

10. KOVÁČOVÁ, B. Sociálne vzt'ahy detí od troch do šiestich rokov a ich možné ohrozenie. In Predškolská výchova. Hliník nad Hronom: REZILIENCIA, 2020/2021. č. 1, roč. LXXV. ISSN 0031-7220. s. 6-11.

11. KUDLÁČOVÁ, B. Fenomén výchovy. 2. vyd. Bratislava: Veda, 2006. 200 s. ISBN 80-224-0904-9. 
12. LECHTA, V. Výchovný aspekt inkluzívnej edukácie a jeho dimenzie: uvedenie do problematiky. In LECHTA, V (ed.). Inkluzívna edukácia ako multidimenzionálny výchovný problém. Bratislava: Iris, 2012. ISBN 978-80-89256-69-3. s. 9 - 19.

13. PODHÁJECKÁ, M. Inklúzia, integrácia. In HAJDÚKOVÁ a kol. Metodika na tvorbu školských vzdelávacích programov pre materské školy. Bratislava, 2009. ISBN 97880-8052-341-1. s.118-121.

14. POŽÁR, L. Psychologické aspekty inklúzie. In LECHTA, V. (ed.) Transdisciplinárne aspekty inkluzívnej pedagogiky. Bratislava: EMITplus s. r. o. 2010. ISBN 978-80970623-2-3. s. 34-39.

15. RASCHKE, D., BRONSON, J. [online]. [citované 02. januára 2011]. Dostupné na : >Www.uni.edu/coe/inclusion/preparing/ $/$.

16. SENDER, B. Riešenie výchovných problémov $\mathrm{v}$ škole $\mathrm{v}$ kompetenciách školského špeciálneho pedagóga. In: MMK 2020 recenzovaný sborník přispěvkỉ mezinárodní vědecké konference: Mezinárodni Masarykova konference pro doktorandy a mladé vědecké pracovníky, ročník 11. 14. - 16. prosince 2020. - Hradec Králové : Magnanimitas, 2020. - ISBN 978-80-87952-33-7.

\section{Kontaktní údaje}

Mgr. Jana Balážová, Ph.D.

UKF Nitra, Pedagogická fakulta

Dražovská 4, 94974 Nitra

mobil: +421908119081

email: johankabalazova@gmail.com 


\title{
ASPEKTY ORGANIZAČNÉHO SPRÁVANIA: VŠEOBECNÝ PRACOVNÝ VÝKON A KONTEXTUÁLNY VÝKON
}

\section{ASPECTS OF ORGANIZATIONAL BEHAVIOR: GENERAL WORK PERFORMANCE AND CONTEXTUAL PERFORMANCE}

\author{
Katarína Hennelová, Laura Ďurinová
}

\begin{abstract}
Abstrakt
Príspevok sa zaoberá výkonovými aspektami práce. Ciel’om štúdie bolo preskúmat' koncepty všeobecného pracovného výkonu a kontextuálneho výkonu. Výskumnú vzorku tvorilo 31 participantov vo veku 25 - 57 rokov. Administrované boli dva dotazníky zamerané na identifikovanie všeobecného pracovného výkonu a kontextuálneho výkonu v troch zložkách. Výsledky potvrdili silné pozitívne vzt’ahy medzi zložkami kontextuálneho výkonu a slabý vzt’ah medzi všeobecným pracovným výkonom a kontextuálnym výkonom.
\end{abstract}

Kl'účové slová: organizačné správanie, všeobecný pracovný výkon, kontextuálny výkon

\begin{abstract}
The paper deals with performance aspects of the work. The aim of the study was to examine concepts of overall performance and contextual performance. Altogether 31 participants aged between 25 and 57 years participated in this study. Two questionnaires administered to them were focused on general work performance and contextual performance measured in three components. There were confirmed strong positive correlations between the components of contextual performance and only weak relationship between general work performance and contextual performance.
\end{abstract}

Key words: organizational behavior, general work performance, contextual performance

\section{1 ÚVOD DO PROBLEMATIKY}

Práca ako psychologická kategória sa týka podmienok plnenia pracovných úloh zamestnanca s uplatnením jeho vlastnej energie, vedomostí a zručností, čo sa prejavuje v pracovnom výkone zamestnanca (Kubáni, 2011). V kontexte pracovného prostredia sa teda psychológia pri skúmaní aspektov organizačného správania zaoberá aj pracovným výkonom.

Definície pracovného výkonu bývajú viazané na výsledky (Armstrong, 2002), ale v odbornej psychologickej literatúre sa kladie dôraz na priebeh a výsledok výkonu v podobe správania zamestnanca (Campbell, 1990, Motowidlo et al., 1997, Motowidlo \& Kell, 2012).

V tejto súvislosti sa zdôrazňuje aj význam takých aktivít zamestnanca, ktoré nie sú organizáciou predpísané a idú nad rámec požiadaviek determinovaných pracovnou rolou (Katz \& Kahn, 1978). Napríklad Campbell (1990) diferencoval správanie a zvládanie úloh na dve oblasti. V prvej ide o správanie, ktorého výsledkom je príspevok k efektivite organizácie prostredníctvom zvládania úloh, a v druhej o správanie, ktoré prispieva k efektivite organizácie iným spôsobom.

Borman a Motowidlo (1993) následne odlíšili úlohový a kontextuálny výkon podl’a troch kritérií: 
- Predpísané správanie vs. správanie realizované nad rámec požiadaviek

- Prvok kooperácie, prosociálnosti, ústretovosti a organizačnej spontánnosti

- Výkon v rámci odbornosti vs. výkon nesúvisiaci s úlohovou profesionalitou.

Úlohový výkon sa teda prejavuje v aktivitách, ktoré sú pre odlišné zamestnania rôzne, kým pre kontextuálny výkon platí, že presahuje pracovnú náplň zamestnanca, prejavuje sa v rôznych zamestnaniach rovnako, a to kooperáciou, dobrovol'nými aktivitami, podporou spolupracovníkov aj ciel’ov organizácie.

Na základe uvedeného možno $\mathrm{k}$ analýze pracovného výkonu pristupovat' $\mathrm{z}$ dvoch hl'adísk. V prvom ide o využitie zručností a vedomostí pri plnení úloh (úlohový resp. všeobecný pracovný výkon), v druhom o kontextuálny výkon. V rámci sledovania kontextuálneho výkonu je typické zameranie na správanie v kontexte vykonávaných úloh. Môže íst' o rôzne prejavy, ako je napríklad pomoc spolupracovníkom dokončit' úlohu, spolupráca s nadriadeným, návrhy na zmeny zamerané na zlepšenie organizácie (Van Scotter et al., 2000). Takto chápaný kontextuálny výkon má značný potenciál pre úspešnost' tímovej práce a prispieva k efektívnosti organizácie (Lisá \& Newman, 2020).

Podla Seitla a Charváta (2018) sa kontextuálny výkon prejavuje v oblasti interpersonálnej a motivačnej. Interpersonálny aspekt kontextuálneho výkonu je zameraný na vzt’ahy, motivačný na sebadisciplínu a iniciatívu. Borman et al. (2001) uvádzajú pre kontextuálny výkon také prejavy správania, ako sú pomáhanie a spolupráca, podporovanie ciel'ov organizácie a svedomitost' pri dosahovaní ciel'ov. Interpersonálny aspekt kontextuálneho výkonu sa vymedzuje ako interpersonálna facilitácia, ktorá sa prejavuje v efektívnej kooperácii, v pomáhaní, načúvaní iným a ich povzbudzovaní. Motivačný aspekt možno identifikovat' prostredníctvom pracovného nasadenia.

V predloženom príspevku sme sa zamerali na obidva výkonové aspekty práce: všeobecný pracovný výkon a kontextuálny výkon. Všeobecný pracovný výkon budeme sledovat' ako úlohový výkon súvisiaci s aplikáciou poznatkov a zručností pri plnení pracovných úloh. Pri analýze kontextuálneho výkonu budeme vychádzat' z troch typov prejavov správania podl'a Motowidla a Van Scottera (1994):

- Medzil'udské pomáhanie a podpora

- Obetavost' a iniciatíva v podobe pracovného nasadenia

- Iné prejavy, ako je poctivost', vonkajšie znaky a zdvorilost'.

Ciel’om predloženej výskumnej štúdie je preskúmanie konceptov všeobecného pracovného výkonu, kontextuálneho výkonu a ich vzájomného vzt’ahu. V rámci exploračného výskumu sme si položili dve výskumné otázky:

1. Aký je vzt’ah medzi všeobecným pracovným výkonom a kontextuálnym výkonom?

2. Aké sú vzt’ahy medzi zložkami kontextuálneho výkonu?

\section{METÓDY}

Výskumu sa zúčastnilo 31 participantov, nich bolo 19 žien (61\%) a 12 mužov (39\%). Priemerný vek participantov bol 37,5 rokov, pričom vekové rozpätie bolo od 25 do 57 rokov.

Zber dát sa uskutočnil v mesiacoch február - apríl 2021 formou zámerného výberu participantov, ked' kritériom bol minimálny vek 19 rokov a trvalý pracovný pomer minimálne 1 rok $\mathrm{v}$ tom istom tíme. Vzhl'adom na epidemiologickú situáciu v čase zberu dát sme 
dotazníky administrovali prostredníctvom Google formulára, ktorého súčast'ou bol aj text informovaného súhlasu.

Úlohový výkon bol zist'ovaný dotazníkom všeobecného pracovného výkonu (Motowidlo \& Van Scotter, 1994). Tento dotazník sa skladá z 3 položiek a každá ponúka možnost' odpovede na 7-bodovej škále. Položka č. 1 je zameraná na hodnotenie plnenia štandardov pracovného výkonu, položka č. 2 sa týka porovnania vlastného výkonu s výkonom iných zamestnancov na rovnakej pozícii a položka č. 3 zist'uje, ako respondent hodnotí svoj príspevok k efektívnosti tímu v porovnaní s ostatnými členmi tímu.

Autori dotazníka uvádzajú vysokú mieru reliability v podobe koeficientu Cronbach alfa na úrovni 0,96 (Motowidlo \& Van Scotter, 1994). Odpovede našich participantov vykazovali vnútornú konzistenciu na úrovni 0,88 , na základe čoho môžeme použitý dotazník považovat' za spol’ahlivý nástroj zist'ovania všeobecného pracovného výkonu.

Dotazník kontextuálneho výkonu (Stone-Romero, Alvarez \& Thompson, 2009) pozostáva z 23 položiek s možnost'ou odpovedí na 5-bodovej škále. Výsledky je možné spracovat' v rámci troch subškál: Medzil'udská pomoc (7 položiek), Obetavost' v kontexte práce (8 položiek) a Iné správanie (8 položiek).

V subškále Medzil'udská pomoc sa sledujú kooperatívne, nápomocné a ohl’aduplné činy zamestnanca. Subškála Obetavost' v kontexte práce zist'uje mieru sebadisciplíny a motivačných činov participanta, akými sú napríklad tvrdá práca, preberanie iniciatívy a podpora spolupracovníkov v pracovnom prostredí. Škála Iné správanie je zameraná na mieru poctivosti, zdvorilosti a celkového prejavu či výzoru participanta.

Reliabilita výskumného nástroja bola zist'ovaná a overovaná viacerými autormi. Motowidlo a Van Scotter (1994) uvádzajú odhad vnútornej konzistencie dotazníka koeficientom Cronbach alfa $=0,95$. Výsledky z nami získaných dát naznačujú dobrú reliabilitu tohto nástroja, ked' koeficient Cronbach alfa dosiahol hodnotu 0,85.

\section{VÝSLEDKY}

V prvom kroku štatistického spracovania sme vyhodnocovali najsilnejšie indikátory sledovaných premenných prostredníctvom frekvenčnej analýzy jednotlivých položiek administrovaných dotazníkov.

V rámci dotazníka všeobecného pracovného výkonu sa ako najsilnejší indikátor potvrdili odpovede v položke č. 2 , v ktorej participanti posudzovali svoje výkony v porovnaní s inými pracovníkmi na tej istej pozícii. V tejto položke až $77 \%$ participantov uviedlo, že podávajú v porovnaní s inými vysoké výkony, pričom na škále $1-7$ vybralo hodnotou $661 \%$ a hodnotu $716 \%$ participantov.

Základné štatistické údaje k všeobecnému pracovnému výkonu sú v tabul'ke č. 1. Vzhl'adom na teoretické rozpätie hrubého skóre dotazníka všeobecného pracovného výkonu $(1-21)$ je hodnota empirického minima posunutá o 11 bodov vyššie (na 12 bodov), kým empirické maximum dosahovalo hodnotu teoretického. Priemerná hodnota a medián sa líšili o 0,74 boda. Priemer na jednu položku je 5,75 bodov v rámci 7-bodovej škály, čo naznačuje skôr vysoké hodnotenie svojho pracovného výkonu vsledovaných parametroch. Skóre v dotazníku všeobecného pracovného výkonu nie je gaussovsky rozložené. Zároveň platí, že v odpovediach na tento dotazník sa nevyskytli žiadne odl'ahlé ani extrémne hodnoty. 
Tabul'ka č. 1. Deskriptívna štatistika dotazníka všeobecného pracovného výkonu

\begin{tabular}{|c|c|c|c|c|c|c|}
\hline M & Mdn & SD & Min & Max & Šikmost' & Strmost' \\
\hline 17,26 & 18 & 2,45 & 12 & 21 &,- 39 &,- 39 \\
\hline
\end{tabular}

Frekvenčnú analýzu odpovedí v dotazníku kontextuálneho výkonu sme realizovali podl’a jeho subškál. V subškále Medzil'udská pomoc je najsilnejším ukazovatel’om férové jednanie s ostatnými zamestnancami. Dokazuje to vysoký podiel odpovedí na najvyššom bode škály, ked' $81 \%$ participantov uviedlo, že jednajú s ostatnými férovo každodenne. Ďalším silným indikátorom $\mathrm{v}$ tejto subškále bola položka o pomáhaní iným bez požiadania. Tento prejav uvádzalo ako každodenný 39\% a frekvenciu 1 - 2 krát za týždeň uviedlo $35 \%$ participantov. V subškále Obetavost' v kontexte práce $52 \%$ respondentov uviedlo, že vytrvalo prekonávajú prekážky s ciel'om dokončenia úlohy. Ďalej $26 \%$ participantov uviedlo, že preberá iniciatívu na vyriešenie pracovného problému denne a $42 \%$ raz - dvakrát týždenne. Medzi položkami subškály Iné správanie bola najvýraznejším indikátorom spolupráca s ostatnými v tíme $-77 \%$ uviedlo na škále hodnotu 5 (denne). K položkám s výraznými odpoved'ami patrí aj dodržiavanie pokynov nadriadených aj v ich neprítomnosti, najvyššiu hodnotu na škále tejto položke prisúdilo $69 \%$ participantov.

V tabul'ke č. 2 je deskriptívna štatistika pre dotazník kontextuálneho výkonu. Rozsah nadobudnutého skóre v subškálach aj v celkovom skóre kontextuálneho výkonu je v empirickom minime vyšší než je teoretické minimum, kým maximálne hodnoty sú prakticky na úrovni teoretického maxima. Priemerné hodnoty a mediány sa výrazne neodlišujú. Skóre v subškálach aj celkové skóre je v rámci 5-bodovej škály posunuté v smere vyšších hodnôt. Dáta získané administráciou dotazníka kontextuálneho výkonu nie sú normálne rozložené a v odpovediach neboli odl'ahlé ani extrémne hodnoty.

Tabul'ka č. 2. Deskriptívna štatistika dotazníka kontextuálneho výkonu

\begin{tabular}{|c|c|c|c|c|c|c|c|}
\hline & $\mathrm{M}$ & $\mathrm{Mdn}$ & $\mathrm{SD}$ & Min & Max & Šikmost' & Strmost' \\
\hline $\begin{array}{c}\text { Medzil'udská } \\
\text { pomoc }\end{array}$ & 27,13 & 28 & 4,52 & 16 & 35 & $-0,34$ & 0,02 \\
\hline $\begin{array}{c}\text { Obetavost' } \\
\text { v kontexte } \\
\text { práce }\end{array}$ & 28,61 & 28 & 4,82 & 22 & 40 & 0,40 & $-0,36$ \\
\hline $\begin{array}{c}\text { Iné } \\
\text { správanie }\end{array}$ & 31,87 & 32 & 4,30 & 22 & 39 & $-0,65$ & 0,07 \\
\hline $\begin{array}{c}\text { Kontextuálny } \\
\text { výkon }\end{array}$ & 87,61 & 89 & 11,50 & 69 & 111 & 0,11 & $-0,64$ \\
\hline
\end{tabular}

Vzt’ah medzi všeobecným pracovným výkonom a kontextuálnym výkonom sme overovali Spearmanovým korelačným koeficientom. Jeho hodnota $r_{S}=.28$ nie je štatisticky signifikantná. Z hl'adiska vecnej významnosti môžeme uvedenú hodnotu charakterizovat' ako pozitívny slabý vzt’ah medzi úlohovým a kontextuálnym výkonom.

Vzt’ahy medzi zložkami kontextuálneho výkonu sme zist'ovali pomocou Spearmanovho poradového korelačného koeficientu. Výsledky sú v tabul'ke č. 3. Potvrdili sa štatisticky významné vzt'ahy medzi jednotlivými subškálami, pričom z hl'adiska vecnej významnosti ide v prípade vzt'ahu subškály Iné správanie so subškálami Medzil'udská pomoc a Obetavost' v kontexte práce o silné vzt'ahy. Vzt’ah subškály Medzil'udská pomoc a subškály Obetavost' v kontexte práce je stredne silný. 
Tabul'ka č. 3. Korelačná matica subškál dotazníka kontextuálneho výkonu (Spearmanov korelačný koeficient)

\begin{tabular}{|c|c|c|}
\hline & Medzil'udská pomoc & Obetavost' v kontexte práce \\
\hline Medzil'udská pomoc & - & - \\
\hline Obetavost' v kontexte práce & $.49^{*}$ & - \\
\hline Iné správanie & $.63^{* * *}$ & $.68^{* * *}$ \\
\hline
\end{tabular}

$* \mathrm{p}<0,05 \quad * * \mathrm{p}<0,01 \quad * * * \mathrm{p}<0,001$

\section{DISKUSIA}

Ciel’om predloženej štúdie bolo preskúmanie konceptov pracovného výkonu a ich vzájomných vzt’ahov. Vychádzali sme pritom z rozlíšenia úlohového t. j. všeobecného pracovného výkonu, ktorý sa prejavuje $\mathrm{v}$ predpísanom správaní v rámci odbornosti, a kontextuálneho výkonu, pre ktorý je typické správanie, ktoré nesúvisí s úlohovou profesionalitou, je nad rámec požiadaviek a obsahuje prvky prosociálnosti (Borman \& Motowidlo, 1993). Vzhl'adom na to, že sme pracovali s dátami získanými administráciou dotazníkov, ktoré zatial' neboli na Slovensku overované, považujeme za dôležité potvrdenie ich dobrej vnútornej konzistencie.

Na základe výsledkov je možné konštatovat', že posudzovanie pracovného a kontextuálneho výkonu v našej vzorke participantov vykazovalo v priemere skôr pozitívne hodnotenie vlastného úlohového aj kontextuálneho výkonu. V prípade úlohového výkonu resp. pracovného výkonu $\mathrm{v}$ užšom slova zmysle sa potvrdili najvyššie hodnoty $\mathrm{v}$ prípade posudzovania výkonu v porovnaní s inými pracovníkmi na tej istej pozícii. Z prejavov správania posudzovaných $\mathrm{v}$ oblasti kontextuálneho výkonu získalo najvyššie hodnotenie férové jednanie s ostatnými pracovníkmi. V rámci troch zložiek kontextuálneho výkonu uvádzali participanti ako najčastejšie iné prejavy správania, ako je poctivost', vonkajšie znaky, zdvorilost' a tiež dobrovol'né angažovanie sa v záujme zvýšenia efektívnosti tímu. Význam posledne menovaného prejavu sa potvrdil aj v rámci štúdie Lisej a Newman (2020), ktorá bola zameraný na očakávania zamestnávatel'ov v súvislosti so zručnost'ami absolventov vysokých škôl. Autorky upozorňujú na význam prejavov angažovanosti a ochoty urobit' niečo navyše, ktoré sa vyskytujú pri vyššej úrovni svedomitosti, proaktivity a pozitívnej emocionality.

Dôležitým ciel'om nášho výskumu bolo testovanie vzt'ahu všeobecného pracovného výkonu a kontextuálneho výkonu. Napriek tomu, že v literatúre sa uvádza potvrdenie silného vzt'ahu medzi výkonom všeobecným a kontextuálnym (Motowidlo \& Van Scotter, 1996), v našom súbore sa nepotvrdil štatisticky významný vzt’ah. Hodnota korelačného koeficientu však naznačuje slabý pozitívny vzt’ah medzi sledovanými premennými. Uvedený výsledok podporuje teda záver, že úlohový a kontextuálny výkon sú dva do istej miery nesúvisiace konštrukty.

Vzt'ahy medzi tromi zložkami kontextuálneho výkonu sa potvrdili korelačnou analýzou a sú v súlade s údajmi uvádzanými v štúdii Motowidlo a Van Scotter (1996). Všetky zložky medzil'udská pomoc, obetavost' v kontexte práce, ako aj iné správanie sú vo vzájomnom, štatisticky významnom, pozitívnom vzt’ahu. Uvedený výsledok považujeme zároveň za potvrdenie zastúpenia jednotlivých zložiek v celkovom skóre kontextuálneho výkonu zist'ovaného použitým dotazníkom. 
V súvislosti s obmedzeniami zovšeobecnenia našich výsledkov je potrebné uviest', že za významný limit považujeme vel'mi nízky počet participantov, nerovnomerné zastúpenie v premenných pohlavie a vek a tiež spôsob administrácie dotazníkov najmä z dôvodu pandémie.

Teoretické i praktické implikácie uvedených zistení spočívajú najmä v empirickom overovaní diagnostických nástrojov ako aj v nových poznatkoch pre zamestnávatel'ov, personalistov aj psychológov kvôli lepšiemu porozumeniu prejavov správania ich zamestnancov. Interpretáciu špecifík kontextuálneho výkonu u zamestnancov je vhodné $\mathrm{v}$ budúcich výskumných zámeroch prepojit' s charakteristikami vzt'ahovej väzby (attachmentu) v pracovnom prostredí. Ide o relatívne novú tému v oblasti organizačného správania, ktorej sa dostáva pozornost' už aj na Slovensku (Greškovičová, 2020). Vzhl'adom na dostupnost' metód zist'ovania vzt'ahovej väzby na pracovisku vidíme perspektívu $\mathrm{v}$ d'alšom skúmaní súvislostí vzt'ahovej väzby a výkonu zamestnancov.

Táto práca bola podporovaná Grantovou agentura Academia aurea 3_5/2020.

\section{Použitá literatúra}

1. ARMSTRONG, M. Ǩizení lidských zdrojů. Praha: Grada, 2002. 856 s. ISBN 80-2470469-2.

2. BORMAN, W. C., \& MOTOWIDLO, S. J. Expanding the criterion domain to include elements of contextual performance. In Schmitt, N., \& Borman, W. C. (Eds.), Personnel selection in organizations, 1993, pp. 71-98. San Francisco: Jossey-Bass. ISBN 978-1555424756.

3. BORMAN, W. C., PENNER, L. A., AlLEN, T. D., MOTOWIDlO, S. J. Personality Predictors of Citizenship Performance. International Journal of Selection and Assessment, vol. 9(1-2), 2001, pp. 52 - 69. ISSN 1468-2389.

4. CAMPBELL, J. P. Modeling the Performance Prediction Problem in Industrial and Organizational Psychology. In Dunnette, M. D. \& Hough, L. M. Handbook of Industrial and Organizational Psychology. 1990, pp. 687-732. PaloAlto: Consulting Psychologists Press. ISBN 978-1-4338-0727-5.

5. GREŠKOVIČOVÁ, K. Attachment in the Work Setting: Analysis and Comparison of Methods. Attachment v pracovnom prostredí: analýza a porovnanie metodík. In Piterová, I., Fedáková, D., Výrost, J. (Eds.), Proceedings of the 19th international conference Work and organizational psychology 2020. Zbornik príspevkov z 19. Medzinárodnej konferencie Psychológia práce a organizácie 2020. 2020, pp. 129140. Košice: Institute of Social Sciences, CSPS SAS. ISBN 978-80-89524-51-8.

6. KATZ, D., \& KAHN, R. L. (1978). The social psychology of organizations. 2nd ed. New York: Wiley \& Sons

7. KUBÁNI, V. Psychológia práce. Prešov: Prešovská univerzita, 2011. 174 s. ISBN 978-80-555-0318-9.

8. LISÁ, E. \& NEWMAN, D. Psychologické aspekty zamestnatelnosti vysokoškolských študentov a absolventov vkontexte očakávaní zamestnávatelov. Žilina: Vydavatel'stvo GEORG, 2020. 127 s. ISBN 978-80-8154-284-8.

9. MOTOWIDLO, S. J., BORMAN, W. C., \& SCHMIT, M. J. A theory of individual differences in task and contextual performance. Human Performance, vol. 10 (2), 1997, pp. 71- 83. ISSN 1532-7043.

10. MOTOWIDLO, S. J., \& KELL, H. J. Job Performance. Handbook of Psychology, vol. 2, 2012, pp. 77-92. https://doi.org/10.1002/9781118133880.hop212005 
11. MOTOWIDLO, S. J., \& VAN SCOTTER, J. R. (1994). Evidence that task performance should be distinguished from contextual performance. Journal of Applied Psychology, vol. 79(4), 1994, pp. 475-480. ISSN 0021-9010.

12. MOTOWIDLO, S. J., \& VAN SCOTTER, J. R. Interpersonal facilitation and job dedication as separate facets of contextual performance. Journal of Applied Psychology, vol. 81(5), 1996, pp. 525-531. ISSN 0021-9010.

13. SEITL, M. \& CHARVÁT, M. Styly vztahové vazby: motivace k projevu osobnostních dispozic při výběru zaměstnanců a pracovním poradenství. Človek a spoločnost', vol. 21(1), 2018, pp. 12-28. ISSN 1335-3608.

14. STONE-ROMERO, E. F., ALVAREZ, K., \& THOMPSON, L. F. The construct validity of conceptual and operational definitions of contextual performance and related constructs. Human Resource Management Review, vol. 19, 2009, pp. 104116. ISSN 1053-4822.

15. VAN SCOTTER, J., MOTOWIDLO, S. J., \& CROSS, T. C. Effects of task performance and contextual performance on systemic rewards. Journal of Applied Psychology, vol. 85(4), 2000, pp. 526-535. ISSN 0021-9010.

\section{Kontaktné údaje}

PhDr. Katarína Hennelová, PhD.

Paneurópska vysoká škola v Bratislave

Fakulta psychológie

Tomášikova 20,82102 Bratislava

Slovenská republika

Tel: +421248208863

email: katarina.hennelova@paneurouni.com 


\title{
VÝSLEDKY AKTIVÍT NÁRODNÝCH PROJEKTOV V OBLASTI ROZVOJA KOMUNIKAČNÝCH SPÔSOBILOSTÍ DETÍ ZO SOCIÁLNE ZNEVÝHODNENÉHO PROSTREDIA
}

\author{
RESULTS OF ACTIVITIES OF NATIONAL PROJECTS IN THE FIELD \\ OF DEVELOPMENT OF COMMUNICATION SKILLS OF CHILDREN \\ FROM SOCIALLY DISADVANTAGED BACKGROUNDS
}

\author{
Alena Vrábl'ová, Milena Lipnická
}

\begin{abstract}
Abstrakt
Príspevok obsahuje prehl'ad vybraných výsledkov aktivít troch národných projektov v zameraní sa na rozvoj komunikačných spôsobilostí detí zo sociálne znevýhodneného prostredia. Ide o Národný projekt Inkluzívny model vzdelávania na predprimárnom stupni školskej sústavy (NP MRK 2, 2013 - 2015), Národný projekt PRojekt INkluzívnej Edukácie (PRINED, 2014 - 2015) a Národný projekt Škola otvorená všetkým (ŠOV, 2016 - 2019). Ciel'om príspevku bolo prezentovat' prehl'ad výsledkov aktivít národných projektov v oblasti rozvoja (teda aj diagnostikovania) komunikačných spôsobilostí detí zo sociálne znevýhodneného prostredia (SZP), prevažne z marginalizovaných rómskych komunít (MRK), ktoré doma komunikujú prevažne rómskym jazykom a v materských školách (MŠ) sa zúčastňujú predprimárneho vzdelávania v slovenskom jazyku. Zistili sme, že výsledkami aktivít troch národných projektov $\mathrm{v}$ tejto oblasti boli dva programy vzdelávania pedagogických a odborných zamestnancov, štyri učebné zdroje pre inkluzívne vzdelávanie v materských školách, dva diagnostické materiály, dva stimulačné programy a výsledky diagnostického a stimulačného procesu svedčiace o ich aplikovatel'nosti v pedagogickej praxi a pokrokoch detí v osobnostnom rozvoji.
\end{abstract}

Kl'účové slová: deti zo sociálne znevýhodneného prostredia, inkluzívne vzdelávanie, komunikačné spôsobilosti, národné projekty, predprimárne vzdelávanie.

\begin{abstract}
The paper contains an overview of selected results of activities of 3 national projects focusing on the development of communication skills of children from socially disadvantaged backgrounds. These are the National Project Inclusive Model of Education at the Pre-Primary Level of the School System (NP MRK 2, 2013 - 2015), the National Project Project of Inclusive Education (PRINED, 2014 - 2015) and the National Project School Open to All (ŠOV, 2016 - 2019). The aim of the paper was to present an overview of the results of activities of national projects in the field of development (thus also diagnosing) communication skills of children from socially disadvantaged backgrounds, mostly from marginalized Roma communities participate in pre-primary education in the Slovak language. We found that the results of the activities of three national projects in this area were two educational programs for pedagogical and professional staff, four teaching resources for inclusive education in kindergartens, two diagnostic materials, two stimulation programs and the results of the diagnostic and stimulation process indicating their applicability in pedagogical education practice and progress of children in personal development.
\end{abstract}

Key words: children from socially disadvantaged backgrounds, inclusive education, communication skills, national projects, pre - primary education. 


\section{INKLUZÍVNE VZDELÁVANIE}

Predprimárne vzdelávanie v materských školách predstavuje klúčový komponent inkluzívneho vzdelávania $\mathrm{v}$ školskom systéme aj u detí zo sociálne znevýhodneného prostredia. Ich včasné zapojenie sa do tohto procesu vytvára osobnostné predpoklady pre kvalitnejší život, sociálne začlenenie a pracovné uplatnenie. Materské školy majú byt' miestom rovnoprávneho prístupu detí k predprimárnemu vzdelávaniu, v ktorom sa uskutočňuje osobnost' rozvíjajúca výučba v podmienkach skupinovej kultúrnosti a spolupráce (Lipnická, 2014). Inkluzívne vzdelávanie spája deti rôznych rás, národov, pohlaví, náboženských vyznaní, zdravotného stavu, schopností, potrieb a záujmov. Deti v predškolskom veku sú otvorené tejto rozmanitosti, dôverujú iným, sú ochotné spolupracovat' a prijímat' iných takých, akí sú, čo považujeme za významný základ inkluzívneho vzdelávania $v$ materských školách. Úlohou pedagogických zamestnancov a odborných zamestnancov je vytvárat' motivujúce a stimulujúce prostredie pre učenie sa detí v triednom spoločenstve, v ktorom vládne spravodlivost', empatia, tolerancia, rovnoprávnost', úcta, deti sú si rovnocenné a každé sa cíti bezpečne. Pri zabezpečovaní optimálnej a efektívnej výučby je dôležité, aby bolo každé diet’a diagnostikované. V tejto štúdii sme sa zamerali na inkluzívne vzdelávanie v MŠ v rámci diagnostikovania a rozvoja komunikačných spôsobilostí detí zo SZP, ktoré doma komunikujú rómskym jazykom a v materskej škole sa učia v štátnom jazyku podl'a výsledkov 3 národných projektov.

\section{2 ŠPECIFICKÉ CIELE NÁRODNÝCH PROJEKTOV}

Ďalej uvedené národné projekty boli realizované pod gesciou Ministerstva školstva, vedy, výskumu a športu Slovenskej republiky. Koordinované boli odborníkmi v zriadených projektových kanceláriách $\mathrm{v}$ rámci Metodicko-pedagogického centra $\mathrm{v}$ Bratislave, ktoré bolo prijímatel'om finančných prostriedkov. V 1. tabul'ke sú názvy, roky riešenia a špecifické ciele projektov zamerané na inkluzívne vzdelávanie detí zo sociálne znevýhodneného prostredia prevažne z marginalizovaných rómskych komunít v materských školách na Slovensku.

Tab. 1. Zameranie národných projektov na proces rozvoja komunikačných spôsobilostí detí zo SZP v inkluzívnom vzdelávaní v MŠ

\begin{tabular}{|l|l|}
\hline Názov projektu & Špecifické ciele projektu \\
\hline $\begin{array}{l}\text { Inkluzívny model } \\
\text { vzdelávania na } \\
\text { predprimárnom stupni } \\
\text { školskej sústavy } \\
\text { (NP MRK 2, 2013-2015) }\end{array}$ & $\begin{array}{l}\text { Skvalitnit' profesijné kompetencie pedagogických } \\
\text { zamestnancov a odborných zamestnancov podiel'ajúcich sa na } \\
\text { edukácii detí pochádzajúcich z marginalizovaných rómskych } \\
\text { komunít a tým podporit' ich sociálnu inklúziu na } \\
\text { predprimárnom stupni školskej sústavy. }\end{array}$ \\
\hline $\begin{array}{l}\text { PRojekt INkluzívnej } \\
\text { EDukácie (PRINED, 2014 } \\
-2015)\end{array}$ & $\begin{array}{l}\text { Obsahovo a personálne podporit' inklúziu v prostredí MŠ } \\
\text { skvalitnením diagnostického procesu a stimulácie, ako aj } \\
\text { zapojením pedagogických asistentov v MŠ a v ZŠ vytvorit' } \\
\text { inkluzívne edukačné prostredie zapojením inkluzívneho tímu } \\
\text { pedagogických a odborných zamestnancov }\end{array}$ \\
\hline $\begin{array}{l}\text { Škola otvorená všetkým } \\
\text { (ŠOV, 2016-2019) }\end{array}$ & $\begin{array}{l}\text { Podporou inkluzívneho vzdelávania a skvalitnením } \\
\text { profesijných kompetencí pedagogických a odborných } \\
\text { zamestnancov zabezpečit' rovnaký prístup ku kvalitnému } \\
\text { vzdelávaniu a zlepšit' výsledky a kompetencie detí a žiakov. }\end{array}$ \\
\hline
\end{tabular}

Zdroj: vlastné spracovanie

Ďalej sú uvedené špecifické ciele týchto národných projektov zamerané na diagnostikovanie a rozvoj komunikačných spôsobilostí detí zo sociálne znevýhodneného prostredia. 
2.1 Národný projekt Inkluzívny model vzdelávania na predprimárnom stupni školskej sústavy (NP MRK 2, 2013 - 2015)

Jedným z ciel'ov NP MRK 2 bol rozvoj profesijných spôsobilostí pedagogických zamestnancov a odborných zamestnancov v oblasti zohl'adňovania vzdelávacích potrieb detí pochádzajúcich z MRK v rámci vzdelávania sa v dvoch programoch (tab. 2).

Tab. 2. Vzdelávanie pedagogických zamestnancov a odborných zamestnancov v národnom projekte Inkluzívny model vzdelávania na predprimárnom stupni školskej sústavy (NP MRK 2, 2013-2015)

\begin{tabular}{|l|l|l|}
\hline $\begin{array}{l}\text { Ciel'ová skupina } \\
\text { vzdelávania }\end{array}$ & $\begin{array}{l}\text { Druh programu } \\
\text { vzdelávania }\end{array}$ & Názov programu vzdelávania \\
\hline $\begin{array}{l}\text { Pedagogickí } \\
\text { zamestnanci }\end{array}$ & $\begin{array}{l}\text { Program inovačného } \\
\text { vzdelávania }\end{array}$ & $\begin{array}{l}\text { Inovačné vzdelávanie pedagogických } \\
\text { zamestnancov v oblasti inkluzívneho } \\
\text { vzdelávania detí z marginalizovaných } \\
\text { rómskych komunít }\end{array}$ \\
\hline Odborní zamestnanci & $\begin{array}{l}\text { Program } \\
\text { aktualizačného } \\
\text { vzdelávania }\end{array}$ & $\begin{array}{l}\text { Odborné poradenstvo v predprimárnom } \\
\text { vzdelávaní detí z marginalizovaných } \\
\text { rómskych komunít. }\end{array}$ \\
\hline
\end{tabular}

Zdroj: vlastné spracovanie

Vzdelávanie v uvedenom národnom projekte absolvovalo 2000 pedagogických zamestnancov a 50 odborných zamestnancov. Súčast’ou programov vzdelávania (tab. 2) bola tiež téma diagnostikovania detí z MRK v MŠ aj v zameraní na ich komunikačné spôsobilosti (tab. 3).

Tab. 3. Vzdelávanie pedagogických zamestnancov a odborných zamestnancov v NP MRK 2 $(2013$ - 2015) v oblasti diagnostikovania detí

\begin{tabular}{|l|l|}
\hline $\begin{array}{l}\text { Poradie } \\
\text { oblastí }\end{array}$ & Oblasti diagnostikovania diet'at'a \\
\hline 1. & Diagnostikovanie hrou; \\
\hline 2. & Diagnostikovanie školskej spôsobilosti; \\
\hline 3. & $\begin{array}{l}\text { Diagnostikovanie špecifík detí pochádzajúcich z prostredia } \\
\text { marginalizovaných rómskych komunít (Lipnická,2014) }\end{array}$ \\
\hline
\end{tabular}

Zdroj: vlastné spracovanie

V programoch vzdelávania si pedagogickí zamestnanci a odborní zamestnanci zdokonal'ovali znalosti o kompetenciách učitel'a a asistenta učitel'a v inkluzívnom vzdelávaní, o procese diagnostikovania výnimočnosti týchto detí aj o prevencii ich problémového správania v MŠ. Analyzovali sociokultúrne odlišnosti detí, špecifiká ich života v chudobe a sociálnom vylúčení, osobitosti ich osobnostného rozvoja, aj čo sa týka komunikačných spôsobilostí. Aktivitou národného projektu Inkluzívny model vzdelávania na predprimárnom stupni školskej sústavy ešte nebolo priamo diagnostikovanie detí. Toto sa cielene uskutočňovalo až v nadväzujúcich národných projektoch v rokoch 2014 -2020.

\subsection{Národný projekt PRojekt INkluzívnej Edukácie (PRINED, 2014 - 2015)}

Cielene reagoval na prioritné odporúčania Koncepcie výchovy a vzdelávania rómskych detí a žiakov vrátane rozvoja stredoškolského a vysokoškolského vzdelávania. V 1. bode tejto koncepcie bola vyslovená požiadavka, aby sa v Operačnom programe Vzdelávanie v rokoch 2008 -2013 vytvorili národné projekty na podporu a rozvoj vzdelávania detí zo SZP (MRK). Jedným z nich bol Národný projekt PRojekt INkluzívnej Edukácie (PRINED, 2014 - 2015). Uvedený projekt tvorili tri hlavé aktivity, ktoré sa prelínali a dopĺn̆ali. 
Tab. 4. Tri podporné aktivity v Národnom projekte PRojekt INkluzívnej Edukácie (PRINED, $2014-2015)$

\begin{tabular}{|l|l|}
\hline Aktivity & Názvov aktivity \\
\hline 1. & Podpora inkluzívneho prostredia \\
\hline 2. & $\begin{array}{l}\text { Podpora celodenného výchovno-vzdelávacieho systému v základnej škole a } \\
\text { podpora užšej spolupráce s rodinou a komunitou detí a žiakov }\end{array}$ \\
\hline 3. & Didaktická a technická podpora ZŠ a MŠ - didaktické balíčky. \\
\hline
\end{tabular}

Zdroj: vlastné spracovanie

Tento projekt podporil inkluzívne vzdelávanie detí zo SZP (MRK) v MŠ a ZŠ aj skvalitnením diagnostického procesu a stimulácie v oblasti komunikačných spôsobilostí detí. Predchádzal d'alšiemu národnému projektu, v ktorom sa tiež uskutočnilo diagnostikovanie a rozvíjanie detí.

\subsection{Národný projekt Škola otvorená všetkým (ŠOV, 2016 - 2019)}

Nadväzoval na výsledky predchádzajúcich národných projektov. Jeho jedinečnost' spočívala vo vytvorení efektívneho modelu spolupráce viacerých zložiek vzdelávacieho systému. Ciel'om bola podpora a spolupráca pedagogických zamestnancov a odborných zamestnancov MŠ a Z Š vrátane pedagogických asistentov, odborných zamestnancov z centier výchovného poradenstva a prevencie, ako aj učitel'ov neformálneho vzdelávania a zákonných zástupcov detí. Aktivity projektu podporovali inkluzívne vzdelávanie v MŠ a ZŠ aj prostredníctvom skvalitňovania profesijných kompetencií pedagogických zamestnancov a odborných zamestnancov, aby boli spôsobilí zabezpečovat' rovnaký prístup ku kvalitnému vzdelávaniu a zlepšovat' osobnostné spôsobilosti a vzdelávacie výsledky detí a žiakov. Aktivity projektu v materských školách boli zamerané na implementáciu modelu inkluzívneho vzdelávania prostredníctvom pedagogických zamestnancov vrátane pedagogických asistentov, odborných zamestnancov a v spolupráci so zákonnými zástupcami. Prispeli k zlepšeniu komunikácie a spolupráce aktérov inkluzívneho vzdelávania a školskej pripravenosti detí zo SZP. Bolo to aj zásluhou kvalitného diagnostického a stimulačného procesu v prevencii zarad'ovania detí do špeciálnych škôl.

\section{PODPORA ROZVOJA KOMUNIKAČNÝCH SPÔSOBILOSTÍ DETÍ V NÁRODNÝCH PROJEKTOCH}

Plnenie úloh v aktivitách týchto národných projektov v oblasti diagnostikovania a rozvíjania komunikačných spôsobilostí detí prebiehalo nepriamo aj priamo. Nepriame skvalitňovanie procesu diagnostikovania a rozvíjania komunikačných spôsobilostí detí zo SZP sa uskutočnilo vzdelávaním pedagogických zamestnancov a odborných zamestnancov materských škôl. Informácie mohli nájst' tiež v učebných zdrojoch, ktoré boli publikované v projekte ako pedagogické alebo odborné skúsenosti z praxe. Priame rozvíjanie komunikačných spôsobilostí detí zo SZP aj na základe diagnostikovania úrovní ich rozvoja prebiehalo pred a po aplikácii stimulačných programov.

Tab. 5. Priama i nepriama podpora rozvoja komunikačných spôsobilostí detí zo SZP aj prostredníctvom diagnostikovania a stimulačných programov v troch národných projektoch

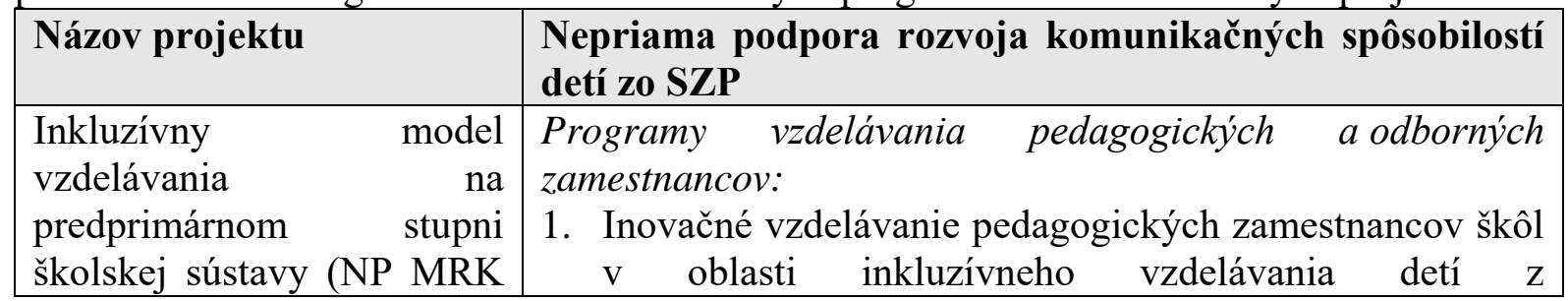




\begin{tabular}{|c|c|}
\hline $2,2013-2015)$ & $\begin{array}{l}\text { marginalizovaných rómskych komunít } \\
\text { 2. Odborné poradenstvo v predprimárnom vzdelávaní detí z } \\
\text { marginalizovaných rómskych komunít } \\
\text { Učebné zdroje pre vzdelávacie programy: } \\
\text { 1. Inkluzívne vzdelávanie detí } \mathrm{z} \text { marginalizovaných } \\
\text { rómskych komunít v materskej škole. Vybrané témy a } \\
\text { stratégie (2014); } \\
\text { 2. Podnetné prostredie } \mathrm{v} \text { materskej škole ako podpora } \\
\text { rozvíjania osobnosti detí marginalizovaných rómskych } \\
\text { komunít; } \\
\text { 3. Problémové správanie a jeho pedagogické riešenie (u } \\
\text { diet'at'a v predškolskom veku pochádzajúceho zo } \\
\text { sociálne znevýhodneného prostredia (2014) } \\
\text { 4. Odborné poradenstvo v predprimárnom vzdelávaní detí z } \\
\text { marginalizovaných rómskych komunít (2015) }\end{array}$ \\
\hline Názov projektu & $\begin{array}{l}\text { Priama podpora rozvoja komunikačných spôsobilostí } \\
\text { detí zo SZP }\end{array}$ \\
\hline 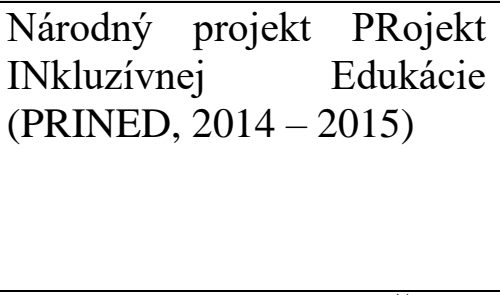 & $\begin{array}{l}\text { Dokumentmi pre analýzu výstupov a výsledkov projektu } \\
\text { PRINED v oblasti diagnostického a stimulačného procesu } \\
\text { detí materských škôl zapojených do projektu boli najmä } \\
\text { Stimulačný program pre deti vo veku od piatich do siedmich } \\
\text { rokov (Guziová a Duríková, 2014) a Manuál pre depistáž } \\
\text { (Leskovjanská, 2014). }\end{array}$ \\
\hline $\begin{array}{l}\text { Národný } \begin{array}{r}\text { projekt } \\
\text { otvorená }\end{array} \text { Š̌ketkým } \\
\text { 2016-2019) }\end{array}$ & $\begin{array}{l}\text { Na strategický ciel’ a 1. aktivitu projektu nadväzovala } \\
\text { podaktivita: Tvorba Manuálu pre depistáž a Manuálu k } \\
\text { stimulačnému programu pre materské školy, ktorých autormi } \\
\text { boli Šilonová, Klein, Šinková, } 2018 \text {. }\end{array}$ \\
\hline
\end{tabular}

Zdroj: vlastné spracovanie

Rozvíjaniu komunikačných spôsobilostí detí zo SZP v inkluzívnom vzdelávaní v materských školách $\mathrm{v}$ rámci národných projektov bola zabezpečená priama alebo nepriama podpora. Kým v NP MRK 2 (2013 - 2015) boli v učebných zdrojoch spracované diagnostické a rozvíjajúce postupy, v NP PRINED (2014 - 2015) a NP ŠOV (2016 - 2019) boli vytvorené, v praxi aplikované a overené stimulačné programy a diagnostické nástroje.

\subsection{Diagnostické a stimulačné materiály v NP PRINED (2014 - 2015)}

Podkladmi pre analýzu výsledkov projektu v diagnostickom a stimulačnom procese v MŠ boli Stimulačný program pre deti vo veku od piatich do siedmich rokov (Guziová, Duríková, 2014) a Manuál pre depistáž (Leskovjanská, 2014).

Stimulačný program pre deti vo veku od piatich do siedmich rokov (Guziová, Duuríková, 2014) tvorí súbor metodických odporúčaní a námetov na realizáciu stimulačných aktivít, hier a cvičení. Program je rozdelený do oblastí, ktorých ciel'om je rozvoj spôsobilostí diet'at'a (tab. 6).

Tab. 6. Oblasti rozvoja diet'at'a v Stimulačnom programe pre deti vo veku od piatich do siedmich rokov (Guziová, Duríková, 2014) v NP PRINED (2014 - 2015)

\begin{tabular}{|l|l|}
\hline $\begin{array}{l}\text { Poradie } \\
\text { oblastí }\end{array}$ & Oblasti rozvoja diet'at'a v stimulačnom programe \\
\hline 1. & Rozvoj percepčných schopností \\
\hline 2. & Priestorová a pravo-l'avá orientácia \\
\hline
\end{tabular}




\begin{tabular}{|l|l|}
\hline 3. & Motorika a grafomotorika \\
\hline 4. & Reč, jazyk a komunikácia \\
\hline 5. & Matematické schopnosti \\
\hline
\end{tabular}

Zdroj: vlastné spracovanie

Manuál pre depistáž (Leskovjanská, 2014) obsahovo a tematicky reflektuje ciele NP PRINED (2014 - 2015). Obsahuje jednak úlohy určené det'om na rozvíjanie rôznych kompetencií, ale aj podrobné inštrukcie pre diagnostikujúce osoby, ako výsledky z pozorovaní detí vyhodnotit' a zaznamenat'. V rámci skupinového aj individuálneho screeningového vyšetrenia bolo týmto manuálom realizované diagnostikovanie detí z MRK vo viacerých oblastiach (tab. 7).

Tab. 7. Oblasti diagnostikovania - Manuál pre depistáž (Leskovjanská, 2014) v NP PRINED $(2014-2015)$

\begin{tabular}{|l|l|}
\hline $\begin{array}{l}\text { Poradie } \\
\text { oblastí }\end{array}$ & Oblasti diagnostikovania diet'at'a \\
\hline 1. & Grafomotorické zručnosti \\
\hline 2. & Pravo - l'avá a priestorová orientácia \\
\hline 3. & Určovanie počtu do 5 \\
\hline 4. & Pozornost' \\
\hline 5. & Správanie diet'at'a v skupine \\
\hline 6. & Samostatnost' pri práci \\
\hline 7. & Pochopenie inštrukcí́ \\
\hline 8. & Správanie a reagovanie diet'at'a \\
\hline 9. & Vedomosti \\
\hline 10. & Matematické a číselné predstavy \\
\hline 11. & Reč, slovná zásoba \\
\hline 12. & Pamät' a koncentrácia pozornosti \\
\hline 13. & Fonematické uvedomovanie \\
\hline 14. & Pravol'avá orientácia na telesnej schéme \\
\hline 15. & Vizuálna diferenciácia \\
\hline
\end{tabular}

Zdroj: vlastné spracovanie

Diagnostikujúce osoby zaznamenávali výsledky depistáže do hárkov. Boli súčast’ou Manuálu pre depistáž (Leskovjanská, 2014). Stimulovanie a diagnostikovanie v rámci tohto projektu bolo zamerané aj na komunikačné spôsobilosti detí (6. a 7. tab). Diagnostický a stimulačný proces bol súčast'ou aj d’alšieho, nadväzujúceho národného projektu.

\subsection{Diagnostické a stimulačné materiály v NP ŠOV (2016 - 2019)}

V 1. aktivite tohto projektu boli pre diagnostikovanie a stimuláciu detí v MŠ vytvorené dva materiály. Slúžili na vstupné a výstupné diagnostikovanie detí zo sociálne znevýhodneného prostredia (MRK) a stimuláciu ich schopností. Šilonová a Klein (2019, s. 77) uviedli, že: „Manuál k depistáži slúži ako konkrétny návod pre pedagogických a odborných zamestnancov $v$ materských školách úspešne viest' depistáž pripravenosti detí predškolského veku. Po zaznamenani jednotlivých oblastí a zmapovaní potenciálnych parciálnych oslabeni sa tak vd'aka kvalitne realizovanej depistáži -prvotného skriningu nasmeruje d'alšia starostlivost'o diet'a. Uplatnením špecifických stimulačných programov je predpoklad, že sa diet’a adekvátne pripraví na vstup do základnej školy." Diagnostikovanie bolo realizované v nasledujúcich oblastiach rozvoja osobnosti diet'at'a (tab. 8). 
Tab. 8. Oblasti diagnostikovania - Manuál k depistáži (Šilonová, Klein, Šinková, 2018) v NP ŠOV $(2016-2019)$

\begin{tabular}{|c|c|}
\hline Diagnostický materiál & Oblasti diagnostikovania diet'at'a \\
\hline \multicolumn{2}{|c|}{$\begin{array}{l}\text { Pomocou párového T-testu meranie nasledujúcich oblasti (vstupná aj výstupná skupinová } \\
\text { depistáž): }\end{array}$} \\
\hline & kresba postavy \\
\hline \multicolumn{2}{|l|}{ Depistáž 1: } \\
\hline & vizuálna diferenciácia figúry a pozadia \\
\hline & vizuálna diferenciácia \\
\hline & vizuálna pamät’ \\
\hline & auditívna diferenciácia figúry a pozadia \\
\hline & auditívna diferenciácia \\
\hline & auditívna pamät' \\
\hline & taktilno- kinestetické vnímanie \\
\hline & telesná schéma \\
\hline & intermodalita \\
\hline & vizuálno - auditívna \\
\hline & intermodalita: auditívno - vizuálna, \\
\hline & serialita vizuálna, \\
\hline & serialita auditívna \\
\hline \multicolumn{2}{|l|}{ Depistáž 2: } \\
\hline & rozsah slovnej zásoby \\
\hline & kategorizácia \\
\hline & rozmer, množstvo, poradie \\
\hline
\end{tabular}

Zdroj: vlastné spracovanie

Diagnostikovanie a rozvíjanie detí v projekte bolo rozsiahle a kvalitne zabezpečené. Prinieslo výsledky, z ktorých sme vybrali len niektoré. Referujú o rozvoji komunikačných spôsobilostí detí zo SZP (MRK).

3.3 Výsledky rozvoja komunikačných spôsobilostí detí v NP PRINED (2014 - 2015)

Diagnostikovanie vo vstupnej a výstupnej depistáži absolvovalo 195 detí zo 14 materských škôl zapojených do NP PRINED. Z nich 110 detí pochádzalo zo sociálne znevýhodneného prostredia. Stimulačný program absolvovalo 167 detí. Vzhl'adom k splneniu ciel'a tejto štúdie prezentujeme len výsledky depistáže detí zo SZP voblasti rozvoja komunikačných spôsobilostí, konkrétne voblasti reč a slovná zásoba, fonematické uvedomovanie a pochopenie inštrukcii. Žilková (2015) v hodnotiacej správe uviedla, že výsledky v každej zo sledovaných oblastí boli vo výstupnej depistáži štatisticky významne lepšie, ako výsledky vo vstupnej depistáži. V oblasti reč, jazyk a komunikácia uvádza, že priemer dosiahnutých bodov sa zvýšil. Kým pri vstupnej depistáži deti dosiahli v oblasti reč, jazyk a komunikácia priemernú hodnotu 4,09 bodu po absolvovaní stimulačného programu bola priemerná hodnota 4,71 bodu. Maximálny počet bodov v tejto oblasti bolo 6 . Celkové výsledky medzi vstupnou a výstupnou depistážou a ich rozdiel podl’a jednotlivých oblastí diagnostikovania sú uvedené v tab. 9. 
Tab. 9. Pokroky detí v rozvoji komunikačných spôsobilostí v projekte v NP PRINED (2014 2015)

\begin{tabular}{|l|l|l|l|}
\hline Oblast' & Vstup & Výstup & Posun \\
\hline Poznatky o sebe (4b) & 3,29 & 3,54 & 0,24 \\
\hline Percepčné schopnosti (5b) & 2,18 & 3,03 & 0,86 \\
\hline Priestorová a pravol'avá orientácia (4b) & 1,79 & 2,63 & 0,85 \\
\hline Motorika a grafomotorika (4b) & 1,96 & 2,88 & 0,91 \\
\hline Reč, jazyk a komunikácia (6b) & 4,27 & 4,87 & 0,59 \\
\hline Matematické schopnosti (5b) & 3,18 & 3,79 & 0,61 \\
\hline Sociálne a emocionálne spôsobilosti (5b) & 4,16 & 4,48 & 0,32 \\
\hline
\end{tabular}

Zdroj: KOLEKTÍV AUTOROV. 2015. Evalvačná správa z projektu PRINED - Projekt Inkluzívnej Edukácie. Záverečná evalvačná správa. Prešov: Metodicko-pedagogické centrum, 2015. ISBN978-80-565-1415-3.

Žilková (2015) d'alej konštatovala, že individuálne posuny detí zo SZP, ktoré absolvovali stimulačný program boli výraznejšie, ako posuny detí, ktoré ho neabsolvovali, a že intenzívna práca s nimi prostredníctvom stimulačného programu priniesla pozitívne výsledky. Ocenila, že išlo o komplexný výsledok kooperácie pedagogických zamestnancov materských škôl a členov inkluzívnych tímov. Podobné zistenia boli zaznamenané aj v nadväzujúcom NP ŠOV.

\subsection{Výsledky rozvoja komunikačných spôsobilostí detí v NP ŠOV (2016 - 2019)}

Do vstupnej a výstupnej depistáže v tomto projekte bolo zapojených 16 materských škôl s počtom 227 detí. Výber materskej školy bol podmienený splnením nasledujúcich kritérií. Muselo íst' o materskú školu, v ktorej odborní zamestnanci ZŠ realizovali vstupné aj výstupné depistážne skríningové vyšetrenie u 5-6 ročných detí, a v ktorej bol realizovaný stimulačný program u diagnostikovaných detí. Šilonová a Klein (2019) konštatovali, že okrem jednej oblasti (kresba postavy) došlo k štatisticky významnému zlepšeniu výsledkov u detí. Poukázali tiež na to, že vo všetkých 12 oblastiach v časti Depistáž 1 zameranej na deficity čiastkových funkcií bolo zaznamenaných štatisticky menej chýb na výstupe, než na vstupe. Výsledky výstupnej depistáže v každej zo sledovaných 38 oblastí bolo 26 štatisticky významne lepších, ako výsledky získané zo vstupnej depistáže. Štatisticky významných nebolo 11 sledovaných oblastí. Štatisticky významnou oblast'ou bol rozsah slovnej zásoby, kde na výstupe (smerodajná odchýlka $=3,286$ ) v porovnaní so vstupom (smerodajná odchýlka $=3,399$ ) došlo k štatisticky významnému zlepšeniu. Štatistická významnost' sa potvrdila aj v položke Kategorizácia. Na výstupe (smerodajná odchýlka $=1,373$ ) v oblasti došlo $\mathrm{k}$ štatisticky významnému zlepšeniu v porovnaní so vstupom (smerodajná odchýlka $=1,654$ ). V 2 položkách oblasti Reč, jazyka komunikácia, t.j. výslovnost' a artikulácia nedošlo k štatisticky významnému zlepšeniu. V položke problém s pochopením inštrukcií v spisovnom jazyku došlo $\mathrm{k}$ štatisticky významnému zlepšeniu (chí-kvadrát $=4,671 ; \mathrm{p}=0,031$ ). Vo výstupnej depistáži získalo viac detí áno (z 30\% detí na vstupe k 40\% detí na výstupe).

\section{EVALVAČNÉ SPRÁVY NÁRODNÝCH PROJEKTOV}

Celkové výsledky národných projektov aj v rámci diagnostických a stimulačných procesov sú uvedené výhradne v priebežných a záverečných evalvačných správach (tab. 10). 
Tab. 10. Evalvačné správy národných projektov

\begin{tabular}{|l|l|}
\hline Názov projektu & Evalvačné správy národných projektov \\
\hline $\begin{array}{l}\text { Národný projekt Inkluzívny } \\
\text { model vzdelávania na } \\
\text { predprimárnom stupni } \\
\text { školskej sústavy (NP MRK } \\
2,2013-2015)\end{array}$ & $\begin{array}{l}\text { Evalvačná správa z implementácie inkluzívneho modelu } \\
\text { vzdelávania v materských školách II. Záverečná evalvačná } \\
\text { správa (Kolektív autorov, 2015) http://npmrk2.mpc- } \\
\text { edu.sk/sites/default/files/Evalvacna-sprava-2.pdf }\end{array}$ \\
\hline $\begin{array}{l}\text { Národný projekt PRojekt } \\
\text { INkluzívnej Edukácie } \\
\text { (PRINED, 2014 - 2015) }\end{array}$ & $\begin{array}{l}\text { Evalvačná správa z projektu PRINED - PRojekt INkluzívnej } \\
\text { Edukácie Záverečná evalvačná správa (Kolektív autorov, } \\
\text { 2015) http://194.160.87.21/sites/default/files/Evalvacna- } \\
\text { sprava-2.pdf }\end{array}$ \\
\hline $\begin{array}{l}\text { a Národný projekt Škola } \\
\text { otvorená všetkým (ŠOV, } \\
\text { 2016-2019) }\end{array}$ & $\begin{array}{l}\text { Záverečná evalvačná správa národného projektu Škola } \\
\text { otvorená všetkým (Kolektív autorov, 2019). } \\
\text { https://archiv.mpc-edu.sk/sk/node/3265 }\end{array}$ \\
\hline
\end{tabular}

Zdroj: vlastné spracovanie

Predmetné dokumenty boli zverejňované na stránkach projektov v čase ich riešenia. V súčasnosti sú $\mathrm{k}$ dispozícií na webovom sídle Metodicko-pedagogického centra v sekcii ukončené projekty. V nich sú podrobné zistenia aj odporúčania, ktoré môžu prispiet' ku kvalite inkluzívneho vzdelávania $\mathrm{v}$ školskom systéme aj v oblasti rozvoja komunikačných spôsobilostí detí zo sociálne znevýhodneného prostredia.

\section{Použitá literatúra}

1. GUZIOVÁ, K. - ĎURÍKOVÁ, E. 2014. Stimulačný program pre deti vo veku od piatich do siedmich rokov. Prešov: Metodicko-pedagogické centrum, 2014. 81 s. ISBN 978-80-565-0374-4. 2.

2. LESKOVJANSKÁ, G. 2014. Manuál pre depistáž. Prešov: Metodicko-pedagogické centrum, 2014. 98 s. ISBN 978-80-565-0375-1.

3. KOLEKTÍV AUTOROV, 2013. Analýza vzdelávacích potrieb pedagogických zamestnancov a odborných zamestnancov $v$ predprimárnom vzdelávani detí $z$ marginalizovaných rómskych komunit. Prešov: Metodicko-pedagogické centrum, 2013. ISBN 978-80-565-0187-0. Dostupné na internete: http://www.npmrk2.sk/sites/default/files/ANAL\%C3\%9DZA_1.1_0.pdf.

4. LIPNICKÁ, M. 2012. Vizia a realita inkluzívnej edukácie v materskej škole. Bratislava: Metodicko-pedagogické centrum. ISBN 978-80-8052-460-9.

5. LIPNICKÁ, M. 2014. Inkluzívne vzdelávanie detí z marginalizovaných rómskych komunit v materskej škole. Bratislava: Metodicko-pedagogické centrum. ISBN 97880-565-0265-5.

6. ŠILONOVÁ, V. - KLEIN, V. - ŠINKOVÁ, P. A. 2018. Manuál k depistáži pre deti predškolského veku pochádzajúce zo sociálne znevýhodneného prostredia - inovovaná čast'. Prešov: Metodicko-pedagogické centrum v Prešove, 2018. 107 s. ISBN 978-80565-1434-4.

7. ŠILONOVÁ, V. - KLEIN, V. 2019. Evalvačná správa v oblasti depistáže a stimulácie 5-6 ročných detí materských škôl. In KOLEKTÍV AUTOROV. Záverečná evalvačná správa národného projektu Škola otvorená všetkým. Prešov: Metodicko-pedagogické centrum v Prešove, 2019. ISBN 978 - 80 - 565 - 1447- 4.

8. ŠINKOVÁ, P. A. 2018. Manuál k stimulačnému programu pre deti predškolského veku pochádzajúce zo sociálne znevýhodneného prostredia - inovovaná čast'. Prešov: Metodicko-pedagogické centrum v Prešove, 2018. 140 s. ISBN 978-80-565-1432-0. 
9. ŽILKOVÁ, K. 2015. Vyhodnotenie výsledkov diagnostického a stimulačného procesu In KOLEKTÍV AUTOROV. Evalvačná správa z projektu PRINED - PRojekt INkluzívnej Edukácie Záverečná evalvačná správa. Prešov: Metodicko-pedagogické centrum v Prešove, 2015. ISBN978-80-565-1415-3.

\section{Kontaktné údaje}

doc. PaedDr. Milena Lipnická, PhD.

Mgr. Alena Vrábl'ová (študentka doktorandského štúdia)

Univerzita Mateja Bela, Pedagogická fakulta,

Ružová 13, 97411 Banská Bystrica 


\title{
LITERÁRNÍ VÝCHOVA NA GYMNÁZIU V DOBĚ COVIDOVÉ: DIDAKTICKÉ ASPEKTY VYUŽITÍ E-LEARNINGU V DISTANČNÍ VÝUCE
}

\author{
LITERATURE AS A PART OF UPPER SECONDARY EDUCATION IN \\ THE TIME OF COVID-19: DIDACTIC ASPECTS OF THE USE OF E- \\ LEARNING STRATEGIES DURING DISTANCE LEARNING
}

\author{
Eva Marková
}

\begin{abstract}
Abstrakt
Text shrnuje terminologické a legislativní ukotvení distanční výuky v českém kontextu s ohledem na dosavadní stav poznání a změny, jimiž české školství prošlo v důsledku pandemie nemoci covid-19. Pojmenovává stěžejní faktory a didaktické aspekty ovlivňující distanční on-line výuku i její plánování, vymezuje v tomto kontextu také specifickou roli učitele. V závěru poukazuje na pozitivní aspekty, které mohla mít distanční výuka pro kompetenční a komunikativní pojetí literární výuky na gymnáziu.
\end{abstract}

Klíčová slova: distanční výuka, e-learning, on-line výuka, literární výchova, covid-19, plánováni výuky, role učitele.

\begin{abstract}
The article summarizes the terminological and legislative background of distance education in the Czech Republic with regard to the current state of knowledge and changes that it has undergone as a result of the COVID-19 pandemic. It defines the role of the teacher, names elearning strategies, demanded skills and didactic aspects. The author concludes that distance learning could have had a positive impact on literature lessons as a part of upper secondary education.
\end{abstract}

Key words: distance learning, e-learning, on-line learning, literature education, COVID-19, lesson plan, role of teacher.

\section{TERMINOLOGICKÉ A LEGISLATIVNÍ UKOTVENÍ DISTANČNÍ VÝUKY V ČESKÉM PROSTŘEDÍ}

V březnu 2020 se čeští učitelé museli kvůli epidemii nemoci covid-19 doslova ze dne na den vyrovnat s přechodem na distanční výuku ${ }^{1}$, aniž na ni byla připravena legislativa, kurikulum či samotné školy, jejich žáci a učitelé. Do té doby bylo distanční vzdělávání ${ }^{2}$ zpravidla chápáno jako možná, avšak nepř́lišs využívaná „multimediální forma řízeného samostatného studia, které je koordinováno vzdělávací institucí a v němž jsou vyučující [...] v průběhu

\footnotetext{
${ }^{1}$ Za tímto účelem během března a dubna vznikly také webové stránky MŠMT, které učitelům pomáhaly s plánováním a realizací dálkové výuky: https://nadalku.msmt.cz/cs, množství dalších zdrojů a informací k online výuce lze najít také na stránkách O2 Chytrá škola: https://www.o2chytraskola.cz/knihovnatemat\#technologie-ve-vzdelavani. Během následujících měsíců MŠMT připravilo jednotný metodický portál https://www.edu.cz, monitorování a vyhodnocování dopadů a př́istupů k distančnímu vzdělávání se během jara 2020 začala věnovat i Česká školní inspekce, obsáhlá je především tematická zpráva z března 2021 Distanční vzdělávání v základních a středních školách.

${ }^{2}$ Distanční vzdělávání bylo do té doby v českém právním řádu pojato jako možnost formy vysokoškolského studia, dlouhodobě se jeho rozvojem a monitoringem zabývalo Národní centrum distančního vzdělávání.
} 
vzdělávání trvale nebo převážně fyzicky oddělení od vzdělávaných. Multimediálnost zde znamená využití všech dostupných a účelných didaktických prvků a technických prostředků, kterými lze prezentovat učivo, komunikovat se studujícími, provádět průběžné hodnocení studijních pokroků a případně také hodnotit závěrečné výsledky studia“ (Zlámalová, 2008, s. 17).

K jasnějšímu ukotvení jak samotného pojmu distančního vzdělávání, tak jeho obsahového vymezení pro školy řídící se tzv. školským zákonem³ došlo až pro školní rok 2020/2021, přičemž zásadní legislativní změny, ${ }^{4}$ doporučení a informace o dalších závažných skutečnostech shrnulo Metodické doporučeni pro vzdělávání distančním způsobem ${ }^{5}$, které bylo zveřejněno k 23. záŕí 2020. Uvádí se zde, že „vzdělávání distančním způsobem nemůže zcela nahradit běžnou výuku se všemi jejími aspekty, včetně socializační role. Přes možné těžkosti při jejím zavádění a realizaci má distanční výuka potenciál pro rozvoj klíčových kompetencí, digitální gramotnosti, rozvoj inovativních metod či posilování role formativní zpětné vazby v procesu učení“ (Metodické doporučení, 2020, s. 3), přičemž MŠMT školám doporučuje, aby prvky distančního vzdělávání s podporou digitálních technologií využívaly i během vzdělávání ve standardních podmínkách, tj. během prezenční výuky ve školách.

Metodické doporučení zavádí také termíny synchronní a asynchronní výuka: „Při synchronní výuce je učitel propojen s dětmi (žáky) zpravidla prostřednictvím nějaké komunikační platformy v reálném (stejném) čase. Skupina ve stejný čas na stejném virtuálním místě pracuje na stejném/podobném úkolu,“ (tamtéž, s. 8) zatímco „při asynchronní výuce děti/žáci/studenti pracují v jimi zvoleném čase vlastním tempem na jim zadaných úkolech a společně se v on-line prostoru nepotkávají. Využívány pro tento druh práce mohou být nejrůznější platformy, portály, aplikace atp., a to jak k samotnému vzdělávání, tak i k zadávání úkolů a poskytování zpětné vazby““ (tamtéž, s. 9).

Podobně kolektiv autorů v knize E-learning: Učeni se s digitálními technologiemi vymezuje e-learning jako „vzdělávací proces s různým stupněm intencionality, v němž jsou používány digitální technologie. Způsob využívání digitálních technologií a dostupnost učebních materiálů jsou závislé především na vzdělávacích cílech a obsahu, charakteru vzdělávacího prostředí, etických principech, potřebách i možnostech všech aktérů vzdělávacího procesu“ (Zounek et al., 2016, 35). ${ }^{6}$

\section{DIDAKTICKÉ ASPEKTY DISTANČNÍ VÝUKY A ROLE UČITELE}

Pro učitele se distanční výuka stala velkou výzvou, protože je on-line výuka do značné míry zbavila přímé, v reálném čase probíhající kontroly nad vzdělávacím procesem žáků. Zásadní $\mathrm{v}$ tomto prŕpadě byla role ředitelů škol, kteří po dohodě se svým pedagogickým sborem museli stanovit způsoby a platformy, na nichž se budou učitelé s žáky setkávat.

\footnotetext{
${ }^{3}$ Zákon č. 561/2004 Sb. toto upravuje v $§ 184$.

${ }^{4}$ Ve školském zákoně byla novelou vyhlášenou pod č. 349/2020 Sb. s účinností od 25. srpna 2020 stanovena pravidla pro vzdělávání distančním způsobem v některých mimořádných situacích, jako je uzavření škol či zavedení zákazu přítomnosti dětí, žáků nebo studentů ve školách. Zde se stanoví, že „vzdělávání distančním způsobem škola uskutečňuje podle příslušného rámcového vzdělávacího programu a školního vzdělávacího programu v míře odpovídající okolnostem“; specifikaci toho, co je míra odpovídající okolnostem a jak má taková výuka probíhat, poskytlo právě Metodické doporučení pro vzdělávání distančním způsobem.

${ }^{5}$ Dále jen Metodické doporučení.

${ }^{6}$ Zatímco MŠMT pracuje s termínem on-line výuka, v odborné literatuře se můžeme setkat také s termínem elearning nebo práce $\mathrm{v}$ digitálním prostředí - tyto tři pojmy používáme jako volně zaměnitelné $\mathrm{s}$ ohledem na citované zdroje, přičemž platí, že je to pojmové označení formy práce, skrze niž lze realizovat distanční výuku. Metodické doporučení zavádějí také termín off-line výuka, kterou chápou jako „takový způsob vzdělávání na dálku, který neprobíhá přes internet a $\mathrm{k}$ realizaci nepotřebuje ve větší míře digitální technologie [...]. Zadávání úkolů při off-line výuce může probíhat písemně, telefonicky, ve specifických př́ípadech také osobně“ (Metodické doporučení, 2020, s. 9).
} 
Učitelé se během e-learningu stávají nejen studijní a technickou oporou žáků, přičemž obé musejí zvládat na dálku, ale především musejí promýšlet, jakým způsobem budou pracovat s učivem jednotlivých vzdělávacích oblastí. Dále je třeba rozhodnout, jak změněným podmínkám přizpůsobí cíle výuky, jak nastaví ověřování jejich plnění a jak budou hodnotit, protože k učebnímu pokroku žáků přispívá především adekvátní a srozumitelná zpětná vazba. Usnadněnou práci měli mnohdy ti učitelé, kteři už před začátkem distanční výuky $\mathrm{v}$ žácích podporovali vnitřní motivaci a vedli je k sebeřízené práci - jinak řečeno je vedli k tomu, aby věděli, jak se učit a rozplánovat si práci. Neopominutelná je ovšem také odvaha učitele svěřit žákům zodpovědnost za jejich učení: musí věřit svým žákům, že adekvátně pracují na zadaných úkolech. Tyto procesy samožrejmě probíhají i při prezenční výuce, ale během výuky distanční je jejich nezvládnutí problematičtější nejen kvůli fyzické nepř́tomnosti učitele, ale také kvůli absenci kolektivu třídy, který je v prezenční výuce důležitým podpůrným prvkem celého vzdělávacího procesu.

Učitel by měl při plánování výukového obsahu pro distanční výuku brát ohled také na samotný třídní kolektiv - důležitou součástí učebního procesu je totiž jeho socializační aspekt, který je při distanční výuce marginalizován, učitel jej však může podpořit vhodně zadávanými úkoly i volbou patřičných digitálních nástrojů pro jejich plnění.

Dostál připomíná, že ,pro e-learning je důležitá i práce s chybou, která pro studenta představuje problém, pro jehož vyřešení má málokdy prostředky $\mathrm{k}$ dispozici v paměti nebo sestavený algoritmus jeho řešení (reproduktivní myšlení), ale musí problém vyřešit aktivním přemýšlením, vytvořením nových myšlenkových prostředků (produktivní myšlení)“ (tamtéž, 123). Je proto dobré mít na paměti, že ačkoli digitální nástroje mohou učitele zbavit nutnosti opravovat např́iklad cvičení zaměřená na základní ověření nabytých znalostí, nesmí se stát, že učitel ztratí přehled o pokrocích jednotlivých žáků a že promarní prŕíležitost právě pro práci s chybou, která může následně jemu i žákovi usnadnit práci při plnění dalších úkolů.

Faktorů, které ovlivňují proces žákova učení v digitálním prostředí, je mnoho: učitel sice může prrímo řídit a ovlivňovat jen některé z nich, to však nemusí mít negativní dopad na samotnou výuku. Dnešní generace žije ve světě internetu a digitálních technologií od narození, mnohdy s nimi tedy zachází přirozeněji a intuitivněji než jejich pedagogové. Žáci jsou zvyklí přizpůsobovat si digitální nástroje tak, aby se jim s nimi dobře pracovalo a aby co nejsnáze dosáhli kýženého cíle. Mají rozvinuté své vlastní strategie pro pohyb v hypertextu, jejich proces učení a řešení složitějších otázek je často nelineární, preferují činnostní učení před pasivní transmisí poznatků. ${ }^{7}$ Právě tyto v zásadě přirozené dovednosti žáků může elearning vhodně rozvíjet a kultivovat.

\section{E-LEARNING A JEHO PLÁNOVÁNí}

Učitel může rovněž skrze zadávané úkoly rozvíjet jejich schopnost sebeř́zení. Podobně jako učitel zpravidla mění způsoby práce během výuky ve třídě, je žádoucí, aby se typy úkolů v rozumné míře lišily také $v$ př́ípadě e-learningu. Primárně je tedy řídícím činitelem výuky učitel, nebot' určuje témata, cíle a nástroje, avšak jejich správné využití vedoucí k učení je závislé spíš na žákově sebeřízení, které musí být podporováno vhodnou zpětnou vazbou ze strany učitele.

Plánuje-li učitel e-learningový kurz libovolného rozsahu, může mu v plánování jednotlivých lekcí a volbě vhodných aktivit pomoci revidovaná Bloomova taxonomie, ${ }^{8}$ oporu lze najít také v teoriích učení - ty mohou určovat bud' celkové zaměření výuky, anebo její dílčí části, a to s ohledem na učební cíle, jichž má být dosaženo.

\footnotetext{
${ }^{7}$ Srov. Zounek et. al., 2016, s. 42-65.

${ }^{8}$ Hudecová (2004, s. 274-283) nabízí tabulku, v níž rozlišuje znalostní dimenzi a dimenzi kognitivního procesu - vytváří tak jisté schéma, které lze s úspěchem aplikovat také př́i plánování e-learningu, nebot' učiteli nabízí jasnou oporu k promýšlení toho, jak naplánovat dílčí úkoly vedoucí k naplnění stanovených výukových cílů.
} 
(Neo)behavioristické pojetí výuky je dobře využitelné pro svou ,jasnou strukturu a bezprostřední zpětnou vazbu“ (Zounek et al., 2016, 118, 72) a hodí se především pro ty fáze výuky, kdy je nutné upevnit určité znalosti - při použití různých aplikací či samoopravovacích cvičení mají žáci možnost cvičit látku, která jim dělá obtíže, tak dlouho, dokud nedojde $\mathrm{k}$ žádoucímu zpevnění. Cílem je zapamatovat si potřebné a porozumět tomu. Nabyté znalosti by měl žák následně umět aplikovat a analyzovat; tehdy lze využít poznatků teorií kognitivistických, v nichž se předmětem zájmu stává „myšlení, řešení problémů, jazyk, získávání i zpracování (nových) informací, jejich začleňování do již existujících poznatkových struktur“ (tamtéž, 73). V této fázi výuky lze využít kvízy ověřující čtení s porozuměním, ale také řešení různých šifrovaček, vkládání otázek do videí, podcasty vystavěné na podobném principu jako čtení (v tomto případě poslouchání) s předvídáním apod.

Na úkoly a cvičení inspirovaná teorií kognitivistickou lze navázat úkoly, které jsou inspirovány konstruktivistickým pojetím výuky: v této fázi se výuka zaměřuje na sebemonitorování a sebekontrolu žáka, žádoucí je tedy zadávat takové úkoly, př́i kterých žák hodnotí sebe či ostatní, sám či s ostatními tvoří (kvízy, texty, videa, podcasty...). Pokud úspěšně zvládl dříve stanovené a méně náročné kognitivní cíle, měl už by nyní být schopný také jistého sebeřizení, protože učivu adekvátně rozumí a může s ním tedy dále pracovat. Z hlediska podpory seberegulace žáka se jako velmi dobře uplatnitelná vzdělávací teorie jeví ta konektivistická, nebot' tak si žák „,buduje svůj učební prostor v rámci sítě, kterým pospojuje další vlastní studium“ (tamtéž, 88); je-li toho žák schopný, získává důležité kompetence pro řešení problémů i mimo konkrétní vzdělávací oblast. ${ }^{9}$

Dostál (2009) také přibližuje několik výzkumů zabývajících se aktivizačním potenciálem elearningových nástrojů - pokud jejich výstupy zobecníme, dojdeme k závěru, že žádný z nástrojů využitelných při digitálním vzdělávání nemůže být využíván samoúčelně: samotný nástroj totiž není zdrojem pedagogického úspěchu, ale je opravdu jen prostředkem $\mathrm{k}$ jeho dosažení, pouhou didaktickou pomůckou. Přri tvorbě studijních opor pro e-learningové vzdělávání by učitel měl dbát zásady názornosti, využít lze také schopnosti digitálních nástrojů působit na více smyslů zároveň. Takové pomůcky mohou mít i podobu hry - je-li gamifikace kvalitně navržená, vede k osvojování poznatků, které není transmisivní, ale jež si studenti konstruují sami. „Při hrách, tedy i počítačových, se dosahuje pouze cílů obsažených ve hře. Těchto tzv. herních cílů je možné zpravidla dosáhnout $s$ určitou náročností a to, $v$ jaké kvantitě či kvalitě jich jedinec dosáhne, se stává předmětem hry [...prričemž] je tř̌eba klást důraz na základní rozdíl mezi činnostmi, které jsou hraní a řízené učení“ (Dostál, 2009, 138). Během e-learningu je dobré dbát také na jeho fyzické dopady, protože „práci s počítačem v délce trvání čtyř hodin [lze považovat] za hraniční. V průběhu činnosti, ale zejména při déletrvající práci se doporučují organizační opatření“ (Dostál, 2009, 155); to je ostatně jeden z důvodů, proč i Metodické doporučení MŠMT zdůrazňuje, že distanční výuka nemá být synchronní formou realizovaná $\mathrm{v}$ takovém rozsahu, jako by tomu bylo při prezenční formě výuky. A tak přestože základní rámec distančního vzdělávání zpravidla nastavuje škola, na přetížení žáka $\mathrm{v}$ důsledku dlouhotrvající práce u počítače může myslet také učitel $\mathrm{v}$ rámci vlastního předmětu a přizpůsobit mu jak časovou dotaci, tak formu úkolů -měl by myslet na to, že i čtení z obrazovky je prací s počítačem, stejně tak jako práce s textovým editorem. V prípadě literární výchovy lze žákům nabízet úkoly, které je naopak odvedou z digitálního

\footnotetext{
${ }^{9}$ Rámcový vzdělávaci program pro gymnázia v oblasti informatiky, resp. informačních a komunikačních technologií mezi očekávané výstupy řadí, že žák „využívá dostupné služby informačních sítí k vyhledávání informací, ke komunikaci, k vlastnímu vzdělávání a týmové spolupráci, využívá nabídku informačních a vzdělávacích portálů, encyklopedií, knihoven, databází a výukových programů“ (RVP G, 2007, 64).
} 
světa, anebo jim alespoň nabídnou takovou alternativu (vytváření ilustrací k textu, natáčení vlastních videí, tvorba podcastů, koláží apod).

\section{CÍLE LITERÁRNÍ VÝCHOVY NA GYMNÁZIU A JEJICH NAPLŇOVÁNÍ BĚHEM DISTANČNÍ VÝUKY}

Rámcový vzdělávací program pro gymnázia ve vzdělávací oblasti Literární komunikace očekává, že žák postihne smysl textu, vysvětlí důvody a důsledky různých interpretací téhož textu, samostatně interpretuje adaptace literárních děl, kriticky hodnotí a tvořivě využívá informace $\mathrm{z}$ odborné literatury i publicistiky - získané schopnosti a dovednosti poté tvořivě využívá v produktivních činnostech rozvíjejících jeho individuální styl. Má číst s porozuměním, získávat tak hluboké čtenářské zážitky a být o nich schopen hovořit, ale rovněž být schopen ve své interpretaci přečteného textu uplatit znalosti o struktuře díla, objasnit jeho funkci a účinek na čtenáře či rozlišit tzv. vážnou literaturu od braku.

Tento výběr je pouze namátkový, cílem je však poukázat na to, že je žádoucí pojímat literární výchovu nikoli pouze jako disciplínu literárněhistorickou, ale jako podstatnou součást našeho života. Tehdy nám pomáhá rozvíjet personální i sociální kompetence a poskytuje nám prostor pro vlastní tvořivost, která může být realizována jak v digitálním, tak přirozeném prostředí, a to s různou mírou využití digitálních nástrojů. ${ }^{10}$ Literární výchova se tak s ohledem na výše uvedené charakteristiky distanční výuky mohla během pandemie najednou stát předmětem, jehož cílem není primárně transmise poznatků, ale rozvoj kompetencí a sebe sama. ${ }^{11}$ Široké $^{\circ}$ možnosti se v distanční výuce ovšem nabízely také pro práci s literárněhistorickými tématy, nebot' internet nabízí žákům nepřeberné množství zdrojů pro badatelsky orientovanou výuku. Kompetenčně zaměřená literární výchova poskytovala možnost kombinovat využití elearningového rozhraní $\mathrm{s}$ prací $\mathrm{v}$ přirozením prostředí - např́iklad tehdy, pokud učitelé po žácích vyžadovali výtvarnou reflexi přečteného provedenou tradičními výtvarnými technikami. Tu bylo možné následně doplnit při synchronní výuce v rámci celé třídy rozhovor nad výsledky žákovské tvorby. Tím se mohlo předcházet jisté sociální deprivaci a rozpadu kolektivu. Žádoucí je také to, že pomocí tvořivých metod a jejich následné reflexe žáci rozvíjejí především náročnější kognitivní procesy.

Autonomie daná žákům během distanční výuky mohla být zásadním impulsem pro rozvoj jejich čtenářství, nebot' jedním z předpokladů celoživotního čtenářství je právě schopnost sebeřízení, s jehož pomocí si vytváŕíme vhodné čtenářské návyky. Je však otázkou budoucích výzkumů a měření, nakolik se českým učitelům povedlo možností distanční výuky využít i v literární výchově a komunikaci tak, aby vedla k rozvoji klíčových kompetencí českých žáků.

\section{Použitá literatura}

1. BALADA, J. et al. Rámcový vzdělávací program pro gymnázia. Praha: Výzkumný ústav pedagogický v Praze, 2007. 104 s. ISBN 978-80-87000-11-3.

2. DOSTÁL, J.: E-learning a možnosti využití aktivizačních prostředků, in KLEMENT, M. et al.: E-learning: elektronické studijni opory a jejich hodnocení. 1. vyd. Olomouc: Agentura Gevak, 2012, s. 112-166. ISBN 978-80-86768-38-0.

3. HUDECOVÁ, D.: Revize Bloomovy taxonomie edukačních cílů, Pedagogika. 2004, 54 (3), s. 274-283.

\footnotetext{
${ }^{10}$ Blíže o pojetí literární výchovy jako expresivního, estetickovýchovného oboru pojednává Hník v monografii Didaktika literatury: výzvy oboru (Praha, 2014).

${ }^{11}$ Četba umělecké literatury mohla žákům například umožnit zaměřit se na vlastní prožívání a zpracovat si emoce, se kterými se do té doby pravděpodobně v takové míře nesetkali, at' už to byl strach, osamění nebo smutek nad ztrátou blízké osoby.
} 
4. Metodické doporučení pro vzdělávání distančním způsobem. Praha: Ministerstvo školství, mládeže a tělovýchovy, 2020. Dostupné z $<$ https://www.edu.cz/method ology/metodika-pro-vzdelavani-distancnim-zpusobem/>, př́istup dne 10. května 2021.

5. ZLÁMALOVÁ, H.: Distanční vzdělávání a eLearning: učebni text pro distanční studium. Praha: Univerzita Jana Amose Komenského, 2008. 144 s. ISBN 978-8086723-56-3.

6. ZOUNEK, J.: E-learning - jedna z podob učení v moderní společnosti. Brno: Masarykova univerzita, 2009. 161 s. ISBN 978-80-210-5123-2.

\section{Kontaktní údaje}

Mgr. Eva Marková

Univerzita Palackého v Olomouci, Pedagogická fakulta, Katedra českého jazyka a literatury Žižkovo náměstí 5, 77900 Olomouc

Tel: (+420) 602595019

email: markova.evca@gmail.com 


\title{
INITIATIVES AGAINST DISINFORMATIONS ON THE INTERNET IN THE FIRST YEAR WITH COVID 19 IN SLOVAKIA
}

\author{
Hedviga Tkáčová
}

\begin{abstract}
Depending on the political systems and legislation of individual countries in the world, the Internet, as an effective tool for obtaining various types of information and services, is not regulated. The creation of a centralized control authority over the digital space also seems impossible. This fact creates space for the growth of disinformation and supports not only their emergence, but also its dissemination on the Internet. Contemporary Homo sapiens technicus struggles in the online space, vaguely distinguishing between true content and those that are false or misleading. During the pandemic, online space became our everyday reality, and the ability to distinguish between truths and half-truths or untruths proved to be a necessary life skill that everyone must purposefully acquire. The article contains own research, focused on initiatives related to the detection of misinformation in connection with Covid 19 in the context of Slovakia.
\end{abstract}

Keywords: Covid 19, misinformation, media, audience, expert groups, media literacy, Facebook, infodemia

\section{INTRODUCTION}

Centralized control over the digital space of the World Wide Web does not currently exist. Nevertheless, the Internet is regulated differently in different countries; in particular, this is the case depending on the applicable legislation and the political system of the particular country. Any regulation of the Internet, for example in the United States, has a sharp impact on Americans' deep-rooted awareness of freedom of speech and would also be seen as a serious interference with the rules of the US Constitution, which guarantees freedom of speech. Slovaks understand the freedom of speech as an (almost) unlimited value. The opposite is the case in North Korea, where many people exist without the Internet because they do not have access to it. Somewhere in the middle is, for example, Russia, where the government regularly defines domains and resources that it does not support and are therefore banned. The situation is also specific in the environment of social networks, where it is possible to see absolutely free creation and movement of content created by users. On the social network Facebook, which will be the subject of our research, there were attempts to regulate problematic content when Facebook signed (along with other platforms) the so-called "Code of Conduct against the Dissemination of EU Misinformation" or introduced new rules to increase transparency in political advertising, experts say, however, it is still insufficient and, according to Klingová, "problems with enforcing and implementing one's own rules persist" (Klingová, 2020). In recent months, we have witnessed that problematic content spread not only on Facebook during the election campaign, but also during the ongoing pandemic. In short, the need for regulation of digital content on the Internet has been the subject of much debate.

The wave of interest in this topic has been growing in recent years, especially with the growing disinformation and dissemination on the Internet (Levy, 2017; Bradshaw, Howard, 2018; Bakir, McStay, 2018; Fitzpatrick, 2018 and so on). Although, for example, practices that may be influenced by public attitudes or the level of critical thinking or media literacy of people between the two ways (and even between different components of people) differ 
(Vrabec, 2013), experts generally warn against the effects of media literacy of the Internet audience (TASR, 2019; Chovančáková, 2020), against not fully understanding the educational potential of digital technologies (Polievková, 2020), against so-called cognitive prejudices as consequences of distorted thinking, stereotyping or suspicion (Ruisel, 2015, p. 212; Kondrla, Tvrdoň, Tkáčová, 2020), warn against the weak ability of people to think critically (Adams, Hamm, 2000; Králik, Máhrik, 2019), against bad habits, due to the use of media (Izrael, 2019), against the tendency to believe in the so-called conspiracy theory, which are under the belief in the action of covert but influential forces (Pipes, 1997) and, for example, against the danger of a rapid increase in the number of conspiracy sites (European Commission, 2021); Hood, 2021), which appeared immediately after the first report of an outbreak of Covid 19 (Bavel van et al., 2020). In the context of Slovakia, terminological inconsistency and the lack of codification of the term "disinformation" or inconsistent understanding of the meaning derived from it (National Security Office, 2021) also prove to be problematic.

What we can say for sure is the fact that especially during the Covid 19 pandemic, misinformation is a powerful entity in society and co-creators of a social culture, which, in addition to the visible disinformation-conspiracy war in the media (so-called Infodemia), is determined by signs of dissatisfaction., low audience confidence in public institutions or individuals' desire for instant solutions, a kind of comfortable "information isolation" or the same (supportive) opinions (so-called information bubbles). This is confirmed by van Prooijen and Douglas's research, according to which conspiracy theories tend to thrive in times of crisis when people are looking for ways to deal with complex and uncertain circumstances (Prooijen van, Douglas, 2017). The issue of intergroup tensions (eg between vaccinated and unvaccinated), to which Douglas points out (Douglas, 2021), is not negligible either. In addition, in a society that is evolving extremely rapidly in the technical and technological field, there is the current Homo sapiens technicus, which is increasingly present in virtual reality. And here he stands in a kind of symbiosis with technology, so that again and again, in the words of Galván and Luppicini, he "transcends the boundaries of humanity" (Galván, Luppicini, 2014, p. 1).

The current situation in connection with the Covid 19 pandemic also wishes for an online space. According to a Digital News Report 2020 survey conducted by the Reuters Institute, it is very likely that a pandemic crisis will accelerate long-term structural change towards digital and mobile journalism (Digital News Report, 2020). The challenge for Homo sapiens technicus is and will be more and more, not only to be able to orientate oneself in virtual reality, but also daily individual efforts to transcend personal boundaries and acquire media literacy in addition to the necessary digital competencies (Hobbs, Jensen, 2009; Cortoni, 2017; Fedorov, Mikhaleva, 2020). Otherwise, according to experts, misinformation is a real threat to the individual and to the security of society; due to the negative impact on society, misinformation has even been identified as a global threat (Webb et al., 2016).

Part of media literacy is also a new life skill, i.e., the ability to distinguish between truths, half-truths and untruths in the media. We are convinced that this skill must ultimately be acquired consciously and purposefully by anyone who wants to benefit and collect good fruit even in the online environment. The main goal of the paper is to conduct research on the activities of individuals and expert groups aimed at detecting misinformation in the online environment. In the first part, we will try to identify them, including a description of their mission. Classification of activities of individuals and groups who contribute to the discovery of misinformation about Covid 19 through their own blogs or on Facebook will be the aim of the second part of the research. The third goal will be to quantify the findings. 


\section{METHODOLOGY}

The research consists of three parts. The aim of the first part of the research is to identify expert groups aimed at revealing misinformation about Covid 19 on the social network Facebook and a brief description of their mission. The research method of the first part of the research was the focus group method, which took place online via the zoom application in May 2020. In order to meet the first research goal, nine respondents $(n=9)$ of both sexes $(4$ men, 5 women) were addressed. Their task was to identify organizations or groups of experts whose long-term perceptions of efforts to expose disinformation about Covid 19 on Facebook. We chose the social network Facebook on the basis of the latest research from the Reuters Institute, which again confirmed that this social network is considered to be the main means of spreading disinformation in the world (Digital News Report, 2020). Similarly, several Slovak analysts agree that Facebook has become a phenomenon of the last parliamentary elections in Slovakia, when the number of disinformation sources on this social network climbed to more than 1,500 (Klingová, 2020).

The second part of the research provides a classification of the activities of selected expert groups in relation to the issue of Covid 19. The research method is a qualitative content analysis. Data collection consists of a total set of 300 selected texts. The condition was that the texts examined were related to Covid 19 and misinformation in contexts with Covid 19. Data collection took place between March 2020 (i.e., the first confirmed case of Covid 19 in Slovakia), until March 2021; i.e., throughout the year, we researched one each week on six official Facebook pages of expert organizations; so, a total of 6 texts every week.

The third part of the research aims to quantify the findings of the content analysis and answer the question of what are the aims of the examined expert groups in relation to the detection of misinformation in the context of Covid 19 on Facebook.

\section{RESULTS}

\subsection{Identification and mission of expert groups in the field of disinformation detection} Currently, the dominant topics, which are often questioned and misinterpreted, include Covid 19 , especially topics related to vaccination and vaccines. In the context of the misinformation about Covid 19, the effectiveness of wearing masks associated with $\mathrm{CO} 2$ poisoning in general and the negative effects of vaccination are generally most questioned. For a more comprehensive picture, it is good to realize that in addition to Covid 19, the topics of refugees, NATO and EU organizations, the foreign policy of Russia, the United States and Ukraine and the topic of the $5 \mathrm{G}$ network are frequent misinformation in the online media space. The most frequent authors of these disinformation are the portals Infovojna, Zem a Vek, Bádatel' or Hlavné správy, and together with them several deputies of the political party Ludová strana Naše Slovensko (Infodémia Covid-19, https://www.fpvmv.umb.sk/pre dnaska/infodemia-covid-19).

According to the focus group respondents, these topics are highlighted mainly by experts on these Facebook pages:

a) Hoaxes and frauds - Police of the Slovak Republic (more than 100 thousand likes, almost 108 thousand followers) - specialized official website of the Police Force of the Slovak Republic to combat hoaxes and fraud in the online space, which detects and draws attention to misinformation, draws attention to specific creators of misinformation on the social network Facebook and reveals fake news related to the Covid 19 virus; it managed 
to draw attention, for example, to the hoax that Covid 19 is a biological weapon or that Slovaks will be evacuated from their country as a result of a pandemic, etc.

b) Globsec (Global security forum) (more than 17 thousand likes, almost 18 thousand followers) - a non-political non-governmental organization that focuses on creating videos, activities and campaigns that fight hoaxes and fake news on the Internet and is considered the creator "Ideas and solutions for a better and safer world" (Globsec, https://www.globsec.org/about/).

c) Demagog.sk (more than 12 thousand like, almost 13 thousand followers) - Facebook's page presents factcheck political discussions. Assess the veracity of specific policy statements on the basis of publicly available information; mainly from primary sources such as databases, statistics, press releases, etc. The findings can be commented on by the public and by the politicians themselves (Demagog.sk, https://demagog.sk/akopracujeme/). He promotes professional literature on Facebook and conducts educational workshops related to the issue of disinformation (distinguishing truth from falsehood, critical thinking, etc.).

d) Infosecurity.sk (more than 11 thousand likes, more than 12 thousand followers) analytical and watchdog (from the English watchdog) platform, which uses digital investigative to reveal anonymous actors in cyberspace. It is also recognized in the society as an educational platform focused on effective and comprehensible communication of key topics in the field of combating misinformation (Infosecurity.sk, https://infosecurity.sk/o-stranke/). In March 2021, the editorial staff announced a connection with the portal Antipropaganda.sk and Digital Infospace Security Initiative portals; Infosecurity.sk thus became a joint project of the Slovak Security Policy Institute and Stratpol - Strategic Policy Institute.

e) Antipropaganda.sk (more than 2 and a half thousand like, almost 3 thousand followers) a team of experts who perceive the social need after the struggle for truth in society and the sovereignty of individuals. The project is characterized as a response of the Slovak Institute for Security Policy to the information war, which has been taking place in the Slovak media space for the past few years.

f) CyberSec.sk (more than 1 and a half thousand like, almost 2 thousand followers) - a nonprofit non-governmental organization whose goal is to respond promptly to the state of cyber security and provide information and analysis about it in the context of Slovak society. A parallel goal is participation in the formation of Slovak cybersecurity policies (CyberSec.sk, https://cybersec.sk/spolupraca/).

\subsection{Categorization of expert group activities aimed at detecting misinformation}

The research sample contained 50 texts in each of the six expert groups presented above; a total of 300 texts. Through qualitative content analysis, it was possible to identify the main focus of the text, i.e., text target. Potential sub-objectives of the text were not included in the research set for fear of increasing the subjectivation of research and its findings. Let us add that in many of the texts examined, the author's goal was clearly stated in the introductory part or even in the title (e.g., topic analysis, selection of disinformation trends; weekly summaries of disinformation, etc.), which significantly facilitated the categorization of these texts.

In the research sample ( $\mathrm{n}=300)$, the choice of texts was conditioned by: (1) The time frame of the research (March 2020 - March 2021) and the relationship of the examined texts to (2) Covid 19, and to (3) disinformation on aspects related to Covid 19. In the texts examined, we identified several goals aimed at revealing misinformation about Covid 19 on Facebook, which we categorized. We were always only interested in the main focus of the text, $t$. j. the main purpose of the text. Our findings are shown in Table 1. 
Table 1. Objectives of texts aimed at revealing misinformation on Facebook

\begin{tabular}{|c|c|}
\hline $\begin{array}{l}\text { Research categories } \\
\text { (i.e., goals of analysed } \\
\text { texts) }\end{array}$ & $\begin{array}{l}\text { Research subcategories } \\
\text { (i.e., research variables) }\end{array}$ \\
\hline $\begin{array}{l}\text { Diagnosis of the current } \\
\text { situation }\end{array}$ & $\begin{array}{l}\text { Political studies and analysis of topics in the field of cyber } \\
\text { security, international politics and security; The state of cyber } \\
\text { security in Slovak society; Aspect of hybrid conflicts; } \\
\text { Vaccine (Sputnik V) as a tool to weaken the EU, Overviews } \\
\text { of Russian misinformation about vaccines, Selection of } \\
\text { disinformation trends; Weekly misinformation reports. }\end{array}$ \\
\hline $\begin{array}{l}\text { Identification of disputed } \\
\text { web content }\end{array}$ & $\begin{array}{l}\text { Mixing of opinion and news texts; Presence of misleading } \\
\text { content; Examples of manipulation from history with } \\
\text { connection to the present; Identification of information } \\
\text { ripped from its original context. }\end{array}$ \\
\hline $\begin{array}{l}\text { Warning of cognitive } \\
\text { prejudices }\end{array}$ & $\begin{array}{l}\text { Misleading notions such as the denial of Covid 19; The belief } \\
\text { that Covid } 19 \text { is a biological weapon; Demonization; } \\
\text { Theories about a hidden "enemy" who is destroying our } \\
\text { society through a pandemic; A vaccine as a tool to blackmail } \\
\text { people. }\end{array}$ \\
\hline $\begin{array}{l}\text { Alerting audience } \\
\text { emotions }\end{array}$ & $\begin{array}{l}\text { Subjectively selected and connected facts, serving to support } \\
\text { one's own opinion; Twisted or false information that has the } \\
\text { power to affect emotions; Emotional lyrics (e.g., "The crown } \\
\text { ends when you put the drape down"). }\end{array}$ \\
\hline $\begin{array}{l}\text { Alert to problematic } \\
\text { narratives with reduced } \\
\text { ethics }\end{array}$ & $\begin{array}{l}\text { Failure to comply with the rules of journalistic ethics; Texts } \\
\text { with elements of manipulation; Propaganda; Dissemination } \\
\text { of vaccination narratives; Legitimization of concepts (e.g., } \\
\text { "devil's plan (vaccination)", "chipping", "ultraliberal } \\
\text { fascism", "covid criminals", geopolitical "holy war", etc.). }\end{array}$ \\
\hline $\begin{array}{l}\text { Alert to argumentation in } \\
\text { the context of the so- } \\
\text { called inclined surface } \\
\text { error }\end{array}$ & $\begin{array}{l}\text { An argument that contains a sequence of statements to give a } \\
\text { picture of the catastrophic consequences; in layman's terms } \\
\text { we can talk about exaggeration, hysteria); Inducing } \\
\text { pessimism; Inadequate generalizations (e.g., everyone } \\
\text { deceives, everything ends badly, etc.). }\end{array}$ \\
\hline $\begin{array}{l}\text { Uncovering actors in } \\
\text { cyberspace }\end{array}$ & $\begin{array}{l}\text { Alert to specific creators of misinformation on the Internet; } \\
\text { Alerts on hacker attacks on government vaccination-related } \\
\text { systems. }\end{array}$ \\
\hline $\begin{array}{l}\text { Clarifications of } \\
\text { misinformation directed } \\
\text { against ad hominem (from } \\
\text { Latin against a person) }\end{array}$ & $\begin{array}{l}\text { Information for the purpose of implementation; Claims to } \\
\text { damage the reputation of a person or organization; } \\
\text { Statements to discredit the expertise or abilities of an } \\
\text { individual or organization. }\end{array}$ \\
\hline Educational activities & $\begin{array}{l}\text { Publications aimed at clarifying and effectively explaining } \\
\text { key topics (e.g., safety of Covid } 19 \text { vaccines); Education on } \\
\text { creating engaging online content without disinformation; } \\
\text { Online cyber security training; A series of calls for caution } \\
\text { against hoaxes and online fraud; A series of online lectures in } \\
\text { schools. }\end{array}$ \\
\hline $\begin{array}{l}\text { Fun text format with } \\
\text { appeal }\end{array}$ & $\begin{array}{l}\text { Satire; Humorous texts relating to vaccination issues; } \\
\text { Humorous animations related to Covid 19; Humorous } \\
\text { reactions to disinformation statements. }\end{array}$ \\
\hline
\end{tabular}




\subsection{Quantification of findings}

The third goal of the research was to quantitatively evaluate the findings, which gives a picture of the goals with which selected texts $(n=300)$ of expert groups on Facebook are created. Our findings are shown in Graph 1.

Graph 1. Quantification of the goals of texts aimed at detecting misinformation on Facebook (in \%)

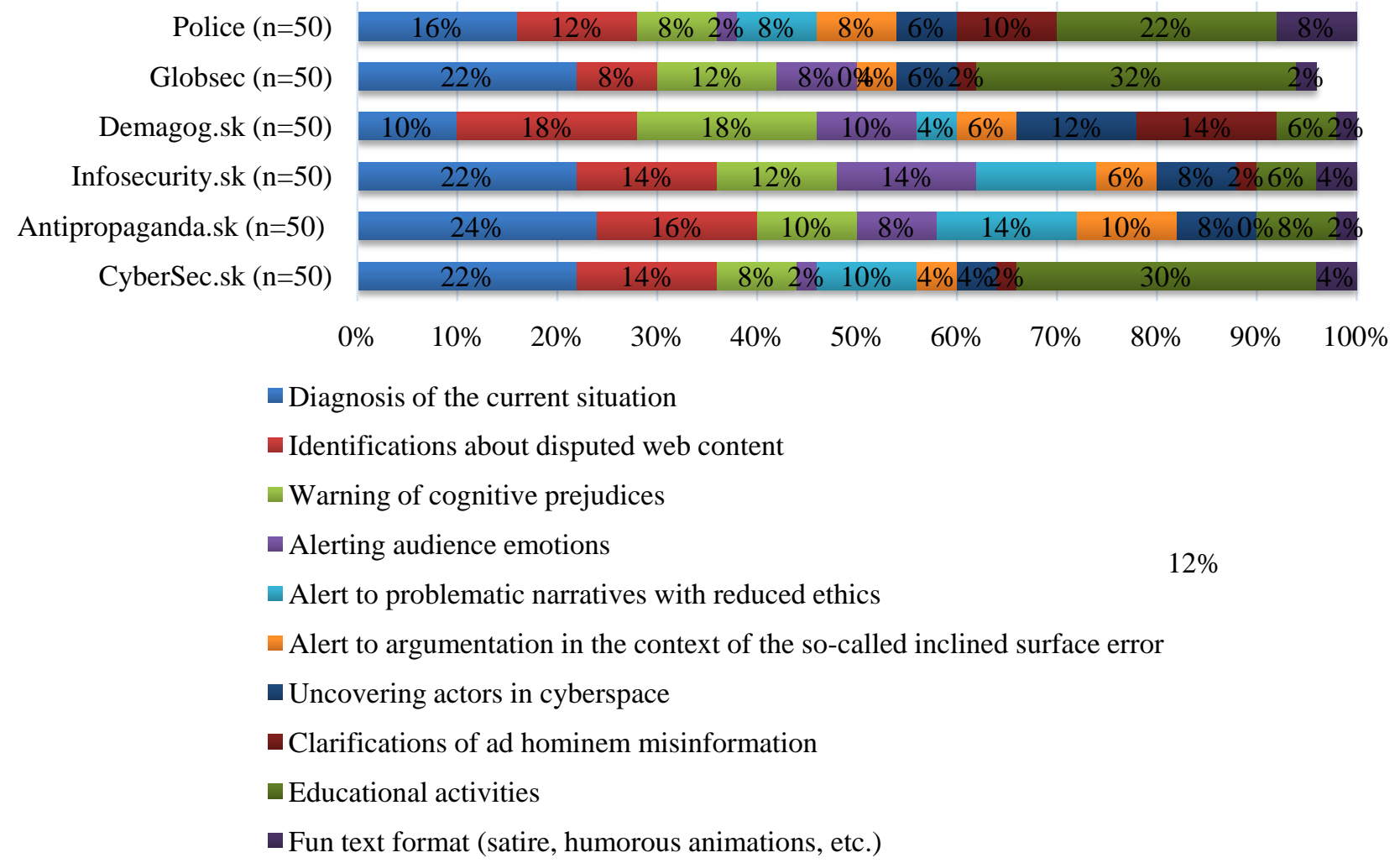

\section{CONCLUSION}

The stage characterized by the existence of Homo sapiens technicus is related to the digital revolution that we can all observe in our surroundings. More and more people are connected to the Internet via a personal computer or mobile phone (which spreads to their cars, watches, glasses, etc.) during most of the day, which became the dominant phenomenon, especially during the Covid 19 pandemic. this fact as positive or as negative (depending on our point of view), we must admit that there is a significant trend here. In the article, we connect it with the term Homo sapiens technicus, which represents a person living in symbiosis with technology, and, among other things, individually (not) builds a life skill, which is the reliable recognition of misinformation in a virtual environment. In the context of media literacy, this skill also proves to be an appropriate way to protect people from negative media effects, such as the audience's inclination towards tabloids, political propaganda or poor-quality journalism with its immediate and often superficial conclusions.

The fight against misinformation is currently taking place through a qualitative analysis of problematic news content or through the algorithmic detection of false reports using a paradigm that analyses patterns of news dissemination on social media. Although both methods are improving and advancing rapidly, the reliable identification of sophisticated manipulative techniques that combine true and credible information with false information is not absolute. This in turn makes it difficult to remove false information from Internet media, 
social media and the entire, unrestricted Internet space. Fortunately, there are currently rare initiatives aimed at uncovering misinformation about Covid 19 in the online space, and in the context of Slovakia they have been the subject of our interest in this paper.

The objectives of the research were: (1) Identification and mission of expert groups aimed at detecting misinformation on the social network Facebook $(n=6)$; (2) Classification of the goals of expert groups in the environment of the social network Facebook and (3) Quantification of findings (in \%). The six researched expert groups that deal with the detection of misinformation on Facebook create texts on a daily basis, in which we have identified, categorized and quantified the ten most common goals. We believe that the findings of the research have a cognitive value even though they are limited by a time frame (the research took place during the first year of the pandemic). We consider the findings to be still valid and up-to-date, as the research was carried out at the time of the "infodemia" in connection with the Covid 19 pandemic, which persists in Slovakia.

When Globsec President R. Vass said in May 2020 (a few weeks since the beginning of the phenomenon we now call the "corona crisis") that the pandemic had caused a transformational crisis that was accelerating trends, he was right (Kačmár, 2020). There are many and many trends are welcome and good. Unfortunately, they are created, renewed, and strengthened even by those that are so negative that they become a social threat (Webb et al., 2016). In conclusion, we will therefore try to formulate three serious dangers, which are closely related to our research findings. In connection with the Covid-19 pandemic, the following can be considered dangerous phenomena:

(1) The ever-increasing volume of misinformation in the online space and its growing popularity also in the social media space;

(2) "Infodemia" (disinformation-war), which is, inter alia, a serious danger to public health;

(3) The growing conviction of an increasing number of people who recklessly confuse their right to their own opinion with the right to create their own facts.

\section{Sources}

1. Adams, D., Hamm, M. 2000. Media and literacy: Learning in an electronic ageissues, ideas and teaching strategies. Springfield, IL: Charles C. Thomas, 236 p. ISBN 13: 978-0398070328.

2. Bakir, V., McStay, A. 2018. Fake news and the economy of emotions: Problems, causes, solutions. In Digital Journalism, 6(2), pp. 154-175. https://doi.org/10.108 0/21670811.2017.1345645

3. Bavel, van J. et al. 2020. Using social and behavioural science to support COVID-19 pandemic response. In Nature Human Behaviour, 4, pp. 460-471. https://doi.org/1 0.1038/s41562-020-0884-z

4. Bradshaw, S., Howard, P. N. 2018. Challenging truth and trust: A global inventory of organized social media manipulation. Oxford: University of Oxford. 25 p.

5. Cortoni, I. 2017. Digital competence and family mediation in the perception of online risk to adolescents. Analysis of the Montenegro case study. In International journal of media and information literacy, 2(2), pp. 68-78 https://doi. org/10.13187/ijmil.2017.2.68

6. CyberSec.sk. 2021. O nás. Availabe at: https://cybersec.sk/spolupraca/

7. Demagog.sk. 2021. Ako pracujeme. Availabe at: https://demagog.sk/ako-pracujeme/ 
8. Digital News Report. 2020. Foreword to the Reuters Institute Digital News Report 2020. Available at: https://reutersinstitute.politics.ox.ac.uk/sites/default/files/202006/DNR_2020_FINAL.pdf

9. Digital News Report. 2020. Foreword to the Reuters Institute Digital News Report 2020. Available at: https://reutersinstitute.politics.ox.ac.uk/sites/default/files/202006/DNR_2020_FINAL.pdf

10. Douglas, K. 2021. COVID-19 conspiracy theories. In Group processes \& intergroup relations , 24(2), pp. 270-275. https://doi.org/10.1177/1368430220982068

11. European Commision. 2021. Identifying conspiracy theories. Available at: https://ec.europa.eu/info/live-work-travel-eu/coronavirus-response/fightingdisinformation/identifying-conspiracy-theories_en

12. Fakulta politických vied a medzinárodných vzt’ahov UMB v Banskej Bystrici. 2020. Infodémia Covid-19. Available at: https://www.fpvmv.umb.sk/prednaska/infodemiacovid-19

13. Fedorov, A., Mikhaleva, G. 2020. Current trends in media and information literacy in research and scientific publications of the early 21 st century. In International journal of media and information literacy, 5(2), pp. 153-163. https://doi.org/10.131 87/ijmil.2020.2.153

14. Fitzpatrick, N. 2018. Media manipulation 2.0: The impact of social media on news, competition, and accuracy. In Athens journal of mass media and communications, 4(1), pp. 45-62. https://doi.org/10.30958/ajmmc.4.1.3

15. Galván, J. M., Luppicini, R. 2014. Redefining the boundaries of humanity and the human body: From homo sapiens to homo technicus, pp. 1-10. In Luppicini, R. (Eds.). Evolving Issues Surrounding Technoethics and Society in the Digital Age. Canada: University of Ottawa, 2014, 317p. ISBN13: 978146666122.

16. Globsec. About Globsec - ideas shaping the world. Availabe at: https://www.glo bsec.org/about/

17. Hobbs, R., Jensen, A. 2009. The past, present, and future of media literacy education. In Journal of media literacy education, 1(1), pp. 1-11. Available at: https://digitalcommons.uri.edu/jmle/vol1/iss1/1

18. Hood, L. 2021. Conspiracy theories: why are they thriving in the pandemic? In The Conversation. Available at: https://theconversation.com/conspiracy-theories-whyare-they-thriving-in-the-pandemic- 153657

19. Chovančáková, K. 2020. Sme na tom horšie ako sa predpokladalo. Slovákom dáva mediálna gramotnost' poriadne zabrat'. Available at: https://www.startitup.sk/smena-tom-horsie-ako-sa-predpokladalo-slovakom-dava-medialna-gramotnost-poriadnezabrat/

20. Infosecurity.sk 2021. Portál Infosecurity.sk. Availabe at: https://infosecurity.sk/ostranke/

21. Izrael, P. 2019. Mediálne návyky detí do osem rokov a rodičovská mediácia používania digitálnych médií. In Izrael, P., Holdoš, J. et. al.: Digitálne detstvo. Ružomberok: Katolícka univerzita, Verbum, 2020, 247 p. ISBN 9788056107195.

22. Kačmár R. 2020. Budú diskutovat' na webe, stretnú sa neskôr. Začína sa Globsec v ére koronavirusu. Available at: https://dennikn.sk/2015289/budu-diskutovat-nawebe-stretnu-sa-neskor-zacina-sa-globsec-v-ere-koronavirusu/

23. Klingová, K. 2020. Dezinformácie ohrozujú vol'by, počas pandémie ohrozujú životy. Available at: https://www.globsec.org/2020/04/05/dezinformacie-ohrozuju-volbypocas-pandemie-ohrozuju-zivoty-citajte-viac-https-komentare-sme-sk-c-22372278dezinformacie-ohrozuju-volby-pocas-pandemie-ohrozuju-zivoty-html/ 
24. Kondrla, P., Tvrdoň, M., Tkáčová, H. 2020. Current challenges for social work: stereotyping as an obstacle to the integration of marginalized groups into society. In ICERI 2020: Proceedings of the 13th International Conference of Education, Research and Innovation, 9th-10th November, 2020, Seville, Spain. Sevilla: IATED Academy, pp. 3837-3843.

25. Králik, R., Máhrik, T. 2019. Metaphysics as a base for improving critical thinking. In ICERI 2019: Proceedings of the 12th International Conference of Education, Research and Innovation, 11th-13th November 2019. Seville: IATED Academy, pp. 8901-8903.

26. Levy, N. 2017. The bad news about fake news. In Social epistemology review and reply collective, 6(8), pp. 20-36.

27. Národný bezpečnostný úrad. 2021. Dezinformácie a informačné operácie. Available at: https://www.nbu.gov.sk/urad/o-urade/hybridne-hrozby-a-dezinformacie/dezinfor macie/index.html

28. Pipes, D. 1997. Conspiracy: How the paranoid style flourishes and where it comes from. New York: The Free Press, 258 p. ISBN 068-483-131-7.

29. Polievková, P. 2020. Family socioeconomic status and parents'education as indicators of the primary use of digital media by children. In Media, literacy and academic research, 3(2), pp. 63-76.

30. Ruisel, M. 2015. Kognitívne skreslenia ako súčast' sprisahaneckých teórií. In Slovenský národopis, 63(3), pp. 207-223.

31. TASR. 2019. Prieskum: Mladí l’udia dôverujú viac blogom ako tradičným médiám. Available at: https://strategie.hnonline.sk/media/1890463-prieskum-mladi-ludia-dove ruju-viac-blogom-ako-tradicnym-mediam

32. Van Prooijen, J. W., Douglas, KM. 2017. Conspiracy theories as part of history: The role of societal crisis situations. In Memory studies, 10(3), pp. 323-333. https://doi.org/10.1177/1750698017701615

33. Vrabec, N. 2013. Paradigmatické prístupy a súčasné trendy vo výskume mediálnej gramotnosti. Trnava: Univerzita sv. Cyrila a Metoda v Trnave. 223 p. ISBN 978-808105-507-2.

34. Webb, H. et al. 2016. Digital wildfires: hyper-connectivity, havoc and a global ethos to govern social media. In ACM SIGCAS computers and society, 45(3), pp. 193-201. https://doi.org/10.1145/2874239.2874267

\section{Contact}

PhDr. ThDr. Hedviga Tkáčová, PhD.

Faculty of Humanities, University in Zilina

Univerzitná 1

01001 Zilina, Slovak Republic

E-mail adress: hedwiga.tkacova@gmail.com

ORCID: http://orcid.org/0000-0003-3062-2284 


\title{
THE IMPACT OF THE USE OF ONLINE EDITORS ON THE QUALITY OF STUDENTS' WRITING
}

\author{
Darina Halašová, Sonia Krajčík Danišová
}

\begin{abstract}
The article presents the results of empirical research in which the authors tried to answer the question to what extent the use of an online editor can increase the quality of writing skills of university students. Even though the communication competencies of EUBA students should correspond to level B2 of the CEFR, for most students, the writing skill is the one in which they score extremely low. One of the problems in practising this communication skill is its time-consuming nature and the need for feedback from the teacher. Regardless of the content of students' written work, these usually contain an unnecessarily high number of such grammatical errors, the occurrence of which would be easily eliminated using an online editor. We examined whether students could improve the quality of their written assignments using Grammarly, an online editor. Comparing the corpora of summaries produced by two groups of students, experimental and control ones, we could see a considerable difference in the quality of their written outputs.
\end{abstract}

Key words: Grammarly, writing skills, self-editing, writing evaluation, summary

\section{INTRODUCTION}

The European Union is a multilingual community that considers respect for linguistic diversity as one of its fundamental values. Simultaneously, multilingualism in the EU single market places great demands on the ability of citizens from the individual member states to communicate in foreign languages in their private lives, and particularly at work. The European Commission has launched several surveys to examine whether insufficient foreign language knowledge can hinder further economic cooperation within the EU. For example, the ELAN study in 2005 showed a close connection between language knowledge and skills and the export success of the enterprises. The study also confirmed the dominant position of English in the business environment. Over a half of small and medium-sized enterprises use English in communication with their foreign partners. The role of the English language as a lingua franca in the economic sphere was also confirmed by another research, according to which English is currently the only language spoken by enough people to have a significant impact on trade flows (Fidrmuc, Fidrmuc 2009). Students at the University of Economics in Bratislava also show interest in English as more than eighty percent of them have been choosing it as their first foreign language for many years, followed by German, French, and Spanish. In their bachelor's studies, they develop their language competencies from level B1 or $\mathrm{B} 2$ to $\mathrm{C} 1$ to start their careers in small, medium-sized enterprises and in multinational companies in which English is usually the language of corporate communication (Halašová 2018). Employers often expect university graduates the ability to communicate in a foreign language not only orally but also in writing.

Although oral communication is fast and effective, each organization needs different forms of written documentation such as letters, minutes, and manuals, a constant overview of what is happening in the organization. Written communication belongs among crucial means of communication in many organizations. "It is used in the process of transmission of information to the addressee" (Harausová, 2013, p. 28). The explosion of electronic and wireless communication in everyday life brings writing skills into play as never before (Graham, Perin, 2007). Therefore, written communication is one of the four skills that L2 
learners must develop and practice, especially if they want to work in professions requiring higher education.

In general, practising written communication is often neglected by teachers due to its time consuming nature. It is often not possible, with the number of students per teacher, to proofread students' assignments to check for grammatical accuracy and to provide feedback to each student. The reluctance to grammar check is typical of many academic learning institutions (McNally, Kooyma, 2017, p.). Another reason for that might be that grammar has perceived status as a lower concern that is not as integral to written feedback as higher-order concerns, such as the organization of ideas and the development of arguments (Winder, Kathpalia and Koo, 2016). However, some studies focused on the most common errors analysis, evidence that grammatical competence remains low with many L2 students. Czech and Slovak economics students still make recurring lexical and typical grammatical errors in their writing assignments even though they have studied English for about eight years or longer before joining the university. In Australia, Tynan, and Johns (2015) note that international students commit surface-level errors in grammar, punctuation, and spelling, rendering their written work rather difficult to read and grade. "Deviations from the standard and violations of language correctness leading to misunderstandings or communication problems are usually considered errors" (Kalousková 2015, p. 87).

One possible solution to this problem might be to recommend the students use an online editor. This tool can save the time of both teachers and students in improving writing skills. In addition, it can train students to learn independently (Cavaleri, Dianati 2016, p.233). While controversy currently exists concerning the application of online editors in a test setting, there is little argument for the time-saving benefits afforded by computer-generated feedback. The accuracy of such programmes increases each year (Bailey, Lee, 2020). According to researchers, they are not only adequate at detecting errors (Burston, 2008) but at rates approaching the effectiveness of teacher corrections (Nadashi, Sinclair, 2007).

\section{PROJECT OBJECTIVES AND METHODS}

The study investigated the possible benefits that an automatic online editor could have had on the quality of written communication. We compared the writing assignments of two groups of students: control and experimental, focusing on their formal side, regardless of the contents. We wanted to verify the hypothesis of whether the use of an online editor may have a considerable impact on the lower incidence of common spelling and grammar errors and to what extent students can benefit from using an online editor to improve their writing skills. Whether it is worth incorporating Grammarly or another similar online editor into the teaching process.

To compare the students' works, we created a corpus of summaries of the control group in which students were to write their summaries without using Grammarly, or another online editor. The second corpus contained summaries written by students from the experimental group who were recommended to use Grammarly. We used Grammarly to get statistics of the pieces of writing of both groups which we analysed and compared.

Although there are several online grammar editors, we decided to use Grammarly in our study. Grammarly is an online editor that can identify more than 300 types of grammar, spelling, punctuation, sentence structure, or vocabulary errors. We also considered certain shortcomings of this tool, which were pointed out by several studies. Hoang and Kunnan (2016) and Perelman (2017) point to unsatisfactory grammatical accuracy. We observed the same problem regarding the use of the passive voice that had been mentioned by Radi (2015). Grammarly evaluated the sentences in the passive voice as erroneous, recommending the active voice instead. However, it does not consider the academic context in which students are writing and where passive voice is appropriate. While not incorrect, the passive voice is often 
considered a bad writing habit. Active voice is preferred because it makes writing stringer and more direct (Bailey, Lee, 2020).

\section{ANALYSIS OF PROJECT PARTICIPANTS}

The students of the Faculty of National Economy at the University of Economics in Bratislava participated in the research. Eighty-five students participated in the project -44 students in the control group and 41 students in the experimental group in their first year of bachelor's study. The original idea was to have the same number of students in both groups. However, some students did not meet the deadline and submitted their summaries too late. The number of students is still comparable and thus suitable for the research. The average age of the students is 19-20 years that, due to the pandemic situation, lost a large part of their full-time secondary education in the final year of their studies. They did not have to pass the usual school-leaving examination consisting of a written and an oral part. The traditional oral part did not take place. In addition, they could start studying at our university without the necessity of passing admission tests of the English language and verifying their preconditions for university studies.

All participants were students who completed one semester of a Business English course at the university. At the end of the semester, they were to go through a final test aimed at mastering vocabulary and grammar. Half of the control group students achieved $\mathrm{C}$ grade (11 students) or D (11 students) in this test. Four students were evaluated with an A grade, and eight students did not achieve enough points, so they did not pass the test (Fx grade). The results of the experimental group students are comparable, almost identical, so we can say that both groups are on the same level of English. When comparing English language competencies based on the test results, we can argue that there are no significant differences between the test scores achieved by students in the control group and those from the experimental group. They were both two heterogeneous groups of students, composed of excellent to weak students.

Size of experimental vs control group of respondents

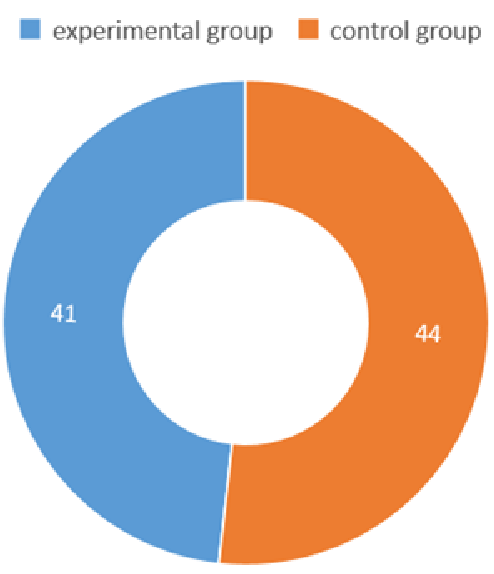

A thorough initial analysis of the students is a crucial part of the project. The graphs below present the statistical data on the students from both groups. They give information concerning their previous studies and their attitude towards English learning, which we obtained through an online questionnaire.

The graph on the left shows how long the students have been learning English. Most respondents report 10 to 15 years of studying English. We have used the length of English language studies as one of the objective indicators of the level of language knowledge though 
it might not always be a reliable source of information. There are students whose language knowledge may be better with a shorter length of study and vice-versa. We also considered the information on the type of secondary school. The chart on the right shows that most respondents (51) attended a secondary grammar school, of which eight students graduated from the Slovak/English bilingual secondary grammar school. The remaining students are graduates from business academies, secondary technical schools, hotel and gastronomy academies, or other secondary comprehensive schools.
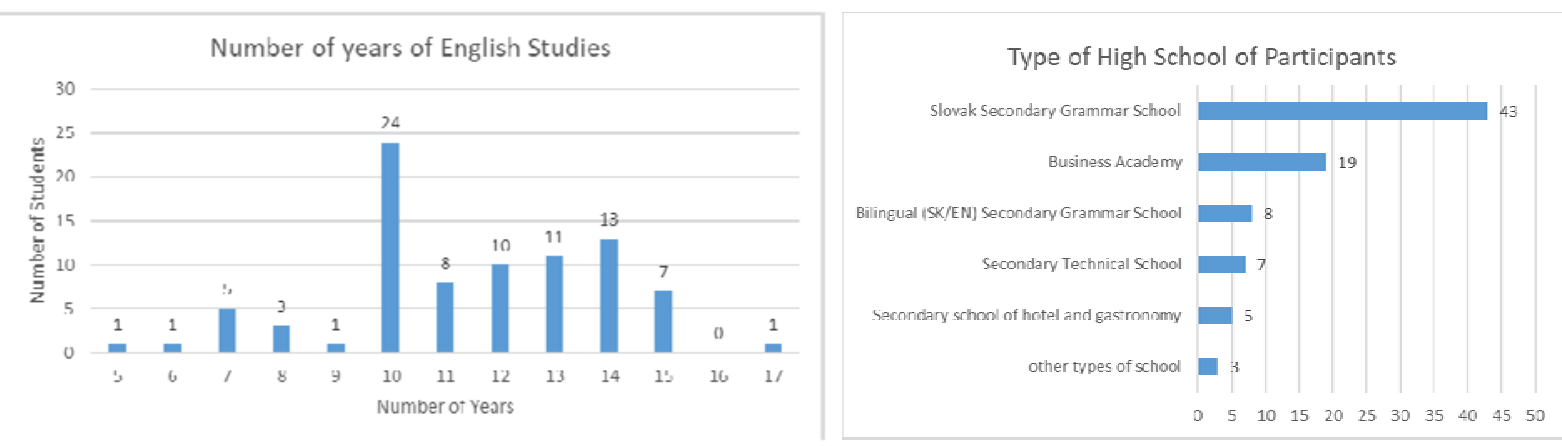

We also used a questionnaire to find out which language textbooks they used at previous levels of education. As can be seen on the left chart below, most of the respondents used Project in elementary schools (76) and most students used Solutions or Maturita Solutions textbooks in secondary schools (32). The remaining three textbooks in the top-five ranking are the following: Yes (16), Headway (15), and Laser (9). Other textbooks listed in the questionnaire were Market Leader (used at the University of Economics - a higher level of it), Real Life, English File, Business Result, Murphy's English Grammar in Use, On Screen, More, Destination, Language Choice, Insight, Gateway, English Plus, English Grammar in Context, New Success, and Ready for Advanced. Regarding the activities aimed at developing writing skills, most students mention practicing writing a kind of formal text (57), as shown in the chart on the right below. A third of respondents (29) state that they participated in creative writing. However, we assume that such activities were probably not very frequent considering the quality of their writing assignments in general.
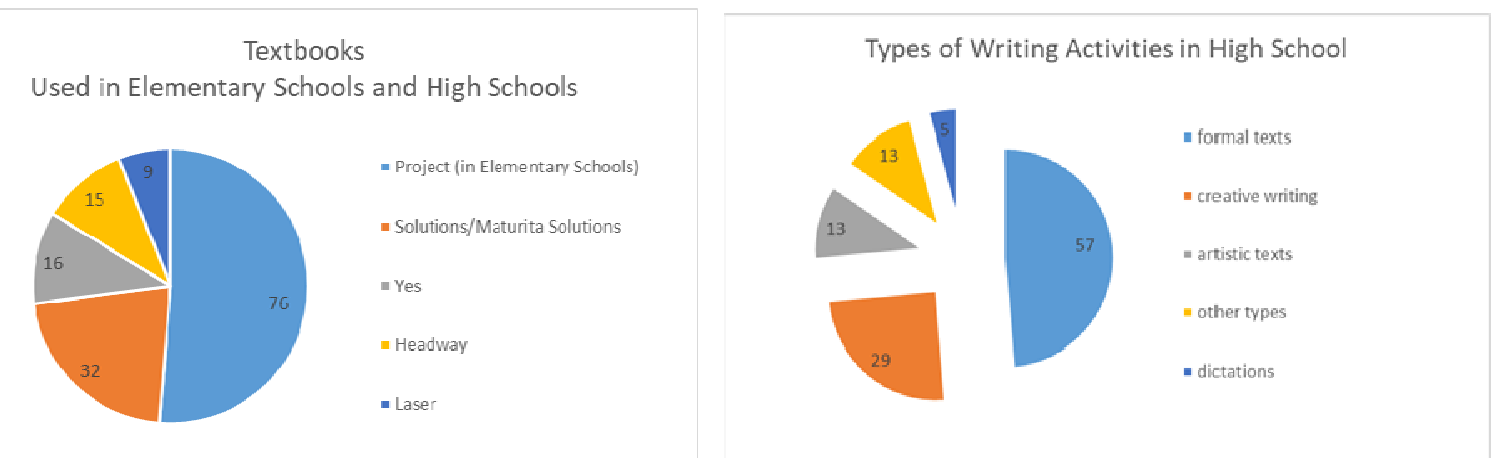

We also took into consideration the respondents' evaluation in secondary school. However, their grades from secondary school probably do not objectively reflect their knowledge of English. Several factors influence it, such as different quality of schools, differently demanding teachers. Despite that, we include it as one of the measurable indicators. The chart on the left below shows that most of the participants (52) got grade 1 (which is the best one of five grades) from the English language, and the rest got grade 2; only two students scored worse than that. The chart on the right demonstrates that most respondents (53) opted to take the school-leaving examination at the B2 level. Fewer students (24) chose a lower B1 level. 
Due to the pandemic situation, they did not complete the final exam in full; it still gives us a kind of idea about their overall level of English proficiency.
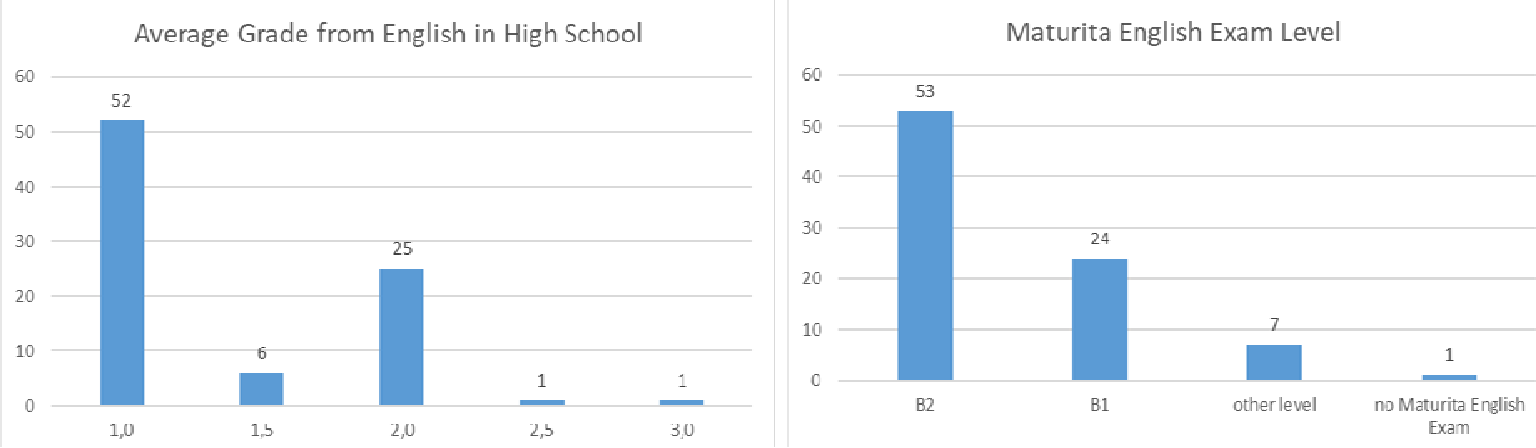

The last part of the initial analysis focused on their current contact with the English language - either at work or in their personal lives, both actively and passively. Even though the respondents are on full-time study programmes, they have either a part-time job or have had some work experience before. The left chart below shows what types of texts they encounter at work - with e-mail communication being the dominant type of written communication (53), followed by many other types of business texts such as contracts, reports, or summaries (39). The chart on the right below gives the number of hours they use English actively and passively every day. Most respondents say that they are in contact with English for about 2.5 hours on average a day (64). Twelve students claim to spend up to 5.5 hours daily, five students up to 16 hours, and only four respondents were in contact with the English language for over 30 hours per week.

As regards types of communication activities, according to the research, listening and reading prevail. For instance, 66 respondents listed listening to music in English, 57 respondents listed watching TV shows and movies simultaneously with audio and subtitles in English and 41 respondents listed watching TV shows and movies with English audio and Slovak or Czech subtitles. The respondents are logically overlapping since this was a multi-choice question in the questionnaire. The rest of the activities included reading books and magazines (40), communication in English with either foreigners and expatriates (19), or with English native speakers (11). As we expected, the writing activities of either formal or informal texts represent the lowest number of respondents (9). It may be one reason why writing as an active communication language skill needs to be enhanced in quantity and quality in the tuition at all levels - from elementary up to the university level.

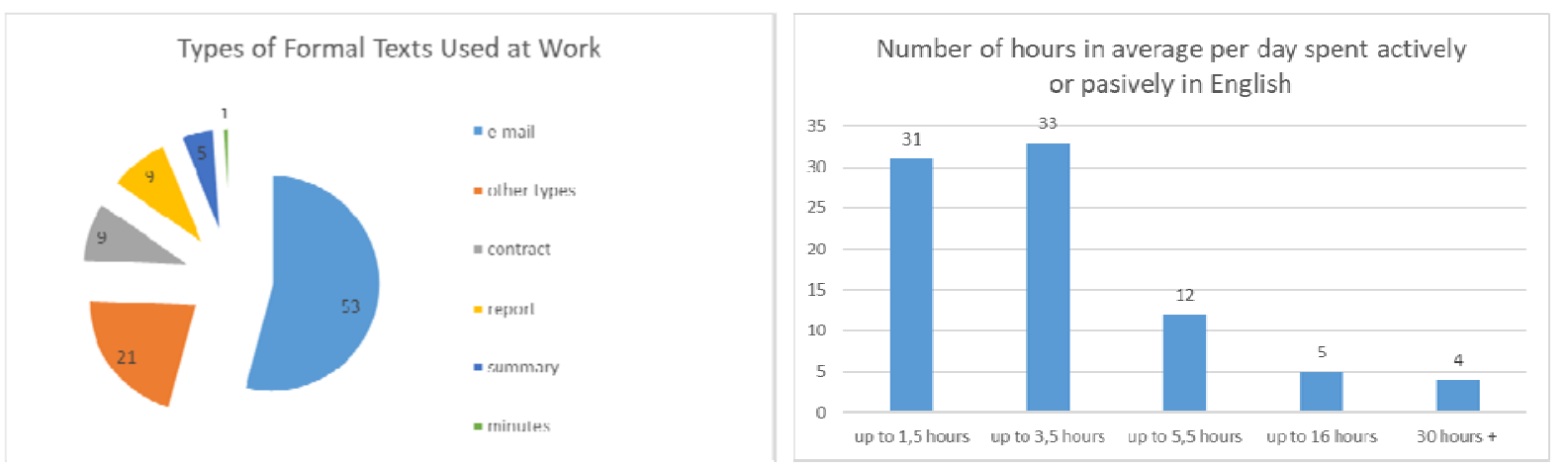

\section{MATERIAL AND PROCEDURE}

The teachers gave both the groups of students an assignment to write a summary of an article published in a daily newspaper. In it, the author informed about the results of international 
research on job satisfaction. The respondents were employees from almost 50 countries. The length of the Slovak article was 484 words, and students could only use 100 words to write a summary, with a tolerance of +/- 10 words. We chose the article because its topic corresponded to the one from their course book. Thus, students could use the vocabulary they learned at school. As it dealt with L2 students, the article was in their first language so that they could not tend to quote sentences or parts of them from the original text when writing the summary. Students were advised to watch a tutorial video on YouTube under the title How to write an effective summary. Watching it, however, did not affect students' grammatical competencies, which were the subject of our study. The teacher in the experimental group introduced the students to the Grammarly editor, the Basic part of which is available online for free. She explained how they could use this tool to edit their pieces of writing. The students from the control group were not aware of any online editors, even though there are some available for free. They claimed that they did not use any when writing the summaries. Students from both groups sent their work to their teacher. The authors used Grammarly to evaluate all 85 summaries, noting the input scores of the individual summaries, their extent, and the number of critical and advanced errors as marked by Grammarly. Table 1 presents the input results separately from both the control and experimental groups giving the mean numbers.

\section{RESULTS AND DISCUSSION}

The figure given in Table 1 in the Input score column shows the average quality of the piece of writings submitted by both control and experimental groups of students. The students from experimental group achieved almost 20 percent. The quality of writing was, according to Grammarly, on average, almost 20 per cent higher for students in the experimental group. The number of so-called critical errors was much higher in the summaries of the control group (5.93 errors per summary vs only 0.51 errors). However, as regards the advanced errors, there was no difference between the two groups, as the students in the experimental group ignored premium suggestions or were unable to improve the quality of the texts on their own.

Table 1. Comparison of mean input data of control group vs. experimental group according to Grammarly

\begin{tabular}{|c|c|c|c|c|}
\hline \multirow{2}{*}{ Group } & \multirow{2}{*}{ Number of words } & \multirow{2}{*}{$\begin{array}{c}\text { Input score } \\
\%\end{array}$} & \multicolumn{2}{|c|}{ Number of errors } \\
\hline & & & critical & advanced \\
\hline Control & 121.88 & 72.13 & 5.93 & 5.25 \\
\hline Experimental & 129.43 & 90.73 & 0.51 & 5.24 \\
\hline
\end{tabular}

We did not include in the error statistics shown in Table 2 errors that appeared in only one, two or three summaries, such as inappropriate colloquialism (1), faulty tense sequence (1), monotonous sentence (1), text inconsistence (1), missing hyphen (1), potentially sensitive language (2), misuse of quantifiers (2), misuse of semicolons (3) and incorrect verb form (3).

Table 2. Statistics of Error Categories (Control Group)

\begin{tabular}{|c|c|c|}
\hline Category & Error type & Occurrence \\
\hline Critical & Determiner use & 100 \\
\hline & Confused words & 20 \\
\hline & Misspelled words & 44 \\
\hline & Faulty subject-verb agreement & 23 \\
\hline & Wrong or missing preposition & 19 \\
\hline & Incorrect noun number & 7 \\
\hline
\end{tabular}




\begin{tabular}{|c|c|c|}
\hline & Pronoun use & 7 \\
\hline & Comma misuse within clauses & 27 \\
\hline Advanced & Word choice & 82 \\
\hline & Punctuation in compound sentences & 68 \\
\hline & Wordy sentences & 34 \\
\hline & Passive voice misuse & 24 \\
\hline & Unclear sentences & 13 \\
\hline & Intricate text & 5 \\
\hline
\end{tabular}

Table 3 shows a statistical overview of the results in the experimental group. When comparing the corpora of control and experimental groups there was a significant difference between them in the category of the so-called critical errors. While the students from the experimental group rarely made these types of errors, in the summaries of students from the control group, critical errors were common. The most frequent occurrence was the determiner-use errors (100 times), followed by spelling errors (44). There were also errors such as faulty subject-verb agreement (23 times), incorrect preposition and confused words (20 times) in the corpus composed by the summaries written by the students from the control group. The situation was different in the so-called advanced errors, for which suggestions for correction are charged. The students in both groups did not use this option, so errors in this category were common in both corpora. The incorrect word choice errors occurred 82 times in the control group and 80 times in the experimental group. The occurrence was similar in other types of advanced errors. We do not list those errors in this category in Table 3 that occurred only rarely. As mentioned by Bailey and Lee (2020) word choice errors are not technically mistakes but characteristics of writing quality that Grammarly attempts to improve.

Table 3. Statistics of Error Categories (Experimental Group)

\begin{tabular}{|c|c|c|}
\hline Category & Error type & Occurrence \\
\hline Critical & Determiner use & 6 \\
\hline & Confused words & 1 \\
\hline & Misspelled words & 0 \\
\hline & Faulty subject-verb agreement & 4 \\
\hline & Wrong or missing preposition & 3 \\
\hline & Incorrect noun number & 1 \\
\hline & Pronoun use & 3 \\
\hline Advanced & Comma misuse within clauses & 80 \\
\hline & Word choice & 58 \\
\hline & Punctuation in compound sentences & 24 \\
\hline & Wordy sentences & 16 \\
\hline & Passive voice misuse & 13 \\
\hline & Unclear sentences & 4 \\
\hline
\end{tabular}

\section{CONCLUSIONS}

This study aimed to find out to what extent the use of an online writing assistant can help to improve the quality of writing of L2 undergraduate students. As the comparison of the results of the summaries produced by the students of the experimental and control groups shows, the former managed, as expected, to create summaries without common errors. On the contrary, the students from the control group most often committed errors like determiner misuse, 
subject-verb agreement, or spelling mistakes. Neither group used the premium version of Grammarly, which is not free and focuses more on stylistic mistakes. So, the results were similar in this category of errors, i. e. both control and experimental groups. Grammarly provides feedback to students on the one hand and saves teachers time on the other. It will also give them a kind of input evaluation criteria of the quality of writing. The study also confirms that students are more interested in L2 writing if there is feedback. It also helps students to become more independent writers. However, they lack practice and experience in formal writing. Thanks to incorporating online writing assistants like Grammarly into classes, teachers can afford to allocate time for practising writing skills.

\section{References}

1. Bailey, D. Rakushin Lee, A. (2020). An Exploratory Study of Grammarly in the Language Learning Context: An Analysis of Test-Based, Textbook-Based and Facebook Corpora. In TESOL International Journal, Vol. 15 (2), 4-27.

2. Burston, J. (2008). Review of BonPatron: An online spelling, grammar, and expression checker. In CALIC Journal, 25 (2), 337-347

3. Cavaleri, M, Dianati, S. (2016). You want me to check your grammar again? The usefulness of an online grammar checker as perceived by students. In Journal of Academic Language \& Learning, Vol. 10 (1), 223-236.

4. Fadhilah, U.,Lizawatti, H., and Saribu, J. D. (2018): Effectiveness of Grammarly Application for Writing English Abstract. In International Journal of Science Research, Vol. 8 (12), 163-166.

5. Fareed, M., Ashraf, A., and Bilal M. (2016). ESL Learners 'Writing Skills: Problems, Factors and Suggestions. In Journal of Education and Social Sciences, Vol. 4 (2): 1, 2016, 81-92.

6. Fidrmuc, J., Fidrmuc, J. (2009): Foreign Languages and Trade. In: Economics and Finance Working Paper Series.

$<$ http://www.brunel.ac.uk/_data/assets/pdf_file/0009/82098/0914.pdf $>$ [25. 9. 2019].

7. Graham, S., Perin, D. (2007). Writing next: Effective strategies to improve writing of adolescents in middle and high schools - A report to Carnegie Corporation of New York. Washington, DC: Alliance for Excellent Education.

8. Halašová, D. (2018). Analýza nedostatkov v písomnom prejave $\mathrm{v}$ hospodárskej angličtine. In

9. Harausová, H. (2013): Komunikácia v organizácii. Online: https://www.upjs.sk/pr acoviska/univerzitna-kniznica/e-publikacia/\#fvs

10. Kalousková, L. (2015): Analýza gramatických chýb v písemných pracích z hospodářske ňemčiny, In: Ligua et vita, Vol. 4, No. 8/2015, s. 87-96.

11. Karyuatry L, Rizqan , M.D and Darayani, N.A. (2018): Grammarly As a Tool to Improve Students'Writing Quality (Free Online Proofreader across Bpundaries). In: Jurnal Sains Sosial dan Humaniora, Vol.2 (1), 2018, 83-89.

12. McNally, D., and Kooyman, B. (2017). Drawing the line: Views from academic staff and skills advisors on acceptable proofreading with low proficiency writers. In Journal of Academic Language and Learning, Vol. 11 (1), 145-158.

13. Nadasdi, T., Sinclair, S. (2007). Anything I can do; CPU can do better: A comparison of human and computer grammar correction for L2 writing using BonPatron. Com. Retrieved from http://bonpatron.com

14. O’Neill, R., Russell A. M. T. (2019): Grammarly: Help or hindrance? Academic Learning Advisors' perceptions of an online grammar checker. In Journal of Academic Language \& Learning, Vol. 13 (1) 2019, 88-107. 
15. Tynan, L. and Jones, K. (2015). Piloting the post-entry language assessment: Outcomes from a new system for supporting research candidates with English as an additional language. In Quality in Higher Education, Vol. 21 (1), 66-78.

\section{Kontaktní údaje}

PaeDr. Darina Halašová, PhD.

Ekonomická univerzita, Fakulta aplikovaných jazykov

Dolnozemská cesta 1, 85235 Bratislava

e-mail: darina.halasova@euba.sk

Ing. Mgr. Sonia Krajčík Danišová, PhD.

Ekonomická univerzita, Fakulta aplikovaných jazykov

Dolnozemská cesta 1, 85235 Bratislava

e-mail: sonia.krajcik.danisova@euba.sk 
INFORMATIKA INFORMATICS

\section{QUAERE}




\title{
ZVYŠOVANIE POČÍTAČOVÝCH KOMPETENCIÍ ŠTUDENTOV ZDRAVOTNÍCKYCH ODBOROV PROSTREDNÍCTVOM VYUŽITIA E-LEARNINGOVÉHO KURZU
}

\author{
INCREASING THE COMPUTER COMPETENCIES OF STUDENTS \\ FROM HEALTH SCIENCE PROGRAMS THROUGH THE USE OF \\ E-LEARNING COURSE
}

\author{
Martina Habiňaková
}

\begin{abstract}
Abstrakt
Rozvíjajúce sa digitálne technológie dnes prinášajú nové možnosti a výzvy aj pre pedagógov. Menia sa očakávania študentov spojené s výučbovým procesom a učením sa, i samotný jeho priebeh. Jednou zo súčasných foriem učenia sa v modernej spoločnosti je e-learning. Podporit' aktívny a samostatný prístup študentov k učeniu je možné aj implementáciou e-learningového kurzu do výučbového procesu. Príspevok poukazuje na nevyhnutnost' zvyšovania digitálnej gramotnosti študentov nielen vysokých škôl. Popisuje ciel', základnú štruktúru a možnosti využitia konkrétneho e-learningového kurzu, ktorý bol vytvorený s ciel'om podporit' výučbu predmetu Informatika pre študentov zdravotníckych odborov na LF UPJŠ v Košiciach.
\end{abstract}

Kl'účové slová: e-learning, e-learningový kurz, informatika, MS Office 2016, IT Fitness test

\begin{abstract}
Nowadays, emerging digital technologies bring new opportunities and challenges also for teachers. The expectations of students associated with the teaching process and learning are changing, as well as its realization. One of the current forms of learning in modern society is e-learning. It is also possible to support the active and independent approach of students to learning by implementing an e-learning course into the teaching process. The paper highlights the need to increase the digital literacy of students not only of higher education institutions. It describes the objective, basic structure and possibilities of using a specific e-learning course, which was created to support the teaching of the subject Informatics for students of health disciplines at FM UPJŠ in Košice.
\end{abstract}

Key words: e-learning, e-learning course, informatics, MS Office 2016, IT Fitness test

\section{E-LEARNING A PROCES ,UČENIA SA“}

Jedným z kl’účových procesov v živote človeka je proces ,učenia sa“. Podl’a Zounek et.al. [6] „učenie sa“ ako také nie je spojené len s tradičným školským vzdelávaním a inštitúciami - ide o proces, ktorý je súčast'ou celého života človeka a ktorý môže mat' rôzne formy a podoby a môže sa odohrávat' $\mathrm{v}$ rôznych kontextoch a prostrediach, vrátane prostredia virtuálneho.

Digitálne technológie (technológie, ktoré umožňujú prácu s dátami v elektronickej podobe) sa stávajú neoddelitel'nou súčast'ou vzdelávacieho procesu. S možnost’ami, ktoré prinášajú sa mení aj samotný kontext učenia sa, jeho priebeh, a tiež očakávania študentov s ním spojené. Jednou z dostupných foriem učenia sa v dnešnej modernej spoločnosti je aj e-learning. Elearning predstavuje proces vzdelávania sa prostredníctvom využitia internetu a informačných a komunikačných technológií (IKT). 
V rámci e-learningu sú dnes pedagógom $\mathrm{k}$ dispozícii rôzne e-learningové nástroje a techniky. Pri výbere vhodného nástroja je potrebné zvážit' predovšetkým ciel' a obsah výuky. Podporit' aktívny prístup študentov $\mathrm{k}$ učeniu je možné aj vytvorením a implementáciou e-learningového kurzu do výučbového procesu.

\section{TESTOVANIE DIGITÁLNYCH ZRUČNOSTÍ ŠTUDENTOV NA SLOVENSKU}

Najrozsiahlejšie testovanie IT zručností a digitálnej gramotnosti na Slovensku od roku 2012 umožňuje komplexný IT Fitness test. Test zostavuje tím odborníkov z Technickej univerzity v Košiciach a pedagógovia pôsobiaci na stredných školách. Ambíciou testu je zábavnou a sút'aživou formou doplnit' výučbu $\mathrm{v}$ oblasti používania informačných technológií (IT) a informatiky. Autori sa v teste snažia rozvíjat' prístup k praktickému riešeniu problémov, kedy sa respondent $\mathrm{k}$ správnemu výsledku dopracuje iba vd’aka reálnemu preukázaniu svojich zručností [7].

V priebehu 10 ročníkov bolo spolu otestovaných už viac ako 220000 účastníkov. Testovanie je zamerané prioritne na študentov stredných a vysokých škôl, žiakov (najmä) druhého stupňa základných škôl, a tiež na učitel'ov. Testovacie úlohy sú rozdelené do 5 kategórií, z ktorých každá obsahuje niekol'ko úloh:

1. internet,

2. bezpečnost' a počítačové systémy,

3. komplexné úlohy,

4. kancelárske nástroje,

5. kolaboratívne nástroje a sociálne siete

Tabul'ka 1 obsahuje orientačný prehl'ad výsledkov IT Fitness testov za obdobie 2017 až 2020 určených pre študentov stredných a vysokých škôl, ktorým umožňuje preverit' si zručnosti zamerané na pokročilejšie znalosti a kompetencie IT gramotnosti.

Tabul'ka 1: IT Fitness testy pre stredné a vysoké školy 2017 - 2020

\begin{tabular}{|l|c|c|c|c|}
\cline { 2 - 5 } \multicolumn{1}{c|}{} & Rok 2017 & Rok 2018 & Rok 2019 & Rok 2020 \\
\hline $\begin{array}{l}\text { Respondentov } \\
\text { spolu: }\end{array}$ & 14541 & 15476 & 10964 & 13649 \\
\hline $\begin{array}{l}\text { Priemerná } \\
\text { úspešnost' (\%): }\end{array}$ & $42,59 \%$ & $36,60 \%$ & $49,87 \%$ & $61,65 \%$ \\
\hline
\end{tabular}

Zdroj: spracované podl'a itfitness.sk

V roku 2020 sa do testovania zapojilo celkom 13649 študentov stredných a vysokých škôl, ktorí dosiahli v priemere úspešnost' $61,65 \%$. V porovnaní s predchádzajúcim rokom 2019 celková priemerná úspešnost' vzrástla o 11,78 \%. Aj ked' ostatný IT Fitness test 2020 prebiehal na rozdiel od predošlých ročníkov za špecifických podmienok a v čase zatvorenia škôl, výsledky testovania IT zručností sa zlepšili. Podl'a autorov testu mohla k zvýšeniu úspešnosti prispiet' aj zmena podmienok testovania, ked'že testovanie prebiehalo v domácom prostredí, bez časového stresu a rušivých vplyvov. IT Fitness test 2020 teda preukázal, že aj počas koronakrízy sa digitálne zručností študentov zlepšili. Aktuálne prebieha už 10. ročník testovania - študenti, učitelia ale aj d'alší používatelia sa doň môžu zapojit' a svoje počítačové zručnosti si otestovat' do 31.7.2021 [8]. 


\section{VYUŽITIE E-LEARNINGOVÉHO KURZU VO VÝUČBE PREDMETU INFORMATIKA NA LF UPJŠ V KOŠICIACH}

Kapitola sa venuje obsahu, možnostiam a ciel'om e-learningového kurzu, ktorý je určený na podporu výučby predmetu Informatika pre študentov zdravotníckych študijných programov v odbore fyzioterapia, verejné zdravotníctvo a ošetrovatel'stvo. Hlavným ciel'om je podporit' u študentov počítačovú gramotnost' na úrovni, ktorá im umožní efektívne využívat' základné prostriedky IKT pri príprave rôznych úloh, zadaní, odborných činností, ako aj vedeckých a záverečných prác.

E-learningový kurz sa nachádza v prostredí LMS Moodle UPJŠ a je členený do 7 tematických celkov, tzv. modulov. Zameriava sa na prácu s osobným počítačom (OS Windows) a správu súborov, na prácu s informačnými zdrojmi internetu a kybernetickú bezpečnost', na zvýšenie kompetencií študentov pri práci s kancelárskymi nástrojmi MS Office a Office 365:

Modul 1: Počítačová zostava

Modul 2: Práca s osobným počítačom a správa súborov

Modul 3: Práca s internetom a bezpečnost' pri práci s internetom

Modul 4: On-line služby v prostredí Office 365

Modul 5: Textový editor MS Word 2016

Modul 6: Štatistické spracovanie údajov v prostredí programu MS Excel 2016

Modul 7: Prezentačný editor MS PowerPoint 2016

Každý z modulov má obdobnú štruktúru $(O b r .1)$, ktorú tvorí výkladová čast' k problematike prezentovanej na cvičeniach informatiky - tá obsahuje študijné materiály, resp. zdroje: a to knihu, zdroje použitej a odporúčanej literatúry, prezentácie, video-tutoriály a pod.; a rôzne d'alšie aktivity: zadania, testy, diskusné fórum a chat, anketa.

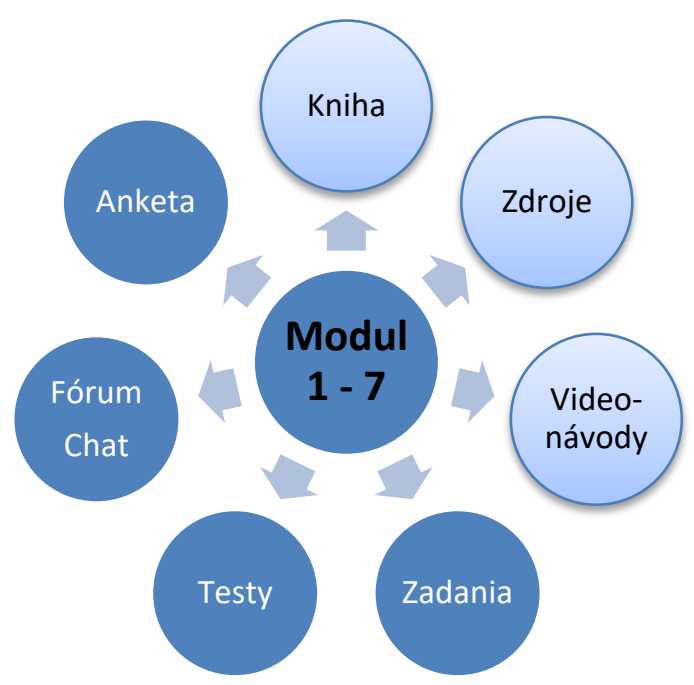

Obr. 1: Štruktúra modulu e-learningového kurzu

Študijné materiály a zdroje, ktoré e-learningový kurz obsahuje podávajú informácie smerom od pedagóga k študentovi, zatial' čo rozličné aktivity kurzu podporujú vzájomnú interakciu medzi pedagógom a študentom, resp. študentmi - ide o:

Zadania - zadanie umožňuje vyučujúcemu zadávat' študentom úlohy, zbierat' práce, hodnotit' a komentovat' ich. Zadania môžu študenti vypracovat' a odovzdat' individuálne, alebo v rámci spolupráce ako členovia tímu. Následne sa odovzdané zadania hodnotia pomocou vytvorenej 
číselnej stupnice, ktorá umožňuje priradit' študentovi hodnotenie A - FX. Aby sa aktivita dala považovat' za splnenú, musí teda študent dosiahnut' minimálnu stanovenú úspešnost'.

Testy - učitel' vytvára a spravuje tzv. banku testových otázok (môžu byt' zaradené do rôznych kategórií), z ktorých potom zostavuje online test. Testy sa realizujú formou „multiple choice“ - z niekol'kých uvedených možností študent vyberie (zvyčajne jednu) správnu odpoved'.

Fórum/chat - súčast’ou každého modulu je aj aktivita fórum, ktorá umožňuje diskusiu medzi účastníkmi kurzu. Na výber je niekol'ko rôznych typov fór, medzi nimi aj tzv. štandardné fórum pre bežné použitie - otvorené fórum, ktoré umožňuje každému účastníkovi (učitel'ovi i študentovi) začat' novú tému.

Anketa - spätná väzba sa od študentov získava aj prostredníctvom jednoduchej aktivity kurzu, akou je anketa. Výsledky ankety môžu byt' tajné, anonymné, alebo verejné.

Príspevok je spracovaný v rámci riešenia projektu KEGA - 011UPJŠ-4/2019: „Zvyšovanie kompetencii a úrovne kritického myslenia študentov medicinskych študijných programov s využitím simulačných nástrojov problémovo orientovaného vzdelávania a medicíny založenej na dôkazoch".

\section{Použitá literatúra}

1. BROWN, J. S.: Growing up digital - How the Web Changes Work, Education, and the Ways People Learn. 2002. [online] http://www.johnseelybrown.com/Gro wing_up_digital.pdf

2. CLARK, R., C., MAYER, R., E.: E-learning and the Science of Instruction. Wiley, 2016. ISBN 978-1119158660.

3. KITSANTAS, A., DABBAGH, N.: Learning to Learn with Integrative Learning Technologies - A Practical Guide for Academic success. Information Age Publishing, 2010. ISBN 978-1607523024.

4. ORBÁNOVÁ, I.: E-learning - Základné črty a princípy. Dostupné online: ppt.

5. SKALKA, J. et al.: Informatika na maturity a prijímacie skúšky. Nitra: Enigma Publishing, 2015. ISBN 978-80-89132-49-2.

6. ZOUNEK, J. et al.: E-learning - Učení (se) s digitálními technologiemi. Praha: Wolters Kluwer, a. s., 2016. ISBN 978-80-7552-217-7. 2.

7. https://minedu.sk [online]

8. https://itfitness.sk [online]

\section{Kontaktné údaje}

Ing. Martina Habiňaková, PhD.

Univerzita Pavla Jozefa Šafárika v Košiciach, Lekárska fakulta, Ústav lekárskej informatiky

Trieda SNP 1, 04011 Košice, Slovenská republika

email: martina.habinakova@gmail.com 
TECHNOLOGIE, STROJÍRENSTVÍ A STAVEBNICTVÍ TECHNOLOGIES, ENGINEERING, BUILDING INDUSTRY

\section{QUAERE}




\title{
NÁVRH MANUÁLU ENERGETICKY EFEKTÍVNEHO RIADENIA OZE V PRIEMYSLE
}

\author{
DRAFT OF THE MANUAL OF ENERGY EFFICIENCY RES \\ MANAGEMENT IN INDUSTRY
}

\author{
Simona Novotná
}

\begin{abstract}
Abstrakt
Využívanie obnovitel'ných zdrojov energie (OZE) sa stáva novodobým fenoménom ako ušetrit' výdavky za energiu a ochránit' životné prostredie. Účelom tohto príspevku bolo mapovat' vybrané aspekty a vyhodnotit' možnosti inovačného potenciálu implementácie zdrojov OZE vo vybranom segmente priemyselných firiem zo segmentu MSP a konkrétne navrhnút' moderný inovatívny prístup formou modelu implementácie OZE v podmienkach príkladu priemyselnej firmy $\mathrm{k}$ riešeniu jej energetickej bázy a predložit’ na odbornú diskusiu konkrétny Manuál pre energeticky efektívne riadenie OZE vo firmách.
\end{abstract}

Kl'účové slová: energetika, ekológia, energetický manažment, inovácia, obnovitel’ný zdroj energie

\begin{abstract}
The usage of renewable energy sources (RES) is becoming a modern phenomenon to save energy costs and protect the environment. The purpose of this paper is to map selected aspects and evaluate the innovative potential of implementing RES resources in a selected segment of industrial companies from the SME segment and specifically to propose a modern innovative principles in the form of RES implementation model in terms of an industrial company to solve its energy base and to propose the manual for energy efficient RES management in companies.
\end{abstract}

Keywords: energy, ecology, energy management, innovation, renewable energy source

\section{VÝCHODISKOVÉ POZNÁMKY K PROBLEMATIKE}

Zadaním súčasnosti $v$ energetike je nájst' také ekologicky čisté, energeticky nenáročné a bezpečné riešenia, ktoré zabezpečia trvalú udržatel'nost' a zásobovanie energiami pre stále rastúcu spotrebu, efektívnost' ekonomiky a prenosnost' energií (siete a rozvody), ako aj stabilitu dodávok energií a zároveň čisté prostredie a znižovanie zátaží z minulosti i kompatibilitu z inými previazanými l'udskými činnost'ami a dostupnost' pre rôzne rozvinuté regióny [6]. Tomu podlieha aj projektovanie a výstavba perspektívnych energetických zdrojov s vysokou účinnost'ou a d'alšie rozsiahle odborné témy súvisiace s procesným a produktovým riadením hospodárstiev priemyselných firiem vo svete i u nás [3]. Preto je vel'mi dôležité vyslovene nastavit' budúcich manažérov firiem $\mathrm{k}$ vnútornému presvedčeniu, že mysliet' ekologicky a energeticky efektívne znamená mysliet' do budúcna a pre vlastné prežitie, hl'adat' konkrétne a jednoduché dielčie riešenia pre aplikáciu nových zdrojov energií a menit' prístup $\mathrm{k}$ životnému prostrediu a to pri znižovaní ekonomických nákladov a snahe zabezpečenia trvalej udržatel'nosti [10]. Takto dnes možno nazerat' na prepojenie energetiky s ekológiou prostredníctvom inovácií a zároveň vnímat' potreby a očakávania kl'účových zákazníkov, ktorí v danej firme odoberajú produkty a užívajú jej služby [1]. Podl'a autorky je organickou súčast’ou tohto diania preukázanie inovatívneho prístupu k riešeniu danej 
problematiky. Invenčná a inovačná schopnost' v každej firme znamená [4] pružnú reakciu na dopyt trhu, rýchlu realizáciu zmien a úpravu ciel'ov i podmienok, kvôli ktorým sa vždy uskutočňuje zavádzanie technológií a ekonomicky efektívneho a ekologicky prijatel'ného energetického hospodárstva do produkcie firmy. Pre správne pochopenie problematiky považuje autorka za dôležité ozrejmit' súvisiace kl’účové pojmy a to sú hlavne: Energetika ako je vedný odbor, ktorý sa zaoberá hospodárnym využitím všetkých zdrojov a zásob energie a tiež priemyselné odvetvie dodávajúce energiu. Úlohou energetiky je riešit' technické, ekonomické a ekologické problémy sprevádzajúce získavanie energie z prírodných zdrojov a jej premenu na využitel'né formy, vrátane transportu a skladovania energie [8]. Environmentalistika je vedný odbor zaoberajúci sa ochranou a tvorbou životného prostredia a takisto aj vplyvom tohto prostredia na utváranie osobnosti a vzt'ahu l'udí k životnému prostrediu. Pojmy ekológia, environmentalistika a životné prostredie sú synergické, navzájom prepojené a neodlúčitel'né výrazy ktorých chápanie a riešenie je pre l'udí existenčne dôležité [3]. Energetický manažment je praktickou činnost'ou, množinou aktivít riadiacich manažérov na dosahovanie ciel'ov; súbor poznatkov o princípoch, metódach a postupoch riadenia; skupina primárne zodpovedných l'udí za riadenie a úspešnost' firiem [2]. Podl'a názoru jedného zo zakladatel'ov teórie P. F. Druckera: „Manažment je vedná disciplína, ktorá je prageologická, má interdisciplinárny charakter a je internacionálna“. Energetický manažment potom možno vnímat' ako špecializovanú odnož manažérskej činnosti, zameriavajúcu sa na energetické zdroje, distribúciu energií, navrhovanie systémov a zariadení pre spotrebu a prevádzkovanie energetických sietí a zariadení a riadenie koncepcií a zmien súvisiacich so znižovaním energetickej náročnosti l’udských činnosti a výrobnej produkcie za požiadavky ochrany životného prostredia [7]. Obnovitel'ný zdroj energie (OZE) je zdroj, ktorého energetický potenciál sa neustále obnovuje prírodnými procesmi alebo l'udskou činnost'ou a vyznačuje sa celkovým potenciálom, čo je energia obnovitel'ného zdroja, ktorú je možné premenit' na iné formy energie za rok a jej kapacita je daná podmienkami z prírody. $\mathrm{V}$ podstate je to faktor nemenný z krátkodobého aj strednodobého hl'adiska a obsahuje v sebe aj technický potenciál, teda čast' celkového potenciálu, ktorá je využitel'ná po zavedení dostupnej technológie a potom ide aj o využitel'ný potenciál, ktorý sa dá vysvetlit' ako technický potenciál znížený $\mathrm{v}$ dôsledku bariér v legislatíve a nevybudovanej infraštruktúry [5].

\section{MODELOVÝ PRÍPAD IMPLEMENTÁCIE OZE V PODMIENKACH FIRIEM}

Potenciál OZE na Slovensku z hl'adiska produkcie energií súvisí najmä so sledovaním atribútu energetickej náročnosti modulových stavieb a investičných projektov a prevádzkové a investičné náklady energetickej náročnosti sú podrobne analyzované v [11]. Hovoria o významnom atribúte - energetickom zabezpečení vykurovania a chladenia, osvetlenia a prevádzkovania elektrických spotrebičov a hlavne výrobných technologických zariadení, strojov a produktových liniek. Prevádzkové energetické nároky sa stavajú hlavným indikátorom ekonomičnosti prevádzky. Ked’že ich hodnoty môžu byt' ovplyvnené už vo fáze tvorby projektov, tu je možné významne zasahovat' [11] do štruktúry objektov a technológií a ich prevádzky a modifikovat' jestvujúce systémy a znalosti novými inováciami. Popis a hodnotenie súčasného stavu, energetická bilancia, výber zdrojov energií s uprednostnením možností OZE, d'alej ekonomické hodnotenie s určením miery návratnosti investícií a definovanie environmentálnych zát'aží a faktorov trvalej udržatel'nosti sú hlavnými vybranými atribútmi pre zameranie sa na inovácie. Zvyšovanie nákladov na energiu a znižovanie vplyvov na klimatické zmeny si u výrobných firiem špecificky z portfólia MSP vyžaduje vybudovat' novú stratégiu v oblasti efektívneho nakladania s energiou pri stanovenej produkcii. Na systém energetického a prevádzkového riadenia v kompetencii manažmentu je preto potrebné nazerat' ako na procesné riadenie, ktoré implementuje inovácie do výroby [12]. 


\subsection{Model energetického manažmentu v priemyselnej firme MSP:}

Vlastný model energetického manažmentu v priemyselnej firme s malosériovou a kusovou výrobou širšieho sortimentu možno predstavit’ na obrázku 1. Posúdenie situácie na mieste je vlastne meranie, s akou účinnost'ou sa využívajú vstupy na vytvorenie požadovaných výstupov. U výrobných zariadení v špecifických podmienkach MSP pri ich možnostiach, reálnom technickom a technologickom vybavení a finančnom i prevádzkovom zázemí sa model zameriava na využitie strojných zariadení a ich prestojov, pričom sa analyzujú spotrebovávané energie a režimy strojov, ktoré ich ovplyvňujú. Hodnotenie spotreby času na produkciu firmy je dôležité nielen k vyjadreniu nákladov na prácu, ale aj k vybalansovaniu jednotlivých operácií s ohl'adom na spotrebu energií, teda energetickú náročnost' firmy [12].

Obrázok 1: Energetický manažment v priemyselnej firme s malosériovou a kusovou produkciou

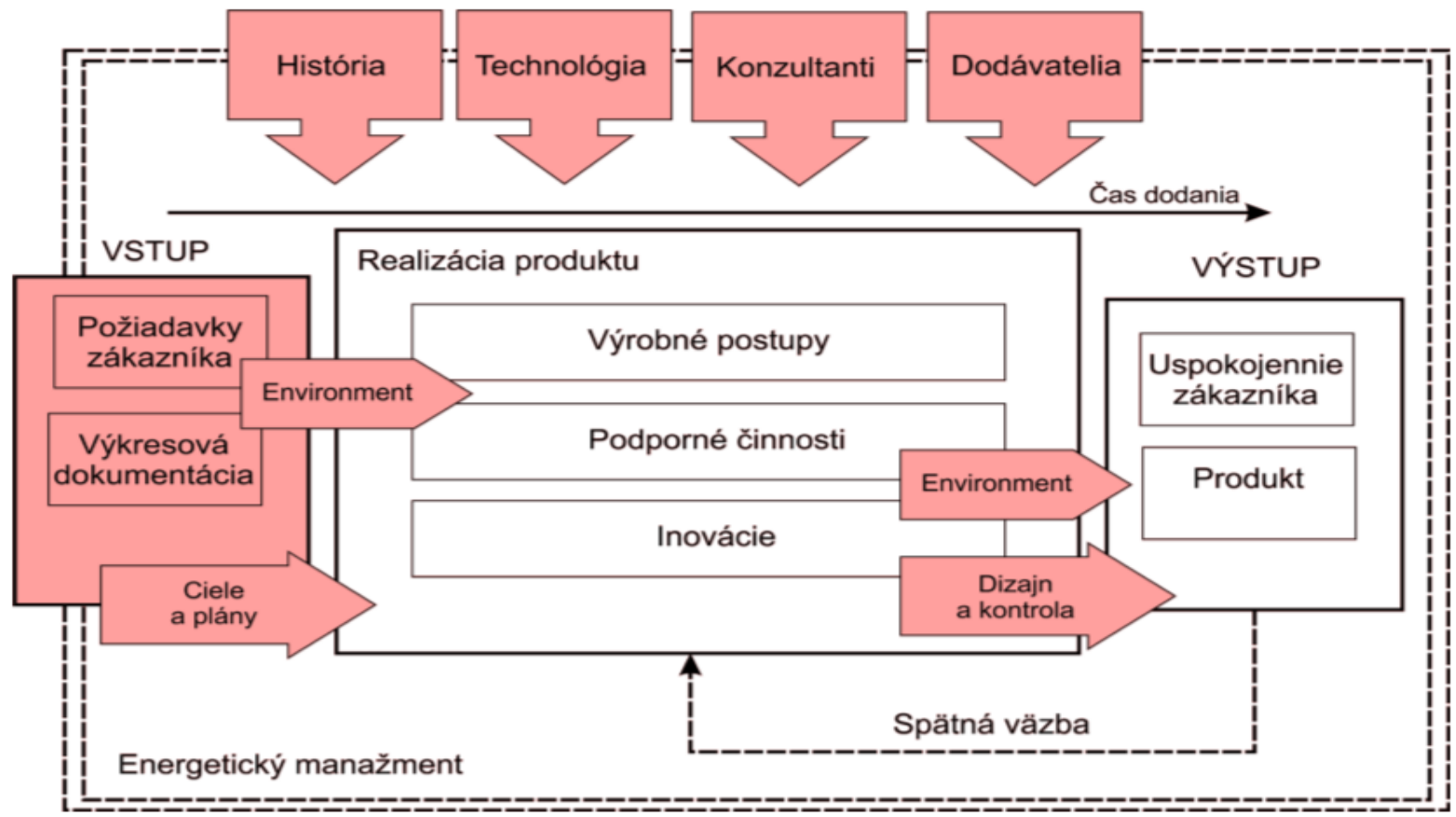

\subsection{Model energetického hospodárstva priemyselnej firmy na báze OZE:}

Podstatnou náležitost'ou zlepšovania inovačného potenciálu vybraných energetických a environmentálnych aspektov OZE v priemysle je podla mienky autorky uvedomenie si faktu, že projektovanie nových a významne úspešnejších firemných energetických modelov riadenia a prevádzkovania produkcie a súvisiaceho energetického hospodárstva je možné iba vtedy, ked' si firmy uvedomia, že ak chcú byt' úspešné a vykazovat' vysokú mieru inovatívnosti a produktivity, tak musia jednoducho skúšat' viac vecí a viac projektov a produktov [9]. Návrh riešenia a opatrení pre tvorbu nového systému energetického hospodárenia firmy sa dá jednoducho zobrazit' formou vlastnej úvahy podl'a obrázku 2 , kde je uvedená schéma, ako sa realizujú v praxi jednotlivé zložky riešenia a kl’účové budúce činnosti pre jej implementáciu vo firme, ktoré d’alej rozoberá tento príspevok. Tento model je v spojení s poznatkami z predchádzajúceho obrázku 1 a podrobnejšie špecifikuje návrh samotného modelu implementácie OZE v podmienkach skúmanej a riešenej vzorovej priemyselnej firmy a zobrazuje celý prístup $\mathrm{k}$ riešeniu problematiky a to rozdelenie činností pri uplatení nového modelu energeticky efektivneho riadenia do jednotlivých zložiek a to: projektová čast', kde sa postavil nový model energetického hospodárstva na báze OZE a zároveň monitoroval súčasný stav hlavných faktorov energetického hospodárstva firmy 
a nadväzne určenie krokov a priorít v rámci výrobno - technologickej zložky a súvisiacej riadiacej a d’alej uvedenej organizačnej zložky vo firme. Samotná tabul'ka 1 popisuje vlastnú analýzu ktorá je spracovaná pri mapovaní súčasného stavu a súvisiacich zistení v prepojení jednotlivých analýz a to konkrétne stavu základného vybavenia firmy, stavu jej energetického hospodárstva a stavu samotného organizačno-technického zabezpečenia.

Obrázok 2: Model riešenia Návrhu riadenia a prevádzkovania produkcie a energetického hospodárstva firmy [autorka]

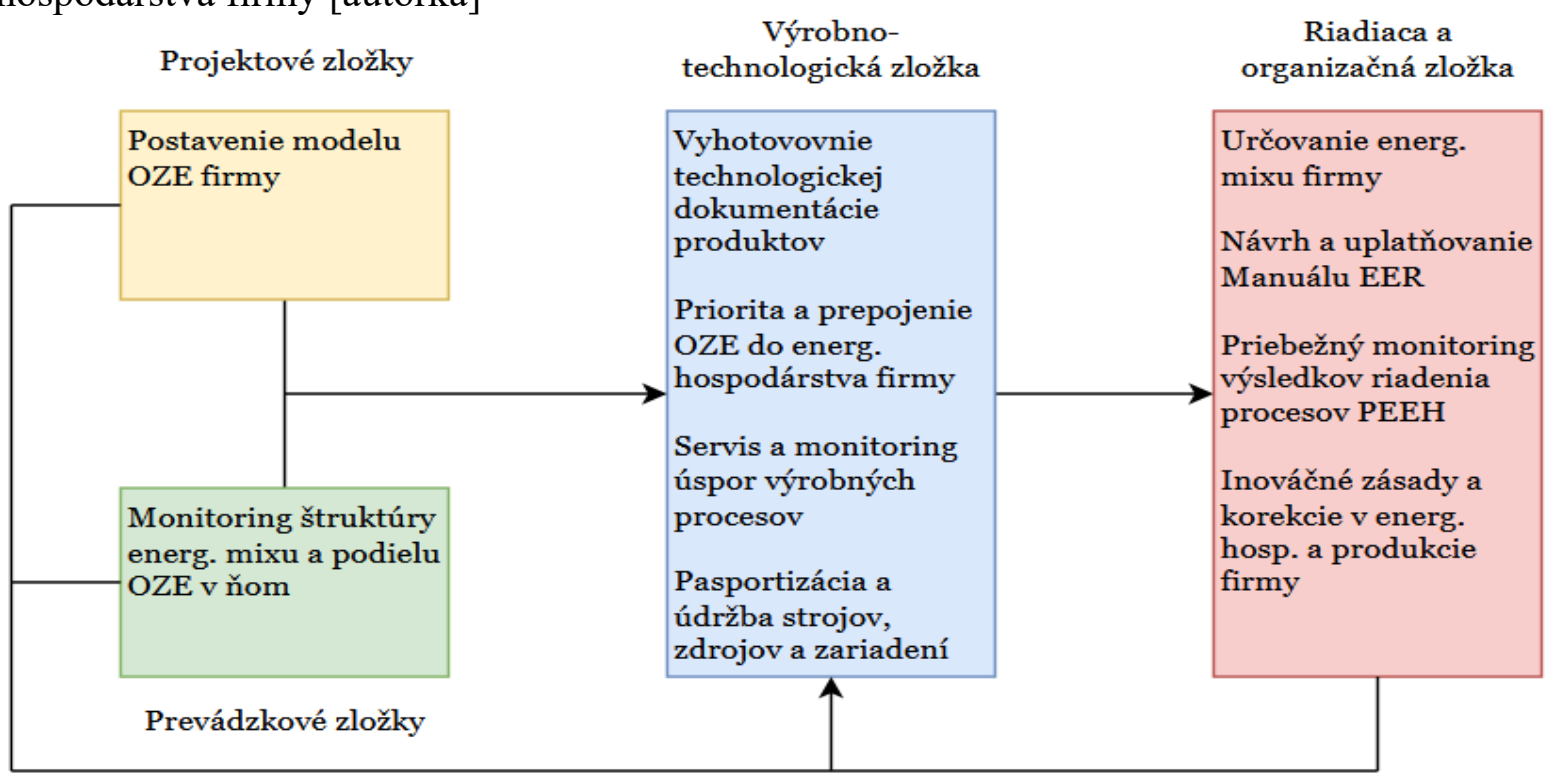

Tabul'ka 1: Príklad analýzy/zistení o súčasnom stave hlavných faktorov energetického hospodárstva firmy [autorka]

\begin{tabular}{|c|c|c|}
\hline ANALÝZY & POPIS SÚČASNÉHO STAVU & ZISTENIA \\
\hline \multirow[t]{2}{*}{$\begin{array}{l}\text { Analýza stavu } \\
\text { základného } \\
\text { vybavenia }\end{array}$} & $\begin{array}{l}\text { 1. Produkcia výrobkov z oblasti v ktorej } \\
\text { firma podnikáa Ročná produkcia firmy. } \\
\text { Obrat a predaj výrobkov a služieb. } \\
\text { 2. Prevádzka prostredníctvom firmou } \\
\text { určených prevádzok - firiem, ktoré } \\
\text { samostatne zabezpečujú príslušný } \\
\text { rozsah výroby a súvisiaceho obchodu } \\
\text { a služieb. Firmy ktoré spolupracujú } \\
\text { alebo sú súčastou firmy a } \\
\text { zaobstarávajú ekonomickú, } \\
\text { administratívnu, personálnu funkciu. } \\
\text { 3. Zázemie firmy, popis interiéru, } \\
\text { budovy a areálu. Popis exteriéru firmy, } \\
\text { poveternostné podmienky, kde a v akej } \\
\text { časti sa firma nachádza (východ, stred, } \\
\text { západ). Zhrnutie napojenia budova } \\
\text { objektov, čo sa týka sietí. Popis činnosti } \\
\text { zamestnancov, externých pracovníkov. } \\
\text { 4. Technologické vybavenie a zároveň } \\
\text { jednotky spotreby energií a elektrické } \\
\text { sušiče výrobkov či v administratívnej } \\
\text { budove alebo výrobných halách }\end{array}$ & $\begin{array}{l}\text { 1. Väčšina firiem je úplne závislá na } \\
\text { dodávkach energií z centrálnych distribučných } \\
\text { zdrojov CZT u ktorých je zrejmé, že sú } \\
\text { v rozhodujúcej miere tvorené konvenčnými } \\
\text { energetickými výrobcami na báze fosílnych } \\
\text { palív, atómovej energie a ropných produktov } \\
\text { a plynov, ktoré zatažujú významne životné } \\
\text { prostredie a navyše ich efektivita, stratovost' } \\
\text { a nejasné vyúčtovania skutočnej spotreby sú } \\
\text { v praxi často otázne. } \\
\text { 2. Súčasne so zmenou primárneho systému } \\
\text { energetického hospodárenia danej firmy } \\
\text { vol'bou nových OZE je potrebné hodnotit' aj } \\
\text { súčasný technický stav zariadení, bez ohladu } \\
\text { na zdroje energií a to riešením } \\
\text { a modernizáciou sekundárnych opatrení ako sú } \\
\text { stavebné úpravy, modernizácia, strojov } \\
\text { a výmena spotrebičov energií a podobne. } 3 . \\
\text { Zváženie nového zateplenia budov a skladov, } \\
\text { opravy striech, výmena vykurovacích jednotiek } \\
\text { a pod. }\end{array}$ \\
\hline & $\begin{array}{l}\text { 1. Popis vykurovania firmy a budov } \\
\text { ktoré sa používajú. } \\
\text { 2. Zabezpečenie elektrickou energiou }\end{array}$ & $\begin{array}{l}\text { 1. Vykurovanie firmy a budov je } \\
\text { zabezpečované prostredníctvom systému CZT } \\
\text { z rozvodov prostredníctvom distribúcie }\end{array}$ \\
\hline
\end{tabular}




\begin{tabular}{|c|c|c|}
\hline $\begin{array}{l}\text { Analýza stavu } \\
\text { energetického } \\
\text { hospodárstva }\end{array}$ & $\begin{array}{l}\text { pre kancelárie, výrobné priestory } \\
\text { a najmä pre strojový a technologický } \\
\text { park je zabezpečené dodávkami } \\
\text { a napojením na distribučnú siet' cez } \\
\text { centrálny pripojovací rozvádzač } \\
\text { inštalovaný vo firme. }\end{array}$ & $\begin{array}{l}\text { správcu areálu, v ktorom je daná firma } \\
\text { dislokovaná. } \\
\text { Vykurovanie je zabezpečené štandardnými } \\
\text { vykurovacími telesami- radiátory, ohrievače, } \\
\text { prietokové ohrievače vody a pod. } \\
\text { 2. Elektrické meranie a rozvádzanie energií je } \\
\text { iba z jedného miesta, bez záložného zdroja } \\
\text { možného prepojenia a bez možnosti } \\
\text { diverzifikácie iných zdrojov elektrickej } \\
\text { energie a tepla v súčasnosti. } \\
\text { 3. Vykurovacie telesá sú povǎčšine zastarané } \\
\text { a v súčasnosti energeticky vel'mi náročné, } \\
\text { s vel'kou zotrvačnost'ou sálania po vypnutí. }\end{array}$ \\
\hline $\begin{array}{l}\text { Analýza stavu } \\
\text { organizačno- } \\
\text { prevádzkového } \\
\text { zabezpečenia }\end{array}$ & $\begin{array}{l}\text { 1. Sledovanie a meranie priebežnej } \\
\text { spotreby energií, vyhodnocovaní } \\
\text { a korekciách ročnej spotreby } \\
\text { technických médií na základe fakturácií } \\
\text { dodávatel'ov tepla a elektrickej energie. } \\
\text { 2. Pomerne pravidelná údržba } \\
\text { jestvujúceho parku strojov a zariadení } \\
\text { pre zabezpečenie pravidelného procesu } \\
\text { výroby bez prestojov. } \\
\text { 3. Formálna evidencia procesov } \\
\text { a produkcie formou zákazkových listov, } \\
\text { interných firemných technologických } \\
\text { postupov s určením základného rozsahu } \\
\text { normohodín spotreby a existencia } \\
\text { ročných, kvartálnych a mesačných } \\
\text { plánov produkcie. }\end{array}$ & $\begin{array}{l}\text { 1. Evidencia a meranie spotreby energií a tepla } \\
\text { sa uskutočňuje iba sprostredkovanie- na } \\
\text { základe fakturácie vonkajším dodávatel’om } \\
\text { energií a zapisovania mesačných spotrieb na } \\
\text { elektromeroch budov } \\
\text { 2. Servis a údržba výrobných zariadení } \\
\text { a strojov sa vykonáva jednak priebežne podl'a } \\
\text { potreby a prípadných havarijných situácií } \\
\text { a porúch a jednak pravidelne, avšak len na } \\
\text { základe rutiny a bez podrobnej hĺbkovej } \\
\text { analýzy skutočnej hodnoty a životnosti strojov. } \\
\text { 3.Technologická príprava a projektovanie } \\
\text { výrobkov a technologických procesov vo } \\
\text { firmách sa z technického aspektu robí } \\
\text { profesionálne, avšak chýbajú analýzy } \\
\text { a vyhodnotenie skutočnej energetickej } \\
\text { náročnosti vytvorenia týchto produktov. }\end{array}$ \\
\hline
\end{tabular}

\section{NÁVRH MODELU IMPLEMENTÁCIE OZE V PRIEMYSELNEJ FIRME}

Na nasledujúcom obrázku 3 je navrhnutý schematicky zobrazený jednoduchý pracovný model implementácie OZE v podmienkach firmy zo segmentu MSP pre riešenie zavedenia konkrétnych návrhov OZE do jej energetického hospodárstva.

Obrázok 3: Model implementácie OZE v podmienkach priemyselnej firmy [autorka]

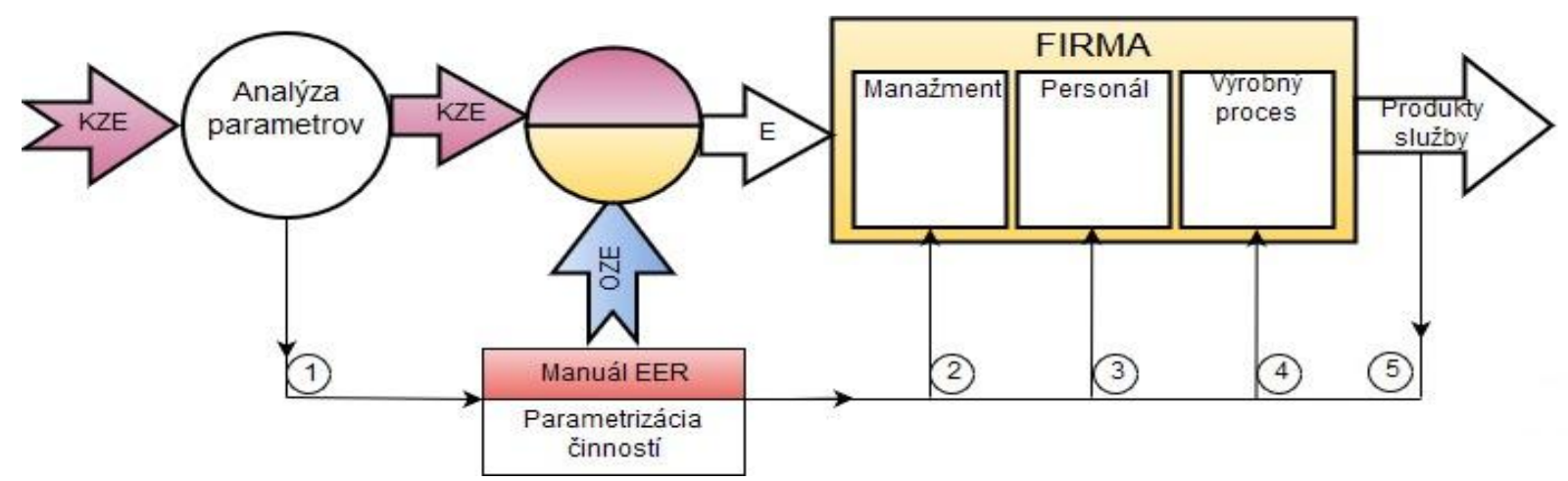

Schéma ukazuje firmu ako systém (obsahujúci činnosti manažmentu, personálu a výrobných procesov), do ktorého vstupuje energia $\mathrm{E}$, ktorá bola pred tým analyzovaná a zhodnotená $\mathrm{v}$ zmene aplikácií pôvodných konvenčných zdrojov energetiky (KZE) na kombináciu OZE s KZE podl'a do budúcna vytváraného účelného firemného energetického mixu. Systémové väzby v schéme : 1, 2, 3, 4, ukazujú proces implementácie zásahov pre zavedenie 
OZE a väzba 5 je spätnou odozvou z realizácie produktov a služieb a ich dopadov na d'alšie informácie a riadenie danej priemyselnej firmy.

\section{NÁVRH MANUÁLU EER}

Energetický manažment firmy spočíva $\mathrm{v}$ stanovení a vyčlenení samostatných riadiacich zásahov a kompetencií $\mathrm{v}$ riadiacich a kontrolných činnostiach, výrobe a prevádzke v rámci internej firemnej organizačnej štruktúry a rozdelenia riadiacich a vykonávacích kompetencií s dôrazom na uplatňovanie autorkou príspevku navrhovaného Manuálu energeticky efektívneho riadenia firmy EER. Navrhnutý a konkrétne definovaný manuál, postavený na uplatnení zásad použitia OZE $\mathrm{v}$ podmienkach danej firmy obsahuje základnú špecifikáciu procesov/činností zovšeobecnených aj pre potreby a podmienky v priemyselných firmách segmentu MSP a sledované vstupy i samostatné, od vstupov závislé konkrétne výstupy a úlohy ktoré navrhujem uskutočňovat' rámcovo pre úspešné energeticky efektívne riadenie manažmentu na báze OZE (tabul'ka 2).

Ide vlastne o prehl'adný návod pre firmu pri riadení jej energetického hospodárstva, ktorý sa dá vnímat' ako samostatný manažérsky riadiaci, rozhodovací, realizačný a kontrolný nástroj, zabezpečujúci najdôležitejšie známe, možné a dostupné zistenia, zásahy a opatrenia ktorými môže firma úspešne zaviest' a uplatňovat' energeticky efektívne a ekologicky bezproblémové a pritom aj vel'mi inovatívne hospodárenie a zásobovanie firmy energiou prostredníctvom OZE. Výhodou tohto manuálu je jeho možnost' spracovania a prepojenia do systému elektronického automatizovaného riadenia a vyhodnocovania $\mathrm{s}$ podporou expertného IT systému v budúcnosti, nakol'ko manuál a jeho segmenty po dostatočnej budúcej dekompozícii prvkov má logicky určený sled jednotlivých prvkov.

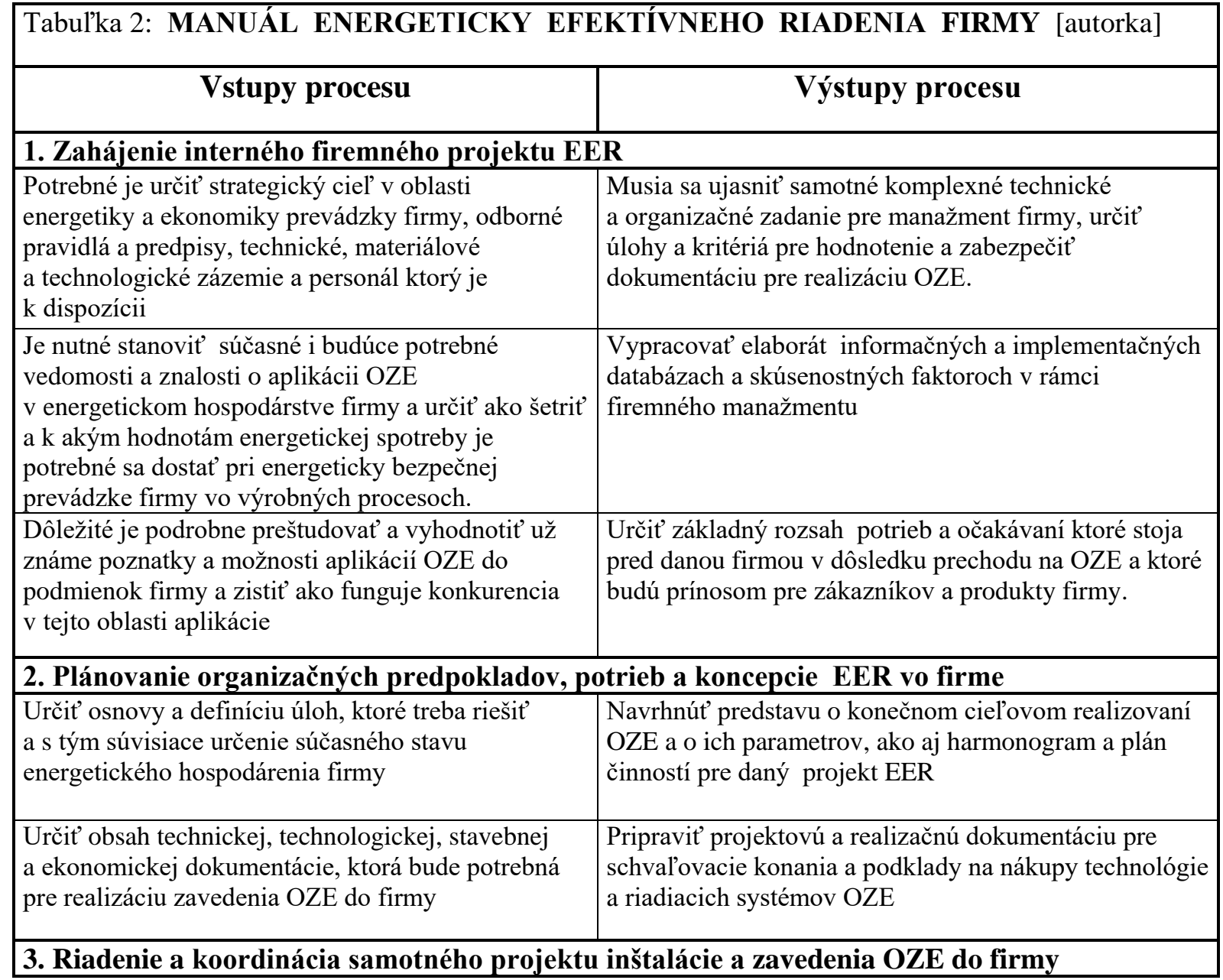


Ide o vstupy o schválení plánu realizácie a kompetencií riadenia projektu ako dokumentu pre manažment, d'alej o popis obsahu a zložiek projektu a spracovanú dokumentáciu schválených zmien, doplnkov, úprav a inovácií
K výstupom sa dá určit’ materiálno-technické a organizačné parametre projektu, požadované a uskutočnené zmeny a opravy, výkon stavebných a montážnych inštalačných prác a porady vedenia firmy o stave realizácie.

\section{Určenie kompetencií a spôsobilosti personálu v prevádzke firmy pri EER}

Vypracovanie Plánu personálneho a organizačného zabezpečenia a kompetencií prevádzkových pracovníkov pri obsluhe a riadení OZE vo firme a tiež určenie rozsahu spôsobilostí a znalostí personálu.

8. Určenie firemnej organizačnej a technickej kultúry vo firme a vypracovanie firemnej metodiky a interných prevádzkových a ekonomických i bezpečnostných predpisov a smerníc
Je nutné mat' rozpis funkcií a náplní prác pre jednotlivých členov personálu v EER a požiadaviek na kvalifikačné náležitosti personálu.

8. Úprava a aktualizácia i doplnenie predpisov a smerníc firmy pre obsluhu a aplikáciu OZE

\section{Koordinácia projektového riadiaceho tímu pre zavedenie a realizáciu EER}

\begin{tabular}{|l|l|}
\hline $\begin{array}{l}\text { Musí sa vyhotovit' Plán realizácie a vykonávania } \\
\text { projektu osadenia OZE, spracovat' všetky } \\
\text { požadované predpisy a prevádzkové normy a určit' } \\
\text { organizačné zabezpečenia personálu dodávatel'ov } \\
\text { a vlastnej firmy pri realizácii }\end{array}$ & $\begin{array}{l}\text { Napísanie hotových správ o riešení technologických } \\
\text { a technických úprav a inštalácií OZE v prevádzke firmy }\end{array}$ \\
\hline $\begin{array}{l}\text { Takisto sa sleduje stav a overovanie výsledkov } \\
\text { prípadných opráv a budúcich čiastkových výstupov } \\
\text { priemyselnej produkcie firmy v zmenených } \\
\text { podmienkach. }\end{array}$ & $\begin{array}{l}\text { Presne sa definujú a sledujú motivačné a stimulačné } \\
\text { kritériá členov tímu }\end{array}$ \\
\hline
\end{tabular}

\section{Rozvíjanie činností manažmentu}

Úlohou je poverenie k uskutočneniu prípravných, realizačných a prevádzkových zásahov a prác pri inštalácii OZE a kreovanie prevádzkového a riadiaceho interného tímu, ako aj Plán obsadzovania pozícií projektového riadenia externými konzultantmi podl'a potreby Súčast'ou sú požiadavky na prevádzkové financovanie činnosti tímu a vlastného motivačného a odmeňovacieho systému firmy

Výstupom je Hodnotenie výkonnosti riešitel'ského projektového tímu, ako aj zápisnice z výsledkov priebežného hodnotenia spokojnosti manažmentu a personálu firmy

Súčast'ou musí byt' i samotné Hodnotenie výkonnosti a profesionálnych výstupov práce jednotlivcov tímu v EER

\section{Výber dodávatel’ov technológií a servisných služieb implementácie OZE do prevádzky firmy}

Tu sa určuje zoznam a mapovanie kvalifikovaných $\quad$ Výsledkom je vždy výber a vyhodnotenie dodávatel'ov, dodávatel'ov pre OZE, obstarávacia dokumentácia, rozpis úloh a termínov plnenia a zmluva o dodávke, ako špecifikácia konkrétnych požiadaviek a zmluvných podmienok pre dodávatel'a vrátane inštalačných a servisných prác, ako aj súvisiace garancie. Tiež je dôležité mat' firemné nákupné pravidlá, postupy a požiadavky. aj riadenie samotnej inštalácie OZE vrátane stavebných sprievodných prác, garancií a zácviku personálu firmy. Sleduje sa aj definícia predmetu a nárokov na energie / spotrebu a ekologické dopady v reálnom prostredí inštalácie.

\section{Informácie o zásahoch do riadenia a povinnostiach organizačných zložiek firmy}

\begin{tabular}{l|l} 
Sem patrí Plán riadenia firemnej komunikácie, & Výstupom má byt’ súpis prípadných požiadaviek na
\end{tabular} určenie zodpovedajúcej organizačnej štruktúry a zmenu v súbore firemných procesov a kompetenčné opatrení pre firmu a jej manažment s presným popisom náplne práce pre každého pracovníka. úpravy v organizačnej štruktúre firmy

Takisto sa vypracujú Súhrnné správy o stave vytvorenia a implementácie projektu
Dôležité sú pre dôsledné komunikovanie firmy so zákazníkmi aj Podklady a hodnotenia pre zákazníkov s uvedením pozitív, prečo sú výrobky firmy dobré v závislosti na zavedení OZE do EER firmy. 


\begin{tabular}{|l|l|}
\hline 9. Monitoring a kontrola \\
\hline $\begin{array}{l}\text { Táto činnost' sa týka hlavne schválených výstupov } \\
\text { projektu inštalácie a zavedenia OZE do EER } \\
\text { firmy, ako aj meraní a priebežných kontrol } \\
\text { budovania celého OZE a dodávatel'ských } \\
\text { inštalačných a servisných vzt'ahov }\end{array}$ & $\begin{array}{l}\text { Firma musí zabezpečit' schválené a odmietnuté zmeny, } \\
\text { nápravné zásahy a preventívne riadiace akcie a opravy } \\
\text { podl'a potreby a neustále kontrolovat' a aktualizovat' celý } \\
\text { systém a odporúčat' inovatívne zásahy. }\end{array}$ \\
\hline $\begin{array}{l}\text { Dôležité je navrhnút' podl'a potreby a uskutočnit' } \\
\text { operatívne zmeny, zásahy a opravy systému } \\
\text { a sledovat' hlásenia o príprave a spustení do } \\
\text { prevádzky. }\end{array}$ & $\begin{array}{l}\text { Tiež treba predkladat' Monitorizačné správy pre } \\
\text { objektívne sledovanie celého procesu zavádzania OZE do } \\
\text { priemyselnej produkcie a prevádzky firmy. }\end{array}$ \\
\hline $\mathbf{1 0 .}$ Ukončenie a vyhodnotenie projektu EER firmy \\
\hline $\begin{array}{l}\text { Musí sa spracovat' projekt skutočného } \\
\text { vyhotovenia a vydat' príslušné interné prevádzkové } \\
\text { predpisy, skontrolovat' či dosiahnuté inštalácie } \\
\text { zariadení OZE sú v súlade s projektom a funkčné. }\end{array}$ & $\begin{array}{l}\text { Tu je treba mat' schválený energetický firemný passport } \\
\text { firmy pre výsledný produkt, a jeho výsledky } \\
\text { v podmienkach aplikácie OZE a uskutočnit' vyúčtovanie } \\
\text { a finančné vyrovnanie inštalácie. }\end{array}$ \\
\hline $\begin{array}{l}\text { Potrebné je vytvorit' zoznam priebežne } \\
\text { doporučených zlepśení a súhrnnú technickú správu } \\
\text { a výsledky meraní zo zahájenia činnosti OZE vo } \\
\text { firme. }\end{array}$ & $\begin{array}{l}\text { Vyúčctovanie celého projektu a vystavenie fakturácie a na } \\
\text { záver urobit' administratívne uzatvorenie a publikovanie } \\
\text { zovšeobecňujúcich poznatkov pre potreby interného } \\
\text { personálu a aj pre odbornú verejnost'. }\end{array}$ \\
\hline $\begin{array}{l}\text { Vhodné je mat' odborné a teoretické vyhodnotenia } \\
\text { z inštalovanej aplikácie OZE a jej EER pre } \\
\text { použitie u iných firiem MSP v tejto oblasti }\end{array}$ & \multicolumn{2}{|l}{} \\
\hline
\end{tabular}

\section{ZHRNUTIE PROBLEMATIKY}

Podstatnou náležitost'ou chápania celého riešenia implementácie OZE do energetického hospodárenia firmy však je uvedomenie si dôležitého faktu, že vzhl'adom k charakteristikám a možným dosiahnutel'ným parametrom OZE v praxi nie je reálne možné navrhnút' energeticky bezpečný a spol’ahlivý systém bez primeraného a najmä stabilného podielu aplikácie vonkajších energetických zdrojov na báze KZE, čo znamená pre firmu na jednej strane vylúčenia aplikácie centrálneho zásobovania teplom CZT a riešenie vykurovania a prípravy teplej úžitkovej vody (TUV) výlučne na báze prípravy prostredníctvom elektrickej energie, avšak zároveň bude potrebné zabezpečit' nad’alej pravidelnú dodávku elektrickej energie z externého zdroja prostredníctvom dodávok distribučných elektrifikačných sietí [6,7]. Publikovaný konferenčný príspevok sa stáva súčast'ou výsledkov mojej práce v rámci doktorandského štúdia na TUKE v Košiciach a zároveň aj riešenia grantového projektu riešitel'a - Národný energetický klaster NEK s označením: NFP313020ANX5, financovaného z prostriedkov EŠIF Ministerstvom hospodárstva SR pod názvom: „Koncipovanie a rozvoj integrovanej inovačnej infraštruktúry a vedomostnej bázy v európskom priestore klastrovej organizácie NEK“, výskumnej úlohy č. 1.1: „Tvorba spoločnej expertnej databázy a analýza energetického a environmentálneho prostredia v EÚ, SR a krajinách V4“ a súvisí s činnostou II.2 projektu: Produktový ekodizajn nových energetických a ekologických investičných projektov.

\section{Použitá literatúra}

1. BURNETT, Ken. Klíčoví zákazníci a péče o ně. Brno: CP Books. 2005 ISBN 807226-655-1.

2. COLLINS, Jim.,PORRAS, Jery. Jak vybudovat trvale úspěšnou firmu. (BUILT to Last). Praha: Grada Publishing. 2016. ISBN 978-80-271-5638-7.

3. DEVALL, Brain., SESSIONS, Gabriel. Hlboká ekológia. Tulčík: ABIES,1997. zborník. 
4. JARÁBEK, Miroslav, LUNKIN, Valerij. Energetická politika SR po Predsedníctve rady EÚ,MH SR, Nitra :Zborník Energofutura 2017. ISBN 978-80-972637-0-6.

5. JANKOVSKÝ, Július. Porovnanie CZT a individuálneho zásobovania teplom $z$ pohl'adu účinkov na životné prostredie. Apertis/ASPEK, Nitra: Zborník Energofutura 2017. ISBN 978-80-972637-0-6.

6. Národný energetický klaster NEK. Expertná báza a stratégia priemyselného klastrovania v energetike a ekológii na Slovensku. Účelová publikácia. Bratislava: MH SR. 2017.

7. NOVOTNÝ, Tomáš. ENERGOFUTURA Stratégia a budúcnost' energetického a environmentálneho prostredia. Bratislava: MH SR a NEK. 2017. Účelová tematická publikácia. ISBN 978-80-972567-4-6.

8. SIEA - Slovenská inovačná a energetická agentúra: Energetický slovník [on-line], Dostupné na internete: https://www.siea.sk/bezplatne-poradenstvo/kamaratka-ener gia/nauc-sa/energeticky-slovnik/.

9. SVOZILOVÁ, Alena. Projektový management. 2. aktualizované. a doplnené vydanie. Praha:Grada. Expert (Grada).2011 ISBN 978-80-247-3611-2.

10. TAUŠ, Peter; RYBÁR, Radim; KUDELAS, Dušan; KUZEVIČ, Štefan; DOMARACKÝ, Dušan. Potenciál obnovitel'ných zdrojov energie na Slovensku z hladiska výroby elektrickej energie. Bratislava: In: AT and P Journal. Roč. 12, č. 3 (2005, s. 52-55). 2005. ISSN 1335-2237 Dostupné na: http://www.atpjournal.sk/cas op isy/atp_05/pdf/atp-2005-03-52.pdf.

11. TIDD, Joe; BESSANT, John; PAVITH, Keit. Řizení inovací. Zavádění technologických, tržních a organizačních změn. Brno: Computer Press. 2007. ISBN 978-80-251-1466-7.

12. TOKARČÍK, Alexander., PAVOLOVÁ, Henrieta. Energetický manažment vo výrobných priestoroch. Zborník prezentácií a úspešných riešení inovačních projektov, medzinárodná konferencia Energofutura, Vydal: Bratislava: NEK. 2019. ISBN 97880-972637-3-7.

\section{Kontaktné údaje}

Ing. Bc. Simona Novotná

Ústav zemských zdrojov, Fakulta BERG, Technická univerzita v Košiciach

Komenského park 26, 04001 Košice

v spolupráci s Národný energetický klaster NEK, Bratislava

Slovenská republika

Tel: 00421911437686

email: snovotna17@gmail.com 


\title{
APPLYING OF VIBRODIAGNOSTIC METHODS ON WATERPUMP'S KEY DEVICES AND EVALUATION SUITABILITY OF THIS METHOD FOR MAINTENANCE REENGINEERING OF THE OFFSET PRINTING MACHINE
}

\author{
Kristýna Kutiová, Michal Podstawka
}

\begin{abstract}
This publication focuses on vibrodiagnostic testing of electromotors and waterpumps and evaluating of this method for using it as a part of maintenance reengineering of offset printing machine. Ten electric motors and water pumps were tested in total and each test was done at least two times in the interval of a minimum at two months. Based on the results applicable intervence were recommended. This method was found as suitable also for reengineering the maintenance of the offset printing machine.
\end{abstract}

Key words: offset printing machine, vibrodiagnostics, maintenance reengineering

\section{OFFSET PRINTING MACHINE}

Offset printing machines are usually used for indirect printing method - colour is printed from printing plate to rubber-coated cylinder and from this cylinder is printed to the paper. Therefore, the colour is transferred twice. Unlike letterpress, these machines allow printing of fine details even on paper of lower quality or cardboard. It is possible due to rubber roller which can adhere to an unsmooth surface.

These machines are usually used in printing companies focuses to printing fee stamps, books and magazines, calendars, but also cardboards and boxes.

Principle of the printing is based on different physical-chemical properties of printing plate surronding the plate cylinder. Printing plate is basically alluminium plate on which are applied two layers with different properties. Colour is hydrophobic liquid that does not mix with water or alcohols. The top layer is hydrophobic and is unweakened, ie. that it repel water, but accept greasy colour. Applying a print pattern damage hydrophobic surface where it will not print. This creates a bottom layer that is weakened and becomes hydrophobic.It takes a solution that prevents the greasy paint from sticking to this surface. The surface is undisturbed where it is to be printed.

Surface weaking is done by film's lightening or by laser burning. Printing plate passes through a developer that washes out the disturbed printing hydrophobic layer from future nonprinting areas.

Subseuently, the printing plate is tighten by pneumatic jaws onto the forming cylinder. As this cylinder rolls, four colour cylinders and one dampering cylinder with solution roll on it. Cylinder and printing plate also contact rubber transfer cylinder, to which the colour adheres to the paper or other printed surface with each revolution. [1]

\section{WATER PUMPS}

Offset printing machines use centrifugal water pumps to transport dampening solution to the printing form, which consists of an electric motor and pumps.

The pump pumps a dampening solution (mixture of water and alcohol) from the device called Technotrans. The solution is pumped into the tanks of the printing tower where the printing form is moistened. A chemical reaction occurs, in which the bottom layer, described in 
chapter 1, is disrupted. Same process is used for moisturing in each printing tower - each tower print one color.

A centrifugal pump is used in the printing machine where maintenance reengineering is going to be done. This pump cosists of an impeller with blades that rotate in a spiral chamber and an electric motor. Fluid inlet is at the axis of the rotor, the outlet is at it's circumference.

The reason why the maintenance reengineering also applies to pumps is their frequent failure rate. The most common defects include cracked spiral chamber, which results in foaming of the liquid. Due to foamed liquid, the $\mathrm{pH}$ values of the water-alcohol solution is affected. $\mathrm{PH}$ and alcohol meters show values unsuitable for the operation of the machine. Another common defect is unbalanced motor shafts as well as bearing defects.

\section{VIBRODIAGNOSTICS}

Vibrodiagnostics is one of the methods of technical diagnostics. It is used in rotary machines such as electric motors, pumps, turbines, compressors, fans, etc. Vibrations, which can be caused by bearing damage, shaft misalignment, imbalace of rotating parts, damaged gears, rotor seizing, poor bearing lubrication etc., provides us information about the technical operating condition of the inspected equipment.

The aim of the vibrodiagnostics is to find the technical condition of the devices or to locate the place of excitation vibrations. This method helps us to plant the shutdown of the machine for maintenance and also to order the necessary parts in time. We can reduce the necessary preventive inspections and prevent unexpected accidents at the same time. [2] [3]

\subsection{Quantities and Evaluation}

The basic quantities for the evaluation of vibrations are based on the basic parameters of mechanical vibration, which is periodic and has a sinusoidal character. These are instaneous deflection, speed and accleration. The time signal is also important, from which we focus on peak, peak-peak, average and effective value.

A fast Fourier transform is used for evaluation, which looks for repetitive events in the vibrational signal, which appear in the frequency spectrum below a certain frequency. The frequency spectrum of a time signal consists of a number of sinusoidal signals with amplitude and initial phase. This is impotant for detecting the technical condition of the device. However, it is difficult to determine the individual components of the original time signal. For this reason, the use of a frequency spectrum is more advantageous.

The most dominant signal that can be observed at the speed is the harmonic signal - a manifestation of imbalance. The imbalance is caused by the weight of the imbalance and is thus manifested by the centrifugal force 1 time per revolution.

The second signal manifested in the freuency spectrum is usually caused by misalignment or defects in the bearings. There you can see higher number of vibration pulses, which are caused by the passage of the rolling elements thru bearing defects. There are formulas for calculating the failure frequencies of the bearing, thanks to which we can determine whether it is an inner or outer ring, a cage or a rolling element. These frequencies are often listed in the bearing catalog.

The third signal is then the tooth frequency, where the damage to the gear teeth manifests itself. We find this frequency by multiplying the rotational frequency of the shaft with the number of gear teeth on the same shaft.

A trend is then created from the measured values. By comparing all measured values, or comparing them with a normal value excluded from the relevant standard, we get information about the technical condition of the machinery and we can begin to consider what caused the higher measured values of vibration. To obtain reliable results, it is necessary to repeat the measurement regularly and compare it with the previous trend. However, it is necessary to 
ensure that the measurement always takes place under the same conditions: measure at the same speed, at the same load, the vibration sensor must be located in the same place.

The most common monitored values include vibrations, acceleration and temperature. The development of the measured values can then be monitored thanks to the created bath curve.

If the development deteriorates, it can be stated that the device reaches the last stage of its service life, and if it does not intervene in time, it may fail. [2] [3]

The ČSN ISO $10816-7$ standard states recommended values of vibrations in the $10-1000 \mathrm{~Hz}$ band. Limits of vibrations bands on non-rotating parts of pumps with power over $1 \mathrm{~kW}$. They can be used for impellers with the number of blades $\mathrm{zl} \geq 3$. The measured value is the effective value of the vibrations speed $v_{R M S}[\mathrm{~mm} / \mathrm{s}]$. The values are given below in table 1 .

Recommended values for vibrations acceleration in the band $500-2500 \mathrm{~Hz}$ are given in table 2. [4] [5] [6]

Table 1: reccomended values of vibrations in the band $10-1000 \mathrm{~Hz}$

\begin{tabular}{|c|c|}
\hline $\mathbf{1 0}-\mathbf{1 0 0 0} \mathbf{~ H z}$ & $\mathbf{v}_{\mathbf{R M S}}$ \\
\hline band interface & effective value of vibration $[\mathbf{m m} / \mathbf{s}]$ \\
\hline $\mathbf{A} / \mathbf{B}$ & 2,5 \\
\hline $\mathbf{B} / \mathbf{C}$ & 4 \\
\hline $\mathbf{C} / \mathbf{D}$ & 6,6 \\
\hline
\end{tabular}

Table 2: reccomended values of vibration acceleration in the band $500-2500 \mathrm{~Hz}$

\begin{tabular}{|c|c|}
\hline $\mathbf{5 0 0}-\mathbf{2 5 6 0 0 ~} \mathbf{~ H z}$ & $\mathbf{a}_{\mathrm{RMS}}$ \\
\hline band interface & effective value of vibration acceleration $[\mathbf{g}]$ \\
\hline A/B & 0,5 \\
\hline B/C & 2 \\
\hline C/D & 4 \\
\hline
\end{tabular}

\subsection{Selection of suitable measuring points}

The measurement results must show the true vibration amplitude as best as possible. We place vibration sensors in the cleaned places as close as possible to the bearings and basically in three directions: horizontal, vertical and axial direction. The greatest vibrations are in the horizontal direction (the motor is the most flexible in this direction), in the axial direction the vibrations are usually the smallest (they are manifestation of misalignment or bent shafts). [7] Measurements are never performed on the covers, but directly on the structure that is in direct contact with the bearing to prevent signal distortion. Safety is also important, so the sensors are never placed where we could come into contact with the rotating part of the machine. In order to prevent damage to the sensor by a large pressing force, it is first applied at an angle and then the entire surface, as the vibration sensor is magnetic.

If we perform measurements on non-magnetic materials, it is necessary to insert a suitable measuring pad, which is glued to the structure with a special glue. 
Figure 1 shows the motor with arrows, which show us suitable places to achieve accurate results.

RED: $\quad$ AMOT L1 radial vertical direction

AMOT L2 radial vertical direcion

YELLOW: $\quad$ AMOT L1 radial angle $45^{\circ}$ for orientation round

AMOT L 2 radial angle $45^{\circ}$ for orientation round

BLUE: $\quad$ AMOT L1 radial horizontal direction

GREY: $\quad$ AMOT L1 axial direction

AMOT L2 axial direction

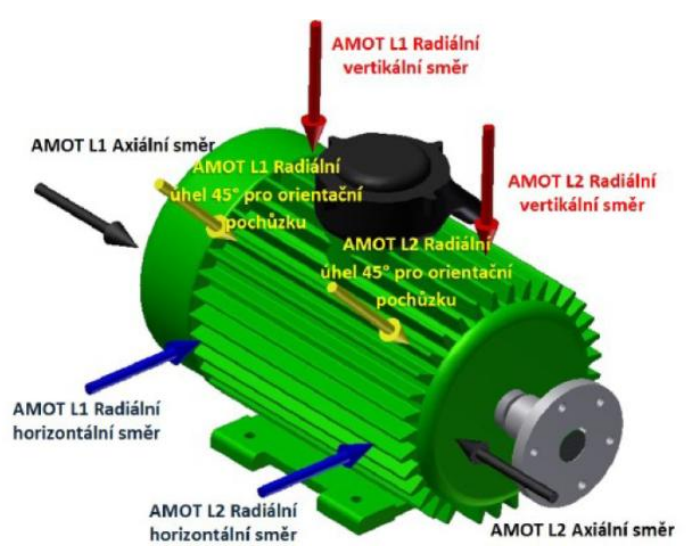

Figure 1: possibility of placing sensors on the motor [2]

\section{PUMP MEASUREMENTS AND RESULTS}

The A440 - VA4 vibrations analyzer from ADASH was used for measurement.

At GWK (Heating and Cooling Technology) company, measurements were performed on an electric motors with a pump with the parameters listed in relevant table. The measurement was performer on a total of ten electric motors with pumps. The measurements were performer on motors marked with numbers 3, 6, 35, 37, 39, 21, 23, 25, 29 and 31.

The measurement of each electric motor with pump was always performed at least twice with an interval of at least 2 months and all electric motors with pumps worked with load during the measurement.

If the first measurement did not reveal any deteriorated or unacceptable values, it was decided to monitor the condition and repeat the measurement. The purpose of this second measurement was to verify whether the electric motor with the pump still remained in a satisfactory condition or whether there was any deterioration.

Due to the shortening of the article, I will not list here tables with electric motors, which had both measurements in terms of values in order, and so were marked as satisfactory. These are electric motors with pumps with numebrs 3, 6, 35, 39, 21, 25, 29 and 31.

\subsection{Mesuring of electric motor and pump \#37}

Table 3: electric motor and pump \#37

\begin{tabular}{|c|c|}
\hline \multicolumn{2}{|c|}{ electric motor } \\
\hline brand & KSB Aktiengesellschaft \\
\hline power & $15 \mathrm{~kW}$ \\
\hline rpm & $2940 \mathrm{~min}-1$ \\
\hline
\end{tabular}




\begin{tabular}{|c|c|} 
mass & $84 \mathrm{~kg}$ \\
\hline & pump \\
\hline & missing parameters - illegible pump label
\end{tabular}

The measurement was first performer on an electric motor at L1 and L2, then the pump was measured at L3. A three-axis vibration sensor was used at all three measuring points. The location of the sensors can be seen in figure 2 .
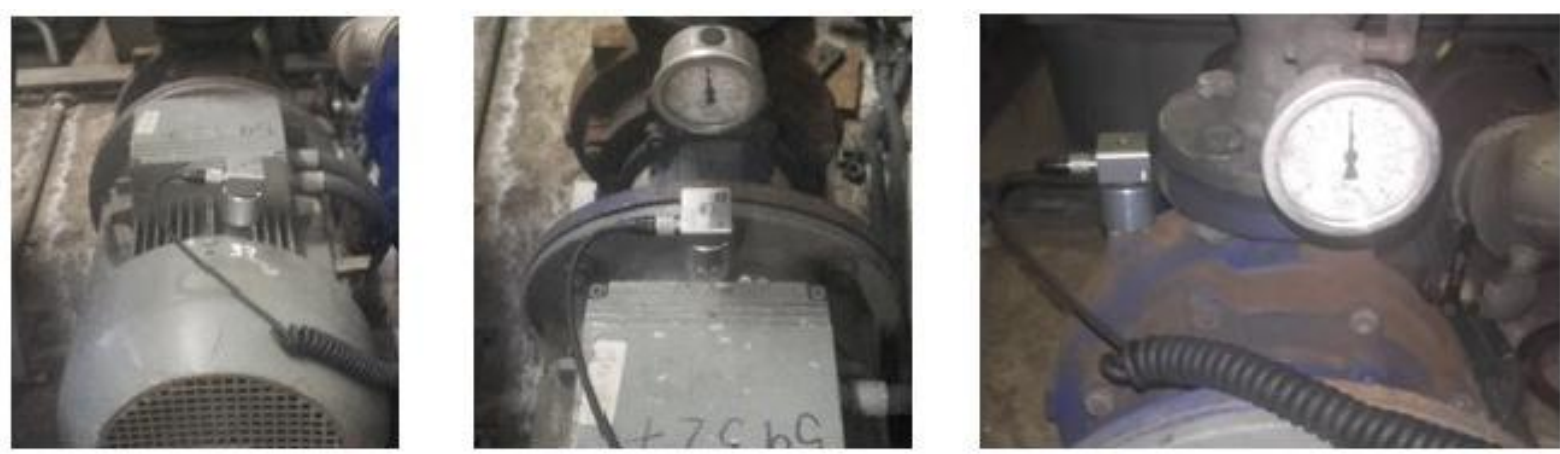

Figure 2: measuring points on electric motor and pum \#37, L1 (left), L2 (middle), L3 (right)

[8]

The measurement of electric motor \#37 was also performed twice in total. Table 3 does not show the parameters of the pump, as the label was damaged and not legible.

The results of the measurements are written in table 4 . The values in the table from measuring points L1, L2 and L3 are color-coded according to the values given in the standard C CN ISO 10316 according to tables 1 and 2 in the previous chapter.

From Table 4 we can see that at the measuring point L1 in the vertical direction there is an increased value of vibrations, which lies in the zone $\mathrm{C}$. This band informs that the vibrations are unsatisfactory for continuous and long-term operation. Below the table is therefore figure 3 , which is the frequency spectrum to determine the reason for increased vibration. Other measured values are satisfactory. As the measured values of the vibration acceleration are low, there is no need to replace the bearings.

From the frequency spectrum in fig. 3, a high peak is visible at the speed frequency $(49.5 \mathrm{~Hz})$ and at the second multiple of the mains frequency $(100 \mathrm{~Hz})$. The reason for the increased value is an imbalance, which can cause damage to the bearings, and side effect is excessive noise. A high peak of $5.71 \mathrm{~mm} / \mathrm{s}$ at twice the mains frequency indicates an asymmetry of the electromagnetic field.

Table 4: measured values on an electric motor with pump \#37

\begin{tabular}{|c|c|c|c|c|c|c|c|}
\hline \multicolumn{8}{|c|}{$\begin{array}{l}\text { table of effective values of vibration speed in the band } 10-1000 \mathrm{~Hz}\left(\mathrm{v}_{\mathrm{RMS}}\right) \text { and } \\
\text { effective values of vibrations acceleration in the band od } 500-25600 \mathrm{~Hz}\left(\mathrm{a}_{\mathrm{RMS}}\right)\end{array}$} \\
\hline \multirow{2}{*}{ quantity } & \multirow{2}{*}{ direction } & \multicolumn{3}{|c|}{ MEASUREMENT 1} & \multicolumn{3}{|c|}{ MEASUREMENT 2} \\
\hline & & L1 & L2 & L3 & L1 & L2 & $\mathbf{L 3}$ \\
\hline \multirow{3}{*}{$\mathbf{V}_{\mathbf{R M S}}$} & horizontal & 2,7 & 2,13 & 2,7 & 5 & 3 & 3,1 \\
\hline & vertical & 5,4 & 3,1 & 3 & 4,4 & 2,5 & 2,7 \\
\hline & axial & 3 & 0,72 & 0,9 & 5,1 & 3,1 & 3,2 \\
\hline \multirow{2}{*}{$\mathbf{a}_{\mathrm{RMS}}$} & horizontal & 0,31 & 0,28 & 0,44 & 0,02 & 0,08 & 0,28 \\
\hline & vertical & 0,13 & 0,29 & 0,43 & 0,04 & 0,08 & 0,24 \\
\hline
\end{tabular}


The second measurement was performed after three months. The purpose of the measurement was to determine whether the increased values at the measuring point L1 in the vertical direction reached the $\mathrm{D}$ band and whether they were not transferred to the other measuring points as well. The increased values have been measured in all directions, but still in the $\mathrm{C}$ band. Unsatisfactory vibrations in terms of long-term operation need to be investigated and appropriate measures taken to reduce the vibrations. The vibration acceleration values were still low, so there was no need to replace the bearings. Below, fig. 4 shows the spectrum of the speed L1 in the axial direction, where the values were the highest.

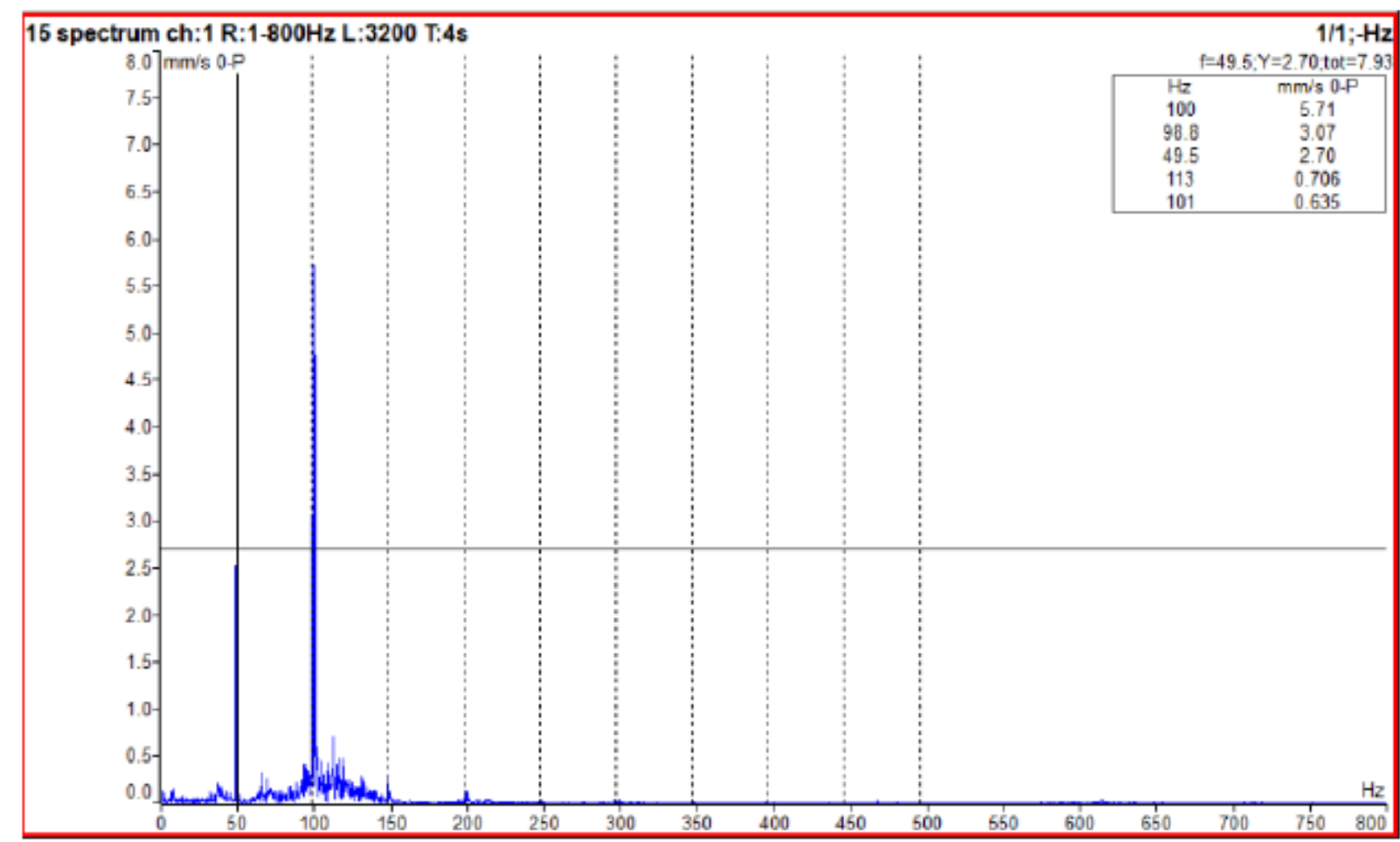

Figure 3: Speed spectrum for electric motor \#37, L1 - $2940 \mathrm{rpm}$, vertical direction, 1st measuring [8]

The frequency spectrum shows similar values as in the first measurement. There is a high peak at the speed frequency $(49.5 \mathrm{~Hz})$ and at the second multiple of the mains frequency $(100$ $\mathrm{Hz}$ ). The reason for the increased value of vibrations at speed is the imbalance. A high peak of $6.00 \mathrm{~mm} / \mathrm{s}$ at twice the mains frequency indicates an asymmetry of the electromagnetic field. It is recommended to disassemble the motor and examine the motor winding during the next shutdown. 


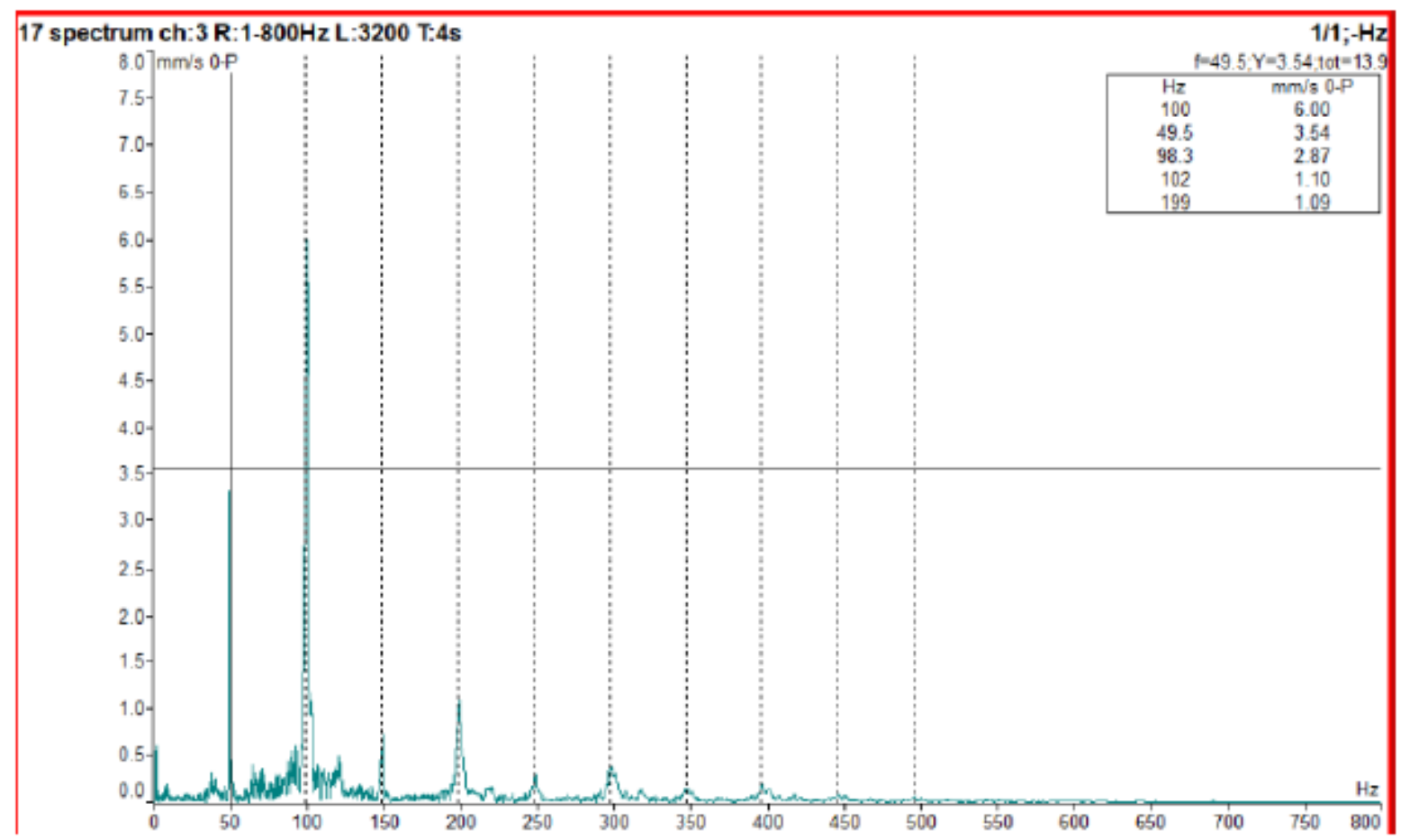

Figure 4: Speed spectrum for electric motor \#37, L1 - 2940 vertical direction, 2nd measuring

[8]

\subsection{Mesuring of Electric Motor and Pump \#23}

Table 5: electric motor and pump \#23

\begin{tabular}{|c|c|}
\hline \multicolumn{2}{|c|}{ electric motor } \\
\hline brand & SIEMENS \\
\hline power & $15 \mathrm{~kW}$ \\
\hline rpm & $2940 \mathrm{~min}-1$ \\
\hline mass & pump \\
\hline & KSB Aktiengesellschaft 67227 Frankenthal \\
\hline brand & $75 \mathrm{~m} 3 / \mathrm{h}$ \\
\hline flow & $42 \mathrm{~m}$ \\
\hline height & $50 \mathrm{~mm}$ \\
\hline nominal diameter of the discharge port & $200 \mathrm{~mm}$ \\
\hline nominal impeller diameter &
\end{tabular}

The first measurement took place on an electric motor at L1, the second at L2 and the third was measured at the pump at L3, the location of the sensors is shown in fig. 5. The parameters of the measured electric motor and pump are given in table 5. The measured values are given in table 6.

From the table of measured values it is evident that after the first measurement the condition of the motor and the pump was satisfactory. Thus, low vibration acceleration values do not indicate that the bearings need to be replaced. The purpose of the second measurement after almost four months was to determine whether the condition had not changed. 

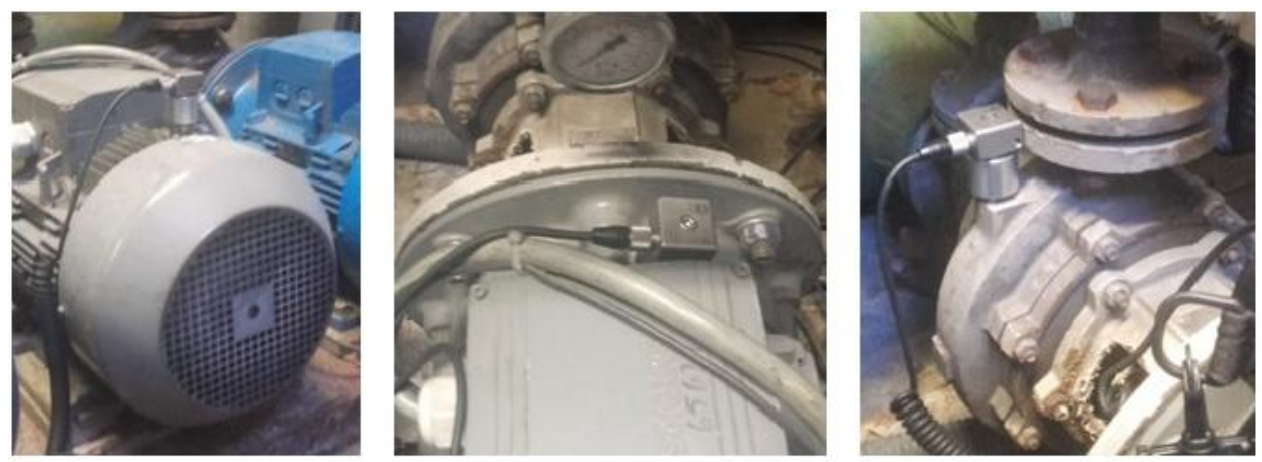

Figure 5: measuring points on the electric motor and pump \#23, L1 (left), L2 (middle), L3 (right) [8]

It is evident that the overall condition worsened in all three measured places, but mostly in the $\mathrm{L} 1$ area, where the vibration values are in the $\mathrm{C}$ band. Again, it is important to find out what is the cause of the increase in vibration and take the necessary measures.

The frequency spectrum in fig. 6 shows a high peak at the speed frequency $(49.5 \mathrm{~Hz})$ and at the second multiple of the mains frequency $(100 \mathrm{~Hz})$. The increased value of vibrations $(5.82$ $\mathrm{mm} / \mathrm{s}$ ) at the speed is caused by imbalance. A high peak of $1.88 \mathrm{~mm} / \mathrm{s}$ at twice the mains frequency indicates an asymmetry of the electromagnetic field.

Table 6: measured values on electric motor and pump \#23

\begin{tabular}{|c|c|c|c|c|c|c|c|}
\hline \multicolumn{8}{|c|}{$\begin{array}{l}\text { table of effective values of vibration speed in the band } 10-1000 \mathrm{~Hz}\left(\mathrm{v}_{\mathrm{RMS}}\right) \text { and effective } \\
\text { values of vibrations acceleration in the band od } 500-25600 \mathrm{~Hz}\left(\mathrm{a}_{\mathrm{RMS}}\right)\end{array}$} \\
\hline \multirow{2}{*}{ quantity } & \multirow{2}{*}{ direction } & \multicolumn{3}{|c|}{ MEASUREMENT 1} & \multicolumn{3}{|c|}{ MEASUREMENT 2} \\
\hline & & $\mathbf{L 1}$ & $\mathbf{L} 2$ & L3 & $\mathbf{L 1}$ & $\mathbf{L} 2$ & $\mathbf{L 3}$ \\
\hline \multirow{3}{*}{$\mathbf{V}_{\text {RMS }}$} & horizontal & 2,3 & 1,8 & 1,4 & 5,7 & 3 & 2,1 \\
\hline & vertical & 3,6 & 2,4 & 1,7 & 4,9 & 2,6 & 1,8 \\
\hline & axial & 2,4 & 1,3 & 1,1 & 5,9 & 3,1 & 2,2 \\
\hline \multirow{3}{*}{ a RMS } & horizontal & 0,28 & 0,19 & 0,1 & 0,02 & 0,05 & 0,08 \\
\hline & vertical & 0,2 & 0,14 & 0,18 & 0,05 & 0,06 & 0,1 \\
\hline & axial & 0,5 & 0,34 & 0,36 & 0,02 & 0,05 & 0,08 \\
\hline
\end{tabular}

It is recommended to continue to monitor the state of vibrations and in the event of an increase in vibrations up to zone $\mathrm{D}$, it is necessary to plan the shutdown of the equipment and replace the motor. 


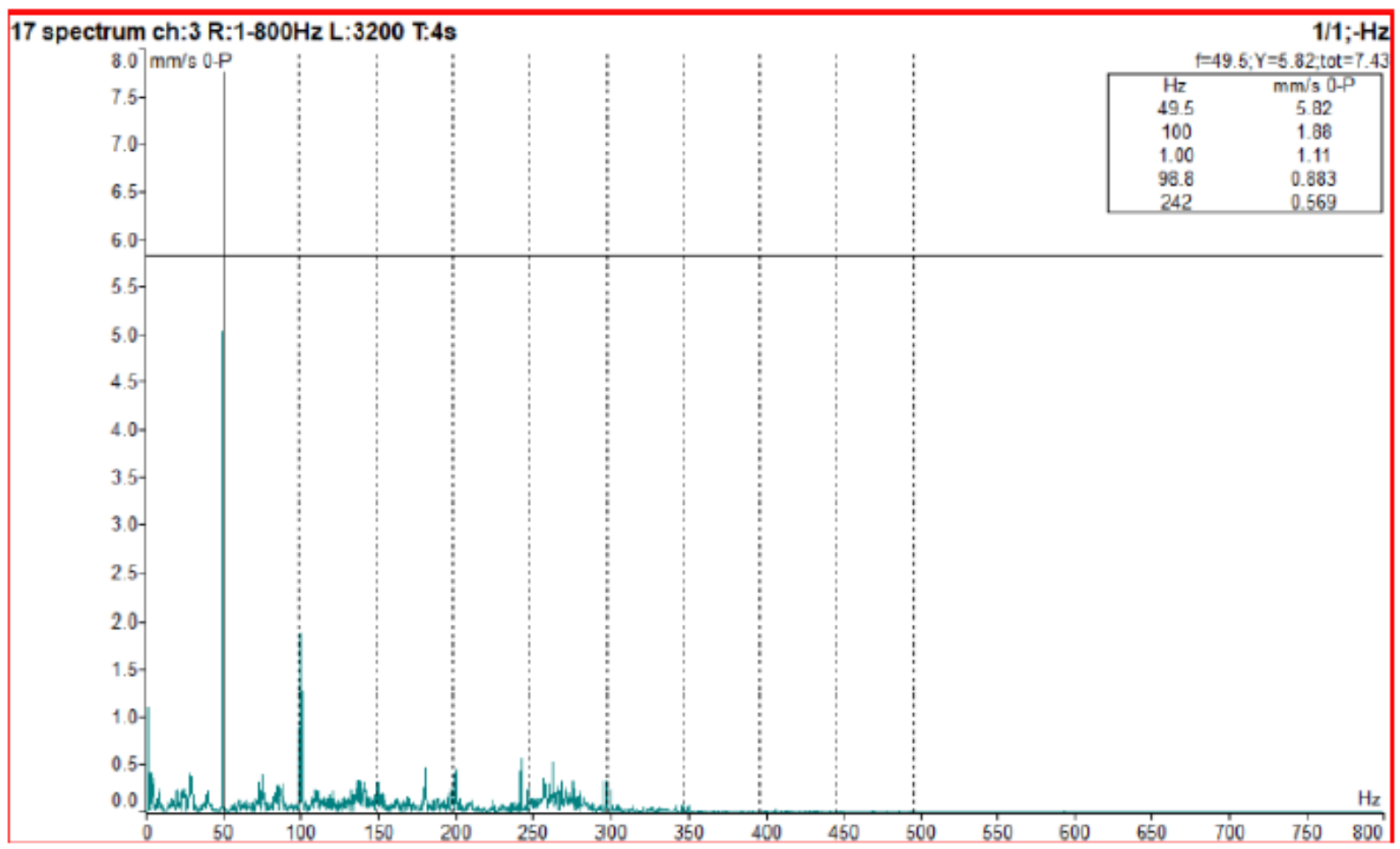

Figure 6: Speed spectrum for electric motor \#37, L1 - $2940 \mathrm{rpm}$, vertical direction, 1st measuring [8]

\subsection{Conclusion From the Measurement}

The measurement was performed on a total of ten electric motors with centrifugal pumps. The values of almost all measurements indicated a satisfactory condition. Except for the electric motor \#37, whose condition was slightly deteriorated and it was recommended to disassemble the motor and check the rotor during the planned shutdown. The values of vibration acceleration reached only minimal values, so there was no need to deal with bearing replacement.

The electric motor \#23 also reached deteriorated values in zone C. As this deterioration occurred within about three months, it was recommended to continue to monitor the motor and replace the motor immediately if the values in zone D are reached. The values of the vibration acceleration reached the minimum values here as well, so it was not necessary to replace the bearings.

\section{CONCLUSION}

Offset printing machines are a complex devices where reengineering maintenance can lead to high savings. Since the offset machine is very complex, it is necessary to determine on which components the reengineering will be performed first.

A common defect of offset printing machines is the failure of pumps, which have the task of pumping a dampening solution of water and alcohol into the tanks of individual printing towers, from where it is then applied to the dampening cylinder. Without this dampening, there is no proper chemical reaction with the ink on the printing form and it is not possible to perform the printing as required.

It is important to choose a suitable measurement method. Vibrodiagnostics comes into consideration, which has the possibility of detecting faults both on the electric motor and on the pump itself, whether it is imbalances or faults on the bearings.

The described measurements were performed on electric motors with centrifugal pumps in the GWK company. They were used to evaluate whether vibrodiagnostics would also be suitable 
for measurements on offset printing machine pumps because they use the same type of pumps.

The measurement results are satisfactory and it is possible to determine the causes of increased vibration values and vibration acceleration, which indicate imbalances and defects in the bearings. Thanks to them, it is also possible to detect the asymmetry of the electromagnetic field.

These values also need to be monitored for pumps of offset printing machines, so vibration diagnostics with the above procedure is suitable for integration into the maintenance of offset printing machines.

This article has been written in connection with the project Research and Development of Modern Technologies in Industrial Practice, reg. no. SP2021/6 supported by Specific Research program financed by the Ministry of Education, Youth and Sports and the project Support for Science and Research.

\section{Sources}

1. KUTIOVÁ, Kristýna. Téze disertační práce: Výzkum možnosti nasazení nedestruktivní diagnostiky za účelem reengineeringu systému údržby ofsetového tiskového stroje. Ostrava, 2021.

2. BLATA, Jan a Janusz JURASZEK. Metody technické diagnostiky: teorie a praxe = Metody diagnostyki technicznej : teorie a praktyka. Ostrava: Vysoká škola báňská Technická univerzita Ostrava, 2013. 134 s. ISBN 978-80-248-2997-5.

3. HELEBRANT, František a Jiř́ ZIEGLER. Technická diagnostika a spolehlivost II. Vibrodiagnostika. Ostrava : VŠB - Technická univerzita, 2004. 178 s. ISBN 80-2480650-9.

4. ČSN ISO 10816-1. Vibrace - Hodnoceni vibrací strojů na základě měření na nerotujících částech - Část 1: Všeobecné směrnice, 1998. 24 s. ISSN 011412.

5. ČSN ISO 10816-7. Vibrace - Hodnocení vibrací strojů na základě měření na nerotujících částech - Část 7: Odstředivá čerpadla pro průmyslová použití včetně měreni na rotujicich hř́delich, 2010. $24 \mathrm{~s}$.

6. ČSN ISO 10816-3. Vibrace - Hodnocení vibraci strojů na základě měrení na nerotujících částech - Část 3: Průmyslové stroje se jmenovitým výkonem nad $15 \mathrm{~kW}$ a jmenovitými otáčkami mezi $120 \mathrm{l} / \mathrm{min}$ a $15000 \mathrm{l} / \mathrm{min}$ při měření in situ, 2010. $20 \mathrm{~s}$.

7. KUDRNA, Lukáš, Petra VÁŇOVÁ, Jitka MALCHARCZIKOVÁ a Tomáš KUBÍN. Material analysis of the engine part for the historical motorcycle jawa 250, 1939. METAL 2020 - 29th International Conference on Metallurgy and Materials, Conference Proceedings. 2020, 29(164995), 984-988. ISBN 978-808729497-0. Dostupné z: doi:10.37904/metal.2020.3594

8. POSPÍŠIL, Vojtěch. Aplikace metod vibrodiagnostiky na kličových zařizeních. Ostrava, 2018. Bakalářská. VŠB - Technická Univerzita Ostrava.

\section{Contact}

Ing. Kristýna Kutiová

VSB - Technical University of Ostrava

Faculty of Mechanical Engineering

17. listopadu 15, 70800 Ostrava

Tel: +420739943289; email: kristyna.kutiova@vsb.cz 


\title{
BIG DATA A PREDIKTIVNÍ ANALYTIKA JAKO SOUČÁST STAVEBNICTVÍ 4.0 SE ZAMĚŘENÍM NA DOPRAVNÍ
}

\author{
BIG DATA AND PREDICTIVE ANALYTICS AS PART OF \\ CONSTRUCTION 4.0 WITH A FOCUS ON TRANSPORT \\ CONSTRUCTIONS
}

\author{
Pavel Krupík
}

\begin{abstract}
The digital and technological innovations that have developed rapidly in recent years are referred to as the 4th Industrial Revolution or Industry 4.0. These changes will fundamentally affect most construction professions and will require changes in their knowledge and skills. Ensuring the competitiveness of the Czech Republic and the Czech construction industry will require targeted monitoring of these trends and support for research and innovation. BIM is a big topic, but it is only one part of the intended Construction 4.0. Other topics such as Big Data and predictive analytics, if not completely neglected, are minimally neglected. The aim of this paper is to describe this topic and use SWOT analysis to identify weaknesses, strengths, opportunities and threats with a focus on the transportation construction industry.
\end{abstract}

Keywords: Big data, predictive analytics, Construction 4.0, transport construction

\section{INTRODUCTION}

It can be said, that the world is currently flooded with data. In addition, rapidly evolving technologies are leading to its steady growth. Today, companies handle petabytes (1015 bytes) of data [1]. The construction industry is no exception to the ubiquitous digital revolution. This industry deals with the significant collection of data from various fields during the entire life cycle of a construction. The main and most researched pillar of Construction 4.0 Building Information Modeling (BIM) systematically captures multidimensional CAD information to support multidisciplinary collaboration between stakeholders. Therefore, a large amount of data is created here, which can be further used [4].

Big data definitions are relative and vary by factors such as time and data type. What can be considered large data today may not meet the threshold in the future, as storage capacity will increase, allowing even larger data sets to be captured. In addition, the type of data discussed within a variety defines what is meant by "large". Two data files of the same size may require different data management technologies based on their type. Thus, the definition of big data also depends on the industry [11].

Predictive analytics deals with forecasting and statistical modeling to determine future possibilities [12].

\section{POSSIBILITIES OF USING BIG DATA AND PREDICTIVE ANALYTICS IN CONSTRUCTION 4.0}

One possible use of these technologies is mark-based positioning of the groover arm, in which optical cameras follow reference marks to determine the three-dimensional location, and the orientation of the articulated machine end effector is cited as a potential low cost alternative to currently available machine control and guidance systems [2].

Another use is to facilitate the automated measurement of road layer thickness in order to prevent adverse effects on vehicles due to poorly maintained roads [3]. 
The growth of construction activity around the world is leading the construction industry to consume large natural resources and produce massive construction and demolition waste. Existing approaches to waste management are based on the design of remedial measures for waste management only after they occur. The use of Big data and predictive analysis allows decisions to be made on the basis of available data already in the design phase of the construction. Waste minimization through design is the future of waste management research. Advanced analytical approaches can be used to predict waste and prescribe best practices for preventive waste minimization [1].

The goal of Generative Design is to generate many designs automatically based on set design goals, such as, but not limited to, functional requirements, material type, manufacturing method, performance criteria, and cost limitations. Generative design uses sophisticated algorithms to synthesize design space and generate a wide range of design solutions that meet requirements. This evaluation allows designers to repeat designs by modifying design goals and limitations if the design is not created to their satisfaction [1].

Big data analysis can be one of methods used to analyze and understand consumers' energy consumption behavior and thus can help to improve energy efficiency in construction and promotion of energy saving [5].

In order to be able to analyze the design performance, it is necessary to compare the current state with the planned state. One way to achieve this is to align visual data with BIM [6].

Problems of strategic decision-making in the field of public policy usually involve comparing competitive possibilities with different stakeholders. As part of the predictive analysis, it is possible to include several conflicting criteria in the research, such as the expected duration of construction work, costs, the number of potential users and new green areas. This encourages the development of robust recommendations to highlight how the performance of actions needs to be adjusted in order to change the recommendations as required. In particular, it emphasizes the minimum improvements that would guarantee the feasibility of a currently impossible outcome [7].

The machine learning (ML) approach can be used to predict energy intensity. ML components were developed at the design level with static prediction of total annual energy consumption for heating and cooling in response and zone-level components with dynamic monthly consumption in response. These cases show that the component-based approach allows for flexibility and generalization of ML beyond parametric parameters, which is necessary for the application of ML in building design. The application of components in test cases, which are structurally different from the training model, has demonstrated flexibility and widespread generalization over training cases, ie the reuse of ML models [8]. The general focus of machine learning is the representation of input data and the generalization of learned formulas for use on future invisible data. [14].

The techniques of "predictive analysis" form the basis of many current social media and consumer "referral systems" and again it can be seen that the basic functional principles of emerging data technologies are beginning to structure public policy facilities. Learning analytical platforms function as anticipatory devices based on technical developments in the field of "machine learning". The importance of machine learning algorithms lies in the fact that they show certain tendencies to the origin, adaptability, prediction and prediction. Machine learning and predictive analytics software is part of a world where "probabilistic outcomes" and predictions about the future now predominate, with significant implications for how individuals think and predict their future [9].

Big data systems are efficiently stored, processed and mined in smart cities in order to produce information to improve the various services of the smart city. In addition, big data can help decision makers plan any expansion of services, resources, or smart city areas. The various characteristics of big data show its considerable potential for gains and progress. Big 
data applications can serve many sectors, providing a better customer experience and service [10].

\section{RESULTS AND DISCUSSION}

Possibilities and possible problems of Big data and predictive analytics in relation to swot analysis have been discussed with fifteen other researchers and experts. The following information was established on the basis of the questioning. In addition, an extensive research of previously published articles was also carried out.

\subsection{Weaknesses/ Threats}

- Extracting the accumulated data in a short time [5]

- Very large amount of information when involving several dimensions [5]

- Limited possibilities existing applications for processing large amounts of data [5]

- The alignment process is a very important challenge for large visual data, because large analysis of visual data would not be feasible without a way to increase this alignment process through automation or even semi-automation [6].

- Despite the popularity of analytics and big data, putting them into practice is still a complex and time-consuming effort [13].

- In big data environments, datasets are much larger and can be too complex for conventional data analysis software [15].

\subsection{Strengths/ Opportunities}

- Advances in this area can bring a number of benefits, in particular resource optimization and waste reduction through design.

- Detection and resolution of conflicts in the preparation phase can prevent some possible problems usually found during construction and thus reduce the cost of the entire construction [1]

- Transport systems can benefit greatly from big data by optimizing routes and timetables, meeting different requirements and increasing environmental friendliness [10]

- Analytics solutions that extract structured and unstructured data are important because they can help organizations gain insight not only into their privately acquired data, but also from the large amount of data publicly available on the Web. The ability to interconnect information can serve to optimize resource utilization [13].

\section{CONCLUSIONS}

The purpose of this article was to examine the current state and nature of Big data and predictive analytics as part of Construction 4.0 with a focus on the Czech Republic and transport construction.

The concept of Construction 4.0 has been implemented in transport construction for some time and the technologies are at various levels of maturity. Technologies such as BIM have evolved significantly, while the remaining technologies are still improving and somehow affecting the sustainability of the industry. The implementation of Construction 4.0 elements in transport constructions is still extremely lacking, even though it is accessible to these technologies. There are practical examples of the use of the concept of Construction 4.0 mentioned in this article, which have been realistically used and have shown significant impacts in this area.

According to the order of keywords, it is clear that BIM plays a leading role in current research. However, in order to develop transport construction, it is also necessary to develop other parts of the Construction 4.0 concept. 
The article described the possible use of Big data and predictive analytics, and by using SWOT analysis, strengths, weaknesses, opportunities and threats were identified.

\section{Acknowledgements}

This work was supported by the Grant Agency of the Czech Technical University in Prague No. SGS20/100/OHK1/2T/11.

\section{Sources}

1. BILAL, Muhammad, Lukumon O. OYEDELE, Junaid QADIR, et al. Big Data in the construction industry: A review of present status, opportunities, and future trends. Advanced Engineering Informatics [online]. 2016, 30(3), 500-521. ISSN 14740346. Available at: doi:10.1016/j.aei.2016.07.001

2. LUNDEEN, Kurt M., Suyang DONG, Nicholas FREDRICKS, Manu AKULA, Jongwon SEO a Vineet R. KAMAT. Optical marker-based end effector pose estimation for articulated excavators. Automation in Construction. 2016, 65, 51-64. ISSN 09265805. Available at: doi:10.1016/j.autcon.2016.02.003

3. LIU, Donghai, You WU, Shuai LI a Yuanze SUN. A real-time monitoring system for lift-thickness control in highway construction. Automation in Construction. 2016, 63, 27-36. ISSN 09265805. Available at: doi:10.1016/j.autcon.2015.12.004

4. EADIE, Robert, Mike BROWNE, Henry ODEYINKA, Clare MCKEOWN a Sean MCNIFF. BIM implementation throughout the UK construction project lifecycle: An analysis. Automation in Construction [online]. 2013, 36, 145-151. ISSN 09265805. Available at: doi:10.1016/j.autcon.2013.09.001

5. KOSELEVA, Natalija a Guoda ROPAITE. Big Data in Building Energy Efficiency: Understanding of Big Data and Main Challenges. Procedia Engineering [online]. 2017, 172, 544-549. ISSN 18777058. Available at: doi:10.1016/j.proeng.2017 .02 .064

6. HAN, Kevin K. a Mani GOLPARVAR-FARD. Potential of big visual data and building information modeling for construction performance analytics: An exploratory study. Automation in Construction [online]. 2017, 73, 184-198. ISSN 09265805. Available at: doi:10.1016/j.autcon.2016.11.004

7. CIOMEK, Krzysztof, Valentina FERRETTI a Miłosz KADZIŃSKI. Predictive analytics and disused railways requalification: Insights from a Post Factum Analysis perspective. Decision Support Systems [online]. 2018, 105, 34-51. ISSN 01679236. Available at: doi:10.1016/j.dss.2017.10.010

8. GEYER, Philipp a Sundaravelpandian SINGARAVEL. Component-based machine learning for performance prediction in building design. Applied Energy [online]. 2018, 228, 1439-1453. ISSN 03062619. Available at: doi:10.1016/j.apenergy.20 18.07.011

9. WILLIAMSON, Ben. Digital education governance: data visualization, predictive analytics, and 'real-time' policy instruments. Journal of Education Policy [online]. 2015, 31(2), 123-141. ISSN 0268-0939. Available at: doi:10.1080/02680939.2015.1 035758

10. HASHEM, Ibrahim Abaker Targio, Victor CHANG, Nor Badrul ANUAR, Kayode ADEWOLE, Ibrar YAQOOB, Abdullah GANI, Ejaz AHMED a Haruna CHIROMA. The role of big data in smart city. International Journal of Information Management [online]. 2016, 36(5), 748-758. ISSN 02684012. Available at: doi:10.1016/j.ijinfomg t.2016.05.002

11. GANDOMI, Amir a Murtaza HAIDER. Beyond the hype: Big data concepts, methods, and analytics. International Journal of Information Management [online]. 
2015, 35(2), 137-144. ISSN 02684012. Available at: doi:10.1016/j.ijinfomgt.2014 .10 .007

12. SIVARAJAH, Uthayasankar, Muhammad Mustafa KAMAL, Zahir IRANI a Vishanth WEERAKKODY. Critical analysis of Big Data challenges and analytical methods. Journal of Business Research [online]. 2017, 70, 263-286. ISSN 01482963. Available at: doi:10.1016/j.jbusres.2016.08.001

13. ASSUNÇÃO, Marcos D., Rodrigo N. CALHEIROS, Silvia BIANCHI, Marco A.S. NETTO a Rajkumar BUYYA. Big Data computing and clouds: Trends and future directions. Journal of Parallel and Distributed Computing [online]. 2015, 79-80, 315. ISSN 07437315. Available at: doi:10.1016/j.jpdc.2014.08.003

14. NAJAFABADI, Maryam M, Flavio VILLANUSTRE, Taghi M KHOSHGOFTAAR, Naeem SELIYA, Randall WALD a Edin MUHAREMAGIC. Deep learning applications and challenges in big data analytics. Journal of Big Data [online]. 2015, 2(1). ISSN 2196-1115. Available at: doi:10.1186/s40537-014-0007-7

15. ZHONG, Ray Y., Xun XU, Eberhard KLOTZ a Stephen T. NEWMAN. Intelligent Manufacturing in the Context of Industry 4.0: A Review. Engineering [online]. 2017, 3(5), 616-630. ISSN 20958099. Available at: doi:10.1016/J.ENG.2017.05.015

\section{Contact}

Ing. Pavel Krupík

Czech Technical University in Prague, Faculty of Civil Engineering

Thakurova 7, Prague 160 00, Czech Republic

Tel: +420608927630

email: pavel.krupik@fsv.cvut.cz 


\title{
COMPUTER MODELING IN MSC ADAMS/VIEW AS PART OF A MODERN APPROACH TO THE DESIGN OF TECHNICAL OBJECTS
}

\author{
Darina Hroncová, Erik Prada, Lubica Miková, Ivan Virgala, Michal Kelemen
}

\begin{abstract}
The paper pays attention to the use of computer simulation in the design of a robot with four degrees of freedom of movement. The matrix method is applied in the kinematic analysis of the robot model. The robot's mechanism is an open kinematic chain. During the simulation, the forward kinematics is used to determine the position of the selected point of the robot effector at prescribed motion in the joints. The MSC Adams / View program is used. The results are presented in graphical form and allow to check the model movement in real time during the simulation.
\end{abstract}

Keywords: manipulator, simulation, kinematic and dynamic analysis, controller, end effector, trajectory

\section{INTRODUCTION}

With the development of computer software, the possibility of using computer simulations is expanding. Computer simulations enable the visualization of new products and their variants. They provide a realistic view of the behavior of the proposed system and its individual variants. We can assess the impact of a model change on its functionality. Possible collisions of members in work cycle can be determined. By creating an animation of the model, we can check the real activity of the model during the working process. The outputs of the simulation in graphical form allow to check the robot behaviour in real time during the work cycle [1].

\section{MODEL OF MANIPULATOR}

The paper is devoted to the created robot model shown in the Fig.1. From the point of kinematics, the mechanical structure of the robot represents an open kinematic chain. We consider 4 degrees of freedom of movement.

The manipulator consists of two arms and an end effector, the arms are mounted on a stand connected to a solid base. The stand provides the stability in operation. The arms are connected to each other by a rotating kinematic pair and by another rotating kinematic pair to the stand. The arms with the end effector rotate in a horizontal plane relative to the fixed stand. The working tool, which in our case is an end effector with two thumbs to hold the object of manipulation, is attached by a rotating kimneatic pair to the second arm of the robot. The robot then performs the working motion with the end effector [2-4].

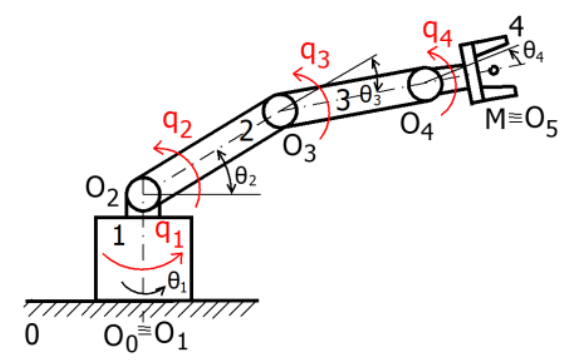

Figure 1. Model of the manipulator 
The aim is to describe the movement of the end-effector. We solve the forward kinematics of the robot [2-4]. The angle of rotation in kinematic pairs is denoted by angles $\theta_{1}, \theta_{2}, \theta_{3}, \theta_{4}$. The generalized coordinates determining the instantaneous position of the body are denoted by $\mathrm{q}_{1}, \mathrm{q}_{2}, \mathrm{q}_{3}, \mathrm{q}_{4}$ (Fig. 1), while for the generalized coordinates applies $\mathrm{q}_{1}=\theta_{1}, \mathrm{q}_{2}=\theta_{2}, \mathrm{q}_{3}=$ $\Theta_{3}, q_{4}=\theta_{4}$. The drives are mounted in rotating kinematic pairs (Fig. 2) [7].

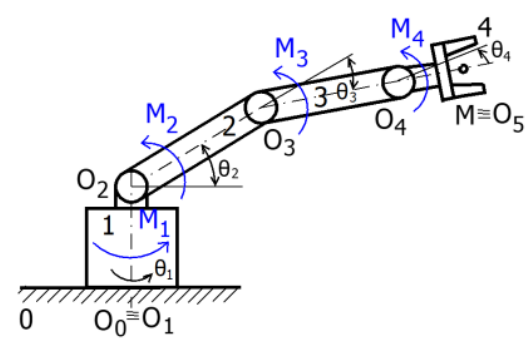

Figure 2. Model of the manipulator with torques in the joints

When solving forward kinematics, we use the matrix method to determine the position of the effector endpoint. There is several methods for building a kinematic model of a robot. The most common method is the Denavit-Hartenberg kinematic modeling convention [1-4].

Fourth order matrices were introduced by J. Denavit and R.S. Hartenberg. Similarly, G.S. Kalicin solved some problems of planar and spherical mechanisms by matrix calculus. The possibility of using quaternions or biquaternions in the kinematics of the body was pointed out by J.Novák. The general methods of analytical solution were dealt with by S.G. Kislicin and J.F. Moroshkin. In the kinematics of spatial mechanisms, the Czech mechanic V.Brát also introduced the use of matrix calculus [1].

For suitability and generality of the use of the matrix method speaks not only the possibility to contain the spaces of individual members directly in the equations, but also the convenience of use of a computer with sophisticated methods of numerical solution of systems of equations. Individual movements that take place at the same time can be described by matrix equations.

We are interested in the position of the selected point of the end effector with respect to the global coordinate system in which the robot is located. A local coordinate system is associated with each member. The motion of a point located on a member with a local coordinate system is then described with respect to the global coordinate system (Fig. 3) .

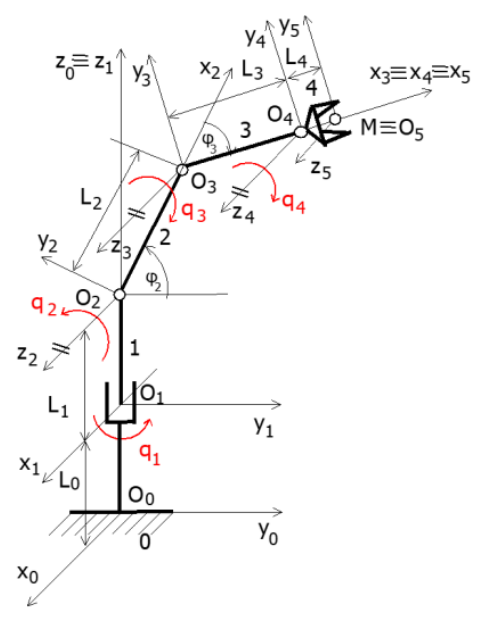

Figure 3. Geometric parameters of the model 
We assign a coordinate system $O_{i}, x_{i}, y_{i}, z_{i}$ to each member and we assign a generalized coordinate $q_{i}$ to each joint defined in the axis of rotation. The axis $\mathrm{z}_{i}$ is oriented in the direction of the axis of the $(i+1)$-th joint. The axis $x_{i}$ is normal to the $z_{i-1}$ and $z_{i}$ and is oriented from joint $i$ to joint $i+1$. The axis $y_{i}$ complements the rectangular, right-handed coordinate system.

Each member of the chain is characterized by two dimensions, a common normal distance $a_{i}$ along a common normal between the axes of the joints $i$ and $(i-1)$, and the second dimension is the angle of rotation $\alpha_{i}$ between these axes in a plane perpendicular to $a_{\mathrm{i}}$ (Fig. 4).

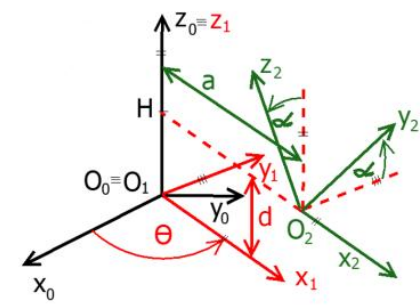

Figure 4. Denavit - Hartenberg parameters $\Theta, d, \alpha$, a

Homogeneous transformation matrices contain information about the rotation between two coordinate systems and information about the distance between their origins. The purpose of introducing these matrices is to allow a more compact notation of position vectors expressed in different coordinate systems.

The position vector $\mathbf{r}_{i-1, M}$ of point $\mathrm{M}$ with respect to the system $i-1$ can be expressed by the relation

$$
\mathbf{r}_{i-1, M}=\mathbf{T}_{i-1, i} \cdot \mathbf{r}_{i M},
$$

where

$\mathbf{r}_{i M}$ is the position vector of point $\mathrm{M}$ with respect to the system $i$,

$\mathbf{r}_{i-1, i}$ is the vector of the distance between the origin of the system $i$ with respect to the system $i-1$,

$\mathbf{T}_{i-1, i}$ is the rotation matrix between the system $i$ and $i-1$

The homogeneous transformation matrix is expressed by the relation

$\mathbf{T}_{i-1, i}=\mathbf{T}_{\mathrm{z} 6}\left(\Theta_{i}\right) \mathbf{T}_{\mathrm{z} 3}\left(\mathrm{~d}_{i}\right) \mathbf{T}_{\mathrm{z} 4}\left(\alpha_{i}\right) \mathbf{T}_{\mathrm{z} 1}\left(a_{i}\right)$

We then write the position vector for Fig. 3

$\mathbf{r}_{0 \mathrm{M}}=\mathbf{T}_{01}\left(\mathrm{q}_{1}\right) \mathbf{T}_{12}\left(\mathrm{q}_{2}\right) \mathbf{T}_{23}\left(\mathrm{q}_{3}\right) \mathbf{T}_{34}\left(\mathrm{q}_{4}\right) \mathbf{r}_{4 \mathrm{M}}$

$\mathbf{r}_{0 \mathrm{M}}=\mathbf{T}_{04} \mathbf{r}_{4 \mathrm{M}}$

where

$\mathbf{T}_{04}=\mathbf{T}_{01} \mathbf{T}_{12} \mathbf{T}_{23} \mathbf{T}_{34}$

In our case, the individual transformation matrices will be in the form:

$\mathbf{T}_{01}=\mathrm{T}_{\mathrm{z} 6}\left(\mathrm{q}_{1}\right) \mathbf{T}_{\mathrm{z} 3}\left(\mathrm{~L}_{0}+\mathrm{L}_{1}\right) \mathbf{T}_{\mathrm{z} 4}(\pi / 2)$

$\mathbf{T}_{12}=\mathbf{T}_{\mathrm{z} 6}\left(\mathrm{q}_{2}\right) \mathbf{T}_{\mathrm{z} 1}\left(\mathrm{~L}_{2}\right)$ 
$\mathbf{T}_{23}=\mathbf{T}_{\mathrm{z} 6}\left(\mathrm{q}_{3}\right) \mathbf{T}_{\mathrm{z} 1}\left(\mathrm{~L}_{3}\right)$

$\mathbf{T}_{34}=\mathbf{T}_{\mathrm{z} 6}\left(\mathrm{q}_{4}\right) \mathbf{T}_{\mathrm{z} 1}\left(\mathrm{~L}_{4}\right)$

Position of point $\mathrm{M}$ with respect to the coordinate system $O_{4}, x_{4}, y_{4}, z_{4}$ is $\mathbf{r}_{4 \mathrm{M}}=\left[\begin{array}{llll}\mathrm{L}_{4} & 0 & 0 & 1\end{array}\right]^{\mathrm{T}}$.

The following table (Tab. 1) shows the Denavit-Hartenberg parameters of the model of the robot (Fig. 3):

Table. 1. Denavit - Hartenberg parameters of the robot

\begin{tabular}{|c|c|c|c|c|}
\hline teleso & $\boldsymbol{\Theta}_{\mathbf{i}}$ & $\boldsymbol{d}_{\mathbf{i}}$ & $\boldsymbol{a}_{\mathbf{i}}$ & $\boldsymbol{\alpha}_{\mathbf{i}}$ \\
\hline $\mathbf{0}$ & 0 & $L_{0}$ & 0 & 0 \\
\hline $\mathbf{1}$ & $q_{1}$ & $L_{1}$ & 0 & $\pi / 2$ \\
\hline $\mathbf{2}$ & $q_{2}$ & 0 & $\mathrm{~L}_{2}$ & 0 \\
\hline $\mathbf{3}$ & $q_{3}$ & 0 & $\mathrm{~L}_{3}$ & 0 \\
\hline $\mathbf{4}$ & $q_{4}$ & 0 & $\mathrm{~L}_{4}$ & 0 \\
\hline
\end{tabular}

\section{COMPUTER SIMULATION}

The next figure (Fig. 5a-b) shows a manipulator model created in the MSC Adams/View.

a)

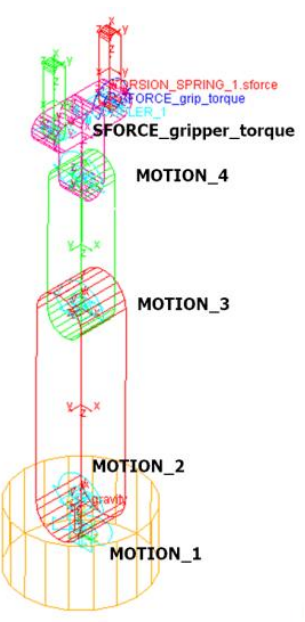

b)

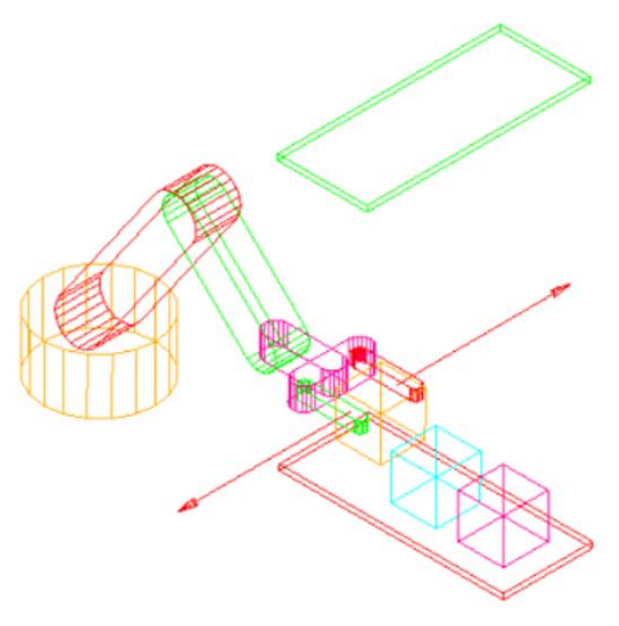

Figure 5. a) Model with MOTION in Joint, b) Views of the model in motion with windows of Measure with kinematic parameters

A 3D computer model of the manipulator is created in MSC Adams [9]. Modelling elements and procedures for the creation of bodies and their kinematic bonds were used. After proposing the model, the functionality is verified and the simulation is started Fig. 6 [7-9].

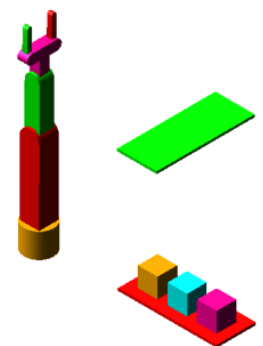

a)

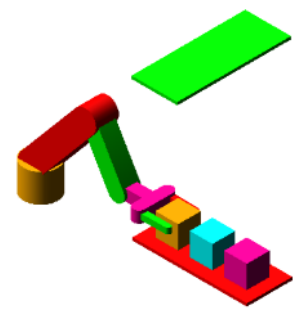

b)

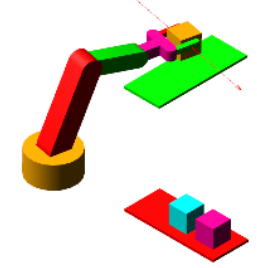

c)

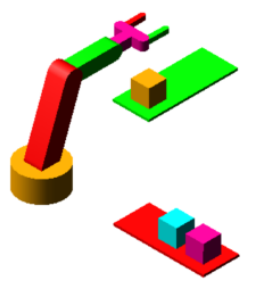

d)

Figure 6. a) - d) The animation of the simulation and displacement of the end efector of the rendered model 
The representation of the trajectory of the gripper's center of gravity in various views (Fig. 7) with defined movement in individual joints in Tab. 2 is shown below. The trajectory of the selected end member point is shown in Fig. 7 a) to d).

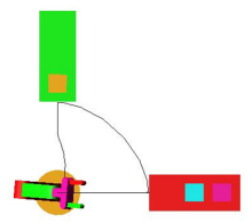

a)

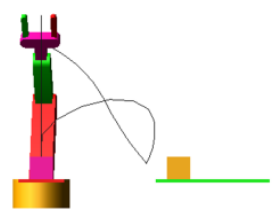

b)

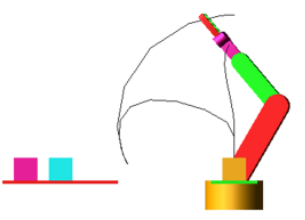

c)

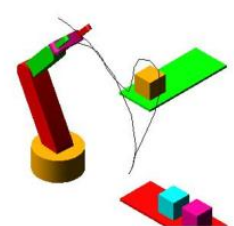

d)

Figure 7. Views of the rendered model a) the upper view, b) the front view, c) the side view, d) the spatial view of the model in motion

In rotational joints of the robot, the movement is defined using the step function (Tab. 2).

Table. 2. MOTION parameters of the RRRR robot

\begin{tabular}{|c|c|c|c|}
\hline MOTION_1 & MOTION_2 & MOTION_3 & MOTION_4 \\
\hline STEP( time $, 1.5,0,2.5,-90 \mathrm{~d}$ ) & $\begin{array}{l}\text { STEP(time, } 0,0,1,-40 \mathrm{~d})+ \\
\text { STEP(time, } 1.1,0,2,20 \mathrm{~d})+ \\
\text { STEP(time, } 2,0,3,-20 \mathrm{~d})+ \\
\text { STEP(time, } 3.1,0,4,20 \mathrm{~d})\end{array}$ & $\begin{array}{l}\text { STEP(time, } 0,0,1,-110 \mathrm{~d})+ \\
\operatorname{STEP}(\text { time }, 1.1,0,2,40 \mathrm{~d})+ \\
\operatorname{STEP}(\text { time }, 2,0,3,-40 \mathrm{~d})+ \\
\operatorname{STEP}(\text { time }, 4.1,0,5,40 \mathrm{~d})\end{array}$ & $\begin{array}{l}\text { STEP(time, } 0,0,1,60 \mathrm{~d})+ \\
\text { STEP(time, } 1.1,0,2,-60 \mathrm{~d})+ \\
\text { STEP(time }, 2,0,3,60 \mathrm{~d})+ \\
\text { STEP(time, } 3.1,0,4,-60 \mathrm{~d} \text { ) }\end{array}$ \\
\hline
\end{tabular}

In the right arm of the gripper the movement in the rotational joint SFORCE_gripper_torque has the shape: STEP(time, 1,0,1.1,8000)+STEP(time, 3,0,3.1,-8000)

\section{RESULTS}

Interactive simulation and visualization allows comfortable simulation of the model, model modifications and visualization of results. The output graphs enable viewing the current values of the measured variables in real time during the actual simulation and its visualization.

Postprocessor is an integral part of the process of computer modeling of a prototype and it is a comfortable tool for creating, processing, modifying and presenting the results of simulation in the form of graphs [9]. It is also possible to display the model in the current state and print the results prepared this way. It is also possible to create a video output of the simulation in AVI format.

We also calculated the position of the end effector point in the axis $x, y, z$ (Fig. 8) [5-8]. Measures of the position of the point of the end-effector are shown.
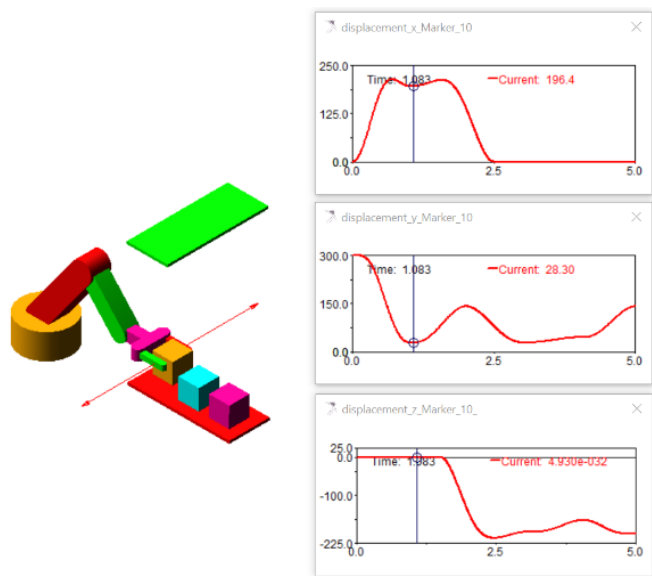
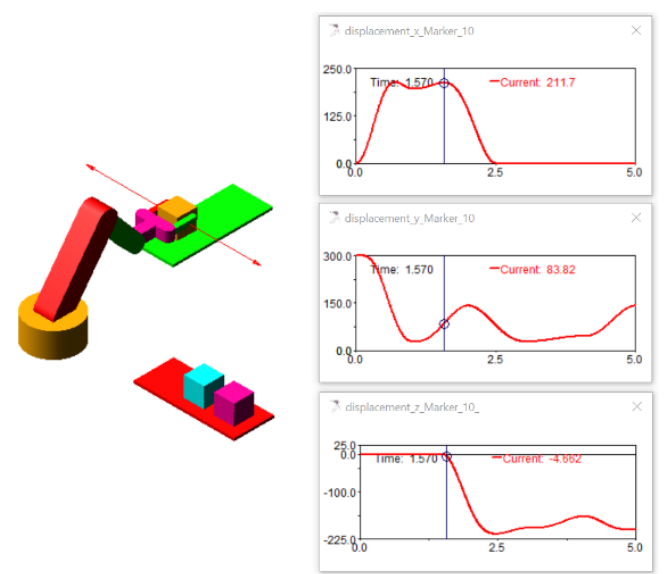
a)

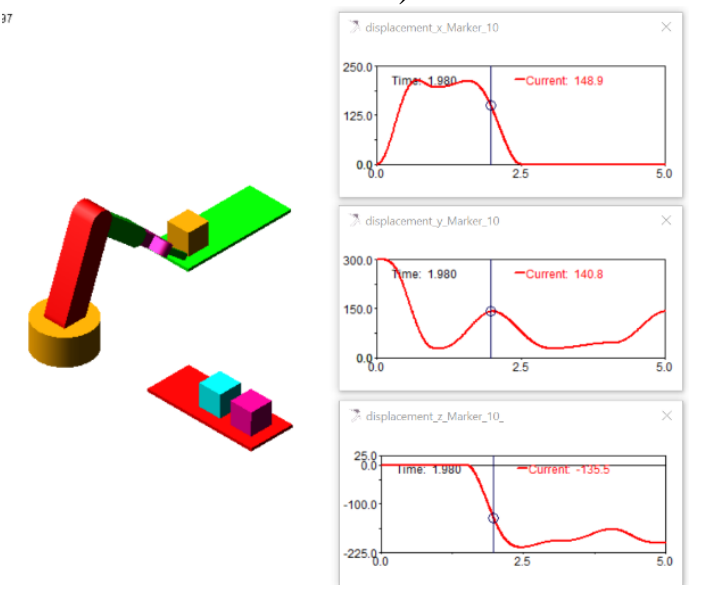

c) b)

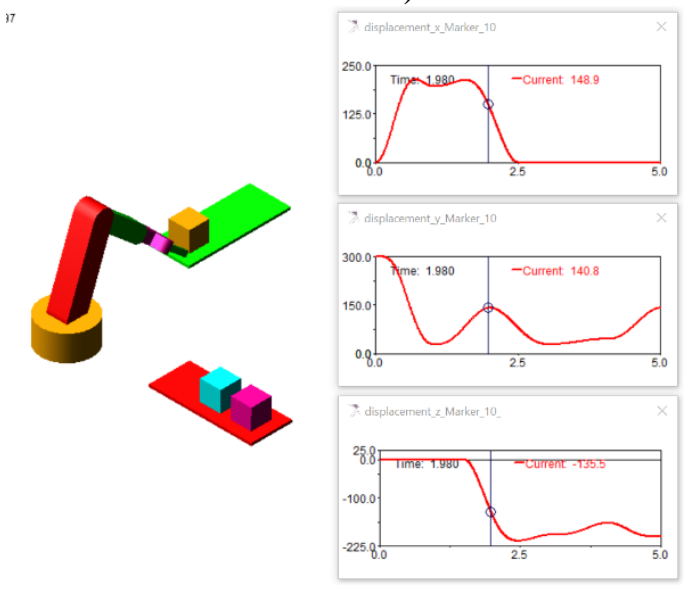

d)

Figure 8. a)-d) The animation of the simulation and displacement of the end efector of the rendered model and the graphs of the position of the end effector point in the axis $\mathrm{x}, \mathrm{y}, \mathrm{z}$ in windows of Measure

The resulting graphs obtained by the simulation are in the following figures (Fig. 9-11).
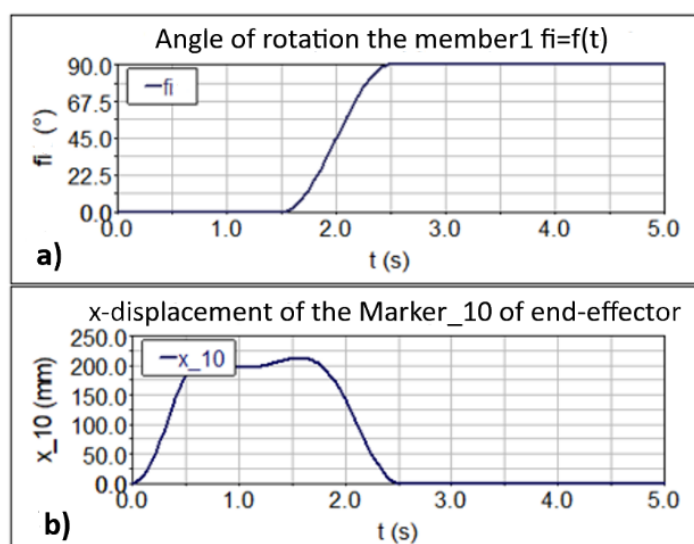

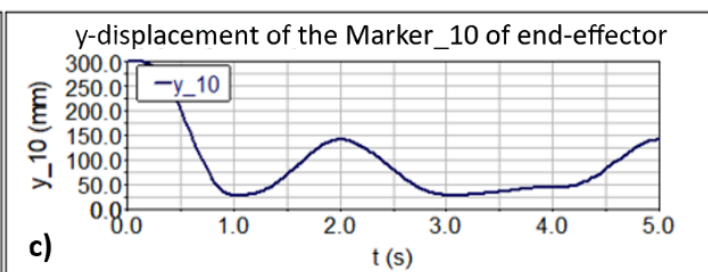

z-displacement of the Marker_10 of end-effector

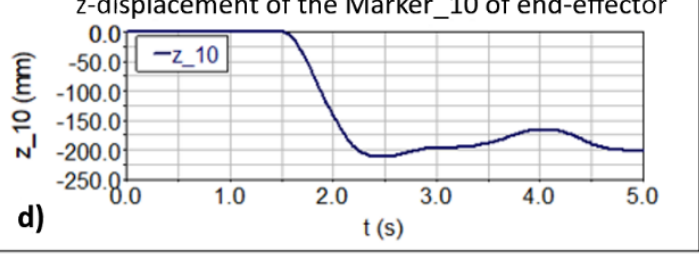

Figure 9. The graphs a) the angle fi4(t) of base 1, b) the position of the end effector point in the axis $x, c)$ the position of the end effector point in the axis $y, d$ ) the position of the end effector point in the axis $\mathrm{z}$

Angular velocity omega(t) in joint 1 is shown in the Fig. 10.

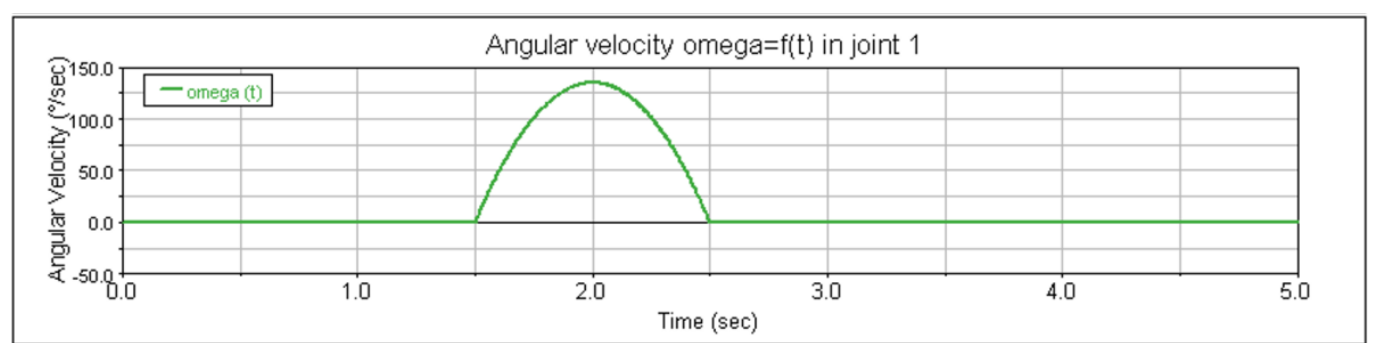

Figure 10. The graph of the angular velocity omega(t) in joint 1

The resulting graphs of trajectory of point of the end-effector obtained by the simulation are displayed in a graphical form with the postprocessor are in the following figures (Fig. 11). 
a)
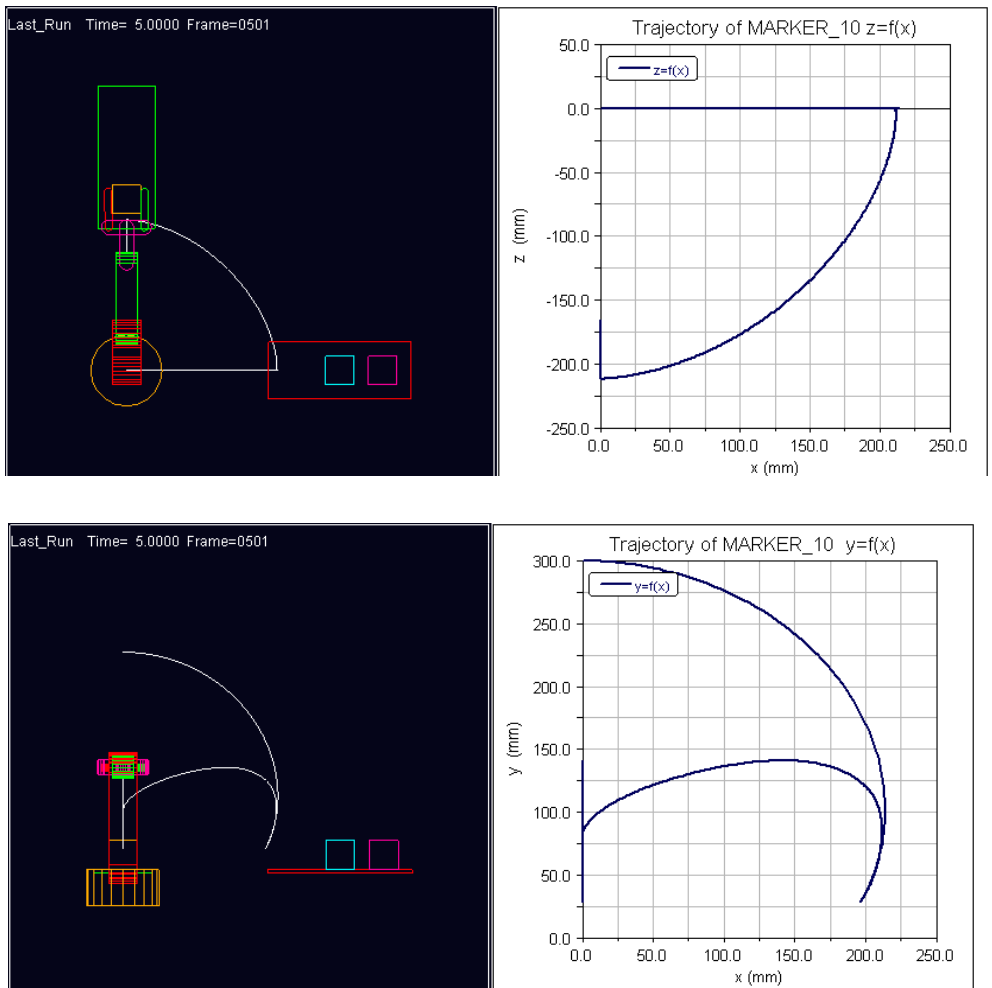

b)
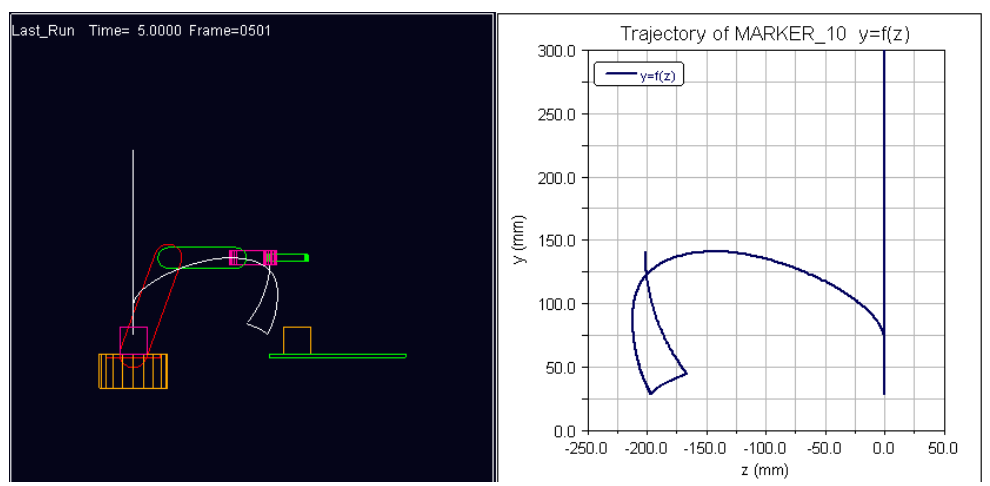

Figure 11. The graphs of the trajectory a) $z=f(x), b) y=f(x), c) y=f(z)$

\section{CONCLUSION}

MSC Adams works with a 3D model [9]. The advantage is the possibility to simulate the motion of the prototype model and its control in the program environment and verification of the functionality in the form of 3D visualization. Based on the results obtained from the simulation it is possible to build a real model and design the drives. When designing drives for a mechanical system it is necessary to pay attention to the maximum magnitudes of the forces when handling various loads and so it is necessary to design the drive with the appropriate parameters for the specific purpose of use of the manipulator.

Simulation software is a suitable tool for design, saving time and resources. It is also suitable for detailed research and investigation of mechanical systems in practice.

\section{Acknowledgement}

The authors would like to thank to Slovak Grant Agency project VEGA 1/0389/18, grant project KEGA 018 TUKE-4/2018, grant project KEGA 030 TUKE-4/2020 supported by the Ministry of education of Slovak Republic. 


\section{Sources}

1. JULIŠ, K., BREPTA, R. 1987. Mechanika II.díl, Dynamika. Praha: SNTL Praha.

2. CRAIG, J.J. 2005. Introduction to robotics: mechanics and control. Upper Saddle River: Pearson Prentice Hall.

3. MURRAY, R.M., Li, Z., SASTRY, S.S. 1994. A Mathematical Introduction to Robotic Manipulation. California: University of California: CRC Press.

4. PAUL, R.P. 1981. Robot manipulators, Mathematics, Programming and Control. Cambridge. MA: MIT Press.

5. MIKOVÁ, L', GMITERKO, A., KELEMEN, M., VIRGALA, I., PRADA, E., HRONCOVÁ, D., VARGA, M. 2020. Motion control of nonholonomic robots at low speed. In: International Journal of Advanced Robotic Systems. Wien:Technische Universität Wien, vol. 17, no. 1, pp.1-12.

6. DELYOVÁ, I., FRANKOVSKÝ, P., HRONCOVÁ, D. 2011. Kinematic analysis of movement of a point of a simple mechanism. In: 4th International Conference Modelling of mechanical and mechatronics systems. Košice: KAMaM, Technical University Košice, Herl'any, Slovakia.

7. MIKOVÁ, L', GMITERKO, A., FRANKOVSKÝ, P., HRONCOVÁ, D. 2016. Impact of dynamics of the frame on the performance of the positioning servosystem. In: International Journal of Advanced Robotic Systems, vol. 13, no. 5, pp. 1-6.

8. VAVRO, J. Jr., VAVRO, J., KOVÁČIKOVÁ, P., BEZDEDOVÁ, R., HÍREŠ, J. 2017. Kinematic and dynamic analysis and distribution of stress in items of planar mechanisms by means of the MSC ADAMS software. In: Manufacturing Technology, vol. 17, no. 2, pp. 267-270, 2017.

9. http://www.mscsoftware.com/product/adams

\section{Contact}

Ing. Darina Hroncová, Ph.D.

Technical University of Kosice

Faculty of Mechanical Engineering,

Department of Mechatronics,

Letná 9, 04200 Košice, Slovakia

email: darina.hroncova@tuke.sk

Tel: 00421556022379

Ing. Erik Prada, Ph.D.

email: erik.prada@tuke.sk

Doc. Ing. Lubica Miková, Ph.D.

email: lubica.mikova@tuke.sk

Doc. Ing. Ivan Virgala, Ph.D.

email: ivan.virgala@tuke.sk

Prof. Ing. Michal Kelemen, Ph.D.

email: michal.kelemen@tuke.sk 


\title{
VPLYV AUTOMOBILOVÉHO PRIEMYSLU NA ŽIVOTNÉ PROSTREDIE
}

\section{THE IMPACT OF THE AUTOMOTIVE INDUSTRY ON THE ENVIRONMENT}

\author{
Matúš Lavčák, Marieta Šoltésová, Michal Puškár
}

\begin{abstract}
Abstrakt
Vzhl’adom na klimatickú situáciu vo svete spôsobenú prevažne produkciou emisií, sa svetové organizácie snažia docielit' čo najväčšiu elimináciu produkcie emisií vo všetkých odvetviach priemyslu. Čo sa týka Európy, Európsky parlament vytvára legislatívne kroky, ktoré majú mat' za následok zníženie emisií do roku 2030 o 60\% v porovnaní s rokom 1990. Tieto kroky sa týkajú všetkých odvetví priemyslu počínajúc s automobilovým, ktorý je najkomplexnejším tvorcom znečistenia v Európe a vo zvyšku sveta.
\end{abstract}

Kl'účové slová: automobil, priemysel, znečistenie, emisie

\begin{abstract}
Given the global climate, caused mainly by emissions, global organizations are working to eliminate emissions as much as possible in all industries. As far as Europe is concerned, the European Parliament is taking legislative steps to reduce emissions by $60 \%$ by 2030 compared to 1990. These steps apply to all sectors of industry, from the automotive industry, which is the most complex polluter in Europe and the rest of the world.
\end{abstract}

Keywords: automobile, industry, pollution, emissions

\section{INTRODUCTION}

The automotive industry as a whole is the most complex polluter in Europe. Starting with the production itself and the subsequent maintenance and recycling of used or discarded car parts, the industry has a significant negative impact on the environment. Despite increasing efforts to mitigate these impacts, the negative effects of the factors are still increasing faster than the environment is able to cope with them. That is why the European Union is adopting increasingly stringent measures and rules. From 2025, a strict new EURO 7 standard is to enter into force, which will reduce emissions by more than $50 \%$ compared to the current EURO 6 standard.

Tab 1 Overview of permitted emissions from cars

\begin{tabular}{|l|l|l|}
\hline & Gasoline $[\mathrm{g} / \mathrm{km}]$ & Diesel $[\mathrm{g} / \mathrm{km}]$ \\
\hline EURO 6 & 60 & 80 \\
\hline EURO 7 & 30 & 30 \\
\hline
\end{tabular}


In Tab. 1, it is possible to find an overview of the maximum permitted emissions for the EURO 6 standard, which is currently in force, and the maximum permitted emissions of the EURO 7 standard, which is planned and should enter into force in 2025. [1,2,6]

\section{TYPES OF POLLUTION ARRISING FROM THE CAR INDUSTRY}

The automotive industry, as a whole, affects almost every sector of the environment. Sectors of environmental pollution can therefore be divided into:

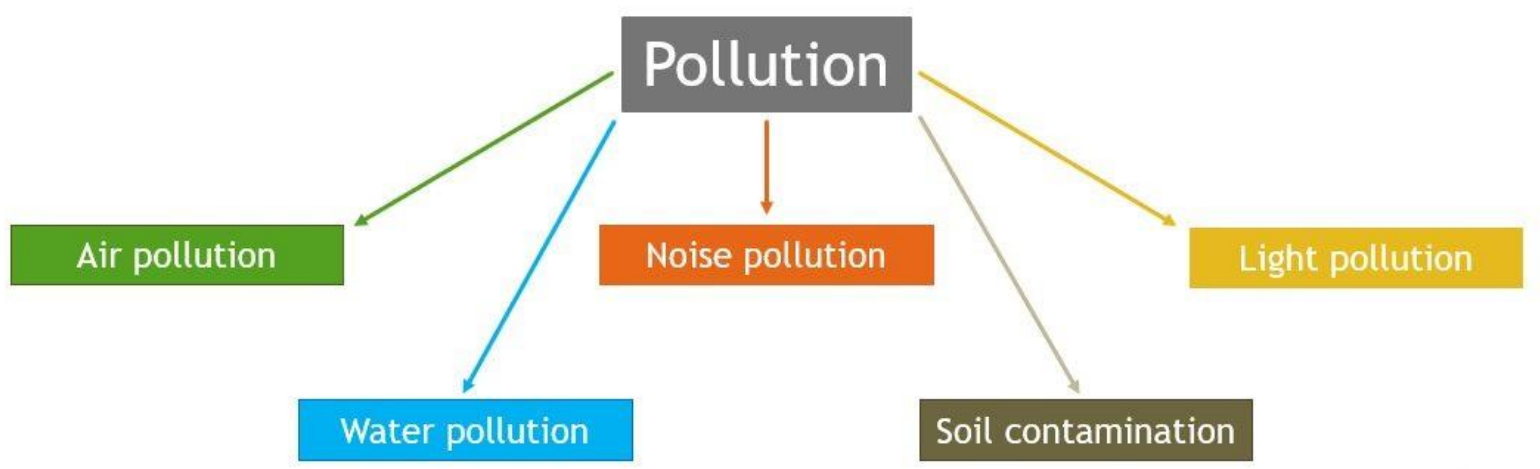

Fig. 1 Distribution of pollution from the automotive industry

\subsection{Air pollution}

Air pollution is defined by the presence of substances in the atmosphere that have a devastating effect on living organisms, but also on the climate and the environment as such. The automotive industry affects the air mainly during the production and operation of cars, when harmful gases such as ammonia, hydroxides, nitrate sulfides and others are formed.

These gases, also called emissions, affect the environment in two ways:

\section{Direct way:}

The most affected are living organisms that inhale these toxic gases when they breathe. Gases and their soot settle in the respiratory system, resulting in many diseases, such as diseases of the respiratory system and the immune system.

\section{Indirect way:}

Emissions into the air accumulate in the atmosphere, where they react with air humidity and also with each other. Such compounds then deplete the ozone layer and the formation of socalled ozone holes, which then transmit high levels of ultraviolet radiation, which also has a negative impact on the environment and living organisms. In recent years, due to the tightening of standards, the ozone layer has begun to recover slowly (Fig. 2). 
In FIG. 2, there is an overview of the levels of ozone in the atmosphere as well as the expected level of ozone in the near future.

\section{Ozone layer value}

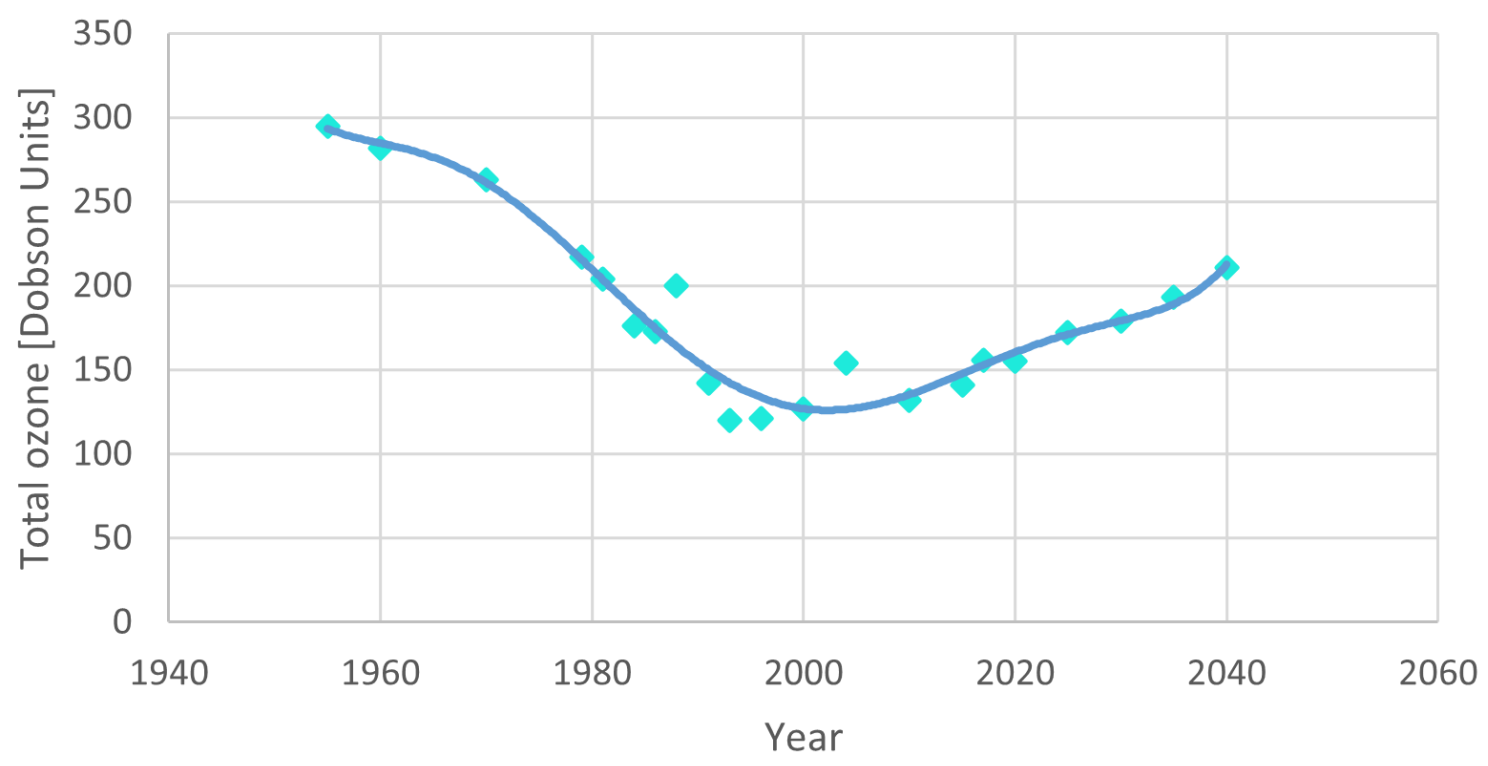

Fig. 2 The value of the level of ozone in the atmosphere

In addition to the depletion of the ozone layer by emissions, acidic rains are also created, which most significantly damage the environment and all the objects contained in it. Acid rain is created by the chemical reaction of atmospheric humidity and emissions contained in the atmosphere, as well as by the interaction of sulfur dioxide and carbon oxides produced by cars and industry. In FIG. 3 shows the formation of acid rain. In FIG. 4 shows a country that has been under the influence of acid rain for a long time. [3,4]

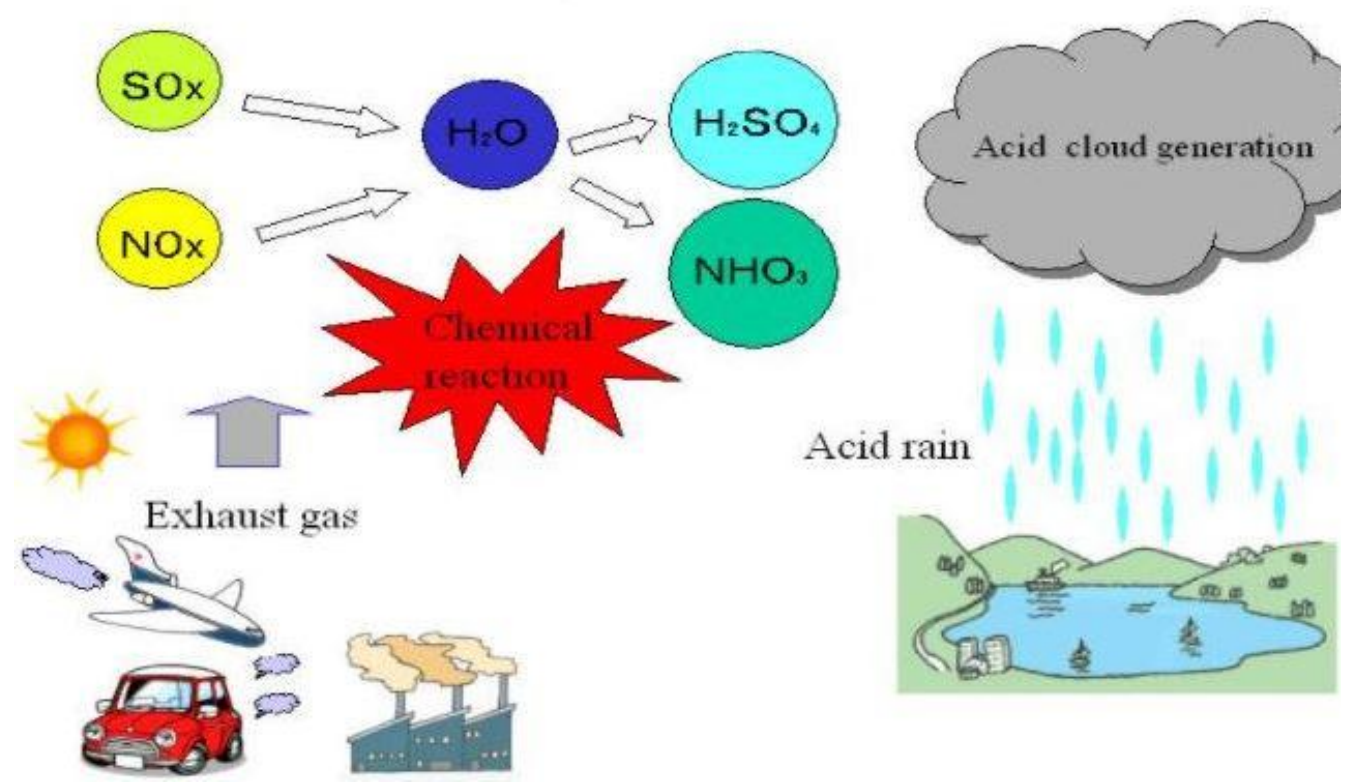

Fig. 3 The formation of acid rain 


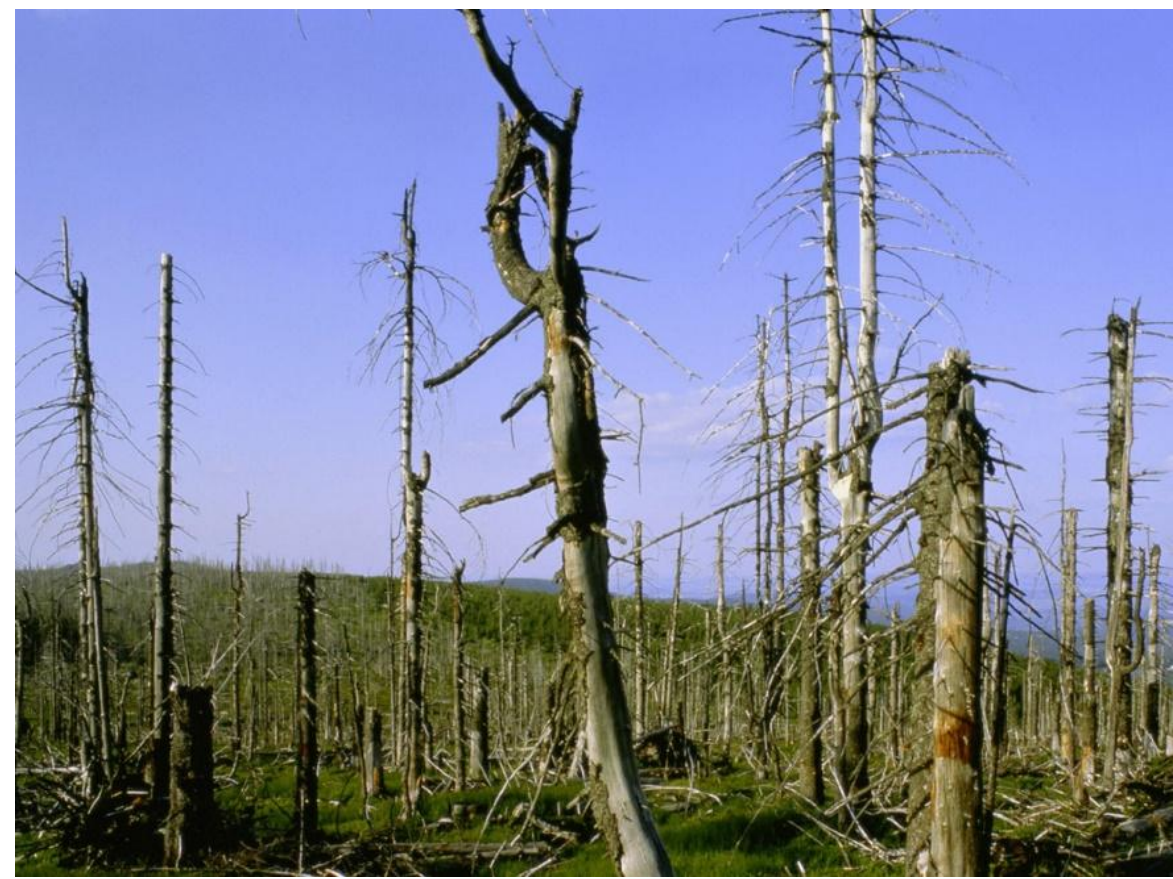

Fig. 4 Country devastated by acid rain

\subsection{Noise pollution}

Sound pollution can be defined as the long-term exposure of the environment and the living organisms living in it to excessive unnatural sound. Cars and the car industry itself are a major producer of this type of pollution.

Despite its apparent harmlessness, this type of pollution affects humans as well as other living organisms. In humans, long-term exposure to excessive noise can cause irreversible health complications in all age groups. The most serious complications include hearing loss, heart disease, increased blood pressure and, to a large extent, insomnia, which results in other serious diseases.

In animals and other living organisms, sound is a tool for communication, echolocation and navigation. Sound pollution thus adversely affects the fauna, where it disrupts the natural environment of animals. [1,4]

\subsection{Light pollution}

Light pollution is defined as the presence of anthropogenic and artificial light in the night environment. Like sound pollution, light pollution affects humans as well as other living organisms and disrupts their natural biorhythm. We observe light pollution at night. Light pollution can cause disorientation in animals. In humans, light pollution is mainly caused by insomnia, which is the cause of many mental and mental disorders, but also increased blood pressure and heart disease.

Larger cities with more traffic are especially infested. Cars and automobiles are a major producer of this pollution, as they need light to operate. [2,3,5] 
In FIG. 5, there is a map of light pollution in Europe, where the places with the lowest pollution levels are drawn in blue and those with the highest pollution levels in red.

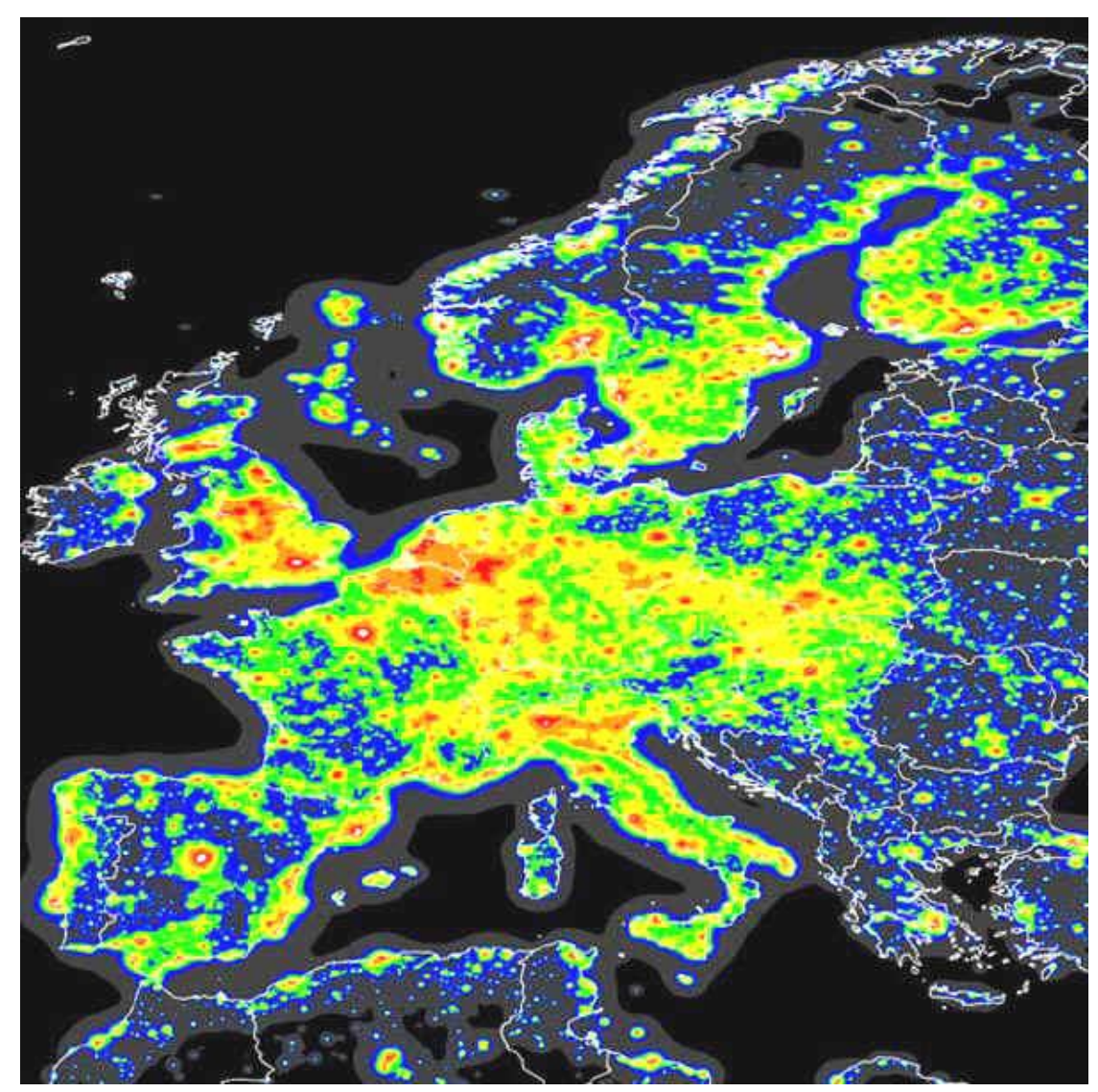

Fig. 5 Map of Light pollution in Europe

\subsection{Water pollution}

Water pollution, also called water contamination, is the result of a predominantly human impact on the environment. By degrading water supplies, lakes, oceans, rivers and the like, it significantly affects the health of people and organisms. This type of pollution comes from various industries. As far as the cars and the car industry are concerned, the main source is the impurities that result from the production and use of cars.

During the operation of vehicles, particles of tires, dust, exhaust emissions are released on the road, which are then carried by rainwater into the soil from where it penetrates into groundwater or air, and in the form of acid rain penetrates into the soil.

These toxic compounds are then absorbed into crops and the natural food of living organisms, which significantly affects the quality of the health. [3,5] 
Pollution of water and watercourses is also significantly affected by the existence of illegal dumps of cars and their parts in the vicinity of water bodies.

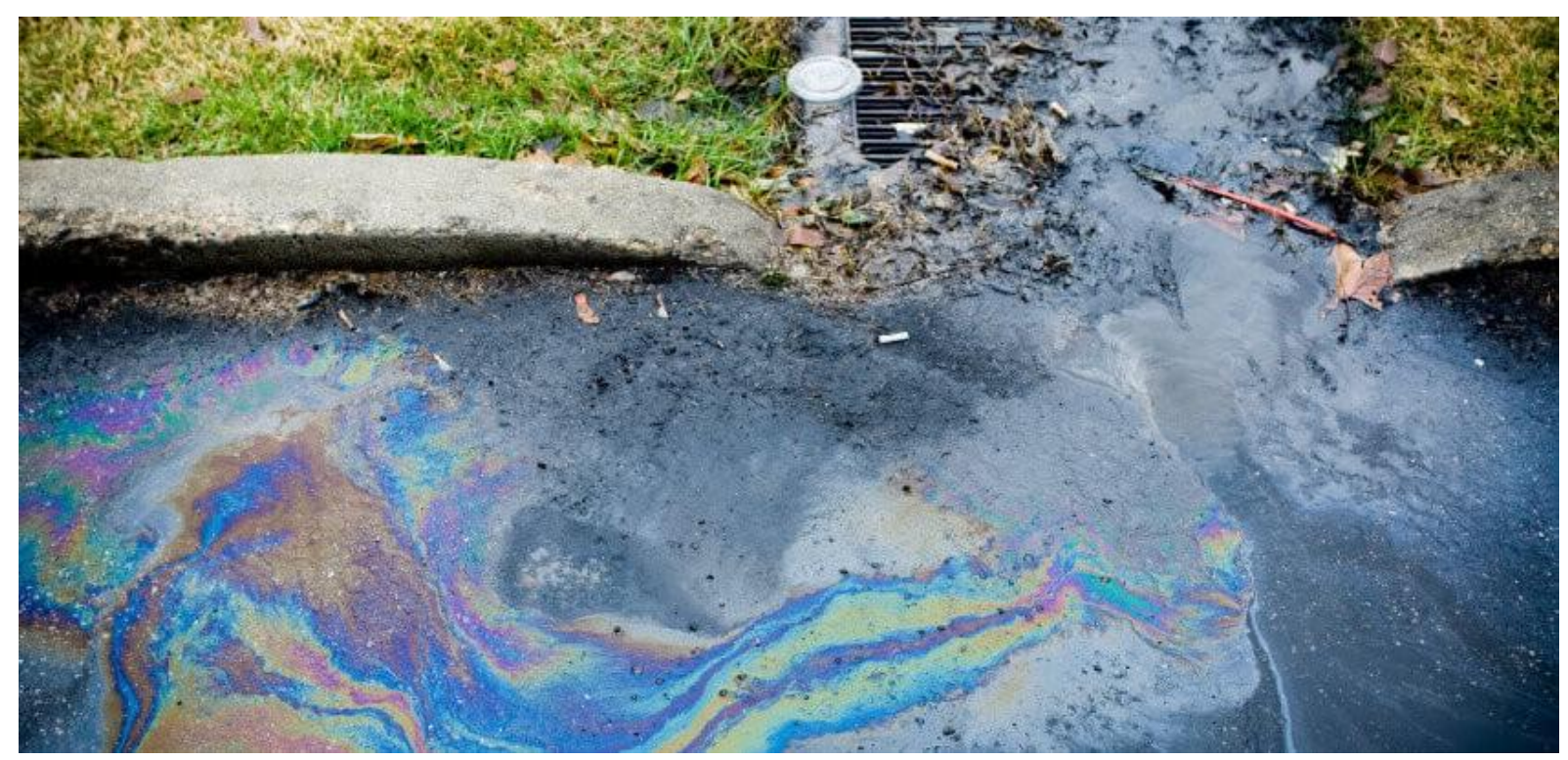

Fig. 6 Water pollution caused by car usage

In FIG. 4 there we can see typical traces of pollution caused by the leakage of car operating fluids on the water surface. These operating fluids then penetrate the soil and are absorbed by the plants, or they are released into the atmosphere by evaporation..

\subsection{Soil contamination}

Soil pollution, like water pollution, is the result of the use, maintenance and production of cars. Especially during the operation of the vehicle, toxic particles are released from it, which are introduced into the vicinity of roads, where they settle in the soil or on the surface of buildings or objects. When vehicles move, dust also swirls, which is inhaled by living organisms. Together with the toxic particles released from vehicles, it thus pollutes the road environment and adjacent fields.

Soil pollution is also caused by the above-mentioned pollution of water and air. In this respect, cars and the industry associated with them are a major producer of soil pollution, but also of pollution as such. $[2,4]$

\section{SOLUTION DESIGN}

More and more manufacturing companies and research organizations are dealing with pollution caused by cars and the car industry. As mentioned in the introduction, the environment is able to cope to some extent with the negative impact caused by industry, but it is essential to create and adhere to measures and look for new design solutions for engines or sources of alternative fuels.

Today, the development of cars with an electric motor and electric cars is at the forefront. Despite the European Parliament's efforts to sell electric cars, their share of the road is only $2.7 \%$. Gradual replacement of internal combustion cars with electric cars would address the 
issue of reducing emissions, but the fact that more than $80 \%$ of world electricity production comes from fossil fuels (oil, coal, natural gas) should be taken into account.

\section{Assumption of the development of the share of electric cars}

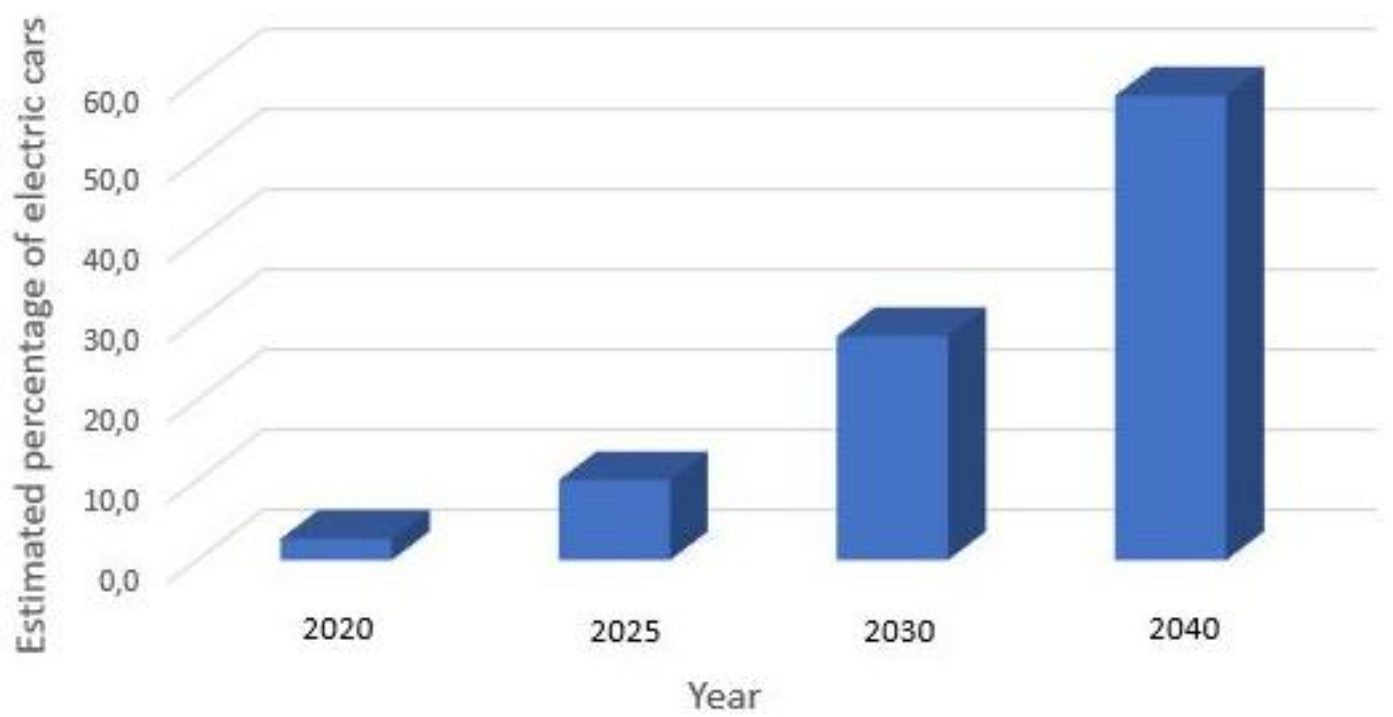

Fig. 7 Assumption of development of the share of electric cars

\section{Elektricity production in the world}

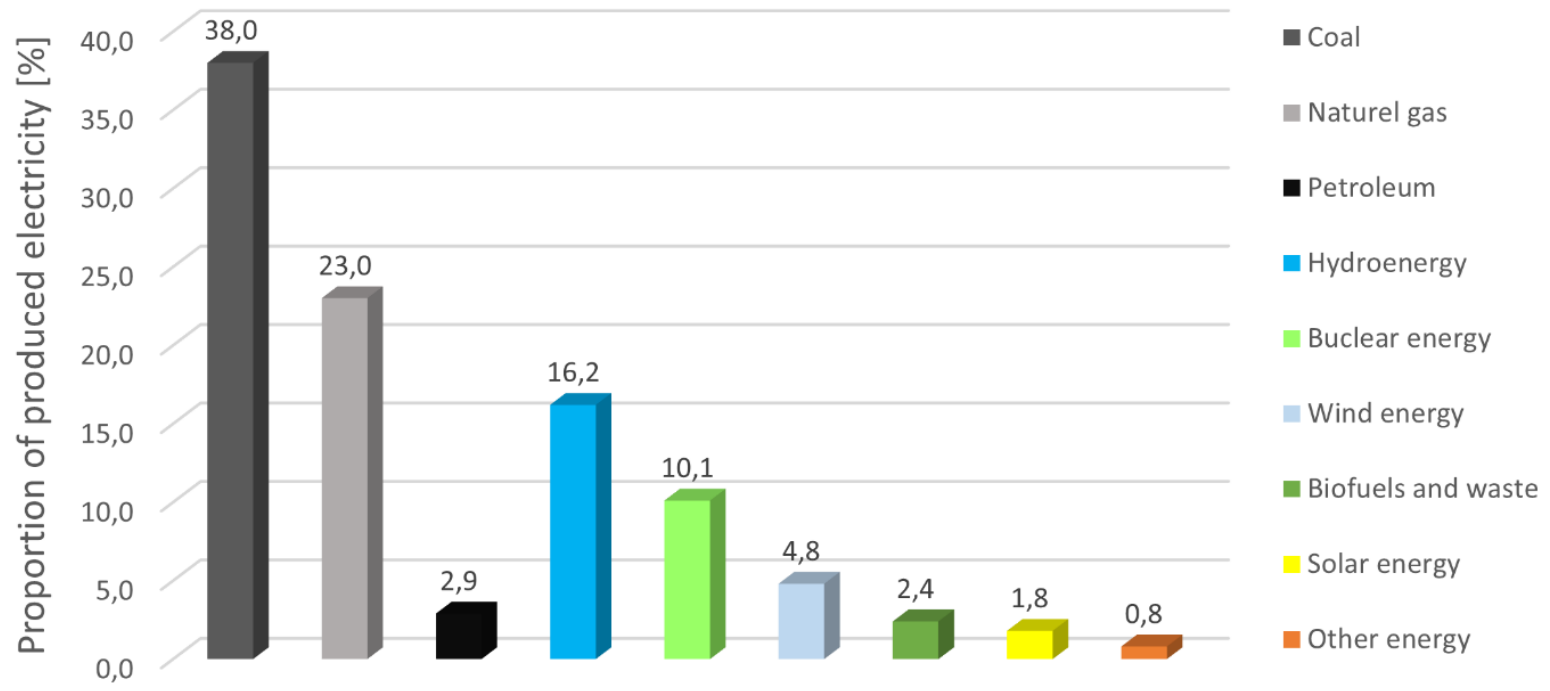

Representation of electricity sources

Fig. 8 Percentage of electricity sources

Another possible solution is research into alternative fuel sources, or research into combinations of existing fuels. Today, research focuses mainly on biofuels, alcohol-based fuels and hydrogen. 


\section{CONCLUSIONS}

From the data obtained, it can be stated that research and development of less environmentally demanding cars is beginning to improve the situation of the global climate issue. With further government measures, the trend of improving levels may continue to increase. However, it is necessary to maintain the development of new technologies and design proposals in order to eliminate emissions as much as possible.

\section{ACKNOWLEDGEMENTS}

This work was supported by the Slovak Research and Development Agency under the Contract no. APVV-19-0328.

The article was written in the framework of Grant Projects: VEGA 1/0318/21 "Research and development of innovations for more efficient utilization of renewable energy sources and for reduction of the carbon footprint of vehicles" and KEGA 006TUKE-4/2020 "Implementation of Knowledge from Research Focused on Reduction of Motor Vehicle Emissions into the Educational Process.".

\section{Sources}

1. Steven, A.; A Low-pollution engine solution. Scientific American 2001, Vol. 284, No.6: 90-95.

2. Syed Yaser Hussaini, Subhash Lahane, N.G. Patil, Analysis of Performance andEmission Characteristics of Homogeneous Charge Compression Ignition (HCCI)Engine, Procedia Technol. 25(2016) 2016 854-861.

3. A. Salvo, Y. Wang; Ethanol-blended gasoline policy and ozone pollution in Sao Paulo, Journal of the Association of Environmental and Resource Economists, 4 (3) (2017), pp. 731-794

4. P. Perez; Air quality forecasting in a large city, WIT Trans. Ecol. Environ., 116 (116) (2008), pp. 21-28

5. R. R. Saraf, S. S. Thipse, P. K. Saxena; Homogenous charge compression ignition (HCCI)- va new technology to reduce pollutants in gasolineinjected engines. Nature Environment and Pollution Technology, 2007, Vol. 6 No.4 pp. 703-708

6. D.E. Newby, P.M. Mannucci, G.S. Tell, et al.; Expert position paper on air pollution and cardiovascular disease,, Eur Heart J, 36 (2015), pp. 83-93

\section{Contact}

Ing. Matúš Lavčák

Faculty of Mechanical Engineering, TU Košice

Letná 9, 04001 Košice, Slovak Republic

Tel: +421907213650

email: michal.puskar@tuke.sk 


\title{
ENVIRONMENTÁLNE RIZIKÁ A CERTIFIKÁCIA VOZIDIEL POMOCOU NEW EUROPEAN DRIVING CYCLE (NEDC)
}

\author{
ENVIRONMENTAL RISKS AND CERTIFICATION OF VEHICLES \\ USING THE NEW EUROPEAN DRIVING CYCLE (NEDC)
}

\author{
Michal Puškár, Marieta Šoltésová, Matúš Lavčák
}

\begin{abstract}
Abstrakt
Testy s využitím Portable Emissions Measurement Systems (PEMS) ukázali, že naftové autá produkujú niekol'kokrát viac $\mathrm{NO}_{\mathrm{X}}$ na ceste než počas certifikácie pomocou New European Driving Cycle (NEDC). Tato skutočnost' vyvolala aféru "dieselgate". Je všeobecne známe, že súčasné emisné limity sú vel'mi prísne a vzniká vážny problém pre automobilové továrne, aby splnili náročné emisné požiadavky. Predmetom tejto štúdie bolo testovanie 10 osobných vozidiel s dieselovým aj benzínovým pohonom, ktoré oficiálne spĺn̆ajú normy Euro 4-6. Na základe výsledkov meraní sa zistilo že, reálne emisie $\mathrm{NO}_{\mathrm{X}}$ dieselových motorov výrazne prevyšujú hodnoty namerané pomocou NEDC. Výsledky získané cyklom NEDC sú rovnako v rozpore so zisteniami pre dva alternatívne jazdné cykly, t.j. CADC a WLTC.
\end{abstract}

Kl'účové slová: merací systém, analýza, spal'ovací motor

\begin{abstract}
The tests performed using the Portable Emissions Measurement Systems (PEMS) discovered a fact that the diesel engine cars produce on the road several times more NOX emissions than during the certification process, which is based on the New European Driving Cycle (NEDC). This unfavourable fact started the "dieselgate" affair. In general, it is well known that the current emission limits are very strict and there is arising a serious problem for the automobile factories to fulfil the demanding emission requirements. The main subject of this study was testing of 10 passenger cars equipped with the diesel and gasoline engines that officially meet the Euro 4-6 standards. However, it was found, according to the measured results that the real NOX emissions in the case of the diesel engines significantly exceed the emissions values from the NEDC testing. The results obtained using the NEDC are also in a conflict with the results from two alternative driving cycles, i.e. CADC and LTC.
\end{abstract}

Keywords: measuring system, analysis, internal combustion engine

\section{1 ÚVOD}

Vyšetrovanie aféry „dieselgate“, ktorá sa týkala manipulácie s emisiami NOx vozidiel vyvolalo diskusiu o efektívnosti laboratórneho testovania. Vzhl'adom na pretrvávajúce znečistenie $\mathrm{v}$ mnohých európskych mestách, je potrebné viac ako kedykol’vek predtým zabezpečit' spol'ahlivé postupy, ktoré presne stanovia produkciu vozidlových emisií v reálnej doprave [1-5].

Testovanie vozidiel s využitím Portable Emissions Measurement Systems (PEMS) v Európe od roku 2007 preukázalo, že l'ahké dieselové vozidlá, certifikované podl'a noriem Euro 4 až Euro 6, produkujú násobne viac NOx než je povolené príslušným emisným limitom. Tieto prekročenia boli spôsobené nedostatkami v schval'ovacom postupe, konkrétne nízkymi zrýchleniami vozidiel a úzkym teplotným rozsahom od $20-30{ }^{\circ} \mathrm{C}$ počas NEDC certifikácie. V súčasnosti sú tie problémy riešené prostredníctvom Worldwide harmonized Light vehicles 
Test Procedure (WLTP) a doplnkovým testom Real-Driving Emissions (RDE). Pri oboch postupoch, ktoré sa nachádzajú na pokraji implementácie, sa venuje málo pozornosti pochopeniu skutočného dôvodu zvýšených NOx emisií dieselových vozidiel v reálnej prevádzke. Je možné konštatovat', že nedostatočná dynamika jazdy a príliš úzky teplotný rozsah NEDC testovania nemusí byt' hlavnou príčinou problémov s NOx u dieselových motorov. Značná čast' zvýšených emisií NOx v doprave môže súvisiet' s používaním rušiacich stratégií. Rušiacim zariadením je akýkol'vek hardvér, softvér alebo dizajn motorového vozidla, ktorý narúša alebo deaktivuje reguláciu emisií za skutočných jazdných podmienok, aj ked' vozidlo prejde formálnym testovaním emisií. Prezentovaná analýza zahŕňa 10 osobných vozidiel, ktoré sú testované prostredníctvom NEDC v laboratóriu a na rôznych trasách $\mathrm{v}$ doprave. Tento výskum poskytuje alternatívu ako preverovat' vozidla a môže poukázat' na tie vozidlá, ktoré vyžadujú hĺbkové posúdenie svojej spôsobilosti [6,7].

\section{METODIKA A PODMIENKY}

Ako experimentálne modely bolo použitých 10 osobných vozidiel, kde boli 3 benzínové vozidlá s Euro 5 and 7 diesel vozidiel s Euro 4-6 (obr. 1-4). Na všetky laboratórne testy a testy v doprave na ceste sa používajú bežné palivá, ktoré sú v súlade so smernicou 2009/30 / ES a špecifikáciami výrobcu pre prevádzku príslušného vozidla. V laboratóriu boli vykonávané emisné skúšky na valcovej stolici, $\mathrm{NO}_{\mathrm{X}}$ a $\mathrm{CO}_{2}$ sa určovali emisným analyzátorom. $\mathrm{Na}$ ceste $\mathrm{v}$ reálnej doprave sa emisie $\mathrm{NO}_{\mathrm{X}}$ a $\mathrm{CO}_{2}$ merali pomocou portable emissions measurement system (PEMS). Teplota prostredia sa meria pri $1 \mathrm{~Hz}$ pričom atmosférická sonda je súčast'ou zariadenia. V súlade s nariadením 2016/427 (ES, 2016) sú vypočítané okamžité emisie NOx a emisie $\mathrm{CO}_{2}$ na cestách $\mathrm{v}$ reálnej doprave $\mathrm{s}$ frekvenciou 1 Hz vynásobením koncentrácie znečist'ujúcich látok a hmotnostným prietokom výfukových plynov. Emisie špecifické pre vzdialenost' $[\mathrm{mg} / \mathrm{km}$ ] sa potom vypočítajú ako súčet okamžitých emisií počas posudzovaného časového intervalu vydelený vzdialenost'ou v tomto časovom intervale. Pri testoch na cestách pomocou PEMS boli vybrané podobné podmienky ako pri NEDC. To znamená, že kombinácia rýchlosti a zrýchlenia boli v súlade $\mathrm{s}$ NEDC, teplota okolia bola v rozsahu homologizácie 20 až $30{ }^{\circ} \mathrm{C}$ a jazdilo sa v rovinatom teréne so stúpaním do $0,1 \%$. Výsledky analýzy sú prezentované v stípcových grafoch, odchýlky medzi laboratórnymi emisiami $\mathrm{NO}_{\mathrm{x}}$ a hodnotami dosiahnutými $\mathrm{v}$ reálnej premávke môžu súvisiet' $\mathrm{s}$ rozdielnou dynamikou jazdy [8].

\section{VÝSLEDKY}

Dieselové a benzínové vozidlá majú tendenciu splňat' požiadavky príslušných emisných noriem pri testovaní NEDC. V súlade $\mathrm{s}$ týmto pozorovaním sa väčšina okamžitých emisií $\mathrm{NO}_{\mathrm{X}}$ všetkých vozidiel počas NEDC nachádza pod emisným limitom (obrázok 1, prvý stípec). Obrázok sa líši pre cestné dáta, kde väčšina okamžitých emisií $\mathrm{NO}_{\mathrm{X}}$ naftových automobilov je umiestnená vysoko nad limitom (obrázok 1, posledný stípec). Pre benzínové vozidlá sú cestné emisie $\mathrm{NO}_{\mathrm{X}}$ rovnako vyššie než emisie na NEDC, ale stále sú pod emisným limitom. Ak sa vyberú iba podmienky jazdy podobné NEDC, grafy (medián hodnôt) sa prevažne prekrývajú s políčkami NEDC (obr. 2, stredný stĺpec). Táto čast' analýzy poukazuje na výrazne odlišné správanie dieselových vozidiel pri NEDC a počas jazdy na ceste $\mathrm{v}$ podmienkach podobných certifikácii. 


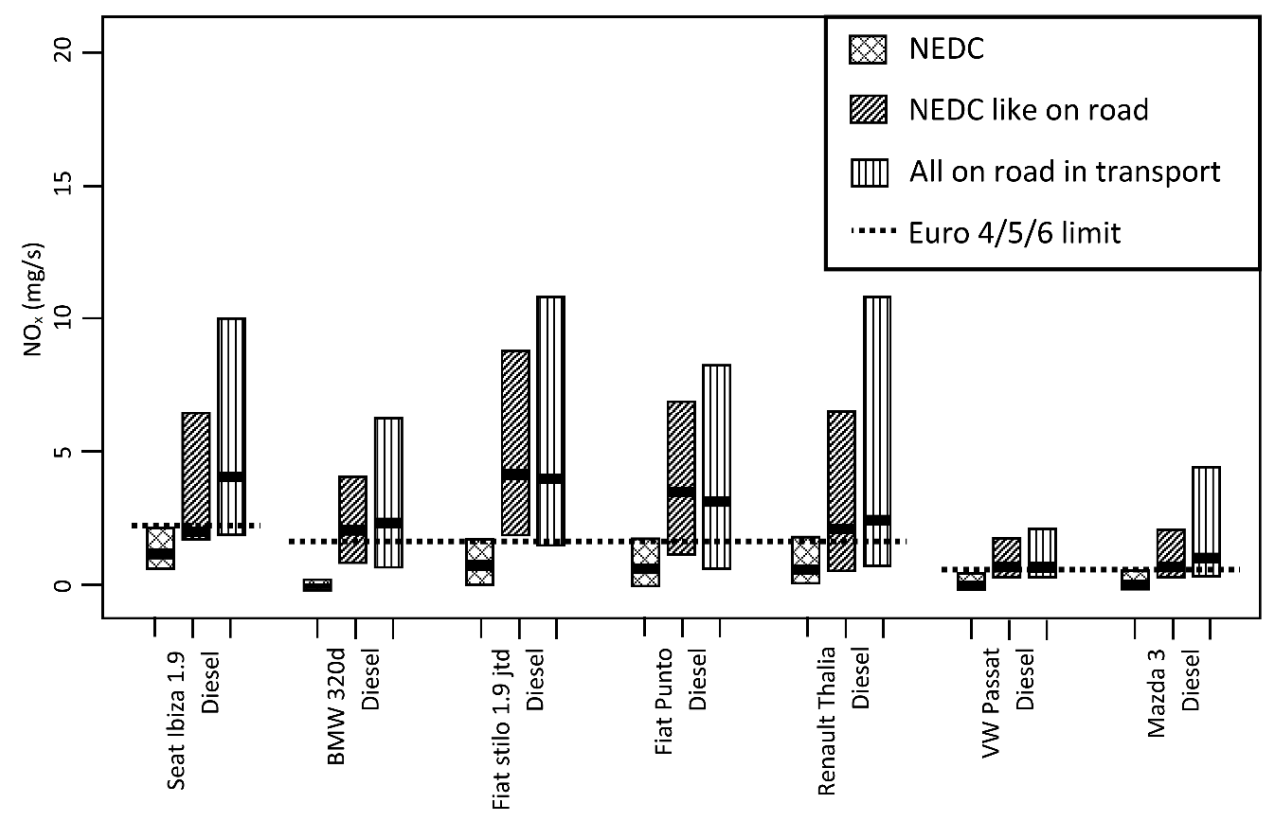

Obrázok 1. Stĺpcové grafy emisií $\mathrm{NO}_{\mathrm{X}}(\mathrm{mg} / \mathrm{s})$ pre dieselové vozidla

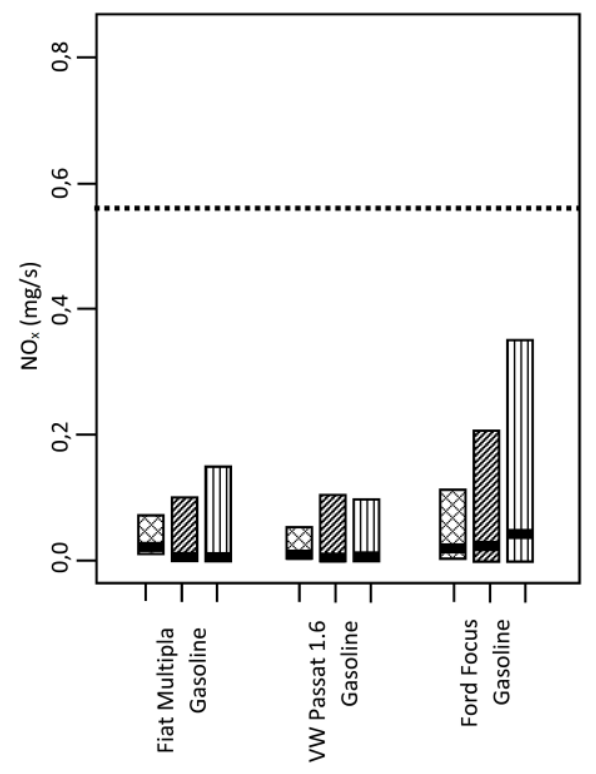

Obrázok 2. Stĺpcové grafy emisií NOX (mg / s) pre benzínové vozidla

Druhá čast’ analyzuje emisie v závislosti na prejdenej vzdialenosti (obrázok 3 ). V prípade ked' sa analyzujú emisie $\mathrm{NO}_{\mathrm{X}}$ pomocou NEDC na testovacom stende pri rôznych jazdných podmienkach, opät' sú tu výrazné rozdiely medzi dieselovými a benzínovými vozidlami. Pre dieselové vozidlá, reálne emisie $\mathrm{NO}_{\mathrm{X}}$ výrazne prevyšujú hodnoty namerané pomocou NEDC. Pri kontrole teploty okolia sa výsledky nemenia. Ked' sa zohl'adňujú všetky údaje získane pomocou PEMS, dieselové automobily prekračujú emisie NEDC niekol'konásobne. Pre benzínové vozidlá však reálne emisie $\mathrm{NO}_{\mathrm{X}}$ prevyšujú hodnoty namerané na NEDC iba $\mathrm{V}$ menšej miere s tým, že sú hlboko pod platnou emisnou normou. 


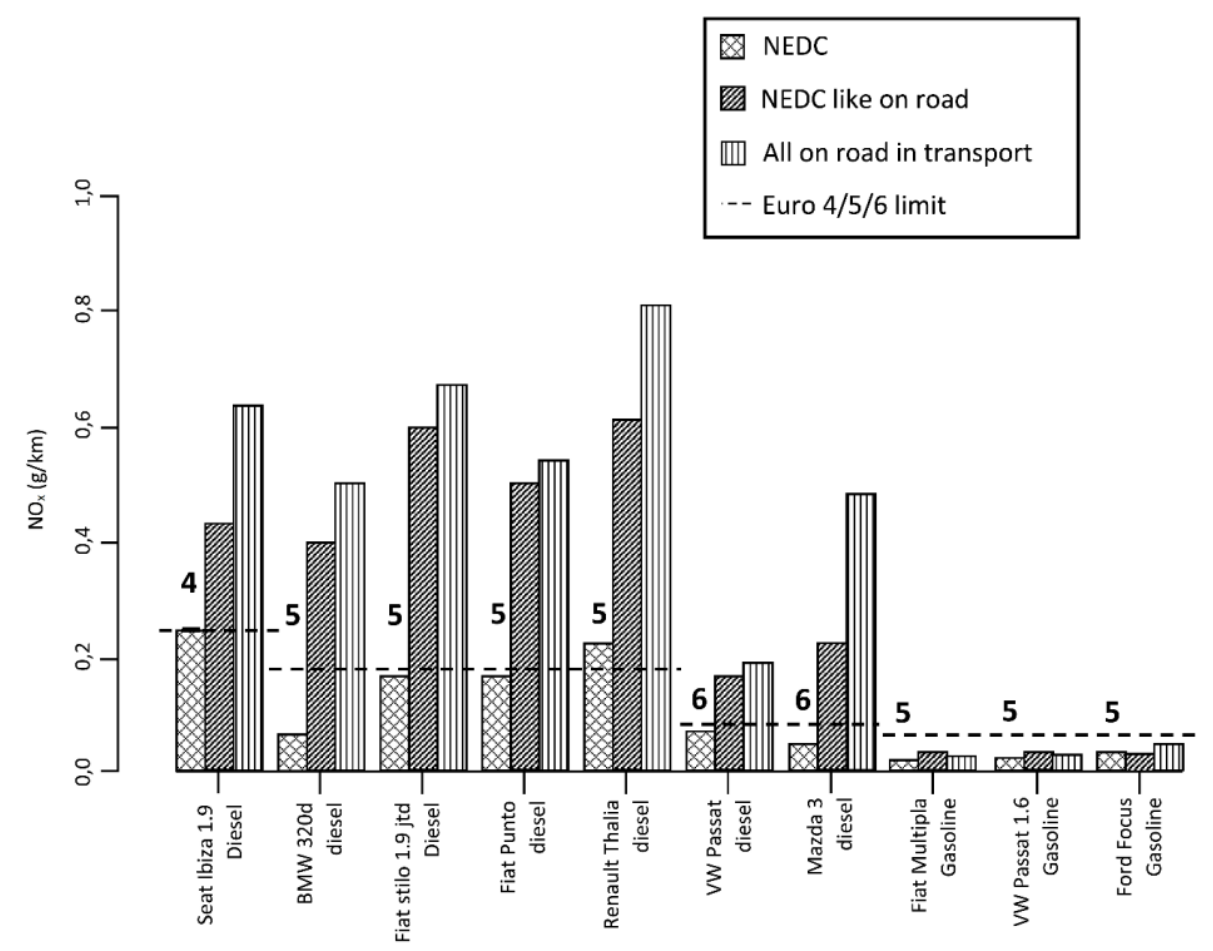

Obrázok 3. Stĺpcové grafy emisií NOX $(\mathrm{g} / \mathrm{km})$ pre dieselové a benzínové vozidla

Výsledky získane cyklom NEDC sú rovnako v rozpore so zisteniami pre dva alternatívne jazdné cykly, t.j. CADC a WLTC (obrázok 4). Pre dieselové vozidlá, priemerné emisie $\mathrm{NO}_{\mathrm{X}} \mathrm{V}$ reálnej cestnej premávke prekračujú priemerné hodnoty namerané v laboratóriu len $5 \%$. Tieto výsledky potvrdzujú opodstatnenost' aplikácie nového jazdného cyklu pre všeobecne záväzné testovanie vozidiel.

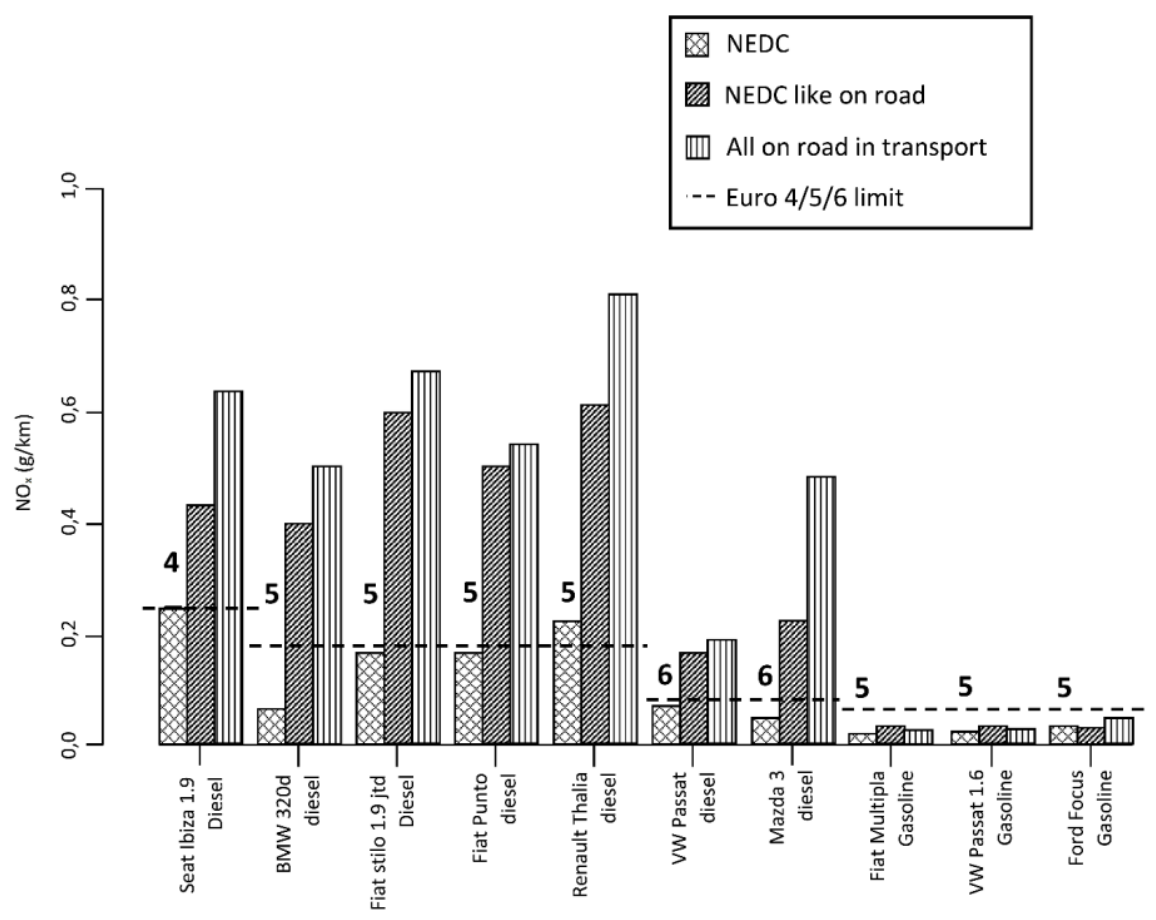

Obrázok 4. Stlípcové grafy emisií $\mathrm{NO}_{\mathrm{X}}(\mathrm{g} / \mathrm{km})$ pre dieselové a benzínové vozidla pre cykly CADC a WLTC 


\section{ENVIROMENTÁLNE RIZIKÁ}

V súčasnosti predstavujú emisie oxidov dusíka vážny problém, ktorý ma priamy súvis so zdravím obyvatel'ov a celkovou kvalitou ovzdušia v mestských oblastiach. Tieto oblasti sú charakterizované zvýšenou hustotou dopravy, ktorú komplikuje zavedenie tzv. emisných zón. Tieto zóny predstavujú problém najme pre návštevníkov a komplikujú ich presun v rámci mestskej destinácie.

Nízko emisné zóny sú oblasti, $\mathrm{v}$ ktorých je $\mathrm{z}$ dôvodu vysokého znečistenia ovzdušia obmedzený vjazd vozidiel, ktoré nespĺn̆ajú stanovené emisné limity výfukových plynov, alebo vstup takýchto vozidiel do takto vymedzeného územia je spoplatnený. V súčasnom období je v rámci Európy vybudovaných viac ako 270 nízko emisných zón, z ktorých je podstatná čast' v Nemecku a Taliansku. Nízko emisné zóny sú všeobecne označené ako LEZ z anglického výrazu Low Emission Zones, avšak v niektorých štátoch je možné sa stretnút' aj s iným označením. Napr. Umweltzonen, Milieuzones, Lavutslippssone, Miljozone, Miljözon. Ciel'om nízko emisnej zóny je vylúčit' $\mathrm{z}$ vymedzeného územia prevádzku motorových vozidiel, ktoré nesplńajú určitú hranicu emisnej triedy motora vozidla, alebo vjazd takýchto vozidiel do vymedzeného územia je spoplatnený. Spoplatnenie je uprednostňované najmä v severných štátoch Európy (napr. Švédsko). Od januára 2012 došlo k viacerým zmenám v požiadavkách nízko emisných zón $\mathrm{v}$ Európe, s ktorými dopravcovia musia uvažovat' pri plánovaní prepráv. Obyčajne ide o úplný zákaz vjazdu vozidla na územie nízko emisnej zóny, pri porušení ktorého hrozí vodičovi pokuta v stovkách eur.

Riešením je návrh mobilnej aplikácie, ktorá by na základe typu vozidla, emisnej normy a doplnkových údajov stanovila optimálnu trasu s ohl'adom na aktuálne podmienky v doprave a zmeny v emisných zónach.

\section{ZÁVER}

Závery je možné zhrnút' do nasledujúcich bodov:

- Testovane vozidlá $\mathrm{s}$ dieselovým motorom oficiálne splňujúcim normy Euro 4 - 6 prekračujú limit emisií $\mathrm{NO}_{\mathrm{X}}$ pri jazde $\mathrm{v}$ doprave niekol'konásobne. Toto pozorovanie je $\mathrm{v}$ rozpore so situáciou pre benzínové vozidlá, ktorých on-road $\mathrm{NO}_{\mathrm{X}}$ emisie zostávajú pod platným limitom.

- Vel'kú čast' zvýšených emisií NOX naftových automobilov na reálnych cestách nemožno zdôvodňovat' nedostatočnou dynamikou NEDC, ani úzkym teplotným rozsahom skúšok počas schval'ovania. Tento výsledok spochybňuje oficiálne stanovisko, podl'a ktorého nedostatočné testovanie NEDC je hlavnou príčinou problému diesel-NOX.

- Orgány na typové schval'ovanie nedávno testovali emisie $\mathrm{NO}_{\mathrm{X}}$ pomocou NEDC on road. Pri normálnych teplotách $\mathrm{v}$ Európe zistili priemerné prekročenia približne na úrovni 4,5 násobku limitnej hodnoty.

- Tento výskum poskytuje alternatívu ako preverovat' vozidla a môže poukázat' na tie vozidlá, ktoré vyžadujú híbkové posúdenie svojej spôsobilosti.

Výsledky výskumu naznačujú, že certifikácia emisií s NEDC by mohla byt’ prípustná, za predpokladu, že sa budú prísne dodržiavat' konkrétne ustanovenia. Nejde totiž len o samotný priebeh merania. Súčasné vol'né pravidla umožňujú namerane hodnoty umelo znižovat' napr. pomocou špeciálnych pneumatík pre zníženie valivého odporu, použitím špeciálneho softvéru a podobne.

\section{POĎAKOVANIE}

Táto práca bola podporená Agentúrou na podporu výskumu a vývoja na základe Zmluvy č. APVV-19-0328.

Príspevok vznikol s podporou projektov: VEGA 1/0318/21 „Výskum a vývoj inovácií pre efektívnejšie využitie obnovitel'ných zdrojov energie a znižovanie uhlíkovej stopy vozidiel.“, 
KEGA 006TUKE-4/2020 „Implementácia poznatkov z výskumu zameraného na redukciu emisií motorových vozidiel do edukačného procesu“ a zároveň práca bola podporená Agentúrou na podporu výskumu a vývoja na základe Zmluvy č. APVV-16-0259.

\section{Použitá literatúra}

1. HOU, J.; QIAO, X.; WANG, Z.; LIU, W.; HUANG Z.: Characterization of knocking combustion in HCCI DME engine using wavelet packet transform. Appl Energy 2010, 87: 1239-1246.

2. JUANG L.-H.: Finite element modelling for a piezoelectric ultrasonic system, Measurement 2010, 43 (10): 1387-1397.

3. PUŠKÁR, M.; BIGOŠ, P.: Output Performance Increase of Two-stroke Combustion Engine with Detonation Combustion Optimization, Strojarstvo 2010: Vol. 52, no. 5 (2010), p. 577-587, ISSN 0562-1887

4. PUŠKÁR, M.; BIGOŠ, P.: Method for accurate measurements of detonations in motorbike high speed racing engine, Measurement 2012, Vol. 45, no. 3 (2012), p. 529-534, ISSN 0263-2241

5. PUŠKÁR, M.; BIGOŠ, P.; PUŠKÁROVÁ, P.: Accurate measurements of output characteristics and detonations of motorbike high-speed racing engine and their optimization at actual atmospheric conditions and combusted mixture composition, Measurement 2012, Vol. 45, no. 5 (2012), p. 1067-1076, ISSN 0263-2241

6. TOMAN, R., POLÓNI, M., CHRÍBIK, A.; Preliminary study on combustion and overall parameters of syngas fuel mixtures for spark ignition combustion engine. In Acta Polytechnica. Vol. 57, no. 1 (2017), s. 38-48. ISSN 1210-2709.

7. Nedeliaková, E., Babin, M., Barta, D., 2011. Rationalization of static transport [Racionalizácia statickej dopravy], Transport and the environment (Vol. 2), proceedings of the 9th SoNorA University Think Tank Conference (Bologna). 19th of October 2011, s. 15-33, ISSN 1868-8411.

8. Czech P. Diagnosis of Industrial Gearboxes Condition By Vibration and TimeFrequency, Scale-Frequency, Frequency-Frequency Analysis. METALURGIJA. Volume: 51, Issue: 4, 2012, Pages: 521-524.

\section{Kontaktné údaje}

doc. Ing. Michal Puškár PhD,

Faculty of Mechanical Engineering, TU Košice

Letná 9, 04001 Košice, Slovak Republic

Tel: +421907213650

email: michal.puskar@tuke.sk 


\title{
OVĚŘENÍ NORMALITY JAKO ZÁKLADNÍHO PŘEDPOKLADU PRO POUŽITÍ NÁSTROJŮ ŘÍZENÍ KVALITY
}

\section{VERIFICATION OF NORMALITY AS A BASIC PRECONDITION FOR THE USE OF QUALITY MANAGEMENT TOOLS}

\author{
Kateřina Bícová, Josef Sklenička
}

\begin{abstract}
Abstrakt
Cílem tohoto př́spěvku je představit možnosti, jak ověřit předpoklad normálního rozdělení dat pro další statistické zpracování, a to bez nutnosti studia nepřeberného množství metod a hypotéz o statistickém zpracování dat. Hlavní myšlenkou je to, aby například podniky v oblasti automobilového průmyslu, kde standardy jako IATF 16949 vyžadují 100\% kontrolu a využívání statistických nástrojů pro monitorování procesů, měly snadný návod jak ověřit relevantní vstupní data pro další statistické zpracování. Normální rozdělení dat je jedním z nejčastějších rozdělení, které data mají. A zároveň je nejvhodnějším pro statistické nástroje, nebot' lze u těch to dat predikovat, že hodnocený proces se bude za stejných vstupních podmínek chovat stejně. Bez tohoto ověření by další zpracování dat nemělo dostatečnou vypovídací schopnost o sledovaném parametru.
\end{abstract}

Klíčová slova: normalita, Gauss, automotive, IATF 16949, kvalita, statistika

\begin{abstract}
The aim of this paper is to present the possibilities of verifying the assumption of a normal distribution of data for further statistical processing, without the need to study an inexhaustible number of methods and hypotheses about statistical data processing. The main idea is that, for example, companies in the automotive industry, where standards such as IATF 16949 require 100\% control and the use of statistical tools for process monitoring, have easy guidance on how to verify relevant input data for further statistical processing. The normal distribution of data is one of the most common distributions that data has. At the same time, it is the most suitable for statistical tools, because it is possible to predict that the evaluated process will behave the same under the same input conditions. Without this verification, further data processing would not have sufficient explanatory power about the monitored parameter.
\end{abstract}

Key words: normality, Gauss, automotive, IATF 16949, quality, statistics

\section{INTRODUCTION}

The correct use of the vast majority of statistical quality management tools, as well as a number of statistical hypotheses, is based on the fact that the probability distribution of data is known in advance. This means that the input data with which the analysis will be performed correspond to the given distribution, in our case normal. The normal distribution of data is one of the most common distributions that data has. At the same time, it is the most suitable for statistical tools, because it is possible to predict that the evaluated process will behave the same under the same input conditions.

The aim of this paper is to present the possibilities of verifying the assumption of a normal distribution of data for further statistical processing, without the need to study an inexhaustible number of methods and hypotheses about statistical data processing. MS Excel, 
which is one of the most widespread and well-known software supports, is mainly used for verification. The main idea is that, for example, companies in the automotive industry, where standards such as IATF 16949 require 100\% control and the use of statistical tools for process monitoring, have easy guidance on how to verify relevant input data for further statistical processing. For example, for data processing using control diagrams and subsequent evaluation of process capability.

\section{THE NORMAL DISTRIBUTION}

The normal distribution or Gaussian distribution (according to Carl Friedrich Gauss) is one of the most important probability distributions of a continuous random variable. Random events occurring in nature or society can be well modelled by normal distribution. The normal distribution includes the often mentioned random errors, such as measurement errors, caused by a large number of unknown and mutually independent causes. Therefore, normal distribution is also referred to as the law of error. According to this law, the distribution of some physical and technical quantities is also theoretically governed. [1] [2]

The normal distribution is fully characterized by two constants: the mean value $\mu$ and the variance $\sigma^{2}$. The Gaussian curve is symmetric, the mean value of $\mu$ lies just below its peak. The shape of the curve with the extreme at the location of the mean value actually means that when repeating a random experiment following a normal distribution, the values around the mean value will most often come out. The symmetry of the curve then says that results deviated above and below the mean will be published about the same time. The parameter $\sigma^{2}$ determines how closely the curve fits the mean value; the lower this parameter, the "sharper" the graph. In practice, the so-called three sigma rule is often used, sometimes even two or one sigma. It holds that the result of a random experiment with the distribution $\mathrm{N}\left(\mu, \sigma^{2}\right)$ lies in the interval [3]:

- $(\mu-\sigma, \mu+\sigma)$ with a probability of $68.27 \%$,

- $(\mu-2 \sigma, \mu+2 \sigma)$ with a probability of $95.45 \%$,

- $(\mu-3 \sigma, \mu+3 \sigma)$ with a probability of $99.73 \%$.

Results near the mean value of $\mu$ are therefore more likely than outliers, see Fig. 1.

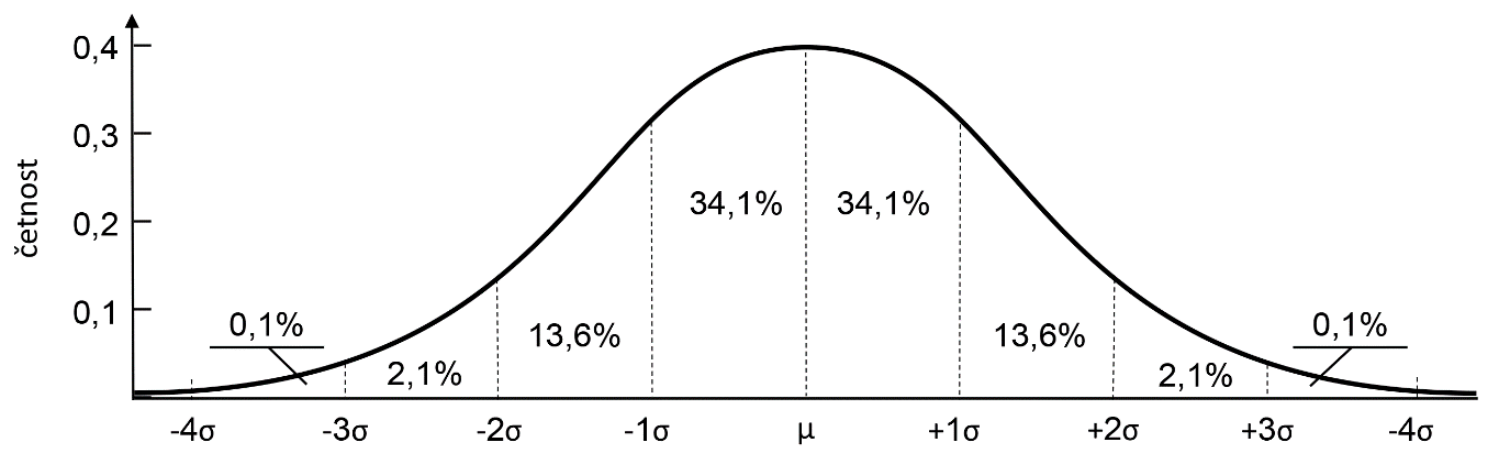

Fig. 1: The normal distribution (Gaussian curve) [3]

\section{SELECTED METHODS FOR VERIFICATION OF NORMALITY}

There are many methods to verify that the data corresponds to a normal probability distribution. These are numerical and graphical methods. Tests of the hypothesis that the random selection $x_{1}, x_{2}, \ldots, x_{n}$ comes from the assumed normal distribution are called goodness-of-fit tests. 
Probably the best known graphic method is the histogram, which is a simple and fast tool. In addition, other simple graphical tools can be used, such as the $Q-Q$ graph (quantile-quantile), which is slightly more accurate than the histogram and is more suitable for testing normality at distribution edges, or the $P-P$ graph (probability-probability), which emphasizes deviations from normal distribution near the mean value.

As for numerical methods, there are a number of tests that vary in strength and complexity. These include, for example, Shapir-Wilk, Anderson-Darling, Kolmogorov-Smirnov, Lilliefors and others. The test is usually not performed manually, but due to the high complexity, the calculations are performed on a computer.

One graphical method and two numerical methods will be discussed in more detail for this paper. A histogram is chosen as a representative of graphic methods. Numerical methods $\chi^{2}-$ goodness-of-fit test or Kolmogorov-Smirnov goodness-of-fit test with normal distribution are also selected. [4] [5] [9]

\subsection{The histogram}

The histogram is one of the basic tools of quality management. It is a graphical representation of the data using a bar graph with columns of the same width, expressing the width of the intervals, while the height of the columns expresses the frequency of the monitored quantity in the given interval. The histogram will help us assess the set of values in terms of data normality, symmetry, multimodality or the occurrence of outliers. Histograms are also a great way to view the results of running data. [6] [7] [8]

The following figures (nr.2 and 3) show the differences in display depending on the selection range. All these histograms represent random selections from the normal distribution with a mean value of $\mu=30$ and a standard deviation of $\sigma=3$. However, it can be seen that the larger the sampling range $\mathrm{n}$, the better the selection distribution shown by the histogram corresponds to the distribution in the base set shown probability density. With the commonly used range $n$ $=100$, the visual assessment may not be objective and the shape of the histogram may be additionally influenced by the choice of interval limits. [5]
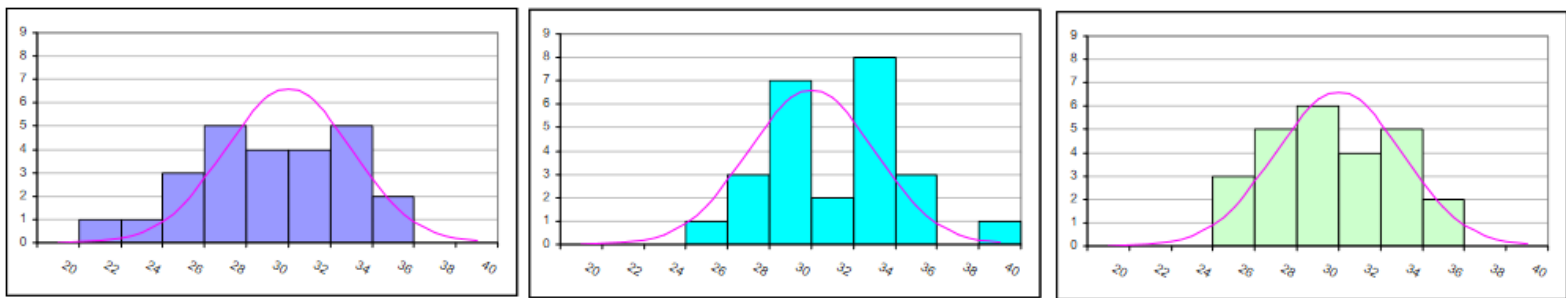

Fig. 2: Data with normal distribution, selection in the range $n=25, \mu=30$ and $\sigma=3$ [5]
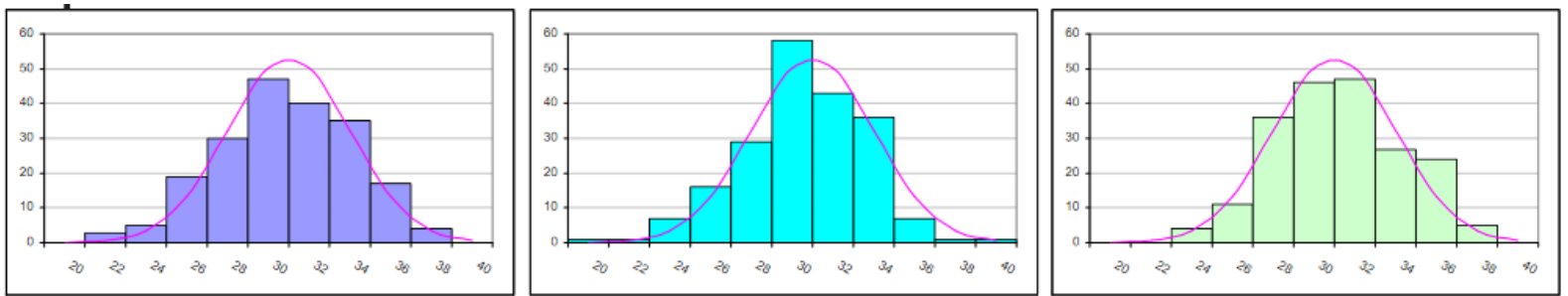

Fig. 3: Data with normal distribution, selection in the range $n=200, \mu=30$ and $\sigma=3$ [5]

\subsection{The Pearson $\chi 2$ - goodness-of-fit test}

It is actually testing a statistical hypothesis, where the last step is to formulate the conclusion of testing, which can be done in two ways [2]: 
a) by comparing the calculated test criterion with the critical value, which is determined depending on the selected level of significance $\alpha$. If the value of the calculated test statistic exceeds the critical value, it means that there is evidence to reject the null hypothesis (ie "that the difference is confirmed"). Conversely, if the calculated test statistic finds itself within the domain of acceptance of the null hypothesis $H_{0}$, the null hypothesis does not have to be rejected and is therefore assumed to be valid. The agreement between the empirical and the theoretical distribution is assessed using the test criterion:

$$
\chi^{2}=\sum_{j=1}^{k} \frac{\left(n_{j}-n p_{j}\right)^{2}}{n p_{j}}
$$

where $n_{j}$ are the empirical (real) frequencies in the interval $j(j=1,2, \ldots, k)$ and $n p_{j}$ are the theoretical frequencies (determined on the basis of probability) in the interval $j$. The formula of the test criterion can be easily adjusted to an equivalent form:

$$
\chi^{2}=\sum_{j=1}^{k} \frac{n_{j}^{2}}{n p_{j}}-n
$$

During the validity of $H_{0}$, the statistics have asymptotically $\chi^{2}$ - distribution of $k-c-1$ degrees of freedom ( $c$ is the number of parameters that are not specified by $H_{0}$, so for a normal distribution 2)

The critical field for the $H_{0}$ test therefore has the form:

$$
K=\left\{\chi^{2}>\chi_{\alpha(k-c-1)}^{2}\right\}
$$

where $\chi_{\alpha(k-c-1)}^{2}$ is the critical value of $\chi^{2}$ - distribution.

If $\chi^{2}>\chi_{\alpha}^{2}$, the null hypothesis is rejected, the alternative hypothesis holds, which states that the random selection is not from a basic set with a given probability distribution. The reliability of the $\chi^{2}$ - goodness - of - fit test increases with increasing range of selection $n$.

b) by converting the test statistic to a probability scale and calculating the probability $p$, which quantifies the probability of realizing the value of the test statistic, if the null hypothesis holds. So the rule for formulating a conclusion is as follows:

* If the $p$-value is less than the significance level $\alpha$ (error $\alpha$ ), the null hypothesis $H_{0}$ is rejected. Symbolically, the conclusion can be used:

$p<0.05$ "statistically significant difference" or

$p<0.01$ "statistically highly significant difference".

* If the $p$-value is greater than the significance level $\alpha$ (error $\alpha$ ), the null hypothesis $H_{0}$ cannot be rejected and it is therefore assumed that it holds. Symbolically it is possible to write: $p>0.05$ ("statistically insignificant difference").

\subsection{The Kolmogorov-Smirnov goodness-of-fit test with normal distribution}

If the theoretical distribution is fully known, ie. its type and relevant parameters, is a very advantageous and simple test of conformity Kolmogorov-Smirnov test, which is applicable even in cases where $\chi^{2}$ - goodness-of-fit test is not applicable (eg in case of small scale selection, large proportion of theoretical frequencies less than 5). 
Its advantage is that it is based on the original individual observed values and not on data sorted into classes (groups). This prevents the information contained in the selection from being lost.

The test is used to verify the hypothesis that the selection obtained comes from a distribution with a continuous distribution function $F(x)$, which, however, must be fully specified, including all parameters. [5] [10]

The test is performed using the test criterion:

$$
D=\frac{1}{n} \max \left|N_{j}-H_{j}\right|,
$$

where $N_{j}$ are the empirical cumulative frequencies, $H_{j}$ the theoretical cumulative frequencies, $n$ the frequency of the observed set and $\max \left|N_{j}-H_{j}\right|$ is the largest difference between cumulative empirical and theoretical frequencies. If the value of the test criterion $D$ exceeds the critical value $D_{\alpha}$ found in the table for a given range of sample $n$ and the chosen level of significance $\alpha$, we reject the null hypothesis of agreement between the empirical and theoretical distribution. [10]

\section{THE VERIFICATION OF NORMALITY}

\subsection{The histogram}

The histogram was subsequently used for the numerical method, namely the KolmogorovSmirnov goodness-of-fit test with the normal distribution. The histogram is compiled so that the data are first divided into individual classes (intervals) of a specified width. The graph then shows the frequencies of values in individual classes. The following table lists the default values for histogram assembly.

Tab. 1: The occurrence of specific measurement values

\begin{tabular}{cc}
\hline Intervals & Frequencies of values \\
\hline 28,005 & 0 \\
28,01 & 0 \\
28,015 & 1 \\
28,02 & 1 \\
28,025 & 3 \\
28,03 & 10 \\
28,035 & 18 \\
28,04 & 32 \\
28,045 & 39 \\
28,05 & 34 \\
28,055 & 26 \\
28,06 & 23 \\
28,065 & 21 \\
28,07 & 8 \\
28,075 & 4 \\
28,08 & 3 \\
28,085 & 0 \\
28,09 & 0 \\
\hline
\end{tabular}




\section{Histogram}

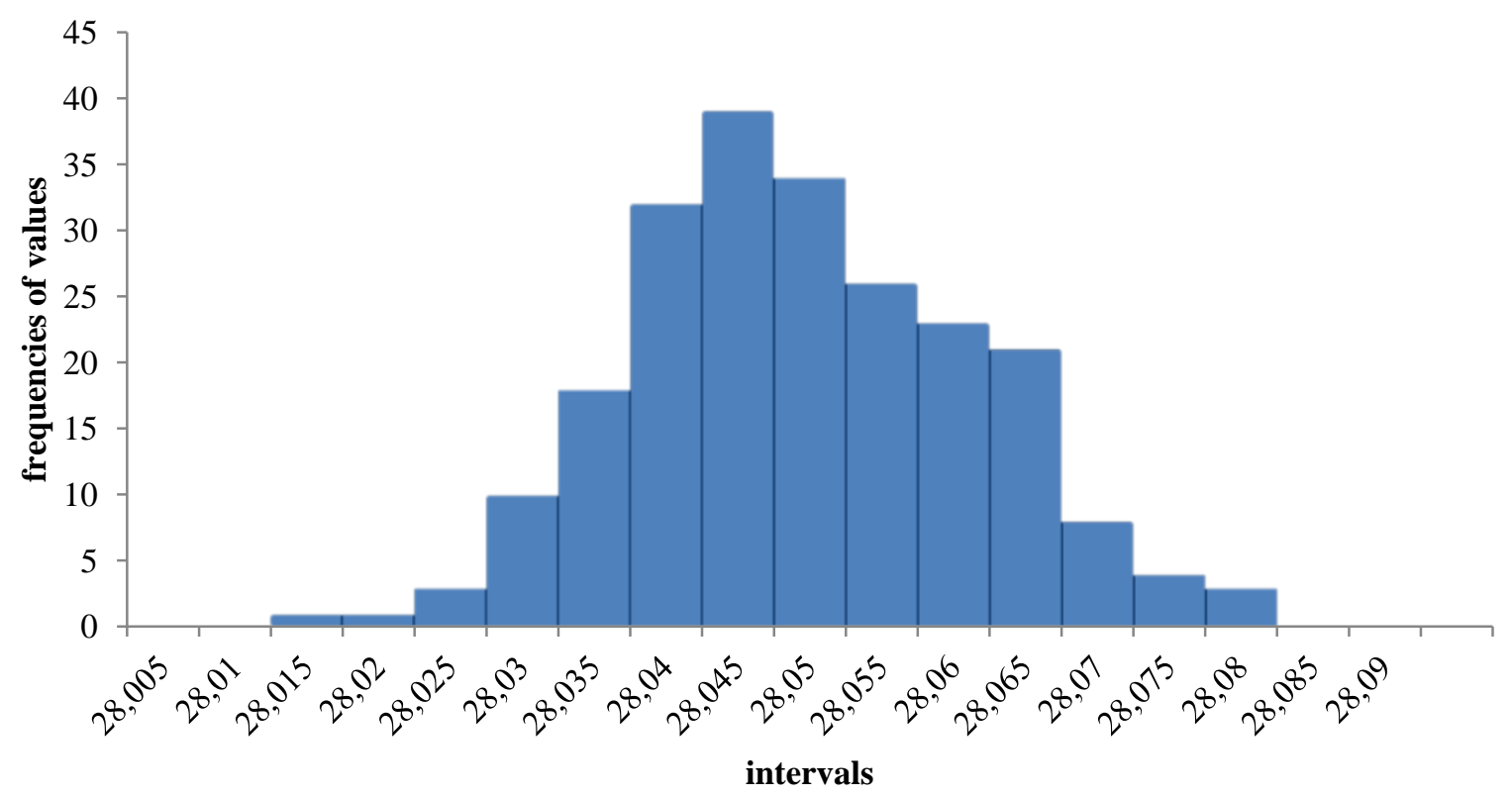

Fig. 4: Histogram of measurement values

From the previous figure we can conclude that this is really a concordance with the normal distribution, but it cannot be said unequivocally. Therefore, to better illustrate compliance, it is appropriate to use other tools or methods to confirm this.

\subsection{The Pearson $\chi 2$ - goodness-of-fit test}

In this test, the calculated test criterion is compared with a critical value, which is determined depending on the selected level of significance $\alpha$. If the value of the calculated test statistic exceeds the critical value, it means that there is evidence to reject the null hypothesis (ie "that the difference is confirmed"). Conversely, if the calculated test statistic finds itself within the scope of $H_{0}$ acceptance, the null hypothesis does not have to be rejected and is therefore assumed to be valid.

For the analysed data, for a $5 \%$ level of significance, the critical value is for $\chi_{\text {crit }}^{2}=6.244766$ (from the tables for $\chi^{2}$ ) [11]

Test criteria:

$$
\chi^{2}=\sum_{j=1}^{k} \frac{\left(n_{j}-n p_{j}\right)^{2}}{n p_{j}}=0,155182574
$$

Since $0.155182574<6.244766$, it follows that the null hypothesis holds $=$ it is an agreement with the normal distribution.

It is a more extensive calculation, so it was performed in MS Excel [12]. In addition, the correctness of the calculation was verified in the Matlab program (see the following figure 5), where again the null hypothesis $H_{0}$ assumes that the sample has a distribution of a certain type, in this case normal. 


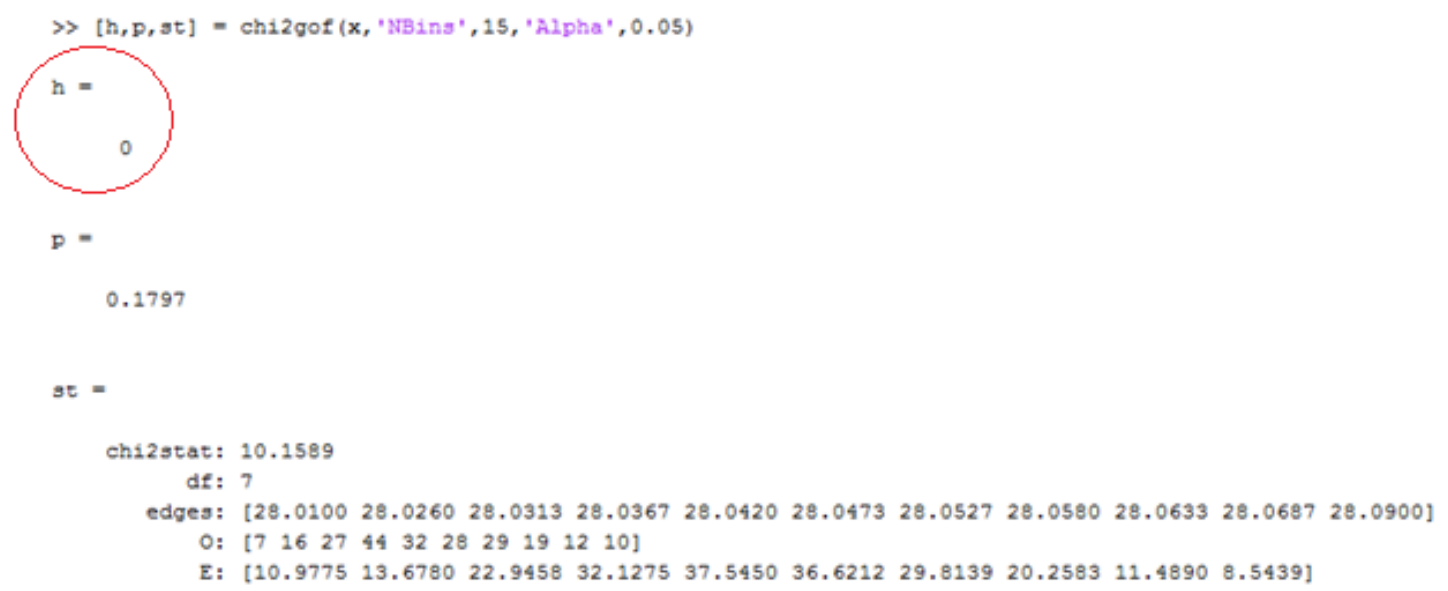

Fig. 5: Verifying the null hypothesis in Matlab

$H=O$ in the Matlab program means that the null hypothesis for the $5 \%$ level of significance is not rejected, ie, the hypothesis holds $=$ it is a coincidence with the normal distribution.

\subsection{The Kolmogorov-Smirnov goodness-of-fit test with normal distribution and histogram}

Another possibility to verify normality is actually a combination of graphical and numerical methods. The graphical method in this case is a previously constructed histogram, which is more for the initial estimation of the shape of the data. Subsequently, the KolmogorovSmirnov test is used, in which the histogram is interpolated by a Gaussian curve. The value of criterion $D$ is compared with the critical value $D_{\alpha}$ for the significance level $\alpha=5 \%$, ie 0.05 .

Tab. 2: Calculated values for the Kolmogorov-Smirnov test

\begin{tabular}{rr}
\hline Intervals & Frequencies of values \\
\hline 28.005 & 0 \\
28.01 & 0 \\
28.015 & 1 \\
28.02 & 1 \\
28.025 & 3 \\
28.03 & 10 \\
28.035 & 18 \\
28.04 & 32 \\
28.045 & 39 \\
28.05 & 34 \\
28.055 & 26 \\
28.06 & 23 \\
28.065 & 21 \\
28.07 & 8 \\
28.075 & 4 \\
28.08 & 3 \\
28.085 & 0 \\
28.09 & 0 \\
\hline &
\end{tabular}

\begin{tabular}{|c|c|}
\hline \multicolumn{2}{|l|}{ Calculated values } \\
\hline Nr.of value $=$ & 224 \\
\hline$x$ bar tot $=$ & 28.0466 \\
\hline stot $=$ & 0.012449 \\
\hline $\operatorname{Max}=$ & 28.09 \\
\hline $\operatorname{Min}=$ & 28.01 \\
\hline Span $=$ & 0.08 \\
\hline Number int. $=$ & 15 \\
\hline Widht intervals $=$ & 0.005333 \\
\hline$\alpha=$ & 0.05 \\
\hline$D=$ & 0.063711 \\
\hline$D ;$ crit. value. $=$ & 0.090869 \\
\hline \multicolumn{2}{|l|}{ Conclusion: } \\
\hline \multicolumn{2}{|c|}{$\begin{array}{c}\mathrm{D}<\mathrm{D} ; \text { crit.value. } \\
\text { Not reject the normality }\end{array}$} \\
\hline
\end{tabular}




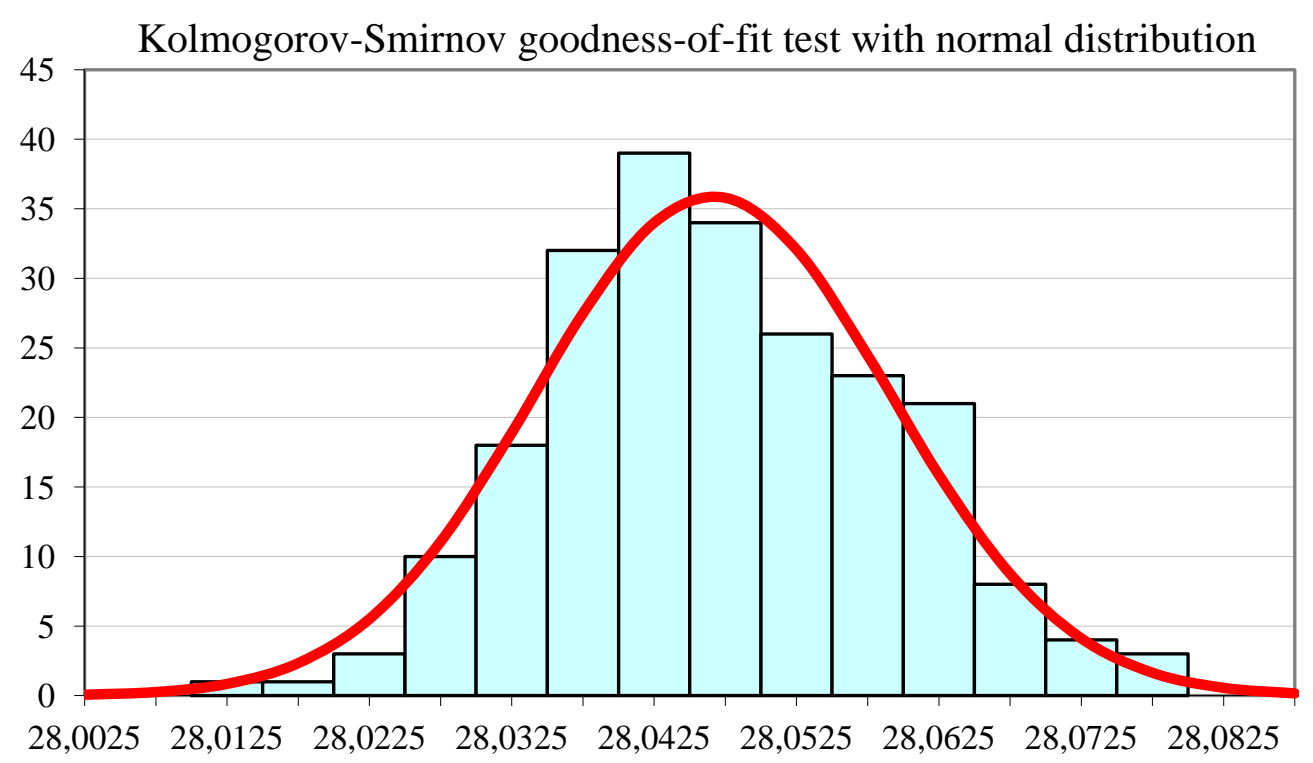

Fig. 6: Kolmogorov-Smirnov test - histogram with interpolated curve of normal probability density

From the previous figure nr.6 it is possible to compare the plotted Gaussian curve with the constructed histogram. The agreement with the normal distribution can therefore be stated not only from the point of view of graphical rendering, but also from the calculated values.

Numerically, the Kolmogorov-Smirnov test is expressed similarly to Pearson's $\chi^{2}$ - goodnessof-fit test, by comparing the test criterion and the critical value. In this particular case, for a $5 \%$ significance level, the critical value is $=0.090869$ (table - source [11]) and the calculated value $=0.063711$.

Since $0.063711<0.090869$, it follows that the hypothesis holds $=$ it is a coincidence with the normal distribution.

For an even better graphical representation of the match, it is possible to construct a distribution function. See the plot in Matlab (fig.7 and 8), where the empirical and theoretical distribution functions are compared.

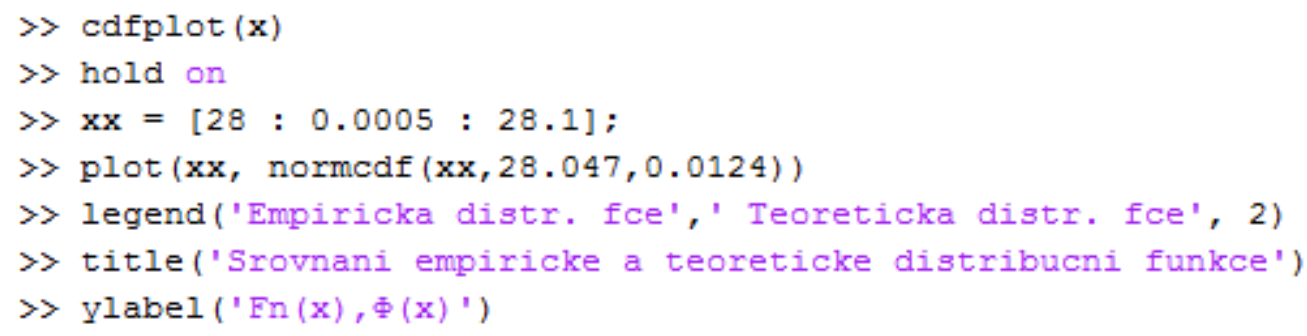

Fig. 7: Plotting a graph - comparison of empirical and theoretical distribution functions in Matlab 


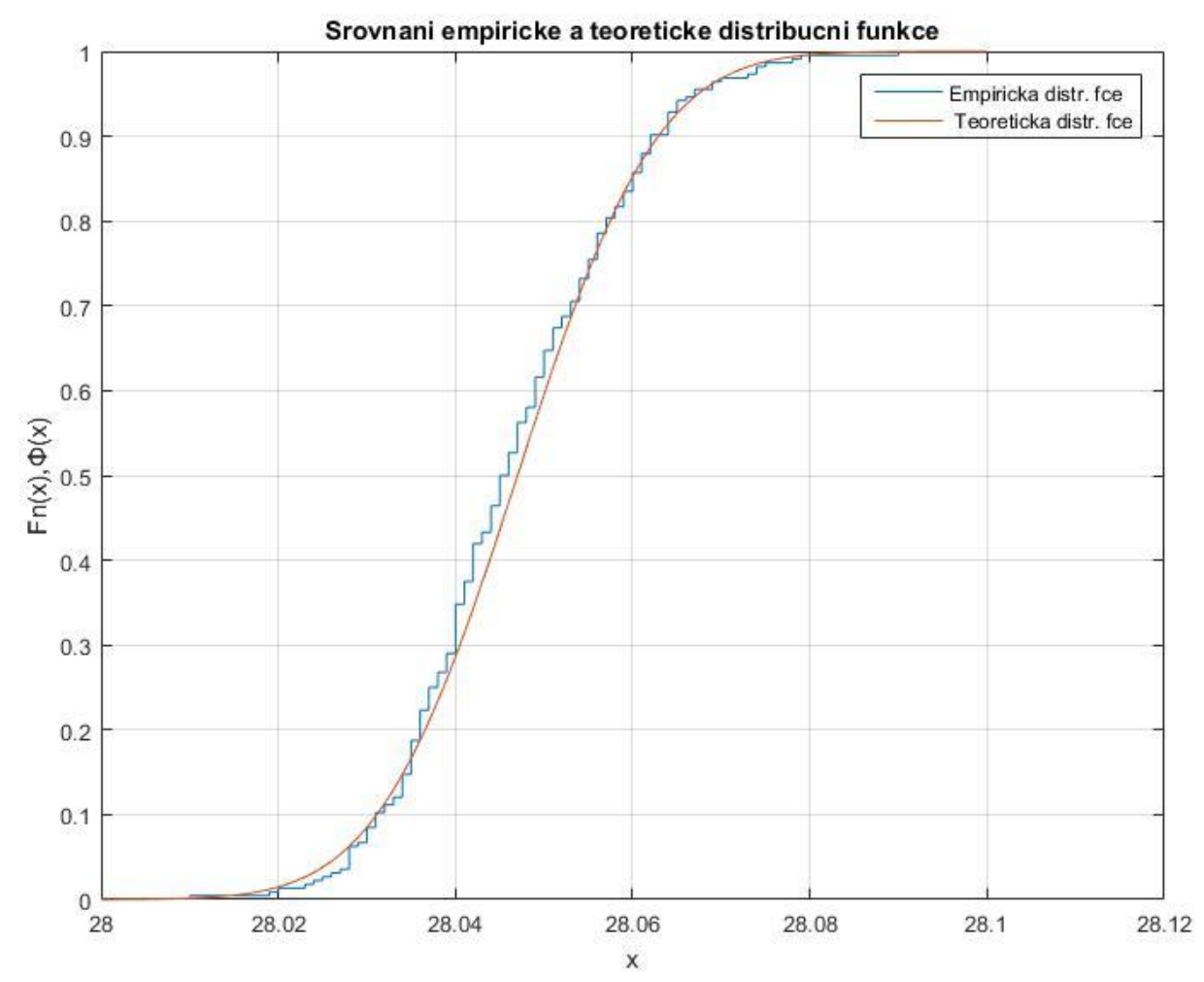

Fig. 8: Comparison of empirical and theoretical distribution functions in Matlab

When comparing the empirical and theoretical distribution functions, the agreement is evident.

\section{THE CONCUSION}

Each method and determination of indicators has its prerequisites for proper use. Therefore, the determination of indicators and further data processing is preceded by, for example, verification of normality, stability, etc.

The aim of this paper was to present the possibilities of verifying the assumption of a normal distribution of data for further statistical processing, without the need to study an inexhaustible number of methods and hypotheses about statistical data processing. The main idea was that, for example, companies in the automotive industry, where standards such as IATF 16949 require $100 \%$ control and the use of statistical tools for process monitoring, should have easy guidance on how to verify relevant input data for further statistical processing. For example, for processing using control diagrams and subsequent evaluation of process capability.

Normal distribution is a prerequisite for most other data processing tools. There are several methods for verification. These are numerical and graphical methods. This paper shows an example of using a simple graphical tool, namely a histogram. An important finding is that the analysed data, the distribution of which at first glance appears to be a normal distribution, is not always true. Therefore, numerical methods are used further.

Regarding numerical methods, two numerical methods were introduced here, namely $\chi^{2}$ goodness-of-fit test or Kolmogorov-Smirnov goodness-of-fit test with normal distribution. All presented methods were processed in MS Excel. 
Overall, the shape of the curve characterizes the production or measurement process. So even on the basis of verifying the normality and evaluating the shape of the data, it is possible to draw conclusions about the properties of the data set or possible adverse effects on the process. In addition to the basic indicators, it is possible to determine other parameters such as accuracy, stability, bias and linearity for a more detailed evaluation of the data set, especially for the measurement system and for the production of skewness and sharpness.

\section{Acknowledgement}

This article was created under the project SGS-2019-008: Research and Development for Innovation in the Field of Manufacturing Technology - Machining Technology III.

\section{Sources}

1. Wikipedia, Normální rozdělení. [Online] [Cited: 28. 5 2021] https://cs.wikipedia.o rg/wiki/Norm\%C3\%A1ln\%C3\%AD_rozd\%C4\%9Blen\%C3\%AD

2. Bícová, K.: Příspěvek $\mathrm{k}$ hodnocení ukazatelů výrobního procesu $\mathrm{v}$ oblasti automobilového průmysl. Disertační práce, ZČU Plzeň 2016

3. WikiSkripta, Normální rozdělení. [Online] [Cited: 2. 6 2021] https://www.wikis kripta.eu/w/Norm\%C3\%A1ln\%C3\%AD_rozd\%C4\%9Blen\%C3\%AD

4. Papáková M.: Využití Chí kvadrát testů na př́kladech experimentálních dat $\mathrm{s}$ využitím Geostatistical Analyst v softwaru ArcMap. Bakalářská práce. Olomouc. [Online] [Cited: 20. 5 2021] http://www.geoinformatics.upol.cz/dprace/bakalar ske/papakova10/testy.html

5. Jarošová, E.; Král, J.: Ověřování předpokladu normality. Národní informační středisko pro podporu jakosti. 2006 [Online] [Cited: 21. 5 2021] http://www.csq. cz/fileadmin/user_upload/Spolkova_cinnost/Odborne_skupiny/Statisticke_metody/sb orniky/2006/05_-_12_-_Testy_normality.pdf.

6. Statistické grafy. [Online] [Cited: 21. 5 2021] https://iastat.vse.cz/stat_grafy.html

7. Histograms. [Online] [Cited: 26. 5 2021] https://www.mathsisfun.com/data/histog rams.html

8. Histogram. [Online] [Cited: 26. 5 2021] https://managementmania.com/cs/histogram

9. Testy normality. [Online] [Cited: 6 . 6 2021] https://www.wikiskripta.eu/w/Test y_normality

10. Kolmogorovův-Smirnovův test. [Online] [Cited: 6. 6 2021] https://cs.wikipedia.or g/wiki/Kolmogorov\%C5\%AFv\%E2\%80\%93Smirnov\%C5\%AFv_test

11. Tabulky kritických hodnot a konstant. [Online] [Cited: 6.6 2021] http://homel.vsb.c z/ dor028/Tabulky.pdf

12. Normality Test Using Microsoft Excel. [Online] [Cited: 6. 6 2021] https://www.inp rolink.com/2019/02/20/normality-test-using-microsoft-excel/

\section{Contact}

Ing. Kateřina Bícová, Ph.D.; Ing. Josef Sklenička, Ph.D.

Západočeská univerzita v Plzni, Fakulta strojní

Univerzitní 22, 30100 Plzeň

Tel: 377638595

email: kbicova@kto.zcu.cz; sklenick@kto.zcu.cz 


\title{
THE ROLE OF ICT IN TRANSFORMING THE FACE OF EDUCATION: BOOK REVIEW
}

\begin{abstract}
Avan Aziz
Book review: Abbott, Ch. (2001). ICT: Changing Education. RoutledgeFalmer. London. (122 P.). The ISBNs of the book for different versions are as follows; ISBN 0203400259; ISBN 0750709510 ; ISBN 0750709502.

Abstract

Information Communication Technology (ICT) brings about a significant improvement in all fields of life particularly the field of education. It has brought the world together and altered the global economic, social, political, and educational landscape. Global growth and progress are heavily reliant on a skilled workforce, which can only be obtained through high-quality education. ICT is a product of education, although it is primarily used by businesses. It has significantly altered the practice and methods of education. The effective role of ICT has changed education from a traditional to a more modernized system and it has improved teaching methods, learning methodologies, scientific research, and information access. In this article, the writer attempted to make a review of "ICT: Change Education" book by Chris Abbott (2001). To shed light on a brief history like of ICT and its impacts on improving different aspects of life especially education.
\end{abstract}

Keywords: ICT, Education

\section{INTRODUCTION}

Education, like every other aspect of human's activity in society, evolves in response to changes in the environment in which it is carried out. The path of these changes is controlled by educational conceptions or is a natural effect of changes in social and technological measures that follow education (Wajszczyk, 2014, p.1). The penetration of Information and Communication Technologies (ICT) in schools has resulted in a substantial transformation of the educational landscape in all parts of the world. Although there is still no consensus on the actual benefits of technology in ensuring quality learning, ICT is becoming a more important aspect of modern education systems. As a result, policymakers are paying close attention to the need to ensure that the rise of ICT in society, their integration in schools, and their application in pedagogy are all in sync (UNESCO, 2011, 1).

Over the decades we've become accustomed to assertions that new technologies, such as the advent of teaching machines and the widespread use of television in classrooms, would revolutionize education procedures. It has been hypothesized that, in a finite time, teachers will become essentially obsolete as new technology takes over. In practice, most of these advancements have proven to provide no more than a tool to assist teachers in performing their regular duties.

It is now plainly evident that ICT development is substantially different. In a variety of ways, education and teaching will be compelled to alter. At one level, we now have to teach computer skills, not least because our students' career prospects may be contingent on their ability to do so. Second, we must prepare them for a society in which many traditional parts of life, such as retailing, banking, and communication via email, have been altered.

This massive technical and societal transformation shows no signs of slowing down. Computers are growing more advanced all the time. Even newer systems, such as the Internet, are endangered by newer advancements, such as interacting via television systems, much as 
mainframe machines were mostly superseded by PCs in the past. Young children appear to be comfortable with most of these tools, but as educators, we have the dual responsibility of staying current while also predicting the forms of future schooling (Head \& Merttens as cited in Abbott, 2001, p.xi). Many years ago, Kolderie (1990) emphasized the impact of ICT on education, stating that new technology represented a substantial shift in the function of the teacher in the classroom. "The teacher is no longer the 'star attraction' in the room," according to Lam and Lawrence (2002, p. 296), and learners uncover more intriguing resources on their own. The computer acts as a third party in the learning process, causing modifications in both the teachers' and students' roles (Lam \& Lawrence, 2002 as cited in Luik \& Kukemelk, 2008, pp.17-18).

\section{REVIEW}

The book "ICT: Change Education", edited by both John Head and Ruth Merttens who are experienced professionals in the field of education. This book is an edited work with seven chapters starting with an introduction demonstrating the book's objective and the primary topics of each chapter. One of the unique features of the book is, it helps the reader to have a clear insight on how the use of technology in education has evolved over time, as well as to speculate on some potential technological consequences on teaching practices. It shows how national education policies in some nations have influenced the development of ICT in education, giving readers a thorough grasp of the use of ICT in education in the past and present.

Chapter 1, Abbott has focused on how the advancement of technology resulted in changing certain habits such as shopping and banking. Education is not immune to the changes brought on by the internet. He also makes an argument regarding the use of technology in education has led to the changes in teaching methods. In other words, unlike in the past, current internet access provides a variety of sources for teaching, including images, videotape, and cassette, so the author predicts that the use of books in education will become obsolete very soon, and that knowledge will be taught through the use of motion pictures. There will be a movement in teaching environments from formal educational settings to home-based educational settings at some point.

The author also is examining how literacy is changing as a result of the usage of ICT. In agreement with the author, the use of ICT in education has a significant impact not only on schooling but also on the concept of literacy. Literacy is now a more complete term that encompasses multimedia, pictures, sounds, and moving images, despite the fact that it was originally limited to simply word-based texts until the end of the twentieth century. So, currently due to the advancement of technology we can talk about multiliteracies.

Chapter 2, 'Virtual communities' reveals how ICT is transforming communities and forming new virtual groupings. Although it may seem impossible at first to connect the words online and community, the chapter demonstrates that these two concepts can be linked. To put it in another way, as a result of advancing technology, there is no need to physically join a community, hence communities can be considered to exist beyond boundaries through the use of technology. This chapter illustrates prior efforts to build online communities in this regard, as well as the intimate relationship that exists between community and identity.

Chapter 2 is primarily concerned with virtual communities and their impact on the construction of identity. It emphasizes that attempts to establish virtual communities predate the invention of computers. The usage of the telephone and Citizens' Band (CB) radio were examples of how technology helped individuals build communities. However, these groups were small in comparison to those that have recently been formed through the use of a computer or the internet. 
It's also discussed how identity and community are intertwined. In the author's viewpoint, young people's self-defining choices enable them to define their identity and grow into autonomous individuals. Due to the rising usage of the internet and the availability of virtual communities, it is reasonable to conclude that online platforms play an important part in defining a young adolescent's identity by allowing them to make decisions about various elements of their lives. People are even believed to regard computers as a means of establishing their identity.

Newsgroups and Into the Dungeons are two examples of virtual communities that contribute to identity creation. Unlike Newsgroups, also known as Usenet, which allows users to join groups related to their practices and hobbies, Into the Dungeons offers users with adventure stories in which they are given choices and asked to choose one thing from among those choices, allowing users to lead the stories with their choices.

Finally, the second chapter demonstrates how long it took for individuals to realize the importance of the internet. Furthermore, it is reported that online communities are primarily made up of young, middle-class, males from either Europe or America. Also, virtual communities were shown to be more friendly than real-life settings, which is why virtual communities were made up of lonely young people.

Chapter 3, 'Changing Schools,' discusses the transition of educational technology from its traditional foundation, the classroom, to the home environment. The chapter begins by emphasizing an important point: learning is not limited to school, and it is not incorrect to assert that the majority of learning occurs outside of school. This chapter also looks at how technological advancements have changed library procedures. The author gives the following example: Since the Blair government recognizes the value of online content in education, it has provided training to its librarians on how to create online content.

In the third chapter, it is also revealed that in the 1960s, there was a widespread misperception among instructors that technology was all about machines that would eventually replace them in teaching. As a result, teachers didn't always seem to appreciate the presence of these teaching tools in their classrooms. Nonetheless, some training programs, such as the New Opportunities Fund, helped teachers see the computer or teaching robots as a useful and helpful tool for teaching. To illustrate, the author has shed lighted on the situation in England in terms of the role of computers in education, both the United Kingdom (UK) and Swedish government, appear to be fully aware of the significant role of ICT in education, and have made investments in education by ensuring teachers receive in-service training in the use of ICT and incorporating ICT into the curriculum.

Chapter 4, 'Learning, Computers, and Social Interaction,' extends on the discussion of how ICT is affecting education and focuses on student social interaction. This section includes a case study of a young individual who obtained professional Information Technology (IT) skills in this manner. The notion of post-geographical learning is offered, which involves learning that occurs through online social networking of communities whose members do not belong to the same physical location.

In the fourth chapter, certain learning theories are used to describe how people's perspectives of learning are evolving. These theories includes different perspectives on how learning happens. The behaviorist viewpoint emphasizes the importance and necessity of "stimulusresponse," as well as drills and practice in the academic setting. As a result, early software developers incorporated this viewpoint into their work. On the other hand, attempts have been made to develop alternative regimens that rely primarily on drill and practice. One of these attempts is Papert's computer software, LOGO, which focuses on getting pupils to use computers to think and explore on their own rather than using computers to program learners. Papert, the program's creator of LOGO. This software was popular all over the world in the 1980s. Papert emphasizes that schools must reform. 
For this purpose, alternative school models that encourage learners to actively participate in learning must be developed. Paper also considers the interaction between learners and computers from the perspectives of two different programmers: the instructionist and the constructionist. The instructionalist delivers school-style learning through a game in which a pre-programmed program poses questions to which learners are expected to respond. Constructionists, on the other hand, emphasize the importance of allowing students to design the game. The fourth chapter also shows how, in the 1960s and 1970s, the home education movement grew in popularity all over the world, notably in the United States, thanks to advances in technology. However, there are several disadvantages to this movement. It has been criticized because it does not give adequate social interaction for the student.

Chapter 5, 'Educational Responses to Technology,' looks at a number of options, from 1960s teaching machines to today's multimedia networked personal computer (PC). It gives a comprehensive overview of the use of technology in education prior to the invention of computers.

The chapter emphasizes how new technology in educational systems is rarely implemented quickly. Because conservative perspectives on commonly recognized procedures and understandings stifle technological advancements in schools. This holds true for teachers as well. This chapter also reveals a clear view of instructional software. As previously stated in the preceding chapter, the early use of computers was based on a behaviorist viewpoint. As a result, for pedagogical reasons, early educational programs mostly emphasized drill and practice exercises.

The chapter emphasizes that in the UK, local governments played a leading role in promoting the use of computers in education, resulting in the development of Computer Software Packages for education in order to improve teaching quality, enable individual learning, reduce teaching time, and increase learner motivation. These bundles included a variety of programs that may be utilized in classrooms. LOGO and Developing Tray, among other applications, have maintained their appeal in recent years. In addition, the chapter goes into great length about a program called Integrated Learning Systems (ILSs) that was developed in the UK. The Integrated Learning System is a computer-assisted software that offers learners with personalized curricular materials and performance feedback in order to help their learning.

Chapter 6, 'The Rise of the Internet and the Race to Connect' focuses on the emergence of the internet and the competition among countries to connect their schools to the internet. Abbott claims that the most typical reaction to the internet has been either crazy unfounded assertions or broad denials of relevance. Furthermore, the internet was once viewed as primarily a paperbased medium, despite the fact that it offered a variety of unique qualities.

Besides, the chapter explains how countries go about defining goals for their schools' use of ICT. The UK government has proposed a series of aims in order to increase the use of ICT in the community, according to the chapter. The UK government recognizes that the internet will significantly alter the educational system, and that a greater emphasis should be placed on distance learning approaches and informal learning.

'Towards a New Understanding of ICT and Schools,' Chapter 7, brings this breadth of change and growth together to provide a new understanding of the possibilities and shortcomings of ICT within a growing educational system. As a result of the rise of the internet and IT, it also touches on several countries' national ICT policy. The chapter asserts, at first, that each county has a unique ICT policy based on its approaches and priorities. In this sense, the chapter considers policies in the UK and Sweden in order to compare and contrast ICT initiatives implemented in different countries. The European Union likewise appears to be increasingly interested in promoting the use of ICT in education. As a result, the European Commission has published a paper titled "Tomorrow's Education: Promoting Innovation with 
New Technologies" with the goal of solving the concerns of equity and access. So, chapter 7 explains the significant impact of ICT on transforming education and schooling once and for all. It also explains how virtual classes will replace traditional classes in terms of allowing students to receive lessons whenever and wherever they desire.

\section{CONCLUSION}

This book is unique because it gives readers in general and teachers in particular a clear overview of the impact of ICT on education from its inception to the present. The author has tried to touch upon the major factors that are affected by ICT to help the reader get a better understanding of how ICT has changed the face of education in schools and in society. By describing various nations such as the UK and Sweden, the author has also provided information on the efforts and educational policies of these nations to integrate ICT into their educational system that have led to the development of ICT in education. Although this book is primarily useful for professionals working in education, it is also of value to other professionals who use ICT in their work and happy to have an overview about the development of ICT since its emergence.

\section{Reference}

1. ABBOTT, CH. ICT: Changing Education. RoutledgeFalmer. London. 2001. ISBN 0203-40025-9

2. LAM, Y. \& LAWRENCE, G. Teacher-student role redefinition during a computerbased second language project: Are computers catalysts for empowering change? Computer Assisted Language Learning. 2002, 15(3), 295-315.

3. LUIK, P. \& KUKEMELK, H. Changes in learning process caused by the implementation of ICT in education in Estonian in-service and pre-service teachers perceptions. US-China Education Review. 2008. Volume 5, No. 10 (Serial No.47). ISSN15486613.

4. WAJSZCZYK, R. A study of the Impact of Technology in Early Education. 2014. Retrieved from http://uu.diva-portal.org/smash/get/diva2:737018/FULLTEXT01.pdf

5. UNESCO,. Transforming Education the Power of ICT Policies. Paris, France. 2011. ISBN: 9789231042126.

\section{Contact}

MA. Avan K. Aziz

Palacky University Olomouc

Zizkovo nám. 5, Olomouc, Czech Republic

Tel: +4917661931807

email: avan.aziz01@upol.cz 


\title{
BARRIERS TO THE EFFECTIVE USE OF INFORMATION AND COMMUNICATION TECHNOLOGIES IN COLLABORATIVE LEARNING CLASSROOMS: A REVIEW OF LITERATURE
}

\begin{abstract}
Avan Aziz.
Abstracts

Collaborative learning (CL) is a method of learning that stimulates and enables learners to study, analyze a subject, to solve a problem, develop a project, or to complete a task or an assignment with teammates. There are several advantages of using Information and communication technologies (ICT) to support such collaborative work. It can not only facilitate specific collaborative tasks, but it can also allow students to collaborate even when they are not located in the same locations and at various times. In addition, the use of ICT for CL enables learners to practice critical 21 st-century skills like collaboration, communication, and constructing knowledge (EDUHACK.EU, 2017). However, the integration of ICT in CL is not problem-free. For this purpose, the researcher aims at studying the barriers of using ICT in CL class for the sake of eliminating and overcoming them during the teaching and learning process.
\end{abstract}

Keywords: ICT, CL, Barriers

\section{INTRODUCTION}

Obviously, the advancement of technology in today's world has improved the habits of life, study, work, etc. Since the emergence of ICT in education, it has proved to be an effective and helpful tool for both teachers and students (Duță \& Martínez-Rivera, 2015, p.1467). ICTs enriched possibilities for communication, collaboration, and learning. Its multimedia features easy and fast worldwide access to information introduced users with new forms of knowledge sharing and group working. As a result, it nurtured the interest of its use in CL. It is worth mentioning that the incorporation of ICT in CL is not only grounded on ICT's features and functionalities, but also it relies on the pedagogical approach practiced in CL (Piki, 2008, p.113).

\section{THE IMPORTANCE OF ICT IN CL CLASS}

The convenience of ICT use in education has transformed the traditional face-to-face CL to Online collaborative learning (OCL) and has made collaboration easier among learners. The intention of using ICT in CL is not to replace face-to-face communication; on the contrary, it is intended to use ICT as a tool for CL to enable users to interact at any time and anywhere. It enables learners to bring different skills to joint or group projects that eliminate time, distance and resource barriers. ICT as a collaborative technology provides various effective features for team work coordination, tools for recording learner's progress and providing feedback, libraries of solution and best practices as well as meta-information (Ezekoka, 2015, p.1006). Also, ICT offers the motivational aspect of collaborative projects. For instance, the use of ICT enables learners to support one another and work collaboratively (Valcárcel, Basilotta \& López, 2014, p. 69).

CL has been increasingly practiced in online education since many curriculum developers and educators of online courses have witnessed its positive impact on students' learning, and as a result, OCL has been implemented as one of the favorite instructional strategies in the online world. Most commonly cited positive impacts of CL in online education are enhancing the learner's critical thinking, problem-solving, self-reflection skills, and the construction of their 
knowledge (Ashong and Commander, 2012 as cited in Kumi-Yeboah, Dogbey \& Yuan, 2017, p. 6). In addition, it makes many-to-many communication possible, which is not feasible in a typical classroom, which leads to impover the discourse pattern of the teacher initiating, students responding, and teachers evaluating that require teachers to play a role of discourse controller rather than facilitator. While in online platforms of learning, the social presence and dominating role of the teacher is reducing and students would have more opportunities to engage in the debate (Chai \& Tan, 2010, p.9).

According to Becta (2008) the use of ICT in CL has increased the students' involvement and partaking during the learning process including quieter students who can work collaboratively online without hesitating to ask questions in front of the teammates. It also affords opportunities for social networking which foster online dialogue and discussion amongst learners outside school hours (Ezekoka, 2015, pp. 1006-1007). Besides, ICT provides a variety of learning platforms, such as Moodle, Blackboard, Blogger, Wikispace, etc. for collaborative and interactive activities to stimulate students' sharing knowledge and online discussion. Social softwares also is another interesting feature for online education, these softwares help both students and teachers more connected with each other, as an example, using feeds such as Really Simple Syndication (RSS) and ATOM which enable learners and teachers to be aware of each other's work, ideas and aims.

The softwares that can be used for learning purposes in schools can be also incorporated into daily online environments and experiments. For instance, With RSS feeds, the advancement in the blogs that are practiced for learning projects can be brought to the regular software of students, such as Facebook, to bring educational settings closer to the world of students outside school. In accordance with Valtonen, easy access to and the active participation of school activities, especially the activities that learners carried out with their classmates, will encourage and inspire the involvement of students in their educational settings work. A greater existence of the work of peers will also offer active outlets for communication, changing of ideas and knowledge building (Valtonen, 2011, pp.12-13).

\section{BARRIERS OF THE USE OF ICT IN CL CLASS}

The act of incorporating ICT into CL is a complicated process that can be fraught with challenges. The challenges are referred to as "barriers" (Schoepp, 2005). A barrier is defined as any condition that makes progress or achievement of an objective difficult (WordNet, 1997 as quoted in Ghavifekr, et al., 2016, p. 41).

Different impediments to online collaborative learning (OCL) have been discussed by researchers (Bell, 2007; Muilenburg \& Berge, 2005; Rogers, 2000). Students' challenges to online Collaborative learning, according to Muilenburg and Berge (2005), include frequent disruptions, lack of motivation to use, infrastructure, perceived skills, technical, and social skills to use ICT in CL. The main challenges to online learning, according to Muilenburg and Berge, are a lack of social interaction, administrative and teacher issues, support, and learner motivation. According to Roger (2000), there are two types of impediments to online learning: internal and external. External barriers are determined by the quality of support, lack of instructional and technical support, and technology issues, whereas internal barriers are determined by technological proficiency (availability and accessibility, confidence, ICT competence, resistance to change and negative attitude toward ICT use, technophobia, etc.). Learners' motivation and cultural resistance can both be obstacles to OCL (Beamish, Armistead, Watkinson, \& Arm eld, 2002). Demographic characteristics such as age and ethnicity (Ke \& Kwak, 2013), gender (Perkowski, 2013), and kind of learning institution (Becker, Newton, \& Sawang, 2013) have also been reported as a part in the barrier of OCL (as cited in Agbejule, et al. 2021, p.11). 
In this study the researcher focuses only on some of the most common intrinsic and extrinsic barriers of ICT in CL.

\subsection{INTRINSIC BARRIERS}

Learning how to use and participate in OCL activities using a range of technologies is a never-ending challenge (Klesinski, Nelson-Weaver and Diamond 2014; Cannell and MacIntyre 2017). One of the fundamental barriers that make the use of ICT in CL challenging is Lack of a teacher's competence. It is directly related to the teacher's confidence in integrating ICT in CL (Becta, 2004). Some teachers see lack of ICT competence as one of the major barriers of using technology in student's learning. According to a research study conducted to examine the viewpoints of instructional materials, classroom teachers mainly had a little knowledge of using technology (Odabasi \& Namlu, 1997 cited in Asan, 2003). Empirica also published research on the use of ICT in European schools (2006). The information in the paper came from a survey of Head Teachers and Classroom Teachers in 27 European nations. The outcome of the research shows that teachers who do not use computers in the classroom believe that "lack of skills" is a barrier to using ICT in teaching (Ghavifekr, et al., 2016, p. 44).

Furthermore, students, in general, are poor at harnessing their digital talents to assist learning (Beetham et al. 2010). This is an especially pressing issue in light of the rising involvement of learners (Cannell and MacIntyre 2017). In OCL contexts, digital literacy or ICT competency remains a challenge, particularly when it comes to teacher and student technological skills and how they navigate media (Olesova, Yang and Richardson 2011). The obstructions are built on top of structural inequities, and when combined with a lack of skills that are required for online learning, they create a "second digital gap" (Cannell and MacIntyre 2017, 112). Even when teachers offer PCs and software, the online learning environment's complexity makes using the technology difficult (Warschauer and Matuchniak 2010). To Lai (2015).The digital gap is not just a matter of haves and have-nots with access to and use of technology and information, rather, it is a social and political challenge related with social stratification and inequality in the digital technology age (as cited in Sator, 2020, p.30).

Another obstruction that hampers educators from integrating ICT into online pedagogical practice is the teacher's lack of confidence. Several researchers reported that lack of confidence is a key barrier for preventing teachers from using ICT (Becta, 2004). To Beggs (2000), teachers' "fear of failure" is a good reason for lack of confidence. In their study, Balanskat et al. (2006) found that teachers' insufficient ICT awareness causes them to be worried about using ICT in the classroom and so insecure about using it in their teaching.

Additionally, many studies of the barriers to ICT integration in education revealed that teachers' attitudes and an inherent resistance to change were a key stumbling block of intergrating ICT in CL (Cox et al., 1999a; Watson, 1999; Earle, 2002; Becta, 2004; Gomes, 2005; Schoepp, 2005). According to Watson (1999), an Australian academic, adopting developing technology into educational contexts involves change, which will be handled differently by different teachers. He thinks it's vital to consider diverse instructors' attitudes about change since their ideas influence what they do in the classroom. One of the most crucial components of teachers' attitudes regarding the use of technology, according to Becta (2004), is their impression of how ICT might help their teaching and students' learning (as cited in Bingimlas, 2009, pp.237-238).

Last but not least, one of the most significant barriers that many students and teachers confront is their fear of technology, sometimes known as technophobia. Teachers and students both lack confidence when it comes to integrating technology teaching and learnnig. Technophobia is defined by Mcilroy, Sadler, and Boojawon (2007) as "anxiety about present or future interactions with computers ... negative global attitudes about computers, their 
operation or societal impact ... self-critical internal dialogues during actual computer interaction or when contemplating future computer interaction" (P.1286 as quoted in Kareem, 2017, p. 39)

In a world where computer interactions are needed, especially in educational settings, computer anxiety is frequently argued to be an issue (Ahmad, et al., 2012, p. 7). Jones (2013) claims that teachers' fear of technology is expected and prevalent. When teachers say they want to teach, they're emphasizing that they like to teach but not with technology. She also notes fast-paced technological updates or updates as another reason why kids or teachers might be afraid of it. The multiplicity of technical resources, each of which can be used for a specific teaching goal, is another source of fear of using technology in CL. As a result of their inability to master a wide range of resources or applications, a learner or instructor may experience anxiety (Kareem, 2017, pp. 39-40).

\subsection{EXTRINSIC BARRIERS}

One of the most significant barriers to education in many parts of the world is a lack of access to technology. According to Fu (2013), ICT equipment affordability and usability are important roadblocks to overcome (Kareem, 2017, pp. 36-37).

In a research conducted in a high school in the United State regarding the teachers' use of ICT, the results declared that shortage of computers, a lack of free time for education, and a lack of computing time for students in the classroom are the major barriers to ICT use. Instructors in larger schools and metropolitan schools were more likely to identify a computer scarcity as a barrier, while teachers at schools with a strong minority student population were more likely to report outdated, malfunctioning computers as a barrier (Salehi \& Salehi, 2012, p. 41). According to Becta (2004), inaccessibility of ICT devices has not always occurred as a result of lack of hardware, software, or other ICT materials inside the school. Sometimes happen due to inadequate resource organization, low-quality hardware, inappropriate software, or a lack of personal access for teachers (Ghavifekr, et al., 2016, p. 42). For instance, In McCollum et. al. 's study (2019) regarding overcoming barriers for implementing international online collaborative assignments, some students reported being unable to focus on their communication practice due to a lack of reliable Wi-Fi (p.12).

In a research study in the United Kingdom, Jones (2004) indicated that dearth of personal confidence and deficient access to ICT services were the main obstacles for the majority of the surveyed teachers to use ICT (Salehi \& Salehi, 2012, p. 41). Similarly, Korte and Hüsing (2007) discovered that certain technology obstacles exist in European schools, such as the lack of broadband connectivity. They found that one-third of European schools still lack broadband Internet access. To illustrate, Video chat is one of the tools that can be used in OCL. This software puts a lot of strain on the internet's bandwidth, resulting in shaky video transmission (Rehn, 2017; Xu, Yu, Li, \& Liu, 2012). This is especially true during periods of high internet usage, such as during the school day, when connection speeds might plummet even further (Bassi, Radice, Bruccoleri, Erba, \& Mazzanti, 2016 as cited in McCollum et. al., 2019 , p. 12). So, any technological problems that appear during online learning has a critical impact on demotivation both teacher and students to use technology for teaching and learning purposes.

If teachers are unfamiliar with online technologies and successful online pedagogies, some of them may be resistant to OCL (Moreira 2016 as cited in Sator, 2020, p.38). Another challenge with practicing ICT in CL is a lack of technology training courses for teachers and students. Many teachers and students throughout the world require training in order to use technology in teaching and learning processes. Some teachers, according to Livingstone (2012), struggle with ICT use because of a lack of ICT competence. So, they must be properly equipped and trained to use ICTs for online learning. 
Several teachers are uninterested in ICTs since they are unfamiliar with how to use them; yet, they must be involved. (Kareem, 2017, p. 37). To illustrate, Newhouse (2002) revealed in Australian research that many teachers lacked the knowledge and skills to handle computers and were uninterested in the improvements and integrating of supplemental learning that came with using computers into their teaching techniques (Ghavifekr, et al., 2016, pp. 43-44).

Students may experience a similar problem because there are so many various sorts of ICT tools and apps, particularly on websites, that they have a difficult time finding out how to utilize them. Some are simple to operate, while others are really challenging. Wilson and Nativio (2002) highlight how students feel bewildered when faced with problems, which leads to late assignments and discontent. They would rather train them to make the applications or websites standardized and easy to use for students, or offer them training classes. Furthermore, another point that is related to this challenge is the teacher's, students' and parent's lack of awareness regarding the effectiveness of ICT in teaching and learning. For instance, parents and teachers may see smartphones and camcorders as a source of distraction, while in reality the advancement of such technological devices have generated new opportunities to be used for language learning purposes (Liakin, Cardoso, and Liakina, 2015 as cited in Kareem, 2017, pp. 37-38).

Newhouse (2002) claims that teachers require technology education (which focuses on the study of technologies) as well as educational technology training (support for teaching in the classroom). Teachers desire to learn how to use new technology in their lectures, but a shortage of professional development resources inhibits them from doing so in particular disciplines, such as science and math (Sicilia, 2005). Other issues with ICT professional development include training courses that aren't tailored to fit teachers' unique learning needs and sessions that aren't updated on a regular basis (Balanskat et al. 2006 as cited in Bingimlas, 2009, P. 240).

In addition, without both strong technical support in the classroom and whole-school resources, teachers would be unable to overcome the barriers of ICT use in CL (Lewis, 2003). In agreement with Pelgrum's research findings (2001) both primary and secondary teachers claim a lack of technical help was one of the most significant barriers to ICT use in education. Technical concerns were cited as a major impediment for teachers in Sicilia's study (2005). Technological impediments include things like waiting for websites to load, being unable to connect to the Internet, printers not printing, computers failing, and teachers having to work on antiquated machines. Technical obstacles obstructing the smooth delivery of the lesson or the natural flow of classroom activity (Sicilia, 2005, p. 43 as cited in Ghavifekr, et al., 2016, p. 42).

According to Gomes (2005), the presence of a technician is required for ICT integration in teaching, and if one is not available, a lack of technical support will be a significant barrier. Many respondents to Becta's survey (2004) claimed that technical issues could dissuade them from utilizing ICT in their classrooms because they are concerned of equipment breaking down during a lecture (as cited in Ghavifekr, et al., 2016, p. 42). Computer breakdown is one of the obstacles in the use of ICT, according to Buabeng-Andoh (2012), causing disruptions in the use of ICT during teaching and learning processes. If there is a lack of technology support, basic computer maintenance will be neglected, resulting in teachers not using ICT for online education purposes. Fear of equipment failure will deter teachers from utilizing computers, as no one will give technical assistance in the event of a technological malfunction (Mwambela, et al., 2019, p. 68).

Furthermore, Several recent research findings reveal that there are many teachers who are proficient and confident in utilizing computers in the classroom, but they utilize them sparingly due to a lack of time. Time restrictions and the difficulty of scheduling appropriate computer time for courses have been identified as a barrier to teachers' use of ICT (Al Alwani, 
2005; Becta, 2004; Beggs, 2000; Schoepp, 2005; Sicilia, 2005). According to Sicilia (2005), the most prevalent problem that all teachers cited was a lack of time to plan lessons to be taught online, explore numerous Internet sites, or investigate various features of educational software. According to Becta's study (2004), some teachers stating the integration of ICT in teaching takes more time. Teachers suffer a shortage of time in many elements of their jobs, reducing their capacity to accomplish teaching tasks. These include time spent searching the Internet for information, designing online learning sessions, discovering and practicing with technology, dealing with technological challenges, and acquiring suitable training (Ghavifekr, et al., 2016, p. 43). Similarly, Sicilia's study (2005) findings state that teachers in Canada spend substantially more time planning experiments that use new ICT than they do preparing traditional classes (as cited in Bingimlas, 2009, p. 239).

\section{DISCUSSION}

This research study aimed at studying some of the most common barriers of ICT use in CL. As a teacher it is important to be aware of those barriers for the sake of overcoming them and trying to make use of the effective use of ICT in CL. Throughout the study the researcher classifies the barriers in two categories (Intrinsic and Extrinsic). Each of these categories of barriers are correlated to each other and lack of any of them causes the shortage of others. For instance, In the intrinsic category the researcher focused on (lack of ICT Competence, lack of Confidence, teachers' attitudes and resistance to change, and technophobia) barriers. According to previous studies, if teachers or students do not have enough ICT literacy, they would not have confidence to practice ICT during teaching and learning. This generates having a negative attitude toward using ICT and there will always be a fear of failing in using them in CL.

Regarding the second category Extrinsic barriers (lack of ICT access, lack of training course, lack of technical support, and lack of time). Throughout literature it is obvious that each of these barriers is an important roadblock in front of a teacher's ICT access for CL. To illustrate, lack of ICT training courses for CL purposes prevent teachers from making use of ICT in CL even if the school can afford enough ICT devices (hardware and software) and technical support. Lack of technical support discourages teachers to use ICT in CL even if teachers experienced training courses and ICT devices are accessible. Lack of time deprives teachers from accessing ICT for teaching purposes even though teachers have enough knowledge about using ICT in CL and technical support is available for them.

Studying barriers of ICT in CL provides us with an insight that each of the above mentioned issues have more than one factor that has an effect on causing the barriers of ICT. See Table 1 . 
Table 1. Factors that cause the ICT barriers in CL class

\begin{tabular}{|c|c|c|c|}
\hline \multicolumn{2}{|l|}{ Intrinsic Barriers } & \multicolumn{2}{|l|}{ Extrinsic Barriers } \\
\hline Cause & 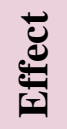 & Cause & 密 \\
\hline $\begin{array}{l}\text { 1. Lack of effective training in ICT } \\
\text { for CL. } \\
\text { 2. Lack of teacher's self-training that } \\
\text { happens as a result of lack of ICT } \\
\text { resources both at school and at } \\
\text { home. } \\
\text { 3. Teacher's lack of time because } \\
\text { teachers have a number of lessons } \\
\text { to be taught in a day and the class } \\
\text { time is not enough to make use of } \\
\text { ICT. } \\
\text { 4. Teacher's resistance to use ICT in } \\
\text { teaching since it needs time and } \\
\text { effort. }\end{array}$ & 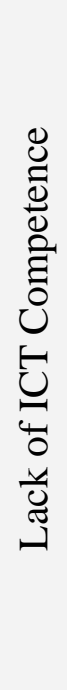 & $\begin{array}{l}\text { 1. Lack of the school's financial } \\
\text { fund to provide enough ICT } \\
\text { devices (hardware \& software) } \\
\text { for both teachers and learners. } \\
\text { 2. Lack of the government's } \\
\text { support to dedicate enough } \\
\text { financial support for affording } \\
\text { devices and opening ICT } \\
\text { training courses. } \\
\text { 3. Lack of the administrator's } \\
\text { support in using ICT in schools } \\
\text { during teaching and learning } \\
\text { processes. }\end{array}$ & 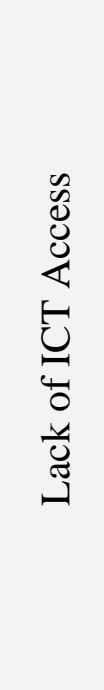 \\
\hline $\begin{array}{l}\text { 1. Lack of teacher's ICT } \\
\text { competence. } \\
\text { 2. Fear of failing during the class } \\
\text { time because of the ICT resources } \\
\text { defect. } \\
\text { 3. Teacher's lack of knowledge } \\
\text { about fixing some technical } \\
\text { problems if it happens. } \\
\text { 4. School's lack of technical support. }\end{array}$ & 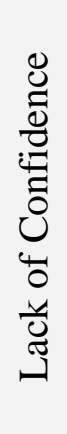 & $\begin{array}{l}\text { 1. Lack of teacher's time since } \\
\text { training in ICT requires lots of } \\
\text { time to master its use. } \\
\text { 2. Lack of administrator's } \\
\text { financial support to open ICT } \\
\text { training course for CL } \\
\text { purposes. }\end{array}$ & 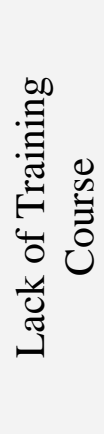 \\
\hline
\end{tabular}


1. Most of the current employed teachers earned their teaching certificates prior to the advent of computer education. It is not easy for them to deal with the use of ICT and its problems when it occurs. Also, since it requires lots of time and effort they prefer traditional forms of teaching rather than virtual teaching.

2. Lack of ICT literacy and lack of confidence to use it.

3. Lack of administration support to meet the teacher's needs such as (providing technical support, affording enough ICT devices (hardware \& software) for both teachers and learners, providing ICT training sessions to improve and update teacher's knowledge regarding ICT use and providing information about the use of the new coming devices that can be used in education.

1. Lack of ICT Competence.

2. Lack of Confidence.

3. Fear of failing during the class time because of the ICT resources defect.

4. Teacher's lack of knowledge about fixing some technical problems if it happens.

5. School's lack of technical support.

6. Lack of access to ICT resources.
1. Lack of expert technicians.

2. School's unable to afford technical support because of lack of financial support.

3. Teacher's lack of knowledge about fixing some technical problems if it happens.
1. Lack of teacher's time to plan lessons to be taught online, explore numerous Internet sites, or investigate various features of educational software, which leads to not integrating ICT in CL.

2. Class time restrictions discourage teachers from integrating ICT in teaching and learning.

The study of the importance of ICT in CL, the level of the barriers and its causes that deprive teachers from ICT use in CL, may help both teachers and administrators to be aware of the advantages of ICT use and the size of the of the barriers they may face. This study helped us to know the complexity of overcoming the ICT barriers and fading its causes. For this purpose, there is a need for teachers, administrators and government through the Ministry of education to work together for the sake of resolving and reducing the reasons for the occurrence of the barriers and how to improve the system of ICT integration in teaching and learning.

First, local authorities need to consider the dedication of enough financial resources for the schools to meet their schools and teacher's needs (e.g. affording ICT devices for teaching and learning, opening consistent ICT training courses, technical support, etc.). Second, the school principal has a great responsibility regarding the ICT implementation, encouraging and supporting teachers to integrate ICT in their teaching and learning, providing effective 
training courses to improve teacher's ICT skills, affording enough ICT resources and technical support, etc. Last but not least, teachers who are the direct recipients of the output. They need to take part in resolving the barriers through allocating time for ICT self-training, taking part in school training courses, most importantly integrating ICT in their teaching and learning, etc. If teachers do not make use of ICT in their teaching, all the money, time, and effort that will be made for this recovery program will be wasted.

\section{CONCLUSION}

Students benefit from CL because it allows them to actively interact with their own learning, connect with and learn from one another, advance conversation and discussion, and build knowledge. Teachers can support CL with a variety of available technology to enable students to produce new information and focus more on classroom activities in a more relaxed learning environment. However, previous research and experience indicate that schools and teachers are still having difficulty in integrating ICT into the CL approach. By the same token, there is a need for making an effective effort and attempt to deal with the difficulty in using ICT in CL, to assist teachers in creating highly collaborative environments that will result in improving student engagement as well as the development of quality of teaching. Integrating ICT in CL class increases student capacity for collaboration as well as experience. At the same time, this will assist teachers ensure that students are completing tasks that are not only more relevant, but also better prepare them for the society and workplaces of the future.

\section{Reference}

1. AGBEJULE, A. NDZIBAH, E. \& LOTCHI, K. Motivation and Barriers of Online Learners in The Era of Covid-19. Vaasa University of Applied Sciences. 2021. ISBN 978-952-5784-46-6 (online).

2. AHMAD, S. A. KAMBA, M. A. \& USMAN, M. Technophobia Versus ICT Acceptance and Use in Teaching and Learning Among Academic Staff of Universities in Northern Nigeria. 2012. Retrieved from http://www.leeds.ac.uk/educol/documen ts/211681.pdf

3. BINGIMLAS, KH. A. Barriers to the Successful Integration of ICT in Teaching and Learning Environments: A Review of Literature. Eurasia Journal of Mathematics, Science \& Technology Education, 2009. 235-245 p. ISSN: 1305-8223.

4. DUŢ̌̆, N. \& MARTÍNEZ-RIVERA, O. Between theory and practice: the importance of ICT in Higher Education as a tool for collaborative learning. Procedia - Social and Behavioral Sciences. 2015. 180.1466 - 1473 p. https://doi.org/10.1016/j.sbspro.20 15.02.294

5. CHAI, C.S., \& TAN, S.C. Collaborative learning and ICT. In C.S. Chai \& Q.Y. Wang (Eds.), ICT for self-directed and collaborative learning. Singapore: Pearson/Prentice Hall. 2010. 52-69 p.

6. EDUHACK.EU. Implement ICT-supported Collaborative Learning. 2017. Retrieved from https://eduhack.eu/course/area-2/activity-2/

7. EZEKOKA, G. K. Maximizing the Effects of Collaborative Learning through ICT. Social and Behavioral Sciences. 2015. 176, 1005-1011 p. doi: 10.1016/j.sbspro.201 5.01.571

8. GHAVIFEKR, S. KUNJAPPAN, TH. RAMASAMY, L. \& ANTHONY, A. Teaching and Learning with ICT Tools: Issues and Challenges from Teachers' Perceptions. Malaysian Online Journal of Educational Technology. 2016. Volume 4, Issue 2.

9. KAREEM, N. N. The Importance of Using Information Communication Technology for Learning and Teaching The English Language in Kurdistan of Iraq. 2017. 
Retrieved from https://scholar.valpo.edu/cgi/viewcontent.cgi?article=1000\&conte $\mathrm{xt}=$ tesol matheses

10. KUMI-YEBOAH, A., DOGBEY, J., \& YUAN, G. Online collaborative learning activities: The perceptions of culturally diverse graduate students. Online Learning. 2017. 21(4), 5-28. doi: 10.24059/olj.v21i4.1277

11. MWAMBELA, CH. MONDOH, H. \& THORUWA, TH. Challenges in Using ICT in Teaching Secondary School Physics and Effect of Teaching Using ICT on Students' Physics Academic Achievement in Mombasa County, Kenya. Journal of Education and Practice. 2019. Vol.10, No.22.

12. MCCOLLUM, B. MORSCH, L. SHOKOPLES, B. \& SKAGEN, D. Overcoming Barriers for Implementing International Online Collaborative Assignments in Chemistry. The Canadian Journal for the Scholarship of Teaching and Learning. 2019. 10(1). https://doi.org/10.5206/cjsotl- rcacea.2019.10.8004

13. PIKI, A. The Visions and Challenges of ICT for Collaborative Learning: A Review of the Literature. Themes in Science and Technology Education. 2008. Volume 1, Number 2, Pages 113-134.

14. SALEHI, H. \& SALEHI, Z. Challenges for Using ICT in Education: Teachers' Insights. International Journal of e-Education, e-Business, e-Management and eLearning. 2012. Vol. 2, No.1.

15. SATOR, A. Removing Barriers to Online Learning Through a Teaching and Learning Lens. 2020. Retrieved from https://bccampus.ca/wp-content/uploads/2020/06/Repo rt_Removing-Barriers-to-Online-Learning-Through-a-Teaching-and-Learning-Lens.pdf

16. SINGHAVI, CH. \& BASARGEKAR, P. Barriers Perceived by Teachers for Use of Information and Communication Technology (ICT) in the Classrooms in Maharashtra, India. International Journal of Education and Development using Information and Communication Technology (IJEDICT). 2019. Vol. 15, Issue 2, 62-78 p.

17. VALCÁRCEL, A. G. BASILOTTA, V. LÓPEZ, C. ICT in Collaborative Learning in the Classrooms of Primary and Secondary Education. Media Education Research Journal. 2014. n. 42, v. XXI, 65-74 p.

18. VALTONEN, T. An insight into collaborative learning with ICT: Teachers' and students' perspectives. Publications of the University of Eastern Finland. Dissertations in Education, Humanities, and Theology. 2011. No. 12.

\section{Contact}

MA. Avan K. Aziz

Palacky University Olomouc

Zizkovo nám. 5, Olomouc, Czech Republic

Tel: +4917661931807

email: avan.aziz01@upol.cz 


\title{
PRODUCTION PROCESS AS A TECHNICAL SYSTEM
}

\author{
Vladimír Sojka, Petr Lepšík
}

\begin{abstract}
There is a need for improvement of production processes. When systematic creativity as TRIZ is used for process innovation, it can be tricky for non-experienced TRIZ users. Because TRIZ principles are aiming at evolution patterns of technical systems, it can be helpful to describe the production system or production process in technical system terminology. This paper aims to the determination of elements of the technical system in production processes. Laws of technical system evolution are reviewed and applied to the process improvement point of view. Results of the paper can be used as a starting point for using TRIZ principles for process improvement or for designing a new method for the use of TRIZ by inexperienced users.
\end{abstract}

Key words: production process, technical system, process improvement, process innovation

\section{INTRODUCTION}

There is a continuous need for improvement of production processes. To achieve significant changes, innovation of the production system is crucial. One of the best approaches how to innovate the technical system is TRIZ. [1-4]

Many authors tried to use the TRIZ itself or with other tools to improve production processes [5]. TRIZ is very powerful, but it can be tricky to use it effectively without experience and good knowledge of TRIZ thinking. Unfortunately, it can take a long time To learn TRIZ principles well. [6-9] There should be a way how to apply a TRIZ easily, but with good results of improving yields [10]. To find a way how to approach to the process innovation by TRIZ principles easily. There is a need for a deeper understanding of a production system or production process represented by a technical system. A Description of the production process as a technical system should be examined.

This paper aims to describe the production system as a technical system in terms of TRIZ methodology, with a goal to find a way how to apply TRIZ principles for process innovation more easily. Laws of the evolution of technical systems are applied in the process improvement context.

\section{TECHNICAL SYSTEM BY TRIZ}

The technical system consists of several elements. The functionality of the technical systém exceeds the functionality from a simple sum of elements functionalities. Technical systems exist to provide positive functions. The main parameters of the technical systems are: functionality, completeness, organization, and systematic quality. [11] The relationship between these parameters is shown in equation (1) below

$$
F+S+O=Q
$$

Where $F$ is a function of the system; $S$ is system structure; $O$ is an organization of the system; $Q$ is quality or system effect. [11] 
The evolution of technical systems is following several laws. Overview of laws of evolution of technicals systems is listed below:

- Law of completeness of a technical system

- Law of an abundance of a technical system

- Law of coordination of a technical system

- Law of energy conductivity in a system

- Law of the existence of links between parts of a technical system

- Law of consistency of rhythm of activities of a technical system

- Law of transition to supersystem

- Mono-bi-poly

- Law of increasing of the degree of the ideality of a technical system

- Law of irregularity of system's part evolution

- Law of increasing of the degree of systems dynamics

- Law of transition of a system from macro- to microlevel

- Changes of a scale

- Changes of linking

- Transition to more complex and energy-saturated forms

- Law of increase of substance-field interactions

- Law of increase of information saturation

- Decreasing the degree of human involvement

- Law of increase of the degree of fragmentation

- Law of increasing the degree of control over a system

$[12,13]$

Representation of technical system essential elements by the law of completeness can be seen in figure (Fig. 1). Where engine represents energy source, transmission is an energy converter, and the working unit can be represented as a tool. Sometimes an object can also be considered.

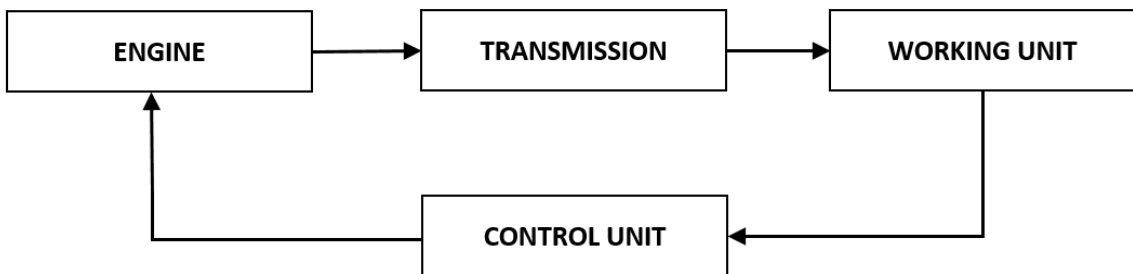

Fig. 1: Essential parts of a technical system $[12,14]$

For the completeness of a system, CTS (Complete Technical System) method can be used. The tool performs the function on the object. The energy makes it possible for the tool to do work. The transmission delivers the energy to the tool. The control adjusts and improves the function (active) or enables the function (passive). The object is the thing that changes as a result of the function. [15]

Tool for understanding relationships between the technical system and its sub and super system evolution is called 9 windows, or system operator. It places the system in the middle of nine windows, where columns represent past, current, and future systems, and rows are system, supersystem, and sub-system. [15] 


\section{PRODUCTION PROCESS DESCRIBED AS A TECHNICAL SYSTEM}

For a description of a production process as a technical system, the function, structure, organization, and effect should be determined. The effect, or quality, is clearly the outcome of the process. It can be a product or service. Functionality can be represented as operations or tasks that have to be done to change process input to final output. The continuity of process steps can represent the structure. The organization is then represented by process management and scheduling of production demands. A technical system has supersystems and subsystems. A Process consists of different levels of processes and sub-processes. The description of the process as a technical system should be applicable for the whole process from order to delivery and for a particular operation in production.

\subsection{Law of completeness of a technical system}

In a pull production system, production only begins when there is demand for final products. The engine of the production process can be represented by order or deadline term. Transmission of order to real processing can be achieved by production planning and order scheduling. The object is material or product, which is changing during the processing operations. The tool is operations or actions in the process. The Control Unit of the process is then reporting and process management with information flow. Essential elements of the technical system for the general production process are shown in the figure (Fig. 2) below.

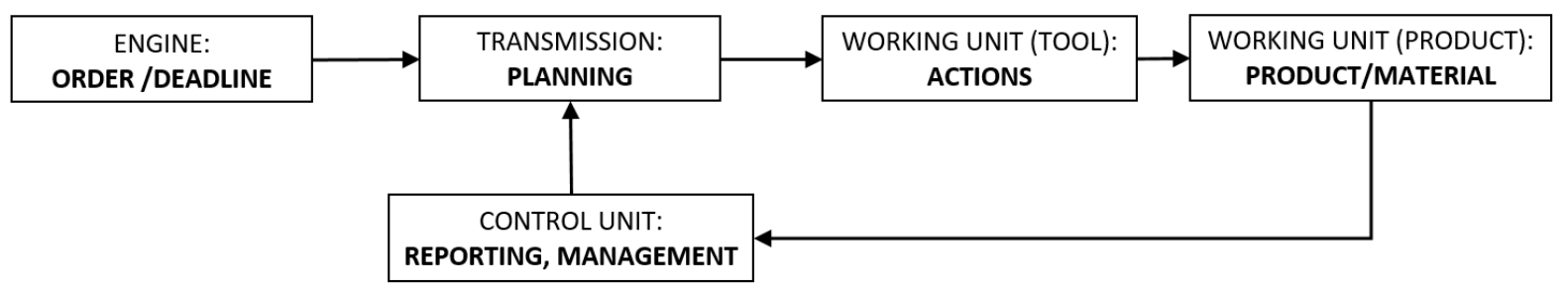

Fig. 2: Essential parts of a technical system for the production process

\subsection{Law of energy conductivity in a system}

The law of energy conductivity in a system or the law of the existence of links between parts of a technical system can be represented as links between operations in a technological process. Or just as a consequence of operations in production. From a value analysis point of view, transporting operations can be understood as links between value-adding operations.

\subsection{Law of consistency of rhythm of activities of a technical system}

The tact of operations represents the rhythm of the process. By balancing tact times, a rhythm of process is the same in the whole system - production process.

\subsection{Law of increasing of the degree of the ideality of a technical system}

Increasing process ideality can be represented by efforts to improve the process continuously. The degree of process' ideality can be calculated by equation (2) below

$$
P I=\sum_{i=1}^{6} p P I_{i}=\sum_{i=1}^{6}\left(\frac{\sum_{j=1}^{n} B_{j}}{\sum_{k=1}^{m} H_{k}}\right)_{i}
$$

Where $P I$ is a degree of Process' Ideality, $p P I$ is partial ideality, $i$ are six main aspects of the process (time, quality, costs, safety, ergonomics, and ecology), $B$ is benefit, $H$ is harm, $n$ is a 
number of benefits for aspect $i, j$ is a specific benefit, $m$ is a number of harms for aspect $i$, and $k$ is specific harm. [16]

\subsection{Law of irregularity of system's part evolution}

This law can be seen in the production process as an unbalanced process or bottleneck of the process. After improvement or innovation of one process in production, other processes are on a lower level, and the whole production system is irregularly evolved.

\subsection{Law of transition to supersystem}

When the process is improved or optimized, innovation can continue by innovation of the supersystem - in this case, the whole production system or the whole company strategy. Then the rules are changed, and the whole production system should be able to innovate or to improve again.

\subsection{Law of increasing of the degree of systems dynamics}

Demands are more and more specific, and production goes into customization. That is why production processes should be more flexible, elastic, and dynamic. The law of increasing of the degree of dynamics fits here too.

\subsection{Law of transition of a system from macro- to microlevel}

There are tools for focusing on micro aspects of the process. Not only the macro state of the process, as process steps, but also operations or movements in the production can be improved. Predetermined motion time system tools as MTM or MOST can be used for the improvement of micro activities in production. This law can also be understood as dividing the overall process into smaller autonomous process units.

\subsection{Law of decreasing the degree of human involvement}

Processes involve more and more robotics, automatization, and autonomy systems. Industry 4.0 leads the way how to follow this law in production processes.

\subsection{Law of increase of the degree of fragmentation}

Hand in hand with a higher degree of dynamics of the process goes the fragmentation. Production cells and different concepts of production arrangements show that fragmentation law works for production processes too.

\subsection{Law of increasing the degree of control over a system}

More measurement, data collection, sensors, and automatized analysis of the production processes and operations give a higher degree of control over the production processes.

\section{DISCUSSION AND CONCLUSION}

In the chapter above, laws of technical systems evolution were used to determine of a production process as a technical system. As it can be seen, laws more or less fit to the general production process. That is why the principles of TRIZ theory should be applicable in efforts for innovation of the processes. By following the laws of evolution, a production system can be innovated. For the application of principles from TRIZ's laws of technical system evolution, there is good to understand how the process is described as a technical system. This can help to use evolution laws to process innovation more easily.

This paper could be used as a starting point for designing a new method or approach for the use of TRIZ for process improvement or innovation. 


\section{Acknowledgement}

This work was supported by the Student Grant Competition of the Technical University of Liberec under the project No. SGS-2020-5027 - Research of new approaches to process improvement.

\section{Sources}

1. ALTSHULLER, G. The innovation algorithm: TRIZ, systematic innovation and technical creativity. 1. ed., 2. print. Worcester, Mass: Technical Innovation Center, 2000. ISBN 978-0-9640740-4-0.

2. HARLIM, J., BELSKI, I. On the Effectiveness of TRIZ Tools for Problem Finding. Procedia Engineering. 2015, 131, TRIZ and Knowledge-Based Innovation in Science and Industry, 892-898. ISSN 1877-7058. doi:10.1016/j.proeng.2015.12.400

3. ANOSIKE, A. I., LIM, M. K. A Synergistic Approach to Process Innovation. International Journal of Knowledge, Innovation and Entrepreneurship. 2014, 2 (1), $33-54$.

4. LI, L., LI, D., YANG, Y. The Design and Application of Synergetic Innovation System for Manufacturing Enterprise Based on TRIZ. 2011 International Conference on Information Management, Innovation Management and Industrial Engineering (ICIII): 2011 International Conference on Information Management, Innovation Management and Industrial Engineering. Shenzhen, China: IEEE, 2011, p. 74-77. ISBN 978-1-61284-450-3. doi:10.1109/ICIII.2011.166

5. SOJKA, V., LEPŠÍK, P. Use of TRIZ, and TRIZ with Other Tools for Process Improvement: A Literature Review. Emerging Science Journal. 2020, 4(5), 319-335. ISSN 2610-9182. doi:10.28991/esj-2020-01234

6. AVERBOUKH, E. A. I-TRIZ for Six Sigma Business Process Management. The TRIZ Journal [online]. 2003. https://triz-journal.com/triz-six-sigma-businessprocess-management/

7. BIRDI, K., LEACH, D., MAGADLEY, W. Evaluating the impact of TRIZ creativity training: an organizational field study: TRIZ training evaluation. R\&D Management 2012, 42(4), 315-326. ISSN 00336807. doi:10.1111/j.1467-9310.2012.00686.x

8. HAINES-GADD, L. Does TRIZ Change People? Evaluating the Impact of TRIZ Training within an Organisation: Implications for Theory and Practice. Procedia Engineering. 2015, 131, 259-269. ISSN 18777058. doi: 10.1016/j.proeng.2015.12 .387

9. NAKAGAWA, T. Education and training of creative problem solving thinking with TRIZ/USIT. Procedia Engineering. 2011, 9, 582-595. ISSN 18777058. doi:10.101 6/j.proeng.2011.03.144

10. SOJKA, V., LEPŠÍK, P. TRIZ Tools for Manufacturing Processes Improvement. 16th International Bata Conference for Ph.D. Students and Young Researchers: DOKBAT 2020. Tomas Bata University in Zlín, 2020, p. 484-491. ISBN 978-807454-935-9. doi:10.7441/dokbat.2020.41

11. JIRMAN, P., LOGVINOV, S. Aplikace TRIZ na mikroúrovni. 2015. ISBN 978-807494-190-0.

12. MAŠÍN, I., JIRMAN, P. Metody systematické kreativity. Liberec: Technická univerzita v Liberci, 2012. ISBN 978-80-7372-853-3.

13. PETROV, V. The Laws of System Evolution. The Triz Journal [online]. 2002. https://triz-journal.com/laws-system-evolution/

14. MANN, D. Laws of System Completeness. The Triz Journal [online]. 2001. https://triz-journal.com/laws-system-completeness/ 
15. DOMB, E., MILLER, J. A. Defining CTS \& the System Operator. The Triz Journal [online]. 2008. https://triz-journal.com/the-complete-technical-system-and-systemoperator/

16. SOJKA, V., ALVES, A. C., LEPSIK, P. Calculation of Process' Ideality Degree Through Ideality Equation of TRIZ. Ad Alta-Journal of Interdisciplinary Research. 2020, 10(2), 367-372. ISSN 1804-7890.

\section{Contact}

Ing. Vladimír Sojka

Technical University of Liberec

Studentská 1402/2, Liberec, Czech Republic

Tel: +420 485353326

email: vladimir.sojka@tul.cz 
FILOSOFIE, DĚJINY, PRÁVO PHILOSOPHY, HISTORY, LAW

\section{QUAERE}




\title{
THE STORY OF RESCUEING OF EUGEN MORGENBESSER
}

\author{
Stanislav Šveda, Eran Mor
}

\begin{abstract}
The Talmud says: "Who will save a life - as if he has saved the whole world." In this article we want to present the destiny of the Morgenbessers - the family from Spisska Nova Ves, especially in the period of the onset of anti-Semitism in Slovakia after 1938, in the period of WW2 and also after its end. The aim of this article is specifically to tell the story of the rescue of a Jewish grammar school student from Spisska Nova Ves. His name was Eugen (Jacob) Morgenbesser. The farmer Mr. Jan Stas from the village of Spissky Stvrtok bravely contributed to his rescue. Mr. Jan Stas together with his wife Maria and daughter Justina formed one team the aim of which was to save Jacob Morgenbesser from deportation. They did it despite of the fact that they all three risked finding and certain death for hiding a Jew. The whole family of Mr. Jan Stas from Spissky Stvrtok underwent that rescue risk in order to save the Jewish grammar school student Jacob Morgenbesser. The rescuers considered every human life to be the most valuable gift and also the highest value in society.
\end{abstract}

Key words: Antisemitiznus, Rescued. Rescuers. Deportation. Jewish Codex.

\section{Introduction}

Human life is the highest value in society. Juridical state must secure its citizens and foreigners the principle of equality and justice in each period. According to the ancient philosophers justice is a virtue which secures proper order in society. Justice from the beginning has been considered by the principel : „To give everyone - what he deserves“. Each human life is sacred, that is why it needs to be protected and developed further with no exception. In next lines we want to present the life stories of the Morgenbesser family and specifically the story of rescuing Jakub Morgenbesser (Kobi Mor) from a certain deportation to the death camp.

\section{Tailor's workshop of the Morgenbesser family}

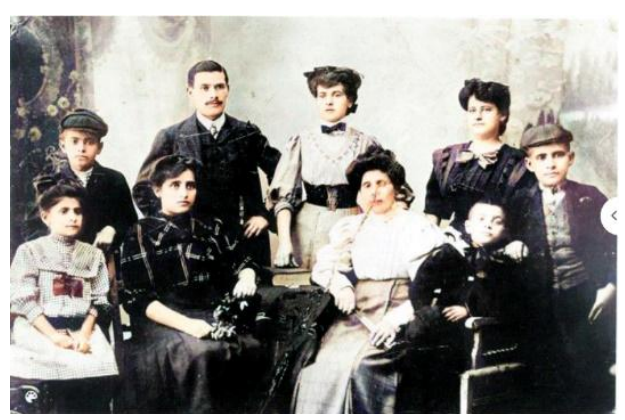

Picture n.1: Grandparents from Kosice, photo from the year of 1902, Standing from left: Eliezer, Mano (Kobi's father), Rose, Regina, Aharon. Seating: Helen, Nettie, Mother Tobi, David

\section{(Source: Eran Mor, son of the rescued Jacoba Mora)}

Father Emanuel (Mano, Menachem) Morgenbesser and mother Frantiska (Funcsi), born Goldsteinova, they lived in the square near the parish office on Hlinka (formerly Masaryk) line, today 68 Letna street in Spisska Nova Ves. Emanuel Morgenbesser's tailoring workshop 
was also located there. Although father Emanuel was a sought-after women's tailor, he also sewed other items of clothes, such as priestly clothing - reverends. Tailoring by Emanuel Morgenbesser in Spisska Nova Ves was housed in the house within and belonging to the Roman Catholic parish in Spisska Nova Ves. There was a Catholic priest and abbot ThDr. Frantisek Rolny. He was a great friend of the Morgenbesser family. From 1905 until 1950, he was a priest in Spisska Nova Ves and held various offices, among other things he also was the abbot of the Stiavnica Abbey. We want to mention that the priest and abbot ThDr. Frantisek Rolny in uncertain times, gave a helping hand and helped hide the valuables of the Morgenbesser family during anti-Jewish raids. After the war, of course, he handed over these valuables back to the Morgenbesser family without any problems. He also experienced persecution by the communist regime.

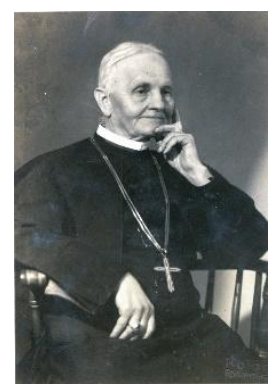

Picture n. 2: ThDr. František Rolny (1864 - 1950) (Source: Eran Mor)

The family of Emanuel (Mano) Morgenbesser. All seven Morgenbesser children were born in the same apartment in Spisska Nova Ves and were born with a help of the same accoucheuse. They all grew in the environment of a traditional Jewish home and were educated for love of Zion. All the seven of their sons were born in the same apartment on Hlinka row, today 68 Letna street in Spisska Nova Ves. The three older sons Samuel (Šani), Wilhelm (Willy), Miklos (Mit'o) were born before and during WW 1 while the four youngest Eugen (Kobi), Ladislav (Laci) a Teodor (Teo) and Walter (Zeev) were born after the return of ftheir father Emanuel (Mano) from captivity in Siberia in November 1920.

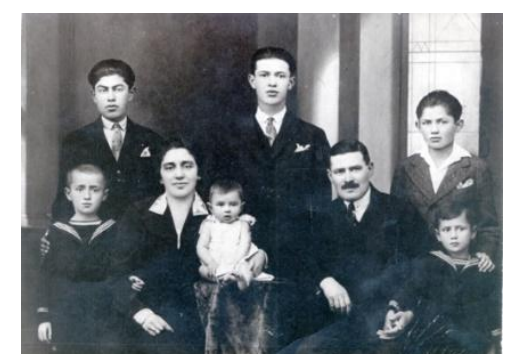

Picture n. 3: The family in Spisska Nova Ves 1928, Standing: Willy, Šani, Mit'o, Seating: Kobi, Mom Funcsi, Teo, Father Mano, Laci, (Walter was born in 1930) (Source: Eran Mor)

\section{The onset of anti-Semitism}

The first manifestations of anti-Semitism appeared in Spisska Nova Ves and its surroundings after the declaration of autonomy in October 1938. Those were throwing stones into the Jewish folk school and other manifestations. After the adoption of the so-called Jewish Code, which was the Regulation of September 9, 1941 on the Legal Status of Jews in 270 paragraphs established in Slovakia a special legal regime of citizens of the Jewish faith, who that way lost their civil rights. It began to manifest by the fact that the Jews had to wear the 
Jewish six-pointed star, they were forbidden to enter the park or the city cinema and they made them other wrongs. In general, we can say that the genocide of the Jewish population already began at the official table, in the application of bureaucratic procedures, which eventually culminated in the transports of death.

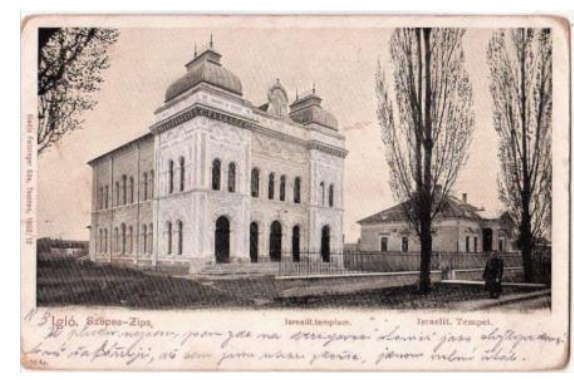

Picture n. 4: Jewish Synagogue in Spisska Nova Ves (Source: Eran Mor)

There were several attempts by the local Germans to set fire to Jewish synagogue as well as to destroy Jewish cemetery in Spisska Nova Ves. On May 1, 1941 a group of the Hitlerjugend came to the city in trucks, young people from the German Empire who came there for a trip. They were accommodated in a spa in the nearby Novoveska Huta. On today's Skolska street in Spisska Nova Ves, which was then called Hitlerova street, they set on fire the synagogue. We assume that it was the largest one in Spis, unfortunately, it was impossible to save it. From February 1942 censuses of Jews were held at the town hall and in the so-called small Redute. Jews were evicted from their homes and forcibly removed to the ghetto. They could take max. $50 \mathrm{~kg}$ of their belongings, which focused on their basic and the most needed things. The ghetto in Spisska Nova Ves was located in the Spisska Nova Ves military barracks, ${ }^{1}$ close to the railway station. Apparently, Nazi propaganda also portrayed life in ghettos through films as a decent and dignified life, claiming that practically the Jewish population lacked nothing. It was a substitution of individual actors who had to play individual roles according to the Nazi scenario. The aim of German propaganda was to point out that differences that prevail in the ghettos are caused by the Jews themselves. It was to be presented that it was essentially the exploitation of Jews by each other. Jews from higher social status were to exploit Jews from lower social status. The real situation in the ghettos was very bad. Jews were already robbed and persecuted there. In some places, there were also public executions carried out for petty offenses in order to intimidate the Jewish population. In general, there was nothing to eat and drink in the ghettos, the water was contaminated. There was also a very bad hygienic situation. People died of starvation and various types of diseases such as typhoid or tuberculosis and others. They died completely exhausted from hunger and cold to hypothermia.

\footnotetext{
${ }^{1}$ KORMOŠOVÁ, R.: Cena života. Zo spomienok Waltera Morgenbessera. Spišská Nová Ves : Gymnázium, Školská 7, Sp. Nová Ves, 2007, s. 19 - 20.
} 


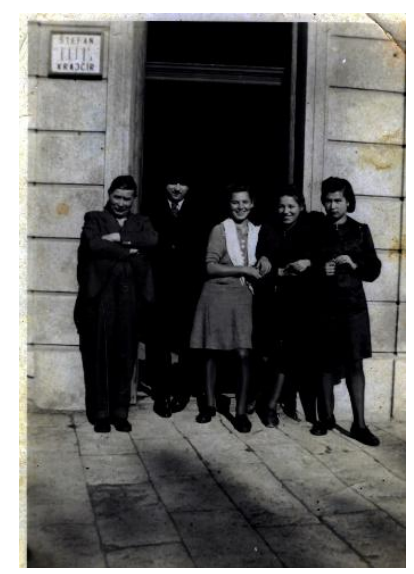

Picture n. 5: The picture shows aryanised tailor's workshop of Mr. Morgenbesser on Hlinka's (formerly Masaryk) line, today 68 Letna street. On the left is Mano Morgenbesser and next to him is the arizator and on the right are the workers. (Source: Eran Mor)

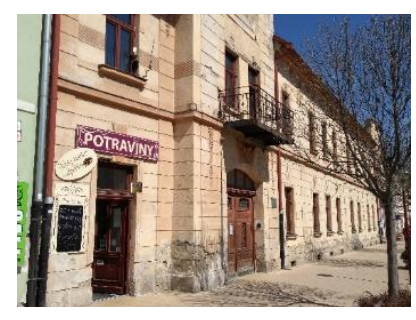

Picture n. 6: The current view, on the left there was the tailor's workshop of the Morgenbesser family part of the Roman Catholic parish office in Spisska Nova Ves (the gate in the middle is an entrance to the parish office). (Source: Stanislav Šveda)

\section{Changers}

The liquidation of Jewish enterprises consisted in the "detention" of the movable property of the original owner, its inventory, valuation and monetization in the so-called liquidation period. The original owner was deprived of the opportunity to do business as well as the company itself without compensation. That fate also affected the Tailoring of Emanuel Morgenbesser in Spisska Nova Ves. It is possible to read the name of the ariser - Stefan Krajcír - in the photo at the top left on the table. I have only found the following information: Morgenbesser Emanuel, the business subject: tailoring. Liquidation number: 22.792-III-41940. Published: Úradné noviny, n.15, March 29, $1941 .^{2}$

\section{Transporty}

Wagons intended for the transport of the Jewish population were wagons originally intended for the cattle movement. Brutally herded them there and more than 45 people were pushing in one wagon, and we want to point out that practically without water and food. They travelled in that way for several days until the train reached the final station, the so-called death camp. The irony was transport itself by rail to the death camp. The German railways charged for each person they transported to the concentration camp. Already in the ghettos, the Jews were robbed of things, valuables and money that were intended to finance the transport of people from the ghetto to the death camp. On March 25, 1942 the Jews from the Spisska Nova Ves

\footnotetext{
${ }^{2}$ Ústav pamäti národa (Nation's Memory Institute). Information on expropriated and liquidated Jewish enterprises (1941 - 1942). Morgenbesser Emanuel, the business subject: tailoring. Liquidation number: 22.792III-4-1940. Published: Úradné noviny, n. 15, March 29, 1941, page 535.
} 
and Levoca districts were crammed into prepared cattle wagons, and on the eve of that day the first transport of death with a thousand Slovak Jewish girls were sent from the railway station in Poprad to the Auschwitz concentration camp. Anti-Jewish actions continued.

First who was seized was Wilhelm (Willy) Morgenbesser. His brother Ladislav was arrested a few days later. The large concentration camp was located in central Slovakia in Zilina. After the detention of Ladislav Morgenbeser, he managed to get out of the transport in Zilina. They needed a nurse at hospital there. At that time, it was youth transports. In May 1942, the family transports began. The Morgenbesser family also got on the list for transport. In the military barracks opposite the railway station in Spisska Nova Ves, parents Emanuel and his wife Frantiska (Fancsi) and sons Teodor, Walter and Eugen (Jaco) were concentrated. The eldest brother Samuel (Šani) was a doctor in hospital in Humenne at that time. He was an economically important Jew who received a yellow ID. That exception meant that he was temporarily exempted from transport. The exception applied not only to the person concerned but also to his closest relatives, parents and siblings up to the age of 18. Their neighbour, Mrs. Keltosova, who was a soulmate of the Morgenbesser family, contacted doctor Samuel Morgenbesser by telephone. It was only after a telephone call of Samuel Morgenbesser with the Ministry of Interior in Bratislava and a reminder that by law he and his family are protected from transport, they returned home, but only for a short time. Two or three weeks later there was again the anti-Jewish action held against the last Jews who remained in Spisska Nova Ves. That scenario was repeated again. Again, the neighbour Mrs. Keltosova contacted Samuel and he again arranged for the exemption to be applied, thus he achieved their release. Only those were left who were economically important in eyes of the regime.

On August 29, 1944, the Slovak National Uprising broke out and it was suppressed. German troops occupied Slovakia in a short time. During the occupation of Slovakia, the Germans saw the first and main task of getting rid of all Jews. The Germans stopped acknowledging the exceptions, they claimed that "we are all equal before German laws." Father Emanuel Morgenbesser was the first to be arrested. Then his wife Francis and their sons. Here, the Gestapo did not lock Jacob, as he managed to hide. (We will talk about in more detail later.) After detention, everyone underwent a search and the looting of suitcases began. Everything had to be spilled on the floor. Rings, which did not go down from fingers were torn from the fingers off brutally, and they also took the clothes they liked. Mother Francis (Fani) Morgenbesser died in a death camp in Ravensbrück, Germany, ${ }^{3}$ just before liberation. Father Emanuel (Mano) Morgenbesser and his son Walter (Zeev) were also deported to the death camp in Ravensbrück. Then, sometime in January or February 1945, there was a sudden evacuation associated with the victorious advance of Allied troops. At that time, the prisoners were transferred from Ravensbrück to Sachsenhausen. This was liberated by the Red Army on April 22, 1945. They both returned home. Wilhelm (Willy) Morgenbesser was sent to the Majdanek death camp in Lublin Poland and was murdered there. Samuel (Šani, Shlomo) Morgenbesser worked as a surgeon in a hospital. On October 23, 1944 shortly before the Red Army took back the area, Gestapo officers came to hospital to arrest him. Samuel (Šani) used a morphine injection which he prepared ahead of time to avoid his arrest. His grave is in the Jewish cemetery in Humenne, the town where he died. His brother Laci arranged for him a commemoration at the local hospital. Just before WW II Miklos (Mit'o) Morgenbesser imigrated to the UK and during the war he volunteered to the Czech Brigade that was constructed in England.

As a Sargent in the Royal Tank Corps he participated in the battle of Dunkirque and with the allied forces he arrived to the city of Pilsen in the western Czech republic. After the war he returned home to Spisska Nova Ves. He married Alice Fraenkel in Slovakia and returned with

\footnotetext{
${ }^{3}$ KORMOŠOVÁ, R.: Cena života. Zo spomienok Waltera Morgenbessera. Spišská Nová Ves : Gymnázium, Školská 7, Sp. Nová Ves, 2007, s. 20 - 35.
} 
her to England. He passed away in London in 1998. Ladislav (Laci) Morgenbesser survived the war. After the independence of the state of Israel, among volunteers in Czechoslovakia were young Jewish people. Laci volunteered to the Air Force and went through pilot training on Messerschmitt aircraft in Lebrec, not far from Praha. During that time he met Fegi Schoenfeld and they got married in Czechoslovakia in December 1948. At the end of February 1949 they have made "Aliyah" to Israel, where he died in 2015. Teo (after Teodor Herzel) Avry Morgenbesser after liberation returned home. On December 24, 1947 he made "Aliyah" to Israel with father and Walter. Initially, he was a member of Kibbutz Shomrat. In May 1948 he joined the "Haganah" and participated in the battle over Acre. On Israel independence declaration he left the IDF. In 1952 he started the X-ray technician school in Beilinson Hospital, during that time he met Lizi Kohan and they got married in 1956 and moved to Nahariya. In March 2021 Teo is the only brother still alive. He made a home visit to Slovakia few years ago.

\section{Spomienky Eugena Morgenbessera (Cobi Mora)}

Now let us return to the story of the rescue of Jacob Morgenbesser, who almost miraculously avoided a certain deportation. This testimony has not been published yet anywhere and forms another link in the historical chain of the Morgenbesser family. We have his diary at our disposal with which we want to reconstruct the story of his rescue in individual contexts.

From the diary of Cobi Mora we are able to read:

„A few days later they came to pick up dad, mom and my brother Walter for transport. In time I made myself a hiding place in the lumberyard behind our yard. I made a wooden box there that I could fit in and covered it with chopped lumbers. On the day of the transport I hid inside it and through the cracks between the crate boards I saw my parents and my brother Walter being taken to the transport. At night I came out of hiding and the neighbours in the yard welcomed me for the night. That's how I escaped the transport. It was November 2, 1944. My brother Teo (Avri) also managed to escape the transport - but in a different way. He worked as an assistant in the dental clinic of the Jew Ernst Ehrenreich. The German military unit of the Wehrmacht at the scene (Spisska Nova Ves) needed the dental care of its soldiers and one of the officers harnessed Ehrenreich for this task. The dentist claimed that he could give the service only if they left in his clinic also his assistant who was my brother Teo. The officer agreed and Teo spent the winter of 1944/45 until his release at this clinic. After several days of hiding at home, at high risk, the dentist, Ehrenreich, found a hiding place for me as well. One of his patients was Mr. Jan Stas, from a village, Spissky Stvrtok, not far from our town. Mr. Jan Stas agreed to take me to his place and hide me. One evening I arrived at a meeting place with Mr. Jan Stas and we drove on his horse-drawn cart to Spissky Stvrtok. I passed the German guards in fear of leaving the city but luckily, I did not arouse suspicion because I was dressed as a peasant. Mr. Jan Stas, who lived in the village of Spissky Stvrtok, was a wealthy man, a former Social Democrat activist who did not support the Slovak fascist regime. He hid me in his stone-built barn with four cows".

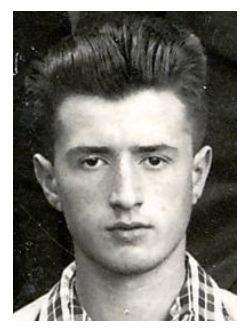

Picture n. 7: Eugen (Jacob) Morgenbesser - 1939 (Source: Eran Mor) 
A note by Eran Mor: „According to Teo's testimony Mr. Stas was not a dental patient but was rather a member in a resistance group and the link was made through a group member in Spissky Nova Ves. In the corner of the barn on a bed of straw with a blanket I had my corner. Mr. Jan Stas made sure to send me food with his daughter Justinka when she came in to milk the cows and in return, I helped him clean the barn and chop firewood. I was there in November, December 1944 and the beginning of January 1945. In January, two gendarmes from the local rural unit entered the yard and saw me at the entrance to the barn. They called me to approach and requested that I identify myself. I did not have any papers. I aroused their suspicion because at that time they were looking for partisans who had fled the revolt and were hiding in the forests near the villages. The practice among the Germans was to eliminate not only the Jews and the hiding partisans but also those who gave them hiding. That night, with the help of Mr. Jan Stas family, I went out dressed in warm clothes carrying a loaf of bread and a piece of fat through the back exit of the yard and started walking towards the surrounding forests. It was January and the forests were covered in snow. In the afternoon I came across a group of farmers in the forest" .

\section{The family of Jan Stas from the village of Spissky Stvrtok}

Jan Stas (1897 - 1980) was a farmer. Spissky Stvrtok was mainly an agrarian village. Thanks to its climatic conditions, the Spis region within Slovakia was almost predestined for growing potatoes. The colder climate, where no more thermophilic crops took hold, was suitable for growing that crop - potatoes, also called second bread. A large part of the village population lived on farming and animal breeding, only a small part on handicrafts. Today's name of the street where Jan Stas lived with his family: 114/17 Obrancov mieru, Spissky Stvrtok.

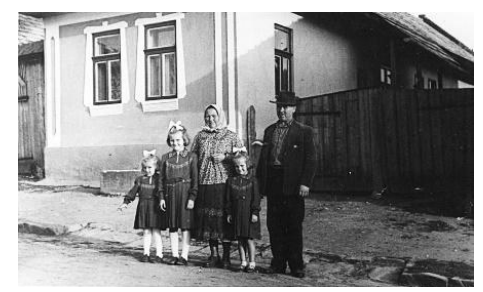

Picture n. 8: Look at Jan Stas and his wife Maria with their grandchildren in front of his house where he hid a Jewish young man, photo from 1954.

(Source: Božena Bajtošová, born Oravcová, granddaughter Ján Staš)

Jan Stas (Staš) was married and had only daughter Justine. Mr. Jan Stas (born on November, 14, 1897 in Spissky Stvrtok and died on May 11, 1980 in Spissky Stvrtok) and his wife Maria (born on April 11, 1899 and died on December 7, 1978 in Spissky Stvrtok). Mrs. Justina Oravcova, born Stasova, daughter of Jan Stas (born on February 24, 1920 in Spissky Stvrtok and died on February 13, 2001 in Spissky Stvrtok)
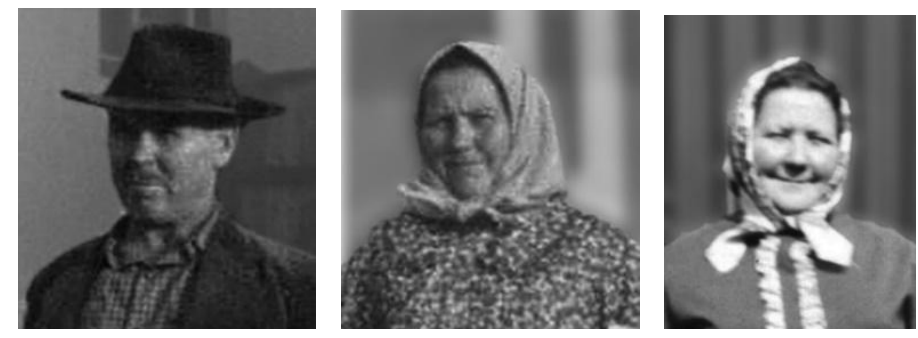

Picture n. 9: Portraits of Jan Stas, his wife Maria Stasova born Bajtosova and daughter Justina Oravcova, born Stasova.

(Source: Božena Bajtošová, rod. Oravcová, granddaughter Ján Staš) 
Kobi Mor was familiarly renamed by Jan Stas with the new name Jozef. It was because Jozef was a traditional and also the most used Slovak name, in contrast to the name Jakub (Jacob/Kobi), so that at first glance it did not arouse the initial suspicion that he might be a Jew. For some time in this period, the Post Office was located in the house of Jan Stas. The result of that fact was a greater movement of people, therefore, it was much more difficult and risky to conceal that he was hiding the Jewish young man. As stated in the Jacobo Mora's Diary, it was also regularly visited by gendarmes as a part of an inspection of the Post Office or a regular inspection of order in the village. Jan Stas offered them in a diplomatic way snaps (alcohol) so that he could tilt them in that way and continue to hide the Jewish boy. As they say - in the village everyone knows everything about everyone. That was also the case of $\mathrm{Mr}$. Jan Stas. Finally it got to ears that he was hiding the Jewish young man. Mr. Jan Stas immediately invented it when he pretended him to be a Romani assistant Jozef on his farm. It is interesting that in letters that Jacob Mor then sent to Justina Oravcova, the daughter of Jan Stas, he himself familiarly addresses as "Your Jozef Morgenbesser", while he immediately mentions his current name "Kobi Mor". 4

„Ján Stas's wife Mrs. Maria was actively involved in rescuing Jacob Morgenbesser. She created one team together with her husband and daughter and they contributed to the rescue. Mrs. Maria regularly cooked as well as washed dirty clothes for her father. Justina, her daughter, took the cooked lunch to J. Morgenbesser to the place where he was hidden. First, in the Jan Stas's farm building, then to the dense forests where he essentially depended on their help. They, all three, consciously and voluntarily decided to save J. Morgenbesser sacrificing their own ones. ${ }^{15}$ At that time, hiding a Jew was punished most often by starvation."

Let's listen to the Kobi Mora's diary:

„,The Germans in their retreat forced the peasants to give them the horse-drawn carts and help them in their retreat. Many peasants preferred to escape to the mountains rather than march with the Germans to the west. Their wives brought them food from the village. I hung out with these groups for about 10 days, during the day I had to walk so as not to freeze cold and only at night we lit ourselves to keep warm. During a day it was impossible to light a fire for fear that the Germans would see the smoke and know that people were hiding there. On January 27, 1945 we heard cannon shells flying over the forest we were walking around and we knew we were between the war front lines. That night my town and the surrounding area were freed by the Red Army. I went home in the morning. It is difficult for me to recreate and describe that tremendous admiration of the feeling of liberation. At that moment the world was completely different - everything was brighter and the air was fresher. Liberated! Liberated! I breathed deeply into the fresh winter air".

\section{Rescued Jacub (Jacob) Morgenbesser (1922 - 2017)}

Jenö, (Eugen, Jacob) Morgenbesser, brother was 4 of seven brothers, no sisters (Changed to Yacov Mor in Israel in 1967). Date of birth - August 7, 1922, Spisska Nova Ves. When he was six years old (August 1928), he started school at the Jewish school "Juedische Volksschule" (Židovská l'udová škola), the principal was Mr. Martin Szekeres. There were 50 kids in the school sharing two rooms, one for grades $1,2,3$ and the other for grades $4,5,6$. The school was in German language. Teachers couldn't speak good Slovak.

\footnotetext{
${ }^{4}$ Private archive Mrs. Božena Bajtošová, born Oravcová, Mr. Ján Staš's granddaughter, Self-made letter by J. Morgenbesser, Showrat, 8th. April 1997.

${ }^{5}$ Private archive Mr. Stanislav Šveda, Oral History: Mrs. Božena Bajtošová, born Oravcová, Mr. Ján Staš's granddaughter, from 15 October 2020.
} 
In the fifth year he passed tests and was transferred to the SNV grammar school. So I understand that his 6th year was the 1st year in Slovak language at grammar school in SNV, September 1, 1933 - June 1934. In June 1939 he graduated the sixth class at grammar school, I assume the 11th grade for him. In September 1, 1939 he attended the 7th grade (his 12th year, he was 17 years old) but on the first day he realized that his teacher is Hlinka's member and he decided to leave. It was interesting that Jacob (Eugen) Morgenbesser was still one of the honored students. Among his favourite subjects were Mathematics, Physics, foreign languages, except for German and Latin. He was popular among his classmates and he always liked to help them, especially with Mathematics. He was also an active member of Martin Kukucín's self-education group. In 1938 he took part in Sokol zlet in Prague. Even before the official ban on studying at high schools, an inscription appeared at the grammar school gate: "Jews out!" Students were not allowed to be at lessons. Jacub (Eugen) Morgenbesser had to leave school similarly to other Jewish high school students. ${ }^{6}$ He had no job. After WWII, he was an officer in the Slovak army, then he completed one semester in Prague university and then immigrated to Israel. When he moved to Israel, he changed his name to Yacov Mor in 1967. There he was a member of Kibbutz Shomrat and he acted as a high school teacher for many years until his retirement. He died on February 27, 2017 in Kibutz Shomrat in Israel.

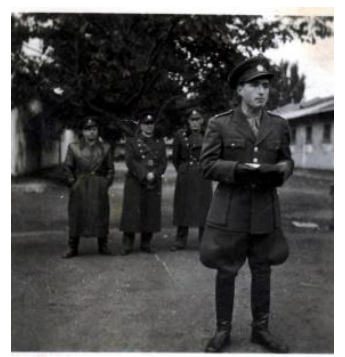

Picture n. 10: Kobi Mor as an officer in the Czecho-slovak army, photo from 1946

(Source: Eran Mor)

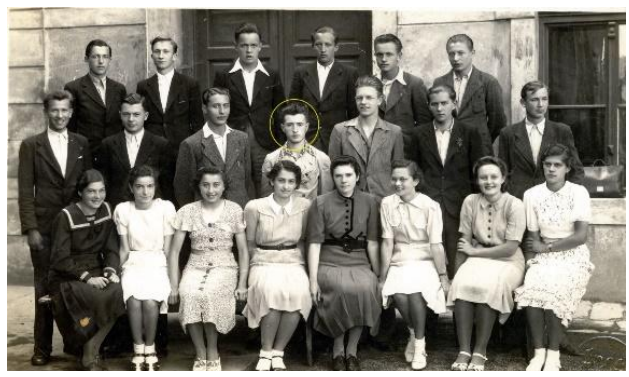

Picture n. 11: The end of the 6th grade at the Real Grammar school in Spisska Nova Ves in June 1939, Jacob Morgenbesser is in the middle. (Source: Eran Mor)

The rescued Kobi Mor (Jenö / Eugen / Jacob Morgenbesser) had the following four children: Eran, Tsip, Abraham and Nili. The eldest son, Eran, was born in Israel in 1951 and has two doughters and five grandchildren. He is the co-author of this article, with whom I have been collaborating on the process of awarding Yad Vashem for Jan Stas and his family. ${ }^{7}$ His daughter, Tsip, was born in 1954 and lives in Kibutz Gaaton, Israel and has four children and six grandchildren. Another son, Avi (Abraham), was born in 1956 and lives in Kibutz

\footnotetext{
${ }^{6}$ KORMOŠOVÁ, R.: Cena života. Zo spomienok Waltera Morgenbessera. Spišská Nová Ves : Gymnázium, Školská 7, Spišská Nová Ves, 2007, s. 63.

${ }^{7}$ YAD VASHEM, Jan STAS - Reference no.CAS-243347.
} 
Shomrat, Israel. Another daughter, Nili, was born in 1963 in Israel and now lives in California and has two daughters. Eran and his sister Tsip were born in Israel and today they are also citizens of the Slovak Republic and they are proud of it. The rescued Jacob Mor, together with his children Eran and Tsipa, visited Spissky Stvrtok in 1997 and met Justinka (daughter of Ján Staš) and her family.

We are honored to inform you that on June 6, 2021 after careful consideration the Commission decided to recognize the rescuers Stas Jan and Maria and their daughter Justina Oravcova as Righteous Among the Nations.
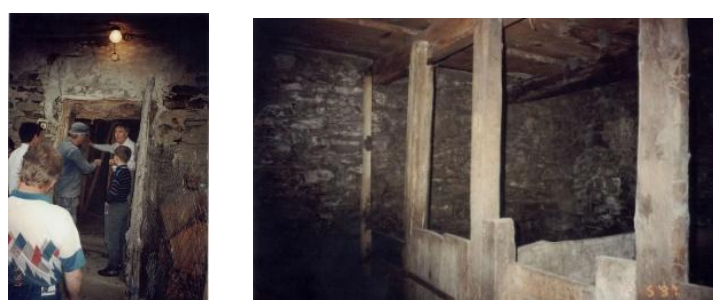

Picture n. 12: Photographs from a Jacob Mor's visit to Slovakia, in Spissky Stvrtok in 1997. The photograph shows the place where Mr. Jan Stas hid Jacob Mor.

(Source: Eran Mor)

Summary of the story of rescuing Jabub Morgenbesser in following questions:

We are interested in the question how and when did the rescued person and the rescuer meet? After the deportation of Jews from SNV, Kobi hid in the house yard and saw his parents and young brother Walter (Zeev, Yom Tov) how they took them for deportation.

Kobi then escaped to the Jewish dentist Dr. Erenrich who was obliged to stay and under the Nazi regime and was not deported. He already employed his brother Teo (Avraham, Avri) as an assistant. Dr. Erenrich introduced Kobi to Jan Stas during a visit to his clinic.

Who initiated the rescue?

Jewish dentist Dr. Erenrich.

When and what places of rescue it happened at?

November 2, 1944.

What was the nature of the aid given like?

Jan Stas hid Kobi on his horse-drawn cart and drove him under great risk from SNV to Spissky Stvrtok. Kobi was hidden for over two months in the cowshed. He helped with farm animals and was secretly fed by the family with a great assistance of Jan's daughter Justina (at that time she was single). When the local Gendarmerie found out that a young boy without documents was present at Jan's farm, asked him to come for a check the following day. Jan understood and had no choice. However, he gave Kobi warm clothes and food and sent him away. Kobi was wandering in the forests for about 10 days and then crossed the front and joined the liberated Slovak army.

The time Kobi was hidden in Spissky Stvrtok saved his life. It was when the Red Army made progress and the front approached eastern Slovakia. If Kobi did not hide in the forest for over three months during the winter, he most likely wouldn't survive.

Basic story: How was the rescued person(s) presence explained to others (rescuer's family / neighbours)?

When he was discovered, he was presented as a young Gipsy boy working at the farm. That basic story gave him one-night opportunity to run away from Spissky Stvrtok to the forest.

Describe the relations between the rescued person(s) and the rescuer at the time.

Kobi worked at the farm but was covered as much as possible. Justina delivered food into his hiding place. 
What, in your opinion, were the rescuers' motivations?

Goodwill help. „Jan Stas's wife Mrs. Maria was actively involved in rescuing Jacob Morgenbesser. She created one team together with her husband and daughter and they contributed to the rescue. Mrs. Maria regularly cooked as well as washed dirty clothes for her father. Justina, her daughter, brought the cooked lunch to J. Morgenbesser to the place where he was hidden. First, into the Jan Stas's farm building, then to the dense forests where he essentially depended on their help. They, all three, consciously and voluntarily decided to save J. Morgenbesser sacrificing their own lives.

\section{Conclusion}

Thanks to his rescue in late 1944 and early 1945, Kobi Morgenbesser was able to return into civilized life and to bulid a family with his wife Aliza. They have four childrens, eight grands and Elevan greatgrands.

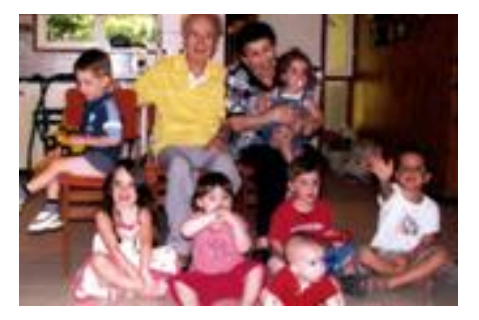

Picture n.13: Kobi and Aliza with Great Grands - 2010

(Source: Eran Mor)

Jan Stas's and his family actions, he and them gave us an important example of human nobility which stems from kindness and human concern for others without any profit on its part. Such sublime deeds which are done under great self-risk and out of a belief in doing good and right in accordance with deep human principles can only be highly appreciated and admired.

\section{Literature}

1. Private archive Mr. Eran Mor

2. Diary Kobi Mor

3. Photography

4. Private archive Mrs. Božena Bajtošová, born Oravcová, Mr. Ján Staš's granddaughter,

5. Self-made letter by J. Morgenbesser, Showrat, 8th. April 1997.

6. Photography

7. Private archive Mr. Stanislav Šveda

8. Oral history: Proposal for award - The fairly-minded among nations

9. Photography

10. Ústav pamäti národa (Nation's Memory Institute). Information on expropriated and liquidated Jewish enterprises (1941 - 1942). Morgenbesser Emanuel, the business subject: tailoring. Liquidation number: 22.792-III-4-1940. Published: Úradné noviny, n. 15, March 29, 1941, page 535.

\section{Book publications}

1. KORMOŠOVÁ, R.: Cena života. Zo spomienok Waltera Morgenbessera. Spišská Nová Ves : Gymnázium, Školská 7, Spišská Nová Ves, 2007, 85 s. ISBN 978-80969752-9-7. 


\section{Contact}

PaedDr. Ing. Stanislav Šveda

Prešovská univerzita v Prešove

Gréckokatolícka teologická fakulta

Katedra historických vied

Ulica biskupa Gojdiča 2

08001 Prešov, Slovakia

e-mail: stanosveda@gmail.com

Eran Mor

Libéria 12 Haifa Izrael 34980,

Tel + 972-54-999-8758

e-mail iemor@bezeqint.net 


\title{
VPLYV REKODIFIKÁCIE CIVILNÉHO PRÁVA PROCESNÉHO NA \\ ČASOVÝ ROZMER ROZHODOVANIA O DOČASNOM \\ POZASTAVENÍ ÚČINNOSTI VŠEOBECNE ZÁVÄZNÉHO \\ NARIADENIA
}

\author{
THE INFLUENCE OF THE RECODIFICATION OF CIVIL \\ PROCEDURAL LAW ON TIMELINE OF THE DECISION OF \\ TEMPORARY SUSPENSION OF THE GENERALLY BINDING \\ REGULATION
}

\author{
Lukáš Tomaš
}

\begin{abstract}
Abstrakt
Príspevok je obsahovo zameraný na rozhodovanie o dočasnom pozastavení účinnosti komunálneho práva v správnom súdnictve so zretel'om na časové zameranie tohto procesu. Rekodifikácia civilného práva procesného v roku 2015 ovplyvnila temporálne aspekty poskytovania avizovanej dočasnej súdnej ochrany. Problematika je skúmaná na podklade výsledkov súdnej praxe pri aplikácii predovšetkým historicko-komparatívnej metódy poznania. Ciel' príspevku tkvie v analýze a vecne nadväzujúcom zhodnotení vplyvu prijatia samostatného správneho súdno-procesného kódexu (Správneho súdneho poriadku) na dočasné pozastavenie účinnosti všeobecne záväzného nariadenia a formulovaní návrhov na prehodnotenie niektorých rozhodovacích prístupov de lege ferenda.
\end{abstract}

Klíčová slova: správne súdnictvo, všeobecne záväzné nariadenie, dočasné pozastavenie účinnosti

\begin{abstract}
The content of the paper is focused on deciding on the temporary suspension of the effectiveness of municipal law in the administrative judiciary with regard to the time focus of this process. The recodification of civil procedural law in 2015 affected the temporal aspects of the provision of the notified temporary judicial protection. The issue is examined on the basis of the results of court practice in the application of primarily the historical-comparative method of knowledge. The aim of the paper is to analyze and follow-up the impact of the adoption of a separate Administrative Judicial Code (Administrative Judicial Code) on the temporary suspension of a generally binding regulation and to formulate proposals to reconsider certain decision-making approaches de lege ferenda.
\end{abstract}

Key words: administrative justice, generally binding regulation, temporary suspension of effectiveness

\section{1 ÚVOD}

Dňa 1. júla 2016 vstúpil do účinnosti samostatný súdno-procesný kódex - Správny súdny poriadok. ${ }^{1}$ Predmetný právny predpis priniesol pomerne rozsiahle zmeny. Viacero z týchto

\footnotetext{
${ }^{1}$ Zákon č. 162/2015 Z. z. Správny súdny poriadok v znení neskorších predpisov. Nahradením právnej úpravy občianskeho súdneho konania z roku 1963 (zákon č. 99/1963 Zb. Občiansky súdny poriadok v znení neskorších predpisov) sa v podstate zavŕšila rekodifikácia súdno-procesných noriem, ktorá započala v roku 2005 rekodifikáciou trestného práva procesného. K týmto otázkam pozri vo všeobecnosti a vo vybraných
} 
zmien môžeme označit' za koncepčné, respektíve systémové. ${ }^{2}$ Popritom však možno nájst' aj nóva, ktoré z platnej a účinnej procesnej úpravy vyplývajú len implicitne. Jednu zo zmien tohto charakteru možno identifikovat' v konaní o súlade právnych predpisov v správnom súdnictve ( $§ 357$ - $§ 367$ Správneho súdneho poriadku) v súvislosti s dočasným pozastavením účinnosti všeobecne záväzného nariadenia (§ 362 Správneho súdneho poriadku).

Dočasné pozastavenie účinnosti právneho predpisu predstavuje inštitút, ktorého ideovým zmyslom je poskytnút' dočasnú súdnu ochranu právnym vzt'ahom, ktoré môžu byt' ohrozené (narušené) pôsobením všeobecne záväzného nariadenia v medziobdobí od začatia správneho súdneho konania o súlade právnych predpisov ${ }^{3}$ do právoplatnosti meritórneho rozhodnutia. Dočasné pozastavenie účinnosti normatívneho správneho aktu teda svojím spôsobom a v určitých aspektoch predstavuje prostriedok, ktorý zabezpečuje materiálne dosiahnutie účelu súdneho konania. Takýmto spôsobom zabraňuje zmareniu jeho účelu, ktoré by mohlo spočívat' $\mathrm{v}$ (hrozbe) vzniku nezvratných následkov vyvolaných nezákonných všeobecne záväzným nariadením. ${ }^{4}$

Aktuálne platná a účinná právna úprava dočasného pozastavovania účinnosti správnych aktov je rozdelená z hl'adiska identifikovania súdneho orgánu, ktorému je zverená právomoc vo veci súdnej kontroly administratívnych noriem. Pokial' skúma súlad všeobecne záväzného nariadenia (a tiež vyhlášky miestneho orgánu štátnej správy) Ústavný súd Slovenskej republiky, postupuje podl'a úpravy obsiahnutej v čl. 125 ods. 2 Ústavy Slovenskej republiky ${ }^{5}$ a $§ 78$ a nasl. zákona o Ústavnom súde Slovenskej republiky. ${ }^{6}$ Ak je všeobecne záväzné nariadenie podrobované transcendentnej kontrole ${ }^{7}$ pred správnym súdom, aplikuje sa $\S 362$ Správneho súdneho poriadku.

konkrétnostiach bližšie napr. MARKOVÁ, V. Zmeny v koncepcii trestných kódexov od roku 1918 až po súčasnost'. In Notitiae iudiciales Academiae collegii aedilium in Bratislava. roč. 4, 2018, č. 2, s. 28-55; MADLIAK, J., PORADA, V. Niekol'ko poznámok k rekodifikáciám trestnoprávnych noriem v Slovenskej republike; In Humanum : miedzynarodowe studia spoleczno-humanistyczne. 2009, č. 3, s. 55-68; FERENČÍKOVÁ, S. Retroaktivita $\mathrm{v}$ trestnom práve. In: Nové trendy $\mathrm{v}$ práve I. : zborník príspevkov z medzinárodnej vedeckej konferencie. Banská Bystrica : Belianum, 2016, s. 39-51. MICHALOV, L. Podmienky ukladania alternatívnych trestov z pohl'adu de lege ferenda. In ROMŽA, S., FERENČÍKOVÁ, S., MICHALOV, L. (eds.) 4. Košické dni trestného práva : privatizácia výkonu trestu odňatia slobody, sci-fi alebo jediná možnost? : zborník vedeckých prác. Košice: Univerzita Pavla Jozefa Šafárika v Košiciach, 2020, s. 293-304.; ŠTEVČEK, M. Pred článkom 1 (doktrinálne východiská novej procesnej úpravy). In ŠTEVČEK, M., FICOVÁ, S., BARICOVÁ, J., MESIARKINOVÁ, S., BAJÁNKOVÁ, J. a kol. Civilný sporový poriadok. Komentár. Praha : C. H. Beck, 2016, s. 1 a nasl.; JOKEL, P. Nové právne inštitúty v Správnom súdnom poriadku. In Studia Iuridica Cassoviensia, roč. 4, č. 2, 2016, s. 67-81.; FILIČKO, V. Nové prostriedky ochrany spotrebitel’a v spotrebitel'ských sporoch podl'a CSP. In Studia Iuridica Cassoviensia, roč. 6, č. 1, 2018, s. 76-88.

${ }^{2}$ VAČOK, J. Čo prinieslo nahradenie odvolania kasačnou st’ažnost'ou vo vzt'ahu k odkladnému účinku? In FRUMAROVÁ, K. (ed.) Správní soudnictví - 15 let existence Soudního řádu správního vs. prvotní zkušenosti s aplikací nového Správneho súdneho poriadku. Olomouc : Iuridicum Olomoucense, 2018, s. 347.

3 V tejto súvislosti pozri napríklad SEMAN, T. Správne súdnictvo v Slovenskej republike (aktuálny stav, problémy a perspektívy). In OROSZ, L. a kol. Ústavný systém Slovenskej republiky (doterajši vývoj, aktuálny stav, perspektívy). Košice: Univerzita Pavla Jozefa Šafárika v Košiciach, 2009. s. 271 a nasl.

${ }^{4} \mathrm{~K}$ tomu vo všeobecnosti HOFFMANN, M. In TEKELI, J., HOFFMANN, M. Zákon o obecnom zriadení. Komentár. Bratislava: Wolters Kluwer, 2014, s. 260 a nasl.

${ }^{5}$ Ústava Slovenskej republiky č. 460/1992 Zb. v znení neskorších ústavných zákonov. Pozri DRGONEC, J. Ústava Slovenskej republiky. Teória a prax. Bratislava: C. H. Beck, 2015, s. 1463 a nasl.

${ }^{6}$ Zákon č. 314/2018 Z. z. o Ústavnom súde Slovenskej republiky a o zmene a doplnení niektorých zákonov v znení neskorších predpisov. Pozri aj MIHAL'OV, J. In MACEJKOVÁ, I., BÁRÁNY, E., BARICOVÁ, J., FIAČAN, I., HOLLÄNDER, P., SVÁK, J. a kol. Zákon o Ústavnom súde Slovenskej republiky. Komentár. Bratislava: C. H. Beck, 2020, s. 698 a nasl.

${ }^{7}$ Pozri NOVÁK, J. Administrativne právo procesné. Bratislava: Právnická jednota v Bratislave, 1943, s. 226. 
Podla $§ 362$ Správneho súdneho poriadku správny súd môže uznesením na návrh žalobcu dočasne pozastavit' účinnost' všeobecne záväzného nariadenia, jeho časti alebo niektorého jeho ustanovenia, ak ich d'alšie uplatňovanie môže ohrozit' základné práva a slobody, ak hrozí značná hospodárska škoda alebo závažná ujma na životnom prostredí, prípadne iný vážny nenapravitel'ný následok. Z predošlej vety je zrejmé, že správny súd môže poskytnút' dočasnú súdnu ochranu, na rozdiel od Ústavného súdu Slovenskej republiky, len pri procesnej aktivite navrhovatel'a. Som toho názoru, že taká úprava plne zodpovedá vzt'ahu prokuratúry a správneho súdnictva pri výkone kontrolných pôsobností. Ak správny súd návrhu žalobcu nevyhovie, teda pri procesnom neúspechu navrhovatel'a, uznesením ho zamietne. Temporálna redukovanost' súdnej ochrany je zvýraznená v tret'om odseku § 362 Správneho súdneho poriadku, podl'a ktorého správny súd zruší uznesenie vo veci dočasného pozastavenia účinnosti všeobecne záväzného nariadenia, ak odpadnú dôvody, pre ktoré bolo vydané; inak dočasné pozastavenie účinnosti všeobecne záväzného nariadenia, jeho časti alebo niektorého jeho ustanovenia zaniká nadobudnutím právoplatnosti rozhodnutia správneho súdu vo veci samej. Procesné aspekty zverejňovania súdneho rozhodnutia upravuje $\S 6$ zákona o obecnom zriadení. $^{8}$ Podl'a tohto ustanovenia ak súd uznesením na návrh prokurátora dočasne pozastavil účinnost' všeobecne záväzného nariadenia obce alebo samosprávneho kraja, jeho časti, prípadne niektorého jeho ustanovenia podl'a osobitného zákona ( $\$ 362$ Správneho súdneho poriadku), obec zverejní právoplatné uznesenie súdu jeho vyvesením na úradnej tabuli. Uznesenie súdu musí byt' zverejnené až do času, kým nie je zrušené alebo nestratí platnost'. Popritom sa obci predpisuje aj povinnost' publikovat' právoplatné uznesenie správneho súdu zverejní aj na webovom sídle obce. Vykonat' tak treba v totožnej lehote. ${ }^{9}$ Vo vzt'ahu k všeobecne záväzným nariadeniam vyšších územných celkov (samosprávnych krajov) je obdobná problematika regulovaní v $§ 8$ zákona o samosprávnych krajoch. ${ }^{10}$

\section{REKODIFIKÁCIA CIVILNÉHO PROCESU A DOČASNÉ POZASTAVENIE ÚČINNOSTI VŠEOBECNE ZÁVÄZNÉHO NARIADENIA}

Správny súdny poriadok neobsahuje priamu úpravu, ktorá by sa týkala časových aspektov rozhodovania správneho súdu o návrhu podl’a $§ 362$ Správneho súdneho poriadku. Nepriamy limit možno podl'a mojej mienky vyvodit' z viacerých ustanovení procesných kódexov, napríklad z $§ 102$ ods. 1 Správneho súdneho poriadku, ktorý prikazuje správnemu súdu konat' tak, aby bola vec čo najrýchlejšie rozhodnutá. Zastávam názor, že aj o návrhu na dočasné pozastavenie účinnosti všeobecne záväzného nariadenia sa teda žiada rozhodnút' čo najrýchlejšie. Už v predošlých prácach, v ktorých sme sa zaoberali touto problematikou, ${ }^{11}$ sme poukazovali na odlišnú úpravu zákona o Ústavnom súde Slovenskej republiky v totožnej veci. Zákon o Ústavnom súde Slovenskej republiky prikazuje vo veci dočasného pozastavenia účinnosti konat' bezodkladne. Ide o špeciálnu úpravu, ktorá dopadá na rýchlost' konania pred nezávislým orgánom ochrany ústavnosti. Domnievam sa, že de lege ferenda by bolo vhodné, aby sa úpravou ústavného súdneho konania zákonodarca inšpiroval aj v súvislosti $\mathrm{s}$ pozastavovaním účinnosti právneho predpisu v administratívnom súdnictve.

\footnotetext{
${ }^{8}$ Zákon Slovenskej národnej rady č. 369/1990 Zb. o obecnom zriadení v znení neskorších predpisov.

${ }^{9}$ Pozri aj FEČÍK, M. In BARICOVÁ, J., FEČÍK, M., ŠTEVČEK, M., FILOVÁ, A. a kol. Správny súdny poriadok. Komentár. Bratislava: C. H. Beck, 2017, s. 1433 a nasl.

${ }^{10}$ Zákon č. 302/2001 Z. z. o samospráve vyšších územných celkov (zákon o samosprávnych krajoch) v znení neskorších predpisov.

${ }^{11}$ Pozri TOMAŠ, L. Dočasné pozastavenie účinnosti normatívnych správnych aktov územnej samosprávy (so zretel'om na iniciovanie a rozhodnutie o dočasnom pozastavení účinnosti všeobecne záväzného nariadenia (1. čast'). In Justičná revue, 73, 2021, č. 4 a TOMAŠ, L. Dočasné pozastavenie účinnosti normatívnych správnych aktov územnej samosprávy (so zretel’om na iniciovanie a rozhodnutie o dočasnom pozastavení účinnosti všeobecne záväzného nariadenia (2. čast'). In Justičná revue, 73, 2021, č. 5.
} 
Z doterajšej aplikačnej praxe vyplývajú dva odlišné prístupy správnych súdov k rozhodnutiu o návrhu na poskytnutie dočasnej justičnej ochrany podl’a $\S 362$ Správneho súdneho poriadku. O návrhu sa rozhoduje (i) bud' pred rozhodnutím vo veci samej, ${ }^{12}$ alebo (ii) zarovno s rozhodnutím vo veci samej. ${ }^{13}$ Druhý prístup v podstate znamená dočasné pozastavenie účinnosti všeobecne záväzného nariadenia (procesné rozhodnutie) v ten istý deň, ako správny súd vysloví nesúlad všeobecne záväzného nariadenia, jeho časti alebo jednotlivého ustanovenia s právnym predpisom vyššej právnej sily (rozhodnutie vo veci samej). V tejto súvislosti vyvstáva závažná otázka, ktorej dopady sú tak doktrinálne, ako aj právno-aplikačné: Aký je materiálny zmysel vydania pozastavujúceho procesného uznesenia $\mathrm{v}$ ten istý deň ako rozhodnutia vo veci samej? Nemíňa sa takýto prístup účelu dočasnej súdnej ochrany, ktorý sa má realizovat' práve v čase do rozhodnutia vo veci samej?

Pri hl'adaní odpovede na nastolenú otázku si je potrebné uvedomit', že s účinnost'ou od 1. júla 2016 došlo v Slovenskej republike k rekodifikácii civilného práva procesného. Doposial' platný Občiansky súdny poriadok sa nahradil tromi procesnými kódexmi (Civilným sporovým poriadkom, ${ }^{14}$ Civilným mimosporovým poriadkom ${ }^{15}$ a Správnym súdnym poriadkom). Dopady realizovaných zmien boli vo všeobecnosti významné a koncepčne neobišli ani oblast' správneho súdnictva. Ako d’alej vyplynie, z vecného hl'adiska sa významne dotkli aj časových súvislostí rozhodovania o dočasnom pozastavení účinnosti lokálnych právnych noriem.

Konanie o súlade právnych predpisov v správnom súdnictve bolo za účinnosti Občianskeho súdneho poriadku upravené $\mathrm{v}$ jedinom paragrafe (§ 250zfa). O návrhu prokurátora na vyslovenie nesúladu komunálneho práva sa rozhodovalo rozsudkom, voči ktorému bolo prípustné odvolanie. ${ }^{16}$ Ked’že odvolanie bolo aj $\mathrm{v}$ správnom súdnictve za účinnosti Občianskeho súdneho poriadku riadnym opravným prostriedkom, rozhodnutie krajského súdu o vyslovení nesúladu všeobecne záväzného nariadenia sa napádalo ako neprávoplatné. Až do rozhodnutia Najvyššieho súdu Slovenskej republiky o podanom odvolaní bol derogačný rozsudok krajského súdu neprávoplatný. Všeobecne záväzné nariadenie bolo d’alej platné a účinné a v dôsledku svojej nezákonnosti, pravda, doposial' len neprávoplatne vyslovenej, mohlo vyvolávat' škodlivé účinky vo vzt’ahu k adresátom verejnomocenskej regulácie.

Po nadobudnutí účinnosti Správneho súdneho poriadku je situácia diametrálne odlišná. V konaní o súlade právnych predpisov v správnom súdnictve sa vo veci samej rozhoduje uznesením ( $\$ 365$ až $§ 367$ Správneho súdneho poriadku), ktoré je právoplatné už doručením, pretože ho nemožno napadnút' riadnym opravným prostriedkom, ba ani st'ažnost'ou ( $\$ 151$ ods. 1 a 2 Správneho súdneho poriadku). Procesná obrana sa konštruuje len ako mimoriadna, $\mathrm{v}$ podobe prípustnosti napadnutia tohto uznesenia kasačnou st’ažnost'ou. ${ }^{17}$ Dovodené do dôsledkov, do rozhodnutia kasačného súdu (de lege lata Najvyššieho súdu Slovenskej

\footnotetext{
${ }^{12}$ Napr. uznesenie Krajského súdu v Košiciach sp. zn. 3Sa/3/2017 zo dňa 03. augusta 2017, uznesenie Krajského súdu v Nitre sp. zn. 15S/20/2020 zo dňa 19. augusta 2020, uznesenie Krajského súdu v Trenčíne sp. zn. $13 \mathrm{~S} / 141 / 2012$ zo dňa 11 . decembra 2012.

${ }_{13}$ Pozri napr. uznesenie Krajského súdu v Banskej Bystrici sp. zn. 24S/114/2012 zo dňa 09. augusta 2013, ktorým konajúci správny súd dočasne pozastavil účinnost’ napadnutého všeobecne záväzného nariadenia, a uznesenie totožnej spisovej značky z totožného dňa, ktorým ten istý súd vyslovil nesúlad tohto všeobecne záväzného nariadenia s hierarchicky nadradenými právnymi predpismi.

${ }^{14}$ Zákon č. 160/2015 Z. z. Civilný sporový poriadok v znení neskorších predpisov.

${ }^{15}$ Zákon č. 161/2015 Z. z. Civilný mimosporový poriadok v znení neskorších predpisov.

16 Pozri DOBROVIČOVÁ, G. Ústavné základy tvorby práva de constitutione ferenda. In OROSZ, L. a kol. Ústavný systém Slovenskej republiky (doterajši vývoj, aktuálny stav, perspektívy). Košice: Univerzita Pavla Jozefa Šafárika v Košiciach, 2009. s. 128 a nasl.

${ }^{17}$ Pozri $§ 438$ a $§ 439$ Správneho súdneho poriadku.
} 
republiky, de lege ferenda Najvyššieho správneho súdu Slovenskej republiky) o podanej kasačnej st’ažnosti je derogačné uznesenie krajského súdu právoplatné. Všeobecne záväzné nariadenie podrobované justičnej kontrole je teda do rozhodnutia kasačného súdu platné, ale neúčinné, pretože ak správny súd po preskúmaní zistí dôvodnost' žaloby, uznesením vysloví nesúlad všeobecne záväzného nariadenia, jeho časti alebo niektorého jeho ustanovenia, pričom dňom nadobudnutia právoplatnosti jeho rozhodnutia stráca všeobecne záväzné nariadenie, jeho čast' alebo niektoré jeho ustanovenie účinnost. ${ }^{18}$ Za súčasnej konštrukcie je teda nezákonnost' všeobecne záväzného nariadenia právoplatne vyslovená už rozhodnutím krajského súdu (v pozícii správneho súdu). Takéto všeobecne záväzné nariadenie už nemôže potenciálne a ani reálne negatívne vplývat' na recipientov.

\section{ZÁVER}

Záverom možno zhrnút', že rekodifikácia civilného práva procesného významne ovplyvnila časové súvislosti rozhodovania vo veci dočasnej ochrany poskytovanej správnym súdom pri súdnej kontrole noriem.

Za účinnosti Občianskeho súdneho poriadku mal prístup správnych súdov, kedy dochádzalo $\mathrm{k}$ dočasnému pozastaveniu účinnosti všeobecne záväzného nariadenia a vydaniu rozhodnutia vo veci samej, reálny význam. Kým rozhodnutie vo veci samej, ktoré konštatovalo nesúlad preskúmavanej právnej normy, bolo napadnutel'né odvolaním (§ 250zfa ods. 4 Občianskeho súdneho poriadku), voči pozastavujúcemu uzneseniu nebol opravný prostriedok prípustný (§ $246 \mathrm{c}$ ods. 1 Občianskeho súdneho poriadku), t. j. bolo právoplatné doručením. ${ }^{19}$ Zmyslom vydania (ihned') právoplatného pozastavujúceho uznesenia a (nie hned') právoplatného rozsudku priznávajúceho prokurátorovi procesný úspech $\mathrm{v}$ ten istý deň teda bolo poskytnutie dočasnej súdnej ochrany $\mathrm{v}$ medziobdobí od právoplatnosti pozastavujúceho uznesenia do právoplatnosti rozsudku.

Ked’že podl'a Správneho súdneho poriadku je rozhodnutie vyslovujúce nesúlad všeobecne záväzného nariadenia právoplatné $\mathrm{v}$ totožný okamih (doručením) ako pozastavujúce uznesenie podl'a bývalého Občianskeho súdneho poriadku, nie je namieste rozhodovat' o návrhu na dočasné pozastavenie účinnosti zarovno s rozhodovaním vecným (rozhodovanie o žalobe podl'a $\S 357$ Správneho súdneho poriadku). Takýto prístup už nemá žiaden význam a nemôže naplnit' účel dočasnej súdnej ochrany. Akútna ${ }^{20}$ ochrana podl’a $§ 362$ Správneho súdneho poriadku sa absolútne míňa účinku. Ak teda podl'a platnej právnej úpravy má mat' dočasné pozastavenie účinnosti materiálny obsah, je nevyhnutné, aby správny súd o návrhu na taký postup rozhodol pred rozhodnutím vo veci samej.

Príspevok predstavuje výstup z projektu VEGA č. 1/0386/19 s názvom „Nové dimenzie metodológie právnej argumentácie - Úloha právnych princípov vo viacúrovňovom právnom systéme“.

\section{Použitá literatura}

1. BARICOVÁ, J., FEČÍK, M., ŠTEVČEK, M., FILOVÁ, A. a kol. Správny súdny poriadok. Komentár. Bratislava: C. H. Beck, 2017. 1824 s. ISBN 9788074006784.

2. DRGONEC, J. Ústava Slovenskej republiky. Teória a prax. Bratislava: C. H. Beck, 2015. 1603 s. ISBN 9788089603398.

\footnotetext{
${ }^{18}$ Porovnaj $§ 367$ ods. 1 a 2 Správneho súdneho poriadku.

19 MAZÁK, J. Súdne rozhodovanie a súdne rozhodnutia. In MAZÁK, J. - JÁNOŠÍKOVÁ, M. Učebnica občianskeho procesného práva. Bratislava: IURIS LIBRI, 2012. s. 405 a nasl.

${ }^{20}$ Uznesenie Krajského súdu v Bratislave sp. zn. 6S/156/2017 zo dňa 12. januára 2018.
} 
3. FILIČKO, V. Nové prostriedky ochrany spotrebitel'a v spotrebitel'ských sporoch podl'a CSP. In Studia Iuridica Cassoviensia, roč. 6, č. 1, 2018, s. 76-88. ISSN 13393995.

4. FRUMAROVÁ, K. (ed.) Správní soudnictví - 15 let existence Soudního řádu správního vs. prvotní zkušenosti s aplikaci nového Správneho súdneho poriadku. Olomouc : Iuridicum Olomoucense, 2018. 363 s. ISBN 9788088266259.

5. JOKEL, P. Nové právne inštitúty v Správnom súdnom poriadku. In Studia Iuridica Cassoviensia, roč. 4, č. 2, 2016, s. 67-81. ISSN 1339-3995.

6. MACEJKOVÁ, I., BÁRÁNY, E., BARICOVÁ, J., FIAČAN, I., HOLLÄNDER, P., SVÁK, J. a kol. Zákon o Ústavnom súde Slovenskej republiky. Komentár. Bratislava : C. H. Beck, 2020. 1640 s. ISBN 9788089603909.

7. MADLIAK, J., PORADA, V. Niekol'ko poznámok k rekodifikáciám trestnoprávnych noriem v Slovenskej republike.; In Humanum : miedzynarodowe studia spoleczno-humanistyczne. 2009, č. 3, s. 55-68. ISSN 1898-8431.

8. MARKOVÁ, V. Zmeny v koncepcii trestných kódexov od roku 1918 až po súčasnost'. In Notitiae iudiciales Academiae collegii aedilium in Bratislava. roč. 4, 2018, č. 2, s. 28-55. ISSN 2453-6954.

9. MAZÁK, J., JÁNOŠÍKOVÁ, M. Učebnica občianskeho procesného práva 1. Bratislava: IURIS LIBRI, 2012. 526 s. ISBN 9788089635009.

10. NOVÁK, J. Administratívne právo procesné. Bratislava: Právnická jednota v Bratislave, 1943. $264 \mathrm{~s}$.

11. OROSZ, L. a kol. Ústavný systém Slovenskej republiky (doterajši vývoj, aktuálny stav, perspektívy). Košice: Univerzita Pavla Jozefa Šafárika v Košiciach, 2009. 374 s. ISBN 9788070977774.

12. ROMŽA, S., FERENČÍKOVÁ, S., MICHALOV, L. (eds.) 4. Košické dni trestného práva : privatizácia výkonu trestu odňatia slobody, sci-fi alebo jediná možnost?? zbornik vedeckých prác. Košice: Univerzita Pavla Jozefa Šafárika v Košiciach, 2020. ISBN 9788081529450.

13. ŠTEVČEK, M., FICOVÁ, S., BARICOVÁ, J., MESIARKINOVÁ, S., BAJÁNKOVÁ, J. a kol. Civilný sporový poriadok. Komentár. Praha : C. H. Beck, 2016. ISBN 9788074006296.

14. TEKELI, J., HOFFMANN, M. Zákon o obecnom zriadení. Komentár. Bratislava: Wolters Kluwer, 2014. 776 s. ISBN 9788081680342.

15. TOMAS̆, L. Dočasné pozastavenie účinnosti normatívnych správnych aktov územnej samosprávy (so zretel'om na iniciovanie a rozhodnutie o dočasnom pozastavení účinnosti všeobecne záväzného nariadenia (1. čast'). In Justičná revue, 73, 2021, č. 4. ISSN 1335-6461.

16. TOMAŠ, L. Dočasné pozastavenie účinnosti normatívnych správnych aktov územnej samosprávy (so zretel'om na iniciovanie a rozhodnutie o dočasnom pozastavení účinnosti všeobecne záväzného nariadenia (2. čast'). In Justičná revue, 73, 2021, č. 5. ISSN 1335-6461.

17. Uznesenie Krajského súdu v Banskej Bystrici sp. zn. 24S/114/2012 zo dňa 09. augusta 2013.

18. Uznesenie Krajského súdu v Bratislave sp. zn. 6S/156/2017 zo dňa 12. januára 2018.

19. Uznesenie Krajského súdu v Košiciach sp. zn. 3Sa/3/2017 zo dňa 03. augusta 2017.

20. Uznesenie Krajského súdu v Nitre sp. zn. 15S/20/2020 zo dňa 19. augusta 2020.

21. Uznesenie Krajského súdu v Trenčíne sp. zn. 13S/141/2012 zo dňa 11. decembra 2012. 


\section{Kontaktní údaje}

JUDr. Lukáš Tomaš

Univerzita Pavla Jozefa Šafárika v Košiciach, Právnická fakulta, Ústav teórie práva Gustava Radbrucha

Kováčska 26, 04075 Košice

Tel: 0917555339

email: lukas.tomas@student.upjs.sk 


\title{
ZMENA VÝPOVEDE SVEDKA AKO DÔVOD OBNOVY TRESTNÉHO KONANIA
}

\section{CHANGE OF WITNESS TESTIMONY AS A REASON FOR THE RENEWAL OF CRIMINAL PROCEEDINGS}

\author{
Lukášs Michal’ov, Martin Baločko
}

\begin{abstract}
Abstrakt
Autori v tomto článku analyzujú problematiku obnovy trestného konania. Prinášajú náhl’ad na normatívne vymedzenie jednotlivých podmienok obnovy konania. Zaoberajú sa štádiami obnovy trestného konania, ich účelom a ideovou podstatou. Ťažiskovú čast' článku predstavuje rozbor modifikácie svedeckej výpovede ako dôvodu obnovy trestného konania. Autori sa vo svetle súdnej praxe zamýšl'ajú nad predpokladmi prípustnosti obnovy konania s poukazom na zmenu výpovede svedka a možnost'ami (kvalitou) prieskumu tohto dôvodu v konaní o povolení obnovy konania a obnovenom konaní vo veci samej. Problematiku skúmajú tak v trestnoprávnych, ako aj v ústavných a l’udsko-právnych súvislostiach.
\end{abstract}

Klíčová slova: trestné konanie, obnova konania, svedecká výpoved'

\begin{abstract}
In this article, the authors analyze the issue of the renewal of criminal proceedings. They provide insight into the normative definition of individual conditions for the renewal of criminal proceedings. They deal with the stages of the renewal of criminal proceedings, their purpose and ideological essence. The central part of the article is the analysis of the modification of the witness testimony as a reason for the resnewal of criminal proceedings. In the light of case law, the authors consider the preconditions for the admissibility of renewal of proceedings with reference to a change in the testimony of a witness and the possibilities (quality) of examining this reason in proceedings for permission to reopen proceedings and renewed proceedings. They examine the issue in criminal law and constitutional and human rights contexts.
\end{abstract}

Key words: criminal proceeding, renewal of proceeding, witness testimony

\section{1 ÚVOD}

Aj $v$ rozhodovacej činnosti orgánov činných $v$ trestnom konaní a súdov môže dôjst' k chybným (napríklad vecne nesprávnym) rozhodnutiam, ktoré nezodpovedajú zákonným požiadavkám. Vylúčenie akýchkol'vek pochybení počas trestného konania je značne utopistická predstava. Generovaniu nedostatkov sa nemožno vyhnút' ani v prípade, pokial' by sa pripustila existencia akokol'vek dokonalej právnej úpravy pri maximálnej snahe o prijatie perfektného rozhodnutia. ${ }^{1}$ Chybám $\mathrm{v}$ decíznych formách môže byt' na príčine viacero skutočností, nezriedka súvisiacich s procesným dokazovaním. Dokazovanie v trestnom konaní je náročnou činnost'ou, ktorej predchádza vyhl'adávanie a zabezpečovanie dôkazných prostriedkov orgánmi činnými v trestnom konaní. Nazhromaždené dôkazy sú v chronologickej postupnosti vykonávané predovšetkým na hlavnom pojednávaní. Pokial' nedôjde k zabezpečeniu všetkých dôkazov v prípravnom konaní, je logické, že tieto nebudú

\footnotetext{
${ }^{1}$ SZABOVÁ, E. Odvolanie v trestnom konaní. Praha: Leges, 2015, s. 7.
} 
môct' byt' vykonané na hlavnom pojednávaní. V prípade, ak dôkazy vyjdú najavo až potom, čo meritórne rozhodnutie nadobudne právoplatnost', dochádza k nežiaducej situácii, ktorá nereflektuje požiadavky spravodlivého rozhodnutia. Vzniknutú situáciu je potrebné (možné) riešit' procesne predpísaným spôsobom. Na ten účel zákonodarca zakotvil inštitút mimoriadnych opravných prostriedkov, konkrétne obnovy konania v trestnom konaní.

Obnovu konania možno chápat’ ako trestnoprávny inštitút, ktorý smeruje k odstráneniu nedostatkov $\mathrm{v}$ rámci skutkového zistenia rozhodnutia, ktoré nadobudlo právoplatnost'. Je prostriedkom na ochranu spravodlivosti pri zachovávaní práv zo strany zákona. Obnova konania predstavuje opravný prostriedok, prostredníctvom ktorého dochádza $\mathrm{k}$ dosiahnutiu zákonnosti v prípade, ak sa objavia skutočnosti alebo dôkazy doteraz neznáme. Jedná sa o skutočnosti či dôkazy, o ktorých súd alebo prokurátor nemali vedomost', a ktoré vyšli najavo až po tom, čo rozhodnutie v danej záležitosti nadobudlo právoplatnost'.

Obnova trestného konania predstavuje mimoriadny opravný prostriedok, ktorého účelom je odstránit' nedostatky v skutkových zisteniach právoplatných rozhodnutí, pokial dodatočne vyšli najavo nové skutočnosti alebo dôkazy, ktoré neboli rozhodujúcemu orgánu skôr známe. ${ }^{2}$ Je potrebné zdôraznit', že návrhom na povolenie obnovy konania možno napadnút' len rozhodnutie, ktorého vlastnost'ou je právoplatnost'. Daná podmienka vychádza z dôvodu, že tento mimoriadny prostriedok zasahuje do právneho stavu, ktorý nastal $\mathrm{v}$ dôsledku právoplatného rozhodnutia. ${ }^{3} \mathrm{Je}$ dôležité pripomenút', že obnova konania sa ako zásah do právoplatného a vykonatel'ného rozhodnutia súdu pripúšt'a iba vo výnimočných prípadoch. ${ }^{4}$ Záujem na zmene nastoleného právneho stavu musí byt' tak závažný, že odôvodňuje zásah do stability a nezmenitel'nosti právoplatného odsudzujúceho rozhodnutia. ${ }^{5}$

Podstatou obnovy konania je odstránenie zistených nedostatkov a vydanie nového meritórneho rozhodnutia. ${ }^{6} \mathrm{Na}$ rozdiel od dovolania a zrušenia právoplatných rozhodnutí $\mathrm{v}$ prípravnom konaní, účel obnovy trestného konania sa žiada hl'adat' v snahe o eliminovanie nedostatkov predovšetkým $\mathrm{v}$ skutkových zisteniach, na ktorých rozhodnutie spočíva. $\mathrm{Z}$ časového hl'adiska je nevyhnutné, aby príčiny takých nedostatkov vyšli najavo po právoplatnosti rozhodnutí, pričom sa žiada, aby ich pôvod tkvel v nových skutočnostiach alebo v nových dôkazoch, ktoré sú spôsobilé odôvodnit' iné rozhodnutie vo veci. Ako už bolo naznačené, zistené okolnosti musia existovat' na úrovni kvality, ktorá vyžaduje (odôvodňuje) prielom do nezamenitel'nosti a záväznosti konkrétnej formy rozhodnutia. Ked' sú dané podmienky obnovy konania a neexistuje dôvod pre jej vylúčenie, je povolenie obnovy konania obligatórne.

\section{PODMIENKY OBNOVY KONANIA}

Nato, aby bolo možné obnovit' trestné konanie, je nevyhnutné splnit' zákonom stanovené podmienky. Podmienky obnovy konania možno vymedzit' ako predpoklady, ktoré musia byt' nevyhnutne splnené nato, aby príslušný orgán mohol konat' a rozhodnút' o návrhu na povolenie obnovy trestného konania. Trestný poriadok neposkytuje legálnu definíciu pojmu

\footnotetext{
${ }^{2}$ ČENTÉŠ, J. a kol. Trestný poriadok. Vel'ký komentár. 2. aktualizované vydanie. Bratislava: EUROKÓDEX, 2015, s. 691.

${ }^{3}$ OLEJ, J., ROMŽA, S., ČOPKO, P., PUCHALLA, M. Trestné právo procesné. Košice: Univerzita Pavla Jozefa Šafárika v Košiciach, 2013, s. 221.

${ }^{4}$ Porovnaj rozhodnutie Najvyššieho súdu Slovenskej republiky sp. zn. 3 Tost 6/2015 zo dňa 20.5.2015.

${ }^{5}$ Porovnaj rozhodnutie Najvyššieho súdu Slovenskej republiky sp. zn. 2 Tost 19/2012 zo dňa 11.7.2012.

${ }^{6}$ SOBIHARD, J. Správny poriadok - Komentár. 5. prepracované vydanie. Bratislava: IURA EDITION, 2011 , s. 196.
} 
„podmienky obnovy konania“, takže uvedené ostáva na právnej teórii. ${ }^{7}$ Prevažne sa uznáva, že avizované podmienky upravuje Trestný poriadok najmä v ust. § 394.

Prvou nevyhnutnou podmienkou je existencia skutočností alebo dôkazov príslušnému orgánu skôr neznámych, ktoré by mohli samy osebe alebo v spojení so skutočnost'ami a dôkazmi už skôr známymi odôvodnit' iné rozhodnutie o vine alebo vzhl'adom na ktoré by pôvodne uložený trest bol v zrejmom nepomere k závažnosti činu alebo k pomerom páchatel'a, alebo uložený druh trestu by bol v zrejmom rozpore s účelom trestu, alebo vzhl'adom na ktoré upustenie od potrestania alebo upustenie od uloženia súhrnného trestu by bolo v zrejmom nepomere k závažnosti činu alebo k pomerom páchatel'a, alebo by bolo v zrejmom rozpore $\mathrm{s}$ účelom trestu. ${ }^{8}$

Za skutočnosti skôr neznáme sa považujú skutkové okolnosti, ktoré neboli predmetom dokazovania alebo zist'ovania v konaní predchádzajúcom rozhodnutiu, ktorého sa týka návrh na povolenie obnovy konania. Takouto skutočnost'ou je objektívne existujúci jav, ktorý nie je $\mathrm{v}$ tej istej veci dôkazom, avšak môže mat' vplyv na zistenie skutkového stavu veci v rozsahu nevyhnutnom pre rozhodnutie. Za dôkazy skôr neznáme sa považujú predovšetkým dôkazy, ktoré neboli vykonané v pôvodnom konaní alebo v pôvodnom konaní boli vykonané, avšak nadobudli nový obsah, teda náplň odlišnú od obsahu, ktorý im bol pripisovaný v pôvodnom konaní. $\mathrm{V}$ podstate teda ide o okolnosti, javy alebo dôkazy, o ktorých súd pôvodného konania nemal a ani nemohol mat' vedomost', ibaže o nich vedel orgán činný v trestnom konaní alebo súd odlišný od súdu, o ktorého rozhodnutie ide, prípadne o nich mala vedomost' niektorá zo strán trestného konania alebo iná osoba bez toho, aby ich procesne predpísaným spôsobom uplatnila. Nezáleží na tom, z akého dôvodu sa nové skutočnosti a dôkazy nestali v pôvodnom konaní predmetom dokazovania alebo prečo neboli účinne uplatnené. Zo súdnej praxe však vyplýva, že ako „skôr neznámu skutočnost' alebo dôkaz“ nemožno kvalifikovat' skutočnost' alebo dôkaz obsiahnutý či zrejmý zo spisu. V týchto prípadoch je zrejmé, že súd alebo orgán činný v trestnom konaní, ktorý pôvodne rozhodoval, sa s avizovanými okolnost'ami nevysporiadal v rozhodnutí napríklad $\mathrm{z}$ toho dôvodu, že ich prehliadol. Domnievame sa, že v týchto prípadoch by možné realizovat' nápravu v dovolacom konaní.

Identifikácia novej skutočnosti je podl'a nášho názoru relatívne problematická. Nové skutočnosti môžu byt' rôznorodej povahy. Významnú úlohu v tomto smere zohráva dotváranie právnej regulácie justičnými autoritami. Súdna prax ide podl’a nášho názoru mnohokrát nad rámec doslovného výkladu Trestného poriadku. Novou skutočnost'ou môže byt' napríklad dodatočné zistenie, že vec, ktorú mal odsúdený neoprávnene užívat' v zmysle ust. § 215 Trestného zákona, mu oprávnená osoba poskytla do nájmu, z čoho vyplýva, že ju používal v súlade s právom. Povahu novej skutočnosti má aj údaj o skutočnej totožnosti obvineného, ktorý bol právoplatne odsúdený pod iným menom. ${ }^{9}$ Naopak, novou skutočnost'ou v zásade nie je zmena právnej úpravy, ku ktorej došlo po právoplatnosti rozhodnutia, ba ani zmena právneho názoru (napríklad Ústavného súdu Slovenskej republiky či Najvyššieho súdu Slovenskej republiky) na výklad a aplikáciu určitej právnej normy, respektíve na právne

\footnotetext{
${ }^{7}$ ŠEVČOVIČ, A. Podmienky obnovy konania v teórii a súdnej praxi. In ROMŽA, S. (ed.) IV. KOŠICKÉ DNI TRESTNÉHO PRÁVA „Privatizácia výkonu trestu odňatia slobody, sci-fi alebo jediná možnost?". Zborník vedeckých prác. Košice: Univerzita Pavla Jozefa Šafárika v Košiciach, 2020, s. 429.

${ }^{8}$ Ust. § 394 ods. 1 Trestného poriadku.

${ }^{9}$ R 57/2002 (stanovisko trestného kolégia Najvyššieho súdu Českej republiky zo dňa 7.8.2002, sp. zn. Tpjn $309 / 2001)$.
} 
posúdenie určitých skutkových okolností. ${ }^{10}$ Zákonodarca však súčasne konštruuje určitý exemplifikatívny výpočet prv neznámych skutočností, ked' dodáva, že skutočnost'ou skôr neznámou môže byt' rozhodnutie Európskeho súdu pre l'udské práva, ktoré preukázalo, že rozhodnutím alebo konaním, ktoré mu predchádzalo, došlo k porušeniu základných l'udských práv alebo slobôd obvineného zo strany prokurátora alebo súdu Slovenskej republiky a negatívne dôsledky nie je možné napravit' inak. Inou možnost'ou nápravy môže byt' napríklad možnost' podania dovolania. ${ }^{11}$ Rovnako je skutočnost'ou skôr neznámou aj strata účinnosti právneho predpisu, jeho časti alebo jeho jednotlivého ustanovenia v súlade s čl. 125 ods. 3 Ústavy Slovenskej republiky vo vzt’ahu k rozsudku, ktorý bol vydaný na základe aplikácie takého predpisu, jeho časti alebo niektorého ustanovenia, pričom rozsudok je právoplatný, ale doposial' nebol vykonaný. ${ }^{12}$ Obnova konania, ktoré sa skončilo niektorým z predpísaných spôsobov, sa s poukazom na ust. § 394 ods. 5 Trestného poriadku povolí aj vtedy, ak sa právoplatným rozsudkom zistí, že policajt alebo prokurátor, sudca alebo prísediaci $\mathrm{v}$ pôvodnom konaní porušením povinnosti spáchal trestný čin. V tomto prípade nie je nevyhnutné, aby porušenie povinnosti týchto osôb malo vplyv na pôvodné rozhodnutie. Stačí, že trestný čin bol spáchaný a osoba bola zaň právoplatne odsúdená. Naposledy zmienený dôvod obnovy konania má zabezpečit' nezávislé a nestranné rozhodovanie organizačných štruktúr trestného konania. ${ }^{13}$

Skutočnosti a dôkazy odôvodňujúce návrh na povolenie obnovy konania súd hodnotí z hl'adiska časového a vecného. V prvom prípade ide o identifikáciu okamihu, v ktorom vyšli najavo. Tu sa skúma, či ide o skutočnosti alebo dôkazy skôr neznáme. Vecné hodnotenie predstavuje posudzovanie skutočností a dôkazov z hl'adiska ich účinku (bez d'alšieho) alebo účinku v spojení s inými už známymi skutočnost’ami či dôkazmi na právoplatné rozhodnutie. V tomto smere súd uvažuje, či dôkazy alebo skutočnosti sú spôsobilé privodit' zásadnejšiu zmenu. Nové skutočnosti alebo dôkazy sa musia v každom prípade týkat' skutkových okolností, ktoré nastali pred nadobudnutím právoplatnosti pôvodného rozhodnutia, v dôsledku čoho mohli ovplyvnit' jeho podobu. Atribút novosti tkvie v tom, že skutočnosti alebo dôkazy vyšli najavo až dodatočne, teda po právoplatnosti pôvodného rozhodnutia. To je dôvod, prečo o nich súd alebo orgán činný v trestnom konaní v dobe rozhodovania nemal vedomost'. Je teda zrejmé, že v rámci obnovy konania nie je možné prihliadat' na skutkové zmeny, ktoré nastali po nadobudnutí právoplatnosti rozhodnutia.

Orgány činné v trestnom konaní nezist'ujú skutočnosti a dôkazy skôr neznáme z úradnej povinnosti (ex offo). Dôkazy a / alebo skutočnosti je potrebné predložit' súdu zarovno s návrhom na povolenie obnovy konania na účel posúdenia, či v prípade pravdivosti môžu sami o sebe alebo v spojení s už známymi skutočnost’ami a dôkazmi odôvodnit' iné rozhodnutie vo veci a tým spochybnit' správnost' pôvodného rozhodnutia na dostatočnej úrovni. Novú skutočnost' je teda v konaní o povolení obnovy konania spravidla nevyhnutné preukázat' dôkazmi. ${ }^{14}$

\footnotetext{
${ }^{10}$ R 13/2002 (rozsudok Najvyššieho súdu Českej republiky sp. zn. 3 Tz 82/2001 zo dňa 3.5.2001). Pozri tiež PÚRY, F. Obnova ř́zení. In CÍSAŘOVÁ, D., FENYK, J., GŘIVNA, T., KLOUČKOVÁ, S., MANDÁK, V., PÚRY, F., REPÍK, B., RŮŽEK, A. Trestni právo procesní. 4. aktualizované a přepracované vydání. Praha: Linde, 2006, s. 667.

${ }^{11}$ ČENTÉŠ, J. Komentár $k \S 394$ Trestného poriadku. In MINÁRIK, Š. a kol. Trestný poriadok. Stručný komentár. 2. prepracované a doplnené vydanie. Bratislava: IURA EDITION, 2010, s. 947.

${ }^{12}$ Ust. § 394 ods. 4 Trestného poriadku.

${ }^{13}$ MARKOVÁ, V. Mimoriadne opravné prostriedky. In KORGO, D., MARKOVÁ, V. a kol. Trestné právo procesné. 2. aktualizované a doplnené vydanie. Plzeň: Aleš Čeněk, 2017, s. 427.

${ }_{14}$ Podobne napríklad rozhodnutie Najvyššieho súdu Slovenskej republiky sp. zn. 2 Tost 42/2016 zo dňa 15.12.2016.
} 
Prípustnost' obnovy konania je obmedzená na trestné stíhanie (i) tej istej osoby a (ii) toho istého skutku za predpokladu, že sa skončilo právoplatným meritórnym rozhodnutím. Kl'účovým prvkom je zachovanie totožnosti skutku. ${ }^{15}$ Totožnost' skutku je pojem, ktorý sa vzt'ahuje na prebiehajúce trestné konanie. Ide teda o kategóriu trestného práva procesného. Tento pojem nemá hmotnoprávny význam. Možno povedat', že totožnost' skutku zaist'uje kontinuitu skutku, čo znamená, že totožný skutok je predmetom všetkých štádií trestného konania. Z uvedeného vyplýva, že orgány činné $\mathrm{v}$ trestnom konaní vždy rozhodujú práve o tomto skutku. Pre skutok, pre ktorý bolo začaté trestné stíhanie a vznesené obvinenie, je následne podaná obžaloba a o takto vymedzenom skutku je konečne rozhodnuté v konaní pred súdom.

\section{FÁZY OBNOVY KONANIA}

Obnova konania je procesom, ktorý je zložený $z$ dvoch fáz. ${ }^{16}$ Prvou fázou je konanie o povolení obnovy konania. Ciel'om tejto etapy je zistit' a objektivizovat' odôvodnenost' a splnenie podmienok obnovy konania. Po autoritatívnom konštatovaní splnenia podmienok obnovy konania sa v časovej a vecnej nadväznosti realizuje konanie po povolení obnovy konania, teda obnovené konanie. ${ }^{17}$

Konanie o povolení obnovy konania je u tohto mimoriadneho opravného prostriedku vlastným prieskumným konaním. ${ }^{18}$ Tento proces má za hlavný ciel' zistit', či sú pre obnovu konania splnené podmienky predvídané Trestným poriadkom a či sú nové skutočnosti a dôkazy skôr neznáme dostatočné na to, aby spochybnili právoplatné meritórne rozhodnutie. ${ }^{19}$

Predložený návrh súd preskúma len zo skutkovej stránky. V prípade, ak na rozhodnutie o návrhu na povolenie obnovy konania je nutné niektoré okolnosti vopred objasnit', potrebné skúmanie je vykonané zo strany súdu alebo orgánu činného $v$ trestnom konaní na jeho žiadost'.

Konanie po povolení obnovy konania nastupuje, ak súd návrhu na povolenie obnovy konania vyhovel, obnovu konania povolil právoplatným uznesením a aspoň z časti zrušil napadnutú čast' rozhodnutia. Konkrétny priebeh konania po povolení obnovy konania (obnovené konanie) je derivatívne závislý od štádia, v ktorom bolo ukončené pôvodné trestné konanie.

\section{ZMENA SVEDECKEJ VÝPOVEDE AKO DÔVOD OBNOVY KONANIA}

V súvislosti s identifikáciou a kvalifikáciou vlastností, skutočností a dôkazov skôr neznámych možno poukázat' na zaujímavý moment. V rámci súdnej praxe sa možno frekventovane stretnút' s prípadmi, kedy po vydaní rozhodnutia, ktoré nadobudlo právoplatnost', podávajú oprávnené osoby návrhy na obnovu konania s tým, že ako novú skutočnost' alebo nový dôkaz označujú zmenenú výpoved' svedka. Argumentuje sa tým, že modifikovaná výpoved' je spôsobilá privodit' zmenu pôvodného rozhodnutia.

\footnotetext{
${ }^{15}$ OSTRICOVÁ, N. Špecifiká obnovy konania v trestnom konaní a aplikačné problémy s ňou spojené pri zrušení rozsudku, ktorý bol vyhlásený na základe dohody o vine a treste. 2020. Dostupné online na doméne: http://82.119.102.197:8080/webisnt/fulltext/clanky/PTaP2015-

3/009\%20\%20OSTRICOV\%C3\%81\%20\%20Obnova\%20konania.pdf [cit. 14.5.2021].

${ }^{16} \mathrm{~K}$ tomu pozri napríklad rozhodnutie Najvyššieho súdu Slovenskej republiky sp. zn. 4 Tost 22/2016 zo dňa 23.6.2016, sp. zn. 3 Tost 18/2017 zo dňa 28.6.2017, sp. zn. 3 Tost 26/2017 zo dňa 4.10.2017

${ }^{17}$ IVOR, J. a kol. Trestné právo procesné. Bratislava: Iura Edition, 2010, s. 748.

${ }^{18}$ HASCH, K. Obnova řízení. In JELÍNEK, J. a kol. Trestní právo procesní. 5. aktualizované vydání. Praha: Leges, 2007, s. 638.

${ }^{19}$ HUSÁR, E. a kol. Trestné právo procesné. 3. prepracované vydanie. Bratislava: Iura Edition, 2003, s. 245.
} 
Ponímanie obsahovo odlišnej svedeckej výpovede v pozícii skôr neznámeho dôkazu však prináša viacero úskalí. Problematickým momentom je vyhodnocovanie pravdivosti a relevantnosti zmenenej svedeckej výpovede $\mathrm{v}$ kontexte možnosti privodit' obsahovo iné rozhodnutie zo strany súdu rozhodujúceho o povolení obnovy konania. Najskôr je potrebné pripomenút', že svedok je povinný pred výsluchom na súde zložit' prísahu. ${ }^{20}$ Hoci sa svedok vzatý do prísahy pri nepravdivej výpovedi vystavuje riziku trestného stíhania, ${ }^{21}$ samotná prísaha nezakladá prezumpciu pravdivosti jeho výpovede. Nie je vylúčené, že svedok vzatý do prísahy nevypovie pravdu. Je zrejmé, že už v konaní o povolení obnovy konania môže byt' súd toho názoru, že zmenená výpoved' svedka nie je v kontexte ostatných v pôvodnom konaní vykonaných dôkazov pravdivá. Sme presvedčení, že súd rozhodujúci v konaní o povolenie obnovy konania sa nemôže obmedzit' len na konštatovanie, že tu nová skutočnost' alebo dôkaz je. Z hl'adiska procesnej metodiky je nevyhnutné, aby súd vykonal aj tzv. predbežnú previerku pravdivosti a relevantnosti svedeckej výpovede (predbežná previerka výpovede). Povedané inými slovami, súd je povinný prioritne vykonat' posúdenie a vyhodnotenie potenciálneho vplyvu nového dôkazu na už ustálený skutkový stav. Až následne, v procedurálnej nadväznosti, má rozhodnút', či obnovu konania povolí, alebo nie.

Otázka znie, do akej miery je prípustná predbežná previerka zmenenej svedeckej výpovede. Hladanie odpovede na nastolenú otázku je vecou ustálenia kvality prieskumu spôsobilosti modifikovanej výpovede dosiahnut' následok zamýšl’aný iniciátorom obnovy konania.

V rámci prejednania návrhu na povolenie obnovy konania totiž súd nemôže preskúmavat' vecnú (ne)správnost' rozhodnutia vydaného v pôvodnom konaní. Namieste nie je ani prieskum legality postupu $\mathrm{v}$ pôvodnom konaní najmä aj $\mathrm{v}$ tom smere, či sa súd v rámci rozhodovania vysporiadal so všetkými okolnost'ami, či reflektoval na obhajobu obvineného alebo či rešpektoval zásadu ústnosti a bezprostrednosti pri dokazovaní. ${ }^{22}$ Tieto okolnosti nepredstavujú integrálne ani marginálne aspekty, ktorých riešenie má byt' ideovým účelom prvého štádia obnovy trestného procesu. Účelom konania o povolení obnovy konania nie je ani posúdit' celkovú zákonnost' a odôvodnenost' pôvodného rozhodnutia a správnost' postupu $\mathrm{v}$ konaní, ktoré mu predchádzalo. ${ }^{23}$ Inak povedané, rozhodovanie v prejednaní podaného návrhu nie je rozhodovaním meritórnym, ale vo vzt'ahu k meritu veci v podstate procesným, i ked' so závažnými potenciálnymi a nezriedka aj reálnymi konzekvenciami. Účelom tohto konania nie je generovat' priame podklady pre nové rozhodnutie vo veci samej. Kvalitatívny a vlastne i obsahový prvok rozhodovania nemá $\mathrm{v}$ tomto štádiu dosahovat' mieru obnoveného konania. V opačnom prípade by dochádzalo k nadpráci v zmysle suplovania činnosti vlastnej obnovenému konaniu. Úsudok o novej skutočnosti alebo dôkaze ako pôvodcovi materiálnej zmeny obnovou konania napádaného výroku nemusí existovat' na úrovni absolútnej istoty.

\footnotetext{
${ }^{20}$ Ust. $§ 265$ Trestného poriadku.

${ }^{21}$ Krivá výpoved' a krivá prísaha (ust. $§ 345$ Trestného zákona)

(1) Kto ako svedok v konaní pred súdom alebo v trestnom konaní alebo na účely trestného konania v cudzine pred prokurátorom alebo policajtom, alebo pred sudcom medzinárodného orgánu uznaného Slovenskou republikou uvedie nepravdu o okolnosti, ktorá má podstatný význam pre rozhodnutie, alebo kto takú okolnost' zamlčí, potrestá sa odňatím slobody na jeden rok až pät' rokov.

(2) Kto v trestnom konaní pred súdom alebo na účely trestného konania v cudzine po zložení prísahy uvedie nepravdu o okolnosti, ktorá má podstatný význam pre rozhodnutie, alebo takú okolnost' zamlčí, potrestá sa odňatím slobody na dva roky až pät' rokov.

${ }^{22}$ Porovnaj napríklad R 35/1988 (rozhodnutie Najvyššieho súdu Slovenskej socialistickej republiky sp. zn. 2 To 39/87 zo dňa 24.8.1987), rozhodnutie Najvyššieho súdu Slovenskej republiky sp. zn. 4 Tost 15/2011 zo dňa 21.6.2011, sp. zn. 1 Tost 25/2015 zo dňa 2.12.2015, sp. zn. 1 Tost 26/2015 zo dňa 30.9.2015.

${ }^{23}$ Porovnaj R 35/1988 (rozhodnutie Najvyššieho súdu Slovenskej socialistickej republiky sp. zn. 2 To 39/87 zo dňa 24.8.1987).
} 
Postačí jeho existencia $\mathrm{v}$ potencionalite. Jednoducho, $\mathrm{v}$ tomto konaní sa rozhoduje len o otázke, či nová skutočnost' alebo dôkaz (zmenená výpoved'), ktorá bola skôr neznáma konajúcim orgánom činným v trestnom konaní a súdu, môže odôvodnit’ iné rozhodnutie.

Ďalej je potrebné koncentrovat' pozornost' na klasifikáciu podmienok obnovy konania vo svetle súdnej praxe. Rozsiahla judikatúra $\mathrm{v}$ oblasti mimoriadnych opravných prostriedkov na jednej strane poukazuje na potrebu existencie tzv. formálnej podmienky obnovy konania. Túto podmienku reprezentuje dôkaz alebo skutočnost', ktoré sú nové, teda ktoré neboli predmetom dokazovania alebo zist'ovania $v$ konaní predchádzajúcom rozhodnutiu, ktorého sa týka návrh na povolenie obnovy konania, a ktoré môžu mat' vplyv na zistenie skutkového stavu veci. Je zrejmé, že zmenená výpoved' svedka atribúty formálnej podmienky napíňa. Ako nevyhnutnost' povolenia obnovy konania však súdna prax uvádza aj tzv. materiálnu podmienku, ktorú predstavuje vy̌šsie uvedený justičný imperatív vyhodnotit' nový dôkaz zhl'adiska jeho novosti a spôsobilosti odôvodnit' iné rozhodnutie o vine.

V úvahách o modifikovanej svedeckej výpovedi je rozhodujúca práve materiálna podmienka, teda požiadavka vyhodnotenia vplyvu nového dôkazu na už ustálený skutkový stav adresovaná konajúcemu súdu. Súd rozhodujúci o návrhu na povolenie obnovy konania nemôže hodnotit' novoobjavené dôkazy z hl'adiska ich vierohodnosti, pretože takéto hodnotenie by slúžilo ako bezprostredný podklad pre nové rozhodnutie o vine. Ako sme uviedli vyššie, v tomto štádiu rozhodovania je potrebné vyhodnotit' nový dôkaz len $\mathrm{v}$ redukovanej miere, teda $\mathrm{z}$ hl'adiska jeho novosti a spôsobilosti odôvodnit' iné rozhodnutie o vine. ${ }^{24}$ Žiada sa dodat', že v týchto prípadoch ide o signifikantné postuláty, ktorých význam je kategorický a konzekventný nielen z pohl'adu trestného práva procesného, ale aj v ústavných a l’udsko-právnych dimenziách (pozri nižšie). Pokial' je napríklad zmenená výpoved' svedka vnútorne rozporuplná, nekonzistentná, protirečivá a koliduje s ostatnými vykonanými dôkazmi, súd nemôže v konaní o povolenie obnovy konania túto skutočnost' ignorovat', ale mal by ju vziat' do úvahy pri rozhodovaní. Na druhej strane, súd sa týmito rozpormi nemôže zaoberat' dopodrobna, nakol'ko by to evidentne presahovalo rámec tohto konania. Rozhodnutie pochádzajúce z konania o povolení obnovy konania by $\mathrm{v}$ takom prípade mohlo slúžit' ako priamy podklad nového rozhodnutia a v podstate by ho minimálne do určitej miery substituovalo. Stotožnenie sa s takým prístupom by bolo v očividnom rozpore s obsahovým zameraním povol'ovacieho konania.

\section{ZÁVER}

Záverom možno vyslovit', že zmenu výpovede svedka nemožno ako spôsobilý dôvod obnovy konania a priori odmietnut'. Obsahovo modifikovaná výpoved' môže byt' v kontexte ostatných vykonaných dôkazov spôsobilá privodit' zmenu právoplatného meritórneho rozhodnutia. Argumentačne sa opätovne žiada podotknút', že predtým neznámy dôkaz sa judikatúrne a teoreticky kvalifikuje dvojakým spôsobom: Ako dôkaz nový, ktorý nebol vykonaný v pôvodnom konaní, alebo ako dôkaz, ktorý síce v pôvodnom konaní vykonaný bol, ale s iným obsahom. Je nepochybné, že modifikácia obsahu dôkazu, teda zmena výpovede svedka, v týchto intenciách skôr neznámy dôkaz predstavuje. Za dôkaz v pôvodnom konaní vykonaný, avšak s novým obsahom, možno bezpochyby považovat' aj výpoved' svedka, ktorý ju v konaní o povolení obnovy konania v podstatných bodoch zmení. V súlade $\mathrm{s}$ aktuálnou judikatúrou sa však žiada dodat', že v takomto prípade musia byt' predmetom hodnotenia aj dôvody, na základe ktorých došlo k obsahovej zmene výpovede. ${ }^{25}$

\footnotetext{
${ }^{24}$ Rozhodnutie Najvyššieho súdu Slovenskej republiky sp. zn. 5 Tost 14/2008 zo dňa 14.10.2008.

${ }^{25}$ Rozhodnutie Krajského súdu v Košiciach sp. zn. 8 Tos 102/2015.
} 
Pokial' ide o metodiku prieskumu dôvodu obnovy konania, súd rozhodujúci v štádiu o povolení obnovy konania musí na jednej strane (primárne) vyhodnotit', či dôkaz alebo skutočnost' skôr neznáme vôbec existujú. Pokial' je odpoved' na takto formulovanú otázku kladná, sekundárne a nadväzne je nevyhnutné vyhodnotit', či sú dôkazy alebo skutočnosti prv neznáme schopné zásadne ovplyvnit' skutkové zistenia v pôvodnej veci. $\mathrm{Z}$ hl'adiska obsahovej náplne hodnotiacich procesov je nevyhnutné podotknút', že judikatúra na jednej strane nepovol'uje a neumožňuje hodnotit' nový dôkaz (v analyzovaných súvislostiach svedeckú výpoved') vo vzájomnej interakcii s pôvodne vykonanými dôkazmi, avšak na strane druhej, z hl'adiska materiálnych podmienok obligatórnych pre povolenie obnovy konania, je nutné tento zhodnotit' z toho pohl'adu, či zásadným spôsobom dokáže ovplyvnit' skutkový stav v danej veci. V platnom právnom poriadku však absentuje explicitné vyjadrenie miery (hranice, limitácie), ktorou sa má tento prieskum spravovat'. Niet všeobecného pravidla pre rozhraničenie prieskumnej kompetencie medzi súd rozhodujúci o povolení obnovy konania a súd konajúci v štádiu povoleného konania. Pokial' by dochádzalo $\mathrm{k}$ prílišnej reštrikcii prieskumného oprávnenia súdu v konaní o povolení obnovy konania, nežiaduci následok by sa mohol prejavit' $\mathrm{v}$ podobe pozitívneho rozhodovania o návrhoch, ktoré nie sú ani elementárne odôvodnené. To by bolo v rozpore s esenciálnym imperatívom výnimočnosti zásahu do právneho stavu, ktorý sa konštituoval v dôsledku právoplatného rozhodnutia. Príliš extenzívne ponímanie možností skúmania dôvodu obnovy konania v prvom štádiu by však mohlo zrejme kolidovat's účelom tohto štádia. Nie je bez významu napríklad ani skutočnost', že oboch štádiách konajú rozdielni zákonní sudcovia. Neúmerné zužovanie či rozširovanie prieskumných oprávnení súdu konajúceho v ktoromkol'vek štádiu obnovy konania by sa takto mohlo dostat', minimálne v potenciálnej rovine, aj do rozporu s ústavnou požiadavkou zachovania príslušnosti súdu. V podstate by mohlo dochádzat' k neústavnému odňatiu veci zákonnému sudcovi. V tomto smere je teda nevyhnutné hl'adat' rozumný balans, a to najmä $\mathrm{v}$ závislosti od podmienok konkrétneho prípadu. Len takýmto spôsobom možno zachovat' podstatu, účel a ideový význam jednotlivých štádií obnovy konania.

Tento príspevok vznikol s podporou a je výstupom riešenia projektu APVV-16-0362 s názvom „Privatizácia trestného práva - hmotnoprávne, procesnoprávne, kriminologické a organizačnotechnické aspekty“.

\section{Použitá literatura}

1. CÍSAŘOVÁ, D., FENYK, J., GŘIVNA, T., KLOUČKOVÁ, S., MANDÁK, V., PÚRY, F., REPÍK, B., RŮŽEK, A. Trestni právo procesní. 4. aktualizované a přepracované vydání. Praha: Linde, 2006. 871 s. ISBN 807201594X.

2. ČENTÉŠ, J. a kol. Trestný poriadok. Vel'ký komentár. 2. aktualizované vydanie Bratislava : EUROKÓDEX, 2015. 955 s. ISBN 9788081550577.

3. HUSÁR, E. a kol. Trestné právo procesné. 3. prepracované vydanie. Bratislava : Iura Edition, 2003. 298 s. ISBN 8089047572.

4. IVOR, J. a kol. Trestné právo procesné. Bratislava : Iura Edition, 2010. 1049 s. ISBN 9788081685941.

5. IVOR, J., ZÁHORA, J. Repetitórium rekodifikovaného trestného práva. Bratislava: Iura Edition, 2007. 183 s. ISBN 9788080871408.

6. JELÍNEK, J. a kol. Trestní právo procesní. 5. aktualizované vydání. Praha : Leges, 2007, 749 s. ISBN 9788072016303.

7. KOPECKÝ, M. Možnosti přzkumu rozhodnutí vodvolacím správním rízení. In V̌̌eobecné správne konanie. Bratislava: Univerzita Komenského v Bratislave, Právnická fakulta, 2010. 161 s. ISBN 9788071602934.

8. KORGO, D., MARKOVÁ, V. a kol. Trestné právo procesné. 2. aktualizované a doplnené vydanie. Plzeň: Aleš Čeněk, 2017, 518 s. ISBN 9788073806507. 
9. MINÁRIK, Š. a kol. Trestný poriadok. Stručný komentár. 2. prepracované a doplnené vydanie. Bratislava : IURA EDITION, 2010. 1392 s. ISBN 9788080783693.

10. OLEJ, J., ROMŽA, S., ČOPKO, P., PUCHALLA, M. Trestné právo procesné. Košice: Univerzita Pavla Jozefa Šafárika v Košiciach, 2013. 298 s. ISBN 9788070979655.

11. OSTRICOVÁ, N. Špecifiká obnovy konania v trestnom konaní a aplikačné problémy s ňou spojené pri zrušení rozsudku, ktorý bol vyhlásený na základe dohody o vine a treste. 2020. Dostupné online na: http://82.119.102.197:8080/webisnt/fulltext /clanky/PTaP2015-/009\%20\%20OSTRICOV\%C3\%81\%20\%20Obnova\%20konania.pdf.

12. SOBIHARD, J. Správny poriadok - Komentár. 5. prepracované vydanie. Bratislava: IURA EDITION, 2011. 374 s. ISBN 9788080784034.

13. SZABOVÁ, E. Odvolanie v trestnom konaní. Praha: Leges, 2015. 127 s. ISBN 9788075021106.

14. ŠEVČOVIČ, A. Podmienky obnovy konania v teórii a súdnej praxi. In ROMŽA, S. (ed.) IV. KOŠICKÉ DNI TRESTNÉHO PRÁVA „,Privatizácia výkonu trestu odňatia slobody, sci-fi alebo jediná možnost?" “. Zborník vedeckých prác. Košice : Univerzita Pavla Jozefa Šafárika v Košiciach, 2020, s. 427-437. ISBN 9788081529450.

15. ŠIMOVČEK, I. a kol. Trestné právo procesné. Plzeň: Aleš Čeněk, 2011. 479 s. ISBN 9788073803247.

16. R 35/1988 (rozhodnutie Najvyššieho súdu Slovenskej socialistickej republiky sp. zn. 2 To 39/87 zo dňa 24.8.1987).

17. R 13/2002 (rozsudok Najvyššieho súdu Českej republiky sp. zn. 3 Tz 82/2001 zo dňa 3.5.2001).

18. R 57/2002 (stanovisko trestného kolégia Najvyššieho súdu Českej republiky zo dňa 7.8.2002, sp. zn. Tpjn 309/2001).

19. Rozhodnutie Krajského súdu v Košiciach sp. zn. 8 Tos 102/2015.

20. Rozhodnutie Najvyššieho súdu Slovenskej republiky sp. zn. 5 Tost 14/2008 zo dňa 15.10.2008.

21. Rozhodnutie Najvyššieho súdu Slovenskej republiky sp. zn. 4 Tost 15/2011 zo dňa 21.6.2011.

22. Rozhodnutie Najvyššieho súdu Slovenskej republiky sp. zn. 2 Tost 19/2012 zo dňa 11.7.2012.

23. Rozhodnutie Najvyššieho súdu Slovenskej republiky sp. zn. 3 Tost 6/2015 zo dňa 20.5.2015.

24. Rozhodnutie Najvyššieho súdu Slovenskej republiky sp. zn. 1 Tost 26/2015 zo dňa 30.9.2015.

25. Rozhodnutie Najvyššieho súdu Slovenskej republiky sp. zn. 1 Tost 25/2015 zo dňa 2.12.2015.

26. Rozhodnutie Najvyššieho súdu Slovenskej republiky sp. zn. 4 Tost 22/2016 zo dňa 23.6.2016.

27. Rozhodnutie Najvyššieho súdu Slovenskej republiky sp. zn. 2 Tost 42/2016 zo dňa 15.12.2016.

28. Rozhodnutie Najvyššieho súdu Slovenskej republiky sp. zn. 3 Tost 18/2017 zo dňa 28.6.2017.

29. Rozhodnutie Najvyššieho súdu Slovenskej republiky sp. zn. 3 Tost 26/2017 zo dňa 4.10.2017.

30. Zákon č. 300/2005 Z. z. Trestný zákon v znení neskorších predpisov.

31. Zákon č. 301/2005 Z. z. Trestný poriadok v znení neskorších predpisov. 


\section{Kontaktní údaje}

JUDr. Lukáš Michal'ov, PhD.

Univerzita Pavla Jozefa Šafárika v Košiciach, Právnická fakulta, Katedra trestného práva Kováčska 26, 04075 Košice

Tel: +421 2344146

email: lukas.michalov@upjs.sk

JUDr. Martin Baločko

Univerzita Pavla Jozefa Šafárika v Košiciach, Právnická fakulta, Katedra trestného práva Kováčska 26, 04075 Košice

Okresný súd Košice I

email: martin.balocko@justice.sk 


\title{
ESSENTIAL ETHICAL CONCEPTS WITH RESPECT TO PUBLIC ADMINISTRATION ETHICS
}

\author{
Petr Ondrušák, Jan Lípa, Ladislav Rozenský, Zdeněk Vrba, Josef Dolista
}

\begin{abstract}
Public administration ethics is part of professional ethics. The Administrative Procedure Code directly defines public administration as a service to the public. Everyone who performs the tasks arising from the competence of the administrative body has to be polite to the persons concerned and, if possible, to accommodate their needs. This also establishes an ethical approach. Ethics has a place in public administration primarily in connection with decisionmaking, and subsequently, behavior inside and outside the office. Morality and ethics have a close relationship to law, though their enforcement is much more difficult. That is why there are attempts to codify through codes of ethics. The code of ethics is constructed as a result of the search for optimal ethical behavior of the subject, which should serve on the one hand as a prevention against various types of corruption, scandals, harm to interests, etc., and on the other hand, as a moral standard that should ensure a minimum of ethics in a person's behavior, professions, and industries.
\end{abstract}

Keywords: Ethics, public administration, ethical code.

\section{INTRODUCTION}

This article aims to summarize the essential concepts of ethics, taking into account public administration ethics.

The article can be divided into two parts. The first part focuses on the origin and definition of the concepts of ethics, ethical values, morality, moral values, conscience, and a brief description of various types of ethics, ethical relations, and the definition of the concept of code of ethics. The second part deals with the basic concepts related to the ethics of public administration.

Public administration is directly defined in Section 4 of the Administrative Procedure Code as a service to the public. Everyone who performs the tasks arising from the competence of the administrative body has to be polite to the persons concerned and, if possible, to accommodate their needs. ${ }^{1}$ This also establishes an ethical approach.

The public interest, i.e., the management of public affairs (i.e., state, regional, municipal, public benefit, etc.), is decisive for public administration. Unlike private administration, the performance of public administration is characterized by a particular limitation, a broader binding by law. It is then assumed that the public interest has a higher value than the private interest since the performance of public administration also means the fulfillment of a legally imposed obligation. $^{2}$

"Ethics in public administration is about decision-making, in which judgment is used. Such decisions are not easy and cannot be made according to formulas. Codes of ethics and setting standards play a role, but they can never absolve a particular person of responsibility." Chapman says. ${ }^{3}$

\footnotetext{
${ }^{1}$ Administrative Procedure Code n. 500/2004 Coll., [cit. 2021-05-16].

${ }^{2}$ Sládeček, V.: Obecné správní právo. 2. edition, Praha: ASPI - Wolters Kluwer, 2009, p. 18.

${ }^{3}$ Chapman, R., A.; Etika ve veřejné službě pro nové tisíciletí, 1. edition, Sociologické nakladatelství, 2003, p. 28.
} 
Morality and ethics are also closely linked to the law, although they are much more difficult to enforce, so there are efforts to codify them through codes. The existence and adoption of a code of ethics in public administration are currently one of the pivotal requirements for organizational professionalism and workers, employees, and managerial competencies. It is also an essential means of professional ethics, including public administration, carried out in codified ethics. As such, codes of ethics also have some opponents and critics.

The code of ethics, which includes moral norms and principles, when applied to managerial or teaching practice, should regulate the relations between professionals and their clients, especially as regards the system of distribution and affordability of services and the relations of professionals who are employees, to their employers, as well as the limits of loyalty or decision-making autonomy of professionals. The code should also regulate experts' relations with third parties and provide a model of contact with state and social institutions and the public. It would also include regulating the relationship within the profession, the restriction or exclusion of their unfair forms, which is also related to the so-called professionalmanagerial etiquette. ${ }^{4}$

\section{ESSENTIAL ETHICAL CONCEPTS}

\subsection{Ethics and Morality}

Etymologically, the word ethics derives from the Greek ethos, habit, custom, character. The Latin term mos, from which the word morality derives, has almost the same meaning. Etymologically, ethics and morality are synonymous. Ethics is commonly used for a scientific discipline, a practical philosophy that deals with moral phenomena. Ethics is often called the "theory of morality." It tries to find common and general principles on which morality is based, or it tries to justify morality. ${ }^{5}$

Aristotle himself, who we rightly consider to be the founder of contemporary ethics today, distinguished between ethos (in the sense of custom) and ethos as the ideal of responsible moral conduct, that is, an ideal "to which one can always only approach and point, but which we never fully achieve", as says Doc. PhDr. MUDr. Jan Payne, Ph.D., in his lectures. This ideal evolves and shifts over time, and man can evolve with it.

Morality, then, as the component of ethics, contains everything that man thinks about and does concerning the most profound plane of his humanity - "what is to be" to realize good. ${ }^{6}$

Wherever morality, "what is to be", the meaning of life and the world is considered through the field of view of ethics, regardless of a specific worldview and belief, there is a remarkable agreement in understanding human dignity, freedom, and the functioning of human society as a whole. ${ }^{7}$

$\mathrm{Vajda}^{8}$ interprets the concept of morality as "a social phenomenon, more precisely an area of human reality defined by the opposition of good and evil and the associated norms of human behavior in the surrounding world, in society in relation to other people or oneself."

According to Janotová ${ }^{2}$, morality refers to how people behave in real life towards each other, towards themselves, towards everything living, and towards the inanimate, material and spiritual.

\footnotetext{
${ }^{4}$ Gosiorovský, I.: Úvod do profesní etiky: (monografie). 1. edition Kunovice: Evropský polytechnický institut, 2008, p. 33.

${ }^{5}$ Dolista, J., Ježek, R.: Etika zaměstnance veřejné správy: vysokoškolská učebnice. 1. edition České Budějovice: Vysoká škola evropských a regionálních studií, 2006, p. 14.

${ }^{6}$ Adamová, L., Dudák, V. Ventura, V.: Základy filosofie, etiky: základy společenských věd. 1. edition Praha: Fortuna, 1995. p. 152.

${ }^{7}$ Adamová, L., Dudák, V. Ventura, V.: Základy filosofie, etiky: základy společenských věd. 1. edition Praha: Fortuna, 1995, p. 152.

${ }^{8}$ Vajda, J.: Úvod do etiky. Nitra: Enigma, 2004, p. 14.
} 
Morality, unlike ethics, always has a specific bearer, a subject of behavior based on personal, free, or collective (here the restriction of personal freedom begins to work) choice, can decide on the appropriate type of behavior. Ethics does not decide how to behave but offers instructions on how to behave, mainly in ethical problem situations and dilemmas. It allows entities to choose a more prudent and responsible approach in a particular situation. Ethics is simply a method. Therefore, it is unrealistic if someone expects from ethics well-defined "recipes" on how to be good at every opportunity. ${ }^{10}$

Definition of the term ethics: Ethics is a theory of morality. Morality requires one to behave in a certain way. Simultaneously, it justifies why he should behave in the same way and not differently. Thus, morality is a social institution that fulfills the role of a regulator of people's behavior and actions in all areas of life. ${ }^{11}$

According to Vanek, ethics is "the science of human intentions and actions in terms of good and evil, of happiness, the meaning of life. It is a theory of morality."12

In contrast to Janotová, Miedzg characterizes ethics as "a science that examines morality and seeks a general principle that would show a person what to do, what to strive for in life, how to treat other people." ${ }^{13}$

\subsection{Other Definitions and Relationships}

Př́ḱkaský defines morality: "Morality is a system of human action rules, ethics is a philosophical discipline that examines these rules." 14

Morality (from the Latin mos, morality, habit, custom) is a variable, historically and culturally conditioned summary of evaluative judgments, customs, opinions, ideals, rules, institutions, and norms that people follow in a certain respect in their practical moral conduct. Morality as a normative system rests on internal sanction; morality constitutes the social identity of a member of the community (feelings of shame, guilt, resentment) and is also required of everyone. $^{15}$

Moral (or, conversely, immoral) does not automatically mean that it is morally good (or bad). Formally speaking, it is only a statement that "it" either belongs or does not belong to the realm of morality. If we want to declare an act or opinion to be morally good (bad), then we evaluate this act or opinion specifically. And in connection with the conscience of the individual. Thus, his/her action or opinion is (or is not) in accordance with the conscience of the individual and in accordance with the currently valid moral rules. The measure of morality is the conscience, which manifests itself in the relationship between conscious action and the moral rules of a given culture, society, community, group, or family. ${ }^{16}$

Putnová and Seknička state: "Moral conduct is one that is in accordance with the norms of valid morality and with one's conscience. While morality may not be the conscience of reflection." ${ }^{17}$

The classic definition refers to Kant or Hegel. Even if the conscience does not reflect the norm's validity, which is a part of the moral code, there are situations where it is necessary for

\footnotetext{
${ }^{9}$ Janotová, H. a kol.: Profesní etika. edition 1. Praha: Eurolex Bohemia, 2005, p. 13.

${ }^{10}$ Janotová, H. a kol.: Profesní etika. edition 1. Praha: Eurolex Bohemia, 2005, p. 13-14.

${ }^{11}$ Gosiorovský, I.: Úvod do profesní etiky: (monografie). 1. edition Kunovice: Evropský polytechnický institut, 2008 , p. 13.

${ }^{12}$ Vaněk, J. Základy sociální a ekonomické etiky. Praha: VŠE, 1997, p. 7.

${ }^{13}$ Miedzgová, J.: Základy etiky. Bratislava: SPN, 1996, p. 12.

${ }_{15}^{14}$ Př́kaský, J., V.: Učebnice základů etiky. edition 1. Kostelní Vydří: Karmelitánské nakladatelství, 2000 , p. 8.

${ }^{15}$ Filosofický slovník. 2., opr. a rozš. edition Olomouc: Nakladatelství Olomouc, 1998, p. 275.

${ }^{16}$ Filosofický slovník. 2., opr. a rozš. edition Olomouc: Nakladatelství Olomouc, 1998, p. 275.

${ }^{17}$ Putnová, A. Seknička, P.: Etické řízení ve firmě: nástroje a metody: etický a sociální audit. 1. edition Praha: Grada, 2007, p. 37.
} 
the individual to nevertheless submit to this norm. It implies the field of social relations. If this does not happen, social exclusion (sanction) necessarily occurs. ${ }^{18}$

\subsection{Categories}

The main category of philosophical ethics is moral values. The sum of moral values is good. The opposite of moral value is moral evil. As dangerous as moral evil is moral indifference. Moral value refers to the value characteristics of a person's actions, which collectively tell about his/her moral context. It follows from the need to observe particular general, enforced, or voluntarily accepted rules of human coexistence. Human behavior can be rational, purposeful, effective, but at the same time also rude, tactless, unjust, etc. ${ }^{19}$

Ethical values speak of only one aspect of human behavior related to the need for selfregulation of the social mechanism based on generally valid norms of desirable or undesirable behavior.

Moral value finds its expression either in good or in evil. This means that both determinations always mean the opposite, and the value is understood in this sense as the unity of two poles. Therefore, value is not only what we accept but also what we reject. Every social act has the opposite effect in its consequences. It is desirable and at the same time undesirable depending on the subject, on the determination of needs and interests. To change moral values means to be without any values, without relation to human needs and interests. They can become obsolete over time and become a brake on dynamic development.

Essential terms in ethics are categories, such as good, evil, freedom, values of life, conscience, etc. Their common feature is a high degree of abstraction and difficulty to define. One such concept is conscience. Conscience is a unique mechanism of moral evaluation of oneself. From this point of view, ethics can be considered a philosophical doctrine of good behavior, which evaluates human activity in terms of categories of good and evil. The history of ethical concepts is marked by a whole system of opposing approaches to understanding good and evil. ${ }^{20}$

\subsection{Types of Ethics}

Dolista $^{21}$ and Friedel $^{22}$ talk about the types of ethics:

- Autonomous ethics, where the ethical principles are set by the person himself/herself or the company itself.

- Heteronomic ethics, where moral principles and rules are understood as given from the outside (eg. by a Higher Intelligence, by God ...).

- Descriptive ethics, which aims to describe as accurately as possible moral behavior and values in diverse cultural forms.

- Normative ethics, seeking to find and analyze the norms of human behavior. This ethic seeks criteria for determining "morally good" and "morally bad" behavior and based on them to formulate specific prohibitions, orders, or taboos.

- Individual ethics, which deals with the moral issues of the individual in his efforts for her/his own well-being.

\footnotetext{
${ }^{18}$ Putnová, A. Seknička, P.: Etické řízení ve firmě: nástroje a metody: etický a sociální audit. 1. edition Praha: Grada, 2007, p. 37.

${ }^{19}$ Dytrt, Z. a kol.: Etika podnikání a veřejné správy. edition 1. Praha: Vuste Envis, 1997, p. 14.

${ }^{20}$ Sapík, M.: Základy filosofie: základní studijní materiál pro kombinované studium. České Budějovice: Jihočeská univerzita, 2002, p. 59.

${ }^{21}$ Dolista, J., Ježek, R.: Etika zaměstnance veřejné správy: vysokoškolská učebnice. 1. edition České Budějovice: Vysoká škola evropských a regionálních studií, 2006, p. 12. Comp.: DOLISTA, J.: Profesní etika. České Budějovice: Vysoká škola evropských a regionálních studií, o.p.s., 2007, p. 16.

${ }^{22}$ Friedel, L.: Etika v podnikání. MBA Rotary klub Ostrava, 2003. [on line]. [cit. 2019-01-21]. Accessible from: $<$ http//www.bestpractices.cz>
} 
- Social ethics, focused on the common, general good, which seeks universal human values.

- Professional ethics, applying general ethical rules to the conditions of specific fields of human activity. One of them is public administration.

- Environmental ethics, which addresses the relationship of man (individual and humanity) to everything "inhuman" (in the sense of the environment).

- Ethics of the economy, solving ethical problems related to the transformation of the existing or building a new economic order in the spirit of the principles of justice, solidarity, social welfare, democracy, humanity, etc.

In his lectures, Payne, as a certain contrast to normative ethics, also uses Dignitive ethics, ethics of values, and Procedural ethics, "which does not have a general rule of conduct, but a rule of choice. " 23

However, public administration ethics, which is part of professional ethics, is essential for this work.

\subsection{Ethical Relationships}

Ethical relationships are one's relationships with other people, with oneself, with one's life, with one's future, and with the future of others. They express an attitude towards the world, reality, and life values in general. Ethical relationships have the following aspects:

- Objective. These are the moral principles of society, actions, behavior, habits of individuals and collectives, social establishment, public institutions, measures in which moral efforts and morality of society are realized ...

- Subjective and psychological. This is the moral consciousness, feelings, beliefs, moral endeavors, character and moral qualities of individuals, and the morality of public opinion $\ldots$

- Ideological and theoretical. These are moral goals, ideas, moral theories, codes of moral values, and norms ... ${ }^{24}$

\subsection{Code of Ethics}

The code of ethics is one of the critical regulators of ethical behavior. At present, it is one of the preferred forms of institutionalizing ethics in the economic field. It represents a summary of basic ethical rules and standards, the observance of which ensures an approximate minimum of ethics in subjects' behavior. The code of ethics is constructed as a result of the search for optimal ethical behavior of the subject, which should serve on the one hand as a prevention against various types of corruption, scandals, harm to interests, etc., and on the other hand, as a moral standard that should ensure a minimum of ethics in a person's behavior, professions, industries, etc.

"From an etymological point of view, the Latin word codex referred to a book. Its appearance was a papyrus scroll, a file, a parchment manuscript, or a wooden board. In a broader sense, a codex meant a file or a list of several files. The code of ethics then refers to a set of written values, ethical principles of standards of conduct normative and binding for a particular profession, professionals, or organizations in a global, national or institutional space." Say Mátel and Mališková. ${ }^{25}$

\footnotetext{
${ }^{23}$ Payne, J.: Etika. Lecture for PhD students Oct 11, 2017, 1. LF UK Praha.

${ }^{24}$ Dytrt, Z. a kol.: Etika podnikání a veřejné správy. edition 1. Praha: Vuste Envis, 1997, p. 14.

${ }^{25}$ Mátel, A. a Mališková, Z.: Etické kodexy sociální práce. Edition 2., přepracované. Př́bram: Ústav sv. Jana N. Neumanna Př́ibram, VŠZaSP sv. Alžbety, 2016, p. 17.
} 


\section{PUBLIC ADMINISTRATION ETHICS}

\subsection{Ethics in Public Administration}

Ethics has a place in public administration primarily in connection with decision-making, and subsequently, behavior inside and outside the office. Every problem or situation with an ethical dimension requires a choice between several options. The individual or organization makes this choice. To improve ethical attitudes, it is necessary to reconcile the ethics of the individual with the ethics of the organization in which the individual works and with the ethics of society. ${ }^{26}$

Administrative ethics then mainly concerns individual officials and generally affects three areas of their decision-making process:

- Choice of the legal position - what are and what the laws should be and whether I want to comply with them, whether I will respect the idea of the legislator or the principle - what is not forbidden is allowed.

- Choice of moral attitude - refers to identity with a general definition of morality and human values.

- Choice of preference for interest - deciding whether we will prefer our interest over the public interest. $^{27}$

\subsection{Ethical Environment}

The traditional definition of morality is based on the thesis that it is a set of rules, values, attitudes, and beliefs that influence and regulate human action in real-time and space. Morality thus concerns the ways and practices defining good and bad; it is meant as a state of de facto prevailing norms. Moral practices, along with other types of customs, rules, and methods, are passed on within a given culture from generation to generation. ${ }^{28}$

Businesses and administrative organizations create their own culture. It reflects the organization and the realization of internal relationships and behavior in the economic and social environment. We understand culture as a set of customs and traditions, unwritten values, attitudes, and norms of behavior of employees who act on behalf of the company or administrative organization. It is about workers' contact with the environment and their relations with each other, especially in difficult situations. ${ }^{29}$

\subsection{Two Approaches}

In general, there are two basic approaches to improve public administration behavior. The first approach is more motivating and encourages desirable behavior rather than punishing mistakes and shortcomings. The second approach focuses on precisely what a public service employee should avoid, what to do and how. This system sets up strict control mechanisms, detailed rules, and administrative procedures. Of course, the very existence of a code of ethics without follow-up measures in personnel management and public control cannot be effective enough. Therefore, it is essential to widely popularize such codes and gradually promote the ethical aspects of administrative work in the thinking and actions of managers. It is necessary to create patterns of desirable behavior, preparation for action in the administration, including clarification of ethical issues, comprehensive support for human resource growth, regular evaluation of employees, and motivation to increase organizational culture and ethical

\footnotetext{
${ }^{26}$ Dytrt, Z. a kol.: Etika podnikání a veřejné správy. edition 1. Praha: Vuste Envis, 1997, p. 36.

${ }^{27}$ Dytrt, Z. a kol.: Etika podnikání a veřejné správy. edition 1. Praha: Vuste Envis, 1997, p. 36.

${ }^{28}$ Dytrt, Z., Myšková, R., Brodský, Z.: Manažerská etika: pro kombinovanou formu studia. edition 1. Pardubice: Univerzita Pardubice, 2007, p. 8.

${ }^{29}$ Dytrt, Z. a kol.: Etika podnikání a veřejné správy. edition 1. Praha: Vuste Envis, 1997, p. 101.
} 
behavior. All rational means of supporting the ethics and culture of public administration must be used.

\subsection{Improving Ethical Behavior}

According to Pomahač and Vidláková ${ }^{30}$, there are three ways to maintain and improve the ethical behavior of public officials:

- Adoption of written rules and, in particular, codes of ethics for public administration employees.

- Pre-service and in-service training.

- The influence of the model role of superiors in employment.

Transparency of internal procedures and all performed operations, sufficient access to information for all involved (including acquainting the client not only with the responsibilities of administration but also with her/his rights - an informed and confident client also increases the level of the organization), internal systems also play an essential role in enforcing ethical principles, controls and the entire organizational structure (clear definition of decision-making powers, appropriate regulation of documents such as organizational rules, rules of procedure, etc.). This is also related to the setting up of control mechanisms - internal and independent controls, supervision, etc. ${ }^{31}$ One of these means is codes of ethics.

The code of ethics also creates a unified corporate culture (possibly the office's culture). The system's elements are understood internally and externally and act in accordance with it (uniformity of the expression of the system elements). A system in which, in addition to clear working frameworks of competence, there is also a framework of shared values and the conditions for their fulfillment, it forms a security framework for all. In the case of public administration, it is a matter of ensuring a safety framework for the Office's employees, elected representatives, and the public. ${ }^{32}$

\subsection{Tools of Institutionalization of Ethics}

The following list defines the tools of institutionalization of ethics in the organization:

- Codes of ethics.

- Codes of conduct.

- Ombudsman's Office - The institution of the Czech "ombudsman", whose task is to resolve complaints not only about the legal procedures of the administration but also about its inaction, delays, inappropriate forms of action, etc., which in the appeal administrative proceedings or administrative courts usually cannot be resolved. The Ombudsman's role is first and foremost to reduce conflicts between the public and the administration as early as possible, and its activities could, under favorable conditions, have significant preventive effects in the direction of "cultivation" of the administration.

- Ethics committees.

- Ethical audit.

- Education for ethical behavior. ${ }^{33}$

\footnotetext{
${ }^{30}$ Pomahač, R., Vidláková, O.: Veřejná správa, 1. edition, Praha: C. H. Beck, 2002, p. 143.

31 Dolista, J., Ježek, R.: Etika zaměstnance veřejné správy: vysokoškolská učebnice. 1. edition České Budějovice: Vysoká škola evropských a regionálních studií, 2006, p. 66. Comp.: DOLISTA, J.: Profesní etika. České Budějovice: Vysoká škola evropských a regionálních studií, o.p.s., 2007, p. 86.

32 Štička, M.: Korupce a protikorupční politika ve veřejné správě. Praha: Transparency International - Česká republika, 2008, p 111.

${ }^{33}$ Dolista, J.: Profesní etika. České Budějovice: Vysoká škola evropských a regionálních studií, o.p.s., 2007, p. 80 .
} 


\subsection{Managerial Ethics}

In public administration, managerial ethics also has an irreplaceable place, for which the critical point of view is the relationship between superior and subordinate, i.e., between managers and other employees. It is one of the particular directions of professional ethics. In this sense, managerial ethics is as important as other specialized professional ethics. ${ }^{34}$

"Good intentions are not enough to achieve the right goals," Dolista points out. ${ }^{35}$ The correctness of institutional structures and legal norms needs constant attention and revision through ethical considerations. Codes of ethics represent a flexible force here, shaped by the daily "living" of these codified rules. Institutionalized codes and procedures are essential, and their importance should not be underestimated in terms of their impact on the so-called legitimization of the law, and thus the cultivation of the system as such."

\subsection{Ethical Values in Codes}

Codes of ethics vary in different fields of activity of organizations, but in principle, they deal with the following range of issues, but also the very ethical values of the organization or public administration body:

- Decency and fidelity of the law.

- Product safety and quality.

- Resolving conflicts of interest.

- Concluding employment contracts.

- Safety and health at work.

- Honesty in sales practices.

- Relationships with suppliers.

- Customer relations.

- The method of setting prices and the principles of handling inside information.

- Solving cases of possible corruption in obtaining information and contracts.

- Environmental Protection.

"The values and principles set out in the code of ethics define the 'ideal' civil/public servant. The Code of Ethics usually contains the following key values: service to the public interest, respect for the Constitution and the law, openness and transparency, impartiality and independence, self-improvement, and professionalism. The main goal is not the formal creation of a code of ethics, but the promotion of its values and principles in everyday life." According to Nemec and Vlach. ${ }^{36}$

\subsection{Fundamental Values of Public Administration}

The fundamental values of public administration, which are required of a public administration employee and which must be recognized by every public administration employee and thus create a basis for building and maintaining public confidence:

- Impartiality.

- Legality.

- Transparency and fairness in decision-making.

- Equal access to all citizens.

- Performance combined with the constant increase of professional level.

\footnotetext{
${ }^{34}$ Dolista, J., Ježek, R.: Etika zaměstnance veřejné správy: vysokoškolská učebnice. 1. edition České Budějovice: Vysoká škola evropských a regionálních studií, 2006, p. 61. Comp.: DOLISTA, J.: Profesní etika. České Budějovice: Vysoká škola evropských a regionálních studií, o.p.s., 2007, p. 81.

${ }^{35}$ Dolista, J.: Profesní etika. České Budějovice: Vysoká škola evropských a regionálních studií, o.p.s., 2007, p. 114.

${ }^{36}$ Nemec, J., Vlach, J.: Etický kódex a Pakt integrity vo verejnom obstarávaní. Bratislava: Transparency International Slovensko, 2003, p. 13.
} 
- The integrity of the official's personality. ${ }^{37}$

Ideally, as stated by Nemec and Vlach: "All public administration employees are aware of the obligation to behave morally and ethically because the code of ethics formulates all "ethical" obligations clearly. Every public employee is aware of what the code of ethics requires of him/her because when he starts working, he/she signs a commitment to know the code of ethics, abides by it, and is aware of the consequences of non-compliance himself. Any of his conduct in violation of the moral and ethical obligations set out in the code is therefore considered not only a deliberate but also an intentional violation - and as such is discussed according to the given rules in the ethics committee." ${ }^{38}$

\section{CONCLUSION}

Ethics has a place in public administration primarily in connection with decision-making, and subsequently, behavior inside and outside the office. Every problem or situation with an ethical dimension requires a choice between several options. The individual or organization makes this choice. To improve ethical attitudes, it is necessary to reconcile the ethics of the individual with the organization's ethics in which the individual works and with company ethics. ${ }^{39}$ The ethical behavior of employees and representatives and its consistent control is not only a question of the prestige of an organization or public administration body (whether officials or elected bodies). However, it is a necessity, as it has a societal overlap.

The article outlines the relationship between morality, ethics, and law, which can also be represented graphically, in the form of three concentric circles, in terms of vulnerability or enforceability. At the very center is a clearly defined law and well enforceable and punishable; a larger circle and area around it occupies a morality that can be harder to punish, so there are efforts to limit it with a code of ethics binding on all beneficiaries. The largest outer circle and area around it is occupied by ethics as a science of morality, which cannot be de facto punished.

Law is an essential regulator of behavior. Law grew out of morality and ethics. The law primarily regulates the ownership and social relations of the perspective of justice. Laws that are created to protect a given status quo can never contain the richness of everyday life, and therefore ethical (moral) norms are a significant complement to legal regulation. Law and ethics (morality) must not contradict each other in a healthy society but must complement each other. For the law to become a fundamental tool of justice, it requires a favorable social environment, which must be supported by a certain level of ethics (morality) and good morals. Ethical norms, unlike legal norms, are not supported or enforced by institutions but by public opinion, which corrects the behavior of the individual.

Public administration ethics is part of professional ethics. Increased demands are placed on public administration employees and today also on elected representatives within the framework of representative democracy, professionally, morally and ethically. One method of enforcing these claims is to codify them with voluntary acceptance but enforceability by public opinion.

\section{Sources}

1. Adamová, L., Dudák, V. Ventura, V.: Základy filosofie, etiky: základy společenských věd. 1. edition Praha: Fortuna, 1995. 149 p. ISBN 80-7168-221-7.

2. Administrative Procedure Code n. 500/2004 Coll., [cit. 2021-05-16].

\footnotetext{
${ }^{37}$ Mládková, L. a kol.: Management. Plzeň: Vydavatelství a nakladatelství Aleš Čeněk, 2009, p. 30-31.

${ }^{38}$ Nemec, J., Vlach, J.: Etický kódex a Pakt integrity vo verejnom obstarávaní. Bratislava: Transparency International Slovensko, 2003, p. 13.

${ }^{39}$ Dytrt, Z. a kol.: Etika podnikání a veřejné správy. edition 1. Praha: Vuste Envis, 1997, p. 36.
} 
3. Dolista, J.: Profesní etika. České Budějovice: Vysoká škola evropských a regionálních studií, o.p.s., 2007, 188 p. ISBN 978-80-86708-33-1

4. Dolista, J., Ježek, R.: Etika zaměstnance veřejné správy: vysokoškolská učebnice. 1. edition České Budějovice: Vysoká škola evropských a regionálních studií, 2006. 122 p. Vysokoškolská učebnice VŠERS. ISBN 80-86708-20-9.

5. Dytrt, Z. a kol.: Etika podnikání a veřejné správy. edition 1. Praha: Vuste Envis, 1997. $120 \mathrm{p}$.

6. Dytrt, Z., Myšková, R. a Brodský, Z.: Manažerská etika: pro kombinovanou formu studia. edition 1. Pardubice: Univerzita Pardubice, 2007. 94 p. ISBN 978-80-7395037-8.

7. Friedel, L.: Etika v podnikání. MBA Rotary klub Ostrava, 2003. [on line]. [cit. 202105-17]. Accessible from: 〈http//www.bestpractices.cz $>$.

8. Filosofický slovnik. 2., corrected and extended edition Olomouc: Nakladatelství Olomouc, 1998, ISBN 80-7182-064-4.

9. Gosiorovský, I.: Úvod do profesni etiky: (monografie). 1. edition Kunovice: Evropský polytechnický institut, 2008. 58 p. Odborné knižní publikace. ISBN 978-80-7314-159-2.

10. Chapman, R., A.: Etika ve veřejné službě pro nové tisíciletí. 1. edition, Sociologické nakladatelství, 2003, ISBN 80-8642-914-8.

11. Janotová, H. a kol.: Profesní etika. edition 1. Praha: Eurolex Bohemia, 2005. 96 p. ISBN 80-86861-42-2.

12. Mátel, A., Mališková, Z.: Etické kodexy sociální práce. Edition 2., přepracované. Př́bram: Ústav sv. Jana N. Neumanna Př́bram, VŠZaSP sv. Alžbety, 2016. 233 p. ISBN 978-80-906146-6-6.

13. Miedzgová, J.: Základy etiky. Bratislava: SPN, 1996. ISBN 80-08-01729-5.

14. Mládková, L. a kol.: Management. Plzeň: Vydavatelství a nakladatelství Aleš Čeněk, 2009. 273 p. ISBN 978-80-7380-230-1.

15. Nemec, J., Vlach, J.: Etický kódex a Pakt integrity vo verejnom obstarávaní. Bratislava: Transparency International Slovensko, 2003. 52 p. ISBN 80-89041-65-5.

16. Pomahač, R., Vidláková, O.: Veřejná správa, 1. edition, Praha: C. H. Beck, 2002, ISBN 80-7179-748-0.

17. Putnová, A. Seknička, P.: Etické ř́zeni ve firmě: nástroje a metody: etický a sociální audit. 1. edition Praha: Grada, 2007. 166 p. ISBN 978-80-247-1621-3.

18. Př́kaský, V.: Učebnice základi̊ etiky. edition 1. Kostelní Vydří: Karmelitánské nakladatelství, 2000. 134 p. ISBN 80-7192-505-5.

19. Sapík, M.: Základy filosofie: základní studijní materiál pro kombinované studium. České Budějovice: Jihočeská univerzita, 2002. 228 p. ISBN 80-7040-595-3.

20. Sládeček, V.: Obecné správní právo. 2. edition, Praha: ASPI - Wolters Kluwer, 2009, 484 p. ISBN 80-7179-314-0.

21. Štička, M.: Korupce a protikorupční politika ve veřejné správě. Praha: Transparency International - Česká republika, 2008. 212 p. ISBN 978-80-87123-04-1.

22. Vajda, Ján: Úvod do etiky. Nitra: Enigma, 2004. 251 p. ISBN 80-89132-12-X.

23. Vaněk, J.: Základy sociální a ekonomické etiky. Praha : VŠE, 1997. ISBN 80-7970344-9.

\section{Authors}

Ing. Petr Ondrušák

Charles University in Prague, First Faculty of Medicine, Institute for Medical Humanities,

Kateřinská 32, 12108 , Praha 2,

Middle West University, Inc., Opletalova 23, 110 00, Praha 1,

E-mail: petr.ondrusak@ seznam.cz 
JUDr. RNDr. PhDr. Ing. Jan Lípa, Ph.D., DBA, M.Div., LL.M.

Charles University in Prague, First Faculty of Medicine, Institute for Medical Humanities, Kateřinská 32, 12108 , Praha 2

Middle West University, Inc., Opletalova 23, 110 00, Praha 1

E-mail: jan.lipa@centrum.cz

JUDr. Ladislav Rozenský, Ph.D., DBA

Charles University in Prague, First Faculty of Medicine, Institute for Medical Humanities, Kateřinská 32, 121 08, Praha 2,

Middle West University, Inc., Opletalova 23, 110 00, Praha 1,

E-mail: rladislav@ seznam.cz

PhDr. Zdeněk Vrba, Ph.D., DBA, LL.D.

Charles University in Prague, First Faculty of Medicine, Institute for Medical Humanities, Kateřinská 32, 121 08, Praha 2,

Middle West University, Inc., Opletalova 23, 110 00, Praha 1,

E-mail:vrba@1az.cz

Prof. Dr. Josef Dolista, Th.D., Ph.D., LL.M., Dr. h. c.

Charles University in Prague, First Faculty of Medicine, Institute for Medical Humanities, Kateřinská 32, 121 08, Praha 2,

Charles University in Prague, Hussite Theological Faculty, Pacovská 350/4, 14021 Praha 4, E-mail: josef.dolista@1f1.cuni.cz 


\title{
BIOPHILIC PHILOSOPHY OF JOSEF ŠMAJS
}

\author{
Jan Lípa, Ladislav Rozenský, Petr Ondrušák, Zdeněk Vrba, Josef Dolista
}

\begin{abstract}
Recently, in the field of ecoethics, in addition to names such as Kohák, Vavroušek, Keller, and Librová, we are increasingly encountering the name of the Czech philosopher Professor Josef Šmajs. In his works, Professor Šmajs brings an entirely new, original, and comprehensive view of human life on Earth and its ethics. His concept combines the humanities and natural sciences into a single organic whole. Šmajs says: „We are the products of a magnificent natural evolution, but we are proud only of our cultural creativity. We think - and we teach it in schools - that we complete humanity with human culture, that we humanize it. However, the truth is different. Nature is original, self-sufficient, and perfect; we cannot complete or humanize it.“ He further claims that „If we want to survive on Earth, we must wisely give way to nature wisely in time. The epoch of the symbiosis of culture and nature is still ahead of us." His philosophy, which can be called biophilic, interprets the current form of the ecological crisis and its causes and provides a clear, realistic guide to ethically saving humanity and earthly life.
\end{abstract}

Keywords: bioethics, ethics, culture, ecology, evolution

\section{INTRODUCTION}

Van R. Potter was the first to use the term Bioethics. In the book Bioethics - Bridge to the Future (Prentice Hall Inc., Englewood Cliffs, New Jersey 1971), no distinction was made between ethical issues related to man's ethical relationship to his environmental problems related to his health care. Later, authors used the name „ecoethics“ and the name „bioethics“. Ecologists Kohák, Vavroušek, Keller, and Librová deal with ecoethics in our environment. We can recently meet with the name of the Czech philosopher and thinker Professor Josef Šmajs, whose work will be discussed in this work. It will be divided into three parts. The first part introduces the basic ideas of his work. The second part discusses the practical issues of the need for change. The third part compares Šmajs's work with other authors. In his works published since the mid-1990s, Professor Šmajs brings an entirely new, original, and comprehensive view of human life on Earth and its ethics. His concept combines the humanities and natural sciences into a single organic whole. His philosophy, which can be called biophilic, as he calls the new policy necessary to change the thinking of modern humanity leading to the preservation of life on Earth, not only explains the current form of ecological crisis and its causes but also provides a clear, realistic guide to saving humanity and earthly life in general, ethically.

\section{S̆MAJS' CONCEPTION OF PHILOSOPHY}

\subsection{About Josef Šmajs}

Josef Šmajs was born in 1938 in Skvrňov, district of Kolín. In 1969 he studied mechanical engineering at the Military Academy in Brno and in 1972 philosophy at the Faculty of Arts, Masaryk University in Brno. In 1986 he obtained the rank of associate professor of philosophy (appointed); in 1993, he received a habilitation with the work „Evolutionary 
Ontology“, and in 1997 he was appointed professor of philosophy at Masaryk University in Brno. ${ }^{1}$

He deals with philosophical issues of the crisis of civilization, which he understands as a conflict of culture with nature. He created an original philosophical conception of evolutionary ontology and is the author of many books on ontological and ecological topics, translating into other languages. In 1995, he published the book Endangered Culture, for which he received the Award of the Minister of the Environment of the Czech Republic. He is the author of several dozen books.

\section{2 Šmajs' conception of philosophy}

Šmajs uses infrequent and used interdisciplinary studies not very often. In many places in his books, he argues that the current global ecological crisis is not a science but de facto says that the natural sciences should examine cultural relations and the humanities of nature.

„We are the products of a magnificent natural evolution, but we are proud only of our cultural creativity. We think - and we teach it in schools - that we complete humanity with human culture, that we humanize it. However, the truth is different. Nature is original, self-sufficient, and perfect; we cannot complete or humanize it." ${ }^{2}$

As the essence of every complex cultural phenomenon, the essence of the global ecological crisis is not shown directly but can be revealed by an appropriate theoretical approach. According to Šmajs, we will not understand this essence in either a pragmatic or traditional philosophical subject-object way. However, we can affect it from the point of view of evolutionary ontology. ${ }^{3}$

Thus, evolutionary ontology attempts to create a new image of the world and man, a new nonanthropocentric cosmology. Nevertheless, it should be neither physical cosmology nor biological cosmology. It is supposed to be a consistently philosophical cosmology, which respects reality in its real structure, i.e. as a conflict between two ontically creative evolutionary processes: spontaneous natural activities and human sociocultural activities. ${ }^{4}$

\subsection{Predatory paradigm of culture}

In his work, Šmajs criticizes the state of contemporary society. It points to current influences and trends not only in society but also in culture and politics. He does not use the term civilization, which is vague and inaccurate for him, but the term culture, in the historical sense. With its development, man deviates from nature and the natural way of life in accordance with it.

„A culture of needs is emerging, primarily created and imposed on people by developing science, technology, and production." ${ }^{\text {5 }}$

Gradually, there is a development of culture and society based on the extraction of natural resources and, at the same time, depletion of the planet.

One of the new terms he introduces and interprets is the predatory paradigm of culture, the complex systemic form of contemporary globalized culture. This is o the fact that man does not live in harmony with nature, but through his culture depletes natural resources in the false

\footnotetext{
${ }^{1}$ Josef Šmajs, životopis, [on line]. [cit. 2. 5. 2021]. Dostupné z: <http://www.databazeknih.cz/zivotopis/josefsmajs-8670>

2 Šmajs, J.: Potřebujeme filosofii přežití - Úvahy o př́rodě, kultuře, ekonomice, práci, poznání a popularizaci vědy. 2. přepracované a doplněné vydání doba, Brno: Doplněk, 2011, p. 7.

3 Šmajs, J.: Filosofie psaná kurzívou. Rozhlasové ekologické eseje. Brno: Doplněk, 2003, p. 16.

${ }^{4}$ Šmajs, J., Krob, J.: Evoluční ontologie. Brno: Masarykova univerzita, 2003, p. 124.

5 Šmajs, J.: Potřebujeme filosofii přžití - Úvahy o př́rodé, kultuře, ekonomice, práci, poznání a popularizaci vědy. 2. přepracované a doplněné vydání doba, Brno: Doplněk, 2011, p. 71.
} 
belief that man is no longer part of nature. ${ }^{6}$ In this context, natural values are replaced by cultural values.

He disagrees with current theories of growth indicators, denies the importance and role of the economy, which he sees as one of the causes of the crisis, and suggests solving the problem by starting to pay nature for resources. Although he disagrees with the statement that we live on debt, he claims that we are preparing some existential issues for our descendants. ${ }^{7}$

\subsection{Global ecological crisis}

According to Šmajs, such a development immediately leads to a global ecological crisis, in which, according to the current view of many ecologists and scientists, the Earth and society, or rather culture, find themselves. This crisis is then devastating not only for the Earth but also for society as a whole. It can then bring and claim to bring an irreversible end to society. However, according to him, knowledge of the very cause, gradual development, and the possibility of a turn for the better cannot be achieved by traditional sciences.

He studied technology and philosophy, and all his life, he dealt with the philosophy of science, whereby he combines natural or technical sciences with humanities in his work and life. In this way, therefore, future science is to set out in order to examine the present state of malignancy and begin to correct it. Only in this way can we come to new knowledge and new results, progress, and further development. The technical sciences have reached their peak on the one hand and are the cause of the crisis on the other, so they should be reformed.

According to his concept, he sees as the culprit not only science and philosophy but also politics and political science, in the first place the free market and liberalism itself. Moreover, it does not presuppose a change that would lead from the individual by changing his conception, attitude, etc., but de facto above all „from above“, i.e., through philosophers, educators, and politicians acting on the broad masses. It is an essentially illiberal attitude, but they do not hide it, and liberalism often denies it. On the other hand, his teachings radiate a strong social and societal subtext.

Nevertheless, we can find evidence in his work of the validity of the much-hated liberalism emanating from the bourgeois revolution, which is the very cause of the state of the last two centuries.

It is his opinion that the global crisis itself will lead to a tendency to liberate humanity. However, this is a somewhat revolutionary view of his work, confirming liberalism, to which we will return. ${ }^{8}$ However, this is a somewhat revolutionary view of his work, confirming liberalism, to which we will return.

\subsection{Evolutionary ontology}

Evolutionary ontology can be briefly characterized as an ontology of civic and sociocultural engagement. It is not only about what a being is and what its structure is, but at the same time about what being is an evolutionary process, what being can be a human being living as a biological species for a long time. Therefore, it strives for a competent, scientifically testable ontological reflection of reality for experts and new metaphors, bon mots, and interpretive schemes for the general public. It seeks to offer a new ontological minimum to all citizens. ${ }^{9}$

\footnotetext{
${ }^{6}$ Šmajs, J.: Potřebujeme filosofii prežití - Úvahy o přirodě, kultuře, ekonomice, práci, poznání a popularizaci vědy. 2. přepracované a doplněné vydání doba, Brno: Doplněk, 2011, p. 71.

7 Šmajs, J.: Potřebujeme filosofii prežití - Úvahy o př́rodě, kultuře, ekonomice, práci, poznání a popularizaci vědy. 2. přepracované a doplněné vydání doba, Brno: Doplněk, 2011, p. 83.

${ }^{8}$ Šmajs, J.: Potřebujeme filosofii prežití - Úvahy o př́rodě, kultuře, ekonomice, práci, poznání a popularizaci vědy. 2. přepracované a doplněné vydání doba, Brno: Doplněk, 2011, p. 139.

9 Šmajs, J., Krob, J.: Evoluční ontologie. Brno: Masarykova univerzita, 2003, p. 349.
} 
In his work, Šmajs presents a new science-based field on the synthesis of natural sciences and humanities, a field in which it is possible to combine knowledge of the laws of development and the possibility of reversal. In addition to describing natural evolution, which he calls "blind biotic evolution," he explains cultural evolution that arises within the process of natural evolution. ${ }^{10}$

Evolutionary ontology thus tries to respond to the ecological turning point; it wants to show the cause of the incompatibility of nature and culture. It attempts to eliminate anthropocentrism and thematize the contradictory role of culture in the fragile biotic community of the Earth. Therefore, the program is not based on man as a modern focus of philosophy, but again on being, on the process of natural evolution, which created the Earth and man and which also carries, includes, and limits today's planetary culture. Moreover, this is what it wants to help change the traditional pre-ecological paradigm. The paradigm of human supremacy over nature is an anthropocentric illusion and must be replaced by the paradigm of human superiority over nature. We must try to transform the anti-natural culture that ravages the Earth radically, says Šmajs. ${ }^{11}$

With the help of an interdisciplinary evolutionary ontology of culture, he makes statements that may be surprising for contemporary science and philosophy, yet it is undoubtedly an acceptable solution for many ecologically minded people. At the same time, this term is the title of one of his books and the central idea of his work.

\section{NATURAL VERSUS CULTURAL EVOLUTION}

\subsection{Natural versus cultural evolution}

From an evolutionary ontological perspective, it is necessary to distinguish between natural evolution and cultural evolution consistently. Natural evolution, which is about as old as the universe itself, takes place throughout the time that separates us from the Big Bang, from the singularity. It created all the galaxies, all the stars, and their planetary systems. ${ }^{12}$

Although cultural evolution is qualitatively different from natural evolution, it relies on a different activity and other constitutive information - even with a significant share of deliberate theoretical human activity, but is also blind in principle. Like biotic evolution, cultural evolution uses the model of testing its creations by complex environmental (especially cultural) conditions. It uses a generally valid biological method of empirical transformation of ,genotype to phenotype“to optimize its constructions. Furthermore, this is why cultural evolution is also relatively unique and cannot proceed according to a rational plan or scenario. ${ }^{13}$

However, we should also know that the dramatic turning point in the relationship of nature and culture does not occur with the failure of the current adaptive human strategy. On the contrary, that reversal is caused by its successful planetary boom, which is only remotely similar to predator-catching prey. The crisis, the essence of which we do not see directly, arises from the loss of naturally arranged structures, places, and spheres of the final Earth's surface. It is created as a result of the extinction of the level of natural being to which man evolutionarily corresponds because he gave birth to him. ${ }^{14}$

After all, Šmajs devotes an independent work to this topic called The Natural Conflict and cultural evolution. ${ }^{15}$

10 Šmajs, J.: Potřebujeme filosofii prežití - Úvahy o prírodě, kultuře, ekonomice, práci, poznání a popularizaci vědy - druhé, přepracované a doplněné vydání doba, Brno: Doplněk, 2011, p. 33.

${ }_{11}$ Šmajs, J., Krob, J.: Úvod do ontologie. 2. opravené a rozšířené vydání. Brno: Masarykova univerzita, 1994, p. 88.

${ }^{12}$ Šmajs, J., Binka, B., Timko, M.: Tři studie z environmentální filosofie. Brno: Masarykova univerzita. 2011, p. 37.

${ }^{13}$ Šmajs, J., Binka, B., Timko, M.: Tři studie z environmentální filosofie. Brno: Masarykova univerzita. 2011, p. 37.

${ }^{14}$ Šmajs, J.: Filosofie psaná kurzívou. Rozhlasové ekologické eseje. Brno: Doplněk, 2003, p. 54.

${ }^{15}$ Cf.: Šmajs, J.: Konflikt prrirozené a kulturní evoluce. Brno: Masarykova univerzita. 1997. 48 p. 


\subsection{Subjectivity of the country}

A very striking cause that emerged during the development of society is the role of work as a factor of production. At this point, he denies the work the added value that Marx and others, for example, give it. He constantly repeats the equation of conservation of energy, by which he explains, or rather only suggests, the mistake of exaggerating the meaning of work on the one hand and transformed matter on the other. It is concluded that the reason for this misunderstanding is to deny the subjectivity of the Earth or nature as such. While any legal entity has subjectivity for us, we are unwilling to acknowledge it to the Earth. However, it would be an ethical solution.

He also talks about who owns the Earth, to which we deny subjectivity. According to our customs, a person is considered to be one, but this is a fundamentally wrong idea, as he was far from the first to begin to inhabit and use it, nor to have the majority population on its surface. For this reason, it would be microorganisms.

Natural resources themselves then have value in themselves and not only in their processing. The intellectual work also has a vital role in this - and not the physical one, but the mental one, according to whose program nature is transformed.

„If left to market regulation alone, it will continue to kill wildlife unnoticed and will not cease to distort human nature. “" 16

\subsection{All the living organisms are recognizing}

One of the essential chapters of his work talks about learning about living organisms. In essence, in accordance with current scientific findings, Šmajs calculates and defines three levels of cognition, such as reading information or decoding. He further argues that "man is, through culture, the only ontically creative animal, as a small, opposition god to nature.",17 However, ,in the context of natural evolution, a strikingly deviating force.“"18

\section{THE NEED FOR CHANGE}

\subsection{The need for change}

According to Šmajs, for a positive ecological transformation of the current anti-natural culture into a biophilic, natural culture, it is unnecessary - but neither possible - for us to change in advance. At the same time, however, it is not enough for scientists, philosophers, and the environmentally sensitive public to understand the necessity of ecological change. State and global politics (although real global politics does not yet exist) must develop a clear and citizen-understandable vision of possible long-term culture. ${ }^{19}$

Although biophilic culture will be created by succession, the ecological policy must openly subscribe to the biophilic paradigm; it must begin with publicly understood, supported, and controlled transformation in two areas simultaneously: in the relatively most straightforward sphere of naturalization of production, material culture, technology, and human settlements, in complicated areas of naturalization of human ontogenesis, education, training, law and people's way of life. However, the environmental problem is global, affecting a socially and technologically structured world where there are considerable political contradictions and tensions. $^{20}$

\footnotetext{
16 Šmajs, J.: Potřebujeme filosofii přežití - Úvahy o přirodě, kultuře, ekonomice, práci, poznání a popularizaci vědy-druhé, přepracované a doplněné vydání doba, Brno: Doplněk, 2011, p. 105.

17 Šmajs, J.: Potřebujeme filosofii přežití - Úvahy o prírodě, kultuře, ekonomice, práci, poznání a popularizaci vědy-druhé, přepracované a doplněné vydání doba, Brno: Doplněk, 2011, p. 120.

18 Šmajs, J.: Potřebujeme filosofii přežití - Úvahy o př́rodě, kultuře, ekonomice, práci, poznání a popularizaci vědy-druhé, přepracované a doplněné vydání doba, Brno: Doplněk, 2011, p. 121.

${ }_{19}$ Šmajs, J., Binka, B., Timko, M.: Tři studie z environmentální filosofie. Brno: Masarykova univerzita. 2011 . s. 73.

${ }^{20}$ Šmajs, J., Binka, B., Timko, M.: Tři studie z environmentální filosofie. Brno: Masarykova univerzita. 2011 . p. 73.
} 


\subsection{The problem of popularization of science}

Because, as we have already said, he sees one of the main reasons for the current crisis in science, philosophy, and politics, he translates a possible strategy in the form of the popularization of science. However, the right one, the one that should succeed for the philosophy of survival. Such a science should be the social sciences, the sciences of culture. "Without their contribution, we will not only not understand science, but we will not be able to change the way of its theoretical focus and popularization. “21

A real planetary solution to the crisis, based for the first time on the absolute priority of the long-term habitability of the Earth, i.e., on a biophilic cultural strategy, must be prepared for the first time by a high theory. Therefore, the positive ecological transformation of existentially endangered culture through the change of its hidden spiritual basis, through its new constitutive information, represents a historically unprecedented attempt by philosophy and politics to end the phase of unnatural cultural evolution in general. It is about starting peaceful cooperation of culture with the Earth, about the timely cessation of the undeclared war of global culture with nature. An older, broader, and the more powerful natural system would unnecessarily end the human species existence prematurely. ${ }^{22}$

Elsewhere, Šmajs formulates seven problems of popularization of science and another seven new popularizations of science. He practically summarizes the book's content, "We need a philosophy of survival," with the fact that he presents the popularization itself as a possible path.

It is only here that he says that although an ecological change of culture from below is complex, its timely start is necessary. ${ }^{23}$ It then offers as a solution its thesis of evolutionary ontology and its popularization - among other things in the form of education. He then translates the 11 points of the thesis of evolutionary ontological minimum for teaching in schools. $^{24}$ (Elsewhere, he describes 11 points of a very similar Evolutionary ontological minimum for economists. ${ }^{25}$ ) Furthermore, he describes the Biophilic orientation of education. It thus creates its system of education in schools, which it recommends for direct use. However, it is not possible to agree that such a process - curriculum regulation - is a bottomup transformation.

It is time, Šmajs says, to show pupils and adults that natural reality is neither a set of objects here nor a clockwork of eternally moving atoms, molecules, planets, and galaxies. Nature, which has managed to create us and to whose structure we belong, is a gigantic evolutionary process; it is the largest and most complex ontically creative activity ever.

\subsection{Lease Agreement with the Earth and Declaration of Dependence}

As a summary of his entire work, Šmajs adds a draft of the so-called Lease Agreement with the Earth. He refers to this throughout many of his books and rightly considers it

\footnotetext{
21 Šmajs, J.: Potřebujeme filosofii přežití - Úvahy o př́rodě, kultuře, ekonomice, práci, poznání a popularizaci vědy. 2. přepracované a doplněné vydání doba, Brno: Doplněk, 2011, p. 127.

${ }^{22}$ Šmajs, J., Binka, B., Timko, M.: Tři studie z environmentální filosofie. Brno: Masarykova univerzita. 2011 . p. 74.

23 Šmajs, J.: Potřebujeme filosofii prežití - Úvahy o př́rodě, kultuře, ekonomice, práci, poznání a popularizaci vědy. 2. přepracované a doplněné vydání doba, Brno: Doplněk, 2011, p. 137.

24 Šmajs, J.: Ohrožená kultura - od evoluční ontologie kekologické politice, třetí přepracované a doplněné vydání doba, Brno: Host, 2011, p. 224.

${ }^{25}$ Srov.: Šmajs, J., Binka, B., Rolný, I.: Etika, ekonomika, př́roda. Praha: Grada. 2012, s. 72.

${ }^{26}$ Šmajs, J., Klíma, I., Cílek, V.: Tři hlasy. Úvahy o povaze konfliktu kultury s prírodou. Brno, Nakladatelství Doplněk, 2010, p. 72.
} 
groundbreaking and important. It is a kind of ecoethical summary of his life's work, where he says that: „,nature will decide our species existence.“ 27

The lease agreement with the Earth contains a preamble and seven points, which can be briefly summarized:

1. The Earth cannot belong to man as a species that creates culture. We are temporary tenants of the Earth.

2. Life is a great experiment of cosmic evolution on our planet, and there is a fantastic amount of natural information written in organisms that is lost through culture.

3. Culture is the planetary creation of man as a species.

4. The conflict of culture with nature causes the loss of the natural environment of the Earth, can not destroy nature, but culture, and thus destroy our possibility of survival.

5. Globalized culture also devalues the traditional structure and content of school education, which it criticizes.

6. Technological progress, which has long been synonymous with human ascension, is becoming its threat.

7. For the first time, man is responsible for his species existence. Understanding presupposes an evolutionary ontological view of the world. In a broken biosphere, man will not be a nature-protected species. ${ }^{28}$

Thus, Šmajs appeals to the intellectual public, philosophers, politicians, lawyers, and all responsible citizens to conclude a treaty with the Earth in the interest of the very survival of humanity. ${ }^{29}$

In later texts, together with other Czech authors, he elaborates a similar summary, but even more strictly, precisely in the spirit of his teachings on the subjectivity of the Earth and the predatory paradigm of culture, in 11 provisions „calls on the public consequences of the expansion of human work. Although anti-natural culture brings previously unknown prosperity to the technically advanced part of humanity, it does not eliminate poverty, war, violence, and inequality. As a whole, it acts as the most powerful destructive force on Earth. The more we work together globally today, the more we hurt nature. Because culture destroys what we have not created, it can destroy everything we create. Today's culture can only be adapted to the Earth and the human biological essence by approaching it as an artificial nonbiological structure with inadequate internal information. Therefore, the biophilic reconstruction of the culture that awaits us is a challenge for all the responsible people of the planet: scientists, politicians, and ordinary citizens... If we want to survive on Earth, we must give way to nature wisely in time. The epoch of the symbiosis of culture with nature is still ahead of us." 30

Surely one can agree with him when he says, „With every breath, with every sip of water,

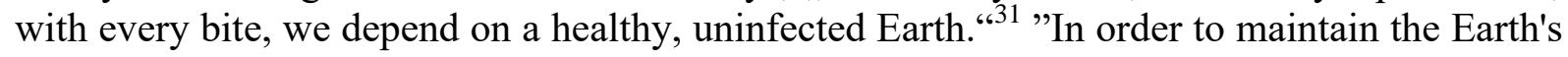
biodiversity, it is necessary to treat it ethically and give it legal personality.

\section{A NEW BIOPHILIC POLICY}

Šmajs calls the new, necessary policy „biophilic“ and says of its necessity and success: „The new biophilic policy needs broad public support. So the part of the available cultural

\footnotetext{
${ }^{27}$ Šmajs, J.: Filosofie - obrat k Zemi: evolučně ontologická reflexe přirody, kultury, techniky a lidského poznání. Praha: Academia, 2008. p. 409.

${ }_{28}^{2}$ Šmajs, J.: Filosofie - obrat k Zemi: evolučně ontologická reflexe př́rody, kultury, techniky a lidského poznání. Praha: Academia, 2008, p. 409-411.

${ }^{29}$ Šmajs, J.: Filosofie - obrat k Zemi: evolučně ontologická reflexe př́rody, kultury, techniky a lidského poznání. Praha: Academia, 2008, p. 409-411.

30 Šmajs, J., Binka, B., Rolný, I.: Etika, ekonomika, př́roda. Praha: Grada. 2012, p. 179-181.

${ }^{31}$ Šmajs, J., Binka, B., Rolný, I.: Etika, ekonomika, př́roda. Praha: Grada. 2012, p s. 181.
} 
information that can bring about the relevant sociocultural change must meet two different requirements at the same time:

1. At a generally acceptable level, it must affect the general public, the individual.

2. At the high professional level, it must intervene in the sphere of power - national, regional, and global politics.

In other words: Because culture is a system with its internal information (general even unique, individual), new sociocultural information is not enough only in the original theoretical form, i.e., abstract theoretical knowledge of philosophers, differentiated knowledge, feelings, and attitudes of experts are not enough. A one-tier academic vision of the world is not enough. If the objectively necessary process of positive ecological transformation of culture is to take place, the two above-mentioned practically applicable layers must be established in the newly emerging ecological consciousness." 32

However, it is up to everyone to decide how specifically they want to contribute to averting the threats that development has prepared for us. ${ }^{33}$

The very practice of environmental protection provides evidence of the rejection of the possibility of radicalization of Šmajs's work. This is generally based on both proposed points. We can therefore state (together with Librová's descriptions, the personal approach of the individual - whether colorful, green, or simply ecological education at school or family or fashion, a trend to which the second way contributes in the form of elites, but also the influence of transnational or international organizations through which ecological ideas can be better enforced) that the necessary development described is already occurring naturally. Šmajs's philosophy is, therefore, a real way to preserve life on Earth.

Let us recall, however, as evidence, for example, the shift and difference that took place in society in the 1980s and 1990s, as evidenced by the books Librová (Varieties and Greens $X$ Lukewarms and Hesitants), when ecology in the 1980s concerned individuals and their voluntary approach, while in the 1990s it became a fashion promoted by social elites. ${ }^{34}$

In addition, the connection of contemporary Czech thinkers with organized groups, which, however, remain in the limited form of Vavroušek's islands ${ }^{35}$, about which it can be assumed that in the future they will not expand into the majority population, but rather only increase the number of individual groups locally, which is also indicated by their trend towards decentralization, which again does not have an extremist effect. Even the very danger of radicalization is possible based on Bink's research ${ }^{36}$ refusal. „Fortunately, both the number of realistic ecologists and the number and importance of economists who can listen to the ecology-mediated message carefully and without prejudice seem to be growing," says Keller. ${ }^{37}$

In his books, Šmajs emphasizes the need to use education and its new reformed, proenvironmental, and at the same time interdisciplinary form as the main step leading to the preservation of nature, which is not understood as an ideology, but a simple necessity of life. It can be a satisfaction and a promise of further development leading from sustainable development to sustainable living on the example of the Policy Priorities of the Ministry of the Environment of 2008 from 2008, which on the one hand are minimized in some way, but on the other voluntary tools and approaches that are the basis of effective ecology and environmental protection. Another positive is that, despite the change of governments and

\footnotetext{
${ }^{32}$ Šmajs, J., Krob, J.: Evoluční ontologie. Brno: Masarykova univerzita. 2003, p. 238

${ }^{33}$ Keller, J.: Přemýšlení s Josefem Vavrouškem. Praha: Nakladatelství Karolinum. 1995, p. 158

${ }^{34}$ Cf.: Librová, H.: Vlažní a váhaví. Kapitoly o ekologickém luxusu. Brno: Doplněk, 2003, p. 271.

${ }^{35}$ Vavroušek, J.: Životni prostředi a sebeřizeni společnosti. Praha: Institut řízení, 1990, p. 81.

${ }^{36}$ Srov.: Binka, B.: Zelený extremismus. Ideje a mentalita českých environmentálních hnutí. Brno: Masarykova univerzita, 2008, p. 220.

${ }^{37}$ Keller, J.: Přemýšlení s Josefem Vavrouškem. Praha: Nakladatelství Karolinum, 1995, p. 73.
} 
ministers (when the latter preferred the priority in the form of Farmers' Markets), the original priorities of supporting volunteering have been maintained.

\section{CONCLUSION}

This work deals with the life work, ethics, and philosophy of Professor Josef Šmajs. It was divided into three parts. The first part introduces the basic ideas of his work. The second part discusses the practical issues of the need for change. The third part compares Šmajs' work with other authors.

Through evolutionary ontology, Šmajs characterizes himself as an ontology that is civically and socioculturally engaged. ${ }^{38}$ From his perspective, he describes the bleak state of contemporary society as a "culture of needs", resulting in a global ecological crisis. He says that the world is ruled by a predatory paradigm of culture that directly causes the devastation and exploitation of the Earth. Šmajs talks about the opposite trends of natural evolution and cultural evolution and their mutual conditionality when the cultural one is based on the natural one.

Furthermore, Šmajs acknowledges the Earth's legal personality and at the same time denies work its added value. He argues that ,nature has the highest possible value in itself, and human labor, on the contrary, reduces this unconditional value and turns it into cultural values only temporary and instrumental. ${ }^{639}$ As part of his proposed need to change the direction of biophilic ethics, together and according to the recognition of subjectivity to the Earth, he translates 11 points of the Evolutionary Ontological Minimum for teaching in schools and proposes to conclude a Lease Agreement with the Earth. It is a seven-point summary text that largely summarizes his teachings. In later texts and lectures, he then presents another proposal, which he is already working on together with many colleagues. It is a Declaration of Addiction, a text of 11 points, which again defines man's relationship to nature in the form in which every person should internally identify with it.

Prof. Šmajs represents one of the peaks of Czech ,green“ philosophy and ethics, among other things, precisely because of the emphasis on today's newly applied interdisciplinary studies. He must be granted a place in Czech philosophy, ethics and literature, and world philosophy and literature.

\section{Sources}

1. Binka, B.: Zelený extremismus. Ideje a mentalita českých environmentálních hnutí. Brno: Masarykova univerzita, 2008, 248 s. ISBN 978-80-210-4791-4

2. Keller, J.: Přemýšlení s Josefem Vavrouškem. Praha: Karolinum, 1995, 180 s. ISBN 80-901896-1-X

3. Librová, H.: Vlažní a váhaví. Kapitoly o ekologickém luxusu. Brno: Doplněk, 2003, 320 s. ISBN 80-7239-149-6

4. Šmajs, J.: Ohrožená kultura - od evolučni ontologie k ekologické politice. 3. přepracované a doplněné vydání doba, Brno: Host, 2011, 272 s. ISBN 978-80-7294458-3

5. Šmajs, J.: Potřebujeme filosofii přežití - Úvahy o př́rodě, kultuře, ekonomice, práci, poznáni a popularizaci vědy. 2. přepracované a doplněné vydání doba, Brno: Doplněk, 2011, 152 s. ISBN 978-80-7239-257-5

6. Šmajs, J.: Filosofie - obrat k Zemi: evolučně ontologická reflexe přirody, kultury, techniky a lidského poznání. Praha: Academia, 2008, 431 s. ISBN 978-80-200-1639-3

\footnotetext{
${ }^{38}$ Cf.: Šmajs, J., Krob, J.: Evoluční ontologie. Brno: Masarykova univerzita, 2003, p. 349.

39 Šmajs, J.: Potřebujeme filosofii přežití - Úvahy o př́rodě, kultuře, ekonomice, práci, poznání a popularizaci vědy. 2. přepracované a doplněné vydání doba, Nakladatelství Doplněk, Brno 2011, p. 87.
} 
7. Šmajs, J.: Filosofie psaná kurzívou. Rozhlasové ekologické eseje. Brno: Doplněk, 2003, 114 s. ISBN 80-7239-152-6

8. Šmajs, J.: Konflikt přirozené a kulturní evoluce. Brno: Masarykova univerzita. 1997. 48 s. ISBN 80-210-1506-3

9. Šmajs, J., Binka, B., Rolný, I.: Etika, ekonomika, príroda. Praha: Grada, 2012, 192 s. ISBN 978-80-247-4293-9

10. Šmajs, J., Binka, B., Timko, M.: Tři studie z environmentální filosofie. Brno: Masarykova univerzita, 2011, 136 s. ISBN 978-80-210-5416-5

11. Šmajs, J., Klíma, I., Cílek, V.: Tři hlasy. Úvahy o povaze konfliktu kultury s př́rodou. Brno, Doplněk, 2010, 168 s. ISBN 978-80-7239-252-0

12. Šmajs, J., Krob, J.: Evoluční ontologie. Brno: Masarykova univerzita, 2003, $400 \mathrm{~s}$. ISBN 80-210-3038-0

13. Šmajs, J., Krob, J.: Úvod do ontologie. 2. opravené a rozšířené vydání. Brno: Masarykova univerzita, 1994, 216 s. ISBN 80-210-0879-2

14. Vavroušek, J.: Životní prostředí a sebeřizení společnosti. Praha: Institut řízení, 1990, 186 s. ISBN 80-7014-026-7

15. Josef Šmajs, životopis, [on line]. [cit. 2. 5. 2021]. Dostupné z: $<$ http://www.databazekn ih.cz/zivotopis/josef-smajs-8670>

\section{Authors}

JUDr. RNDr. PhDr. Ing. Jan Lípa, Ph.D., DBA, M.Div., LL.M.

Charles University in Prague, First Faculty of Medicine, Institute for Medical Humanities, Kateřinská 32, 121 08, Praha 2,

Middle West University, Inc., Opletalova 23, 110 00, Praha 1

E-mail: jan.lipa@centrum.cz

JUDr. Ladislav Rozenský, Ph.D., DBA

Charles University in Prague, First Faculty of Medicine, Institute for Medical Humanities, Kateřinská 32, 121 08, Praha 2,

Middle West University, Inc., Opletalova 23, 110 00, Praha 1

E-mail: rladislav@seznam.cz

Ing. Petr Ondrušák

Charles University in Prague, First Faculty of Medicine, Institute for Medical Humanities, Kateřinská 32, 121 08, Praha 2,

Middle West University, Inc., Opletalova 23, 110 00, Praha 1

E-mail: petr.ondrusak@ seznam.cz

PhDr. Zdeněk Vrba, Ph.D., DBA, LL.D.

Charles University in Prague, First Faculty of Medicine, Institute for Medical Humanities, Kateřinská 32, 121 08, Praha 2,

Middle West University, Inc., Opletalova 23, 110 00, Praha 1

E-mail: vrba@1az.cz

Prof. Dr. Josef Dolista, Th.D., Ph.D., LL.M., Dr. h. c.

Charles University in Prague, First Faculty of Medicine, Institute for Medical Humanities, Kateřinská 32, 12108 , Praha 2,

Charles University in Prague, Hussite Theological Faculty, Pacovská 350/4, 14021 Praha 4

E-mail: josef.dolista@1f1.cuni.cz 


\title{
FENOMÉN TÁRANINY \\ V MEDIÁLNEJ CELEBRITIZÁCII MARIÁNA KOČNERA
}

\author{
THE PHENOMENON OF BULLSHIT \\ IN THE MEDIA CELEBRITIZATION OF MARIÁN KOČNER
}

\author{
Anna Sámelová
}

\begin{abstract}
Abstrakt
Termíny táranina, zmediálnenie, infotainment, tri významné príspevky k spoločenskovednému poznaniu poslednej tretiny 20. storočia, súviseli s akceleráciou i nárastom intenzity médiami sprostredkovanej komunikácie. $\mathrm{V}$ tom čase však ešte nemohli reflektovat' realitu sociálnych médií nadchádzajúceho 21 . storočia. Tá posunula komunikačné štandardy mediálnych obrazov do výrazne emocionálnejšej roviny než zvykli stále ešte racionálne inštitúcie tradičných vydavatel'ov a vysielatel'ov. Prevalencia emocionality v médiami sprostredkovanej komunikácii však viedla aj $\mathrm{k}$ nárastu táranín ako fenoménu verejného priestoru $\mathrm{v}$ online dobe. Na príklade verejného imidžu Mariána Kočnera ako celebrity sa $\mathrm{v}$ tejto súvislosti štúdia zaoberá miestom táraniny $\mathrm{v}$ dnešných mediálnych štandardoch.
\end{abstract}

Kl'účové slová: médiami sprostredkovaná komunikácia, infotainment, celebritizácia, racionalita, emocionalita, Marián Kočner

\begin{abstract}
The terms "bullshit", "mediatization", and "infotainment", the three distinguished contributions to the social science knowledge of the last third of the $20^{\text {th }}$ century, were related to the increase of intensity as well as acceleration of media-mediated communication. At the time, however, they could not yet reflect the reality of social media of the upcoming $21^{\text {st }}$ century. It has shifted the communication standards of the media outputs to a significantly more emotional level than the still rational institutions of traditional publishers and broadcasters. The prevalence of emotionality in media-mediated communication also results in an increase of bullshit as the phenomenon of public arena in the online era. In this context, the study deals with the role of the phenomenon of bullshit in today's media standards on the example of Marian Kočner's public image as a celebrity.
\end{abstract}

Key words: media-mediated communication, infotainment, celebritization, rationality, emotionality, Marián Kočner

\section{1 ÚVOD}

Termín „táranina“ zaviedol do komunikačných štúdií americký filozof Harry G. Frankfurt v roku 1986, čiže v rovnakom čase ako Švéd Kent Asp vo svojej dizertačnej práci odhalil a pomenoval „zmediálnenie“ (medialitizáciu), a americký teoretik médií, Neil Postman, vydal monografiu Amusing Ourselves to Death (angl. Pobavit' sa na smrt'), ktorá precízne vysvetl'ovala zmeny komunikačných štandardov tzv. veku zábavy, t. j. obdobia po vstupe vysielacích médií (rozhlasov a televízií) do života spoločnosti. Každý z týchto termínov odkazuje na špecifickú oblast' reality - vzt'ah rečníka k pravde, vzt'ah verejných aktérov k médiám, nároky médií na publikum - všetky tri spoločne však umožňujú pochopit' 
mechanizmus mediálnej celebritizácie a dôvody, pre ktoré tak rýchlo a l’ahko ovládla verejnú sféru.

V nasledujúcom texte najskôr stručne vysvetlíme, čo je táranina, zmediálnenie a infotainment, v druhej kapitole sa sústredíme na premeny mediálneho obrazu Mariána Kočnera $\mathrm{v}$ uplynulých troch dekádach a v závere zhodnotíme ich podiel na mediálnej celebritizácii tejto kontroverznej osobnosti slovenskej podnikatel'skej a spoločenskej scény.

\section{TÁRANINA, MEDIALITIZÁCIA, INFOTAINMENT}

Táranina je eufemizmom anglického výrazu bullshit. Presnejším prekladom by boli kecy, alebo dokonca ktorýkol'vek z expresívnych výrazov so živočíšnym odkazom: kravina, volovina, capina, somarina, hovadina. Pre ich spoločenskú nedôstojnost' však zostaneme pri eufemizme táranina. Americký filozof Harry G. Frankfurt ju definoval ako reč bez vzt'ahu k pravde. Vo svojej eseji On Bullshit (1986) analyzoval tárajstvo (bullshitting) na pozadí pojmov klamstva (lie), klamlivého skreslenia (deceptive misrepresentation) a humbugu (humbug), čiže švindl'a či balamutenia. Z tejto filozofickej reflexie vyplynulo, že táranina je taký obsah, ktorý sa nijako nemá k pravde. Táraja totiž pravdivost' či nepravdivost' jeho výpovede vôbec nezaujíma. Presnejšie, nestará sa o ňu. „Práve tento nedostatok záujmu o pravdu - túto l'ahostajnost' $k$ tomu, ako sa veci v skutočnosti majú“, označil Frankfurt ,za podstatu táraniny " (Frankfurt, online, s. 10). Dôležitým je tu práve moment zlyhania - táraj nie je klamár ani fabulant, on nezlyháva v tom, že by klamal, zahmlieval, alebo si vymýšl’al. Jeho zlyhaním je, že sa o pravdivost' svojej výpovede ,,ani neusiluje “ (Frankfurt, online, s. 10), že je mu to jedno. On si len tak reční bez ohl'adu na to, aké prázdne, bezobsažné, neužitočné či nezmyselné jeho reči sú. Sú to skrátka táraniny.

Zmediálnenie (medialitizácia) je prekladom švédskeho termínu medialisering ( $\mathrm{v}$ angličtine mediatization). ${ }^{1}$ Termín zaviedol Švéd Kent Asp vo svojej dizertačnej práci Mäktiga massmedier: Studier i politisk opinionsbildning (švéd. Mocné masové médiá: Štúdie o formovani politickej mienky) (Asp, 1986), samotnú teóriu medialitizácie kultúry a spoločnosti potom vypracoval dánsky teoretik médií Stig Hjarvard (2013). Aspove analýzy ukázali, že masmédiá významne zmenili politickú komunikáciu a politiku vôbec, ked' dosiahli, že sa politici a verejnost' začali prispôsobovat' ich redakčným požiadavkám. Nielen v oblasti vystupovania, vizáže či termínov nahrávania relácií, ale aj v oblasti vhodnosti či nevhodnosti konkrétnej témy, udalosti, javu alebo osoby na prezentáciu v médiách, t. j. na medializáciu: „politický systém vo vel'kej miere ovplyvňujú médiá a upravuje sa podla dopytu masových médií na mediálne pokrytie politiky" (Asp, 1986, s. 359). K rovnakým zisteniam dospel tiež v polovici 80. rokov 20. storočia aj americký teoretik médií, Neil Postman: ,,ve světě televize a ostatnich vizuálních médii se pod pojmem "politická zkušenost « skrývá spíše schopnost disponovat obrazy než vládnout slovy“ (Postman, 1999, s. 138). Postmana zaujala „změna významu pojmu »být informován«, vyvolaná jistým druhem televizí produkovaných informací, jimž by ovšem slušelo označeni dezinformace. [...] Dezinformace není nepravdivá informace. Je to zavádějicí informace - nepatřičně užitá, nepodstatná, útržkovitá nebo povrchní -, informace, která vytvář́ iluzi, že něco víme, ale ve skutečnosti nás od poznání odvádí (Postman, 1999, s. 115). Všíma si tiež absenciu kontextu a kontinuity v mediálnych posolstvách vysielacích médií, ktorá spôsobuje, že jednotlivé informácie nemožno integrovat' do rozumného a konzistentného celku, pretože „,médium jež informaci předkládá v podobě, která ji trestuhodně zjednodušuje, zbavuje ji podstaty, historického rozměru a kontextu; výsledkem je informace v rouše zábavy" (Postman, 1999, s. 146-149). V neposlednom rade zaujala Postmana trivializácia verejných informácií: „,Tím, že nám předkládá zprávy v podobě

\footnotetext{
${ }^{1}$ Podrobnosti o dôvodoch, prečo by sa nemal anglický termín mediatization, ktorý pochádza z tohto švédskeho medialisering, prekladat' $\mathrm{v}$ slovenčine ani $\mathrm{v}$ češtine ako mediatizácia, ale práve ako medialitizácia, t. j. zmediálnenie, uvádzam v Sámelová, 2016, s. 120.
} 
kabaretu, vyvolává televize podobné chování i u ostatnich médií, takže celkové informační prostředí se postupně stává zrcadlovým obrazem televize“ (Postman, 1999, s. 119). A tu sa dostávame $\mathrm{k}$ tretiemu termínu - infotainment.

Infotainment je informovanie prostredníctvom zábavy a zároveň zábava prostredníctvom informovania. Termín vznikol zlúčením dvoch anglických výrazov information (informácia) a entertainment (zábava), jeho používanie v spoločenských a humanitných vedách sa tiež datuje do polovice 80. rokov minulého storočia, hoci samotný výraz je starší (viac: Thussu, 2007). Princípom je zistenie, že každú dôležitú serióznu informáciu možno v médiách zobrazit' a prezentovat' formou zábavy, a zároveň sa z každej banálnej informácie dá vytvorit' mediálny obraz jej významnosti a serióznosti. „,V̌semu vládne predpoklad, že jakoukoli informaci, př́běh nebo myšlenku lze předložit okamžitě srozumitelným způsobem; nejvyšší metou totiž není obohacení diváka o nové poznatky, nýbrž jeho spokojenost " (Postman, 1999, s. 157). Infotainment sa tak stal súčast'ou informovania rovnako o parlamentných rokovaniach, ako aj o celebritných večierkoch (viac: Vögele, 2011).

\section{MEDIÁLNA CELEBRITIZÁCIA MARIÁNA KOČNERA}

Celebritizmus je médiami sprostredkovaná forma slávy. Verejnou úlohou celebrity je urobit' všetko pre to, aby bola a zostala slávnou. Nemusí to nutne byt' niečo hodné verejného uznania či nasledovania, stačí, aby to bolo dostatočne atraktívne na zaujatie publika. Pozitívne alebo negatívne konotácie medializácie nehrajú v kontexte celebritizácie zásadnú rolu. Celebritou sa tak môže stat', a často sa aj stáva, nielen úspešný odborník, športovec, herec či filantrop, ale aj človek s pochybnou povest’ou, dokonca kriminálnik (viac: Sámelová, 2020). Práve takú rolu mediálnej celebrity zastáva na Slovensku kontinuálne od 90. rokov 20. storočia Marián Kočner.

Vplyv slovenských médií na jeho celebritizácii je predmetom širšieho grantového výskumu, ktorého súčast’ou je aj táto štúdia. Ked’že sme však s výskumným tímom len na začiatku analýz mediálnych výstupov, ktoré viedli k celebritnému obrazu tohto spoločensky i politicky vplyvného muža na Slovensku, nateraz budem vychádzat' zo záverov nedávnych analýz kolegov z Paneurópskej vysokej školy v Bratislave, Martina Kasardu a Antona Szomolányiho: Analýza - Marián Kočner v médiách v rokoch od 2006 do 2018, ako aj zo skorších vlastných výskumov týkajúcich sa Mariána Kočnera a kauzy Gamatex (Sámelová, 2018a, 2018b, 2019). „Mediálny obraz Mariána Kočnera odkrýva nielen príbeh vzostupu a pádu konkrétneho človeka, ale ukazuje aj pochybenia, omyly i krehkost' mediálnej scény a jej interpretácie spoločenského a politického diania “ (Kasarda, Szomolányi, online, s. p.).

Marián Kočner je vyštudovaný žurnalista, no jeho mediálna sláva sa nespája s výkonom novinárskeho povolania, ale s luxusným spôsobom života, bohatstvom, okázalým vystupovaním, podnikaním, politikou, tajnými službami i organizovaným zločinom. Do intenzívneho záujmu slovenských médií vstúpil v roku 1995 po zavlečení syna vtedajšieho prezidenta republiky Michala Kováča do Rakúska. Bol totiž spolu s prezidentovým synom aktérom medzinárodného vyšetrovania fiktívneho obchodu $\mathrm{s}$ textilom a neuhradenými pohl'adávkami v kauze Technopol. Z mediálneho hl'adiska vznikla vtedy relatívne neprehl'adná situácia oficiálneho vyšetrovania v zahraničí na jednej strane, spravodajských hier slovenskej tajnej služby nepriatel'ských k prezidentovi Kováčovi, a teda aj k jeho synovi, na strane druhej a kontroverzného zneužívania verejnoprávnej televízie a rozhlasu na prezentáciu takého mediálneho obrazu aktérov, ktorý vyhovoval vtedajšej vládnej moci na čele s Vladimírom Mečiarom. Marián Kočner tak požíval mediálny status podnikatel'a $\mathrm{v}$ problémoch, ktorých zavinenie nemuselo byt' nutne na jeho strane. Amnestie prezidenta Kováča udelené (v záujme vyšetrenia kauzy Technopol nemeckými orgánmi) tak svojmu synovi, ako aj Mariánovi Kočnerovi, tomuto mediálnemu obrazu napomohli. 
Diametrálne odlišný mediálny obraz Mariána Kočnera vznikol v roku 1998 v súvislosti s kauzou Gamatex. Išlo v nej o vlastnícky boj o súkromnú televíziu Markíza medzi pôvodnými vlastníkmi (P. Rusko a S. Volzová) a novými vlastníkmi zo spoločnosti Gamatex, ku ktorým patril aj Marián Kočner. Spory vyústili do obsadenia sídla televízie ozbrojenou súkromnou bezpečnostnou službou Gamatexu, do otvoreného odporu zamestnancov, ktorí vyzvali občanov, aby ich prišli podporit' pred budovu televízie, a napokon aj do obdobia občianskych protestov za slobodu tlače, t. j. televízie Markíza. Mediálny obraz Mariána Kočnera sa posunul do roviny nového majitel'a súkromnej televízie, ktorý považoval za normálne, že svoju televíziu obsadí armádou ozbrojených mužov, aby zabránil vstupu bývalého majitel'a do budovy.

V nasledujúcich rokoch bol nad’alej predmetom záujmu médií ako podnikatel' v oblasti prevodu majetkov, budov, obchodovania s informáciami, prepájania biznisu a politiky. Jeho meno sa vyskytuje aj v tzv. Mafiánskych zoznamoch. Býval pravidelným objektom celebritného magazínu televízie Markíza, Smotánka, kde ho zobrazovali ako úspešného, št’astného muža žijúceho luxusný život podnikatel'a. Mediálny obraz Mariána Kočnera postupne získaval prívlastky od „,známa tvár“, „,boháč“, „rekreant a hotelier z Donovalov“ cez „kontroverzný podnikatel' z Mafiánskych zoznamov“ a „závadová osoba“ až po „podozrivý z daňových podvodov“, „trestne stíhaný“, „zatknutý podnikatel““, či „možný objednávatel' vraždy“ (Kasarda, Szomolányi, online, s. p.). Nedávne odsúdenie Mariána Kočera v kauze falošných zmeniek na 19 rokov väzenia a jeho obžalovanie ako zadávatel’a vraždy investigatívneho novinára Jána Kuciaka (2018) opät' menia optiku náhl'adu slovenských médií na túto kontroverznú, no stále celebritnú postavu súčasnosti.

\section{ZÁVER}

Tridsat' rokov trvajúca prítomnost' Mariána Kočnera ako celebrity v slovenskom mediálnom mainstreame, hoci s ambivalentnými prívlastkami, je dôsledkom prelínania prehlbujúcej sa medialitizácie spoločnosti a kultúry, infotainmentu a tárania vo verejnom priestore. S osobitným dôrazom práve na akceleráciu fenoménu tárania v médiách po nástupe internetu a sociálnych sietí. Tie si vynútili odklon aj tradičných médií od bývalých novinárskych štandardov. Jednak $\mathrm{v}$ oblasti ústupu prezentácie ucelených príbehov $\mathrm{v}$ prospech fragmentárnych informácií, jednak $\mathrm{v}$ akceptovaní špecifického posudzovania kvality mediálneho výstupu na základe publikom pridelených páčikov - „lajkov“. Vzt’ah médií k pravdivému zobrazeniu skutočnosti sa významne zmenil. Niežeby prestali platit’ nároky na overené a overitel'né fakty, no oddel'ovanie faktov od názorov, správ od komentárov sa rozostrilo. Podstatným kritériom redakčnej činnosti je získat' vysoký počet kliknutí na daný text, zvuk, obraz zo strany publika. Preto sa redakcie uchyl'ujú k publikovaniu fragmentov oddelených od kontextu.

Táto prax má svojho predchodcu v televíznom a rozhlasovom infotainmente druhej polovice 20. storočia, ktorý si postupne osvojila aj periodická tlač, no jej rozsah a intenzita sa technologickými možnost’ami online médií znásobila. Mediálne výstupy aj profesionálnych renomovaných redakcií tak čoraz viac pripomínajú táraniny z Frankfurtovej definície. Neodvážia sa publikovat' otvorené lži, to by bolo pre tradičné médiá likvidačné aj imidžovo aj doslova, no táranie v podobe bezkontextových fragmentov je, zdá sa, nateraz bezpečným východiskom. Každý jeden publikovaný dielec je pravdivým obrazom, ale bez kontextu sa mozaika nevytvorí, alebo vytvorí len t’ažko. A to platilo už aj v čase pred nástupom internetu: „Nechte zmizet kontext - nebo jej rozbijte -, a zmizi $i$ kontradikce. [...] Základním předpokladem tohoto světa není koherence, ale diskontinuita. A ve světě diskontinuity je protiklad jako zkouška pravdivosti či hodnoty zbytečný, protože protikladnost $v$ něm jednoduše neexistuje " (Postman, 1999, 118). 
Práve diskontinuita $\mathrm{v}$ medializácii bezkontextových fragmetárnych informatizácií, nazdávam sa, nielenže prispela, ale priamo umožnila celebritizáciu Mariána Kočnera. Ucelený príbeh jeho verejného pôsobenia $\mathrm{v}$ úplnom kontexte, ktorý bol $\mathrm{v}$ danom čase médiám $\mathrm{k}$ dispozícii, by totiž bez sklonu médií $\mathrm{k}$ táraninám vytvoril nepochybne iný mediálny obraz. Zároveň však platí, že by to bol obraz podstatne menej prít'ažlivý pre čitatel'ov, poslucháčov a divákov slovenských médií, ktorí, podobne ako mediálne publikum v mnohých d’alších krajinách Západu, je od čias zrodu moderných masmédií nastavené viac na zábavné táraniny než na kritické zvažovanie serióznych informácií. „Diktátorští vládci všeho druhu odjakživa dobře věděli, jakou hodnotu má zábava jako prostředek otupení nespokojenosti mas. Většina z nich se však neodvážila doufat, že by někdy mohla nastat situace, kdy masy budou všechno, co není zábava, zcela ignorovat" (Postman, 1999, 150).

Pod’akovanie: Príspevok vznikol v rámci výskumného projektu VEGA č. 1/0203/21: Vplyv médii na spoločenský status celebrit: premeny mediálneho obrazu Mariána Kočnera $v$ slovenskej spoločnosti.

\section{Použitá literatúra}

1. ASP, K. (1986). Mäktiga massmedier: Studier $i$ politisk opinionsbildning. Stockholm: Förlaget Akademilitteratur AB. ISBN 91-7410-334-2. https://www.g u.se/jmg/maktiga-massmedier

2. FRANKFURT, H. G. (1986). On Bullshit. In Raritan Qaurterly, 6 (2), [s. p.]. ISSN 0275-1607.

3. FRANKFURT, H. G. On Bullshit. In www2.csudh.edu. http://www2.csudh.edu/ccauthen/576f12/frankfurt_harry_-_on_bullshit.pdf.

4. HJARVARD, S. (2013). The Mediatization of Culture and Society. New York: Routledge. ISBN 978-0-415-69237-3.

5. KASARDA, M. - SZOMOLÁNYI, A. [s. a.]. Analýza - Marián Kočner v médiách v rokoch od 2006 do 2018. Kontroverzný podnikatel': glorifikácia podvodov, rešpekt k manipulácii a naivná reflexia zločinu. Bratislava: Fakulta masmédií PEVŠ. https://www.paneurouni.com/aktuality-masmedii/analyza-marian-kocner-v-mediachv-rokoch-od-2006-do-2018/.

6. POSTMAN, N. (1999). Ubavit se k smrti: Veřejná komunikace ve věku zábavy. Praha: Mladá fronta. ISBN 80-204-0747-2.

7. SÁMELOVÁ, A. (2020). Celebrity v mediálnom priestore: metamorfóza obyčajnej nezvyčajnosti na nezvyčajnú obyčajnost'. In Otázky žurnalistiky, 63(1-2), s. 12-18. ISSN 0322-7049.

8. SÁMELOVÁ, A. (2016). Medialitizácia a zábavné umlčanie: dva aspekty sociálnej konformity. In Normativita ako vôl'a kporiadku. Bratislava: Univerzita Komenského, s. 120-148. ISBN 978-80-223-4216-2.

9. SÁMELOVÁ, A. (2018a). Naratívy a diskurz mediálnej normalizácie 1998, 2008, 2018. In Otázky žurnalistiky, 61(3-4), s. 37-49. ISSN 0322-7049.

10. SÁMELOVÁ, A. (2018b). Paradigmy mediálnej normalizácie 1998, 2008, 2018. In Otázky žurnalistiky, 61(1-2), s. 37-49. ISSN 0322-7049.

11. SÁMELOVÁ, A. (2019). Sloboda médií ako dráma a fraška slovenskej mediálnej normalizácie. In Acta moralia Tyrnaviensia IX : Dráma slobody v slovanskom svete 20. storočia. Krakow: Tovarzystwo Słowakóv w Polsce, s. 243-250. ISBN 978-838111-119-5.

12. THUSSU, D. K. (2007). News as Entertainment: The Rise of Global Infotainment. London: Sage. ISBN 978-0-7619-6879-5. 
13. VÖGELE, M. (2011). Infotainment. Characteristics, History and Problems. Munich: Grin Verlag. https://www.grin.com/document/210681.

\section{Kontaktné údaje}

PhDr. Anna Sámelová, PhD.

Univerzita Komenského v Bratislave, Filozofická fakulta

Štúrova 9, 81102 Bratislava, Slovenská republika

Tel.: +421290132419

email: anna.samelova@uniba.sk 


\title{
LABOR LEGISLATION UNDER THE INFLUENCE OF THE COVID-19 PANDEMIC AND THE NEED OF HOME OFFICE / TELEWORK
}

\author{
Silvia Trel'ová
}

\begin{abstract}
As a result of the spread of the COVID-19 disease, as in other countries, as well as in the Slovak Republic, several extraordinary measures were taken, which significantly affected the area of employment relations of employees. Legislative changes were also brought about by the amendment to the Labor Code, in relation to several labor law institutes - performance of work outside the employer's workplace (domestic work, telework, home office), scheduling of working hours, paid holiday, quarantine measures as an obstacle on the part of the employee, suspension or restriction of the employer's activities as an obstacle to work on his part. In our article, we point out the changes of a temporary and permanent nature that the new legislation brought during the pandemic.
\end{abstract}

Key words: COVID-19, domestic work, telework, home office, right to disconnect, paid leave, obstacle to work, employee, employer

\section{INTRODUCTION}

From 12 March 2020, the Government of the Slovak Republic declared an emergency situation and an immediate state of emergency in connection with the risk of the spread of the COVID-19 disease throughout the Slovak Republic. The coronavirus pandemic, its causes and consequences significantly affect labor relations, which ultimately has a negative impact on the lives of employees, lives of employers, as well as on the lives of families as such, as they are dependent on regular income, respectively profits for entrepreneurs in the positions of employers.

Given that the protective function of labor law is characteristic of this branch of law and continues to hold a dominant position among the functions of labor law, several legislative changes in the field of employment relations, which regulate the rights and obligations of employees and employers, were adopted during the pandemic period. In our article, we will focus only on that part of the legislative measures that have been taken to mitigate the effects of the spread of COVID-19, specifically those that have affected employees and employers in the performance of dependent work.

\section{LEGISLATIVE ARRANGEMENTS FOR THE TIME OF EXTRAORDINATION, EMERGENCY OR EXCEPTIONAL STATE}

Act no. 66/2020 Coll. which supplements Act no. 311/2001 Coll. The Labor Code, as amended, and which also supplements certain other laws (hereinafter referred to as the "amendment to the Labor Code"), entered into force on 4 April 2020 in order to implement a measure to prevent the emergence and spread of communicable diseases or measures to endanger public health. The amendment to the Labor Code legislated some institutes and ordered that the legislation be applied not only during the time of extraordination, emergency or exceptional state, but also during the period following two months after their revocation. The mentioned legal regulation has the nature of a new, eleventh part of the Labor Code, which has become a permanent part of the Labor Code - measures in the form of these provisions are of a long-term nature. The temporary provisions are in the form of special legal 
regulations concerning the termination of employment for a definite time, which supplemented the transitional provisions with Section 252o with effect from 17 June 2020.

\subsection{Home office}

The first area that required legislation in order to continue to work and at the same time restrict the association of employees in one place was the area of the place of work. With this amendment to the Labor Code, the employer gained a temporary right to order the employee to work from the employee's household (the so-called ordered home office) and the employee acquired the right to perform work from his household. The precondition for the exercise of this right is the fact that the work performed by the employee allows it and there are no serious operational reasons on the part of the employer that do not allow the performance of work from home. As far as the employer is concerned, this employer may order a home office, even if the employee does not agree with this procedure. As a result of the exercise of these rights, the Slovak Republic also recorded a large increase in the number of employees who worked from their households as a result of the pandemic situation.

The fact that the possibility to work from home is a significant corporate benefit, as well as one of the forms of work performance that employers have often offered to their employees, cannot be denied. Despite this fact, it should be pointed out that teleworking "has not been more widely used so far, as many participants in labor relations have resisted this form of cooperation, pointing to the need to ensure sufficient social contacts and team building and fears of reduced labor productivity. However, these forms have proved to be not only possible, but in many cases may also be appropriate, economically and less time-consuming, and yet effective, both in terms of the amount of work performed and in terms of reconciling work and family life." "Given that the home office is also expanding into sectors and professions where it was unimaginable before the COVID-19 pandemic, it will probably no longer be associated only with "good employment" and will also overcome the view of this form of work organization as a benefit.",

However, in connection with the performance of work outside the employer's workplace, we emphasize that the obligation to agree with the employee on the performance of domestic work, which has a permanent character (so-called domestic work, teleworking), remains.

\subsection{An important personal obstacle to work on the part of the employee for special reasons}

The mentioned legislative regulation also touched on important personal obstacles to work, which are "a specific group of obstacles which, in terms of their name, already expressly lie in the specific subjective reasons of the employee ${ }^{3 "}$. This amendment to the Labor Code manifested the protective function of labor law, as it concerns the protection of the employee before the termination of employment, as well as the return of the employee to employment after the end of the obstacle.

Act no. 311/2001 Coll. The Labor Code, as amended (hereinafter referred to as the "Labor Code"), extensively formulates the reasons for the ban on dismissal (protection period) and exhaustively defines the obstacles to work on the part of the employee, where the employer is

\footnotetext{
${ }^{1}$ LANG, R. Závislá práce v době koronaviru - sociálněprávní souvislosti. AUC IURIDICA 67(2), Máj 2021, s. 132. [online]. DOI: https://doi.org/10.14712/23366478.2021.18

${ }^{2}$ KYZLINKOVÁ, R., VEVERKOVA, S., VYCHOVÁ, H. Práce z domova - popis stavu před pandemií a možné konsekvence do nových poměrů organizace práce. In FÓRUM sociální politiky 5/2020, s. 9.

${ }^{3}$ HAMULÁK. J. Prekážky v práci. In: Slovenské pracovné právo, Bratislava, Sprint 2 s.r.o., 2019, s. 449.
} 
obliged to place the employee in his original job and workplace. One of these facts is temporary incapacity for work. According to $\S 64$ par. 1 letter a) of the Labor Code, the employer may not give the employee dismissal during the protection period, which also means the period "when the employee is temporarily declared incapable of work due to illness or injury, unless he intentionally caused this incapacity or caused it under the influence of alcohol, drugs or psychotropic substances". An employee who is temporarily recognized as incapacitated for work is considered, temporarily in a crisis situation, also an employee who has an important personal obstacle at work due to quarantine measures, isolation, personal and full-time care of a sick family member or personal and full-time care for a natural person and to whom the nursing benefit belongs. It follows from the above that this employee is also subject to a prohibition on dismissal. It is true that ,in the presence of obstacles to work for which sickness insurance benefits are provided, the employee does not have to apply to the employer for leave, but it is sufficient if he proves the obstacle to work. The Labor Code stipulates the obligation of the employee to inform the employer about the obstacle to work without undue delay. The employer is obliged to justify the absence of the employee at work. ${ }^{4 "}$

Based on the provisions of $\S 157$ par. 3 of the Labor Code, ,if the employee returns to work after the end of temporary incapacity for work or quarantine (quarantine measure), the employer is obliged to assign him to the original work and workplace. If reassignment to the original job and workplace is not possible, the employer is obliged to reassign him to another job corresponding to the employment contract." Even in this case, temporarily in a crisis situation, an employee who returns to work after isolation, personal and full-time treatment of a sick family member according to a special regulation or personal and full-time care of a natural person is considered for these purposes as an employee who returns to work after temporary incapacity for work and the employer is obliged to assign him to his original job and workplace.

\subsection{Working time and its schedule}

One of the basic issues of labor law is the issue of dependent work. From the legislative point of view, the definition of the term dependent work is enshrined in $\S 1$ par. 2 of the Labor Code, while one of the defining features of dependent work is working time as a special category of labor law. This legislation defines the concept of working time as the period of time during which the employee is available to the employer, performs work and fulfills obligations in accordance with the employment contract. „Working time is one of the basic characteristics of the protective function of labor law, as it determines the boundary between working and non-working life (currently the more commonly used term of personal life) of the employee." ${ }^{5}$ Although working time is an important tool for the employer with elements of flexibility, the distribution of working time, respectively. changes in the schedule of working hours, the employer is obliged to notify the employee at least one week in advance and valid for at least a week. In times of crisis, the employer has to fulfill this obligation in a shorter period, at least two days in advance and valid for at least a week, while the employer has the opportunity to agree with the employee on a shorter notice period of working hours.

\subsection{Paid leave}

While during working hours the employee is obliged to fulfill the obligations arising from the employment contract, he does not have this obligation during non-working hours, ie during

\footnotetext{
${ }^{4}$ BARANCOVÁ, H. a kol. Zákonník práce. Komentár. 2. vydanie. Bratislava: C.H. Beck, 2019, s. 1107

${ }^{5}$ HAMULÁK. J. Pracovný čas a doby odpočinku. In: Slovenské pracovné právo, Bratislava, Sprint 2 s.r.o., 2019, s. 383.
} 
rest periods. The most important period of rest is leave, as an institute aimed at ensuring the regeneration of the workforce and should therefore represent a longer-term rest for the work performed. In view of this fact, the legislator set the minimum amount of leave per calendar year and adjusted the rules for drawing it.

The basic period of leave is at least four weeks, for an employee who reaches the age of at least 33 by the end of the relevant calendar year, and for employees who are permanently caring for a child ${ }^{6}$, the period of leave is at least five weeks. Leave shall be for at least eight weeks in a calendar year in the case of a teaching and professional staff member, university teacher, researcher and artist of a public or public university, staff member with at least a second-cycle university degree pursuing research or teaching or scientific activities. activity, research activity and development activity at the research workplace of the SAS organization, a public research institution or a state budget organization or a state contributory organization carrying out research established by a central state administration body.

The use of leave is determined by the employer after consultation with the employee according to the leave plan determined with the prior consent of the employees' representatives so that the employee can usually take the leave in full and by the end of the calendar year. The employer is obliged to notify the employee at least 14 days in advance of the use of leave. This period may exceptionally be shortened with the consent of the employee.

The amendment to the Labor Code in connection with the crisis situation interferes with only one rule regarding the determination of drawing leave. Due to the dynamically changing situation, the time in which the employer notifies the employee in advance of the use of leave is reduced from at least 14 days to at least 7 days. The rule still applies that the employee can give consent, resp. request a drawdown in a shorter time. This amendment to the Labor Code did not affect either the provisions on the rights of employees' representatives or the rules according to which the tasks of the employer and the legitimate interests of the employee must be taken into account when determining leave.

\subsection{Obstacle to work on the part of the employer}

With regard to obstacles to work on the part of the employer, as well as with obstacles to work on the part of the employee, they represent facts in which the fulfillment of rights and obligations arising from a specific employment relationship is temporarily suspended. The current legislation distinguishes between four areas of obstacles to work on the part of the employer, namely: downtime, adverse weather conditions, other obstacles to work and obstacles to work due to serious operational reasons. In the case of each of these obstacles to work, the employee is entitled to paid leave, in a certain amount of the employee's average earnings. In case of adverse weather conditions it is at least $50 \%$ of the employee's average earnings, in case of other obstacles to work at least $60 \%$ of the employee's average earnings, in case of downtime and obstacles to work due to serious operational reasons defined in the employer's written agreement with employees' representatives i tis a $100 \%$ compensation of the employee's wage. In the event of the time of extraordination, emergency or exceptional state and for two months after their dismissal with effect from 4 April 2020, if the employee is unable to work in whole or in part to suspend or restrict the employer's activity by decision of

\footnotetext{
${ }^{6}$ An employee permanently caring for a child for the purposes of the Labor Code is an employee who personally cares for his or her own minor, including alternating personal care of both parents, and an employee who personally cares for a minor child entrusted to his or her care in place of parental care. ( $\$ 40$ par. 11 of the Labor Code)
} 
the competent authority (Public Health Authority decision) or for the cessation or restriction of the employer's activities (closure of the operation as a preventive measure based on a voluntary decision of the employer), this is another set of obstacles to work on the part of the employer. In this area of obstacles to work on the part of the employer, the employee is entitled to compensation of wages in the amount of $80 \%$ of his average earnings, but at least in the amount of the minimum wage. In this context, however, it should be noted that the legislation is without prejudice to any written agreements between employers and employees' representatives governing obstacles to work on the part of the employer for serious operational reasons. This provision does not apply to employees of economic mobilization entities in which a duty of employment has been imposed.

\subsection{Termination of employment for a definite time}

Under current legislation, a fixed-term employment relationship can be agreed for a maximum of two years and can be extended or renegotiated within a maximum of two years, up to a maximum of twice (exceptions exist).

Pursuant to the amendment to the Labor Code, this restriction on the extension of the employment relationship does not apply at the time of extraordination, emergency or exceptional state declared in connection with the COVID-19 disease or within a period of two months after their revocation. In those periods, if the fixed-term employment relationship is to end on the expiry of the agreed period in this defined period of time and it is not a fixed-term employment relationship for which the conditions for its extension are met in accordance with applicable law, it can be extended once and for a maximum of one year. The same applies to the renegotiation of a fixed-term employment relationship.

The employer is obliged to discuss such extension or renegotiation of the employment relationship for a certain period in advance with the employees' representatives. In the absence of a negotiation, such an employment relationship would be considered to be an employment contract of indefinite duration.

\section{CURRENT LEGISLATIVE ADJUSTMENTS OUTSIDE THE TIME OF EXTRAORDINATION, EMERGENCY OR EXCEPTIONAL STATE}

\subsection{Domestic work, telework, home office}

With effect from 1 March 2021, the concept of domestic work and teleworking is redefined. Both of these types of work are defined by the Labor Code as regular performance of work within the established weekly working hours or part thereof in the employee's household, based on the agreement of both entities within the employment contract. This is work that could be performed at the employer's workplace. Teleworking means work performed ,using information technologies in which electronic data transmission at a distance takes place on a regular basis" (Section 52 (1) (d) of the Labor Code). The household must be understood in a broader sense, as it is desirable to understand any agreed place of work outside the employer's workplace, i.e. it is not an exactly specified place of work. From the point of view of application practice, such a definition of the term place of work can cause problems e.g. during a business trip, with the employer's liability for damage in the event of an accident at work.

It may be agreed in the employment contract that all or part of the domestic work or telework will be carried out in a place determined by the employee, if the nature of the work so permits, as well as the fact that the employee will schedule working hours for this type of work. within a whole week, or the work will be carried out in flexible working hours. If, 
during domestic work or teleworking, the employee schedules his own working hours (as Dolobác states: „the legislation has the ambition to give the employee the freedom to manage his own time“" 7 ), the provisions on the allocation of specified weekly working hours, continuous daily rest and continuous rest during the week, the provisions on downtime, except for downtime for which the employer is responsible, do not apply. The employee is not entitled to compensation of wages in the event of important personal obstacles at work, except for compensation of wages in the event of the death of a family member. It also does not include wages for overtime work, wage benefits for work on holidays, wages benefits for work on Saturdays, wages benefits for work on Sundays, wages benefits for night work and wage compensation for difficult work, unless the employee agrees otherwise with the employer.

In domestic work and teleworking, the employer is obliged to provide and maintain technical equipment in the employee's household, and the employee is obliged to immediately inform the employer about technical problems associated with the malfunction of technical equipment and software. It is also possible to agree between the employer and the employee on the use of the employee's own technical and software equipment. It is in this context that the amendment to the Labor Code emphasized the employer's obligation to reimburse the employee for demonstrably increased expenses associated with the use of his own tools, equipment and his own items needed to perform domestic work or telework. The Czech Republic had the motive for similar legislation in 2016, but there was no change in the legislation ${ }^{8}$.

A very important legislative change is the enshrinement of the right to disconnect. An employee engaged in domestic or teleworking work shall have the right during his uninterrupted daily rest and uninterrupted weekly rest (unless on-call or overtime work is ordered or agreed with him at that time), during leave, on a holiday for which work has lapsed, and obstacles to work not to use work equipment for domestic work or teleworking. As the employee has the right to adequate rest after work, for the employer this "means the admissibility of the allocation of only the extent of work that the teleworker is able to work within the established weekly working hours“" 9 .

The negative definition of the term domestic work and telework is the defining features of a home office. The home office is work performed by an employee occasionally or in exceptional circumstances with the consent of the employer or in agreement with him from the employee's household, provided that the type of work performed by the employee under the employment contract allows it.

It follows from the above that domestic work and teleworking is the performance of long-term activities conditioned by an agreement between the employer and the employee with the obligation to explicitly state the performance of the employment contract, so it is not possible to order this form of performance by the employer. In the case of work from home in the form of a home office, this can be ordered only exceptionally, during the time of extraordination,

\footnotetext{
${ }^{7}$ DOLOBÁČ, M. Legislatívne výzvy priemyselnej revolúcie 4.0, s. 23. In: Švec, M., Bulla, M. Práca 4.0, digitálna spoločnost' a pracovné právo. Bratislava 2018, 111 s. ISBN 978-80-89149-58-2 (e-dokument online PDF)

${ }^{8}$ See more details: STONJEK, P. Koronavirus - šance přenést část nákladů závislé práce na zaměstnance? AUC IURIDICA 67(2), Máj 2021, s. 63-70. [online]. DOI: 10.14712/23366478.2021.12

${ }^{9}$ ŽUL'OVÁ, J. Sociálne práva zamestnancov vykonávajúcich teleprácu, s. 90. In: Barancová, H., Olšovská, A. (eds.): Pracovné právo v digitálnej dobe. Praha: Leges, 2017, 304 s.
} 
emergency or exceptional state and for two months after their dismissal, when the employer is entitled to order work from the employee's household, if it allows agreed type of work. In other cases, the employer should agree with the employee to work from home.

\subsection{Paid leave of an employee who takes care of the child permanently}

The findings of the application practice pointed to certain ambiguities in the interpretation of the provisions of the Labor Code concerning the length of paid leave due to childcare. According to $\S 103$ par. 2 of the Labor Code, the paid leave of an employee who reaches the age of at least 33 by the end of the relevant calendar year and the employee who takes permanent care of a child is at least five weeks. The amendment to the Labor Code defined the concept of an employee who permanently takes care of a child. Such a person is to be understood as an employee who personally takes care of the minor's own child, including the alternate personal care of both parents, as well as an employee who personally takes care of a minor child entrusted to him or her by substituting the parents' care. The acquisition of this status is conditional on the employee's written notification of this fact to the employer, it arises on the day of this notification and expires on the day when the employee ceased to take permanent care of this child. The employee is obliged to notify the employer in writing of the termination of permanent childcare without undue delay. As the Labor Code does not grant increased leave to only one parent, both parents are entitled to a higher amount of leave if they have the status of an employee who takes care of the child permanently.

Experience has further shown that the current legislation is incomplete and in order to maintain the rule of proportionality, $\S 103$ para. 2 of the Labor Code has been amended. This is especially the case when the scope of the employee's right to leave, which acquired or lost the status of employee permanently caring for a child during a calendar year, is not clearly clear from the current legislation. With effect from 1 January 2022, an employee who begins or ceases to have permanent custody of a child during a calendar year shall be entitled to an increase in annual paid leave of at least five weeks in excess of the basic period of paid leave (i.e. in excess of at least four weeks) to the extent determined as the ratio of the number of days of permanent care of the child in the relevant calendar year to the number of days of the calendar year. We therefore point out that the current legal regulation does not yet prevent the granting of the right to paid leave for a calendar year of an employee under the age of 33 who acquires, during the calendar year, resp. lose the status of employee permanently caring for the child, even in the full range of acreage for at least five weeks.

\subsection{Catering for employees}

The latest legislative amendments also affected the area of the employer's social policy, especially the issue of catering. In all work shifts, the employer is obliged to provide employees with meals in accordance with the principles of proper nutrition directly at or near the workplace, in particular by providing one hot main meal, including a suitable drink, to the employee during the work shift. This catering is provided by the employer in his own catering facility, in the catering facility of another employer or provides catering for his employees through a legal entity or natural person authorized to provide catering services.

From 1 March 2021, the employer may provide employees with a earmarked financial contribution for meals as part of catering. This contribution may be provided by the employer if catering is excluded by the conditions of work at the workplace, if the employer cannot provide catering in another form, if the employee cannot use any of the manners of catering provided by the employer on the basis of a medical certificate from a specialized doctor for health reasons. The meal contribution may also be provided to an employee performing 
domestic work or teleworking, unless the employer provides him with other manner of catering.

An employer who does not provide catering in his own catering facility or in the catering facility of another employer is obliged to allow employees to choose between providing catering through a legal entity or a natural person authorized to provide catering services, in the form of a meal voucher or financial contribution for meals. The employee is bound by his choice for a period of 12 months from the day to which the choice is tied.

\subsection{Student Temporary Work Agreement}

Based on the Labor Code, the employer may exceptionally enter into agreements on work performed outside the employment relationship (work performance agreement, agreement on work activity and agreement on temporary job of students) with natural persons within the framework of employment relations to fulfill its tasks or to ensure its needs. Within these agreements, the agreement on temporary job of students has a special status, which must be in writing under the penalty of invalidity and can be concluded by the employer with a natural person who has the status of a secondary school pupil or a student in full-time higher education under a special regulation and who has not completed 26 years of age. The previous legislation excluded former secondary school pupils and former first-level university students from the possibility of concluding an agreement on temporary job of students if they wanted to perform work on the basis of this agreement between the end of their studies and enrollment in the relevant university level. From 1 March 2021, the presumption of maintaining student status was introduced until 31 October of the current calendar year. This means that a natural person who has the status of a secondary school pupil and the status of a full-time university student is also considered a natural person in the time from the proper completion of secondary school studies and the time from the regular completion of full-time university studies until 31 October of the same calendar year. Work on the basis of an agreement on temporary job of students may be performed no later than the end of the calendar year in which the natural person reaches the age of 26.

\subsection{Reaching a certain age as a reason for termination of employment}

While in the current period reaching a certain age is not a reason for termination of employment, with effect from 1 January 2022, the grounds for dismissal by the employer are extended. The employer will be able to give notice to the employee even if two cumulative conditions are met, namely if the employee reaches the age of 65 and the age for entitlement to a retirement pension. According to the current legislation, the retirement age of the insured is in any case lower than 65 years, so far only the condition of reaching the age of 65 will have to be examined.

\section{CONCLUSION}

Legislative changes in labor relations in the recent period have responded mainly to the emergency situation related to the coronavirus pandemic, as well as to problems arising from application practice. In many cases, these changes need to be assessed positively, but some issues will need to continue to be addressed and respond to the demands of practice. It will be primarily a matter of telework, the use of which brings both advantages and disadvantages. Despite that emphasize the positive effects of teleworking on the workers' performance in terms of productivity, quality of life, and well-being, some studies have shown that telehome working is not always the best solution due to the lack of adequate technology, 
sense of loneliness, risks of isolation, and low work-life balance. “10 Interesting is the Study on the Application of the Techniques of Telework in the Portuguese Business Association with the aim to identify the necessary conditions to implement telework in a business association. On the one hand, the results revealed the employee's profiles as being adequate to a successful implementation of telework, an interesting potential of savings, and a minimum technological capability, on the other hand, they also showed some difficulties at the human resources management level and the organizational adaptability to a new model of work, like telework $^{11}$. The question of the need for technology education also arises, as telework requires a certain degree of use of ICT. In the future, ,research about telework and lifelong learning has the potential to contribute to a sustainable working life in terms of providing more flexible arrangements for employees and to support the lifelong learning that takes place in contexts such as the office, home, online meetings, and virtual reality" ${ }^{12}$. The recommendations of the empirical research carried out in France also indicate the need of improving the IT proficiency of employees and developing the telework skills of employees ${ }^{13}$.

In addition to the positive legislative changes, certainly one of the most unpleasant changes that have been approved by the amendment to the Labor Code in the last period, in relation to employees, is the new reason for dismissal for the employee. Experience will show to what extent employers will use this reason for dismissal and what impact it will have on the labor market.

\section{Sources}

1. BARANCOVÁ, H. a kol. Zákonnik práce. Komentár. 2. vydanie. Bratislava: C.H. Beck, 2019, 1520 s. ISBN 978-80-89603-78-7.

2. BJURSELL, C., BERGMO-PRVULOVIC, I., HEDEGAARD, J. Telework and Lifelong Learning. Frontiers in Sociology 6, March 2021. [online]. DOI: 10.3389/fsoc.2021.642277

3. CARDOSO, A., VAZ, P., SOUSA PEREIRA, M. J., FIGUEIREDO, J., D'OREY, F. G. Sustainability of Telework: Study on the Application of the Techniques of Telework in the Portuguese Business Association. 35th EBES, Rome, Italy, Volume: Vol. 1. April 2021. [online]. Available from: https://www.researchgate.net/pu blication/350979069_Sustainability_of_Telework_Study_on_the_Application_of_th e_Techniques_of_Telework_in_the_Portuguese_Business_Association

4. CARILlOA, K., CACHAT-ROSSETB, G., MARSANC, J., SABAB, T., KLARSFELD, A. Adjusting to epidemic-induced telework: empirical insights from teleworkers in France. European Journal of Information Systems. 30:1, 69-88, [online]. DOI: 10.1080/0960085X.2020.1829512

\footnotetext{
${ }^{10}$ MANZINI CEINARM I., MARIOTTI, I. Teleworking in post-pandemic times: May local coworking spaces be the future trend? Romanian Journal of Regional Science, Vol. 15, No. 1, Summer 2021, p. 65.

${ }^{11}$ CARDOSO, A., VAZ, P., SOUSA PEREIRA, M. J., FIGUEIREDO, J., D'OREY, F. G. Sustainability of Telework: Study on the Application of the Techniques of Telework in the Portuguese Business Association. 35th EBES, Rome, Italy, Volume: Vol. 1. April 2021. [online]. Available from: https://www.researchgate.net/publication/350979069_Sustainability_of_Telework_Study_on_the_Application_o f_the_Techniques_of_Telework_in_the_Portuguese_Business_Association

${ }^{1}$ BJURSELL, C., BERGMO-PRVULOVIC, I., HEDEGAARD, J. Telework and Lifelong Learning. Frontiers in Sociology 6, March 2021. [online]. DOI: 10.3389/fsoc.2021.642277

${ }^{13}$ CARILlOA, K., CACHAT-ROSSETB, G., MARSANC, J., SABAB, T., KLARSFELD, A. Adjusting to epidemic-induced telework: empirical insights from teleworkers in France. European Journal of Information Systems. 30:1, 69-88, [online]. DOI: 10.1080/0960085X.2020.1829512
} 
5. DOLOBÁČ, M. Legislatívne výzvy priemyselnej revolúcie 4.0, s. 19-25. In: Švec, M., Bulla, M. Práca 4.0, digitálna spoločnost' a pracovné právo. Bratislava 2018, 111 s. ISBN 978-80-89149-58-2 (e-dokument online - PDF)

6. HAMULÁK. J. Pracovný čas a doby odpočinku. In: Slovenské pracovné právo, Bratislava, Sprint 2 s.r.o., 2019, 664 s. ISBN 978-80-89710-48-5.

7. HAMULÁK. J. Prekážky v práci. In: Slovenské pracovné právo, Bratislava, Sprint 2 s.r.o., 2019, 664 s. ISBN 978-80-89710-48-5.

8. KYZLINKOVÁ, R., VEVERKOVA, S., VYCHOVÁ, H. Práce z domova - popis stavu před pandemií a možné konsekvence do nových poměrů organizace práce. In FÓRUM sociální politiky 5/2020, s. 9-15.

9. LANG, R. Závislá práce $\mathrm{v}$ době koronaviru - sociálněprávní souvislosti. AUC IURIDICA 67(2), Máj 2021, s. 131-139. [online]. DOI: https://doi.org/10.1471 2/23366478.2021.18

10. MANZINI CEINARM I., MARIOTTI, I. Teleworking in post-pandemic times: May local coworking spaces be the future trend? Romanian Journal of Regional Science, Vol. 15, No. 1, Summer 2021, pp. 52-76.

11. STONJEK, P. Koronavirus - šance přenést část nákladů závislé práce na zaměstnance? AUC IURIDICA 67(2), Máj 2021, s. 63-70. [online]. DOI: 10.1471 2/23366478.2021.12

12. ŽUL’OVÁ, J. Sociálne práva zamestnancov vykonávajúcich teleprácu, s. 90. In: Barancová, H., Olšovská, A. (eds.): Pracovné právo v digitálnej dobe. Praha: Leges, 2017, 304 s.

\section{Contact}

Doc. JUDr. PhDr. Silvia Trel'ová, PhD.

Comenius University in Bratislava

Faculty of Management

Odbojárov 10, 82005 Bratislava 25

Slovak Republic

Phone: 02/501 17486

email: silvia.trelova@fm.uniba.sk 


\title{
A CAMP OF THREE TOTALITARIAN REGIMES IN SLOVAK MEMOIR AND FICTION ${ }^{1}$
}

\author{
Sylvia Hrešková, Monika Adamická
}

\begin{abstract}
The article deals with the labour camp in Nováky, which is known as the camp of three totalitarian regimes - fascist, post-war (democratic) and socialist. Memories of the camp were included in the Slovak memoir of authors of Jewish origin, Rudolf Vrba and Juraj Špitzer, who had personal experience with the camp from World War II, when it served as an internment camp for Jews. The conditions and functioning of the camp during the second and third totalitarianism were captured in the work of the Slovak author of non-Jewish origin, Anton Baláž. He dealt with this topic in non-fiction as well as in fiction and, on the basis of collected testimonies and studies of archival documents, gives an insight into the camp in the post-war period.
\end{abstract}

Key words: Nováky, Forced Labour Camp, Memoir, Jews, Socialist Regime

\section{LABOUR CAMPS IN SLOVAKIA}

Jewish labour camps in Slovakia were officially established by the decree of the Commissioner of the Interior no. 137/1941 from 2 April 1941. They were intended for ablebodied Jews excluded from economic life (Danko, 2010, p. 29). In the years 1942 - 1944, there were several camps for Jews in Slovakia (for example in Ilava, on Kysucká cesta in Žilina, in Kostolná near Trenčín, in Nitra, in Devínska Nová Ves and others), but the main attention was paid to the camps in Sered', in Nováky and Vyhne.

The largest labour camp was located in Nováky. It was established on the territory of former military barracks and consisted of three several-hectare buildings. There were interned two groups of people - Jews destined for deportations to German concentration camps and Jews destined to work - together with their family members. In addition to other activities, the Nováky camp focused mainly on tailoring manufacture, the main branch was the production of men's, women's and children's clothing, but especially the sewing of uniforms. The technical equipment came from liquidated Jewish companies. The peculiarity of Slovak Jewish labour camps was the existence of crèches, nurseries and primary schools. The camp in Nováky ceased to exist in 1944 after the beginning of the Slovak National Uprising.

Labour camps were established in Slovakia also in the post-war period, the camps established during World War II continued their existence continuously during the three totalitarian regimes. Vladimír Varinský distinguishes three stages of forced labour in Slovakia (Varinský, 2009, p. 220):

1. period of the first Slovak Republic - more precisely the years 1941 - 1944,

2. the years 1945 - 1948 (this period also refers to the term democratic intermezzo surrounded by two totalitarians, but it is the proof of the functioning of labour camps that negates the impression of a democratic establishment),

3. period from autumn 1948 to May 1953 - it is a period since the beginning of building socialism in Czechoslovakia.

\footnotetext{
${ }^{1}$ This work was supported by research project UGA "The Prose of Naturism in Film Processing" based on the contract n. X/2/2021.
} 
A common feature of all three stages is the effort to re-educate non-conformist people with work. The idea of using those layers of society for forced labour was justified in the years 1945-1948 by the need to reconstruct the war-torn economy. After 1948, forced labour camps were established (by act nr. 247/48), which were also based on the idea of re-education through labour in order to minimize antisocial people. Gradually, however, educational intentions were abandoned and attention shifted to their economic benefits. Due to the predominance of people of Roma origin among the prisoners, their internment on a racial basis is compared to war persecution against Jews. After finding out that this form of reeducation is ineffective, the decision of the Commissioner of Interior Daniel Okáli ${ }^{2}$ of 5 March 1949 resulted in the widespread dismissal of internees (Varinský, 2009, p. 226).

In the post-war period, the Forced Labour Camp in Nováky served for the internment of Carpathian Germans before their transfer from the territory of Slovakia. In the years 1946 1947, antisocial elements were located here. After the communist establishment in 1948, the camp was determined mainly for political prisoners. The camp was abolished in September 1951. The buildings of the former labour camp fell into decay over time and were gradually dismantled. On September 26, 2017, a memorial to the Jewish victims was unveiled by two surviving Shoah Ružena Becková and Dagmar Lieblová between the villages of Koš and the former village of Laskár, on the place where the camp once stood. In addition to the memorial to the Jewish victims, there is also a memorial dedicated to the Carpathian Germans. During their internment in the camp, they experienced similar inhuman conditions as Jews during the war, many of them became victim to the typhus epidemic. The monument was built by the village of Koš in 2017, and was consecrated in August 2018. ${ }^{3}$ However, a monument of the third totalitarianism was missing there. Baláž in his book Two Slovak Destinies. Špitzer Mach (2019, Dva slovenské osudy. Špitzer - Mach) writes: "Today, two modest memorials stand on the place of the camp of the three totalitarians. One recalls the suffering experienced by Slovak Jews here, the other the suffering of the Carpathian Germans. The memorial of the third totalitarianism is still missing. Communism is probably still not a thing of the past in our country " (Baláž, 2019a, p. 268). On May 25, 2019, however, a memorial plaque was unveiled at the municipal office building in the village of Koš, which complemented the triad of memorials to the victims of the three totalitarian systems.

\section{NOVÁKY IN SLOVAK MEMOIR LITERATURE}

The labour camp in Nováky also got into the Slovak memoir literature of authors with Jewish origin. Rudolf Vrba (real name Valter Rosenberg) captured the conditions in the camp in his work I Cannot Forgive (2015, Nemôžem zabudnút'. Utiekol som z Osvienčimu). While his fellow prisoner from Auschwitz, with whom they fled the camp, Alfred Wetzler was interned in Slovakia in Sered' and his book What Dante Did Not See (1965, Čo Dante nevidel) begins with a transport from Sered' to Auschwitz, Vrba returns in his memoirs to the period before Auschwitz. ${ }^{4}$

\footnotetext{
${ }^{2}$ Daniel Okáli (1903 - 1987) was Slovak politician, lawyer, writer and literary critic. He was one of the founders of the group DAV, which brought together left-wing writers and politicians. Between 1946 and 1948 he worked as the Government Plenipotentiary for Exchange of Population with Hungary and as Head of the Czechoslovak Resettlement Commission. From 1948 he was Commissioner of the Interior. In 1951 he was accused of bourgeois nationalism. He was in prison until 1960, then rehabilitated in 1963.

${ }^{3}$ See also: Obete internačného tábora pripomína posvätený pomník. 2018. Online on: https://myho rnanitra.sme.sk/c/20892857/obete-internacneho-tabora-pripomina-posvateny-pomnik.html [cit. 06-02-2021].

${ }^{4}$ Rudolf Vrba (1924 - 2006, real name: Valter Rosenberg) and Alfred Wetzler (1918 - 1988) were interned in Auschwitz during World War II for their Jewish origin. On the early evening of April 7, 1944, they hid in a space of stacked wood in the outer guard circuit of the camp. On the night, after three days, when SS members stopped looking for them near the camp, they climbed out of hiding and fled to Slovakia. After more than 10
} 
Vrba got to Nováky in June 1942. It was for him a place "with serious faces, defeatist words, lamentations and whining" (Vrba - Bestic, 2015, p. 63). From these words follows his character as a rebel, a man who did not want to look passively at the fate of the Jewish minority, but wanted to defy this predestination. Even before interning in Nováky, he tried to escape to Hungary, but without success. He tried a second escape from the Nováky camp with his fellow prisoner Jozef Knapp. Not even the second attempt worked, he was betrayed by two pairs of socks he was wearing - they were suspicious for the gendarme who caught him: "Those two pairs of socks helped me on my way to Auschwitz" (Vrba - Bestic, 2015, p. 69). Vrba's actions contradict the common notions and remorse of the non-Jews towards the Jews that they did not try to do anything to save themselves.

While Vrba only marginally depicted the camp in Nováky due to the scope of the book, he focuses primarily on Auschwitz and depicting a successful escape from there, Nováky plays an important role in the work of Juraj Spitzer. ${ }^{5}$ The book I Did Not Want to Be a Jew (1994, Nechcel som byt' žid) is, in addition to a hint of narration, a kind of philosophical reflection (in the spirit of the philosophy of existentialism) on the events of World War II in connection with the final solution of the Jewish question. In addition to depicting the conditions in the camp, he also devotes space to capturing its atmosphere. He writes on the introductory pages: "Years go by and nothing remarkable is happening. At that time, the days were full of events, but they took place in the distance, while here, as if time stood still" (Špitzer, 1994, p. 15). Despite the fact that the prisoners in the camp were not aware of the events of the war, it was something foreign for them, something that did not affect them in essence, Špitzer then negates the impression that ignorance of what is happening in the world would make life easier for them: "When you get behind prison walls or prickly wires, it seems to you that life here will be simple, as if less dimensional. Later, it turns out to be more complicated and demanding than out there. Out there, it is possible to escape from a difficult situation. Here is no place for it" (ibid., p. 69).

In the question of the guards, Špitzer stated that not everyone was the same, raw, because in every person "fails to mobilize sadistic instincts and contentment from the suffering of others" (ibid., p. 77). Despite all the negative phenomena that accompanied interned Jews, such as inhuman living conditions, imprisonment, corporal punishment and other forms of bullying, which served as a tool for isolating and degradation of prisoners (ibid., p. 137), Nováky cannot be compared with Auschwitz and other German concentration camps in which were conditions worse, not to mention the massacre machinery. Because: "Nováky were not

days of walking, they covered almost $100 \mathrm{~km}$ before crossing the state border. Between Poland and Slovakia. In Žilina, on April 25-28, 1944, they testified before the Jewish Labor Council about what was happening in the death camp. They received fake documents with the names Jozef Lánik and Rudolf Vrba, both of whom used them as pseudonyms when writing memoirs about Auschwitz. Rosenberg used this name for the rest of his life. According to their testimony, the 32-page Wetzler and Vrba Report, also known as the Auschwitz and Birkenau Report or the Auschwitz Report, was written. Its text was immediately translated into other languages and distributed by the competent authorities in the West in order to prevent further deportations of Jews to German death camps. See also: https://www.upn.gov.sk/sk/sprava-alfreda-wetzlera-a-rudolfa-vrbu-1944/

${ }^{5}$ Juraj Špitzer $(1919$ - 1995) was a Slovak literary historian and publicist of Jewish origin. From 1938 he studied medicine at Comenius University in Bratislava, but he had to interrupt his studies due to racial reasons. In 1942 he was interned in a camp in Nováky. After the outbreak of the Slovak National Uprising, he became commander of a Jewish partisan unit. After the war, he studied French and philosophy at Comenius University, then he became editor-in-chief of the magazine Cultural Life (Kultúrny život) and secretary of the Union of Czechoslovak Writers. After 1969, he was expelled from the writers' organization, at the same time fired and banned from publishing. He could return to public life only after 1989 - after the fall of socialism in Czechoslovakia. 
Auschwitz. But here it began" (ibid., p. 118). For thousands of interned Jews, Nováky meant "destruction and hope" (ibid., P. 175). Assignment to the labour unit was at least some hope for them that they would not be included in transports to German death camps.

Based on Špitzer's work, Jews, Jewish officials "whose names remain sadly connected with the tragedy of Slovak Jews" (ibid., p. 152) can be considered a parallel to Gejza Vámoš's ${ }^{6}$ cut out branch of Judaism. For Gejza Vámoš, in his novel Cut Out Branch (1934, Odlomená haluz), those Jews who broke away from the inheritance of their ancestors were cut out branch of Judaism. In a metaphorical sense, one can also assign here those who remained Jews but betrayed their own. Cooperation in transporting Jews to German camps was a preliminary certainty for them to save themselves and their family members. These Jews were a kind of counterpoint to the so-called white Jews - non-Jews who cared about Jewish fate and tried to save at least part of the Jewish population by hiding or fleeing. Špitzer sees the reason why the Jews also contributed to the solution of the Jewish question in the fact that "the orders of the liquidators were obeyed if they were carried out and brought to life by the Jews" (ibid., p. 162). He mentions two Jewish officials, Hochberg and Ost, who worked in a special department of the Central Office of the Jews in Bratislava and collaborated with German Adviser Dieter von Wisliczeny ${ }^{7}$ (ibid.). The fictional depiction of the character of a Jew who was saved by cooperation during deportations is Áron Katz (Kalina) from the novel The Land of Forgetting (2000, Krajina zabudnutia). Baláž worked on this topic in its most tragic shade Kalina saved himself, but sent his loved ones to a certain death to German camps. After the war, remorse drove him to suicide.

At the end of the book, Špitzer describes the feelings when leaving the camp, which became a home for many Jews for a long time (together with other Jews he left Nováky in August 1944 and joined the Slovak National Uprising). Leaving this place was on the one hand accompanied by happiness from regained freedom, on the other hand it was associated with a certain sadness and nostalgia: "We longed for freedom and yet we were sad. We hated fascism, but we remember Nováky with emotion, because they were not only slavery, but also victory over it" (ibid., p. 197).

\section{NOVÁKY IN FICTION AND NON-FICTION}

Anton Baláž ${ }^{8}$ non-Jewish Slovak writer, captures the environment of labour camp in Nováky in two books of non-fiction, Vydrica, historical - sinful (2007, Vydrica, historická - hriešna)

\footnotetext{
${ }^{6}$ Gejza Vámoš $(1901$ - 1956) was a Slovak author of Jewish origin who, despite being a Jew, was critical of Slovak Jewry. He expressed this especially in the novel Cut Out Branch from 1934, in which he speaks about Jews with a certain sarcasm, he is critical of their way of life influenced by religion, which often borders on religious fanaticism. Despite his sharp criticism of Jews, he does not condemn Judaism as such, but rather reflects how the positive qualities of Jews could be used for the good of Slovak society, for the assimilation of Jews with Slovaks through religiously mixed marriages. During the growing anti-Semitism in Slovak society, Vámoš felt a hostile attitude towards the Jews. In 1939, he saved himself by fleeing to China, later to Brazil, where he survived the rest of his life.

${ }^{7}$ Dieter Wisliczeny (1911 - 1948) was from August 1940 to January 1943 an adviser on the Jewish question at the German embassy in Bratislava. In 1944 cooperated in the deportations of Hungarian Jews. After the war, he was extradited to Czechoslovakia, where he was convicted in 1948 and hanged for war crimes.

${ }^{8}$ Anton Baláž (1943) is a Slovak author who was born in a village near Nováky at a time when the Forced Labour Camp stood there and was active. This circumstance aroused in him an interest in the issues of this camp as well as in Jewish themes, which was also reflected in his fiction and non-fiction. Apart from the already mentioned, the novel The Land of Forgetting (2000, Krajina zabudnutia) and the short stories The Rift (Trhlina) and Simon the Pilgrim (Šimon Pútnik) were published with the theme of Judaism - together they were published in a book Portraits of Survival (2014, Portréty prežitia), as well as nonfiction Transports of Hope (2010, Transporty nádeje), and the radio play Ophelia is Not Dead (2003, Ofélia nie je mŕtva).
} 
and Two Slovak Destinies. Špitzer - Mach (2019, Dva slovenské osudy. Špitzer - Mach), as well as in the novel The Camp of Fallen Women (1993, Tábor padlých žien). The book about sinful Vydrica ${ }^{9}$ and the novel on the re-education of prostitutes are thematically related. While in the non-fiction literature, originally published in 2007 and in 2019 its third reissue was published, it provides a historical view of the Bratislava part known for industrial prostitution and the subsequent efforts of the socialist regime in the postwar period to re-educate women of the oldest craft by work, the novel is a fictional elaboration of this issue with an emphasis on their internment in the Forced Labour Camp in Nováky.

In Baláž's work, the camp in Nováky is not primarily connected with the Jewish topic, although even in the post-war period, Jews were also placed in the camp before emigrating from Czechoslovakia. ${ }^{10}$ In this case, he captures the Jewish issue only marginally, especially in the novel The Camp of Fallen Women. The post-war use of the camp is essential for the author, especially after 1948 during the period of the third totalitarian establishment socialist regime. At the same time, Baláž ideologically connects the period of fascist totalitarianism with socialist one, as even the politicians of the new regime after 1948 "professed the motto Arbeit macht frei" (Baláž, 2019b, p. 136). In this quote, there is a direct allusion to the effort of both regimes to re-educate antisocial people by work, the only difference is in the focus on the target group. While the fascists tried to convince the public that they were re-educating the non-adaptable - the Jews, the socialist regime was reeducating the non-adaptable - antisocial people, prostitutes, but also Gypsies and others.

As Baláž writes in a book about Vydrica, the camp commanders soon encountered a fundamental problem in the case of prostitutes - this circumstance was captured very humorously, grotesquely in the novel The Camp of Fallen Women. He quotes from a letter sent to the Commissioner of the Interior, Daniel Okáli, on December 16, 1948: "as experience shows - it does not work well in camps when women and men are together and especially when these women are prostitutes" (ibid., p. 154). The consequence of these fears was the separation of prostitutes in a separate barracks and building a fence around it so that the male part of the camp would not have access to it.

In both books of non-fiction, he describes the functioning of the camp. While in the book Vydrica, historical - sinful he captures the conditions in the camp only in the period after 1948, in the book Two Slovak Destinies. Špitzer-Mach he also deals with an earlier period from the period of German occupation during the World War II (since autumn 1944). He remembers a Jewish family - his parents helped them escape the machinery of the Jewish extermination (Baláž, 2019a, p. 13). It could be said that they became white Jews, too, even if

\footnotetext{
${ }^{9}$ Vydrica is a former settlement below Bratislava Castle in the Old Town, which was established around 1360. From the 18th century until World War II, it was known for prostitution. Most of the settlement was demolished around 1960 and 1970 in connection with the construction of the New Bridge. This part of the capital of Slovakia is currently being restored.

${ }^{10}$ In the post-war period, a large Jewish alija (bricha) took place in Czechoslovakia - the effort of Jews to emigrate to Palestine in the post-war period, resp. to Israel after May 14, 1948, when Ben Gurion declared a Jewish state. The question of alia was dealt with by the Palestinian Authority (Slovak branch of the Jewish Agency for Palestine), headed by Dr. L'udovít Kalina, after his emigration to Israel by Adolf Reich. Their activities were financially supported by the American Joint Distribution Committee. However, the Commission of the Interior also played a significant role in the emigration of Jews. In addition to Israel, Jewish migration routes also led to the USA, Australia and South America. After the defeat of the Communist Party of Israel, the Jewish state began to be perceived as a servant of American imperialism, and the activities of Jewish associations in the Eastern bloc were condemned as part of hostilities against the socialist establishment. Zionist organizations were monitored by the State Security, and the transport of Jews to Israel was declared illegal. The organizers of the great Jewish alija were condemned in the trials of bourgeois nationalists.
} 
only for one night. He also depicts the events after the Jews and commanders left the camp. In the introductory chapter he writes: "And what happened to the abandoned camp? There was a robbery. [...] When the Jews began to leave the camp and it was also left by a guard unit made up of young Jews, it was a signal for looting" (ibid.). The inhabitants of the surrounding villages knew about the good technical equipment of the workshops and the abandoned camp became their easy way to get to this facility.

In the book Two Slovak Destinies. Śpitzer - Mach Baláž devoted a separate chapter to the description of the camp in Nováky. He called this chapter for him a typical name for this environment as The Camp of Three Totalitarians. At the beginning of the chapter, he gives an explanation and the reason for this designation:

From March 1942 to August 1944, Slovak citizens who had the wrong ethnic origin - Jews were interned in the camp; from September 1945 to the end of 1946 those who had the wrong nationality - Carpathian Germans; and from March 1948 to mid-1951 those of incorrect class descent - politically unreliable opponents of the communist regime. (Baláž, 2019a, p. 253)

In this part, the author emphasized, among other things, the fact that the Jews were Slovak citizens and so the Slovak state was not authorized to transport them outside its territory. In connection with the internment of Jews in Nováky, he mentions transports from 1942, two, which were sent to the summer of 1942, and the last from 22.09.1942, which is also called as Yom Kippur transport, because it was sent on the day of the largest Jewish holiday Yom Kippur (Day reconciliation).

In this work, the author also deals with the period when the Carpathian Germans were placed in the camp, because "information about the collection and internment camp for the Carpathian Germans was kept until 1990 only 'by oral testimony'" (ibid., p. 255). The description of the camp from this period is based on the case file of the District Court in Prievidza, which was written on the basis of a visit by a commission from 7 August 1945. The case file records the inhuman conditions in which the detainees lived and which are comparable to the conditions during the internment of Jews:

The detainees do not have beds, not even bunk beds, they lie on the ground without straw, they have only their own coats and rags under them. Water supply, namely drinking water, is insufficient [...] detainees drink water from an open stream into which sewage from the camp is flowing. [...] it happened very often that the detainees did not receive a regular ration of bread. [...] Between 7 July and 31 July 1945, about 17 children under the age of three died as a result of malnutrition. (ibid., pp. $256-257$ )

In addition to starvation and poor hygiene, prisoners were also exposed to brutality by guards. From this report it is possible to deduce the practices that were used against the detainees and which were in a way identical to the practices of the fascists. Their goal was to degrade one's personality by creating conditions that were incompatible with a physical and mental being of people. In general, it could be argued that those are the techniques that the fascists started not only in this but also in other concentration camps and continued in the periods of the second and third totalitarianism.

Anton Baláž also introduced the theme of The Forced Labour Camp Nováky to fiction, specifically to the novel The Camp of Fallen Women. The plot of the novel takes place in the Vydrica and in Nováky in 1949, when, among others, prostitutes from Bratislava were 
interned there. Daniel Okáli can be detected in the character of the Commissioner of the Interior, although the author does not mention him directly. The characters, who are inspired by real personalities of Slovak history, appear in his fiction under changed or symbolic names. The character of Belo Blažený was also inspired by a real personality, namely by associate professor Miroslav Bažány, ${ }^{11}$ who at that time was the director of the Institute of Psychotechnics and came to Nováky with his research team to perform psychotechnical tests with prostitutes. "I found out that they were in the camp from the camp report to the Commission of the Interior, but my search for tests, even for the institute, was fruitless" (personal interview with the author, December 13, 2018). However, the novel is a fictional depiction of Bažány's fate. While Belo Blažený goes to prison for his work, the real Bažány was only fired from his job and only the events of the Prague Spring and the subsequent normalization $^{12}$ forced him to emigrate.

As the work is the result of many years of study of archival materials (some of which are part of the appendix to the third edition of the novel) and the collection of personal testimonies, the novel contains many realities from that period. In addition to prostitution in the post-war period, there are allusions to Jewish themes. On the one hand, there are the characters of the Jews interned in the camp (especially Dr. Zigmund), and on the other hand, there can be found the manifestations of the prevailing anti-Semitism in the figure of Carmen, when she finds the Star of David sewn on her clothes after arriving to the camp. In this case, Baláž pointed out the tragedy of a time when, despite the fact that racial laws had not been valid for a few years, the ideas of anti-Semitism persisted. At the same time, the novel mentions the broadcasting of The White Legion radio, ${ }^{13}$ thanks to which the illegal slogan began to spread in the camp: "During the day for Stalin, at night against Stalin!" (Baláž, 2017, p. 220). On the other hand, several events that the author used to depict the time seem grotesque. The event of the potato beetle harvest sent to us by the Americans is grotesque, as well as the lecture of Belo Blažený about the unnecessary of women's fashion in a socialist state.

The novel The Camp of Fallen Women was adapted into a film version in 1997, directed by Laco Halama. In general, it could be said that the film follows the storyline of the book,

${ }^{11}$ Doc. PhDr. Miroslav Teofil Bažány, Csc. studied linguistics and psychology. From 1946 to 1948 he worked in Paris, later in London. In 1948 he returned to Czechoslovakia. He became the director of the Institute of Psychotechnics and the Central Vocational Counseling Center, where he worked until 1953. At that time, he was analysing the drawdown of time deposits in the Czech lands and in Slovakia, which showed how much Slovakia was cut. He was dismissed on the basis of the publication of the study with the results of the analysis. In a later period, he participated in the establishment of the Psychological Laboratory of the Slovak Academy of Sciences. In 1968 he was a supporter of Dubček and the Prague Spring, in 1969 he was forced into exile, where he got to work for UNESCO. On December 18, 1995, Ambassador of the French Republic in Slovakia, Mr. Michel Perrin, received the appointment of an officer of Ordre des Palmes académiques. Perrin appreciated his 20-year work in UNESCO and his mission to almost 20 countries, especially the Third World, where he helped improve education systems.

12 The Prague Spring is called the period from the end of 1967 to the occupation of Czechoslovakia in August 1968. In these months, the political situation in Czechoslovakia gradually eased, society was democratized and an attempt was made to carefully reform the socialist political system. With the invasion of the Warsaw Pact troops into Czechoslovakia (August 21, 1968), a period of normalization begins. The regime was not as harsh as it was in the 1950s in the period of trials against bourgeois nationalists, but it persecuted its opponents, especially by preventing their adequate social application. In the years of normalization, several political trials took place.

13 The White Legion was an anti-communist Christian organization operating in the territory of Slovakia and Austria, which aim was to inform the general public and foreigners about the communist terror. In May 1950 to June 1953, it broadcast radio news from Austria. Radio Broadcast The White Legion was a model for the later broadcasting of the Free Europe radio. The main founders and leading members were Jozef Vicen and Jozef Mikula.. 
perhaps also due to the fact that the author of the novel was also the author of the screenplay. It can therefore be stated that in the case of this adaptation it is a complex connection of posttext to pretext, which is the purest form, the core of intertextuality (Žilka, 2015b, p. 90). However, when writing the screenplay, Baláž had to take into account the technical and financial possibilities for making the film. The technical problem was the non-existence of the camp in Nováky - in the mid-1990s, there was nothing in Slovakia that resembled this camp. For this reason, a film camp was built in the military forests in Záhorie. The second problem was the finances, which did not allow to place the plot of the film in the mine.

There is a significant shift in the case of the secondary importance of the novel. On the one hand, the novel can be understood as a novel with elements of eroticism, from the environment of Bratislava prostitutes. As Valentová - Beličová writes: "... he sang an ode to a woman's body and gave a strongly erotic dimension to the story" (Valentová - Beličová, 2018, p. 35). However, in the socialist establishment, the female body becomes the object of torture, something that must be abolished. On the other hand, it cannot be forgotten the other side of the novel, namely the re-education of prostitutes and antisocial elements in the forced labour camp in Nováky, which was known from World War II as a camp in which Jews were interned before deportation to extermination camps. The author is known for his knowledge of Jewish issues from the Holocaust even in the first post-war years. In the novel, therefore, in addition to the re-education process, Anton Baláž also mentions the circumstances regarding the internment of Jews (especially Hungarian Jews) in Nováky, when they had to prove their Jewish origin again. Although this event is captured in the film, it is only in a light form. It could be said that the film focuses more on the erotic side of the novel, rather than the historical one, which is captured in the novel.

\section{Sources}

1. BALÁŽ, A. Dva Slovenské osudy. Špitzer - Mach. Bratislava: Marenčin PT, 2019a. 296 s. ISBN 978-80-569-0425-1.

2. BALÁŽ, A. Tábor padlých žien. Bratislava: Marenčin PT, 2017, 296 s. ISBN 97880-569-0074-1.

3. BALÁŽ, A. Transporty nádeje. Bratislava: Marenčin PT, 2010. 229 s. ISBN 978-808114-034-1.

4. BALÁŽ, A. Vydrica, historická - hriešna. Bratislava: Marenčin PT, 2019b. $190 \mathrm{~s}$. ISBN 978-80-569-0579-1.

5. DANKO, M. Internačné zariadenia v Slovenskej republike $(1939$ - 1945) so zretel'om na pracovné útvary. In Človek a spoločnost', roč. 13, 2010, č. 1, s. 23 - 36. ISSN 1335-3608.

6. LÁNIK, J. Čo Dante nevidel. Bratislava: Obzor, 1989. 264 s.

7. Obete internačného tábora pripomína posvätený pomník. 2018. Dostupné online na: https://myhornanitra.sme.sk/c/20892857/obete-internacneho-tabora-pripominaposvateny-pomnik.html [cit 06-02-2021].

8. $\quad$ ŠPITZER, J. Nechcel som byt’ žid. Bratislava: Kalligram, 1994. 304 s. ISBN 807149-047-4.

9. VALENTOVÁ-BELIĆOVÁ, Z. Pät' slovenských románov o slobode. In Slovenské pohl'ady, roč. IV. + 134, 2018, č. 11, s. 33 - 42. ISSN 1335-7786.

10. VÁMOŠ, G. Odlomená haluz. Bratislava: Smena, 1969. 270 s.

11. VARINSKÝ, V. Komparácia nútených prác na Slovensku v rokoch 1941 - 1953. In Acta Acad. Paed. Agriensis, Sectio Historiae. Eger: 2009, s. 219 - 239. ISSN 17853117. 
12. VRBA, R. - BESTIC, A. Nemôžem odpustit'. Utiekol som z Osvienčimu. Bratislava: Citadella, 2015. 504 s. ISBN 978-80-89628-83-4.

\section{Contact}

PhDr. Sylvia Hrešková

Constantine the Philosopher University in Nitra

Faculty of Central European Studies

Dražovská Street 4, Nitra, Slovakia

Email: sylvia.hreskova@gmail.com

PhDr. Monika Adamická

Constantine the Philosopher University in Nitra

Faculty of Central European Studies

Dražovská Street 4, Nitra, Slovakia

Email: monika.adamicka@ukf.sk 


\title{
DRAK SA VRACIA V ZNAMENÍ OHŇA ${ }^{1}$ \\ THE DRAGON RETURNS IN A SIGN OF FIRE
}

\author{
Sylvia Hrešková
}

\begin{abstract}
Téma príspevku sa primárne sústredí na semiotickú analýzu diela Drak sa vracia, autora prózy naturizmu Dobroslava Chrobáka a jeho filmovej adaptácie od režiséra Eduarda Grečnera. Zameriava sa na význam a symboliku ohňa, cyklickost' času, mýtus, znakovo-estetické zobrazenie, krest'anské a pohanské motívy, ambivalentnost' postáv, protiklad dobra a zla a archetypy, ktoré sú symbolickými klasifikáciami v podobe sémantických opozícií $\mathrm{v}$ literárnom diele, pričom sa stali predlohou k filmovému spracovaniu.
\end{abstract}

Key words: Filmová adaptácia, Drak sa vracia, semiotika

\begin{abstract}
The topic of the paper focuses primarily on the semiotic analysis of the film Dragon Returns, the author of the prose of naturism by Dobroslav Chrobák and its film form by the director Eduard Grečner. It focuses on character-aesthetic depiction, Christian and pagan motives, ambivalence of characters, the opposite of good and evil in a literary work which became a model for film processing.
\end{abstract}

Keywords: film adaptation, intertextuality, interpretional perspectives

\section{ZRODENIE LITERÁRNEJ POSTAVY DRAKA}

Ked' mal Dobroslav Chrobák sedemnást' rokov uverejnil svoju prvú poviedku s krátkym názvom Les. V tej je stvárnený šarkan, čiže drak, ktorý vystupuje prostredníctvom negatívnych úkazov. Aj v expozícii románu Drak sa vracia je taká sekvencia: „, A zrazu zašiel mesiac za hustú chmáru... domy celkom znehybneli, akoby vich útrobách vyhasli všetky ohne a celá dedina... " (Chrobák, 1943, s. 9). Podobne je tomu aj vo filme, kedy dedina náhle stíchne a kontrastuje s každodenným pohybom a pripravuje sa na udalost', ktorá naruší tradičný chod. Ticho sa mení na krik, ked' niekto zvolá horí. Za touto epizódou bezprostredne nasleduje príchod Draka. A preto aj tu sa „Drak“ spája s úkazmi, ktoré narúšajú každodenný a ustálený cyklus.

Súvislost' Draka s ohňom sa odzrkadl'uje tiež cez spomienky Evy - „Zahnal ich všetkých do kúta, schytil zo židovej police flašu čistého špiritusu, vylial ho na nich a podpálil “ (Chrobák, 1943, s.16). A preto sa na úrovni kolektívneho vedomia skonštruovala rovnica Drak = oheň. Drakov návrat je spätý nielen s výkrikom a narušením pravidelného kolobehu v dedine, ale aj v prírode. „Drak sa vrátil o Jane“, teda čase, ked’ aj príroda by mala vyjavovat' príznak úrody. Všade navôkol je však sucho a na horách sú ohne, významový opak ohňov svätojánskych. Takáto situácie sa opakuje už druhýkrát. Prvý raz, ked' Drak odchádzal z dediny a druhý, ked' sa opät' vracia. Kolektívne vedomie to hodnotí vedome takto: oheň je sucho, sucho je hlad, hlad je smrt', a to všetko je „Drak“. Dedinčania Drakovi pripisovali všetky nepriaznivé udalosti, a to najmä požiare a záhadné úmrtia. Preto príchod Draka je

\footnotetext{
${ }^{1}$ Štúdia vznikla v rámci riešenia projektu UGA „Židovská kultúra v Zemplínskom regióne“ na základe zmluvy č.X/2/2021.
} 
symbolom negatívneho, kedy dedina verí, že odstránením Draka by sa automaticky odstránili všetky nežiadúce okolnosti (Šútovec, 2005, s. 77).

\subsection{FILMOVÁ ADAPTÁCIA DRAK SA VRACIA}

Jedným z popredných režisérov najzásadnejšej éry slovenskej filmovej tvorby je Eduard Grečner, ktorý sa pričinil o vznik Československej novej vlny. Za najlepší režisérov film je bezpochybne považovaná adaptácia novely Drak sa vracia. Sústredí sa najmä na emocionálne stavy a pocity hlavných hrdinov, na krehkost' vnútorného sveta človeka, a to všetko poprepájané v súvislostiach so spoločenským kontextom. Poetika filmu d’alej prostredníctvom introspekcie nazerá do híbky človeka, čo sa pretavuje aj v symbióze s prírodnými úkazmi a svetom navôkol. Snímku môžeme chápat' tiež ako psychologickú sondu a zaradit' ju možno do kategórie psychologických filmov. V súvislosti s touto problematikou kategorizovania filmu Macek s Paštekovou nazerajú na túto snímku cez pojem pocitového filmu (Macek, Pašteková, 2016, s. 227). Zámer filmu nie je určený explicitne a tomu sú prispôsobené aj herecké výkony. Napríklad dialógy medzi hrdinami nie sú typické prehovory l'udí, ktorí vedú konverzáciu. Sú zašifrované v jednotlivých scénach filmu. Percipient ich dokáže pochopit' na základe správneho dekódovania napríklad pohybov, mimiky alebo iných hereckých stvárnení a reakcií. Zámerom filmu a jednou zo základných tvorivých metód sa stal princíp tajomstva. Postava Draka je od začiatku zahalená rúškom tajomstva. Záhadnost' je vyzdvihnutá aj vo vizuálnej podobe prostredníctvom Draka, ktorý má cez jedno oko prelepenú pásku a na svet nazerá len jedným okom. Film Drak sa vracia priniesol podl'a kritikov do slovenskej kinematografie prvky ,introvertného realizmu“ vyplývajúceho zo základného konfliktu diela, kde v opozícii stojí individualizmus a kolektivizmus. Filozoficky sa ponára do ticha, práve prostredníctvom ktorého sa snaží povedat' čo najviac.

Z kúskov emócií, pocitov, myšlienok a nevyslovených slov režisér vyskladal mozaiku individualistického príbehu, ktorý je nevtieravý a stále aktuálny.

\section{CYKLICKOSŤ ŽIVOTA V DRAKOVOM STVÁRNENÍ NA POZADÍ BINÁRNYCH OPOZÍ́CIÍ}

Už v úvode diela sa stretávame s kolobehom a cyklom života prostredníctvom Drakovho opätovného príchodu do dediny. Cyklus života je pretavený v cykle prírody, ktorá sa správa ako živá a je priamo zapojená do l'udských osudov a príbehov. Vidíme symbiózu medzi životom ako takým a životom prírodným. Mená hlavných postáv nie sú vybrané náhodné. Predznamenávajú svoju osudovost'. Hlavný protagonista má síce pôvodné meno Martin Lepiš, ale - ako vieme - jeho pôvod je nejasný a komplikovaný. Jeho prezývka Drak sa v našich krest’anských reáliách vníma negatívne, tiež je považovaný za mytologické zviera. Je stelesnením chaosu a devastovania i cez zápasenie sv. Juraja s drakom, ktoré môžeme vnímat' z hl'adiska profánno-démonického a sakrálneho.

Meno hlavnej ženskej postavy Eva je vôbec najfrekventovanejšie ženské meno v našich literárnych reáliách. Vol’ný preklad mena Eva znamená „tá, čo dáva život“, opät’ motív cyklickosti a kolobehu. Eva, vôbec prvá žena a podl'a l'udovej etymológie „matka všetkých žijúcich“, pochádzajúca z Adamovho rebra. Prví dvaja l'udia stojaci pri zrode sveta. Eva symbolizujúca dedičný hriech a vinu, začiatok stvorenia a jeho pád, života a smrti. Tieto paralely viditel'ne badat's hlavnými postavami a dejom príbehu. Drakova Eva sa najprv slepo zamilovala do nenávideného a odsudzovaného Draka, čím na seba prevzala vinu. Rovnako ako aj Adamova Eva, ktorá sa svojím skutkom previnila. Tá neposlúchla Boha a ochutnala zo stromu poznania dobrého a zlého, čím sa dopustila hriechu. Ústrednou postavou, ktorá vystupuje v diele je aj postava Šimona Jariabka. V Biblii sa meno Šimona spája so zradou. Sv. Šimon Peter, jeden $z$ dvanástich Ježišových apoštolov pôvodným menom Šimon sa previnil tým, že trikrát zaprel Ježiša, hoci to neskôr ol’utoval a Ježiš mu odpustil. V našom 
kontexte dochádza ku konfliktu práve medzi dvomi výraznými postavami - Drakom a Šimonom, podobne ako v biblickej analógii. Konflikt medzi Drakom a Šimonom sa dá chápat' ako konkurenčný boj dvoch mužských elementov. Postava Šimona v diele ukrýva najvýraznejší transformačný potenciál. Vystupuje ako nositel' tradičných hodnôt, konzervatívneho poriadku, a napriek tomu sa nechá ovplyvnit' pudmi žiarlivosti, podla ktorých napokon aj koná. Drakov pôvod zahalený tajomstvom a predurčenie jeho inakosti z neho vyprofilovali okrem vydedenca aj postavu tuláka. Tuláctvo je oblúbeným a častým motívom v próze naturizmu. Emblematickú postavu Draka od jeho prvopočiatku sprevádzajú temné sily a pripisujú sa mu nevysvetlitel'né deje od požiarov, enormného sucha, neúrody až po smrt'. Cyklickost' času je jedným z hlavných znakov prózy naturizmu. Všetko je nemenné a všetko sa opakuje. Nie je zadefinovaný žiadny reálny, historický čas. Práve tento uzatvorený, ba priam až klaustrofobický priestor času predznamenáva jeho tragickost'. Tragický rozmer uzavretosti poukazuje na neschopnost' vymanit' sa spod l'udského odsúdenia. V rámci cyklickosti je potrebné zamerat' sa na posvätný čas a mýty z hl'adiska profánnosakrálneho.

\subsection{DRAK V ZAJATÍ OHŇA}

Symbolika živlov sa vyskytuje ako v profánnom, tak aj v sakrálnom ponímaní. Symbol ohňa môže indikovat' nepochopenie a neprijatie hlavnej postavy. Aj človek niekedy stráca kontrolu nad ohňom, tak rovnako aj postavu vydedenca nemožno skrotit' ani nijak podmanit' či pochopit'. Oheň od dávnych čias predznamenával niečo spal'ujúce, niečo, čo dodáva element energie. V krest'anstve je symbol ohňa znakom Ducha Svätého. Pri ohni musíme rozlišovat' pojmy ako zapal'ovat' a spal'ovat'. Niečo sa v nás zapáli alebo sme zapálení pre niečo je vnímané skôr z kladnej stránky. Z pohl'adu náboženského sa v nás môže zapálit' Duch Svätý, ktorý sa rovnako ako oheň nedá uchopit'. Je to niečo, čo vanie akýmkol'vek smerom bez našej kontroly. V prepojení s analýzou diela Drak sa vracia sa symbolika ohňa premieta v negatívnom slova zmysle. V zmysle spal'ovania, horenia a z toho prameniaceho nepokoja. V krest'anstve sa tento výraz môže vnímat' aj ako spal'ovanie, pálenie alebo t'ažoba. Najčastejšie v prepojení na hriech, ktorý je nežiadúci a treba ho odstránit'. V pohanskej mytológii sú známe povery a symboly týkajúce sa ohňa. Ten sa nesmel 13. decembra požičiavat' a ani prenášat'. Bol prísny zákaz manipulovania s ohňom a približenia sa $\mathrm{k}$ peci (Maretta, 2013, s. 32). Oheň v tomto kontexte je d'alej chápaný ako obranný prostriedok. Známy je ochranný rituál pochádzajúci od starých Keltov. Človek, ktorý sa chce ochránit’ by si mal sadnút' pred ohnisko a predstavovat' si, ako ho oheň obklopuje ochranným svetlom a vytvára bariéru. Pre umocnenie je potrebné použit' rituálnu formulku: „Kúzlo v ohni utkané okolo mn̆a nech vystane a obklopí ma svojou žiarou ako ochrannou stenou. Nikto tú stenu neprestúpi. Nikto skrz ňu neprejde. Nikto v nej škáru nenájde“ (ibid. s. 49). V súvislosti s daným ponímaním ohňa konštatujeme, že výber symbolu horiaceho ohňa a plameňov, ktorý je spätý s Drakom nebol náhodný. Medzi Drakom a dedinčanmi je vytvorená bariéra, ktorá slúži podobne ako ochrana pomocou ohňa. Drak je tak izolovaný od ostatných, čo ešte viac vyzdvihuje jeho individualita a vzt’ah vopozícií ku kolektívu. Zachované sú aj rituály a povery vzt'ahujúce sa na oheň a konkrétne na ohnivé ret'aze. Tie majú podobu bud' ohnivej gule alebo hada. Súvislost' s hadom, ktorý predznamenáva zlé sily je prenesená aj do vizuálnej podoby. Drak okrem toho, že cez oko má prelepenú čiernu pásku, tak na tvári má jazvu v tvare hada. Opät' viditel'ný negatívny symbol a odkaz na predurčenie jeho osudovosti. Vzt'ah symbolu ohňa a ohnivej gule je častým motívom vo viacerých zaznamenaných rozprávaniach. Ohnivému zjavu sa niekedy hovorí aj rarašek, rarach, na Ukrajine rarig a v ruských oblastiach rarog alebo rach. Obraz ohnivej gule je geneticky spojený so staroslovanským bohom ohňa Svarogom alebo Svarožičom, spomínaný v ruských a baltských 
letopisoch. V našich slovenských reáliách sa výskyt ohnivého zjavu pripisuje zlému duchovi. Ohnivá gul'a alebo ohnivý had má výlučne negatívny charakter (ibid. s. 50).

Konkrétny odkaz na staroslovenskú minulost' nemôžeme prehliadnut' ani v súvislosti s naším bádatel'ským kontextom. Z vyššie uvedeného je zrejmé, že motív ohňa v prepojení na dielo je vnímané ako negatívne. Postava Draka tak vystupuje vnegatívnom svetle a hodnotí sa záporne. Výber takého elementu ako je oheň symbolizuje hlbokú spätost' človeka s krajinou a prírodou, charakteristickú pre celú prózu naturizmu. Porozumenie prírodnému rytmu, cyklickosti a vedomie vlastnej závislosti od prírody je d’alším dominantným prvkom vyskytujúcim sa v dielach autorov daného obdobia. Takmer celé dielo sa nesie v znamení opozície krest'anské - pohanské a je zahalené rúškom tajomstva. Explicitne je to vyjadrené prostredníctvom dediny, ktorá vystupuje ako kolektívne vedomie - jedna duša. Správaním a slovami dedinčanov ožívajú povery, predsudky, kliatby, ale tiež i strach zo všadeprítomného Božieho trestu. Na tomto príklade najlepšie vidiet' rozkol, resp. opozíciu v myslení l'udí. Na jednej strane viera $v$ povery a na strane druhej viera $v$ Boha. Aj napriek tomuto rozporu v myslení l'udí, dedina stále vystupuje ako jeden celok. Rozhoduje o vine a treste a často svojím správaním koná ako jednotlivec.

Próza naturizmu pôsobí dojmom priameho postoja k prírode, dedine a nefalšovaným citom. Práve za týmto priamym postojom, vyjadreným explicitne, sa ukrýva vnútorná podoba prózy naturizmu, ktorá je založená na opozíciách dobra a zla, života a smrti, zrodu a zániku, profánneho i sakrálneho. Jednotlivé opozície tak nevytvárajú protiklady, ale naopak tvoria jednotný celok, ktorý je prít’ažlivý svojou nejednoznačnost'ou. V štúdii sme sa zamerali na význam a symboliku ohňa, cyklickost' času, mýtus, znakovo-estetické zobrazenie, krest'anské a pohanské motívy, ambivalentnost' postáv, protiklad dobra a zla a archetypy, ktoré sú symbolickými klasifikáciami v podobe sémantických opozícií v literárnom diele, pričom sa stali predlohou k filmovému spracovaniu.

\section{Sources}

1. CHROBÁK, D. Drak sa vracia. Tatran: 1943, 252 s.

2. MACEK, PAS̆TÉKOVÁ: Dejiny slovenskej kinematografie 1896 - 1969. Slovenský filmový ústav, 2017, 624 s. ISBN 9788085739688.

3. MARETTA, J. 2013. Povery ničiace rodiny. Vydavatel'stvo PETRA, 2013, 87 s. ISBN 978-80-8099-068-8.

4. ŠÚTOVEC, M. 2005. Mýtus a dejiny v próze naturizmu. Literárne informačné centrum. 2005. 248 s. ISBN 808-88-78985.

\section{Kontakt}

PhDr. Sylvia Hrešková

Constantine the Philosopher University in Nitra

Faculty of Central European Studies

Dražovská Street 4, Nitra, Slovakia

Email: sylvia.hreskova@gmail.com 


\title{
FILOSOFIE A VĚDA V KONTEXTU LIDSKÉHO ZDRAVÍ \\ PHILOSOPHY AND SCIENCE IN THE CONTEXT OF HUMAN \\ HEALTH
}

\author{
Klára Doláková
}

\begin{abstract}
Abstrakt
Příspěvek se zabývá oblastí vědeckého a filosofického bádání v kontextu lidského zdraví. První část stručně přibližuje, jakým způsobem pracuje filosofie, jak postupuje věda, jak se tyto přístupy vzájemně liší a co mají naopak společného. Představeny jsou i některé nevšední myšlenky zástupců filosofie vědy, kteří upozorňují na určité limity nastavených vědeckých metod. Druhá část je věnována dvěma specifickým konceptům, se kterými se můžeme setkat v moderním světovém zdravotnictví. Prvním z nich je koncept evidence-based medicine (EBM), druhý je koncept complementary and alternative medicine (CAM). Cílem př́spěvku je přiblížit obě oblasti a poukázat tak na možné směry vývoje filosofie i vědy v oblasti lidského zdraví.
\end{abstract}

Klićová slova: filosofie, věda, filosofie vědy, evidence based medicine (EBM), complementary alternative medicine (CAM)

\begin{abstract}
The paper deals with the field of scientific and philosophical research in the context of human health. The first part briefly describes how philosophy works, how science proceeds, how these approaches differ from each other and, moreover, what they have in common. Several unusual ideas of representatives of the philosophy of science are also presented, who point out some limits of the set scientific methods. The second part is devoted to two specific concepts that might be encountered in modern healthcare. The first is the concept of evidence-based medicine (EBM), the second is the concept of complementary and alternative medicine (CAM). The aim of the paper is to approach both areas and thus point out the possible directions of development of philosophy and science in the field of human health.
\end{abstract}

Key words: philosophy, science, philosophy of science, evidence based medicine (EBM), complementary alternative medicine (CAM)

\section{FILOSOFIE A VĚDA}

Ve svých počátcích sloužila filosofie především ke zpochybňování pověr a mýtů, čehož dosahovala zejména pokládáním otázek. Právě touha po poznání podstaty života a světa kolem nás, která přináší tyto filosofické otázky, je základem, ze kterého později vzešly i další vědní obory. Pro oblast filosofie a vědy je společné, že mají snahu o rozumové pochopení a obecnou formulaci závazných pojmů. Právě tato snaha je odlišuje od mýtů. ${ }^{1}$

\subsection{Jak pracuje filosofie}

Filosofie by neměla přinášet hotové odpovědi na základní otázky, ale naopak přimět člověka, aby dané odpovědi nalezl vlastní úvahou a nepřijímal bez výhrad konvenční názory nebo

\footnotetext{
${ }^{1}$ SOKOL, Jan. Malá filosofie člověka a Slovník filosofických pojmů. 3. rožšřr. vyd. Praha: Vyšehrad, 1998, ISBN 80-7021253-5.
} 
tradiční autority. ${ }^{2}$ Tuto myšlenku snad vystihují slova J. A. Komenského: „Nevěřte všemu, co se vám $k$ věrení předkládá. Zkoumejte vše a přesvédčujte se o všem sami. "Ve filosofii nejde o ideje, ale představuje určitý způsob myšlení, který člověku umožňuje, aby si na jednotlivé problémy utvářel vlastní názor bez ohledu na společnost, učitele, politiky, média, náboženství a další vlivové oblasti, ale naopak pouze vlastním uvažováním o daném konkrétním problému. Nové ideje vznikají nejčastěji diskuzí, během které jsou názory přezkoumávány, analyzovány či kritizovány myšlenkami druhých. Již v antickém Řecku sloužil dialog jako metoda filosofického zkoumání, která se pokoušela zachytit nejednoznačnost a mnohostrannost různých světonázorů s cílem dobrat se pravdy nebo alespoň shodného mínění. Mimo Sokrata a Platóna používala formu dialogu i řada dalších filosofů a ve svých spisech kladli důraz spíše na shrnutí argumentů a protiargumentů než na jasně stanovené závěry svého uvažování. ${ }^{2}$ Dialog přitom nemusí být omezen na dvě osoby, ale může se týkat všech, kteří mají potřebu se $\mathrm{k}$ dané problematice vyjádřit. Tak je tomu např́iklad v Platónově díle Symposion, ve kterém se z historického hlediska jedná o hostinu, po které následovala výměna a tř́ibení názorů na zvolené téma. ${ }^{3}$

\subsection{Jak pracuje věda}

Vědecká činnost se za poslední století velmi proměnila. Zcela běžná je institucionalizace vědy, tedy její oddělení od běžného života a soustředění v rámci výzkumných institucí. Dále došlo ke specializaci jednotlivých vědců na konkrétní oblasti výzkumu. Důležitou roli hrají ve vědeckém bádání také děje, které se aktuálně odehrávají ve společnosti, nebot' platí, že věda je produktem vědců, kteř́ žijí v určité době a určité společnosti, která na ně má nějaký vliv. ${ }^{4}$ Př́kladem je bezesporu koronavirová pandemie, která mj. v oblasti medicíny významným způsobem urychlila vývoj a použití genetického templátu v podobě mRNA na výrobu vakcín. ${ }^{5}$ Samotná definice a klasifikace vědy je velmi složitá, nicméně vědecké disciplíny mají společného jmenovatele - vědecké závěry by měly být ověřitelné. Také platí, že byla vědci stanovena pravidla vědecké práce, resp. vědecké metody, které by měly ověřitelnost vědeckých závěrů garantovat. ${ }^{4}$ Dle J. Heřta je pro vědecké poznání klíčové, aby byly dané výsledky reprodukovatelné a intersubjektivní. Jako metodiku vědy pak uvádí zejména pozorování, induktivní a deduktivní procesy, logickou analýzu, myšlenkový experiment a reálný experiment. Obecně lze uvedené př́iklady vyjádřit termínem redukcionistická metoda, tzn. rozdělení celku na části a dále jejich analýza a syntéza. ${ }^{6}$

\subsection{Filosofie vědy}

Ačkoliv má oblast filosofie vědy kořeny již v antice, více se rožšririla až s novodobým vědeckým rozvojem. Předmětem fillosofie vědy je např́íklad zkoumání, jak vznikají a jak se odůvodňují vědecké hypotézy nebo čím jsou specifické induktivní procesy. ${ }^{7}$ I. Holzbachová uvádí, že se filosofie vědy pokouší zařadit vědu do kontextu společenské struktury. Autorka rozlišuje dva hlavní proudy filosofie vědy: neoticko-logický a společensko-historický. První zmíněný se pokouší především o logickou analýzu metod, které se užívají ve vědě a důsledky použití těchto metod. Pro filosofy tohoto proudu je velmi důležitá otázka demarkace, tedy jaká jsou kritéria, která umožňují rozlišit co je a co není věda. Druhý zmíněný proud vychází

\footnotetext{
${ }^{2}$ BUCKINGHAM, Will. Kniha filozofie. Praha: Knižní klub, 2013. Universum (Knižní klub). ISBN 978-80-242-3912-5.

${ }^{3}$ PTÁČEK, Radek a Petr BARTŮNĚK, ed. Kontroverze současné mediciny. Praha: Mladá fronta, 2016. Edice celoživotního vzdělávání ČLK. ISBN 978-80-204-4360-1.

${ }^{4}$ NOVOTNÝ, Jan a Jindřiška SVOBODOVÁ. Jak pracuje věda V.2. 2. vyd. Brno: Masarykova univerzita, 2014. $112 \mathrm{~s}$. TeePee. ISBN 978-80-210-6942-8.

${ }^{5}$ STRUNECKÁ, Anna a Jiří PATOČKA. Doba jedová a covidová. Petrovice: ProfiSales, [2021]. ISBN 978-80-87494-38-7.

6 HEŘT, Jiří. Věda. Sysifos, český klub skeptiků [online]. ČR: Red Peppers, 2007 [cit. 2021-6-20]. Dostupné z: https://www.sisyfos.cz/clanek/860-ve-i-i-da

${ }^{7}$ BERKA, Karel. Filosofie vědy. Sociologická encyklopedie [online]. ČR: Sociologický ústav AV ČR, 2017 [cit. 2021-6-20]. Dostupné z: https://encyklopedie.soc.cas.cz/w/Filozofie_v\%C4\%9Bdy
} 
především ze změn, které přinesly kvantová a relativistická fyzika a dále je pro tento proud typické, že klade důraz na vlivy, které vědu ovlivňují. To jsou např́klad vlivy politické, kulturní apod. Tyto vlivy mohou např́íklad významně ovlivnit, zda bude či nebude ve svém vývoji věda podporována či brzděna. Níže jsou představeny myšlenky a úvahy vybraných představitelů filosofie vědy.

Dle Karla Poppera, jednoho z předních představitelů filosofie vědy 20. století, reprezentuje věda soustavné a nikdy nekončící kritické ověřování hypotéz. Popper zavádí termín falibilismus, který vyjadřuje vědeckou omylnost a soustavné hledání pravdy, resp. neustálé odstraňování omylů. ${ }^{8} \mathrm{~V}$ díle Logika vědeckého bádání v této souvislosti např́klad uvádí, že „Hra vědy je v principu bez konce. Ten, kdo by se jednoho dne rozhodl, že vědecká tvrzení už nevyžaduji dalšiho testováni a že mohou být pokládána za verifikovaná s konečnou platností, ten by tuto hru prestal hrát." 9

Předchůdce Poppera, P. K. Feyerabend v díle Rozprava proti metodě, upozorňuje na určité limity, které představuje idea neměnné metody vědeckého bádání. V rámci historického zkoumání se totiž ukázalo, že daná vědecká pravidla byla $v$ průběhu času porušena a $v$ řadě př́padů některými mysliteli zcela záměrně. Feyerabend to zdůvodňuje tím, že jediný princip, který nebrání pokroku je ,anything goes“, tedy „,cokoliv je možné“. Uvádí, že za určitých okolností je žádoucí a vhodné „,propracovat ad hoc hypotézy, které odporuji dobře ustaveným a přijatým experimentálním výsledkưm “. Taková praxe je dle něj nejen žádoucí, ale i nutná, nebot' platí, že pro jakékoliv pravidlo existují situace a okolnosti, kdy je vhodné prrijmout jeho opak. ${ }^{10}$

Komplexní teorii, v níž mají omyly vědy své místo, popisuje v díle Struktura vědeckých revoluci Thomas S. Kuhn. Dle Khuna se vědecká teorie vyvíjí ve dvou etapách - v etapě normální vědy a v etapě vědecké revoluce. Pro etapu normální vědy je charakteristické určité vědecké paradigma, tzn. hlavní teorie, která určuje, jak mohou vypadat řešení dílčích problémů, aby mohla být obecně přijatelná. V tomto období většinou nedochází k objevování něčeho zásadně nového. Po určitém čase však dojde k vyčerpání daného paradigmatu, nebot' se budou vědci čím dál častěji setkávat s odpověd'mi, resp. anomáliemi, které neodpovídají danému paradigmatu. Jakmile dojde k nahromadění takových anomálií, započne hledání paradigmatu nového. Období hledání nového, vyhovujícího paradigmatu nazývá Khun krizí teorie, která vždy předchází období vědecké revoluce. Ta je ukončena vítezstvím některého z nových paradigmat a opět nastává období normální vědy. ${ }^{11}$

\section{FILOSOFIE A VĚDA V KONTEXTU LIDSKÉHO ZDRAVÍ}

Ve starověkém Řecku byla za ideál zdravého a dobrého života považována „kalokaghatia“ (z řec. kalos $=$ krásný a aghatos $=$ dobrý). Starověcí Řekové vnímali kalokaghatii jako harmonii těla a duše a považovali ji za lidskou snahu o dobro. ${ }^{11}$ Definice zdraví dle Světové zdravotnické organizace z r. 1948 je ,stav úplné duševní, fyzické a sociální pohody, a nikoliv pouze absence nemoci“. Můžeme se setkat i s dalšími definicemi jako např. „zdraví je stav, který jednotlivci umožňuje se adekvátně vyrovnávat se všemi požadavky každodenního života“ nebo ,zdraví je stav rovnováhy, kterou si člověk vytvořil sám v sobě a mezi sebou a svým sociálním a fyzickým prostředím“. ${ }^{12}$

Rozvoj vědy v posledních desetiletích hraje v kontextu lidského zdraví významnou roli. Expanze medicínských poznatků a jejich přesah do oblastí, které svou povahou nepředstavují

\footnotetext{
${ }^{8}$ HOLZBACHOVÁ, Ivana. Filozofické a metodologické problémy vědy. Vyd. 2. Brno: Masarykova univerzita, 2000. ISBN isbn80-210-2394-5.

${ }^{9}$ POPPER, Karl R. Logika vědeckého bádání. Praha: OIKOYMENH, 1997. Oikúmené (OIKOYMENH). ISBN 80-8600545-3.

${ }^{10}$ FEYERABEND, Paul K. Rozprava proti metodě. Praha: Aurora, 2001. ISBN 80-7299-047-0.

${ }^{11}$ RYBÁŘ, Radovan. Filosofické souvislosti zdraví. In 7. konference Škola a zdraví 21. 2011.

${ }^{12}$ Sartorius N. The meanings of health and its promotion. Croat Med J. 2006;47(4):662-664.
} 
nemoc vystihuje termín medicinalizace. Jedná se o určitou dominanci medicíny i v dříve nemedicínských oborech jako je např. stravování, pohybová aktivita, začátek a konec života apod. Tento jev má své výhody i nevýhody. Výhodou je např́klad prodlužování lidského života nebo vliv na úspěšné léčení nemocí, nevýhodu pak představuje např́íklad sociální a kulturní iatrogeneze neboli ztráta schopnosti vnímat pohnutky a impulsy vlastního organismu nebo odevzdávání odpovědnosti za své zdraví do rukou lékař̆o ${ }^{13}$

Níže jsou představeny dva velmi diskutované koncepty voblasti lidského zdraví, které v posledních dekádách zaznamenaly značný rozvoj i určité kontroverze. Ačkoliv jsou někdy vnímány antagonisticky, zůstává otázkou, jaký vztah, resp. jakou pozici budou mít tyto koncepty $\mathrm{v}$ budoucích letech.

\subsection{Koncept Evidence-based medicine (EBM)}

Přibližně od poloviny 90 . let 20 . století se můžeme setkat s pojmem evidence-based medicine (dále jen EBM), tj. medicínou založenou na důkazech, která postupně nahradila medicínu založenou na zkušenostech. Tento všeobecně používaný anglický termín se již od svého vzniku masově rozšiŕíil po celém světě - byla založena univerzitní školící centra pro EBM, odborné časopisy věnované EBM i mezinárodně uznávané směrnice, jak lékařský výzkum provádět. Na vypracování samotných zásad EBM se významně podílel D. L. Sackett, podle kterého je EBM „,péčí, která integruje klinickou zkušenost se zájmy pacienta a s védeckými dưkazy o účinnosti léčby. "14 Za tzv. zlatý standard lékařského výzkumu se dnes považují klinické studie na principu dvojitého zaslepení, systematické přehledy a metaanalýzy. J. Heřt uvádí, že koncept EBM je nezbytné považovat spíše za cílový stav medicíny než ten nynější, nebot' i ve vědecké medicíně se můžeme setkat s dosud neověřenými či neúčinnými prostředky. Připouští i možnost určité kritiky EBM, která může až př́liš důvěřovat výsledkům multicentrických studií, a to na úkor původní Sackettovy koncepce EBM. ${ }^{15}$ Na některá úskalí EBM upozorňuje také R. Ptáček, který označuje EBM za „kličové paradigma moderní medicíny. " V př́spěvku Evidence based medicine: centrálni kontroverze současné medicíny např́iklad uvádí, že princip EBM je aplikací statistických metod, které však mohou představovat určitá omezení, protože mj. dochází k redukci nebo vyřazení některých implicitiních faktorů (např̀. hledisko pacienta, klinický úsudek vyplývající ze zkušenosti apod.), a proto se dle něj nejedná o skutečný vědecký př́stup založený na ověřování platnosti hypotéz, které mají svá teoretická východiska, a mnohdy navazují na předchozí stav vědeckého poznání. Autor uvádí celkem tři hlavní argumenty kritiky přístupu EBM:

1) metodologické souvislosti, konkrétně chybný úsudek, že statistická významnost popisuje skutečnou kauzalitu a že EBM představuje pouhé měření velikosti efektu dané metody

2) odborné souvislosti: upřednostňování doporučených postupů vyplývajících z výsledků EBM namísto klinické zkušenosti lékaře, který daný př́ípad posuzuje vždy v souvislosti s konkrétním pacientem

3) etické souvislosti: EBM může mít značný vliv na směřování výzkumu, na vytváření „zlatého standardu“ a rovněž může ovlivňovat, jaké druhy znalostí budou preferovány; autor také upozorňuje na změnu ve vědecké terminologii, resp. na výraz „důkaz“, který v EBM neznamená to, čemu ř́káme důkaz v metodologii a filosofii vědy, tedy „,nepochybné nebo alespoň důkladné zdůvodnění a ověrení nebo odhad pravdivosti/skutečnosti " 3

V kontextu výše uvedených argumentů je na místě zmínit souvislost s některými myšlenkami filosofie vědy, konkrétně představou o zcela nezávislé vědě, která není ovlivněna názory či

\footnotetext{
${ }^{13}$ IVANOVÁ, Kateřina, Lubica JURÍČKOVÁ a Ivan GLADKIJ. Medicína a společnost. Olomouc: Univerzita Palackého v Olomouci, 2013. ISBN 978-80-244-3446-9.

${ }^{14}$ HEŘT, Jiří. Alternativní medicína a léčitelství. V Praze: Věra Nosková, 2011. ISBN 978-80-87373-15-6.

${ }^{15}$ Evidence-based medicine. Sysifos, český klub skeptiků [online]. ČR, 2007 [cit. 2021-6-21]. Dostupné z: https://www.sisyf os.cz/clanek/1057-evidence-based-medicine
} 
hodnotami pozorovatele. O tom, zda je či není věda ovlivněna hodnotami v dané společnosti se vedou čilé diskuze. Lze však konstatovat, že vědecké a výzkumné instituce neexistují jako oddělené jednotky, ale fungují v určitém kontextu hodnot občanů či zájmů a politických cílů vlád. ${ }^{4}$

\subsection{Koncept Complementary alternative medicine (CAM)}

Komplementární a alternativní medicína (dále CAM) je jedno z řady označení pro preventivní a léčebné metody a postupy, které nevycházejí z teoretických konceptů moderní medicíny. ${ }^{16}$ Protože tato oblast není z hlediska terminologie unifikována, bude představena širší definice evropské výzkumné sítě CAMbrella: „CAM, využivaná evropskými občany, predstavuje širokou škálu léčebných systému a terapií, založených na znalostech, dovednostech a praxi; odvozených z teorii, filozofii a zkušeností použivaných k udržování a zlepšování zdraví, jakož $i$ $k$ prevenci, diagnostice, zmírněni nebo léčbě fyzických a duševnich chorob. Terapie a metody CAM se použivaji predevším mimo konvenční zdravotní péči, ale v mnoha zemích jsou některé terapie prijaty nebo upraveny $i$ v rámci běžně poskytované zdravotní péče. " 17

J. Heřt v souvislosti s CAM poukazuje na to, že metody, které lze zařadit mezi alternativní, vychází mj. z místní lidové tradice, jinými slovy metody a postupy, které jsou v některých zemích považovány za alternativní, v jiných zemích být považovány za alternativní nemusí. $\mathrm{Na}$ místní tradici v souvislosti s alternativní medicínou upozorňuje také T. Pfeiffer, který uvádí, že zejména pro místní mimo-medicínskou léčbu používá Světová zdravotnická organizace termín tradiční medicína. Ve své podstatě se však pojmy tradiční medicína, alternativní či komplementární medicína svým významem překrývají, nebot' právě tradiční terapie jsou čím dál častěji používány ve vyspělých západních zemích, kde se pro takové terapie používá označení komplementární a alternativní medicína. ${ }^{18}$

Dle výše uvedeného evropského výzkumného projektu využívá metod CAM na 100000000 Evropanů. I v tuzemsku je o oblast CAM patrný zájem. Dle průzkumu agentury STEM/MARK z roku 2014 vyplývá, že až 85 \% Čechů (celkem 500 respondentů ve věku 1559 let) by uvítalo, kdyby některé metody CAM byly uznány jako oficiální doplněk konvenční léčby a byly by hrazeny v rámci zdravotního pojištění. ${ }^{19} \mathrm{H}$. Haškovcová uvádí, že CAM jako „fenomén u nás existuje a bude ji nutné v blízké budoucnosti reflektovat “. ${ }^{20}$ Značný zájem o oblast CAM se promítl také do oblasti vědeckého výzkumu. Narostl počet vědeckých časopisů v oblasti CAM (největší počet je v Číně, následuje USA, Indie a Velká Británie) a prudce stoupla také citovanost článků v této oblasti. V roce 1998 založil Kongres Spojených Států Národní centrum pro komplementární a alternativní medicínu (NCCAM, z angl. National Center for Complementary and alternative Medicine), které je součástí Národního centra zdraví. NCCAM financuje univerzitní centra pro výzkum v oblasti CAM, což napomáhá stimulovat vědecké pracovníky, aby žádali o granty a prováděli výzkum v této oblasti. ${ }^{21}$ Národní výzkumná centra v oblasti CAM mají i mnohé evropské státy (např. VB, Španělsko, Francie, Rakousko, Německo a další). V ČR výzkumné centrum pro oblast CAM není. ${ }^{18}$

\footnotetext{
${ }^{16}$ KŘÍŽOVÁ, Eva. Alternativní medicína v České republice. Praha: Karolinum, 2015. ISBN 978-80-246-2498-3.

${ }^{17}$ Complementary and Alternative Medicine CAM - for a healthier Europe. EUROCAM [online]. Belgium: EUROCAM, 2014 [cit. 2019-23-03]. Dostupné z: http://www.cam-europe.eu/cam-definition.php

${ }_{18}$ Alternativní medicína (CAM) ve světě: o čem se mlčí. 2. přepracované vydání. Praha: Tomáš Pfeiffer, nakladatelství Dimenze 2+2, 2018. ISBN 978-80-85238-99-0.

19 Uznání alternativní medicíny by uvítalo $85 \%$ lidi, zjistil průzkum [online]. [cit. 2019-23-03]. Dostupné z: https://www.denik.cz/z_domova/uznani-alternativni-mediciny-by-uvitalo-85-procent-lidi-zjistilpruzkum-20140826.html

${ }^{20}$ HAŠKOVCOVÁ, Helena. Lékařská etika. Čtvrté, aktualizované a rozšířené vydání. Praha: Galén, [2015]. ISBN 978-807492-204-6.

${ }^{21}$ HALEVI, Gali. Ancient medicine in modern times. Research trends [online]. 2013, 12(35), 13-16 [cit. 2021-6-22]. Dostupné z: https://www.researchgate.net/publication/262871815_Ancient_medicine_in_modern_times
} 
Z celoevropského výzkumného projektu CAMbrella mj. vyplývá, že by mělo dojít k vypracování modelů možného začlenění CAM do zdravotnictví. Integraci některých metod CAM do zdravotnictví dlouhodobě podporuje i Světová zdravotnická organizace v dokumentu Strategie pro tradiční medicínu 2014-2023 (z angl. The WHO Traditional Medicine Strategy 2014-2023). ${ }^{22}$

\subsection{Jaká je vize vědeckého bádání v oblasti lidského zdraví v př̌íším tisíciletí?}

Z etického hlediska je zcela neoddiskutovatelné, že hlavním cílem by vždy měl být maximální možný prospěch pacienta. Připomínají nám to i nesmrtelná Hippokratova slova: „Jediným velkým lékařským uméním je vyléčit pacienta a je lhostejno, jakým způsobem se to podaří.

At' už se tedy věda v oblasti lidského zdraví bude ubírat jakoukoliv cestou, vždy by měla ve svém vývoji reflektovat tento základní princip. O to významnější roli pak představuje filosofie a její praktické aplikace čili etika. Otázkou však zůstává, jakým směrem se bude medicína, resp. vědecké bádání v oblasti lidského zdraví do budoucna ubírat? Je EBM skutečně cílovým stavem medicíny, jak uvádí např́klad J. Heřt? Dojde celosvětově k větší integraci některých metod CAM do lokálních systémů zdravotnictví, jak doporučuje Světová zdravotnická organizace? Na tyto otázky nyní neznáme odpověd', lze však konstatovat, že právě budoucí vývoj vědeckého paradigmatu může významně ovlivnit další směřování vědy i filosofie v oblasti lidského zdraví.

\section{Použitá literatura}

1. Alternativní medicína (CAM) ve světě: o čem se mlčí. 2. přepracované vydání. Praha: Tomáš Pfeiffer, nakladatelství Dimenze 2+2, 2018. ISBN 978-80-85238-99-0.

2. BERKA, Karel. Filosofie vědy. Sociologická encyklopedie [online]. ČR: Sociologický ústav AV ČR, 2017 [cit. 2021-6-20]. Dostupné z: https://encyklo pedie.soc.cas.cz/w/Filozofie_v\%C4\%9Bdy

3. BUCKINGHAM, Will. Kniha filozofie. Praha: Knižní klub, 2013. Universum (Knižní klub). ISBN 978-80-242-3912-5.

4. Complementary and Alternative Medicine CAM - for a healthier Europe. EUROCAM [online]. Belgium: EUROCAM, 2014 [cit. 2019-23-03]. Dostupné z: http://www.cam-europe.eu/cam-definition.php

5. Evidence-based medicine. Sysifos, český klub skeptiků [online]. ČR, 2007 [cit. 2021-6-21]. Dostupné z: https://www.sisyfos.cz/clanek/1057-evidence-basedmedicine

6. FEYERABEND, Paul K. Rozprava proti metodě. Praha: Aurora, 2001. ISBN 807299-047-0.

7. HALEVI, Gali. Ancient medicine in modern times. Research trends [online]. 2013, 12(35), 13-16 [cit. 2021-6-22]. Dostupné z: https://www.researchgate.net/pu blication/262871815_Ancient_medicine_in_modern_times

8. HAŠKOVCOVÁ, Helena. Lékařská etika. Čtvrté, aktualizované a rozšiřrené vydání. Praha: Galén, [2015]. ISBN 978-80-7492-204-6.

9. HEŘT, Jiří. Alternativní medicína a léčitelství. V Praze: Věra Nosková, 2011. ISBN 978-80-87373-15-6.

10. HEŘT, Jiří. Věda. Sysifos, český klub skeptiků [online]. ČR: Red Peppers, 2007 [cit. 2021-6-20]. Dostupné z: https://www.sisyfos.cz/clanek/860-ve-i-i-da

11. HOLZBACHOVÁ, Ivana. Filozofické a metodologické problémy vědy. Vyd. 2. Brno: Masarykova univerzita, 2000. ISBN isbn80-210-2394-5.

\footnotetext{
${ }^{22}$ WHO traditional medicine strategy 2014-2023 [online]. Geneva: World Health Organization, 2013 [cit. 2021-6-22]. ISBN 9241506091. Dostupné z: http://apps.who.int/iris/bitstream/handle/10665/92455/9789241506090_eng.pdf;jsessionid=8A 3602A9DE43E86557A31 AF66DED088C? sequence=1
} 
12. IVANOVÁ, Kateřina, Lubica JURÍČKOVÁ a Ivan GLADKIJ. Medicína a společnost. Olomouc: Univerzita Palackého v Olomouci, 2013. ISBN 978-80-2443446-9.

13. KŘÍŽOVÁ, Eva. Alternativní medicína v České republice. Praha: Karolinum, 2015. ISBN 978-80-246-2498-3.

14. NOVOTNÝ, Jan a Jindřiška SVOBODOVÁ. Jak pracuje věda V.2. 2. vyd. Brno: Masarykova univerzita, 2014. 112 s. TeePee. ISBN 978-80-210-6942-8.

15. POPPER, Karl R. Logika vědeckého bádání. Praha: OIKOYMENH, 1997. Oikúmené (OIKOYMENH). ISBN 80-86005-45-3.

16. PTÁČEK, Radek a Petr BARTŮNĚK, ed. Kontroverze současné mediciny. Praha: Mladá fronta, 2016. Edice celoživotního vzdělávání ČLK. ISBN 978-80-204-4360-1.

17. RYBÁŘ, Radovan. Filosofické souvislosti zdraví. In 7. konference Škola a zdraví 21. 2011.

18. SARTORIUS, N. The meanings of health and its promotion. Croat Med J. 2006;47(4):662-664.

19. SOKOL, Jan. Malá filosofie člověka a Slovník filosofických pojmů. 3. rozšíŕ. vyd. Praha: Vyšehrad, 1998, ISBN 80-702-1253-5.

20. STRUNECKÁ, Anna a Jiř́ PATOČKA. Doba jedová a covidová. Petrovice: ProfiSales, [2021]. ISBN 978-80-87494-38-7.

21. Uznání alternativní medicíny by uvítalo 85\% lidí, zjistil průzkum [online]. [cit. 201923-03]. Dostupné z: https://www.denik.cz/z_domova/uznani-alternativni-medicinyby-uvitalo-85-procent-lidi-zjistilpruzkum-20140826.html

22. WHO traditional medicine strategy 2014-2023 [online]. Geneva: World Health Organization, 2013 [cit. 2021-6-22]. ISBN 9241506091. Dostupné z: http://apps.w ho.int/iris/bitstream/handle/10665/92455/9789241506090_eng.pdf;jsessionid=8A360 2A9DE43E86557A31AF66DED088C? sequence=1

\section{Kontaktní údaje}

Ing. Klára Doláková, MBA

Univerzita Karlova v Praze, Fakulta humanitních studií

Jindřicha Plachty 13, Praha 5

Tel: +420 775757239

email: klara.dolak@gmail.com 


\title{
POTREBA ZMENY PRÁVNEJ ÚPRAVY PO ZAVEDENÍ INŠTITÚTU EURÓPSKEHO PROKURÁTORA DO PRAXE
}

\section{THE NEED FOR A CHANGEIN LEGISLATION FOLLOWING THE IMPLEMENTATION OF THE EUROPEAN PUBLIC PROSECUTOR'SINSTITUTE IN PRACTICE}

\author{
Veronika Tóthová
}

\begin{abstract}
Abstrakt
Autor sa v článku venuje inštitútu euróspkej prokuratúry, dôvodmi jej vzniku a existujúcej štruktúry. Vymenúva jednotlivé základné právomoci európskej prokuratúry a vymedzuje jej príslušnost' $\mathrm{v}$ rámci nariadenia. Poukazuje na fakty, ako prijatie nariadenia o európskej prokuratúre ovplyvnilo vnútorštátnu úpravu $\mathrm{v}$ Slovenskej republike. $\mathrm{V}$ neposlednom rade poukazuje na problemtiku vykonávania právomoci európskej prokuratúry a to tak $\mathrm{V}$ jednotlivých zúčastnených štátoch, ktorí sú signatármi nariadenia, ale poukazuje aj na problematiku výkonu právomoci európskej prokuratúry medzi nezúčastnenými štátmi a taktiež tretími krajinami, ktoré nie sú ani členskými štátmi európskej únie.
\end{abstract}

Kl'účové slová: európska prokuratúra, európsky prokurátor, právomoc, nariadenie, vyšetrovanie, spolupráca

\begin{abstract}
In the article, the author deals with the institute of the European Public Prosecutor's Office, the reasons for its creation and the existing structure. It lists the various fundamental powers of the European Public Prosecutor's Office and defines its competence under the Regulation. She points out the facts how the adoption of the Regulation on the European Public Prosecutor's Office affected the national regulation in the Slovak Republic. Last but not least, the author points to the issue of exercising the powers of the European Public Prosecutor's Office in the individual participating states that are signatories to the Regulation, but also points to the issue of exercising the powers of the European Public Prosecutor's Office between non-participating states and third countries that are not even members of the European Union.
\end{abstract}

Key words: European Public Prosecutor's Office, European Prosecutor, competence, regulation, investigation, co-operation

\section{1. ÚVOD}

Európska prokuratúra je novým orgánom Európskej únie s právnou subjektivitou, ktorá vznikla v roku 2017, ale svoju činnost' doposial' ešte nezačala. Jedná sa o unikátny orgán Európskej únie, ktorého hlavnou úlohou bude vyšetrovanie a trestné stíhanie páchatel'ov v prípade spáchania trestných činov poškodzujúcich finančné záujmy Európskej únie. Obdobný orgán, ktorý by na úrovni členských štátov chránil rozpočet Európskej únie doposial' nebol nikdy vytvorený a preto zriadenie Európskej prokuratúry môžeme považovat' za významný krok k ochrane finančných zdrojov Európskej únie. Európska prokuratúra bola založená na základe Nariadenia Rady (EÚ) 2017/1939 z 12. októbra 2017 ktorým sa vykonáva posilnená spolupráca na účely zriadenia Európskej prokuratúry (d’alej v texte tiež ako „nariadenie“). Je možné stotožnit’ sa s názorom, že tento projekt je významným prejavom 
unifikácie európskeho trestného práva a odklonom od tradičnej justičnej spolupráce medzi štátmi smerom k zjednocovaniu a riadenému vyšetrovaniu trestných činov proti finančným záujmom Európskej únie na celom jej území. ${ }^{1}$ Prvotnou myšlienkou založenia Európskej prokuratúry bola podl'a názorov Komisie a Európskeho parlamentu potreba účinného nástroja na ochranu európskeho rozpočtu, ktorú členské štáty neboli schopné dostatočne zabezpečit'. Európska únia sa preto rozhodla už pred vyše 20-timi rokmi vypracovat' návrh harmonizácie trestného práva spoločne s návrhom na vznik Európskej prokuratúry pod názvom Corpus Juris, ktorý po následnej diskusii a zapracovaní pripomienok bol publikovaný pod označením Corpus Juris $2000 .^{2} \mathrm{Z}$ uvedeného vyplýva, že diskusie o zriadení tohto inštitútu mali svojich prívržencov ale aj odporcov ${ }^{3}$, čo nakoniec viedlo ku skutočnosti, že dňa 8. júna 2017 dosiahlo 20 členských štátov EÚ v rámci posilnenej spolupráce politickú dohodu o zriadení Európskej prokuratúry. Nariadenie, ktorým sa zriad'uje Európska prokuratúra prijala Rada pre spravodlivost' a vnútorné veci 12. októbra 2017 s účinnost'ou od 20. novembra 2017. Komisia 1. augusta 2018 potvrdila, že Holandsko sa zapojilo do činnosti Európskej prokuratúry a 7. augusta 2018 taktiež potvrdila, že Malta sa stala 22. členským štátom EÚ, ktorý sa zapojil do činnosti Európskej prokuratúry. Nezúčastnenými členskými štátmi tak do týchto dní zostali už len Pol'sko, Mad'arsko, Švédsko a Dánsko. V zmysle nariadenia je oprávnená Európska prokuratúra prevziat' právomoc dňom, ktorý určí Európska komisia, ktorý nesmie byt' skorší ako tri roky odo dňa nadobudnutia účinnosti nariadenia. $Z$ vyššie uvedeného de facto vyplýva, že Európska prokuratúra bude oprávnená vykonávat' svoju právomoc až od 20 . novembra 2020. Dátum vykonávania právomoci neznamená len personálne obsadit' tento úrad, ale ho aj materiálne a finančne zabezpečit', čo v súčasnej dobe môže značit' nemalé problémy, ktoré sa v konečnom dôsledku prejavili v skutočnosti, že do dnešného dňa nemáme ani v Slovenskej republike menovaný dostatočný počet delegovaných európskych prokurátorov. Zmeny, ktoré Európska prokuratúra prinesie sa netýkajú len samotnej Európskej únie, ale najmä samotných štátov v rámci posilnenej spolupráce, ktoré sa týkajú zmien ich vnútroštátnych právnych poriadkov. Úlohou tohto článku, preto nie je skúmat' štruktúru samotnej Európskej prokuratúry, ale najmä poukázat' na fakt, ako vykonávanie právomoci európskych prokurátorov, ale najmä delegovaných európskych prokurátorov môže ovplyvnit' spoluprácu pri plnení úloh súvisiacich $\mathrm{s}$ vyšetrovaním a trestným stíhaním a najmä či vykonávanie právomoci bude skôr priestorom na spoluprácu, alebo bude v praxi spôsobovat' nemalé problémy.

\section{2. ŠTRUKTÚRA EURÓPSKEJ PROKURATÚRY}

Aj ked' bolo vyššie spomenuté, že nebudeme skúmat' problematiku štruktúry Európskej prokuratúry, považujeme za dôležité zhrnút' aspoň najdôležitejšie fakty. Európska prokuratúra je nedelitel’ný orgán EÚ, ktorý bude mat’ štruktúru vybudovanú na dvoch úrovniach: ústrednej a decentralizovanej. Ústrednú úroveň, ktorá bude sídlit' v Luxemburgu, bude tvorit': kolégium, stále komory, hlavný európsky prokurátor, 22 európskych prokurátorov (jeden z

\footnotetext{
${ }^{1}$ JELINEK, J.: The future of the european public prosecutor's office. In the colection of scientosic Contributions of the nationwidw interdisciplinary scientific conference with an international participation: „I. Košice days of criminal law Perspectives on the development of European criminal law perspectives“., p. 424, EQUILIBRIA, s. r. o., ISBN: 978- 808162- 613-8

${ }^{2}$ DELMAS- MARTY M., VERVAELE J. A. E., Corpus Juris 2000: trestné právo na ochranu finančných záujmov Európskej únie (Európsky verejný prokurátor), Bratislava: Iura Edition, 2003. Úrad európskeho prokurátora mal byt' orgánom Európskeho spoločenstva zodpovedným za vyšetrovanie, trestné stíhanie, podanie obžaloby, zastupovanie obžaloby na hlavnom pojednávaní a výkon rozhodnutí v členských štátoch týkajúcich sa taxatívne vymenovaných trestných činov proti financiám Európskeho spoločnenstva. Bližšie tiež in FENYK, J.: Projekt modelového trestného práva Corpus Juris a právo na spravodlivý proces, in Ochrana základných práv a slobôd v procese europeizácie trestného práva, AUC Iuridica 1/2006, s. 37. ${ }^{3}$ Dôvodom diskusie vzniku inštitútu Európskeho prokurátora, vychádzal aj zo skutočnosti, že jednotlivé členské štáty nie sú schopné zaistit' adekvátnu ochranu finančných záujmov Európskej únie. Avšak považuje za dôležité zdôraznit' tú skutočnost', že návrhu nariadenia na zriadenie Európskej prokuratúry nepredchádzali podklady a analýzy, či ochrana finančných záujmov EÚ nemôže byt' dostatočne dosiahnutá na úrovni členských štátov.
} 
každého zúčastneného členského štátu), z ktorých dvaja budú zástupcami hlavného európskeho prokurátora a administratívny riaditel'. Európski prokurátori z jednotlivých členských štátov, budú tvorit' kolégium a po rozdelení do skupín po troch budú pôsobit' aj v stálych komorách. Kolégium EP tvori hlavný európsky prokurátor a jeden európsky prokurátor za každý členský štát. Hlavný európsky prokurátor predsedá zasadnutiam kolégia a je zodpovedný za ich prípravu. ${ }^{4}$ Kolégium zriadi stále komory, ktoré v trojčlennom stálom zložení sledujú a usmerňujú vyšetrovanie a trestné stíhanie, ktoré vedú európski prokurátori. ${ }^{5}$ Počet stálych komôr ako aj ich zloženie ešte nie je v súčasnosti známe, pretože bude vychádzat' na základe potrieb EP, v súlade s vnútorným rokovacím poriadkom EP, ktorý príjme kolégium. Európski prokurátori budú vykonávat' dozor nad trestným stíhaním alebo vyšetrovaním, za ktoré sú zodpovední európski delegovaní prokurátori konajúci vo veci v ich členskom štáte pôvodu. Zároveň je ich úlohou zabezpečovat' informácie medzi stálymi komorami a európskymi delegovanými prokurátormi. Rada sa dohodla na vymenovaní Laury Codruţy Kövesiovej do úlohy hlavnej európskej prokurátorky a túto vol'bu potvrdil následne aj Európsky parlament. Laura Kövesiová bola vybraná zo zoznamu troch kandidátov, ktorých navrhla nezávislá výberová komisia na základe verejnej výzvy na podávanie prihlášok. Graf na Obr.1 zobrazuje prehl'adnú štruktúru a personálne obsadenia Európskej prokuratúry.

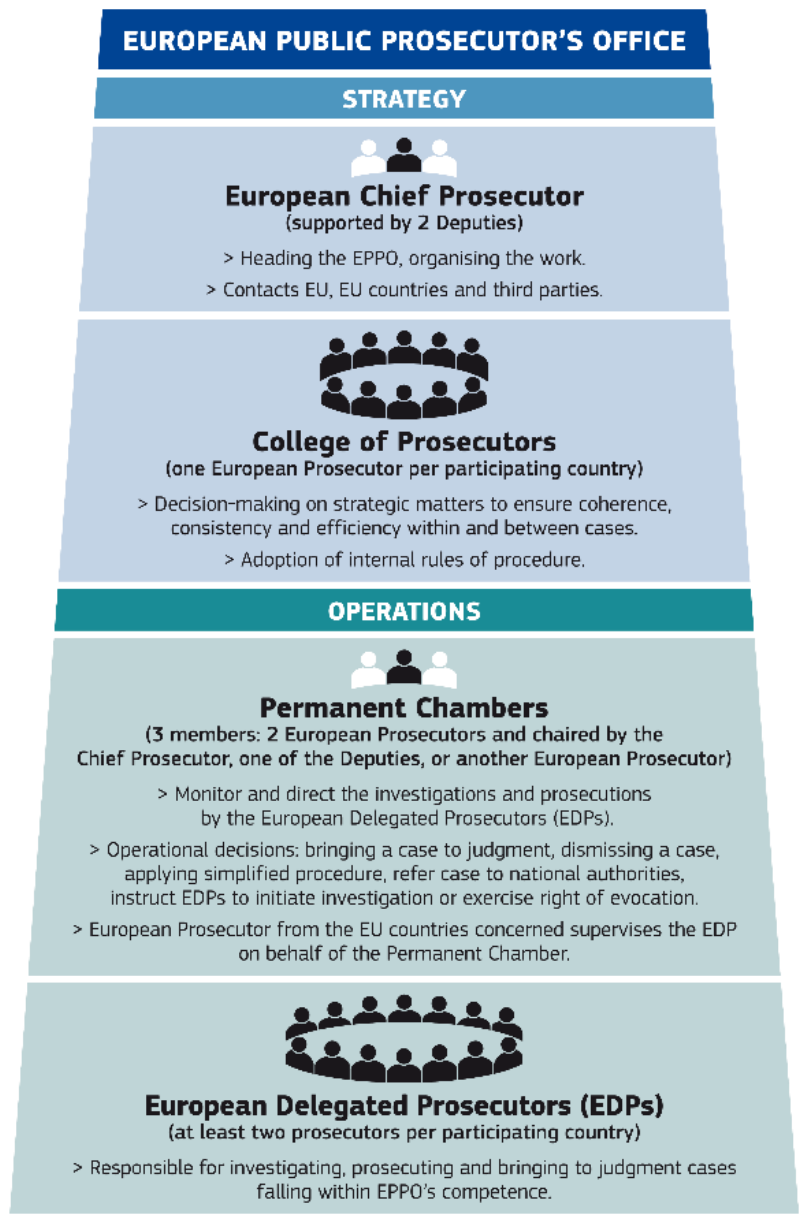

Obr.1: Štruktúra personálneho obsadenia Európskej prokuratúry ${ }^{6}$

\footnotetext{
${ }^{4}$ Článok 9 Nariadenia.

${ }^{5}$ Stále komory v zmysle nariadenia rozhodujú o podaní obžaloby, o odmietnutí veci, o uplatnení zjednodušeného postupu trestného stíhania, o postúpení veci alebo o pokračovaní vo vyšetrovaní na základe nových skutočností. Čl. 28 ods. 4 nariadenia.

${ }^{6}$ Dostupné na: https://www.consilium.europa.eu/sk/press/press-releases/2019/10/14/eu-public-prosecutor-s-office-eppo-lau ra-codruta-kovesi-to-become-the-first-european-chief-prosecutor/
} 
Tak ako bolo aj vyššie uvedené, prijatie Nariadenia o organizácii a štruktúre EP, spôsobilo zmenu vo vnútroštátnej úprave Slovenskej republiky, kedy bol prijatý zákon č. 286/2018 Z. z. o výbere kandidátov na funkciu európskeho prokurátora a európskeho delegovaného prokurátora v Európskej prokuratúre. ${ }^{7}$ Tento zákon stanovil predpoklady, ktoré musí spíňat' kandidát na funkciu európskeho prokurátora a európskeho delegovaného prokurátora, zloženie výberovej komisie, ako aj priebeh výberového konania. Postup vymenovania európskych prokurátorov a európskych delegovaných prokurátorov by mal zarucit' ich nezávislost' a odbornost'. Každý členský štát by mal nominovat' troch kandidátov na pozíciu európskeho prokurátora, ktorého vyberie a vymenuje Rada. ${ }^{8}$ Funkciu európskeho prokurátora za Slovenskú republiku bude na neobnovitel'né funkčné obdobie 6 rokov zastávat' JUDr. Juraj Novocký, PhD. Predpokladá sa, že európski prokurátori by mali začat' vykonávat' svoju činnost' k 1. septembru 2020. Hlavná európska prokurátorka zaslala členským štátom listy s predpokladaným počtom európskych delegovaných prokurátorov pre jednotlivé štáty a požiadala ich o zaslanie nominácii do 30. septembra 2020. Slovenská republika by mala mat' pät' delegovaných európskych prokurátorov, s tým, že úspešne zvládli výberové konanie zatial' dvaja kandidáti. Tri miesta tak do dnešného dňa ostávajú neobsadené. Tak ako bolo v úvode spomenuté, samotné personálne zabezpečenie Európskej prokuratúry zrejme značne skomplikuje situácia súvisiaca s pandémiou, o čom svedčí teda už len samotný fakt, že proces výberového konania delegovaných európskych prokurátorov nebol do dnešného dňa ukončený, čím sa zrejme aj predíži samotný dátum fungovania inštitúcie Európskej prokuratúry ako takej.

\section{PRÁVOMOC A PRÍSLUŠNOSŤ EURÓPSKEJ PROKURATÚRY}

Vecná príslušnost' Európskej prokuratúry je upravená v 1. oddiele IV. kapitoly nariadenia, konkrétne v článkoch 22 a 23 nariadenia. Do vecnej príslušnosti Európskej prokuratúry patria trestné činy poškodzujúce finančné záujmy Únie ustanovené v smernici Európskeho parlamentu a Rady (EÚ) 2017/1371 z 5. júla 2017 o boji proti podvodom, ktoré poškodzujú finančné záujmy Únie (d’alej len „Smernica“). Smernica nie je všeobecne záväzná pre jednotlivé štáty a z uvedeného dôvodu musí byt' transponovaná do vnútroštátneho práva. Taktiež samotná smernica ani nemôže určovat' ako majú zniet' jednotlivé skutkové podstaty trestných činov vo vnútroštátnom poriadku a je teda $v$ právomoci jednotlivých štátov upravit' si znenia jednotlivých skutkových podstát, minimálne $\mathrm{v}$ takom štandarde, aby zodpovedali podmienkam uvedeným v smernici. V Slovenskej republike prijatím zákona č. 214/2019 Z. z., ktorým sa mení a dopĺn̆a zákon č. 300/2005 Z. z. Trestný zákon v znení neskorších predpisov a ktorým sa menia a dopíňajú niektoré zákony sa vykonala úplná transpozícia Smernice do právneho poriadku Slovenskej republiky. Citovaná smernica nahrádza Dohovor EÚ z 26. júla 1995 o ochrane finančných záujmov Európskych spoločenstiev (Ú. v. ES C 316, 27. 11. 1995) a jeho protokoly, ku ktorému Slovenská republika pristúpila v roku 2004 a ktorého obsah bol premietnutý do slovenského právneho poriadku. Preto väčšina požiadaviek vyplývajúcich zo smernice je už splnená. Smernica však oproti dohovoru posilňuje ochranu finančných záujmov Európskej únie a stanovuje minimálne pravidlá týkajúce sa vymedzenia trestných činov a sankcii $v$ súvislosti $s$ bojom proti podvodom a iným protiprávnym konaniam poškodzujúcim finančné záujmy Európskej únie. Vzhl'adom na súvis smernice s nariadením Rady (EÚ) 2017/1939 z 12. októbra 2017, ktorým sa vykonáva posilnená spolupráca na účely zriadenia Európskej prokuratúry (Ú. v. EÚ L 283, 31.10.2017), ustanovenia smernice sú rozhodujúce pre dobré fungovanie Európskeho prokurátora, ktorý odkazuje na smernicu

\footnotetext{
${ }^{7}$ Zákon č. 286/2018 Z. z. o výbere kandidátov na funkciu európskeho prokurátora a európskeho delegovaného prokurátora $\mathrm{v}$ Európskej prokuratúre, stanovuje podrobné podmienky na predpoklady kandidáta na funkciu európskeho prokurátora, európskeho delegovaného prokurátora, zloženie výberových komisií na tieto funkcie ako aj samotný priebeh výberového konania.

${ }^{8}$ Dôvodová správa k návrhu zákonu č. 286/2018 Z. z.
} 
obsahujúcu vymedzenie jeho príslušnosti. ${ }^{9}$ Prijatie zákona č. 214/2019 Z. z. ktorým sa mení a dopĺn̆a zákon č. 300/2005 Z. z. Trestný zákon, nastala vo vzt’ahu k skutkovej podstate trestného činu upraveného v $§ 261$ „Poškodzovanie finančných záujmov Európskej únie“ len minimálna zmena, kedy do skutkovej podstaty trestného činu poškodzovania finančných záujmov Európskej únie definovaných v § 261 Trestného zákona č. 300/2005 Z. z., pribudli nové odseky 2 a $3 .{ }^{10}$ Smernica síce stanovuje minimálne pravidlá týkajúce sa vymedzenia trestných činov a sankcií $\mathrm{v}$ súvislosti s bojom proti podvodom a iným protiprávnym konaniam poškodzujúcim finančné záujmy Európskej únie, avšak nevymedzuje právomoc Európskej prokuratúry. Právomoc Európskej prokuratúry je vymedzená v nariadení. V zmysle článku 22 nariadenia „Do právomoci Európskej prokuratúry patria trestné činy poškodzujúce finančné záujmy Únie ustanovené v smernici (EÚ) 2017/1371, ako je vykonaná vo vnútroštátnom práve, bez ohl'adu na to, či by sa tá istá trestná činnost' mohla podl'a vnútroštátneho práva klasifikovat' ako iný druh trestného činu, “ Právomoc Európskej prokuratúry je v zmysle nariadenia vymedzená aj o niečo užšie. Jedná sa najmä o trestné činy poškodzujúce finančné záujmy Európskej únie, menšej závažnosti, ktoré ponecháva $\mathrm{v}$ kompetencii vnútroštátnych orgánov. ${ }^{11}$ Územná právomoc Európskej prokuratúry v zmysle nariadenia ${ }^{12}$ je daná len v prípade ak trestná činnost', ktorá patrí do vecnej právomoci Európskej prokuratúry bola spáchaná na území jedného alebo viacerých štátov. ${ }^{13}$

\section{VYŠETROVANIE TRESTNEJ ČINNOSTI}

V tejto kapitole sa budeme zaoberat' vyšetrovaním trestnej činnosti samotnými európskymi prokurátormi, $\mathrm{v}$ rámci trestnej spolupráce $\mathrm{v}$ tzv. zúčastnených štátoch a štátoch, ktorí nie sú signatármi nariadenia, ktoré v praxi spôsobuje asi najväčšie otázniky.

\subsection{Vedenie vyšetrovania Európskou prokuratúrou v zúčastnenom štáte}

V zmysle čl. 4 nariadenia je vymedzená základná úloha Európskej prokuratúry „Európska prokuratúra je zodpovedná za vyšetrovanie, trestné stíhanie páchatelov a spolupáchatelov trestných činov poškodzujúcich finančné záujmy Únie, ktoré sú stanovené v smernici (EÚ) 2017/1371 a určené v tomto nariadení, a za podanie obžaloby na nich. V tejto súvislosti Európska prokuratúra vedie vyšetrovania, vykonáva úkony trestného stíhania a vystupuje vo funkcii prokurátora na príslušných súdoch členských štátov až do konečného rozhodnutia vo veci.“ Ako uvádza Ondrejová: „Pre všetky zúčastnené štáty sa bude doslovne aplikovat' článok 4 nariadenia v rozsahu „Európska prokuratúra ,je zodpovedná“ za vyšetrovanie a trestné stíhanie vo veciach patriacich do jej právomoci. ${ }^{14}$ Zodpovednost' Európskeho prokurátora za vyšetrovanie a trestné stíhanie, je síce daná nariadením, avšak v realite je sam444otný európsky prokurátor pri vedení vyšetrovania a trestného stíhania, vykonávania úkonov trestného konania, odkázaný na fungovanie vnútroštátnych orgánov. Vzhl'adom k tomu, že Európsky prokurátor, napriek skutočnosti, že je subjektom Európskej únie, stále má postavenie aj v rámci vnútroštátnych štruktúr, čo podl'a nášho názoru môže spôsobovat' vo

\footnotetext{
${ }^{9}$ Dôvodová správa k návrhu zákona č. 214/2019 Z. z.

${ }^{10}$ Bližšie pozri zákon č. 214/2019 Z. z., znenie skutkovej podstaty § 261 Trestného zákona v jeho platnom znení.

${ }^{11}$ Ako príklad možno uviest' finančné podvody s DPH, kde je právomoc Európskej prokuratúry len ak úmyselné konanie týka územia dvoch alebo viacerých členských štátov a spôsobená celková škoda je najmenej 10000000 eur. Nariadenie vymedzuje právomoc Európskej prokuratúry aj negatívne, kedy stanovuje, že do právomoci Európskej prokuratúry nepatria trestné činy týkajúce sa vnútroštátnych priamych daní. Čo značí, že Európska prokuratúra nemá právomoc vo vzt’ahu k fungovaniu daňovej správy členských štátov. Bližšie pozri: ONDREJOVÁ, A.,: Európska prokuratúra - štruktúra a právomoc. In: Bulletin advokacie, roč. 3. 2018, str. 31.

${ }^{12}$ Bižšie pozri č. 23 nariadenie o Európskej prokuratúre.

${ }^{13}$ Samozrejme v naznačenom zmysle sa jedná len o členské štáty, ktoré sa zúčastňujú na posilnenej spolupráci v zmysle nariadenia.

${ }^{14}$ ONDREJOVÁ, A.: Európska prokuratúra - nový subjekt, nové otázniky, 1. čast': Rozsah prokurátorského dozoru oprávnenie vykonávat’ vyšetrovanie a iné opatrenia. In: Bulletin advokácie, roč. 4, 2018s. 6.
} 
vedení vyšetrovania nemalé problémy $\mathrm{v}$ jeho činnosti, nakol'ko právomoci prokurátorov a vnútroštátnych orgánov pri vedení vyšetrovania $\mathrm{v}$ jednotlivých zúčastnených štátoch nemusia byt' rovnaké. Uvedené opätovne len posilňuje skutočnost', že do dnešného dňa nedošlo k zmene vnútroštátnej právnej úpravy, ktorá by jednoznačne vymedzovala zodpovednost' a spôsob vedenia vyšetrovania.

V zmysle článku 4 nariadenia Európska prokuratúra vedie vyšetrovanie a vykonáva úkony trestného stíhania. Článok 28. ods. 1 nariadenia umožňuje, aby európsky delegovaný prokurátor $\mathrm{v}$ súlade $\mathrm{s}$ nariadením a vnútroštátnym právom sám vykonal vyšetrovacie a iné opatrenia alebo nariadit' ich vykonanie príslušným orgánom vo svojom členskom štáte. V zmysle článku 26 nariadenia Európsky delegovaný prokurátor začne vo svojom členskom štáte vyšetrovanie ak v súlade $\mathrm{s}$ vnútroštátnym právom existujú opodstatnené dôvody, že sa pácha alebo bol spáchaný trestný čin, ktorý patrí do právomoci Európskej prokuratúry. Najčastejšie pôjde zrejme o skutky, ktoré boli spáchanie na území viacerých štátov, preto Nariadenie upravuje, že „konat' vo veci začne a vecou sa zaoberá spravidla európsky delegovaný prokurátor z členského štátu, v ktorom bola trestná činnost' sústredená, alebo ak bolo spáchaných niekol'ko súvisiacich trestných činov, ktoré patria do právomoci Európskej prokuratúry, európsky delegovaný prokurátor z členského štátu, v ktorom bola spáchaná väčsina trestných činov "'15

Natíska sa tak otázka, $v$ akých prípadoch budú viest' vyšetrovanie delegovaní prokurátori sami a v akých prípadoch využijú možnost' nariadit' ho príslušným vnútroštátnym orgánom. Článok 30 nariadenia čiastočne odpovedá na otázku kedy európsky delegovaný prokurátor bude vediet' nariadit' vykonanie vyšetrovacích úkonov a opatrení. Aspoň v prípadoch, ked' možno trestný čin, ktorý je predmetom vyšetrovania, potrestat' trestom odňatia slobody s hornou hranicou trestnej sadzby najmenej štyri roky, členské štáty zabezpečia, aby boli delegovaní európski prokurátori oprávnení nariadit' tieto vyšetrovacie opatrenia alebo o ne požiadat'. Jedná sa o štandardné zabezpečovacie úkony v rámci vyšetrovania ako je odpočúvanie, záznam telekomunikačnej činnosti, sledovanie kontrolovaných dodávok, vykonanie prehliadky všetkých priestorov a iné. ${ }^{16}$

Ondrejová $^{17}$ uvádza, že európsky delegovaný prokurátor nemôže zverit' vyšetrovanie ako celok vnútroštátnym orgánom, ale musí na ňom priebežne participovat'. Z uvedeného vyplýva, že aktívna participácia európskeho delegovaného prokurátora by mala obsahovat' najmä nariad’ovanie vykonanie potrebných úkonov v rámci vyšetrovania a vykonávaním neustále dozoru, ktorý musí byt' aktívny. Zodpovednost' za činnost' vnútroštátnych orgánov bude realizovaná prostredníctvom dozoru Európskej prokuratúry, vykonávaného prostredníctvom dozoru delegovaného európskeho prokurátora. Tu narážame na jeden zásadný problém a teda, že európsky delegovaný prokurátor môže v zmysle zákona o prokuratúre plnit' aj úlohy prokurátora v zmysle vnútroštátneho postavenia. „Európsky delegovaný prokurátor môže plnit’ počas dočasného pridelenia aj úlohy prokurátora Úradu špeciálnej prokuratúry, a to $v$ rozsahu, ktorý mu nebráni v plneni jeho povinností vyplývajúcich $z$ osobitného predpisu. Európsky delegovaný prokurátor, ak plní úlohy prokurátora Úradu špeciálnej prokuratúry, má postavenie prokurátora Úradu špeciálnej prokuratúry. “18 Európsky delegovaný prokurátor sa tak vel'mi l'ahko podl'a nášho názoru môže dostat' do rozporu so svojou nezávislost'ou, nakol'ko jednak podlieha pri výkone právomoci delegovaného európskeho prokurátora priamo nariadeniu a pri plnení úloh vnútroštátnym predpisom. Ďalším problémom, ktorý je potrebné vel'mi citlivo vnímat' je vzájomná

\footnotetext{
${ }^{15}$ Článok 26 ods. 4 Nariadenia.

${ }^{16}$ Bližšie článok 30 nariadenia

${ }^{17}$ ONDREJOVÁ, A.: Európska prokuratúra - nový subjekt, nové otázniky, 1. čast': Rozsah prokurátorského dozoru oprávnenie vykonávat' vyšetrovanie a iné opatrenia. In: Bulletin advokácie, roč. 4, 2018s. 26.

${ }^{18}$ Bližšie zákon. č. 153/2001 Z. z. o prokuratúre v znení neskorších predpisov.
} 
spolupráca delegovaného európskeho prokurátora s vnútroštátnymi orgánmi. V zmysle nariadenia, je európsky delegovaný prokurátor plne odkázaný na činnost' vnútroštátnych orgánov, ba dokonca aj samotných vnútroštátnych prokurátorov. Európsky delegovaný prokurátor sa tak bude musiet' spoliehat', nie úplne na l'ubovôl'u, ale na efektivitu práce jednotlivých vnútroštátnych orgánov. Svetlo do tejto problematiky neprinieslo ani ustanovenie nariadenia, ktoré ustanovuje, že vnútroštátne orgány prijímajú neodkladné opatrenia $\mathrm{v}$ súlade $\mathrm{s}$ vnútroštátnym právom, potrebné na zabezpečenie efektívneho vyšetrovania. ${ }^{19}$ Ondrejová sa domnieva, že ide o širší okruh úkonov akými sú neodkladné úkony v zmysle $\S 10$ ods. 17 zákona č. 301/2005 Z. z. Trestný poriadok v jeho platnom znení. De facto by malo íst' o úkony, ktoré je potrebné vykonat' na zabezpečenie efektívneho vyšetrovania. Ondrejová však už bližšie nešpecifikuje tieto úkony, a teda hoci by sme sa s jej názorom na uvedenú problematiku stotožnili, vo vnútroštátnych poriadkoch jednotlivých štátov by mali byt' tieto úkony vymedzené približne rovnako, aby aj v tomto smere mohlo dochádzat' $\mathrm{k}$ efektívnej spolupráci. Riešením by sa mohlo javit' prijatie samostaného zákona vo svojich vnútroštátnych úpravách jednotlivých štátov, ktoré by jednoznačne upravovali v zmysle nariadenia, spoluprácu delegovaných prokurátorov a jednotlivých vnútroštátnych orgánov, ich právomoci a pôsobnost'. Zákon by mal jednoznačne vymedzovat' rozsah právomocí delegovaných prokurátorov, aby nedochádzalo k rôznym priet’ahom $\mathrm{v}$ konaní, v rámci vyšetrovania. Domnievame sa tiež, že tento samostatný zákon, by mal jednoznačne upravovat' spôsob a podmienky vykonávania dozoru delegovaného európskeho prokurátora, čím by sa vyhlo dezinterpretáciám možnosti zasahovania delegovaných európskych prokurátorov do samotného vyšetrovania.

Ďalší problém, ktorý je možné identifikovat', a ktorý možno považovat' za kl'účový vo vzt'ahu k postaveniu Európskej prokuratúry, je skutočnost', že trestné činy, na ktorých má právomoc Európska prokuratúra participovat' majú cezhraničný charakter, a teda tieto trestné činy sú páchané na území viacerých štátov. Akokol'vek je Európska prokuratúra nezávislým orgánom, aj v tomto prípade sa bude musiet' spoliehat' na trestnú spoluprácu medzi členskými štátmi. Uvedené sa bude týkat' aj vnútroštátnych orgánov, ktoré vykonávajú vyšetrovanie pod dozorom Európskej prokuratúry. Je zrejmé, že vnútroštátne poriadky jednotlivých štátov nemajú jednotnú legislatívu týkajúcu sa tak trestného práva hmotného, či procesného. Týka sa to najmä, no nielen, otázky získavania dôkazov v trestných veciach, ktoré sa dejú v rámci cezhraničnej spolupráce, len podl'a pravidiel vnútroštátneho práva, ktoré sa môžu zásadne líšit'. Ak úrad Európskej prokuratúry proklamuje ako svoj ciel' zefektívnenie vyšetrovania trestných činov poškodzujúcich záujmy Európskej únie, je potrebné, aby sa Európska únia v tomto smere zamyslela nad minimálnym spoločným štandardom získavania dôkazov v trestných veciach. Spolupráca vnútroštátnych orgánov zúčastnených členských štátov, za tejto situácie, môže naozaj spôsobovat' spory, týkajúce sa prípustnosti dôkazov, ale taktiež v otázke zabezpečenia základných procesných práv osôb obvinených, týkajúcich sa aj uplatňovanie možných a prípustných opravných prostriedkov. Nezodpovedanou otázkou ostáva aj prípad odňatia vyšetrovania $z$ jedného členského štátu a jeho pridelenia inému členskému štátu. V zmysle uplatnenie článku 26 ods. 5 Nariadenia, podl'a ktorého môže stála komora až do podania obžaloby rozhodnút' o zmene pridelenia veci. Stála komora teda môže zmenit' štát, v ktorom má byt' podaná obžaloba a tým aj právnu úpravu trestného konania, čo vyvoláva otázky či takéto konanie bude v súlade s právom obvineného na spravodlivé súdne konanie, a v ktorých prípadoch toto svoje právo stála komora využije Ak sa vykoná čast' vyšetrovania $\mathrm{v}$ jednom zo zúčastnených štátov podl'a pravidiel vnútroštátneho práva, nie je zárukou, že členský štát, ktorému bude vec pridelená na vyšetrovanie nebude musiet' procesné úkony zopakovat', z dôvodu, že vykonané úkony nezodpovedajú štandardom tohto členského štátu a tak sú v trestnom konaní nepoužitel'né. Uvedené sa nedá odstránit' ani vykonávaním

${ }^{19}$ Čl. 28 ods. 2 Nariadenia. 
samotného dozoru Európskou prokuratúrou, nakol'ko táto nevie zabezpečit' záruky zákonnosti v jednotlivých zúčastnených štátoch, pokial' sa tieto realizujú na základe vnútroštátnych predpisov, a to aj napriek skutočnosti, že samotná spolupráca bude regulovaná predpismi Únie. Naznačené komplikácie sa budú prejavovat' aj v spolupráci jednotlivých delegovaných prokurátorov zúčastnených štátov. Nakol'ko nie vo všetkých zúčastnených štátoch má prokurátor rovnaké postavenie najmä čo sa týka predsúdnej časti trestného konania. V Slovenskej republike sú dozor a úkony prokurátora upravené jednak v zákone č. 301/2005 Z. z. Trestný poriadok v jeho platnom znení (d’alej len ako „Trestný poriadok“) a taktiež v zákone č. 153/2001 Z. z. o prokuratúre v jeho platnom znení (d’alej len ako zákon o prokuratúre). V zmysle $\S 230$ Trestného poriadku. Dozor nad dodržiavaním zákonnosti pred začatím trestného stíhania a v prípravnom konaní vykonáva prokurátor. Obdobne v zmysle zákona o prokuratúre je prokurátor vykonáva dozor nad dodržiavaním zákonnosti pred začatím trestného stíhania a v prípravnom konaní. V rámci oprávnenie vykonávat' dozor je prokurátor oprávnený vykonat' $\mathrm{v}$ zmysle spomínaných ustanovení aj sám celé vyšetrovanie. Uvedené oprávnenie sa dôsledne neaplikuje, ked’že väčšinou vykonáva vyšetrovanie policajt, ktorému je prokurátor bezprostredne nadriadený a vydáva policajtovi pokyny ako má v uvedenej trestnej veci postupovat'. Dozor prokurátora, možno nazvat' následným dozorom, po vykonaní jednotlivých procesných úkonov a po skončení samotného vyšetrovania, resp. po vykonaní niektorých $\mathrm{z}$ procesných úkonov $\mathrm{v}$ rámci trestného konania. Rozsah právomoci vnútroštátnych prokurátorov a európskych prokurátorov sa zásadne nelíši, ked’že aj európsky prokurátor vie sám vykonat' vyšetrovanie. Rozdielnost' vidíme hlavne v limitoch vykonávania právomocí európskych delegovaných prokurátorov. Kým právna úprava v Slovenskej republike umožňuje $\mathrm{v}$ zmysle zákona prokuratúre a taktiež trestného poriadku, prokurátorovi samostatne rozhodnút' o podaní obžaloby, vplýva to $\mathrm{z}$ ustanovenia $\S 231$ Trestného poriadku ${ }^{20}$, európsky delegovaní prokurátori túto právomoc nemajú. Túto právomoc majú v zmysle nariadenia len stále komory Európskej prokuratúry. Teda európsky delegovaný prokurátor bude musiet' po ukončení vyšetrovania zaslat' celý spisový materiál príslušnej stálej komore, ktorá rozhodne o d'alšom postupe. ${ }^{21}$ Ak konajúci európsky delegovaný prokurátor považuje vyšetrovanie za skončené, predloži dozorujúcemu európskemu prokurátorovi správu obsahujúcu zhrnutie veci a návrh rozhodnutia, či sa má podat obžaloba na vnútroštátny súd alebo zvážit' postúpenie alebo odmietnutie veci, alebo zjednodušený postup trestného stíhania podl'a článku 34, 39 alebo 40. Dozorujúci európsky prokurátor postúpi tieto dokumenty príslušnej stálej komore a ak to považuje za potrebné, pripojí vlastné stanovisko. ${ }^{22}$ Akákolvvek efektivita spolupráce, resp. právomoci fungovanie Európskej prokuratúry sa tu stráca. Tak ako bolo vyššie uvedené, stále komory majú troch členov, ktorí tvoria jednotliví európsky prokurátori. Títo si budú musiet' celý spis naštudovat' a rozhodnút'. ${ }^{23}$ Takéto oprávnenie majú v podmienkach slovenskej republiky samostatne prokurátori. Nie je jasné, z akého dôvodu nemôže sám európsky prokurátor rozhodnút' o podaní obžaloby, ale musí toto stanovisko predkladat' stálej komore, ktorá sa skladá z európskych prokurátorov viacerých zúčastnených štátov a teda celý spisový materiál musí byt' preložený do jedného z rokovacích jazykov, čo značne komplikuje a určite nie zefektivňuje spoluprácu pri výkone právomoci Európskej prokuratúry.

\footnotetext{
${ }^{20}$ Zákon č. 301/2005 Z. z. Trestný poriadok v jeho platnom znení.

${ }^{21}$ DESET, M, SZABOVÁ, E.: Perpectives of european public prosecuto's office. . In the colection of scientosic Contributions of the nationwidw interdisciplinary scientific conference with an international participation: „, I. Košice days of criminal law - Perspectives on the development of European criminal law perspectives“., p. 424, EQUILIBRIA, s. r. o., ISBN: 978- 80- 8162- 613-8.

22 Článok 35 ods. 1 Nariadenia.

${ }^{23}$ DESET, M, SZABOVÁ, E.: Perpectives of european public prosecuto's office. . In the colection of scientosic Contributions of the nationwidw interdisciplinary scientific conference with an international participation: „I. Košice days of criminal law - Perspectives on the development of European criminal law perspectives“., p. 424, EQUILIBRIA, s. r. o., ISBN: 978- 80- 8162- 613-8.
} 
Problémom však je, že uvedené právomoci prokuratúry sa vo vnútroštátnych poriadkoch môžu zásadne líšit'. Hoci aj v právnej úprave Slovenskej republiky v naznačenom zmysle, prokurátor je síce oprávnený vykonat' vyšetrovanie sám, ale v praxi sa to neaplikuje. Práve naopak prokurátor je $\mathrm{v}$ pozícii dozoru nad vnútroštátnymi orgánmi teda pri výkone vyšetrovací ch úkonov polície. $\mathrm{V}$ tomto sa postavenie európskeho prokurátora a delegovaných európskych prokurátorov nelíši. V naznačenom zmysle môže spolupráce v jednotlivých štátoch, ktoré nie sú zúčastnenými štátmi spôsobovat' praktické problémy.

\subsection{Vedenie vyšetrovania a spolupráca $v$ rámci cezhraničnej spolupráce zúčastnených štátov}

Vzt'ahy medzi zúčastnenými štátmi $\mathrm{v}$ rámci cezhraničnej spolupráce rieši článok 31 nariadenia pod názvom cezhraničné vyšetrovanie, ktoré by malo nahradit' aspoň z vel'kej časti klasickú právnu pomoc, realizovanú doteraz $\mathrm{v}$ trestných veciach. ${ }^{24}$ „Európski delegovaní prokurátori konajú vúzkej spolupráci na základe vzájomného poskytovania pomoci a pravidelných vzájomných konzultácií v cezhraničných prípadoch. Ak je potrebné prijat' opatrenie v inom členskom štáte, než je členský štát konajúceho európskeho delegovaného prokurátora, tento európsky delegovaný prokurátor rozhodne o prijati potrebného opatrenia a postúpi ho európskemu delegovanému prokurátorovi nachádzajúcemu sa v členskom štáte, $v$ ktorom je toto opatrenie potrebné vykonat. " $\mathrm{Z}$ citovaného textu nariadenia by tak európski delegovaní prokurátori $\mathrm{v}$ jednotlivých zúčastnených štátoch mali spolupracovat' vúzkej súčinnosti. Nariadenie d’alej ustanovuje, že európsky delegovaný prokurátor, ktorému bolo postúpené prijatie opatrenie $\mathrm{v}$ inom zúčastnenom štáte, ho môže vykonat' sám, alebo ho postúpi na vykonanie príslušnému vnútroštátnemu orgánu. Tu sa opät' dostávame k vyššie vysvetlenému problému odkázanosti delegovaných prokurátorov na vnútroštátne orgány a taktiež spôsob získavania dôkazov, ktorý $\mathrm{v}$ jednotlivých vnútroštátnych úpravách môže kolidovat'. Taktiež nariadenie nevysvetl'uje, v prípade postúpenia vykonávaného opatrenia, či dozor nad vykonávaním týchto úkonov bude stále vykonávat' európsky prokurátor členského štátu, kde sa vedie vyšetrovanie alebo zúčastneného členského štátu, kde európsky delegovaný prokurátor vykonáva postúpené opatrenie. Aký dosah bude mat' európsky prokurátor zúčastneného štátu vykonávajúceho postúpené opatrenia, ak delegovaný prokurátor tohto zúčastneného štátu začína byt' zainteresovaný do vyšetrovania.

Nariadenie $\mathrm{v}$ citovanom článku rieši aj problematiku účasti súdov zúčastnených štátov na postúpených opatreniach. Ak sa podl'a práva členského štátu asistujúceho európskeho delegovaného prokurátora vyžaduje pre dané opatrenie súhlas súdu, takýto súhlas tento asistujúci európsky delegovaný prokurátor ziska v súlade s právom tohto členského štátu. $\mathrm{Na}$ uvedenej formulácii nariadenia nie je nič nezvyčajné, nakol'ko európsky prokurátor vykonávajúci postúpené nariadenie získava súhlas súdu v zmysle platných právnych predpisov svojho štátu, je teda plne oprávnenou osobou vystupovat' pred súdmi a v zmysle platných právnych predpisov je aj osobou, ktorá je vôbec oprávnená so súdmi komunikovat'. Nariadenie však pokračuje ustanovením podl'a ktorého Ak sa však podl'a práva členského štátu asistujúceho európskeho delegovaného prokurátora takýto súhlas súdu nevyžaduje, ale vyžaduje sa podl'a práva členského štátu konajúceho európskeho delegovaného prokurátora, súhlas musí získat' konajúci európsky delegovaný prokurátor a predložit' ho spolu s postúpením.

Ako uvádza Ondrejová, v uvedenom prípade európsky delegovaný prokurátor zasahuje do integrity iného zúčastneného štátu, ked' vykonáva právnu pomoc bez ingerencie zúčastneného členského štátu. Vyššie spomínaný nejednotný postup získavania a predkladania dôkazov

\footnotetext{
${ }^{24}$ ONDREJOVÁ, A.: Európska prokuratúra - nový subjekt, nové otázniky, 2. čast': Európska prokuratúra a cezhraničná právomoc. In: Bulletin advokácie, roč. 5, 2018, s. 6 .
} 
v rámci cezhraničného vyšetrovania čiastočne rieši ustanovenie článku 37 nariadenia, ktorý uvádza, že „Dôkazy, ktoré prokurátori Európskej prokuratúry alebo obvinený predložia súdu, sa nesmú odmietnut' pripustit' výlučne z dôvodu, že boli ziskané v inom členskom štáte alebo v súlade s právom iného členského štátu. " Týmto ustanovením by sa čiastočne mohlo eliminovat' odmietanie dôkazov $\mathrm{v}$ rámci súdneho konania, $\mathrm{z}$ dôvodu že neboli získané v súlade s pravidlami vnútroštátneho práva. Netreba vak zabúdat' na fakt, že európsky prokurátor podáva obžalobu na vnútroštátny súd, kde nemôže byt' právom únie vylúčená jeho možnost' súdu slobodne tieto dôkazy posúdit'.

Komplikovanejšia situácia vzniká pri spolupráci v trestných veciach, medzi štátmi, ktoré nepatria medzi zúčastnené členské štáty $\mathrm{v}$ zmysle prijatého nariadenia o Európskej prokuratúre. Nariadenie o európskej prokuratúre sa na nezúčastnené štáty nevzt'ahuje a teda európsky prokurátori nemôžu za žiadnych okolností vykonávat' svoje právomoci v zmysle nariadenia v nezúčastnenom členskom štáte. V zmysle článku 105 nariadenia Ak neexistuje právny akt týkajúci sa spolupráce $v$ trestných veciach a vydania medzi Európskou prokuratúrou a príslušnými orgánmi členských štátov Európskej únie, ktoré sa nezúčastňujú na posilnenej spolupráci na účely zriadenia Európskej prokuratúry, členské štáty oznámia Európsku prokuratúru ako príslušný orgán na účely vykonávania uplatnitelných aktov Únie o justičnej spolupráci v trestných veciach v prípadoch patriacich do právomoci Európskej prokuratúry vo svojich vztahoch s členskými štátmi Európskej únie, ktoré sa nezúčastňujú na posilnenej spolupráci na účely zriadenia Európskej prokuratúry. V zmysle znenia nariadenia tak na účely spolupráce pri vyšetrovaní bude európsky prokurátor označovaný za vnútroštátny orgán, čo môže spôsobovat' jeho značnú rozpoltenost' vo vykonávaní svojich právomocí. Jednak ako európsky prokurátor je nezávislý a je viazaný výlučne pri výkone svojich právomocí únijným právom, avšak nad'alej bude musiet' postupovat' $\mathrm{v}$ zmysle právnej pomoci v trestných veciach len na základe právnych aktov jednotlivých štátov, ktoré však uzatvárajú štáty ako také a neriadi sa právom únie. Pri vykonávaní jednotlivých úkonov musí byt' jasné v ktorých prípadoch vystupuje prokurátor ako európsky prokurátor a kedy ako vnútroštátny prokurátor. Neexistuje žiadna viazanost' nezúčastnených členských štátov nariadením. Preto sa domnievame, že $\mathrm{v}$ prípade, aj ked' zúčastnené štáty za účelom spolupráce $\mathrm{v}$ trestných veciach sú oprávnené označovat' európskych prokurátorov ako vnútroštátny orgán, neexistuje žiaden akt, ktorý by upravoval postup nezúčastnených štátov pri výkone spolupráce $\mathrm{v}$ rámci fungovanie európskej prokuratúry, z čoho vyplýva, že tieto štáty nie sú povinné strpiet' výkon právomoci európskej prokuratúry na svojom území, ktorý by značne zasahoval do integrity jednotlivých štátov.

Za najdiskutabilnejší bod považujeme spoluprácu v trestných veciach medzi zúčastnenými štátmi, ktorí sú signatármi nariadenia a medzi štátmi, ktoré nielenže nie sú štátmi zúčastnenými, ale nie sú ani členskými štátmi európskej únie. Problémom je tu práve postavenie Európskej prokuratúry ako inštitúcie. Nakol'ko spolupráca v trestných veciach medzi členskými štátmi a tretími krajinami vo väčšine prípadov funguje na základe medzinárodného práva a teda medzinárodných dohovorov, ktorých signatármi sú tieto jednotlivé štáty. Európska únia a tým pádom aj sama európska prokuratúra nie je oprávnená byt' stranou takéhoto dohovoru a realizovat' akúkol'vek spoluprácu v trestných veciach. Ustanovenie článku 104 ustanovuje, že „Medzinárodné dohody s jednou alebo viacerými tretími krajinami, ktoré Únia podl'a článku 218 ZFEÚ uzavrela voblasti patriacej do právomoci Európskej prokuratúry alebo ku ktorým pristúpila, napríklad medzinárodné dohody o spolupráci v trestných veciach medzi Európskou prokuratúrou a uvedenými tretími krajinami, sú pre Európsku prokuratúru záväzné. “ Takéto dohody však do dnešného dňa neboli uzavreté. Nariadenie tak pomýšl'alo aj na tento možný scenár, kedy sa v nariadení uvádza, Ak neexistuje dohoda podl'a odseku 3 tohto článku ani uznanie podl’a odseku 4 tohto článku, konajúci európsky delegovaný prokurátor môže v súlade s článkom 13 ods. 1 použit' 
právomoci vnútroštátneho prokurátora alebo člena súdnictva svojho členského štátu, aby orgány tretích krajín požiadal o právnu pomoc $v$ trestných veciach na základe medzinárodných dohôd, ktoré daný členský štát uzavrel, alebo uplatnitel'ného vnútroštátneho práva a, ak to je potrebné, prostredníctvom prislušných vnútroštátnych orgánov. V takom prípade európsky delegovaný prokurátor informuje orgány tretich krajín o tom, že dôkazy ziskané na takom základe použije Európska prokuratúra na účely tohto nariadenia, a ak je to vhodné, usiluje sa ziskat' od nich na to súhlas. V každom prípade je tretia krajina náležite informovaná, že konečným príjemcom odpovede na žiadost’ je Európska prokuratúra. Problémom však stále ostáva výkon právomoci európskej prokuratúry, tak ako je to naznačené vyššie, ked'že tretie krajiny nie sú povinné akceptovat' európsku prokuratúru ako inštitúciu a teda nie je domyslená spolupráca $v$ trestných veciach za účelom začatia fungovania európskej prokuratúry ako takej.

\section{ZÁVER}

Je zrejmé, že európska prokuratúra by mala začat' svoje fungovanie už onedlho. Tak ako bolo naznačené v úvode článku, zrejme pandémia COVID 19 celé fungovanie a materiálne ako aj personálne obsadenie európskej prokuratúry značne zdrží. Pozitívom zostáva, že nie je možné upriet' snahu európskej únie o unifikáciu trestného práva a to aj prostredníctvom zavedenia inštitútu európskej prokuratúry do praxe. Netreba zabúdat', že len samotná prax ukáže množstvo aplikačných problémov, ktoré sa ukážu ako zásadné. My sme sa v článku snažili poukázat' na problémy, ktoré považuje za najakútnejšie, ktoré je potrebné riešit' za účelom efektívneho fungovania európskej prokuratúry. Ako najpálčivejšie sme identifikovali problémy súvisiace $\mathrm{s}$ výkonom právomoci európskej prokuratúry a to jednak $\mathrm{v}$ rámci zúčastnených štátov, ale štátov nezúčastnených, a taktiež spoluprácu v trestných veciach s tretími štátmi. Ako najmenej problematická sa javí spolupráca medzi zúčastnenými štátmi, teda štátmi, ktorí prijali nariadenie Rady (EÚ) 2017/1939 z 12. októbra 2017 ktorým sa vykonáva posilnená spolupráca na účely zriadenia Európskej prokuratúry. Ako bolo aj v článku spomenuté, európsky prokurátori a najmä európsky delegovaní prokurátori musia mat' pri výkone svojich právomocí stále na pamäti svoju príslušnost' a nezávislost', ktorá im vyplýva z ich postavenia a taktiež by nemali zabúdat' na úzku spoluprácu medzi sebou, tak ako im to prikazuje priamo nariadenie. Spolupráca medzi jednotlivými európskymi prokurátormi a delegovanými európskymi prokurátormi môže byt' vel'mi efektívna pri dodržiavaní prísnych pravidiel vyplývajúcich z nariadenia a pri vyvarovaní sa určitých aplikačných problémov, na ktoré sme v článku poukázali. Za najproblematickejšiu považujeme výkon právomoci európskej prokuratúry v rámci nezúčastnených štátov a tretích krajín. Je povinnost'ou únie, ak chce aby európska prokuratúra mohla fungovat' od začiatku, aby prijala také opatrenia, ktoré by problematiku a vznik sporov pri výkone právomoci, čo najviac eliminovali. Je potrebné, aby európska únia pristúpila k prijatiu takých dokumentov, ktoré by riešili spoluprácu $\mathrm{v}$ trestných veciach medzi nezúčastnenými štátmi - najmä teda ako majú európsky prokurátori postupovat' pi výkone svojich právomocí, no najmä ako akútny problém riešila problematiku výkonu právomoci európskej prokuratúry s tretími krajinami. Na prvý pohl'ad sa zdá fungovanie európskej prokuratúry pri výkone jej právomoci ako celkom jednoznačné. Vyšetrovanie vedie európsky prokurátor aj prostredníctvom európskych delegovaných prokurátorov, ktorí vedia túto právomoc delegovat' na vnútroštátne orgány. Obhajobu obvinených osôb budú vykonávat' osoby na to podl'a vnútroštátnych orgánov oprávnené (väčšinou advokáti), obžaloby budú podávané na vnútroštátnych súdoch. Tu je však potreba sa zamysliet' nad skutočnost'ou, že výkon jednotlivých profesií bude ovplyvnená výkonom právomocí samotnej európskej prokuratúry, a preto sa vyžaduje minimálne znalost' nariadenia o európskej prokuratúre, aby vedeli efektívne zabezpečit' právo na obhajobu osôb obvinených, ich základné právo na obhajobu, a taktiež u sudcov dodržat' literu princípu práva 
na spravodlivý proces. Taktiež sme v článku poukázali na potrebu úpravy právomoci delegovaných európskych prokurátorov vo vzt’ahu k vnútroštátnym orgánom vykonávajúcim vyšetrovanie, ktoré by mohlo byt' riešené prijatím samostatného zákona na základe vnútroštátnych úprav jednotlivých štátov, ktorú sú zapojené do posilnenej spolupráce.

Predložený článok vznikol s podporou a je výstupom riešenia výskumného projektu APVV18 - 0421- „Európska prokuratúra v súradniciach ústavného poriadku Slovenskej republiky ako posilnenie európskej integrácie prostredníctvom práva"“،

\section{Použitá literatúra}

1. DELMAS- MARTY M., VERVAELE J. A. E., Corpus Juris 2000: trestné právo na ochranu finančných záujmov Európskej únie (Európsky verejný prokurátor), Bratislava: Iura Edition, 2003.

2. DESET, M, SZABOVÁ, E.: Perpectives of european public prosecuto's office. . In the colection of scientosic Contributions of the nationwidw interdisciplinary scientific conference with an international participation: , I. Košice days of criminal law - Perspectives on the development of European criminal law perspectives“", p. 424, EQUILIBRIA, s. r. o., ISBN: 978- 80- 8162- 613-8.

3. Dôvodová správa k návrhu zákona č. 214/2019 Z. z.

4. Dôvodová správa k návrhu zákonu č. 286/2018 Z. z.

5. FENYK, J.: Projekt modelového trestného práva Corpus Juris a právo na spravodlivý proces, in Ochrana základných práv a slobôd v procese europeizácie trestného práva, AUC Iuridica 1/2006, s. 37.

6. https://www.consilium.europa.eu/sk/press/press-releases/2019/10/14/eu-publicprosecutor-s-office-eppo-laura-codruta-kovesi-to-become-the-first-european-chiefprosecutor/

7. JELINEK, J.: The future of the european public prosecutor's office. In the colection of scientosic Contributions of the nationwidw interdisciplinary scientific conference with an international participation: , I. Košice days of criminal law - Perspectives on the development of European criminal law perspectives“., p. 424, EQUILIBRIA, s. r. o., ISBN: 978- 80- 8162- 613-8.

8. Nariadenia Rady (EÚ) 2017/1939 z 12. októbra 2017 ktorým sa vykonáva posilnená spolupráca na účely zriadenia Európskej prokuratúry

9. ONDREJOVÁ, A.,: Európska prokuratúra - štruktúra a právomoc. In: Bulletin advokacie, roč. 3. 2018, str. 31.

10. ONDREJOVÁ, A.: Európska prokuratúra - nový subjekt, nové otázniky, 1. čast': Rozsah prokurátorského dozoru - oprávnenie vykonávat' vyšetrovanie a iné opatrenia. In: Bulletin advokácie, roč. 4, 2018s. 6.

11. ONDREJOVÁ, A.: Európska prokuratúra - nový subjekt, nové otázniky, 2. čast': Európska prokuratúra a cezhraničná právomoc. In: Bulletin advokácie, roč. 5, 2018, s. 6.

12. Zákon č. 286/2018 Z. z. o výbere kandidátov na funkciu európskeho prokurátora a európskeho delegovaného prokurátora $\mathrm{v}$ Európskej prokuratúre, stanovuje podrobné podmienky na predpoklady kandidáta na funkciu európskeho prokurátora, európskeho delegovaného prokurátora, zloženie výberových komisií na tieto funkcie ako aj samotný priebeh výberového konania.

13. zákon. č. $153 / 2001$ Z. z. o prokuratúre v znení neskorších predpisov. 


\section{Kontaktné údaje}

JUDr. Veronika Tóthová, PhD.

Odborný asistent Katedry trestného práva Právnickej fakulty v Košiciach

Právnická fakulta Univerzity Pavla Jozefa Šafárika v Košiciach

Kováčska 26, 04001 Košice

e-mail: veronika.perdukova@upjs.sk 


\title{
MARKANTNÉ ZNAKY PÁCHATELA TRESTNÉHO ČINU Z POHLADU TRESTNÉHO PRÁVA, KRIMINOLÓGIE, PSYCHOLÓGIE A ICH EVENTUÁLNY VPLYV NA EFEKTÍVNOSŤ PRÍPRAVNÉHO KONANIA
}

\author{
MARKANT CHARACTERISTICS OF THE CRIME OFFICER FROM \\ THE PERSPECTIVE OF CRIMINAL LAW, CRIMINOLOGY, \\ PSYCHOLOGY AND THEIR EVENT IMPACT ON THE \\ EFFECTIVENESS OF THE PREPARATORY PROCEDURE
}

\author{
Patrícia Krásná
}

\begin{abstract}
Abstrakt
Znalost', resp. poznanie markantných znakov páchatel'a trestného činu je vel'mi dôležité. Máme za to, že znalost' o typických znakoch páchatel'a je vel'mi nápomocná tak ako pri práci so samotnými páchatel'mi, tak i pri činnostiach priamo súviasicich s trestným konaním a teda aj prípravným konaním. V našom odbornom príspevku sme sa zamerali na vymedzenie znakov, ktoré sú charakteristické pri popise osoby páchatel'a tresného činu ako eventuálnych prvkov, ktoré vplyývajú na efektívnost' prípravného konania.
\end{abstract}

Kl'účové slová: páchatel', prípravné konanie, znaky páchatel’a

\begin{abstract}
Knowledge, resp. Understanding the distinctive features of the offender is very important. We believe that knowledge of the typical features of the offender is very helpful both in working with the perpetrators themselves, as well as in activities directly related to criminal proceedings and thus also preparatory proceedings. In our professional contribution, we focused on defining the features that are characteristic in the description of the perpetrator of the crime as possible elements that affect the effectiveness of the preparatory proceedings.
\end{abstract}

Key words: offender, preparatory proceedings, signs of the offender

\section{ÚVOD}

Čast'ou trestného konania a tiež aj obligatórnym štádiom predsúdneho konania je prípravné konanie. Prípravné konanie Zákon č. 301/2005 Z. z. Trestný poriadok v znení neskorších predpisov (d’alej už len „Trestný poriadok“) v § 10 ods. 15 charakterizuje ako „úsek trestného konania od začatia trestného stíhania do podania obžaloby, návrhu na schválenie dohody o uznaní viny a prijatí trestu alebo do právoplatnosti rozhodnutia orgánu činného $\mathrm{v}$ trestnom konaní vo veci samej“. Počas prípravného konania majú byt’ orgánmi činnými v trestnom konaní čo najrýchlejšie $\mathrm{v}$ potrebnom rozsahu objasnené všetky skutočnosti dôležité pre posúdenie prípadu vrátane osoby páchatel'a a následkov činu. Ciel’om orgánov činných v trestnom konaní je hl'adat' možnosti zrýchlenia a zjednodušenia prípravného konania, čo by umožnilo posilnit' disponibilné kapacity na úseku boja so závažnou trestnou činnost'ou. ${ }^{1}$ Vychádzajúc z legálnej definície prípravného konania, ale aj z ustanovenia § 201 ods. 2

ŠIŠULÁK, S. Kritéria efektívnosti prípravného konania. In ČENTÉŠ, J. (ed.) a kol. „Efektívnost' prípravného konania - jej skúmanie, výzvy a perspektívy“. Bratislava: Univerzita Komenského v Bratislave, Právnická fakulta, 2020, s. 127. 
Trestného poriadku, jeho základnou úlohou je zabezpečit' podklady pre rozhodnutie, či má byt' podaná obžaloba alebo návrh na schválenie dohody o vine a treste a vecou sa má zaoberat' súd alebo zabezpečit' podklady pre iné rozhodnutia vo veci samej. ${ }^{2}$

Z uvádzaného vyplýva aj náš zámer počas spracovania nášho príspevku a to poukázat' na jednotlivé markantné, partikulárne, znaky páchatel'a a zistit', resp. poukázat' na skutočnost', či majú eventuálny vplyv na efektívnost' prípravného konania. Dôležité je, že efektívnost' je kritériom vyjadritel’ným $\mathrm{v}$ podmienkach komparácie určitých javov, ako kategória porovnávania určitých množín, či javov. ${ }^{3} \mathrm{Na}$ skúmanie a posúdenie vplyvu markantných znakov páchatel'a na efektívnost' prípravného konania je bezpodmienečne potrebné, aby sme jednotlivé, markantné, znaky páchatel'a poznali a špecifikovali. Efektívnost' prípravného konania možno najdôslednejšie vyjadrit' pomocou zmapovania rýchlosti prípravného konania a s ňou súvisiacimi objektívnymi a subjektívnymi okolnost'ami, ktoré majú možnost' ju ovplyvňovat'. ${ }^{4}$ Preto je potrebné počas prípravného konania skúmat' a hodnotit' všetky možné vplyvy a podmienky.

Tak ako vyplýva aj z názvu nášho príspevku znaky páchatel'a trestného činu je možné kategorizovat' z niekol'kých hl'adísk. My sme si dovolili zamerat' sa na znaky páchatel'a trestného činu z pohl'adu trestného práva, kriminológie a psychológie. Máme za to, že tieto markantné znaky sú kl'účové a predurčujú samotnú osobnost' páchatel'a.

V kontexte uvádzaného sme si vytýčili hypotézy, ktoré budeme overovat'.

H1: Aké markantné znaky páchatel’a trestného činu môžu mat' eventuálny vplyv na prípravné konanie?

H2: Majú markantné znaky páchatel’a trestného činu vplyv na efektívnost' prípravného konania?

Na základe nami predurčených ciel'ov a vytýčených hypotéz budeme využívat' kvalitatívnu a deskriptívnu metódu hodnotenia jednotlivých informácií z dostupnej odbornej literatúry, $\mathrm{z}$ informácií nadobudnutých $\mathrm{z}$ riadených rozhovorov $\mathrm{s}$ odborníkmi $\mathrm{z}$ aplikačnej praxe a ukazovatel'ov o znakoch páchatel'a pre čo najúčelnejšie poznanie. Tejto problematike sa venujeme účelne aj $\mathrm{v}$ kontexte aplikovaného výskumu realizovaného prostredníctvom agentúry APVV s názvom: „Efektívnost' prípravného konania - skúmanie, hodnotenie, kritériá a vplyv legislatívnych zmien.“ Naším ciel'om okrem už spomínaného je tiež prispiet' svojou činnost'ou k skúmaniu prípravného konania z hl'adiska posúdenia osoby páchatel'a a tým účelovo zamerat' svoju činnost' na jednotlivé markantné znaky páchatel'a.

\section{VYMEDZENIE ZÁKLADNÝCH POJMOV}

Pre posúdenie osoby páchatel'a, čo je podstatné pri činnostiach v rámci prípravného konania, je potrebné rozlišovat' markantné znaky páchatel'a, ktoré sú predurčené pre jeho činnosti, konanie a teda aj vymedzenie základných pojmov.

Páchatel' trestného činu, tento pojem je možné špecifikovat' z viacerých hl'adísk a to konkrétne z hl'adiska trestného práva, kriminológie, ale aj z pohl'adu psychológie, či penológie. V našom príspevku sa budeme prioritne venovat' vymedzeniu páchatel'a trestného činu z pohl'adu kriminológie, trestného práva a psychológie ako multidisciplinárnych vedných disciplín. Dovolíme si začat’ poukázaním na všeobecné pojmy, ako na základné atribúty nami zvolenej problematiky. Považujeme to za dôležité, pretože základné chápanie a ozrejmenie si

2 POLÁK, P. Postup a obsah jednotlivých foriem prípravného konania. In Záhora, J. (ed.) Prípravné konanie možnosti a perspektívy. Praha: Leges, 2016, s. 74.

3 MIHÁLIK, S. Dopady tzv. superrýchleho konania ako osobitnej formy vedenia trestného konania. In ČENTÉŠ, J. (ed.) a kol. „Efektívnost' prípravného konania - jej skúmanie, výzvy a perspektívy“. Bratislava: Univerzita Komenského v Bratislave, Právnická fakulta, 2020, s. 96.

4 DRUGDA, J. Vývoj právnej úpravy vybraných inštitútov prípravného konania. In ČENTÉŠ, J. (ed.) a kol. „Efektívnost' prípravného konania - jej skúmanie, výzvy a perspektívy“. Bratislava: Univerzita Komenského v Bratislave, Právnická fakulta, 2020, s. 43. 
problematiky týkajúcej sa samotného páchatel'a je podstatné pre celkový náhl'ad na dané. Ked'že charakteristika páchatel'a, resp. jeho špecifickost', náhl'adom jednotlivých disciplín je odlišná dovolili sme si vymedzit' aj jednotlivé rozdiely, ktoré sú charakteristické, pre tú ktorú vednú disciplínu. Od všeobecností a charakteristík jednotlivých spomínaných pojmov následne prejdeme ku konkrétnostiam a špecifikám príznačným pre páchatel’a trestného činu. Osobnost' páchatel’a je vo väčšine vedných disciplín chápaná ako organický celok duševného života človeka, ktorý zahŕňa biologický základ jedinca, spoločenské podmienky života jedinca a tiež jeho spoločenské vzt’ahy. Táto charakteristika nám predurčuje skutočnost', že páchatel' trestného činu sa vyznačuje jednotlivými markantnými znakmi, ktoré ho opisujú a zároveň špecifikujú jeho jedinečnost'. Následne si vymedzíme podstatné skutočnosti, ktoré vplývajú, resp. sú charakteristické pre páchatel'a trestného činu a tým určujú aplikáciu efektívnych činností aj orgánov činných v trestnom konaní počas prípravného konania.

Kriminálne správanie jednotlivca spoločnost' vyhodnocuje ako neakceptovatel'né a preto sa snaží o jeho regres zákonom stanoveným spôsobom, akým je uloženie trestu, ktoré má zabezpečit' stav vyrovnanosti ujmy páchatel'a a poškodeného. ${ }^{5}$ Protispoločenské, deviantné správanie pramení od jednotlivých jedincov, ktorí sa vyznačujú určitými znakmi. Znaky popisujúce jednotlivcov, deviantov sú skúmané už niekol'ko storočí a v nasledujúcom texte sa budeme zameriavat' na priblíženie a objasnenie daných skutočností a odborných faktov súvisiacich s jednotlivými vymedzeniami týkajúcich sa páchatel'ov trestnej činnosti.

Kriminológia ako veda, ktorá sa neustále vyvíja a mení sa spolu s vývojom spoločnosti je vedou, ktorá poukazuje na špecifiká tak ako páchatel'ov, ${ }^{6}$ tak aj obetí, ale aj na špecifiká samotnej trestnej činnosti. Samotná kriminológia vymedzuje páchatel'a trestného činu ako osobu, ktorá nie len konala v intenciách porušenia Zákona č. 300/2005 Z. z. Trestného zákona v znení neskorších predpisov (d’alej už len „Trestný zákon“) ale aj osobu, ktorá napríklad pre nedostatok veku alebo nepríčetnost' nie je za spáchaný trestný čin zodpovedná. Vel'mi jednoducho povedané, kriminológia považuje za páchatela každého kto spácha trestný čin, ale i toho, kto spácha čin inak trestný. Po vymedzení charakteristiky páchatel'a z pohl'adu kriminológie si dovolíme uviest' aj niekol'ko charakteristík jednotlivých príznačných pojmov spojených práve s páchatel'om, s trestnou činnost'ou v kontexte kriminológie. Toto poznanie nám napomáha pri určení a vymedzení jednotlivých markantných znakov páchatel'a a tým, samozrejme, aj pri napíňaní nami vytýčených cielov.

Kriminalita alebo častokrát nazývaná aj zločinnost' predstavuje a popisuje súčet trestných činov, ktoré boli spáchané na určitom mieste $v$ danom určitom čase. ${ }^{7}$ Kriminalitu je možné nachádzat' v každej spoločnosti. Dovolíme si uviest', že kriminalita bola, je aj bude súčast'ou každej spoločnosti. Nedokážeme úplne eliminovat' jej vznik, či jej existenciu. Je preto potrebné poznávat' jej znaky, jej faktory, a následne pôsobit' preventívne, aby sa kriminalita nezvyšovala, ale v čo možno najvyššej miere eliminovala. Uvedené trestné činy spáchané a evidované pod pojmom ,kriminalita“ spáchali trestnoprávne zodpovední jedinci.

Stav kriminality opisuje aktuálnu situáciu za príslušné obdobie, ktoré predstavuje v často opisovanej miere výsledky za jeden kalendárny rok. Pokladáme za dôležité spomenút' fakt, že kriminológia zameriava svoje pole pôsobnosti však i na trestné činy, ktoré neboli nahlásené, resp. nie sú evidované v oficiálnych štatistikách a to sú, takzvané, latentné trestné činy. Latentná kriminalita môže nadobúdat' charakter čiernych čísel - čo predstavujú trestné činy

5 KURILOVSKÁ, L. Možnosti riešenia postavenia obetí v intenciách riešenia postavenia obetí v intenciách restoratívnej spravodlivosti ako inštitútu posilnenia dôvery obetí v justičný systém Slovenskej republiky. In KURUC, P. (ed.). Obete kriminality a ich práva. 1. vydanie. Žilina: Spoločnost' pre trestné právo a kriminológiu, 2015, s. 5.

6 KOLEKTÍV AUTOROV. Kriminológia II. 1. diel. Akadémia Policajného zboru v Bratislave, 2006, s. 6.

7 KOLEKTÍV AUTOROV. Kriminológia - všeobecná čast’. 1. diel. Akadémia Policajného zboru v Bratislave, 2003, s. 12. 
neodhalené a tiež charakter šedých čísel, čo predstavujú čísla trestnej činnosti, ktorej páchatelia neboli odhalení a stíhaní.

Ďalším pojmom, ktorý je z nášho pohl'adu vel'mi dôležité charakterizovat' je pojem delikvencia. Delikvencia v rozmedzí zahrňujúcich faktov a prvkov je obšírnejším pojmom ako kriminalita. ${ }^{8}$ Uvedenému je tak preto, lebo delikvencia obsahuje i trestné činy, ktoré spáchali osoby, ktoré nie sú trestne zodpovedné. Teda osoby mladšie ako 14 rokov a osoby nepríčetné. Dovolíme si uviest', že úzadie delikvencie a delikventných trestných činov tvoria negatívne spoločenské javy, ktoré sú narušitel'mi ustanovení rodinného, občianskeho práva a iných noriem akceptovatel'ných spoločnost'ou. Je teda možné tvrdit', že negatívne spoločenské javy sú pre spoločnost' nežiaduce. Negatívnymi spoločenskými javmi sú napríklad prostitúcia, alkoholizmus, rozvodovost', samovražednost', xenofóbia a iné.

\section{PÁCHATEL TRESTNÉHO ČINU V TRESTNOM PRÁVE, V KRIMINOLÓGII A V PSYCHOLÓGII. TEORETICKÝ A APLIKAČNÝ ASPEKT}

Vymedzenie páchatel'a a jeho markantných znakov v multidisciplinárnom kontexte zohráva vel'mi podstatnú a dôležitú úlohu v našom bádaní. Z uvádzaného dôvodu následne pristúpime k jednotlivým charakteristikám. Vo všeobecnosti je možné tvrdit', že z pohl'adu kriminológie ako vedného odboru, ktorý sa zaoberá skúmaním kriminality, je ucelený pohl'ad na páchatel'a kriminality odlišný, ako to je možné badat' $\mathrm{v}$ rámci jeho trestnoprávneho chápania. Páchatel'om trestného činu môže byt' fyzická osoba a právnická osoba za podmienok ustanovených osobitným predpisom. ${ }^{9} \mathrm{~V}$ ponímaní trestného práva je páchatel'om trestnej činnosti ten, kto trestný čin spáchal sám. V prípade, že sa pozastavíme nad daným zákonným vymedzeným páchatel’a je vhodné poukázat' na pojem fyzická osoba. V slovenskom právnom poriadku by sme však márne hl'adali definíciu pojmu fyzická osoba. Napriek tomu však pod pojmom fyzická osoba môžeme rozumiet' každého človeka od jeho narodenia, resp. už od počatia, až do jeho smrti. ${ }^{10} \mathrm{~V}$ tomto prípade je ale potrebné pre potreby trestného práva, i pre potreby nami uvádzaných skutočností, uviest', že pri ponímaní fyzickej osoby - páchatel'a trestného činu je to osoba staršia ako 14 rokov. U sexuálnych trestných činov je veková hranica 15 rokov. Taktiež je podmienkou aj fakt o príčetnosti, teda vyžaduje sa, aby bola daná osoba $\mathrm{v}$ čase spáchania trestného činu príčetnou. V súčasnej dobe podl'a aktuálnej právnej úpravy sa trestného činu môže dopustit' aj právnická osoba, my sa však budeme venovat' len páchatel'ovi - fyzickej osobe, ktorá napín̆a podmienky subjektu skutkovej podstaty trestného činu.

Naopak, z hl'adiska kriminológie je rovina chápania páchatel’a trestného činu a jeho samotného vnímania $v$ procese trestného činu ponímaná širšie. Ked’že $z$ pohl'adu kriminologického chápania je páchatel'om trestného činu ten, kto sa dopustí určitého trestného činu, neprihliadajúc na to, či bol alebo nebol za tento skutok trestne stíhaný. V kriminologickom ponímaní tu zarad’ujeme taktiež aj možného potencionálneho páchatel’a a tiež aj osoby, u ktorých je v ich konaní možné badat' znaky sociálnej patológie.

Kriminológia tiež poníma páchatel'a trestnej činnosti $v$ zmysle chápania trestného práva s rozšírením úvah a faktov o páchatel'och, ktorí sú trestne nezodpovední alebo nepríčetní, ako aj l'udí prispievajúcich k negatívnym spoločenským javom. Páchatel' je ponímaný ako jeden zo základných prvkov procesu kriminogenézy. Kriminologické poznatky o páchatel'och sú využívané predovšetkým v kriminalistike, súdnej psychiatrii, psychopatológii a v trestnom

\footnotetext{
Poznámka autora: pojem delikvencia sa objavuje v odbornej literatúre asi od 19. storočia - Joly, 1989. Fouiller, 1897, 1899. Autori hovoria o tom, že delikvencia zahŕňa delikty, aj tzv. civilné delikty, teda skutky, ktoré zahŕňajú zodpovednost' za náhradu škody v občianskom práve a tiež do pojmu delikvencie zahŕňali aj tzv. prekriminalitu- trestné činy spáchané maloletými.

9 § 19 zákona č. 300/2005 Z. z. Trestného zákona v znení neskorších predpisov.

10 IVOR, J. a kol. Trestné právo procesné. Bratislava: IURA EDITION, 2006, s. 26.
} 
práve. Obraz páchatel'a, predovšetkým, popis jeho osobnosti je nevyhnutným zdrojom pre pochopenie a vysvetlenie kriminálneho jednania. Určité poznatky a informácie spojené s osobou páchatel'a je potrebné sumarizovat', vyhodnocovat' a striktne štrukturalizovat' aby bolo možné s nimi následne aj patrične zaobchádzat' i počas prípravného konania. Získanie poznatkov o páchatel'ovi jeho individualite a súčasne poznatkov o páchatel'ovi ako členovi sociálnej skupiny, o jeho predpokladanej odlišnosti od jedincov a skupín, u ktorých sa kriminálne správanie nevyskytuje sa zaoberá kriminologický výskum. ${ }^{11}$ Pri zohl’adnení a uvažovaní o osobe páchatel'a trestnej činnosti z pohl'adu trestného práva je možné vyvodit' fakt, že trestné právo chráni literu zákona a nachádza fakty o jeho porušení zo strany spoločnosti.

Dovolíme si konštatovat', že na rozdiel od uvedeného kriminológia však nachádza príčiny a podmienky porušenia litery zákona a jej snahou je dostat' sa k podstate spáchaného trestného činu z viacerých pohl'adov a nielen cez optiku zákona. Kriminológia sa taktiež zaoberá o individuálnu stránku spáchaného trestného činu, ale i o spoločenské vymedzenia. Z nášho pohl'adu je možné tvrdit', že kriminológia skúma uvedené determinanty nie len kvôli odhaleniu špecifických znakov u jedincov, ktorý páchajú trestnú činnost', ale i kvôli faktu, že je možné z jej získaných informácií vyvodit’ a určit' prognózu do budúcna. Na základe daného je možné teda určit’ patričný prístup v danej oblasti záujmu pre zníženie a elimináciu určitých nežiaducich javov. Spomínané opatrenia, ktoré sú prognózované slúžia napríklad i pre možné zmeny aplikovatel'né pri resocializácii páchatel'a.

\section{Páchatel’ trestného činu v kriminológii}

V nasledujúcom texte sa zameriame na kriminologické charakteristiky páchatel'a trestnej činnosti. Medzi spomínané kriminologické charakteristiky patrí vek, pohlavie, rodinný stav, vzdelanie, povolanie, tiež charakter skupinového a celospoločenského prostredia a mnohé iné. ${ }^{12}$ Okrem uvedených, spomínaných, faktorov je vel'mi dôležité, čo nám vyplynulo i z tvrdení odborníkov z aplikačnej praxe, prihliadat' na skutočnost' o kriminálnej minulosti páchatel'a. Pri uvedenom ponímaní je závažná skutočnost' o tom, či je páchatel' prvopáchatel' alebo či ide o recidivistu. Tieto skutočnosti, ako nám to vyplýva $\mathrm{z}$ riadených rozhovorov, $\mathrm{v}$ podstatnej miere ovplyvňujú priebeh trestného konania a teda aj prípravného konania.

Vek páchatel'a je dôležitým faktorom nie len v trestnom práve, ale samozrejme i v kriminológii. Vek ako faktor odráža psychologické osobitosti určitých jednotlivých vývinových a vývojových období. Vývinové obdobia je možné podla našej úvahy rozdelit' na niekol'ko etáp, ktoré sú pre život jedinca dôležité. Vývinové etapy sa vyznačujú určitými charakteristickými črtami. Každá etapa je typická rozdielnou dynamikou rozvoja osobnosti všeobecne, ale aj konkrétne, kde hrozí fakt rizika sociálneho zlyhania. Pod sociálnym zlyhaním môžeme rozumiet' skutočnost', kedy sa jedinec stane obet'ou alebo na strane druhej páchatel'om trestnej činnosti. Danou problematikou sa zaoberá ontogenetická psychológia z pohl'adu možného sociálneho zlyhania. Dané skutočnosti, ktorými sa zaoberá ontogenetická psychológia, d’alej podsúva a poskytuje napr. i orgánom činným v trestnom konaní. Forenzná psychológia sa zaoberá problematikou poukázania na rôzne špecifické znaky jedinca v rámci veku na biologické, psychologické a sociálne osobitosti v období detského, juvenilného, dospelého a regresného veku. Uvedené poznatky však nemajú vplyv len na právnu prax

11 MEDELSKÝ, J. Minulost', prítomnost' a budúcnost’ sankcionovania v Trestnom práve v Slovenskej republike. In MARKOVÁ, V. (ed.). Aktuálne otázky trestného práva v teórii a praxi. Zborník príspevkov z 2. roč. interdisciplinárnej celoštátnej vedeckej konferencie $\mathrm{s}$ medzinárodnou účastou. Bratislava: Akadémia Policajného zboru v Bratislave, 2014, s. 43.

12 DIANIŠKA, G. a kol. Kriminológia. 2. Rozšírené a doplnené vydanie. Plzeň: Aleš Čenek, 2011, s. 116. 
a odpovede na jej riešené problémy, ale zastupujú významnú úlohu i v penitenciárnej a postpenitenciárnej starostlivosti. ${ }^{13}$

Pohlavie páchatel’a je taktiež opisným prvkom v rámci špecifikácie páchatel’a trestnej činnosti. Je všeobecne známe, že počet páchatel'ov mužov je ovel'a vyšší i napriek skutočnosti, že v populácii je vyšší počet žien ako mužov. Muži sú typický v páchaní násilných trestných činov a až 89 \% z celkového počtu vrážd páchajú práve muži. ${ }^{14}$ Myslíme si však, že u niektorých trestných činov bude možné v budúcnosti badat' zvýšenie počtu páchateliek trestných činov z dôvodu vyššej zainteresovanosti žien v spoločenskom nažívaní. Vyšší počet páchatel'ov mužov je však logický vzhl'adom na predispozície, ktorými chlapi disponujú. Je možné badat' rozdiely medzi mužmi a ženami v psychických i fyzických znakoch. $^{15}$

Taktiež môžeme povedat', že v konotáciách kriminálnej cesty páchatel'a, konkrétne teda s recidívou páchatel'a trestnej činnosti je dominantná agresia ako osobnostná vlastnost' jedinca. Môžeme ju považovat' i za osobnostnú dimenziu kriminálnej agresie. Považujeme tiež za dôležité vymedzit' rozdiely a značné charakteristiky agresie a agresivity z dôvodu, že laickou verejnost’ou dochádza často $\mathrm{k}$ ich zamieňaniu. Agresia je násilná, deštrukčná jednotka, ktorá vzniká pri podnete útočnou reakciou, agresivita je relatívne trvalá dispozícia, či vlastnost' osobnosti správat' sa agresívne. ${ }^{16}$ Agresivita je v značnej miere spojená s poruchami osobnosti, napríklad so psychopatiami - agresívny psychopat, paranoidný psychopat a podobne. ${ }^{17}$

Vzdelanie páchatel’a je dynamickým faktorom, ktorý postupom času nadobúda významnejšiu úlohu pri poznávaní páchatel'ovej osobnosti a pri poznávaní jeho sociálneho správania. Môžeme však badat' na jednej strane predispozície z minulosti, kedy sa vyznačovali páchatelia nedokončeným základným vzdelaním alebo so značnými problémami pri štúdiu a naopak $v$ dnešnej dobe, kedy $v$ čoraz vyšších intenciách nadobúda charakter sofistikovanejšia ekonomická trestná činnost', kedy sú páchatel'mi vzdelaní páchatelia, často i s vysokoškolským vzdelaním.

$\mathrm{Na}$ základe vymedzenia jednotlivých kriminologických charakteristík (znakov) páchatel'a trestného činu je možné determinovat', že jednotlivé osobnosti majú vyššie alebo nižšie percento preddispozície stat' sa páchatel'om trestného činu. Uvádzame to z toho z dôvodu, že každý z nás je potenciálnym páchatel'om trestného činu a to, či sa staneme páchatel'om reálnym je podmienené i spomínanými kriminologickými znakmi. Tieto kriminologické znaky a ich poznanie je vel'mi dôležité i pri hodnotení počas prípravného konania. Pri nepoznaní uvádzaných skutočností je možné, že dôjde k zbytočným komplikáciám a tým aj $\mathrm{k}$ neefektívnej činnosti počas prípravného konania.

\section{Súčasné ponímanie osobnosti páchatel’a trestnej činnosti z psychologického hl'adiska}

V kriminológii rovnako ako v psychológii je osobnost' páchatel'a najčastejšie chápaná ako organický celok duševného života človeka zahrňujúci ako biologický základ jedinca, tak i spoločenské podmienky jeho života so spoločenskými vzt'ahmi. Osobnost' je špecifikovaná ako psychická konkrétnost' jedinca a súčasne sú študované jeho odlišnosti i zhoda $\mathrm{s}$

13 KOLEKTÍV AUTOROV. Kriminológia - všeobecná čast'. 2. diel. Akadémia Policajného zboru v Bratislave, 2003, s. 27.

14 DiANIŠKA, G., STRÉMY, T., VRÁBLOVÁ, M. a kol. Kriminológia. 3. vyd. Plzeň: Aleš Čenek, 2016 , s. 118.

15 KASSIN, S. Psychologie. Computer Press, 2007, s. 302.

16 HERETIK, A. Základy forenznej psychológie. Slovenské pedagogické nakladatel'stvo, 1994, s. 144.

17 Poznámka autora: mnohí odborníci však kladú dôraz na fakt, že agresivita je podmienená vrodenými biologickými faktormi a tiež sociálnym učením. U páchatel'ov je agresivita vel'mi často podporená psychosociálnymi vplyvmi, ktorú u páchatel’a môžu vytvárat' a podporovat' hostilitu. 
osobnost'ami d'alších jedincov a skupín jedincov. Osobnost' je možné rozdelit' na tri skupiny javov: psychické vlastnosti, psychické črty a formát.

Psychické vlastnosti označujeme ako inventár osobnosti, čo je akoby jej obsahom. Patria sem záujmy, schopnosti, nadanie a temperament. Záujmy sú dlhodobým zameraním na určité objekty a úzko súvisia s motívmi a orientáciou osobnosti. Záujmy najviac podliehajú zmene a vplyvu prostredia. Spolu s postojmi obklopujúcimi vlastný sebaobraz sú vel'mi dôležité, lebo sa spoluzúčastňujú na formovaní životného zmyslu jednotlivca. V patológii sú zvlášs' nápadné a môžeme ich opísat' ako chorobne znížené, alebo chorobne úchylné. Psychické črty neoznačujú jednotlivé stránky osobnosti, ale jej celok. Nemožno ich vzt'ahovat' len na určitú vlastnost', ale spolu charakterizujú obraz osobnosti. Rozlišujeme tieto psychické črty: celistvost' osobnosti, súdržnost', výraznost' a diferencovanost'. Celistvost' osobnosti tvorí za normálnych okolností ucelenú jednotku, hoci sú v nej protirečivé črty a pôsobia protikladné sily. Platí to najmä vtedy, ked' jedinec nie je vystavený vel'kej zát'aži a náporu, vtedy osobnost' pôsobí ako harmonická. Súdržnost' je odolnost' proti náporom, stresom, ktoré môžu viest' $\mathrm{k}$ deformácii osobnosti, prípadne k rozštiepeniu, dokonca k jej rozpadu. Výraznost' je črta, ktorá robí osobnost' nápadne výraznou. Výraznost' neznamená vždy pozitívnost' črty. Napríklad medzi zločincami sú typy, ktoré sú určitým spôsobom výrazné v negatívnom slova zmysle.

V nasledujúcom texte sa budeme bližšie venovat' samotnej špecifikácii osobnosti páchatel'a trestnej činnosti. Pojem osobnost', ako taká pochádza ako mnoho slov z iného jazyka, konkrétne z latinského slova ,,persona“. Každý páchatel' je osobnostne iný a aj spôsob, metódy a formy spáchania trestného činu vypovedajú o jeho osobnosti. Aj v prípade prípravného konania nachádzame vel'mi dôležitý charakter práve v osobnosti páchatel'a trestného činu. Pri vnímaní a skúmaní osobnosti páchatel’a je podstatné si uvedomit', že určité spoločenské znaky tvoria teoretický základ a skúsenosti z aplikačnej praxe zase tvoria empirický základ bádania osobnosti páchatel’a trestného činu. Tvrdené skutočnosti je možné podložit' i nasledovnými faktami. Výskumy intenzívne zaoberajúce sa osobnost’ou páchatel’a potvrdzujú skutočnost’ o existencii spoločných znakov pre každú skupinu trestných činov. Súčasne tiež vyplývajú z výskumov skutočnosti, že neexistuje globálna osobnostná štruktúra, ktorá by bola typická pre páchatel'a trestného činu, a teda prostredníctvom ktorej je možné odlíšit' páchatel'a od potenciálneho páchatel'a. Tieto fakty sú podl'a odborníkov pôsobiacich v aplikačnej praxi v súčasnosti vel'mi dôležité pretože často napomáhajú v podstatnej miere identifikovat' jednotlivé rysy napomáhajúce pri charakteristike páchatel'a.

Aplikačná prax prízvukuje, že je potrebné venovat' sa v aktuálnej dobe i miere dynamiky stotožňovania sa a osvojovania si viacerých faktorov, ktoré sú výsledkom exogénnych a endogénnych činitel'ov a následne aj ich reálnemu odrazu v osobnosti páchatel'a. Považujeme preto za dôležité sa v kontexte nášho príspevku vyjadrit' sa aj k samotným exogénnym a endogénnym kriminogénnym faktorom, ktoré v značnej miere ovplyvňujú osobnost' páchatel’a trestného činu.

Exogénne kriminogénne faktory je možné vymedzit' nasledovne. Badatel'né negatívne javy $\mathrm{v}$ rodine. Ide napríklad o narušené vzt’ahy v rodine medzi jednotlivými členmi, nesprávne výchovné štýly, neprimeraná miera rodičovského dohl'adu, nevhodné spôsoby riešenia konfliktov $\mathrm{v}$ rodine a pod. Tiež ide o negatívne javy $\mathrm{v}$ škole - nevhodné vzdelávacie, výchovné procesy, neadekvátna reakcia školy na zistené asociálne správanie mládeže, neprimerané uplatňovanie disciplíny, šikanovanie $\mathrm{v}$ triede. Taktiež je možné poukázat' na nevhodné pôsobenie referenčnej skupiny - členstvo je častokrát spojené so spáchaním trestného činu, holdovaním alkoholu, drogám, sexuálnou promiskuitou. V nasledujúcom rade je taktiež možné hovorit' o nevhodnom spôsobe využívania vol'ného času, tiež o negatívnych javoch v spoločnosti - alkoholizmus, toxikománia, hráčstvo, problémy s pracovným zapojením mládeže, negatívne pôsobenie médií - v širokej miere zobrazované násilie, 
agresivita zameraná proti niektorým náboženským, politickým, sociálnym, etnickým či iným skupinám, vulgárne zobrazované l'udské telo a sexualita ako taká. ${ }^{18}$

Endogénne kriminogénne faktory je možné v krátkosti a stručnosti vymedzit' ako príčiny súvisiace napríklad i s dospievaním jedincov - poruchy správania podmienené pubertálnou a adolescentnou nevyrovnanost'ou, disharmónia v oblasti sociálnej, somatickej a psychickej odrážajúca sa najmä v kritických situáciách vývoja jedinca. Môžeme hovorit' taktiež o prejavoch generačného vzdoru, o poruchách osobnosti jedinca, ktoré sú podmienené geneticky, napr. syndróm hyperaktivity prejavujúci sa trvalým nekl’udom, kolísaním pozornosti, zmenami nálad, impulzivitou alebo chorobnou osobnostnou poruchou psychopatiou, mentálnou retardáciou.

K najviac frekventovaným zložkách psychickej štruktúry osobnosti aj u osobnosti páchatel'a patria: motivácia, zameranost', schopnosti, charakter a temperament. ${ }^{19}$ Vybrané zložky si dovolíme v stručnosti i charakterizovat'. Pri páchaní a spáchaní trestného činu zohráva neodmyslitel'nú úlohu i ráz páchatel'ových schopností. Schopnosti páchatel'a trestného činu predurčujú do istej miery i spáchanie samotného trestného činu, ale i následné činnosti, ktoré páchatel' vykoná po spáchaní trestného činu. Schopnosti páchatel'a sú vel'mi podstatnou zložkou a opodstatnene je im potrebné venovat' našu pozornost'. Kl'účovú pozíciu medzi všeobecnými schopnost'ami zohráva všeobecná rozumová schopnost' čiže inteligencia. Táto schopnost' umožňujúca riešit' nové situácie preniknutím $\mathrm{k}$ ich podstate účelne konat' a vyrovnávat' sa so zmenami prostredia dlhé obdobie pútala najväčšiu pozornost' výskumníkov osobnosti páchatel'a. Pohl'adom do minulosti je možné bádat', že v rámci niekol'kých výskumov bolo skúmané, zist'ované, a na základe toho aj tvrdené, že je možné postrehnút' abnormálny výskyt rozumovo zaostalých jedincov $\mathrm{v}$ delikventnej populácii. Z uvádzanej skutočnosti sa následne začali vyvodzovat' mylné domnienky, že mentálna zaostalost' je kauzálnym faktorom delikventného správania. Postupne sa stále viac potvrdzovalo, že prvé práce o vzt'ahu medzi delikventným správaním a inteligenciou vyšli z nesprávnych predpokladov a tento vzt'ah sa posúval na reálnejšiu platformu. Na porovnanie uvádzame aj odborné tvrdenie, že osoby s hlbším stupňom mentálnej retardácie sa dopúšt’ajú trestnej činnosti zriedkavejšie, ked’že ich stav si vyžaduje intenzívnejšiu starostlivost' a asistenciu blízkej alebo školenej osoby, čím čiastočne klesá riziko spáchania trestného činu. Takisto mentálna náročnost' mnohých trestných činov prekračuje možnosti týchto osôb. ${ }^{20}$

Charakter $^{21}$ každej osobnosti predstavuje podstatnú regulačnú konštantu, odrážajúcu jej vzt'ahy k spoločnosti, druhým l’udom, práci a samozrejme i k sebe samému. Charakter, ako vlastnost' osobnosti významne ovplyvňuje aj vôl'ové úsilie každého človeka.

Temperament $^{22} \mathrm{v}$ úzkej nadväznosti na ostatné štrukturálne prvky dynamizuje psychickú činnost'. Dynamizácia psychickej činnosti významne ovplyvňuje silu reakcií každej osobnosti, samozrejme teda aj páchatel'a trestného činu na vonkajšie podnety i schopnost' ovládnut' vlastné prežívanie a správanie. Na základe uvedených faktov je podla nášho názoru

18 DIANIŠKA, G. a kol. Kriminológia. 2. Rozšírené a doplnené vydanie. Plzeň: Aleš Čenek, 2011, s. 85.

19 VRÁBLOVÁ, M., RÍSOVÁ, V. Kriminologické súvislosti ADHD a kriminality mládeže. In ŠČERBA, F. (ed.). Kriminologické dny 2018. Sborník z VI. ročníku mezinárodní konference Kriminologické dny pořádaný ve dnech 18.-19. 1. 2018 Českou kriminologickou společností ve spolupráci s Právnickou fakultou Univerzity Palackého v Olomouci. 2. vydání Olomouc: Iuridicum Olomoucense, o.p.s., 2018, s. 173.

20 HOLCR, K. a kol. Kriminológia. IURA EDITION, 2008, str. 89.

21 Charakter je možné považovat' za zložku psychiky a tiež za jednu zo zložiek tvoriacu osobnost'. Vlastnosti charakteru sa prejavujú relatívne stálym adekvátnym alebo nežiaducim správaním k okolitému svetu, k hodnotám spoločnosti, ale i k sebe samému. Prejavy charakterových vlastností v správaní osobnosti počas života osobnosti je možné hodnotit' z pohl'adu určitých hl'adísk a vyjadrovat' v pojmoch povahových rysov, ako je napríklad lenivost', poctivost', čestnost', nespol'ahlivost' a v iných.

22 POLIACH V. Základy psychológie osobnosti. Individualita - psychické vlastnosti a ich individuálna variabilita. Banská Bystrica: Pedagogická fakulta UMB v Banskej Bystrici, Katedra psychológie Inštitút priemyselnej výchovy v Žiline, 2016, s. 3. 
opodstatnené vyvodit' skutočnost', že temperament ako taký má vplyv na samotné konanie a prežívanie páchatel'a trestnej činnosti.

Z uvádzaného vyplýva, že už minulost' priniesla poznanie o fakte, že osobnost' páchatel'a v porovnaní s osobnost'ou bežného občana charakterizuje spoločenská neprispôsobilost' a nebezpečnost'. Samozrejme uvedená predispozícia môže byt' umocnená vlastnost’ami, ktoré sa opierajú o endogénny zdroj alebo exogénny zdroj vzniku. Páchatelia trestných činov sú všeobecne výrazní v oblasti emocionálnej lability, impulzivity, spontánnej a reaktívnej agresivity, dobrodružnosti, neznášanlivosti, pohotovosti k riziku, v negatívnom sebahodnotení a zníženej sebakontrole.

\section{ZÁVER, NÁMETY DO DISKUSIE A PODNETY DO BUDÚCNOSTI}

Poznatky z viacerých disciplín o samotnej osobnosti páchatel'a sú vel'mi široké avšak nie ešte ukončené. Každé bádanie je neustály proces, ktorý sa postupom času vyvíja a neustále hl'adá nové formy o jeho obohatenie. Takto je to i pri osobnosti páchatel'a a vplyvu markantných znakov páchatel'a na efektívnost' a účelnost' prípravného konania. Máme za to, že predkladaný príspevok vo svojich konotáciách predkladá teoretické poznatky, ktoré sú doplnené o poznatky z aplikačnej praxe. Preto vytvára súbor relevantných informácií, ktoré je možné abstrahovat' a využit' pri skúmaní vplyvov podmieňujúcich efektívnost' prípravného konania.

V úvode sme si stanovili hypotézy, ktoré sme počas spracovania príspevku verifikovali. $H 1$ : Aké markantné znaky páchatel'a trestného činu môžu mat' eventuálny vplyv na prípravné konanie? Na základe nami zistených skutočností je možné vyvodit' záver, že markantné znaky a charakteristiky páchatel'a trestného činu môžu mat' eventuálny vplyv na prípravné konanie. Uvádzané je potvrdené nami spracovaným obsahom príspevku, kedy si dovolíme tvrdit', že posúdenie samotného páchatel'a v kontexte prípravného konania vyžaduje komplexný, ucelený a najmä multifaktorový systémový prístup. Bez týchto skutočností prípravné konanie, dovolíme si tvrdit', nebude dostatočne efektívne a práve i skúmanie markantných znakov páchatel'ov súvisí s posúdením jeho efektívnosti.

H2: Majú markantné znaky páchatel'a trestného činu vplyv na efektívnost' prípravného konania? Tak ako nám to vyplynulo $\mathrm{z}$ verifikácie prvej, nami vytýčenej hypotézy zhodnotenie, skúmanie a hodnotenie markantných znakov páchatel'a trestného činu majú vplyv aj na efektívnost' prípravného konania a na jeho účelnost'.

Máme za to, že s prihliadnutím na nami zistené skutočnosti a pohl'adom do budúcnosti je potrebné sa danému neustále venovat' a hodnotit' všetky eventuálne aspekty, ktoré v určitej miere zásadne alebo menej zásadne, ale predsa ovplyvňujú prípravné konanie a jeho efektívnost'.

Táto práca bola podporená Agentúrou na podporu výskumu a vývoja na základe Zmluvy č. APVV-19-0102.

\section{Použitá literatúra}

1. DIANIŠKA, G. a kol. Kriminológia. 2. Rozširené a doplnené vydanie. Plzeň: Aleš Čenek, 2011, 351 s. ISBN 978-80-7380-344-5.

2. DRUGDA, J. Vývoj právnej úpravy vybraných inštitútov prípravného konania. In ČENTÉŠ, J. (ed.) a kol. „Efektívnost' prípravného konania - jej skúmanie, výzvy a perspektívy“. Bratislava: Univerzita Komenského v Bratislave, Právnická fakulta, 2020, s. 42-48. ISBN 978-80-7160-577-5.

3. HERETIK, A. Základy forenznej psychológie. Slovenské pedagogické nakladatel'stvo, 1994, s. 144. ISBN 80-0801-870-4. 
4. HOLCR, K. a kol. Kriminológia. IURA EDITION, 2008, 404 s. ISBN 978-80-8078206-1.

5. IVOR, J. a kol. Trestné právo procesné. Bratislava: IURA EDITION, 2006, $993 \mathrm{~s}$. ISBN 80-8078-101-X.

6. KASSIN, S. Psychologie. Computer Press, 2007, s. 302. ISBN 80-2511-71-63.

7. KOLEKTÍV AUTOROV. Kriminológia II, 1. diel. Bratislava: Akadémia Policajného zboru v Bratislave, 2006. 191 s. ISBN 978-80-8054-393-8.

8. KOLEKTÍV AUTOROV. Kriminológia - všeobecná čast’. 1. diel. Akadémia Policajného zboru v Bratislave, 2003, 106 s. ISBN 80-8054-298-8.

9. KOLEKTÍV AUTOROV. Kriminológia - všeobecná čast'. 2. diel. Akadémia Policajného zboru v Bratislave, 2003, 96 s. ISBN 80-854-299-6.

10. KURILOVSKÁ, L. Možnosti riešenia postavenia obetí v intenciách riešenia postavenia obetí $v$ intenciách restoratívnej spravodlivosti ako inštitútu posilnenia dôvery obetí v justičný systém Slovenskej republiky. In KURUC, P. (ed.). Obete kriminality a ich práva. 1. vydanie, Žilina: Spoločnost' pre trestné právo a kriminológiu, 2015, s. 5-18. ISBN: 978-80-971911-0-8.

11. MEDELSKÝ, J. Minulost', prítomnost' a budúcnost' sankcionovania v Trestnom práve v Slovenskej republike. In MARKOVÁ, V. (ed.). Aktuálne otázky trestného práva $\mathrm{v}$ teórii a praxi. Zborník príspevkov z 2. roč. interdisciplinárnej celoštátnej vedeckej konferencie s medzinárodnou účast’ou. Bratislava: Akadémia Policajného zboru v Bratislave, 2014, s. 43-50.

12. MIHÁLIK, S. Dopady tzv. superrýchleho konania ako osobitnej formy vedenia trestného konania. In ČENTÉŠ, J. (ed.) a kol. „Efektívnost' prípravného konania - jej skúmanie, výzvy a perspektívy“. Bratislava: Univerzita Komenského v Bratislave, Právnická fakulta, 2020, s. 96-106. ISBN 978-80-7160-577-5.

13. POLÁK, P. Postup a obsah jednotlivých foriem pripravného konania. In Záhora, J. (ed.) Prípravné konanie - možnosti a perspektívy. Praha: Leges, 2016, s. 74-96. ISBN 978-80-7502-153-3.

14. POLIACH V. Základy psychológie osobnosti. Individualita - psychické vlastnosti a ich individuálna variabilita. Banská Bystrica: Pedagogická fakulta UMB v Banskej Bystrici, Katedra psychológie Inštitút priemyselnej výchovy v Žiline, 2016, 18 s.

15. ŠIŠULÁK, S. Kritéria efektívnosti prípravného konania. In ČENTÉS̆, J. (ed.) a kol. „Efektívnost' prípravného konania - jej skúmanie, výzvy a perspektívy“. Bratislava: Univerzita Komenského v Bratislave, Právnická fakulta, 2020, s. 127-138. ISBN 978-80-7160-577-5.

16. VRÁBLOVÁ, M., RÍSOVÁ, V. Kriminologické súvislosti ADHD a kriminality mládeže. In ŠČERBA, F. (ed.). Kriminologické dny 2018. Sborník z VI. ročníku mezinárodní konference Kriminologické dny pořádaný ve dnech 18.-19. 1. 2018 Českou kriminologickou společností ve spolupráci s Právnickou fakultou Univerzity Palackého v Olomouci. 2. vydání Olomouc: Iuridicum Olomoucense, o.p.s., 2018, s. 173-186. ISBN 978-80-88266-24-2.

17. Zákon č. 300/2005 Z. z. Trestný zákon v znení neskorších predpisov.

18. Zákon č. 301/2005 Z. z. Trestný poriadok v znení neskorších predpisov.

\section{Kontaktné údaje}

JUDr. Patrícia Krásná, PhD., LL.M.

Akadémia Policajného zboru v Bratislave, Katedra kriminológie

Sklabinská 1, 83517 Bratislava 35

Tel: 0961057425

Email: patricia.krasna@akademiapz.sk 


\title{
OPODSTATNENIE A VÝZNAM IMPLEMENTÁCIE KYBERŠIKANY DO LEGISLATÍVY V SLOVENSKEJ REPUBLIKE
}

\author{
JUSTIFICATION AND SIGNIFICANCE OF THE IMPLEMENTATION \\ OF CYBERBALLS INTO LEGISLATION IN THE SLOVAK REPUBLIC
}

\author{
Patrícia Krásná
}

\begin{abstract}
Abstrakt
Počas spracovania príspevku sa budeme venovat' problematike online priestoru a to konkrétne kyberšikane. Poukážeme na skutočnosti negatívneho dopadu kyberšikany na spoločnost', resp, na deti, ako obzvlášt' zranitel'né obete. V súčasnej dobe je táto problematika, dovolíme si uviest', vel'mi aktuálna a predstavuje hrozbu pre široké spektrum potenciálních obetí. V súčasnej dobe je kyberšiakana subsumovaná, resp. postihovaná v paragrafovom znení iných trestných činov a preto je, podl'a nášho názoru, vel'mi dôležité aby bola i byberšikana vymedzená ako samostatný trestný čin. V kontexte nášho odborného článku sa budeme venovat' všeobecným, ale i konkrétnym artiklom kyberšikany a jej opodstatneniu v rámci legislatívy v Slovenskej republike.
\end{abstract}

Kl'účové slová: obet', agresor, kyberšikana, trestný čin, prevencia

\begin{abstract}
During the elaboration of the article, we will deal with the issue of online space, specifically cyberbullying. We will point out the facts of the negative impact of cyberbullying on society, or on children, as particularly vulnerable victims. At present, this issue, we dare say, is very topical and poses a threat to a wide range of potential victims. At present, cyberbullying is subsumed, resp. punished in the paragraph wording of other criminal offenses and therefore, in our opinion, it is very important that even bullying is defined as a separate criminal offense. In the context of our professional article, we will focus on general as well as specific articles of cyberbullying and its justification within the legislation in the Slovak Republic.
\end{abstract}

Key words: victim, aggressor, cyberbullying, crime, prevention

\section{ÚVOD}

Súčasná spoločenská situácia je poznačená nielen pandémiou, ale i skutočnost'ou o „online existencii““ takmer všetkých z nás. Akákol'vek činnost' v prípade, že je to možné je presunutá do online priestoru. Samozrejme, nie je možné tvrdit', že tomu je tak iba teraz. Aj v predchádzajúcej dobe bol online priestor vel'mi využívaný, či už na pracovné účely alebo na súkromné. Aktuálne je však „online existencia“ priam bezpodmienečná. Dovolíme si uviest', že pri komplexnom posúdení a úvahe o danej situácia je často nevyhnutné využívat' všetky výdobytky novej doby a adekvátne sa prispôsobovat' požiadavkám rýchlo rozvíjajúcej sa doby. Máme za to, že právo online priestor, nové technológie a spôsoby komunikácie nám napomáhajú vo vel'mi vel’a prípadoch efektívne a účelne. Avšak, podl'a nášho názoru, je vždy potrebné prihliadat' aj na stranu druhú a to skutočnost', že technológie, online priestor sú pre spoločnost' i nebezpečné a môžu mat' negatívny dopad na každého člena spoločnosti. Obzvlášt' v prípade detí, ktoré sú práve vel'mi často obet'ou kyberšikany. V našom príspevku sme sa rozhodli venovat' tejto problematike z dôvodu, že tak ako to vyplýva i nášho poznania, kedy sme osobne realizovali besedy so žiakmi základných škôl a strednej školy s témou 
kyberšikany je to vel'mi aktuálna téma. ${ }^{1}$ Používanie rôznych moderných výdobytkov, ktoré nám táto doba prináša je $\mathrm{v}$ súčasnosti už bežná a samozrejmá vec. Útoky, ktoré sa stávajú v reálnom svete sú nebezpečné a taktiež aj útoky, ktoré sa realizujú prostredníctvom sociálnych sietí sú nebezpečné a niekedy aj život ohrozujúce. Ak chceme vytvorit' ucelený koncept útokov na sociálnych siet'ach, je potrebné uvedomit' si skutočnost', že hranice týchto útokov sú t'ažko determinované. ${ }^{2} \mathrm{~V}$ tomto momente, je ale dôležité podotknút', že využívanie moderných výdobytkov nie je podmienené vekom, či inou skutočnost'ou - týka sa to každého z nás. Je preto bezpodmienečne potrebné, aby sa venovala kyberšikane náležitá pozornost'. Naša vedecká činnost' bola už niekol'ko krát smerovaná i na spracovanie aplikovaného výskumu, ktorý by sa venoval práve fenoménu kyberšikany, avšak bezúspešne s odôvodnením nedostatku finančných prostriedkov pre navrhovaný aplikovaný výskum. ${ }^{3}$

Následne $v$ našom spracovanom príspevku poukážeme na fenomén kyberšikany s prihliadnutím na odôvodnenú potrebu úpravy kyberšikany i v kontexte legislatívy platnej v Slovenskej republike. Okrem spomínaného sa budeme tiež venovat' všeobecným skutočnostiam spojeným s kyberšikanou pre reálne a opodstatnené odôvodnenie potreby jej legislatívnej úpravy. Máme za to, že postup vedeckej činnosti je adekvátny práve v prípade postupu od všeobecných skutočností ku konkrétnym, ktoré vyústia následne do aplikačnej praxe. Na základe uvedeného sme si vytýčili niekol'ko ciel'ov, ktoré máme za úlohu počas spracovania nášho príspevku naplnit'. Jedným z ciel'ov je, samozrejme, poukázat' na samotný fenomén kyberšikany ako na nebezpečenstvo, ktoré je v súčasnej dobe vel'mi aktuálne. Tiež je naším ciel'om poukázat' na fakt, že problematika spojená s kyberšikanovou často presahuje medze uznávané spoločnost'ou, ale i medze zákona a práve preto je potrebné kvalitne a efektívne upravit' kyberšikanu i prostredníctvom vhodnej legislatívy. Samozrejme okrem daného je bezpodmienečne potrebné aplikovat' aj získané skutočnosti počas vedeckého skúmania či už do aplikačnej praxe, ale aj do prípravy efektívnej legislatívy. Tak ako tvrdia aj iní autori počas vedeckej činnosti a prístupu k právnej legislatíve v našej spoločnosti. Je preto na mieste predmetné legislatívne úpravy zhodnotit', nahliadnut' nie len na ich znenie, ale primárne ich odôvodnenost' zákonodarcom, resp. dôvodnost' pre prax, a v neposlednom rade poukázat' (primárne merítkom štatistickým) na reálne dopady v oblasti aplikácie práva. ${ }^{4}$

\section{KYBERŠIKANA - NEBEZPEČNÝ FENOMÉN SÚČASNOSTI}

Doterajšie výskumy preukazujú, že kyberšikanovanie je jedným z najčastejších negatívnych javov na internete. Pre agresorov je totiž l'ahšie ubližovat' niekomu, komu sa nemusia pozerat' priamo do očí, menej vnímajú emócie a zranenie obete, menej si uvedomujú závažnost' svojho konania a zodpovednost' zaň ako je napríklad pri sociálnom kontakte face to face. Agresora totiž pred priamym odhalením chráni jeho zdanlivá anonymita. ${ }^{5}$ Tak, ako bolo už nami spomínané kyberšikana je novodobým fenoménom, ktorý sa týka každého $\mathrm{z}$ nás. Je preto podl'a nášho názoru vel'mi potrebné o tejto téme diskutovat' a poukazovat' na nástrahy virtuálneho sveta. Pretože tak, ako nám internet a sociálne siete dokážu pomôct', tak nám dokážu i ubližit'. Vel'mi dôležitou skutočnost’ou, na ktorú chceme poukázat' je to, že v rámci online priestoru nepoznáme hranice, ktoré by obmedzili šírenie negatívnych dopadov v intenzívnej forme, práve na obet' kyberšikany. Ale tiež tieto hranice neobmedzujú páchatel'a, resp. agresora.

\footnotetext{
Poznámka autora: preventívne besedy sme absolvovali počas odbornej stáže v mesiaci jún 2021.

2 KURILOVSKÁ, L., ŠIŠULÁK, S. 2015. Sociálne siete ako kybernetická hrozba. In Bezpečnostné fórum, s. 86.

3 Návrh aplikovaného výskumu bol podaný v rámci výziev APVV agentúry.

4 MIHÁLIK, S. Trest domáceho väzenia v Slovenskej republike v kontexte legislatívnych zmien. In GŘIVNA, T., ŠIMÁNOVÁ, H. (eds.). Ukládaní trestü a jejich výkon. Plzeň: Aleš Čeněk, 2020, s. 325.

5 ZODPOVEDNE.sk. [online]. [cit.2021.06.20.]. Dostupné na internete: https://www.zodpovedne.sk/index.ph p/sk/ohrozenia/kybersikanovanie.
} 
Dovolíme si uviest' skutočnost', že správanie l'udí vo virtuálnom priestore je ovplyvnené troma základnými charakteristikami, tzv. AAA princípom:

Dostupnost' (accessibility) - internet a virtuálny priestor je dostupný 24 hodín denne, 7 dní v týždni. Pripojit' sa na internet je možné doma, v škole, v práci a v podstate kdekol'vek.

Dosiahnutel'nost' (affordability) - cena internetového pripojenia sa pohybuje v rozmedzí niekol'kých eur, čím sa internet stal dosiahnutel'ným takmer pre každého, vrátane detí.

Anonymita (anonymity) - jednou z najvýraznejších charakteristík, ktoré sa viažu na internet a virtuálny priestor, je práve anonymita. Z uvádzaného vyplýva, že miera kontroly nad odhalením seba má dotyčný vo svojich rukách. Sám sa môže rozhodnút', či odhalí svoju identitu alebo bude vystupovat' pod prezývkou, či zverejní svoje fotografie alebo použije cudzie. ontroly, ktorá ovplyvňuje naše správanie v realite. ${ }^{6}$

V online priestore vládnu bezhraničné možnosti a teda aj stým spojená bezhraničná anonymita. Vo virtuálnom svete sa teda takto môže stat' ktokol'vek kýmkol'vek. ${ }^{7}$ Online realita prebieha mimo časového rámca a mimo všetkých všeobecne platných spoločenských noriem. Považujeme za potrebné poukázat' i na základné pojmy súvisiace s kyberšikanou. Tak ako samotný pojem i podstata kyberšikany vychádza z pojmu škana, resp. šikanovanie. Dovolíme si konštatovat', že kyberšikana je šikana prostredníctvom internetu, teda prebieha v online svete. Rovnako ako pri iných formách šikanovania aj kyberšikanovanie je opakované a zámerné správanie, ktorého ciel'om je vysmievat' sa, ubližovat' niekomu, ponižovat' ho, zranit', resp. mu ublížit' a získat' z toho často i prospech. Agresor zneužíva svoju moc nad obet'ou.

- Kyberšikana - samotný pojem kyberšikana má niekol'ko relevantných synoným, s ktorými je možné sa počas odborných diskusií stretnút'. Kyberšikanu je možné pomenovat' i ako kybernetické šikanovanie, cyberbullying, cybermobbing elektronické šikanovanie alebo online šikanovanie.

- V prípade kyberšikany ide o jednu z foriem šikanovania, kedy páchatel' využíva pri svojej činnosti technológie (počítač, internet, mobilný telefón, tablet a pod.) a svoje útoky alebo ich čast' voči obeti realizuje vo virtuálnom priestore s využitím rôznych služieb a nástrojov (e-mail, messenger, Skype, Viber, WhatsApp, Snapchat), čet, diskusné fóra, sociálne siete, SMS správy, telefonáty). Za autora a tvorcu pojmu kyberšikana je považovaný Bill Belsey. Kyberšikanu charakterizoval ako ,ako úmyselné, opakované a nepriatel'ské správanie zo strany jednotlivca alebo skupiny za účelom ubližit' ostatným. Zároveň uviedol, že takéto správanie zahrňuje využitie informačných a komunikačných technológii". 8

- Obet' kyberšikany - obet'ou kyberšikany sa môže stat' ktokol'vek. Jej charakteristické črty je však možné zhrnút' a na základe nich vytvorit', okrem iného, i typológiu obetí kyberšikany. $\mathrm{V}$ rámci nášho vedeckého skúmania sme dospeli $\mathrm{k}$ možnému názoru, a síce, že deti, resp. detské obete sú najviac ohrozenou skupinou. Deti nepoznajú nástrahy, ktoré na nich číhajú vo virtuálnom svete a preto sú l'ahko zmanipulovatel'né.

- Agresor - agresor je práve osoba, ktorá pácha kyberšikanu. Úmyselne ubližuje obeti a pokúša sa rôznymi formami obet' ovplyvňovat' a manipulovat'. Agresor sa snaží obet' zmanipulovat' až do takej podoby, kedy obet' nie je už ani schopná sa bránit' a vo svojej podstate podlieha tlaku agresora. Je však potrebné si uvedomit', že všetky činnosti i v rámci ochrany obetí je potrebné, aby smerovali práve k zabráneniu takýmto situáciám. Agresor prostredníctvom online priestoru získava nad obet'ou ovel'a l'ahšie vplyv.

6 DROBNÝ, M. GREGUSSOVÁ, M. KYBERŠIKANOANIE.sk. Bratislava: CeSlovensko o.z., 2015, prvé vydanie, s. 21.

7 OSTER, J., MAKATURA, I., PAULUS, T. Ako na nástrahy internetu - top témy z www.preventista.sk. 2 aktualizované vydanie. Nitra: ForPress NITRIANSKE TLAČIARNE, s. r. o., 2015, s. 13.

8 BILL BELSEY. [online]. [cit.2021.06.20.]. Dostupné na internete: https://billbelsey.com/?cat=13. 
- Publikum - zohráva vel'mi často práve tú kl'účovú úlohu. Publikum, ktoré podporí obet' kyberšikany jej adekvátnym spôsobom pomôže a zároveň odradí agresora od d’alšej činnosti. Naopak ak publikum podporí agresora utvrdzuje ho v tom, že to čo koná je správne a tým ho aj motivuje k d'alšej činnosti. Je vel'mi dôležité preto na túto skutočnost' prihliadat' a venovat' sa i odlišnému prvku kyberšikany ako je obet' a agresor.

Práve tieto skutočnosti a dopady kyberšikany na celú spoločnost' sú podmieňujúce preto, aby bola kyberšikana i právne regulovaná.

\section{REGULÁCIA KYBERŠIKANY PROSTREDNÍCTVOM LEGISLATÍVY}

V súčasnej dobe v podmienkach našej krajiny legislatívne nie je upravená problematika kyberšikany. Avšak netvrdíme, že kyberšikana nie je právne postihnutel'ná. Práve prostredníctvom subsumovania kyberšikany s prihliadnutím na jej špecifickú charakteristiku je ju možné postihnút' v rámci iných trestných činov, ktoré sú upravené v Zákone č. 300/2005 Z. z. Trestnom zákone v znení neskorších predpisov (d’alej už len „Trestný zákon“). Zmyslom vyšetrovania akéhokol'vek trestného činu je objasnenie veci, ktorá má znaky protiprávneho konania, vyhl'adanie a zákonné zadokumentovanie dôkazov a zistenie a usvedčenie jedného, prípadne viacerých páchatel'ov niektorého $\mathrm{z}$ trestných činov vymedzených $\mathrm{v}$ osobitnej časti Trestného zákona. ${ }^{9}$ I práve preto je potrebné, podl'a nášho názoru, kyberšikanu aplikovat' do aktuálne platnej legislatívy v Slovenskej republike. V súčasnosti je kyberšikanu možné subsumovat' napr. pod následne nami uvádzané vybrané trestne činy.

Nebezpečné prenasledovanie, tzv. „kyberstalking“ - § 360a Trestného zákona. Kde je objektom ochrana súkromia jednotlivca, ktorý je pernamentne prenasledovaný páchatel'om. Prenasledovanie je takej intenzity, že sa u poškodeného vzbudí obava, že takýmto konaním je ohrozený jeho život alebo zdravie. Dochádza aj k podstatnému zhoršeniu kvality života obete. Takéto konanie definuje je prínačné dlhodobost'ou, čiže určitým opakujúcim sa konaním. ${ }^{10}$

Vydieranie - § 189 Trestného zákona. O vydieranie ide v prípadoch, ked' určitá osoba inú osobu núti násilím, hrozbou násilia alebo hrozbou inej t’ažkej ujmy, aby táto osoba niečo konala, opomenula alebo trpela. V kontexte vydierania je chránená slobodná vôl'a jednotlivca. Obet' je pod tlakom násilia, hrozby násilia alebo inej t’ažkej ujmy nútená niečo konat'. Ide napríklad o situáciu, kedy obet' musí zaslat'(teda konat') agresorovi kompromitujúce fotografie, opomenút' - neoznámit' spáchanie trestného činu alebo niečo strpiet' - neustále zasielanie SMS správ a dožadovanie sa odpovede na tieto správy.

Nátlak - § 192 Trestného zákona. Potrestanie nátlaku vel'mi úzko súvisí s vydieraním. Obet' však musí byt' páchatel'om nútená, aby niečo konala, opomenula, trpela, pričom páchatel' zneužíva poškodeného hmotnú núdzu, naliehavú nemajetkovú potrebu alebo tieseň vyvolanú nepriaznivými osobnými pomermi. Čo je vel'mi dôležité, nátlak zo strany páchatel'a voči obeti je možné samozrejme vyvolávat', resp. spôsobovat' aj za pomoci využitia informačnotechnologických prostriedkov, teda online priestoru. Dôležité je tiež podotknút', že páchatel' $\mathrm{v}$ tomto prípade využíva danú situáciu vo svoj prospech - napríklad strach obete o svojich blízkych.

Sexuálne zneužívanie - § 201, § 201a, § 201b Trestného zákona. Páchatel' sa potrestá, ak prostredníctvom elektronickej komunikačnej služby navrhne diet’at'u mladšiemu ako pätnást' rokov osobné stretnutie $\mathrm{v}$ úmysle spáchat' na ňom trestný čin sexuálneho zneužívania alebo trestný čin výroby detskej pornografie, pričom sám páchatel' nie je diet'at'om. Tu si dovolíme uviest', že trestná zodpovednost' páchatel'a, ktorý takto koná je upravená pomerne krátky čas (od roku 2013). Ciel'om tejto právnej úpravy je snaha o ochranu osoby mladšej ako 15 rokov

\footnotetext{
9 DRUGDA, J. Prostriedky operatívno-pátracej činnosti a ich využitie na účely vyšetrovania obzvlášt' závažnej trestnej činnosti. In MARKOVÁ, V., JANKO, S., eds. Aktuálne otázky trestného práva v teórii a praxi. Zborník príspevkov [online]. Bratislava: Akadémia Policajného zboru v Bratislave, s. 166.

10 Poznámka autora: dlhodobé písanie SMS správ, sledovanie obete, atd'.
} 
pred zneužívaním prostredníctvom elektronických komunikačných služieb. Trestným bude už i len navrhnutie osobného stretnutia za účelom sexuálneho styku s diet'at'om.

Ohováranie - § 373 Trestného zákona. O trestný čin ohovárania ide vtedy, ak páchatel' o obeti, poškodenom, oznámi nepravdivý údaj, pričom tento údaj je spôsobilý značnou mierou ohrozit' vážnost' tejto osoby v spoločnosti, poškodit' jej meno napr. v zamestnaní, v podnikaní, alebo narušit' osobe rodinné vzt’ahy, či jej spôsobit' inú vážnu ujmu.

Poškodzovanie cudzích práv - § 376 Trestného zákona. Páchatel’ bude potrestaný, ak voči poškodenému, obeti, poruší tajomstvo listiny alebo inej písomnosti, zvukového záznamu, obrazového záznamu alebo iného záznamu, počítačových dát alebo iného dokumentu uchovávaného v súkromí iného, a to tým, že tento páchatel' ich zverejní alebo sprístupní tretej osobe. Podstatou je ochrana súkromných dokumentov pred ich zverejnením. Ide napríklad o listy, e-mailové správy, nahrávky rozhovorov, fotografií či zdravotných záznamov.

Výroba detskej pornografie - § 368 Trestného zákona. Páchatel'om je osoba, ktorá využije, získa, ponúkne alebo inak zneužije diet'a na výrobu detskej pornografie alebo detského pornografického predstavenia. Potrestá sa aj osoba, ktorá umožní takéto zneužitie diet'at'a, alebo sa inak podiel'a na takejto výrobe. Samozrejme, páchatel' sa potrestá i ked' spácha takýto čin verejne, teda napr. prostredníctvom internetu.

Rozširovanie detskej pornografie - § 369 Trestného zákona. Páchatel’om je ten, kto rozmnožuje, prepravuje, zadovažuje, sprístupňuje alebo inak rozširuje detskú pornografiu. Ide o trestný postih páchatel'a, ktorý zabezpečuje akúkol'vek distribúciu detskej pornografie tlačou, audiovizuálne, elektronicky ale aj zasielaním či zdiel'aním IP adries s tematikou detskej pornografie.

Ohrozovanie mravnosti - §371, § 372 Trestného zákona. Kedy sa páchatel' potrestá, ak vyrába, kupuje, dováža, inak zadovažuje a následne predáva, požičiava, inak uvádza do obehu, rozširuje, robí verejne prístupnými, zverejňuje pornografiu, nosiče zvuku alebo obrazu, zobrazenia alebo iné predmety ohrozujúce mravnost'.

Tak ako sme uviedli samotný pojem šikany, resp. kyberšikany nie je právne v našej krajine regulovaný. Ojedinelým prípadom výslovnej regulácie šikany v podmienkach našej krajiny je jej úprava v oblasti školstva, a to na základe Smernice MŠVVaŠ č. 36/2018 (d’alej už len „Smernica“) $\mathrm{k}$ prevencii a riešeniu šikanovania detí a žiakov $\mathrm{v}$ školách a školských zariadeniach. Teda nejde o trestnoprávnu úpravu šikany a kyberšikany. ${ }^{11}$

Kyberšikanovaním je podl'a tejto Smernice priama forma šikanovania, pri ktorej ide o zneužitie informačno-komunikačných technológií (najmä telefónu, tabletu, internetu a sociálnych sietí) na úmyselné ohrozenie, ublíženie alebo zastrašovanie, pričom sa často vyskytuje v spojení s d'alšími formami šikanovania.

Kyberšikanovanie má podl'a Smernice najčastejšie tieto znaky:

- sociálna prevaha alebo psychická prevaha agresora, nie je nutná fyzická prevaha,

- agresor vystupuje často anonymne,

- útok nevyžaduje fyzický kontakt agresora a obete,

- agresor spravidla nevidí priamu emocionálnu reakciu obete na útok s ohl'adom na anonymitu a odstup, ktoré informačno-komunikačné technológie umožňujú,

- útoky sa šíria prostredníctvom internetu podstatne rýchlejšie ako inými spôsobmi,

- útoky sú prístupné vel'kému množstvu osôb,

- agresor je schopný uskutočnit' útok z rôznych miest,

- útoky môžu mat' dlhšie trvanie v čase,

- obet' nemusí o napadnutí dlhšiu dobu vediet',

- obet' nemusí byt' schopná identifikovat' agresora,

11 Smernica č. 36/2018 k prevencii a riešeniu šikanovania detí a žiakov v školách a školských zariadeniach. 
- zverejnené informácie, fotografie a audiozáznamy a videozáznamy môže byt' náročné odstránit' z internetu.

Vo vzt’ahu $\mathrm{k}$ postihu kyberšikany a šikany prostriedkami trestného práva súčasný stav nepovažujeme za dostačujúci tak, ako sme to už niekol'ko krát výslovne uviedli. Dovolíme si tiež konštatovat' náš opodstatnený súhlas $\mathrm{s}$ výrokom uvedeným vo výročnej správe generálneho prokurátora za rok 2019, kedy v uvádzanom bolo spomenuté nasledovné. „Tzv. kyberšikanu je možné v niektorých prípadoch, v závislosti od konania páchatel'a, posúdit' ako trestné činy vydierania, ohovárania, nebezpečného vyhrážania alebo nebezpečného prenasledovania, nie_vždy je však takéto konanie trestnoprávne postihnutel'né, hoci jeho následok by si trestný postih určite vyžadoval.“"12

V nadväznosti na nami uvádzané trestné činy, pod ktoré je možné v odôvodnených prípadoch subsumovat' kyberšikanu si dovolíme uviest' niekol'ko konkrétnych nedostatkov, ktoré vnímame $\mathrm{v}$ súčasnej trestnoprávnej úprave. V prípade ak ide o spojitost' kyberšikany $\mathrm{k}$ aktuálne existujúcemu trestnému činu nebezpečného prenasledovania - § 360a Trestného zákona je badatel'ný nedostatok v tom, že skutková podstata trestného činu nebezpečného prenasledovania zásadne neposkytuje ochranu pred šikanou vcelom jej rozsahu. Prenasledovanie je totiž iba jedným $z$ aspektov šikany. Iné aspekty šikany, než je prenasledovanie, táto skutková podstata aktuálne nerieši. Kontaktovanie prostredníctvom elektronickej komunikačnej služby, ktorá nezahŕňa vel'kú množinu d’alších nástrojov a služieb informačnej spoločnosti, cez ktoré sa kyberšikana realizuje táto skutková podstata viaže iba na také zasielanie správ, ktoré je „prenasledovaním“. Nezohl'adňuje, že šikana je naopak takým kontaktovaním, ktoré má za ciel' nie prenasledovat', ale ponižovat' a zastrašovat'.

V prípade ak ide o súvis s trestným činom vydierania - $\$ 189$ pri kyberšikane o žiadnu hrozbu násilím nemusí íst' a ani obet' nemusí byt' nútená čokol'vek konat', či opomenút'. Ak aj má niečo strpiet', tiež to nemusí byt' pod hrozbou násilia, čo znamená, že v takom prípade sa táto skutková podstata trestného činu nedá na kyberšikanu subsumovat'.

Kyberšikana má pomerne blízko tiež k trestnému činu ohovárania - § 373. Vo svojej podstate sa však líšia. V prípade ohovárania je v prvom rade nutné, aby zo strany páchatel'a došlo $\mathrm{k}$ oznámeniu nepravdivej informácie. Kyberšikana však naopak vo vel'kej miere spočíva v oznamovaní a zverejňovaní pravdivých, intímnych a citlivých informácií (skutočností), údajov, dokonca obrazových, zvukových alebo obrazovo-zvukových záznamov. V takom prípade teda nie je naplnený základný znak skutkovej podstaty trestného činu ohovárania, ktorý vyžaduje, aby páchatel' o poškodenom, resp. obeti oznámil nepravdivý údaj. Kybernetická šikana spočívajúca v neoprávnenom zverejnení pravdivej informácie tak nemôže byt' postihnutá ako čin zodpovedajúci trestnému činu ohovárania.

Zverejnenie pravdivého údaju by v rámci hypotetickej úvahy, dovolíme si uviest', mohlo naplnit' skutkovú podstatu trestného činu podla § 376 Trestného zákona. Na spáchanie tohto trestného činu sa však vyžaduje, aby páchatel' voči poškodenému porušil „tajomstvo listiny alebo inej písomnosti, zvukového záznamu, obrazového záznamu alebo iného záznamu, počítačových dát alebo iného dokumentu uchovávaného v súkromí iného“, a to tým, že tento páchatel' ich zverejní alebo sprístupní tretej osobe alebo iným spôsobom zneužije. Podstatou je ochrana súkromných dokumentov pred ich zverejnením, napríklad listov, emailovej pošty, nahrávok rozhovorov, fotografií či zdravotných záznamov, tak ako sme už uvádzali. Vyžaduje sa však pritom, aby sa páchatel' najprv zmocnil dokumentu uchovávaného v súkromí iného, čomu priebeh mnohých foriem kyberšikany nezodpovedá.

12 SPRÁVA GENERÁLNEHO PROKURÁTORA SLOVENSKEJ REPUBLIKY O ČINNOSTI PROKURATÚRY V ROKU 2019 A POZNATKOCH PROKURATÚRY O STAVE ZÁKONNOSTI V SLOVENSKEJ REPUBLIKE. [online]. [cit.2021.06.21.]. Dostupné na internete: https://www.nrsr.sk /web/Dynamic/DocumentPreview.aspx?DocID=486924. 
Podobne, vo vzt'ahu k skutkovej podstate trestného činu porušenia dôvernosti ústneho prejavu a iného prejavu osobnej povahy - § 377 Trestného zákona platí, že podl'a skutkovej podstaty tohto trestného činu sa páchatel' dopustí trestného činu porušenie dôvernosti „neverejne prednesených slov alebo iného prejavu osobnej povahy tým, že ho neoprávnene zachytí záznamovým zariadením a takto zhotovený záznam sprístupní tretej osobe alebo ho iným spôsobom použije a inému tým spôsobí vážnu ujmu na právach“. V prípade kyberšikany často ide o prejavy, ktoré sú zaznamenané oprávnene, resp. so súhlasom dotknutej osoby, ale následne zneužité (tzv. revenge porn).

Predkladaná novelizácia Trestného zákona je nasledovná. Trestný zákon sa doplńa novou skutkovou podstatou trestného činu nebezpečného obtažovania, ktorá pokrýva najnebezpečnejšie prípady kybernetickej šikany. Skutočnost', že sa prostriedkami trestného práva postihujú iba najzávažnejšie prípady kybernetickej šikany poukazuje na vyjadrenie skutkovej podstaty, pracujúcej s pojmami dlhodobosti a úmyselného zhoršovania kvality života. Už v úvodnej vete trestného činu nebezpečného obt’ažovania je totiž zdôraznené vymedzenie úmyselnosti a zhoršenia kvality života a následne $\mathrm{v}$ písm. a) aj zdôraznenie dlhodobosti úmyselného konania, a v písm. b) sa postihuje iba také zverejňovanie záznamov osobných prejavov, ktoré je spôsobilé privodit' vážnu ujmu poškodenému.

Uvedené vymedzenia predstavujú záruku, že v praxi nemôže dôjst' $\mathrm{k}$ neprimeranému trestaniu údajných páchatel'ov týchto trestných činov. Navyše, vzhl'adom na to, že ide o prečin, platí ust. $§ 10$ ods. 2 Trestného zákona, podl'a ktorého „Nejde o prečin, ak vzhl'adom na spôsob vykonania činu a jeho následky, okolnosti, za ktorých bol čin spáchaný, mieru zavinenia a pohnútku páchatel'a je jeho závažnost' nepatrná.“ Novozavádzanú skutkovú podstatu tak nemožno vnímat' ako nadmernú kriminalizáciu. Naopak, je to reakcia na trestnoprávne nepostihovanie spoločensky nebezpečného konania. ${ }^{13}$

\section{ZÁVER}

Problematike implementácie kyberšikany sme sa rozhodli venovat' z dôvodu jej aktuálnosti, kedy sa takmer každá naša činnost' presunula do online priestoru. Je potrebné, podl'a nášho názoru, venovat' danému náležitú pozornost' a poukázat' na všetky skutočnosti, ktoré s kyberšikanou súvisia. Považujem za vel'mi vhodný krok v kontexte aktualizácie našej platnej legislatívy, kedy sa do čítania, s súčasnosti, posunul návrh aktualizácie Trestného zákona s prihliadnutím na identifikáciu kyberšikany. Máme za to, že prostredníctvom nami spracovaného príspevku tiež prispejeme k podpore a odôvodneniu potreby zakotvenia kyberšikany do nášho právneho poriadku. Samozrejme, je tiež potrebné podotknút', že efektívna právna úprava bude účelná pri vykonávaní a uplatnení v aplikačnej praxi.

Kyberšikana sa týka každého z nás, pretože jej hranice nie sú obmedzené a práve táto skutočnost' je vel'mi nebezpečná. Dovolíme si predpokladat', že práve i účelnou aplikáciou kyberšikany do Trestného zákona dôjde k účelnej aplikácii v aplikačnej praxi.

Táto práca bola podporená Agentúrou na podporu výskumu a vývoja na základe Zmluvy č. APVV-190102 .

\section{Použitá literatúra}

1. DROBNÝ, M. GREGUSSOVÁ, M. KYBERŠIKANOANIE.sk. Bratislava: CeSlovensko o.z., 2015, prvé vydanie, 117 s. ISBN 978-80-89774-00-5.

2. DRUGDA, J. Prostriedky operatívno-pátracej činnosti a ich využitie na účely vyšetrovania obzvlášt’ závažnej trestnej činnosti. In MARKOVÁ, V., JANKO, S., eds. Aktuálne otázky trestného práva $\mathrm{v}$ teórii a praxi. Zborník príspevkov [online].

13 DÔVODOVÁ SPRÁVA k Návrhu zákona, ktorým sa dopíňa Zákon č. 300/2005 Z. z. Trestný zákon v znení neskorších predpisov. 
Bratislava: Akadémia Policajného zboru v Bratislave, s. 166-174. ISBN ISBN 978-808054-860-5.

3. KURILOVSKÁ, L., ŠIŠULÁK, S. Sociálne siete ako kybernetická hrozba. In Bezpečnostné fórum 2015. I. zväzok: zborník vedeckých prác. Banská Bystrica: Belianum. Vydavatel'stvo Univerzity Mateja Bela v Banskej Bystrici, 2015. s. 86-94. ISBN 978-80-557-0849-2.

4. MIHÁLIK, S. Trest domáceho väzenia $v$ Slovenskej republike $v$ kontexte legislativnych zmien. In GŘIVNA, T., ŠIMÁNOVÁ, H. (eds.). Ukládaní trestü a jejich výkon. Plzeň: Aleš Čeněk, 2020, s. 324-337. ISBN 978-80-7380-833-4.

5. OSTER, J., MAKATURA, I., PAULUS, T. Ako na nástrahy internetu - top témy $z$ www.preventista.sk. 2 aktualizované vydanie. Nitra: ForPress NITRIANSKE TLAČIARNE, s. r. o., 2015, 230 s. ISBN 978-80-9721000-0-7.

6. BILL BELSEY. [online]. [cit.2021.06.20.]. Dostupné na internete: https://billbelsey $. c o m /$ ?cat $=13$.

7. DÔVODOVÁ SPRÁVA k Návrhu zákona, ktorým sa dopĺn̆a Zákon č. 300/2005 Z. z. Trestný zákon v znení neskorších predpisov.

8. Smernica č. $36 / 2018$ k prevencii a riešeniu šikanovania detí a žiakov v školách a školských zariadeniach.

9. SPRÁVA GENERÁLNEHO PROKURÁTORA SLOVENSKEJ REPUBLIKY O ČINNOSTI PROKURATÚRY V ROKU 2019 A POZNATKOCH PROKURATÚRY O STAVE ZÁKONNOSTI V SLOVENSKEJ REPUBLIKE. [online]. [cit.2021.06.21.]. Dostupné na internete: https://www.nrsr.sk/web/Dynamic/Doc umentPreview.aspx?DocID=486924.

10. Zákon č. 300/2005 Z. z. Trestný zákon v znení neskorších predpisov.

11. ZODPOVEDNE.sk. [online]. [cit.2021.06.20.]. Dostupné na internete: https://www.zodpovedne.sk/index.php/sk/ohrozenia/kybersikanovanie.

\section{Kontaktné údaje}

JUDr. Patrícia Krásná, PhD., LL.M.

Akadémia Policajného zboru v Bratislave

Katedra kriminológie

Sklabinská 1, 83517 Bratislava 35

Tel: 0961057425

Email: patricia.krasna@akademiapz.sk 


\title{
PRÍČINY VZNIKU PRIEŤAHOV V PRÍPRAVNOM KONANÍ A ICH VPLYV NA JEHO EFEKTÍVNOSŤ
}

\section{CAUSES OF DELAYS IN PRE-TRIAL PROCEEDINGS AND THEIR IMPACT ON ITS EFFECTIVENESS}

\author{
Juraj Drugda
}

\begin{abstract}
Abstrakt
Príspevok je zameraný na analýzu častých príčin vzniku priet’ahov v prípravnom konaní so špeciálnym zameraním na preskúmanie vplyvu týchto priet’ahov na efektívnost' a rýchlost' trestného konania. Autor sa $\mathrm{v}$ tejto súvislosti venuje tiež právnej analýze obsahu najdôležitejších právnych dokumentov upravujúcich základné l’udské práva a slobody, ktorých porušovanie je negatívnym následkom spojeným so vzniknutými priet’ahmi v trestnom konaní. Podkladom pre lepšie preskúmanie a priblíženie jednotlivých druhov priet'ahov v prípravnom konaní a príčin ich vzniku je aj analýza časového priebehu prípravného konania vo vzt'ahu ku fakultatívnym zákonným lehotám. Autor sa venuje takisto možnostiam riešenia tohto negatívneho fenoménu v právnej praxi.
\end{abstract}

Kl'účové slová: priet'ahy, trestné konanie, prípravné konanie, efektívnost', rýchlost'

\begin{abstract}
The article is focused on analysing common causes of delays in pre-trial criminal proceedings with special focus on examining the impact of these delays on the overall efficacy and rapidity of criminal proceedings. In this context, the author also analyses the legal content of some of the most important legal documents on the matter of fundamental human rights that provide framework for their protection against negative consequences of delays in criminal proceedings, which could be in certain situations considered as violations of these rights. Basis for better examination and understanding of the individual types of delays in pre-trial criminal proceedings and their origins is also achieved by the analysis of the pre-trial proceedings time course in relation to the facultative procedural deadlines. The author also addresses possible solutions to this negative phenomenon applicable in legal practice.
\end{abstract}

Key words: delays, criminal proceedings, pre-trial proceedings, effectiveness, rapidity

\section{1 ÚVOD}

Efektívnost' trestného konania, ktorú možno vyjadrit’ najmä prostredníctvom jeho rýchlosti môžeme považovat' za jeden $\mathrm{z}$ významných faktorov ovplyvňujúcich vnímanie výkonu spravodlivosti a dôvery v bezpečnostné orgány a súdny systém $\mathrm{v}$ očiach občanov a verejnosti. Je preukázané, že čím dlhší čas prejde od momentu začatia trestného stíhania, až po právoplatné a vykonatel'né odsúdenie páchatel'ov trestnej činnosti, tým menší je represívny efekt trestného konania na odsúdených, ale aj preventívny efekt trestného konania na spoločnost' a osoby, ktoré uvažujú nad budúcim spáchaním trestnej činnosti. Z týchto, ale aj mnohých iných dôvodov je potreba zabezpečenia adekvátnej rýchlosti trestného konania a zamedzovanie vzniku priet’ahov vyjadrená vo viacerých vnútroštátnych ale aj medzinárodných právnych aktoch a dokumentoch.

V ustanovení článku 48 ods. 2 zákona č. 460/1992 Zb. Ústavy Slovenskej republiky (d’alej „Ústava“) je vymedzené, že „,každý má právo, aby sa jeho vec verejne prerokovala bez 
zbytočných prietahov a vjeho pritomnosti a aby sa mohol vyjadrit’ ku všetkým vykonávaným dôkazom." Významom tohto práva nie je zaručit osobám konanie bez akýchkol'vek priet'ahov, ale docielit' taký postup štátnych orgánov, ktorý je zbavený zbytočných priet’ahov. Účel práva na konanie bez zbytočných priet’ahov je v judikatúre Ústavného súdu Slovenskej republiky vymedzený nasledovne: „Účelom práva na prerokovanie veci bez zbytočných prietahov je odstránenie stavu právnej neistoty, v ktorej sa nachádza osoba domáhajúca sa rozhodnutia štátneho orgánu. Samotným prerokovaním veci na štátnom orgáne sa právna neistota osoby neodstráni. Až právoplatným rozhodnutím sa vytvára právna istota. Preto na splnenie ústavného práva čl. 48 ods. 2 nestačí, aby štátny orgán vec prerokoval. Ústavné právo na prerokovanie veci bez zbytočných prietahov sa splni až právoplatným rozhodnutím štátneho orgánu, na ktorom sa osoba domáha odstránenia právnej neistoty ohl'adne svojich práv. "l

Obdobným spôsobom je toto právo vyjadrené v ustanovení článku 6 ods. 1 Dohovoru o ochrane l'udských práv a základných slobôd: „,každý má právo na to, aby jeho záležitost' bola spravodlivo, verejne a v primeranej lehote prejednaná nezávislým a nestranným súdom zriadeným zákonom, ktorý rozhodne o občianskych právach alebo záväzkoch alebo o oprávnenosti akéhokol'vek trestného obvinenia proti nemu. Toto ustanovenie zabezpečuje nižšiu mieru ochrany ako čl. 48 ods. 2 Ústavy, pretože zaručuje právo na prejednanie veci $\mathrm{v}$ primeranej lehote iba vo vzt'ahu $\mathrm{k}$ súdom. Ústavná právna úprava sa vzt'ahuje aj na činnost' orgánov verejnej moci. ${ }^{2}$

Potreba zabezpečenia efektívnosti trestného konania prostredníctvom jeho rýchlosti je vyjadrená aj $\mathrm{v}$ základných zásadách trestného konania, konkrétne $\mathrm{v}$ znení ustanovenia $\S 2$ ods. 7 zákona č. 301/2005 Z. z. Trestného poriadku (d'alej „Trestný poriadok") v tzv. zásade spravodlivého prejednania veci a to nasledovne: „každý má právo, aby jeho trestná vec bola spravodlivo a v primeranej lehote prejednaná nezávislým a nestranným súdom v jeho pritomnosti tak, aby sa mohol vyjadrit' ku všetkým vykonávaným dôkazom, ak tento zákon neustanovuje inak." Určitá špecifikácia práva na prejednanie veci v primeranej lehote je vymedzená aj v tzv. zásade oficiality, ktorá je upravená v $§ 2$ ods. 6 Trestného poriadku. Zdôraznená je potreba čo najrýchlejšieho prejednania väzobných vecí. Inými slovami vo veciach obvinených stíhaných vo väzbe majú orgány činné v trestnom konaní a súdy konat' prednostne a urýchlene. ${ }^{3}$

\section{2 ČASOVÉ OHRANIČENIE PRÍPRAVNÉHO KONANIA S OHLADOM NA MOŽNOSTI VZNIKU PRIEŤAHOV}

Problematika priet’ahov je spomínaná najmä v súvislosti s konaním pred súdom, čo však neznamená, že počas prípravného konania taktiež nedochádza k prípadom, kedy sú kvôli priet’ahom obmedzované základné práva a slobody dotknutých osôb.

Prípravné konanie môžeme charakterizovat' ako úsek trestného konania od začatia trestného stíhania do podania obžaloby, návrhu na schválenie dohody o vine a treste alebo do právoplatnosti rozhodnutia orgánu činného v trestnom konaní vo veci samej. Prípravné konanie môžeme rozdelit' na dve základné časti a to postup pred začatím trestného stíhania a vyšetrovanie, pričom vyšetrovanie d’alej klasifikujeme na skrátené vyšetrovanie, vyšetrovanie a osobitne skrátené vyšetrovanie alebo tzv. super rýchle konanie. Zabezpečenie efektívnosti prípravného konania je naviazané na rešpektovanie systému lehôt. Štádium pred začatím trestného stíhania je potrebné vnímat' vo vzt'ahu k zdroju a pôvodu prvotnej informácie, ktorá obsahuje podozrenie, že došlo k spáchaniu trestnej činnosti. V prípade, že týmto zdrojom je oznamovatel', ktorý takúto prvotnú informáciu adresuje orgánu činnému

\footnotetext{
${ }^{1}$ III. ÚS 85/02 Nález z 25 septembra 2002

${ }^{2}$ DRGONEC, J. Právo na prerokovanie veci bez zbytočných priet’ahov. In. Justičná revue. 2002, roč. 54, č. 1, s. 7-8

3 ŠIMOVČEK, I. a kol. Trestné právo procesné. Plzeň: Aleš Čeňek, 2016. s. 46
} 
v trestnom konaní napríklad vo forme trestného oznámenia, tak okrem povinnosti prijat' toto oznámenie taktiež začína 30-dňová lehota na rozhodnutie, či vo veci bude začaté trestné stíhanie, alebo bude vec odovzdaná, odložená alebo odmietnutá. Prvotné informácie indikujúce podozrenie, že bola spáchaná trestná činnost' však môžu byt' získané aj vlastnou iniciatívnou a vyhl'adávacou činnost'ou pracovníkov príslušných služieb Policajného zboru. V týchto prípadoch prebieha vyhl'adávanie, získavanie a preverovanie trestnoprávne relevantných informácií taktiež v štádiu pred začatím trestného stíhania, avšak bez existencie určitej zákonom stanovej lehoty. Zavádzanie striktnej lehoty v týchto prípadoch by bolo kontraproduktívne a to $\mathrm{z}$ dôvodu potreby primerane trvajúceho časového obdobia na získanie informácií o častokrát závažnej kriminalite latentného charakteru, ktoré v mnohých prípadoch nemožno získat' inak ako použitím špecifických dôkazných prostriedkov realizovaných v utajovanej forme. Používanie špecifických dôkazných prostriedkov, ktorými sú najmä prostriedky operatívno-pátracej činnosti a informačno-technické prostriedky so sebou prináša určité zákonné limity, medzi ktoré okrem iného zarad'ujeme aj príkazy vydávané na určitú vopred stanovenú dobu. Ďalšou skutočnost'ou, je kvalita takto získaných informácií, ktoré aj v súvislosti s už spomínanou povahou objasňovanej kriminality spol’ahlivo preukazujú všetky potrebné skutočnosti oprávňujúce orgány činné v trestnom konaní realizovat' zaist'ovací úkon, ktorým súčasne začnú trestné stíhanie, aj vznesú obvinenie voči konkrétnym osobám za konkrétnu trestnú činnost'.

Prípravné konanie oficiálne začína momentom začatia trestného stíhania. Čast' prípravného konania od začatia trestného stíhania až po vznesenie obvinenia nie je ohraničená žiadnou konkrétnou zákonnou lehotou. Snaha o zachovanie rýchlosti je vyjadrená v požiadavke na orgán činný v trestnom konaní, ktorý má po nadobudnutí dostatočne odôvodneného záveru, že trestný čin spáchala určitá osoba povinnost' bez meškania vydat' uznesenie o vznesení obvinenia. „Pre vznesenie obvinenia nestačl, aby zistené skutočnosti nasvedčovali záveru, že bol spáchaný trestný čin, ale je potrebné, aby sa odôvodnil záver, že trestný čin spáchala určitá osoba. Kzáveru o spáchani trestného činu určitou osobou stači vyšši stupeň pravdepodobnosti, ktorý však musí byt’ konkrétne zistenými skutočnostami dostatočne odôvodnený. Nie je však potrebné, aby trestná činnost' bola spol'ahlivo preukázaná ako v prípade obžaloby. Nestači však všeobecné podozrenie z trestnej činnosti, ktoré nie je konkrétne doložené. “4

Momentom vznesenia obvinenia začínajú plynút' zákonné lehoty na ukončenie vyšetrovania. V prípade osobitne skráteného vyšetrovania sa jedná o lehotu 48 hodín od zadržania podozrivej osoby pri páchaní prečinu, ktorého horná hranica zákonom stanovenej trestnej sadzby trestu odňatia slobody neprevyšuje pät' rokov. Skrátené vyšetrovanie je potrebné ukončit' v lehote do dvoch mesiacov od vznesenia obvinenia a skončenie vyšetrovania rozlišuje prípady obzvlášt' závažnej trestnej činnosti, kedy je daná lehota na ukončenie v dížke 6 mesiacov od vznesenia obvinenia a vostatných prípadoch je lehota v dížke 4 mesiace od vznesenia obvinenia.

Spomínané lehoty sú síce zákonnými lehotami, pretože sú vymedzené v ustanoveniach Trestného poriadku, avšak ide o lehoty poriadkové. To znamená, že dodržanie týchto lehôt nie je povinné, pretože sa nejedná o lehoty prekluzívne, po ktorých zaniká možnost' vykonat' úkon. ${ }^{5} \mathrm{Na}$ jednej strane síce existujú prípady, kedy je dôvodné a oprávnené nedodržanie spomínaných lehôt, čo predpokladá aj znenie ustanovenia $\S 203$ ods. 2 a $\S 209$ ods. 3 Trestného poriadku, ktoré pojednávajú o možnostiach riešenia prípadov, kedy nie je možné ukončit' vyšetrovanie a skrátené vyšetrovanie v zákonných lehotách, avšak miera vol'nosti

\footnotetext{
${ }^{4}$ MINÁRIK, Š. a kol. Trestný poriadok stručný komentár. Bratislava: Iura Edition, 2010. s. 567

5 MACHÁC̆EK, L. 2017. 30 dñová lehota na rozhodnutie o trestnom oznámení - zbytočná dogma [online]. Právne listy [cit. 2021-06-14]. Dostupné na internete: http://www.pravnelisty.sk/clanky/a610-30-dnova-lehotana-rozhodnutie-o-trestnom-oznameni-zbytocna-dogma
} 
takto sformulovanej právnej úpravy so sebou prináša aj zvýšené riziko vzniku priet'ahov, ktoré spôsobia, že prípravné konanie bude trvat' neprimerane dlhú dobu, čo môže významne ovplyvnit' úspešnost' následného súdneho konania.

\section{DRUHY PRIEŤAHOV V PRÍPRAVNOM KONANÍ A PRÍČINY ICH VZNIKU}

Vznik a pretrvávanie priet’ahov v prípravnom konaní so sebou prináša vel'ké množstvo negatívnych faktorov, ktoré môžu nežiadúcim spôsobom vplývat' na úspešnost' ukončenia prípravného konania, ale aj na d’alší vývoj konania pred súdom. Medzi tieto negatívne faktory môžeme zaradit' znižovanie preventívneho účinku rýchleho trestného postihu a odstrašujúceho účinku trestného konania na potencionálnych páchatel'ov, zvýšenú mieru traumatizácie obete trestného činu, kedy opakovaná realizácia vyšetrovacích úkonov spôsobuje potenciálne častejší kontakt s páchatel'om, ktorý môže spôsobit' sekundárnu viktimizáciu obete. Preto je aplikácia prevencie sekundárnej viktimizácie vel'mi dôležitá. „Systémový prístup aplikovaný pri realizovanej sekundárnej prevencii viktimizácie sa aplikuje tak, že javy sa odhalujú, skúmajú, hodnotia a vysvetlujú ako systém. To potvrdzuje skutočnost', že tieto formy poznávania sú konštruktívne orientované na genézu systému, jeho prvky, vzt'ahy medzi nimi, ich vztahy kokoliu a vztahy okolia na nich (napriklad vztahy personálne, organizačné, sociálne, ekonomické, kriminálne, technické, politické a pod.). “6

Nehospodárnost' trestného konania, ktoré nadmerne finančne a kapacitne zat'ažuje orgány činné $v$ trestnom konaní a súdy. Vplyv na množstvo a kvalitu dôkazov, kedy napríklad nositelia pamätových stôp plynutím času zabúdajú dôležité detaily, prípadne vecné stopy a iné dôkazy sa nenávratne poškodzujú a v neposlednom rade negatívny vplyv na obvineného, ktorý je vystavený psychickému a sociálnemu tlaku a to obzvlášt' v prípade väzobného stíhania. ${ }^{7}$

Všeobecne ustanovit' ideálnu dížku a rýchlost' prípravného konania je prakticky nemožné z dôvodu individuality každého jedného vyšetrovaného trestného činu v spojení s vel'kým množstvom objektívnych a subjektívnych faktorov vplývajúcich na rýchlost' prípravného konania.

Senáty ústavného súdu Slovenskej republiky uverejnili svoje názory na porušenie práva na prejednanie veci bez zbytočných priet'ahov v dokumente s názvom „Extrémne, opakované zbytočné prietahy okresných súdov a orgánov činných v trestnom konaní. " Najpodstatnejšie z nich boli definované ako: nečinnost' súdu alebo jeho nesústredená a neefektívna činnost', priznanie zodpovednosti štátu nielen za organizovanie súdneho systému, ale aj za organizáciu práce sudcu, individuálne posúdenie rýchlosti konania podl’a troch základných kritérií a to: právnej a skutkovej zložitosti, správania sa účastníka konania a postupu samotného súdu, primeranost' dížky trestného konania nie je možné vyjadrit' numericky, pretože je potrebné skúmat' a preverovat' osobitosti každého prípadu vaspekte konkrétnych okolností prerokovávanej veci a skutočnost', že dížka trestného konania by mala v rozumnej miere zodpovedat' intenzite faktorov, ktoré môžu konanie predlžovat'. V tomto dokumente boli stanovené taktiež aj skutočnosti, ktoré neospravedlňujú orgán činný v trestnom konaní a súd za jeho nečinnost' a to nasledovne: skutková a právna zložitost' veci neodôvodňuje mnohomesačnú nečinnost', ak po nej nasledujú jednoduché úkony nevyžadujúce zvláštnu prípravu, do obdobia nečinnosti orgánu činného v trestnom konaní a súdu je potrebné zahrnút' aj obdobia, vktorých bola vec ponechaná u znalcov bez účinného úkonu na zrýchlenie znaleckého dokazovania, situácie, kedy orgán činný v trestnom konaní alebo súd svojím nesprávnym konaním zapríčiní, že konkrétne procesné právo sa stane pre účastníka konania nedostupné, vyšší počet účastníkov konania nedokazuje zložitost' veci a problémy spojené

\footnotetext{
${ }^{6}$ KRÁSNÁ, P. Prevencia sekundárnej viktimizácie. In Prevencia kriminality - výzva spoločnosti: zborník z medzinárodnej vedeckej konferencie. Bratislava: Akadémia Policajného zboru v Bratislave, 2019, s. 91

${ }^{7}$ MUSIL, J. Rychlost trestního řízení. In Kriminalistika. 2010, roč. 43, č. 1, s. 12
} 
so zabezpečovaním ich prítomnosti na úkonoch prípravného konania tiež nemožno pokladat' za dôvod na hodnotenie veci ako zložitej a vec nemožno hodnotit' ako zložitú ani v prípade, ked' sa orgán činný v trestnom konaní alebo súd má vysporiadat' s príčinnou súvislost'ou medzi radom právnych noriem, resp. viaceré právne normy sa nenachádzajú v jednom právnom predpise. ${ }^{8}$

Priet’ahy v prípravnom konaní na strane orgánov činných $\mathrm{v}$ trestnom konaní sú taktiež spôsobované aj súborom objektívnych a subjektívnych skutočností, medzi ktoré zarad'ujeme: „,vysokú zat'aženost' policajtov a rozpracovanost' vecí, nedostatok potrebných skúseností s novými formami kriminality, nedodržiavanie lehôt na skončenie vyšetrovania (skráteného vyšetrovania), nerešpektovanie záväzných pokynov prokurátorov policajtmi, nedôsledný dozor prokurátorov nad vyšetrovanim, podstatné chyby v procesnom postupe a pod. Najčastejšimi príčinami zbytočných prietahov sú procesné pochybenia spojené sformálnou či nedostatočnou kontrolou riadiaceho aparátu orgánov činných v trestnom konani pri plynulosti trestného konania. “9

Priet'ahy v prípravnom konaní môžu spôsobovat' aj osoby a d'alšie subjekty dotknuté prebiehajúcim vyšetrovaním. Zvláštnost' týchto druhov priet'ahov spočíva $\mathrm{v}$ tom, že niektoré zo subjektov trestného konania vedome zneužívajú nedostatky právnej úpravy, ktorými vytvárajú obštrukcie, ktoré síce nie sú protizákonné, ale spôsobujú nezmyselné priet’ahy v prípravnom konaní.

Podozrivé osoby v procesnom postavení svedka sa pri ich predvolávaní na výsluch prostredníctvom poštovej zásielky do vlastných rúk považujú za upovedomené momentom fyzického prevzatia tejto zásielky. V prípadoch, kedy tieto osoby nie sú zastihnuté v mieste svojho bydliska v čase doručenia zásielky sa táto ukladá na pošte na dobu 18 dní. Svedkovia (podozriví) si túto zásielku častokrát prevezmú až v posledný deň jej uloženia, čo v prípade skoršie naplánovaného termínu procesného úkonu spôsobuje jeho zmarenie. V takýchto prípadoch musí policajt opakovane zaslat' predvolanie s novým termínom úkonu, čo v praxi spôsobuje niekol'kotýždňový posun vo vyšetrovaní.

V prípadoch prevzatia predvolania svedka (podozrivého) na výsluch v zákonnej lehote, ale jeho úmyselného nedostavenia sa na príslušné oddelenie Policajného zboru na účely realizácie vyšetrovacieho úkonu prichádza do úvahy použitie inštitútu predvedenia. Podozrivé osoby sa v mnohých prípadoch snažia vyhýbat' predvedeniu a to bud' uvedením fiktívnej adresy doručovania písomností, zatajovaním svojej prítomnosti na mieste ich trvalého pobytu alebo neuvedením presných informácií o mieste svojho pobytu najmä pokial' sa jedná o budovy, v ktorých má trvalé bydlisko väčšie množstvo osôb. Zist'ovanie presného miesta, kde sa podozrivý zdržiava alebo skúmanie jeho zvykov za účelom predvedenia z verejne prístupného miesta spôsobuje neodôvodnené ale stále zákonné priet’ahy v prípravnom konaní. $^{10}$

Priet’ahy v prípravnom konaní v mnohých prípadoch vznikajú aj na strane obvinených osôb. Najideálnejším priestorom na priet’ahy na strane obvineného je situácia, kedy sa uplatňuje inštitút osobitne skráteného vyšetrovania alebo tzv. super rýchleho konania a to práve z dôvodu mimoriadne krátkej lehoty (48 hodín) určenej na vznesenie obvinenia a vypracovanie návrhu na podanie obžaloby. Ked’že podmienky použitia inštitútu osobitne skráteného vyšetrovania predpokladajú zadržanie podozrivej osoby pri páchaní prečinu, čiže

\footnotetext{
${ }^{8}$ Ústavný súd Slovenskej republiky 2013. Extrémne, opakované zbytočné priet’ahy okresných súdov a orgánov činných v trestnom konani [online]. Ústavný súd Slovenskej republiky [cit. 2021-06-14]. Dostupné na internete: https://www.ustavnysud.sk/documents/10182/992260/5_extremne_prietahy_final-1-4.pdf/874ef431-cfb7-420792bb-3bde9fb5f278

9 ČENTÉŠ, J. 2011. Priet'ahy pri vyšetrovani [online]. Učená právnická spoločnost' [cit. 2021-06-14]. Dostupné na internete: http://www.ucps.sk/Prietahy_pri_vysetrovani

${ }^{10}$ ŠIDLO, M. Zákonná obštrukcia - spôsob ako marit’ priebeh prípravného konania. In. Justičná revue. 2016, roč. 68 , č. 1, s. $52-56$
} 
menej závažného trestného činu v praxi častokrát dochádza k prípadom, kedy sú zadržaní páchatelia pod vplyvom alkoholu alebo omamnej a psychotropnej látky či už pri vedení motorového vozidla alebo pri krádežiach a pod. V takýchto situáciách nemožno zadržaného páchatel'a vypočut' pokial' užitý alkohol alebo omamné a psychotropné látky vplývajú na jeho rozpoznávacie schopnosti, čo tieto osoby využívajú na predstieranie zlého zdravotného stavu tak, aby bolo potrebné ich ošetrenie v zdravotníckom zariadení. Ošetrenie týchto osôb a následné pozorovanie ich zdravotného stavu má za následok nemožnost' stihnutia 48 hodinovej lehoty na realizáciu všetkých potrebných procesných úkonov a vypracovanie k nim prislúchajúcim písomností vyšetrovania. Vznik takejto síce opätovne zákonnej obštrukcie má za následok nemožnost' využitia inštitútu osobitne skráteného vyšetrovania a potrebu riešenia prípadu v rámci skráteného vyšetrovania, čo spôsobuje okrem dlhšieho trvania prípravného konania aj d'alšiu neodôvodnenú zat'aženost' poverených príslušníkov Policajného zboru.

Azda najjednoduchším spôsobom zmarenia osobitne skráteného vyšetrovania alebo tzv. super rýchleho konania zo strany osoby obvineného je po tom, ako mu bolo oznámené obvinenie vyhlásit', že využíva trojdňovú lehotu na podanie st’ažnosti proti vznesenému obvineniu. V tomto prípade obvinený nielenže spôsobí priet’ah v prípravnom konaní, ale aj musí byt' okamžite prepustený z cely policajného zaistenia pokial nie sú naplnené dôvody na jeho väzobné stíhanie. ${ }^{11}$

\section{MOŽNOSTI RIEŠENIA VZNIKNUTÝCH PRIEŤAHOV}

Dlhotrvajúce priet’ahy v trestnom konaní sú mimoriadne nepríjemné pre všetky zúčastnené osoby. Z tohto dôvodu boli prijaté viaceré opatrenia, ktoré umožňujú takéto situácie bud' vyriešit' alebo získat' po priznaní dôvodnosti určitú výhodu alebo kompenzáciu.

V konaní pred súdom existujú striktnejšie a účinnejšie mechanizmy na vysporiadanie sa s priet’ahmi alebo prípadnou nečinnost'ou štátnych orgánov. Po zistení akejkol'vek objektívne neodôvodnenej nečinnosti súdu majú oprávnené osoby možnost' podat' st'ažnost' na nečinnost' súdu, ktorá sa podáva predsedovi súdu, ktorý rozhoduje o jej dôvodnosti a spôsobe vybavenia. Ak bola st'ažnost' dôvodná dotknuté osoby sú informované o spôsobe jej vybavenia a o rozsahu prijatých opatrení. Ak prijaté opatrenia nad'alej neodstraňujú priet’ahy v súdnom konaní, tak prichádza do úvahy podanie ústavnej st'ažnosti na priet'ahy v konaní súdu v rámci ktorej majú oprávnené osoby právo žiadat' o finančné odškodnenie. V prípade spol'ahlivého preukázania subjektívnych dôvodov na strane súdu vo veci vzniknutých a pretrvávajúcich priet’ahov prichádza do úvahy podanie žaloby o náhradu škody spôsobenej nesprávnym úradným postupom. Predpokladmi na podanie tejto žaloby sú ,,nesprávny úradný postup, škoda a príčinná súvislost’ medzi nimi. “

Všetky spomínané mechanizmy na vysporiadanie sa s priet'ahmi v súdnom konaní zarad’ujeme medzi vnútroštátne mechanizmy, ktoré je potrebné kumulatívne vyčerpat'. Pre prípady, v ktorých napriek použitiu všetkých dostupných vnútroštátnych spôsobov nápravy stále nedošlo k odstráneniu priet'ahov má oprávnená osoba možnost' podat' st'ažnost' v tejto veci na Európsky súd pre l'udské práva. Konanie o st'ažnosti pred Európskym súdom pre l'udské práva v prípade jej vyhoveniu môže dotknutej osobe priznat' bud' finančnú kompenzáciu alebo ustanovit' postup, ktorý je spôsobilý urýchlit' konanie vo veci st’ažovatel'a. $\mathrm{V}$ prípadoch, kedy vznikajú priet’ahy v prípravnom konaní existuje taktiež súbor postupov a mechanizmov, ako tieto priet’ahy odstránit'. Základným spôsobom ako namietat' existenciu priet'ahov v prípravnom konaní je žiadost' o preskúmanie postupu policajta, ktorú sú oprávnení podat' obvinený, poškodení alebo zúčastnená osoba kedykol'vek v priebehu vyšetrovania dozor vykonávajúcemu prokurátorovi, ktorý je povinný túto žiadost' preskúmat'

\footnotetext{
${ }^{11}$ ŠIDLO, M. Zákonná obštrukcia - spôsob ako marit' priebeh prípravného konania. (vol’né pokračovanie) In. Justičná revue. 2016, roč. 68, č. 4, s. 430-431

${ }^{12}$ PECNÍKOVÁ, M. Právo na účinný prostriedok nápravy. In. Justičná revue. 2001, roč. 53, č. 12, s. 1293
} 
a o výsledku tohto preskúmania upovedomit' žiadatel'a. Tento mechanizmus však pri jeho zneužití môže spôsobit' d'alšie priet’ahy v prípravnom konaní. Obvinená osoba má právo podat' žiadost' na preskúmanie postupu policajta po každom vykonanom procesnom úkone. Policajt následne bude musiet' zakaždým predložit' dozor vykonávajúcemu prokurátorovi vyšetrovací spis na preskúmanie a rozhodnutie, pričom až po vyjadrení sa dozor vykonávajúceho prokurátora $\mathrm{k}$ obsahu žiadosti bude umožnené vykonávat' d'alšie procesné úkony a pokračovat' vo vyšetrovaní. ${ }^{13}$

Ďalší spôsob, ktorým prichádza do úvahy riešit' neodôvodnené priet’ahy v trestnom konaní, ktoré vznikli na základe pochybenia štátnych orgánov je mimoriadne zníženie trestu pre existenciu zbytočných priet'ahov v konaní. Inštitút mimoriadneho zníženia trestu je upravený v ustanovení § 39 ods. 1 zákona č. 300/2005 Trestného zákona nasledovne: „,ak súd vzhl’adom na okolnosti prípadu alebo vzhl'adom na pomery páchatel'a má za to, že by použitie trestnej sadzby ustanovenej týmto zákonom bolo pre páchatel'a neprimerane prísne a na zabezpečenie ochrany spoločnosti postačuje aj trest kratšieho trvania, možno páchatel'ovi uložit' trest aj pod dolnú hranicu trestu ustanoveného týmto zákonom." Aby boli splnené podmienky uloženia mimoriadne zníženého trestu $\mathrm{z}$ dôvodu priet'ahov v trestnom konaní je potrebné preskúmat' splnenie viacerých podmienok ako napríklad: postoj obvineného k trestnému stíhaniu, či obvinený úmyselne nespôsoboval priet’ahy v trestnom konaní, preskúmavanie odôvodnenosti vzniknutých priet'ahov zo strany orgánov verejnej moci - či boli skutočne zbytočné alebo či išlo o obvyklý spôsob riešenia veci v praxi a preskúmavanie reálnej dížky vzniknutých zbytočných priet’ahov vo vzt'ahu k celkovému časovému obdobiu, kedy sa vo veci konalo plynulo, čiže bez priet'ahov. ${ }^{14}$

Spôsob kompenzácie za neodôvodnené priet'ahy v trestnom konaní, ktorý vyvoláva dlhodobú diskusiu medzi odborníkmi na trestné právo je zastavenie trestného stíhania $\mathrm{v}$ dôsledku priet'ahov v konaní. Názory na tento spôsob odškodnenia sú rozporuplné od úplnej nemožnosti využitia tohto inštitútu na spomínané účely z dôvodu absencie právneho zakotvenia tejto možnosti, až po odvolávanie sa na rozhodnutia súdov niektorých členských štátov Európskej únie a na judikatúru Európskeho súdu pre l'udské práva. ,, $V$ Českej republike už bol nastolený problém zastavenia trestného stíhania z dôvodu jeho neprimeranej dlžky $a$ všeobecné súdy vyniesli v tomto smere viaceré rozhodnutia. Niektoré súdy odôvodnili zastavenie trestného stíhania práve ustanovením Trestného poriadku, podl'a ktorého trestné stíhanie nemožno začat', a ak už bolo začaté, nemožno v ňom pokračovat' a musí byt' zastavené, ak tak ustanovuje medzinárodná zmluva, ktorou je Česká republika viazaná “15

\section{ZÁVER}

Prítomnost' či už viac alebo menej závažných priet’ahov môžeme detegovat' vo všetkých štádiách trestného konania. Vyskytujú sa rovnako na strane štátnych orgánov ale aj na strane subjektov trestného konania. Priet’ahy v trestnom konaní je potrebné rozlišovat' na objektívne, ktoré sú častokrát dôvodné a v daných podmienkach im nie je možné zabránit' a subjektívne, ktoré majú vo väčšine prípadov formu bud' vedomej alebo nevedomej nečinnosti štátnych orgánov alebo formu úmyselného marenia trestného konania zo strany jeho subjektov, ktoré využívajú medzery a nedostatky v právnej úprave alebo sa nezákonným spôsobom vyhýbajú trestnému stíhaniu. Snahám o riešenie negatívnych vplyvov priet’ahov na trestné konanie sa dlhodobo venujú rôzne iniciatívy zo strany príslušných štátnych aj európskych orgánov.

\footnotetext{
13 ŠIDLO, M. Zákonná obštrukcia - spôsob ako marit’ priebeh prípravného konania. (vol’né pokračovanie) In. Justičná revue. 2016, roč. 68 , č. 4 , s. 437

${ }^{14}$ REPA, O. 2017. Prietahy v trestnom konaní a ich kompenzácia [online]. Právne listy [cit. 2021-06-14]. Dostupné na internete: http://www.pravnelisty.sk/clanky/a542-prietahy-v-trestnom-konani-a-ich-kompenzacia

${ }^{15}$ PECIKOVÁ, M. Zastavenie trestného konania, zniženie trestu v dôsledku priet'ahov v konaní. In. Justičná revue. 2003 , roč. 55 , č. 5 , s. 555-556
} 
Napriek snahám má väčšina možností riešenia tohto negatívneho fenoménu kompenzačný charakter či už vo forme finančného odškodnenia alebo vo forme zmiernenia trestu, čo v konečnom dôsledku nemá želaný efekt na predchádzanie vzniku alebo prípadné úplné eliminovanie priet'ahov. Problematiku priet'ahov v trestnom konaní, ich vznik, dôvody ich pretrvávania a možnosti ich riešenia môžeme pokladat' za mimoriadne aktuálnu tému, čo zdôvodňuje potrebu d’alšieho vedeckého skúmania a rozpracovania za účelom zvýšenia miery aktívnych snáh o nájdenie efektívneho a účinného riešenia.

Táto práca bola podporená Agentúrou na podporu výskumu a vývoja na základe Zmluvy č. APVV-19-0102.

\section{Použitá literatúra}

1. ČENTÉŠ, J. 2011. Priet’ahy pri vyšetrovaní [online]. Učená právnická spoločnost' [cit. 2021-06-14]. Dostupné na internete: http://www.ucps.sk/Prietahy_pri_vysetro vani

2. Dohovor o ochrane l’udských práv a základných slobôd

3. DRGONEC, J. Právo na prerokovanie veci bez zbytočných priet’ahov. In. Justičná revue. ISSN 1335-6461, 2002, roč. 54, č. 1, s. 6-21

4. KRÁSNÁ, P. Prevencia sekundárnej viktimizácie. In Prevencia kriminality - výzva spoločnosti: zborník z medzinárodnej vedeckej konferencie. Bratislava: Akadémia Policajného zboru v Bratislave, 2019, s. 91-100. ISBN 978-80-8054-840-7.

5. MACHÁČEK, L. 2017. 30 dňová lehota na rozhodnutie o trestnom oznámení zbytočná dogma [online]. Právne listy [cit. 2021-06-14]. Dostupné na internete: http://www.pravnelisty.sk/clanky/a610-30-dnova-lehota-na-rozhodnutie-o-trestnomoznameni-zbytocna-dogma

6. MINÁRIK, Š. a kol. Trestný poriadok stručný komentár. Bratislava: Iura Edition, 2010. 1393 s. ISBN 978-80-8078-369-3

7. MUSIL, J. Rychlost trestního řizení. In Kriminalistika. ISSN 1210-9150, 2010, roč. 43, č. 1 , s. 12-24

8. PECNÍKOVÁ, M. Právo na účinný prostriedok nápravy. In. Justičná revue. ISSN 1335-6461, 2001, roč. 53, č. 12, s. 1286-1296

9. PECNÍKOVÁ, M. Zastavenie trestného konania, zniženie trestu v dôsledku prietahov $v$ konaní. In. Justičná revue. ISSN 1335-6461, 2003, roč. 55, č. 5, s. 554-566

10. REPA, O. 2017. Prietahy v trestnom konaní a ich kompenzácia [online]. Právne listy [cit. 2021-06-14]. Dostupné na internete: http://www.pravnelisty.sk/clanky/a54 2-prietahy-v-trestnom-konani-a-ich-kompenzacia

11. ŠIDLO, M. Zákonná obštrukcia - spôsob ako marit’ priebeh prípravného konania. In. Justičná revue. ISSN 1335-6461, 2016, roč. 68, č. 1, s. 52-65

12. ŠIDLO, M. Zákonná obštrukcia - spôsob ako marit’ priebeh prípravného konania. (volné pokračovanie) In. Justičná revue. ISSN 1335-6461, 2016, roč. 68, č. 4, s. 428-438

13. ŠIMOVČEK, I. a kol. Trestné právo procesné. Plzeň: Aleš Čeňek, 2016. s. 407 s. ISBN 978-80-7380-617-0

14. Ústavný súd Slovenskej republiky 2013. Extrémne, opakované zbytočné prietahy okresných súdov a orgánov činných v trestnom konani [online]. Ústavný súd Slovenskej republiky [cit. 2021-06-14]. Dostupné na internete: https://www.ustavny sud.sk/documents/10182/992260/5_extremne_prietahy_final-1-4.pdf/874ef431-cfb74207-92bb-3bde9fb5f278

15. III. ÚS $85 / 02$ Nález z 25 septembra 2002

16. Zákon č. 460/1992 Zb. Ústava Slovenskej republiky v znení neskorších predpisov

17. Zákon č. 300/2005 Z. z. Trestný zákon v znení neskorších predpisov 
18. Zákon č. 301/2005 Z. z. Trestný poriadok v znení neskorších predpisov

\section{Kontaktné údaje}

JUDr. Juraj Drugda, PhD.

Akadémia Policajného zboru v Bratislave, Katedra vyšetrovania

Sklabinská 1, 83517 Bratislava

Tel: +421961 057468

email: juraj.drugda@akademiapz.sk 


\title{
VYDÁVANIE PRÍKAZOV NA POUŽITIE PROSTRIEDKOV OPERATÍVNO-PÁTRACEJ ČINNOSTI A INFORMAČNO- TECHNICKÝCH PROSTRIEDKOV V PRÍPRAVNOM KONANÍ
}

\author{
ISSUING OF ORDERS FOR THE USE OF OPERATIVE- \\ INVESTIGATIVE MEASURES AND INFORMATION-TECHNOLOGY \\ MEASURES IN PRE-TRIAL PROCEEDINGS
}

\author{
Juraj Drugda
}

\begin{abstract}
Abstrakt
Príspevok sa zameriava na problematiku vydávania príkazov na použitie špeciálnych druhov dôkazných prostriedkov, ktorými sú prostriedky operatívno-pátracej činnosti a informačnotechnické prostriedky, na účely získania trestnoprávne relevantných informácií v prípravnom konaní. Autor sa venuje priblíženiu základného pojmoslovia a právnych východísk skúmanej problematiky a takisto stručne analyzuje samotnú právnu úpravu týchto príkazov. Súčasne sa venuje aj riadnemu postupu orgánov činných $\mathrm{v}$ trestnom konaní v procese vydávania príkazov na použitie prostriedkov operatívno-pátracej činnosti a informačno-technických prostriedkov vrátane hierarchie schval'ovacieho procesu. Ďalšej analýze sú podrobené aj najdôležitejšie obsahové náležitosti celého radu písomností vydávaných orgánmi činnými v trestnom konaní pri schval'ovaní a realizácii príkazov.
\end{abstract}

Kl'účové slová: príkaz, prostriedky operatívno-pátracej činnosti, informačno-technické prostriedky, prípravné konanie

\begin{abstract}
The article is focused on the subject of issuing of orders for the use of special investigative measures - namely operative-investigative measures and information-technology measures for the purpose of obtaining the information relevant for the criminal investigation during the pre-trial proceedings. The author addresses the basic concepts and legal starting points of the researched topic and also briefly analyses the legal regulation of these orders as such. Further focus is dedicated to the proper procedure of the law enforcement authorities in criminal proceedings in the process of issuing of orders for the use of operative-investigative measures and information-technology measures, including the hierarchy of the approval process. The further analysis is dedicated also to the most important requirements of form of various documents issued by the law enforcement authorities in criminal proceedings in the process of submitting the orders in question for approval and their later execution.
\end{abstract}

Key words: order, operative-investigative measures, information-technology measures, pretrial proceedings

\section{1 ÚVOD}

Orgány činné v trestnom konaní a súdy aplikujú právo prostredníctvom súboru rozhodnutí, ktorých obsahom je vyjadrenie právneho názoru a autoritatívne riešenie otázok týkajúcich sa skutku, ktorý je predmetom trestného konania. Oprávneniami na vydávanie rozhodnutí v trestnom konaní disponujú výlučne orgány činné v trestnom konaní a súdy. V prípravnom konaní prokurátor, vyšetrovatel' a poverený príslušník Policajného zboru vydávajú tri druhy rozhodnutí, ktorými sú uznesenie, príkaz a opatrenie. Každé z týchto rozhodnutí má vlastné 
formálne a obsahové náležitosti a vyvoláva rôzne druhy právnych následkov. „Príkazom sa rozhoduje najmä o zásahoch do základných práv a slobôd v trestnom konaní. "“

\section{VYMEDZENIE ZÁKLADNÝCH POJMOV A PRÁVNA ÚPRAVA PRÍKAZOV V PRÍPRAVNOM KONANÍ}

$\mathrm{Na}$ účely lepšieho pochopenia nasledujúcich častí príspevku je potrebné priblížit' systém základných pojmov a východísk súvisiacich so skúmanou problematikou a právnu úpravu príkazov v prípravnom konaní. Prípravné konanie je vel'mi dôležitou parciálnou čast'ou trestného konania i pre obete trestných činov. „Je preto nevyhnutné nahliadat' na túto skutočnost' i so zretel'om včasnej aplikácie konkrétnych krokov, ktoré prispejú k pomoci a podpore obetí trestných činov počas prípravného konania. “2

Príkaz je možné definovat' ako „osobitnú formu rozhodnutia v prípadoch ustanovených Trestným poriadkom, proti ktorému nie je prípustný opravný prostriedok. "3 Riadnym opravným prostriedkom voči rozhodnutiam vydávaným prípravnom konaní je st'ažnost'. Neprípustnost' opravného prostriedku voči príkazom znamená, že osoby, ktorých základné práva a slobody môžu byt' narušené alebo obmedzené ich výkonom nemajú možnost' podania st'ažnosti voči dôvodom vydania príkazu, odôvodnenosti príkazu a okolnostiam, ktoré podmienili vydanie príkazu. Príkaz tým pádom nadobúda ,ihned' po jeho vydaní právnu moc a je zároveň vykonatelný. “4 Praktické nasadzovanie prostriedkov operatívno-pátracej činnosti a informačno-technických prostriedkov zo svojej podstaty predpokladá potrebu zachovania čo najväčšej možnej miery utajenia týchto aktivít slúžiacich na účely získavania trestnoprávne relevantných informácií takým spôsobom, aby záujmové osoby nemali vedomost' o ich monitorovaní, ináč môže dôjst' $\mathrm{k}$ čiastočnému alebo úplnému zmareniu použitia týchto špecifických druhov dôkazných prostriedkov, čo môže mat' mimoriadne negatívny vplyv na realizáciu niektorých $\mathrm{z}$ nich vyplývajúcich vyšetrovacích úkonov $\mathrm{v}$ d’alších častiach prípravného konania. Z týchto dôvodov logicky vyplýva nemožnost' podania st'ažnosti dotknutých osôb voči vydaným príkazom, pretože v záujme zachovania náležitej miery utajenia realizovaných vyšetrovacích úkonov tieto osoby nemôžu byt' informované o ich existencii a ich plánovanom využití.

Pojem špecifické druhy dôkazných prostriedkov môžeme charakterizovat' ako vybrané druhy vyšetrovacích úkonov určených na zaistenie vecí a informácií na účely trestného konania vyznačujúcich sa prvkami spravodajskej činnosti. Medzi špecifické druhy dôkazných prostriedkov zarad'ujeme prostriedky operatívno-pátracej činnosti a informačno-technické prostriedky.

Informačno-technické prostriedky sú definované v ustanovení $\S 10$ ods. 21 zákona č. 301/2005 Z. z. Trestného poriadku (d’alej „Trestný poriadok“) ako: „elektrotechnické, rádiotechnické, fototechnické, optické, mechanické, chemické a iné technické prostriedky a zariadenia alebo ich súbory použité utajovaným spôsobom pri odpočúvaní a zázname prevádzky v elektronických komunikačných siet'ach, obrazových, zvukových alebo obrazovozvukových záznamov alebo pri vyhl'adávaní, otváraní a skúmaní zásielok, ak sa ich použitím zasahuje do základných l'udských práv a slobôd." Medzi konkrétne informačno-technické prostriedky zarad'ujeme: vyhotovovanie obrazových, zvukových alebo obrazovo-zvukových

\footnotetext{
${ }^{1}$ ZÁHORA, J. Prikaz v trestnom konaní. In. Justičná revue. 2004, roč. 56, č. 5, s. 537

${ }^{2}$ KRÁSNÁ, P. Zákon o obetiach trestných činov - legislativna zmena, ktorá upevnila postavenie obetí trestných činov v prípravnom konani. In ČENTÉŠ a kol. Efektívnost' prípravného konania - jej skúmanie, výzvy a perspektívy. Bratislava: Univerzita Komenského v Bratislave, Právnická fakulta, 2020, s. 70.

${ }^{3}$ VIKTORYOVÁ, J. - STRAUS, J. a kol.: Vyšetrovanie. Bratislava: Akadémia Policajného zboru v Bratislave, 2015, s. 53

${ }^{4}$ KYJAC, Z. Použitie informačno-technických prostriedkov v trestnom konaní. Bratislava: Wolters Kluwer, 2015. s. 143
} 
záznamov, odpočúvanie a záznam telekomunikačnej prevádzky a porovnávanie údajov $\mathrm{v}$ informačných systémoch.

„Operatívno-pátracou činnostou sa rozumie systém spravidla utajených spravodajských opatreni vykonávaných políciou na účely predchádzania, zamedzovania, odhalovania a dokumentovania trestnej činnosti a zistovania jej páchatel'ov. "5 Prostriedkami operatívnopátracej činnosti na účely trestného práva rozumieme: zámenu obsahu zásielok, kontrolovanú dodávku, predstieraný prevod, inštitút agenta a sledovanie osôb a vecí.

Praktická realizácia prostriedkov operatívno-pátracej činnosti a informačno-technických prostriedkov prebieha $\mathrm{v}$ dvoch základných právnych rovinách podl'a štádia, v ktorom sa konkrétne trestné konanie nachádza. Prostriedky operatívno-pátracej činnosti a informačnotechnické prostriedky sa uplatňujú v štádiu pred začatím trestného stíhania na účely preverenia existujúcich podozrení o páchaní trestnej činnosti záujmovými osobami a vyhl'adaniu d’alších doplňujúcich informácií a dôkazov. Informácie získané v tomto štádiu prípravného konania slúžia ako podklad pre začatie trestného stíhania a nie je možné ich použit' ako dôkazy. Z týchto dôvodov používanie prostriedkov operatívno-pátracej činnosti a informačno-technických prostriedkov $\mathrm{v}$ štádiu pred začatím trestného stíhania nie je naviazané na existenciu vydaného príkazu. Spôsob a limity ich využívania sú obsiahnuté v osobitných právnych predpisoch, medzi ktoré zarad'ujeme napríklad zákon č. 166/2003 Z. z. o ochrane súkromia pred neoprávneným použitím informačno-technických prostriedkov a zákon č. 171/1993 Z. z. o Policajnom zbore.

V štádiu po začatí trestného stíhania, ktoré sa vo väčšine prípadov vyšetrovania obzvlášt' závažnej trestnej činnosti a organizovanej kriminality začína pre skutok, prípadne vo veci, kde v uznesení o začatí trestného stíhania ešte nie sú uvedené údaje o páchatel'och sa prostriedky operatívno-pátracej činnosti a informačno-technické prostriedky využívajú na získanie informácií o druhoch páchanej trestnej činnosti, spôsoboch páchania a utajovania tejto trestnej činnosti alebo inými slovami mode operandi páchatel’ov, obsahu komunikácie medzi páchatel'mi, rozsahu páchanej trestnej činnosti, počtu páchatel'ov a ich del'by práce a o pohybe páchatel'ov a miestach, kde sa frekventovane zdržiavajú alebo kde dochádza k páchaniu trestnej činnosti. Tieto informácie slúžia na získanie dostatočných podkladov pre realizáciu zaist'ovacieho úkonu, ako napríklad domovej prehliadky alebo prehliadky iných priestorov a pozemkov, v rámci ktorej sa predpokladá zadržanie páchatel’ov priamo pri páchaní trestnej činnosti. Všetky spomínané informácie získané použitím prostriedkov operatívno-pátracej činnosti a informačno-technických prostriedkov $\mathrm{v}$ štádiu po začatí trestného stíhania sú využitel'né ako dôkazy $\mathrm{v}$ trestnom konaní, preto je realizácia týchto špecifických druhov dôkazných prostriedkov viazaná na predchádzajúcu alebo dodatočnú existenciu príkazu na ich použitie.

Príkaz nemá striktne stanovené formálne náležitosti, avšak vo väčšine prípadov má formu vlastnú pre všetky bežné druhy rozhodnutí v prípravnom konaní. Obsahové náležitosti príkazu sú vymedzené v ustanovení § 181 Trestného poriadku nasledovne: „Príkaz musí obsahovat: označenie orgánu, o ktorého rozhodnutie ide, dátum a miesto rozhodnutia, výrok príkazu s uvedením zákonných ustanoveni, ktoré boli použité a skutok s uvedením právnej kvalifikácie trestného činu ak z povahy nevyplýva niečo iné. Písomné vyhotovenie príkazu musí obsahovat' odôvodnenie vtedy, kde to zákon výslovne ustanovuje. "Príkazy vydávané na účely použitia špecifických dôkazných prostriedkov musia obsahovat' „také odôvodnenie, aby bol z neho zrejmý sledovaný legitímny ciel' "“6 v ktorom sú vysvetlené všetky skutočnosti zdôvodňujúce potrebu obmedzenia a zásahu do základných l’udských práv a slobôd dotknutých osôb. Detaily a najdôležitejšie súčasti obsahu odôvodnenia si priblížime v nasledujúcich častiach príspevku.

\footnotetext{
${ }^{5}$ IVOR. J. et al.: Optimalizácia prípravného konania trestného. Praha: Leges, 2017, s. 338

${ }^{6}$ ČENTÉŠ, J. Odpočúvanie - procesnoprávne a hmotnoprávne aspekty. Bratislava: C. H. Beck, 2013, s. 144
} 


\section{POSTUP PRI VYDÁVANí PRÍKAZOV NA POUŽITIE PROSTRIEDKOV OPERATÍVNO-PÁTRACEJ ČINNOSTI A INFORMAČNO- TECHNICKÝCHPROSTRIEDKOV}

Vydaniu právoplatného príkazu na použitie niektorého zo špecifických dôkazných prostriedkov predchádza niekol'ko stupňový schval'ovací proces. Podmienky, ktoré je potrebné splnit' pre vydanie príkazu sú rozličné podl'a druhu prostriedku operatívno-pátracej činnosti alebo informačno-technického prostriedku $\mathrm{v}$ závislosti od miery predpokladaného zásahu do základných práv a slobôd dotknutých osôb.

O vydaní príkazu na použitie špecifických dôkazných prostriedkov, ktoré zasahujú v menšej miere do základných práv a slobôd rozhoduje prokurátor na základe návrhu na vydanie príkazu, ktorý vypracováva vyšetrovatel'. Medzi tieto zarad’ujeme kontrolovanú dodávku, predstieraný prevod, sledovanie osôb a vecí a porovnávanie údajov $\mathrm{v}$ informačných systémoch.

V prípadoch používania prostriedkov operatívno-pátracej činnosti a informačno-technických prostriedkov, ktoré predpokladajú závažný zásah do základných práv a slobôd dotknutých osôb o vydaní príkazu rozhoduje sudca pre prípravné konanie na návrh prokurátora, pričom prokurátor svoj návrh vypracováva na podklade podnetu na podanie návrhu na vydanie príkazu, ktorý spracováva vyšetrovatel'.

V praxi dochádza k situáciám, kedy sa vyšetrovatel' alebo operatívni pracovníci dostanú do kontaktu s informáciami dôležitými pre trestné konanie, ktoré potrebujú bezodkladne zadokumentovat', avšak nedisponujú príslušným príkazom. Pre ilustráciu je možné si predstavit' prípad, kedy je napríklad voči záujmovej osobe realizované sledovanie, na ktoré bol vydaný príkaz, a počas realizácie tohto sledovania operatívni pracovníci spozorujú stretnutie s doteraz neznámou osobou, pri ktorej dôjde k spáchaniu trestného činu. Okolnosti tohto stretnutia je kvôli náležitému preukázaniu skutkového stavu potrebné zadokumentovat' ideálne na obrazovo-zvukový záznam, pričom na realizáciu takéhoto úkonu nemajú vyšetrovatel' ani operatívni pracovníci príslušný príkaz. $\mathrm{V}$ takýchto prípadoch právna úprava umožňuje použitie potrebného prostriedku operatívno-pátracej činnosti alebo informačnotechnického prostriedku aj bez existencie príslušného príkazu. Tento je však potrebné dodatočne zabezpečit' $\mathrm{v}$ rôznych lehotách od 24 hod. až po 72 hod. v závislosti od toho, ktorého nasadeného špecifického dôkazného prostriedku. V prípade, že prokurátor alebo sudca pre prípravné konanie $\mathrm{v}$ tejto lehote nevydá požadovaný príkaz, tak získané informácie nemožno použit' na účely trestného konania a musia sa predpísaným spôsobom bez meškania zničit. Na tieto informácie sa vo vztahu k trestnému konaniu a prebiehajúcemu dokazovaniu hladí ako keby nikdy neexistovali. ${ }^{7}$

Zásahy do základných práv a slobôd nemôžu trvat' nekonečne dlhé časové obdobie. Preto je v každom vydanom príkaze stanovená doba, počas ktorej možno realizovat' tie ktoré špecifické dôkazné prostriedky. Pri väčšine $\mathrm{z}$ nich je maximálna hranica času stanovená na dobu 6 mesiacov s možnost'ou predlžovania tejto lehoty $\mathrm{v}$ odôvodnených prípadoch o d'alšie 2 mesiace a to aj opakovane. V súvislosti s obmedzenou dobou platnosti príkazu je však neustále potrebné skúmat' pretrvávanie dôvodov, ktoré viedli k vydaniu príkazu a v prípade, že tieto dôvody pominuli sa realizácia špecifického dôkazného prostriedku musí ukončit’ a to aj pred uplynutím schválenej lehoty.

\footnotetext{
${ }^{7}$ ŠIMOVČEK, I. a kol. Trestné právo procesné. Plzeň: Aleš Čeňek, 2016. s. 132-133
} 


\section{PÍSOMNOSTI VYTVÁRANÉ ORGÁNMI ČINNÝMI V TRESTNOM KONANÍ V PROCESE ROZHODOVANIA O VYDANÍ PRÍKAZU NA POUŽITIE PROSTRIEDKOV OPERATÍVNO-PÁTRACEJ ČINNOSTI A INFORMAČNO- TECHNICKÝCH PROSTRIEDKOV}

V predchádzajúcej časti príspevku sme $\mathrm{v}$ rámci približovania postupu pri vydávaní príkazov na použitie prostriedkov operatívno-pátracej činnosti a informačno-technických prostriedkov spomenuli názvy vytváraných písomností a subjekty, ktoré sú oprávnené na ich vyhotovovanie a schval'ovanie. Rovnako potrebné je venovat' sa obsahu týchto písomností vo svetle všetkých náležitostí, ktoré musia byt’ splnené pre úspešné schválenie a vydanie príslušného príkazu.

Ked'sa znova budeme venovat' hierarchii schval'ovacieho procesu pri vydávaní príkazov, tak postrehneme, že bez ohl'adu na to, či je schval'ovací proces dvojstupňový alebo trojstupňový, je vždy na prvom stupni vyšetrovatel', ktorý vyhotovuje bud' návrh na vydanie príkazu adresovaný prokurátorovi alebo podnet na podanie návrhu na vydanie príkazu, ktorí je opät' adresovaný prokurátorovi, avšak ten od prokurátora d’alej smeruje ku sudcovi pre prípravné konanie $\mathrm{v}$ podobe návrhu na vydanie príkazu. Z prvostupňového postavenia vyšetrovatel’a v procese rozhodovania o vydaní príkazu priamo vyplýva fakt, že úspešnost' schválenia a vydania príkazu vo vel'kej miere závisí práve od kvality ním vytváraných písomností. Čo logicky vyplýva z procesného postavenia vyšetrovatel'a, ako subjektu, ktorý má na starosti riadenie, plánovanie a organizovanie vyšetrovania so zodpovednostou za jeho riadny, zákonný a včasný priebeh.

Skutočnost', že vyšetrovatel' má najväčší prehl'ad o prebiehajúcom vyšetrovaní a všetkých získaných aj chýbajúcich informáciách, ktoré je možné zabezpečit použitím špecifických dôkazných prostriedkov sa odráža v obsahu písomností, ktoré slúžia ako podklady na vydanie a schválenie príkazov. Obsah týchto písomností, či už podnetov na podanie návrhu na vydanie príkazu, alebo návrhu na vydanie príkazu má zákonom upravenú podobu, ktorá musí byt' dodržaná a to: z hladiska formy - označenie orgánu, čiže údaje o oddelení, prípadne útvare Policajného zboru na ktorom je služobne zaradený príslušný vyšetrovatel', prijímatel'a písomnosti, ktorým je $\mathrm{v}$ tomto prípade prokurátor príslušnej prokuratúry a názov písomnosti. Z hladiska obsahu d’alej nasleduje výroková čast' písomnosti, v rámci ktorej je približená charakteristika vyšetrovaného trestného činu, právny titul, na základe ktorého bolo začaté trestné stíhanie a druh stíhaného trestného činu, vrátane jeho právnej kvalifikácie. Nasledujúca čast' písomnosti obsahuje vyjadrenie návrhu, v rámci ktorého vyšetrovatel' navrhuje prokurátorovi príslušnej prokuratúry aby bud' vydal príkaz na použitie niektorého zo špecifických druhov dôkazných prostriedkov alebo aby podal v súlade s príslušnými ustanoveniami Trestného poriadku návrh na vydanie príkazu sudcovi pre prípravné konanie. Ďalej sa v písomnosti uvádzajú identifikačné údaje o monitorovaných miestach, osobách, telefónnych číslach alebo iných veciach a skutočnostiach $\mathrm{v}$ takom rozsahu, aby nedošlo $\mathrm{k}$ zámene týchto monitorovaných skutočností spolu s časovým úsekom počas ktorého má dané monitorovanie prebiehat' $\mathrm{v}$ súlade $\mathrm{s}$ lehotami uvedenými $\mathrm{v}$ príslušných ustanoveniach Trestného poriadku. V nasledujúcej časti písomnosti sú uvedené osobné údaje záujmových osôb a d'alších zainteresovaných osôb, ktorými môžu byt' napríklad majitelia nehnutel'ností alebo telefónnych čísiel a ich osobné údaje, prípadne údaje o právnických osobách, taktiež ,,je potrebné uviest' okrem osobných údajov aj ich vztah k predmetu trestného konania, prípadne osobe podozrivej či obvinenej. “\$

Najdôležitejšou čast'ou týchto písomností je odôvodnenie, ktoré obsahuje vyjadrenie dosiahnutia právneho stavu potvrdzujúceho splnenie všetkých zákonných podmienok stanovených pre úspešné vydanie rozhodnutia, ktorými sú: základné služobné údaje

\footnotetext{
${ }^{8}$ KYJAC, Z. Použitie informačno-technických prostriedkov v trestnom konaní. Bratislava: Wolters Kluwer, 2015. s. 150
} 
vyšetrovatel'a, ktorý začal trestné stíhanie v súlade s príslušnými ustanoveniami Trestného poriadku, ktoré bolo zaradené pod číslom vyšetrovacieho spisu, pre určitý druh trestnej činnosti (zločin, obzvlášt’ závažný zločin) s vymedzením právnej kvalifikácie tohto trestného činu. Opis skutkového základu s ohl'adom na vyjadrenie naplnenia všetkých znakov príslušnej skutkovej podstaty trestného činu obsahuje deskripciu všetkých podstatných skutočností spojených s páchanou trestnou činnost’ou, ako napríklad údaje o osobách páchajúcich trestnú činnost', prípadne d'alších doposial' nestotožnených osobách, forma páchania trestnej činnosti - spolupáchatel'stvo, organizovaná forma, modus operandi - spôsob páchania trestnej činnosti - protizákonné aktivity podozrivých osôb, miesta, kde dochádza k týmto protizákonným aktivitám, hierarchia organizovanej skupiny a postavenie jednotlivých členov $v$ tejto hierarchii, del'ba činností, časové obdobie počas ktorého dochádzalo k páchaniu trestnej činnosti a predpokladaná výška vzniknutej škody, spolu s d’alšími následkami páchania trestnej činnosti, ktorými sú najmä porušovanie všeobecného záujmu spočívajúceho v ochrane niektorej zo spoločenských hodnôt chránenej Trestným zákonom. V d'alšej časti odôvodnenia sa uvádzajú všetky doposial' vykonané vyšetrovacie úkony a najdôležitejšie zistenia z nich vyplývajúce a dôkazy, ktoré nimi boli zaistené a zadokumentované. Ďalej sa v odôvodnení uvádzajú detaily a informácie získané použitím prostriedkov operatívno-pátracej činnosti alebo informačno-technických prostriedkov v štádiu pred začatím trestného stíhania (pokial' bolo pristúpené $\mathrm{k}$ ich realizácii). V odôvodnení musia byt' dôsledne opísané dôvody nevyhnutnosti použitia príslušného prostriedku operatívno-pátracej činnosti alebo informačno-technického prostriedku jednak vo vzt’ahu ku konkrétnym informáciám a dôkazom, ktoré vyšetrovatel' predpokladá, že budú touto činnost'ou zmapované a taktiež aj vo vzt'ahu $\mathrm{k}$ faktu, že realizácia predpokladá zistenie skutočností významných pre trestné konanie, ktoré po vyčerpaní všetkých dostupných prostriedkov v danom štádiu prípravného konania nie je možné získat' iným spôsobom alebo by získanie predpokladaných dôkazov bez zásahu do základných práv a slobôd bolo podstatne st’ažené.

Záverečná čast' analyzovanej písomnosti vyjadruje podstatu návrhu na vydanie príkazu, v rámci ktorej je vo svetle obsahu predchádzajúcich častí potrebné prezentovat' právnu úvahu o splnení podmienok na realizáciu požadovaného špecifického druhu dôkazného prostriedku, spolu s úvahou o informáciách a dôkazoch, ktoré môžu byt' získané a samotným slovným vyjadrením návrhu pre príslušného prokurátora aby vydal v súlade $\mathrm{s}$ ustanoveniami Trestného poriadku bud' príkaz alebo aby podal návrh na vydanie príkazu sudcovi pre prípravné konanie.

Písomnost' sa označuje podpisovou doložkou vyšetrovatel'a, ktorý ju zhotovil a červenou okrúhlou pečiatkou na spodnej časti každej strany s označením „Vyhradené!“‘

Ostatné druhy súvisiacich písomností, ktoré sú vyhotovované majú v zásade takmer totožný obsah ako analyzovaná písomnost'. Rozdiely môžu nastat' vo formálnej stránke písomnosti, ktorá však nie je zákonne stanovená alebo v obsahovej stránke, pokial' prokurátor alebo sudca pre prípravné konanie návrhu nevyhovel a vrátil ho na prepracovanie. Najpodstatnejšou čast'ou týchto písomností je v každom prípade odôvodnenie, ktorého podoba sa pri predpoklade jeho náležite kvalitného spracovania vyšetrovatel'ov výrazne nemení počas celého schval'ovacieho procesu.

\section{ZÁVER}

Príkazy môžeme chápat' ako vyjadrenie právneho názoru orgánov činných v trestnom konaní a súdov, ktoré zakladajú trestno-procesné vzt’ahy súčelom poskytnutia oprávnenia na nevyhnutné zásahy do základných l’udských práv a slobôd za účelom získania podstatných trestnoprávne relevantných informácií, ktoré nie je možné získat' iným spôsobom. Tenká hranica medzi potrebou ochrany základných l’udských práv a slobôd a prekračovanie tejto ochrany pre zabezpečenie dosiahnutia ciel'ov trestného konania je sprevádzaná dlhodobou 
polemikou expertov z akademickej oblasti aj zástupcov praxe. Viacstupňový schval'ovací proces pri vydávaní príkazov a potreba neustáleho skúmania trvania dôvodov, ktoré viedli k vydaniu príkazu počas lehoty jeho platnosti spolu s vyhodnocovaním legitimity, legality a proporcionality zásahov do l'udských práv a slobôd vo vzt'ahu k sledovaným výsledkom trestného konania podl'a môjho názoru zabezpečujú dostatočnú ochranu pred akýmikol'vek neoprávnenými zásahmi do základných l'udských práv a slobôd.

Príspevok je publikovaný v rámci realizácie vedecko-výskumnej úlohy Katedry vyšetrovania Akadémie Policajného zboru v Bratislave s označením VÝSK. 248 s názvom „,Využívanie špecifických druhov dôkazných prostriedkov na účely vyšetrovania obzvlášt' závažnej trestnej činnosti. “

\section{Použitá literatúra}

1. ČENTÉŠ, J. Odpočúvanie - procesnoprávne a hmotnoprávne aspekty. Bratislava: C. H. Beck, 2013. 250 s. ISBN 978-80-89603-09-1

2. IVOR. J. et al. Optimalizácia prípravného konania trestného. Praha: Leges, 2017. 608 s. ISBN 978-80-7502-216-5

3. KRÁSNÁ, P. Zákon o obetiach trestných činov - legislatívna zmena, ktorá upevnila postavenie obeti trestných činov $v$ prípravnom konaní. In ČENTÉS̆ a kol. Efektívnost' prípravného konania - jej skúmanie, výzvy a perspektívy. Bratislava: Univerzita Komenského v Bratislave, Právnická fakulta, 2020, s. 62-73. ISBN 97880-7160-577-5

4. KYJAC, Z. Použitie informačno-technických prostriedkov $v$ trestnom konaní. Bratislava: Wolters Kluwer, 2015. 306 s. ISBN 978-80-8168-266-7

5. ŠIMOVČEK, I. a kol. Trestné právo procesné. Plzeň: Aleš Čeňek, 2016. s. 407 s. ISBN 978-80-7380-617-0

6. VIKTORYOVÁ, J. - STRAUS, J. a kol. Vyšetrovanie. Bratislava : Akadémia Policajného zboru v Bratislave, 2015. 686 s. ISBN 978-80-8054-643-4

7. ZÁHORA, J. Príkaz v trestnom konaní. In. Justičná revue. ISSN 1335-6461, 2004, roč. 56, č. 5, s. 537-545

8. Zákon č. $166 / 2003$ Z. z. o ochrane súkromia pred neoprávneným použitím informačno-technických prostriedkov $\mathrm{v}$ znení neskorších predpisov

9. Zákon č. 171/1993 Z. z. o Policajnom zbore v znení neskorších predpisov

10. Zákon č. 301/2005 Z. z. Trestný poriadok v znení neskorších predpisov

11. Zákon č. 300/2005 Z. z. Trestný zákon v znení neskorších predpisov

\section{Kontaktné údaje}

JUDr. Juraj Drugda, PhD.

Akadémia Policajného zboru v Bratislave, Katedra vyšetrovania

Sklabinská 1, 83517 Bratislava

Tel: +421961 057468

email: juraj.drugda@akademiapz.sk 


\title{
ZROD NÁRODNEJ OPERY V POLSKU
}

\section{THE BIRTH OF THE NATIONAL OPERA IN POLAND}

\section{Dominika Sondorová}

\begin{abstract}
Abstrakt
Príspevok sa zaoberá vznikom a vývojom národnej opery v Pol’sku. Reflektuje spoločenskopolitickú situáciu, ktorá mala počas 19 . storočia výrazný vplyv nielen na formovanie pol'skej opernej tvorby. Nahliada do rozvoja pol'skej opery a približuje úsilie pol'ských skladatel'ov a šlachty o vznik národnej opery. Osobitne sa venuje Stanisławovi Moniuszkovi a pol'skej národnej opere Halka, ktorá je od roku 1858 trvale prítomná na pol’ských javiskách.
\end{abstract}

Kl'účové slová: pol’ská národná opera, Halka, Stanistaw Moniuszko

\begin{abstract}
The paper deals with the birth and development of the national opera in Poland. It reflects the socio-political situation, which had a significant influence during the 19th century not only on the formation of polish opera. It looks at the development of polish opera and describes the efforts of polish composers and the nobility to establish a national opera. It pays special attention to Stanisław Moniuszko and the polish national opera Halka, which has been permanently present on polish stages since 1858 .
\end{abstract}

Key words: polish national opera, Halka, Stanisław Moniuszko

\section{1 ÚVOD}

Konštituovanie národov $\mathrm{v}$ procese vývoja európskej národnej identity sa zintenzívnilo predovšetkým v 19. storočí. Oproti minulým obdobiam zaznamenalo výraznú premenu vo všetkých oblastiach spoločenského i kultúrneho života. Vytvorila sa koncepcia národného štátu, kodifikovali sa národné jazyky, politika definovala svoje národné programy, inštitucionalizoval sa spoločenský záujem o národný princíp a koncipovala sa národná kultúra. Každé národné hnutie sa usilovalo pozdvihnút' sociálnu i kultúrnu úroveň svojho národa, presadit' spisovnú reč, kultúrne práva a postupne dosiahnut' štátoprávnu svojbytnost', vyplývajúcu $\mathrm{z}$ idey národného štátu. Pol'ský l'ud sa $\mathrm{k}$ národnému princípu sebarealizácie dopracoval v zložitých podmienkach národnej nesamostatnosti. Aj napriek tomu si vybudoval všetky črty národnej symboliky a naplnil obsah nielen politického, ale i kultúrneho národa. Jedným z hlavných ciel'ov pol'ského národného hnutia bola otázka obnovy pol'ského štátu, ktorého územie ostávalo počas celého 19. storočia súčast'ou troch mocností - Ruska, Rakúska a Pruska. Činnost' pol'ských národovcov bola vo väčšine prípadov tajná a jej predstavitel'mi bola nielen inteligencia, ale i predstavitelia pol'skej armády a podnikatel'ských kruhov. Čast' pol'skej obrodeneckej inteligencie pôsobila vemigrácii a tak hlasy mnohých pol'ských národovcov často zaznievali spoza hraníc pol’ských zemí. ${ }^{1}$

\section{VZNIK POLSKEJ NÁRODNEJ OPERY}

Pol'sko vd'aka svojej rozlohe a kultúrnej vyspelosti zohralo niekol'kokrát v dejinách Európy dôležitú úlohu. Jeho hudba dosahovala značnú umeleckú úroveň už v období renesancie

\footnotetext{
${ }^{1}$ SMOLÍK, P. et al. 2018. On the Definition of the Notion of National in Slavic Operatic Production. In Ad Alta: Journal of Interdisciplinary Research. 2018, roč. 8, č. 2. s. 265-270.
} 
a baroka. Vývoj novších dejín však skomplikovala prítomnost' troch mocností - Ruska, Rakúska a Pruska, ktorá postupne viedla $\mathrm{k}$ strate pol'skej samostatnosti. ${ }^{2}$ Pol'sko sa pod vplyvom nepriaznivých spoločenských podmienok až do obdobia romantizmu významnejšie nepodiel'alo na európskom hudobnom vývoji. 19. storočie však prinieslo rozmach nacionalizmu. U kultúrne vyspelých, ale politicky roztrieštených národov sa práve opera stala mocným symbolom kultúrnej jednoty. Pre mnohé národy bola tvorba vlastnej svojbytnej opery jednou z hlavných úloh pri dokazovaní kultúrnej vyspelosti, samostatnosti a rovnocennosti. V dôsledku nepriaznivých podmienok sa v pol'skej hudbe nerozvíjali vel'ké symfonické formy, ale udržiavali sa tradície národnej hudby.

Prvý impulz pre vznik pol'skej hudobno-dramatickej tvorby prišiel už v druhej polovici 18 . storočia, kedy sa prejavil vzostup meštianskej spoločnosti a národného uvedomenia. Založenie prvého pol'ského Národného divadla (Varšava, 1765) podnietilo rozvoj pol'skej opery, ktorej najväčší rozkvet spadá do obdobia vlády Stanisława Augusta Poniatowského. ${ }^{3}$ Práve v tomto období sa v Pol'sku objavili výraznejšie osobnosti nadväzujúce väčšinou na francúzsku a taliansku operu. Najznámejším z nich bol prvý novodobý pol'ský hudobný skladatel' Maciej Kamieński (1734 - 1821), pochádzajúci zo Slovenska. Úspech dosiahol svojou spevohrou Nedza uszcześliwiona (Obšt'astnená bieda, 1778) na text Wojciecha Boguslavského. Bola to umelecky menej zrelá skladba, v ktorej sa autor snažil zdôraznit' pol'ský národný charakter použitím pol'ského jazyka a melódiami opierajúcimi sa o národnú pieseň. Úspech tejto spevohry podnietil vznik d’alších diel podobného charakteru. L'udovou melodikou sa vyznačovala aj d'alšia opera Cud Mniemany czyli Krakowiacy i Górale (1794) od pražského rodáka Jana Stefaniho (1746 - 1829). Opera Cud Mniemany czyli Krakowiacy i Górale dosiahla množstvo prevedení.

Na vytváraní moderného umenia sa intenzívne podiel'ala i pol'ská šlachta, čo dokazuje aj tvorba Antoniho Jerzy Radziwilla (1755 - 1833), ktorý sa úspešne pokúsil o skomponovanie hudby ku Goetheovmu Faustovi. Jedným z d’alších šl'achticov, ktorí sa pričinili o rozvoj pol'skej hudby bol Michał Kleofas Ogiński (1765 - 1833). Ťažisko jeho tvorby tvorí množstvo vlasteneckých piesní, medzi ktorými dominuje pieseň Jeszcze Polska nie zginela, neskôr pol'ská hymna. ${ }^{4}$

Spoločenské prevraty na prelome 18. a 19. storočia značne zmenili aj postavenie opery. Popri dovtedajšej reprezentačnej a zábavnej funkcii jej pripadla významná spoločenská, vzdelávacia i politická úloha. Javisko opery sa stalo jediným miestom rodného jazyka. Ruský cársky režim sa nikdy nepokúsil operu celkom zničit' a odnárodnit' (uvažovalo sa i o rusifikácii), hoci formy cenzúry a útlaku boli rôzne a rafinované (napr. eliminácia pol'ských spevákov a pol'ských titulov, uprednostňovanie zahraničného repertoáru a interpretov, zákaz účinkovania pol'ských spevákov na charitatívnych koncertoch mimo opery, odoberanie penzií a štipendií atd'.). Takmer každý boj pol'ských intendantov, dirigentov a umelcov bol bojom o pol'ský národ. ${ }^{5}$

Nástup romantizmu so sebou priniesol predstavu o opere ako o vrcholnej, syntetickej umeleckej forme. Členovia miestneho operného publika tak očakávali prvé pol'ské opery séria, ktoré by sa vyrovnali európskemu štandardu hudobno-dramatických produkcií. Naliehanie na operných skladatel'ov, aby hl'adali hlbšie umelecké ambície bolo vyjadrené už v

\footnotetext{
2 ŠAFǍ̌ÍK, J. 2006. Dejiny hudby: 19. storočie. II. diel. Věrovany: Nakladatelství Jan Piszkiewicz, 2006. s. 63.

${ }^{3}$ ČERNUŠÁK, G. a kol. 1974. Dějiny evropské hudby. Praha: Panton, 1974. s. 237.

4 S̆AFǍ̌ÍK, J. 2006. Dejiny hudby: 19. storočie. II. diel. Věrovany: Nakladatelství Jan Piszkiewicz, 2006. s. 64.\#

${ }^{5}$ HRČKOVÁ, N. 2011. Dejiny hudby V. Bratislava: Ikar, 2011. s. 450-452.
} 
prvej polovici 19. storočia aktivitami Józefa Elsnera a Karola Kurpińského. ${ }^{6}$ Józef Elsner (1769 - 1854) bol rodák zo Sliezka. Istú dobu pôsobil v Brne, L’vove a v roku 1799 sa natrvalo usadil vo Varšave. Vytvoril 19 opier (spočiatku nemecké, neskôr už pol'ské), operiet a baletov. Z jeho početnej opernej tvorby dominuje najmä opera Król Lokietek (1818). Rovnako dôležitá bola i jeho dirigentská, pedagogická a spisovatel'ská činnost'. Od roku 1820 viedol varšavskú Vysokú hudobnú školu, vychoval generáciu pol'ských skladatel'ov a v neposlednom rade založil hudobné vydavatel'stvo. Jeho najslávnejším žiakom bol Fryderyk Chopin. ${ }^{7}$ Karol Kurpiński $(1785$ - 1857) viedol 30 rokov varšavskú operu, pre ktorú napísal množstvo národne ladených opier. Presadil sa aj ako autor operiet a baletov. Z jeho rozsiahleho diela dosiahli najväčší úspech opery Zabobon (1816) a Zamek na Czorzstynie (1819). ${ }^{8}$ Obaja skladatelia sa vo vlastnej opernej tvorbe nevyhýbali ani kompozíciám pre zvláštne príležitosti. Prostredníctvom svojej pedagogickej a publikačnej činnosti prispeli k zvyšovaniu estetického povedomia komunity miestnych skladatel'ov a $\mathrm{k}$ postupnému presúvaniu dôrazu na kompozičnú prácu.

Po neúspešnej Novembrovej revolúcii v 30. rokoch 19. storočia boli mnohé pol’ské inštitúcie zatvorené (vrátane konzervatória, ktoré založil Elsner). Zhoršenie politickej situácie v značnej miere ovplyvnilo aj umeleckú slobodu prejavu. ${ }^{9}$ Politická lojalita umelcov bola neustále monitorovaná oficiálnou cenzúrou. Hudobný život v Pol’sku zmíkol na takmer 20 rokov. ${ }^{10}$ Počas týchto rokov sa pol'ská inteligencia i nad'alej usilovala využívat' umenie na sociálne a politické účely v boji za udržiavanie národnej identity. Vd’aka tomu sa proces zvyšovania umeleckej úrovne pôvodnej opery obnovil koncom 50. rokov 20. storočia. ${ }^{11}$

Premiéra Moniuszkovej Halky, znamenala vo vývoji pol'skej hudobno-dramatickej tvorby prelomovú udalost'. Halka však za vlády cára Nikolaja neprešla cez cenzúru. Následne Moniuzsko prepracoval operu, dokomponoval ešte niekol'ko scén, árií a rozšíril počet dejstiev na štyri. ${ }^{12}$ Po prvých uvedeniach vo Vil'niuse v roku 1848 a 1854 sa Halka dočkala skutočnej premiéry až v roku 1858 (Varšava) a odvtedy je trvale prítomná na pol'ských javiskách. ${ }^{13}$ Halka je sociálna dráma znázorňujúca feudálne pomery na príbehu lásky šlachtica Janusza k chudobnému dievčat’u. V prvom dejstve prichádza Halka na zámok, kde sa chystá Januszova svadba so Žofiou, dcérou bohatého Stolnika. Janusz posiela Halku preč s prísl'ubom, že spolu začnú nový život. V druhom dejstve čaká Halka na Janusza pri rieke, no namiesto neho prichádza jej priatel' Jontek, ktorý Halku úprimne miluje. Tretie dejstvo sa odohráva v goralskej dedine, kam Jontek priviedol zarmútenú Halku. Do dediny prichádza Janusz so Žofiou, aby sa $\mathrm{v}$ miestnom kostole zosobášili. Nešt’astná Halka, ktorá prišla o Januszove diet’a, sa v závere opery utopí v rieke. ${ }^{14}$ Básnik Wlodzimiercs Wolski vytvoril

\footnotetext{
${ }^{6}$ ZIEZIULA, G. 2007. Betweenutilitarian and autonomous: polish opera in the second half of thenineteenth century. In De musica disserenda III/1, 2007. s. 39.

${ }^{7}$ ŠAFAŘÍK, J. 2006. Dejiny hudby: 19. storočie. II. diel. Věrovany: Nakladatelství Jan Piszkiewicz, 2006. s. 64.

${ }^{8}$ ČERNUŠÁK, G. a kol. 1974. Dějiny evropské hudby. Praha: Panton, 1974. s. 238.

${ }^{9}$ ZIEZIULA, G. 2007. Between utilitarian and autonomous: polish opera in the second half of thenineteenth century. In De musica disserenda III/1, 2007. s. 39.

${ }^{10}$ HRČKKOVÁ, N. 2011. Dejiny hudby V. Bratislava: Ikar, 2011. s. 450-452.

${ }^{11}$ ZIEZIULA, G. 2007. Between utilitarian and autonomous: polish opera in the second half of thenineteenth century. In De musica disserenda III/1, 2007. s. 39.

12 TVRDOŇ, J., HRČKOVÁ, N. 1967. Dejiny pol'skej hudby. Bratislava: Slovenské pedagogické nakladatel'stvo, 1967. s. 33, 35.

13 POLAKOVIČOVÁ, V. 2020. Triumf Moniuszkovej opery Halka vo Viedni. [online]. [cit.10. júna 2021]. Dostupné na internete: https:/vierapolakovicova.blog.sme.sk/c/524950/triumf-moniuszkovej-opery-halka-voviedni.html

${ }^{14}$ MOJŽIŠOVÁ, M. 2019. Moniuszkova Halka vo Viedni ako rekonštrukcia hriechu. [online]. [cit.10. júna 2021]. Dostupné na internete: https://operaslovakia.sk/moniuszkova-halka-vo-viedni-ako-rekonstrukcia-hriechu/
} 
libreto opery podl'a novely Karola Wójcického. Dej opery je založený na trpko pocit’ovanom protiklade triednych rozporov medzi šlachtou a nevol'níkmi. ${ }^{15}$

Vd’aka Halke získal Moniuszko post šéfdirigenta Národnej opery vo Varšave, kde následne 15 rokov dirigoval, o.i. aj svoje d'alšie diela. ${ }^{16}$ Stanisław Moniuszko sa ako hudobný dramatik uberal cestou, ktorú mu naznačili Weber a Glinka. Pôvab jeho Halky spočíval v kombinácii talianskeho operného typu (melodika, rozvrhnutie scén, melodramatickost') a využitia pol'ských hudobných prvkov, najmä mazúrkových a polonézových rytmov či harmonických osobitostí. V opere vynikajú sólové lyrické výstupy, ale aj brilantné zborové a tanečné scény so znamenito štylizovanými mazúrkami a krakoviakmi, ale i veristické vykreslenie jednotlivých postáv. Halka prenikla aj do zahraničia, v Čechách bola prvýkrát predvedená pod taktovkou Bedřicha Smetany v Prozatímnom divadle (1868). Od premiéry Halky sa operné divadlá vo Varšave a Lvove čoraz viac sústred’ovali na umelecky náročné opery.

Úspešnou bola aj d’alšia Moniuszkova komická opera Hrabina (1860) s dejom zo šl'achtického prostredia. Počas Januárového povstania (1863) napísal Moniuszko svoju v poradí tretiu operu Straszny dvor. Aj táto opera zaznamenala úspech na scéne opery Národného divadla v Prahe (1891). Napriek pozitívnemu ohlasu ju stiahli z repertoáru už po tret’om predstavení. Stiahnutie opery $\mathrm{z}$ repertoáru spustilo nekonečnú ret’az represií. Významní pol'skí speváci boli z opery vyhnaní a Moniuszko musel dokonca prepracovat' niektoré časti v Halke, ktorá sa udržala na scéne ako zástupná opera, ked' vypadol nejaký taliansky, či iný titul.

Moniuszko výrazne prispel k zvýšeniu umeleckej úrovne pol'skej hudby. Ked’že neopustil Pol'sko, dokázal reagovat' na potreby a záujmy pol'skej spoločnosti. Stvoril pol'skú národnú pieseň a operu. Tvorcovia opery (skladatelia, libretisti a režiséri) sa doposial' príliš nezaoberali štýlom a dramaturgiou opery. V mnohých prípadoch tak hudba často skĺzavala $\mathrm{k}$ obyčajnému sprievodu diela. Moniuszko tento stav zmenil, rozvíjal hudobnú akciu a dramatickost'. Jadro jeho diel tvoril národný tanec a pieseň, hlavne polonéza či mazúrka. Opery Stanisława Moniuszku tvoria základný kameň pol’ského repertoáru a prenikli i do zahraničia.

Koncom 19. storočia sa pokúsil vzkriesit' národnú operu Władysław Żeleński (predstavitel' moniuszkovskej generácie). Jeho tvorba však už nezohrala takú historickú úlohu ako Moniuszkove opery. Skomponoval celkovo štyri opery - Konrad Wallenrod (Lvvov, 1885), Goplana (Krakov, 1896), Janek (L’vov, 1900) vychádzajúca z melódie podhalánskych piesní, Stara Baśn (L’vov, 1907). Všetky Żeleńskeho opery sa vyznačujú romantickými prvkami, l'udovými príbehmi i piesňami. ${ }^{17}$

Posledným z moniuszkovskej generácie bol Roman Statkowski (1860 - 1925), ktorý je tvorcom dvoch opier, Philaenis na libreto Hermanna Erlera a Maria na libreto Malczewského. Statkowski v oboch operách využíval niektoré prvky Wagnerovho štýlu.

\footnotetext{
${ }^{15}$ ŠAFAŘíK, J. 2006. Dejiny hudby: 19. storočie. II. diel. Věrovany: Nakladatelství Jan Piszkiewicz, 2006. s. 264, 265.

${ }^{16}$ POLAKOVIČOVÁ, V. 2020. Triumf Moniuszkovej opery Halka vo Viedni. [online]. [cit.15. júna 2021]. Dostupné na internete: https://vierapolakovicova.blog.sme.sk/c/524950/triumf-moniuszkovej-opery-halka-voviedni.html

${ }^{17}$ TVRDOŇ, J., HRČKOVÁ, N. 1967. Dejiny pol'skej hudby. Bratislava: Slovenské pedagogické nakladatel'stvo, 1967. s. 33-40.\#
} 


\section{ZÁVER}

Len u niektorých utláčaných národov sa národný cit a romantické sebavyjadrenie prepojili do takej miery ako u Poliakov. Vedomie, že národ môže žit' aj bez vlastnej štátnosti ako jednota kultúry a jazyka sa odrážalo aj vo verejnej mienke. Pol'ský l'ud čakal na každé uvol'nenie a oslabenie cenzúry a s entuziazmom bojoval o pol'ské diela a pol'ských umelcov s ciel'om udržat' národný cit širokej pospolitosti. Aj napriek výraznej snahe pol'ských operných skladatel'ov Varšava, L'vov či Poznaň zaostávali na konci 19. storočia za európskym repertoárom niekol'ko desat'ročí. Pol'ská opera v tom období nevyprodukovala diela takých umeleckých kvalít ako ruská a česká opera. Avšak tradícia usilujúca o zachovanie pol’skej hudby (a tým i národa) mala svoju dôležitost' a priniesla i zaujímavé podnety.

\section{Použitá literatúra}

1. ČERNUŠÁK, G. a kol. 1974. Dějiny evropské hudby. Praha: Panton, 1974. 527 s.

2. HRČKOVÁ, N. 2011. Dejiny hudby V. Bratislava: Ikar, 2011. 464 s.

3. MOJŽIŠOVÁ, M. 2019. Moniuszkova Halka vo Viedni ako rekonštrukcia hriechu. [online]. Dostupné na internete: https://operaslovakia.sk/moniuszkova-halka-voviedni-ako-rekonstrukcia-hriechu/

4. POLAKOVIČOVÁ, V. 2020. Triumf Moniuszkovej opery Halka vo Viedni. [online]. Dostupné na internete: https://vierapolakovicova.blog.sme.sk/c/524950/triumfmoniuszkovej-opery-halka-vo-viedni.html

5. SMOLÍK, P. et al. 2018. On the Definition of the Notion of National in Slavic Operatic Production. In Ad Alta: Journal of Interdisciplinary Research. 2018, roč. 8, č. 2, s. 265-277. ISSN 1804-7890

6. S̆AFǍ̌ÍK, J. 2006. Dejiny hudby: 19. storočie. II. diel. Věrovany: Nakladatelství Jan Piszkiewicz, 2006. 359 s. ISBN 80-86768-16-3.

7. TVRDOŇ, J., HRČKOVÁ, N. 1967. Dejiny pol'skej hudby. Bratislava: Slovenské pedagogické nakladatel'stvo, 1967. $96 \mathrm{~s}$.

8. ZIEZIULA, G. 2007. Between utilitarian and autonomous: polish opera in the second half of thenineteenth century. In De musica disserenda III/1, 2007. s. 37-46.

\section{Kontaktné údaje}

Mgr. Dominika Sondorová, PhD.

Katedra hudby, Pedagogická fakulta UKF v Nitre

Dražovská 4, 94974 Nitra

email: dsondorova@ukf.sk 


\title{
SVOBODA MÉDIÍ V MONGOLSKU
}

\section{FREEDOM OF THE MEDIA IN MONGOLIA}

\author{
Hana Brodská
}

\begin{abstract}
Abstrakt
Jedním z úspěchů demokracie v Mongolsku je uznání svobody médií, které vedlo ke vzniku a rozvoji nezávislého tisku a mediálního sektoru. V tř́milionové zemi je registrováno na 2 miliony uživatelů internetu, na sociální síti Facebook má účet 1,2 milionů Mongolů a v zemi působí na 140 televizních a rozhlasových stanic. Svoboda médií, autorská práva, veřejnoprávní vysílání či vydávání obchodních licencí jsou garantovány Ústavou a př́slušnými zákonnými akty. Přesto se média i novináři ocitají ve složité situaci. Článek osvětluje její důvody, kterými jsou mimo jiné legislativní nedostatečnost, kumulace médií v rukou omezeného počtu subjektů, netransparentní vlastnická struktura nebo legislativní ustanovení omezující obsah tisku, vysílání a přístup k informacím, a zkoumá možnosti dalšího vývoje.
\end{abstract}

Klíčová slova: cenzura, COVID-19, kriminalizace pomluvy, legislativní prostředí, sdělovací prostředky, sociální média, státní a úředni tajemství, svoboda projevu, vlastnictví médií

\begin{abstract}
One of the achievements of democracy in Mongolia is the recognition of freedom of the media, which has led to the emergence and development of an independent press and media sector. There are 2 million Internet users registered in the three million-population country, 1.2 million Mongols have a Facebook account and there are 140 television and radio stations in the country. Freedom of the media, copyright, public broadcasting or the issuance of commercial licenses are guaranteed by the Constitution and the relevant legal acts. Nevertheless, the media and journalists find themselves in a difficult situation. The article elucidates the reasons such as legislative inadequacies, media accumulation in the hands of a limited number of entities, a non-transparent ownership structure or legislative provisions restricting the content of the press, broadcasting and access to information, and examines the possibilities for further development.
\end{abstract}

Key words: censorship, COVID-19, criminalization of defamation, freedom of speech, legislative environment, media, media ownership, social media, state and official secrets

\section{1. ÚVOD}

Svoboda projevu řadící se mezi základní lidská práva je coby svoboda šiřit názory mluveným či psaným projevem provázána se škálou aktivit podřaditelných svobodě projevu. Za výkon svobody projevu se pokládá rozšiřování informací a názorů, jejich zastávání, přijímání, vyhledávání a rovněž zákaz cenzury nebo právo vyžadovat informace po orgánech veřejné moci. Evropská úmluva o lidských právech explicitně označuje za další složky svobody projevu také právo nezveřejnit identitu novinářských zdrojů, právo mlčet či právo na ochranu technických způsobů realizace projevu. ${ }^{1}$ Média tak lze pokládat za svobodná, nepodléhají-li cenzuře a kontrole vlády ve smyslu udělování licencí nebo jiných typů ovládání; mají-li právo komunikovat (a občané právo přijímat zprávy a názory); mají-li svobodu získávat informace z

\footnotetext{
${ }^{1}$ MOLEK, Politická práva, 2014, s. 59-60.
} 
relevantních zdrojů; nebo nejsou-li vystavena skrytému vlivu vlastníků médií a zadavatelů reklam při zaujímání názorů a zpracování zpravodajských informací.

Mediální a tiskové odvětví se v Mongolsku etabluje již více než 100 let. Historie svobodných a nezávislých médií se tvoří poslední 30 let. První noviny Nové zrcadlo („Шинэ толь“) byly založeny v roce 1913. První rozhlasový program byl s pomocí Sovětského svazu vysílán po celém Mongolsku od roku 1934 a první pravidelné televizní vysílání bylo zahájeno v roce 1967. V období socialismu však média byla pod plnou kontrolou vlády. Politická, sociální a ekonomická transformace v 90. letech vytvořila prostor pro rozvoj svobodných médií. První nezávislé noviny vyšly 8. 4. 1990 pod názvem Demokracie („Ардчилал“), ${ }^{2}$ které třikrát měsíčně vychází doposud. Současné mediální prostředí v Mongolsku je různorodé. Při klesajícím počtu a šíření tištěných médií přebírají dominanci na místním mediálním trhu televize a online média coby hlavní zdroje politických informací.

Článek zkoumá zájem a úsilí mongolské vlády, občanských organizací a veřejnosti o zajištění podmínek pro svobodu projevu, názoru a tisku v zemi, prověruje dodržování platných zákonných opatření, jejich dostatečnost ve smyslu zajištění prostoru pro nezávislá média a práci investigativní žurnalistiky, odkrývá nedostatky v legislativě, zamýšlí se nad budoucností médií a novinářů ve smyslu svobodného provozování jejich činnosti bez obav z př́ípadných trestů, a uvažuje nad možnostmi politického vlivu státu na mediální sféru a svobodná média ve světle výsledků nedávných parlamentních a prezidentských voleb.

\section{SVOBODA PROJEVU, NÁZORU, ŠÍŘIT MYŠLENKY...}

Obdobím rozkvětu teoretických úvah hájících svobodu projevu bylo osvícenství, což ilustruje úvodní výrok francouzského představitele Voltaira: „Nesouhlasím s tím, co říkáte, ale udělám všechno pro to, abyste to mohl svobodně říkat i nadále.". V reakci na osvícenství se objevují první ústavní zakotvení svobody projevu, počínaje francouzskou Deklarací práv člověka a občana z roku 1789 a Prvního dodatku $k$ Ústavě USA z roku $1791 .^{3}$ Právo na svobodu projevu a všech ostatních práv a svobod se ve všech státech světa obecně uplatňuje od přijetí prohlášení Mezinárodní konference o lidských právech v Teheránu 13. 5.1968 k projednání pokroku dosaženého od přijetí Všeobecné deklarace lidských práv v roce 1948.

S právy na svobodu projevu a názorů úzce souvisí svoboda komunikace a médií, ve smyslu právního zajištění svobody vysílání a vydávání, zajištění nezávislosti na ekonomických a politických tlacích, záruk kvality služeb a přistupu recipientů k médii nabízeným informacím. Sdělovací prostředky ovlivňují vnímání faktů i diskuzi o nich ve společnosti, čímž přispívají k vytváření veřejného názoru. Nezávislost a rozmanitost médií, názorů a postojů, vč. kritiky lidí u moci, představují garance zdravého demokratického systému.

\section{LEGISLATIVNÍ PROSTŘEDÍ SVOBODY PROJEVU A JEHO NEDOSTATKY}

Vývoj ochrany svobody projevu na mongolském území počíná v 90. letech 20. století s rozpadem východního bloku socialistických států. Do Ústavy Mongolska z roku 1992 byl vložen rozsáhlý seznam základních práv. Jednotlivci přitom poživají základních práv zaručených jak Ústavou, tak v souladu s čl. 10 Ústavy také mezinárodními smlouvami o lidských právech. Od roku 1992 je v Mongolsku v čl. 16 ústavně garantována „svoboda myšlení, názoru, vyjadřování, tisku a pokojného shromažd’ováni'“ občanů.

Zásadní reforma, kterou v 90. letech prošla mediální scéna, vedla k její vysoké diverzifikaci a stala se jednou z nejsvobodnějších v regionu Asie. Cenzura je zakázána od roku 1998 přijetím zákona o svobodě sdělovacích prostředkü. Čl. 3 zakazuje nejen dohled nad obsahem

\footnotetext{
${ }^{2}$ Security Sector Governance in Mongolia. Almanac 2017, 149 s. [online], [cit. 9. 6. 2021]. Dostupné z: https://www.dcaf.ch/sites/default/files/publications/documents/Security\%20sector\%20governance\%20Mongolia $\% 20$ Almanac\%202017.pdf. S. 137.

${ }^{3}$ MOLEK, Politická práva, 2014, s. 32-33.
} 
veřejných informací, ale i zrrizování nebo financování jakékoli organizace umožňující sledovat nebo regulovat informace šířené v mediích. Čl. 2 dále stanoví, že svoboda tisku nesmí být žádnými zákonnými opatřeními omezena. V souladu s čl. 4 nesmí vládní organizace vlastnit žádné státní sdělovací prostředky. Revizi tohoto zákona, který od roku 1998 nedoznal změn, avizovala vláda $v$ rámci procesu Univerzálního periodického přezkumu stavu lidských práv zemi v roce 2020 zpracovat a předložit do Státního velkého churalu v roce 2021.

$\mathrm{Na}$ zvýšení ochrany svobody slova a tisku Státní velký chural (parlament) v roce 2005 přijal zákon o veřejnoprávním televizním a rozhlasovém vysilání. Zákon o ústřední volební komisi byl přijat $\mathrm{v}$ roce 2006, $\mathrm{v}$ roce 2011 parlament schválil revidovaný zákon o svobodě informací. Do právního rámce lze zařadit také zákon o politických stranách nebo protikorupčni zákon z let 2005 a 2006. Do roku 2019 nebylo přijato žádné legislativní opatření, které by řešilo problematiku oznamovatelů, tzv. whistleblowers, důvěrnost novinářských zdrojů, spravedlivou soutěž nebo transparentnost vlastnictví. Zákon o vysílání z 12. 12. 2019 již upravuje alespoň prostředí pro hospodářskou soutěž na trhu a vztahy týkající se vysílacích služeb. Mezi další regulační opatření patří zákon o komunikacích, zákon o rádiových vlnách, zákon o reklamé, zákon o autorských právech a právech souvisejících, zákon o obchodních licencích nebo volební legislativa upravující vztahy související s volební kampaní. Vláda rovněž přijala Národni protikorupčni program na léta 2017-2023 zaměřený na právní ochranu novinárú a dưvěrných novinářských zdrojů.

Podle Mediální rady Mongolska (MCM) v zemi chybí potřebná legislativní omezení týkající se koncentrace a vlastnictví médií. V zemi o 3,3 milionu obyvatel dnes existuje 488 médií (v roce 2020 na trhu působilo 140 TV a rozhlasových stanic, vč. veřejnoprávní Mongolské národní stanice (MNB), která vlastní 2 televizní a 4 rozhlasové stanice; soukromé vysílací společnosti disponují 18 televizními a 33 rozhlasovými stanicemi vysílajícími v Ulánbátaru a 56 televizními a 27 rozhlasovými stanicemi dostupnými místně po celé zemi ${ }^{4}$ a Facebook zde má 1,2 milionu uživatelů; ${ }^{5}$ celkově statistiky vykazují 2,6 milionů uživatelů sociálních médií. V lednu 2021 se zvýšil počet uživatelů internetu na 2,01 milionu obyvatel. ${ }^{6}$ Média jsou většinově soukromá a mají omezenou lokální působnost. Někdejší mongolský státní rozhlas a televize se v roce 2005 staly veřejnoprávní institucí zachovávající si u posluchačů a diváků vysokou popularitu. ${ }^{7}$ Země i nadále postrádá právní záruky redakční nezávislosti nebo regulační opatření na ochranu důvěrných zdrojů novinářů. Novináři mají pouze etickou povinnost chránit důvěrnost svých zdrojů, a to $\mathrm{v}$ souladu se standardy stanovenými $\mathrm{v}$ Mediálních etických zásadách ${ }^{8}$ schválených etickým výborem MCM 14. 4. 2015.

$\mathrm{Na}$ složitou situaci novinářů $\mathrm{v}$ Mongolsku poukázal ve své zprávě pro Úřad vysokého komisaře pro lidská práva $\mathrm{v}$ Ženevě zvláštní zpravodaj pro lidskoprávní obránce Michel Forst, který zemi navštívil v květnu 2019, ${ }^{9}$ Mimo jiné potvrdil, že média jsou koncentrována u omezeného počtu podnikatelských subjektů, a varoval před autocenzurou, ke které se uchylují zejména investigativní novináŕi kvưli obavám z hrozících ekonomických nebo politických

\footnotetext{
${ }^{4}$ OSCE. Mongolia - Presidential Election, 9 June 2021. ODIHR Needs Assessment Mission Report [online 28. 4. 2021], 18 s. [cit. 3. 6. 2021]. Dostupné z: https://www.osce.org/files/f/documents/0/3/484910_0.pdf. S. 12.

${ }^{5}$ Media Council of Mongolia (MCM). Mongolian Media Situation during the Pandemic [online 9. 10. 2020], [cit. 21. 5. 2021]. Dostupné z: https://www.osce.org/files/f/documents/7/1/466689.pdf.

${ }^{6}$ Digital 2021: Mongolia [online 12. 2. 2021], [cit. 8. 6. 2021]. Dostupné z: https://datareportal.com/reports/ digital-2021-mongolia.

7 Média v Mongolsku: https://www.mzv.cz/ulaanbaatar/cz/media_a_prezentace_zu/media_v_mongols ku/index.html.

${ }^{8}$ MCM. Mongolian Media Ethics Principles [online], [cit. 1. 6. 2021]. Dostupné z: https://www.mediacouncil $. \mathrm{mn} / \mathrm{p} / 14$.

${ }^{9}$ OHCHR. Visit to Mongolia 2019, UN Special Rapporteur on the situation of human rights defenders Michel Forst [online], [cit. 1. 6. 2021]. Dostupné z: https://www.ohchr.org/EN/NewsEvents/Pages/DisplayNews. aspx?NewsID=24603\&LangID=E.
} 
postihů a možných následných soudních žalob. Je na vládě podle Forsta, aby veřejnost ujistila o beztrestnosti kritiky působení vládních institucí a poskytla právní garance, že v takových př́padech nebude tato média či jedince pronásledovat, kriminalizovat ani obtěžovat.

Předpisy Komunikační regulační komise (Communications Regulatory Commission of Mongolia, CRC) týkající se digitálního obsahu a televizních a rozhlasových služeb ukládají obecná obsahová omezení, např́klad v př́ípadě extrémního násilí. Vláda však také jmenuje předsedu a členy $\mathrm{CRC}$, která uděluje licence na televizní a rozhlasové vysílání bez veřejné konzultace. Tento proces spolu s nedostatkem transparentnosti během procesu zadávání veřejných zakázek na licence znemožňuje spravedlivý př́istup $\mathrm{k}$ vysílacím frekvencím a nahrává osobám s politickými vazbami, což rovněž vede $\mathrm{k}$ určité autocenzuře novinářò ${ }^{10}$

Řada legislativních úprav, jako zákon o právech ditěte, zákon o prevenci kriminality, zákon o kontrole oběhu omamných a psychotropních látek, zákon o boji proti pornografii a zákon o prostituci, protialkoholni zákon, zákon o boji proti obchodováni s lidmi nebo zákon o autorských a souvisejících právech obsahují omezující ustanovení, která jsou uložena za účelem ochrany veřejného zájmu. Tato ustanovení nicméně vyvolávají obavy, aby za určitých okolností nebyla nadužita, protože terminologie a oblast působnosti nejsou jasně definovány, což může rovněž poškodit novináře. Omezují např́íklad obsah publikací a vysílání, a to v souladu s čl. 20 Mezinárodního paktu o občanských a politických právech, který ř́ká, že: „Jakákoli válečná propaganda je zakázána zákonem. Jakákoli národní, rasová nebo náboženská nenávist, jež představuje podněcování $\mathrm{k}$ diskriminaci, neprrátelství nebo násilí, musí být zakázána zákonem." Vzhledem k příliš široké nebo nedostatečně jasné definici zákonných ustanovení však existuje riziko jejich zneužití.

Nedostatečnost legislativní ochrany se projevuje i v neuspokojivém zajištění bezpečnosti novinářro 67 \% z 300 dotazovaných respondentů v roce 2019 uvedlo, že oni sami nebo jejich blízcí čelili minimálně jednou v kariéře nátlaku, obtěžování nebo zastrašování. 58 \% novinářů zaznamenalo poškození profesionálního vybavení a $36 \%$ se setkalo s nátlakem ze strany soudů a právo vymáhajících úředníků. U 18 \% došlo k př́imému fyzickému napadení. ${ }^{11}$

Z on-line debaty dne 3. 5. 2021 u př́ležitosti Světového dne svobody tisku organizované mongolskou nevládní Organizací Globe International Center (GIC) ve spolupráci s Národní komisí (NK) Mongolska pro UNESCO zazněla kritika vlády, která pro prevenci rizik ve vztahu $\mathrm{k}$ veřejnosti a zveřejňování oficiálních informací a údajů využívá především platformu Facebook (FB). Zveřejňování vládních politik a reakcí na šíření pandemie prostřednictvím sociálních sítí je považováno za efektivní způsob komunikace, ne však ze strany samotných médií. Vláda by měla účinně a efektivně podporovat mediální rozmanitost a prostréedí, ve kterém komerční, sociální a komunitní média spolupracují, aby se posílila efektivita celého mediálního ekosystému. Podle právního experta GIC Purevsuren Boldkhuyag/a vedl v roce 2020 monitoring právního prostředí médií, vč. ustanovení přijatých v souvislosti s pandemií COVID-19, jednotlivých případů porušení svobody projevu a přezkum př́padů občanskoprávní a trestní pomluvy projednávaných mongolským soudem ke zjištění 76 porušení občanských a politických práv. ${ }^{12}$

\section{VLASTNICTVÍ MÉDIÍ}

Monitoring vlastnictví médií představuje důležitý krok k nezávislosti. Občané mohou stěží posoudit spolehlivost informací, neznají-li jejich původce a stejně tak novináŕi nemohou

\footnotetext{
${ }^{10} 2020$ Country Reports on Human Rights Practices: Mongolia [online 30. 3. 2021], [cit. 3. 6. 2021]. Dostupné z: https://www.state.gov/reports/2020-country-reports-on-human-rights-practices/mongolia/.

${ }^{11}$ GIC. 2020 Universal Periodic Review Mongolia. Freedom of Opinion and Expression [online], [cit. 31.5. 2021]. Dostupné z: https://www.gic.mn/public/docs/publications/factsheet_Eng.pdf.

${ }^{12}$ GIC. Online Discussion Dedicated to World Press Freedom Day 2021 Highlighted Three Key Issues [online 5. 5. 2021], [cit. 31. 5. 2021]. Dostupné z: https://www.gic.mn/en/post/r/1598.
} 
náležitě vykonávat svou práci, jestliže nevědí, kdo ovládá společnost, pro kterou pracují. Rovněž mediální úřady nejsou schopny řešit nadměrnou koncentraci médií, pokud jejich vlastník není znám. Pouze jedno z deseti mongolských sdělovacích prostředků je aktivně transparentní ohledně svých vlastnických práv.

Koncepce národní bezpečnosti Mongolska z roku 2010 zapracovala ustanovení o transparentnosti vlastnictví a afilaci médií. K uzákonění tohoto ustanovení došlo v zákoně o vysílání platném ke 12. 12. 2019, který v čl. 19.1 stanoví, že: „Vlastnictví musí být transparentní, aby bylo zajištěno nezávislé, otevřené a etické vysílání." Rovněž CRC je v čl. 30.1.2 ukládáno za povinnost zveřejňovat informace o vlastnictví poskytovatelů služeb rozhlasového a televizního vysílání veřejnosti, a přijímat preventivní opatření proti nadměrné koncentraci vlastnictví. Přes právní povinnost zveřejňovat vlastnická práva, vlastnictví i politická př́íslušnost médií často nebývají veřejnosti odhaleny. ${ }^{13}$ Rovněž organizace Freedom House ve své zprávě z roku 2020 konstatuje, že vlastnictví médií zůstává v Mongolsku neprůhledné a předmětem mnoha spekulací. ${ }^{14}$

\section{STÁTNÍ TAJEMSTVÍ}

Od počátku demokratické transformace Mongolska v 90. letech procházely reformou i ozbrojené složky a vojenské právní prostředí. Civilně-vojenské vztahy však nebyly podrobeny řádné analýze a právní reformy $\mathrm{v}$ této oblasti tak cele neplní požadavky na demokratickou správu. V zemi se nadto stále zachovává tradice udržovat širokou škálu bezpečnostních a obranných otázek nepř́stupných veřejnosti.

Zákon o státním a úředním tajemství Státní velký chural přijal 1. 12. 2016, čímž došlo ke zrušení platnosti zákona o seznamu státnich tajemství z roku 2004 a zákona o státním tajemství z roku 1995. Nový zákon snížil období trvání ochrany vysoce důležitých utajovaných informací z 60 na 30 let. Některá jeho ustanovení však podle GIC vyžadují pozornost i nadále. Zákon překračuje rámec veřejného zájmu a rozsah utajovaných informací zůstává i v novém zákoně široký. Dotýká se státní politiky, hospodářství, vědy a techniky, obrany, zpravodajských služeb, kontrarozvědky, vymáhání práva a informační bezpečnosti. Vláda získala rovněž pravomoc určovat, kdy se jedná o utajované informace. Následně došlo k významnému navýšení počtu utajovaných informací z 60 v roce 2017 na 565 v roce 2019. Nezákonné získávání utajovaných informací kriminalizuje od roku 2017 trestní zákoník z roku (čl. 19.11), čímž se však současně ohrožuje právo veřejnosti na informace. Nerozpracované postupy pro úpravu seznamu státních a úředních tajemství představují další riziko umožňující trestní stíhání občanů a novinářủ a tlak na odhalení jejich důvěrných zdrojů podle trestního zákoníku. ${ }^{15}$

Čl. 5.1.2 zákona o státním a úředním tajemství obsahuje definici úředního tajemství: „Úřední tajemství prredstavují takové informace, které mohou v př́padě jejich zveřejnění a ztráty poškodit zájmy státního sektoru, státních organizací a jiných subjektů, a které jsou proto pod ochranou státu.“. Při jeho př́pravě však nebyla brána v potaz záruka práv na svobodu projevu a informace a položky zařazené do státního tajemství nezohledňují ve své úplnosti právní zájmy veřejnosti. Čl. 10.1.5 nadto vládě dává pravomoc určit informační tajemství, přenést, zveřejnit a kategorizovat utajované informace a měnit a prodlužovat ochranné lhůty. To je v rozporu s ústavními ustanoveními o právní ochraně státních tajemství a osobních údajů (čl. 16 Ústavy, bod 17) a vládě je tak umožněno klasifikovat jakékoliv informace jako státní nebo úřední tajemství, což může vést ke stíhání novinářů odhalujících korupční jednání. Jako státní tajemství jsou klasifikovány např́klad informace o finanční spolupráci vlády se zahraničními

\footnotetext{
132020 Country Reports on Human Rights Practices: Mongolia, 2021.

${ }^{14}$ Freedom House. Freedom in the World 2020 - Mongolia [online], [cit. 3. 6. 2021]. Dostupné z: https://freed omhouse.org/country/mongolia/freedom-world/2020.

${ }^{15}$ GIC. Media Freedom Report, May 2019 - April 2020. S. 48.
} 
zeměmi a mezinárodními organizacemi (bod 13.1.1. g, čl. 13), podrobné informace o státních návštěvách na vysoké úrovni (bod 13.1.1. d, čl. 13) nebo podrobné informace o mezinárodních smlouvách (bod 13.1.1. e, čl. 13). To brání veřejnosti zjistit, jaký druh a obsah důvěrných dohod vláda uzavírá s cizími státy a mezinárodními organizacemi. ${ }^{16}$

\section{KRIMINALIZACE POMLUVY}

$\mathrm{V}$ dalších legislativních úpravách je svoboda slova a tisku v Mongolsku regulována ne ve smyslu jejich záruk, nýbrž omezení. Občanský zákoník v čl. 21 ukládá, že ten, jenž zneváží důvěru v občana, pověst, čest a jeho důstojnost, musí pravost takových informací doložit. Trestní zákoník, v novelizaci z ledna 2020, kriminalizuje v hlavě XIII v čl. 13.14 šíření očividně nepravdivých informací urážejících pověst nebo čest právnické osoby pod trestem omezení práva cestovat nebo pracovat $\mathrm{v}$ délce 1-3 měsíců nebo pokuty. Poslanci tak rozšíríili omezení z roku 2017, kdy bylo do trestního zákoníku ze zákona o přestupcích přesunuto ustanovení kriminalizující šíření nepravdivých informací během voleb a znevážení pověsti politické strany či kandidáta (čl. 14.8). ${ }^{17}$

V listopadu 2020 Mediální rada Mongolska přezkoumala praktické dopady čl. 13.14 trestního zákoníku od počátku jeho platnosti. Potvrdila doporučení poslanců, kteří ji v této věci oslovili, že některé termíny je třeba $\mathrm{v}$ souladu $\mathrm{s}$ mezinárodními standardy revidovat. Pojmy jako „,zjevně nepravdivé informace“ a „nepravdivé/klamné informace“ vyžadují právní definici. Celý čl. 13.14 by měl být koncepčně pozměněn. Každý novinář, mediální organizace nebo občan, který někoho úmyslně pomlouvá šířením nepravdivých faktů a informací, by měl podle MCM nést odpovědnost. Škody a pomluvy způsobené v důsledku záměrně šířených zjevných nepravdivých informací tak mají zůstat v řešení trestního zákoníku. Neúmyslná pochybení se však mají řešit samoregulací médií v rámci čl. 3.1 zákona o svobodě médií. $\mathrm{V}$ souladu s principy novinářské etiky novináři mohou zveřejnit podezřelé či nepotvrzené informace, musí však také uvést, že se o spekulace a nepotvrzené informace jedná. ${ }^{18}$

Od vstupu ustanovení čl. 13.14 trestního zákoníku v platnost bylo ke konci listopadu 2020 na veřejném soudním portálu zveřejněno osm soudních rozhodnutí, přičemž více než polovinu žalobců tvořili politici a veřejní činitelé. Všichni obžalovaní byli shledáni vinnými za šíření nepravdivých informací hanobících čest a pověst stěžovatelů. Téměř všechny př́pady se týkaly online př́spěvků, komentářù a vyjádření na sociálních médiích. ${ }^{19}$ Podle organizace Reportéři bez hranic (RSF) je více než polovina př́ípadů pomluvy v Mongolsku vedena proti novinářům a médiím, což je nutí $\mathrm{k}$ cenzuře. ${ }^{20} \mathrm{Na}$ index svobody tisku, který RSF zveřejňuje, je Mongolsko zařazováno od roku 2013, kdy dosáhlo na 98. př́čku ze 179 zemí. V roce 2021 se už Mongolsko umístilo již na 68. místě ze 180 zemí. $^{21}$ Oproti roku 2020, kdy obsadilo 73 pozici, tedy poté, co v roce 2019 prrijalo zákon o vysílání, si polepšilo o celých 5 příček. ${ }^{22}$

\section{SVOBODA MÉDIÍ V DOBĚ PANDEMIE COVID-19}

Mezi zákonná opatření relevantní pro zmírnění a řešení dopadů epidemie koronaviru v Mongolsku se řadí zákon o prevenci a potírání pandemie COVID-19 a snižování negativních dopadi̊ na společnost a ekonomiku přijatý 29. 4. 2020 (aktuálně platný do 30. 6. 2021; platnost může být prodlužována každých 6 měsíců), který zakazuje šíření

\footnotetext{
${ }^{16}$ Security Sector Governance in Mongolia, 2017, s. 140.

${ }^{17}$ ODIHR Needs Assessment Mission Report, 2021, s. 12.

${ }^{18}$ MCM. Dostupné z: https://www.mediacouncil.mn/a/187.

19 International Center for Non-profit Law. Mongolia [online 17. 3. 2021], [cit. 20. 5. 2021]. Dostupné z: https://www.icnl.org/resources/civic-freedom-monitor/mongolia.

${ }^{20}$ RSF. Defamation suits and self-censorship [online], [cit. 20. 5. 2021]. Dostupné z: https://rsf.org/en/mongolia.

${ }^{21}$ RSF. World Press Freedom Index [online], [cit. 20. 5. 2021]. Dostupné z: https://rsf.org/en/world-pressfreedom-index-2013.

${ }^{22}$ RSF. World Press Freedom Index [online], [cit. 20. 5. 2021]. Dostupné z: https://rsf.org/en/ranking/2021.
} 
„nepravdivých informací“ a zavazuje k poskytování „pravdivých a objektivních informací ze spolehlivých zdrojü“ (čl. 14.2); revize zákona o mimořádných situacích a zákona o prevenci katastrof, které zakazují šíření zjevně nepravdivých informací prostřednictvím novinářských médií i sociálních sítí (čl. 10.4.13, přijaté 4. 5. 2020); novela zákona o správních deliktech (čl. 5.13, přijatá 13. 5. 2020); jež se uplatní společně s čl. 13.14 trestního zákoníku v př́ípadě porušení těchto výše zmíněných zákonů. Tato zákonná opatření tak mohou mít omezující účinek na svobodu médií.

Průzkum MCM z roku 2021, do kterého se zapojilo 300 novinářů, zjistil, že od nabytí účinnosti opatření přijatých v souvislosti s pandemií COVID-19 bylo na svobodě tisku omezeno $59 \%$ dotázaných. Dvě třetiny dotázaných uvedly, že u většiny zveřejněných informací dominovaly vládní zdroje. Vláda by měla revidovat svá opatření v oblasti prevence a boje proti dezinformacím, včetně omezujících ustanovení o nepravdivých informacích $\mathrm{v}$ zákonech souvisejících s pandemií COVID-19, a zajistit, aby nebyly zneužíány $\mathrm{k}$ potlačování lidských práv a spravedlivé kritiky uplatňováním práv na informace a svobodu projevu. Měla by dále přijmout oficiální politiku podporující základní mediální a informační gramotnost a poskytnout potřebnou finanční podporu. ${ }^{23}$

23. 9. 2020 zrrídila Národní policejní agentura (NPA) nezávislé oddělení pro boj s nepravdivými informacemi s pravomocí prošetřovat údajně nepravdivé informace šířené prostřednictvím sociálních sítí, které by mohly ohrozit národní bezpečnost nebo poškodit čest a pověst jednotlivců. 25. 11. 2020 zveřejnila NPA prohlášení, že v souvislosti s omezujícími opatřeními přijatými po potvrzení prvního případu komunitního přenosu v zemi 11. 11. 2020 policie uložila tresty 590 fyzickým a právnickým osobám za uvádění veřejnost v omyl a za šíření nepravdivých informací prostřednictvím sociálních médií. S cílem zajistit dodržování přijatých mimořádných protiepidemických opatření vydala 11. 11. 2021 CRC na základě stanoveného postupu pro prevenci šíření online dezinformací o pandemii doporučení pro zpravodajské weby uzavřít sekci komentářủ u zpráv týkajících se COVID-19 a vyhnout se tak možnosti šiření zjevně nepravdivých informací a soukromých údajů jednotlivců. Kdo tato doporučení nedodrží, bude blokován. ${ }^{24}$

\section{MÉDIA A VOLBY}

Volební legislativu tvoří v Mongolsku volební zákon (25. 12. 2015), zákon o parlamentních volbách (20. 12. 2019), zákon o volbách do zastupitelstev krajů (ajmagů), hlavního města, okresů (somonů) a obcí (30. 1. 2020) a zákon o volbě prezidenta (24. 12. 2020). Zákon o parlamentních volbách (LPE), v části týkající se volební kampaně a propagace prostřednictvím tisku, rozhlasového vysílání, televize a digitálních médií stanoví, že oblasti pro komentáře uživatelů budou $\mathrm{v}$ digitálních médiích $\mathrm{v}$ období předvolební kampaně uzavřeny (čl. 47.3). Zákon o svobodě médií (čl. 3.1) dále stanoví, že „,mediální organizace by měly nést odpovědnost za informace, které zveřejňují a vysílají. LPE (čl. 46.19) však tuto odpovědnost částečně přenáší i na jejich zaměstnance a novináře, což je $\mathrm{v}$ rozporu s uvedeným ustanovením zákona o svobodě médií.

Navzdory zákazu státní cenzury v médiích podle zákona o svobodě médií, pouze mediální subjekty se zvláštní licencí mají podle LPE povoleno zapojit se do volební kampaně; v př́padě vysílání informací o volebních programech $\mathrm{v}$ pro tyto účely nepovolených televizních a rozhlasových vysíláních budou Komunikační regulační komisí udělené licence pozastaveny. O vládní cenzuře lze hovořit $\mathrm{i} v$ souvislosti $\mathrm{s}$ kontrolou $\mathrm{v}$ př́padě Úř́adu pro spravedlivou hospodářskou soutěž a ochranu spotřebitele (AFCCP) a CRC, které zůstávají

\footnotetext{
${ }^{23}$ GIC. Online Discussion Dedicated to World Press Freedom Day 2021 Highlighted Three Key Issues [online 5. 5. 2021], [cit. 31. 5. 2021]. Dostupné z: https://www.gic.mn/en/post/r/1598.

${ }^{24}$ GIC. Globe International Center asks Mongolia to uphold freedom of expression in pandemic response [online 28. 11. 2020], [cit. 31. 5. 2021]. Dostupné z: https://www.gic.mn/en/post/r/1560.
} 
vládními agenturami. V souvislosti se schvalováním volebních zákonů přijala Ústř̌ední volební komise (GEC) Mongolska postup týkající se vysílání programů volební kampaně v rádiích a televizních stanicích, postup pro využívání internetu pro volební kampaň a mechanismy dohledu. ${ }^{25}$ Zákony o parlamentních a prezidentských volbách nicméně neobsahují žádná ustanovení, která by explicitně vyžadovala oddělení pracovních povinností od aktivit kampaně.

LPE reguluje použivání online médií a sociálních sítí ve volební kampani a uděluje široké pravomoci GEC a CRC online kampaně sledovat a omezovat. Stanovené webové stránky a profily na sociálních sítích pro každého kandidáta, stranu a koalici musí být u CRC registrovány do tří dnů od registrace kandidáta. Používání neregistrovaných webů nebo profilů sociálních sítí pro volební kampaň je zakázáno a funkce komentářu na registrovaných webech kampaní musí být deaktivována. CRC může deaktivovat webové stránky kandidáta bez soudního příkazu, je-li zjištěno porušení, a to i na základě šiřrení nepravdivých informací, které napadají jiného kandidáta.

Účastníci předvolební hodnotící mise Organizace pro demokratické instituce a lidská práva (ODIHR) popsali před parlamentními volbami v Mongolsku (24. 6. 2020) praxi, kdy si soutěžící kandidáti kupují placený „,zpravodajský“ čas, který má být vysílán mezi obvyklými zpravodajskými segmenty, a který je třeba považovat za politickou reklamu. Soukromé sdělovací prostředky však mohou přidělit maximálně 60 minut politické reklamy na den a ne více než pět minut denně na informační pokrytí každého soutěžícího, což několik účastníků kritizovalo jako př́liš omezující redakční svobodu. Zákon o vysílání z roku 2019 udělil významné pravomoci CRC, ponechal však omezené kontrolní kompetence také AFCCP, který dohlíží na mediální pokrytí volebních kampaní, na dodržování zásad nestrannosti a rovného zacházení se soutěžícími, zákaz zveřejňovat průzkumy veřejného mínění před volbami nebo zákaz uzavírání smluv s politickými subjekty za př́znivé pokrytí. ${ }^{26}$

\section{ZÁVĚR}

Stav svobody médií v Mongolsku lze z regionálního pohledu hodnotit jako velmi dobrý a stále se zlepšující, což indikuje i jeho pohyb vzhůru po indexu svobody tisku organizace Reportéři bez hranic. Před Mongolskem se na indexu v roce 2020 umístily již jen Jižní Korea, Tchaj-wan a Japonsko. V Mongolsku však, přestože obecně respektuje zásady svobody tisku a plurality médií, je mediální prostředí sužováno např́klad střety zájmů, které brání vydavatelské nezávislosti, v mongolské legislativě je pak také řada opomenutí a nedokonalostí.

V rozporu s Mezinárodním paktem o občanských a politických právech mongolská legislativa např́iklad nezajistila v zákonu o telekomunikacích nezávislost CRC. Přes své původní kroky parlament vrátil pomluvu v roce 2017 do trestního zákoníku, což dále posílil v roce 2020 kriminalizací urážky cti a obchodní pověsti právnických osob, aniž by zajistil, že kritika nebo podávání zpráv o činnosti státních a krajských úřadů nebudou kriminalizovány, a tedy investigativní novináŕi mohou bez obav z trestu vykonávat svou práci, která je pro upevňování demokracie zásadní. Vláda doposud nezavedla právní ochranu pro důvěrně zdroje novinářů a pro oznamovatele (whistleblowers). Zákon o státním tajemství z roku 2016 neodpovídá rozsahem omezení práv zásadám legality, nezbytnosti a proporcionality. Nově přijatý zákon v souvislosti s pandemií COVID-19 spolu s novelizací zákonů o extrémních situacích a prevenci katastrof představují hrozbu cenzury médií a umenšení prostoru pro občanskou angažovanost, a to jak v online, tak off-line prostoru. Veřejnost by měla mít př́stup $\mathrm{k}$ aktuálním informacím a analýzám, a to nejen z vládních zdrojů. Zákon o státním a

\footnotetext{
${ }^{25}$ GIC. Media Freedom Report, May 2019 - April 2020, s. 16.

${ }^{26}$ OSCE. Mongolia - Parliamentary Elections, 24. 6. 2020. ODIHR Needs Assessment Mission Report [online 22. 4. 2020], 16 s. [cit. 3. 6. 2021]. Dostupné z: https://www.osce.org/files/f/documents/9/3/450535.pdf. S. 10.
} 
úředním tajemství by neměl omezovat př́istup $\mathrm{k}$ informacím pouhým usnesením vlády a vnitřními směrnicemi veřejných orgánů, ale pouze zákonem, a měl by reflektovat principy legitimity, nezbytnosti a přiměřenosti. Př́ípadná škoda způsobená odhalením utajených informací by měla být větší než veřejný zájem na jejich zpř́ístupnění.

Svoboda médií je v Mongolsku nepochybně jednou z nejvyšších v regionu Asie a její legislativní prostř̌edí se neustále rozvíjí. Je však zřejmé, že zájem vlády, poslanců, politických a ekonomických činitelů naráží na strop jejich ochoty více se otevřít veřejné společenské kontrole a přijmout, respektive prosazovat své vyšší závazky vůči veřejnosti. Nadto jak legislativní nedostatečností tak finančními a vlastnickými vlivy zamezují médiím lépe plnit roli veřejného supervizora. Státní velký chural by měl proto také jednat o prrijetí právních předpisů o uznávání a kategorizaci osobností veřejného života.

Mongolsko se rovněž ještě nevymanilo z důsledků hluboké humanitární krize 90 . let. Politici a volební lídři dneška tak lidem slibují především převzetí kontroly nad vlastním nerostným bohatstvím, což bylo i hlavní téma prezidentských voleb 9. 6. 2021. Většinou $68 \%$ hlasů zvítězil bývalý premiér Khurelsukh. Jeho dalšími politickými př́ísliby, vedle návratu nerostných surovin lidem, jsou pro jeho nadcházející šestiletý mandát např. rozvoj venkova, bezpečné bydlení, pokračující úsilí o snižování znečištění ovzduší, boj proti korupci nebo zdanění bohatých. Svoboda tisku zjevně není prioritou nového prezidenta Khurelsukha. Navíc Khurelsukh a jeho Mongolská lidová strana (MLS), které doposud coby nedávný premiér předsedal, tímto vítězstvím zcela zvrátili již tak narušenou rovnováhu vlády v zemi mezi MLS a Demokratickou stranou, která neuspěla s opětovným získáním prezidentského úřadu. V loňských parlamentních volbách MLS získala 62 ze 76 křesel; zastává úrad premiéra; vláda je složena výhradně z jejích zástupců; získala post primátora Ulánbátaru a 34 zastupitelů ze 45; jmenovala 13 z 21 guvernérů krajů (ajmagů) a v místních volbách zvítězila ve 185 z 330 okresů (somonů). S prezidentským úrradem tak MLS získala absolutní moc $\mathrm{v} z e m i$. Mocenskou provázanost dokládá postup vítězné MLS, která v průběhu předvolební kampaně ve prospěch svého kandidáta využila veškeré dostupné zdroje stranické i státní, zapojila všechny své ministry a například k převozu vybavení pro setkání kandidáta Khurelsukha s jeho voliči využívala nákladních vozů mongolské státní policie. Lze tak předpokládat, že další vývoj v oblasti svobody tisku a mediální sektoru bude záviset především na tlaku mongolské občanské společnosti, mezinárodních organizací a samotných médií.

\section{Použitá literatura}

1. 2020 Country Reports on Human Rights Practices: Mongolia. Dostupné z: https://www.state.gov/reports/2020-country-reports-on-human-rights-practices/mo ngolia/.

2. Freedom House. Freedom in the World 2020 - Mongolia. Dostupné z: https://freedomhouse.org/country/mongolia/freedom-world/2020.

3. Globe International Center. Media Freedom Report, May 2019 - April 2020, $52 \mathrm{~s}$. Dostupné z: https://www.gic.mn/public/docs/freedom_report/media_freedom_repor t_2019_en.pdf. S. 19-21.

4. Globe International Center. Online Discussion Dedicated to World Press Freedom Day 2021 Highlighted Three Key Issues. Dostupné z: https://www.gic. $\mathrm{mn} / \mathrm{en} / \mathrm{post} / \mathrm{r} / 1598$.

5. Globe International Center. Globe International Center asks Mongolia to uphold freedom of expression in pandemic response. Dostupné z: https://www.gic.mn/en/po $\mathrm{st} / \mathrm{r} / 1560$.

6. Media Council of Mongolia. Mongolian Media Ethics Principles. Dostupné z: https://www.mediacouncil.mn/p/14. 
7. Media Council of Mongolia. Mongolian Media Situation during the Pandemic. Dostupné z: https://www.osce.org/files/f/documents/7/1/466689.pdf.

8. MOLEK, Pavel. Politická práva. 1. vyd. Praha: Wolters Kluwer, 2014, 616 s. ISBN 978-80-7478-502-3.

9. OHCHR. Visit to Mongolia 2019, UN Special Rapporteur on the situation of human rights defenders Michel Forst. Dostupné z: https://www.ohchr.org/EN/NewsEv ents/Pages/DisplayNews.aspx?NewsID=24603\&LangID=E.

10. OSCE. Mongolia - Parliamentary Elections, 24. 6. 2020. ODIHR Needs Assessment Mission Report. Dostupné z: https://www.osce.org/files/f/documents/9/3/450535.pdf.

11. OSCE. Mongolia - Presidential Election, 9 June 2021. ODIHR Needs Assessment Mission Report. Dostupné z: https://www.osce.org/files/f/documents/0/3/48491 0_0.pdf.

12. Reporters without borders. Defamation suits and self-censorship. Dostupné z: https://rsf.org/en/mongolia.

13. Reporters without borders. World Press Freedom Index. Dostupné z: https://rsf.org/en/ranking/2021.

14. Security Sector Governance in Mongolia. Almanac 2017, 149 s. Dostupné z: https://www.dcaf.ch/sites/default/files/publications/documents/Security\%20sector\%2 Ogovernance\%20Mongolia\%20Almanac\%202017.pdf.

\section{Kontaktní údaje}

Mgr. Hana Brodská, LL.M.

Ministerstvo zahraničních věcí ČR

Loretánské nám. 5, Praha 1, 11800

Tel: 602277802

email: hanabrodska@post.cz 


\title{
CORPORATE GOVERNANCE A ZÁKLADNÉ POVINNOSTI ŠTATUTÁRNYCH ORGÁNOV ${ }^{1}$
}

\section{CORPORATE GOVERNANCE AND FUNDAMENTAL DUTIES OF STATUTORY BODIES}

\author{
Michal Sokol
}

\begin{abstract}
Abstrakt
Autor sa v predkladanom príspevku zameriava na charakteristiku corporate governance a analýzu základných povinností členov štatutárnych orgánov podl'a slovenského právneho poriadku. Pozornost' autora je koncentrovaná na povinnost' štatutárnych orgánov postupovat's odbornou starostlivost'ou a povinnost' lojality, a to v kontexte zodpovednosti členov štatutárnych orgánov za škodu. V danom kontexte autor analyzuje aj pravidlo podnikatel'ského úsudku a jeho prítomnost' v slovenskom práve.

Kl'účové slová: corporate governance, lojalita, odbornost', zodpovednost' štatutárneho orgánu

Abstract

In the presented paper, the author focuses on the characteristics of corporate governance and analysis of the fundamental duties of members of statutory bodies under Slovak law. The author's attention is focused on the obligation of statutory bodies to proceed with professional care and the duty of loyalty, in the context of the liability of members of statutory bodies for damage. In this context, the author also analyzes the business judgment rule and its presence in Slovak law.
\end{abstract}

Key words: corporate governance, loyalty, expertise, liability of statutory body

\section{POJEM CORPORATE GOVERNANCE}

Základným predpokladom pochopenia predstavovanej problematiky je komplexné vymedzenie anglického pojmu corporate governance. V súčasnom ponímaní možno konštatovat', že ide o určitý druh súvisiacich a vzájomne podmienených pravidiel, prostredníctvom ktorých sa zabezpečuje riadne fungovanie obchodnej spoločnosti. ${ }^{2}$ Odborná literatúra uvádza, že predmetný termín sa postupne začal používat' už od 80 . rokov minulého storočia. $^{3}$ Je však nutné poznamenat', že corporate governance predstavuje moderné pomenovanie javov a súvislostí, ktoré sú v modifikovanej podobe v spoločnosti prítomné podstatne dlhšie. Podl'a Moravca a Andreisovej základným prvkom corporate governance je oddelenie „vlastníctva od správy“, pričom s uvedeným sa možno stretnút' už pri zámorských plavbách, kedy investori poverili kapitána lode nielen jej riadením, ale aj rozhodovaním o d’alších podstatných záležitostiach, ako napríklad rozdelenie výnosov. ${ }^{4}$

\footnotetext{
${ }^{1}$ Táto práca bola podporená Agentúrou na podporu výskumu a vývoja na základe Zmluvy č. APVV-19-0424. This work was supported by the Slovak Research and Development Agency under the Contract no. APVV-190424.

2 OVEČKOVÁ, O., CSACH, K., ŽITŇANSKÁ, L. Obchodné právo 2. Obchodné spoločnosti a družstvo. Bratislava: Wolters Kluwer SR s. r. o., 2020. s. 224.

${ }^{3}$ OKRUHLICA, F. Vlastnícka správa spoločnosti (Corporate governance). 1. vydanie. Bratislava: Iura Edition, spol. s r. o., 2013. s. 19.

${ }^{4}$ MORAVEC, T., ANDREISOVÁ, L. Obchodní společnosti pohledem Corporate Governance. 1. vydání. Praha: GRADA Publishing, a.s., 2021. s. 112.
} 
Z terminologického hl'adiska sa zvykne pojem corporate governance do slovenského jazyka prekladat' ako „správa a riadenie obchodnej spoločností“. Po hlbšom skúmaní predmetnej problematiky však možno ustálit', že univerzálna definícia slovného spojenia corporate governance neexistuje a je určená iba doktrinálne, pričom sa líši v závislosti od konkrétneho autora. Na strane druhej možno konštatovat', že väčšina odborníkov sa v zásade zhodne na tom, čo tvorí podstatný obsah daného pojmu. Bez ohl'adu na uvedené skutočnosti je nesporné, že problematika corporate governance nepredstavuje výsostne právnu kategóriu, ba naopak, má vysoko interdisciplinárny charakter a zohl’adňuje aj pravidlá ekonómie, etiky, sociológie a d'alších disciplín. V predkladanom príspevku sa však zameriame najmä právny rozmer predostieranej oblasti.

Ako sme už uviedli, súčasné poňatie corporate governance predstavuje určitý súhrn pravidiel a princípov, ktorých úlohou je zabezpečit' správne fungovanie obchodných spoločností (prevažne s rozptýlenejšou vlastníckou štruktúrou). V rámci ich života totiž možno badat' vznik záujmov subjektov v rôznom postavení (vlastníci podielov/akcií, zamestnanci, štatutárne orgány, veritelia a pod.), medzi ktorými môže dôjst' k vzájomnému konfliktu. Zjednodušene povedané, pravidlá a princípy corporate governance by mali prispiet' $\mathrm{k}$ predídeniu, obmedzeniu, resp. $\mathrm{k}$ riešeniu potenciálnych konfliktov medzi spomenutými skupinami osôb. Zdrojom predmetných pravidiel sú právne predpisy, zakladajúce dokumenty či stanovy obchodných spoločností, dohody medzi spoločníkmi, ale aj kódexy vypracované rôznymi subjektmi.

V predmetných intenciách sa $\mathrm{v}$ odbornej literatúre takmer so železnou pravidelnost'ou skloňuje meno Adrian Cadbury, ktorý v roku 1992 vytvoril tzv. Cadburyho kódex, predstavujúci prvý ucelený dokument zameraný na dobrú správu obchodných spoločností. ${ }^{5}$ Zameral sa predovšetkým na úlohu správnej rady (the board), jej vnútornú kontrolu, audit a podobne. ${ }^{6}$ Vývoj pravidiel dobrej správy obchodných spoločností na medzinárodnej úrovni pokračoval prijatím princípov správy a riadenia spoločností OECD, a to v rokoch 2009, 2004 a najnovšie 2015 (G20/OECD Principles of Corporate Governance ${ }^{7}$ ). Predmetný dokument obsahuje sedem základných princípov, ktoré majú napomôct' tvorcom politík vylepšit' právny a inštitucionálny rámec pre správu a riadenie obchodných spoločností; zároveň však uvádza, že tieto princípy nemajú záväzný charakter a nemajú za ciel' vytvorit' presný návod pre národných legislatívcov. ${ }^{8}$

Je potrebné podotknút', že ostatná verzia princípov OECD sa stala vzorom pre vypracovanie d'alších dokumentov. V tomto smere možno poukázat' na Kodex správy řízení společností ČR, ktorý bol vypracovaný spoločnost'ami Czech Institute of Directors a Deloitte a d'alšími odborníkmi. ${ }^{9}$ V podmienkach Slovenskej republiky možno spomenút' neziskové občianske združenie Slovenská asociácia corporate governance, združujúce členov štatutárnych a kontrolných orgánov obchodných spoločností, ale aj akademikov a manažérov. ${ }^{10}$ Obdobne,

\footnotetext{
${ }^{5}$ Bližšie pozri MORAVEC, T., ANDREISOVÁ, L. Obchodní společnosti pohledem Corporate Governance. 1. vydání. Praha: GRADA Publishing, a.s., 2021. s 116. ako aj OKRUHLICA, F. Vlastnícka správa spoločnosti (Corporate governance). 1. vydanie. Bratislava: Iura Edition, spol. s r. o., 2013. s. 19.

${ }^{6}$ Cadburyho kódex, dostupné na webovej adrese: https://ecgi.global/sites/default/files//codes/docum ents/cadbury.pdf

7 Dostupné na webovej adrese: https://read.oecd-ilibrary.org/governance/g20-oecd-principles-of-corporategovernance-2015_9789264236882-en\#page1

${ }^{8}$ OECD. G20/OECD Principles of Corporate Governance. OECD Publishing. Paris, 2015. s. 9-11.

${ }^{9}$ MORAVEC, T., ANDREISOVÁ, L. Obchodní společnosti pohledem Corporate Governance. 1. vydání. Praha: GRADA Publishing, a.s., 2021. s. 117.

${ }^{10}$ Bližšie: https://sacg.sk/
} 
aj táto organizácia po vzore OECD vydala v roku 2016 Kódex správy spoločností na Slovensku. ${ }^{11}$

Okrem načrtnutých súvislostí je dôležité poukázat' na prostriedky pôsobenia corporate governance. Moravec a Andreisová z hl'adiska klasifikácie rozlišujú vnútorné a vonkajšie nástroje:

I. vnútorné nástroje

a) práva a povinnosti spoločníkov,

b) organizačná štruktúra spoločnosti,

c) pravidlo podnikatel'ského úsudku a inštitút „péče řádneho hospodáře“ , ${ }^{12}$

II. vonkajšie nástroje

a) verejné publikovanie stanovených informácii o obchodnej spoločnosti,

b) pôsobenie trhu,

c) koncernové právo,

d) externý audit. ${ }^{13}$

Z uvedeného členenia je zrejmé, že corporate governance inkorporuje množstvo čiastkových aspektov, ktoré vytvárajú koherentný celok. Z dôvodu zjavne rozsiahleho záberu predmetnej problematiky sa $\mathrm{v}$ nasledujúcich častiach predloženého príspevku budeme venovat' iba odbornej, resp. náležitej starostlivosti štatutárnych orgánov, povinnosti lojality a pravidlu podnikatel'ského úsudku.

Napriek tomu však považujeme za osobitne dôležité v stručnosti poukázat' na úlohu trhu pri správe obchodných spoločností, ktorá má podl’a nášho názoru osobitný význam. V uvedenom kontexte totiž v zásade platí pomerne jednoduché pravidlo: „Je-li totiž daná korporace ř́zená špatně, vetšinou zaostáva za svými konkurenty, čímž dochádzí k přirozenému poklesu cen jejich akcií. Ten pak logicky vyvoláva odchod akcinářu “"14. Trh teda predstavuje regulujúci prvok, ktorý je spôsobilý „odstavit'“ subjekty, ktoré v dôsledku zlého riadenia a správy nie sú schopné priniest’ želaný výsledok.

\section{POVINNOSTI ŠTATUTÁRNYCH ORGÁNOV KAPITÁLOVÝCH OBCHODNÝCH SPOLOČNOSTÍ}

Členovia štatutárneho orgánu, ktorý koná v mene obchodnej spoločnosti, musia dodržiavat' určité povinnosti, ${ }^{15}$ ktoré im vyplývajú nielen z právnych predpisov, ale aj zakladajúcich

\footnotetext{
${ }^{11}$ Dostupné na webovej adrese: https://sacg.sk/wp-content/uploads/2019/10/web_kodex_2016_02.pdf

${ }^{12}$ Slovenský právny poriadok na rozdiel od českej úpravy vyslovene nepoužíva slovné spojenie „starostlivost' riadneho hospodára“. Možno však konštatovat', že ekvivalentom je povinnost' štatutárneho orgánu postupovat' s náležitou, resp. odbornou starostlivost'ou. K rozdielom a spoločným znakom predmetných pojmov pozri DURAČINSKÁ, J. Povinnost' starostlivosti riadneho hospodára alebo povinnost' odbornej starostlivosti z hl'adiska právnej komparatistiky. In: Dny práva - 2012 - Days of Law. 6. ročník mezinárodní konference pořádané Právnickou fakultou Masarykovy univerzity. Sborníky př́íspěvků. Brno: Masarykova univerzita, 2013. dostupné na webovej adrese: https://www.law.muni.cz/sborniky/dny_prava_2012/index.html

13 Spracované podla MORAVEC, T., ANDREISOVÁ, L. Obchodní společnosti pohledem Corporate Governance. 1. vydání. s. 114.

${ }^{14}$ MORAVEC, T., ANDREISOVÁ, L. Obchodní společnosti pohledem Corporate Governance. 1. vydání. Praha: GRADA Publishing, a.s., 2021. s. 113.

${ }^{15}$ K predmetnej problematike pozri aj DOLNÝ, J. Zodpovednost' štatutárneho orgánu za nepodanie návrhu na vyhlásenie konkurzu: komparácia slovenského a nemeckého právneho poriadku. In: Právo, obchod, ekonomika 9. Košice: Univerzita Pavla Jozefa Šafárika v Košiciach. 2019. s. 111-118.
} 
dokumentov $^{16}$ či stanov obchodnej spoločnosti, zmluvy o výkone funkcie prípadne z rozhodnutia valného zhromaždenia. ${ }^{17} \mathrm{~S}$ ohl'adom na zameranie príspevku však budeme analyzovat' iba povinnost' odbornej/náležitej starostlivosti a povinnosti lojality.

\subsection{Povinnost' odbornej/náležitej starostlivosti a povinnost' lojality}

Povinnost' postupovat' s odbornou, resp. náležitou starostlivost'ou a v súlade so záujmami spoločnosti a jej spoločníkov (akcionárov) je legislatívne zakotvená v ustanoveniach $\S 135 \mathrm{a} a$ $\S 194$ ods. 5 zákona č. 513/1991 Zb. Obchodný zákonník v znení neskorších predpisov (d’alej len „ObZ“ alebo „Obchodný zákonník“). Úvodom poukazujeme na to, že ObZ hovorí o odbornej starostlivosti pri konatel'och spoločnosti s ručením obmedzeným a o náležitej starostlivosti pri členoch predstavenstva akciovej spoločnosti. V d'alšom texte budeme tieto povinnosti označovat' súhrnne ako „odborná starostlivost““.

Obchodný zákonník pojem odborná starostlivost' nedefinuje. V širších súvislostiach iba exemplifikatívne uvádza, že štatutárny orgán je povinný zaobstarat' si a zohl'adnit' všetky podklady týkajúce sa predmetu rozhodnutia, zachovávat' mlčanlivost' vo vzt'ahu ku skutočnostiam, ktorých vyzradenie by mohlo spôsobit' škodu spoločnosti alebo spoločníkom (akcionárom) a neuprednostnit' svoje záujmy alebo záujmy tretích osôb pred záujmami spoločnosti. $^{18}$

Odbornost' $\mathrm{v}$ rámci konania štatutárneho orgánu do istej miery doplńa rozhodovacia činnost' Najvyššieho súdu Slovenskej republiky (d’alej len „NS SR“), ktorý uvádza: „Konatelia sú povinni vykonávat' svoju pôsobnost' štatutárneho orgánu $s$ odbornou starostlivostou $a v$ súlade so záujmami spoločnosti a všetkých jej spoločníkov. Konatelia teda majú konat' odborne a lojálne voči spoločnosti a jej spoločnikom. Odbornost' sa vzt'ahuje na schopnost' rozhodovania so znalostou veci, v celej zložitosti problematiky podnikania spoločnosti. Odbornost' zahŕňa aj vytvorenie zodpovedajúcej informačnej sústavy spoločnosti v záujme ziskavania všetkých informácií relevantných vo vzt’ahu k predmetu rozhodovania. "19

Pojem „odborník“ je vo všeobecnej rovine vnímaný ako istý prívlastok osoby pôsobiacej v určitej oblasti s výsledkami hodnými osobitného uznania. V intenciách povinnosti člena štatutárneho orgánu, ktorý v zásade spravuje cudzí majetok, však odbornost' nemožno vnímat' ako požiadavku vo vzt’ahu k jeho vzdelaniu či skúsenostiam v predmete podnikania. Ponímanie odbornosti je nutné vzt'ahovat' na prístup danej osoby k samotnému výkonu funkcie štatutárneho orgánu, spočívajúcej napríklad v zaobstaraní a zohl'adnení dostatočného množstva informácií pre uskutočnenie konkrétneho rozhodnutia. Uvedené znamená, že člen štatutárneho orgánu nemusí byt' v pravom slova zmysle odborník, resp. profesionál v predmete podnikania obchodnej spoločnosti. Opačný výklad by v praktickej rovine znamenal, že výkon funkcie člena štatutárneho orgánu by bol podmienený splnením podmienky určitého vzdelania či iných znalostí. ${ }^{20}$ Odbornost'ou tak v predmetnom kontexte

\footnotetext{
${ }^{16}$ Bližšie k spoločenskej zmluve pozri aj MICHAL'OV, L. Zmena spoločenskej zmluvy spoločnosti s ručením obmedzeným: Vybrané problémy a rekodifikačné tendencie. In Právo, obchod, ekonomika. Zborník vedeckých prác. Košice: Univerzita Pavla Jozefa Šafárika v Košiciach, 2011. s. 493 a nasl.

17 OVEČKOVÁ, O., CSACH, K., ŽITŇANSKÁ, L. Obchodné právo 2. Obchodné spoločnosti a družstvo. Bratislava: Wolters Kluwer SR s. r. o., 2020. s. 264.

${ }^{18}$ Ustanovenie $\S 135 \mathrm{a}$ a $\S 194$ ods. 5 ObZ.

${ }^{19}$ Uznesenie Najvyššieho súdu Slovenskej republiky, sp. zn. 1 Obo 16/2008, zo dňa 19.02.2009.

20 Je potrebné poznamenat', že od uvedených súvislostí je nutné odlišovat' napríklad povinnost' spíňat' podmienku odbornej, resp. inej spôsobilosti pri výkone určitých druhov podnikatel'ských činností (napríklad viazané či remeselné živnosti).
} 
možno rozumiet' dodržanie právnych predpisov, ako aj realizáciu informovaných rozhodnutí. $^{21}$

Okrem povinnosti odbornej starostlivosti majú členovia štatutárnych orgánov aj povinnost' lojality. Z už citovaného rozhodnutia NS SR taktiež vyplýva, že: „Lojalita vo vzt’ahu $k$ spoločnosti a jej spoločníkom zahŕn̆a povinnost' zachovávania mlčanlivosti o dôverných informáciách a skutočnostiach, ktorých prezradenie by mohlo spôsobit' spoločnosti škodu alebo ohrozit' jej záujmy alebo záujmy jej spoločníkov akcionárov, ako aj povinnost' neuprednostňovat'svoje záujmy, záujmy len niektorých spoločníkov alebo záujmy tretích osôb pred záujmami spoločnost’ami. “.22

Ustanovenia $\S 135 \mathrm{a}$ a $\S 194$ ods. 5 ObZ okrem povinnosti odbornej starostlivosti de facto zakotvujú aj povinnost' lojality. Členovia štatutárnych orgánov musia zachovávat' mlčanlivost' o niektorých skutočnostiach a pred svojimi záujmami a záujmami tretích osôb uprednostňovat' záujmy samotnej spoločnosti, resp. jej spoločníkov (akcionárov). Okrem uvedeného však možno do tejto kategórie subsumovat' aj zákaz konkurencie či povinnost' zabezpečit' predchádzajúci súhlas dozornej rady v prípadoch podl’a ustanovenia $§ 196 \mathrm{a} O b Z{ }^{23}$

\subsection{Zodpovednost' štatutárnych orgánov za škodu a pravidlo podnikatel'ského úsudku}

Ako sme už viackrát uviedli, členovia štatutárnych orgánov by v ideálnom prípade mali postupovat' $\mathrm{v}$ zmysle im stanovených povinností, vyplývajúcich z rôznych prameňov. Prirodzene, porušenie týchto povinností so sebou prináša určitú formu postihu, resp. plejádu rôznych následkov. ${ }^{24}$ Jedným $\mathrm{z}$ nich je zodpovednost' člena štatutárneho orgánu za spôsobenú škodu, ktorá má charakter objektívnej zodpovednosti a predstavuje špeciálnu právnu úpravu $\mathrm{k}$ všeobecnej úprave zodpovednosti za škodu obsiahnutú v ObZ. ${ }^{25}$

Konanie člena štatutárnych orgánov je nutné posudzovat' z hl'adiska splnenia jeho povinností. V kontexte predloženého príspevku tak bude v konkrétnom prípade nutné ustálit', či konanie člena štatutárneho orgánu napíňalo požiadavku odbornej starostlivosti a či je možné takéto konanie považovat' za lojálne.

V danom smere je nutné analyzovat' tzv. business judgement rule, teda pravidlo podnikatel'ského úsudku. Výkon podnikatel'skej činnosti, motivovaný dosahovaním zisku, je častokrát spojený so zvýšeným rizikom straty či neúspechu (podnikatel'ské riziko). Na strane druhej je však nutné sa zamysliet' nad skutočnost'ou, resp. hranicou, kedy možno za neúspech sankcionovat' konkrétnu osobu a kedy je takýto postup neprípustný.

V prvom rade si je potrebné uvedomit', že v podnikatel'skej sfére nie je možné vždy a presne predpokladat' budúci vývoj a trendy. Za daných okolností však možno mat' určitú predstavu, ktorá môže byt' determinantom pre realizáciu d'alších investícií alebo smerovania podnikania konkrétneho subjektu. Avšak v prípade, ak sa následne predmetná predstava prejaví ako nie úplne zodpovedajúca reálnemu stavu, ktorý nastal, môže to viest' k stratám. Zjednodušene

\footnotetext{
${ }^{21}$ CSACH, K. Postavenie a zodpovednost' člena orgánu SOE delegovaného verejnou mocou. In: CSACH, K., HAVEL, B. (eds). Corporate governance společností s účastí státu. Praha: Wolters Kluwer ČR, 2020. s. 21.

${ }^{22}$ Uznesenie Najvyššieho súdu Slovenskej republiky, sp. zn. 1 Obo 16/2008, zo dňa 19.02.2009.

${ }^{23}$ DURAČINSKÁ, J. Povinnost' lojality člena štatutárneho orgánu verzus jeho povinnost' riadit' sa pokynmi. In: HURYCHOVÁ, K., BORSÍK, D. (eds.). Corporate governance. 1. vydání. Praha: Wolters Kluwer, 2015. s. 138.

${ }^{24}$ Bližšie pozri aj HUSÁR, J. Zodpovednost' členov štatutárnych orgánov kapitálových obchodných spoločností a ochrana záujmov ich spoločníkov (akcionárov) a veritel’ov. In: Vybrané otázky zodpovednosti za škodu spôsobenú nesprávnym profesijným postupom. Košice: Univerzita Pavla Jozefa Šafárika, 2010. s. 93-122.

${ }^{25}$ SUCHOŽA, J. - HUSÁR, J. a kol. Obchodné právo. Prvé vydanie. Bratislava: IURA EDITION, 2009. s. 500.
} 
povedané, je prakticky nemožné v každej situácii predpokladat' presné dopady konkrétneho rozhodnutia.

Pravidlo podnikatel'ského úsudku vo svojej podstate a za istých okolností pripúšsta určitú mieru riskovania. Podl'a Geržovej, pravidlo podnikatel’ského úsudku vychádza z judikatúry súdov USA a je založené na teste s troma aspektmi:

a) informovanost' štatutárneho orgánu,

b) konanie štatutárneho orgánu v dobrej viere,

c) odôvodnenie záujmu obchodnej spoločnosti. ${ }^{26}$

V prípade, ak člen štatutárneho orgánu uvedené predpoklady naplnil, nemožno jeho konanie posúdit' ako konanie v rozpore s povinnost'ou postupovat' odborne. Slovenský právny poriadok obdobu daných pravidiel obsahuje v ustanovení $\S 135 \mathrm{a}$ ods. 3 či $\S 194$ ods. 7 ObZ ako možnost' liberácie člena štatutárneho orgánu, podl'a ktorých konatel' (člen predstavenstva) nezodpovedá za škodu, ak preukáže, že postupoval pri výkone svojej pôsobnosti s odbornou starostlivost'ou a v dobrej viere, že koná v záujme spoločnosti. ${ }^{27}$

NS SR v predmetnej súvislosti ustálil: „,Konatel’ nebude zodpovedat’ za škodu, ak preukáže, že postupoval pri výkone funkcie s odbornou starostlivost'ou, nakol'ko v takomto prípade nedôjde $k$ porušeniu povinnosti, a teda naplneniu predpokladu vzniku povinnosti k náhrade škody. $V$ prípade, že neunesie dôkazné bremeno o tom, že konal s odbornou starostlivostou, zákon zavádza osobitný liberačný dôvod, a to subjektívnej povahy. Týmto dôvodom je dobrá viera konatel'a, že koná $v$ záujme spoločnosti. Takýmto spôsobom je záujem spoločnosti vždy preferovaný pred záujmom spoločníkov. Týmto mechanizmom právnej úpravy zákonodarca ponecháva konatelom tzv. právo na omyl pri rozhodovaní. Vecná správnost' rozhodnutia závisí od mnohých okolností a nemôže byt' priradená bez splnenia d'alšich podmienok automaticky na vrub konatel'ov. “28

Ako sme už uviedli, zodpovednost' člena štatutárneho orgánu má charakter objektívnej zodpovednosti, teda rozhodujúce je samotné porušenie povinnosti, nie jeho následok. Na strane druhej, uplatnenie liberačných dôvodov obsiahnutých v ObZ vyúst'uje do komplexného posúdenia relevantných aspektov konania člena štatutárneho orgánu, ktoré je potrebné analyzovat' vo vzájomnej súvzt'ažnosti. V danom smere je prirodzené, že splnenie povinností člena štatutárneho orgánu sa posudzuje ku dňu realizácie konkrétneho rozhodnutia, teda spätne. ${ }^{29} \mathrm{Z}$ uvedenej konštrukcie je zrejmé, že dôkazné bremeno pri preukazovaní naplnenia podmienok liberácie spočíva na samotnom členovi štatutárneho orgánu.

Z komparatívneho hl'adiska možno poukázat' na českú právnu úpravu, explicitne obsahujúcu povinnost' tzv. „péče řádneho hospodáře“. Zákon č. 90/2012 Sb. o obchodních společnostech a družstvech (d’alej len „zákon o obchodních korporacích“) v ustanovení $§ 51$ ods. 1 uvádza, že: „Pečlivě a s potřebnými znalostmi jedná ten, kdo mohl při podnikatelském rozhodování v dobré víre rozumně predpokládat, že jedná informovaně a v obhajitelném zájmu obchodní korporace; to neplatí, pokud takovéto rozhodování nebylo učiněno s nezbytnou loajalitou. “30

\footnotetext{
26 Spracované podl'a GREŽOVÁ, R. Odborná starostlivost' člena štatutárneho orgánu. In: FINANČNÝ MANAŽÉR. Slovenská asociácia podnikových finančníkov. Bratislava, 2015. ISSN 1335-5813. Ročník XV. číslo 1.

${ }^{27}$ Ustanovenie $\S 135$ a ods. 3 a $§ 194$ ods. 7 ObZ.

${ }^{28}$ Uznesenie Najvyššieho súdu Slovenskej republiky, sp. zn. 1 Obo 16/2008, zo dňa 19.02.2009.

${ }^{29}$ OVEČKOVÁ, O., CSACH, K., ŽITŇANSKÁ, L. Obchodné právo 2. Obchodné spoločnosti a družstvo. Bratislava: Wolters Kluwer SR s. r. o., 2020. s. 267.

${ }^{30}$ Ustanovenie $§ 51$ ods. 1 zákona o obchodních korporacích.
} 
Zároveň v ustanovení § 52 ods. 1 stanovuje: „Při posouzení, zda člen voleného orgánu jednal s péči rádného hospodáře, se vždy přihlédne $k$ péči, kterou by v obdobné situaci vynaložila jiná rozumně pečlivá osoba, byla-li by v postavení člena obdobného orgánu obchodni korporace. “31

Pri posudzovaní naplnenia podmienok povinnosti péče řádneho hospodáře Česká právna úprava vytvára koncept určitej domnelej „rozumně pečlivej“ osoby. ${ }^{32}$ Predmetným spôsobom dochádza k objektivizácii určitých predpokladov a očakávaní, resp. k vytvoreniu určitej normy či štandardu, ktorý bude spoločne pri zohl'adnení konkrétnych skutkových okolností prípadu vodítkom pre ustálenie splnenia či nesplnenia stanovených povinností. Avšak pre zachovanie komplexného pohl'adu je nutné podotknút', že podl'a Moravca a Andreisovej v korporačnej praxi zvyknú byt' členovia štatutárneho orgánu menovaní do svojich funkcií práve z dôvodu ich odborných skúseností a znalostí, čo prirodzene zvyšuje očakávania a nároky na výkon ich činnosti. Z uvedeného dôvodu tak aj samotná požiadavka postupu dodržujúceho povinnost' péče řádneho hospodáře a tomu zodpovedajúca zodpovednost' člena štatutárneho orgánu môže v praxi dosahovat' rôznu intenzitu a môže byt' posudzovaná odlišne v závislosti od predpokladov konkrétnej osoby. ${ }^{33}$

\section{ZÁVER}

V predloženom príspevku sme sa zaoberali rozsiahlou problematikou corporate governance vo svetle vybraných konkrétnych povinností členov štatutárnych orgánov obchodných spoločností. Predmetom záujmu bola charakteristika a vyzdvihnutie významu súvisiacich pravidiel a princípov. Bližšie sme sa zameriavali, aj s využitím komparatívnej metódy, na povinnost' členov štatutárnych orgánov postupovat's odbornou starostlivost'ou a dodržiavanie povinnosti lojality, a to vo svetle zodpovednosti za ich porušenie.

Štatutárny orgán by v zmysle povinnosti zachovania odbornej starostlivosti mal pristupovat' k výkonu svojej funkcie zodpovedne a pri realizácii určitého rozhodnutia zohl'adnit' všetky dostupné a relevantné informácie, teda mal by urobit' rozhodnutie informované. Jedným z viacerých následkov nedodržania tejto povinnost' je aj vznik zodpovednosti za škodu, ktorá má v slovenskom právnom poriadku objektívny charakter.

V uvedených intenciách je však nutné poukázat' na skutočnost', že vykonávanie podnikatel'skej činnosti je spojené s možným rizikom straty, resp. neúspechu. V praktickej rovine nevyhnutne nastanú prípady, kedy člen štatutárneho orgánu v dobrej viere a na základe určitej sumy informácií učiní rozhodnutie, ktorého budúce následky nemôže objektívne poznat'. Je preto na mieste ustanovit' podmienky liberácie člena štatutárneho orgánu v prípade, ak jeho rozhodnutie sa síce následne prejavilo ako nesprávne, avšak nemožno tu nevyhnutne hovorit' o porušení jeho povinností. V tomto smere poukazujeme na pravidlo podnikatel'ského

\footnotetext{
${ }^{31}$ Ustanovenie $\S 51$ ods. 2 zákona o ocbhodních korporacích.

${ }^{32} \mathrm{~V}$ uvedenom kontexte je nutné poukázat' na to, že objektivizácia určitého štandardu ako podklad pre posudzovanie určitých skutočností nie je v právnej rovine ničím nezvyčajným. Obdobným príkladom je koncept tzv. priemerného spotrebitel'a. K predmetnej otázke bližšie pozri FILIČKO, V. Spotrebitel'ské zmluvy (ochrana spotrebitel'a). In: VOJČÍK, P. a kol. Občianske právo hmotné. 2. vydanie. Plzeň: Aleš Čeněk, 2018. s. 102-128. alebo FILIČKO, V. Princíp ochrany spotrebitel'a a princíp predvídatel'nosti súdnych rozhodnutí a ich uplatnenie v otázke rozpisu splátok v zmluve o spotrebitel’skom úvere. In: Banskobystrické zámocké dni práva : Princípy súkromného práva ako stabilizačný faktor pri tvorbe a interpretácii právnych predpisov : sekcia súkromného práva. - Banská Bystrica : Vydavatel'stvo Univerzity Mateja Bela v Banskej Bystrici - Belianum, 2020. s. $70-78$. 33 MORAVEC, T., ANDREISOVÁ, L. Obchodní společnosti pohledem Corporate Governance. 1. vydání. Praha: GRADA Publishing, a.s., 2021. s. 156.
} 
úsudku, pripúšs’ajúceho tzv. právo na podnikatel'ský omyl. V prípadoch, kedy štatutárny orgán preukáže, že konal s odbornou starostlivost'ou (teda zaobstaral si a zohl'adnil dostupné informácie) a v dobrej viere, že predmetné rozhodnutie je v záujme obchodnej spoločnosti, za prípadnú škodu zodpovedat' nebude.

$\mathrm{Na}$ základe predložených skutočností možno konštatovat', že corporate governance predstavuje rýchlo rozvíjajúcu sa a dynamickú interdisciplinárnu oblast'. Vytvára pravidlá a princípy dobrej správy obchodných spoločností (najmä tých s rozptýlenou vlastníckou štruktúrou), ktoré majú prispiet' $\mathrm{k}$ prevencii a riešeniu potenciálnych konfliktov osôb s rôznymi záujmami. Možno konštatovat', že dodržiavanie predmetných princípov môže byt' významným determinantom úspešnosti a konkurencieschopnosti konkrétneho podnikatel'ského subjektu. Z uvedeného dôvodu je podl'a nášho názoru vhodné, ba až priam žiadúce zvyšovat' povedomie osôb vo vlastníckej a riadiacej štruktúre obchodných spoločností o existencii a potrebe ich dodržiavania.

\section{Použitá literatúra}

1. CSACH, K., HAVEL, B. (eds.). Corporate governance společností s účastí státu. Praha: Wolters Kluwer ČR, 2020. ISBN 978-80-7598-896-6.

2. DOLNÝ, J. Zodpovednost' štatutárneho orgánu za nepodanie návrhu na vyhlásenie konkurzu: komparácia slovenského a nemeckého právneho poriadku. In: Právo, obchod, ekonomika 9. Košice: Univerzita Pavla Jozefa Šafárika v Košiciach. 2019. ISBN 978-80-815-2776-0.

3. DURAČINSKÁ, J. Povinnost' starostlivosti riadneho hospodára alebo povinnost' odbornej starostlivosti z hl'adiska právnej komparatistiky. In: Dny práva - 2012 Days of Law. 6. ročník mezinárodní konference pořádané Právnickou fakultou Masarykovy univerzity. Sborníky př́spěvků. Brno: Masarykova univerzita, 2013. ISBN 978-80-210-6319-8.

4. FILIČKO, V. Spotrebitel'ské zmluvy (ochrana spotrebitel'a). In: VOJČÍK, P. a kol. Občianske právo hmotné. 2. vydanie. Plzeň: Aleš Čeněk, 2018. ISBN 978-80-7380-719-1.

5. FILIČKO, V. Princíp ochrany spotrebitel'a a princíp predvídatel'nosti súdnych rozhodnutí a ich uplatnenie $\mathrm{v}$ otázke rozpisu splátok $\mathrm{v}$ zmluve o spotrebitel'skom úvere. In: Banskobystrické zámocké dni práva : Princípy súkromného práva ako stabilizačný faktor pri tvorbe a interpretácii právnych predpisov : sekcia súkromného práva. - Banská Bystrica : Vydavatel'stvo Univerzity Mateja Bela v Banskej Bystrici - Belianum, 2020. ISBN 978-80-5571-714-2.

6. GREŽOVÁ, R. Odborná starostlivost' člena štatutárneho orgánu. In: FINANČNÝ MANAŽÉR. Slovenská asociácia podnikových finančníkov. Bratislava, 2015. ISSN 1335-5813. Ročník XV. číslo 1.

7. HUSÁR, J. Zodpovednost' členov štatutárnych orgánov kapitálových obchodných spoločností a ochrana záujmov ich spoločníkov (akcionárov) a veritel'ov. In: Vybrané otázky zodpovednosti za škodu spôsobenú nesprávnym profesijným postupom. Košice: Univerzita Pavla Jozefa Šafárika, 2010. ISBN 978-80-892-8454-2.

8. HURYCHOVÁ, K., BORSÍK, D. (eds.). Corporate governance. 1. vydání. Praha: Wolters Kluwer, 2015. ISBN 978-80-7478-654-9.

9. MICHAL'OV, L. Zmena spoločenskej zmluvy spoločnosti s ručením obmedzeným: Vybrané problémy a rekodifikačné tendencie. In: Právo, obchod, ekonomika. Zborník vedeckých prác. Košice: Univerzita Pavla Jozefa Šafárika v Košiciach, 2011. ISBN 978-80-7097-903-7. 
10. MORAVEC, T., ANDREISOVÁ, L. Obchodní společnosti pohledem Corporate Governance. 1. vydání. Praha: GRADA Publishing, a.s., 2021. ISBN 978-80-2714169-2.

11. OECD. G20/OECD Principles of Corporate Governance. OECD Publishing. Paris, 2015. ISBN 978-92-64-23688-2. Dosutpné na webovej adrese:

https://read.oecd-ilibrary.org/governance/g20-oecd-principles-of-corporate-govern ance-2015_9789264236882-en\#page1

12. OKRUHLICA, F. Vlastnícka správa spoločnosti (Corporate governance). 1. vydanie. Bratislava: Iura Edition, spol. s r. o., 2013. ISBN 978-80-8078-603-8.

13. OVEČKOVÁ, O., CSACH, K., ŽITŇANSKÁ, L. Obchodné právo 2. Obchodné spoločnosti a družstvo. Bratislava: Wolters Kluwer SR s. r. o., 2020. ISBN 978-80571-0291-5.

14. SUCHOŽA, J. - HUSÁR, J. a kol. Obchodné právo. Prvé vydanie. Bratislava: IURA EDITION, 2009. ISBN 978-80-8078-290-0.

15. Uznesenie Najvyššieho súdu Slovenskej republiky, sp. zn. 1 Obo 16/2008, zo dňa 19.02.2009.

\section{Kontaktné údaje}

Mgr. Michal Sokol

Univerzita Pavla Jozefa Šafárika v Košiciach, Právnická fakulta

Katedra obchodného práva a hospodárskeho práva

Kováčska 26, 04075 Košice, Slovenská republika

email: michal.sokol@student.upjs.sk 


\title{
VYUŽITÍ GRAFICKÝCH DĚL V SOUVISLOSTI S FANFICTION A JEHO AUTORSKOPRÁVNÍ ASPEKTY
}

\section{USE OF GRAPHIC WORKS IN CONNECTION WITH FANFICTION AND ITS COPYRIGHT ASPECTS}

\author{
Tereza Šmídová, Martin Šmíd, Barbora Kovářová
}

\begin{abstract}
Abstrakt
Př́spěvek je zaměřen na problematiku využití grafických děl (fotografických, výtvarných) v souvislosti s fanouškovskou literární produkcí (fanfiction). Př́íspěvek vymezuje základní pojmy a analyzuje současnou podobu využití grafických děl v rámci československého Harry Potter fandomu. Různé způsoby využití grafických děl jsou potom analyzovány z pohledu autorského práva.
\end{abstract}

Klíčová slova: fandom, fanfiction, fanart, Harry Potter, autorské dílo

\begin{abstract}
The paper focuses on the use of graphic works (photographic, art) in connection with fan literary production (fanfiction). The paper defines the basic concepts and analyzes the current form of use of graphic works within the Czechoslovak Harry Potter fandom. Different ways of using graphic works are then analyzed from the point of view of copyright.
\end{abstract}

Key words: fandom, fanfiction, fanart, Harry Potter, copyright work

\section{1 ÚVOD}

Př́íspěvek se zabývá autorskoprávními otázkami spojenými s využitím grafických děl (fotografických, výtvarných) v souvislosti s fenoménem fanouškovské literární produkce (fanfiction), a to jak využití částí díla původního, z kterého fanfiction čerpá, tak děl jiných (např. osobních fotografií). Cílem př́ispěvku je identifikovat různé způsoby využití grafických děl ve webovém prostoru, a to na prríkladu československého Harry Potter fandomu; v návaznosti na to analyzovat danou problematiku po autorskoprávní stránce.

V rámci př́spěvku budou nejprve vymezeny základní pojmy (fandom, fanfiction, fanart atd.), poté se zaměři na samotný grafický doprovod fanfiction. Ten lze identifikovat ve dvou základních podobách: zaprvé ve vizuální podobě webových stránek (archivů, blogů), zadruhé v grafickém doprovodu konkrétních povídek (bannery, ilustrace). Na základě charakteristiky konkrétních př́kladů budou identifikovány základní způsoby využití grafických děl ve fanfiction, které budou následně analyzovány v kontextu autorského práva.

\section{ZÁKLADNÍ POJMY}

Než přistoupíme k samotné analýze, je třeba vytyčit pojmy, s nimiž bude příspěvek pracovat. Jedná se především o fandom, fanart, fanfiction a s ním související pojmy kánon a fánon.

Fandom je sociokulturní fenomén spojovaný převážně s kapitalistickými společnostmi, elektronickými médii, masovou kulturou a veřejnými vystoupeními. ${ }^{1}$ Termín byl původně spojován spíše se sportem, než ho ve 20. letech 20 . století převzali fanoušci science fiction

\footnotetext{
${ }^{1}$ DUFFETT, M. Understanding Fandom: An Introduction to the Study of Media Fan Culture. New York: Bloomsbury, 2013, s. 5.
} 
sdružení kolem časopisu Amazing Stories Huga Gernsbacka. ${ }^{2}$ Československý fandom existuje až od 70. let, ačkoliv až do roku 1989 fungoval spíše v pololegální podobě. ${ }^{3}$ Fandom zastř̌šuje mnoho různorodých aktivit: pořádání conů (setkání fanoušků), vydávání amatérských či profesionálních časopisů (tzv. fanzinů), vlastní uměleckou produkci fanoušků (fanfiction, fanarty, fanvidea ad.), ale také poskytuje prostor pro více či méně odborné debaty týkající se tohoto fenoménu a jeho jednotlivých částí. $Z$ fandomu vzešli nejen mnozí autoři fantastiky, ale často také vědci, kteř́ se fandomem ve své odborné práci zabývají. ${ }^{4}$ Vedle všeobecného fandomu existují také fandomy menší, úžeji zaměřené na konkrétní oblasti (japonské komiksy), autory (J. R. R. Tolkien) či díla, a to jak literární (Harry Potter, Sherlock Holmes), tak audiovizuální (Star Trek, Doctor Who).

Fanart (fanouškovské výtvarné umění) je pojem, který byl původně použiván pro jakékoliv amatérské žánrové obrázky, ale postupem času se jeho význam proměnil, dnes zahrnuje výhradně díla vytvořená na základě konkrétního zdroje (seriálu, filmu, knihy apod.). Termín fanart je nejčastěji používán v souvislosti s kresbami a malbami (tradičními i digitálními), ale spadají pod něj i další druhy umění: sochy, fotografie, a to i upravené, videa, ruční výrobky, textil, kovové výrobky i móda. Historie fanartu sahá nejméně do 60. a 70. let 20. století, a to k Star Trek a Star Wars fandomům. V předinternetové době byly fanarty neodmyslitelnou součástí fanfiction a fanzinů, at' už jako ilustrace k povídkám, či titulní ilustrace časopisů, ale po přesunu fandomu do webového prostoru se fanfiction do jisté míry osamostatnilo a v rámci online fandomu převládlo. ${ }^{5}$ Ačkoliv existuje mnoho druhů fanartu, pro účely tohoto př́spěvku jsou podstatné především kresby, malby a fotografie. Kresby a malby patří přirozeně k nejstarším typům fanartu, často zobrazují postavy či prostředí, v němž se př́iběh odehrává, a tíhnou k ilustrativnosti a realističnosti, ačkoliv se běžně objevují také díla v komiksovém stylu a ve stylu chibi ${ }^{6}$. Fotografie samy o sobě př́liš často používány nejsou, běžnější je jejich úprava. Bývají různě manipulovány, kombinovány, ohýbány či přebarvovány, používány jsou přitom nejen fotografie ze zdrojového média, ale také fotografie z jiných audiovizuálních děl, a dokonce i civilní fotografie herců. Zatímco některé manipulace jsou viditelné na první pohled a často nechtěně komické, jiné působí značně realisticky, což s sebou může nést značné problémy, obzvlášt' zobrazují-li erotická či pornografická témata. ${ }^{7}$

Fanfiction, neboli fanouškovská literatura, je vlastní tvorba fanoušků určitého díla, která $\mathrm{z}$ tohoto díla (případně děl) vychází, přetváří ho či se jím inspiruje. Jak už bylo řečeno, zdrojovým materiálem mohou být díla literární i audiovizuální. Podobně jako v př́ípadě fanartu, i pojem fanfiction se v současném významu používá cca od 60 . let 20. století. ${ }^{8}$ Jak již bylo naznačeno, fanfiction se $\mathrm{z}$ původních tištěných fanzinů přesunulo do internetového prostoru, což vedlo k možnosti publikovat neomezené množství textů prakticky neomezeným počtem autorů, a to bud' na osobních blozích, nebo na specializovaných stránkách, tzv. archivech. Ty mohou být mezinárodní či národní, všeobecné či konkrétně zaměřené, např́klad na jeden fandom, jeden žánr, dokonce na jedinou postavu. Texty bývají psány a

\footnotetext{
${ }^{2}$ COPPA, F. A Brief History of Media Fandom. In: HELLEKSON, K., BUSSE, K. Fan Fiction and Fan Communities in the Age of the Internet. Jefferson: McFarland \& Company, 2006, s. 42.

${ }^{3}$ MACEK, J. Fandom a text: fandom - subkultura textu: profesionální česká SF a F periodika pred rokem 2000. Praha: Triton, 2006.

${ }^{4}$ MACEK, J. Fandom a text: fandom - subkultura textu: profesionální česká SF a F periodika před rokem 2000. Praha: Triton, 2006, s. 33.

${ }^{5}$ Je třeba zdůraznit, že toto platí především pro západní prostředí. V asijských fandomech je fanart mnohem rozšířenější, především pak v japonské tradici. Rozšíření japonských manga komiksů v 90. letech v USA pak vedlo nejen k nové vlně zájmu o fanart, především u mladších generací fanoušků, ale často také k úpravě stylu. Fanart. In: Fanlore [online]. [cit. 2021-6-19]. Dostupné z: https://fanlore.org/wiki/Fanart.

${ }^{6}$ Zobrazuje charaktery jako roztomilé, s nepřirozeně velkými hlavami. Chibi. In: Fanlore [online]. [cit. 2021-619]. Dostupné z: https://fanlore.org/wiki/Chibi.

${ }^{7}$ Fanart. In: Fanlore [online]. [cit. 2021-6-19]. Dostupné z: https://fanlore.org/wiki/Fanart.

${ }^{8}$ Fanfiction. In: Fanlore [online]. [cit. 2021-6-19]. Dostupné z: https://fanlore.org/wiki/Fanfiction.
} 
uveřejňovány na pokračování a vždy jsou opatřeny prostorem pro komentáře, který umožňuje fanouškům (autorům i čtenářum) sdílet a prodiskutovávat vlastní interpretace originálního textu. $^{9}$

S fanouškovským sdílením významů úzce souvisí pojmy kánon a fánon. Zatímco kánon je to, co je jasně řečeno v originálním díle, ${ }^{10}$ jako fánon označujeme informace, které v originálním díle řečeny nejsou, ale $\mathrm{v}$ rámci fanouškovské komunity jsou všeobecně přijímány jako faktické; zpravidla proto, že byly v textech používány tak často, že je ostatní fanoušci přijali za své.

\section{VYUŽITÍ GRAFICKÝCH DĚL VE FANFICTION}

Ačkoliv ve fandomu Harry Potter (HP) se vyskytují i další jmenované typy fanartu, v tomto př́spěvku se zaměříme především na kresby, malby a fotografie. Jak již bylo řečeno, rozeznáváme dvě základní podoby grafického zpracování fanfiction: vizuální podobu webových stránek a grafický doprovod konkrétních povídek.

\subsection{Vizuální podoba webových stránek}

V případě fandomu Harry Potter (ale také ostatních fandomů vycházejících z audiovizuálního díla) existují kromě postav, prostředí a artefakti̊ samozřejmě i jiné charakteristické rysy, které mohou fanoušci při vytváření svých děl použít, především logo, použité fonty písma či celkové barevné ladění. To se projevuje především v designu tematických webových stránek, ale také při vytváření bannerů a tapet na plochu.

Podívejme se nejprve na první jmenovaný př́pad. Zkoumané webové stránky lze rozdělit do tř́ typů: první typ žádné specifické vizuální prvky neobsahuje, druhý typ sice s vizuální stránkou pracuje, ale nepřebírá prvky z Harryho Pottera, třetí typ vizuální prvky Harryho Pottera přebírá.

Př́ikladem prvního typu jsou např́ílad stránky Labyrintem slov... ${ }^{11}$, Potter Povídky $C Z^{12}$, wattpad $^{13}$ či mezinárodní archiv FanFiction ${ }^{14}$. Ve všech př́padech se jedná o graficky velmi jednoduché weby se světlým pozadím, běžným fontem a chybějícími obrázky. Všechny tři weby fungují jako archivy a kromě druhého zmíněného se nespecializují pouze na HP fandom.

K druhému typu patří např́íklad stránky Tremendum ${ }^{15}$, OurStories.cz ${ }^{16}$ či Blesk ${ }^{17}$. V prvním př́ípadě se jedná o blog, na němž kromě fanfiction najdeme i autorčiny osobnější příspěvky, je využit běžný font $\mathrm{v}$ černé barvě na bílém pozadí a obrázky v záhlaví jsou spíše romantického rázu (lapač snů apod.). Ve druhém př́padě jde o československé stránky otevřené všem autorům, výjev v záhlaví evokuje slovanskou mytologii a použito je bílé písmo na černém pozadí. V posledním př́padě jde o blog jedné autorky, zabývající se také jinými tématy než fanfiction. Úvodní obrázky tematizují autorčinu přezdívku (jde o blesky), použito je převážně

\footnotetext{
${ }^{9}$ JENKINS, H. Textual Poachers: Television Fans and Participatory Culture. New York: Routledge, 2013, s. 76.

${ }^{10} \mathrm{Ne}$ vždy ovšem panuje shoda na tom, co všechno je možné zařadit do kánonu. V př́ípadě Harryho Pottera jsou jednoznačně kanonické knihy. Filmová zpracování část fanoušků za kánon nepovažuje, zatímco druhá část čerpá kanonické informace pouze $\mathrm{z}$ nich (pokud nečetli knihy). Ještě problematičtější jsou další vyjádř̌ní J. K. Rowlingové včetně projektu Wizarding World (původně Pottermore), jež sama autorka za kanonické považuje, zatímco značná část fanoušků s nimi spíše nesouhlasí.

${ }^{11}$ Labyrintem slov [online]. [cit. 2021-6-19]. Dostupné z: http://labyrintem.4fan.cz/.

${ }^{12}$ Potter Povídky CZ - Harry Potter Fanfiction: Povídková sekce stránek Potter Web CZ [online]. [cit. 2021-619]. Dostupné z: http://www.potterpovidky.cz/web/index.php.

${ }^{13}$ Wattpad [online]. c2021 [cit. 2021-6-19]. Dostupné z: https://www.wattpad.com/.

${ }^{14}$ Fanfiction: Unleash your imagination [online]. [cit. 2021-6-19]. Dostupné z: https://www.fanfiction.net/.

${ }^{15}$ Tremendum [online]. [cit. 2021-6-19]. Dostupné z: https://tremendum.wordpress.com/.

${ }^{16}$ Our Stories: Príbehy českých a slovenských autorov [online]. [cit. 2021-6-19]. Dostupné z: https://www.our stories.czl.

${ }^{17}$ Blesk [online]. c2006 [cit. 2021-6-19]. Dostupné z: http://www.blesk.xf.cz/index.htm.
} 
modré písmo na černém pozadí, ačkoliv některé záložky se liší. Jak u webu Tremendum, tak u Bleska se ale HP tematika objevuje na záložkách věnovaných fanfiction - u prvně jmenovaného se jedná o ilustraci spojených rukou, přičemž z detailů je jasný potterovský původ, u Bleska pak o obrázek Bradavic. Lehce na pomezí pak stojí nový archiv FanFikce.cz ${ }^{18}$, který sice vytváří vlastní logo, zdánlivě se světem HP nesouvisející, nicméně jedná se o psací brk, navíc vyvedený žlutou barvou na černém pozadí, odkaz na HP je tedy jasný. ${ }^{19}$

Stránek tř́etího typu najdeme nejvíce, jedná se jak o soukromé blogy, tak o archivy. Bývá $\mathrm{v}$ nich použit běžný font černé barvy na světlém pozadí. V jejich záhlaví se obvykle nachází banner pojatý jako koláž z vystupujících postav, a to bud' kreslený (Povídky od Patoložky ${ }^{20}$ ), nebo poskládaný z fotografií. Použity mohou být pouze postavy z HP (Fanfiction poviedky o Harrym Potterovi ${ }^{21}$ ), nebo se na koláži objevují i postavy z jiných fandomů, o nichž autorka píše (Moje bláznivá múza $a^{22}$ ). Některé webové stránky používají také filmové logo HP, např́iklad HP fan fiction ${ }^{23}$.

\subsection{Grafický doprovod povídek}

Stejné tři kategorie jako $\mathrm{v}$ př́ípadě vizuální podoby webových stránek rozeznáváme také u grafického doprovodu jednotlivých povídek, tedy první typ bez doprovodu, druhý typ $\mathrm{s}$ doprovodem, který nevychází z HP, a třetí typ s doprovodem pocházejícím z HP.

U prvního typu se prríklady částečně překrývají s prvním typem předchozí kategorie, výjimkou jsou stránky wattpad a FanFiction, které grafický doprovod obsahují. Naopak sem můžeme zařadit některé stránky, které vizuální podobou HP tematiku využívají, ale povídky nechávají bez grafického doprovodu (Moje bláznivá múza).

Druhý typ zahrnuje především obecné obrázky či fotografie tematicky odpovídající ději či názvu povídky, nejčastěji pak zvířata a budovy (Blesk, Povidky od Patoložky).

Př́kladem třetího typu jsou nejčastěji bannery či ikony různých velikostí, které mohou, ale nemusí být vytvořeny př́mo pro danou povídku. Při tvorbě těchto bannerů jsou nejčastěji používána zobrazení prostředí (obvykle Bradavice), různých kouzelnických artefaktů (např. hůlky, v povídkách s tematikou cestování časem to bývá obraceč času atd.). Fotografie zř́ídka figurují samy o sobě, nejčastěji bývají použity do různých koláží. Zatímco u některých postav jsou nejčastěji užívány oficiální fotografie z filmu, at' už propagační, z natáčení či screeny z filmů, u jiných převažují fotografie civilní; to je dáno jednak věkem postav, jednak specifičností jejich filmového vzhledu. ${ }^{24}$

Některé vytvořené bannery jsou tak oblíbené, že bývají používány opakovaně, a to nejen pro povídky jednoho autora, ale také napříč blogy. Například Blesk pro některé povídky využívá

\footnotetext{
${ }^{18}$ FanFikce.cz: Černá kniha | Harry Potter [online]. c2018 [cit. 2021-6-19]. Dostupné z: https://www.fan-fikce.cz/.

${ }^{19}$ Barva a podtitul „Černá kniha“ odkazují také na původní webový archiv fanfiction.potterharry.net, jehož pozadí bylo černé a na nějž tyto stránky navazují. Původní archiv přestal ze dne na den fungovat a nepodařilo se domluvit jeho opětovné zpř́ístupnění, což byla pro čtenáře ztráta, jednalo se totiž o jeden z nejrozsáhlejších československých archivů.

${ }^{20}$ Povídky od Patoložky: Vitejte ve světě fanfiction [online]. [cit. 2021-6-19]. Dostupné z: https://patolozk a.wordpress.com/.

${ }^{21}$ Fanfiction poviedky o Harrym Potterovi [online]. [cit. 2021-6-19]. Dostupné z: https://hpkizi.sk/

22 Moje bláznivá múza [online]. c2012-2017 [cit. 2021-6-19]. Dostupné z: https://www.mojeblazni vamuza.cz/vitejte/.

${ }^{23}$ Harry Potter fan fiction [online]. c2008 [cit. 2021-6-19]. Dostupné z: https://harrypotterfanfiction.eu/

${ }^{24}$ Pokud vezmeme v úvahu, že fotografie z filmu bývají používány u starších postav (Brumbál, Snape, Lucius Malfoy), zatímco civilní fotografie častěji u postav mladších (Hermiona, Draco, Harry), je př́íčina zrrejmá a oba zmíněné důvody spolu souvisí. Značná část fanfiction a tedy i fanartu je situována do budoucnosti, tedy do dospělosti dětských postav. Zatímco u starších postav lze předpokládat, že svůj vzhled během např. deseti let př́liš nezmění, a je tedy možné využít fotografie z osmi filmů, mladší postavy se měnily výrazně a i fotografie z posledního filmu se autorům mohou zdát příliš dětské. S tím souvisí i specifičnost vzhledu - zatímco mladším postavám zůstal ve filmech víceméně civilní vzhled, starší postavy vypadají v civilu výrazně jinak a nebyly by tedy k poznání.
} 
bannery individuální (např. pro povídku Neprritel $l^{25}$ kresbu ústředního páru), zatímco pro jiné banner standardizovaný (koláž postav), opakující se napříč povídkami. Naopak překladový archiv Fanfiction poviedky o Harrym Potterovi si zakládá na individualizovaných bannerech, které jsou bud' přejaty z původních stránek, nebo vytvořeny přímo pro uveřejněný překlad. Kromě názvu povídky a jména autorky se na bannerech často vyskytuje úryvek textu a také hlavní postavy, nejčastěji formou koláže z civilních fotografií, ${ }^{26}$ případně kombinace civilních a filmových fotografií, ${ }^{27}$ ale objevují se také kreslené ilustrace ${ }^{28}$ či počítačově upravené fotografie, na nichž je hlava herce přilepena na cizí tělo. ${ }^{29}$ Takové úpravy jsou často využívány u párů, které spolu v originálním textu nejsou - vzhledem $\mathrm{k}$ faktu, že se nezř́́dka jedná o erotická až pornografická zobrazení, jedná se o poměrně závažný etický problém. V př́ípadě, že v textu vystupuje hlavní postava, která se ve filmovém zpracování bud' nevyskytuje, nebo se od něj výrazně liší, mohou být použity odpovídající kresby ${ }^{30}$ či fotografie jiných herců. ${ }^{31}$

Klasické ilustrace, jak je známe z tištěných knih či původních fanzinů, tedy obrázky využité př́mo u textu, se ve fanfiction příliš nevyskytují. Fanarty bývají spíše shromažd'ovány na specializovaných webových stránkách ${ }^{32}$ a běžný čtenář s jejich existencí nemusí být vủbec obeznámen. Autoři povídek tedy tyto kresby spíše než jako ilustrace využívají k tvorbě bannerů.

Objevují se různé typy kreseb a maleb, a to jak tradičních, tak digitálně zpracovaných. Najdeme zde díla ilustrativní, realistická, ale i stylizovaná, kvalitativně od téměř dětských kreseb po takřka profesionální díla, dle schopností a zaměření autorů. Kromě ilustrací k fanfiction se často vyskytují obecné výjevy ze života postav a také ilustrace k originálnímu textu, také u kreseb bývá vedle postav zobrazováno prostředí a kouzelnické artefakty. Podobně jako u fotografií jsou specifickou kategorií obrázky různých párů, od nevinných výjevů, přes jemně erotická témata, až po pornografii. Postavy jsou vyobrazovány bud' podle filmového zpracování (tedy podle herců), nebo podle autorovy vlastní fantazie, i tak ale většinou odpovídají popisům $\mathrm{z}$ knih.

\section{AUTORSKOPRÁVNÍ ROVINA VYUŽITÍ GRAFICKÝCH DĚL V RÁMCI FANDOMU}

Aspekt v rámci fanfiction, kterým se fanoušci při dotváření webových stránek a šperkování svých povídek spíše nezabývají, nebo na který při tvorbě zapomínají, je otázka autorských práv. Grafická díla, at' už ta dotvářející vizuální podobu webových stránek nebo ta, která slouží jako grafický doprovod jednotlivých př́běhů, lze bezesporu považovat za autorská díla dle zákona č. 121/2000 Sb., o právu autorském, o právech souvisejících s právem autorským a

\footnotetext{
25 BLESK. Nepř́itel. In: Blesk [online]. c2006 [cit. 2021-6-19]. Dostupné z: https://www.blesk.xf.cz/po vidky/HG-SS/nepritel.htm.

${ }^{26}$ VA VONNE. Vysielačka. Přeložila Jimmi. In: Fanfiction poviedky o Harrym Potterovi [online]. [cit. 2021-619]. Dostupné $\mathrm{z}$ : https://hpkizi.sk/modules.php?name=Preklady\&new_topic=376.

${ }^{27}$ KAILIN. Za trest s Hermionou Grangerovou, Přeložila Denice. In: Fanfiction poviedky o Harrym Potterovi [online]. [cit. 2021-6-19]. Dostupné z: https://hpkizi.sk/modules.php?name=Preklady\&new_topic=348.

${ }^{28}$ MAYA. Ked' máš pripravenú mysel', Přeložili Jimmi, OnlinePreklady, doda357. In: Fanfiction poviedky o Harrym Potterovi [online]. [cit. 2021-6-19]. Dostupné z: https://hpkizi.sk/modules.php?name=Preklad y\&new_topic=222.

${ }^{29}$ NINGLORETH. Zapírání. Přeložila Rapidez. In: Fanfiction poviedky o Harrym Potterovi [online]. [cit. 20216-19]. Dostupné z: https://hpkizi.sk/modules.php?name=News\&file=article\&sid=2898.

${ }^{30}$ LESS WRONG. Harry Potter a Metody racionality. Přeložila Tersa. In: Fanfiction poviedky o Harrym Potterovi [online]. [cit. 2021-6-19]. Dostupné z: https://hpkizi.sk/modules.php?name=News\&new_topic=99.

${ }^{31}$ MERRICK MAYFAIR. Pavučina. Přeložila Jacomo. In: Fanfiction poviedky o Harrym Potterovi [online]. [cit. 2021-6-19]. Dostupné z: https://hpkizi.sk/modules.php?name=News\&new_topic=389.

32 Typicky stránka Deviant Art. Deviant Art [online]. [cit. 2021-6-19]. Dostupné z: https://www.deviantart.com/.
} 
o změně některých zákonů (dále jen ,autorský zákon“) a jako taková požívají příslušné autorskoprávní ochrany.

Pokud budeme na grafická díla užitá v rámci fandomu nahlížet dle typologie popsané v čl. 3.1 i čl. 3.2, v následujícím textu se budeme zabývat pouze třetí kategorií, tedy přímým využitím prvků Harryho Pottera. V takových př́padech se totiž bude jednat o relativně problematickou množinu př́padů, u nichž by jejich povahu mohla relativizovat pouze výjimečná okolnost. První kategorie totiž žádné autorské rysy původních děl nepřebírá a druhá kategorie vizuálně podobná, avšak nepřebírající prvky Harryho Pottera, bude odvislá od povahy a míry vizuální podobnosti, avšak paušálně ji nebude možné označit jako neoprávněné užití původních autorských děl. Pro úplnost ještě nutno doplnit, že z pohledu autorského práva nespatřujeme mezi kategoriemi 3.1 a 3.2 žádný rozdíl.

Obecná charakteristika autorských děl vychází z $§ 2$ odst. 1 autorského zákona, který za předmět práva autorského označuje ,„dílo literární a jiné dílo umělecké a dílo vědecké, které je jedinečným výsledkem tvưrči činnosti autora a je vyjádřeno v jakékoli objektivně vnímatelné podobě včetně podoby elektronické, trvale nebo dočasně, bez ohledu na jeho rozsah, účel nebo význam“. Toto ustanovení zároveň nabízí výčet jednotlivých druhů děl. Pro účely tohoto příspěvku je stěžejní, že vedle dalších se za dílo považuje rovněž dílo fotografické, dílo vyjádřené postupem podobným fotografii, dílo audiovizuální a dílo výtvarné (tedy např́iklad kresba). Právě fotografie, kresby a další nejrůznější prvky audiovizuálních děl využívají fanoušci při své tvorbě k doladění prostředí, ve kterém literární nebo jinou fanprodukci sdílejí.

Teoretická část př́spěvku se zabývá jakýmkoliv grafickým dílem s Harry Potterem souvisejícím, tedy rovněž fotografiemi pořízenými v průběhu natáčení, upravenou kresbou apod. Pro snadnější pochopení právního výkladu budeme v následujícím textu rozebírat pouze prvky filmové.

Pokud se zaměříme na fandom Harryho Pottera jako díla audiovizuálního, tímto druhem autorského díla se zabývá autorský zákon v § 62 a následujících, když jej definuje jako “.... dílo vytvořené uspořádáním děl audiovizuálně užitých, at’ již zpracovaných, či nezpracovaných, které sestává z řady zaznamenaných spolu souvisejících obrazů, vyvolávajících dojem pohybu... “. Jednotlivá díla audiovizuálně užitá pak jsou samostatná díla, která jsou užita právě za účelem vytvoření dalšího samostatného díla - díla audiovizuálního. ${ }^{33}$ Dílem audiovizuálně užitým je tedy v podstatě jakékoliv dílo, které je do hlavního audiovizuálního díla zahrnuto, tedy rovněž díla fotografická a výtvarná, bez ohledu na to, zda vznikla jako díla vytvořená na zakázku výrobce celkového díla nebo zda se jedná o díla již existující (neboli preexistentní). ${ }^{34}$

Osoba, která je chráněna před zásahy do jejího autorského práva, je primárně autor díla. Autorem dle $\S 5$ odst. 1 autorského zákona je člověk, tedy pouze fyzická osoba, která autorské dílo vytvořila. Autorem v podstatě musí být osoba nadaná nějakou tvůrčí schopností, což ztělesňuje tzv. zásadu objektivní pravdivosti autorství, tedy bezpodmínečnou tvưrčí závislost díla a jeho tvưrce. ${ }^{35}$ Autorem audiovizuálního díla pak je jeho režisér, tedy osoba, která jednotlivá audiovizuálně užitá díla uspořádala $s$ tím, že autoři jednotlivých audiovizuálně užitých děl pak požívají samostatné ochrany. ${ }^{36}$

\footnotetext{
${ }^{33}$ TELEC, I., TƯMA, P. § 62 [Obecná ustanovení]. In: TELEC, I., TƯMA, P. Autorský zákon. 2. vydání. Praha: C. H. Beck, 2019, s. 676.

${ }^{34}$ TELEC, I., TƯMA, P. § 64 [Díla audiovizuálně užitá]. In: TELEC, I., TƯMA, P. Autorský zákon. 2. vydání. Praha: C. H. Beck, 2019, s. 707.

${ }^{35}$ TELEC, I., TŮMA, P. § 5 [Autor]. In: TELEC, I., TŮMA, P. Autorský zákon. 2. vydání. Praha: C. H. Beck, 2019, s. 90.

${ }^{36}$ CHAlOUPKOVÁ, H., HOLÝ, P. § 63 [Autor audiovizuálního díla]. In: CHALOUPKOVÁ, H., HOLÝ, P. Autorský zákon. 5. vydání. Praha: C. H. Beck, 2017, s. 136.
} 
Z obsahu práva autorského obecně vyplývá, že pouze autor má v souladu s $\S 11$ odst. 1 autorského zákona právo rozhodnout o zveřejnění svého díla a pouze autor je oprávněn své dílo užít, případně udělit jiné osobě smlouvou oprávnění k takovému užití.

Právo rozhodnout o zveřejnění díla je vedle práva osobovat si autorství a práva na nedotknutelnost svého díla součástí tzv. osobnostních autorských práv, která jsou úzce spojena s osobou autora. Osobnostních práv se autor nemůže vzdát, jsou nepřevoditelná a smrtí autora zanikají. ${ }^{37}$

Naopak oprávnění dílo užít je skupina práv řadících se do tzv. majetkových autorských práv, která jsou převoditelná na jinou osobu. Pokud autor udělí oprávnění k užití svého díla jiné osobě, neznamená to, že autorovi toto právo zaniká, ten pouze musí strpět zásah oprávněné osoby do svého uživatelského práva v rozsahu uděleného oprávnění. Do této kategorie práv je možné zařadit právo dílo rozmnožovat (neboli zpřístupnit prodejem), rozšiřovat (ve hmotné podobě za účelem hospodářského nebo obchodního prospěchu), půjčovat (zpř́ístupňovat ve hmotné podobě nikoliv za účelem hospodářského nebo obchodního prospěchu), vystavovat (zpř́stupňovat $\mathrm{v}$ hmotné podobě umožněním shlédnutí) a sdělovat veřejnosti (v nehmotné podobě, živě nebo ze záznamu, po drátě nebo bezdrátově). ${ }^{38}$ Výčet způsobů užití díla v autorském zákoně byl v roce 2006 pozměněn z původně taxativního pojetí přidáním slova „zejména“ na výčet demonstrativní (neboli př́íkladný), který zákonodárce odůvodnil technologickým rozvojem, kdy s rozvojem techniky přichází neustále nové možnosti využívání děl, s nimiž nemohl autorský zákon při jeho přijetí přirozeně počítat. ${ }^{39}$

\subsection{Kvalifikace děl užitých v rámci fandomu}

Pokud bychom se pokoušeli o podřazení užívání již existujících autorských děl v rámci fandomů pod některou z forem užití dle $\S 12$ autorského zákona, jednalo by se nejspíše, z podstaty fandomů a jejich publikace na webových stránkách, o užití díla formou sdělování veřejnosti dle $\S 18$ autorského zákona. Autorský zákon popisuje sdělování díla veřejnosti jako „,zpřistupňováni díla v nehmotné podobě, živě nebo ze záznamu, po drátě nebo bezdrátově “, a zároveň také ,sdělováni díla veřejnosti způsobem, že kdokoliv může mit k němu přistup na místě a v̌̌ase podle své vlastní volby zejména počitačovou nebo obdobnou sití. " 40 Jedná se o jedinou formu užití díla, která počítá rovněž $\mathrm{s}$ užitím $\mathrm{v}$ nehmotné podobě, tedy $\mathrm{v}$ př́padě fandomů prostřednictvím internetu. Jelikož lze ale dle výše zmíněného demonstrativního výčtu možných užití užít dílo i jiným než v zákoně explicitně uvedeným způsobem, není nezbytné užívání jednotlivých děl audiovizuálně užitých či jejich prvků podřazovat pod jakoukoli konkrétní kategorii a lze zjednodušeně konstatovat, že fanoušci v rámci své tvorby díla užívají bez autorem poskytnutého oprávnění.

Vzhledem k výše uvedenému je možné dojít k závěru, že se fanoušci Harryho Pottera, kteří na webových stránkách používají loga, fonty, grafiku nebo fotografie z tohoto audiovizuálního díla, svým postupem dopouští neoprávněného užití, tedy zásahu do autorských práv, a to nejen autora (režiséra) konkrétního dotčeného audiovizuálního díla, ale rovněž do autorských práv autorů jednotlivých děl audiovizuálně užitých.

Z nedovoleného užití však existují určité výjimky, kterými se zabývá rovněž autorský zákon, a to $\mathrm{v} \S 29$ a následujících. Výjimka, která by mohla přicházet $\mathrm{v}$ př́padě fanfiction $\mathrm{v}$ úvahu, je v zákoně hned první uvedená, která popisuje situaci tzv. volného užití.

${ }^{37}$ CHALOUPKOVÁ, H., HOLÝ, P., URBÁNEK, J. § 11 [Osobnostní práva]. In: CHALOUPKOVÁ, H., HOLÝ, P., URBÁNEK, J. Mediální právo. 1. vydání. Praha: C. H. Beck, 2018, s. 418.

${ }^{38} \S 12$ zákona č. 121/2000 Sb., o právu autorském, o právech souvisejících s právem autorským a o změně některých zákonů (autorský zákon), ve znění pozdějších předpisů.

${ }^{39}$ TELEC, I., TƯMA, P. § 12 [Práva dílo užít]. In: TELEC, I., TƯMA, P. Autorský zákon. 2. vydání. Praha: C. H. Beck, 2019, s. 160.

${ }^{40}$ TELEC, I., TƯMA, P. § 17 [Vystavování]. In: TELEC, I., TƯMA, P. Autorský zákon. 2. vydání. Praha: C. H. Beck, 2019, s. 212. 
Dle ustanovení $\$ 30$ autorského zákona se ,za užití díla podle tohoto zákona nepovažuje užití pro osobni potřebu fyzické osoby, jehož účelem není dosažení přimého nebo nepř́mého hospodářského nebo obchodního prospěchu, nestanoví-li tento zákon jinak“.

Pro účely výkladu, zda se v případě fanouškovské tvorby a využívání grafických námětů, kreseb či fotografií z původního audiovizuálního díla jedná o volná užití dle $\S 30$ autorského zákona či nikoliv, je nutné si vyložit pojem osobní potřeby. Osobní potřebu je nutno chápat jako užití autorského díla v prvé řadě výlučně v soukromí člověka, tedy pouze $\mathrm{v}$ rámci domácnosti a okruhu osob jemu blízkých (do této kategorie se mohou řadit i osoby pozvané, př́padně hosté domácnosti). Druhou podmínkou je, že účelem osobní potřeby může být pouze omezená škála činností (kupříkladu sebevzdělání, samostudium nebo osobní zábava). A v neposlední řadě je $\mathrm{z}$ podstaty pojmu osobní potřeba samožrejmě nutné vyloučit veškerá užití za účelem př́mého či nepřímého hospodářského nebo obchodního prospěchu.

Máme za to, že poslední dvě podmínky by pravděpodobně fanouškovská tvorba byla schopna naplnit. Jako účel osobní potřeby by zřejmě bez větších problémů obstála forma zábavy. Absence osobního prospěchu by (odhlédneme-li od možnosti výdělku formou reklam v rámci některých kanálů) rovněž byla v případě fanfiction naplněna, jelikož většina fanoušků uživá obrázky a fotografie pouze ke zpestření a doplnění prostředí povídek a celkově vizuálního vzezření webových stránek, nikoliv za účelem dosažení zisku. U soukromí člověka však bude situace poněkud komplikovanější, jelikož si lze jen těžko představit, že by užití autorského díla na veřejných webových stránkách mohlo v tomto ohledu obstát. Užití pro „osobní potřebu“ je totiž ze své podstaty vždy povahově neveřejné. ${ }^{41}$ Pokud bychom navíc uvažovali o fanouškovské tvorbě jako o užití díla sdělováním díla veřejnosti dle $\S 18$ a násl. autorského zákona, konstitutivní prvek ,veřejnosti“ takového užití díla z povahy věci vylučuje z rozsahu autorského práva užití způsobem, které se děje pro „osobní potřebu““. ${ }^{4}$

Lze tedy konstatovat, že česká právní úprava autorského práva, jakož i ochrany před neoprávněnými zásahy přistupuje k užívání fotografií, obrázků a dalších prvků audiovizuálních děl spíše restriktivně a pokud si fanoušci při jejich zveřejňování neobstarají oprávnění k výkonu takového práva, jednají v rozporu s majetkovými zájmy autora.

Vzhledem $\mathrm{k}$ tomu, že je článek zaměřen zejména na fanfiction spojené s audiovizuálním dílem Harryho Pottera, které má své kořeny ve Velké Británii, nelze pominout institut tzv. Fair use (ve Velké Británii označené termínem Fair dealing). Jedná se o institut anglosaského autorského práva, který za splnění specifických podmínek dovoluje i bez souhlasu držitele autorských práv některá využití chráněného díla. Princip „fair use“ je posuzován př́pad od př́ípadu. Obecně lze použít část díla chráněného autorskými právy pro účely kritiky (recenze), komentáře, zpravodajství, výuky, studia nebo výzkumu. Fair use nelze v rámci českého práva př́mo aplikovat, i kdyby se jednalo o původní dílo autora z jiného státu, právní rád s ním nepočítá a zná pouze jeho dílčí prvky, které $\mathrm{k}$ nám postupně pronikají.

\section{ZÁVĚR}

Grafická díla jsou v rámci československého Harry Potter fandomu využívána poměrně často. Jedná se především o využití fotografií z filmů o Harrym Potterovi, a to jak v neupravené, tak v upravené podobě. Tyto fotografie se objevují především v záhlaví webových stránek zaměřených na fanfiction, dále jako takzvané bannery doprovázející jednotlivé povídky či témata, př́padně jako ilustrace povídek. Méně často se lze setkat také s vlastními fanouškovskými ilustracemi (kresbami), které však také využívají postavy či jiné motivy ze světa Harryho Pottera.

\footnotetext{
${ }^{41}$ TELEC, I., TU゚MA, P. § 30 [Volná užití]. In: TELEC, I., TƯMA, P. Autorský zákon. 2. vydání. Praha: C. H. Beck, 2019, s. 386.

${ }_{42}$ TELEC, I., TƯMA, P. $\$ 30$ [Volná užití]. In: TELEC, I., TƯMA, P. Autorský zákon. 2. vydání. Praha: C. H. Beck, 2019, s. 386.
} 
Takto využitá díla (např. fotografie) či jejich části (např. zobrazení postav) mají charakter autorských děl podle $\S 2$ odst. 1 autorského zákona. Jako taková by tato díla měla být využívána pouze v souladu s autorským právem. Autorský zákon sice umožňuje v určitém rozsahu užít cizí dílo pro osobní potřeby ( $\$ 30$ autorského zákona), nicméně základním předpokladem takového užití je jeho soukromá povaha. $V$ př́padě fanfiction, které je veřejně dostupné na webových stránkách, však tento znak nemůže být naplněn. Ne všechny právní řády však přistupují k dané problematice stejně, např. anglosaský systém práva zná tzv. princip „fair use“, který umožňuje širší nekomerční využití díla než české autorské právo.

Závěrem nutno podotknout, že v praxi se nositelé práv k audiovizuálnímu ztvárnění Harryho Pottera nesnaží uplatňovat rozsah svých práv v oblasti fanouškovské tvorby a bud' ji mlčky tolerují, nebo dokonce podporují.

\section{Použitá literatura}

1. COPPA, F. A Brief History of Media Fandom. In: HELLEKSON, K., BUSSE, K. Fan Fiction and Fan Communities in the Age of the Internet. Jefferson: McFarland \& Company, 2006. 290 s. ISBN 978-0-7864-2640-9.

2. DUFFETT, M. Understanding Fandom: An Introduction to the Study of Media Fan Culture. New York: Bloomsbury, 2013. 342 s. ISBN 978-1-4411-6693-7.

3. CHALOUPKOVÁ, H., HOLÝ, P. Autorský zákon. 5. vydání. Praha: C. H. Beck, 2017. 392 s. ISBN 978-80-7400-671-5.

4. CHALOUPKOVÁ, H., HOLÝ, P., URBÁNEK, J. Mediální právo. 1. vydání. Praha: C. H. Beck, 2018. 560 s. ISBN 978-80-7400-725-5.

5. JENKINS, H. Textual Poachers: Television Fans and Participatory Culture. New York: Routledge, 2013. 370 s. ISBN 978-0-415-53329-4.

6. MACEK, J. Fandom a text: fandom - subkultura textu: profesionální česká SF a F periodika před rokem 2000. Praha: Triton, 2006. 152 s. ISBN 80-7254-856-5.

7. TELEC, I., TŮMA, P. Autorský zákon. 2. vydání. Praha: C. H. Beck, 2019. 1320 s. ISBN 978-80-7400-748-4.

8. Zákon č. 121/2000 Sb., o právu autorském, o právech souvisejících s právem autorským a o změně některých zákonů (autorský zákon), ve znění pozdějších předpisů.

9. Blesk [online]. c2006 [cit. 2021-6-19]. Dostupné z: http://www.blesk.xf.cz/index.htm

10. Deviant Art [online]. [cit. 2021-6-19]. Dostupné z: https://www.deviantart.com/

11. Fanfiction poviedky o Harrym Potterovi [online]. [cit. 2021-6-19]. Dostupné z: https://hpkizi.sk/

12. Fanfiction: Unleash your imagination [online]. [cit. 2021-6-19]. Dostupné z: https://www.fanfiction.net/

13. FanFikce.cz: Černá kniha | Harry Potter [online]. c2018 [cit. 2021-6-19]. Dostupné z: https://www.fan-fikce.cz/

14. Fanlore [online]. [cit. 2021-6-19]. Dostupné z: https://fanlore.org/wiki/

15. Harry Potter fan fiction [online]. c2008 [cit. 2021-6-19]. Dostupné z: https://harrypotterfanfiction.eu/

16. Labyrintem slov [online]. [cit. 2021-6-19]. Dostupné z: http://labyrintem.4fan.cz/

17. Moje bláznivá múza [online]. c2012-2017 [cit. 2021-6-19]. Dostupné z: https://www.mojeblaznivamuza.cz/vitejte/

18. Our Stories: Príbehy českých a slovenských autorov [online]. [cit. 2021-6-19]. Dostupné z: https://www.ourstories.cz/

19. Potter Povídky CZ - Harry Potter Fanfiction: Povídková sekce stránek Potter Web $C Z$ [online]. [cit. 2021-6-19]. Dostupné z: http://www.potterpovidky.cz/we b/index.php 
20. Povidky od Patoložky: Vitejte ve světě fanfiction [online]. [cit. 2021-6-19]. Dostupné z: https://patolozka.wordpress.com/

21. Tremendum [online]. [cit. 2021-6-19]. Dostupné z: https://tremendum.wordpr ess.com/

22. Wattpad [online]. c2021 [cit. 2021-6-19]. Dostupné z: https://www.wattpad.com/

\section{Kontaktní údaje}

Mgr. Tereza Šmídová

Univerzita Hradec Králové, Pedagogická fakulta

Hradecká 1227/4, 50003 Hradec Králové

Tel: 493331351

tereza.smidova@uhk.cz

JUDr. Martin Šmíd, Ph.D.

Univerzita Pardubice, Fakulta ekonomicko-správní

Studentská 95, 53210 Pardubice

Tel: 466036164

email: martin.smid@upce.cz

JUDr. Barbora Kovářová

Univerzita Pardubice, Fakulta ekonomicko-správní Studentská 95, 53210 Pardubice

Tel: 466036164

email: barbora.kovarova@upce.cz 


\title{
POSTAVENÍ ŽEN V MONGOLSKÉ SPOLEČNOSTI
}

\section{THE POSITION OF WOMEN IN MONGOLIAN SOCIETY}

\author{
Hana Brodská
}

\begin{abstract}
Abstrakt
V Mongolsku, jedné z posledních nomádských kultur na světě s tisíciletou, avšak nelehkou historií, $\mathrm{v}$ níž se snoubí tibetský buddhismus, šamanismus či víra $\mathrm{v}$ př́rodní bohy, je žena vzdělanou a silnou osobností, na jejichž bedrech stojí vedle vlastní kariéry také, či spíše hlavně, péče o rodinu a domácnost. Přesto musí i dnes bojovat o svá práva a rovné zacházení ve společnosti. Článek zkoumá postavení mongolských žen, jejich sociální status, posuzuje kvalitu jejich účasti na politickém a ekonomickém životě ovládaném mužskou částí populace, analyzuje příčinné souvislosti a zamýšlí se nad možnostmi zlepšení jejich situace.
\end{abstract}

Klíčová slova: COVID-19, děti, diskriminace, participace, právní prostředí, rodina, rovnost mužů a žen, sociální a ekonomický status žen, tradiční kulturní vzorce, vzdělání

\begin{abstract}
In Mongolia, one of the last nomadic cultures in the world with a millennial but challenging history, in which Tibetan Buddhism, Shamanism and belief in natural gods encounter, the woman is an educated and strong personality, who has to bear on her shoulders not only her own career but also, or rather mainly, the family and household keeping. Nevertheless, she still has to fight for her rights and equal treatment in the society. The article examines the status of Mongolian women, their social situation, reviews the quality of their participation in the political and economic life controlled by the male part of the population, analyzes the causalities and considers potentialities for improving their situation.
\end{abstract}

Key words: children, COVID-19, discrimination, education, family, gender equality, legal environment, participation, social and economic status of women, traditional cultural patterns

\section{1. ÚVOD}

„Muži a ženy mají stejná práva na politický, hospodářský, společenský a kulturní život a v manželství; manželstvi je založené na rovnosti a vzájemném souhlasu manželü. "

(Ústava Mongolska, čl. 16 bod 11)

Mongolské ženy mívaly ve společnosti, která dnes čítá zhruba 3,3 milionů obyvatel, tradičně vyšší postavení a byly nezávislejší než ženy v islámských středoasijských společnostech nebo ženy v buddhistické Č́íně či Koreji. Byly odpovědné za chov a dojení zviŕrat, za chod domácnosti a za výchovu dětí, což v zásadě platí i pro dnešní kočovné rodiny. Když bylo potřeba, převzaly úkoly za své muže, jako pasení dobytka. Hlavní rolí ženy však bylo přispívat $\mathrm{k}$ růstu populace. Bylo běžné, že jedna žena porodila deset a více dětí. $\mathrm{S}$ přihlédnutím $\mathrm{k}$ významu plodnosti $\mathrm{v}$ mongolské společnosti není proto překvapivé, že pro Mongoly byla plodnost důležitější než panenství či manželská věrnost, na rozdíl od ostatních asijských zemí. Účast žen na ekonomické produkci však byla díky tomu zásadně omezena a i své domácí povinnosti mohly ženy mnohdy plnit pouze tak, že starší děti přebíraly péči o ty nejmladší. A přece mongolští muži cítili nadřazenost nad manželkami, a to i poté, co v roce 1921 v tandemu se Sovětským svazem ustavená komunistická Mongolská lidová revoluční 
strana v principu hlásala rovnost mužů a žen. Ženy měly právo a př́ležitost získat vzdělání, vstupovat do pracovního procesu, zastávat politické funkce. Míra gramotnosti žen se zásadně zvýšila a vláda zavedla poskytování zdravotní péče a dalších sociálních výhod, což usnadnilo posílání dětí do škol. Dosah centrální vlády do všech koutů této rozsáhlé, převážně stepní země kočovných pastevců však byl omezený.

Konec socialistického systému Mongolům v roce 1990 přinesl demokracii a tržní hospodářství. Země současně přišla o partnerskou finanční a ekonomickou spolupráci se zeměmi Rady vzájemné hospodářské pomoci. Nová vláda tak byla nucena zrušit podpůrné dotace pro své občany, což mnoho Mongolů přivedlo do existenční nouze. V 90. letech následně převládla nezaměstnanost a nezměrná chudoba, tíha největšího břemene přitom zůstala na ženách, které od roku 1991 do poloviny 20. let čelily vyšší míře nezaměstnanosti. S pomocí masivní rozvojové spolupráce se postupně transformovala sociální a ekonomická politika státu, což vedlo ke zlepšení vyhlídek a možností mongolského národa, vč. vytvoření nových př́ležitostí pro ženy. Rovněž rodiče začali opětovně investovat do vzdělání svých dcer, chlapci často museli i nadále zůstávat doma $\mathrm{k}$ ruce svým rodičům a pomáhat $\mathrm{v}$ pastevectví. Ženy s vyšší vzdělaností získaly i více zaměstnaneckých př́ležitostí.

Článek zkoumá současné postavení žen v mongolské společnosti, na nichž mnohdy leží odpovědnost nejen za péči o vlastní děti, ale i celou domácnost a ty členy širší rodiny, kteří nejsou schopni se o své živobytí postarat sami at' již ze zdravotních důvodů, věku či nedostatku finančních prostředků. Mongolsko dnes disponuje relativně silnými regulačními rámci, které garantují rovné postavení žen a mužů a široce dostupnou vzdělanost. Ženy mají právo volit a být voleny a participují na hospodářském, kulturním i politickém životě. Odpovídá však realita legislativnímu zázemí? A jsou legislativní opatření dostatečná, aby ženy měly nejen právo participovat, ale i uspět, a to jak v hospodářském sektoru či v politice? Při hledání odpovědí na uvedené otázky se článek dále zamýšlí nad tím, jak případně ženám pomoci získat srovnatelné postavení v mongolské společnosti s muži.

\section{PRÁVNÍ A POLITICKÉ PROSTŘEDÍ}

Rovnost žen a mužů zaručuje Ústava Mongolska (1992) v článku 16 v bodě 11: „Muži a ženy mají stejná práva v politickém, hospodářském, sociálním a kulturním životě a v manželství.“ Článek 14 v bodě 2 dále stanoví, že: „Žádná osoba nemůže být diskriminována na základě etnického původu, jazyka, rasy, věku, pohlaví, sociálního původu nebo statutu, majetku, zaměstnání nebo pozice v zaměstnání, náboženství, názoru nebo vzdělání.“.

Zákon o podpoře rovnosti žen a mužủ mongolská vláda přijala v roce $2011 \mathrm{~s}$ cílem garantovat rovnost žen a mužů v politické, právní, ekonomické, sociální a kulturní sférée a v domácnosti. V současném pracovním právu ani $\mathrm{v}$ návrhu jeho revize se však nezabývá nepřátelským prostředím nebo sexuálním obtěžováním, které je sice zahrnuto v zákoně o podpoře rovnosti a v př́padě sexuálního obtěžování si tak poškozená osoba může stěžovat, není již ale řečeno komu a mají být přijata pouze blíže nespecifikovaná nápravná opatření. ${ }^{1} \mathrm{~K}$ realizaci zákona byly přijaty dva národní programy rovnosti žen a mužů na období 2012-2015 a 2017-2021. Posledně jmenovaný národní program si uložil za cíl usnadnit zlepšování genderových statistik a analýz a začleňování hlediska rovnosti žen a mužů do sektorových politik a politik na lokálních úrovních. Státní politika v oblasti populačního rozvoje (2016-2025), Národní program na ochranu a rozvoj dětí (2017-2021), Národní program podpory zdravotně postižených osob a rozvoje (2018-2022) jsou rovněž koncipovány tak, aby odrážely koncept rovnosti žen a mužů.

\footnotetext{
1 European Commission: The EU Special Incentive Arrangement for Sustainable Development and Good Governance ('GSP+') assessment of Mongolia covering the period 2018-2019 [online 10. 2. 2020] Brussels, 26. s. [cit. 19. 6. 2021]. Dostupné z: https://ec.europa.eu/transparency/regdoc/rep/10102/2020/EN/SWD-2020-23F1-EN-MAIN-PART-1.PDF. S. 10.
} 
K zajištění rovné a spravedlivé účasti na společenském životě a sociální spravedlnosti pro ženy, muže, dívky a chlapce slouží další právní předpisy, jako například zákon proti domácímu násilí (2016), který oproti původnímu zákonu z roku 2010 např́íklad ukládá právní odpovědnost sousedovi oznámit policii domácí násilí, především však překvalifikoval domácí zneužívání z drobného přestupku, sankcionovaného do té doby pouze pokutou, na trestný čin; zákon o rodině (1999, pozměněný v červnu 2018), který rozpracovává ústavní ustanovení o závazku státu chránit rodinu, mateřství a dítě; zákon o volbách (2015, novelizovaný v listopadu 2018); zákon o boji proti obchodování s lidmi (2012, pozměněný v roce 2018); zákon o osobách se zdravotním postižením (2016); zákon o vzdělávání (2002, pozměněný v prosinci 2016); zákon na ochranu svědkủ a obětí násilného činu (2013, novelizovaný v dubnu 2021); trestní zákoník (2015, novelizovaný v roce 2020), který kriminalizuje diskriminaci osob podle pohlaví pod trestem až 5 let odnětí svobody; občanský zákoník (2002, aktualizovaný v roce 2019); nebo pracovní zákoník (1999, pozměněný v roce 2019). Vláda ve svém př́stupu k zajištění rovných práv žen deklaruje reflexi principů Úmluvy OSN $o$ odstraněni všech forem diskriminace žen.

\section{INSTITUCIONÁLNÍ OCHRANA ROVNOSTI ŽEN A MUŽŮ}

V roce 2002 byl při Ministerstvu práce a sociální péče zrízen Národní výbor pro rovnost pohlaví (National Committee for Gender Equality, NCGE). V roce 2005 byl přesunut do gesce Úřadu vlády. NCGE má 26 členů zastupujících státní instituce a organizace občanské společnosti. $\mathrm{Na}$ okresních úrovních byly zřízeny genderové rady a genderové výbory. $\mathrm{Na}$ jednotlivých vládních úřadech byla ustavena genderová kontaktní místa, která dohlížejí na otázky týkající se pohlaví. Do roku 2015 fungoval NCGE nezávisle, v letech 2015-2018 však byl vládním rozhodnutím svěřen pod přímé vedení Odboru rozvoje populace Ministerstva práce a sociální ochrany, což vyvolalo kritiku mnoha organizací, občanské společnosti i vládní Národni komise pro lidská práva (NHRC). Vláda následně z iniciativy předsedy vlády rozhodla v roce 2018 o poskytnutí Sekretariátu NCGE nezávislého statusu; i nadále však působí pod předsedou vlády jako součást sekretariátu jeho kabinetu a výdaje NCGE jsou zahrnuty do rozpočtové kapitoly Úřadu vlády.

Vláda Mongolska dále pověřila vládní rezorty a agentury, aby ve své sektorové politice a plánech podpory rovnosti žen a mužů zajistily, aby veškeré jejich plány, projekty a aktivity počítaly s rozlišováním získaných dat a údajů podle pohlaví. Rovněž Statistický úřad Mongolska (NSO) byl pověřen vést genderově citlivou informační databázi. V roce 2013 bylo přijato 216 základních statistických genderových ukazatelů. Statistiky obsahující data reflektující zmíněných 216 ukazatelů ve vztahu k pohlaví jsou vydávány jednou za dva roky. Databázový systém je umístěn na webu http://www.1212.mn. ${ }^{2}$

Ve spolupráci s mezinárodní nevládní organizací Asia Foundation mongolská vláda ustavila Centrum genderové rovnosti (GEC), ${ }^{3}$ které na svém webovém portálu ${ }^{4}$ podává informace o otázkách obchodování s lidmi, o relevantních orgánech vymáhajících právo, oběti zde mohou nalézt potřebné rady a je zde $\mathrm{k}$ dispozici horká linka pomoci. V hlavním městě Ulánbátaru a v osadě u čínské hranice Zamyn-Uud nechala GEC s pomocí Švýcarské rozvojové agentury vystavět přístřešky, kam se mohou uchýlit oběti sexuálního zneuživání a obchodování s lidmi.

\footnotetext{
${ }^{2}$ Mongolia: Comprehensive National-Level Review. Responses to questionnaire on implementation of the Beijing Declaration and Platform for Action [online], Ministry of Labour and Social Protection, Ulaanbaatar, May 2019, 69 s. [cit. 18. 6. 2021]. Dostupné z: https://asiapacificgender.org/sites/default/files/docu ments/Mongolia_(English).pdf. S. 4-5.

${ }^{3}$ Facebooková stránka GEC: https://www.facebook.com/MongolianGenderEqualityCenter/.

${ }^{4}$ Internetová stránka GEC s informacemi o potírání obchodování s lidmi: https://www.stoptrafficking.mn/.
} 


\section{SOCIÁLNÍ POSTAVENÍ ŽEN}

Sociálně ekonomické ukazatele týkající se pohlaví, jako je míra zápisu dívek do škol nebo poměr účasti žen na trhu práce, se v Mongolsku výrazně zlepšily. Ženy a muži však čelí odlišným překážkám, protože $\mathrm{v}$ Mongolsku je kvůli přetrvávajícím kulturním normám a vzorcům chování podporována stereotypní dělba práce podle pohlaví. Od žen se nadto vyžaduje, aby se zabývaly dvojí zátěží jak pro produktivní, tak pro reprodukční práci, včetně komplexní péče o děti. Mezi ženami a muži dále existují rozdíly v platech, ženy přitom mají tendenci bez protestů přijímat nižší př́ijem než muži z důvodu péče o děti, která je chápána jako samožrejmost a nikoli jako př́spěvek pro společnost. Domácnosti v čele se ženami vdovami, rozvedenými nebo nesezdanými čelí dalším obtížím z důvodu nedostatečné podpory a chudoby.

Míra gramotnosti dospělých (ve věku 15 let a starších) je v Mongolsku pozoruhodně vysoká (od roku 2010 se pohybuje na úrovni $98,3 \%$ ) bez rozdílu pohlaví. Chlapci z rodin pastevců, horníků atp. nicméně školu mnohdy na čas nebo předčasně opouštějí, aby podpořili rodinné podnikání a přispěli ke zvýšení př́ijmu domácnosti. Muži jsou tak po generace naučeni, že oni vykonávají fyzickou práci $\mathrm{v}$ těžkých pracovních podmínkách, což se odráží i ve volbě studijních oborů. Kromě vyšší míry dosaženého vzdělání mají i ženy tendenci kumulovat se $\mathrm{v}$ oborech odlišných od oborů, které si volí chlapci. Obecně preferují studium ve zdravotnictví, sociální péči nebo v kulturních službách. Muži mají naopak tendence věnovat se oborům technickým a vědeckým, čemuž odpovídají i rodinné preference. Tyto rozdíly však dále posilují genderové rozdíly v typech pracovních míst obsazovaných muži a ženami a omezují šance žen těžit $\mathrm{z}$ nových pracovních príležitostí $\mathrm{v}$ povoláních souvisejících $\mathrm{s}$ prírodními vědami, technologiemi, strojírenstvím nebo matematikou. ${ }^{5}$

Jako jsou chlapci z určitých sociálních skupin nuceni občasně vypouštět školní docházku, tak bývají ženy z důvodů péče o děti a domácnost nuceny $\mathrm{k}$ předčasnému odchodu do důchodu. Neaktivita práceschopných žen má dopady na jejich kariérní rozvoj, výši důchodů a životní standard. Do roku 2017 byl důchodový věk v Mongolsku stanoven na 50 let u žen a u mužů na 55. Zákon o sociálním blahobytu z roku 2012 v úpravě z dubna 2017 zvýšil věk odchodu do důchodu na 55 pro ženy a 60 pro muže (čl. 21.1.1). Důchody jsou však př́iliš nízké, než aby zajistily důstojný život ženám jak mužům. Více než 330000 lidí dnes v Mongolsku pobírá důchod a u $80 \%$ z nich je nižší než současná minimální měsíční mzda 420000 MNT (zhruba 3550 Kč). 53,8 \% dủchodců dostává méně než 350000 MNT. Minimální plný důchod je přibližně $320000 \mathrm{MNT},{ }^{6} \mathrm{z}$ nějž lze však obtížně pokrýt veškeré nároky na provoz domácnosti, nájem, léky, oblečení a další věci. Jedinou možností pro mongolské seniory zůstává podpora ze strany rodin. Mongolské ženy, které odchází do důchodu dříve, se také dřive ocitají v chudobě, zejména pokud již nemají manžela. ${ }^{7}$

\section{EKONOMICKÝ STATUS ŽEN}

Na konci 20. století se s vyšším vzděláním žen zvýšila i jejich zaměstnanost. Počet žen zaměstnaných v různých hospodářských odvětvích se mezi léty 1969 a 1989 zvýšil o 87,3\% oproti nárůstu o 68,4 \% u mužů. Do roku 1989 tvořily ženy 47 \% zaměstnanecké pracovní síly. Rozdíly ve mzdách pro ženy a muže byly malé, což je charakteristické pro komprimované mzdové stupnice socialistických ekonomik; kdiferenciaci docházelo

\footnotetext{
${ }^{5}$ Ariunzaya A., Mnkhmandakh M. Women and the future of work in Mongolia [online]. Friedrich Ebert Stiftung, September 2019, 28 s. [cit. 18. 6. 2021]. Dostupné z: http://library.fes.de/pdf-files/bueros/mongolei /15735.pdf. S. 1.

${ }^{6} \mathrm{~S}$ manželem v Ulánbátaru nakoupíme potraviny pro dvě osoby týdně za cca 200-350 000 tugriků. Měsíčně tak utratíme pouze za potraviny průměrně 1200000 tugriků.

${ }^{7}$ Pension system requires overhaul [online 17. 12. 2020], [cit. 19. 6. 2021]. Dostupné z: https://theubposts.com /pension-system-requires-overhaul/.
} 
přidělováním odměn, výhod a dalších privilegií. V roce 1990 ztratilo Mongolsko podporu partnerských států na čele se Sovětským svazem ve výši $30 \%$ HDP. Hospodářský přechod proběhl pod názvem „šoková terapie“, protože vláda byla schopna učinit jen málo pro zmírnění dopadů. Krizi tak prezentovala jako př́ležitost $\mathrm{k}$ tomu, aby provedla strukturální změny a vyvolala změny $\mathrm{v}$ př́stupech a chování, a $\mathrm{k}$ podnícení individuální iniciativy. Strukturální reformy vyvolaly zásadní změny ve struktuře zaměstnanosti, současně však prohloubily rozdíly v participaci mužů i žen na ekonomice. ${ }^{8}$

Zákon o podpoře rovnosti žen a mužù zajišt'uje jejich rovnost v zaměstnaneckých a pracovněprávních aktivitách (čl. 11). Pracovní zákoník omezuje diskriminaci na základě pohlaví (čl. 7), přičemž stanoví, že „diskriminace, omezení nebo privilegia se v pracovněprávních vztazích zakazují na základě národnosti, rasy, pohlaví, sociálního původu nebo postavení, bohatství, náboženství nebo ideologie“, a že omezí-li zaměstnavatel práva a svobodu zaměstnance na základě specifických požadavků na pracovní povinnosti při jeho zaměstnávání, je povinen to odůvodnit.“ Zákon však již nestanoví stejnou odměnu za práci téže hodnoty. Rovněž neexistují žádné právní předpisy, které by vyžadovaly nediskriminaci na základě pohlaví při přijímání zaměstnanců. Podle Světové banky je Mongolsko na devátém místě mezi 18 zeměmi ve východní Asii a Tichomoří, pokud jde o právní předpisy, které umožňují rozdílné zacházení s muži a ženami. ${ }^{9}$

V současnosti se pracovní síla $\mathrm{v}$ Mongolsku přesouvá z tradičního zemědělství do sektoru průmyslu a služeb. Zaměstnanost v zemědělství poklesla ze $40,2 \%$ v roce 2004 na $28,2 \%$ v roce 2018. Od konce roku 2009 se počet pracovníků zvyšuje zejména v těžebním sektoru, který se rozvíjí v návaznosti na zvyšování globálních cen minerálních produktů. Současně s poskytováním hypoték, které začalo na konci roku 2012, se začal zvyšovat i počet pracovníků ve stavebnictví. V zemědělství je zaměstnána zhruba 1/3 ekonomicky aktivního obyvatelstva. $^{10}$

Jsou-li v pracovním režimu, i přes míru svého vzdělání bývají ženy vystaveny markantní nerovnosti v odměňování. Rozdíl v odměňování žen a mužủ činí více než 12,6 \%, což představuje nárůst oproti předchozím letům, i když ženy zastávají stejné pozice jako muži. Je stále pravděpodobnější, že ženy budou mít i nadále lepší vzdělání než jejich mužské protějšky. Jsou to hlavně tradiční normy a hodnoty, které brání ženám plně dosáhnout rovnosti, svou roli pak hraje nedostatek institucionální péče o děti a sociálních dávek. Ženy rovněž mívají problém získat pracovní uplatnění po 35. roku života, kdy bývají kvalifikovány již jako „moc staré“, což je nutí k předčasnému odchodu do důchodu nebo přesunu do neformálního sektoru (pomocné práce v zemědělství, důlním sektoru, posluhy v domácnostech, neplacená rodinná práce, pouliční prodej, sběr odpadků a další servisní služby). S rostoucí emancipací žen se však vzdělané ženy stále aktivněji chápou nabízených pracovních př́ležitostí a dokáží uspět v privátním sektoru, at’ již v zaměstnaneckém poměru nebo coby zakladatelky vlastních společností. ${ }^{11}$

NCGE ve zprávě ${ }^{12}$ z března 2021 o implementaci zákona o podpoře rovnosti žen a mužủ konstatuje, že princip garance rovného přístupu mužů a žen $\mathrm{k}$ benefitům rozvoje společnosti a sociálnímu bohatství se vytratil. Ve vysoko př́jmových sektorech s vysokou produktivitou a růstem i nadále dominují muži. Ti rovněž převládají na rozhodovacích úrovních, ve

\footnotetext{
${ }^{8}$ Women in Mongolia. Mapping Progress under Transition [online]. United Nations Development Fund for Women, 2001, 80 s. [cit. 19. 6. 2021]. Dostupné z: https://www.refworld.org/pdfid/46cadabb0.pdf. S. 36-37.

${ }^{9}$ Idem, s. 1.

${ }^{10}$ Ariunzaya, Mnkhmandakh. Women and the future of work in Mongolia 2019, s. VIII.

11 The Borgen Project. 6 Facts about Women's Rights in Mongolia [online 17. 12. 2020], [cit. 18. 6. 2021]. Dostupné z: https://borgenproject.org/womens-rights-in-mongolia/.

${ }^{12}$ Evaluation of the Implementation of the Law of Mongolia on Promotion of Gender Equality. Summary Report [online]. NCEG, 11. 3. 2021, 57 s. [cit. 19. 6. 2021]. Dostupné z: https://www.gender.gov.mn/uploads/books/ attach/Evaluation\%20of\%20the\%20implementation\%20of\%20LPGE_EN-converted.pdf. S. 4.
} 
finančních a rozpočtových úřadech, podobně jako v pozicích konečných vlastníků soukromých podniků. Povýšení do seniorních pozic ve státních službách závisí na faktorech jako je stávající politická situace, zaměstnanecké př́ležitosti pro ženy nebo sociální stereotypy. Zákon o státní službě nereflektuje koncept genderové rovnosti, významnou roli hraje i nedostatečná informovanost a pasivita zaměstnanců, stejně jako jejich nedostatečná znalost a úsilí chránit svá legitimní práva.

Ke zvýšení nerovnosti žen a mužů přispěla i vládní opatření přijatá v souvislosti s pandemií COVID-19, a to jak sociálně, tak ekonomicky. Vládní opatření mongolské vlády se nejvíce dotkla sektoru služeb, jako je maloobchod, vzdělávání, restaurace, bary, pohostinství, cestovní ruch a zábava, kde ženy tvoří velkou část pracovníků. Př́ijem žen se tak snížil, zvýšila se však jejich pracovní zátěž, protože jim připadla zvýšená péče o děti, které téměř rok a půl nemohly docházet do škol a zavřeny byly i denní stacionáře, o osoby se zdravotním postižením a chronickými nemocemi a o starší osoby v rodině. Zásadní dopady zaznamenalo vzdělávání, zdravotnictví a sociální péče, které se dotklo mnoha Mongolů, jež tyto služby využívají na denní bázi, a kde jsou převážnou většinou zaměstnány ženy. Přes $80,2 \%$ učitelských a 81,9 \% zdravotních profesí zastávají v Mongolsku ženy. Nejvíce důsledky pandemie zasáhly domácnosti vedené ženami, mladé dívky a starší a handicapované osoby. Výsledky dopadů opatření proti šíření COVID-19 ukazují, že pandemie prohloubila již existující nerovnosti mezi muži a ženami. ${ }^{13}$

\section{POLITICKÁ PARTICIPACE ŽEN}

V tradiční nomádské společnosti ženy byly vyloučeny z formálního politického systému a sféra jejich vlivu na rozhodovací procesy byla ohraničena jejich domácností. Revoluce v roce 1921 přinesla rozsáhlé změny $\mathrm{v}$ politickém postavení žen, ukončila jejich formální podřízenost mužům a byla jim udělena občanská práva. Mongolsko se také v následujících letech přihlásilo ke Všeobecné deklaraci lidských práv a stalo se smluvní stranou Mezinárodních pakti̊ o občanských a politických právech a o ekonomických, sociálních a kulturních právech, a rovněž např́iklad v roce 1981 Úmluvy o odstranění všech forem diskriminace žen (CEDAW). ${ }^{14}$ Právo mongolským ženám volit a být zvoleny zaručila $\mathrm{v}$ listopadu 1924 nová Ústava Mongolska. Mongolsko se tak stalo jednou z prvních zemí asijsko-pacifického regionu, které k tomuto kroku přistoupily. V letech 1924 až 1990 měly ženy v parlamentních volbách uzákoněnu kvótu $25 \%$. Po roce 1990 došlo zejména z důvodu oživení tradičních společenských vzorců k oslabení politické účasti žen, která se zvýšila po opětovném zavedení kvóty pro ženy ve výši $20 \%$ před parlamentními volbami v roce $2012 .^{15}$ Obyvatelstvo Mongolska v počtu $3385793^{16}$ tvoři z 50,7 \% ženy. Ve státní správě jsou zastoupeny z více než $60,4 \%$, jen minimální procento však zaujímá vysoké pozice. Do 76 členného parlamentu bylo ve volbách v červnu 2020 zvoleno 13 žen, což představuje $17 \%$. Mongolsko tak nenaplnilo kvótu $20 \%$ žen stanovenou v novele volebního zákona $\mathrm{z}$ roku 2019, současně se pohybuje pod světovým průměrem. Podle volebního zákona mají být ženy dále zastoupeny ve výši $25 \%$ ve vyšším vedení politických stran. Doposud však ženy nestanuly v čele ajmagů (krajů) ani hlavního města. Nedosáhly tak ani na pozici předsedkyně vlády, neřku-li prezidentky republiky. Další kvóty na počet vyšších státních úředníků (15\%)

\footnotetext{
${ }^{13}$ COVID-19 Impact on Women \& Girls in Mongolia [online]. UNDP, March 2021, 62 s. [cit. 20. 6. 2021]. Dostupné z: https://www.mn.undp.org/content/mongolia/en/home/library/-covid-19-impact-on-women-and-girl s-in-mongolia--study.html. S. 12-14.

${ }^{14}$ Women in Mongolia. Mapping Progress under Transition, 2001, s. 53.

15 The State of Women's Suffrage in Mongolia Parliament [online 11. 6. 2020], [cit. 19. 6. 2021]. Dostupné z: https://asiapacificmemo.ca/women-part-of-a-major-turnover-in-mongolian-parliament/\#: :text=Women\%E 2\%80\%99s $\% 20$ suffrage $\% 20$ in $\% 20$ Mongolia $\% 20$ became $\% 20$ law $\% 20$ on $\% 201$,a $\% 20$ greater\%20participation $\% 20$ of\%20women $\% 20$ in $\% 20$ political\%20life.

${ }^{16}$ Národní statistický úrúad Mongolska [online], [cit. 20. 1. 2021]. Dostupné z: https://www.nso.mn/home.
} 
nebo zastoupení v řadách ozbrojených složek (40 \%) obsahuje zákon o rovnosti žen a mužů. Žádný zákon však již neřeší a nestanovuje postihy za nenaplnění kvót. ${ }^{17}$

Parlamentní volby v létě roku 2020 nebyly zcela obvyklé, protože probíhaly v době globální pandemie COVID-19. V mnoha zemích byly volby odloženy. Mongolsko, kde až do 10. listopadu 2020 nebyl zaznamenán ani jeden př́pad komunitního přenosu COVID-19, bylo rozhodnuto volby zrealizovat podle plánu. Kampaň za bezprecedentních okolností byla poměrně náročná. Uchazeči byli vládou vyzýváni, aby kampaň prováděli pokud možno online a přes sociální média, což nahrávalo mladší generaci politiků. I tak nebyla splněna stanovená kvóta na procento žen v parlamentu. Problém je ten, že politické strany kvótu $20 \%$ pokládají za maximální hranici a nikoli minimální, když zvažují nominace svých kandidátů. A i když žena uspěje, není vnímána jako vůdkyně, ale je jí zpravidla nabídnuta agenda tradičně spojovaná s ženskou rolí ve společnosti, tedy agenda dětí, žen a sociální otázky.

$\mathrm{K}$ dosažení vyšší rovnosti žen a mužů v politice by mohla přispět už delší dobu chystaná revize zákona o politických stranách z roku 2005. Prospět by mohlo např́klad zahrnutí ustanovení vyžadující vytvoření vzdělávacích programů pro ženy, které by jim umožnilo více proniknout do mužského světa politiky, a aby se vláda zavázala uvolnit více finančních prostředků ze státního rozpočtu pro politické strany. Významnější roli v podpoře političek by $\mathrm{v}$ tomto ohledu měly převzít $\mathrm{v}$ zemi samotné politické strany a dále $\mathrm{v}$ zemi početné občanské společnosti a nevládní organizace. Mohly by se zaměřit na vytváření fondů na podporu začínajících političek a podporu zájmu mladších žen o politickou kariéru. Stejně tak je důležité zapojení médií, která by měla více informovat o rovnosti žen a mužů a o výzvách, kterým ženy $\mathrm{v}$ politice čelí. Až př́liš často se mediální zprávy o politických kandidátkách, pokud se vůbec objeví, soustředí více na jejich osobní život více než jejich politické návrhy a postoje. ${ }^{18}$

\section{ZÁVĚR}

V průběhu dějin Mongolska se postavení žen v mongolské společnosti nejednou změnilo. Navzdory patriarchálním hodnotám Mongolů, které nahradily původní matriarchální uspořádání, se investice do vzdělávání žen ukázala být plodná. Jejich postavení je však i nadále vzdáleno ideálnímu stavu. Ženy se musí vyrovnávat s nižšími platy, nerovnostmi ve společenském, ekonomickém i politickém životě a vnemalé míre i se sexuálním obtěžováním. Podle zprávy agencií a výborů $\mathrm{OSN}^{19}$ prezentované v rámci univerzálního periodického přezkumu stavu lidských práv v Mongolsku v roce 2020 zažilo 57,9 \% žen nějakou formou sexuálního obtěžování. Antidiskriminační ustanovení obsahuje celá řada zákonů, žádný z nich však explicitně nechrání ženy před obtěžováním mužů ani nedefinuje prrípadná nápravná opatření, což je problém na pracovištích, kde zastoupení žen převládá.

Míra nezaměstnanosti žen je v Mongolsku na nižší úrovni než nezaměstnanost mužů. V uplynulém roce dosáhla $2,6 \%$, zatímco nezaměstnanost mužů $7,1 \%,{ }^{20}$ což ke zlepšení práv žen paradoxně nemusí přispívat. V letech 2020 a 2021, kdy vláda kvůli pandemii COVID-19 průběžně zaváděla přísná omezující opatření v podobě přísných domácích karantén pro veškeré obyvatelstvo, vč. dlouhodobých uzávěr závodů, obchodů, škol, restaurací, nebo

\footnotetext{
${ }^{17}$ Více např. národní zpráva Mongolska (CEDAW/C/MNG/10) o naplňování závazků vyplývajících z CEDAW z 22. 4. 2020 [online 4. 5. 2020], 40 s. [cit. 20. 6. 2021]. Dostupná z: https://tbinternet.ohchr.org/_layouts/15 /treatybodyexternal/Download.aspx?symbolno=CEDAW\%2fC\%2fMNG\%2f10\&Lang=en. S. 26.

${ }^{18}$ A new generation of politicians in Mongolia [online 13. 7. 2020], Friedrich Ebert Stiftung [cit. 20. 6. 2021]. Dostupné z: https://asia.fes.de/news/a-new-generation-of-politicians-in-mongolia.

${ }^{19}$ Human Rights Council. Report of the OHCHR. Compilation on Mongolia [online 6. 3. 2020], 13 s. [cit. 20. 6. 2021]. Dostupné z: https://documents-dds-ny.un.org/doc/UNDOC/GEN/G20/061/32/PDF/G2006132.pdf?O penElement. S. 8.

${ }^{20}$ The Borgen Project. 6 Facts about Women's Rights in Mongolia, 2020.
} 
zákazu prodeje alkoholu, vedla $\mathrm{k}$ dalšímu zvýšení nezaměstnanosti, včetně zvýšené domácí konzumace alkoholu a následnému zvýšení prŕípadů domácího násilí.

Parlamentem schválená a novelizovaná legislativní opatření a související politické aktivity vlády nepochybně $\mathrm{v}$ posledních letech přispěly $\mathrm{k}$ zajištění účinnějšího př́stupu $\mathrm{k}$ zajišsění práv a postavení žen ve společnosti. V legislativě, exekutivě i ve vedení politických stran však panuje genderová nevyváženost a nevyrovnaná je i politická participace žen. Účast žen v politických stranách a aktivitách na elementární a sekundární úrovni je uspokojivá, zatímco účast $\mathrm{v}$ rozhodovacích procesech na manažerských úrovních je nedostatečná. ${ }^{21}$

Problémem zůstává praktická realizace zákonných nařízení, k níž je potřebné podstatně významnější finanční zajištění, personální a technická podpora, kontinuální monitoring a intenzivnější práce s veřejností za účelem zvyšování povědomí o rovných právech mužů a žen. Přetrvávající je i legislativní nedostatečnost, která stojí i za propadem žen z formální do šedé ekonomiky, nebo za neschopností žen dosáhnout větší ekonomické nezávislosti.

Nejobtížnější bariéru na cestě $\mathrm{k}$ dosažení rovnosti žen a mužů $\mathrm{v}$ mongolské společnosti nicméně představují kulturní stereotypy, které brání rychlejší změně obecného vnímání genderových otázek coby záležitostí soukromí a rodiny, a to jak u mužů, tak i samotných žen a dokonce i úředních osob. Specifické geografické a klimatické podmínky Mongolska a po staletí provozovaný kočovný způsob života Mongolů vedly v zemi k pevnému ukotvení patriarchálních hodnot a etablování specifických národních kulturních zvyků a tradic, jejichž prizmatem je v zemi nahlíženo na práva žen, a které nedokázala vymýtit ani po 70 let trvající vláda komunistické strany, která fakticky uvrhla zemi do područí Sovětského svazu.

Rostoucí úroveň vzdělanosti, více př́iležitostí k zaměstnanosti, vyjma krizového období pandemie COVID-19, pomalu se zlepšující povědomí veřejnosti o právech žen, tlak mezinárodních i místních nevládních organizací na úpravu legislativních aktů ve smyslu vyššího zohlednění genderové otázky ve všech jejích aspektech a na jejich důslednou implementaci, a zejména úsilí samotných žen převážně mladší generace zastoupených v parlamentu a v organizacích občanské společnosti o zajištění účinných záruk pro naplňování práv žen nicméně napovídá, že v mongolské sociální, ekonomické i politické sféře dochází k průběžnému zlepšování, které by mělo provázet zlepšování postavení žen.

\section{Použitá literatura}

1. A new generation of politicians in Mongolia [online], Friedrich Ebert Stiftung, 2020. Dostupné z: https://asia.fes.de/news/a-new-generation-of-politicians-in-mongolia.

2. Ariunzaya A., Mnkhmandakh M. Women and the future of work in Mongolia [online]. Friedrich Ebert Stiftung, September 2019, 28 s. [cit. 18. 6. 2021]. Dostupné z: http://library.fes.de/pdf-files/bueros/mongolei/15735.pdf

3. COVID-19 Impact on Women \& Girls in Mongolia [online]. UNDP, March 2021, 62 s. Dostupné z: https://www.mn.undp.org/content/mongolia/en/home/library/-covid19-impact-on-women-and-girls-in-mongolia--study.html.

4. European Commission: The EU Special Incentive Arrangement for Sustainable Development and Good Governance ('GSP+') assessment of Mongolia covering the period 2018-2019, Brussels, 26. s. Dostupné z: https://ec.europa.eu/transparenc y/regdoc/rep/10102/2020/EN/SWD-2020-23-F1-EN-MAIN-PART-1.PDF.

5. Evaluation of the Implementation of the Law of Mongolia on Promotion of Gender Equality. Summary Report [online]. NCEG, 11. 3. 2021, 57 s. Dostupné z: https://www.gender.gov.mn/uploads/books/attach/Evaluation\%20of\%20the\%20impl ementation\%20of\%20LPGE_EN-converted.pdf.

\footnotetext{
${ }^{21}$ Evaluation of the Implementation of the Law of Mongolia on Promotion of Gender Equality. Summary Report [online]. NCEG, 11. 3. 2021, 58 s. [cit. 20. 6. 2021]. Dostupné z: https://www.gender.gov.mn/publications ?lang_id=2. S. 4, 7.
} 
6. GEC: Facebooková stránka: https://www.facebook.com/MongolianGenderEqu alityCenter/.

7. GEC: Internetová stránka $\mathrm{s}$ informacemi o potírání obchodování $\mathrm{s}$ lidmi: https://www.stoptrafficking.mn/.

8. Human Rights Council. Report of the OHCHR. Compilation on Mongolia, 2020, 13 s. Dostupné z: https://documents-dds-ny.un.org/doc/UNDOC/GEN/G20/061/32/PD F/G2006132.pdf?OpenElement.

9. Mongolia: Comprehensive National-Level Review. Responses to questionnaire on implementation of the Beijing Declaration and Platform for Action [online], Ministry of Labour and Social Protection, Ulaanbaatar, May 2019, 69 s. Dostupné z: https://asiapacificgender.org/sites/default/files/documents/Mongolia_(English).pdf.

10. Národní statistický úřad Mongolska [online]. Dostupné z: https://www.nso.mn/home.

11. Národní zpráva Mongolska (CEDAW/C/MNG/10) o naplňování závazků vyplývajících z CEDAW z 22. 4. 2020, 40 s. Dostupná z: https://tbinternet.Ohc hr.org/_layouts/15/treatybodyexternal/Download.aspx?symbolno=CEDAW\%2fC\%2 fMNG\%2f10\&Lang=en.

12. The Borgen Project. 6 Facts about Women's Rights in Mongolia [online 17. 12. 2020]. Dostupné z: https://borgenproject.org/womens-rights-in-mongolia/.

13. The State of Women's Suffrage in Mongolia Parliament, 2020. Dostupné z: https://asiapacificmemo.ca/women-part-of-a-major-turnover-in-mongolian-parliame nt/\#: :text=Women\%E2\%80\%99s\%20suffrage\%20in\%20Mongolia\%20became $\% 20$ law\%20on\%201,a\%20greater\%20participation\%20of\%20women\%20in\%20political $\% 201$ ife.

14. Women in Mongolia. Mapping Progress under Transition [online]. United Nations Development Fund for Women, 2001, 80 s. Dostupné z: https://www.refwor ld.org/pdfid/46cadabb0.pdf.

15. https://www.legalinfo.mn (mongolský legislativní portál)

\section{Kontaktní údaje}

Mgr. Hana Brodská, LL.M.

Ministerstvo zahraničních věcí ČR

Loretánské nám. 5, Praha 1, 11800

Tel: 602277802

email: hanabrodska@post.cz 


\title{
KRIZE LIDSKÉHO VZTAHU V SOUČASNOSTI? LÁSKA JAKO KRITÉRIUM LIDSKÉHO VZTAHU
}

\section{THE CRISIS OF A HUMAN RELATIONSHIP TODAY? LOVE AS A CRITERION OF A HUMAN RELATIONSHIP}

\author{
Michal Prívara
}

\begin{abstract}
Abstrakt
Člověk 21. století zažívá a je svědkem krizí v mnoha ohledech. Tato krize neobchází ani pojmy jako láska a vztah, které jsou pro člověka důležité v mnoha dimenzích. Navzdory tomu, že člověk žije v moderní společnosti, která je ovlivněna velkým pokrokem, dochází v ní $\mathrm{k}$ relativizaci toho, co je pro každého jedince existenciálně důležité, co není možné jen tak nahradit, a to je právě láska a vztah. Rovněž tyto pojmy postihuje v dnešní moderní době dočasnost, konzum, individualismus, které popírají etiku a morálku, které předpokládají odpovědné jednání. I když o lásce a vztahu mluví v historii lidstva mnoho myslitelů, právě dnešní doba mnohem víc vybízí k poukazování na význam a důležitost těchto pojmů.
\end{abstract}

Klíčová slova: láska, vztah, krize, člověk

\begin{abstract}
In the 21 st century a human being sees and lives throught various crisis. These crisis do not bypass love or relationship. Terms that are significant to a man in number of dimensions. Despite the fact that human lives in modern society affected by great progress, a lot of significant and existential issues become relative. Things that cannot be replaced are love and relationship. In today's modern society these terms also have to face temporality, consumption and individualism. Those, however, disclaim ethics and morality for which a responsible behavior is presupposed. Even though many scholars have spoken of love and relationship in history. It is necessary to point out the importance of further discussion of these terms.
\end{abstract}

Key words: love, relationship, crisis, human

\section{1 Úvod}

V přirozeném světě člověka má láska a vztah důležité místo. Tento fenomén byl a je předmětem zájmu zejména filozofie, psychologie, antropologie a sociologie. Tato skutečnost je podporována tím, že život člověka je vlastně jeho vztahováním k sobě, druhým lidem, ale také k ostatnímu světu. V tomto smyslu vztah je jeden ze základních pilírư lásky. Vztah bez lásky existovat může, ale láska bez vztahu je nemyslitelná. Francouzsko-židovský fillozof Emmanuel Levinas poukazuje, že k základním zkušenostem člověka patří vztah a stojí v samém základu lidské existence. ${ }^{1}$ V podobném duchu se vyjadřuje filozof Martin Buber: „Kdo říká „Ty“, nemá žádné něco, nemá nic. Ale stojí ve vztahu.“2 $\mathrm{V}$ kontrastu k dnešní moderní době vyvstává paradox, že člověk přijetím odpovědnosti, se stává svobodným a plodným. Př́ekonáváním sebe sama se pak může potkat $\mathrm{s}$ tváří druhého. ${ }^{3}$ Tvář druhého předpokládá na druhé straně člověka. Lidé se ve vztahu potkávají tváří v tvář. Vnímají se navzájem. V pohledu do tváře člověka je možné vidět jeho nahotu, která není něčím

\footnotetext{
${ }^{1}$ Srov. LEVINAS, E. Totalita a nekonečno. Praha: Oikoymenh, 2020, s. 190-191.

${ }^{2}$ BUBER, M. Já a Ty. Praha: Portál, 2016, s. 8.

${ }^{3}$ Srov. LEVINAS, E. Totalita a nekonečno. Praha: Oikoymenh, 2020, s. 60.
} 
negativním, ale spíš vybídnutím k vnímavosti k potřebám druhého člověka. Ve vztahu dvou lidí by mělo jít o proces dávání, ne jenom jednostranné poskytování pomoci. Dnešní společnost ve své krizi nemá často schopnost pohlédnout do tváří. Je zde možnost být vnímavý, protože společnost je plná pohledů, které prosí a žádají. Zjevují nám nahotu skutečnosti a hlad druhého. ${ }^{4}$ Ovšem zde je možné pozorovat rozpor v tom, zda společnost chce vidět reálně význam vztahu a lásky pro jedince a společnost vzájemně, anebo odosobněním a konzumem tyto skutečnosti přehlížet. Výstižně o tom mluví německý filozof, sociolog a psycholog Erich Fromm: „Jsme společenstvím notoricky nešt'astných lidí: osamělých, úzkostných, depresivních, destruktivních, závislých - lidí, kteří rádi zabíjejí čas, jejž se tak snaží ušetřit.“" ${ }^{5} \mathrm{~V}$ tomto smyslu se v 21. století stále častěji mluví o rozvráceném životním prostředí ${ }^{6}$, rozvrácených vztazích a o rozvráceném světě. Tyto výrazy se již staly běžnou součástí vyjadřování ${ }^{7}$, ale poukazují na reálný stav a autenticitu. Rozvrácenému prostředí chybí fungující vztahy. V něm nejde ani tak o to rozvíjet, budovat vztah kjiné osobě, který je nezávislý, ale zároveň i blízký. Současnost ukazuje, že jsou zde pokusy o to, že člověk jakoby chtěl nahradit lásku i vztahy vlastněním anebo moderní technikou, ale to už není podmět vztahu, ale předmět. Podobně Erich Fromm poukazuje na fakt, že „lidé jsou dnes přitahováni mechaničnem, silnými stroji, absencí života a stále více i destrukcí. “8 Jak v tomto smyslu dále uvádí Emmanuel Levinas, „,vztah předpokládá členy, tedy substantiva.“ ${ }^{9} \mathrm{Z}$ toho se také odvíjí další krizový moment dnešní doby, a to je skutečnost, že navzdory popsaným manuálům, jak přistupovat naprííklad k pacientům, ale také třeba ve vztazích obecně platí, že tím, co člověk žije, se podílí na životě dalších lidí. Tím se ovšem stává, že takový vztah je nerovnoměrný a často jednostranný. Není to vztah dvou substantiv, ale člověka, který má dle svého postavení nějaký předmět své touhy nebo realizace. Ve vztahu je ovšem důležité, aby v něm byla aktivita $\mathrm{s}$ emočním nábojem, která respektuje vzájemnou integritu osob, ale zároveň se tato aktivita podílí na existenci obou osob, a to tvoří běh života. ${ }^{10} \mathrm{~V}$ takhle myšleném vztahu mají díky svému konání vliv jedna na druhou a tento aspekt se podílí na uspokojování potřeb. Uspokojování potřeb je žití, a to někdy vyžaduje velké úsilí o každodenní život. To, že se každý člověk snaží žít a bojovat v dennodenních zápasech o svou existenci, mu už nemusí dovolovat pochopit toho druhého v hloubce jeho existence. ${ }^{11}$ Z toho vyplývá, že vztah je pro člověka velice důležitý, ale také komplikovaný fenomén.

\section{2 Únava společnosti a setkání dvou světů}

Ve vztahu se potkávají minimálně dva světy různých lidí. Zde se odehrává celé spektrum dějů, kterými se lidé vzájemně přímo anebo nepř́imo ovlivňují. Člověk v pomáhající profesi, ale také v rovině intimní, může zažívat konflikt, únavu, ale také současně výzvu k odpovědnosti ve vztahu k druhé osobě. Každý člověk má své kvality, potřeby a hodnoty. Na jejich základě se projevuje jeho chování ve vztahu k druhému člověku. Dnešní moderní společnost si myslí, že pokrok umožní lepší prŕístup k člověku. Lidé by měli mít na sebe víc času a pozornosti. Ovšem tempo současné společnosti nepřináší to důležité, a to je prohloubení vztahu a v tom lásku, která by měla být jednou z hlavních motivací lidského jednání. Místo toho je ve společnosti možné vnímat únavu a určitý druh otrávení. Často je možné pozorovat rezignaci na žití opravdových vztahů v profesní, ale také osobní rovině.

\footnotetext{
${ }^{4}$ Srov. LEVINAS, E. Totalita a nekonečno. Praha: Oikoymenh, 2020, s. 61.

${ }^{5}$ FROMM, E. Mit, nebo být? Praha: Portál, 2020, s. 19.

${ }^{6}$ Srov. FROMM, E. Mit, nebo být? Praha: Portál, 2020, s. 21.

${ }^{7}$ Srov. LEVINAS, E. Existence a ten, kdo existuje. Praha: Oikoymenh, 2009, s. 18.

${ }^{8}$ FROMM, E. Mit, nebo být? Praha: Portál, 2020, s. 21.

${ }^{9}$ LEVINAS, E. Existence a ten, kdo existuje. Praha: Oikoymenh, 2009, s. 18.

${ }^{10}$ Srov. LEVINAS, E. Existence a ten, kdo existuje. Praha: Oikoymenh, 2009, s. 18.

${ }^{11}$ Srov. LEVINAS, E. Existence a ten, kdo existuje. Praha: Oikoymenh, 2009, s. 20.
} 
Existuje několik druhů únavy, které přispívají k únavě člověka. Existuje únava ze společnosti, ze všech lidí, ale také z člověka ze sebe sama. V podobném duchu mluví také Emmanuel Levinas. V jeho myšlenkách se objevuje to, co se děje v současné společnosti. Vypadá to, že je zde mezi lidmi únava ze všeho, ale jako by zde chyběla odpovědnost, která by měla člověku připomínat závazek, který vyplývá z jeho existence. ${ }^{12}$ Vyžaduje se aktivita, akce, nějaké konání, které člověka vytrhne z jeho osobní únavy. Zde je ale potřebná odpovědnost a vědomí, že takové jednání už není jenom sobecké realizování jednoho jedince, ale že takové jednání ovlivňuje i svět druhého člověka se všemi důsledky. Únava může způsobit, že člověk rezignuje, vzdává se kultivace, proměňování sebe a okolí. Vzdává se pohybu, který je nesmírně důležitý pro to, aby se mohlo něco změnit. Tento fenomén je pozorovatelný také v pomáhajících profesích, ale i v osobních vztazích. Na jedné straně člověk může být vzdělaný, odborník ve svém oboru, ale vlivem nastavení společnosti, fungování organizace, ale i např́íklad díky charakterovému nastavení, se může stát, že takový člověk upadne do stavu únavy a neaktivity. Sice si vykonává svou práci, plní si své povinnosti, ale chybí zde něco víc, co by ho vybízelo k jednání a usilování. Místo toho se lidé nechávají unášet svým životem. Nějakým způsobem naplňují svůj život - existenci, ale u mnohých jedinců v jednání chybí odpovědnost za své jednání k sobě samotným, k lidem, se kterými vstupují do nějaké formy vztahu, ale rovněž ke společnosti. Pokud se tedy člověk vzdává jednání, tedy pohybu, tak v určitém slova smyslu se vzdává možnosti pohybu k dobru. Tento typ pohybu se dá nazvat jako dobrodružství, která vybízí člověka k jednání. Součástí takového dobrodružství jsou rovněž neúspěchy a zklamání, ale to patř́i do dynamiky života. ${ }^{13}$ Každý lidský život v sobě nese tíhu břemena a komplikací. ${ }^{14}$ Aby se člověk udržel v pohybu, aby se nedostal do ochromení z únavy, tak je důležité mít v sobě úsilí, které ho povede k odpovědnému jednání $\mathrm{k}$ druhým lidem. Ovšem taková forma úsilí není hra ${ }^{15}$, protože to pak má důsledky na další lidi. To, co člověk dělá a jak jedná, jak se vztahuje k sobě, k druhým lidem a ke společnosti, by měla být určitá forma mystiky. Emmanuel Levinas říká, že „radost nikdy nespočívá v práci samotné. “16 A to je něco, co je vidět v dnešní společnosti. Současný člověk, ale i společnost, chce vidět efekt $\mathrm{z}$ vykonaného díla hned, ale často tomu tak není. Je to spíš nějakou dobu trvající úsilí, intenzivní práce krok za krokem, které provází celé dílo člověka a postupně vede k nějaké formě završení. Ovšem takové úsilí chce čas a trpělivost. Umění pracovat s neúspěchy, ale i s progresem, ale také vnímat a reflektovat důsledky svého jednání. V tom spočívá mystika. Celý tento fenomén můžeme pozorovat např́iklad u lékařů, ale i u jiných pomáhajících profesí, kde lidé chtějí hned vidět výsledky své práce. V tomto zaměření na výsledek se může stát, že před sebou nebudou vidět člověka, ale jenom předmět své práce. V případě, že efekt jejich nasazení nebude adekvátní, tak jak si představovali, tak se může dostavit únava, znechucení. Ten druhý, kterému je pomáháno, je člověk a úsilím mu pomoct, se vstupuje do jeho světa. Toto setkání dvou světů se odehrává ve vztahu. Tím, že člověk žije v dnešní společnosti, tak podléhá tlaku, aby viděl efekt své práce, pokud možno, co nejrychleji, ale ve vztazích je určitá dynamika, která potřebuje čas. Proto se jeví jako důležité, aby se $\mathrm{v}$ dnešních pomáhajících profesích, ale i osobních vztazích znovu promýšlela a rozvíjela osobní mystika, díky které bude moci člověk lépe pochopit a vstoupit do života druhého člověka. Vztah je fenomén, ve kterém se odehrává velká dynamika. Podle Martina Bubera: „Vztah je vzájemnost." ${ }^{17}$ Nemělo by to být jenom v tom, že konkrétní člověk bude vyškolen $\mathrm{v}$ komunikačních schopnostech, technikách př́stupu $\mathrm{k}$ člověku, bude náležitě

\footnotetext{
${ }^{12}$ Srov. LEVINAS, E. Existence a ten, kdo existuje. Praha: Oikoymenh, 2009, s. 20.

${ }^{13}$ Srov. LEVINAS, E. Existence a ten, kdo existuje. Praha: Oikoymenh, 2009, s. 23.

${ }^{14}$ Srov. LEVINAS, E. Existence a ten, kdo existuje. Praha: Oikoymenh, 2009, s. 24.

${ }^{15}$ Srov. LEVINAS, E. Existence a ten, kdo existuje. Praha: Oikoymenh, 2009, s. 28.

${ }^{16}$ LEVINAS, E. Existence a ten, kdo existuje. Praha: Oikoymenh, 2009, s. 28.

${ }^{17}$ BUBER, M. Já a Ty. Praha: Portál, 2016, s. 17.
} 
vzdělán ve svém oboru, ale mělo by to být o větších charakterových kvalitách člověka, které by měl v sobě objevit a postupně kultivovat. Jsou určité věci, které se nedají naučit a vyškolit a ty pak jsou často lidé schopni ve vztahu vycítit v tom, jak je k nim přistupováno. Mnoho vztahů v pomáhajících profesích je totiž asymetrických a jsou to vztahy z moci k bezmoci. V tomto ohledu se jeví jako důležité, aby si člověk ve svých profesních, ale také osobních vztazích udělal odstup, reflexi. Měl by si pojmenovat své touhy a motivy svého jednání. Rovněž je důležité udělat si odstup mezi ním samotným a tím, co je žádoucí. ${ }^{18}$ Vztah se odehrává v setkávání s druhým člověkem. Potřebný člověk se stává součástí člověka pomáhajícího a opačně. To samé platí i v osobní rovině vztahů. Ve vztahu k druhému člověku je důležitá bezprostřednost, protože dochází k setkání se skutečným člověkem. ${ }^{19}$ Člověk ve vztahu není věc, ale bytost se svým světem a tyto světy se vzájemně prostupují v určité míře vzájemného poznání. Proto pro bioetiku je v tomto kontextu důležité analyzovat procesy, které ve společnosti probíhají a neuspokojit se jenom s tím, že neseme označení moderní a vyspělé společnosti. Protože pod tímto označením mohou již probíhat skryté procesy, které postupně díky reflexi mohou poukazovat na postupné vyprazdňování některých důležitých fenoménů, $v$ tomto př́padě lásky a vztahu, které se rovněž mohou dostávat do krize.

\section{Hodnota druhého člověka}

Pro hodnotu člověka, ke kterému se přistupuje v nějaké formě vztahu, je důležité si uvědomit, že ,je to, co já nejsem: je slabý, zatímco já jsem silný, je chudý, je „vdova a sirotek““،"20 Do jakéhokoliv typu vztahu vstupují lidé, kteří mají hodnotu už jenom tím, že mají svůj čas a svůj osobní př́běh. Tuto hodnotu druhého člověka je možné uznat už jenom tím, že k němu bude pomáhající člověk přistupovat $\mathrm{s}$ tím, co má ve svém vlastním světě. Tím, co nabyl ve svém životě svým studiem, prací a dalšími aspekty. ${ }^{21} \mathrm{Je}$ potřeba vykročit dál za egoistické naplňování slasti, protože tomuto riziku je pomáhající profesionál vystaven. To znamená mít vědomí, že ve vztahu jde také o hodnotu člověka a ten druhý by neměl být obětí egoismu člověka, který pomáhá. Člověk, který potřebuje pomoc není předmětem, ale partnerem ve vztahu a jeho role nespočívá v tom, aby díky své bezmocnosti, byl v zajetí něčí moci. Toto tvrzení také potvrzuje výrokem Martin Buber, když říká: „Člověk, jemuž říkám „Ty“, není předmětem mé zkušenosti. Ocitám se však ve vztahu k němu, ve svatém základním slově. Teprve když z něho vystoupím, je tento člověk znovu předmětem mé zkušenosti. Zkušenost mě vzdaluje mému Ty. “22 Když se na trpícího člověka nahlíží z titulu poskytované pomoci, tak se často neví nic o jeho hodnotách, jak on vnímá svět, společnost. Proto by se mělo na člověka, kterému je poskytovaná pomoc nebo podpora, nahlížet v rámci možností komplexně. Také je důležité si ve vztahu uvědomovat, kdo je člověk, zvláště ten, kterému se poskytuje pomoc, ten, který stojí, sedí anebo leží před člověkem, který v tomto vztahu mu (tomu druhému) poskytuje pomoc. V současném uvažování o člověku vystupuje do popředí jeho hodnota, úcta ke každému lidskému jedinci, úcta k životu, jedinečnost každého lidského jedince. Co ovšem schází v dnešním postmoderním světě je to, že se často rezignuje na větší implementování těchto poznatků do praxe. Podobně jak se investuje např́íklad do př́strojového vybavení nemocnic, tak je v současné době neméně důležité investovat do lidského vybavení lidí, kteří vstupují do vztahů na základě poskytování pomoci. Někdy mezilidský chlad ve vztazích umí spíš zhoršit stav člověka než mu prospět. Podobně i ten druhý, jiný člověk, je ve vztahu jako bližní pro pomáhajícího člověka. Ovšem tato blízkost

\footnotetext{
${ }^{18}$ Srov. LEVINAS, E. Existence a ten, kdo existuje. Praha: Oikoymenh, 2009, s. 33.

${ }^{19}$ Srov. BUBER, M. Já a Ty. Praha: Portál, 2016, s. 14.

${ }^{20}$ LEVINAS, E. Existence a ten, kdo existuje. Praha: Oikoymenh, 2009, s. 80.

${ }^{21}$ Srov. LEVINAS, E. Totalita a nekonečno. Praha: Oikoymenh, 2020, s. 61.

${ }^{22}$ BUBER, M. Já a Ty. Praha: Portál, 2016, s. 12.
} 
člověka by se neměla nějak degradovat, ale spíš posouvat, vylepšovat. ${ }^{23}$ Podobně i pomáhající pracovník může v tomto vztahu získat mnoho aspektů, které mohou posunout jeho život a profesní zrání. Sám Emmanuel Levinas říká, že nestačí jenom utřít slzu, nebo vykonat nějaké dostiučinění, př́padně pomstu, ale že nesmí se ztratit žádná slza z lidské bolesti a utrpení. $^{24}$ V tomto kontextu David Velleman poukazuje na to, že každá osoba má mimořádnou hodnotu a je hodna milování. ${ }^{25}$ Ovšem již neřeší otázku konfliktu mezi láskou a povinností. ${ }^{26} \mathrm{~V}$ tomto smyslu se $\mathrm{v}$ rámci etického jednání od člověka, který pomáhá, očekává, že poskytovaná pomoc nebude jen a pouze pracovní výkon, za který dostane nějakou mzdu, ale očekává se nějaká emoce, postoj, který nepřehlédne trápení člověka. Co si pod tím představit? Ten přesah, který dnes chybí ve vztahu k člověku spočívá pravděpodobně v tom, co uvádí Emmanuel Levinas: „Laskavost utěšitele, který se v bolesti lehce dotýká, neslibuje konec utrpení, neohlašuje náhradu, ve svém doteku se netýká potom ekonomického času. Souvisí se samým okamžikem bolesti, který pak už není odsouzen sám k sobě, který, unášen „jinam“ pohybem laskavosti, se osvobozuje ze sevření „sebe sama“, dostává „,̌erstvý vzduch“, svoji dimenzi a budoucnost.“27 Z výše uvedeného vyplývá, že ve vztahu je důležitá autenticita. Tato forma autenticity si všímá velké hodnoty člověka, ale současně by si pomáhající profesionál měl uvědomovat své limity a možnost pochybení. Je důležité, aby pomáhající profesionál měl odpovědnost za své jednání a činy.

\section{Motivace a způsob jednání}

Rozhodnutí pro nějaké povolání a jeho výkon, ale také rozhodnutí pro vstup do osobní roviny vztahu vyžaduje nějakou motivaci. Takové rozhodnutí má svůj začátek, určitý typ narození. V člověku se postupně utváŕí. Dá se říct slovy Emmanuela Levinase, že „každý okamžik je nějaký počátek, narození.“28 Tyto okamžiky často na sebe navazují a ve vztazích je potřebné je aktualizovat, aby bylo možné reflektovat další směřování k druhému člověku. Díky chybějící reflexi původní motivace v kontextu současnosti, toho, co člověk žije tady a ted', se může stát, že někde ve své existenci uvízne. V tomto smyslu by měl pomáhající profesionál konat v nejlepším zájmu ve vztahu k lidem, kterým poskytuje nějakou formu intervence. Podobně mu může pomáhat zdravě reflektující svědomí jako určující motivační síla. Kvalitně fungující mezilidský vztah je velká hodnota a motivace. Nedostatek v tomto ohledu může způsobit vyhoření, zranění, zneužití moci atp. Další velkou motivací ve vztahu je postoj $\mathrm{k}$ milované osobě. Zde jde primárně o osobu a ta je důležitá bez ohledu na nějaký výsledek snažení. Tím postojem je láska k osobě, která potřebuje pomoc. ${ }^{29}$ Ovšem takový postoj je možné realizovat $\mathrm{v}$ aktu lásky. V tomto kontextu vhodně poznamenává Erich Fromm: „Milovat znamená být tvořivě činný. Obsahuje péči, poznávání, odpovídání, stvrzování, radování: z člověka, ze stromu, z obrazu, z myšlenky. Znamená oživovat, zvyšovat životnost druhých lidí i věcí. Je to proces sebeobnovování a růstu. ${ }^{\text {“30 }} \mathrm{V}$ tomto ohledu podle Martina Bubera: „,...láska se děje. City přebývají v člověku, ale člověk přebývá ve své lásce. To není metafora, nýbrž skutečnost: láska nevězí v Já v tom smyslu, že by Ty bylo pouze jejím „obsahem“, jejím předmětem; láska je mezi Já a Ty. ... Láska je působení zasahující celý

\footnotetext{
${ }^{23}$ Srov. LEVINAS, E. Existence a ten, kdo existuje. Praha: Oikoymenh, 2009, s. 80.

${ }^{24}$ Srov. LEVINAS, E. Existence a ten, kdo existuje. Praha: Oikoymenh, 2009, s. 76.

${ }^{25}$ Srov. VELLEMAN, J. D., Love as a Moral Emotion [online]. 1999 [cit. 2021-06-15]. Dostupné na WWW: https://archive.nyu.edu/bitstream/2451/34645/2/Velleman_Love.pdf

${ }^{26}$ Srov. VELLEMAN, J. D., Love as a Moral Emotion [online]. 1999 [cit. 2021-06-15]. Dostupné na WWW: https://archive.nyu.edu/bitstream/2451/34645/2/Velleman_Love.pdf

${ }^{27}$ LEVINAS, E. Existence a ten, kdo existuje. Praha: Oikoymenh, 2009, s. 76.

${ }^{28}$ LEVINAS, E. Existence a ten, kdo existuje. Praha: Oikoymenh, 2009, s. 64.

${ }^{29}$ Srov. VELLEMAN, J. D., Love as a Moral Emotion [online]. 1999 [cit. 2021-06-15]. Dostupné na WWW: https://archive.nyu.edu/bitstream/2451/34645/2/Velleman_Love.pdf

${ }^{30}$ FROMM, E. Mit, nebo být? Praha: Portál, 2020, s. 59.
} 
svět.“31 Z uvedeného vyplývá, že pro akt lásky je důležitý vztah. Vztah je ten prostor, kde je možné realizovat lásku, která je silně kreativním dynamismem pro člověka. Člověk dává, ale také dostává. Je to proces vzájemného působení.

\section{Závěr}

Toto pojednání nenabízí konkrétní řešení a formu jednání, ale chce přinést a otevř́ít diskusi k uvedené problematice, která se jeví jako aktuální v mnoha rozměrech. Každý jeden lidský jedinec stojí ve vztahu k druhému člověku vždy před volbou, zda mu v nějaké formě ublíží, zneužije, ovládne, anebo díky lásce se bude druhého člověka snažit pochopit, spolupracovat, naslouchat mu, slyšet volání člověka o pomoc a následně bude schopen reagovat a poskytnout adekvátní pomoc. Konstatování myslitele své doby Ericha Fromma se zdá být znovu aktuální a vybízí k hluboké reflexi, když zdůrazňuje: „Potřeba hluboké proměny člověka se nejeví jen jako etický nebo náboženský požadavek ani jako pouze psychologický požadavek plynoucí z patogenní povahy našeho současného společenského charakteru, ale také jako podmínka pro samo přežití lidského rodu. Správné žití není již jenom naplněním etického nebo náboženského požadavku. Poprvé v dějinách přežití lidského rodu závisí na radikální změně lidského srdce. Avšak změna lidského srdce je možná jen v té míře, v níž dojde k drastickým ekonomickým a společenským změnám, které poskytnou lidskému srdci šanci změnit se a odvahu a vizi tuto změnu provést. “32 Z uvedeného textu je zřejmé, že reflexe je důležitá zvláště v kontextu toho, jaký je význam lidského vztahu pro člověka, co je kritériem jeho jednání, v čem spočívá jeho motivace v profesionální rovině, ale také v té osobní. Neméně důležitá se ukazuje potřeba provést analýzu toho, jakým způsobem se klade důraz na problematiku fenoménu ,vztah“ a pojmenovat stav krize tohoto jevu.

\section{Literatura}

1. BUBER, M. Já a Ty. Praha: Portál, 2016. 128 s. ISBN 978-80-262-1093-1.

2. FROMM, E. Mit, nebo být? Praha: Portál, 2020, 238 s. ISBN 978-80-262-1646-9.

3. LEVINAS, E. Existence a ten, kdo existuje. Praha: Oikoymenh, 2009. $84 \mathrm{~s}$. ISBN 80-86005-36-4.

4. LEVINAS, E. Totalita a nekonečno. Praha: Oikoymenh, 2020. 273 s. ISBN 978-80-7298-535-7.

5. VELlEMAN, J. D., Love as a Moral Emotion [online]. 1999 [cit. 2021-06-15]. Dostupné na WWW: https://archive.nyu.edu/bitstream/2451/34645/2/Velleman_L ove.pdf (anglicky).

\section{Kontaktní údaje}

ThLic. Mgr. Michal Prívara

Ústav humanitních studií v lékařství

1. lékařská fakulta, Univerzita Karlova

Karlovo náměstí 40, 12108 Praha 2

Email: michalprivara@seznam.cz

\footnotetext{
${ }^{31}$ BUBER, M. Já a Ty. Praha: Portál, 2016, s. 16-17.

${ }^{32}$ FROMM, E. Mít, nebo být? Praha: Portál, 2020, s. 23.
} 


\title{
TEOLOGIA CHRZTU W KATECHIZMIE RAKOWSKIM (1605) NA TLE NAUCZANIA ORTODOKSYJNEJ REFORMACJI
}

\author{
THEOLOGY OF BAPTISM IN RACOVIAN CATEHISM (1605) IN \\ COMPARSION WITH REFORMED ORTHODOXY
}

\author{
Karolina Szymczyk
}

\begin{abstract}
Abstrakt
Celem artykułu jest analiza fragmentu Katechizmu Rakowskiego poświęconego problematyce ponurzania (chrztu). Autorka rekonstruuje zawartość dogmatyczną wyżej wskazanego ustępu zarówno z perspektywy teologii historycznej jak i historyczno-literackiej. Innymi słowy ustęp dzieła zostanie odczytany jako materializacja dyskursu teologicznego Braci Polskich, który podlega uwarunkowaniom wewnątrz tekstualnym (rozpoznania natury dogmatycznej są efektem procesu egzegetycznego, czyli interpretacją i wyborem passusów biblijnych, tak aby wskazać na zachodzącą między nimi zależność i tym samym utrzymać spójność wywodu, argumentacji) i zewnątrz tekstualnymi (odmienne rozumienie „sakramentu” ponurzania buduje poczucie odrębności członków Zboru Mniejszego od ortodoksyjnych Kościołów reformacyjnych - luterańskiego i kalwińskiego). Rozstrzygnięcia dogmatyczne zwerbalizowane przez redaktorów Katechizmu Rakowskiego w tym artykule zostaną zestawione z nauczaniem o chrzcie przyjętym w Zborach luterańskich i kalwińskich. Treść Katechizmu Rakowskiego zostanie zestawiona z wybranymi katechizmami „ojców reformacji”, które były szczególnie istotne dla formującej się na terenie Rzeczpospolitej Obojga Narodów teologii protestanckiej.
\end{abstract}

Stowa kluczowe: chrzest, ponurzanie, Katechizm Rakowski, reformacja, protestantyzm, Rzeczpospolita Obojga Narodów, Faust Socyn, Bracia Polscy, close-reading, Katechizm Kościoła w Genewie, Mały Katechizm, Duży Katechizm, Zasady religii chrześcijańskiej, pedobaptyzm, antypedobaptyzm, Marcin Luter, Jan Kalwin, Huldrych Zwingli, arianizm, socynianizm

\begin{abstract}
The purpose of this article is to analyze the fragment of Rakovskovian Catechism devoted to the problem of baptism. The author reconstructs the dogmatic content of the above-mentioned passage from the perspective of both historical theology and literary history. In other words, the passage will be read as a materialization of the theological discourse of the Polish Brethren, which is exposed to within-textual conditions, i.e. recognition of dogmatic nature is the effect of the exegetical process (the interpretation and selection of biblical passages), and outside of the text conditions (the different understanding of the "sacrament" of baptism builds the sense of separateness among the members of the Church Minor from the orthodox churches of the Reformation - Lutheran and Calvinist). The dogmatic solutions verbalized by the editors of Rakovian Catechism in this article will be juxtaposed with the teaching on baptism adopted in the Lutheran and Calvinist Churches. The content of Rakovsky's Catechism will be compared with selected catechisms of the "fathers of the Reformation," which were particularly important for the Protestant theology that was forming in the PolishLithuanian Commonwealth.
\end{abstract}


Keywords: baptism by immersion, immesionism, Institutio religionis christianae, Luther's Large Catechism, Luther's Small Catechism, Catechism of Church of Geneva, Rackovian Catechism, Polish-Lithuanian Commonwealth, reformation, Polish Brethren, Faust Socyn, socinianism, arianism, pedobaptism, antipedobaptism, adult baptsim, Martin Luther, John Calvin, , Huldrych Zwingli, close-reading

\section{Wprowadzenie: kontekst historyczny}

Przybycie do Polski Fausta Socyna (w roku 1579) wywołało ideologiczny ferment w zborach Braci Polskich, który dotyczył w znacznej mierze problemu chrztu. Ostentacyjna odmowa przyjęcia chrztu udzielona przez Socyna Jerzemu Szomanowi i Marcinowi Czechowcowi spowodowała, że włoski myśliciel nie mógł być uznany za pełnoprawnego członka Zboru i uczestniczyć w sakramencie Wieczerzy Pańskiej (Szczucki 2006: 178). Odosobnienie z jakim musiał się mierzyć, niezrozumienie ze strony wpływowych teologów kształtujących doktrynę poszczególnych zborów - mowa tutaj o Jerzym Szomanie twórcy katechizmu Catchechesis et confesio fidei ... (1574) i Marcinowi Czechowicowi twórcy Rozmów Chrystjańskich sprawiło, że Włoch zmienił strategię i zaprzestał głoszenia swoich radykalnych, poglądów, dopóki nie wychował pokolenia swoich uczniów (Moskorzowskiego, Volkela, Stoińskiego. Szmalca) spod których pióra wyszedł Katechizm Zboru tych ludzi... (Ogonowski 2015:291)

Doktryna wyrażona chrztu wyrażona w katechizmach Braci Polskich, czyli Rozmowach Chrystyjańskich (1575) i Catchechesis et confesio fidei ... (1574), traktuje ten sakrament jako „skuteczny znak odpuszczenia grzechów”, co stanowi czytelne nawiązanie do protestanckiej nauki o zbawieniu przez łaskę. W obu katechizmach potwierdzenie skuteczności chrztu zawarte zostaje już w pytaniu wyjściowym: „Quid est baptismo” i „(...) co o ponurzeniu rozumieć mam".

Wątpliwości, co do konieczności udzielania sakramentu chrztu, jakie na początku swojego pobytu w Polsce wyraził Socyn od razu spotkały się z polemicznym responsem (Marcin Czechowic m.in. w tym celu napisał traktat De paedobaptistarum errorum origine et de ea opinione) Konflikt pomiędzy Marcinem Czechowiczem a Faustem Socynem zasadzała się na tym, że pierwszy uznawał chrzest jako obowiązujący nakaz Boga (universale mandatum). Zatem jako konieczny do zbawienia. Drugi z adwersarzy traktował go jako adiaforę, czyli rzecz obojętną dla zbawienia (Szczucki 1964:112). Ponadto teologia Braci Polskich do tej pory zachowała łączność z kalwinizmem, zwłaszcza w rozumieniu pojęcia „odkupienie”. Zdaniem Czechowica dokonuje się ono tylko poprzez krew i mękę Chrystusa. W tej tajemnicy partycypuje się poprzez chrzest, będący zaproszeniem do niesienia krzyża i walki z grzechem w sobie (Czechowic 1979: 245-246). Z kolei zdaniem Fausta Socyna teologia chrztu wykładana przez Zbór jest „sekcarską” spuścizną anabaptyzmu, zamiast otwierać Kościół dla wszystkich wierzących tworzy z niego ekskluzywną wspólnotę, która karmi się poczuciem wyższości nad pozostałymi braćmi i siostrami (Socyn 1613: 202-217). Przykładanie nadmiernej wagi do rytuału chrztu sprawia, że wierzący tracą z oczu to, co naprawdę istotne. Jego zdaniem nie potrzeba praktykować obrzędu, który fałszywie włącza w Zbawienie. W Zbawienie włącza jedynie naśladowanie Chrystusa, który jest wzorem pobożności i sprawiedliwości danym ludziom przez Boga (Chmaj 1958: 171). 


\section{Przyczyny zestawienia i selekcja tekstów - Katechizm Kościoła Genewskiego Jana Kalwina (1545) ${ }^{1}$ i Katechizm Heidelberski (1563) ${ }^{2}$}

Wybór katechizmów, $\mathrm{z}$ których treścią konfrontuję nauczanie zawarte w Katechizmie Rakowskim podyktowany tym jak ważną rolę odegrały one w kształtowaniu się postaw teologii reformacyjnej zarówno w całej Europie jak i w Rzeczpospolitej Obojga Narodów. Należy traktować je jako dzieła, które stanowiły doktrynalny fundament, umożliwiający rozwój rodzimej reformacji. Teksty te zainspirowały poszczególne zbory do tworzenia polskojęzycznych katechizmów (m.in. działalność Piotra Gilowskiego). Do czasu wydania Katechizmu Heidelberskiego (1564) Katechizm Kościoła Genewskiego (1563) stanowił ważną lekturę formacyjną dla tradycji kalwińskiej. Przekłady obu dzieł na język polski powstały symultanicznie i ujrzały światło dzienne w roku 1564 - Katechizm Heidelberski spod pióra Andrzeja Prażmowskiego (Estraicher 1912) i Katechizm Genewski wydany anonimowo jako Kathechizmus, to iest, sposob nauczania y ćwiczenia dziatek $w$ prawdziwey y ssczyrey naucze Krześcijańskiey vczyniony na kstatt rozmowy. Za intersujący fakt uznać należy, że drugie z wymienionych dzieł, zostało zapomniane przez historyków polskiej reformacji. O jego istnieniu i wadze przypomniała badaczka Margarita Korzo (Korzo 2012: 127). Z kolei w odniesieniu do polskiej recepcji Katechizmu Heidelberskiego trzeba wskazać, że podejmowano niezależne od siebie prace tłumaczeniowe w poszczególnych Zborach, co świadczy zarówno o zapotrzebowaniu na to dzieło jak i słabej wymianie informacji pomiędzy poszczególnymi wspólnotami protestanckimi (Korzo 2013: 53-63). Szczególną popularnością cieszyło się jego wydanie polsko-łacińskie z roku 1605 - Catechesis religionis christianae. Popularność tego katechizmu również była wynikiem specyficznego profilu polskiej reformacji (zwłaszcza kalwinizmu), która przede wszystkim pozostała pod wpływem Filipa Melachtona (Tazbir, Szczucki 1959: 27). Badacze toczą spory nad tym czy wyżej wymieniony katechizm można uznać za przejaw ortodoksji kalwińskiej, czy też luterańskiej. Rozwiązania tego problemu winno się upatrywać w fascynacji współtwórcy tego dzieła, czyli Zachariasa Ursinusa, teologią Melanchtona (Sthom 2014: 24). Skłaniam się ku traktowaniu go jako hybrydy melachtońsko-kalwińskiej.

\subsection{Argumenty za udzielaniem chrztu niemowlętom (pedobaptyzm).}

W Katechizmie Kościoła Genewskiego argumentów za udzielaniem chrztu uaptruje się we właściwym rozumieniu stosunku znaku do znaczenia. Skoro rzeczywistość „niższego rzędu” odsyła do tej „wyższego rzędu” to pozbawienie dziecka znaku obietnicy bożej nie wyłącza go spod działania łaski (Q 337). Próba pomniejszenia łaski poprzez całkowite uzależnienie jej od obecności znaku to wystawienie miłosierdzia Boga na próbę (Q 337).

W myśli Jana Kalwina dostrzec można konsekwencję w stosowaniu wyrażenia znak (signum) bez poprzedzania go przymiotnikami ,widzialny”, „zewnętrzny”. Jedynym wyjątkiem od reguły jest użycie terminu (signo visibli) w odniesieniu do obrzezania (Q 338). Powyższy zabieg ma na celu wskazanie na relacją zachodzącą pomiędzy obietnicami Starego i Nowego Testamentu. Księgi te reprezentują dwa porządki obietnic - cielesny i duchowy, który jest dany tylko potomkom „nowego Adama” (McGrath 2009: 225).

\footnotetext{
${ }^{1}$ Korzystam z wydania Katechizmu Jana Kalwina - Catechismus ecclesiae Genevensis hoc est, formula erudiendi pueros in doctrina Christi, wyd. apud Wendelinum Rihelium, 1545. Wydanie łacińskie nie posiada paginowanych stron. Numery pytań podaję w oparciu o numerację zastosowaną we współczesnym tłumaczeniu opublikowanym na stronie internetowej:

${ }^{2}$ Korzystam również z dwóch wydań Katechizmu - wersji trójjęzycznej, czyli łacińskiej, angielskiej ,niemieckiej (The Heidelberg catechism, in German, Latin and English with an historical introduction, New York 1830) i polskiego thumaczenia Katechizm Heidelberski 1563 dostępnego online: https://cdn.websiteeditor.net/7f4141ff6b0846b4afea3bcd7564ea25/files/uploaded/Katechizm\%2520Heidelberski.pdf
} 
Podkreślić należy, że wykonanie znaku chrztu niekoniecznie wiąże się z aktem otrzymania darów duchowych. Zostają one udzielone przez Boga w dowolnym momencie (zasada suwerenności Boga). Ponadto każdy człowiek rozumie i rozpoznaje je (proferant) poprzez osobisty akt wiary (Q 339) na mocy, którego partycypuje w łasce umartwienia cielesnego człowieka (Q 332), wszczepienia go w Chrystusa i włączenia w Kościół (Q 323, Q 330). Skuteczność sakramentu chrztu nie wiąże się z koniecznością posiadania wiary (Q 333). Jednocześnie nie jest ona „obiektywnie wiążąca” jako obietnica udzielona całej ludzkości, ale subiektywnie (jako obietnica dana konkretnemu człowiekowi). Powyższą refleksją należy powiązać z doktryną Kalwina (duplex gratia). Proces uświęcania poprzez wiarę wymaga poruszenia ludzkiego serca i zarazem odpowiedzi człowieka na wołanie Boga, co wpisuje się w humanistyczną antropologię (Billings 2007: 106-107).

Wymienić należy również słabości w argumentacji Jana Kalwina, za które uznać należy jego rozważania nad warunkami godziwego przyjęcia chrztu (posiadanie wiary, odbycie pokuty Q 332). Nie tylko wymaga on osobistego zaangażowania od osoby, chcącej się ochrzcić, ale musi one być dowiedzione również przed wspólnotą - tj. ,...) że Duch Boży mieszaka w nas” (Q 332). Z kolei w następnym punkcie Katechizmu zaprzecza, aby posiadanie wiary było niezbędne, aby ochrzcić niemowlę (Q333).

„Nieprzejrzystość wywodu” wynikać może z faktu, że reformator zmieniał zdanie, co do posiadania przez dzieci wiary. W pierwszej edycji Nauki religii chrześcijańskiej wyrażał pogląd, iż ją posiadają. W następnych edycjach stwierdzał, że niemowlęta posiadają jedynie „,ziarno wiary”, czyli zadatek pełnej wiary (Barnett 2017: 627). Ponadto w Katechizmie Kościoła Genewskiego nie zostają jasno wskazane związki pomiędzy obrzezaniem i chrztem. Powyższe ceremonie nie mogą być traktowane równorzędnie. Jedyną wspólną dla nich płaszczyzną jest to, że wymagają aktu pokuty (Q 332, Q336). Kalwin nie powołał się w tym wywodzie na pominął w tym wywodzie najbardziej oczywisty element łączący te obrzędy, czyli wejście do wspólnoty wierzących - Przymierza i Kościoła Bożego.

Słabość argumentacji zawartej w powyższym Katechizmie twki w pominięciu fragmentu (Mk 10; 13-16), który przemawia za praktyką pedobaptyzmu. Analiza filologiczna tego passusu zostaje przeprowadzona przez genewskiego reformatora w Nauce religii. Wskazuje, że w języku greckim określenia ( $\pi \alpha \iota \delta ı \alpha$, paidia) używa się w stosunku do dzieci nieumiejących jeszcze chodzić, zatem niemowląt.

Z kolei w Katechizmie Heidelberskim zostaje historyczna i zbawcza ciągłość pomiędzy chrztem a obrzezaniem (pyt. 74). W powyższym punkcie autorzy wskazują, że dzieci w takim samym stopniu są członkami Kościoła jak osoby dorosłe. Takie rozwiązanie problemu możliwe możliwe było tylko w przypadku uznania tożsamości obrzędu wejścia do Przymierza i chrztu. Zarazem ceremonia nakazana w Starym Testamencie, po wypełnieniu zawartych w nim obietnic, zastąpiona zostaje przez chrzest. Nakaz ponurzania małych dzieci wiążę się również z charakterem Kościoła, który nie przestaje istnieć i zachowuje ciągłość. Tą prawdę wyraża obrządek chrztu. Powyższe dowodzenie inspirowane jest poglądami Marcina Lutra, który w Katechizmie Większym uzasadnił praktykę chrztu niemowląt odwołując się natury Kościoła i do „tradycji” (Luter 1859: 204). Twórcy Katechizmu odwoływali się również do luterańskiego rozumienia wiary, która jest po prostu „darem Ducha Świętego”.

\subsection{Określenia chrztu i rozumienie tego Sakramentu}

Kolejność poruszonych w Katechizmie Kościoła Genewskiego zagadnień odzwierciedla sposób, w jaki o tym obrzędzie myślał Kalwin. Na początku wskazuje na eklezjalny wymiar chrztu (Q 323), który to buduje wspólnotę (widzialną i niewidzialną) chrześcijan: „in ecclesiam aditus nobis est". Ponadto wejście do Bożej rodziny wiąże się z duchową adopcją człowieka, która dokonała się poprzez śmierć Chrystusa. Zmycie win człowieka 
spowodowało, iż mógł być on $\mathrm{z}$ powrotem nazywany dzieckiem przez wgląd na sprawiedliwość i ofiarę Jezusa (Q 323, Q 330).

W kolejnych punktach katechizmu (Q 324, Q327) reformator wymienia duchowe konsekwencje chrztu odpuszczenie grzechów (Ef 5:26) i odnowę ducha (Rz 6:4). Za kwestię istotą uznaje Kalwin ukazanie związku pomiędzy wodą a Sakramentem chrztu. Otóż, aby nie przypisywać samej materii nadprzyrodzonego działania, zatem uchronić wiernych od idolatrii, ukazuje, iż widzialny aspekt Sakramentu potrzeby jest tylko wiernym. Poprzez to, co widzialne Bóg objaśnia znaczenie swoich działań, które podejmuje w duszy człowieka. (Q 325).

Kalwin zdaje sobie sprawę, że zredukowanie Sakramentu tylko do aspektu jego podobieństwa (similitudinis) do działania duchowego godzi w integralność znaku i znaczenia. Stąd niewiele brakuje już do uznania Sakramentów za zbędne, pozbawione boskiej mocy. Dlatego też Kalwin uzupełnia swój wywód. Wyjaśnia, że uznanie obmycia wodą jedynie za „metaforę” (figuro) obmycia duchowego jest tylko częściowo prawdą. Pomimo, że woda nie ma takiej mocy, aby zgładzić grzechy, co może uczynić tylko Chrystus, to owa rzeczywistość odkupienia została zamknięta w symbolu wody (Q 328). Otrzymane „nowe życie” naznaczone jest wciąż zmaganiami ze starym człowiekiem, czyi pozostałościami grzechu. Chrzest, który jest pieczęcią (signo) danych człowiekowi obietnic zapewnia go, że nie powróci już więcej w niewolę grzechu (Q327, Q 330, Q 332).

W Katechizmie Palatyńskim chrzest zostaje określony jako „zewnętrzna kąpiel” (externus baptismus). Ta nazwa pojawia się dwukrotnie. Po raz pierwszy w celu zbudowania analogii pomiędzy kąpielą a obmyciem z win (69), po raz drugi, aby wskazać, kto jest prawdziwym dawcą chrztu (72). W zasadzie owo określenie stanowi największą doktrynalną różnicę pomiędzy omawianymi dziełami. Zapewne pierwotnie intencją autorów Katechizmu Heidelberskiego była polemika z katolicyzmem. Określenie to wyjęte z kontekstu sporu doktrynalnego z katolicyzmem uznać można za dosyć niefortunne. Umniejsza ono wagę Sakramentów i w konsekwencji sprowadza do rangi obrzędów pobawionych znaczenia.

Autorzy Katechizmu Heidelberskiego koncentrują się jedynie na wyjaśnieniu duchowego, a zatem niewidzialnego aspektu obrzędu, pomijając objaśnienia dotyczące znaku. Stanowi to największą różnicę pomiędzy omawianymi katechizmami. Rozdźwięk pomiędzy Katechizmami ujawnia się szczególnie w pytaniach (Q 326 i Q 327) i (70). Genewski reformator kładzie nacisk na opisanie jak dokonuje się odnowienie natury ludzkiej i obmycie grzechów. Kładzie nacisk na działanie sakramentu w przeciwieństwie do autorów Katechizmu Heidelberskiego, którzy preferują wyjaśnianie znaczeń poszczególnych „duchowych jakości” (krew Chrystusa, Duch).

Sakrament chrztu w obu przypadkach postrzegany jest jako „obietnica”, „rękojma”, „znak” obmycia z grzechów (73). Celem ponurzania jest umocnienie w wierze i zapewnienie o odpuszczeniu grzechów $(69,70)$. Za doskonałe rozwiązanie z perspektyw apologetycznej uznaję odwołanie do konkretnych fragmentów, w których mowa o konieczności udzielania chrztu i obietnicy na jaką on wskazuje (70). Poza bezpośrednio zacytowanymi fragmentami (Mt 18:19), (Mk 16;16) w Katechizmie tym podkreśla się, iż wszystkie słowa mówiące o kąpieli odrodzenia” i „obmyciu z grzechów” (Tyt 3:5, Dz 22,16) odnoszą się do bożej obietnicy.

Za istotną różnicę uznać należy inne rozłożenie akcentów Jan Kalwin rozpatruje ponurzanie przede wszystkim w kontekście wspólnotowym, zaś w Katechizmie Heidelberskim chrzest jest indywidualnym, zbawczym wydarzeniem ${ }^{3}$.

\footnotetext{
${ }^{3}$ Qua ratione in Baptismo admoneris et confirmaris te [podkr. K. Sz] unicii illius sacrificii Christi particpum esse (69)".
} 


\section{Analiza fragmentu (Katechizmu Rakowskiego) O ponurzaniu ${ }^{4}$}

$\mathrm{W}$ omawianym fragmencie widoczna jest dysproporcja pomiędzy wykładem negatywnym (wyjaśnienie, czym nie jest ponurzanie) a wykładem pozytywnym (wyjaśnienie, w jaki sposób należy rozumieć ponurzanie). Ukształtowanie formalne tego rozdziału jasno wskazuje, że kluczową intencją jest przede wszystkim polemika z błędnymi przekonaniami na temat chrztu wśród wyznawców reformacji Uwaga redaktorów koncentruje się przede wszystkim na wykazaniu nieprawidłowości w egzegezie następujących fragmentów: Tyt 3:5, Dz 22:10, J 3:5. Zdaniem autorów dzieła właśnie za pomocą tych passusów swoje błędne nauczanie głoszą „drudzy” (przeciwnicy Braci Polskich). Ponadto warto wskazać na obraną przez twórców Katechizmu Rakowskiego strategię egzegetyczną. Czytają oni wyżej wymienione passusy osadzając je w ich najbliższym kontekście, bez odnoszenia do całości Pisma Świętego ${ }^{5}$. Zapewne rezygnacja $z$ ich lektury w kluczu typologicznym i alegorycznym ułatwia negację łączności pomiędzy przymierzem, a chrztem (na co z kolei na ogół kładła nacisk teologia ortodoksyjna).

Ponurzenie zostało w Katechizmie zdefiniowane jako „zwierzchowna ceremonia”, z publicznym wyznaniem wiary. Jest rodzajem „widzialnej deklaracji” przystąpienia do Kościoła i odejścia od pogaństwa. Określenie „zwierzchowna ceremonia” nie posiada umocowania w Piśmie Świętym, co wydaje się świadomym zabiegiem zastosowanym przez redaktorów dzieła. Decyzja o skonstruowaniu definicji w oparciu o „niebiblijne” określenie wynikała $\mathrm{Z}$ pobudek natury pragmatycznej. Postrzeganie ponurzenia jako tylko „Zwierzchownej ceremonii” pomniejszało rangę tego obrzędu (jest to jedynie zewnętrzna forma, od której nie jest zależne zbawienie). Ponadto służyło podważeniu zasadności terminologii stosowanej przez przedstawicieli kalwinizmu, czy też szerzej reformacji, która zasadzała się na metaforyce „odnowienia” i „odrodzenia” i „obmycia w krwi Chrystusa”. Autorzy katechizmów kładli nacisk m.in. na łączność pomiędzy elementami sprawczymi chrztu, czyli omyciem wykonywanym za pomocą wody, działaniem Ducha Świętego i Słowa Bożego $^{7}$. Innymi słowy utożsamiano działanie chrztu z duchowym odrodzeniem. Redaktorzy Katechizmu Rakowskiego, aby obalić to przekonanie powołują się na passusy wskazujące na suwerenność Słowa Bożego, przez które jedynie dokonuje się odrodzenie (Jk 1:18, 1P 1:23).

\subsection{List do Tytusa (Tyt. 3,5)}

Zdaniem redaktorów Katechizmu Rakowskiego kluczem do zrozumienia tego fragmentu jest określenie ,figurowanie" 8 . Apostoł wcale nie naucza o tym, że przyczyną odrodzenia jest

\footnotetext{
${ }^{4}$ Analizie poddany jest fragment Katechizmu Rakowskiego, który znajduje się na stronach: 232-235.

5 Ten styl lektury tekstu można porównać do metody współcześnie określanej jako close reading (czytania uważnego).

${ }^{6}$ W Stowniku pojęciowym języka staropolskiego określenie ,zwierzchnie” zostaje wyjaśnione jako ściśle powiązane z praktyką egzegetyczną. Otóż jest to interpretacja tekstów „w sposób ukazujący przenośne, skryte znaczenie pisma (w odniesieniu do królestwa bożego w niebie)". Innymi słowy chrzest może być uznany za rodzaj metafory mówiącej o wejściu do Królestwa Bożego (Słownik pojęciowy języka staropolskiego, w: https://spjs.ijp.pan.pl/haslo/index/22230).

7 Zob. Katechizm Brzeski 1553/1554, oprac. F. Puławski, Warszawa 1908, s. 47, Katechizm albo krótkie zebranie wiary i powinności Chrześcijańskiej z Modlitwami, Psalmami i Pieśniami, Lubcz 1621, s.7, K. Kraiński, Katechizm: to iest Nauka krotka Wiary Krześćiańskiey, Kraków 1609, s. 62-63.

${ }^{8}$ Warto zwrócić uwagę w jakim kontekście pojawia się wyrażenie figurować. Na przykład Marcin Czechowic używa go, aby wskazać na stosunek pomiędzy Starym a Nowym Przymierzem: „,a takbyśmy cień z jasną a własną rzeczą, ciemność $\mathrm{z}$ światłością, figurę $\mathrm{z}$ rzeczą figurowaną, zakon $\mathrm{z}$ Ewanjelijum, Chrystusa $\mathrm{z}$ Mojżeszem pomieszać musieli (Czechowic 1578: 25-26). Odrzucenie Starego Przymierza jako zawierającego tylko obietnice cielesne, nieopartego na wierze, która zbawia, było stanowiskiem powszechnym wśród Braci Polskich (wyłączywszy nieliczną grupę judaizantów z Szymonem Budnym na czele). W momencie powstawania Katechizmu Rakowskiego panowała powszechna zgoda, co do niższości Starego Testamentu. Został on unieważniony przez Nowe Przymierze (Zob. Ogonowski 2015:68).
} 
ponurzenie (chrzest). Powyższy fragment zostaje oświetlony poprzez passus (Ef 5:26), który również wskazuje na to, że założenie o łączności chrztu z obmyciem jest błędne. Jedyną przyczyną oczyszczenia jest Słowo, czyli „omycie wody w Słowie” (Ef 5,26). Intencją apostoła nie jest zalecanie chrztu, ale zachęcanie członków wspólnoty do życia w zgodzie z nauczaniem Chrystusa. Owa zachęta apostoła - zdaniem redaktorów - uwydatnia prawdę o tym, że chrześcijaninem może być (lub stać się) człowiek dojrzały i świadomy, który bierze odpowiedzialność za swoje życie. Dlatego też sakrament ponurzania powinien być udzielany tylko ludziom dorosłym, którzy są w stanie na mocy aktu woli wstąpić w poczet członków Zboru: „A należą niemowniątka do tej ceremonii? Nie należą, bo o tym ani rozkazania, ani przykładu żadnego w Piśmie św. nie mamy”.

\subsection{Dzieje Apostolskie (Dz. 22, 16)}

Powyższe słowa kierowane przez Jezusa do Szawła odczytać można jako wykład na temat tego, czym są sakramenty. Są one po prostu „oświadczeniem”, potwierdzeniem rzeczywistego działania Boga który udziela łaski przebaczenia. Rozumienie terminu „oświadczenie”, na które wskazują redaktorzy Katechizmu Rakowskiego, jest podobne do interpretacji jakiej dokonał na kartach Nauki o Sakramecniech Świętych Jan Kalwin. Porównał on sakrament do „pieczęci” zamieszczonej na liście. Pieczęć (jako znak) sama w sobie nie jest obietnicą, na której widnieje, ani nie czyni jej skuteczną (Kalwin 1626: 21). Zadaniem pieczęci jest poświadczanie zgodności treści $\mathrm{z}$ opisem, autoryzowanie jej. Pieczęć pozbawiona jest jakiejkolwiek mocy, pomaga człowiekowi za pomocą zmysłów utwierdzić się w tym, że Bóg podejmuje konkretne działanie.

Należy podkreślić, że Bracia Polscy przypisują Słowu znacznie większą autonomię (niż teologowie ortodoksyjnej reformacji), czego konsekwencją jest całkowite oderwanie elementu znaczonego do znaczenia. Powyższy proces można omówić na przykładzie egzegezy fragmentu dotyczącego nawrócenia Pawła. Zostało ono zainicjowane przez Słowo, przez które zostały odpuszczone winy. Zatem proces nawrócenia rozpoczęła łaska uprzedzająca wymagająca od człowieka odpowiedzi dokonanej na mocy jego aktu woli. Odpowiedzią na nią jest „wzywanie imienia Chrystusa”, czyli złożenie wyznania wiary. Zatem ceremonia ponurzania wpisana w kontekst nawrócenia Pawła, powinna być traktowana tylko jako znak zapewniający o odpuszczeniu grzechów. Z takim rozumieniem chrztu zgodziłby się jeszcze Jan Kalwin: „Pawle, abyś był pewniejszy, że grzechy Twoje są już odpuszczone" (Kalwin 1626: 21-22)

Zdaniem Braci Polskich prawdziwe ,ponurzanie w Chrystusa” nie dokonałoby się, gdyby wola człowieka nie została najpierw (jednoznacznie) nakierowana ku dobru - Bogu, co wiąże się z „odmianą jego woli i umysłu”. Sprawczość człowieka w tym zakresie zostaje uwypuklona poprzez fakt, że dokonany przez niego ,akt woli” odnośnie przemiany życia ma prawdziwą moc sprawczą - dzięki zaangażowaniu człowieka Bóg może nieodwracalnie przemienić jego życie. Powyższa przemiana nie ma charakteru procesualnego, ponieważ nakierowanie wolnej woli na Boga przywraca człowiekowi „czystość” (której de facto nigdy nie utracił) i usuwa skłonność do grzechu. Trzeba podkreślić, że takie rozumienie ponurzania neguje jego ekspiacyjny charakter. Zatem nie powinno się wskazywać na jedność pomiędzy chrztem Janowym, czyli pokuty a Chrystusowym ${ }^{9}$. Wiąże się to z faktem, że ludzkość uwolniona od Starego Zakonu wkracza w nowy etap rozwoju duchowego, na którym osiągnięcie doskonałości chrześcijańskiej jest możliwe. Toteż chrzest Jana był nieustanną pokutą w oczekiwaniu na Chrystusa, zaś teraz „szczera pokuta” wystarcza człowiekowi, aby

\footnotetext{
${ }^{9}$ Powyższa myśl zostaje rozwinięta w rozdziale (Katechizmu Rakowskiego) O urzędzie ofiarowniczym, który traktuje o oczyszczeniu wszystkich grzechów w Nowym Przymierzu. W tym czynów skierowanych jawnie przeciwko Bogu.
} 
nie powracał już więcej do grzesznego życia: ,przez prawdziwe pokajanie zaraz z tego powstał i do niego więcej nie wracał".

W ramach podsumowania winno się wskazać z jakich określeń chrztu, które można by było wywieść z omawianego fragmentu Dz 22:20, Bracia Polscy świadomie rezygnują. W przeciwieństwie do zawartości katechizmów kalwińskich nie pojawia się określenie „kąpiel wodna”, „kąpiel odrodzenia”10. Autorzy przy objaśnianiu tego fragmentu konsekwentnie nie posiłkują się analogią zachodzącą pomiędzy obmyciem wodą a zmyciem grzechów. Powyższa egzemplifikacja zostaje dokonana na innym przykładzie - Wieczerzy Pańskiej. Materialna reprezentacja „chleb i wino” razem z błogosławieństwem (w połączeniu ze słowem) potwierdzają partycypowanie w misterium krwi i ciała Chrystusa $\mathrm{w}$ takim samym stopniu jak ponurzenie uzmysławia przynależność do Zboru. Również za znaczące uznać należy „przemilczenie” analogii zachodzącej pomiędzy działaniem wody a chrztem. Taki zabieg ma na celu wykorzenienie błędnej egzegezy Tyt 3:5. Samo, zaś wyrażenie ,ponurzenie wodne” pada tylko w pierwszym pytaniu, dalej określenie ,ponurzenie” funkcjonuje już samoistnie.

\section{Podsumowanie}

Podobieństwa pomiędzy teologią chrztu zawartą na kartach Katechizmu Rakowskiego, a doktryną zawartą w ortodoksyjnych katechizmach protestanckich są nieznaczne. Powinny być tratowane raczej jako jedynie zbieżności w doborze terminologii teologicznej, której obecność w dyskursie Braci Polskich obarczona jest innymi konotacjami niż w przypadku „ortodoksyjnego" rozumienia chrztu. Sformułowanie „zwierzchowna ceremonia” występujące w polskojęzycznym wydaniu Katechizmu Rakowskiego można uznać za dosłowne thumaczenie utrwalonego $\mathrm{w}$ tradycji reformacji wyrażenia externus baptismus. Powyższe nawiązanie należy traktować jako wyraźny akcent polemiczny wobec tradycji reformacji (kalwińskiej i luterańskiej). W zamyśle redaktorów ma jasno wskazywać na fakt, że chrzest nie jest rozumiany jako „sakrament”, czyli jako nośnik łaski bożej (por. Nimmo 2016: 79-95). Inaczej niż w przypadku reformatorów, podkreślających znaczenie sakramentów jako źródła pomnażania wiary i zapewnianie o tym, że wiara i łaska potrzebna do zbawienie staje się udziałem członków Zboru, Bracia Polscy kładą nacisk na znacznie samej wiary (jako daru Ducha Świętego) wzmacnianej przez życie zgodne z etyką chrześcijańską. Sądzę, że w omawianym rozdziale Katechizmu Rakowskiego egzegeza została poporządkowana $\mathrm{w}$ pełni zamierzeniom polemicznym. Wykorzystano passusy biblijne, na które powoływano się w ortodoksyjnych katechizmach, by uzasadnić niesakramentalny charakter chrztu i zanegować związek zachodzący pomiędzy pobożnym życiem chrześcijańskim (przemianą życia) i obrzędem ponurzania.

Należy zauważyć, że w wersji łacińskojęzycznej katechizmu z kolei pojawia się określenie ritus initationis, które to należy rozumieć jako „wprowadzenie do służby bożej, udział w niej samej”. Pomimo że sam Faust Socyn w swoim katechizmie Religionis christianae brevis institutio powoływał się na formułę externus baptismus, autorzy Katechizmu Rakowskiego i w tym przypadku zdecydowali się na wybór innego określenia, by zamanifestować odrębność własnej doktryny chrzcielnej od doktryny ortodoksyjnej reformacji (Socyn 1629: 52-53). Właściwe rozumienie chrztu jest warunkiem wstąpienia do wspólnoty i podporządkowania się zasadom w niej panującym.

Doktrynę chrzcielną Jana Kalwina i Braci Polskich łączyć może głębokie przekonanie o tym, że bezwzględnie powinno się dążyć do poznania i zrozumienia natury darów udzielanych człowiekowi przez Stwórcę, co jest warunkiem wstąpienia do Zboru (Jan Kalwin używa w tym kontekście formuły ritus initationis). Powyższa przesłanka prowadzi członków Zboru

\footnotetext{
${ }^{10}$ Odnoszą się one w większym stopniu do fragmentu Tyt 3:5.
} 
Mniejszego do zgoła innych rozstrzygnięć: dzieci nie powinny być ponurzane. Jan Kalwin z kolei podkreślał, że poznanie może nadejść później. Ponadto należy wskazać na jeszcze jedno wspólne rozstrzygnięcie teologiczne. Deprecjonowanie przez Jana Kalwina wartości Starego Testamentu (McGrath 2009: 225-227) mogło stać się impulsem dla członków Zboru Braci Polskich, którzy doprowadzili do negacji Starego Testamentu i tym samym poddali krytyce ryt obrzezania jako praktykę o proweniencji „pogańskiej”. Odrzucenie sakramentalnego znaczenia chrztu było następstwem tego rozpoznania. Sądzę, że oddzielenie znaku jakim jest chrzest od znaczenia wpisanego w ten ryt wydaje się mieć swoje źródła nie tyle w teologii Jana Kalwina, co przede wszystkim Urlicha Zwingliego. Najbardziej dobitnie spośród przedstawicieli ortodoksyjnej reformacji wskazywał na symboliczne znaczenie sakramentów, zaś w nauczaniu o Chrystusie uwypuklał jego człowiecze posłannictwo (Misiurek 1983:17). Fakt, że jego teologia stała się inspiracją dla rozwoju szwajcarskiego odłamu anabaptyzmu (w tym wpłynęła na Baltazara Hubmaiera) wskazuje na szerszy problem. Otóż biorąc pod uwagę intensywność kontaktów utrzymywanych przez Braci Polskich z różnymi ugrupowaniami anabaptystów, na co wskazuje G.H. Williams w artykule Anabaptsim and spiritualism in Poland and Lithuania warto dokonać wnikliwej analizy porównawczej pomiędzy teologią chrztu wykładaną przez przedstawicieli anabaptyzmu (m.in. Menno Simensa, Baltazara Hubmaiera, Piotra Riedmanna, Jakuba Huttera) i nauczaniem Braci Polskich w tej materii (por. Williams 1958: 215-262). Ten obszar badawczy, choć ciekawy wykracza poza ramy tego artykułu.

\section{Bibliografia}

1. Billings, J, T., 2007, Calvin, Participation and the Gift, Oxford.

2. Barret, M., 2017. Reformation Theology: Systematic summary. Illinois: Crossway.

3. Catechesis et confessio fidei, 1574, brak miejsca wydania.

4. Czechowic, M., 1578, De paedobaptistarum errorum origine et de ea opinione. Lublin.

5. Czechowic, M., 1979, Rozmowy chrystyjańskie (oprac. A. Linda). Warszawa: PWN.

6. Czechowic, M, 1578, Trzech dni rozmowa o niektórych artykułach tych czasów wzruszonych, Łosk.

7. Chmaj, L., 1958, Wykłady Rakowskie. W: L. Chmaj, ed. Studia nad arianizmem. Warszawa: PWN, s. 169- 202.

8. Kalwin, J., 1545. Catechismus ecclesiae Genevensis hoc est, formula erudiendi pueros in doctrina Christi, Wendelinum Rihelium.

9. Kalwin, J., 1626. Nauka o sakramenciech swiętych Nowego Testamentu :wzięta z czwartych ksiąg Institucii nabożeństwa krześćiańskiego Iana Kalwina. Lubcz.

10. Korzo, M., 2013. Psalmy Dawidowe (Gdańsk 1606). Przyczynek do recepcji Katechizmu Heidelberskiego w Polsce. Biblioteka nr 17, s. 53-63.

11. Korzo, M., Jeszcze raz w sprawie nieznanego w Polsce ttumaczenia Jana Kalwina $w$ Polsce, Odrodzenie i reformacja w Polsce, nr 56, s. 191-201.

12. McGrath, A. E., Jan Kalwin studium kształtowania kultury zachodu, tłum. J. Wolak, Warszawa 2009,

13. Misiurek, J., 1983. Chrystologia Braci Polskich. Okres przedsocyniański, Lublin: Redakcja Wydawnictwo Uniwersytetu Lubelskiego.

14. Ogonowski Z., 2015, Socynianizm. Dzieje poglądy, oddziaływanie. Warszawa: Oficyna wydawnicza Aspra

15. Socyn F., 1613. De baptismo aquae disputatio. Raków.

16. Katechizm zboru tych ludzi, 1605, Raków.

17. Socyn, F., 1629. Religionis christianae brevis institutio. Raków. 
18. Szczucki, L., 1964. Marcin Czechowic. Studium z dziejów antytrynitaryzmu polskiego XVI wieku. Warszawa: PWN.

19. Szczucki L., 2006, Humaniści heretycy inkwizytorzy. Studia z dziejów kultury XVI i XVII wieku. Kraków: Polska Akademia Umiejętności.

20. Szczucki, L., Tazbir, J., Wstęp: W: Literatura ariańska w Polsce XVI wieku: antologia. Warszawa: 1959.

\section{Kontakt}

Karolina Szymczyk, Mgr

Uniwersytet im. Adama Mickiewicza w Poznaniu

Wieniawskiego 1, 61-712 Poznan

Poland

karszymczyk@gmail.com, 517327389 


\title{
UTRPENÍ, ZÁRMUTEK A NADĚJE V SOUVISLOSTI S PERINATÁLNÍ ZTRÁTOU - VYBRANÉ ETICKÉ ASPEKTY
}

\section{SUFFERING, GRIEF AND HOPE ASSOCIATED WITH PERINATAL LOSS - SELECTED ETHICAL ASPECTS}

\section{Markéta Královcová}

\begin{abstract}
Abstrakt
Příspěvek vychází z praktických zkušeností z práce s rodinami, které zažily perinatální ztrátu, a zamýšlí se nad několika vybranými situacemi, které jsou charakterizovány výrazným etickým rozměrem.
\end{abstract}

Klíčová slova: utrpení, zármutek, naděje, perinatální ztráta

\begin{abstract}
The article is based on practical work with families who suffered perinatal loss and deals with several specific situations selected for their distinctive ethical dimension.
\end{abstract}

Key words: suffering, grief, hope, perinatal loss

"Těhotenství a porod, ale také nemoc a smrt očekávaného ditěte jsou soukromé rodinné události, které vyžaduji co největši míru soukromi a podpory okolí. Úkolem zdravotniku je poskytnout rodině co nejširši škálu možností a podpořit je, aby se svobodně a informovaně rozhodli udělat to, co považují za správné."

Lenka Pazdera (7)

\section{UVEDENÍ DO TÉMATU}

Při své praktické práci (pracuji v dětském hospici Nadačního fondu Klíček a také jako dula) se už více než dvacet let setkávám s rodiči, jejichž miminko zemřelo. Setkávám se také s profesionály, kteří rodiče při perinatální ztrátě doprovázejí: s porodními asistentkami, lékaři a kolegyněmi dulami.

V uplynulých dvou letech jsem byla součástí expertní skupiny projektu "Začít znovu", věnovanému perinatální ztrátě; projekt s podporou Evropské unie realizovala Unie porodních asistentek. Jedním z výstupů projektu jsou samostatné webové stránky "Informační portál o perinatální ztrátě pro zdravotnické a pečující profese", v rámci projektu se rovněž podařilo pořídit dvě průmyslově vyráběné chladicí podložky, umožňující delší uchování tělíčka zemřelého dítěte v prostředí mimo márnici, pro dvě vybrané tuzemské nemocnice $-\mathrm{s}$ jednou $\mathrm{z}$ nich řadu let spolupracuji, a dostala jsem možnost ji coby př́jemce chladicí podložky doporučit.

Ve svém příspěvku se dotýkám několika eticky citlivých situací, s nimiž jsem se v souvislosti s perinatální ztrátou v poslední době setkala a které ovlivňují způsob, jakým rodina tuto ztrátu prožívá. 


\section{2 (NE)PŘIPRAVENOST NEMOCNIČNÍCH TÝMŮ NA SITUACI, KDY SI RODINA PŘEJE STRÁVIT VÍCE ČASU SE ZEMŘELÝM DÍTĚTEM}

"Když jsem se ted's tou maminkou znovu setkala, bylo to rok od úmrtí jejího miminka, teprve otevřela ten baliček, co ji dali v porodnici, a zjistila, že tam byly informace, které by bývala využila, " reflektovala kolegyně dula svou osobní zkušenost se ženou - cizinkou, která si prála zůstat s tělíčkem svého mrtvě narozeného dítěte delší dobu, než jakou jí personál české porodnice, v níž své dětátko přivedla na svět, umožnil (11). V zemi, odkud žena pochází, není kontakt s mrtvým dítětem nijak významně časově omezen: mezi běžnou výbavu tamějších porodnic patří průmyslově vyráběná chladicí podložka - ta se umístí do postýlky či košíku pod dítě a propojí s chladicí jednotkou, která zajišt’uje průběžnou cirkulaci chladicí směsi. Díky chlazení je možné tělo zemřelého dítěte ponechat v blízkosti jeho rodičů - podložka se v řadě zemí anglosaského světa hojně využívá v hospicích, porodnicích, na novorozeneckých odděleních - a rodiče si ji také mohou půjčovat domů; v Británii tuto službu dokonce zajištují i některé pohřební ústavy.

V písemných materiálech, které zmíněná žena po narození svého mrtvého dítěte $\mathrm{v}$ porodnici dostala, byla mimo jiné obsažena informace o tom, že naše organizace touto podložkou disponuje a může ji okamžitě zapůjčit. Personál porodnice však sám s touto informací nijak nepracoval a ženě možnost zápůjčky přímo nenabídl ani nezprostředkoval. K bolesti ze ztráty dítěte tak v tomto př́padě přistoupila ještě další bolest způsobená tím, že rodiče nedostali dostatek času na rozloučení.

Střetly se tu dvě kultury, dva odlišné systémy a hodnotové přístupy: v obou zemích je zdravotnictví na podobné úrovni, ale prristup $\mathrm{k}$ potřebám truchlících rodičů je $\mathrm{v}$ tuzemských nemocnicích stále relativně nepoučený; personálu zde často chybí zkušenost (i otevřenost a odvaha, jež by mu umožnily potřebné zkušenosti získat), a někdy i autentický zájem o to, co rodina ve skutečnosti prožívá. Kontakt tuzemských zdravotníků se světem i potřeba dostát podmínkám mezinárodních akreditací vede často $\mathrm{k}$ tomu, že se české nemocnice a porodnice svým zahraničním protějškům po vizuální stránce podobají - jejich proměna však často nepřekročí hranici formální imitace, nepropíše se z předmětné roviny do funkční roviny sociální. V právě popsané kazuistice nic technicky nebránilo tomu, aby rodiče dostali čas navíc, který si přáli - formální přístup personálu, spočívající víceméně jen v pasivní distribuci balíčku pro rodiče zaživší ztrátu dítěte, pravděpodobně ovlivnil i to, že rodiče necítili potřebu balíček otvírat. (Více k tématu též v Kapitole 5.)

Onu maminku ovšem zjištění, že v ČR není zatím vůbec běžné, aby rodiče dostali dost času na rozloučení se svým zemřelým dět’átkem, pohnulo natolik, že se rozhodla vytvořit vlastní iniciativu na podporu rodičů v podobné situaci a uspořádala sbírku na zakoupení chladicí podložky pro využití v ČR. Celou iniciativu věnovala památce svého zemřelého dět’átka.

Nezájem o změnu situace $\mathrm{v}$ přístupu $\mathrm{k}$ tělíčku zemřelého dítěte má své hlubší kořeny a nelze jej dávat za vinu samotným zdravotníkům, kteří se na péči dnes podílejí: systém nemocniční péče se opírá o celý propracovaný mechanismus, jehož součástí jsou i závazné postupy, metodiky a pravidla pro situace, jež mohou nastat. Étos porodnic, kam se v našem kulturním prostředí ve druhé polovině dvacátého století postupně přesunuly prakticky všechny porody, stojí na tom, že porodnice má pomáhat rodit děti, nikoli věnovat se ženám, jejichž dítě zemřelo. Na smrt novorozence bylo dokonce dlouho nahlíženo jako na událost potenciálně podezřelou, takže např́klad v sedmdesátých letech minulého století nebylo výjimkou, když truchlící ženu ještě v nemocnici vyslechl vyšetřující kriminalista - aby zjistil, zda smrt svého dítěte nezpůsobila záměrně.

V tuzemských porodnicích se také ve druhé polovině 20. století rozšíríil tzv. rituál “zmizení mrtvého novorozence".

Tento rituál byl zkonstruován zdravotníky s cílem minimalizovat psychické utrpení rodičů po perinatální ztrátě. Novorozenec byl rychle odnesen z porodního sálu, aby žena své dítě 
neviděla a často nedostala ani informace o tom, kolik dítě váǎilo a měřilo, někdy ani to, jakého bylo pohlaví. (8, s. 63)

Tým dětského hospice Nadačního fondu Klíček, jehož jsem součástí, během svých přednášek předvedl $\mathrm{v}$ uplynulých třech letech chladicí podložku studentům zdravotnických oborů, ale také dulám a zaměstnancům některých hospiců a porodnic. Teoretický zájem byl veliký, ovšem připravenost využít podložku v praxi zatím velká není.

"Je to určitě dobře vymyšlené, ale tady na porodnici bych to nechtěl, měl bych strach, že nám to bude prinášet smůlu," upřímně přiznal svůj pocit primář porodnice $\mathrm{v}$ jednom českém okresním městě. (11)

"A neni to pro rodiče spíš protahování toho trápení, když pak mají to tělo delší dobu u sebe?" vyjadřovala se lékařka s dlouhou praxí v jedné velké tuzemské porodnici. (11)

Tento typ reakce sice dokládá relativně malé povědomí o prožívání a potřebách rodin čelících ztrátě, není ale proč se nad ním pohoršovat - otevřené vyjádření pocit'ovaných rozpaků je $\mathrm{v}$ důsledku lepší, než snaha přizpůsobit se možnému módnímu trendu a vybavit oddělení zařízením, o jehož potřebnosti není personál ve skutečnosti přesvědčen: v takovém př́padě by se totiž chladicí podložka $s$ největší pravděpodobností stala jen nevyužívanou součástí inventáře. Vnitřní postoj zdravotníka k prostředkům, které svému pacientovi nabízí, se totiž zásadním způsobem odráží ve způsobu, jakým na ně pak pacient reaguje (3, s. 34).

"Chce to určitě čas, ale u nás jsme na to už připravení, pracovali jsme na zménách v prístupu několik let, rodiče třeba povzbuzujeme, aby pozvali i prarodiče, aby se mohla s dětátkem rozloučit celá rodina, " komentovala praxi na svém pracovišti porodní asistentka při přebírání chladicí podložky do užívání (12) - jen několik hodin po slavnostním předání se tato nová pomůcka dočkala prvního využití. Osobní nasazení několika porodních asistentek a jejich osobní zájem na změně přístupu tu napomohly změnám, jež mají výrazný pozitivní dopad na kvalitu péče na celém oddělení. Změna $\mathrm{v}$ prŕstupu $\mathrm{k}$ tělu zemřelého dítěte přitom není vázaná na průmyslově vyráběnou chladicí podložku, jejíž pořízení je poměrně nákladné. Taková podložka se sice snadno používá a její rozšíření v západním světě má až rysy jisté okázalosti a módnosti (výrobce má na svém webu řadu referenčních odkazů, a dokonce i pasáž z populárního amerického televizního seriálu z nemocničního prostředí, v níž se jeho podložka explicitně objevila): v podstatě je ale největším prrínosem tohoto výrobku uživatelský komfort. $\mathrm{V}$ praxi je totiž samozřejmě možné tělíčko zemřelého dítěte stejně účinně chladit i běžnými namrazovacími destičkami, jaké se standardně použivají např́iklad v potravinářství - jsou levné a dostupné, docílí se jimi stejného efektu, jen jejich používání není tak pohodlné, nebot' je nutné je v pravidelných intervalech vyměňovat.

Levnou alternativu zmiňuji proto, že $\mathrm{v}$ tomto př́padě není systémová změna závislá na finančních prostředcích, ale na připravenosti zdravotnického personálu. Nelze očekávat, že by změnu vyvolal jen zájem zdola, tedy od rodičovské veřejnosti: je to pečující zdravotník, kdo výrazně ovlivňuje atmosféru příslušného pracoviště a kdo svým - i neverbálním - jednáním a postojem sděluje a dává najevo, co je zde považováno za možné, normální, vítané nebo nevítané, žádoucí či nežádoucí. V situacích, které představují provozní problém či výzvu, má kompetenci přinášet možná řešení také pouze zdravotník - povaha zdravotnického systému, charakterizovaného asymetrickým vztahem mezi poskytovateli a př́ijemci služby, ani jiné uspořádání prakticky neumožňuje.

Po těžkém období, kdy byl v tuzemských porodnicích výše popsaný rituál “zmizení mrtvého novorozence" běžnou praxí, tak s používáním chladicí podložky přichází zásadní změna a pro pečující personál může být významným posílením a povzbuzením.

Jde o změnu se silným etickým nábojem, nebot' se dotýká velmi zásadní a současně velmi intimní oblasti lidského prožívání. Pro rodiče, zažívající ztrátu svého dítěte, jde o účinný způsob, jak projít touto těžkou dobou bez přítěže dalších emočních zranění - možnost významněji neomezovaného kontaktu s tělíčkem dítěte rodičům dovoluje lépe a trvaleji se se 
ztrátou vyrovnat. Situace se mění i pro personál - mohou-li rodičům nabídnout více času, tak důležitého pro normální prožívání zármutku, stává se jejich péče citlivější a adekvátnější.

Jako každý systémový krok, i využití chladicí podložky otvírá pomyslné dveře navazujícím změnám $\mathrm{v}$ dosud zavedené praxi, včetně možnosti odvézt tělíčko zemřelého dítěte z nemocnice - napřr. domů nebo do dětského hospice.

\section{DOPAD NOVELY ZÁKONA O POHŘEBNICTVÍ NA PRAXI PŘI PERINATÁLNÍM ÚMRTÍ V SITUACI, KDY SE RODIČE ROZHODNOU ODVÉZT TĚLÍČKO ZEMŘELÉHO DÍTĚTE ČI PLOD PO POTRATU MIMO NEMOCNICI}

Přijetí novely zákona č. 256/2001 Sb o pohřebnictví a o změně některých zákonů, která vstoupila v platnost $\mathrm{k}$ 1. 9. 2017, provázely pochvalné komentáře, zejména $\mathrm{z}$ úst vedoucího oddělení pohřebnictví Ministerstva pro místní rozvoj, který stávající podobu zákona prezentuje jako svůj osobní úspěch. Novela přinesla několik zásadních změn - jedna z nich spočívá v definování tzv. jiných lidských pozůstatků, kam spadají i plody po potratu - ty byly dříve označovány jako biologický odpad - a s ním také končily v nemocničních spalovnách. Na tuto špatnou praxi řadu let poukazovala nezisková organizace Tobit, která se mj. snažila aktivně přispět k tomu, aby bylo pietně zacházeno se všemi potracenými plody, bez ohledu na jejich gestační věk, což se novelou podařilo prosadit. Podle současného znění zákona je tedy možné vyžádat si i plod po potratu k pohřbení - pokud si takový plod ve stanovené lhůtě 96 hodin rodiče k pohřbení nevyžádají, je na náklady nemocnice zpopelněn společně s dalšími jinými lidskými pozůstatky a zpopelněné ostatky jsou pak uloženy na veřejném pohřebišti.

Zákonná úprava $\mathrm{v}$ tomto bodě tedy vypadá na první pohled rozumně a vstřícně - má pomáhat pozůstalým rodinám a má šetřit jejich city. V praxi se ovšem ukazuje, že nová norma dostatečně nereflektuje realitu a je v některých praktických ohledech nedomyšlená:

Rodiče se sice už mohou rozhodnout pro převezení potraceného plodu z nemocnice domů, ale nemohou $\mathrm{k}$ tomu - přesto, že takový plod je organismem nepatrných rozměrů - využít třeba vlastního automobilu, jak je to běžné např́íklad ve Velké Británii. Zákon o pohřebnictví v $§ 9$, odst. 1 totiž výslovně stanovuje, že "lidské pozůstatky" (což je kategorie zahrnující podle $§ 2$ písm. c) téhož zákona "tělo zemrelého a jiné lidské pozůstatky" - tedy i plod po potratu) "mohou být po pozemních komunikacích přepravovány pouze ve vozidle zvláštního určení, které musí být k takovému účelu schváleno podle jiného právního predpisu jako pohrební." V praxi to tedy znamená, že i pro převoz malinkého plodu je třeba objednat a zaplatit běžný pohřební vůz. Etický problém spatřuji nejen ve vynuceném ekonomickém zatížení rodiny, tedy v tom, že rodina musí využít relativně nákladných komerčních služeb (aniž má ovšem současně nárok na pohřebné), ale také v tom, že se tu intimní soukromá záležitost, jakou je rozloučení s bytostí, která přitom jinak nepožívá prakticky žádné právní ochrany a o jejímž morálním statu se vedou dlouhé a rozporuplné diskuse, absurdně posouvá do roviny, která byrokraticky kopíruje postupy typicky vyhrazené pro nakládání s tělem zemřelého.

Pokud mrtvě narozený plod váźí méně než $500 \mathrm{~g}$, př́padně (nelze-li přesnou hmotnost zjistit) je-li těhotenství kratší než 22 týdnů, spadá podle Zákona o zdravotních službách do definice potratu a rodina $\mathrm{v}$ takovém př́padě nemá nárok na pohřebné. Jediný gram tedy může rozhodnout o tom, zda rodině vznikne nárok státní podporu ve formě jednorázové dávky (v současné době činí výše pohřebného 5.000,- Kč), nebo zda veškeré náklady spojené s pohřbením svého dítěte bude muset hradit sama. Rodiče, kteří zvažují vypravení pohřbu, se tak ocitají před dilematem, zda vypravením pohřbu zatížit rodinný rozpočet. Rozhodnout se přitom musejí $\mathrm{v}$ zákonem dané lhůtě, tedy do 96 hodin. Ze strany prátel a rodiny mohou v této době přijít jak podpůrné argumenty a nabídka finanční pomoci, tak zrazování od vypravení pohřbu - např. s poukazem na to, že jde o vyhozené peníze a rodiče budou jen jitřit ránu ze ztráty svého dítěte a vystavovat se dotěrným pohledům okolí - zvláště na vesnicích a malých 
městech, kde není velká anonymita, sledují příběh rodiny a její momentání situaci sousedé a někdy celá komunita. Ne vždy je rodičům takový zájem prř́jemný a ne vždy je okolí podpůrné. Postoj zdravotníků a povzbuzení rodičů ze strany širšího týmu (např. dětského hospice) může dát rodičům potřebné informace, povzbuzení a podporu. Vhodné by bylo iniciovat změnu zákona, aby i rodiče, kteří se rozhodnou pohřbít své dítě, jehož narození by spadalo do zákonné definice potratu, měli nárok na finanční podporu státu (obdobu pohřebného) - zmizel by tak jeden zásadní argument a s ním i tlak v době rozhodování, zda se vypravení pohřbu ujmout. Ne vždy jsou navíc rodiče ohledně vypravení pohřbu zajedno, a otázka financí se tak může stát zdrojem dalšího napětí v už tak náročné životní situaci.

Podání srozumitelných informací, nejlépe v písemné podobě a nejlépe hned v porodnici, pomáhá rodičům v orientaci ohledně možností, které mají - včetně možností souvisejících s rozloučením. Oblast pohřebnictví je pro mnoho lidí poněkud nepřehledná a pro oblast perinatální ztráty dosud neexistují běžně dostupné materiály, které by bylo možné účinně osvětově využít. I z toho důvodu bylo druhé vydání materiálu "Když zemře miminko" (7) zásadním způsobem rozšířeno; první vydání této brožury, ač byla určena převážně rodičům, vítali totiž také zaměstnanci porodnic, ale rovněž duly, zaměstnanci hospiců, vyučující zdravotních a sociálních oborů a pracovníci pohřebních služeb .

Zejména role pracovníků pohřebních služeb by se měla ve vztahu k rodinám, kterým zemřelo dítě, proměnit a prohloubit. Elisabeth Kübler-Rossová už v sedmdesátých letech minulého století popsala, jak velký profesní přelom znamenalo pro ředitele jednoho amerického pohřebního ústavu jeho rozhodnutí podpořit rodiče, kteří se o tělo svého zemřelého dítěte chtěli postarat doma a sami je připravit k pohřbu: "Ačkoli tyto nové postupy zaměrené na pomoc rodičưm, kteři neočekávaně ztratí své ditě, ještě zdaleka nejsou běžné, lze doufat, že si podobný přistup začne časem osvojovat stále více pohřebnich ústavů, a jejich zaměstnanci se tak konečně stanou tím, čím by měli být: dalšimi př́slušníky takzvaných pomáhajicích profesí." (5, s. 213)

\section{DŮSLEDKY NEOBEZNÁMENOSTI PEČUJÍCÍHO PERSONÁLU S PRINCIPY FAMILY-CENTRED CARE A NERESPEKTOVÁNÍ AUTONOMIE PŘÍJEMCŮ SLUŽEB}

Principy péče, jež je $\mathrm{v}$ anglosaských pediatrických institucích známá od počátku 80 . let minulého století jako family-centred care (FCC) - tedy takové péče, která na dětského pacienta nahlíží v jeho sociálním kontextu, a bere tak v potaz i potřeby jeho rodiny -, nemají jednu ustálenou definici, ale vyskytují se v celé řadě různých variant. Všechny verze však sdílejí minimálně jeden společný klíčový rys - a tím je respekt ke svobodné vůli rodiny, do níž dětský klient patří.

Principy FCC se snaží korigovat asymetrii vztahu mezi zdravotníky na jedné straně a př́ijemci jejich služeb na straně druhé - z klasických principů medicínské etiky akcentuje zejména princip autonomie a nonmaleficence: př́jemce služeb vrací z postavení objektu do role subjektu a znovu jim přiznává rozhodovací hlas.

Čím je dítě menší, tím silnější hlas má jeho rodinné okolí - a v situaci, kdy se zabýváme perinatální ztrátou, tedy dítětem zemřelým, je hlas rodinného okolí dokonce jediným hlasem, jemuž tu můžeme naslouchat.

Během své práce na projektu "Začít znovu" jsem byla účastna diskuse porodních asistentek z několika českých a moravských porodnic - vesměs šlo o motivované profesionálky, které se tématu perinatální ztráty nevyhýbaly, byly připravené stát rodinám nablízku a udělat vše pro to, aby jim $v$ těžkých chvílích co nejvíce pomohly. Ona touha pomoci ale současně jakoby opomíjela skutečnost, že rodiče zemřelého dítěte jsou dospělými, svéprávnými a samostatnými bytostmi, které vůbec nemusejí stát o nabízenou formu pomoci či o interventivní angažmá cizích lidí ve svém příběhu. 
Zmíněná diskuse se týkala pořizování fotografíi zemřelého miminka - mnoho rodičů chce pořídit snímek svého zemřelého nebo mrtvě narozeného dítěte, aby na ně a jeho podobu měli nějakou hmatatelnou vzpomínku; nastávají ale i situace, kdy rodiče takovou fotografii pořídit nechtějí; někteří z nich pak později mohou tohoto svého rozhodnutí litovat.

V některých porodnicích proto porodní asistentky zemřelé miminko vyfotografují, i když si to rodiče nepřjí, a snímky pak uschovají pro případ, že by o ně rodiče někdy v budoucnu přece jen začali stát. Předmětem debaty bylo, zda lze pro takový postup najít oporu ve stávající legislativě: zda je tedy možno nesouhlas rodičů - v jejich vlastním zájmu - nerespektovat a s použitím účelové interpretace zákona nějakým způsobem obejít.

Uvedený př́iklad vnímám jako konkrétní ilustraci jevu daleko obecnějšího - dobře míněného paternalismu, který je ovšem z etického hlediska zcela nepřijatelný. Svobodná vůle zahrnuje i právo na takové rozhodnutí, s nímž člověk při zpětném ohlédnutí nemusí být spokojen; a je nezbytné, aby se př́slušníci pomáhajících profesí naučili v tomto směru rozeznávat a ctít hranice, jejichž nerespektováním překračují své lidské i profesní kompetence.

Tam, kde je dosud rozšiřen (a tolerován) paternalismus a kde jsou pomáhající profesionálové upř́mně přesvědčeni, že jejich názor, dobrá vůle a snaha pomoci jsou tak nějak nadřazeny vưli jejich pacientů a klientů, tam bývá skutečná vưle pacienta často respektována jen formálně a pouze do té míry, do jaké se shoduje s vůlí pomáhajících: někteří pečující profesionálové si dokonce zvykli trochu spoléhat na to, že jim zákon nakonec vždycky nabízí nějakou možnost, jak se $v$ prípadě potřeby bez souhlasu pacienta či klienta obejít - a to se netýká pouze zdravotnických zařízení.

Dobrá praxe ovšem vyžaduje především hledání a využívání takových cest, kdy je pomoc rodinám poskytována $\mathrm{v}$ souladu $\mathrm{s}$ jejich vůlí.

\section{VZPOMÍNKOVÉ BALÍČKY}

$\mathrm{V}$ několika posledních letech začaly některé české porodnice využívat tzv. vzpomínkové baličky. Inspirace přišla z Velké Británie, kde vzpomínkové baličky vytváří - a porodnicím pravidelně zdarma dodává - řada charitativních organizací zaměřených na pomoc rodičům, jejichž dět’átko zemřelo. Balíčky (či krabičky) mají různý formát a mohou se navzájem lišit svým obsahem, účel ale mají shodný: představují citlivý způsob, jak na zemřelé dětátko vytvořit hmatatelnou vzpomínku. Balíčky většinou obsahují bezinkoustovou sadu na pořízení otisku nožiček a ručiček, krabičku nebo obálku na ústřižek vlásků, někdy svíčku, vzpomínkový list, informační letáček, nějakou milou drobnost a často také dvě stejné, malé, nejčastěji ručně vyráběné hračky - např. medvídky. S nimi pak rodiče mohou podle svého uvážení naložit různě - jednu např́íklad pohřbít spolu s dět'átkem a druhou si ponechat jako připomínku trvalého symbolického spojení. (6)

Zemře-li starší dítě, mají jeho blízcí mnoho vzpomínek na společně prožité chvíle; když ale zemře miminko v době kolem porodu, zůstává rodině po jeho pobytu na světě jen nepatrná stopa. Pokud o to rodiče stojí, mohou si na své dět'átko, se kterým neměli možnost strávit mnoho času, vytvořit nějaké vzpomínky, včetně fotografií, sami; vzpomínkový balíček jim tento proces pouze usnadňuje.

Při správném použití tedy vzpomínkový balíček představuje jednoduchý způsob, jak rodině pomoci nejen při hojení akutní emoční rány, ale jak zároveň pozitivně ovlivnit prožívání zármutku a hledání naděje $\mathrm{v}$ době, která následuje. Mít něco na památku, schovat si něco, co umožní vzpomínat, co vytvoří nějaký most, linku, vazbu - to je přirozená lidská potřeba. Rodiče potřebují dostatek času, dostatek soukromí a také dostatek informací k tomu, aby se mohli rozhodnout, jak budou dál vše organizovat, jaká z nabízených možností je pro ně nejlepší. 
Správné využití vzpomínkových balíčků tedy předpokládá a vyžaduje přiměřený postoj a postup pečujících zdravotníků: dostatek času a soukromí a citlivě vyváženou směs informací, podpory, povzbuzení a respektu k individuálním potřebám a rozhodnutím.

Při mechanickém aplikování, kdy se nabídka vzpomínkového balíčku stane jen jednou z položek na seznamu bodů, které je třeba splnit při práci s klientkou po perinatální ztrátě, tato pomůcka ztratí svůj účel a nefunguje.

Při své práci jsem se už setkala i s naprostým nepochopením smyslu vzpomínkových balíčků, kdy se mechanické obdarovávání pozůstalých rodičů sadami pro vytváření vzpomínek nejenom míjelo účinkem a $\mathrm{z}$ hlediska zamýšleného účelu se naopak jevilo jako kontraproduktivní, a v některých nemocnicích se dokonce stávalo nástrojem neetické praxe (o tom podrobněji níže). Porodnice jsou totiž pro řadu komerčních firem marketingově velmi cenným prostředím, kam se snaží směřovat reklamní nabídky kojeneckého zboží, kosmetiky či potravinových doplňků nebo třeba náhražek mateřského mléka. Chybí-li porodnici v tomto směru etická či faktická regulace, mohou být rodičům nabízeny vzorky a dárky od nejrůznějších společností a firem. Mechanicky předaný vzpomínkový balíček se pak zařadí mezi ostatní nabídku - s tím, že pozůstalé rodiče přirozeně není vhodné obdarovávat vzorky výrobků, jež cílí na péči o novorozence. Nesprávně nabídnutý vzpomínkový balíček může být mylně chápán jako jakási "cena útěchy" - zvláště necitlivé pak v tomto směru může být nabízení balíčků větších rozměrů: ty pak působí dojmem, že mají doslova zaplnit prázdnou náruč a rodiče je mohou interpretovat jako soucitnou snahu o útěchu ze strany personálu, jako "chabý flastr" na hlubokou ránu.

Ničím z toho ale vzpomínkový balíček není a být nemá. Nejde o jakýsi dáreček památku na porodnici, ale o účinný nástroj, díky němuž lze pomoci procesu hojení rány ze ztráty: pomáhá vytvářet situaci, v níž se setrvává, prodlévá, při níž se zažívá vztah a posiluje vazba, která mezi rodiči a dětátkem vznikla dávno předtím, než přišlo na svět. Nejde přitom o žádný paradox: zármutek a truchlení nemají pomáhat zapomenout, ale mají pomáhat žít s vědomím ztráty.

Mưžete mít třeba 24 dalšich dětí, ale žádné vám nikdy nenahradí to, které jste ztratili. Lidé budou řikat: "To překonáte. To přebolí." I kdybyste žili 95 let, smrt svého dítěte "prekonat" nemi̊žete. Můžete jen doufat, že si privyknete na jiný způsob žití - na život, kdy už své dítě nemáte živé vedle sebe. Tolik, tolik "dobrých rad". Tolik naléhání ze strany všemožných profesionálů, abyste začali s "pozitivními činy" dř̀v, než jste toho vnitřně schopni. (2, s. 10)

Vzpomínkový balíček pomáhá k zachycení času, který je př́liš krátký na to, aby v něm mohly spontánně vzniknout situace, na něž si bude možné uchovat i pozitivní vzpomínky. V domácím prostředí nebo $\mathrm{v}$ dětském hospici je samozřejmě mnohem více přirozených možností, jak se zemřelým dětátkem pobýt, kam jeho tělíčko uložit, kde si je vyfotit. V prostředí porodnice jsou tyto možnosti velmi omezené, stejně tak bývá omezený čas, po nějž tu rodiče smějí být svému zemřelému miminku nablízku - vzpomínkové balíčky mohou tato omezení do jisté míry kompenzovat a napomoci vytvoření podmínek pro přirozenější prožívání ztráty.

V souvislosti s českou praxí práce se vzpomínkovými balíčky jsem opakovaně narazila na negativní zkušenost některých porodnic s jednou tuzemskou neziskovou organizací, která své vzpomínkové krabice zprvu do nemocnic prodávala, a nyní jejich bezplatné poskytnutí podmiňuje výměnou za kontaktní údaje na rodiče, kteří budou vzpomínkovou krabicí obdarováni. Smyslem takového směnného obchodu, odporujícímu nejen pravidlům GDPR, ale i základní lidské slušnosti, je - podle vyjádření kompetentní osoby jednající za organizaci - shromáždění kontaktních údajů na rodiče, aby je mohla tato organizace aktivně kontaktovat a dále jim nabízet své služby (letáček s kontaktem na organizaci je přitom v krabici obsažen). 
Ani zde - podobně, jako v př́padě fotografování zemřelých dětí bez souhlasu jejich rodičů není možné obcházet platnou legislativu a dobré mravy a omlouvat špatnou praxi deklarací dobrých úmyslů.

\section{ZÁVĚR}

Téma perinatální ztráty se $\mathrm{v}$ posledních několika letech těší mezi zdravotníky zvýšenému zájmu - jistě i proto, že jde o téma, které vyvolává mnoho obav a konfrontací, jimž by se mnozí přirozeně raději vyhnuli. Svůj podíl tu nepochybně má i sílící hlas rodičů, kteří zažili ztrátu svého dítěte a cítí potřebu spolupodílet se na změně dosavadního stavu v této oblasti. Jak se ale v praxi ukazuje, pouhá tematizace problémů a rozvoj dalšího vzdělávání ještě k hluboké a systémové změně nestačí.

Jedním z hlavních pilířu, o něž se současná příprava pomáhajících profesionálů opírá, je psychologický př́istup, který s sebou ovšem nese riziko patologizování zármutku a př́lišného spoléhání na naučené techniky na úkor autentického vztahu. Dalším velkým úskalím nevhodně pojímaného psychologizujícího př́stupu je tendence některých pomáhajících profesionálů interpretovat realitu, s níž se při své práci setkávají, na pozadí didakticky zjednodušených a z kontextu vytržených kazuistik a umělých modelových situací - reálné poznání je $\mathrm{v}$ takovém prípadě nahrazeno pouhou iluzí skutečného vhledu, a tato iluze se následně snadno stává zdrojem falešné jistoty a živnou půdou paternalistických postojů.

$\mathrm{V}$ praxi je prritom možné poměrně jednoduše aplikovat principy péče zaměřené na celou rodinu (FCC), přiznat tím rodičům kompetence a také schopnosti, které se zčásti přirozeně rodí právě při prožívaném trápení a jejichž objevování je cennou individuální zkušeností, o niž by personál neměl rodiče připravit svou př́ípadnou horlivostí nebo vehemencí. Dopad prožitého trápení totiž nemusí být nutně destruktivní, jeho hodnota může být pro další život dokonce pozitivní a posilující.

Změna přístupu zdravotníků s sebou v budoucnu pravděpodobně přinese i další formy péče, pro které se rodiče budou rozhodovat, včetně využití služeb dětských hospiců nebo převozu těla zemřelého dítěte $\mathrm{z}$ nemocnice do domácího prostředí - zprvu bude tato praxe zrrejmě vyvolávat údiv a nebude se jí dostávat velké podpory, je dokonce možné, že se proti ní někteří odborníci budou negativně vymezovat - na fyzickém kontaktu se zemřelým dítětem ale není nic divného, a jak ukazuje už takřka čtyřicetiletá praxe dětských hospiců ve Velké Británii, takový kontakt je nejen přirozený, ale má velký pozitivní vliv na proces truchlení a nalézání nové naděje. (1)

Aplikace principů FCC také mění nesymetrické postavení rolí rodičů na jedné a poskytovatelů péče na druhé straně: $\mathrm{z}$ rodičů zažívajících ztrátu samozřejmě nesnímá jejich bolest, křehkost a zranitenost, ale současně z těchto daností nečiní negativa, k nimž pak směřují (byt' dobře míněné) odborné intervence. Bolest a slabost tu už nepředstavují rizikové faktory, které je za každou cenu nutné diagnostikovat, analyzovat, ošetřovat a řešit; role poskytovatelů péče se promění a v jistém smyslu upozadí - tak, aby rodina dostala prostor pro nastoupení vlastní cesty, jejíž směřování $v$ tu chvíli ani sami rodiče nemohou znát, stejně jako je nemohou znát ani zdravotníci. Důvěra ve schopnosti a kompetence rodičů, zažívajících ztrátu svého dítěte, je navíc oboustranně osvobozující - rodičům dá potřebný prostor a ze zdravotníků sejme tíži přehnaného očekávání, které na rodičovské straně často předpokládají. Některé porodní asistentky mají obavy, že by situaci kolem úmrtí dítěte nezvládly, a namítají, že jejich posláním je pomáhat dětem na svět, ne řešit situace, kdy dítě z tohoto světa odejde. Současně je to ale právě profese porodní asistentky, která v sobě obsahuje dotek stvoření a $\mathrm{v}$ níž se kromě nezbytné odbornosti silně uplatňuje lidskost a zralost, upřímná laskavost a nehrané účastenství. Tyto vlastnosti se těžko uchopují a měří, ale přitom právě ony zároveň povyšují porodní asistenci mezi ty profese, jež opatrují, chrání a generacemi pronášejí nejcennější lidské hodnoty. 
Pro rodiče jsou obvykle při pobytu v nemocnici nejdůležitějši lidé - sestry, porodní asistentky, lékaři a dalši zaměstnanci. I v situaci, kdy nemocnice působí ponuře a úředně, $k d y$ není vybavena místnostmi, $v$ nichž by rodič měl soukromí, ale nevyhovujicími pokoji a kdy rutinní chováni většiny zaměstnanců nevycházi vstřic potřebám prakticky nikoho, může zkušenost rodičů z pobytu $v$ nemocnici změnit i jediná osoba, která projeví porozuměni a zájem. $(4$, s. 86$)$

Vždyt' vedle odborné stránky ošetřovatelské a lékařské jde při setkání nad zemřelým dět'átkem stále také o setkání lidských bytostí, jimž je úděl smrtelníků společný - a my, kdo se ocitáme truchlícím nablízku, bychom jim především neměli stát v cestě; už proto, že odchod $\mathrm{z}$ tohoto světa je pro ně i pro nás obestřen stejným tajemstvím.

Je důležité, abychom se pro ty, komu se snažíme pomáhat, nestávali kamenem úrazu - ale abychom spíše byli jako jeden z kamenů ochranné zdi, hájící jejich bezpečný prostor, nebo jako součást pevného kamenného schodiště, po němž mohou stoupat ve svém poznání.

\section{Použitá literatura}

1. DAVIS, Deborah L. Providing After-Death Care at Home When a Baby Dies. In: Psychogy Today [online] 3. březen 2014. [cit. 2021-06-25] Dostupné z: https://www.psychologytoday.com/intl/blog/laugh-cry-live/201403/providing-afterdeath-care-home-when-baby-dies

2. $\quad$ DOMINICA, Frances. Helen House. Praha: Nadační fond Klíček, 2019. ISBN 97880-905881-3-4.

3. HONZÁK, Radkin. Naděje medicíny. In: R. Ptáček, P. Bartůněk, eds. Naděje v medicině. Praha: Grada, 2020. ISBN 978-80-271-3077-1.

4. KOHNER, Nancy a Alix HENLEY. Když ditě zemře: zkušenosti se spontánním potratem $v$ pozdním stadiu těhotenství, narozením mrtvého dítěte a úmrtím novorozence. Praha: Triton, 2013. ISBN 978-80-7387-643-2.

5. KÜBLER-ROSS, Elisabeth. O dètech a smrti. Praha: ERMAT, 2003. ISBN 80903086-1-9.

6. PAZDERA, Lenka. Perinatální hospic. [online] www.perinatalnihospic.cz

7. PAZDERA, L., M. KRÁLOVCOVÁ a M. DOUCHA. Když zemře miminko. Druhé, doplněné vydání. Praha: Nadační fond Klíček, 2021. ISBN 978-80-905881-4-1.

8. RATISLAVOVÁ, Kateřina. Perinatální paliativní péče: péče o ženu a její rodinu, rituály rozloučení, proces truchlení a vyrovnávání se se ztrátou. Praha: Grada, 2016. ISBN 978-80-271-0121-4.

9. Zákon č. 256/2001 Sb., o pohřebnictví a o změně některých zákonů, ve znění pozdějších předpisů

10. Zákon č. 372/2011 Sb., o zdravotních službách a podmínkách jejich poskytování, ve znění pozdějších předpisů

11. Záznamy rozhovorů. Archiv Nadačního fondu Klíček. 1991-2019.

12. Záznamy rozhovorů. Archiv Nadačního fondu Klíček. 2020-2021.

\section{Kontaktní údaje}

Mgr. Markéta Královcová, DiS.

Univerzita Karlova, Fakulta humanitních studií

Pátkova 2137/5, 18200 Praha 8

Tel: 775204109

email: marketa@klicek.org 


\title{
ŠPECIFIKÁ KÚPNEJ ZMLUVY V OBČIANSKOM PRÁVE ČESKEJ REPUBLIKY
}

\section{THE PURCHASE AGREEMENT SPECIFICS IN THE CZECH CIVIL LAW}

\author{
Marian Horváth
}

\begin{abstract}
Abstrakt
Predmetom štúdie je čiastkový právny rozbor občiansko-právnej úpravy kúpnej zmluvy, ktorá vo fungujúcom trhovom hospodárstve predstavuje jeden z najvýznamnejších právnych titulov vzniku záväzkovo-právnych vzt’ahov medzi fyzickými osobami, nepodnikatel'mi a je jedným z najfrekventovanejších zmluvných vzt’ahov, základným účelom ktorých je prevod vlastníckeho práva.
\end{abstract}

Klíčová slova: kúpna zmluva, občianske právo, české občianske právo

\begin{abstract}
The subject of the study is a partial legal analysis of the civil law of the purchase agreement, which in a functioning market economy represents one of the most important legal titles of obligations between natural persons, non-entrepreneurs and is one of the most frequent contracts, the basic purpose of which is the transfer of ownership.
\end{abstract}

Key words: purchase agreement, civil law, Czech civil law

Význam kúpnej zmluvy, ako jedného zo základných právnych titulov vzniku záväzkovoprávneho vzt’ahu, je vo fungujúcej trhovej ekonomike nepochybný. Kúpna zmluva je najfrekventovanejším kontraktom a z ekonomického hl'adiska aj najvýznamnejším, nakol'ko v dôsledku globalizácie a čoraz väčšej potrebe l'udí uspokojovat' svoje potreby stúpa aj jej frekventovanost' a význam. Jej základnou podstatou a základným ciel'om je prevod vlastníckeho práva k veci, či už hnutel'nej alebo nehnutel'nej, z predávajúceho na kupujúceho a preto predstavuje jednu z najdôležitejších scudzovacích zmlúv v súčasnom právnom systéme. Do konca roka 2013 bola kúpna zmluva predmetom právnej úpravy dvoch kódexov, a to Občianskeho zákonníka a Obchodného zákonníka. Občiansky zákonník obsahoval právnu úpravu neobchodnej kúpnej zmluvy uzatváranej medzi nepodnikatel'mi, a podnikatel'mi a nepodnikatel'mi, pričom predmetom tejto právnej úpravy bola aj kúpna zmluva spotrebitel'ského charakteru. Obchodný zákonník, na rozdiel od občiansko-právnej úpravy, upravoval tzv. obchodnú kúpnu zmluvu, ktorá je využívaná výlučne v podnikatel'skom prostrední medzi podnikatel'mi, pri výkone ich podnikatel'skej činnosti. V Českej republike bola teda do konca roka 2013 právna úprava kúpnej zmluvy charakteristická svojim dualizmom právnych úprav, ktorý sa odstránil v roku 2014 prijatím nového Občianskeho zákonníka v rámci celkovej rekodifikácie súkromného práva v Českej republike.

\section{KÚPNA ZMLUVA V OBČIANSKOM PRÁVE}

1.1 Právna úprava kúpnej zmluvy v Českej republike do roku 2013

Právna úprava kúpnej zmluvy v Českej republike bola podobná dualistickej nemeckej právnej úprave, ked' na základe kúpnej zmluvy vzniká záväzkovo-právny vzt'ah. Kúpna zmluva je len právnym titulom nadobudnutia vlastníckeho práva k veci, ku ktorému musí pristúpit' aj 
právny spôsob (modus) nadobudnutia vlastníckeho práva. Týmto právnym spôsobom je samotné odovzdanie a prevzatie hnutel'nej veci a v prípade nehnutel'nosti, ktorá je predmetom zápisu v príslušnej evidencii katastra nehnutel’ností, je právnym spôsobom nadobudnutia vlastníckeho práva vklad vlastníckeho práva do príslušného katastra nehnutel’ností.

Do konca roku 2013 bola v Českej republike právna úprava kúpnej zmluvy nielen predmetom občianskoprávnej úpravy, ale taktiež predmetom obchodnoprávnej úpravy a to v závislosti od subjektov tohto právneho úkonu. Kúpna zmluva, ktorá bola predmetom právnej úpravy zákona č. 40/1964 Sb. Občiansky zákonník (d’alej ako „Občiansky zákonník“) predstavovala tzv. neobchodnú kúpnú zmluvu, ktorá bola uzatváraná medzi nepodnikatel'mi a rovnako medzi podnikatel'mi a nepodnikatel'mi. Kúpna zmluva, ktorá bola predmetom právnej úpravy zákona č. 513/1991 Sb. Obchodný zákonník (d’alej ako „Obchodný zákonník“) predstavovala tzv. obchodnú kúpnu zmluvu, nakol'ko bola uzatváraná výlučne medzi podnikatel'skými subjektmi. Čo sa týka kúpnej zmluvy v medzinárodnom obchodnom styku, jej právna úprava sa riadila Dohovorom OSN o zmluvách o medzinárodnej kúpe tovaru.

V občianskoprávnom ponímaní bola kúpna zmluva dvojstranným právnym úkonom, prostredníctvom ktorého dochádzalo ku vzniku záväzkovo-právneho vzt’ahu. Občiansky zákonník definoval záväzkovo-právny vzt'ah ako právny vzt’ah, z ktorého veritel'ovi vzniká právo na plnenie (pohl'adávka) od dlžníka a dlžníkovi vzniká povinnost' splnit' záväzok ${ }^{1}$, pričom z platného záväzku je dlžník povinný niečo dat', konat', niečoho sa zdržat' a veritel' je oprávnený to od neho požadovat'. Záväzkovo-právny vzt'ah vždy predpokladá existenciu minimálne dvoch strán. Subjekty týchto strán vystupujú vždy v opačnom postavení.

Záväzkovo-právny vzt'ah sa od ostatných občianskoprávnych vzt’ahov odlišuje predovšetkým svojou relatívnost'ou, početnost'ou subjektov, vznikom záväzku. Záväzkovo-právny vzt'ah môže byt' jednoduchý, avšak spravidla sú tieto záväzkovo-právne vzt'ahy zložité.

Kúpnu zmluvu, ako právny titulu vzniku záväzkovo-právneho vzt'ahu, možno charakterizovat' ako dvojstranný právny úkon, základným účelom ktorého je prevod vlastníckeho práva k veci z predávajúceho na kupujúceho, pričom samotná kúpna zmluva je len titulom, zaväzujúcim právnym dôvodom tohto prevodu vlastníckeho práva $\mathrm{k}$ veci, teda nejde o zmluvu reálnu, ale zmluvu konsenzuálnu. Kúpnou zmluvou sa totiž jeden účastník vzniknutého záväzkovoprávneho vzt'ahu zaväzuje odovzdat' predmet kúpy druhému účastníkovi, ktorý sa zaväzuje predmet kúpy prevziat' a súčasne zaň zaplatit' kúpnu cenu, pričom k prevodu vlastníckeho práva dochádza až na základe právneho spôsobu, t. j. odovzdania a prevzatia veci, príp. vkladom do katastra nehnutel'ností.

Skutočnost', že kúpna zmluva je dvojstranným právnym úkonom však nevylučuje, aby na niektorej zo zmluvných strán vystupovalo viacero účastníkov. Nakol'ko kúpna zmluva zakladá záväzkovo-právny vzt’ah, ktorý musí mat' minimálne dve strany a to veritel'skú strana a stranu dlžnícku, aj táto zmluva musí mat minimálne dva subjekty, z ktorých je jeden subjektom práva a druhý subjekt je subjektom povinnosti. Každý z týchto subjektov musí mat' iné postavenie, opačné. Ako už bolo uvedené, kúpna zmluva je zmluvou konsenzuálnou, nie zmluvou reálnou.

\subsection{Osobitosti právnej úpravy kúpnej zmluvy v Občianskom zákonníku ČR od roku 2014}

Po všeobecnej právnej úprave kúpnej zmluvy pokračuje zákon č. 89/2012 Sb. Občanský zákoník Sb.. (d’alej ako „nový Občiansky zákonník“) pododdielom s názvom „Koupě movité věci“, ktorého obsahom je právna úprava kúpnej zmluvy, predmetom ktorej je vec hnutel'ná, pričom túto právnu úpravu vo väčšej časti možno porovnat's komplexnou právnou úpravou

\footnotetext{
${ }^{1} \S 488$ Občianskeho zákonníka: Záväzkovo-právnym vzt’ahom je právny vzt’ah, z ktorého veritel’ovi vzniká právo na plnenie (pohl'adávka) od dlžníka a dlžníkovi vzniká povinnost' plnit’ záväzok.
} 
obchodnej kúpnej zmluvy, ktorá bola predmetom Obchodného zákonníka. Ide o tzv. mobiliárnu kúpu.

V ustanoveniach $\S 2085$ a $§ 2086$ nový Občiansky zákonník charakterizuje mobiliárnu kúpu negatívnym spôsobom aj pozitívnym spôsobom, pričom táto kúpa je vymedzená hnutel'ným predmetom plnenia, ktorého charakter je rozhodujúci v čase nadobudnutia vlastníckeho práva $^{2}$. Mobiliárnou kúpu sa tak rozumie každá kúpa, predmetom ktorej nie je nehnutel’ná vec. Mobiliárnou kúpou sa rozumie ak kúpa súčasti nehnutel'nosti, pokial' má kupujúci podl’a zmluvy nadobudnút' súčast' veci po oddelení ako vec hnutel'nú ${ }^{3}$.

Vo všeobecných ustanoveniach o mobiliárnej kúpe nový Občiansky zákonník upravuje aj kritériá pre odlíšenie kúpnej zmluvy, predmetom ktorej má byt' vec, ktorá ešte nie je vyrobená, od zmluvy o dielo, čo má neocenitel’ný praktický význam ${ }^{4}$. Tieto kritériá sú formulované $\mathrm{z}$ hl'adiska materiálu, ako aj $\mathrm{z}$ hl'adiska práce, pričom táto právna úprava vychádza $z$ doterajšej obchodnoprávnej úpravy. Na základe týchto kritérií nový Občiansky zákonník za mobiliárnu kúpu považuje aj zmluvu o dodaní spotrebného tovaru, ktorý je potrebné zostavit' alebo vytvorit" a zmluvu o dodaní veci, ktorá má byt' ešte len vyrobená, pokial' sa osoba, ktorej má byt' vec dodaná, nezaviazala predat' druhej strane podstatnú čast' toho, čo je k výrobe veci potrebné ${ }^{6}$. Mobiliárnou kúpou však nie je zmluva, podla ktorej prevažná čast' plnenia dodávatel'a spočíva vo výkone činnosti ${ }^{7}$.

Vo všeobecných ustanoveniach o kúpe hnutel'nej veci nový Občiansky zákonník určitým spôsobom modifikuje všeobecnú právnu úpravu o určitosti dohody účastníkov kúpnej zmluvy o kúpnej cene, ked' ustanovuje, že účastníci kúpnej zmluvy sú oprávnení dohodnút' kúpnu zmluvu bez určenia kúpnej ceny. Je zrejmé, že v tomto prípade ide o vzt'ah špeciálnej právnej úpravy a všeobecnej právnej úpravy, preto pri mobiliárnej kúpe zákon jednoznačne upravuje možnost' uzatvorit' túto mobiliárnu kúpu bez dohody o kúpnej cene, avšak v tomto prípade platí domnienka, že kúpna cena bola dohodnutá v takej výške, v akej sa rovnaký alebo porovnatel'ný predmet kúpnej zmluvy v dobe uzatvorenia kúpnej zmluvy za obdobných podmienok obvykle predáva ${ }^{8}$. Je potrebné uviest', že kúpna zmluva je platne uzatvorená aj v prípade, ak výška kúpnej ceny nie je dohodnutá, príp. nie je dohodnutý ani spôsob jej dodatočného určenia, ked’že zákon ustanovuje domnienku určenia výšky kúpnej ceny. Avšak ked' absentuje dohoda o kúpnej cene v tom zmysle, že absentuje záväzok kupujúceho kúpnu cenu zaplatit', nemožno takúto zmluvu považovat' za platne uzatvorenú z dôvodu absencie podstatnej náležitosti kúpnej zmluvy.

Pre platné uzatvorenie tejto mobiliárnej kúpnej zmluvy zákonník nevyžaduje žiadnu osobitnú formu, teda možno túto zmluvu uzatvorit' akýmkol'vek spôsobom, z ktorého je zrejmé, že predávajúci sa zaväzuje odovzdat' kupujúcemu hnutel'nú vec, prípadne budúcu hnutel'nú vec, a kupujúci sa zaväzuje túto vec prevziat' a zaplatit' za ňu predávajúcemu kúpnu cenu, ktorej výška je bud' presne dohodnutá, alebo je dohodnutý aspoň spôsob určenia jej výšky, inak platí domnienka porovnatel'nej ceny.

V nasledujúcich zákonných ustanoveniach nový Občiansky zákonník venuje svoju pozornost' povinnostiam predávajúceho ${ }^{9}$, pričom $\mathrm{v}$ týchto zákonných ustanoveniach nie sú obsiahnuté len povinnosti predávajúceho (napr. povinnost' odovzdat' spolu s predmetom kúpy aj doklady) vzt'ahujúce sa k veci, ale aj jeho práva (napr. právo určit' dodatočne vlastnosti predmetu kúpy), a dokonca aj práva kupujúceho (napr. určit’ iné vlastnosti predmetu kúpy, ako určil

\footnotetext{
${ }^{2}$ Vid’ Eliáš, K. a kol.: Nový občanský zákoník a sktualizovanou důvodovou správou a řejstř́kem.

${ }^{3}$ Vid' § 2085 ods. 1 prvá veta nového Občianskeho zákonníka.

${ }^{4}$ Vid' $\$ 2086$ nového Občianskeho zákonníka.

${ }^{5}$ Vid' $\$ 2085$ ods. 1 druhá veta nového Občianskeho zákonníka.

${ }^{6}$ Vid' § 2086 ods. 1 nového Občianskeho zákonníka.

${ }^{7}$ Vid' § 2086 ods. 2 nového Občianskeho zákonníka.

${ }^{8}$ Vid' § 2085 ods. 2 nového Občianskeho zákonníka.

${ }^{9}$ Vid' § 2087 až $§ 2094$ nového Občianskeho zákonníka.
} 
predávajúci bez zbytočného odkladu po oznámení predávajúceho o vlastnostiach). Tieto ustanovenia však sú svojim obsahom určujúce ako ustanovenia upravujúce povinnosti predávajúceho, a určité práva predávajúceho, ako aj práva kupujúceho, ktoré sú taktiež obsahom týchto zákonných ustanovení, nie je možné z tejto právnej úpravy vyňat' a to zo systematického hl'adiska, ako aj v záujme zrozumitel’nosti navrhovanej právnej úpravy. ${ }^{10}$

Následne sa nový Občiansky zákonník venuje predmetu kúpy, najmä jeho vlastnostiam. ${ }^{11} \mathrm{Na}$ tieto zákonné ustanovenia o predmete kúpnej zmluvy nadväzuje právna úprava práv $\mathrm{z}$ vadného plnenia ${ }^{12}$, ktorá taktiež vychádza z právnej úpravy Obchodného zákonníka, avšak skresaná o určité nadbytočné, všeobecné a kauzuistické zákonné pravidlá a normy. Táto právna úprava posilňuje postavenie kupujúceho v prípade vadného plnenia predávajúcim, pričom ako základné kritérium pre určenie vady veci je dané hl'adisko intenzity vadnosti poskytnutého plnenia, nie kritérium určené podl'a neupotrebitel'nosti veci. Nový Občiansky zákonník rozlišuje medzi podstatným a nepodstatným porušením zmluvy poskytnutím vadného plnenia, kedy sa pri podstatnom porušení rozširujú oprávnenie kupujúceho. Nová právna úprava zodpovednosti za vady upúšt’a od preklúzie práv vyplývajúcich zo zodpovednosti za vady, čo znamená že oneskorená notifikácia, príp. reklamácia, nespôsobuje zánik práv kupujúceho, ale len zánik vymáhatel’nosti plnenia ${ }^{13}$.

$\mathrm{Na}$ právnu úpravu práv $\mathrm{z}$ vadného plnenia nadväzuje právna úprava záruky za akost ${ }^{14}$, ktorá je v právnej úprave novinkou. Ide o právnu úpravu zmluvnej záruky za akost’ predmetu kúpy, ktorou je možné doplnit' zákonnú záruku, z čoho vyplýva, že táto zmluvná záruke nemôže byt' vymedzená striktnejšie a nemôže ani vylučovat' zákonnú záruku. Túto záruku možno bud' dohodnút' medzi účastníkmi záväzkovo-právneho vzt’ahu, alebo môže byt' poskytnutá jednostranný prehlásení predávajúceho, napríklad na obale výrobku, alebo aj v reklame.

Nasledujúce zákonné ustanovenia sú venované právam kupujúceho ${ }^{15}$, súčast’ou ktorých sú aj jeho povinnosti, najmä určenie jeho povinnosti zaplatit' kúpnu cenu a vec prevziat', ako aj povinnosti predávajúceho, ktoré však na účely prehl'adnosti a systematiky nie je možné od tejto právnej úpravy oddelit'. Následne nový Občiansky zákonník prechádza k právnej úprave prechodu nebezpečenstva škody na veci ${ }^{16}$, ktorej venuje pozornost' z rôznych hl'adísk, inšpirovaný obchodnoprávnou úpravou. Následne sa venuje svojpomocnému predaju ${ }^{17}$.

Nový Občiansky zákonník rozdel'uje právnu úpravu kúpnej zmluvy, predmetom ktorej je vec hnutel'ná a právnu úpravu kúpnej zmluvy, predmetom ktorej je nehnutel'nost'.

Nový Občiansky zákonník v samostatnom pododdiele 3 upravuje v nevyhnutnom rozsahu osobitosti kúpy veci nehnutel'nej, najmä čo sa týka formy uzatvorenia tejto kúpnej zmluvy, ked' vyžaduje písomnú formu, rovnako formy uzatváraných vedlajších dojednaní k tejto kúpnej zmluve, ked' vyžaduje písomnú formu týchto dojednaní v prípade, ak sa nimi zriad’uje vecné bremeno, ktoré vzniká až zápisom do verejného zoznamu ${ }^{18}$. V tomto pododdiele taktiež nový Občiansky zákonník dáva účastníkom kúpnej zmluvy možnost' dohodnút' si dobu prevzatia veci, pričom $\mathrm{v}$ prípade existencie takejto dohody rieši aj režim nadobudnutia plodov a úžitkov nehnutel'nosti a prechodu nebezpečenstva škody ${ }^{19}$. Rovnako upravuje osobitosti právnych následkov vadného plnenia a práv $\mathrm{z}$ toho plynúcich ${ }^{20}$.

\footnotetext{
${ }^{10}$ Vid' Eliáš, K. a kol.: Nový občanský zákoník a sktualizovanou důvodovou správou a řejstř́íkem.

${ }^{11}$ Vid' $\$ 2095$ až $\$ 2098$ nového Občianskeho zákonníka.

${ }^{12}$ Vid' § 2099 až § 2112 nového Občianskeho zákonníka.

${ }^{13} \mathrm{~V}$ tomto prípade nová právna úprava mení charakter lehôt z prekluzívnych na premlčacie lehoty.

${ }^{14}$ Vid' $\$ 2113$ až $\$ 2117$ nového Občianskeho zákonníka.

${ }^{15}$ Vid' $\$ 2118$ až 2120 nového Občianskeho zákonníka.

${ }^{16}$ Vid' $\$ 2121$ až $\$ 2125$ nového Občianskeho zákonníka.

${ }^{17}$ Vid' $\$ 2126$ až $\$ 2127$ nového Občianskeho zákonníka.

${ }^{18}$ Vid' § 2128 nového Občianskeho zákonníka.

${ }^{19}$ Vid' § 2130 nového Občianskeho zákonníka.

${ }^{20}$ Vid' § 2129 nového Občianskeho zákonníka.
} 
Následný pododdiel je venovaný vedl'ajším dojednaniam ku kúpnej zmluve, v ktorom je obsiahnutá právna úprava výhrady vlastníckeho práva, výhrady spätnej kúpy, výhrady spätného predaja, právna úprava predkupného práva a kúpy na skúšku, výhrady lepšieho kupca a taktiež aj právna úprava cenovej doložky, pričom výpočet týchto vedlajších dojednaní je nad'alej demonštratívny.

Pri právnej úprave výhrady vlastníckeho práva ${ }^{21}$ dochádza k výraznému rozšíreniu jej konštrukcie, ktorá bola inšpirovaná Obchodným zákonníkom ${ }^{22}$. V dôsledku tejto konštrukcie sa zmluvným stranám umožňuje viazat' nadobudnutie vlastníckeho práva aj na splnenie odkladacej podmienky, nielen na zaplatenie celej kúpnej ceny. Návrh právnej úpravy tohto právneho inštitútu sa taktiež inšpiroval nemeckou právnou úpravou a samozrejme reaguje aj na praktické skúsenosti s nedokonalost’ami doterajšej právnej úpravy.

Výhrada vlastníckeho práva v právnej úprave bude vyžadovat' aj overený podpis strán zmluvy, inak nebude účinná voči veritel'om dlžníka, čiže neochráni veritel'a napríklad pred exekúciou. $^{23}$

V právnej úprave výhrady spätnej kúpy ${ }^{24}$ dochádza taktiež k posunu, ked’ nový Občiansky zákonníka dáva možnost' túto výhradu uplatnit' nielen pri veci hnutel'nej, ale aj pri veci nehnutel'nej. Na rozdiel od doterajšej právnej úpravy túto výhradu možno dohodnút' $\mathrm{v}$ akejkol'vek forme, nielen $\mathrm{v}$ písomnej, okrem prípadu, ak sa má takouto dohodou zriadit' vecné bremeno.

Právna úprava výhrady spätnej kúpy predlžuje lehotu jej trvania v prípade hnutel'ných vecí na dobu troch rokov, pričom doposial' platila jednoročná lehota, a v prípade nehnutel'ností na dobu desiatich rokov. Táto právna úprava je dispozitívnou právnou úpravou, teda účastníci zmluvných strán si môžu dohodnút' dobu trvania výhrady spätnej kúpy odlišne od zákona.

Novinkou v súkromnoprávnej úprave je právna úprava výhrady spätného predaja ${ }^{25}$, ktorého povaha zostáva zachovaná a pre tento prípad sa primerane použitú zákonné ustanovenia týkajúce sa výhrady spätného predaja. Novinkou je taktiež výhrada lepšieho kupca ${ }^{26}$.

Výrazný posun nastal aj v právnej úprave predkupného práva ${ }^{27}$, kde nový Občiansky zákonník vymedzuje strany tohto inštitútu ako predkupník, t. j. osoba oprávnená z predkupného práva a kúpychtivý, t. j. osoba, ktorej sa má vec predat'. Podl'a novej právnej úpravy predkupné právo zaväzuje aj dedičov oprávnenej osoby, pričom podl'a doterajšej právnej úpravy predkupné právo na dedičov neprechádzalo.

Kúpa na skúšku ${ }^{28}$ a cenová doložka neboli predmetom právnej úpravy Občianskeho zákonníka, avšak Obchodný zákonník tieto právne inštitúty upravoval dost' podrobne, preto aj právna úprava nového Občianskeho zákonníka bola inšpirovaná práve obchodnoprávnou úpravou

\section{ZÁVER}

Právna úprava kúpnej zmluvy bola do konca roka 2013 v právnom poriadku Českej republiky roztrieštená, ked’že bola predmetom nielen občianskoprávnej úpravy, ale aj predmetom obchodnoprávnej úpravy. Obchodný zákonník kúpnu zmluvu upravoval podrobne, táto právna úprava bola komplexná, jednotná, prispôsobená jeho potrebám, na rozdiel od právnej úpravy občianskoprávnej, ktorá bola v niektorých svojich častiach nedokonalá a obmedzená. V súčasnosti v právnom poriadku Českej republiky je kúpna zmluva upravená výlučne

\footnotetext{
${ }^{21}$ Vid' § 2132 až $\$ 2134$ nového Občianskeho zákonníka.

${ }^{22}$ Vid' § 445 Obchodného zákonníka.

${ }^{23}$ Vid' § 2134 nového Občianskeho zákonníka.

${ }^{24}$ Vid' $\$ 2135$ až $§ 2138$ nového Občianskeho zákonníka.

${ }^{25}$ Vid' § 2139 nového Občianskeho zákonníka.

${ }^{26}$ Vid' § 2152 a 2153 nového Občianskeho zákonníka.

${ }^{27}$ Vid' $\$ 2140$ až $\$ 2149$ nového Občianskeho zákonníka.

${ }^{28}$ Vid' $\$ 2150$ a $§ 2151$ nového Občianskeho zákonníka.
} 
v novom Občianskom zákonníku, ktorý nahradil Obchodný zákonník i čast' Obchodného zákonníka. Kúpna zmluva je bezpochyby jedným z najdôležitejších a najfrekventovanejších právnych úkonov realizovaných $\mathrm{v}$ súkromnoprávnych vzt'ahoch, ktorého základným účelom je prevod vlastníckeho práva k veci, ktorým môže byt' akákol'vek vec v právnom zmysle, pokial' nie je zákonom vylúčená z bežného obchodovania. Pre platný vznik kúpnej zmluvy, ako dvojstranného právneho úkonu, je tak nevyhnutná existencia nielen dvoch identifikovatel'ných zmluvných strán, ale aj konsenzus týchto dvoch strán o predmete kúpy, ktorý musí byt' spôsobilým predmetom kúpnej zmluvy, a o kúpnej cene, pričom tento konsenzus musí byt' vyjadrený takým prejavom vôle, ktorý spĺn̆a všetky náležitosti požadované zákonom.

\section{Použitá literatura}

1. ELIÁS̆, K. a kol. Nový občanský zákoník s aktualizovanou di̊vodovou správou a řejstřikem. Ostrava: Sagit, 2012. 1119 s. ISBN 978-80-7208-922-2.

2. HORVÁTH, M. Kúpna zmluva. Rigorózna práca. Praha, Karlova Univerzita, Právnická fakulta, 2013.

3. HORVÁTH, M. Právna úprava kúpnej zmluvy v súkromnom práve - komparácia platnej právnej úpravy s predchádzajúcou právou úpravou v Českej republike. Rigorózna práca. Bratislava, Univerzita Komenského, Fakulta managementu, 2015.

4. Zákon č. 513/1991 Sb. - Obchodní zákoník.

5. Zákon č. 89/2012 Sb. - Občanský zákoník.

\section{Kontaktní údaje}

JUDr. PhDr. Ing. Marian Horváth, Ph.D.

Katedra súkromno-právnych disciplín

Fakulta práva Janka Jesenského

Vysoká škola Danubius

Richterova ul. 1171

92521 Sládkovičovo

Tel: 00421908794985

email: marian.horvath@vsdanubius.sk 


\title{
ATRIBÚTY PRACOVNÉHO PRÁVA V DIGITÁLNEJ ÉRE
}

\author{
LABOUR LAW ATRIBUTES IN THE DIGITAL ERA
}

\author{
Slávka Krásna
}

\begin{abstract}
Abstrakt
Pracovno-právne zákonodarstvo determinujú moderné technológie a nové trendy. Aktuálne platné znenie Zákonníka práce tvoria princípy ochranného zákonodarstva garanciami potrebnej miery ochrany zamestnancovi vo vzt'ahu k zamestnávatel'ovi v relatívne stabilných, opakujúcich sa, predpovedatel'ných a predvídatel'ných podmienkach. Avšak ročná skúsenost' počas pandémie COVID19 naznačuje, že nové požiadavky na pracovné právo nesúvisia so striktnou reguláciou pracovno-právnych vzt’ahov medzi zamestnancom a zamestnávatel'om, iba $\mathrm{v}$ relatívne stabilných a predvídatel'ných pracovných podmienkach. Naopak, ukázalo sa, že inovovanou požiadavkou na pracovné právo je očakávaná maximálne možná flexibilita pracovno-právnych vzt’ahov. Je zrejmé, že technologický pokrok prináša rad právnych problémov s presahom do celospoločenských komponentov, od pracovného práva sa však očakáva pružne a jasné stanovisko. Na druhej strane dávame do pozornosti, že významnú čast' technologického pokroku nie je možné $\mathrm{v}$ dostatočnom predstihu a ani $\mathrm{v}$ dostatočnom rozsahu predpovedat'.
\end{abstract}

\section{Kličcová slova: právo, pracovné právo, digitálna éra}

\begin{abstract}
Labor law is determined by modern technologies and new trends. The current valid wording of the Labor Code consists of principles protection legislation by guaranteeing the necessary level of protection for the employee in relation to the employer in relatively stable, recurring, predictable and foreseeable conditions. However, a year of experience during the pandemic COVID19 suggests new requirements for labor law are not related to the strict regulation of labor relations between employees and employers, in relatively stable and predictable working conditions. Technological progress raises a number of legal issues beyond societywide components, but labor law is expected to take flexible, but also a clear position. On the other hand, we pay attention to that a significant part of technological progress is not possible well in advance nor to predict to a sufficient extent.
\end{abstract}

Key words: law, labour law, digital era

\section{ATRIBÚTY PRACOVNÉHO PRÁVA V DIGITÁLNEJ ÉRE}

Stratégia digitálnej transformácie Slovenska 2030 (2019) počíta s digitálnou transformáciou verejnej správy napr. tak, že budú zrušené alebo zlúčené jednotky verejnej správy, vykonávajúce prácu, ktorá spolu súvisí alebo sa prekrýva, Vo verejnej správe sú naplánované zmeny na zvýšenie atraktivity práce vo verejnej správe, pričom citovaná Stratégia avizuje zmeny v domáckej práci, čiastočných úväzkoch, plánuje sa zavedenie video konferenčnej komunikácie a podobne.

Predpokladáme, že štát - vd’aka novým technológiám a službám - perspektívne dokáže operatívne manažovat' všetky dáta, teda aj aktualizácie v zákonoch, zákonníkoch, vyhláškach a podobne, s digitálnym online sledovaním všetkých zmien, vrátane pripomienkového konania k zákonom, zákonníkom a vyhláškam zainteresovaných prijímatel’ov - ministerstvá, 
úrady, podnikatelia, podniky a pod. S tým súvisí aj zámer mechanizmu efektívneho a operatívneho premietania inovácií do legislatívy $\mathrm{v}$ oblasti príležitostí, ale aj hrozieb, pracovné právo nevynímajúc.

Vo vzt’ahu k jednotnému digitálnemu trhu (Digital Single Market, DSM), kam patria aj online podnikatel'ské aktivity bez geografického obmedzenia, priamo súvisiace s pracovným právom, konštatujeme výzvu pre pracovné právo vo vzt’ahu $\mathrm{k}$ harmonizácii s právom Európskej únie a špecifikami jednotlivých pracovných príležitosti, digitálnych tovarov a digitálnych služieb, elektronických produktov a elektronických služieb, digitálne siete a inovácie a využívania digitálnych technológii na výkon práce.

V súlade s Horváthom a kol. (2021) d’alej konštatujeme, že aktuálne platný Zákonník práce vo vzt'ahu k digitalizácii a novým trendom na pracovnom trhu, sa ukazuje ako nepostačujúca právna norma $\mathrm{v}$ úprave pracovno-právnych vzt’ahov najmä $\mathrm{z}$ dôvodu, že neponúka v dostatočnej miere d'alšie flexibilné možnosti zmluvnej úpravy výkonu práce a nepostačujúco tak reaguje na zmenené potreby zamestnancov a zamestnávatel'ov vo vzt'ahu k možných situáciám v blízkej budúcnosti. V nasledujúcom texte naznačíme niektoré z nich.

- Pracovné právo v aktuálnom znení už nedokáže pokryt' celé spektrum novo vzniknutých pracovno-právnych situácií - príkladom môže byt' prvá čast', § 1 Zákonníka práce, ktorá hovorí o závislej práci, avšak v dobe globálnej digitalizácie zamestnávatelia závislú prácu nahradzujú inými formami, lebo digitálna éra to umožňuje. Tu vzniká priestor pre nové kategórie zamestnancov a zamestnávatel'ov.

- Digitalizáciou, robotizáciou a automatizáciou je reálne ohrozené právo na prácu ako základné l’udské právo, ktoré uvádza Článok 1 Zákonníka práce. Väčšina autorov sa domnieva, že Priemysel 4.0 je zameraný v prospech zamestnancov. V blízkej budúcnosti sa predpokladá vyššia autonómia strojov a zariadení, a tým vyššia humanizácia práce. Taktiež sa predpokladá, že zamestnanci budú iba koordinátormi, ktorí sa manuálne budú zúčastňovat' procesov iba „na podnet“ zariadení. Tým sa, pochopitel'ne zmení aj status zamestnanca (Fusko a Bučková 2019a,b; Krajňáková a Vyhnička, 2020), čo bude mat' významný vplyv na pracovné právo. Na to, že až $53 \%$ pracovných aktivít (čo predstavuje približne 1,2 milióna pracovných pozícií) na Slovensku môže byt' do roku 2030 nahradených automatizáciou, poukazuje aj štúdia Novaka a kol. (2019). Podl'a Brynjolfsson a McAfee (2016) sa ukazuje, že robot nahradí prácu človeka, čo povedie $\mathrm{k}$ poklesu podielu priamej fyzickej l'udskej práce. Článok 1 Zákonníka práce konštatuje, že fyzické osoby majú právo na prácu. Ukazuje sa však, že digitalizácia, robotizácia a automatizácia zamestnancov nahradí technológiami. Aj ked' je možné, že zachované pracovné miesta budú čistejšie, bezpečnejšie a efektívnejšie, na druhej strane však existuje reálna hrozba straty pracovného miesta človeka práve z dôvodov digitalizácie, robotizácie a automatizácie. To, podl'a nášho názoru predstavuje podnet na reálne zmeny či opatrenia vo vzt’ahu k Článku 1 Zákonníka práce.

- Digitalizáciou, robotizáciou a automatizáciou je reálne ohrozené právo na rovnaké zaobchádzanie - Článok 1 Zákonníka práce hovorí o zásade rovnakého zaobchádzania, ktorá je ustanovená pre oblast' pracovno-právnych vzt'ahov osobitným zákonom Zákonom č. 365/2004 Z. z. o rovnakom zaobchádzaní v niektorých oblastiach a o ochrane pred diskrimináciou a o zmene a doplnení niektorých zákonov (Antidiskriminačný zákon). V tejto súvislosti dávame do pozornosti niektoré zamestnávatel'mi $\mathrm{v}$ bežnej praxi uplatňované mechanizmy, nesúce znaky diskriminácie vo vzt'ahu (sub)dodávatel'ských subjektov je reálna diskriminácia vlastných zamestnancov. Ako to bude vo vzt’ahu človek verzus umelá inteligencia, je, myslíme si, jasné, lebo napr. robot má, v porovnaní s človekom, vyšší výkon, nižšiu chybovost', menej nepodarkov, nepotrebuje prestávky, dokáže pracovat' 24/7 atd', preto naznačujeme obavu z d’alšej diskriminácie človeka 
v postavení zamestnanca vo vzt’ahu k robotickým systémom s vyšším výkonom, nižšou chybovost'ou a podobne (podrobnejšie aj Horváth a kol., 2021).

\section{PREDPOKLADANÉ TRENDY V PRACOVNOM PRÁVE V DIGITÁLNEJ ÉRE}

Podl'a Galatu (2021) bude preferovaný spôsob a štýl vykonávania práce mobilný, plynulý a viac lokálne prepojený, čo by sa malo odzrkadlit' aj v pracovnom práve.

V súlade s Orthom (2017), Brynjolfsson a McAfee (2016), Ješkom (2016) a inými, je vel'mi pravdepodobná transformácia technológii $\mathrm{v}$ podobe komplexnejšieho a rýchlejšieho prepojenia digitálnych zariadení, taktiež schopnost' vytvorit' a použivat' čoraz vyspelejšie technológie. V zhode s citovanými autormi predpokladáme, že virtuálna realita splynie $\mathrm{s}$ reálnym životom, čo, podl'a nášho názoru znie skôr ako hrozba, nie ako príležitost' pre pokrok l'udstva, aj napriek nesporným poskytovaným výhodám (napr. cena, ekologický prístup v tom, že nebude nutné cestovanie a znečist'ovanie ovzdušia, dostupnost' $24 / 7$ a podobne). Toto stojí pred výzvou pre pracovné právo, ako nad'alej zabezpečit' človeku ako kl'účovému článku práce a výrobného procesu primeranú bezpečnost' pri práci a ochranu zdravia pri práci.

Nastáva tu aj otázka virtuálnej bezpečnosti (Orth, 2017), ktorá má vel'a aspektov, avšak vo vzt'ahu k pracovnému právu myslíme napr. na zabezpečenie autorských práv k produktu, službe pri výsledku pracovnej činnosti zamestnanca (Merril a Raduchel, 2013); spôsob vyplácania mzdy zamestnancov za prácu vo virtuálnej mene; zabezpečenie virtuálnej bezpečnosti pracoviska a bezpečnost' pôvodu virtuálnych dát; spôsobenie škody zamestnancom pri práci s virtuálnymi dátami a pod. Tiež predpokladáme, v zhode s Orthom (2017), existenciu virtuálnej polície, ktorá bude dohliadat' na dodržiavanie zákonov, platných vo virtuálnom prostredí.

Myslíme si, že nastane aj zmena vo vzt'ahu k mene, ktorou budú zamestnanci v budúcnosti vyplácaní a tým je predpokladaná aj zmena $\mathrm{v}$ pracovných benefitoch, ktorú je $\mathrm{v}$ tomto momente náročné odhadnút'.

Vo vzt'ahu $\mathrm{k}$ budúcim trendom pracovného práva $\mathrm{v}$ digitálnej ére, sa podl'a Brynjolfsson a McAfee (2016) ukazuje, že robot nahradí prácu človeka, čo povedie k poklesu podielu priamej fyzickej l'udskej práce. Tým, že zamestnancov nahradia technológie, bude viest' $\mathrm{k}$ tomu, že zachované pracovné miesta budú čistejšie, bezpečnejšie a efektívnejšie. V tom prípade bude musiet' zareagovat' aj pracovné právo na zmenené podmienky, napr. pracovnej zmluvy, napr. $v$ častiach prítomnosti na pracovisku, bezpečnosti a zdravia pri práci a podobne. Pravdepodobne sa zvýšia aj kvalitatívne štandardy pracovných podmienok a miest výkonu práce človekom.

Ješko (2016) tvrdí, že inteligentné podniky sú výsledkom štvrtej etapy priemyselnej revolúcie vo vzt’ahu $\mathrm{k}$ internetu vecí, kedy existuje predpoklad, že mechanizmy, zariadenia budú schopné navzájom komunikovat' a tým sa autonómne riadit' a organizovat'. Spojenie technológií napr. s digitálnym podnikom, s inteligentnými robotmi, prvkami umelej inteligencie, ktoré spolupracujú s l’ud'mi, vzniknú kyberneticko-fyzikálne systémy.

Ako píše Orth (2017), l’udská práca bude obmedzená najmä na tvorbu technológií a ich ochranu, d’alšie činnosti budú pravdepodobne vykonávat' zariadenia technického alebo biologického pôvodu. Citovaný autor predpokladá, že aj napriek vyspelým technológiám bude riadiacim a kl'účový článkom fungovania sveta stále človek (podrobnejšie aj Horváth a kol., 2021).

Príspevok vznikol v rámci riešenia projektu VEiGA Digitálna éra ako výzva pre občianske právo a pracovné právo. 


\section{Použitá literatura}

1. BRYNJOLFSSON, E. - McAFEE, A. The Second Machine Age: Work, Progress, and Prosperity in a Time of Brilliant Technologies. W. W. Norton \& Company, 2016. 336 s. ISBN 978-0-39335-064-7.

2. FUSKO, M., BUČKOVÁ, M. Smart technológie $\mathrm{v}$ podnikoch budúcnosti. In: Technológ. Žilina : Žilinská univerzita v Žiline. ISSN 1337-8996. Roč. 11, č. 2 (2019a), s. 79-84.

3. FUSKO, M. - BUČKOVÁ, M. Pracovníci v Priemysle $4.0=$ Staff in Industry 4.0. In: Národné fórum údržby 2019 : zborník prednášok. 1. vyd. Žilina : Žilinská univerzita v Žiline, 2019b. ISBN 978-80-554-1562-8, s. 185-193.

4. GALATA, O. Kancelárie a koronavírus: Po uplynutí krízy nastúpia nové trendy $v$ pracovnom prostredí. [online]. 2021. [cit. 2021-04-04]. Dostupné na internete: https://spojenaba.sk/kancelarie-a-koronavirus-po-uplynuti-krizy-nastupia-novetrendy-v-pracovnom-prostredi/

5. HORVÁTH, M. a kol. Digitálna éra jako výzva pre občianske a pracovné právo $v$ kontexte personálního manažmentu. Týn nad Vltavou - Malá Strana, Nová forma s.r.o., 2021.

6. JEŠKO, V. Štvrtá priemyselná revolúcia. [online]. 2016. [cit. 2021-03-14]. Dostupné na internete: https://www.quark.sk/tovarne-buducnosti/

7. KRAJŇÁKOVÁ, E.,VYHNIČKA, J. Vplyv priemyslu 4.0 na zmeny v štruktúre a počte pracovných miest $=$ Impact of industry 4.0 on changes in the structure and number of jobs. In: Vplyv Industry 4.0 na tvorbu pracovných miest 2019 : zborník vedeckých príspevkov z medzinárodnej vedeckej konferencie. 1. vyd. Trenčín : Trenčianska univerzita Alexandra Dubčeka v Trenčíne, 2020. ISBN 978-80-8075903-2, s. 247-253.

8. MERRIL, S. A. - RADUCHEL, W. J. (eds.) Copyright in the digital era : building evidence for policy. Washington, D.C.: National Academies Press, 2013. 85 s. ISBN 978-0-309-27895-9.

9. NOVAK, J.et al. The Rise of Digital Challangers. How digitization can become the next growth engine for Central and Eastern Europe. Perspective on Slovakia. [online]. 2019. [cit. 2021-04-04]. Dostupné na internete: https://digitalchalleng ers.mckinsey.com/files/The-rise-of-Digital-Challengers_Perspective-on-SK.pdf

10. ORTH, V. Digitálna doba ako súčast' evolúcie. [online]. 2017. [cit. 2021-04-14]. Dostupné na internete: https://www.unitedlife.sk/digitalna-doba-ako-sucast-evolucie/

11. Stratégia digitálnej transformácie Slovenska 2030 - Stratégia pre transformáciu Slovenska na úspešnú digitálnu krajinu. [online]. 2019. [cit. 2021-04-25]. Dostupné na internete: https://www.mirri.gov.sk/wp-content/uploads/2019/06/Strategia-digita Inej-transformacie-Slovenska-2030.pdf

12. Zákon č. 311/2001 Z. z. - Zákonník práce

13. Zákon č. 365/2004 Z. z. - Antidiskriminačný zákon

\section{Kontaktní údaje}

doc. PhDr. PaedDr. Slávka Krásna, PhD. et Ph.D.

Vysoká škola DTI v Dubnici nad Váhom

Sládkovičova 533/20

01841 Dubnica nad Váhom

Tel: +421905990973

email:krasna@dti.sk 


\title{
OSOBA PŘÍMO POSTIŽENÁ SPÁCHÁNÍM PŘESTUPKU - RETROSPEKTIVA A PERSPEKTIVA
}

\author{
PERSON DIRECTLY AFFECTED BY VIOLATION - \\ RETROSPECTIVE AND PERSPECTIVE FOCUS
}

\author{
Michal Márton
}

\begin{abstract}
Abstrakt
Novým institutem v přestupkovém řízení, který přinesl zákon č. 250/2016 Sb., o přestupcích a řízení o nich, je osoba př́mo postižená spácháním přestupku. Nahrazuje navrhovatele u přestupků, které bylo možno projednat na návrh, ovšem oproti navrhovateli není v postavení účastníka ř́zení, ale toliko osoby zúčastněné na řízení. Cestou komparace s trestním právem, jakož i pohledem do historie právní úpravy se př́spěvek snaží nalézt odpověd', zda je tento institut př́nosem pro správní praxi či nikoli.
\end{abstract}

Klíčová slova: Osoba př́mo postižená spácháním přestupku, poškozený, adhezni řizení, přestupek, škoda, nemajetková újma

\begin{abstract}
Person directly affected by vilolation is new institute in administrative proceeding deals with violations, which have brought act. n. 250/2016, violation and violation proceedings act. It supply offender in cases of violations which could be ruled only on his proposal, but on the oposite side, this person is not participant in proceeding with full rights in process, but only person with cathalogized rights in process. Through the comparation with criminal law as well as through the focus into the history of the acts, the ambition of the paper is to answer, whether this institute will have possitive of negative affects on administrative proceedings.
\end{abstract}

Keywords: Person directly affected by vilolation, person requested damages, addicted proceedings, vilotation, damage, immaterial prejudice

\section{1 ÚVOD}

Cílem př́íspěvku je zhodnotit novinku v podobě institutu osoby př́ímo postižené spácháním přestupku, kterou přinesl nový přestupkový zákon. Jedná se o institut, který zná pouze právo přestupkové, které ovšem, stejně jako právo trestní, aprobuje poškozeného jako účastníka řízení, resp. stranu v trestním řízení. ${ }^{1} \mathrm{Na}$ institut je nahlíženo, pokud jde o jeho význam, v souvislosti s odstraněním tzv. návrhových přestupků, přičemž součástí je i historické okénko, jehož cílem je pátrat, zda jde o institut, který našel inspiraci v minulosti či nikoli, a to rovněž v kontextu legální definice poškozeného $\mathrm{v}$ trestním a přstupkovém řízení. Následně se začíná odhalovat snaha zákonodárce vykrýt procesními právy garantovanými osobě př́mo postižené spácháním přestupku užší definici poškozeného jako účastníka řízení o přestupku oproti okruhu poškozených v řízení trestním. Závěr př́spěvku se pak zabývá otázkou, zda trestní právo, jež se stalo inspirací pro rekodifikaci přestupkového práva, resp. jeho procesní instituty, by samy o sobě nepokryly potřeby práva přestupkového, aniž by byl zaváděn institut osoby prímo postižené spácháním přestupku. Vliv trestního práva na přestupkové je totiž patrný nejen z litery a systematiky zákona č. 250/2016 Sb., o odpovědnosti za přestupky a

\footnotetext{
${ }^{1} \S 68$ ZOP ̌̌, $\S 12$ odst. 6 tr. řádu.
} 


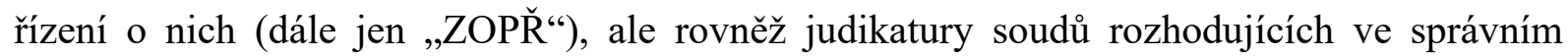
soudnictví, která mnohokrát deklarovala s odkazem na rozhodovací činnost Evropského soudu pro lidská práva, že práva garantovaná Úmluvou o ochraně lidských práv se vztahují na širokou kategorii „obvinění“ stran vnitrostátního členění na jednání zakládající trestně právní či správně právní odpovědnost. ${ }^{2}$

\section{NÁVRHOVÉ PŘESTUPKY VS. SOUHLAS OSOBY PŘÍMO POSTIŽENÉ}

Stávající přestupkový zákon upustil od konceptu tzv. návrhových přestupků, a nahradil institutu navrhovatele $\mathrm{v}$ řizení o přestupku institutem souhlasu osoby př́mo postižené spácháním přestupku se zahájením a prŕípadným pokračováním v řízení o přestupku.

\subsection{Návrhové přestupky $\mathrm{v}$ předchozí právní úpravě}

V tuto chvíli je vhodné se na chvíli pozastavit nad předchozí právní úpravou. Podle $§ 72$ písm. d) zákona č. 200/1990 Sb., o přestupcích, ve znění účinném do 30. 06.2017 (dále jen „ZP“) byl účastníkem řízení navrhovatel, na jehož návrh bylo zahájeno řízení o přestupku. Ustanovení $\S 68 \mathrm{ZP}$ pak vymezovalo okruh návrhových přestupků, a těmito byly přestupky dle $\S 49$ odst. 1 písm. b), $\S 49$ odst. 2 ZP, $\S 50 \mathrm{ZP}$ a $\S 125 \mathrm{c}$ odst. 1 písm. h) zákona č. 361/2000 Sb., o provozu na pozemních komunikacích, ve znění pozdějších předpisů (dále jen „,zákon o silničním provozu“") spáchané mezi osobami blízkými ${ }^{3}$ a přestupky podle $\S 49$ odst. 1 písm. a) ZP. Náhledem na konkrétní skutkové podstaty pak lze shrnout, že osoba blízká musela iniciovat zahájení řízení v případě ublížení na zdraví, ublížení na zdraví při způsobení dopravní nehody, přestupků narušujících občanské soužití a přestupků proti majetku. Specifickou kategorií byl přestupek urážky na cti. Zde podle zákona není navrhovatelem blízká osoba, ale jakákoli osoba, u níž došlo k nactiutrhání. Zákon použivá pro navrhovatele termín „postižená osoba“ osoba. Toliko k přestupkovému zákonu č. 200/1990 Sb., o přestupcích, účinnému od 01. 01. 1991 do 30. 06. 2017. Jde-li právní úpravu, která předcházela jemu, pak zákon č. 60/1961 Sb., o úkolech národních výborů při zajišt'ování socialistického pořádku, účinný do 31. 12. 1990 neřešil otázku návrhových přestupků, přičemž současně je nutno uvést, že jejich počet byl oproti předchozí úpravě značně redukován. Současně ve vztahu k předchozí právní úpravě představované zákonem č. 88/1950 Sb., trestním zákonem správním a zákonem č. 89/1950 Sb., trestním řádem správním, nelze pominout poměrně zásadní laicizaci přestupkového řízení. I když nelze nepochybně upřít stopy doby, ve které vstoupily v účinnost trestní zákon správní a trestní řád správní, pokud jde o ideologické proklamace, jedná se ze systematického hlediska o poměrně logické a sofistikované právní předpisy. Z ustanovení $§ 61$ - 63 trestního řádu správního se pak podává, že přestupek spočívající v urážce na cti byl koncipován jako návrhový přestupek, přičemž pro podání návrhu byla stanovena subjektivní lhůta 15 dnů ode dne, kdy se uražený o urážce dozvěděl, objektivní lhůta pak podání návrhu ohraničovala nejpozději třemi měsíci, ode dne, kdy k urážce došlo. Dlužno pak dále dodat, že to byly právě tyto předpisy, které kodifikovaly přestupkové právo a řízení o přestupcích pro celé území tehdejšího Československa. Úprava přestupků nebyla kodifikována a až do období první republiky byla roztř́ištěna do desítek předpisů různé právní síly. Tento stav byl nevhodný a objevovaly se různé názory na jeho řešení. Vedle úvah o kodifikaci se zamýšlelo, že by se řízení o přestupcích a rozhodování o

\footnotetext{
${ }^{2}$ Např. rozsudek Nejvyššího správního soudu ze dne 20. 1. 2006, čj. 4 As 2/2005-62, rozsudek Nejvyššího správního soudu ze dne 31. 5. 2007, čj. 8 As 17/2007-135.

${ }^{3} \S 68$ odst. 4 ZP; $§ 22$ zákona č. 89/2012 Sb., občanský zákoník. V tomto ohledu definice osoby blízké pojatá do ustanovení § 68 odst. 4 ZP pokrývá širší demonstrativní výčet osob stanovených vyvratitelnou právní domněnkou $\S 22 \mathrm{OZ} \mathrm{tím,} \mathrm{že} \mathrm{je} \mathrm{stanovena} \mathrm{v} \mathrm{zásadě} \mathrm{identická} \mathrm{domněnka} \mathrm{kdy} \mathrm{se} \mathrm{za} \mathrm{osobu} \mathrm{blízkou} \mathrm{jiná} \mathrm{osoba}$ „považuje“, a to jen tehdy, kdyby újmu, kterou utrpěla jedna z nich, druhá právem pocit’ovala jako újmu vlastní. Blíže viz Jemelka, L., Vetešník, P. Zákon o prestupcích a přestupkové řizení. Komentář. 2. Vydání, str. 375.
} 
nich svěřilo výhradně do působnosti soudů, což obhajoval zejména Prof. Jiř́i Pražák. Nakonec ale nedošlo ani $\mathrm{k}$ jednomu a současný stav přetrval do období první republiky, přičemž kodifikace se nepodařilo docílit ani vobdobí let 1918-1938, v rámci normotvorby protektorátu představované množstvím trestních norem pak bylo dále do systému zasaženo tím, že bylo vydáváno široké množství vládních nařízení, která následně po okupaci zůstala v platnosti. ${ }^{4}$

Výsledek pátrání v historické úpravě přestupků je ten, že zákonodárce při reflexi osoby př́mo postižené spácháním přestupku a jejich práv nevycházel z historické úpravy přestupkového práva, minimálně ohraničené jeho kodifikací. Dosavadní právní úprava vycházela z přestupků, u nichž se ř́zení zahajuje ex offo a tzv. návrhových přsestupků.

\subsection{Souhlas osoby př́mo postižené - inspirace trestním právem}

Nynější zákon o přestupcích upouští od taxativního výčtu návrhových přestupků, nyní již přestupků, o nichž lze vést správní řízení se souhlasem osoby př́mo postižené spácháním přestupku. To, že nová právní úprava nerecipovala ustanovení obdobné $§ 68$ ZP s taxativním výčtem návrhových přestupků, však neznamená, že by věc byla ponechána úvaze správního orgánu, který přestupky určí. Okruh přestupků, jež lze stíhat se souhlasem osoby prímo postižené spácháním přestupku, je vymezen skrze ustanovení zvláštních zákonů, jak vyplývá ze znění $§ 79$ odst. 1 ZOPŘ. I nyní dává osoba blízká souhlas s řízením o přestupku, pokud jde o ublížení na zdraví, přestupků narušujících občanské soužití, přestupků proti majetku, jakož i způsobení dopravní nehody, jejímž následkem je ublížení na zdraví. ${ }^{5}$ Souhlasu postižené osoby s řízením o přestupku je i nadále potřeba, pokud jde o urážku na cti. Nezměněný okruh přestupků je pro přehlednost vhodné demonstrovat následující tabulkou.

\begin{tabular}{|c|c|}
\hline Návrhové přestupky podle $\S 68 \mathrm{ZP}$ & $\begin{array}{l}\text { Přestupky, o nichž lze řízení zahájit nebo } \\
\text { v něm pokračovat se souhlasem osoby přímo } \\
\text { postižené podle } \S 79 \text { ZOPŘ }\end{array}$ \\
\hline $\begin{array}{l}\text { ublížení na zdraví jinému ( } § 49 \text { odst. } 1 \text { písm. } \\
\text { b) ZP) }\end{array}$ & $\begin{array}{l}\text { ublížení na zdraví jinému ( } \$ 7 \text { odst. } 1 \text { písm. } \\
\text { b) ZNP }\end{array}$ \\
\hline $\begin{array}{l}\text { vyhrožování újmou na zdraví, nepravdivé } \\
\text { obvinění z přestupku, schválnost, jiné hrubé } \\
\text { jednání ( } \$ 49 \text { odst. } 2 \mathrm{ZP})\end{array}$ & $\begin{array}{l}\text { vyhrožování újmou na zdraví, nepravdivé } \\
\text { obvinění z přestupku, schválnost, jiné hrubé } \\
\text { jednání ( } § 7 \text { odst. } 1 \text { písm. c) ZNP) }\end{array}$ \\
\hline přestupky proti majetku $(\S 50 \mathrm{ZP})$ & přestupky proti majetku (§ 8 odst. 1 ZNP) \\
\hline $\begin{array}{l}\text { způsobení dopravní nehody s ublížením na } \\
\text { zdraví ( } \$ 125 \mathrm{c} \text { odst. } 10 \text { zákona o silničním } \\
\text { provozu) }\end{array}$ & $\begin{array}{l}\text { způsobení dopravní nehody s ublížením na } \\
\text { zdraví ( } \S 125 \mathrm{c} \text { odst. } 10 \text { zákona o silničním } \\
\text { provozu) }\end{array}$ \\
\hline
\end{tabular}

Odstoupení od taxativního výčtu v přestupkovém právu je logicky odůvodnitelné skutečností, že zákonodárce s ohledem na množství skutkových podstat přestupků, jichž je okolo 6.000, upravených $\mathrm{v}$ různých hmotně právních předpisech, preferuje př́ípadné zakotvení souhlasu u jednotlivých skutkových podstat ve zvláštních zákonech.

Trestní právo ani historicky neznalo na rozdíl od práva přestupkového trestné činy, které bylo možno projednat na návrh; ${ }^{6}$ institut souhlasu poškozeného $\mathrm{s}$ trestním stíháním u vyjmenovaných trestných činů byl zaveden velkou novelou trestního řádu - zákonem č.

\footnotetext{
${ }_{5}^{4}$ Štěpánek, B. Správní trestání na území České republiky v minulosti.

${ }^{5} \S 7$ odst. 7; § 8 odst. 7, zákona č. 251/2016 Sb., o některých přestupcích (dále jen „ZNP“), § 125c odst. 1 písm. h) zákona o silničním provozu.

${ }^{6}$ Procesní předpisy historicky: ř.z. 119/1873, jímž se uvádí trestní řád; zákon č. 87/1950 Sb., o trestním řízení soudním (trestní řád), zákon č. 64/1956 Sb., o trestním řízení soudním (trestní řád); zákon č. 141/1961 Sb., trestní řád
} 
178/1990 Sb., kterým se mění a doplňuje trestní řád. Skrze jednotlivé dílčí novely upravující především rozsah taxativně vyjmenovaných trestných činů, je institut souhlasu poškozeného s trestním stíháním zachován do dnešních dnů.

Stávající právní úprava v $§ 163$ tr. řádu stanoví taxativní výčet trestných činů, k jejichž stíhání je potřeba souhlasu poškozeného v př́ípadě, že jde o osobu blízkou. Právní úpravy jsou si nepochybně podobné $\mathrm{s}$ tím, že jak osoba prímo postižená spácháním přestupku, pokud jde o výše uvedené přestupky, tak i poškozený v trestním právu v případě trestných činů podle $\S$ 163 tr. řádu, mohou svým souhlasem ovlivnit to, zda bude vedeno řízení o přestupku (trestní stíhání) či v nich pokračováno.

V rámci trestního řádu však zákonodárce ponechává taxativní výčet trestných činů, u nichž je potřeba souhlasu poškozeného za předpokladu, že tento je osobou blízkou ve vztahu k pachateli. I zde to může nacházet své opodstatnění, přičemž se nic nezmění na závěrech týkající se úpravy přestupkového práva. Na rozdíl od množství skutkových podstat přestupků v různých zákonech, jsou trestné činy kodifikovány v zákoně č. 40/2009 Sb., trestní zákoník, a taxativní výčet bude přiléhavější pro práci s jedním zákonem o přibližně 300 skutkových podstatách trestných činů.

Lze tedy shrnout, že inspiraci přestupkové právo nalezlo nepochybně v trestním právu. V ustanovení $\S 163$ trestního řádu jsou taxativně jmenovány přibližně dvě desítky trestných činů, přičemž valná většina $\mathrm{z}$ nich není pokryta skutkovou podstatou upravující jednání nižší společenské škodlivosti (přestupkem), a naopak - výše taxativně uvedené přestupky jsou drtivou většinou odrazem relevantních trestných činů, ${ }^{7} k$ jejichž stíhání je potřeba souhlasu. Díky této koncepci $\mathrm{v}$ přestupkovém zákoně se tak otevřely dveře pro př́padné další přestupky, o nichž by správní rízení bylo vázáno na souhlas osoby přímo postižené spácháním přestupku.

Jako krok pozitivním směrem lze nepochybně hodnotit skutečnost, že došlo k odstranění institutu navrhovatele $\mathrm{z}$ přestupkového řádu, přičemž zde není snad potřeba dodávat více, než že přestupkové řízení je ovládáno stejně jako trestní zásadou oficiality a správní orgány, stejně jako orgány činné $\mathrm{v}$ trestním řízení, by měly přestupky odhalovat z úřední povinnosti, a nikoli na základě návrhu, který správní řád v nejširším kontextu vnímá jako ,žádost““. ${ }^{8}$

\subsection{Souhlas poškozeného s trestním stíháním i řízením o přestupku aneb proč není úprava jednotná}

Jelikož si trestní právo vystačí s institutem souhlasu poškozeného, je nutno si položit otázku, proč tomu není i v př́padě práva přestupkového.

Odpověd' může přinést teze, že souhlas osoby přímo postižené spácháním přestupku dopadá na specifické kategorie přstupků ve vztahu k nárokům na náhradu škody, které jsou uplatnitelné podle přestupkového práva. V tuho chvíli je vhodné položit si další otázku, a sice jaký nárok $\mathrm{z}$ hlediska občanského práva by byl v prŕípadě spáchání jednotlivých přestupků uplatněn: urážka cti - nemajetková újma podle § 2956 občanského zákoníku, ubližení na zdravi (prosté či v di̊sledku autonehody) - škoda v podobě nákladů spojených s léčením a nemajetková újma v podobě bolestného, př́ípadně ztráty lepší budoucnosti podle $\S 2951$ a $\S$ 2958 občanského zákoníku, přestupky narušujicí občanské soužití - nemajetková újma. Na druhou stranu se se souhlasem poškozeného zahajuje řízení o přestupku i v prípadě přestupki

\footnotetext{
${ }^{7}$ Např. přestupky proti majetku podle $\S 8$ odst. 1 ZNP k trestnému činu krádeže ( $\left.§ 205 \mathrm{TZ}\right)$, zpronevěry ( $\$ 206$ TZ), podvodu (§ 209), poškození cizí věci ( $\$ 228 \mathrm{TZ}$ ).

${ }^{8} \mathrm{Na}$ jednu stranu byla označena tato osoba jako navrhovatel, avšak je problematické ji podř́dit ji pod definici navrhovatele v $\S 27$ odst. 1 správního řádu, nebot' předmětem řízení je otázka vyslovení viny obviněného, což není subjektivním právem žadatele v řízení o žádosti. Blíže viz Jemelka, L., Vetešník, $P$. Zákon o přestupcích a přestupkové řízení. Komentář. 2. Vydání, str. 384-385. Pokud jde o pojmosloví srov. např. též $§ 45$ správního řádu. Žádost (potažmo návrh) je specifický druh podání, kterým se zahajuje správní řízení. Potěšil, L., Hejč, D., Rigel, F., Marek, D. Správní ř́d. Komentář. 2. vydání. Praha: C. H. Beck, 2020, str. 275.
} 
proti majetku (krádež, zpronevěra, podvod, zničení nebo poškození věci), tedy přestupků, v jejichž důsledku vzniká v zásadě výhradně majetková škoda.

$\mathrm{V}$ tento okamžik je vhodné zaměřit se na definice poškozeného v přestupkovém a trestním zákoně.

Ustanovení § 68 ZOPŘ zahrnuje mezi účastníky řízení vedle obviněného a vlastníka věci, jež byla nebo může být $\mathrm{v}$ řízení zabrána, též poškozeného. Poškozený je $\mathrm{v}$ přestupkovém zákoně definován cestou $\S 70$ odst. 1, odst. 2, přičemž jde o osobu, které byla spácháním přestupku způsobena škoda nebo na jejiž úkor se obviněný spácháním přestupku obohatil, pokud je mu tato osoba známa. Poškozeným se tato osoba stává okamžikem uplatnění nároku na náhradu škody nebo nároku na vydání bezdůvodného obohacení. ${ }^{9} \mathrm{~V}$ trestním právu je poškozený definován v $\S 43$ odst. 1 tr. řádu jako ten, komu bylo trestným činem ubliženo na zdraví, způsobena majetková škoda nebo nemajetková újma, nebo ten, na jehož úkor se pachatel trestným činem obohatil. Úprava přestupkového práva v sobě oproti trestnímu právu nezahrnuje dvojí okruh poškozených - jednak osobu, které bylo ublíženo na zdraví a jednak osobu, které byla způsobena nemajetková újma. Pozornost je pak nutno věnovat zejména otázce nemajetkové újmy, nebot' osoba, které bylo ublíženo na zdraví, může uplatňovat jak majetkovou škodu (náklady spojené s léčením), tak nemajetkovou újmu (např. bolestné, ztížení společenského uplatnění), jak bylo ostatně výš již demonstrováno. Je tak evidentní, že bez kategorie „,ubližení na zdravi" by se obešlo i právo trestní.

Důvod, proč je rozsah př́padné náhrady újmy koncipován v přestupkovém právu úžeji než $\mathrm{v}$ trestním, ozřejmil zákonodárce $\mathrm{v}$ rámci důvodové zprávy, kde udává, že často bude rozhodování o náhradě škody nad odborné a kapacitní možnosti správního orgánu, tím spíše pak rozhodováni o nemajetkové újmě, nebot' toto rozhodování vyžaduje re šení složitých skutkových a právních otázek. ${ }^{10}$ Je právě tato skutečnost odpovědí nad smyslem existence institutu osoby př́mo postižené spácháním přestupku?

Je-li vzata do úvahy skutečnost, že definice poškozeného v řízení trestním je všeobjímající, resp. nárok může v rámci adhezního řízení uplatnit nejširší množství osob, kterým byla trestným činem způsobena újma, pak je logické, že trestní právo umožňuje kterémukoli poškozenému rozhodnout o trestním stíhání blízké osoby tím, že dá k němu souhlas.

Takto širokým okruhem poškozených, tedy osob, které mohou $\mathrm{v}$ přsestupkovém řízení dosáhnout postavení účastníka řízení, přestupkové právo nedisponuje a je tedy nasnadě, aby i těmto osobám, potažmo dřívějším navrhovatelům jako účastníkům řízení, byla katalogizována určitá práva tak, jak podává $\S 71$ ZOPŘ. Osoba prŕmo dotřená spácháním přestupku je širší pojem než poškozený $\mathrm{v}$ přestupkovém řízení a dopadá tak i na osoby, které by jinak neměly procesní práva poškozeného. Lze proto uzavřít, že okruh osob, které mohou dát souhlas s řízením o přestupku je stejného rozsahu jako v trestním právu (všeobjímající rozsah postavení poškozeného $\mathrm{v}$ trestním řádu a osoba přímo postižená spácháním přestupku v právu přestupkovém), avšak pokud jde o procesní práva, poškozený má tato plná jako účastník řízení o přestupku, zatímco osoba přímo postižená spácháním přestupku toliko katalogizovaná. Institut osoby přímo postižené spácháním přestupku tak zjevně vykrývá situace, kdy osoba, která by jinak mohla $\mathrm{v}$ trestním řízení docílit postavení poškozeného, toto v přestupkovém rrízení nemůže.

\footnotetext{
${ }^{9} \S 68$ písm. b) ZOPŘ, $\S 70$ odst. 2 ZOPŘ

${ }^{10}$ Důvodová zpráva k zákonu č. 250/2016 Sb., o odpovědnosti za přestupky a řízení o nich. Stejně tak Jemelka, L, Vetešník, P. Zákon o odpovédnosti za prestupky a řizení o nich, Zákon o některých přestupcích. Komentár. 1. Vydání, str. 585, kde autoři hovoří o škodě, nikoli nemajetkové újmě.
} 


\section{ZÁVĚR ANEB JE OSOBA PŘÍMO POSTIŽENÁ NEZBYTNÝM INSTITUTEM?}

V rámci př́spěvku byl zhodnocen institut osoby přímo postižené spácháním přestupku v historickém kontextu trestního práva i správního práva, přičemž inspirativní zdroj v tomto směru nalezen nebyl. Institut se do právního řádu dostal $v$ souvislosti s odstraněním návrhových přestupků a po vzoru trestního práva je v souvislosti se zahájením řízení o přestupku, resp. jeho pokračováním, nutný souhlas osoby př́mo postižené spácháním přestupku. Tento v trestním právu dává poškozený, který je osobou blízkou pachateli, avšak $\mathrm{v}$ rámci přestupkového práva je poškozený definován výrazně úžeji. $Z$ tohoto důvodu souhlas dává osoba př́mo postižená spácháním přestupku, která má dále katalogizována práva, kterýžto pojem je co do rozsahu na úrovni poškozeného v trestním řízení.

Lze mít za to, že samotný institut osoby př́mo postižené spácháním přestupku nemusel být do právního řádu zaváděn a $\mathrm{v}$ rámci rekodifikace přestupkového práva bylo možno jít cestou práva trestního, což lze opř́ít o následující teze:

1) existence procesního ustanovení umožňujícího poškozeného odkázat s nárokem na náhradu škody na řízení ve věcech občanskoprávních $\mathrm{v}$ situacích, kdy by dokazování škody způsobilo průtahy v řízení o přestupku;

2) skutečnost, že na rozdíl od soudu si správní orgán za předpokladu, že má odborné znalosti, může odborné otázky vyhodnotit sám;

3) podstata adhezního řízení, která dává možnost o náhradě škody rozhodnout v rámci řízení o přestupku, což je pro poškozeného nepochybně šetrnější než čelit škůdci v rámci kontradiktorního řízení.

Obhajuje-li zákonodárce cestou důvodové zprávy užší definici poškozeného z důvodu skutkových a právních složitostí uplatněného nároku, pak podle ustanovení $§ 89$ odst. 2 věta III. ZOPŘ lze poškozeného odkázat se svým nárokem na soud nebo jiný orgán veřejné moci, obdobně jako v trestním řízení podle ustanovení $§ 229$ odst. 1 trestního řádu. Přitom v obou př́padech jde o materiálně o zcela identický důvod - řádné zjišt’ování nároku by vedlo $\mathrm{k}$ průtahům $\mathrm{v}$ řízení. Existují-li tedy materiálně identická procesní ustanovení v přestupkovém zákoně i trestním řádu, není důvod konstruovat institut „osoby př́mo postižené spácháním přestupku“ jako širší pojem nežli poškozený. Nemá-li správní orgán v řízení časové či personální kapacity o nároku rozhodnout, mohl by tak učinit i v př́ipadě nemajetkové újmy; vždy je totiž nutno reflektovat, že primárním účelem je rozhodnout o přestupku a rozhodování o uplatněném nároku nemá vést $\mathrm{k}$ průtahům řízení o samotném přestupku.

Jde-li o odbornou stránku věci, pak zřejmě klíčovým argumentem bude, že u soudce se oproti pracovníkovi správního orgánu předpokládá v souladu se starou zásadou „iura novit curia“ vyšší míra právních znalostí, což nelze vyvrátit. Lze však na druhou stanu oponovat jistou výhodou správního orgánu, který si může na rozdíl od soudu vyhodnotit odborné otázky sám. Podle ustanovení § 56 správního řádu závisí-li rozhodnutí na posouzení skutečností, k nimž je třeba odborných znalostí, které úřední osoby nemají, a jestliže odborné posouzení skutečností nelze opatřit od jiného správního orgánu, správní orgán usnesením ustanoví znalce. A contrario, má-li úrúední osoba odborných znalostí, př́ípadně lze-li odborné posouzení opatřit od jiného orgánu, znalec se neustanoví. Naproti tomu soud, i když př́slušné odborné znalosti má, znalce přibírá, nebot' litera zákona hovoří o přibrání znalce v situaci, kdy jsou třeba odborné znalosti. Podle ustanovení $§ 105$ odst. 1 trestního řádu je-li k objasnění skutečnosti důležitých pro trestní řízení třeba odborných znalostí, vyžádá orgán činný v trestním řízení odborné vyjádření. Jestliže pro složitost posuzované otázky takový postup není postačující, přibere orgán činný $\mathrm{v}$ trestním řízení znalce. I když lze u správního orgánu předpokládat deficit v komplexním právním rozhledu, na druhou stranu může úřední osoba řízení výrazně urychlit v situaci, disponuje-li sama odbornými znalostmi.

Zúžením okruhu poškozených v rámci přestupkového řízení dochází $\mathrm{k}$ situaci, že osoby, které se nevlezou do legální definice poškozeného $\mathrm{v}$ přestupkovém řízení, jsou osobami na řízení 
zúčastněnými s katalogizovanými právy, a již tímto postupem je zákonodárce postavil do situace, kdy jsou nuceny čelit škůdci v rámci kontradiktorního řízení, přitom skutečnost, že byla osoba napadena v nočních hodinách na ulici, může být stejně traumatizující bez ohledu, zda zranění spadá do kategorie trestného činu či přstupku. Konečně, nelze pak poukázat na jistou nesystematičnost při práci z legální definicí poškozeného v přestupkovém řízení. Byl-li v dřivějším přestupkovém zákoně definován jako osoba, které byla způsobena majetková škoda nebo nemajetková újma, je pak nově definován jako osoba, které byla způsobena škoda (zjevně majetková), nebo na jejíž úkor se pachatel bezdůvodně obohatil, přičemž bezdůvodné obohacení bude v praktické rovině jako zbytková kategorie závazku z protiprávního jednání v občanském právu pokrývat minimum situací.

Nezbývá tedy než uzavřít, že institut osoby přímo postižené spácháním přestupku je účelovou konstrukcí reagující na zúžení definice poškozených v přestupkovém řízení, který je možno bez dalšího nahradit přijetím definice poškozeného $\mathrm{z}$ trestního řádu a $\mathrm{v}$ návaznosti na to $\mathrm{i}$ jeho právo udělovat souhlas se zahájením či př́ípadným pokračováním u vybraných přestupků.

\section{Použitá literatura}

1. Poslanecká sněmovna Parlamentu České republiky. Dưvodová zpráva k zákonu č. 250/2016 Sb., o odpovědnosti za prestupky a ř́zení o nich. Poslanecká sněmovna Parlamentu České republiky. [on-line], zobrazeno dne 15. 06. 2021. Dostupné na: https://www.psp.cz/sqw/sbirka.sqw?cz $=250 \& \mathrm{r}=2016$

2. JEMELKA, L., VETEŠNÍK, P. Zákon o přestupcích a přestupkové řizení. Komentár. 2. vydání. Praha: C. H. Beck, 2013, 632 s. ISBN 978-80-7400-501-5.

3. JEMELKA, L., VETEŠNÍK, P. Zákon o odpovědnosti za přestupky a řízení o nich, Zákon o některých prestupcích. Komentář. 1. vydání. Praha: C. H. Beck, 2017, 1153 s. ISBN 978-80-7400-772-9.

4. POTĚŠIL, L., HEJČ, D., RIGEL, F., MAREK, D. Správní řád. Komentář. 2. vydání. Praha: C. H. Beck, 2020, 920 s., ISBN 978-80-7400-804-7.

5. ŠTĚPÁNEK, B. Správní trestání na územi České republiky v minulosti. E-pravo, 2016. [on-line], zobrazeno dne 15. 06. 2021. Dostupné na: https://www.epravo.cz/top/clanky/spravni-trestani-na-uzemi-ceske-republiky-vminulosti-100286.html.

\section{Právní předpisy}

ř.z. 119/1873, jímž se uvádí trestní řád, účinný do 1.1 .1951

zákon č. 88/1950 Sb., trestní zákon správní, účinný do 1. 1.1961

zákon č. 89/1950 Sb., trestní řád správní, účinný do 1. 1. 1961

zákon č. 87/1950 Sb., o trestním ř́zení soudním (trestní řád), účinný do 31. 12. 1956

zákon č. 64/1956 Sb., o trestním řízení soudním (trestní rád); účinný do 31. 12. 1961

zákon č. 141/1961 Sb., trestní řád, ve znění pozdějších předpisů

zákon č. 61/1960 Sb., o úkolech národních výborủ při zajišt'ování socialistického pořádku, účinný do 1. 1.1991

zákon č. 200/1990 Sb., o přestupcích, ve znění účinném do 30. 06. 2017

zákon č. 361/2000 Sb., o provozu na pozemních komunikacích, ve znění pozdějších předpisů

zákon č. 500/2004 Sb., správní řád, ve znění pozdějších předpisů

zákon č. 40/2009 Sb., trestní zákoník, ve znění pozdějších předpisů

zákon č. 250/2016 Sb., o přestupcích a řízení o nich, ve znění pozdějších předpisů

zákon č. 251/2016 Sb., o některých přestupcích, ve znění pozdějších předpisů

\section{Judikatura}

rozsudek Nejvyššího správního soudu ze dne 20. 1. 2006, čj. 4 As 2/2005-62,

rozsudek Nejvyššího správního soudu ze dne 31. 5. 2007, čj. 8 As 17/2007-135 


\section{Kontaktní údaje}

JUDr. Michal Márton, Ph.D.

Slezská univerzita v Opavě, Obchodně podnikatelská fakulta v Karviné Univerzitní náměstí

Tel: +420 596398318

email: marton@opf.slu.cz 


\title{
PÉČE NEFORMÁLNÍCH (LAICKÝCH, RODINNÝCH) PEČOVATELŮ O NEVYLÉČITELNĚ NEMOCNÉ DÍTĚ V ZÁVĚRU JEHO ŽIVOTA - NÁHLED Z ETICKÉ PERSPEKTIVY
}

\author{
CARE GIVEN BY INFORMAL (LAY, FAMILY) CARERS \\ TO INCURABLY SICK CHILD IN THE END OF HIS/HER LIFE - \\ ETHICAL PERSPECTIVES
}

\author{
Markéta Královcová
}

\begin{abstract}
Abstrakt
Příspěvek se zamýšlí nad působením a postavením laických pečovatelů se specifickým přihlédnutím $\mathrm{k}$ péči o dítě $\mathrm{v}$ konci života. Všímá si situace laických pečovatelů $\mathrm{v}$ konfrontaci $\mathrm{s}$ prostředím, $\mathrm{v}$ němž $\mathrm{k}$ úmrtí dítěte dochází nejčastěji - tedy nemocnice, domova a dětského hospice.
\end{abstract}

Klíčová slova: neformální péče, laická péče, rodina, dítě, konec života

\begin{abstract}
The article focuses on the role and position of informal carers looking after an incurably sick child in the end of his/her life. Attention is paid to different type of settings where the death typically takes place - i.e. hospital, home and children's hospice.
\end{abstract}

Key words: informal care, lay care, family, child, end-of-life

„Skoro každá žena má za svého živobytí občas zdraví jiných na starosti, bud' ditěte neb churavé, věkem sešlé osoby - jinými slovy: každá žena jest občas ošetřovatelkou.(...) Když tedy skoro každá žena někdy ve svém živobytí ošetřovatelkou státi se musí, $t$. když občas zdraví té neb oné osoby na starosti má, jak nesmirně důležitý, jak veliký a prospěšný byl by výsledek spojených zkušeností, kdyby všechny o tom přemýšlely, jak by svému úkolu nejlépe dostály. "

Florence Nightingalová (12)

\section{ROLE NEFORMÁLNÍHO PEČOVATELE V ŠIRŠÍM KONTEXTU}

Téma tzv. neformální péče a neformálních pečovatelů je v posledních několika letech velmi aktuální, ačkoli nejde o téma ve své podstatě nijak nové, o čemž mj. svědčí i citát v úvodu a nebylo by jistě těžké udělat mnohem hlubší historický exkurz, abychom nalezli neformální pečovatele všude tam, kde bychom se setkali s ošetřovaným nemocným - dlouho ovšem bez potřeby hledat pro tuto roli formální vymezení a samostatné označení. Péče lidí o své blízké je stará jako lidstvo samo; přelom 20. a 21. století je ovšem v rozvinutých průmyslových společnostech, které $\mathrm{z}$ péče o nemocné učinily doménu profesionálů a institucí a zodpovědnost státního systému, charakterizován tlakem na to, aby se role a postavení "pečujícího laika", tedy někoho, kdo péči o druhé nevykonává v rámci pracovně právního vztahu a profesionální služby, definovala a formálně ukotvila.

Systémy zdravotnických a sociálních služeb - zejména tam, kde byly velkoryse koncipovány v souladu s představou tzv. welfare state - začaly narážet na četné ekonomické a personální limity. Rozpoznání těchto limitů zároveň začalo rezonovat $\mathrm{s}$ hlasy mnoha pacientských a občanských iniciativ i některých kritiků zevnitř systému, kteří upozorňovali na neúnosnou 
míru, $v$ jaké si instituce klienty přivlastňují, vytrhujíce je $\mathrm{z}$ jejich přirozeného prostředí a přirozených vazeb. To všechno vedlo $\mathrm{k}$ pozvolné renesanci svépomoci poskytované na půdorysu kdysi běžných (a s postupujícím individualismem vyhasínajících až vyhaslých) rodinných a komunitních vazeb; situace si vynutila potřebu formalizovat roli pečujícího laika tak, aby neformální pečovatelé získali v systému institucionalizované péče dostatečný prostor a odpovídající podporu a zázemí.

Neoddiskutovatelný př́nos a nezpochybnitelná technická efektivita moderní institucionální (zejména nemocniční) péče však odpočátku jakoby zúžila prostor pro verbalizaci pochybností a pro otevřenou a poctivou diskusi o potenciálních negativech zdravotnického průmyslu úvahy o možných škodlivých vedlejších dopadech pobytu v nemocničním prostředí a o obětech, jež institucionální péče po svých př́ijemcích vyžaduje (obětí zde míním to, čeho všeho se jedinec musí ve jménu institucionálně zprostředkované úzdravy zř́íci a co musí strpět), byla - a mnohdy dosud je - pocit’ována málem jako kacířství. Uvažování o takovéto oběti je ovšem důležitou součástí rozkrývání hodnot, k nimž se společnost vztahuje, které považuje za podstatné - a v pediatrii navíc dostává velmi silný etický rozměr, protože zejména malé děti, na rozdíl od dospělých, nejsou schopny takové abstrakce a takového vnímání času, aby uvědoměle a dobrovolně dokázaly obětovat konkrétní a bezprostřední prožívání přítomné chvíle abstraktní vizi teoretického budoucího prospěchu; vnímání příčinné souvislosti mezi aktuálním nepř́ijemným omezením a budoucí úzdravou je tu mnohdy znemožněno dlouhým časovým odstupem, který přesahuje dimenze skutečnosti, jakou si dítě dokáže představit, s jakou ve svých úvahách dokáže smysluplně nakládat. Nejde tu ale jen o chápání konceptů, o něž svou naději a svou představu budoucnosti opírají dospělí - podle zkušeností, které jsem během trrí desítek let své praktické práce učinila, často i děti staršího školního věku operují ve vztahu k existenciálním otázkám s prvky magického myšlení, příběh svého života nahlížejí $\mathrm{v}$ souvislostech, které jsou $\mathrm{s}$ racionalitou technicky uvažujících odborníků nekompatibilní, což jen dále rozšiřuje prostor pro možná nedorozumění a míjení a tedy pro další trápení.

Léčení v prostř̌edí lůžkového zdravotnického zařízení zásadním způsobem proměnilo poměry mezi těmi, kdo péči poskytují, a těmi, kdo ji přijímají. Změny se z hlediska historické perspektivy udály poměrně rychle a stávající podoba nemocniční péče, včetně výrazné asymetrie ve vztahu poskytovatel x prŕijemce péče, není nijak starého data - společnost však tuto asymetrii zpravidla nezpochybňuje, ale toleruje ji a přijímá - v četných rozhovorech $\mathrm{s}$ rodiči se dokonce opakovaně setkávám s názorem, že institucí diktovaná omezení prostě musejí mít nějaký důvod, protože jinak by nemohla být vyžadována. Tento postoj apriorní důvěry vůči institucionální autoritě a současně nedůvěry vůči relevantnosti vlastních názorů udržuje převládající asymetrii a brání tomu, aby podoba zdravotnického průmyslu byla podrobena - a průběžně podrobována - otevřené kritické diskusi, aby vyžadovaná omezení individuální autonomie byla posuzována z hlediska svého účelu a smyslu.

Jsme tak svědky ze své podstaty paradoxního jevu, kdy se dostává předpokládaná, očekávatelná a očekávaná spolupráce a shodný zájem (na úzdravě a pomoci) do nového postavení a potenciálně také do konfliktu: ti, kdo péči poskytují, a ti, kdo ji přijímají, mají mezi sebou instituci, na jejíž platformě k setkání a poskytování a přijímání péče dochází; instituce přitom na sebe váže řadu byrokratických mechanismů, jež celý proces ovlivňují tím, že mohou ze hry relativně snadno vyřadit rozměr individuální osobní zodpovědnosti za působené trápení - pro připomenutí toho, kam může taková disociace dospět, zmiňme v této souvislosti zkušenost Š́́a, brilantně a nesmlouvavě zachycenou třeba prostřednictvím filmového dokumentu Clauda Lanzmana nebo odvážnou analýzou banality zla v díle Hannah Arendtové.

Současná moc institucí je důsledkem dlouhodobé, dalekosáhlé a mnohovrstevné proměny, která začala už průmyslovou revolucí a netýká se jen způsobu života a jeho společenské 
organizace, ale vůbec samotného způsobu nazírání na svět: představ o tom, kde je místo lidského jedince a jaká je jeho konkrétní individuální odpovědnost ve vztahu k sobě i k druhým, jaké jsou jeho povinnosti a jaká má práva. Zásadně se proměnila perspektiva lidského života - horizont, vǔči němuž člověk vztahuje své naděje a samotný smysl své existence. Zatímco $\mathrm{v}$ minulých staletích byla představa o lidském životě prakticky vždy nějakým způsobem zasazena do kontextu transcendence - člověk vnímal své bytí jako součást smysluplného plánu, který přesahoval oblast fyzického světa -, postupující sekularizace západní společnosti měla za následek to, že se transcendentní rozměr ze společenského života do značné míry vytratil a že lidé začali drtivou většinu svých nadějí vztahovat takřka výhradně ke své pozemské existenci a k tomu, co pozemskou existenci může zaštítit, ochránit a prodloužit.

Důležitým faktorem a katalyzátorem této změny byl i vývoj medicíny v polovině dvacátého století: s objevem penicilínu a překotným rozvojem diagnostických a chirurgických technik začala medicína nabízet řešení i tam, kde byla dosud bezmocná; díky tomu se zásadně změnil její étos, její obraz i její společenská autorita, proměnila se také tváŕ zdravotnických institucí. $\mathrm{S}$ nově nabytou a postupně sílící mocí získávala medicína také právo stále výrazněji zasahovat do autonomie jednotlivců - této proměny si už od šedesátých let dvacátého století začala všímat celá řada kriticky uvažujících odborníků; připomeňme třeba Ervinga Goffmana a jeho koncept totální instituce či Ivana Illiche, který už v sedmdesátých letech patrně jako první upozornil na četné iracionální rysy vztahu společnosti k medicíně a výmluvně zachytil proměnu obecného vztahu $\mathrm{k}$ bolesti a utrpení, omezení práv člověka $\mathrm{k}$ vlastnímu tělu a etablování profesí, které díky své - nezasvěceným laikům nepřístupné - expertnosti získávají státem posvěcený monopol; Illich v této souvislosti mluví o tzv. "disabling professions", "zneschopñujících profesích". (6)

Jedním z populárních autorů současné doby, jehož pronikavý kritický pohled je umocněn faktem, že je zároveň sám lékařem, je v USA žijící Ind Atul Gawande. Dramatickou proměnu v souvislosti s medicínským pokrokem charakterizuje slovy:

"V polovině 20. století procházela naše medicina proměnou. Jestliže člověk onemocnèl $v$ dř́vějši době, lékaři o něho pečovali obvykle v jeho vlastní posteli. Nemocniční péče nemèla tehdy takový význam jako dnes. Lewis Thomas, tehdejši velký lékař-spisovatel, napsal v roce 1937 v ličeni své stáže v Bostonské městské nemocnici: "Jestliže pobyt v nemocnici člověku pomohl, pak predevším proto, že zde dotyčný měl teplo jídlo a bedlivou, přátelskou péči, kterou mu poskytovaly zkušené ošetřovatelky. To, zda přežil nebo ne, záviselo na přirozeném vývoji choroby. Medicína na to měla pramalý vliv." Po druhé světové válce se však tento obraz začal rychle ménit. Rozšíril se penicilin a mnohá dalši antibiotika, která znamenala zásadní změnu v léčbě infekcí. Byly objeveny léky na vysoký krevni tlak a na hormonální nerovnováhu. Došlo $k$ významným objeviom na poli kardiochirurgie, do praxe se dostaly př́stroje na umělou plicní ventilaci, uskutečnily se první transplantace. Z lékařu se stali hrdinové a nemocnice, dřive domy nemoci a smrti, se staly místem naděje a uzdravení. (5, s. 64)

Takto nastavený systém je charakteristický tím, že je vůči jedinci dominantní: instituce definuje problém a přináší řešení - a od nemocného vyžaduje především to, aby se podvolil jejímu řádu a řídil se jejími pokyny. Někdejší étos služby tak byl zastíněn jiným étosem: étosem dominující expertnosti.

Obraz odborníka, který si ví rady v každé situaci, je ale vystaven těžké zkoušce tam, kde dochází ke konfrontaci $\mathrm{s}$ nakonec vždy nevyhnutelným koncem pozemského života: v situacích, kdy se musíme začít tázat po účelu a smyslu lidského údělu. Taková konfrontace odhaluje limity možností, které zdravotnictví jako instituce má - a přiznání a poctivé reflektování těchto limitů by logicky mělo začít rozvolňovat moc, kterou si systém nad pacientem nárokuje; $\mathrm{k}$ tomu ovšem takřka nedochází. Atul Gawande k tomu poznamenává: 
"(...) naše medicínské uvažování selhalo do té míry, že dnes raději aktivně ubližujeme nemocným, než abychom se postavili tvář́ v tvár smrtelnosti." (5, s. 155)

Výše naznačený popis společenské proměny je samozřejmě v mnoha ohledech zjednodušující - považuji ale za důležité z něj vyjít, nebot' zásadním způsobem definuje prostředí a okolnosti, v nichž se dnes - kdysi spontánní a samozřejmá - neformální péče odehrává.

\section{NEFORMÁLNÍ PEČOVATELÉ V ČESKÉM PROSTŘEDÍ}

Politickým tématem se neformální péče v České republice stala relativně nedávno - do své gesce ji u nás dostalo Ministerstvo práce a sociálních věcí (MPSV). Aby se práce neformálních pečovatelů tematizovala a neformální pečovatelé se mohli stát součástí sociální a veřejné politiky státu (a aby stát mohl neformální péči začít finančně podporovat), bylo třeba nějakým způsobem zhodnotit a posoudit prínos této péče a začlenit ji do systému. $\mathrm{Na}$ jedné straně je povzbudivé, že se ve společenském prostoru s neformálními pečovateli už v nějaké míře počítá a že je stát připraven občany motivovat, aby se pro tuto formu péče o svého blízkého rozhodli, na druhé straně zde existuje riziko, že se nálepka "neformální péče" začne používat způsobem, který společenské vnímání laické péče zdeformuje tím, že se soustředí jen na některé její podoby, projevy a aspekty, zatímco jiné, zejména ty hưre kvantifikovatelné, potlačí. To je ale omezení a riziko spjaté s tvorbou všech závazných definic - a bez ohledu na definice tu vždy bude pomoc jednoho člověka druhému, péče skutečně charakterizovaná nikoli vymezením pečovatelských úkonů, ale povahou vztahu mezi dvěma lidskými bytostmi, péče, která přes svou zdánlivou jednosměrnost obsahuje rozměr vzájemnosti.

Instituce, které péči o nemocného a handicapovaného člověka mohou na nějakou dobu převzít, mají vždy své limity, at' už dané složením pečujícího týmu, kapacitou zařízení, indikací $\mathrm{k}$ pobytu, délkou pobytů či cenovými nároky. $\mathrm{Z}$ mnoha různých důvodů tak vzniká prostor pro aktivní zapojení rodiny nemocného, a to nejen $\mathrm{z}$ důvodů limitů instituce, ale často i z přirozeně lidských pohnutek dopřát nemocnému co nejlepší, nejkvalitnější život (jakkoli třeba plný omezení) doma, v důvěrně známém prostředí, v blízkosti svých blízkých. Nemocný člověk (a to i člověk v konci svého života) se tak může $z$ vysoce specializovaného prostředí nemocničního oddělení ocitnout zpátky doma. Jaké nároky to na jeho laické, neformální pečovatele klade, jaké oběti musejí takové péči přinášet, si lze bez osobní zkušenosti či zprostředkovaných informací jen těžko představit.

Péče $\mathrm{v}$ rodině má pochopitelně také své limity, ovšem na rozdíl od péče institucionální nebývá pod tlakem standardů, pevně daných rozpočtů a pravidelných kontrol: doma se i s velmi omezenými zdroji prostě vždy musí nějak vyjít, a kvalita péče i její faktická dosažitelnost pak pochopitelně mohou kolísat v závislosti na momentálních možnostech pečující rodiny a také na vztazích, které v ní panují.

Kromě jisté garantované finanční podpory od státu je totiž důležité, aby se každý takový pečovatel zodpovědně a podle svých možností pokusil zorganizovat si péči tak, aby ji mohl zvládnout, což nebývá $\mathrm{v}$ praxi vůbec snadné. V príípadě dětských pacientů aktivní role neformálního pečovatele (nejčastěji rodiče) navíc nemusí končit (a často ani nekončí) ani v př́ípadě přijetí dítěte do institucionální péče.

\section{RODIČ NEVYLÉČITELNĚ NEMOCNÉHO DÍTĚTE V POZICI NEFORMÁLNÍHO PEČOVATELE}

„Vztahy, které si nevolíme a nevybiráme, nýbrž přijímáme jako uložené, se od jiných liši $v$ několika ohledech. Předně tím, že jsou naléhavé a nepodmíněné: o dítě se matka postarat musí, i kdyby se ji třeba nelíbilo a chovalo se pod vši kritiku. “ (15, s. 237)

Ve své úvaze se soustředím na velmi specifickou skupinu neformálních pečovatelů, a to na rodiče dětí s diagnózou život ohrožujícího onemocnění či život ohrožujícím stavem, a 
zamyslím se nad vybranými etickými aspekty péče v konci života dítěte: na dilemata, která před pečujícími rodiči (neformálními pečovateli) vyvstávají, na problémy etické povahy, jež musejí řešit, a pokusím se naznačit, jakým způsobem by bylo možné neformální pečovatele (tedy nejčastěji rodiče) $\mathrm{v}$ jejich situaci podpořit a alespoň část těžkého břemene $\mathrm{z}$ nich sejmout. Zmíním také některé - dle mého soudu relevantní - souvislosti, zásadní pro porozumění tématu, a krátce se ohlédnu za významnými změnami, které se na poli rodičovského pečování odehrály zejména za posledních třicet let.

Během posledních tří desetiletí jsem měla díky své práci možnost vstupovat do úzkého osobního kontaktu se stovkami rodin, jejichž dítě vážně onemocnělo; mnohé děti svému onemocnění podlehly - některé $\mathrm{v}$ nemocnici, některé doma. Vztah, který mezi mnou a rodinami vznikl, mi dovolil nahlédnout do velkého množství př́iběhů - toto sdílení často trvalo po dobu několika měsíců až let. Měla jsem tak možnost zúčastněného pozorování par excellence, aniž bych o ně ovšem v tu dobu opírala výzkum nebo z něj čerpala statistická data: smyslem mé práce byla individualizovaná praktická pomoc konkrétním lidem v konkrétní situaci. Během let jsem získala důvěru mnoha dětí a jejich blízkých (rodičů, prarodičů, sourozenců, kamarádů, dalších rodinných př́íslušníků) a měla možnost vstupovat do intimního osobního rodinného prostoru, ze kterého je realita vážné nemoci a všeho, co s ní souvisí, nahlížena ze zcela jiné perspektivy, než při pohledu zvenčí.

Jak je z povahy vztahu mezi dítětem a jeho rodičem zřejmé, neformálním pečovatelem se rodič nestává na základě své volby, nerozhoduje se pro tuto roli až v určité fázi vážné nemoci svého dítěte: rodič dítěte $\mathrm{s}$ život ohrožující diagnózou se v této roli ocitá přirozeně, z podstaty své rodičovské role. Vyřčením vážné diagnózy se jeho dosavadní rodičovská role spontánně rozšiřuje o další rozměr, a to bez ohledu na to, zda je jako formální pečovatel někým označen nebo uznán. Rozhodovací akt je $\mathrm{v}$ tomto př́padě obrácen - rodič může rozhodnout naopak o tom, že se této role nebo některých jejích aspektů vzdá. Vzhledem ke zmíněné specifičnosti vztahu mezi rodičem a dítětem nepřestává rodič plnit úlohu neformálního pečovatele ani $\mathrm{v}$ průběhu hospitalizace, kdy je odborná a ošetřovatelská péče o dítě v rukou zdravotnické instituce. Roli rodiče coby neformálního pečovatele o vlastní nemocné či postižené dítě nelze vnímat obecně a staticky: je nástrojem neustálého budování vztahů $\mathrm{s}$ dítětem i s okolím, dynamickým vrůstáním do měnící se situace, a současně prostředkem, který tuto situaci určitým způsobem reflektuje a dále formuje. Z perspektivy rodinného př́běhu jde současně o hledání smyslu, účinné pomoci a naděje, mnohdy spojené s hledáním a nacházením nových zdrojů opor a naděje, včetně těch nejhlubších, spirituálních.

\section{NEVYLÉČITELNĚ NEMOCNÉ DÍTĚ V ZÁVĚRU ŽIVOTA}

\subsection{Prostředí nemocnice}

K léčbě dítěte trpícího život ohrožující chorobou patří opakované hospitalizace a náročná, často dlouhodobá a zatěžující léčba.

Velkou zátěží je pro dítě už samo prostředí nemocnice - jak tvář nemocničního prostředí, tak i podoba samotné hospitalizace je mimořádně důležitým faktorem, který zásadním způsobem utváŕí způsob, jakým dítě a jeho blízcí nemoc a její směřování vnímají, je velmi výrazným, často dokonce dominantním formativním prvkem jimi prožívaného prŕběhu, je zkušeností, která mění a polarizuje jejich nazírání.

I proto se nemocnici budu věnovat podrobněji a dotknu se i některých historických okolností a souvislostí, které z hlediska svého př́spěvku považuji za podstatné.

Ohlédneme-li se do minulosti, shledáme, že koncept nemocnice, jež by přijímala dětské pacienty, byl mezi pediatry dlouho zpochybňován; forma institucionální lůžkové péče, poskytované mimo důvěrně známé předmětné a sociální prostředí vlastního domova, totiž pro dětské pacienty nebyla vnímána jako vhodná. 
Za zdi nemocnic se tak pediatrická péče dostala relativně pozdě, až koncem 18. století. Vůbec první zařízení, které začalo $\mathrm{v}$ Evropě poskytovat institucionalizovanou péči nemocným dětem, i když se ještě nejednalo o dětskou nemocnici, založil v dubnu 1769 anglický lékař George Armstrong. Jeho Ošetřovna pro chudé (nebo též nemocné) děti (Dispensary for the Infant Poor) stála na Red Lions Square v londýnské čtvrti Holborn a za dvanáct let svého působení posloužila pětatřiceti tisícům nemocných dětí. Nemocní sem docházeli pouze ambulantně, vlastní léčení probíhalo doma. V roce 1772, v době, kdy byla Ošetřovna v plném rozkvětu, začali na Armstronga jeho prrátelé naléhat, aby zřídil také lůžkové zařízení, kde by děti mohly zůstávat i přes noc, stejně, jako v různých špitálech zůstávali pacienti dospělí. George Armstrong takový návrh rázně odmítl - řekl k tomu:

„Každému myslícímu člověku musí být hned jasné, že něco takového se prostě nedá uskutečnit. Když dítě oddělite od rodiče nebo od chưvy, na kterou je zvyklé, v okamžení mu zlomite srdce; a když ke každému ditěti prijimete také chůvu, co by to muselo byt za nemocnici, aby je všechny pojala? A nebyl by $v$ takovém př́padě, kdyby odděleni bylo přeplněno dètmi $i$ dospélými lidmi, vzduch $v$ nemocnici silně znečištěn? A nebyly by matky a chưvy neustále v rozepřich, kdyby jich bylo tolik pohromadě? A nerušily by se děti navzájem neustále svým pláčem?" (11, s. 6)

Fakt, že dětské nemocnice nakonec přece jen vznikat začaly, Armstrongovy postřehy ani jejich pravdivost nijak nesnižuje: pediatrická lůžková péče byla (a leckde dosud je) vykoupena obětí, o níž George Armstrong už z principu nebyl ochoten vůbec uvažovat: totiž oním "zlomením dětského srdce".

U dětského pacienta, na rozdíl od pacienta dospělého, tak během pobytu v nemocnici daleko zřetelněji vstupuje do hry aspekt psychosociálních potřeb, který souvisí zejména s nezdravotnickou oblastí poskytované péče: jeho klíčovým prvkem je přítomnost a aktivní podpora blízkého člověka, nejčastěji rodiče dítěte. Role rodiče během institucionálního léčení dítěte prošla ve druhé polovině 20. století v zemích západní Evropy a v zámoří ohromnou proměnou - od separace hospitalizovaného dítěte až po aktivní podporu partnerské role rodičů při péči o jejich dítě. Tento proces ovšem nebyl samozřejmý ani samovolný a vyžadoval velké úsilí na straně rodičů a otevřenost ke změně na straně zdravotnického systému: základním bodem, od nějž se tato transformace pediatrického zdravotnictví začala odvíjet, bylo prokázané zjištění, že dosavadní podoba hospitalizace, spojená s odloučením od blízkých lidí, představuje pro dítě zdroj trápení.

Smutek a pláč hospitalizovaných dětí byl dlouhou dobu připisovaný nemoci dětí, teprve průkopnické práce Jamese Robertsona $(13,14)$ a Johna Bowlbyho $(1,2,3,4)$ pomohly ukázat, že zdrojem velkého a zbytečného trápení dětí v nemocnici je jejich separace od rodičů (případně chův, pěstounů nebo jiných blízkých lidí). S velkým ohlasem se setkal vědecký film „Dvouletá jde do nemocnice“ (1952), v němž James Robertson natočil skrytou kamerou dvouletou Lauru, jak jde do nemocnice bez doprovodu své maminky. Natočený materiál pak použil pro to, aby ukázal, jak separaci od své maminky holčička prožívá. Základ pro ukončení neetické praxe separování dětí od jejich rodičů byl položen.

Robertsonův kolega z londýnského Tavistock Institute, již zmíněný psycholog John Bowlby, zasvětil zkoumání vazeb mezi rodiči a dětmi velkou část svého profesního života - a jakkoli byly závěry prováděných studií jasné a průkazné, cestu do zdravotnické praxe si razily pomalu a ztěžka. Sám Bowlby k tomu poznamenal:

"Kdyby nepanovalo tolik mylných představ o normách chování, jež lze očekávat u malých dětí ponechaných, byt’ jen krátce, $v$ neznámém prostředí s neznámými lidmi, nebylo by nutné prezentovat tato data $v$ takové úplnosti. Přesto mylné názory pretrvávají, zejména mezi odborníky. Znovu a znovu se poukazuje na to, že zdravé normální dítě by nemělo vyvádèt, když od něj matka odchází, a že pokud to dělá, znamená to, bud’ že je matka rozmazluje, nebo 
že trpí nějakou patologickou úzkostí. Doufám, že tyto reakce budou nahliženy v novém a realističtějším světle, až porozumíme přirozenému vývoji a vazebnému chování." (2, s. 51)

Následovaly mnohé další práce, z nichž velký užitek přinesla např. kniha zkušené britské zdravotní sestry June Jolly Pediatrie z druhé strany (The Other Side of Paediatrics) (8): ta v roce 1980 svižnou a čtivou formou seznámila britskou pediatrickou veřejnost s praxí, označovanou jako family-centred care, tedy péče zaměřená na rodinu dětského pacienta. Kniha $\mathrm{v}$ mnoha zemích posloužila jako učebnice nového přístupu $\mathrm{k}$ nemocným dětem, kdy rodič není nahlížen jako narušitel, ale jako klíčový spolupracovník utvářející konkrétní podobu péče, jež je jeho nemocnému dítěti poskytována, a především jako jeho nezastupitelná opora.

Specifická situace nastane, jsou-li rodina a pečující tým konfrontováni se smrtí dítěte - at' už jde o př́pad, kdy se léčba nemocného dítěte ukáže jako marná a jeho život spěje ke konci, nebo o situaci, kdy smrt dítěte vstoupí do života rodiny jinak, kupříkladu jako následek nehody, úrazu či třeba trestného činu.

Konfrontace $\mathrm{s}$ realitou konečnosti pozemské existence má potenciál změnit povahu komunikace mezi rodinou a zdravotníky - otevřít dimenzi, která už není primárně charakterizována vztahem expert x laik, ale vztahem lidských bytostí, které, ač samozřejmě nejsou ve stejné situaci a stejném postavení, přesto sdílí stejný úděl, kladou si tytéž otázky a do určité míry čelí stejné nejistotě. Smrt je vždy zahalena tajemstvím a vždy přináší více otázek, než skutečných odpovědí.

Ukazuje se ale, že nemocnice pro tento druh komunikace a podpory dosud není vhodným prostředím - nevylučuje sice možnost individuálního lidského sblížení a souznění mezi konkrétním zdravotníkem a konkrétní rodinou, ale jakožto expertní instituce považuje uznání existenciální nejistoty $\mathrm{v}$ podstatě za slabost. Navzdory často laskavému přístupu se vnitřně nevzdává určité mocenské převahy, převahy odborníka nad laikem. Nemocniční instituce vnímá jako svou povinnost vědět si vždy rady, mít za všech okolností co nabídnout - ale tento postoj v principu sleduje potřebu instituce naplnit vlastní představu o sobě samé a izolovat se od potenciálně zraňujícího primárně lidského, nikoli primárně expertního kontaktu $\mathrm{s}$ ohrožujícím neznámem.

Jak koncem šedesátých let ve své knize O smrti a umírání (10) upozornila Elisabeth KüblerRossová, nemocnice je systémově nastavena na léčení a uzdravování - a neví si rady $\mathrm{v}$ situaci, kdy už tuto službu nabídnout nemůže. Důsledkem pak často byla izolace, v níž se umírající pacienti a jejich blízcí $\mathrm{v}$ nemocnici ocitali, poprŕípadě vzájemné předstírání zdravotníků, př́buzných i pacientů, ve snaze vyhnout se otevřenému pojmenování skutečného stavu věcí.

V uplynulých letech se tento trend začíná měnit, a to i v českém prostředí - smrt už dávno není tabu tématem, stále větší prostor získává paliativní péče, v nemocnicích, včetně těch, které pečují o děti, začínají působit paliativní týmy. Během své práce jsem měla možnost vést rozhovory s několika rodinami nemocných či umírajících dětí, které s péčí paliativního týmu přišly do kontaktu - jejich počet je zatím natolik nízký, že se neodvažuji vyslovovat zobecňující závěry, zdá se však, že praxe paliativních týmů někdy spíše posiluje odbornou dominanci instituce a pro rodinu vůbec nemusí být prínosem.

\subsection{Prostředí domova}

Na umírání v domácím prostředí se dnes často nahlíží ambivalentně - domov je synonymem bezpečného prŕístavu, člověk v něm má svůj prostor, své soukromí, své blízké. Kritici někdy namítají, že domov není vhodným prostředím tam, kde společnou domácnost s umírajícím dítětem sdílejí jeho sourozenci - tento postoj ale vychází z představy, že konfrontace $\mathrm{s}$ konečností je něco, před čím je dětskou duši třeba chránit.

Elisabeth Kübler-Rossová podobné námitky odmítala: 
"Děti, které byly - bez ohledu na svůj věk - zapojeny do domácí péče o terminálně nemocného bratřička či sestřičku, pak $v$ konci nešokuje ani netraumatizuje pohled na vyhublého sourozence s vydutým bríškem a modrými skvrnami na rukou a pažích. Vnímaji nemocného jinýma očima; komunikují spolu na jiné úrovni. Takový pohled šokuje jen ty, kdo nebyli součástí každodenni péče o nemocné dítě - takové návštěvníky je ovšem třeba, než vstoupi do pokoje k ditěti, nutné patřičně pripravit a poučit." (9, s. 20)

"Aby člověk dokázal bolest prekonat, musí ji prožit, ne obejít. Ti, kdo k tomu najdou odvahu, si pak v dlouhodobé perspektivě vedou lépe a uměji snáze - bez uhýbání a snahy o útěk - čelit také všem dalším životním otřesưm." (9, s. 20)

Problém samozřejmě může nastat v situaci, kdy si rodina umírajícího dítěte není jista vlastní schopností zastat odborné ošetřovatelské úkony, které mohou (byt' nemusejí) být v souvislosti $\mathrm{s}$ péčí o dítě zapotřebí - pak je pobyt $\mathrm{v}$ domácím prostředí spojen $\mathrm{s}$ jistým neklidem a psychickým dyskomfortem. Velkou úlevou může být kvalitní domácí paliativní či hospicová péče, praxe se ovšem opět velmi liší - pokud je ošetřování náročné a pokud si v něm rodina nevěří a dojíždějící tým jí současně nedokáže dát pocit setrvalého bezpečí a opory, může být lepším řešením pobyt $\mathrm{v}$ dětském hospici, který dá rodině jak pocit bezpečí, tak svobodu, soukromí a prostor.

\subsection{Prostřredí dětského hospice}

Dětský hospic je velmi specifickou institucí, která se snaži kombinovat výhody ošetřovatelského zázemí a domácího prostředí. První dětský hospic vznikl v roce 1982 ve Velké Británii, a jeho zakladatelka, zdravotní a řádová sestra Frances Dominica, jím reagovala na potřeby rodin ve svém okolí. Byla svědkem toho, jak je péče o vážně nemocné dítě pro rodiče náročná, a současně si uvědomovala, že žádná rodina nepotřebuje jen technický servis, odbornou službu - ale že je pro ně důležitý rozměr autentického lidského zájmu, skutečný nepředstíraný vztah; to, v čem podle ní musí spočívat podstata dětského hospice, pojmenovala "rošířeným prrátelstvím" (extended friendship).

Koncept dětského hospice byl inovativní i tím, že od počátku nebyl vázán na pevné fyzické místo, ale představoval spíše druh př́stupu, filosofii péče, specifický étos - a svého naplnění mohl dosáhnout v jakémkoli prostředí, kde jeho idea dostala adekvátní prostor.

Zkušenosti z dětských hospiců (jejich tradice je nejdelší a jejich sít' nejhustší ve Velké Británii), kde se neformálním pečovatelům z řad rodiny dostává prostoru a účastné podpory, ukazují, jak je důležité, aby rodina mohla prožívat alespoň poslední úsek života dítěte co nejsvobodněji, nejklidněji a nejradostněji, bez svazujícího očekávání svého okolí. Důležité je také to, aby se blízcí mohli s dítětem po jeho smrti v klidu, beze spěchu a bez tlaků a podle svého rozloučit - což nezahrnuje jen pohřební rituál, ale také veškerý předcházející čas trávený s tělem zemřelého dítěte. Pokud se takový malý zázrak podaří, hojí se rány, které ztráta způsobila, rychleji a snáz.

Dětské hospice, mají-li podobu konkrétního zařízení, jsou vybavené speciální místností, připomínající dětský pokoj, kde je možné uchovat tělo zemřelého dítěte i několik dní až týden, podle přání rodiny. Pro situaci perinatálního úmrtí je možné přímo na porodnici nebo doma využít přenosnou chladicí podložku.

Mají-li rodiče v konci života svého dítěte i po jeho úmrtí možnost zařizovat si věci podle svého a dostane-li se jim soucitné a zároveň nevtíravé podpory, procházejí fázemi smutku způsobem, který je sice stále bolí, ale neničí. Bolest jako reakce na ztrátu prožívaná s perspektivou nějaké naděje je pak normální životní cestou, která má pokračování a vede $\mathrm{k}$ hojení rány.

„Po celou tu dobu nám rodiny vyprávěji o tom, jak se změnily jejich priority, jak se změnily jejich hodnoty, jak najednou všechno začaly vnímat mnohem citlivěji. Rozhodně to neni něco, pro co byste se sami dobrovolně rozhodli - existuji ale požehnání, která objevíte uprostřed 
zármutku. “

Zakladatelka dětského hospicového hnutí Sestra Frances Dominica (17)

\section{ZÁVĚREM}

Svůj př́spěvek bych ráda zakončila krátkou vzpomínkou, která je vlastně i shrnutím toho, na čem při péči o nemocné bližní záleží nejvíc, jakýmsi spontánním etickým imperativem:

Je to vzpomínka na chlapce, který se svou maminkou prrijížděl na opakované pobyty do dětského hospice, který jsem s přáteli založila, po dobu více než deseti let. Jak se jeho zdravotní stav postupně zhoršoval, byla péče o něj čím dál náročnější a maminka, která se doma o chlapce starala sama, už bývala velice fyzicky i psychicky vyčerpaná. S odstupem několika let po synově úmrtí, když jsme spolu rekapitulovaly její př́iběh, na mou vážně a uprímně míněnou, ale v podstatě řečnickou otázku - kdo by v tak náročné životní zkoušce obstál stejně skvěle, jako ona - zareagovala slovy: "Každý...., kdo své ditě miluje." (16)

\section{Použitá literatura}

1. BOWLBY, John. Child Care and the Growth of Love. Harmondsworth: Penguin Books, 1968.

2. BOWLBY, John. Odloučeni: kritické obdobi raného vztahu mezi matkou a ditětem. Praha: Portál, 2012. ISBN 978-80-262-0076-5.

3. BOWLBY, John. Vazba: teorie kvality raných vztahů mezi matkou a dítětem. Praha: Portál, 2010. ISBN 978-80-7367-670-4.

4. BOWLBY, John. Ztráta: smutek a deprese. Praha: Portál, 2013. ISBN 978-80-2620355-1.

5. GAWANDE, Atul. Nežijeme věčně: medicína a poslední věci člověka. Praha: Dokořán, 2016. ISBN 978-80-7363-702-6.

6. ILLICH, Ivan. Disabling professions. New York: Distributed in the U.S. by Kampmann, 1977. ISBN 9780714525105.

7. ILLICH, Ivan. Limits to Medicine: Medical Nemesis, the Expropriation of Health. M. Boyars, 2013. ISBN: 9780714529936

8. JOLLY, June. The Other Side of Paediatrics: a Guide to the Everyday Care of Sick Children. Macmillan, 1981.

9. KÜBLER-ROSS, Elisabeth. $O$ dětech a smrti. Praha: ERMAT, 2003. ISBN 80903086-1-9.

10. KÜBLER-ROSS, Elisabeth. O smrti a umírání: co by se lidé měli naučit od umirajicich. Praha: Portál, 2015. ISBN 978-80-262-0911-9.

11. LANSDOWN, Richard. Children in hospital : a guide for family and carers. Oxford New York: Oxford University Press, 1996. ISBN: 0-19-262357-5.

12. NIGHTINGALE, Florence. Kniha o ošetřování nemocných. Přel. P. Králova. Praha: J. Otto, 1874.

13. ROBERTSON, James. Hospitals \& Children: A Parent's Eye View. London: Tavistock Institute of Human Relations, 1962.

14. ROBERTSON, James a Joyce ROBERTSON. Separation and the very young. London: Free Association Books, 1989. ISBN 1-85343-096-x.

15. SOKOL, Jan. Člověk jako osoba: filosofická antropologie. Třetí, rozširřrené vydání. Praha: Vyšehrad, 2016. Moderní myšlení. ISBN 978-80-7429-682-6.

16. Záznamy rozhovorů. Archiv Nadačního fondu Klíček. 1991-2019.

17. Životy dětí [film]. Scénář a režie Tomáš Škrdlant. Energeia, 2007. 


\section{Kontaktní údaje}

Mgr. Markéta Královcová, DiS.

Univerzita Karlova, Fakulta humanitních studií

Pátkova 2137/5, 18200 Praha 8

Tel: 775204109

email: marketa@klicek.org 
ISBN 978-80-87952-34-4

Vol. XI., 2021

Příspěvky publikované v tomto sborníku vyjadřují názory a stanoviska nezávislých autorů. | Papers published in this conference proceedings express the viewpoints of their independent authors.

Tato publikace neprošla redakční ani jazykovou úpravou.

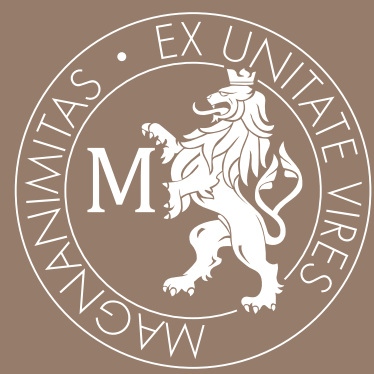

